\title{
REVista INTernacional de
}

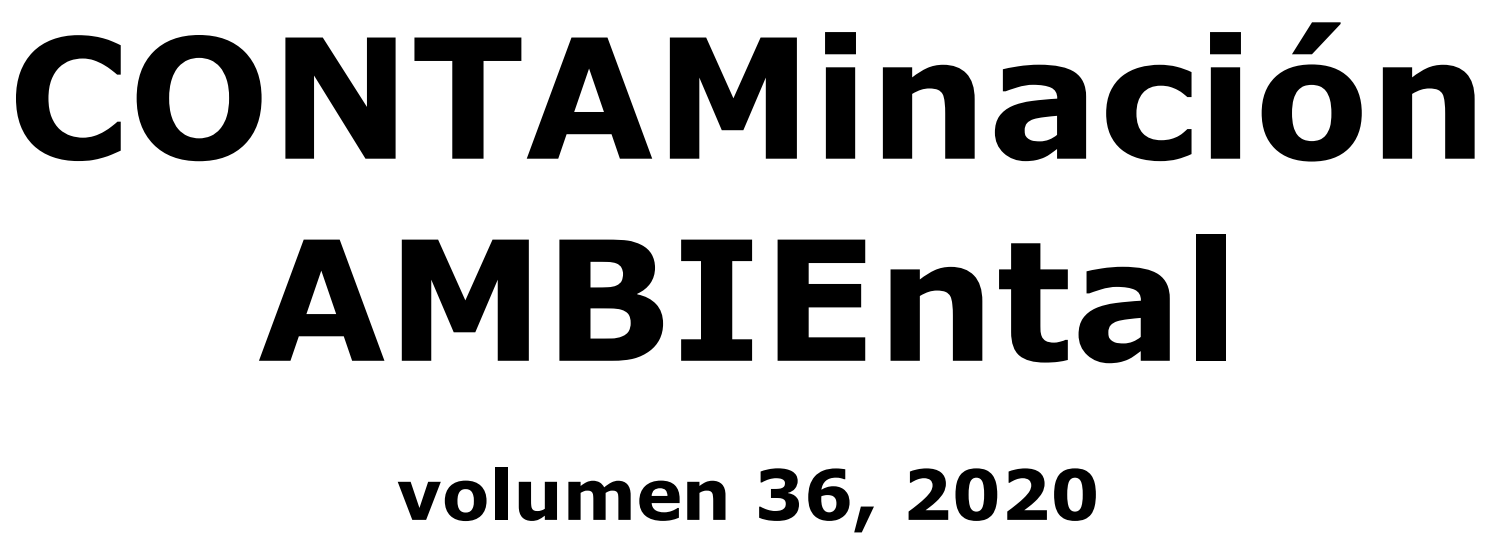

http://www.revistas.unam.mx/index.php/rica/

\section{MEMORIAS}

\section{CONGRESO INTERNACIONAL Y XXIV CONGRESO NACIONAL DE CIENCIAS AMBIENTALES}

03-07 Junio/2019 Mazatlán, Sinaloa

\section{Academia Nacional de Ciencias Ambientales}

\section{Editores}

\author{
Evaristo MÉndez Gómez \\ ANA MARÍA RIVAS MONTAÑO \\ MARÍA FERNANDA ESPINOZA BARRIOS \\ Luz del Carmen PÉrez González \\ ROSA MARÍa OREA PADILLA \\ JUANA SÁNCHEZ ALARCÓN \\ Rafael Valencia Quintana
}




\section{REVista INTernacional de}

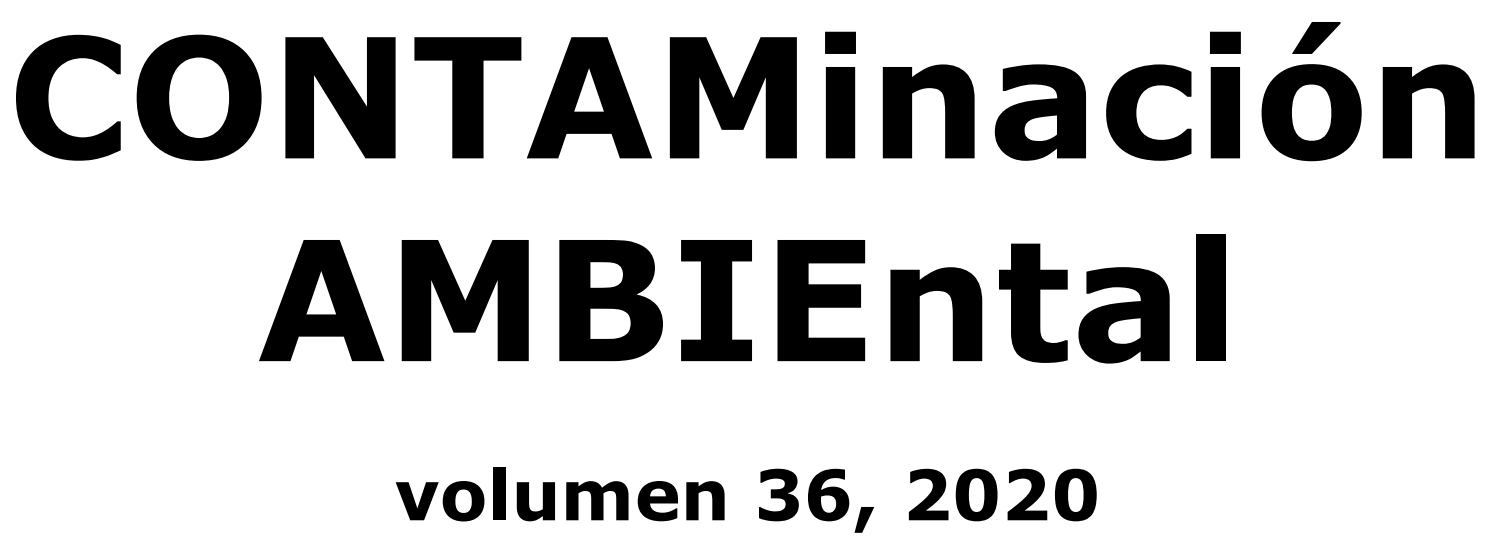

ISSN - 01884999

http://www.revistas.unam.mx/index.php/rica/

MEMORIAS

XVIII CONGRESO INTERNACIONAL Y XXIV CONGRESO NACIONAL DE CIENCIAS AMBIENTALES 03-07 Junio/2019 Mazatlán, Sinaloa

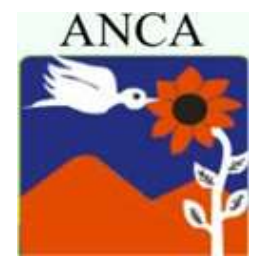




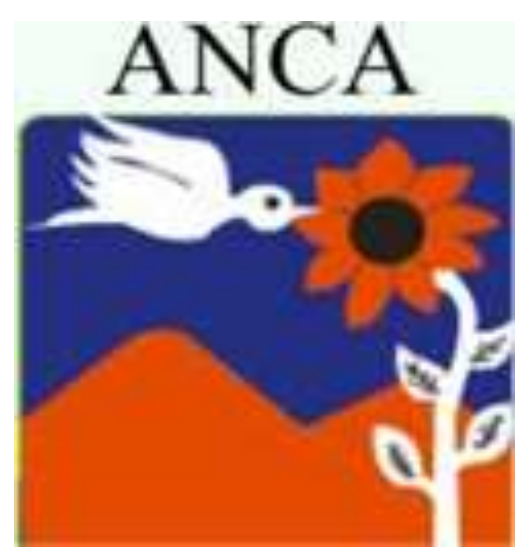

MEMORIAS

\title{
XVIII CONGRESO INTERNACIONAL Y XXIV CONGRESO NACIONAL DE CIENCIAS AMBIENTALES 03-07 Junio/2019 Mazatlán, Sinaloa
}

\author{
Editores \\ Evaristo MÉndez GÓmez \\ ANA MARÍA RIVAS MONTAÑO \\ MARÍA FERNANDA ESPINOZA BARRIOS \\ LUZ DEl Carmen PÉrez GONZÁlez \\ ROSA MARÍA OREA PADILLA \\ JUANA SÁNCHEZ ALARCÓN \\ RAFAel VALENCiA Quintana
}




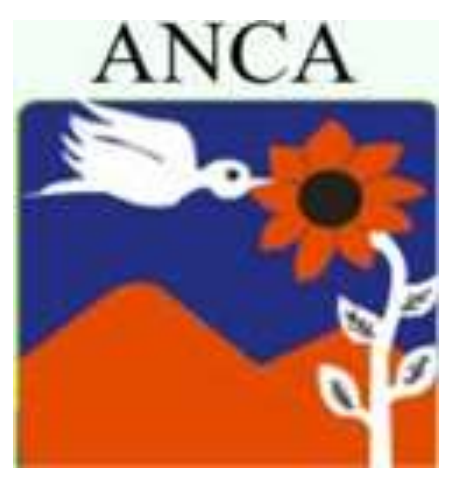

MEMORIAS

\section{CONGRESO INTERNACIONAL Y XXIV CONGRESO NACIONAL DE CIENCIAS AMBIENTALES \\ 03-07 Junio/2019 Mazatlán, Sinaloa \\ Índice}

Página

Mesa directiva

Academia Nacional de Ciencias Ambientales 2017-2019

Autoridades del Instituto Tecnológico de Mazatlán

viii

Comité científico

ix

Comités organizadores

Agradecimientos

Índice general de autores

$X V$

Índice de autores por Área Temática

Ivii

Resúmenes por Área Temática

I Calidad del Agua y Saneamiento

CV

II Energías Limpias y Acciones por el Clima

cliv

III Legislación, Valores Sociales y Educación Ambiental

cxciii

IV Medio Ambiente y Alimentación de Calidad con Inocuidad

cclxx

$\checkmark$ Medio Ambiente, Contaminación, Enfermedad y Genotoxicidad

ccxcvii

VI Recursos Naturales, Ecosistemas y Deterioro Ambiental

ccclviii

VII Tecnología y Biotecnología para el Tratamiento de

Contaminantes y Biorremediación

dxcix 


\section{CONGRESO INTERNACIONAL Y XXIV CONGRESO NACIONAL DE CIENCIAS AMBIENTALES}

03-07 Junio/2019 Mazatlán, Sinaloa

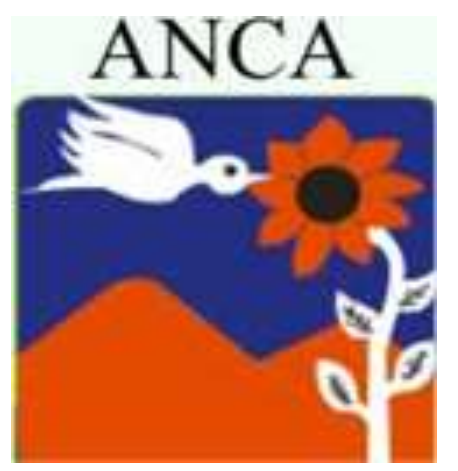

\section{Mesa directiva ANCA 2018-2019}

Dr. Santiago Valle Rodríguez

Presidente

Dr. Evaristo Méndez Gómez

Secretario

Dra. Ana María Rivas Montaño

Tesorera 


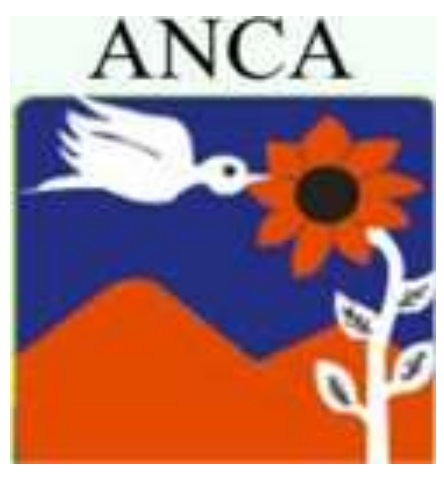

\section{EX-PRESIDENTES}

Dr. A. Alberto Pereira Corona (2018, 2011, 2006) Universidad de Quintana Roo

Dra. Gisela Campos Ángeles (2017)

Instituto Tecnológico del Valle de Oaxaca

Dr. Miguel Ángel Valera Pérez (2016)

Benemérita Universidad Autónoma de Puebla

Dra. María Laura Sampedro Rosas (2001, 2015) Universidad Autónoma de Guerrero

Dra. Alba Yadira Corral Avitia (2014) Universidad Autónoma de Ciudad Juárez

Dra. Ma. Guadalupe Ibarra Ceceña (2013) Universidad Autónoma Indígena de México

M. en C. Gustavo Pedraza Aboytes (2012) Universidad Autónoma de Querétaro

Dr. Pedro Rafael Valencia Quintana (2011) Universidad Autónoma de Tlaxcala

Dr. Rodrigo González Enríquez (2010) Instituto Tecnológico de Sonora

Dra. María Laura Ortiz Hernández (2007) Universidad Autónoma del Estado de Morelos 


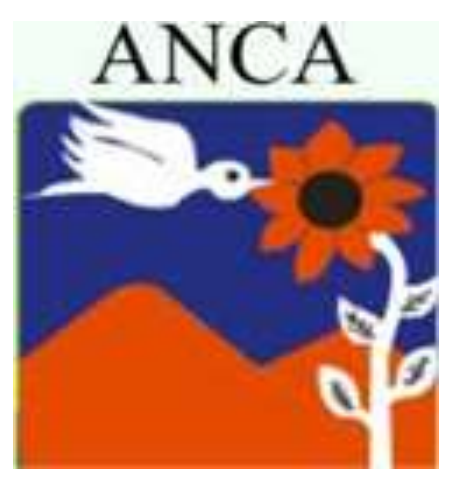

\section{EX-PRESIDENTES}

Dra. Nelda Xanath Martínez Galero (2005) Universidad del Mar

M. en A. Antonio Aranda Regalado (2004) Universidad Autónoma de Querétaro

Dr. Alberto José Gordillo Martínez (2002) Universidad Autónoma del Estado de Hidalgo

Dr. Arturo Colín Cruz (2000)

Universidad Autónoma del Estado de México

Dr. Evaristo Méndez Gómez

Instituto Tecnológico del Mar Mazatlán

M. en C. Hermilo Santoyo Reyes (2009)

Universidad Autónoma de Baja California Sur

Dr. Manuel Sosa Cerecedo (2008)

Universidad Autónoma de Chihuahua

Dr. en C. Raudel Ramos Olmos Universidad Autónoma de Baja California

Dra. Amada Carrasco

Universidad Autónoma de Nayarit 


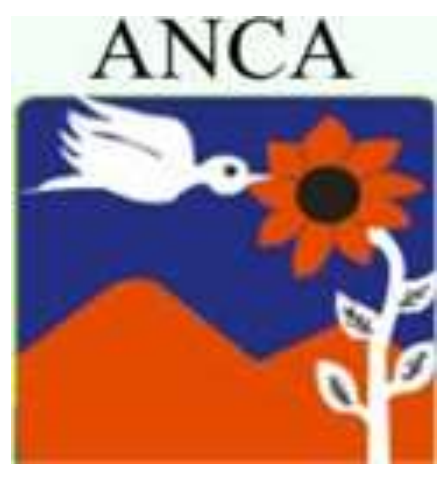

\section{VOCALES}

Dr. Miguel Ángel Valera Pérez

Benemérita Universidad Autónoma de Puebla

Dra. Sonia EMILIA Silva Gómez BenemÉRITA UNIVERSidAd AUtÓNOMA DE PUebla

Dr. Ignacio Villanueva Fierro CIIDIR-IPN DURANGO

Dr. Juan Manuel Vigueras Cortés CIIDIR-IPN DURANGO

Dr. Mario Alberto Tornero Campante Colegio de Postgraduados Campus Puebla

Dra. Elisa Cortes BadilLo

INSTITUTO TECNOLÓGICO DE ACAPULCO

Dr. Rolando Palacios Ortega INSTITUTO TECNOLÓGICO DE ACAPULCO

Dra. Gisela Campos Ángeles Instituto TeCNOLÓGICO del VALLE DE OAXACA

DR. MARTIN VILLA IBARRA

Instituto TECNOLógico SuPERIOR DE CAJEME

Dra. Claudia M. Agraz Hernández UNIVERSIDAD AUTÓNOMA DE CAMPECHE 


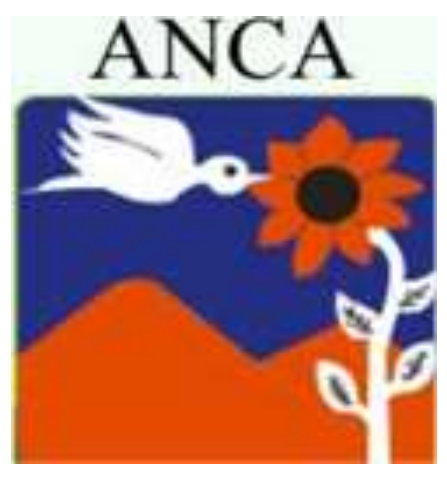

\section{VOCALES}

Dr. Carlos Armando Chan Keb UNIVERSIDAD AUTÓNOMA DE CAMPECHE

Dra. Alba Yadira Corral Avitia UNIVERSIDAD AUTÓNOMA DE CIUDAD JUÁREZ

Dra. Katya AimeÉ Carrasco UrRutia UNIVERSIDAD AUTÓNOMA DE CIUDAD JUÁREZ

Dra. María Laura SAMPEdRo Rosas UNIVERSIDAD AUTÓNOMA DE GUERRERO

DR. Justiniano GonZÁlez GONZÁlEZ UNIVERSIDAD AUTÓNOMA DE GUERRERO

Dra. Irma paz Hernández Rosales UNIVERSIDAD AUTÓNOMA DE NAYARIT

DR. Jesús BERnARDino VelÁzQuez UNIVERSIDAD AUTÓNOMA DE NAYARIT

M. en C. Gustavo Pedraza Aboytes UNIVERSIDAD AUTÓNOMA DE QUERÉTARO

Dr. Miguel Ángel Rico RodRÍGUeZ UNIVERSIDAD AUTÓNOMA DE QUERÉTARO

DR. JULIO CÉSAR Rolón Aguilar UNIVERSIDAD AUTÓNOMA DE TAMAULIPAS 


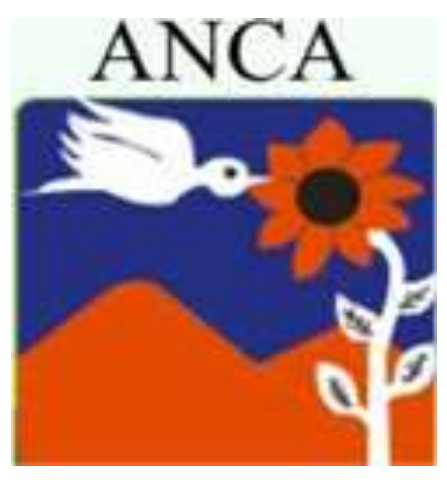

\section{VOCALES}

Dr. René Bernardo Elías Cabrera Cruz

UNIVERSIDAD AUTÓNOMA DE TAMAULIPAS

M. en C. A. Juana SÁnchez Alarcón UNIVERSIDAD AUTÓNOMA DE TLAXCALA

M. en C. José Mariano Rigoberto Montiel GonzÁlez UNIVERSIDAD AUTÓNOMA DE TLAXCALA

Dr. en C. Santiago Valle Rodríguez UNIVERSIDAD AUTÓNOMA DE ZACATECAS

Dra. EN C. Josefina HuERTA García UNIVERSIDAD AUTÓNOMA DE ZACATECAS

Dr. Alberto José Gordillo Martínez UNIVERSIDAD AUTÓNOMA DEL ESTADO DE HIDALGO

DRA. GRISELDA PULIDO FloRES UNIVERSIDAD AUTÓNOMA DEL ESTADO DE HIDALGO

Dr. Arturo Colín Cruz

UniverSidAd AUtónOMA DEL ESTADO DE MÉXICO

M. en C. José Guadalupe Michel Parra UNIVERSIDAD DE GUADALAJARA

M.C. Esther Barragán Bautista UNIVERSIDAD DE GUADALAJARA 


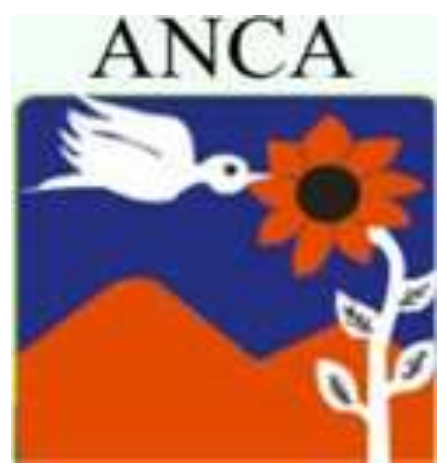

\section{VOCALES}

Dra. Nelda Xanath Martínez Galero UNIVERSIDAD DE PAPALOAPAN

M. en C. Benito Prezas Hernández UNIVERSIDAD DE QUINTANA ROO

Dr. Alberto Pereira Corona UNIVERSIDAD DE QUINTANA ROO

M. en E. Víctor Manuel Mancha YÁÑEZ UNIVERSIDAD DEL NOROESTE

M.D.E.S. ROdOLFO VILCHIS AGUIRRE UNIVERSIDAD DEL NOROESTE

BIÓL. JosÉ ViCCON ESQUIVEL UNIVERSIDAD LOYOLA DEL PACÍFICO

Ecól. Pedro Antonio Nava Aguilera UNIVERSIDAD LOYOLA DEL PACÍFICO

DRA. SANDRA GÓmEZ ARROYO UniVERSidAd NACIONAL AUtónOMA DE MÉXICO

DR. Stefan WaLiszeWSKI Kubiak UNIVERSIDAD VERACRUZANA 


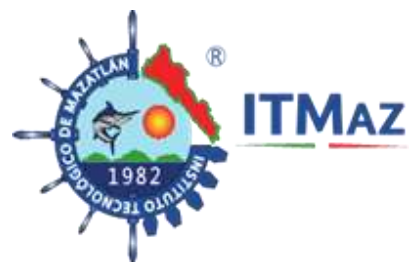

\title{
Tecnológico Nacional de México
}

Dr. Enrique Fernández Fassnacht

Director General TNM

\section{Instituto Tecnológico de Mazatlán}

\author{
Dr. Sergio Efraín Beltrán Beltrán \\ Director \\ Dra. Laura Raygoza Solís, \\ Subdirectora Académico
}

\section{Instituto de Apoyo a la Investigación e Innovación de Sinaloa}

Lic. Quirino Ordaz Coppel, Gobernador del Estado de Sinaloa

Ing. Bernardino Antelo Esper Director General INAPI

Biól. Guillermo Verdugo Velázquez

Director de Comunicación y Divulgación

Lic. Marisol Sánchez Hernández

Dirección de Comunicación y Divulgación 


\section{ANCA \\ XVIII CONGRESO INTERNACIONAL Y XXIV CONGRESO NACIONAL DE CIENCIAS AMBIENTALES \\ 03-07 Junio/2019 Mazatlán, Sinaloa}

\section{Comité Científico - ACADÉmico}

Dra. Ana María Rivas Montaño

Tecnológico Nacional de México

Dra. Sarahí Ross Muñoz

Tecnológico Nacional de México

Dr. Juan Antonio Cortés Ruiz

Tecnológico Nacional de México

Dr. Jorge Ricardo Ruelas Inzunza

Tecnológico Nacional de México

Dr. Evaristo Méndez Gómez

Tecnológico Nacional de México

M. en C. Heimy Franceline Sánchez Martínez

Tecnológico Nacional de México

Dr. Jesús Antonio Ramírez López

Dirección de Ciencia y Tecnología del Mar

Dr. José Luis Peña Manjarrez

Dirección de Ciencia y Tecnología del Mar

Dr. Jushiro Carlos Adolfo Cepeda Morales

Centro Nayarita de Innovación y Transferencia de Tecnología

Universidad Autónoma de Nayarit

Dr. Pedro Rafael Valencia Quintana

Laboratorio "Rafael Villalobos Pietrini" de TGyQA

Universidad Autónoma de Tlaxcala 


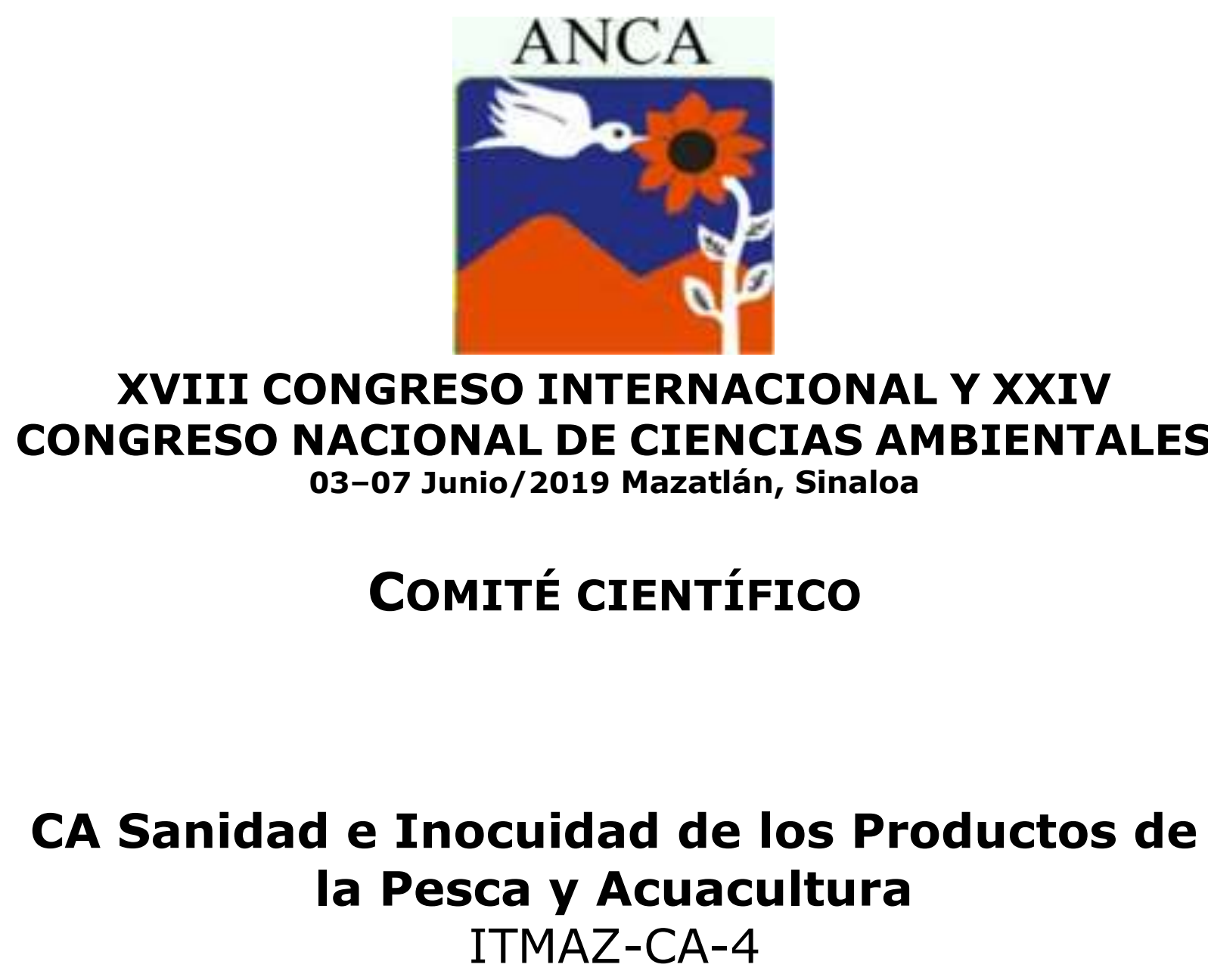

CA Ambiente y Genética

UATLX-CA-223 


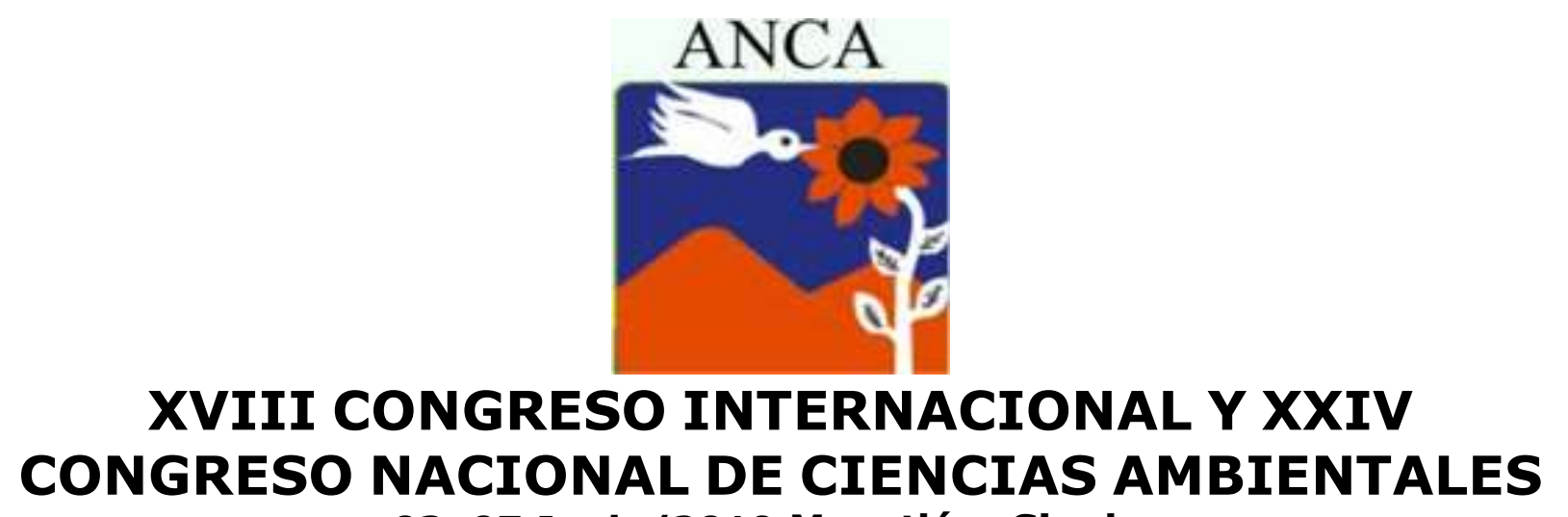

03-07 Junio/2019 Mazatlán, Sinaloa

COMITÉS OGANIZADORES

\title{
Academia Nacional de Ciencias Ambientales
}

\author{
Dr. Santiago Valle Rodríguez, Presidente \\ Dr. Evaristo Méndez Gómez, Secretario \\ Dra. Ana María Rivas Montaño, Tesorera
}

\section{Tecnológico Nacional de México / IT Mazatlán}

Dr. Enrique Fernández Fassnacht, Director General

Dr. Sergio Efraín Beltrán Beltrán, Subdirector Académico

Dra. Laura Raygoza Solís, Subdirector Académico

\section{Instituto de Apoyo a la Investigación e Innovación}

Ing. Bernardino Antelo Esper, Director General

Biól. Guillermo Verdugo Velázquez,

Director de Comunicación y Divulgación

Lic. Marisol Sánchez Hernández,

Dirección de Comunicación y Divulgación 


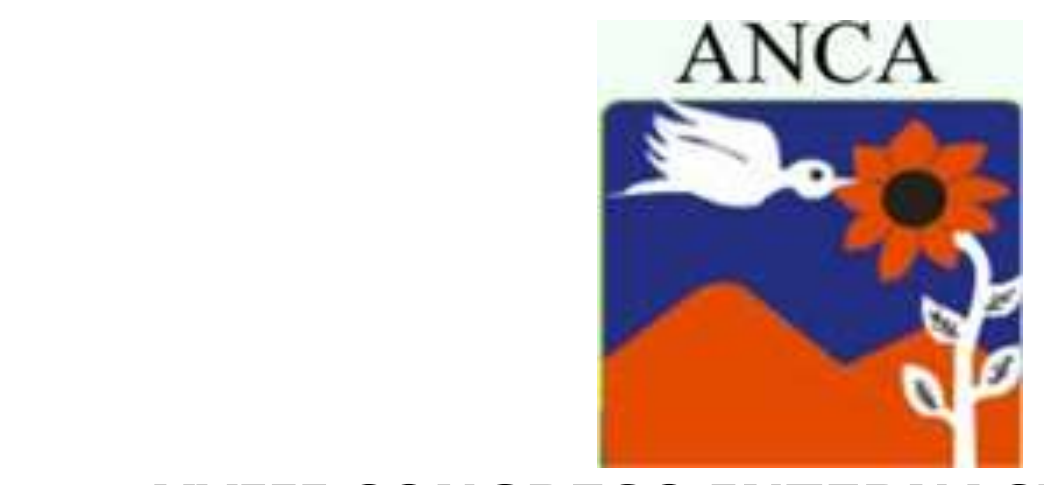

XVIII CONGRESO INTERNACIONAL Y XXIV CONGRESO NACIONAL DE CIENCIAS AMBIENTALES

03-07 Junio/2019 Mazatlán, Sinaloa

\title{
COMITÉS OgANIZADORES
}

\author{
Logística \\ I.B.Q. María Guadalupe Salazar Durán \\ I.B.Q. María Fernanda Espinoza Barrios \\ Dra. Ana María Rivas Montaño
}

CA Sanidad e Inocuidad de los Productos de la Pesca y Acuacultura

ITMAZ-CA-4

CA Ambiente y Genética

UATLX-CA-223 


\author{
ANCA

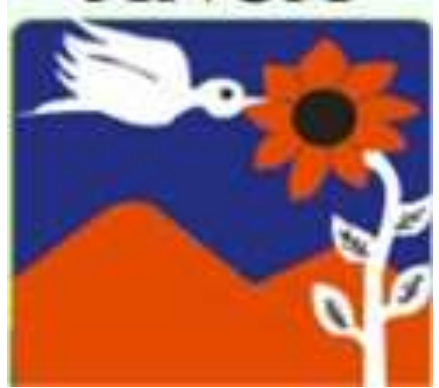 \\ XVIII CONGRESO INTERNACIONAL Y XXIV \\ CONGRESO NACIONAL DE CIENCIAS AMBIENTALES \\ 03-07 Junio/2019 Mazatlán, Sinaloa \\ AgRADECIMIENTOS \\ LA ACADEMIA NACIONAL DE CIENCIAS AMBIENTALES \\ AGRADECE EL APOYO OTORGADO POR
}

\author{
Lic. Quirino Ordaz Coppel \\ Gobernador Constitucional del Estado de Sinaloa
}

por su decidido apoyo para la difusión de la ciencia y tecnología

y por su respaldo para el desarrollo del magno evento de la Academia Nacional de Ciencias

\author{
Dr. Enrique Fernández Fassnacht \\ Director General del Tecnológico Nacional de México
}

por su apoyo para la realización del evento en el seno de la comunidad Tecnológica

\title{
Dr. Sergio Efraín Beltrán Beltrán \\ Director del Instituto Tecnológico de Mazatlán
}

por su apoyo incondicional y total para la realización de este congreso 


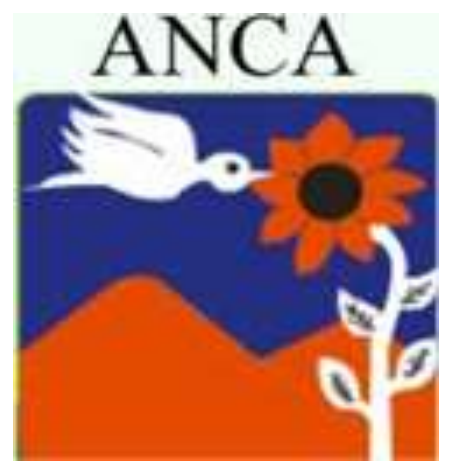

\title{
XVIII CONGRESO INTERNACIONAL Y XXIV CONGRESO NACIONAL DE CIENCIAS AMBIENTALES
}

03-07 Junio/2019 Mazatlán, Sinaloa

\author{
AgRADECIMIENTOS \\ LA ACADEMIA NACIONAL DE CIENCIAS AMBIENTALES \\ AGRADECE EL APOYO OTORGADO POR LA
}

\author{
REVista INTernacional de \\ CONTAMinación \\ AMBIEntal
}




\section{CONGRESO INTERNACIONAL Y XXIV CONGRESO NACIONAL DE CIENCIAS AMBIENTALES 03-07 Junio/2019 Mazatlán, Sinaloa \\ Índice general de autores AUTOR \\ ÁreA \\ TEMÁTICA \\ PÁGINAS}

A

Abarca Pérez A

Abarca Urquiza JR

Acevedo Sandoval O

Agraz Hernández CM

Agüelles Hernández E

Aguilar B

Aguilar Becerra CD

Aguilar Santana M

Aguilar Urrutia $P$

Aguilera Alvarado AF

Aguilera Flores $M$

Aguíniga García S

Aguirre García Z

Aguirre Ramírez M

Aguirre Terrazas K

Agular Ortega $F$

Airasca A

Alarcón Barrón M

Alba Romero J

Alcántara Ángeles A

Alcaraz Novoa J

Alcazar Medina F

Aldana Llanos L

Alfaro Martínez V

Alférez Chávez J
VII TyBTCyB

III LVSyEA

II ELyAC

VI RNEyDA

VII TyBTCyB

VI RNEyDA

III LVSyEA

VII TyBTCyB

VI RNEyDA

VII TyBTCyB

$\checkmark$ MACEYG

VI RNEyDA

VII TyBTCyB

I CAyS
II ELyAC
VI RNEyDA
VI RNEyDA
VII TyBTCyB
VII TyBTCyB
II ELyAC
VII TyBTCyB
VII TyBTCyB
V MACEyG
VII TyBTCyB
III LVSyEA
VII TyBTCyB
VII TyBTCyB
VII TyBTCyB
I CAyS
VII TyBTCyB

1, 2

1,2

35,36

$1,2,35,36,37,38$

1,2

1,2

3,4

3,4

67,68

159,160

55,56

$33,34,75,76$

$167,168,197,198,199,200,223$,

224

11,12

37,38

9,10

3,4

95, 96

217, 218

33,34

33,34

5,6

21,22

31,32

65,66

151,152

7,8

$43,44,45,46$

1,2

131,132 


\section{CONGRESO INTERNACIONAL Y XXIV CONGRESO \\ NACIONAL DE CIENCIAS AMBIENTALES}

03-07 Junio/2019 Mazatlán, Sinaloa

\section{Índice general de autores \\ AUTOR \\ ÁrEA \\ TEMÁtICA \\ PÁGINAS}

VII TyBTCyB

I CAyS

VII TyBTCyB

I CAyS

VI RNEyDA

Alonso Calderón A

Alonso-Eguia LP

Altanasa L

Alva Chavarría D

Alvarado Fierro $O$

Alvarado Lassman A

Alvarado MS

Alvarado Villanueva $\mathrm{R}$

Alvarez Bernal D

Álvarez Contreras CA

Álvarez Domínguez A

Álvarez Fuentes $G$

Álvarez Gallegos A

Álvarez Ortega $O$

Amabilis L

Amábilis Sosa $L$

Amador-Muñoz O

Amador-Valencia $T$

Amaya Chávez $\mathrm{A}$

Ambriz Pérez D

Andrade Hernández F

VII TyBTCyB

VI RNEyDA
101, 102

39,40

97, 98

3,4

87,88

$23,24,137138,155,156$

5,6

39,40

5,6

97,98

$85,86,109110$

17,18

57,58

$5,6,177,178,179,180$

17,18

147, 148

9,10

7,8

101, 102

87,88

11,12

117, 118

5,6

45,46

$13,14,179,180$

1,2

1,2

33,34

53,54

177, 178

$5,6,19,20$

81,82
79,180 


\section{CONGRESO INTERNACIONAL Y XXIV CONGRESO \\ NACIONAL DE CIENCIAS AMBIENTALES}

03-07 Junio/2019 Mazatlán, Sinaloa

\section{Índice general de autores AUTOR \\ ÁrEA \\ TEMÁTICA \\ PÁGINAS}

Angoa-Cortés R
Angoa-Perez V
Anguas Cabrera D
Antonio Robles J
Aquino De Los Ríos G

Aranda Figueroa MG

Aranda Vivas LI

Arce Camacho I

Arce García I

Arce Martínez GI

Arce Romero $P$

Arcos Ramos $\mathrm{R}$

Arcos Severo M

Arellano Wences $\mathrm{H}$

Arenas-Espinosa $\mathrm{R}$

Arenas-Sánchez H

Argumedo Macías A

Arredondo Ríos A

Arreola Lizárraga A

Arriola Morales J

Arroyo-Galván A

Avelino Flores $\mathrm{F}$

Ávila Galarza A

Ávila Martínez AK

Ávila $P$

Ávila Pérez $\mathrm{P}$

Ávila Vázquez V

Avilés Flores M
V MACEYG

IV MAYACI

I CAyS

VI RNEyDA

VI RNEyDA

VI RNEyDA

VII TyBTCyB

VII TyBTCyB

VII TyBTCyB

III LVSyEA

III LVSyEA

II ELyAC

VI RNEyDA

I CAyS

VI RNEyDA

III LVSyEA

IV MAyACI

V MACEYG

VI RNEyDA

II ELyAC

VI RNEyDA

VI RNEyDA

VII TyBTCyB

V MACEYG

I CAYS

VI RNEyDA

VII TyBTCyB

VII TyBTCyB

VI RNEyDA

VII TyBTCyB

V MACEYG

VI RNEyDA

I CAyS
49,50

21,22

11,12

9,10

11,12

7, 8, 155, 156

135,136

15,16

$17,18,19,20$

5,6

7,8

29,30

13,14

33,34

15,16

$23,24,55,56$

7,8

43,44

219,220

9,10

65,66

11,12

$37,38,39,40$

3,4

21,22

109, 110, 145, 146

101,102

125,126

77,78

103, 104

55,56

$65,66,71,72,75,76$

7, 8 


\section{CONGRESO INTERNACIONAL Y XXIV CONGRESO \\ NACIONAL DE CIENCIAS AMBIENTALES}

03-07 Junio/2019 Mazatlán, Sinaloa

\section{Índice general de autores \\ AUTOR \\ ÁreA \\ TEMÁTICA \\ PÁGINAS}

Avilés Pineda $\mathrm{H}$

Ayala Espinoza M

Ayala Ramirez L

Azua-Alonso D

B

Bahena Galindo ME

Bailón Salas A

Balderas Hernández P

Balderas Plata MA

Bandala ER

Bañuelos Arcos F

Bañuelos Romero $\mathrm{F}$

Barajas Mojarro J

Barragán Aroche JF

Barragán Bautista $\mathrm{E}$

Barragán Peña $P$

Barrena R

Barrera Díaz CE

Barrón Hernández L

Batalla Mayoral J

Batista García RA

Bautista Bautista R

Bautista Capetillo C

Bautista Mulia J

Bautista Rodríguez CM

Becerra Rodríguez J

Becerril Bravo J

Bedolla Hernández M
III LVSyEA

III LVSyEA

VI RNEyDA

V MACEyG

VI RNEyDA

II ELyAC

VII TyBTCYB

VI RNEyDA

VII TyBTCyB

III LVSyEA

VI RNEyDA

V MACEyG

III LVSyEA

VII TyBTCyB

I CAyS

I CAyS

III LVSyEA

VI RNEyDA

VII TyBTCyB

VII TyBTCyB

VII TyBTCyB

VII TyBTCyB

VII TyBTCyB

VI RNEyDA

I CAyS

VII TyBTCyB

VII TyВTCyB

VII TyВTCyB

VII TyBTCyB

VII TyBTCyB
39,40

25,26

203, 204

3, 4
$17,18,175,176$

27,28

153,154

53,54

$75,76,111,112,177,178$

43,44

15,16

45,46

31,32

225, 226

15,16

43,44

9,10

19,20

105,106

75,76

21,22

93, 94

165, 166

213, 214

35,36

$23,24,137,138$

159, 160

25,26

113, 114

1, 2

xviii 


\section{CONGRESO INTERNACIONAL Y XXIV CONGRESO NACIONAL DE CIENCIAS AMBIENTALES 03-07 Junio/2019 Mazatlán, Sinaloa \\ Índice general de autores AUTOR \\ ÁrEA \\ TEMÁTICA \\ PÁGINAS}

Bedolla Solano R

Bello Velázquez JA

Bello-González O

Beltrán Cortes $\mathrm{R}$

Beltrán Ramírez M

Benítez Paz RF

Benítez Pineda C

Benítez-Martínez E

Beristaín Cardoso R

Berlanga Robles CA

Bernal-Mendoza $\mathrm{H}$

Bluhm Gutiérrez J

Bonassi S

Bonillas García G

Botello de la Peña DC

Bravo Pablo L

Brito García C

Burrola Aguilar C

Bustamante Montes LP

Bustos Terrones J

Bustos Terrones $Y$
III LVSyEA

$\checkmark$ MACEYG

VI RNEyDA

VII TyBTCyB

$\checkmark$ MACEYG

VII TyBTCyB

VII TyBTCyB

VI RNEyDA

VI RNEyDA

V MACEYG

VII TyBTCyB

VI RNEyDA

IV MAYACI

II ELyAC

VI RNEyDA

$\checkmark$ MACEYG

VI RNEyDA

VI RNEyDA

VII TyBTCyB

VII TyBTCyB

I CAyS

VI RNEyDA

III LVSyEA

VII TyBTCyB

V MACEYG

VII TyBTCyB
39,40

51,52

69,70

$17,18,19,20$

5,6

27,28

187,188

19,20

21,22

$25,26,27,28$

169,170

$29,30,161,162,213,214,227,228$

$3,4,5,6$

33,34

105,106

57,58

219,220

19,20

29,30

137,138

9,10

$21,22,239,240$

33,34

87,88

45,46

69,70

\section{C}

Caballero Hernandez D

VI RNEyDA

223, 224

Cabanillas García Z

Cabral Lares M

Cabrera Cruz RBE

VI RNEyDA

I CAyS

III LVSyEA
229, 230

47,48

11,12 


\section{CONGRESO INTERNACIONAL Y XXIV CONGRESO NACIONAL DE CIENCIAS AMBIENTALES}

03-07 Junio/2019 Mazatlán, Sinaloa

\section{Índice general de autores AUTOR \\ ÁrEA \\ TEMÁtICA \\ PÁGINAS}

Cabrera Cruz RBE

Cáceres RK

Caiola $\mathrm{N}$

Calderón-Fernández L

Calero De Hoces M

Calleros-Rincón E

Camacho Cruz K

Camacho Sanabria $\mathrm{R}$

Camarena Gómez B

Camarena Morales A

Camarillo-Romero $\mathrm{M}$

Cambranis-Miñon JH

Campaña $\mathrm{H}$

Campos Angeles $\mathrm{G}$

Campos Reales Pineda A

Campos Verduzco $\mathrm{R}$

Candal R

Canizales Romo M

Capulin Grande J

Carbajal Ávila J

Carbajal de la Torre G

Cardiel Pérez L

Careaga Ruiz J

Carlos Márquez M

Caro Becerra J

Carrasco Campos $\mathrm{P}$

Carrasco Urrutia K

Carreño Aguilera G

Carrillo Birkhahn JA
VI RNEyDA

VI RNEyDA

VII TyBTCyB

IV MAyACI

VII TyBTCyB

$\checkmark$ MACEYG

VII TyBTCyB

I CAyS

VI RNEyDA

I CAyS

III LVSyEA

III LVSyEA

V MACEYG

$\checkmark$ MACEYG

VI RNEyDA

VII TyBTCyB

VI RNEyDA

VII TyBTCyB

VI RNEyDA

VII TyBTCyB

$\checkmark$ MACEYG

VI RNEyDA

VI RNEyDA

II ELyAC

VII TyBTCyB

VI RNEyDA

VI RNEyDA

I CAyS

VII TyBTCyB

III LVSyEA

VII TyBTCyB

VII TyBTCyB

II ELyAC
205, 206

23, 24

193, 194

$3,4,5,6$

71,72

$21,22,47,48$

31,32

11,12

9,10

13,14

19,20

13,14

53,54

7,8

$25,26,133,134$

$33,34,147,148$

137, 138, 207, 208

231, 232

125,126

237, 238

33,34

199, 200

131, 132

3,4

187, 188

115,116

171,172

$15,16,23,24$

35,36

$15,16,61,62$

217, 218

149, 150

37,38 


\section{CONGRESO INTERNACIONAL Y XXIV CONGRESO \\ NACIONAL DE CIENCIAS AMBIENTALES}

03-07 Junio/2019 Mazatlán, Sinaloa

\section{Índice general de autores AUTOR \\ ÁreA \\ TEMÁtICA \\ PÁGINAS}

Carrillo L

Carvajal Hernández GR

Casas Huerta E

Casas Valdez M

Castañeda López $O$

Castañeda Roldán E

Castañón Bautista $\mathrm{C}$

Castellanos Juárez $\mathrm{F}$

Castellanos Tapia F

Castellanos-Moguel J

Castillo Elías B

Castillo Morales M

Castrejón Godínez ML

Ceballos Corona JGA

Ceceña MG

Cedillo Herrera C

Ceniceros Gómez A

Cerón Bracamontes M

Cerrillos Valle G

Cervantes Aguilar M

Cervantes Duarte R

Chacón Aguilar J

Chaírez-Hernández I

Chan Keb C

Chavarría Murillo CD

Chavez Barrera J

Chávez Bravo $\mathrm{E}$

Chavez Castellanos K Chávez Guajardo AE
I CAyS

VII TyBTCyB

VI RNEyDA

VI RNEyDA

VI RNEyDA

I CAyS

VI RNEyDA

VI RNEyDA

VI RNEyDA

V MACEYG

VI RNEyDA

IV MAyACI

VII TyBTCyB

VII TyBTCyB

VI RNEyDA

III LVSyEA

I CAyS

VII TyBTCyB

VI RNEyDA

II ELyAC

VI RNEyDA

VI RNEyDA

VI RNEyDA

VI RNEyDA

III LVSyEA

IV MAyACI

VI RNEyDA

VII TyBTCyB

VI RNEyDA

I CAyS

VII TyBTCyB

I CAyS

VII TyBTCyB
11,12

203, 204

27,28

11,12

$123,124,125,126,171,172$

1,2

229, 230

111,112

29,30

15,16

69,70

7, 8

$37,38,39,40$

117, 118

5,6

57,58

5,6

13,14

101, 102

1, 2

93, 94

31,32

33,34

11,12

31,32

9,10

$35,36,37,38$

41,42

$35,36,37,38$

$1,2,21,22$

23, 24, 155, 156

17,18

171, 172 


\section{CONGRESO INTERNACIONAL Y XXIV CONGRESO NACIONAL DE CIENCIAS AMBIENTALES}

03-07 Junio/2019 Mazatlán, Sinaloa

\section{Índice general de autores AUTOR \\ ÁreA \\ TEMÁtICA \\ PÁGINAS}

Chávez Heredia V

Chávez Ramírez EA

Chávez Ramírez SC

Chávez Ríos BP

Chávez Soto $M$

Chavez Varela KI

Chavira Alvarado A

Chi Cabrera G

Cobian Cervantes R

Cobián del Toro $S$

Colín Cruz A

Colín JG

Colmenero A

Colmenero Robles A

Concepción Acosta C

Conde Barajas E

Conde Hernández A

Contreras López D

Contreras Medina P

Contreras Molina A

Cordero Lezama A

Corona Loya LE Ríos

Corral Avitia A

Corrales Burgueño V

Correa Arredondo J

Correa García A
VI RNEyDA

VI RNEyDA

III LVSyEA

VII TyBTCyB

III LVSyEA

VII TyBTCyB

VII TyBTCyB

VII TyBTCyB

VI RNEyDA

VI RNEyDA

VI RNEyDA

VII TyBTCyB

V MACEYG

VI RNEyDA

II ELyAC

III LVSyEA

VI RNEyDA

VII TyBTCyB

VI RNEyDA

VII TyBTCyB

VII TyBTCyB

VII TyBTCyB

VI RNEyDA

II ELyAC

VI RNEyDA

I CAyS

III LVSyEA

III LVSyEA

IV MAyACI

VII TyBTCyB

III LVSyEA

VI RNEyDA

II ELyAC
$39,40,67,68$

41,42

47,48

43, 44, 45, 46

31,32

221, 222

47,48

23, 24

43,44

143, 144

45,46

63,64

17,18

181,182

25,26

47, 48

$47,48,211,212$

49,50

$25,26,133,134$

147, 148

137, 138

159,160

49,50

7,8

61,62

19, 20

1,2

15,16

23, 24

35,36

45,46

223, 224

3, 4 


\section{CONGRESO INTERNACIONAL Y XXIV CONGRESO \\ NACIONAL DE CIENCIAS AMBIENTALES}

03-07 Junio/2019 Mazatlán, Sinaloa

\section{Índice general de autores \\ AUTOR \\ ÁrEA \\ TEMÁTICA \\ PÁGINAS}

Correa Jiménez KF

Correa Ramírez M

Cortés Badillo $\mathrm{E}$

Cortes Guerrero V

Cortés Palacios $L$

Cortes Ruiz JA

Cortés-Badillo $E$

Cortés-Eslava J

Costilla Salazar R

Cotero Villegas A

Cruz Aviña R

Cruz Benitez M

Cruz Cobos $F$

Cruz Flores $G$

Cruz García F

Cruz González D

Cruz Herrera A

Cruz Jiménez $A$

Cruz Jiménez $G$

Cruz Mondragon C

Cruz Ruiz G

Cuellar González J

Cuevas Arteaga C

Cuevas González J

Cuevas Medina M
VII TyBTCyB

VI RNEyDA

VI RNEyDA

VII TyBTCyB

VI RNEyDA

VII TyBTCyB

VI RNEyDA

IV MAyACI

$\checkmark$ MACEYG

VI RNEyDA

VI RNEyDA

III LVSyEA

VI RNEyDA

VII TyBTCyB

VI RNEyDA

VI RNEyDA

V MACEYG

VI RNEyDA

VII TyBTCyB

III LVSyEA

VII TyBTCyB

VI RNEyDA

VII TyBTCyB

VI RNEyDA

II ELyAC

VI RNEyDA

VII TyBTCyB

VII TyBTCyB

VII TyBTCyB
161, 162

181,182

131, 132

51,52

$7,8,155,156$

135,136

209, 210

1,2

$9,10,23,24,57,58$

219, 220

195,196

7, 8

171,172

53, 54

$51,52,97,98,127,128$

149, 150, 193, 194

11,12

51,52

$163,164,231,232$

17,18

3,4

49,50

67, 68, 201, 202

53,54

7,8

61,62

15,16

$11,12,141,142$

55,56 


\section{CONGRESO INTERNACIONAL Y XXIV CONGRESO NACIONAL DE CIENCIAS AMBIENTALES 03-07 Junio/2019 Mazatlán, Sinaloa

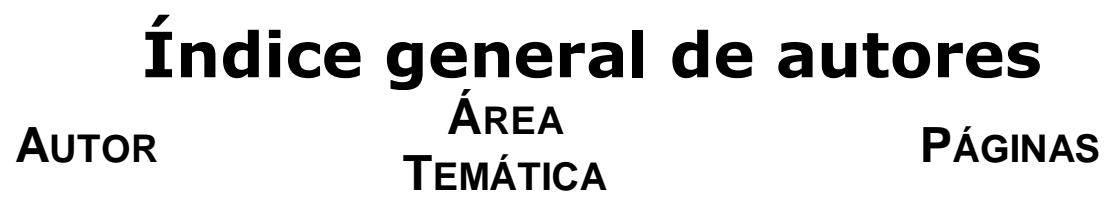

De la Cruz Cornelio MG

De la Llata-López ME

De la Mora Covarrubias A

De la Peña Arellano LA

De la Rosa Mera CJ

De la Rosa Velázquez M

De León González $\mathrm{E}$

Del Ángel Coronel OA

Del Ángel Ruiz K

Del Angel Soto J

Del Carmen Niño V

Del Rosario de Jesús K

Delgado Díaz MA

Delgado-Ríos M

Díaz Alvarado J

Díaz Chávez R

Díaz Delgado $\mathrm{C}$

Díaz Godoy R

Díaz Larrea J

Díaz Medrano A

Díaz Ordáz L

Díaz Pazos J

Díaz Plascencia D

Díaz-Godoy RV

Dietrich $\mathrm{N}$

Domínguez Gómez TG

Domínguez Romero RJ

Donohué Cornejo A

Duarte López C
VII TyBTCyB

V MACEyG

VI RNEyDA

II ELyAC

VII TyBTCyB

VI RNEyDA

III LVSyEA

VI RNEyDA

VII TYBTCYB

V MACEYG

VII TYBTCYB

III LVSyEA

VII TyBTCyB

VII TyBTCyB

VII TyBTCyB

V MACEYG

VI RNEyDA

III LVSyEA

VI RNEyDA

V MACEYG

VI RNEyDA

VI RNEyDA

VII TyBTCyB

VII TyBTCyB

II ELyAC

III LVSyEA

V MACEYG

VII TyBTCyB

$\checkmark$ MACEYG

VI RNEyDA

VII TyBTCyB

VII TyBTCyB

VII TyBTCyB
89,90

13,14

163, 164

21,22

$29,30,123,124,233,234$

31,32

19,20

169,170

115,116

3,4

159, 160

53,54

57,58

39,40

59,60

29,30

55,56

9,10

87,88

37,38

153,154

$123,124,125,126,171,172$

61,62

123,124

$5,6,19,20$

27,28

15,16

33,34

17,18

57,58

15,16

$11,12,141,142$

63,64 


\section{CONGRESO INTERNACIONAL Y XXIV CONGRESO NACIONAL DE CIENCIAS AMBIENTALES 03-07 Junio/2019 Mazatlán, Sinaloa \\ Índice general de autores \\ AUTOR \\ ÁrEA \\ TEMÁTICA \\ PÁGINAS}

Durán Moreno A

Durón Torres S

Dzul García O

E

Encarnación Guevara S

Enriquez Anchondo I

Enríquez del Valle JR

Escalante Estrada VE

Escalante Pérez B

Escalona Alcázar $F$

Escamilla Azuara A

Escobar Flores J

Escobar González J

Escobedo Bautista R

Esparza García F

Espinoza Arías JA

Espinoza Cristóbal L

Espinoza García G

Espinoza Prieto $R$

Esteller Alberich MV

Estrada Ávalos J

Estrada Feregrino I

Estrada Johnson E

Estrada Ovando D

Estrada Vázquez $R$ Estrada Zúñiga ME
VII TyBTCyB

V MACEYG

II ELyAC
73,74

55,56

33,34
VII TyBTCyB

165, 166

VI RNEyDA

VI RNEyDA

III LVSyEA

III LVSyEA

II ELyAC

III LVSyEA

VI RNEyDA

VII TyBTCyB

VI RNEyDA

II ELyAC

VI RNEyDA

VI RNEyDA

VII TyBTCyB

III LVSyEA

VII TyBTCyB

VI RNEyDA

III LVSyEA

I CAyS

VI RNEyDA

VI RNEyDA

VII TyBTCyB

VII TyBTCyB

$\checkmark$ MACEYG

VI RNEyDA

VII TyBTCyB

VI RNEyDA
189,190

137, 138, 207, 208

21,22

23, 24

33,34

59,60

105, 106

65,66

7,8

61,62

7,8

67, 68, 201, 202, 227, 228

1,2

$11,12,141,142$

157,158

$25,26,27,28$

3,4

87,88

129,130

67,68

155,156

37,38

153, 154

69,70

$21,22,239,240$
$59,60,225,226$ 


\section{CONGRESO INTERNACIONAL Y XXIV CONGRESO \\ NACIONAL DE CIENCIAS AMBIENTALES}

03-07 Junio/2019 Mazatlán, Sinaloa

\section{Índice general de autores AUTOR \\ ÁrEA \\ TEMÁTICA \\ PÁGINAS}

Estrella Rodríguez J

Etienne J

Expósito Castillo JL

$\mathbf{F}$

Fajardo V

Falcón Ordaz J

Fall C

Fernández Martínez L

Fernandez Roque $T$

Fernández Tapia S

Fernández Zepeda M

Ferrera Cerrato $\mathrm{R}$

Filomeno-Marcelino $\mathrm{E}$

Flores Cruz J

Flores Higuera $\mathrm{F}$

Flores Margez J

Flores Márquez AR

Flores Munguía E

Flores Sanchez O

Flores Sotelo T

Flores Trujillo A

Flores Trujillo K

Flores Villegas M

Flores-Marguez JP

Flores-Martínez M

Florez MG

Folch Mallol J
II ELyAC

VI RNEyDA

I CAyS

III LVSyEA

VI RNEyDA

VII TyBTCyB

VII TyBTCyB

VI RNEyDA

VII TyBTCyB

VII TyBTCyB

VII TyBTCyB

IV MAyACI

VII TyBTCyB

VI RNEyDA

VI RNEyDA

V MACEYG

VI RNEyDA

VII TyBTCyB

VII TyBTCyB

II ELyAC

III LVSyEA

VII TyBTCyB

III LVSyEA

VII TyBTCyB

II ELyAC

VII TyBTCyB

V MACEYG

V MACEYG

II ELyAC

VII TyBTCyB
17, 18

1,2

3,4
69,70

3,4

21,22

39,40

223, 224

213, 214

213, 214

227, 228

3,4

65,66

13,14

189,190

$9,10,23,24,57,58$

219,220

113,114

225, 226

9,10

41,42

71,72

63,64

117,118

27,28

153,154

29,30

19,20

11,12

49, 50, 165, 166 


\section{CONGRESO INTERNACIONAL Y XXIV CONGRESO NACIONAL DE CIENCIAS AMBIENTALES 03-07 Junio/2019 Mazatlán, Sinaloa \\ Índice general de autores Autor \\ ÁrEA \\ TEMÁtICA \\ PÁGINAS}

VII TyBTCyB

II ELyAC

VII TyBTCyB

III LVSyEA

VI RNEyDA

I CAyS

VI RNEyDA

VI RNEyDA

II ELyAC

V MACEYG

III LVSyEA

III LVSyEA

VI RNEyDA

VI RNEyDA

Franco Plata $\mathrm{R}$

Franco Rivas B

Franco Villegas $\mathrm{E}$

Frausto Martínez O

Frausto Mena R

Frausto V

Frías Espericueta M

G

Galaviz Acosta S

Galindo Mendoza TV

Gallardo Hernández M

Gallegos Navarro Y

Gallegos Padierna A

Galván Camargo A

Galván Ortega C

Gamboa Escobedo S

Gámez-Domínguez V

Gandarilla Esparza D

Garate Osuna A

García A

García Amador E

García Carrizales A

García Casas K

III LVSyEA

I CAyS

VI RNEyDA

VI RNEyDA

VI RNEyDA

I CAyS

VI RNEyDA

III LVSyEA

IV MAyACI

VII TyBTCyB

II ELyAC

VI RNEyDA

VI RNEyDA

VII TyBTCyB

VII TyBTCyB

VI RNEyDA
53,54

29,30

105, 106

51,52

113,114

17,18

147,148

95, 96

27,28

55,56

3,4

29,30

71,72

13,14

75,76

21,22

229, 230

63,64

65,66

39,40

67,68

31,32

5,6

31,32

$5,6,19,20$

71,72

31,32

$119,120,229,230$

65,66

211,212 


\section{CONGRESO INTERNACIONAL Y XXIV CONGRESO \\ NACIONAL DE CIENCIAS AMBIENTALES}

03-07 Junio/2019 Mazatlán, Sinaloa

\section{Índice general de autores AUTOR \\ ÁrEA \\ TEMÁtICA \\ PÁGINAS}

VII TyBTCyB

III LVSyEA

VI RNEyDA

VII TyBTCyB

III LVSyEA

VI RNEyDA

García García E

García Gaytán B

García González SA

García Ibáñez S

García Meraz H

García Niño AL

Garcia Noria E

García R

García Reynoso JA

García Rivas J

García Sánchez M

García Solano A

García Xochititla M

García-Castro M

García-Mora L

García-Rojas JL

García-Torres E

Garibaldi Carrasco D

Garibay Alvarado J

Garrido Hoyos S

Gastón Pérez D

Gavilán García A

Gavilán García IC
VII TyBTCyB

VII TyBTCyB

VII TyBTCyB

III LVSyEA

VI RNEyDA

VI RNEyDA

VII TyBTCyB

III LVSyEA

I CAyS

III LVSyEA

VII TyBTCyB

VII TyBTCyB

VII TyBTCyB

III LVSyEA

V MACEyG

IV MAYACI

V MACEYG

$\checkmark$ MACEYG

VI RNEyDA

VII TyBTCyB

I CAyS

VI RNEyDA

VII TyBTCyB

VII TyBTCyB

VI RNEyDA

III LVSyEA

VI RNEyDA 


\section{CONGRESO INTERNACIONAL Y XXIV CONGRESO NACIONAL DE CIENCIAS AMBIENTALES 03-07 Junio/2019 Mazatlán, Sinaloa \\ Índice general de autores Autor \\ ÁrEA \\ TEMÁtICA \\ PÁGINAS}

Germán Báez L

Gervacio Jiménez H

Giner Chávez $O$

Gómez Aldapa C

Gómez Arellano E

Gómez Demetrio W

Gómez Ensastegui C

Gómez Hinojos AM

Gómez Martínez F

Gómez Mesino J

Gómez-Arroyo S

Gómez-Moreno V

Gómez-Olivares JL

Gómez-Tagle Chavez A

Gonsebatt ME

Gonzales Alonso S

Gonzales Flores E

González Adame R

González Arenas B

González Arenas $Y$

González Fernández R

González Flores E

González González J

González González M
VI RNEyDA

VII TyBTCyB

VI RNEyDA

III LVSyEA

VII TyBTCyB

VI RNEyDA

VI RNEyDA

VI RNEyDA

I CAyS

II ELyAC

VI RNEyDA

II ELyAC

VI RNEyDA

VI RNEyDA

V MACEYG

VI RNEyDA

V MACEYG

VI RNEyDA

$\checkmark$ MACEYG

VI RNEyDA

VI RNEyDA

V MACEyG

VII TyBTCyB

VII TyBTCyB

VII TyBTCyB

VII TyBTCyB

VII TyBTCyB

VII TyBTCyB

VI RNEyDA

VII TyBTCyB

III LVSyEA

VI RNEyDA

VII TyBTCyB
139,140

105, 106

69,70

$25,26,27,28$

53,54

75,76

233, 234

77,78

25,26

13,14

79,80

13,14

79,80

17,18

$9,10,23,24,57,58$

219,220

$25,26,27,28$

167, 168

57,58

219, 220

203, 204

47,48

145,146

99,100

7,8

81,82

81,82

133, 134, 173, 174

121,122

113,114

67,68

81,82

65,66

xxix 


\section{CONGRESO INTERNACIONAL Y XXIV CONGRESO NACIONAL DE CIENCIAS AMBIENTALES 03-07 Junio/2019 Mazatlán, Sinaloa \\ Índice general de autores AUTOR \\ ÁrEA \\ TEMÁtICA \\ PÁGINAS}

González Juárez JC

González Leal M

González Mireles V

González Ocampo H

González Pérez B

González Quemada A

González Rodríguez L

González Trinidad J

González U

González-Delgado MF

González-Gaona O

González-Güereca C

González-Maldonado B

González-Quiñones JS

González-Rodríguez H

González-Zamora A

Gracía Matías F

Granjeno Colín AE

Grutter-de la Mora M

Guerra González R

Guerra Hernández $\mathrm{E}$

Guevara Espinosa M

Guevara Fisher $Y$

Guevara Herrera R

Guevara N

Gurrola Amaya G

Gutiérrez Cedillo A
VII TyВTСув

VII TyBTCyB

VII TyBTCyB

VI RNEyDA

VI RNEyDA

VI RNEyDA

VII TyBTCyB

I CAyS

VI RNEyDA

V MACEYG

$\checkmark$ MACEYG

IV MAYACI

VI RNEyDA

IV MAyACI

VI RNEyDA

V MACEYG

VI RNEyDA

V MACEyG

$\checkmark$ MACEYG

VII TyBTCyB

II ELyAC

VI RNEyDA

$\checkmark$ MACEYG

VII TyBTCyB

VI RNEyDA

II ELyAC

VI RNEyDA

VI RNEyDA

I CAyS

VI RNEyDA

II ELyAC

III LVSyEA

VI RNEyDA
169,170

83,84

$17,18,19,20$

183,184

87,88

89,90

$61,62,129,130$

35,36

71,72

47,48

$25,26,27,28$

$9,10,11,12$

$83,84,85,86$

$9,10,11,12$

$83,84,85,86$

17,18

57,58

17,18

21,22

31,32

9, 10

$91,92,175,176$

$9,10,23,24$

189, 190

149, 150, 193, 194

23, 24

51,52

185,186

31,32

127, 128

1,2

49,50

93,94 


\section{CONGRESO INTERNACIONAL Y XXIV CONGRESO NACIONAL DE CIENCIAS AMBIENTALES}

03-07 Junio/2019 Mazatlán, Sinaloa

\section{Índice general de autores AUTOR \\ ÁrEA \\ TEMÁTICA \\ PÁGINAS}

III LVSyEA

VI RNEyDA

VI RNEYDA

III LVSyEA

I CAyS

III LVSyEA

Gutiérrez Ochoa M

Gutiérrez Ramírez A

Gutiérrez Ruiz M

Gutiérrez Segura EE

Gutiérrez Silva L

Guzmán Aragón E

Guzmán Mar J

Guzmán Mar M

H

Hermosillo Nevarez J

Hernández Alarcón ME

Hernández Aldana F

Hernández Arias AN

Hernández Crisóstomo $C$

Hernández $\mathrm{F}$

Hernández González N

Hernández Guzmán R

Hernández Jasso J

Hernández Jiménez $P$

Hernández López A

Hernández López J

Hernández Ortiz J

Hernández Peña $C$

Hernández Pérez YY
VII TyBTCyB

II ELyAC

VII TyBTCyB

VI RNEyDA

VII TyBTCyB

VI RNEyDA

VI RNEyDA

VII TyBTCyB

VI RNEyDA

VI RNEyDA

VI RNEyDA

VII TyBTCyB

III LVSyEA

II ELyAC

I CAyS

II ELyAC
43,44

15, 16, 95, 96, 233, 234

93,94

59,60

43,44

37,38

$43,44,45,46$

23, 24

101, 102

43,44

83,84

85,86

$25,26,107,108$

59,60
87,88

15,16

89,90

109,110

127, 128

43,44

$51,52,97,98$

65,66

213, 214

99, 100

221,222

91,92

49,50

35,36

41,42

15,16 


\section{CONGRESO INTERNACIONAL Y XXIV CONGRESO NACIONAL DE CIENCIAS AMBIENTALES 03-07 Junio/2019 Mazatlán, Sinaloa \\ Índice general de autores \\ AUTOR \\ ÁrEA \\ TEMÁtICA}

Hernández Ramírez A Hernández Ramírez JL Hernández Romero JC Hernández Sabas E Hernández Tenorio $\mathrm{C}$ Hernández Trejo ME Hernández Valdez A Hernández Zepeda JS

Hernández Zúñiga D Hernández-Carreón S Hernández-Linares $G$ Hernández-Salinas U

Herrera Gamboa J Herrera García S Herrera Perez JL Heyer L

Hinojosa Reyes L Houndjinou EM Hueletl- Soto ME

Huerta García J

Huerta Hernández V

Huerta Lara M Huerta-Reza E
VII TyВTCyВ

VII TyBTCyB

VI RNEyDA

VII TyBTCyB

VII TyBTCyB

VII TyBTCyB

VI RNEyDA

II ELyAC

III LVSyEA

VII TyBTCyB

V MACEYG

IV MAyACI

IV MAYACI

VI RNEyDA

VI RNEyDA

VII TyBTCyB

VII TyBTCyB I CAyS

VII TyBTCyB

VI RNEyDA

$\checkmark$ MACEYG

VI RNEyDA

III LVSyEA

VI RNEyDA

VI RNEyDA

II ELyAC

V MACEYG
$25,26,237,238$

59,60

95,96

79,80

139,140

93,94

101,102

9, 10

41,42

199,200

29,30

$3,4,5,6$

11,12

$83,84,85,86$

$103,104,181,182,235,236$

95, 96

225, 226

31,32

$25,26,59,60$

1,2

$35,36,43,44,49,50,57,58$

219,220

59,60

105,106

105,106

9,10

31,32

\section{I}

lbáñez C

VII TyBTCyB

193, 194

I CAyS

29,30

VI RNEyDA 


\section{CONGRESO INTERNACIONAL Y XXIV CONGRESO \\ NACIONAL DE CIENCIAS AMBIENTALES}

03-07 Junio/2019 Mazatlán, Sinaloa

\section{Índice general de autores \\ AUTOR \\ ÁrEA \\ TEMÁTICA \\ PÁGINAS}

Inchaurregui Méndez H

Iñiguez Pérez F
Jaimes Compean AJ

Jaimez Melgoza $R$

Jara Marini M

Jaramillo Sierra B

Jáuregui Rincón J

Jiménez Cedillo MJ

Jiménez García LF

Jiménez Hernández M

Jiménez Núñez M

Jimenez Pelcastre C

Jiménez Vargas $P$

Juárez Aguilar $\mathrm{R}$

Juárez Barojas I

Juárez Cadena $F$

Juárez López AL

Juárez Ruanova L

Juárez Soto $R$

Júnez Ferreira $\mathrm{H}$
VI RNEyDA

VII TyBTCyB

I CAyS
$65,66,71,72$

$61,62,129,130$

15,16

$$
\begin{array}{r}
\text { III LVSyEA } \\
\text { III LVSyEA } \\
\text { VI RNEyDA } \\
\text { VII TyBTCyB } \\
\text { VII TyBTCyB } \\
\text { VII TyBTCyB } \\
\text { V MACEyG } \\
\text { VII TyBTCyB } \\
\text { VII TyBTCyB } \\
\text { VI RNEyDA } \\
\text { VI RNEyDA } \\
\text { VI RNEyDA } \\
\text { VII TyBTCyB } \\
\text { VI RNEyDA } \\
\text { III LVSyEA } \\
\text { V MACEyG } \\
\text { VII TyBTCyB } \\
\text { VI RNEyDA } \\
\text { VII TyBTCyB } \\
\text { I CAyS }
\end{array}
$$

39,40

5,6

87,88

127,128

131,132

127,128

$9,10,23,24$

115,116

103, 104

185,186

27,28

107, 108

109,110

221, 222

$39,40,61,62$

$13,14,51,52$

57,58

109,110

97, 98

35,36

\section{K}

Kašuba V

Konde Medina KP
V MACEYG

VI RNEyDA

VI RNEyDA
57,58

219,220

37,38 


\section{CONGRESO INTERNACIONAL Y XXIV CONGRESO NACIONAL DE CIENCIAS AMBIENTALES 03-07 Junio/2019 Mazatlán, Sinaloa \\ Índice general de autores Autor ÁrEA \\ TEMÁTICA \\ PÁGINAS}

Ladino LA

Lara Ponce E

Lara $\mathrm{RH}$

Lara-Martínez R

Lazcano-Escobar JF

Leal Rodríguez A

Ledezma Pérez E

Legorreta-Soberanis $\mathrm{J}$

Lejarde Florez DA

León Hernández $\mathrm{V}$

Linares Campos JA

Linares Fleites $G$

Linares Salazar D

Llera García E

Loaiza J

López Alemán M

López Baena J

López Chávez LAJ

López Cruz JY

López Díaz N

López E

López Escobar LA

López Felix G

López González Y

Lopez Gutierrez JM

López Hernández A

López Mancilla A

López Márquez ES

López Nieto J
V MACEyG

II ELyAC

VI RNEyDA

VII TyBTCyB

VI RNEyDA

V MACEyG

IV MAyACI

VII TyBTCyB

VI RNEyDA

V MACEyG

VII TyBTCyB

III LVSyEA

III LVSyEA

VI RNEyDA

VI RNEyDA

II ELyAC

VI RNEyDA

VII TyBTCyB

VII TyBTCyB

III LVSyEA

VII TyBTCyB

VII TyBTCyB

I CAyS

VII TyBTCyB

III LVSyEA

VII TyBTCyB

VI RNEyDA

VI RNEyDA

VI RNEyDA

VI RNEyDA

VII TyBTCyB
1,2

31,32

201, 202

97, 98

111,112

$9,10,23,24$

13,14

99, 100

113,114

51,52

161,162

71,72

41,42

$109,110,115,116,145,146$

27,28

17,18

117,118

175,176

195, 196

47,48

157, 158

101, 102

31,32

115,116

57, 58, 75, 76

183, 184

195, 196

45,46

167,168

119,120

55,56 


\section{CONGRESO INTERNACIONAL Y XXIV CONGRESO \\ NACIONAL DE CIENCIAS AMBIENTALES}

03-07 Junio/2019 Mazatlán, Sinaloa

\section{Índice general de autores \\ AUTOR \\ ÁreA \\ TEMÁTICA \\ PÁGINAS}

López Ramírez S

López Sánchez E

López Velasco A

López Vicente L

López-Monroy J

López-Trejo M

Lora Urías $\mathrm{C}$

Loza-Gómez P

Lozano Alvarez J

Lucho Chigo R

Lucio García J

Lucio Porto $\mathrm{R}$

Luevano Gurrola S

Luis Villaseñor I

Lujan Godínez R

Luna Avelar K

Luna Barcenas G

Luna Reséndiz E

Lungo Rodríguez A
I CAyS

VI RNEyDA

VII TyBTCyB

VII TyBTCyB

V MACEYG

IV MAyACI

VII TyBTCyB

V MACEyG

VII TyBTCyB

VII TyBTCyB

VI RNEyDA

VII TyBTCyB

I CAyS

VI RNEyDA

VI RNEyDA

I CAyS

II ELyAC

VI RNEyDA

VII TyBTCyB

VII TyBTCyB

VII TyBTCyB

III LVSyEA
43,44

121,122

103,104

119,120

15,16

1,2

97, 98

23,24

131,132

$29,30,205,206,207,208,211,212$

169,170

107,108

37,38

67,68

13,14

23,24

$5,6,19,20$

139,140

$81,82,105,106$

5,6

107,108

53,54

\section{M}

Macedo Miranda G

VI RNEyDA

77,78

VII TyBTCyB

169,170

Macías Patiño M

Madrid del Palacio M

VII TyBTCyB

II ELyAC

VII TyBTCyB

Maldonado Astudillo Y

III LVSyEA

III LVSyEA

III LVSyEA

145,146

27,28

153,154

61,62

27,28

59,60 


\section{CONGRESO INTERNACIONAL Y XXIV CONGRESO \\ NACIONAL DE CIENCIAS AMBIENTALES \\ 03-07 Junio/2019 Mazatlán, Sinaloa \\ Índice general de autores \\ Autor \\ ÁrEA \\ TEMÁTICA \\ PÁGINAS}

\author{
Manjarrez Hernández D \\ Manjarrez J \\ Marcial Juárez $\mathrm{R}$ \\ Mares Cuevas MJ \\ Marín Allende MJ \\ Marín Castro MA \\ Marín Peña O \\ Marín Tinoco RI
}

Marmolejo Rodríguez A

Marmolejo Rodríguez J

Marmolejo Sánchez ME

Márquez $\mathrm{H}$

Márquez MC

Martínez A

Martínez Acuña M

Martínez Ávila A

Martínez Batallar G

Martínez Eixarch M

Martínez Espinosa E

Martínez Frías U

Martínez Gallegos S

Martínez García CG

Martínez Gómez V

Martínez Guzmán MJ

Martínez Hernández S

Martinez Ibarra JA

Martínez Marú M

Martínez Munguía $\mathrm{R}$

Martínez Olivas A

Martínez Orgániz A
I CAyS

III LVSyEA

VI RNEyDA

II ELyAC

VII TyBTCyB

VII TyBTCyB

VII TyВTCyB

IV MAyACI

VI RNEyDA

VII TyBTCyB

I CAyS

VI RNEyDA

VI RNEyDA

I CAyS

VI RNEyDA

VI RNEyDA

I CAyS

VII TyBTCyB

VII TyBTCyB

VI RNEyDA

VII TyBTCyB

I CAyS

VI RNEyDA

VII TyBTCyB

VI RNEyDA

VII TyBTCyB

II ELyAC

I CAyS

VI RNEyDA

VII TyBTCyB

II ELyAC

VII TyBTCyB

VII TyBTCyB
25,26

69,70

165, 166

13,14

127, 128

219,220

109, 110

9, 10

191, 192

203, 204

11,12

9,10

217, 218

27,28

$123,124,125,126$

71,72

35,36

221, 222

165, 166

215,216

65,66

43,44

77,78

163, 164, 169, 170

15,16

207, 208

21,22

19,20

141,142

83,84

23,24

$111,112,215,216$

113,114 


\section{CONGRESO INTERNACIONAL Y XXIV CONGRESO NACIONAL DE CIENCIAS AMBIENTALES 03-07 Junio/2019 Mazatlán, Sinaloa \\ Índice general de autores Autor ÁREA TEMÁTICA \\ PÁGINAS}

Martínez P

Martínez Ramírez M

Martínez Rivas A

Martínez Roldán A

Martínez Romero L

Martínez Salomón E

Martínez Sibaja A

Martínez Sifuentes A

Martínez Tavera E

Martínez Torralba M

Martínez Valencia A

Mata Carrillo E

Matheus-Hernández $\mathrm{A}$

Maturano Cisneros M

Max O

Maya Mancera $P$

Maya Treviño L

Maya Treviño $M$

Mayett Moreno $Y$

Mayoral Ruiz PA

Medellín Castillo N

Medina A

Medina Acevedo

Medina Ávila J

Medina Bautista S

Medina Herrera M

Medina Llamas J

Medina Llamas M
II ELyAC

VII TyBTCyB

VI RNEyDA

VII TyBTCyB

VII TyBTCyB

I CAyS

VI RNEyDA

VII TyBTCyB

VI RNEyDA

VII TyBTCyB

VII TyBTCyB

II ELyAC

IV MAYACI

VI RNEyDA

IV MAYACI

VI RNEyDA

I CAyS

VI RNEyDA

VII TyBTCyB

VII TyBTCyB

VI RNEyDA

VII TyBTCyB

I CAyS

VII TyBTCyB

VI RNEyDA

VII TyBTCyB

VI RNEyDA

VII TyBTCyB

VI RNEyDA

VII TyBTCyB

VII TyBTCyB

VII TyBTCyB
11,12

159,160

127,128

$123,124,205,206,211,212,233$,

234

195, 196

29,30

231,232

109,110

129,130

163,164

115, 116

3,4

1,2

131,132

15,16

45,46

31,32

89,90

59,60

107,108

155,156

135, 136

23,24

$77,78,125,126,191,192$

71,72

117,118

203, 204

119,120

133,134

147,148

$129,130,171,172$

171,172 


\section{CONGRESO INTERNACIONAL Y XXIV CONGRESO NACIONAL DE CIENCIAS AMBIENTALES}

03-07 Junio/2019 Mazatlán, Sinaloa

\section{Índice general de autores AUTOR \\ ÁREA \\ TEMÁTICA \\ PÁGINAS}

Medina Márquez M

Medina Mejia M

Medina Miranda MD

Medina Orendain D

Medina Puente A

Medina Ramírez I

Medina Rocha AE

Medina Sarmiento J

Medina-Orendain D

Medrano Enríquez A

Mejía Bermúdez D

Mejia Rivas CA

Mejias Brizuela N

Meléndez Estrada I

Meléndez MR

Melgoza Castillo A

Mena Covarrubias J

MenaViolante $\mathrm{H}$

Méndez Andoney M

Méndez Contreras J

Méndez Gómez E

Méndez Ramírez $\mathrm{E}$

Mendía Santana $\mathrm{R}$

Mendieta Rodríguez $\mathrm{L}$

Mendivil Garcia K

Mendoza Gaona H

Mendoza Hernández JC

Mercado Méndez A

Mercado Silva N
III LVSyEA

VI RNEyDA

III LVSyEA

VII TyBTCyB

VI RNEyDA

VII TyBTCyB

VII TyBTCyB

III LVSyEA

V MACEyG

$\checkmark$ MACEYG

VII TyBTCyB

VII TyBTCyB

II ELyAC

VII TyBTCyB

VII TyBTCyB

I CAyS

VI RNEyDA

VI RNEyDA

IV MAyACI

VII TyBTCyB

VII TyBTCyB

VI RNEyDA

I CAyS

VI RNEyDA

VII TyBTCyB

I CAyS

VII TyBTCyB

VII TyBTCyB

IV MAyACI

VI RNEyDA

VII TyBTCyB

III LVSyEA

V MACEYG
$7,8,71,72$

135,136

43,44

121,122

169,170

131,132

239, 240

45,46

41,42

33,34

79,80

123,124

$5,6,19,20$

81,82

$11,12,125,126,141,142$

31,32

$39,40,187,188,197,198$

157,158

21,22

127,128

85,86

209, 210

33,34

57,58

129,130

5,6

13,14

51,52

7,8

$55,56,111,112$

$37,38,39,40,93,94$

1,2

5,6 


\section{CONGRESO INTERNACIONAL Y XXIV CONGRESO NACIONAL DE CIENCIAS AMBIENTALES 03-07 Junio/2019 Mazatlán, Sinaloa \\ Índice general de autores Autor \\ ÁrEA \\ TEMÁTICA \\ PÁGINAS}

\begin{abstract}
Mercado Silva N
Mérida-Cortés $\mathrm{P}$

Merino Negrete $O$

Merlo Ruiz F

Meza Ayala K

Meza Rangel J

Meza-Montenegro MM

Michel Hernández AE

Michel Parra JG
\end{abstract}

Milić M

Millán Aguilar E

Miranda Aviles R

Molina Sánchez K

Monares Escalera I

Monárrez González C

Monfil Hernández $F$

Monks S

Monserrat V

Montañez Valdez OD

Montaño Castrellón $\mathrm{H}$

Montaño Gómez A

Montelongo Hernández I

Montiel-González JMR

Montijo Galindo A

Montoya Mar F

Montoya Murillo J

Mora Barrera L
VI RNEyDA

$\checkmark$ MACEYG

VI RNEyDA

VII TyBTCyB

VI RNEyDA

VI RNEyDA

$\checkmark$ MACEYG

VI RNEyDA

I CAyS

II ELyAC

III LVSyEA

VI RNEyDA

VII TyBTCyB

$\checkmark$ MACEYG

VI RNEyDA

VI RNEyDA

VII TyBTCyB

VII TyBTCyB

VI RNEyDA

$\checkmark$ MACEYG

VI RNEyDA

VI RNEyDA

VI RNEyDA

VI RNEyDA

III LVSyEA

VII TyBTCyB

VII TyВTCyB

$\checkmark$ MACEYG

VI RNEyDA

VI RNEyDA

$\checkmark$ MACEYG

VII TyBTCyB

III LVSyEA 


\section{CONGRESO INTERNACIONAL Y XXIV CONGRESO NACIONAL DE CIENCIAS AMBIENTALES 03-07 Junio/2019 Mazatlán, Sinaloa \\ Índice general de autores Autor ÁrEA TEMÁTICA}

Mora Félix ZD

Mora Soto $Y$

Morales Benítez B

Morales García JM

Morales Juarez LR

Morales Nieto C

Morales Zepeda F

Morán-Moscoso R

Moreno Alcántara J

Moreno Julimez L

Moreno Lucio M

Moreno Luna FB

Moreno Martínez B

Moreno Pérez J

Munguia Martín J

Munguía Pérez $\mathrm{R}$

Muñiz Salazar $R$

Muñoz Escobar A

Muñoz-Ruiz CV

Murcia Rodríguez M

Muro González D

Murúa Figueroa $E$

Mussali Galante P
VI RNEyDA

VI RNEyDA

III LVSyEA

VII TyBTCyB

VII TyBTCyB

VI RNEyDA

III LVSyEA

IV MAYACI

$\checkmark$ MACEYG

VI RNEyDA

VI RNEyDA

VII TyBTCyB

VI RNEyDA

VII TyBTCyB

VII TyBTCyB

VII TyBTCyB

VII TyBTCyB

I CAyS

VI RNEyDA

VII TyBTCyB

IV MAyACI

VI RNEyDA

V MACEYG

VI RNEyDA

III LVSyEA

V MACEYG

VI RNEyDA

VII TyBTCyB
151,152

$177,178,179,180$

53,54

9, 10

225, 226

7,8

45,46

17,18

$15,16,37,38$

153,154

155,156

135,136

157,158

225, 226

139,140

137,138

139, 140

1,2

1,2

141,142

9,10

159, 160, 173, 174

39,40

161,162

63,64

39,40

41,42

$49,50,71,72,117,118$

\section{$\mathbf{N}$}

Nájera Bastida A

VII TyBTCyB

221, 222

Nájera Luna A

$51,52,97,98,127,128$ 


\section{CONGRESO INTERNACIONAL Y XXIV CONGRESO NACIONAL DE CIENCIAS AMBIENTALES 03-07 Junio/2019 Mazatlán, Sinaloa \\ Índice general de autores Autor \\ ÁrEA \\ TEMÁTICA \\ PÁGINAS}

VI RNEyDA

VII TyBTCyB

II ELyAC

III LVSyEA

VI RNEyDA

Narváez Ortiz I

Nava Juárez D

Nava Valente $\mathrm{N}$

Navarro Frómeta A

Navarro García K

Navarro Hernández AG

Navarro Salazar I

Navarro Salazar M

Navarro Solís O

Negrete Rodríguez X

Niño Maldonado S

Niño-Lozano A

Noguerol J

Noriega Luna B

Novelo Castilla J

Núñez de la Vega $\mathrm{E}$

Núñez García L

Núñez Vilchis $A$

Núñez-Cardona MT

Núñez-Gastélum JA
VI RNEyDA

VI RNEyDA

VII TyBTCyB

VII TyBTCyB

VI RNEyDA

VI RNEyDA

VII TyBTCyB

VII TyBTCyB

I CAyS

VII TyBTCyB

VI RNEyDA

VII TyBTCyB

$\checkmark$ MACEYG

VI RNEyDA

V MACEYG

VI RNEyDA

VII TyBTCyB

I CAyS

VI RNEyDA

VI RNEyDA

VII TyBTCyB

V MACEyG

V MACEyG
163,164

143,144

25,26

47,48

$47,48,103,104,181,182,211,212$,

235,236

23,24

165,166

115,116

161,162

167,168

213,214

91,92

145,146

35,36

$91,92,145,146$

133,134

147,148

$25,26,27,28$

$167,168,169,170$

19,20

215,216

149,150

9,10

113,114

123, 124, 125, 126, 171, 172

83,84

15,16

29,30

0

Oceguera Flores $\mathrm{P}$

VII TyBTCyB

151,152 


\section{CONGRESO INTERNACIONAL Y XXIV CONGRESO NACIONAL DE CIENCIAS AMBIENTALES \\ 03-07 Junio/2019 Mazatlán, Sinaloa \\ Índice general de autores \\ AUTOR \\ ÁrEA \\ TEMÁtICA \\ PÁGINAS}

Ochoa Leyva A

Ochoa Ochoa LM

Ochoa Reyes P

Ochoa-Ocaña MA

Olivas Calderón E

Oliver Guadarrama R

Oliveros González N

Olivier Salomé B

Olmedo García K

Olmos Marquez M

Olmos Martínez E

Olvera Olvera C

Ordaz Díaz L

Ordoñez Baquera $P$

Orea-Lara G

Oregel Zamudio E

Orendain Verduzco T

Oropeza Miranda N

Orozco Robles J

Orozco Villafañe A

Ortega JA

Ortega Murillo MR

Ortiz Hernández $\mathrm{C}$

Ortiz Hernández ML

Ortíz Méndez JD

Ortiz Ruiz A
III LVSyEA

VI RNEyDA

VI RNEyDA

V MACEYG

VI RNEyDA

V MACEYG

VII TyBTCyB

VI RNEyDA

VII TyBTCyB

III LVSyEA

VI RNEyDA

VII TyBTCyB

$\checkmark$ MACEYG

VI RNEyDA

II ELyAC

VII TyBTCyB

III LVSyEA

IV MAyACI

I CAyS

IV MAYACI

VI RNEyDA

III LVSyEA

VI RNEyDA

VII TyBTCyB

III LVSyEA

VII TyBTCyB

IV MAYACI

VI RNEyDA

I CAyS

VI RNEyDA

VII TyBTCyB

VII TyBTCyB

VI RNEyDA
63,64

41,42

$159,160,173,174$

$35,36,43,44,49,50,57,58$

219, 220

21,22

31,32

$17,18,91,92,175,176$

27,28

55,56

229,230

135,136

13,14

157,158

27,28

153,154

27,28

9, 10

17,18

$21,22,25,26$

147,148

49,50

143,144

155, 156

11,12

157, 158

19,20

$5,6,177,178,179,180$

11,12

9,10

71,72

37,38

89,90 


\section{CONGRESO INTERNACIONAL Y XXIV CONGRESO NACIONAL DE CIENCIAS AMBIENTALES}

03-07 Junio/2019 Mazatlán, Sinaloa

\section{Índice general de autores AUTOR \\ ÁrEA \\ TEMÁTICA \\ PÁGINAS}

Ortiz Ruiz A

Osornio Rubio R

Osornio Rubio R

Ostin Sáenz J

Otlíca Rosario A

Oyedotun TDT

Oyoque-Salcedo $G$
VII TyBTCyB

I CAyS

VI RNEyDA

VII TyBTCyB

VI RNEyDA

VI RNEyDA

VI RNEyDA

IV MAyACI
$27,28,147,148$

39,40

27, 28, 89, 90

$27,28,55,56$

$35,36,37,38$

221, 222

213, 214

25, 26

Pacheco H

I CAyS

27, 28

VI RNEyDA

115,116

VII TyBTCyB

159,160

IV MAyACI

VI RNEyDA

VII TyBTCyB

VI RNEyDA

VI RNEyDA

III LVSyEA

VII TyBTCyB

VI RNEyDA

V MACEyG

VII TyBTCyB

VI RNEyDA

VI RNEyDA

VII TyBTCyB

VII TyBTCyB

III LVSyEA

VI RNEyDA

VI RNEyDA

$21,22,25,26$

$103,104,181,182,235,236$

161,162

189,190

199, 200

25,26

25,26

23, 24

41,42

121,122

107,108

183,184

65,66

79,80

51,52

35,36

183,184

VII TyBTCyB

9,10

V MACEyG 


\section{CONGRESO INTERNACIONAL Y XXIV CONGRESO NACIONAL DE CIENCIAS AMBIENTALES 03-07 Junio/2019 Mazatlán, Sinaloa \\ Índice general de autores AUTOR \\ ÁrEA \\ TEMÁtICA \\ PÁGINAS}

VII TyBTCyB

VI RNEyDA

I CAyS

IV MAyACI

VII TyBTCyB

III LVSyEA

II ELYAC

VI RNEyDA

V MACEYG

$\checkmark$ MACEYG

I CAyS

III LVSyEA

II ELyAC

I CAyS

VI RNEyDA

II ELyAC

VI RNEyDA

VII TyBTCyB

VII TyBTCyB

VI RNEyDA

VI RNEyDA

VI RNEyDA

III LVSyEA

VI RNEyDA

V MACEYG

VI RNEyDA

VII TyBTCyB
31,32

185,186

9,10

7,8

$37,38,39,40$

35,36

33,34

89,90

11,12

43,44

45,46

11,12

33,34

47,48

187, 188, 197, 198

31,32

11,12

163, 164

213, 214

111,112

67,68

159, 160, 173, 174

51,52

129,130

$25,26,27,28$

$3,4,237,238$

149,150

\section{Q}

Quezada Aldaco MG

VI RNEyDA

191, 192

V MACEYG

45,46

VI RNEyDA 


\section{CONGRESO INTERNACIONAL Y XXIV CONGRESO NACIONAL DE CIENCIAS AMBIENTALES}

03-07 Junio/2019 Mazatlán, Sinaloa

\section{Índice general de autores AUTOR \\ ÁrEA \\ TEMÁTICA \\ PÁGINAS}

Quijano Parra A

Quintero García OJ

Quintero Hernández M

Quintero Romanillo AL

Quintero Romanillo AL

Quiñones CA

Quiñonez Barraza G

Quiñonez Martínez M

Quirarte Brambila M

$\mathbf{R}$

Raga GB

Ramírez Carranza DR

Ramirez García JJ

Ramirez Hernandez J

Ramírez López C

Ramírez López EM

Ramírez Martínez $\mathrm{R}$

Ramírez Mosqueda $\mathrm{E}$

Ramírez Ortega AA

Ramírez Pereda B

Ramírez Rejogochi S

Ramos Cassellis ME

Ramos Delgado N

Ramos-Escamilla $\mathrm{F}$

Rangel D

Rangel G
II ELyAC

VII TyBTCyB

VII TyBTCyB

II ELyAC

VI RNEyDA

I CAyS

VI RNEyDA

IV MAyACI

VI RNEyDA

III LVSyEA

V MACEYG

VII TyBTCyB

VI RNEyDA

VI RNEyDA

IV MAyACI

VII TyBTCyB

VI RNEyDA

II ELyAC

VI RNEyDA

II ELyAC

VII TyBTCyB

VII TyBTCyB

I CAyS

VI RNEyDA

VI RNEyDA

VII TyBTCyB

VII TyBTCyB

V MACEYG

VI RNEyDA

VI RNEyDA
11,12

165,166

167, 168

31,32

201, 202

31,32

51,52

23, 24

163, 164, 189, 190

9,10
169,170

79,80

135,136

$13,14,15,16$

185,186

217, 218

29,30

195, 196

29,30

171,172

$87,88,179,180$

37,38

197, 198

145,146

219,220

237, 238

3,4

71,72

117, 118 


\section{CONGRESO INTERNACIONAL Y XXIV CONGRESO \\ NACIONAL DE CIENCIAS AMBIENTALES}

03-07 Junio/2019 Mazatlán, Sinaloa

\section{Índice general de autores \\ AUTOR \\ ÁreA \\ TEMÁTICA \\ PÁGINAS}

Rángel Peraza A

Rangel Peraza J

Razo Zárate $\mathrm{R}$

Razo Zárate $\mathrm{R}$

Rendón Caro J

Rendón López MB

Rentería Alvarez G

Rentería Villalobos $\mathrm{M}$

Reyes Barajas S

Reyes Calderon F

Reyes Castellanos J

Reyes Castro S

Reyes García A

Reyes Gutiérrez JA

Reyes Hernández V

Reyes López SY

Reyes Muñoz J

Reyes Pérez EM

Reyes Pérez J

Reyes Prado $\mathrm{M}$

Reyes Romero $\mathrm{F}$

Reyes Umaña M

Rico Arzate E

Rico Barragán A

Ríos Gerardo J

Ríos Leal E

Ríos-Sánchez E

\author{
I CAyS \\ V MACEYG \\ VI RNEyDA \\ VII TyBTCyB \\ II ELyAC \\ VI RNEyDA \\ III LVSyEA \\ VI RNEyDA \\ VI RNEyDA \\ I CAyS \\ VI RNEyDA \\ VII TyBTCyB \\ VI RNEyDA \\ VI RNEyDA \\ VII TyBTCyB \\ III LVSyEA \\ VI RNEyDA \\ VI RNEyDA \\ VII TyBTCyB
}

VI RNEyDA

VII TyBTCyB

VII TyВTCyB

VII TyBTCyB

VII TyBTCyB

III LVSyEA

VII TyBTCyB

II ELyAC

VII TyBTCyB

VI RNEyDA

VII TyBTCyB

V MACEYG 


\section{CONGRESO INTERNACIONAL Y XXIV CONGRESO NACIONAL DE CIENCIAS AMBIENTALES 03-07 Junio/2019 Mazatlán, Sinaloa \\ Índice general de autores Autor \\ ÁrEA \\ TEMÁTICA \\ PÁGINAS}

Rivas Herrera M

Rivas Montaño AM

Rivera B

Rivera Hernández K

Rivera Wong J

Rivera-Hernández KN

Roa Morales G

Robledo Zacarías V

Robles Magdaleno J

Rodríguez Alviso C

Rodríguez Apodaca JR

Rodríguez Casasola F

Rodríguez Casasola $T$

Rodríguez Flores F

Rodríguez García P

Rodríguez González B

Rodríguez Herrera $A$

Rodríguez Laguna $\mathrm{R}$

Rodríguez Luna IC

Rodríguez Mata A

Rodríguez Meza G

Rodríguez Narváez OM

Rodríguez Ontiveros A

Rodríguez Ortiz G

Rodríguez Piñeros S

Rodríguez Plascencia EL
I CAyS

VI RNEyDA

I CAyS

VII TyBTCyB

VI RNEyDA

IV MAyACI

VI RNEyDA

VII TyBTCyB

VII TyBTCyB

VII TyBTCyB

III LVSyEA

II ELyAC

VII TyBTCyB

VII TyBTCyB

II ELyAC

VII TyBTCyB

VII TyBTCyB

II ELyAC

III LVSyEA

VII TyBTCyB

II ELyAC

VI RNEyDA

VII TyBTCyB

I CAyS

VI RNEyDA

VII TyBTCyB

VI RNEyDA

VII TyBTCyB

VII TyBTCyB

VI RNEyDA

VI RNEyDA

VII TyBTCyB

VII TyВTCyB
39,40

209, 210

33,34

185,186

1,2

$13,14,15,16$

53,54

$75,76,177,178$

187,188

179,180

39,40

31,32

$67,68,201,202,227,228$

201, 202

27,28

153, 154

187, 188

33,34

$53,54,55,56$

57,58

35,36

199,200

$17,18,19,20$

5,6

151,152

179,180

183, 184

121,122

83,84

137, 138, 207, 208

$7,8,155,156$

135,136

239, 240

xIvii 


\section{CONGRESO INTERNACIONAL Y XXIV CONGRESO NACIONAL DE CIENCIAS AMBIENTALES 03-07 Junio/2019 Mazatlán, Sinaloa \\ Índice general de autores Autor \\ ÁrEA \\ TEMÁTICA \\ PÁGINAS}

Rodríguez Robles LF

Rodríguez Rosales MDJ

Rodríguez Sauceda EN

Rodríguez Solís A

Rodríguez VG

Rodríguez-Narváez O

Roé Sosa A

Rojas Herrera AA

Rojas Ruíz E

Rolón Aguilar E

Rolón Aguilar J

Rolón García J

Román S

Romero Leyva $\mathrm{F}$

Romero López A

Romero Mota D

Romero Zaragoza M

Ronquillo Gorgúa N

Roque Ruiz J

Rosano Ortega $\mathrm{G}$

Rosas Acevedo JL

Rosas I

Rosas Medina I

Rosas Mendoza E

Rosas Pérez I
II ELyAC

II ELyAC

VII TyBTCyB

VI RNEyDA

VII TyBTCyB

III LVSyEA

V MACEYG

VII TyBTCyB

VI RNEyDA

VII TyBTCyB

VI RNEyDA

I CAyS

III LVSyEA

VI RNEyDA

VI RNEyDA

VI RNEyDA

III LVSyEA

VII TyBTCyB

VII TyBTCyB

VI RNEyDA

II ELyAC

VII TyBTCyB

VII TyBTCyB

III LVSyEA

V MACEYG

VI RNEyDA

VI RNEyDA

II ELyAC

III LVSyEA

VI RNEyDA

VII TyBTCyB

VII TyBTCyB
29,30

$21,22,27,28$

$7,8,29,30,123,123,153,154,205$, $206,207,208,211,212,233,234$

201, 202

117,118

1,2

41,42

13,14

63,64

$181,182,189,190$

205, 206

45,46

11,12

99,100

205, 206

71,72

57,58

51,52

85,86

45,46

35,36

$77,78,125,126,191,192$

$1,2,163,164$

$3,4,61,62$

$13,14,51,52$

63,64

181,182

25,26

47,48

$47,48,103,104,211,212,235,236$

109,110

195, 196 


\section{CONGRESO INTERNACIONAL Y XXIV CONGRESO \\ NACIONAL DE CIENCIAS AMBIENTALES \\ 03-07 Junio/2019 Mazatlán, Sinaloa \\ Índice general de autores \\ AUTOR \\ ÁrEA \\ TEMÁtICA \\ PÁGINAS}

Rosas-Sánchez D

V MACEyG

1,2

$\checkmark$ MACEyG

3,4

Rubio Rosas E

VII TyBTCyB

99,100

Ruiz Font A

Ruiz García CS

Ruiz Gonzalez M

VII TyBTCyB

99,100

III LVSyEA

59,60

VI RNEyDA

207, 208

III LVSyEA

19,20

VI RNEyDA

213, 214

\section{S}

Saavedra Chávez A

VI RNEyDA

209, 210

VI RNEyDA

13,14

Saavedra Sotelo N

VI RNEyDA

135,136

VI RNEyDA

215,216

VII TyBTCyB

193, 194

Salaza Batres KJ

VII TyBTCyB

203, 204

Salazar Fernández C

VII TyBTCyB

51,52

Salazar Hernández E

Salazar Hernández MM

VII TyВTCyB

183, 184

VII TyBTCyB

149,150

Salazar Muñoz Y

II ELyAC

21,22

Salazar Salazar GC

Salcedo Rosales M

Saldaña Almazán M

Saldaña De la Vega JA

Saldaña-Blanco M

VII TyBTCyB

183, 184

VII TyBTCyB

213, 214

III LVSyEA

61,62

VII TyBTCyB

193, 194

V MACEYG

31,32

$\checkmark$ MACEYG

19,20

VII TyBTCyB

195, 196

VI RNEyDA

131,132

VI RNEyDA

99,100

VII TyBTCyB

55,56

III LVSyEA

$39,40,61,62$

V MACEyG

13,14

xlix 


\section{CONGRESO INTERNACIONAL Y XXIV CONGRESO NACIONAL DE CIENCIAS AMBIENTALES 03-07 Junio/2019 Mazatlán, Sinaloa \\ Índice general de autores Autor \\ ÁrEA \\ TEMÁtICA \\ PÁGINAS}

VI RNEyDA

VII TyBTCyB

VII TyBTCyB

VII TyBTCyB

I CAyS

II ELyAC

VI RNEyDA

VI RNEyDA

VII TyBTCyB

VII TyBTCyB

III LVSyEA

V MACEYG

VI RNEyDA

VII TyBTCyB

Sánchez Rodríguez $O$

Sánchez Román $\mathrm{R}$

Sánchez Ruiz F

Sánchez Sánchez H

Sánchez Torres-Esqueda G

Sánchez Varela A

Sánchez Zarza M

Sánchez-Alarcón J

Sánchez-Gervacio B

Sánchez-Humarán IL

Sánchez-Mendoza $\mathrm{H}$

Sandoval Lezama JC

Sandoval S

Sandoval Segura D

Sanhouse A

Sanhouse García AJ

Santamaría Juárez D
VII TyBTCyB

VI RNEyDA

VII TyBTCyB

VI RNEyDA

I CAyS

VII TyBTCyB

I CAyS

V MACEYG

VI RNEyDA

V MACEYG

IV MAYACI

V MACEYG

VI RNEyDA

VI RNEyDA

VII TyBTCyB

VI RNEyDA

VI RNEyDA

I CAyS

VII TyBTCyB
69,70

$57,58,113,114$

105, 106

197, 198

11,12

37,38

$9,10,11,12$

$5,6,179,180$

183, 184

199, 200

33,34

53,54

135,136

$51,52,79,80$

201, 202

221, 222

1,2

21,22

45,46

$17,18,19,20$

7,8

$35,36,43,44,49,50,57,58$

219,220

51,52

19,20

53,54

223, 224

$59,60,225,226$

65,66

117,118

151,152

21,22

93,94 


\section{CONGRESO INTERNACIONAL Y XXIV CONGRESO NACIONAL DE CIENCIAS AMBIENTALES \\ 03-07 Junio/2019 Mazatlán, Sinaloa \\ Índice general de autores AUTOR \\ ÁreA \\ TEMÁTICA \\ PÁGINAS}

Santana Flores D

Santellano Estrada E

Santillanes Flores M

Santos Ballardo D

Santos Ballardo D

Sarabia-Aparicio JL

Schiaffini Aponte R

Segovia García JD

Segovia Torres $\mathrm{R}$

Segura García V

Segura Maldonado V

Serafín Muñoz A

Serrano Barquín $R$

Serrano Gonzaga $R$

Serrano Lerma M

Siebe Grabach C

Sierra Alvarado E

Sierra-Vargas MP

Silva Gómez S

Silva Holguin PN

Silva Marrufo $O$

Silva P

Silveti Loeza A

Solís Lerma L

Solís Sánchez L

Sonder K

Sosa Rodríguez F

Sosa Rodríguez M

Soto Padilla M

Soto Retana M
III LVSyEA

VII TyBTCyB

I CAyS

II ELyAC

VI RNEyDA

VII TyBTCyB

IV MAyACI

VI RNEyDA

VII TyBTCyB

VI RNEyDA

VI RNEyDA

VII TyBTCyB

VII TyBTCyB

VI RNEyDA

III LVSyEA

VII TyBTCyB

VII TyBTCyB

VII TyBTCyB

$\checkmark$ MACEYG

II ELyAC

VII TyВTCyB

VII TyBTCyB

VI RNEyDA

VII TyBTCyB

VII TyBTCyB

VI RNEyDA

V MACEYG

VI RNEyDA

VI RNEyDA

VI RNEyDA

III LVSyEA

I CAyS

VII TyBTCyB 


\section{CONGRESO INTERNACIONAL Y XXIV CONGRESO \\ NACIONAL DE CIENCIAS AMBIENTALES \\ 03-07 Junio/2019 Mazatlán, Sinaloa \\ Índice general de autores \\ AUTOR \\ ÁrEA \\ TEMÁtICA \\ PÁGINAS}

Soto Silva CA

Suárez Alonso ML

$\mathbf{T}$

Tahuilan Garcia J

Tamaríz Flores JV

Tapia Acosta J

Tapia Morales J

Tapia Ponce S

Tejocote Pérez M

Tenorio-Arvide MG

Tobías Jaramillo $\mathrm{R}$

Torres Aquino M

Torres Jiménez M

Torres Pérez J

Torres Ricario $\mathrm{R}$

Torres Rojas YE

Torres Salazar M

Tovar Carrillo K

Tovar Sánchez E

Trejo Albarrán R

Trejo Osuna OI

Turnes Palomino G
VI RNEyDA

VI RNEyDA

VI RNEyDA

135,136

VII TyBTCyB

I CAyS

VI RNEyDA

VII TyBTCyB

VI RNEyDA

IV MAyACI

I CAyS

III LVSyEA

VI RNEyDA

VII TyBTCyB

III LVSyEA

III LVSyEA

VII TyBTCyB

VI RNEyDA
II ELyAC
III LVSyEA
VII TyBTCyB
III LVSyEA
V MACEyG
VI RNEyDA
VII TyBTCyB
VI RNEyDA
VI RNEyDA
VII TyBTCyB

57,58

203, 204

219, 220

7, 8

221, 222

213,214

53,54

17,18

45,46

11,12

205, 206

215,216

67,68

15,16

$35,36,41,42,47,48,63,64,95,96$, $111,112,125,126,133,134,143$, $144,173,174,175,176,191,192$,

$215,216,217,218,235,236$

181,182

37,38

$7,8,71,72$

141,142

63,64

39,40

41,42

117,118

91,92

227, 228

25,26 


\section{CONGRESO INTERNACIONAL Y XXIV CONGRESO NACIONAL DE CIENCIAS AMBIENTALES 03-07 Junio/2019 Mazatlán, Sinaloa \\ Índice general de autores \\ Autor \\ ÁrEA \\ TEMÁtICA}

U

Urbina Sánchez GI

Uribe Etchevarría M

Uribe Soto $\mathrm{N}$

Urióstegui Acosta MO

V

Valdez Mendoza N

Valdez Ortiz A

Valdez Román L

Valdivia Cabral GI

Valencia Flores E

Valencia García L

Valenciana-Valdez G

Valencia-Quintana $\mathrm{R}$

Valente Ramírez LA

Valentin Islas $R$

Valera Pérez MA

Valero Galán J

Valero Ortiz S

Valladares Cisneros MG

Valle Cervantes S

Valle Rodríguez S

Vallejo Aguilar A

Vallejo Cantú N
VI RNEyDA

VI RNEyDA

VI RNEyDA

$\checkmark$ MACEyG

VI RNEyDA
VI RNEyDA

VI RNEyDA

VII TyBTCyB

III LVSyEA

VI RNEyDA

III LVSyEA

VII TyBTCyB

IV MAYACI

V MACEYG

VI RNEyDA

I CAyS

VI RNEyDA

VI RNEyDA

VII TyBTCyB

III LVSyEA

III LVSyEA

VII TyBTCyB

II ELyAC

VII TyBTCyB

III LVSyEA

VI RNEyDA

VII TyBTCyB

VII TyBTCyB
$123,124,125,126,171,172$

25,26

103, 104, 211, 212

57,58

219,220
229, 230

139,140

105,106

57,58

33,34

69,70

23, 24

23,24

$35,36,43,44,49,50,51,52,57,58$

219,220

43,44

185,186

145,146

$133,134,173,174$

71,72

$7,8,71,72$

$15,16,43,44,45,46$

21,22

7, 8, 205, 206, 207, 208

59,60

105, 106

219,220

109,110 


\section{CONGRESO INTERNACIONAL Y XXIV CONGRESO \\ NACIONAL DE CIENCIAS AMBIENTALES}

03-07 Junio/2019 Mazatlán, Sinaloa

\section{Índice general de autores AUTOR \\ ÁrEA \\ TEMÁtICA \\ PÁGINAS}

VII TyBTCyB

Varela Mata K

Varela Ruíz M

Vargas Castilleja R

Vargas Martínez E

Vargas Nedzelsky AE

Vargas-Moreno J

Vásquez Gutierrez AR

Vazquez Arenas J

Vázquez Cuchillo $\mathrm{O}$

Vázquez Lara AY

Vázquez Lepe MO

Vázquez López N

Vázquez Martinez A

Vázquez Silva $G$

Vega Hernández M

Vega Pérez S

Vega Torres A

Vela Vázquez $R$

Velasco Amaro $P$

Velasco Flores $Y$

Velasco Hernández M

Velázquez Cortés JM

Velázquez Olalde B

Velázquez Pizano $\mathrm{P}$

Velázquez-García O

Véliz Gurrola J

Vences Martínez J
VII TyBTCyB

I CAyS

VI RNEyDA

VI RNEyDA

III LVSyEA

IV MAyACI

VI RNEyDA

VI RNEyDA

VI RNEyDA

VII TyBTCyB

VII TyBTCyB

VII TyВTCyB

VII TyBTCyB

VII TyBTCyB

VI RNEyDA

VI RNEyDA

VII TyBTCyB

III LVSyEA

VII TyBTCyB

VII TyBTCyB

$\checkmark$ MACEYG

VII TyBTCyB

V MACEYG

VI RNEyDA

VII TyBTCyB

VI RNEyDA

VI RNEyDA

VII TyBTCyB

IV MAyACI

VII TyBTCyB

III LVSyEA
II ELyAC
221, 222

223, 224

45,46

99,100

49,50

73,74

$21,22,25,26$

97,98

111,112

121,122

225, 226

149, 150

5,6

185, 186

67, 68, 227, 228

125,126

55,56

93, 94

17,18

229, 230

231, 232

55,56

233, 234

23,24

$19,20,31,32$

215, 216

193, 194

55,56

27,28

83,84

13,14

235, 236

53,54 


\section{CONGRESO INTERNACIONAL Y XXIV CONGRESO NACIONAL DE CIENCIAS AMBIENTALES 03-07 Junio/2019 Mazatlán, Sinaloa \\ Índice general de autores AUTOR \\ ÁreA \\ TEMÁtICA \\ PÁGINAS}

Venegas Barrera C

Vera García S

Vergara Flórez $M$

Veyna Gómez A

Viana Lases J

Vidal Abarca MR

Vigil Castillo $\mathrm{H}$

Vigueras Cortés JM

Villa Ramírez S

Villanueva Díaz J

Villanueva Rodríguez L

Villanueva Rodríguez M

Villa-Ramírez MS

Villarreal Vega A

Villegas Dueñas Martín

Villegas Martínez D

Viñas M

Violante González J

Viramontes Lizardo J

Viramontes Olivas OA

Vixta Haro JA

Vizcaíno Rodríguez LA

Vón Ostén J
III LVSyEA

VII TyBTCyB

VI RNEyDA

I CAyS

III LVSyEA

VI RNEyDA

VII TyBTCyB

VII TyBTCyB

VII TyBTCyB

VI RNEyDA

VII TyBTCyB

VII TyBTCyB

IV MAyACI

I CAyS

$\checkmark$ MACEYG

VI RNEyDA

VI RNEyDA

VI RNEyDA

VII TyBTCyB

III LVSyEA

VI RNEyDA

VI RNEyDA

VII TyBTCyB

I CAyS

VI RNEyDA

VI RNEyDA
69,70

201, 202

159, 160

35,36

$7,8,71,72$

203, 204

237, 238

239, 240

185, 186

129,130

59,60

237, 238

$13,14,15,16$

47,48

59,60

233, 234

215, 216

63,64

91, 92

75,76

231, 232

55,56

93, 94

$15,16,23,24$

119,120

43,44

\section{W}

Wehenkel C

V MACEYG

11,12 


\section{CONGRESO INTERNACIONAL Y XXIV CONGRESO \\ NACIONAL DE CIENCIAS AMBIENTALES \\ 03-07 Junio/2019 Mazatlán, Sinaloa \\ Índice general de autores \\ AUTOR \\ ÁrEA \\ TEMÁtICA \\ PÁGINAS}

Z

Zamora Alvarado $\mathrm{R}$

VI RNEyDA

137,138

Zapata Mariscal M

VI RNEyDA

235, 236

Zaragoza Tapia F

Zaragoza Yacuta E

VI RNEyDA

237, 238

VI RNEyDA

45,46

Zarazúa Ortega G

VI RNEyDA

77,78

Zavala Arce R

Zavala Trejo M

Zepeda Gómez C

Zepeda Orellan A

Zequera García C

VII TyBTCyB

I CAyS

$5,6,103,104,139,140$

35,36

VI RNEyDA

III LVSyEA

$21,22,77,78,239,240$

VI RNEyDA

67,68

167, 168 


\section{CONGRESO INTERNACIONAL Y XXIV CONGRESO NACIONAL DE CIENCIAS AMBIENTALES 03-07 Junio/2019 Mazatlán, Sinaloa \\ Índice de autores por Área Temática \\ Autor \\ ÁrEA \\ TEMÁtICA \\ PÁGINAS}

\begin{tabular}{|c|c|c|}
\hline \multicolumn{3}{|l|}{$\mathbf{A}$} \\
\hline $\begin{array}{l}\text { Aguíñiga García S } \\
\text { Alfaro Martínez V } \\
\text { Almanza Rangel S } \\
\text { Almazán Benítez B } \\
\text { Altanasa L } \\
\text { Alvarez Bernal D } \\
\text { Amábilis Sosa L } \\
\text { Anguas Cabrera D } \\
\text { Arcos Ramos R } \\
\text { Avelino Flores F } \\
\text { Avilés Flores M }\end{array}$ & $\begin{array}{l}\text { I CAyS } \\
\text { I CAyS } \\
\text { I CAyS } \\
\text { I CAyS } \\
\text { I CAyS } \\
\text { I CAyS } \\
\text { I CAyS } \\
\text { I CAyS } \\
\text { I CAyS } \\
\text { I CAyS } \\
\text { I CAyS }\end{array}$ & $\begin{array}{r}11,12 \\
1,2 \\
39,40 \\
3,4 \\
39,40 \\
17,18 \\
5,6 \\
11,12 \\
33,34 \\
21,22 \\
7,8\end{array}$ \\
\hline \multicolumn{3}{|l|}{$\mathbf{B}$} \\
\hline $\begin{array}{l}\text { Barajas Mojarro J } \\
\text { Barragán Aroche JF } \\
\text { Bautista Capetillo C } \\
\text { Brito García C }\end{array}$ & $\begin{array}{l}\text { I CAyS } \\
\text { I CAyS } \\
\text { I CAyS } \\
\text { I CAyS }\end{array}$ & $\begin{array}{r}15,16 \\
43,44 \\
35,36 \\
9,10\end{array}$ \\
\hline \multicolumn{3}{|l|}{$\mathbf{C}$} \\
\hline $\begin{array}{l}\text { Cabral Lares M } \\
\text { Camacho Cruz K } \\
\text { Camacho Sanabria R } \\
\text { Caro Becerra J } \\
\text { Carrillo L } \\
\text { Castañeda Roldán E } \\
\text { Cedillo Herrera C } \\
\text { Chávez Bravo E } \\
\text { Chavez Castellanos K } \\
\text { Cordero Lezama A }\end{array}$ & $\begin{array}{l}\text { I CAyS } \\
\text { I CAyS } \\
\text { I CAyS } \\
\text { I CAyS } \\
\text { I CAyS } \\
\text { I CAyS } \\
\text { I CAyS } \\
\text { I CAyS } \\
\text { I CAyS } \\
\text { I CAyS }\end{array}$ & $\begin{array}{r}47,48 \\
11,12 \\
13,14 \\
15,16,23,24 \\
11,12 \\
1,2 \\
5,6 \\
1,2,21,22 \\
17,18 \\
19,20\end{array}$ \\
\hline \multicolumn{3}{|l|}{$\mathbf{E}$} \\
\hline $\begin{array}{l}\text { Esteller Alberich MV } \\
\text { Expósito Castillo JL }\end{array}$ & $\begin{array}{l}\text { I CAyS } \\
\text { I CAyS }\end{array}$ & $\begin{array}{l}3,4 \\
3,4\end{array}$ \\
\hline
\end{tabular}




\section{CONGRESO INTERNACIONAL Y XXIV CONGRESO \\ NACIONAL DE CIENCIAS AMBIENTALES}

03-07 Junio/2019 Mazatlán, Sinaloa

\section{Índice de autores por Área Temática \\ AUTOR \\ ÁrEA \\ TEMÁtICA \\ PÁGINAS}

\author{
$\mathbf{F}$ \\ Franco Hernandez MO \\ G \\ Galindo Mendoza TV \\ Galván Camargo A \\ García R \\ Garrido Hoyos S \\ Gómez Hinojos AM \\ González Trinidad J \\ Guevara N \\ Gutiérrez Lara MR
}

H

Hernández Peña C

Heyer L

I

Ibarra Ceceña MG

Iñiguez Pérez $F$

J

Júnez Ferreira H

\section{L}

López E

López Ramírez S Luevano Gurrola S

Lujan Godínez R

\section{M}

Manjarrez Hernández D
I CAyS

I CAyS

I CAyS

17,18

I CAyS

21,22

I CAyS

I CAyS

I CAyS

I CAyS

I CAyS

I CAyS

I CAyS

39,40

31,32

3,4

25,26

35,36

31,32

43,44

41,42

31,32

I CAyS

I CAyS

29,30

15,16

I CAyS

35,36

I CAyS

I CAyS

I CAyS

I CAyS

31,32

43, 44

37, 38

23, 24

25,26

I CAyS

Iviii 


\section{CONGRESO INTERNACIONAL Y XXIV CONGRESO \\ NACIONAL DE CIENCIAS AMBIENTALES}

03-07 Junio/2019 Mazatlán, Sinaloa

\section{Índice de autores por Área Temática \\ AUTOR \\ ÁrEA \\ TEMÁTICA \\ PÁGINAS}

\author{
Marmolejo Rodríguez A \\ Márquez $\mathrm{H}$ \\ Martínez Acuña M \\ Martínez Frías U \\ Martínez Hernández S \\ Martínez Salomón E \\ Max O \\ Mayoral Ruiz PA \\ Meléndez MR \\ Méndez Ramírez E \\ Mendivil Garcia K \\ Michel Parra JG \\ Munguía Pérez $\mathrm{R}$
}

I CAyS

I CAyS

I CAyS

I CAyS

I CAyS

I CAyS

I CAyS

I CAyS

I CAyS

I CAyS

I CAyS

I CAyS

I CAyS

I CAyS

I CAyS

Novelo Castilla J

\section{$\mathbf{N}$}

\section{0}

Oregel Zamudio $\mathrm{E}$ Ortiz Hernández C Osornio Rubio R

I CAyS

I CAyS

I CAyS

17,18

11,12

39,40

$\mathbf{P}$

Pacheco H

Pérez Osorio C

Pichardo Ramírez $\mathrm{R}$

Pinedo Alvarez C

$\mathbf{Q}$

Quiñones CA

I CAyS

31,32

$\mathbf{R}$

Ramírez Rejogochi S

I CAyS

37,38

I CAyS

27, 28

I CAyS

9,10

I CAyS

45,46

47, 48

I CAyS

35,36
9,10

27, 28

43,44

19,20

29, 30

23, 24

31,32

5,6

23, 24

1, 2

ICAys

37,38

lix 


\section{CONGRESO INTERNACIONAL Y XXIV CONGRESO NACIONAL DE CIENCIAS AMBIENTALES 03-07 Junio/2019 Mazatlán, Sinaloa \\ Índice de autores por Área Temática \\ Autor \\ ÁrEA \\ TEMÁTICA \\ PÁGINAS}

Rángel Peraza A

Rentería Villalobos M

Rivas Herrera M

Rivera B

Rodríguez Mata A

Rolón Aguilar J
I CAyS

I CAyS

I CAyS

I CAyS

I CAyS

I CAyS

I CAyS

I CAyS

I CAyS

I CAyS

I CAyS

I CAyS

Soto Padilla M

$\mathbf{T}$

Tapia Acosta J

Tobías Jaramillo $R$

V

Valente Ramírez LA

Vargas Castilleja $R$

Veyna Gómez A

Villarreal Vega A

Vizcaíno Rodríguez LA

Z
I CAyS

I CAyS

I CAyS

I CAyS

I CAyS

I CAyS

I CAyS
I CAyS
5,6

47,48

39,40

33,34

5,6

45,46

11,12

45,46

7,8

21,22

41,42

41,42

7,8

45,46

43,44

45,46

35,36

47,48

$15,16,23,24$

Zavala Trejo M 


\section{CONGRESO INTERNACIONAL Y XXIV CONGRESO \\ NACIONAL DE CIENCIAS AMBIENTALES \\ 03-07 Junio/2019 Mazatlán, Sinaloa \\ Índice de autores por Área Temática \\ Autor \\ Área Temática \\ II Energía Limpias y Acciones por el Clima}

Páginas

A

Acevedo Sandoval O

II ELyAC

35,36

Aguíñiga García S

II ELyAC

II ELyAC

37,38

II ELyAC

II ELyAC

33, 34

Ambriz Pérez D

Arce Martínez Gl

II ELyAC

5, 6. 19, 20

Argumedo Macías A

29, 30

9,10

B

Bailón Salas A

Bluhm Gutiérrez J

II ELyAC

27,28

II ELyAC

33, 34

C

Carbajal de la Torre G

II ELyAC

II ELyAC

II ELyAC

II ELyAC

II ELyAC

II ELyAC

II ELyAC

3,4

37,38

1,2

Cerón Bracamontes $M$

25,26

Contreras Molina A

7, 8

Correa García A

Cuellar González J

3,4

7, 8

D

De la Peña Arellano LA

II ELyAC

II ELyAC

Díaz Pazos J

Dzul García O

II ELyAC

21,22

$5,6,19,20$

33,34

E

Escalona Alcázar $F$

II ELyAC

33,34

II ELyAC

7,8

Estrella Rodríguez J

II ELyAC

17,18 


\section{CONGRESO INTERNACIONAL Y XXIV CONGRESO \\ NACIONAL DE CIENCIAS AMBIENTALES \\ 03-07 Junio/2019 Mazatlán, Sinaloa \\ Índice de autores por Área Temática \\ Autor \\ Área Temática \\ II Energía Limpias y Acciones por el Clima}

Páginas

$\mathbf{F}$

Flores Sotelo T

Flores Villegas M

Florez MG

Fonseca Mendoza MM

Franco Rivas B

G

Garate Osuna A

Gómez Hinojos AM

Gómez Martínez F

Gracía Matías F

Guevara Espinosa M

Gutiérrez Cedillo A

H

Hernández Alarcón ME

Hernández Ortiz J

Hernández Pérez YY

Hernández Zepeda JS

Huerta Lara M

L

Lara Ponce E

Llera García E

Luna Avelar K

M

Madrid del Palacio M

Mares Cuevas MJ

Martínez Guzmán MJ

Martínez Munguía R

Martínez P
II ELyAC

II ELyAC

II ELyAC

II ELyAC

II ELyAC

II ELyAC

II ELyAC

II ELyAC

II ELyAC

II ELyAC

II ELyAC

II ELyAC

II ELyAC

II ELyAC

II ELyAC

II ELyAC

II ELyAC

II ELyAC

II ELyAC

31,32

17,18

$5,6,19,20$
9, 10

27, 28

11,12

29, 30

27,28
15,16

35,36

15,16

9, 10

9, 10
13,14

13,14

9, 10

23, 24

1,2
II ELyAC

II ELyAC

II ELyAC

II ELyAC

II ELyAC
27, 28

13,14

21,22

23, 24

11,12 


\section{CONGRESO INTERNACIONAL Y XXIV CONGRESO \\ NACIONAL DE CIENCIAS AMBIENTALES \\ 03-07 Junio/2019 Mazatlán, Sinaloa \\ Índice de autores por Área Temática \\ Autor \\ Área Temática \\ II Energía Limpias y Acciones por el Clima}

Páginas

Martínez Valencia A

II ELyAC

II ELyAC

II ELyAC

3,4

Mejias Brizuela N

IIELAC

$5,6,19,20$

Michel Parra JG

$\mathbf{N}$

Naranjo Jiménez $\mathrm{N}$

II ELyAC

25,26

0

Ordaz Díaz L

II ELyAC

27,28

$\mathbf{P}$

Perez Roble E

II ELyAC

33,34

Pineda Martínez F

II ELyAC

33,34

Piña Ruiz HH

II ELyAC

31,32

Q

Quijano Parra A

Quintero Romanillo AL

II ELyAC

II ELyAC

11,12

31,32

R

Ramírez Martínez R

II ELyAC

29,30

II ELyAC

29,30

II ELyAC

35,36

Razo Zárate $\mathrm{R}$

II ELyAC

II ELyAC

3,4

Rodríguez Apodaca JR

II ELyAC

31,32

27,28

II ELyAC

33,34

Rodríguez González B

II ELyAC

35,36

II ELyAC

29,30

Rodríguez Robles LF

II ELyAC

II ELyAC

27,28

Ronquillo Gorgúa N

II ELyAC

35,36

25,26 


\section{CONGRESO INTERNACIONAL Y XXIV CONGRESO NACIONAL DE CIENCIAS AMBIENTALES 03-07 Junio/2019 Mazatlán, Sinaloa \\ Índice de autores por Área Temática \\ Autor \\ Área Temática \\ II Energía Limpias y Acciones por el Clima}

Páginas

S

Salazar Muñoz Y

Sánchez González A

Santos Ballardo D

Silva Gómez S

T

Torres Rojas YE

V

Valle Cervantes S

Velasco Hernández M
II ELyAC

II ELyAC

II ELyAC

II ELyAC

II ELyAC

II ELyAC

II ELyAC
37,38

21,22

37,38

$5,6,19,20$

9,10

21,22

23, 24 


\section{CONGRESO INTERNACIONAL Y XXIV CONGRESO \\ NACIONAL DE CIENCIAS AMBIENTALES}

03-07 Junio/2019 Mazatlán, Sinaloa

\section{Índice de autores por Área Temática}

Autor

Área Temática

III Legislación, Valores Sociales y Educación Ambiental

Páginas

\begin{abstract}
A
Abarca Urquiza JR

Aguilar Becerra CD

Alcántara Ángeles A

Alva Chavarría D

Amaya Chávez A

Arce Camacho I

Arce García I

Arellano Wences $\mathrm{H}$

Avilés Pineda $\mathrm{H}$

Ayala Espinoza M
\end{abstract}

\section{B}

Balderas Plata MA

Bañuelos Arcos $F$

Barragán Bautista $\mathrm{E}$

Bedolla Solano R

Bustamante Montes LP

\section{C}

Cabrera Cruz RBE

Camarena Gómez B

Camarena Morales A

Carrasco Urrutia K

Ceceña MG

Chacón Aguilar J

Chávez Ramírez SC

Chávez Soto M

Colmenero Robles A

Corona Loya LE Ríos

Corral Avitia A

Corrales Burgueño V

Cotero Villegas A

Cruz Herrera $A$
III LVSyEA

III LVSyEA

III LVSyEA

III LVSyEA

III LVSyEA

III LVSyEA

III LVSyEA

III LVSyEA

III LVSyEA

III LVSyEA

III LVSyEA

III LVSyEA

III LVSyEA

III LVSyEA

III LVSyEA

III LVSyEA

III LVSyEA

III LVSyEA

III LVSyEA

III LVSyEA

III LVSyEA

III LVSyEA

III LVSyEA

III LVSyEA

III LVSyEA

III LVSyEA

III LVSyEA

III LVSyEA

III LVSyEA
43, 44

31,32

9,10

39,40

33, 34

11,12

19,20

13,14

$15,16,61,62$

57,58

31,32

47,48

31,32

47,48

1,2

15,16

45,46

7,8

17,18 


\section{CONGRESO INTERNACIONAL Y XXIV CONGRESO \\ NACIONAL DE CIENCIAS AMBIENTALES}

03-07 Junio/2019 Mazatlán, Sinaloa

\section{Índice de autores por Área Temática}

Autor

Área Temática

III Legislación, Valores Sociales y Educación Ambiental

Páginas

D

Dantán Gonzalez E

III LVSyEA

63,64

De la Rosa Velázquez M

III LVSyEA

19,20

Del Carmen Niño V

III LVSyEA

Díaz Chávez R

III LVSyEA

Díaz Plascencia D

III LVSyEA

53,54

9,10

27,28

E

Escalante Estrada VE

III LVSyEA

21,22

Escalante Pérez B

III LVSyEA

23,24

Escalona Alcázar $F$

III LVSyEA

59,60

III LVSyEA

1,2

Espinoza Prieto $R$

III LVSyEA

$25,26,27,28$

F

Fajardo V

Flores Sotelo T

Flores Trujillo $\mathrm{K}$

Fragoso Servón $P$

Frausto Martínez $\mathrm{O}$

Frausto Mena R

III LVSyEA

69,70

III LVSyEA

41,42

III LVSyEA

63,64

III LVSyEA

51,52

III LVSyEA

3,4

III LVSyEA

29,30

G

Galaviz Acosta S

Gamboa Escobedo $S$

García Del Ángel G

García Fabila MM

García Ibáñez S

Garcia Noria E

García Reynoso JA

García Xochititla M

Gavilán García IC

Giner Chávez O

González González M

III LVSyEA

75,76

III LVSyEA $\quad 31,32$

III LVSyEA $\quad 11,12$

III LVSyEA 33, 34

III LVSyEA $\quad 3,4$

III LVSyEA 35, 36

III LVSyEA 37, 38

III LVSyEA $\quad 9,10$

III LVSyEA 37, 38

III LVSyEA 25, 26, 27, 28

III LVSyEA 67,68

Ixvi 


\section{CONGRESO INTERNACIONAL Y XXIV CONGRESO \\ NACIONAL DE CIENCIAS AMBIENTALES}

03-07 Junio/2019 Mazatlán, Sinaloa

\section{Índice de autores por Área Temática}

Autor
Área Temática

III Legislación, Valores Sociales y Educación Ambiental
Gutiérrez Cedillo A

Gutiérrez Cedillo JG

Gutiérrez JB

Gutiérrez Lara MR

Gutiérrez Ramírez A

Gutiérrez Segura EE

H

Hernández López J

Hernández Zepeda JS

Huerta García J

\section{J}

Jaimes Compean AJ

Jaimez Melgoza $R$

Juárez López AL

$\mathbf{L}$

León Hernández $\mathrm{V}$

Linares Campos JA

López Chávez LAJ

López Felix G

Lungo Rodríguez A

M

Maldonado Astudillo $Y$ Mancillas Flores $P$

Mandujano García CD

Manjarrez J

Medina Márquez M

Medina Miranda MD

Medina Sarmiento J

Mercado Méndez A

Michel Parra JG
III LVSyEA

III LVSyEA

III LVSyEA

III LVSyEA

III LVSyEA

III LVSyEA

III LVSyEA

III LVSyEA

III LVSyEA

III LVSyEA

III LVSyEA

III LVSyEA

39,40

5,6

$39,40,61,62$

III LVSyEA

III LVSyEA

III LVSyEA

III LVSyEA

III LVSyEA

71,72

41,42

47,48

$57,58,75,76$

53,54

III LVSyEA

61,62

III LVSyEA 27, 28

III LVSyEA

59,60

III LVSyEA

69,70

III LVSyEA

III LVSyEA

$7,8,71,72$

43,44

III LVSyEA 45,46

III LVSyEA

1,2

III LVSyEA

$1,2,49,50$

Ixvii 


\section{CONGRESO INTERNACIONAL Y XXIV CONGRESO \\ NACIONAL DE CIENCIAS AMBIENTALES}

03-07 Junio/2019 Mazatlán, Sinaloa

\section{Índice de autores por Área Temática}

Autor

Área Temática

III Legislación, Valores Sociales y Educación Ambiental

Páginas

Montaño Castrellón H

III LVSyEA

25,26

Mora Barrera L

III LVSyEA

5,6

Morales Benítez B

III LVSyEA

53,54

Morales Zepeda F

III LVSyEA

45,46

Mussali Galante P

III LVSyEA

63,64

$\mathbf{N}$

Naranjo Jiménez N

III LVSyEA

47,48

0

Ochoa Leyva A

Olivier Salomé B

Ordoñez Baquera $P$

Orendain Verduzco T

Orozco Robles J

III LVSyEA

III LVSyEA

III LVSyEA

III LVSyEA

III LVSyEA

63,64

55,56

27,28

49,50

11,12

\section{$\mathbf{P}$}

Palma Rosas $Y$

Pereira Corona A

III LVSyEA

25,26

III LVSyEA

51,52

III LVSyEA

35,36

III LVSyEA

11,12

Pichardo Ramírez R

III LVSyEA

51,52

Q

Quirarte Brambila M

III LVSyEA

9, 10

$\mathbf{R}$

Rendón Caro J

Reyes García A

Reyes Umaña M

Rodríguez Alviso C

Rodríguez Herrera A

Rodríguez VG

III LVSyEA

III LVSyEA

III LVSyEA

III LVSyEA

III LVSyEA

III LVSyEA
53,54

33,34

3,4

39,40

$53,54,55,56$

1,2

Ixviii 


\section{CONGRESO INTERNACIONAL Y XXIV CONGRESO \\ NACIONAL DE CIENCIAS AMBIENTALES \\ 03-07 Junio/2019 Mazatlán, Sinaloa}

\section{Índice de autores por Área Temática}

Autor

Área Temática

III Legislación, Valores Sociales y Educación Ambiental

Páginas

Rolón Aguilar J

Romero Leyva $\mathrm{F}$

Rosas Acevedo JL

Rosas Medina I

Ruiz García CS

Ruiz Luna A

S

Saldaña Almazán M

Sampedro Rosas ML

Sánchez Meza J

Santana Flores D

Serrano Gonzaga $R$

Sosa Rodríguez M

$\mathbf{T}$

Tobías Jaramillo $\mathrm{R}$

Torres Jiménez $M$

Torres Pérez J

Torres Salazar M

Tovar Sánchez E

\section{V}

Valdez Román L

Valencia Flores $\mathrm{E}$

Valero Ortiz S

Valladares Cisneros MG

Valle Rodríguez $\mathrm{S}$

Vargas Nedzelsky AE

Vega Pérez S

Vences Martínez J

Venegas Barrera C

Viana Lases J

Viramontes Olivas OA
III LVSyEA

III LVSyEA

III LVSyEA

III LVSyEA

III LVSyEA

III LVSyEA

III LVSyEA

III LVSyEA

III LVSyEA

III LVSyEA

III LVSyEA

III LVSyEA

III LVSyEA

III LVSyEA

III LVSyEA

III LVSyEA

III LVSyEA

III LVSyEA

III LVSyEA

III LVSyEA

III LVSyEA

III LVSyEA

III LVSyEA

III LVSyEA

III LVSyEA

III LVSyEA

III LVSyEA

III LVSyEA
11,12

57,58

$3,4,61,62$

47,48

59,60

19,20

61,62

$39,40,61,62$

33,34

63,64

$35,36,65,66$

31,32

11,12

67,68

15,16

$7,8,71,72$

63,64

57,58

69,70

71,72

$7,8,71,72$

59,60

73,74

17,18

53,54

69,70

$7,8,71,72$

75,76

Ixix 


\section{CONGRESO INTERNACIONAL Y XXIV CONGRESO \\ NACIONAL DE CIENCIAS AMBIENTALES \\ 03-07 Junio/2019 Mazatlán, Sinaloa}

\section{Índice de autores por Área Temática}

Autor

Área Temática

III Legislación, Valores Sociales y Educación Ambiental

Páginas

Z

Zepeda Orellan A

III LVSyEA

67,68 


\section{CONGRESO INTERNACIONAL Y XXIV CONGRESO \\ NACIONAL DE CIENCIAS AMBIENTALES}

03-07 Junio/2019 Mazatlán, Sinaloa

\section{Índice de autores por Área Temática}

Autor

Área Temática

IV M Ambiente, Contaminación, Enfermedad y Genotoxicidad

Páginas

A

Angoa-Perez V

Arenas-Espinosa $\mathrm{R}$

B

Bernal-Mendoza $\mathrm{H}$

C

Calderón-Fernández L

Castillo Morales M

Chaírez-Hernández I

Corral Avitia A

Cortés-Badillo $\mathrm{E}$

F

Filomeno-Marcelino E

G

Gámez-Domínguez V

García-Mora L

González-Güereca C

González-Maldonado B

H

Hernández-Linares G

Hernández-Salinas U

$\mathbf{L}$

Lazcano-Escobar JF

López-Trejo M
IV MAyACI

IV MAyACI

IV MAyACI

$3,4,5,6$

IV MAyACI

IV MAyACI

IV MAyACI

IV MAyACI

IV MAyACI

3, 4, 5, 6

7,8

9,10

23, 24

1,2

IV MAyACI

3,4

IV MAyACI

IV MAyACI

IV MAYACI

IV MAyACI

$9,10,11,12$

$9,10,11,12$

5,6

7,8

$3,4,5,6$

11,12

IV MAyACI

IV MAyACI

13,14

IV MAyACI

1, 2 


\section{CONGRESO INTERNACIONAL Y XXIV CONGRESO \\ NACIONAL DE CIENCIAS AMBIENTALES}

03-07 Junio/2019 Mazatlán, Sinaloa

\section{Índice de autores por Área Temática}

Autor

Área Temática

IV M Ambiente, Contaminación, Enfermedad y Genotoxicidad

Páginas

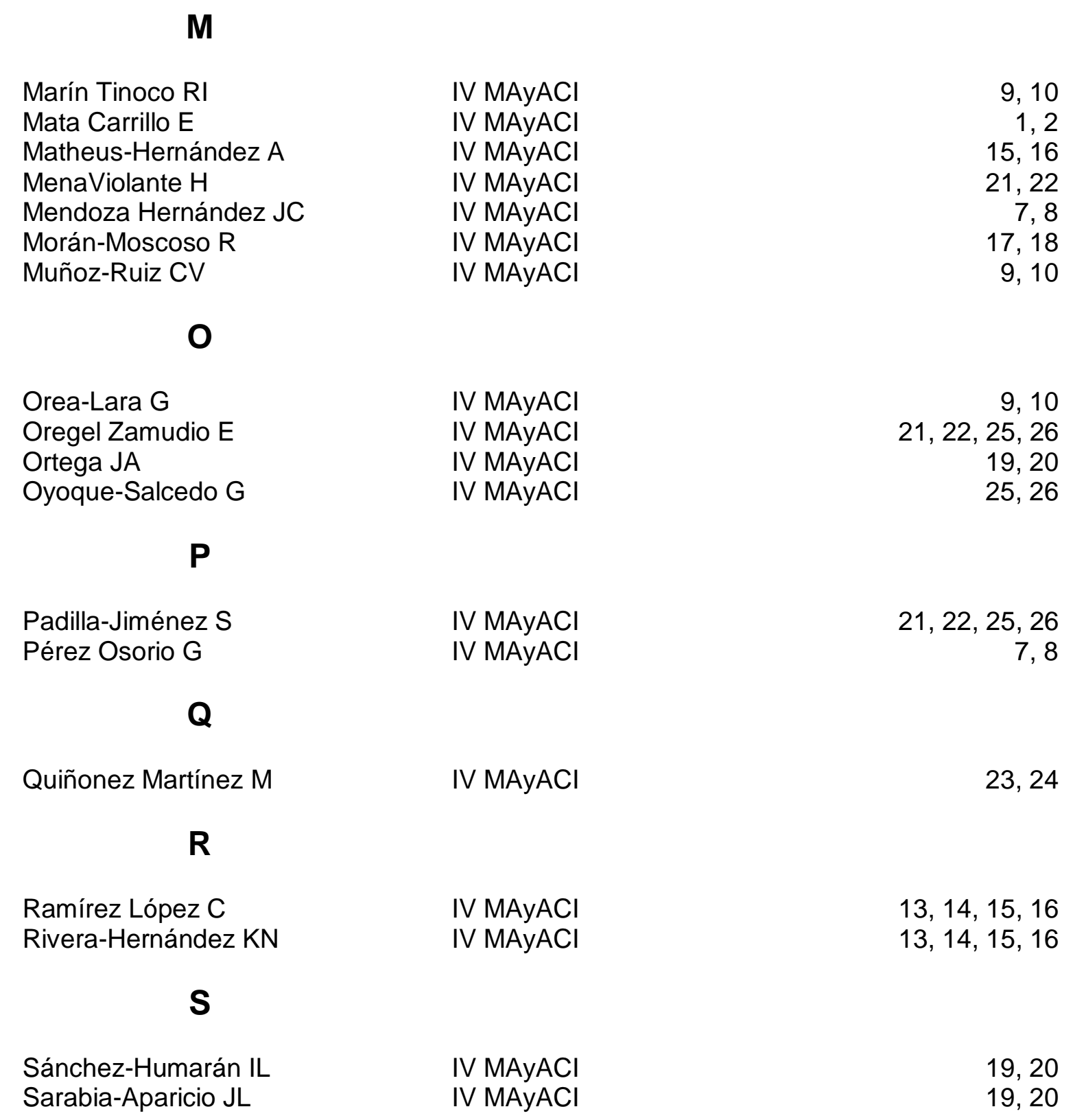




\section{CONGRESO INTERNACIONAL Y XXIV CONGRESO \\ NACIONAL DE CIENCIAS AMBIENTALES}

03-07 Junio/2019 Mazatlán, Sinaloa

\section{Índice de autores por Área Temática}

Autor

Área Temática

IV M Ambiente, Contaminación, Enfermedad y Genotoxicidad

Páginas

$\mathbf{T}$

Tenorio-Arvide MG

IV MAyACI

17,18

V

Valenciana-Valdez G

IV MAYACI

23,24

Vargas-Moreno J

IV MAYACI

$21,22,25,, 26$

Velázquez-García O

IV MAYACI

13,14

Villa-Ramírez MS

IV MAyACI

$13,14,15,16$ 


\section{CONGRESO INTERNACIONAL Y XXIV CONGRESO \\ NACIONAL DE CIENCIAS AMBIENTALES \\ 03-07 Junio/2019 Mazatlán, Sinaloa}

\section{Índice de autores por Área Temática \\ Autor \\ Área Temática \\ V M Ambiente, Contaminación, Enfermedad y Genotoxicidad}

Páginas

A

Aguilera Flores M

Alba Romero J

Alonso-Eguia LP

Alvarado MS

Amábilis Sosa $L$

Amador-Muñoz O

Amador-Valencia $T$

Amaya Chávez $A$

Angoa-Cortés $\mathrm{R}$

Arenas-Sánchez $\mathrm{H}$

Arroyo-Galván A

Ávila Vázquez V

Azua-Alonso D

B

Bandala ER

Bedolla Solano R

Bello-González O

Benítez-Martínez E

Bonassi S

Bustos Terrones $Y$

C

Calleros-Rincón E

Camarillo-Romero M

Cambranis-Miñon JH

Canizales Romo M

Castellanos-Moguel J

Colín JG

Cortés-Eslava J

Cruz García F
V MACEyG

V MACEYG

$\checkmark$ MACEYG

$\checkmark$ MACEYG

$\checkmark$ MACEYG

$\checkmark$ MACEYG

$\checkmark$ MACEYG

$\checkmark$ MACEYG

$\checkmark$ MACEYG

$\checkmark$ MACEYG

$\checkmark$ MACEYG

$\checkmark$ MACEYG

V MACEYG

V MACEyG

$\checkmark$ MACEYG

$\checkmark$ MACEYG

$\checkmark$ MACEYG

$\checkmark$ MACEYG

V MACEYG

V MACEYG

$\checkmark$ MACEYG

V MACEYG

V MACEYG

V MACEYG

$\checkmark$ MACEYG

$\checkmark$ MACEYG

V MACEYG
55,56

21,22

5,6

17,18

45,46

1,2

1,2

53,54

49,50

43,44

3,4

55,56

3,4

45,46

51,52

5,6

$25,26,27,28$

57,58

45,46

$21,22,47,48$

53,54

7,8

33,34

15,16

17,18

$9,10,23,24,57,58$

11,12 


\title{
XVIII CONGRESO INTERNACIONAL Y XXIV CONGRESO \\ NACIONAL DE CIENCIAS AMBIENTALES
}

03-07 Junio/2019 Mazatlán, Sinaloa

\section{Índice de autores por Área Temática}

Autor

\author{
Área Temática
}

V M Ambiente, Contaminación, Enfermedad y Genotoxicidad

Páginas

D

De la Llata-López ME

Del Ángel Ruiz K

Delgado-Ríos M

Díaz Godoy R

Díaz-Godoy RV

Domínguez Gómez TG

Durón Torres S

E

Estrada Ovando D

F

Flores Márquez AR

Flores-Marguez JP

Flores-Martínez M

Franco Villegas $\mathrm{E}$

G

García-Castro M

García-Rojas JL

García-Torres E

Gómez-Arroyo $S$

Gómez-Moreno V

Gómez-Olivares JL

Gonsebatt ME

González-Delgado MF

González-Gaona O

González-Quiñones JS

González-Rodríguez H

González-Zamora A

Grutter-de la Mora M
V MACEYG

$\checkmark$ MACEYG

V MACEYG

$\checkmark$ MACEYG

$\checkmark$ MACEYG

$\checkmark$ MACEyG

V MACEyG

V MACEyG

37,38

13,14

3,4

29,30

37,38

15,16

17,18

55,56

V MACEyG

$\checkmark$ MACEYG

$\checkmark$ MACEYG

V MACEYG

$9,10,23,24,57,58$

29,30

19,20

55,56

31,32

V MACEyG

V MACEYG

V MACEYG

$\checkmark$ MACEYG

$\checkmark$ MACEYG

$\checkmark$ MACEYG

$\checkmark$ MACEYG

V MACEYG

$\checkmark$ MACEYG

$\checkmark$ MACEYG

V MACEYG

V MACEYG

V MACEYG
7, 8

21,22

$9,10,23,24,57,58$

$25,26,27,28$

57,58

47,48

47,48

$25,26,27,28$

17,18

17,18

21,22

$9,10,23,24$ 


\title{
XVIII CONGRESO INTERNACIONAL Y XXIV CONGRESO \\ NACIONAL DE CIENCIAS AMBIENTALES
}

03-07 Junio/2019 Mazatlán, Sinaloa

\section{Índice de autores por Área Temática}

Autor

\author{
Área Temática
}

V M Ambiente, Contaminación, Enfermedad y Genotoxicidad

Páginas

H

Hernández-Carreón S

Hueletl- Soto ME

Huerta-Reza E

J

Jiménez García LF

Juárez López AL

K

Kašuba V

$\mathbf{L}$

Ladino LA

Lara-Martínez $\mathrm{R}$

Legorreta-Soberanis $\mathrm{J}$

López-Monroy J

Loza-Gómez P

M

Medina-Orendain D

Medrano Enríquez A

Mercado Silva N

Mérida-Cortés $\mathrm{P}$

Meza-Montenegro MM

Milić M

Monárrez González C

Montiel-González JMR

Montoya Mar F

Moreno Alcántara J

Muro González D

Mussali Galante P
V MACEyG

$\checkmark$ MACEYG

V MACEYG

V MACEyG

V MACEYG

V MACEyG

V MACEYG

V MACEYG

$\checkmark$ MACEYG

$\checkmark$ MACEYG

V MACEYG

V MACEYG

$\checkmark$ MACEYG

$\checkmark$ MACEYG

$\checkmark$ MACEYG

$\checkmark$ MACEYG

$\checkmark$ MACEYG

V MACEYG

V MACEYG

V MACEYG

$\checkmark$ MACEYG

V MACEYG

V MACEYG
57,58

$9,10,23,24$

$13,14,51,52$

29,30

$35,36,43,44,49,50,57,58$

31,32

51,52

15,16

23, 24

41,42

33,34

5,6

$9,10,23,24$

29,30

57,58

11,12

$35,36,43,44,49,50,57,58$

33,34

$15,16,37,38$

39,40

39,40
$9,10,23,24$ 


\section{CONGRESO INTERNACIONAL Y XXIV CONGRESO \\ NACIONAL DE CIENCIAS AMBIENTALES}

03-07 Junio/2019 Mazatlán, Sinaloa

\section{Índice de autores por Área Temática}

Autor

Área Temática

V M Ambiente, Contaminación, Enfermedad y Genotoxicidad

Páginas

\begin{abstract}
$\mathbf{N}$
Niño Maldonado S

Niño-Lozano A

Núñez-Cardona MT

Núñez-Gastélum JA
\end{abstract}

V MACEyG

$\checkmark$ MACEYG

0

Ochoa-Ocaña MA

Olivas Calderón E

Olmos Martínez E

P

Partida Joya D

Pérez Morales $\mathrm{R}$

Pérez Verdín $\mathrm{G}$

Pérez-Sánchez M

Puga-Zapata T

Q

Quevedo-Castro A

R

Raga GB

Ramos-Escamilla $F$

Rangel-Peraza J

Ríos-Sánchez E

Rodríguez-Narváez O

Rosas Acevedo JL

Rosas-Sánchez D

Rostro Segura A
V MACEYG

V MACEYG

V MACEYG

V MACEYG

V MACEYG

V MACEYG

$\checkmark$ MACEYG

V MACEYG

$\checkmark$ MACEYG

V MACEYG

V MACEyG

45, 46

$21,22,47,48$

11,12

43,44

$25,26,27,28$

19,20

15,16

29,30
21,22

13,14

$35,36,43,44,49,50,57,58$

41,42

(n)




\title{
XVIII CONGRESO INTERNACIONAL Y XXIV CONGRESO \\ NACIONAL DE CIENCIAS AMBIENTALES
}

03-07 Junio/2019 Mazatlán, Sinaloa

\section{Índice de autores por Área Temática}

Autor

\author{
Área Temática
}

V M Ambiente, Contaminación, Enfermedad y Genotoxicidad

Páginas

S

Saldaña-Blanco M

Salgado-Villaviencio E

Sampedro Rosas ML

Sánchez Meza J

Sánchez-Alarcón J

Sánchez-Gervacio B

Sánchez-Mendoza $\mathrm{H}$

Sierra-Vargas MP

Solís Lerma L

$\mathbf{T}$

Tovar Sánchez E

U

Urióstegui Acosta MO

V

Valencia-Quintana R

Velasco Amaro $P$

Velasco Hernández M

Villegas Dueñas Martín

W
V MACEYG

$\checkmark$ MACEYG

$\checkmark$ MACEYG

$\checkmark$ MACEYG

$\checkmark$ MACEYG

V MACEYG

$\checkmark$ MACEYG

$\checkmark$ MACEYG

$\checkmark$ MACEYG

V MACEYG

39,40

$35,36,43,44,49,50,57,58$

51,52

53,54

15,16

55,56

V MACEyG

57,58

V MACEYG

$\checkmark$ MACEYG

$\checkmark$ MACEYG

V MACEYG

$35,36,43,44,49,50,51,52,57,58$

55,56

$19,20,31,32$

59,60

Wehenkel C
V MACEyG

11,12 


\section{CONGRESO INTERNACIONAL Y XXIV CONGRESO \\ NACIONAL DE CIENCIAS AMBIENTALES \\ 03-07 Junio/2019 Mazatlán, Sinaloa}

\section{Índice de autores por Área Temática \\ Autor \\ Área Temática \\ VI Recursos Naturales, Ecosistemas y Deterioro Ambiental}

Páginas

A

Agraz Hernández CM

Aguilar B

Aguilar Urrutia P

Aguilera Flores M

Aguíñiga García S

Aguirre García Z

Almazán Benítez B

Alvarado MS

Alvarado Villanueva $R$

Alvarez Bernal D

Álvarez Domínguez A

Amabilis $\mathrm{L}$

Andrade Hernández $F$

Anguas Cabrera D

Antonio Robles J

Aquino De Los Ríos G

Arce Romero P

Arcos Severo M

Arenas-Sánchez H

Arredondo Ríos A

Arreola Lizárraga A

Avelino Flores $\mathrm{F}$

Ávila $P$

Ávila Vázquez V

Ayala Ramirez L

B

Bahena Galindo ME

Balderas Hernández $P$

Balderas Plata MA

Barragán Peña $P$

Bautista Bautista R

Bedolla Solano R

Benítez Paz RF

Benítez Pineda C

Berlanga Robles CA
VI RNEyDA

VI RNEyDA

VI RNEyDA

VI RNEyDA

VI RNEyDA

VI RNEyDA

VI RNEyDA

VI RNEyDA

VI RNEyDA

VI RNEyDA

VI RNEyDA

VI RNEyDA

VI RNEyDA

VI RNEyDA

VI RNEyDA

VI RNEyDA

VI RNEyDA

VI RNEyDA

VI RNEyDA

VI RNEyDA

VI RNEyDA

VI RNEyDA

VI RNEyDA

VI RNEyDA

VI RNEyDA

VI RNEyDA

VI RNEyDA

VI RNEyDA

VI RNEyDA

VI RNEyDA

VI RNEyDA

VI RNEyDA

VI RNEyDA

VI RNEyDA
$1,2,35,36,37,38$

1,2

67,68

$33,34,75,76$

9,10

3,4

87,88

57,58

$5,6,177,178,179,180$

147,148

7,8

117,118

$5,6,179,180$

9,10

11,12

$7,8,155,156$

13,14

15,16

219,220

65,66

11,12

$109,110,145,146$

77,78

$65,66,71,72,75,76$

203, 204

$17,18,175,176$

53,54

15,16

19,20

213,214

69,70

19,20

21,22

$29,30,161,162,213,214,227,228$

Ixxix 


\section{CONGRESO INTERNACIONAL Y XXIV CONGRESO NACIONAL DE CIENCIAS AMBIENTALES 03-07 Junio/2019 Mazatlán, Sinaloa}

\section{Índice de autores por Área Temática Autor \\ Área Temática \\ VI Recursos Naturales, Ecosistemas y Deterioro Ambiental}

Páginas

Bluhm Gutiérrez J

Bonassi S

Bonillas García G

Burrola Aguilar C

C

Caballero Hernandez D

Cabanillas García Z

Cabrera Cruz RBE

Cáceres RK

Camacho Cruz K

Campaña H

Campos Angeles G

Campos Verduzco R

Capulin Grande J

Carbajal Ávila J

Careaga Ruiz J

Carlos Márquez M

Casas Huerta E

Casas Valdez M

Castañeda López $\mathrm{O}$

Castañón Bautista C

Castellanos Juárez $F$

Castellanos Tapia F

Castillo Elías B

Ceballos Corona JGA

Ceniceros Gómez A

Cerón Bracamontes M

Cerrillos Valle G

Cervantes Aguilar M

Cervantes Duarte $R$

Chan Keb C

Chavez Barrera J

Chávez Heredia V

Chávez Ramírez EA

Chi Cabrera G

Cobian Cervantes $R$

Cobián del Toro S
VI RNEyDA

VI RNEyDA

VI RNEyDA

VI RNEyDA

VI RNEyDA

VI RNEyDA

VI RNEyDA

VI RNEyDA

VI RNEyDA

VI RNEyDA

VI RNEyDA

VI RNEyDA

VI RNEYDA

VI RNEyDA

VI RNEyDA

VI RNEyDA

VI RNEyDA

VI RNEyDA

VI RNEyDA

VI RNEyDA

VI RNEyDA

VI RNEyDA

VI RNEyDA

VI RNEyDA

VI RNEyDA

VI RNEyDA

VI RNEyDA

VI RNEyDA

VI RNEyDA

VI RNEyDA

VI RNEyDA

VI RNEyDA

VI RNEyDA

VI RNEyDA

VI RNEyDA

VI RNEyDA
105, 106

219,220

19,20

$21,22,239,240$

223, 224

229,230

205, 206

23,24

9,10

$25,26,133,134$

$137,138,207,208$

125,126

199,200

131,132

115,116

171,172

27,28

11,12

$123,124,125,126,171,172$

229,230

111,112

29,30

69,70

5,6

101,102

93,94

31,32

33,34

11,12

$35,36,37,38$

$35,36,37,38$

$39,40,67,68$

41,42

43,44

143,144

45,46

Ixxx 


\section{CONGRESO INTERNACIONAL Y XXIV CONGRESO NACIONAL DE CIENCIAS AMBIENTALES 03-07 Junio/2019 Mazatlán, Sinaloa}

\section{Índice de autores por Área Temática Autor \\ Área Temática \\ VI Recursos Naturales, Ecosistemas y Deterioro Ambiental}

Colmenero A

Colmenero Robles A

Conde Barajas E

Contreras Medina P

Contreras Molina A

Correa Arredondo J

Correa Ramírez M

Cortés Badillo $E$

Cortés Palacios L

Cortes Ruiz JA

Cortés-Eslava J

Costilla Salazar R

Cruz Aviña R

Cruz Cobos F

Cruz Flores $G$

Cruz García F

Cruz Jiménez $G$

Cruz Ruiz G

Cuellar González J
VI RNEyDA

VI RNEyDA

VI RNEyDA

VI RNEyDA

VI RNEyDA

VI RNEyDA

VI RNEyDA

VI RNEyDA

VI RNEyDA

VI RNEyDA

VI RNEyDA

VI RNEyDA

VI RNEyDA

VI RNEyDA

VI RNEyDA

VI RNEyDA

VI RNEyDA

VI RNEyDA

VI RNEyDA

Páginas

181,182

$47,48,211,212$

$25,26,133,134$

49,50

61,62

223, 224

181,182

131,132

$7,8,155,156$

209, 210

219,220

195,196

171,172

$51,52,97,98,127,128$

$149,150,193,194$

51,52

49,50

53,54

61,62

D

De la Mora Covarrubias A

VI RNEyDA

163,164

VI RNEyDA

31,32

VI RNEyDA

169,170

VI RNEyDA

55,56

VI RNEyDA

87,88

VI RNEyDA

153,154

VI RNEyDA

VI RNEyDA

$123,124,125,126,171,172$

57,58

E

Enriquez Anchondo I

Enríquez del Valle JR

VI RNEyDA

189,190

Escalona Alcázar $\mathrm{F}$

Escobar Flores J

VI RNEyDA

VI RNEyDA

VI RNEyDA

VI RNEyDA

VI RNEyDA

137, 138, 207, 208

105,106

$59,60,225,226$

61,62

7,8

Ixxxi 


\section{CONGRESO INTERNACIONAL Y XXIV CONGRESO \\ NACIONAL DE CIENCIAS AMBIENTALES}

03-07 Junio/2019 Mazatlán, Sinaloa

\section{Índice de autores por Área Temática \\ Autor \\ Área Temática \\ VI Recursos Naturales, Ecosistemas y Deterioro Ambiental}

Páginas

Espinoza García G

Esteller Alberich MV

Estrada Ávalos J

Estrada Ovando D

Estrada Zúñiga ME

Etienne J

$\mathbf{F}$

Falcón Ordaz J

Fernandez Roque T

Flores Higuera $\mathrm{F}$

Flores Margez J

Flores Márquez AR

Franco Cervantes S

Franco Hernandez MO

Franco Plata $R$

Frausto V

Frías Espericueta M

G

Gallardo Hernández M

Gallegos Navarro Y

Gallegos Padierna A

Galván Ortega C

García A

García Amador E

García Casas K

García Domínguez Y

García Fabila MM

García Ibáñez S

García Meraz H

Garibaldi Carrasco D

Garrido Hoyos S

Gavilán García A

Gavilán García IC

Germán Báez L

Gervacio Jiménez H
VI RNEyDA

VI RNEyDA

VI RNEyDA

VI RNEyDA

VI RNEyDA

VI RNEyDA

VI RNEyDA

VI RNEyDA

VI RNEyDA

VI RNEyDA

VI RNEyDA

VI RNEyDA

VI RNEyDA

VI RNEyDA

VI RNEyDA

VI RNEyDA

VI RNEyDA

VI RNEyDA

VI RNEyDA

VI RNEyDA

VI RNEyDA

VI RNEyDA

VI RNEyDA

VI RNEyDA

VI RNEyDA

VI RNEyDA

VI RNEyDA

VI RNEyDA

VI RNEyDA

VI RNEyDA

VI RNEyDA

VI RNEyDA

VI RNEyDA
157, 158

87,88

129,130

153, 154

$21,22,239,240$

1, 2

3,4

223, 224

13,14

189, 190

219, 220

113,114

147,148

95,96

71,72

13,14

229,230

63,64

65,66

67,68

71,72

31,32

211,212

69,70

79,80

63, 64

65,66

67,68

87,88

73,74

73,74

139, 140

69,70 


\section{CONGRESO INTERNACIONAL Y XXIV CONGRESO NACIONAL DE CIENCIAS AMBIENTALES 03-07 Junio/2019 Mazatlán, Sinaloa}

\section{Índice de autores por Área Temática Autor \\ Área Temática \\ VI Recursos Naturales, Ecosistemas y Deterioro Ambiental}

Gómez Arellano E

Gómez Demetrio W

Gómez Ensastegui C

Gómez Hinojos AM

Gómez Martínez F

Gómez Mesino J

Gómez-Arroyo S

Gómez-Moreno V

Gómez-Olivares JL

Gómez-Tagle Chavez A

González Flores E

González González M

González Ocampo H

González Pérez B

González Quemada A

González U

González-Güereca C

González-Maldonado B

González-Quiñones JS

Granjeno Colín AE

Guerra Hernández E

Guevara Fisher $Y$

Guevara Herrera R

Gurrola Amaya G

Gutiérrez Cedillo A

Gutiérrez Cedillo JG

Gutiérrez Cedillo P

Gutiérrez Ruiz M

H

Hernández Aldana F

Hernández Crisóstomo $C$

Hernández $\mathrm{F}$

Hernández Guzmán R

Hernández Jasso $\mathrm{J}$

Hernández Jiménez $P$

Hernández Romero JC

Hernández Valdez A
VI RNEyDA

VI RNEyDA

VI RNEyDA

VI RNEyDA

VI RNEyDA

VI RNEyDA

VI RNEyDA

VI RNEyDA

VI RNEyDA

VI RNEyDA

VI RNEyDA

VI RNEyDA

VI RNEyDA

VI RNEyDA

VI RNEyDA

VI RNEyDA

VI RNEyDA

VI RNEyDA

VI RNEyDA

VI RNEyDA

VI RNEyDA

VI RNEyDA

VI RNEyDA

VI RNEyDA

VI RNEYDA

VI RNEyDA

VI RNEyDA

VI RNEyDA

VI RNEyDA

VI RNEyDA

VI RNEyDA

VI RNEyDA

VI RNEyDA

VI RNEyDA

VI RNEyDA

VI RNEyDA

Páginas

75,76

233, 234

77,78

79,80

79,80

17,18

219,220

167, 168

219,220

203, 204

121,122

81,82

183,184

87,88

89,90

71,72

$83,84,, 85,86$

$83,84,85,86$

57,58

$91,92,175,176$

149, 150, 193, 194

51,52

185,186

127,128

93,94

$15,16,95,96,233,234$

93,94

101, 102

109,110

43,44

$51,52,97,98$

213, 214

99,100

221,222

95,96

101, 102

Ixxxiii 


\section{CONGRESO INTERNACIONAL Y XXIV CONGRESO NACIONAL DE CIENCIAS AMBIENTALES 03-07 Junio/2019 Mazatlán, Sinaloa}

\section{Índice de autores por Área Temática Autor \\ Área Temática \\ VI Recursos Naturales, Ecosistemas y Deterioro Ambiental}

Páginas

Hernández-Salinas U

Herrera Gamboa J

Houndjinou EM

Hueletl- Soto ME

Huerta García J

Huerta Hernández V

I

Ibarra Ceceña MG

Inchaurregui Méndez H

J

Jara Marini M

Jimenez Pelcastre C

Jiménez Vargas $P$

Juárez Aguilar $\mathrm{R}$

Juárez Cadena $F$

Juárez Ruanova L

K

Kašuba $\mathrm{V}$

Konde Medina KP

$\mathbf{L}$

Lara Ponce $\mathrm{E}$

Lara $\mathrm{RH}$

Ledezma Pérez E

Linares Fleites $\mathrm{G}$

Linares Salazar D

Loaiza J

Lopez Gutierrez JM

López Hernández A

López Mancilla A

López Márquez ES
VI RNEyDA

VI RNEyDA

VI RNEyDA

VI RNEyDA

VI RNEyDA

VI RNEyDA

VI RNEyDA

VI RNEyDA

VI RNEyDA

VI RNEyDA

VI RNEyDA

VI RNEyDA

VI RNEyDA

VI RNEyDA

VI RNEyDA

VI RNEyDA

219,220

37,38

103, 104, 181, , 182, 235, 236

1,2

219,220

105,106

105,106

231,232

$65,66,71,, 72$

87,88

185,186

27,28

107, 108

221,222

109,110
VI RNEyDA

201, 202

VI RNEyDA

111,112

113,114

VI RNEyDA

VI RNEyDA

VI RNEyDA

VI RNEyDA

VI RNEyDA

VI RNEyDA

VI RNEyDA

VI RNEyDA
$109,110,115,116,145,146$
27,28

117,118

195, 196

45,46

167,168

119,120

Ixxxiv 


\section{CONGRESO INTERNACIONAL Y XXIV CONGRESO \\ NACIONAL DE CIENCIAS AMBIENTALES \\ 03-07 Junio/2019 Mazatlán, Sinaloa}

\section{Índice de autores por Área Temática \\ Autor \\ Área Temática \\ VI Recursos Naturales, Ecosistemas y Deterioro Ambiental}

Páginas

López Sánchez E

Lucio García J

Luevano Gurrola S

Luis Villaseñor I

Luna Avelar K

M

Macedo Miranda G

Marcial Juárez R

Marín Tinoco RI

Marmolejo Rodríguez J

Marmolejo Sánchez ME

Márquez MC

Martínez A

Martínez Eixarch M

Martínez Gallegos S

Martínez García CG

Martinez Ibarra JA

Martínez Rivas A

Martínez Salomón E

Martínez Sifuentes A

Mata Carrillo E

Maturano Cisneros $\mathrm{M}$

Maya Mancera P

Mayett Moreno $Y$

Medina A

Medina Ávila J

Medina Herrera M

Medina Mejia M

Medina Puente A

Melgoza Castillo A

Mena Covarrubias J

Méndez Gómez E

Mendía Santana $R$

Mendoza Hernández JC

Mercado Silva N

Merino Negrete $\mathrm{O}$

Meza Ayala K
VI RNEyDA

VI RNEyDA

VI RNEyDA

VI RNEyDA

VI RNEyDA

VI RNEyDA

VI RNEyDA

VI RNEyDA

VI RNEyDA

VI RNEyDA

VI RNEyDA

VI RNEyDA

VI RNEyDA

VI RNEyDA

VI RNEyDA

VI RNEyDA

VI RNEyDA

VI RNEyDA

VI RNEyDA

VI RNEyDA

VI RNEyDA

VI RNEyDA

VI RNEyDA

VI RNEyDA

VI RNEyDA

VI RNEyDA

VI RNEyDA

VI RNEyDA

VI RNEyDA

VI RNEyDA

VI RNEyDA

VI RNEyDA

VI RNEyDA

VI RNEyDA

VI RNEyDA

VI RNEyDA
121, 122

169,170

67,68

13,14

139,140

77,78

165,166

191, 192

9,10

217,218

123-124, 125, 126

71,72

215, 216

77,78

15,16

141,142

127,128

231,232

129,130

131,132

45,46

89,90

155,156

71,72

203, 204

133, 134

135,136

169,170

$39,40,187,188,197,198$

157,158

209, 210

57,58

$55,56,111,112$

41,42

137,138

139,140 


\section{CONGRESO INTERNACIONAL Y XXIV CONGRESO NACIONAL DE CIENCIAS AMBIENTALES 03-07 Junio/2019 Mazatlán, Sinaloa}

\section{Índice de autores por Área Temática Autor \\ Área Temática \\ VI Recursos Naturales, Ecosistemas y Deterioro Ambiental}

\author{
Meza Rangel J \\ Michel Hernández AE \\ Michel Parra JG \\ Milić $M$ \\ Millán Aguilar E \\ Monares Escalera I \\ Monfil Hernández F \\ Monks S \\ Monserrat V \\ Montañez Valdez OD \\ Montiel-González JMR \\ Montijo Galindo A \\ Mora Félix ZD \\ Mora Soto $Y$ \\ Morales Nieto C \\ Moreno Alcántara J \\ Moreno Julimez L \\ Moreno Lucio M \\ Muñiz Salazar R \\ Murcia Rodríguez M \\ Murúa Figueroa E \\ Mussali Galante P
}

\section{$\mathbf{N}$}

Nájera Luna A

Najera Medellin J

Naranjo Jiménez $\mathrm{N}$

Narváez Ortiz I

Nava Juárez D

Navarro García K

Navarro Hernández AG

Negrete Rodríguez $X$

Niño Maldonado S

Noguerol J

Núñez de la Vega $E$

Núñez García L
VI RNEyDA

VI RNEyDA

VI RNEyDA

VI RNEyDA

VI RNEyDA

VI RNEyDA

VI RNEyDA

VI RNEyDA

VI RNEyDA

VI RNEyDA

VI RNEyDA

VI RNEyDA

VI RNEyDA

VI RNEyDA

VI RNEyDA

VI RNEyDA

VI RNEyDA

VI RNEyDA

VI RNEyDA

VI RNEyDA

VI RNEyDA

VI RNEyDA

VI RNEyDA

VI RNEyDA

VI RNEyDA

VI RNEyDA

VI RNEyDA

VI RNEyDA

VI RNEyDA

VI RNEyDA

VI RNEyDA

VI RNEyDA

VI RNEyDA

VI RNEyDA

Páginas

199, 200

$141,142,143,144$

$93,94,141,142,143,144$

219,220

145,146

147,148

149,150

$3,4,63,64,237,238$

25,26

$141,142,143,144$

219,220

213,214

151,152

$177,178,179,180$

7,8

153,154

155,156

157,158

1,2

$159,160,173,174$

161,162

41,42

$51,52,97,98,127,128$

163,164

$47,48,103,104,181,182,211,212$,

235, 236

23,24

165,166

167,168

213,214

133,134

$167,168,169,170$

215,216

113,114

$123,124,125,126,171,172$ 


\section{CONGRESO INTERNACIONAL Y XXIV CONGRESO \\ NACIONAL DE CIENCIAS AMBIENTALES \\ 03-07 Junio/2019 Mazatlán, Sinaloa}

\section{Índice de autores por Área Temática \\ Autor \\ Área Temática \\ VI Recursos Naturales, Ecosistemas y Deterioro Ambiental}

Páginas

\begin{tabular}{ll}
\multicolumn{1}{c}{ O } & \\
& \\
Ochoa Ochoa LM & VI RNEyDA \\
Ochoa Reyes P & VI RNEyDA \\
Ochoa-Ocaña MA & VI RNEyDA \\
Oliver Guadarrama R & VI RNEyDA \\
Olmedo García K & VI RNEyDA \\
Olvera Olvera C & VI RNEyDA \\
Oregel Zamudio E & VI RNEyDA \\
Orendain Verduzco T & VI RNEyDA \\
Ortega Murillo MR & VI RNEyDA \\
Ortiz Hernández C & VI RNEyDA \\
Ortiz Ruiz A & VI RNEyDA \\
Osornio Rubio R & VI RNEyDA \\
Ostin Sáenz J & VI RNEyDA \\
Otlíca Rosario A & VI RNEyDA \\
Oyedotun TDT & VI RNEyDA \\
& \\
\multicolumn{1}{c}{ P } & \\
Pacheco Ríos A & \\
Páez Olivan L & VI RNEyDA \\
Palacios Ramirez K & VI RNEyDA \\
Palacios Romero A & VI RNEyDA \\
Parra Rodríguez N & VI RNEyDA \\
Pavón Hernández N & VI RNEyDA \\
Pedraza Cervantes I & VI RNEyDA \\
Pérez Balan R & VI RNEyDA \\
Pérez González E & VI RNEyDA \\
Pérez Olivares S & VI RNEyDA \\
Pérez Tapia S & VI RNEyDA \\
Pinedo Alvarez C & VI RNEyDA \\
Piñón Gimate A & VI RNEyDA \\
Ponce Peña P & VI RNEyDA \\
Portillo Almanza C & VI RNEyDA \\
Poveda Gómez F & VI RNEyDA \\
Puentes Gutiérrez J & VI RNEyDA \\
Pulido Flores G & VI RNEyDA \\
& VI RNEyDA
\end{tabular}

41,42

$159,160,173,174$

219,220

$17,18,91,92,175,176$

229,230

157,158

147,148

143,144

$5,6,177,178,179,180$

9,10

89,90

$27,28,89,90$

$35,36,37,38$

221,222

213, 214

VI RNEyDA

115,116

$103,104,181,182,235,236$

189,190

199,200

23, 24

107,108

183,184

35,36

183,184

185,186

89,90

187, 188, 197, 198

11,12

111,112

67,68

$159,160,, 173,174$

129,130

$3,4,237,238$

Ixxxvii 


\section{CONGRESO INTERNACIONAL Y XXIV CONGRESO \\ NACIONAL DE CIENCIAS AMBIENTALES \\ 03-07 Junio/2019 Mazatlán, Sinaloa}

\section{Índice de autores por Área Temática \\ Autor \\ Área Temática \\ VI Recursos Naturales, Ecosistemas y Deterioro Ambiental}

Páginas

\begin{abstract}
Q
Quezada Aldaco MG

Quijada Cuevas D

Quintero Romanillo AL

Quiñonez Barraza G

Quiñonez Martínez M
\end{abstract}

$\mathbf{R}$

Ramirez García JJ

Ramirez Hernandez J

Ramírez López EM

Ramírez Mosqueda E

Ramírez Rejogochi S

Ramos Cassellis ME

Rangel D

Rangel G

Rangel Peraza J

Razo Zárate $\mathrm{R}$

Rendón López MB

Rentería Alvarez $\mathrm{G}$

Rentería Villalobos M

Reyes Calderon F

Reyes Castellanos J

Reyes Gutiérrez JA

Reyes Hernández V

Reyes Muñoz J

Ríos Gerardo J

Rivas Montaño AM

Rivera Wong J

Roa Morales G

Rodríguez Laguna $R$

Rodríguez Mata A

Rodríguez Meza G

Rodríguez Ortiz G

Rodríguez Piñeros S

Rodríguez Sauceda EN

Rojas Herrera AA
VI RNEyDA

VI RNEyDA

VI RNEyDA

VI RNEyDA

VI RNEyDA

VI RNEyDA

VI RNEyDA

VI RNEyDA

VI RNEyDA

VI RNEyDA

VI RNEyDA

VI RNEyDA

VI RNEyDA

VI RNEyDA

VI RNEyDA

VI RNEyDA

VI RNEyDA

VI RNEyDA

VI RNEyDA

VI RNEyDA

VI RNEyDA

VI RNEyDA

VI RNEyDA

VI RNEyDA

VI RNEyDA

VI RNEyDA

VI RNEyDA

VI RNEyDA

VI RNEyDA

VI RNEyDA

VI RNEyDA

VI RNEyDA

VI RNEyDA

VI RNEyDA
191, 192

193, 194

201, 202

51,52

163, 164, 189, 190
79,80

135,136

217,218

195, 196

197, 198

145,146

71,72

117,118

151,152

199,200

203, 204

201, 202

$39,40,187,188,197,198$

45,46

$35,36,37,38$

141,142

207, 208

169,170

205, 206

209, 210

1,2

53,54

199,200

151,152

183, 184

137, 138, 207, 208

$7,8,155,156$

201, 202

63,64

Ixxxviii 


\section{CONGRESO INTERNACIONAL Y XXIV CONGRESO NACIONAL DE CIENCIAS AMBIENTALES 03-07 Junio/2019 Mazatlán, Sinaloa}

\section{Índice de autores por Área Temática Autor \\ Área Temática \\ VI Recursos Naturales, Ecosistemas y Deterioro Ambiental}

Páginas

Rolón Aguilar E

Rolón Aguilar J

Rolón García J

Román S

Romero Zaragoza M

Rosas Acevedo JL

Rosas I

Rosas Medina I

Ruiz Gonzalez M

Ruiz Luna A

S

Saavedra Chávez A

Saavedra Sotelo N

Salamanca Rodriguez M

Salas de la Vega MA

Salmerón Calvario A

Salmerón Gallardo $Y$

Sampedro Rosas ML

Sánchez González A

Sánchez Heredia JD

Sánchez Ramirez H

Sánchez Román $\mathrm{R}$

Sánchez Sánchez H

Sánchez-Alarcón J

Sandoval Lezama JC

Sandoval S

Sanhouse A

Sanhouse García AJ

Santos Ballardo D

Schiaffini Aponte R

Segovia Torres R

Segura García V

Serrano Barquín $\mathrm{R}$

Silva Marrufo $O$

Silveti Loeza A

Solís Sánchez L

Sonder K
VI RNEyDA

VI RNEyDA

VI RNEyDA

VI RNEyDA

VI RNEyDA

VI RNEyDA

VI RNEyDA

VI RNEyDA

VI RNEyDA

VI RNEyDA

VI RNEyDA

VI RNEyDA

VI RNEyDA

VI RNEyDA

VI RNEyDA

VI RNEyDA

VI RNEyDA

VI RNEyDA

VI RNEyDA

VI RNEyDA

VI RNEyDA

VI RNEyDA

VI RNEyDA

VI RNEyDA

VI RNEyDA

VI RNEyDA

VI RNEyDA

VI RNEyDA

VI RNEyDA

VI RNEyDA

VI RNEyDA

VI RNEyDA

VI RNEyDA

VI RNEyDA

VI RNEyDA

VI RNEyDA
205, 206

99, 100

205, 206

71,72

45,46

63,64

181,182

$47,48,103,104,211,212,235,236$

207, 208

213,214

209,210

13,14

135,136

215,216

131,132

99,100

69,70

$9,10,11,12$

$5,6,179,180$

135,136

221,222

21,22

219,220

223,224

$59,60,225,226$

117,118

151,152

139,140

109,110

19,20

$177,178,179,180$

49,50

191,192

55,56

157,158

69,70

Ixxxix 


\section{CONGRESO INTERNACIONAL Y XXIV CONGRESO \\ NACIONAL DE CIENCIAS AMBIENTALES \\ 03-07 Junio/2019 Mazatlán, Sinaloa}

\section{Índice de autores por Área Temática \\ Autor \\ Área Temática \\ VI Recursos Naturales, Ecosistemas y Deterioro Ambiental}

Páginas

Sosa Rodríguez F

Soto Silva CA

Suárez Alonso ML

$\mathbf{T}$

Tahuilan Garcia J

Tapia Morales J

Tejocote Pérez M

Tobías Jaramillo $R$

Torres Ricario $\mathrm{R}$

Tovar Sánchez E

Trejo Albarrán R

Trejo Osuna OI

\section{U}

Urbina Sánchez GI

Uribe Etchevarría M

Uribe Soto N

Urióstegui Acosta MO

V

Valdez Mendoza N

Valdez Ortiz A

Valdivia Cabral GI

Valencia-Quintana R

Valentin Islas $R$

Valera Pérez MA

Valle Rodríguez S

Vargas Castilleja R

Vargas Martínez E

Vásquez Gutierrez AR

Vazquez Arenas J

Vázquez Cuchillo $O$

Vázquez Silva G

Vega Hernández M

Velasco Hernández M
VI RNEyDA

VI RNEyDA

VI RNEyDA

VI RNEyDA

VI RNEyDA

VI RNEyDA

VI RNEyDA

VI RNEyDA

VI RNEyDA

VI RNEyDA

VI RNEyDA

VI RNEyDA

VI RNEyDA

VI RNEyDA

VI RNEyDA

VI RNEyDA

VI RNEyDA

VI RNEyDA

VI RNEyDA

VI RNEyDA

VI RNEyDA

VI RNEyDA

VI RNEyDA

VI RNEyDA

VI RNEyDA

VI RNEyDA

VI RNEyDA

VI RNEyDA

VI RNEyDA

VI RNEyDA
111,112

57,58

203, 204

135,136

221,222

53,54

205, 206

181,182

41,42

91,92

227,228
$123,124,125,126,171,172$

25,26

$103,104,211,212$

219,220
229, 230

139, 140

33,34

219, 220

185, 186

145, 146

105, 106

99,100

49,50

97, 98

111,112

121,122

125,126

55,56

215, 216 


\section{CONGRESO INTERNACIONAL Y XXIV CONGRESO NACIONAL DE CIENCIAS AMBIENTALES}

03-07 Junio/2019 Mazatlán, Sinaloa

\section{Índice de autores por Área Temática}

Autor

Área Temática

VI Recursos Naturales, Ecosistemas y Deterioro Ambiental

Páginas

Velázquez Cortés JM

Velázquez Olalde B

Vergara Flórez M

Vidal Abarca MR

Villanueva Díaz J

Villegas Martínez D

Viñas M

Violante González J

Viramontes Olivas OA

Vixta Haro JA

Vizcaíno Rodríguez LA

Vón Ostén J

\section{Z}

Zamora Alvarado $\mathrm{R}$

Zapata Mariscal M

Zaragoza Tapia F

Zaragoza Yacuta E

Zarazúa Ortega G

Zepeda Gómez C

Zequera García C
VI RNEyDA

VI RNEyDA

VI RNEyDA

VI RNEyDA

VI RNEyDA

VI RNEyDA

VI RNEyDA

VI RNEyDA

VI RNEyDA

VI RNEyDA

VI RNEyDA

VI RNEyDA

VI RNEyDA

VI RNEyDA

VI RNEyDA

VI RNEyDA

VI RNEyDA

VI RNEyDA

VI RNEyDA
55,56

27,28

159,160

203, 204

129, 130

233, 234

215,216

63,64

231,232

55,56

119,120

43,44

137,138

235,236

237, 238

45,46

77,78

$21,22,77,78,239,240$

167, 168 


\section{CONGRESO INTERNACIONAL Y XXIV CONGRESO \\ NACIONAL DE CIENCIAS AMBIENTALES \\ 03-07 Junio/2019 Mazatlán, Sinaloa}

\section{Índice de autores por Área Temática}

Área Temática

Autor

VII Tecnología y Biotecnología

para el Tratamiento de Contaminantes y Biorremediación

Páginas

\author{
A \\ Abarca Pérez A \\ Agüelles Hernández $\mathrm{E}$ \\ Aguilar Santana M \\ Aguilera Alvarado AF \\ Aguilera Flores M \\ Aguirre Ramírez M \\ Aguirre Terrazas K \\ Airasca A \\ Alarcón Barrón M \\ Alba Romero J \\ Alcaraz Novoa J \\ Alcazar Medina F \\ Aldana Llanos L \\ Alférez Chávez J \\ Algara Siller M \\ Almaral Sánchez J \\ Alonso Calderón A \\ Alvarado Fierro $O$ \\ Alvarado Lassman A \\ Álvarez Contreras CA \\ Álvarez Fuentes $\mathrm{G}$ \\ Álvarez Gallegos A \\ Álvarez Ortega O \\ Amábilis Sosa $L$ \\ Amaya Chávez A \\ Ambriz Pérez D \\ Aquino De Los Ríos G \\ Aranda Figueroa MG \\ Aranda Vivas LI \\ Arriola Morales J \\ Ávila Galarza A \\ Ávila Martínez AK \\ Ávila Pérez $\mathrm{P}$
}

VII TyBTCyB

VII TyBTCyB

VII TyBTCyB

VII TyВTCyB

VII TyBTCyB

VII TyВTCyB

VII TyBTCyB

VII TyBTCyB

VII TyBTCyB

VII TyBTCyB

VII TyBTCyB

VII TyBTCyB

VII TyBTCyB

VII TyВTCyB

VII TyВTCyB

VII TyBTCyB

VII TyBTCyB

VII TyВTCyB

VII TyВTCyB

VII TyBTCyB

VII TyBTCyB

VII TyBTCyB

VII TyВTCyB

VII TyBTCyB

VII TyBTCyB

VII TyBTCyB

VII TyBTCyB

VII TyBTCyB

VII TyBTCyB

VII TyBTCyB

VII TyBTCyB

VII TyBTCyB

VII TyBTCyB
1,2

1,2

3,4

159,160

$167,168,197,198,199,200,223,224$

95, 96

217,218

33.34

5, 6

31,32

151,152

7,8

$43,44,45,46$

131,132

101,102

97, 98

$23,24,137138,155,156$

97, 98

$85,86,109110$

9,10

101,102

87,88

11,12

$13,14,179,180$

177,178

81,82

135,136

15,16

$17,18,19,20$

$37,38,39,40$

101,102

125,126

103, 104 


\section{CONGRESO INTERNACIONAL Y XXIV CONGRESO \\ NACIONAL DE CIENCIAS AMBIENTALES \\ 03-07 Junio/2019 Mazatlán, Sinaloa}

\section{Índice de autores por Área Temática}

Área Temática

Autor

VII Tecnología y Biotecnología

para el Tratamiento de Contaminantes y Biorremediación

Páginas

B

Bailón Salas A

Balderas Hernández $P$

Bañuelos Romero $\mathrm{F}$

Barrena R

Barrera Díaz CE

Barrón Hernández L

Batalla Mayoral J

Batista García RA

Bautista Mulia J

Bautista Rodríguez CM

Becerra Rodríguez J

Becerril Bravo J

Bedolla Hernández M

Bello Velázquez JA

Beltrán Cortes $\mathrm{R}$

Beltrán Ramírez M

Beristaín Cardoso R

Botello de la Peña DC

Bravo Pablo L

Bustos Terrones $\mathrm{J}$

Bustos Terrones $\mathrm{Y}$

C

Caiola N

Calero De Hoces M

Calleros-Rincón E

Campaña H

Campos Reales Pineda A

Candal R

Cardiel Pérez L

Carrasco Campos P

Carrasco Urrutia K

Carreño Aguilera G

Carvajal Hernández GR

Castillo Morales M
VII TyBTCyB

VII TyBTCyB

VII TyBTCyB

VII TyBTCyB

VII TyBTCyB

VII TyBTCyB

VII TyBTCyB

VII TyBTCyB

VII TyBTCyB

VII TyBTCyB

VII TyBTCyB

VII TyBTCyB

VII TyBTCyB

VII TyBTCyB

VII TyВTCyB

VII TyВTCyB

VII TyBTCyB

VII TyBTCyB

VII TyBTCyB

VII TyBTCyB

VII TyBTCyB
153,154

$75,76,111,112,177,178$

225, 226

105,106

75,76

21,22

93,94

165,166

$23,24,137,138$

159,160

25,26

113,114

1,2

$17,18,19,, 20$

27,28

187, 188

169,170

29,30

137,138

87,88

69,70
VII TyВTCyB

VII TyBTCyB

VII TyBTCyB

VII TyBTCyB

VII TyBTCyB

VII TyBTCyB

VII TyBTCyB

VII TyBTCyB

VII TyBTCyB

VII TyBTCyB

VII TyBTCyB

VII TyBTCyB
193, 194

71,72

31,32

$33,34,147,148$

231, 232

237, 238

187,188

35,36

217,218

149,150

203, 204

$37,38,39,40$

xciii 


\section{CONGRESO INTERNACIONAL Y XXIV CONGRESO NACIONAL DE CIENCIAS AMBIENTALES 03-07 Junio/2019 Mazatlán, Sinaloa}

\section{Índice de autores por Área Temática}

Área Temática

Autor

VII Tecnología y Biotecnología

para el Tratamiento de Contaminantes y Biorremediación

\author{
Castrejón Godínez ML \\ Cedillo Herrera C \\ Chavarría Murillo CD \\ Chávez Bravo $\mathrm{E}$ \\ Chávez Guajardo AE \\ Chávez Ríos BP \\ Chávez Soto $M$ \\ Chavez Varela KI \\ Chavira Alvarado A \\ Colín Cruz A \\ Concepción Acosta C \\ Conde Barajas E \\ Conde Hernández A \\ Contreras López D \\ Corral Avitia A \\ Correa Jiménez KF \\ Cortes Guerrero V \\ Cortés Palacios L \\ Cruz Benitez M \\ Cruz González D \\ Cruz Jiménez A \\ Cruz Mondragon C \\ Cuevas Arteaga C \\ Cuevas González J \\ Cuevas Medina M
}

De la Cruz Cornelio MG De la Peña Arellano LA Del Ángel Coronel OA Del Angel Soto J Del Carmen Niño V Del Rosario de Jesús K Delgado Díaz MA Díaz Medrano A Díaz Ordáz L Dietrich N
VII TyBTCyB

VII TyВTCyB

VII TyBTCyB

VII TyBTCyB

VII TyBTCyB

VII TyBTCyB

VII TyBTCyB

VII TyBTCyB

VII TyBTCyB

VII TyBTCyB

VII TyBTCyB

VII TyBTCyB

VII TyBTCyB

VII TyBTCyB

VII TyBTCyB

VII TyBTCyB

VII TyBTCyB

VII TyBTCyB

VII TyBTCyB

VII TyBTCyB

VII TyBTCyB

VII TyBTCyB

VII TyBTCyB

VII TyBTCyB

VII TyBTCyB

Páginas

117,118

13,14

41,42

23, 24, 155, 156

171,172

$43,44,45,46$

221,222

47,48

23,24

63,64

49,50

147,148

137,138

159,160

35,36

161,162

51,52

135,136

53,54

$163,164,231,232$

3,4

$67,68,201,202$

15,16

$11,12,141,142$

55,56
VII TyBTCyB

VII TyBTCyB

VII TyBTCyB

VII TyBTCyB

VII TyBTCyB

VII TyBTCyB

VII TyBTCyB

VII TyBTCyB

VII TyBTCyB

VII TyBTCyB
89,90

$29,30,123,124,233,234$

115,116

159,160

57,58

39,40

59,60

61,62

123,124

33.34 


\section{CONGRESO INTERNACIONAL Y XXIV CONGRESO \\ NACIONAL DE CIENCIAS AMBIENTALES \\ 03-07 Junio/2019 Mazatlán, Sinaloa}

\section{Índice de autores por Área Temática}

Área Temática

Autor

VII Tecnología y Biotecnología

para el Tratamiento de Contaminantes y Biorremediación

Páginas

Domínguez Romero RJ

Donohué Cornejo A

Duarte López C

Durán Moreno A

$\mathbf{E}$

Encarnación Guevara S

Escamilla Azuara A

Esparza García F

Espinoza Cristóbal L

Estrada Feregrino I

Estrada Johnson $E$

Estrada Vázquez $\mathrm{R}$

F

Fall C

Fernández Martínez L

Fernández Tapia S

Fernández Zepeda $M$

Ferrera Cerrato $\mathrm{R}$

Flores Cruz J

Flores Munguía E

Flores Sanchez O

Flores Trujillo A

Flores Trujillo $\mathrm{K}$

Flores Villegas $M$

Folch Mallol J

Fonseca Florido $\mathrm{H}$

Font Xavi

G

Gandarilla Esparza D

García Amador E

García Carrizales A

García Cruz R
VII TyBTCyB

VII TyBTCyB

VII TyBTCyB

VII TyBTCyB

VII TyBTCyB

VII TyBTCyB

VII TyBTCyB

VII TyBTCyB

VII TyBTCyB

VII TyBTCyB

VII TyBTCyB

VII TyBTCyB

VII TyBTCyB

VII TyBTCyB

VII TyBTCyB

VII TyBTCyB

VII TyBTCyB

VII TyBTCyB

VII TyBTCyB

VII TyBTCyB

VII TyBTCyB

VII TyВTСуB

VII TyBTCyB

VII TyBTCyB

VII TyBTCyB

VII TyВTCyB

VII TyBTCyB

VII TyBTCyB

VII TyBTCyB
15,16

$11,12,141,142$

63,64

73,74

165,166

65,66

67, 68, 201, 202, 227, 228

$11,12,141,142$

67,68

155,156

69,70

21,22

39,40

213, 214

213, 214

227,228

65,66

113,114

225, 226

71,72

117,118

153,154

$49,50,165,166$

53,54

105, 106

31,32

$119,120,229,230$

65,66

9,10 


\section{CONGRESO INTERNACIONAL Y XXIV CONGRESO NACIONAL DE CIENCIAS AMBIENTALES 03-07 Junio/2019 Mazatlán, Sinaloa}

\section{Índice de autores por Área Temática}

Área Temática

Autor

VII Tecnología y Biotecnología

para el Tratamiento de Contaminantes y Biorremediación

Páginas

García Elías J

García García E

García Gaytán B

García González SA

García Niño AL

García Rivas J

García Sánchez M

García Solano A

Garibay Alvarado J

Garrido Hoyos S

Gastón Pérez D

Germán Báez L

Gómez Aldapa C

Gonzales Alonso S

Gonzales Flores E

González Adame R

González Arenas B

González Arenas $Y$

González Fernández R

González González J

González González M

González Juárez JC

González Leal M

González Mireles V

González Rodríguez L

González-Zamora A

Guerra González R

Gutiérrez Ochoa M

Gutiérrez Silva L

Guzmán Aragón E

Guzmán Mar J

Guzmán Mar M

H

Hermosillo Nevarez J

Hernández Alarcón ME Hernández Arias AN
VII TyBTCyB

VII TyBTCyB

VII TyBTCyB

VII TyBTCyB

VII TyBTCyB

VII TyBTCyB

VII TyBTCyB

VII TyВTCyB

VII TyBTCyB

VII TyBTCyB

VII TyBTCyB

VII TyBTCyB

VII TyBTCyB

VII TyBTCyB

VII TyBTCyB

VII TyBTCyB

VII TyBTCyB

VII TyBTCyB

VII TyBTCyB

VII TyBTCyB

VII TyBTCyB

VII TyBTCyB

VII TyBTCyB

VII TyBTCyB

VII TyBTCyB

VII TyВTСуB

VII TyBTCyB

VII TyBTCyB

VII TyBTCyB

VII TyBTCyB

VII TyBTCyB

VII TyBTCyB

VII TyBTCyB

VII TyBTCyB

VII TyBTCyB
171,172

27,28

$5,6,103,104,139,140$

73,74

37,38

$5,6,103,104$

75,76

229,230

47, 48, 77, 78, 191, 192

163,164

79,80

105, 106

53,54

145,146

99,100

7,8

81,82

81,82

133, 134, , 173, 174

113,114

65,66

169,170

83,84

$17,18,19,20$

$61,62,129,130$

31,32

189,190

$43,44,, 45,46$

83,84

85,86

$25,26,107,108$

59,60
87,88

89,90

127, 128 


\section{CONGRESO INTERNACIONAL Y XXIV CONGRESO \\ NACIONAL DE CIENCIAS AMBIENTALES \\ 03-07 Junio/2019 Mazatlán, Sinaloa}

\section{Índice de autores por Área Temática}

Área Temática

Autor

VII Tecnología y Biotecnología

para el Tratamiento de Contaminantes y Biorremediación

Páginas

Hernández González N

Hernández López A

Hernández Ramírez A

Hernández Ramírez JL

Hernández Sabas E

Hernández Tenorio $\mathrm{C}$

Hernández Trejo ME

Hernández Zúñiga D

Herrera García S

Herrera Perez JL

Hinojosa Reyes L

I

lbáñez C

Inchaurregui Méndez H

J

Jaramillo Sierra B

Jáuregui Rincón J

Jiménez Cedillo MJ

Jiménez Hernández $M$

Jiménez Núñez M

Juárez Barojas I

Juárez López AL

Juárez Soto $R$
VII TyBTCyB

VII TyBTCyB

VII TyBTCyB

VII TyBTCyB

VII TyBTCyB

VII TyBTCyB

VII TyBTCyB

VII TyBTCyB

VII TyBTCyB

VII TyBTCyB

VII TyBTCyB

VII TyВTCyB

VII TyBTCyB

193, 194

$61,62,129,130$

65,66

91,92

$25,26,237,238$

59,60

79,80

139,140

93, 94

199,200

95,96

225, 226

$25,26,59,60$
VII TyBTCyB

127, 128

VII TyBTCyB

VII TyBTCyB

VII TyBTCyB

VII TyВTCyB

VII TyBTCyB

VII TyBTCyB

VII TyBTCyB

131,132

127,128

115,116

103, 104

109,110

57,58

97,98
Lara Ponce E

Leal Rodríguez A

Lejarde Florez DA

López Alemán M

López Baena J

López Cruz JY

López Díaz N

López Escobar LA
VII TyBTCyB

VII TyBTCyB

VII TyBTCyB

VII TyBTCyB

VII TyBTCyB

VII TyBTCyB

VII TyBTCyB

VII TyBTCyB
97,98

99,100

161,162

175,176

195, 196

157, 158

101,102

115,116

xcvii 


\section{CONGRESO INTERNACIONAL Y XXIV CONGRESO \\ NACIONAL DE CIENCIAS AMBIENTALES \\ 03-07 Junio/2019 Mazatlán, Sinaloa}

\section{Índice de autores por Área Temática}

Área Temática

Autor

VII Tecnología y Biotecnología

para el Tratamiento de Contaminantes y Biorremediación

Páginas

López González Y

López Nieto J

López Velasco A

López Vicente $L$

Lora Urías C

Lozano Alvarez J

Lucho Chigo $\mathrm{R}$

Lucio Porto $\mathrm{R}$

Luna Avelar K

Luna Barcenas G

Luna Reséndiz E

M

Macedo Miranda G

Macías Patiño M

Madrid del Palacio M

Marín Allende MJ

Marín Castro MA

Marín Peña O

Marín Tinoco RI

Martínez Ávila A

Martínez Batallar G

Martínez Espinosa E

Martínez Gallegos S

Martínez Gómez V

Martínez Marú M

Martínez Olivas A

Martínez Orgániz A

Martínez Ramírez M

Martínez Roldán A

Martínez Romero L

Martínez Sibaja A

Martínez Tavera E

Martínez Torralba M

Maya Treviño L

Maya Treviño M

Mayett Moreno $Y$
VII TyВTCyВ

VII TyBTCyB

VII TyBTCyB

VII TyBTCyB

VII TyBTCyB

VII TyBTCyB

VII TyВTCyB

VII TyBTCyB

VII TyВTCyB

VII TyBTCyB

VII TyBTCyB

VII TyВTCyB

VII TyВTCyB

VII TyBTCyB

VII TyBTCyB

VII TyBTCyB

VII TyBTCyB

VII TyBTCyB

VII TyBTCyB

VII TyBTCyB

VII TyBTCyB

VII TyВTCyB

VII TyBTCyB

VII TyBTCyB

VII TyBTCyB

VII TyBTCyB

VII TyBTCyB

VII TyBTCyB

VII TyBTCyB

VII TyBTCyB

VII TyBTCyB

VII TyBTCyB

VII TyBTCyB

VII TyBTCyB

VII TyBTCyB
183, 184

55,56

103,104

119,120

97,98

131,132

29, 30, 205, 206, 207, 208, 211, 212

107,108

$81,82,105,106$

5,6

107,108

169,170

145,146

153,154

127,128

219,220

109,110

203,204

221,222

165,166

65,66

$163,164,169,170$

207,208

83,84

$111,112,215,216$

113,114

159,160

$123,124,205,206,211,212,233,234$

195,196

109,110

163,164

115,116

59,60

107,108

135, 136 


\section{CONGRESO INTERNACIONAL Y XXIV CONGRESO NACIONAL DE CIENCIAS AMBIENTALES 03-07 Junio/2019 Mazatlán, Sinaloa}

\section{Índice de autores por Área Temática}

Área Temática

Autor

VII Tecnología y Biotecnología

para el Tratamiento de Contaminantes y Biorremediación

Páginas

Medellín Castillo N

Medina Acevedo

Medina Bautista S

Medina Herrera M

Medina Llamas J

Medina Llamas M

Medina Orendain D

Medina Ramírez I

Medina Rocha AE

Mejía Bermúdez D

Mejia Rivas CA

Mejias Brizuela N

Meléndez Estrada I

Méndez Andoney M

Méndez Contreras J

Mendieta Rodríguez L

Mendivil Garcia K

Mendoza Gaona H

Mendoza Hernández JC

Merlo Ruiz F

Michel Parra JG

Miranda Aviles R

Molina Sánchez K

Montaño Gómez A

Montelongo Hernández I

Montoya Murillo J

Morales García JM

Morales Juarez LR

Moreno Julimez L

Moreno Luna FB

Moreno Martínez B

Moreno Pérez J

Munguia Martín J

Muñoz Escobar A

Mussali Galante P
VII TyBTCyB

VII TyBTCyB

VII TyBTCyB

VII TyBTCyB

VII TyBTCyB

VII TyBTCyB

VII TyBTCyB

VII TyВTCyB

VII TyВTCyB

VII TyBTCyB

VII TyBTCyB

VII TyBTCyB

VII TyBTCyB

VII TyBTCyB

VII TyBTCyB

VII TyBTCyB

VII TyBTCyB

VII TyBTCyB

VII TyBTCyB

VII TyBTCyB

VII TyBTCyB

VII TyBTCyB

VII TyBTCyB

VII TyBTCyB

VII TyBTCyB

VII TyBTCyB

VII TyBTCyB

VII TyBTCyB

VII TyBTCyB

VII TyBTCyB

VII TyBTCyB

VII TyBTCyB

VII TyBTCyB

VII TyBTCyB

VII TyBTCyB
$77,78,125,126,191,192$

117,118

119,120

147,148

$129,130,171,172$

171,172

121,122

131,132

239,240

79,80

123,124

81,82

$11,12,125,126,141,142$

127,128

85,86

129,130

13,14

51,52

$37,38,39,40,93,94$

99,100

151,152

149,150

131,132

133,134

187,188

223, 224

9,10

225, 226

135,136

225, 226

139, 140

137,138

139,140

141,142

$49,50,71,72,117,118$ 


\title{
XVIII CONGRESO INTERNACIONAL Y XXIV CONGRESO \\ NACIONAL DE CIENCIAS AMBIENTALES \\ 03-07 Junio/2019 Mazatlán, Sinaloa
}

\section{Índice de autores por Área Temática}

Área Temática

Autor

VII Tecnología y Biotecnología

para el Tratamiento de Contaminantes y Biorremediación

Páginas

\author{
$\mathbf{N}$ \\ Nájera Bastida A \\ Nájera Olivas J \\ Nava Valente $\mathrm{N}$ \\ Navarro Frómeta A \\ Navarro Salazar I \\ Navarro Salazar M \\ Navarro Solís O \\ Negrete Rodríguez $X$ \\ Noriega Luna B \\ Núñez Vilchis A \\ 0 \\ Oceguera Flores $\mathrm{P}$ \\ Olivas Calderón E \\ Oliveros González N \\ Olmos Marquez M \\ Ordaz Díaz L \\ Oropeza Miranda N \\ Orozco Villafañe A \\ Ortiz Hernández ML \\ Ortíz Méndez JD \\ Ortiz Ruiz A \\ Osornio Rubio R

\section{$\mathbf{P}$} \\ Padilla Ontiveros AA \\ Palomino Cabello C \\ Partida Joya D
}

VII TyBTCyB

221,222

VII TyВTCyB

143,144

VII TyBTCyB

115,116

VII TyBTCyB

161,162

VII TyBTCyB

91,92

VII TyBTCyB

145,146

VII TyBTCyB

VII TyBTCyB

VII TyBTCyB

VII TyBTCyB

$91,92,145,146$

147,148

149,150

83,84

VII TyBTCyB

151, 152

VII TyBTCyB

31,32

VII TyBTCyB

27,28

VII TyBTCyB

135, 136

VII TyBTCyB

153,154

VII TyBTCyB

155,156

VII TyBTCyB

157,158

VII TyBTCyB

71,72

37,38

VIT TYCy

VII TyBTCyB

$27,28,147,148$

$27,28,55,56$

VII TyBTCyB

159, 160

VII TyBTCyB

161,162

VII TyBTCyB

25,26

VII TyBTCyB

121,122

VII TyBTCyB

65,66

VII TyBTCyB

79,80

VII TyBTCyB

9,10

VII TyBTCyB

31,32

VII TyBTCyB

$37,38,39,40$ 


\section{CONGRESO INTERNACIONAL Y XXIV CONGRESO NACIONAL DE CIENCIAS AMBIENTALES 03-07 Junio/2019 Mazatlán, Sinaloa}

\section{Índice de autores por Área Temática}

Área Temática

Autor

VII Tecnología y Biotecnología

para el Tratamiento de Contaminantes y Biorremediación

Páginas

Pitalúa Sánchez D

Plascencia Salcedo J

Puy Alquiza MJ

VII TyВTCyB

163,164

VII TyBTCyB

213,214

VII TyBTCyB

149, 150

Q

Quintero García OJ

Quintero Hernández M

VII TyВTCyB

165,166

VII TyBTCyB

167, 168

$\mathbf{R}$

Ramírez Carranza DR

VII TyВTСуB

169,170

VII TyBTCyB

185,186

VII TyBTCyB

171,172

Ramírez Ortega AA

Ramírez Pereda B

Ramos Cassellis ME

VII TyBTCyB

VII TyBTCyB

$87,88,179,, 180$

VII TyBTCyB

219,220

Ramos Delgado N

Rangel Peraza J

Reyes Barajas S

Reyes Castro S

Reyes López SY

VII TyBTCyB

237, 238

VII TyBTCyB

13,14

VII TyBTCyB

VII TyBTCyB

9,10

173,174

$11,12,47,48,77,78,111,112,125$, 126, 141, 142, 143, 144, 175, 176, 191,

VII TyВTСуВ

VII TyВTCyB

Reyes Pérez J

Reyes Prado M

Reyes Romero F

Reyes Umaña M

Rico Barragán $A$

Ríos Leal E

Rivera Hernández K

Roa Morales G

Robledo Zacarías V

Robles Magdaleno J

Rodríguez Casasola F

Rodríguez Casasola T

Rodríguez Flores $\mathrm{F}$

Rodríguez García P

VII TyВTCyB

VII TyBTCyB

VII TyBTCyB

VII TyBTCyB

VII TyBTCyB

VII TyBTCyB

VII TyВTСуB

VII TyВTСуB

VII TyBTCyB

VII TyBTCyB

VII TyBTCyB

VII TyBTCyB

VII TyBTCyB

$$
\begin{aligned}
& \begin{array}{r}
13,14,179,180 \\
81,182,189,190
\end{array} \\
& 57,58 \\
& 183,184 \\
& 227,228 \\
& 185,186 \\
& 75,76,177,178 \\
& 187,188 \\
& 179,180 \\
& \text { 67, 68, 201, 202, 227, } 228 \\
& 201,202 \\
& 153,154 \\
& 187,188
\end{aligned}
$$

ci 


\section{CONGRESO INTERNACIONAL Y XXIV CONGRESO NACIONAL DE CIENCIAS AMBIENTALES 03-07 Junio/2019 Mazatlán, Sinaloa}

\section{Índice de autores por Área Temática}

Área Temática

Autor

VII Tecnología y Biotecnología

para el Tratamiento de Contaminantes y Biorremediación

Páginas

Rodríguez Herrera A

Rodríguez Luna IC

Rodríguez Mata A

Rodríguez Narváez OM

Rodríguez Ontiveros A

Rodríguez Piñeros S

Rodríguez Plascencia EL

Rodríguez Rosales MDJ

Rodríguez Solís A

Roé Sosa A

Rojas Ruíz E

Romero López A

Romero Mota D

Roque Ruiz J

Rosano Ortega G

Rosas Mendoza E

Rosas Pérez I

Rubio Rosas E

Ruiz Font $A$

\section{S}

Salas de la Vega MA

Salaza Batres KJ

Salazar Fernández C

Salazar Hernández E

Salazar Hernández MM

Salazar Salazar GC

Salcedo Rosales M

Saldaña De la Vega JA

Salinas Cortés E

Samaniego Hernández M

Sampedro Rosas ML

Sanchez Antoni

Sánchez Castro A

Sánchez Juan KL

Sánchez Mata $O$
VII TyBTCyB

VII TyBTCyB

VII TyBTCyB

VII TyВTCyB

VII TyBTCyB

VII TyBTCyB

VII TyBTCyB

VII TyBTCyB

VII TyBTCyB

VII TyBTCyB

VII TyBTCyB

VII TyBTCyB

VII TyBTCyB

VII TyBTCyB

VII TyBTCyB

VII TyBTCyB

VII TyBTCyB

VII TyBTCyB

VII TyBTCyB
57,58

$17,18,19,20$

179,180

121,122

83,84

135,136

239,240

$7,8,29,30,123,123,153,154,205$, 206, 207, 208, 211, 212, 233, 234

117,118

13,14

$181,182,189,190$

51,52

85,86

$77,78,125,126,191,192$

$1,2,163,164$

109,110

195,196

99,100

99,100
VII TyBTCyB

VII TyBTCyB

VII TyBTCyB

VII TyBTCyB

VII TyBTCyB

VII TyBTCyB

VII TyBTCyB

VII TyBTCyB

VII TyBTCyB

VII TyBTCyB

VII TyBTCyB

VII TyBTCyB

VII TyBTCyB

VII TyBTCyB

VII TyBTCyB
193, 194

203, 204

51,52

183, 184

149,150

183, 184

213,214

193, 194

195, 196

55,56

$57,58,113,114$

105,106

197, 198

183, 184

199, 200 


\section{CONGRESO INTERNACIONAL Y XXIV CONGRESO NACIONAL DE CIENCIAS AMBIENTALES}

03-07 Junio/2019 Mazatlán, Sinaloa

\section{Índice de autores por Área Temática}

Área Temática

Autor

VII Tecnología y Biotecnología

para el Tratamiento de Contaminantes y Biorremediación

Páginas

Sánchez Ramirez H

Sánchez Rodríguez $\mathrm{O}$

Sánchez Ruiz F

Sánchez Varela A

Sandoval Segura D

Santamaría Juárez D

Santellano Estrada E

Santos Ballardo D

Segovia García JD

Segura Maldonado V

Serafín Muñoz A

Serrano Lerma M

Siebe Grabach C

Sierra Alvarado E

Silva Gómez S

Silva Holguin PN

Silva Marrufo $O$

Silva $P$

Soto Retana M

\section{$\mathbf{T}$}

Tamaríz Flores JV

Tapia Ponce S

Torres Aquino M

Torres Pérez J

Tovar Carrillo K

Tovar Sánchez E

Turnes Palomino G

V

Valdez Ortiz A

Valencia García L

Valero Galán J
VII TyВTCyB

VII TyBTCyB

VII TyBTCyB

VII TyBTCyB

VII TyBTCyB

VII TyBTCyB

VII TyBTCyB

VII TyBTCyB

VII TyBTCyB

VII TyBTCyB

VII TyBTCyB

VII TyBTCyB

VII TyBTCyB

VII TyBTCyB

VII TyBTCyB

VII TyBTCyB

VII TyBTCyB

VII TyBTCyB

VII TyBTCyB

VII TyBTCyB

VII TyВTCyB

VII TyВTCyB

VII TyBTCyB

VII TyBTCyB

VII TyBTCyB

VII TyBTCyB
$51,52,79,80$

201, 202

1,2

$17,18,19,20$

65,66

93,94

135,136

81, 82, 105, 106

203, 204

65,66

149,150

205, 206

195, 196

207, 208

57,58

209, 210, 241, 242

203, 204

175,176

211,212
219,220

213, 214

215,216

$35,36,41,42,47,48,63,64,95,96$, $111,112,125,126,133,134,143,144$, 173, 174, 175, 176, 191, 192, 215, 216 , $217,218,235,236$ 141,142 117,118

25,26
VII TyBTCyB

VII TyBTCyB

VII TyBTCyB
105, 106

23,24

$133,134,173,174$ 


\section{CONGRESO INTERNACIONAL Y XXIV CONGRESO \\ NACIONAL DE CIENCIAS AMBIENTALES}

03-07 Junio/2019 Mazatlán, Sinaloa

\section{Índice de autores por Área Temática}

Área Temática

Autor

VII Tecnología y Biotecnología

para el Tratamiento de Contaminantes y Biorremediación

Páginas

Valladares Cisneros MG

Valle Cervantes S

Vallejo Aguilar A

Vallejo Cantú N

Varela Mata K

Varela Ruíz M

Vázquez Cuchillo O

Vázquez Lara AY

Vázquez Lepe MO

Vázquez López N

Vázquez Martinez A

Vega Hernández M

Vega Torres A

Vela Vázquez $R$

Velasco Flores $Y$

Velasco Hernández M

Velázquez Pizano P

Véliz Gurrola J

Vera García S

Vigueras Cortés JM

Villa Ramírez S

Villanueva Rodríguez L

Villanueva Rodríguez M

Viramontes Lizardo J

Vixta Haro JA

\section{Z}

Vigil Castillo $\mathrm{H}$
VII TyВTCyB

VII TyBTCyB

VII TyBTCyB

VII TyBTCyB

VII TyBTCyB

VII TyBTCyB

VII TyBTCyB

VII TyBTCyB

VII TyBTCyB

VII TyBTCyB

VII TyBTCyB

VII TyBTCyB

VII TyBTCyB

VII TyBTCyB

VII TyBTCyB

VII TyBTCyB

VII TyBTCyB

VII TyBTCyB

VII TyBTCyB

VII TyBTCyB

VII TyBTCyB

VII TyBTCyB

VII TyBTCyB

VII TyBTCyB

VII TyBTCyB

VII TyBTCyB

VII TyBTCyB
$15,16,43,44,45,46$

7, 8, 205, 206, 207, 208

219,220

109,110

221,222

223, 224

225, 226

149,150

5,6

185,186

$67,68,227,228$

93, 94

229, 230

231,232

233, 234

193, 194

83,84

235, 236

201, 202

237,238

239, 240

185,186

59,60

237, 238

91,92

93,94

Zavala Arce R

$5,6,103,104,139,140$ 


\section{REVista INTernacional de}

\section{CONTAMinación AMBIEntal volumen 36, 2020}

http://www.revistas.unam.mx/index.php/rica/

\section{Calidad del Agua y Saneamiento}

Academia Nacional de Ciencias Ambientales

XVIII CONGRESO INTERNACIONAL XXIV CONGRESO NACIONAL De Ciencias ambientales

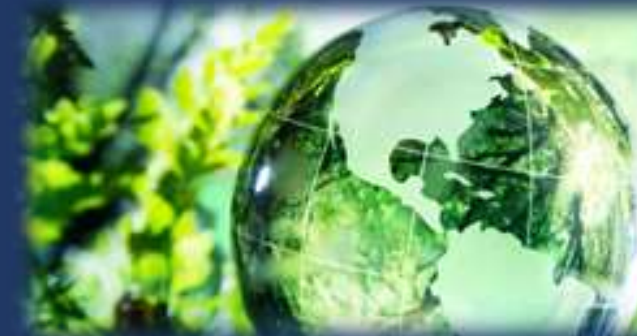

\section{Matatlán, Ninaloa \\ ila Perla del Paćfico!}

03-07 Junio/2019 

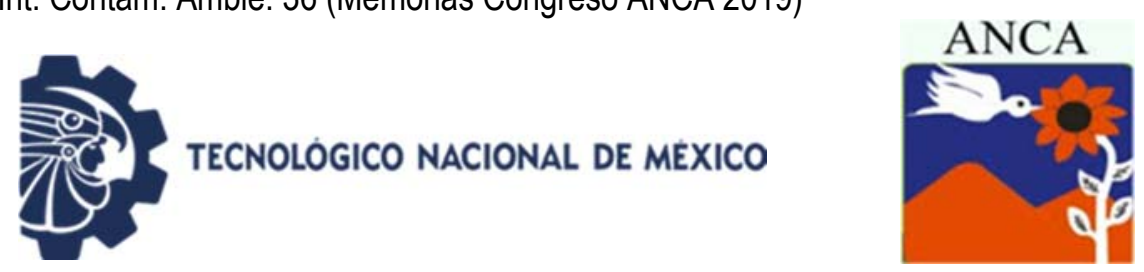

\title{
Monitoreo de la contaminación biológica del agua residual del río Alseseca, por cepas de Escherichia coli patógenas
}

\author{
Alfaro Martínez V*, Castañeda Roldán E, Munguía Pérez R, Chávez Bravo E \\ Facultad de Ingeniería Química. Instituto de Ciencias-CICM. BUAP. México \\ *vic_tor-1992@hotmail.com
}

\section{RESUMEN}

La contaminación biológica en el agua residual por bacterias patógenas representa causa principal de mortalidad y morbilidad en la niñez del mundo, siendo más en los países en desarrollo como México. Los dearrogónicos de $E$. coli como la $E$. coli enterotoxigénica (ETEC) y E. coli enteropatógena (EPEC), son los agentes los causales de la infección. Por lo que el objetivo de este trabajo fue determinar la contaminación microbiológica por agua residual del río Alseseca por cepas ETEC y EPEC. Para ello se recolectaron durante un periodo anual muestras del agua residual en el río a partir de 5 septiembre 2017 al 6 de julio del 2018. Las muestras se tomaron dos veces al mes y se les realizó un análisis molecular, el cual consistió en extraer DNA total, ayudado por un Kit Sample Power Viral Environmental RNA/DNA. Después se utilizaron primers de genes específicos para detectar ETEC y EPEC mediante PCR, seguido de un corrimiento de electroforético para visualizar los amplicones. A partir de un total de 21 muestras de agua residual, se detectó que el $57.14 \%$ de las muestras presentan ambos patogrupos, el $23.80 \%$ presentó solo ETEC, el $9.52 \%$ solo EPEC y un $9.5 \%$ no se detectó ningún patógeno. El agua residual del río Alseseca presentó una contaminación biológica con el $90 \%$ por ETEC y EPEC, lo que sugiere atención para el saneamiento del agua residual y evitar brotes diarreicos.

Palabras clave: Contaminación, E coli, patógena, Río Alseseca

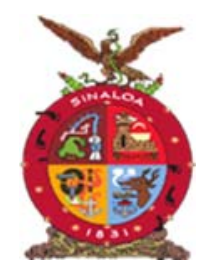

XVIII Congreso Internacional XXIV Congreso Nacional de Ciencias ambientales
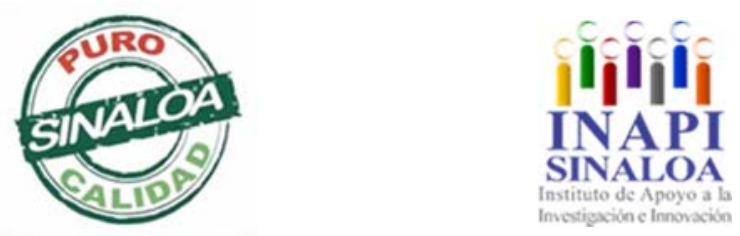

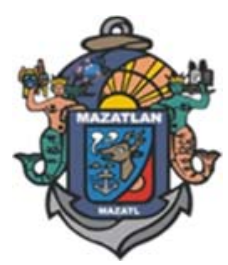

Mazatlán, Sinaloa 3-7 junio 2019 Calidad del Agua y Saneamiento 

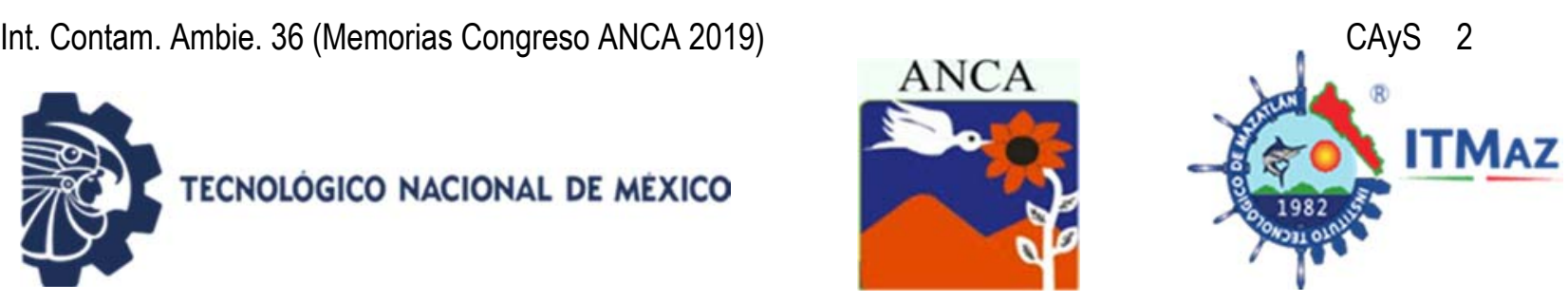

\title{
Monitoring the biological contamination of wastewater from the Alseseca River, by pathogenic Escherichia coli strains
}

\author{
Alfaro Martínez V*, Castañeda Roldán E, Munguía Pérez R, Chávez Bravo E \\ Facultad de Ingeniería Química. Instituto de Ciencias-CICM. BUAP. México \\ *vic_tor-1992@hotmail.com
}

\begin{abstract}
The biological contamination in the wastewater by pathogenic bacteria, represents a focus of infection to acquire contagious diseases such as diarrheal diseases, these are the main cause of mortality and morbidity in the children of the world and frequent in developing countries like Mexico. The pathogenic groups of $E$. coli such as enterotoxigenic $E$. coli (ETEC) and enteropathogenic $E$. coli (EPEC), are agent most frequently cause gastrointestinal diseases as the diarrheas. The objective of this study was to determine the biological contamination of wastewater from Alseseca River by ETEC and EPEC strains during an annual period. The wastewater samples were collected at the coordinates of the river $18^{\circ} 59^{\prime} 43.2$ "N $98^{\circ} 11^{\prime} 12.8^{\prime \prime}$ W from September 5, 2017 to July 6,2018 . These were collected twice a month and molecularly analyzed to extract total DNA, helped by a Kit Sample Power Viral Environmental RNA/DNA and using primers specific genes of ETEC and EPEC employing the PCR technique, followed by an electrophoresis running to visualize the amplicons. From 21 wastewater samples, it was detected that $57.14 \%$ of the samples present both pathogenic groups, $23.80 \%$ presented only ETEC, $9.52 \%$ only EPEC and another $9.5 \%$ no pathogen was detected. The wastewater from the Alseseca River presented a biological contamination with $90 \%$ by ETEC and EPEC, suggesting attention to the sanitation of wastewater and avoid a public health problem such as gastrointestinal infections.
\end{abstract}

Keywords: Pollution, E coli, pathogenic, Alseseca River

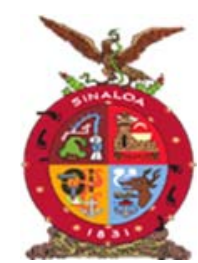

XVIII Congreso Internacional XXIV Congreso Nacional de Ciencias ambientales
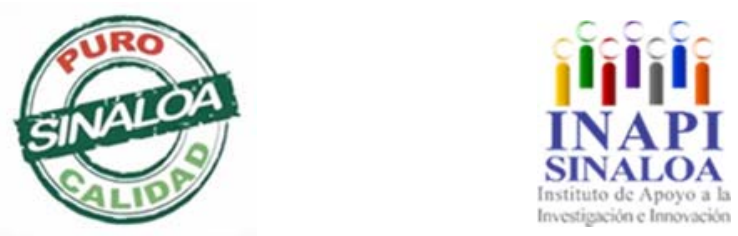

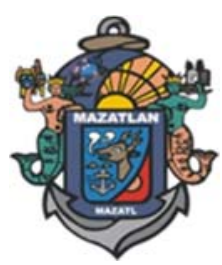

Mazatlán, Sinaloa 3-7 junio 2019 Calidad del Agua y Saneamiento 

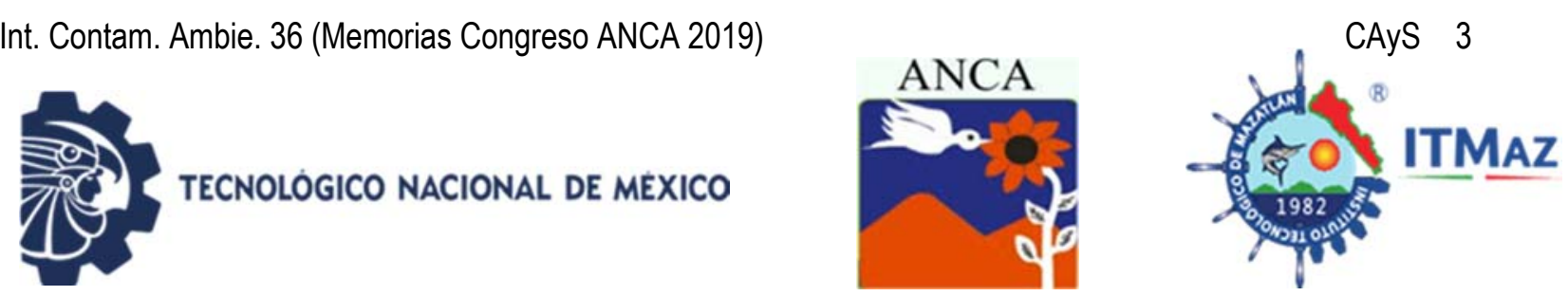

\title{
Evaluación de la calidad del agua superficial y subterránea (en un área piloto) del distrito de riego del Valle del Yaqui, Sonora, México
}

\author{
Almazán Benítez B, Esteller Alberich MV*, Garrido Hoyos S, \\ Expósito Castillo JL \\ Instituto Interamericano de Tecnología y Ciencias del Agua. Universidad \\ Autónoma del Estado de México. C.P. 50200, Toluca, México \\ Instituto Mexicano de Tecnología del Agua, C.P. 62574, Jiutepec, Morelos, \\ México \\ *mvestellera@uaemex.mx
}

\begin{abstract}
RESUMEN
La actividad agrícola en el Distrito de Riego del Valle del Yaqui, Sonora, se desarrolla de manera intensiva, principalmente; con cultivos de trigo y maíz, aplicándose grandes cantidades de fertilizantes que no son aprovechados al $100 \%$ por los cultivos. El excedente de dichos fertilizantes es transportado por el agua de escorrentía, a través del sistema de drenaje, hacia la bahía del Tóbari, así como por lixiviación hacia el acuífero. Por ello se caracterizó el agua de riego, el agua drenada y el agua subterránea para evaluar su calidad, realizando dos muestreos (noviembre 2017 y marzo 2018) correspondientes al primer y último riego, tomando muestras de agua en 2 canales de riego, en 15 puntos del sistema de drenaje y en 4 pozos para analizar en laboratorio (aniones y cationes mayoritarios). En campo se tomaron datos de temperatura, $\mathrm{pH}$, conductividad eléctrica y sólidos disueltos totales. El agua de riego es del tipo bicarbonatada cálcica, el agua de drenaje varía de bicarbonatada sódica a clorurada cálcica y el agua subterránea es clorurada cálcica. Con respecto a la calidad para agua de uso y consumo humano (NOM-127-SSA1-1994), ninguno de los parámetros medidos supera el valor límite, así por ejemplo, el valor máximo de $\mathrm{NO}_{3}{ }^{-e n}$ noviembre, 2017 es $33.8 \mathrm{mg} / \mathrm{L}$ y en marzo, 2018 es $35.7 \mathrm{mg} / \mathrm{L}$. El fósforo, de acuerdo con la Ley Federal de Derechos Disposiciones Aplicables en Materia de Aguas Nacionales (2016), se encuentra en concentraciones mayores a las permisibles para la vida acuática $(0.5 \mathrm{mg} / \mathrm{L})$.
\end{abstract}

Palabras clave: Contaminación, agua, nitrógeno, fósforo, agricultura.

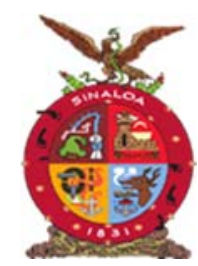

XVIII Congreso Internacional XXIV Congreso Nacional de Ciencias ambientales

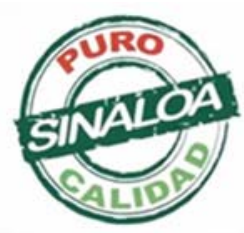

Mazatlán, Sinaloa 3-7 junio 2019

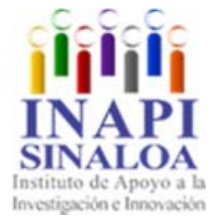

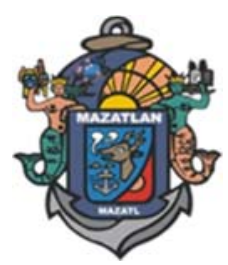

Calidad del Agua y Saneamiento 

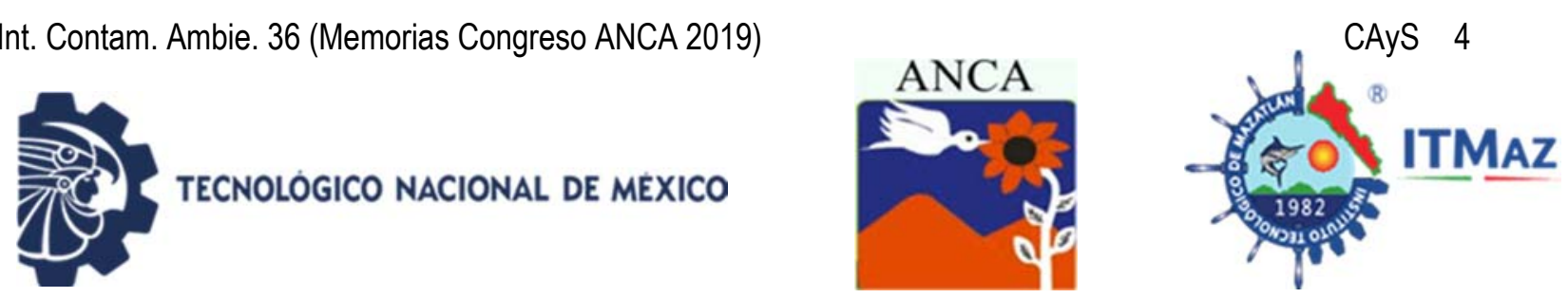

\title{
Surface water and groundwater quality assessment (in a pilot area) of the irrigation district in the Yaqui Valley, Sonora, Mexico
}

\author{
Almazán Benítez B, Esteller Alberich MV*, Garrido Hoyos S, \\ Castillo JL
}

Instituto Interamericano de Tecnología y Ciencias del Agua. Universidad

Autónoma del Estado de México. C.P. 50200, Toluca, México

Instituto Mexicano de Tecnología del Agua; C.P. 62574, Jiutepec, Morelos,

México

*mvestellera@uaemex.mx

\begin{abstract}
Agricultural activity in the Irrigation District of the Yaqui Valley, Sonora, intensively developed with wheat and corn crops, mainly; applying large amounts of fertilizers that are not used $100 \%$ by crops. The surplus of fertilizers transported by the runoff water, through the drainage system, to the Tóbari bay, as well as by leaching to the aquifer.

In this research, irrigation water, drained water and groundwater were characterized to evaluate their quality. Two samplings were carried out (November 2017 and March 2018) corresponding to the first and last irrigation. Water samples taken in two irrigation channels, in 15 points of the drainage system and in four wells to be analyzed in the laboratory (anions and cations). In the field, temperature, $\mathrm{pH}$, electrical conductivity and total dissolved solids data were taken. The irrigation water is of the calcium bicarbonate type, the drainage water varies from sodium bicarbonate to calcium chloride and the groundwater is calcium chloride. With respect to the quality for water for human consumption and use (NOM-127-SSA1-1994), none of the parameters measured exceeds the limit value. For example, the maximum value of $\mathrm{NO}_{3}$-in November, 2017 is $33.8 \mathrm{mg} / \mathrm{L}$ and in March, 2018 is $35.7 \mathrm{mg} / \mathrm{L}$. Phosphorus, in accordance with the Federal Law of Rights Applicable Dispositions in Matters of National Waters (2016), is found in concentrations higher than those permissible for aquatic life $(0.5 \mathrm{mg} / \mathrm{L})$.
\end{abstract}

Keywords: Pollution, water, nitrogen, phosphorus, agriculture.

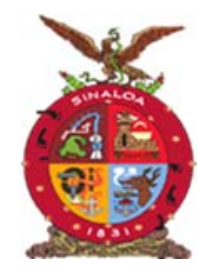

XVIII Congreso Internacional XXIV Congreso Nacional de Ciencias ambientales
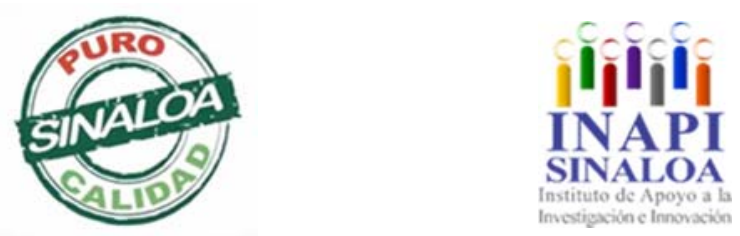

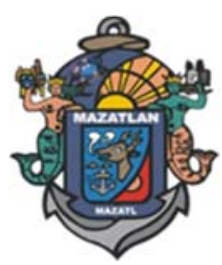

Mazatlán, Sinaloa 3-7 junio 2019

Calidad del Agua y Saneamiento 


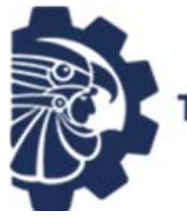

ACIONAL DE MEXICO

\title{
Estudio del azolvamiento y calidad del agua de la presa Sanalona, Sinaloa, México
}

\author{
Amábilis Sosa L, Mendivil Garcia K, Rodríguez Mata A, Rángel Peraza A, \\ Cedillo Herrera C
}

CONACYT-Instituto Tecnológico de Culiacán,

Instituto Tecnológico Nacional de México. Instituto Tecnológico de Culiacán, Av. Juan de Dios Batiz, No. 310, Culiacán, México.

kim.mendivil@gmail.com

\section{RESUMEN}

La presa Sanalona se ubica en la cuenca del río Culiacán, al noroeste de México. Proporciona energía potencial a la central termoeléctrica Salvador Alvarado de $14 \mathrm{MW}$ y abastece 273,475 hectáreas de cultivo del Valle de Culiacán. El diseño de la presa se basó en características geohidrológicas de la zona. Sin embargo, el cambio de uso del suelo incrementa el transporte de contaminantes alterando la calidad del agua y el azolvamiento del reservorio. Se realizó un seguimiento de la calidad del agua en 12 puntos de una red estratificada con tres profundidades. Los parámetros evaluados fueron $\mathrm{pH}, \mathrm{pOR}, \mathrm{DQO}$, sólidos suspendidos totales, sólidos disueltos totales, fósforo total, sílice y nitrógeno amoniacal. Todos los parámetros fueron evaluados en época de lluvias y estiaje. Además, se utilizaron los registros históricos hidrológicos y de SST, en conjunto con el modelo batimétrico, para calcular el aporte de sedimentos a la presa. Los resultados indicaron que la tasa de aporte de sedimentos ha incrementado en los últimos 25 años y que el volumen de la presa puede ser modelado dinámicamente. También, la variación espacial de la calidad del agua está en función de la profundidad del embalse que a su vez depende del azolvamiento. Además, se registró que las concentraciones más elevadas de los nutrientes se presentan durante la época de lluvias, reflejando el transporte de contaminantes. Esta información contribuye al manejo integral de cuerpos de agua de Sinaloa para garantizar la continuidad de la agricultura con sus respectivas y necesarias medidas de mitigación.

Palabras clave: Reservorio, azolvamiento, calidad del agua, contaminante, sedimento.

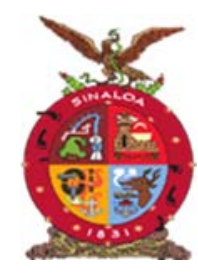

XVIII Congreso Internacional XXIV Congreso Nacional de Ciencias ambientales
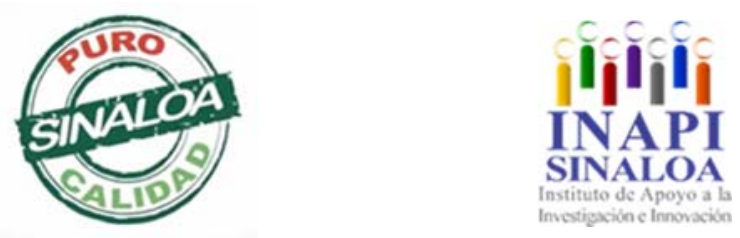

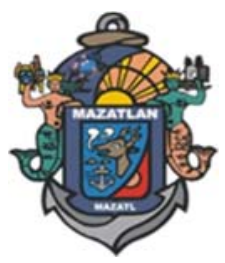

Calidad del Agua y Saneamiento 

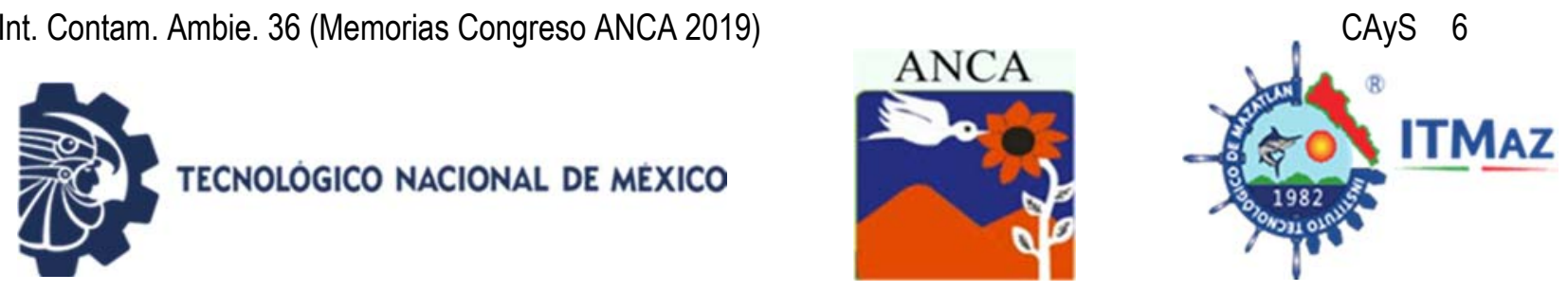

\title{
Sanalona Dam, Sinaloa, Mexico, water quality and sedimentation study
}

\author{
Amábilis Sosa L, Mendivil Garcia K, Rodríguez Mata A, Rángel Peraza A, \\ Cedillo Herrera C \\ CONACYT-Instituto Tecnológico de Culiacán, \\ Instituto Tecnológico Nacional de México. Instituto Tecnológico de Culiacán, \\ Av. Juan de Dios Batiz, No. 310, Culiacán, México. \\ kim.mendivil@gmail.com
}

\begin{abstract}
Sanalona Dam is in the Culiacan River basin, northwest of Mexico. It generates potential energy to the $14 \mathrm{MW}$ Salvador Alvarado thermoelectric power plant and supplies 273,475 hectares of Culiacan Valley crops. The design of the reservoir was based on geohydrological attributes of the zone. However, the change in land use increases the transport of pollutants, changing the quality of the water and the sedimentation of the reservoir. Water quality was monitored at 12 points of a stratified network with three depths. The parameters tested were $\mathrm{pH}, \mathrm{pOR}, \mathrm{COD}$, total suspended solids, total dissolved solids, total phosphorus, silica and ammoniacal nitrogen. Parameters were tested during the rainy and dry seasons. In addition, it used historical hydrological and TSS records, together with the bathymetric model to calculate the sediment contribution to the reservoir. The results showed that the sediment contribution rate has increased in the last 25 years and the volume of the reservoir can be modeled. The spatial variation in water quality follows the depth of the reservoir, which depends on sedimentation. Besides, the highest concentrations of nutrients recorded during the rainy season reflects the transport of pollutants. This information contributes to the integrated management of water bodies in Sinaloa to guarantee the continuity of agriculture with their respective and necessary mitigation measures.
\end{abstract}

Keywords: Reservoir, sedimentation, water quality, contaminant, sediment.

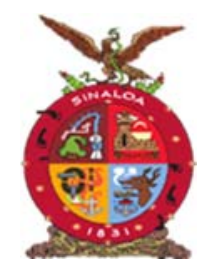

XVIII Congreso Internacional XXIV Congreso Nacional de Ciencias ambientales
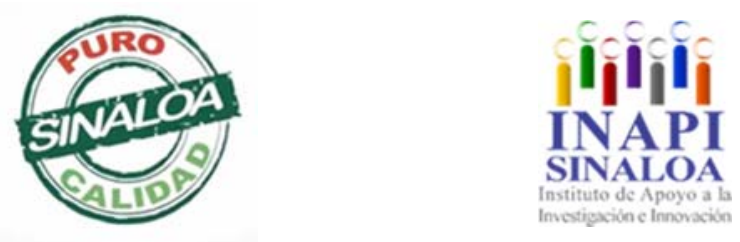

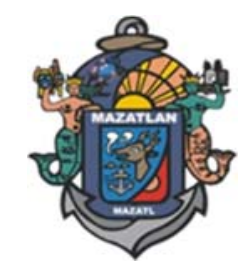

Calidad del Agua y Saneamiento 

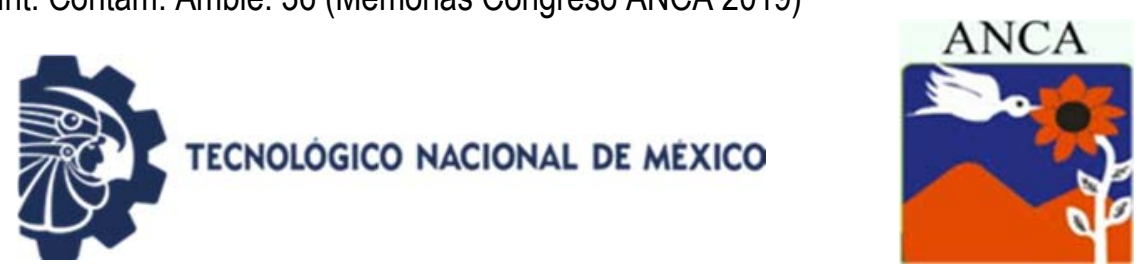

Determinación de $\beta$-bloqueadores en muestras de agua de distintas matrices por cromatografía de líquidos espectrometría de masas (LC-MS)

\author{
Avilés Flores M*, Sánchez Zarza M, Tapia Acosta J \\ Instituto Mexicano de Tecnología del Agua. \\ Coordinación de Tratamiento y Calidad del Agua. \\ Paseo Cuauhnáhuac 8532, Col. Progreso, C.P. 62550, Jiutepec, Morelos, \\ México \\ *maviles@tlaloc.imta.mx
}

\title{
RESUMEN
}

Aguas subterráneas se considera un riesgo ambiental de salud pública. Estos incluyen los productos farmacéuticos, de cuidado personal, surfactantes, aditivos industriales, plastificantes, plaguicidas y una gran diversidad de compuestos químicos que aun cuando se encuentran en concentraciones traza $\left(\mu \mathrm{gL}^{-1} \mathrm{y} \mathrm{ngL}^{-}\right.$ $\left.{ }^{1}\right)$ alteran las funciones endocrinas. Los contaminantes emergentes son de gran interés-científico, ya que sus emisiones en el ambiente pueden aumentar la presencia de bacterias resistentes, además debido a sus propiedades fisicoquímicas son capaces de llegar a cualquier medio natural y representar un grave riesgo para el consumo de agua potable. En México no se cuenta con información suficiente de la presencia y destino de fármacos presentes en el ambiente, específicamente en fuentes de abastecimiento, considerando esta problemática es esencial desarrollar métodos analíticos para cuantificar productos farmacéuticos en agua. El objetivo de este trabajo es evaluar la presencia de cuatro $\beta$-bloqueadores, en agua de pozo, río y efluente de agua residual tratada de dos municipios del estado de Morelos. Se desarrollaron y validaron metodologías analíticas para los compuestos metroprolol, bisoprolol, atenolol y betaxolol. La identificación de los analitos se realizó en base al tiempo de retención, la masa del ion del analito (ion molecular) y las masas de los iones producto. El método se realizó por cromatografía de líquidos-espectrometría de masas triple cuadrupolo (LC-MS), implica extracción en fase sólida (SPE), la separación se realizó en una columna C18 en fase reversa. La eficiencia de remoción para metroprolol fue 95.12: bisoprolol $89 \%$; atenolol fue $.90 \%$ y betaxolol $94 \%$.

Palabras clave: Extracción en fase sólida, compuestos emergentes, iones moleculares.

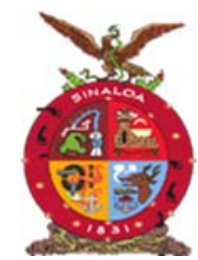

XVIII Congreso Internacional XXIV Congreso Nacional de Ciencias ambientales
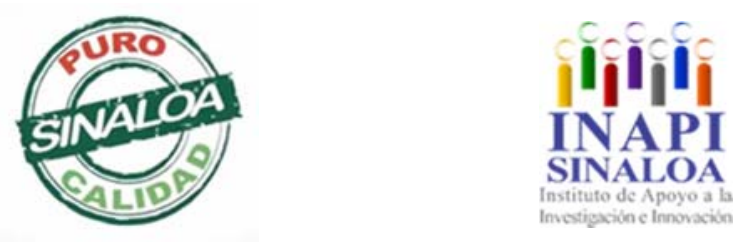

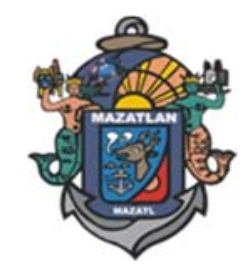

Calidad del Agua y Saneamiento 

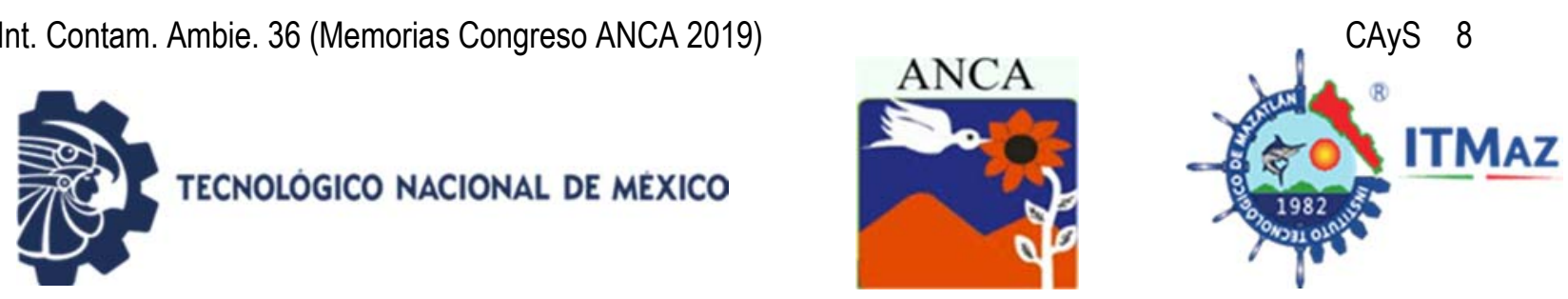

\title{
Determination of $\beta$-blockers in water samples from different matrices by liquid chromatography mass spectrometry (LC-MS)
}

\author{
Avilés Flores M*, Sánchez Zarza M, Tapia Acosta J \\ Instituto Mexicano de Tecnología del Agua. \\ Coordinación de Tratamiento y Calidad del Agua. \\ Paseo Cuauhnáhuac 8532, Col. Progreso, C.P. 62550, Jiutepec, Morelos, \\ México \\ *maviles@tlaloc.imta.mx
}

\begin{abstract}
Currently, the presence of emerging contaminants in surface water and groundwater is considered an environmental public health risk. These include pharmaceuticals, personal care products, surfactants, industrial additives, plasticizers, pesticides and a wide variety of chemical compounds that even when they are in trace concentrations $\left(\mathrm{ggL}^{-1}\right.$ and $\left.\mathrm{ngL}^{-1}\right)$ alter the endocrine functions. Emerging contaminants are of great scientific interest, since their emissions in the environment can increase the presence of resistant bacteria, also due to their physical-chemical properties they are able to reach any natural environment and represent a serious risk for consumption of drinking water. In Mexico there is not enough information on the presence and destination of drugs present in the environment, specifically in sources of supply, considering this problem is essential to develop analytical methods to quantify pharmaceutical products in water. The objective of this work is to evaluate the presence of four $\beta$-blockers, in well water, river and treated wastewater effluent from two municipalities in the state of Morelos. Analytical methodologies for the compounds metroprolol, bisoprolol, atenolol and betaxolol were developed and validated. The identification of the analytes was carried out based on the retention time, the mass of the analyte ion (molecular ion) and the masses of the product ions. The method was performed by liquid chromatography-triple quadrupole mass spectrometry (LC$\mathrm{MS}$ ), involves extraction in solid phase (SPE), separation was performed on a C18 column in reverse phase. The removal efficiency for metroprolol was 95.12: bisoprolol $89 \%$; atenolol was $.90 \%$ and betaxolol $94 \%$.
\end{abstract}

Keywords: Solid phase extraction, emerging contaminants, molecular ions.

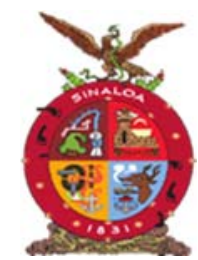

XVIII Congreso Internacional XXIV Congreso Nacional de Ciencias ambientales

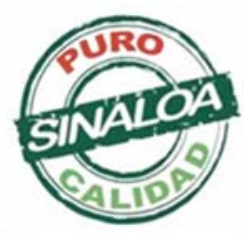

Mazatlán, Sinaloa 3-7 junio 2019

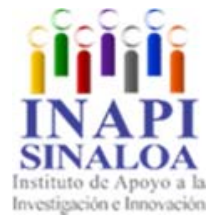

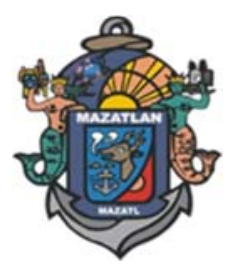

Calidad del Agua y Saneamiento 

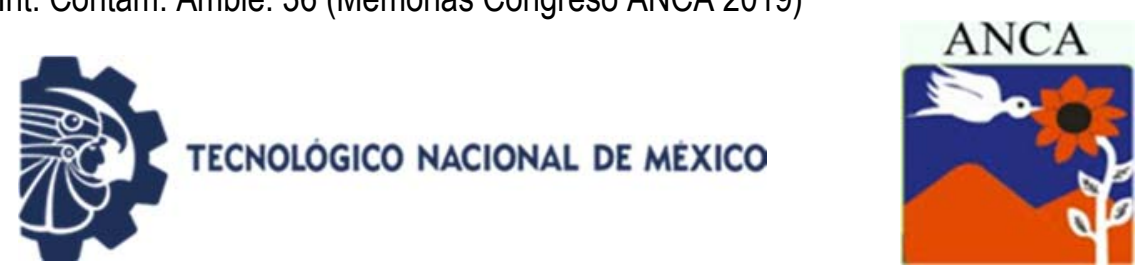

\title{
Evaluación de la calidad del agua para uso y consumo humano en la comunidad de Mayapán, Yucatán, México
}

\author{
Brito García C, Novelo Castilla J, Pérez Osorio C \\ Licenciatura en Química. Facultad de Química de la Universidad Autónoma de \\ Yucatán Calle 43 No. 613 x Calle 90 Col. Inalámbrica Mérida, Yucatán, \\ Facultad de Medicina. Universidad Autónoma de Yucatán. \\ Avenida Itzáes No. 498 x 59 y 59A Col. Centro Mérida, Yucatán México \\ chel9823@gmail.com
}

\begin{abstract}
RESUMEN
En el estado de Yucatán la fuente que provee casi la totalidad de agua dulce para la población es el acuífero kárstico, sin embargo, la estructura geológica de la región lo hace vulnerable a la contaminación. El objetivo de este trabajo es evaluar de manera temporal la calidad del agua subterránea para uso y consumo humano en la comunidad de Mayapán a través del índice de calidad del agua (ICA) propuesto por Ávila Pacheco. La comunidad de Mayapán se encuentra localizada en la región sur del estado, es considerada una de las comunidades con mayor índice de pobreza en el estado. En este trabajo se muestrearon un total de 15 pozos (12 pozos someros y 3 pozos de abastecimiento). La recolección de muestras de agua subterránea se llevó a cabo durante los meses de mayo, septiembre y diciembre del 2018. En cada muestra se determinaron 18 parámetros (físicos, químicos y bacteriológicos). Los resultados mostraron que la mayoría de los ICA's se clasificaron en categoría buena. Sin embargo, en calidad microbiológica la mayoría de los pozos sobrepasaron el límite máximo permisible de coliformes fecales (ausente o no detectable), los porcentajes son los siguientes, $87 \%$ para el mes de mayo, $93 \%$ para el mes de septiembre y $79 \%$ correspondiente al mes de diciembre. Debido a lo anterior, se concluye que la calidad fisicoquímica del agua es relativamente buena, pero la calidad bacteriológica no es aceptable, por lo tanto, se recomienda continuar con el proceso de desinfección, antes de usarla y/o consumirla.
\end{abstract}

Palabras clave: Índice de calidad del agua, calidad microbiológica, comunidad de Mayapán, pozos someros.

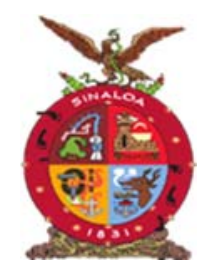

XVIII Congreso Internacional XXIV Congreso Nacional de Ciencias ambientales
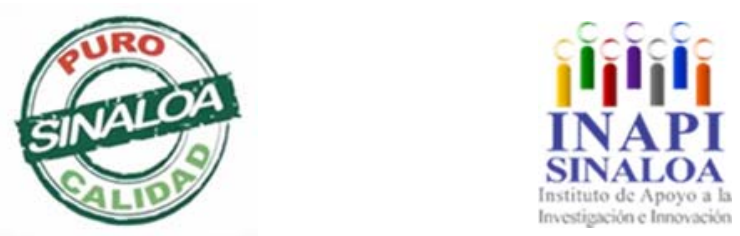

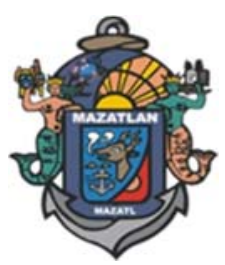

Mazatlán, Sinaloa 3-7 junio 2019

Calidad del Agua y Saneamiento 

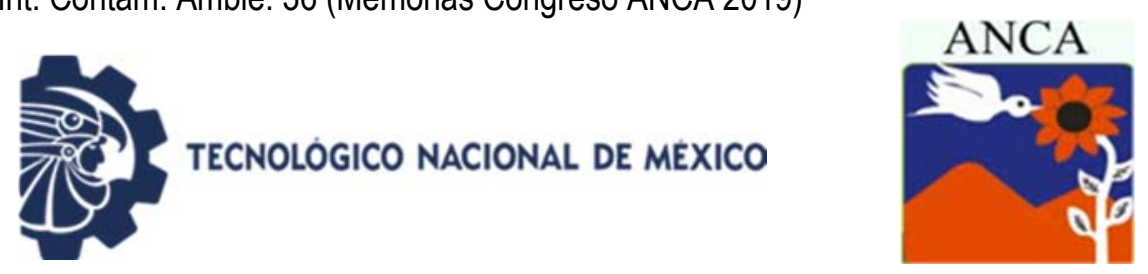

\title{
Evaluation of water quality for human use and consumption in the community of Mayapán, Yucatán, México
}

\author{
Brito García C, Novelo Castilla J, Pérez Osorio C \\ Licenciatura en Química. Facultad de Química de la Universidad Autónoma de \\ Yucatán Calle 43 No. 613 x Calle 90 Col. Inalámbrica Mérida, Yucatán, \\ Facultad de Medicina. Universidad Autónoma de Yucatán. \\ Avenida Itzáes No. 498 x 59 y 59A Col. Centro Mérida, Yucatán México \\ chel9823@gmail.com
}

\begin{abstract}
In the state of Yucatan, the source that provides almost all of the fresh water for the population is the karstic aquifer; however, the geological structure of the region makes it vulnerable to contamination. The objective of this work is to temporarily evaluate the quality of groundwater for human use and consumption in the community of Mayapán through the water quality index (ICA) proposed by Ávila Pacheco. The community of Mayapán is located in the southern region of the state, is considered one of the communities with the highest poverty rate in the state. In this work, 15 wells were sampled (12 shallow wells and 3 supply wells). The collection of groundwater samples was carried out during the months of May, September and December 2018. In each sample, 18 parameters were determined (physical, chemical and bacteriological). The results showed that most of the ICAs were classified as good category. However, in microbiological quality most of the wells exceeded the maximum permissible limit of fecal coliforms (absent or not detectable), the percentages are as follows, $87 \%$ for the month of May, $93 \%$ for the month of September and $79 \%$ corresponding to the month of December. Due to the above, it is concluded that the physicochemical quality of the water is relatively good, but the bacteriological quality is not acceptable, therefore, it is recommended to continue with the disinfection process, before using it and/or consuming it.
\end{abstract}

Keywords: Water quality index, microbiological quality, Mayapán community, shallow wells.

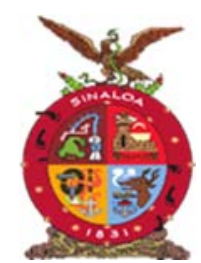

XVIII Congreso Internacional XXIV Congreso Nacional de Ciencias ambientales
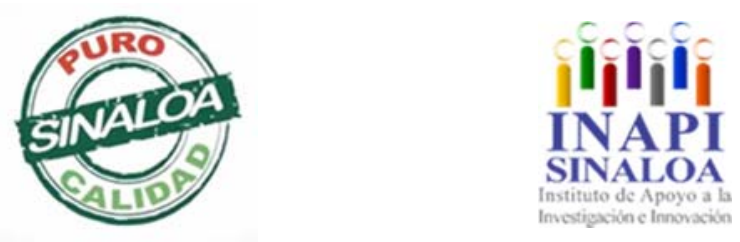

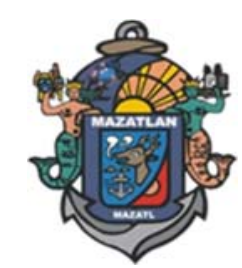

Mazatlán, Sinaloa 3-7 junio 2019

Calidad del Agua y Saneamiento 

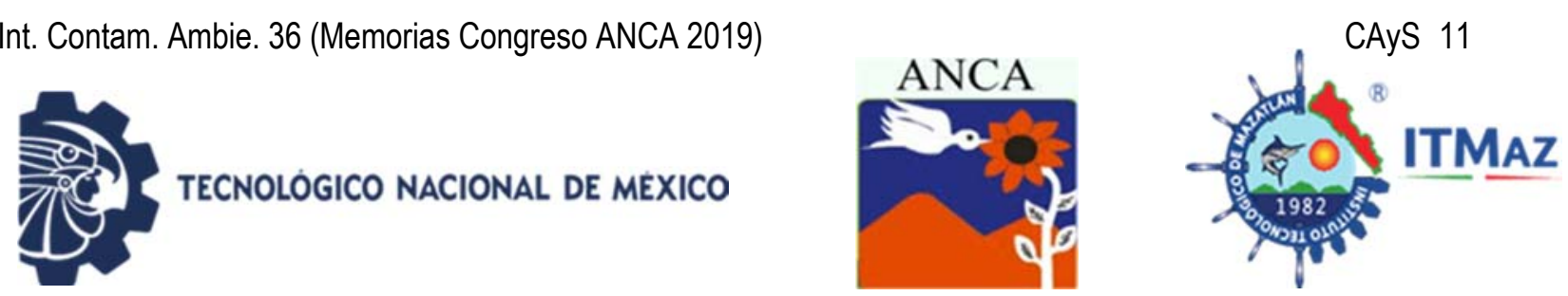

\title{
Variabilidad de nutrientes en sitios costeros cársticos, Riviera Maya, Quintana Roo
}

\author{
Camacho Cruz K*, Anguas Cabrera D, Sánchez González A, Carrillo L, \\ Ortiz Hernández C, Aguíñiga García S, Marmolejo Rodríguez A \\ Instituto Politécnico Nacional CICIMAR-IPN. El Colegio de la Frontera Sur. \\ México \\ *krla_2307@hotmail.com
}

\section{RESUMEN}

En regiones cársticas como la Península de Yucatán, las descargas de aguas subterráneas (DAS) son la única entrada de agua dulce al mar, siendo fuentes importantes de nutrientes que afectan el equilibrio de los ecosistemas. Con el objetivo de identificar la contribución de las DAS y evaluar la calidad del agua, se analizaron las concentraciones de nitrógeno inorgánico disuelto (NID), fósforo total (FT) y silicatos ( $\mathrm{Si}$ ) en muestras de agua superficial tomadas durante marzo, julio y octubre 2017 en cuatro sitios costeros de la Rivera Maya y los resultados se compararon con los máximos permisibles establecidos en la CE-CCA-89. Las concentraciones de nutrientes se analizaron por colorimetría usando un espectrofotómetro UV visible SHIMADZU. Tankah, Shambala y Chávez registraron concentraciones altas de Si $41.8 \pm 22.8 \mu \mathrm{M}$ y NO${ }^{-}+\mathrm{NO}_{2}-38.5 \pm 19 \mu \mathrm{M}$. En marzo se registraron las mayores concentraciones de FT en Tulum $(6.14 \mu \mathrm{M})$ y de $\mathrm{NO}_{3}{ }^{-}+\mathrm{NO}_{2}$-en Tankah $(71.1 \mu \mathrm{M})$. Las mayores concentraciones de amonio se detectaron durante julio en Tulum $(3.7 \mu \mathrm{M})$, y en octubre, la mayoría de los sitios presentaron concentraciones mayores de $1 \mu \mathrm{M}$, evidenciando la presencia de desechos antrópicos. Tres de los puntos monitoreados mostraron concentraciones de $\mathrm{Si}$, NID y FT similares a las detectadas en otros trabajos para sitios continentales (cenotes) y en presencia de DAS, evidenciando la conexión entre las aguas subterráneas y costeras. Las concentraciones de FT y NID registradas fueron valores por arriba del límite establecido en CE-CCA-001/89 para la protección de vida acuática.

Palabras clave: Contaminación, Caribe Mexicano, norma mexicana, agua subterránea.

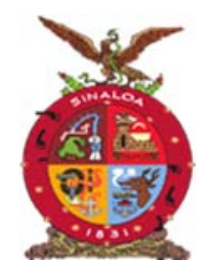

XVIII Congreso Internacional XXIV Congreso Nacional de Ciencias ambientales
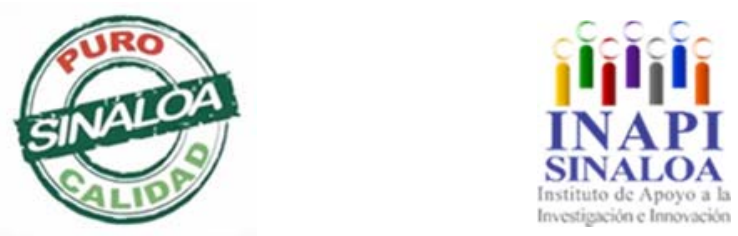

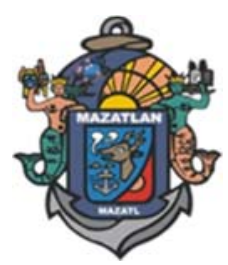

Mazatlán, Sinaloa 3-7 junio 2019

Calidad del Agua y Saneamiento 

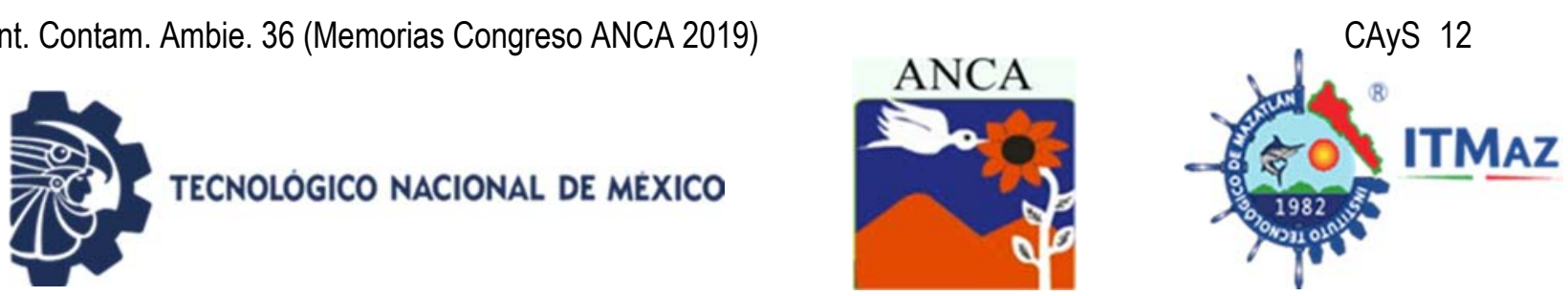

Nutrient variability in coastal coastal sites, Riviera Maya, Quintana Roo

\author{
Camacho Cruz K*, Anguas Cabrera D, Sánchez González A, Carrillo L, \\ Ortiz Hernández C, Aguíñiga García S, Marmolejo Rodríguez A \\ Instituto Politécnico Nacional CICIMAR-IPN. El Colegio de la Frontera Sur. \\ México \\ *krla_2307@hotmail.com
}

\begin{abstract}
In karst regions such as the Yucatan Peninsula, groundwater discharges (DAS) are the only freshwater input to the sea, being important sources of nutrients that affect the balance of ecosystems. In order to identify the contribution of the DAS, and evaluate the quality of the water, concentrations of dissolved inorganic nitrogen (NID), total phosphorus (FT) and silicates (Si), were analyzed in surface water. Samples were taken during March, July and October 2017, in four coastal sites of the Mayan Riviera, and the results were compared with the maximum allowable established in the CE-CCA-89. The nutrient concentrations were analyzed by colorimetry using a SHIMADZU visible UV spectrophotometer. Tankah, Shambala and Chávez recorded high concentrations of Si $41.8 \pm 22.8$ $\mu \mathrm{M}$ and $\mathrm{NO}_{3-+} \mathrm{NO}_{2}-38.5 \pm 19 \mu \mathrm{M}$. In March, the highest concentrations of FT were registered in Tulum $(6.14 \mu \mathrm{M})$ and of $\mathrm{NO}_{3}-+\mathrm{NO}_{2}$-in Tankah $(71.1 \mu \mathrm{M})$. The highest concentrations of ammonium were detected during July in Tulum $(3.7 \mu \mathrm{M})$, and in October, most of the sites showed concentrations higher than $1 \mu \mathrm{M}$, evidencing the presence of anthropic waste. Three of the monitored points showed concentrations of $\mathrm{Si}, \mathrm{NID}$ and FT similar to those detected in other works for continental sites (cenotes) and in the presence of DAS, evidencing the connection between groundwater and coastal waters. The concentrations of FT and NID recorded were values above the limit established in CE-CCA-001/89 for the protection of aquatic life.
\end{abstract}

Keywords: Pollution, Mexican Caribbean, mexican standard, groundwater.

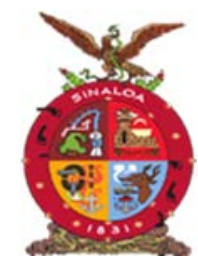

XVIII Congreso Internacional XXIV Congreso Nacional de Ciencias ambientales
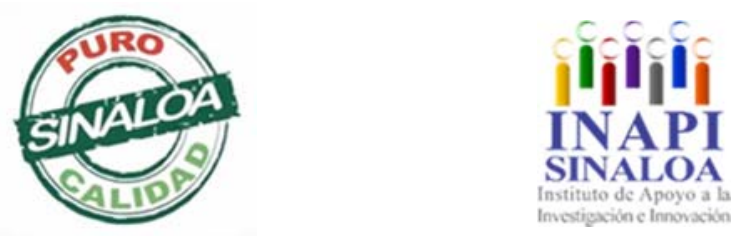

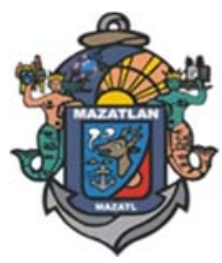

Mazatlán, Sinaloa 3-7 junio 2019

Calidad del Agua y Saneamiento 

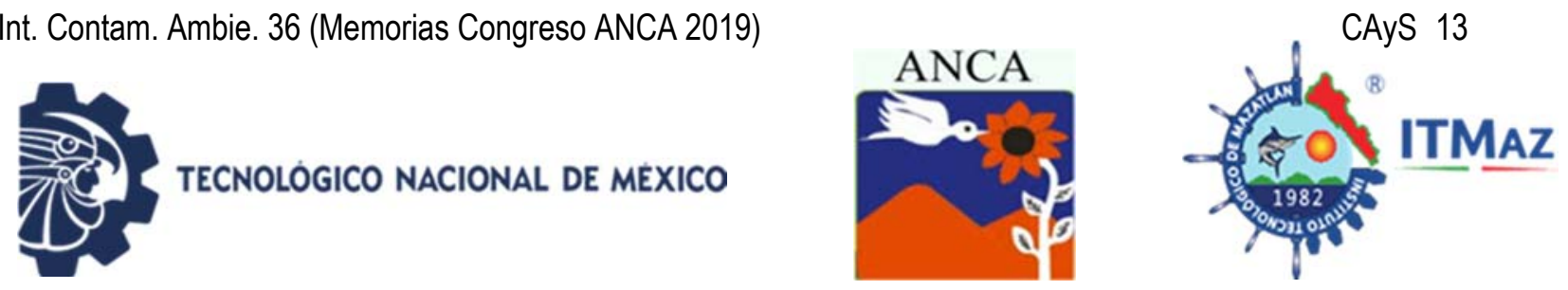

\title{
Crecimiento urbano y su efecto en los componentes del ambiente en Toluca de Lerdo (1986-2018)
}

\author{
Camacho Sanabria R \\ Ciencias Ambientales. Facultad de Química. \\ Universidad Autónoma del Estado de México, México \\ r_3camacho@hotmail.com
}

\section{RESUMEN}

En Toluca de Lerdo el aumento demográfico, en combinación con la expansión y desarrollo de actividades secundarias y terciarias, producen la demanda de nuevos espacios para la implementación de zonas habitacionales, industriales y comerciales, generando con ello cambios en la cobertura y uso del suelo. Estos cambios, a su vez, provocan afectaciones en los diferentes componentes del ambiente, por lo cual, es necesario analizar el crecimiento urbano y su efecto en los componentes ambientales. Dicho análisis se realizó a través de la obtención de mapas de uso de suelo, vegetación y consulta de información estadística histórica relacionada con: temperatura ambiental, recarga-consumo del recurso agua, y tasas de hundimiento del terreno. Los resultados obtenidos expresan que, Toluca de Lerdo en el periodo de 1986-2018 presentó un cambio aumento de su superficie urbana del $46.37 \%$ con $6,760.68$ ha de superficie. Ante dichos cambios, las coberturas que contienen las mayores pérdidas son la agricultura (6 $006.87 \mathrm{ha}$ ) y el bosque (637.75 ha). Por su parte, las categorías que presentaron las mayores ganancias son; equipamiento urbano (705.18 ha) y zona habitacional (5 475.84 ha). Los efectos ambientales en Toluca de Lerdo de 1986 a 2018 son múltiples y se perciben en el incremento en las temperaturas $\left(0.6-2^{\circ} \mathrm{C}\right)$, la sobreexplotación de acuíferos (déficit hídrico de-139.2 Mm3) y deformaciones en el terreno (hundimientos que van de-9 a-79 mm/a). Los efectos ambientales en la zona de estudio están ligados al crecimiento urbano debido a la demanda y sobreexplotación de recursos que estos espacios ejercen.

Palabras clave: Componentes ambientales, crecimiento urbano, hundimiento del terreno, gestión ambiental, sobreexplotación acuífera.

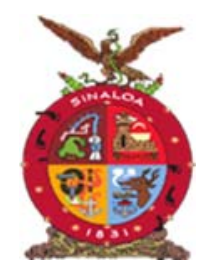

XVIII Congreso Internacional XXIV Congreso Nacional de Ciencias ambientales
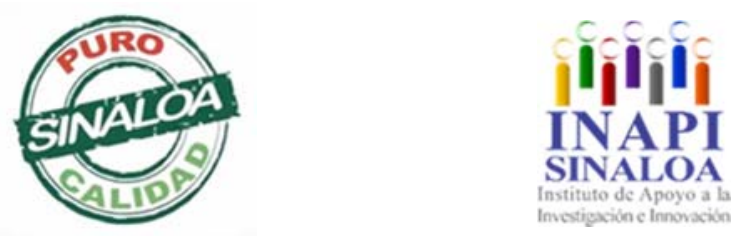

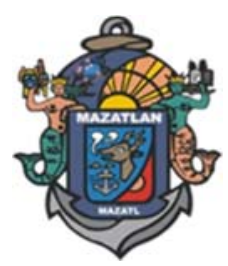

Mazatlán, Sinaloa 3-7 junio 2019

Calidad del Agua y Saneamiento 

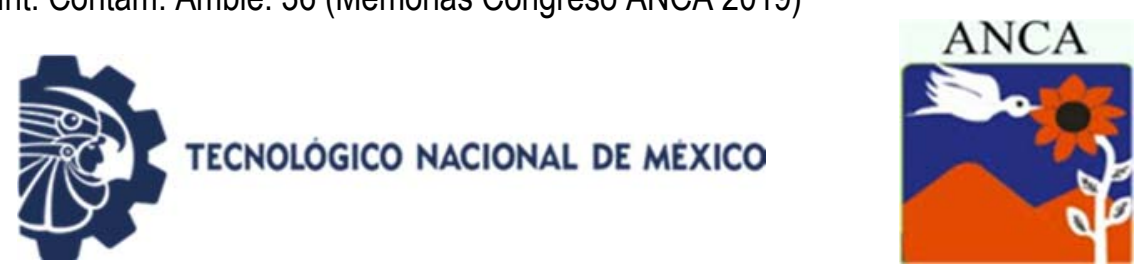

\title{
Urban growth and its effect on the components of the environment in Toluca de Lerdo (1986-2018)
}

\author{
Camacho Sanabria R \\ Ciencias Ambientales. Facultad de Química. \\ Universidad Autónoma del Estado de México, México \\ r_3camacho@hotmail.com
}

\begin{abstract}
In Toluca de Lerdo the demographic increase, in combination, with the expansion and development of secondary and tertiary activities, produces the demand for new spaces for the implementation of residential, industrial and commercial zones, thereby generating changes in coverage and land use. These changes, in turn, cause implications in the different components of the environment, which is why it is necessary to analyze urban growth and its effect on the environmental components in Toluca de Lerdo. Said analysis was carried out through the obtaining of maps of land use and vegetation and the compilation and consultation of historical statistical information related to the environmental temperature, recharge-consumption of the water resource, and land sinking rates. The obtained results express that, Toluca de Lerdo in the period of 1986-2018 presented a total change of 6760.68 ha $(46.37 \%)$. In view of these changes, the coverages containing the greatest losses are agriculture $(6,006.87 \mathrm{ha})$ and the forest $(637.75$ ha). On the other hand, the categories that presented the greatest gains are the urban equipment (705.18 ha) and the housing area (5 $475.84 \mathrm{ha})$. The environmental effects in Toluca de Lerdo (1986-2018) are multiple and are perceived by the increase in temperatures $\left(0.6-2{ }^{\circ} \mathrm{C}\right)$, aquifer overexploitation (water deficit of-139.2 Mm3) and deformations in the land (subsidence of-79 to-9 $\mathrm{mm} / \mathrm{a}$ ). The environmental effects in the study area are linked to urban growth, due to the demand and overexploitation of resources that these spaces exert.
\end{abstract}

Keywords: Environmental components, urban growth, sinking of the ground, environmental management, overexploitation aquifer.

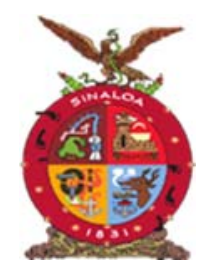

XVIII Congreso Internacional XXIV Congreso Nacional de Ciencias ambientales
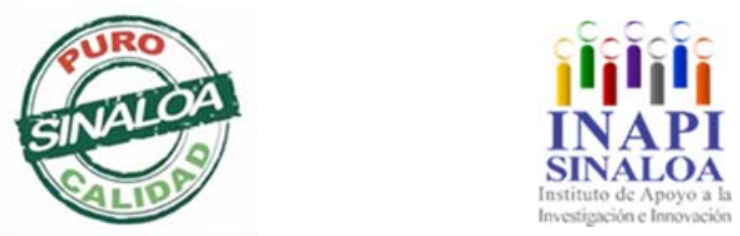

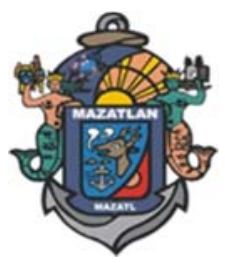

Mazatlán, Sinaloa 3-7 junio 2019

Calidad del Agua y Saneamiento 

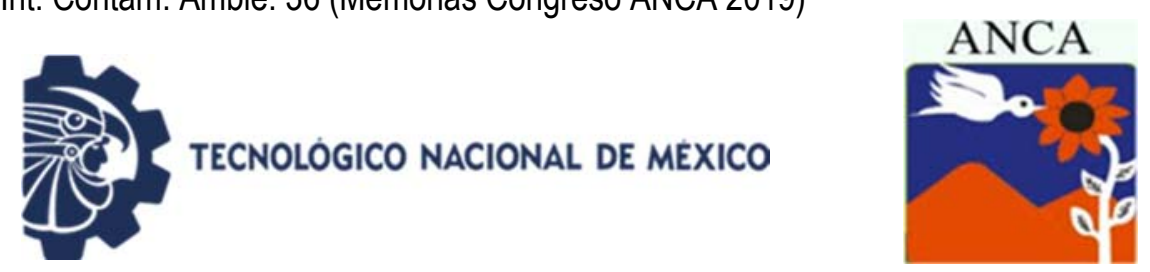

\title{
Implementación de humedales comunitarios, utilizando plantas acuáticas para el saneamiento de la Rivera de Cuexcomatitlán
}

\author{
Caro Becerra J*, Vizcaíno Rodríguez A, Iñiguez Pérez F, Barajas Mojarro J \\ Unidad Académica de Ingeniería Civil. Unidad Académica de Ingeniería \\ Biotecnología. \\ Centro Regional de Servicios Integrales para la Agricultura Protegida. \\ Universidad Politécnica de la Zona Metropolitana de Guadalajara. \\ Carr. Tlajomulco-Santa Fe km. 3.5 \# 595, Col. Lomas de Tejeda, C.P. 45640, \\ Tel. (0133)30409910, Tlajomulco de Zúñiga, Jalisco, México \\ *juancarobecerra@gmail.com
}

\section{RESUMEN}

Los humedales comunitarios son tecnologías ecológicas diseñadas para purificar el agua por medio de: fitorremediación sin alterar el ambiente, ya que son ecotecnias que permiten alcanzar la sustentabilidad y el desarrollo de una sociedad. El objetivo de esta investigación ha sido la implementación de jardines de plantas acuáticas, utilizando plantas depuradoras con el propósito de eliminar el exceso de nutrientes, fosfatos y nitratos entre otros. Esto fue posible mediante la creación de estructuras flotantes a las cuales se le instalaron plantas tales como: Typha latifolia, Lemna minor, Canna indica, Iris pseudacorus, Equisetum arvense, etc. cuya función básica es la limpieza de las aguas de la laguna mediante procesos de filtración, fitorremediación y purificación de agua (ozonificador), con el objeto de eliminar metales pesados y lodos activados que consisten en filtrar las aguas de la laguna mediante gravedad por distintas capas granulométricas de piedra y tierra donde se sedimentan los sólidos en suspensión, además de que ayudan a la separación de los contaminantes del agua. Los resultados de esta investigación fue la obtención de un DBO de $5 \mathrm{mg} / \mathrm{L}$ en un humedal de proporciones $2: 1$ y una profundidad en el sustrato de $0.60 \mathrm{~cm}$ a partir del tiempo de retención hidráulica. Una vez validados los resultados en comparación a los valores estándar de DBO de $3.7 \mathrm{mg} / \mathrm{L}$ se concluye que los humedales comunitarios presentan una alternativa nueva, natural, económica y sustentable que ha podido lograr el saneamiento de la rivera de Cuexcomatitlán ocasionada por descargas de aguas residuales vertidas directamente al lago.

Palabras Clave: Humedales comunitarios, fitorremediación, sustentable.

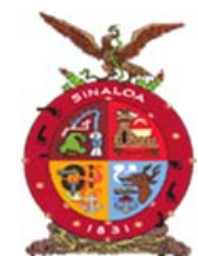

XVIII Congreso Internacional XXIV Congreso Nacional de Ciencias ambientales

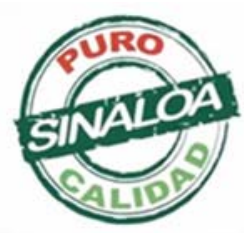

Mazatlán, Sinaloa 3-7 junio 2019

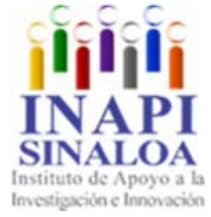

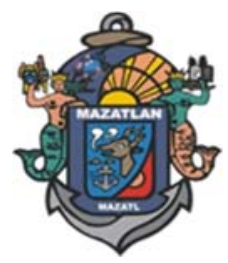

Calidad del Agua y Saneamiento 

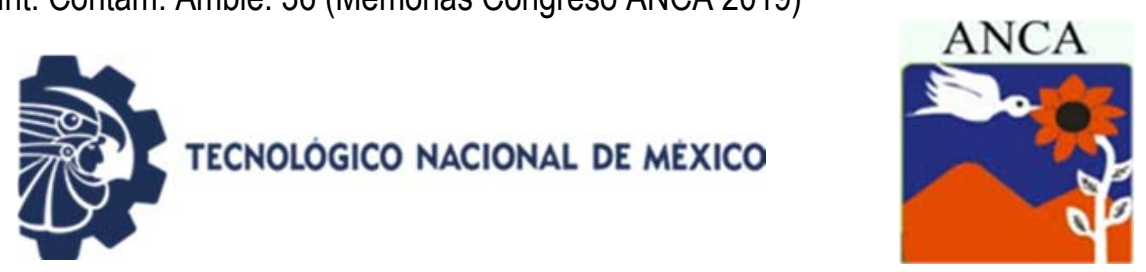

\title{
Implementation of community wetlands, using aquatic plants for the sanitation of the Rivera de Cuexcomatitlán
}

\author{
Caro Becerra J*, Vizcaíno Rodríguez A, Iñiguez Pérez F, Barajas Mojarro J \\ Unidad Académica de Ingeniería Civil. Unidad Académica de Ingeniería \\ Biotecnología. \\ Centro Regional de Servicios Integrales para la Agricultura Protegida. \\ Universidad Politécnica de la Zona Metropolitana de Guadalajara. \\ Carr. Tlajomulco-Santa Fe km. 3.5 \# 595, Col. Lomas de Tejeda, C.P. 45640, \\ Tel. (0133)30409910, Tlajomulco de Zúñiga, Jalisco, México \\ *juancarobecerra@gmail.com
}

\begin{abstract}
The community wetlands are ecological technologies designed to purify the water by means of infiltration and phytoremediation without altering the environment, since it is hardware that there allow reaching the sustainability and the development of a society. The goal of this investigation has been the implementation of community wetlands in town Cuexcomatitlán using clarifiers (sewage plants) with the purpose of eliminating the excess of nutrients, phosphate and nitrates between others. This was possible by means of the creation of floating structures, to which they will install such plants to themselves as: Typha latifolia, Lemna minor, Canna indicates, Iris Pseudacorus, Equisetum arvense, etc. Whose basic function is the cleanliness of the waters of the lake by means of filtration processes and fitorremediación, with the object to eliminate heavy metals and activated muds. The above-mentioned technology consists of leaking the water of the lake by means of gravity for different granulometric layers of stone and ground where sediment the solid ones in suspension, in addition to which they help to the separation of the pollutants of the water. The results of this work are the determination of the time of hydraulic retention of the water to reach the level of wished BOD, as well as the Valuation of Organic Load to design the depth of the substratum. As soon as the results were validated, the dimensions of the wetland are proposed estimating of empirical form a DBO 5 . The community wetlands present a new, economic and sustainable alternative that will manage to contribute the sanitation of the riverside of Cuexcomatitlán caused by discharges of wastes water poured directly to the lake.
\end{abstract}

Keywords: Community wetlands, phytoremediation, sustainability.

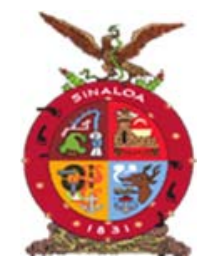

XVIII Congreso Internacional

XXIV Congreso Nacional de Ciencias ambientales

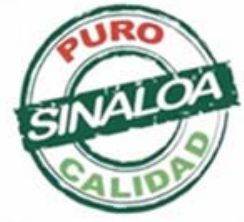

Mazatlán, Sinaloa 3-7 junio 2019

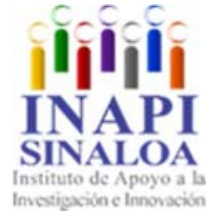

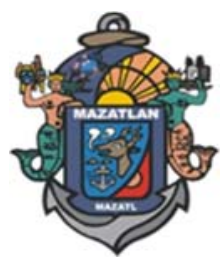

Calidad del Agua y Saneamiento 


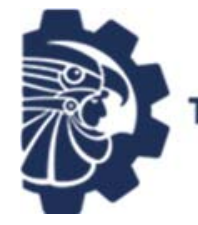

\title{
作
}

\section{Monitoreo de parámetros relacionados con la calidad del agua del lago de Chapala}

\author{
Chavez Castellanos K, Alvarez Bernal D, Franco Hernandez MO, \\ Oregel Zamudio E
}

Centro Interdisciplinario de Investigación para el Desarrollo Integral Regional. Instituto Politécnico Nacional. Unidad Michoacán.

Justo Sierra No. 28 Jiquilpan, C. P. 59510, Michoacán, México

Unidad Profesional Interdisciplinaria de Biotecnología. Instituto Politécnico

Nacional. Av. Acueducto, Barrio la Laguna Ticoman, 07340, México, México

\section{RESUMEN}

El lago de Chapala el cuerpo de agua más grande de México, Michoacán y Jalisco comparten su cuenca, se considera importante debido a los servicios económicos, recreativos y ecológicos que ofrece. El lago de Chapala ha estado expuesto a diferentes fuentes y niveles de contaminación emergente, provenientes de descargas municipales de varias comunidades, aguas de retorno agrícola y aguas residuales vertidas por industrias, principalmente provenientes del río Lerma. El Lago de Chapala está catalogado como uno de los recursos naturales más amenazados en el hemisferio occidental por el Programa Ambiental de las Naciones Unidas. El objetivo fue determinar algunos parámetros fisicoquímicos correspondientes a la calidad del agua del lago de chapla. Se tomó registro de algunos parámetros fisicoquímicos correspondientes a la época de lluvias del ciclo anual 2018. Se analizaron un total de siete muestras compuestas de agua, elaboradas a partir de un muestreo de 42 puntos. Se utilizaron técnicas analíticas como cromatografía de gases, espectrometría de masas, espectroscopia de absorción atómica y técnicas colorimétricas, entre otras. Fueron registrados: carbonatos $(0.92-0.32 \mathrm{meq} / \mathrm{L})$, bicarbonatos $(5 .-3.43 \mathrm{meq} / \mathrm{L})$, cloruros $(61-28 \mathrm{mg} / \mathrm{L})$, dureza $(232-125 \mathrm{mg} / \mathrm{L})$, fosforo $(5.29-8.33 \mathrm{ppm})$, Boro (0.18-0.02 ppm), sulfatos (28.5-47.8 ppm), magnesio (18.35-30.6 ppm), Calcio $(\mathrm{ppm})$, Potasio (9.05-43.21 ppm), Sodio (53.89-91.85 ppm), conductividad eléctrica $(0.52-0.93 \mathrm{~ms})$ y $\mathrm{pH}(7.6-8.7)$. El monitoreo contante es necesario para tener evidencia documental de la calidad actual del cuerpo de agua, sin embargo, falta acometer más investigación relacionada con las condiciones del lago de Chapala.

Palabras clave: Lago de Chapala, carbonatos, cloruros, sulfatos, sodio.

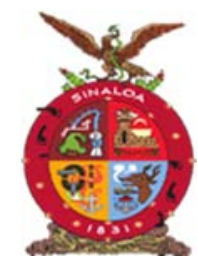

XVIII Congreso Internacional XXIV Congreso Nacional de Ciencias ambientales

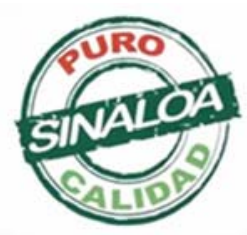

Mazatlán, Sinaloa 3-7 junio 2019
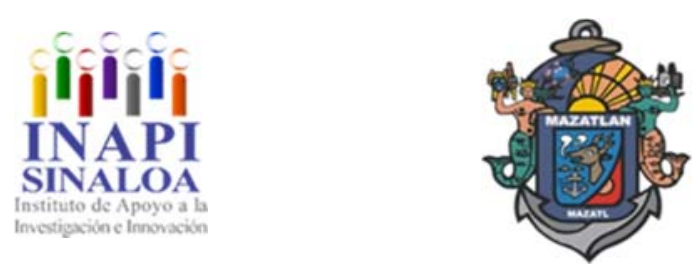

Calidad del Agua y Saneamiento 

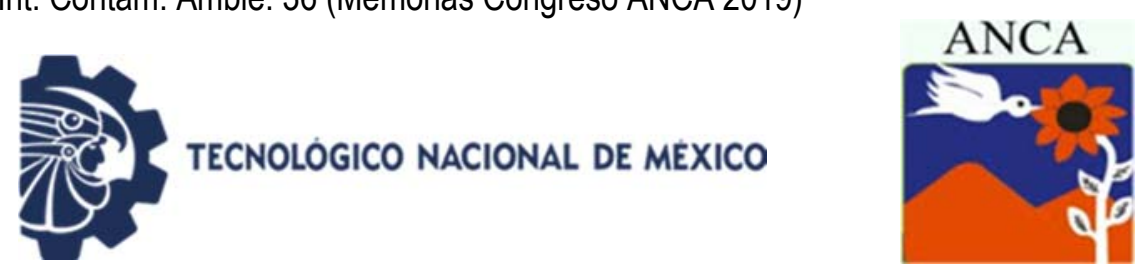

\title{
Monitoring of parameters related to water quality of Chapala lake
}

\author{
Chavez Castellanos K, Alvarez Bernal D, Franco Hernandez MO, \\ Oregel Zamudio $\mathrm{E}$
}

Centro Interdisciplinario de Investigación para el Desarrollo Integral Regional. Instituto Politécnico Nacional. Unidad Michoacán. Justo Sierra No. 28 Jiquilpan, C. P. 59510, Michoacán, México

Unidad Profesional Interdisciplinaria de Biotecnología. Instituto Politécnico

Nacional. Av. Acueducto, Barrio la Laguna Ticoman, 07340, México, México

\begin{abstract}
Chapala Lake, the largest body of water in Mexico, Michoacán and Jalisco share its basin, is considered important due to the economic, recreational and ecological services it offers. Chapala Lake has been exposed to different sources and levels of emerging pollution, from municipal discharges from several communities, agricultural return waters and wastewater discharged by industries, mainly from the Lerma River. The United Nations Environmental Program lists Chapala Lake as one of the most threatened natural resources in the Western Hemisphere. The objective was to determine some physicochemical parameters corresponding to the water quality of the Chapla Lake. A record was taken of some physicochemical parameters corresponding to the rainy season of the 2018 annual cycle. A total of seven water samples composed of a sample of 42 points were analyzed. Analytical techniques such as gas chromatography, mass spectrometry, atomic absorption spectroscopy and colorimetric techniques, among others, were used. They were recorded: carbonates $(0.92-0.32 \mathrm{meq} / \mathrm{L})$, bicarbonates $(5.3 .33 \mathrm{meq} / \mathrm{L})$, chlorides (61-28 mg/L), hardness (232-125 mg/L), phosphorus (5.29-8.33 ppm), Boron (0.18-0.02 ppm), sulfates (28.5-47.8 ppm), magnesium (18.35-30.6 ppm), Calcium (ppm), Potassium (9.05-43.21 ppm), Sodium (53.89-91.85 ppm), electrical conductivity (0.52)-0.93 ms) and $\mathrm{pH}(7.6-8.7)$. The constant monitoring is necessary to have documentary evidence of the current quality of the water body; however, it is necessary to undertake more research related to the conditions of Chapala Lake.
\end{abstract}

Keywords: Chapala Lake, carbonates, chlorides, sulphates, sodium.

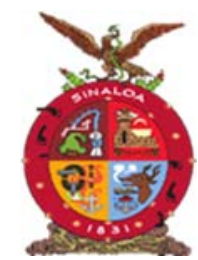

XVIII Congreso Internacional XXIV Congreso Nacional de Ciencias ambientales

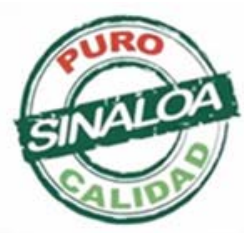

Mazatlán, Sinaloa 3-7 junio 2019

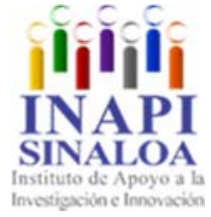

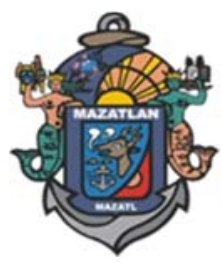

Calidad del Agua y Saneamiento 

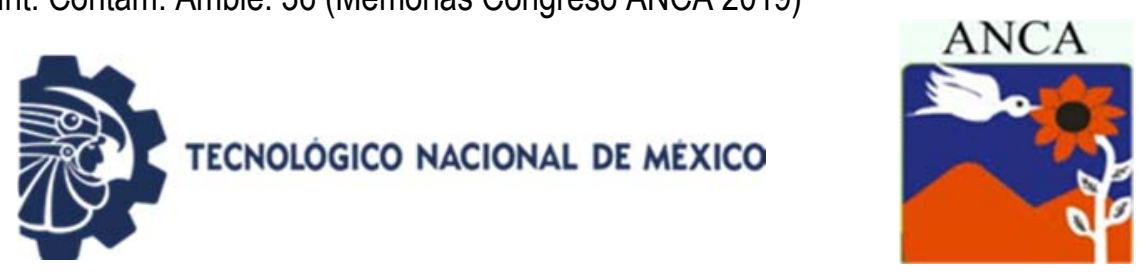

\title{
Evaluación de la calidad del agua del sitio Ramsar: Laguna de Tecocomulco
}

\author{
Cordero Lezama A*, Martínez Hernández S
}

Instituto de Ciencias Básicas e Ingeniería. Centro de Investigaciones Biológicas. Universidad Autónoma del Estado de Hidalgo. Carr. Pachuca-Tulancingo, Km. 4.5, Col. Carboneras, C.P. 42074, Mineral de la Reforma, Hidalgo, México *arthurcordero@gmail.com

\section{RESUMEN}

La Laguna de Tecocomulco es el último humedal relicto de los históricos lagos que existieron en la gran cuenca de México. Hábitat de peces, anfibios y aves características de los antiguos lagos de Anáhuac, declarada sitio Ramsar en el 2003; fuente de trabajo para los habitantes de la zona que dependen de la pesca y del turismo. A pesar de su importancia, existen pocos estudios sobre el estado de degradación del cuerpo de agua, por ello y de valorar la calidad del agua, se compilaron y analizaron datos históricos de parámetros fisicoquímicos, mismos que fueron comparados con datos recientes, para determinar el actual grado de eutroficación, dilucidar la situación ambiental de la Laguna. Primero se realizó una búsqueda bibliográfica identificando parámetros comúnmente reportados, posteriormente se realizaron tres muestreos durante el 2018 evaluando $\mathrm{pH}$, conductividad, temperatura, fósforo total, sólidos suspendidos totales y $\mathrm{DBO}_{5}$, así como las concentraciones de clorofila $\alpha$. Las muestran que; desde finales de la década de los 90 hasta el 2014 el humedal presenta una significativa eutrofización por nitrógeno, nitratos y fósforo asociados a las descargar y los lixiviados naturales, observando la variación de algunos parámetros fisicoquímicos relacionado con las épocas de lluvia y estiaje. Siendo notable la presencia de metales pesados, cuya movilidad es favorecida por las variaciones temporales de los parámetros fisicoquímicos.

Palabras claves: Eutrofización, humedal, clorofila $\alpha$.

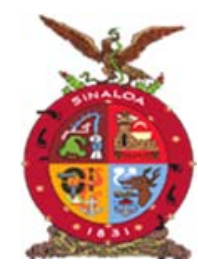

XVIII Congreso Internacional XXIV Congreso Nacional de Ciencias ambientales
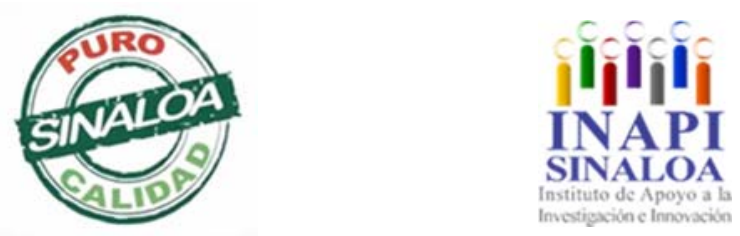

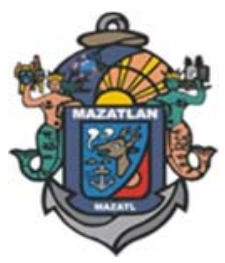

Mazatlán, Sinaloa 3-7 junio 2019

Calidad del Agua y Saneamiento 

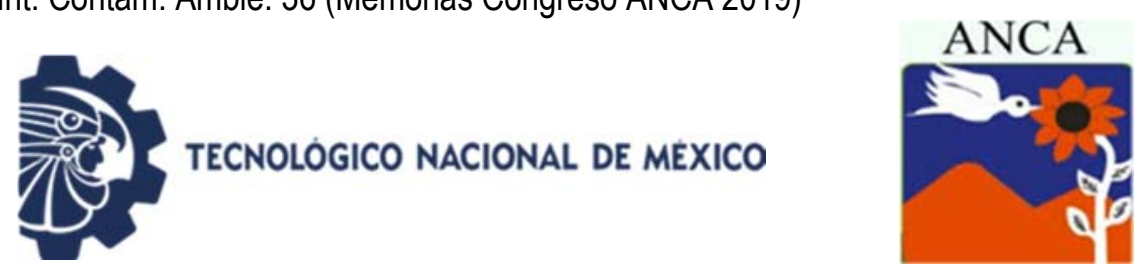

\title{
Water quality assessment of the Ramsar site: Laguna de Tecocomulco
}

\author{
Cordero Lezama A*, Martínez Hernández S
}

Instituto de Ciencias Básicas e Ingeniería. Centro de Investigaciones Biológicas. Universidad Autónoma del Estado de Hidalgo. Carr. Pachuca-Tulancingo, Km. 4.5, Col. Carboneras, C.P. 42074, Mineral de la Reforma, Hidalgo, México *arthurcordero@gmail.com

\begin{abstract}
The Tecocomulco Lagoon is the last relict wetland of the historic lakes that existed in the great basin of Mexico. Habitat of fish, amphibians and birds characteristic of the ancient lakes of Anáhuac, declared a Ramsar site in 2003; source or employment for the inhabitants of the area who depend on fishing and tourism. Despite its importance, there are few studies on the state of degradation of the water body. In order to assess water quality over the last few decades, historical data on physicochemical parameters were compiled and analysed, same that were compared with recent data, at the same time the current degree of eutrophication was determined, with the purpose of elucidating the environmental situation of the Lagoon. First, a bibliographic search was carried out identifying commonly reported parameters; subsequently three samplings were carried out during 2018, evaluating the parameters $\mathrm{pH}$, conductivity, temperature, total phosphorus, total suspended solids and $\mathrm{BOD}_{5}$, as well as chlorophyll a concentration. Studies show that since the end of the 90s until 2014 the wetland has a significant eutrophication by nitrogen, nitrates and phosphorus associated with agriculture and natural processes, it is also observed the variation of some physicochemical parameters related to the rainy and dry seasons. The presence of heavy metals is remarkable, whose mobility is favoured by the temporal variations of the physicochemical parameters. Additionally, during the rainy season, high concentrations of fecal coliforms and $\mathrm{BOD}_{5}$ have been documented.
\end{abstract}

Keywords: Eutrophication, wetland, chlorophyll $\alpha$.

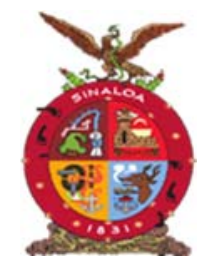

XVIII Congreso Internacional XXIV Congreso Nacional de Ciencias ambientales
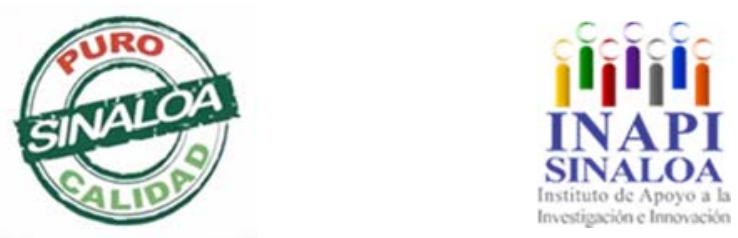

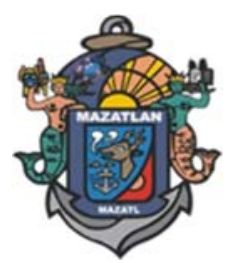

Mazatlán, Sinaloa 3-7 junio 2019 Calidad del Agua y Saneamiento 

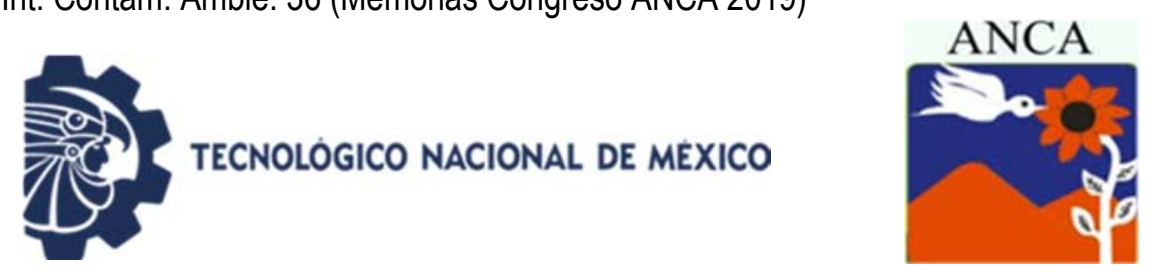

\title{
作
}

\section{Contaminación por metales pesados y la susceptibilidad de las bacterias a un efluente de la ciudad de Puebla}

\author{
Galindo Mendoza TV*, Santamaría Juárez D, Avelino Flores F, Chávez Bravo E \\ Facultad de Ingeniería Química. Instituto de Ciencias-CICM, BUAP. México \\ *tavegame@hotmail.com
}

\section{RESUMEN}

Los metales pesados son contaminantes inorgánicos persistentes en el ambiente, su concentración se magnifica hasta llegar a ser tóxica en algunos ecosistemas acuáticos y predispone la resistencia de bacterias a tales contaminantes. Los metales son bioacumulables y representan un riesgo a la salud pública, por lo que el objetivo de este estudio es determinar la presencia de metales pesados en el agua residual del río Alseseca e identificar la susceptibilidad de bacterias aisladas del efluente. Para ello, se tomó un total de 18 muestras de agua residual durante los periodos otoño-invierno 2017 y primavera-verano 2018, cada una de ellas se trasladó al laboratorio de Patogenicidad Microbiana del CICM-ICUAP para la determinar su calidad microbiológica atendiendo a la NMX-AA-042-SCFI-2015 y su presencia de metales pesados bajo la NOM-001-SEMARNAT-1996. A partir, de las muestras de agua residual se asilaron los géneros Salmonella y Escherichia para identificar su susceptibilidad a metales como: $\mathrm{V}, \mathrm{Co}, \mathrm{Cr}, \mathrm{Cu}, \mathrm{Fe}, \mathrm{Mo}, \mathrm{Ni}$ y $\mathrm{Pb}$ a concentraciones de 100 y 200 ppm. Las muestras de agua residual rebasaron los límites permisibles de coliformes totales y fecales indicando una mala calidad microbiológica del río Alseseca. Se determinó la presencia de $\mathrm{Cu}, \mathrm{Cd}, \mathrm{He}, \mathrm{Hg}$, $\mathrm{As}, \mathrm{Pb}$ en el efluente a diferentes concentraciones. El $100 \%$ de las bacterias aisladas presentaron resistencia a metales, lo que sugiere sobrevivencia y/o adaptabilidad a estos compuestos. Los resultados de este estudio evidencian la contaminación por metales en el efluente y determina que las bacterias aisladas del mismo este efluente son resistentes a dichos contaminantes.

Palabras claves: Metales pesados, contaminación, aguas residuales, enterobacterias.

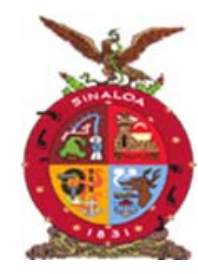

XVIII Congreso Internacional XXIV Congreso Nacional de Ciencias ambientales
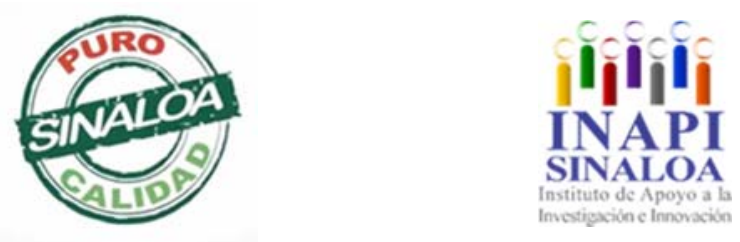

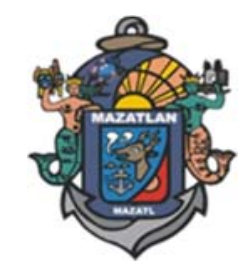

Mazatlán, Sinaloa 3-7 junio 2019

Calidad del Agua y Saneamiento 

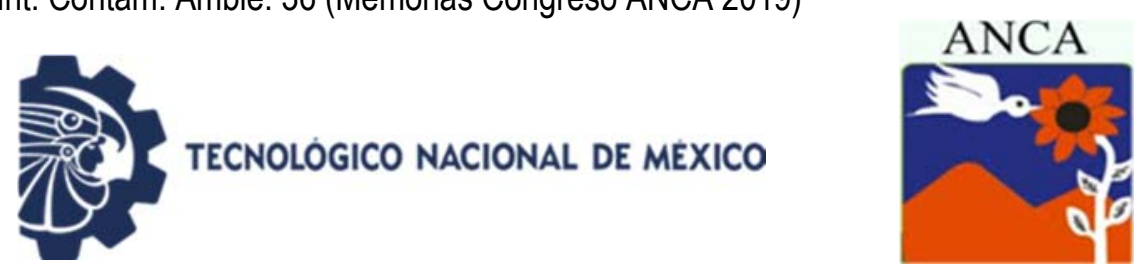

\title{
Pollution by heavy metals and susceptibility of bacteria in effluent from the city of Puebla
}

\author{
Galindo Mendoza TV*, Santamaría Juárez D, Avelino Flores F, Chávez Bravo E \\ Faculty of Chemical Engineering. Institute of Sciences-CICM, BUAP. Mexico \\ *tavegame@hotmail.com
}

\begin{abstract}
Heavy metals inorganic pollutants are persistent in the environment, its concentration is magnified to be toxic in some aquatic ecosystems aquatic ecosystems and predisposes the resistance of bacteria to such contaminants. Metals are bioaccumulative and represent a risk to public health, so the objective of this study is to determine the presence of heavy metals in the wastewater of the Alseseca River and to identify the susceptibility of bacteria isolated from the effluent. To do so, were collected a total of 18 samples of wastewater were taken during the fall-winter 2017 and spring-summer 2018 periods, moved to the laboratory of microbial pathogenicity of CICM-ICUAP for the determining of its microbiological quality according to the NMX-AA-042-SCFI-2015 and its presence of heavy metals under NOM-001-SEMARNAT-1996. From the wastewater samples, the genera Salmonella and Escherichia were isolated. For identify their susceptibility to the metals: $\mathrm{V}, \mathrm{Co}, \mathrm{Cr}, \mathrm{Cu}, \mathrm{Fe}, \mathrm{Mo}, \mathrm{Ni}$ and $\mathrm{Pb}$ at concentrations of 100 and 200ppm. The wastewater samples exceeded the allowable limits of fecal and total coliforms indicating a bad microbiological quality of the Alseseca River. It was determined the presence of $\mathrm{Cu}, \mathrm{Cd}, \mathrm{He}, \mathrm{Hg}, \mathrm{As}, \mathrm{Pb}$ in the effluent at different concentrations. The $100 \%$ of isolated bacteria showed resistance to metals, which suggests survival or adaptability to these compounds. The results of this study demonstrate the pollution by metals in the effluent and determines that the bacteria isolated from the same are resistant to these pollutants.
\end{abstract}

Keywords: Heavy metals, pollution, wastewater, enterobacteriaceae.

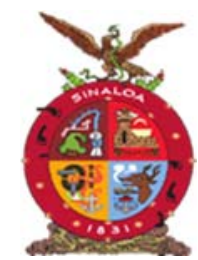

XVIII Congreso Internacional XXIV Congreso Nacional de Ciencias ambientales

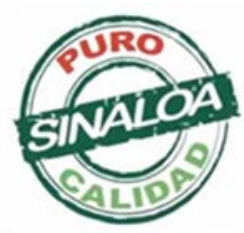

Mazatlán, Sinaloa 3-7 junio 2019

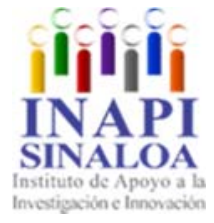

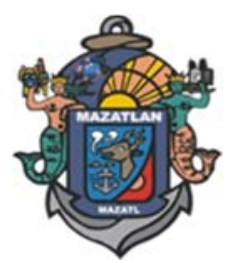

Calidad del Agua y Saneamiento 

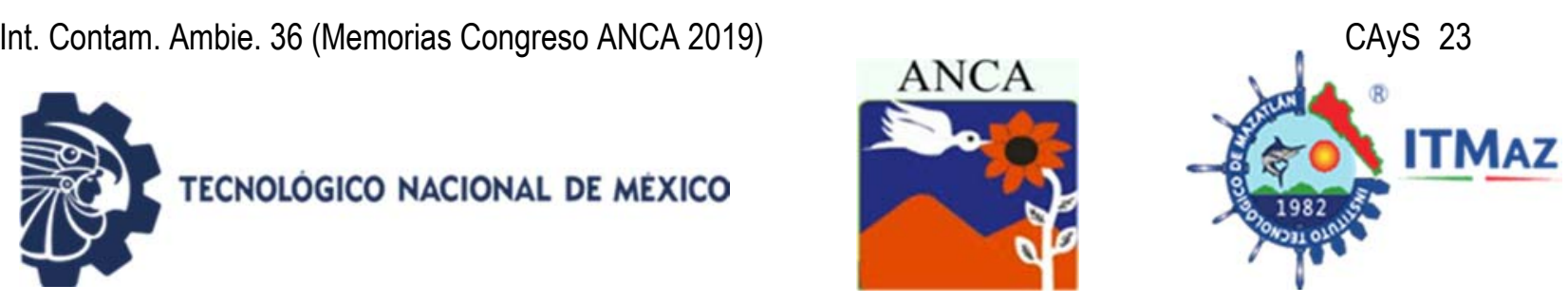

Gobernanza del agua y ambiente en la cuenca del Río Santiago

Lujan Godínez R, Michel Parra JG, Vizcaíno Rodríguez LA, Mayoral Ruiz PA, Caro Becerra JL

Programa de Ingeniería Civil. Centro Universitario Sur. Universidad de Guadalajara.

Universidad Politécnica de la Zona Metropolitana de Guadalajara.

Carr. Tlajomulco-Santa Fe, km. 3.5, No. 595, Col. Lomas de Tejeda,

Tel. (33) 30409900, Tlajomulco de Zúñiga, Jalisco, México

ramen5302@hotmail.com

\section{RESUMEN}

Gobernanza del agua es la buena gestión y participación social en la toma de decisiones en relación con ese recurso. En México, una forma de gobernanza son los Consejos de Cuenca, los cuales promueven el manejo eficiente e integrado de los recursos hídricos en los respectivos ámbitos territoriales. El Consejo de Cuenca del Río Santiago tiene entre sus objetivos el coordinar y apoyar en la formulación y ejecución de programas y acciones dirigidos entre otros propósitos a la conservación de los ecosistemas de la cuenca, los cuales están estrechamente relacionados con el agua en la región. El Río Santiago presenta en numerosos sitios de su cauce severos problemas de contaminación que afectan la salud y permanencia de los ecosistemas. Para definir e implementar alternativas de solución los integrantes del Consejo de Cuenca elaboraron en el 2017 mediante un proceso de planeación participativa, un Programa de Gestión de esa cuenca. Como resultado de los trabajos se definieron estrategias y programas para proteger y conservar el agua y los ecosistemas regionales. No obstante, la importancia del Programa, su aplicación ha estado obstaculizada por las limitaciones que enfrenta el Consejo. Es imprescindible fortalecer las funciones y capacidades del organismo a fin de poder aplicar el Programa de Gestión y lograr el manejo eficiente y sustentable del agua que beneficie a los ecosistemas de la región; de no lograrlo, la condición y disponibilidad de los recursos hídricos se tornará crítica afectando severamente a la población y los ecosistemas de la cuenca.

Palabras clave: Agua, ecosistemas, consejo de cuenca, Río Santiago.

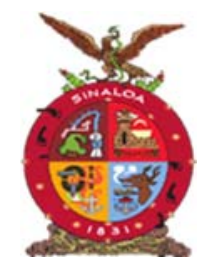

XVIII Congreso Internacional XXIV Congreso Nacional de Ciencias ambientales

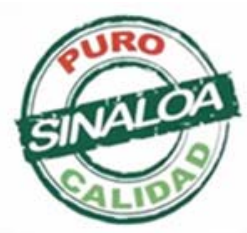

Mazatlán, Sinaloa 3-7 junio 2019
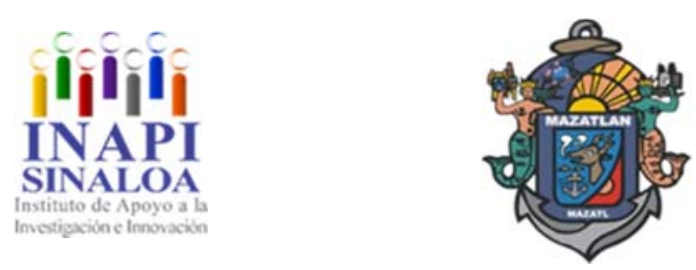

Calidad del Agua y Saneamiento 

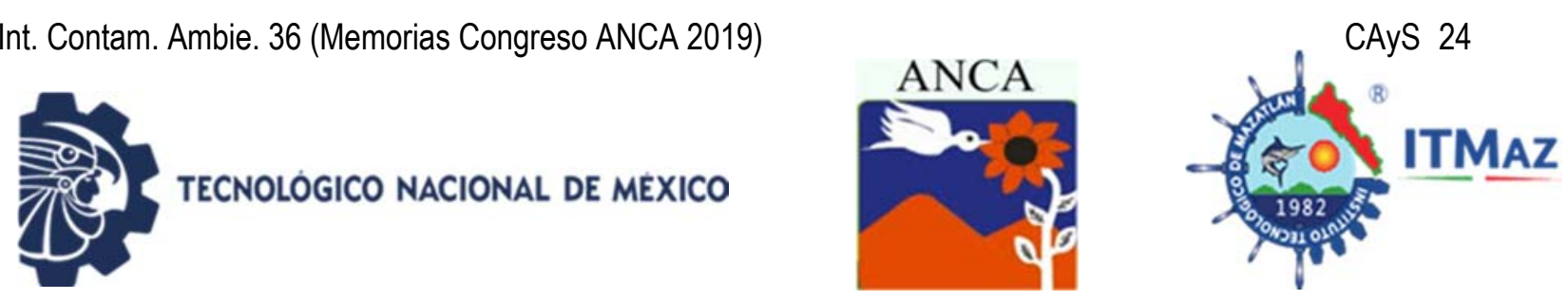

\title{
Water governance and environment in the Santiago River watershed
}

\author{
Lujan Godínez R, Michel Parra JG, Vizcaíno Rodríguez LA, Mayoral Ruiz PA, \\ Caro Becerra JL
}

Programa de Ingeniería Civil. Centro Universitario Sur. Universidad de Guadalajara.

Universidad Politécnica de la Zona Metropolitana de Guadalajara.

Carr. Tlajomulco-Santa Fe, km. 3.5, No. 595, Col. Lomas de Tejeda,

Tel. (33) 30409900, Tlajomulco de Zúñiga, Jalisco, México

ramen5302@hotmail.com

\begin{abstract}
Water governance refers to good water management and water decision taking through social participation. In Mexico, water governance is procured by means of River Basin Councils which promote the efficient and integral management of the regional hydric resources. The Santiago River Basin Council coordinates and supports among other objectives, the creation and implementation of programs and actions aimed to preserve and protect the basin environment due to its close dependence on regional water use. The Santiago River is heavily contaminated in numerous sites located along its path, thus severely affecting the well-being and permanency of the regional ecosystems. The Santiago River Council developed in 2017, by means of a participatory planning process, a Basin Management Program, which identifies a series of programs and strategies aimed to protect and preserve the water and ecosystems of the region. In despite of the importance of the Program its implementation faces many obstacles due to a series of River Basin Council constraints. It is of outmost importance to strengthen the River Basin Council so that it can continue developing actions aimed to attain an efficient and sustainable water management, and hence to benefit the ecosystems of the region; otherwise, the conditions and availability of the water resources will deteriorate severely affecting the watershed's population and ecosystems.
\end{abstract}

Keywords: Water, ecosystems, river basin council, Santiago River.

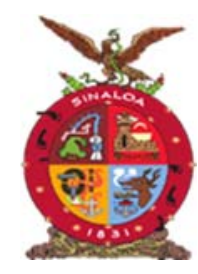

XVIII Congreso Internacional XXIV Congreso Nacional de Ciencias ambientales
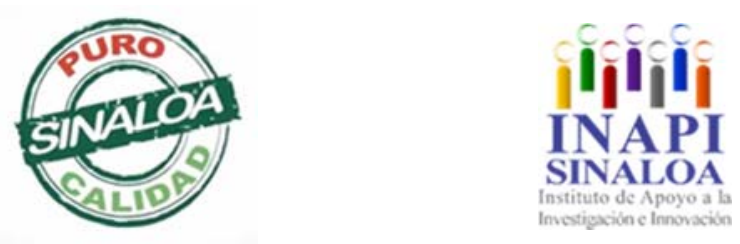

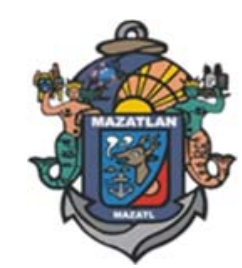

Calidad del Agua y Saneamiento 


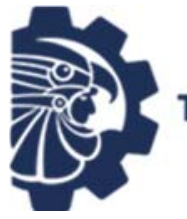

\title{
作
}

\section{Captación de agua de lluvia, caso Facultad de Odontología de la UAEMex}

\author{
Manjarrez Hernández D*, Gómez Hinojos AM \\ Licenciatura en Ciencias Ambientales. Facultad de Planeación Urbana \\ y Regional de la Universidad Autónoma del Estado de México. \\ Mariano Matamoros Sur casi esquina Paseo Tollocan, \\ Col. Universidad Toluca, C.P. 50130, México \\ *david.manjarrez26@gmail.com
}

\section{RESUMEN}

Una de las principales problemáticas que se ha presentado a nivel global, es el desabasto de agua, gracias a que la población crece. Las Instituciones de Educación Superior (IES), presentan de igual manera mayor demanda de este recurso y en el caso de la Universidad Autónoma del Estado de México (UAEMex) la Facultad de Odontología busca dar un uso eficiente del recurso hídrico, es por ello que se planteó la factibilidad de desarrollar un Sistema de Captación de Agua de Lluvia (SCALL), para favorecer el ahorro de agua. La Facultad ocupa al recurso agua como una de sus principales herramientas de trabajo, debido a los servicios que ofrece: como son los diversos tratamientos a los pacientes, así como la limpieza del instrumental; entre otras actividades cotidianas se encuentra el riego de jardines y uso de sanitarios, así como el abastecimiento de dos sistemas de purificación de agua para consumo humano. Determinar la factibilidad de la instalación SCALL, implicó el análisis de la infraestructura de la Facultad de Odontología: sus techos y edificios; los niveles de precipitación de la zona con los datos recabados en la estación Centro (CE) de la Red Automática de Monitoreo Atmosférico de la Zona Metropolitana del Valle de Toluca (RAMAZMVT), así como la evaluación de la calidad del agua de lluvia en la zona de estudio y el análisis general de los costos de material y equipo. Si bien parte de los resultados técnicos apoyan la implementación del SCALL, la inversión económica para su puesta en marcha resulta uno de los principales problemas, tomando en cuenta la inversión.

Palabras clave: Captación de agua, lluvia, urbanismo

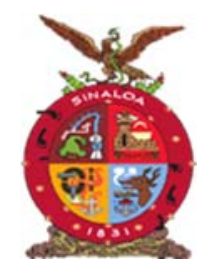

XVIII Congreso Internacional XXIV Congreso Nacional de Ciencias ambientales

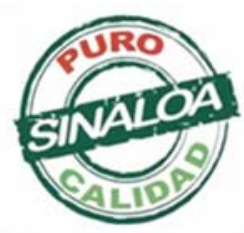

Mazatlán, Sinaloa 3-7 junio 2019
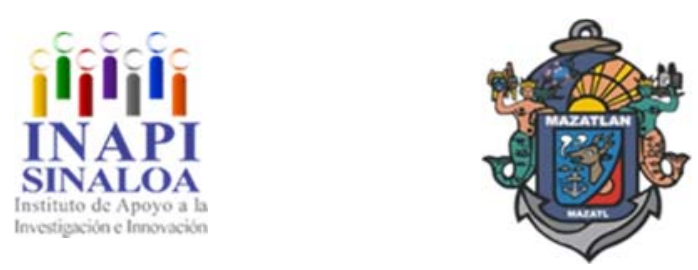

Calidad del Agua y Saneamiento 

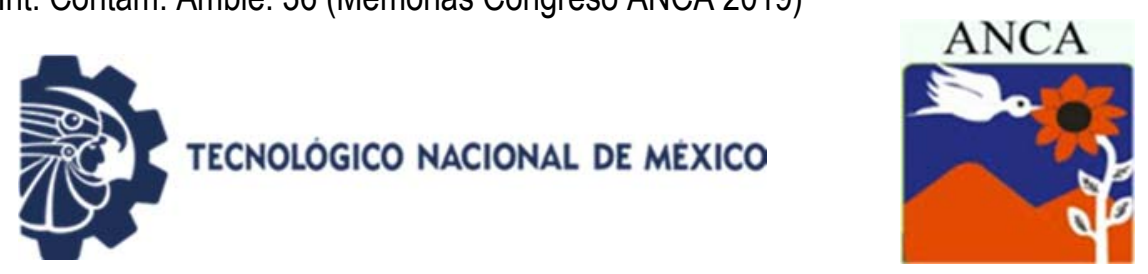

\title{
Rainwater harvesting, case Faculty of Dentistry of the UAEMex
}

\author{
Manjarrez Hernández D*, Gómez Hinojos AM \\ Licenciatura en Ciencias Ambientales. Facultad de Planeación Urbana \\ y Regional de la Universidad Autónoma del Estado de México. \\ Mariano Matamoros Sur casi esquina Paseo Tollocan, \\ Col. Universidad Toluca, C.P. 50130, México \\ *david.manjarrez26@gmail.com
}

\begin{abstract}
One of the main problems that has been presented globally is the case of water, due to the growing population. The Faculty of Dentistry at the University Autonomous of State of Mexico seeks an effective use of water resources, which is why the feasibility was raised. For developing a Rainwater Collection System (RCS), to favour water savings. The Faculty takes care of the water resource as one of its main tools of services is offered to the community and the patients, like treatments; the cleaning of the instrument, among other daily activities, such as irrigation of grass and the use of health services as well as with two water purification systems for human. Determine the feasibility of the RCS installation, involved the analysis of the infrastructure of the Faculty of Dentistry, its roofs and buildings. The levels of the zone with the data collected in the downtown station (CE) of the Automatic Atmospheric Monitoring Network of the Metropolitan Area of Toluca Valley (RAMA-ZMVT), as well as the evaluation of the quality of the rainwater in the study area; as well as the general analysis of the costs of material and equipment. Although it is part of the technical results supported in the implementation of RCS, the economic investment for its implementation in the main problems, taking into account the investment.
\end{abstract}

Keywords: Water collection, rain, urban planning.

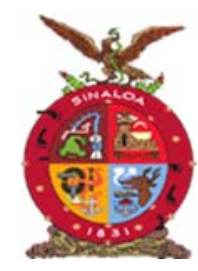

XVIII Congreso Internacional XXIV Congreso Nacional de Ciencias ambientales
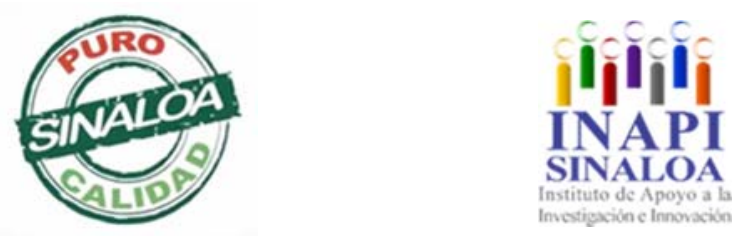

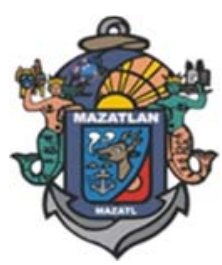

Calidad del Agua y Saneamiento 

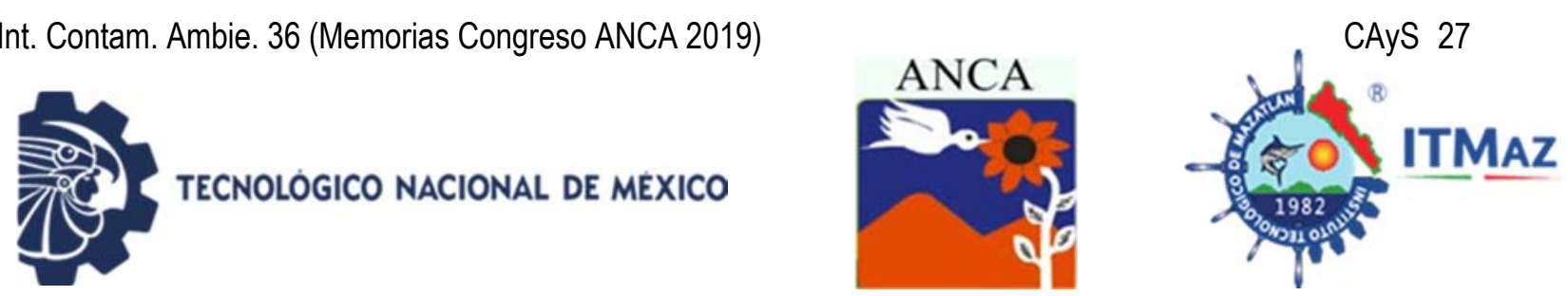

\title{
Espesor de sedimento donde se libera el fósforo en una presa eutroficada
}

\author{
Márquez $\mathrm{H}$, Pacheco $\mathrm{H}$ \\ Universidad Politécnica del Mar y la Sierra, Carr. a Potrerillos del Norote Km. 3, \\ La Cruz, Elota, 82700, Tel.+52(696) 112 5054, Sinaloa, México \\ hmarquez@upmys.edu.mx
}

\section{RESUMEN}

El sedimento juega un papel importante en la dinámica de fósforo $(P)$ en lagos eutróficos. Las concentraciones de $P$ se elevan en los sedimentos superficiales en comparación con las capas más profundas, lo que representa una gran reserva de $\mathrm{P}$ que puede ser liberado a la columna de agua. En este proyecto se determinó la profundidad del sedimento donde se produce la liberación de $\mathrm{P}$, analizando la cantidad de P liberado y la porosidad en el perfil de sedimento del reservorio eutrofizado en Valle de Bravo. El análisis se realizó en núcleos de 5, $10,15,20$ y $25 \mathrm{~cm}$ de espesor de sedimento a partir de la interfase con el agua. Se encontró que en los primeros $15 \mathrm{~cm}$ de espesor de sedimento se llevó a cabo la mayor liberación de $\mathrm{P}$ y a medida que la profundidad en el sedimento aumenta la tasa de liberación se mantiene igual. Además, se encontró que existe una relación entre la porosidad y la liberación de $\mathrm{P}$ en el perfil de sedimento, siendo mayor en las secciones de superficie $(0 \mathrm{a} 10 \mathrm{~cm})$ que en secciones más profundas. Esta relación indica que el flujo de $\mathrm{P}$ en agua intersticial tiende a ser mayor en sedimentos menos compactos. En este contexto, podemos concluir que la liberación de $\mathrm{P}$ en un reservorio eutroficado se presenta en un espesor de aproximadamente $15 \mathrm{~cm}$ de sedimento.

Palabras clave: Núcleos de sedimento, porosidad de sedimento, perfil de sedimento, flujo de fósforo.

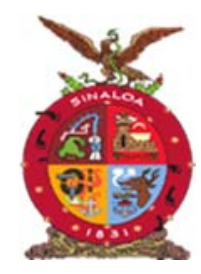

XVIII Congreso Internacional XXIV Congreso Nacional de Ciencias ambientales
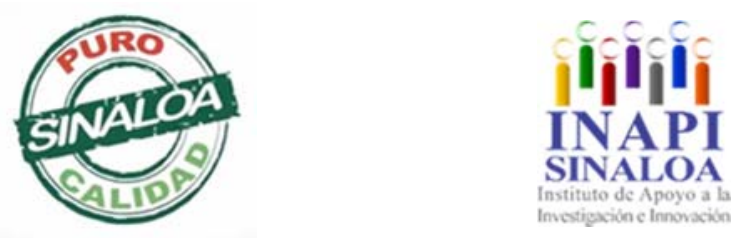

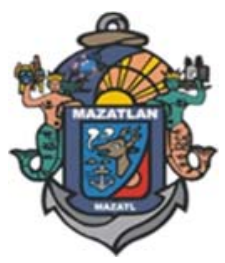

Mazatlán, Sinaloa 3-7 junio 2019

Calidad del Agua y Saneamiento 

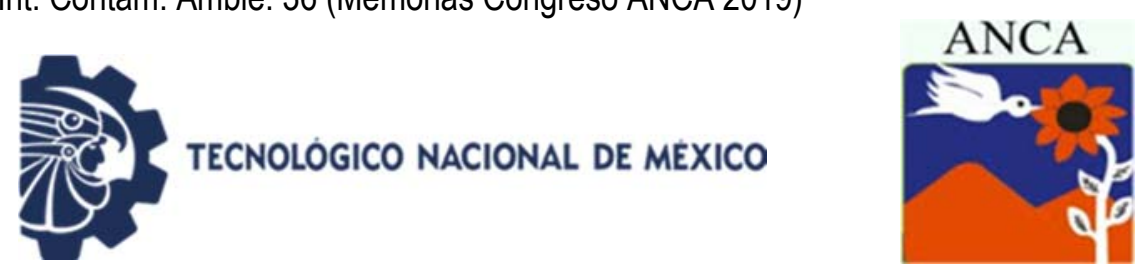

\title{
Sediment thickness where phosphorus released in a eutrophic dam
}

\author{
Márquez $\mathrm{H}$, Pacheco $\mathrm{H}$ \\ Universidad Politécnica del Mar y la Sierra, Carr. a Potrerillos del Norote Km. 3, \\ La Cruz, Elota, 82700, Tel.+52(696) 112 5054, Sinaloa, México \\ hmarquez@upmys.edu.mx
}

\begin{abstract}
Sediment plays an important role in phosphorus $(P)$ dynamics in eutrophic lakes. $\mathrm{P}$ concentrations rise in the surface sediments compared to the deeper layers, which represents a large pool of $P$ that can be released into the water column. In this document, the depth of the sediment where the release of $P$ is produced was determined, analyzing the amount of $P$ released and the porosity in the sediment profile of the eutrophic Valle de Bravo reservoir. The analysis was carried out in cores of $5,10,15,20$ and $25 \mathrm{~cm}$ thickness of sediments from the interface with the water. It was found that the highest release of $P$ was carried out in the first 15 $\mathrm{cm}$ of sediment thickness and as the sediment depth increases the rate of release remains the same. In addition, it was found that there is a relationship between the porosity and the release of $\mathrm{P}$ in the sediment profile, being higher in the surface layer $(0$ to $10 \mathrm{~cm})$ than in deeper layers. This relationship indicates that the flow of $P$ in interstitial water tends to be greater in less compact sediments. In this context, we can say that the release of $P$ in an eutrophized reservoir occurs in a thickness of approximately $15 \mathrm{~cm}$.
\end{abstract}

Keywords: Sediment cores, sediment porosity, sediment profile, Flux phosphorus

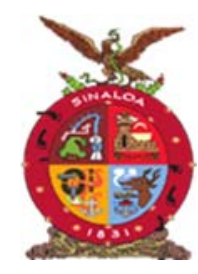

XVIII Congreso Internacional XXIV Congreso Nacional de Ciencias ambientales
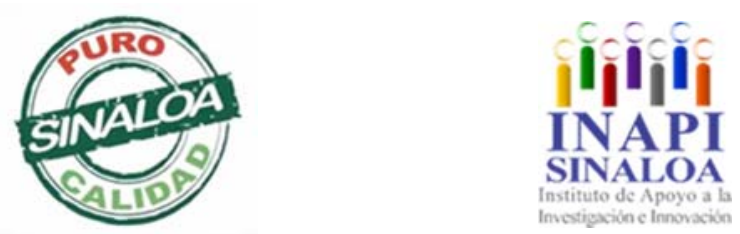

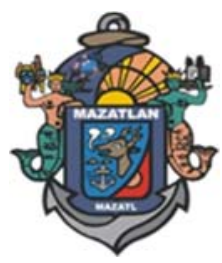

Mazatlán, Sinaloa 3-7 junio 2019

Calidad del Agua y Saneamiento 

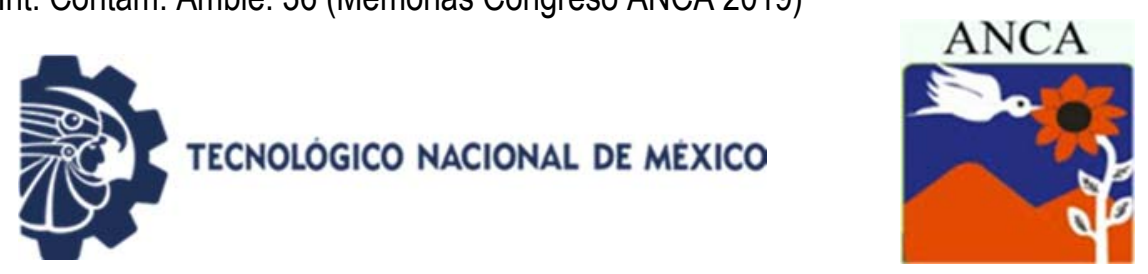

\title{
La vulnerabilidad de los productores rurales y el uso del agua ante el riesgo del cambio climático
}

\author{
Martínez Salomón E, Ibarra Ceceña MG \\ martinez_salomon@uais.edu.mx
}

\begin{abstract}
RESUMEN
La presente investigación, tiene como objetivo principal el aportar un conocimiento respecto de la percepción de los productores rurales, que enfrentan el riesgo del cambio climático, en especial de las heladas atípicas que se han venido presentando durante los últimos años, en la zona norte del estado de Sinaloa, en México, que ha generado que los productores opten por cultivos que utilicen menores cantidades de agua, así como la modificación de los ciclos agrícolas que ofrecen mayor resistencia de los cultivos ante el riesgo del clima. La zona de estudio elegida es El Carrizo, Ahome, Sinaloa, siendo este espacio el más afectado por el riesgo climático y además el menos beneficiado en el acceso al agua; la investigación se realizó en el año 2018. La justificación del tema de estudio está sustentada en que el cambio climático está afectando seriamente a la zona de estudio, provocando la vulnerabilidad económica y social del productor, se requiere de nuevas políticas respecto del uso del agua, para realizar la resiembra de los cultivos en el mismo ciclo en el cual se ve afectado. La metodología del estudio está basada en la teoría fundamentada, que nos ofrece gran flexibilidad, así como el enfoque de análisis cualitativo, histórico, descriptivo, que nos ofrece una manera de pensar como están actuando los productores rurales, ante el riesgo del cambio climático, como mirarlos, en el campo de las ciencias sociales, la metodología aplicada refleja la forma de adquirir el conocimiento sobre una realidad social.
\end{abstract}

Palabras Claves: Vulnerabilidad, agua, cambio climático.

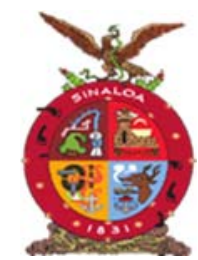

XVIII Congreso Internacional XXIV Congreso Nacional de Ciencias ambientales
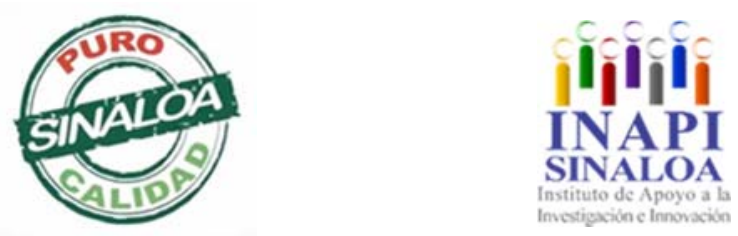

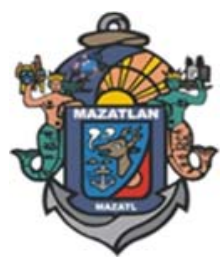

Mazatlán, Sinaloa 3-7 junio 2019

Calidad del Agua y Saneamiento 

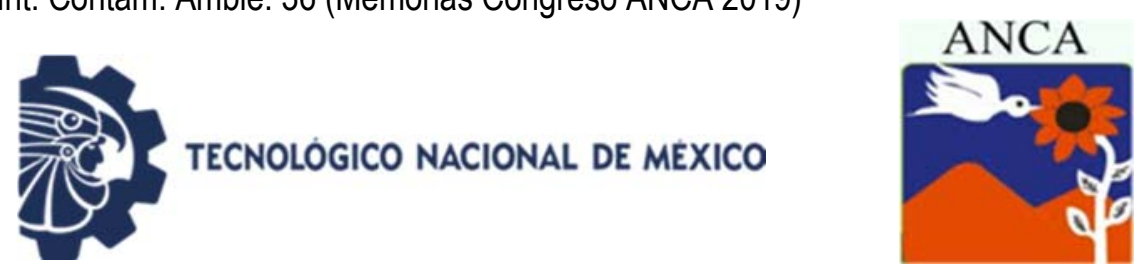

\title{
The vulnerability of rural producer and the use of water on the risk of climatic change
}

\author{
Martínez Salomón E, Ibarra Ceceña MG \\ martinez_salomon@uais.edu.mx
}

\begin{abstract}
The research main objective is to provide knowledge about the perception of rural producers, who face the risk of climate change, especially the atypical frosts that have been occurring in the last recent years. In the north of the country, state of Sinaloa, in Mexico, which generated that the producers have to change the kind of crops for others that use smaller amounts of water, as well as the modification of the agricultural cycles that offer more resistance of the crops to the risk of the climate. The study area is El Carrizo, Ahome, Sinaloa, this place is being the most affected by climate risk and also the least benefited in access to the water for agricultural; The research was conducted in 2018. The justification of the study topic is based on the fact that climate change is seriously affecting the study area, causing economic and social vulnerability to the producer, new policies are required regarding the use of water, to carry out the overseeding of crops in the same cycle in which been affected. The methodology of the study is based on the well-founded theory, which offers us great flexibility, as well as the qualitative, historical, and descriptive analysis approach, which offers us the knowledge of how the way of the producers is thinking and acting, face to the risk of climate change. Also, how we can look at them, in the field of social sciences, the applied methodology reflects the way of acquiring knowledge about a social reality.
\end{abstract}

Keywords: Vulnerability, water, climate change.

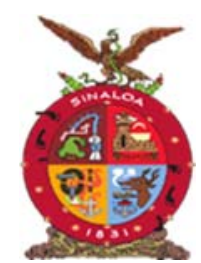

XVIII Congreso Internacional XXIV Congreso Nacional de Ciencias ambientales
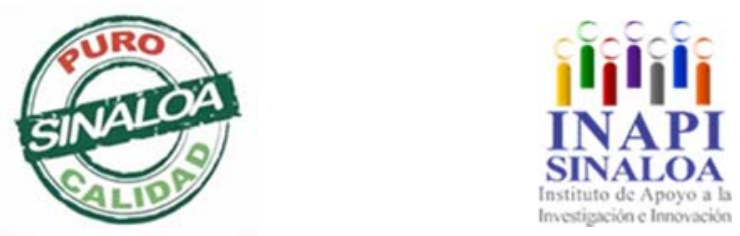

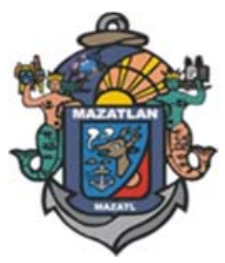

Mazatlán, Sinaloa 3-7 junio 2019

Calidad del Agua y Saneamiento 

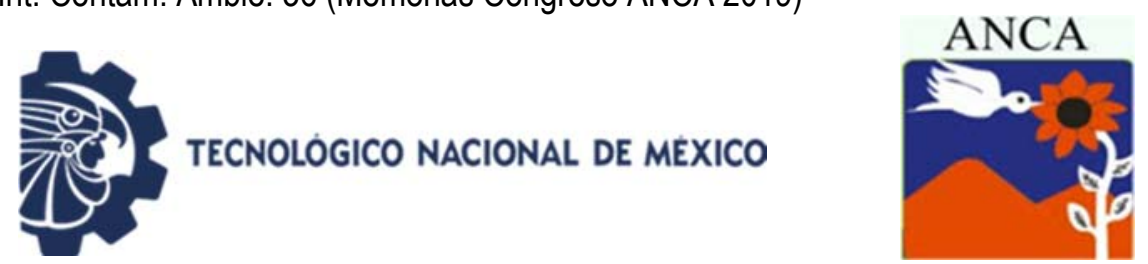

\title{
Toxicidad del agua clorada en peces Cebra
}

\author{
Meléndez MR, García R, Quiñones CA, Max O, Heyer L*, Guevara N, López E \\ Universidad Autónoma de Tamaulipas. México \\ *Iheyer@docentes.uat.edu.mx
}

\section{RESUMEN}

El pez cebra (Danio rerio) es una especie utilizada ampliamente como modelo biológico para estudios ecotoxicologicos. El objetivo de este trabajo fue medir el efecto del agua clorada sobre el desarrollo de embriones y la toxicidad aguda en larvas de $D$. rerio. Los bioensayos se realizaron en el Laboratorio de la Facultad de Ingeniería y Ciencias de la UAT, en el periodo septiembre-diciembre 2018. Los huevos y larvas se obtuvieron de cultivos de laboratorio de $D$. rerio, establecidos en el laboratorio. La sustancia de prueba fue agua del grifo de $\mathrm{Cd}$. Victoria, Tamaulipas, la cual tenía una concentración de Cloro de 620 mg/L, como testigo se utilizó agua libre de cloro. Los especímenes fueron expuestos 96 horas a diluciones de la sustancia de prueba en concentraciones de 12.5, 25, 50 y $100 \%$. Los resultados indican una reducción del 80 al 100\% en la eclosión de huevos y muerte de larvas, también se observaron efectos teratogénicos manifestado por escoliosis en las larvas provenientes de huevos expuestos. La presencia de cloro en el agua puede tener efectos ecotoxicológicos sobre los organismos acuáticos.

Palabras claves: Ecotoxicología, cloro, peces cebra, Toxicidad, agua.

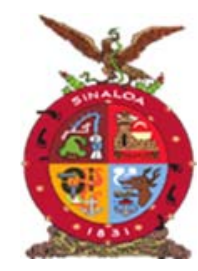

XVIII Congreso Internacional XXIV Congreso Nacional de Ciencias ambientales
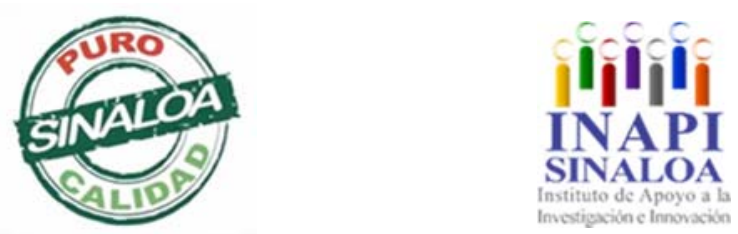

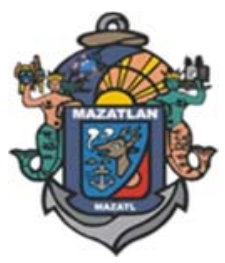

Calidad del Agua y Saneamiento 

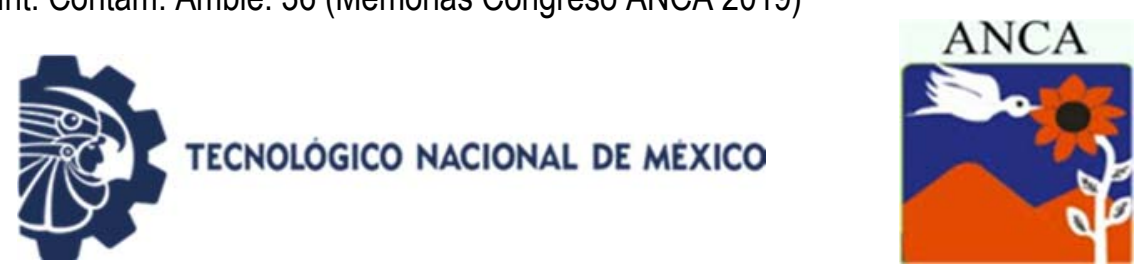

\title{
Toxicity of chlorinated water in Zebra fish
}

Meléndez MR, García R, Quiñones CA, Max O, Heyer Lorenzo*, Guevara N, López E

\author{
Universidad Autónoma de Tamaulipas. México \\ *Iheyer@docentes.uat.edu.mx
}

\begin{abstract}
The zebrafish (Danio rerio) is a species widely used as a biological model for ecotoxicological studies. The objective of this work was to measure the effect of chlorinated water on embryo development and acute toxicity in $D$. rerio larvae. The bioassays were performed in the Laboratory of the Faculty of Engineering and Sciences of the UAT, in the period September-December 2018. The eggs and larvae were obtained from laboratory cultures of $D$. rerio, established in the laboratory. The test substance was tap water from Cd. Victoria, Tamaulipas, which had a chlorine concentration of $620 \mu \mathrm{g} / \mathrm{L}$, chlorine-free water was used as control. The specimens were exposed 96 hours to dilutions of the test substance in concentrations of $12.5,25,50$ and $100 \%$. The results indicate a reduction of 80 to $100 \%$ in the hatching of eggs and death of larvae, also observed teratogenic effects manifested by scoliosis in larvae from exposed eggs. The presence of chlorine in water can have ecotoxicological effects on aquatic organisms.
\end{abstract}

Keywords: Ecotoxicology, chlorine, zebrafish, toxicity, water.

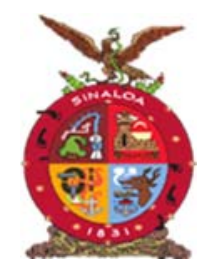

XVIII Congreso Internacional XXIV Congreso Nacional de Ciencias ambientales
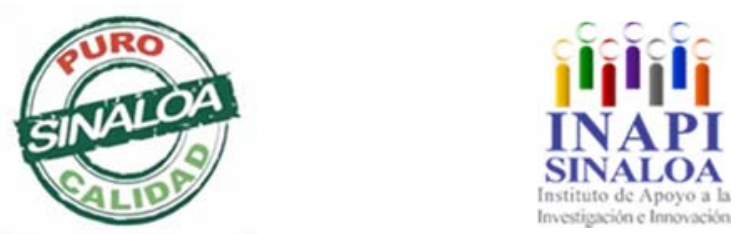

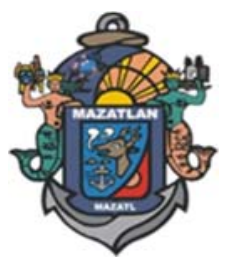

Calidad del Agua y Saneamiento 

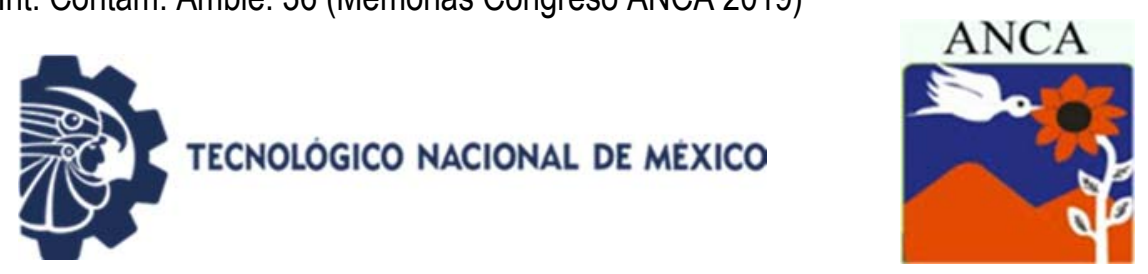

\title{
Calidad del agua de la laguna costera de Coyuca de Benítez, Guerrero, mediante la evaluación de nutrimentos, período 2016-2017
}

\author{
Méndez Ramírez E, Arcos Ramos R, Rivera B \\ Facultad de Estudios Superiores Zaragoza. UNAM. México \\ biolrar13@gmail.com
}

\begin{abstract}
RESUMEN
La base de la pirámide trófica en los ecosistemas acuáticos está dada principalmente por los productores primarios, los cuales están determinados principalmente en su desarrollo y proliferación por la luz, el $\mathrm{CO}_{2}$ de nutrientes. En este estudio se determinó la calidad del agua en la Laguna tomando en cuenta los nutrientes realizando muestreos mensuales de noviembre del 2016 a mayo el 2017, en cinco puntos de monitoreo y dos niveles de profundidad, se realizaron evaluaciones químicas usando el multiparámetro HANNA modelo HI9829 y el multifotómetro $\mathrm{HI} 83200$. Con los resultados obtenidos se realizaron gráficas para evaluar el comportamiento en los parámetros físicos y químicos, así como en los $\mathrm{NH}_{4}{ }^{+}, \mathrm{NO}_{3}, \mathrm{NO}_{2}$ y $\mathrm{PO}_{4}$ para establecer el grado trófico además de un análisis estadístico a los resultados con el programa Statgraphic Centurion 5.2, XVI. EI análisis de resultados demostró que la mayoría de los parámetros tuvieron una distribución no normal, contrario a los nitritos, nitratos y fosfatos los cuales no mostraron diferencias significativas; los parámetros presentaron en su totalidad concentraciones más elevadas en los puntos cercanos a la Barra y al Embarcadero. En conclusión, se establece que el sistema presenta características mesotróficas, con una ligera tendencia hacia la eutrofia y se determinaron tres puntos de monitoreo con mayor impacto en la contaminación de la Laguna, por lo que es necesario la intervención de programas de conservación, mitigación y mejoramiento, así como un monitoreo constante.
\end{abstract}

Palabras clave: Nutrimentos, mesotrófico, eutrofia.

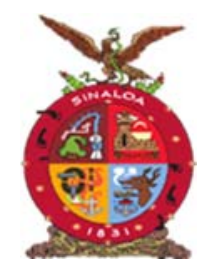

XVIII Congreso Internacional XXIV Congreso Nacional de Ciencias ambientales
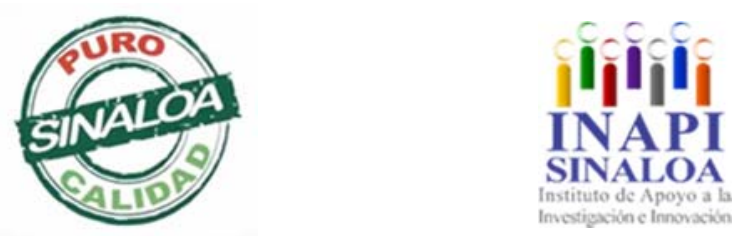

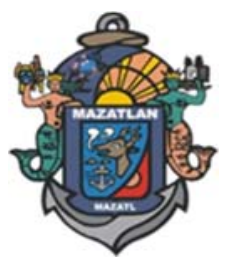

Calidad del Agua y Saneamiento 

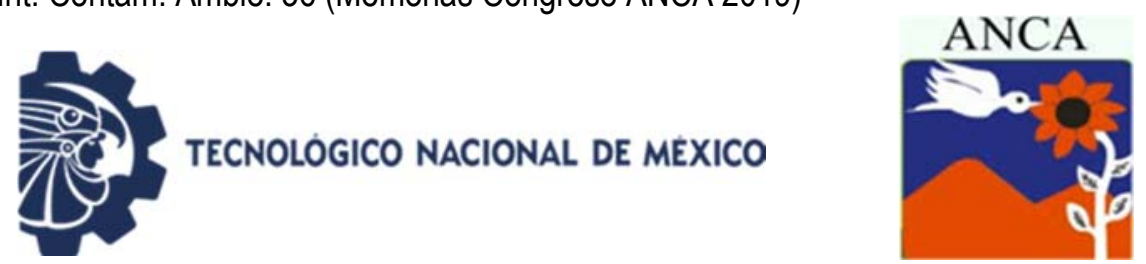

\title{
Water quality of the coastal lagoon of Coyuca de Benítez, Guerrero, through the evaluation of nutrients, period 2016-2017
}

\author{
Méndez Ramírez E, Arcos Ramos R, Rivera B \\ Facultad de Estudios Superiores Zaragoza. UNAM. México \\ biolrar13@gmail.com
}

\begin{abstract}
The base of the trophic pyramid in aquatic ecosystems is mainly given by the primary producers, which are determined in their development and proliferation by light, $\mathrm{CO}_{2}$ as well as nutrients. In this study the water quality in the lagoon was determined taking into account the nutrients, through monthly sampling from November 2016 to May 2017 using five monitoring points at two depth levels, chemical evaluations were performed using the HANNA model HI9829 multiparameter and the HI83200 multiphotometer. With the obtained results, graphs were made to evaluate the behavior in the physical and chemical parameters as well as in the $\mathrm{NH}_{4}+, \mathrm{NO}_{3}, \mathrm{NO}_{2}$ and $\mathrm{PO}_{4}$ to establish the trophic degree in addition to a statistical analysis with the program Statgraphic Centurion 5.2 , XVI. The analysis of results showed that most of the parameters had a nonnormal distribution, contrary to nitrites, nitrates and phosphates, which did not show significant differences; the parameters presented in their entirety higher concentrations in the points close to the Barra and the Embarcadero. In conclusion, it is established that the system has mesotrophic characteristics, with a slight tendency toward eutrophy and three monitoring points are established with greater impact on the Laguna contamination, so it is necessary to intervene in conservation, mitigation and improvement programs. , as well as constant and preferably permanent monitoring.
\end{abstract}

Keywords: Nutrients, mesotrophic, eutrophy.

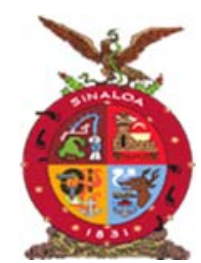

XVIII Congreso Internacional XXIV Congreso Nacional de Ciencias ambientales
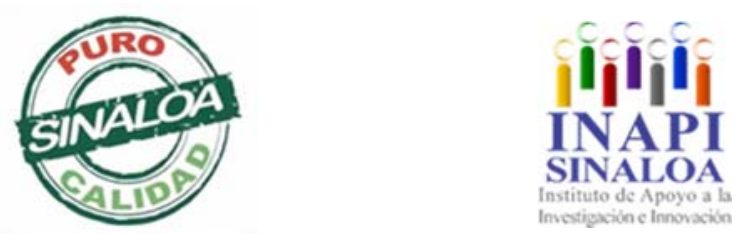

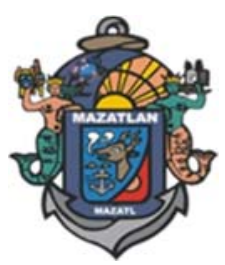

Mazatlán, Sinaloa 3-7 junio 2019

Calidad del Agua y Saneamiento 

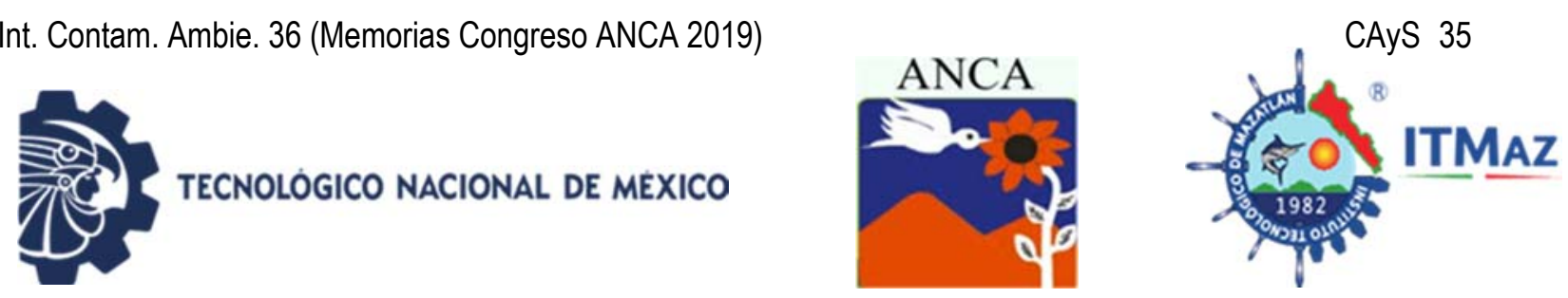

\section{Caracterización del agua subterránea utilizada en comunidades rurales al poniente de la ciudad de Zacatecas}

Navarro Solís O*, Martínez Acuña M, González Trinidad J, Júnez Ferreira H, Bautista Capetillo C, Zavala Trejo M, Veyna Gómez A

Ciencias de la Ingeniería. Unidad Académica de Ciencias Químicas.

Universidad Autónoma de Zacatecas. México

*navarrosoliso@yahoo.com.mx

\section{RESUMEN}

El suministro de agua para consumo humano es crítico en la principal zona socioeconómica del estado de Zacatecas, en esta, hay comunidades rurales con limitaciones en suministra e incumplimiento de los parámetros normativos, específicamente fluoruros $\left(\mathrm{F}^{-}\right)$y arsénico (As) cuyos límites máximos permisibles (LMP) son $1.5 \mathrm{mg} / \mathrm{L}$ y $0.010 \mathrm{mg} / \mathrm{L}$ respectivamente, por lo que el monitoreo constante es primordial para una adecuada gestión de esta problemática. El objetivo de esta investigación fue caracterizar el agua utilizada en 6 comunidades rurales ubicadas al poniente de la ciudad de Zacatecas, mediante muestreo de enero a marzo del 2019 durante el tiempo de extracción diaria, obteniendo 5 muestras en el pozo 1, siete en el 2, cuatro en el 3, siete en el 4 , seis en el 5 y siete en el 6 , con mediciones en campo de $\mathrm{pH}$, conductividad eléctrica, oxígeno disuelto, potencial óxido-reducción y alcalinidad, cuantificando en el laboratorio: $\mathrm{Ca}^{2+}, \mathrm{Mg}^{2+}, \mathrm{Na}^{+}, \mathrm{K}^{+}, \mathrm{HCO}_{3}{ }^{-}, \mathrm{SO}_{4}{ }^{2-}, \mathrm{Cl}^{-}, \mathrm{NO}_{3}{ }^{-}, \mathrm{F}^{-} \mathrm{y}$ As. Los resultados muestran 3 pozos con facies hidrogeoquímicas bicarbonatadas cálcicas, 2 bicarbonatadas sódicas y 1 sulfatada mixta. Los F-se obtuvieron por arriba del LMP (1.66 y 2.22 $\mathrm{mg} / \mathrm{L}$ ) en 2 pozos, implicando posible extracción de flujos regionales, mientras que el As, presenta en el pozo la misma situación, con la particularidad de mostrar tendencia creciente en la concentración respecto al tiempo en 3 de los aprovechamientos (0.058 a $0.067,0.033$ a 0.038 y 0.051 a $0.067 \mathrm{mg} / \mathrm{L}$ ) como posible condición geológica natural de movilidad facilitado por la actividad extractiva.

Palabras claves: Agua subterránea, facies hidrogeoquímicas, arsénico, fluoruro.

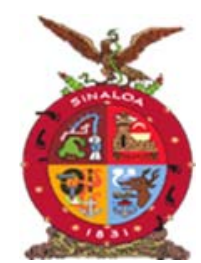

XVIII Congreso Internacional XXIV Congreso Nacional de Ciencias ambientales
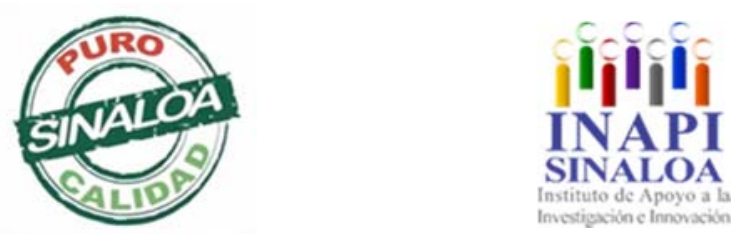

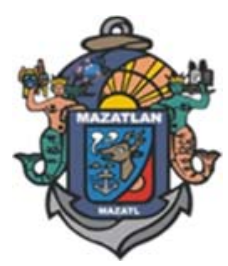

Mazatlán, Sinaloa 3-7 junio 2019

Calidad del Agua y Saneamiento 

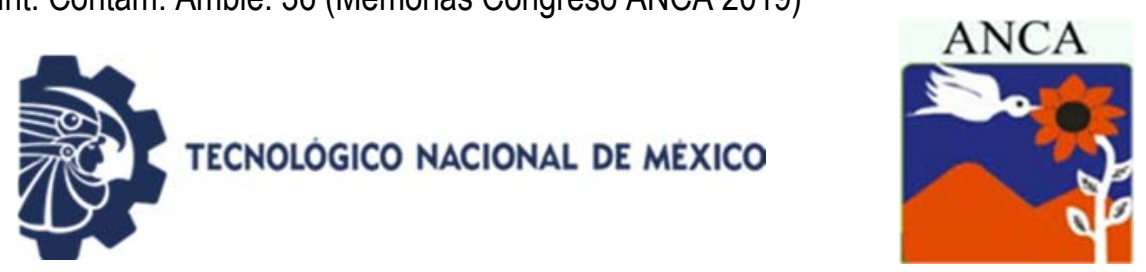

\title{
Characterization of groundwater used in rural communities west of the city of Zacatecas
}

Navarro Solís O*, Martínez Acuña M, González Trinidad J, Júnez Ferreira H, Bautista Capetillo C, Zavala Trejo M, Veyna Gómez A

Ciencias de la Ingeniería. Unidad Académica de Ciencias Químicas.

Universidad Autónoma de Zacatecas. México

*navarrosoliso@yahoo.com.mx

\begin{abstract}
The supply of water for human consumption is critical in the main socioeconomic zone of the state of Zacatecas. In this, there are rural communities with limitations in quantity supplied and noncompliance with normative quality parameters, specifically fluorides (F-) and arsenic (As) whose maximum permissible limits (LMP) are $1.5 \mathrm{mg} / \mathrm{L}$ and $0.010 \mathrm{mg} / \mathrm{L}$ respectively, so a follow-up is essential for proper management of this problem. The objective of this research was to characterize the water used in 6 rural communities west of the city of Zacatecas. The methodology used was by sampling from January to March 2019. During the daily extraction time, obtaining 5 samples in the well 1 , seven in the 2 , four in the 3 , seven in the 4 , six in the 5 and seven in the 6 . With measurements in the field of $\mathrm{pH}$, electrical conductivity, dissolved oxygen, oxide-reduction potential and alkalinity, quantifying in laboratory: $\mathrm{Ca}^{2+}, \mathrm{Mg}^{2+}, \mathrm{Na}^{+}, \mathrm{K}^{+}, \mathrm{HCO}_{3}{ }^{-}, \mathrm{SO}_{4}{ }^{2-}, \mathrm{Cl}^{-}, \mathrm{NO}_{3}{ }^{-}$, $\mathrm{F}$-and As. The results show 3 wells with hydrogeochemical calcium bicarbonated facies, 2 sodium bicarbonates and 1 mixed sulphated. The F-were obtained above the LMP (1.66 and $2.22 \mathrm{mg} / \mathrm{L})$ in 2 uses, implying possible extraction of regional flows. While that the As presents in the 6 the same situation, with the particularity of increasing trend with respect to time in 3 wells $(0.058$ to $0.067,0.033$ to 0.038 and 0.051 to $0.067 \mathrm{mg} / \mathrm{L}$ ) as possible natural geological condition of mobility facilitated by the mining activity nearby.
\end{abstract}

Keywords: Groundwater, hydrogeochemical facies, arsenic, fluoride.

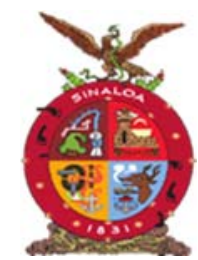

XVIII Congreso Internacional XXIV Congreso Nacional de Ciencias ambientales

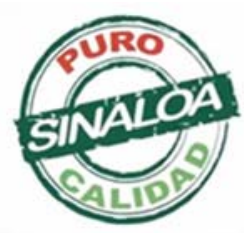

Mazatlán, Sinaloa 3-7 junio 2019

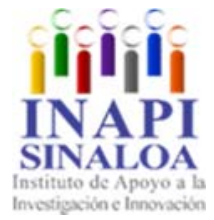

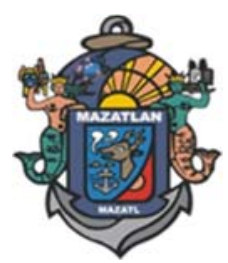

Calidad del Agua y Saneamiento 

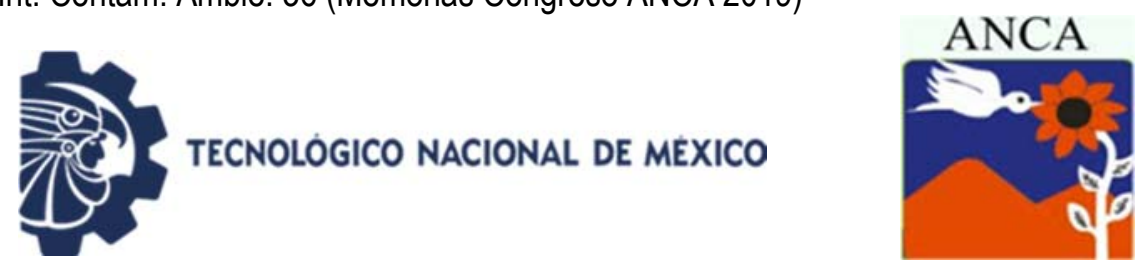

\title{
Calidad del agua del Rio Sacramento, Chihuahua, Chihuahua
}

\author{
Ramírez Rejogochi S, Luévano Gurrola S \\ Facultad de Zootecnia y Ecología. Universidad Autónoma de Chihuahua. \\ Periférico Francisco R. Almada km. 1, 31453, Chihuahua, México \\ a291052@uach.mx
}

\section{RESUMEN}

El objetivo general de este trabajo consistió en analizar la calidad del agua del rio Sacramento, para determinar si es adecuado para el riego de hortalizas, el consumo de ganado. Evaluando un sector del rio, cuya poligonal está ubicada a lo largo de 7 kilómetros del rio Sacramento a la altura del kilómetro 16 carretera Aldama Chihuahua y la intersección con el Boulevard Juan Pablo II, por encontrarse en esa área la mayor densidad población por el ejido Tabalaopa, colonia Palestina y otros pos-lados que utilizan el agua del Rio Sacramento para el riego agrícola, hortalizas y ganado. Dentro de esta área se fijaron 5 puntos de muestreo para levantar muestras representativas para aplicarles análisis fisicoquímico del agua y en laboratorio se identificaron los metales pesados que fueron comparados posteriormente con los límites máximos permisibles en la Norma Oficial Mexicana NOM-SSA1-127-1994 y asegurar la confiabilidad en el uso agrícola.

Palabras clave: Agua, evaluar, calidad, aptitud, normas mexicanas, contaminación.

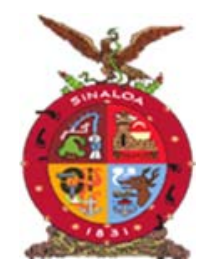

XVIII Congreso Internacional XXIV Congreso Nacional de Ciencias ambientales
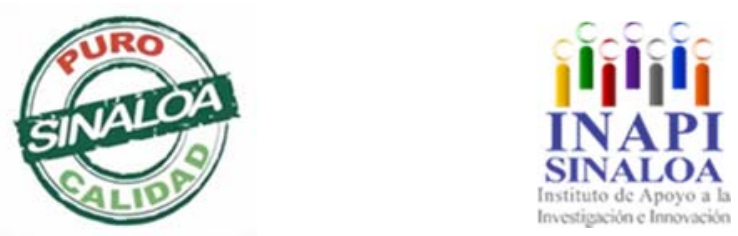

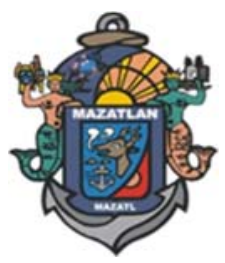

Mazatlán, Sinaloa 3-7 junio 2019

Calidad del Agua y Saneamiento 

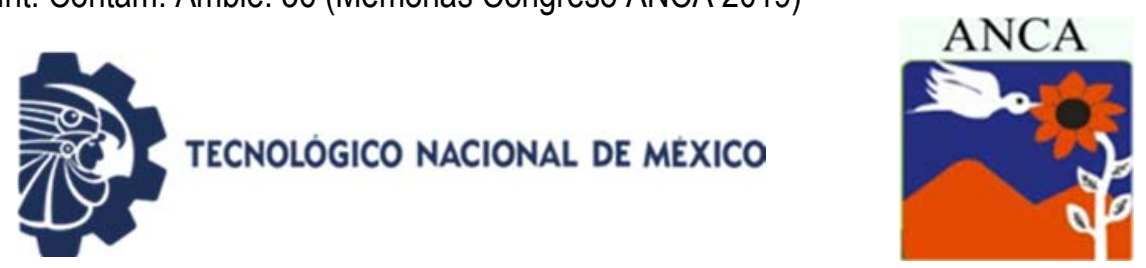

\title{
Water quality of the Sacramento River, Chihuahua, Chihuahua
}

\author{
Ramírez Rejogochi S, Luévano Gurrola S \\ Facultad de Zootecnia y Ecología. Universidad Autónoma de Chihuahua. \\ Periférico Francisco R. Almada km. 1, 31453, Chihuahua, México \\ a291052@uach.mx
}

\begin{abstract}
The general objective of this work was to analyze the water quality of the Sacramento River, to determine the appropriate use in the irrigation of vegetables, vegetables and livestock consumption. Evaluated from a sector of the river, whose polygon is located along 7 kilometers of the Sacramento River at the kilometer 16 of the Aldama Chihuahua highway and the intersection with the Juan Pablo II Boulevard. Due to the fact that the highest population density is in that area (ejido Tabalaopa, Palestina colony among others) that use the water of the river sacramento for agricultural irrigation of vegetables and livestock. Within this area, the distribution of the 5 sampling points of interest was identified to collect the representative samples corresponding to the physicochemical analysis of the water, which from the laboratory analysis were identified the heavy metals that were later compared with the maximum permissible limits in Official Mexican Standard NOM-SSA1-127-1994 and ensure reliability in agricultural use.
\end{abstract}

Keywords: Water, evaluate, quality, aptitude, Mexican standards, pollution.

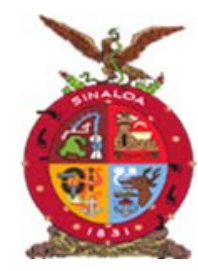

XVIII Congreso Internacional XXIV Congreso Nacional de Ciencias ambientales
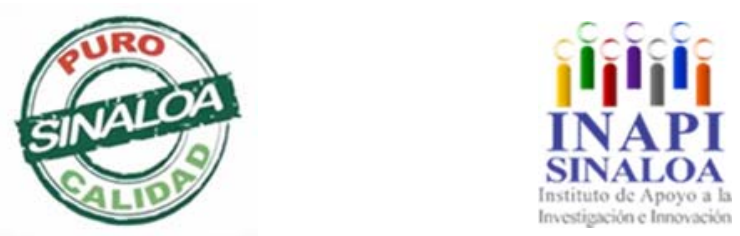

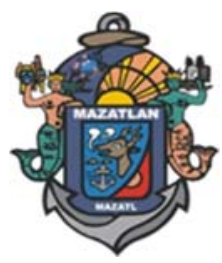

Calidad del Agua y Saneamiento 

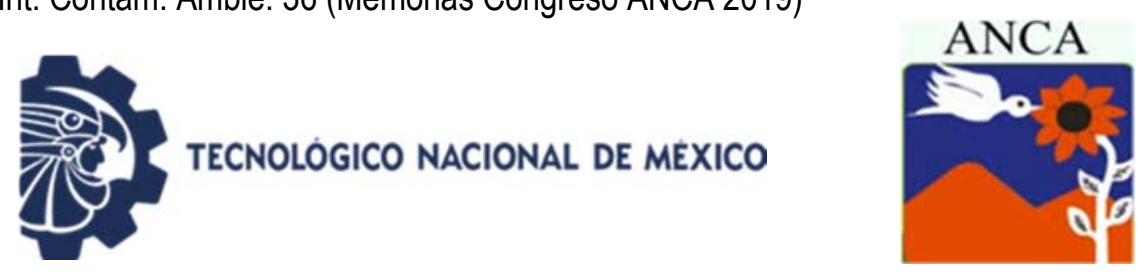

\title{
Estudio del potencial de la semilla de guayaba para la remoción de arsénico de agua
}

\author{
Rivas Herrera M, Galván Camargo A, Altanasa L, Osornio Rubio R, \\ Almanza Rangel $S^{*}$
}

Departamento de Ingeniería Ambiental. Tecnológico Nacional de MéxicoInstituto Tecnológico de Celaya. Antonio García Cubas Pte. No. 600 esq. Av. Tecnológico, 38010, Celaya, Guanajuato, México

*susana.almanza@itcelaya.edu.mx

\section{RESUMEN}

En la actualidad, la contaminación del agua es un tema apremiante en cuestiones ambientales, la ONU reporta que las principales fuentes de contaminación son los efluentes industriales, que genera entre otros contaminantes la presencia de metales pesados en cuerpos de agua. Por lo que la presente investigación tiene como finalidad evaluar el potencial de la semilla de guayaba para la remoción de arsénico en agua. Se estudió este metal pesado debido a su alta toxicidad y que ha sido reportado en altas concentraciones en 2,500 pozos ubicados en el Estado de Guanajuato. Se seleccionó la semilla de guayaba como adsorbente debido a su alto contenido de fibra ( $80 \%)$, la cual posee acción floculante, que genera mediante intercambio iónico y adsorción de metales. Las semillas de guayaba fueron obtenidas de frutos de la región del Bajío en Gto. México, fueron caracterizadas evaluando su\%humedad,\%cenizas, PZC y FTIR. Pruebas de adsorción las semillas en base seca fueron colocadas en matraces Erlenmeyer con $50 \mathrm{~mL}$ de una solución de arsénico a $5 \mathrm{ppm}$, en una relación $1: 10 \mathrm{~g} / \mathrm{mL}$, a temperatura ambiente, y diferentes valores de $\mathrm{pH}(4,5$ y 6$)$ de adsorción del 150 rpm durante 5 horas tomando muestras cada 30 minutos, para la cuantificación de adsorción por UV-VIS. EI PZC es un parámetro importante en estudios de remoción, para establecer la contribución de cargas en la superficie del material. Las semillas presentaron un PZC de 5.2, consistente con los resultados de remoción, ya que se logró una remoción eficiente en los sistemas a $\mathrm{pH} 4$, debido a que la carga de la superficie a este $\mathrm{pH}$ favorece la retención de los iones $\left(\mathrm{AsO}_{4}\right)^{3-}$. El mayor porcentaje de remoción obtenido fue del $92 \%$, logrando el equilibrio del sistema a las $3 \mathrm{~h}$. La cinética de remoción fue de primer orden y la isoterma de Langmuir fue el modelo que mejor ajustó al proceso, por lo que se concluye que es viable el uso de la semilla de guayaba para la remoción de arsénico.
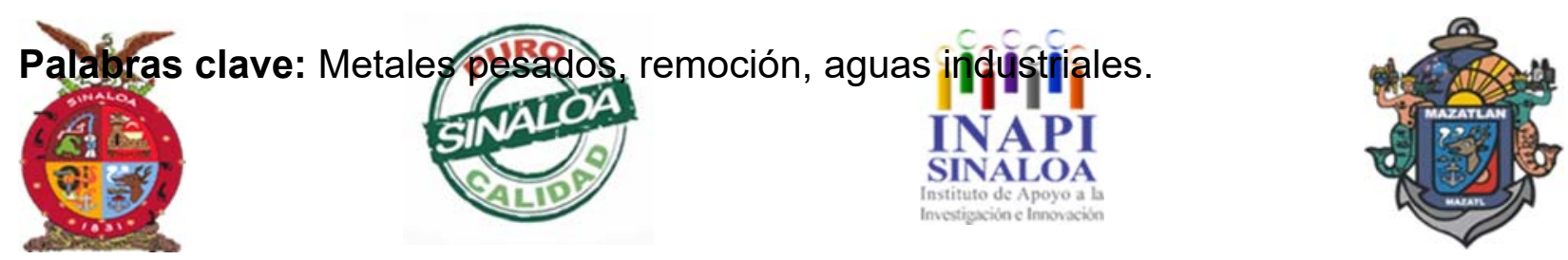

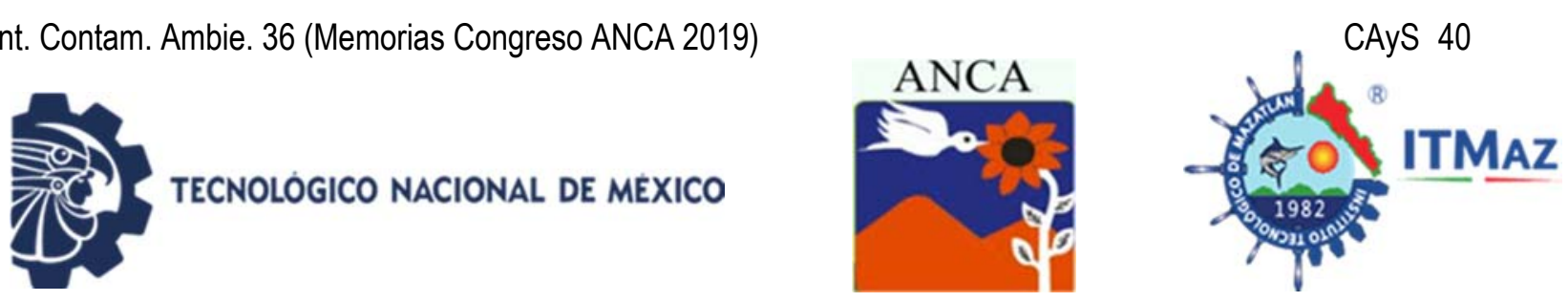

\title{
Study of the potential of the guava seed for the removal of water arsenic
}

\author{
Rivas Herrera M, Galván Camargo A, Altanasa L, Osornio Rubio R, \\ Almanza Rangel $\mathrm{S}^{*}$
}

Departamento de Ingeniería Ambiental. Tecnológico Nacional de MéxicoInstituto Tecnológico de Celaya. Antonio García Cubas Pte. No. 600 esq. Av. Tecnológico, 38010, Celaya, Guanajuato, México

*susana.almanza@itcelaya.edu.mx

\begin{abstract}
Currently, water pollution is a pressing issue in environmental issues, the UN reports that the main sources of pollution are industrial effluents, which generates among other pollutants the presence of heavy metals in bodies of water. Therefore, the purpose of this research is to evaluate the potential of guava seed for the removal of arsenic in water. This heavy metal was studied due to its high toxicity and has been reported in high concentrations in 2,500 wells located in the State of Guanajuato. The guava seed was selected as an adsorbent due to its high fiber content (80\%), which possesses flocculant action, generated by ion exchange and metal adsorption. Guava seeds were obtained from fruits of the Bajío region in Gto. Mexico, were characterized by evaluating their\% humidity, $\%$ ash, PZC and FTIR. Adsorption tests seeds in dry base were placed in Erlenmeyer flasks with $50 \mathrm{~mL}$ of a solution of arsenic at $5 \mathrm{ppm}$, in a ratio $1: 10 \mathrm{~g} / \mathrm{mL}$, at room temperature, and different $\mathrm{pH}$ values (4,5 and 6) of adsorption of 150 rpm for 5 hours taking samples every 30 minutes, for the quantification of adsorption by UV-VIS. The PZC is an important parameter in studies of removal, to establish the contribution of charges on the surface of the material. The seeds presented a PZC of 5.2, consistent with the removal results, since an efficient removal was achieved in the systems at $\mathrm{pH} 4$, because the surface charge at this $\mathrm{pH}$ favors the retention of the ions (AsO4) 3-The highest percentage of removal obtained was $92 \%$, achieving the balance of the system at 3 o'clock. The kinetics of removal was of the first order and the Langmuir isotherm was the model that best adjusted the process, so it is concluded that the use of guava seed for the removal of arsenic is viable.
\end{abstract}

Keywords: Heavy metals, removal, industrial waters.

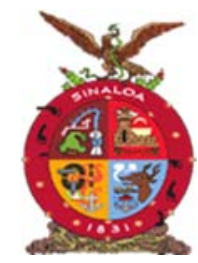

XVIII Congreso Internacional XXIV Congreso Nacional de Ciencias ambientales

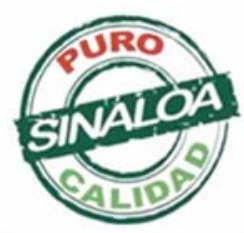

Mazatlán, Sinaloa 3-7 junio 2019

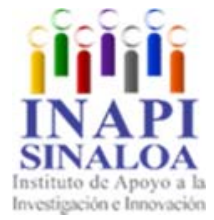

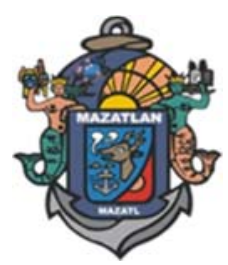

Calidad del Agua y Saneamiento 

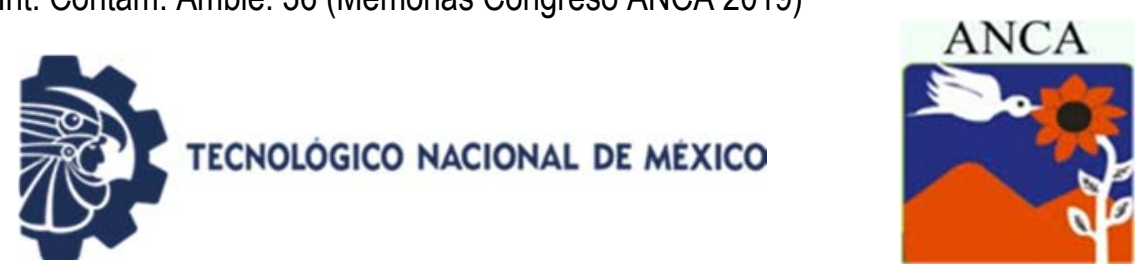

\title{
Parámetros fisicoquímicos y microbiológicos para la determinación de la calidad de agua para uso y consumo en Ciudad Juárez
}

\author{
Santillanes Flores M, Soto Padilla M, Hernández Peña C \\ Licenciatura en Biología. Departamento Ingeniería Civil y Ambiental. \\ Instituto de Ingeniería y Tecnología. Departamento de Ciencias Químico \\ Biológicas. Instituto de Ciencias Biomédicas. Universidad Autónoma de Ciudad \\ Juárez, \\ Chihuahua, México \\ carolina.hernandez@uacj.mx
}

\section{RESUMEN}

Ciudad Juárez, cuenta con un recurso acuático importante que comprende a los mantos acuíferos, estos no solamente abastecen a la frontera norte, sino que se encargan de abastecer algunas ciudades del vecino país. Por lo cual, la calidad del agua se ve comprometida por distintos factores. Es por ello que se busca tener una evaluación de las distintas zonas de la ciudad para determinar si el agua cumple con los estándares permisibles que marca la NOM-127-SSA1-1994. Se realizó un estudio donde se tomaron tres muestras de agua de grifo en tres colonias de la ciudad: Anapra, Libramiento y San Ángel, en los meses de febrero a marzo del 2019 donde se evaluaron cloruros, dureza, turbidez, pH, conductividad, acidez, alcalinidad y coliformes totales y fecales. Todos estos análisis se hicieron conforme la metodología que marca cada norma respectivamente. En las tres colonias fueron negativas para coliformes totales y fecales, con respecto a $\mathrm{pH}$ y turbidez no exceden los límites permisibles, la conductividad presenta diferencia significativa entre colonias, mientas que la alcalinidad en Anapra es menor pero es mucho más ácida que en San Ángel y Libramiento, en cloruros todas las colonias sobrepasan los límites y en Anapra es la única colonia donde no sobrepasa los límites con respecto a la dureza. Por lo tanto, algunos parámetros no cumplen con lo que marca la norma, a pesar de que se tiene un monitoreo constante es necesario implementar otro tipo de tecnologías para que haya una mejor calidad del agua que sale del grifo.

Palabras clave: Calidad de agua, agua de grifo, agua de consumo, Ciudad Juárez.

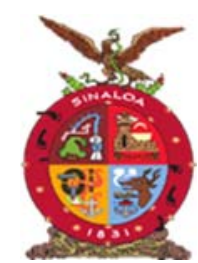

XVIII Congreso Internacional XXIV Congreso Nacional de Ciencias ambientales

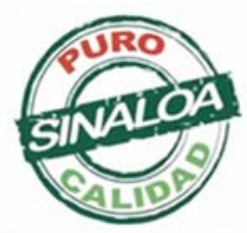

Mazatlán, Sinaloa 3-7 junio 2019
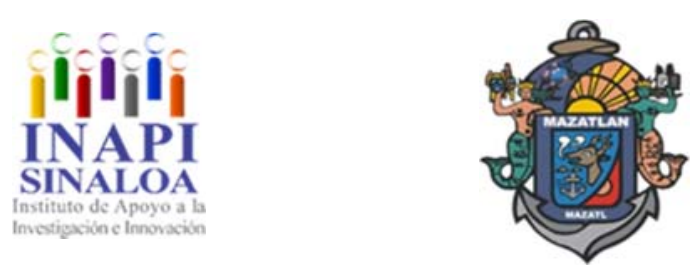

Calidad del Agua y Saneamiento 

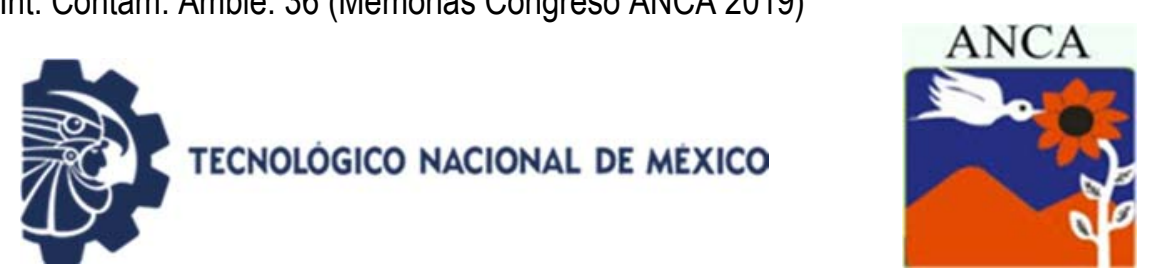

\title{
TECNOLOGICO NACIONAL DE MEXICO
}

\section{Physicochemical and microbiological parameters for the determination of water quality for use and consumption in Ciudad Juarez}

\author{
Santillanes Flores M, Soto Padilla M, Hernández Peña C \\ Licenciatura en Biología. Departamento Ingeniería Civil y Ambiental. \\ Instituto de Ingeniería y Tecnología. Departamento de Ciencias Químico \\ Biológicas. Instituto de Ciencias Biomédicas. Universidad Autónoma de Ciudad \\ Juárez, \\ Chihuahua, México \\ carolina.hernandez@uacj.mx
}

\begin{abstract}
Ciudad Juárez, has an important hydrographic resource that includes aquifers, these not only supply the northern border, but are responsible for supplying some cities in the neighboring country. Therefore, water quality is compromised by different factors. That is why we seek to have an evaluation of the different areas of the city to determine if the water meets the permissible standards set by NOM127-SSA1-1994. A study was conducted where three samples of tap water were taken in three colonies of the city: Anapra, Libramiento and San Angel, in the months of February to March 2019 where chlorides, hardness, turbidity, $\mathrm{pH}$, conductivity, acidity were evaluated, alkalinity and total and fecal coliforms. All these analyzes were made according to the methodology that marks each norm respectively. In the three colonies, there were negative tests for total and fecal coliforms; in pH and turbidity do not exceed the permissible limits; the conductivity presents significant differences between colonies, while the alkalinity in Anapra is lower but is much more acidic than in San Angel and Libramiento. In chlorides all the colonies exceed the limits and Anapra it is the only colony where it does not exceed the limits with respect to the hardness. Therefore, some parameters do not comply with what the standard says, although there is constant monitoring, it is necessary to implement other types of technologies so that there is a better quality of the water that comes out of the tap.
\end{abstract}

Keywords: Water quality, tap water, drinking water, Ciudad Juárez.

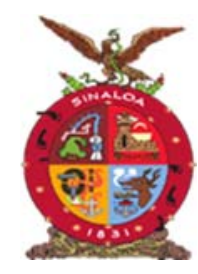

XVIII Congreso Internacional XXIV Congreso Nacional de Ciencias ambientales
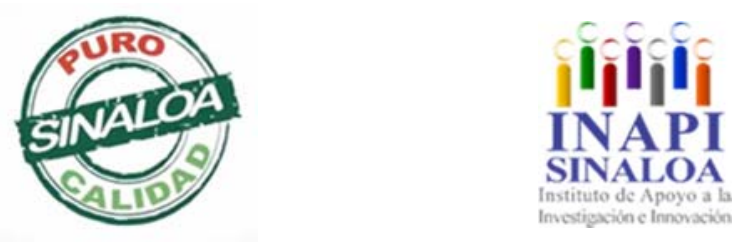

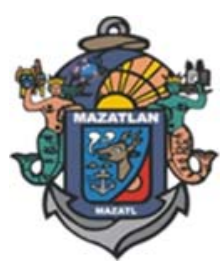

Mazatlán, Sinaloa 3-7 junio 2019

Calidad del Agua y Saneamiento 

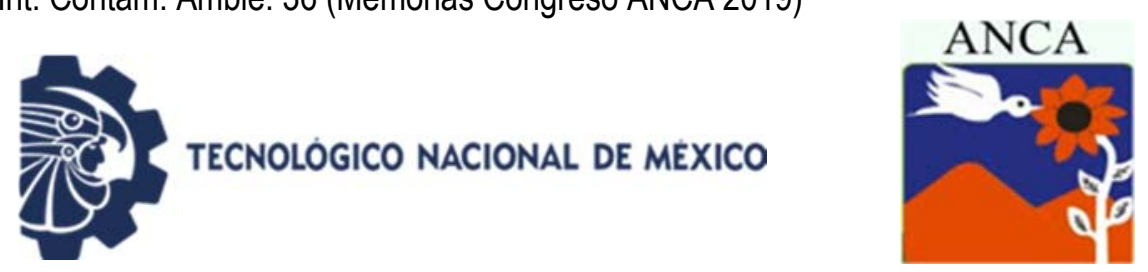

\title{
Propuesta de tratamiento de agua congénita por ablandamiento químico y los lodos generados
}

\author{
Valente Ramírez LA, Martínez Frías U, Gutiérrez Lara MR, López Ramírez S, \\ Barragán Aroche JF
}
Departamento de Ingeniería Química. Facultad de Química UNAM. México rafaelag@unam.mx

\section{RESUMEN}

El proyecto de investigación surge de la necesidad constante de proveer de agua a la industria petrolera para evitar el consumo de agua potable para los procesos de recuperación mejorada (EOR) en los campos petrolíferos mexicanos. Cada vez se requieren grandes cantidades de agua para los procesos de EOR. Actualmente no se dispone de otra fuente de agua, más que el agua congénita o bien el agua de mar. Para el tratamiento de agua congénita y la reinyección en pozos petroleros; se busca minimizar el efecto de la corrosión de los equipos debida al contenido de sales en el agua, utilizando los métodos de tratamiento de agua de como el Ablandamiento Químico. En este trabajo se presentan resultados de un tratamiento por ablandamiento químico aplicado a lotes del agua congénita proveniente de un pozo petróleo de Poza Rica Veracruz, así como una propuesta de disposición de los lodos que se generan. Los resultados obtenidos al utilizar un tren de tratamiento el cual consistió en llevar acabo la reacción de ablandamiento químico, un sedimentador para separar los lodos generados y finalmente un proceso de filtración logrando remociones del $98 \%$ en la dureza total con respecto a la inicial, DQO en un $58 \%$. La caracterización de los lodos mostro que se tienen principalmente sales de $\mathrm{OH}$ y $\mathrm{C}=\mathrm{O}$ por lo que una propuesta de disposición final sería como relleno en suelo.

Palabras clave: Ablandamiento químico, agua congénita, remoción, lodos.

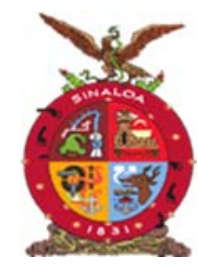

XVIII Congreso Internacional XXIV Congreso Nacional de Ciencias ambientales
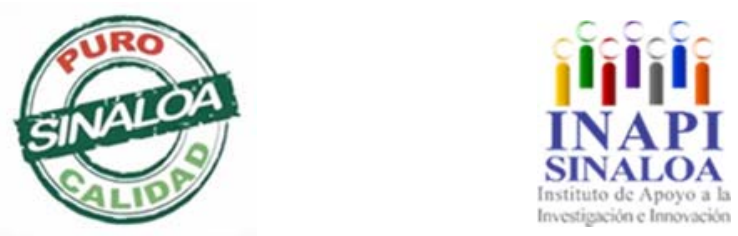

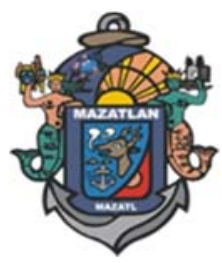

Mazatlán, Sinaloa 3-7 junio 2019

Calidad del Agua y Saneamiento 

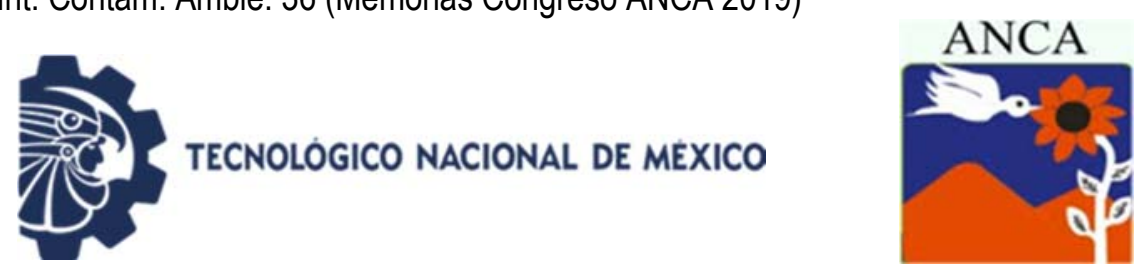

\title{
Congenital water treatment proposal by chemical softening and the sludge generated
}

\author{
Valente Ramírez LA, Martínez Frías U, Gutiérrez Lara MR, López Ramírez S, \\ Barragán Aroche JF \\ Departamento de Ingeniería Química. Facultad de Química UNAM. México \\ rafaelag@unam.mx
}

\begin{abstract}
The research project arises from the constant need to supply water to the oil industry to avoid drinking water for improved recovery processes (EOR) in Mexican oil fields. Each time large amounts of water are required for EOR processes. Currently there is no other source of water, plus congenital water or seawater. For the treatment of congenital water and reinjection in oil wells; It seeks to minimize the effect of corrosion of equipment due to sales content in water, using water treatment methods such as Chemical Softening. This paper presents results of a chemical softening treatment applied to lots of congenital water from an oil well in Poza Rica Veracruz, as well as a proposal for disposal of the sludge being handled. The results obtained when using a treatment train, which consists of carrying out the chemical softening reaction, a settler to separate the generated sludge and finally a filtration process achieving $98 \%$ removals in the total duration with respect to the initial, COD in $58 \%$. The characterization of the sludge showed that they mainly have sales of $\mathrm{OH}$ and $\mathrm{C}=$ $\mathrm{O}$, so a final disposal proposal would be as landfill.
\end{abstract}

Keywords: Chemical softening, congenital water, removal, sludge.

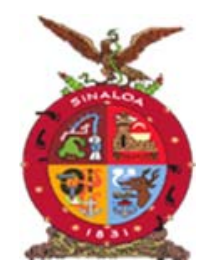

XVIII Congreso Internacional XXIV Congreso Nacional de Ciencias ambientales
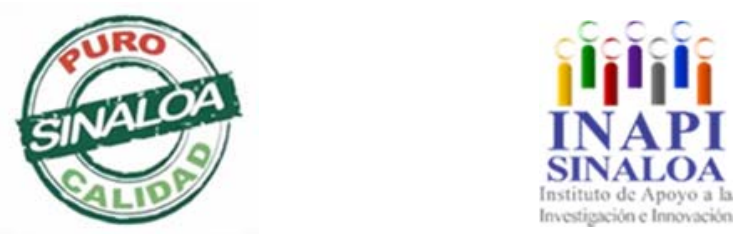

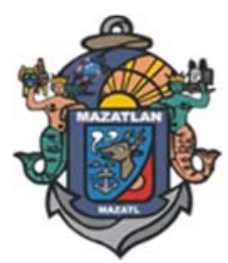

Mazatlán, Sinaloa 3-7 junio 2019

Calidad del Agua y Saneamiento 

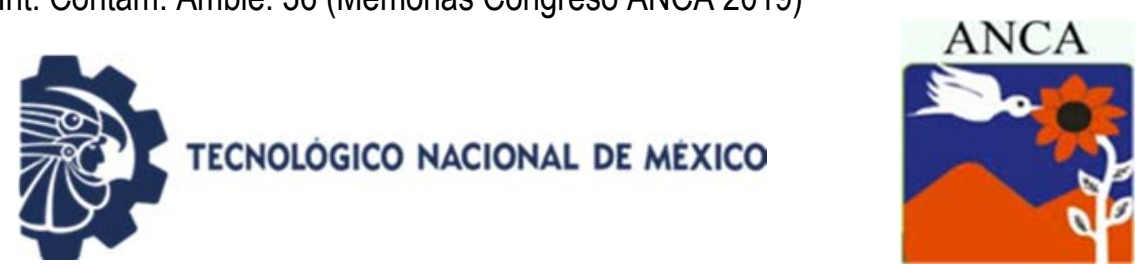

\title{
Análisis de la disponibilidad de agua ante de un incremento de temperatura global de $2^{\circ} \mathrm{C}$ mediante WEAP
}

\author{
Vargas Castilleja R*, Rolón Aguilar J, Pichardo Ramírez R, Tobías Jaramillo R, \\ Sánchez Torres-Esqueda G \\ Facultad de Ingeniería "Arturo Narro Siller". \\ División de Estudios de Posgrado e Investigación. \\ Universidad Autónoma de Tamaulipas. \\ Ingenieros sin Fronteras México, A.C. \\ *rocvargas@docentes.uat.edu.mx
}

\section{RESUMEN}

La investigación fue diseñada para evaluar los recursos hídricos superficiales para diferentes usuarios de agua, considerando infraestructura y políticas del aprovechamiento en la cuenca del Río Soto la Marina en Tamaulipas. El modelo se construyó en WEAP (Water Evaluation and Planning), para simular los gastos medios mensuales base y bajo dos escenarios de emisiones RCP $4.5 \mathrm{~W} / \mathrm{m}^{2}$ (bajo) y $8.5 \mathrm{~W} / \mathrm{m}^{2}$ (alto), para dos Modelos de Circulación General (MCG) al 2051, considerando que en esa fecha se alcanzará en México un incremento de temperatura global de $2^{\circ} \mathrm{C}$ de continuar bajo las mismas tendencias actuales. El modelo GFDL-CM3 muestra que la demanda de agua no satisfecha en el Centro de Demanda (CD) Río Purificación 1 con actividad agrícola será del 25.23\% y $25.04 \%$ para el escenario bajo y alto respectivamente, mientras que para el modelo HADGEM2-ES la demanda insatisfecha será de $22.74 \%$ y $23.34 \%$ para ambos escenarios del mismo $C D$. Se encontraron $C D$ con una eficiencia 0 confiabilidad en la demanda de tal sólo el $41 \%$, tales como Río Purificación 1 y 2 y Río San Antonio cuyas actividades son la agrícola, pecuaria y acuícola. La cobertura de la demanda de agua para un mes seco como enero, indica que casi en el $50 \%$ de los CD no cubrirán la demanda para el 2051 para ambos escenarios del modelo GFDL-CM3. Se resalta la importancia de activar los mecanismos de adaptación en las actividades económicas. Los resultados demuestran la necesidad de una planeación previsora y de adaptación en el manejo de los recursos hídricos.

Palabras clave: Disponibilidad de agua, cambio climático, planeación hídrica, cuenca hidrológica.

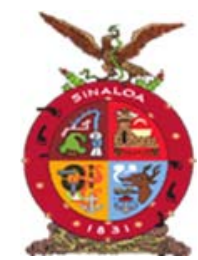

XVIII Congreso Internacional XXIV Congreso Nacional de Ciencias ambientales
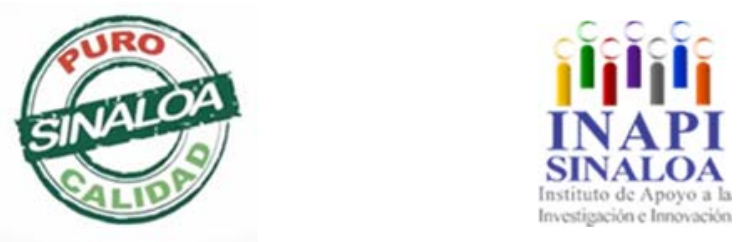

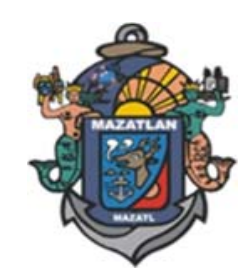

Calidad del Agua y Saneamiento 

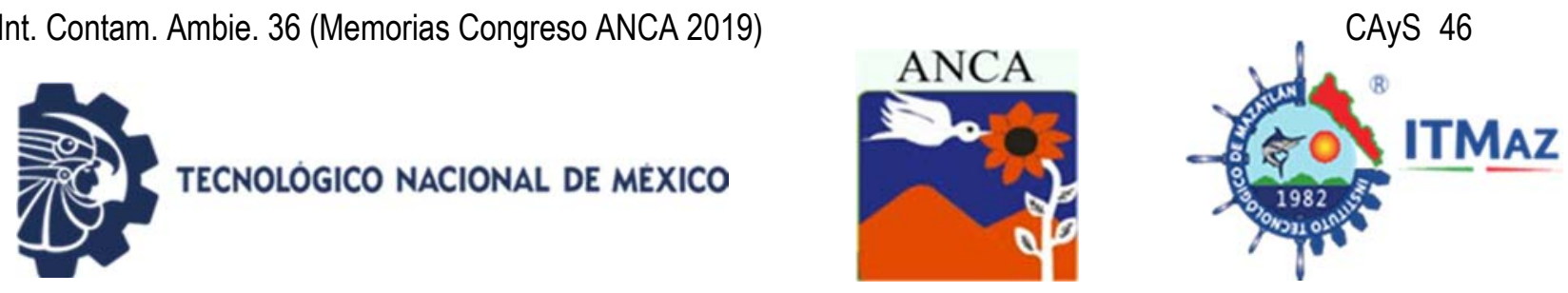

\title{
Analysis of water availability in the face of an increase global temperature of $2^{\circ} \mathrm{C}$ using WEAP
}

Vargas Castilleja $R^{*}$, Rolón Aguilar J, Pichardo Ramírez R, Tobías Jaramillo R, Sánchez Torres-Esqueda G

Faculty of Engineering "Arturo Narro Siller". Division of Postgraduate Studies and Research, Universidad Autónoma de Tamaulipas

Engineers Without Borders México, C.A

*rocvargas@docentes.uat.edu.mx

\begin{abstract}
The research was designed to evaluate surface water resources for different water users, considering infrastructure and development policies in the Soto la Marina River basin in Tamaulipas. The model was constructed in WEAP (Water Evaluation and Planning). To simulate the average monthly flows base and under two scenarios of emissions RCP $4.5 \mathrm{~W} / \mathrm{m}^{2}$ (low) and $8.5 \mathrm{~W} / \mathrm{m}^{2}$ (high), for two Models of General Circulation (MCG) to 2051, considering that in that date a global temperature increase of $2^{\circ} \mathrm{C}$ will be reached in Mexico to continue under the same current trends. The GFDL-CM3 model shows that the unsatisfied water demand in the Demand Center (CD) Rio Purificación 1 with agricultural activity will be $25.23 \%$ and $25.04 \%$ for the low and high scenarios respectively, while for the HADGEM2-ES model the unsatisfied demand will be $22.74 \%$ and $23.34 \%$ for both scenarios of the same CD. Demand Centers were found with an efficiency or reliability in demand of only $41 \%$, such as Purificación 1, Purificación 2 and San Antonio Rivers whose activities are agriculture, livestock and aquaculture. Water demand coverage for a dry month such as January indicates that almost $50 \%$ of the CDs will not meet demand by 2051 for both GFDL-CM3 scenarios. The importance of activating adaptation mechanisms in economic activities is highlighted. The results demonstrate the need for forward-looking and adaptive planning in water resource management
\end{abstract}

Keywords: water availability, climate change, water planning, watershed.

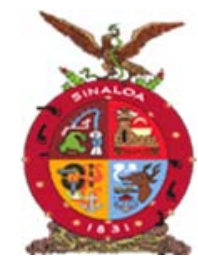

XVIII Congreso Internacional XXIV Congreso Nacional de Ciencias ambientales
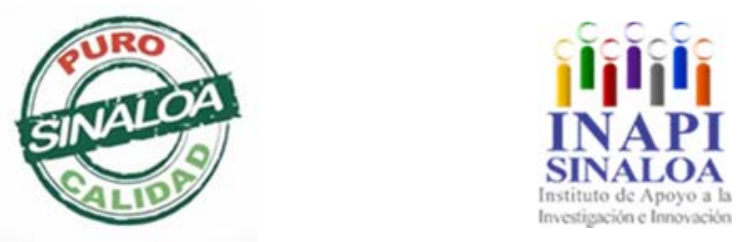

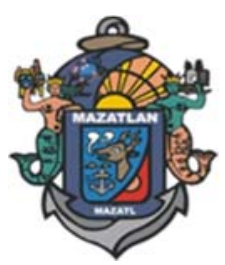

Calidad del Agua y Saneamiento 


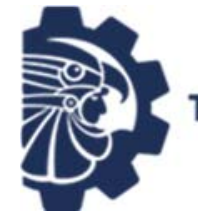

\title{
TECNOLOGICO NACIONAL DE MEXICO
}

\section{Evaluación de la hidroquímica en el acuífero Chihuahua-Sacramento}

\author{
Villarreal Vega A, Cabral Lares M, Pinedo Alvarez C, Rentería Villalobos M*
}

Facultad de Zootecnia y Ecología. Universidad Autónoma de Chihuahua.

Periférico Francisco R. Almada, Km. 1, 31000, Chihuahua, México

Centro de Investigación de Materiales Avanzados. Vigilancia Radiológica

Ambiental. Avenida Miguel de Cervantes Saavedra 120,

Complejo Industrial Chihuahua, 31136, Chihuahua, México

*mrenteria@uach.mx

\begin{abstract}
RESUMEN
Existen problemas globales en cuanto a la calidad y cantidad de agua dulce. No solo las fuentes superficiales sufren de este problema, ya que a nivel mundial más de la mitad del agua potable usada por los humanos proviene del agua subterránea. El objetivo del presente trabajo fue determinar distribución y cambio de la calidad del agua en el acuífero Chihuahua-Sacramento, durante un periodo de tiempo de 15 años. Se seleccionaron 24 pozos que cuenta con información sobre conductividad eléctrica, solidos disueltos totales, dureza, alcalinidad, nitratos, sulfatos y flúor, por 3 años: 1996, 2005 y 2011. Se utilizó el programa ArcGis 10.3 para la generación de mapas de distribución de los parámetros de calidad de agua. El $45 \%$ de los pozos rebasan el LMP establecido para la concentración de nitratos, aún, en el periodo evaluado los parámetros de CE, SDT y dureza aumentaron su concentración, mientras que el flúor disminuyó en el $96 \%$ de los pozos. El impacto antropogénico es el principal factor al que se atribuye el cambio de la calidad del agua, ya que este acuífero se encuentra en estatus de sobreexplotado. La geología de la zona puede hacer una contribución de flúor de manera natural. Se recomienda tomar medidas de sostenibilidad para la conservación tanto de la calidad como de la cantidad de agua en el acuífero, ya que la mayoría de la población de la ciudad de Chihuahua depende de él.
\end{abstract}

Palabras clave: Sobreexplotación, calidad de agua, agua subterránea, región árida.

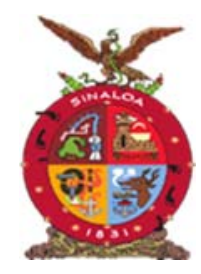

XVIII Congreso Internacional XXIV Congreso Nacional de Ciencias ambientales
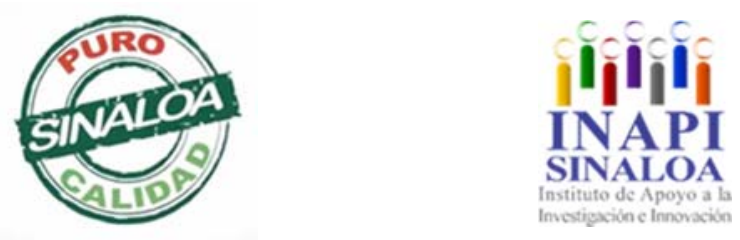

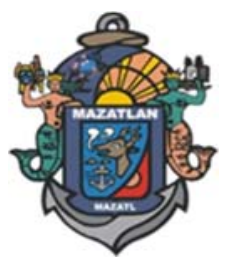

Calidad del Agua y Saneamiento 

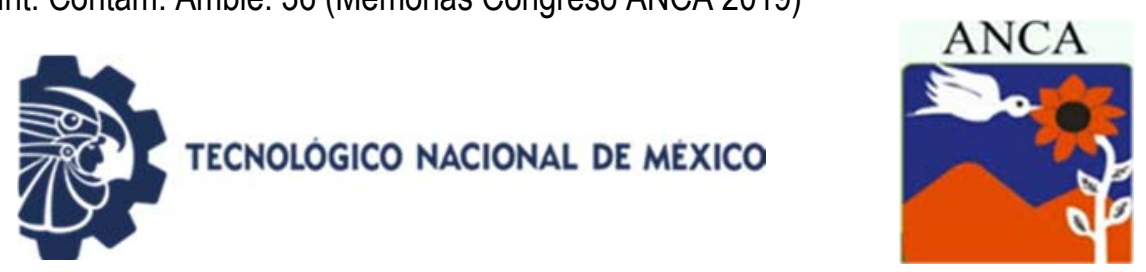

\title{
Hydrochemistry evaluation of Chihuahua-Sacramento aquifer
}

\author{
Villarreal Vega A, Cabral Lares M, Pinedo Alvarez C, Rentería Villalobos M* \\ Facultad de Zootecnia y Ecología. Universidad Autónoma de Chihuahua. \\ Periférico Francisco R. Almada, Km. 1, 31000, Chihuahua, México \\ Centro de Investigación de Materiales Avanzados. Vigilancia Radiológica \\ Ambiental. Avenida Miguel de Cervantes Saavedra 120, \\ Complejo Industrial Chihuahua, 31136, Chihuahua, México \\ *mrenteria@uach.mx
}

\begin{abstract}
There are global problems regarding the quality and quantity of fresh water. Not only superficial sources suffer from this problem, because worldwide more than half of the drinking water used by humans comes from groundwater. The objective of this work was to determine the distribution and changes in water quality of Chihuahua-Sacramento aquifer, over 15 years period. Information of electrical conductivity, total dissolved solids, hardness, alkalinity, nitrates, sulfates, and fluoride were obtained in a 24 wells for the years: 1996, 2005, and 2011. In add, the ArcGis 10.3 program was used to obtain distribution maps of water quality parameters. For evaluated period, the $45 \%$ of the wells exceed the established limits of nitrates concentrations. Furthermore, EC, TDS, and hardness increased their concentrations while fluorine concentrations decreased in $96 \%$ of the wells. The anthropogenic impact is the main factor of these water quality changes, due to the overexploitation of the aquifer. Additionally, the geology may contribute with fluoride of natural way. It is recommended to take sustainability practices for the conservation of both the quality and quantity of groundwater, to the wellness of Chihuahua inhabitants.
\end{abstract}

Keywords: Overexploitation, water quality, well water, arid region.

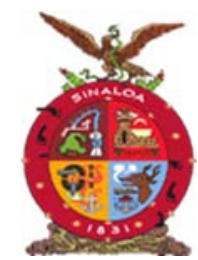

XVIII Congreso Internacional XXIV Congreso Nacional de Ciencias ambientales
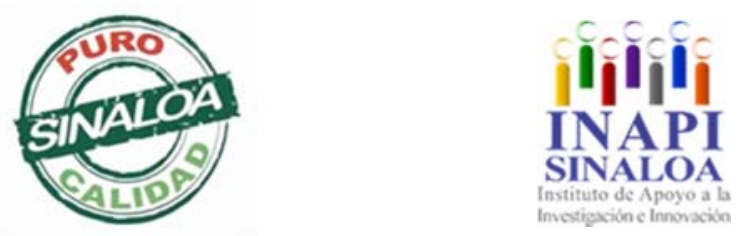

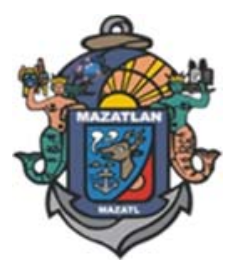

Mazatlán, Sinaloa 3-7 junio 2019

Calidad del Agua y Saneamiento 


\section{REVista INTernacional de}

\section{CONTAMinación \\ AMBIEntal \\ volumen 36, 2020}

http://www.revistas.unam.mx/index.php/rica/

\section{Energías Limpias y Acciones por el Clima}

Academia Nacional de Ciencias Ambientales

XVIII CONGRESO INTERNACIONAL

XXIV CONGRESO NACIONAL

De Ciencias ambientales

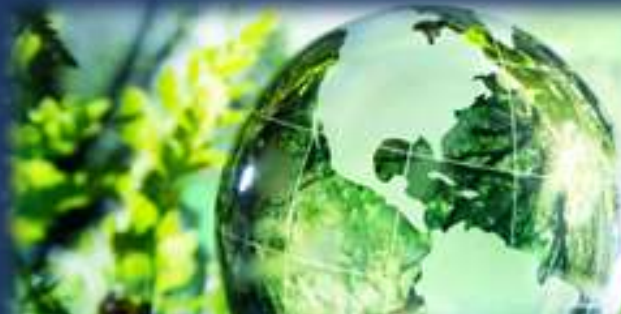

Maratláln, Sinaloa

ila Perla del Pacííco!

03-07 Junio/2019 
TECNOLOGICO NACIONAL DE MEXICO
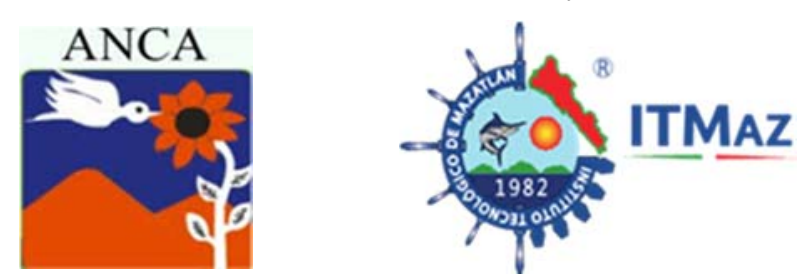

El uso de la educación ambiental como apoyo a la sustentabilidad de las PyMe's de Ciudad Guzmán, Jalisco

\author{
Cerón Bracamontes M*, Michel Parra JG, Gutiérrez Cedillo AB
}

Universidad de Guadalajara. Centro Universitario del Sur. Av. Enrique Arreola Silva, No. 883, Tel. (341) 5752222, Ext. 46074, Cd. Guzmán, Jalisco, México

*ceronbm@gmail.com

\title{
RESUMEN
}

Las Pequeñas y Medianas Empresas (PyMe's) poseen grandes ventajas debido a su adaptabilidad en su infraestructura organizacional y su ambiente. Sin embargo, las PyMe's se enfrentan a un proceso dinámico de mejora continua cada vez más competitivo, estas deben buscar una opción más accesible para integrar la sustentabilidad, es decir, el impacto social, político y económico que produce su actividad, desarrollando nuevas formas de aprendizaje donde faciliten su interacción dentro de la sociedad del conocimiento. Este estudio tiene como objetivo contribuir a la sustentabilidad de las empresas mediante la utilización de la educación ambiental haciendo uso de talleres y conferencias en la localidad de Ciudad Guzmán, Jalisco. El presente trabajo se realizó la localidad de Ciudad Guzmán, municipio de Zapotlán el Grande, Jalisco, de agosto de 2018 a marzo de 2019. El estudio se dividió en tres partes, los antecedentes de las empresas que están implementando la sustentabilidad, la recolección de datos y el avance de los resultados. Fue de tipo cuantitativo exploratorio-descriptivo, donde se identificó las características importantes del estudio, en este caso los 382 empresarios de la ciudad. El $85 \%$ de las empresas encuestadas se dedica al sector comercio, sus principales clientes son a nivel regional; además utilizan el concepto de sustentabilidad como una tendencia para atraer más clientes. Es fundamental que clientes y empresarios, asuman la responsabilidad del impacto sustentable de las empresas, basado en la educación ambiental, ya que se requieren sinergias y alianzas que favorezcan su desarrollo y extensión hacia nuevas comunidades de aprendizaje.

Palabras clave: Educación ambiental, PyMe's, sustentabilidad, desarrollo económico.

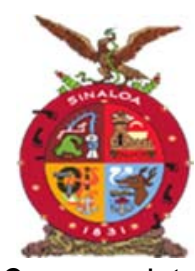

XVIII Congreso Internacional
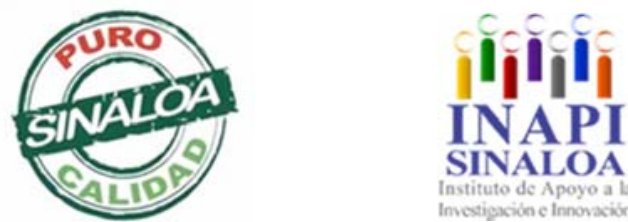

Mazatlán, Sinaloa 3-7 junio 2019

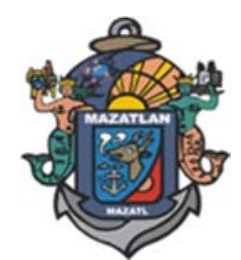

Energías Limpias

y Acciones por el Clima 

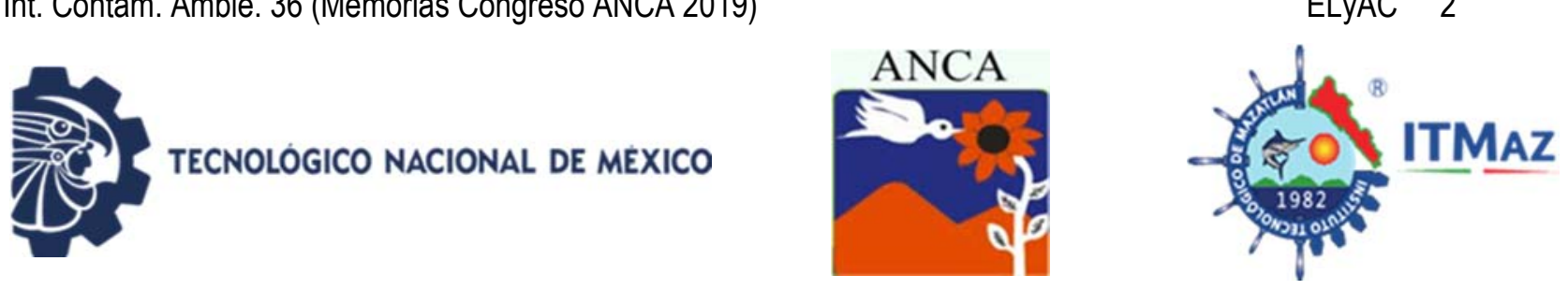

\title{
The use of environmental education to support the sustainability of the PyMe's of Ciudad Guzmán, Jalisco
}

\author{
Cerón Bracamontes M*, Michel Parra JG, Gutiérrez Cedillo AB \\ Universidad de Guadalajara. Centro Universitario del Sur. Av. Enrique Arreola \\ Silva, No. 883, Tel. (341) 5752222, Ext. 46074, Cd. Guzmán, Jalisco, México \\ *ceronbm@gmail.com
}

\begin{abstract}
Small and medium-sized enterprises (SMEs) have great advantages due to their adaptability in their organizational infrastructure and environment. SMEs are faced with a dynamic process of continuous improvement increasingly competitive, they must seek a more accessible option to integrate sustainability, that is, the social, political and economic impact that their activity produces, developing new forms of learning where they facilitate their interaction within the knowledge society in their organizational infrastructure and environment. This study aims to contribute to the sustainability of companies through the use of environmental education using workshops and conferences in the town of Ciudad Guzman, Jalisco. This work was carried out the locality of Ciudad Guzman, municipality of Zapotlán El Grande, Jalisco, from August 2018 to March 2019. The study was divided into three parts, the antecedents of the companies that are implementing the sustainability, the data collection and the progress of the results. It was of exploratory-descriptive quantitative type, where the important characteristics of the study were identified, in this case the 382 entrepreneurs of the city. $85 \%$ of the companies surveyed are engaged in the trade sector, their main customers are at the regional level; they also use the concept of sustainability as a trend to attract more customers. It is essential that customers and entrepreneurs assume responsibility for the sustainable impact of companies based on environmental education, as synergies and alliances are required to promote their development and extension to new learning communities.
\end{abstract}

Keywords: Environmental education, SMEs, sustainability, economic development.

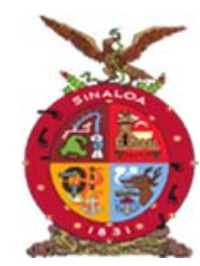

XVIII Congreso Internacional
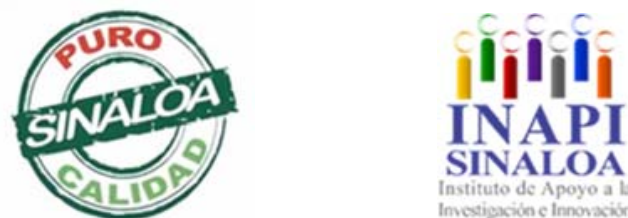

Mazatlán, Sinaloa 3-7 junio 2019

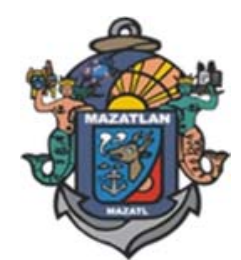

Energías Limpias

y Acciones por el Clima 

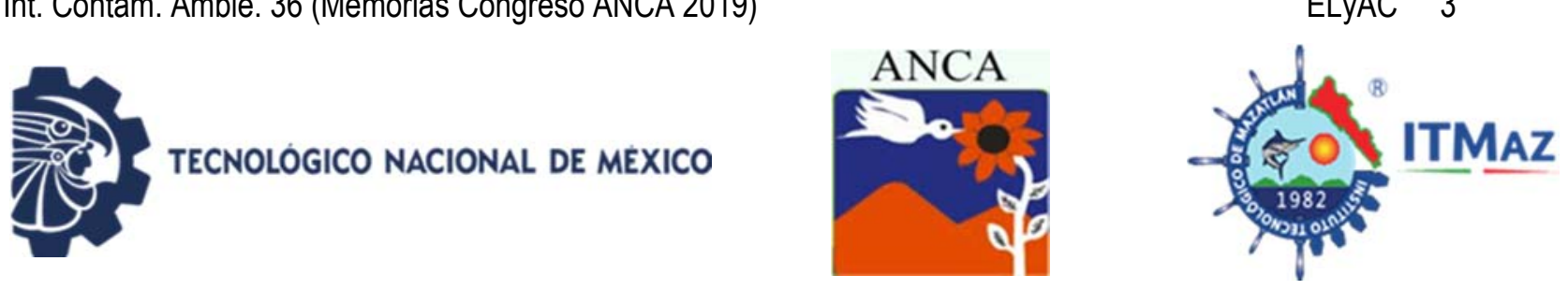

\section{Valoración de modelos de regresión aplicada a contaminación del aire en Morelia, Michoacán}

Correa García A, Carbajal de la Torre G, Martínez Valencia A, Rico Arzate E

Secretaría de Desarrollo Rural y Medio Ambiente del Municipio de Morelia.

Fac. de Ing. Mecánica. Universidad Michoacana de San Nicolás de Hidalgo. Escuela Superior de Ingeniería Química e Industria Extractiva IPN cientifico148@gmail.com

\section{RESUMEN}

El municipio de Morelia Michoacán, con base en el análisis de la información del periodo 2008 al 2017; empleando estadística descriptiva, y el método de correlación y regresión, reportó en el 2017 una guía sobre el valor promedio anual y por mes, de los contaminantes del aire $\mathrm{CO}, \mathrm{NO}_{2}, \mathrm{O}_{3}, \mathrm{PM}_{10}$ y $\mathrm{PM}_{2.5}$ que podrían registrarse en el 2018. Algunos resultados, indican que el $\mathrm{O}_{3}$ cambia debido al efecto combinado del paso del tiempo y el descenso del $\mathrm{NO}_{2}$ con coeficiente de correlación aceptable $\mathrm{R}=0.99 \mathrm{p}<0.00937$ y error estimado en 0.001 ppm; según este modelo, en 2018 el ozono podría alcanzar un promedio de $0.029 \mathrm{ppm}$ con un intervalo de confianza $\pm 95 \%$ entre $0.028 \mathrm{ppm}$ y $0.030 \mathrm{ppm}$. Se concluye que entre el periodo 2008 y marzo 2018, la contaminación del aire en la ciudad de Morelia por ozono tiende a bajar; sin embargo, la concentración media anual de $\mathrm{O}_{3}$ sigue subiendo. En este trabajo, se revisó la información del año 2018, con el propósito de evaluar la eficacia de algunas de las predicciones reportadas por el municipio de Morelia; se confirma, un nuevo aumento de $\mathrm{O}_{3}$ por cuarto año consecutivo. Este resultado, podría explicar por qué las autoridades encargadas de la protección al medio ambiente del Gobierno del Estado de Michoacán decidieron cambiar el programa de verificación vehicular en forma voluntaria, por uno de control obligatorio, bajo la hipótesis de que esta acción podría amortiguar la tendencia ascendente de la contaminación por $\mathrm{O}_{3}$.

Palabras clave: Ozono, modelos de regresión, contaminación atmosférica.

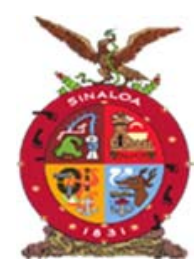

XVIII Congreso Internacional

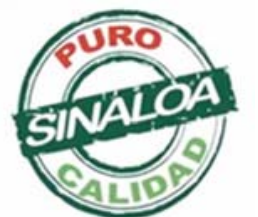

Mazatlán, Sinaloa 3-7 junio 2019

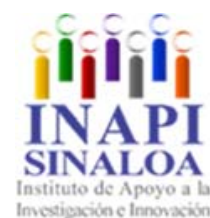

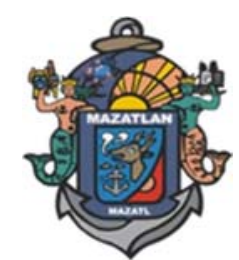

Energías Limpias

y Acciones por el Clima 

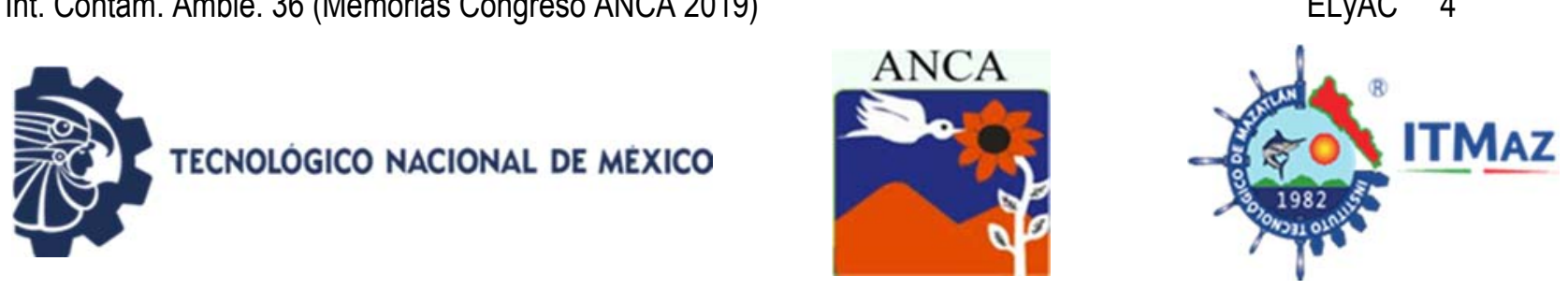

\title{
Valuation of regression models applied to air pollution in Morelia Michoacán
}

Correa García A, Carbajal de la Torre G, Martínez Valencia A, Rico Arzate E

Secretaría de Desarrollo Rural y Medio Ambiente del Municipio de Morelia.

Fac. de Ing. Mecánica. Universidad Michoacana de San Nicolás de Hidalgo. Escuela Superior de Ingeniería Química e Industria Extractiva IPN cientifico148@gmail.com

\begin{abstract}
The municipality of Morelia Michoacán, based on the analysis of information from the period 2008 to 2017; Using descriptive statistics, and the correlation and regression method, in 2017 it reported a guide on the average annual value and per month, of air pollutants $\mathrm{CO}, \mathrm{NO}_{2}, \mathrm{O}_{3}, \mathrm{PM}_{10}$ and $\mathrm{PM}_{2.5}$ that could be registered in 2018. Some results indicate that $\mathrm{O}_{3}$ changes due to the combined effect of the passage of time and the decrease of $\mathrm{NO}_{2}$ with an acceptable correlation coefficient $R=0.99 p<0.00937$ and estimated error in $0.001 \mathrm{ppm}$; According to this model, in 2018 ozone could reach an average of $0.029 \mathrm{ppm}$ with a confidence interval of $\pm 95 \%$ between $0.028 \mathrm{ppm}$ and $0.030 \mathrm{ppm}$. It is concluded that between the period 2008 and March 2018, the air pollution in the city of Morelia by ozone tends to fall; however, the average annual concentration of $\mathrm{O}_{3}$ continues to rise. In this work, the information of the year 2018 was reviewed, with the purpose of evaluating the effectiveness of some of the predictions reported by the municipality of Morelia; it is confirmed, a new increase of $\mathrm{O}_{3}$ for the fourth consecutive year. This result could explain why the authorities in charge of protecting the environment of the Government of the State of Michoacán, decided to change the vehicle verification program voluntarily, by one of mandatory control, under the hypothesis that this action could cushion the upward trend of pollution by $\mathrm{O}_{3}$.
\end{abstract}

Keywords: Ozone, regression models, air pollution.

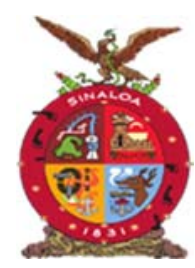

XVIII Congreso Internacional

XXIV Congreso Nacional de Ciencias ambientales

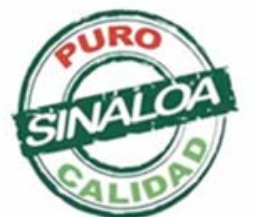

Mazatlán, Sinaloa 3-7 junio 2019

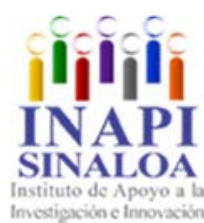

SINALOA

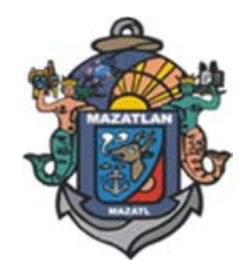

Energías Limpias

y Acciones por el Clima 

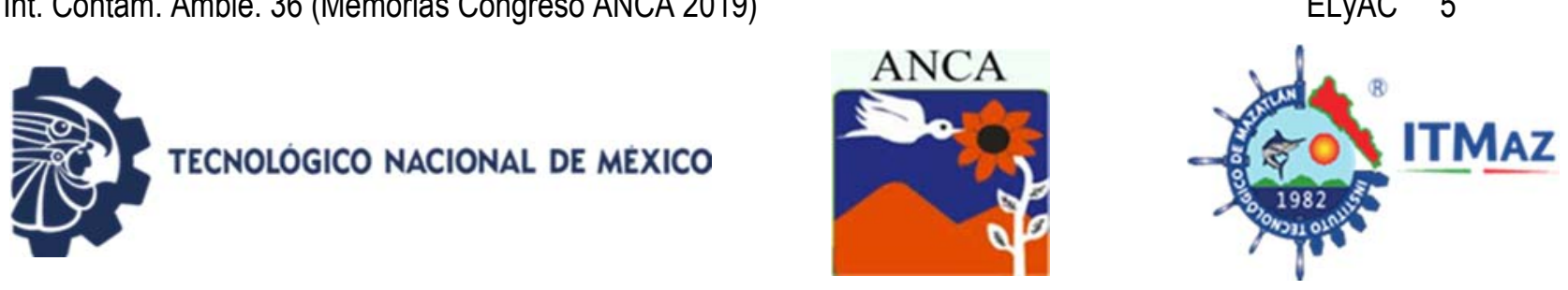

\title{
Potencial de producción de biogás a partir de la biomasa residual de Neem (Azadirachta Indica)
}

\author{
Díaz Pazos J, Garate Osuna AJ, Mejias Brizuela NY, Luna Avelar KD, \\ Ambriz Pérez DL, Santos Ballardo DU*
}

Maestría en Ciencias Aplicadas. Ingeniería en Energía. Posgrado en Ciencias y Tecnología de Alimentos. Universidad Politécnica de Sinaloa. México *dsantos@upsin.edu.mx

\section{RESUMEN}

Una opción de la aplicación del concepto de biorrefinería es acoplar la producción de biocombustibles (biodiesel, bioetanol) previo a la digestión anaeróbica (DA) de la biomasa. La presente investigación aborda el potencial de producción de biogás a partir de biomasa residual (BR) de Neem (Azadirachta indica). Se extrajo aceite a partir de la semilla de Neem mediante dos métodos: extracción mecánica y por solventes, a la BR se le analizó el potencial metanogénico (PM) individual y en cogestión con glicerol (residuo de la trans-esterificación), adicionalmente, se analizó también el PM de hoja y tallo (considerados BR). A cada sustrato y al inóculo se les determinó sólidos totales (ST) y volátiles (SV). Posteriormente, se realizó la DA de cada muestra con inóculos de la cervecería Pacífico. Las pruebas se realizaron en condiciones mesofílicas $\left(37 \pm 1^{\circ} \mathrm{C}\right)$ durante 29 días. La producción acumulada de biogás y metano se midió utilizando eudiómetro. La digestión de BR derivada de solvente + glicerol presentó la producción más elevada (385 mLbiogásgSV ${ }^{-1}$ ) con $77.43 \%$ de metano. Dicho comportamiento puede deberse al efecto de sinergia entre la BR y el glicerol (compuesto de alta degradabilidad). A partir de los resultados obtenidos se concluye que las distintas BR de Neem presentan potenciales metanogénico adecuados, con altas posibilidades de mejorarse. Cabe mencionar que, en cuanto a la producción de biogás a partir de BR de Neem, prácticamente no se encuentra información relevante, por lo que estos resultados pueden abrir la puerta a futuras investigaciones para el desarrollo de biorrefinerías utilizando dicho material.

Palabras clave: Neem, biorrefinerías, digestión anaeróbica, biomasa residual, digestión.

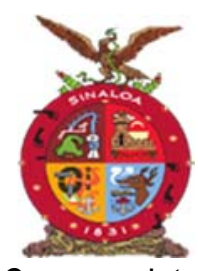

XVIII Congreso Internacional

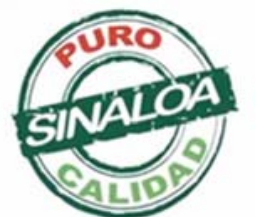

Mazatlán, Sinaloa 3-7 junio 2019

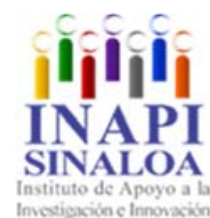

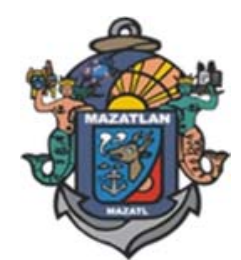

Energías Limpias

y Acciones por el Clima 

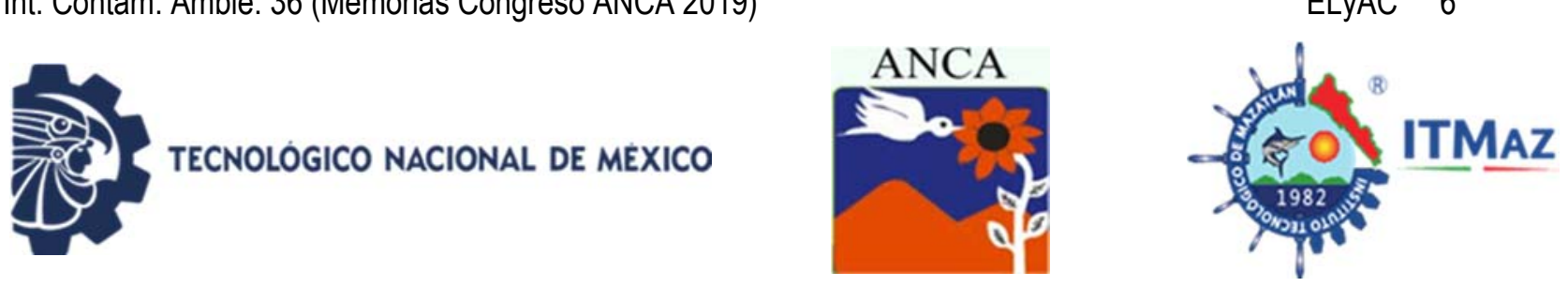

\title{
Biogas production potential from residual biomass of Neem (Azadirachta indica)
}

\author{
Díaz Pazos J, Garate Osuna AJ, Mejias Brizuela NY, Luna Avelar KD, \\ Ambriz Pérez DL, Santos Ballardo DU* \\ Maestría en Ciencias Aplicadas. Ingeniería en Energía. Posgrado en Ciencias y \\ Tecnología de Alimentos. Universidad Politécnica de Sinaloa. México \\ *dsantos@upsin.edu.mx
}

\begin{abstract}
One option for applying the biorefinery concept is to couple biofuel production (biodiesel-bioethanol) prior to biomass anaerobic digestion (DA). The present research addresses the potential of biogas production from residual biomass (BR) of neem (Azadirachta indica). Oil was extracted from the neem seed by two methods: mechanical and solvent extraction, the individual methanogenic potential (PM) from BR was analyzed, also co-digestion with glycerol (transesterification residue) was evalueated, additionally, and the PM of leaf and stem was also analyzed (considered as BR). Total (ST) and volatile (SV) solids were determined for each substrate and inoculum. Subsequently, the DA of each sample is performed with inocula from the brewery Pacífico. The tests were carried out under mesophilic conditions $\left(37 \pm 1^{\circ} \mathrm{C}\right)$ for 29 days. Cumulative biogas production and methane was measured using eudiometer. The codigestión of BR derived from solvent + glycerol presented the highest production ( $\mathrm{mL}$ biogas $\mathrm{gSV}^{-}$ ${ }^{1}$ ) with $77.43 \%$ methane. This behavior may be due to the effect of synergy between the biomass and glycerol (compound of high degradability). Based on the results obtained, it is concluded that the different neem BR have adequate methanogenic potential, with high possibilities of improvement. It is worth mentioning that as regards the production of biogas from neem BR, relevant information is practically not found, so these results are able to open the door to future research for the development of biorefineries using said.
\end{abstract}

Keywords: Neem, Biorefineries, anaerobic digestion, residual biomass, codigestion.

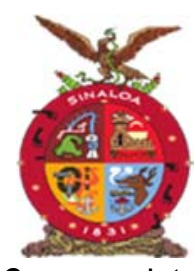

XVIII Congreso Internacional
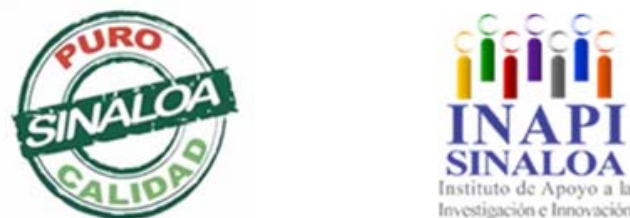

Mazatlán, Sinaloa 3-7 junio 2019

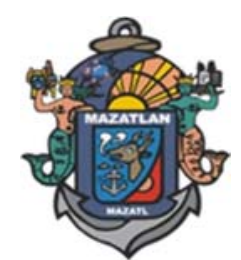

Energías Limpias

y Acciones por el Clima 
TECNOLOGICO NACIONAL DE MEXICO
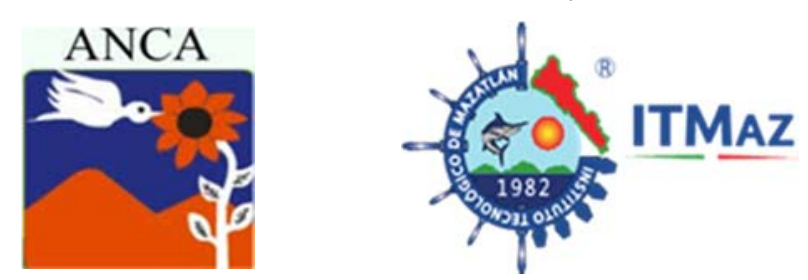

\title{
Determinación de la absorción de dióxido de carbono y producción de oxígeno de árboles de "Casa de la Naturaleza", Tampico, Tamaulipas
}

\author{
Escobar González J, Cuellar González J, Contreras Molina A \\ Dirección de Cuerpos de Agua. Universidad del Noreste A.C. \\ Tampico, Tamaulipas, México \\ georgeescobar2008@hotmail.com
}

\section{RESUMEN}

El dióxido de carbono $\left(\mathrm{CO}_{2}\right)$ es el gas de efecto invernadero más importante producido por las actividades humanas. Actualmente, cerca de un $20 \%$ de las emisiones de $\mathrm{CO}_{2}$ resultan de la eliminación y degradación de los ecosistemas forestales. Por medio de datos estadísticos se determinará que especies de la zona estudiada, son más eficientes en el secuestro de $\mathrm{CO}_{2}$ y en su generación de $\mathrm{O}_{2}$, esta investigación se realizó en el parque recreativo "Casa de la Naturaleza" Tampico, Tamaulipas, en un periodo de junio a diciembre del 2018. Se realizo un análisis de varianza a nivel de significancia de $a=0.05$; y para determinar la significancia de los promedios entre clase diamétrica; se aplicó la prueba estadística de Tukey. Como resultado se obtuvo que las clases diamétricas más productivas para la absorción de $\mathrm{CO}_{2}$ y generación de $\mathrm{O}_{2}$, fueron las clases $(>50-75)$ y $(>75>100)$ con un promedio de 155.66 toneladas de secuestro de $\mathrm{CO}_{2}$. Mientras que las clases diamétricas con más generación de $\mathrm{O}_{2}$, fueron $(>50-75)$ y $(>75->100)$, con un promedio de 253.95 toneladas de oxígeno. Por lo tanto, los arboles con una mayor biomasa y clase diamétrica tienen un elevado índice de absorción de $\mathrm{CO}_{2}$ y una gran generación de $\mathrm{O}_{2}$. Entre los árboles que destacaron ser más eficientes fueron; Orejón (Enterolobium cyclocarpum) y Ceiba (Ceiba pentandra), las cuales son nativas de la región y se encuentran dentro de la "Casa de la Naturaleza".

Palabras clave: Dióxido de carbono, oxígeno, censo arbóreo, clase diamétrica, Anova.

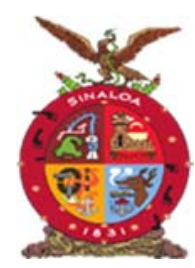

XVIII Congreso Internacional
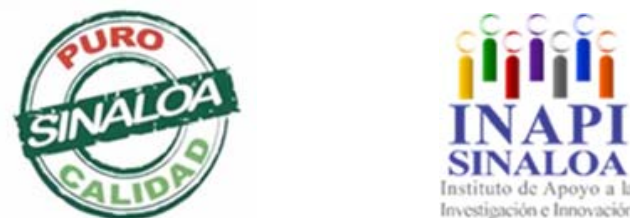

Mazatlán, Sinaloa 3-7 junio 2019

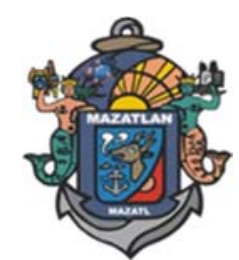

Energías Limpias

y Acciones por el Clima 

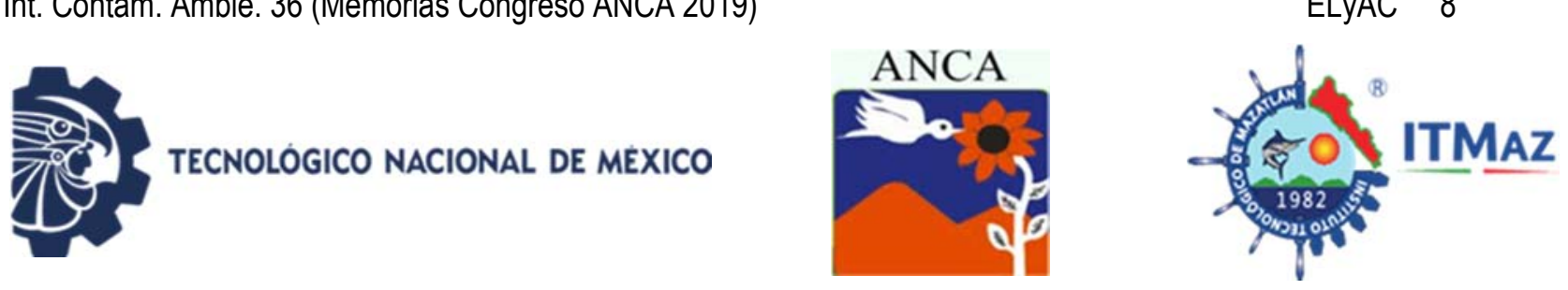

\title{
Determination of the absorption of carbon dioxide and production of oxygen from trees of "Casa de la Naturaleza", Tampico, Tamaulipas
}

\author{
Escobar González J, Cuellar González J, Contreras Molina A \\ Dirección de Cuerpos de Agua. Universidad del Noreste A.C. \\ Tampico, Tamaulipas, México \\ georgeescobar2008@hotmail.com
}

\begin{abstract}
Carbon dioxide $\left(\mathrm{CO}_{2}\right)$ is the most important greenhouse gas produced by human activities. Currently, about $20 \%$ of $\mathrm{CO}_{2}$ emissions result from the elimination and degradation of forest ecosystems. By means of statistical data it will be determined which species of the studied zone are more efficient in the sequestration of $\mathrm{CO}_{2}$ and in its generation of $\mathrm{O}_{2}$, the research was carried out in the recreational park "Casa de la Naturaleza" Tampico, Tamaulipas in a period from June to December 2018. An analysis of variance was carried out at a significance level of $a=0.05$; and to determine the significance of the averages between the diameter classes, Tukey's statistical test was performed. As a result it was obtained that the most productive diameter classes for the absorption of $\mathrm{CO}_{2}$, and generation of $\mathrm{O}_{2}$ were the classes (> 50-75) and (> 75-> 100) with an average of 155.66 tons of sequestration of $\mathrm{CO}_{2}$. While the diametric classes with the highest generation production of $\mathrm{O}_{2}$ were $(>50-75)$ and $(>75->100)$, with an average of 253.95 tons of oxygen. Therefore, trees with a higher biomass and diametric class have a high rate of absorption of $\mathrm{CO}_{2}$ and a large generation of $\mathrm{O}_{2}$, among the trees that stood out being more efficient were; Orejón (Enterolobium cyclocarpum) and Ceiba (Ceiba pentandra) of which are native to the region and are located within the House of Nature.
\end{abstract}

Keywords: Carbon dioxide, oxygen, arboreal census, diametric class, Anova.

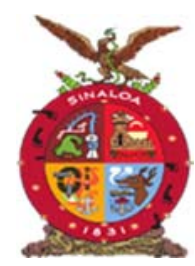

XVIII Congreso Internacional

XXIV Congreso Nacional de Ciencias ambientales

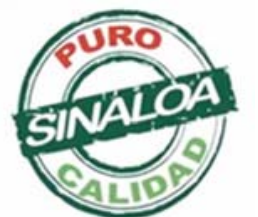

Mazatlán, Sinaloa 3-7 junio 2019

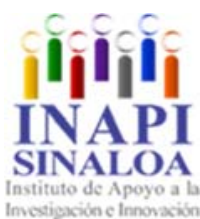

SINALOA

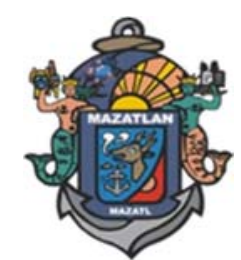

Energías Limpias

y Acciones por el Clima 

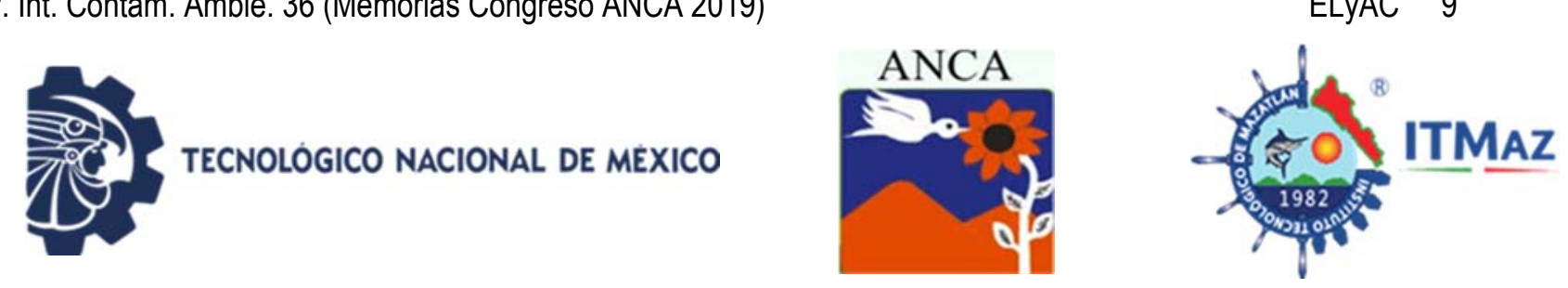
La estufa ahorradora de leña Tlecalli, modelo y apropiación tecnológica por usuarias de origen Náhuatl en Cuentepec, Morelos, México

\author{
Flores Sotelo T*, Gracía Matías F, Argumedo Macías A, Silva Gómez S, \\ Hernández Zepeda JS, Huerta Lara M
}

BUAP-PRODEP-CA.165. Posgrado en Ciencias Ambientales.

Facultad de Ciencias Agropecuarias. UAEMorelos, México

Colegio de Posgraduados-Campus Puebla. Boulevard Forjadores de Puebla,

No. 205, Santiago Momoxpan, San Pedro Cholula, Puebla, México

Posgrado en Ciencias Ambientales. Departamento de Universitario para el

Desarrollo Sustentable. Instituto de Ciencias, BUAP

14 Sur No. 6301, C.P. 72570, Col. San Manuel, Puebla, México

*terefmx@yahoo.com.mx

\title{
RESUMEN
}

Las estufas ahorradoras de leña (EAL), generan beneficios sociales, económicos y ambientales; principalmente familias que viven en comunidades rurales. Las EAL propician un ambiente favorable para la convivencia familiar al disminuir el humo en el interior de la cocina (arriba del 90\%), con una combustión adecuada y ahorro de leña de hasta más del $50 \%$ del que normalmente se consume en un fogón abierto. La metodología aplicada en esta investigación estuvo dirigida a 45 mujeres usuarias y 4 no usuarias de estufas ahorradoras de leña Tlecalli (EALT) en Cuentepec, Temixco, Morelos, México. El método utilizado fue de tipo cualitativo etnográfico, que se basa en la observación participante. Se demuestra con la investigación que las EALT incrementan la eficiencia en el uso de calor, y la opinión de las usuarias de facilidad de uso de las estufas, eficiencia al cocinar y la conservación del calor por más tiempo en la misma. La apropiación tecnológica de las EALT es positiva debido a que el abandono fue de tan solo un $5 \%$, por cambio de domicilio, enfermedad o remodelación del espacio donde se ubicaba la estufa (después de más de siete años de haber sido implementada en el hogar), hacerla parte cotidiana e indispensable para la elaboración de sus alimentos y percibir una mejora a nivel familiar que impacta en su calidad de vida.

Palabras clave: Apropiación tecnológica, estufa ahorradora de leña Tlecalli, eficiencia y calidad de vida.

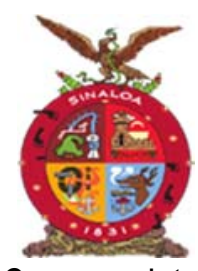

XVIII Congreso Internacional

XXIV Congreso Nacional de Ciencias ambientales
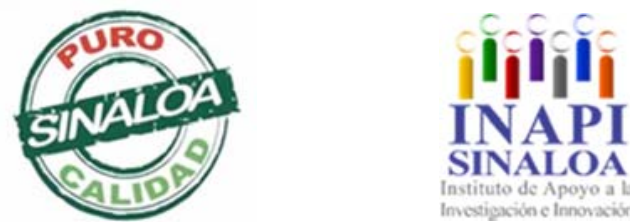

Mazatlán, Sinaloa 3-7 junio 2019

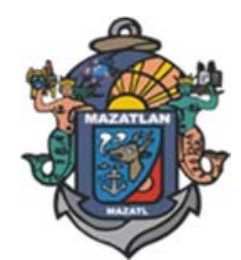

Energías Limpias

y Acciones por el Clima 
TECNOLOGICO NACIONAL DE MEXICO
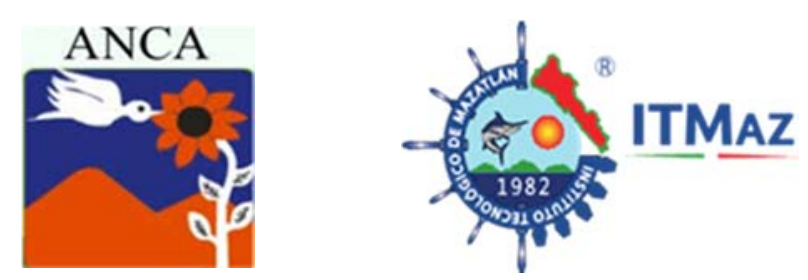

\title{
The Tlecalli wood saving stove, model and technological appropriation by users of Nahuatl Origin in Cuentepec, Morelos, Mexico
}

\author{
Flores Sotelo T*, Gracía Matías F, Argumedo Macías A, Silva Gómez S, \\ Hernández Zepeda JS, Huerta Lara M
}

BUAP-PRODEP-CA.165. Posgrado en Ciencias Ambientales.

Facultad de Ciencias Agropecuarias. UAEMorelos, México

Colegio de Posgraduados-Campus Puebla. Boulevard Forjadores de Puebla,

No. 205, Santiago Momoxpan, San Pedro Cholula, Puebla, México

Posgrado en Ciencias Ambientales. Departamento de Universitario para el

Desarrollo Sustentable. Instituto de Ciencias, BUAP

14 Sur No. 6301, C.P. 72570 , Col. San Manuel, Puebla, México

*terefmx@yahoo.com.mx

\begin{abstract}
Wood-saving stoves (EAL) generate social, economic and environmental benefits; mainly families living in rural communities. The EALs provide a favorable environment for family living by reducing smoke inside the kitchen (above 90\%), with adequate combustion and saving wood for up to more than $50 \%$ of what is normally consumed in an open hearth. The methodology applied in this research was aimed at 45 women users and 4 non-users of Tlecalli wood-saving stoves (EALT) in Cuentepec, Temixco, Morelos, Mexico. The method used was of ethnographic qualitative type, which is based on participant observation. The research shows that EALTs increase the efficiency in the use of heat, and the opinion of the users of ease of use of the stoves, efficiency in cooking and the conservation of heat for longer in it. The technological appropriation of the EALT is positive because the abandonment was only $5 \%$, due to change of address, illness or remodeling of the space where the stove was located (after more than seven years of having been implemented in the home), make it a daily and indispensable part for the preparation of their food and perceive an improvement at the family level that impacts their quality of life.
\end{abstract}

Keywords: Technological appropriation, Tlecalli wood-saving stove, efficiency and quality of life.

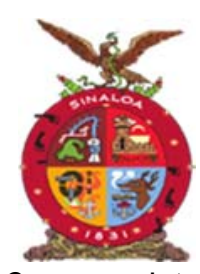

XVIII Congreso Internacional

XXIV Congreso Nacional de Ciencias ambientales
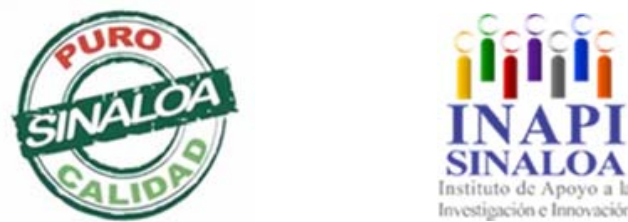

Mazatlán, Sinaloa 3-7 junio 2019

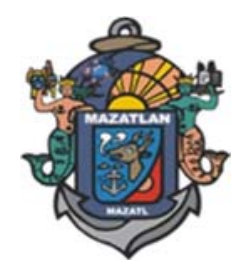

Energías Limpias

y Acciones por el Clima 

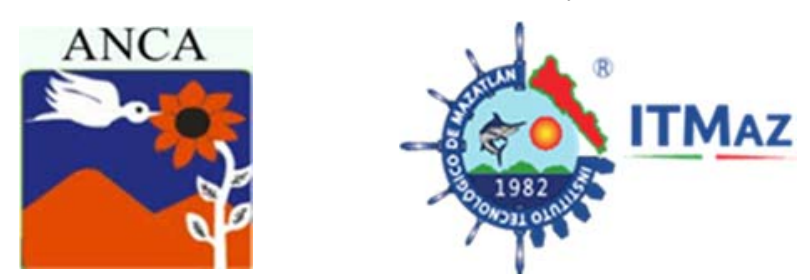

\title{
Chlorophytum comosum bioindicador de la calidad del aire al interior de la biblioteca de la Universidad de Pamplona-Norte de Santander, Colombia
}

\author{
G. Florez M*, Martínez P, Quijano Parra A \\ Grupo de Investigación Sirena. Departamento de Biología. \\ Facultad de Ciencias Básicas \\ Grupo de investigación de Química de la Atmósfera. \\ Departamento de Química. \\ Facultad de Ciencias Básicas. Universidad de Pamplona. Colombia \\ *marthaflorez@unipamplona.edu.com
}

\section{RESUMEN}

La exposición a partículas suspendidas en el aire (PM) es uno de los riesgos ambientales más significativos a los que se enfrentan las personas, los contaminantes del aire ocurre en interiores, donde las personas pasan la mayor parte de su tiempo, sin darse cuenta de que podrían estar permanentemente expuestos a la contaminación del aire. Se evaluó a Chlorophytum comosum como bioindicador y fitorremediador de la contaminación del aire interior en la biblioteca de la Universidad de Pamplona-Colombia. Se identificó en la raíz y en la hoja la presencia de hidrocarburos aromáticos policíclicos (HAPs) y metales pesados. Inicialmente la materia orgánica presente en la raíz y hoja de la planta se obtuvo por ultrasonido, se concentró por rotaevaporación, el extracto global se utilizó para la determinación de los HAPs por cromatografía de gases (FID). Los HAPs encontrados en el aire interior fueron fluoranteno, pireno, benzo(a)antraceno, criseno, benzo (b) fluoranteno, benzo (k) fluoranteno, benzo (a) pireno Para la identificación de metales, las plantas fueron sometidas a desecación por 48 horas, y fueron digeridas con $\mathrm{HCl}$. Los extractos se analizaron por medio del Espectrofotómetro de Absorción Atómica. Los metales pesados encontrados en el aire interior fueron $\mathrm{Cr}, \mathrm{Cu}, \mathrm{Fe}, \mathrm{Mn}, \mathrm{Pb}$ y $\mathrm{Zn}$. Los (HAPs) y metales pesados encontrados en los extractos de las plantas analizados (aire interior) coinciden con los encontrados en los filtros de $\mathrm{PM}_{2.5}$ utilizados para monitoreo de la calidad del aire de ambientes exteriores en la Universidad de Pamplona con el Partisol 2025 Plus.

Palabras clave: Chlorophytum comosum, bioindicador, fitorremediación, aire interior, material particulado, HAPs, metales pesados.

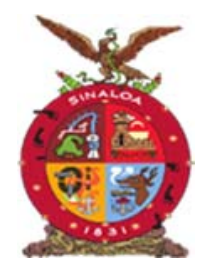

XVIII Congreso Internacional

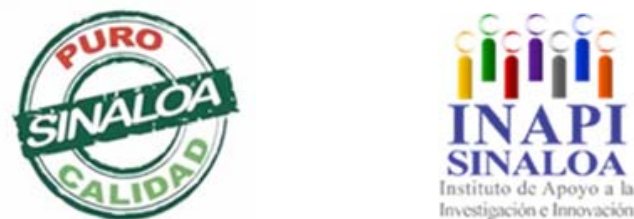

Mazatlán, Sinaloa 3-7 junio 2019

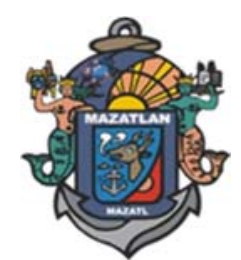

Energías Limpias

y Acciones por el Clima 

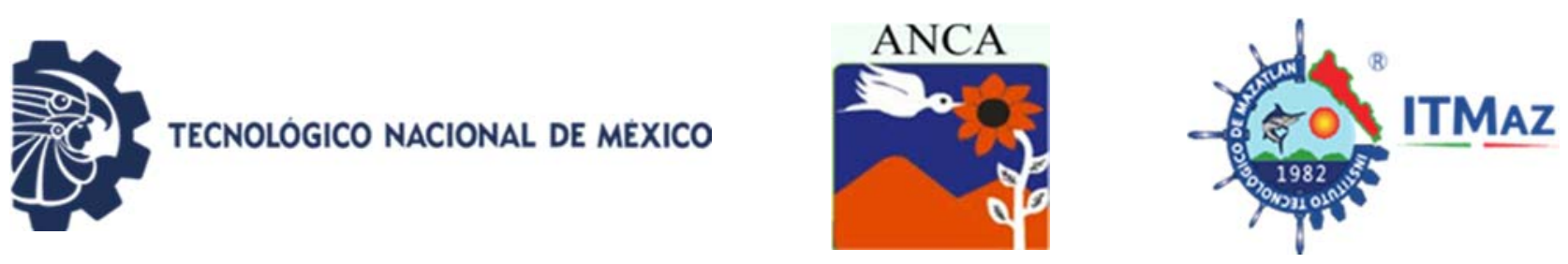

\title{
Chlorophytum comosum bioindicator of indoor air quality of the library of the University of Pamplona-Norte de Santander, Colombia
}

\author{
G. Florez $\mathrm{M}^{*}$, Martínez P, Quijano Parra A \\ Grupo de Investigación Sirena. Departamento de Biología. \\ Facultad de Ciencias Básicas \\ Grupo de investigación de Química de la Atmósfera. \\ Departamento de Química. \\ Facultad de Ciencias Básicas. Universidad de Pamplona. Colombia \\ *marthaflorez@unipamplona.edu.com
}

\begin{abstract}
Exposure to airborne particles (PM) is one of the most significant environmental risks people face, air pollutants occur indoors, where people spend most of their time, without realizing that could be permanently exposed to air pollution. Chlorophytum comosum was evaluated as a bioindicator and phytoremediator of indoor air pollution in the library of the University of Pamplona-Colombia. The presence of polycyclic aromatic hydrocarbons (PAHs) and heavy metals was identified in the root and leaf. Initially the organic matter present in the root and leaf of the plant was obtained by ultrasound, concentrated by rotaevaporation, the global extract was used for the determination of PAHs by gas chromatography (FID). The PAHs found in the indoor air were fluorantene, pyrene, benzo(a) anthracene, chromene, benzo (b) fluorantene, benzo (k) fluorantene, benzo(a) pyrene. For the identification of metals, the plants were subjected to desiccation by 48 hours, and were digested with $\mathrm{HCl}$. The extracts were analyzed by means of the Atomic Absorption Spectrophotometer. The heavy metals found in the indoor air were $\mathrm{Cr}, \mathrm{Cu}, \mathrm{Fe}, \mathrm{Mn}, \mathrm{Pb}$ and $\mathrm{Zn}$. The (HAPs) and heavy metals found in the extracts of the plants analyzed (indoor air) coincide with those found in the $\mathrm{PM}_{2.5}$ filters used to monitor the air quality of outdoor environments at the University of Pamplona with the Partisol 2025 Plus .
\end{abstract}

Keywords: Chlorophytum comosum, bioindicador, phytoremediation, indoor air, particulate matter, PAHs, heavy metals.

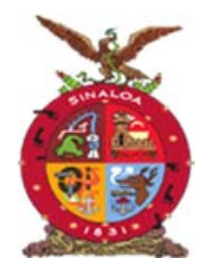

XVIII Congreso Internacional

XXIV Congreso Nacional de Ciencias ambientales

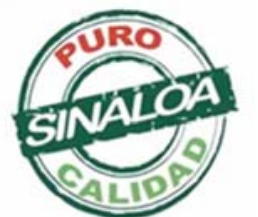

Mazatlán, Sinaloa 3-7 junio 2019
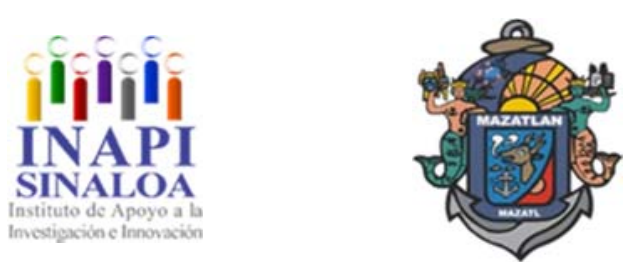

Energías Limpias

y Acciones por el Clima 
TECNOLOGICO NACIONAL DE MEXICO
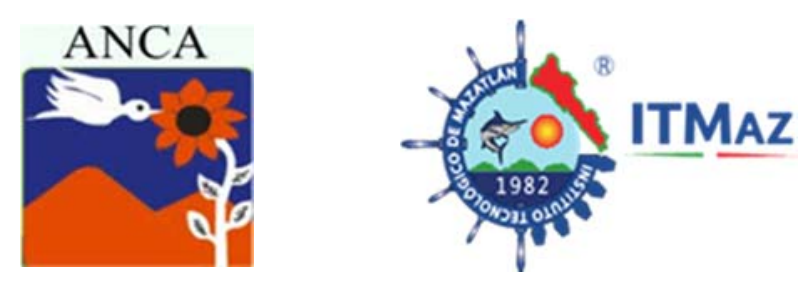

Material particulado ( $\left.\mathrm{PM}_{2.5}\right)$ en la atmósfera de la Ciudad de Toluca

Gómez Hinojos AM, Mares Cuevas MJ, Gómez Martínez F

Licenciatura en Ciencias Ambientales.

Facultad de Planeación Urbana y Regional.

Facultad de Química. Universidad Autónoma del Estado de México. Mariano Matamoros Sur Esq. Paseo Tollocan, Col. Universidad, Toluca, *nicemarcelagomez@yahoo.com.mx

\section{RESUMEN}

El Índice de Desempeño Ambiental 2018 muestra que México se ha visto afectado por uno de los principales problemas ambientales y de salud que es la contaminación del aire, desplazándose el EPI del lugar 86 al 75 de 180. La contaminación atmosférica es un problema derivado principalmente de actividades antropogénicas seguido de algunos procesos naturales. En la Ciudad de Toluca se observa que el Material Particulado (PM), es un contaminante criterio que favorece la mala calidad del aire, denominado así con base en las afectaciones a la salud. Se evalúa con base en los límites máximos permisibles establecidos en la NOM-025-SSA1 2014, la cual se establece $45 \mu \mathrm{g} / \mathrm{m}^{3}$ promedio para 24 horas y $12 \mu \mathrm{g} / \mathrm{m}^{3}$ en concentración anual de $\mathrm{PM}_{2.5}$. En la presente investigación se llevó a cabo el análisis de valores promedio y máximos de este contaminante analizando los datos registrados por la Red Automática de Monitoreo Atmosférico de la Zona Metropolitana del Valle de Toluca (RAMAZMVT). La presencia de PM en la atmósfera es una problemática difícil de mantener bajo control pues su presencia es multifactorial, vehículos, industrias y actividades diarias resultan ser fuentes de emisión, las $\mathrm{PM}_{2.5}$ al ser aerotransportadas, ingresan en las vías respiratorias y torrente sanguíneo de los seres vivos, generando afectaciones a la salud que dependerán en su gravedad del tiempo de exposición, composición y características químicas y físicas del PM. El análisis estadístico de las concentraciones de $\mathrm{PM}_{2.5}$ de 2011 a 2017, permitió observar en los resultados que se superaban los valores promedio y máximos establecidos por la NOM en repetidas ocasiones y en diferentes estaciones de monitoreo de la ciudad.

Palabras clave: Contaminación atmosférica, contaminante criterio, estaciones de monitoreo atmosférico.

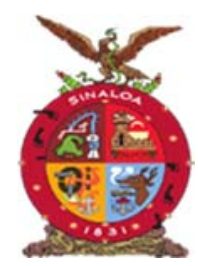

XVIII Congreso Internacional

XXIV Congreso Nacional de Ciencias ambientales

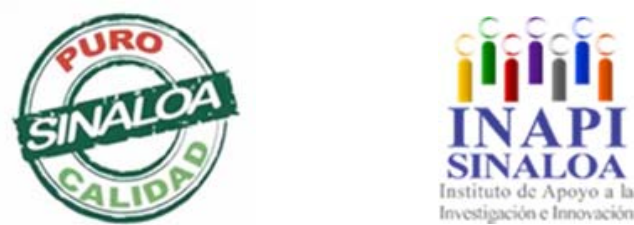

Mazatlán, Sinaloa 3-7 junio 2019

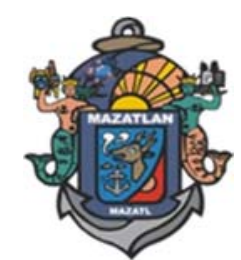

Energías Limpias

y Acciones por el Clima 

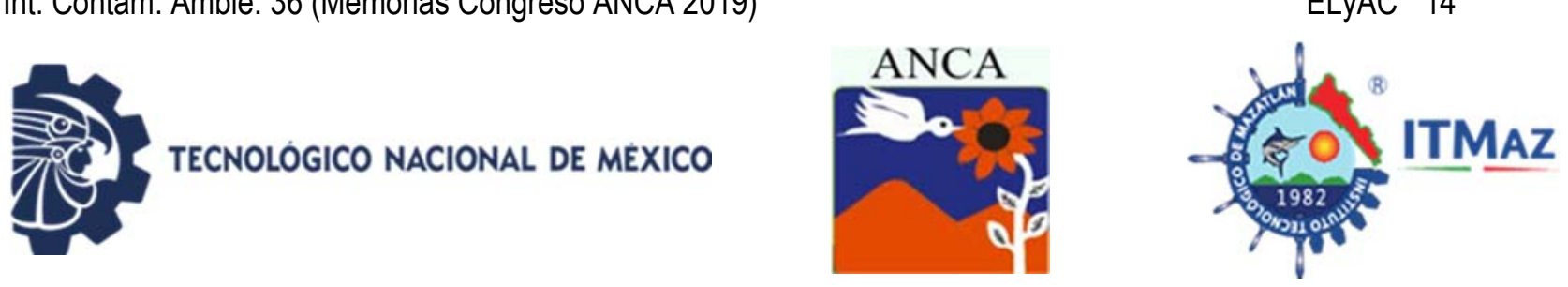

Particulate material $\left(\mathrm{PM}_{2.5}\right)$ in the atmosphere of the City of Toluca

Gómez Hinojos AM*, Mares Cuevas MJ, Gómez Martínez F

Licenciatura en Ciencias Ambientales.

Facultad de Planeación Urbana y Regional.

Facultad de Química. Universidad Autónoma del Estado de México.

Mariano Matamoros Sur Esq. Paseo Tollocan, Col. Universidad, Toluca,

*nicemarcelagomez@yahoo.com.mx

\begin{abstract}
The Environmental Performance Index 2018 shows that Mexico has been affected by one of the main environmental and health problems that are air pollution, displacing the EPI from place 86 to 75 of 180 . Air pollution is a problem derived from anthropogenic activities followed by some natural processes. In the City of Toluca, it is observed that particulate material (PM) is one of the significant pollutants that allows poor air quality and bad health effects. It is evaluated based on the maximum permissible limits in NOM-025-SSA1 2014, which is $45 \mu \mathrm{g} / \mathrm{m}^{3}$ average for 24 hours and $12 \mu \mathrm{g} / \mathrm{m}^{3}$ in the annual concentration of $\mathrm{PM}_{2.5}$. In the present investigation, an analysis of average and maximum values of this pollutant was carried out analyzing the data of the Automatic Network of Atmospheric Monitoring of the Metropolitan Zone of the Valley of Toluca (RAMAZMVT). The presence of PM in the atmosphere is a difficult problem to keep under control because its presence is multifactorial, vehicles, industries and activities in the emissions sources, $\mathrm{PM}_{2.5}$ is in the air and it enters into the respiratory tract and bloodstream of the living, these generating affectations in the health that depends on their time of exhibition. Composition and chemical and physical characteristics of PM. The statistical analysis of the results of $\mathrm{PM}_{2.5}$ from 2011 to 2017, shows that the results are exceeded by the average and maximum values established by the NOM on repeated occasions and in the different monitoring stations of the city.
\end{abstract}

Keywords: Atmospheric pollution, criteria pollutant, atmospheric monitoring stations.

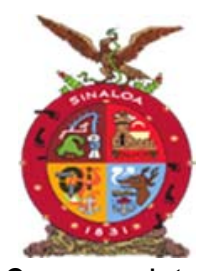

XVIII Congreso Internacional

XXIV Congreso Nacional de Ciencias ambientales

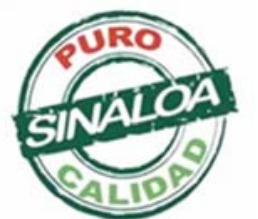

Mazatlán, Sinaloa 3-7 junio 2019
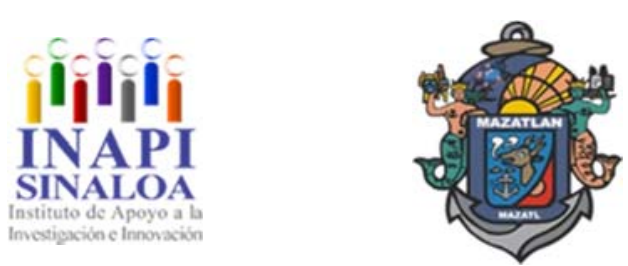

Energías Limpias

y Acciones por el Clima 

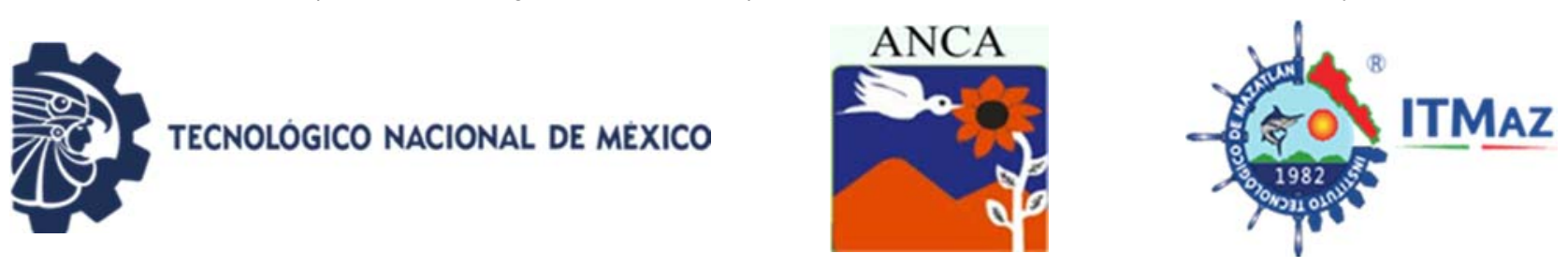

\title{
Liberación de oxígeno radial por plantas nativas y no nativas de humedales tropicales y su relación con la emisión de metano
}

\author{
Hernández Alarcón ME*, Hernández Pérez YY \\ Red de manejo biotecnológico. Instituto de Ecología A.C. \\ Carretera antigua a Coatepec, 352, Col. El Haya, Xalapa, Veracruz, México \\ *elizabeth.hernandez@inecol.mx
}

\section{RESUMEN}

El metano se produce en los suelos anegados de los humedales por microorganismos anaerobios. Las plantas de los humedales liberan oxigeno por la raíz favoreciendo condiciones aerobias que favorecen la oxidación aerobia del metano, lo cual podría mitigar las emisiones de este gas de efecto invernadero con un potencial de calentamiento global 25 veces mayor que el bióxido de carbono. Nuestro objetivo fue medir la liberación de oxígeno en plantas nativas y no nativas de humedales, y la emisión de metano en suelos de microcosmos de humedales sembrados con dichas plantas. El mesocosmos se realizó en contenedores de plástico de $24 \times 38 \times 45 \mathrm{~cm}$ largo ancho y alto, con suelo de humedales y sembrados con dos individuos de las plantas nativas (Sagitaria latifolia, Pontederia cordata) y no nativas (Echinocloa pyramidalis) y sin plantas para el control. Se midio la liberación de oxígeno por el método del azul de metileno y las emisiones de metano por cromatografía de gases, durante enerofebrero 2019 en Xalapa, Veracruz. Se encontró que las plantas nativas tuvieron más altas liberaciones de oxígeno $\left(28.4\right.$ y $\left.19 \mathrm{~mm}^{2} \mathrm{~h}^{-1}\right)$ que el pasto no nativo $(6.46$ $\mathrm{mm}^{2} \mathrm{~h}^{-1}$ ) y que las emisiones de metano fueron más bajas en los microcosmos con plantas nativas $\left(-0.022 \mathrm{y}-0.0050 \mathrm{mg} \mathrm{m}^{-2} \mathrm{~min}^{-1}\right)$ que con E. pyramidalis $(0.050$ $\left.\mathrm{mg} \mathrm{m}^{-2} \mathrm{~min}^{-1}\right)$ y los microcosmos sin plantas tuvieron emisiones de metano significativamente $(P=0.03)$ más altos $(0.077)$ que aquellos con plantas. Se concluye que la liberación de oxígeno por las plantas nativas ayuda a mitigar las emisiones de metano.

Palabras clave: Aerénquima, oxidación de metano, gases de efecto invernadero, calentamiento global.

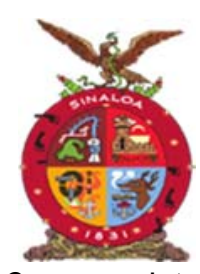

XVIII Congreso Internacional

XXIV Congreso Nacional de Ciencias ambientales
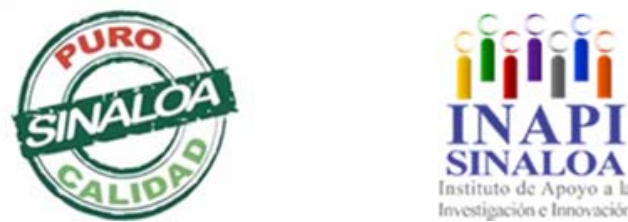

Mazatlán, Sinaloa 3-7 junio 2019

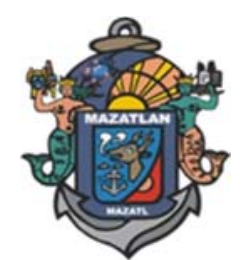

Energías Limpias

y Acciones por el Clima 

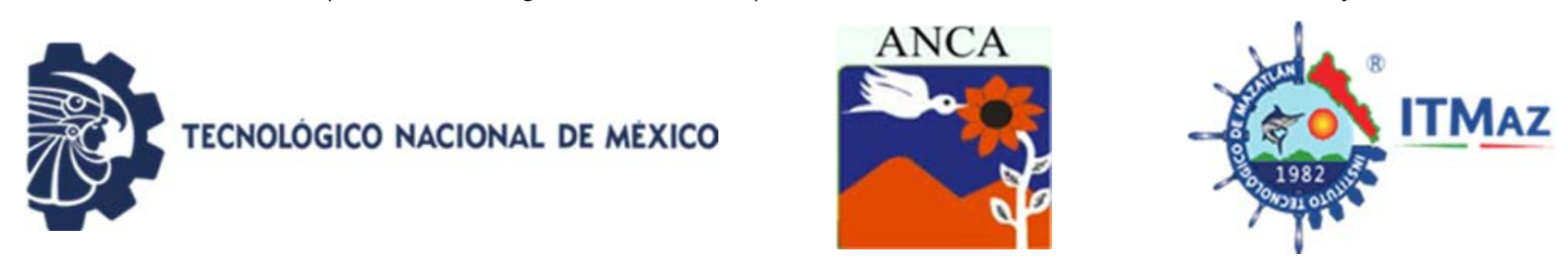

\title{
Radial oxygen loss in native and no native wetland plants and their relationship with methane emissions
}

\author{
Hernández Alarcón ME*, Hernández Pérez YY \\ Red de manejo biotecnológico. Instituto de Ecología A.C. \\ Carretera antigua a Coatepec, 352, Col. El Haya, Xalapa, Veracruz, México \\ *elizabeth.hernandez@inecol.mx
}

\begin{abstract}
Methane is produced in flooded wetland soils, by anaerobic microorganisms. Wetland plant roots release oxygen, enhancing aerobic conditions that favor the aerobic oxidation of methane, which could help to mitigate the emissions of this potent greenhouse gas with a global warming potential of 25 times than carbon dioxide. Our objective was to measure the radial oxygen release and the methane emissions in microcosms with native and no native wetland plants and without plants (control). Microcosm were plastic containers $(24 \times 38 \times 45 \mathrm{~cm}$ large, wide and tall), with wetland soils and planted with 2 native (Sagitaria latifolia, Pontederia cordata) and two no native wetland plants (Echinocloa pyramidalis) and without plants (control). Radial oxygen release was measured by the blue methylene method and methane emissions by gas chromatography, during January and February 2019 in Xalapa, Veracruz. Native wetland plants showed higher radial oxygen reléase $\left(28.4\right.$ y $\left.19 \mathrm{~mm}^{2} \mathrm{~h}^{-1}\right)$ than no native grass $\left(6.46 \mathrm{~mm}^{2} \mathrm{~h}^{-}\right.$ $\left.{ }^{1}\right)$. Methane emissions were lower in the microcosms with native plants $(-0.022 \mathrm{y}-$ $\left.0.0050 \mathrm{mg} \mathrm{m}^{-2} \mathrm{~min}^{-1}\right)$ than with E. pyramidalis $\left(0.050 \mathrm{mg} \mathrm{m}^{-2} \mathrm{~min}^{-1}\right)$ and the control microcosmos had significantly higher $(P=0.03)$ methane emissions $\left(0.077 \mathrm{mg} \mathrm{m}^{-}\right.$ ${ }^{2} \mathrm{~min}^{-1}$ ) than microcosms with plants. It was concluded that radial oxygen release by native wetland plants helps to mitigate methane emissions.
\end{abstract}

Keywords: Aerenchyma, methane oxidation, greenhouse gases, global warming, pollution.

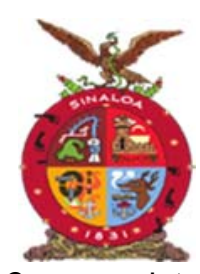

XVIII Congreso Internacional

XXIV Congreso Nacional de Ciencias ambientales
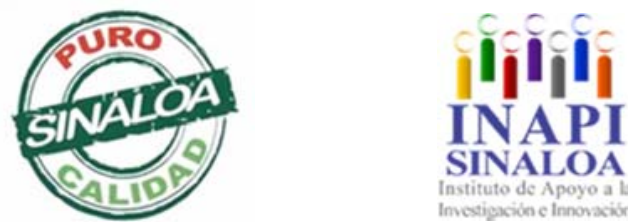

Mazatlán, Sinaloa 3-7 junio 2019

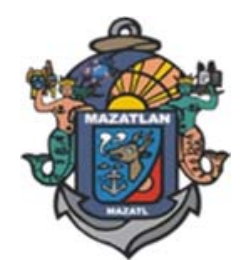

Energías Limpias

y Acciones por el Clima 

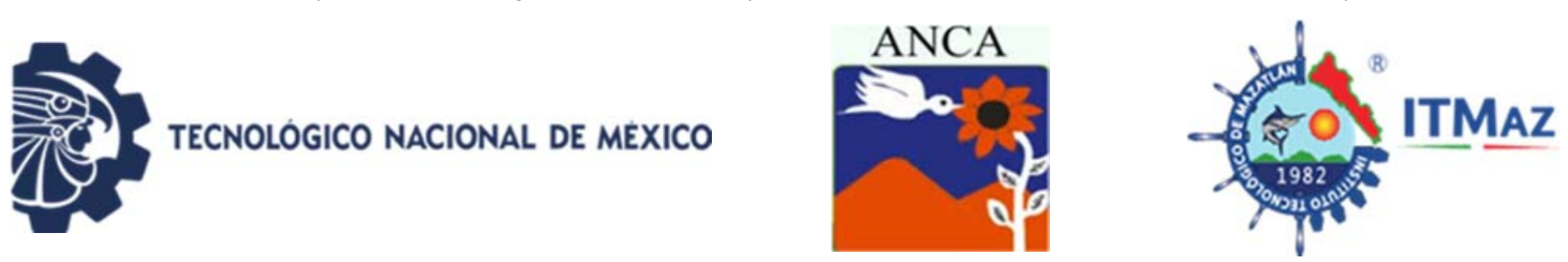

\title{
Diseño de un sistema fotovoltaico interconectado a la red para ahorro de energía eléctrica en la Universidad del Noreste, Tampico, Tamaulipas
}

\author{
Llera García E*, Estrella Rodríguez J \\ Universidad del Noreste \\ *edllera1995@gmail.com
}

\begin{abstract}
RESUMEN
Las instituciones de educación media superior y superior registran un gasto considerable de electricidad, debido a las actividades llevadas a cabo en ellas. La Universidad del Noreste consume en promedio diario 267 kilowatts hora en periodo punta; además, no utiliza fuentes renovables. El objetivo de esta investigación es proponer un sistema fotovoltaico interconectado a la red que permita ahorrar un porcentaje del $30 \%$ respecto al gasto de energía total que presenta la Universidad, para recuperar la inversión realizada en un periodo máximo de 12 años. La investigación se realizó en la Universidad del Noreste, Tampico, Tamaulipas, entre los meses de agosto de 2018 y febrero de 2019. Para el diseño del sistema, se seleccionaron dos edificios correspondientes a la Universidad tomando en cuenta la altura, las dimensiones utilizables para su implementación y la inexistencia de obstáculos que pudiesen interferir con la captación de luz solar por parte de los paneles solares. Se tomó como parámetro principal del gasto de electricidad el mes de agosto de 2018 debido a la afluencia de alumnado y personal de la institución, además de ser el verano la estación del año donde existe un mayor consumo de electricidad. Tomando en cuenta la producción de electricidad y el porcentaje que se pretende ahorrar, se propuso un sistema de 63 paneles solares y dos inversores distribuidos en los dos edificios. Como conclusión, el ahorro de energía del sistema fotovoltaico y el costo del mismo se cubrieron satisfactoriamente de acuerdo al objetivo establecido, presentando además potencial de crecimiento.
\end{abstract}

Palabras clave: Sistema fotovoltaico, paneles solares, kilowatts hora, inversor.

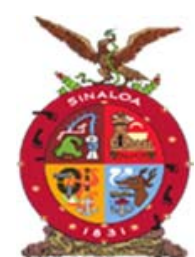

XVIII Congreso Internacional

XXIV Congreso Nacional de Ciencias ambientales

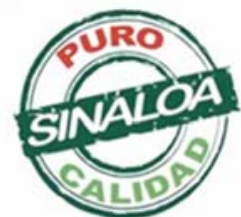

Mazatlán, Sinaloa 3-7 junio 2019

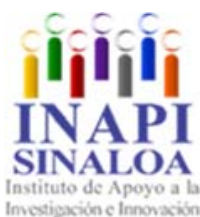

SINALOA

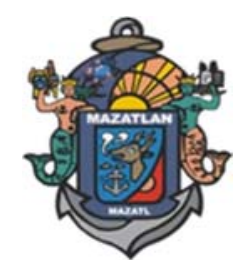

Energías Limpias

y Acciones por el Clima 

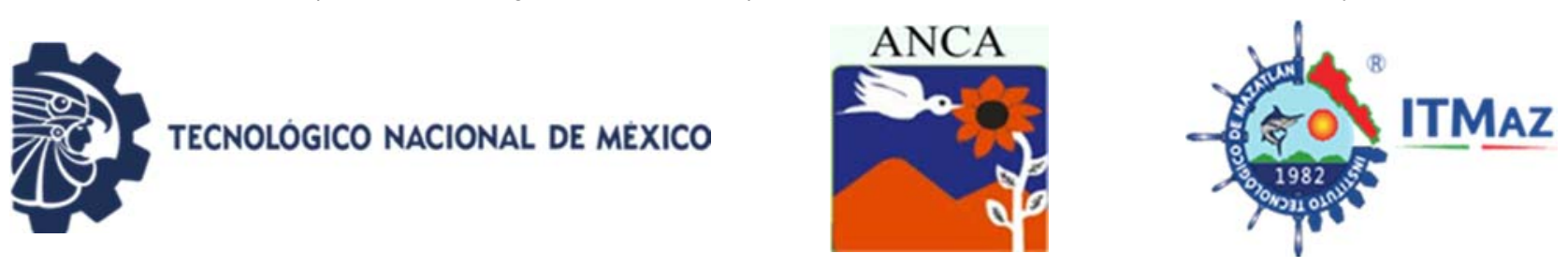

\title{
Design of a photovoltaic system interconnected to grid to save energy in Universidad del Noreste, Tampico, Tamaulipas
}

\author{
Llera García E*, Estrella Rodríguez J \\ Universidad del Noreste \\ *edllera1995@gmail.com
}

\begin{abstract}
Upper secondary and superior education institutions register a considerable electricity expense, due to the developed activities in them. Universidad del Noreste spends an average of 267 kilowatts per hour in its peak period; besides, it doesn't work with renewable energies. The research's objective is to propose a photovoltaic system interconnected to the grid which allows to save a $30 \%$ of energy consumption in the University, in order to regain the investment in a 12year period. The research was made in Universidad del Noreste, Tampico, Tamaulipas, between August 2018 and January 2019. In order to propound the system's design, two buildings were selected taking as advantages the height, the dimensions which can be used for the design and the few obstacles that could interfere with the sunlight input in the solar panels. The main parameter was the electricity consumption in August 2018 due to the student body and personnel attendance, plus summer is meant to be the season in which exists a higher electricity expense. Considering the electricity production and the percentage that is intended to cover, 63 solar panels and two inverters system was proposed; this system was distributed between the two selected buildings. In conclusion, the energy saving of the photovoltaic system and its cost were satisfactorily covered according to the stablished objective, presenting in addition a growth potential.
\end{abstract}

Keywords: Photovoltaic system, solar panels, kilowatts per hour, inverter.

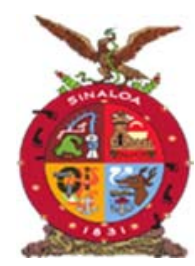

XVIII Congreso Internacional

XXIV Congreso Nacional de Ciencias ambientales

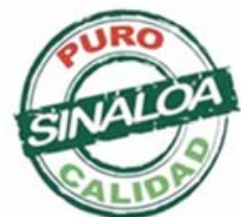

Mazatlán, Sinaloa 3-7 junio 2019

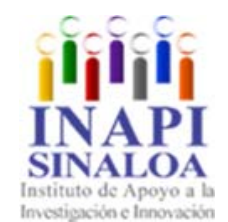

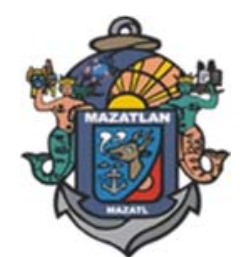

Energías Limpias

y Acciones por el Clima 

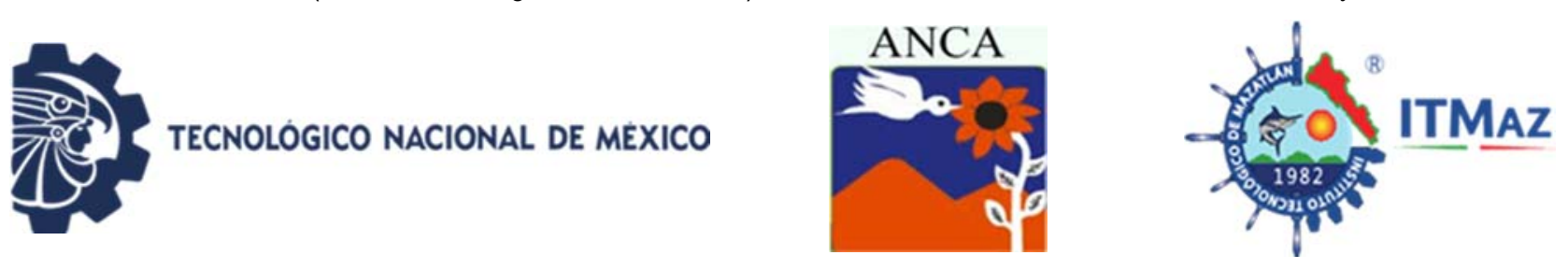

\section{Análisis del potencial de biorrefinerías energéticas a partir de materiales vegetales emergentes (Neem (Azadirachta indica) y Moringa (Moringa oleífera))}

Luna Avelar K*, Ambriz Pérez D, Mejias Brizuela N, Díaz Pazos J, Garate Osuna A, Santos Ballardo D

Posgrado en Ciencia y Tecnología de Alimentos. Universidad Autónoma de Sinaloa. México

Ingeniería en Energía. Universidad Politécnica de Sinaloa. México Maestría en Ciencias Aplicadas. Universidad Politécnica de Sinaloa. México *ibtkarlaluna@gmail.com

\section{RESUMEN}

México es considerado un país megadiverso por lo que presenta un alto potencial para generación de materia prima para obtención de biocombustibles, una de las alternativas es el aprovechamiento sostenible de fuentes de origen vegetal emergentes para la producción de biocombustibles, dentro de las posibles opciones para este fin, surge la Moringa $(\mathrm{Mo})$ y el Neem (Ne), cuyo potencial no se ha explorado por completo. Debido a su presencia en el estado de Sinaloa, el objetivo del trabajo fue determinar el potencial de las semillas de Mo y Ne como materia prima para biorrefinería energética. En el presente trabajo, se realizó la extracción de aceite a partir de $\mathrm{Mo}$ y $\mathrm{Ne}$, mientras que con la biomasa residual (BR) se realizaron digestiones anaeróbicas (DA) para analizar su potencial metanogénico (PM), esto con el objetivo explorar su potencial como biorefinería energética. Los resultados arrojaron porcentajes de extracción de aceite de 27.44 $\pm .0 .74 \%$ para Mo y $28.45 \pm 5.58$ para Ne. A partir de la biomasa residual se obtuvieron $59.43 \pm 1.4 \mathrm{~mL} \mathrm{CH} / \mathrm{gr}$ SV para Mo y $33.53 \pm 1.6 \mathrm{~mL} \mathrm{CH} 4 / \mathrm{gr} \mathrm{SV}$. Mostrando un potencial adecuado para utilizar este producto como materia prima de biorefinería energética. Se concluye que las semillas de Mo y Ne pueden ser una buena fuente de lípidos para obtención de biodiesel; por otro lado, la BR obtenida de dicho proceso presenta un PM alto, con posibilidades de mejorarse. Por otro lado, en cuanto al PM de estos materiales, prácticamente no se encuentra información científica relevante.

Palabras clave: Biorrefinería energética, Moringa, Neem, aceite, potencial metanogénico.

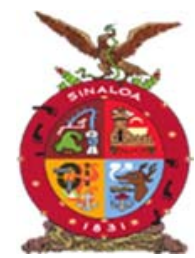

XVIII Congreso Internacional

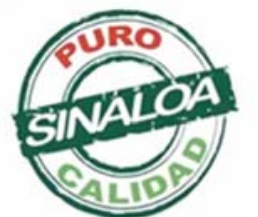

Mazatlán, Sinaloa 3-7 junio 2019

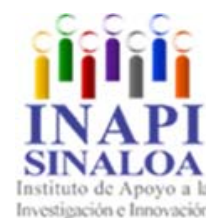

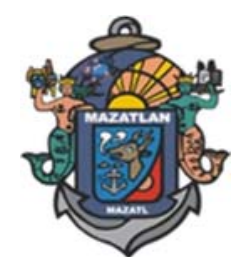

Energías Limpias

y Acciones por el Clima 

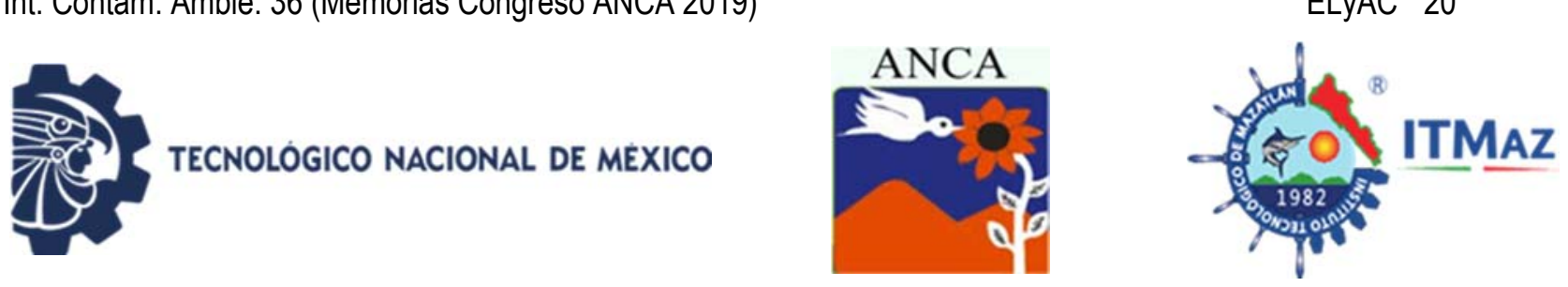

\title{
Analysis of the potential of energy biorrefineries from emerging vegetable materials (Neem (Azadirachta indica) y Moringa (Moringa oleífera))
}

\author{
Luna Avelar K*, Ambriz Pérez D, Mejias Brizuela N, Díaz Pazos J, \\ Garate Osuna A, Santos Ballardo D \\ Posgrado en Ciencia y Tecnología de Alimentos. \\ Universidad Autónoma de Sinaloa. México \\ Ingeniería en Energía. Universidad Politécnica de Sinaloa. México \\ Maestría en Ciencias Aplicadas. Universidad Politécnica de Sinaloa. México \\ *ibtkarlaluna@gmail.com
}

\begin{abstract}
Mexico is considered a megadiverse country so it has a high potential for generating raw material to obtain biofuels, one of the alternatives is the sustainable use of emerging plant sources for the production of biofuels, within the possible options for this purpose, there is Moringa (Mo) and $\mathrm{Neem}(\mathrm{Ne})$, whose potential has not been fully explored. Due to its presence in the state of Sinaloa, the objective of the work was to determine the potential of Mo and $\mathrm{Ne}$ seeds as raw material for energy biorefinery. In the present work, the extraction of oil from Mo and Ne was carried out, while with the residual biomass (BR) anaerobic digestion (DA) was performed to analyze its methanogenic potential $(P M)$, this with the objective to explore its potential as energy biorefinery. The results showed oil extraction percentages of $27.44 \pm .0 .74 \%$ for Mo and $28.45 \pm$ 5.58 for Ne. From the residual biomass, $59.43 \pm 1.4 \mathrm{~mL} \mathrm{CH}_{4} / \mathrm{grSV}$ for Mo and $33.53 \pm 1.6 \mathrm{~mL} \mathrm{CH}_{4} / \mathrm{grSV}$ were obtained. Showing an adequate potential to use this product as raw material for energy biorefinery. It is concluded that the seeds of Mo and $\mathrm{Ne}$ can be a good source of lipids to obtain biodiesel; On the other hand, the BR obtained from this process has a high MP, with possibilities of improvement. On the other hand, as regards the PM of these materials, virtually no relevant scientific information is found.
\end{abstract}

Keywords: Energy biorefinery, Moringa, Neem, oil, methanogenic potential.

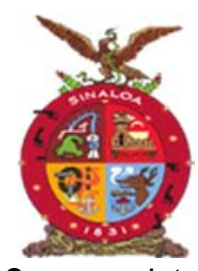

XVIII Congreso Internacional

XXIV Congreso Nacional de Ciencias ambientales

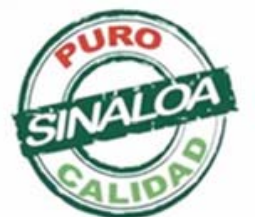

Mazatlán, Sinaloa 3-7 junio 2019

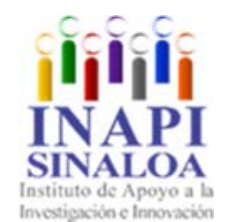

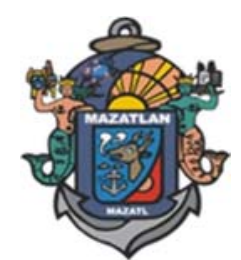

Energías Limpias

y Acciones por el Clima 

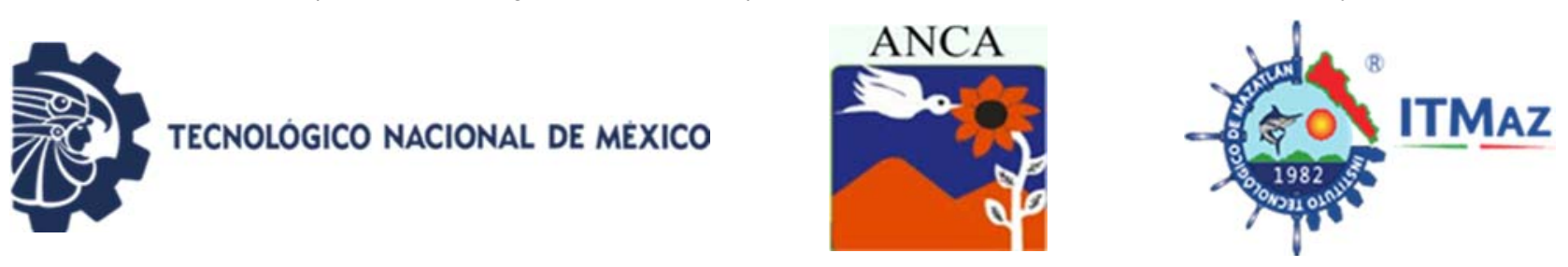

\section{Evaluación de la calidad del aire empleando un vehículo aéreo no tripulado}

Martínez Guzmán MJ, De la Peña Arellano LA, Valle Cervantes S, Rodríguez Rosales MDJ, Salazar Muñoz Y

Maestría en Sistemas Ambientales. Departamento de Ing. Química y Bioquímica. UPIDET.

Maestría en Ingeniería. Departamento de Ing. Eléctrica-Electrónica. UPIDET.

Tecnológico de Durango. Tecnológico Nacional de México/ Instituto

Blvd. Felipe Pescador 1830 Ote. C.P. 34080, Durango, México azulaqua19@hotmail.com

\section{RESUMEN}

Un sistema de medición de la calidad del aire está formado por una red de casetas de monitoreo de los contaminantes criterio $\left(\mathrm{O}_{3}, \mathrm{CO}, \mathrm{NOx}, \mathrm{SO}_{2}\right.$ y $\mathrm{PM}_{10}$ y $\mathrm{PM}_{2.5}$ ) y su objetivo es medir, registrar y procesar información sobre la cantidad de estos contaminantes. La mayoría de estos sistemas de medición consisten en estaciones fijas que representan un alto costo para la supervisión de zonas extensas, es por ello que surge la necesidad de combinarlos con unidades móviles de fácil manejo e independencia. Los vehículos aéreos no tripulados son considerados una solución factible y aplicable a este problema pues permiten que su manipulación sea más fácil. Se evalúa la calidad del aire en la ciudad de Durango mediante el uso de un vehículo aéreo no tripulado (VANT) para proporcionar y validar una herramienta de mayor alcance y practicidad, para ello, se instrumentó un sistema de medición en un VANT para la realización de las mediciones, luego se efectuó la construcción del sistema de medición, con la utilización de una placa ARDUINO y sensores correspondientes a las variables seleccionadas (temperatura, humedad, presión, ozono, $\mathrm{PM}_{2.5}$, etc.), y se realizó su calibración con ayuda de los equipos de medición de la caseta de monitoreo. Se diseñó y construyó el sistema de medición para que permitiera adquirir los datos de las variables seleccionadas anexo al VANT y se analizaron los datos obtenidos de las mediciones utilizando el método "series de tiempo".

Palabras clave: Contaminación, calidad del aire, monitoreo, VANT.

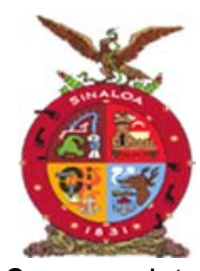

XVIII Congreso Internacional

XXIV Congreso Nacional de Ciencias ambientales

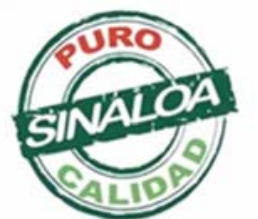

Mazatlán, Sinaloa 3-7 junio 2019
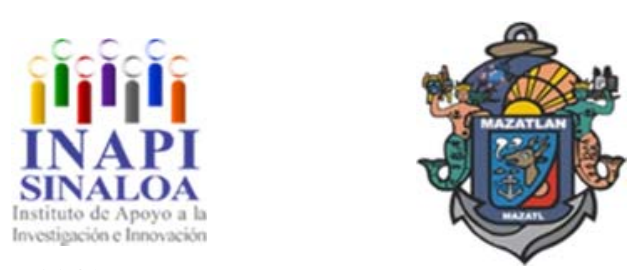

Energías Limpias

y Acciones por el Clima 

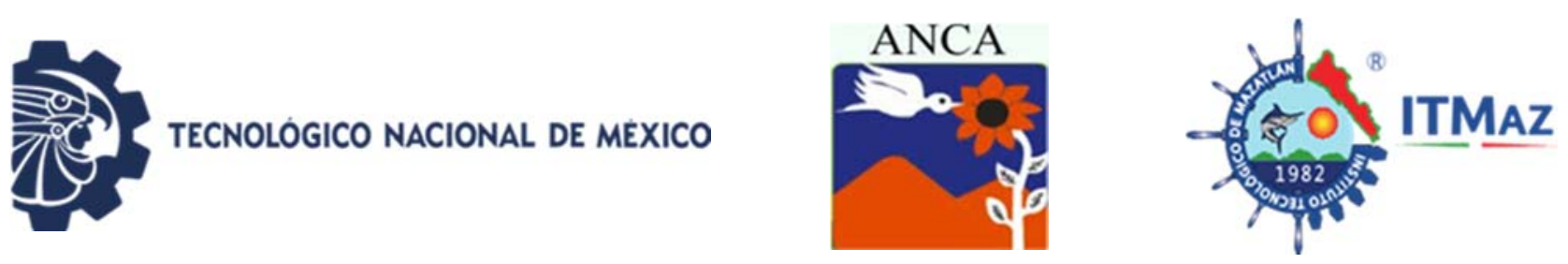

Evaluation of air quality using an unmanned aerial vehicle

Martínez Guzmán MJ, De la Peña Arellano LA, Valle Cervantes S, Rodríguez Rosales MDJ, Salazar Muñoz Y

Maestría en Sistemas Ambientales. Departamento de Ing. Química y Bioquímica. UPIDET.

Maestría en Ingeniería. Departamento de Ing. Eléctrica-Electrónica. UPIDET.

Tecnológico de Durango. Tecnológico Nacional de México/ Instituto

Blvd. Felipe Pescador 1830 Ote. C.P. 34080, Durango, México azulaqua19@hotmail.com

\begin{abstract}
An air quality measurement system is formed by a network of measures to monitor pollutants $\left(\mathrm{O}_{3}, \mathrm{CO}, \mathrm{NOx}, \mathrm{SO}_{2}\right.$ y $\mathrm{PM}_{10}$ y $\left.\mathrm{PM}_{2.5}\right)$ and its objective is to measure, record and process information on these pollutants. Most of these air quality measurement systems are fixed stations that represent a high cost for the supervision of large areas, which is why there is a need to combine them with mobile units that are easy to handle and independent. Unmanned aerial vehicles are considered a feasible and applicable solution to this problem because they allow their handling to be easier. Therefore, the objective of this investigation was to evaluate the air quality in the city of Durango through the use of an unmanned aerial vehicle (UAV) to provide and validate a tool of greater scope and practicality. First a measuring system was instrumented and the UAV was purchased for the realization of the measurements, then the construction of the measurement system was carried out, with the use of an ARDUINO plate and the sensors corresponding to the selected variables (temperature, humidity, pressure, ozone, $\mathrm{PM}_{2.5}$, etc.) and its calibration was carried out with the help of the measuring equipment of the monitoring house. The measurement system was designed and constructed to allow the acquisition of the data of the selected variables annexed to the UAV, and the data obtained from the measurements were analyzed using the "time series" method.
\end{abstract}

Keywords: Pollution, air quality, monitoring, UAV.

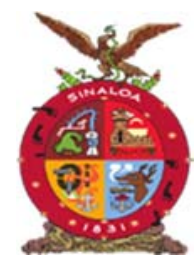

XVIII Congreso Internacional

XXIV Congreso Nacional de Ciencias ambientales

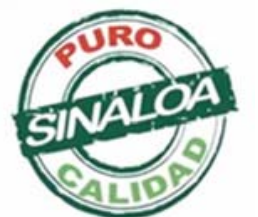

Mazatlán, Sinaloa 3-7 junio 2019

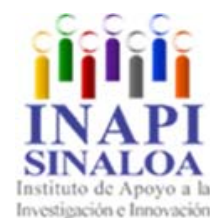

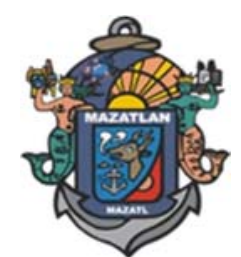

Energías Limpias

y Acciones por el Clima 

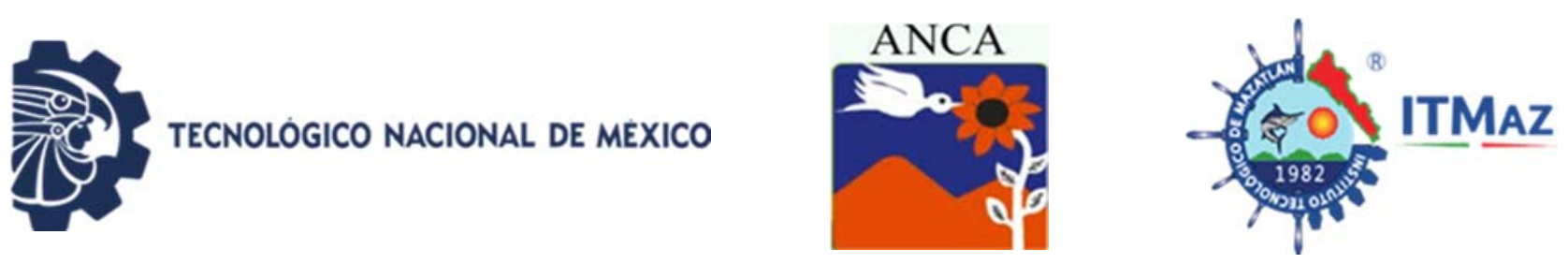

\title{
Aplicación de la NOM-025-STPS-2008, para el análisis de iluminación en la Facultad de Ingeniería Química, BUAP
}

\author{
Martínez Munguía R, Velasco Hernández M, Guevara Espinosa M \\ Licenciatura en Ingeniería Ambiental. Facultad de Ingeniería Química. \\ Benemérita Universidad Autónoma de Puebla. México \\ ambientalbuap@yahoo.com.mx
}

\section{RESUMEN}

El ahorro y el consumo responsable de energía, es importante debido a que contribuye con la reducción de la emisión de Gases de Efecto Invernadero. Sin embargo, se requiere de un diagnóstico para poder establecer medidas que a contribuya a una disminución del consumo energético, menor impacto sobre el medio ambiente, contribuyendo a reducir la generación de calor la lucha contra el cambio climático y un cambio sostenible. Por lo que se planteó el siguiente objetivo: Identificar la cantidad de luxes que se emiten en la Facultad, durante el periodo de enero a abril de 2019, para hacer un análisis de los límites máximos permisibles de la Norma Oficial Mexicana NOM-025-STPS-2008, condiciones de iluminación en los centros de trabajo. Se utilizó un equipo portátil para la medición de luxes modelo HS1010. Se realizaron mediciones en los salones, laboratorios, oficinas, baños y se compararon con el valor límite máximo permisible de 300 luxes. Los resultados muestran que se rebasa la norma en un $74 \%$ de los sitios muestreados, lo cual indica que existe un uso inadecuado de lámparas, un exceso de flujo lumínico e importante pérdida de electricidad, que conlleva a un gasto energético innecesario. Por lo que la investigación contribuyó a identificar un cambio en los hábitos de consumo, actividades de buenas práctica e innovación tecnológica.

Palabras clave: Luxes, energía, tecnología, concientización, mantenimiento.

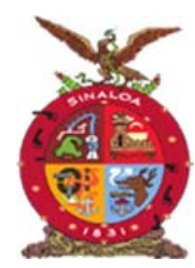

XVIII Congreso Internacional

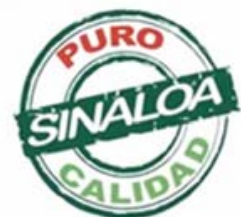

Mazatlán, Sinaloa 3-7 junio 2019

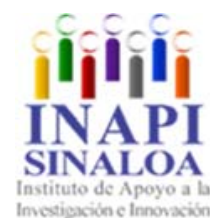

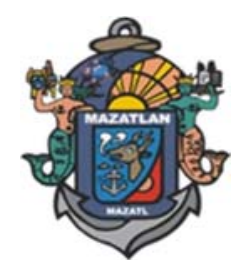

Energías Limpias

y Acciones por el Clima 

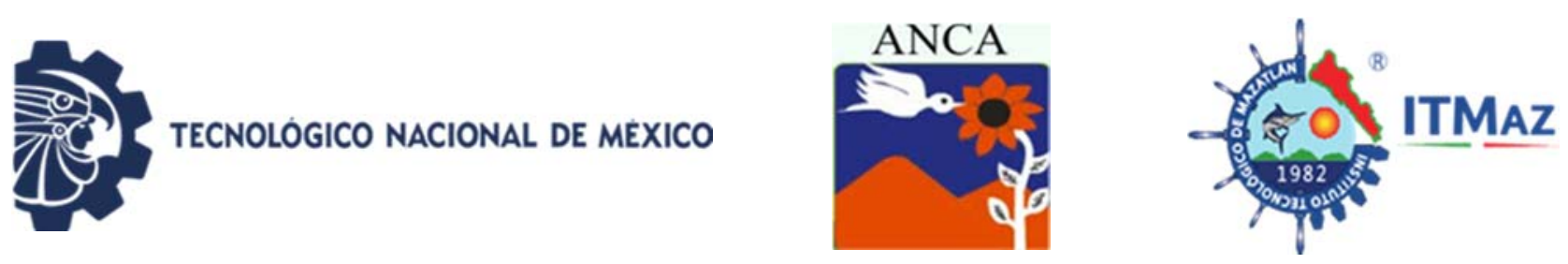

\title{
Application of NOM-025-STPS-2008, for the analysis of lighting in the Faculty of Chemical Engineering, BUAP
}

\author{
Martínez Munguía R, Velasco Hernández M, Guevara Espinosa M \\ Licenciatura en Ingeniería Ambiental. Facultad de Ingeniería Química. \\ Benemérita Universidad Autónoma de Puebla. México \\ ambientalbuap@yahoo.com.mx
}

\begin{abstract}
The saving and responsible consumption of energy is important because it contributes to the reduction of the emission of Greenhouse Gases. However, a diagnosis is required to establish measures that contribute to a decrease in energy consumption, less impact on the environment, contributing to reduce heat generation, the fight against climate change and sustainable change. Therefore, the following objective was set: Identify the amount of luxes that are issued in the Faculty, during the period from January to April 2019, to make an analysis of the maximum permissible limits of the Official Mexican Standard NOM-025-STPS2008 , lighting conditions in work centers. A portable device was used to measure luxes model HS1010. Measurements were made in classrooms, laboratories, offices, bathrooms and compared with the maximum permissible limit value of 300 lux. The results show that the norm is exceeded in $74 \%$ of the sampled sites, which indicates that there is an inappropriate use of lamps, an excess of luminous flux and significant loss of electricity, which leads to unnecessary energy expenditure. Therefore, the research helped identify a change in consumption habits, good practice activities and technological innovation.
\end{abstract}

Keywords: Luxes, energy, technology, awareness, maintenance.

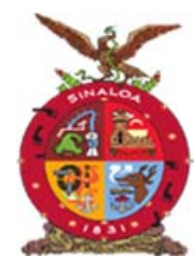

XVIII Congreso Internacional XXIV Congreso Nacional de Ciencias ambientales
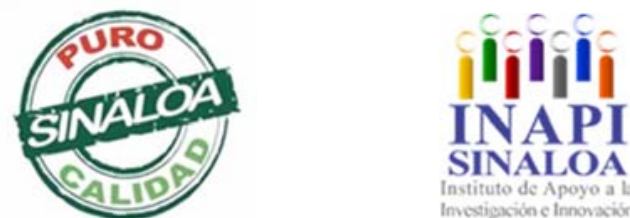

Mazatlán, Sinaloa 3-7 junio 2019

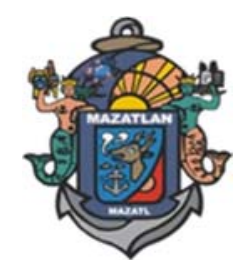

Energías Limpias

y Acciones por el Clima 

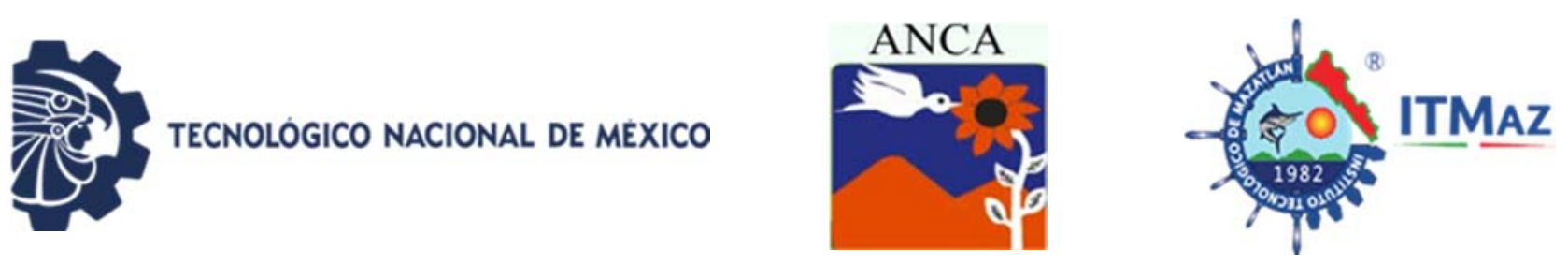

Los hongos un atractivo ecoturístico en Durango, México

\author{
Naranjo Jiménez $\mathrm{N}^{*}$, Rosas Medina I, Colmenero Robles A \\ Centro Interdisciplinario de Investigación para el Desarrollo Integral Regional. \\ Instituto Politécnico Nacional. Unidad Durango. \\ Sigma 119, Fracc. 20 de noviembre II, INFONAVIT, Durango, México \\ COFAA y/o EDI. Secretaria de Investigación y Posgrado-IPN \\ *nnestor@hotmail.com
}

\begin{abstract}
RESUMEN
Los bosques de El Salto, Pueblo Nuevo, Durango albergan una gran diversidad de hongos silvestres que se colectan y consumen algunas especies comestibles. No existen programas para su manejo, de ahí la necesidad de realizar trabajos e investigaciones para su manejo y las gestiones para el establecimiento de un parque micológico para promover el conocimiento, aprovechamiento sustentable y conservación de los hongos silvestres. El objetivo fue realizar las gestiones para la implementación de un parque micológico en El Salto, Pueblo Nuevo, Durango. Se eligió al Centro Ecoturístico "Puentecillas", para el posible establecimiento, se realizó el inventario de los hongos del lugar, se diseñaron y aplicaron dos encuestas, para el estudio etnomicológico y para conocer el interés de la población a visitar el parque micológico. El inventario arrojo 55 especies entre micorrízicas y saprobios/lignícolas de estas; Amanita caesarea, Boletus edulis y Cantharellus cibarius fueron las especies comestibles más representativas. En relación con la abundancia y biodiversidad fúngica del lugar se establecieron tres senderos micológicos. De los encuestados el $85 \%$ manifestaron tener conocimientos sobre los hongos lo cual sería de utilidad para fungir como guías en el parque micológico. En suma, los parques micológicos pueden manejarse como Unidades de Manejo para la Conservación de la Vida Silvestre y con la normatividad existente pueden brindar a las visitantes actividades de recreación y aprendizaje sobre el recurso fúngico y del medio ambiente en general. De los encuestados el $86 \%$ mostro interés en asistir al parque micológico y brindar un pago por el servicio.
\end{abstract}

Palabras clave: Micológico, ecoturismo, hongos, micorrizicos.

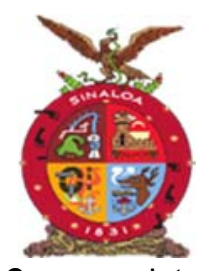

XVIII Congreso Internacional

XXIV Congreso Nacional de Ciencias ambientales

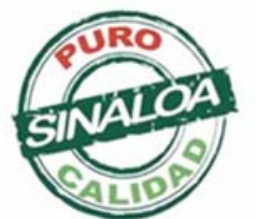

Mazatlán, Sinaloa 3-7 junio 2019

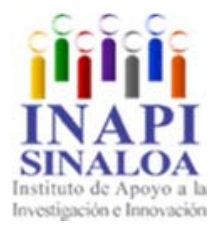

19
Energías Limpias
y Acciones por el Clima



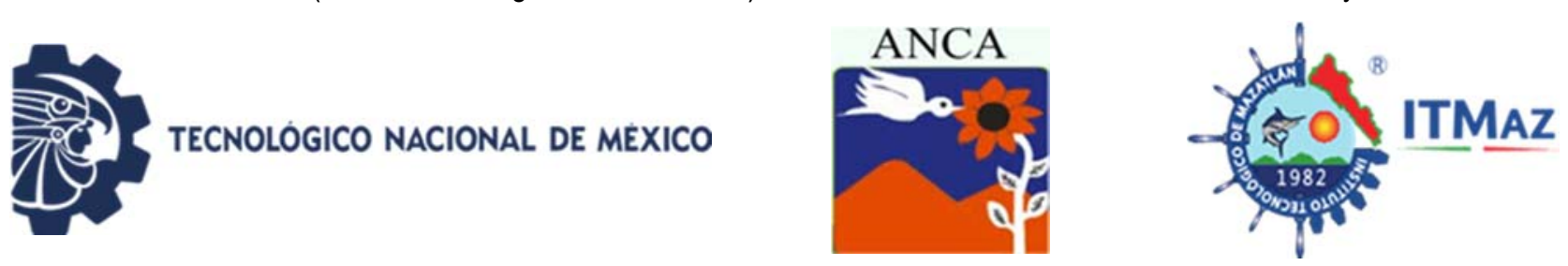

Fungi an ecotourism attraction in Durango, Mexico

Naranjo Jiménez $\mathrm{N}^{*}$, Rosas Medina I, Colmenero Robles A

Centro Interdisciplinario de Investigación para el Desarrollo Integral Regional. Instituto Politécnico Nacional. Unidad Durango.

Sigma 119, Fracc. 20 de noviembre II, INFONAVIT, Durango, México COFAA y/o EDI. Secretaria de Investigación y Posgrado-IPN

*nnestor@hotmail.com

\begin{abstract}
The forests of El Salto, Pueblo Nuevo, Durango are home to a great diversity of wild mushrooms that are collected and consumed by some edible species. There are no programs for its management, hence the need to carry out work and research for its management and the procedures for the establishment of a mycological park to promote knowledge, sustainable use and conservation of wild fungi. The objective was to carry out the procedures for the implementation of a mycological park in El Salto, Pueblo Nuevo, Durango. The "Puentecillas" Ecotourism Center was chosen, for the possible establishment, the inventory of the fungi of the place was carried out, two surveys were designed and applied, for the ethnomicological study and to know the interest of the population to visit the mycological park. The inventory yielded 55 species between mycorrhizal and saprobios / lignícolas of these; Amanita caesarea, Boletus edulis and Cantharellus cibarius were the most representative edible species. In relation to the abundance and fungal biodiversity of the place, three mycological paths were established. Of those surveyed, $85 \%$ said they had knowledge about fungi which would be useful to serve as guides in the mycological park. In sum, mycological parks can be managed as Management Units for Wildlife Conservation and with existing regulations they can provide visitors with recreation and learning activities on the fungal resource and the environment in general. Of those surveyed, $86 \%$ showed interest in attending the mycological park and providing a payment for the service.
\end{abstract}

Keywords: Mycological, ecotourism, fungi, mycorrhizal.

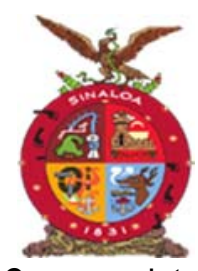

XVIII Congreso Internacional

XXIV Congreso Nacional de Ciencias ambientales

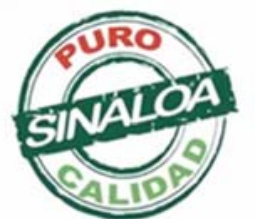

Mazatlán, Sinaloa 3-7 junio 2019
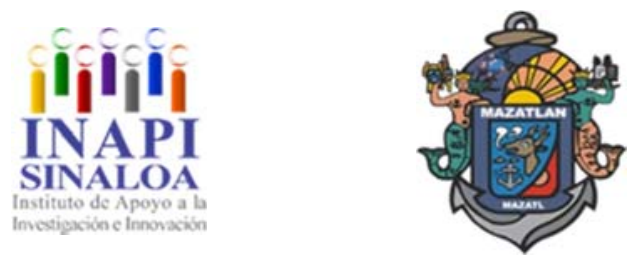

Energías Limpias

y Acciones por el Clima 

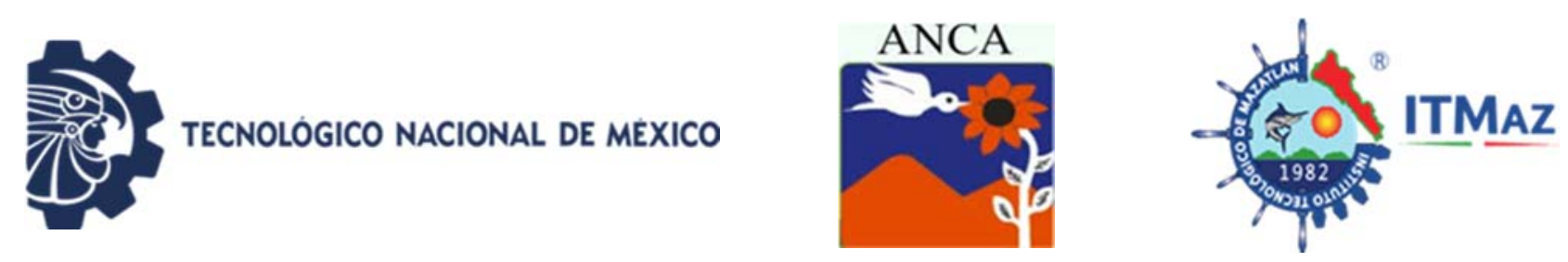

\section{Caracterización y estudio del potencial energético de vinaza de Agave durangensis en la industria mezcalera}

\section{Ordaz Díaz L*, Franco Rivas B, Madrid del Palacio M, Rodríguez Flores F, Flores Villegas M, Rodríguez Rosales J, Bailón Salas A}

Ingeniería en Tecnología Ambiental. Universidad Politécnica de Durango.

Carr. Dgo-Mex Km. 9.5, Col. Dolores Hidalgo, 34300, Durango, México

Maestría en Sistemas Ambientales. Instituto Tecnológico de Durango.

Blvd. Felipe Pescador 1830 Ote., Col. Nueva Vizcaya, 34080, Durango, México

*luis.ordaz@unipolidgo.edu.mx

\section{RESUMEN}

El mezcal se ha convertido en uno de los productos más representativos de México a nivel internacional, debido a su carácter artesanal y su variedad de presentaciones. Es el resultado final de la destilación del tronco o piña del agave, cocido en un horno de piedra excavado en la tierra. Se procesa en pequeñas destilerías, obteniendo dos residuos uno sólido llamado bagazo y otro líquido llamado vinaza. En Durango la Industria Mezcalera representa uno de los grandes aportes económicos de la región. En este estudio se llevó a cabo la caracterización del residuo evaluando ST, SVT, SSV, DQO, NT, PT, además se evaluó la producción de biogás mediante la fermentación anaerobia de vinazas, a nivel de laboratorio, utilizando un reactor UASB de 3 gal. Y evaluando la producción de biogás. Evaluando los resultados de la producción de biogás, se encontró que la vinaza puede ser utilizada para la obtención de metano como fuente de energía renovable. Las cantidades producidas de biogás y la reducción de DQO del reactor UASB, dependieron del tiempo de retención hidráulica (TRH) $y$ de las concentraciones de M.O. en el fluido en tratamiento.

Palabras clave: Vinaza, Agave durangensis, UASB, biogás.

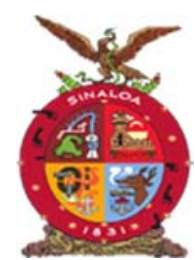

XVIII Congreso Internacional

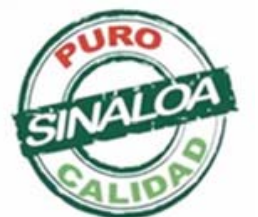

Mazatlán, Sinaloa 3-7 junio 2019

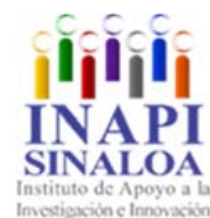

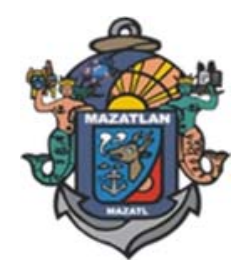

Energías Limpias

y Acciones por el Clima 

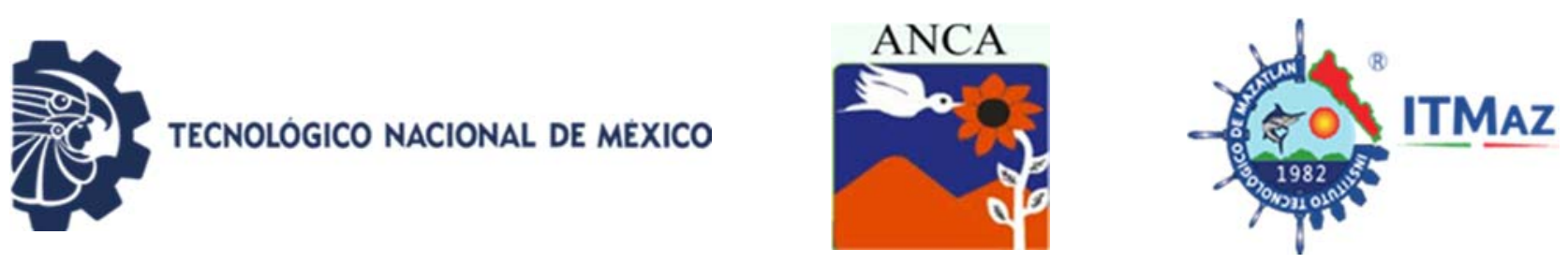

\title{
Characterization and study of the energy potential of Agave durangensis vinegar in the mezcalera industry
}

\section{Ordaz Díaz L*, Franco Rivas B, Madrid del Palacio M, Rodríguez Flores F, Flores Villegas M, Rodríguez Rosales J, Bailón Salas A}

Ingeniería en Tecnología Ambiental. Universidad Politécnica de Durango. Carr. Dgo-Mex Km. 9.5, Col. Dolores Hidalgo, 34300, Durango, México Maestría en Sistemas Ambientales. Instituto Tecnológico de Durango.

Blvd. Felipe Pescador 1830 Ote., Col. Nueva Vizcaya, 34080, Durango, México *luis.ordaz@unipolidgo.edu.mx

\begin{abstract}
Mezcal has become one of the most representative products of Mexico at an international level, due to its artisanal nature and its variety of presentations. The mezcal is the final result of the distillation of the trunk or pineapple of the mezcalero agave, cooked in a stone oven dug in the ground. The mezcal is processed in small distilleries, obtaining two residues, a solid one called bagasse and another liquid called vinasse. In Durango the Mezcalera Industry represents one of the great contributions within the region. In this study the characterization of the substrate was carried out, evaluating TS, TVS, VSS, COD, TN, TP, in addition the biogas production was evaluated by the anaerobic fermentation of vinasses, at laboratory level, using a UASB reactor of 3 gal. Theoretical calculations of biogas production were carried out, the vinasse can be used in anaerobic digestion processes to obtain methane as a source of renewable energy, the quantities produced of biogas and the COD reduction of the UASB reactor, depended on the hydraulic retention time (HRT) and the fluid under treatment.
\end{abstract}

Keywords: Vinasse, Agave durangensis, UASB, biogas.

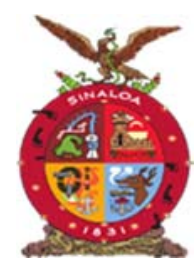

XVIII Congreso Internacional

XXIV Congreso Nacional de Ciencias ambientales

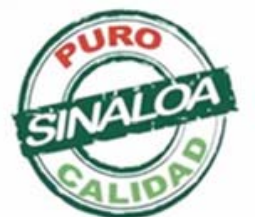

Mazatlán, Sinaloa 3-7 junio 2019

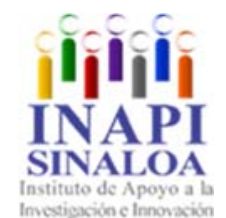

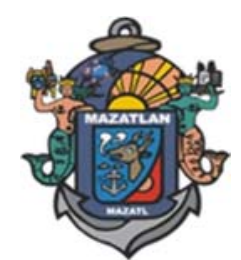

Energías Limpias

y Acciones por el Clima 
TECNOLOGICO NACIONAL DE MEXICO
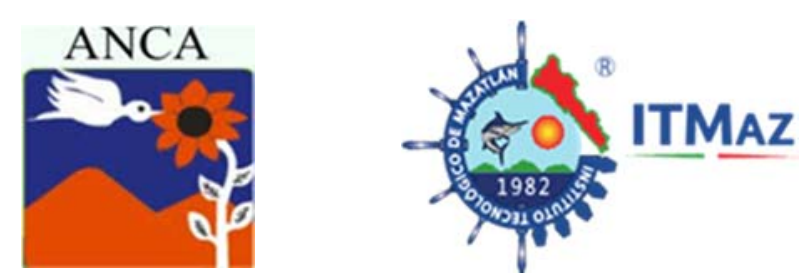

\title{
Efecto de las partículas presentes en la atmosfera en la evaporación del agua, caso de Zacatecas
}

\author{
Ramírez Martínez R, Rodríguez Robles LF, Ramírez Ortega AA, \\ Fonseca Mendoza MM, Arce Martínez GI \\ Universidad Autónoma de Zacatecas. UAPUAZ. Programa IV, \\ 98090, Zacatecas, México \\ Unidad Académica de Ciencias de la Tierra. \\ Universidad Autónoma de Zacatecas. 98058, Zacatecas, México \\ aod_alexander@hotmail.com
}

\section{RESUMEN}

La atmósfera es una capa gaseosa de suma importancia pues su contenido es vital para los organismos, se han estudiado diversos efectos provocados por las actividades humanas como el aumento en la concentración de Gases de Efecto Invernadero (GEI) y más recientemente el fenómeno oscurecimiento global. El trabajo consistió en un estudio de calidad de agua potable de acuerdo a la NOM127-SSA1-1994, captada en tres zonas urbanas con valores para sólidos disueltos totales (SDT), pH y cloruro de sodio $(\mathrm{NaCl})$. Dicho trabajo tiene como objetivo observar como los elementos que "pululan" en la atmósfera influyen en el oscurecimiento global, para hacerlo se tomaron 3 muestras diarias, de octubre a diciembre de 2018, en baldes de 20 litros que se dejaron a la intemperie donde fueron captados los elementos del ambiente, midiendo por semana la evaporación del agua en el balde con regla milimétrica. Cada muestra, fue revisada por comparación potenciométrica, y se determinaron determinando parámetros STD, $\mathrm{NaCl}, \mathrm{pH}$, y conductividad eléctrica. Los resultados obtenidos registraron disminuciones del volumen de agua en intervalos casi constantes por semana, hacia el último mes se vio que disminuía con menor regularidad, pero más rápido, la concentración de STD aumentó más en los días lluviosos, los niveles de $\mathrm{NaCl}$ se mantuvieron constantes y la conductividad eléctrica aumentó indicando presencia de partículas disueltas en el fondo del balde se encontraron partículas sedimentables. Conclusión: la evaporación y la concentración de partículas muestran poca relación en cuanto a su influencia para la evaporación del agua.

Palabras clave: Contaminación atmosférica, oscurecimiento global, partículas disueltas.

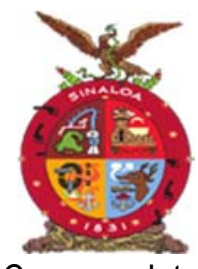

XVIII Congreso Internacional

XXIV Congreso Nacional de Ciencias ambientales

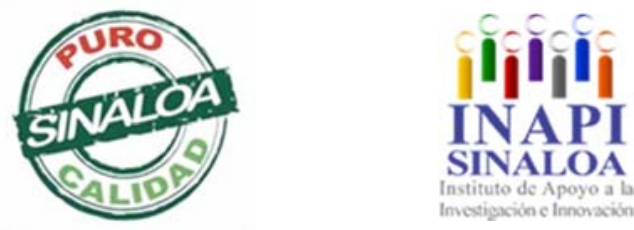

Mazatlán, Sinaloa 3-7 junio 2019

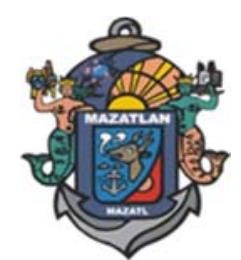

Energías Limpias

y Acciones por el Clima 

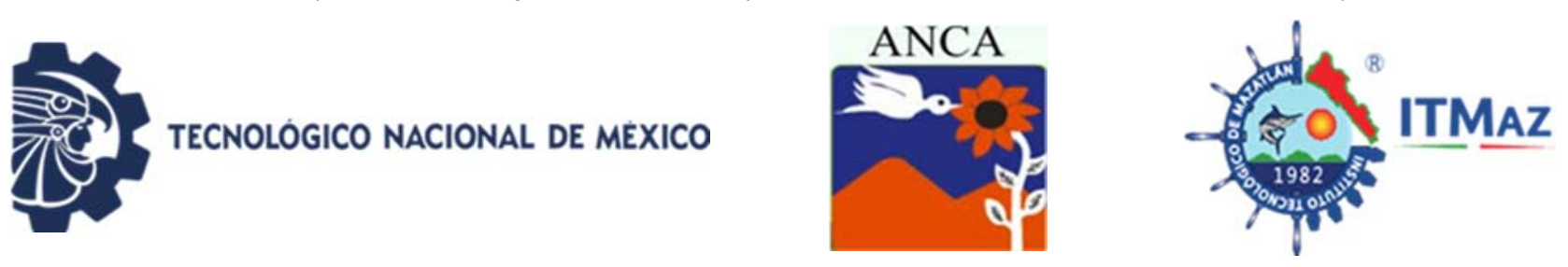

\title{
Effect of the particles present in the atmosphere in the evaporation of water, case of Zacatecas
}

\author{
Ramírez Martínez R, Rodríguez Robles LF, Ramírez Ortega AA, F \\ onseca Mendoza MM, Arce Martínez GI \\ Universidad Autónoma de Zacatecas. UAPUAZ. Programa IV, \\ 98090, Zacatecas, México \\ Unidad Académica de Ciencias de la Tierra. \\ Universidad Autónoma de Zacatecas. 98058, Zacatecas, México \\ aod_alexander@hotmail.com
}

\begin{abstract}
Atmosphere is a very important gaseous because its content is vital for organisms, various effects caused by human activities have been studied such as the increase in the concentration of greenhouse gases (GHGs) and more recently the phenomenon global darkening. This work consisted in a study of quality of drinking water according to NOM-127-SSA1-1994, captured in three urban areas with values for total dissolved solids (TDS), $\mathrm{pH}$ and sodium chloride $(\mathrm{NaCl})$. This work aims to observe how the elements that "swarm" in the atmosphere influence the global darkening, we made it by taking 3 samples daily, from October to December 2018, in buckets of 20 liters that were left outdoors where they were captured the elements of the environment, measuring per week the evaporation of the water in the bucket with millimeter rule. Each sample was reviewed by a pontenciometric comparison, determining parameters STD, $\mathrm{NaCl}, \mathrm{pH}$, and electrical conductivity. The results obtained were decreases in the volume of water in almost constant intervals per week, towards the last month it was seen that it decreased with less constancy and faster, the concentration of STD increased more in rainy days, the $\mathrm{NaCl}$ levels remained constant and the Electrical conductivity increased indicating the presence of particles. Sedimentable particles were found at the bottom of the bucket. Conclusion: evaporation and particle concentration show little relationship in terms of their influence on water evaporation, although it is interesting to know what these particles contain.
\end{abstract}

Keywords: Atmospheric pollution, global darkening, dissolved particles.

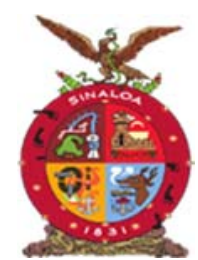

XVIII Congreso Internacional

XXIV Congreso Nacional de Ciencias ambientales

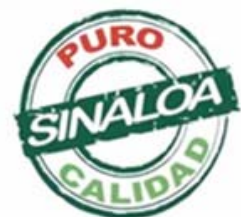

Mazatlán, Sinaloa 3-7 junio 2019

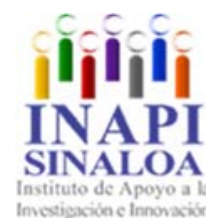

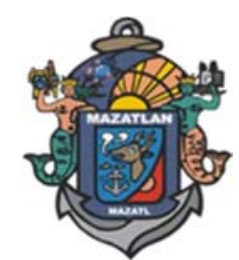

Energías Limpias

y Acciones por el Clima 

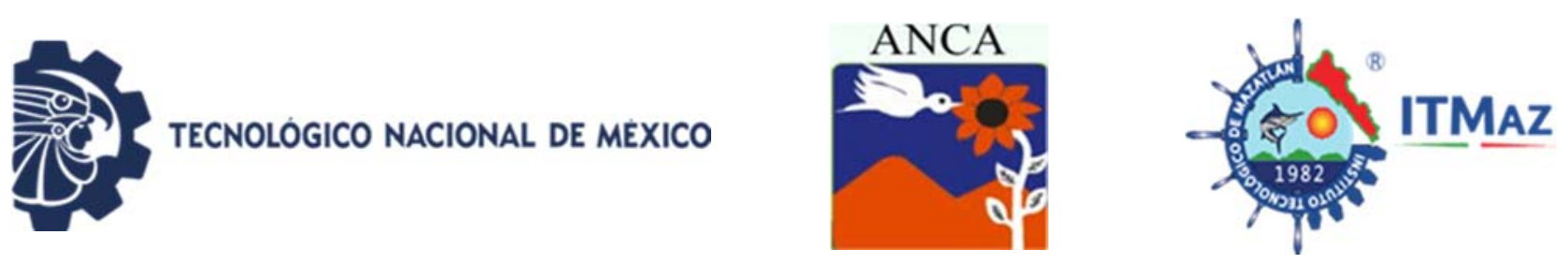

\section{Energía y sostenibilidad: el uso de las energías limpias en el norte de Sinaloa}

Rodríguez Apodaca JR*, Piña Ruiz HH, Lara Ponce E, Quintero Romanillo AL

Universidad Autónoma Intercultural de Sinaloa. Unidad Mochicahui. Prolongación 5 de Mayo S/N, Ejido Poblado de Mochicahui, C.P. 81890,

El Fuerte, Sinaloa, México

*jramon@uais.edu.mx

\section{RESUMEN}

El objetivo de la siguiente ponencia se enfoca en la necesidad de relacionar algunas de las metas del Objetivo 7: Garantizar el acceso a una energía asequible, segura, sostenible y moderna para todos, con acciones que se han estado implementando en el Norte de Sinaloa, para poder determinar el área de oportunidad y el futuro de las metas plasmadas en la Agenda 2030 referente a los Objetivos del Desarrollo Sostenible. La generación de energía eléctrica a través de fuentes renovables a partir de biomasa, de energía solar, energía mareomotriz, energía eólica, entre otras, ha sido estudiada en las últimas décadas teniendo un amplio impulso en países con alto poder adquisitivo para poder solventar investigación, desarrollo, implementación y evaluación de los novedosos sistemas para la generación de energía a partir de energías renovables, limpias y de fuente inagotable. Realmente, el avance o retroceso en las diferentes fuentes de energía dependerá finalmente del apoyo económico, que cada país en el mundo pueda aportar para la investigación, desarrollo e implementación y evaluación de las diferentes formas de generar energía eléctrica, dependiendo las necesidades geográficas e hidrológicas, por mencionar algunas. A forma de conclusión, se hace un análisis de la posible respuesta de la comunidad indígena hacia la implementación de las metas del Objetivo 7 de la Agenda 2030.

Palabras clave: Energía limpia, sostenibilidad, energías renovables, agenda 2030.

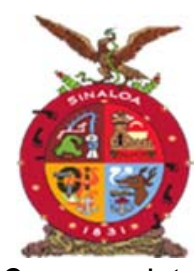

XVIII Congreso Internacional

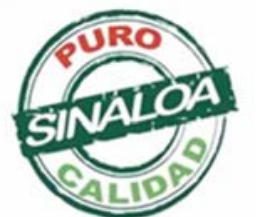

Mazatlán, Sinaloa 3-7 junio 2019

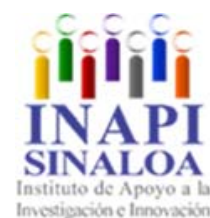

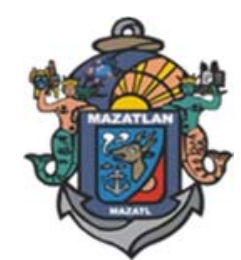

Energías Limpias

y Acciones por el Clima 

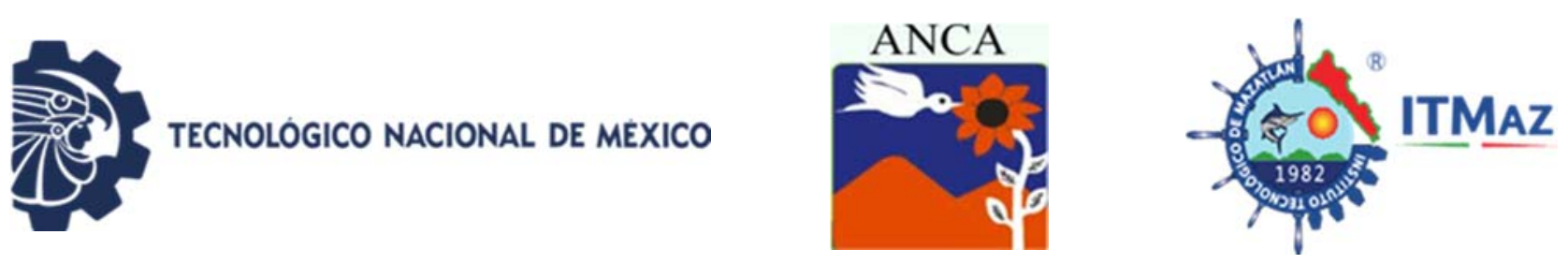

Energy and sustainability: the use of clean energies in north Sinaloa

Rodríguez Apodaca JR*, Piña Ruiz HH, Lara Ponce E, Quintero Romanillo AL

Universidad Autónoma Intercultural de Sinaloa. Unidad Mochicahui.

Prolongación 5 de Mayo S/N, Ejido Poblado de Mochicahui, C.P. 81890,

El Fuerte, Sinaloa, México

*jramon@uais.edu.mx

\section{SUMMARY}

The objective of the following presentation focuses on the need to relate some of the goals of Objective 7: Ensure access to affordable, safe, sustainable and modern energy for all, with actions that have been implemented in North Sinaloa, in order to determine the area of opportunity and the future of the goals embodied in the 2030 Agenda regarding the Sustainable Development Goals. The generation of electrical energy through renewable sources from biomass, solar energy, tidal energy, wind energy, among others, has been studied in recent decades having a wide boost in countries with high purchasing power to solve research, development, implementation and evaluation of the new systems for the generation of energy from renewable, clean and inexhaustible energy sources. Actually, the advance or retreat in the different energy sources will ultimately depend on the economic support that each country in the world can provide for research, development and implementation and evaluation of the different ways of generating electricity, depending on geographical and hydrological needs, to mention a few. In conclusion, an analysis is made of the possible response of the indigenous community towards the implementation of the goals of Objective 7 of the 2030 Agenda.

Keywords: Clean energy, sustainability, renewable energy, 2030 agenda.

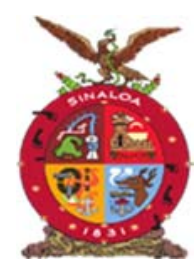

XVIII Congreso Internacional

XXIV Congreso Nacional de Ciencias ambientales

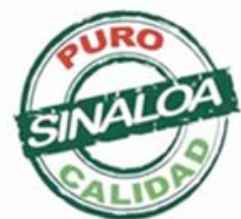

Mazatlán, Sinaloa 3-7 junio 2019

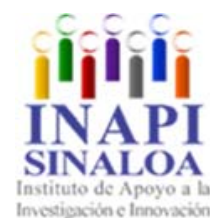

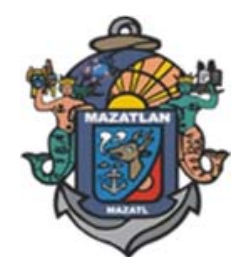

Energías Limpias

y Acciones por el Clima 

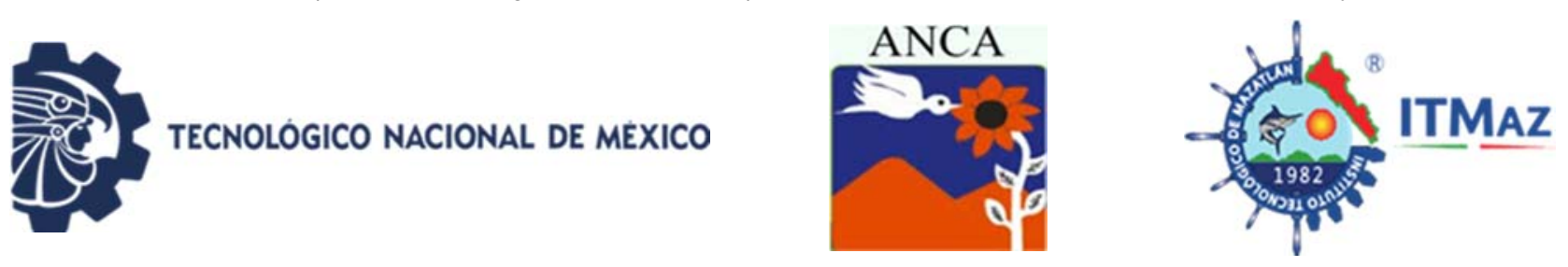

\title{
Elaboración de adobe que se adapte a diversas regiones dependiendo de sus recursos y clima
}

\author{
Rodríguez González B*, Perez Roble E, Pineda Martínez F, Bluhm Gutiérrez J, \\ Escalona Alcázar F, Dzul García O, Agular Ortega F \\ Unidad Académica de Ciencias de la Tierra. \\ Unidad Académica de Ciencias Sociales. \\ Unidad Académica de Ingeniería. \\ LCA. Universidad Autónoma de Zacatecas. \\ Calzada de la Universidad, No. 108, Zacatecas, México \\ *baudebrg@uaz.edu.mx
}

\section{RESUMEN}

La tierra es probablemente uno de los materiales más antiguos con los que el hombre ha contado para construir; ha sido usado por su abundancia sobre la superficie del planeta, ser económico, además de ser amigable con el ambiente, esto último aplicándose a la época presente. La construcción de tierra es adaptada según las necesidades de la localidad donde se vaya a construir; dependiendo principalmente de las condiciones climatológicas. Hoy en día el usar las mejores características del suelo, puede ser fundamental para que las unidades de adobe resultantes puedan soportar una mayor carga y rendir mejor cuando se exponen a la intemperie. Recientemente, las preocupaciones medioambientales han llevado a un mayor interés en la utilización de fibras "alternativas", incluidos los residuos sólidos y los materiales derivados para mejorar la capacidad de carga. En este estudio se trabajó sobre el uso correcto del adobe, comprendiendo sus propiedades y en qué aspectos aventajan a los materiales convencionales, haciendo énfasis en el nivel socioeconómico de la población. Para este trabajo se revisó la composición clásica del adobe, el método en el cual se elabora y las pruebas de calidad adecuadas para la construcción habitacional. Se dividió en regiones el estado de Zacatecas, México, en el cual se analizó las carencias, el tipo de viviendas, los recursos con los que cuenta y su clima, factor determinante a la hora de implementar hogares elaborados con tierra. A partir de este análisis se generó una metodología de elaboración del adobe para cada región que permita una alternativa más económica, que mitigue inclemencias climáticas y que sea amigable con el medio ambiente en la construcción de viviendas.

Palabras clave: Adobe, fibras, clima, viviendas, medio ambiente.

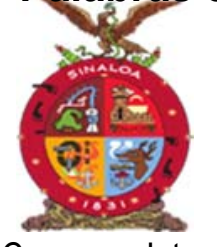

XVIII Congreso Internacional

XXIV Congreso Nacional de Ciencias ambientales

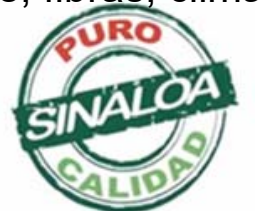

Mazatlán, Sinaloa 3-7 junio 2019

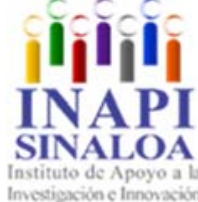

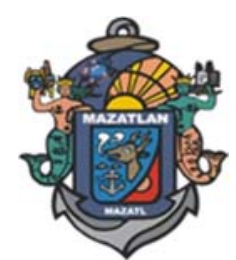

Energías Limpias

y Acciones por el Clima 

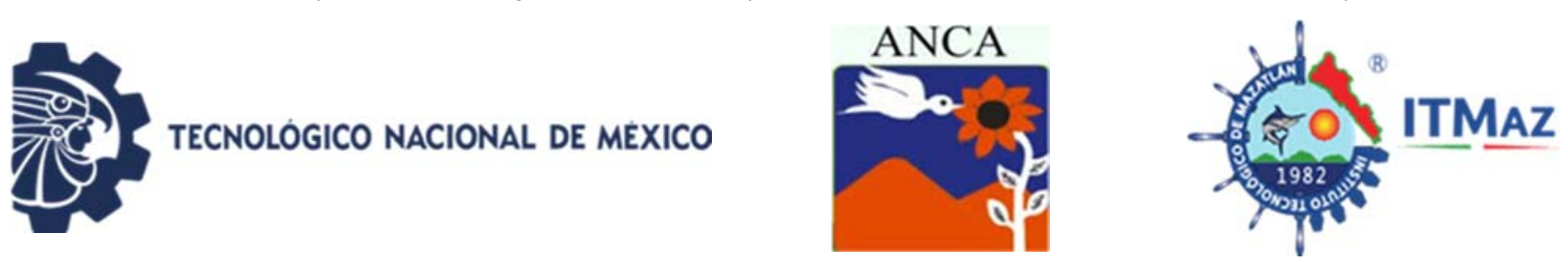

\title{
Preparation of adobe that adapts to different regions depending on its resources and climate
}

\author{
Rodríguez González B*, Perez Roble E, Pineda Martínez F, Bluhm Gutiérrez J, \\ Escalona Alcázar F, Dzul García O, Agular Ortega F \\ Unidad Académica de Ciencias de la Tierra. \\ Unidad Académica de Ciencias Sociales. \\ Unidad Académica de Ingeniería. \\ LCA. Universidad Autónoma de Zacatecas. \\ Calzada de la Universidad, No. 108, Zacatecas, México \\ *baudebrg@uaz.edu.mx
}

\begin{abstract}
The earth is probably one of the oldest materials that man has counted on to build; It has been used for its abundance on the surface of the planet, to be economical, in addition to being friendly to the environment, the latter being applied to the present time. The construction of land is adapted according to the needs of the locality where it will be built; depending mainly on the weather conditions. Today he uses the best soil characteristics, it can be essential for the resulting adobe units to withstand a greater load and perform better when exposed to the weather. Recently, environmental concerns have led to increased interest in the use of "alternative" fibers, including solid waste and derivative materials to improve loading capacity. In this study, we worked on the correct use of adobe, understanding its properties and in what aspects they outperform conventional materials, emphasizing the socioeconomic level of the population. For this work, the classic composition of the adobe, the method in which it is made and the appropriate quality tests for the residential construction were reviewed. The state of Zacatecas, Mexico, was divided into regions, in which the gaps, the type of housing, the resources it has and its climate were analyzed, a determining factor when implementing homes made with land. Based on this analysis, an adobe elaboration methodology was generated for each region that allows a more economical alternative, that mitigates inclement weather and is friendly to the environment in the construction of houses.
\end{abstract}

Keywords: Adobe, fibers, climate, housing, environment.

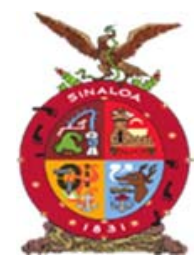

XVIII Congreso Internacional

XXIV Congreso Nacional de Ciencias ambientales

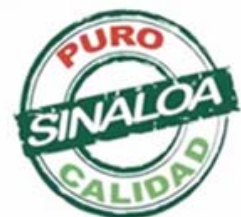

Mazatlán, Sinaloa 3-7 junio 2019
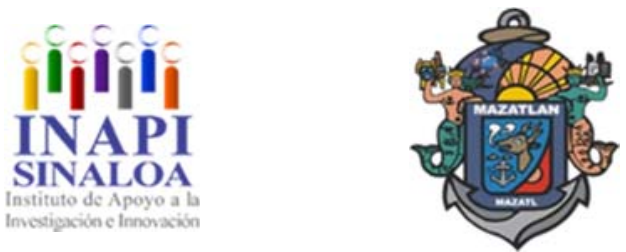

Energías Limpias

y Acciones por el Clima 

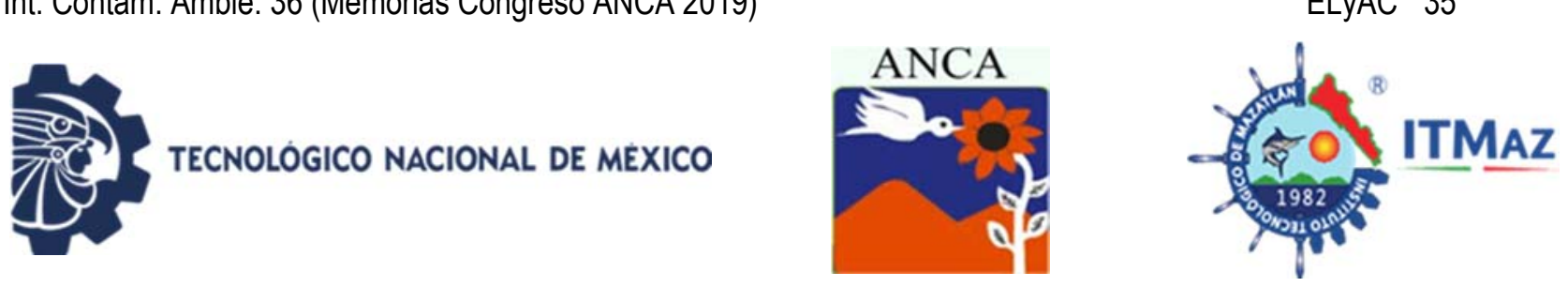

\title{
Sumideros de carbono y su mercado
}

Ronquillo Gorgúa N, Razo Zárate $\mathrm{R}^{*}$, Rodríguez Laguna R, Acevedo Sandoval O, Hernández Ortiz J

\section{Área Académica de Ciencias Agrícolas y Forestales. Instituto de Ciencias Agropecuarias.}

División de Investigación. Desarrollo e Innovación. UAEH. Rancho Universitario, Av. Universidad, Km. 1, C.P. 43600, Tulancingo de Bravo, Hidalgo, México Div. de Ciencias Económico Administrativas. Universidad Autónoma Chapingo Carr. México-Texcoco km. 38.5, C.P. 56230, Texcoco, México *rrazo29@yahoo.com.mx

\begin{abstract}
RESUMEN
Se presenta una revisión bibliográfica enfocada en identificar la conceptualización del mercado de carbono, así como su origen, utilidad, experiencias adquiridas, tendencias y perspectivas del mercado de carbono como medida de mitigación de los efectos del cambio climático. Para comprender la situación actual del mercado de carbono, así como papel que juegan los bosques como sumideros de carbono, los factores que modifican su funcionamiento y las acciones que se basan en él para mitigar o adaptar su función ante el cambio climático, se presenta información sobre las fuentes de carbono y los ecosistemas forestales, considerados como el principal sumidero de carbono terrestre. El documento explica la importancia del mercado de carbono y de los bosques como sumideros de carbono, sobre los factores que afectan los procesos biológicos nutrición-respiración que están relacionados con su capacidad de secuestro de carbono y como se adicionan factores socioeconómicos, culturales y biofísicos, que requieren ser investigados con el propósito de definir medidas precisas de adaptación-mitigación.
\end{abstract}

Palabras clave: Reservorio, carbono atmosférico, mercado de carbono, bosque.

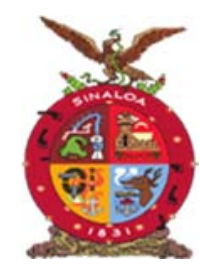

XVIII Congreso Internacional
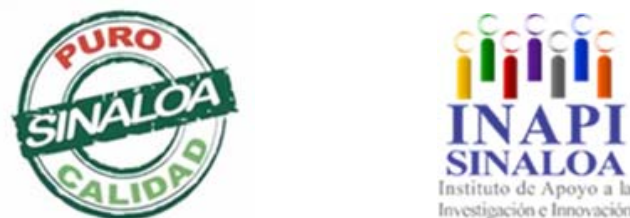

Mazatlán, Sinaloa 3-7 junio 2019

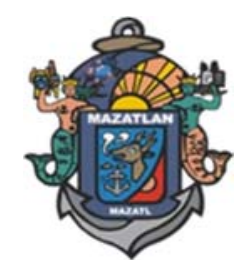

Energías Limpias

y Acciones por el Clima 

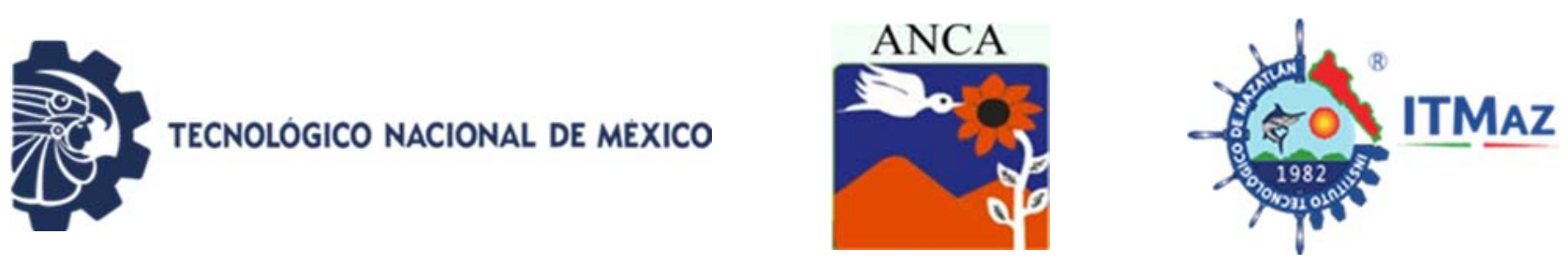

\title{
Carbon sinks and its market
}

Ronquillo Gorgúa N, Razo Zárate $\mathrm{R}^{*}$, Rodríguez Laguna R, Acevedo Sandoval O, Hernández Ortiz J

Área Académica de Ciencias Agrícolas y Forestales. Instituto de Ciencias Agropecuarias.

División de Investigación. Desarrollo e Innovación. UAEH. Rancho Universitario, Av. Universidad, Km. 1, C.P. 43600, Tulancingo de Bravo, Hidalgo, México Div. de Ciencias Económico Administrativas. Universidad Autónoma Chapingo Carr. México-Texcoco km. 38.5, C.P. 56230, Texcoco, México *rrazo29@yahoo.com.mx

\begin{abstract}
This proposal is a bibliographic review, focused on identifying the carbon market conceptualization, as well as its origins, applications, acquired experiences, trends and perspectives of the carbon market as a mitigation measure to the climate change effects. Trying to understand the current situation of the carbon market, as well as which role plays the forests as carbon sinks, factors that modify its functioning and the actions that are based on to mitigate or adapt its role in facing to climate change, we presented information about carbon sources and forest ecosystems, as the main terrestrial carbon sink. The paper explain importance of the carbon market and the forests as carbon sinks, factors related to biological processes nutrition-respiration, which related with socioeconomic, cultural and biophysical concerns that require to be further investigated aiming to define precise adaptation-mitigation measures.
\end{abstract}

Keywords: Reservoir, atmospheric carbon, carbon market, forest.

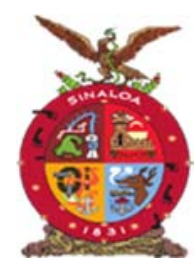

XVIII Congreso Internacional XXIV Congreso Nacional de Ciencias ambientales
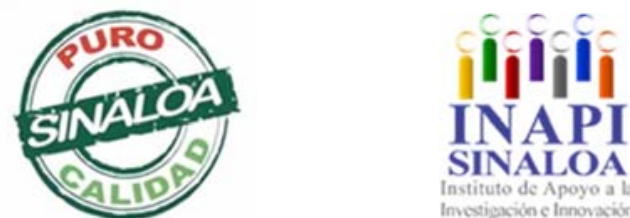

Mazatlán, Sinaloa 3-7 junio 2019

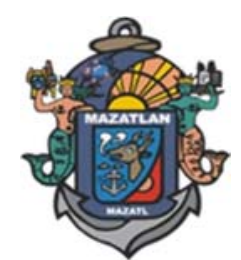

Energías Limpias

y Acciones por el Clima 
TECNOLOGICO NACIONAL DE MEXICO
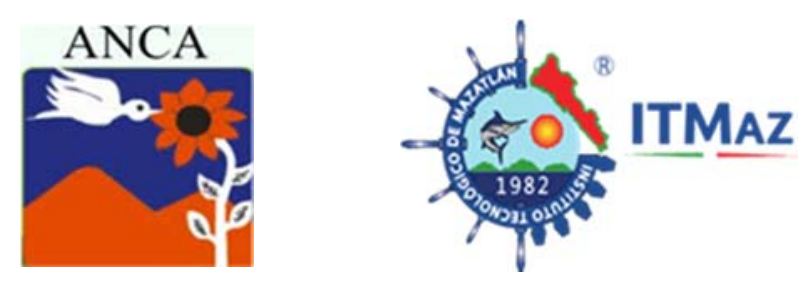

\title{
El uso de $\delta^{18}$ o para el estudio del cambio climático: un caso de estudio en Laguna de Términos, Campeche, México
}

\author{
Torres Rojas YE*, Carrillo Birkhahn JA, Aguíniga García S, \\ Sánchez González A \\ Instituto de Ecología Pesquerías y Oceanografía del Golfo de México \\ Av. Héroe de Nacozari 480, C.P. 24079, San Francisco de Campeche, México \\ Licenciatura en Ingeniería Bioquímico Ambiental. \\ Fac. de Ciencias Químico-Biológicas. Universidad Autónoma de Campeche. \\ Calle Av. Agustín Melgar S/N, Buena Vista, 24039, \\ San Francisco de Campeche, México \\ Centro Interdisciplinario de Ciencias Marinas. Instituto Politécnico Nacional. \\ Av. Instituto Politécnico Nacional, S/N, Playa Palo de Santa Rita, La Paz, B.C.S., México \\ *yetorres@uacam.mx
}

\section{RESUMEN}

La presencia de fenómenos como el cambio climático generan interrogantes sobre el posible impacto en diferentes ecosistemas (e.g. lagunas costeras). En este sentido, el presente trabajo analizó el $\delta^{18} \mathrm{O}$ presente en otolitos de Bairdiella chrysoura capturados en 17 estaciones presentes dentro de Laguna de Términos de septiembre de 2016 hasta agosto de 2017, para establecer la relación del otolito con cambios de temperatura (equilibrio isotópico) a nivel espacio temporal. Se analizaron un total de 70 muestras de otolitos correspondiente organismo con tallas promedio $(\mathrm{LT})$ de $11.37 \pm 3.23 \mathrm{~cm}$, los cuales registrando valores promedio de $\delta^{18} \mathrm{O}=-1.15 \%$ o $( \pm 0.15)$, lo que equivale a $26^{\circ} \mathrm{C}$ de acuerdo con ecuaciones de paleo-temperatura. Los datos in situ indican que la temporada de secas fue la que registro el mayor valor de salinidad (31.71 \pm 5.22 UPS), mientras que la temporada de lluvias presento la temperatura más alta $\left(30.44 \pm 1.48{ }^{\circ} \mathrm{C}\right)$. No se encontraron diferencias significativas a nivel espacial $(P=0.16)$, sin embargo, se encontraron a nivel temporal $(P=0.01)$, donde el otolito de $B$. chrysoura presento un valor de $\delta^{18} \mathrm{O}=-1.09 \%$, correspondiente a temperatura y salinidad de $28.1 \mathrm{y}$ 31.7 , respectivamente. En conclusión, el $\delta^{18} \mathrm{O}$ presente en otolito de $B$. chrysoura presentó equilibrio isotópico con el medio, por lo que se confirma su utilidad como indicador de cambios abióticos (temperatura y salinidad) registrados en laguna de Términos a nivel temporal, siendo de gran ayuda para estudiar el impacto de fenómenos climáticos en la ecología de organismos marinos, por ende, en medio ambiente.

Palabras clave: Golfo de México, isótopos estables, peces, lagunas costeras,

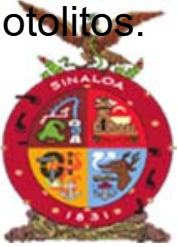

XVIII Congreso Internacional

XXIV Congreso Nacional de Ciencias ambientales

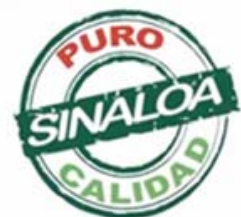

Mazatlán, Sinaloa 3-7 junio 2019
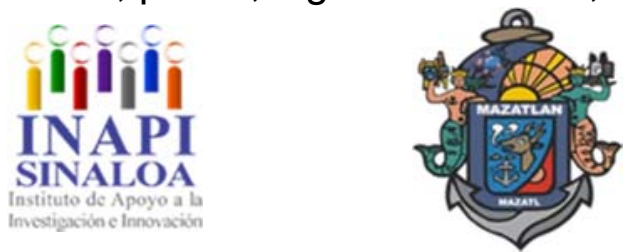

Energías Limpias

y Acciones por el Clima 

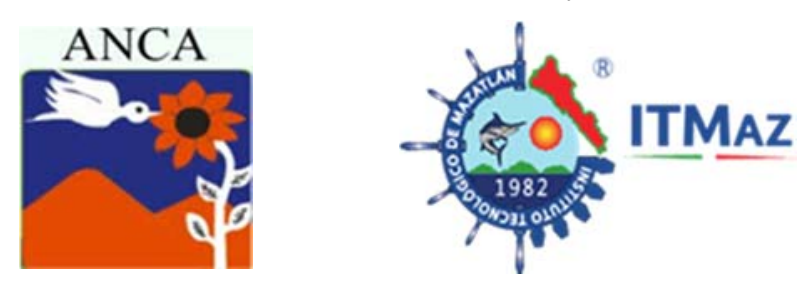

\title{
The use of $\delta^{18} 0$ for the study of climatic change: a case study in terms Lagoon, Campeche, Mexico
}

\author{
Torres Rojas YE*, Carrillo Birkhahn JA, Aguíniga García S, \\ Sánchez González A \\ Instituto de Ecología Pesquerías y Oceanografía del Golfo de México \\ Av. Héroe de Nacozari 480, C.P. 24079, San Francisco de Campeche, México \\ Licenciatura en Ingeniería Bioquímico Ambiental. \\ Fac. de Ciencias Químico-Biológicas. Universidad Autónoma de Campeche. \\ Calle Av. Agustín Melgar S/N, Buena Vista, 24039, \\ San Francisco de Campeche, México \\ Centro Interdisciplinario de Ciencias Marinas. Instituto Politécnico Nacional. \\ Av. Instituto Politécnico Nacional, S/N, Playa Palo de Santa Rita, La Paz, B.C.S., México \\ *yetorres@uacam.mx
}

\begin{abstract}
The presence of phenomena such as climate change raises questions about the possible impact on different ecosystems (e.g. coastal lagoons). In this sense, the present work analyzed the $\delta^{18} \mathrm{O}$ present in otoliths of Bairdiella chrysoura captured in 17 stations present within Laguna de Términos from September 2016 to August 2017, to establish the relation of the otolith with changes in temperature (isotopic equilibrium) to temporary space level. We analyzed a total of 70 samples of otoliths corresponding organism with average sizes (LT) of $11.37 \mathrm{~cm}( \pm 3.23)$, which recorded average values of $\delta^{18} \mathrm{O}=-1.15 \%$ ( \pm 0.15$)$, which is equivalent to $26^{\circ} \mathrm{C}$ according to with paleo-temperature equations. In situ data indicate that the dry season recorded the highest salinity value $(31.71 \pm 5.22$ UPS), while the rainy season showed the highest temperature $\left(30.44 \pm 1.48^{\circ} \mathrm{C}\right)$. No significant differences were found at the spatial level $(P=0.16)$, however, they were found at the temporal level $(P=0.01)$, where the otolith of $B$. chrysoura presented a value of $\delta^{18} \mathrm{O}=-1.09 \%$, corresponding to temperature and salinity of 28.1 and 31.7 , respectively. In conclusion, the $\delta^{18} \mathrm{O}$ present in the otolith of $B$. chrysoura presented an isotopic equilibrium with the medium, which confirms its usefulness as an indicator of abiotic changes (temperature and salinity) registered in the Temporal level lagoon, being of great help for study the impact of climatic phenomena on the ecology of marine organisms and consequently on the environment.
\end{abstract}

Keywords: Gulf of Mexico, stable isotopes, fish, coastal lagoons, otoliths.

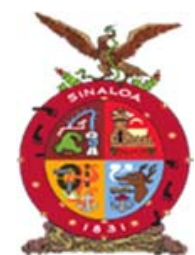

XVIII Congreso Internacional

XXIV Congreso Nacional de Ciencias ambientales

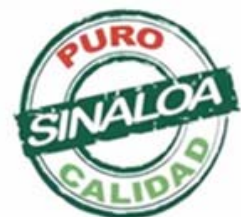

Mazatlán, Sinaloa 3-7 junio 2019
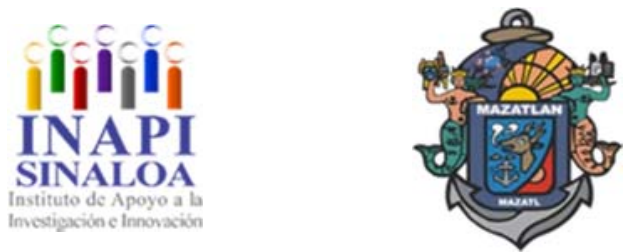

Energías Limpias

y Acciones por el Clima 


\section{REVista INTernacional de}

\section{CONTAMinación AMBIEntal volumen 36, 2020}

http://www.revistas.unam.mx/index.php/rica/

\section{Legislación, Valores Sociales y Educación Ambiental}

ACademia Nacional de Ciencias Ambientales

XVIII CONGRESO INTERNACIONAL XXIV CONGRESO NACIONAL De Ciencias ambientales

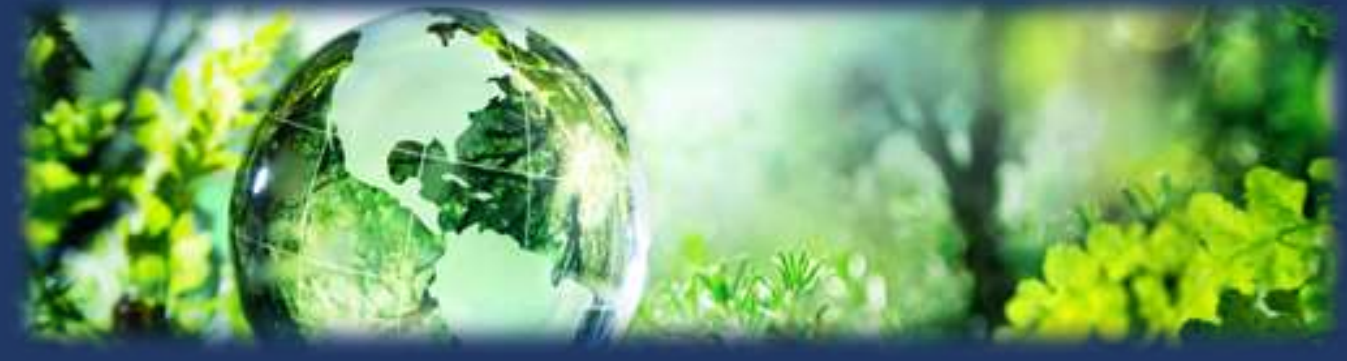

\section{Mazatlán, sinaloa ila Perla del Pacífico!}

03-07 Junio/2019 

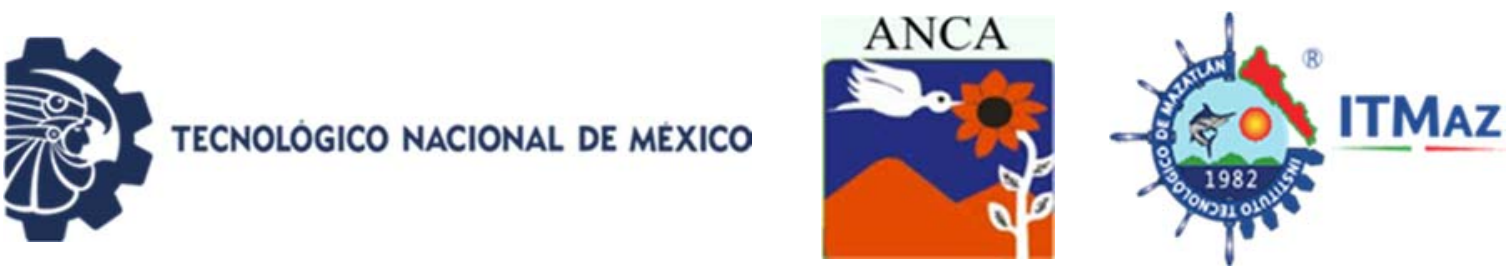

Agenda ambiental ciudadana, Tuxpan, Jalisco 2019-2021

\author{
Abarca Urquiza JR*, Michel Parra G, Espinoza Arías JA, Mercado Méndez A, \\ Corona Loya LE, Ríos Rodríguez VG
}

\begin{abstract}
Centro de Investigación de la Laguna Zapotlán y Cuencas. Laboratorio de Estudios Turísticos para la Sustentabilidad. CA "Gobernanza y derechos humanos"

Centro Universitario del Sur, Universidad de Guadalajara

Av. Enrique Arreola Silva \# 883, Cd. Guzmán, Jalisco

*rabarca@cusur.udg.mx
\end{abstract}

\title{
RESUMEN
}

El Desarrollo Sustentable (DS), a nivel internacional es un imperativo para todos los países miembros de la Organización de las Naciones Unidas ONU, así como el cumplimiento de la 2030 y sus 17 objetivos respectivos. Esto tiene relación directa con la Gestión Ambiental para restaurar los ecosistemas y mantener los servicios ecosistémicos, toda vez que son la base para obtener los bienes y servicios necesarios para la subsistencia de todo tipo de vida en nuestro planeta, incluido la especie humana. El "Observatorio Ciudadano para el Cuidado del Agua (bien común público) en el sur del estado de Jalisco" OCCA, es un proyecto adscrito al Centro de Investigación de la Laguna Zapotlán y Cuencas CILZyC, y al Laboratorio de Estudios Turísticos para la Sustentabilidad LETS, pertenecientes al Departamento de Ciencias de la Naturaleza, del Centro Universitario del Sur Red de la Universidad de Guadalajara, de este observatorio se derivó la Agenda Ambiental Ciudadana de Tuxpan, Jalisco 2019-2021 AACT. El objetivo de esta AACT es: analizar la causa y sus consecuencias de los problemas ambientales y del uso, aprovechamiento y explotación del agua potable en la cabecera municipal de Tuxpan, Jalisco, con la finalidad de socializar la información y la sociedad civil participe en la toma de decisiones en las políticas públicas ambientales y del agua. La constitución de esta agenda Ambiental, debe ser producto de un trabajo conjunto entre los actores sociales, públicos y privados del lugar, trabajo que se inició en agosto del año pasado, ya se realizó el diagnóstico con la participación de los diversos actores, se analizaron los problemas y sus causas, y se acordaron trabajar en 4 cuatro ejes de trabajo, a saber. 1. Gestión integral de agua. 2. Gestión Integral de Residuos Sólidos Urbanos. 3. Conservación de biodiversidad y suelos y 4. Educación ambiental. Se sigue trabajando para que esta AACT, se integre al Plan Municipal de Desarrollo. El desarrollo de esta Agenda ambiental, constituirá un plan piloto, para después de evaluar sus aplicaciones, y replicarse en los otros 6 municipios que se encuentran dentro del acuífero ciudad Guzmán 1406, área de estudio del proyecto Observatorio Ciudadano para el Cuidado del Agua en el Sur de Jalisco.

Palabras clave: Agenda, ciudadanía, gestión, sustentabilidad, políticas públicas.

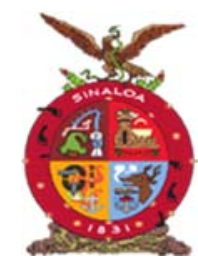

XVIII Congreso Internacional

XXIV Congreso Nacional de Ciencias ambientales

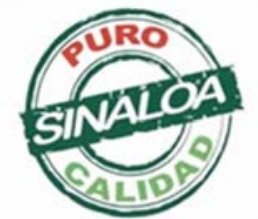

Mazatlán, Sinaloa 3-7 junio 2019

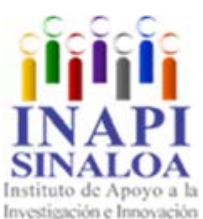



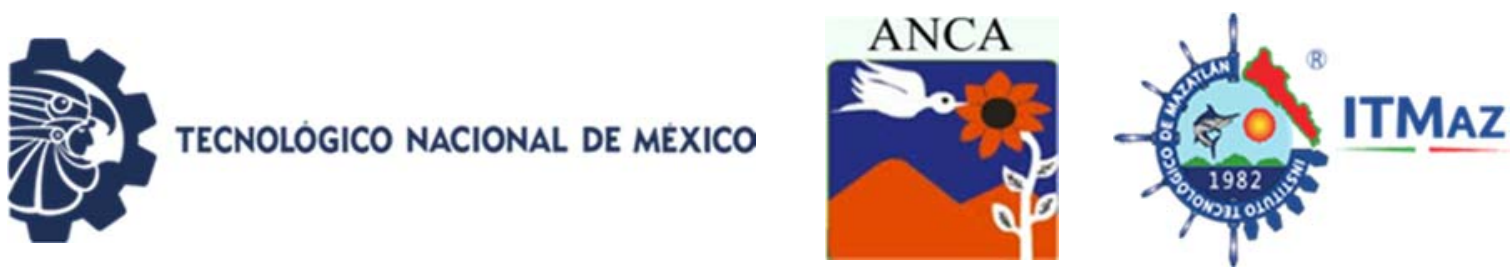

\title{
Citizen environmental agenda, Tuxpan, Jalisco 2019-2021
}

\author{
Abarca Urquiza JR*, Michel Parra G, Espinoza Arías JA, Mercado Méndez A, \\ Corona Loya LE, Ríos Rodríguez VG
}

\begin{abstract}
Centro de Investigación de la Laguna Zapotlán y Cuencas. Laboratorio de Estudios Turísticos para la Sustentabilidad. CA "Gobernanza y derechos humanos" Centro Universitario del Sur, Universidad de Guadalajara Av. Enrique Arreola Silva \# 883, Cd. Guzmán, Jalisco *rabarca@cusur.udg.mx
\end{abstract}

\begin{abstract}
Sustainable Development (SD), at the international level is an imperative for all member countries of the United Nations Organization, as well as the fulfillment of 2030 and its 17 respective objectives. This is directly related to Environmental Management to restore ecosystems and maintain ecosystem services, since they are the basis for obtaining the necessary goods and services for the subsistence of all types of life on our planet, including the human species. The "Citizen Observatory for Water Care (public common good) in the south of the state of Jalisco" OCCA, is a project attached to the Research Center of the Zapotlán Lagoon and CILZyC Basins, and the LETS Sustainability Tourism Studies Laboratory, belonging to the Department of Nature Sciences, of the University Center of the South Network of the University of Guadalajara, from this observatory the Citizen Environmental Agenda of Tuxpan, Jalisco 2019-2021 AACT was derived. The objective of this AACT is: to analyze the cause and its consequences of environmental problems and the use, exploitation and exploitation of drinking water in the municipal capital of Tuxpan, Jalisco, in order to socialize information and civil society participate in the decision making in environmental and water public policies. The constitution of this Environmental agenda, must be the product of a joint work between the social, public and private actors of the place, work that began in August last year, the diagnosis was made with the participation of the various actors, they were analyzed the problems and their causes, and they agreed to work on 4 four work axes, namely. 1. Integral water management. 2. Integral Management of Urban Solid Waste. 3. Conservation of biodiversity and soils and 4 . Environmental education. Work continues so that this AACT is integrated into the Municipal Development Plan. The development of this Environmental Agenda will constitute a pilot plan, after evaluating its applications, and replicating in the other 6 municipalities that are located within the city of Guzmán 1406 aquifer, a study area of the Citizen Observatory project for Water Care in the South of Jalisco.
\end{abstract}

Keywords: Agenda, citizenship, management, sustainability, public politics.

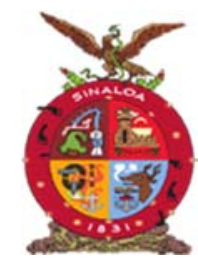

XVIII Congreso Internacional

XXIV Congreso Nacional de Ciencias ambientales

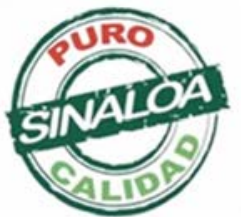

Mazatlán, Sinaloa 3-7 junio 2019

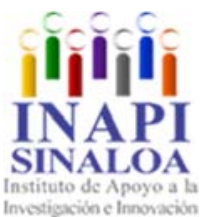



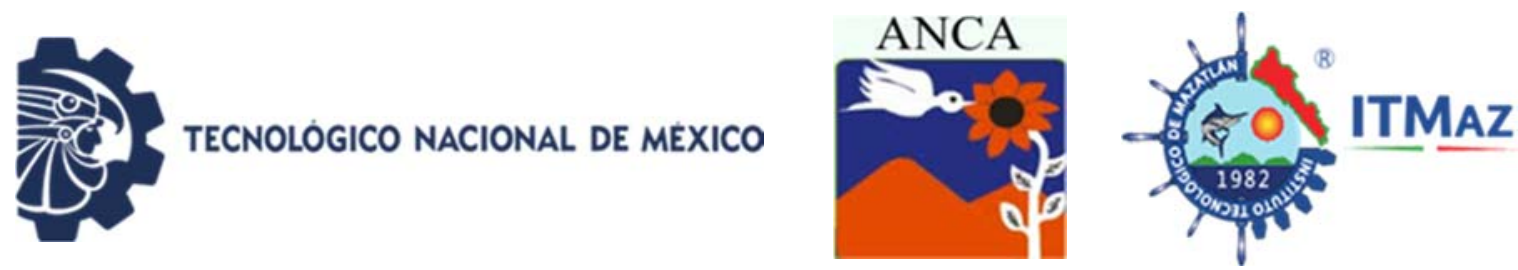

\title{
Turismo y sustentabilidad en comunidades rurales costeras de Guerrero México
}

\author{
Aguilar Becerra CD*, Frausto Martínez O, García Ibáñez S, Reyes Umaña M, \\ Rosas Acevedo JL
}

Doctorado en Ciencias Ambientales. Universidad Autónoma de Guerrero Universidad de Quintano Roo, Campus Cozumel

Centro de Ciencias de Desarrollo Regional. Universidad Autónoma de Guerrero "cesar-daniel@msn.com

\section{RESUMEN}

Las comunidades rurales costeras (CRC) son un segmento de turismo en México: las playas primigenias, gastronomía, cultura, arquitectura, el contacto con la naturaleza y la tranquilidad, son algunas de las características por lo cuál son visitadas. El estado de Guerrero cuenta con 514 kilómetros de litoral costero, es reconocido a nivel mundial por sus dos principales destinos de sol y playa, IxtapaZihuatanejo y Acapulco. Sin embargo, a lo largo de la costa coexisten CRC que cuentan con importantes espacios turísticos. En la literatura académica se reconoce ampliamente que el turismo provoca tanto impactos positivos como negativos, no obstante, las CRC son más susceptibles a los cambios acelerados que emanan de esta actividad. En este sentido, surge la interrogante de investigación ¿Cuál es papel que juega el turismo como detonador en el desarrollo sustentable en las CRC de Guerrero? En consecuencia, el objetivo de este trabajo de investigación, parte de la premisa de identificar los impactos positivos y negativos del turismo para CRC de Guerrero. La metodología empleada se basa en la observación directa del investigador y de entrevistas abiertas con informantes clave, el trabajo se realizó en cuatro CRC: Playa Ventura, Tecomate pesquería; Hacienda de Cabañas y Barra de Coyuca. Los resultados indican que el turismo ayuda a mejorar la calidad de vida de los residentes. No obstante, la falta de servicios públicos; como el drenaje, recolección de residuos sólidos, son bloqueos para el crecimiento sustentable de las CRC de Guerrero.

Palabras clave: Comunidades rurales costeras, turismo y sustentabilidad, Guerrero México.

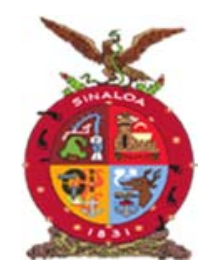

XVIII Congreso Internacional

XXIV Congreso Nacional de Ciencias ambientales
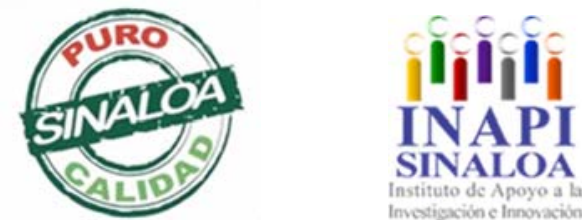

Mazatlán, Sinaloa 3-7 junio 2019

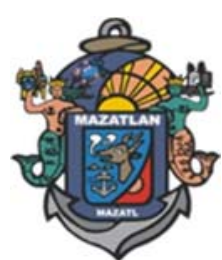

Legislación, Valores Sociales y Educación Ambiental 

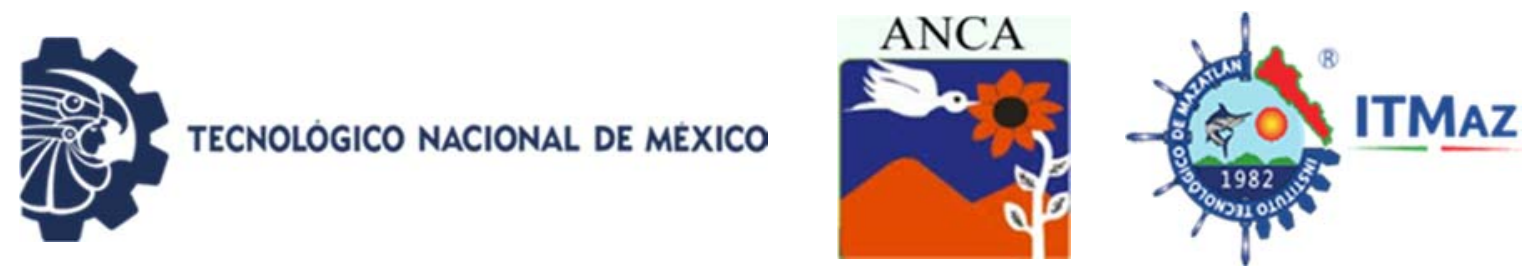

\title{
Tourism and sustainability in coastal rural communities of Guerrero México
}

\author{
Aguilar Becerra CD*, Frausto Martínez O, García Ibáñez S, Reyes Umaña M, \\ Rosas Acevedo JL
}

Doctorado en Ciencias Ambientales. Universidad Autónoma de Guerrero Universidad de Quintano Roo, Campus Cozumel

Centro de Ciencias de Desarrollo Regional. Universidad Autónoma de Guerrero "cesar-daniel@msn.com

\begin{abstract}
Rural coastal communities (RCC) are a tourism segment in Mexico: original beaches, gastronomy, culture, architecture, contact with nature and peacefulness, are some of the attributes for which they are visited. The State of Guerrero has 514 kilometers of coastline. It is recognized worldwide knowns for its two main sun-and-beach destinations: Ixtapa-Zihuatanejo and Acapulco. However, along the coast, RCCs coexist with important tourist areas. In scholarly literature, it is widely recognized that tourism causes both positive and negative impacts. However, RCCs are more sensitive to the accelerated changes that emanate from this activity. This is the point where the research sentence arises: What is the role of tourism as a trigger for sustainable development in Guerrero's RCCs? Therefore, the aim of this research work was based on the premise of identifying the positive and negative impacts of tourism on Guerrero's RCCs. The methodology used was the researcher's direct observation and open interviews with key informants. The work was carried out in four RCCs: Playa Ventura, Tecomate Fishery; Hacienda de Cabañas and Barra de Coyuca. The outcomes indicated that tourism helps to improve the residents' quality of life. However, the lack of public services; as drainage, collection of municipal solid waste, are blocks for the sustainable growth of Guerrero's RCCs.
\end{abstract}

Keywords: Rural coastal communities, tourism and sustainability, Guerrero México.

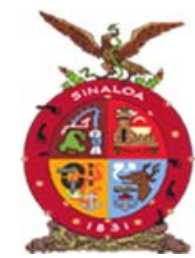

XVIII Congreso Internacional XXIV Congreso Nacional de Ciencias ambientales
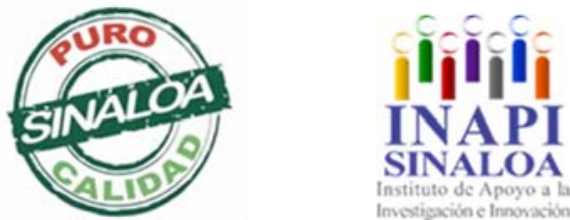

Mazatlán, Sinaloa 3-7 junio 2019

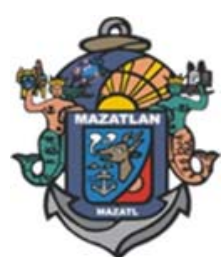

Legislación, Valores Sociales y Educación Ambiental 

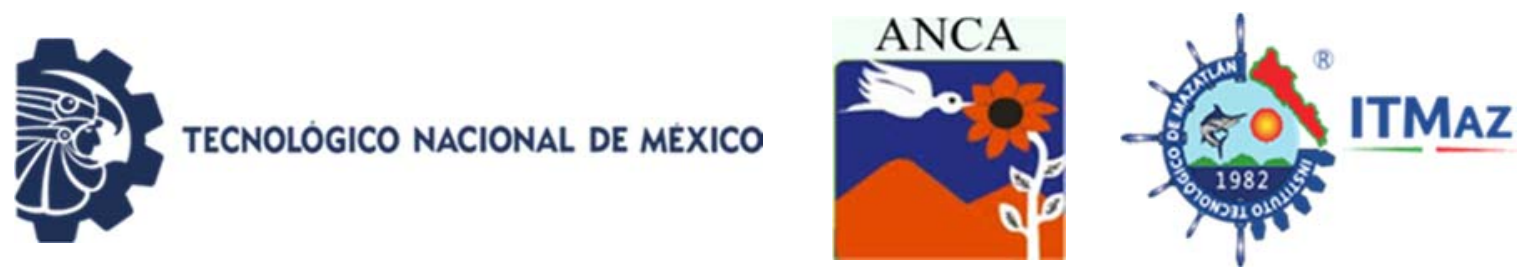

\section{Capacitación continua en materia de educación ambiental en la Facultad de Medicina de la UNAM}

Arce Camacho I, Mora Barrera L, Jaimez Melgoza R, Alva Chavarría D

Facultad de Medicina. Facultad de Química. División de Investigación.

Circuito interior, Ciudad Universitaria. Av. Universidad 3000. Coyoacán, CDMX, *arcecamacho@unam.mx

\section{RESUMEN}

La Comisión de Bioseguridad de la Facultad de Medicina de la UNAM, consciente de la importancia de generar una cultura ambiental, dentro de su programa de manejo integral de residuos peligrosos, ha diseñado diversos cursos de capacitación en el área de bioseguridad desde 2017 con el objetivo: Concientizar y capacitar a todo el personal que realiza actividades de investigación, docencia y práctica clínica en la Facultad de Medicina. La planeación de los cursos de Introducción a la Bioseguridad se calendariza de forma anual y la inscripción se realiza en línea en la página de internet de la División de Investigación de la Facultad de Medicina que se anuncia previo al inicio del curso. Estos cursos contemplan temas apegados a la normatividad vigente con respecto al correcto manejo y disposición de residuos peligrosos químicos y biológico-infecciosos. Actualmente, se imparten cinco cursos a lo largo del año, con un número de asistencia de 200 personas provenientes de los diferentes departamentos de esta Facultad. A partir de los cursos impartidos dentro de esta institución, se ha logrado generar una conciencia de responsabilidad ambiental y mejora en el manejo adecuado y disposición de los residuos tóxicos generados en los diferentes laboratorios.

Palabras clave: Bioseguridad, capacitación, normatividad, educación ambiental.

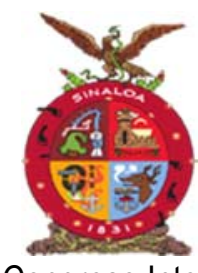

XVIII Congreso Internacional
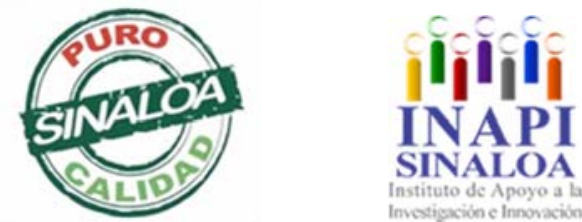

Mazatlán, Sinaloa 3-7 junio 2019

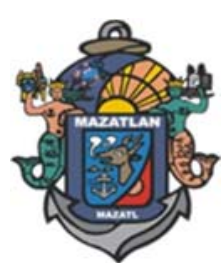

Legislación, Valores Sociales y Educación Ambiental 

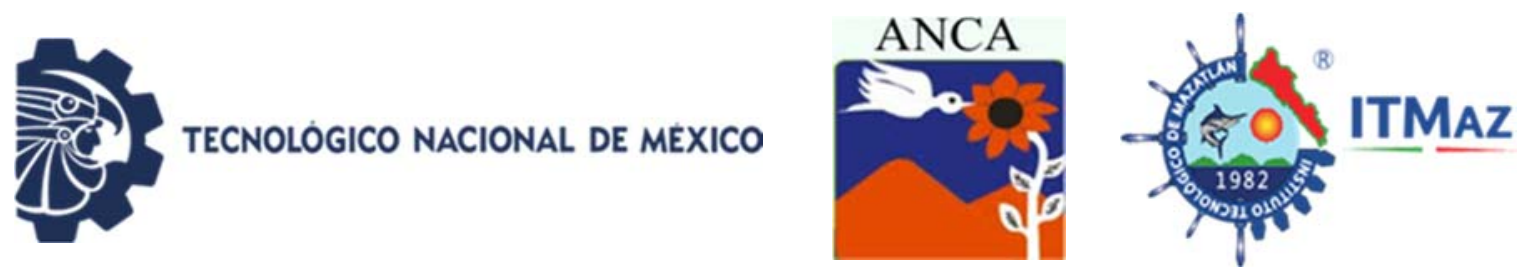

\title{
Permanent training in environmental education at the Faculty of Medicine, UNAM
}

Arce Camacho I, Mora Barrera L, Jaimez Melgoza R, Alva Chavarría D

Facultad de Medicina. Facultad de Química. División de Investigación.

Circuito interior, Ciudad Universitaria. Av. Universidad 3000. Coyoacán, CDMX, *arcecamacho@unam.mx

\begin{abstract}
The Biosafety Commission at the Faculty of Medicine of UNAM, aware of the significance of creating an environmental culture, within its global handling of hazardous waste program, has designed diverse training courses in the area of biosafety since 2017 . To raise awareness and to train all personnel that carry out research, teaching and clinical practice activities at the Faculty of Medicine. The planning of Introduction to Biosafety courses is scheduled annually and registration is made online at the Research Division website of the Faculty of Medicine, which is published in advance. The topics of these courses follow the current regulations regarding the correct handling and disposal of hazardous chemical and biological-infectious waste. There are currently five courses taught throughout the academic year, with an attendance of 200 people from different departments. Since the implementation of these courses, it has been possible to raise awareness of environmental responsibility and improvement in the adequate handling and disposal of toxic waste generated from the different labs.
\end{abstract}

Keywords: Biosafety, training, normativity, environmental education.

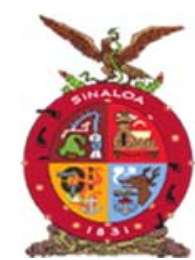

XVIII Congreso Internacional XXIV Congreso Nacional de Ciencias ambientales

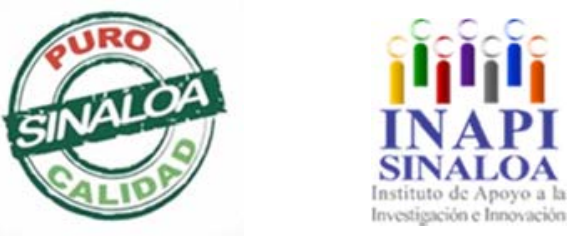

Mazatlán, Sinaloa 3-7 junio 2019

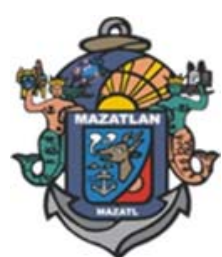

Legislación, Valores Sociales y Educación Ambiental 

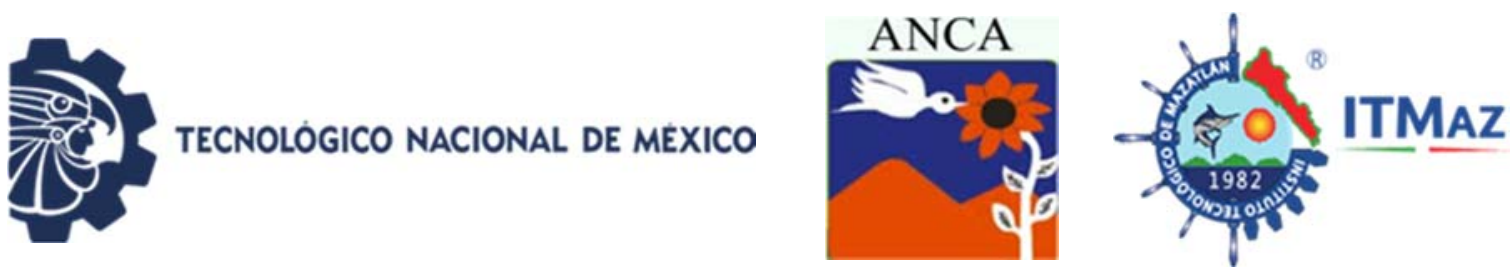

\section{Gestión del agua urbana: Caso de estudio, Unidad Habitacional de Cuernavaca, Morelos}

Arce García I, Valladares Cisneros M*, Medina Márquez M, Viana Lases J, Torres Salazar M, Cotero Villegas A

Maestría en Ingeniería Ambiental y Tecnologías Sustentables, PITC Facultad de Ciencias Químicas e Ingeniería,

PITC Facultad de Arquitectura,

Centro de Investigación en Ciencias Biológicas, UAE Morelos,

Av. Universidad No. 1001, Col Chamilpa 62209, Cuernavaca, Morelos, México.

*mg.valladares@uaem.mx

\section{RESUMEN}

El proceso de gestión del agua, en sus diferentes escalas tanto a nivel macro como micro cada vez es más complejo. Esta situación de escasez del recurso hídrico en las zonas urbanas aunada a la necesidad de disponer del líquido para el desarrollo y mantenimiento del estilo de vida de los habitantes, se refleja en particular en las unidades habitacionales (UHs). El objetivo de este trabajo a nivel exploratorio es describir en forma general algunos elementos sobre la gestión del agua potable en una unidad habitacional de interés social en la ciudad de Cuernavaca, Morelos. Para lo cual se toma como muestra un edificio de un total de 14 que integran el conjunto habitacional. La información se obtiene de registros de documentos del edificio, observación y entrevistas. Para el procesamiento y análisis de la información se utiliza la técnica del árbol del problema, la elaboración de tablas y gráficas. El resultado de dichos análisis muestra como principales problemas: la captación insuficiente de recurso económico por concepto de cuotas de mantenimiento para el pago de servicio del bombeo de agua potable es insuficiente agua para uso doméstico y descarga de aguas residuales hacia un cuerpo de agua receptor. En conclusión, la gestión del agua se ha venido presentando como problema, afectando de manera progresiva a la misma población usuaria, debido a que la participación económica y social, que se requiere es del total de la población de la UH, no consiguiendo lo anterior y acentuando la problemática.

Palabras Clave: Gestión del agua, población participativa, unidades habitacionales.

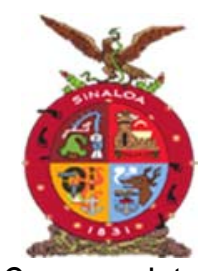

XVIII Congreso Internacional

XXIV Congreso Nacional de Ciencias ambientales
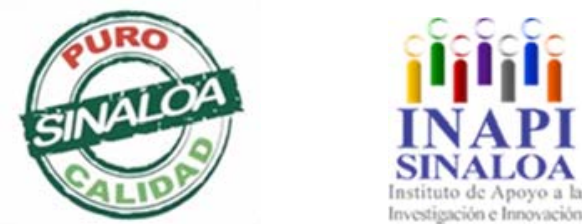

Mazatlán, Sinaloa 3-7 junio 2019

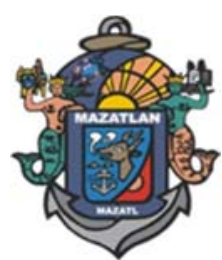

Legislación, Valores Sociales y Educación Ambiental 

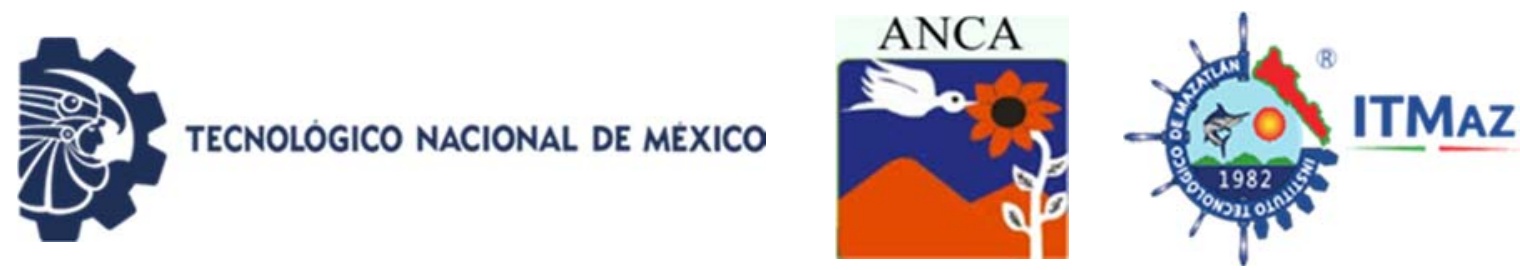

\title{
Urban water management. Case Study: housing unit in Cuernavaca, Morelos
}

\author{
Arce García I, Valladares Cisneros M*, Medina Márquez Ma, Viana Lases J, \\ Torres Salazar M, Cotero Villegas A \\ Maestría en Ingeniería Ambiental y Tecnologías Sustentables, \\ PITC Facultad de Ciencias Químicas e Ingeniería, \\ PITC Facultad de Arquitectura, \\ Centro de Investigación en Ciencias Biológicas, UAE Morelos, \\ Av. Universidad No. 1001, Col Chamilpa 62209, Cuernavaca, Morelos, México. \\ *mg.valladares@uaem.mx
}

\begin{abstract}
The process of water management, in its different scales both at the macro and micro level is increasingly complex. This situation of water resource scarcity in urban areas coupled with the need to have the liquid for the development and maintenance of the lifestyle of the inhabitants, in particular is reflected in the housing units (UHs). The objective of this work at an exploratory level is to describe in general terms some elements about the management of drinking water in a housing unit of social interest in the city of Cuernavaca, Morelos. For which a building of a total of 14 that make up the housing complex is taken as a sample. The information is obtained from records of building documents, observation and interviews. For the processing and analysis of the information, the problem tree technique, the creation of tables and graphs, is used. The result of these analyzes shows as main problems: the insufficient collection of economic resources for maintenance fees for the payment of the service of pumping drinking water is insufficient water for domestic use and discharge of wastewater into a body of natural water. In conclusion, water management has been presented as a problem, progressively affecting the same user population, because the economic and social participation required is of the total population of the $\mathrm{UH}$, not achieving the above and accentuating the problem.
\end{abstract}

Keywords: Water management, participatory population, housing units.

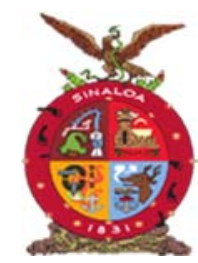

XVIII Congreso Internacional

XXIV Congreso Nacional de Ciencias ambientales
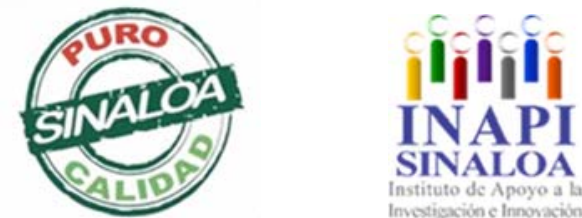

Mazatlán, Sinaloa 3-7 junio 2019

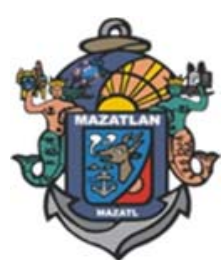

Legislación, Valores Sociales y Educación Ambiental 


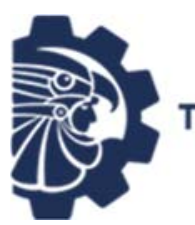

TECNOLOGICO NACIONAL DE MEXICO
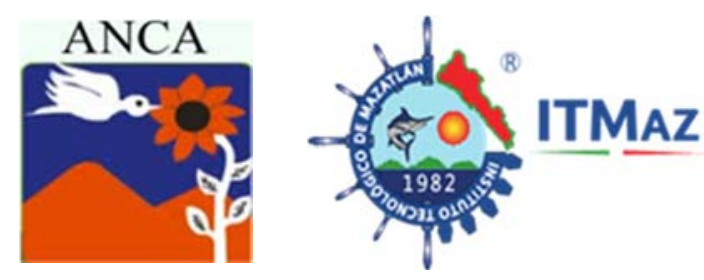

Implementación de talleres de educación ambiental no formal en escolares
de sexto año. Municipio de Zapotlán el Grande, Jalisco, México

Barragán Bautista E*, Díaz Chávez R, Quirarte Brambila M, García Xochititla M

Departamento de Promoción, Preservación y Desarrollo de la Salud.

Centro Universitario del Sur. Universidad de Guadalajara.

Av. Enrique Arreola Silva No. 883. Cd. Guzmán, Jalisco. México. C.P. 49000

*estherb@cusur.udg.mx.

\section{RESUMEN}

La vida del planeta tierra y nuestro futuro están en juego. Al asumir la presidencia para la Biodiversidad 2017-2018, México colocó en la agenda global del desarrollo sostenible la conservación de los organismos vivos, su genética, los ecosistemas y su uso. La Educación Ambiental ha tomado un papel relevante en la educación de la niñez, especialmente en las primeras etapas de enseñanza, ya que se asientan los conocimientos básicos que serán fundamentales en el desarrollo del niño (a). Con el objetivo de implementar y evaluar talleres de Educación Ambiental no Formal en escolares de sexto año de la primaria "José María Pino Suarez" turno matutino en Ciudad Guzmán, Municipio de Zapotlán el Grande, Jalisco. Período: agosto-diciembre 2017. Con cuatro módulos (Medio Ambiente, Recursos Naturales, Problemática Ambiental y Legislación Ambiental) y 17 talleres, los lunes 8:00-10:00 hrs, participaron 25 escolares. Se utilizó la Investigación-acción y estrategias de enseñanza (preinstruccionales, coinstruccionales y postinstruccionales), técnicas pedagógicas participativas y actividades lúdicas plasmadas en las secuencias didácticas. Se realizaron evaluaciones: Una al inicio, al término, de los facilitadores y talleres, en escala de Likert. En la diagnóstica $64 \%$ respondieron que no tenían idea, 25\% tenían poco conocimiento y $11 \%$ sabían perfectamente, en la final $4 \%, 11 \%$ y $85 \%$ respectivamente. $84 \%$ fueron excelente y $8 \%$ bien, resultados de los facilitadores y $87 \%$ excelente y $5 \%$ bien, para talleres. Los problemas ambientales son problemas de la sociedad y la mejor forma de iniciar es con la educación, el entorno escolar es una fuente inagotable de aprendizaje ambiental.

Palabras clave: Educación ambiental no formal, escolares, investigaciónacción, valores y talleres.

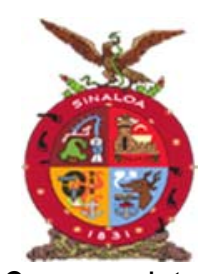

XVIII Congreso Internacional

XXIV Congreso Nacional de Ciencias ambientales

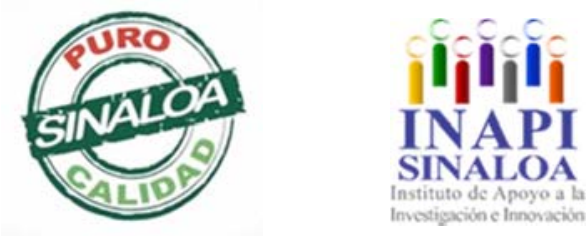

Mazatlán, Sinaloa 3-7 junio 2019

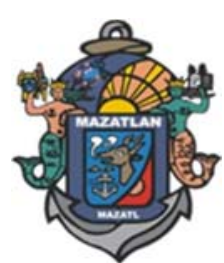

Legislación, Valores Sociales y Educación Ambiental 

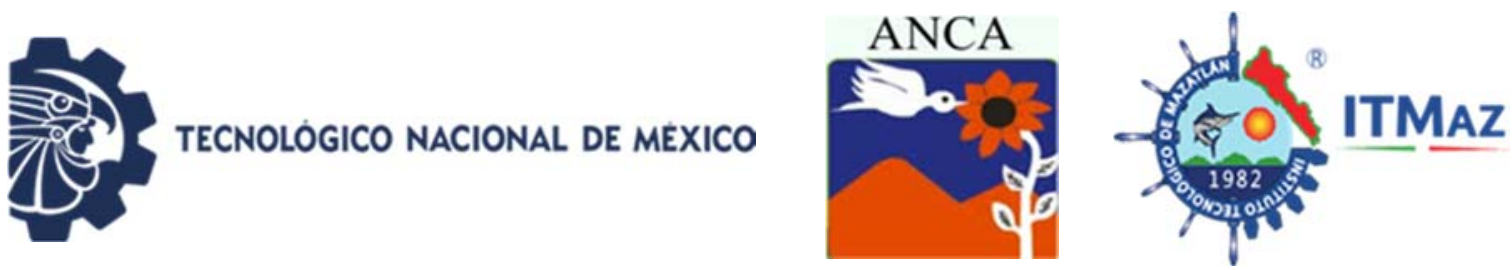

Implementation of non-formal environmental education workshops for sixth-year students. Municipality of Zapotlán el Grande, Jalisco, Mexico

Barragán Bautista E*, Díaz Chávez R, Quirarte Brambila M, García Xochititla M

Departamento de Promoción, Preservación y Desarrollo de la Salud.

Centro Universitario del Sur. Universidad de Guadalajara.

Av. Enrique Arreola Silva No. 883. Cd. Guzmán, Jalisco. México. C.P. 49000

*estherb@cusur.udg.mx..

\begin{abstract}
The life of planet Earth and our future are at stake. Assuming the presidency for biodiversity 2017-2018, Mexico placed in the global agenda of Sustainable development the conservation of living organisms, their genetics, the ecosystems and their use Environmental education has taken an important role in the education of children, especially in the early stages of teaching, since it because the basic knowledge that will be fundamental to the development of the child is established. In order to implement and evaluate workshops on of non-Formal environmental education in sixth grade schoolchildren "José María Pino Suarez" Morning shift In Ciudad Guzmán, municipality of Zapotlán El Grande, Jalisco. Period: August-December 2017. With four modules (environment, natural resources, environmental issues and environmental legislation) and 17 workshops, on Monday 8:00-10:00 hrs, participated 25 schoolchildren. We used research-action and teaching Strategies (preinstructional, Coinstructional and postinstructional), techniques Participative pedagogical and recreational activities embodied in the didactic sequences. Evaluations we recarried out: one at the beginning, at the end of the facilitators and workshops, in scale of Likert. In the diagnostic $64 \%$ responded that they had no Idea, $25 \%$ had little knowledge and $11 \%$ knew perfectly, in the final $4 \%, 11 \%$ and $85 \%$ respectively. $84 \%$ were excellent and $8 \%$ well, results of the Facilitators and $87 \%$ excellent and $5 \%$ well, for workshops. Environmental problems are societal problems and the best way to start is with education, the school environment is an inexhaustible source of environmental learning.
\end{abstract}

Keywords: Nonformal environmental education, school, action research, values and workshops.

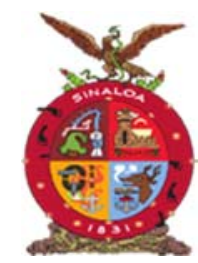

XVIII Congreso Internacional

XXIV Congreso Nacional de Ciencias ambientales
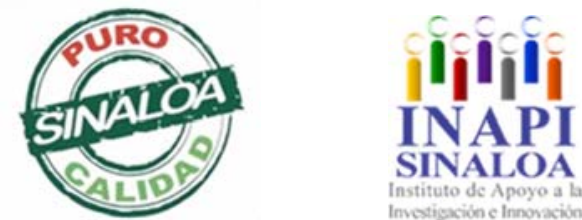

Mazatlán, Sinaloa 3-7 junio 2019

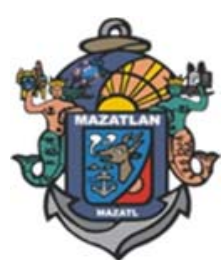

Legislación, Valores Sociales y Educación Ambiental 

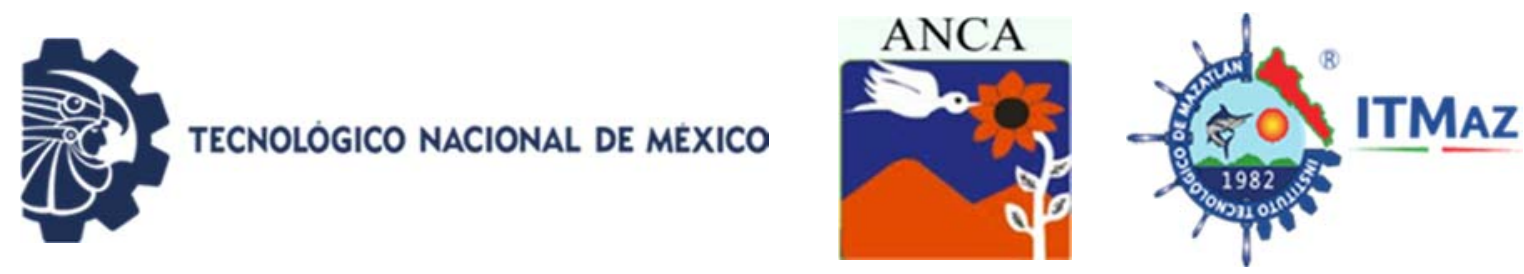

\title{
Análisis del síndrome del edificio enfermo en Universidades Mexicanas: Campus de la Región Sur de la Universidad Autónoma de Tamaulipas
}

\author{
Cabrera Cruz RBE*, Orozco Robles J, Rolón Aguilar J, Pichardo Ramírez R, \\ Tobías Jaramillo R, García Del Ángel G \\ Cuerpo Académico UAT-CA-29 Medio Ambiente y Desarrollo Sustentable. \\ Facultad de Ingeniería Arturo Narro Siller. \\ Universidad Autónoma de Tamaulipas. \\ *rcabreracruz@docentes.uat.edu.mx
}

\section{RESUMEN}

En el presente trabajo se evaluó el Síndrome del Edificio Enfermo (SEE) en el campus Sur de la Universidad Autónoma de Tamaulipas. La metodología empleada se basó en la Norma Técnica Preventiva 380. Los resultados se analizaron por métodos estadísticos para encontrar una correlación entre síntomas y ocupación del edificio. Se empleó el lenguaje $R$ que es un software de acceso libre de investigación reproducible aplicando la prueba de Chi cuadrada para encontrar la relación entre las diferentes variables con el objetivo SEE. Los edificios analizados se encuentran en el municipio de Tampico, Tamaulipas, México. La región cuenta con un clima subtropical húmedo siendo una de las ciudades más húmedas de todo México, por lo cual el uso de sistemas de ventilación es común. Se analizaron las Facultades de Ingeniería, Derecho, Arquitectura, Comercio, Enfermería, Odontología y Música, así como los edificios del Gimnasio Olímpico, Biblioteca Central y Guardería Universitaria. Se identificaron resultados que avalan la presencia del SEE como lo son el uso de aires acondicionados, partículas de polvo en ciertas áreas de las aulas, falta de ventilación e iluminación artificial excesiva. Se correlacionaron las variables independientes: síntomas como dolor de cabeza; aletargamiento; picor de ojos; y garganta, entre otros. Con la aparición del SEE mediante una prueba estadística para asociar los principales síntomas que se presentan en los edificios del Campus Sur. Este tipo de estudios podrían llevar a que la normatividad laboral mexicana contemple la salud ocupacional de centros educativos y hospitales.

Palabras clave: Síndrome edificio enfermo, campus, Tampico.

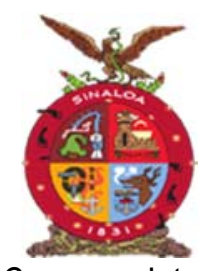

XVIII Congreso Internacional

XXIV Congreso Nacional de Ciencias ambientales
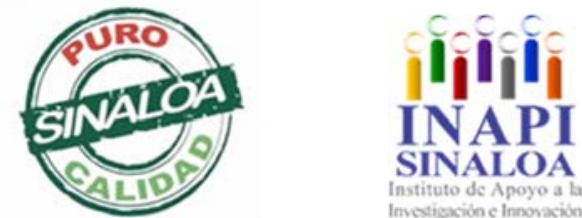

Mazatlán, Sinaloa 3-7 junio 2019

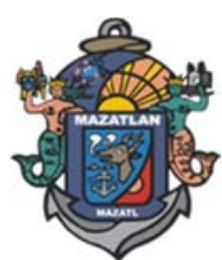

Legislación, Valores Sociales y Educación Ambiental 

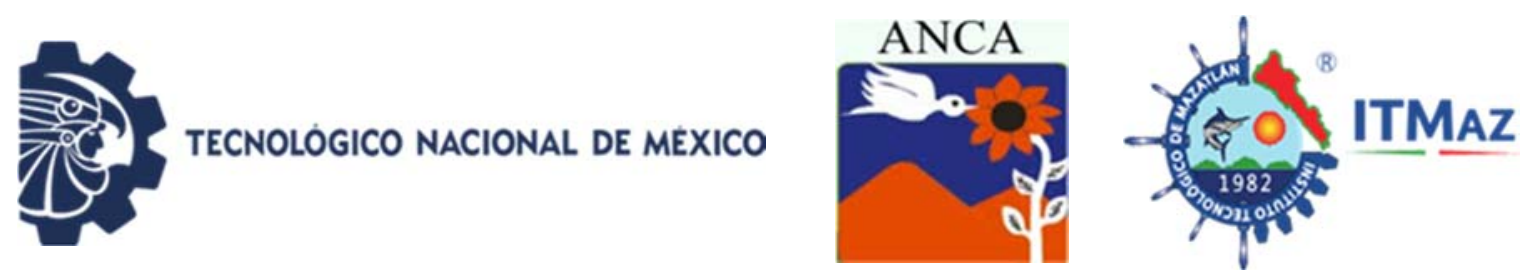

\title{
Analysis of the sick building syndrome in Mexican Universities: Campus of the Southern Region of the Autonomous University of Tamaulipas
}

\author{
Cabrera Cruz RBE*, Orozco Robles J, Rolón Aguilar J, Pichardo Ramírez R, \\ Tobías Jaramillo R, García Del Ángel G \\ Cuerpo Académico UAT-CA-29 Medio Ambiente y Desarrollo Sustentable. \\ Facultad de Ingeniería Arturo Narro Siller. \\ Universidad Autónoma de Tamaulipas. \\ *rcabreracruz@docentes.uat.edu.mx
}

\begin{abstract}
In the present work, the Sick Building Syndrome (SBS) was detected on the southern campus of the Autonomous University of Tamaulipas. The methodology used was based on the Preventive Technical Standard 380, whose results were analyzed by statistical methods to find a correlation between symptoms and occupancy of the building. The R language was used, which is an open-access software of reproducible research applying the Chi square test to find a relationship between the different variables in order to find out if the building is sick. The analyzed buildings are in the municipality of Tampico, Tamaulipas, Mexico. The region has a humid subtropical climate, being one of the wettest cities in Mexico, so the use of ventilation systems is common. The Faculties of Engineering, Law, Architecture, Commerce, Nursing, Dentistry and Music were analyzed, as well as the buildings of the Olympic Gymnasium, Central Library and University Nursery. Indications were identified that support the presence of SBS such as the use of air conditioners, dust particles in certain areas of the classrooms, lack of ventilation and excessive artificial lighting. The independent variables (symptoms such as headache, lethargy, itching eyes and throat, among others) were correlated with the appearance of the SBS by means of a statistical test to associate the main symptoms presented in the buildings of the South Campus. This type of study could lead to Mexican labor regulations contemplating the occupational health of educational centers and hospitals.
\end{abstract}

Keywords: Sick building syndrome, campus, Tampico.

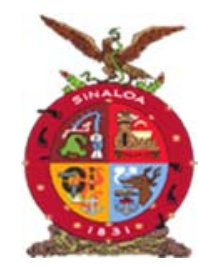

XVIII Congreso Internacional

XXIV Congreso Nacional de Ciencias ambientales
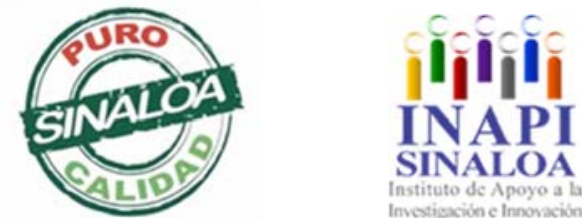

Mazatlán, Sinaloa 3-7 junio 2019

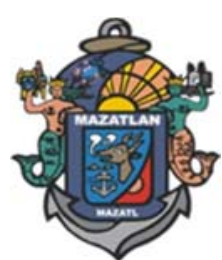

Legislación, Valores Sociales y Educación Ambiental 

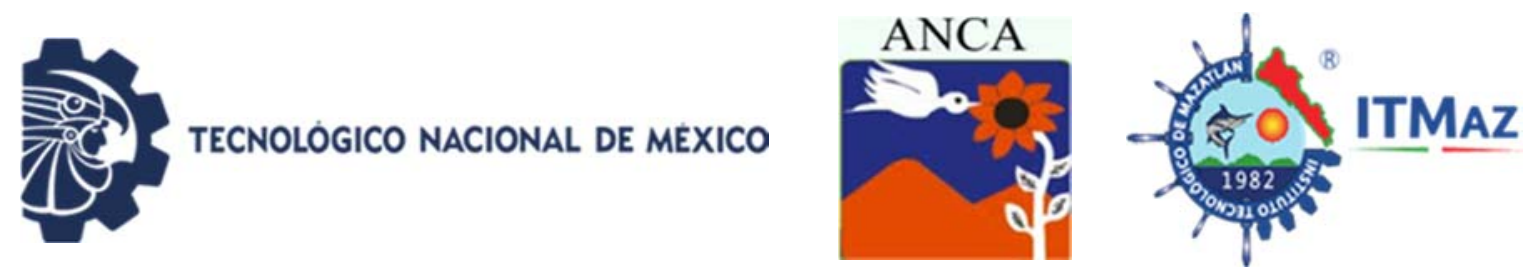

Evaluación de los aspectos ambientales en los laboratorios del área de Ciencias Químico-Biológicas de la Universidad del Noreste, Tamaulipas

\author{
Camarena Morales A \\ Universidad del Noreste (UNE) \\ *alexcam2895@gmail.com
}

\begin{abstract}
RESUMEN
La administración de aspectos ambientales y sus impactos es fundamental para la gestión ambiental de procesos dentro de una organización. En la Universidad del Noreste, a pesar del compromiso adquirido por parte de la institución hacia la sustentabilidad, no se tiene conocimiento exacto de los efectos al ambiente que tiene una de sus áreas más críticas, los laboratorios experimentales. En base a la norma internacional ISO 14001:2015, se realizó durante el 2018 un mapeo de los procesos dentro de los laboratorios, identificando las actividades realizadas junto con los aspectos ambientales derivados de ellas. Se establecieron 3 criterios de evaluación (Frecuencia, Extensión y Consecuencia) para determinar los aspectos significativos para los laboratorios, proponiendo acciones para su control operacional. Se identificaron 4 aspectos ambientales significativos y 14 potenciales, de los cuales el $80 \%$ está en los procesos de almacenamiento de residuos peligrosos, preparación de materiales y desarrollo de prácticas. Los aspectos más críticos fueron la generación de residuos peligrosos y vertido de sustancias a drenaje, donde las principales causas radican en la inducción educativa hacia los alumnos y la falta de consideración del impacto ambiental en el diseño de los manuales de prácticas.
\end{abstract}

Palabras clave: ISO, sistemas de gestión, impacto ambiental

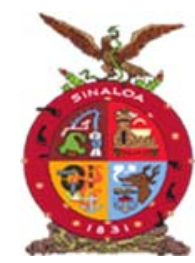

XVIII Congreso Internacional

XXIV Congreso Nacional de Ciencias ambientales
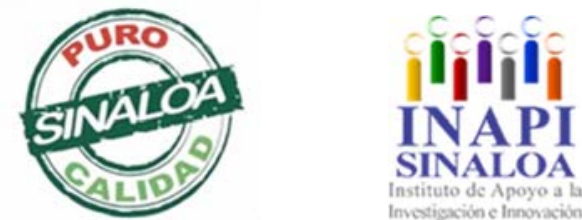

Mazatlán, Sinaloa 3-7 junio 2019

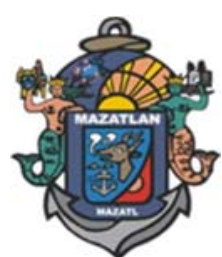

Legislación, Valores Sociales y Educación Ambiental 

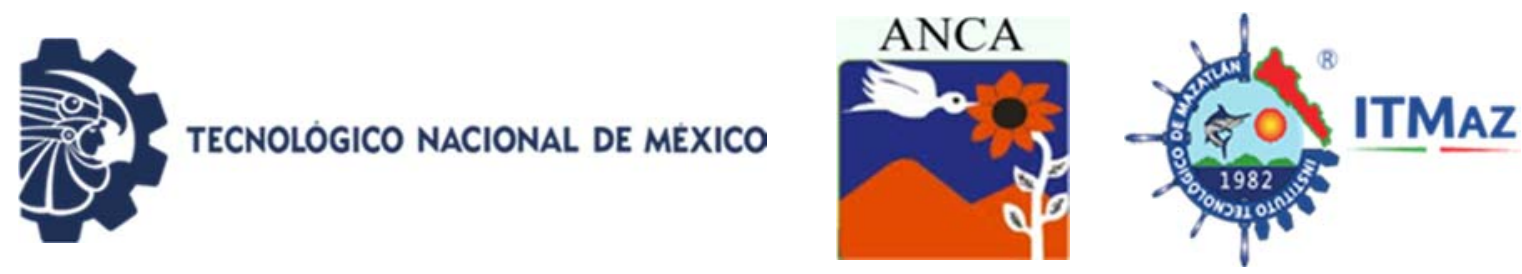

\title{
Evaluation of environmental aspects in the laboratories of the Chemical- Biological Sciences area of the University of the Northeast, Tamaulipas
}

\author{
Camarena Morales A \\ Universidad del Noreste (UNE) \\ *alexcam2895@gmail.com
}

\begin{abstract}
The management of environmental aspects and their impacts is essential in the environmental process management within an organization. In the "Universidad del Noreste", despite the acquired commitment by the institution with society, there is no exact knowledge of the environmental effects that have its more critical areas, the experimental laboratories. Based on the international standard ISO 14001:2015, throughout 2018, a survey of the processes was carried out, identifying the activities and environmental aspects derived from them. To assess the significance of the environmental aspects, evaluation criteria was established, proposing operational controls. In the process, 4 significant environmental aspects and 14 potential ones were identified, of which $80 \%$ are from the processes of storage of hazardous waste, preparation of materials and lab work. The most critic aspects were hazardous waste generation and discharge of substances into drainage, being the main causes a deficient induction to students and lack of consideration of the environmental impact in the design of practice manuals.
\end{abstract}

Key words: ISO, management systems, environmental impact.

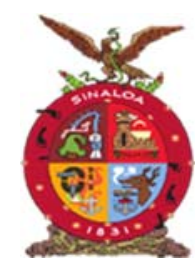

XVIII Congreso Internacional

XXIV Congreso Nacional de Ciencias ambientales

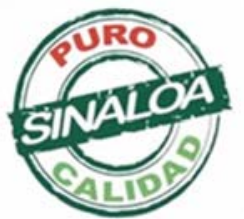

Mazatlán, Sinaloa 3-7 junio 2019

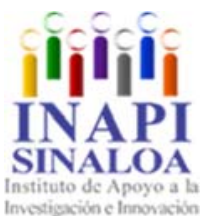

SINALOA 

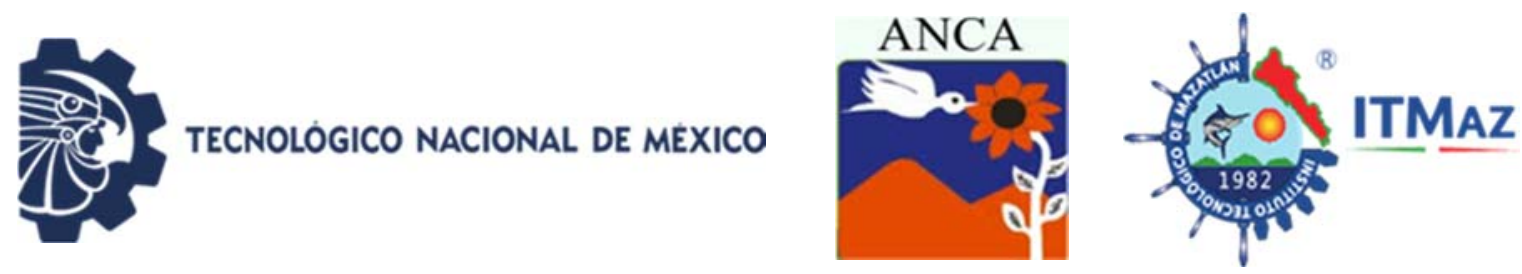

\title{
Análisis retrospectivo del procedimiento para el manejo de residuos peligrosos en la Universidad Autónoma de Ciudad Juárez
}

\author{
Carrasco Urrutia K*, Corral Avitia A, Torres Pérez J \\ Universidad Autónoma de Ciudad Juárez. Instituto de Ciencias Biomédicas \\ Anillo Envolvente del PRONAF y Estocolmo, Cd. Juárez, Chihuahua, México \\ *kcarrasc@uacj.mx
}

\section{RESUMEN}

En función del cumplimiento con la normatividad, las Instituciones de Educación Superior han establecido programas para el control de residuos químicos generados durante las actividades de prácticas de laboratorio, clínicas o talleres. En la Universidad Autónoma de Ciudad Juárez se plantearon una serie de estrategias de manejo integral de residuos peligrosos (RP) que implicó acciones que disminuyeron el impacto ambiental producido por los residuos producto de las actividades propias. Después de la implementación del programa el objetivo fue realizar un análisis retrospectivo de los avances en los procedimientos para el manejo integral de RP en el periodo de 2012 a 2018. Las características, el procedimiento de identificación, clasificación y los listados de los RP se realizaron en base a la Norma Oficial Mexicana NOM-052-SEMARNAT-2005. El análisis realizado corresponde a una cohorte retrospectiva que identifica la generación de residuos dentro de la institución a lo largo de 6 años. Los resultados obtenidos demuestran que se han disminuido en un $11.3 \%$ la cantidad de residuos peligrosos por fuente específica, en un $8.2 \%$ los residuos peligros resultados de desechos de productos químicos fuera de especificaciones o caducos (tóxicos agudos), y en un $12.7 \%$ los residuos enmarcados en la clasificación de RP resultado del desecho de productos químicos fuera de especificaciones 0 caducos (tóxicos crónicos). En conclusión, se ha logrado la disminución de los residuos generados ya que se ha mejorado el manejo y disposición, además de que se ha fomentado una conciencia ambiental en la Comunidad Universitaria.

Palabras clave: Normatividad, residuos peligrosos, educación.

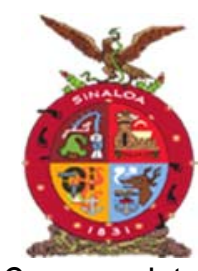

XVIII Congreso Internacional

XXIV Congreso Nacional de Ciencias ambientales
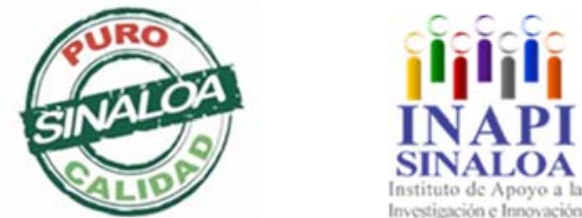

Mazatlán, Sinaloa 3-7 junio 2019

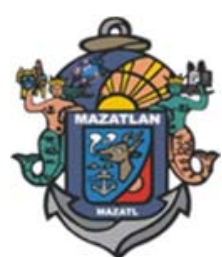

Legislación, Valores Sociales y Educación Ambiental 

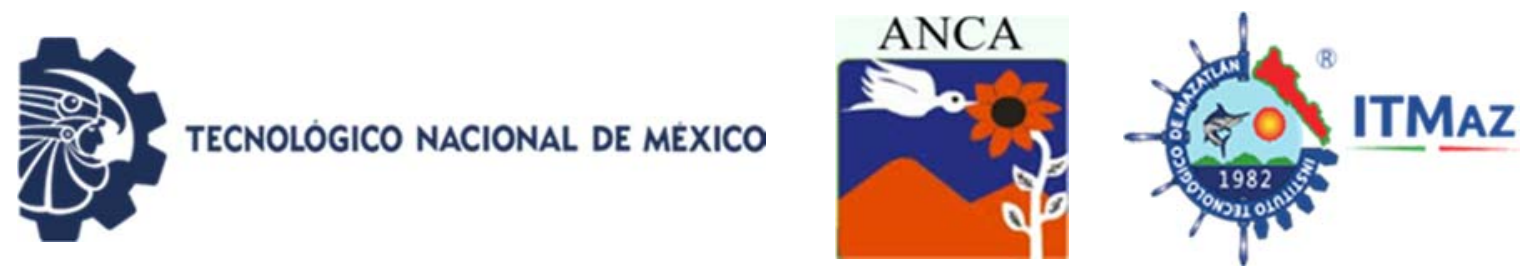

\title{
Retrospective analysis of the procedure for the management of hazardous waste at the Autonomous University of Ciudad Juárez
}

\author{
Carrasco Urrutia K*, Corral Avitia A, Torres Pérez J \\ Universidad Autónoma de Ciudad Juárez. Instituto de Ciencias Biomédicas \\ Anillo Envolvente del PRONAF y Estocolmo, Cd. Juárez, Chihuahua, México. \\ *kcarrasc@uacj.mx
}

\begin{abstract}
Based on compliance with regulations, Higher Education Institutions have established programs for the control of chemical waste generated during laboratory, clinic or workshop practice activities. At the Autonomous University of Ciudad Juárez, a series of strategies for the integral management of hazardous waste (PR) were proposed that implied actions that diminished the environmental impact produced by the waste produced by the own activities. After the implementation of the program, the objective was to carry out a retrospective analysis of the advances in the procedures for the integral management of PR in the period from 2012 to 2018 . The characteristics, the identification procedure, classification and the listings of the PRs were carried out based on the Official Mexican Standard NOM-052-SEMARNAT-2005. The analysis carried out corresponds to a retrospective cohort that identifies the generation of waste within the institution over 6 years. The results obtained show that the amount of hazardous waste by specific source has been reduced by $11.3 \%$, by $8.2 \%$ the hazardous waste resulting from chemical waste out of specifications or expired (acute toxic), and by $12.7 \%$ residues framed in the classification of RP resulting from the disposal of chemical products out of specifications or expired (chronic toxic). In conclusion, the reduction of the waste generated has been achieved since the management and disposal has been improved, in addition to an environmental awareness in the University Community.
\end{abstract}

Keywords: Regulations, hazardous waste, education.

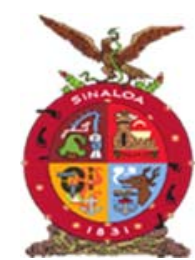

XVIII Congreso Internacional

XXIV Congreso Nacional de Ciencias ambientales

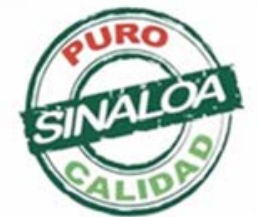

Mazatlán, Sinaloa 3-7 junio 2019

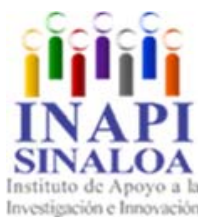

$\underset{\text { SINALAto de Apoyo a }}{\text { Int }}$ 

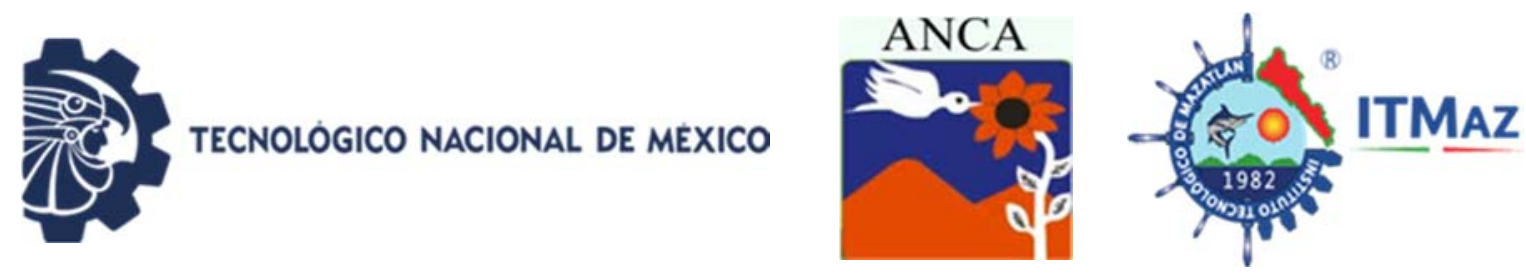

\title{
Ética y valores en la educación superior para cuidar hoy el ambiente
}

\author{
Cruz Herrera $A^{*}$, Vega Pérez S \\ Escuela Superior de Ingeniería Mecánica y Eléctrica. IPN \\ *anahamburgo@hotmail.com
}

\begin{abstract}
RESUMEN
Los gobernantes de los países del mundo han dedicado esfuerzos para atender el contenido del documento emitido por la UNESCO, titulado "Transformar Nuestro Mundo: Agenda 2030 para el Desarrollo Sostenible"; dicho documento contiene 17 Objetivos del Desarrollo Sostenible (ODS), y entre otros propone "Garantizar una educación inclusiva, equitativa y de calidad, que promueva oportunidades de aprendizaje durante toda la vida y para todos. El objetivo de este trabajo es elaborar una propuesta de organización informal de un programa denominado: "Acciones personalistas saludables que promuevan el Desarrollo Sostenible". Éticamente requiere de la aplicación de dos principios fundamentales: el compromiso y; la comunicación. Filosóficamente se promueven acciones personalistas. La metodología se basa en la realización de acciones personalistas concretas encaminadas hacia una vida moralmente saludable. La razón que sostiene la presente investigación es que las acciones encaminadas al cuidado del ambiente, requiere de una suma de conocimientos, que generalmente se adquieren por medio de la educación. El marco de referencia para la presente investigación son los objetivos 15 y 4 de la Agenda 2030 para el Desarrollo Sostenible, referentes al cuidado de los ecosistemas para detener la pérdida de la biodiversidad y brindar una educación con calidad. Se han utilizado dos indicadores básicos, alimentación y empoderamiento. Los resultados que se han obtenido a partir de la realización del programa han sido poco halagüeños.
\end{abstract}

Palabras clave: Personalista, organización informal, compromiso, comunicación.

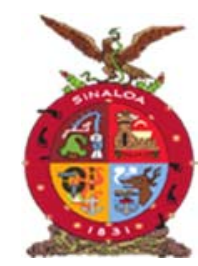

XVIII Congreso Internacional XXIV Congreso Nacional de Ciencias ambientales

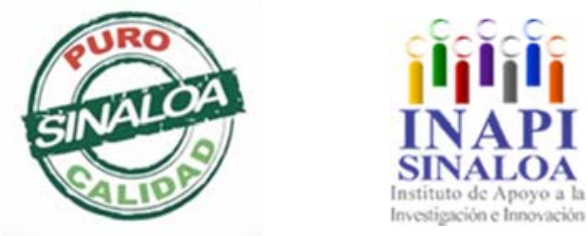

Mazatlán, Sinaloa 3-7 junio 2019

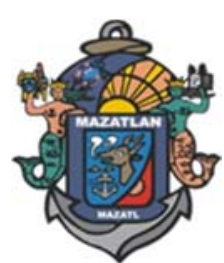

Legislación, Valores Sociales

y Educación Ambiental 

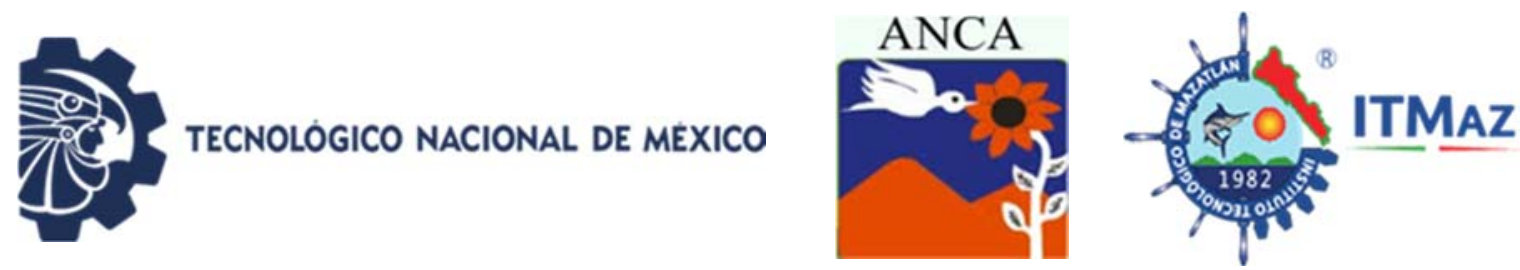

\title{
Ethics and values in higher education to take care of the environment today
}

\author{
Cruz Herrera $A^{*}$, Vega Pérez S \\ Escuela Superior de Ingeniería Mecánica y Eléctrica. IPN \\ *anahamburgo@hotmail.com
}

\begin{abstract}
The rulers of the countries of the world have dedicated efforts to attend the content of the document issued by UNESCO, entitled "Transforming Our World: 2030 Agenda for Sustainable Development". This document contains 17 Sustainable Development Goals (SDGs), and among others it proposes "To guarantee an inclusive, equitable and quality education that promotes lifelong learning opportunities for all. The objective of this work is to elaborate a proposal for the informal organization of a program called "Healthy personalistic Actions that promote Sustainable Development". Ethically requires the application of two fundamental principles: commitment and; the communication. Philosophically, personalist actions are promoted. The methodology is based on the realization of concrete personalist actions aimed at a morally healthy life. The reason behind this research is that actions aimed at caring for the environment require a sum of knowledge, which is generally acquired through education. The frame of reference for this research are objectives 15 and 4 of the 2030 Agenda for Sustainable Development, referring to the care of ecosystems to stop the loss of biodiversity and provide quality education. Two basic indicators, food and empowerment have been used. The results that have been obtained from the realization of the program have been little promising.
\end{abstract}

Keywords: Personalist, informal organization, commitment, communication.

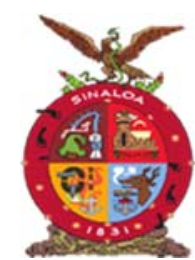

XVIII Congreso Internacional XXIV Congreso Nacional de Ciencias ambientales
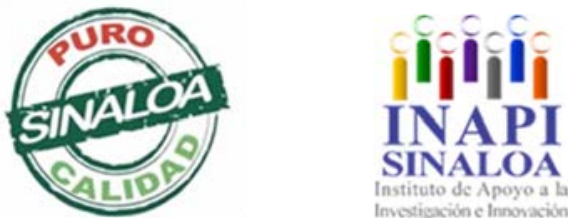

Mazatlán, Sinaloa 3-7 junio 2019

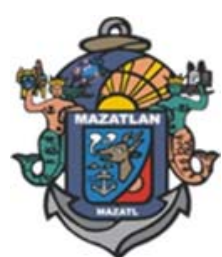

Legislación, Valores Sociales y Educación Ambiental 

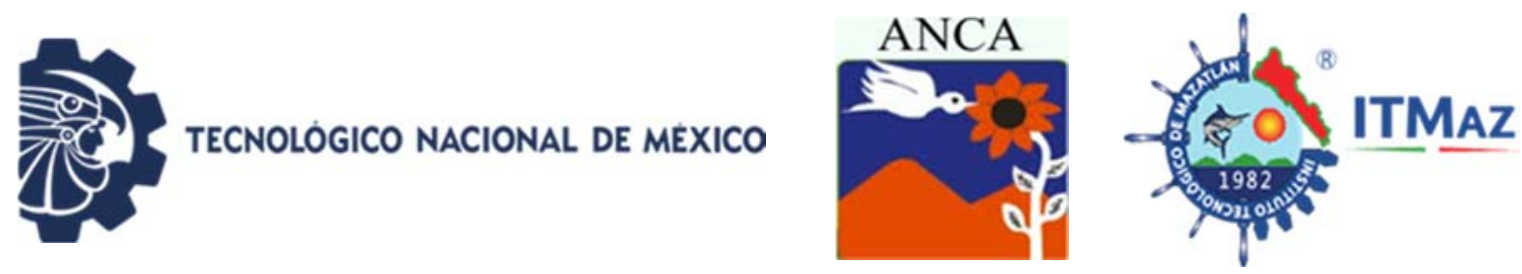

\title{
La belleza escénica como un servicio ecosistémico en humedales del Sur de Sinaloa, México
}

\author{
De la Rosa Velázquez M*, Camarena Gómez B, Ruiz Luna A
}

Doctorado en Ciencias. Centro de Investigación en Alimentación y Desarrollo

Unidad Mazatlán en Acuicultura y Manejo Ambiental. Mazatlán, Sinaloa.

Coordinación de Desarrollo Regional. CIAD, A.C. Unidad Hermosillo, Sonora. México Laboratorio de Manejo Ambiental. CIAD, A.C. Unidad Mazatlán, Sinaloa.

*mayra.delarosadc18@estudiantes.ciad.mx

\section{RESUMEN}

El paisaje mantiene elementos que aportan bienes tangibles e intangibles que resultan fundamentales para el bienestar humano y que, junto con otros servicios y productos derivados de la naturaleza, se denominan servicios ecosistémicos. Sin embargo, el análisis de elementos inmateriales del paisaje como la belleza escénica puede contribuir a entender el origen de las respuestas emocionales y fortalecer la relación naturaleza - sociedad en un momento que parece debilitarse contribuyendo al deterioro de los recursos en distintas escalas. Como parte de una investigación más amplia, encaminada a valorar socialmente los humedales costeros de la zona sur de Sinaloa, en el presente estudio se presentan avances de la caracterización del paisaje, identificando elementos de belleza escénica preferidos socialmente. El trabajo empírico se realizó durante el mes de abril de 2019, en dos visitas de campo a Escuinapa, Sinaloa, México, donde se identificaron unidades de paisaje con métodos de cerramientos visuales conformes a la valoración indirecta y rápida del paisaje, seguido de la aplicación de encuestas a turistas (ocho) y entrevistas a profundidad a residentes originarios del sitio (dos), además de la observación participante del investigador. Los resultados refieren cuatro hallazgos: a) Presencia de agua (estero y playa) seguido de vegetación con elementos enclaves que dan valor al paisaje; b) Continuar las tradiciones familiares es la principal motivación para visitar Escuinapa; c) La presencia de basura y de edificios físicos en mal estado fueron considerados elementos negativos del paisaje; y d) las personas están dispuestas a contribuir a mantener su valor paisajístico.

Palabras clave: Ambiente, Escuinapa, paisaje, percepción, valor social.

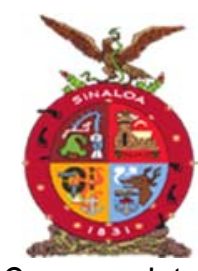

XVIII Congreso Internacional

XXIV Congreso Nacional de Ciencias ambientales
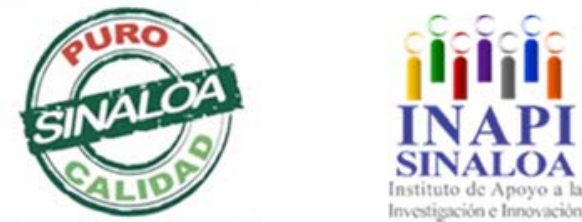

Mazatlán, Sinaloa 3-7 junio 2019

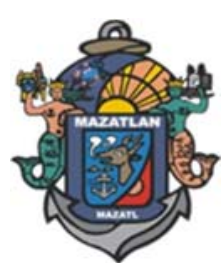

Legislación, Valores Sociales y Educación Ambiental 

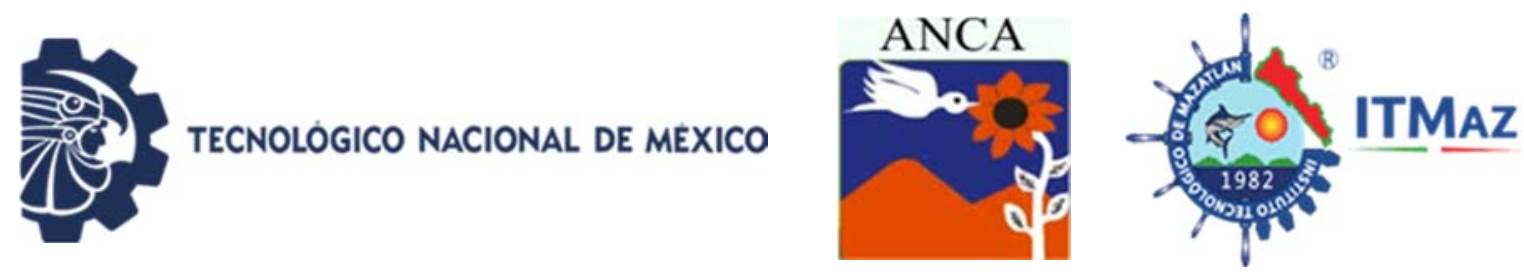

\title{
Scenic beauty as an ecosystem service in wetlands of Southern Sinaloa, Mexico
}

\author{
De la Rosa Velázquez M*, Camarena Gómez B, Ruiz Luna A
}

Doctorado en Ciencias. Centro de Investigación en Alimentación y Desarrollo

Unidad Mazatlán en Acuicultura y Manejo Ambiental. Mazatlán, Sinaloa.

Coordinación de Desarrollo Regional. CIAD, A.C. Unidad Hermosillo, Sonora. México Laboratorio de Manejo Ambiental. CIAD, A.C. Unidad Mazatlán, Sinaloa.

*mayra.delarosadc18@estudiantes.ciad.mx

\begin{abstract}
The landscape maintains elements that provide tangible and intangible goods that are fundamental for human well-being and that, along with other services and products derived from nature, are called ecosystem services. However, the analysis of intangible elements of the landscape such as scenic beauty can help to understand the origin of emotional responses and strengthen the nature-society relationship at a time that seems to weaken contributing to the deterioration of resources at different scales. As part of a larger investigation, aimed at socially assessing the coastal wetlands of the southern area of Sinaloa, this study presents advances in the characterization of the landscape, identifying elements of scenic beauty that are socially preferred. The empirical work was carried out during the month of April 2019, in two field visits to Escuinapa, Sinaloa, Mexico, where landscape units were identified with visual enclosure methods according to the indirect and rapid assessment of the landscape, followed by the application of tourist surveys (eight) and in-depth interviews with residents of the site (two), as well as participant observation by the researcher. The results refer to four findings: a) Presence of water (estuary and beach) followed by vegetation are enclave elements that give value to the landscape; $b$ ) Continuing family traditions is the main motivation to visit Escuinapa; c) The presence of garbage and physical buildings in poor condition were considered negative elements of the landscape; and d) people are willing to contribute with actions to maintain their landscape value.
\end{abstract}

Keywords: Environment, Escuinapa, landscape, perception, social value.

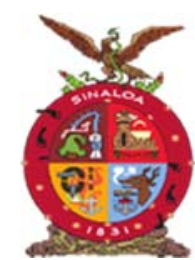

XVIII Congreso Internacional

XXIV Congreso Nacional de Ciencias ambientales
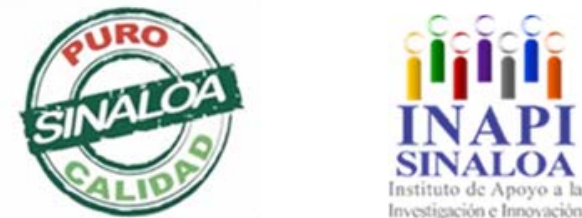

Mazatlán, Sinaloa 3-7 junio 2019

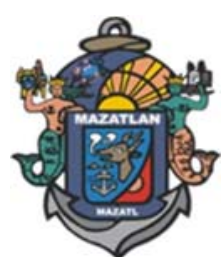

Legislación, Valores Sociales y Educación Ambiental 

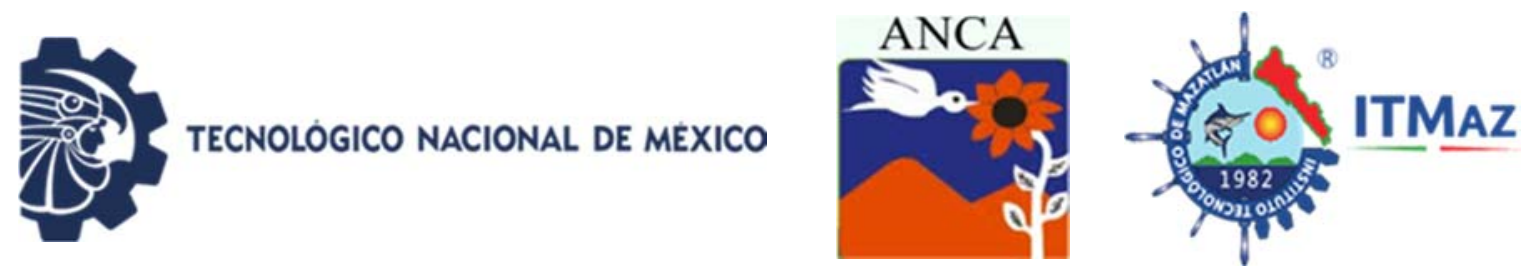

\title{
Determinación del comportamiento hidráulico de reactores empacados
}

\author{
Escalante Estrada VE \\ Instituto Mexicano de Tecnología del Agua, \\ Paseo Cuauhnáhuac 8532, C.P. 62550, Col. Progreso Jiutepec, Morelos \\ *vescalan@tlaloc.imta.mx
}

\begin{abstract}
RESUMEN
En el tratamiento de las aguas residuales (AR) el estudio del comportamiento hidráulico de un proceso es de importancia, determinando el tiempo de retención hidráulico (TRH) real, la existencia de cortos circuitos y zonas muertas en el reactor. Se determinó el comportamiento hidráulico de tres reactores. Cada reactor estuvo empacado con tezontle de varias granulometrías (colocadas en forma ascendente de mayor a menor tamaño). Como trazador se utilizó cloruro de sodio, el que fue aplicado mediante la técnica estímulo-respuesta; el trazador fue agregado en el influente y con alimentación de flujo ascendente. Las pruebas se realizaron por duplicado para cada reactor. Se tomaron muestras realizando las mediciones de sólidos disueltos totales (SDT) durante un periodo de tres veces el TRH teórico para cada reactor. Se desarrollaron curvas de concentración del trazador con respecto al tiempo y las curvas de distribución. Los reactores (uno, dos y tres) presentaron comportamiento de flujo pistón 97, 83 y $86 \%$, la no existencia de corto circuito y la presencia de zonas muertas 29,25 , $31 \%$ respectivamente. No se observó una relación lineal entre el porcentaje de flujo pistón y el porcentaje de zonas muertas.
\end{abstract}

Palabras clave: Trazadores, flujo pistón, zonas muertas, reactor.

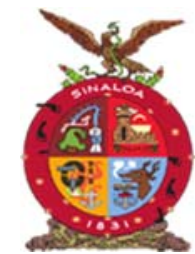

XVIII Congreso Internacional

XXIV Congreso Nacional de Ciencias ambientales

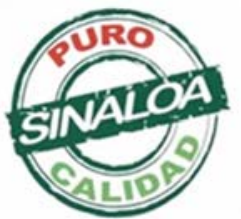

Mazatlán, Sinaloa 3-7 junio 2019

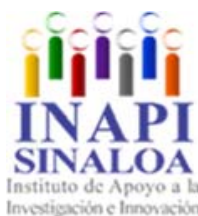

SINALOA

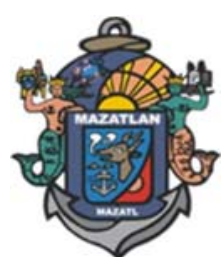

Legislación, Valores Sociales y Educación Ambiental 

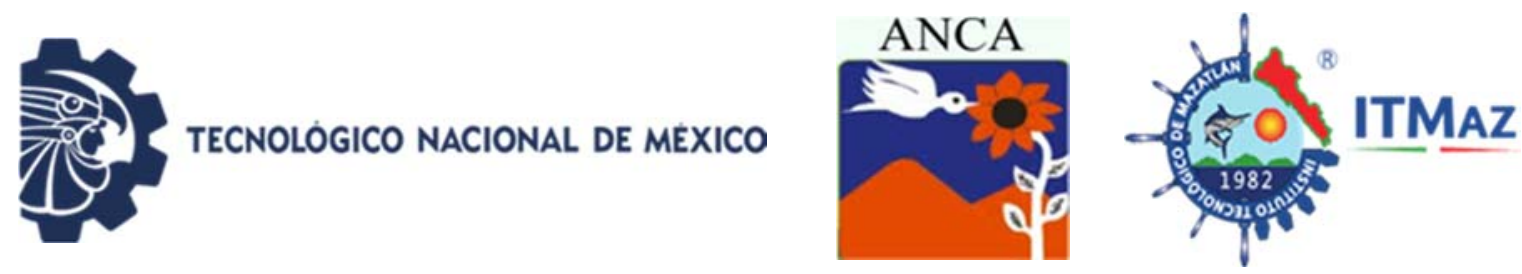

\title{
Determination of hydraulic behavior of packed reactors
}

\author{
Escalante Estrada VE \\ Instituto Mexicano de Tecnología del Agua, \\ Paseo Cuauhnáhuac 8532, C.P. 62550, Col. Progreso Jiutepec, Morelos \\ *vescalan@tlaloc.imta.mx
}

\begin{abstract}
In the wastewater treatment (WWT) the study of the hydraulic behavior of a process is of importance, determining the real hydraulic retention time (TRH), the existence of short circuits and dead zones in the reactor. The hydraulic behavior of three reactors was determined. Each reactor was packed with tezontle of several granulometries (placed in ascending form of greater to smaller size). As a tracer, sodium chloride was used, which was applied by the stimulus-response technique; the tracer was added in the influent and with upflow feeding. The tests were performed in duplicate for each reactor. Samples were taken by measuring total dissolved solids (TDS) over a period of three times the theoretical HRT for each reactor. Tracer concentration curves with respect to time and the distribution curves were developed. The reactors (one, two and three) presented piston flow behavior 97,83 and $86 \%$, the non-existence of short circuit and the presence of dead zones 29, 25, 31\% respectively. Linear relationship was not observed between the percentage of piston flow and the percentage of dead zones.
\end{abstract}

Keywords: Tracers, piston flow, dead zones, reactor.

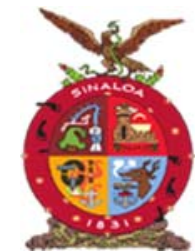

XVIII Congreso Internacional

XXIV Congreso Nacional de Ciencias ambientales
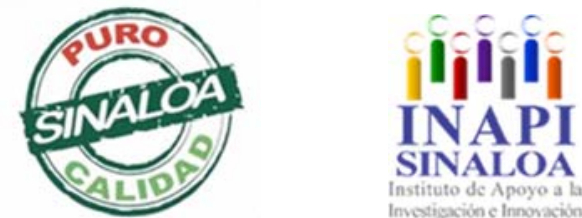

Mazatlán, Sinaloa 3-7 junio 2019

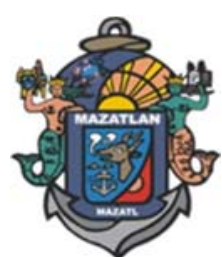

Legislación, Valores Sociales y Educación Ambiental 

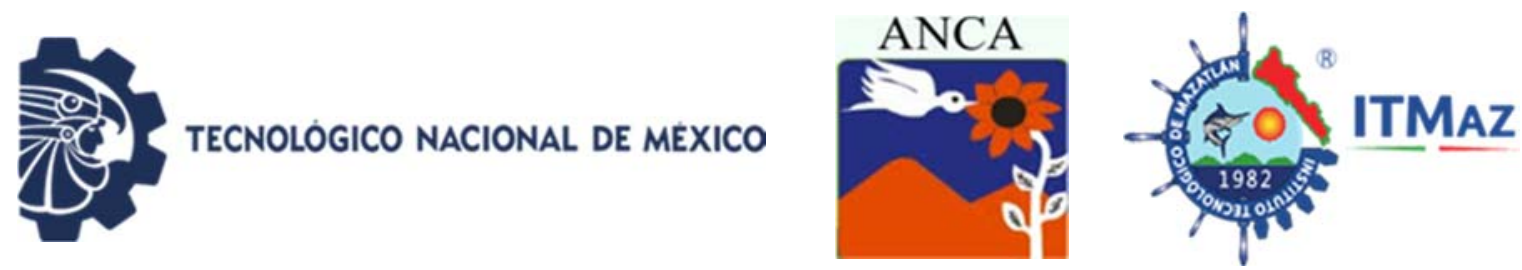

\title{
Auditoría ambiental en la Facultad de Lenguas Extranjeras de la UAGro
}

\author{
Escalante Pérez B*, Arellano Wences H, Gutiérrez Ramírez A \\ Universidad Autónoma de Guerrero \\ *blancaelizabeth72@hotmail.com
}

\begin{abstract}
RESUMEN
El presente trabajo de investigación consiste en una auditoría ambiental llevada a cabo en la Facultad de Lenguas Extranjeras (FALE) de la Universidad Autónoma de Guerrero durante el mes de octubre del 2018 con la finalidad de conocer la situación real y problemáticas relacionadas con la conservación y mejora del ambiente. La auditoría ambiental es parte inicial de los pasos que esta institución educativa necesita tomar para la implementación de un Sistema de Gestión Ambiental que ayude a minimizar los efectos de su operación sobre el entorno natural. En el proceso de recolección de datos, se utilizó el cuestionario de eco-auditoria para facultades proporcionado por la ADEAC-FEE, 2013 (Asociación de Educación Ambiental y del Consumidor-Foundation for Environmental Education). Tal instrumento evalúa diez áreas ambientales en la que esta facultad puede perjudicar al ambiente. En la recolección de datos participo un comité ambiental específicamente formado como parte de esta investigación, el cual apoyó en la realización de actividades de observación, revisión de documentos y entrevistas a personas clave. Los resultados de la Auditoría Ambiental demostraron que la situación ambiental de la FALE no es satisfactoria porque se realizan muy pocas actividades en favor del entorno, pero si permitieron identificar, cuantificar y jerarquizar problemas como contaminación, uso irracional de recursos, falta de una cultura de separación de residuos, entre otros.
\end{abstract}

Palabras clave: Auditoría ambiental, implementación, participación activa, estado ambiental.

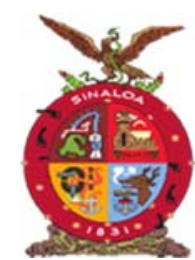

XVIII Congreso Internacional

XXIV Congreso Nacional de Ciencias ambientales
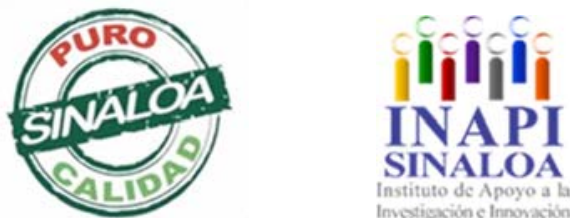

Mazatlán, Sinaloa 3-7 junio 2019

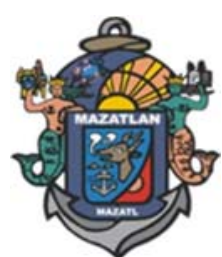

Legislación, Valores Sociales y Educación Ambiental 

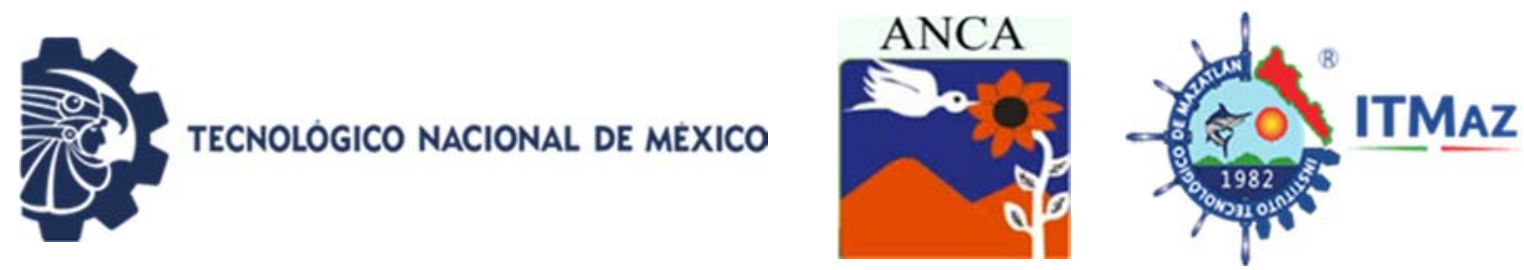

\title{
Environmental audit at the Faculty of Foreign Languages of UAGro
}

\author{
Escalante Pérez B*, Arellano Wences H, Gutiérrez Ramírez A \\ Universidad Autónoma de Guerrero \\ *blancaelizabeth72@hotmail.com
}

\begin{abstract}
This research work consists of an environmental audit carried out in the Facultad de Lenguas Extranjeras (FALE) de la Universidad Autónoma de Guerrero during the month of October 2018 with the purpose to know the status and problematic situation related to conservation and improvement of the environment. The environmental audit is an initial part of the steps that this educational institution needs to implement an Environmental Management System to help minimize the effects of its operation on the environment. An Eco-audit questionnaire for faculties provided by the ADEAC-FEE, 2013 (Association for Environmental Education and consumer-Foundation for Environment Education) was used in the data collection process such instrument evaluates ten environmental areas in which the faculty can harm the environment. The data collection involved an environmental committee specifically formed as part of this research, which supported the conduct of activities such as observation, document review and interviews with stakeholders. The environmental audit showed that the state of the FALE is not satisfactory because there are very few activities in favour of the environment, yet it allowed to identify, quantify and prioritize certain problems of pollution, irrational use of resources, lack of culture in sorting waste, among others.
\end{abstract}

Keywords: Environmental audit, implementation, active participation, environmental status.

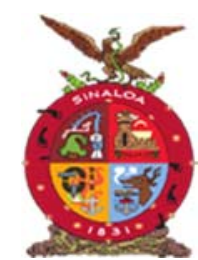

XVIII Congreso Internacional XXIV Congreso Nacional de Ciencias ambientales
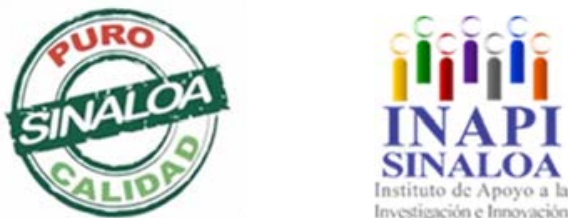

Mazatlán, Sinaloa 3-7 junio 2019

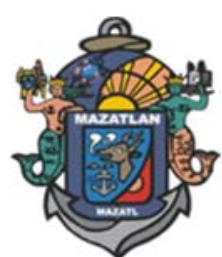

Legislación, Valores Sociales y Educación Ambiental 

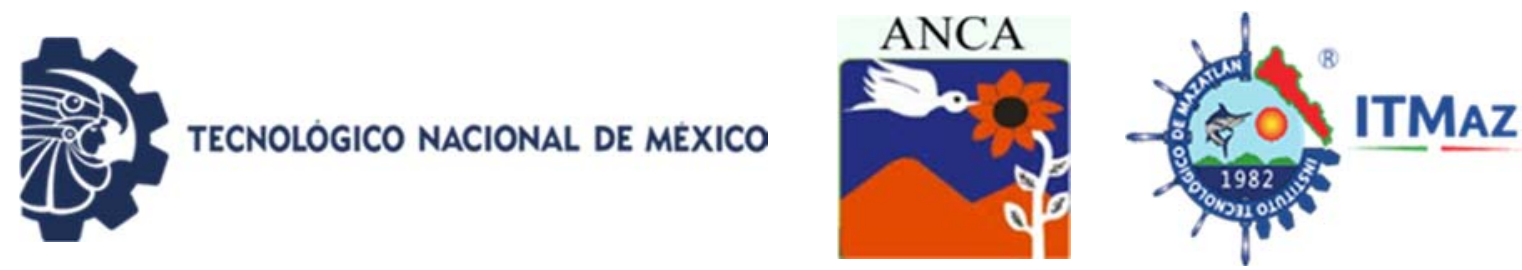

Análisis de las empresas más sustentables del mundo

Espinoza Prieto R*, Ayala Espinoza M, Giner Chávez O, Palma Rosas Y, Montaño Castrellón H

Facultad de Zootecnia y Ecología. Universidad Autónoma de Chihuahua.

Periférico Francisco R. Almada km.1 Chihuahua, Chih. Mex., Universidad Autónoma de Baja California Sur

*jespinoza@uach.mx

\section{RESUMEN}

El propósito de este trabajo de investigación es presentar un análisis de las 100 Empresas mejor posicionadas a nivel mundial en materia de Sustentabilidad en base al ranking de la Revista Forbes y Corporate Knights en el 2018. De acuerdo al Foro Económico Mundial más del $40 \%$ de la riqueza mundial está en variables intangibles como reputación, ética, valores, lealtad por parte de sus diferentes grupos de interés, etc. Entre los indicadores que se analizaron son: energía, emisiones de carbono, consumo de agua, residuos sólidos, capacidad de innovación, pago de impuestos, la relación entre el salario medio del trabajador y el de los directivos, equidad de género, inclusión, calidad de vida en el trabajo, plan de pensiones y de retiro, etc. Fue necesario establecer criterios como ingresos "limpios" como motor de salud comercial y contribuyen a la sustentabilidad. La Empresa Chr. Hansen de Dinamarca obtuvo el primer lugar con el $82.99 \%$, Kering de Francia segundo puesto con $81.55 \%$, Neste tercer sitio con $80.92 \%$. Ninguna empresa mexicana figura Empresas de consumo como Wal-Mart, Soriana y Chedraui; de alimentos y bebidas como Bimbo, Heineken, Nestlé y Grupo Modelo han implementado acciones para reducir el consumo energético, contaminación de sus plantas y reducción de huella hídrica., etc. Pero deben de mejorar la desigualdad en los salarios de sus trabajadores y de directivos, como también una mayor inclusión de mujeres en puestos gerenciales y directivos. Grupo Bimbo, como CEMEX deben de redoblar esfuerzos y comunicar mejor su Responsabilidad Social.

Palabras clave: Empresas, sustentables, mundo.

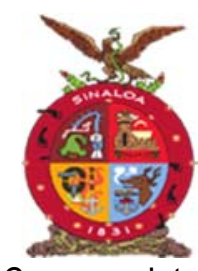

XVIII Congreso Internacional XXIV Congreso Nacional de Ciencias ambientales
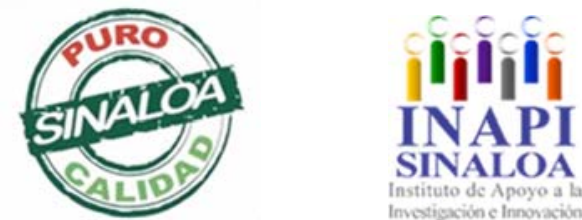

Mazatlán, Sinaloa 3-7 junio 2019

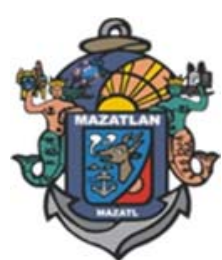

Legislación, Valores Sociales y Educación Ambiental 

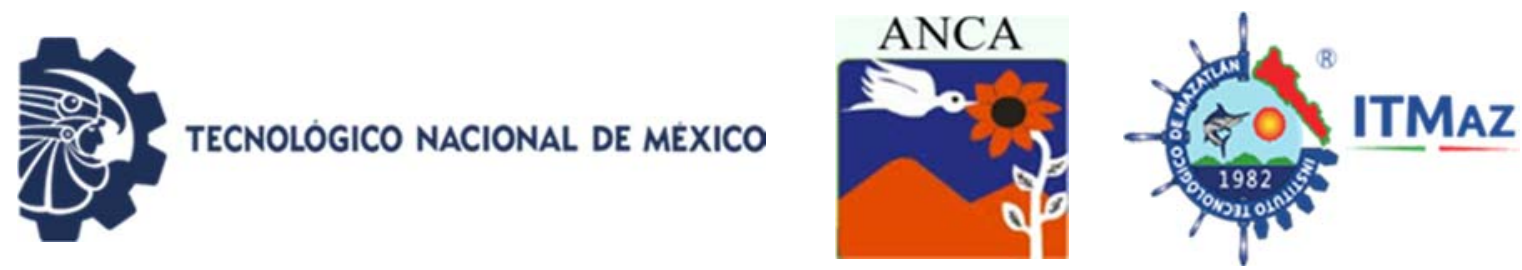

\title{
Analysis of the world's most sustainable companies
}

\author{
Espinoza Prieto $\mathrm{R}^{*}$, Ayala Espinoza M, Giner Chávez O, Palma Rosas Y, \\ Montaño Castrellón H \\ Facultad de Zootecnia y Ecología. Universidad Autónoma de Chihuahua. \\ Periférico Francisco R. Almada km.1 Chihuahua, Chih. Mex., \\ Universidad Autónoma de Baja California Sur \\ *jespinoza@uach.mx
}

\begin{abstract}
The purpose of this research work is to present an analysis of the 100 best positioned companies in the world in terms of Sustainability based on the ranking of Forbes Magazine and Corporate Knights in 2018. According to the World Economic Forum more than 40 \% of the world's wealth is in intangible variables such as reputation, ethics, values, loyalty on the part of its different interest groups, etc. Among the indicators that were analyzed are: energy, carbon emissions, water consumption, solid waste, innovation capacity, tax payments, the relationship between the average salary of the worker and the managers, gender equity, inclusion, quality of life at work, pension and retirement plan, etc. It was necessary to establish criteria such as "clean" income as a commercial health engine and contribute to sustainability. Company Chr. Hansen of Denmark won first place with $82.99 \%$, Kering of France second place with $81.55 \%$, Neste third place with $80.92 \%$. No Mexican company figures, consumer companies such as Wal-Mart, Soriana and Chedraui; of food and beverages such as Bimbo, Heineken, Nestlé and Grupo Modelo have implemented actions to reduce energy consumption, pollution of their plants and reduction of water footprint, etc. But they must improve inequality in the salaries of their workers and managers, as well as a greater inclusion of women in managerial and managerial positions. Grupo Bimbo, like CEMEX should redouble their efforts and better communicate their Social Responsibility.
\end{abstract}

Keywords: Companies, sustainable, world.

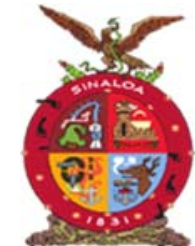

XVIII Congreso Internacional

XXIV Congreso Nacional de Ciencias ambientales

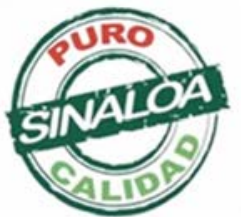

Mazatlán, Sinaloa 3-7 junio 2019

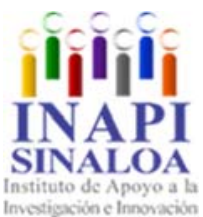

SINALOA

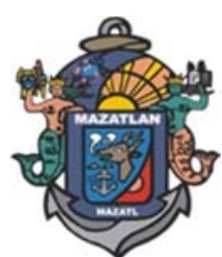

Legislación, Valores Sociales y Educación Ambiental 

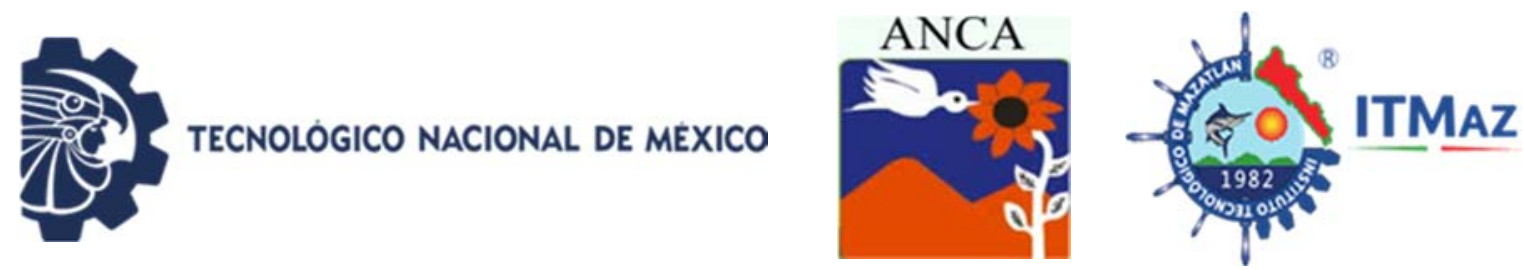

\title{
Modelo de responsabilidad social compartida de la Fundación del Empresariado Chihuahuense
}

\author{
Espinoza Prieto $R^{*}$, Díaz Plascencia D, Ordoñez Baquera $P$, \\ Mancillas Flores $\mathrm{P}$, Giner Chávez O
}

Facultad de Zootecnia y Ecología. Universidad Autónoma de Chihuahua. Periférico Francisco R. Almada km.1 Chihuahua, Chih. Mex. *jespinoza@uach.mx

\section{RESUMEN}

El objetivo de esta investigación es presentar el Caso de estudio de Responsabilidad Social compartida de la Fundación del Empresariado Chihuahuense, sus retos y logros para la implementación y gestión en otras entidades en el país. El cual marca una manera innovadora y prometedora de trabajar juntos entre el Gobierno, el Sector Empresarial y la Sociedad Civil organizada a favor de su comunidad. La Fundación surgió de un fenómeno climatológico atípico, una tromba en la capital de Chihuahua en 1990, propiciando una situación de necesidad y de auxilio por parte de toda la población; dando origen a una iniciativa por parte del Sector Empresarial para la creación de un Fidecomiso para recaudar recursos económicos mediante una Ley recaudatoria sobre el Impuesto sobre nómina respaldada por las 52 cámaras empresariales de Chihuahua que representan a todas las empresas del Estado, con el propósito principal de la reconstrucción y de promover proyectos sociales de bienestar. Desde sus inicios hasta la fecha se ha cofinanciado más de 5,190 proyectos, con una inversión mayor de 2,331 millones de pesos. Estos proyectos incluyen la construcción, reconstrucción de escuelas, hospitales, albergues, dispensarios y hogares sociales, y el financiamiento de programas de intervención que buscan resolver desde raíz problemas sociales específicos en las áreas de la salud, educación y capital social.

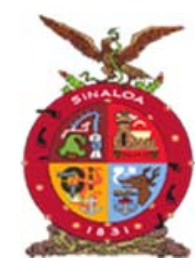

XVIII Congreso Internacional
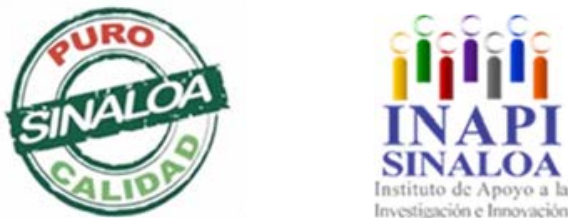

Mazatlán, Sinaloa 3-7 junio 2019

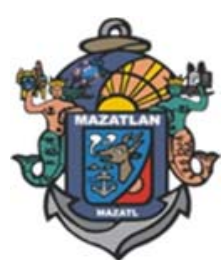

Legislación, Valores Sociales y Educación Ambiental 

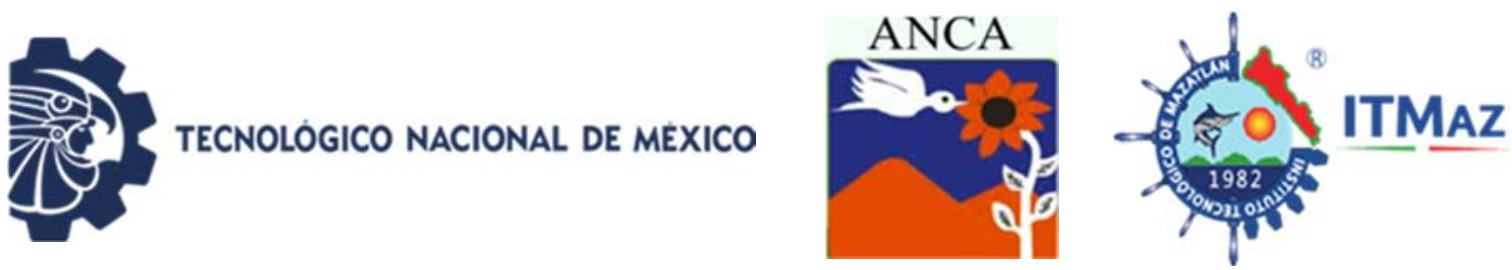

\title{
Model of shared social responsibility of the Fundación del Empresariado Chihuahuense
}

\author{
Espinoza Prieto $R^{*}$, Díaz Plascencia D, Ordoñez Baquera $P$, \\ Mancillas Flores P, Giner Chávez O
}

Facultad de Zootecnia y Ecología. Universidad Autónoma de Chihuahua. Periférico Francisco R. Almada km.1 Chihuahua, Chih. Mex. *jespinoza@uach.mx

\begin{abstract}
The objective of this research is to present the Case Study of Social Responsibility shared by the Chihuahuense Business Foundation as well as its challenges and achievements for its implementation and management in other entities in the country. Which marks an innovative and promising way to work together between the Government, the Business Sector and Civil Society organized in favor of their community. The Foundation is the result of an atypical climatological phenomenon, a waterspout in the capital of Chihuahua in 1990, propitiating a situation of need and help from the population; giving rise to an initiative by the Business Sector for the creation of a Trust Fund to collect economic resources through a tax law on payroll tax supported by the 52 business chambers of Chihuahua representing all state companies, with the main purpose of reconstruction and to promote social welfare projects. Since its inception to date, more than 5,190 projects have been cofinanced, with an investment of more than 2,331 million pesos. These projects include the construction, reconstruction of schools, hospitals, shelters, dispensaries and social homes, and the financing of intervention programs that seek to resolve specific social problems in the areas of health, education and social capital.
\end{abstract}

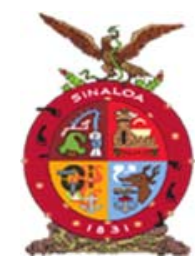

XVIII Congreso Internacional XXIV Congreso Nacional de Ciencias ambientales
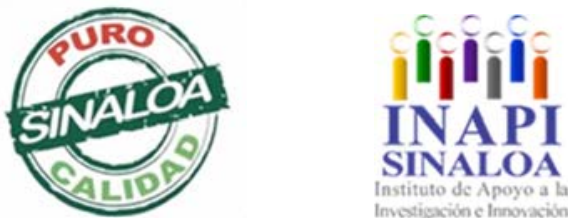

Mazatlán, Sinaloa 3-7 junio 2019

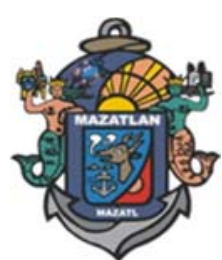

Legislación, Valores Sociales y Educación Ambiental 

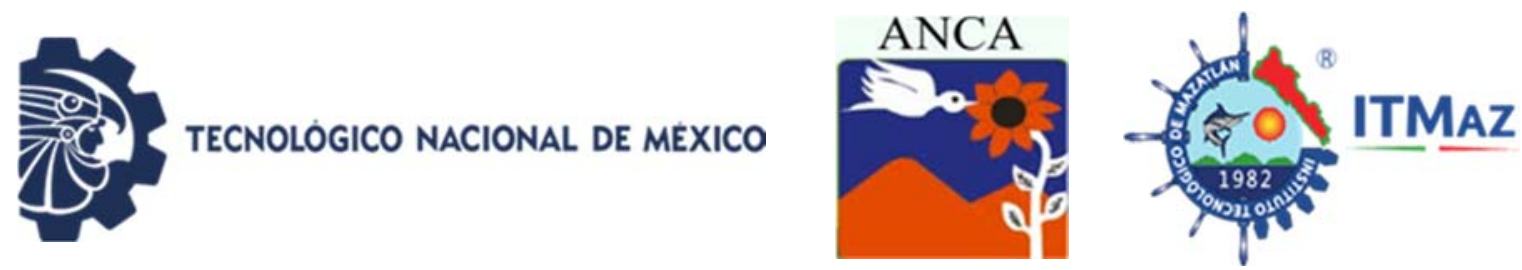

\section{El papel de las instituciones educativas en la solución al problema ambiental ocasionado por la globalización}

Frausto Mena $\mathrm{R}^{*}$

\section{RESUMEN}

En las últimas décadas ha habido un avance muy significativo en la tecnología, misma que ha traído consigo un número importante de instrumentos diseñados y aplicados para aumentar el bienestar de la humanidad, pero estos también ha traído consigo impactos negativos, que afectan en forma importante, "al ser humano": Como es el caso; Que, por el uso desmedido de los productos obtenidos por estos conocimientos, se esté ocasionando entre otros resultados: Se dice que la humanidad es la responsable de los desequilibrios ambientales ocasionados, al talar los árboles y con ello la destrucción de los bosques, contaminando las aguas de los ríos, lagos y mares, de modificar genéticamente los animales y las plantas; somos los responsables de la desaparición de especies animales y vegetales, por el consumo desmedido de estos; por la extracción de agua, gas y petróleo y otros materiales de los mantos del subsuelo etc. Colaborando con estas acciones hacer de verdaderos vergeles convertirlos en desiertos, al cambio de las condiciones climáticas y la alteración de nuestra atmósfera, destruyendo la capa de ozono modificando y alterando nuestra biodiversidad; agotamos irreversiblemente los recursos no renovables provocando con ello la escasez alimentaría, bienes y servicios para nuestros conciudadanos y amenazando el bienestar de las futuras generaciones. Las Instituciones educativas de Nivel Superior; desempeñan una sucesión de papeles en relación con el problema mencionado; se analizan los papeles intervinientes de las universidades Como lo son: la formación, la investigación científica, la vinculación, Divulgación y Aplicación de la Tecnología y la extensión de la cultura de desarrollo científica y tecnológica.

Palabras clave: No-gubernamentales, redes sociales, globalización, ambiente.

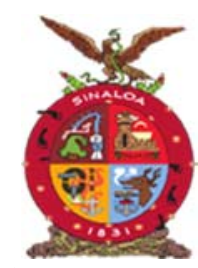

XVIII Congreso Internacional
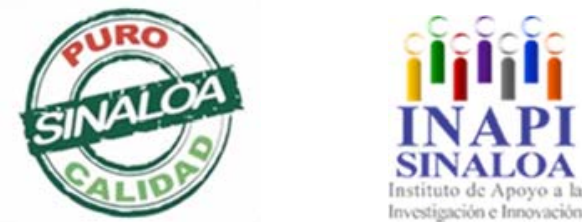

Mazatlán, Sinaloa 3-7 junio 2019

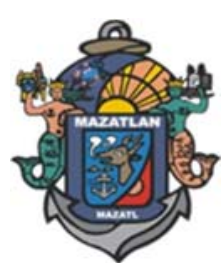

Legislación, Valores Sociales y Educación Ambiental 

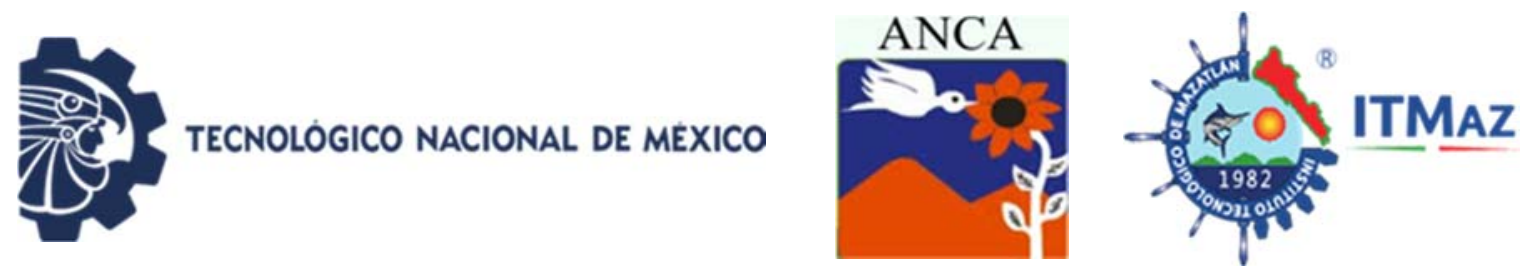

\title{
The role of educational institutions in the solution to the environmental problem caused by globalization
}

\author{
Frausto Mena $\mathrm{R}^{*}$
}

\begin{abstract}
In recent decades there has been a very significant advance in technology, which has brought with it a significant number of instruments designed and applied to increase the well-being of humanity, but these have also brought with them negative impacts, which significantly affect, "To the human being": As is the case; That, due to the excessive use of the products obtained by this knowledge, it is causing among other results: It is said that humanity is responsible for the environmental imbalances caused by cutting down trees and thereby destroying forests, contaminating the waters of rivers, lakes and seas, of genetically modifying animals and plants; we are responsible for the disappearance of animal and plant species, due to their excessive consumption; by the extraction of water, gas and oil and other materials from the subsoil mantles etc. By collaborating with these actions, we can turn them into true deserts, changing climate conditions and altering our atmosphere, destroying the ozone layer by modifying and altering our biodiversity; We irreversibly deplete non-renewable resources, thereby causing food shortages, goods and services for our fellow citizens and threatening the well-being of future generations. Higher Level Educational Institutions; they play a succession of roles in relation to the problem mentioned. The intervening roles of universities are analyzed, such as: training, scientific research, linking, dissemination and application of technology and the extension of the culture of scientific and technological development.
\end{abstract}

Keywords: No-governmental, social networks, globalization, environment.

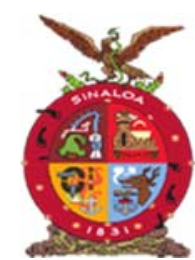

XVIII Congreso Internacional XXIV Congreso Nacional de Ciencias ambientales
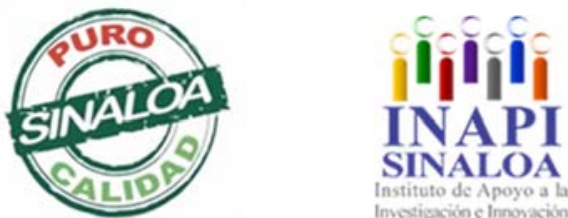

Mazatlán, Sinaloa 3-7 junio 2019

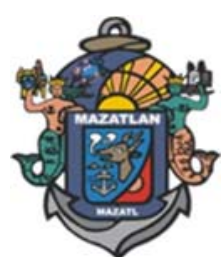

Legislación, Valores Sociales y Educación Ambiental 

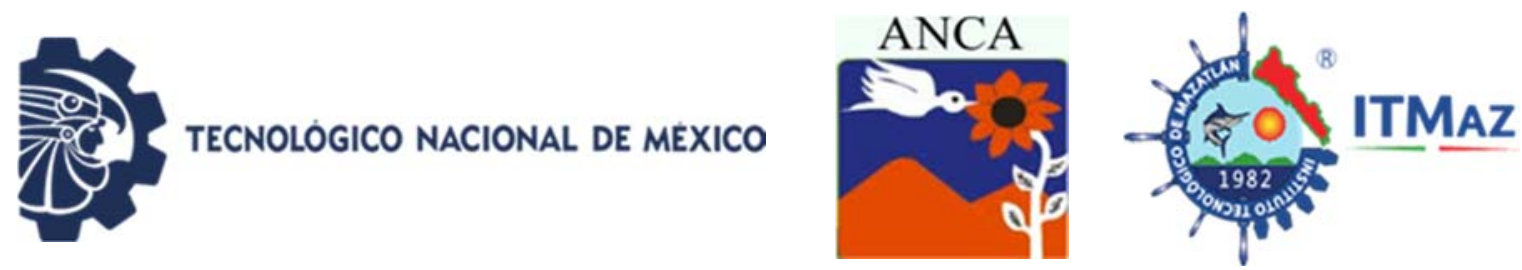

\title{
Residuos sólidos con potencial de aprovechamiento de la Unidad Académica del IPN Campus Zacatecas
}

\author{
Gamboa Escobedo S, Bañuelos Arcos F, Chacón Aguilar J, \\ Sosa Rodríguez M, Chávez Soto $\mathrm{M}^{*}$
}

\begin{abstract}
Unidad Profesional Interdisciplinaria. Ingeniería Campus Zacatecas (UPIIZ). Instituto Politécnico Nacional (IPN).

*mjchavezs@ipn.mx
\end{abstract}

\section{RESUMEN}

La cantidad y calidad de los residuos no son homogéneos y dependen de las actividades que se realicen y de la temporada del año, por lo que, es necesario determinar su composición y con esta información implementar mecanismos que permitan el manejo específico y coordinado de los residuos, como lo es la separación y tratamiento. El Programa Estratégico de Desarrollo de Mediano Plazo (PEDMP 2016-2018), establece generar un Plan para el Manejo Adecuado de los Residuos Sólidos y Peligrosos que se generen en el IPN, aplicable a la Unidad Zacatecas. Con el objetivo de determinar la composición de residuos sólidos generados. La Unidad Académica está conformada por la UPIIZ, por el CECyT18 y el Centro de Lenguas Extranjeras (Celex), que cuenta con una planta académica de 1391 personas, en septiembre del 2018. Se aplicó la Forma 1 PROCED RSURP-A para reevaluar los residuos generados, así como la NMX-AA-015-1985. Resultando que en septiembre del 2018 se generaron $455.10 \mathrm{~kg}$ de residuos. Con características de sólidos urbanos, $258.10 \mathrm{~kg}$ de los cuales $35.16 \%$ corresponden a restos de alimentos, el $12.96 \%$ a sanitarios y el $22.18 \%$ a materiales reciclables como envases de PET (tereftalato de polietileno), cartón, aluminio y vidrio. Sin potencial de aprovechamiento se encontraron $146.37 \mathrm{~kg}$ (teclados, carcazas de pantalla). Con esta información se realizó una proyección mensual para los restos de alimentos obteniendo $654.21 \mathrm{~kg}$ mensuales, siendo éste el residuo que se encuentra en mayor cantidad, se propone la conversión biológica (composta). Para materiales valorizables, deben acopiarse por separado para facilitar su venta.

Palabras clave: Residuos sólidos, composición, segregación.

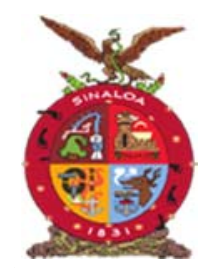

XVIII Congreso Internacional

XXIV Congreso Nacional de Ciencias ambientales
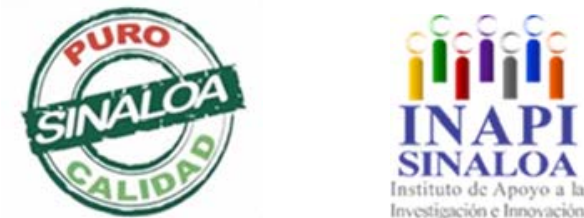

Mazatlán, Sinaloa 3-7 junio 2019

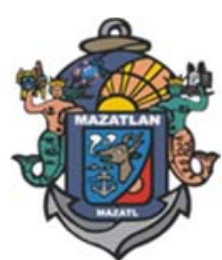

Legislación, Valores Sociales y Educación Ambiental 

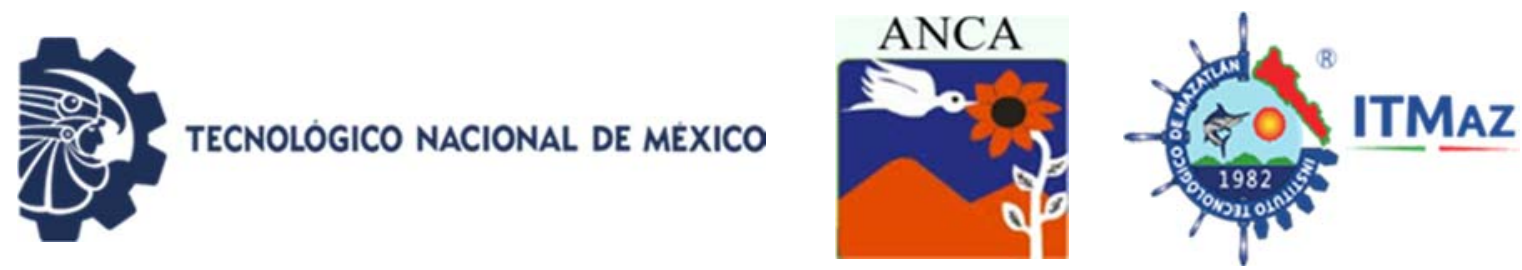

\title{
Solid waste with potential uses of the Academic Unit of the IPN Campus Zacatecas
}

\author{
Gamboa Escobedo S, Bañuelos Arcos F, Chacón Aguilar J, \\ Sosa Rodríguez $\mathrm{M}$, Chávez Soto $\mathrm{M}^{*}$
}

Unidad Profesional Interdisciplinaria. Ingeniería Campus Zacatecas (UPIIZ). Instituto Politécnico Nacional (IPN).

*mjchavezs@ipn.mx

\begin{abstract}
The quantity and quality of waste are not homogeneous and depend on the activities carried out and the season of the year, so it is necessary to determine its composition and with this information implement mechanisms that allow the specific and coordinated management of waste, as is the separation and treatment. The Medium-Term Strategic Development Program (PEDMP 20162018), establishes to generate a Plan for the Adequate Management of Solid and Dangerous Waste generated in the IPN, applicable to the Zacatecas Unit. In order to determine the composition of solid waste generated. The Academic Unit is made up of UPIIZ, CECyT18 and the Center for Foreign Languages (Celex), which has an academic plant of 1391 people, in September 2018. Form 1 PROCED RSURP-A was applied to re-evaluate waste generated, as well as NMX-AA-015-1985. It turns out that in September $2018,455.10 \mathrm{~kg}$ of waste. With characteristics of urban solids were generated, $258.10 \mathrm{~kg}$ of which $35.16 \%$ correspond to food scraps, $12.96 \%$ to sanitary ware and $22.18 \%$ to recyclable materials such as PET containers (terephthalate polyethylene), cardboard, aluminum and glass. No exploitation potential found $146.37 \mathrm{~kg}$ (keyboards, screen housings). With this information a monthly projection was made for the remains of food obtaining $654.21 \mathrm{~kg}$ per month, this being the residue that is in greater quantity, the biological conversion (compost) is proposed. For recoverable materials, they must be collected separately to facilitate their sale.
\end{abstract}

Keywords: Solid waste, composition, segregation.

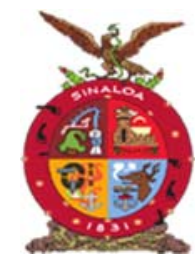

XVIII Congreso Internacional XXIV Congreso Nacional de Ciencias ambientales
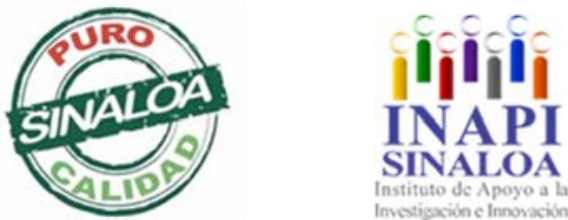

Mazatlán, Sinaloa 3-7 junio 2019

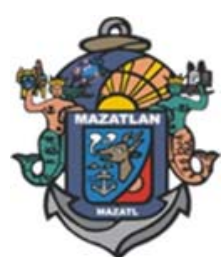

Legislación, Valores Sociales y Educación Ambiental 

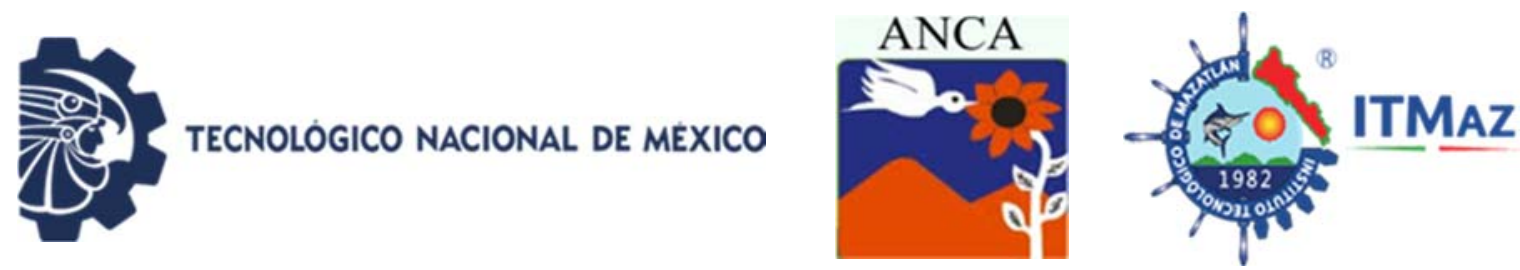

Ftalatos-impacto a la salud infantil a través de la dieta

García Fabila $\mathrm{MM}^{1 *}$, Amaya Chávez $\mathrm{A}^{1}$, Bustamante Montes LP², Sánchez Meza JC ${ }^{1}$, Reyes García $A^{1}$

${ }^{1}$ Universidad Autónoma del Estado de México

${ }^{2}$ Facultad de Química. Universidad Autónoma de Guadalajara.

Paseo Colón esquina Paseo Tollocan S/N, Toluca Estado de México

*mmgafa@yahoo.com.mx

\section{RESUMEN}

Los ftalatos son compuestos sintéticos derivados del ácido o-ftálico. Al ser encontrados en alimentos, constituyen una vía de exposición para la población. En niños están asociados al desorden de atención e hiperactividad, asma, rinitis, obesidad y autismo. El objetivo fue analizar el impacto a la salud por el consumo de alimentos de los que se ha encontrado reportes de concentración de ftalatos en diferentes países, en niños de la Zona Metropolitana del Valle de Toluca (ZMVT), Edo. Méx. en el periodo enero 2018-marzo 2019. Se aplicó una encuesta a 384 niños de 6 a 12 años, de 5 municipios de la ZMVT, para conocer sus datos generales, tipo de alimentos, cantidad y frecuencia de consumo elegidos con base en la canasta básica mexiquense. Se investigó bibliográficamente el grado de contaminación de dichos alimentos con ftalatos. Los alimentos se agruparon en 6 grupos, identificando los más consumidos para cada grupo, los cuales se contrastaron con 4 factores: frecuencia de consumo, contenido de grasa, empacado y reporte de alto contenido de ftalatos. Los alimentos identificados como probables fuentes de exposición a ftalatos de los niños que los consumen fueron: pan dulce, pollo, res, leche pasteurizada, papitas, jugo de frutas embasado y yogurth. Se calculó la dosis de exposición de acuerdo a la ATSDR, USA. Existe un riesgo potencial en la población infantil del ZMVT por en el consumo de algunos alimentos en función de su contenido de grasa y su empaque.

Palabras clave: Inocuidad alimentaria, alimentación infantil, Impacto a la salud infantil.

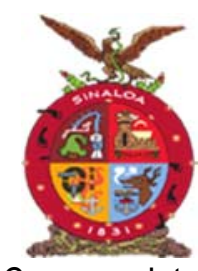

XVIII Congreso Internacional XXIV Congreso Nacional de Ciencias ambientales

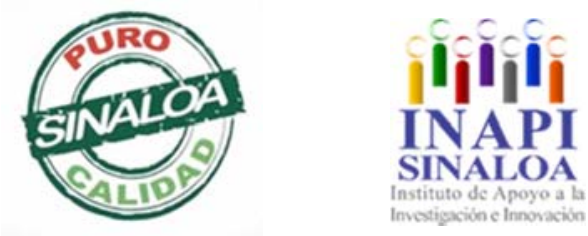

Mazatlán, Sinaloa 3-7 junio 2019

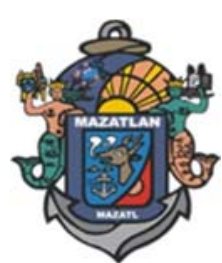

Legislación, Valores Sociales y Educación Ambiental 

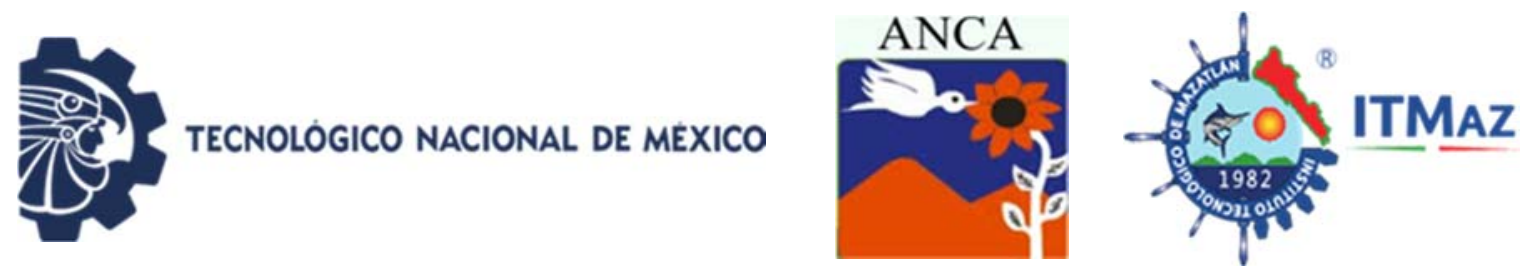

\title{
Phthalates-impact to children's health through the diet
}

\author{
García Fabila $\mathrm{MM}^{1 *}$, Amaya Chávez A ${ }^{1}$, Bustamante Montes LP², \\ Sánchez Meza JC ${ }^{1}$, Reyes García $\mathrm{A}^{1}$ \\ ${ }^{1}$ Universidad Autónoma del Estado de México \\ ${ }^{2}$ Universidad Autónoma de Guadalajara. Facultad de Química. \\ Paseo Colón esquina Paseo Tollocan S/N, Toluca Estado de México \\ *mmgafa@yahoo.com.mx
}

\begin{abstract}
Phthalates are synthetic compounds derived from o-phthalic acid. When found in food, they constitute a route of exposure for the population. In children, they are associated with attention and hyperactivity disorder, asthma, rhinitis, obesity and autism. The objective was to analyze the health impact by food consumption, has been reported in phthalates concentration in different countries. Methodology was applied to 384 children from the Toluca Valley Metropolitan Area (ZMVT), Edo. Mex. at the period January 2018-March 2019. Ages of children were 6 to 12 years old, from 5 municipalities of the ZMVT. To know their general data, type of food, quantity and frequency of consumption chosen based on the basic Mexican basket. The degree of contamination of these foods with phthalates was researched bibliographically. The foods were grouped into 6 groups, identifying the most consumed for each one; contrasting with 4 factors: consumption frequency, fat content, packaging and high phthalate content report. The foods identified as probable source of exposure to phthalates were: sweet bread, chicken, beef, pasteurized milk, chips, fruit juice and yogurt. The exposure dose was calculated according to the ATSDR, USA. There is a potential risk in the infant population of the ZMVT for the consumption of some foods that depend on their fat content and packing.
\end{abstract}

Keywords: Food safety, infant feeding, Impact on children's health.

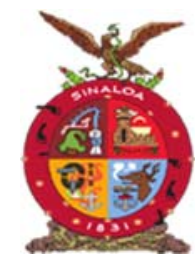

XVIII Congreso Internacional

XXIV Congreso Nacional de Ciencias ambientales

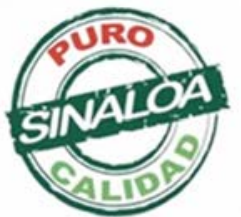

Mazatlán, Sinaloa 3-7 junio 2019

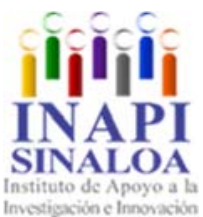

SINALOA

Instituto de Apoyo a

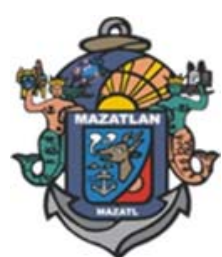

Legislación, Valores Sociales y Educación Ambiental 

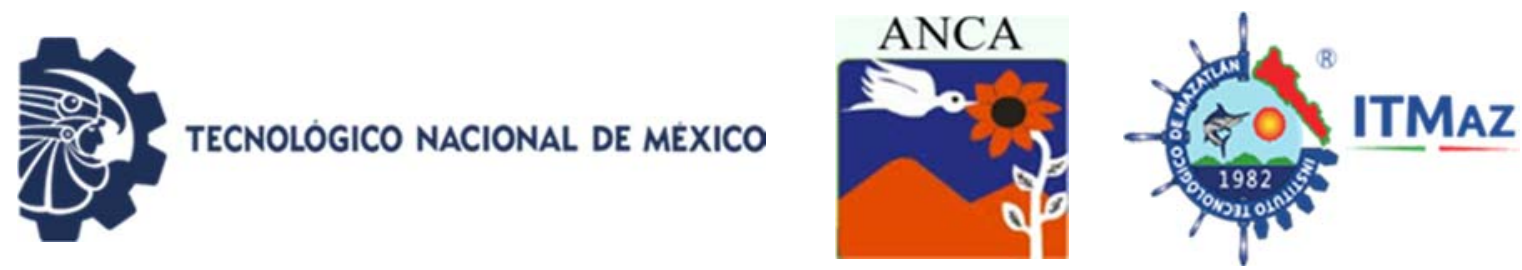

\title{
Diagnóstico socioambiental del aprovechamiento turístico de la biodiversidad de Akumal, Quintana Roo
}

\author{
Garcia Noria E*, Pérez Ramírez C, Serrano Gonzaga R \\ Facultad de Planeación Urbana y Regional. \\ Universidad Autónoma del Estado de México. \\ *eloisa.jimena@hotmail.com
}

\begin{abstract}
RESUMEN
El aprovechamiento recreativo de la biodiversidad en Akumal, localidad del municipio de Tulum en el Estado de Quintana Roo, en particular, el proceso de anidación y liberación de tres especies importantes de Tortugas Marinas, con categoría "en peligro de extinción": la tortuga Verde, Caguama y Carey, genera diversos problemas ambientales relacionados con la falta de sensibilización que ha provocado una disminución en el número de tortugas que desovan. Por ello el trabajo tuvo como objetivo realizar un diagnóstico socioambiental del aprovechamiento turístico del quelonio marino con la finalidad de proponer estrategias que contribuyan a la conservación ambiental. Para ello se empleó una matriz de diagnóstico que permitió relacionar los componentes ambientales con las actividades turísticas y la conservación de la biodiversidad. Se concluye que la actividad turística genera impactos económicos positivos en la zona de estudio a través de la oferta de servicios turísticos para el aprovechamiento de los reptiles, sin embargo, también se presentan acciones que afectan directamente a la conservación de esta especie relacionado con la generación de ruidos y presencia masivas de visitantes que alteran a las especies. De esta forma deben formularse estrategias que contribuyan a la adecuada gestión de visitantes favoreciendo tanto la experiencia de viaje como la conservación de la biodiversidad.
\end{abstract}

Palabras clave: Turismo, tortugas marinas, impactos, diagnóstico y conservación ambiental.

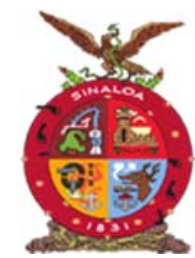

XVIII Congreso Internacional

XXIV Congreso Nacional de Ciencias ambientales
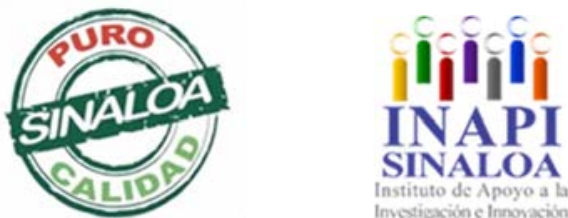

Mazatlán, Sinaloa 3-7 junio 2019

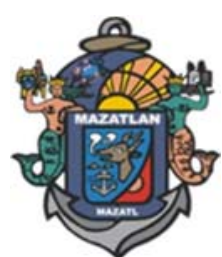

Legislación, Valores Sociales y Educación Ambiental 

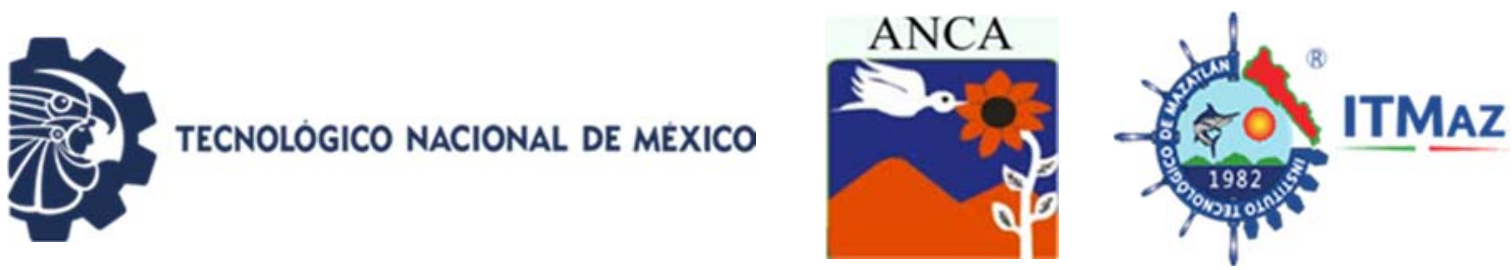

\title{
Socioenvironmental diagnosis of tourism uses of biodiversity in Akumal, Quintana Roo
}

\author{
Garcia Noria E*, Pérez Ramírez C, Serrano Gonzaga R \\ Facultad de Planeación Urbana y Regional. \\ Universidad Autónoma del Estado de México. \\ *eloisa.jimena@hotmail.com
}

\begin{abstract}
The recreational use of biodiversity in Akumal, municipality of Tulum in the State of Quintana Roo the process of nesting and releasing the three important species of marine turtles, with category "endangered": the turtle Green, the Caguama and Carey, is generating various environmental problems related to the lack of awareness that has caused a decrease in the number of turtles that spawn. Therefore, the objective of the work was to carry out a socioenvironmental diagnosis of the tourist use of the marine chelonians with the purpose of proposing strategies that contribute to environmental conservation. For this purpose, a diagnostic matrix was used that allowed linking the environmental components with tourism activities and the conservation of biodiversity. It is concluded that the tourism activity generates positive economic impacts in the study area through the offer of tourism services for the use of reptiles, however, there are also actions that directly affect the conservation of this species related to the generation of noise and massive presence of visitors that alter the species. In this way, strategies must be formulated that contribute to the proper management of visitors, favouring both the travel experience and biodiversity conservation.
\end{abstract}

Keywords: Tourism, sea turtles, impacts, diagnosis and environmental conservation.

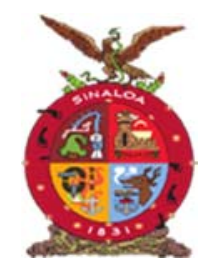

XVIII Congreso Internacional

XXIV Congreso Nacional de Ciencias ambientales
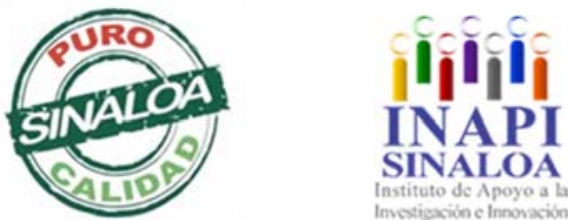

Mazatlán, Sinaloa 3-7 junio 2019

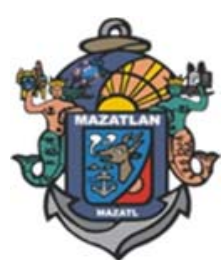

Legislación, Valores Sociales

y Educación Ambiental 

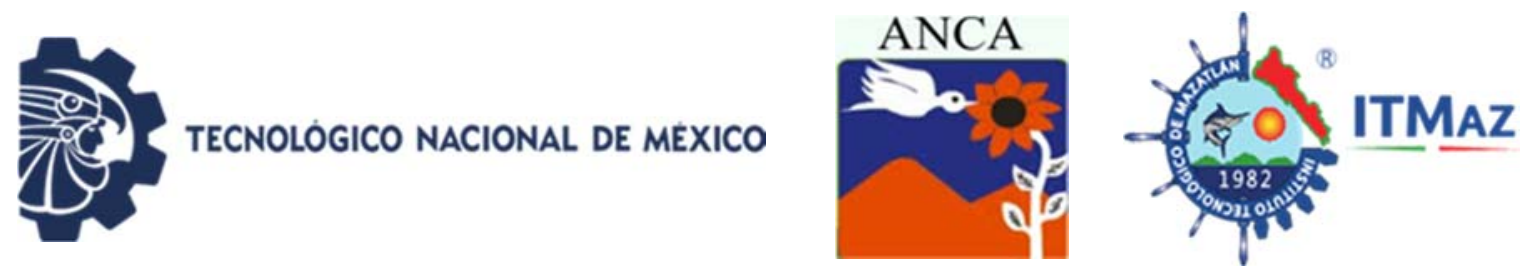

\title{
Casos de estudio en el curso de protección ambiental III de la Facultad de Química de la UNAM como herramienta didáctica
}

\author{
Gutiérrez Lara MR, Gavilán García IC*, García Reynoso JA \\ Facultad de Química. UNAM. México. \\ Centro de Ciencias de la Atmósfera, UNAM, México \\ *irmac@unam.mx
}

\begin{abstract}
RESUMEN
Los estudiantes de la carrera de Ingeniería Química de la Facultad de Química de la UNAM, cuenta con un paquete terminal en el currículo relacionado a la Protección Ambiental como asignaturas optativas, en la Protección Ambiental III se ha desarrollado un sistema de aprendizaje basado en casos de estudio aplicados a los temas de análisis de riesgo, auditoría ambiental y análisis de ciclo de vida. Durante un curso llevado por semestre el estudiante aplica diversas competencias como la habilidad, el trabajo en equipo y liderazgo por mencionar algunas. Este trabajo tiene como objetivo proponer una serie de estudios de caso como una herramienta didáctica, en la cual pueden aplicar los conocimientos adquiridos en los cursos previos de Protección Ambiental I y II, los temas seleccionados son 1) Análisis de Riesgo Ambiental, 2) Auditoría Ambiental y 3) Análisis de Ciclo de Vida. Los elementos fundamentales en la elaboración de los casos fueron, elegir el objeto de estudio y describirlo de la forma más completa posible. Nuestra propuesta se ha implementado en los semestres 2018-2 y 2019-2, en los cuales se pudo contar con la retroalimentación de los estudiantes sobre los estudios de casos que fueron trabajados en el curso. Finalmente, reconocemos que es indispensable que las instituciones de nivel superior base su educación en competencias, ya que de esta manera al alumno se le prepara para ser capaz de aplicar los conocimientos adquiridos de manera práctica en su desempeño en el mundo laboral.
\end{abstract}

Palabras clave: Herramientas didácticas, estudio de casos y habilidades.

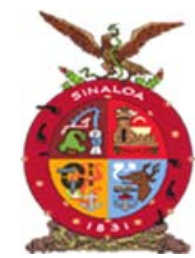

XVIII Congreso Internacional

XXIV Congreso Nacional de Ciencias ambientales
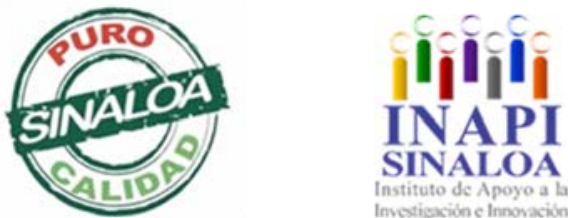

Mazatlán, Sinaloa 3-7 junio 2019

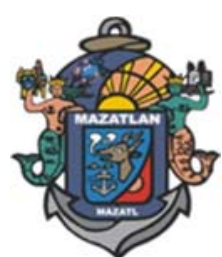

Legislación, Valores Sociales y Educación Ambiental 

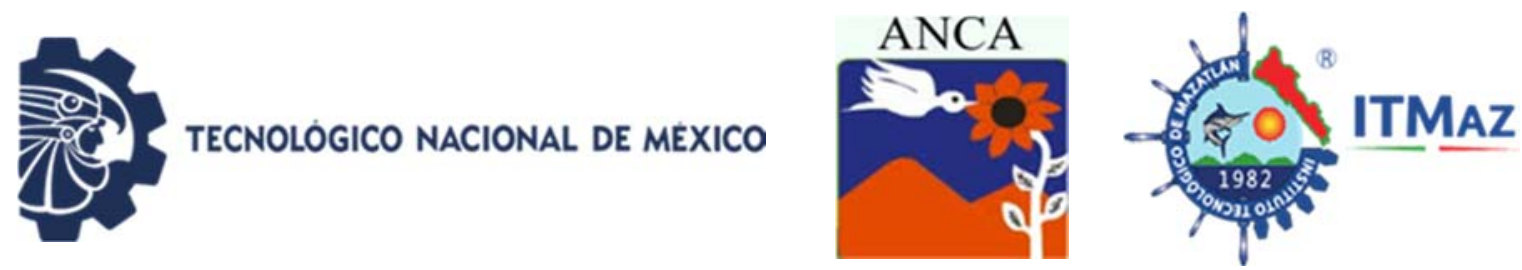

\title{
Cases of study in the course of environmental protection III of the Faculty of Chemistry of the UNAM as a didactic tool
}

\author{
Gutiérrez Lara MR, Gavilán García IC*, García Reynoso JA \\ Facultad de Química. UNAM. México. \\ Centro de Ciencias de la Atmósfera, UNAM, México \\ *irmac@unam.mx
}

\begin{abstract}
Students of the Chemical Engineering degree at the Faculty of Chemistry of the UNAM, have a terminal package in the curriculum related to Environmental Protection as optional subjects, in Environmental Protection III a learning system based on cases of study applied to the topics of risk analysis, environmental audit and life cycle analysis. During a semester course the student applies various competencies such as skill, teamwork and leadership to name a few. This work aims to propose a series of case studies as a didactic tool, in which they can apply the knowledge acquired in the previous Environmental Protection courses I and II, the selected topics are 1) Environmental Risk Analysis, 2) Audit Environmental and 3) Life Cycle Analysis. The fundamental elements in the elaboration of the cases were, choosing the object of study and describing it in the most complete way possible. Our proposal has been implemented in the semesters 2018-2 and 2019-2, in which it was possible to have the feedback of the students on the case studies that were worked on in the course. Finally, we recognize that it is essential that higher level institutions base their education on competencies, since in this way the student is prepared to be able to apply the knowledge acquired in a practical way in their performance in the workplace.
\end{abstract}

Keywords: Didactic tools, case studies and skills.

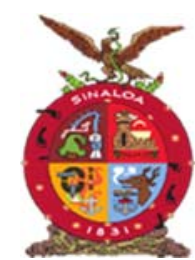

XVIII Congreso Internacional XXIV Congreso Nacional de Ciencias ambientales
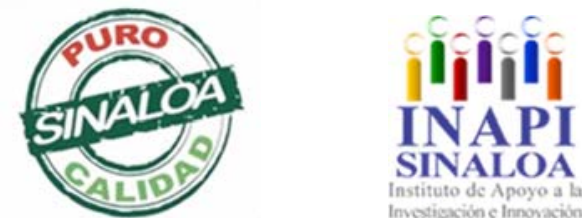

Mazatlán, Sinaloa 3-7 junio 2019

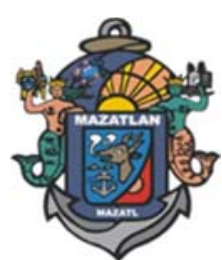

Legislación, Valores Sociales y Educación Ambiental 

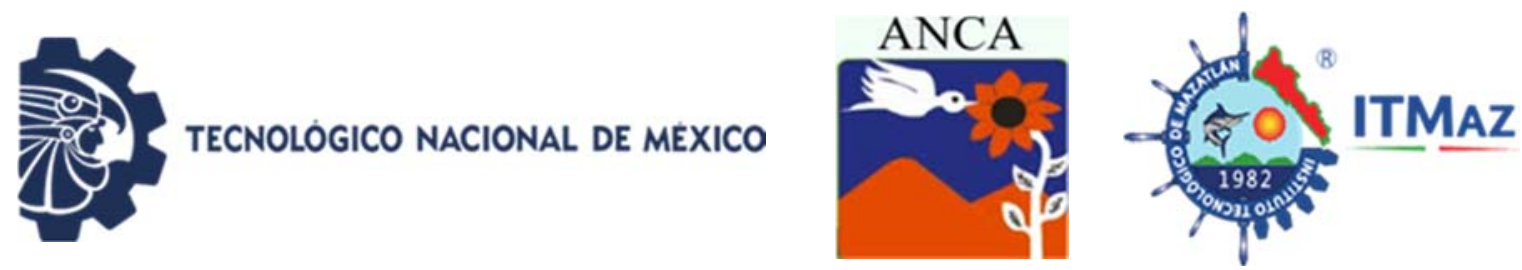

\title{
Percepción ambiental de turistas en playas certificadas: Caso Acapulco
}

\author{
Jaimes Compean A de $\mathrm{J}^{*}$, Rodríguez Alviso C, Avilés Pineda $\mathrm{H}$, \\ Sampedro Rosas ML, Juárez López AL, Bedolla Solano R \\ Doctorado en Ciencias Ambientales. \\ Centro de Ciencias de Desarrollo Regional. \\ Facultad de Turismo. Universidad Autónoma de Guerrero \\ *angelcompean@live.com.mx
}

\section{RESUMEN}

El turismo representa para Acapulco su principal actividad económica, es el destino tradicional de sol y playa más visitado por turistas de la ciudad de México en un $70 \%$, sus playas son el principal atractivo natural y turístico, sin embargo, enfrentando problemas de contaminación ambiental ocasionados por diversos factores, como las actividades antropogénicas, fenómenos naturales y la actividad turística. Una de las herramientas para intentar solucionarlo para buscar el equilibrio entre la naturaleza y el turismo para obtener playas sustentables mediante la certificación de playas. En México existen dos tipos de certificaciones, Blue Flag y la NMX 2016, estas certificaciones contemplan varios criterios para su aplicación entre los que se encuentran educación ambiental e información, calidad del agua, gestión y manejo ambiental, seguridad y servicios. El objetivo principal fue conocer la percepción ambiental de los turistas que visitan playas certificadas, para realizar una propuesta de programa de educación ambiental que fortalezca la concientización y conservación de las playas. La investigación se realizó en las playas certificadas por Blue Flag Icacos I y II en la temporada de verano 2018, se elaboró una encuesta que se aplicó a los turistas. Con los resultados se pudo demostrar la percepción ambiental negativa de la playa, al encontrar el turista una playa sucia y sin servicios, se constató la falta de casi todos los indicadores con los que debe contar una playa certificada, y más del $90 \%$ de los turistas desconocían que se encontraban en una playa certificada.

Palabras clave: Percepción ambiental, playas certificadas, educación ambiental.

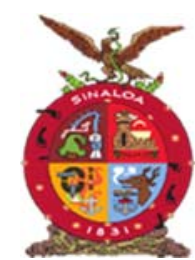

XVIII Congreso Internacional

XXIV Congreso Nacional de Ciencias ambientales
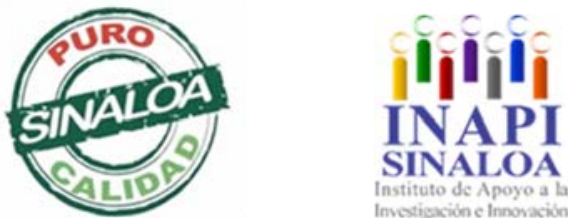

Mazatlán, Sinaloa 3-7 junio 2019

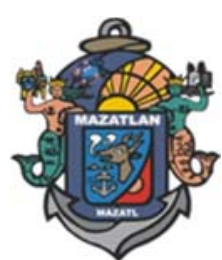

Legislación, Valores Sociales y Educación Ambiental 

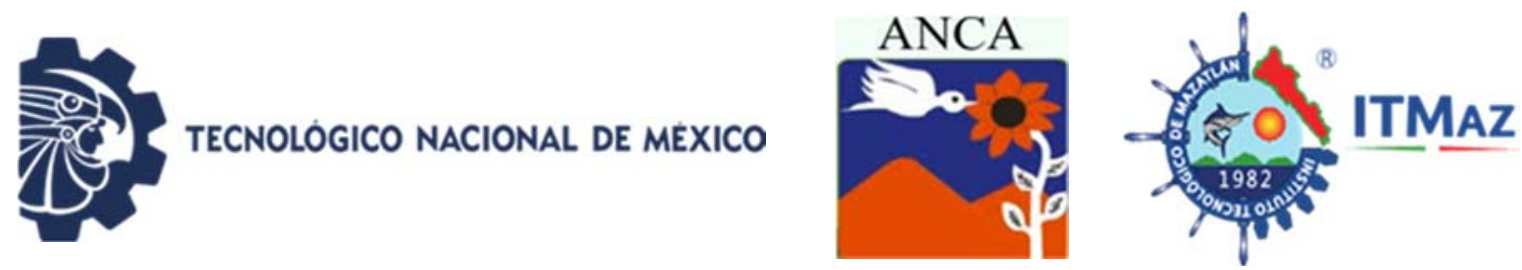

\title{
Enviromental perceptions of tourists on certified beaches: Acapulco case
}

\author{
Jaimes Compean A de J*, Rodríguez Alviso C, Avilés Pineda $\mathrm{H}$, \\ Sampedro Rosas ML, Juárez López AL, Bedolla Solano R \\ Doctorado en Ciencias Ambientales. \\ Centro de Ciencias de Desarrollo Regional. \\ Facultad de Turismo. Universidad Autónoma de Guerrero \\ *angelcompean@live.com.mx
}

\begin{abstract}
The tourism represents for Acapulco its main economic activity, it is traditional destination of sun and beach most visited by tourists of the city of Mexico in $70 \%$ its beaches are the main natural and tourist attraction, having problems of environmental contamination caused by diverse factors, such as anthropogenic activities, natural disasters and tourist activity. One of the solutions worldwide to find the balance between nature and tourism to obtain sustainable beaches is the certification of beaches, in Mexico there are two types of certification the Blue Flag and NMX 2016, these certifications contemplate several aspects to be granted in those that are, education environmental and information, wáter quality, management and, environmental management, security and services. The main objective was to show the enviromental perception of the tourists that seen the certified beaches to make a proposal of environmental education program that strengthens the awareness and the conservation of the beaches. The research was conducted on the beaches market by Blue Flag Icacos I and Icacos II in the summer season 2018, an instrument was developed that was applie to tourists. In this study, the negative enviromental perception of the beach could be demonstrated, when the tourist finds a dirty beach without services, the lack of almost all indicators that a certified beach should have was noted, and more than $90 \%$ of tourists were unaware that they were on a certified beach.
\end{abstract}

Keywords: Environmental perception, certified beaches, environmental education.

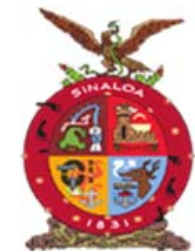

XVIII Congreso Internacional

XXIV Congreso Nacional de Ciencias ambientales
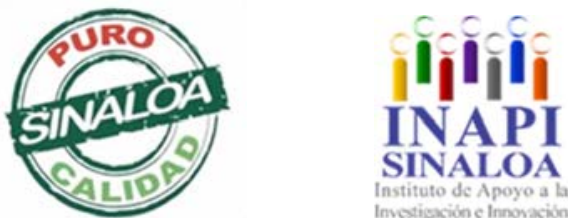

Mazatlán, Sinaloa 3-7 junio 2019

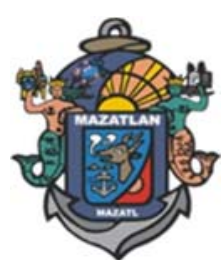

Legislación, Valores Sociales y Educación Ambiental 

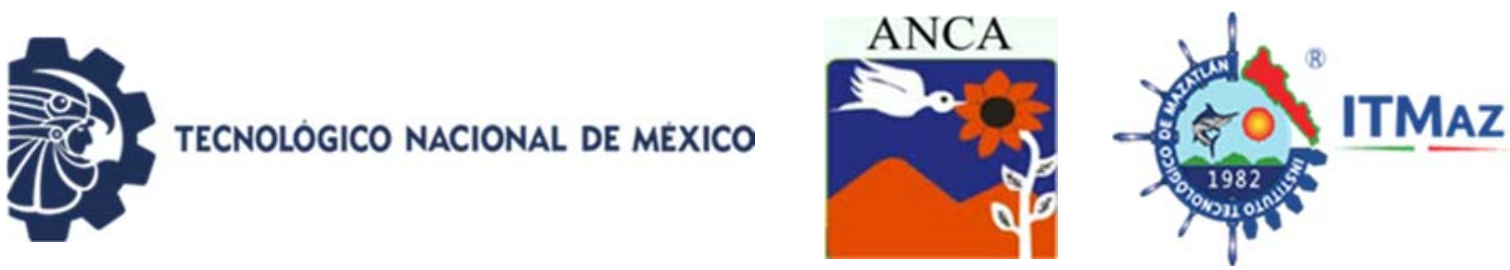

\title{
Logística inversa en la producción de neumáticos en la Zona Centro Sur de México y percepción de su importancia ambiental
}

\author{
Linares Campos JA*, Hernández Zepeda S, Flores Sotelo T \\ Posgrado en Ciencias Ambientales \\ Departamento de Desarrollo Sustentable, Instituto de Ciencias, \\ Benemérita Universidad Autónoma de Puebla. \\ 14 Sur No. 6301 Col. San Manuel, Puebla, Pue. C.P. 72570 \\ *alinares_campos@hotmail.com
}

\section{RESUMEN}

Uno de los problemas presentes en México es la contaminación ambiental derivada de los neumáticos de desecho, como resultado de su fabricación masiva y de las dificultades para procesarlos una vez desechados. Esta investigación se aplica a la identificación de las empresas manufactureras de neumáticos que implementan la logística inversa como una estrategia dentro de sus procesos de producción e inferir la existencia o no de relaciones con el incremento o disminución de contaminantes, en el entendido de que considerarla permite la oportunidad de reducir la contaminación ambiental. El objetivo fue describir a las empresas manufactureras de neumáticos de la zona centro sur de México y su logística inversa. Para este estudio de tipo descriptivo, se tomó como base la información del Directorio Estadístico Nacional de Unidades Económicas (DENUE, 2019), aplicándose una encuesta telefónica estructurada a los encargados de producción de las empresas. Como resultados se detectaron 24 empresas clasificadas en este rubro, pero de las cuales 15 solamente 3 son manufactureras de neumáticos y 12 manejan y/o distribuyen productos del hule, pero no son fabricantes de neumáticos. En este sentido el DENUE, tiene mal clasificadas a las empresas. En las tres manufacturas se detecta el conocimiento del término "Logística Inversa", aunque no lo tiene implementado y solo se practican algunas actividades intrínsecas como son: la reducción de emisiones contaminantes, la introducción del reencauchamiento, entre otras y también expresaron que consideran que es posible ayudar al ambiente y al mismo tiempo aumentar las ganancias de la empresa.

Palabras Clave: Neumáticos, logística inversa, zona centro sur, empresas manufactureras.

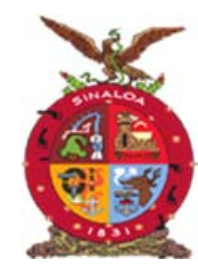

XVIII Congreso Internacional

XXIV Congreso Nacional de Ciencias ambientales
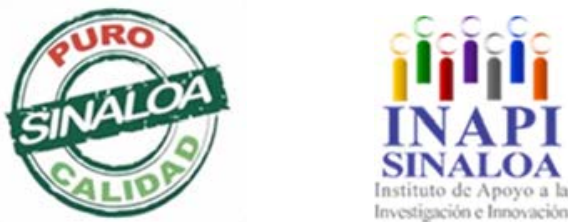

Mazatlán, Sinaloa 3-7 junio 2019

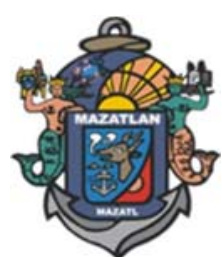

Legislación, Valores Sociales y Educación Ambiental 

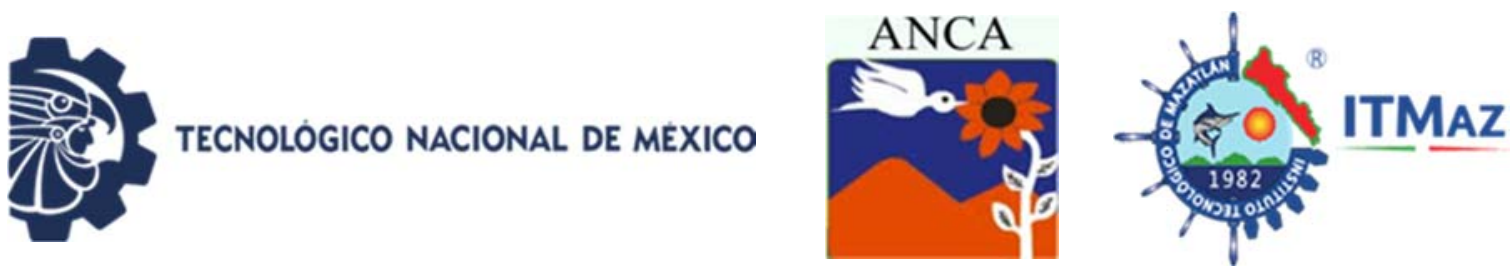

\title{
Reverse logistics in the production of tires in the South Central Area of Mexico and perception of its environmental importance
}

\author{
Linares Campos JA*,Hernández Zepeda S,Flores Sotelo T
}

Posgrado en Ciencias Ambientales

Departamento de Desarrollo Sustentable, Instituto de Ciencias, Benemérita Universidad Autónoma de Puebla.

14 Sur No. 6301 Col. San Manuel, Puebla, Pue. C.P. 72570

*alinares_campos@hotmail.com

\begin{abstract}
One of the problems present in Mexico is the environmental contamination derived from waste tires, as a result of its massive manufacturing and the difficulties to process them, once discarded. This research is applied to the identification of tire manufacturing companies that implement reverse logistics as a strategy within their production processes and infer the existence or not of relations with the increase or decrease of pollutants, in the understanding that considering it allows. The opportunity to reduce environmental pollution. The objective was to describe the tire manufacturing companies in the central south zone of Mexico and their reverse logistics. For this descriptive study, the information of the National Statistical Directory of Economic Units (DENUE, 2019) was taken as a basis, applying a structured telephone survey to the production managers of the companies. As a result, 24 companies classified in this area were detected, but of which 15 only 3 are tire manufacturers and 12 handle and / or distribute rubber products, but are not tire manufacturers. In this sense the DENUE, has poorly classified companies. In the three manufactures, the knowledge of the term "Inverse Logistics" is detected, although it is not implemented and only some intrinsic activities are practiced, such as: the reduction of polluting emissions, the introduction of the retreading, among others, and they also expressed that they consider it possible to help the environment and at the same time increase the profits of the company.
\end{abstract}

Keywords: Tires, reverse logistics, south central zone, manufacturing companies.

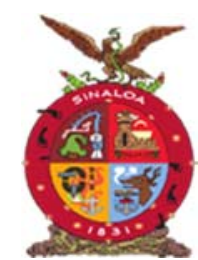

XVIII Congreso Internacional XXIV Congreso Nacional de Ciencias ambientales
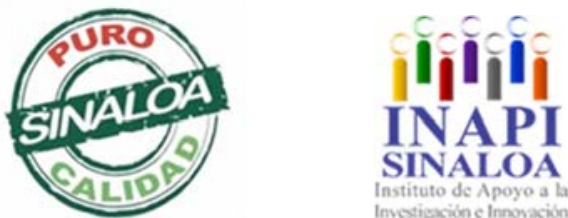

Mazatlán, Sinaloa 3-7 junio 2019

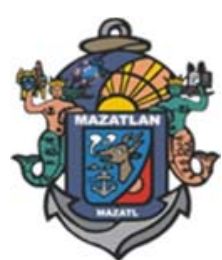

Legislación, Valores Sociales y Educación Ambiental 

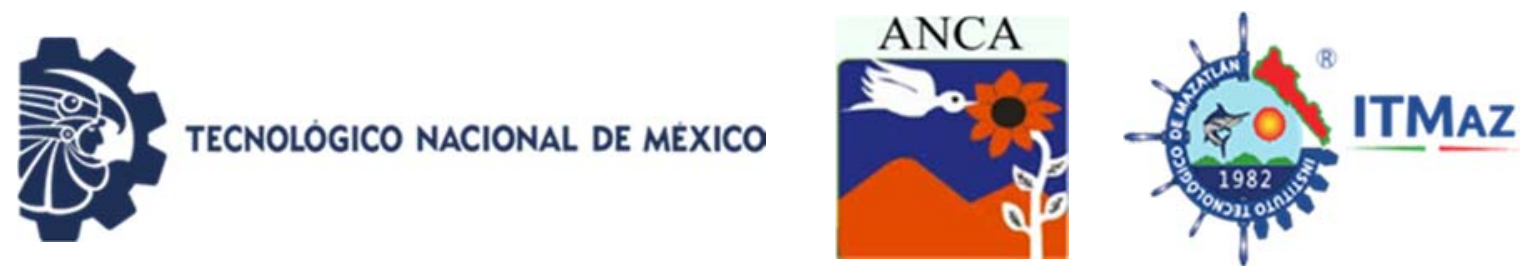

\title{
Reutilización de residuos agrícolas para la producción de Pleurotus ostreatus. Una evaluación de la eficiencia biológica de diversos sustratos
}

\author{
Medina Miranda $\mathrm{MD}^{1 *}$, Gutiérrez Segura EE ${ }^{1}$, Gutiérrez Cedillo JG², \\ Balderas Plata $\mathrm{MA}^{2}$ \\ ${ }^{1}$ Facultad de Química, Universidad Autónoma del Estado de México \\ ${ }^{2}$ Facultad de Geografía, Universidad Autónoma del Estado de México \\ *mdmedina@hotmail.com.
}

\section{RESUMEN}

La necesidad de tener seguridad alimentaria como una manera de combatir el hambre y la pobreza llevan a analizar otras alternativas a la reutilización de residuos agrícolas que además proporcionen alimentos saludables. El presente estudio tiene como objetivo la evaluación de la eficiencia biológica del cultivo del hongo Pleurotus ostreatus validando de manera experimental la producción sustentable del hongo, con diversos residuos agrícolas que abundan en la región, que pueden ser utilizados como sustrato para su crecimiento. Los residuos que se evaluaron son la paja de maíz, paja de avena y vaina de haba, que son de los cultivos principales en la región central de México. Se aplica el diseño de experimentos completamente al azar con seis tratamientos y tres repeticiones por tratamiento. La variable para determinar el mejor sustrato para el cultivo del hongo es la Eficiencia Biológica (EB); las variables económicas a monitorear son el ingreso por concepto de venta del hongo cosechado y el tiempo de cosecha. Se realiza una producción del hongo de manera semi industrial desde la preparación del sustrato hasta la cosecha del mismo, se obtiene por un lado el hongo para su comercialización y por otro el sustrato agotado. Los resultados obtenidos muestran que el tratamiento 4 con la combinación de maíz $4.26 \mathrm{~kg}$, paja de avena $8.55 \mathrm{~kg}$ y vaina de haba $2.14 \mathrm{~kg}$ son los que mayor eficiencia biológica tuvieron, no así la producción total de hongo en kilogramos, variable para la que el tratamiento 5 mostró mayor producción $(4.560 \mathrm{~g})$.

Palabras clave: Eficiencia biológica, Pleurotus ostreatus, seguridad alimentaria, sustrato, sustrato agotado.

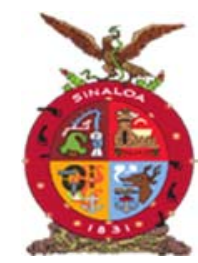

XVIII Congreso Internacional

XXIV Congreso Nacional de Ciencias ambientales
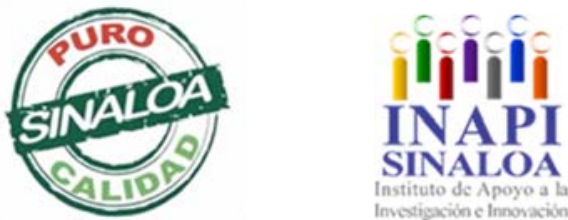

Mazatlán, Sinaloa 3-7 junio 2019

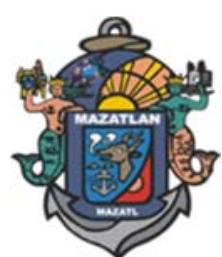

Legislación, Valores Sociales y Educación Ambiental 

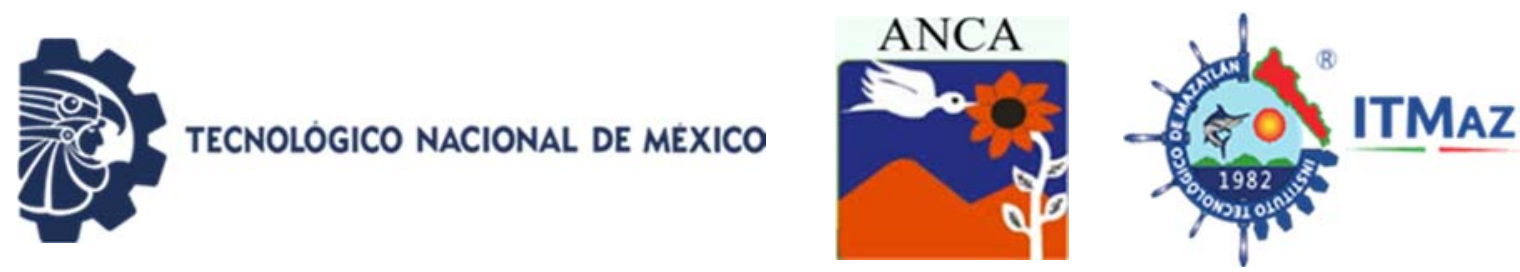

Reuse of agricultural waste for the production of Pleurotus ostreatus. An evaluation of the biological efficiency of various substrates

\author{
Medina Miranda $\mathrm{MD}^{1 *}$, Gutiérrez Segura EE ${ }^{1}$, Gutiérrez Cedillo JG², \\ Balderas Plata $\mathrm{MA}^{2}$ \\ ${ }^{1}$ Facultad de Química, Universidad Autónoma del Estado de México. \\ ${ }^{2}$ Facultad de Geografía, Universidad Autónoma del Estado de México. \\ *mdmedina@hotmail.com
}

\begin{abstract}
The need to have food security to fight hunger and poverty leads to analyze other alternatives to the reuse of agricultural waste that also provide healthy food. The objective of this study is to evaluate the biological efficiency of the cultivation of the fungus Pleurotus ostreatus by experimentally validating the sustainable production of the fungus, with various agricultural residues that abound in the region, which can be used as a substrate for its growth. The residues that were evaluated are corn straw, oat straw and bean pod, which are the main crops in the central region of Mexico. The design of experiments is applied completely randomly with six treatments and three repetitions per treatment. The variable to determine the best substrate for the cultivation of the fungus is Biological Efficiency (EB); the economic variables to be monitored are the income from the sale of the harvested fungus and the harvest time. The production of the fungus is carried out in a semi-industrial way from the preparation of the substrate to the harvest there of, on the one hand, the fungus is obtained for commercialization and on the other hand the spent substrate. The results obtained show that treatment 4 with the combination of corn 4.26 $\mathrm{kg}$, oat straw $8.55 \mathrm{~kg}$ and bean pod $2.14 \mathrm{~kg}$ are the ones that had the highest biological efficiency, but not the total production of fungus in kilograms, variable for which the treatment 5 showed higher production $(4,560 \mathrm{~g})$.
\end{abstract}

Keywords: Biological efficiency, Pleurotus ostreatus, food safety, substrate, spent substrate.

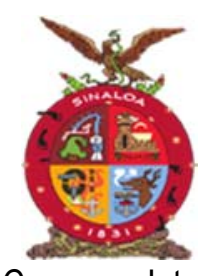

XVIII Congreso Internacional

XXIV Congreso Nacional de Ciencias ambientales
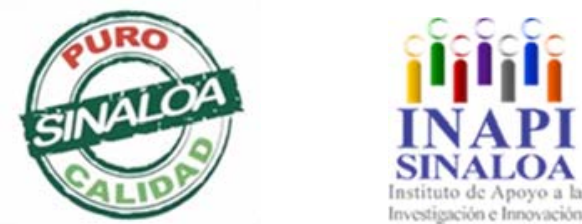

Mazatlán, Sinaloa 3-7 junio 2019

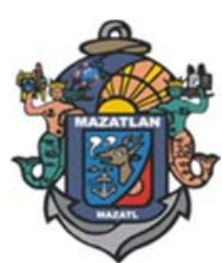

Legislación, Valores Sociales

y Educación Ambiental 

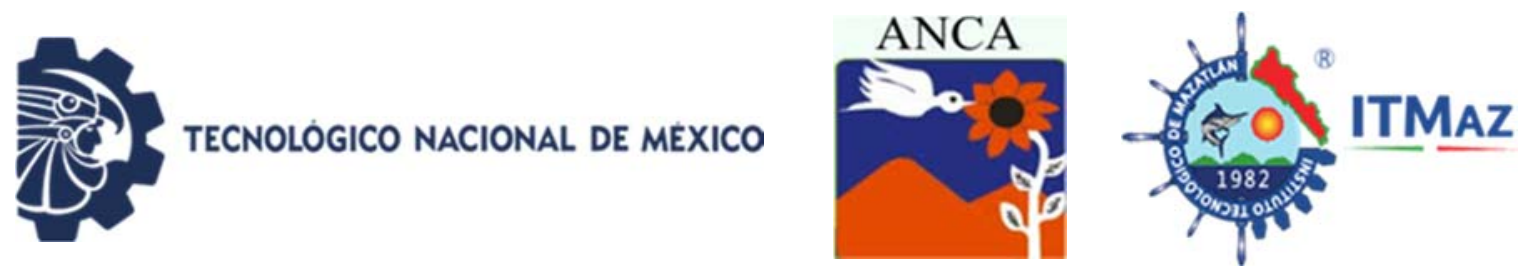

\title{
Método Delphi para el análisis de las políticas públicas ambientales en Sinaloa
}

\author{
Medina Sarmiento J*, Corrales Burgueño V, Morales Zepeda F \\ Universidad Autónoma de Sinaloa \\ *gama_09@hotmail.com
}

\begin{abstract}
RESUMEN
Esta investigación aborda la problemática que surge sobre la gestión e implementación de Políticas Públicas Ambientales; donde se realiza un análisis de la opinión de expertos en el tema ambiental y sobre las políticas públicas en Educación Ambientales implementadas en Sinaloa para el desarrollo de una conciencia ambiental desde el ámbito educativo. Es una investigación de corte cualitativo, donde se ha utilizado el método Delphi y Análisis de Contenido a cuestionarios dirigidos a expertos en Educación Ambiental y entrevista semiestructurada para la triangulación; asimismo, la revisión y análisis de documentos oficiales emitidos por la SEP, Guías del maestro por asignaturas, Planes y Programas de Estudio de Educación Básica, al igual que los decretos gubernamentales Ley de Ingreso y Presupuesto de Egresos del Estado de Sinaloa de 1998 al 2016, en materia ambiental. Además, se presenta la postura teórica ante la pertinencia de la acción política en la problemática ambiental a través de políticas públicas, su análisis y la participación ciudadana responsable frente a un contexto de globalización abordando autores como José Luis Orozco, Manuel Tamayo, Luis Aguilar, Miguel Vásquez, Jorge Cano. Para ello, se plantean las siguientes preguntas: ¿Las Políticas Públicas en Educación Ambiental implementadas en el Estado de Sinaloa, han contribuido al desarrollo de una Conciencia Ambiental en educación?; ¿Qué opinan los expertos en Educación Ambiental sobre el impacto en el Desarrollo de una Conciencia Ambiental de la implementación de las Políticas Públicas Ambientales, en el Estado de Sinaloa?
\end{abstract}

Palabras clave: Educación ambiental, políticas públicas, método Delphi, expertos, educación.

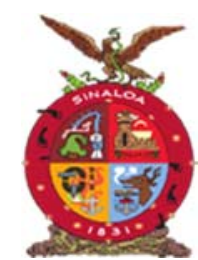

XVIII Congreso Internacional XXIV Congreso Nacional de Ciencias ambientales
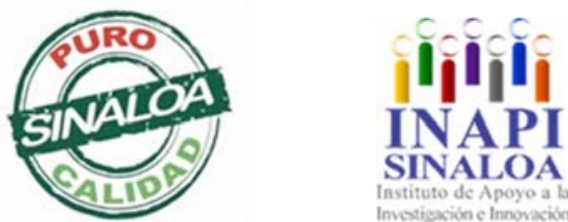

Mazatlán, Sinaloa 3-7 junio 2019

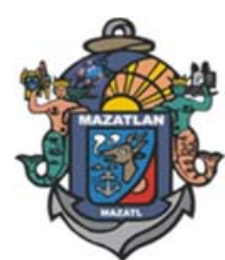

Legislación, Valores Sociales y Educación Ambiental 

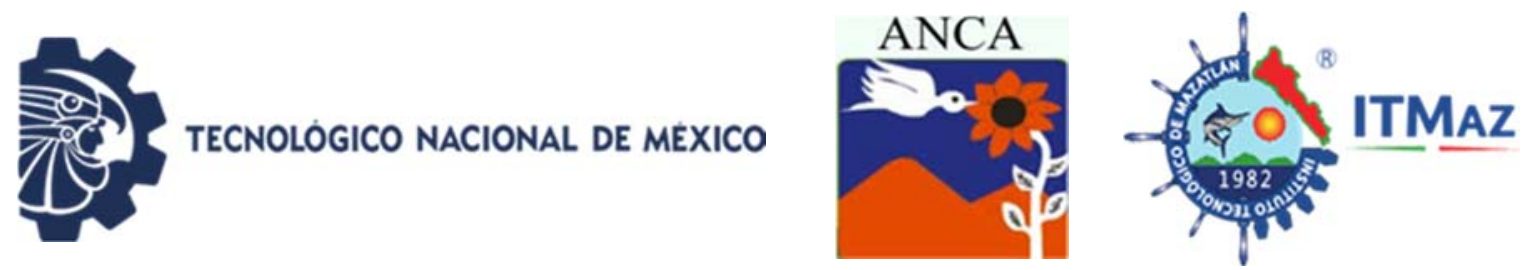

\title{
Delphi method for the analysis of public environmental politics in Sinaloa
}

\author{
Medina Sarmiento J*, Corrales Burgueño V, Morales Zepeda F \\ Universidad Autónoma de Sinaloa \\ *gama_09@hotmail.com
}

\begin{abstract}
This research addresses the problem of the management and implementation of Environmental Public Politics, where the analysis of the opinion of experts in the environmental issue and on the public politics in Environmental Education implemented in Sinaloa for the development of an environmental awareness from the scope is made educational. It is a qualitative research, where the Delphi method and Content Analysis have been used for questionnaires addressed to experts in Environmental Education and semi-structured interviews for triangulation; Also, the review and analysis of official documents issued by the SEP, Teacher Guides by subjects, Basic Education Plans and Programs, as well as the governmental decrees of the Income and Expenditures Budget of the State of Sinaloa from 1998 to 2016, in environmental matters. Also, the theoretical position is presented before the relevance of political action on environmental issues through public politics, their analysis and responsible citizen participation in a context of globalization posed by authors such as Jose Luis Orozco, Manuel Tamayo, Luis Aguilar, Miguel Vásquez, Jorge Cano. For this, the following questions are posed: The Public Politics on Environmental Education implemented in the State of Sinaloa, have contributed to the development of an Environmental Awareness in education ?; What do the experts in Environmental Education think about the impact on the Development of an Environmental Awareness of the implementation of Environmental Public Politics in the State of Sinaloa?
\end{abstract}

Keywords: Environmental education, public politics, Delphi method, experts, education.

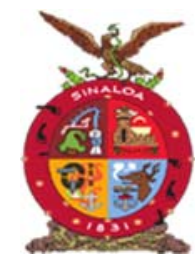

XVIII Congreso Internacional
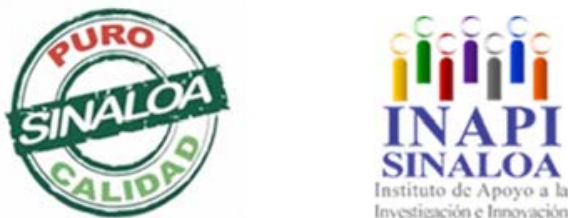

Mazatlán, Sinaloa 3-7 junio 2019

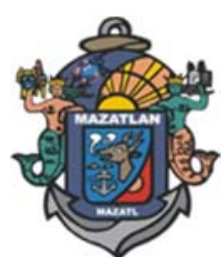

Legislación, Valores Sociales y Educación Ambiental 

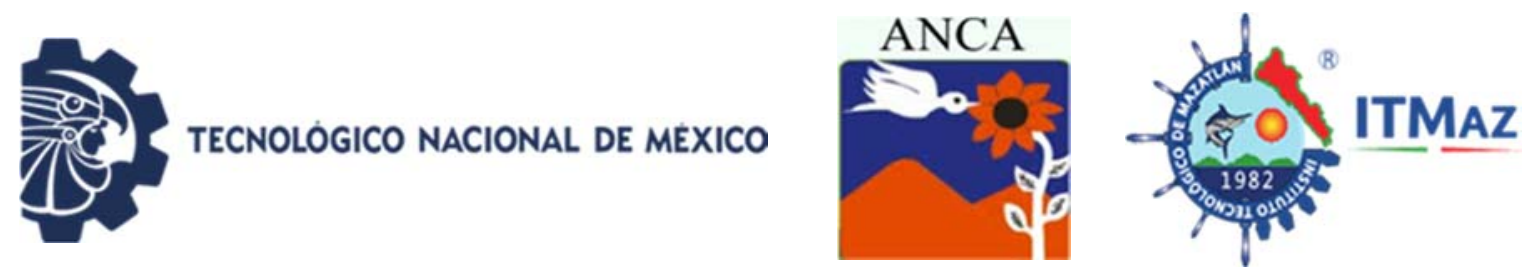

\section{Estimación de la población de perros callejeros en la Cd de Durango: enfoque Socio-Ambiental}

Naranjo Jiménez N*, López Chávez LAJ,Chávez Ramírez SC,

Rosas Medina I, Colmenero Robles A

Centro Interdisciplinario de Investigación para el Desarrollo Integral Regional Unidad Durango. Instituto Politécnico Nacional, COFAA y/o EDI.

Maestría en Gestión Ambiental, CIIDIR-Durango IPN

Secretaria de Investigación y Posgrado-IPN

*nnestor@hotmail.com

\section{RESUMEN}

Para iniciar en el tema el perro callejero es aquel sin supervisión (OMS) y no está vacunado. En México se calcula que existen alrededor de 22 millones y de ellas aproximadamente 10 viven en situación de calle. Se estiman 670 toneladas de heces fecales al año. La población de canes se ha convertido en un foco de infección de aproximadamente 140 enfermedades zoonoticas y de inseguridad. El objetivo fue estimar la población de perros callejeros en la ciudad de Durango. Se utilizo la metodología propuesta por la "World Society for the Protection of Animals" (WSPA), se estimo el tamaño de muestra, con un $90 \%$ de confianza, siendo 81 bloques o áreas de muestreo que se dividió entre dos para quedar en 40 sitios con una extensión de 1000 x $1000 \mathrm{~m}$. la toma de datos se hizo diurno y nocturno. Del 01 al 23 de agosto del 2017 se contaron el número de perros avistados. El promedio de avistamientos en el día fue de 34 perros y de noche fue de 22, en suma, el número total fue 7208 en el día y de 4664 por noche, esta variación se debe, que algunos perros se resguardan en casas de sus dueños o abandonadas. La producción estimada de heces de canidos por año fue de 219 kilos, con las implicaciones zoonóticas.

Palabras clave: Perros, zoonosis, heces, callejero.

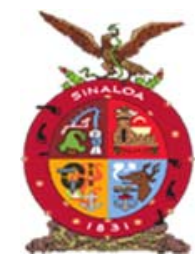

XVIII Congreso Internacional

XXIV Congreso Nacional de Ciencias ambientales

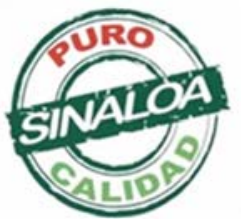

Mazatlán, Sinaloa 3-7 junio 2019

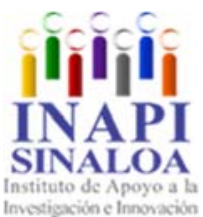

SINALOA

Instituto de Apoyo a

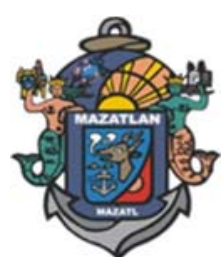

Legislación, Valores Sociales y Educación Ambiental 

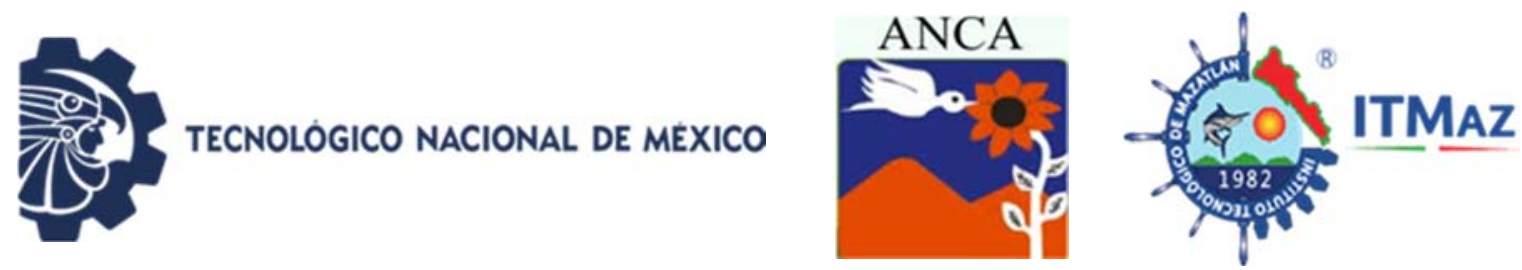

\title{
Estimation of the population of stray dogs in the Cd de Durango: Socio- Environmental approach
}

Naranjo Jiménez N*, López Chávez LAJ,Chávez Ramírez SC,

Rosas Medina I, Colmenero Robles A

Centro Interdisciplinario de Investigación para el Desarrollo Integral Regional Unidad Durango. Instituto Politécnico Nacional, COFAA y/o EDI.

Maestría en Gestión Ambiental, CIIDIR-Durango IPN

Secretaria de Investigación y Posgrado-IPN

*nnestor@hotmail.com

\begin{abstract}
To start on the topic the stray dog is the one without supervision (OMS) and is not vaccinated. In Mexico it is estimated that there are around 22 million and approximately 10 live in street situations. An estimated 670 tons of fecal waste per year. The dog population has become a source of infection of approximately 140 zoonotic diseases and insecurity. The objective was estimating the population of stray dogs in the city of Durango. The methodology proposed by the World Society for the Protection of Animals (WSPA) was used, the sample size was estimated, with a $90 \%$ confidence, being 81 blocks or sampling areas and it was divided between two to be 40 Sites with an extension of $1000 \times 1000 \mathrm{~m}$. the data collection was made Diurnal and nocturnal, from 01 to 23 August 2017 the number of dogs sighted was counted. The average sightings on the day was 34 dogs and at night it was 22 , in total the total number was 7208 on the day and 4664 per night, this variation is due, that some dogs are safeguarded in their owners' houses or abandoned. The estimated production of canid feces per year was 219 kilos, with the zoonotic implications.
\end{abstract}

Keywords: Dogs, zoonoses, feces, stray.

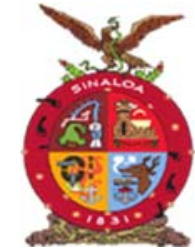

XVIII Congreso Internacional XXIV Congreso Nacional de Ciencias ambientales
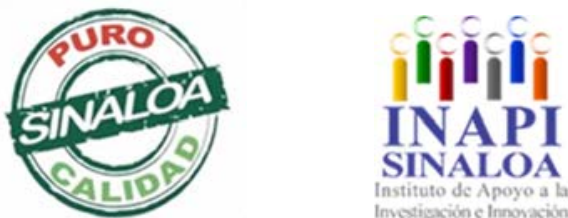

Mazatlán, Sinaloa 3-7 junio 2019

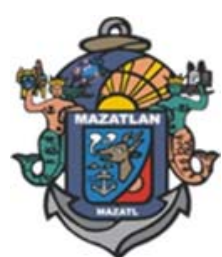

Legislación, Valores Sociales y Educación Ambiental 

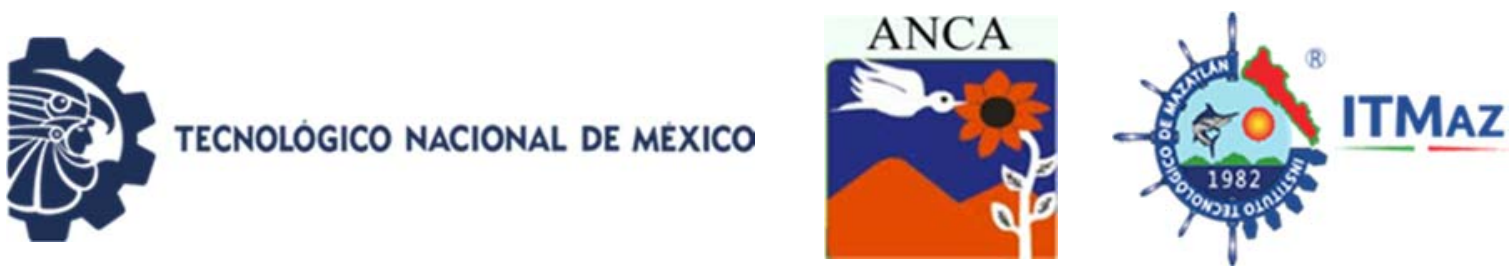

El paisaje agavero y las antiguas instalaciones de Tequila; Plan de manejo, actualización a 12 Años de su declaratoria por la UNESCO

Orendain Verduzco T*, Hernández López J, Michel Parra G, Gutiérrez Cedillo A

Universidad de Guadalajara.

Centro Universitario de Arte, Arquitectura y Diseño, Calzada Independencia Norte No. 5075, Huentitán El Bajo, Jalisco.

El Colegio de Michoacán A.C.,

Universidad de Guadalajara, Centro Universitario del Sur, Av. Enrique Arreola Silva No. 883, Colón, Cd. Guzmán, Jalisco

*orendaintome@yahoo.com.mx

\section{RESUMEN}

El Plan contiene las propuestas y lineamientos, para asegurar la Conservación y Desarrollo Sustentable de la Región, que durante varios siglos se ha distinguido por ser el corazón de las plantaciones del Agave Azul, para elaborar el tequila bebida distintiva de México. El documento es fundamental para que los agentes que gestionan el territorio puedan ubicar su papel y responsabilidad en la conservación de todos sus elementos de este Paisaje Domesticado por el hombre. Este Plan ha sido elaborado en consulta directa con los principales actores; organizaciones, Instituciones y portadores, tomando en cuenta el documento patrimonial de la declaratoria de UNESCO. Así como de la problemática detectada producto de la actualización del diagnóstico. Se describe el valor de cada uno de los aspectos que conforman el Paisaje y las propuestas para su adecuada conservación, gestión. Así como los instrumentos que han sido diseñados y acordados con las Instituciones gubernamentales, particulares y sociales. El Plan pretende contribuir a detonar procesos de desarrollo sustentable y, por ende, acortar la brecha entre los diferentes actores que participan a través de la conservación del Paisaje. Las oportunidades que existen en el ámbito industrial con la producción tequilera, No han significado un crecimiento equilibrado de los segmentos poblacionales más desfavorecidos que son, paradójicamente, donde mejor se ha conservado la esencia del Paisaje. Por ello en esta actualización se vuelve a enfatizar que el centro de interés de la protección está puesto en el sujeto colectivo, histórico y social, en relación con, El Ecosistema.

Palabras clave: Paisaje, cultural, patrimonio, ecosistema, territorio.

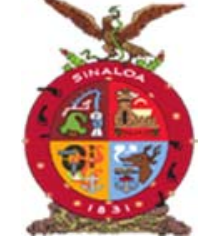

XVIII Congreso Internacional

XXIV Congreso Nacional de Ciencias ambientales

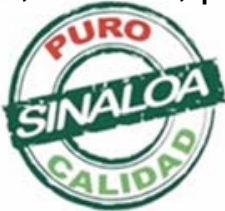

Mazatlán, Sinaloa 3-7 junio 2019

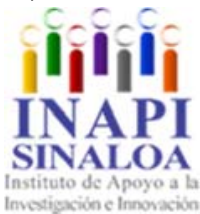

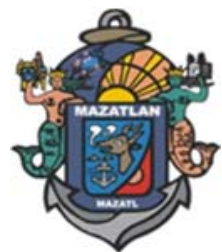

Legislación, Valores Sociales

y Educación Ambiental 

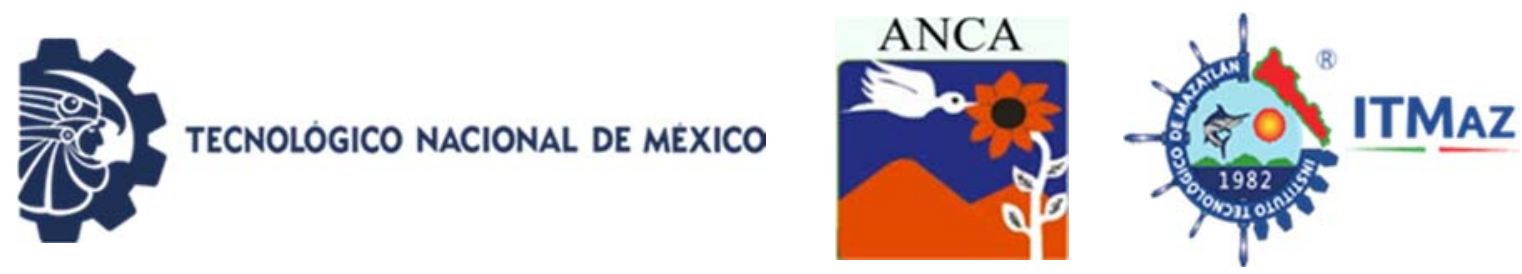

The agave landscape and the old Tequila facilities; management plan, update to 12 years of its declaration by the UNESCO

\author{
Orendain Verduzco T*, Hernández López J, Michel Parra G, \\ Gutiérrez Cedillo A \\ Universidad de Guadalajara. \\ Centro Universitario de Arte, Arquitectura y Diseño, \\ Calzada Independencia Norte No. 5075, Huentitán El Bajo, Jalisco. \\ El Colegio de Michoacán A.C., \\ Universidad de Guadalajara, Centro Universitario del Sur, \\ Av. Enrique Arreola Silva No. 883, Colón, Cd. Guzmán, Jalisco \\ *orendaintome@yahoo.com.mx
}

\begin{abstract}
The Plan contains the proposals and guidelines, to ensure the conservation and sustainable development of the region, which for several centuries has been distinguished as the heart of the blue Agave plantations, to make the tequila distinctive beverage Mexico. The document is essential so that the agents that manage the territory can locate their role and responsibility in the conservation of all its elements of this landscape domesticated by man. This Plan has been elaborated in direct consultation with the main actors; Organizations, institutions and carriers, taking into account the patrimonial document of the declaration of UNESCO. As well as the problem detected product of the update of the diagnosis. It describes the value of each of the aspects that make up the landscape and the proposals for its proper conservation, management. As well as the instruments that have been designed and agreed with governmental, private and social institutions. The Plan aims to help to detonate processes of sustainable development and thus to shorten the gap between the different actors who participate through the conservation of the landscape. The opportunities that exist in the industrial field with the tequila production, have not meant a balanced growth of the population segments more disadvantaged that are, paradoxically, where better the essence of the landscape has been preserved. Therefore, in this update it is emphasized again that the center of interest of the protection is put in the collective subject, historical and social, in relation with, the ecosystem.
\end{abstract}

Keywords: Landscape, cultural, heritage, ecosystem, territory.

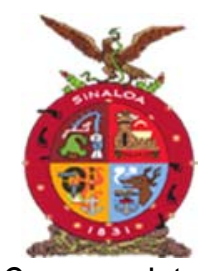

XVIII Congreso Internacional

XXIV Congreso Nacional de Ciencias ambientales

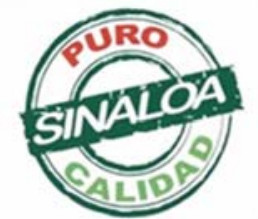

Mazatlán, Sinaloa 3-7 junio 2019

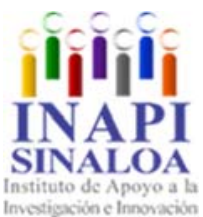

SINALOA 

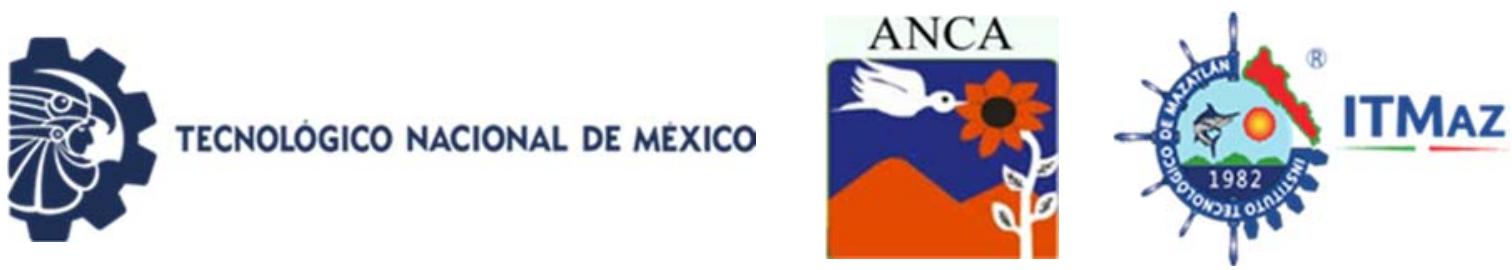

\title{
Carbono orgánico en suelos como criterio para el ordenamiento territorial Urbano
}

\author{
Pereira Corona A*, Fragoso Servón P, Prezas Hernández B \\ Laboratorio de Ecología y Ordenamiento Territorial \\ División de Ciencias e Ingeniería. Universidad de Quintana Roo. \\ *apereira@uqroo.edu.mx
}

\section{RESUMEN}

La necesidad de proveer de espacios más sanos en zonas urbanas, así como la necesidad de preservar valiosos recursos naturales como los germoplasmas nativos en particular de vegetación, requieren de la conservación de los recursos base para su existencia, entre ellos uno de los más importantes es el suelo y sus atributos. El objetivo del trabajo fue determinar las variaciones en contenidos de carbono orgánico de suelos en áreas con diferentes grados de urbanización en una zona tropical en Quintana Roo, México. El trabajo de muestreo se llevó a cabo desde abril hasta septiembre de 2018 ubicando un total de 40 sitios de muestreo distribuidos en tres localidades con diferentes grados de urbanización. En cada sitio los tipos de suelo fueron identificados y se cuantificó el carbono inorgánico $(\mathrm{Cl})$, orgánico $(\mathrm{CO})$ y total usando la determinación por calcinación y la determinación por oxidación de dicromato de potasio respectivamente. Los resultados se asociaron a los puntos geográficos para determinar patrones de distribución al interior de cada sitio y se compararon entre sitios para relacionar el grado de urbanización y la intensidad con los contenidos de carbono. Se hallaron diferencias significativas tanto al interior de los sitios como entre sitios como áreas totales, las zonificaciones resultantes pueden ser usadas para determinar el destino de predios baldíos o zonas de conservación ya sea para creación de áreas jardinadas o para conservación de la cobertura natural, aportando así un criterio objetivo para la planeación de este tipo de atributos en zonas urbanas.

Palabras clave: Materia orgánica, planeación, conservación, urbanización.

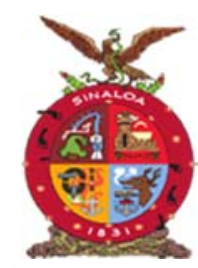

XVIII Congreso Internacional XXIV Congreso Nacional de Ciencias ambientales
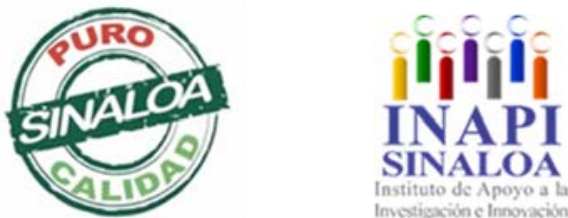

Mazatlán, Sinaloa 3-7 junio 2019

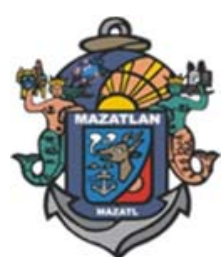

Legislación, Valores Sociales y Educación Ambiental 

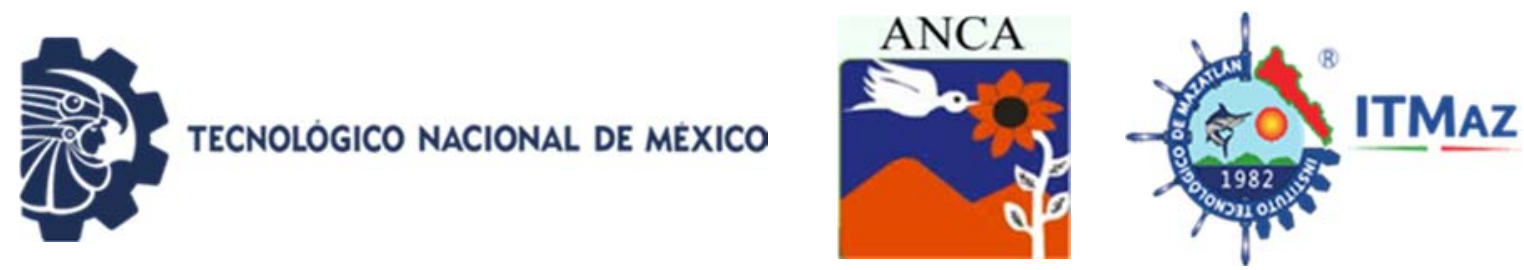

\title{
Organic carbon in soils as a criterion for urban territorial planning
}

\author{
Pereira Corona A*, Fragoso Servón P, Prezas Hernández B \\ Laboratorio de Ecología y Ordenamiento Territorial \\ División de Ciencias e Ingeniería. Universidad de Quintana Roo. \\ *apereira@uqroo.edu.mx
}

\begin{abstract}
The need to provide healthier spaces in urban areas, as well as the need to preserve valuable natural resources such as native germplasms in particular of vegetation, require the conservation of core resources for their existence, among them one of the most important is the soil and its attributes. The objective of the work was to determine the variations in organic carbon contents of soils in areas with different degrees of urbanization in a tropical zone in Quintana Roo, Mexico. The sampling work was carried out from April to September 2018, locating a total of 40 sampling sites distributed in three locations with different degrees of urbanization. At each site soil types were identified and the inorganic (IC), organic (OC) and total carbon were quantified using the determination by calcination and determination by oxidation of potassium dichromate respectively. The results were associated to the geographic points to determine patterns of distribution within each site and were compared between sites to relate the degree of urbanization and the intensity with the carbon contents. Significant differences were found both, within the sites and between sites as whole areas, the resulting zoning can be used to determine the fate of vacant lots or conservation areas, either for the creation of landscaped areas or for conservation of natural cover, contributing thus with an objective criterion for the planning of this type of attributes in urban areas.
\end{abstract}

Keywords: Organic matter, planning, conservation, urbanization.

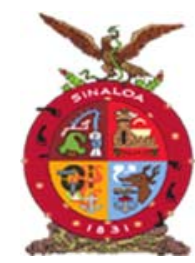

XVIII Congreso Internacional

XXIV Congreso Nacional de Ciencias ambientales
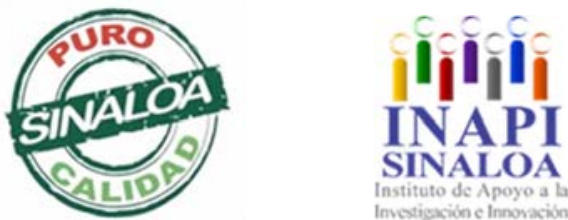

Mazatlán, Sinaloa 3-7 junio 2019

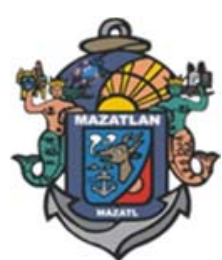

Legislación, Valores Sociales

y Educación Ambiental 

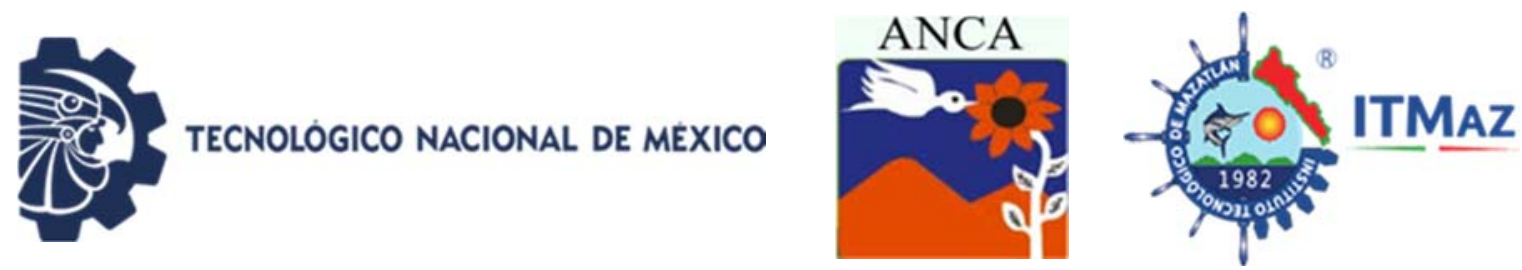

\section{Categorización de tiraderos a cielo abierto en la cabecera municipal de Tecpan de Galeana, Guerrero, México}

Rendón Caro J, Lungo Rodríguez A, Vences Martínez J, Rodríguez Herrera A, Del Carmen Niño V, Morales Benítez B

Centro Regional de Educación Superior Costa Grande, Escuela Superior en Desarrollo Sustentable. Universidad Autónoma de Guerrero.

Carretera Nacional Acapulco-Zihuatanejo Km. $106+900$

Col. Las Tunas, Tecpan de Galeana, Guerrero C.P.40900 Doctorado en Ciencias Ambientales Centro de Ciencias de Desarrollo Regional. Universidad Autónoma de Guerrero.

Privada de Laurel No. 13, Colonia El Roble, Acapulco, Guerrero. C.P. 39840. Licenciatura de Cultura Física y Deporte. Campus Llano Largo

\section{RESUMEN}

La problemática de los Tiraderos a Cielo Abierto (TCA) residuos sólidos es multicausal, principalmente por deficiencias en el sistema de aseo público, recolección, tratamiento y disposición final de los residuos sólidos, así mismo, la falta de educación ambiental y algunas prácticas culturales de los pobladores contribuyen a perpetuar su presencia en distintos puntos de la cabecera del municipio de Tecpan de Galeana. Se buscó categorizar los 12 TCA encontrados en la cabecera municipal y aledaños, para analizar la situación de los tiraderos, tomando en cuenta las variables; topografía, climatología, meteorología y generación de residuos propuesta por la SEDESOL (2001), para rehabilitar y clausurar tiraderos a cielo abierto; por otro lado para el análisis social se tomó en cuenta los criterios establecidos por la OPS (2004), que considera el tamaño de los tiraderos, ubicación de poblados, tipos de residuos, entorno ambiental (presencia de aguas subterráneas), así mismo, actividades socioeconómicos tales como separación de basura, quema de basura y cría de animales. Finalmente se tomó una muestra de 50 $\mathrm{Kg}$ de los diferentes tipos de residuos estos se clasificaron según lo establecido en la NMX-AA-022-1985, se analizó el riesgo con respecto a las áreas de cultivo agrícola dando como resultado que de los 12 tiraderos 10 implican un alto riesgo y 2 implican un riesgo moderado. El estudio recomienda la clausura de los tiraderos, por el riesgo que implican.

Palabras clave: Residuos, tiraderos, clasificación.

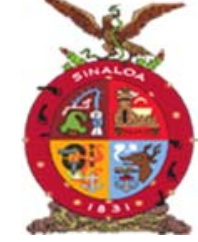

XVIII Congreso Internacional

XXIV Congreso Nacional de Ciencias ambientales

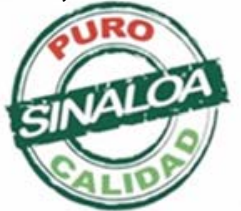

Mazatlán, Sinaloa 3-7 junio 2019

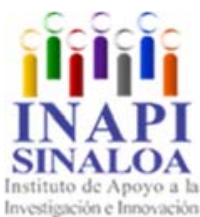

SINALOA

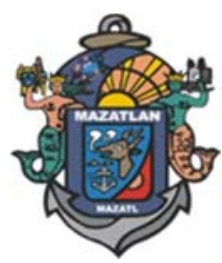

Legislación, Valores Sociales

y Educación Ambiental 

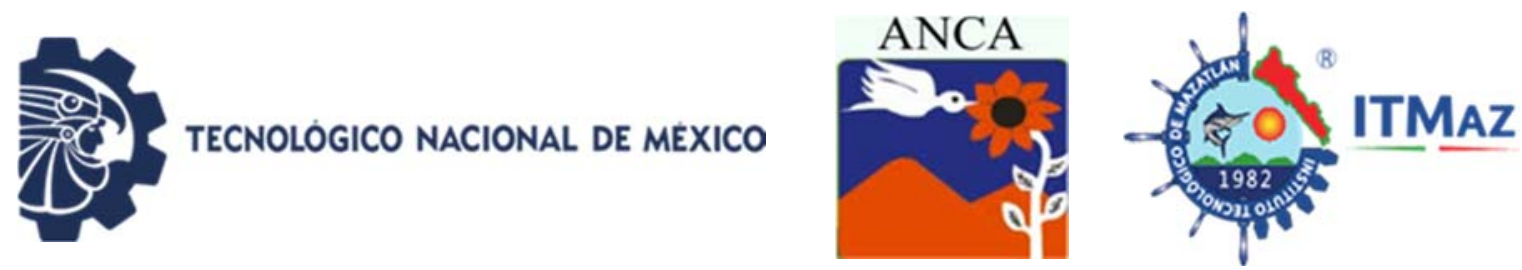

\title{
Open waste dumps classification in the county seat of Tecoan de Galeana, Guerrero, México
}

Rendón Caro J, Lungo Rodríguez A, Vences Martínez J, Rodríguez Herrera A, Del Carmen Niño V, Morales Benítez B

Centro Regional de Educación Superior Costa Grande, Escuela Superior en Desarrollo Sustentable.

Universidad Autónoma de Guerrero.

Carretera Nacional Acapulco-Zihuatanejo Km. $106+900$

Col. Las Tunas, Tecpan de Galeana, Guerrero C.P.40900

Doctorado en Ciencias Ambientales Centro de Ciencias de Desarrollo

Regional. Universidad Autónoma de Guerrero.

Privada de Laurel No. 13, Colonia El Roble, Acapulco, Guerrero. C.P. 39840.

Licenciatura de Cultura Física y Deporte. Campus Llano Largo

\begin{abstract}
The problems with open solid waste dumps have many origins, mainly due to dysfunction of the department of cleanliness, rubbish collection and the final treatment of solid rubbish, as well as the lack of environmental education and some cultural practices form the population that promote and endure the existence in different points in the district of Tecpan de Galeana. This researched is aimed to categorize the 12 different open dumps found within the district and in the outskirts, to analyze the current situation of these garbage dumps spaces, different facts were considered such as the topography and climatology variants and the waste production proposed by SEDESOL (2001) to rebuilt and shot down open garbage dumps. Furthermore for the social analysis the establish criteria form OPS (2004) was considered, that contemplates the size of dumps, the location of population, the kinds of waste, the environmental setting (presence of groundwater) additionally the socioeconomic activities such as household garbage separation, burning trash and animal breeding. Lastly, a $50 \mathrm{~kg}$ sample, of the different kind of waste, was taken and classified according to what is established in NMX-AA-022-1985. The risk was analyzed regarding the farming area and getting as a result that 10 out of 12 waste dumps lead to high risk and 2 have medium risk. This analysis suggest the immediate shot down of the landfills due to the risk they generate.
\end{abstract}

Keywords: Waste, landfills, classified.

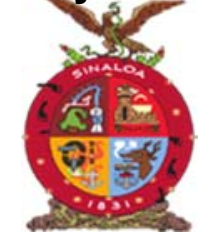

XVIII Congreso Internacional

XXIV Congreso Nacional de Ciencias ambientales

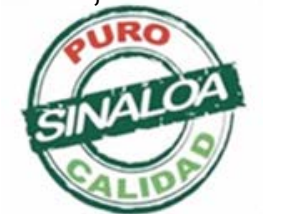

Mazatlán, Sinaloa 3-7 junio 2019

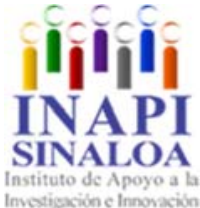

SINALOA

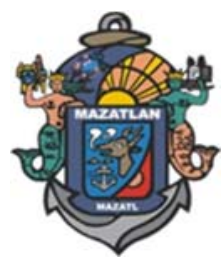

Legislación, Valores Sociales

y Educación Ambiental 

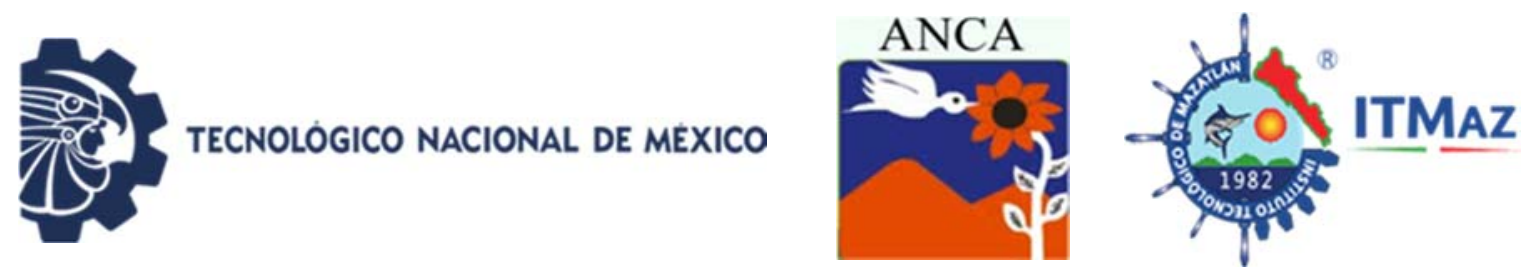

\title{
Conservación de la microcuenca del Río Tecoanapa, disyuntivas y conflictos en torno al agua
}

\author{
Rodríguez Herrera AL, Olivier Salomé B, Arellano Wences HJ \\ Centro de Ciencias del Desarrollo Regional. \\ Doctorado en Ciencias Ambientales. CCDR \\ Universidad Autónoma de Guerrero. \\ Calle Pino S/N, Col. El Roble, Acapulco, Gro. 39640
}

\section{RESUMEN}

Se estudia la experiencia conservacionista a través del Pago por Servicios ambientales hidrológicos en la localidad rural de San Francisco, cuenca alta del río Tecoanapa en 2006. Pronto los beneficios en los ecosistemas fueron evidentes, sin embargo, en el ámbito social de la microcuenca, los resultados fueron negativos pues se generó un agudo conflicto por el agua que se prolongó durante los siguientes siete años. Durante este período se impuso en la microcuenca un esquema conservacionista alterno al del estado, donde las relaciones de cooperación entre comunidades regidas por usos y costumbres se imponían a las relaciones económicas basadas en una valoración económica de la naturaleza. El estudio muestra que las experiencias de conservación cargadas de particularidades son invisibilizadas por los programas oficiales, aún y cuando ellas conllevan alternativas democráticas en espacios regionales. Este estudio se realizó a partir de entrevistas, grupos focales y seguimiento hemerográfico.

Palabras clave: Servicios ambientales, conservación, conflictos por el agua, usos y costumbres.

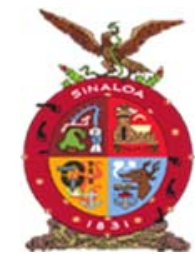

XVIII Congreso Internacional XXIV Congreso Nacional de Ciencias ambientales
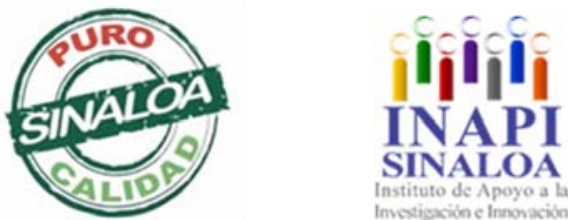

Mazatlán, Sinaloa 3-7 junio 2019

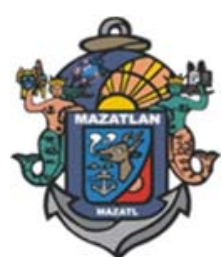

Legislación, Valores Sociales y Educación Ambiental 

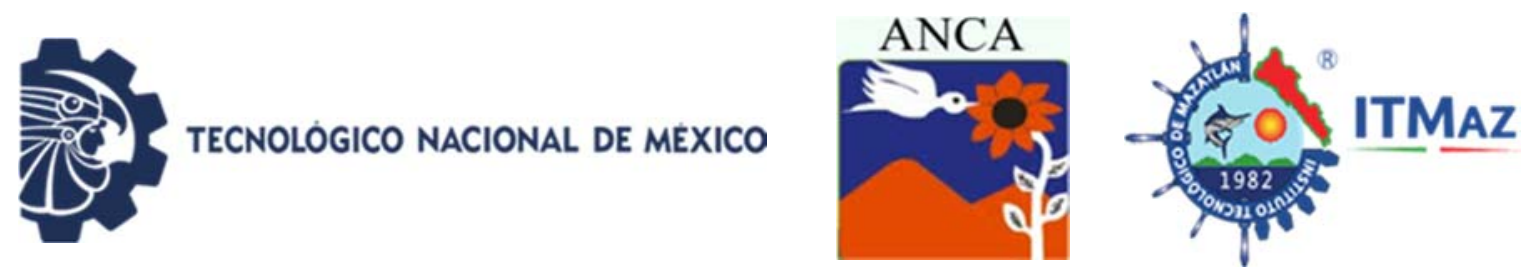

\title{
Conservation of the Tecoanapa River micro-basin, disjunctives and conflicts in water turning
}

\author{
Rodríguez Herrera AL, Olivier Salomé B, Arellano Wences HJ \\ Centro de Ciencias del Desarrollo Regional. \\ Doctorado en Ciencias Ambientales. CCDR \\ Universidad Autónoma de Guerrero. \\ Calle Pino S/N, Col. El Roble, Acapulco, Gro. 39640
}

\begin{abstract}
Conservation experience is studied through the payment for hydrological environmental services in the rural town of San Francisco, upper basin of the Tecoanapa River in 2006. Soon the benefits in the ecosystems were evident, however, in the social context of the microbasin the results they were negative because there was an acute conflict over water that lasted for the next seven years. During this period, a conservationist scheme alternated with that of the state was imposed in the micro-basin, where relations of cooperation between communities governed by uses and customs were imposed on economic relations based on an economic valuation of nature. The study shows that conservation experiences laden with particularities are made invisible by official programs, even when they entail democratic alternatives in regional spaces. This study was conducted from interviews, focus groups and hemerographic follow-up.
\end{abstract}

Keywords: Environmental services, conservation, conflicts over water, uses and customs.

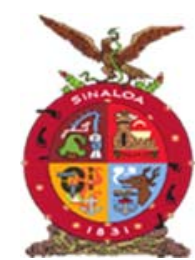

XVIII Congreso Internacional XXIV Congreso Nacional de Ciencias ambientales
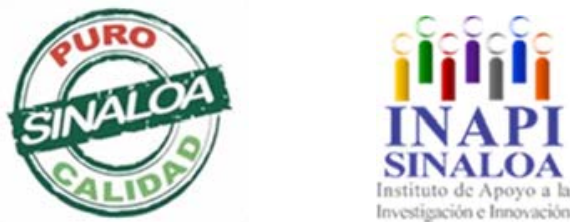

Mazatlán, Sinaloa 3-7 junio 2019

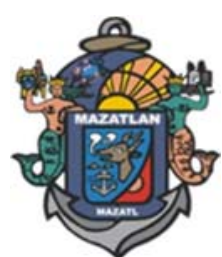

Legislación, Valores Sociales y Educación Ambiental 

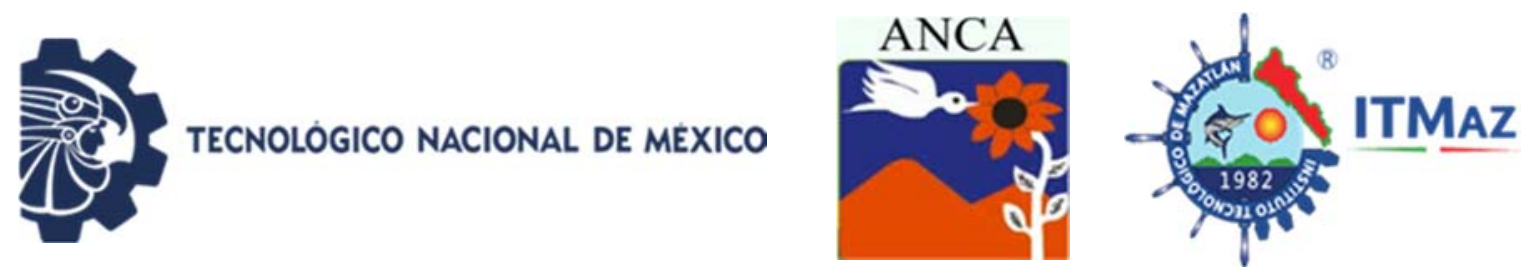

El buen vivir, paradigma emergente de educación ambiental

Romero Leyva $F^{*}$, Ceceña MG, Valdez Román L, López Félix G

Universidad Autónoma Intercultural de Sinaloa

*fromero@uais.edu.mx

\section{RESUMEN}

El buen vivir es un paradigma incipiente que se sustenta en el respeto y uso armonioso de los recursos naturales y la relación hombre/tierra, derivado de los desastres ambientales que se suscitan de manera cotidiana producto de lo irresponsable de las políticas públicas que se fundamentan en la irracionalidad y la sobreexplotación de la madre tierra.

Palabras clave: Buen vivir, paradigmas, educación ambiental.

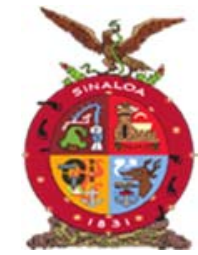

XVIII Congreso Internacional XXIV Congreso Nacional de Ciencias ambientales

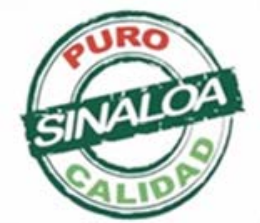

Mazatlán, Sinaloa 3-7 junio 2019

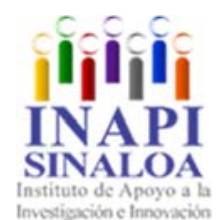

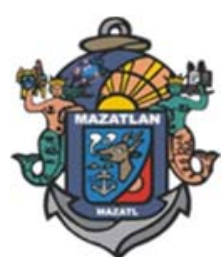

Legislación, Valores Sociales

y Educación Ambiental 

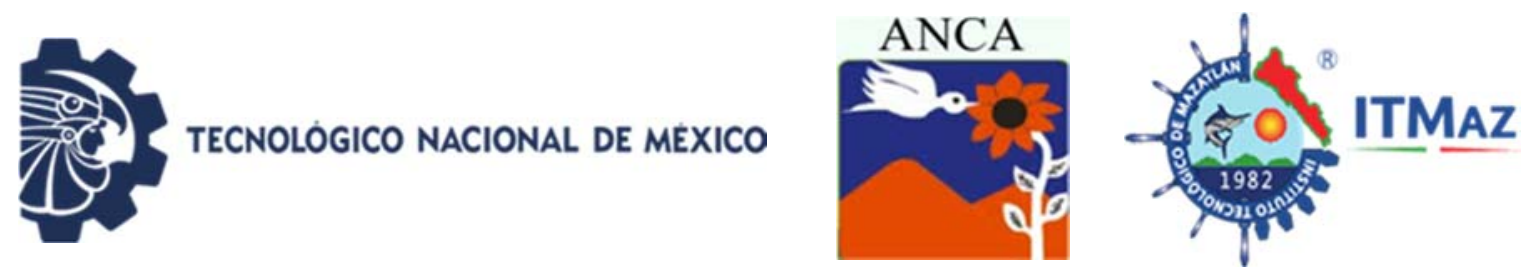

Good living, emerging paradigm of environmental education

Romero Leyva F*, Ceceña MG, Valdez Román L, López Félix G

Universidad Autónoma Intercultural de Sinaloa

*fromero@uais.edu.mx

\begin{abstract}
Good living is an incipient paradigm that is based on the respect and harmonious use of natural resources and the man / earth relationship, derived from the environmental disasters that arise on a daily basis due to the irresponsible nature of public policies. They are based on the irrationality and overexploitation of Mother Earth.
\end{abstract}

Keywords: Good living, paradigms, environmental education.

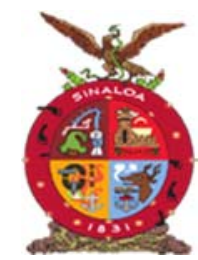

XVIII Congreso Internacional XXIV Congreso Nacional de Ciencias ambientales

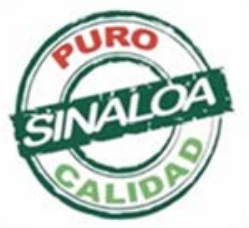

Mazatlán, Sinaloa 3-7 junio 2019

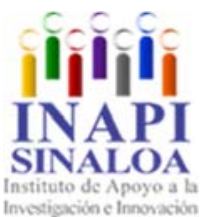

instituto de A poyo a

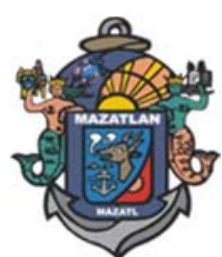

Legislación, Valores Sociales

y Educación Ambiental 

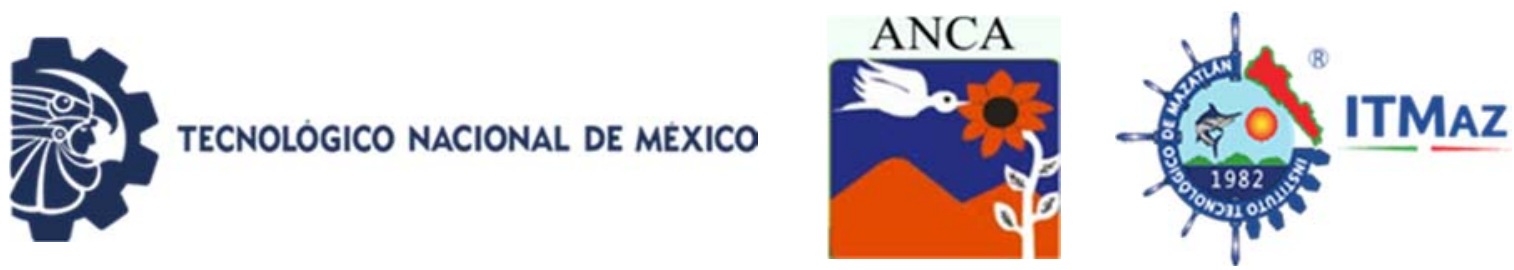

\title{
Efecto del plomo sobre la imbibición, germinación y crecimiento de Hordeum vulgare $L$
}

\author{
Ruiz García CS, Huerta García J, Mandujano García CD, Gutiérrez JB, \\ Valle Rodríguez S, Escalona Alcázar FJ \\ Laboratorio de Biología Ambiental y Molecular. \\ Unidad Académica de Ciencias Biológicas \\ Universidad Autónoma de Zacatecas. \\ Unidad Académica de Ciencias de la Tierra \\ *jhuga@msn.com
}

\section{RESUMEN}

Los metales pesados (MPs) son parte de la corteza terrestre como componentes naturales. Sin embargo, las múltiples actividades antropogénicas entre las que se encuentran principalmente la minería y la agricultura han contribuido de manera importante a incrementar las concentraciones de estos MPs al suelo, y como consecuencia de ello se han derivado serios problemas asociados a la contaminación de suelos agrícolas. El Plomo (Pb), el arsénico (As), el cadmio (Cd) y el zinc ( $\mathrm{Zn}$ ) entre otros MPs pueden ser absorbidos por las plantas. $\mathrm{El} \mathrm{Pb}$ es un elemento sin función biológica conocida para plantas y animales. Se une preferentemente al oxígeno, grupos amino y grupos sulfhidrilo, ocasionando estrés iónico debido a su elevado índice de covalencia, en la mayoría de los casos, el catión libre $\left(\mathrm{Pb}^{+2}\right)$ suele ser la forma más tóxica, sin embargo todas las formas del $\mathrm{Pb}$ pueden ser absorbidas por las raíces de las plantas, y una vez absorbido por las raíces causa efectos fitotóxicos según la concentración y su disponibilidad en el suelo, que a su vez depende de sus características químicas y físicas como el pH, humedad, salinidad, capacidad de intercambio catiónico y materia orgánica. Es por ello que es importante evaluar diversas técnicas ecotoxicológicas que empleen organismos de prueba (o blanco) de diferentes niveles tróficos como bioindicadores de contaminación ambiental. La germinación de semillas y la prueba de la elongación radicular son de los indicadores más simples del biomonitoreo ambiental. Estos indicadores en combinación con la longitud del brote son parámetros que pueden mostrar cambios en la calidad ambiental, los resultados de estas pruebas se basan en la sensibilidad de las plantas centinela cuando se exponen a muestras de agua, suelo o sedimento contaminado. Las plantas de importancia económica, que son de fácil acceso y que, además, germinan y crecen rápidamente, como la cébada, resultan excetentes para ensayos ce toxicidad basados

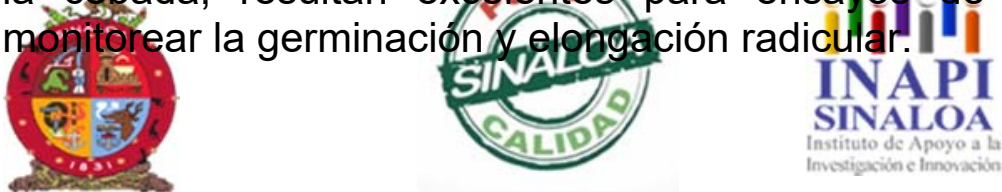

XVIII Congreso Internacional

XXIV Congreso Nacional de Ciencias ambientales
Mazatlán, Sinaloa 3-7 junio 2019

Mazatlan
Legislación, Valores Sociales

y Educación Ambiental 

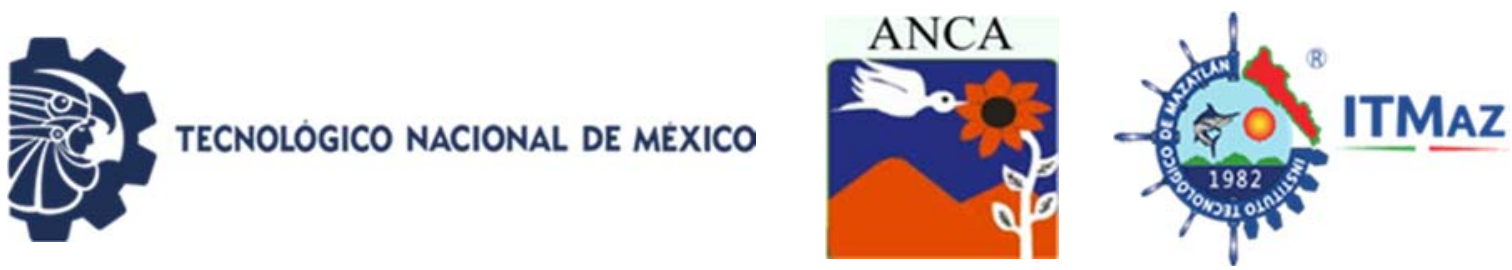

\title{
Effect of lead on imbibition, germination and growth from Hordeum vulgare $\mathbf{L}$
}

\author{
Ruiz García CS, Huerta García J, Mandujano García CD, Gutiérrez JB, \\ Valle Rodríguez S, Escalona Alcázar FJ \\ Laboratorio de Biología Ambiental y Molecular. \\ Unidad Académica de Ciencias Biológicas \\ Universidad Autónoma de Zacatecas. \\ Unidad Académica de Ciencias de la Tierra \\ *jhuga@msn.com
}

\begin{abstract}
Heavy metals (MPs) are part of the earth's crust as natural components, however, the multiple anthropogenic activities that include mining and agriculture have contributed significantly to increasing the concentrations of these MPs to the soil, and As a result, serious problems associated with the contamination of agricultural soils have resulted. Lead $(\mathrm{Pb})$, arsenic (As), cadmium (Cd) and zinc (Zn) among other MPs can be absorbed by plants. Pb is an element with no known biological function for plants and animals. It binds preferentially to oxygen, amino groups and sulfhydryl groups, causing ionic stress due to its high covalence index, in most cases, the free cation $\left(\mathrm{Pb}^{+2}\right)$ is usually the most toxic form, however all forms of $\mathrm{Pb}$ can be absorbed by the roots of the plants, and once absorbed by the roots causes phytotoxic effects according to the concentration and its availability in the soil, which in turn depends on its chemical and physical characteristics such as $\mathrm{pH}$, humidity, salinity, cation exchange capacity and organic matter. That is why it is important to evaluate various ecotoxicological techniques that use test organisms (or targets) of different trophic levels as bioindicators of environmental pollution. Seed germination and root elongation test are one of the simplest indicators of environmental biomonitoring. These indicators in combination with the length of the outbreak are parameters that can show changes in environmental quality, the results of these tests are based on the sensitivity of sentinel plants when exposed to samples of contaminated water, soil or sediment. Economically important plants, which are easily accessible and also germinate and grow rapidly, such as barley, are excellent for toxicity tests based on monitoring germination and root elongation.
\end{abstract}

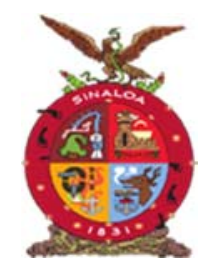

XVIII Congreso Internacional

XXIV Congreso Nacional de Ciencias ambientales
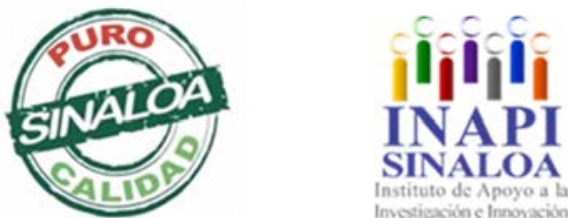

Mazatlán, Sinaloa 3-7 junio 2019

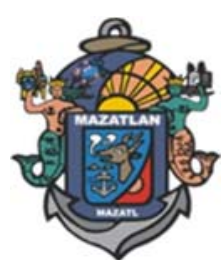

Legislación, Valores Sociales

y Educación Ambiental 

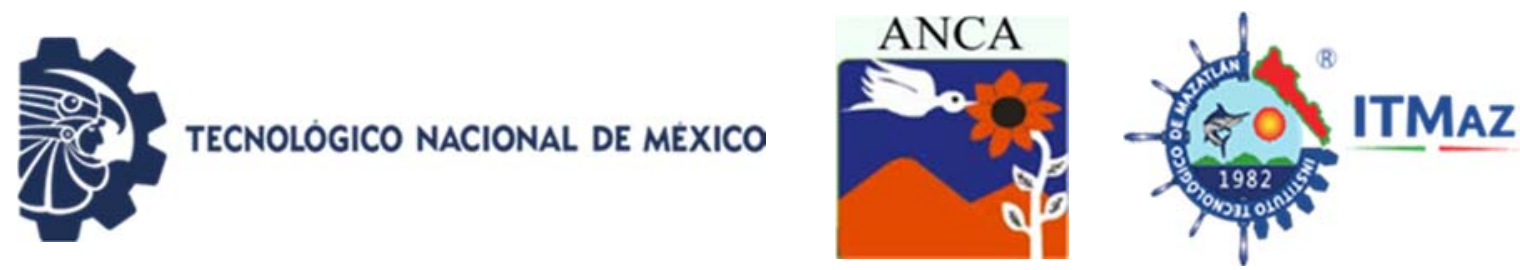

\title{
Comportamiento pro ambiental en estudiantes de la Universidad Autónoma de Guerrero en Acapulco
}

\author{
Saldaña Almazán $\mathrm{M}^{*}$, Sampedro Rosas M, Carrasco Urrutía K, \\ Rosas Acevedo J, Maldonado Astudillo Y, Juárez López A \\ Centro de Ciencias de Desarrollo Regional (CCDR-UAGro). \\ Universidad Autónoma de Ciudad Juárez \\ *mirellasal@hotmail.com
}

\section{RESUMEN}

El deterioro de los recursos naturales ha ido colapsando el ambiente, la falta de concientización en el manejo desmedido de estos recursos son el principal problema, es necesario crear un cambio de actitudes e implementar políticas ambientales que contribuyan en la conservación del ambiente. El objetivo es realizar un análisis de la autoevaluación del comportamiento proambiental (CPA) en los estudiantes de nivel medio superior, superior y posgrado de la Universidad Autónoma de Guerrero (UAGro) en Acapulco. La metodología consistió en aplicar un cuestionario con 25 ítems donde los estudiantes autoevaluaron diferentes acciones que realizan para cuidar el ambiente en su hogar, escuela y comunidad, en el ciclo escolar 2017-2018, para el análisis de los datos se utilizó SPSS 20, donde a partir de 80 puntos tiene CPA. Algunos de los resultados obtenidos entre los estudiantes de nivel medio superior señalaron el $49 \%$ tienen CPA $\square 80$ pts, de licenciatura el $40 \%$ y en los estudiantes de posgrados el $74 \%$ tiene CPA, como conclusión los estudiantes de posgrado tienen mejor conocimiento sobre la importancia de cuidar el ambiente y por tanto un gran porcentaje tiene una mejor autoevaluación en comparación con los demás niveles educativos.

Palabras clave: Actitudes, concientización, educación.

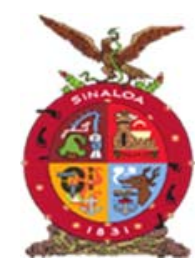

XVIII Congreso Internacional
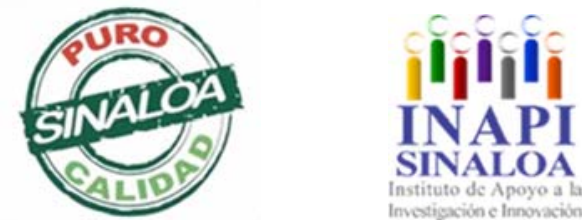

Mazatlán, Sinaloa 3-7 junio 2019

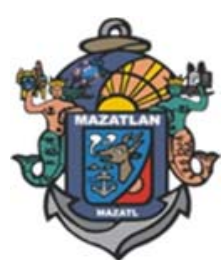

Legislación, Valores Sociales y Educación Ambiental 

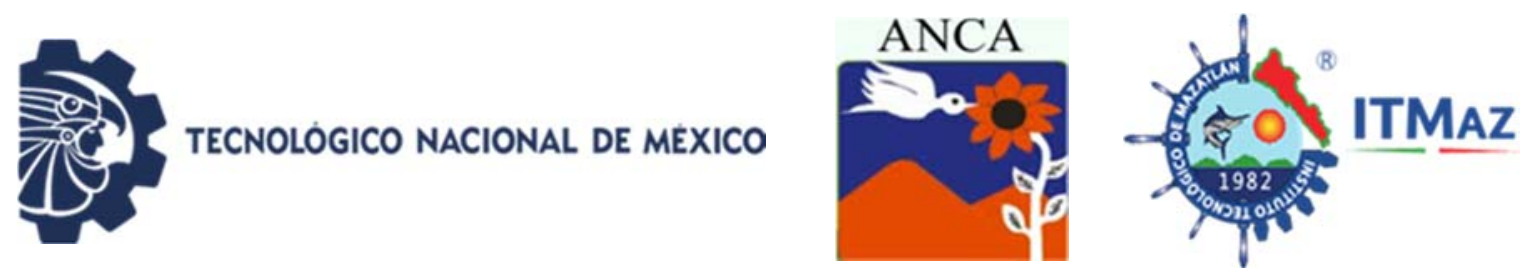

\title{
Pro-environmental behavior in students of the Autonomous University of Guerrero in Acapulco
}

\author{
Saldaña Almazán $\mathrm{M}^{*}$, Sampedro Rosas M, Carrasco Urrutía K, \\ Rosas Acevedo J, Maldonado Astudillo Y, Juárez López A \\ Centro de Ciencias de Desarrollo Regional (CCDR-UAGro). \\ Universidad Autónoma de Ciudad Juárez \\ *mirellasal@hotmail.com
}

\begin{abstract}
The deterioration of natural resources has been collapsing the environment, the lack of awareness in the excessive management of these resources are the main problem, it is necessary to create a change of attitudes and implement environmental policies that contribute to the conservation of the environment. The objective is to carry out an analysis of the self-assessment of the proenvironmental behavior (CPA) in students of upper, upper and postgraduate levels of the Autonomous University of Guerrero (UAGro) in Acapulco. The methodology consisted of applying a questionnaire with 25 items where the students self-evaluated different actions they perform to care for the environment in their home, school and community, in the 2017-2018 school year, for the analysis of the data was used SPSS 20 , where from 80 points has CPA. Some of the results obtained were that the students of high school level have $49 \%$ have CPA $\square 80$ pts, $40 \%$ have a bachelor's degree and $74 \%$ have a CPA in postgraduate students, as a conclusion graduate students have better knowledge about the importance of taking care of the environment and therefore a large percentage has a better self-evaluation compared to other students. It is necessary after evaluating the CPA, to implement environmental policies on the care of the environment.
\end{abstract}

Keywords: Attitudes, awareness, education.

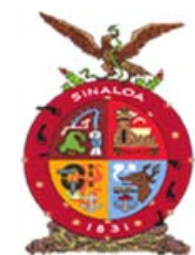

XVIII Congreso Internacional

XXIV Congreso Nacional de Ciencias ambientales
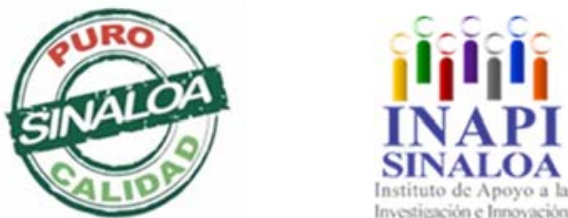

Mazatlán, Sinaloa 3-7 junio 2019

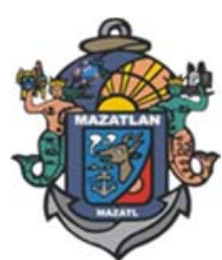

Legislación, Valores Sociales y Educación Ambiental 

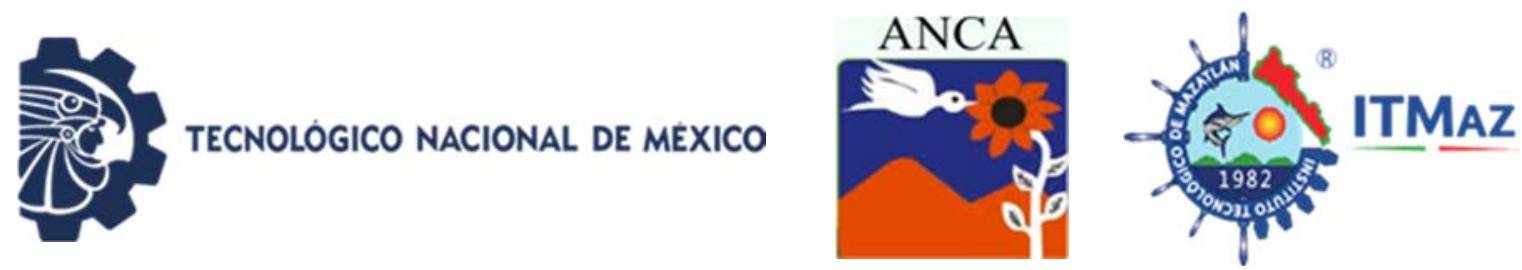

\title{
Caracterización de la microbiota intestinal de roedores expuestos a metales pesados en los jales de Huautla, Morelos
}

\author{
Santana Flores D*, Mussali Galante P, Dantán Gonzalez E, \\ Tovar Sánchez E, Ochoa Leyva A, Flores Trujillo K
}

Centro de Investigación en Biotecnología.

Centro de Investigación en Biodiversidad y Conservación.

Universidad Autónoma del Estado de Morelos. Av. Universidad 1001, Col.

Chamilpa, C.P. 62209. Cuernavaca, Morelos

Instituto de Biotecnología, Universidad Nacional Autónoma de México.

Av. Universidad 1001, Col. Chamilpa, C.P. 62209. Cuernavaca, Morelos

*damarisa_santana@hotmail.com

\section{RESUMEN}

La exposición ambiental a metales pesados puede generar alteraciones severas sobre la salud de los organismos expuestos. La absorción de metales pesados resulta en su acumulación en distintos órganos entre ellos hígado e intestino, donde pueden tener un impacto directo sobre la microbiota intestinal, la cual juega un papel importante en la homeostasis y en procesos fisiológicos del individuo. El objetivo de esta investigación es analizar el efecto de la bioacumulación de los metales pesados sobre la diversidad de la microbiota intestinal del roedor $L$. irroratus que habita en zonas mineras abandonadas del Estado de Morelos. El presente trabajo se llevó a cabo en los desechos mineros (jales) que se encuentran en la localidad de Huautla, Morelos donde se colectaron 15 roedores $L$. irroratus. Posteriormente, se extrajo ADN de las heces de los roedores para su secuenciación en la unidad de secuenciación masiva del Instituto de Biotecnología de la UNAM. Para medir la bioacumulación de los metales pesados en hígado e intestino, éstos fueron sometidos a digestión acida en un horno de microondas Accelerated Reaction System con una mezcla de $\mathrm{HNO}_{3}$ al $65 \%$ y $\mathrm{HCl}$ al $37 \%$ en bombas de teflón cerradas. Una vez que la muestra se solubilizó fue disuelta en un volumen final de $50 \mathrm{~mL}$ y se analizó la concentración de los metales pesados $(\mathrm{Cu}, \mathrm{Cd}, \mathrm{Pb}$ y Zn) mediante espectrofotometría de absorción atómica.

Palabras clave: Roedores, metales pesados, microbiota.

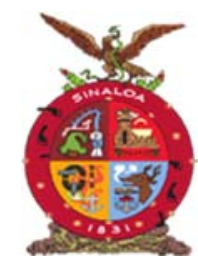

XVIII Congreso Internacional

XXIV Congreso Nacional de Ciencias ambientales

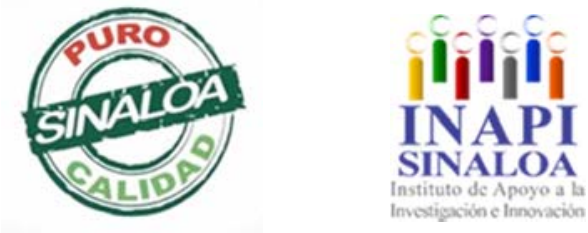

Mazatlán, Sinaloa 3-7 junio 2019

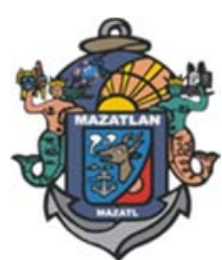

Legislación, Valores Sociales y Educación Ambiental 

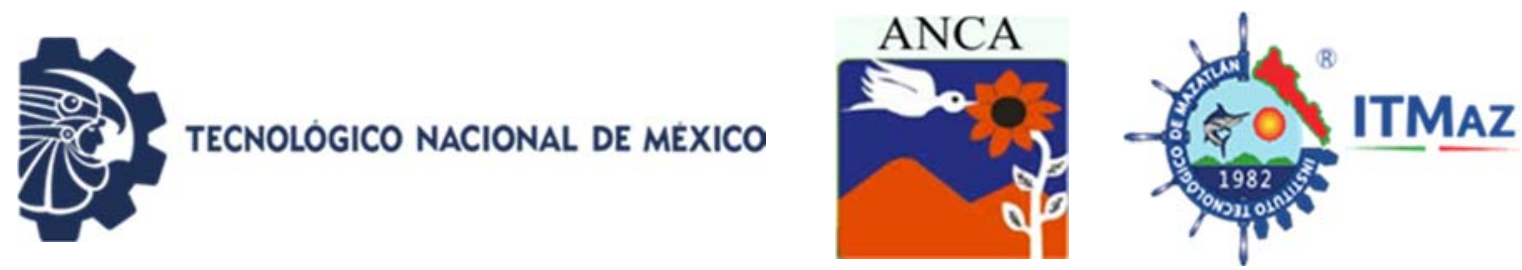

\title{
Characterization of the intestinal microbiota of rodents exposed to heavy metals in the tailings of Huautla, Morelos
}

\author{
Santana Flores D*, Mussali Galante P, Dantán Gonzalez E, \\ Tovar Sánchez E, Ochoa Leyva A, Flores Trujillo K
}

Centro de Investigación en Biotecnología.

Centro de Investigación en Biodiversidad y Conservación.

Universidad Autónoma del Estado de Morelos. Av. Universidad 1001, Col.

Chamilpa, C.P. 62209. Cuernavaca, Morelos

Instituto de Biotecnología, Universidad Nacional Autónoma de México.

Av. Universidad 1001, Col. Chamilpa, C.P. 62209. Cuernavaca, Morelos

*damarisa_santana@hotmail.com

\begin{abstract}
The environmental exposition to heavy metals can generate severe alterations on the health of the exposed organisms. The absorption of heavy metals results in their accumulation in different organs including liver and intestine, where they can have a direct impact on the gut microbiota, which plays an important role in the homeostasis and physiological processes of the individual. The objective of this research is to analyze the effect of the bioaccumulation of heavy metals on the diversity of the intestinal microbiota of the rodent $L$. irroratus that lives in abandoned mining areas of the State of Morelos. The present work was carried out in the mining waste (tailings) that are found in the town of Huautla, Morelos where 15 rodents $L$. irroratus were collected. Subsequently, DNA was extracted from the stool of rodents for sequencing in the massive sequencing unit of the Institute of Biotechnology of the UNAM. To measure the bioaccumulation of heavy metals in liver and intestine, they were subjected to acid digestion in an Accelerated Reaction System microwave oven with a mixture of $65 \% \mathrm{HNO} 3$ and $37 \% \mathrm{HCl}$ in closed Teflon pumps. Once the sample was solubilized it was dissolved in a final volume of $50 \mathrm{~mL}$ and the concentration of heavy metals $(\mathrm{Cu}, \mathrm{Cd}, \mathrm{Pb}$ and $\mathrm{Zn})$ was analyzed by atomic absorption spectrophotometry.
\end{abstract}

Keywords: Rodents, heavy metals, microbiota.

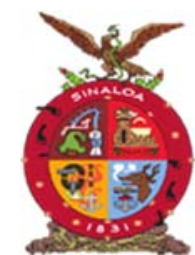

XVIII Congreso Internacional

XXIV Congreso Nacional de Ciencias ambientales
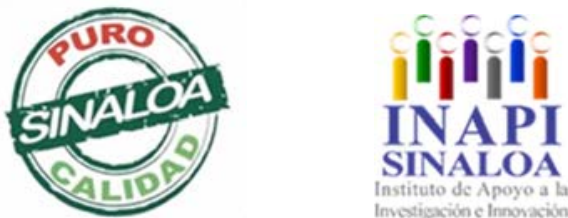

Mazatlán, Sinaloa 3-7 junio 2019

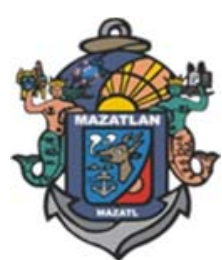

Legislación, Valores Sociales y Educación Ambiental 

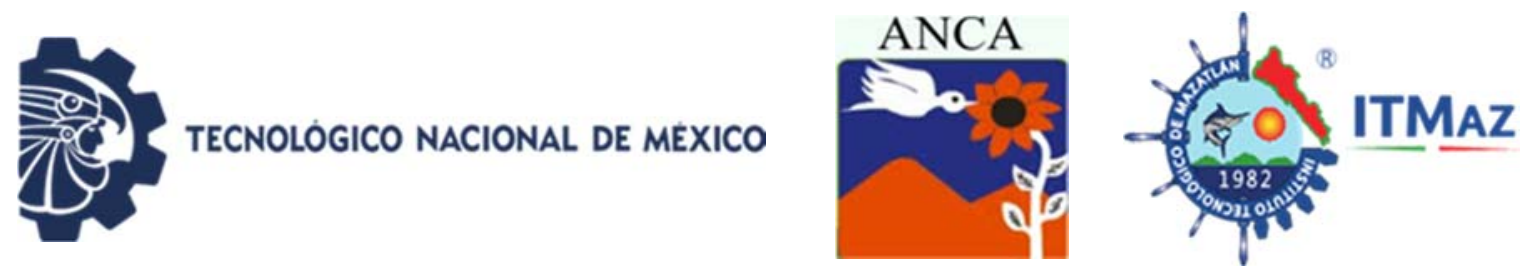

\title{
Propuesta de ordenamiento ecológico territorial como estrategia de mitigación y adaptación al cambio de uso de suelo por actividad florícola
}

\author{
Serrano Gonzaga R*, Alcántara Ángeles A \\ Universidad Autónoma del Estado de México \\ *raserranog@uaemex.mx
}

\begin{abstract}
RESUMEN
En la actualidad, el crecimiento de huertas en el sur del Estado de México deriva del sector agrícola en invernaderos, asociados a las condiciones favorables del clima y suelos ricos en materia orgánica. Por lo anterior, se emplean fertilizantes para mejorar la productividad de la siembra de la flor principalmente en la subcuenca del río Amacuzac, generando el cambio de uso de suelo del bosque de la montaña por usos agrícolas. El objetivo de esta investigación es realizar una propuesta con marco metodológico del programa de Ordenamiento Ecológico-Territorial para formular estrategias de mitigación y/o adaptación al cambio de uso de suelo por la actividad Florícola, Estado de México en el periodo de 2017 a 2019. Para ello se aplicará el análisis multicriterio-multiobjetivo como eje metodológico en la construcción de un modelo de Ordenamiento Ecológico, el cual considere los intereses y conflictos de los diferentes sectores para encontrar el mejor arreglo espacial y dar un uso adecuado del territorio. Es así que el Ordenamiento Ecológico, como herramienta de gestión, entrelazar la problemática con los intereses y conflictos de los distintos sectores; y provea los mecanismos para gestionar el uso racional de la ocupación del suelo mediante el análisis de aptitud, se utilizará como un proceso confiable para obtener el análisis socioeconómico y geográfico apegado a las políticas de planificación y manejo sustentable además de contribuir a las estrategias de mitigación y/o adaptación a este proceso.
\end{abstract}

Palabras clave: Ordenamiento, cambio de uso de suelo, subcuenca, invernaderos, análisis multicriterio.

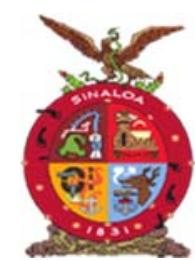

XVIII Congreso Internacional

XXIV Congreso Nacional de Ciencias ambientales
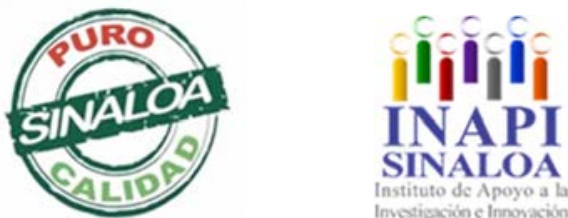

Mazatlán, Sinaloa 3-7 junio 2019

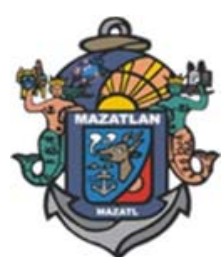

Legislación, Valores Sociales y Educación Ambiental 

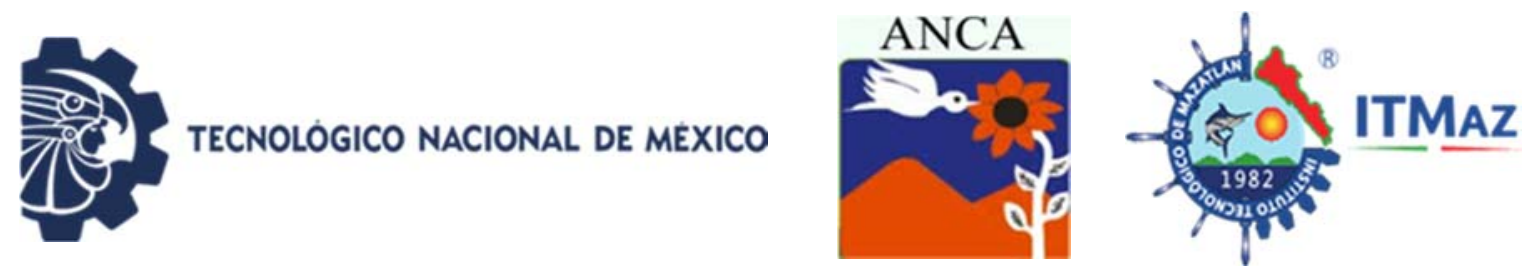

\title{
Proposal of territorial ecological ordering as a mitigation strategy and adaptation to the change of land use by floricultural activity
}

\author{
Serrano Gonzaga R*, Alcántara Ángeles A \\ Universidad Autónoma del Estado de México \\ *raserranog@uaemex.mx
}

\begin{abstract}
At present, the growth of orchards in the south of the State of Mexico derives from the agricultural sector in greenhouses, associated with favorable weather conditions and soils rich in organic matter. Therefore, fertilizers are used to improve the productivity of planting the flower mainly in the sub-basin of the Amacuzac River, generating the change of land use of the mountain forest for agricultural uses. The objective of this research is to make a proposal with a methodological framework of the Ecological-Territorial Planning program to formulate mitigation strategies and / or adaptation to the change of land use by the Floricultural activity, State of Mexico in the period from 2017 to 2019. For this, the multicriteria-multiobjective analysis will be applied as a methodological axis in the construction of an Ecological Planning model, which considers the interests and conflicts of the different sectors to find the best spatial arrangement and give adequate use of the territory. Thus, the Ecological Planning, as a management tool, intertwines the problem with the interests and conflicts of the different sectors; and provide the mechanisms to manage the rational use of land use through aptitude analysis, it will be used as a reliable process to obtain socioeconomic and geographical analysis attached to sustainable planning and management policies as well as contributing to mitigation strategies and / or adaptation to this process.
\end{abstract}

Keywords: Land use, land use change, sub-basin, greenhouses, multi-criteria analysis.

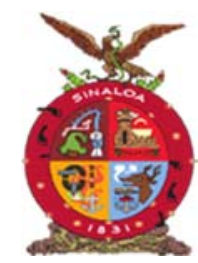

XVIII Congreso Internacional

XXIV Congreso Nacional de Ciencias ambientales
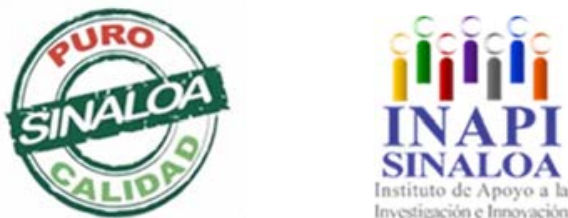

Mazatlán, Sinaloa 3-7 junio 2019

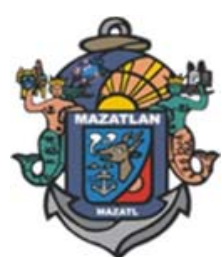

Legislación, Valores Sociales

y Educación Ambiental 

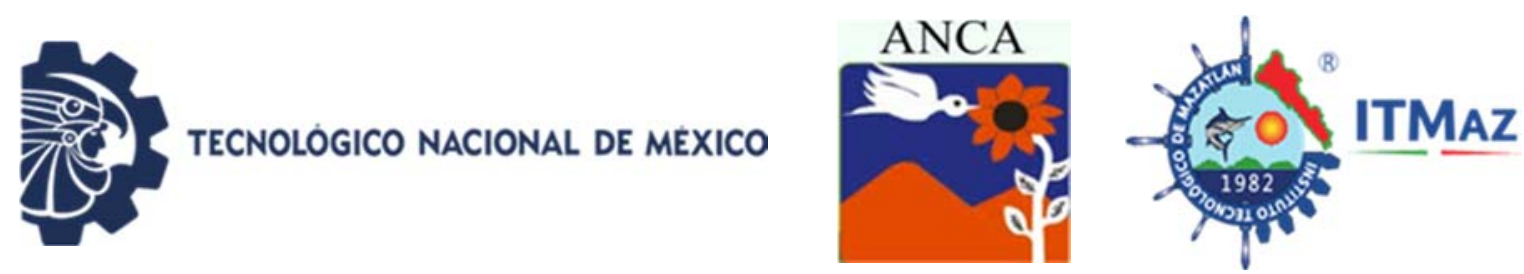

\title{
Diseño de un sistema de gestión ambiental para la Universidad del Noreste, Tampico, Tamaulipas
}

\author{
Torres Jiménez M*, Zepeda Orellan A, González González M \\ Universidad del Noreste \\ *mariotjim@hotmail.com
}

\begin{abstract}
RESUMEN
Un sistema de gestión ambiental es una estructura regulatoria que surge dentro de una organización para definir políticas, planeación e implementación de actividades que mejoran su desempeño ambiental. Actualmente la Universidad del Noreste no cuenta con un sistema que le permita conocer su situación ambiental actual ni el cumplimiento de los requisitos legales que le apliquen. El objetivo principal de esta investigación es proponer un sistema de gestión ambiental para las actividades educativas e institucionales de la Universidad del Noreste, para cumplir la normatividad ambiental mediante los criterios establecidos en la norma internacional ISO 14001;2015. La investigación se realizo en la Universidad del Noreste de Tampico, Tamaulipas en el periodo de junio a diciembre del 2018. Para diseñar el sistema de gestión ambiental se consultó el contenido de la norma mexicana NMX-SAA-14001-IMNC-2015, partiendo desde identificar el contexto de la organización y definiendo el alcance que tendrá el sistema en la Universidad, una matriz de evaluación de aspectos ambientales significativos, entre otros. Como parte de los resultados, se definió una política ambiental, se identificaron como aspectos ambientales significativos el uso de energía eléctrica, generación de residuos de manejo especial y generación de residuos peligrosos. Se identificaron los requisitos legales a nivel federal, estatal y municipal aplicables a la organización y se establecieron objetivos ambientales con controles operacionales para promover el cumplimiento legal. En base al diseño del sistema de gestión ambiental se concluye que se requiere el compromiso de la alta dirección para su correcta implementación y lograr la mejora continua.
\end{abstract}

Palabras clave: Desempeño ambiental, normatividad, aspectos ambientales significativos.

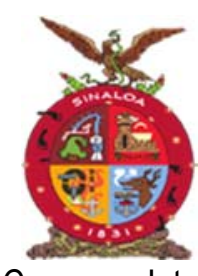

XVIII Congreso Internacional

XXIV Congreso Nacional de Ciencias ambientales
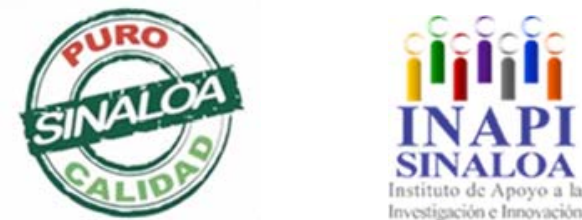

Mazatlán, Sinaloa 3-7 junio 2019

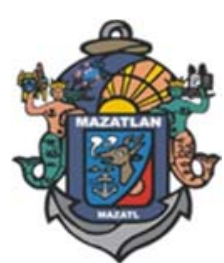

Legislación, Valores Sociales y Educación Ambiental 

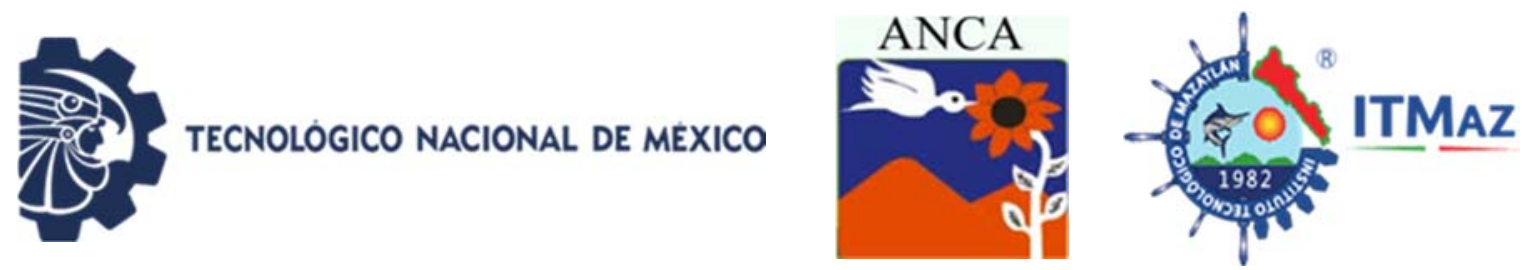

\title{
Design of an environmental management system for the Universidad del Noreste, Tampico, Tamaulipas
}

\author{
Torres Jiménez M, Zepeda Orellan A, González González M \\ Universidad del Noreste \\ *mariotjim@hotmail.com
}

\begin{abstract}
An environmental management system is a regulatory structure that arises within an organization to define policies, planning and implementation of activities that improve its environmental performance. Currently the University of the Northeast does not have a system that allows you to know your current environmental situation or compliance with the legal requirements that apply. The main objective of this research is to propose an environmental management system for educational and institutional activities of the University of the Northeast, to comply with environmental regulations through the criteria established in the international standard ISO 14001, 2015. The research was carried out at the Northeastern University of Tampico, Tamaulipas, from June to December 2018. In order to design the environmental management system, the content of the Mexican standard NMX-SAA-14001-IMNC-2015 was consulted, starting from identify the context of the organization and defining the scope that the system will have in the University, a matrix of evaluation of significant environmental aspects, among others. As part of the results, an environmental policy was defined, the use of electrical energy, generation of special handling waste and generation of hazardous waste were identified as significant environmental aspects. The legal requirements at federal, state and municipal levels applicable to the organization were identified and environmental objectives were established with operational controls to promote legal compliance. Based on the design of the environmental management system, it is concluded that the commitment of top management is required for its correct implementation and to achieve continuous improvement.
\end{abstract}

Keywords: Environmental performance, regulations, significant environmental aspects.

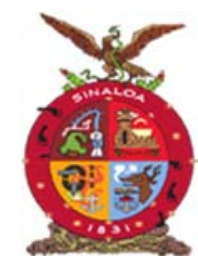

XVIII Congreso Internacional

XXIV Congreso Nacional de Ciencias ambientales
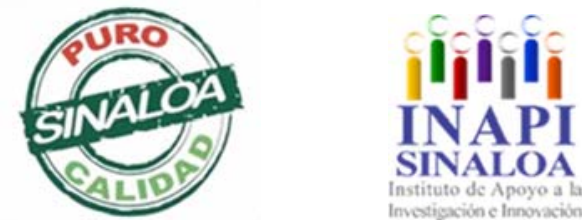

Mazatlán, Sinaloa 3-7 junio 2019

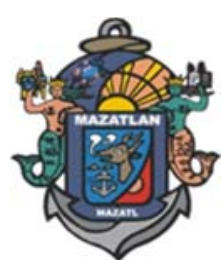

Legislación, Valores Sociales

y Educación Ambiental 

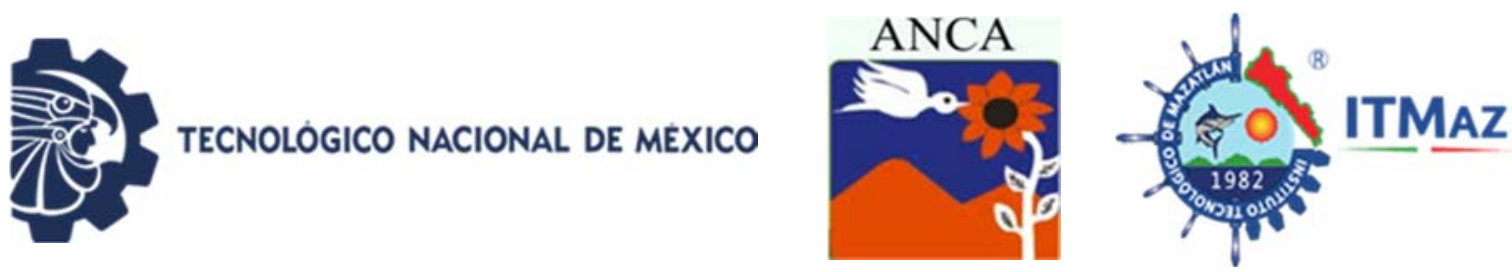

\title{
Variación microgeográfica en la condición corporal de tres especies de serpientes del Centro de México
}

\author{
Valencia Flores $\mathrm{E}^{1}$, Venegas Barrera $\mathrm{C}^{2}$, Fajardo $\mathrm{V}^{3}$, Manjarrez $\mathrm{J}^{1^{*}}$ \\ ${ }^{1}$ Facultad de Ciencias. Universidad Autónoma del Estado de México \\ 2 Tecnológico Nacional de México. Instituto Tecnológico de Ciudad Victoria \\ ${ }^{3}$ Facultad de Medicina Veterinaria y Zootecnia, UAEMex \\ *jsilva@uaemex.mx
}

\section{RESUMEN}

La variación geográfica en la condición corporal puede revelar una adaptación local diferencial a la disponibilidad de recursos o factores climáticos. El tamaño y la condición corporal están relacionados con la condición física en serpientes del genero Thamnophis, por lo que una buena condición corporal puede aumentar la supervivencia, la fecundidad en las hembras y el éxito reproductivo en los machos. Se predice que las especies filogenéticamente relacionadas en simpatría exhiben una condición corporal similar cuando experimentan condiciones ambientales similares. En este estudio nos enfocamos en la variación interespecífica y geográfica del tamaño y la condición corporal en tres serpientes simpátricas mexicanas del Centro de México. Se evaluaron la longitud hocico-cloaca, el peso y la condición corporal (residuales de una regresión del Logaritmo natural (Ln) del peso corporal sobre Ln-LHC) en adultos y juveniles de ambos sexos de las culebras Thamnophis eques, $T$. melanogaster y $T$. scalaris muestreados en diferentes localidades y años, dentro de un período de 20 años. Se encontró un patrón heterogéneo de variaciones en el estado reproductivo sexual y ontogénico del tamaño y la condición corporal entre las poblaciones de las culebras. Cada especie de serpiente mostró lugares con buena o mala condición corporal; las serpientes juveniles mostraron una condición corporal similar entre poblaciones, los adultos mostraron una condición corporal variable entre las poblaciones y los adultos también mostraron diferencias sexuales en la condición corporal. Discutimos las variaciones en la condición corporal como posiblemente relacionadas con las diferencias en el ciclo de vida de las serpientes.

Palabras clave: Thamnophis, variación geografica, variación interespecifica, estado reproductivo.

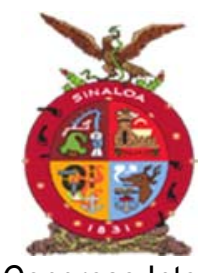

XVIII Congreso Internacional

XXIV Congreso Nacional de Ciencias ambientales
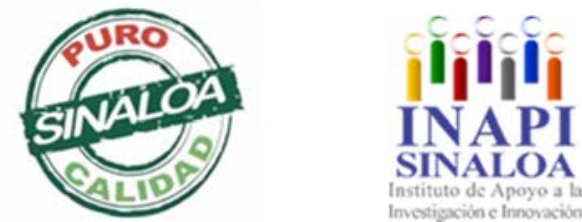

Mazatlán, Sinaloa 3-7 junio 2019

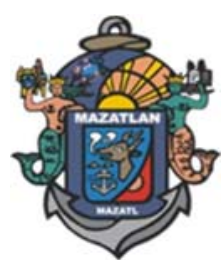

Legislación, Valores Sociales y Educación Ambiental 

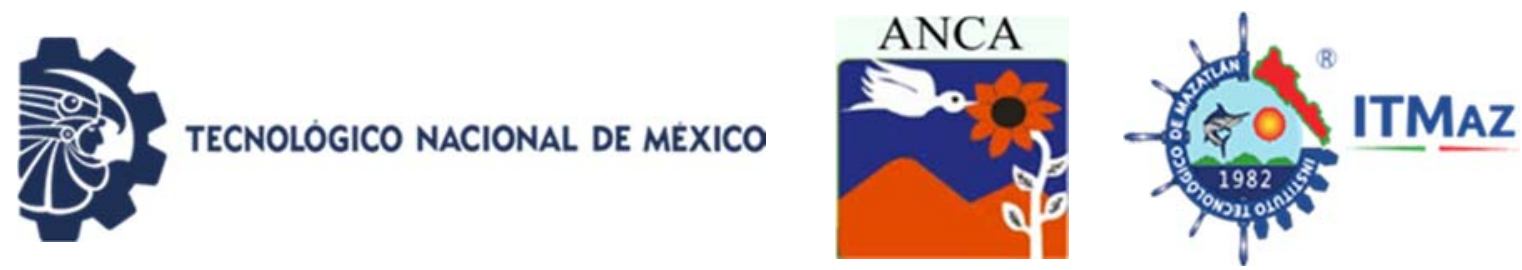

\title{
Microgeographic variation in body condition of three Mexican garter snakes in Central Mexico
}

\author{
Valencia Flores $\mathrm{E}^{1}$, Venegas Barrera $\mathrm{C}^{2}$, Fajardo $\mathrm{V}^{3}$, Manjarrez $\mathrm{J}^{1^{*}}$ \\ ${ }^{1}$ Facultad de Ciencias. Universidad Autónoma del Estado de México \\ 2 Tecnológico Nacional de México. Instituto Tecnológico de Ciudad Victoria \\ ${ }^{3}$ Facultad de Medicina Veterinaria y Zootecnia, UAEMex \\ *jsilva@uaemex.mx
}

\begin{abstract}
Geographic variation in body size and condition can reveal differential local adaptation to resource availability or climatic factors. Body size and condition are related to fitness in garter snakes (Thamnophis), thus good body condition may increase survival, fecundity in females, and mating success in males. Phylogenetically related species in sympatry are predicted to exhibit similar body condition when they experience similar environmental conditions. We focused on interspecific and geographical variation in body size and condition in three sympatric Mexican garter snakes from the highlands of Central Mexico. We assessed SVL, mass, and body condition (obtained from Major axis linear regression of In-transformed body mass on In-transformed SVL) in adults and juveniles of both sexes of Thamnophis eques, $T$. melanogaster, and $T$. scalaris sampled at different locations and ranges from 3-11 years over a 20-year period. We provide a heterogeneous pattern of sexual and ontogenic reproductive status variations of body size and condition among local populations. Each garter snake species shows locations with good and poor body condition; juvenile snakes show similar body condition between populations, adults show varying body condition between populations, and adults also show sex differences in body condition. We discuss variations in body condition as possibly related to the snakes' life cycle differences.
\end{abstract}

Key words: Thamnophis, geographical variation, interspecific variation, reproductive status.

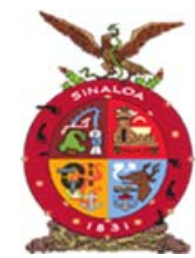

XVIII Congreso Internacional

XXIV Congreso Nacional de Ciencias ambientales
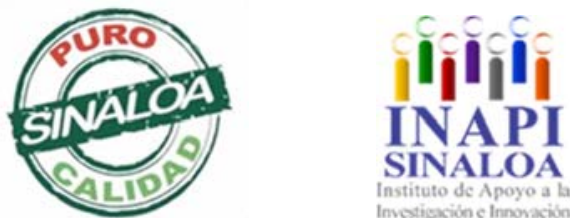

Mazatlán, Sinaloa 3-7 junio 2019

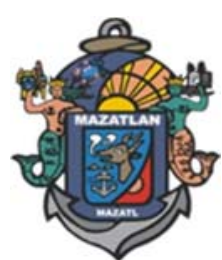

Legislación, Valores Sociales y Educación Ambiental 

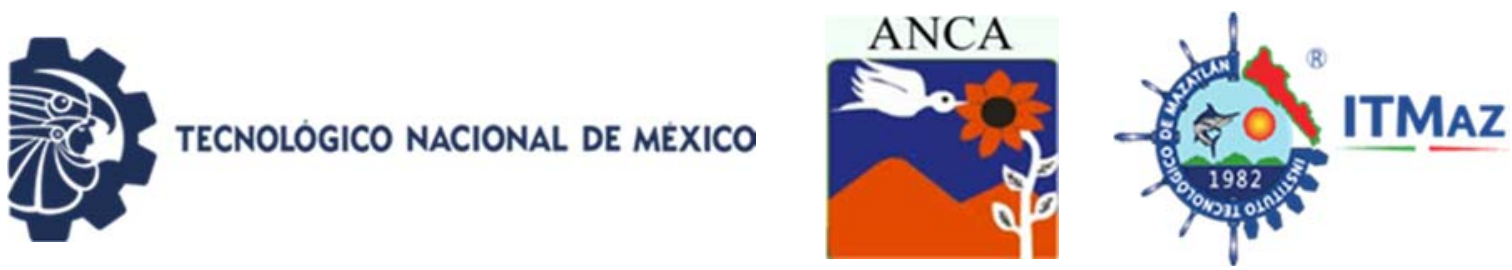

\title{
Responsabilidad social del sector hotelero en los Pueblos Mágicos del Estado de Morelos
}

\author{
Valero Ortiz S, Valladares Cisneros MG*, Medina Márquez MG, \\ Torres Salazar MC, León Hernández V, Viana Lases J \\ Maestría. Ingeniería Ambiental y Tecnologías Sustentables, \\ PITC Facultad de Ciencias Químicas e Ingeniería, \\ PITC Facultad de Arquitectura, \\ PITC Centro de Investigación en Ciencias Biológicas. \\ *mg.valladares@uaem.mx
}

\begin{abstract}
RESUMEN
"Pueblos Mágicos" interesante y beneficioso programa creado por el gobierno federal mexicano en el año 2001, para detonar los atributos simbólicos y las riquezas culturales y al mismo tiempo desarrollar una economía, mediante la generación de empleo tras incrementarse los servicios turísticos, demandado al mismo tiempo el desarrollo sustentable del sector turístico principalmente de las localidades mexicanas que han conservado a través del tiempo: tradición, cultura y sus recursos naturales. Por lo que es importante canalizar la atención requerida a los "Pueblos Mágicos" porque son sitios naturales de gran valor para nuestro país y hoy brindan servicios turísticos, por lo que se deben modificar, adaptar, y programar las actividades cotidianas, para cuidar los aspectos socioculturales y preservar el medio ambiental natural, que los caracteriza. Al no existir los indicadores específicos en materia de "Turismo Sustentable" que estén normativizados, a través de los cuales sea posible distinguir que se están aplicando prácticas de sustentabilidad en el servicio, y que hagan posible estimar el grado o nivel de aplicación. El presente estudio tuvo por objetivo analizar las prácticas sustentables que se realizan actualmente en diferentes hoteles de dos Pueblos Mágicos del estado de Morelos: Tepoztlán y Tlayacapan. El estudio se realizó a través de indicadores cualitativos y cuantitativos que permitieron diagnosticar el grado de sustentabilidad que guardan estos establecimientos. Los resultados preliminares muestran la necesidad de impulsar vínculos entre gobierno, comunidad y empresarios y para detonar en estos Pueblos Mágicos un desarrollo sustentable turístico en el sector hotelero.
\end{abstract}

Palabras clave: Turismo sustentable, hotel sector, responsabilidad social, legislación ambiental y pueblos mágicos.

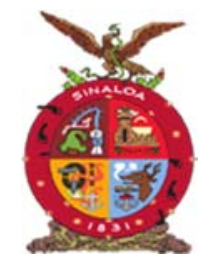

XVIII Congreso Internacional

XXIV Congreso Nacional de Ciencias ambientales

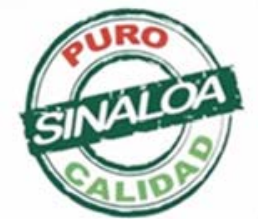

Mazatlán, Sinaloa 3-7 junio 2019

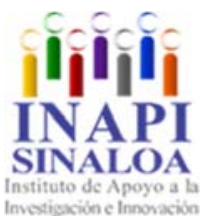

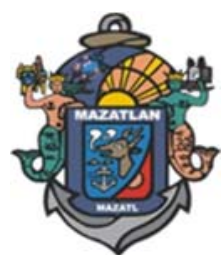

Legislación, Valores Sociales y Educación Ambiental 

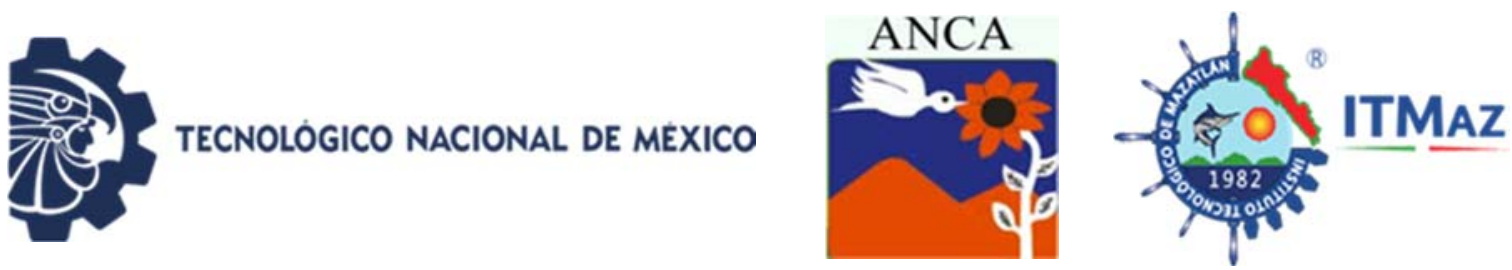

\title{
Social responsibility of the hotel sector in the Magic Towns from City of Morelos
}

\author{
Valero Ortiz S, Valladares Cisneros MG*, Medina Márquez MG, \\ Torres Salazar MC, León Hernández V, Viana Lases J \\ Maestría. Ingeniería Ambiental y Tecnologías Sustentables, \\ PITC Facultad de Ciencias Químicas e Ingeniería, \\ PITC Facultad de Arquitectura, \\ PITC Centro de Investigación en Ciencias Biológicas. \\ *mg.valladares@uaem.mx
}

\begin{abstract}
"Pueblos Magicos" is an interesting and beneficial program created by the Federal Mexican Government in 2001, to detonate the symbolic attributes and cultural richness and at the same time to develop an economy by employs generation to increasing of tourism services, that demanding the sustainable development in the hospitality sector to specially for Mexican localities that have been preserved over time: tradition, culture, but above all, their natural resources. That for important to funnel requiting attention to the "Pueblos Magicos" because are the natural sites to grant valium of our country and today offers hospitality services, that why should be management and modified, adapting and programmer of daily activities to care the sociocultural aspects and preserve the natural environment, that characterized them. In the absence of specific indicators on "Sustainable Tourism" that are regulated, through which it is possible to distinguish that apply the sustainable practices in the service, and that makes it possible to estimate the degree or level of application. The present study aimed to analyze the sustainable practices that are carried out currently in different hotels of two Magical Towns of the state of Morelos: Tepoztlán and Tlayacapan. It was carried out through qualitative and quantitative indicators that allowed to diagnose the degree of sustainability of these establishments keep. The preliminary results show the need to promote links between government, community, and businessmen and to detonate a sustainable tourism development in the hotel sector.
\end{abstract}

Keywords: Sustainable tourism, hotel sector, social, environmental legislation, magical towns.

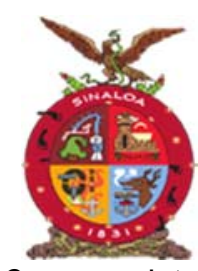

XVIII Congreso Internacional

XXIV Congreso Nacional de Ciencias ambientales
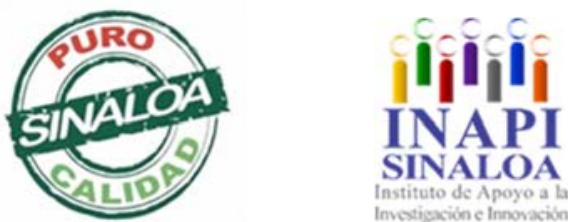

Mazatlán, Sinaloa 3-7 junio 2019

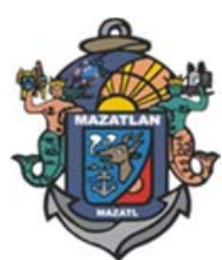

Legislación, Valores Sociales y Educación Ambiental 

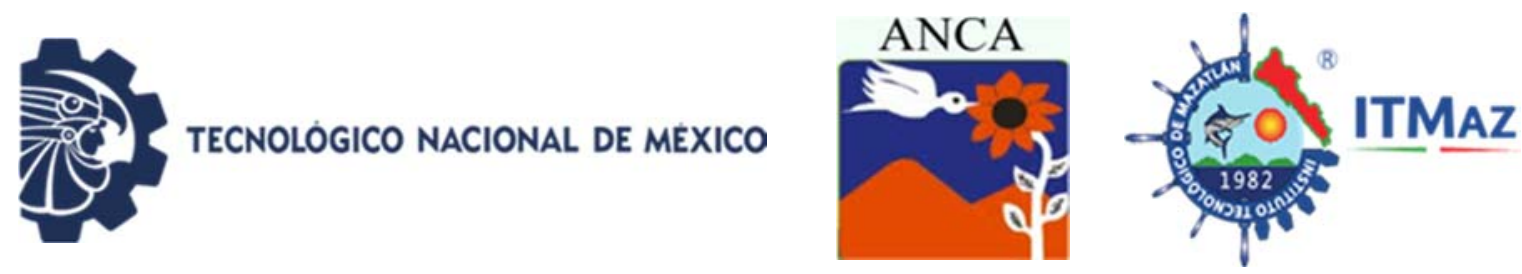

\title{
Actualización de plan de manejo de residuos de manejo especial en la industria de fabricación de película plástica
}

\author{
Vargas Nedzelsky $A E^{*}$ \\ Universidad del Noreste, \\ Prolongación Av. Hidalgo No. 6315, Nuevo Aeropuerto, 89337 Tampico, Tamps. \\ *alexia_vn1996@outlook.com

\section{RESUMEN}

Los residuos de manejo especial, al no ser catalogados como peligrosos o sólidos urbanos, presentan problemas al momento de ser aprovechados y terminan en rellenos sanitarios. Estos residuos se presentan comúnmente en la industria, por lo cual es importante contar con un plan de manejo actualizado que permita reducir y darles un uso a estos, evitando impactos al ambiente derivados de su disposición final. Durante el 2018 se trabajó con una empresa dedicada a la fabricación de película plástica, localizada en Altamira, Tamaulipas, para actualizar su plan de manejo para estos residuos. En base a la normatividad mexicana vigente, se realizaron varias visitas técnicas con el fin de recabar información de los residuos generados y las medidas tomadas con anterioridad para el aprovechamiento de estos. En total se identificaron 29 tipo de residuos, de los cuales 21 se consideraron para el plan de manejo. Como resultado, se elaboraron diversas estrategias de minimización para cada residuo, entre las cuales se incluyen capacitación al personal, mantenimiento a equipos y reutilización del material. Se espera que, a finales de 2019, la cantidad de cada residuo disminuya entre un $2 \%$ a un $5 \%$ de su generación.

Palabras clave: Residuo, plan de manejo, industria.

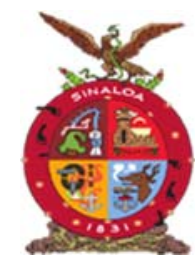

XVIII Congreso Internacional XXIV Congreso Nacional de Ciencias ambientales
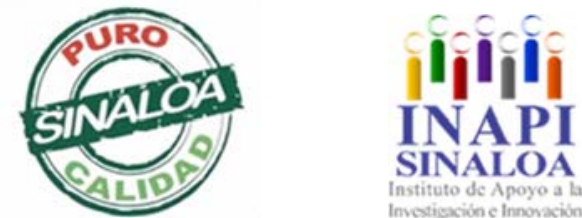

Mazatlán, Sinaloa 3-7 junio 2019

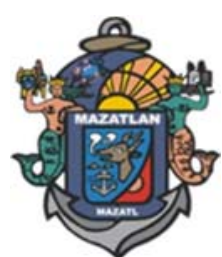

Legislación, Valores Sociales y Educación Ambiental 

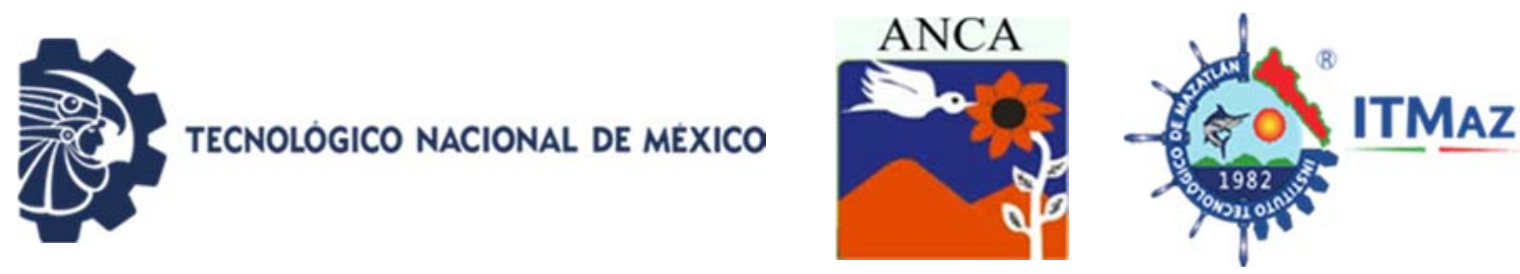

\title{
Update of management plan of waste of special management in the industry of plastic film manufacturing
}

\author{
Vargas Nedzelsky $A E^{*}$ \\ Universidad del Noreste, \\ Prolongación Av. Hidalgo No. 6315, Nuevo Aeropuerto, 89337 Tampico, Tamps. \\ *alexia_vn1996@outlook.com
}

\begin{abstract}
Special handing waste, not being cataloged like dangerous or solid urban waste, present challenges when trying to find a use for them and end up in landfills. This type of waste is commonly generated in the industry, which is why it is important to have an updated management plan that allows to reduce and reuse them, preventing environmental issues from their disposal. Through 2018, we worked with a company dedicated to the manufacture of plastic film, located in Altamira, Tamaulipas, to update their waste management plan. Based on the current Mexican regulations, several visits were made in order to collect information on the waste generation and measures taken previously for the use of these. In total, 29 types of waste were identified, of which 21 were classified for the management plan. As a result, various minimization strategies were developed for each waste, including personnel training, equipment maintenance and material reuse. It is expected that, at the end of 2019, the amount of each type of waste will decrease between $2 \%$ and $5 \%$.
\end{abstract}

Keywords: Waste, management plan, industry.

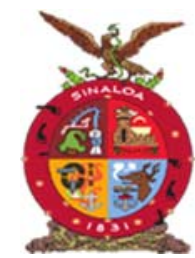

XVIII Congreso Internacional

XXIV Congreso Nacional de Ciencias ambientales

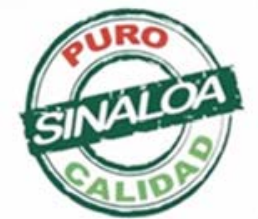

Mazatlán, Sinaloa 3-7 junio 2019

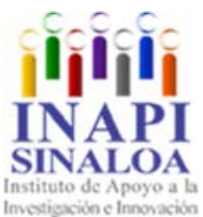

nintituto de Apoyo a

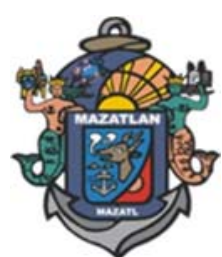

Legislación, Valores Sociales y Educación Ambiental 

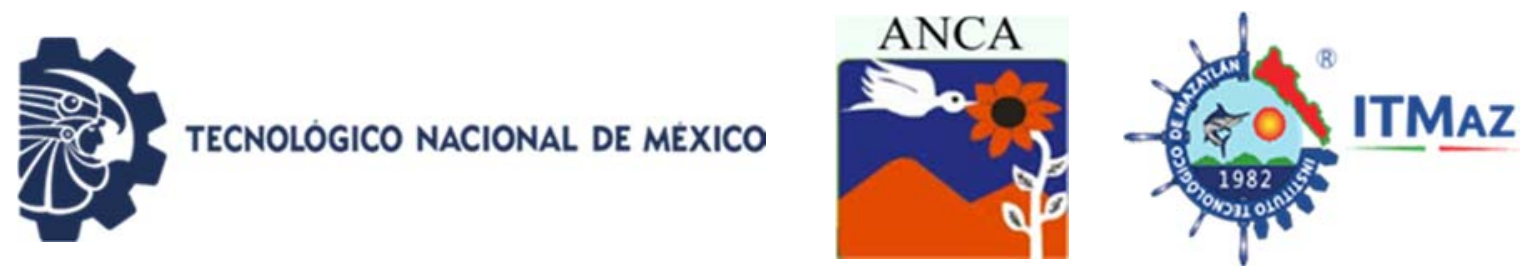

\title{
Ambiente físico y clima-organizacional sobre bienestar educativo en estudiantes de una institución de diversidad cultural, Mochis, Sinaloa
}

\author{
Viramontes Olivas OA*, Galaviz Acosta S, López Felix G \\ Universidad Autónoma Intercultural de Sinaloa \\ Universidad Autónoma de Chihuahua. \\ *viramontes@uais.edu.mx
}

\section{RESUMEN}

El ambiente físico donde se desarrollan actividades académicas y deportivas influye sobre los estudiantes en la motivación por encontrar condiciones de limpieza, mantenimiento de baños, aulas iluminadas, ventiladas, con equipo necesario (cañón, pantallas, internet, computadoras), agua potable, oficinas, patios, jardines, cafetería, auditorios, áreas externas y perimetrales limpios, que ofrezcan un Clima Organizacional (Co) armonioso y confortable. El objetivo fue determinar la influencia del ambiente físico (Af) y Co, sobre el bienestar estudiantil en ambientes de diversidad cultura. Se aplicó un instrumento de encuesta de escala Likert (siete grados de medición); para la obtención de muestra, fue por Muestreo Aleatorio Estratificado por Afijación Proporcional $n=1,176$ de $N=5,375$ con nivel de confianza (97\%), con margen de error (2.8\%), aplicando un modelo de correlación lineal de Pearson. El $67.8 \%$ sintió estar de moderado a muy satisfecho; $16.4 \%$, no le interesa involucrarse en estos temas y $15.8 \%$, está de moderada a muy insatisfechos. Las correlaciones encontradas entre Af y Co, fueron estadísticamente significativas $(P<0.01)$, con una correlación lineal Pearson $r=0.796$, lo que significa que Af aporta positivamente al mejoramiento de Co. Mantener condiciones funcionales en Af, contribuirá a mejorar el Co, ofreciendo alternativas de confort y salud para estudiantes. Es la institución existen limitaciones materiales y humanas, pero no se debe descuidar el mantenimiento de edificios para proporcionar condiciones físicas adecuadas en aulas, ofreciendo espacios limpios, ordenados que contribuyan al bienestar de estudiantes.

Palabras clave: Confort, ventilación, iluminación, mantenimiento de instalaciones.

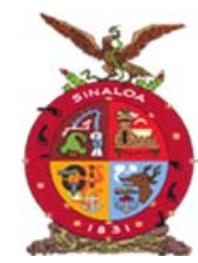

XVIII Congreso Internacional

XXIV Congreso Nacional de Ciencias ambientales
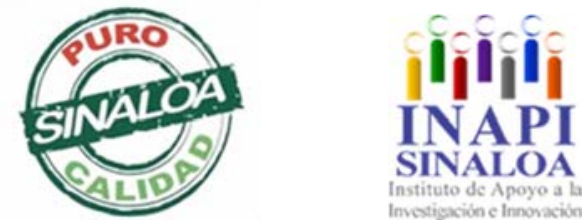

Mazatlán, Sinaloa 3-7 junio 2019

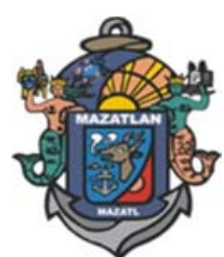

Legislación, Valores Sociales y Educación Ambiental 

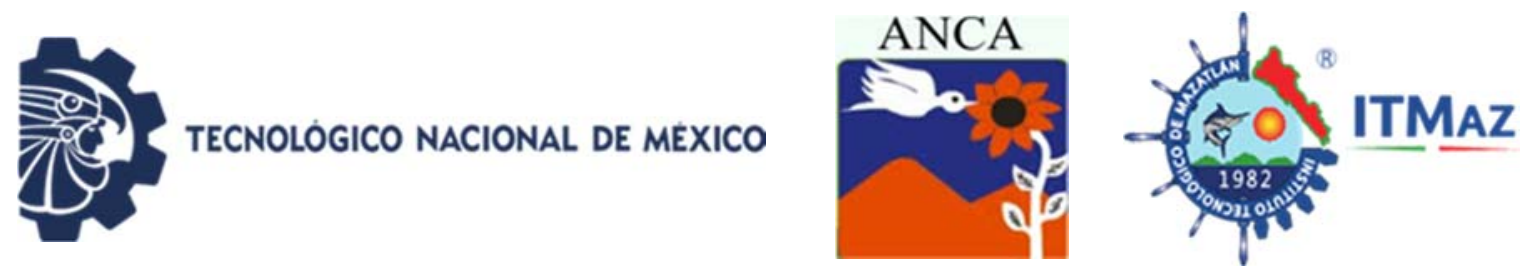

\title{
Physical and climate-organizational environment on educational well- being instudents of an institution of cultural diversity, Mochis, Sinaloa
}

\author{
Viramontes Olivas OA*, Galaviz Acosta S, López Felix G \\ Universidad Autónoma Intercultural de Sinaloa \\ Universidad Autónoma de Chihuahua. \\ *viramontes@uais.edu.mx
}

\begin{abstract}
The physical environment where academic and sports activities take place, influences students in the motivation to find cleaning conditions, maintenance of bathrooms, illuminated classrooms, ventilated, with necessary equipment (cannon, screens, internet, computers), drinking water, offices, courtyards, gardens, cafeteria, auditoriums, external and perimeter clean areas, that offer a harmonious and comfortable Organizational Climate (Co). The objective was to determine the influence of the physical environment (Af) and Co, on student welfare in environments of cultural diversity. A Likert scale survey instrument (seven measurement grades) was applied; to obtain the sample, it was by Random Sampling Stratified by Proportional Affiliation $n=1,176$ of $N=5,375$ with confidence level $(97 \%)$, with margin of error (2.8\%), applying a Pearson linear correlation model. $67.8 \%$ felt moderate to very satisfied; $16.4 \%$, is not interested in getting involved in these issues and $15.8 \%$ is moderate to very dissatisfied. The correlations found between Af and $\mathrm{Co}$, were statistically significant $(P<0.01)$, with a linear correlation Pearson $r=0.796$, which means that Af contributes positively to the improvement of Co. Keeping functional conditions in Af, will contribute to improve the Co, offering comfort and health alternatives for students. The institution has material and human limitations, but the maintenance of buildings must not be neglected to provide adequate physical conditions in classrooms, offering clean, orderly spaces that contribute to the well-being of students.
\end{abstract}

Keywords: Comfort, ventilation, lighting, maintenance of facilities.

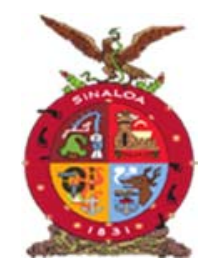

XVIII Congreso Internacional

XXIV Congreso Nacional de Ciencias ambientales
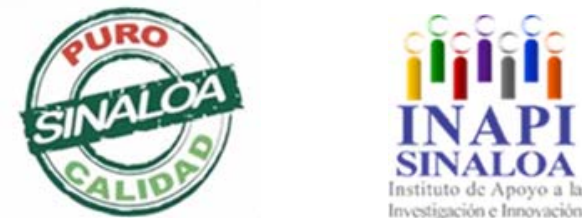

Mazatlán, Sinaloa 3-7 junio 2019

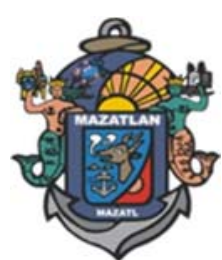

Legislación, Valores Sociales y Educación Ambiental 


\section{REVista I NTernacional de}

\section{CONTAMinación \\ AMBI Ental \\ volumen 36, 2020}

http://www.revistas. unam.mx/index. php/rica/

I V Medio Ambiente y Alimentación de Calidad con I nocuidad

ACademi a Naci onal de Cienci as Ambientales

XVIII CONGRESO INTERNACIONAL

XXIV CONGRESO NACIONAL

De Ciencias ambientales

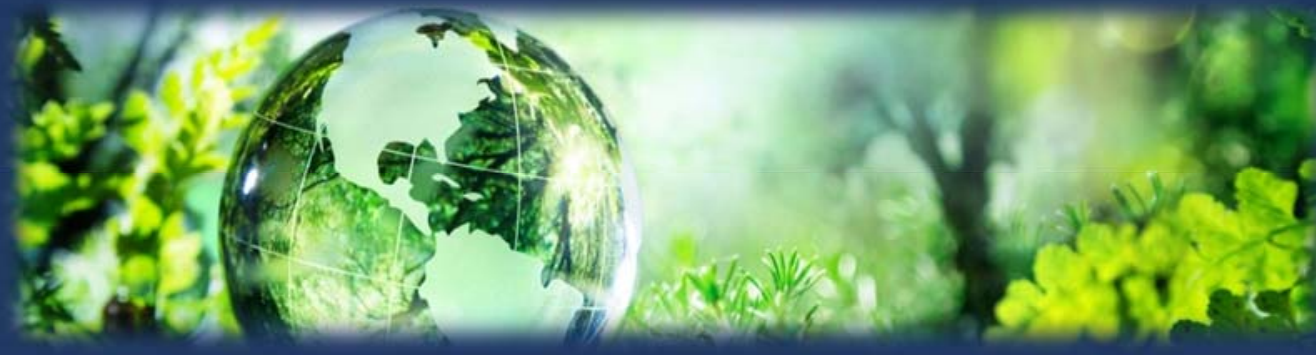

\section{Maratlán, Sinaloa \\ ila Perla del Paćfico!}

03-07 Junio/2019 
TECNOLOGICO NACIONAL DE MEXICO
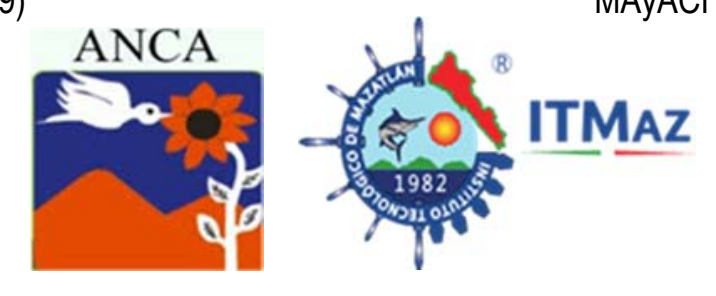

\title{
Certificaciones de calidad para las empresas turísticas de alimentos con inocuidad que midan la competitividad y sustentabilidad en Acapulco, Guerrero
}

\author{
Cortés-Badillo E, Mata-Carrillo E, López-Trejo M \\ Instituto Tecnológico de Acapulco \\ Av. Instituto Tecnológico S/N, Crucero de Cayaco. Acapulco, Gro., México, \\ elicorbad@gmail.com
}

\section{RESUMEN}

Se realizó una investigación en 2018 a empresas Turísticas del Estado de Guerrero que cuentan con establecimientos que expenden alimentos y bebidas, cuya preocupación es ofrecer a sus clientes un servicio de excelencia, aplicando prácticas que aseguren la inocuidad del lugar y a los alimentos. El enfoque del Distintivo H, Sistema de Gestión de Calidad enfoca las mejoras de las prácticas del personal, creando hábitos higiénicos, ayudando a la empresa a proporcionar un servicio o producto con inocuidad, y promueve el crecimiento hacia la dirección esperada. Contempla un programa de capacitación al personal operativo, al personal de mandos medios y altos. Analizar el impacto del Distintivo $\mathrm{H}$ en las empresas turísticas de Guerrero que ofrecen alimentos con inocuidad para medir su competitividad. Se utilizó el método cuantitativo para el análisis, tomando como base los parámetros numéricos para detectar los cambios que se presentaron en las organizaciones, empleando herramientas estadísticas para determinar la mejora presentada. De las visitas a las empresas turísticas evaluadas en relación al Distintivo $\mathrm{H}$, reflejaron una mejora a partir del punto de partida que inicio con el diagnóstico y la obtención de los porcentajes para poder obtenerlo. Se observó después de implementar el Distintivo H. Cuando una empresa que cuenta con una Certificación de Calidad en la Higiene de los Alimentos; mejora su servicio, incrementa sus utilidades, impulsa su estatus y el cliente logra la tranquilidad de que su salud está en buenas manos.

Palabras clave: Evaluación, higiene, alimentos y bebidas, empresas turísticas, sistema de gestión de calidad.

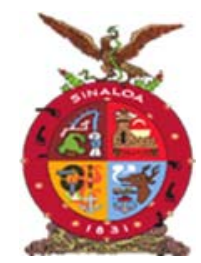

XVIII Congreso Internacional XXIV Congreso Nacional de Ciencias ambientales
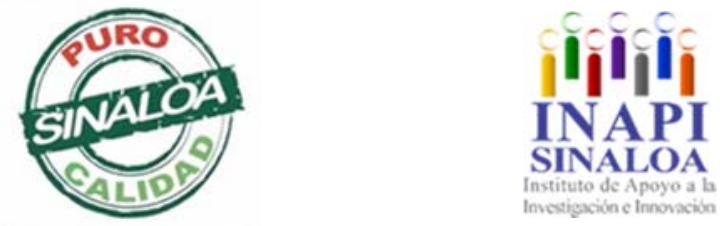

Mazatlán, Sinaloa 3-7 junio 2019

Medio Ambiente y

Alimentación de Calidad con Inocuidad 


\title{
TECNOLOGICO NACIONAL DE MEXICO
}
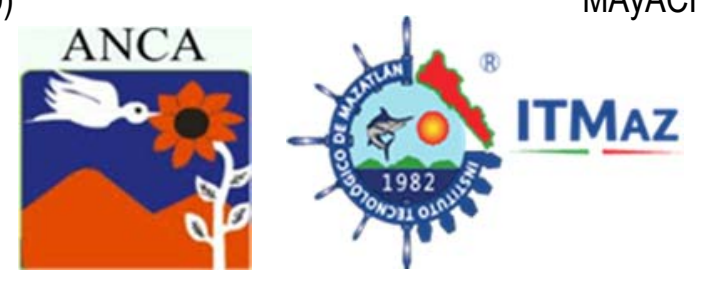

\section{Certifications of quality for tourism businesses of food safety that measure or its competitiveness and sustainability in Acapulco, Gro.}

\author{
Cortés-Badillo E, Mata-Carrillo E, López-Trejo M \\ Instituto Tecnológico de Acapulco \\ Av. Instituto Tecnológico S/N, Crucero de Cayaco. Acapulco, Gro., México, \\ elicorbad@gmail.com
}

\begin{abstract}
An investigation was carried out in 2018 to Tourist companies of the State of Guerrero that have establishments that sell food and drinks, whose concern is to offer their customers an excellent service, applying practices that ensure the safety of the place and food.. The focus of the $\mathrm{H}$ distinction, quality management system that improves the practices of staff, creating hygienic habits, is help the company to provide a service or product with safety, promoting growth the direction expected. It envisages a training program to operating personnel, middle and senior staff. Analyze the impact of the $\mathrm{H}$ distinction in tourist companies of warrior offering foods with safety to measure their competitiveness..: Quantitative method was used for the analysis, on the basis of the numerical parameters to detect changes that arose in organizations, having the support of statistical tools to determine the submitted improvement. Of visits to tourist companies evaluated in relation to the $\mathrm{H}$ distinction, reflected an improvement from the starting point that started with the diagnosis and the obtaining of the percentages to get it. This evaluation is observed after implementing distinctive $\mathrm{H}$. When a company has a quality certification of food hygiene: improves its service, increases profits, boosts their status and the client achieves the peace of mind that your health is in good hands.
\end{abstract}

Keywords: Evaluation, hygiene, food and beverages, tourism companies, quality management system.

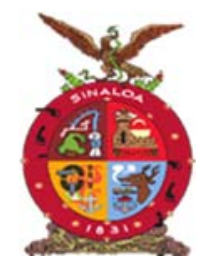

XVIII Congreso Internacional XXIV Congreso Nacional de Ciencias ambientales
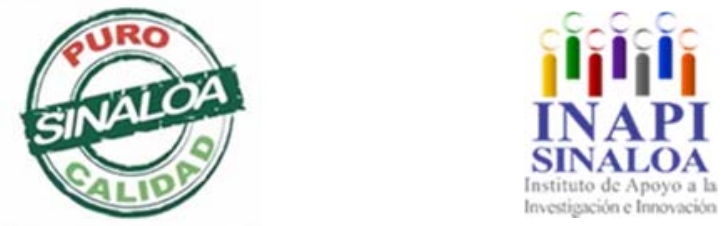

Mazatlán, Sinaloa 3-7 junio 2019

Medio Ambiente y

Alimentación de Calidad con Inocuidad 
TECNOLOGICO NACIONAL DE MEXICO
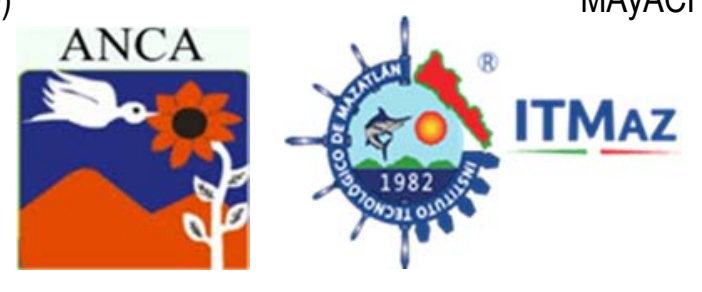

\title{
Perspectiva agroecológica e inocua para el control del gorgojo del Maíz (Sitophilus zeamais MOTSCHULSKY) para graneros tradicionales poco tecnificados
}

\author{
Filomeno-Marcelino E, Bernal-Mendoza H, Hernández-Linares G, \\ Calderón-Fernández L
}

BUAP. Puebla, México.

Complejo Regional Centro /ICUAP. BUAP. Puebla, México Laboratorio de Investigación del Jardín Botánico. BUAP. Puebla, México. Facultad de Ingeniería Química. BUAP. Puebla, México.

h_bernal@hotmail.com

\section{RESUMEN}

Ante una posible retracción de la agricultura convencional, basada en uso excesivo de agroquímicos, maquinaria y equipo de alto consumo energético por los efectos negativos en la salud medioambiental y humana, el presente estudio realizado en 2018, se centra en proteger granos básicos para la alimentación humana, particularmente maíz, por pérdidas frecuentemente considerables por plagas en almacenes tradicionales poco tecnificados. El control de "Gorgojo del maíz" (Sitophilus zeamais Motschulsky) ha sido principalmente con agroquímicos, no importando que se trate de granos para alimentación humana o para animales de autoconsumo, por lo que el objetivo se centró en evaluar la efectividad de dos plantas arvenses comunes en el centro de Puebla, México, el Eucalipto (Eucaliptus camaldulensis) y Chicalote (Argemone ochroleuca), y Neem (Azadirachta indica A. Juss), en condiciones poco controladas de temperatura y humedad relativa, análogas a la mayoría de los almacenes de los productores regionales del centro de Puebla. El diseño experimental fue completamente al azar y consistió de 7 tratamientos con 4 repeticiones y un testigo, preparando en laboratorio parejas fértiles de Sitophilus zeamais y evaluando mortalidad, emergencia, pérdida de peso y dureza del grano antes y después de la infestación. Los resultados demuestran que $A$. ochroleuca, puede controlar hasta el $31.25 \%$ de la incidencia de este insecto y combinado con $E$. camaldulensis puede dificultar la eclosión de $\mathrm{S}$. zeamais durante el almacenamiento, ya que este tratamiento solo permitió el $14.5 \%$ de eclosión de las parejas y menor pérdida de peso del grano.

Palabras clave: Agroecología, Sitophilus zeamais.

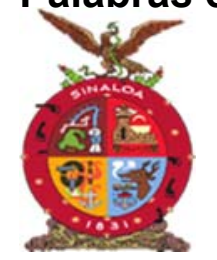

XVIII Congreso Internacional XXIV Congreso Nacional de Ciencias ambientales
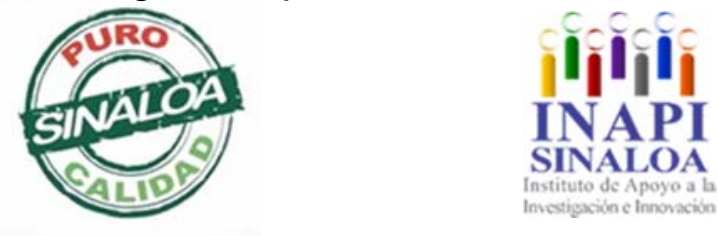
Mazatlán, Sinaloa 3-7 junio 2019

Medio Ambiente y Alimentación de Calidad con Inocuidad 
TECNOLOGICO NACIONAL DE MEXICO

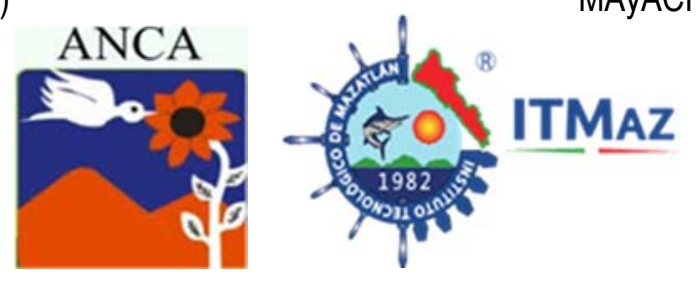

Agroecological and innocuous perspective for the control of the corn weevil (Sitophilus zeamais MOTSCHULSKY) for traditional low-tech barns

Filomeno-Marcelino E, Bernal-Mendoza H, Hernández-Linares G, Calderón-Fernández $\mathrm{L}$

BUAP. Puebla, México.

Complejo Regional Centro /ICUAP. BUAP. Puebla, México

Laboratorio de Investigación del Jardín Botánico. BUAP. Puebla, México.

Facultad de Ingeniería Química. BUAP. Puebla, México.

h_bernal@hotmail.com

\begin{abstract}
Before a possible retraction of conventional agriculture, based on excessive use of agrochemicals, machinery and equipment of high energy consumption due to the negative effects on environmental and human health, the present study carried out in 2018 , focuses on protecting basic grains for food human, particularly maize, for frequently considerable losses due to pests in traditional low tech stores. The control of "Corn weevil" (Sitophilus zeamais Motschulsky) has been mainly with agrochemicals, regardless of whether they are grains for human consumption or for self-consumption animals, so the objective was to evaluate the effectiveness of two weed plants common in the center of Puebla, Mexico, Eucalyptus (Eucaliptus camaldulensis) and Chicalote (Argemone ochroleuca), and Neem (Azadirachta indica A. Juss), under poorly controlled conditions of temperature and relative humidity, analogous to most warehouses the regional producers of the center of Puebla. The experimental design was completely random and consisted of 7 treatments with 4 repetitions and one control, preparing fertile pairs of Sitophilus zeamais in the laboratory and evaluating mortality, emergency, weight loss and grain hardness before and after the infestation. The results show that $A$. ochroleuca, can control up to $31.25 \%$ of the incidence of this insect and combined with $E$. camaldulensis can hinder the hatching of $\mathrm{S}$. zeamais during storage, since this treatment only allowed the $14.5 \%$ hatching of couples and less grain weight loss.
\end{abstract}

Keywords: Agroecology, Sitophilus zeamais.

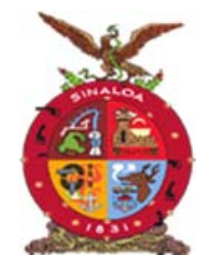

XVIII Congreso Internacional XXIV Congreso Nacional de Ciencias ambientales
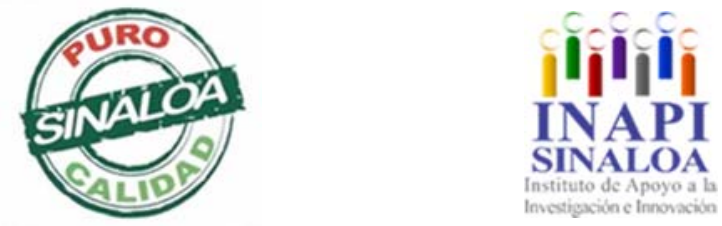

Mazatlán, Sinaloa 3-7 junio 2019

Medio Ambiente y 
TECNOLOGICO NACIONAL DE MEXICO
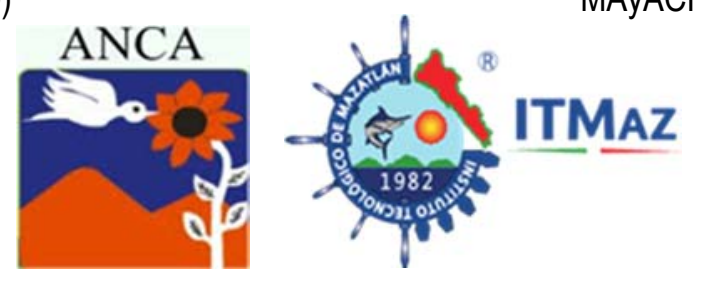

\title{
El huitlacoche (Ustilago maydis) como alternativa de producción de alimentos nutritivos y funcionales de bajo costo
}

\author{
Gámez-Domínguez V, Calderón-Fernández L, Bernal-Mendoza $\mathrm{H}$, \\ Hernández-Linares $\mathrm{G}$. \\ BUAP. Puebla, México. \\ Facultad de Ingeniería Química. BUAP. Puebla, México. \\ Complejo Regional Centro/ICUAP. BUAP. Puebla, México. \\ ICUAP-Laboratorio de Investigación del Jardín Botánico. BUAP. Puebla. \\ *malecafe@yahoo.com.mx
}

\begin{abstract}
RESUMEN
México enfrenta un gran problema de salud producido por una mala nutrición ocasionando desnutrición, sobrepeso y obesidad, y otras enfermedades no transmisibles como anemia, algunos tipos de cáncer, la diabetes tipo 2, hipertensión y enfermedades cardiovasculares, principalmente resultado de una inadecuada o insuficiente alimentación, debido a malos hábitos alimenticios, falta de ingresos económicos, poca disponibilidad de alimentos naturales. La producción de "huitlacoche" [Ustiligo maydis (DC) Corda] es una forma de producción económica, sostenible y alternativa importante para lograr una nutrición adecuada, debido a que cuenta con características sensoriales, nutritivas y funcionales importantes. Por ello, que en una localidad de la región de Acatzingo de Hidalgo, Puebla, se realizó en el año de 2017, un estudio de dos métodos de producción (espolvoreo e inyección), determinando que para su producción se pudo obtener ventaja de las condiciones climáticas de la región, las plagas que se presentaron se pudieron controlar fácilmente sin causar daño a la naturaleza, se utilizaron maíces de la región susceptibles al hongo: blanco, azul, cacahuacintle blanco y cacahuacintle morado, utilizando teliosporas y basidiosporas de la región. Se obtuvo un rendimiento de huitlacoche limpio de 30. $22 \mathrm{Kg} / \mathrm{ha}$, con $100 \%$ de infección en maíz cacahuacintle blanco y cobertura de huitlacoche del $75 \%$ de las mazorcas.
\end{abstract}

Palabras clave: Desnutrición, alimentos funcionales, desarrollo sustentable, seguridad alimentaria, soberanía alimentaria.

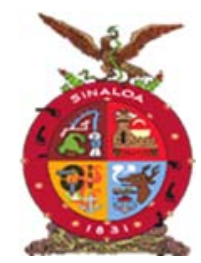

XVIII Congreso Internacional XXIV Congreso Nacional de Ciencias ambientales
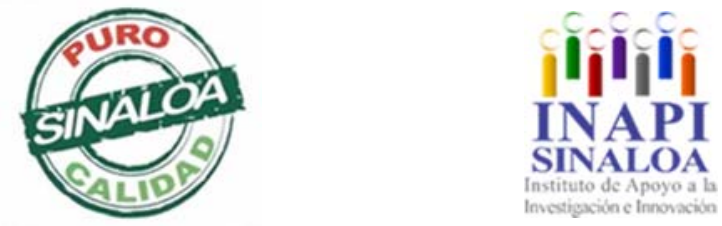

Mazatlán, Sinaloa 3-7 junio 2019

Medio Ambiente y

Alimentación de Calidad con Inocuidad 
TECNOLOGICO NACIONAL DE MEXICO
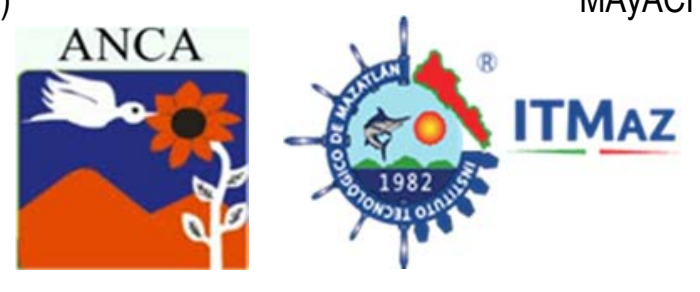

\title{
Huitlacoche (Ustilago maydis) as an alternative for the production of nutritious and functional food at low cost
}

\author{
Gámez-Domínguez V, Calderón-Fernández L, Bernal-Mendoza $\mathrm{H}$, \\ Hernández-Linares $\mathrm{G}$. \\ BUAP. Puebla, México. \\ Facultad de Ingeniería Química. BUAP. Puebla, México. \\ Complejo Regional Centro/ICUAP. BUAP. Puebla, México. \\ ICUAP-Laboratorio de Investigación del Jardín Botánico. BUAP. Puebla. \\ *malecafe@yahoo.com.mx
}

\begin{abstract}
Mexico faces a major health problem, caused by poor nutrition (malnutrition, overweight and obesity), and other non-communicable diseases (anemia, some types of cancer, type 2 diabetes, hypertension and cardiovascular diseases, mainly) resulting from inadequate or insufficient food, the result of various factors (bad eating habits, lack of income and little availability of natural foods, and problems that agriculture presents as scarce resources and extreme weather, which lead to insufficient food production). The production of "huitlacoche" [Ustiligo maydis (DC) Corda] is a form of economic production, sustainable and an important alternative to contribute to the sovereignty and food security, as well as to achieve adequate nutrition, because it has characteristics sensory, nutritious and functional important. For this reason, in a locality of the Acatzingo de Hidalgo region, Puebla, a study of two production methods (dusting and injection) was carried out in the year 2017 , determining that for its production it was possible to obtain advantage of the conditions climatic conditions of the region, pests that were presented could be easily controlled without causing harm to nature, were used maize from the region susceptible to the fungus (white, blue, white cacahuacintle and purple cacahuacintle), as well as teliospores and basidiospores of the region. And on the other hand a considerable amount of huitlacoche was obtained (clean huitlacoche yield of $30.22 \mathrm{Kg} /$ ha, with $100 \%$ infection in white cacahuacintle corn and $75 \%$ huitlacoche coverage of covered of the ears).
\end{abstract}

Keywords: Malnutrition, functional foods, sustainable development, food security, food sovereignty.

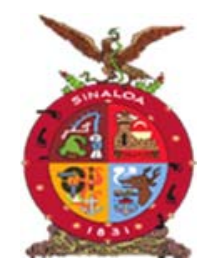

XVIII Congreso Internacional XXIV Congreso Nacional de Ciencias ambientales
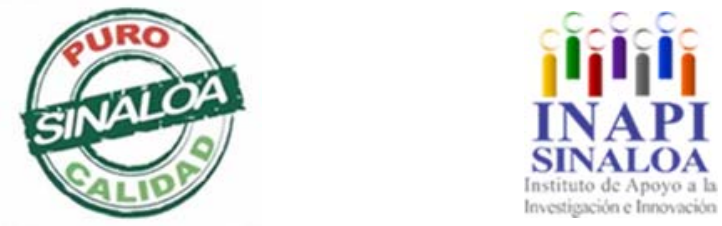

Mazatlán, Sinaloa 3-7 junio 2019

Medio Ambiente y

Alimentación de Calidad con Inocuidad 
TECNOLOGICO NACIONAL DE MEXICO
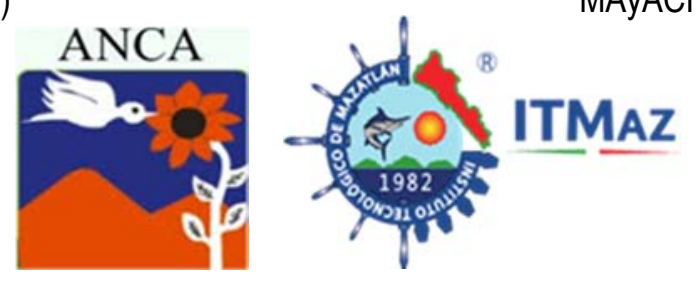

\section{Efecto de las bacterias promotoras del crecimiento vegetal en las plantas de frijol}

García-Mora L, Arenas-Espinosa R, Mendoza Hernández JC, Pérez-Osorio G, Castillo-Morales M

Facultad de Ingeniería Química. Benemérita Universidad Autónoma de Puebla. josecarlos.mendozahdez@gmail.com

\section{RESUMEN}

El crecimiento poblacional conlleva a lograr una seguridad agrícola y alimentaria dependiendo de la sociedad, cambio climático, los ecosistemas, las características del suelo y su biodiversidad microbiana. En la actualidad se deben tomar medidas y ampliar los estudios para asegurar la agricultura sustentable, entre lo que resalta la importancia de la relación entre los microorganismos rizosféricos, los procesos de mineralización y la coevolución con las plantas, por lo que se incrementa el estudio del uso de biofertilizantes como son las Bacterias Promotoras del Crecimiento Vegetal (BPCV). La intensificación agrícola sostenible es una estrategia importante para responder al reto combinado de lograr la seguridad alimentaria y la provisión de bienes públicos y servicios de los ecosistemas a la sociedad, incluyendo la mitigación y adaptación del cambio climático. El objetivo de este trabajo fue analizar el efecto de las BPCV en los cultivos de frijol. Las plantas de frijol fueron inoculadas con BPCV del género Serratia y Pantoea, en un ensayo por lotes y triplicado, cada maceta fue inoculada con $25 \mathrm{~mL}$ de bacterias en una concentración $1 \times 10^{9} \mathrm{UFC} / \mathrm{mL}$. A los frutos se les determinó el rendimiento y la calidad nutricional del mismo (micronutrientes, $\mathrm{N}$ y $P$ ). En las plantas inoculadas con las bacterias de ambos géneros se obtuvieron diferencias significativas en el crecimiento de la planta, el rendimiento del producto y la calidad nutricional fundamentalmente en $\mathrm{Fe}, \mathrm{N}$ y P. Las BPCV sirven como biofertilizantes para las plantas de frijol, mejorando el rendimiento de producción y la calidad nutricional de las mismas.

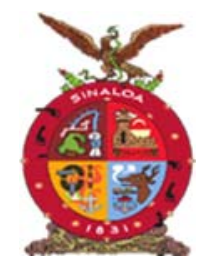

XVIII Congreso Internacional XXIV Congreso Nacional de Ciencias ambientales
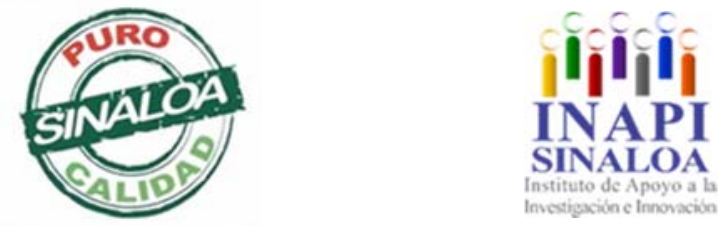

Mazatlán, Sinaloa 3-7 junio 2019

Medio Ambiente y

Alimentación de Calidad con Inocuidad 
TECNOLOGICO NACIONAL DE MEXICO

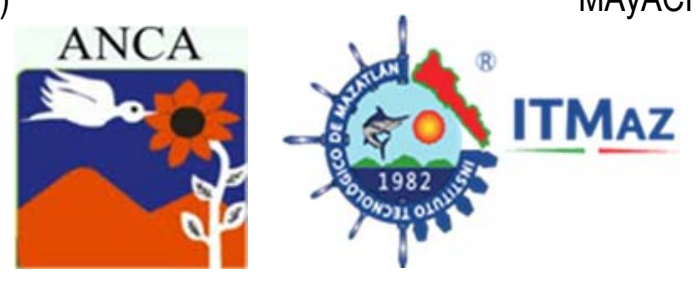

Effect of promoting bacteria of vegetable growth on bean plants

García-Mora L, Arenas-Espinosa R, Mendoza Hernández JC, Pérez-Osorio G, Castillo-Morales M

Facultad de Ingeniería Química. Benemérita Universidad Autónoma de Puebla. josecarlos.mendozahdez@gmail.com

\begin{abstract}
Population growth leads to achieving agricultural and food security depending on society, climate change, ecosystems, soil characteristics and microbial biodiversity. At present, measures must be taken and studies expanded to ensure sustainable agriculture, among which the importance of the relationship between rhizospheric microorganisms, mineralization processes and coevolution with plants stands out, which is why the study of the use of biofertilizers such as Plant Growth Promoting Bacteria (BPCV). Sustainable agricultural intensification is an important strategy to respond to the combined challenge of achieving food security and the provision of public goods and ecosystem services to society, including the mitigation and adaptation of climate change. To analyze the effect of BPCV on bean crops. The bean plants were inoculated with BPCV of the genus Serratia and Pantoea, in a batch and triplicate assay, each pot was inoculated with $25 \mathrm{~mL}$ of bacteria at a concentration of $1 \times 109 \mathrm{CFU} / \mathrm{mL}$. The fruits and their nutritional quality were determined (micronutrients, $N$ and $P$ ). In the plants inoculated with the bacteria of both genera, significant differences were obtained in the growth of the plant, the yield of the product and the nutritional quality fundamentally in Fe, N and P. The BPCV serve as biofertilizers for bean plants, improving the yield of production and the nutritional quality of the same.
\end{abstract}

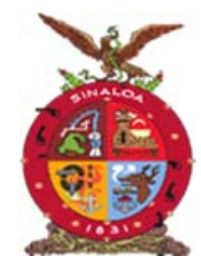

XVIII Congreso Internacional XXIV Congreso Nacional de Ciencias ambientales
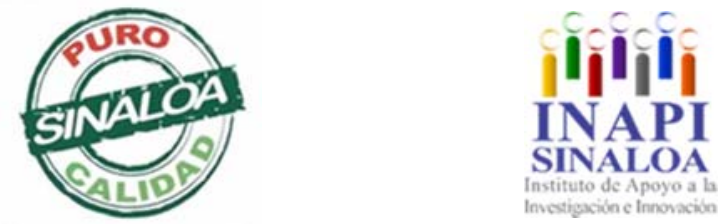

Mazatlán, Sinaloa 3-7 junio 2019

Medio Ambiente y

Alimentación de Calidad con Inocuidad 
TECNOLOGICO NACIONAL DE MEXICO
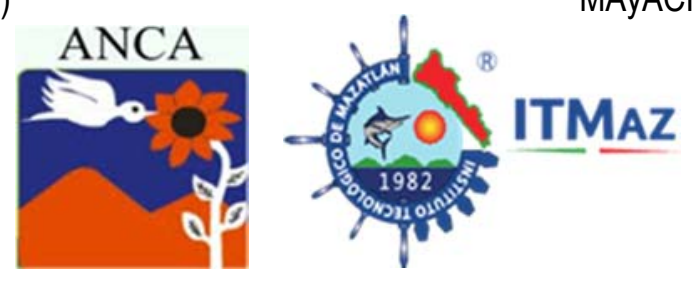

\title{
Variación de biomasa en almácigos de chile Guajillo por adición de aceites esenciales de orégano con distintas concentraciones de timol y carvacrol
}

\author{
González-Güereca MC, Chaírez-Hernández I, González-Maldonado MB, \\ Orea-Lara G, Muñoz-Ruiz CV, Marín-Tinoco RI \\ Instituto Politécnico Nacional, CIIDIR-Unidad Durango. \\ Instituto Politécnico Nacional, CIIDIR-Unidad Michoacán. \\ Universidad Tecnológica de Rodeo, Durango \\ celina.ciidirdgo@gmail.com
}

\begin{abstract}
RESUMEN
Actualmente se buscan alternativas naturales con productos compatibles al ambiente para el control de enfermedades o plagas que incrementen el rendimiento de los cultivos. Se evaluaron aceites esenciales del orégano silvestre (Lippia graveolens HBK) en los municipios de El Mezquital, Nombre de Dios y Lerdo en Durango, con distintas concentraciones de timol y carvacrol, con la finalidad de observar cambios en la producción de biomasa en fresco en almácigos de Capsicum annuum (Guajillo), bajo condiciones de invernadero. Analizando 250 plántulas de 145 días de edad, formando cinco grupos de acuerdo al tratamiento: tres con aceites esenciales, uno con fungicida comercial y un testigo, aplicándoles a partir de la aparición de las primeras cuatro hojas ocho fumigaciones quincenales de los formulados. Al final del experimento se obtuvo su peso en fresco, sus longitudes de la parte aérea y las raíces. El análisis comparativo de medias de Fisher para una $p<0.05$, demostraron que las plántulas tratadas con aceite esencial de orégano con $53.2 \%$ de timol y $6 \%$ de carvacrol, indujeron el mayor tamaño de plántulas comparadas con las del testigo. El tratamiento con aceite esencial de orégano sin carvacrol y $46 \%$ de timol, produjo plántulas de menor peso, incluso que el formulado con $2 \%$ de carvacrol y $41 \%$ de timol. El carvacrol es un compuesto clave en el aceite esencial de orégano, que podría mejorar la producción de plantas e incrementar los rendimientos de producción bajo condiciones de invernadero.
\end{abstract}

Palabras clave: Biomasa, chile Guajillo, orégano, timol, carvacrol.

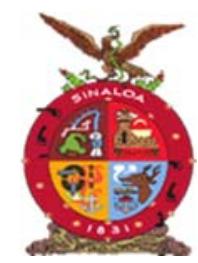

XVIII Congreso Internacional XXIV Congreso Nacional de Ciencias ambientales
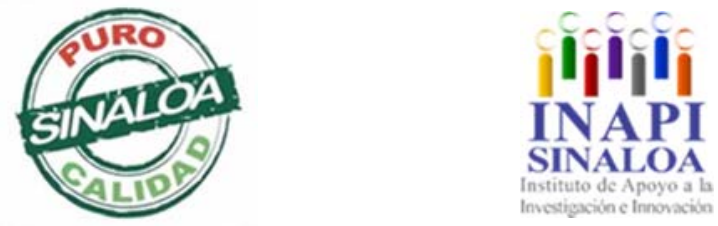

Mazatlán, Sinaloa 3-7 junio 2019

Medio Ambiente y Alimentación de Calidad con Inocuidad 

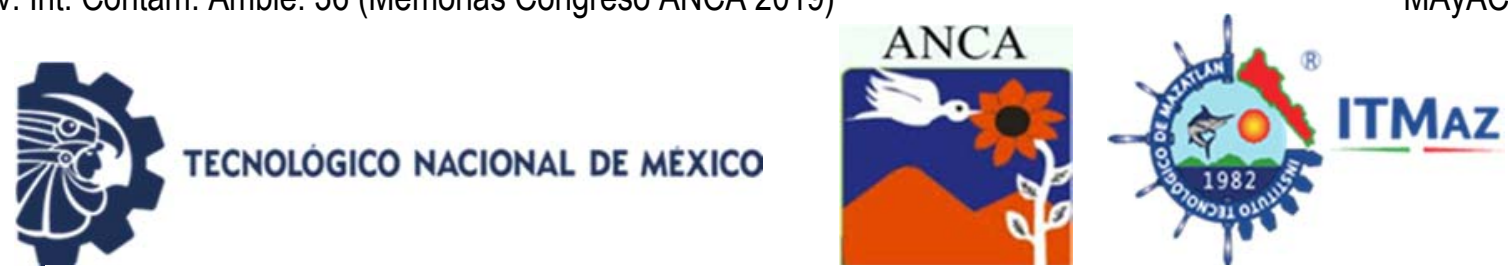

\title{
Biomass variation in Guajillo chili seedlings by the addition of oregano essential oils with different concentrations of thymol and carvacrol
}

\author{
González-Güereca MC, Chaírez-Hernández I, González-Maldonado MB, \\ Orea-Lara G, Muñoz-Ruiz CV, Marín-Tinoco RI
}

Instituto Politécnico Nacional, CIIDIR-Unidad Durango. Instituto Politécnico Nacional, CIIDIR-Unidad Michoacán.

${ }^{3}$ Universidad Tecnológica de Rodeo, Durango

celina.ciidirdgo@gmail.com

\begin{abstract}
Currently, natural alternatives with compatible products are sought for the control of disease, pests or additives to increase crop yields. Here essential oil of wild oregano (Lippia graveolens HBK) were evaluated from the municipalities of El Mezquital, Nombre de Dios and Lerdo in Durango, with different concentrations of thymol and carvacrol, in order to observe changes in the production of fresh biomass in seedlings of Capsicum annuum, variety Guajillo under greenhouse conditions. We analyzed 250 seedlings of 145 days of age, from the sowing in seed. Five groups were formed according to the treatment three with essential oils, a commercial fungicide and a control. Eight biweekly applications of the formulated ones were made from the appearance of the first four leaves. At the end of the experiment, their fresh weight, aerial part lengths and roots were obtained. Very significant data were found for $p<0.05$. The comparative analysis of Fisher's means showed that the seedlings treated with oregano essential oils with $53.2 \%$ thymol and $6 \%$ carvacrol, induced the largest seedling size compared with those of the control. The treatment with essential oil of oregano without carvacrol and $46 \%$ of thymol, produced seedlings of lower weight, even than the one formulated with $2 \%$ carvacrol and $41 \%$ thymol. Carvacrol is a key compound in the essential oil of oregano, which could improve plant production and increase production yields under greenhouse conditions.
\end{abstract}

Keywords: Biomass, Guajillo chili, oregano, Thymol, carvacrol.

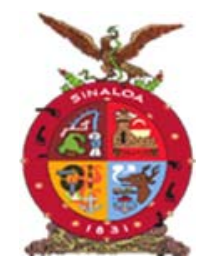

XVIII Congreso Internacional XXIV Congreso Nacional de Ciencias ambientales
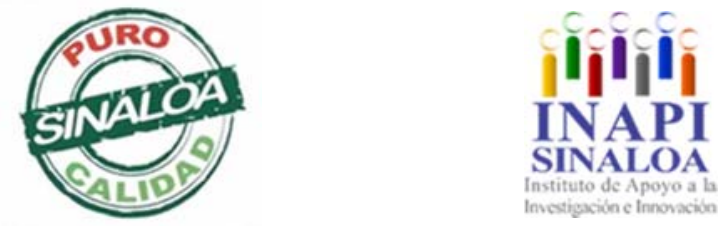

Mazatlán, Sinaloa 3-7 junio 2019

Medio Ambiente y

Alimentación de Calidad con Inocuidad 

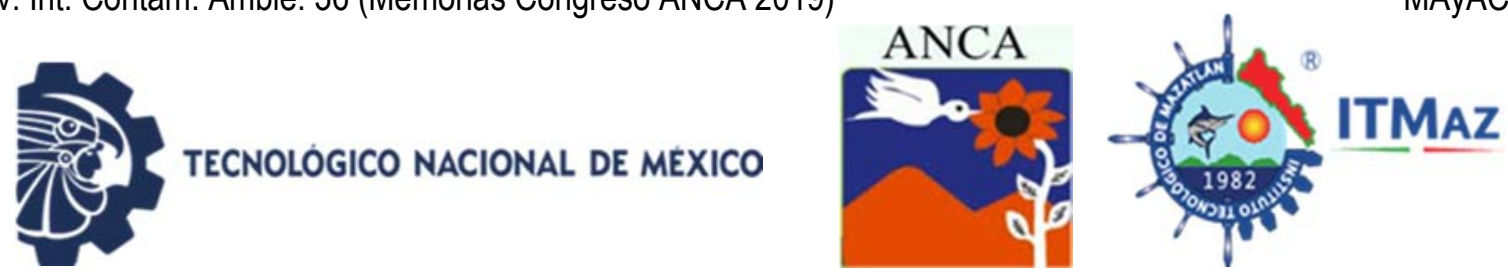

\title{
Inocuidad alimentaria del maíz a partir de la variabilidad genética de Chelonus sp. parásito del gusano cogollero.
}

\author{
González-Maldonado B, Hernández-Salinas U, González-Güereca C. \\ Doctorado en Biotecnología del Instituto Politécnico Nacional. \\ CIIDIR-IPN Unidad Durango. \\ Sigma 119, Fracc. 20 de Nov. II. C.P. 34234 Durango, Dgo. \\ bereciidir@hotmail.com
}

\section{RESUMEN}

Se determinó la variabilidad genética presente en Chelonus sp., parasitoides de gusano cogollero plaga de maíz en Durango, México empleando caracteres genéticos. Para la extracción de ADN se utilizaron 19 individuos. EI ADN genómico total se aisló por individuo. A partir del ADN aislado se realizó la amplificación de un fragmento del gen mitocondrial citocromo $c$ oxidasa I. Al revisar la diagnosis de las especies de Chelonus, los ejemplares analizados en este trabajo se agruparon en tres especies nominales: Ch. insularis, $C h$. sonorensis, Ch. cautus. Respecto al AMOVA, se observó la máxima distribución de la varianza al formarse dos grupos, 1 : Ch. insularis $+C h$. sonorensis y 2: Ch. cautus esto indica que los grupos son distintos entre sí ( $F s c=0.02289, p=0.011 \mathrm{al}$ $95 \%$ de confianza), no existe diferencia al interior de éstos ( $F_{\text {ST }}=0.97679, p=0.43$ al $95 \%$ de confianza), estos fueron comparados con el grupo 3: Ch. insularis de diferentes estados de la República Mexicana. De acuerdo a la red haplotípica y a la matriz de distancias se puede observar que aun cuando se comparan especies diferentes como $\mathrm{Ch}$. insularis y $\mathrm{Ch}$. sonorensis, la diferenciación genética entre éstas es de $0.3 \%$, formando un solo grupo, siendo genéticamente cercanos; a excepción de Ch. cautus, que se encuentra a una distancia de este grupo compacto del $17.8 \%$, lo cual lo sitúa muy lejos de este grupo, además el tamaño de los individuos del parasitoide $C h$. cautus es significativamente más pequeño que las especies $C h$. insularis y $C h$. sonorensis siendo considerado como un Microchelonus.

Palabras clave: Maíz, variabilidad, plagas, ADN, haplotipos.

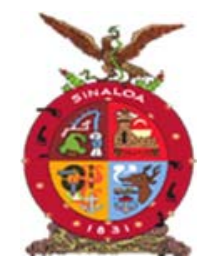

XVIII Congreso Internacional XXIV Congreso Nacional de Ciencias ambientales
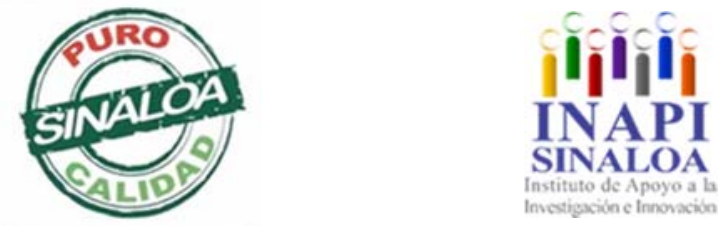

Mazatlán, Sinaloa 3-7 junio 2019

Medio Ambiente y Alimentación de Calidad con Inocuidad 
TECNOLOGICO NACIONAL DE MEXICO

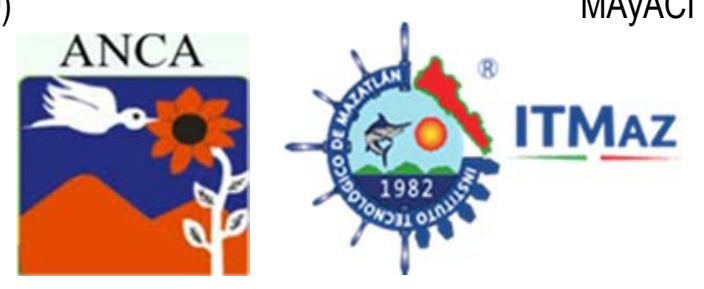

\title{
Food safety of corn from the genetic variability of Chelonus sp. bud of the worm bud
}

\author{
González-Maldonado B, Hernández-Salinas U, González-Güereca C \\ Doctorado en Biotecnología del Instituto Politécnico Nacional. \\ CIIDIR-IPN Unidad Durango. \\ Sigma 119, Fracc. 20 de Nov. II. C.P. 34234 Durango, Dgo. \\ bereciidir@hotmail.com
}

\begin{abstract}
We determined the genetic variability present in Chelonus sp., parasitoids of the corn plague fall armyworm in Durango, Mexico, using genetic characters. For the extraction of DNA, 19 individuals were used. The total genomic DNA was isolated per individual. The fragment of the mitochondrial cytochrome c oxidase I gene was isolated from the isolated DNA. In reviewing the diagnosis of the Chelonus species, the specimens analyzed in this work were grouped into three nominal species: Ch. insularis, Ch. sonorensis, Ch. cautus. Regarding AMOVA, the maximum variance distribution was observed when two groups were formed, 1: Ch. insularis $+C h$. sonorensis and 2: Ch. cautus. This indicates that the groups are different from each other ( $F S C=0.02289, p=0.011$ at $95 \%$ confidence), there is no difference within these (FST $=0.97679, p=0.43$ at $95 \%$ confidence), these were compared with group 3: Ch. insularis from different states of the Mexican Republic. According to the haplotypic network and the distances matrix, it can be observed that even when different species such as Ch. insularis and Ch. sonorensis are compared, the genetic differentiation between them is $0.3 \%$, forming a single group, being genetically close; with the exception of Ch. cautus, which is located at a distance of this compact group of $17.8 \%$, which places it very far from this group, in addition the size of the individuals of the parasitoid $\mathrm{Ch}$. cautus is significantly smaller than the species. Ch. insularis and Ch. sonorensis being considered a Microchelonus.
\end{abstract}

Keywords: Corn, variability, pests, DNA, haplotypes.

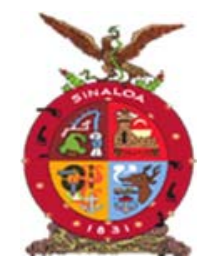

XVIII Congreso Internacional XXIV Congreso Nacional de Ciencias ambientales
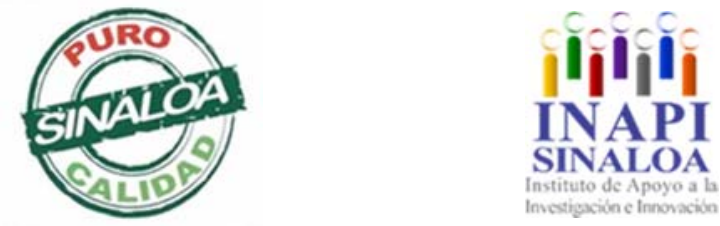

Mazatlán, Sinaloa 3-7 junio 2019

Medio Ambiente y Alimentación de Calidad con Inocuidad 
TECNOLOGICO NACIONAL DE MEXICO
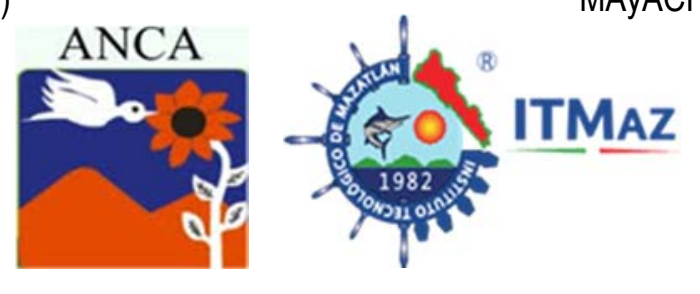

Evaluación de medios de crecimiento y nutrición vegetal para la producción de germinados a partir de semillas de interés comercial

\author{
Lazcano-Escobar JF, Ramírez-López C, Velázquez-García O, \\ Rivera-Hernández KN, Villa-Ramírez MS \\ Centro de Investigación en Biotecnología Aplicada (CIBA-IPN), \\ Ex-Hacienda San Juan Molino Carretera Estatal Tecuexcomac-Tepetitla \\ Km 1.5, Tlaxcala C.P. 90700, México. \\ crl81@hotmail.com
}

\begin{abstract}
RESUMEN
Los germinados al ser consumidos en la fase de crecimiento de la planta, se caracterizan por ser alimentos con alto valor nutritivo, son fuentes excepcionales de proteínas, vitaminas y minerales, además de contener nutrientes que son auxiliares en el mantenimiento de la salud, tales como sustancias fenólicas, isoflavonas, antocianinas y otros compuestos con reconocida actividad antioxidante. Bajo esta premisa, el objetivo del presente trabajo consistió en evaluar tres diferentes soluciones minerales de nutrición vegetal sobre el crecimiento y desarrollo de germinados de semillas de interés comercial (trigo, calabaza y brócoli). El proceso de germinación consistió primero en la desinfección de las semillas, seguido de un remojo en agua, posteriormente un número determinado de semillas escurridas fueron colocadas en cajas Petri, y se evaluó por separado la suplementación con soluciones nutritivas (Adelusi-Oseni, Ruakura y Maeda), alternando fotoperiodos de $12 \mathrm{~h}$ de luz por $12 \mathrm{~h}$ de oscuridad durante 96 horas. Bajo las condiciones evaluadas, el medio Adelusi-Oseni resultó ser el mejor para todas las semillas, registrándose un incremento en la longitud de la parte aérea de la semilla de calabaza hasta 2.5 veces mayor con respecto al control e incrementos del $5.18 \%$ y $32 \%$ para brócoli y trigo, respectivamente. Con base al análisis de los resultados se observó que el uso de medios minerales nutritivos permitió mejorar el crecimiento y desarrollo en los germinados de estas semillas incrementándose el rendimiento y calidad de las mismas.
\end{abstract}

Palabras clave: Medio de crecimiento y nutrición vegetal, semillas, germinados.

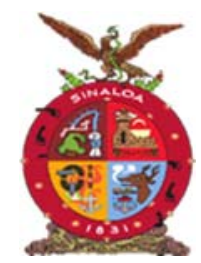

XVIII Congreso Internacional XXIV Congreso Nacional de Ciencias ambientales
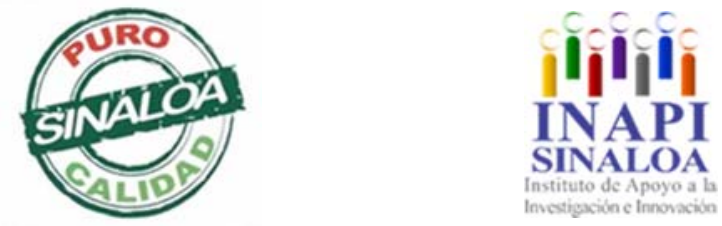

Mazatlán, Sinaloa 3-7 junio 2019

Medio Ambiente y

Alimentación de Calidad con Inocuidad 

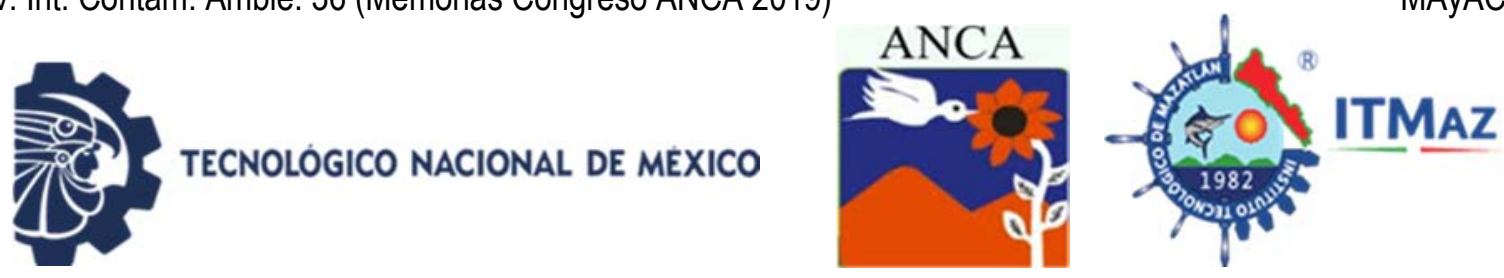

\title{
Evaluation of growing and nutrition media of plants for the production of sprouts from seeds with commercial interest
}

\author{
Lazcano-Escobar JF, Ramírez-López C, Velázquez-García O, \\ Rivera-Hernández KN, Villa-Ramírez MS \\ Centro de Investigación en Biotecnología Aplicada (CIBA-IPN), \\ Ex-Hacienda San Juan Molino Carretera Estatal Tecuexcomac-Tepetitla \\ Km 1.5, Tlaxcala C.P. 90700, México. \\ crl81@hotmail.com
}

\begin{abstract}
The sprouts generally consumed during de exponential growth of the plant are foods characterized by their high nutritional value. They contain excellent sources of proteins, vitamins, and minerals, also contain a type of nutrients that are auxiliary in health-promoting, such as phenolic substances, isoflavones, anthocyanins and other compounds with recognized antioxidant capacity. Under this premise, the objective of this project was to evaluate three different mineral solutions of plant nutrition on the growth and development of germinated seeds of commercial interest (wheat, pumpkin, and broccoli). The sprouting process consists of the seeds disinfection, soaking and posteriorly certain drained seeds were put on Petri dishes. Supplementation with nutrient solutions (Adelusi-Oseni, Ruakura, and Maeda) was evaluated separately, alternating photoperiods of $12 \mathrm{~h}$ of light by $12 \mathrm{~h}$ of darkness for 96 hours. Under the evaluated conditions, the Adelusi-Oseni mineral media was the best for all seeds, increasing 2.5 times the aerial part for pumpkin seed with respect of control assay, an improvement of $5.18 \%$ y $32 \%$ for broccoli and wheat, respectively. Based on the analysis of the results, it was observed that the use of nutritious mineral media allowed improving the growth and development in the sprouts of these seeds, increasing their yield and quality.
\end{abstract}

Keywords: Growing and nutrition media, seeds, sprouts.

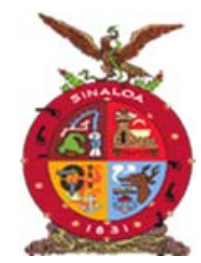

XVIII Congreso Internacional XXIV Congreso Nacional de Ciencias ambientales
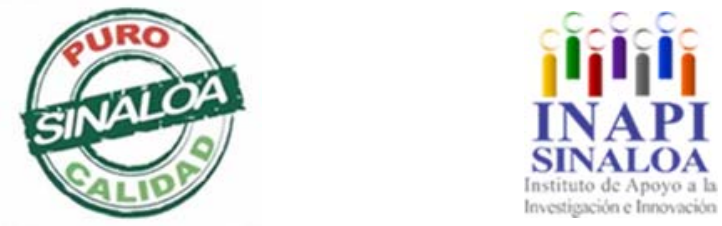

Mazatlán, Sinaloa 3-7 junio 2019

Medio Ambiente y

Alimentación de Calidad con Inocuidad 

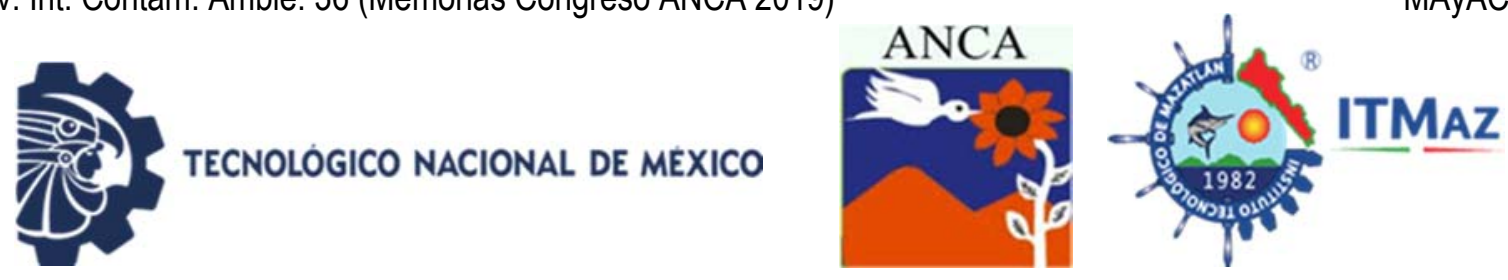

\title{
Métodos de hidrólisis para cuantificación de azúcares en Yuca Manihot esculenta (Crantz)
}

\author{
Matheus-Hernández A, Ramírez-López C, Rivera-Hernández KN, \\ Villa-Ramírez MS
}

Centro de Investigación en Biotecnología Aplicada. IPN

sugeyrol@hotmail.com

\section{RESUMEN}

La planta Manihot esculenta (Crantz) conocida como Yuca, posee un tubérculo amiláceo comestible con altos contenidos de almidón, es la tercera fuente más importante de carbohidratos, por ello se evaluó el proceso de hidrólisis y sacarificación para estimar el posible rendimiento en producción de bioetanol. Primeramente se realizó un lavado y rallado, se evaluó la gelatinización a los de 20 minutos y la relación de yuca: agua (1:1). La evaluación se realizó en 2 pretratamientos: uno usando hidróxido de potasio $(\mathrm{KOH})$; y otro ácido clorhídrico $(\mathrm{HCl})$ en proporción a 1 y $2 \mathrm{~N}$ respectivamente, y se realizaron tratamientos de hidrólisis enzimática usando a-amilasa, glucoamilasa, HTec, CTec. Los mejores resultados se obtuvieron en dos tratamientos: $\alpha$-amilasa seguida de glucoamilasa sin previo pretratamiento y $\mathrm{HTec}$ con previo tratamiento ácido, los cuales permiten una liberación de azúcares reductores del $71.7 \%$ y $67.6 \%$ y los carbohidratos totales $89.9 \%$ y $72.5 \%$ respectivamente. Posteriormente se realizó un segundo tratamiento a los insolubles, seleccionando 2 tratamientos que tuvieron rendimiento máximo de glucosa de $96.8 \%$ al tratar con $\mathrm{HCl}$ y posteriormente con $\mathrm{HTec}$ a los insolubles provenientes de la hidrólisis de $\alpha$-amilasa seguida de glucoamilasa.

Palabras clave: Hidrólisis, glucosa, hidrólisis enzimática, azúcares reductores.

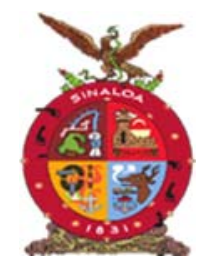

XVIII Congreso Internacional XXIV Congreso Nacional de Ciencias ambientales
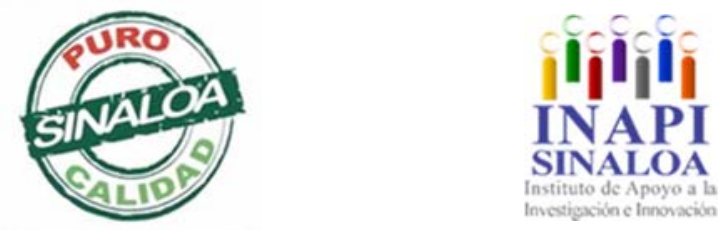

Mazatlán, Sinaloa 3-7 junio 2019

Medio Ambiente y Alimentación de Calidad con Inocuidad 

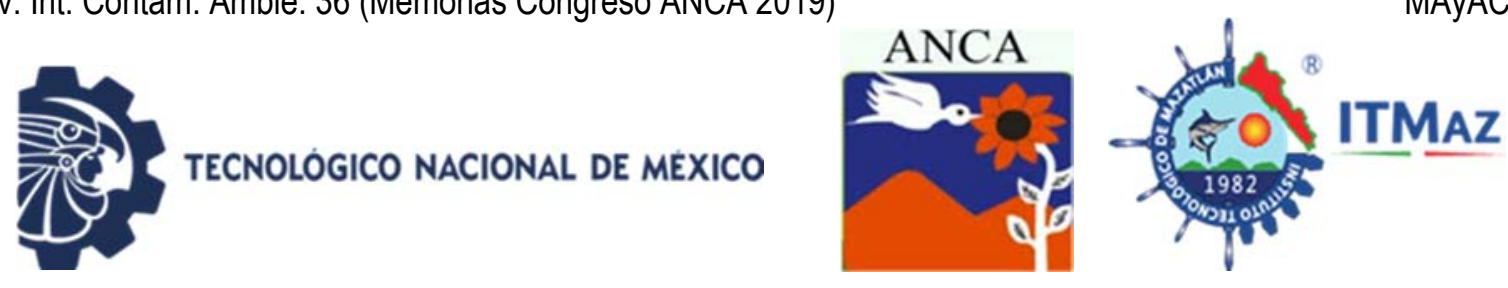

\title{
Hydrolysis methods for sugars quantification in Manihot esculenta (Crantz Cassava)
}

\author{
Matheus-Hernández A, Ramírez-López C, Rivera-Hernández KN, \\ Villa-Ramírez MS
}

Centro de Investigación en Biotecnología Aplicada. IPN

sugeyrol@hotmail.com

\begin{abstract}
Manihot esculenta Crantz plant, is Known how Cassava, is a edible amillabic tuber with high starch contents, is the third source more important of carbohydrates. In this work it was evaluated the process of hydrolysis and sacarification of Cassava materials. The evaluation served, for to estimate to future, the posibles yields in bioethanol production. For the analysis First, the Cassava materials, there were added doing a dry and grated, later, it was evaluated, the time of gelatination of 20 minutes and relation of yuca:water (1:1). Then it has been made the evaluation of 2 treatments used potassium hydroxide $(\mathrm{KOH})$, hydrochloric acid $(\mathrm{HCl})$ to 1 and $2 \mathrm{~N}$ respectively treatments were performed of enzimatic hydrolyisis used a-amilase, glucoamilase, HTEC. CTec. The best results were obtained in two treatments $\alpha$-amilase followed by glucoamilase without previous pretreatment and $\mathrm{HTec}$ with previous acid treatment which allow a release of reducing sugars of $71.7 \%$ and $67.6 \%$ and total carbohydrates of $89.9 \%$ and $72.5 \%$ respectively. Later a second treatment was performed to the insolubles and and 2 treatments were selected that obtained máximum glucose yield of $96.8 \%$ when dealing with $\mathrm{HCL}$ and later with $\mathrm{HTec}$ when dealing with of hydrolysis of a-amilase followed glucoamilase
\end{abstract}

Keywords: Hydrolysis, glucose, enzimatic Hydrolysis, reducing sugars.

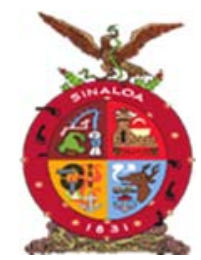

XVIII Congreso Internacional XXIV Congreso Nacional de Ciencias ambientales
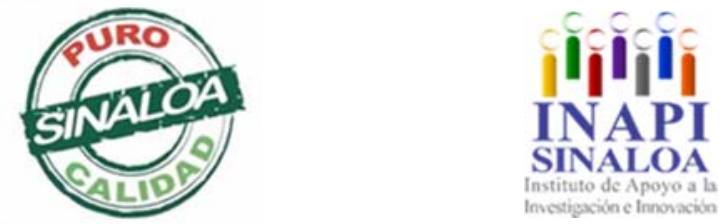

Mazatlán, Sinaloa 3-7 junio 2019

Medio Ambiente y

Alimentación de Calidad con Inocuidad 
TECNOLOGICO NACIONAL DE MEXICO
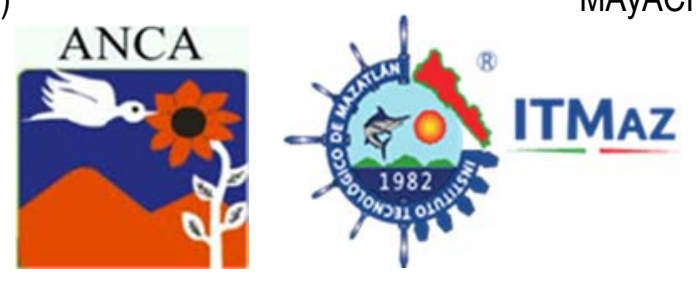

\title{
Análisis y detección de cafeína en Lactuca sativa, mediante dos variedades, romana e iceberg
}

\author{
Morán-Moscoso R, Tenorio-Arvide MG \\ Ingeniería Ambiental, Fac. Ing. Quím. BUAP \\ Departamento de investigación en Agrícolas (DICA), ICUAP. \\ Benemérita Universidad Autónoma de Puebla (BUAP) \\ Ciudad Universitaria, 14 sur 6301, Col. Jardines de San Manuel Puebla, México \\ tenorio.arvide@correo.buap.mx
}

\begin{abstract}
RESUMEN
La agricultura urbana juega un papel importante ya que cumple con funciones ambientales y de servicios ecológicos, es una fuente alterna en el suministro sostenible de alimentos, sin embargo, estos generalmente son irrigados con agua reciclada que puede contener contaminantes emergentes, y estos potencialmente son transferidos a los vegetales, representando riesgos de salud y seguridad alimentaria. En particular la cafeína es la sustancia más ingerida en el mundo, presente en café, té, bebidas gaseosas y medicamentos. Razón por la cual el objetivo de esta investigación es conocer qué variedad de lechuga tiene la mayor capacidad de adsorber la cafeína. Para ello, se prepararon $50 \mathrm{ml}$ de solución a concentración conocida, además se preparó la curva de calibración correspondiente. Se utilizó espectroscopia UV/Vis, para la detección de cafeína, utilizando una longitud de onda de $273 \mathrm{~nm}$, a cada matraz con $50 \mathrm{ml}$ de solución con concentración conocida se adicionaron $40 \mathrm{~g}$ de lechuga romana o iceberg, la concentración remanente se monitoreo cada 24 hrs durante 7 días. Ambas variedades de Lactuca sativa fueron capaces de disminuir la concentración inicial de cafeína, teniendo un $75.3 \%$ y un $88.6 \%$ de adsorción de esta sustancia, siendo la variedad romana la de mayor capacidad de adsorción. Con la primera etapa del trabajo se concluye el riesgo de irrigar vegetales en particular lechuga con agua reciclada potencialmente contaminada con cafeína, ya que después del análisis realizado estas son capaces de absorber.
\end{abstract}

Palabras clave: Cafeína, contaminante emergente, adsorción, lechuga.

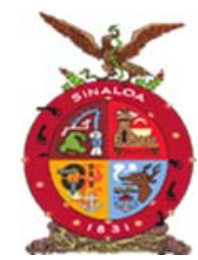

XVIII Congreso Internacional XXIV Congreso Nacional de Ciencias ambientales
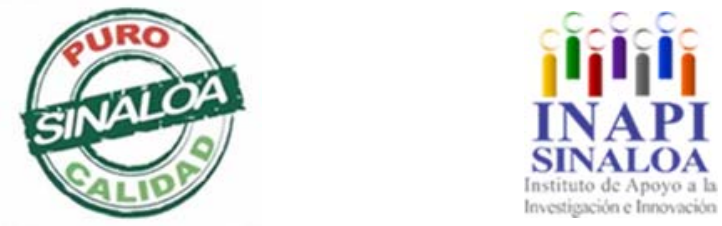

Mazatlán, Sinaloa 3-7 junio 2019

Medio Ambiente y

Alimentación de Calidad con Inocuidad 

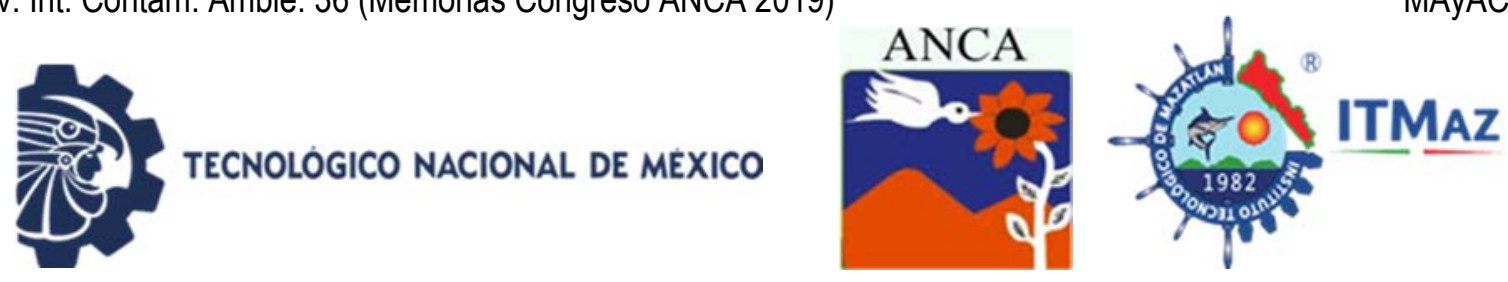

Analysis and detection of caffeine in Lactuca sativa, by two varieties, romana and iceberg

\author{
Morán-Moscoso R, Tenorio-Arvide MG \\ Ingeniería Ambiental, Fac. Ing. Quím. BUAP \\ Departamento de investigación en Agrícolas (DICA), ICUAP. \\ Benemérita Universidad Autónoma de Puebla (BUAP) \\ Ciudad Universitaria, 14 sur 6301, Col. Jardines de San Manuel Puebla, México \\ tenorio.arvide@correo.buap.mx
}

\begin{abstract}
Urban agriculture plays an important role since it fulfills environmental functions and ecological services, it is an alternate source in the sustainable supply of food, however, these are generally irrigated with recycled water that may contain emerging contaminants, and these are potentially transferred to vegetables, representing health risks and food safety. In particular, caffeine is the most ingested substance in the world, present in coffee, tea, soft drinks and medicines. Reason why the objective of this research is to know which variety of lettuce has the greatest capacity to adsorb caffeine. For this, $50 \mathrm{ml}$ of solution at a known concentration was prepared, and the calibration curve was prepared. UV / Vis spectroscopy was used for the detection of caffeine, using a wavelength of 273 $\mathrm{nm}$, to each flask with $50 \mathrm{ml}$ of solution with known concentration were added 40 $\mathrm{g}$ of romaine or iceberg lettuce, the remaining concentration was monitored every 24 hrs for 7 days. Both varieties of Lactuca sativa were able to reduce the initial concentration of caffeine, with $75.3 \%$ and $88.6 \%$ adsorption of this substance, with the Roman variety having the highest adsorption capacity. With the first stage of the work, the risk of irrigating vegetables in particular lettuce with recycled water potentially contaminated with caffeine is concluded, since after the analysis performed they are able to absorb it.
\end{abstract}

Keywords: Caffeine, emerging contaminant, absorbance, lettuce,

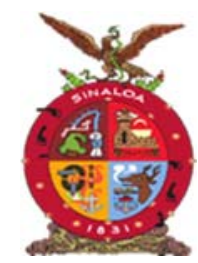

XVIII Congreso Internacional XXIV Congreso Nacional de Ciencias ambientales
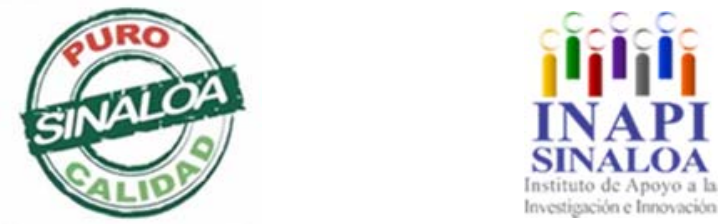

Mazatlán, Sinaloa 3-7 junio 2019

Medio Ambiente y Alimentación de Calidad con Inocuidad 


\title{
TECNOLOGICO NACIONAL DE MEXICO
}
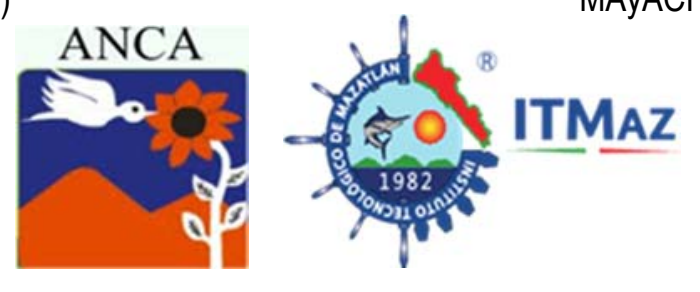

\section{Aprovechamiento de los residuos de pescado en forma de ensilado adicionado con harina de Jartropha curcas para alimentar a pollos}

\author{
Ortega JA, Sánchez-Humarán IL, Sarabia-Aparicio JL \\ Instituto Tecnológico de Mazatlán \\ Calle Corsario 1 No. 203 Colonia Urías Mazatlán, Sinaloa \\ jortega@itmazatlan.edu.mx
}

\section{RESUMEN}

En México las pérdidas de pescado post-cosecha ascienden al 10\% tan solo en la fase de la captura, descarte de la fauna de acompañamiento, manipuleo, almacenamiento, distribución, procesamiento y comercialización, siendo necesario promover el máximo aprovechamiento de esa proteína animal desechada, aplicando tecnologías simples y de baja inversión, como el ensilado de pescado, para usarlos como fuente de alimento para la industria agropecuaria, principalmente en el sector avícola. Se elaboraron tres dietas experimentales: 1:control a base de alimento comercial y; 2 y 3 con inclusión de ensilado de vísceras de la tilapia Oreochromis niloticus adicionada con Jatropha curcas las cuales se denotaron como ACE (22\% ensilado / $0 \%$ Jatropha curcas) y ACEJ (22\% ensilado / 1\% Jatropha curcas, fueron evaluadas por parámetros de crecimiento con diferentes porcentajes de inclusión en las dietas experimentales con las que se alimentaron diariamente los pollos (Gallus gallus domesticus), para evaluar el crecimiento, mediante las biometrías en los primeros 21 días correspondientes a la etapa de iniciación. Los pollos fueron alimentados ad libitum una vez al día (10:00 hrs) por 3 semanas. Diariamente los pollos fueron pesados para calcular el peso ganado y al final obtener el factor de conversión alimenticia (FCA). El peso ganado (PG) fue positivo por la inclusión del ensilado de pescado (ACE) en la dieta para pollos; y negativamente para los pollos alimentados con la dieta con inclusión de ensilado/Jatropha (ACEJ) .La inclusión de Jatropha curcas como fuente proteica no mostró promoción del crecimiento. Nuestros resultados coinciden con otros estudios realizados al utilizar Jatropha curcas al $10 \%$ en dietas para pollos en los cuales se utilizaron la clase tóxica y no tóxica, existiendo índices de supervivencia del $5 \%$ y 95\% respectivamente.

Palabras clave: Ensilado de pescado, factor de conversión alimenticia, Jatropha curcas, alimentación avícola.

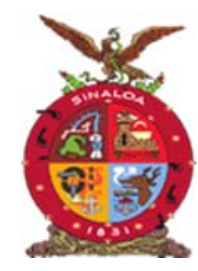

XVIII Congreso Internacional XXIV Congreso Nacional de Ciencias ambientales
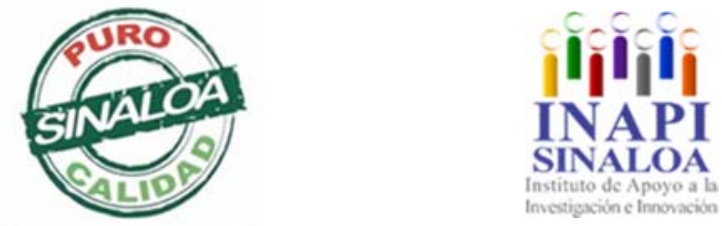

Mazatlán, Sinaloa 3-7 junio 2019

Medio Ambiente y

Alimentación de Calidad con Inocuidad 

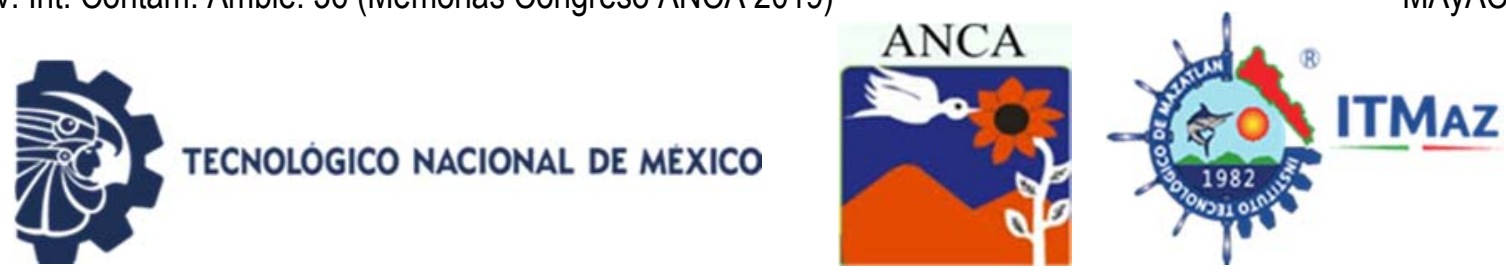

\title{
Harvesting of fish waste in the form of added silage with Jatropha curcas flour to feed chickens
}

\author{
Ortega JA, Sánchez-Humarán IL, Sarabia-Aparicio JL \\ Instituto Tecnológico de Mazatlán \\ Calle Corsario 1 No. 203 Colonia Urías Mazatlán, Sinaloa \\ jortega@itmazatlan.edu.mx
}

\begin{abstract}
In Mexico, losses of post-harvest fish amount to only $10 \%$ in the phase of the capture, discarding of the accompanying fauna, handling, storage, distribution, processing and marketing, being necessary to promote the maximum use of this discarded animal protein, applying simple technologies and low investment, such as fish silage, to use as a source of food for the agricultural industry, mainly in the poultry sector. Three experimental diets were developed: 1-Control based on commercial feed and 2 and 3 including silage of viscera of the tilapia Oreochromis niloticus added with Jatropha curcas which were denoted as ACE $(22 \%$ silage / $0 \%$ Jatropha curcas) and ACEJ (22\% silage / 1\% Jatropha curcas, were evaluated by growth parameters with different percentages of inclusion in the experimental diets with which they fed daily to chickens (Gallus gallus domesticus), to assess growth, through biometrics in the first 21 days to the initiation stage. The chickens were fed ad libitum once a day (10:00 hrs) for 3 weeks. Daily the chickens were weighed to calculate the gained weight and in the end obtain the feed conversion factor (FCA). The weight gained (PG) was positive because of the inclusion of fish silage (ACE) in the diet for chickens and negatively for chickens fed with the diet including silage / Jatropha (ACEJ). The inclusion of Jatropha curcas as a protein source showed no growth promotion. Our results coincide with other studies conducted using Jatropha curcas at $10 \%$ in diets for chickens in which the toxic and non-toxic class were used, existing survival rates of $5 \%$ and $95 \%$ respectively.
\end{abstract}

Keywords: Fish silage, feed conversion factor, Jatropha curcas, poultry feed

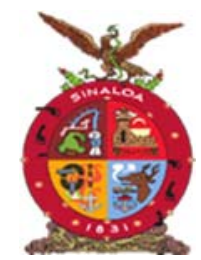

XVIII Congreso Internacional XXIV Congreso Nacional de Ciencias ambientales
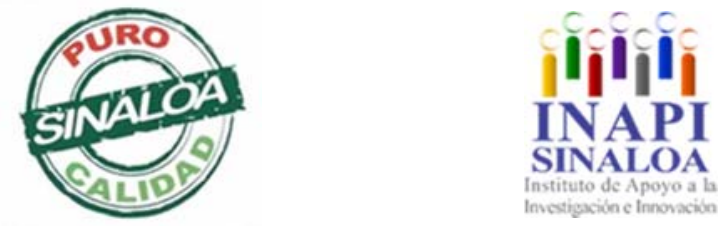

Mazatlán, Sinaloa 3-7 junio 2019

Medio Ambiente y

Alimentación de Calidad con Inocuidad 

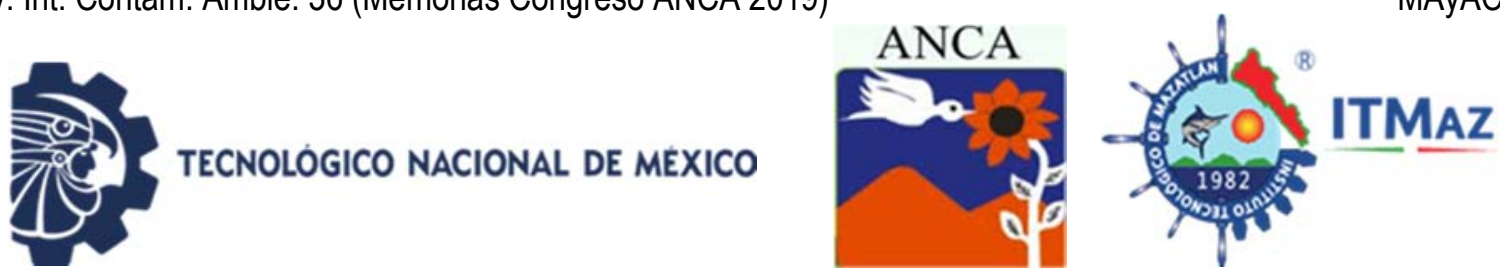

\title{
Películas comestibles una alternativa amigable con el ambiente para el empaqué de frutos
}

\author{
Padilla-Jiménez S, Angoa-Perez V, Mena-Violante H, Vargas-Moreno J, \\ Oregel-Zamudio E
}
Centro Interdisciplinario de Investigación para el Desarrollo Integral Regional, Unidad Michoacán. Instituto Politécnico Nacional. Justo Sierra No. 28 Jiquilpan, Michoacán, México. C. P. 59510

\begin{abstract}
RESUMEN
Los plásticos son polímeros sintéticos utilizados para fabricar envases destinados al empaque de alimentos, sin embargo, estos envases han causado grandes problemas de contaminación a nivel mundial, principalmente porque su degradación en muchos de los casos es muy lenta, actualmente las películas comestibles (PC) se presentan como una alternativa sustentable para el empaque de frutos, por lo cual posee las características necesarias para mantener la vida útil de dichos productos, además, al ser elaborados partir de componentes naturales y comestibles se degradan rápidamente o se consumen como parte del alimento, por tanto contaminan menos, el objetivo de este trabajo fue elaborar una formulación de PC con componentes naturales y determinar sus características fisicoquímicas. La elaboración y caracterización de la película comestible se llevó acabo en el laboratorio de alimentos del CIIDIR IPN Unidad Michoacán durante el periodo de agosto diciembre del 2018. Los componentes de la formulación fueron: goma guar $(0.4 \%)$, cera de candelilla $(0.2 \%)$, glicerol $(0.2 \%)$, ácido gálico $(0.1 \%)$ todos los componentes fueron adquiridos de grado alimentario. A la formulación se le determino grosor $(0.05 \mathrm{~mm})$, solubilidad $(93.70 \%)$, densidad $\left(0.006 \mathrm{~g} / \mathrm{mm}^{3}\right)$ y humedad $(15.05 \%)$. La PC evaluada posee las características necesarias para un empaque óptimo y puede ser aplicada sobre frutos frescos y al ser elaborada de productos alimenticios la convierte en una alternativa amigable con el ambiente ya que puede ser consumida y no generar desperdicios.
\end{abstract}

Palabras clave: Empaques, empaques plásticos, frutos, películas comestibles, vida de anaquel.

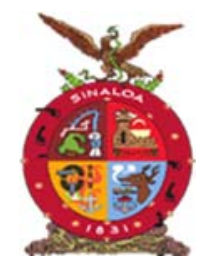

XVIII Congreso Internacional XXIV Congreso Nacional de Ciencias ambientales
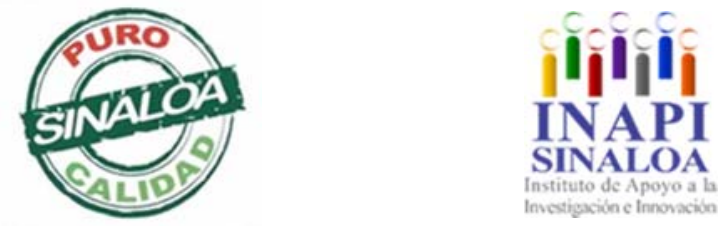

Mazatlán, Sinaloa 3-7 junio 2019

Medio Ambiente y

Alimentación de Calidad con Inocuidad 

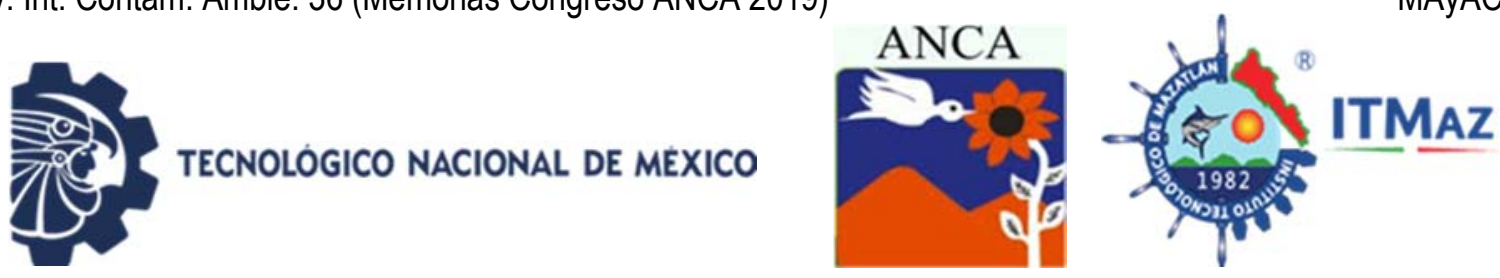

Edible films an environmentally friendly alternative for fruit packaging

Padilla-Jiménez S, Angoa-Perez V, Mena-Violante H, Vargas-Moreno J, Oregel-Zamudio E

Centro Interdisciplinario de Investigación para el Desarrollo Integral Regional, Unidad Michoacán. Instituto Politécnico Nacional.

Justo Sierra No. 28 Jiquilpan, Michoacán, México. C. P. 59510

\begin{abstract}
Plastics are synthetic polymers used to make containers for food packaging. However, these containers have caused major pollution problems worldwide mainly because their degradation in many cases is very slow. Currently edible films (EF) are presented as a sustainable alternative for the packaging of fruits because they have the necessary characteristics to maintain the shelf life of these products. Furthermore, when they are made from natural and edible components, they are rapidly degraded or consumed as part of the food therefore they contaminate less. The objective of this work was to formulate an EF with natural components and to determine its physicochemical characteristics. The elaboration and characterization of the EF was carried out in the food laboratory of CIIDIR IPN Unidad Michoacán during the period of August, December 2018. The components of the formulation were: guar gum $(0.4 \%)$, candelilla wax $(0.2 \%)$, glycerol $(0.2 \%)$, gallic acid $(0.1 \%)$. All the components were purchased with food grade. The formulation was determined thickness $(0.05 \mathrm{~mm})$, solubility $(93.70 \%)$, density $(0.006 \mathrm{~g} / \mathrm{mm} 3)$ and humidity $(15.05 \%)$. The evaluated EF has the necessary characteristics for an optimal packaging and can be applied on fresh fruits. Also, because it is elaborated from food products it results in a friendly environmental alternative since it can be consumed and it does not generate waste.
\end{abstract}

Keywords: Packaging, shelf life, fruits, edible films, plastic packaging.

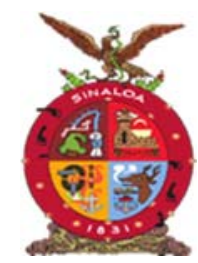

XVIII Congreso Internacional XXIV Congreso Nacional de Ciencias ambientales
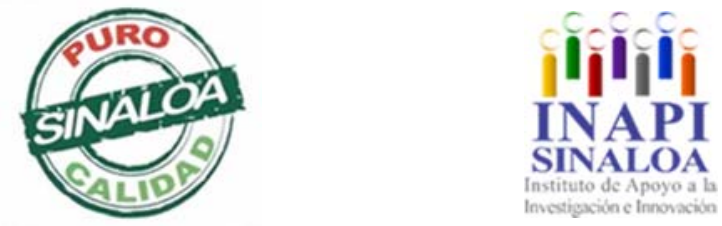

Mazatlán, Sinaloa 3-7 junio 2019

Medio Ambiente y

Alimentación de Calidad con Inocuidad 
TECNOLOGICO NACIONAL DE MEXICO
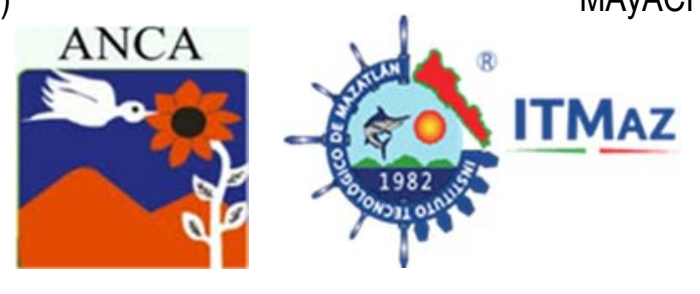

\title{
Actividad antioxidante y cuantificación de fenoles totales en seis hongos comestibles de Chihuahua, México
}

\author{
Valenciana-Valdez G, Corral-Avitia A, Quiñonez-Martínez M \\ Laboratorio de Ciencias Ambientales. \\ Laboratorio de Biodiversidad. Universidad Autónoma de Ciudad Juárez, \\ Anillo Envolvente del Pronaf y Estocolmo S/N, C.P. 32300, A.P. 1595-D, \\ Ciudad Juárez, Chihuahua, México \\ *acorral@uacj.mx
}

\begin{abstract}
RESUMEN
Los compuestos fenólicos son moléculas bioactivas de interés por sus propiedades farmacológicas, entre la que destaca la actividad antioxidante. Los hongos son una fuente natural de fenoles, e inducen su síntesis en respuesta a factores ambientales. Los fenoles responden principalmente a procesos de estrés oxidativo, a través de la eliminación de radicales libres (actividad antioxidante). En la actualidad, la literatura sugiere que no existen estudios sobre el contenido fenólico y actividad antioxidante de los hongos Amanita caesarea, Amanita rubescens, Hypomyces lactifluorum, Lactarius piperatus, Suillus granulatus y Suillus pictus crecidos en Bocoyna, Chihuahua, México. El objetivo de este estudio fue comparar el contenido de fenoles totales (TPC, por sus siglas en inglés) y la actividad antioxidante de los cuerpos fructíferos de los hongos mencionados, por medio del ensayo de Folin-Ciocalteu y DPPH ${ }^{\bullet}$. Estos ensayos fueron realizados en el Laboratorio de Ciencias Ambientales de la Universidad Autónoma de Ciudad Juárez (Juárez, Chihuahua, México) en el periodo de enero 2018 a marzo 2019. Las seis especies analizadas mostraron un alto TPC y mayor actividad antioxidante respecto a sus homólogos de otras regiones geográficas. Además, se mostró una diferencia significativa (ANOVA, $p<0.05$ ) entre el TPC de las especies de hongos, siendo $A$. rubescens la especie de mayor TPC, con $14.48 \mathrm{mgGAE} / \mathrm{g}$. S. granulatus mostró la mayor actividad antioxidante entre las seis especies, con un $\mathrm{IC}_{50}$ de $35.56 \pm 0.93 \mathrm{ppm}$. Lo anterior indica que las condiciones ambientales de Bocoyna, Chihuahua, promueven la síntesis de altas cantidades de fenoles y antioxidantes.
\end{abstract}

Palabras clave: Antioxidantes, IC50, fenoles totales, hongos comestibles

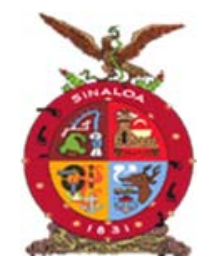

XVIII Congreso Internacional XXIV Congreso Nacional de Ciencias ambientales
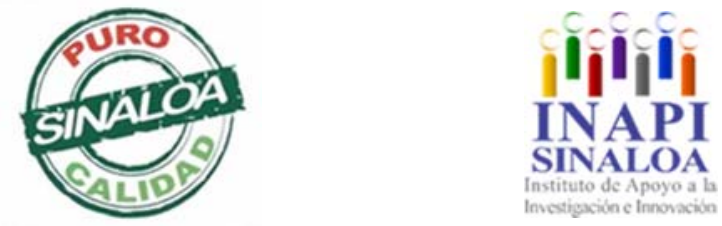

Mazatlán, Sinaloa 3-7 junio 2019

Medio Ambiente y

Alimentación de Calidad con Inocuidad 
TECNOLOGICO NACIONAL DE MEXICO
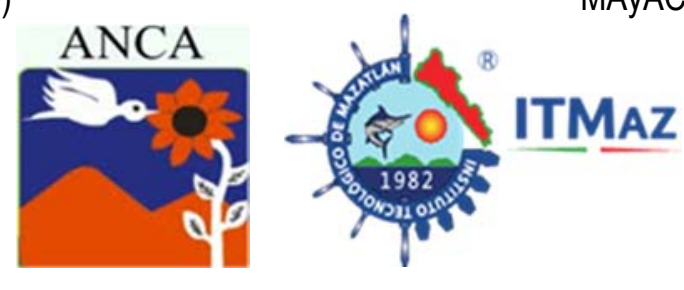

\title{
Antioxidant activity and quantification of total phenols of six edible mushrooms from Chihuahua, Mexico
}

\author{
Valenciana-Valdez G, Corral-Avitia A, Quiñonez-Martínez M \\ Laboratorio de Ciencias Ambientales. \\ Laboratorio de Biodiversidad. Universidad Autónoma de Ciudad Juárez, \\ Anillo Envolvente del Pronaf y Estocolmo S/N, C.P. 32300, A.P. 1595-D, \\ Ciudad Juárez, Chihuahua, México \\ *acorral@uacj.mx
}

\begin{abstract}
Phenolic compounds are bioactive molecules of interest due to their pharmacological properties, among which the antioxidant activity stands out. Mushrooms are a natural source of phenols and they induce phenols synthesis in response to environmental factors. Phenols respond mainly to processes of oxidative stress, through the elimination of free radicals (antioxidant activity). Currently, the literature suggests that there are no studies on total phenolic content (TPC) and antioxidant activity of the fungi Amanita caesarea, Amanita rubescens, Hypomyces lactifluorum, Lactarius piperatus, Suillus granulatus and Suillus pictus grown in Bocoyna, Chihuahua, Mexico. The objective of this study was to compare the content of total phenols and the antioxidant activity of the fruiting bodies of the mushrooms mentioned, through the Folin-Ciocalteu and $\mathrm{DPPH}^{\bullet}$ assay. These tests were carried out in the Environmental Sciences Laboratory of the Autonomous University of Ciudad Juarez (Juárez, Chihuahua, Mexico) in the period from January 2018 to March 2019. The six species analyzed showed a high TPC and greater antioxidant activity compared to their counterparts. from other geographic regions. In addition, there was a significant difference (one-way ANOVA, $p<0.05$ ) between the TPC of fungal species, with A. rubescens being the highest TPC species, with $14.48 \mathrm{mgGAE} / \mathrm{g}$. S. granulatus showed the highest antioxidant activity among the six species, with an IC50 of $35.56 \pm 0.93 \mathrm{ppm}$. These results suggest that the environmental factors of the municipality of Bocoyna, Chihuahua, favor the synthesis of phenolic compounds on the mushrooms.
\end{abstract}

Keywords: Antioxidants, IC50, total phenolic content, edible mushrooms.

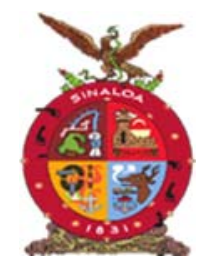

XVIII Congreso Internacional XXIV Congreso Nacional de Ciencias ambientales
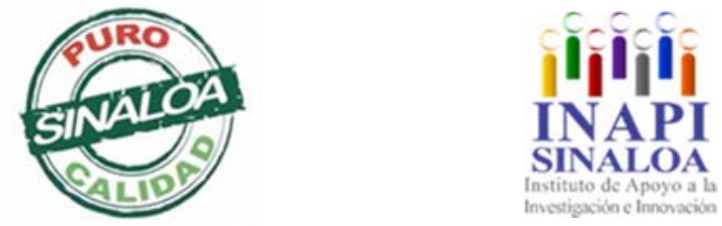

Mazatlán, Sinaloa 3-7 junio 2019

Medio Ambiente y

Alimentación de Calidad con Inocuidad 
TECNOLOGICO NACIONAL DE MEXICO
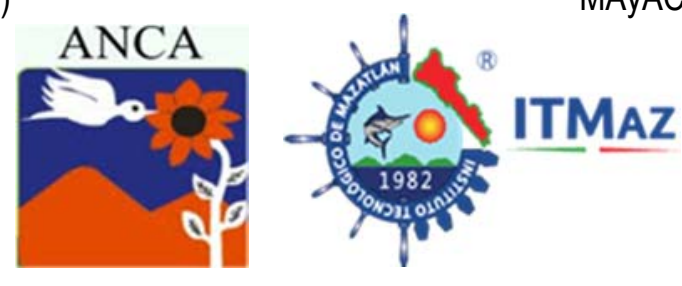

\title{
El encalado orgánico como alternativa para mejorar la calidad del orégano mexicano (Lippia graveolens) cultivado en Michoacán
}

\author{
Vargas-Moreno J, Padilla-Jiménez S, Oyoque-Salcedo G, Oregel-Zamudio E
}

. Centro interdisciplinario de Investigación para el Desarrollo Integral Regional. Instituto Politécnico Nacional Unidad Michoacán.

Justo Sierra \# 28, colonia Centro, Jiquilpan, Michoacán, México, C.P. 59510.

eoregel@ipn.mx

\section{RESUMEN}

Las técnicas de agricultura intensiva generan una elevada productividad, en muchos casos, a costa de una alta contaminación al ambiente. Los cultivos al desarrollarse en medios ricos en nutrientes no necesitan la elaboración de metabolitos secundarios (MS), estos funcionan como defensa natural y aportan importantes propiedades. En el orégano los MS más importantes son timol y carvacrol. El objetivo de esta investigación fue evaluar el efecto del encalado agrícola sobre la concentración de timol y carvacrol en el orégano cultivado. Se sembró orégano mexicano en invernadero (2018), y aplicaron dos tratamientos con cal agrícola $(25$ y $50 \mathrm{Ton} / \mathrm{Ha}$ ) y un testigo (sin tratamiento). El orégano se cosechó, se secó y se molió para facilitar la extracción del aceite esencial. La extracción se realizó mediante destilación por arrastre de vapor. Se analizó mediante GC-MS para identificar y cuantificar empleando estándar interno para el contenido de timol y carvacrol. El contenido de timol fue de 104.4620, 319.4897 у $219.3119 \mu \mathrm{l}$ para los tratamientos control, $25 \mathrm{Ton} / \mathrm{Ha}$ y $50 \mathrm{Ton} / \mathrm{Ha}$ respectivamente, mientras que de carvacrol fue $40.2835,13.9948$ y $26.6606 \mu \mathrm{l}$ para los tratamientos control, $25 \mathrm{Ton} / \mathrm{Ha}$ y $50 \mathrm{Ton} / \mathrm{Ha}$. Los resultados mostraron un efecto positivo sobre el contenido de timol, sin embargo, disminuyeron el contenido de carvacrol, siendo el tratamiento de $25 \mathrm{Ton} / \mathrm{Ha}$ el que presentó el mejor resultado. La aplicación de un tratamiento alcalino fue capaz de incrementar el contenido de MS, no obstante, debe aplicarse según el MS de interés.

Palabras clave: Orégano mexicano, metabolitos secundarios, tratamiento agronómico, estrés agrícola.

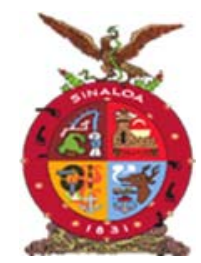

XVIII Congreso Internacional XXIV Congreso Nacional de Ciencias ambientales
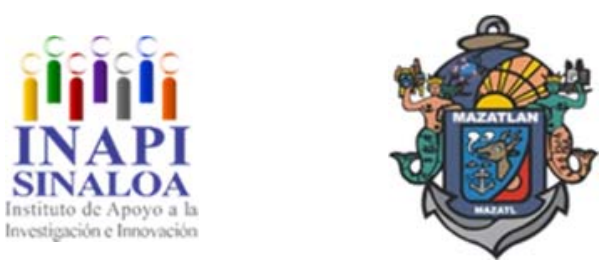

Medio Ambiente y Alimentación de Calidad con Inocuidad 
TECNOLOGICO NACIONAL DE MEXICO
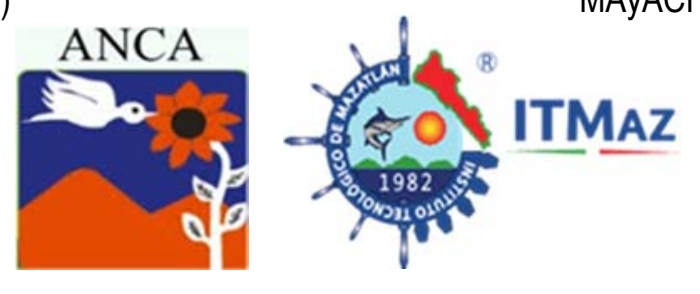

Organic liming as an alternative to improve the quality of mexican oregano (Lippia graveolens) grown in Michoacán

Vargas-Moreno J, Padilla-Jiménez S, Oyoque-Salcedo G, Oregel-Zamudio E

. Centro interdisciplinario de Investigación para el Desarrollo Integral Regional. Instituto Politécnico Nacional Unidad Michoacán.

Justo Sierra \# 28, colonia Centro, Jiquilpan, Michoacán, México, C.P. 59510. eoregel@ipn.mx

\begin{abstract}
The techniques of intensive agriculture generate a high productivity, in many cases, at the cost of a high contamination to the environment. Cultures when grown in nutrient rich media do not need the elaboration of secondary metabolites $(\mathrm{SM})$, these function as natural defense and provide important properties. In oregano the most important SM are thymol and carvacrol due to their properties. The objective of this investigation was to evaluate the effect of agricultural liming on the concentration of thymol and carvacrol in the cultivated oregano. Mexican oregano was planted in greenhouse (2018), two treatments were applied with agricultural lime ( 25 and $50 \mathrm{t} / \mathrm{ha}$ ) and one control (without treatment). The oregano was harvested, dried and ground to facilitate the extraction of the essential oil. The extraction was carried out by steam distillation. It was analyzed by GC-MS to identify and quantify the thymol and carvacrol content by internal standard. The thymol content was $104.4620,319.4897$ and $219.3119 \mu \mathrm{l}$ for the control treatments, $25 \mathrm{t} / \mathrm{ha}$ and $50 \mathrm{t} / \mathrm{ha}$ respectively, while carvacrol was 40.2835, 13.9948 and $26.6606 \mu \mathrm{l}$ for the control treatments, $25 \mathrm{t} / \mathrm{ha}$ and $50 \mathrm{t} / \mathrm{ha}$. The results showed a positive effect on the thymol content, however, the content of carvacrol decreased, being the treatment of $25 \mathrm{t} / \mathrm{ha}$ the one that presented the best result. The application of an alkaline treatment was able to increase the SM content, however, it should be applied according to the SM of interest.
\end{abstract}

Keywords: Mexican oregano, secondary metabolites, agronomic treatment, agricultural stress.

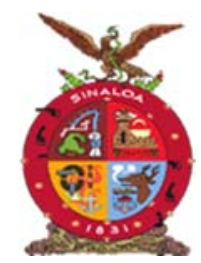

XVIII Congreso Internacional XXIV Congreso Nacional de Ciencias ambientales
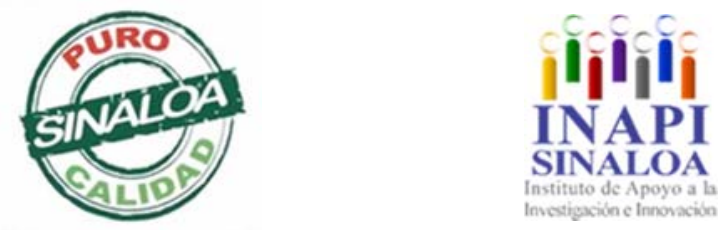

Mazatlán, Sinaloa 3-7 junio 2019

Medio Ambiente y

Alimentación de Calidad con Inocuidad 


\section{REVista INTernacional de}

\section{CONTAMinación AMBIEntal volumen 36, 2020}

http://www.revistas.unam.mx/index.php/rica/

\section{Medio Ambiente, Contaminación, Enfermedad y Genotoxicidad}

Academia Nacional de Ciencias Ambientales

XVIII CONGRESO INTERNACIONAL

XXIV CONGRESO NACIONAL

DE CIENCIAS ambIENTALES

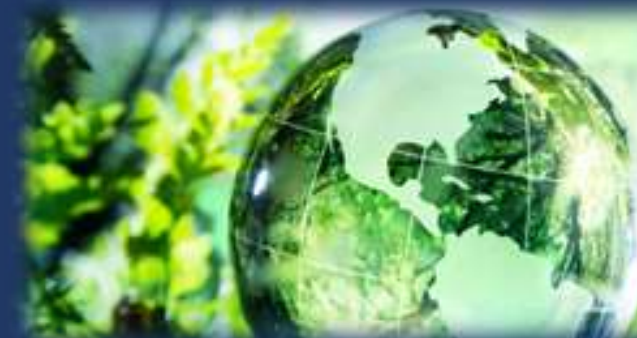

Mayatán, Sinaloa

ila Perla iel Pacífico!

03-07 Junio/2019 


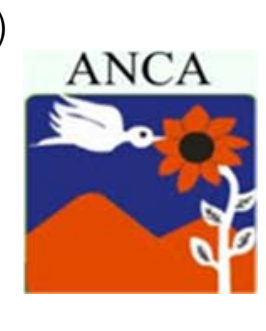

\title{
Estudio exploratorio de la presencia y concentración de hidrocarburos aromáticos policíclicos en fase particulada (PPAHs) en la ciudad de Mérida, Yucatán, México
}

\author{
Amador-Valencia $\mathrm{T}^{1 *}$, Amador-Muñoz $\mathrm{O}^{2}$, Ladino $\mathrm{LA}^{2}$, Raga GB ${ }^{2}$, \\ Rosas-Sánchez $\mathrm{D}^{1}$ \\ ${ }^{1}$ Facultad de Química. Universidad Autónoma de Yucatán \\ ${ }^{2}$ Centro de Ciencias de la Atmósfera. \\ Universidad Nacional Autónoma de México \\ *talibamador@hotmail.com
}

\begin{abstract}
RESUMEN
Los hidrocarburos policíclicos aromáticos en fase particulada (PPAHs) son un grupo de contaminantes emitidos por la combustión de materia orgánica como gasolina y biomasa. Esta familia de compuestos presenta una alta toxicidad y se ha demostrado su efecto mutagénico en humanos. Para determinar la presencia y concentración de PPAHs en Mérida, se realizó un muestreo del aerosol atmosférico entre abril y junio del 2017. Las partículas de aerosol colectadas en filtros de fibra de vidrio cada $24 \mathrm{~h}$ se analizaron por cromatografía de gases acoplado a masas, para determinar el número total de PPAHs. Simultáneamente a la recolección de los filtros, se midió el material particulado (PM10) y se realizaron análisis de retro-trayectorias de viento. Los análisis confirmaron la presencia de PPAH en concentraciones que alcanzaron hasta $2.22 \mathrm{ng} / \mathrm{m}^{3}$. En algunos días específicos se encontraron concentraciones de benzo[a]pireno que superan los promedios de $24 \mathrm{~h}$ en lugares como Xiamen (China) y París (Francia), sin embargo, estas siguen siendo menores a las reportadas en lugares como la Ciudad de México.
\end{abstract}

Palabras clave: Hidrocarburos aromáticos policíclicos, aerosol atmosférico.

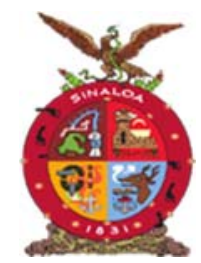

XVIII Congreso Internacional XXIV Congreso Nacional de Ciencias ambientales
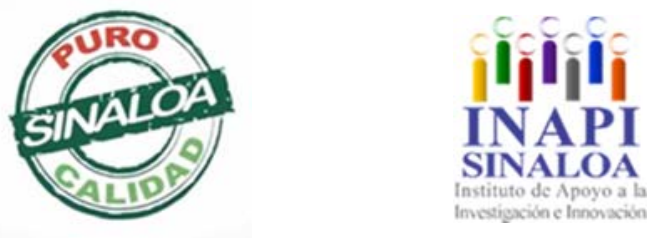

Mazatlán, Sinaloa 3-7 junio 2019

Medio Ambiente, Contaminación,

Enfermedad y Genotoxicidad 
TECNOLOGICO NACIONAL DE MEXICO
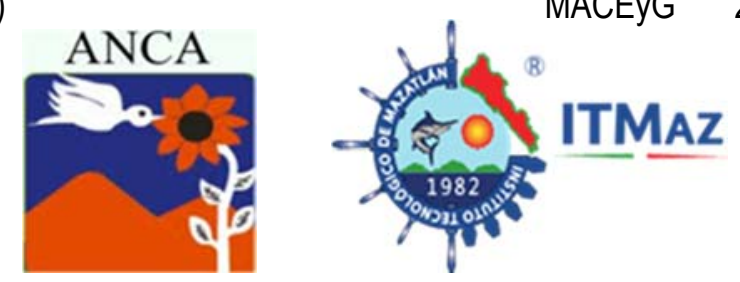

Exploratory study of the presence and concentration of polycyclic aromatic hydrocarbons in particulate phase (PPAHs) in the city of Mérida, Yucatán, Mexico

\author{
Amador-Valencia $\mathrm{T}^{1}$, Amador-Muñoz $\mathrm{O}^{2}$, Ladino $\mathrm{LA}^{2}$, Raga $\mathrm{GB}^{2}$, \\ Rosas-Sánchez $\mathrm{D}^{1}$
}

${ }^{1}$ Facultad de Química. Universidad Autónoma de Yucatán

${ }^{2}$ Centro de Ciencias de la Atmosfera.

Universidad Nacional Autónoma de México.

*talibamador@hotmail.com

\begin{abstract}
Particle bound polycyclic aromatic hydrocarbons (PPAHs) are a group of pollutants released by burning of organic matter such as gasoline and biomass. These families of compounds have high toxicity and mutagenic effects in humans. To determine the presence and concentration of PPAHs, atmospheric aerosol samples were collected during between April and June of 2017. Samples collected in fiberglass filters every $24 \mathrm{~h}$ were analyzed with gas chromatography coupled to mass detector. Simultaneous to filter sampling, particulate matter (PM10) was also measured and wind back-trajectories were analyzed to determine potential sources. The PPAH presence was confirmed with concentrations that reached $2.22 \mathrm{ng} / \mathrm{m}^{3}$. On certain individual days, benzo[a]pyrene (BAP) concentration surpassed mean $24 \mathrm{~h}$ values for places like Xiamen (China) and Paris (France) however, these are still lower than those reported in places like Mexico City.
\end{abstract}

Keywords: particle bound polycyclic aromatic hydrocarbons, atmospheric aerosol.

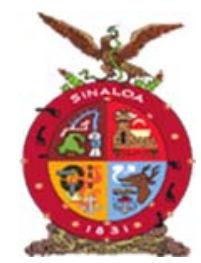

XVIII Congreso Internacional XXIV Congreso Nacional de Ciencias ambientales
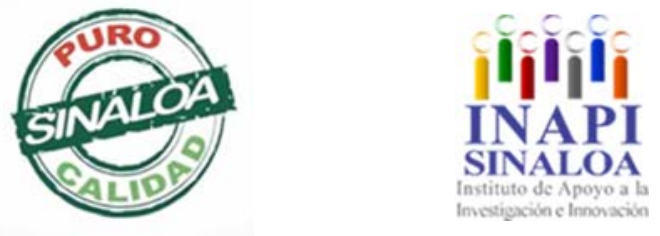

Mazatlán, Sinaloa 3-7 junio 2019

Medio Ambiente, Contaminación,

Enfermedad y Genotoxicidad 
TECNOLOGICO NACIONAL DE MEXICO
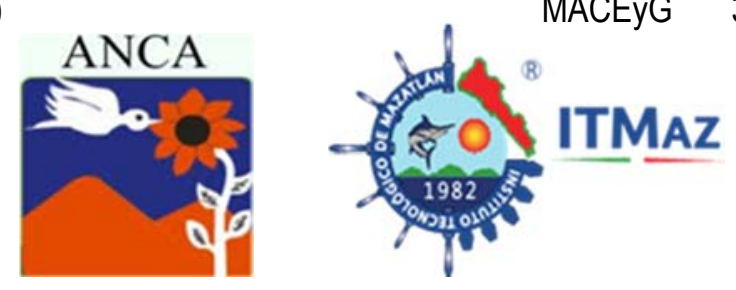

\title{
Análisis microbiológico del aire interior en centros de atención de la Universidad del Noreste en Tampico, México
}

\author{
Arroyo-Galván A*, Rostro Segura A, Del Ángel Ruiz K, Azua-Alonso D, \\ Ramos-Escamilla $\mathrm{F}$ \\ Universidad del Noreste (UNE) \\ *adrian.arroyo.g7@hotmail.com.
}

\begin{abstract}
RESUMEN
La calidad microbiológica del aire está relacionada con la salud laboral, pues se ha demostrado que la contaminación biológica en interiores es un hecho y que estos pueden provocar síntomas o enfermedades en los trabajadores, además de estar relacionada con el síndrome del edificio enfermo. El $40 \%$ y $25 \%$ del personal que labora en dos centros de atención de la Universidad del Noreste, tiene la percepción que ha adquirido alguna enfermedad o molestia como consecuencia de estar en su lugar de trabajo. Anteriormente no se había realizado alguna investigación sobre la calidad microbiológica del aire en esta universidad. Esto implica el desconocimiento sobre el riesgo a la salud en las oficinas de la institución. Un estudio de la calidad microbiológica del aire interno representaría conocer el ambiente en que se labora y saber si se corren riesgos de enfermedades por altas concentraciones de microorganismos. El objetivo fue realizar un estudio de la densidad microbiana del aire interior de distintos espacios de la universidad, con la finalidad de evaluar las condiciones sanitarias en las que se labora, mediante la técnica de sedimentación por gravedad en placas de Petri. El trabajo se realizó de agosto a noviembre de 2018, con dos muestreos en diferentes fechas por sitio. Como resultado se obtuvo una concentración promedio en ambos muestreos de 610.02 y $206.31 \mathrm{UFC} / \mathrm{m}^{3}$ para el sitio $A$ y el sitio $B$, respectivamente. Se concluyó que existe poca contaminación y no contaminación, respectivamente.
\end{abstract}

Palabras clave: Calidad microbiológica del aire, contaminación, salud laboral, sedimentación por gravedad.

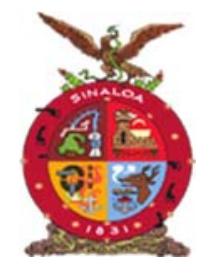

XVIII Congreso Internacional

XXIV Congreso Nacional de Ciencias ambientales
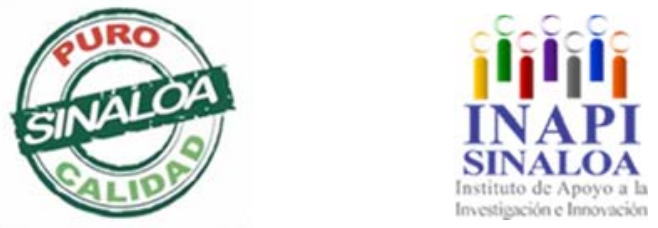

Mazatlán, Sinaloa 3-7 junio 2019

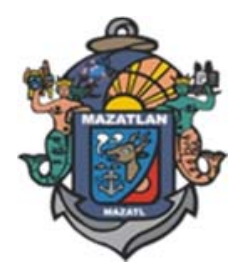

Medio Ambiente, Contaminación, Enfermedad y Genotoxicidad 
TECNOLOGICO NACIONAL DE MEXICO
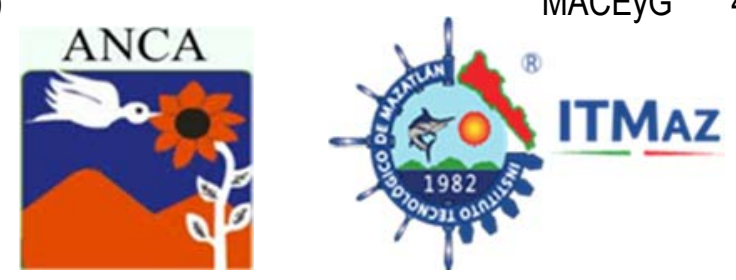

\title{
Microbiological analysis of indoor air in care centers of the Universidad del Noreste in Tampico, México
}

\author{
Arroyo-Galván A*, Rostro Segura A, Del Ángel Ruiz K, Azua-Alonso D, \\ Ramos-Escamilla $\mathrm{F}$ \\ Universidad del Noreste (UNE) \\ *adrian.arroyo.g7@hotmail.com.
}

\begin{abstract}
The microbiological quality of air is related to occupational health, since it has been shown that indoor biological contamination is a fact and that these can cause symptoms or illnesses in workers, in addition to being related to the sick building syndrome. The $40 \%$ and $25 \%$ of the staff working in two care centers of the Universidad del Noreste have the perception that they have acquired some illness or discomfort as a result of being in their place of work. Previously there had been no research on the microbiological quality of air in the university. This implies the ignorance about the risk to health in the offices of the institution. The air is an important natural resource for the human being, a study of the microbiological quality of the internal air would represent knowing the environment in which it is worked and if there are risks of diseases due to high concentrations of microorganisms. The objective was to conduct a study of the microbial density of indoor air in different areas of the university, with the purpose of evaluating the sanitary conditions in which it works, by means of the technique of sedimentation by gravity in Petri dishes. The work was carried out from August to November 2018, with two samplings in different dates per site. An average concentration was obtained in both samples of 610.02 and $206.31 \mathrm{CFU} / \mathrm{m}^{3}$ for site $A$ and site $B$, respectively. It was concluded that there is little pollution and no pollution, respectively.
\end{abstract}

Keywords: Microbiological quality of air, pollution, occupational health, sedimentation by gravity, university.

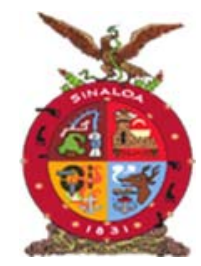

XVIII Congreso Internacional XXIV Congreso Nacional de Ciencias ambientales
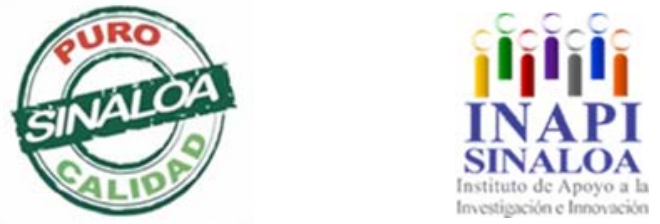

Mazatlán, Sinaloa 3-7 junio 2019

Medio Ambiente, Contaminación,

Enfermedad y Genotoxicidad 

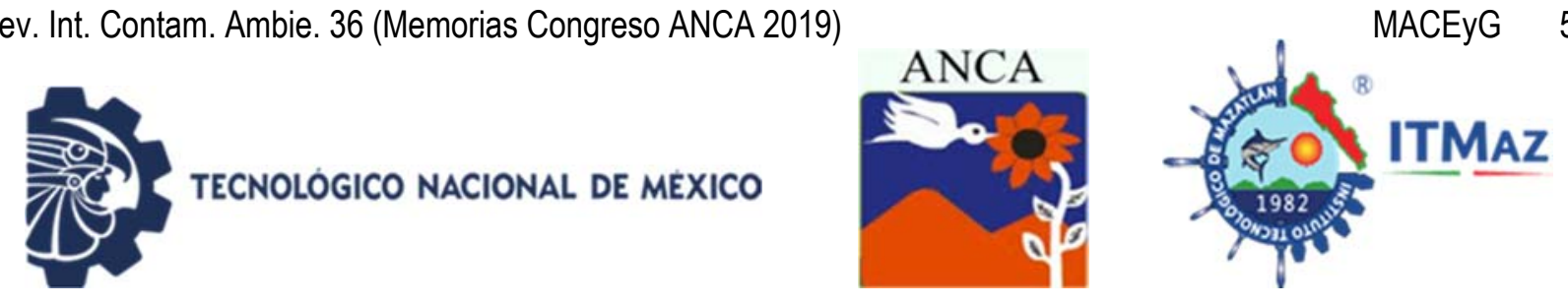

Análisis de deformidades en el mentón de larvas de quironómidos (Diptera, Chironomidae) en una cuenca impactada por metales pesados

\author{
Bello-González $\mathrm{O}^{1 *}$, Alonso-Eguia LP², Mercado-Silva $\mathrm{N}^{3}$ \\ ${ }^{1}$ Maestría en Biología Integrativa de la Biodiversidad y la Conservación. \\ Centro de Investigación en Biodiversidad y Conservación (CIByC). UAEMorelos \\ ${ }^{2}$ Laboratorio de Bioindicadores. Instituto Mexicano de Tecnología del Agua. \\ Paseo Cuauhnáhuac 8532. C.P 62550. Progreso, Jiutepec, Morelos, México \\ ${ }^{3}$ Centro de Investigación en Biodiversidad y Conservación (CIByC). \\ Universidad Autónoma del Estado de Morelos. \\ Av. Universidad 1001, Col. Chamilpa, Cuernavaca, Morelos, México \\ *ocbellog@gmail.com
}

\title{
RESUMEN
}

Las deformidades en el mentón de larvas de quironómidos han sido asociadas con contaminantes, incluyendo metales. Para el biomonitoreo deberían conocerse los niveles "naturales" de deformidades y su variación espacial en relación con las potenciales fuentes de impacto. Analizamos la incidencia de deformidades en el mentón de aproximadamente 4000 larvas de quironómidos, en relación con la concentración de cobre en los sedimentos de 11 sitios distribuidos a lo largo de un probable gradiente de impacto por el vertimiento de una solución de cobre acidulado en la parte alta de la cuenca del río Sonora. El mentón de las larvas se estudió a aumentos de 400X y se calculó el Toxic Score Index (TSI) a partir de los datos de frecuencia y severidad de deformidades. Los géneros comunes fueron: Polypedilum, Tanytarsiini (tribu), Dicrotendipes, Chironomus y Cricotopus. El TSI mostró una relación positiva con la concentración de cobre durante los muestreos de $2015\left(\mathrm{R}^{2}=0.87\right)$ y Junio/2017 $\left(R^{2}=0.51\right)$. Tanto el TSI como la concentración de cobre muestran una reducción de sus valores a medida que se incrementa la distancia al vertimiento. Sin embargo, se observa un repunte del TSI en el tercio inferior de la cuenca sugiriendo la acción de otro factor diferente a laconcentración de cobre como causal, al punto que en Noviembre/2016 encontramos una relación negativa, aunque débil $\left(R^{2}=0.31\right)$ entre ambas variables. En la parte alta de la cuenca, la mayor incidencia de deformidades severas y los mayores valores del TSI se encontraron en Bacanuchi, el sitio más próximo al vertimiento, único lugar en el que se registró evidencias de "Toxicidad" de acuerdo a la escala del TSI. EI estudio de la incidencia de deformidades en el mentón de larvas de quironómidos podría ser viable para la detección de efectos subletales de contaminación particularmente en la parte alta de las cuencas.

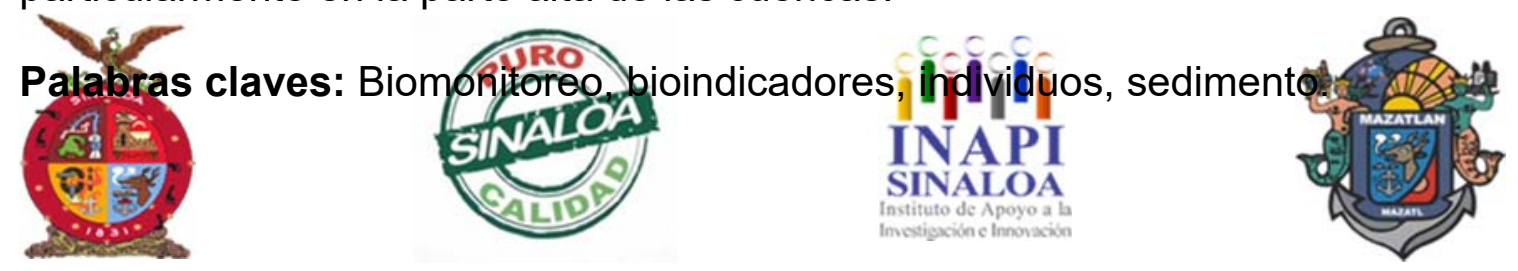




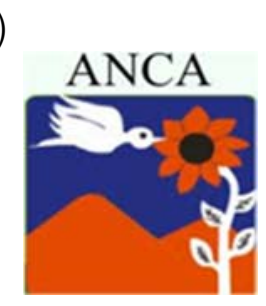

\title{
Analysis of deformities in the chin of chironomid larvae (Diptera, Chironomidae) in a basin impacted by heavy metals
}

\author{
Bello-González $\mathrm{O}^{1 *}$, Alonso-Eguia LP², Mercado-Silva $\mathrm{LN}^{3}$ \\ ${ }^{1}$ Maestría en Biología Integrativa de la Biodiversidad y la Conservación. \\ Centro de Investigación en Biodiversidad y Conservación (CIByC). UAEMorelos \\ ${ }^{2}$ Laboratorio de Bioindicadores. Instituto Mexicano de Tecnología del Agua. \\ Paseo Cuauhnáhuac 8532. C.P 62550. Progreso, Jiutepec, Morelos, México \\ ${ }^{3}$ Centro de Investigación en Biodiversidad y Conservación (CIByC). \\ Universidad Autónoma del Estado de Morelos. \\ Av. Universidad 1001, Col. Chamilpa, Cuernavaca, Morelos, México \\ *ocbellog@gmail.com
}

\begin{abstract}
Deformities in the mentun of chironomid larvae have been associated with contaminants, including metals. For biomonitoring, the "natural" levels of deformities and their spatial variation in relation to the potential sources of impact should be known. We analyzed the incidence of deformities in the mentun of approximately 4000 chironomid larvae, in relation to the concentration of copper in the sediments of 11 sites distributed along a probable gradient of impact by the discharge of a solution of acidulated copper in the part high of the Sonora river basin. The mentun of the larvae was studied at 400X magnification and the Toxic Score Index (TSI) was calculated from the frequency and severity of deformities data. The common genera were: Polypedilum, Tanytarsiini (tribe), Dicrotendipes, Chironomus and Cricotopus. The TSI showed a positive relationship with the copper concentration during the 2015 samplings $\left(R^{2}=0.87\right)$ and June / $2017\left(R^{2}\right.$ $=0.51)$. Both the TSI and the copper concentration show a reduction in their values as the distance to the shed increases. However, an upturn of the TSI is observed in the lower third of the basin, suggesting the action of another factor different from the copper concentration as causal, to the point that in November / 2016 we found a negative, albeit weak $\left(R^{2}=0.31\right)$ between both variables. In the upper part of the basin, the highest index of severe deformities and the highest TSI values were found in Bacanuchi, the site closest to the discharge, the only place where evidence of "Toxicity" was recorded according to the scale of the TSI. The study of the incidence of deformities in the mentun of chironomid larvae could be feasible for the detection of sublethal effects of contamination particularly in the upper part of the basins.
\end{abstract}

Keywords: Biomonitoring, bioindicators, individuals, sediment.

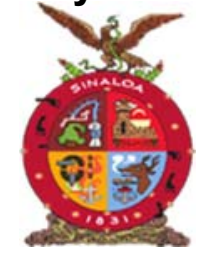

XVIII Congreso Internacional

XXIV Congreso Nacional de Ciencias ambientales

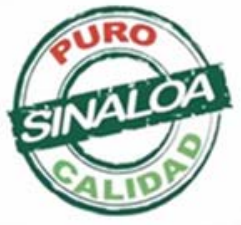

Mazatlán, Sinaloa 3-7 junio 2019
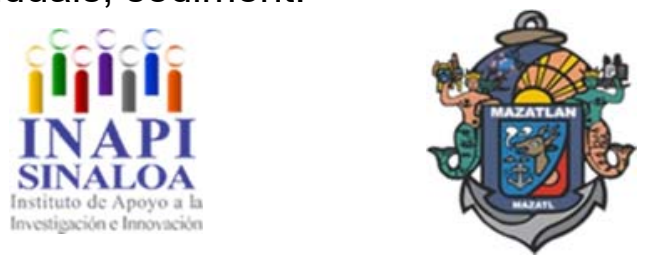

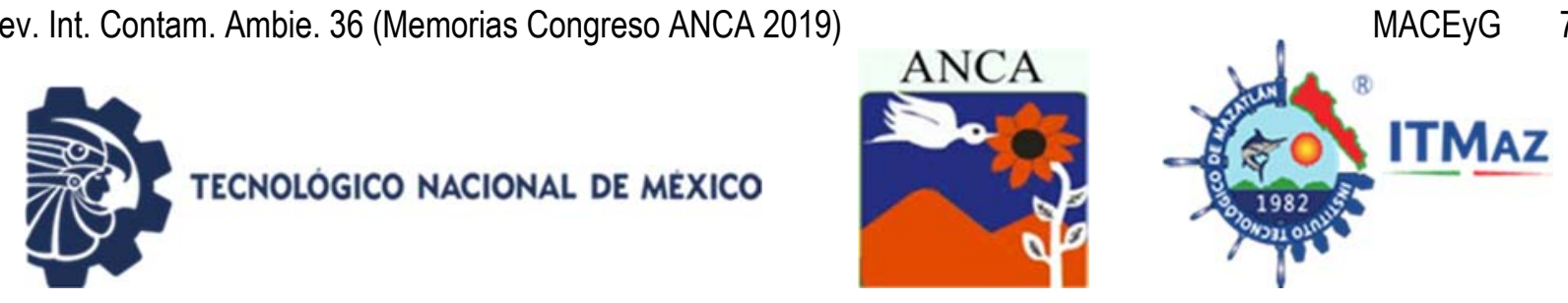

\title{
Identificación de enterobacterias y registro de protozoos de lodos activados en una planta de tratamiento de aguas residuales
}

\author{
Cambranis-Miñon $\mathrm{JH}^{*}$, García-Rojas JL \\ Instituto Mexicano de Tecnología del Agua. \\ Coordinación de Tratamiento y Calidad del Agua. \\ Paseo Cuauhnáhuac No. 8532, Col. Progreso, Jiutepec, Morelos. \\ *lecambranis@gmail.com
}

\section{RESUMEN}

La contaminación de cuerpos de agua por el vertido de aguas residuales, es uno de los principales problemas ambientales del país. Las aguas residuales se generan como resultado del uso del agua en cualquier actividad, ya sea agrícola, industrial o doméstica. Estas, además de contener una alta carga de materia orgánica e inorgánica, acarrean microorganismos que pueden generar problemas sanitarios y ambientales. Para contrarrestar esta problemática, se han desarrollado diversos sistemas de tratamiento para aguas residuales. Entre estos, el sistema de lodos activados, es una alternativa eficaz y económica. El principio del sistema es la degradación de materia orgánica aprovechando el metabolismo de los microorganismos en las aguas residuales. El objetivo de este trabajo fue la identificación de enterobacterias en un sistema de lodos activados y el registro de protozoos de la planta de tratamiento de aguas residuales del Instituto Mexicano de Tecnología en Agua (IMTA). Se realizaron muestreos de agua durante cinco meses en donde se identificó, mediante técnicas de microscopia y pruebas bioquímicas miniaturizadas, la microbiología del sistema de tratamiento. Además se buscaron correlaciones entre los valores de DBO y DQO y las variaciones en la diversidad microbiológica registrada. Los resultados permitieron la identificación de diversas especies de enterobacterias y otras bacterias poco comunes en aguas residuales domésticas, además de múltiples géneros de protozoos. Se encontraron correlaciones positivas entre la DBO $(r=0.6)$ y DQO $(r=0.66)$ y la diversidad de enterobacterias y, de igual manera, con la diversidad de protozoos DBO $(r=-0.95)$ y DQO $(r=-0.84)$ se registraron correlaciones inversas.

Palabras clave: Calidad del agua, enterobacterias, aguas residuales domésticas.

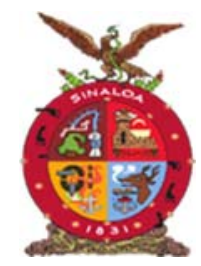

XVIII Congreso Internacional XXIV Congreso Nacional de Ciencias ambientales
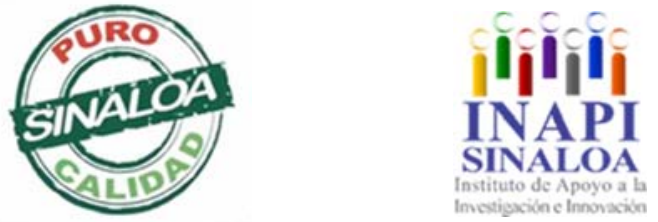

Mazatlán, Sinaloa 3-7 junio 2019

Medio Ambiente, Contaminación,

Enfermedad y Genotoxicidad 
TECNOLOGICO NACIONAL DE MEXICO
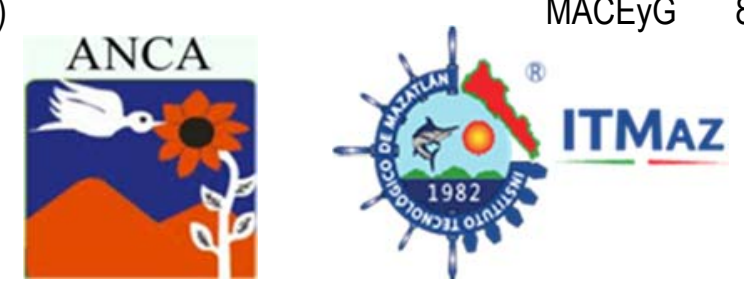

\title{
Identification of enterotype and registration of activated sludge protozoa in a wastewater treatment plant
}

\author{
Cambranis-Miñon $\mathrm{JH}^{*}$, García-Rojas JL \\ Instituto Mexicano de Tecnología del Agua. \\ Coordinación de Tratamiento y Calidad del Agua. \\ Paseo Cuauhnáhuac No. 8532, Col. Progreso, Jiutepec, Morelos. \\ *lecambranis@gmail.com
}

\begin{abstract}
The contamination of bodies of water by the discharge of wastewater is one of the main environmental problems in the country. Wastewater is generated as a result of the use of water in any activity, such as in agricultural, industrial or domestic activities. These, in addition to containing a high load of organic and inorganic matter, carry microorganisms that can generate health and environmental problems. To counteract this problem, a range of wastewater treatment systems have been developed. Among these, the one carried out by activated sludge has been an effective and economical alternative. The principle of this system is the degradation of organic matter taking advantage of the metabolism of microorganisms in the wastewater. The aim of this work was the identification of enterotype in activated sludge system and the registration of protozoa of the plant wastewater treatment of the Mexican Institute of Water Technology (IMTA). Water samples were taken during a period of five months where the microbiology of the treatment system was identified by microscopy techniques and miniaturized biochemical tests. In addition, correlations were sought between BOD and COD values and variations in recorded microbiological diversity. The results allowed the identification of several enterotype species, and other not common bacteria in domestic wastewater, as well the registry of multiple protozoan genera. Positive correlations were found between the BOD $\quad(r=0.6)$ and COD $(r=0.66)$ and the diversity of enterotype bacteria and, as well, with the diversity of protozoa, BOD $(r=-0.95)$ and COD $(r=-0.84)$ inverse correlations were recorded.
\end{abstract}

Keywords: Water quality, enterotype, domestic wastewater.

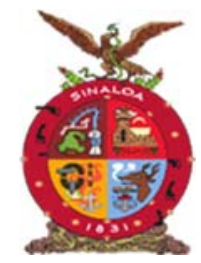

XVIII Congreso Internacional XXIV Congreso Nacional de Ciencias ambientales
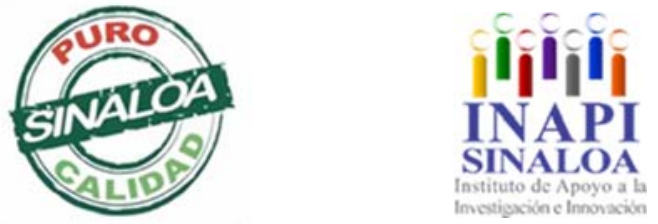

Mazatlán, Sinaloa 3-7 junio 2019

Medio Ambiente, Contaminación,

Enfermedad y Genotoxicidad 
TECNOLOGICO NACIONAL DE MEXICO
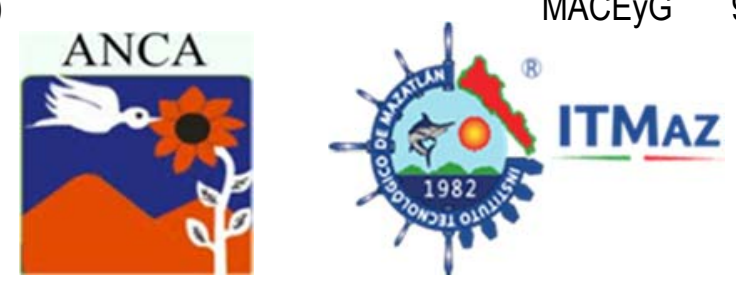

\title{
Análisis de muerte celular programada en Gnaphalium lavandulifolium inducida por contaminación del aire
}

\author{
Cortés-Eslava $\mathrm{J}^{1}$, Mérida-Cortés $\mathrm{PA}^{1^{*}}$, Gómez-Arroyo $\mathrm{S}^{1}$, Flores Márquez $\mathrm{AR}^{1}$, \\ Grutter-de la Mora $\mathrm{M}^{2}$, Lara-Martínez $\mathrm{R}^{3}$, Jiménez García LF $^{3}$ \\ ${ }^{1}$ Laboratorio de Genotoxicología y Mutagénesis Ambientales \\ ${ }^{2}$ Espectroscopia y Percepción Remota. Centro de Ciencias de la Atmósfera. \\ Universidad Nacional Autónoma de México. Ciudad Universitaria, \\ Coyoacán, 04510 Ciudad de México \\ ${ }^{3}$ Departamento de Biología Celular. Facultad de Ciencias. UNAM, \\ Ciudad Universitaria, Coyoacán, 04510 Ciudad de México \\ *pabloantoniomc@gmail
}

\section{RESUMEN}

Se ha señalado a la mezcla de contaminantes atmosféricos como una de las principales causas del daño celular y genético en los organismos. La muerte celular programada (MCP), implica una secuencia de eventos controlados genéticamente que conducen a la destrucción organizada de la célula. En vegetales se ha identificado una MCP parecida a la apoptótica: AL-PCD (por sus siglas en inglés), debido a su similitud con la apoptosis de células animales; una característica fundamental es la condensación del protoplasto separándose de la pared. Con el objetivo de analizar los cambios morfológicos a nivel celular, indicativos de AL-PCD en las hojas de la planta silvestre G. lavandulifolium, se expuso a las atmosferas de Coyoacán, Ecatepec, Tlalnepantla y Altzomoni dentro de la Zona Metropolitana del Valle de México. La exposición se realizó durante 0, 2, 4 y 8 semanas. Posteriormente las muestras se fijaron con para-formaldehído, para su análisis, se deshidrataron con metanol, incluyeron en lowicryl, elaboraron cortes semifinos, se tiñeron con azul de toluidina y se observaron al microscopio. Los resultados obtenidos mostraron cambios morfológicos en las células dependiendo del sitio y tiempo de exposición, siendo mayor en Ecatepec y menor en Altzomoni, esto de acuerdo a la contracción del protoplasto separándose de la pared celular, típica de la AL-PCD. Se puede concluir que los cambios morfológicos observados en las células son atribuibles a la contaminación atmosférica de cada sitio.

Palabras clave: AL-PCD, apoptosis, contaminación atmosférica.

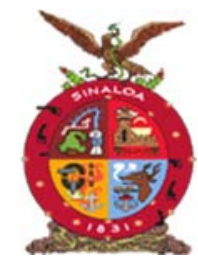

XVIII Congreso Internacional

XXIV Congreso Nacional de Ciencias ambientales
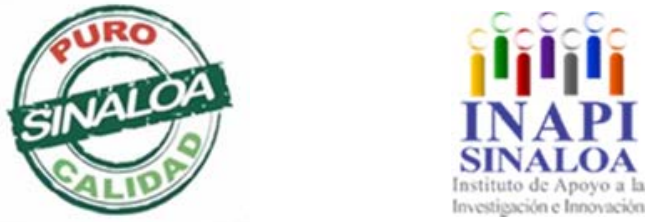

Mazatlán, Sinaloa 3-7 junio 2019

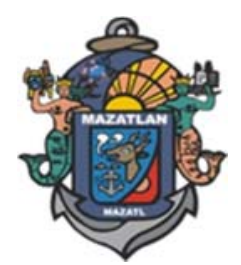

Medio Ambiente, Contaminación, Enfermedad y Genotoxicidad 
TECNOLOGICO NACIONAL DE MEXICO
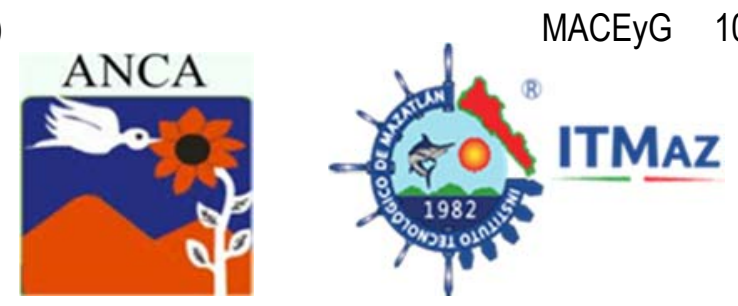

\title{
Analysis of programmed cell death induced in Gnaphalium lavandulifolium induced by air pollution
}

Cortés-Eslava $\mathrm{J}^{1}$, Mérida-Cortés $\mathrm{PA}^{1^{*}}$, Gómez-Arroyo $\mathrm{S}^{1}$, Flores Márquez $\mathrm{AR}^{1}$, Grutter-de la Mora $\mathrm{M}^{2}$, Lara-Martínez $\mathrm{R}^{3}$, Jiménez García LF ${ }^{3}$

${ }^{1}$ Laboratorio de Genotoxicología y Mutagénesis Ambientales

${ }^{2}$ Espectroscopia y Percepción Remota. Centro de Ciencias de la Atmósfera, UNAM. Ciudad Universitaria, Coyoacán, 04510 Ciudad de México

${ }^{3}$ Departamento de Biología Celular. Facultad de Ciencias. UNAM,

Ciudad Universitaria, Coyoacán, 04510 Ciudad de México

*pabloantoniomc@gmail

\begin{abstract}
The mixture of air pollutants has been described as one of the main causes of cell and genetic damage in organisms. The programmed cell death (MCP) involves a sequence of genetically controlled events leading to the organized destruction of the cell. In plants a PCM similar to apoptotic has been identified: AL-PCD (for its acronym in English), due to its similarity with the apoptosis of animal cells; a fundamental characteristic is the condensation of the protoplast separating itself from the wall. In order to analyze the morphological changes at the cellular level, indicative of AL-PCD in the leaves of the wild plant G. lavandulifolium, it was exposed to the atmospheres of the Coyoacán, Ecatepec, Tlalnepantla and Altzomoni within the Metropolitan Zone of the Valley of Mexico. The exposure was done for $0,2,4$ and 8 weeks. The samples were then fixed with paraformadehyde, dehydrated with methanol, included in lowicryl and semifine cuts were made, stained with toluidine blue and observed under a microscope. The obtained results showed morphological changes in the cells depending on the site and time of exposure, being greater in Ecatepec and smaller in Altzomoni, this according to the contraction of the protoplast separating from the cell wall, typical of AL-PCD. It can be concluded that the morphological changes observed in cells are attributable to the air pollution of each site.
\end{abstract}

Key words: AL-PCD, apoptosis, air pollution.

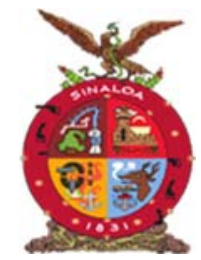

XVIII Congreso Internacional XXIV Congreso Nacional de Ciencias ambientales
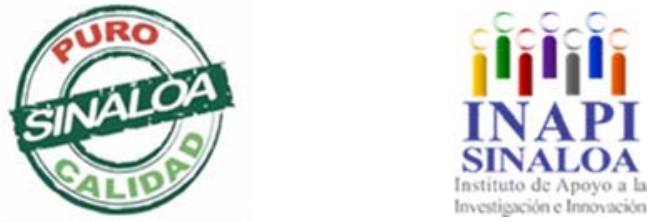

Mazatlán, Sinaloa 3-7 junio 2019

Medio Ambiente, Contaminación Enfermedad y Genotoxicidad 
TECNOLOGICO NACIONAL DE MEXICO
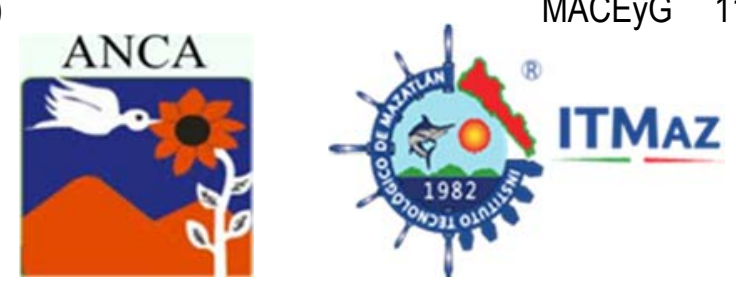

\title{
Escurrimiento superficial y fustal en bosques de pino-encino bajo manejo forestal en Durango, México
}

\author{
Cruz García F ${ }^{1}$, Pérez VerdínG ${ }^{1}$, Monárrez González C², Wehenkel C ${ }^{3}$ \\ ${ }^{1}$ CIIDIR.Instituto Politécnico Nacional, Sigma 119, Durango, México \\ ${ }^{2}$ INIFAP. Campo Experimental Valle del Guadiana. \\ CIR-Norte Centro, Durango, México \\ ${ }^{3}$ ISIMA. Universidad Juárez del Estado de Durango, Durango, México \\ *guarimochi_494@hotmail.com
}

\begin{abstract}
RESUMEN
Los escurrimientos del agua en bosques templados dependen, entre otros factores, de la cobertura forestal. Esta cobertura puede ser modificada a través de la aplicación de tratamientos silvícolas, cuyos efectos se manifiestan en la calidad y cantidad de agua y en el transporte de sedimentos y nutrientes del suelo. El objetivo de este estudio fue analizar el efecto que tiene la aplicación de los tratamientos silvícolas en los escurrimientos superficial (ES) y fustal (EF) del agua en bosques templados del norte de México, mediante la relación que existe entre el diámetro normal, área basal, cobertura de copas y volumen. Para esto, se establecieron parcelas de monitoreo de $1000 \mathrm{~m}^{2}$ en el P.P. Molinillos en el municipio de Durango, donde se midieron variables dasométricas del arbolado, precipitación incidental y los escurrimientos antes mencionados. Se utilizó la regresión lineal y no lineal por cuantiles, y regresión lineal utilizando Random Forests y Machine Learning, todo, mediante el paquete estadístico $R$ versión 3.5.1. Los modelos resultantes indican que entre más grande es el área basal y el diámetro normal del arbolado el ES y EF será mayor respectivamente. Los modelos por cuantil nos permiten predecir los niveles máximos, medios y mínimos de escurrimientos superficial, mientras que los modelos para EF nos permiten predecir el escurrimiento entre los géneros por diámetro en el arbolado de la zona de estudio.
\end{abstract}

Palabras clave: Servicios ecosistémicos, regresión por cuantiles, Random Forests, Machine Learning.

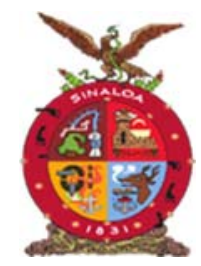

XVIII Congreso Internacional XXIV Congreso Nacional de Ciencias ambientales
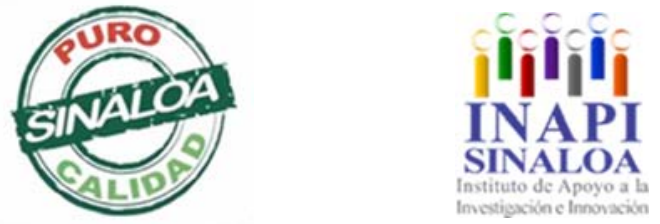

Mazatlán, Sinaloa 3-7 junio 2019

Medio Ambiente, Contaminación, Enfermedad y Genotoxicidad 
TECNOLOGICO NACIONAL DE MEXICO
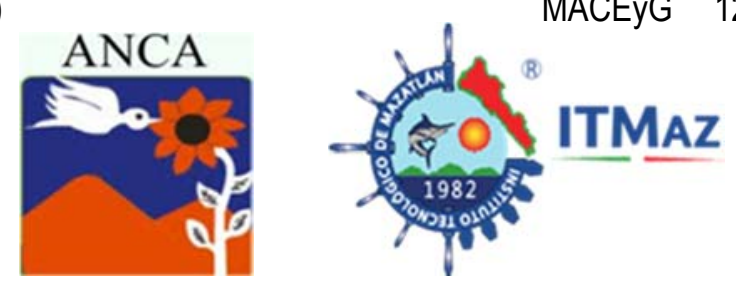

\title{
Stream flow and stem flow in pino-oak forests under forest management in Durango, Mexico
}

\author{
Cruz García F ${ }^{1}$, Pérez VerdínG ${ }^{1}$, Monárrez González C ${ }^{2}$, Wehenkel $C^{3}$ \\ ${ }^{1}$ CIIDIR. Instituto Politécnico Nacional, Sigma 119, Durango, México \\ ${ }^{2}$ INIFAP. Campo Experimental Valle del Guadiana. \\ CIR-Norte Centro, Durango, México \\ 3ISIMA. Universidad Juárez del Estado de Durango, Durango, México \\ *guarimochi_494@hotmail.com
}

\begin{abstract}
Water flows in temperate forests depends, among other factors, on forest coverage. This coverage can be modified through the application of silvicultural treatments, whose effects are manifested in the quality and quantity of water and in the sediments transport and soil nutrients. The objective of this study was to analyze the effect of the application of silvicultural treatments on surface flows (ES) and stem flow (EF) of the water in temperate forests of northern Mexico, through the relationship between the normal diameter, basal area, canopy cover and volume. To do this, monitoring plots of $1000 \mathrm{~m}^{2}$ were established in the P.P. Molinillos in the municipality of Durango, where tree dasometric variables, incidental precipitation and previous mentioned flows variables were measured. We used linear and non-linear regression by quantiles, and linear regression through Random Forests and Machine Learning, all through the statistical package $R$ version 3.5.1. The resulting models indicate that the larger the basal area and the normal diameter of the trees the ES and EF will be greater respectively. The models by quantile allow us to predict the maximum, average and minimum levels of surface flows, while the models for EF allow us to predict the flows between the genera by diameter in the trees of the study area.
\end{abstract}

Keywords: Ecosystem services, regression by quantiles, Random Forests, Machine Learning.

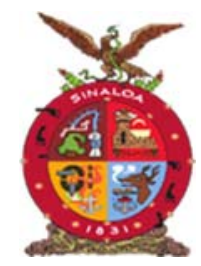

XVIII Congreso Internacional XXIV Congreso Nacional de Ciencias ambientales
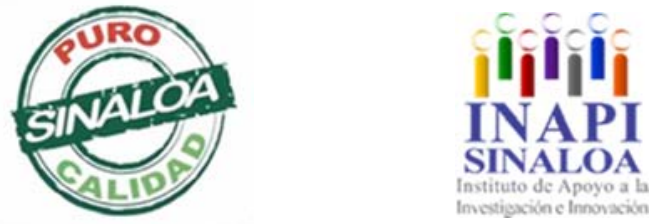

Mazatlán, Sinaloa 3-7 junio 2019

Medio Ambiente, Contaminación,

Enfermedad y Genotoxicidad 
TECNOLOGICO NACIONAL DE MEXICO
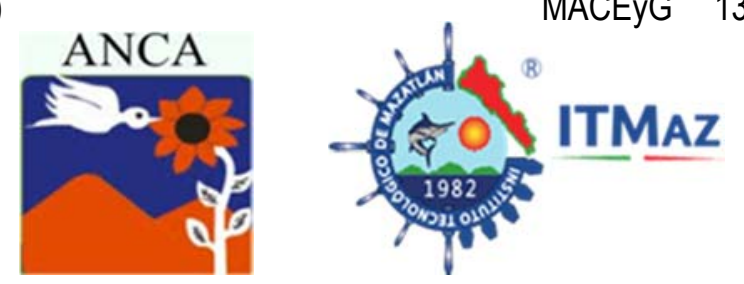

\section{Despilfarro doméstico de recursos naturales por el uso y manejo ineficientes de residuos orgánicos}

De la Llata-López ME¹, Juárez-López $\mathrm{AL}^{2 *}$, Sampedro-Rosas $\mathrm{ML}^{2}$, Rosas-Acevedo $\mathrm{J}^{2}$, Olmos Martínez $\mathrm{E}^{3}$

${ }^{1}$ Sede Educacional de Cultura Ambiental.

Av. Universidad 5-103. Fracc. Magallanes, C. P. 39670, Acapulco, Gro. México

${ }^{2}$ UCDR. Universidad Autónoma de Guerrero.

Calle Pino s/n, Col. El Roble, C.P. 39640, Acapulco, Gro. México

3Universidad Autónoma de Occidente. Unidad Mazatlán, Sinaloa

*analaura43@hotmail.com

\section{RESUMEN}

La huella del despilfarro de alimentos es contraria a la conservación de recursos naturales; equivale a desperdiciar alimento; independientemente de ser causa de pérdidas económicas. Con el objetivo de evitar que ocurra el despilfarro de recursos naturales en el hogar y reutilizar o reciclar cuando no haya forma de impedirlo, del 27 de mayo al 30 de junio de 2017, se aplicó una encuesta, a una muestra no probabilística de 81 adultos, residentes del área urbana de Acapulco. Para esta investigación descriptiva, se aplicó un cuestionario, de 8 ítems, para determinar la disponibilidad y frecuencia del servicio de recolección y la existencia de áreas verdes; y una lista de 10 tipos de residuos y 7 espacios domésticos, para relacionar tipos y sitios de generación. Para el análisis e interpretación de resultados, se empleó el método de estadística descriptiva. Las modas refieren que disponen del servicio 2 o 3 veces por semana; y que hay áreas verdes intra y peri domiciliarias. Ambos grupos señalaron, que en la cocina, generan más tipos de residuos. Sin embargo, en 17 de las 18 colonias donde residen, prevalecen y proliferan puntos negros y/o tiraderos a cielo abierto. Se concluyó que el manejo y disposición de residuos inadecuados en el hogar, equivale a permitir que su disposición final, por la parte corresponsable, sea todavía más ineficiente; situación que, con educación ambiental no formal, podrá minimizarse.

Palabras clave: Residuos domésticos, residuos de alimentos, recursos naturales, biodiversidad y corresponsabilidad.

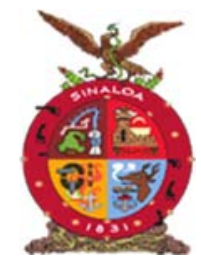

XVIII Congreso Internacional XXIV Congreso Nacional de Ciencias ambientales
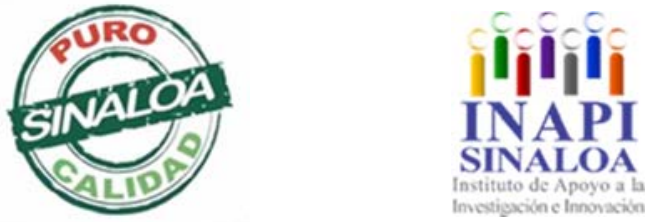

Mazatlán, Sinaloa 3-7 junio 2019

Medio Ambiente, Contaminación,

Enfermedad y Genotoxicidad 
TECNOLOGICO NACIONAL DE MEXICO
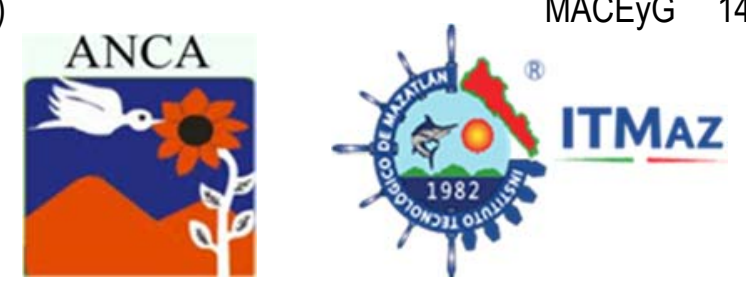

\title{
Domestic wastage of natural resources for inefficient use and management of organic waste
}

De la Llata-López ME¹, Juárez-López $\mathrm{AL}^{2 *}$, Sampedro-Rosas $\mathrm{ML}^{2}$, Rosas-Acevedo $\mathrm{J}^{2}$, Olmos Martínez $\mathrm{E}^{3}$

'Sede Educacional de Cultura Ambiental.

Av. Universidad 5-103. Fracc. Magallanes, C. P. 39670, Acapulco, Gro. México

${ }^{2}$ UCDR. Universidad Autónoma de Guerrero.

Calle Pino s/n, Col. El Roble, C.P. 39640, Acapulco, Gro. México

3Universidad Autónoma de Occidente. Unidad Mazatlán, Sinaloa

*analaura43@hotmail.com

\begin{abstract}
The foot wastage footprint is against natural resources conservation. It is equivalent to wasting food; regardless of the economic losses it implies. In order to avoid household waste of natural resources in the home and reuse or recycle when there is no way to prevent it, a non-probabilistic sample of 81 adults, residents of the urban area of Acapulco, was administered a survey. For this descriptive research, an eight-item questionnaire, to determine the availability and frequency of the municipal collection service and the existence of green areas in the neighborhood and homes; together with list of 10 types of waste and 7 domestic spaces, to relate their type and generation site, was designed. For the analysis and interpretation of data, descriptive statistics method was used. The modes referred that they counted with the service from 2 to 3 times a week; and that there were common and private green areas. Both groups pointed out that it was in the kitchen where they generated more types of waste. But, waste points and open-air dumps prevail and proliferate, along 17 out of the 18 home areas where they reside. It was concluded that inadequate household waste management and disposal is equivalent to allowing the co-responsible part to do the final waste disposal, even more inefficiently; a situation that can be minimized with non-formal environmental education.
\end{abstract}

Keywords: Household waste, food waste, natural resources, biodiversity and co-responsibility.

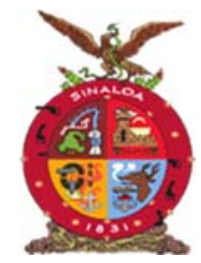

XVIII Congreso Internacional XXIV Congreso Nacional de Ciencias ambientales
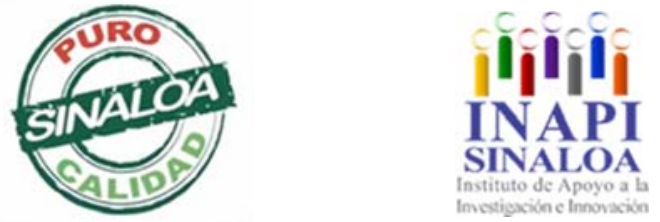

Mazatlán, Sinaloa 3-7 junio 2019

Medio Ambiente, Contaminación,

Enfermedad y Genotoxicidad 
TECNOLOGICO NACIONAL DE MEXICO
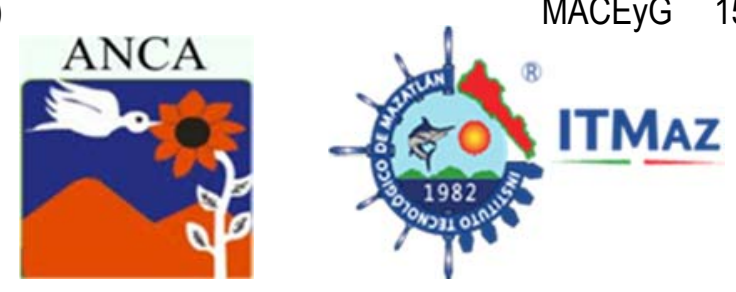

\title{
Comparación del riesgo a la salud ocasionado por la inhalación de PM2.5 en las áreas metropolitanas del Valle de Toluca y el Valle de México
}

\author{
Díaz-Godoy $\mathrm{RV}^{1 *}$, López-Monroy $\mathrm{J}^{1}$, Moreno-Alcántara $\mathrm{J}^{1}$, \\ Castellanos-Moguel $\mathrm{J}^{1}$, Núñez-Cardona $\mathrm{MT}^{2}$, Sierra-Vargas $\mathrm{MP}^{3}$ \\ ${ }^{1}$ Instituto Nacional de Investigaciones Nucleares (ININ), \\ Carretera México Toluca S/N, La Marquesa Ocoyoacac, México. \\ 2Universidad Autónoma Metropolitana-Xochimilco. \\ Departamento El Hombre y Su Ambiente, \\ Calzada del Hueso 1100, Col. Villa Quietud, Coyoacán, CDMX, México \\ ${ }^{3}$ Instituto Nacional de Enfermedades Respiratorias (INER), \\ Calz. de Tlalpan No. 4502, Del. Tlalpan, Col. Sección XVI, CDMX \\ *raul.diaz@.inin.gob.mx
}

\section{RESUMEN}

Las áreas metropolitanas de los valles de Toluca y México tienen altos niveles de mortalidad y morbilidad debido a la inhalación de partículas conocidas como $\mathrm{PM}_{2.5}$. En este trabajo, se evaluó espacialmente el riesgo para la salud por inhalación de contaminantes $\mathrm{PM}_{2.5}$ en ambas áreas. Se realizó una campaña de muestreo simultáneo en los valles de Toluca y México en días alternos desde el 22 de septiembre hasta el 29 de noviembre de 2009. De las muestras recolectadas, se obtuvo su concentración gravimétrica y utilizando la técnica de emisión de rayos $X$ inducida por partículas (PIXE) la concentración elemental para $\mathrm{S}, \mathrm{Cl}, \mathrm{K}, \mathrm{Ca} \mathrm{Ti}, \mathrm{V}, \mathrm{Mn}, \mathrm{Fe}, \mathrm{Ni}, \mathrm{Cu}, \mathrm{Zn}$ y $\mathrm{Pb}$ fue determinada. Con las concentraciones elementales obtenidas en ambas zonas, se obtuvieron los componentes antropogénicos ( $\mathrm{S}$ altamente enriquecido; $\mathrm{Cl}, \mathrm{V}, \mathrm{Ni}, \mathrm{Cu}$ y $\mathrm{Zn}$ enriquecidos) y naturales (K, $\mathrm{Ca}, \mathrm{Mn}, \mathrm{Fe})$. El riesgo para la salud por inhalación de $\mathrm{PM}_{2.5}$ se obtuvo más alto para el valle de Toluca (2.09 para adultos, 6.25 para niños de 6 a 12 años y 6.58 para niños de 2 a 6 años) en contraste con el valle de México (1.67 para adultos, 5.20 para niños de 6 a 12 años y 5.28 para niños de 2 a 6 años). Por lo que hay riesgos para la salud por la inhalación de PM2.5 en las áreas de estudio y existe un mayor riesgo de contraer una enfermedad respiratoria en el valle de Toluca en comparación con el de México.

Palabras clave: Área metropolitana del Valle de Toluca, área metropolitana del Valle de México, PIXE, riesgo de salud, componente antropogénica y naturales.

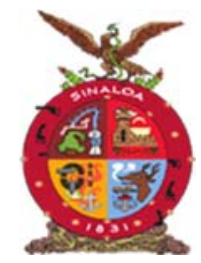

XVIII Congreso Internacional XXIV Congreso Nacional de Ciencias ambientales
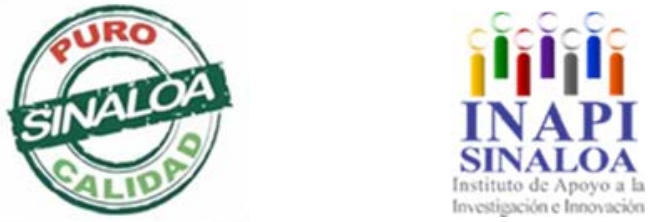

Mazatlán, Sinaloa 3-7 junio 2019

Medio Ambiente, Contaminación,

Enfermedad y Genotoxicidad 
TECNOLOGICO NACIONAL DE MEXICO
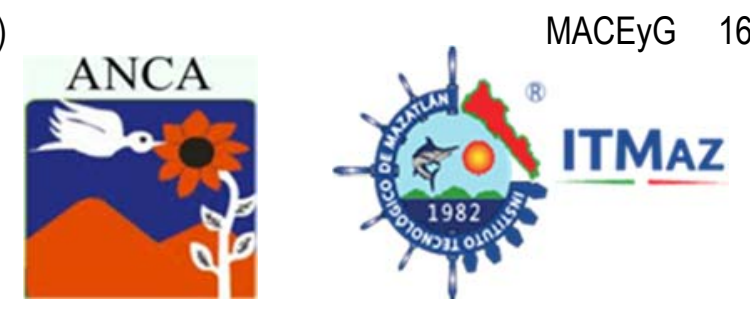

\title{
Compared with the health risk caused by the inhalation of $\mathrm{PM}_{2.5}$ in the metropolitan areas of the Valley of Toluca and the Valley of México
}

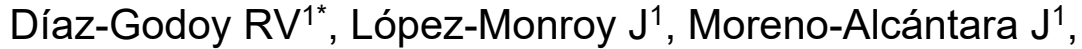 \\ Castellanos-Moguel $\mathrm{J}^{1}$, Núñez-Cardona $\mathrm{MT}^{2}$, Sierra-Vargas MP ${ }^{3}$ \\ ${ }^{1}$ Instituto Nacional de Investigaciones Nucleares (ININ), \\ Carretera México Toluca S/N, La Marquesa Ocoyoacac, México. \\ 2Universidad Autónoma Metropolitana-Xochimilco. \\ Departamento El Hombre y Su Ambiente, \\ Calzada del Hueso 1100, Col. Villa Quietud, Coyoacán, CDMX, México \\ ${ }^{3}$ Instituto Nacional de Enfermedades Respiratorias (INER), \\ Calz. de Tlalpan No. 4502, Del. Tlalpan, Col. Sección XVI, CDMX \\ *raul.diaz@.inin.gob.mx
}

\begin{abstract}
The metropolitan areas of the valleys of Toluca and Mexico have high levels of mortality and morbidity due to the inhalation of particles known as PM2.5. In this work, the health risk due to inhalation of $\mathrm{PM}_{2.5}$ pollutants in both areas was spatially evaluated. A simultaneous sampling campaign was conducted in the valleys of Toluca and Mexico on alternate days from September 22 to November 29 , 2009. From the collected samples, their gravimetric concentration was obtained and using the technique of induced X-ray emission per particle (PIXE) the elemental concentration for $\mathrm{S}, \mathrm{Cl}, \mathrm{K}, \mathrm{Ca} \mathrm{Ti}, \mathrm{V}, \mathrm{Mn}, \mathrm{Fe}, \mathrm{Ni}, \mathrm{Cu}, \mathrm{Zn}$ and $\mathrm{Pb}$ was determined. With the elemental concentrations obtained in both zones, the anthropogenic components (highly enriched $\mathrm{S}, \mathrm{Cl}, \mathrm{V}, \mathrm{Ni}, \mathrm{Cu}$ and $\mathrm{Zn}$ enriched) and natural components $(\mathrm{K}, \mathrm{Ca}, \mathrm{Mn}, \mathrm{Fe})$ were obtained. The risk for health by inhalation of $\mathrm{PM}_{2.5}$ was highest for the Toluca Valley (2.09 for adults, 6.25 for children from 6 to 12 years and 6.58 for children from 2 to 6 years) in contrast to the Valley of Mexico (1.67 for adults, 5.20 for children from 6 to 12 years old and 5.28 for children from 2 to 6 years old). So there are health risks from the inhalation of $\mathrm{PM}_{2.5}$ in the study areas and there is a greater risk of contracting a respiratory disease in the valley of Toluca compared to Mexico.
\end{abstract}

Keywords: Metropolitan area of the Toluca Valley, metropolitan area of the Mexico Valley, PIXE, health risk, anthropogenic and natural components.

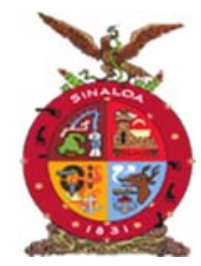

XVIII Congreso Internacional

XXIV Congreso Nacional de Ciencias ambientales
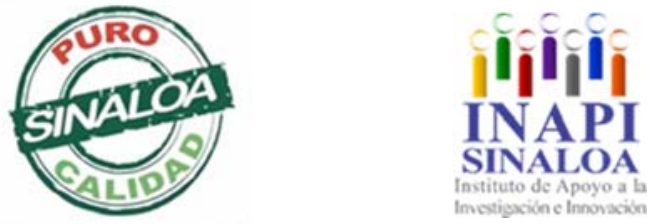

Mazatlán, Sinaloa 3-7 junio 2019

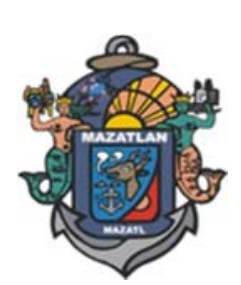

Medio Ambiente, Contaminación, Enfermedad y Genotoxicidad 
TECNOLOGICO NACIONAL DE MEXICO
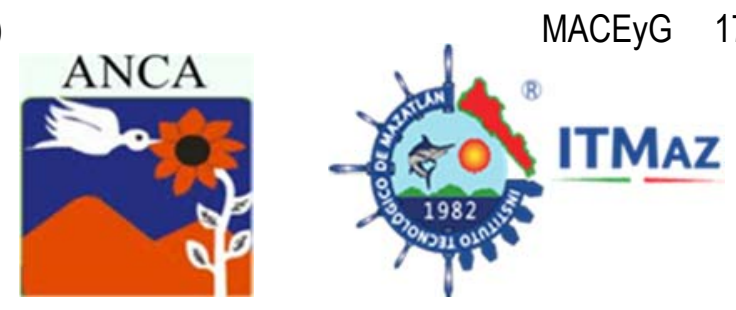

\title{
Deposición de necro-masa en el ejido Adolfo Ruíz Cortines, Pueblo Nuevo, Durango, México
}

\author{
Domínguez-Gómez $\mathrm{TG}^{1 *}$, Alvarado $\mathrm{MS}^{2}$, González-Rodríguez $\mathrm{H}^{3}$, \\ González-Quiñones JS ${ }^{1}$, Colín JG ${ }^{1}$ \\ ${ }^{1}$ Instituto Tecnológico El Salto. \\ División de Estudios de Posgrado e Investigación. \\ Mesa del Tecnológico S/N, El Salto, Durango, México. \\ ${ }^{2}$ Centro de Investigación en Alimentación y Desarrollo, A.C. \\ Carr. La Victoria Km 0.6, Hermosillo, Sonora, México. \\ ${ }^{3}$ Facultad de Ciencias Forestales. Universidad Autónoma de Nuevo León, \\ Carr. Nac. No 85, Km 145, Linares, Nuevo León, México. 67700. \\ *gustavo_dguezg@hotmail.com
}

\section{RESUMEN}

La producción de hojarasca es un proceso fundamental en el ciclo de nutrientes, ya que representa la principal transferencia de materia orgánica al suelo. El objetivo de este estudio fue estimar la deposición de la hojarasca. Se estableció un experimento en el ejido Adolfo Ruiz Cortines del municipio de Pueblo Nuevo; Durango en el estado de Durango. Los constituyentes de la hojarasca (hojas, estructuras reproductivas, ramas, corteza, heces e insectos y otros) se cuantificaron a un intervalo de un año (nov del 2015 a nov 2016). Se ubicó una parcela de $(50 \times 50 \mathrm{~m})$, en donde se instalaron diez trampas de hojarasca de 1.0 $\mathrm{m}^{2}$ para la captura de la hojarasca. Dado que la mayoría de los datos para las fechas de muestreo y componentes de la hojarasca no presentaron igualdad en las varianzas, se empleó la prueba no paramétrico de Kruskal-Wallis para detectar diferencias entre cada fecha de muestreo. La deposición total anual de hojarasca fue de $5025 \mathrm{~kg} \mathrm{ha}^{-1} \mathrm{año}^{-1}$. Las hojas representaron el componente principal con una contribución del 76.15 , las ramas aportaron un $8.35 \%$, las estructuras reproductivas aportaron $7.33 \%$ el componente corteza $6.34 \%$; el componente otros un $0.97 \%$ y por último el componente heces e insectos represento un $0.86 \%$. Los resultados revelaron que la diferencia en la deposición de cada uno de los componentes de la hojarasca obedece a la diferencia de las condiciones climáticas, edáficas y la vegetación existente en los sitios de estudio, así como al manejo de forestal.

Palabras clave: Producción de hojarasca, Adolfo Ruiz Cortines, trampas, estructuras reproductivas.

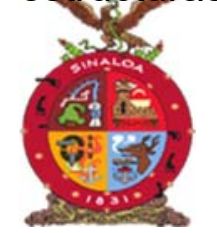

XVIII Congreso Internacional XXIV Congreso Nacional de Ciencias ambientales

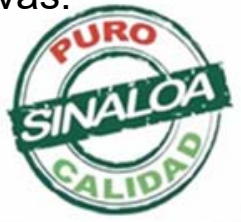

Mazatlán, Sinaloa 3-7 junio 2019

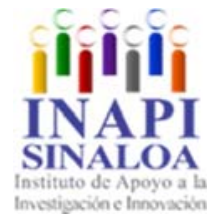

Medio Ambiente, Contaminación, Enfermedad y Genotoxicidad 
TECNOLOGICO NACIONAL DE MEXICO
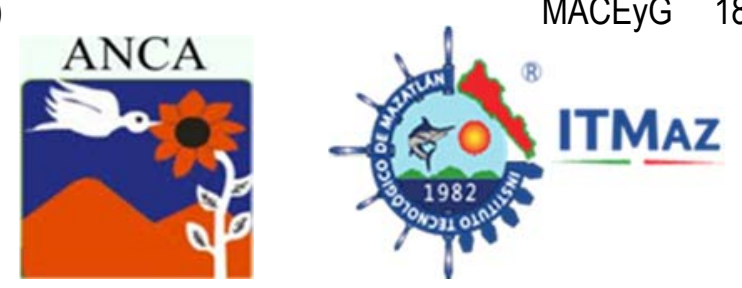

\title{
Necro-mass deposition in the ejido Adolfo Ruíz Cortines, Pueblo Nuevo, Durango, México
}

\author{
Domínguez-Gómez $\mathrm{TG}^{1 *}$, Alvarado $\mathrm{M}$ del $\mathrm{S}^{2}$, González-Rodríguez $\mathrm{H}^{3}$, \\ González-Quiñones JS ${ }^{1}$, Colín JG ${ }^{1}$ \\ Domínguez-Gómez $\mathrm{TG}^{1^{*}}$, Alvarado $\mathrm{M}$ del $\mathrm{S}^{2}$, González-Rodríguez $\mathrm{H}^{3}$, \\ González-Quiñones JS ${ }^{1}$, Colín JG ${ }^{1}$ \\ ${ }^{1}$ Instituto Tecnológico El Salto. \\ División de Estudios de Posgrado e Investigación. \\ Mesa del Tecnológico S/N, El Salto, Durango, México. \\ ${ }^{2}$ Centro de Investigación en Alimentación y Desarrollo, A.C. \\ Carr. La Victoria Km 0.6, Hermosillo, Sonora, México. \\ ${ }^{3}$ Facultad de Ciencias Forestales. Universidad Autónoma de Nuevo León, \\ Carr. Nac. No 85, Km 145, Linares, Nuevo León, México. 67700. \\ *gustavo_dguezg@hotmail.com
}

\begin{abstract}
Litter production is a fundamental process in the nutrient cycle, which represents the main transfer of organic matter to the soil. The objective of this study was to estimate the deposition of litter. An experiment was experienced in the Adolfo Ruiz Cortines Ejido in the municipality of Pueblo Nuevo Durango in the state of Durango. The litter components (leaves, reproductive structures, branches, bark, feces and insects and others) are quantified over a period of one year (November 2015 to November 2016). A plot of $(50 \times 50 \mathrm{~m})$ was located, where ten $1.0 \mathrm{~m}^{2}$ litter traps were installed to catch litter. Since most of the data for the sampling dates and litter components without equal reflection in the variances, the KruskalWallis non-parametric test was used to detect differences between each sampling data. The total annual litter deposition was $5025 \mathrm{~kg}$ ha-1 year-1. The leaves represented the main component with a contribution of 76.15 , the branches contributed $8.35 \%$, the reproductive structures contributed $7.33 \%$ the cortex component $6.34 \%$; the other component $0.97 \%$ and finally the component feces and insects represent $0.86 \%$. The results revealed that the difference in the deposition of each of the litter components is due to the difference in climatic, edaphic conditions and vegetation existing in the study sites, as well as forest management.
\end{abstract}

Keywords: Litter production, Adolfo Ruiz Cortines, traps, reproductive

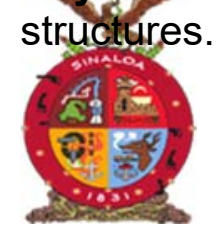

XVIII Congreso Internacional

XXIV Congreso Nacional de Ciencias ambientales
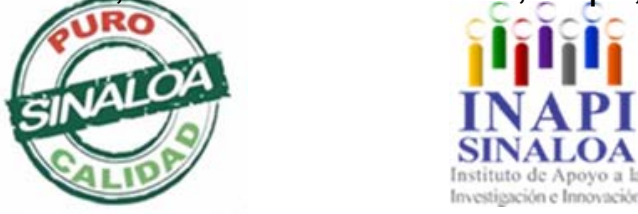

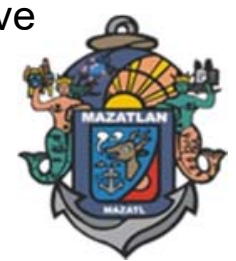

Medio Ambiente, Contaminación, Enfermedad y Genotoxicidad 
TECNOLOGICO NACIONAL DE MEXICO
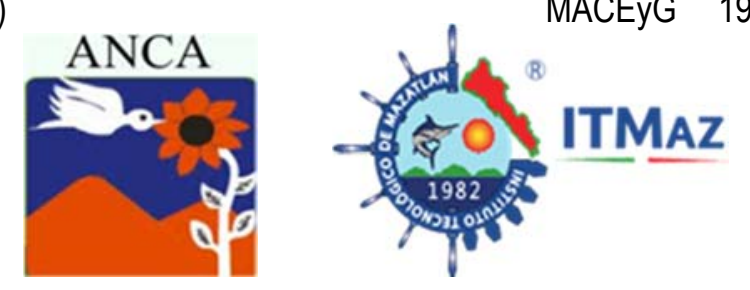

\section{Monitoreo de partículas de 0.3-2.5 micras en el interior de la Facultad de Ingeniería Química, BUAP}

Flores-Martínez M, Velasco-Hernández M, Niño-Lozano A, Salgado-Villaviencio $\mathrm{E}$

Licenciatura en Ingeniería Ambiental. Facultad de Ingeniería Química.

Benemérita Universidad Autónoma de Puebla

ambientalbuap@yahoo.com.mx

\section{RESUMEN}

Uno de los indicadores de la calidad del aire es el material particulado (MP), el cual tiene impactos negativos en particular a la salud. Con respecto a las propiedades del MP, destaca el diámetro de la partícula el cual está relacionado con enfermedades cardiovasculares y la formación de tumores con diámetros menores a 0.1 y un 1 micrómetro (partículas ultrafinas), además de enfermedades de la piel y los ojos con diámetros menores o iguales de 2.5 micrómetros. Por lo que el presente trabajo tiene como objetivo monitorear las partículas en espacios académicos (salones, laboratorios y oficinas dentro de la Facultad de Ingeniería Química de la BUAP, durante el periodo escolar otoño 2018 y primavera 2019, para conocer la calidad del aire en relación a las partículas. Se utilizó un contador de partículas modelo EXTECH-PCE-PCO1, para monitorear los espacios académicos, aparato que identifica 3 tamaños de partículas: $0.3 ; 0.5 ;$ y 2.5 micrómetros consideradas ultrafinas y finas, respectivamente se midió además la temperatura y humedad relativa en los sitios muestreados. De acuerdo con la norma ISO de cuarto limpio (ISO 14644-1:1999), los resultados muestran que del total de sitios muestreados el $62.5 \%$ corresponde a condiciones aceptables, el $12.5 \%$ se encuentran sitios de advertencia y el $25 \%$ presenta riesgos significativos hacia la salud humana, por lo que es necesario minimizar las fuentes de emisión y realizar estrategias de limpieza para mejorar la calidad del aire al interior de la Facultad.

Palabras clave: Limpieza, aire, muestreo, salud, normatividad.

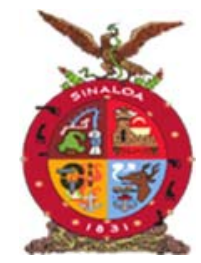

XVIII Congreso Internacional XXIV Congreso Nacional de Ciencias ambientales
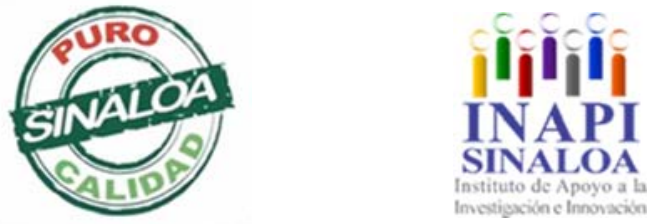

Mazatlán, Sinaloa 3-7 junio 2019

Medio Ambiente, Contaminación,

Enfermedad y Genotoxicidad 

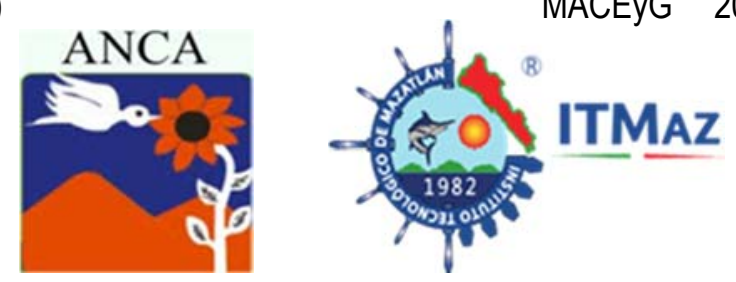

\title{
Monitoring of particles of 0.3-2.5 microns inside the Faculty of Chemical Engineering, BUAP
}

\author{
Flores-Martínez M, Velasco-Hernández M, Niño-Lozano A, \\ Salgado-Villaviencio $\mathrm{E}$ \\ Licenciatura en Ingeniería Ambiental. Facultad de Ingeniería Química. \\ Benemérita Universidad Autónoma de Puebla. \\ ambientalbuap@yahoo.com.mx
}

\begin{abstract}
One of the indicators of air quality is the particulate material (PM), which has negative impacts in particular on health. With respect to the properties of PM, the diameter of the particle which is related to cardiovascular diseases and the formation of tumors with diameters smaller than 0.1 and 1 micrometer (ultrafine particles), as well as diseases of the skin and eyes with diameters less than or equal to 2.5 micrometers (fine particles). Therefore, the objective of this work is to monitor the particles in academic spaces (classrooms, laboratories and offices within the School of Chemical Engineering of the BUAP, during the school period fall 2018 and spring 2019), to know the air quality in relation To the particles, an EXTECH-PCE-PCO1 particle counter was used to monitor the academic spaces, the team identified 3 particle sizes of $0.3,0.5,2.5$ considered ultrafine and fine, in addition, the temperature and relative humidity were measured. The sites show that, according to the clean room ISO standard (ISO 14644-1: 1999), the results show that of thetotal sampled sites, $62.5 \%$ correspond to acceptable conditions, $12.5 \%$ are warning sites and $25 \%$ presents significant risks, which is why it is necessary to minimize the emission sources and carry out cleaning strategies to improve the air quality inside the Faculty.
\end{abstract}

Keywords: Cleaning, air, sampling, health, normativity.

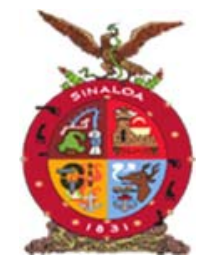

XVIII Congreso Internacional

XXIV Congreso Nacional de Ciencias ambientales
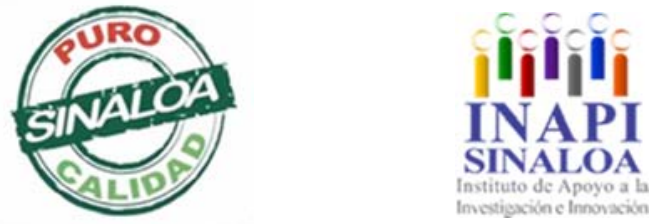

Mazatlán, Sinaloa 3-7 junio 2019

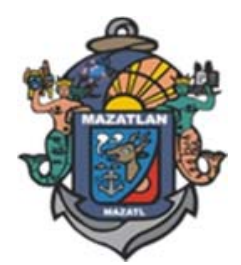

Medio Ambiente, Contaminación, Enfermedad y Genotoxicidad 
TECNOLOGICO NACIONAL DE MEXICO
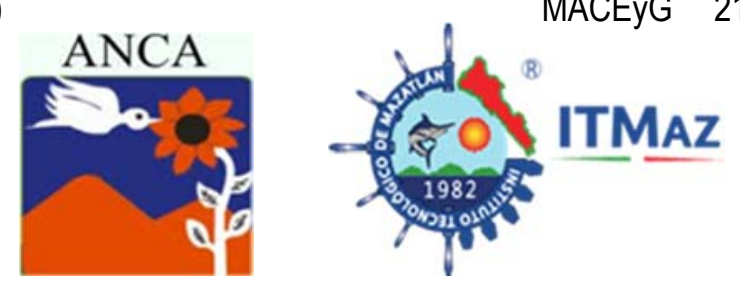

\title{
Metahemoglobina y nitritos en plasma y orina como biomarcadores de exposición en población expuesta a nitratos
}

\author{
García-Torres E ${ }^{1}$, Pérez-Morales $\mathrm{R}^{2}$, Olivas-Calderón E${ }^{1}$, González-Zamora A², \\ Alba-Romero $\mathrm{J}^{1}$, Calleros-Rincón $\mathrm{E}^{2 *}$ \\ ${ }^{1}$ Facultad de Ciencias Químicas. Universidad Juárez del Estado de Durango, \\ ${ }^{2}$ Laboratorio de Biología Evolutiva, Facultad de Ciencias Biológicas, \\ Universidad Juárez del Estado de Durango, \\ Av. Universidad S/N Fracc. Filadelfia, Gómez Palacio, Durango, México \\ *dra.ecallerosrincon@ujed.mx
}

\section{RESUMEN}

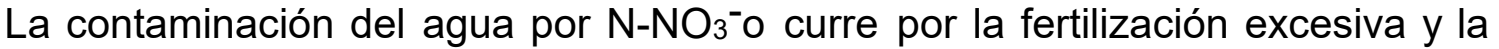
ganadería intensiva, que mediante lixiviación se depositan y contaminan los mantos acuíferos. La ingesta de agua con niveles mayores de $10 \mathrm{mg} / \mathrm{L}^{\mathrm{de} \mathrm{N}} \mathrm{NO}^{-}$ 3 que marca NOM 127-SSA-1994, como nivel máximo permisible, ésta norma protege a los infantes de 0 a 12 años de metahemoglobina (MetaHb). Sin embargo, ésta contaminación puede producir efectos subcrónicos y crónicos como hipotiroidismo y cáncer. El objetivo fue establecer cómo biomarcadores de exposición los niveles de MetaHb y nitritos $\left(\mathrm{NO}_{2}^{-}\right)$en plasma y orina en presencia elevada de $\mathrm{N}-\mathrm{NO}_{3}$ en agua. Se muestrearon 86 individuos, de la zona rural de Cd. Lerdo, Dgo, La medición de MetaHb se realizó por espectrofotometría y la medición de $\mathrm{NO}_{2}$-en plasma y orina por reacción de Griess. A los resultados se les aplicó un análisis ANOVA de un factor, entre el valor medio de metahemoglobina, $\mathrm{NO}_{2}$-en plasma y orina, sobre la concentración de nitratos en varias localidades $(p=0.003),(p=0.001),(p=0.000)$, respectivamente. El análisis post hoc sugiere la diferencia de los niveles de MetaHb y NO en plasma y orina a medida que aumentan los niveles de $\mathrm{N}-\mathrm{NO}_{2}{ }^{-}$en el agua de consumo. Concluyendo que la MetaHb y los $\mathrm{NO}_{3}$-en plasma y orina fungen como buenos biomarcadores de exposición.

Palabras clave: Biomarcador de exposición, contaminación, nitrógeno de nitrato, nitrito, agua.

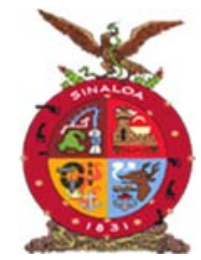

XVIII Congreso Internacional

XXIV Congreso Nacional de Ciencias ambientales
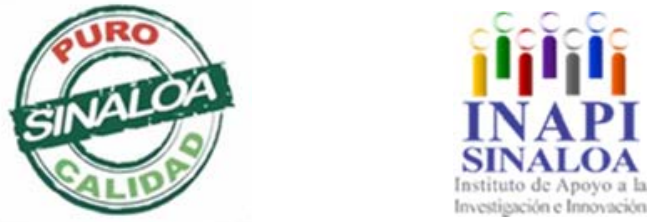

Mazatlán, Sinaloa 3-7 junio 2019

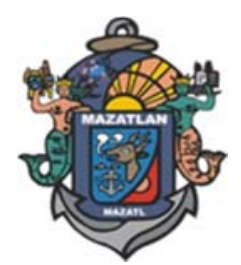

Medio Ambiente, Contaminación, Enfermedad y Genotoxicidad 
TECNOLOGICO NACIONAL DE MEXICO
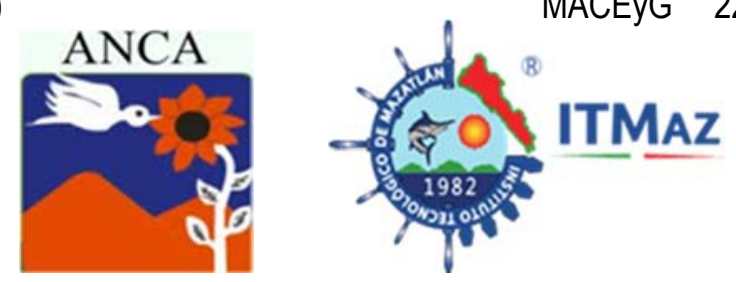

\title{
Metahemoglobin and nitrites in plasma and urine as biomarkers of exposure in the population exposed to nitrates
}

\author{
García-Torres E ${ }^{1}$, Pérez-Morales $R^{2}$, Olivas-Calderón E1 , González-Zamora A², \\ Alba-Romero J1 ${ }^{1}$, Calleros-Rincón $\mathrm{E}^{2 *}$ \\ ${ }^{1}$ Facultad de Ciencias Químicas. Universidad Juárez del Estado de Durango, \\ ${ }^{2}$ Laboratorio de Biología Evolutiva, Facultad de Ciencias Biológicas, \\ Universidad Juárez del Estado de Durango, \\ Av. Universidad S/N Fracc. Filadelfia, Gómez Palacio, Durango, México \\ *dra.ecallerosrincon@ujed.mx
}

\begin{abstract}
The contamination of water by $\mathrm{N}-\mathrm{NO}_{3}$-is due to excessive fertilization and intensive livestock farming, which is deposited and contaminates aquifers through leaching. The intake of water with levels greater than $10 \mathrm{mg} / \mathrm{L}$ of $\mathrm{N}^{-\mathrm{NO}_{3}}{ }^{-}$which is what NOM 127-SSA-1994 marks, as the maximum permissible level, this standard protects infants from 0 to 12 years of methemoglobin (MetaHb). However, this contamination can produce subchronic and chronic effects such as hypothyroidism and cancer. The objective was to establish how biomarkers of exposure levels of MetaHb and nitrites $\left(\mathrm{NO}_{2}{ }^{-}\right)$in plasma and urine in high presence of $\mathrm{N}-\mathrm{NO}_{3}{ }^{-i n}$ water. 86 individuals were sampled from the rural area of $\mathrm{Cd}$. Lerdo, Dgo. The measurement of MetaHb was by spectrophotometry and $\mathrm{NO}_{2}$-in plasma and urine by Griess reaction. An ANOVA analysis of one factor was performed between the mean value of methaemoglobin, $\mathrm{NO}^{2}$-in plasma and urine, on the nitrate concentration in several localities $(p=0.003),(p=0.001),(p=0.000)$, respectively . The post hoc analysis suggests the difference of the levels of MetaHb and $\mathrm{NO}^{2-}$

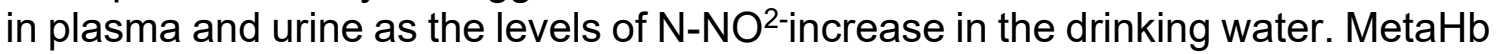
and $\mathrm{NO}^{3}$-in plasma and urine serve as good biomarkers of exposure.
\end{abstract}

Keywords: Biomarker of exposure, pollution, nitrate nitrogen, nitrite, water.

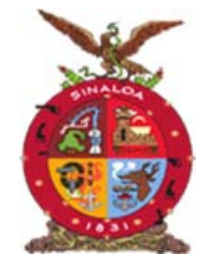

XVIII Congreso Internacional XXIV Congreso Nacional de Ciencias ambientales
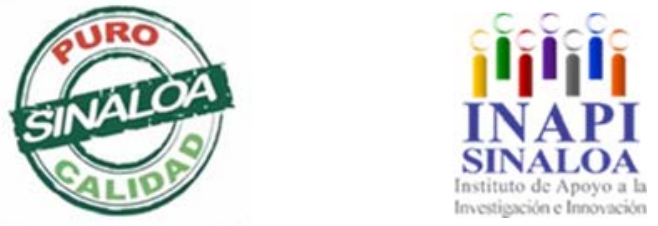

Mazatlán, Sinaloa 3-7 junio 2019

Medio Ambiente, Contaminación,

Enfermedad y Genotoxicidad 
TECNOLOGICO NACIONAL DE MEXICO
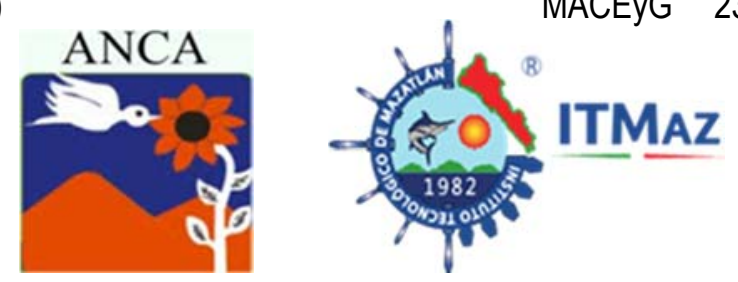

\title{
Evaluación de la expresión de genes de muerte celular por exposición a contaminantes atmosféricos en Senecio roseus
}

\author{
Gómez-Arroyo $\mathrm{S}^{1}$, Loza-Gómez $\mathrm{P}^{{ }^{*}}$, Cortés-Eslava $\mathrm{J}^{1}$, Flores-Márquez $\mathrm{AR}^{1}$, \\ Mérida-Cortés $\mathrm{P}^{1}$, Grutter-de la Mora $\mathrm{M}^{2}$, Lara-Martínez $\mathrm{R}^{3}$, \\ Jiménez García LF ${ }^{3}$ \\ ${ }^{1}$ Laboratorio de Genotoxicología y Mutagénesis Ambientales \\ ${ }^{2}$ Espectroscopia y Percepción Remota, Centro de Ciencias de la Atmósfera, \\ Universidad Nacional Autónoma de México. \\ ${ }^{3}$ Departamento de Biología Celular, Facultad de Ciencias. \\ Universidad Nacional Autónoma de México. \\ Universitaria, Coyoacán, 04510 Ciudad de México. \\ *paolaloza.12@gmail.com
}

\section{RESUMEN}

Los procesos de apoptosis, necrosis y autofagia son indicadores del efecto de los contaminantes atmosféricos en la expresión génica. Los sistemas vegetales son utilizados como modelo debido a su papel ecológico y por ser ideales para el biomonitoreo in situ. Se estudió el efecto de la contaminación atmosférica en cuatro sitios del Área Metropolitana de la Ciudad de México (Tlalnepantla, Ecatepec, Coyoacán y Altzomoni) en la expresión de genes de muerte celular en Senecio roseus durante las temporadas de secas y lluvias del 2018. Se expusieron plantas por $0,4,8$ y 12 semanas en cada lugar y temporada. Se realizó el análisis por PCR de punto final con los marcadores de muerte celular Metacaspasa 8, Nep 1 y Beclina 1 y de estrés miR403 a partir de la extracción de RNA, síntesis del cDNA y electroforesis en gel de poliacrilamida. Los resultados indicaron la expresión de Beclina 1 en las atmósferas de Tlalnepantla, Ecatepec y Altzomoni y el gen M8 en Tlalnepantla y CCA durante la temporada de lluvias. El miR403 mostró una sub-regulación en Altzomoni durante secas y en Tlalnepantla y Altzomoni en lluvias, desde la semana 4 de exposición, sugiriendo estrés oxidante causado por factores abióticos. Ninguna condición indujo la expresión de Nep 1. Se puede concluir que la exposición a contaminantes atmosféricos fue dañina para $S$. roseus, desencadenando los eventos de autofagia y apoptosis en lluvias, así como estrés oxidante en ambas temporadas.

Palabras clave: Biomonitoreo, plantas, apoptosis, autofagia, miR403.

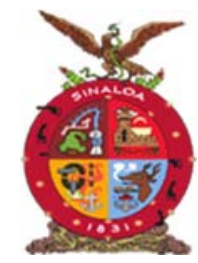

XVIII Congreso Internacional XXIV Congreso Nacional de Ciencias ambientales
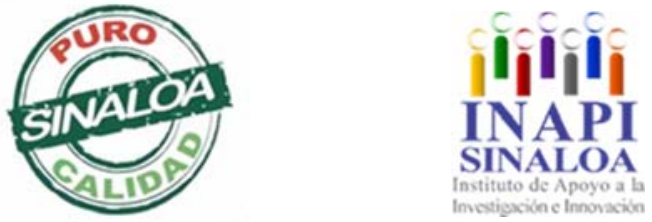

Mazatlán, Sinaloa 3-7 junio 2019

Medio Ambiente, Contaminación,

Enfermedad y Genotoxicidad 
TECNOLOGICO NACIONAL DE MEXICO
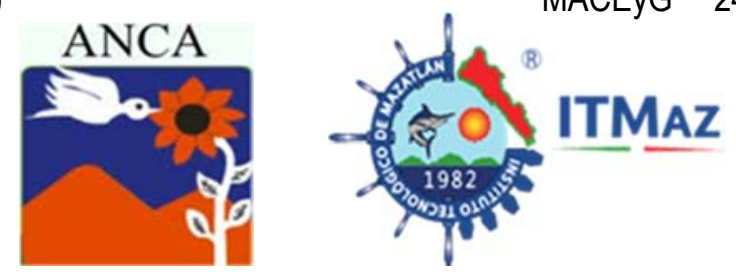

\title{
Evaluation of the expression of cell death genes by exposure to atmospheric pollutants in Senecio roseus
}

\author{
Gómez-Arroyo $\mathrm{S}^{1}$, Loza-Gómez $\mathrm{P}^{1^{*}}$, Cortés-Eslava $\mathrm{J}^{1}$, Flores-Márquez $\mathrm{AR}^{1}$, \\ Mérida-Cortés $\mathrm{P}^{1}$, Grutter-de la Mora $\mathrm{M}^{2}$, Lara-Martínez $\mathrm{R}^{3}$, \\ Jiménez García LF ${ }^{3}$ \\ ${ }^{1}$ Laboratorio de Genotoxicología y Mutagénesis Ambientales \\ ${ }^{2}$ Espectroscopia y Percepción Remota, Centro de Ciencias de la Atmósfera, \\ Universidad Nacional Autónoma de México. \\ ${ }^{3}$ Departamento de Biología Celular, Facultad de Ciencias. \\ Universidad Nacional Autónoma de México. \\ Universitaria, Coyoacán, 04510 Ciudad de México. \\ *paolaloza.12@gmail.com
}

\begin{abstract}
The processes of apoptosis, necrosis and autophagy are indicators of the effect of air pollutants on gene expression. Plant systems are used as models because of their ecological role and because they are ideal for in situ biomonitoring. The effect of air pollution was studied at four sites in the Metropolitan Area of México City (Tlalnepantla, Ecatepec, Coyoacán and Altzomoni) in the expression of cell death genes in Senecio roseus during dry and rainy seasons of 2018. Plants were exposed for 0, 4, 8 and 12 weeks in each place and season. Endpoint PCR analysis was performed with Metacaspase 8, Nep 1 and Beclin 1 cell death markers and miR403 stress marker from the RNA extraction, cDNA synthesis and polyacrylamide gel electrophoresis. The results indicated the expression of Beclin 1 in plants exposed in the atmospheres of Tlalnepantla, Ecatepec and Altzomoni and the gene M8 in Tlalnepantla and Coyocán during the rainy season. The miR403 showed a down regulation in Altzomoni during dry and in Tlalnepantla and Altzomoni in rainy, from the week 4 of exposure, suggesting oxidative stress caused by abiotic factors. No condition induced the expression of Nep 1. It can be concluded that the exposure to air pollutants was harmful to $S$. roseus triggering the events of autophagy and apoptosis in rainy, as well as oxidative stress in both seasons.
\end{abstract}

Keywords: Biomonitoring, plants, apoptosis, autophagy, miR403.

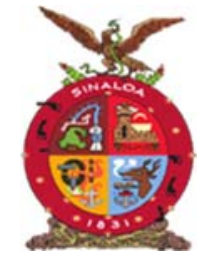

XVIII Congreso Internacional XXIV Congreso Nacional de Ciencias ambientales
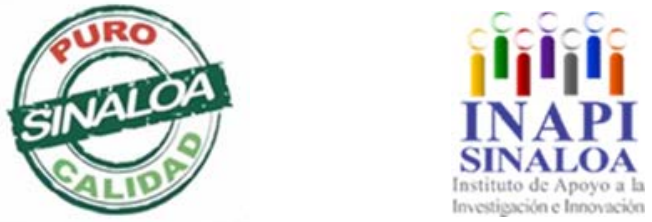

Mazatlán, Sinaloa 3-7 junio 2019

Medio Ambiente, Contaminación, Enfermedad y Genotoxicidad 
TECNOLOGICO NACIONAL DE MEXICO
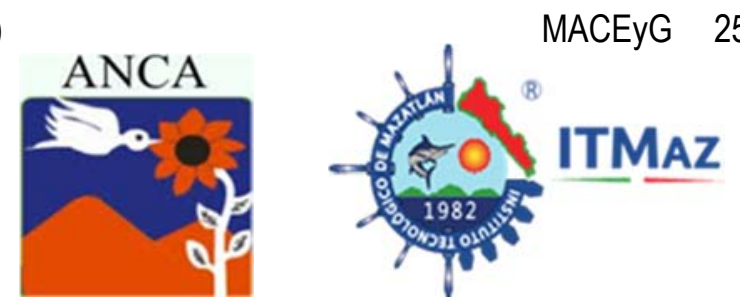

\title{
Anidación de las aves en el entorno urbano de Ciudad Victoria, Tamaulipas, México
}

\author{
Gómez-Moreno V ${ }^{1}$, Niño-Maldonado $\mathrm{S}^{2^{*}}$, Puga-Zapata $\mathrm{T}^{2}$, González-Gaona O ${ }^{1}$, \\ Benítez-Martínez $\mathrm{E}^{3}$ \\ ${ }^{1}$ Instituto Tecnológico de Ciudad Victoria. \\ Boulevard Emilio Portes Gil No. 1301, Ciudad Victoria, Tamaulipas, México \\ ${ }^{2}$ Facultad de Ingeniería y Ciencias (FIC), Centro Universitario Victoria. \\ Universidad Autónoma de Tamaulipas. \\ Adolfo López Mateos, C.P. 87149, Ciudad Victoria, Tamaulipas, México \\ ${ }^{3}$ Dirección de Participación Estudiantil \\ Universidad Autónoma de Tamaulipas, México \\ *coliopteranino@hotmail.com
}

\section{RESUMEN}

En la actualidad la expansión de las áreas urbanas hacia los hábitats nativos puede tener efectos perjudiciales en las poblaciones y comunidades de aves. Sin embargo, se sabe muy poco sobre las especies que anidan en los entornos urbanizados, así como las preferencias por los árboles urbanos y el éxito que pueden llegar a tener en dichos sitos. El objetivo de este estudio fue conocer las especies que usan estas áreas para anidar y el éxito de anidación. El estudio se realizó en las áreas verdes de la FIC, donde se recorrieron y contabilizaron los nidos de las diferentes especies de aves durante los meses de marzo a octubre de 2018. En total identificamos 183 nidos pertenecientes a cuatro órdenes, siete familias, 11 géneros y 12 especies. Las especies de mayor abundancia fueron Zenaida asiática, Zenaida macroura y Turdus grayi; mientras que las especies de menor abundancia le corresponden a Cynanthus latirostris y Mimus polyglottos. Se identificó que algunas especies son abundantes anidando en estas áreas, sin embrago es muy poco el éxito que pueden llegar a tener al eclosionar los huevos o crianza de los polluelos debido a la depredación, las condiciones climáticas, las características de los árboles e incluso afectadas o amenazadas por el hombre. Estudios previos señalan que el área de estudio cuenta con 57 especies residentes de las cuales la mayoría de las aves la usan para perchar, refugios o alimentación; mientras que el $21.1 \%$ de las especies usan las áreas verdes como sitio de anidación.

Palabras Clave: Anidación, arbolado, censo, ornitofauna.

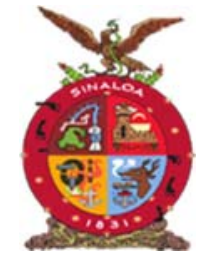

XVIII Congreso Internacional XXIV Congreso Nacional de Ciencias ambientales
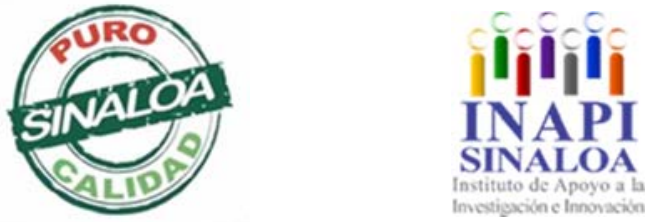

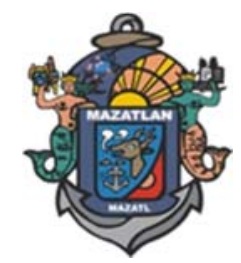

Medio Ambiente, Contaminación, Enfermedad y Genotoxicidad 

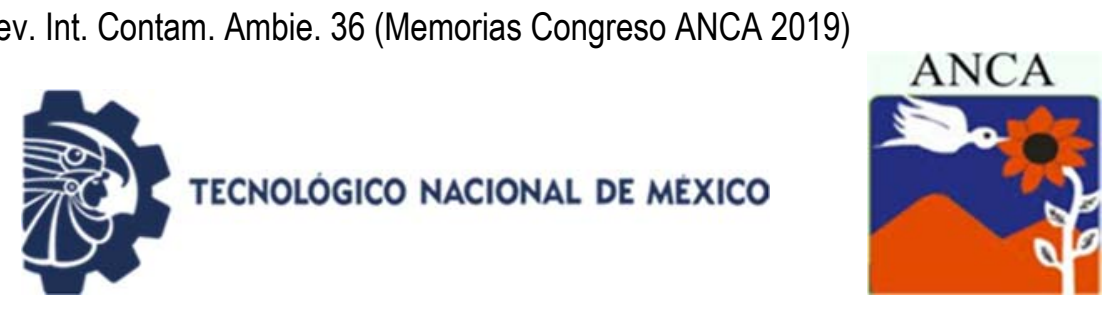

TECNOLOGICO NACIONAL DE MEXICO

\title{
Bird nesting in an urban environment of Ciudad Victoria, Tamaulipas, México
}

\author{
Gómez-Moreno V¹, Niño-Maldonado $\mathrm{S}^{2 *}$, Puga-Zapata $\mathrm{T}^{2}$, González-Gaona $\mathrm{O}^{1}$, \\ Benítez-Martínez $\mathrm{E}^{3}$ \\ ${ }^{1}$ Instituto Tecnológico de Ciudad Victoria. \\ Boulevard Emilio Portes Gil No. 1301, Ciudad Victoria, Tamaulipas, México \\ ${ }^{2}$ Facultad de Ingeniería y Ciencias (FIC), Centro Universitario Victoria. \\ Universidad Autónoma de Tamaulipas. \\ Adolfo López Mateos, C.P. 87149, Ciudad Victoria, Tamaulipas, México \\ ${ }^{3}$ Dirección de Participación Estudiantil \\ Universidad Autónoma de Tamaulipas, México \\ *coliopteranino@hotmail.com
}

\begin{abstract}
At present, the expansion of urban areas into native habitats can have detrimental effects on bird populations and communities. However, very little is known about the species that nest in urbanized environments, as well as the preferences for urban trees and the success they can have in such sites. The objective of this study was to know the species that use these areas for nesting and the success of nesting. The study was conducted in the green areas of the FIC, where the nests of the different bird species were traveled and counted during the months of March to October 2018. In total we identified 183 nests belonging to four orders, seven families, 11 genera and 12 species. The most abundant species were Zenaida asiatica, Zenaida macroura and Turdus grayi; while the less abundant species correspond to Cynanthus latirostris and Mimus polyglottos. It was identified that some species are abundant nesting in these areas, however, there is very little success they can have when hatching the eggs or raising the chicks due to predation, climatic conditions, and the characteristics of trees and even affected or threatened by man. Previous studies indicate that the study area has 57 resident species of which most birds use it for perching, shelters or feeding; while $21.1 \%$ of the species use green areas as a nesting site.
\end{abstract}

Keywords: Nesting, woodland, census, ornithofauna.

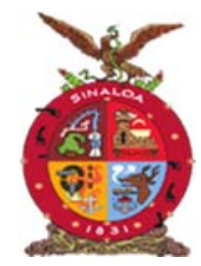

XVIII Congreso Internacional XXIV Congreso Nacional de Ciencias ambientales
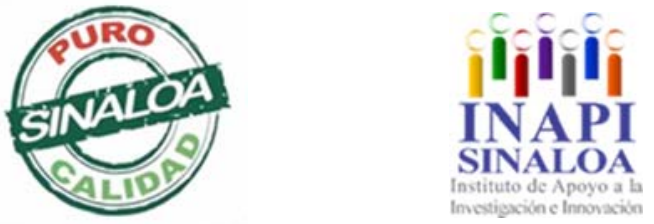

Mazatlán, Sinaloa 3-7 junio 2019

Medio Ambiente, Contaminación,

Enfermedad y Genotoxicidad 
TECNOLOGICO NACIONAL DE MEXICO
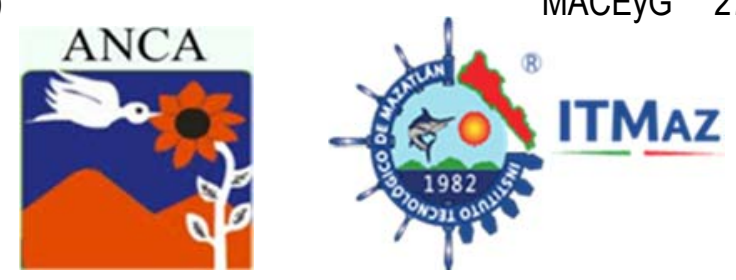

\title{
Uso de residuos de las fibras del maguey para hacer adobes
}

\author{
González-Cruz M, López-Cruz JY* \\ CIIDIR Unidad Oaxaca. Instituto Politécnico Nacional. \\ *jylopez@ipn.mx
}

\begin{abstract}
RESUMEN
En la producción artesanal del mezcal se utilizan aproximadamente $10 \mathrm{~kg}$ de piña de agave para generar un litro de mezcal, generando también de 6 a $7 \mathrm{~kg}$ de bagazo húmedo más vinazas, ambos considerados como desperdicios. Residuos que son acumulados a cielo abierto en los terrenos aledaños a los palenques o vertidos en ríos o arroyos, ocasionando con ello contaminación medio ambiental; además de proliferación de plagas como roedores, insectos y otros microorganismos. El objetivo fue identificar las alternativas de uso de estas fibras en Santa Catarina Minas, Ocotlán de Morelos, Oaxaca. La metodología utilizada es mixta (cuantitativa-cualitativa) para determinar los volúmenes generados y usos que se dan a los residuos generados en el proceso de fermentación (bagazo) y de destilación (vinazas). Entre los principales resultados se encontró que el bagazo y vinazas son utilizadas en la elaboración artesanal de adobes para la construcción de viviendas, adicionando a la tierra (yocuela o a la misma tierra de la región), los residuos de bagazo seco o fresco y en algunos casos también las vinazas, e inclusive heces de burro. Estos adobes, según los pobladores, presentan mayor resistencia en relación al adobe tradicional. Así también el uso de estos adobes permite el ahorro energético, porque al ser más térmico reducen el consumo de energía para la climatización de la vivienda. Esta opción de aprovechamiento integral de los subproductos derivados en el procesamiento del mezcal, puede beneficiar tanto a la población en general como a los productores de mezcal, y contribuir a la consolidación económica y a la mejora de las condiciones y rentabilidad de sus recursos naturales.
\end{abstract}

Palabras clave: Residuos, bagazo, vinazas, aprovechamiento integral.

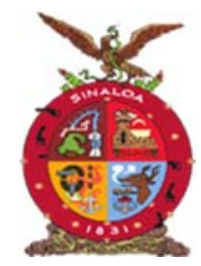

XVIII Congreso Internacional XXIV Congreso Nacional de Ciencias ambientales
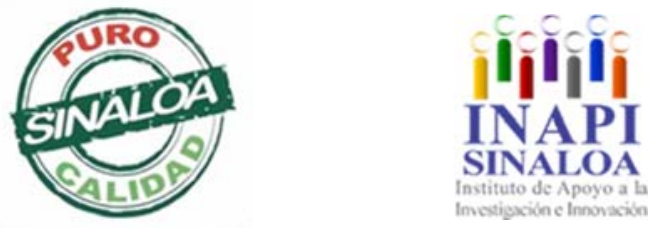

Mazatlán, Sinaloa 3-7 junio 2019

Medio Ambiente, Contaminación,

Enfermedad y Genotoxicidad 

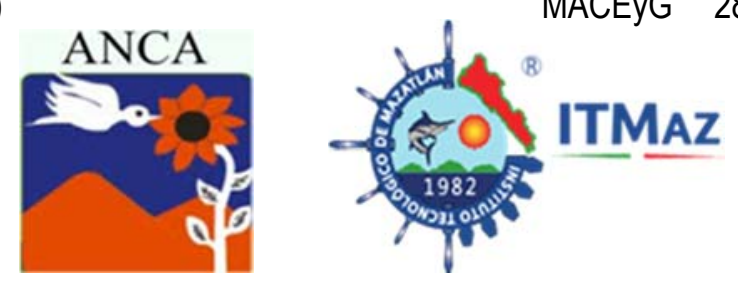

Use of maguey fiber residues to make adobes

\author{
González-Cruz M, López-Cruz JY* \\ CIIDIR Unidad Oaxaca. Instituto Politécnico Nacional. \\ *jylopez@ipn.mx
}

\begin{abstract}
In the artisanal production of mezcal approximately $10 \mathrm{~kg}$ of agave pineapple are used to generate a liter of mezcal, also generating 6 to $7 \mathrm{~kg}$ of wet bagasse plus vinasses, both considered as waste. Wastes that are accumulated in the open sky on land adjacent to palenques or discharged into rivers or streams, thereby causing environmental pollution; In addition to proliferation of pests such as rodents, insects and other microorganisms. The objective was to identify the alternatives for using these fibers in Santa Catarina Minas, Ocotlán de Morelos, Oaxaca. The methodology used is mixed (quantitative-qualitative) to determine the volumes generated and uses given to the waste generated in the fermentation (bagasse) and distillation (vinasse) process. Among the main results it was found that bagasse and vinasse are used in the artisan elaboration of adobes for the construction of houses, adding to the land (yocuela or to the same land of the region), dry or fresh bagasse residues and in some also the vinasses, and even donkey feces. These adobes, according to the residents, have greater resistance in relation to the traditional adobe. Likewise, the use of these adobes allows energy saving, because being more thermal, they reduce the energy consumption for the air conditioning of the house. This option of integral use of by-products derived from mezcal processing can benefit both the general population and mezcal producers, and contribute to economic consolidation and to the improvement of the conditions and profitability of their natural resources.
\end{abstract}

Keywords: Waste, bagasse, vinasse, integral use.

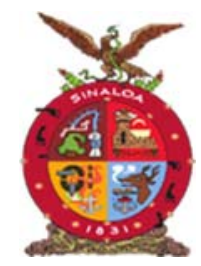

XVIII Congreso Internacional XXIV Congreso Nacional de Ciencias ambientales
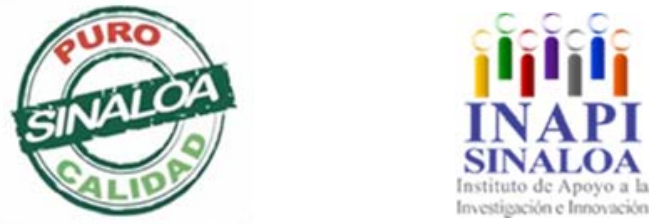

Mazatlán, Sinaloa 3-7 junio 2019

Medio Ambiente, Contaminación, Enfermedad y Genotoxicidad 
TECNOLOGICO NACIONAL DE MEXICO
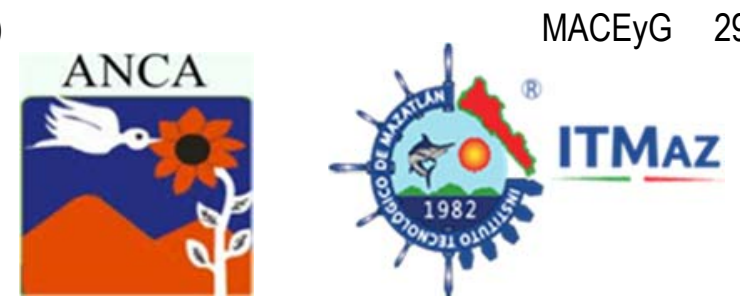

\title{
Determinación de plaguicidas organoclorados y metales pesados en suelos agrícolas del Valle de Juárez, Chihuahua, México
}

\author{
Hernández-Carreón $\mathrm{S}^{{ }^{*}}$, Delgado-Ríos $\mathrm{M}^{1}$, Flores-Marguez JP${ }^{1}$, \\ Meza-Montenegro $\mathrm{MM}^{2}$, Núñez-Gastélum JA ${ }^{1}$ \\ ${ }^{1}$ Departamento de Ciencias Químico-Biológicas.
}

Instituto de Ciencias Biomédicas. Universidad Autónoma de Ciudad Juárez.

${ }^{2}$ Departamento de Biotecnología y Ciencias Alimentarias.

Instituto Tecnológico de Sonora. Cd. Obregón, Sonora, 85000, México

*al171420@alumnos.uacj.mx

\begin{abstract}
RESUMEN
El Valle de Juárez es una región agrícola importante localizada en el norte de México, sin embargo, no cuenta con estudios que muestren un diagnóstico sobre la contaminación del suelo con plaguicidas organoclorados y la presencia de metales pesados. El objetivo de la presente investigación fue analizar muestras de suelo de los tres módulos agrícolas del Valle de Juárez, tomadas en junio del 2018, para la determinación de plaguicidas y metales pesados mediante cromatografía de gases y espectrofotometría de absorción atómica, respectivamente. Se encontraron cinco plaguicidas: DDT $(7.38 \pm 31.6 \mu \mathrm{g} / \mathrm{kg})$, DDE $(9.67 \pm 18.88 \mu \mathrm{g} / \mathrm{kg})$, DDD $(12.60 \pm 16.63 \mu \mathrm{g} / \mathrm{kg})$, Isodrín $(10.63 \pm 5.47$ $\mu \mathrm{g} / \mathrm{kg})$, y Endosulfán $(2.83 \pm 3.32 \mu \mathrm{g} / \mathrm{kg})$. DDT y DDE que fueron los que se distribuyeron a lo largo de toda el área analizada. Los valores encontrados se encuentran dentro de los límites establecidos en normas internacionales. Por otro lado, un total de seis metales fueron detectados: Fe (1659.28 $\pm 332.73 \mathrm{ppm}), \mathrm{Mn}$ (316.98 \pm 88.6 ppm), Zn (24.48 \pm 21.7 ppm), Pb (17.58 \pm 7.25 ppm), Cu (8.34 \pm $3.6 \mathrm{ppm})$ y $\mathrm{Cd}(1.82 \pm 0.96 \mathrm{ppm})$. Las concentraciones de $\mathrm{Fe}, \mathrm{Mn}, \mathrm{Pb}, \mathrm{Zn}$ y $\mathrm{Cu}$ no sobrepasaron los límites propuestos por la legislación internacional o nacional, mientras que la concentración promedio máxima determinada para $\mathrm{Cd}$ sí sobrepasó los límites de la normatividad mexicana.
\end{abstract}

Palabras clave: Valle de Juárez, metales pesados, plaguicidas, suelos contaminados.

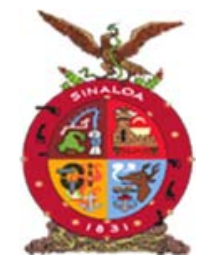

XVIII Congreso Internacional XXIV Congreso Nacional de Ciencias ambientales
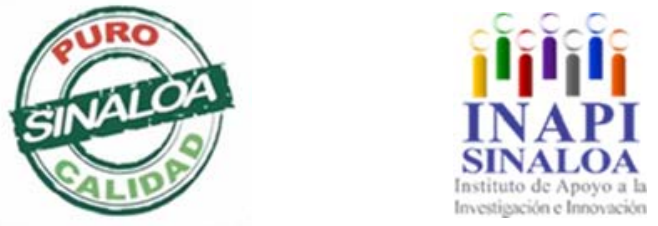

Mazatlán, Sinaloa 3-7 junio 2019

Medio Ambiente, Contaminación Enfermedad y Genotoxicidad 
TECNOLOGICO NACIONAL DE MEXICO
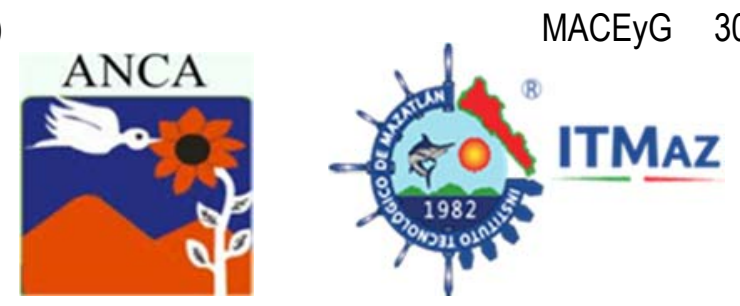

\title{
Organ chlorine pesticides and heavy metal determination in agricultural soils of the Valle de Juarez, Chihuahua, México
}

\author{
Hernández-Carreón $\mathrm{S}^{1 *}$, Delgado-Ríos $\mathrm{M}^{1}$, Flores-Marguez $\mathrm{JP}^{1}$, \\ Meza-Montenegro $\mathrm{MM}^{2}$, Núñez-Gastélum JA ${ }^{1}$ \\ ${ }^{1}$ Departamento de Ciencias Químico-Biológicas.
}

Instituto de Ciencias Biomédicas. Universidad Autónoma de Ciudad Juárez

${ }^{2}$ Departamento de Biotecnología y Ciencias Alimentarias.

Instituto Tecnológico de Sonora, Cd. Obregón, Sonora, 85000, México

*al171420@alumnos.uacj.mx

\begin{abstract}
The Juarez Valley is an important agricultural region in the north of Mexico, however, there are no studies regarding soil pollution with organ chlorine pesticides and heavy metals. The aim of this study was to analyze soil samples, taken in June 2018, from the three modules in which the Valley is divided, to determine the presence of organ chlorine pesticides and heavy metals by using $\mathrm{GC}-\mu \mathrm{ECD}$ and atomic absorption spectrometry, respectively. Five pesticides were registered: DDT $(7.38 \pm 31.6 \mu \mathrm{g} / \mathrm{kg})$, DDE $(9.67 \pm 18.88 \mu \mathrm{g} / \mathrm{kg})$, DDD $(12.60 \pm$ $16.63 \mu \mathrm{g} / \mathrm{kg})$, Isodrin $(10.63 \pm 5.47 \mu \mathrm{g} / \mathrm{kg})$, and Endosulfan $(2.83 \pm 3.32 \mu \mathrm{g} / \mathrm{kg})$. DDT and DDE were the ones with the greatest distribution throughout the area. The registered values are within the limits established by international regulations. On the other hand, six heavy metals were identified: Fe (1659.28 $\pm 332.73 \mathrm{ppm})$, $\mathrm{Mn}(316.98 \pm 88.6 \mathrm{ppm}), \mathrm{Zn}(24.48 \pm 21.7 \mathrm{ppm}), \mathrm{Pb}(17.58 \pm 7.25 \mathrm{ppm}), \mathrm{Cu}(8.34$ $\pm 3.6 \mathrm{ppm})$, and $\mathrm{Cd}(1.82 \pm 0.96 \mathrm{ppm})$. The concentrations for $\mathrm{Fe}, \mathrm{Mn}, \mathrm{Pb}, \mathrm{Zn}$ and $\mathrm{Cu}$ did not exceed the maximum allowable limits found in the national and international regulations; however, the highest average concentration for $\mathrm{Cd}$ did exceed the limits proposed by the Mexican norms.
\end{abstract}

Keywords: Juarez Valley, heavy metals, pesticides, soil pollution.

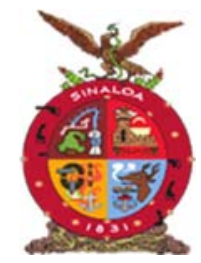

XVIII Congreso Internacional XXIV Congreso Nacional de Ciencias ambientales
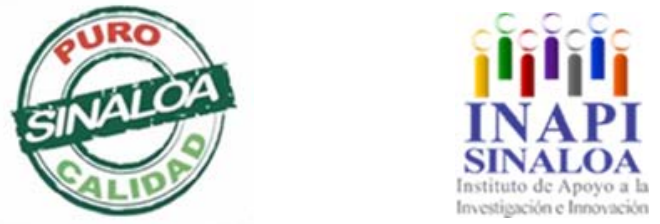

Mazatlán, Sinaloa 3-7 junio 2019

Medio Ambiente, Contaminación,

Enfermedad y Genotoxicidad 
TECNOLOGICO NACIONAL DE MEXICO
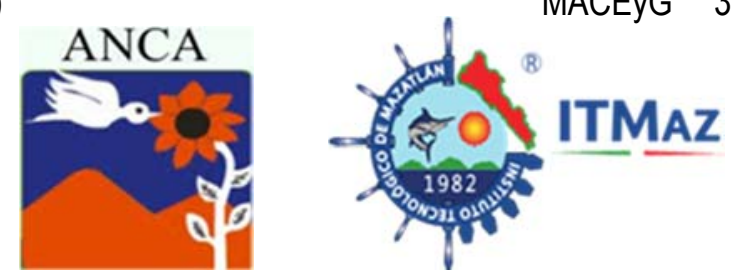

\title{
Monitoreo de partículas de 5 y 10 micrómetros en Ciudad Universitaria de
} la BUAP

\author{
Huerta-Reza E, Velasco-Hernández M, García-Castro M, Saldaña-Blanco M \\ Licenciatura en Ingeniería Ambiental. Facultad de Ingeniería Química. \\ Benemérita Universidad Autónoma de Puebla \\ ambientalbuap@yahoo.com.mx
}

\begin{abstract}
RESUMEN
Las partículas entre 5 y 10 micrómetros son consideradas como gruesas y son retenidas básicamente en las vías respiratorias superiores y eliminadas en su mayor parte, por el sistema de limpieza natural de los bronquios respiratorios, por lo que no son consideradas significativamente dañinas para la salud, sin embargo, la exposición continua a altas concentraciones puede causar irritación de garganta y mucosas, además de reducir la capacidad pulmonar. El objetivo de la presente investigación fue monitorear los principales sitios de mayor afluencia de personas universitarias para identificar la calidad del aire y comparar los resultados con la norma ISO de cuarto limpio (ISO 14644-1:1999). Para ello, se realizaron monitoreos en institutos, departamentos, biblioteca principal, y gimnasios. Durante el otoño 2018 y primavera 2019. Se utilizó un contador de partículas de 5 y 10 micrómetros modelo EXTECH-PCE-PCO1, los resultados se les analizo la relación con respecto a la temperatura ambiente y la humedad relativa. Los resultados obtenidos muestran que del total de los sitios muestreados; el $75 \%$ corresponde a niveles aceptables; el $12.5 \%$ son valores de advertencia y el $12.5 \%$ son niveles de riesgo. Por lo que es importante realizar un programa de limpieza para mejorar los indicadores, así como para cambiar el tipo de combustible del LOBOBUS y concientizar a los universitarios a reducir el uso del automóvil.
\end{abstract}

Palabras clave: Calidad, aire, muestreo, salud, normatividad.

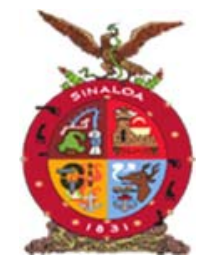

XVIII Congreso Internacional XXIV Congreso Nacional de Ciencias ambientales
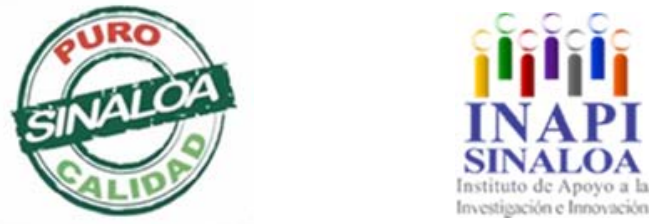

Mazatlán, Sinaloa 3-7 junio 2019

Medio Ambiente, Contaminación

Enfermedad y Genotoxicidad 

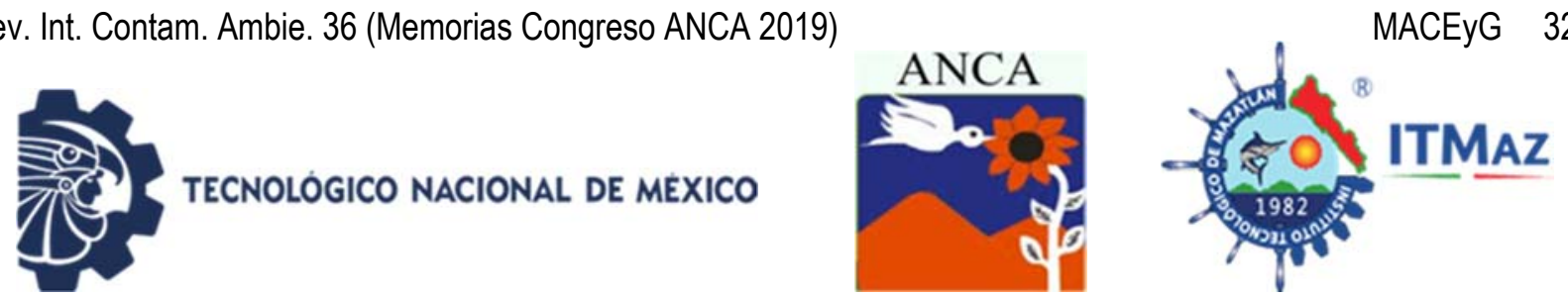

\title{
Monitoring of particles of $\mathbf{5}$ and $\mathbf{1 0}$ micrometers in University Campus of the BUAP
}

\author{
Huerta-Reza E, Velasco-Hernández M, García-Castro M, Saldaña-Blanco M \\ Licenciatura en Ingeniería Ambiental. Facultad de Ingeniería Química. \\ Benemérita Universidad Autónoma de Puebla \\ ambientalbuap@yahoo.com.mx
}

\begin{abstract}
The particles between 5 and 10 micrometers are considered as thick and thoracic are retained basically in the upper respiratory tract and eliminated for the most part, by the system of natural cleansing of the respiratory tract, so they are not considered significantly harmful to health, However, continuous exposure to high concentrations can cause irritation of the throat and mucous membranes, as well as reduced lung capacity. The objective of the present investigation is to monitor the main academic sites of higher university campus affluence to identify air quality in relation to the ISO standard of clean room (ISO 14644-1: 1999). Monitoring was done in institutes, departments, main library, gyms, etc. During fall 2018 and spring 2019. A 5 and 10 micron particle counter model EXTECH-PCE-PCO1 was used to sample academic, administrative and sports spaces. In addition, the results were related to the ambient temperature and relative humidity. The results obtained show that $75 \%$ of the total sampled sites correspond to acceptable levels, $12.5 \%$ are warning values and $12.5 \%$ are risk levels. So it is important to carry out a cleaning program to improve the identified indicators, as well as change the fuel type of the LOBOBUS and raise awareness among university students to reduce the use of the car.
\end{abstract}

Keywords: Quality, air, sampling, health, normativity.

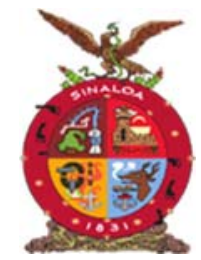

XVIII Congreso Internacional XXIV Congreso Nacional de Ciencias ambientales
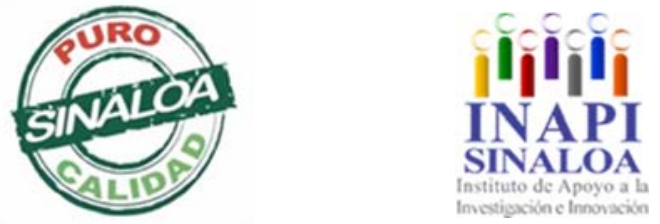

Mazatlán, Sinaloa 3-7 junio 2019

Medio Ambiente, Contaminación,

Enfermedad y Genotoxicidad 
TECNOLOGICO NACIONAL DE MEXICO
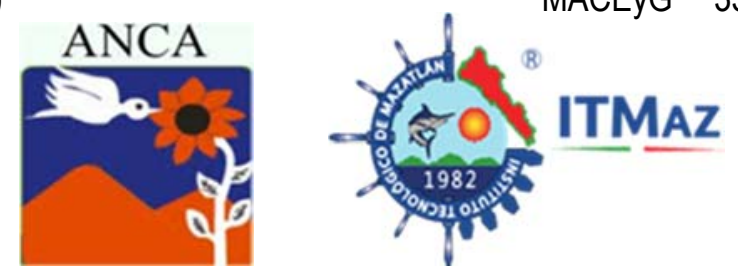

Condiciones de salud de la población minera Zacatecana, siglos XVIII y XIX

\author{
Medrano Enríquez A, Montoya Mar F, Canizales Romo M* \\ Unidad Académica de Historia. Universidad Autónoma de Zacatecas \\ *margil_canizales@yahoo.com.mx
}

\begin{abstract}
RESUMEN
Entre las regiones mineras mexicanas más sobresalientes se encuentra Zacatecas. Su época de máxima producción de plata fue durante el periodo virreinal, por lo que el eje de la economía residió en la explotación de este metal precioso, lo que causó una fuerte estratificación social entre sus pobladores, así como un ambiente altamente contaminado que repercutió en la salud de la población. El estudio de los restos óseos ayuda a definir las condiciones de vida y salud de las poblaciones pretéritas, a través del registro de las patologías observadas en los restos humanos, tanto momificados como esqueletizados. En esta investigación, se presentan los resultados de las investigaciones bioarqueológicas, de la colección de restos humanos procedentes del ex templo de la Compañía de Jesús, de la ciudad de Zacatecas, correspondiente a los siglos XVIII y XIX. Esos resultados denotan fuertes problemas de condiciones de salud, como la deficiencia de hierro detectada por medio de la criba orbitaria e hiperostosis porótica, así como la carencia de vitamina C y D (escorbuto y raquitismo, respectivamente), además de una alta frecuencia de procesos infecciosos manifestados por la inflamación del periostio. La mortalidad es altamente fuerte entre los individuos infantiles, sobre todo en niños menores de dos años. Los padecimientos detectados están vinculados al ambiente insalubre en el que estuvieron expuestos los antiguos pobladores zacatecanos.
\end{abstract}

Palabras clave: Paleopatologías, minería, insalubridad, Compañía de Jesús.

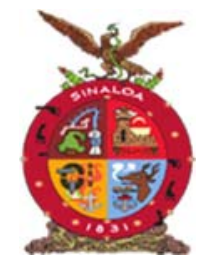

XVIII Congreso Internacional XXIV Congreso Nacional de Ciencias ambientales
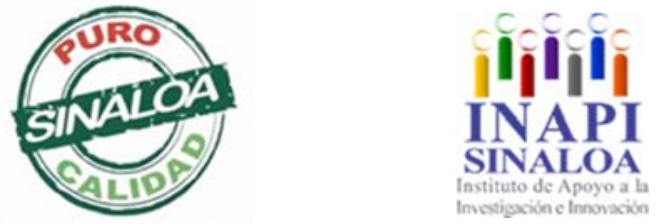

Mazatlán, Sinaloa 3-7 junio 2019

Medio Ambiente, Contaminación,

Enfermedad y Genotoxicidad 
TECNOLOGICO NACIONAL DE MEXICO
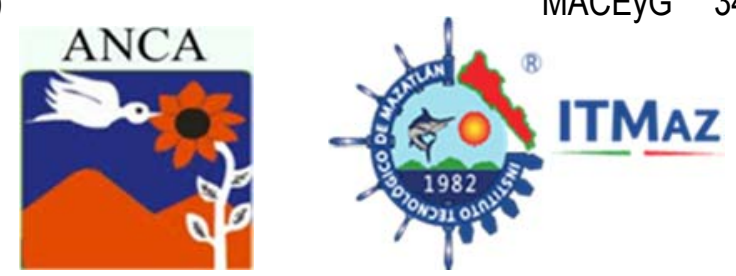

\title{
Health conditions of the Zacatecan mining population, XVIII and XIX centuries
}

\author{
Medrano Enríquez A, Montoya Mar F, Canizales Romo M* \\ Unidad Académica de Historia. Universidad Autónoma de Zacatecas \\ *margil_canizales@yahoo.com.mx
}

\begin{abstract}
One of the most outstanding Mexican mining regions is Zacatecas, its peak silver production was during the vice regal period, so the axis of the economy resided in the exploitation of this precious metal, which caused a strong social stratification between its inhabitants, as well as a highly contaminated environment that affected the health of the population. The study of bone remains helps to define the living and health conditions of past populations, through the recording of the pathologies observed in human remains, both mummified and skeletonized. On this occasion, the results of the bio archaeological research of the collection from the ex temple of Compañía de Jesus, of the city of Zacatecas, corresponding to the eighteenth and nineteenth centuries, will be presented. These results show strong problems of health conditions, such as iron deficiency detected by the criba orbitalia and porotic hyperostosis, as well as vitamin C and D deficiency (scurvy and rickets, respectively), also a high frequency of processes infectious manifested by the inflammation of the periosteum. Mortality is highly strong among children, especially in children under two years of age. The diseases detected are linked to the unhealthy environment in which the ancient inhabitants of Zacatecas were exposed.
\end{abstract}

Keywords: Paleopathologies, mining, unhygienic, Compañía de Jesús.

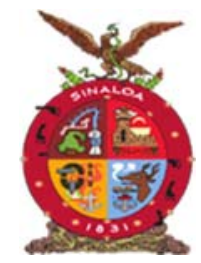

XVIII Congreso Internacional XXIV Congreso Nacional de Ciencias ambientales
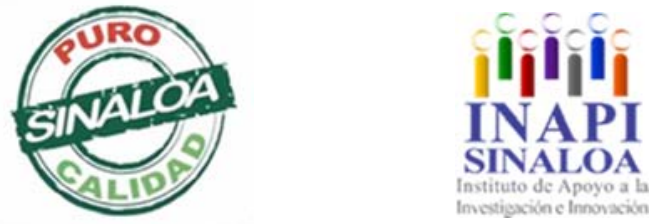

Mazatlán, Sinaloa 3-7 junio 2019

Medio Ambiente, Contaminación,

Enfermedad y Genotoxicidad 
TECNOLOGICO NACIONAL DE MEXICO
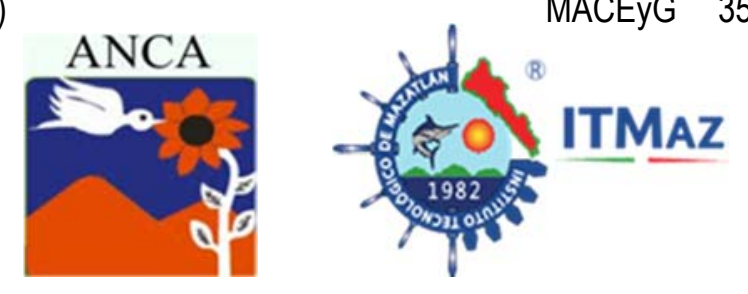

\title{
Características sociodemográficas y factores de riesgo de agricultores laboralmente expuestos a plaguicidas en Michoacán, México
}

\author{
Montiel-González JMR ${ }^{1,2}$, Sánchez-Alarcón $\mathrm{J}^{1,2,3}$, Ochoa-Ocaña MA ${ }^{3,4}$, \\ Hueletl-Soto $\mathrm{ME}^{1,2}$, Valencia-Quintana $\mathrm{R}^{1,2,3 *}$ \\ ${ }^{1}$ Laboratorio "Rafael Villalobos-Pietrini" de Toxicología Genómica \\ y Química Ambiental. Facultad de Agrobiología. \\ Universidad Autónoma de Tlaxcala. Tlaxcala, México \\ ${ }^{2}$ CA UATLX-CA-223 Ambiente y Genética, UATx, México \\ ${ }^{3}$ Red Temática Toxicología de Plaguicidas CONACyT-UA Nayarit, México \\ ${ }^{4}$ Unidad Académica de Estudios Regionales, Coordinación de Humanidades, UNAM \\ *prvq2004@yahoo.com.mx
}

\section{RESUMEN}

Los plaguicidas son compuestos ampliamente utilizados para el control de plagas y la población con mayor riesgo de exposición a estos xenobióticos son los trabajadores agrícolas, debido al mal manejo y desconocimiento del peligro que representan. El objetivo del presente trabajo es determinar las conductas asociadas al uso de plaguicidas en una población de agricultores del estado de Michoacán. Se contó con la participación de 72 agricultores, 69 hombres y 3 mujeres. De acuerdo con la información obtenida a través de un cuestionario estructurado, la edad promedio fue de 37.7 años. $56.9 \%$ lleva más de seis años aplicando plaguicidas. $30.5 \%$ consume alimentos durante la aplicación y de estos solo $66.6 \%$ se lava las manos después de la aplicación. Los carbamatos son los plaguicidas más usados, seguidos de abamectina, organofosforados y piretroides. 52.7\% menciona haber recibido una capacitación para el uso y aplicación de los agroquímicos y el $41.6 \%$ lee las instrucciones correspondientes. Sin embargo, el $83.33 \%$ no usa el equipo de protección personal adecuado, por lo cual el $15.2 \%$ se ha intoxicado por lo menos en una ocasión, los síntomas que se presentan con más frecuencia son dolor de cabeza $(65 \%)$, mareos $(55 \%)$, gripe y cansancio con $54 \%$. Los datos obtenidos en este trabajo sugieren que en Michoacán como en el resto del país y de muchas regiones agrícolas del mundo no solo se requiere de capacitación para el uso de los plaguicidas sino de una concientización del peligro asociado a estas sustancias con la finalidad de disminuir los riesgos.

\section{Agradecimientos: Proyecto respaldado por FOINS-CONACyT referencia} 3203. A la Red Temática de Toxicología de Plaguicidas

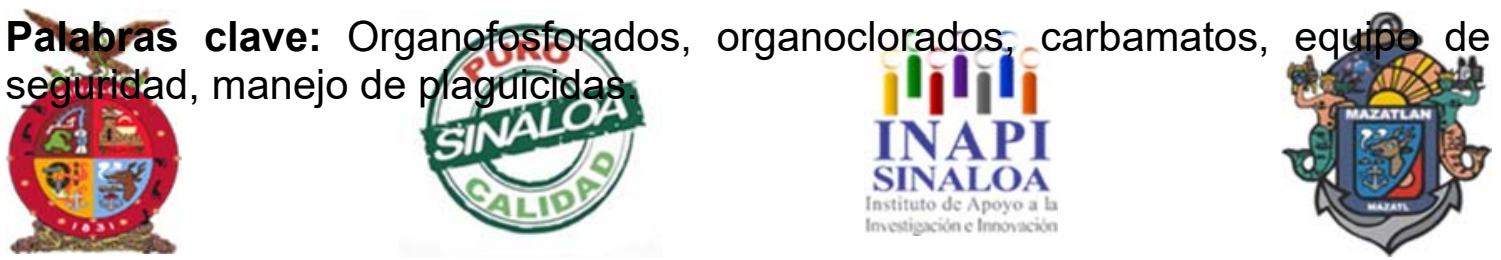


TECNOLOGICO NACIONAL DE MEXICO
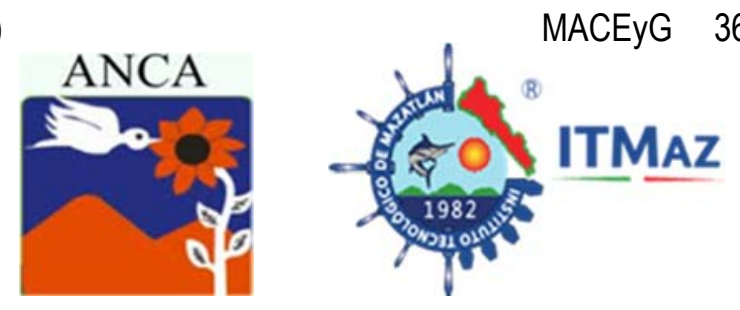

\title{
Socio-demographic characteristics and risk factors of farmers laborally exposed to pesticides in Michoacán, México
}

\author{
Montiel-González JMR ${ }^{1,2}$, Sánchez-Alarcón J1,2,3 , Ochoa-Ocaña MA ${ }^{3,4}$, \\ Hueletl-Soto $\mathrm{ME}^{1,2}$, Valencia-Quintana $\mathrm{R}^{1,2,3 *}$ \\ ${ }^{1}$ Laboratorio "Rafael Villalobos-Pietrini" de Toxicología Genómica \\ y Química Ambiental. Facultad de Agrobiología. \\ Universidad Autónoma de Tlaxcala. Tlaxcala, México \\ ${ }^{2}$ CA UATLX-CA-223 Ambiente y Genética, UATx, México \\ ${ }^{3}$ Red Temática Toxicología de Plaguicidas CONACyT-UA Nayarit, México \\ ${ }^{4}$ Unidad Académica de Estudios Regionales, Coordinación de Humanidades, UNAM \\ *prvq2004@yahoo.com.mx
}

\begin{abstract}
Pesticides are compounds widely used for the control of pests and population with the highest risk of exposure to these xenobiotics are the agricultural workers, due to mismanagement and ignorance of danger that they represent. The objective of this paper is to determine behaviors associated with use of pesticides in a population of farmers in the state of Michoacán. It was attended by 72 farmers, 69 men and 3 women. According to the information obtained through a structured questionnaire, average age was 37.7 years, $56.9 \%$ have more than six years applying pesticides. $30.5 \%$ consume food during the application and of these only $66.6 \%$ wash their hands after application. Carbamates are most commonly used pesticides, followed by abamectin, organophosphates and pyrethroids. $52.7 \%$ mentioned having received training for use and application of agrochemicals and $41.6 \%$ read the corresponding instructions. However, $83.33 \%$ do not use appropriate personal protective equipment, so $15.2 \%$ have been poisoned at least once, the symptoms that occur most often are headache $(65 \%)$, dizziness $(55 \%)$, flu and fatigue with $54 \%$. Data obtained in this work suggest that in Michoacán, as in the rest of the country and many agricultural regions of the world, not only training is required for use of pesticides, but also an awareness of danger associated with these substances in order to reduce risks.
\end{abstract}

Agradecimientos: Proyecto respaldado por FOINS-CONACyT referencia 3203. A la Red Temática de Toxicología de Plaguicidas

Keywords: Organophosphorus, organochlorine, carbamates, safety equipment, pesticide management.

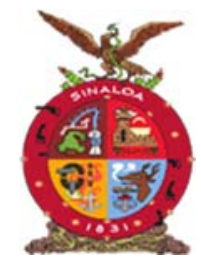

XVIII Congreso Internacional

XXIV Congreso Nacional de Ciencias ambientales
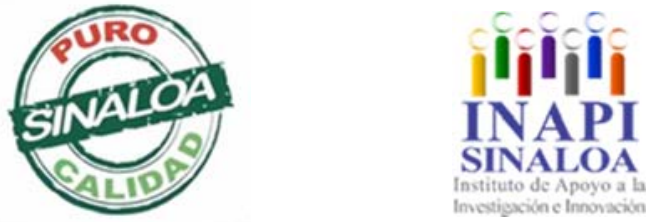

Mazatlán, Sinaloa 3-7 junio 2019

Medio Ambiente, Contaminación,

Enfermedad y Genotoxicidad 
TECNOLOGICO NACIONAL DE MEXICO
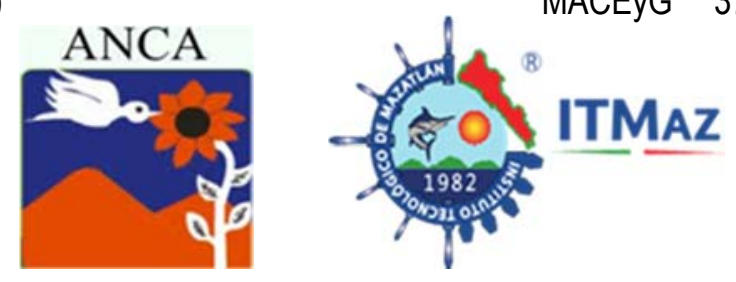

\title{
Distribución temporal de HAPs en la zona metropolitana del Valle de Toluca y sus implicaciones en la salud pública
}

\author{
Moreno Alcántara $\mathrm{J}^{1^{*}}$, Díaz Godoy $\mathrm{R}^{1}$, Estrada Ovando $\mathrm{D}^{2}$ \\ ${ }^{1}$ Instituto Nacional de Investigaciones Nucleares \\ 2Universidad Politécnica del Valle de Toluca \\ *jaime.moreno@inin.gob.mx
}

\begin{abstract}
RESUMEN
Los hidrocarburos aromáticos policíclicos (HAPs) son contaminantes tóxicos que pueden ocluirse en el material particulado o estar presentes en fase vapor. Pueden ser inhalados por el ser humano y llegar a los alveolos pulmonares y favorecer enfermedades respiratorias como el cáncer de pulmón. Durante un año se monitorearon HAPs en el aire del centro, norte y sur de la Zona Metropolitana del Valle de Toluca (ZMVT) y se determinó su implicación en la salud. Se colectaron de manera simultánea los HAPs ocluidos en las $\mathrm{PM}_{2.5}$ y en fase vapor. La extracción se realizó en aparato Soxhlet de manera secuencial con benceno y acetona en muestras compuestas durante ocho horas para cada solvente, el extracto se concentró con evaporador rotatorio y se almacenó a- $18^{\circ} \mathrm{C}$ hasta su análisis por cromatografía de Gases-Masas. Con benceno se extrajeron; naftaleno, fluoreno, fenantreno, antraceno, fluoranteno, pireno, benzo(b)fluoranteno y benzo(ghi)perileno; Con acetona se extrajeron; naftaleno, fluoreno, y fenantreno. En fase vapor se identificaron HAPs de 2 y hasta de 6 anillos y en las $\mathrm{PM}_{2.5}$ de 2 y 3 anillos. La concentración promedio total (CPT) de HAPs fue de $4,403.52 \mathrm{ng} / \mathrm{m}^{3}$ con una participación de $783.90 \mathrm{ng} / \mathrm{m}^{3}$ en la temporada de lluvias y $219.90 \mathrm{ng} / \mathrm{m}^{3}$ en la época seca fría. La CPT arroja una concentración tóxica equivalente total de $4.55 \mathrm{ng} / \mathrm{m}^{3}$ superando el valor de referencia del benzo $(\alpha)$ pireno $\left(1.0 \mathrm{ng} / \mathrm{m}^{3}\right)$. Los HAPs identificados, representan un riesgo potencial a la salud de la población de ZMVT pudiendo los habitantes ser susceptibles de contraer enfermedades respiratorias crónicas, tales como el asma, bronquitis hasta cáncer de pulmón.
\end{abstract}

Palabras claves: contaminación, atmosfera, salud pública, cáncer.

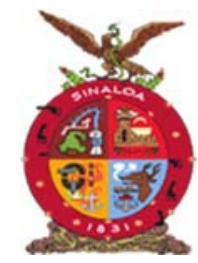

XVIII Congreso Internacional

XXIV Congreso Nacional de Ciencias ambientales
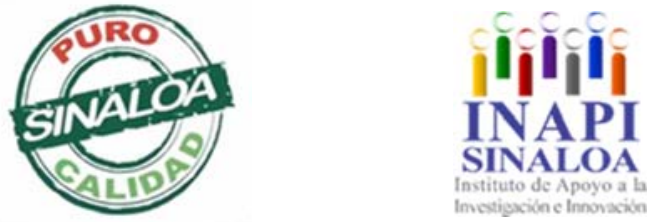

Mazatlán, Sinaloa 3-7 junio 2019

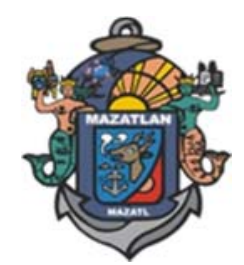

Medio Ambiente, Contaminación, Enfermedad y Genotoxicidad 

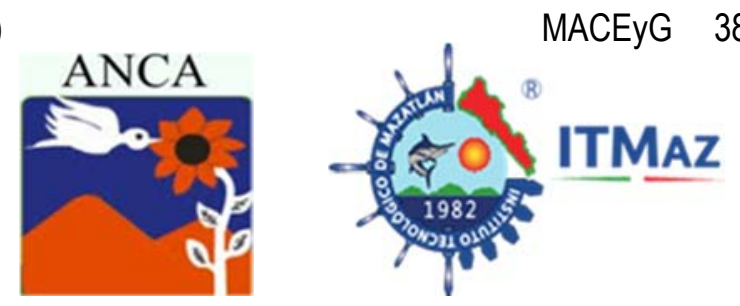

\title{
Temporary distribution of PAHs in the metropolitan area of Toluca Valley and its implications on public health
}

\author{
Moreno Alcántara $\mathrm{J}^{1^{*}}$, Díaz Godoy $\mathrm{R}^{1}$, Estrada Ovando $\mathrm{D}^{2}$ \\ ${ }^{1}$ Instituto Nacional de Investigaciones Nucleares \\ 2 Universidad Politécnica del Valle de Toluca \\ * jaime.moreno@inin.gob.mx
}

\begin{abstract}
Polycyclic aromatic hydrocarbons (PAHs) are toxic contaminants that can be occluded in the particulate material or present in the vapor phase they can be inhaled by the human being and reach the pulmonary alveoli and favor respiratory diseases such as lung cancer. During one year, PAHs were monitored in the center, north and south of the Metropolitan Area of Toluca Valley (ZMVT) and their involvement in health was determined. The occluded PAHs in $\mathrm{PM}_{2.5}$ and in the vapor phase were collected simultaneously. The extraction was carried out sequentially with benzene and acetone in composite samples in Soxhlet for eight hours for each solvent. The extract was concentrated with a rotary evaporator and stored at $18^{\circ} \mathrm{C}$ until analysis by GC/MS. With benzene, naphthalene, fluorene, phenanthrene, anthracene, fluoranthene, pyrene, benzo (b) fluoranthene and benzo (ghi) perylene, with acetone naphthalene, fluorene, and phenanthrene were extracted. In the vapor phase, PAHs of 2 and up to 6 rings were identified, while in $\mathrm{PM}_{2.5}, 2$ and 3 rings were identified. The total average concentration (TAC) of PAHs was $4,403.5236236 \mathrm{ng} / \mathrm{m}^{3}$ with a participation of $783.9042 \mathrm{ng} / \mathrm{m}^{3}$ in the rainy season and $219.9095 \mathrm{ng} / \mathrm{m}^{3}$ in the dry cold. The TAC yields a total equivalent toxic concentration of $4.5596 \mathrm{ng} / \mathrm{m}^{3}$ exceeding the reference value of benzo (a) pyrene $\left(1.0 \mathrm{ng} / \mathrm{m}^{3}\right)$. The PAHs identified represent a potential risk to the health of the ZMVT human population and may be susceptible to chronic respiratory diseases such as asthma, bronchitis and lung cancer.
\end{abstract}

Keywords: pollution, atmosphere, public health, cancer.

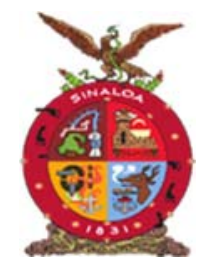

XVIII Congreso Internacional XXIV Congreso Nacional de Ciencias ambientales
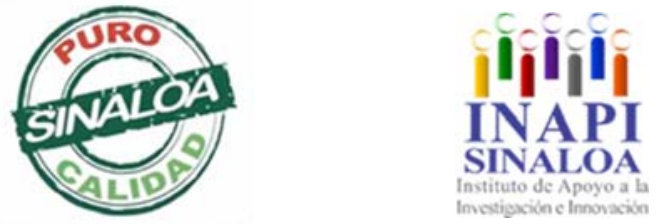

Mazatlán, Sinaloa 3-7 junio 2019

Medio Ambiente, Contaminación,

Enfermedad y Genotoxicidad 
TECNOLOGICO NACIONAL DE MEXICO
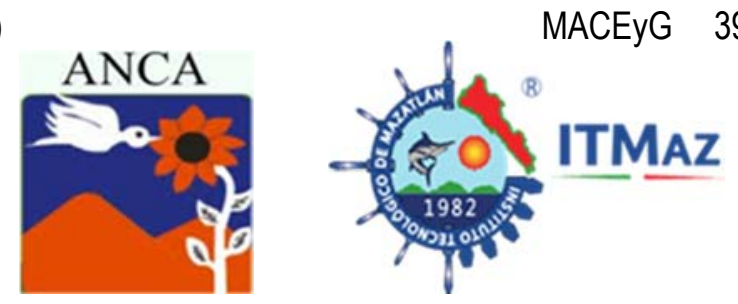

\title{
Determinación del potencial fitorremediador de Prosopis laevigata en jales mineros
}

\author{
Muro González D ${ }^{1 *}$, Tovar Sánchez E , Mussali Galante $\mathrm{P}^{2}$ \\ ${ }^{1}$ Centro de Investigación en Biodiversidad y Conservación (CIByC) \\ ${ }^{2}$ Centro de Investigación en Biotecnología (CEIB). \\ Universidad Autónoma del Estado de Morelos. \\ Av. Universidad No. 1001, Col. Chamilpa, Cuernavaca, Morelos, CP. 62209 \\ *biodalia@gmail.com
}

\section{RESUMEN}

La minería es una actividad económica que genera residuos contaminantes (jales) que contienen elementos potencialmente tóxicos y causan daño a los organismos. En Huautla, Morelos, México, esta actividad ocasionó el depósito de miles de toneladas de residuos, que se bioacumulan en tejidos de las plantas, provocando afectaciones morfológicas, fisiológicas y genéticas, pero algunas especies vegetales son resistentes a los efectos de los metales. Algunas plantas nativas hiper-acumuladoras de metales, pueden ser utilizadas para fitorremediación y por ello contribuir a limpiar suelos contaminados así la especie arbórea Prosopis laevigata, que tolera altas concentraciones de algunos metales, puede ser utilizada para remediar suelos contaminados. Este estudio se realizó utilizando individuos de $P$. laevigata en dos tratamientos de sustrato: jal vs testigo, tomando datos cada 60 días, midiendo la bioacumulación de metales en hojas, caracteres micro y macro-morfológicos, daños fisiológicos y genéticos. Se registraron individuos de $P$. laevigata que bioacumulan metales en las hojas en la siguiente secuencia: $\mathrm{Fe}>\mathrm{Pb}>\mathrm{Zn}>\mathrm{Cu}$. La relación entre la bioacumulación de $\mathrm{Pb}$ y el daño genético en el tejido foliar que presentan árboles adultos de $P$. laevigata expuestos a metales pesados y establecidos en jales de Huautla, Morelos es positiva y significativa. Los individuos expuestos al sustrato jal bajo condiciones de invernadero mostraron una reducción estadísticamente significativa en los caracteres micro y macro-morfológicos en relación con los individuos establecidos en sustrato testigo. El contenido de clorofila en individuos de $P$. laevigata no se modificó entre tratamientos pero si se observó una relación positiva y significativa entre la concentración de $\mathrm{Pb}$ en tejido foliar y el contenido de clorofila.

Palabras clave: Bioacumulación de metales, daño genético, efectos morfológicos y fisiológicos.

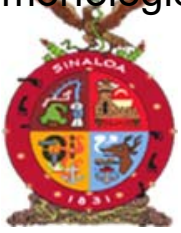

XVIII Congreso Internacional

XXIV Congreso Nacional de Ciencias ambientales
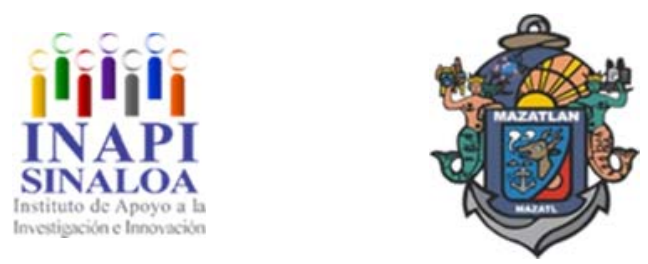

Medio Ambiente, Contaminación, Enfermedad y Genotoxicidad 

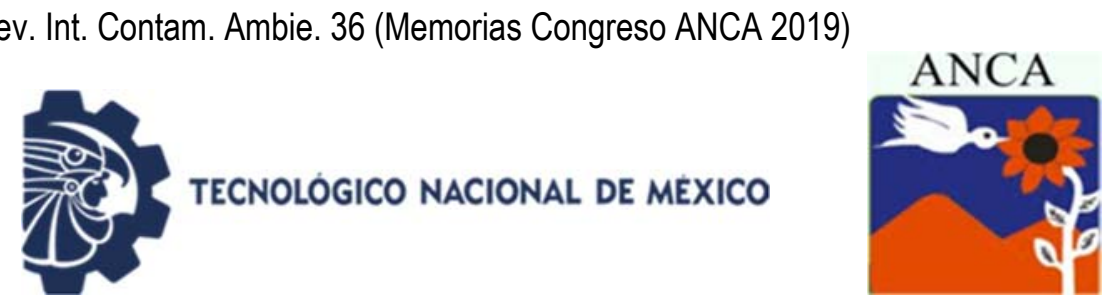

\title{
Determination of the potencial in phytorremediation of Prosopis laevigata in mining tailings
}

\author{
Muro González D ${ }^{1 *}$, Tovar Sánchez E , Mussali Galante $\mathrm{P}^{2}$ \\ ${ }^{1}$ Centro de Investigación en Biodiversidad y Conservación (CIByC) \\ ${ }^{2}$ Centro de Investigación en Biotecnología (CEIB). \\ Universidad Autónoma del Estado de Morelos. Av. Universidad No. 1001, Col. \\ Chamilpa, Cuernavaca, Morelos, CP.62209 \\ *biodalia@gmail.com
}

\begin{abstract}
Mining is an economic activity that generates polluting residues (tailings) that contain potentially toxic elements and cause damage to organisms. In Huautla, Morelos, Mexico, this activity caused the deposit of thousands of tons of waste, which bio accumulate in plant tissues, causing morphological, physiological and genetic effects (1 and 2), but some plant species are resistant to the effects of metals. Phytoremediation uses native hyper accumulative plants (3) and can clean soils contaminated by heavy metals. The tree species Prosopis laevigata, tolerates high concentrations of some metals, and can be used to remedy contaminated soils. The study was carried out using $P$. laevigata individuals in two substrate treatments: tailing substrate vs. control, substrate, taking data every 60 days, such as the bioaccumulation of metals in leaves, micro and macro morphological characters, physiological and genetic damage. Individuals of $P$. laevigata that bio accumulate on $\mathrm{Fe}>\mathrm{Pb}>\mathrm{Zn}>\mathrm{Cu}$ sheet were recorded. The relationship between the bioaccumulation of $\mathrm{Pb}$ and the genetic damage in foliar tissue that present adult trees of $P$. laevigata exposed to heavy metals and established in tailings of Huautla, Morelos is positive and significant. The individuals exposed to the tailings substrate under greenhouse conditions showed a statistically significant reduction in the micro and macro morphological characters in relation to the individuals established in the control substrate. The chlorophyll content in $P$. laevigata individuals was not modified between treatments but a positive and significant relationship between the concentration of $\mathrm{Pb}$ in leaf tissue and the chlorophyll content.
\end{abstract}

Keywords: Bioaccumulation of metals, genetic damage, morphological and physiological effects.

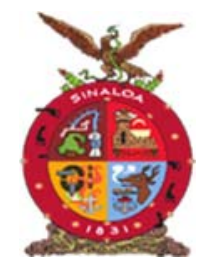

XVIII Congreso Internacional XXIV Congreso Nacional de Ciencias ambientales
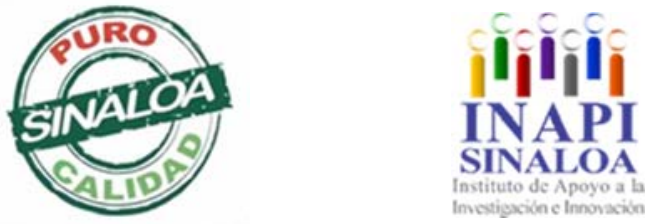

Mazatlán, Sinaloa 3-7 junio 2019

Medio Ambiente, Contaminación,

Enfermedad y Genotoxicidad 

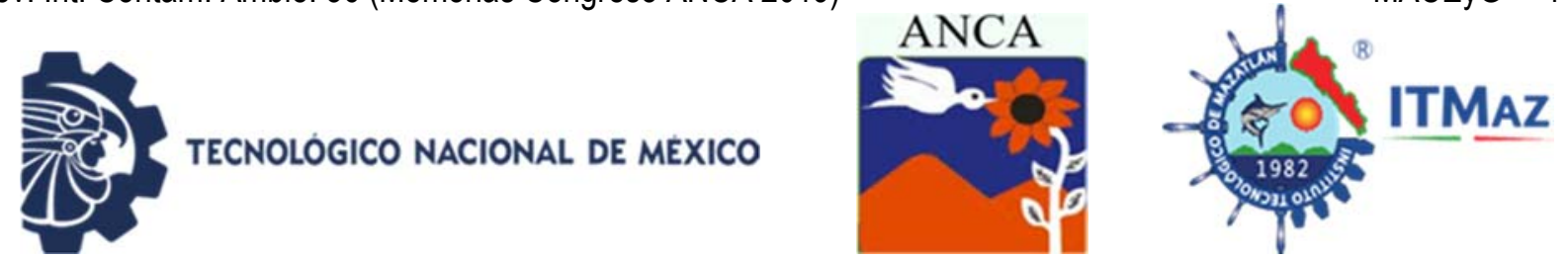

\title{
Descomposición del peroxi-monosulfato (PMS) a partir de irradiación de luz UV-C para la degradación del colorante anilínico Fucsia B
}

\author{
Partida-Joya $D^{1}$, Medina-Orendain $D^{1}$, Rodríguez-Narváez O \\ ${ }^{1}$ Ingeniería Bioquímica. Instituto Tecnológico de Tepic, Nayarit, México \\ ${ }^{2}$ Doctorado en Química. Universidad de Guanajuato, \\ Guanajuato, México \\ *om.rodrigueznarvaez@ugto.mx
}

\section{RESUMEN}

En el presente trabajo se realizó la descomposición fotoquímica del peroximonosulfato (PMS) con irradiación de luz UV-C, para su aplicación en la degradación de un colorante utilizado en la industria textil, denominado Fucsia B. Dichos experimentos se realizaron a diferentes irradiaciones de luz UV-C (Irradiación= 2.8, 18.5, y $39.1 \mathrm{Wm}^{-2}$ ) y concentraciones de PMS (15, 30 y $45 \mathrm{mM}$ ). Se caracterizó el flujo fotónico de la lámpara, mostrando que para una irradiación de $2.8,18.5$ y $39.1 \mathrm{Wm}^{-2}$, el flujo fotónico era de $5.24 \times 10^{-4}, 1.86 \times 10^{-4}$ y $3.15 \times 10^{-}$ ${ }^{4}$ Einsteinmin $^{-1}$. A partir de los datos experimentales, se determinó que las mejores condiciones experimentales $\left(P M S=30 \mathrm{mM}\right.$ e Irradiación $\left.=39.1 \mathrm{Wm}^{-2}\right)$, removerían $52 \%$ del Fucsia del agua. La modelación de los datos fue realizada con un modelo cinético de pseudo primer orden.

Palabras clave: Procesos avanzados de oxidación, peroximonosulfato, irradiación UV-C, flujo fotónico, decoloración.

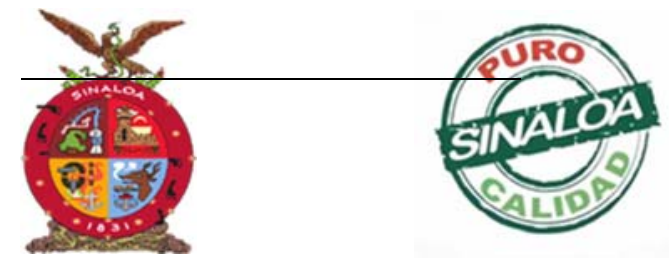

Mazatlán, Sinaloa 3-7 junio 2019

XVIII Congreso Internacional XXIV Congreso Nacional de Ciencias ambientales

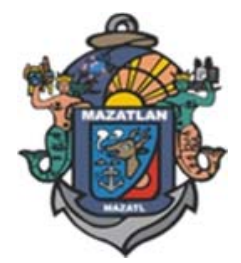

Medio Ambiente, Contaminación,

Enfermedad y Genotoxicidad 

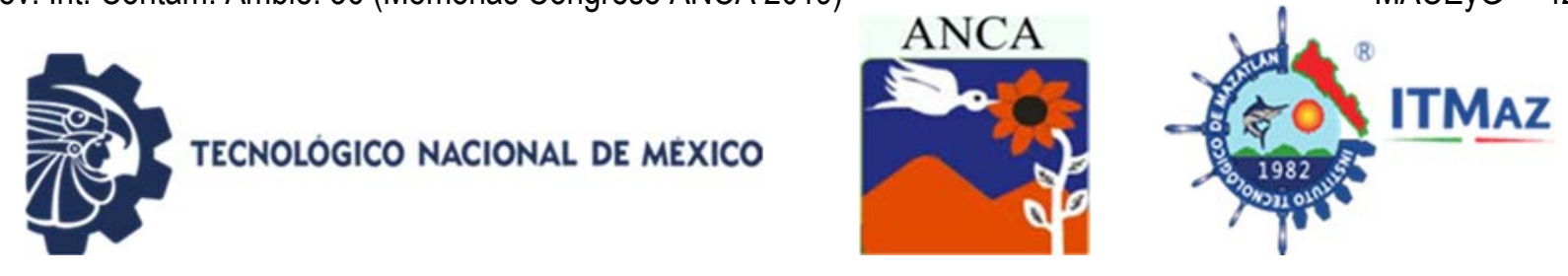

\title{
Decomposition of peroximonosulfate (PMS) from irradiation of UV-C light for degradation of the Fuchsia B aniline dye
}

\author{
Partida-Joya $\mathrm{D}^{1}$, Medina-Orendain $\mathrm{D}^{1}$, Rodríguez-Narváez O \\ ${ }^{1}$ Ingeniería Bioquímica. Instituto Tecnológico de Tepic, Nayarit, México \\ ${ }^{2}$ Doctorado en Química. Universidad de Guanajuato, \\ Guanajuato, México \\ *om.rodrigueznarvaez@ugto.mx
}

\begin{abstract}
In this study, peroxymonosulfate (PMS) photochemical decomposition with UV-C irradiation was carried out, for Fucsia B degradation, an industrial textile dye. Experiments were carried out at different UV-C irradiations (Irradiation= 2.8, 18.5, $39.1 \mathrm{Wm}-2)$ and PMS concentrations (15, 30 y $45 \mathrm{mM}$ ). Lamp photonic flux was determinate $(5.24 \times 10-4,1.86 \times 10-4$ y $3.15 \times 10-4$ Einsteinmin-1) at different irradiations $(2.8,18.5$ y $39.1 \mathrm{Wm}-2$, respectively). Best experimental conditions were obtained $(P M S=30 \mathrm{mM}$ and Irradiation= $39.1 \mathrm{Wm}-2)$, where $52 \%$ discoloration of Fucsia was achieved. A pseudo first order kinetic model was done with the experimental data.
\end{abstract}

Keywords: Advanced oxidation processes, peroximonosulfate, UV-C irradiation, photonic flow, discoloration.

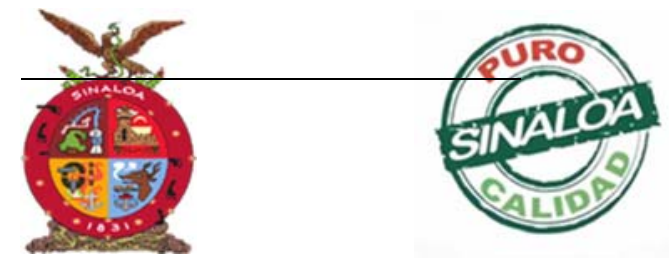

Mazatlán, Sinaloa 3-7 junio 2019

XVIII Congreso Internacional XXIV Congreso Nacional de Ciencias ambientales
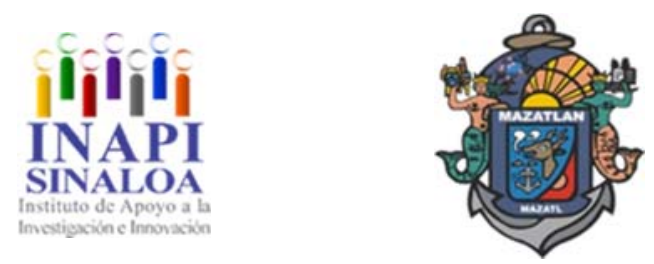

Medio Ambiente, Contaminación,

Enfermedad y Genotoxicidad 


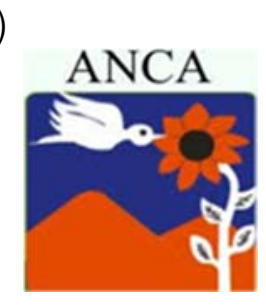

\title{
Daño citogenético en personas laboralmente expuestas a plaguicidas en Michoacán, México
}

\author{
Pérez-Sánchez $\mathrm{M}^{1}$, Sánchez-Alarcón $\mathrm{J}^{2,3,4}$, Ochoa-Ocaña MA ${ }^{4,5}$, \\ Arenas-Sánchez $\mathrm{H}^{2}$, Hueletl-Soto $\mathrm{ME}^{2,3}$, Montiel-González $\mathrm{JMR}^{2,3}$, \\ Valencia-Quintana $\mathrm{R}^{2,3,4 *}$ \\ ${ }^{1}$ Maestría en Ciencias Biológicas, CTBC, Universidad Autónoma de Tlaxcala. \\ ${ }^{2}$ Laboratorio "Rafael Villalobos-Pietrini" de Toxicología Genómica \\ y Química Ambiental. Facultad de Agrobiología. Universidad Autónoma de Tlaxcala. \\ Km. 10.5 Autopista San Martín Texmelucan-Tlaxcala S/N, Ixtacuixtla Tlaxcala, México \\ ${ }^{3}$ Cuerpo Académico Ambiente y Genética UATLX-CA-223 \\ ${ }^{4}$ Red Temática de Toxicología de Plaguicidas CONACyT-UANayarit \\ ${ }^{5}$ Unidad Académica de Estudios Regionales, Coordinación de Humanidades, UNAM \\ *prvq2004@yahoo.com.mx
}

\section{RESUMEN}

El empleo de biomarcadores de genotoxicidad en el monitoreo de poblaciones humanas expuestas laboral o ambientalmente a contaminantes ambientales, es una herramienta útil para estimar el daño genotóxico inducido y evaluar el riesgo potencial de efectos en la salud. Aunque con algunas controversias, diversas investigaciones han demostrado que la exposición a plaguicidas induce daño citogenético en poblaciones laboral y/o ambientalmente expuestas. Michoacán es un estado con gran actividad agrícola y el uso de plaguicidas es un factor indispensable para la protección de sus cultivos. Por ello, objetivo de este estudio es evaluar el daño citogenético en trabajadores agrícolas de las comunidades de Zamora y Jacona. Los participantes firmaron un consentimiento informado después de conocer los propósitos del proyecto y de contestar un cuestionario para conocer diversos factores que pudieran influir en los resultados tales como la presencia de enfermedades, consumo de alcohol, tabaco o medicamentos, entre otros datos generales y estilos de vida. El proyecto fue aprobado por el Comité de Ética del estado de Tlaxcala. Se tomaron muestras de sangre periférica y llevó a cabo el ensayo de micronúcleos en células binucleadas con bloqueo de la citocinesis, empleando citocalasina-B. Las laminillas fueron teñidas con Giemsa y analizadas al microscopio. Al momento se presentan las frecuencias de micronúcleos de 43 agricultores. Los resultados indican que la exposición laboral a plaguicidas causa daño citogenético, al incrementarse la frecuencia de $\mathrm{MN}$, factor que ha sido relacionado con un mayor riesgo de cáncer, por lo que es necesario implementar medidas de remediación.

\section{Agradecimientos: Proyecto respaldado por FOINS-CONACyT referencia} 3203. A la Red Temática de Toxicología de Plaguicidas

Palabras clave: Genotoxicidad, plaguicidas, biomonitoreo, micronúcleos, células

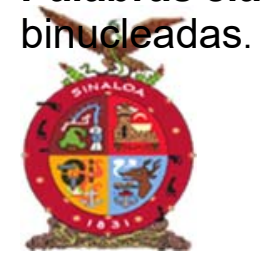

XVIII Congreso Internacional

XXIV Congreso Nacional de Ciencias ambientales
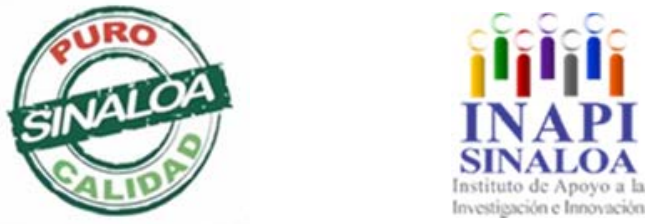

Mazatlán, Sinaloa 3-7 junio 2019

Medio Ambiente, Contaminación,

Enfermedad y Genotoxicidad 

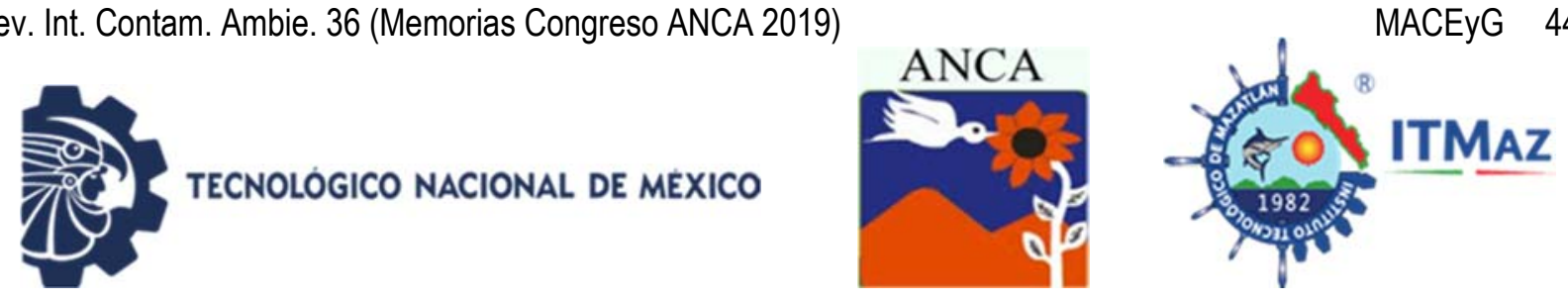

\title{
Cytogenetic damage in people laborally exposed to pesticides in Michoacán, México
}

\author{
Pérez-Sánchez $\mathrm{M}^{1}$, Sánchez-Alarcón $\mathrm{J}^{2,3,4}$, Ochoa-Ocaña $\mathrm{MA}^{4,5}$, \\ Arenas-Sánchez $\mathrm{H}^{2}$, Hueletl-Soto $\mathrm{ME}^{2,3}$, Montiel-González $\mathrm{JMR}^{2,3}$, \\ Valencia-Quintana $\mathrm{R}^{2,3,4 *}$ \\ ${ }^{1}$ Maestría en Ciencias Biológicas, CTBC, Universidad Autónoma de Tlaxcala. \\ ${ }^{2}$ Laboratorio "Rafael Villalobos-Pietrini" de Toxicología Genómica \\ y Química Ambiental. Facultad de Agrobiología. Universidad Autónoma de Tlaxcala. \\ Km. 10.5 Autopista San Martín Texmelucan-Tlaxcala S/N, Ixtacuixtla Tlaxcala, México \\ ${ }^{3}$ Cuerpo Académico Ambiente y Genética UATLX-CA-223 \\ ${ }^{4}$ Red Temática de Toxicología de Plaguicidas CONACyT-UANayarit \\ ${ }^{5}$ Unidad Académica de Estudios Regionales, Coordinación de Humanidades, UNAM \\ *prvq2004@yahoo.com.mx
}

\begin{abstract}
The use of biomarkers of genotoxicity in the monitoring of human populations occupational or environmentally exposed to environmental pollutants is a useful tool to estimate the genotoxic damage induced and evaluate the potential risk of health effects. Although with some controversies, several investigations have shown that exposure to pesticides induces cytogenetic damage in occupational and/or environmentally exposed populations. Michoacán is a state with great agricultural activity and the use of pesticides is an indispensable factor for the protection of their crops. Therefore, the objective of this study is to evaluate the cytogenetic damage in agricultural workers of Zamora and Jacona communities. The participants signed an informed consent after knowing the purposes of the project and answering a questionnaire to know various factors that could influence the results such as the presence of diseases, alcohol, tobacco or medicine consumption, among other general data and life styles. The project was approved by the Ethics Committee of the state of Tlaxcala. Peripheral blood samples were taken and the micronucleus assay was performed in binucleated cells with cytokinesis block, using cytochalasin-B. The slides were stained with Giemsa and analyzed under a microscope. At the moment, the micronucleus frequencies of 43 farmers are presented. The results indicate that occupational exposure to pesticides causes cytogenetic damage, since the frequency of $\mathrm{MN}$ increases, a factor that has been related with an increased risk of cancer, which makes necessary to implement remediation measures.
\end{abstract}

\section{Agradecimientos: Proyecto respaldado por FOINS-CONACyT referencia} 3203. A la Red Temática de Toxicología de Plaguicidas

Keywords: Genotoxicity, pesticides, biomonitoring, micronuclei, binucleated cells

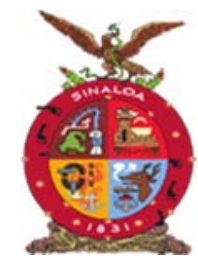

XVIII Congreso Internacional

XXIV Congreso Nacional de Ciencias ambientales
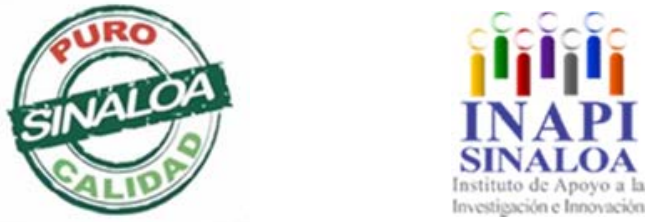

Mazatlán, Sinaloa 3-7 junio 2019

Medio Ambiente, Contaminación

Enfermedad y Genotoxicidad 
TECNOLOGICO NACIONAL DE MEXICO
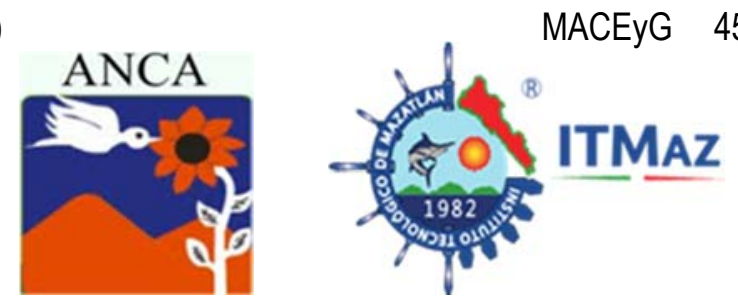

\title{
Estudio espacio temporal de la calidad del agua y el estado trófico de un gran embalse tropical ubicado en una región agrícola
}

\author{
Quevedo-Castro $A^{1}$, Bustos-Terrones $\mathrm{YA}^{2}$, Bandala $\mathrm{ER}^{3}$, Amábilis Sosa LE², \\ Rangel-Peraza $\mathrm{JG}^{{ }^{*}}$ \\ ${ }^{1}$ CONACYT-División de Estudios de Posgrado e Investigación. \\ Instituto Tecnológico de Culiacán. Juan de Dios Bátiz 310. \\ Col. Guadalupe, Culiacán, Sinaloa, México \\ 2División de Estudios de Posgrado e Investigación. Instituto Tecnológico de \\ Culiacán. Juan de Dios Bátiz 310. Col. Guadalupe, Culiacán, Sinaloa, México \\ ${ }^{3}$ Division of Hydrologic Sciences, Desert Research Institute. \\ 755, Flamingo Road, Las Vegas, Nevada 89119-7363 \\ * jesus.rangel@itculiacan.edu.mx
}

\section{RESUMEN}

Se realizó un estudio de calidad del agua en el embalse Adolfo López Mateos (ALM), uno de los reservorios tropicales más grandes de México, ubicado dentro de una región agrícola intensiva. En este estudio, las variaciones estacionales y espaciales de nueve parámetros de calidad del agua se evaluaron semestralmente en cuatro sitios diferentes a lo largo del reservorio durante un período de 7 años (2012-2018), considerando las estaciones de primavera (seca) y otoño (lluviosa). El análisis de varianza se realizó para comparar los valores medios de los parámetros de calidad del agua para los diferentes sitios de muestreo. Luego, se llevó a cabo un análisis de clasificación multiparamétrico para estimar la densidad espacial de los puntos de muestreo que fue desarrollado por un clasificador de redes neuronales probabilístico (PNN). Las observaciones (estacionales y espaciales) de los parámetros de calidad del agua en el reservorio de ALM no revelaron una influencia significativa de la red de arrastre de contaminantes. El estado trófico se evaluó utilizando el Índice de Estado Trófico Modificado de Carlson, encontrando que se encuentra en estado trófico mesotrófico, siendo el nutriente limitante el nitrógeno. Se detectó una importante variación de la relación nitrógeno/fósforo en 2017 y 2018. El PNN reveló interacciones neuronales entre los sólidos suspendidos totales (SST) y otros cuatro parámetros, lo que indica que los rangos de concentración de cinco parámetros se distribuyen por igual y se clasifican en los cuatro puntos de muestreo establecidos, lo que hace que estos sitios de muestreo sean altamente significativos para estudios posteriores.

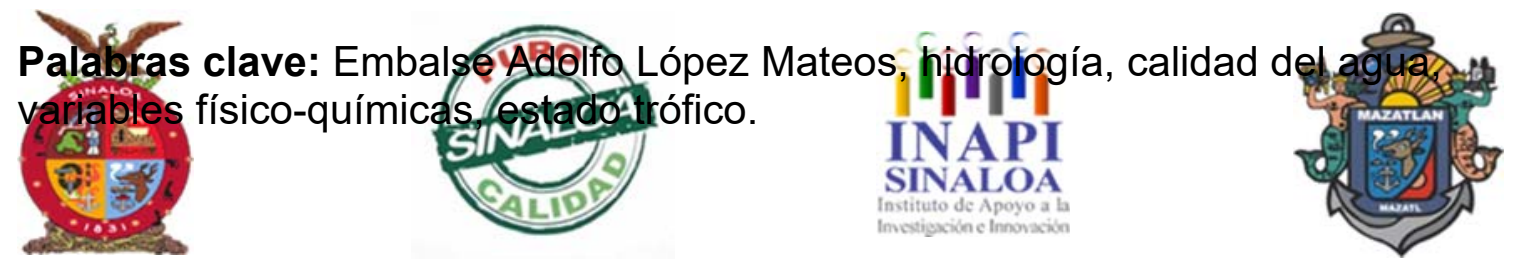


TECNOLOGICO NACIONAL DE MEXICO
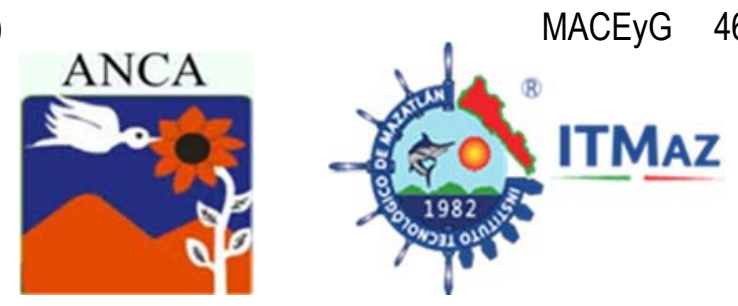

\title{
Temporal and spatial study of water quality and trophic status of a large tropical reservoir located in an agricultural region
}

\author{
Quevedo-Castro A ${ }^{1}$, Bustos-Terrones YA², Bandala ER ${ }^{3}$, Amábilis Sosa LE², \\ Rangel-Peraza JG ${ }^{1^{*}}$ \\ ${ }^{1}$ CONACYT-División de Estudios de Posgrado e Investigación. \\ Instituto Tecnológico de Culiacán. Juan de Dios Bátiz 310. \\ Col. Guadalupe, Culiacán, Sinaloa, México \\ ${ }^{2}$ División de Estudios de Posgrado e Investigación. Instituto Tecnológico de \\ Culiacán. Juan de Dios Bátiz 310. Col. Guadalupe, Culiacán, Sinaloa, México \\ ${ }^{3}$ Division of Hydrologic Sciences, Desert Research Institute. \\ 755, Flamingo Road, Las Vegas, Nevada 89119-7363 \\ * jesus.rangel@itculiacan.edu.mx
}

\begin{abstract}
A water quality study was carried out at the Adolfo López Mateos Reservoir (ALM), one of the largest tropical reservoirs in Mexico, located within an intensive agricultural region. In this study, the seasonal and spatial variations of nine water quality parameters were evaluated at four different sites along the reservoir semiannually over a period of 7 years (2012-2018), considering spring (dry) and fall (rainy) seasons. The analysis of variance was performed to compare the mean values of the water quality parameters for the different sampling sites. Then a multiparametric classification analysis was carried out to estimate the spatial density of sampling points was developed by a Probabilistic Neural Network Classifier (PNN). The observations (seasonal and spatial) of water quality parameters at ALM reservoir revealed no significant influence of the trawl of pollutants. The trophic status was evaluated using the Carlson Modified Trophic State Index, finding the trophic state of the reservoir at mesotrophic level, being nitrogen the limiting nutrient. An important variation of the nitrogen/phosphorus relation was detected in 2017 and 2018. The PNN revealed neuronal interactions between total suspended solids (TSS) and four other parameters, indicating that concentration ranges of five parameters are equally distributed and classified at the four sampling points established in this study, making these sampling sites highly significant for further studies.
\end{abstract}

Keywords: Adolfo López Mateos Reservoir, hydrology, water quality, physicchemical variables, trophic state.

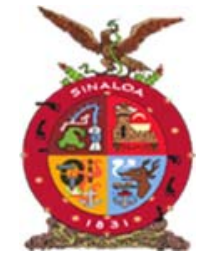

XVIII Congreso Internacional

XXIV Congreso Nacional de Ciencias ambientales
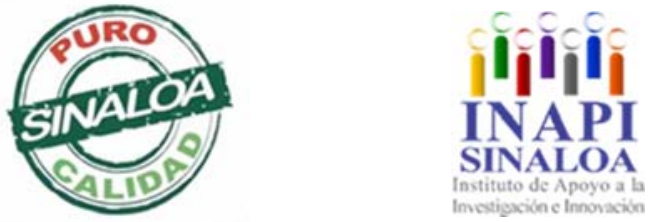

Mazatlán, Sinaloa 3-7 junio 2019

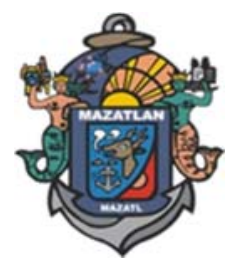

Medio Ambiente, Contaminación, Enfermedad y Genotoxicidad 
TECNOLOGICO NACIONAL DE MEXICO
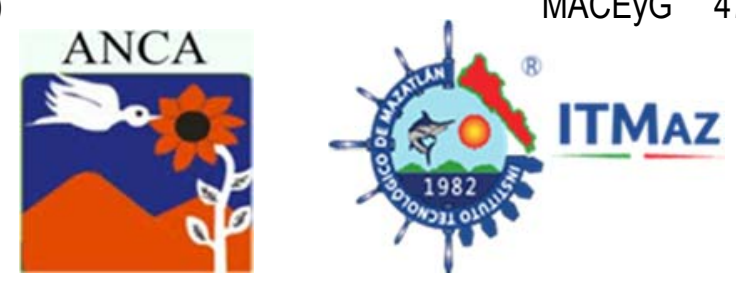

\title{
Evaluación de los efectos ocasionados por la exposición subcrónica a nitrato de sodio en ratas hembras Wistar
}

\author{
Ríos-Sánchez E1 , González-Delgado $\mathrm{MF}^{1}$, Calleros-Rincón EY ${ }^{1}$,
} Gonsebatt $\mathrm{ME}^{2}$, Pérez-Morales $\mathrm{R}^{1^{*}}$

${ }^{1}$ Laboratorio de Biología Celular y Molecular. Facultad de Ciencias Químicas. Universidad Juárez del Estado de Durango.

Av. Artículo 123 S/N, Col. Filadelfia 35010 Gómez Palacio, Durango, México

${ }^{2}$ Departamento de Medicina Genómica y Toxicología Ambiental.

Instituto de Investigaciones Biomédicas.

Universidad Nacional Autónoma de México. CDMX 04510, México

*rebecapms@ujed.mx

\section{RESUMEN}

Los nitratos se encuentran en el suelo por el uso excesivo de fertilizantes en la agricultura permitiendo su acumulación en vegetales y contaminación de mantos acuíferos para consumo humano. El deterioro ambiental y la ausencia de programas de control, provocan la exposición crónica en humanos y animales que se ha asociado a condiciones patológicas como metahemoglobinemia, alteraciones hematológicas, hepáticas, metabólicas y ciertos tipos de cáncer. El objetivo de este trabajo es evaluar el efecto de la exposición subcrónica a nitrato de sodio sobre parámetros hematológicos, bioquímicos y tiroideos en ratas hembra Wistar. El estudio consistió en exposición oral a 3 grupos experimentales tratados con dosis diarias de 66, 150 y $300 \mathrm{mg} / \mathrm{kg} / \mathrm{día}$ y un grupo control por un periodo de 8 semanas, cada grupo fue formado por 10 ratas. Posterior al periodo de exposición se realizó el sacrificio para la determinación de los parámetros de interés. No se encontraron diferencias en los parámetros relacionados a los eritrocitos y porcentaje de metahemoglobina. Sin embargo, se encontró un aumento en plaquetas y leucocitos $(p<0.0001)$; el análisis diferencial de leucocitos también mostró diferencias $(p<0.0001)$. Los parámetros bioquímicos no encontraron cambios significativos, mientras que en los niveles de hormonas tiroideas (T3, T4 y TSH) se observa una tendencia a la disminución, aunque no es significativa. Los resultados sugieren que la exposición subcrónica podría desencadenar un mecanismo de inflamación sistémica, mientras que en los otros parámetros se alcanza adaptación metabólica ante el contaminante. En conclusión, la exposición subcrónica a nitratos genera alteraciones hematológicas e inflamación.

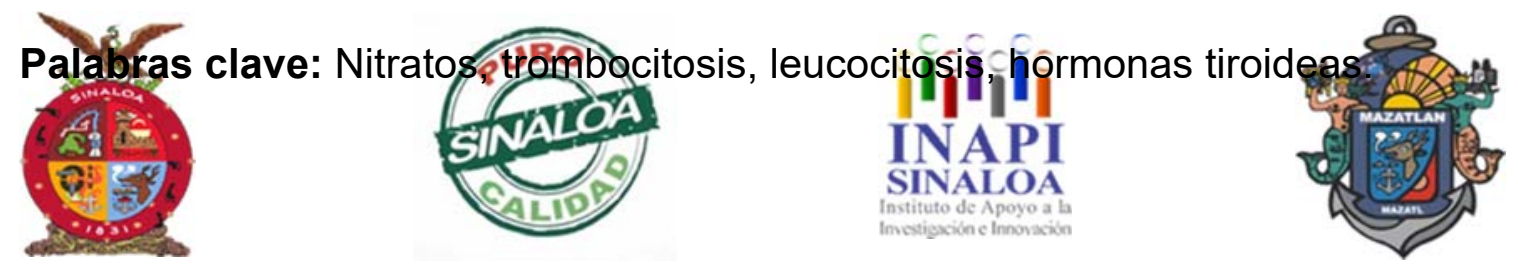


TECNOLOGICO NACIONAL DE MEXICO
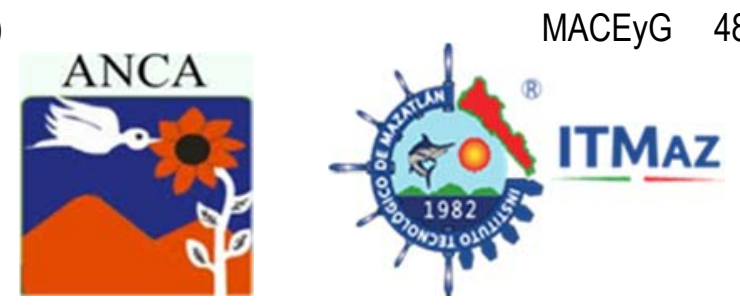

\title{
Evaluation of the effect of subchronic exposure with sodium nitrate in female Wistar rats
}

\author{
Ríos-Sánchez E1 , González-Delgado $\mathrm{MF}^{1}$, Calleros-Rincón EY ${ }^{1}$,
} Gonsebatt $\mathrm{ME}^{2}$, Pérez-Morales $\mathrm{R}^{1^{*}}$

${ }^{1}$ Laboratorio de Biología Celular y Molecular. Facultad de Ciencias Químicas. Universidad Juárez del Estado de Durango.

Av. Artículo 123 S/N, Col. Filadelfia 35010 Gómez Palacio, Durango, México

${ }^{2}$ Departamento de Medicina Genómica y Toxicología Ambiental.

Instituto de Investigaciones Biomédicas.

Universidad Nacional Autónoma de México. CDMX 04510, México

*rebecapms@ujed.mx

\begin{abstract}
Nitrates are present in farmland due to excessive use of fertilizers in agriculture activities allowing their accumulation in vegetables and contamination of human consumption water. Environmental deterioration and the lack of control programs, trigger chronic exposure in humans and animals, which is associated with methemoglobinemia, hematological, biochemical and metabolic alterations as well as some types of cancer. The aim of this study is to evaluate the effect of sub chronic exposure with sodium nitrate on hematological, biochemical and thyroid hormones parameters in female Wistar rats. The study consisted in oral exposition of sodium nitrate to 3 experimental groups treated with 66, 150 y 300 $\mathrm{mg} / \mathrm{kg} /$ day and a control group for 8 weeks, each one formed with 10 rats. Subsequent sacrifice was performed for the determination of the parameters of interest. In the results of the model, there were no differences in erythrocytes and methemoglobin levels, however, there was significant differences in platelets and leucocytes $(p<0.0001)$; differential analysis of leucocytes shown differences $(p<0.0001)$. Biochemical parameters showed no statistical differences as well as thyroid hormones parameters (T3, T4 and TSH) even though a slight negative tendency is remarkable. These results suggest that subchronic exposure may trigger a systemic inflammation process and metabolic adaptation that compensates the exposure to the pollutant. In conclusion, subchronic exposure with nitrates generates hematological alterations and inflammation
\end{abstract}

Keywords: Nitrate, thrombosis, leukocytosis, thyroid hormones.

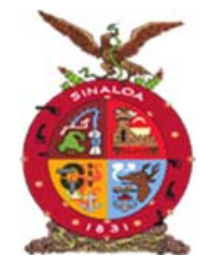

XVIII Congreso Internacional XXIV Congreso Nacional de Ciencias ambientales
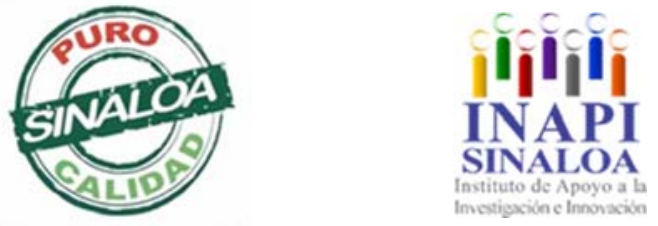

Mazatlán, Sinaloa 3-7 junio 2019

Medio Ambiente, Contaminación,

Enfermedad y Genotoxicidad 

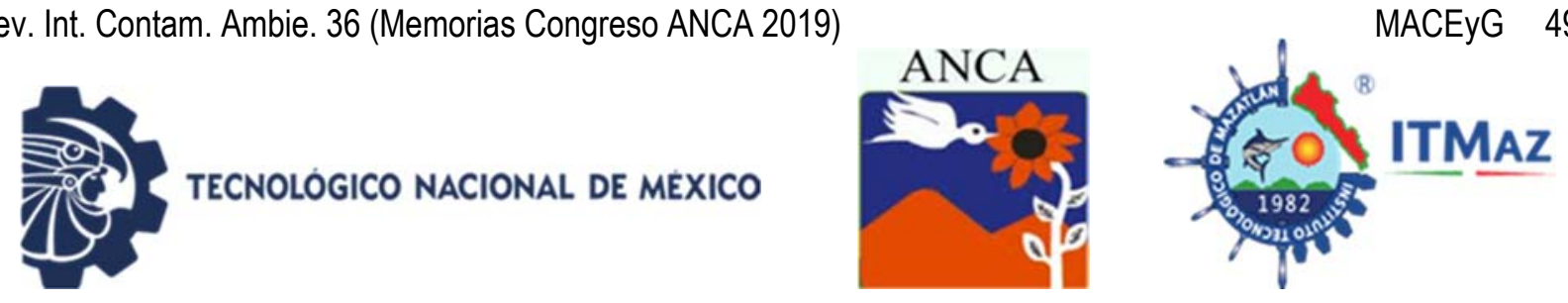

\title{
Efecto citogenético en mucosa oral por exposición laboral a plaguicidas en Michoacán, México
}

\author{
Sánchez-Alarcón $\mathrm{J}^{1,2,3}$, Angoa-Cortés $\mathrm{R}^{1}$, Ochoa-Ocaña $\mathrm{MA}^{3,4}$, \\ Hueletl-Soto $\mathrm{ME}^{1,2}$, Montiel-González JMR ${ }^{1,2}$, Valencia-Sánchez AG, \\ Valencia-Quintana $\mathrm{R}^{1,2,3 *}$ \\ ${ }^{1}$ Laboratorio "Rafael Villalobos-Pietrini" de Toxicología Genómica \\ y Química Ambiental. Facultad de Agrobiología. Universidad Autónoma de Tlaxcala, Tlaxcala, \\ ${ }^{2}$ CA UATLX-CA-223 Ambiente y Genética, UATx, México \\ ${ }^{3}$ Red Temática Toxicología de Plaguicidas CONACyT-UA Nayarit, México \\ ${ }^{4}$ Unidad Académica de Estudios Regionales. Coordinación de Humanidades, UNAM \\ *prvq2004@yahoo.com.mx
}

\section{RESUMEN}

Los plaguicidas, son agentes químicos utilizados para prevenir, controlar o combatir organismos capaces de producir daños a plantas y animales. Sin embargo, la exposición continua a estos productos altera algunos sistemas celulares y diversas funciones biológicas, capaces de producir una miríada de efectos nocivos en la salud humana. Enfermedades como Parkinson, Alzheimer, diabetes y diversos tipos de cáncer, como consecuencia de los efectos genotóxicos de algunos de ellos, han sido relacionadas con éstos. A pesar de las evidencias acumuladas de la relación entre los efectos genotóxicos y la exposición a plaguicidas, los estudios que abordan esta problemática en México y particularmente en Zamora y Jaconá, Michoacán son escasos. Por lo anterior, el objetivo de este estudio fue determinar las frecuencias de micronúcleos y anormalidades nucleares (células binucleadas, cariolisis, cariorrexis cromatina condensada, núcleos lobulados y picnosis), en células epiteliales de la mucosa oral, de trabajadores agrícolas en Michoacán, México. Para ello, se contó con la participación de 47 trabajadores del cultivo de hortalizas y fresas y una población de 31 individuos, no ocupacionalmente expuestos a plaguicidas, como grupo testigo, de los municipios de Zamora y Jacona. Después de explicarles los propósitos del proyecto, firmaron un consentimiento informado y se les aplicó una encuesta. Las frecuencias de anormalidades nucleares se incrementaron significativamente $(p<0.001)$, en la población expuesta. Sin embargo, no se encontraron diferencias significativas en las frecuencias de $\mathrm{MN}$ al compararse con los testigos. De acuerdo con los resultados obtenidos, la exposición a plaguicidas es factor que induce muerte celular.

\section{Agradecimientos: Proyecto respaldado por FOINS-CONACyT referencia} 3203. A la Red Temática de Toxicología de Plaguicidas

Palabras clave: Micronúcleos, anormalidades nucleares, células binucleadas, genotoxicidad

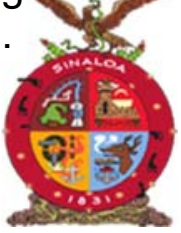

XVIII Congreso Internacional

XXIV Congreso Nacional de Ciencias ambientales
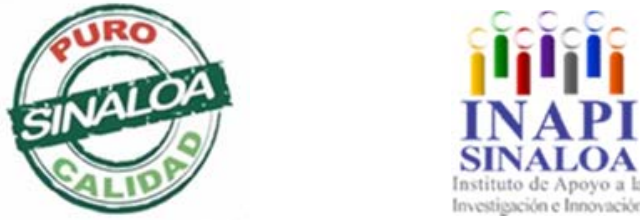

Mazatlán, Sinaloa 3-7 junio 2019

Medio Ambiente, Contaminación,

Enfermedad y Genotoxicidad 


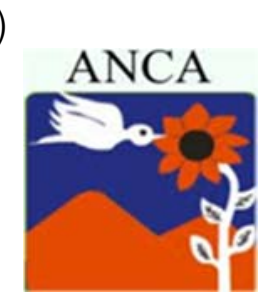

\title{
Cytogenetic effect on oral mucosa by laboral exposure to pesticides in Michoacán, México
}

\author{
Sánchez-Alarcón $\mathrm{J}^{1,2,3}$, Angoa-Cortés $\mathrm{R}^{1}$, Ochoa-Ocaña $\mathrm{MA}^{3,4}$, \\ Hueletl-Soto $\mathrm{ME}^{1,2}$, Montiel-González JMR ${ }^{1,2}$, Valencia-Sánchez AG, \\ Valencia-Quintana $\mathrm{R}^{1,2,3 *}$ \\ ${ }^{1}$ Laboratorio "Rafael Villalobos-Pietrini" de Toxicología Genómica \\ y Química Ambiental. Facultad de Agrobiología. \\ Universidad Autónoma de Tlaxcala, Tlaxcala, México \\ ${ }^{2}$ CA UATLX-CA-223 Ambiente y Genética, UATx, México \\ ${ }^{3}$ Red Temática Toxicología de Plaguicidas CONACyT-UA Nayarit, México \\ ${ }^{4}$ Unidad Académica de Estudios Regionales. Coordinación de Humanidades, UNAM \\ *prvq2004@yahoo.com.mx
}

\begin{abstract}
Pesticides are chemical agents used to prevent, control or combat organisms capable of causing damage to plants and animals. However, continuous exposure to these products alters some cellular systems and various biological functions, capable of producing a myriad of harmful effects on human health. Diseases such as Parkinson's, Alzheimer's, diabetes and various types of cancer, as a result of the genotoxic effects of some of them, have been related to the pesticide exposure. Despite the accumulated evidence of the relationship between genotoxic effects and exposure to pesticides, the studies that address this problem in Mexico and particularly in Zamora and Jacona, Michoacán, are scarce. Therefore, the objective of this study was to determine the frequencies of micronuclei and nuclear abnormalities (binucleate cells, cariolysis, caryorrexis, condensed chromatin, lobulated nuclei and pycnosis), in epithelial cells of the oral mucosa, of agricultural workers in Michoacán, Mexico. To this purpose, we got the collaboration of 47 workers involved in the cultivation of vegetables and strawberries and a population of 31 individuals, not occupationally exposed to pesticides, as a control group, from the municipalities of Zamora and Jacona. After explaining the purposes of the project, they signed an informed consent and a survey was applied. The frequencies of nuclear abnormalities increased significantly $(p<0.001)$, in the exposed population. However, no significant differences were found in the $M N$ frequencies when compared with the controls. According to the results obtained, exposure to pesticides is a factor that induces cell death.
\end{abstract}

Agradecimientos: Proyecto respaldado por FOINS-CONACyT referencia 3203. A la Red Temática de Toxicología de Plaguicidas

Keywords: Micronuclei, nuclear abnormalities, binucleated cells, genotoxicity.

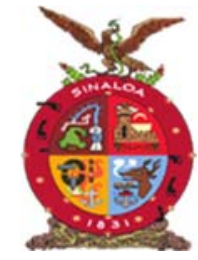

XVIII Congreso Internacional

XXIV Congreso Nacional de Ciencias ambientales
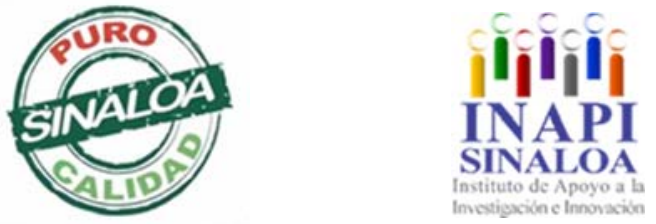

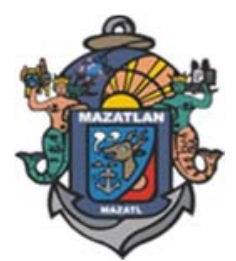

Medio Ambiente, Contaminación, Enfermedad y Genotoxicidad 
TECNOLOGICO NACIONAL DE MEXICO
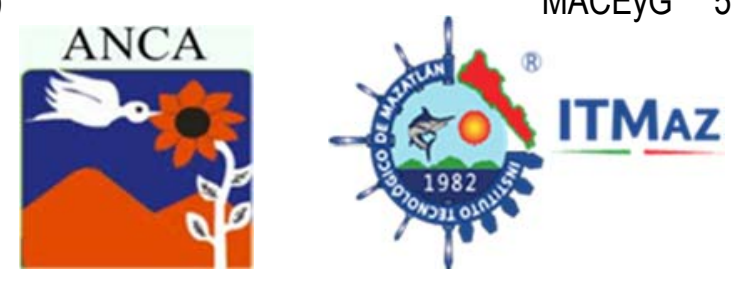

\title{
Uso y manejo de plaguicidas y estimación de daño citogenético con la prueba micronúcleos en campesinos de Atoyac, Guerrero, México
}

\author{
Sánchez-Gervacio $\mathrm{B}^{1 *}$, Juárez-López $\mathrm{A}^{1}$, Bedolla-Solano $\mathrm{R}^{1}$, \\ Rosas-Acevedo $\mathrm{J}^{1}$, Legorreta-Soberanis $\mathrm{J}^{2}$, Valencia-Quintana $\mathrm{R}^{3}$ \\ ${ }^{1}$ CCDR, Universidad Autónoma de Guerrero. \\ ${ }^{2}$ Centro de Investigación de Enfermedades Tropicales, UAGuerrero \\ ${ }^{3}$ Proyecto CONACyT PN-2016-01 3203 \\ Laboratorio "Rafael Villalobos-Pietrini" de Toxicología Genómica \\ y Química Ambiental. Facultad de Agrobiología. \\ Universidad Autónoma de Tlaxcala, Tlaxcala, México \\ *madegervacio@uagro.mx
}

\section{RESUMEN}

Manejar y disponer inadecuadamente los envases vacíos de plaguicidas ha generado contaminación ambiental y daño a la salud de usuarios. La prueba de micronúcleos en mucosa oral permite estimar efectos genotóxicos de agentes químicos como los plaguicidas. El objetivo de este trabajo fue describir el uso y manejo de plaguicidas y sus envases, además de estimar el daño citogenético, en campesinos de tres localidades de Atoyac, Guerrero, México. Estudio transversal, línea de base de un Programa de Educación Ambiental, realizada en diciembre de 2018. Previo consentimiento informado, se encuestaron 44 campesinos y 26 familiares sobre variables sociodemográficas, uso y manejo de plaguicidas. Se tomó muestra de mucosa oral para detectar micronúcleos. Los campesinos fueron hombres y las familiares mujeres, la mayoría sus esposas. Todos los campesinos usan plaguicidas, principalmente en cultivos de maíz, frijol y café, los que son de autoconsumo. Usan principalmente Paraquat, Glifosato y Esteron, el uso osciló entre tres y 58 años. Entre las medidas de seguridad usadas para el manejo de plaguicidas destacaron uso de pañuelo de tela para cubrir nariz y boca, guantes y botas de hule. Mencionaron traje especial para protegerse, el que no usan por incomodidad y economía. La presencia de micronúcleos por cada 1000 células fue 2.4. Se espera que la implementación de Programas de Educación Ambiental enfocados al manejo correcto de plaguicidas contribuiríapara disminuir el daño ambiental y a la salud de usuarios.

Palabras clave: Plaguicidas, micronúcleos, campesinos, agricultura de autoconsumo, medidas de protección.

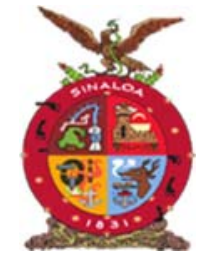

XVIII Congreso Internacional XXIV Congreso Nacional de Ciencias ambientales
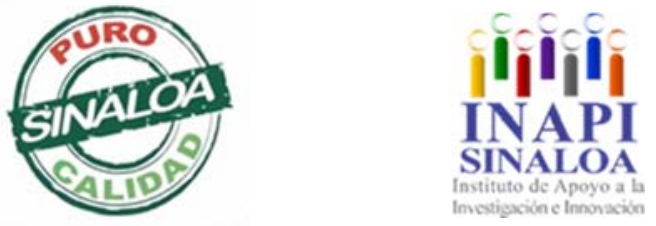

Mazatlán, Sinaloa 3-7 junio 2019

Medio Ambiente, Contaminación,

Enfermedad y Genotoxicidad 
TECNOLOGICO NACIONAL DE MEXICO
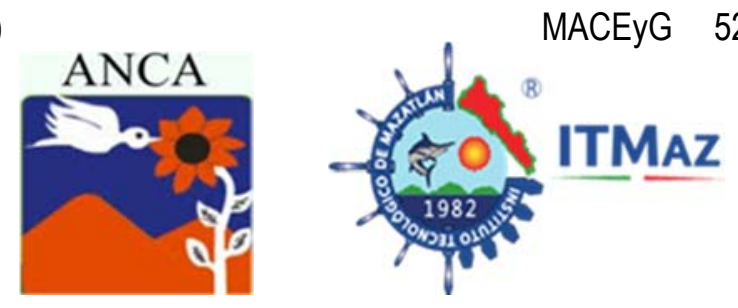

\title{
Use and management of pesticides and estimation of cytogenetic damage with the micronucleus test in farmers of Atoyac, Guerrero, México
}

\author{
Sánchez-Gervacio $\mathrm{B}^{1 *}$, Juárez-López $\mathrm{A}^{1}$, Bedolla-Solano $\mathrm{R}^{1}$, \\ Rosas-Acevedo $\mathrm{J}^{1}$, Legorreta-Soberanis $\mathrm{J}^{2}$, Valencia-Quintana $\mathrm{R}^{3}$ \\ ${ }^{1}$ CCDR, Universidad Autónoma de Guerrero. \\ ${ }^{2}$ Centro de Investigación de Enfermedades Tropicales, UAGuerrero \\ ${ }^{3}$ Proyecto CONACyT PN-2016-01 3203 \\ Laboratorio "Rafael Villalobos-Pietrini" de Toxicología Genómica \\ y Química Ambiental. Facultad de Agrobiología. \\ Universidad Autónoma de Tlaxcala, Tlaxcala, México \\ *madegervacio@uagro.mx
}

\begin{abstract}
Improper handling and disposal of empty pesticide containers has generated environmental contamination and damage to the health of users. The micronucleus test in oral mucosa allows estimating genotoxic effects of chemical agents such as pesticides. Describe the use and management of pesticides and their containers and estimate cytogenetic damage in farmers in three localities of Atoyac, Guerrero, Mexico. Cross-sectional study, baseline of an Environmental Education Program, held in December 2018. After informed consent, 44 peasants and 26 relatives were surveyed on sociodemographic variables, use and management of pesticides. A sample of oral mucosa was taken to detect micronuclei. The peasants were men and the women relatives, mostly their wives. All farmers use pesticides, mainly in crops of corn, beans and coffee, which are self-consumption. They mainly use Paraquat, Glyphosate and Esteron, the use ranged between three and 58 years. Among the safety measures used for the handling of pesticides, they highlighted the use of a cloth handkerchief to cover nose and mouth, gloves and rubber boots. They mentioned the use of a special suit to protect themselves, the one they do not wear because of discomfort and economy. The presence of micronuclei per 1000 cells was 2.4. The implementation of Environmental Education Programs focused on the correct management of pesticides would contribute to reduce environmental damage and the health of users.
\end{abstract}

Keywords: Pesticides, micronuclei, farmers, self-consumption agriculture, protection measures.

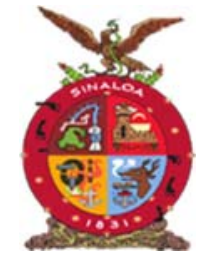

XVIII Congreso Internacional XXIV Congreso Nacional de Ciencias ambientales
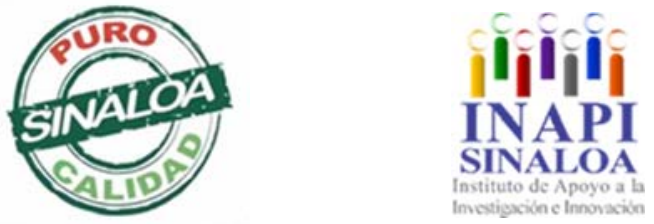

Mazatlán, Sinaloa 3-7 junio 2019

Medio Ambiente, Contaminación,

Enfermedad y Genotoxicidad 
TECNOLOGICO NACIONAL DE MEXICO
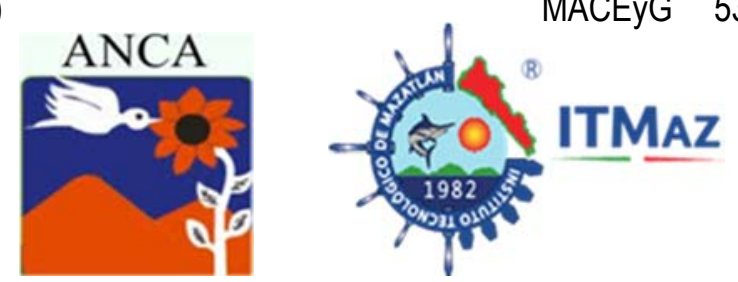

\title{
Inmunotoxicidad y estrés oxidante en agricultores expuestos crónicamente a plaguicidas en Calimaya, Estado de México
}

\author{
Sánchez-Mendoza $\mathrm{H}^{1}$, Amaya-Chávez $\mathrm{A}^{1 *}$, Sánchez-Meza J1', \\ Camarillo-Romero $\mathrm{M}^{2}$ \\ 1Facultad de Química, Universidad Autónoma del Estado de México. \\ Paseo Tollocán S/N, Toluca, Estado de México 50180, México. \\ 2 Centro de Investigaciones en Ciencias Médicas, \\ Universidad Autónoma del Estado de México. \\ Jesús Carranza 205, Col. Universidad, 50130 Toluca, México. \\ *amayacha8789@gmail.com
}

\section{RESUMEN}

En el municipio de Calimaya, aledaño el área de protección de la flora y la fauna (APFF) del Nevado de Toluca, Edo. Méx., se detectó el uso de 63 plaguicidas, de los cuales 14 tienen características de persistencia (organofosforados, carbamatos y organoclorados), aplicados en de papa, avena y maíz. La exposición a plaguicidas puede generar estrés oxidante, neurotoxicidad, inmunotoxicidad, entre otras alteraciones a la salud. En este estudio se analizó el estado de salud, de 85 voluntarios sanos (grupo testigo) y 85 agricultores ocupacionalmente expuestos (POE) a plaguicidas, en un área aledaña al volcán, mediante una exploración médica, determinación de biometría hemática, biomarcadores de estrés oxidante (SOD, CAT, LIPOX) e inmunoglobulinas (lgE, IgG e IgM). Los resultados muestran en el grupo $\mathrm{POE}$, individuos con alteraciones del tracto respiratorio superior (rinitis, faringitis) y conjuntivitis. De la Biometría hemática, solo los valores de las bandas de neutrófilos fueron mayores $(p=0.004)$ en relación a las del grupo testigo. La actividad enzimática de SOD y CAT, en este grupo, fue mayor significativamente ( $p<0.05$, U Mann-Whitney) y en los niveles de peroxidación lipídica hubo una tendencia también a ser mayores, sin ser significativos. Con respecto a las inmunoglobulinas, se encontraron resultados por arriba de los valores de referencia y con los obtenidos en el grupo testigo para IgG e IgE ( $p<0.05$, U Mann-Whitney). Se encontró que hay una asociación ( $\mathrm{p}<$ 0.05: correlación de Spearman) entre los valores de lgE, la antigüedad laboral y las sintomatologías descritasanteriormente.

Palabras clave: Plaguicidas, inmunotoxicidad, estrés oxidante.

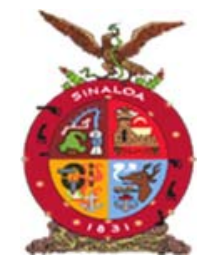

XVIII Congreso Internacional XXIV Congreso Nacional de Ciencias ambientales
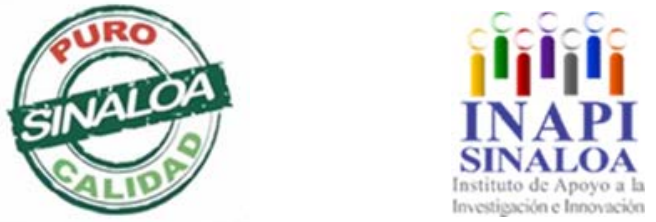

Mazatlán, Sinaloa 3-7 junio 2019

Medio Ambiente, Contaminación, Enfermedad y Genotoxicidad 
TECNOLOGICO NACIONAL DE MEXICO
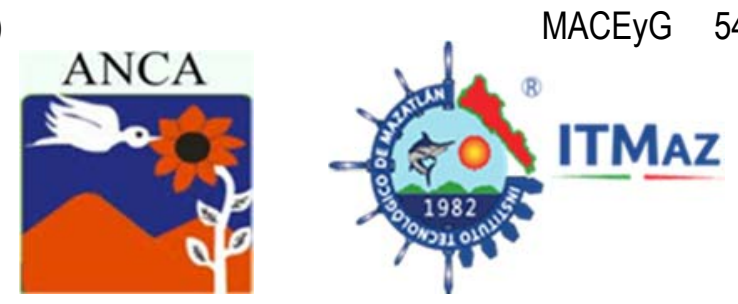

\title{
Immunotoxicity and oxidative stress in farmers chronically exposed to pesticides in Calimaya, State of Mexico
}

\author{
Sánchez-Mendoza $\mathrm{H}^{1 *}$, Amaya-Chávez $\mathrm{A}^{1 *}$, Sánchez-Meza J1", \\ Camarillo-Romero $\mathrm{M}^{2}$ \\ ${ }^{1}$ Facultad de Química, Universidad Autónoma del Estado de México. \\ Paseo Tollocán S/N, Toluca, Estado de México 50180, México. \\ 2 Centro de Investigaciones en Ciencias Médicas, \\ Universidad Autónoma del Estado de México. \\ Jesús Carranza 205, Col. Universidad, 50130 Toluca, México. \\ *amayacha8789@gmail.com
}

\begin{abstract}
In the municipality of Calimaya, the area of protection of flora and fauna (APFF) of the Nevado de Toluca, Edo. Mex., the use of 63 pesticides was detected, of which 14 have persistence characteristics (organophosphorus, carbamates and organochlorines), applied in potato, oats and corn. Pesticide exposure can generate oxidative stress, neurotoxicity, immunotoxicity, among other health disorders. In this study, the health status of 85 healthy volunteers (control group) and 85 occupationally exposed farmers (SOPs) to pesticides was analyzed, in an area adjacent to the volcano, through a medical examination, determination of blood count, biomarkers of oxidative stress (SOD, CAT, LIPOX) and immunoglobulins ( $\lg E, \lg G$ and $\operatorname{lgM})$. The results show in the POE group, individuals with alterations of the upper respiratory tract (rhinitis, pharyngitis) and conjunctivitis. Of the blood count, only the values of the neutrophil bands were higher $(p=0.004)$ in relation to those of the control group. The enzymatic activity of SOD and CAT, in this group, was significantly higher $(p<0.05$, Mann-Whitney $U)$ and in lipid peroxidation levels there was also a tendency to be higher, without being significant. With respect to immunoglobulins, results were found above the reference values and with those obtained in the control group for $\lg G$ and $\lg E$ ( $p$ $<0.05$, U Mann-Whitney). It was found that there is an association ( $p<0.05$ : Spearman's correlation) between $\lg \mathrm{E}$ values, seniority and the symptoms described above.
\end{abstract}

Keywords: Pesticides, immunotoxicity, oxidative stress

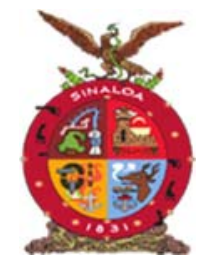

XVIII Congreso Internacional

XXIV Congreso Nacional de Ciencias ambientales
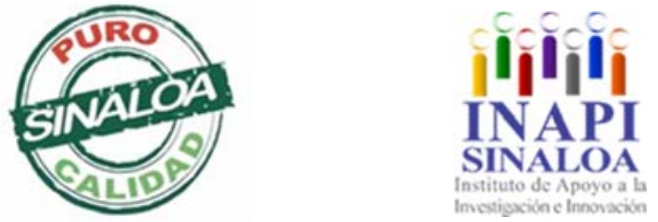

Mazatlán, Sinaloa 3-7 junio 2019

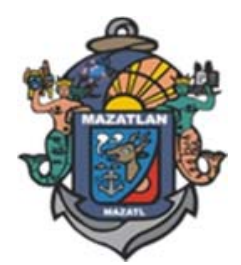

Medio Ambiente, Contaminación, Enfermedad y Genotoxicidad 
TECNOLOGICO NACIONAL DE MEXICO
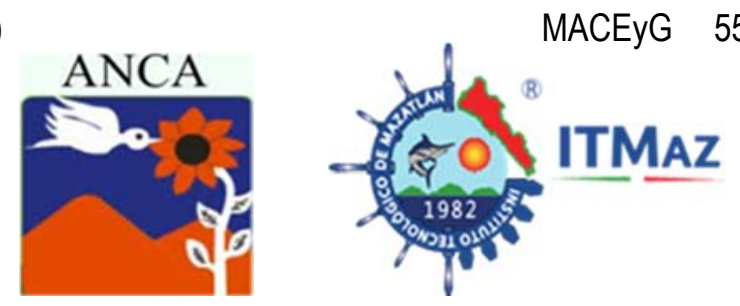

\title{
Determinación de plomo en manzana cultivada en las cercanías a una mina en Zacatecas
}

\author{
Solís Lerma $L^{1}$, Durón Torres $S^{2}$, Ávila Vázquez $V^{1}$, Franco Villegas $E^{1}$, \\ Velasco Amaro $\mathrm{P}^{1}$, Aguilera Flores $\mathrm{M}^{{ }^{*}}$ \\ ${ }^{1}$ Unidad Profesional Interdisciplinaria de Ingeniería Campus Zacatecas \\ Instituto Politécnico Nacional- \\ ${ }^{2}$ Universidad Autónoma de Zacatecas, Área de Ciencias Químicas. \\ *maguileraf@ipn.mx
}

\begin{abstract}
RESUMEN
En Zacatecas, la minería es la principal actividad económica, siendo responsable de una de las fuentes de contaminación por metales pesados más persistentes en el ambiente, que incluso pueden absorbidos por las plantas e incorporarse a las cadenas tróficas. La presente investigación tuvo por objetivo analizar la concentración de $\mathrm{Pb}$ en manzanas (pulpa) de una huerta cercana a una presa de jales en el municipio de Sombrerete, Zacatecas, México. Dicho análisis se hizo utilizando una técnica electroquímica, método de Voltamperometría de Redisolución Anódica de Pulso Diferencial (DPASV, por sus siglas en inglés) por su bajo costo; y su posterior validación con Absorción Atómica (AA), que es la técnica usualmente utilizada. Los resultados obtenidos fueron que el promedio de las concentraciones de $\mathrm{Pb}$ encontradas en las 15 muestras de manzana fue de $16.85 \pm 5.18 \mathrm{ppm}$, es decir que superan hasta 168 veces el NM establecido por el Codex Alimentarius. Para corroborar la confiabilidad del método se analizaron las mismas muestras por AA resultando un promedio de $25.38 \mp 12.94$ ppm. De acuerdo a estos datos se requieren medidas de control y prevención inmediatas en la huerta para que posteriormente las concentraciones encontradas disminuyan. Las opciones más recomendables para mitigar la contaminación en este lugar, dado las condiciones actuales del sitio, son llevar a cabo la remediación de la presa de jales o bien que se le aplique una cubierta de suelo compactada en toda su superficie para evitar la dispersión del jal.
\end{abstract}

Palabras clave: Absorción atómica, jales, salud poblacional, técnica electroquímica.

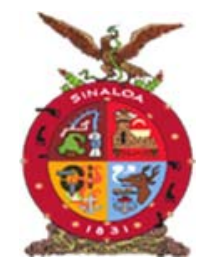

XVIII Congreso Internacional XXIV Congreso Nacional de Ciencias ambientales
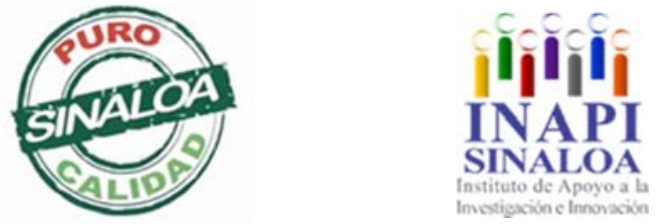

Mazatlán, Sinaloa 3-7 junio 2019

Medio Ambiente, Contaminación, Enfermedad y Genotoxicidad 
TECNOLOGICO NACIONAL DE MEXICO
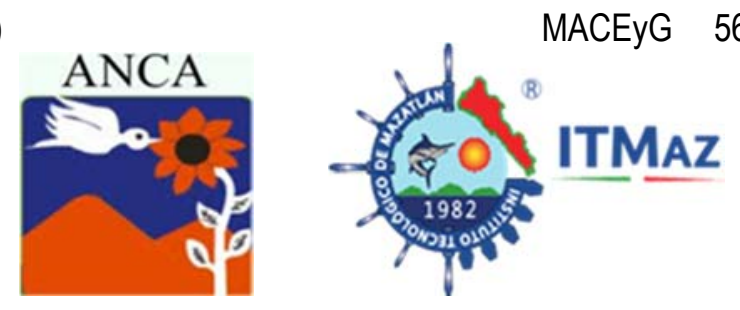

\title{
Determination of lead in apple grown in the vicinity of a mine in Zacatecas
}

\author{
Solís Lerma $L^{1}$, Durón Torres $S^{2}$, Ávila Vázquez $V^{1}$, Franco Villegas $E^{1}$, \\ Velasco Amaro $\mathrm{P}^{1}$, Aguilera Flores $\mathrm{M}^{1 *}$ \\ ${ }^{1}$ Unidad Profesional Interdisciplinaria de Ingeniería Campus Zacatecas \\ Instituto Politécnico Nacional- \\ ${ }^{2}$ Universidad Autónoma de Zacatecas, Área de Ciencias Químicas_ \\ *maguileraf@ipn.mx
}

\begin{abstract}
In Zacatecas, mining is the main economic activity, being responsible for one of the most persistent heavy metal pollution sources in the environment, which can even be absorbed by plants and incorporated into trophic chains. The objective of this research was to analyze the concentration of $\mathrm{Pb}$ in apples (pulp) from an orchard near a dam of jales in the municipality of Sombrerete, Zacatecas, Mexico. Said analysis was done using an electrochemical technique, method of Differential Pulse Anodic Redisolution Voltammetry (DPASV) for its low cost; and its subsequent validation with Atomic Absorption (AA), which is the technique usually used. The results obtained were that the average of the concentrations of $\mathrm{Pb}$ found in the 15 apple samples was $16.85 \mp 5.18 \mathrm{ppm}$, that is, they exceed up to 168 times the ML established by the Codex Alimentarius. To corroborate the reliability of the method, the same samples were analyzed by AA resulting in an average of $25.38 \mp 12.94 \mathrm{ppm}$. According to these data, immediate control and prevention measures are required in the garden so that later the concentrations found decrease. The most recommended options to mitigate pollution in this place, given the current conditions of the site, are to carry out the remediation of the dam or to have a compacted soil cover applied to its entire surface to avoid dispersion of the jal.
\end{abstract}

Keywords: Atomic absorption, jerks, population health, electrochemical technique.

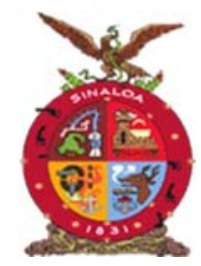

XVIII Congreso Internacional XXIV Congreso Nacional de Ciencias ambientales
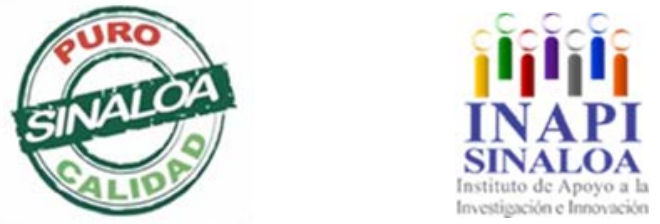

Mazatlán, Sinaloa 3-7 junio 2019

Medio Ambiente, Contaminación,

Enfermedad y Genotoxicidad 

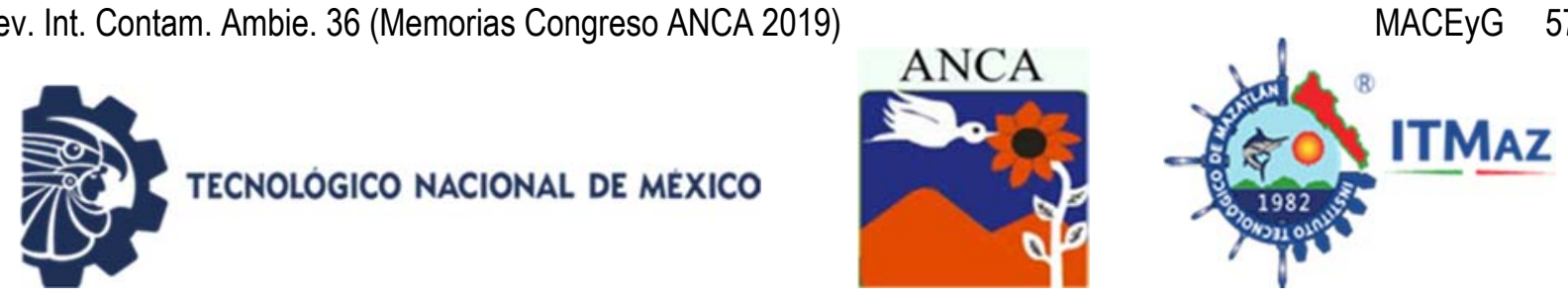

\title{
Evaluación del daño al ADN en trabajadores agrícolas de Zamora-Jacona, Michoacán México
}

\author{
Valencia-Quintana $\mathrm{R}^{1,2,3 *}$, Sánchez-Alarcón $\mathrm{J}^{1,2,3}$, Ochoa-Ocaña $\mathrm{MA}^{3,4}$, Milić $\mathrm{M}^{5}$, Kašuba $\mathrm{V}^{5}$, \\ Urióstegui-Acosta $\mathrm{MO}^{6}$, Gómez-Arroyo $\mathrm{S}^{7}$, Flores-Márquez $\mathrm{AR}^{7}$, Cortés-Eslava $\mathrm{J}^{7}$, \\ Hueletl-Soto $\mathrm{ME}^{1}$, Gómez-Olivares $\mathrm{JL}^{8}$, Bonassi $\mathrm{S}^{9}$, Montiel-González JMR ${ }^{1,2}$ \\ ${ }^{1}$ Laboratorio "Rafael Villalobos-Pietrini" de Toxicología Genómica y Química Ambiental, \\ Facultad de Agrobiología, Universidad Autónoma de Tlaxcala, Tlaxcala, México \\ ${ }^{2}$ CA UATLX-CA-223 Ambiente y Genética, UATx, México \\ ${ }^{3}$ Red Temática Toxicología de Plaguicidas CONACyT-UA Nayarit, México \\ ${ }^{4}$ Unidad Académica de Estudios Regionales, Coordinación de Humanidades, UNAM \\ ${ }^{5}$ Mutagenesis Unit, Institute for Medical Research and Occupational Health, Zagreb, Croatia \\ ${ }^{6}$ Escuela Superior de Ciencias Naturales, Universidad Autónoma de Guerrero \\ ${ }^{7}$ Laboratorio de Genotoxicología Ambiental, Centro de Ciencias de la Atmósfera, UNAM, México \\ ${ }^{8}$ Departamento de Ciencias de la Salud, Universidad Autónoma Metropolitana-Iztapalapa, \\ ${ }^{9}$ Unit of Clinical and Molecular Epidemiology, IRCCS San Raffaele Pisana, Rome, Italy \\ *prvq2004@ahoo.com.mx
}

\section{RESUMEN}

La zona de Zamora-Jacona es un área urbana resultante de la conurbación de los municipios de Zamora y de Jacona, siendo el tercer núcleo urbano más poblado del Estado de Michoacán, México. El cultivo de frutos rojos (fresa, zarzamora, arándano y frambuesa), es una de las principales actividades económicas de la zona, siendo la más importante productora de éstas a nivel nacional. Su cultivo es fuente de empleos permanentes y temporales en toda la cadena de producción agroalimentaria, favoreciendo a productores, comercializadores, industrializadores y consumidores. Cabe mencionar que las principales plagas que llegan a afectar los cultivos de estas frutillas son los ácaros y botrytis (hongos), que si se desatienden pueden ocasionar grandes perjuicios a la cantidad, calidad y evolución del cultivo, por lo que los trabajadores agrícolas están expuestos a gran cantidad y variedad de plaguicidas que emplean con el propósito de proteger los cultivos. Por lo anterior se llevó a cabo un estudio para evaluar el daño genético inducido en trabajadores agrícolas empleando el ensayo cometa, para evidenciar la fragmentación del ADN en leucocitos humanos. Se contó con la participación de 77 residentes (47 trabajadores y 30 testigos), los cuales firmaron un consentimiento informado después de conocer los propósitos del proyecto y contestar una encuesta. Los momentos de la cauda encontrados fueron de $1.865 \pm 0.249$ y de $5.852778445 \pm 0.723$ para el grupo testigo y expuesto respectivamente. Los resultados demuestran daño al ADN, estableciendo el posible riesgo a la salud humana asociada con la exposición a plaguicidas.

Agradecimientos: Proyecto respaldado por FOINS-CONACyT referencia 3203. A la Red Temática de Toxicología de Plaguicidas

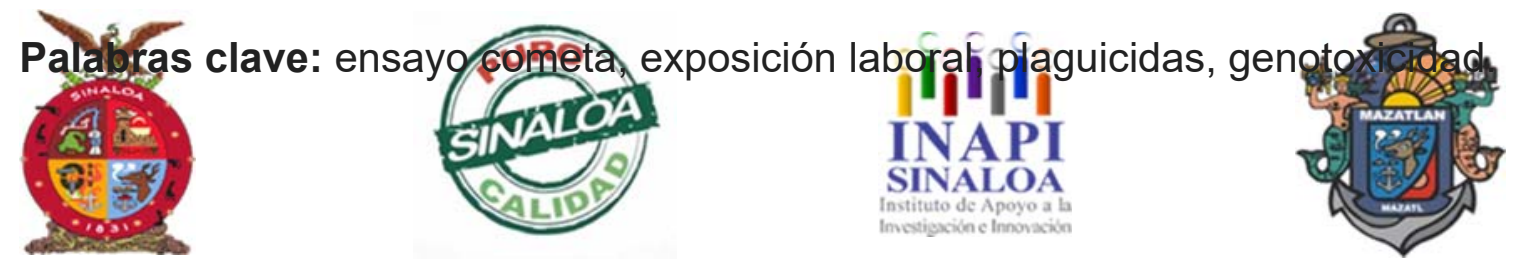



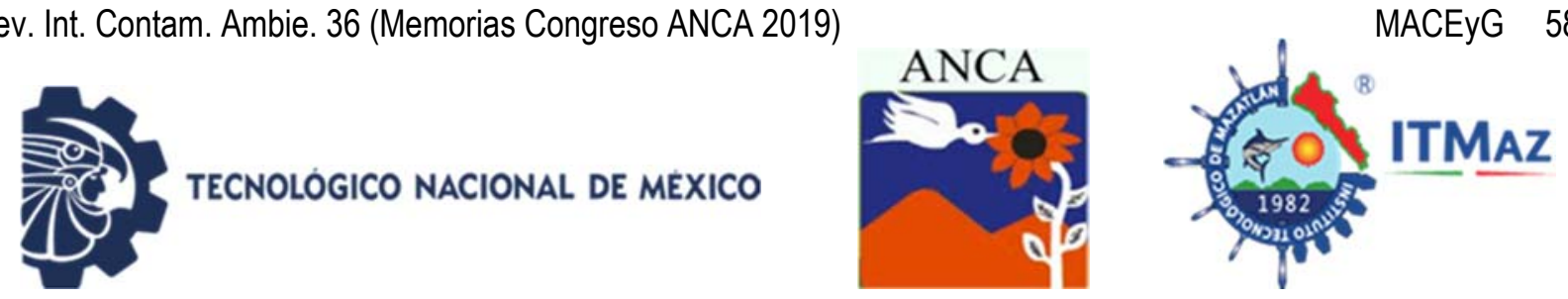

\title{
Evaluation of DNA damage in agricultural workers of Zamora-Jacona, Michoacán México
}

\author{
Valencia-Quintana $R^{1,2,3 *}$, Sánchez-Alarcón $\mathrm{J}^{1,2,3}$, Ochoa-Ocaña $M A^{3,4}$, Milić $\mathrm{M}^{5}$, Kašuba $\mathrm{V}^{5}$, \\ Urióstegui-Acosta $\mathrm{MO}^{6}$, Gómez-Arroyo $\mathrm{S}^{7}$, Flores-Márquez $\mathrm{AR}^{7}$, Cortés-Eslava $\mathrm{J}^{7}$, \\ Hueletl-Soto $\mathrm{ME}^{1}$, Gómez-Olivares $\mathrm{JL}^{8}$, Bonassi $\mathrm{S}^{9}$, Montiel-González JMR ${ }^{1,2}$ \\ ${ }^{1}$ Laboratorio "Rafael Villalobos-Pietrini" de Toxicología Genómica y Química Ambiental, \\ Facultad de Agrobiología, Universidad Autónoma de Tlaxcala, Tlaxcala, México \\ ${ }^{2}$ CA UATLX-CA-223 Ambiente y Genética, UATx, México \\ ${ }^{3}$ Red Temática Toxicología de Plaguicidas CONACyT-UA Nayarit, México \\ ${ }^{4}$ Unidad Académica de Estudios Regionales, Coordinación de Humanidades, UNAM \\ ${ }^{5}$ Mutagenesis Unit, Institute for Medical Research and Occupational Health, Zagreb, Croatia \\ ${ }^{6}$ Escuela Superior de Ciencias Naturales, Universidad Autónoma de Guerrero \\ ${ }^{7}$ Laboratorio de Genotoxicología Ambiental, Centro de Ciencias de la Atmósfera, UNAM, México \\ ${ }^{8}$ Departamento de Ciencias de la Salud, Universidad Autónoma Metropolitana-Iztapalapa, \\ ${ }^{9}$ Unit of Clinical and Molecular Epidemiology, IRCCS San Raffaele Pisana, Rome, Italy \\ *prvq2004@ahoo.com.mx
}

\begin{abstract}
The zone of Zamora-Jacona is an urban area resulting from the conurbation of the municipalities of Zamora and Jacona, being the third most populated urbannucleus of the State of Michoacán, Mexico. The cultivation of berries (strawberry, blackberry, blueberry and raspberry), is one of the main economic activities in the area, being the most important producer of these at national level. Their cultivation is a source of permanent and temporary jobs throughout the agri-food production chain, favoring producers, traders, industrializers and consumers. It is noteworthy that the main pests that affect the crops of these berries are mites and botrytis(fungi), which if neglected can cause great damage to the quantity, quality and evolution of the crop, which is why agricultural workers are exposed to large quantities and wide variety of pesticides used for the purpose of protecting crops. Therefore, a study was conducted to evaluate the genetic damage induced in agricultural workers using the comet assay, to demonstrate the fragmentation of DNA in human leukocytes. It was attended by 77 residents ( 47 workers and 30 controls), who signed an informed consent after knowing the purposes of the project and answering a survey. The tail moment found were $1.865+0.249$ and $5.853+0.723$ for the control and exposed group respectively. The results show DNA damage, establishing the possible risk to human health associated with pesticide exposure.
\end{abstract}

\section{Agradecimientos: Proyecto respaldado por FOINS-CONACyT referencia} 3203. A la Red Temática de Toxicología de Plaguicidas

Keywords: comet assay, occupational exposure, pesticides, genotoxicity

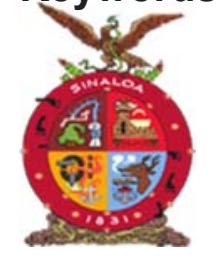

XVIII Congreso Internacional

XXIV Congreso Nacional de Ciencias ambientales
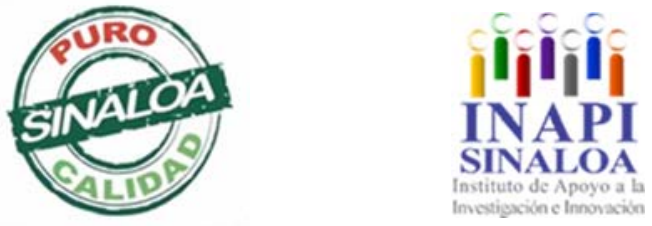

Mazatlán, Sinaloa 3-7 junio 2019

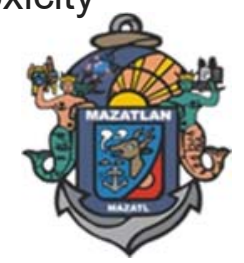

Medio Ambiente, Contaminación,

Enfermedad y Genotoxicidad 

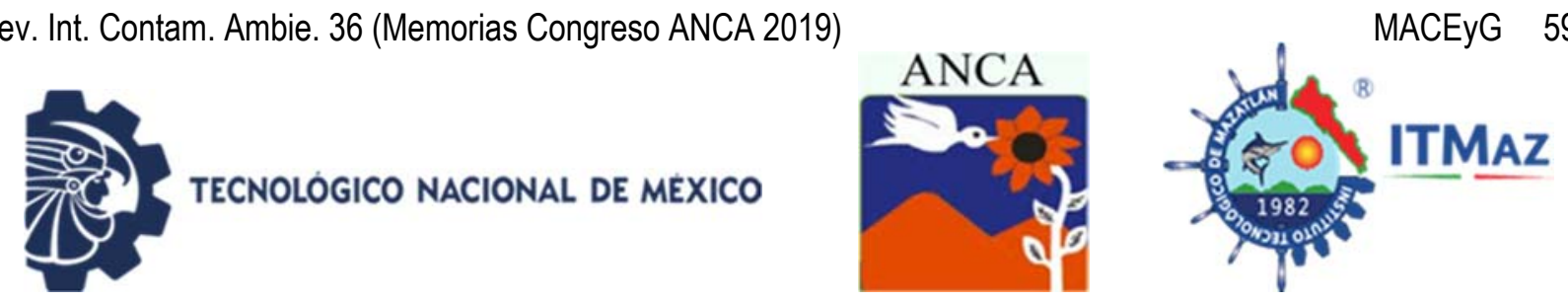

\title{
Efectos de la contaminación ambiental en la morfología de la hoja de Xylopia aromática (Lam.) Mart. (Malagueto) en el Departamento de Casanare
}

\author{
Villegas Dueñas Martín* \\ Universidad Autónoma de Zacatecas "Francisco García Salinas". \\ *martinevd29@gmail.com
}

\section{RESUMEN}

La investigación fue realizada en el Departamento de Casanare, Colombia, de enero a junio del año 2018, con el objetivo de analizar la respuesta estructural en la hoja de Xylopia aromática en zonas contaminadas y en no contaminadas para comparar efectos. Para ello se recolectaron 10 muestras de árboles, 5 en la zona contaminada en el área urbana del municipio de Yopal, y 5 para la zona conservada en la reserva natural en el municipio de Trinidad. Se eligieron 5 hojas por cada árbol, para tener un total de 25 hojas por zona y de cada hoja, se analizaron 5 campos visuales para tener un total de 125 campos visuales por zona, mediante la técnica de esmalte trasparente, fueron observados por microscopio en objetivo 40x y capturadas en fotografías digitales, empleando un procesamiento de imágenes con el software Image $\mathrm{J}^{\circledR}$ se generó el conteo de estomas, tricomas y de células epidérmicas por cada campo visual. Para el análisis estadístico de las variables se utilizó el software $R$ Studio ${ }^{\circledR}$ complementado con el software Statgraphics $®$. El resultado del conteo arroja que existe un mayor número de estomas en árboles de zonas contaminadas y mayor número de tricomas en zonas no polutas, además de que existe mayor promedio de estomas y células epidérmicas en las muestras de zona poluta. El análisis estadístico encontró diferencias entre las varianzas de los dos grupos. El análisis del mesófilo de la hoja, evidenció que el parénquima en empalizado presenta mayores rangos de longitudes en las muestras de zona poluta.

Palabras clave: Bioindicador, estomas, tricomas, mesófilo, Malagueto.

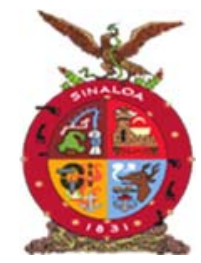

XVIII Congreso Internacional

XXIV Congreso Nacional de Ciencias ambientales
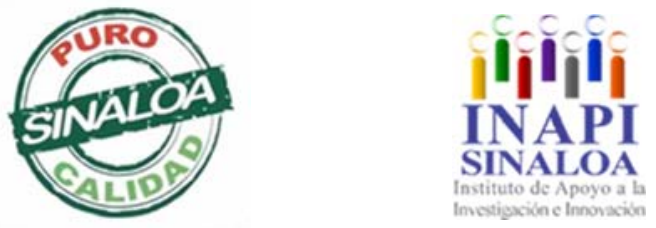

Mazatlán, Sinaloa 3-7 junio 2019

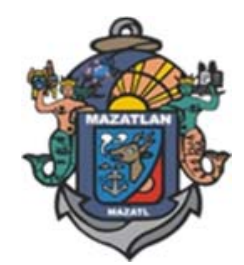

Medio Ambiente, Contaminación, Enfermedad y Genotoxicidad 
TECNOLOGICO NACIONAL DE MEXICO
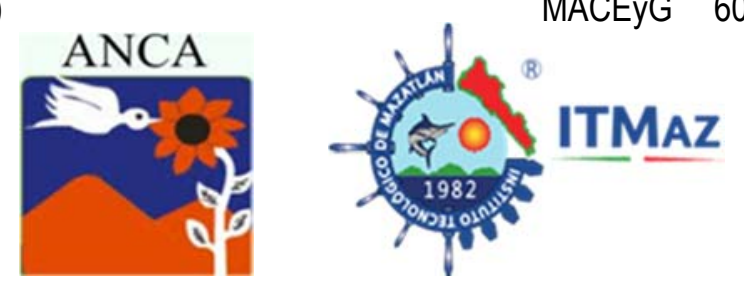

\title{
Effects of environmental contamination on leaf morphology of aromatic Xylopia (Lam.) Mart. (Malagueto) in the Department of Casanare
}

\author{
Villegas Dueñas $\mathrm{M}^{*}$ \\ Universidad Autónoma de Zacatecas "Francisco García Salinas". \\ *martinevd29@gmail.com
}

\begin{abstract}
The research was conducted in the Department of Casanare, Colombia, from January to June 2018. The objective of this work was to analyze the physiological behavior of the plant in contaminated and contaminated areas. For this, 10 samples of trees were collected, 5 in the contaminated area within the urban area of the municipality of Yopal, and 5 for the area conserved in the natural reserve in the municipality of Trinidad. Five leaves were chosen for each tree, to have a total of 25 leaves per area and each leaf 5 visual fields to have a total of 125 visual fields per area, using the transparent enamel technique, were observed by microscope in objective 40x and captured in digital photographs, by means of an image processing in Image $\mathrm{J}$ software that generated the count of stomata, trichomes and epidermal cells for each visual field. For the statistical analysis of the variables, the $\mathrm{R}$ Studio software was used and supplemented with the Statgraphics software. The result of the count shows us that there is a greater number of stomata in trees present in contaminated areas and a greater number of trichomes in non-polluting areas. There is a greater average of stomata within the samples of the poluta zone, in addition to epidermal cells. The statistical analysis finds differences between the variances of the two groups. For the analysis of the leaf mesophile, the palisade in palisades presents greater ranges of lengths in the samples of the polutal zone.
\end{abstract}

Keywords: Bioindicator, stomata, trichomes, mesophile, Malagueto.

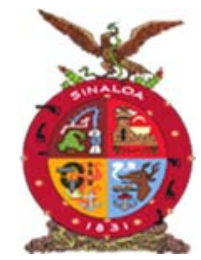

XVIII Congreso Internacional

XXIV Congreso Nacional de Ciencias ambientales
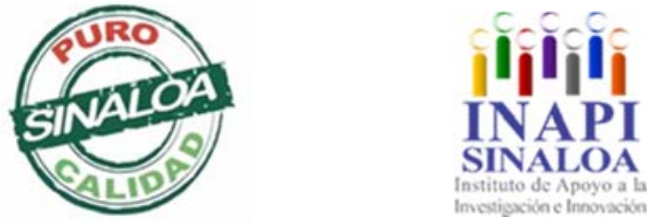

Mazatlán, Sinaloa 3-7 junio 2019

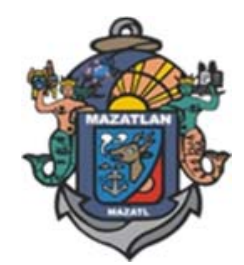

Medio Ambiente, Contaminación, Enfermedad y Genotoxicidad 


\section{REVista INTernacional de}

\section{CONTAMinación AMBIEntal volumen 36, 2020}

http://www.revistas.unam.mx/index.php/rica/

\section{Recursos Naturales, Ecosistemas y Deterioro Ambiental}

ACademia Nacional de Ciencias Ambientales

XVIII CONGRESO INTERNACIONAL

XXIV CONGRESO NACIONAL

De Ciencias ambientales

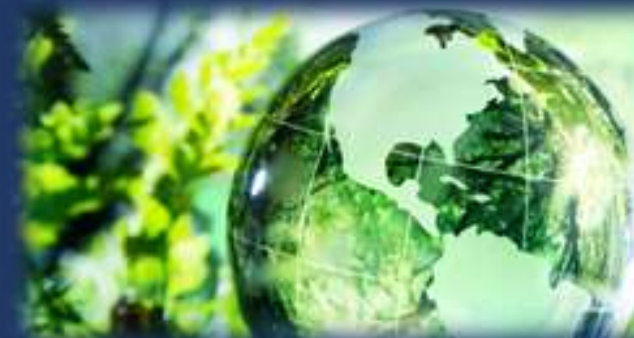

Maratián, Ninaloa

ila Perla del Pacífico!

03-07 Junio/2019 
TECNOLOGICO NACIONAL DE MEXICO
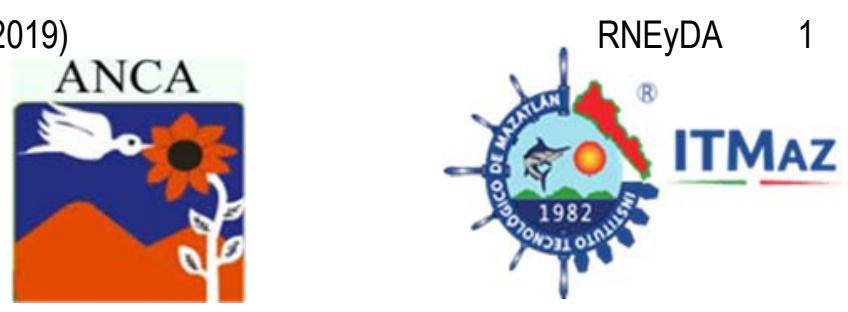

\title{
Experiencias de restauración ecológica en manglares degradados en Costa Rica, África y México: transferencia tecnológica internacional
}

\author{
Agraz Hernández $\mathrm{CM}^{1 *}$, Houndjinou $\mathrm{EM}^{2}$, Aguilar $\mathrm{B}^{3}$, Rivera Wong J4, \\ Etienne $\mathrm{J}^{5}$, Muñiz Salazar $\mathrm{R}^{6}$ \\ ${ }^{1}$ EPOMEX, Universidad Autónoma de Campeche, México \\ ${ }^{2}$ ONG-CORDE. Benín, África \\ ${ }^{3}$ Neotrópica-ONG. San José, Costa Rica \\ ${ }^{4}$ Sistema Nacional de Áreas de Conservación de Costa Rica, Costa Rica \\ ${ }^{5}$ Secrétariat du Fonds Français pour l'Environnement Mondial \\ 6Universidad Autónoma de Baja California, México \\ *clmagraz@uacam.mx
}

\section{RESUMEN}

En los últimos años, se ha observado una modificación en la estructura y función de los ecosistemas de mangle, provocada tanto por actividades antropogénicas como por eventos hidrometereológicos. Durante esta investigación se desarrolló la restauración ecológica integral a nivel piloto en dos sitios de manglares degradados de Costa Rica (Cuajiniquil y Sierpe) y uno en Benin (Ouidah), África. Se realizó la transferencia tecnológica de programas de restauración ecológica aplicada desde 1999 en México. La restauración consiste en el manejo hidrológico, utilizando la información de modelos hidrodinámicos y de análisis químicos del agua intersticial que garanticen la dinámica hidrológica y la recuperación de la cobertura vegetal, mediante la reforestación de propágulos con tres especies de mangle. Se aplicó un diagnóstico ambiental antes de la restauración y el monitoreo de las condiciones fisicoquímicas del agua intersticial durante y posterior a la restauración. Así como, el uso de indicadores de respuesta biológica como es la regeneración natural, con el fin de evaluar el cambio en las condiciones ambientales y del grado de éxito de ésta. Se establecieron tres estrategias de rehabilitación hidrológica, aplicando diferentes diseños basados en un diagnóstico ambiental anual por sitio. Con el fin de desplazar dos especies invasoras de hábitat de mangle y sustitución de una salinera para recuperar cobertura de mangle, esto mediante la excavación de canales y la participación de 380 personas en los tres sitios restaurados. La tecnología de restauración se transfirió exitosamente, logrando restaurar 43 hectáreas.

Palabras clave: Restauración, manglares, rehabilitación hidrológica,

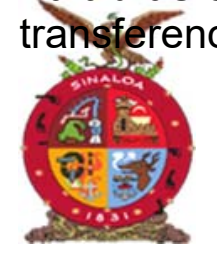

XVIII Congreso Internacional

XXIV Congreso Nacional de Ciencias ambientales

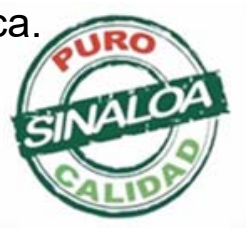

Mazatlán, Sinaloa 3-7 junio 2019

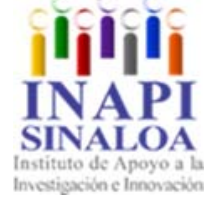

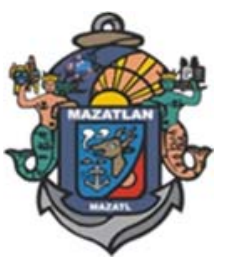

Recursos Naturales, Ecosistemas y Deterioro Ambiental 

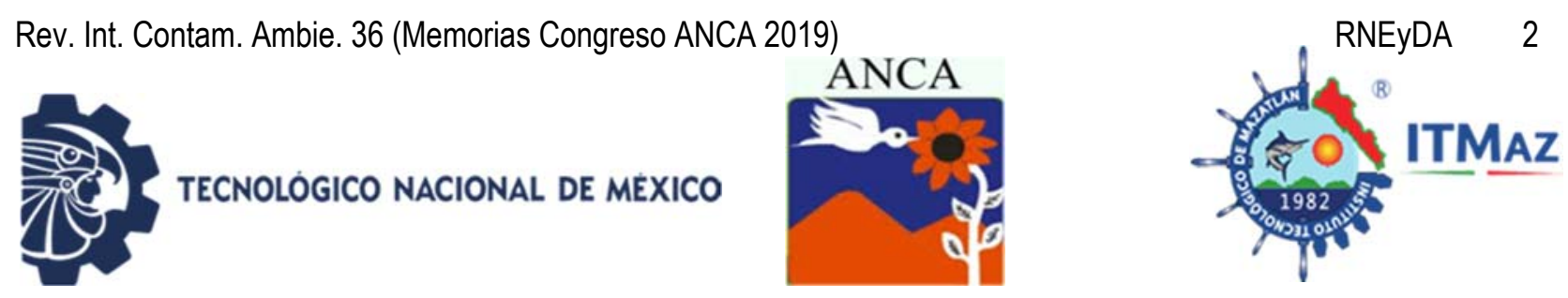

\title{
Ecological restoration experiences in degraded mangroves in Costa Rica, Africa and Mexico: international technology transfer
}

\author{
Agraz Hernández $\mathrm{CM}^{1 *}$, Houndjinou $\mathrm{EM}^{2}$, Aguilar $\mathrm{B}^{3}$, Rivera Wong $\mathrm{J}^{4}$, \\ Etienne $\mathrm{J}^{5}$, Muñiz Salazar $\mathrm{R}^{6}$ \\ ${ }^{1}$ EPOMEX, Universidad Autónoma de Campeche, México \\ ${ }^{2}$ ONG-CORDE. Benín, África \\ ${ }^{3}$ Neotrópica-ONG. San José, Costa Rica \\ ${ }^{4}$ Sistema Nacional de Áreas de Conservación de Costa Rica, Costa Rica \\ ${ }^{5}$ Secrétariat du Fonds Français pour l'Environnement Mondial \\ 6Universidad Autónoma de Baja California, México \\ *clmagraz@uacam.mx
}

\begin{abstract}
In recent years, there has been a change in the structure and function of mangrove ecosystems, caused both by anthropogenic activities and by hydrometeorological events. During this research, a pilot integral ecological restoration was applied in two degraded mangrove sites of Costa Rica (Cuajiniquil and Sierpe) and one in Benin (Ouidah), Africa. The technological transfer of environmental restoration programs applied since 1999 in Mexico was carried out. The restoration consists of hydrological management, using the information of hydrodynamic models and chemical analyses of the interstitial water that guarantee the hydrological dynamics and the recovery of the vegetal cover, through the reforestation of propagules with three species of mangrove. An environmental diagnosis before the restoration was applied and monitoring of the physicochemical conditions of the interstitial water during and after the restoration. Biological response indicators such as natural regeneration, to assess the change in environmental conditions and the degree of success of this. Three hydrological rehabilitation strategies were established, applying different designs based on an annual environmental diagnosis per site. To displace two invasive species of mangrove habitat and substitute a salt mine to recover mangrove cover, this through the excavation of canals and the participation of 380 people in the three restored sites. The restoration technology was transferred successfully, managing to restore 43 hectares.
\end{abstract}

Keywords: Restoration, mangroves, hydrological rehabilitation, technology transfer.

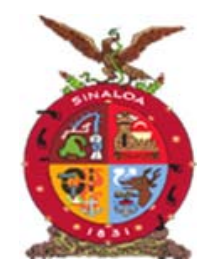

XVIII Congreso Internacional XXIV Congreso Nacional de Ciencias ambientales

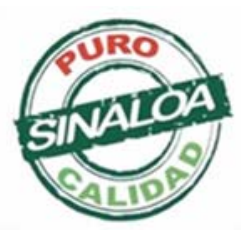

Mazatlán, Sinaloa 3-7 junio 2019
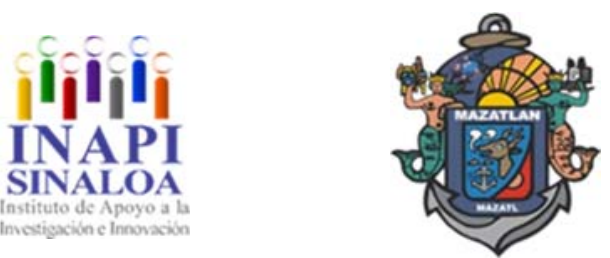

Recursos Naturales, Ecosistemas y Deterioro Ambiental 

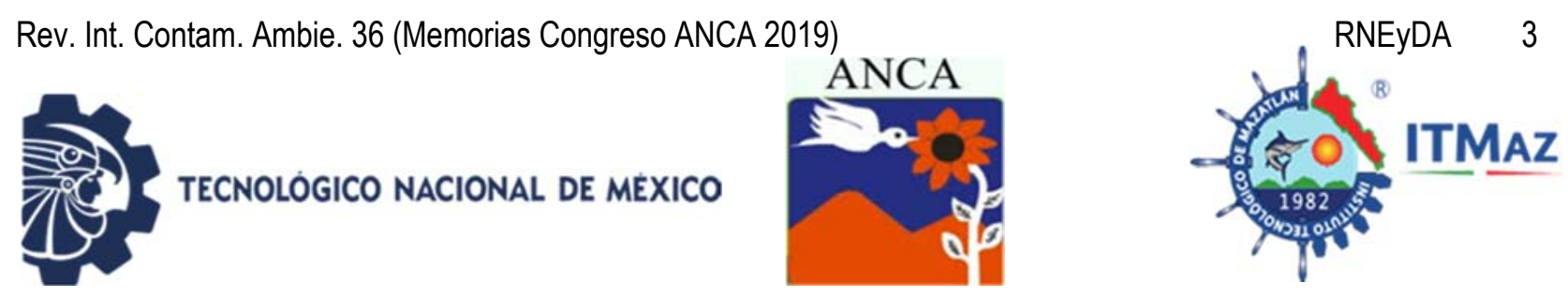

\title{
Registros del género Neoechinorhynchus (Acanthocephala) en Peces y Tortugas de México
}

\author{
Aguirre García Z, Pulido Flores G, Falcón Ordaz J, Monks S* \\ Universidad Autónoma del Estado de Hidalgo. \\ Carretera Pachuca-Tulancingo Km. 4.5, Cd. Universitaria, C.P. 42090, \\ Mineral de la Reforma, Hidalgo, México \\ *scottmonks@hotmail.com
}

\section{RESUMEN}

Los acantocéfalos son un grupo de parásitos muy exitoso debido a su capacidad de infección. Aunque la biología de los acantocéfalos de algunas áreas geográficas ha sido bien descrita, en la actualidad existe poca información de este grupo en México. Las especies del género Neoechinorhynchus se encuentran entre los acantocéfalos más comunes de América del Norte. Son endoparásitos de peces de agua dulce y salobre y tortugas de agua dulce, con aproximadamente 117 especies descritas distribuidas en todo el mundo. En el continente americano, se han descrito un total de 49 especies: 33 de América del Norte y 16 de América Central y del Sur. El propósito del presente estudio es conocer la diversidad de especies de Neoechinorhynchus en dos grupos de vertebrados con base en la literatura. Se reunió la información registrada para este género en el mundo y se plasmó en una tabla, posteriormente se calculó: la riqueza específica y el porcentaje de especies registradas en México en comparación con las que existen en el mundo. La riqueza actual de Neoechinorhynchus asociado a vertebrados silvestres en México asciende a 11 especies, lo que representa el $16 \%$ de la diversidad conocida para este grupo en el mundo. Este valor fue obtenido a partir de 55 especies de hospederos distribuidos en 17 estados de la República, entre los que destaca Cichlasoma urophthalmus como la especie de hospedero más intensamente estudiada y Neoechinorhynchus golvani la especie de acantocéfalo con mayor distribución geográfica y con el más amplio espectro hospedatorio.

Palabras clave: Parásitos, Acanthocephala, biodiversidad, Cichlasoma urophthalmus, Neoechinorhynchus golvani.

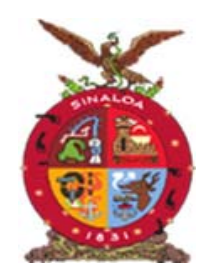

XVIII Congreso Internacional XXIV Congreso Nacional de Ciencias ambientales
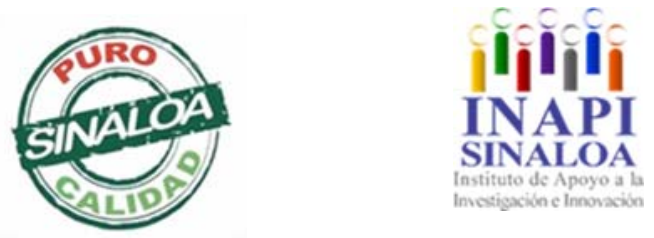

Mazatlán, Sinaloa 3-7 junio 2019

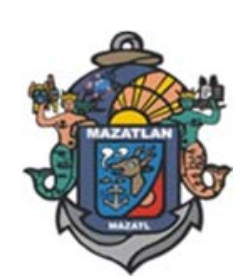

Recursos Naturales, Ecosistemas y Deterioro Ambiental 

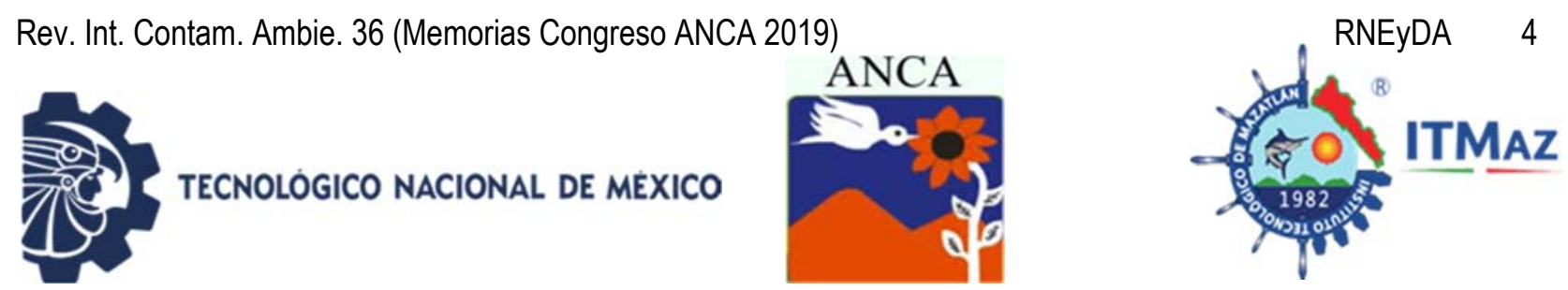

\title{
Records of the genus Neoechinorhynchus (Acanthocephala) in Fish and Turtles of Mexico
}

\author{
Aguirre García Z, Pulido Flores G, Falcón Ordaz J, Monks S* \\ Universidad Autónoma del Estado de Hidalgo. \\ Carretera Pachuca-Tulancingo Km. 4.5, Cd. Universitaria, C.P. 42090, \\ Mineral de la Reforma, Hidalgo, México \\ *scottmonks@hotmail.com
}

\begin{abstract}
Acanthocephalans are a highly successful helminth group because of their ability to infect. Although the biology of the Acanthocephala of some geographic areas has been well described, currently there is little information about this group in Mexico. Species of the genus Neoechinorhynchus are among the most common Acanthocephalans in North America. They are endoparasites of freshwater and brackish water fish and freshwater turtles, with approximately 117 described species distributed throughout the world. In the Americas, 49 species have been described: 33 from North America and 16 from Central and South America. The objective of the present study is to know the diversity of species of Neoechinorhynchus as adults in two groups of vertebrates. Based on reports in the literature, the number of species and their distribution worldwide was gathered and recorded. Later, calculations of specific richness and the percentage of species registered in Mexico in comparison with those known from the world. Current richness of species of Neoechinorhynchus associated with wild vertebrates in Mexico is 11 species, which represents $16 \%$ of the diversity known for the genus worldwide. These species infect 55 species of host distributed in 17 states of the Republic, among which Cichlasoma urophthalmus (a fish) stands out as the most intensively studied host and Neoechinorhynchus golvani as the species with the greatest geographic distribution and with the broadest host spectrum.
\end{abstract}

Keywords: Parasites, Acanthocephala, biodiversity, Cichlasoma urophthalmus, Neoechinorhynchus golvani.

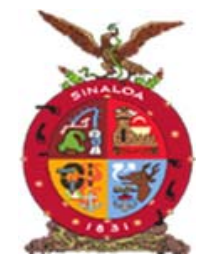

XVIII Congreso Internacional XXIV Congreso Nacional de Ciencias ambientales
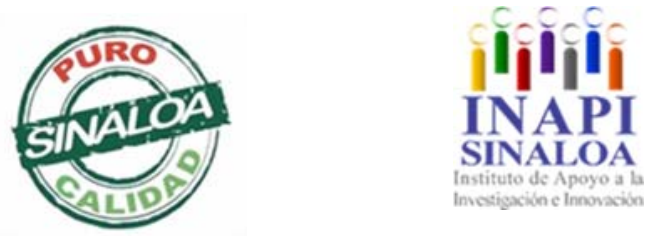

Mazatlán, Sinaloa 3-7 junio 2019

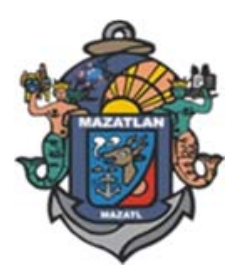

Recursos Naturales, Ecosistemas y Deterioro Ambiental 

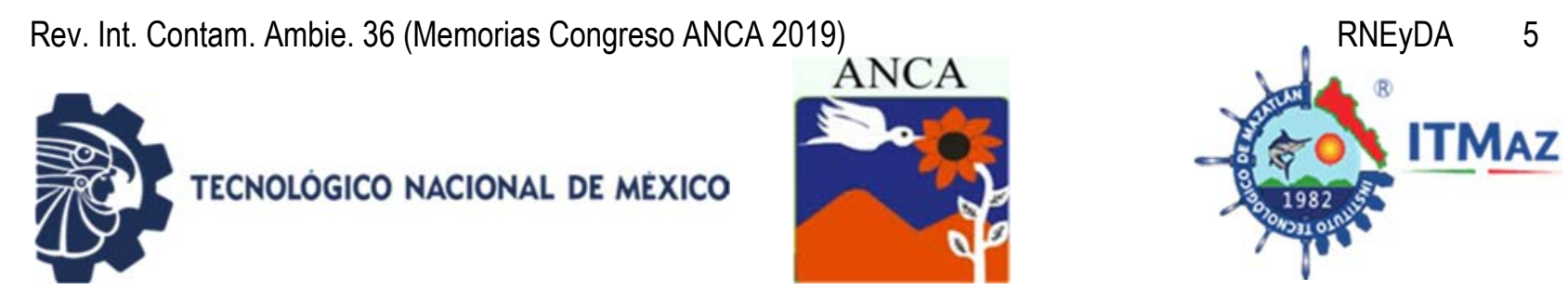

\section{Las macroalgas de la costa Michoacana enero 2019}

Alvarado Villanueva $R^{*}$, Ortega Murillo MR, Andrade Hernández SF, Ceballos Corona JGA, Sánchez Heredia JD

Laboratorio de Biología Acuática "J. Javier Alvarado Díaz". Facultad de Biología. Universidad Michoacana de San Nicolás de Hidalgo. México.

*alvareyna@yahoo.com

\section{RESUMEN}

La presente investigación se realizó en seis playas de la costa michoacana, durante el mes de enero del presente año. El objetivo fue conocer las macroalgas que viven en estas localidades. Las muestras biológicas se obtuvieron con ayuda de una espátula, raspando las rocas tratando de tomar todas sus partes, se fijaron con formol al $5 \%$, a las verdes se les adiciono carmín acético, se liquearon y posteriormente se identificaron con literatura especializada. Se determinaron 41 especies, que pertenecen a 3 divisiones 3 clases, 6 subclases, 16 órdenes, 10 tribus, 28 familias, 4 subfamilias, 33 géneros y 41 especies. La división Rhodophyta aporta el $48.8 \%$, le sigue la Chlorophyta $26.8 \%$ y finalmente la Phaeophyceae $24.4 \%$. Por playas Morro Colorado fue en donde se obtuvieron más especies 21, le sigue Carrizalillo (20), La Salada (18), Maruata (16), Manzanillera (13), y finalmente la Colorada (12). En cuanto a la frecuencia de aparición destaca Chaetomorpha antennina, Jania adhaerens, Chnoospora minima y Padina crispata con el 100 de aparición. Se concluye que hay diferencias en cuanto a las especies observadas por localidad, sin embargo, en todas sobresale la presencia de las algas rojas, seguido de las verdes y por último las cafés.

Palabras clave: Macroalgas, riqueza, frecuencia de aparición.

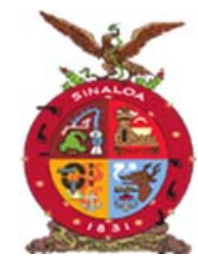

XVIII Congreso Internacional

XXIV Congreso Nacional de Ciencias ambientales
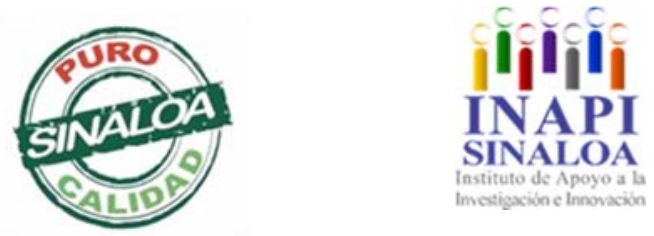

Mazatlán, Sinaloa 3-7 junio 2019

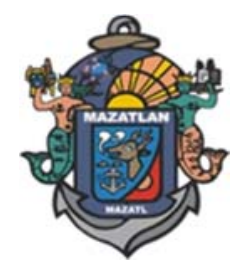

Recursos Naturales, Ecosistemas y Deterioro Ambiental 

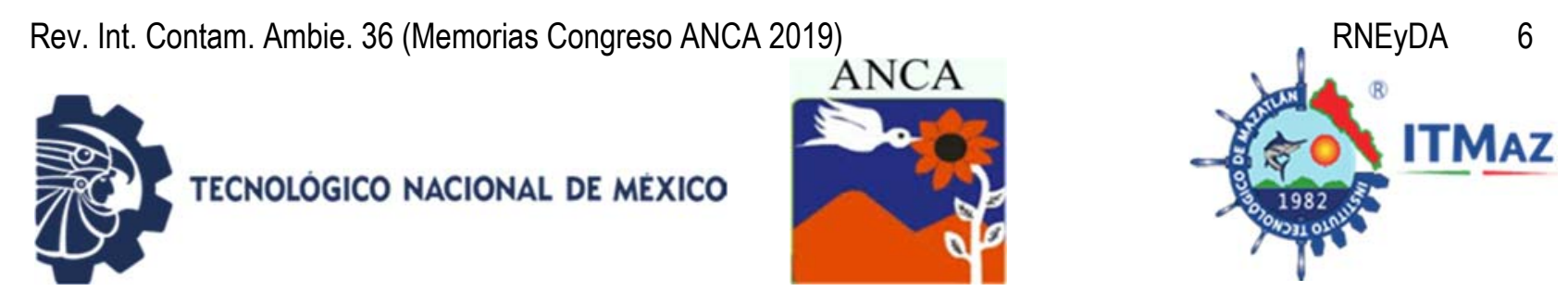

The macroalgaes of the Michoacan coast January 2019

Alvarado Villanueva $\mathrm{R}^{*}$, Ortega Murillo MR, Andrade Hernández SF, Ceballos Corona JGA, Sánchez Heredia JD

Laboratorio de Biología Acuática "J. Javier Alvarado Díaz". Facultad de Biología. Universidad Michoacana de San Nicolás de Hidalgo. Mexico

*alvareyna@yahoo.com

\begin{abstract}
The present investigation was carried out in six beaches of the Michoacan coast, during the month of January of this year. The objective was to know the macroalgae that live in these localities. The biological samples were obtained with the help of a spatula, scraping the rocks trying to take all their parts, fixed with $5 \%$ formaldehyde, the green ones were added acetic carmine, they were liquefied and later they were identified with specialized literature. We determined 41 species, which belong to 3 divisions 3 classes, 6 subclasses, 16 orders, 10 tribes, 28 families, 4 subfamilies, 33 genera and 41 species. The Rhodophyta division contributes $48.8 \%$, followed by Chlorophyta $26.8 \%$ and finally the Phaeophyceae $24.4 \%$. By beaches Morro Colorado was where they obtained more species 21, followed by Carrizalillo (20), La Salada (18), Maruata (16), Manzanillera (13), and finally La Colorada (12). Regarding the frequency of appearance, Chaetomorpha antennina, Jania adhaerens, Chnoospora minima and Padina crispata stand out with the 100 appearance. It is concluded that there are differences in the species observed by locality, however, in all of them the presence of red algae stands out, followed by the green ones and finally the coffees.
\end{abstract}

Keywords: Macroalgae, wealth, frequency of appearance.

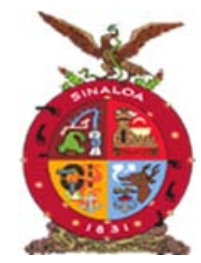

XVIII Congreso Internacional

XXIV Congreso Nacional de Ciencias ambientales
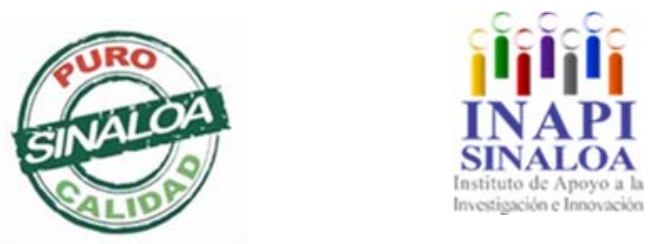

Mazatlán, Sinaloa 3-7 junio 2019

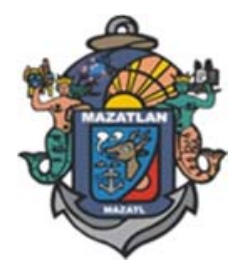

Recursos Naturales, Ecosistemas y Deterioro Ambiental 

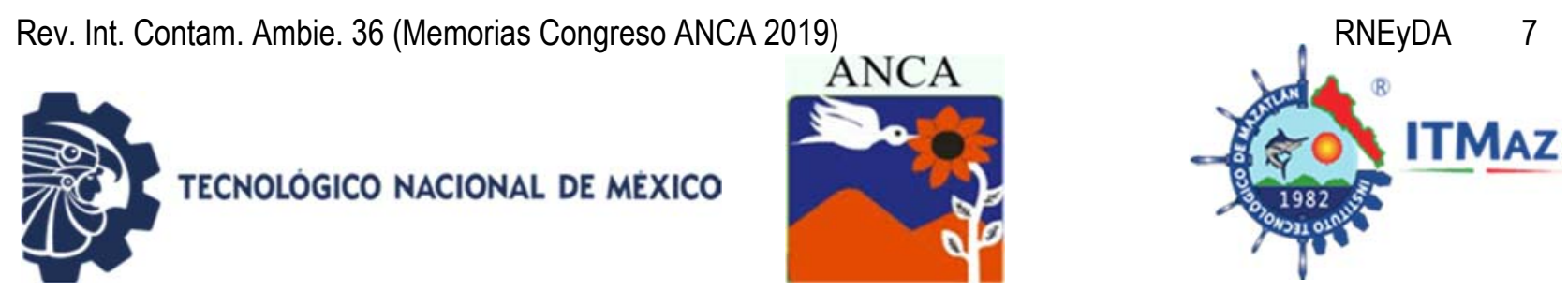

\title{
Concentración de metales y nutrientes en suelo y agua en: Ciudad Deportiva, Chihuahua, México
}

\author{
Álvarez Domínguez A, Cortés Palacios L*, Escobedo Bautista R, \\ Rodríguez Piñeros S, Morales Nieto C, Aquino De Los Ríos G \\ Facultad de Zootecnia y Ecología. \\ Universidad Autónoma de Chihuahua. México \\ *Icortes@uach.mx
}

\begin{abstract}
RESUMEN
Los parques forman una parte importante en las ciudades, estos tienen varios beneficios sociales, económicos y ecológicos, además de que son refugio de diversas especies. El objetivo de la investigación fue buscar los posibles factores causantes de alteraciones en algunos árboles de un parque público. La investigación se llevó acabo en la Ciudad Deportiva en Chihuahua, Chih., durante febrero y marzo 2019. Para las muestras de suelo se siguió la NMX-AA-132SCFI-2006. Se dividió en 13 áreas la Ciudad Deportiva y de cada una se tomaron muestras de suelo. Para los nutrientes y otros parámetros se dio seguimiento a la NOM-021-RECNAT-2000. Se escarbó a una profundidad de $5 \mathrm{~cm}$. Las dos muestras de agua se tomaron conforme a la NMX-AA-003-1980. Los resultados muestran que hay un metal que excede el límite de la norma mexicana en el suelo, el hierro ( $\mathrm{Fe}$ ), con una concentración promedio de $13538.72 \mathrm{mg} / \mathrm{kg}$ y según la NOM-021-RECNAT-2000, debe de tener una concentración de no más de 50 $\mathrm{mg} / \mathrm{kg}$. En el agua no se encontró ninguna concentración fuera del rango de alguna norma mexicana. Los valores en nutrientes en suelo, concentración de metales en sueloy agua y los hábitos de riego ayudaron al análisis para encontrar la causa por el cual algunos árboles han perecido.
\end{abstract}

Palabras clave: Metales, parque público, suelo y agua, normas mexicanas, árboles.
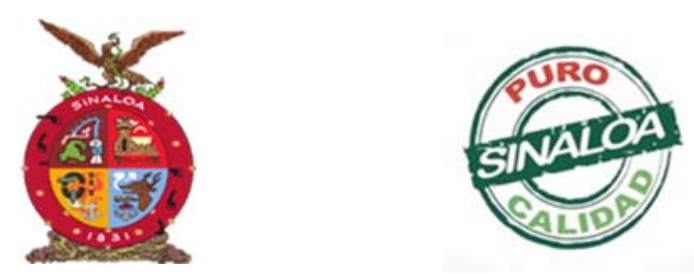

Mazatlán, Sinaloa 3-7 junio 2019
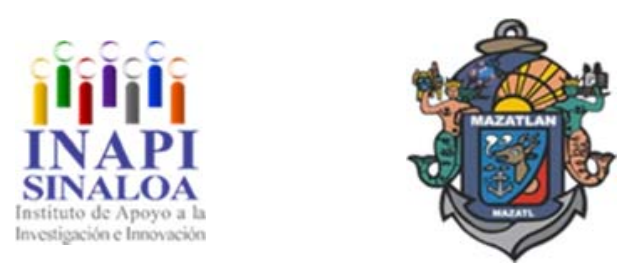

Recursos Naturales, Ecosistemas y Deterioro Ambiental 

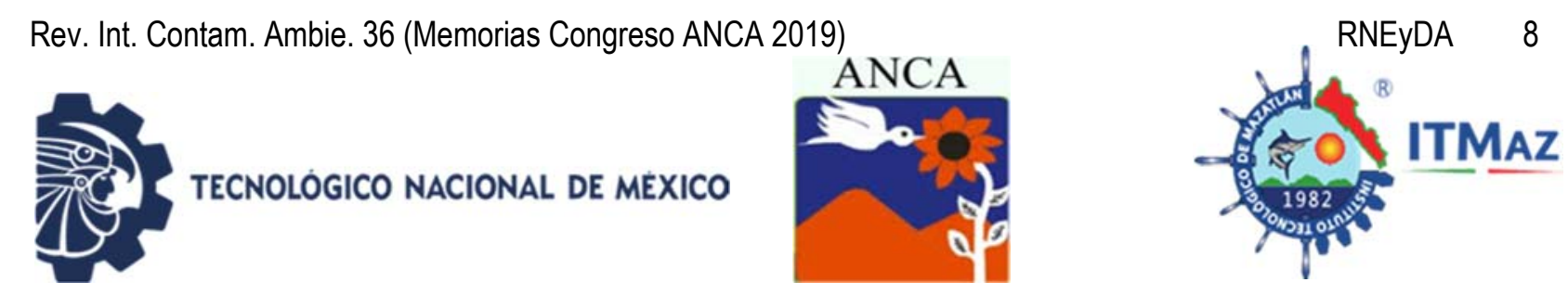

\title{
Concentration of metals and nutrients in soil and water in a public park, case study: Ciudad Deportiva, Chihuahua, Mexico
}

\author{
Álvarez Domínguez A, Cortés Palacios L*, Escobedo Bautista R, \\ Rodríguez Piñeros S, Morales Nieto C, Aquino De Los Ríos G
}

Facultad de Zootecnia y Ecología.

Universidad Autónoma de Chihuahua. México

*Icortes@uach.mx

\begin{abstract}
Parks are a very important part of cities, they have several social, economic and ecological benefits. In addition, hundreds of species find refuge in them. The objective of the research was to look for the possible factors that cause alterations in some trees of a public park. The investigation was carried out at the Ciudad Deportiva in Chihuahua, Chih., during February and March 2019. For the soil samples, the NMX-AA-132-SCFI-2006 was followed. The Sports City was divided into 13 areas and soil samples were taken from each one. For the nutrients and other parameters, the NOM-021-RECNAT-2000 was followed up. It was dug to a depth of $5 \mathrm{~cm}$. The two water samples were taken according to NMX-AA-0031980 and the basic data were taken. The results show that there is a metal that exceeds the limit of the Mexican norm in the soil. Iron (Fe), with an average concentration of $13538.72 \mathrm{mg} / \mathrm{Kg}$ and according to NOM-021-RECNAT-2000, must have a concentration of not more than $50 \mathrm{mg} / \mathrm{Kg}$. Regarding water, no concentration was found outside the range of any Mexican norm. Nutrient values in soil, concentration of metals in soil and water, and irrigation habits helped the analysis to find the cause for which some trees have perished.
\end{abstract}

Keywords: Metals, public park, soil and water, Mexican standards, trees.
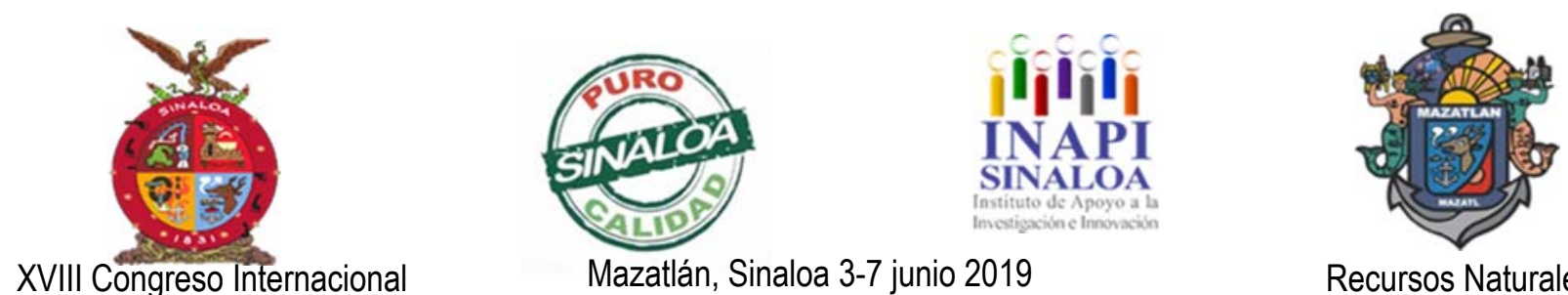

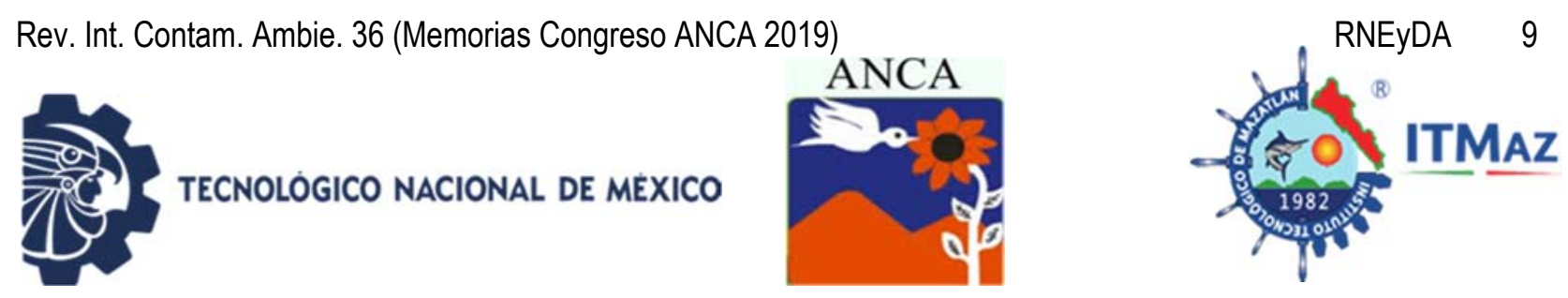

\title{
Valores de $\delta^{15} \mathrm{~N}$, en Thalassia testudinum en tres lagunas con diferente afluencia turística en el Caribe Mexicano
}

\author{
Anguas Cabrera $\mathrm{D}^{1 *}$, Camacho Cruz K $\mathrm{K}^{1}$, Sánchez González $\mathrm{A}^{1}$, \\ Aguíñiga García $\mathrm{S}^{1}$, Marmolejo Rodríguez J $\mathrm{J}^{1}$, Ortiz Hernández $\mathrm{C}^{2}$ \\ ${ }^{1}$ Centro Interdisciplinario de Ciencias Marinas. Unidad Chetumal. \\ Instituto Politécnico Nacional. México \\ ${ }^{2}$ Colegio de la Frontera Sur (ECOSUR), Unidad Chetumal. México \\ *dianguas@yahoo.com
}

\section{RESUMEN}

Los pastos marinos son considerados productores primarios más importantes de aguas someras, siendo vulnerables al impacto antropogénico. Thalassia testudinum es la especie dominante y abundante en el Caribe Mexicano, habita en aguas con baja concentración nitrógeno inorgánico disuelto $(\mathrm{NID}<1 \mu \mathrm{M})$. El exceso de NID por periodos prolongados afecta la estructura de las praderas de pastos, favoreciendo la dominancia de macroalgas, pérdida de biodiversidad y alteración de cadenas tróficas. Para evaluar los aportes de NID una herramienta utilizada son los Isótopos estables de nitrógeno $\left(\delta^{15} \mathrm{~N}\right)$ en tejidos, los cuales proveen información de la biodisponibilidad del NID y sus fuentes. En el Caribe mexicano las principales actividades productivas son la industria turística y urbana, debido a que las aguas-residuales son vertidas directamente a las aguas subterráneas o cuerpos costeros, lo anterior, hace suponer un aporte de NID a estas praderas. Sin embargo, se desconoce cómo estos aportes cambian el $\delta^{15} \mathrm{~N}$ en $T$. testudinum. Los objetivos de este trabajo son evaluar los cambios a nivel espacial de $\delta^{15} \mathrm{~N}$ en $T$. testudinum y sugerir su uso como indicador de influencia antropogénica en localidades costeras. Las muestras fueron recolectadas en 2010-2016, durante época de lluvias. El análisis isotópico de N se llevó a cabo en un espectrómetro de masas (CICIMAR-IPN). Los valores del $\delta^{15} \mathrm{~N}$ en $T$. testudinum en sitios de mayor desarrollo turístico (e.g., Cancún) fueron similares al $\delta^{15} \mathrm{~N}$ de aguas residuales (10 a $20 \%$ ) y en sitios con menor desarrollo turístico fue similar al aporte atmosférico (-2 a $4 \%)$.

Palabras clave: Thalassia testudinum, $\delta^{15} \mathrm{~N}$, Caribe Mexicano, afluencia turística, aguas residuales y subterráneas.
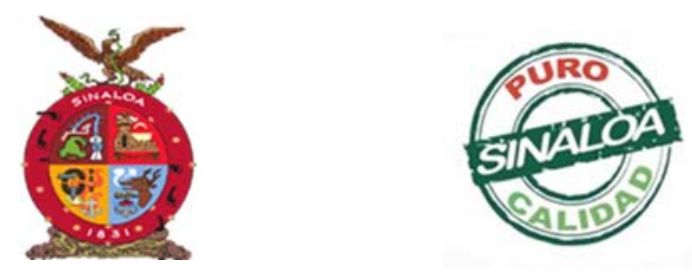

Mazatlán, Sinaloa 3-7 junio 2019

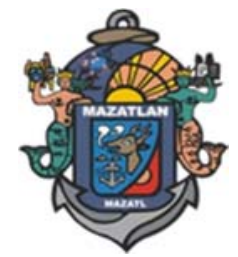

Recursos Naturales, Ecosistemas y Deterioro Ambiental 

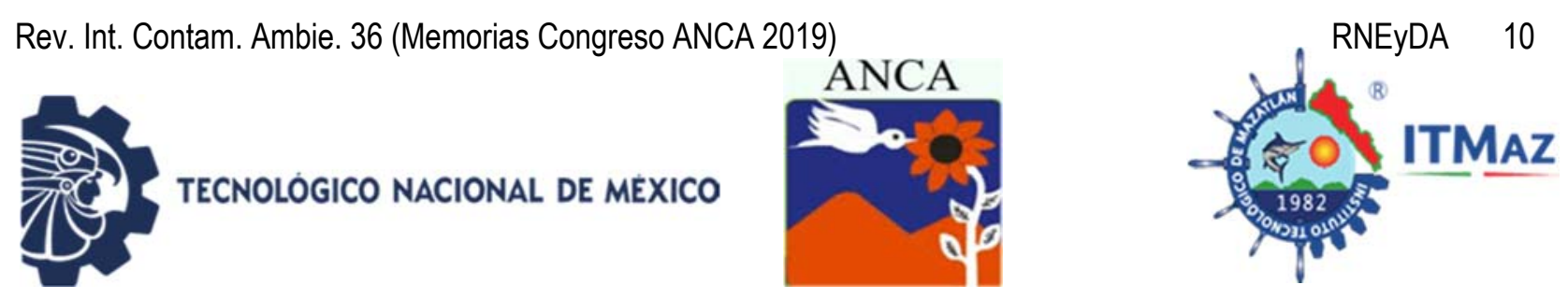

\title{
Values of $\delta^{15} \mathrm{~N}$, en Thalassia testudinum in three lagoons with different tourist influx in the Mexican Caribbean
}

\author{
Anguas Cabrera $\mathrm{D}^{1 *}$, Camacho Cruz K${ }^{1}$, Sánchez González $\mathrm{A}^{1}$, \\ Aguíñiga García $\mathrm{S}^{1}$, Marmolejo Rodríguez J $\mathrm{J}^{1}$, Ortiz Hernández $\mathrm{C}^{2}$ \\ ${ }^{1}$ Centro Interdisciplinario de Ciencias Marinas. Unidad Chetumal. \\ Instituto Politécnico Nacional. México \\ ${ }^{2}$ Colegio de la Frontera Sur (ECOSUR), Unidad Chetumal. México \\ *dianguas@yahoo.com
}

\begin{abstract}
Seagrasses are considered the most important primary producers of shallow waters, being vulnerable to anthropogenic impact. Thalassia testudinum is the dominant and abundant species in the Mexican Caribbean, it lives in waters with low concentration of dissolved inorganic nitrogen (NID $<1 \mu \mathrm{M})$. The excess of NID for prolonged periods affects the structure of pasture meadows, favoring the dominance of macroalgae, loss of biodiversity and alteration of trophic chains. To evaluate the contributions of NID, a tool used is stable isotopes of nitrogen $\left(\delta^{15} \mathrm{~N}\right)$ in tissues, which provide information on the bioavailability of the NID and its sources. In the Mexican Caribbean, the main productive activities are the tourism and urban industry, because the wastewater is discharged directly to the groundwater or coastal bodies, the foregoing, makes a contribution of NID to these grasslands. However, it is unknown how these contributions change $\delta^{15} \mathrm{~N}$ in $T$. testudinum. The objectives of this work are to evaluate the changes at the spatial level of $\delta^{15} \mathrm{~N}$ in $T$. testudinum and to suggest its use as an indicator of anthropogenic influence in coastal locations. The samples were collected in 20102016, during the rainy season. The isotopic analysis of $\mathrm{N}$ was carried out on a mass spectrometer (CICIMAR-IPN). The values of $\delta^{15} \mathrm{~N}$ in T. testudinum in sites of greater tourism development (eg, Cancun) were similar to $\delta^{15} \mathrm{~N}$ of wastewater (10 to $20 \%$ ) and in sites with less tourism development it was similar to atmospheric contribution (-2 to $4 \%$ ).
\end{abstract}

Keywords: Thalassia testudinum, $\delta^{15} \mathrm{~N}$, Mexican Caribbean, tourist influx, sewage and groundwater.

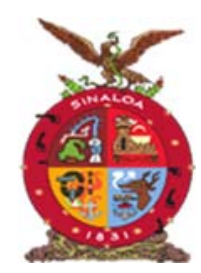

XVIII Congreso Internacional XXIV Congreso Nacional de Ciencias ambientales
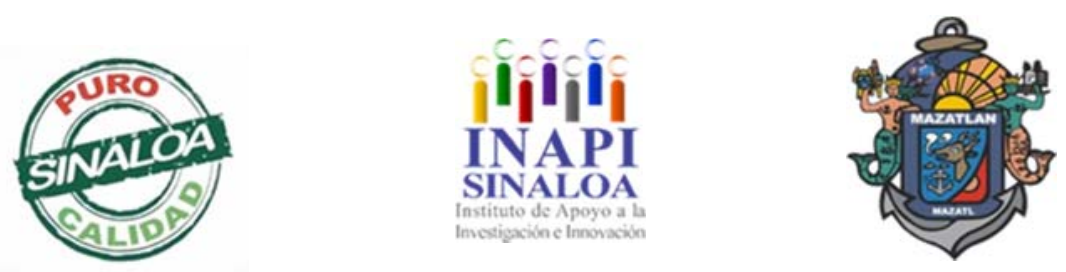

Mazatlán, Sinaloa 3-7 junio 2019

Recursos Naturales, Ecosistemas y Deterioro Ambiental 

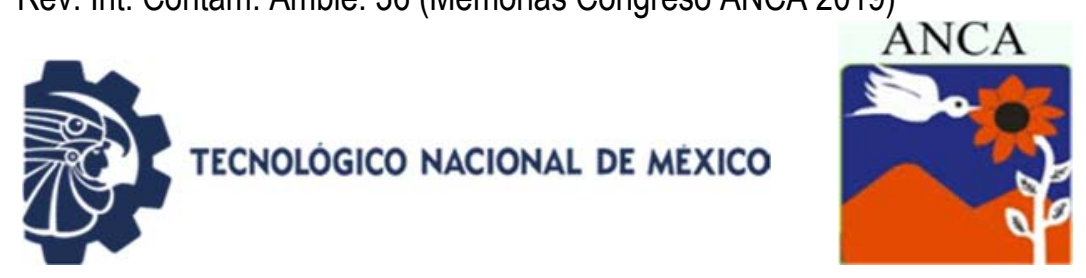

\title{
Estado trófico de una bahía subtropical y su relación con la biomasa de macroalgas
}

\author{
Antonio Robles $\mathrm{J}^{1 *}$, Piñón Gimate $\mathrm{A}^{1}$, Sánchez González $\mathrm{A}^{1}$, \\ Cervantes Duarte $R^{1}$, Casas Valdez $M^{1}$, Arreola Lizárraga $A^{2}$ \\ ${ }^{1}$ Centro Interdisciplinario de Ciencias Marinas. \\ Instituto Politécnico Nacional. México \\ ${ }^{2}$ Centro de Investigaciones Biológicas del Noroeste. México \\ *antonioroblesjaime@gmail.com
}

\begin{abstract}
RESUMEN
La evaluación de la calidad del agua de zonas costeras puede realizarse mediante índices que integran variables físicas, químicas y biológicas. El objetivo de este estudio fue evaluar el estado trófico de sitios con presencia de macroalgas en La Bahía de La Paz. San Juan de la Costa (SJC), Casa del Marino (CM) y Tecolote (TE) en febrero, mayo, agosto y noviembre (2018), se registraron variables hidrográficas, nitrógeno inorgánico disuelto (NID), ortofosfatos $\left(\mathrm{PO}_{4}{ }^{-3}\right)$, clorofila ( $\mathrm{Cla}$ ) y biomasa macroalgal (transectos-cuadrantes). El estado trófico se estimó mediante el índice TRIX (0-10). Temperatura, oxígeno disuelto, NID, $\mathrm{PO}_{4}{ }^{-}$ ${ }^{3}$, Cla y TRIX mostraron diferencias significativas $(p<0.05)$, la salinidad no tuvo diferencias. EI NID fue mayor en mayo en SJC $(21.7 \mu \mathrm{M})$ respecto a CM y TE. Los $\mathrm{PO}^{-3}$ fueron mayores en agosto en SJC $(22 \mu \mathrm{M})$ respecto CM y TE. La Cla fue mayor en febrero en $\mathrm{CM}\left(2.1 \mathrm{mg} \mathrm{m}^{-3}\right)$ respecto a SJC y TE. El mayor estado trófico (eutrófico) se presentó en SJC en agosto $(6.6 \pm 0.36)$, y el menor (mesotrófico) en TE $(4.2 \pm 0.25)$ y CM $(4.2 \pm 0.04)$ en el mismo mes. Se encontraron 13 especies de macroalgas abundantes, las de mayor biomasa fueron Ulva rigida $\left(100.3 \mathrm{~g} \mathrm{~m}^{-2}\right)$, Acanthophora spicifera $\left(35.9 \mathrm{~g} \mathrm{~m}^{-2}\right)$ y U. clathrata (32.1 $\mathrm{g} \mathrm{m}^{-2}$ ) en mayo en $\mathrm{CM}$, lo que coincide con la estacionalidad de cada especie. Los nutrientes no son limitantes en la bahía. Al parecer, la biomasa macroalgal está relacionada con valores medios del estado trófico sin llegar al estado eutrófico.
\end{abstract}

Palabras clave: Calidad de agua, estado trófico, índice TRIX, macroalgas.
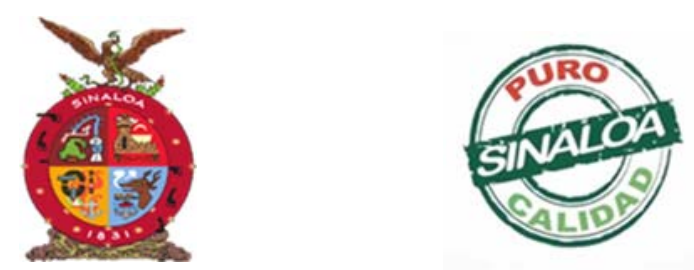

Mazatlán, Sinaloa 3-7 junio 2019
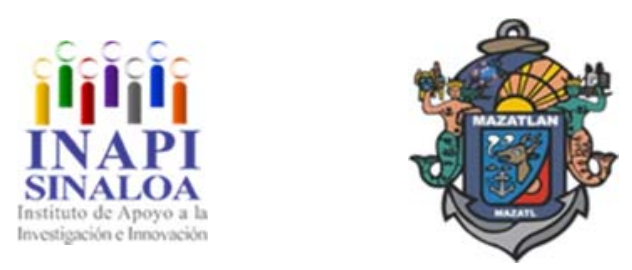

Recursos Naturales, Ecosistemas y Deterioro Ambiental 

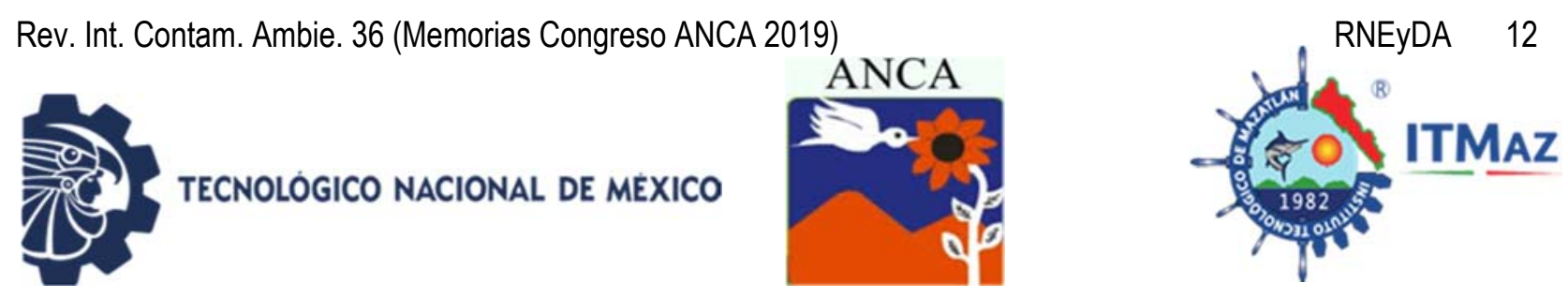

\title{
Trophic state of a subtropical bay and its relationship with macroalgae biomass
}

\author{
Antonio Robles $\mathrm{J}^{1 *}$, Piñón Gimate $\mathrm{A}^{1}$, Sánchez González $\mathrm{A}^{1}$, \\ Cervantes Duarte $R^{1}$, Casas Valdez $M^{1}$, Arreola Lizárraga $A^{2}$ \\ ${ }^{1}$ Centro Interdisciplinario de Ciencias Marinas. \\ Instituto Politécnico Nacional. México \\ ${ }^{2}$ Centro de Investigaciones Biológicas del Noroeste. México \\ *antonioroblesjaime@gmail.com
}

\begin{abstract}
The evaluation of water quality in coastal areas can be carried out through indices that integrate physical, chemical and biological variables. The objective of this study was to evaluate the trophic status of sites with presence of macroalgae in La Paz Bay. San Juan de la Costa (SJC), Casa del Marino (CM) and Tecolote (TE) in February, May, August and November (2018), registered hydrographic variables, dissolved inorganic nitrogen (NID), orthophosphate $\left(\mathrm{PO}_{4}{ }^{-3}\right)$, chlorophyll (Cla) and macroalgal biomass (transects-quadrants). The trophic state was estimated using the TRIX index (0-10). Temperature, dissolved oxygen, NID, $\mathrm{PO}^{-3}$, Cla and TRIX showed significant differences $(p<0.05)$, salinity did not differ. The NID was higher in May at SJC $(21.7 \mu \mathrm{M})$ compared to CM and TE. $\mathrm{PO}_{4}{ }^{-3}$ were higher in August in SJC $(22 \mu \mathrm{M})$ compared to CM and TE. Cla was higher in February in CM $\left(2.1 \mathrm{mg} \mathrm{m}^{-3}\right)$ compared to SJC and TE. The highest trophic state (eutrophic) was presented in SJC in August $(6.6 \pm 0.36)$, and the lowest (mesotrophic) in TE $(4.2 \pm 0.25)$ and CM $(4.2 \pm 0.04)$ in the same month. We found 13 species of abundant macroalgae, the highest biomass were Ulva rigida $\left(100.3 \mathrm{~g} \mathrm{~m}^{-2}\right)$, Acanthophora spicifera $\left(35.9 \mathrm{~g} \mathrm{~m}^{-2}\right)$ and $U$. clathrata $(32.1 \mathrm{~g}$ $\mathrm{m}^{-2}$ ) in May in CM, which it coincides with the seasonality of each species. The nutrients are not limiting in the bay. Apparently, the macroalgal biomass is related to average values of the trophic state without reaching the eutrophic state.
\end{abstract}

Keywords: Water quality, trophic state, TRIX index, macroalgae.
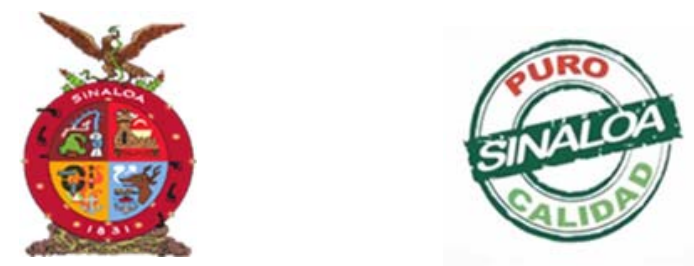

Mazatlán, Sinaloa 3-7 junio 2019
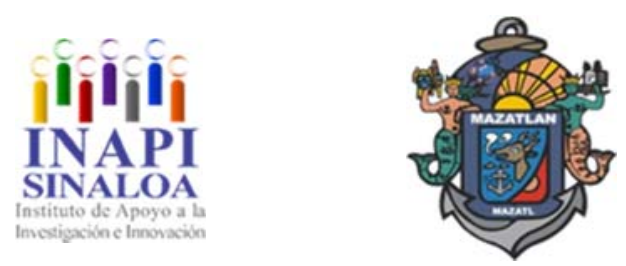

Recursos Naturales, Ecosistemas y Deterioro Ambiental 

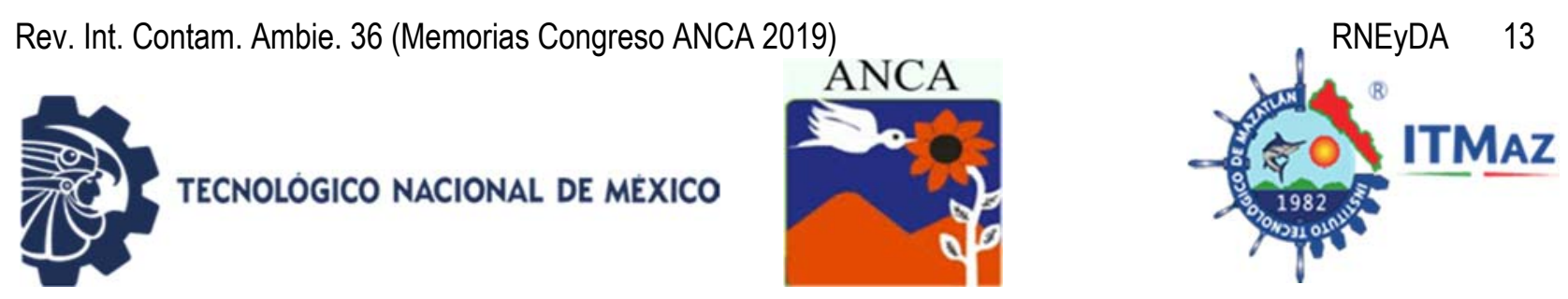

\title{
Respuesta inmune de juveniles de Crassostrea gigas bajo condición de estrés por pH y en presencia de Vibrio harveyi
}

\author{
Arce Romero $\mathrm{P}^{1}$, Luis Villaseñor $\mathrm{I}^{1}$, Flores Higuera F, Frías Espericueta $\mathrm{M}^{1}$, \\ Saavedra Sotelo $\mathrm{N}^{3}$ \\ ${ }^{1}$ Facultad de Ciencias del Mar. Universidad Autónoma de Sinaloa, México \\ ${ }^{2}$ Catedra CONACYT. Facultad de Ciencias del Mar. \\ Universidad Autónoma de Sinaloa, México \\ ${ }^{3}$ Instituto de Ciencias del Mar y Limnología, UNAM. \\ Universidad Nacional Autónoma de México \\ p.arcer.facimar@uas.edu.mx
}

\section{RESUMEN}

El estrés de la acidificación de los océanos y el aumento de la temperatura pueden afectar la función de la respuesta inmune ante la presencia de un patógeno. En el presente trabajo se cuantificó la respuesta inmune de $C$. gigas bajo condiciones de estrés por $\mathrm{pH}$ y temperatura y en presencia de $V$. harveyi. Se realizaron dos bioensayos con juveniles de $C$. gigas, en el primer bioensayo para la exposición prolongada a un bajo $\mathrm{pH}$ (7.7) y como control a pH actual (8.1), cultivados a 25 y $21^{\circ} \mathrm{C}$ durante 4 semanas, donde se cuantificó el nivel de expresión de ecSOD y Hsp68. Para el segundo bioensayo se realizó una prueba reto contra $V$. harveyi, determinando: supervivencia, crecimiento y la expresión relativa de los genes: ecSOD, Hsp68, CgLec-C y Cas7 por qPCR, así como posibles daños en las conchas mediante Microscopía Electrónica de Barrido (MEB). Resultados indican una sobreexpresión de los genes ecSOD y Hsp68 a las dos semanas de cultivo a pH bajo $(7.7)$ a $25^{\circ} \mathrm{C}$ así como en el control (pH 8.1 a $\left.21^{\circ} \mathrm{C}\right)$, (ANOVA, $\left.P<0.05\right)$. No se observaron diferencias significativas en supervivencia y crecimiento (ANOVA, $p=0.382$ y $p=0.108$ ), el análisis de MEB evidenció daño en la estructura de la concha. El tratamiento de $\mathrm{pH} 7.7$ y $25^{\circ} \mathrm{C}$ provocó sobreexpresión de los genes ecSOD y Hsp68 en los organismos cultivados, lo cual los hace más susceptibles y puede disminuir su resistencia a posibles infecciones por patógenos.

Palabras clave: ecSOD, Hsp68, expresión génica, qPCR, acidificación del océano.
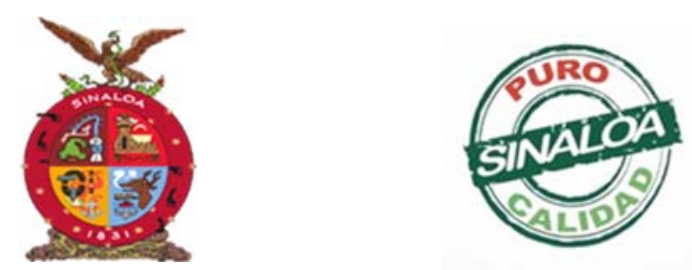

Mazatlán, Sinaloa 3-7 junio 2019
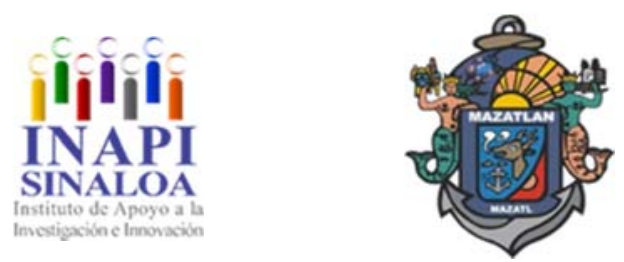

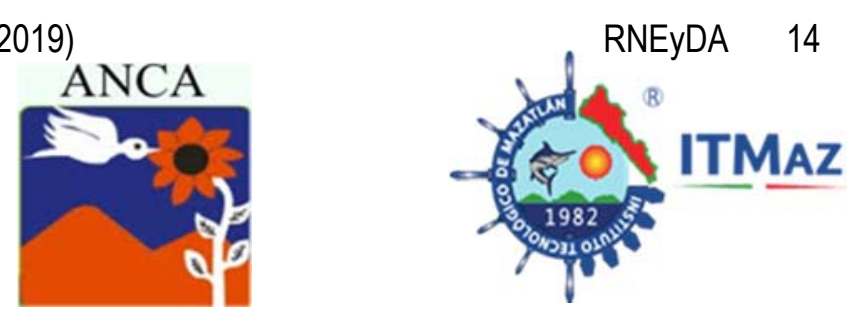

\title{
Immune response of juveniles of Crassostrea gigas under the condition of $\mathrm{pH}$ stress and in the presence of Vibrio harveyi
}

\author{
Arce Romero $\mathrm{P}^{1}$, Luis Villaseñor $\mathrm{I}^{1}$, Flores Higuera F, Frías Espericueta $\mathrm{M}^{1}$, \\ Saavedra Sotelo $\mathrm{N}^{3}$ \\ ${ }^{1}$ Facultad de Ciencias del Mar. Universidad Autónoma de Sinaloa, México \\ ${ }^{2}$ Catedra CONACYT. Facultad de Ciencias del Mar. \\ Universidad Autónoma de Sinaloa, México \\ ${ }^{3}$ Instituto de Ciencias del Mar y Limnología, UNAM. \\ Universidad Nacional Autónoma de México \\ p.arcer.facimar@uas.edu.mx
}

\begin{abstract}
The stress of ocean acidification and the increase of temperature can affect the function of the immune response in the presence of a pathogen. In the present work, the immune response of $C$. gigas was quantified under stress conditions by $\mathrm{pH}$ and temperature and in the presence of $V$. harveyi. Two bioassays were performed with juveniles of $C$. gigas, in the first bioassay for prolonged exposure at a low $\mathrm{pH}(7.7)$ and as a control at current $\mathrm{pH}(8.1)$, cultured at 25 and $21^{\circ} \mathrm{C}$ for 4 weeks, where it was quantified the expression level of ecSOD and Hsp68. For the second bioassay, a challenge test against $V$. harveyi was carried out, determining: survival, growth and the relative expression of the genes: ecSOD, Hsp68, CgLec-C and Cas7 by qPCR, as well as possible damage to the shells by means of Electron Microscopy Sweep (MEB). Results indicate an overexpression of the ecSOD and Hsp68 genes at two weeks of culture at low pH $(7.7)$ at $25^{\circ} \mathrm{C}$ as well as in the control $\left(\mathrm{pH} 8.1\right.$ at $21^{\circ} \mathrm{C}$ ), (ANOVA, $\left.\mathrm{P}<0.05\right)$. No significant differences were observed in survival and growth (ANOVA, $p=0.382$ and $p=$ 0.108 ), the MEB analysis showed damage to the shell structure. The treatment of $\mathrm{pH} 7.7$ and $25^{\circ} \mathrm{C}$ caused overexpression of the ecSOD and Hsp68 genes in cultured organisms, which makes them more susceptible and may decrease their resistance to possible pathogen infections.
\end{abstract}

Keywords: ecSOD, Hsp68, gene expression, qPCR, ocean acidification.

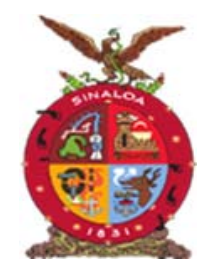

XVIII Congreso Internacional

XXIV Congreso Nacional de Ciencias ambientales
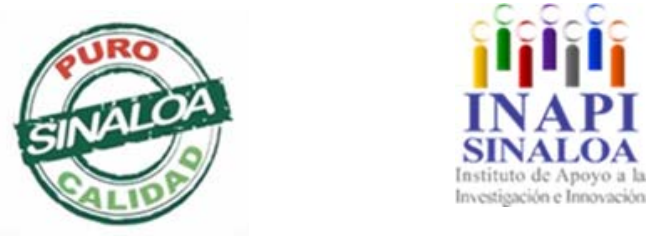

Mazatlán, Sinaloa 3-7 junio 2019

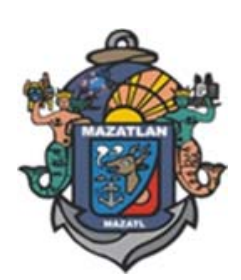

Recursos Naturales, Ecosistemas y Deterioro Ambiental 

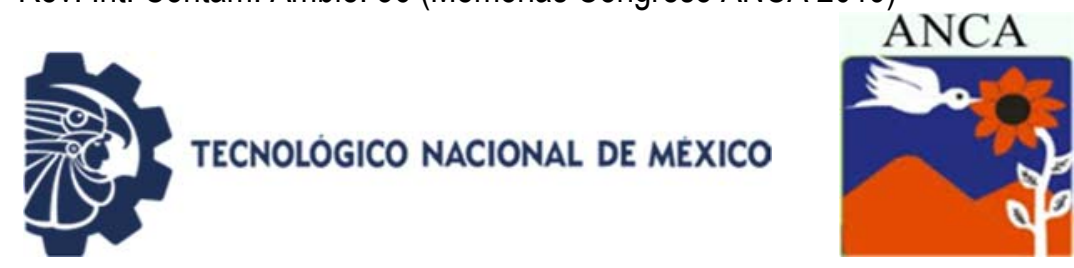

\title{
Servicios ecosistémicos de huertos familiares al sur del Estado de México: Una propuesta metodológica
}

\author{
Arcos Severo $\mathrm{M}^{1 *}$, Gutiérrez Cedillo $\mathrm{JG}^{2}$, Balderas Plata $\mathrm{MÁ}^{2}$, \\ Martínez García $\mathrm{CG}^{3}$ \\ ${ }^{1}$ Facultad de Química. Universidad Autónoma del Estado de México \\ ${ }^{2}$ Facultad de Geografía. UAEMex \\ ${ }^{3}$ Instituto de Ciencias Agropecuarias y Rurales (ICAR). UAEMex \\ *min.arcos@hotmail.com
}

\begin{abstract}
RESUMEN
Los huertos familiares constituyen uno de los principales medios de vida para las familias rurales, razón por la cual han sido ampliamente estudiados, no obstante, los aportes que se tienen están relacionados con los trabajos florísticos, botánicos, etnobotánicos y agroecológicos principalmente y con escasas aproximaciones metodológicas. Así el objetivo del presente trabajo es presentar una propuesta metodológica que permita analizar los servicios ecosistemicos (SE) de los agroecosistemas de huertos familiares (AEHF), al sur del estado de México. La propuesta tiene sus fundamentos metodológicos en la planeación geográfica integral (PGI), el método etnográfico, el análisis FODA y el enfoque del marco lógico (EML). A partir de estos métodos y metodologías se planteó el análisis de los servicios ecosistemicos de AEHF desde sus componentes: sociales, culturales, ambientales y económicos, mismos que para su abordaje se dividieron en cinco etapas metodológicas: 1) análisis los SE de importancia sociocultural, 2) identificación de los SE de regulación y soporte, 3) análisis de los SE de provisión y su valoración económica, 4) análisis de las implicaciones que tienen los SE de $A E H F$ en el bienestar de las familias rurales y 5) fundamentación e Integración de la propuesta metodológica. Este análisis permitirá abordar la complejidad de los agroecosistemas de HF, bajo el enfoque de servicios ecosistemicos, contribuyendo con ello en la creación de estrategias de manejo sustentable con énfasis en la conservación de los recursos naturales de los AEHF.
\end{abstract}

Palabras clave: Servicios ecosistemicos, agroecosistemas, huertos familiares, sistemas complejos, familias rurales.

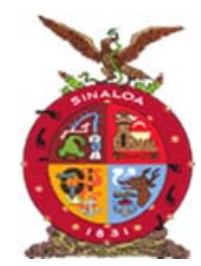

XVIII Congreso Internacional

XXIV Congreso Nacional de Ciencias ambientales
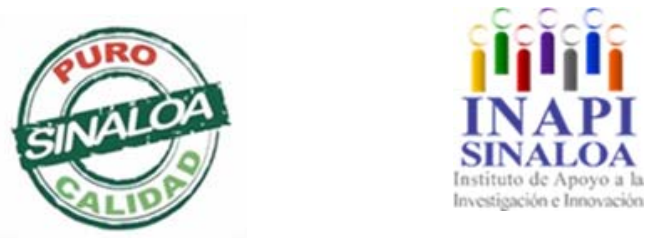

Mazatlán, Sinaloa 3-7 junio 2019

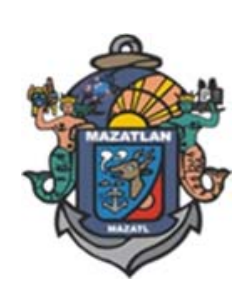

Recursos Naturales, Ecosistemas y Deterioro Ambiental 

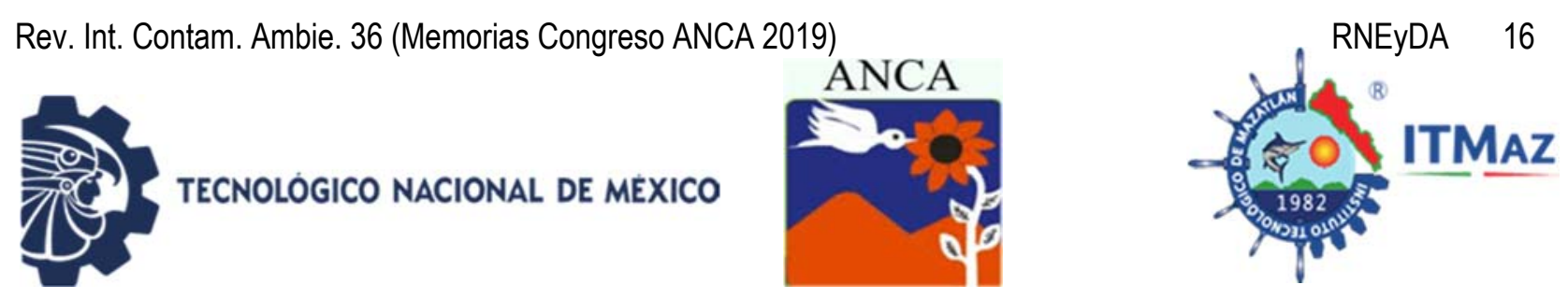

\title{
Ecosystem services of family orchards at south of the State of Mexico: A methodological proposal
}

\author{
Arcos Severo $\mathrm{M}^{1 *}$, Gutiérrez Cedillo $\mathrm{JG}^{2}$, Balderas Plata $\mathrm{MÁ}^{2}$, \\ Martínez García $\mathrm{CG}^{3}$ \\ ${ }^{1}$ Facultad de Química. Universidad Autónoma del Estado de México \\ ${ }^{2}$ Facultad de Geografía. UAEMex \\ ${ }^{3}$ Instituto de Ciencias Agropecuarias y Rurales (ICAR). UAEMex \\ *min.arcos@hotmail.com
}

\begin{abstract}
Family gardens are one of the main livelihoods for rural families, which is why they have been widely studied, however, the contributions are in relation to floristic, botanical, ethnobotanical and agroecological works mainly and with scarce Approaches in relation to methodological approaches. Thus, the objective of this paper is to present a methodological proposal to analyze ecosystem services (SE) of agroecosystems of family gardens (AEHF), in the south of the state of Mexico. The proposal has its methodological foundations in the integral geographic planning (PGI), the ethnographic method, the SWOT analysis and the logical framework approach (LME). Based on these methods and methodologies, the analysis of the ecosystem services of AEHF was raised from its components: social; cultural; environmental; and economic. Which for their better understanding were divided into five methodological stages. 1) SE analysis of importance social and cultural; 2) identification of the SEs for regulation and support; 3) analysis of the SEs for provision and their economic valuation; 4) analysis of the implications that the SE of AEHF has on the well-being of rural families, and; 5) the rationale and Integration of the methodological proposal. This analysis will allow to approach the complexity of HF agroecosystems, under the ecosystem services approach, allowing to create sustainable management strategies with emphasis on the conservation of the natural resources of the AEHF.
\end{abstract}

Keywords: Ecosystem services, agroecosystems, family gardens, complex systems, rural families.

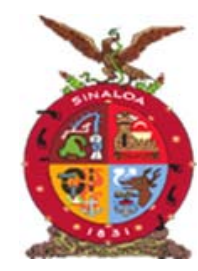

XVIII Congreso Internacional XXIV Congreso Nacional de Ciencias ambientales
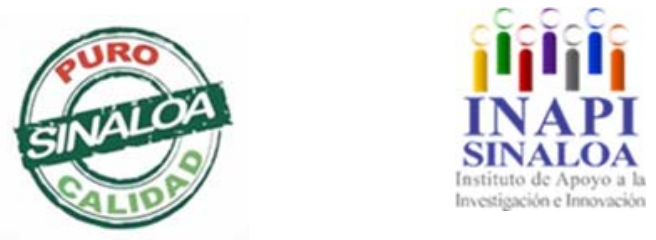

Mazatlán, Sinaloa 3-7 junio 2019

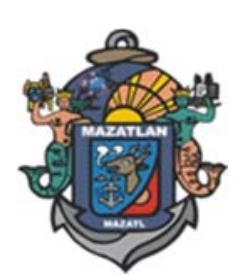

Recursos Naturales, Ecosistemas y Deterioro Ambiental 

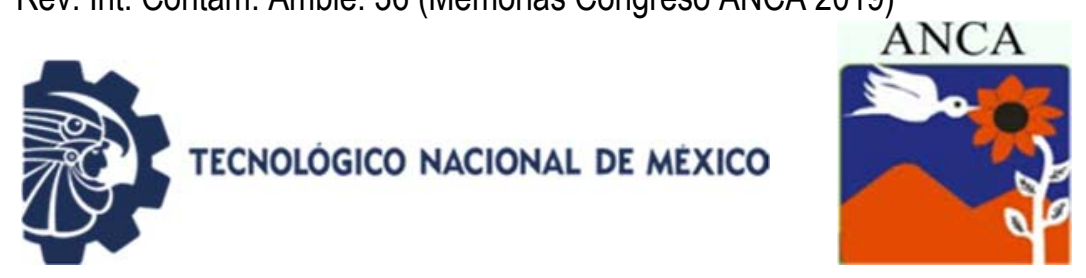

\title{
Captura de carbono en suelo de huertos frutícolas, Yautepec, Morelos, México
}

\author{
Bahena Galindo ME, Oliver Guadarrama R, Gómez Mesino J \\ Laboratorio de Edafoclimatología. Departamento de Biología Vegetal. \\ Centro de Investigaciones Biológicas. UAEMorelos. México \\ *olivergr@uaem.mx
}

\section{RESUMEN}

Se ha determinado que el $\mathrm{CO}_{2}$ es el principal generador del efecto Invernadero, por las grandes cantidades en las que se emite por actividades antropogénicas principalmente. La vegetación tiene la capacidad de asimilar el carbono e incorporarlo a su estructura, es decir, lo fija y lo mantiene almacenado por largos periodos lo cual es una forma de reducir la cantidad de carbono en la atmósfera y mitigar sus efectos negativos, almacenándolo en la biomasa (arriba del suelo), mediante la fotosíntesis; y en el suelo, a través de la acumulación de materia orgánica. Por esta razón el secuestro de carbono aparece como una propuesta que intenta disminuir las actuales tasas de liberación de $\mathrm{CO}_{2}$ en la atmósfera, pero la deforestación tan alta resulta un obstáculo que la limita, en este sentido la captación de carbono por huertos de traspatio resulta una alternativa viable a nivel local. La metodología utilizada en este proyecto fue el método estándar para el análisis químico de carbono en suelo por medio de combustión seca, el estudio fue enfocado únicamente al estudio de la parte subterránea de huertos de traspatio. El promedio de carbono mineral oscila entre 43.96 (huerto 1) y 76.34 (huerto 4). Para el caso del carbono en raíz el huerto 5 (1.00) captó una menor cantidad de carbono comparado con el huerto 4 (9.41). Los resultados muestran que el huerto 1 captó la menor cantidad de carbono total con 44.98 a diferencia del huerto 4 el cual captó una mayor cantidad con 85.75. Los valores obtenidos en este estudio van de 44.98 a 85.75 comparado con el estudio realizado por Acosta et al. 2001 en cultivos mixtos (frutales y anuales) con cantidades totales de carbono que van de 63.08 a 77.59 y permanentes (praderas, café y árboles) oscilando de 76.58 a 80.18; Lo cual demuestra que independientemente del tipo de cultivo que se maneje, el mayor aporte de carbono lo realiza la parte mineral (suelo). Es importante mencionar que la profundidad del muestreo se realizó a 30 $\mathrm{cm}$ de profundidad coincidiendo con la metodología usada por Acosta. Se concluyó que los huertos con menos cantidad de especies fueron también los que contenían mayores cantidades de carbono.

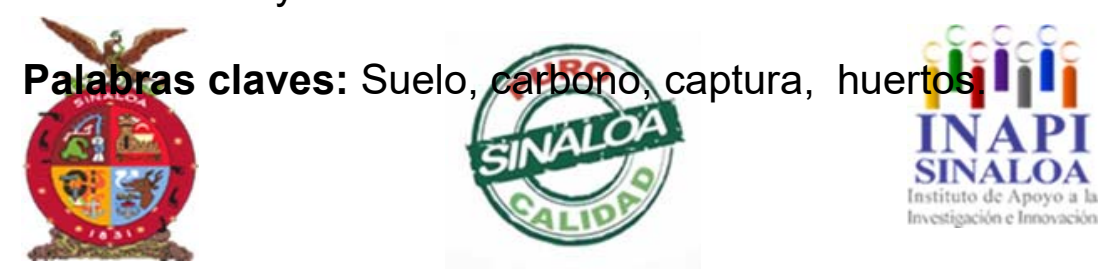

XVIII Congreso Internacional XXIV Congreso Nacional de Ciencias ambientales

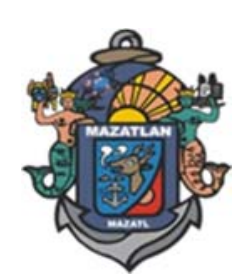

Recursos Naturales, Ecosistemas y Deterioro Ambiental 

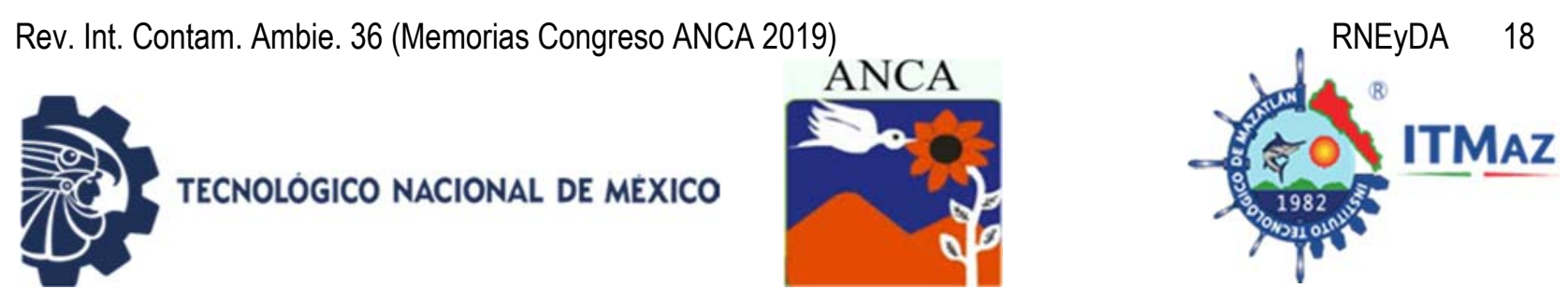

\title{
Partly underground carbon capture in soil of fruit orchards, Yautepec, Morelos, Mexico
}

\author{
Bahena Galindo ME, Oliver Guadarrama R*, Gómez Mesino J \\ Laboratorio de Edafoclimatología. Departamento de Biología Vegetal. \\ Centro de Investigaciones Biológicas. UAEMorelos. México \\ *olivergr@uaem.mx
}

\begin{abstract}
It has been determined that $\mathrm{CO}_{2}$ is the main Generator of Greenhouse Effect, due to the large quantities in which it is emitted mainly through anthropogenic activities. Vegetation has the ability to assimilate carbon and incorporate it into its structure. That is, it fixes it and keeps it stored for long periods of time, which is a way to reduce the amount of carbon in the atmosphere and mitigate its negative effects, storing it in the biomass (above ground), through photosynthesis; and in the soil, through the accumulation of organic matter. For this reason carbon sequestration appears as a proposal that attempts to reduce the current rates of $\mathrm{CO}_{2}$ release in the atmosphere, but such high deforestation is an obstacle that limits it, in this sense the carbon sequestration through backyard orchards is a viable alternative at the local level. The methodology used in this project was the standard method for the chemical analysis of carbon in soil through dry combustion, the study was focused only on the study of the underground part of backyard orchards. The average mineral carbon ranges between 43.96 (garden 1) and 76.34 (garden 4). In the case of the root carbon, garden 5 (1.00) captured a smaller amount of carbon compared to garden 4 (9.41). The results show that garden 1 captured the lowest amount of total carbon with 44.98 as opposed to garden 4 which captured a greater amount with 85.75 . The values obtained in this study range from 44.98 to 85.75 . Compared to the study conducted in mixed crops (fruit and annual) with total amounts of carbon ranging from 63.08 to 77.59 and permanent (grasslands, coffee and trees) ranging from 76.58 to 80.18 . Which shows that regardless of the type of crop that is managed, the greatest contribution of carbon is made by the mineral part (soil). It is important to mention that the depth of sampling was performed at $30 \mathrm{~cm}$ depth coinciding with the methodology used by Acosta. It was concluded that the orchards with the least amount of species were also those that contained the highest amounts of carbon.
\end{abstract}

Keywords: Soil, carbon, capture, orchards.

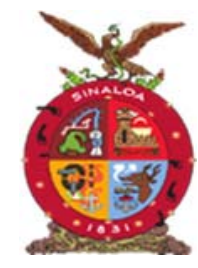

XVIII Congreso Internacional

XXIV Congreso Nacional de Ciencias ambientales
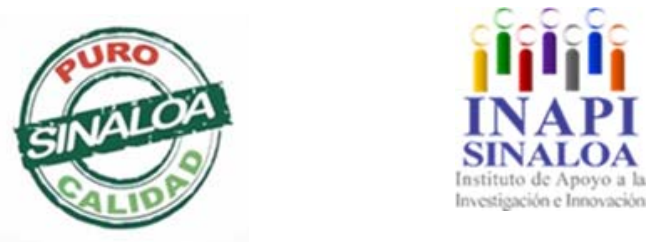

Mazatlán, Sinaloa 3-7 junio 2019

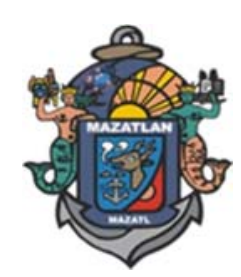

Recursos Naturales, Ecosistemas y Deterioro Ambiental 

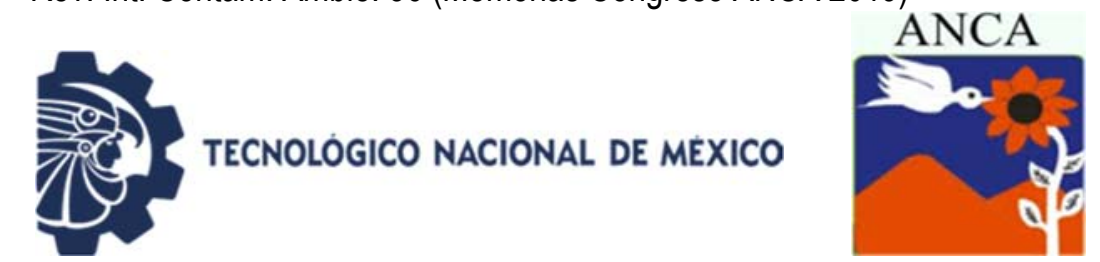

\title{
Restitución de flora en un humedal sostenido por agua residual tratada en la cuenca Los Alisos
}

\author{
Barragán Peña P, Bonillas García G, Benítez Paz RF, Segovia Torres R \\ Instituto Tecnológico de Nogales. Tecnológico Nacional de México. México \\ eudiar7@gmail.com
}

\section{RESUMEN}

Previa caracterización del suelo y del agua, se construyó un sistema para promover infiltración y sostener flora nativa seleccionada tanto en las orillas de tres canales como en un estanque; esta agua proviene de un tratamiento secundario de una planta cercana. El sitio de estudio está ubicado en las coordenadas $31^{\circ} 07^{\prime} 53^{\prime \prime} \mathrm{N}, 110^{\circ} 56^{\prime} 12.23^{\prime \prime} \mathrm{O}$ al sur de Nogales, Sonora; y se extiende por 1.5 ha de terreno. Especies polinizadoras han poblado el sitio, mientras que la mariposa Monarca es una vista prometedora del potencial del humedal.

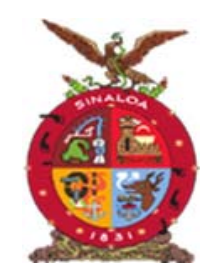

XVIII Congreso Internacional

XXIV Congreso Nacional de Ciencias ambientales
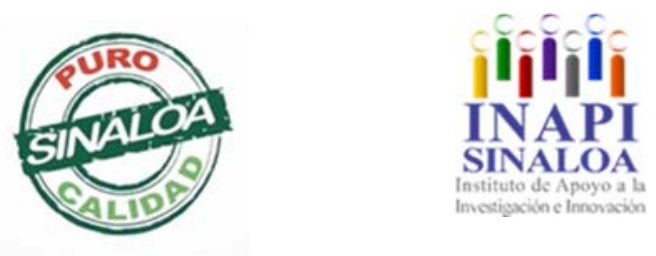

Mazatlán, Sinaloa 3-7 junio 2019

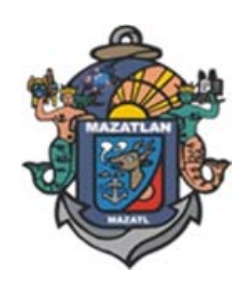

Recursos Naturales, Ecosistemas y Deterioro Ambiental 

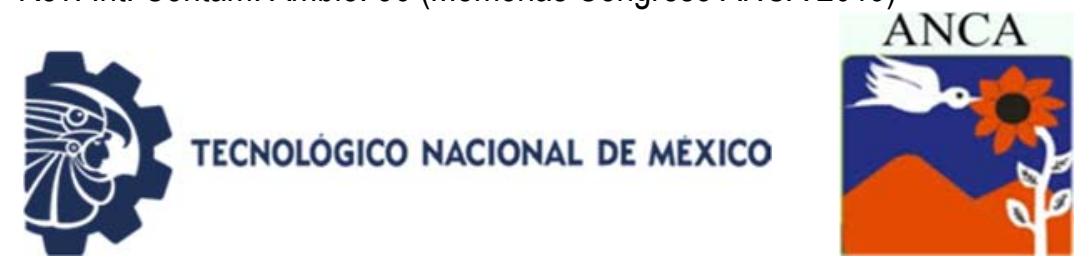

\title{
Restitution of flora in a wetland sustained by residual water treated in the Los Alisos basin
}

\author{
Barragán Peña P, Bonillas García G, Benítez Paz RF, Segovia Torres R \\ Instituto Tecnológico de Nogales. Tecnológico Nacional de México. México \\ eudiar7@gmail.com
}

\begin{abstract}
After soil and water characterization, a system was built to promote water infiltration, support selected native flora both along three channels, and in a pond; this water supply comes from a tertiary treatment in a nearby plant. The site of research is located south to Nogales, Sonora, with $31^{\circ} 07^{\prime} 53^{\prime \prime} \mathrm{N}, 110^{\circ} 56^{\prime} 12.23^{\prime \prime}$ W as coordinates; it covers 1.5 ha of land. Pollination species have populated the site whereas Monarch butterflies are a promising view of the wetland potential.
\end{abstract}

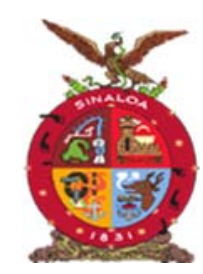

XVIII Congreso Internacional XXIV Congreso Nacional de Ciencias ambientales
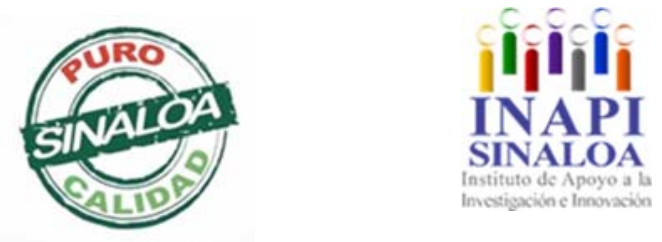

Mazatlán, Sinaloa 3-7 junio 2019

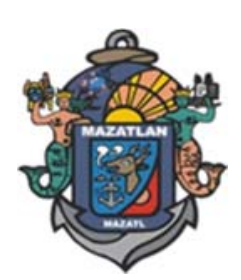

Recursos Naturales, Ecosistemas y Deterioro Ambiental 

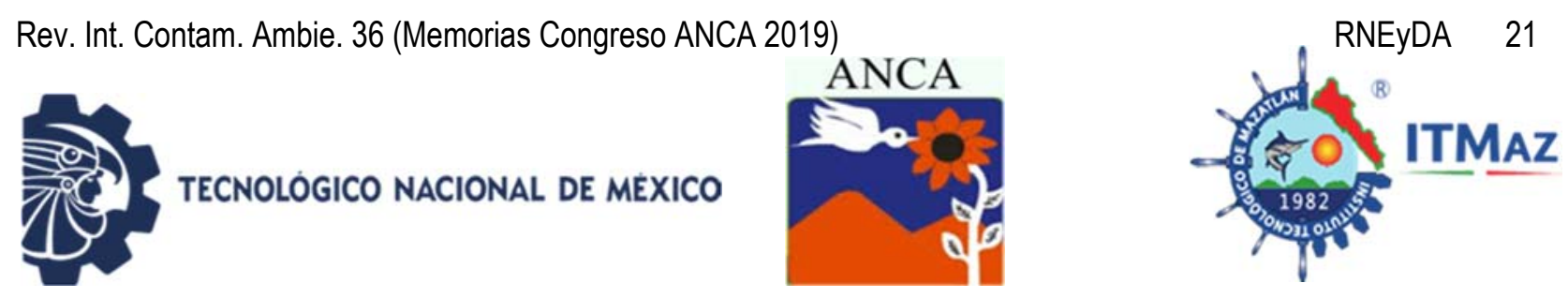

Análisis de la estructura poblacional y potencial regenerativo de Abies
religiosa en el Santuario del Agua "Corral de Piedra", Estado de México

\author{
Benítez Pineda $\mathrm{C}^{1}$, Zepeda Gómez $\mathrm{C}^{1 *}$, Burrola Aguilar $\mathrm{C}^{2}$, \\ Sánchez Sánchez $\mathrm{H}^{2}$, Estrada Zúñiga $\mathrm{ME}^{2}$ \\ ${ }^{1}$ Facultad de Ciencias. Universidad Autónoma del Estado de México \\ ${ }^{2}$ Centro de Investigación en Recursos Bióticos. UAEMex \\ *zepedacar@yahoo.com.mx
}

\title{
RESUMEN
}

El bosque de oyamel (Abies religiosa) se desarrolla a lo largo de la zona ecológica subhúmeda templada de México, es un ecosistema frágil e importante para la recarga de los mantos acuíferos. El análisis de la distribución de los organismos de especies arbóreas permite conocer su estado de conservación y es útil para poder predecir su viabilidad a futuro, sobre todo en poblaciones de interés forestal. Este estudio investiga la estructura y regeneración de la población de $A$. religiosa del Santuario de Agua Presa Corral de Piedra, en el centro de México. De mayo a agosto del 2016, se establecieron 20 unidades de muestreo de 200 $\mathrm{m}^{2}$ cada uno, en los cuales se contó y midió la altura, cobertura de copa y DAP de todas las plantas de oyamel. Se realizó un análisis de la distribución de frecuencias de la altura y el DAP. Los datos incluyen cerca de 560 individuos con una densidad total de 2472.36 individuos/ha, los organismos con DAP $\leq 5 \mathrm{~cm}$ (brinzales) presentaron la mayor densidad (1031.57 individuos/ha). El análisis de frecuencias revelo que la distribución de alturas y DAP de la población tiene una curva en forma de "J" invertida, los organismos con DAP $<15 \mathrm{~cm}$ constituyeron el $85.5 \%$ de la población. Se observa la presencia de al menos tres estratos, que junto con los datos de densidad sugieren que la población analizada está conformando un bosque primario consolidado, relativamente conservado y con un alto potencial regenerativo debido a la alta densidad de plántulas.

Palabras clave: Oyamel, regeneración, estratos, organización espacial, plántulas.

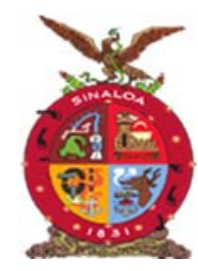

XVIII Congreso Internacional XXIV Congreso Nacional de Ciencias ambientales
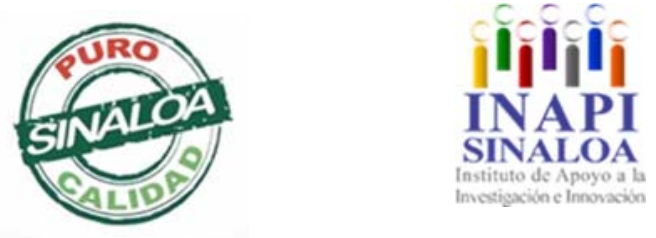

Mazatlán, Sinaloa 3-7 junio 2019

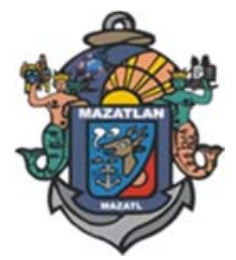

Recursos Naturales, Ecosistemas y Deterioro Ambiental 

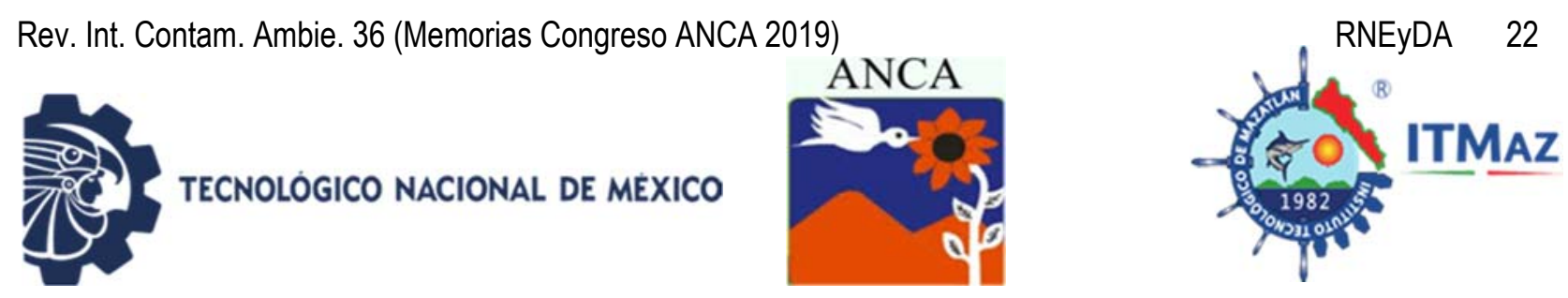

\title{
Structure and regenerative potential analysis of Abies religiosa population in the Santuario del Agua "Corral de Piedra", State of Mexico
}

\author{
Benítez Pineda $\mathrm{C}^{1}$, Zepeda Gómez $\mathrm{C}^{1^{*}}$, Burrola Aguilar $\mathrm{C}^{2}$, \\ Sánchez Sánchez $\mathrm{H}^{2}$, Estrada Zúñiga $\mathrm{ME}^{2}$ \\ ${ }^{1}$ Facultad de Ciencias. Universidad Autónoma del Estado de México \\ ${ }^{2}$ Centro de Investigación en Recursos Bióticos. UAEMex \\ *zepedacar@yahoo.com.mx
}

\begin{abstract}
The fir forest (Abies religiosa) in Mexico is developed along the temperate subhumid ecological zone, it is a fragile and important ecosystem for the recharge of aquifers. The distribution analysis of trees species allows to know their conservation status and it is useful to predict their viability in the future, especially in populations of forestry interest. This study investigates the structure and regeneration of the $A$. religiosa population of Water Sanctuary Corral de Piedra, in central Mexico. From May to August 2016, 20 sampling units of $200 \mathrm{~m}^{2}$ each were established, in each the height, canopy cover and DBH of all the oyamel plants were counted and measured. An analysis of the frequency distribution of the height and the DAP was made. The data included about 560 individuals with a total density of 2472.36 individuals / ha, organisms with $\mathrm{DBH} \leq 5 \mathrm{~cm}$ (saplings) had the highest density (1031.57 individuals / ha). The frequency analysis revealed that the distribution of height and $\mathrm{DBH}$ of the population has an inverted "J" curve, the organisms with $\mathrm{DBH}<15 \mathrm{~cm}$ constituted $85.5 \%$ of the population. The presence of at least three strata is observed, which together with the density data suggest that the analyzed population is forming a consolidated and relatively conserved primary forest with a high regenerative potential due to the high density of seedlings.
\end{abstract}

Keywords: Fir, regeneration, strata, spatial organization, seedlings.

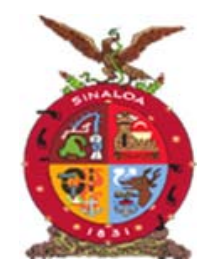

XVIII Congreso Internacional XXIV Congreso Nacional de Ciencias ambientales
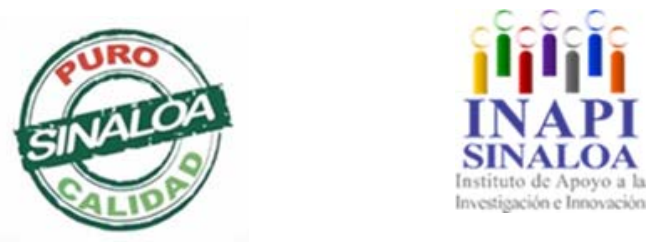

Mazatlán, Sinaloa 3-7 junio 2019

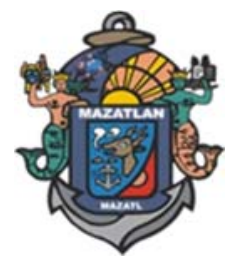

Recursos Naturales, Ecosistemas y Deterioro Ambiental 

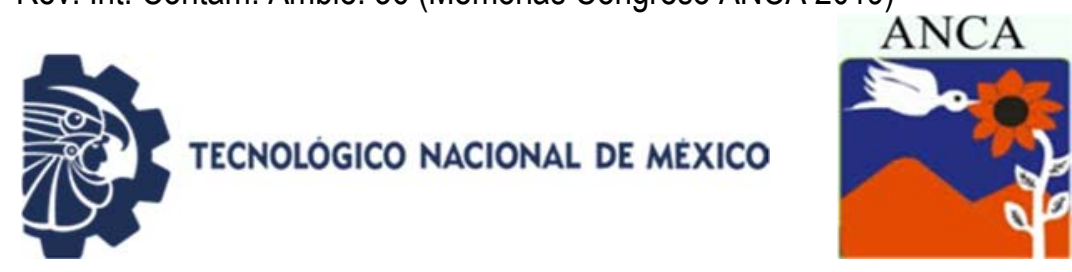

\title{
Propuesta de zonificación ambiental de la microcuenca La Chichaca municipio de Aguazul-Casanare
}

\author{
Cáceres $\mathrm{RK}^{1^{\star}}$, Narváez Ortiz I², Parra Rodríguez $\mathrm{N}^{1}$ \\ ${ }^{1}$ Profesional en Ingeniería Agroforestal. \\ Fundación Universitaria Internacional del Trópico Americano \\ 2Universidad Autónoma de Chapingo. México \\ *karenlica@gmail.com
}

\begin{abstract}
RESUMEN
Esta investigación se desarrolló en la microcuenca La Chichaca exactamente en el sector del municipio de Aguazul-Casanare, Colombia en el periodo de agosto a junio del 2018. La investigación tiene como finalidad realizar una zonificación ambiental en la que se identifiquen ecosistemas estratégicos o áreas geográficas sensibles a cambios y daños ocasionados por la población, ubicada dentro de la microcuenca, además de eventos naturales y condiciones biofísicas relevantes, reconociendo el servicio ecosistémicos que presta la microcuenca, para tal fin se realizara un análisis socioeconómico, y un análisis de información geográfica apoyada de los SIG, de esta manera se generaron mapas de clima predominante, pendientes, erosión, hidrografía, rondas protectoras, uso actual y potencial del suelo, estos criterios se analizaron mediante la construcción de cartografía especifica del área de la microcuenca. Finalmente se aplica una encuesta que busca eliminar la subjetividad, ante la decisión de jerarquizar los anteriores criterios y su influencia en un territorio para la conservación, mediante el uso de la metodología de comparación por pares de Saaty, con la técnica de aproximación por punto ideal obtuvimos una clasificación de niveles de importancia que permitió asignar adecuadamente y según la necesidad un área importante dentro de la zonificación. Como resultado se obtuvo un mapa de zonificación ambiental con un diagnóstico cercano a la situaciónactual y de la tendencial en la zona, luego de hacer el análisis de los mapas generados para los criterios siendo estos traslapados y analizados por medio del SIG.
\end{abstract}

Palabras claves: Microcuenca hidrográfica, zonificación ambiental, SIG, ordenamiento territorial, mapa.

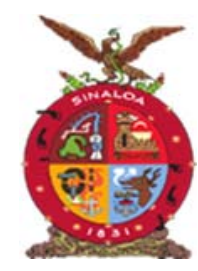

XVIII Congreso Internacional

XXIV Congreso Nacional de Ciencias ambientales
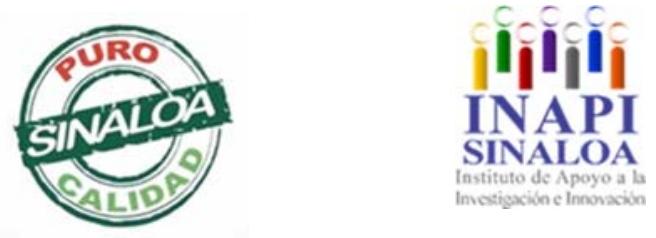

Mazatlán, Sinaloa 3-7 junio 2019

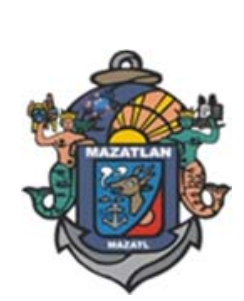



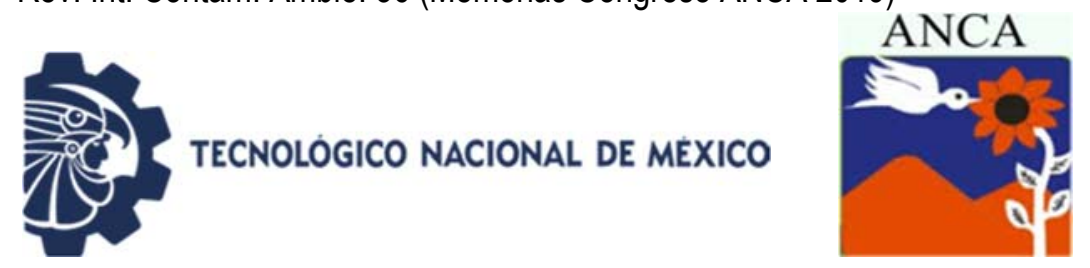

\title{
Environmental zoning proposal for the La Chichaca microbasin municipality of Aguazul-Casanare
}

\author{
Cáceres $\mathrm{RK}^{1^{*}}$, Narváez Ortiz $\mathrm{I}^{2}$, Parra Rodríguez $\mathrm{N}^{1}$ \\ ${ }^{1}$ Profesional en Ingeniería Agroforestal. \\ Fundación Universitaria Internacional del Trópico Americano \\ 2Universidad Autónoma de Chapingo. México \\ *karenlica@gmail.com
}

\begin{abstract}
This research was developed in the La Chichaca microbasin, exactly in the sector of the municipality of Aguazul-Casanare, Colombia, from August to June 2018. The research aims to perform an environmental zoning, in which strategic ecosystems or geographical areas sensitive to changes and damages caused by the population, located within the micro-basin, are identified. In addition to natural events, and relevant biophysical conditions, recognizing the ecosystem service that provides the microbasin, for this purpose a socio-economic analysis will be carried out, and an analysis of geographic information supported by GIS. This will generate maps of prevailing climate, slopes, erosion, hydrography, protective rounds, current use and potential of the soil, these The criteria were analyzed through the construction of specific cartography of the micro-watershed area. Finally, a survey is applied that seeks to eliminate subjectivity, before the decision, to prioritize the previous criteria and their influence in a territory for conservation. By using the methodology of comparison by pairs of Saaty, with the technique of approximation by ideal point we obtained a classification of levels of importance that allowed us to appropriately allocate an important area within the zoning according to need. As a result, an environmental zoning map was obtained with a diagnosis close to the current situation and the trend in the area, after making the analysis of the generated maps for the criteria being overlapped and analyzed by means of the GIS.
\end{abstract}

Keywords: Hydrographic watershed, environmental zoning, GIS, territorial ordering, map.

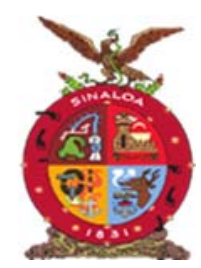

XVIII Congreso Internacional XXIV Congreso Nacional de Ciencias ambientales
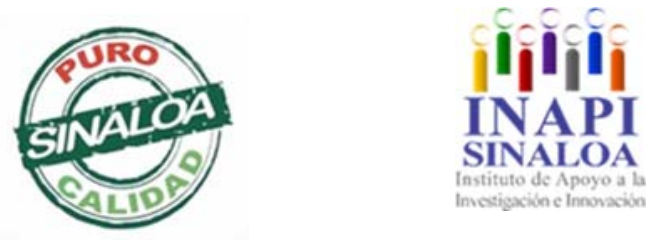

Mazatlán, Sinaloa 3-7 junio 2019

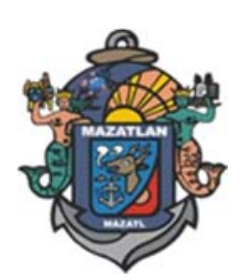

Recursos Naturales, Ecosistemas y Deterioro Ambiental 

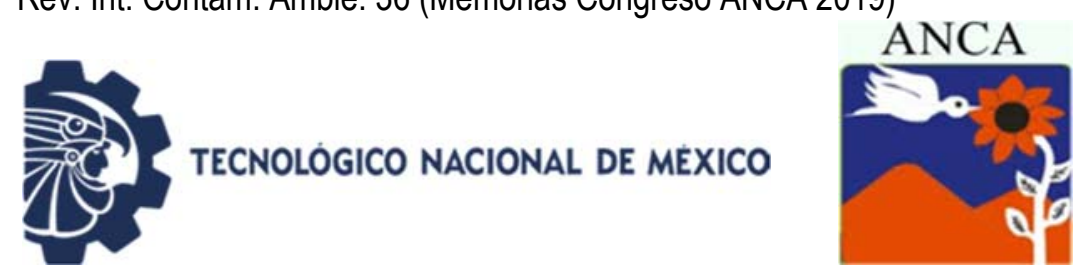

\title{
Calidad de suelos en climas semiáridos estudio de actividades enzimáticas
}

\author{
Campaña $\mathrm{H}^{1 *}$, Conde Barajas $\mathrm{E}^{2}$, Monserrat $\mathrm{V}^{1}$, Uribe Etchevarría $\mathrm{M}^{1}$ \\ ${ }^{1}$ Grupo de Estudio Ambiente Química y Biología. \\ Facultad Regional Bahía Blanca. Universidad Tecnológica Nacional \\ ${ }^{2}$ Tecnológico Nacional de México en Celaya. Guanajuato, México \\ *hcampana@frbb.utn.edu.ar
}

\section{RESUMEN}

La expansión de la agricultura requiere evaluar la sostenibilidad de la gestión de suelos, para ello, la aplicación de enmiendas orgánicas es una herramienta apropiada para mejorar la fertilidad, especialmente en áreas marginales $\mathrm{y} / \mathrm{o}$ climas semiáridos. Entre los indicadores físicos en suelos destacan: humedad, porosidad y densidad, en los químicos: $\mathrm{C}$ y $\mathrm{N}$ total, nutrientes, $\mathrm{MO}$ y $\mathrm{CIC}$. Las propiedades bioquímicas se utilizan como indicadores de calidad, pero todavía no hay consenso en su interpretación. El objetivo de este trabajo fue revisar el "estado del arte" de los indicadores bioquímicos y estudiar las actividades enzimáticas en suelos (Molisoles-Argiustol típico) del sudoeste de Buenos Aires (Argentina). Se implementaron ensayos de carácter exploratorio durante 3 meses de 2017 en suelos con biosólidos agroindustriales (con y sin estabilización, sin crecimiento de vegetales, en macetas con 2,6 kg de suelo con enmienda equivalente a $5 \mathrm{Tn}$ MS de biosólidos/ha. Las experiencias a escala macrocosmos con urea (mismo suelo utilizado en macetas, 3 meses durante el 2018, con 40,60, $100 \mathrm{~kg}$ urea/ha. Las actividades enzimáticas en suelos enmendados y fertilizados con respecto al suelo control escala micro fueron entre 5 y $15 \%$ mayores para el caso de la betaglucosidasa, entre 25 y $250 \%$ mayores para la ureasa (escala macro). La deshidrogenasa mostró un comportamiento similar a la ureasa y la betaglucosidasa para la experiencia en campo, en cambio la fosfatasa no arrojó diferencias entre ensayo macetas. Los resultados obtenidos permiten concluir que, para cuantificar la calidad de los suelos, las actividades enzimáticas deberían complementarse con información de otras propiedades físicas, químicas y bioquímicas.

Palabras claves: Actividades enzimáticas, indicadores bioquímicos, calidad de suelos, enmienda de suelos, suelos semiáridos.

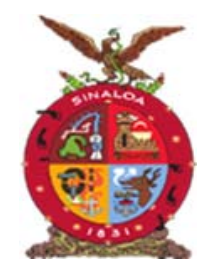

XVIII Congreso Internacional

XXIV Congreso Nacional de Ciencias ambientales
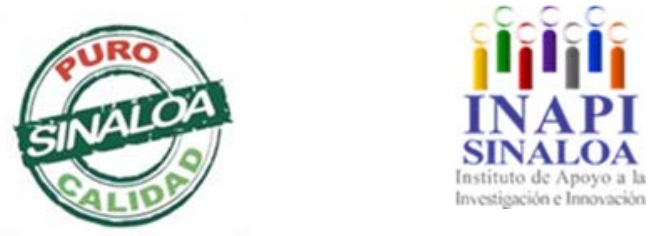

Mazatlán, Sinaloa 3-7 junio 2019

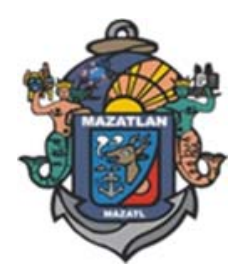

Recursos Naturales, Ecosistemas y Deterioro Ambiental 

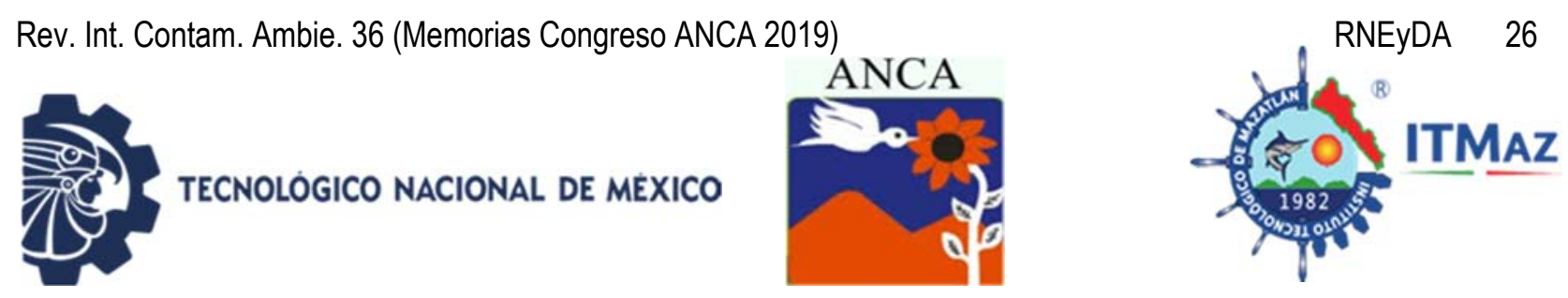

\title{
Semiarid environments soil quality enzymatic activities studies
}

\author{
Campaña $\mathrm{H}^{1 *}$, Conde Barajas $\mathrm{E}^{2}$, Monserrat $\mathrm{V}^{1}$, Uribe Etchevarría $\mathrm{M}^{1}$ \\ ${ }^{1}$ Grupo de Estudio Ambiente Química y Biología. \\ Facultad Regional Bahía Blanca. Universidad Tecnológica Nacional \\ ${ }^{2}$ Tecnológico Nacional de México en Celaya. Guanajuato, México \\ *hcampana@frbb.utn.edu.ar
}

\begin{abstract}
The expansion of agriculture make it necessary to evaluate sustainable management of soils. Application of organic amendments is considered a suitable tool for improving soil fertility, few studies have been conducted in semiarid climates. Among the physical indicators, moisture, porosity, and bulk density have been used, while among chemical indicators total $\mathrm{C}$ and $\mathrm{N}$, mineral nutrients, organic matter, cation exchange capacity. Soil biochemical properties are indicators of soil quality, but there is still no consensus as to how they should be used. The aims of thiswork were literature review of biochemical indicators and to studied enzymatic activities to assess soil quality south west of Buenos Aires State (Argentina) Mollisols (Typic Argiustol). Therefore, were implemented exploratories tests (2017) studying effect of amendment (agroindustrial biosolids with and without stabilization without vegetable grow) and synthetic fertilization on soil enzymatics activities. Experiments were: microcosm scale (greenhouse pots) $2,6 \mathrm{~kg}$ soil with organic amendment equivalent to $5 \mathrm{Tn} \mathrm{DM} / \mathrm{ha}$ and macrocosm scale with urea (same soil but plot experience 3 months 2018-with 40,60, $100 \mathrm{~kg}$ urea/ha). Enzymatic activities in amended and fertilized soils with respect to control soils (greenhouse pots) were between 5 and $>15 \%$ higher for bglucosidase. Between 25 and $250 \%$ higher for urease at plot experiments. Deshydrogenase, showed same trend urease and betaglucosidase (macrocosm). Fosfatases did not show differences (microcosm test). It is concluded that quantification of soil quality should require that enzymes activities be complemented with information other physical, chemical and biochemical soil properties.
\end{abstract}

Keywords: Enzymatic activities, biochemical indicator, soil quality, soil amendments, semiarid soils.

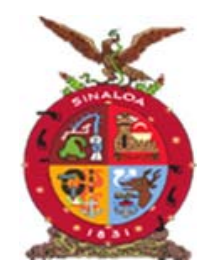

XVIII Congreso Internacional

XXIV Congreso Nacional de Ciencias ambientales
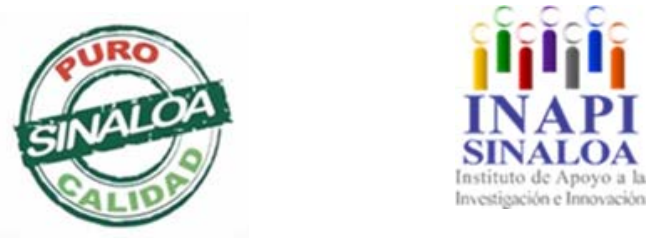

Mazatlán, Sinaloa 3-7 junio 2019

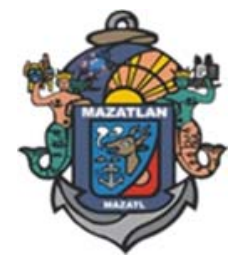

Recursos Naturales, Ecosistemas y Deterioro Ambiental 

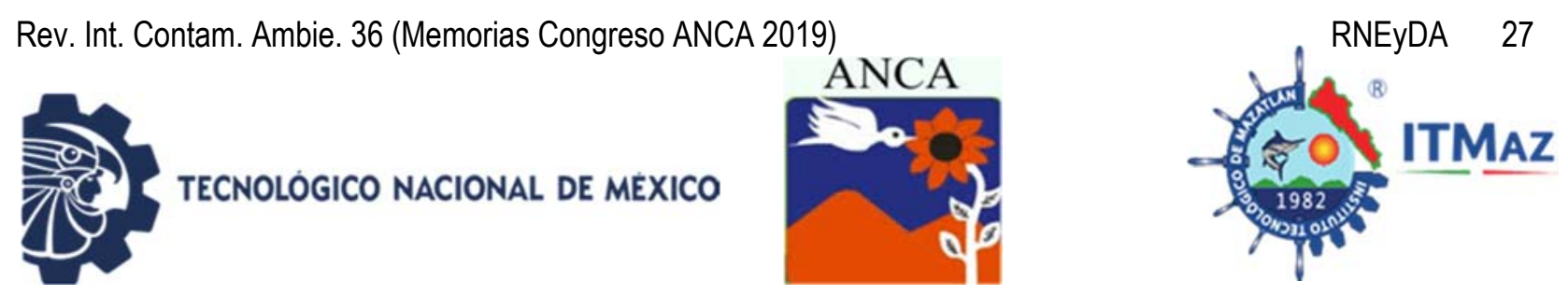

\section{Formulación de un repelente natural}

Casas Huerta E, Jiménez Vargas P, Linares Salazar D, Velázquez Olalde B, Osornio Rubio R $^{*}$

Departamento de Ingeniería Ambiental. Instituto Tecnológico de Celaya. Tecnológico Nacional de México. Guanajuato, México

*nadia.osornio@itcelaya.edu.mx

\section{RESUMEN}

El efecto de los insecticidas y plaguicidas sobre la salud humana, animal y ambiental ha sido una preocupación de la comunidad científica. La OMS por medio de la FAO ha propuesto nuevas estrategias para el control de plagas y evitar los problemas causados por los insecticidas sintéticos. Con este proyecto se pretende continuar con los esfuerzos de la FAO para evitar la contaminación ambiental, y el desequilibrio sustentable mediante la formulación de un repelente a base de ajo. El repelente se obtuvo mediante la maceración de ajo y adición de otros agentes para potencializar el efecto repelente, bajo un diseño de experimentos multifuncional para la obtención de 4 formulaciones, teniendo como respuesta la erradicación en tiempo y cantidad de cucaracha Blattella germanica. Se realizaron análisis por FTIR para el estudio de cada formulación, identificando las variaciones más significativas en el cambio de intensidad en las vibraciones de los grupos O-H (2931 y $\left.1406 \mathrm{~cm}^{-1}\right), \mathrm{S}=\mathrm{O}\left(1130 \mathrm{~cm}^{-1}\right)$ y C-N $\left(1107 \mathrm{~cm}^{-1}\right)$, asociadas a la presencia de alicina. Para las pruebas se generaron sistemas por duplicado de 5 cajas interconectadas, cada una de ellas rociada con una formulación diferente y una caja sin repelente, en cada caja se colocaron números iguales individuos prueba, y se analizó cual fue el comportamiento de la población a través del sistema interconectado durante 30 días, identificando que la formulación 2 no presentó presencia de individuos en la caja, con reaplicaciones del repelente cada 10 días, por lo que tentativamente sería la formulación con mayor potencial.

Palabras clave: Repelente, alicina, contaminación ambiental.

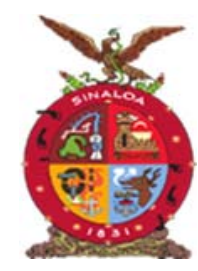

XVIII Congreso Internacional XXIV Congreso Nacional de Ciencias ambientales
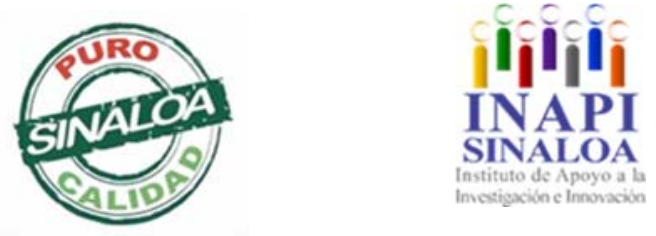

Mazatlán, Sinaloa 3-7 junio 2019

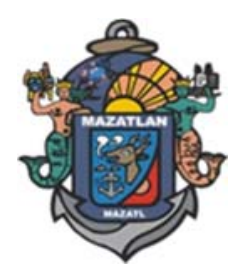

Recursos Naturales, Ecosistemas y Deterioro Ambiental 

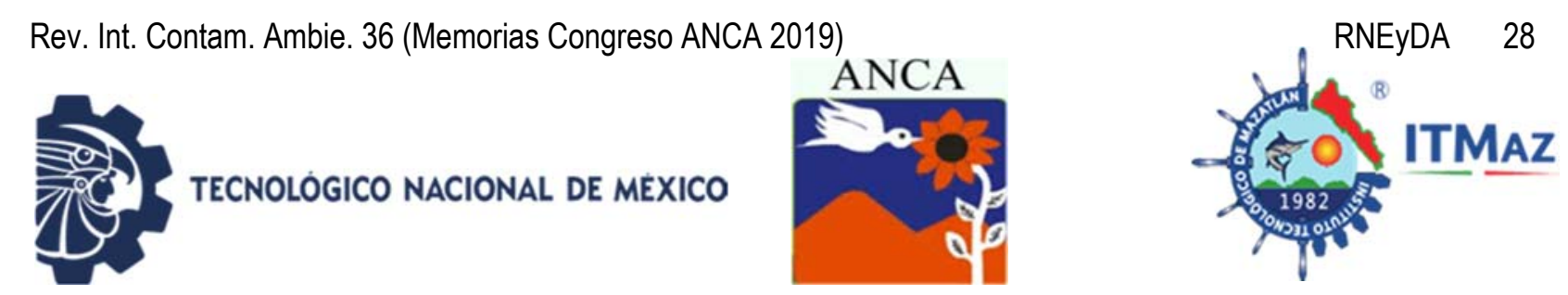

\title{
Formulation of a natural repellent
}

Casas Huerta E, Jiménez Vargas P, Linares Salazar D, Velázquez Olalde B, *Osornio Rubio R

Departamento de Ingeniería Ambiental. Instituto Tecnológico de Celaya. Tecnológico Nacional de México. Guanajuato, México

*nadia.osornio@itcelaya.edu.mx

\begin{abstract}
The effect of insecticides and pesticides on human, animal and environmental health has been a concern of the scientific community. WHO through FAO has proposed new strategies for pest control and avoiding problems caused by synthetic insecticides. This project aims to continue FAO's efforts to avoid environmental pollution, and sustainable imbalance by formulating a garlic-based repellent. The repellent was obtained by mashing garlic and adding other agents to potentiate the repellent effect, under a design of multifunctional experiments to obtain 4 formulations, having as response the eradication in time and quantity of cockroach Blattella germanica. FTIR analyzes were performed to study each formulation, identifying the most significant variations in the intensity change in the vibrations of the $\mathrm{OH}$ groups (2931 and $\left.1406 \mathrm{~cm}^{-1}\right), \mathrm{S}=\mathrm{O}\left(1130 \mathrm{~cm}^{-1}\right)$ and $\mathrm{CN}$ $\left(1107 \mathrm{~cm}^{-1}\right)$, associated with the presence of allicin. For the tests, duplicate systems of 5 interconnected boxes were generated. Each one sprayed with a different formulation and a box without repellent. In each box equal numbers were placed test individuals, and the population's behavior was analyzed through of the interconnected system for 30 days, identifying that formulation 2 did not present the presence of individuals in the box, with reapplications of the repellent every 10 days, so tentatively it would be the formulation with the greatest potential.
\end{abstract}

Keywords: Repellent, allicin, environmental pollution.

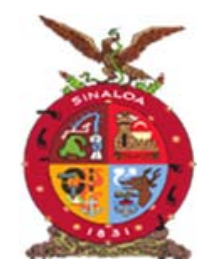

XVIII Congreso Internacional XXIV Congreso Nacional de Ciencias ambientales
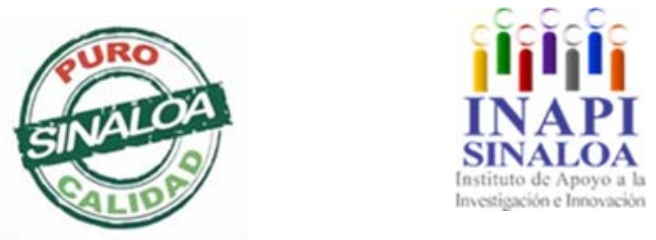

Mazatlán, Sinaloa 3-7 junio 2019

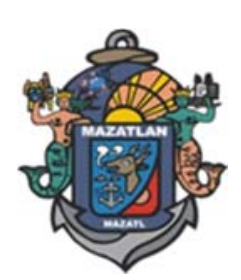

Recursos Naturales, Ecosistemas y Deterioro Ambiental 

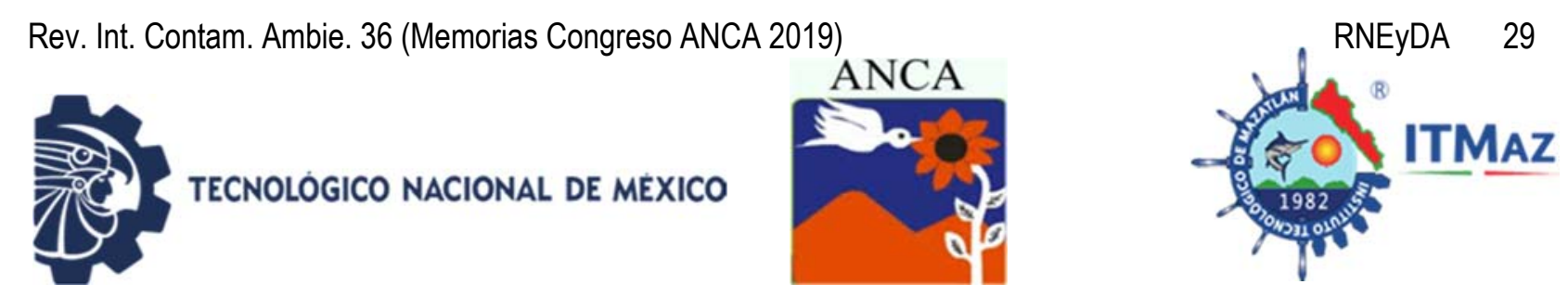

\title{
Impactos de la camaronicultura sobre los humedales costeros de Bahía Santa María-La Reforma, Sinaloa, México
}

\author{
Castellanos Tapia F*, Berlanga Robles CA \\ Centro de Investigación en Alimentación y Desarrollo A. C. \\ Coordinación Regional Mazatlán \\ *fernando.castellanos17@estudiantes.ciad.mx
}

\begin{abstract}
RESUMEN
Los humedales costeros son de los ecosistemas más vulnerables del planeta, siendo los cambios de cobertura y uso del suelo una de las causas principales de su pérdida. En este estudio se analizaron los cambios generados por la camaronicultura en la zona de humedales de la región de Laguna Playa Colorada-Santa María-La Reforma, localizada en el noroeste de México. A partir de la clasificación supervisada y fotointerpretación de imágenes de satélite Landsat se generaron mapas temáticos de la cobertura y uso del suelo de 1985, 1994, 2002 y 2017, en los cuales se estimaron las tendencias de cambio y se modelaron escenarios futuros (2027 y 2037) por medio de modelos estocásticos (cadenas de Márkov) y evaluaciones multicriterio. En tres décadas, la estanquería para cultivo de camarón, de estar ausente en la región, pasó a cubrir alrededor de 20000 ha, siendo las marismas (planicies de inundación mareal con sustrato no consolidado) el humedal más afectado, perdiendo un tercio de su cobertura en 1985 por cambios directos en el uso de suelo (marismacamaronicultura). De mantenerse esta tendencia, se estima que para el $2027 \mathrm{se}$ mantendrá un tercio de la extensión original de marismas y para 2037 sólo un cuarto.
\end{abstract}

Palabras clave: Humedales costeros, percepción remota, cambios de cobertura y uso del suelo, camaronicultura, cadenas de Markov.

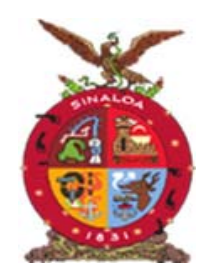

XVIII Congreso Internacional XXIV Congreso Nacional de Ciencias ambientales
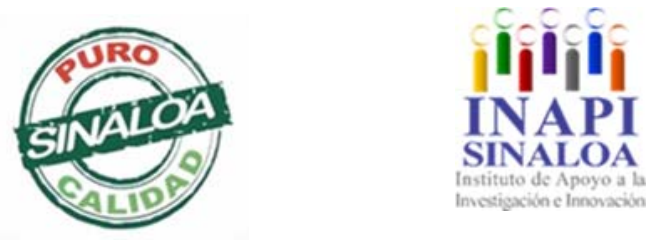

Mazatlán, Sinaloa 3-7 junio 2019

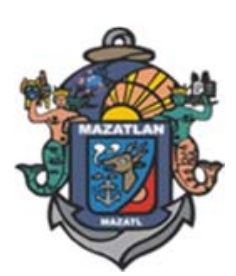

Recursos Naturales, Ecosistemas y Deterioro Ambiental 

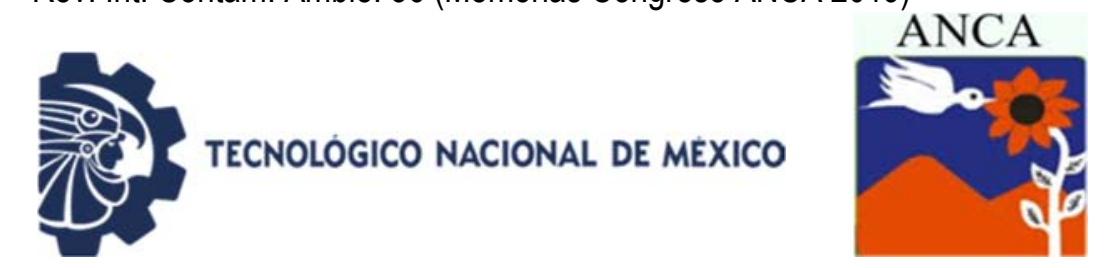

\title{
Shrimp farming impacts of on the coastal wetlands of Bahía Santa Maria-La Reforma, Sinaloa, Mexico
}

\author{
Castellanos Tapia F*, Berlanga Robles CA \\ Centro de Investigación en Alimentación y Desarrollo A. C. \\ Coordinación Regional Mazatlán \\ *fernando.castellanos17@estudiantes.ciad.mx
}

\begin{abstract}
Coastal wetlands are one of the most vulnerable ecosystems on the planet, with land cover and land use cover changes being one of the main causes of their loss. In this study, the changes generated by shrimp farming in the wetland area of the Laguna Playa Colorada-Santa Maria-La Reforma region, located in the Northwestern of Mexico, were analysed. From the supervised classification and photointerpretation of Landsat satellite images, land cover and land use thematic maps of 1985, 1994, 2002 and 2017 were edited, which the trend changes were estimated, and future scenarios were modelled (2027 and 2037) with stochastic models (Markov chains) and multicriteria evaluations. In three decades, the shrimp farm, to be absent in the region, went on to cover around 20000 ha, with the saltmarsh (tidal floodplains with unconsolidated soil) the most affected wetland, losing one third of its coverage in 1985 due to direct changes in land use (saltmarsh-shrimp farming). If this trend continues, it is estimated that by 2027 one third of the original saltmarsh area will remain and by 2037 only one quarter.
\end{abstract}

Keywords: Coastal wetlands, remote sensing, land coverage and land use changes, shrimp culture, Markov chains.

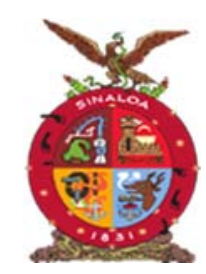

XVIII Congreso Internacional

XXIV Congreso Nacional de Ciencias ambientales
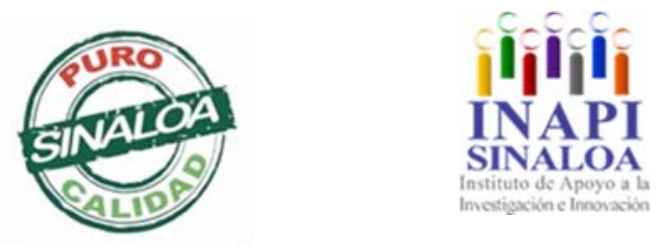

Mazatlán, Sinaloa 3-7 junio 2019

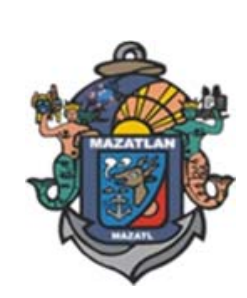

Recursos Naturales, Ecosistemas y Deterioro Ambiental 

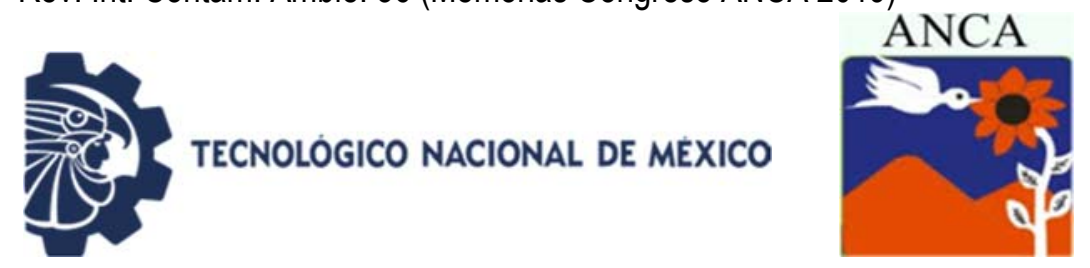

\title{
Recuperación de cubierta vegetal y control de erosión por medio de técnicas de bioingeniería con Agave salmiana y Opuntia robusta
}

\author{
Cerrillos Valle G*, García Amador EM, De la Rosa Mera CJ \\ Laboratorio de Fitorremediación. Facultad de Estudios Superiores Zaragoza. \\ Universidad Nacional Autónoma de México \\ *tavocerrillos@gmail.com
}

\section{RESUMEN}

En el Parque Ecológico "Cubitos", Pachuca, Hidalgo, la erosión es un problema grave debido a sus laderas con pendiente superior a los $6^{\circ}$, incendios en la sequía y lluvias torrenciales, lo que propicia pérdida de cubierta vegetal, por lo que se pretende recuperarla y controlar la erosión mediante la aplicación de técnicas de bioingeniería, con plantas, geotextiles y abono orgánico. Para estabilizar y mejorar la estructura del suelo y aumentar su fertilidad; se seleccionó un área con un bajo porcentaje de vegetación (3.9\%) y se procedió a la implementación de cuatro tratamientos: tratamiento 1 composta más geotextil, tratamiento 2 composta, tratamiento 3 yute, tratamiento 4 testigo, todos con hijuelos de maguey y nopal, de octubre de 2017 a noviembre de 2018. Se realizaron visitas mensuales, para evaluar crecimiento, supervivencia y tasa relativa de crecimiento. Los resultados muestran un aumento en promedio de $4 \mathrm{~cm}$ en altura y cobertura, incremento del $1.0 \%$ de M.O., lo que permitió una mayor concentración de nutrientes, y en la época de lluvias permitió que el agave y el nopal actuaran como nodrizas de diferentes familias, permitiendo la creación de islas de vegetación, los mejores resultados se obtuvieron con el tratamiento de composta más yute, en el maguey, con una supervivencia del (100\%), control de erosión $\left(0.35 \mathrm{~cm}\right.$ de retención del suelo ) y una tasa relativa de crecimiento $\left(0.01 \mathrm{~cm} / \mathrm{d}^{-1}\right)$. En conclusión, el empleo del yute y composta mejora el establecimiento vegetal y el control de la erosión en esta zona semiárida.

Palabras clave: Geotextiles, composta, establecimiento vegetal.

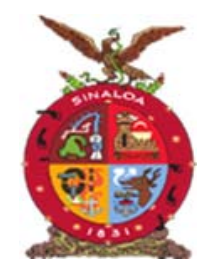

XVIII Congreso Internacional XXIV Congreso Nacional de Ciencias ambientales
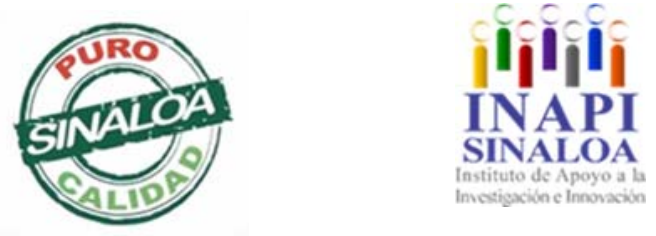

Mazatlán, Sinaloa 3-7 junio 2019

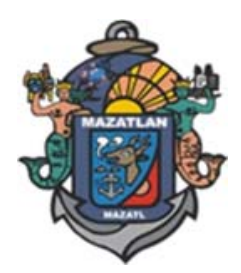

Recursos Naturales, Ecosistemas y Deterioro Ambiental 

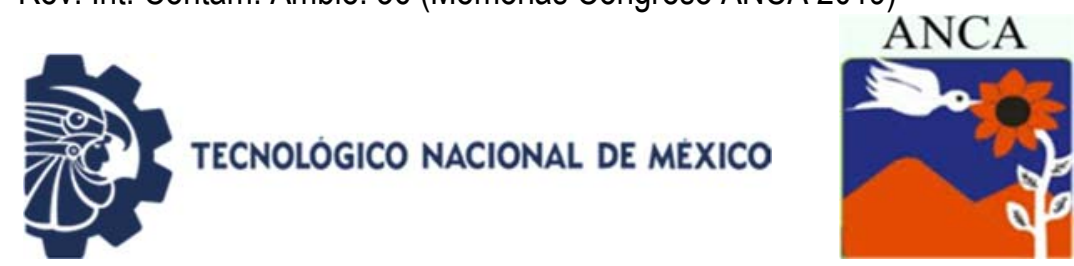

\title{
Vegetation cover recovery and erosion control applying bioengineering techniques with Agave salmiana and Opuntia robusta
}

\author{
Cerrillos Valle G*, García Amador EM, De la Rosa Mera CJ \\ Laboratorio de Fitorremediación. Facultad de Estudios Superiores Zaragoza. \\ Universidad Nacional Autónoma de México \\ *tavocerrillos@gmail.com
}

\begin{abstract}
Erosion is a serious problem in the "Cubitos" ecological park, in Pachuca, Hidalgo, due to its hillsides with slopes greater than $6^{\circ}$, fires in the drought and torrential rains, which causes loss of vegetation cover. It is intended to recover the vegetation cover and control the erosion through the application of bioengineering techniques with plants, geotextiles and organic fertilizers. To stabilize and improve the soil structure and increase its fertility, a low vegetation percentage $(3.9 \%)$ area was selected. Four treatments were applied. 1st treatment: compost with geotextile. 2nd treatment: only compost. 3rd treatment: only jute. 4th treatment: control (no treatment). All of which with maguey and nopal seedlings, and monthly visits were made from October 2017 to November 2018, to asses growth, survival and relative growth rates. The results show an average increase of $4 \mathrm{~cm}$ in height and coverage, an increase of $1.0 \%$ of organic matter (OM), which allowed a higher concentration of nutrients, and in the rainy season, the agave and nopal behaved as a breeding place for different plant families, allowing the creation of vegetation islands. The 1st treatment showed the most promising results, with the maguey, showing a survival rate of $100 \%$, erosion control $(0.35$ $\mathrm{cm}$ of soil retention) and a relative growth rate of $0.01 \mathrm{~cm} / \mathrm{d}$. In conclusion, the use of both jute and compost plant establishment and erosion control in this semi-arid zone.
\end{abstract}

Keywords: Geotextiles, compost, plant establishment.

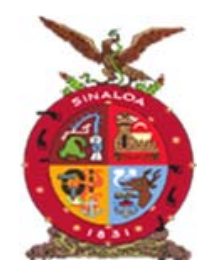

XVIII Congreso Internacional

XXIV Congreso Nacional de Ciencias ambientales
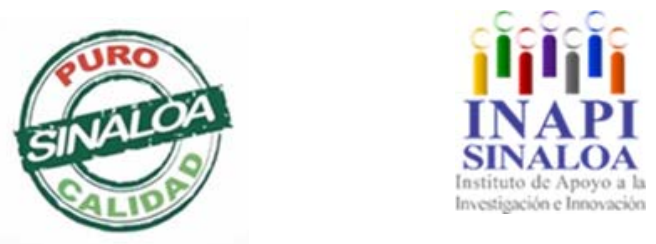

Mazatlán, Sinaloa 3-7 junio 2019

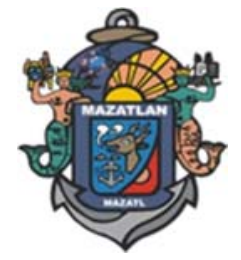

Recursos Naturales, Ecosistemas y Deterioro Ambiental 

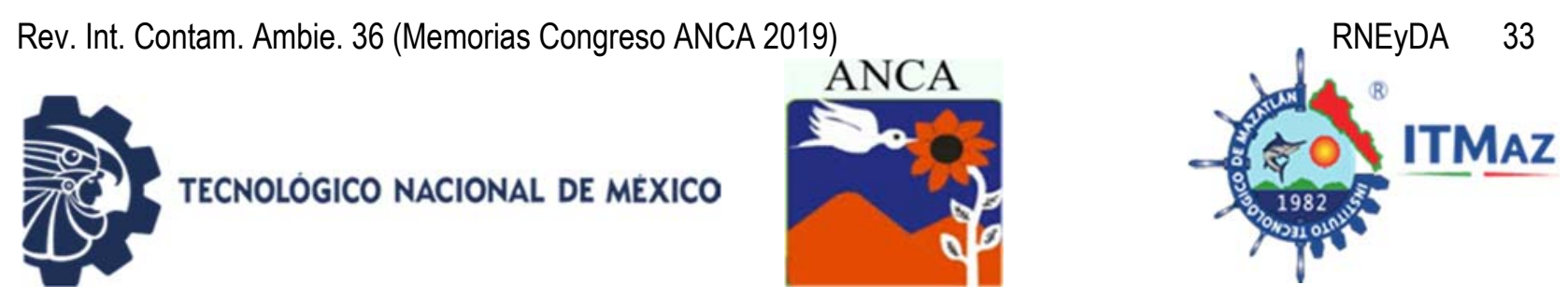

\title{
Caracterización de los residuos sólidos urbanos domiciliarios por estrato económico, en la zona metropolitana del municipio de Guadalupe, Zacatecas, México
}

\author{
Cervantes Aguilar M, Valdivia Cabral GI ${ }^{*}$, Aguilera Flores M \\ Unidad Profesional Interdisciplinaria de Ingeniería Campus Zacatecas. \\ Instituto Politécnico Nacional. México \\ *gloria.valdivia123@gmail.com
}

\section{RESUMEN}

El desarrollo de un Plan de Manejo Integral de Residuos Sólidos Urbanos (PMIRSU), implica el estudio y actualización de todos los factores e instituciones involucradas en el manejo de los Residuos Sólidos Urbanos (RSU), realizar un diagnóstico de RSU en el municipio, es esencial para la toma de decisiones en un PMIRSU, asegurando la viabilidad técnica-económica, para una gestión adecuada. El municipio de Guadalupe, Zacatecas; dentro del país, es uno de los municipios con mayor crecimiento poblacional, el cual a su vez tiene relación directa con una mayor generación de RSU, provocando que el manejo de los mismos se vuelva complicado, generando impactos negativos al ambiente y a la salud de la población. En este estudio se realizó la caracterización de los RSU generados en la zona metropolitana del municipio de Guadalupe, Zac., evaluando la generación y caracterización de RSU tomando como base las norma mexicanas NMX-AA-61-1985 y la NMX-AA-15-1985, ambas fueron realizadas durante los primeros tres meses del año y por niveles socioeconómicos, estableciendo 3 agrupaciones, de los 7 niveles socioeconómicos establecidos por el AMAI, acorde a las características de cada nivel, siendo delimitadas por áreas geoestadísticas básicas (AGEB). Obteniendo una generación per-cápita de 0.82 $\mathrm{kg} / \mathrm{hab}^{*} \mathrm{~d}$ en general, las principales fracciones fueron: orgánico $(48 \%)$, papel $(16 \%)$ y plástico (12\%). Los resultados muestran una mayor generación de residuos asociada al nivel socioeconómico más alto, demostrando que a mayores ingresos económicos al hogar, se genera una mayor cantidad de RSU.

Palabras clave: Área geoestadística básica, crecimiento poblacional, estrato económico, urbanización.

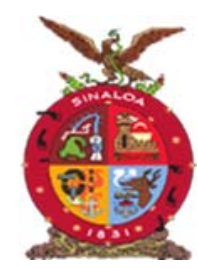

XVIII Congreso Internacional

XXIV Congreso Nacional de Ciencias ambientales
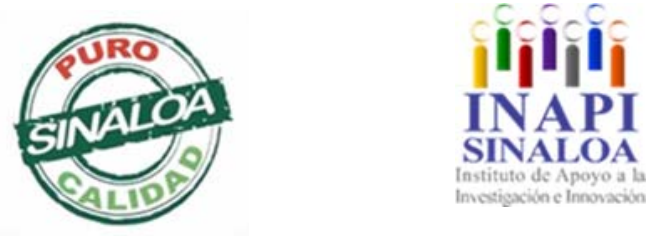

Mazatlán, Sinaloa 3-7 junio 2019

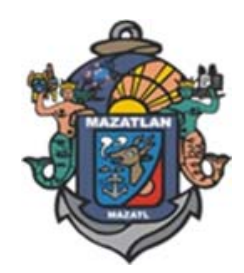

Recursos Naturales, Ecosistemas y Deterioro Ambiental 

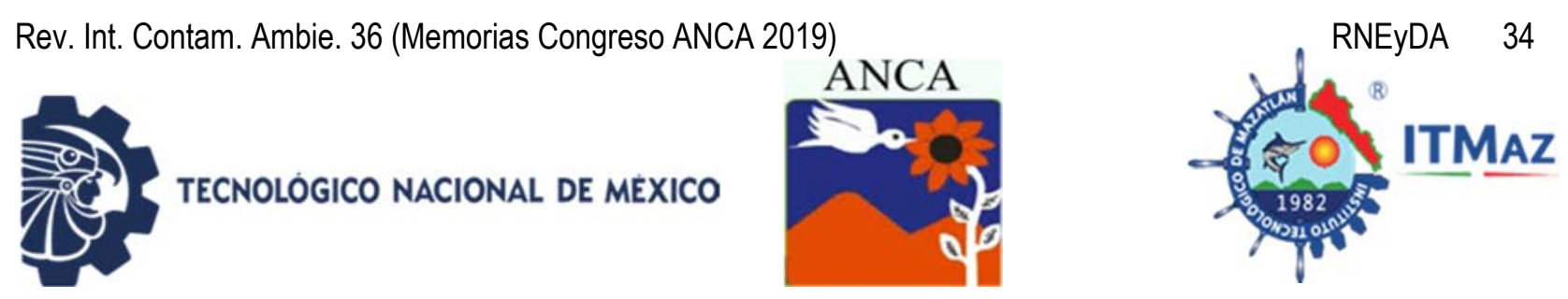

\title{
Characterization of domiciliary urban solid residues by economic stratum, in the metropolitan zone of the municipality of Guadalupe, Zacatecas, Mexico
}

\author{
Cervantes Aguilar M, Valdivia Cabral GI*, Aguilera Flores M \\ Unidad Profesional Interdisciplinaria de Ingeniería Campus Zacatecas. \\ Instituto Politécnico Nacional. México \\ *gloria.valdivia123@gmail.com
}

\begin{abstract}
The development of an Integral Solid Waste Management (ISWM), involves the study and updating of all the factors and institutions involved in the management of Urban Solid Waste (USW), making a diagnosis of MSW in the municipality, is essential for decision making in an ISWM, ensuring technical-economic viability, for proper management. The municipality of Guadalupe, Zacatecas; within the country, it is one of the municipalities with the highest population growth, which in turn is directly related to a greater generation of MSW, causing the management of them to become complicated, generating negative impacts on the environment and the health of the population, besides giving a "bad image". The objective of this study was to characterize the USW generated in the metropolitan area of the municipality of Guadalupe, Zac. Where the generation and characterization of USW was evaluated from the Mexican standard NMX-AA-61-1985 to determine the generation and the NMX-AA-15-1985, in which it establishes the methodology of characterization of UWS by method of the "cut-up". These were realized by socioeconomic levels, establishing 3 groups, of the 7 socioeconomic levels established by the IMAI, according to the socio-economic characteristics are delimited by basic geostatistical areas, carried out during the first months of the year. Obtaining a generation per-capita of $0,82 \mathrm{~kg} / \mathrm{hab}{ }^{*} \mathrm{~d}$ in general, the main fractions were: organic (48\%), paper $(16 \%)$ and plastic $(12 \%)$. The results show a higher generation of waste associated with the highest socioeconomic level. Demonstrating that greater economic income to the home generates a greater amount of USW.
\end{abstract}

Keywords: Basic geostatistical areas, economic stratum, municipal growth, urbanization.

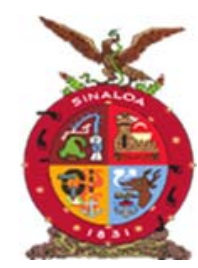

XVIII Congreso Internacional

XXIV Congreso Nacional de Ciencias ambientales
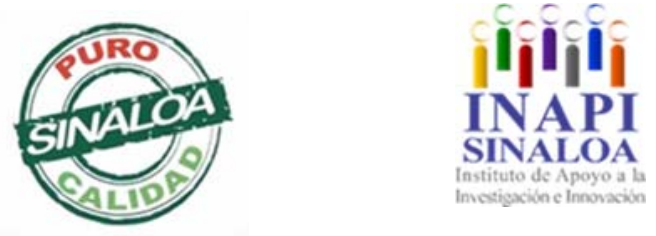

Mazatlán, Sinaloa 3-7 junio 2019

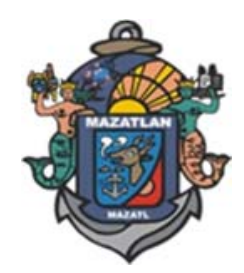

Recursos Naturales, Ecosistemas y Deterioro Ambiental 

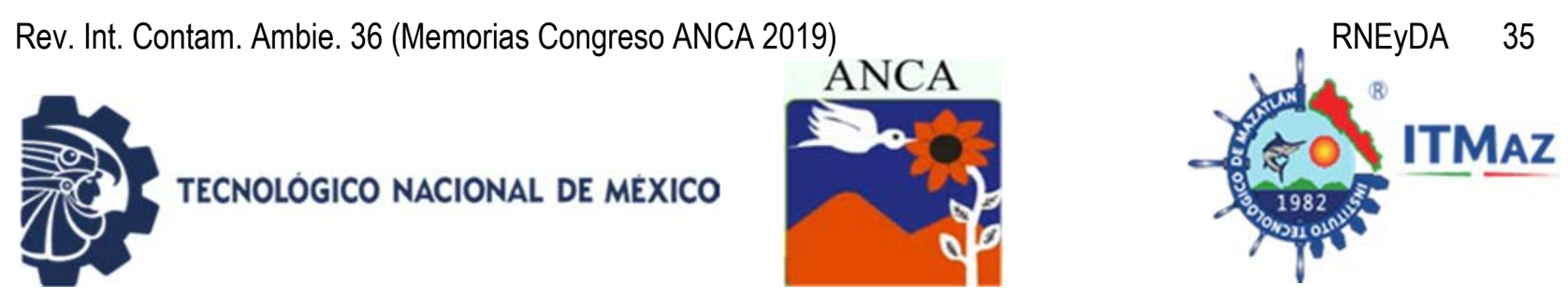

\title{
Secuestro de carbono y emisión de metano, en relación a la hidroquímica en manglares del litoral de Campeche, México
}

\author{
Chan Keb $\mathrm{C}^{1^{*}}$, Agraz Hernández $\mathrm{C}^{2}$, Ostin Sáenz $\mathrm{J}^{2}$, Reyes Castellanos $\mathrm{J}^{2}$, \\ Pérez Balan $\mathrm{R}^{1}$, Chavez Barrera J² \\ ${ }^{1}$ Facultad de Ciencias Químico Biológicas. \\ Universidad Autónoma de Campeche. México \\ ${ }^{2}$ Instituto de Ecología, Pesquerías y Oceanografía del Golfo de México. \\ Universidad Autónoma de Campeche. México \\ *carachan@uacam.mx
}

\begin{abstract}
RESUMEN
Los manglares almacenan gran cantidad de carbono, sin embargo, las actividades antrópicas han generado cambios en el patrón hidrológico, afectando la acumulación del carbono y emisión del metano. En esta investigación se estimó, la cantidad de carbono, la emisión de metano y su relación con los parámetros fisicoquímicos del suelo y agua intersticial en tres sitios del litoral de Campeche. El pH, Potencial Redox del agua intersticial fueron medidos con un Hach SENSIÓN-1, para suelo se usó un Hach IQ150, la salinidad fue determinado con un refractómetro $A \& O$, el metano fue colectado en cámaras estáticas usando bolsas fabricadas con películas duPont $\circledast$, el metano fue determinado por cromatografía de gases y el carbono en un analizador elemental Flash 2000. La cantidad de carbonoregistrado en la Reserva de la Biosfera los Petenes (RBP) fue de $174.6 \pm 37 \mathrm{Mg} \mathrm{ha}^{-1}$, en Champotón presento $169 \pm 43 \mathrm{Mg} \mathrm{ha}^{-1}$ y en la Laguna de Términos (LT) con $168 \pm 98 \mathrm{Mg}^{\text {ha }}{ }^{-1}$ sin embargo no fueron significativos ( $p>0.05$ ). La emisión de metano en la RBP fue $109.80 \pm 111 \mathrm{mg} \mathrm{m}^{-2}$ $\mathrm{h}^{-1}$, las menores cantidades en Champotón $\left(51.73 \pm 48 \mathrm{mg} \mathrm{m}^{-2} \mathrm{~h}^{-1}\right)$ y las mayores en la LT $\left(673.24 \pm 922 \mathrm{mg} \mathrm{m}^{-2} \mathrm{~h}^{-1}\right)$, las emisiones de metano fueron significativos $(p<0.05)$. El secuestro de carbono en la RBP estableció una relación inversa con la emisión de metano $\left(R^{2}=0.67\right)$. Para Champotón el secuestro del carbono presentó una correlación directa entre la salinidad $\left(R^{2}=0.70\right)$. La emisión de metano para la $L T$ estableció una relación inversa con el $\mathrm{pH}$ del suelo $\left(\mathrm{R}^{2}=0.77\right)$. Lo anterior es atribuido a las diferentes condiciones ambientales y presiones antrópicas.
\end{abstract}

Palabras clave: Manglares, secuestro de carbono, emisión de metano, época de lluvia, parámetro fisicoquímico.
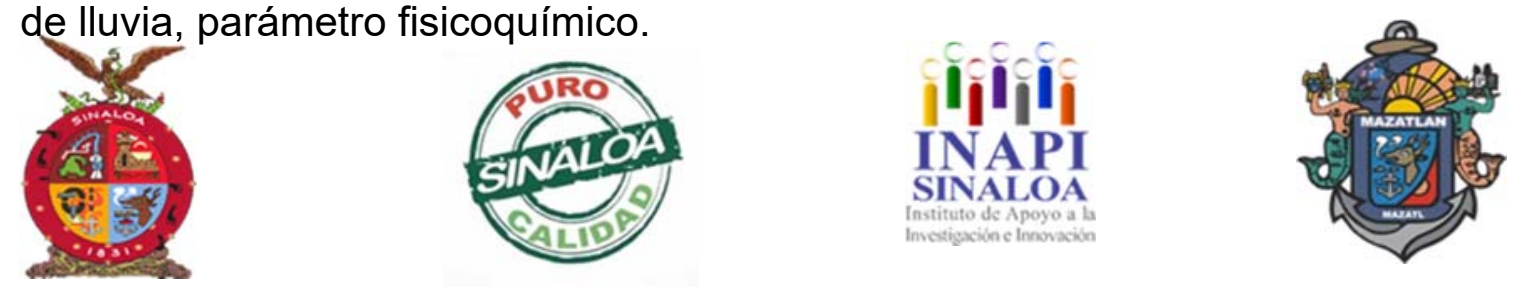

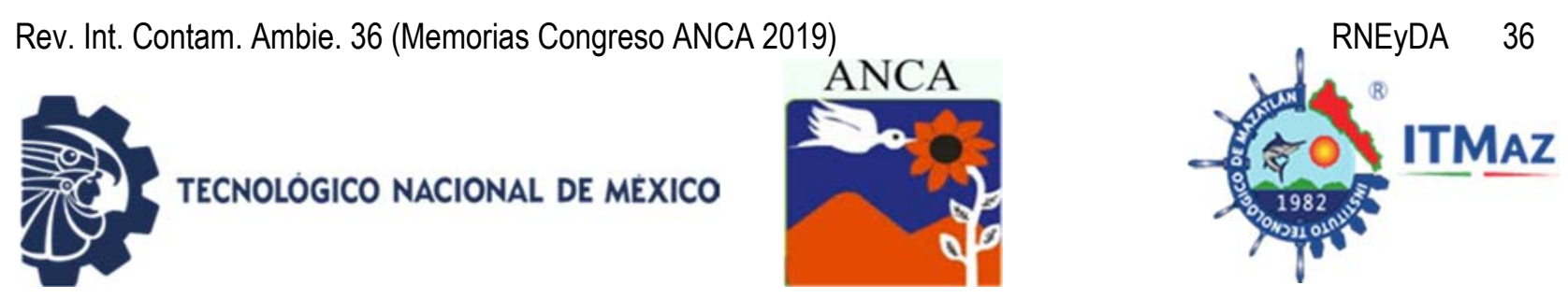

\title{
Carbon sequestration and methane emission and its relation to hydrochemistry in mangroves at the coast of Campeche, Mexico
}

\author{
Chan Keb $\mathrm{C}^{1 *}$, Agraz Hernández $\mathrm{C}^{2}$, Ostin Sáenz $\mathrm{J}^{2}$, Reyes Castellanos $\mathrm{J}^{2}$, \\ Pérez Balan $\mathrm{R}^{1}$, Chavez Barrera J ${ }^{2}$ \\ ${ }^{1}$ Facultad de Ciencias Químico Biológicas. \\ Universidad Autónoma de Campeche. México \\ ${ }^{2}$ Instituto de Ecología, Pesquerías y Oceanografía del Golfo de México. \\ Universidad Autónoma de Campeche. México \\ *carachan@uacam.mx
}

\begin{abstract}
Mangroves store a large amount of carbon; however, anthropogenic activities have generated changes in the hydrological pattern that have affected carbon accumulation and methane emission. In this research, the amount of carbon, the emission of methane and its relation with the physicochemical parameters of soil and interstitial water in three mangrove zones of the Campeche coast were estimated. The $\mathrm{pH}$, Redox potential of the interstitial water were measured with a Hach SENSIÓN-1, for soil a Hach IQ150 was used, the salinity was determined with an $\mathrm{A}$ \& $O$ refractometer, methane was collected in static chambers using bags made with duPont $₫$ films, methane was determined by gas chromatography and carbon was quantified in a Flash 2000 elemental analyzer. The amount of carbon registered in the Petenes Biosphere Reserve (RBP) was $174.6 \pm 37 \mathrm{Mg} \mathrm{ha}^{-1}$, in Champotón presented $169 \pm 43 \mathrm{Mg} \mathrm{ha}^{-1}$ and Laguna de Terminos (LT) with 168 $\pm 98 \mathrm{Mg} \mathrm{ha}{ }^{-1}$, however, they were not significant $(p>0.05)$. The emission of methane in the RBP was $109.80 \pm 111 \mathrm{mg} \mathrm{m}^{-2} \mathrm{~h}^{-1}$, the lowest amounts were detected in Champoton $\left(51.73 \pm 48 \mathrm{mg} \mathrm{m}^{-2} \mathrm{~h}^{-1}\right)$ and the highest in LT (673.24 \pm $\left.\left.922 \mathrm{mg} \mathrm{m}^{-2}\right) . \mathrm{h}^{-1}\right)$, the methane emissions were significant $(\mathrm{p}<0.05)$. The carbon sequestration in the RBP established an inverse relationship with the emission of methane $\left(R^{2}=0.67\right)$. For Champoton, carbon sequestration shown a direct correlation with salinity $\left(R^{2}=0.70\right)$. The methane emission for the $L T$ established an inverse relationship with the soil $\mathrm{pH}\left(\mathrm{R}^{2}=0.77\right)$. The above is attributed to the different environmental conditions and anthropogenic pressures
\end{abstract}

Keywords: Mangroves, carbon sequestration, methane emission, rainy season, physicochemical parameter.

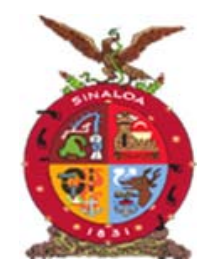

XVIII Congreso Internacional

XXIV Congreso Nacional de Ciencias ambientales
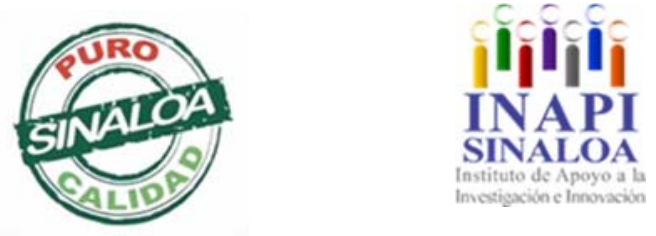

Mazatlán, Sinaloa 3-7 junio 2019

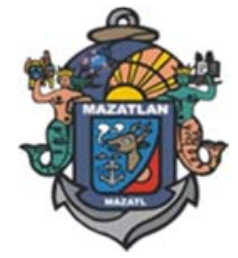

Recursos Naturales, Ecosistemas y Deterioro Ambiental 

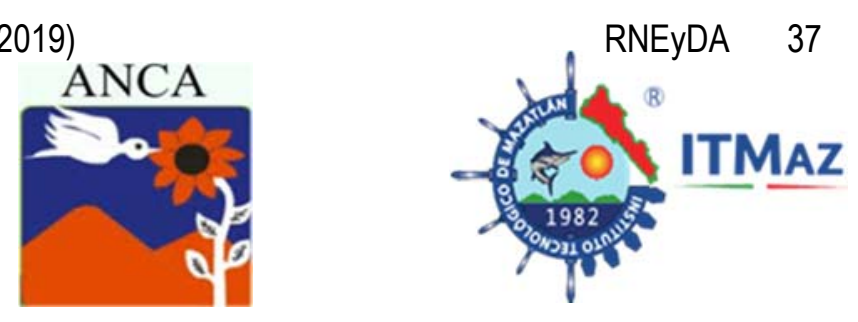

\title{
Almacenes de carbono y grado de conservación en manglares asociados al gradiente ambiental de un río en los pantanos de Centla
}

\author{
Chavez Barrera $\mathrm{JC}^{1}$, Agraz Hernández $\mathrm{CM}^{2}$, Konde Medina $\mathrm{KP}^{3}$, \\ Chan Keb $\mathrm{CA}^{3}$, Reyes Castellanos $\mathrm{JE}^{2}$, Ostin Sáenz $\mathrm{J}^{2}$ \\ ${ }^{1}$ Maestría multidisciplinaria para el manejo de la zona costero-marina. \\ Instituto de Ecología, Pesquerías y Oceanografía del Golfo de México. \\ Universidad Autónoma de Campeche. México \\ ${ }^{2}$ Instituto de Ecología, Pesquerías y Oceanografía del Golfo de México. \\ Universidad Autónoma de Campeche. México \\ ${ }^{3}$ Facultad de Ciencias Químico Biológicas. \\ Universidad Autónoma de Campeche. México \\ al048930@uacam.mx
}

\begin{abstract}
RESUMEN
Esta investigación estableció los factores ambientales clave para evaluar el almacenamiento de carbono azul y el estado de conservación en los manglares del río San Pedro y San Pablo, Tabasco. Esto mediante la evaluación de la biomasa y densidad de la madera en árboles vivos en 10 sitios, así como los parámetros fisicoquímicos y nutrientes en el agua intersticial y sedimento. Se definieron tres escenarios ambientales aplicando un análisis de clúster, con diferencias en la dominancia de especies de mangle $(p<0.05)$, almacén de carbono en el sedimento $(p=0.029)$ y biomasa $(p<0.05)$. Un análisis de componentes principales explica el $78.3 \%$ del comportamiento de los datos, condiciones de mayor salinidad para la producción de biomasa en Avicennia germinans. En el caso de Laguncularia racemosa y Rhizophora mangle se define con la alta concentración del carbono y nitrógeno en el sedimento. Se observó la sustitución en la producción de biomasa de $R$. mangle por $L$. racemosa, atribuido a la menor densidad de la madera de $L$. racemosa $(p<0.0001)$, factor que favorece su rápido crecimiento ante a los cambios ambientales, debido a la deforestación y descargas de nutrientes. Se determinó que el almacenamiento de carbono en el sedimento depende de la fuente de materia orgánica y las condiciones oxido-reducción, validado esto por la relación entre el porcentaje de carbono orgánico (\%Corg) y el potencial redox del agua intersticial $(r=-0.65)$ y el mínimo \%Corg en sitios con alta concentración de sulfatos y dominados $A$. germinans. En su conjunto, al aplicar un modelo estocástico, estos parámetros definieron que el $33.4 \%$ de los sitios presentaran un grado de conservación impactado y $66.6 \%$ con mediano impacto.
\end{abstract}

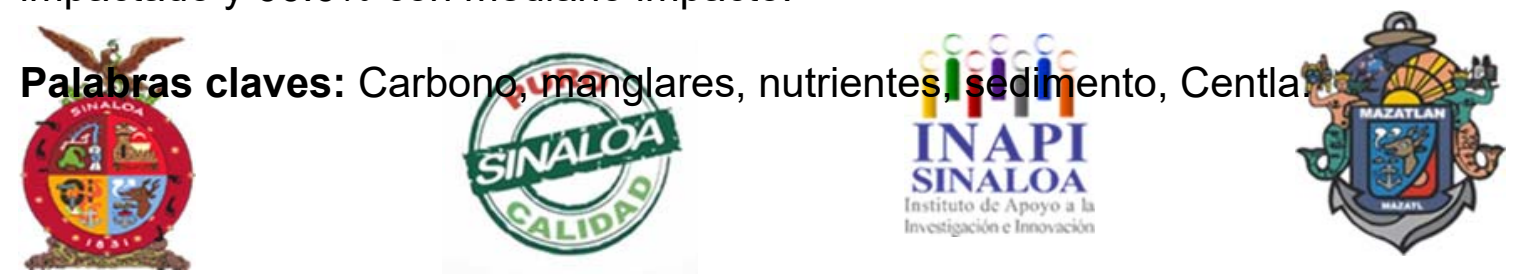




\title{
Carbon storage and conservation degree in mangroves associated with the environmental gradient of a river in the swamps of Centla
}

\author{
Chavez Barrera $\mathrm{JC}^{1}$, Agraz Hernández $\mathrm{CM}^{2}$, Konde Medina $\mathrm{KP}^{3}$, \\ Chan Keb $\mathrm{CA}^{3}$, Reyes Castellanos $\mathrm{JE}^{2}$, Ostin Sáenz $\mathrm{J}^{2}$ \\ ${ }^{1}$ Maestría multidisciplinaria para el manejo de la zona costero-marina. \\ Instituto de Ecología, Pesquerías y Oceanografía del Golfo de México. \\ Universidad Autónoma de Campeche. México \\ ${ }^{2}$ Instituto de Ecología, Pesquerías y Oceanografía del Golfo de México. \\ Universidad Autónoma de Campeche. México \\ ${ }^{3}$ Facultad de Ciencias Químico Biológicas. \\ Universidad Autónoma de Campeche. México \\ al048930@uacam.mx
}

\begin{abstract}
This research established the key environmental factors to evaluate the storage of blue carbon and the conservation status in the mangroves of the San Pedro and San Pablo River, Tabasco. This through the evaluation of the biomass and density of the wood in live trees in 10 sites, as well as the physicochemical parameters and nutrients in the interstitial water and sediment. Three environmental scenarios were defined applying a cluster analysis, with differences in the dominance of mangrove species $(p<0.05)$, sediment carbon store $(p=0.029)$ and biomass $(p<0.05)$. An analysis of main components explains $78.3 \%$ of the behavior of the data, conditions of greater salinity for the production of biomass in Avicennia germinans. In the case of Laguncularia racemosa and Rhizophora mangle it is defined by the high concentration of carbon and nitrogen in the sediment. The substitution in the biomass production of $R$. mangle by $L$. racemosa was observed, attributed to the lower density of $\mathrm{L}$. racemosa wood $(p<0.0001)$, a factor that favors its rapid growth in the face of environmental changes, due to deforestation and nutrient discharges. It was determined that the storage of carbon in the sediment depends on the source of organic matter and the oxide-reduction conditions, validated by the relationship between the percentage of organic carbon (\% Corg) and the redox potential of interstitial water ( $r=-0.65)$ and the minimum\% Corg in sites with high sulfate and dominate concentrations A. germinans. As a whole, when applying a stochastic model, these parameters defined that $33.4 \%$ of the sites had an impacted conservation level and $66.6 \%$ with medium impact.
\end{abstract}

Keywords: Carbon, mangroves, nutrients, sediment, Centla.

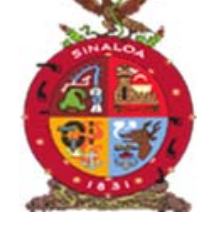

XVIII Congreso Internacional

XXIV Congreso Nacional de Ciencias ambientales

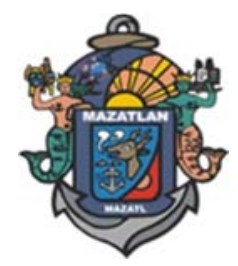

Recursos Naturales, Ecosistemas y Deterioro Ambiental 

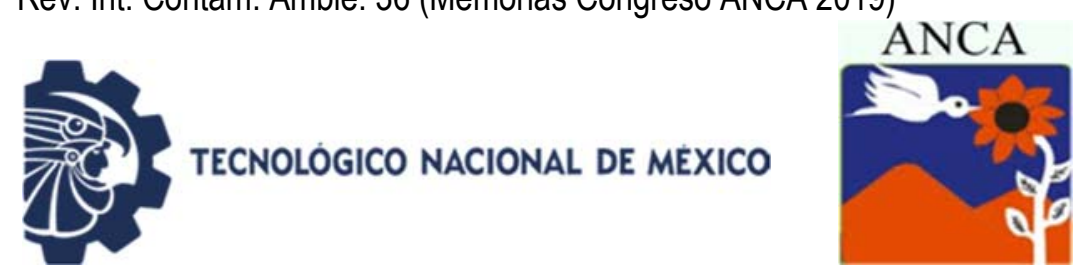

\title{
Evaluación de especies químicas en suelos agrícolas Cuauhtémoc, Chihuahua, México
}

\author{
Chávez Heredia V, Melgoza Castillo A, Rentería Villalobos M* \\ Facultad de Zootecnia y Ecología. Universidad Autónoma de Chihuahua. \\ *mrenteria@uach.mx
}

\section{RESUMEN}

Los metales pesados pueden contaminar y disminuir la calidad del suelo, estos provienen de fuentes naturales y antropogénicas. La agricultura en México es una de las principales fuentes económicas. Dicha actividad conlleva a un uso desmedido de sustancias químicas, las cuales favorecen la disponibilidad de algunos elementos. El objetivo de este estudio fue evaluar la distribución de la composición de especies químicas en suelos agrícolas en el municipio de Cuauhtémoc, Chihuahua, México. El muestreo se realizó en marzo del 2018. Se colectaron 16 muestras de suelo, las cuales se midieron parámetros fisicoquímicos ( $\mathrm{pH}$, humedad, textura, materia orgánica y conductividad eléctrica) y composición elemental. La caracterización elemental se determinó usando espectroscopia de plasma acoplado de emisión óptica (ICP-OES, Perkin Elmer, Optima 8300). Los elementos encontrados en altas concentraciones fueron $\mathrm{Fe}$ (14005 mg/kg), Ca $(2165 \mathrm{mg} / \mathrm{kg}), \mathrm{Mg}(2132 \mathrm{mg} / \mathrm{kg})$ y Ti $(576.3 \mathrm{mg} / \mathrm{kg})$. Además, se encontró Mn $(419.2 \mathrm{mg} / \mathrm{kg})$ y $\mathrm{Zn}(131.7 \mathrm{mg} / \mathrm{kg})$ como los elementos traza abundantes. El As se encontró alto en un $12.5 \%$ de las muestras, excediendo los límites máximos permisibles de la NOM-147-SEMARNAT/SSA1-2004. Esto se debe a la aplicación de fertilizantes fosfatados y a los óxidos metálicos, ya que favorecen la disponibilidad de dicho elemento. Las correlaciones significativas $(\mathrm{P}>0.80)$ fueron $\mathrm{V}-\mathrm{Fe}$, Ni-Co y Ni-Cr. No se encontraron metales pesados por encima de los límites permisibles. Es necesario tomar medidas de control sobre la aplicación de fertilizantes, ya que esto puede llevar a la degradación de los suelos.

Palabras clave: Contaminación, agroquímicos, campo de cultivo.

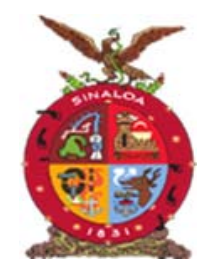

XVIII Congreso Internacional

XXIV Congreso Nacional de Ciencias ambientales
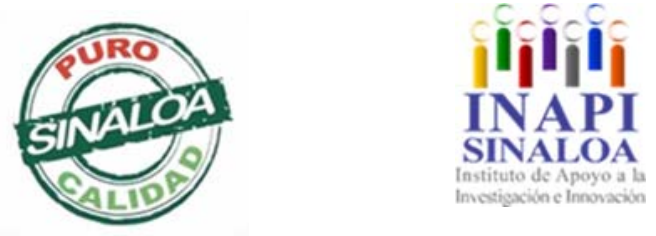

Mazatlán, Sinaloa 3-7 junio 2019

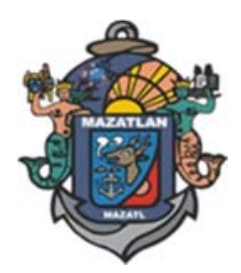

Recursos Naturales, Ecosistemas y Deterioro Ambiental 


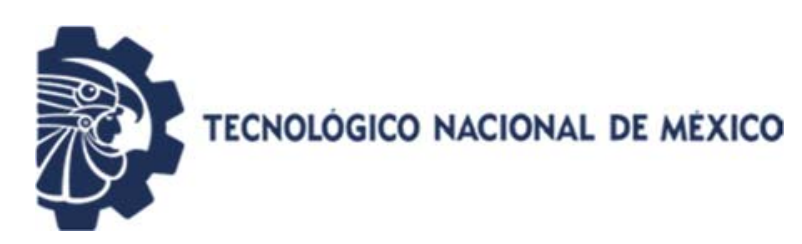

\title{
Chemical species on agricultural soils of Cuauhtémoc, Chihuahua, México
}

\author{
Chávez Heredia V, Melgoza Castillo A, Rentería Villalobos $\mathrm{M}^{*}$ \\ Facultad de Zootecnia y Ecología. Universidad Autónoma de Chihuahua. \\ *mrenteria@uach.mx
}

\begin{abstract}
Heavy metals can contaminate and decrease the quality of the soil, these come from natural and anthropogenic sources. Agriculture in México is one of the main economic sources. This activity leads to an excessive use of chemical substances, which favor the availability of some elements. The objective of this study was to evaluate the distribution of chemical species composition on agricultural soils present in the municipality of Cuauhtémoc. The sampling was carried out in March 2018 in the agricultural fields. Sixteen soil samples were collected, from which physicochemical parameters $(\mathrm{pH}$, humidity, texture, organic matter and electrical conductivity) and elemental composition were measured. The elemental characterization was developed in an Inductively Coupled Plasma atomic Emission Spectroscopy (ICP-OES, Perkin Elmer, Optima 8300). The elements with high contents were Fe (14005 mg/kg), Ca (2165 mg/kg), Mg (2132 $\mathrm{mg} / \mathrm{kg})$, and Ti (576.3 mg/kg). In addition, $\mathrm{Mn}(419.2 \mathrm{mg} / \mathrm{kg})$ and $\mathrm{Zn}(131.7 \mathrm{mg} / \mathrm{kg})$. The As was found high in $12.5 \%$ of the samples, exceeding the maximum permissible limits of NOM-147-SEMARNAT/SSA1-2004. This is due to the application of phosphate fertilizers and metal oxides; they promote the availability of that element. The significant correlations $(P>0.80)$ were $\mathrm{V}-\mathrm{Fe}, \mathrm{Ni}-\mathrm{Co}$ and $\mathrm{Ni}-\mathrm{Cr}$. No heavy metals were found above the permissible limits. It is necessary to take control practices on the application of fertilizers, as this can lead to soil degradation.
\end{abstract}

Keywords: Contamination, agrochemicals, crop fields

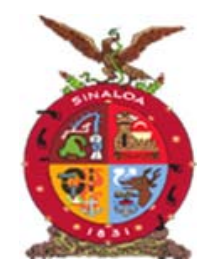

XVIII Congreso Internacional

XXIV Congreso Nacional de Ciencias ambientales
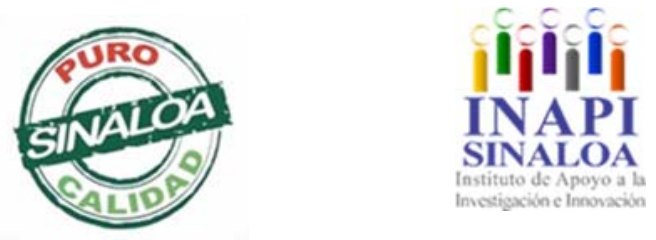

Mazatlán, Sinaloa 3-7 junio 2019

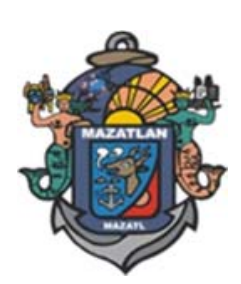

Recursos Naturales, Ecosistemas y Deterioro Ambiental 

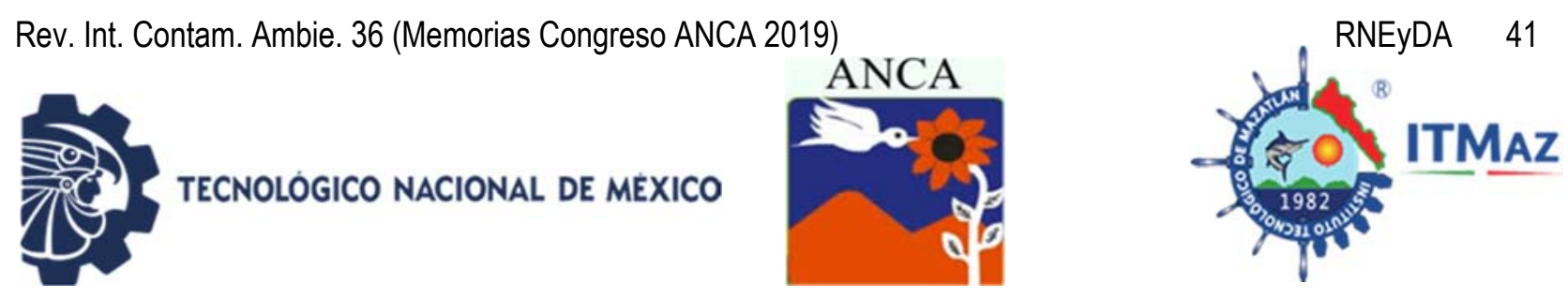

\title{
Efecto de metales pesados provenientes de jales mineros sobre la comunidad de anuros en sierra de Huautla, Morelos, México
}

\author{
Chávez Ramírez EA ${ }^{1 *}$, Mercado Silva N ${ }^{1}$, Mussali Galante $\mathrm{P}^{2}$, \\ Tovar Sánchez E , Ochoa Ochoa LM ${ }^{3}$
}

${ }^{1}$ Centro de Investigación en Biodiversidad y Conservación. Universidad Autónoma del Estado de Morelos.

${ }^{2}$ Laboratorio de Investigaciones Ambientales.

Centro de Investigación en Biotecnología. UAEMolrelos

Av. Universidad 1001, Col. Chamilpa, C.P. 62209, Cuernavaca, Morelos, México

${ }^{3}$ Departamento de Biología Evolutiva. Facultad de Ciencias.

Universidad Nacional Autónoma de México.

Av. Universidad, CU, Coyoacán, C.P. 04510

*chavez.ramirezea@gmail.com

\section{RESUMEN}

El ejido Huautla, en Tlaquiltenango, Morelos, México es un distrito minero inactivo en el que se ha cuantificado un estimado de 780 mil toneladas de jales mineros. Estos contienen metales pesados (MP). Que tienen efectos negativos en los niveles de organización biológica. Los efectos de los MP sobre las comunidades biológicas se reflejan en cambios en su composición, dominancia, riqueza y diversidad. Se ha estudiado la relación de los MP sobre distintos componentes biológicos en Sierra de Huautla, sin embargo, no se han analizado las comunidades de anuros. El objetivo de este estudio fue cuantificar la acumulación de metales ( $\mathrm{Zn}, \mathrm{Fe}, \mathrm{Cr}, \mathrm{Cd}, \mathrm{Cu}, \mathrm{Pb}, \mathrm{Mn}$ ) en el agua del Río Huautla y sus efectos potenciales sobre la comunidad de anuros. Se registraron nueve especies, ocho géneros y cinco familias en la temporada de lluvias del 2018. Se observan diferencias en valores de diversidad de Shannon y Simpson, dominancia y equidad, y resultados similares en las curvas de rango-abundancia. Las concentraciones promedio registradas fueron de $\mathrm{Pb}=3.676 \pm 1.019 \mathrm{mg} / \mathrm{L}, \mathrm{Cu}$ $1.524 \pm 0.219 \mathrm{mg} / \mathrm{L}, \mathrm{Mn}=0.160 \pm 0.173 \mathrm{mg} / \mathrm{L}, \mathrm{Zn}=0.111 \pm 0.050 \mathrm{mg} / \mathrm{L}, \mathrm{Cd}=$ $0.094 \pm 0.026 \mathrm{mg} / \mathrm{L}$, Fe y $\mathrm{Cr}$ no fueron detectados. Las concentraciones de $\mathrm{Cd}$, $\mathrm{Cu}, \mathrm{Cr}, \mathrm{Pb}$ y $\mathrm{Zn}$ están por encima de la NOM-001-SEMARNAT-1996 y NOM-027SSA1-1994.

Palabras clave: Jales, metales, comunidades, anuros, composición.

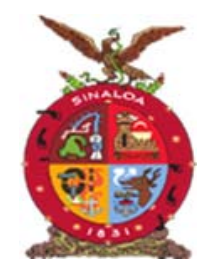

XVIII Congreso Internacional

XXIV Congreso Nacional de Ciencias ambientales
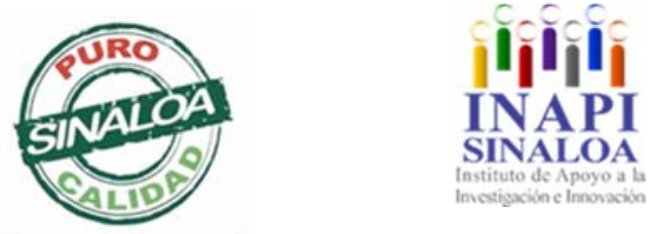

Mazatlán, Sinaloa 3-7 junio 2019

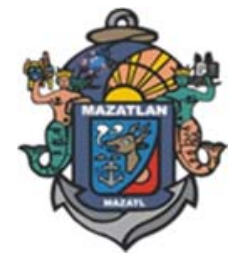

Recursos Naturales, Ecosistemas y Deterioro Ambiental 

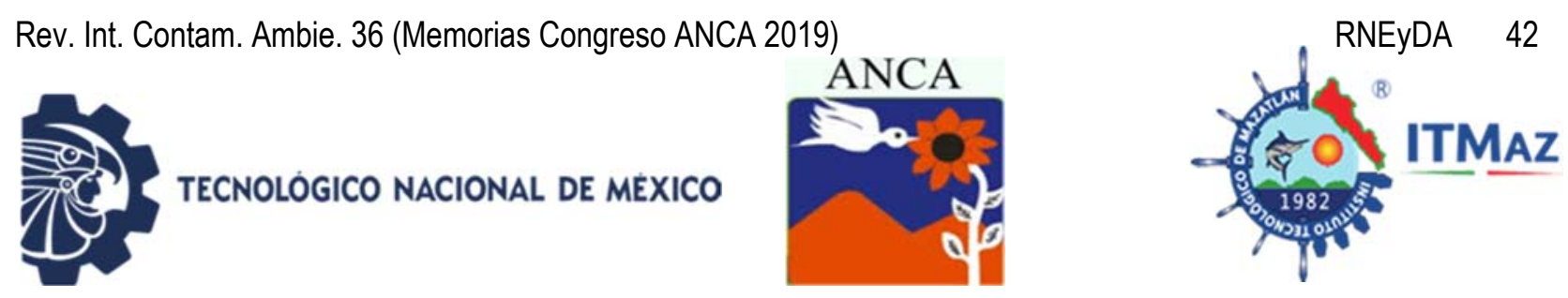

\title{
Effect of heavy metals from mine tailings on the anuran community in sierra de Huautla, Morelos, Mexico
}

\author{
Chávez Ramírez EA ${ }^{1 *}$, Mercado Silva $\mathrm{N}^{1}$, Mussali Galante $\mathrm{P}^{2}$, \\ Tovar Sánchez E , Ochoa Ochoa LM ${ }^{3}$
}

${ }^{1}$ Centro de Investigación en Biodiversidad y Conservación. Universidad Autónoma del Estado de Morelos.

${ }^{2}$ Laboratorio de Investigaciones Ambientales.

Centro de Investigación en Biotecnología. UAEMolrelos

Av. Universidad 1001, Col. Chamilpa, C.P. 62209, Cuernavaca, Morelos, México

${ }^{3}$ Departamento de Biología Evolutiva. Facultad de Ciencias.

Universidad Nacional Autónoma de México.

Av. Universidad, CU, Coyoacán, C.P. 04510

*chavez.ramirezea@gmail.com

\begin{abstract}
The Huautla region, in Tlaquiltenango, Morelos, Mexico has an estimated 780 thousand tons of mine tailings from now suspended mining activity. These contain heavy metals which can have negative effects on the composition, dominance, richness and diversity of biological communities. The effects of heavy metals have been studied for several biological groups, but anurans had not been analyzed. We report on heavy metal concentrations $(\mathrm{Zn}, \mathrm{Fe}, \mathrm{Cr}, \mathrm{Cd}, \mathrm{Pb})$ in water from the Huautla river, and discuss their potential effects on the anuran community. Nine species, eight genera and five families of anurans were recorded during the rainy season of 2018. Differences in Shannon and Simpson diversity indices, dominance and equity were observed, with similar results in range-abundance curves. On average, heavy metal concentrations in water from three river sites were $\mathrm{Pb}=3,676 \pm 1,019 \mathrm{mg} / \mathrm{L}, \mathrm{Cu}=1,524 \pm 0.219 \mathrm{mg} / \mathrm{L}, \mathrm{Mn}=0.160 \pm 0.173$ $\mathrm{mg} / \mathrm{L}, \mathrm{Zn}=0.111 \pm 0.050 \mathrm{mg} / \mathrm{L}$ ) and $\mathrm{Cd}=0.094 \pm 0.026 \mathrm{mg} / \mathrm{L}$. Changes in concentrations were detected among sampling sites. Fe and $\mathrm{Cr}$ were not detected. Concentrations for $\mathrm{Cd}, \mathrm{Cu}, \mathrm{Cr}, \mathrm{Pb}$ and $\mathrm{Zn}$ exceeded levels indicated in Mexican norms NOM-001-SEMARNAT-1996 y NOM-027-SSA1-1994.
\end{abstract}

Keywords: Tailings, metals, communities, anurans, composition.

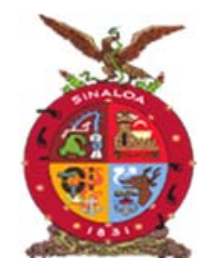

XVIII Congreso Internacional

XXIV Congreso Nacional de Ciencias ambientales
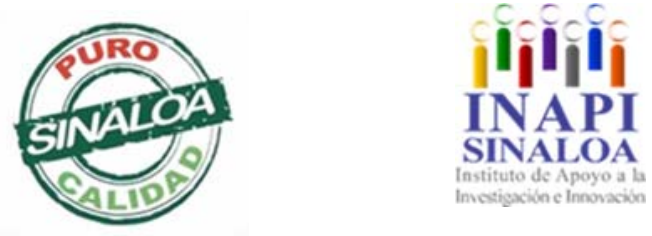

Mazatlán, Sinaloa 3-7 junio 2019

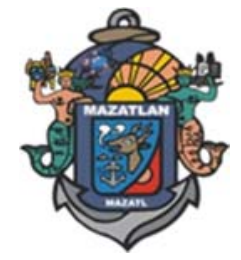

Recursos Naturales, Ecosistemas y Deterioro Ambiental 

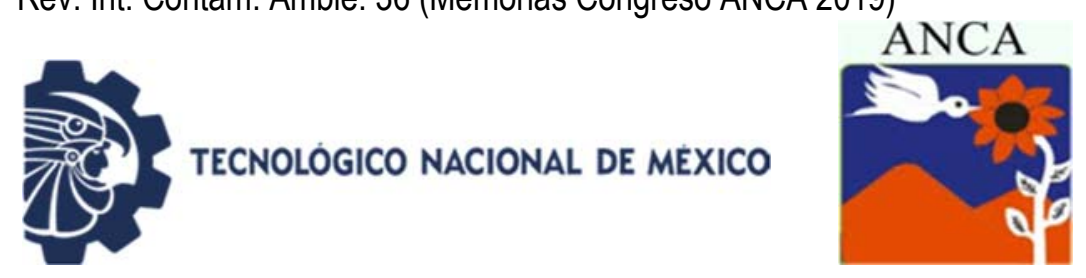

\title{
Microplásticos en sedimentos y peces en la costa de Campeche
}

\author{
Chi Cabrera $\mathrm{G}^{1}$, Vón Ostén $\mathrm{J}^{2}$, Hernández Crisóstomo $\mathrm{C}^{1^{*}}$ \\ ${ }^{1}$ Instituto Tecnológico Superior de Champotón. Carr. Champotón-Isla Aguada \\ Km. 2, Col. El Arenal, C.P. 24400, Champotón, Campeche, México \\ ${ }^{2}$ Instituto de Ecología, Pesquería y Oceanografía del Golfo de México \\ Universidad Autónoma de Campeche. \\ Av. Héroe de Nacozari 480, 24079 Campeche, México \\ *cintia.hc@champoton.tecnm.mx
}

\begin{abstract}
RESUMEN
La mayor parte de los plásticos en el medio marino proceden de las actividades antropogénicas, y estos pueden llegar a fragmentarse por la temperatura, rayos UV, entre otros factores, en partículas pequeñas son difíciles de ver a simple vista y por ello son microplásticos. El objetivo de la presente investigación fue evaluar la presencia de microplásticos en sedimentos e intestino de los peces de consumo en la costa de Campeche, entre los meses de septiembre y noviembre del 2018. De acuerdo a la metodología de Hidalgo y colaboradores (2012), se seleccionaron dos sitios de muestreo para la toma de sedimentos en la costa frente a la ciudad de Champotón; en cada sitio de muestreo se ubicaron dos transectos de un metro de distancia a la línea de la costa en la cual se colocaron cuadrantes de $50 \times 50 \mathrm{~cm}$, en el centro de estos cuadrantes se colocaron otros cuadrantes con medida de $20 \times 20 \mathrm{~cm}$, para la recolección de muestra de sedimentos. Para el análisis del contenido intestinal de peces, se recolectaron 15 en el mercado de la ciudad de Champotón y 29 en la ciudad de San Francisco de Campeche. Los resultados indican que el tipo de Microplástico encontrado en los sedimentos fueron, hilos de cordel, fibra, pintura, bolsas y hule. En tanto que de las 44 muestras de peces, solamente 2 tuvieron presencia de partículas de pintura de color rojo.
\end{abstract}

Palabras claves: Microplásticos, sedimentos, peces, costa.

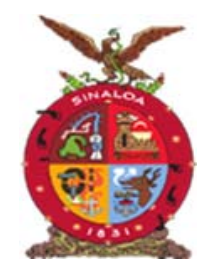

XVIII Congreso Internacional XXIV Congreso Nacional de Ciencias ambientales
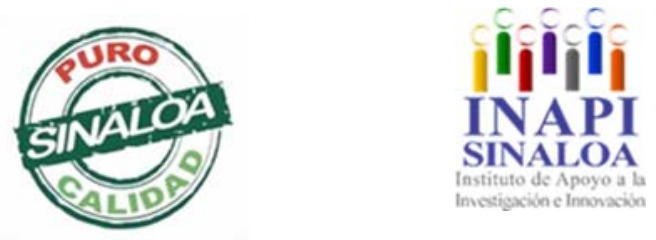

Mazatlán, Sinaloa 3-7 junio 2019

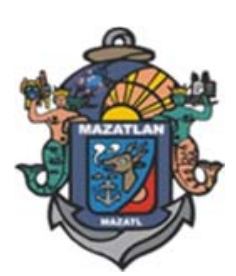

Recursos Naturales, Ecosistemas y Deterioro Ambiental 

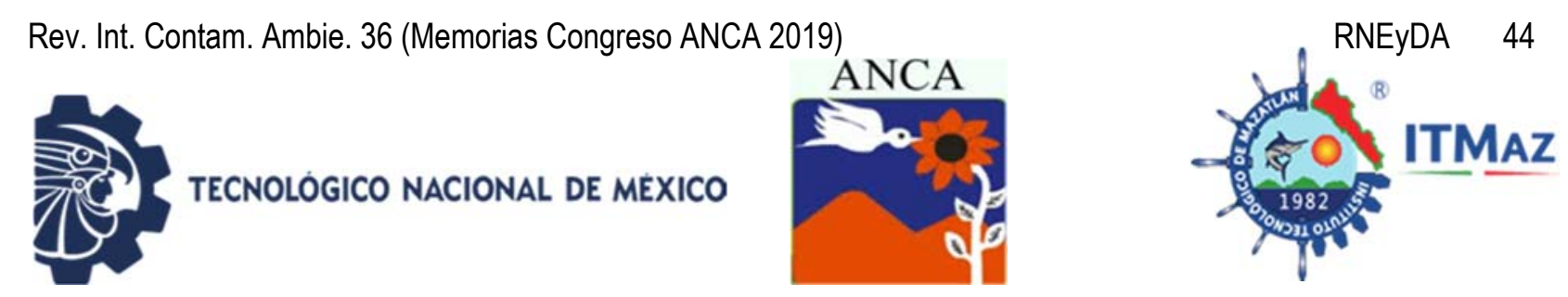

\title{
Microplastics in sediments and fish on the coast of Campeche
}

\author{
Chi Cabrera $\mathrm{G}^{1}$, Vón Ostén $\mathrm{J}^{2}$, Hernández Crisóstomo $\mathrm{C}^{1^{*}}$ \\ ${ }^{1}$ Instituto Tecnológico Superior de Champotón. Carr. Champotón-Isla Aguada \\ Km. 2, Col. El Arenal, C.P. 24400, Champotón, Campeche, México \\ ${ }^{2}$ Instituto de Ecología, Pesquería y Oceanografía del Golfo de México \\ Universidad Autónoma de Campeche. \\ Av. Héroe de Nacozari 480, 24079 Campeche, México \\ *cintia.hc@champoton.tecnm.mx
}

\begin{abstract}
The generality of plastics in the marine environment is due to anthropogenic activities, these can be fragmented by environmental factors like, the temperature, UV rays, among others, in small particles that is difficult to see with the naked eye known as microplastics. The objective of the present investigation was to evaluate the presence of Microplastic in sediments and fish consumption in the coast of Campeche, between the months of September and November of 2018, according to the methodology of Hidalgo and collaborators (2012). Two sampling sites were selected for sediment collection in the city of Champotón; In each sampling site, two transects one meter away from the coast line were placed, in which quadrants of $50 \times 50 \mathrm{~cm}$ were placed, in the center of these quadrants were placed other quadrants measuring $20 \times 20 \mathrm{~cm}$, for the collection of sediment sample. Regarding the stomachs of fish, they were collected 15 in the market of the city of Champotón and 29 in the city of San Francisco de Campeche. The results indicate that the type of Microplastic found in the sediments were string, fiber, paint, bags and rubber. While of the 44 fish samples, only 2 had the presence of red paint particles, so it is recommended to carry out further studies, using different methodologies, to obtain more information on the subject.
\end{abstract}

Keywords: Microplastics, sediments, fish, coast.

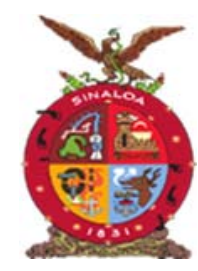

XVIII Congreso Internacional XXIV Congreso Nacional de Ciencias ambientales
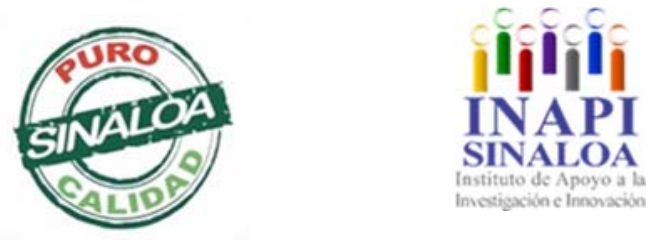

Mazatlán, Sinaloa 3-7 junio 2019 

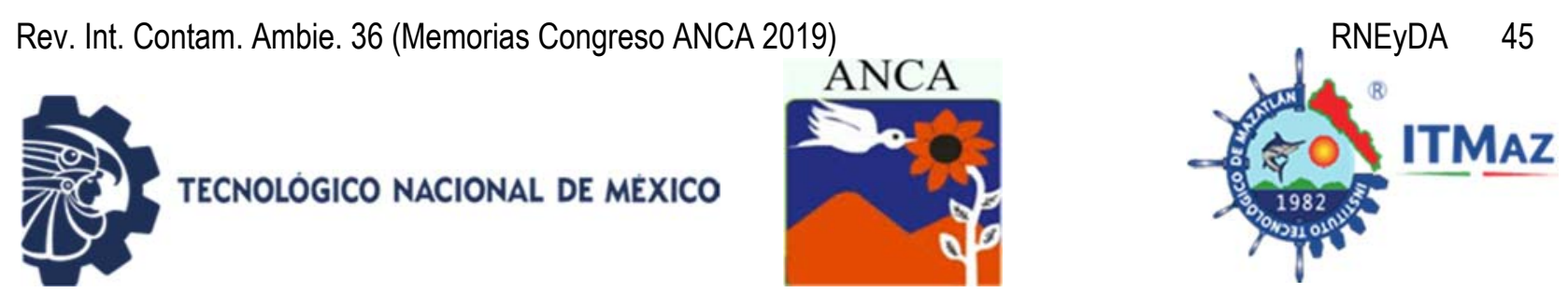

\title{
Recubrimiento Ecológico de Canales de Riego (RECR)
}

\author{
Cobián del Toro $\mathrm{S}^{1}$, Reyes Calderon $\mathrm{F}^{2}$, López Hernández $\mathrm{A}^{1}$, Zaragoza Yacuta \\ $\mathrm{E}^{1}$, Maturano Cisneros $\mathrm{M}^{1}$, Romero Zaragoza $\mathrm{M}^{1}$ \\ ${ }^{1}$ Instituto Tecnológico Superior de Apatzingán. Michoacan, México \\ ${ }^{2}$ Instituto Tecnológico de Morelia. Michoacán, México \\ scobian7415@gmail.com
}

\section{RESUMEN}

El uso de plástico reciclado (RECR) como recubrimiento para los canales de riego, se ha considerado como una opción factible para substituir el uso del concreto, ya que se pueden construir láminas con la forma y tamaño de acuerdo al canal que se necesite recubrir. Al adoptar el uso del RECR como material para el recubrimiento de canales, se obtienen además de ahorros económicos, tecnológicos y ecológicos, se logra una mejor eficiencia en la administración del agua utilizada al reducir las infiltraciones. El distrito 097 ubicado en "Lázaro Cárdenas", Michoacán, cuenta con 13,917 usuarios instalados en 114,765 hectáreas de riego, donde la infraestructura de distribución del agua se encuentra en mal estado, ocasionando que la eficiencia sea de tan solo de un $65 \%$, debido a fugas que han alcanzado una pérdida de 800 litros por segundo en un tramo de $6 \mathrm{Km}$. Por otro lado, en tan solo la mitad del estado de Michoacán se genera diariamente alrededor de 20 toneladas de diferentes plásticos, siendo necesario realizar el reciclaje, por ello hemos desarrollado con base en el PET, polietileno y otros productos poliméricos, una "madera plástica" (RECR) en forma de placas, con características de ser ligeras, baratas, fáciles de instalar y útiles para recubrir los canales de riego. Los resultados preliminares señalan que el empleo del RECR comparado con el uso del concreto, ofrece un ahorro en la construcción del $36.3 \%$ en los gastos y una reducción del $98 \%$ de las pérdidas por filtraciones en el concreto dañado.

Palabras clave: Madera plástica sustentable, canales de riego, reciclar.

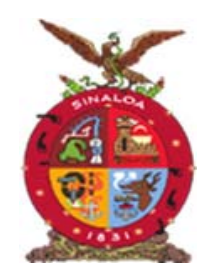

XVIII Congreso Internacional

XXIV Congreso Nacional de Ciencias ambientales
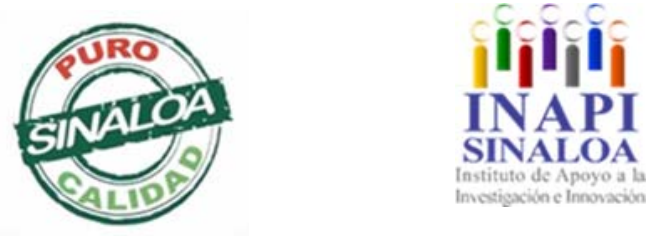

Mazatlán, Sinaloa 3-7 junio 2019

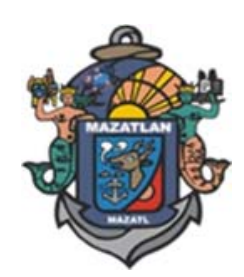

Recursos Naturales, Ecosistemas y Deterioro Ambiental 

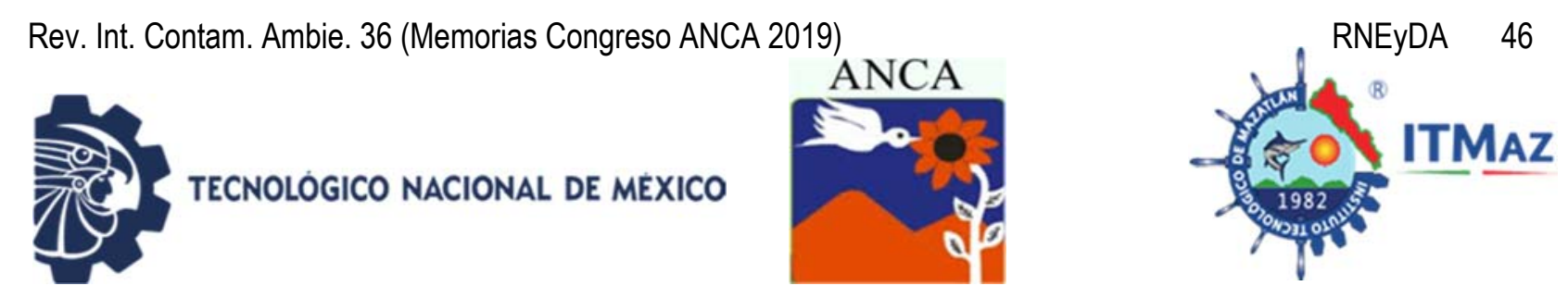

\title{
Ecological Coating of Irrigation Canals (RECR)
}

\author{
Cobián del Toro $\mathrm{S}^{1}$, Reyes Calderon $\mathrm{F}^{2}$, López Hernández $\mathrm{A}^{1}$, Zaragoza Yacuta \\ $\mathrm{E}^{1}$, Maturano Cisneros $\mathrm{M}^{1}$, Romero Zaragoza $\mathrm{M}^{1}$ \\ ${ }^{1}$ Instituto Tecnológico Superior de Apatzingán. Michoacan, México \\ ${ }^{2}$ Instituto Tecnológico de Morelia. Michoacán, México \\ scobian7415@gmail.com
}

\begin{abstract}
The use of recycled plastic (RECR) as a coating for irrigation canals, has been considered as a feasible option to replace the use of concrete, since sheets with the shape and size can be constructed according to the channel that needs to be coated. By adopting the use of the RECR as a material for the coating of channels, in addition to economic, technological and ecological savings, better efficiency is achieved in the administration of the water used to reduce infiltration. The 097 district located in "Lázaro Cárdenas", Michoacán, has 13,917 users installed in 114,765 hectares of irrigation. Where the water distribution infrastructure is in poor condition, causing efficiency to be only $65 \%$. due to leaks that have reached a loss of 800 liters per second in a section of $6 \mathrm{Km}$. On the other hand, in only half of the state of Michoacán, around 20 tons of different plastics are generated daily, and recycling is necessary, so we have developed a "plastic wood, based on PET, polyethylene and other polymeric products. " (RECR) in the form of plates, with characteristics of being light, cheap, easy to install and useful to cover the irrigation channels. Preliminary results indicate that the use of RECR compared to the use of concrete, offers a construction savings of $36.3 \%$ in expenses and a $98 \%$ reduction in losses due to leaks in damaged concrete.
\end{abstract}

Keywords: Sustainable plastic wood, irrigation canals, recycle.

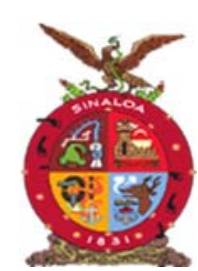

XVIII Congreso Internacional XXIV Congreso Nacional de Ciencias ambientales
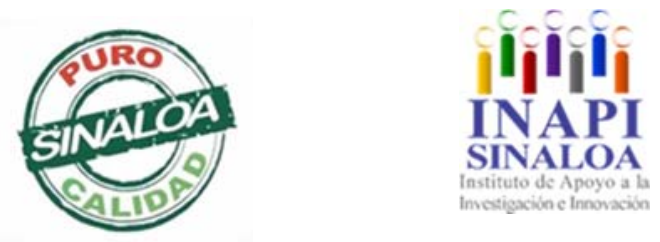

Mazatlán, Sinaloa 3-7 junio 2019

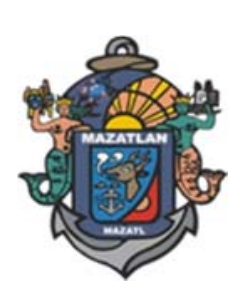

Recursos Naturales, Ecosistemas y Deterioro Ambiental 

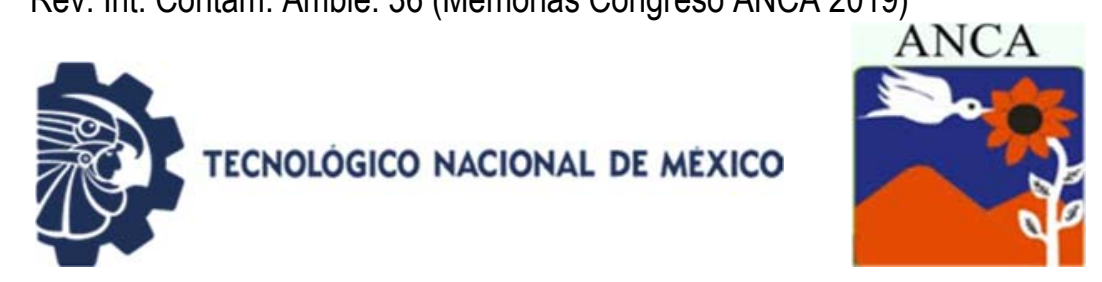

\title{
Censo preliminar de pteridofitas de la Sierra Norte de Puebla, México
}

\author{
Colmenero Robles $\mathrm{A}^{1}$, Rosas Medina $\mathrm{I}^{1 *}$, Naranjo Jíménez $\mathrm{N}^{2}$ \\ ${ }^{1}$ Secretaria de Investigación y Posgrado (SIP) Instituto Politécnico Nacional. \\ Becarios-COFAA-IPN \\ ${ }^{2}$ Centro Interdisciplinario de Investigación para el Desarrollo Integral Regional \\ (CIIDIR). Unidad Durango del IPN. Becarios-COFAA-IPN \\ *imelros@hotmail.com
}

\section{RESUMEN}

En el planeta existen aproximadamente 12000 especies de las pteridofitas o helechos y la mayoría de ellas se ubica en las regiones intertropicales. Se estima alrededor de 1000 especies que representa el $5 \%$ en la flora mexicana. La Sierra Norte de Puebla pertenece a la provincia biogeográfica de la Sierra Madre Oriental, abarca cerca de $100 \mathrm{Km}$ de largo por $50 \mathrm{Km}$ de ancho y corresponde al $19 \%$ de la superficie del estado de Puebla. El propósito fue conocer la diversidad genérica de las pteridofitas de la Sierra Norte de Puebla, para definir estrategias de conservación. A partir de la revisión de trabajos florísticos publicados en la Sierra Norte de Puebla, se elaboró una base de datos de pteridofitas registrando el nombre de la familia y el género de acuerdo a la nomenclatura de Christenhusz. Como datos adicionales se registró la forma biológica (terrestre o epífita) y el tipo de vegetación de acuerdo a Rzedowski. Se compilaron un total de 29 familias, 63 géneros y 179 especies. Las familias con más géneros fueron: Polypodiaceae (8), Dryopteridaceae (7), Adianthaceae (7), Cyatheaceae (3), Dicksoniaceae (3), Pteridaceae (3), Blechnaceae (2) y Telypteraceae (2). De acuerdo al tipo de vegetación los bosque mesófilo de montaña con 76 , bosque tropical subcaducifolio con 26 y en los ecotonos entre el bosque mesófilo y el bosque subtropical contienen 26 especies respectivamente. Se confirma que la mayor cantidad de especies de helechos se localizan en el bosque mesófilo de montaña, de ahí su conservación.

Palabras claves: Pteridofitas, flora, mesófilo, vegetación

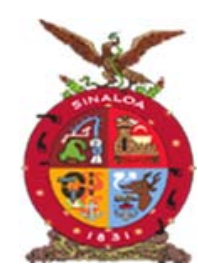

XVIII Congreso Internacional XXIV Congreso Nacional de Ciencias ambientales
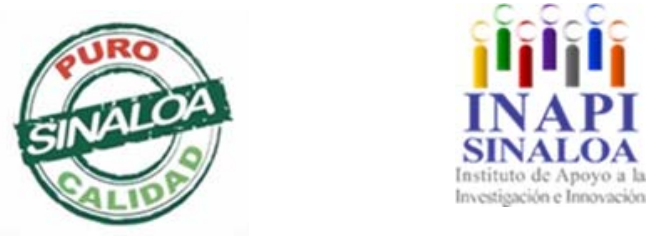

Mazatlán, Sinaloa 3-7 junio 2019

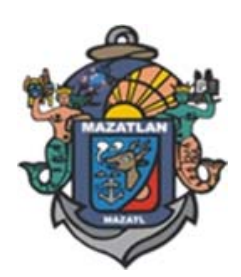

Recursos Naturales, Ecosistemas y Deterioro Ambiental 

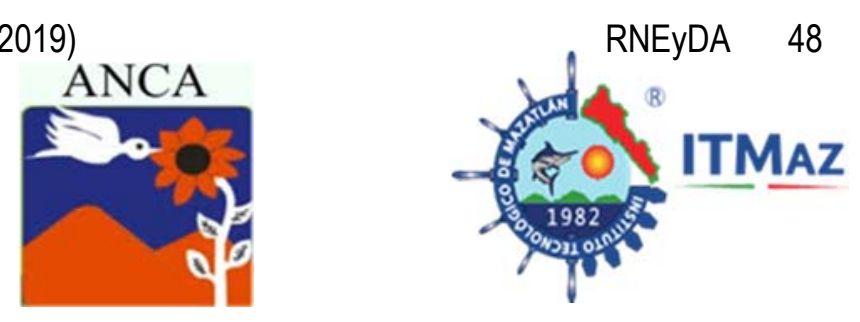

\title{
Preliminary study of pteridophytes from the Sierra Norte of Puebla, Mexico
}

\author{
Colmenero Robles $\mathrm{A}^{1}$, Rosas Medina $\mathrm{I}^{1^{*}}$, Naranjo Jíménez $\mathrm{N}^{2}$ \\ ${ }^{1}$ Secretaria de Investigación y Posgrado (SIP) del Instituto Politécnico Nacional. \\ Becarios-COFAA-IPN \\ ${ }^{2}$ Centro Interdisciplinario de Investigación para el Desarrollo Integral Regional
}

(CIIDIR). Unidad Durango del IPN. Becarios-COFAA-IPN

*imelros@hotmail.com

\begin{abstract}
The Pteridophytes or ferns exist on the planet approximately 12,000 species and most of them in the intertropical regions. It is estimated around 1000 species that represents $5 \%$ of the Mexican flora. The Sierra Norte de Puebla belongs to the biogeographic province of the Sierra Madre Oriental, covers about $100 \mathrm{Km}$ long by $50 \mathrm{Km}$ wide and corresponds to $19 \%$ of the surface of the state of Puebla. The purpose was to know the generic diversity of the pteridophytes of the Sierra Norte de Puebla, to define conservation strategies. From the review of floristic works published in the Sierra Norte de Puebla, a database of pteridophytes was elaborated registering the name of the family and the genus according to the Christenhusz nomenclature. As additional data was recorded the biological form (terrestrial or epiphytic) and the type of vegetation according to Rzedowski. A total of 29 families, 63 genera and 179 species were compiled. The families with more genera were: Polypodiaceae (8), Dryopteridaceae (7), Adianthaceae (7), Cyatheaceae (3), Dicksoniaceae (3), Pteridaceae (3), Blechnaceae (2) and Telypteraceae (2). According to the type of vegetation the mountain mesophilic forest with 76 , subcaducifolio tropical forest with 26 and in the ecotones between mesophilic forest and subtropical forest contain 26 species respectively. It is confirmed that the largest number of fern species are located in the mountain mesophilic forest, hence its conservation.
\end{abstract}

Keywords: Pteridophytes, flora, mesophyll, vegetation.

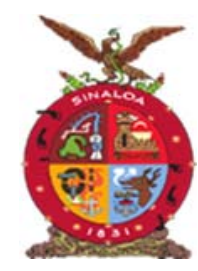

XVIII Congreso Internacional

XXIV Congreso Nacional de Ciencias ambientales
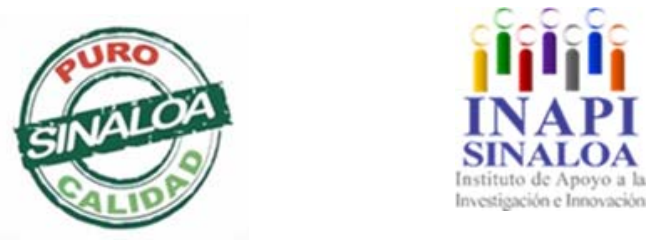

Mazatlán, Sinaloa 3-7 junio 2019

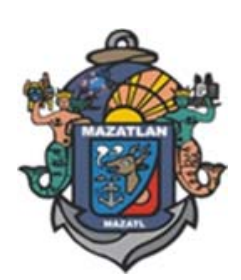

Recursos Naturales, Ecosistemas y Deterioro Ambiental 

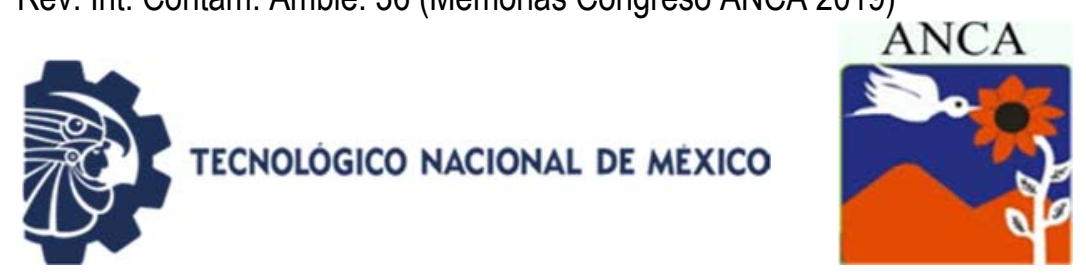

\title{
Productos forestales no maderables como medio de emprendimiento femenino
}

\author{
Contreras Medina $\mathrm{P}^{1^{*}}$, Vargas Martínez $\mathrm{E}^{2}$, Cruz Jiménez $\mathrm{G}^{2}$, \\ Serrano Barquín $\mathrm{R}^{2}$ \\ ${ }^{1}$ Posgrado en Ciencias Ambientales. \\ ${ }^{2}$ Facultad de Turismo. \\ Universidad Autónoma del Estado de México \\ *geopaolacontreras@gmail.com
}

\section{RESUMEN}

El análisis bibliográfico del emprendimiento femenino en la utilización y aprovechamiento de los productos forestales no maderables (PFNM), señala que están relacionados como medios de producción económica y la utilización manejo y proceso de toma de decisiones de los bosques que han correspondido a los hombres, mientras que las actividades de recolección es utilizada por las mujeres. Para conocer la evolución de estas posturas, se realizó una ecuación de búsqueda y análisis de un total de 27 artículos en el periodo de 10 años (del 2008 a 2018), los cuales señalan la orientación teórica del emprendimiento como un proceso de oportunidades con enfoque creativo, agregando que es un factor importante para el desarrollo económico generador de cambio e innovación (Monitor Global de Emprendimiento (GEM). Actualmente se ha reorientado este paradigma hacia el desarrollo de las capacidades emprendedoras en oportunidades de empoderamiento de las mujeres, a través de la adquisición de mayores habilidades y conocimientos, obteniendo la capacidad para incidir en las decisiones al interior de la familia, la comunidad y el uso de los recursos naturales. Se encontró que los países con más estudios sobre emprendimiento femenino son Ecuador, México y España, enfatizados en el emprendimiento rural y el desarrollo comunitario, y los estudios de casos relacionados con los emprendimientos femeninos y utilización de los recursos forestales no maderables son Chile y Colombia resaltando en la temática el impacto y aprovechamiento.

Palabras clave: Productos forestales no maderables, emprendimiento femenino, aprovechamiento ambiental.

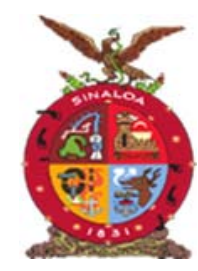

XVIII Congreso Internacional

XXIV Congreso Nacional de Ciencias ambientales
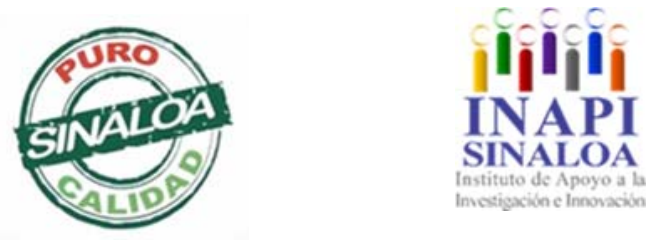

Mazatlán, Sinaloa 3-7 junio 2019

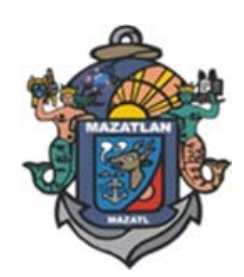

Recursos Naturales, Ecosistemas y Deterioro Ambiental 

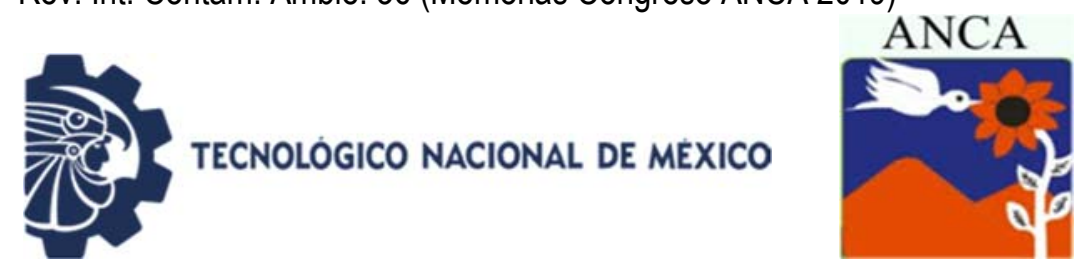

\title{
Non-timber forest products as a means female entrepreneurship
}

\author{
Contreras Medina $\mathrm{P}^{1^{*}}$, Vargas Martínez $\mathrm{E}^{2}$, Cruz Jiménez $\mathrm{G}^{2}$, \\ Serrano Barquín $\mathrm{R}^{2}$ \\ ${ }^{1}$ Posgrado en Ciencias Ambientales. \\ ${ }^{2}$ Facultad de Turismo. \\ Universidad Autónoma del Estado de México \\ *geopaolacontreras@gmail.com
}

\begin{abstract}
The objective of this paper is to carry out a bibliographic analysis of female entrepreneurship in the use and exploitation of non-timber forest products (NWFP), these related as means of economic and environmental production, since the use management and decision-making process of forests correspond to men, while harvesting activities are used by women. To know these positions, a search equation was made analyzing a total of 27 articles in English and Spanish with a periodicity from 2008 to 2018. Which argue the theoretical orientation of entrepreneurship as a process of opportunities with a creative approach. Also in an important factor for economic development that generates change and innovation [Global Entrepreneurship Monitor (GEM)]. But this economic paradigm has been reoriented towards the development of entrepreneurial capacities in opportunities for the empowerment of women, through the acquisition of greater skills and knowledge, and the ability to influence decisions within the family, the community and natural resources. In the results it was found that the countries with the most studies on female entrepreneurship are Ecuador, Mexico and Spain, emphasized in rural entrepreneurship and community development, and the case studies related to women's entrepreneurship and use of non-timber forest resources are Chile and Colombia highlighting their impact and use.
\end{abstract}

Keywords: Non-timber forest products, female entrepreneurship, environmental use.

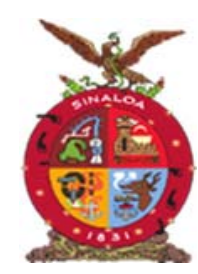

XVIII Congreso Internacional

XXIV Congreso Nacional de Ciencias ambientales
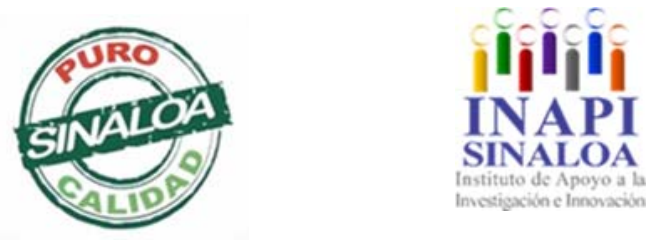

Mazatlán, Sinaloa 3-7 junio 2019

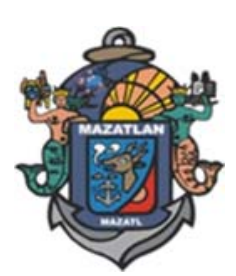

Recursos Naturales, Ecosistemas y Deterioro Ambiental 

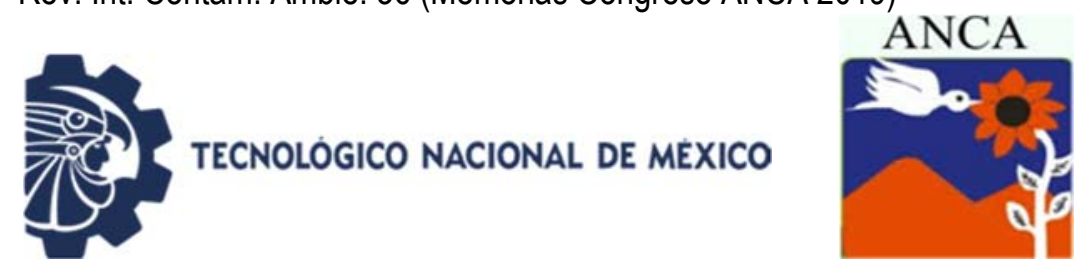

\title{
Efecto de la corta a matarrasa en la diversidad arbórea en el Ejido la Ciudad, Pueblo Nuevo, Durango, México
}

\author{
Cruz Cobos $\mathrm{F}^{1^{*}}$, Guevara Fisher $\mathrm{Y}^{1}$, Hernández $\mathrm{F}^{1}$, Cruz García $\mathrm{F}^{2}$, \\ Quiñonez Barraza $\mathrm{G}^{3}$, Nájera Luna $\mathrm{A}^{1}$ \\ ${ }^{1}$ El Instituto Tecnológico El Salto, Durango, México \\ ${ }^{2}$ Facultad de Química, Universidad Nacional Autónoma de México \\ ${ }^{3}$ Instituto Nacional de Investigaciones Forestales, Agrícolas y Pecuarias \\ (INIFAP), Campo Experimental Valle del Guadiana, Durango, Mexico \\ *cobos_cruz@yahoo.com.mx
}

\section{RESUMEN}

Con el propósito de incrementar la producción y productividad de los bosques en el estado de Durango, se realizaron cortas a matarrasa en rodales naturales de pino y encino que fueron sustituidos por plantaciones con una o dos especies de pino. Por lo que el objetivo de este trabajo fue evaluar el efecto de las cortas de matarrasa en la biodiversidad de las plantaciones forestales comerciales realizadas en el ejido La Ciudad, Pueblo Nuevo, Durango. El área de estudio consideró tres plantaciones y en cada una se colectó información de 20 sitios de $150 \mathrm{~m}^{2}(2.24 \times 12.24 \mathrm{~m})$. Con el fin de comparar la biodiversidad dentro y fuera de las plantaciones, estableciendo 10 sitios de 0.10 ha en los rodales adyacentes de cada plantación. A cada árbol se identificó a nivel de especie; para todos los árboles con diámetro normal mayor o igual a $7.5 \mathrm{~cm}$, se midió el diámetro normal, el diámetro basal y la altura. Para evaluar la biodiversidad se utilizaron índices de riqueza, de abundancia proporcional, de equidad, de similitud, de valor de importancia ecológica y curvas de rarefacción. El análisis de rarefacción mostró cambios en la biodiversidad en dos de las tres plantaciones, esto para el índice de riqueza de especies, mientras que con el índice de Shannon, hubo diferencias significativas en la biodiversidad de las tres plantaciones evaluadas. Las cortas de matarrasa con plantaciones modifican la estructura, abundancia proporcional y riqueza de especies.

Palabras clave: Bosques de pino, índices de dominancia, índices de similitud, plantaciones forestales, rarefacción.

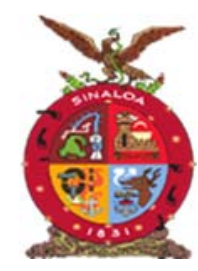

XVIII Congreso Internacional XXIV Congreso Nacional de Ciencias ambientales
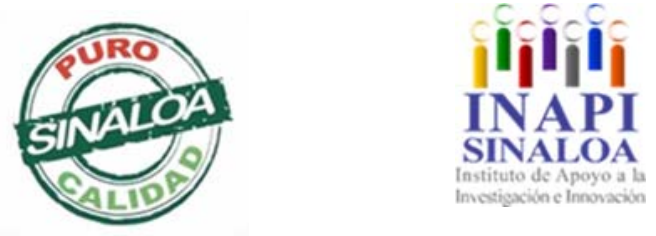

Mazatlán, Sinaloa 3-7 junio 2019

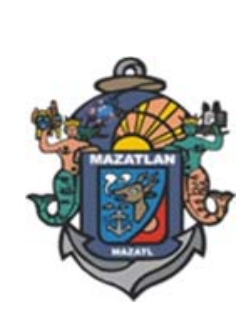



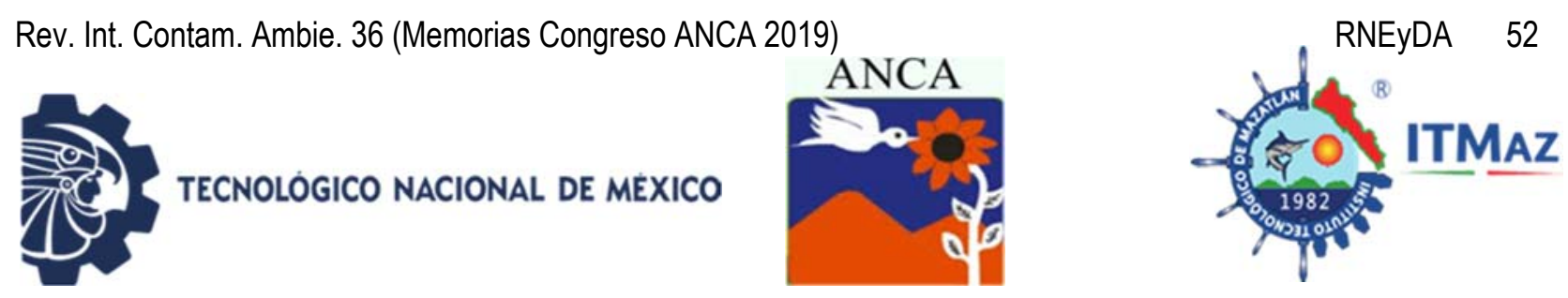

\title{
Effect of the short to matarrasa in the tree diversity in the Ejido the City, New Town, Durango, Mexico
}

\author{
Cruz Cobos $\mathrm{F}^{1^{*}}$, Guevara Fisher $\mathrm{Y}^{1}$, Hernández $\mathrm{F}^{1}$, Cruz García $\mathrm{F}^{2}$, \\ Quiñonez Barraza $\mathrm{G}^{3}$, Nájera Luna $\mathrm{A}^{1}$ \\ ${ }^{1}$ El Instituto Tecnológico El Salto, Durango, México \\ ${ }^{2}$ Facultad de Química, Universidad Nacional Autónoma de México \\ ${ }^{3}$ Instituto Nacional de Investigaciones Forestales, Agrícolas y Pecuarias \\ (INIFAP), Campo Experimental Valle del Guadiana, Durango, Mexico \\ *cobos_cruz@yahoo.com.mx
}

\begin{abstract}
Effect of the clearcutting in the arboreal diversity in the ejido la Ciudad, Pueblo Nuevo, Durango, with the purpose of increasing the production and productivity of the forests in the state of Durango, clearcuttings were made in natural pine and oak stands that were replaced by plantations with one or two pine species. Therefore, the objective of this work was to evaluate the effect of the clearcuttings on the biodiversity of the commercial forest plantations carried out in the ejido La Ciudad, Pueblo Nuevo, Durango. The study area considered three plantations and each one collected information from 20 sites of $150 \mathrm{~m}^{2}$. In order to compare the biodiversity inside and outside the plantations, 10 sites of 0.10 ha were established in the adjacent stands of each plantation. The species was identified for each tree, for all trees with a normal diameter greater than or equal to $7.5 \mathrm{~cm}$, the normal diameter, basal diameter and height were measured. In order to evaluate biodiversity, indices of wealth, proportional abundance, equity, similarity, value of ecological importance and rarefaction curves were used. The rarefaction analysis showed changes in biodiversity in two of the three plantations, this for the species richness index, while with the Shannon index there were significant differences in the biodiversity of the three plantations evaluated. The clearcuttings with plantations modify the structure, proportional abundance and species richness.
\end{abstract}

Keywords: Pine forests, dominant indices, similarity indices, forest plantations, rarefaction.

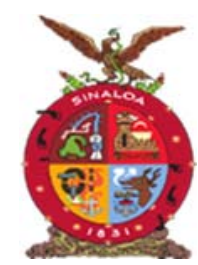

XVIII Congreso Internacional

XXIV Congreso Nacional de Ciencias ambientales
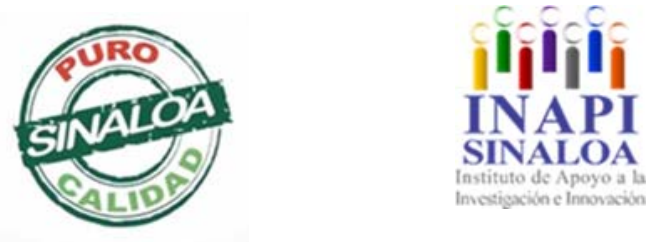

Mazatlán, Sinaloa 3-7 junio 2019

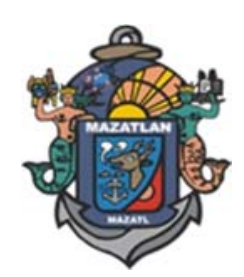

Recursos Naturales, Ecosistemas y Deterioro Ambiental 

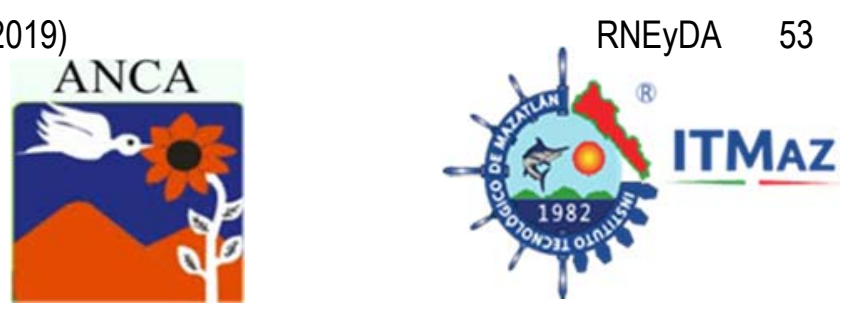

Características de Salix babylonica para prácticas de fitoremediación

Cruz Ruiz $\mathrm{G}^{1}$, Tejocote Pérez $\mathrm{M}^{2 *}$, Balderas Hernández $\mathrm{P}^{1}$, Roa Morales $\mathrm{G}^{1}$

${ }^{1}$ Centro Conjunto de Investigación en Química Sustentable UAEM-UNAM.

${ }^{2}$ Centro de Investigación en Ciencias Biológicas Aplicadas.

Universidad Autónoma del Estado de México.

*moytej@yahoo.com

\section{RESUMEN}

Los sauces, árboles del género Salix son aptos para prácticas de fitoremediación debido a su tolerancia a efectos citotóxicos de contaminantes y alta producción de biomasa. La tolerancia a contaminantes y eficiencia de remoción depende de la especie y del origen de los clones, siendo más eficientes los provenientes de áreas naturales en comparación con clones comerciales. El objetivo de este trabajo fue comparar las características fenotípicas y metabólicas de ejemplares de Salix babylonica presentes en humedales del Valle de Toluca elegir los fenotipos aptos para fitoremediación. Se monitorearon durante los años de 20172018 individuos adultos de S. babylonica. A cada individuo se le midió en campo características fenotípicas: diámetro del tronco a altura del pecho (DAP), altura (h) y cobertura (c); en laboratorio se midió mediante espectrofotometría UV-vis la concentración de pigmentos: clorofila a, b y carotenos. Se evaluó un total de 68 árboles distribuidos en seis localidades. Las características fenotípicas mostraron diferencias significativas entre localidades: altura $(F=4.38, p<0.05, n=68)$; DAP $(F=19.33, p<0.05, n=68)$; cobertura $(F=13.97, p<0.05, n=68)$. Los árboles de la localidad "San Lucas" presentaron las características fenotípicas con valores más altos (DAP: $83.2 \mathrm{~cm}$; h: $13.99 \mathrm{~m}$; c: $11.73 \mathrm{~m}^{2}$ ). La relación clorofila total/carotenos fue menor a 4.2 para todas las localidades: este valor indica que se encuentran bajo condiciones de estrés; no se encontraron diferencias significativas entre localidades y años. Los árboles de la localidad "San Lucas" presentan las mejores características para fitoremediación.

Palabras clave: Salix, sauces, clorofila total, carotenos.

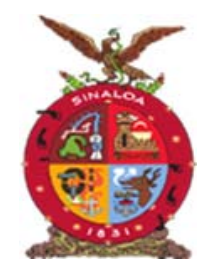

XVIII Congreso Internacional

XXIV Congreso Nacional de Ciencias ambientales
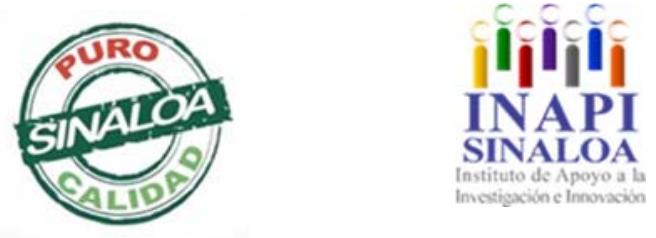

Mazatlán, Sinaloa 3-7 junio 2019

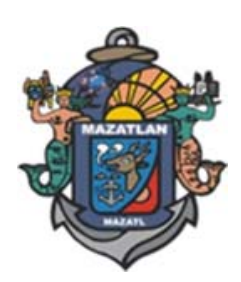

Recursos Naturales, Ecosistemas y Deterioro Ambiental 

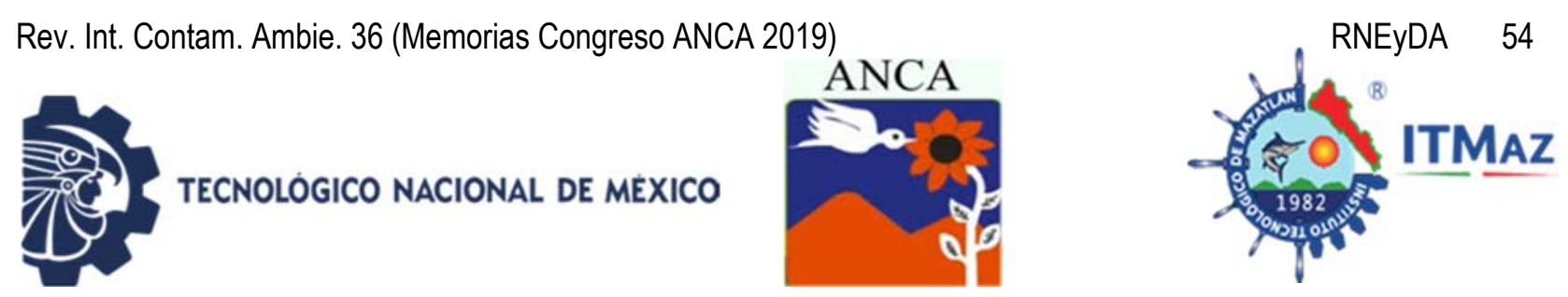

\title{
Some Salix babylonica features for phytoremediation practices
}

\author{
Cruz Ruiz $\mathrm{G}^{1}$, Tejocote Pérez $\mathrm{M}^{2 *}$, Balderas Hernández $\mathrm{P}^{1}$, Roa Morales $\mathrm{G}^{1}$ \\ ${ }^{1}$ Centro Conjunto de Investigación en Química Sustentable UAEM-UNAM. \\ ${ }^{2}$ Centro de Investigación en Ciencias Biológicas Aplicadas. \\ Universidad Autónoma del Estado de México. \\ *moytej@yahoo.com
}

\begin{abstract}
Willows, trees of the genus Salix are suitable for phytoremediation practices due to their tolerance to the cytotoxic effects of contaminants and their high production of biomass. The tolerance to contaminants and removal efficiency depends on the species and the origin of the clones, being more efficient those from natural areas compared to commercial clones. The objective of this work was to compare the phenotypic and metabolic characteristics of Salix babylonica specimens present in the Toluca Valley wetlands that allow us to choose phenotypes suitable for phytoremediation. Adult individuals of $S$. babylonica were monitored during the years of 2017-2018. For everyone, phenotypic characteristics were measured in the field: trunk diameter at chest height ( $\mathrm{DBH})$, height $(\mathrm{h})$ and coverage $(\mathrm{c})$; in the laboratory the concentration of pigments: chlorophyll $\mathrm{a}, \mathrm{b}$ and carotenes were measured by UV-vis spectrophotometry. A total of 68 trees distributed in six locations were evaluated. The phenotypic characteristics showed significant differences between localities: height $(F=4.38, p<0.05, n=68)$; DAP $(F=19.33$, $p<0.05, n=68)$; coverage $(F=13.97, p<0.05, n=68)$. The trees of the locality "San Lucas" presented phenotypic characteristics with higher values (DBH: 83.2 $\mathrm{cm}, \mathrm{h}: 13.99 \mathrm{~m}, \mathrm{c}: 11.73 \mathrm{~m}^{2}$ ). The total chlorophyll / carotene ratio was less than 4.2 for all locations: this value indicates that they are under stress conditions; no significant differences were found between localities and years. The trees of the locality "San Lucas" present the best characteristics for phytoremediation.
\end{abstract}

Keywords: Salix, willows, total chlorophyll, carotenes.

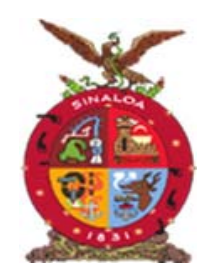

XVIII Congreso Internacional

XXIV Congreso Nacional de Ciencias ambientales
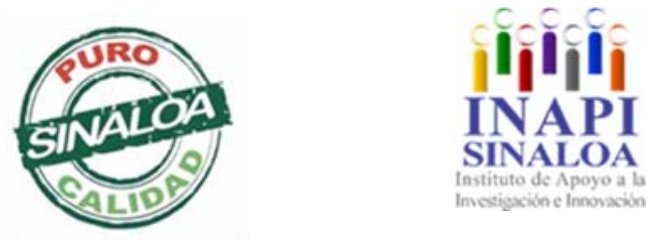

Mazatlán, Sinaloa 3-7 junio 2019

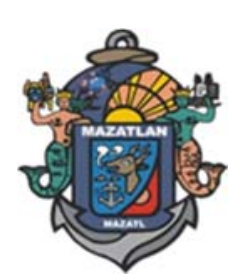

Recursos Naturales, Ecosistemas y Deterioro Ambiental 

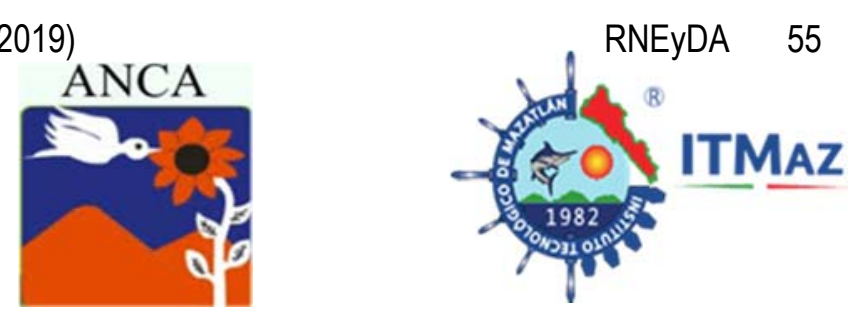

\section{Movilidad de Mn, Ni y Zn en jales mineros sometidos a tratamientos de biorremediación}

Díaz Alvarado J, Vixta Haro JA, Velázquez Cortés JM, Vega Hernández M*, Mendoza Hernández JC, Silveti Loeza A

Facultad de Ingeniería Química. Benemérita Universidad Autónoma de Puebla Cd. Universitaria. Av. San Claudio y 18 Sur, Puebla, Pue.

*vegahm@gmail.com

\section{RESUMEN}

La determinación total de los elementos potencialmente tóxicos (EPT) manifiesta el grado de contaminación de un sitio. Evaluar la movilidad de estos elementos mediante técnicas de extracción y fraccionamiento permiten obtener de forma química el resultado de las interacciones biológicas, indicando así su biodisponibilidad y riesgo al ambiente. En este trabajo, se efectuó un estudio comparativo de las concentraciones de $\mathrm{Mn}$, Ni y $\mathrm{Zn}$ en jales sometidas a ensayos de fitorremediación con Ricinus communis y sustrato comercial; combinandos en proporciones del $10 \%$ de sustrato mezclado $(\mathrm{TJ}+\mathrm{SM})$ y $5 \%$ del sustrato sin mezclar $(\mathrm{TJ}+\mathrm{S} / \mathrm{SM})$. Se emplearon métodos de extracción química secuencial BCR y Hall. Los resultados obtenidos para manganeso y níquel la concentración predominante fue hallada en la fracción residual, es decir, para Mn, Hall (557.34 $\mathrm{mg} / \mathrm{kg}$ ) en el TJ + SM es mayor que BCR $(413.84 \mathrm{mg} / \mathrm{kg})$ en el TJ + SS/M; y por otra parte para Ni, Hall $(20.84 \mathrm{mg} / \mathrm{kg})$ en el TJ + SM es superior que BCR $(20.26$ $\mathrm{mg} / \mathrm{kg}$ ) en el TJ (Jal). Respecto al zinc, muestra una mayor concentración en la fracción reducible con el TJ + SM en la técnica BCR $(2003.53 \mathrm{mg} / \mathrm{kg})$, en contraste con la fracción de materia orgánica en Hall $(1323.45 \mathrm{mg} / \mathrm{kg})$ con el TJ $+\mathrm{SM}$. Se presentaron diferencias significativas $(p<0.05)$ en el uso de Ricinus communis y en la distribución de las fracciones dependiendo del método químico secuencial utilizado, atribuibles al número de fracciones en que se dividen las especies químicas, reactivos extractantes utilizados, afinidad de los EPT, tiempo de retención y temperatura utilizada.

Palabras clave: Extracción química secuencial, jale, fitorremediación, elementos potencialmente tóxicos.

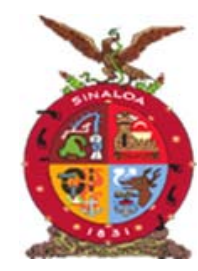

XVIII Congreso Internacional XXIV Congreso Nacional de Ciencias ambientales
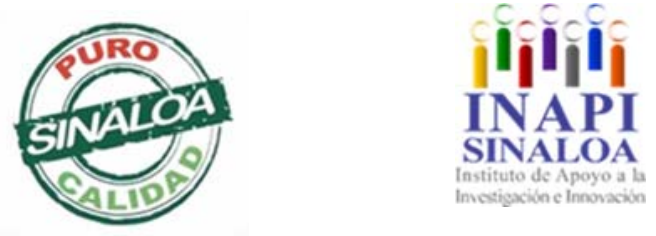

Mazatlán, Sinaloa 3-7 junio 2019

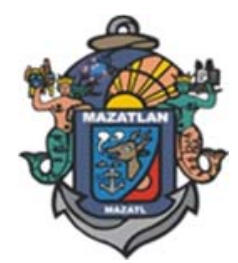

Recursos Naturales, Ecosistemas y Deterioro Ambiental 

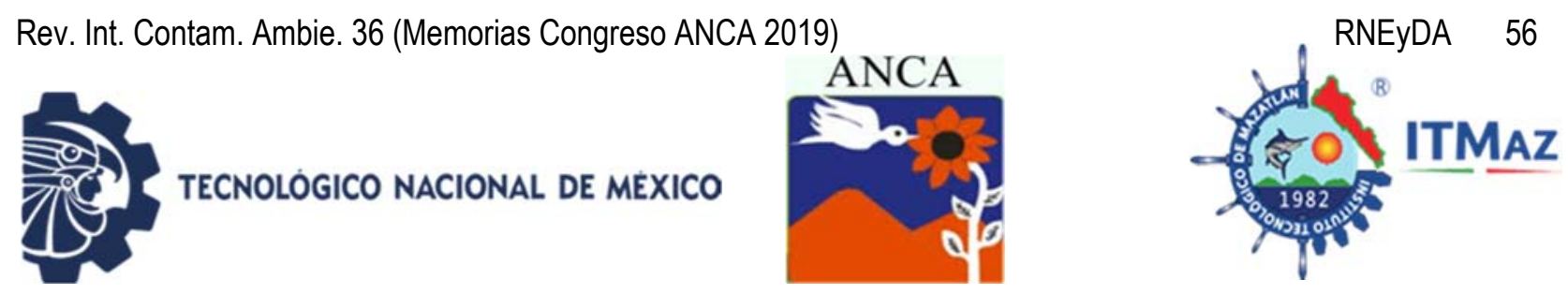

\title{
Mobility of $\mathrm{Mn}, \mathrm{Ni}$, and $\mathrm{Zn}$ by Two Sequential Chemical Extraction Techniques in Tailings Undergoing Bioremediation Treatments
}

\author{
Díaz Alvarado J, Vixta Haro JA, Velázquez Cortés JM, Vega Hernández M*, \\ Mendoza Hernández JC, Silveti Loeza A
}

Facultad de Ingeniería Química. Benemérita Universidad Autónoma de Puebla Cd. Universitaria. Av. San Claudio y 18 Sur, Puebla, Pue.

*vegahm@gmail.com

\begin{abstract}
Total or pseudototal determination of potentially toxic elements (PTEs) shows the contamination degree of a site. Mobility evaluation of PTEs through extraction and fractionation techniques allow to obtain the results of biological interactions in a chemical form, indicating its bioavailability and environmental risks. In this work, a comparative study of the concentrations of $\mathrm{Mn}, \mathrm{Ni}$ and $\mathrm{Zn}$ in tailings undergoing phytoremediation tests with Ricinus communis and commercial substrate was carried out, combined in proportions of $10 \%$ with mixed substrate (TJ + SM) and $5 \%$ with the unmixed substrate (TJ $+S / S M)$. Methods of sequential chemical extraction, BCR and Hall were used. These are the results of both methodologies: for Manganese and Nickel, the highest concentration is found in the residual fraction. For Mn, Hall $(557.34 \mathrm{mg} / \mathrm{Kg})$ in the TJ + SM is greater than BCR (413.84 $\mathrm{mg} / \mathrm{Kg}$ ) in the TJ + SS / M. By the other hand for Ni, Hall $(20.84 \mathrm{mg} / \mathrm{Kg})$ in TJ + $\mathrm{SM}$ is greater than BCR $(20.26 \mathrm{mg} / \mathrm{Kg})$ in TJ (mine tailings). Zinc shows a higher concentration in the reducible fraction with $\mathrm{TJ}+\mathrm{SM}$ in the BCR technique $(2003.53 \mathrm{mg} / \mathrm{Kg})$, in contrast to the organic matter fraction in Hall $(1323.45 \mathrm{mg} / \mathrm{Kg})$ with TJ + SM. There were significant differences $(p<0.05)$ in the use of Ricinus communis and in the fraction's distribution depending on the sequential chemical method used, attributable to the number of fractions in which the chemical species are divided, extractant reagents, affinity of the PTEs, retention time and temperature.
\end{abstract}

Keywords: Sequential chemical extraction, tailing, phytoremediation, potentially toxic elements.
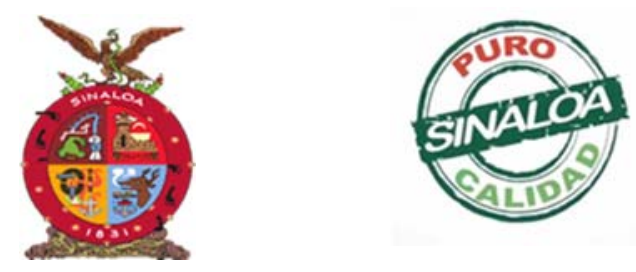

Mazatlán, Sinaloa 3-7 junio 2019

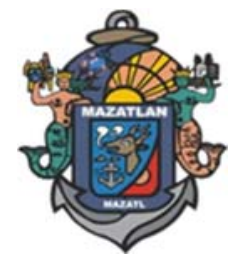

Recursos Naturales, Ecosistemas y Deterioro Ambiental 

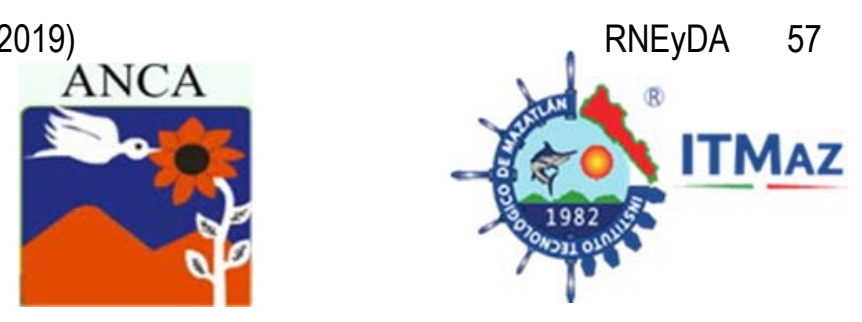

\title{
Propiedades hidrológicas de Quercus rugosa Neé y Pinus durangensis Martínez en el Ejido Adolfo Ruiz Cortines, Pueblo Nuevo, Durango, México
}

\author{
Domínguez Gómez $\mathrm{TG}^{1 *}$, Mendía Santana $\mathrm{R}^{1}$, Soto Silva $\mathrm{CA}^{2}$, Alvarado $\mathrm{MS}^{3}$, \\ González Quiñones JS ${ }^{1}$ \\ ${ }^{1}$ Instituto Tecnológico de El Salto. \\ División de Estudios de Posgrado e Investigación. \\ Mesa del Tecnológico S/N, El Salto, Durango, México \\ ${ }^{2}$ Centro Bachillerato Tecnológico Forestal. \\ Calle Ing. Blanco Vicente Guerrero, El Salto, Durango, México \\ ${ }^{3}$ Centro de Investigación en Alimentación y Desarrollo, A. C. \\ Carr. La Victoria Km 0.6, C.P. 83304, Hermosillo, Sonora, México \\ *gustavo_dguezg@hotmail.com
}

\section{RESUMEN}

Con el objetivo de conocer las propiedades hidrológicas dentro del ecosistema pino-encino del estado de Durango, se estableció un experimento en el ejido Adolfo Ruiz Cortines del municipio de Pueblo Nuevo; Durango. El análisis de 28 eventos de lluvia registrados entre los meses junio a diciembre del 2017, los cuales sumaron un total de $761.29 \mathrm{~mm}$ de precipitación, mostró que la precipitación directa para Quercus rugosa Neé y Pinus durangensis Martínez representó $81 \%$ y $36 \%$, respectivamente, del total de la precipitación incidente. El escurrimiento fustal presentó valores de $2.01 \%$ para $Q$. rugosa y $6.29 \% P$. durangensis. Las pérdidas por intercepción del dosel vegetal fueron estimadas en 5.92 y $8.81 \%$ para $Q$. rugosa y $P$. durangensis. Los rangos del coeficiente de determinación para las pérdidas por intercepción fueron de $r^{2}=0.26$ para $Q$. rugosa y 0.022 en $P$. durangensis. En el análisis del pluviolavado, el valor de $\mathrm{pH}$ obtenido para la precipitación incidente fue de 6.71, para la precipitación directa de $P$. durangensis fue de 5.48 y para $Q$. rugosa fue de 6.22 , el escurrimiento fustal presento un $\mathrm{pH}$ para $P$. durangensis de 4.96 y para $Q$. rugosa fue de 7.55 , En el escurrimiento fustal la conductividad eléctrica mostró valores con un promedio de $26.34 \mu \mathrm{S} \mathrm{cm}^{-1}$ correspondiente a $P$. durangensis, mientras que el valor aumento considerablemente para la especie $Q$. rugosa con un promedio de $113.29 \mu \mathrm{S} \mathrm{cm}-$ ${ }^{1}$. La capacidad de almacenamiento fue mayor para $P$. durangensis debido a diferencias en las características dasométricas de las especies.

Palabras clave: Incidente, directa, escurrimiento fustal, intercepción y pluviolavado.

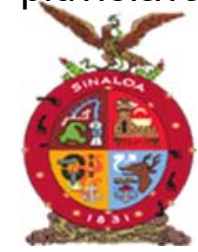

XVIII Congreso Internacional

XXIV Congreso Nacional de Ciencias ambientales
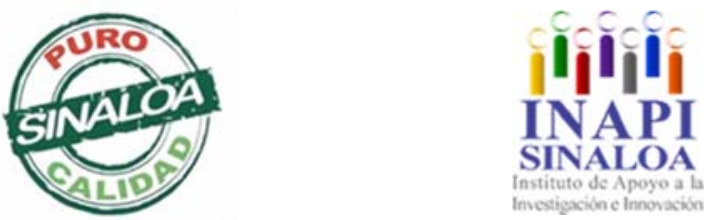

Mazatlán, Sinaloa 3-7 junio 2019

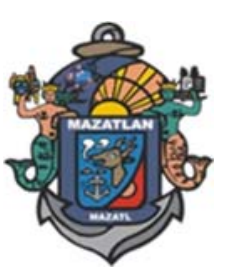

Recursos Naturales, Ecosistemas y Deterioro Ambiental 

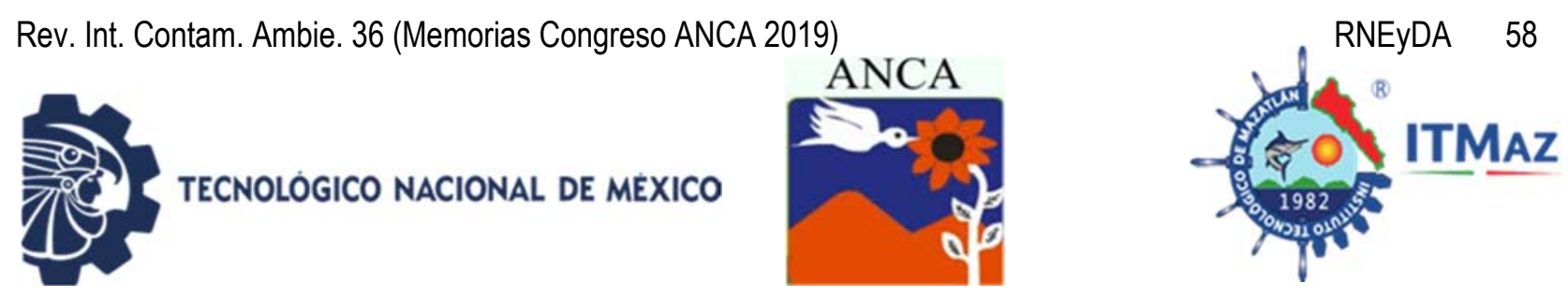

\title{
Hydrological properties of Quercus rugged Née and Pinus durangensis Martínez in the Ejido Adolfo Ruiz, Pueblo Nuevo, Durango, Mexico
}

\author{
Domínguez Gómez $\mathrm{TG}^{1 *}$, Mendía Santana $\mathrm{R}^{1}$, Soto Silva $\mathrm{CA}^{2}$, Alvarado $\mathrm{MS}^{3}$, \\ González Quiñones JS ${ }^{1}$ \\ ${ }^{1}$ Instituto Tecnológico de El Salto. \\ División de Estudios de Posgrado e Investigación. \\ Mesa del Tecnológico S/N, El Salto, Durango, México \\ ${ }^{2}$ Centro Bachillerato Tecnológico Forestal. \\ Calle Ing. Blanco Vicente Guerrero, El Salto, Durango, México \\ ${ }^{3}$ Centro de Investigación en Alimentación y Desarrollo, A. C. \\ Carr. La Victoria Km 0.6, C.P. 83304, Hermosillo, Sonora, México \\ *gustavo_dguezg@hotmail.com
}

\begin{abstract}
In order to know the hydrological properties within the pine-oak ecosystem of the state of Durango, an experiment was established in the Adolfo Ruíz Cortines ejido of the municipality of Pueblo Nuevo; Durango. The analysis of 28 rain events recorded between June and December 2017, added a total of $761.29 \mathrm{~mm}$ of rainfall, showed that direct precipitation for Quercus rugosa Neé and Pinus durangensis Martínez represented $81 \%$ and $36 \%$, respectively, of the total incident precipitation. The fustal runoff presented values of $2.01 \%$ for $Q$. rugosa and $6.29 \%$ P. durangensis. Plant canopy interception losses were estimated at 5.92 and $8.81 \%$ for $Q$. rugosa and $P$. durangensis. The ranges of the coefficient of determination for interception losses were $r^{2}=0.26$ for $Q$. rugosa and 0.022 for $P$. durangensis. In the rainwater analysis, the $\mathrm{pH}$ value obtained for the incident precipitation was 6.71 , for the direct precipitation of $P$. durangensis it was 5.48 and for $Q$. rugosa it was 6.22. The fustal runoff presented a pH for $P$. durangensis of 4.96 and for $Q$. rugosa was 7.55, In the fustal runoff the electrical conductivity showed values with an average of $26.34 \mu \mathrm{S} \mathrm{cm}{ }^{-1}$ corresponding to $P$. durangensis, while the value increased considerably for the species $Q$. rugosa with an average of $113.29 \mu \mathrm{S} \mathrm{cm}^{-1}$. The storage capacity was higher for $P$. durangensis due to differences in the dasometric characteristics of the species.
\end{abstract}

Keywords: Incident, direct, fustal runoff, interception and pluviolavado.

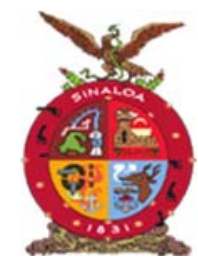

XVIII Congreso Internacional

XXIV Congreso Nacional de Ciencias ambientales

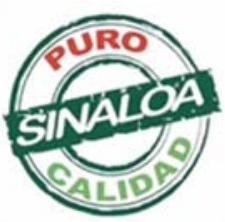

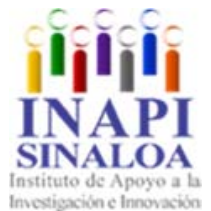

Mazatlán, Sinaloa 3-7 junio 2019

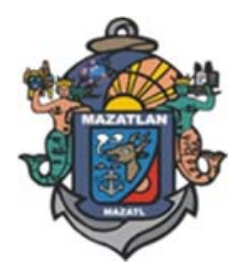

Recursos Naturales, Ecosistemas y Deterioro Ambiental 

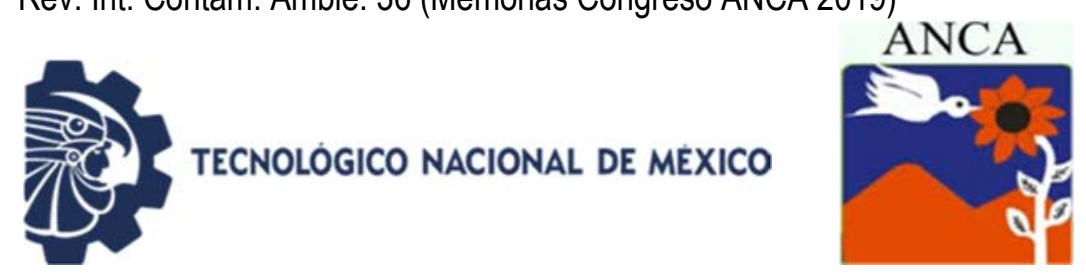

\title{
Uso de vehículos aéreos no tripulados para el conteo de aves en humedales
}

\author{
Escobar Flores $\mathrm{JG}^{1 *}$, Sandoval $\mathrm{S}^{2}$ \\ ${ }^{1}$ CIIDIR, Instituto Politécnico Nacional. 34220, Durango, Durango, México \\ ${ }^{2}$ CONACYT, CIIDIR,. Instituto Politécnico Nacional. 34220, Durango, México \\ *jonas286@hotmail.com
}

\begin{abstract}
RESUMEN
En esta investigación se probaron dos tipos de vehículos aéreos no tripulados, con un ala fija y un cuadroptero con el objetivo de determinar cuál de estos dos vehículos es más adecuado para el conteo de aves en humedales. Primero se realizaron mediciones de ruido para determinar a qué altura de vuelo las aves pueden ser contadas sin perturbarlas y, enseguida, mediante un algoritmo de detección de objetivos se cuantificaron las aves durante las misiones de conteo. Se encontró que los vuelos del ala fija uno programados a elevaciones de 30 y 50 m superaban los $60 \mathrm{~dB}$ ocasionando que las aves se asustarán y comenzaran a volar antes de que fueran contadas, el nivel de ruido con ala fija a partir de los $80 \mathrm{~m}$ fue menor a los $50 \mathrm{~dB}$ y la mayoría de las aves no se asustaron. En el caso de los resultados del cuadroptero, los niveles de ruido fueron más altos, en elevaciones de $30 \mathrm{~m}$ llegaron a superar los $75 \mathrm{~dB}$, y solo cuando se superaban los $100 \mathrm{~m}$ los niveles de ruido fueron menores a $50 \mathrm{~dB}$. El conteo de aves fue más eficiente con el ala fija principalmente porque esta aeronave realiza vuelos continuos sin detenerse y por lo tanto las aves no se sienten amenazadas, contrario a lo que sucedió con el cuadroptero que se detiene en cada vértice para fotografiar el recorrido. Estudios de ruido mencionan que más de $50 \mathrm{~dB}$ es suficiente para provocar que las aves no se sientan seguras en sus sitios de percha o alimentación, por lo que se recomienda el uso de vehículos aéreos de tipo ala fija los cuales pueden volar por más de 40 minutos y a elevaciones mayores a los $100 \mathrm{~m}$ donde el ruido es menor a $50 \mathrm{~dB}$ y no perturban a las aves.
\end{abstract}

Palabras clave: Aves, drone, ruido, humedales.

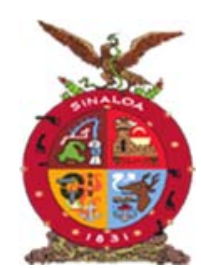

XVIII Congreso Internacional XXIV Congreso Nacional de Ciencias ambientales

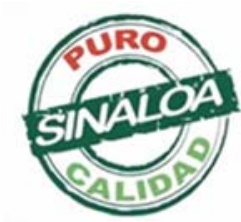

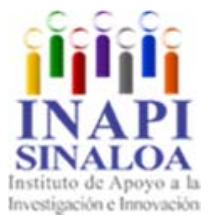

Mazatlán, Sinaloa 3-7 junio 2019

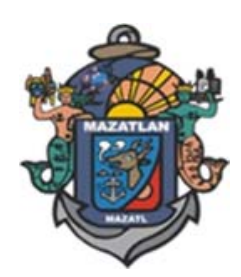

Recursos Naturales, Ecosistemas y Deterioro Ambiental 

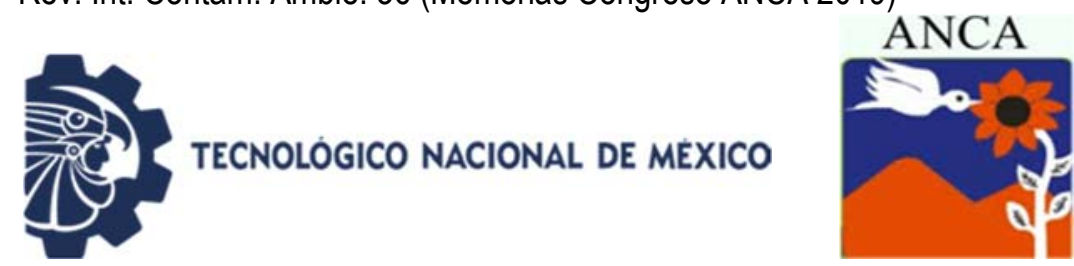

\title{
Use of unmanned aerial vehicles for the counting of birds in wetlands
}

\author{
Escobar Flores $\mathrm{JG}^{1 *}$, Sandoval $\mathrm{S}^{2}$ \\ ${ }^{1}$ CIIDIR, Instituto Politécnico Nacional. 34220, Durango, Durango, México \\ ${ }^{2}$ CONACYT, CIIDIR,. Instituto Politécnico Nacional. 34220, Durango, México \\ *jonas286@hotmail.com
}

\begin{abstract}
In this research, two types of unmanned aerial vehicles, a fixed wing and a quadropter were tested to determine which of these vehicles is suitable for counting birds in wetlands. Noise measurements were made to determine at which flight height the birds can be counted without disturbing them, and by means of a goal detection algorithm the birds were quantified during the missions. We found that the flights of the fixed wing programmed to elevations of $30 \mathrm{~m}$ and $50 \mathrm{~m}$ exceeded $60 \mathrm{~dB}$ which caused the birds to be frightened and to begin flying before they were counted. The noise level of the fixed wing from $80 \mathrm{~m}$ was less than $50 \mathrm{~dB}$ and most birds were not scared. In the case of the quadropter the noise levels were higher, in elevations of $30 \mathrm{~m}$ they reached over $75 \mathrm{~dB}$, and only when they exceeded 100 meters the noise levels were less than $50 \mathrm{~dB}$. The bird count was more efficient with the fixed wing mainly because this aircraft performs continuous flights without stopping and therefore the birds do not feel threatened, contrary to what happened with the quadropter that stops at each vertex to photograph the route. Noise studies mention that more than $50 \mathrm{~dB}$ is enough to cause birds do not feel safe in their perch or feeding sites, so it is recommended the use of fixed-wing aerial vehicles which can fly for more than 40 minutes and at elevations greater than $100 \mathrm{~m}$ the noise is less than $50 \mathrm{~dB}$ and does not disturb the birds.
\end{abstract}

Keywords: Birds, drone, noise, wetlands.

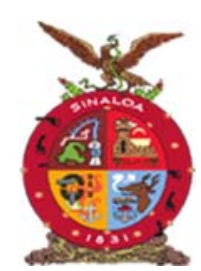

XVIII Congreso Internacional XXIV Congreso Nacional de Ciencias ambientales
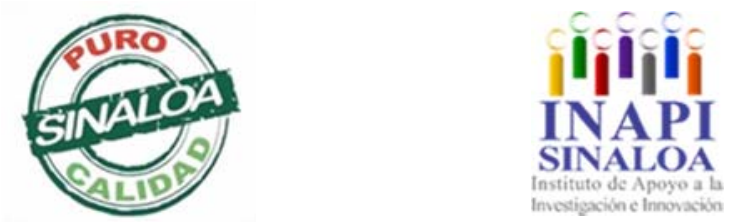

Mazatlán, Sinaloa 3-7 junio 2019

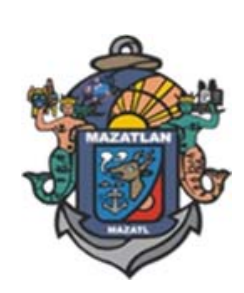

Recursos Naturales, Ecosistemas y Deterioro Ambiental 

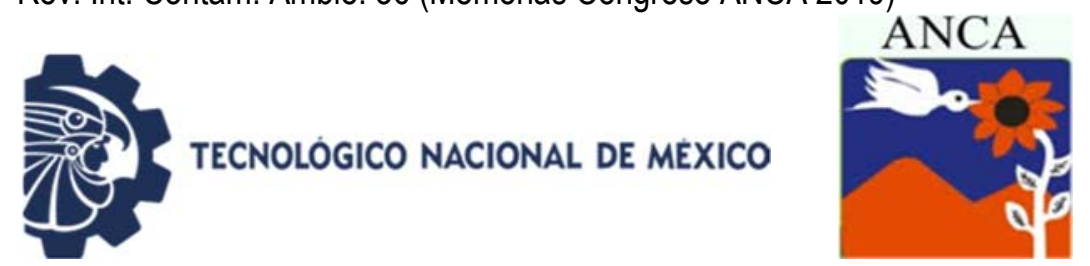

\title{
Determinación de la absorción de dióxido de carbono y producción de oxígeno de árboles de Casa de la Naturaleza, Tampico, Tamaulipas, México
}

\author{
Escobar Gonzalez $\mathrm{J}^{1^{*}}$, Cuellar Gonzalez J¹, Contreras Molina A² \\ ${ }^{1}$ Dirección de Cuerpos de Agua. Universidad del Noreste A. C. \\ Tampico, Tamaulipas, México \\ ${ }^{2}$ Address of Bodies of Water. Tampico, Tamaulipas, México \\ *georgeescobar2008@hotmail.com
}

\section{RESUMEN}

El dióxido de carbono $\left(\mathrm{CO}_{2}\right)$ es el gas de efecto invernadero más importante producido por las actividades humanas. Actualmente, cerca de un $20 \%$ de las emisiones de $\mathrm{CO}_{2}$ resultan de la eliminación y degradación de los ecosistemas forestales. Por medio de datos estadísticos se determinará que especies de la zona estudiada, son más eficientes en el secuestro de $\mathrm{CO}_{2}$ y en su generación de $\mathrm{O}_{2}$, la investigación se realizó en el parque recreativo" Casa de la Naturaleza" Tampico, Tamaulipas en un periodo de junio a diciembre del 2018. Se realizó un análisis de varianza a nivel de significancia de $a=0.05$; y para determinar la significancia de los promedios entre clase diamétrica se realizó la prueba estadística de Tukey. Como resultado se obtuvo que las clases diamétricas más productivas para la absorción de $\mathrm{CO}_{2}$, y generación de $\mathrm{O}_{2}$ fueron las clases $(>50$ $75)$ y (>75->100) con un promedio de 155.66 toneladas de secuestro de $\mathrm{CO}_{2}$. Mientras que las clases diamétricas con más producción de generación de $\mathrm{O}_{2}$ fueron (>50-75) y (>75->100), con un promedio de 253.95 toneladas de oxígeno. Por lo tanto, los arboles con una mayor biomasa y clase diamétrica tienen un elevado índice de absorción de $\mathrm{CO}_{2}$ y una gran generación de $\mathrm{O}_{2}$, entre los árboles que destacaron ser más eficientes fueron; Orejón (Enterolobium cyclocarpum) y la Ceiba (Ceiba pentandra) de las cuales son nativas de la región y se encuentran dentro de la Casa de la Naturaleza.

Palabras clave: Dióxido de carbono, oxígeno, censo arbóreo, clase diamétrica, anova.

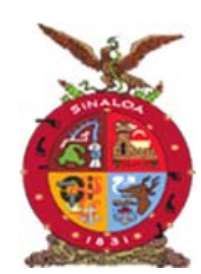

XVIII Congreso Internacional

XXIV Congreso Nacional de Ciencias ambientales

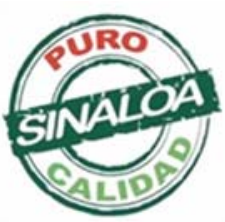

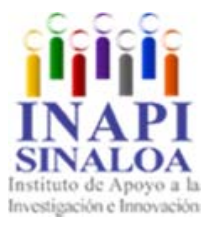

Mazatlán, Sinaloa 3-7 junio 2019

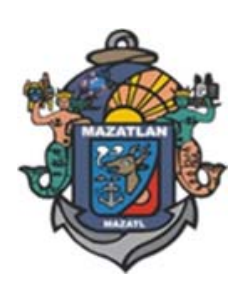

Recursos Naturales, Ecosistemas y Deterioro Ambiental 

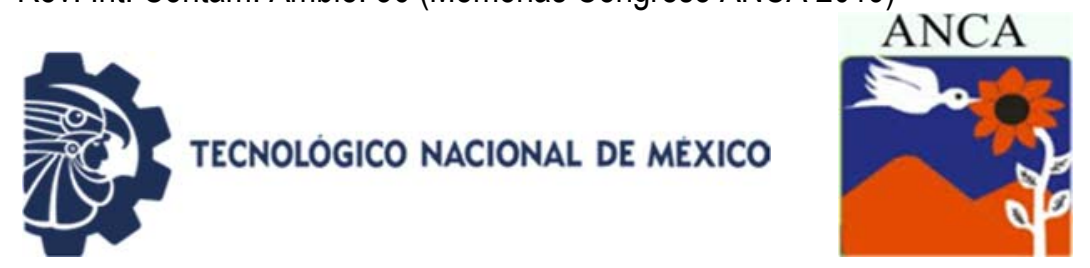

\title{
Determination of the Absorption of Carbon Dioxide and Production of Oxygen from Trees of Nature House, Tampico, Tamaulipas, Mexico
}

\author{
Escobar Gonzalez $\mathrm{J}^{1^{*}}$, Cuellar Gonzalez $\mathrm{J}^{1}$, Contreras Molina $\mathrm{A}^{2}$ \\ ${ }^{1}$ Dirección de Cuerpos de Agua. Universidad del Noreste A. C. \\ Tampico, Tamaulipas, México \\ ${ }^{2}$ Address of Bodies of Water. Tampico, Tamaulipas, México \\ *georgeescobar2008@hotmail.com
}

\begin{abstract}
Carbon dioxide $\left(\mathrm{CO}_{2}\right)$ is the most important greenhouse gas produced by human activities. Currently, about $20 \%$ of $\mathrm{CO}_{2}$ emissions result from the elimination and degradation of forest ecosystems. By means of statistical data it will be determined which species of the studied zone are more efficient in the sequestration of $\mathrm{CO}_{2}$ and in its generation of $\mathrm{O}_{2}$, the research was carried out in the recreational park "Casa de la Naturaleza" Tampico, Tamaulipas in a period from June to December 2018. An analysis of variance was carried out at a significance level of $a=0.05$; and to determine the significance of the averages between the diameter classes, Tukey's statistical test was performed. As a result it was obtained that the most productive diameter classes for the absorption of $\mathrm{CO}_{2}$, and generation of $\mathrm{O}_{2}$ were the classes (>50-75) and (> 75-> 100) with an average of 155.66 tons of sequestration of $\mathrm{CO}_{2}$. While the diametric classes, with the highest generation production of $\mathrm{O}_{2}$ were (>50-75) and (>75->100), with an average of 253.95 tons of oxygen. Therefore, trees with a higher biomass and diametric class have a high rate of absorption of $\mathrm{CO}_{2}$ and a large generation of $\mathrm{O}_{2}$, among the trees that stood out being more efficient were; Orejón (Enterolobium cyclocarpum) and Ceiba (Ceiba pentandra) of which are native to the region and are located within the House of Nature.
\end{abstract}

Keywords: Carbon dioxide, oxygen, arboreal census, diametric class, anova.

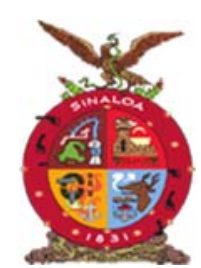

XVIII Congreso Internacional

XXIV Congreso Nacional de Ciencias ambientales

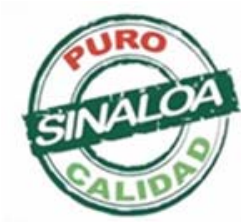

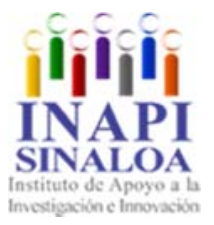

Mazatlán, Sinaloa 3-7 junio 2019

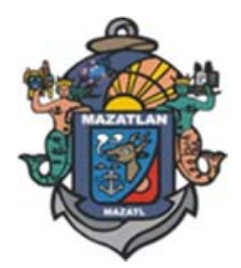

Recursos Naturales, Ecosistemas y Deterioro Ambiental 

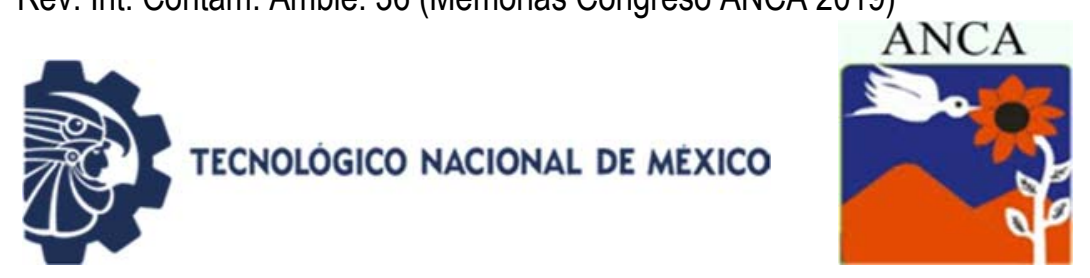

\title{
Comunidades de parásitos metazoarios de Selar crumenophthalmus y Decapterus muroadsi (Piscis: Carangidae) de las costas del Pacífico Mexicano
}

\author{
Gallegos Navarro ${ }^{1} \mathrm{Y}$, Violante González J1,2, Monks $\mathrm{S}^{3}$, García lbáñez $\mathrm{S}^{2}$, \\ Rojas Herrera $\mathrm{AA}^{1,2}$, Rosas Acevedo $\mathrm{JL}^{1}$ \\ ${ }^{1}$ Centro de Ciencias de Desarrollo Regional. \\ Universidad Autónoma de Guerrero. Acapulco, México \\ ${ }^{2}$ Facultad de Ecología Marina. \\ Universidad Autónoma de Guerrero. Acapulco, México \\ ${ }^{3}$ Centro de Investigaciones Biológicas. \\ Universidad Autónoma del Estado de Hidalgo. Pachuca, México
}

\section{RESUMEN}

Las comunidades de parásitos metazoos de peces marinos pueden incluir tanto adultos, como etapas larvarias de varios grupos de endoparásitos, que usan a peces como hospederos intermediarios o paraténicos. La riqueza de especies y la abundancia de larvas parasitarias que infecta a un pez son buenos indicadores en su papel como hospedero intermediario de especies endoparásitas. Las comunidades de parásitos de dos peces pequeños carángidos (Selar crumenophthalmus y Decapterus muruadsi) de la costa sur del Pacífico de México, fueron cuantificados y analizados. Quinientos sesenta y tres carángidos (S. crumenophthalmus, $\mathrm{n}=402$; y $D$. muroadsi, $\mathrm{n}=161$ ), se recolectaron entre abril de 2014 y abril de 2018 en tres lugares. Se identificaron veinticuatro especies de parásitos metazoarios de los dos hospederos: cinco especies de Monogenea (adultos), ocho de Digenea (7 adultos y 1 metacercaria), dos de Cestoda (larvas), dos Nematoda (una adulta y 1 larva), dos de Acanthocephala (adultos ), y cinco de Copepoda. Los helmintos en etapa de larva dominaron numéricamente las comunidades de endoparásitos en ambas especies de hospederos, lo que sugiere que estos carángidos desempeñan un papel importante como hospederos intermediarios. La riqueza y composición de especies de las comunidades componentes de parásitos diferían entre el huésped, las ubicaciones y los años de muestreo. Las variaciones en el comportamiento de alimentación del huésped y el tamaño corporal se consideraron factores importantes que influyen en estas diferencias.

Palabras clave: Parásitos metazoarios, peces marinos, carángidos, Costa del Pacífico, México.

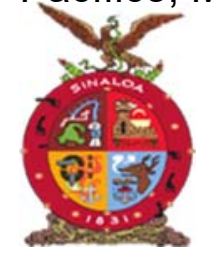

XVIII Congreso Internacional

XXIV Congreso Nacional de Ciencias ambientales

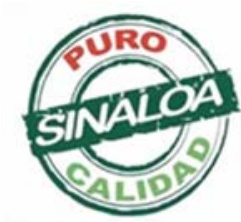

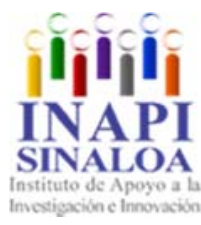

Mazatlán, Sinaloa 3-7 junio 2019

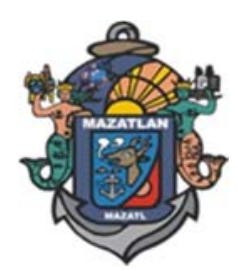

Recursos Naturales, Ecosistemas y Deterioro Ambiental 

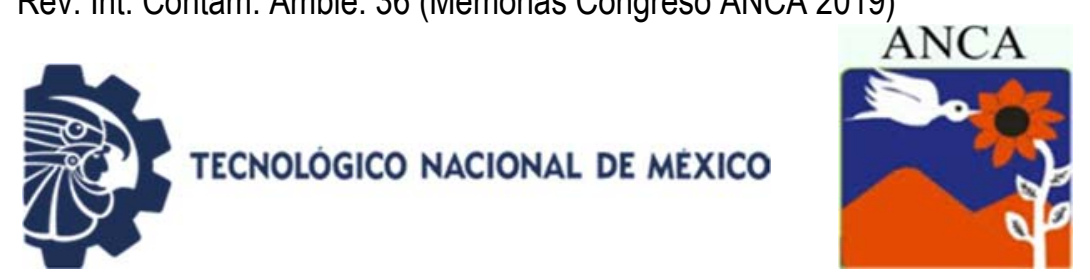

\title{
Metazoan parasite communities of Selar Crumenophthalmus and Decapterus muroadsi (Pisces: Carangidae) from Mexican Pacific coasts
}

\author{
Gallegos Navarro ${ }^{1} \mathrm{Y}$, Violante González $\mathrm{J}^{1,2}$, Monks $\mathrm{S}^{3}$, García Ibáñez $\mathrm{S}^{2}$, \\ Rojas Herrera $\mathrm{AA}^{1,2}$, Rosas Acevedo $\mathrm{JL}^{1}$ \\ ${ }^{1}$ Centro de Ciencias de Desarrollo Regional. \\ Universidad Autónoma de Guerrero. Acapulco, México \\ ${ }^{2}$ Facultad de Ecología Marina. \\ Universidad Autónoma de Guerrero. Acapulco, México \\ ${ }^{3}$ Centro de Investigaciones Biológicas. \\ Universidad Autónoma del Estado de Hidalgo. Pachuca, México
}

\begin{abstract}
The communities of metazoan parasites of marine fish can include either adults and larvae stages of several groups of endoparasites, that use fish as intermediate or paratenic hosts. The species richness and abundance of parasite larvae that infect a fish are good indicators of its role as intermediate host of endoparasite species. The parasite communities of two small carangid fish (Selar crumenophthalmus and Decapterus muroadsi) from the southern Pacific coasts of México, were quantified and analyzed. Five hundred sixty-three carangids ( $S$. crumenophthalmus, $\mathrm{n}=402$; and $D$. muroadsi, $\mathrm{n}=161$ ) were collected between April 2014 an April 2018 from three locations. Twenty-four species of metazoan parasites were identified from the two host: five species of Monogenea (adults), eigth of Digenea (7 adults and 1 metacercariae), two of Cestoda (larvae), two Nematoda (one adult and 1 larvae), two of Acanthocephala (adults), and five of Copepoda. Helminths in larvae stage numerically dominated the endoparasite communities of both species of hosts, suggesting that these carangids play an important role as intermediate hosts. Richness and species composition of component parasite communities differed between host, locations, and sampling years. Variations in host feeding behavior, and body size were considered as important factors that influence these differences.
\end{abstract}

Keywords: Metazoan parasites, marine fish, carangids, Pacific coast, México.

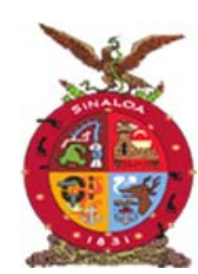

XVIII Congreso Internacional

XXIV Congreso Nacional de Ciencias ambientales

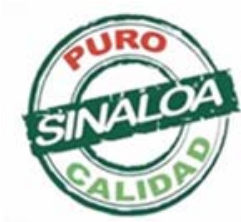

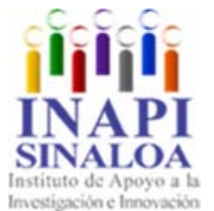

Mazatlán, Sinaloa 3-7 junio 2019

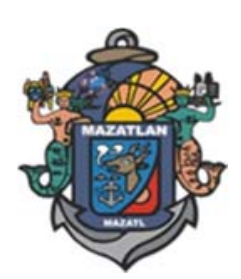

Recursos Naturales, Ecosistemas y Deterioro Ambiental 

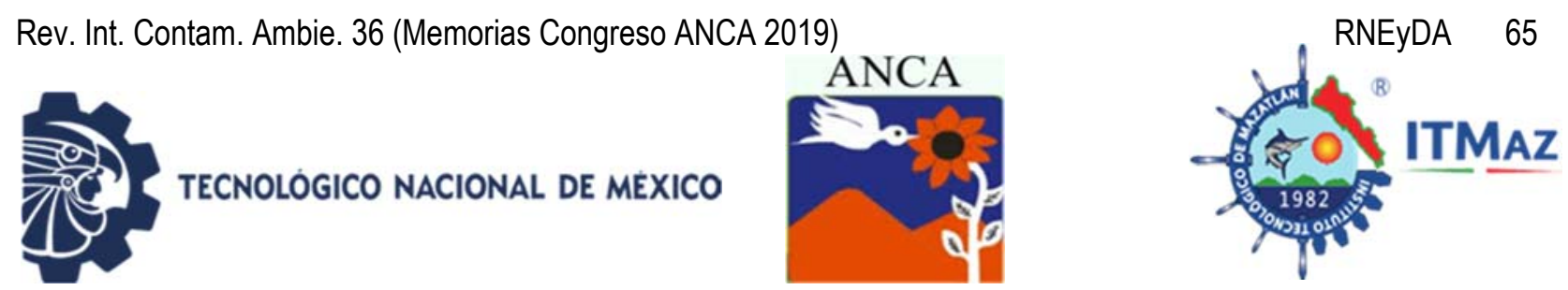

\title{
Efecto de la agricultura intensiva como precursor de la degradación del suelo en dos localidades del Estado de Zacatecas, México
}

\author{
Gallegos Padierna A*, García Meraz H, Arredondo Ríos A, \\ Inchaurregui Méndez H, Ávila Vázquez V \\ Unidad Interdisciplinaria de Ingeniería Campus Zacatecas. \\ Calle Circuito del Gato 202, Ciudad Administrativa, Zacatecas, México \\ *galpadadriana@gmail.com
}

\section{RESUMEN}

El manejo intensivo de la agricultura provoca la erosión y desertificación del suelo, reduciendo su eficiencia e incrementando la necesidad del uso de fertilizantes que satisfagan los requerimientos nutrimentales de los cultivos, problemática que caracteriza en su mayoría los suelos agrícolas de Zacatecas. Con el propósito de identificar los efectos del uso de fertilizantes aplicados sin control en zonas agrícolas para cultivo de maíz se realizó la caracterización del suelo, evaluando la disponibilidad de macronutrientes y micronutrientes en muestras provenientes de dos predios, ubicados en Chalchihuites, Zacatecas y de La Zacatecana en Guadalupe, Zacatecas, basándose en la metodología descrita en la Norma Oficial Mexicana NOM-021-SEMARNAT-2000 modificación 2010, en la cual establece las especificaciones de fertilidad, salinidad y clasificación de suelos. Estudios, muestreo y análisis, para un suelo que no ha sufrido procesos de cultivo o labranza durante cinco años la disponibilidad de nutrientes nitrógeno, fósforo y materia orgánica y valores de capacidad de intercambio catiónico y capacidad de retención de agua $(44.38 \mathrm{cmol} / \mathrm{kg}$ y $65.484 \%$ respectivamente) fueron mayores respecto a aquél en que la última siembra y aplicación de un fertilizante nitrogenado fue hace un año (18.93 $\mathrm{cmol} / \mathrm{kg}$ y $22.03 \%)$.

Palabras clave: Uso del suelo, propiedades físicas del suelo, fertilidad, nutrientes, desertificación.

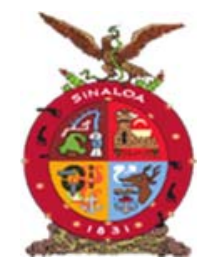

XVIII Congreso Internacional

XXIV Congreso Nacional de Ciencias ambientales

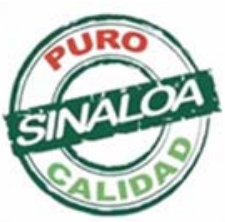

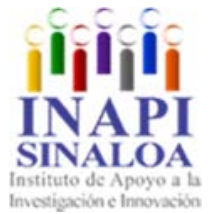

Mazatlán, Sinaloa 3-7 junio 2019

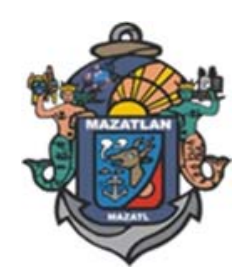

Recursos Naturales, Ecosistemas y Deterioro Ambiental 

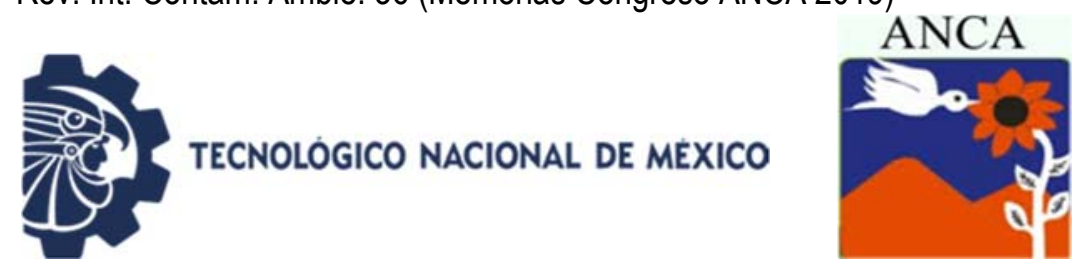

\title{
Effect of intensive agriculture as precursor in soil degradation in two localities of Zacatecas State, Mexico
}

\author{
Gallegos Padierna A*, García Meraz H, Arredondo Ríos A, \\ Inchaurregui Méndez H, Ávila Vázquez V
}

Unidad Interdisciplinaria de Ingeniería Campus Zacatecas.

Calle Circuito del Gato 202, Ciudad Administrativa, Zacatecas, México

*galpadadriana@gmail.com

\begin{abstract}
The intensive management of agriculture has caused erosion and desertification effects in the environment, reducing soil efficiency and increasing the prevailing need for fertilizer use that meets the nutritional requirements of crops, a problem that characterizes most of the agriculture soil of Zacatecas. In order to identify the effects of uncontrolled fertilizer use in agricultural areas for corn cultivation, soil characterization was carried out. identifying the availability of macronutrients and micronutrients in samples from two farms, located in Chalchihuites and the locality of La Zacatecana in Guadalupe, Zacatecas. The latter taken as a target from the methodology described in the Mexican Official Norm NOM-021-SEMARNAT2000 modification 2010, That establish the especifications of fertility, salinity and soil clasification. Studies, sampling and analysis. For a soil that hasn't undergone cultivation or tillage processes for five years the nutrient availability (nitrogen, phosphorus and organic matter). and values of cation exchange capacity, and water retention capacity $(44.38 \mathrm{cmol} / \mathrm{kg}$ and $65.484 \%$ respectively) were higher with respect to that in which last sowing and application of a nitrogen fertilizer were a year ago $(18.93 \mathrm{cmol} / \mathrm{kg}$ and $22.03 \%$ respectively).
\end{abstract}

Keywords: Soil use, physical properties of the soil, fertility, nutrients, desertification.

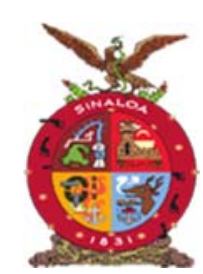

XVIII Congreso Internacional XXIV Congreso Nacional de Ciencias ambientales
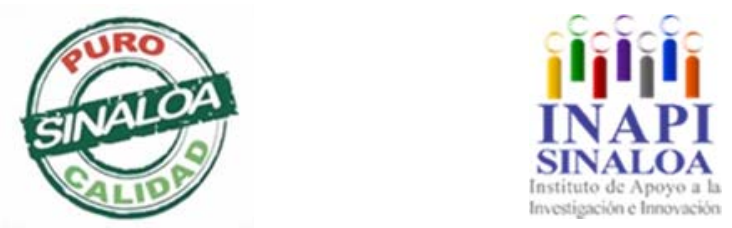

Mazatlán, Sinaloa 3-7 junio 2019

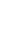



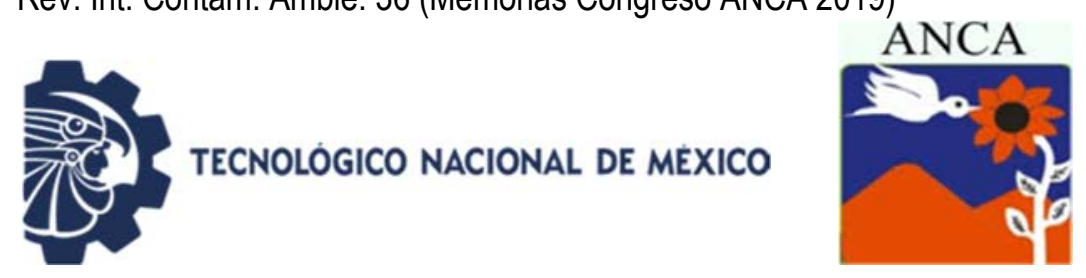

\title{
Concentración de plomo en arbustos Mimosa biuncifera y Prosopis Glandulosa aledaños a la ex Fundidora Avalos
}

\author{
Galván Ortega C, Portillo Almanza C, Garibaldi Carrasco D, Chávez Heredia V, \\ Chávez Heredia V, Aguilar Urrutia P, Luevano Gurrola S* \\ Universidad Autónoma de Chihuahua, México \\ *dluevano@uach.mx
}

\section{RESUMEN}

La mala disposición de los residuos mineros genera un impacto negativo en la salud y el ambiente. La ex fundidora Ávalos ubicada en Chihuahua, México fue una empresa minera muy importante a nivel mundial por su productividad de plomo. Los jales mineros de la zona representan un pasivo ambiental al contener elementos tóxicos. La fitorremediación reduce la concentración de compuestos mediante procesos bioquímicos realizados por plantas y microorganismos. El objetivo de este estudio fue evaluar la concentración de plomo en raíz, tallo y hoja de los arbustos de Mimosa biuncifera y Prosopis glandulosa aledaños a la ex fundidora y verificar su viabilidad para fitorremediación. En marzo del 2019 se recolectaron ocho muestras de arbustos Mimosa biuncifera y Prosopis glandulosa, las cuales son especies dominantes alrededor de la zona. Como referencia se recolectó una muestra control de cada especie, alejadas a la zona contaminada con las mismas condiciones de suelo y relieve. Se realizó un proceso de digestión con $\mathrm{HCl}, \mathrm{HNO}_{3}$ y $\mathrm{H}_{2} \mathrm{O}_{2}$. Cada muestra se analizó mediante un ICP (Perkin Elmer, Optima 8300). Mimosa biuncifera obtuvo altas concentraciones, siendo los valores máximos $3,118 \mathrm{mg} / \mathrm{kg}$ en raíz y $1,110 \mathrm{mg} / \mathrm{kg}$ en hoja. En Prosopis glandulosa se encontró una sola concentración de 291.7 $\mathrm{mg} / \mathrm{kg}$ en raíz. En tallo no se encontraron concentraciones en las especies. Las muestras de referencia no obtuvieron concentraciones de Pb. Mimosa biuncifera absorbe grandes cantidades de $\mathrm{Pb}(>1000 \mathrm{mg} / \mathrm{kg}$ ) en raíz y hoja, por lo cual es una especie hiperacumuladora y viable para fitorremediación de la zona contaminada.

Palabras clave: Fitorremediación, jales mineros, minería.

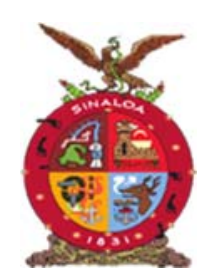

XVIII Congreso Internacional

XXIV Congreso Nacional de Ciencias ambientales
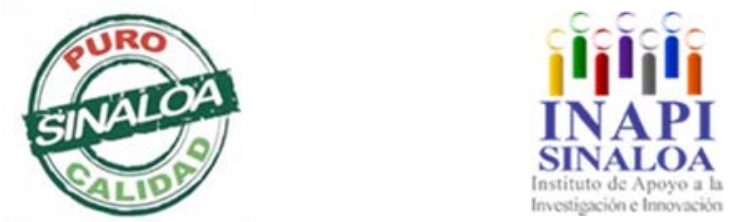

Mazatlán, Sinaloa 3-7 junio 2019

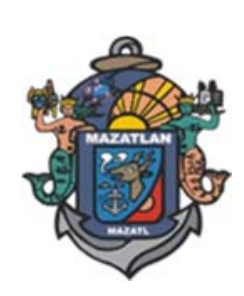

Recursos Naturales, Ecosistemas y Deterioro Ambiental 

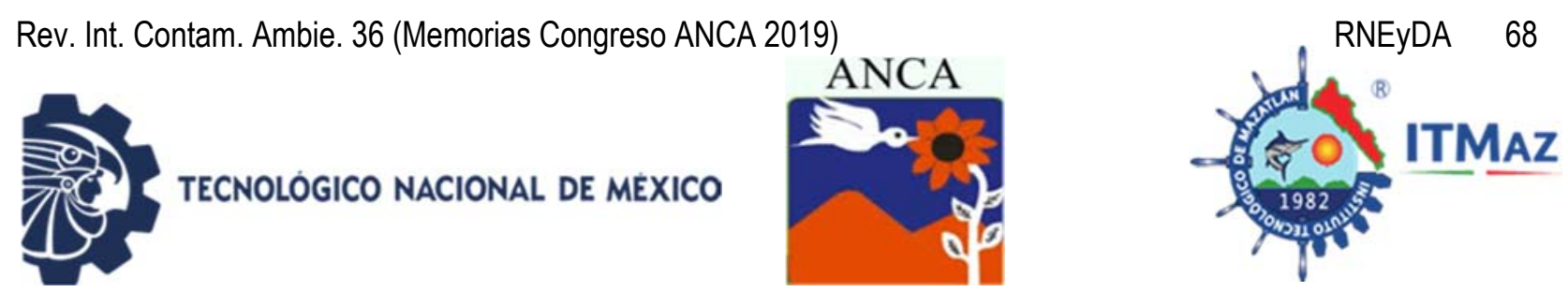

\title{
Concentration of sinker in shrubs Mimosa biuncifera and Prosopis Alandulosa Allowances to the former Avalos Foundry
}

\author{
Galván Ortega C, Portillo Almanza C, Garibaldi Carrasco D, Chávez Heredia V, \\ Chávez Heredia V, Aguilar Urrutia P, Luevano Gurrola S* \\ Universidad Autónoma de Chihuahua, México \\ *dluevano@uach.mx
}

\begin{abstract}
The poor disposal of mining waste generates a negative impact on health and the environment. The former foundry Avalos located in Chihuahua, Mexico was a very important mining company worldwide for its sinker productivity. Mine quarries in the area represent an environmental liability because they contain toxic elements. Phytoremediation reduces the concentration of compounds through biochemical processes carried out by plants and microorganisms. The objective of this study was to evaluate the concentration of sinker in root, stem and leaf of the shrubs of Mimosa biuncifera and Prosopis glandulosa adjacent to the former smelter and verify its viability for phytoremediation. In March 2019, eight samples of Mimosa biuncifera and Prosopis glandulosa shrubs were collected, which are dominant species around the area. As a reference, a control sample of each species was collected, far from the contaminated area with the same soil and relief conditions. A digestion process was carried out with $\mathrm{HCl}, \mathrm{HNO}_{3}$ and $\mathrm{H}_{2} \mathrm{O}_{2}$. Each sample was analyzed by means of an ICP (Perkin Elmer, Optima 8300). Mimosa biuncifera obtained high concentrations, being the maximum values $3,118 \mathrm{mg} / \mathrm{kg}$ in root and $1,110 \mathrm{mg} / \mathrm{kg}$ in leaf. In Prosopis glandulosa a single concentration of $291.7 \mathrm{mg} / \mathrm{kg}$ was found in the root. In stems no concentrations were found in the species. The reference samples did not obtain $\mathrm{Pb}$ concentrations. Mimosa biuncifera absorbs large amounts of $\mathrm{Pb}(>1000 \mathrm{mg} / \mathrm{kg})$ in root and leaf, making it a hyperaccumulating and viable species for phytoremediation of the contaminated area.
\end{abstract}

Keywords: Hytoremediation, mine tailings, mining.

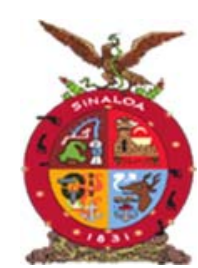

XVIII Congreso Internacional

XXIV Congreso Nacional de Ciencias ambientales

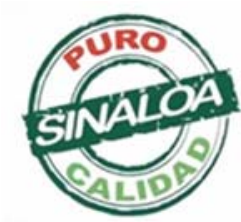

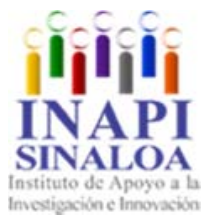

Mazatlán, Sinaloa 3-7 junio 2019

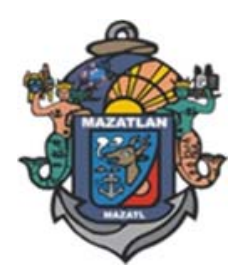

Recursos Naturales, Ecosistemas y Deterioro Ambiental 

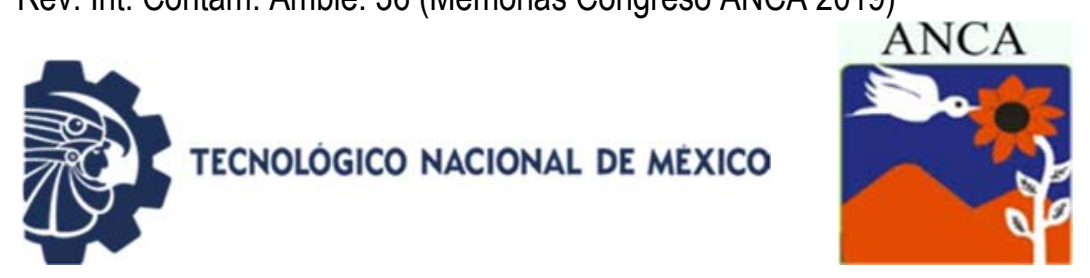

\title{
Identificación de impactos antropogénicos en los manglares de la Laguna de Nuxco, Guerrero, México
}

\author{
García Domínguez $Y^{1}$, Castillo Elías $\mathrm{B}^{2 *}$, Gervacio Jiménez $\mathrm{H}^{3}$, \\ Sampedro Rosas $\mathrm{M}^{3}$, Sonder $\mathrm{K}^{4}$, Bedolla Solano $\mathrm{R}^{5}$ \\ ${ }^{1}$ Centro de Ciencias de Desarrollo Regional. \\ Universidad Autónoma de Guerrero. \\ ${ }^{2}$ Instituto de Investigación Científica Humanístico Social y Posgrado. \\ Universidad Autónoma de Guerrero. \\ ${ }^{3}$ Escuela Preparatoria No. 2. Universidad Autónoma de Guerrero. \\ ${ }^{4}$ Centro Internacional de Mejoramiento de Maíz y Trigo \\ ${ }^{5}$ Escuela Superior de Sociología de la Universidad Autónoma de Guerrero. \\ *bcastilloe@hotmail.com
}

\begin{abstract}
RESUMEN
Los manglares tienen una amplia relación con las comunidades ribereñas, donde surgen beneficios sociales y económicos. Estos ecosistemas influyen sobre la situación económica de los habitantes, algunos ejemplos: la madera del mangle es utilizada para diferentes actividades domésticas. El objetivo del presente estudio fue identificar los impactos de las actividades antropogénicas en una localidad rural del pacífico sur de México denominada Veinte de Noviembre (EI Veinte), adjunta a la Laguna costera de Nuxco, Municipio de Tecpan de Galeana, en el estado de Guerrero. Se aplicó una encuesta a una muestra de 158 personas de un total de 705 pobladores, para obtener información sobre el impacto que provocan las actividades antropogénicas, definir usos que se le da al manglar y actividades que lo afectan directamente. De acuerdo con los resultados, se identificó la problemática socio-económico-ambiental en las que están inmersos. Con esta investigación, se logró conocer y documentar los diferentes usos y afectaciones sobre el manglar, permitiendo integrar a corto plazo un proyecto viable de sustentabilidad económica regional.
\end{abstract}

Palabras clave: Laguna costera, actividades antropogénicas, manglares, impacto, sustentabilidad.

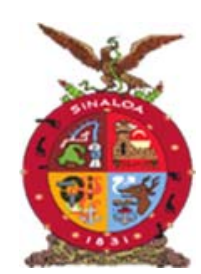

XVIII Congreso Internacional

XXIV Congreso Nacional de Ciencias ambientales

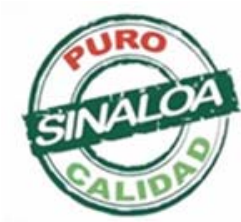

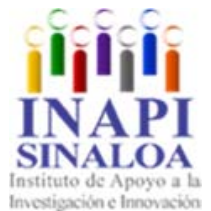

Mazatlán, Sinaloa 3-7 junio 2019

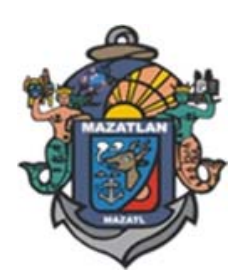

Recursos Naturales, Ecosistemas y Deterioro Ambiental 

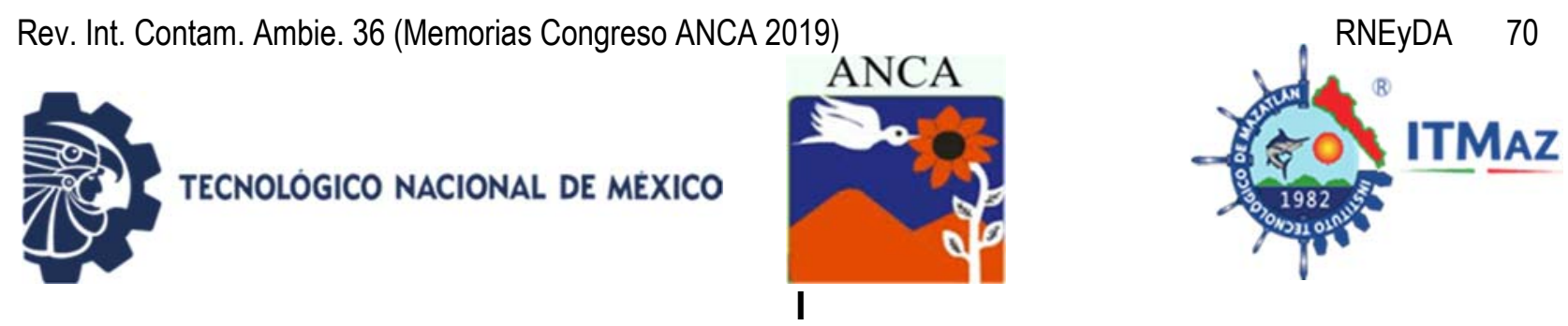

\title{
Identification of anthropogenic impacts in the mangroves of the Nuxco Lagoon, Guerrero, Mexico
}

\author{
García Domínguez $\mathrm{Y}^{1}$, Castillo Elías $\mathrm{B}^{2 *}$, Gervacio Jiménez $\mathrm{H}^{3}$, \\ Sampedro Rosas $\mathrm{M}^{4}$, Sonder $\mathrm{K}^{5}$, Bedolla Solano $\mathrm{R}^{6}$ \\ ${ }^{1}$ Centro de Ciencias de Desarrollo Regional. \\ Universidad Autónoma de Guerrero. \\ ${ }^{2}$ Instituto de Investigación Científica Humanístico Social y Posgrado. \\ Universidad Autónoma de Guerrero. \\ ${ }^{3}$ Escuela Preparatoria No. 2. Universidad Autónoma de Guerrero. \\ ${ }^{4}$ Centro Internacional de Mejoramiento de Maíz y Trigo \\ ${ }^{5}$ Escuela Superior de Sociología de la Universidad Autónoma de Guerrero. \\ *bcastilloe@hotmail.com
}

\begin{abstract}
Mangroves have a wide relationship with riparian communities, where social and economic benefits arise. These ecosystems influence the economic situation of the inhabitants, some examples: mangrove wood is used for different domestic activities. The objective of the present study was to identify the anthropogenic activities in a rural town in the south pacific of Mexico called Veinte de Noviembre (El Veinte), attached to the Coastal Lagoon of Nuxco, Municipality of Tecpan de Galeana, in the state of Guerrero. A survey was applied to a sample of 158 people out of a total of 705 inhabitants. Information was obtained on the impact caused by anthropogenic activities such as: uses of the mangrove resource and activities that directly affect it. According to the results, the socio-economic-environmental problems in which they are immersed were identified. With this research, it was possible to know and document the different uses and effects on the mangrove, allowing to integrate in the short term a viable project of regional economic sustainability.
\end{abstract}

Keywords: Coastal lagoon, anthropogenic activities, mangroves, impact, sustainability.

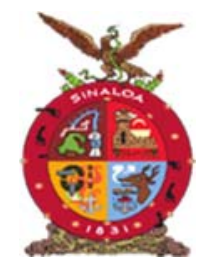

XVIII Congreso Internacional

XXIV Congreso Nacional de Ciencias ambientales

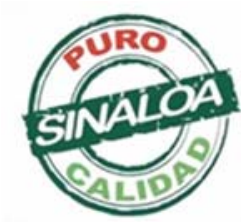

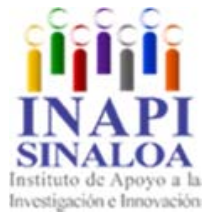

Mazatlán, Sinaloa 3-7 junio 2019

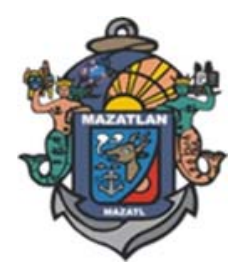

Recursos Naturales, Ecosistemas y Deterioro Ambiental 

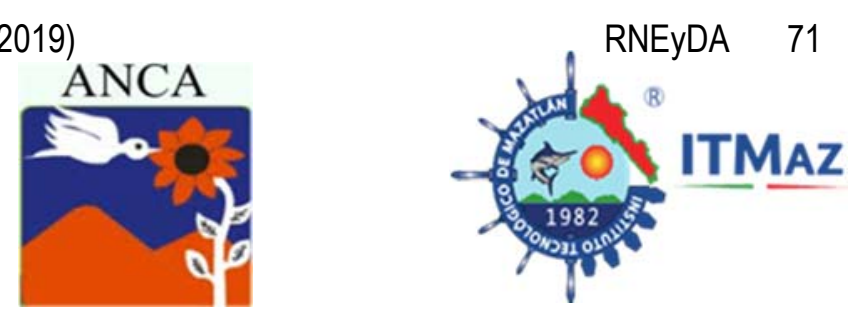

\section{Análisis de suelo no expuesto a rotación de cultivo en Zacatecas, México}

García A, Medina A, Martínez A, Rangel D, Román S*, González U, Frausto V, Ávila Vázquez V, Inchaurregui Méndez H

Unidad Profesional Interdisciplinaria de Ingenieria Campus Zacatecas. Instituto Politécnico Nacional.

Blvd. del Bote S/N, Cerro del Gato, Ejido La Escondida, 98160, Zacatecas

*silvia_jrh@hotmail.com

\section{RESUMEN}

La rotación de cultivos es una práctica agrícola para aumentar la productividad de la tierra y optimizar el uso de los recursos del suelo. Sin embargo, dicha práctica no siempre se lleva a cabo; el suelo del cual se realizó el análisis proveniente de Estancia de Animas, Villa González Ortega, Zac., en el cual se cultiva la Vid (Vitis vinífera), donde no se ha practicado la rotación de cultivos en ocho años. Por lo que, a través de una serie de determinaciones fisicoquímicas, se evaluó el impacto de esto. El muestreo, la preparación de la muestra y las determinaciones de las propiedades fisicoquímicas del suelo, fueron llevadas a cabo siguiendo las especificaciones de la Norma Oficial Mexicana NOM-021SEMARNAT-2000 (Mod. 2002). A partir de las pruebas realizadas se obtuvieron resultados de concentraciones bajas para los distintos parámetros de análisis. Aun así, según los requerimientos para el cultivo de Vid, las concentraciones de macro y micronutrientes suelen ser considerados como óptimos, siempre y cuando la concentración en el suelo sea entre baja y media. Sin embargo, se prevé un agotamiento de nutrientes si se sigue con el régimen de producción, puesto que no permitirá la recarga de nutrientes que la rotación de cultivos favorece, por lo que puede llegar a afrontar con un problema de erosión y, como consecuencia, la perdida monetaria, así como de afrontar la posibilidad de que se tenga que conseguir un nuevo terreno para el cultivo de Vid de nueva cuenta.

Palabras clave: Rotación, erosión, suelo agrícola, nutrientes.

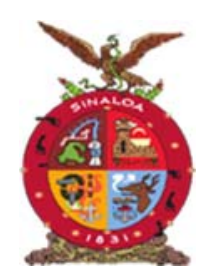

XVIII Congreso Internacional

XXIV Congreso Nacional de Ciencias ambientales

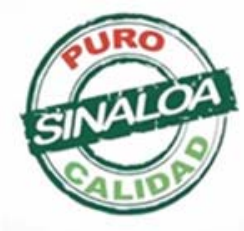

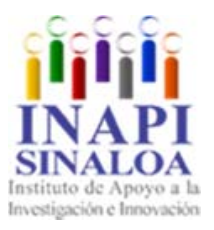

Mazatlán, Sinaloa 3-7 junio 2019

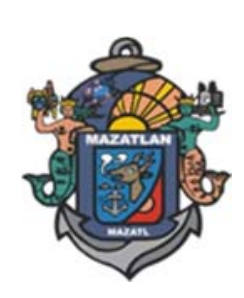

Recursos Naturales, Ecosistemas y Deterioro Ambiental 


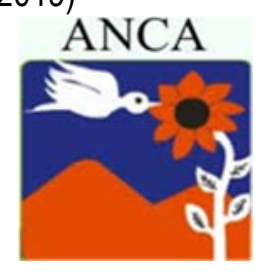

Analysis of soil not exposed to crop rotation in Zacatecas, Mexico

García A, Medina A, Martínez A, Rangel D, Román S*, González U, Frausto V, Ávila Vázquez $\mathrm{V}$, Inchaurregui Méndez $\mathrm{H}$

Unidad Profesional Interdisciplinaria de Ingenieria Campus Zacatecas. Instituto Politécnico Nacional.

Blvd. del Bote S/N, Cerro del Gato, Ejido La Escondida, 98160, Zacatecas

*silvia_jrh@hotmail.com

\begin{abstract}
Crop rotation is an agricultural practice to increase the productivity of the land and optimize the use of soil resources. However, such practice is not always carried out; the soil from which the analysis was carried out from Estancia de Animas, Villa González Ortega, Zac., in which the vine (Vitis vinifera) is cultivated, where crop rotation has not been practiced for eight years. Therefore, through a series of physicochemical determinations, the impact of this was evaluated. Sampling, sample preparation and determinations of soil physicochemical properties, were carried out following the specifications of the Official Mexican Standard NOM-021SEMARNAT-2000 (Mod. 2002). From the tests carried out, results of low concentrations were obtained for the different analysis parameters. Even so, according to the requirements for the cultivation of Vine, The concentrations of macro and micronutrients are usually considered optimal, as long as the concentration in the soil is between low and medium. However, a depletion of nutrients is expected if the production regime continues, since it will not allow the recharge of nutrients that crop rotation favors,so it can face a problem of erosion and, as a consequence, the monetary loss, as well as facing the possibility of having to obtain new land for the cultivation of new vine.
\end{abstract}

Keywords: Rotation, erosion, agricultural soil, nutrients.

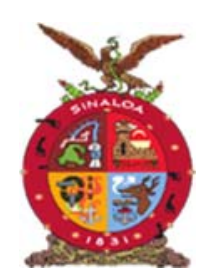

XVIII Congreso Internacional

XXIV Congreso Nacional de Ciencias ambientales

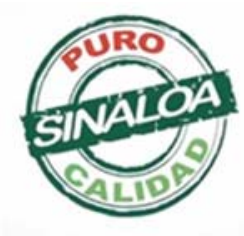

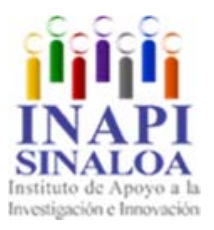

Mazatlán, Sinaloa 3-7 junio 2019

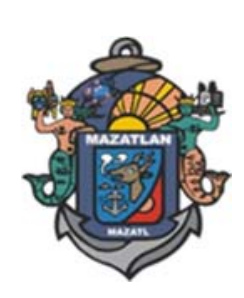

Recursos Naturales, Ecosistemas y Deterioro Ambiental 

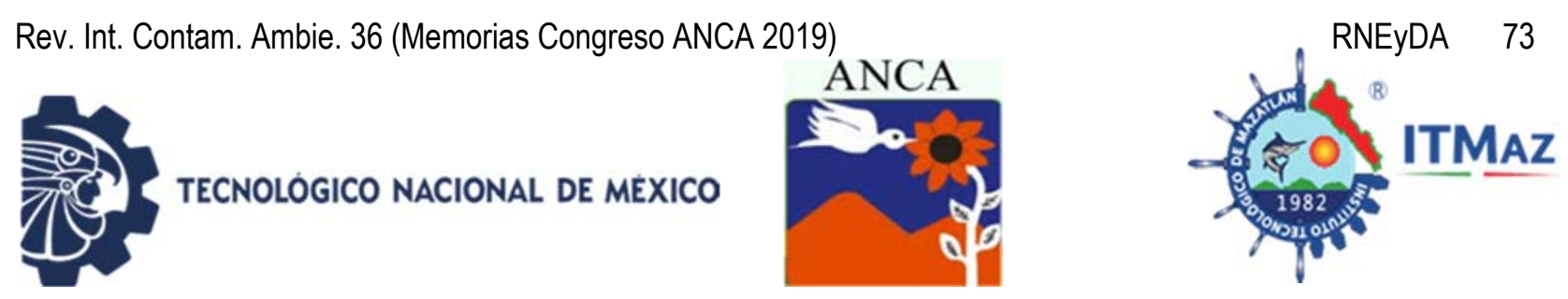

\title{
Análisis de ciclo de vida del impacto ambiental de la fabricación de adobe comprimido comparado con ladrillo artesanal y bloques de cemento
}

\author{
Gavilán García IC ${ }^{1}$, Gavilán García A \\ ${ }^{1}$ Facultad de Química. UNAM, \\ Av. Universidad 3000, Col. Copilco, C.P. 04510, México \\ ${ }^{2}$ Instituto Nacional de Ecología y Cambio Climático. \\ Blvd. Adolfo Ruíz Cortines 4209, Jardines en la Montaña, C.P. 14210, México \\ irmac@unam.mx
}

\section{RESUMEN}

En el presente trabajo se utiliza la herramienta de Análisis de Ciclo de Vida (ACV) (ISO Serie 14040) para modelar comparativamente la producción de bloques para de concreto, ladrillos artesanales (rojo) y adobe comprimido, desde la extracción de recursos naturales (suelos y arcillas), procesamiento, fabricación y uso final del producto en México durante el año base 2016. La modelación del flujo de materiales y los cálculos de impactos ambientales se realizaron mediante el software Umberto; para la integración de los Inventarios de Ciclo de Vida (ICV) se empleó base de datos de Ecoinvent. La obtención de los datos necesarios de las entradas y salidas del proceso para alimentar el software fueron recabados por medio del acercamiento directo con las empresas de producción de ladrillos de adobe comprimido, bloques de cemento y los ladrillos artesanales, la información fue proporcionada por personal operativo mediante entrevistas realizadas directamente en cada planta. Para los fines de este trabajo, se estableció que la unidad funcional del ACV sería un metro cuadrado de pared, traducida como $19 \mathrm{~kg}$ de material necesario para construir una pared con 38 ladrillos o bloques de dimensiones $6 \mathrm{~cm} \times 12 \mathrm{~cm} \times 24 \mathrm{~cm}$. Los principales hallazgos demostraron como opción más sustentable y con menores cargas ambientales al proceso de producción de adobe comprimido, mientras los otros dos procesos presentaron los mayores impactos ambientales en las principales categorías de Cambio Climático [AP], Potencial de Acidificación [AP], Potencial de Eutrofización [EP] y Potencial de Agotamiento de Recursos Abióticos [ADP]. En conclusión, la producción de ladrillos de adobe comprimido es una opción sustentable que debe ser promovida por los beneficios ambientales que presentan al colocarse como la opción con los impactos ambientales más bajos y con los procesos menos contaminantes.

Palabras clave: Ciclo de vida, ladrillo, impactos ambientales.

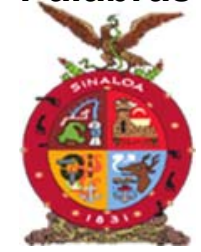

XVIII Congreso Internacional

XXIV Congreso Nacional de Ciencias ambientales

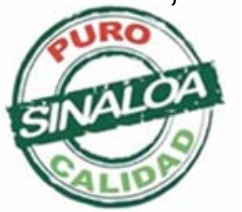

Mazatlán, Sinaloa 3-7 junio 2019
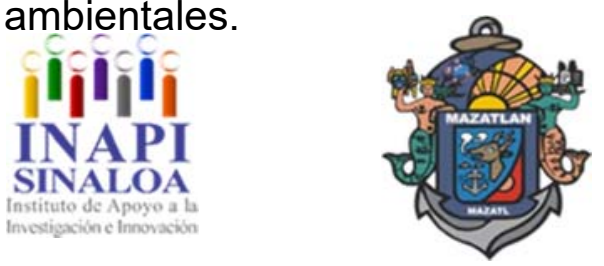

Recursos Naturales, Ecosistemas y Deterioro Ambiental 

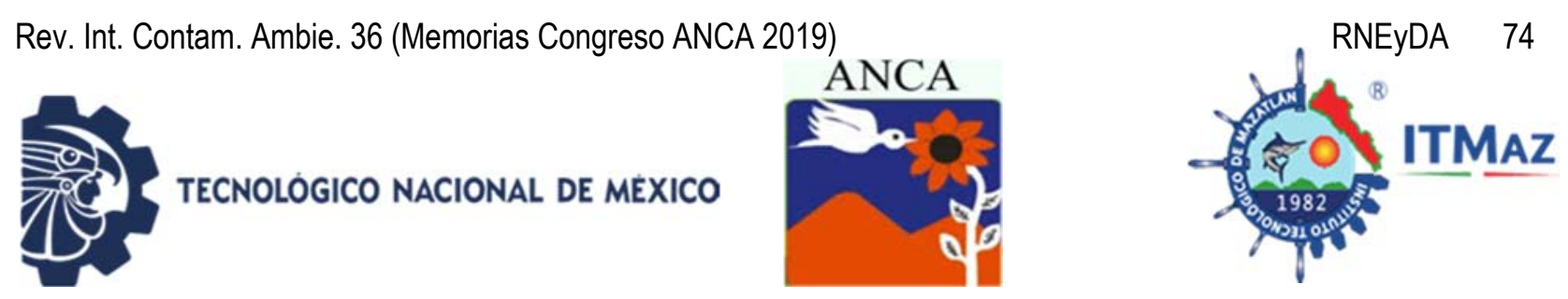

\title{
Life cycle assessmen $t$ of the environmental impact of the manufacture of compressed adobe compared to artisanal bricks and cement blocks
}

\author{
Gavilán García IC ${ }^{1}$, Gavilán García A \\ ${ }^{1}$ Facultad de Química. UNAM, \\ Av. Universidad 3000, Col. Copilco, C.P. 04510, México \\ ${ }^{2}$ Instituto Nacional de Ecología y Cambio Climático. \\ Blvd. Adolfo Ruíz Cortines 4209, Jardines en la Montaña, C.P. 14210, México \\ irmac@unam.mx
}

\begin{abstract}
In this work, the Life Cycle Analysis (LCA) tool (ISO 14040 Series) is used to comparatively model the production of concrete blocks, artisanal bricks (red) and compressed adobe, from the extraction of natural resources (soils and clay), processing, manufacturing and final use of the product in Mexico during the base year 2016. The modeling of the flow of materials and the calculations of environmental impacts were made using the software Umberto; for the integration of Life Cycle Inventories (ICV), the Ecoinvent database was used. To obtain the necessary data of the entrance and exit of the process to feed the software, a direct approach was done with the manufacturers of compressed adobe bricks, cement blocks and artisanal bricks. Operative personnel, through interviews conducted directly in each plant, provided the information. For the purposes of this work, the functional unit of the LCA was established as one square meter of wall, translated as $19 \mathrm{~kg}$ of material needed to build a wall with 38 bricks or blocks of dimensions $6 \mathrm{~cm} \times 12 \mathrm{~cm} \times 24 \mathrm{~cm}$. The main findings demonstrated that the most sustainable option, with lower environmental burdens, is the compressed adobe production process, while the other two processes presented the greatest environmental impacts to the main categories of Climate Change [AP], Acidification Potential [AP], Potential for Eutrophication [EP] and Depletion Potential of Abiotic Resources [ADP]. In conclusion, the production of compressed adobe bricks is a sustainable option that should be promoted by the environmental benefits presented by placing it as the option with the lowest environmental impacts and with the least polluting processes.
\end{abstract}

Keywords: Life Cycle Assessment, environmental impact.

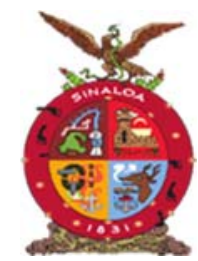

XVIII Congreso Internacional

XXIV Congreso Nacional de Ciencias ambientales

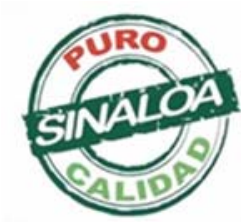

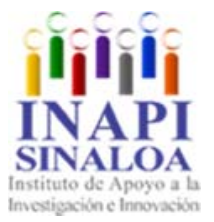

Mazatlán, Sinaloa 3-7 junio 2019

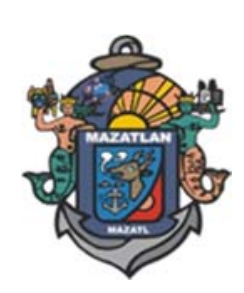

Recursos Naturales, Ecosistemas y Deterioro Ambiental 

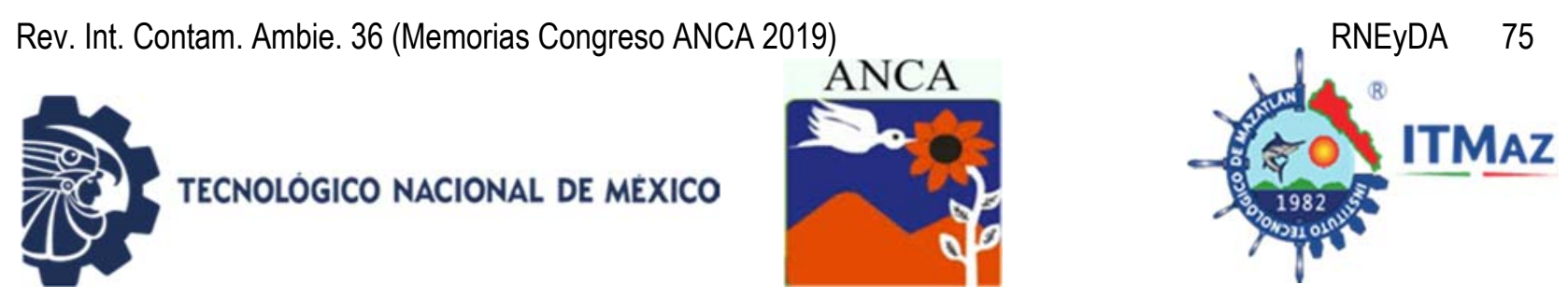

\title{
Huella de carbono generada por la comunidad de una institución educativa
}

\author{
Gómez Arellano E, Aguilera Flores M, Ávila Vázquez V \\ Instituto Politécnico Nacional-Ingeniería Ambiental \\ Eega960503@gmail.com
}

\section{RESUMEN}

La huella de carbono $(\mathrm{HC})$ es un indicador ambiental que permite conocer la totalidad de los gases de efecto invernadero (GEI) emitidos por forma directa o indirecto por un individuo, organización, evento o producto. En el presente trabajo se realizó una propuesta en conjunto con el Comité Ambiental Escolar (CAE) de la Unidad Profesional Interdisciplinaria de Ingeniería Campus Zacatecas (UPIIZ) del Instituto Politécnico Nacional (IPN) para la elaboración de un diagnóstico mediante metodología aplicable que permita estimar la $\mathrm{HC}$ que la comunidad de la UPIIZ genera a través del uso de combustibles en el transporte público y privado y para servicios (consumo eléctrico). El cálculo de HC se realizó mediante software del (IPCC) (Panel Intergubernamental de Cambio Climático), calculadora de SEMARNAT, (Secretaria de Medio Ambiente y Recursos Naturales) así como con la metodología RENE (Registro Nacional de Emisiones) para el RENE para la comparación de resultados, mismos que facilitaron la estimación para obtener un diagnóstico. El estudio fue completado a través de la aplicación de encuestas enfocadas a la recopilación de información sobre tiempo, puntos de partida y distancia recorrida por los usuarios para transportarse de su casa a la escuela y viceversa, así como del uso del gas Licuado de Petróleo (LP), la generación de residuos y consumo eléctrico para servicios en la Unidad, Obteniendo un total de HC para el IPCC de 324.94 tCO2eq, Metodología RENE de 344.88 tCO2eq y Calculadora de SEMARNAT de 343.95 tCO2eq. La diferencia de los resultados radica en la aplicación de Factores de emisión de los combustibles para el software del IPCC, este resultado tiene una propuesta de mitigación con la plantación de Pinos Piñoneros (17 especies).

Palabras clave: UPIIZ, mitigación, SEMARNAT, IPCC, carbono, emisiones.

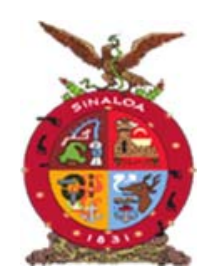

XVIII Congreso Internacional XXIV Congreso Nacional de Ciencias ambientales
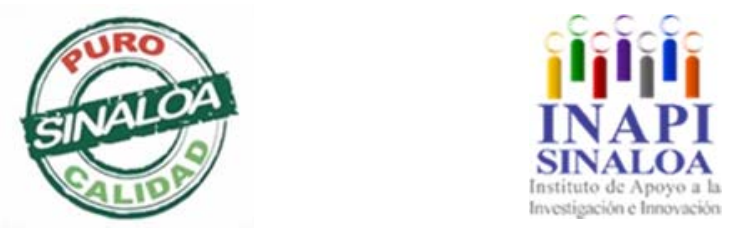

Mazatlán, Sinaloa 3-7 junio 2019

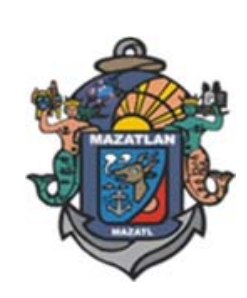

Recursos Naturales, Ecosistemas y Deterioro Ambiental 

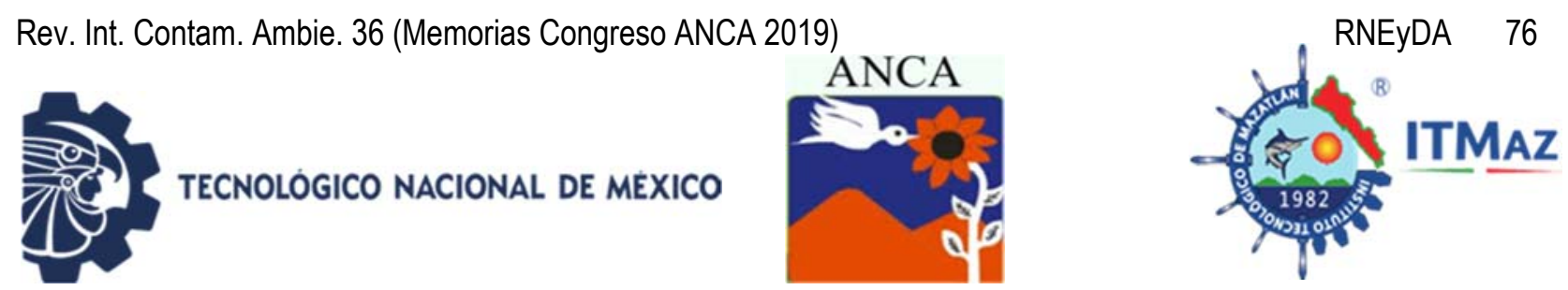

\title{
Carbon footprint generated by the community of an educational institution
}

\author{
Gómez Arellano E, Aguilera Flores M, Ávila Vázquez V \\ Instituto Politécnico Nacional-Ingeniería Ambiental \\ Eega960503@gmail.com
}

\begin{abstract}
The carbon footprint $(\mathrm{HC})$ is an environmental indicator that allows knowing all the greenhouse gases (GHG) emitted by direct or indirect effect by an individual, organization, event or product. In the present work, a proposal was made in conjunction with the School Environmental Committee (CAE) of the Unidad Profesional Interdisciplinaria de Ingeniería Campus Zacatecas (UPIIZ) of the Instituto Politécnico Nacional (IPN), for the elaboration of a diagnosis. Using the applicable methodology to estimate the $\mathrm{HC}$ that the community of UPIIZ generates through the use of fuels in public and private transport and for services (electricity consumption and LP Gas). The calculation of HC was made using software from the IPCC (Panel Intergubernamental de Cambio Climático), calculator from SEMARNAT, (Secretary of Environment and Natural Resources) as well as the methodology for the RENE (Registro Nacional de Emisiones) for the comparison of results, which facilitated the estimation to obtain a diagnosis. The study was completed through the application of surveys focused on the collection of information on time, points of departure and distance traveled by users to transport from home to school and vice versa. As well as the use of Liquefied Petroleum Gas (LP), the generation of waste and electricity consumption for services in the Unit Obtaining a total of HC for the IPCC of 324.94 tCO2eq, RENE Methodology of 344.88 tCO2eq and SEMARNAT Calculator of 343.95 tCO2eq. The difference of the results lies in the application of emission factors of the fuels for the IPCC software, this result has a proposal of mitigation with the plantation of Pinos Piñoneros (17 species)
\end{abstract}

Keywords: UPIIZ, mitigation, SEMARNAT, IPCC, carbon, emissions.

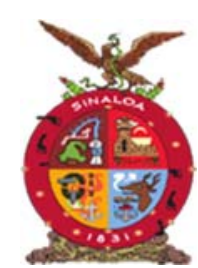

XVIII Congreso Internacional XXIV Congreso Nacional de Ciencias ambientales
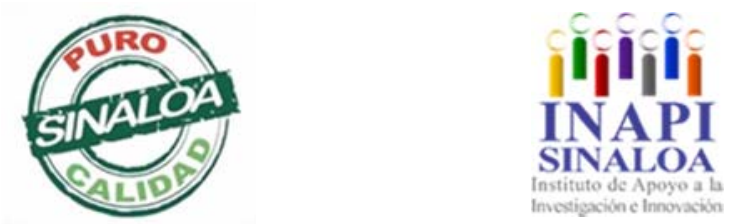

Mazatlán, Sinaloa 3-7 junio 2019

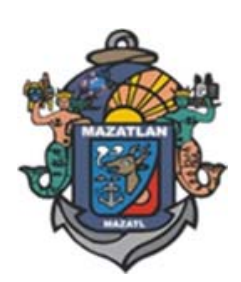

Recursos Naturales, Ecosistemas y Deterioro Ambiental 

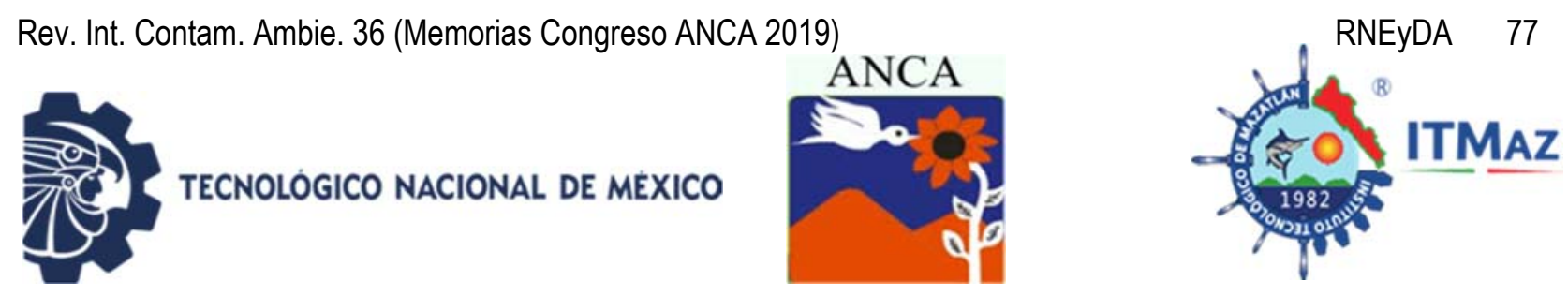

\title{
Evaluación de las características morfológicas de la briofita acuática Ricciocarpus natans para su uso como monitor a metales pesados
}

\author{
Gómez Ensastegui $\mathrm{C}^{1 *}$, Ávila PP ${ }^{1}$, Macedo Miranda $\mathrm{G}^{1}$, Zepeda Gómez $\mathrm{C}^{2}$, \\ Martínez Gallegos $S^{1}$, Zarazúa Ortega $\mathrm{G}^{3}$ \\ ${ }^{1}$ Instituto Tecnológico de Toluca. \\ Av. Tecnológico S/N Agrícola Bella Vista, C.P. 52149, Metepec, México \\ ${ }^{2}$ Facultad de Ciencias Universidad Autónoms frl Estafo de México \\ Carretera Toluca-Ixtlahuaca, Km. 15.5, C.P. 50200, México \\ ${ }^{3}$ Instituto Nacional de Investigaciones Nucleares, \\ Carretera México-Toluca S/N, C.P. 52750, La Marquesa, Ocoyoacac, México \\ *clarita.ensastegui@gmail.com
}

\begin{abstract}
RESUMEN
La contaminación atmosférica ha ido incrementado debido al aumento de la población y las actividades antropogénicas, por ello, se han desarrollado nuevas alternativas para monitorear la calidad del aire. Así, surgen los bioindicadores y biomonitores, donde las briofitas han sido utilizadas. Para conocer si una briofita es buen bioindicador es primordial conocer su capacidad de sorción y acumulación de contaminantes como los metales pesados. El objetivo de esta investigación fue determinar la morfología de Ricciocarpus natans y algunas características fisicoquímicas del agua en el cual se desarrolla para su posible uso como monitor. Se obtuvieron muestras de la briofita y de agua en el Polígono 1 de las Ciénegas de Lerma, Laguna de Almoloya del Río. Se caracterizó a la briofita mediante microscopía electrónica de barrido (SEM), Área Superficial (BET) y Análisis de Infrarrojo con transformada de Fourier. Al agua de la laguna se le determinó in "situ" el pH y temperatura. En el laboratorio determinó el oxígeno disuelto, alcalinidad, demanda química de oxígeno, amonio, nitrato, fosforo total y los metales pesados $\mathrm{Cd}, \mathrm{Cr}, \mathrm{Pb}$ y Fe. Los resultados por SEM mostraron que este organismo está compuesto principalmente de $\mathrm{Si}, \mathrm{C}$ y $\mathrm{O}$. El análisis BET mostró que la briofita es un material mesoporoso lo que la hace adecuada para la adsorción de metales pesados. La caracterización del agua de la laguna mostró un $\mathrm{pH}$ de 7 , OD de $4.60 \mathrm{mg} / \mathrm{L}$, alcalinidad $2.6 \mathrm{mg} \mathrm{CaCO} / \mathrm{L}$, DQO total $90 \mathrm{mg} / \mathrm{L}$, DQO soluble $70 \mathrm{mg} / \mathrm{L}$, amonio 0.36 $\mathrm{mg} / \mathrm{L}$, nitrato $38.08 \mathrm{mg} / \mathrm{L}$ y fósforo total $2.57 \mathrm{mg} / \mathrm{L}$. Los resultados del agua, nos muestran que este sitio se encuentra en un elevado estado de eutrofización. Por ser un material orgánico su composición es de $\mathrm{C}$ y $\mathrm{O}$, el $\mathrm{Si}$ se debe a alguna diatomea unida a la briofita, al ser un material mesoporoso, reúne las características para sorber metales pesados. El agua del hábitat de esta briofita, se encuentra en un estado de alta eutrofización, con alto contenido de nitratos.
\end{abstract}

Palabras clave: Ricciocarpus natans, metales pesados, sorción, briofita aeática,

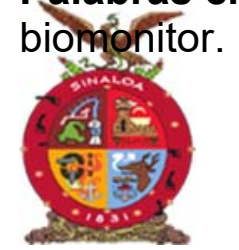

XVIII Congreso Internacional

XXIV Congreso Nacional de Ciencias ambientales
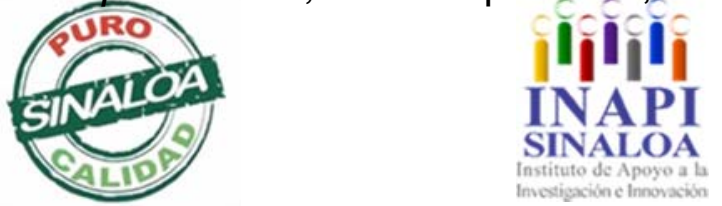

Mazatlán, Sinaloa 3-7 junio 2019

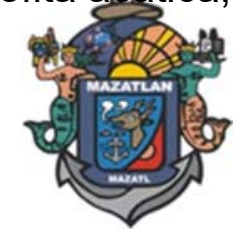

Recursos Naturales, Ecosistemas y Deterioro Ambiental 

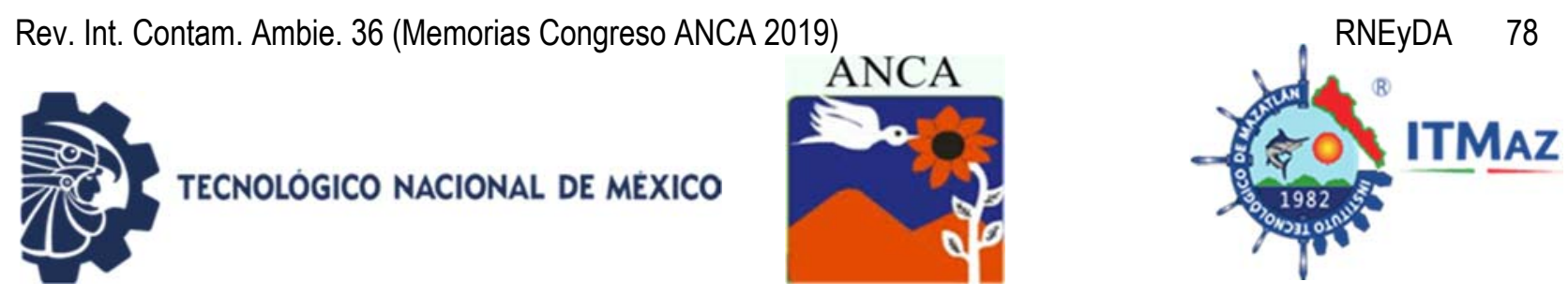

\title{
Evaluation of the morphological characteristics of the aquatic bryophyte Ricciocarpus natans for use as a heavy metal monitor
}

\author{
Gómez Ensastegui $\mathrm{C}^{1^{*}}$, Ávila P. P ${ }^{1}$, Macedo Miranda ${ }^{1}$, Zepeda Gómez $\mathrm{C}^{2}$, \\ Martínez Gallegos $S^{1}$, Zarazúa Ortega $\mathrm{G}^{3}$ \\ ${ }^{1}$ Instituto Tecnológico de Toluca. \\ Av. Tecnológico S/N Agrícola Bella Vista, C.P. 52149, Metepec, México \\ ${ }^{2}$ Facultad de Ciencias Universidad Autónoms frl Estafo de México \\ Carretera Toluca-Ixtlahuaca, Km. 15.5, C.P. 50200, México \\ ${ }^{3}$ Instituto Nacional de Investigaciones Nucleares, \\ Carretera México-Toluca S/N, C.P. 52750, La Marquesa, Ocoyoacac, México \\ *clarita.ensastegui@gmail.com
}

\begin{abstract}
Air pollution has increased due to the increase in population and anthropogenic activities, therefore, new alternatives have been developed to monitor air quality. Thus, bioindicators and biomonitors emerge, where bryophytes have been used. To know if a bryophyte is a good bioindicator, it is essential to know its sorption capacity and the accumulation of pollutants such as heavy metals. The objective of this investigation was to determine the morphology of Ricciocarpus natans and some physicochemical characteristics of the water in which it is developed for its possible use as a monitor. Samples of the bryophyte and water were obtained in Polygon 1 of the Ciénegas de Lerma, Laguna de Almoloya del Río. The bryophyte was characterized by scanning electron microscopy (SEM), surface area (BET) and infrared analysis with Fourier transform. The $\mathrm{pH}$ and temperature of the lagoon were determined in situ. In the laboratory he determined the dissolved oxygen, alkalinity, chemical demand of oxygen, ammonium, nitrate, total phosphorus and the heavy metals $\mathrm{Cd}, \mathrm{Cr}, \mathrm{Pb}$ and $\mathrm{Fe}$. The results by SEM showed that this organism is composed mainly of $\mathrm{Si}, \mathrm{C}$ and $\mathrm{O}$. The BET analysis showed that the bryophyte is a mesoporous material which makes it suitable for the adsorption of heavy metals. The water characterization of the lagoon showed a pH of 7, OD of 4.60 $\mathrm{mg} / \mathrm{L}$, alkalinity $2.6 \mathrm{mg} \mathrm{CaCO} 3 / \mathrm{L}$, total COD $90 \mathrm{mg} / \mathrm{L}$, soluble COD $70 \mathrm{mg} / \mathrm{L}$, ammonium $0.36 \mathrm{mg} / \mathrm{L}$, nitrate $38.08 \mathrm{mg} / \mathrm{L}$ and total phosphorus $2.57 \mathrm{mg} / \mathrm{L}$. The results of the water show us that this site is in a high state of eutrophication. Being an organic material, its composition is $\mathrm{C}$ and $\mathrm{O}, \mathrm{Si}$ is due to some diatom attached to the bryophyte, being a mesoporous material, it has the characteristics to suck heavy metals. The water of this bryophyte's habitat is in a state of high eutrophication, with a high nitrate content.
\end{abstract}

Keywords: Ricciocarpus natans, heavy metals, sorption, aquatic bryophyte, biomonitor.

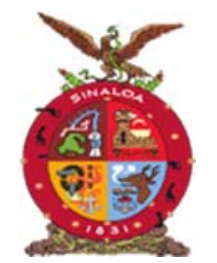

XVIII Congreso Internacional

XXIV Congreso Nacional de Ciencias ambientales

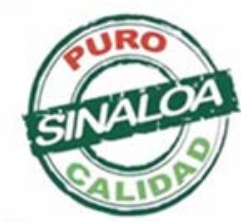

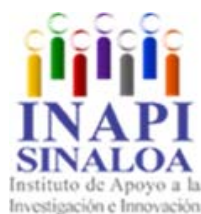

Mazatlán, Sinaloa 3-7 junio 2019

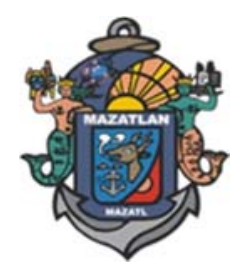

Recursos Naturales, Ecosistemas y Deterioro Ambiental 

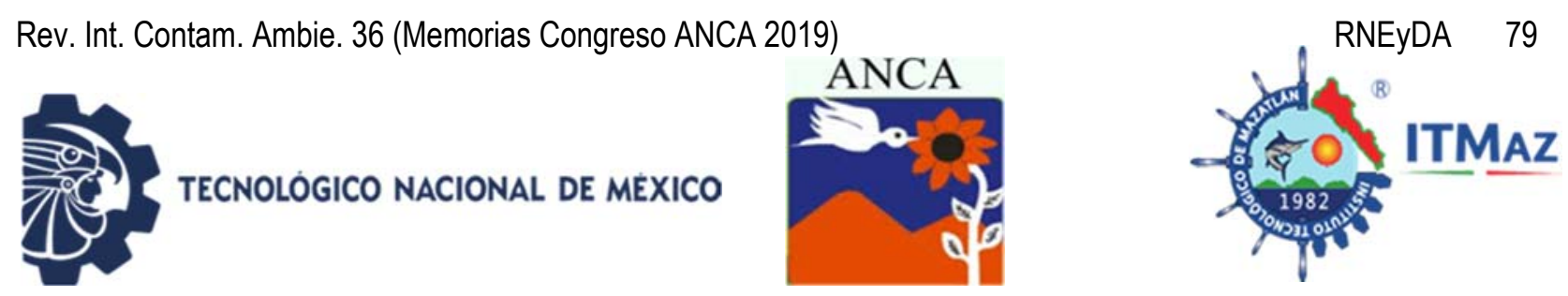

\title{
Identificación de compuestos de degradación como evidencia de la contaminación de efluentes de hospitales por Naproxeno
}

\author{
Gómez Martínez F ${ }^{1 *}$, Ramirez García JJ1 , García Fabila MM, \\ Gómez Hinojos $\mathrm{AM}^{2}$ \\ ${ }^{1}$ Facultad de Química. Universidad Autónoma del Estado de México \\ ${ }^{2}$ Facultad de Planeación Urbana y Regional. \\ Universidad Autónoma del Estado de México. \\ Paseo Colón esquina Paseo Tollocan, C.P. 50120, Toluca, México \\ *fgomezm@uaemex.mx
}

\begin{abstract}
RESUMEN
Los compuestos farmacéuticos elaborados para modificar funciones biológicas son sometidos a rigurosos estudios clínicos antes de su comercialización, éstos sin embargo llegan al ambiente por el uso que se les da en el hogar, la agricultura y los hospitales. Analgésicos, antibióticos, antiinflamatorios y hormonas son los grupos identificados con mayor frecuencia en agua residual, agua tratada, agua superficial y agua subterránea, hecho que demuestra que las plantas de tratamiento son ineficientes para depurar este tipo de contaminantes. El grupo de medicamentos clasificado como antiinflamatorios no esteroideos AINES, por su venta libre es de los más consumidos. La presencia de Naproxeno en el agua se ha relacionado con la disminución de plancton y muerte de peces. En el agua los fármacos pueden sufrir cambios estructurales, la identificación de los productos degradados se dificulta por la falta de estándares de referencia. Se desarrollo un método analítico para identificar por cromatografía de líquidos los derivados formados por degradación fotolítica, el método validado comprobó la formación bajo diferentes condiciones de dos derivados y se utilizó para analizar durante seis meses el efluente de dos hospitales de la ciudad de Toluca. Se detectó la presencia de derivados en el agua proveniente de uno de los hospitales hecho que infiere contaminación por Naproxeno.
\end{abstract}

Palabras clave: Identificación, derivados, contaminación del agua.

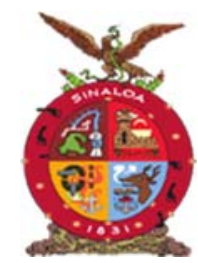

XVIII Congreso Internacional

XXIV Congreso Nacional de Ciencias ambientales

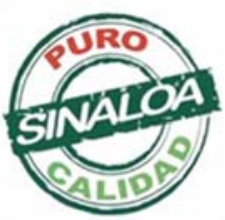

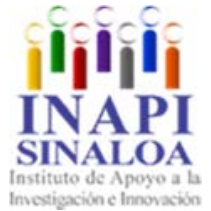

Mazatlán, Sinaloa 3-7 junio 2019

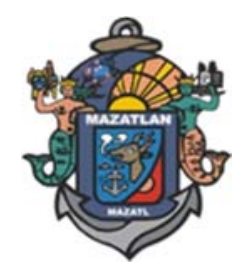

Recursos Naturales, Ecosistemas y Deterioro Ambiental 

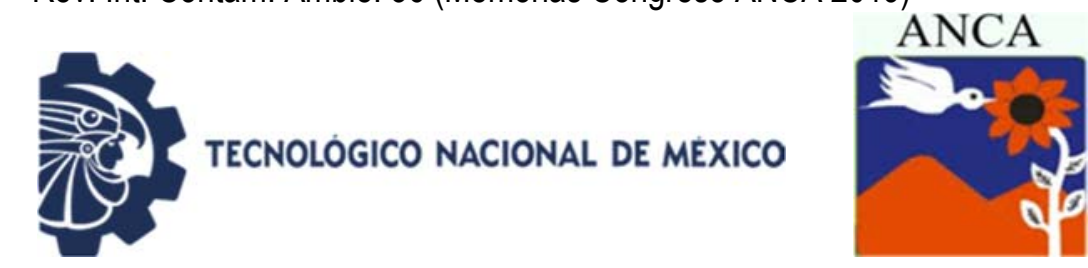

\title{
Identification of degradation compounds as evidence of contamination of hospital effluents by Naproxen
}

\author{
Gómez Martínez $\mathrm{F}^{1^{\star}}$, Ramirez García JJ¹, García Fabila MM, \\ Gómez Hinojos AM $^{2}$ \\ ${ }^{1}$ Facultad de Química. Universidad Autónoma del Estado de México \\ ${ }^{2}$ Facultad de Planeación Urbana y Regional. \\ Universidad Autónoma del Estado de México. \\ Paseo Colón esquina Paseo Tollocan, C.P. 50120, Toluca, México \\ *fgomezm@uaemex.mx
}

\begin{abstract}
The pharmaceutical compounds elaborated to modify biological functions are submitted to rigorous clinical studies before their commercialization, these nevertheless arrive at the environment by the use that is given to them in the home, the agriculture and the hospitals. Analgesics, antibiotics, antiinflammatories and hormones are the groups most frequently identified in wastewater, treated water, surface water and groundwater, which shows that treatment plants are inefficient to purify this type of contaminants. The group of medicines classified as non-steroidal anti-inflammatories NSAIDs, for its free sale is the most consumed. The presence of Naproxen in the water has been related to the decrease of plankton and death of fish. In the water, drugs can suffer structuralchanges, the identification of degraded products is made difficult by the lack of reference standards. An analytical method was developed to identify by liquid chromatography the derivatives formed by photolytic degradation, the validated method proved the formation under different conditions of two derivatives and was used to analyze for six months the effluent from two hospitals in the city of Toluca. The presence of derivatives was detected in the water from one of the hospitals that infers contamination by Naproxen.
\end{abstract}

Keywords: Identification, derivatives, water pollution.

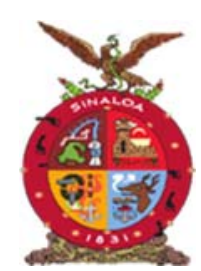

XVIII Congreso Internacional XXIV Congreso Nacional de Ciencias ambientales
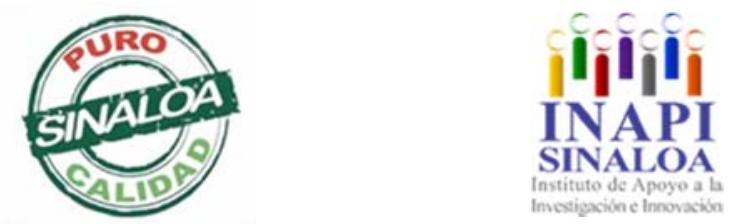

Mazatlán, Sinaloa 3-7 junio 2019

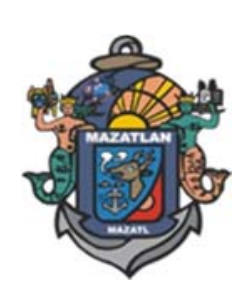

Recursos Naturales, Ecosistemas y Deterioro Ambiental 

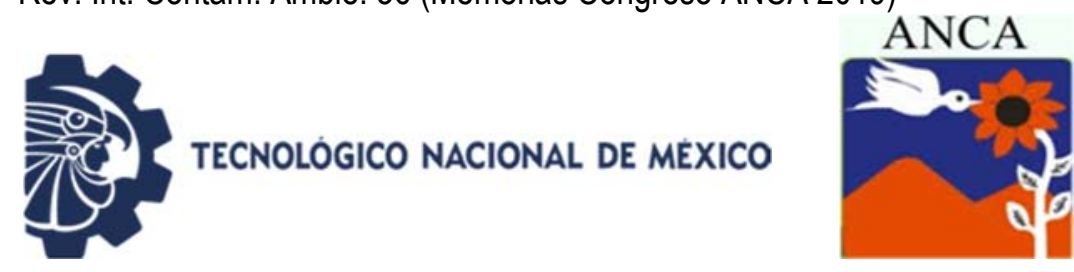

\title{
Grupos biológicos prioritarios de conservación en Tamaulipas, México: Caso de estudio Región Mante
}

\author{
González González MA \\ Universidad del Noreste (UNE), \\ Prolongación Avenida Hidalgo No. 6315, Nuevo Aeropuerto, \\ Tampico, Tamaulipas, México \\ marco.gonzalez@une.edu.mx
}

\section{RESUMEN}

Conservar la biodiversidad significa garantizar uno de los bienes más importantes para la humanidad, es una prioridad en todos los niveles debido a la crisis ambiental por la que atraviesa el planeta, como es el cambio de uso de suelo, caza inmoderada, deforestación, cambio climático, degradación ambiental, entre otros. Estas problemáticas se han ido incrementado en México durante las últimas décadas. Frecuentemente, la gran biodiversidad tamaulipeca ha sido atribuida al resultado de la confluencia de dos regiones biogeográficas (Neártica y Neotropical) y la confluencia de tres provincias que son las grandes llanuras de Norteamérica, las Ilanuras costeras del Golfo norte y la Sierra Madre Oriental. El presente trabajo se realizó en el Estado de Tamaulipas en la Región Mante que incluye a los municipios: Antiguo Morelos, Gómez Farías, Mante, Nuevo Morelos, Ocampo y Xicoténcatl, durante el periodo 2017-2018. Se utilizó el método de evaluación rápida de biodiversidad para estimar prioridad biológica (ERPBIO) cuyo objetivo es establecer criterios que permitan evaluar de manera rápida y fácil la biodiversidad de un área determinada, con base en datos publicados que permitan establecer una preferencia biológica enfocada a su conservación. La base de datos utilizados fue de la Comisión Nacional para el Conocimiento y uso de la Biodiversidad (CONABIO), actualizada al 2017. Encontrándose que los anfibios son prioritarios en Mante y Xicoténcatl; aves en Gómez Farías; en Ocampo los mamíferos, reptiles y bryophytas; los reptiles y gimnospermas en Mante.

Palabras clave: Degradación ambiental, biodiversidad, Neártica.

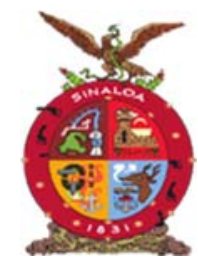

XVIII Congreso Internacional XXIV Congreso Nacional de Ciencias ambientales

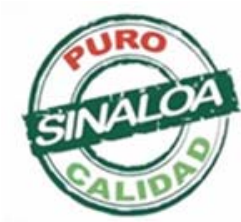

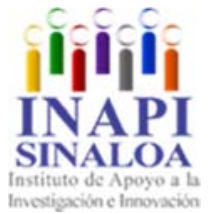

Mazatlán, Sinaloa 3-7 junio 2019

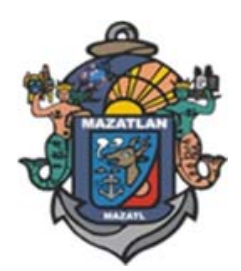

Recursos Naturales, Ecosistemas y Deterioro Ambiental 

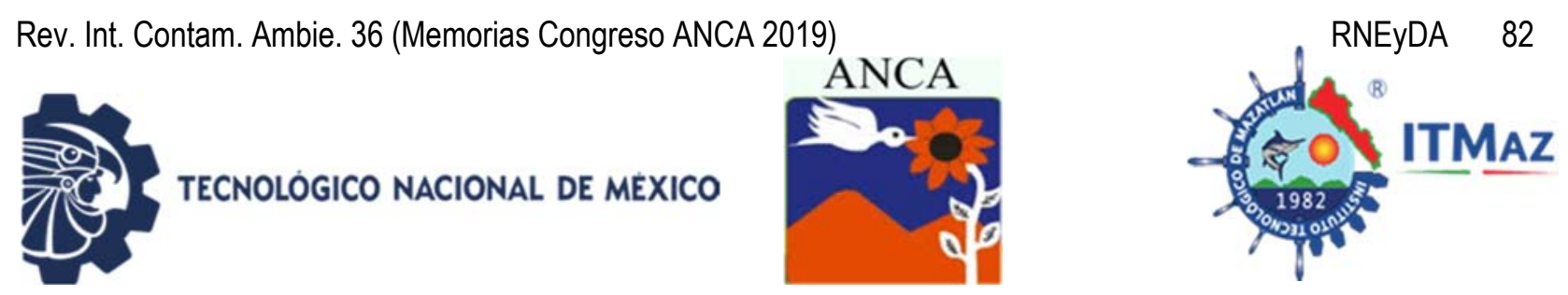

\title{
Priority conservation biological groups in Tamaulipas, México: Mante Región case study
}

\author{
González González MA \\ Universidad del Noreste (UNE), \\ Prolongación Avenida Hidalgo No. 6315, Nuevo Aeropuerto, \\ Tampico, Tamaulipas, México \\ marco.gonzalez@une.edu.mx
}

\begin{abstract}
Conserving biodiversity means guaranteeing one of the most important goods for humanity, it is a priority at all levels due to the environmental crisis that the planet is going through, such as land use change, immoderate hunting, deforestation, climate change, environmental degradation, among others, these problems have been increased in Mexico during the last decades. Frequently, the great biodiversity of Tamaulipas has been attributed to the result of the confluence of two biogeographic regions (Nearctic and Neotropical) and the confluence of three provinces that are the great plains of North America, the coastal plains of the North Gulf and the Sierra Madre Oriental. The present work was carried out in the State of Tamaulipas in the Mante Region that includes the municipalities: Antiguo Morelos, Gómez Farías, Mante, Nuevo Morelos, Ocampo and Xicoténcatl, during the period 2017-2018. The Rapid Biodiversity Assessment Method was used to estimate biological priority (ERPBIO), the objective of which is to establish criteria that allow the rapid and easy assessment of the biodiversity of a given area, based on published data that establish a biological preference focused on its conservation. The database used was from the National Commission for the Knowledge and Use of Biodiversity (CONABIO), updated to 2017. Finding that amphibians are a priority in Mante and Xicoténcatl; birds in Gómez Farías; in Ocampo the mammals, reptiles and bryophytas; the reptiles and gymnosperms in Mante.
\end{abstract}

Keywords: Environmental degradation, biodiversity, Nearctic.

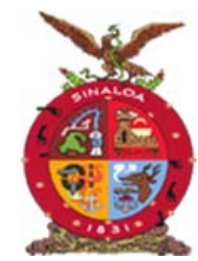

XVIII Congreso Internacional

XXIV Congreso Nacional de Ciencias ambientales

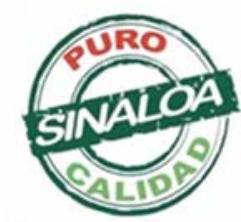

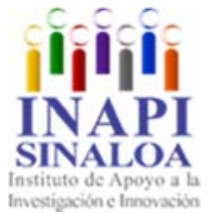

Mazatlán, Sinaloa 3-7 junio 2019

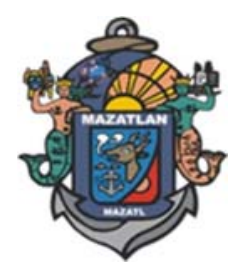

Recursos Naturales, Ecosistemas y Deterioro Ambiental 

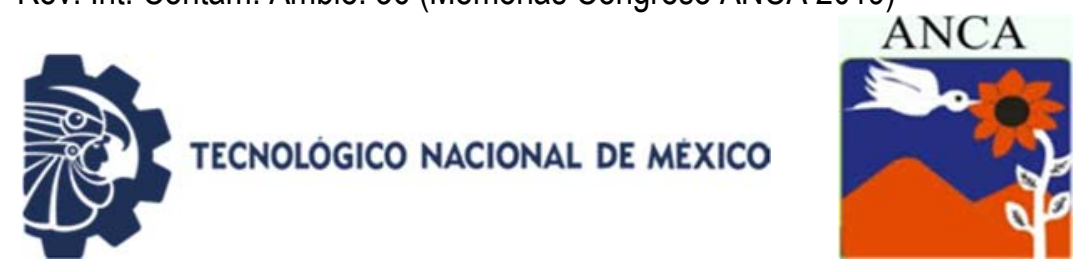

\title{
Control biológico de Gusano Cogollero a través de la diversidad de dípteros parasitoides
}

\author{
González Maldonado $\mathrm{B}^{1^{*}}$, Hernández Salinas $\mathrm{U}^{2}$, González Güereca $\mathrm{C}^{2}$ \\ 1Doctorado en Biotecnología del Instituto Politécnico Nacional \\ 2IPN. CIIDIR-IPN Unidad Durango \\ Sigma 119, Fracc. 20 de Nov. II. C.P. 34234, Durango, México \\ *mbgonzalez@ipn.mx
}

\section{RESUMEN}

El maíz (Zea mays L.) es el cultivo agrícola anual más importante en México. El gusano cogollero Spodoptera frugiperda (Smith, 1797) es la plaga que causa mayores daños cuando no se aplican medidas de control. En este trabajo se registró la diversidad de especies de taquínidos parasitoides presentes en la región maicera del Estado de Durango, para utilizarlos en su control biológico. Debido a que son pocos los estudios que se han realizado para su identificación taxonómica, se realizaron colectas semanales de larvas del gusano cogollero en maíz, del 16 de junio al 31 de agosto del 2016, los parasitoides se identificaron con apoyo de claves taxonómicas. De 2,100 larvas de gusano cogollero colectadas, 202 fueron parasitadas por taquínidos, con $6.8 \%$ de parasitismo por Lespesia aletiae (Riley, 1879) y L. archippivora (Riley, 1871), el $2.48 \%$ por Archytas marmoratus (Townsend, 1915) y el $0.28 \%$ por Winthemia deilephilae (Osten Sacken, 1887). L. archippivora y L. aletiae constituyen nuevos registros para el Estado de Durango, son pocos los reportes que se tienen de $L$. aletiae parasitando a gusano cogollero. A. marmoratus en Durango se ha encontrado en menor abundancia que el género Lespesia, sin embargo, se presentó en los tres meses muestreados (junio-agosto), en seis de los siete sitios. W. deilephilae, también constituye un nuevo registro para Durango y además es un nuevo registro de hospedero para $S$. frugiperda. En Durango, W. deilephilae fue la especie menos frecuente y menos abundante, solo seis individuos en tres de los siete sitios muestreados.

Palabras clave: Maíz, plagas, dípteros, diversidad, parasitoides.

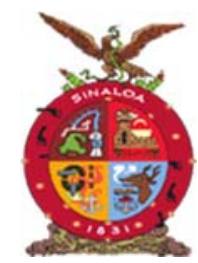

XVIII Congreso Internacional

XXIV Congreso Nacional de Ciencias ambientales

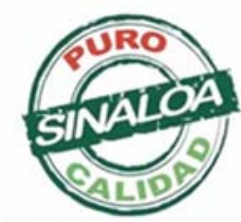

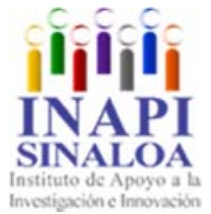

Mazatlán, Sinaloa 3-7 junio 2019

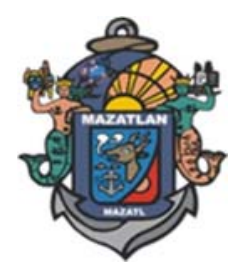

Recursos Naturales, Ecosistemas y Deterioro Ambiental 

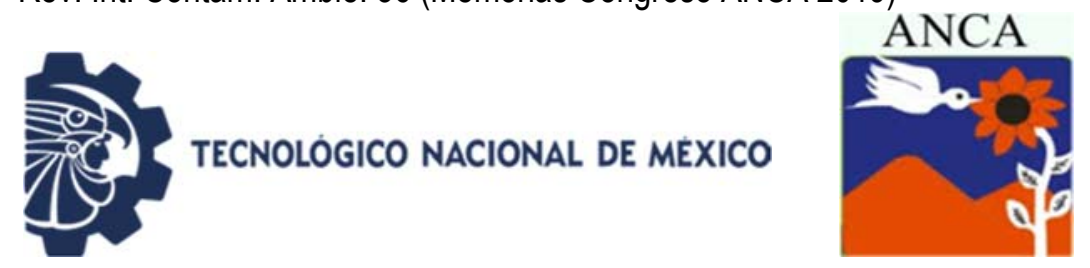

\title{
Biological control of Fall Armyworm through the diversity of dipteros parasitoids
}

\author{
González Maldonado $\mathrm{B}^{1^{*}}$, Hernández Salinas $\mathrm{U}^{2}$, González Güereca $\mathrm{C}^{2}$ \\ 1Doctorado en Biotecnología del Instituto Politécnico Nacional \\ 2IPN. CIIDIR-IPN Unidad Durango \\ Sigma 119, Fracc. 20 de Nov. II. C.P. 34234, Durango, México \\ *mbgonzalez@ipn.mx
}

\begin{abstract}
Corn (Zea mays L.) is the most important annual agricultural crop in Mexico. The fall armyworm Spodoptera frugiperda (Smith, 1797) is the pest that causes the most damage when control measures are not carried out, in this work the diversity of parasitoid taquinid species present in the corn region of the State of Durango is recorded, to use them in their biological control. Due to the fact that few studies have been carried out for their taxonomic identification, weekly collections of corn worm larvae were carried out in corn, from June 16 to August 31, 2016, the parasitoids were identified with the support of taxonomic keys. Of 2,100 collected fall armyworm larvae, 202 were parasitized by tachinids, with $6.8 \%$ parasitism by Lespesia aletiae (Riley, 1879) and L. archippivora (Riley, 1871), $2.48 \%$ by Archytas marmoratus (Townsend, 1915) and the $0.28 \%$ by Winthemia deilephilae (Osten Sacken, 1887). L. archippivora and $L$. aletiae are new records for the State of Durango, there are few reports of $L$. aletiae parasitizing the armyworm. $A$. marmoratus in Durango has been found in lower abundance than the genus Lespesia, however, it was presented in the three sampled months (June-August), in six of the seven sites. W. deilephilae, also constitutes a new record for Durango and is also a new host record for $S$. frugiperda. In Durango, $W$. deilephilae was the least frequent and least abundant species, only six individuals in three of the seven sites sampled.
\end{abstract}

Keywords: Corn, pests, diptera, diversity, parasitoids.

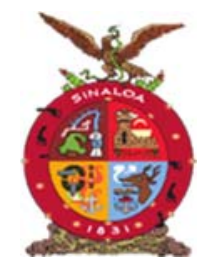

XVIII Congreso Internacional

XXIV Congreso Nacional de Ciencias ambientales

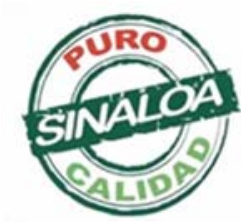

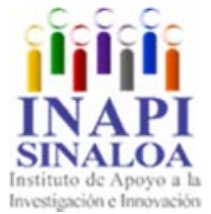

Mazatlán, Sinaloa 3-7 junio 2019

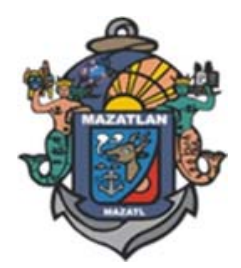

Recursos Naturales, Ecosistemas y Deterioro Ambiental 


\title{
Variabilidad genética de Chelonus sp., parasitoides de Gusano Cogollero
}

\author{
González Maldonado B ${ }^{1 *}$, Hernández Salinas U², González Güereca $C^{2}$ \\ ${ }^{1}$ Doctorado en Biotecnología del Instituto Politécnico Nacional \\ ${ }^{2}$ CIIDIR-IPN Unidad Durango. IPN. \\ Sigma 119, Fracc. 20 de Nov. II. C.P. 34234, Durango, México \\ *mbgonzalez@ipn.mx
}

\section{RESUMEN}

Se determinó la variabilidad genética presente en Chelonus sp., parasitoides, gusano cogollero plaga del maíz en Durango, México. Para la extracción de ADN se utilizaron 19 individuos. EI ADN genómico total se aisló por individuo. A partir del ADN aislado, se realizó la amplificación de un fragmento del gen mitocondrial "citocromo $c$ oxidasa I". Al revisar la diagnosis de las especies de Chelonus, los ejemplares analizados en este trabajo se agruparon en tres especies nominales: Ch. insularis, Ch. sonorensis, Ch. cautus. Respecto a la distribución de la varianza, se muestran dos grupos, 1: Ch. insularis + Ch. sonorensis y 2: Ch. cautus, esto indica que los grupos son distintos entre sí (FSC $=0.02289, p=$ 0.011 al $95 \%$ de confianza), no existe diferencia al interior de éstos (FST = $0.97679, p=0.43$ al $95 \%$ de confianza), estos fueron comparados con el grupo 3 : Ch. insularis de diferentes estados de la República Mexicana, de acuerdo a la red haplotípica y a la matriz de distancias se puede observar que aun cuando se comparan especies diferentes como Ch. insularis y Ch. sonorensis, la diferenciación genética entre éstas es de $0.3 \%$, formando un solo grupo, siendo genéticamente cercanos; a excepción de Ch. cautus, que se encuentra a una distancia de este grupo compacto del $17.8 \%$, lo cual lo sitúa muy lejos de este grupo. Fenotípicamente el tamaño de los individuos del parasitoide Ch. cautus es significativamente más pequeño que las especies $C h$. insularis y Ch. sonorensis siendo considerado como un Microchelonus.

Palabras clave: Maíz, variabilidad, plagas, ADN, haplotipos.

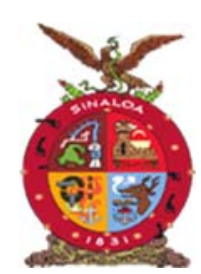

XVIII Congreso Internacional XXIV Congreso Nacional de Ciencias ambientales
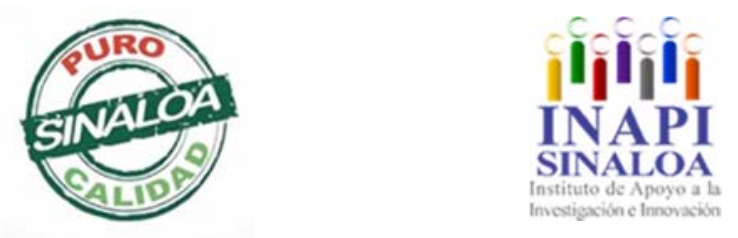

Mazatlán, Sinaloa 3-7 junio 2019

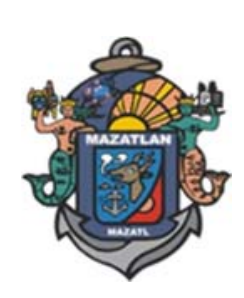

Recursos Naturales, Ecosistemas y Deterioro Ambiental 

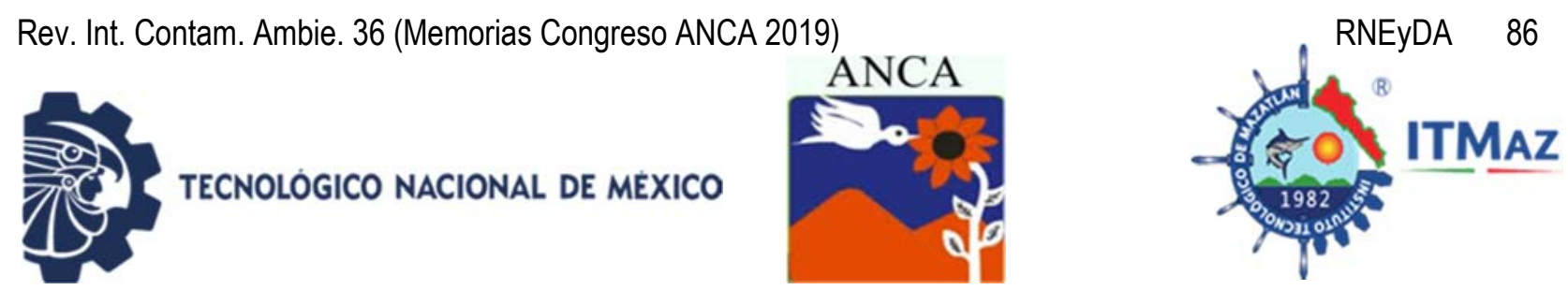

\title{
Genetic variability of Chelonus sp., parasitoides of the Cogollero Worm
}

\author{
González Maldonado $\mathrm{B}^{1^{*}}$, Hernández Salinas U², González Güereca $\mathrm{C}^{2}$ \\ ${ }^{1}$ Doctorado en Biotecnología del Instituto Politécnico Nacional \\ ${ }^{2}$ CIIDIR-IPN Unidad Durango. IPN. \\ Sigma 119, Fracc. 20 de Nov. II. C.P. 34234, Durango, México \\ *mbgonzalez@ipn.mx
}

\begin{abstract}
We determined the genetic variability present in Chelonus sp., parasitoids of the corn plague fall armyworm in Durango, Mexico, using genetic characters. For the extraction of DNA, 19 individuals were used. The total genomic DNA was isolated per individual. The fragment of the mitochondrial cytochrome $c$ oxidase I gene was isolated from the isolated DNA. In reviewing the diagnosis of the Chelonus species, the specimens analyzed in this work were grouped into three nominal species: Ch. insularis, Ch. sonorensis, Ch. cautus. Regarding AMOVA, the maximum variance distribution was observed when two groups were formed, 1 : Ch. insularis $+C h$. sonorensis and 2: Ch. cautus. This indicates that the groups are different from each other ( $F S C=0.02289, p=0.011$ at $95 \%$ confidence), there is no difference within these (FST $=0.97679, p=0.43$ at $95 \%$ confidence), these were compared with group 3: Ch. insularis from different states of the Mexican Republic. According to the haplotypic network and the distances matrix, it can be observed that even when different species such as Ch. insularis and Ch. sonorensis are compared, the genetic differentiation between them is $0.3 \%$. Forming a single group, being genetically close; with the exception of Ch. cautus, which is located at a distance of this compact group of $17.8 \%$, which places it very far from this group, in addition the size of the individuals of the parasitoid Ch. cautus is significantly smaller than the species. Ch. insularis and Ch. sonorensis being considered a Microchelonus.
\end{abstract}

Keywords: Corn, variability, pests, DNA, haplotypes.

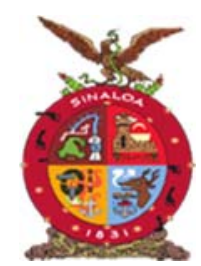

XVIII Congreso Internacional XXIV Congreso Nacional de Ciencias ambientales

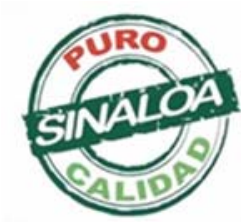

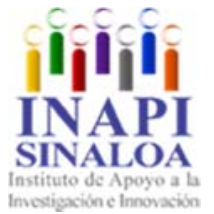

Mazatlán, Sinaloa 3-7 junio 2019

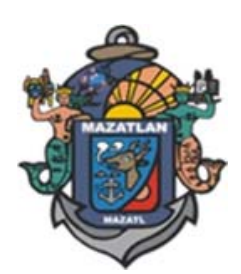

Recursos Naturales, Ecosistemas y Deterioro Ambiental 


\title{
Elementos metálicos traza en los sedimentos de la Bahía del Tóbari, Sonora y su Riesgo Ecológico
}

\author{
González Pérez $\mathrm{B}^{1}$, Esteller Alberich $\mathrm{MV}^{* 1}$, Garrido Hoyos $\mathrm{S}^{2}$, Díaz Delgado $\mathrm{C}^{1}$, \\ Jara Marini $\mathrm{M}^{3}$, Almazán Benítez $\mathrm{B}^{1}$ \\ ${ }^{1}$ Instituto Interamericano de Tecnología y Ciencias del Agua. \\ Universidad Autónoma del Estado de México. \\ ${ }^{2}$ Instituto Mexicano de Tecnología del Agua Jiutepec, Morelos, México \\ ${ }^{3}$ Centro de Investigación en Alimentación y Desarrollo, Hermosillo, Sonora \\ *mvestellera@uaemex.mx
}

\section{RESUMEN}

El estado de Sonora es de gran importancia a nivel nacional, debido a las actividades productivas y económicas que en él se desarrollan (primeros lugares de producción minera, agrícola, pecuaria y acuícola); sin embargo, ello ha tenido como consecuencia diversas alteraciones en el ambiente. Un ejemplo es la región del Valle del Yaqui (con una intensa actividad agrícola) y la Bahía del Tobari, sitio clasificado RAMSAR, y donde se descarga el agua de drenaje agrícola del Valle de Yaqui. El objetivo del estudio fue la evaluación de la biodisponibilidad de elementos metálicos traza (EMT) en sedimentos de la bahía (As, $\mathrm{Cd}, \mathrm{Cr}, \mathrm{Cu}, \mathrm{Hg}, \mathrm{Fe}, \mathrm{Mn}, \mathrm{Ni}, \mathrm{Pb}, \mathrm{Zn}$ ), y su impacto potencial en la biota acuática. Se tomaron muestras de sedimentos en 14 puntos de la bahía, en tres periodos (junio y noviembre 2017 y marzo 2018). El análisis de metales se llevó a cabo mediante extracción secuencial utilizando el método Kartal et al., (2006). Los resultados muestran presencia de todos los EMT en las diferentes muestras. El orden de biodisponibilidad de EMT es el siguiente: $\mathrm{Fe}>\mathrm{Mn}>\mathrm{Zn}>\mathrm{Cu}>\mathrm{Ni}>\mathrm{Cr}>\mathrm{Cd}>\mathrm{Pb}>\mathrm{Hg}>\mathrm{As}$ (tres periodos de muestreo); seguir los $\mathrm{Mn}, \mathrm{Hg}, \mathrm{As}, \mathrm{Zn}$ y Ni los más movilizables. En cuanto al riesgo ecológico Criterios de Mac Donald et al. (2000), el Hg es potencialmente tóxico, el Cd raramente tóxico y el resto de los elementos no son considerados como tóxicos. Los sedimentos de la bahía del Tóbari muestran altas concentraciones de ETM, principalmente $\mathrm{Mn}, \mathrm{Hg}$, As y $\mathrm{Zn}$, con un comportamiento de movilidad similar, evidenciando riesgo ecológico en el ecosistema.

Palabras clave: Tóbari, sedimentos, elementos metálicos traza, extracción secuencial, riesgo ecológico.

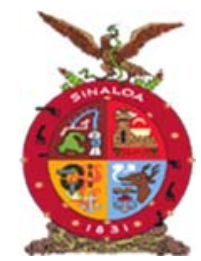

XVIII Congreso Internacional XXIV Congreso Nacional de Ciencias ambientales

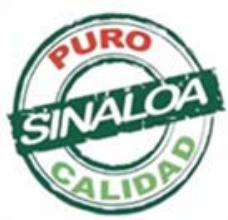

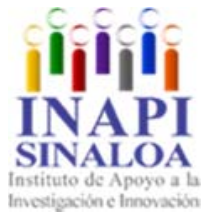

Mazatlán, Sinaloa 3-7 junio 2019

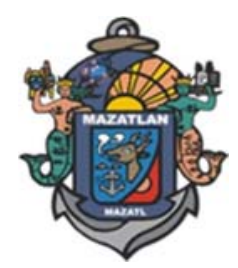

Recursos Naturales, Ecosistemas y Deterioro Ambiental 

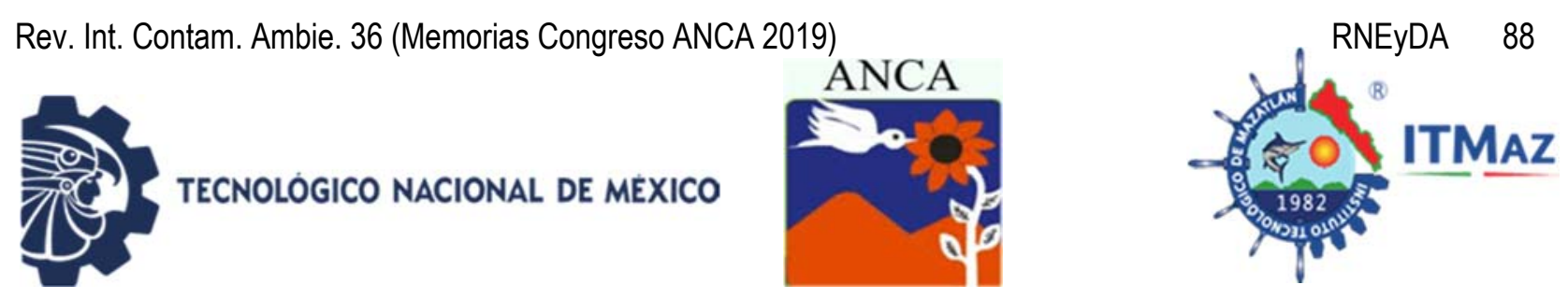

\title{
Metal Trace Elements in the sediments of the Tóbari Bay, Sonora; and their Ecological Risk
}

\author{
González Pérez $\mathrm{B}^{1}$, Esteller Alberich $\mathrm{MV}^{* 1}$, Garrido Hoyos $\mathrm{S}^{2}$, Díaz Delgado $\mathrm{C}^{1}$, \\ Jara Marini $\mathrm{M}^{3}$, Almazán Benítez $\mathrm{B}^{1}$ \\ ${ }^{1}$ Instituto Interamericano de Tecnología y Ciencias del Agua. \\ Universidad Autónoma del Estado de México. \\ ${ }^{2}$ Instituto Mexicano de Tecnología del Agua Jiutepec, Morelos, México \\ ${ }^{3}$ Centro de Investigación en Alimentación y Desarrollo, Hermosillo, Sonora \\ *mvestellera@uaemex.mx
}

\begin{abstract}
The state of Sonora is of great importance at national level, due to the productive and economic activities that take place there (first places of mining, agricultural, livestock and aquaculture production); however, this has resulted in various alterations in the environment. One of the examples is the region of the Yaqui Valley (with intense agricultural activity) in the Tobari Bay, which is a RAMSAR classified site, and where the agricultural drainage water of the Yaqui Valley is discharged. The main of this study was the evaluation of the bioavailability of metallic trace elements (MTE) in bay sediments (As, Cd, Cr, Cu, Hg, $\mathrm{Fe}, \mathrm{Mn}, \mathrm{Ni}$, $\mathrm{Pb}, \mathrm{Zn}$ ), and their potential impact on the aquatic biota. Sediment samples were taken at 14 points of the bay, in three periods (June and November 2017 and March 2018). The metal analysis was carried out by sequential extraction according to Kartal et al. (2006) method. The results show the presence of all the MTE in the different fractions. The order of bioavailability of MTE is as follows: $\mathrm{Fe}>\mathrm{Mn}>\mathrm{Zn}>\mathrm{Cu}>\mathrm{Ni}>\mathrm{Cr}>\mathrm{Cd}>\mathrm{Pb}>\mathrm{Hg}>\mathrm{As}$ (three sampling periods); being Mn, $\mathrm{Hg}, \mathrm{As}, \mathrm{Zn}$ and $\mathrm{Ni}$ the most mobilizable. Regarding the ecological risk (Criteria of Mac Donald et al., 2000), the $\mathrm{Hg}$ is potentially toxic, the $\mathrm{Cd}$ is rarely toxic and the rest of the non-toxic elements. The sediments of the Tóbari bay show high concentrations of MTE, mainly Mn, As, $\mathrm{Hg}$ and $\mathrm{Zn}$, with a similar mobility behavior, evidencing ecological risk of the ecosystem.
\end{abstract}

Keywords: Tóbari, sediments, metallic trace elements, sequential extraction, ecological risk.

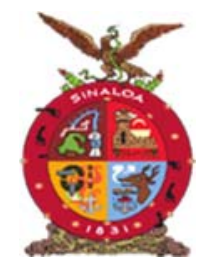

XVIII Congreso Internacional

XXIV Congreso Nacional de Ciencias ambientales

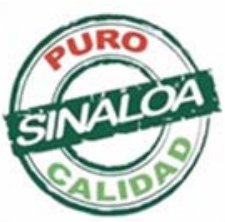

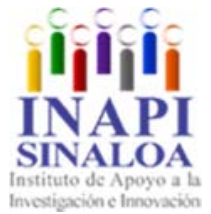

Mazatlán, Sinaloa 3-7 junio 2019

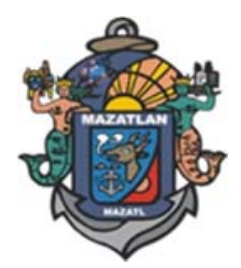

Recursos Naturales, Ecosistemas y Deterioro Ambiental 

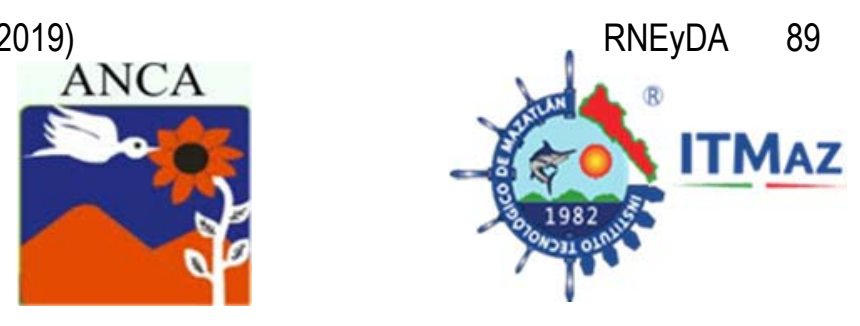

\title{
Estudio del potencial de Eichhornia crassipes como enraizador orgánico
}

\author{
González Quemada A, Maya Mancera P, Pérez Tapia S, Ortiz Ruiz A, \\ Osornio Rubio $\mathrm{R}^{*}$ \\ 1Departamento de Ingeniería Ambiental. Instituto Tecnológico de Celaya TNM. \\ Antonio García Cubas Pte \# 600 Esq. Av. Tecnológico, 38010, \\ Celaya, Guanajuato, México \\ nadia.osornio@itcelaya.edu.mx
}

\section{RESUMEN}

La principal problemática asociada al lirio acuático (Eichhornia crassipes) es su comportamiento como una maleza, enlistada en el lugar 33 según el GEEl, ya que presenta una gran rapidez de crecimiento, que le permiten cubrir en un corto plazo la superficie de los cuerpos de agua que invaden, y su principal forma de control está basado en su retiro periódico. Con el fin de identificar un uso del lirio residual, mediante la evaluación de su potencial como enraizador para plantas ornamentales de rápido crecimiento, el lirio empleado fue muestreado de la Laguna de Yuridia, Guanajuato con base en el Protocolo de Muestreo y Laboratorio de Flora Acuática en Ríos. La obtención del enraizador se realizó mediante dos procesos diferentes: 1) Proceso de fermentación (Enraizador F) y 2) proceso térmico (Enraizador T). Los enraizadores fueron caracterizados por FTIR y posteriormente aplicados en helechos, mediante aplicaciones cada 7 días durante 28 días, empleando 4 plantas por enraizador y 4 plantas testigo. Se analizó la eficiencia mediante un seguimiento del crecimiento de tallos, raíz y hojas. Con base en los resultados obtenidos, se identificó por FTIR diferencias en la estructura de enlace de los enraizadores en función del método empleado para su obtención. Se pudo identificar que las especies a las que se les aplico el enraizador $F$ presentaron un ligero incremento en las dimensiones de sus raíces, por lo que se perfila con un mayor potencial, pero se considera conveniente realizar un seguimiento durante un lapso de tiempo mayor.

Palabras clave: Lirio acuático, enraizador, aprovechamiento de residuos.

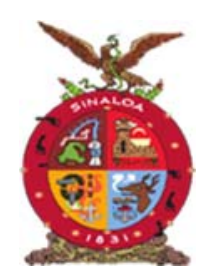

XVIII Congreso Internacional XXIV Congreso Nacional de Ciencias ambientales
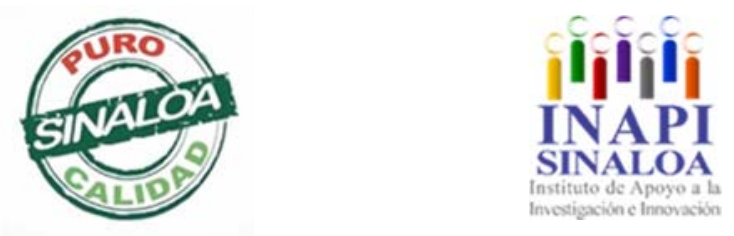

Mazatlán, Sinaloa 3-7 junio 2019

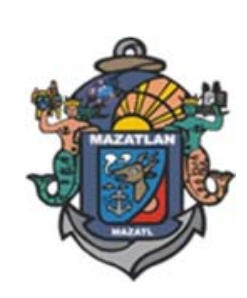

Recursos Naturales, Ecosistemas y Deterioro Ambiental 

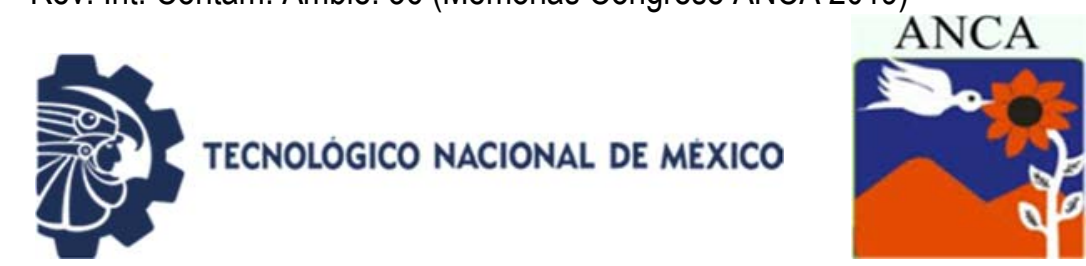

\title{
Study of the potential of Eichhornia crassipes as an organic rider
}

\author{
González Quemada A, Maya Mancera P, Pérez Tapia S, Ortiz Ruiz A, \\ Osornio Rubio $\mathrm{R}^{*}$
}

Departamento de Ingeniería Ambiental. Instituto Tecnológico de Celaya TNM. Antonio García Cubas Pte \# 600 Esq. Av. Tecnológico, 38010,

Celaya, Guanajuato, México

nadia.osornio@itcelaya.edu.mx

\begin{abstract}
The main problem associated with water lily (Eichhornia crassipes), is its behavior as a weed, listed in place 33 according to the GEEl. Since it has a great rapidity of growth, which allows it to cover in a short term the surface of the bodies of water they invade, and their main form of control is based on their periodic withdrawal. In order to identify a use of the residual lily, by evaluating its potential as a root for ornamental fast-growing plants, the lily used was sampled from Yuridia Lagoon, Guanajuato based on the Aquatic Flora Laboratory and Sampling Protocol in rivers. The rooting was obtained through two different processes: 1) fermentation process (Root $F$ ) and 2) thermal process (Root $T$ ). Rooters were characterized by FTIR and subsequently applied in ferns, using applications every 7 days for 28 days, using 4 plants per root and 4 control plants. Efficiency was analyzed by monitoring the growth of stems, roots and leaves. Based on the results obtained, differences in the linker structure of the rooters were identified by FTIR according to the method used to obtain them. It was possible to identify that the species to which the Root $F$ was applied had a slight increase in the dimensions of its roots, so it is profiled with a greater potential, but it is considered convenient to follow up for a longer period of time.
\end{abstract}

Keywords: Water lily, root, waste disposal.

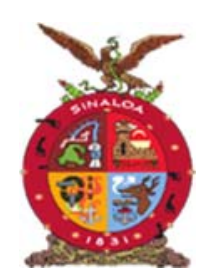

XVIII Congreso Internacional XXIV Congreso Nacional de Ciencias ambientales

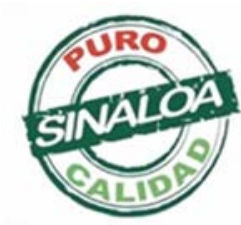

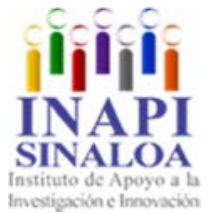

Mazatlán, Sinaloa 3-7 junio 2019

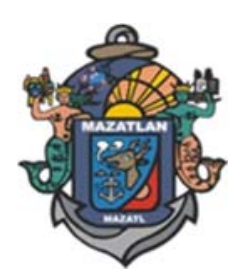

Recursos Naturales, Ecosistemas y Deterioro Ambiental 

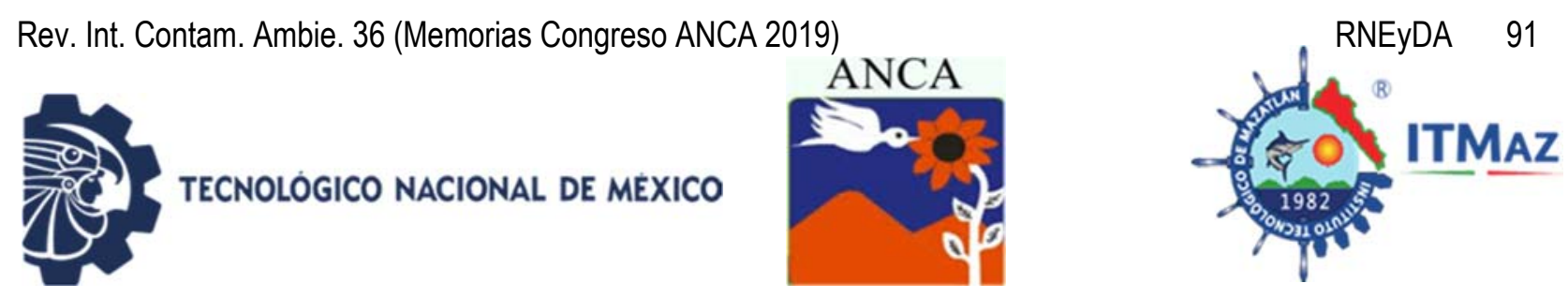

\title{
Patrón de comportamiento entre la precipitación y la sequía intraestival
}

\author{
Granjeno Colín $A E^{1^{*}}$, Trejo Albarrán $\mathrm{R}^{2}$, Oliver Guadarrama $\mathrm{R}^{1}$ \\ ${ }^{1}$ Departamento de Biología Vegetal, Laboratorio de Edafoclimatología \\ ${ }^{2}$ Departamento de Biología Animal, Laboratorio de Hidrobiología. \\ Centro de Investigaciones Biológicas. UAEMorelos. \\ Av. Universidad 1001, Col. Chamilpa, 62209, Cuernavaca, Morelos, México \\ *granjeno@uaem.mx
}

\section{RESUMEN}

La precipitación es un hidrometeoro que forma parte del ciclo del agua, que mantiene el equilibrio y sustento de todos los ecosistemas; un descenso en la precipitación por mínimo que éste sea se traduce en sequía. El presente trabajo, se realizó en el municipio de Cuernavaca, capital del estado de Morelos, mediante la evaluación de los datos pluviométricos registrados por la estación climatológica No. 17 ubicada en la parte norte de la entidad a 1911 msnm, misma que funciona desde el año 2006 hasta la fecha. El objetivo principal fue estimar cuantitativamente la precipitación y determinar si su efecto respecto a la sequía intraestival es inverso o directo. Los datos diarios obtenidos fueron analizados y cuantificados, siendo el resultado de los registros de doce años consecutivos (2006-2018) y que han sido recopilados en un digitalizador de datos climatológicos. Respecto a la cantidad de precipitación total anual (PTA), ésta ha oscilado entre $1236.35 \mathrm{~mm}$ (2007) y $1998.36 \mathrm{~mm}$ (2014). En lo referente a la determinación de la sequía intraestival, del total de años analizados (12), siete de ellos, registraron el fenómeno, lo que representa un $58.3 \%$ del total y cuyos valores oscilaron entre $4.3 \%$ (2007) y $28.6 \%$ (2014), Asimismo, cabe mencionar que hubo cuatros años con sequía de dos meses $(2007,2011,2016$ y 2018) y que los años con registro de tres meses de la misma fueron: 2013, 2014 y 2015. Finalmente se concluye que 2014 fue el año con mayor precipitación (1998.36) y con mayor \% de sequía (28.6).

Palabras clave: Canícula, lluvia, inverso, directo, precipitación.

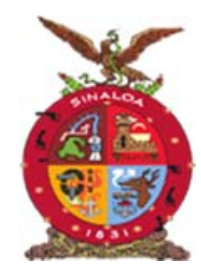

XVIII Congreso Internacional XXIV Congreso Nacional de Ciencias ambientales

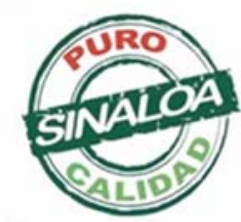

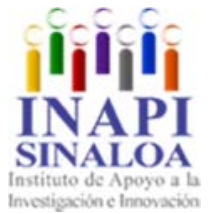

Mazatlán, Sinaloa 3-7 junio 2019

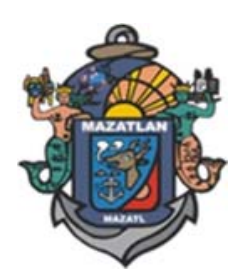

Recursos Naturales, Ecosistemas y Deterioro Ambiental 

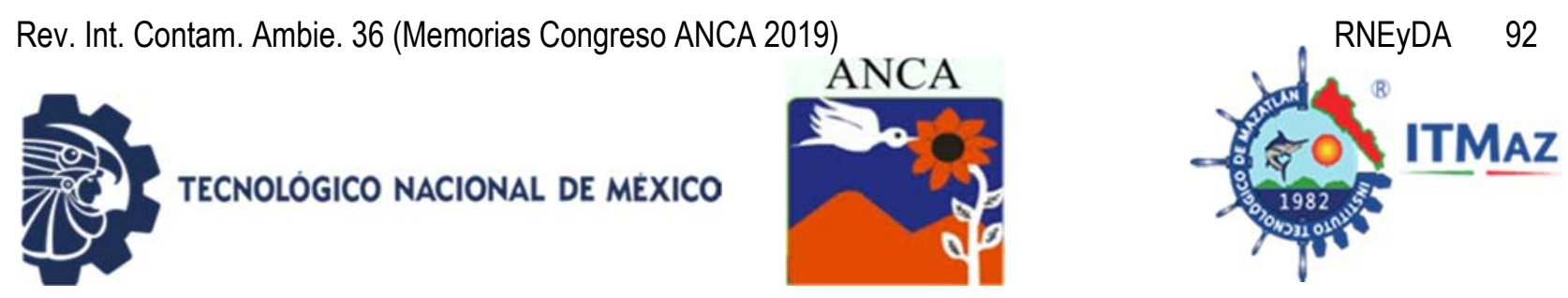

\title{
Behavior pattern between precipitation and intraestival drought
}

\author{
Granjeno Colín $\mathrm{AE}^{1 *}$, Trejo Albarrán $\mathrm{R}^{2}$, Oliver Guadarrama $\mathrm{R}^{1}$ \\ ${ }^{1}$ Departamento de Biología Vegetal, Laboratorio de Edafoclimatología \\ 2Departamento de Biología Animal, Laboratorio de Hidrobiología. \\ Centro de Investigaciones Biológicas. UAEMorelos. \\ Av. Universidad 1001, Col. Chamilpa, 62209, Cuernavaca, Morelos, México \\ *granjeno@uaem.mx
}

\begin{abstract}
Precipitation is a hydrometeor that is part of the water cycle, which maintains the balance and sustenance of all ecosystems; a decrease in precipitation, at least, which results in drought. The present work was carried out in the municipality of Cuernavaca, capital of the state of Morelos, through the evaluation of rainfall data recorded by the weather station No. 17 located in the northern part of the entity at 1911 meters above sea level, which operates from the 2006 to date. The main objective was to quantitatively estimate precipitation and determine if its effect on intra-festival drought is inverse or direct. The daily data obtained were analyzed and quantified, being the result of the records of twelve consecutive years (20062018) and that have been compiled in a digitizer of climatological data. Regarding the amount of total annual precipitation (PTA), it has ranged between 1236.35 $\mathrm{mm}$ (2007) and $1998.36 \mathrm{~mm}$ (2014). Regarding the determination of the intrafestival drought, of the total number of years analyzed (12), seven of them recorded the phenomenon. Which represents $58.3 \%$ of the total and whose values ranged between $4.3 \%$ (2007) and $28.6 \%$ (2014), It is also worth mentioning that there were four years with a two-month drought $(2007,2011,2016$ and 2018) and that the years with a three-month record of it were: 2013, 2014 and 2015. Finally, it is concluded that 2014 It was the year with the highest rainfall (1998.36) and with the highest \% of drought (28.6).
\end{abstract}

Keywords: Cannula, rain, inverse, direct, precipitation.

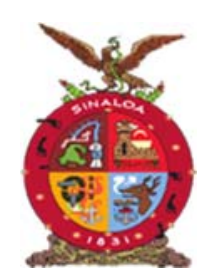

XVIII Congreso Internacional XXIV Congreso Nacional de Ciencias ambientales
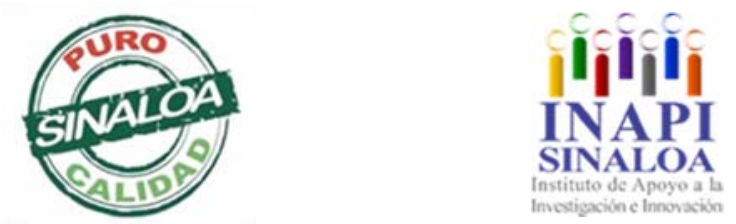

Mazatlán, Sinaloa 3-7 junio 2019

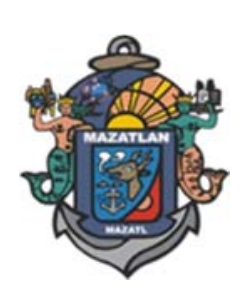

Recursos Naturales, Ecosistemas y Deterioro Ambiental 

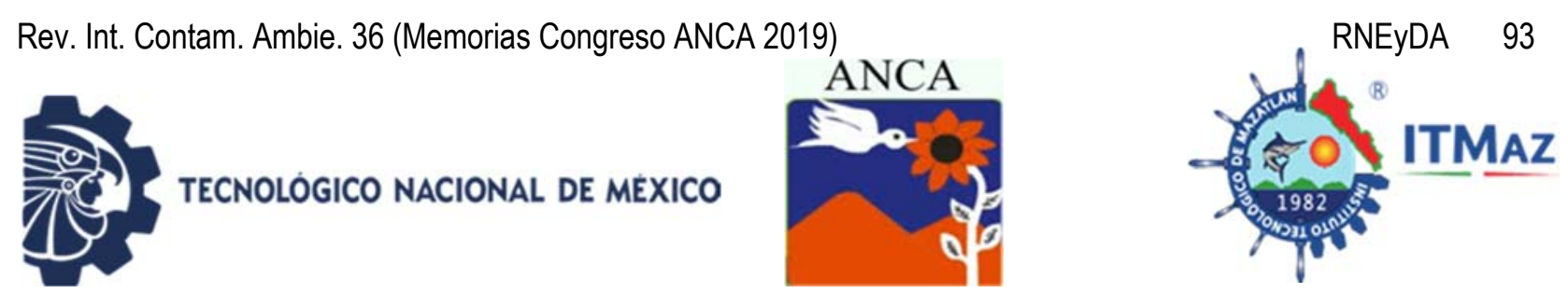

\section{Desarrollo de un sistema integral de producción de tilapia}

Gutiérrez Cedillo A*, Michel Parra G, Gutiérrez Cedillo P, Cerón Bracamontes M

Universidad de Guadalajara. Centro Universitario del Sur, Av. Enrique Arreola Silva No. 883, Colón, Cd. Guzmán Jalisco, México

*auro_bere15@hotmail.com

\section{RESUMEN}

El cambio climático ha ocasionado conflictos que empiezan a verse y sentirse en algunas partes del mundo, uno de estos son los problemas por los recursos naturales, los que se han visto afectados por presentar un decremento en su disponibilidad. Estas situaciones afectan directamente la producción de alimentos debido a esto se deben de implementar alternativas de producción sustentable que logren un aprovechamiento óptimo e integral de los recursos naturales. Uno de los recursos que se ha visto afectadas es el agua. El objetivo del presente trabajo fue desarrollar un sistema integral de producción de tilapia para contribuir a las buenas prácticas en el uso y aprovechamiento del agua. El presente trabajo se realizó en Ciudad Guzmán y Gómez Farías, Jalisco, de octubre de 2018 a abril de 2019. El desarrollo del sistema se dividió en cuatro etapas la primera llamada: inversión, producción, transformación o venta y; manejo de desechos. Para llevar a cabo el trabajo se requirió de preparación del terreno, compra e instalación de geomembranas, alevines, alimento, maquinaria y equipo. Se tiene la primera etapa concluida y la segunda se encuentra con un $15 \%$ de avance ya que para esta se tiene una duración de 30 semanas tiempo necesario para que el alevín se desarrolle y tenga peso óptimo para su consumo. Es de suma importancia el desarrollo de proyectos en los que se tenga un aprovechamiento integral de los recursos naturales debido a las situaciones ambientales que se viven hoy en día en nuestro planeta.

Palabras clave: Agua, aprovechamiento, integral, producción.

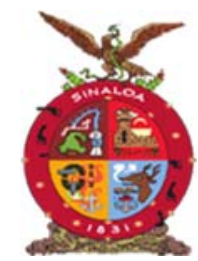

XVIII Congreso Internacional

XXIV Congreso Nacional de Ciencias ambientales

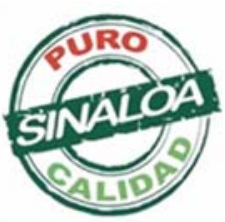

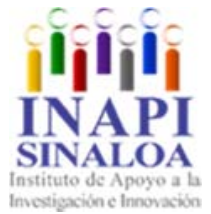

Mazatlán, Sinaloa 3-7 junio 2019

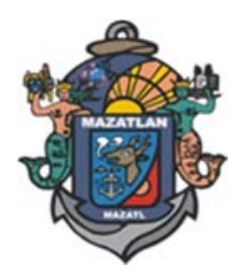

Recursos Naturales, Ecosistemas y Deterioro Ambiental 

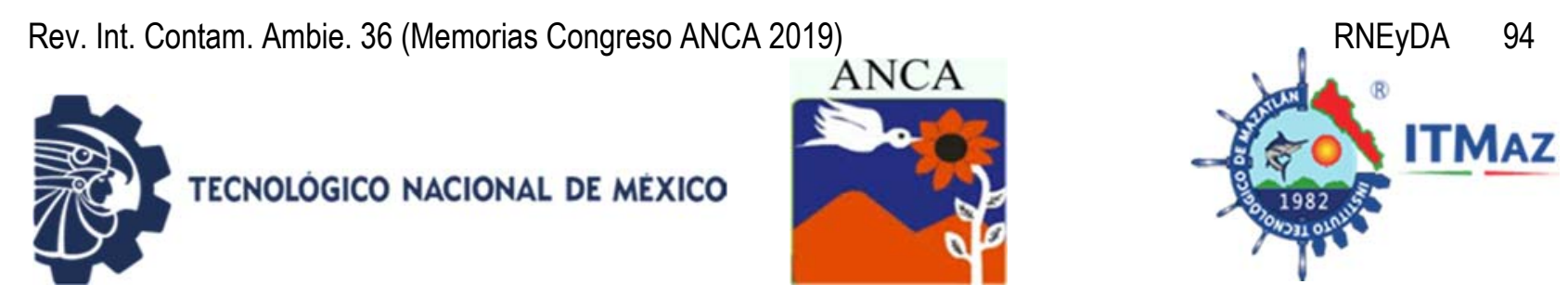

\title{
Development of a complete tilapia production system
}

Gutiérrez Cedillo A*, Michel Parra G, Gutiérrez Cedillo P, Cerón Bracamontes M

Universidad de Guadalajara. Centro Universitario del Sur, Av. Enrique Arreola Silva No. 883, Colón, Cd. Guzmán Jalisco, México

*auro_bere15@hotmail.com

\begin{abstract}
Climate change has caused conflicts that start to look and feel in some parts of the world, one of these are the problems for the resources, which have been affected by a decrease in their availability. These situations directly affect food production because of this they must implement sustainable production alternatives that achieve ideal and complete utilization of natural resources. One of the resources that have been affected is water. The aim of this study was to develop a complete tilapia production system to contribute to good practices in water use and utilization. The study was held in Ciudad Guzmán and Gómez Farías, Jalisco, from October 2018 to April 2019. The development of the system was divided into four stages the first call investment, production, transformation or sale, and waste management. The work was required to prepare the land, purchase and install geomembranes, fry, food, machinery, and equipment. It has the first stage completed and the second is a 15\% advance because for this one has a duration of 30 weeks time necessary for the fry to develop and has an ideal weight for consumption. It is of paramount importance the development of projects in which they have complete use of the natural resources because of the environmental situations that are lived today on our planet.
\end{abstract}

Keywords: Water, use, complete, production.

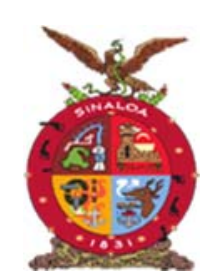

XVIII Congreso Internacional

XXIV Congreso Nacional de Ciencias ambientales

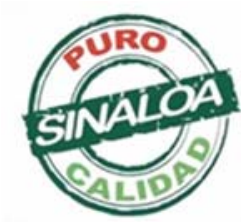

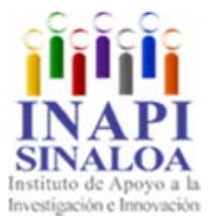

Mazatlán, Sinaloa 3-7 junio 2019

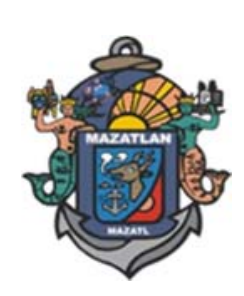

Recursos Naturales, Ecosistemas y Deterioro Ambiental 

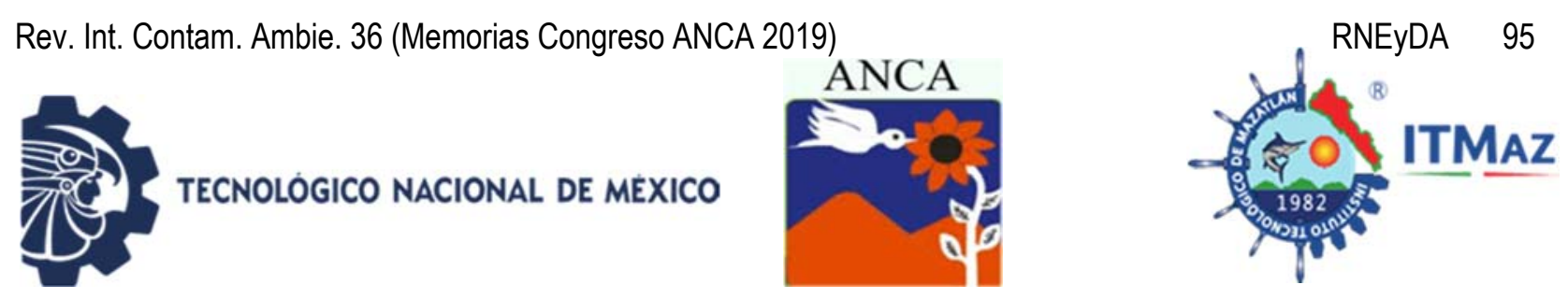

\title{
Calidad de vida urbana en la ciudad de Toluca. Un análisis de las áreas verdes y los contaminantes del aire
}

\author{
Gutiérrez Cedillo JG ${ }^{1}$, Hernández Romero JC², Franco Plata R ${ }^{1}$ \\ ${ }^{1}$ Facultad de Geografía. Universidad Autónoma del Estado de México. \\ Paseo Universidad, $50110 \mathrm{Cd}$. Universitaria, Toluca de Lerdo, México \\ ${ }^{2}$ Facultad de Química. Universidad Autónoma del Estado de México. \\ Paseo Colón S/N, Residencial Colón, Toluca de Lerdo, México
}

\section{RESUMEN}

El objetivo de este estudio es analizar las condiciones existentes que influyen en la calidad de vida de los habitantes de la Zona metropolitana de la Ciudad de Toluca; las condiciones analizadas son la distribución espacial de las áreas verdes urbanas y el comportamiento de los contaminantes del aire. Mediante fotointerpretación cartográfica de imágenes de satélite Sentinel 2, se ubicaron y dimensionaron las áreas verdes; con trabajo sistemático en campo fueron identificadas e inventariadas; entrevistas no estructuradas fueron enfocadas a conocer su localización geopolítica y el tipo de administración que tienen, lo que permitió finalmente su cuantificación, análisis estadístico; representación gráfica y cartográfica. Los resultados muestran las áreas verdes existentes en cada municipio integrante de la zona metropolitana, los tipos de áreas verdes existentes en la zona, su tamaño, distribución espacial y tendencia de distribución. El análisis de los contaminantes del aire que son monitoreados por la la Red Automática de Monitoreo Atmosférico de la Ciudad de Toluca (RAMA Toluca), se seleccionó la información de siete años (2011-2017), para cinco contaminantes atmosféricos; los datos fueron codificados y analizados estadísticamente mediante el programa Excel versión 2013, lo que permitió obtener las medias mensuales, estacionales (verano e invierno) y anuales; para toda la zona y para cada estación de monitoreo. El análisis espacial y su representación mediante cartografía automatizada se elaboró en SIG Arc Gis versión 10.2. El resultado obtenido sobre las tendencias espaciales y temporales puede ser considerado una herramienta en apoyo a la toma de decisiones en materia de ordenamiento territorial.

Palabras clave: Areas verdes, calidad de vida, contaminantes atmosféricos, ciudad de Toluca, zona metropolitana.

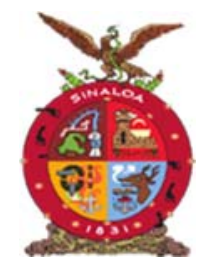

XVIII Congreso Internacional

XXIV Congreso Nacional de Ciencias ambientales

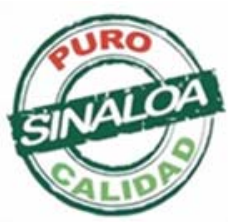

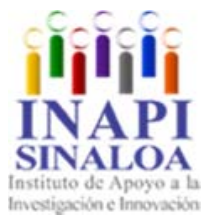

Mazatlán, Sinaloa 3-7 junio 2019

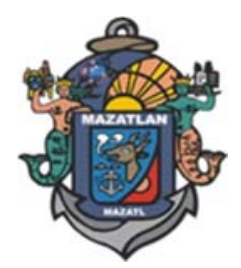

Recursos Naturales, Ecosistemas y Deterioro Ambiental 

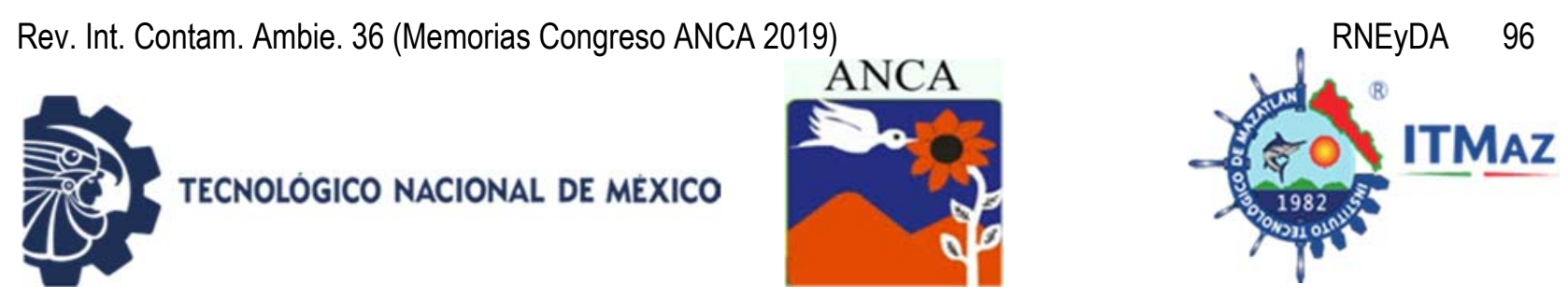

\title{
Quality of urban life in the city of Toluca. An analysis of the green areas and air pollutants
}

\author{
Gutiérrez Cedillo JG ${ }^{1}$, Hernández Romero JC², Franco Plata R ${ }^{1}$ \\ ${ }^{1}$ Facultad de Geografía. Universidad Autónoma del Estado de México. \\ Paseo Universidad, $50110 \mathrm{Cd}$. Universitaria, Toluca de Lerdo, México \\ ${ }^{2}$ Facultad de Química. Universidad Autónoma del Estado de México. \\ Paseo Colón S/N, Residencial Colón, Toluca de Lerdo, México
}

\begin{abstract}
The objective of this study is to analyze the existing conditions that influence the quality of life of the inhabitants of the metropolitan area of the city of Toluca; The conditions analyzed are the spatial distribution of urban green areas and the behavior of air pollutants. Through cartographic photointerpretation of Sentinel 2 satellite images, green areas were located and sized; with systematic field work they were identified and inventoried; Unstructured interviews were focused on knowing their geopolitical location and the type of administration they have, which finally allowed their quantification, statistical analysis; graphic and cartographic representation. The results show the existing green areas in each municipality of the metropolitan area, the types of green areas in the area, their size, spatial distribution and distribution trend. The analysis of the air pollutants that are monitored by the Automatic Network of Atmospheric Monitoring of the City of Toluca (RAMA Toluca), selected the information of seven years (2011-2017), for five air pollutants. The data were coded and statistically analyzed using the Excel version 2013 program, which allowed obtaining monthly, seasonal (summer and winter) and annual averages; for the whole area and for each monitoring station. The spatial analysis and its representation by automated cartography was developed in GIS Arc Gis version 10.2. The result obtained on spatial and temporal trends can be considered a tool in support of decision-making regarding territorial planning.
\end{abstract}

Keywords: Green areas, quality of life, air pollutants, city of Toluca, metropolitan area.

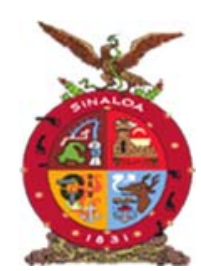

XVIII Congreso Internacional

XXIV Congreso Nacional de Ciencias ambientales

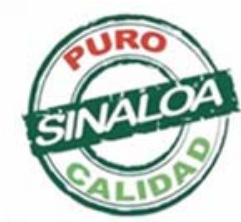

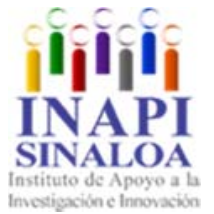

Mazatlán, Sinaloa 3-7 junio 2019

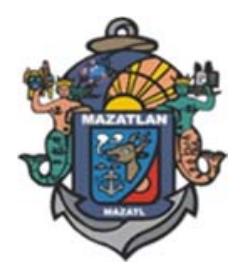

Recursos Naturales, Ecosistemas y Deterioro Ambiental 

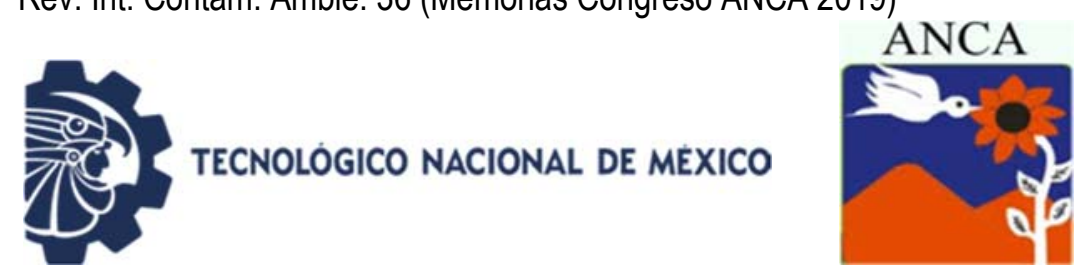

\title{
Análisis fitosociológico de la vegetación arbórea de la región de El Salto, Durango
}

\author{
Hernández FJ*, Vásquez Gutierrez AR, Cruz Cobos F, Najera Luna A \\ Instituto Tecnológico El Salto. \\ División de Estudios de Posgrado e Investigación. El Salto, Durango México \\ *fcojhernan@yahoo.com.mx
}

\begin{abstract}
RESUMEN
Independientemente del sistema de manejo forestal con fines de producción de madera aplicado, un indicador del buen manejo es la conservación de la diversidad, evaluada a través de indicadores de él, valor de importancia de especies y el estado fitososiológico de la vegetación arbórea. El objetivo de este estudio fue describir la diversidad de especies, estado fitosociológico, valor de importancia de especies y patrón de distribución de la vegetación arbórea del bosque manejado por el Método de Desarrollo Silvícola. Para la realización de este estudio durante el año 2017, se seleccionaron seis comunidades forestales de la region de El Salto, Durango sujetos al Método de Desarrollo Silvícola, donde se distribuyeron aleatoriamente 195 sitios circulares de 0.1 ha $^{-1}$ para registrar el nombre de la epecie, altura y diámetro de cada individuo. A cada comunidad se le estimó indice de riqueza de especies, índices de Shannon-Wiener y Simpson, valor de importancia de especies, posición sociológica por género y distribucion espacial de la vegetación árborea a traves del indice de Morisita. La riqueza de especies entre comunidades varío de 10 a 23 especies, mientras que los índices de Shannon-Wiener y Simpson occilaron entre 1.46 y 2.44 y 0.66 y 0.88 , respectivamente. Las especies que presentaron mayor valor de importancia en la mayoria de las comunidades fueron $P$. durangensis, $P$. cooperi y $Q$. sideroxyla. Sociológicamente, el género Pinus es el de mayor representación en cada uno de los estratos seguido del género Quercus, mientras que el patrón de distribución espacial en cada comunidad fue agrupado.
\end{abstract}

Palabras clave: Shannon-Wiener, Simpson, valor de importancia de especies, posición sociológica, patrón de distribución.

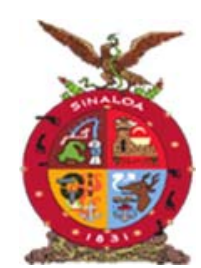

XVIII Congreso Internacional XXIV Congreso Nacional de Ciencias ambientales

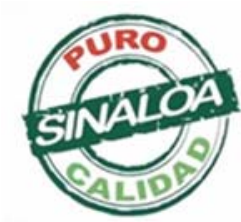

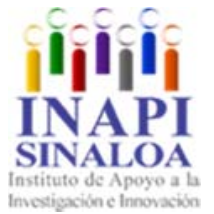

Mazatlán, Sinaloa 3-7 junio 2019

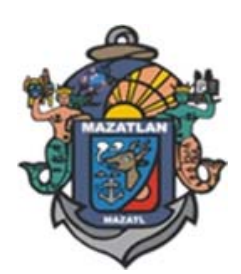

Recursos Naturales, Ecosistemas y Deterioro Ambiental 

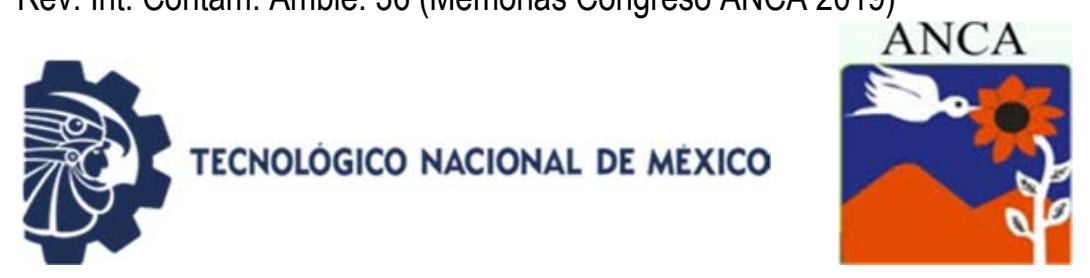

\title{
Phytosociological analysis of the arboreal vegetation from El Salto, Durango región
}

\author{
Hernández FJ*, Vásquez Gutierrez AR, Cruz Cobos F, Najera Luna A \\ Instituto Tecnológico El Salto. \\ División de Estudios de Posgrado e Investigación. El Salto, Durango, México \\ *fcojhernan@yahoo.com.mx
}

\begin{abstract}
Independently of the forest management system, an indicator of the well forest management is the conservation of the diversity, evaluated through diversity indexes, species importance value, phytosociological state of the tree species. The objective of this study was to describe the species diversity, phytosociological status of the vegetation, species importance value and spatial distribution of the arboreal vegetation managed by a regular method called Silvicultural Development Method. In order to realize this study, during the year 2017 were selected six forest communities from El Salto, Durango region that were treated by the Silvicultural Development Method. Inside of these communities were randomly distributed 196 plots of $0.1 \mathrm{ha}^{-1}$. The data taken was species name, height and diameter at breast height of each one of the trees. For each community was estimated Shannon-Wiener and Simpson Indexes, species importance value, sociological position by genus and spatial distribution of the arboreal vegetation through the Morisita Index. The results indicated that species richness varied from 10 to 23 species and the Shannon-Wiener and Simpson indexes from 1.46 to 2.44 and 0.66 to 0.88 , respectively. The species with the highest importance value in the majority of the communities were $P$. durangensis, $P$. cooperi and $Q$. sideroxyla. Sociologically, the Pinus species had the highest representation in each one of the stratum, followed by Quercus species. The spatial distribution of the arboreal vegetation at each community was grouped.
\end{abstract}

Keywords: Shannon-Wiener, Simpson, species importance value, sociological position, tree distribution pattern.

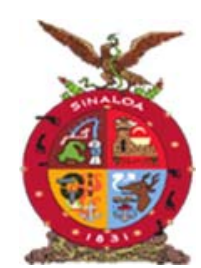

XVIII Congreso Internacional

XXIV Congreso Nacional de Ciencias ambientales

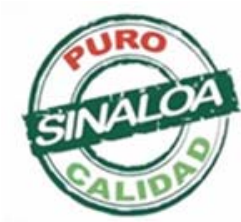

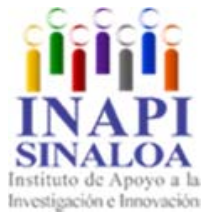

Mazatlán, Sinaloa 3-7 junio 2019

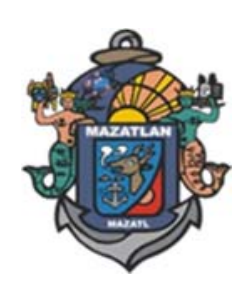

Recursos Naturales, Ecosistemas y Deterioro Ambiental 

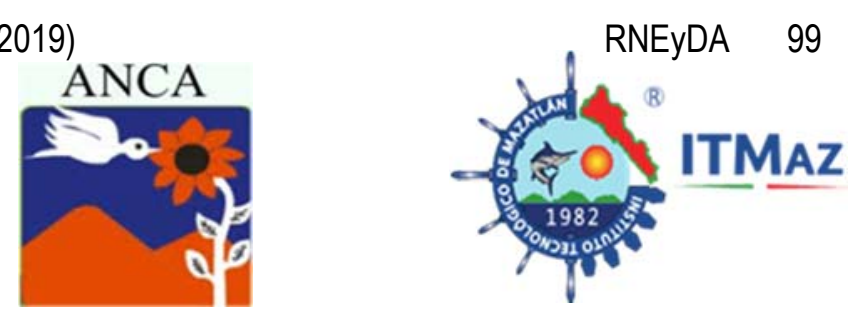

\title{
Evaluación de impacto ambiental de residuos no peligrosos generados en una industria petroquímica del sur de Tamaulipas
}

\author{
Hernández Jasso J, Vargas Castilleja R*, Rolón Aguilar J, Salmerón Gallardo Y \\ Facultad de Ingeniería "Arturo Narro Siller". \\ División de Estudios de Posgrado e Investigación. \\ Universidad Autónoma de Tamaulipas. México \\ *rocvargas@docentes.uat.edu.mx
}

\section{RESUMEN}

El cambio en la composición química de la atmósfera plantea la responsabilidad de llevar a cabo acciones en la gestión de residuos. El objetivo de la investigación fue evaluar el impacto ambiental en términos de emisiones GEI totalizadas en $\mathrm{CO}_{2}$-eq, mediante la herramienta GEI-MRS en una Industria Petroquímica ubicada al Sur de Tamaulipas. El proceso metodológico integró la construcción de escenarios base, referencia y futurible con indicadores clave para el cálculo de emisiones por Residuos No Peligrosos (RNP) de la Planta Resinas Vinílicas en las áreas de producción y no producción. El $E B 1_{2016}$ reporta 614 ton/a/RNP, $71 \%$ RNP/reciclados y $29 \%$ RNP/depositados en Sitios de Disposición Final controlados; esto representa cargos de 312 ton/a/ $/ \mathrm{CO}_{2}$-eq, créditos de-222 ton/a/ $/ \mathrm{CO}_{2}$-eq y un resultado neto de 90 ton/a/ $/ \mathrm{CO}_{2}$-eq. El EB22017 presenta 608 ton/a/RNP, $64 \%$ RNP/reciclados, 36\% RNP/depositados; cargos: 351 ton/a/CO eq, créditos:-284 ton/a/CO $/ \mathrm{CO}_{2}$-eq, resultado neto: 67 ton/a/CO $/ \mathrm{CO}_{2}$-eq. El $E B 3_{2018}$ indica 799 ton/a/RNP, 64\% RNP/reciclados, 36\% RNP/depositados; cargos: 469 ton/a/ $/ \mathrm{CO}_{2}$-eq, créditos:-433 ton/a/ $/ \mathrm{CO}_{2}$-eq, resultado neto: 36 ton/a/ $\mathrm{CO}_{2}$-eq. El $E_{\text {Referencia }}$ basado en históricos determina 674 ton/a/RNP, 66\% RNP/reciclados, $34 \%$ RNP/depositados; cargos: 380 ton/a/ $\mathrm{CO}_{2}$-eq, créditos:-307 ton/a/ $\mathrm{CO}_{2}$-eq, resultado neto: 73 ton/a/ $/ \mathrm{CO}_{2}$-eq. El $E_{\text {Futurible }}$ proyecta el $1.5 \%$ de incremento en la generación con 684 ton/a/RNP, 68\% RNP/reciclados, 32\% RNP/depositados; cargos: 387 ton/a/CO $/ \mathrm{CO}_{2}$-eq, créditos:-325 ton/a/ $\mathrm{CO}_{2}$-eq, resultado neto: 62 ton/a/CO $/ \mathrm{CO}_{2}$-eq. Los valores obtenidos aportan una visión prospectiva de las situaciones de vulnerabilidad que pueden manifestarse en el ámbito localparticular, con perspectivas de incorporación como evidencia científica en la toma de decisiones de estrategias para la mitigación frente al cambio climático.

Palabras clave: GEI, industria petroquímica, residuos no peligrosos.

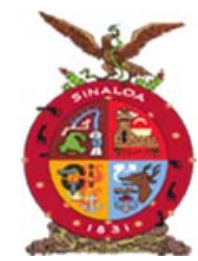

XVIII Congreso Internacional

XXIV Congreso Nacional de Ciencias ambientales

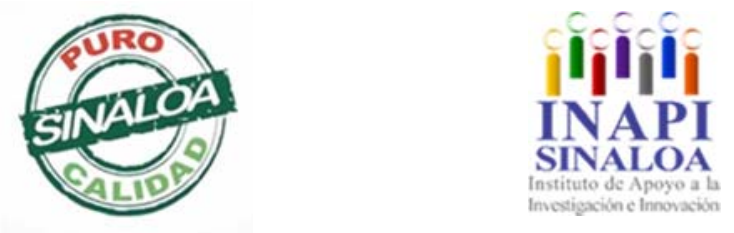

Mazatlán, Sinaloa 3-7 junio 2019

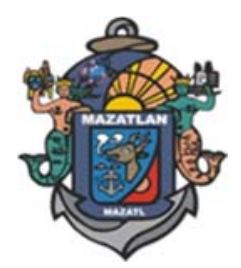

Recursos Naturales, Ecosistemas y Deterioro Ambiental 

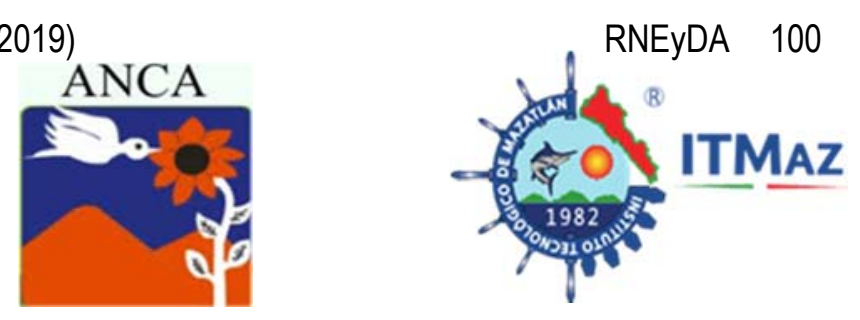

\title{
Environmental impact assessment of non-hazardous waste generated in a petrochemical industry in the south of Tamaulipas
}

\author{
Hernández Jasso J, Vargas Castilleja R*, Rolón Aguilar J, Salmerón Gallardo Y \\ Facultad de Ingeniería "Arturo Narro Siller". \\ División de Estudios de Posgrado e Investigación. \\ Universidad Autónoma de Tamaulipas. México \\ *rocvargas@docentes.uat.edu.mx
}

\begin{abstract}
The change in the chemical composition of the atmosphere raises the responsibility of carrying out actions in waste management. The objective of the research was to evaluate the environmental impact in terms of total GHG emissions in $\mathrm{CO}_{2}$-eq, using the GHG-SWM tool in a Petrochemical Industry of the South of Tamaulipas. The methodological process integrated the construction of base, reference and future scenarios with key indicators for the calculation of emissions by Non-Hazardous Waste (NWR) from the Vinyl Resins Plant in the production and non-production areas. The $B S 1_{2016}$ reports 614 ton/y/NHW, $71 \%$ $\mathrm{NHW} /$ recycled and $29 \% \mathrm{NHW} /$ deposited in controlled Disposal Sites; this represents charges of $312 \mathrm{ton} / \mathrm{y} / \mathrm{CO}_{2}$-eq, credits of-222 ton/y/CO result of $90 \mathrm{ton} / \mathrm{y} / \mathrm{CO}_{2}$-eq. The $B S 22017$ presents 608 ton/y/NHW, $64 \%$ $\mathrm{NHW} /$ recycled, $36 \% \mathrm{NHW} /$ deposited; charges: 351 ton/y/CO $/ \mathrm{CO}_{2}$-eq, credits:-284 ton/y/CO $/ \mathrm{CO}_{2}$-eq, net result: $67 \mathrm{ton} / \mathrm{y} / \mathrm{CO}_{2}$-eq. The $B S 3_{2018}$ indicates 799 ton/y/NHW, 64\% NHW/recycled, 36\% NHW/deposited; charges: 469 ton/y/ $\mathrm{CO}_{2}$-eq, credits:433 ton/y/CO $/ \mathrm{CO}_{2}$-eq, net result: 36 ton/y/CO $/ \mathrm{CO}_{2}$-eq. The $S_{\text {Reference }}$ based on historical determines 674 ton/y/NHW, 66\% NHW/recycled, 34\% NHW/deposited; charges: 380 ton $/ \mathrm{y} / \mathrm{CO}_{2}$-eq, credits:-307 ton $/ \mathrm{y} / \mathrm{CO}_{2}$-eq, net result: $73 \mathrm{ton} / \mathrm{y} / \mathrm{CO}_{2}$-eq. The $S_{\text {Future }}$ projects $1.5 \%$ increase in generation with 684 ton/y/NHW, $68 \%$ $\mathrm{NHW} /$ recycled, $32 \% \mathrm{NHW} /$ deposited; charges: 387 ton/y/ $\mathrm{CO}_{2}$-eq, credits:-325 ton/y/CO $/ \mathrm{CO}_{2}$-eq, net result: $62 \mathrm{ton} / \mathrm{y} / \mathrm{CO}_{2}$-eq. The values obtained provide a forwardlooking view of the situations of vulnerability that can manifest themselves at the local-particular level, with prospects of incorporation as scientific evidence in decision-making on strategies for mitigation of climate change.
\end{abstract}

Keywords: GHG, petrochemical industry, non-hazardous waste.

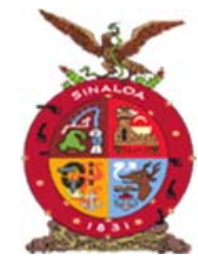

XVIII Congreso Internacional

XXIV Congreso Nacional de Ciencias ambientales

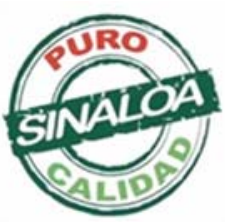

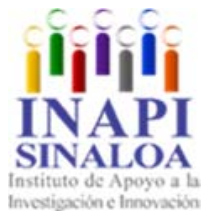

Mazatlán, Sinaloa 3-7 junio 2019

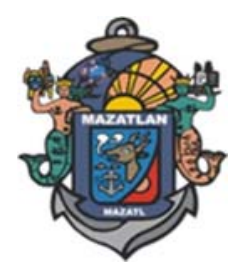

Recursos Naturales, Ecosistemas y Deterioro Ambiental 

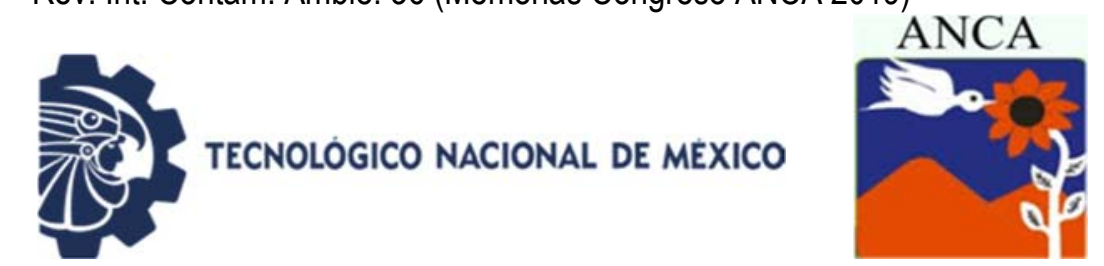

\title{
Caracterización y evaluación de suelos contaminados con residuos mineros
}

\author{
Hernández Valdez A*, Ceniceros Gómez A, Gutiérrez Ruiz M \\ Laboratorio de Biogeoquímica Ambiental. Facultad de Química. \\ Universidad Nacional Autónoma de México \\ *hdzvldz.andrea@gmail.com
}

\section{RESUMEN}

La caracterización, evaluación y remediación de suelos contaminados por actividades mineras es uno de los principales retos ambientales actuales. El objetivo de esta investigación, realizada en el presente año en el Laboratorio de Biogeoquímica Ambiental de la UNAM, fue evaluar las concentraciones totales, solubilidad, biodisponibilidad y distribución de los elementos traza y metales pesados, de suelos de un predio que ocupaba una planta metalúrgica de zinc. Las concentraciones de $\mathrm{Pb}, \mathrm{Cd}$ y As sobrepasan los límites de referencia totales establecidas en la NOM-147-SEMARNAT/SSA1-2004. Las concentraciones solubles no sobrepasan $0.1 \mathrm{mg} / \mathrm{kg}$ en la mayoría de los elementos. Sin embargo, las fracciones biodisponibles de elementos como $\mathrm{Pb}, \mathrm{Cd}$ y As van desde el 50 al $100 \%$. Se determinó que los metales están asociados principalmente a compuestos reducibles del suelo (óxidos y oxihidróxidos de Mn y Fe).

Palabras clave: Contaminación de suelos, metales pesados, elementos traza.

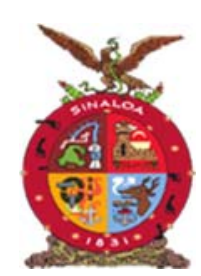

XVIII Congreso Internacional XXIV Congreso Nacional de Ciencias ambientales
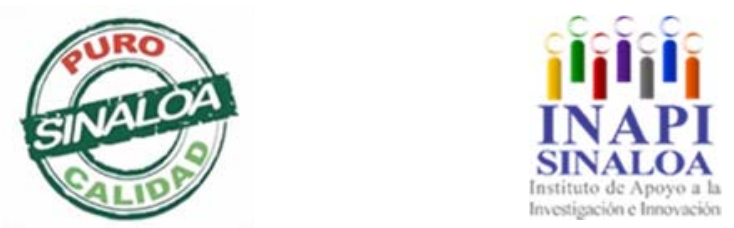

Mazatlán, Sinaloa 3-7 junio 2019

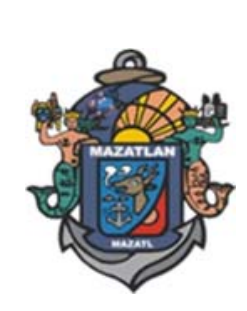

Recursos Naturales, Ecosistemas y Deterioro Ambiental 

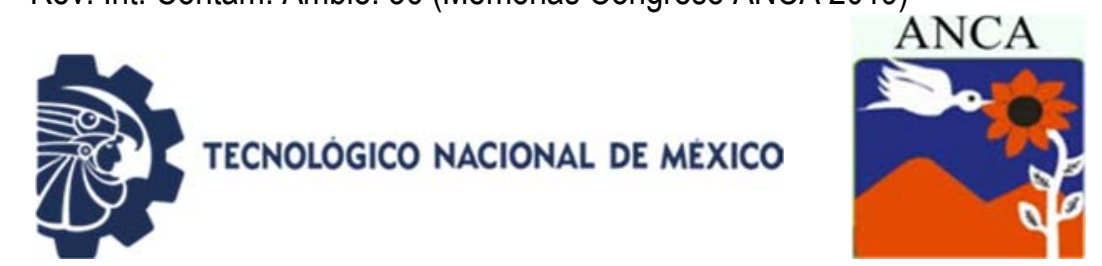

\title{
Characterization and evaluation of soils contaminated with mining waste
}

\author{
Hernández Valdez A*, Ceniceros Gómez A, Gutiérrez Ruiz M \\ Laboratorio de Biogeoquímica Ambiental. Facultad de Química. \\ Universidad Nacional Autónoma de México \\ *hdzvldz.andrea@gmail.com
}

\begin{abstract}
The characterization, evaluation and remediation of soils contaminated by mining activities is one of the main environmental challenges. The objective of this research, carried out this year, was to perform the evaluation of total concentrations, solubility, bioavailability and distribution of trace elements and heavy metals, of soils inside a zinc metallurgical plant. The concentrations of $\mathrm{Pb}$, $\mathrm{Cd}$ and As exceed the reference limits established in NOM-147-SEMARNAT/ SSA1-2004. The soluble concentrations did not exceed $0.1 \mathrm{mg} / \mathrm{Kg}$ in most of the elements. However, bioavailable fractions of elements such as $\mathrm{Pb}, \mathrm{Cd}$ and $\mathrm{As}$ range from 50 to $100 \%$. It was determined that metals are mainly associated with reducible soil compounds (oxides and oxihydroxides of $\mathrm{Mn}$ and $\mathrm{Fe}$ ).
\end{abstract}

Keywords: Soil contamination, heavy metals, trace elements.

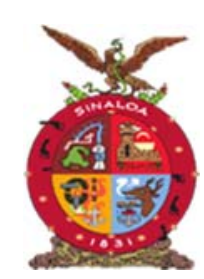

XVIII Congreso Internacional XXIV Congreso Nacional de Ciencias ambientales
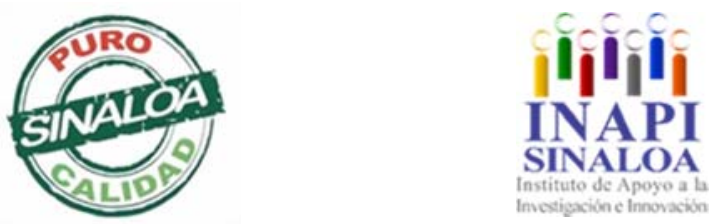

Mazatlán, Sinaloa 3-7 junio 2019

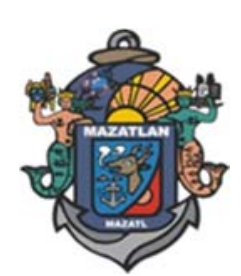

Recursos Naturales, Ecosistemas y Deterioro Ambiental 

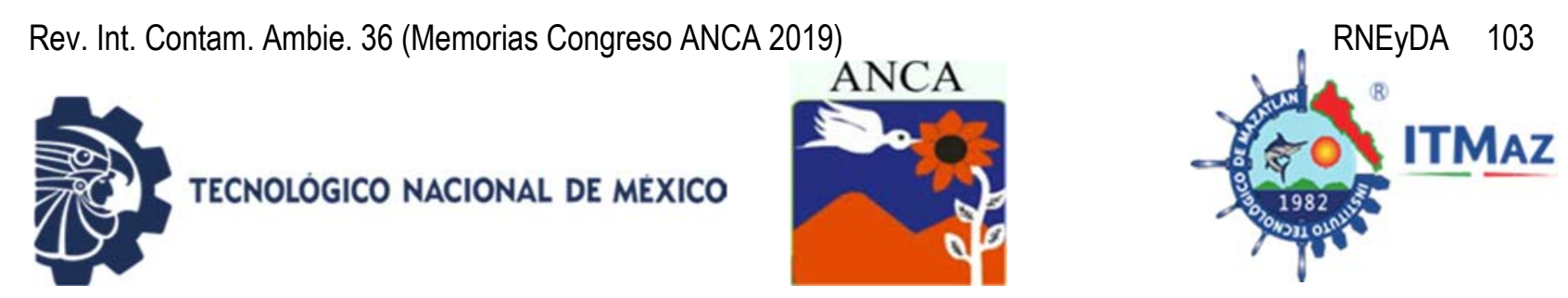

Residuos de la producción de hongos comestibles (Pleurotus spp.) aplicados como biofertilizante en cultivo de tomate rojo (Lycopersicum esculentum Mill.) en invernadero

\author{
Herrera Gamboa J1,2*, Naranjo Jiménez $\mathrm{N}^{2}$, Uribe Soto $\mathrm{N}^{2}$, Páez Olivan LA², \\ Rosas Medina $\left.\right|^{3}$
}

${ }^{1}$ Instituto Tecnológico del Valle del Guadiana-Tecnológico Nacional de México. Carretera Durango-México Km 22.5, Durango, México

${ }^{2}$ Centro Interdisciplinario de Investigación para el Desarrollo Integral Regional Unidad Durango. Instituto Politécnico Nacional.

Sigma 119, Fracc. 20 de noviembre II, 34200, Durango, México

${ }^{3}$ Secretaria de investigación y posgrado-Instituto Politécnico Nacional.

Av. Luis Enrique Erro S/N, Unidad Profesional Adolfo López Mateos, Zacatenco,

Del. Gustavo A. Madero, México

*gherrera-j@hotmail.com

\title{
RESUMEN
}

En el cultivo y producción de hongos Pleurotus se emplean subproductos agrícolas como pajas de cereales (avena, trigo, cebada, entro otros); se generan residuos al término de la producción conocidos como Spent Mushroom Substrate (SMS), estos materiales presentan características benéficas para su aplicación en suelo como biofertilizante, presentan avances de mineralización por la acción enzimática del hongo, contienen nutrientes disponibles, alta composición de materia orgánica, estimula la microbiota del suelo, responsable de transformar componentes orgánicos e inorgánicos hasta elementos que puedan ser asimilados por las plantas, contribuyendo en la fertilidad del suelo. El objetivo fue evaluar residuos de la producción de hongos comestibles (Pleurotus spp.) aplicados como biofertilizante en el desarrollo de plantas y calidad de frutos de tomate rojo en invernadero. En un diseño experimental al azar con 8 tratamientos y 3 dosis de aplicación: 1.5, 2.5 y $3.5 \mathrm{~kg} / \mathrm{m}^{2}$ de SMS con diferente fertilización: orgánica y convencional. Las variables evaluadas fueron: Iongitud de crecimiento, grosor de tallo, longitud de hoja, numero de flores, frutos cuajados, diámetro, peso de frutos, concentración de grados brix y rendimiento. El tratamiento con 1.5 $\mathrm{kg} / \mathrm{m}^{2}$ de SMS y fertilización orgánica presento los mayores valores en las determinaciones. Encontrando diferencias significativas $(p<0.05)$ en las variables evaluadas. Por lo anterior los residuos de la producción de hongos Pleurotus spp., es una alternativa para su reutilización en agricultura orgánica.

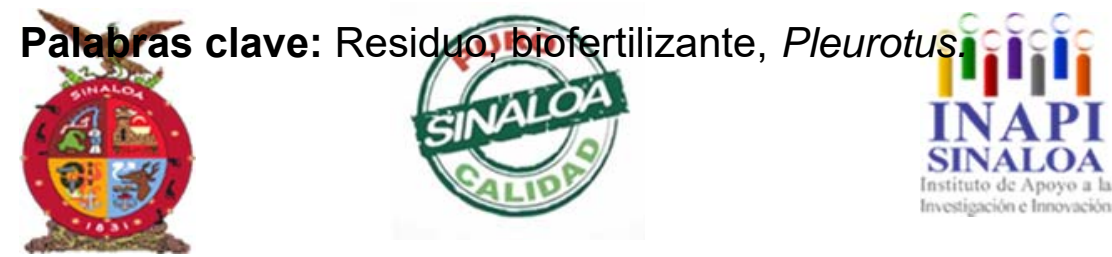

XVIII Congreso Internacional XXIV Congreso Nacional de Ciencias ambientales

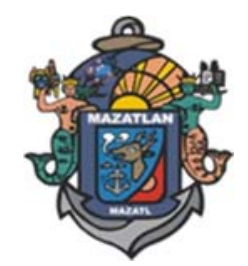

Recursos Naturales, Ecosistemas y Deterioro Ambiental 

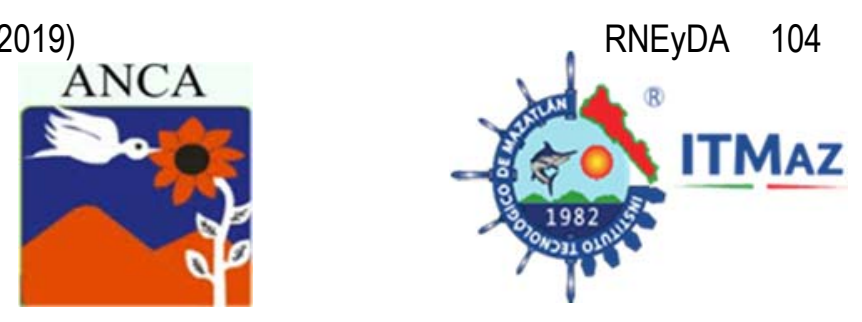

\title{
Waste from the production of edible fungi (Pleurotus spp.) Applied as biofertilizer in red tomato cultivation (Lycopersicum esculentum Mill.) in greenhouse
}

\author{
Herrera Gamboa $\mathrm{J}^{1,2^{*}}$, Naranjo Jiménez $\mathrm{N}^{2}$, Uribe Soto $\mathrm{N}^{2}$, Páez Olivan LA², \\ Rosas Medina $\left.\right|^{3}$
}

${ }^{1}$ Instituto Tecnológico del Valle del Guadiana-Tecnológico Nacional de México. Carretera Durango-México Km 22.5, Durango, México

${ }^{2}$ Centro Interdisciplinario de Investigación para el Desarrollo Integral Regional Unidad Durango. Instituto Politécnico Nacional.

Sigma 119, Fracc. 20 de noviembre II, 34200, Durango, México

${ }^{3}$ Secretaria de investigación y posgrado-Instituto Politécnico Nacional.

Av. Luis Enrique Erro S/N, Unidad Profesional Adolfo López Mateos, Zacatenco,

Del. Gustavo A. Madero, México

*gherrera-j@hotmail.com

\begin{abstract}
In the cultivation and production of mushrooms Pleurotus agricultural by-products are used as straws of cereals (oats, wheat, barley, among others). Waste is generated at the end of production known as Spent Mushroom Substrate (SMS). These materials have beneficial characteristics for application in soil as biofertilizer, present mineralization advances by the enzymatic action of the fungus, contain available nutrients, high composition of matter organic, stimulates the soil microbiota, responsible for transforming organic and inorganic components to elements that can be assimilated by plants, contributing to soil fertility. The objective was to evaluate residues of the production of edible fungi (Pleurotus spp.) applied as a biofertilizer in the development of plants and quality of red tomato fruits in the greenhouse. In a randomized experimental design with 8 treatments and 3 application doses: $1.5,2.5$ and $3.5 \mathrm{~kg} / \mathrm{m}^{2}$ of SMS with different fertilization: organic and conventional. The evaluated variables were: growth length, stem thickness, leaf length, number of flowers, fruits set, diameter, fruit weight, concentration of brix degrees and yield. The treatment with $1.5 \mathrm{~kg} / \mathrm{m}^{2}$ of SMS and organic fertilization presented the highest values in the determinations. Finding significant differences $(p<0.05)$ in the variables evaluated. Therefore, the residues of mushroom production Pleurotus spp. is an alternative for reuse in organic agriculture.
\end{abstract}

Keywords: Residue, fertilizer, Pleurotus.

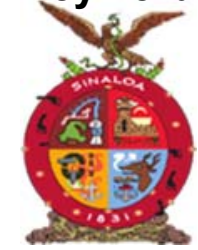

XVIII Congreso Internacional

XXIV Congreso Nacional de Ciencias ambientales

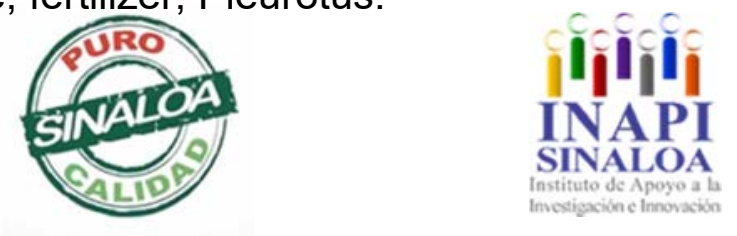

Mazatlán, Sinaloa 3-7 junio 2019

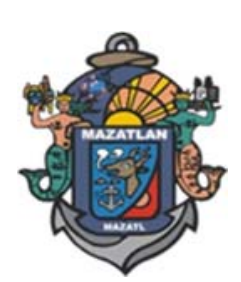

Recursos Naturales, Ecosistemas y Deterioro Ambiental 

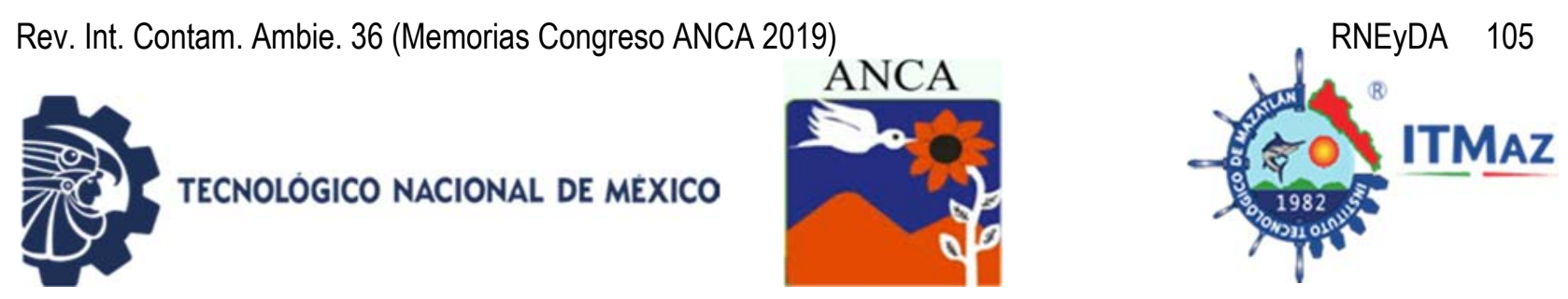

\title{
Estudio de la generación de RSU en islotes del Parque Nacional Bahía de Loreto, Baja California Sur
}

\author{
Huerta Hernández V ${ }^{1}$, Bluhm Gutiérrez $\mathrm{J}^{2}$, Huerta García $\mathrm{J}^{3}$, \\ Escalona Alcázar $\mathrm{F}^{2}$, Valle Rodríguez $\mathrm{S}^{2}$ \\ ${ }^{1}$ Comisión Nacional de Áreas Naturales Protegidas (CONANP). \\ ${ }^{2}$ Unidad Académica de Ciencias de la Tierra. \\ Universidad Autónoma de Zacatecas, México \\ ${ }^{3}$ Unidad Académica de Ciencias Biológicas, UAZ \\ Calzada de la Universidad No. 108, C.P. 98058, Zacatecas, México \\ *jorgebg5@yahoo.com.mx
}

\section{RESUMEN}

El "Parque Nacional Bahía de Loreto" se encuentra ubicado en la península de California, frente a las costas de Loreto, Baja California en la porción central de Baja California Sur. Este ecosistema es de gran importancia ya que cuenta con una gran riqueza natural, en la costa anidan una gran variedad de aves marinas, por lo que es de suma importancia mantenerlo en óptimas condiciones. El objetivo de esta investigación fue analizar los residuos sólidos detectados en ocho islotes (islita, Cholla, Pardo, Tijeretas, Blanco, Mestiza, Galeras I y Galeras II) de enero a mayo de 2018. Los ocho islotes se visitaron cada semana y durante los recorridos se llevaron bolsas de basura para recolectar los residuos sólidos encontrados. Cada bolsa se etiquetó con el nombre del islote y fue llevada a una sala donde se separaron y clasificaron. Se pesaron y se buscó establecer su procedencia. Se recolectaron en total $20.5 \mathrm{~kg}$ de residuos, principalmente RSU, restos de moluscos listados en la NOM-059-SEMARNAT-2010, partes de embarcaciones y restos de utensilios de pesca. El islote que resultó más afectado por residuos antropogénicos, fue "La Islita", el cual se encuentra muy cercano a la Isla Coronado, la isla más turística dentro del PNBL y también es el más cercano al basurero municipal.

Palabras clave: RSU, islote, Parque Nacional Bahía de Loreto, Baja California Sur.

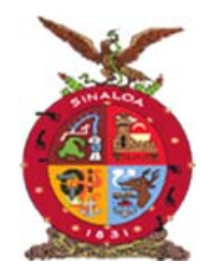

XVIII Congreso Internacional

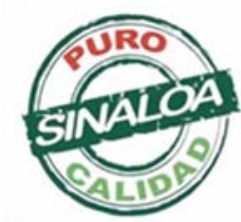

Mazatlann

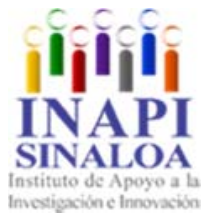

Mazatlán, Sinaloa 3-7 junio 2019

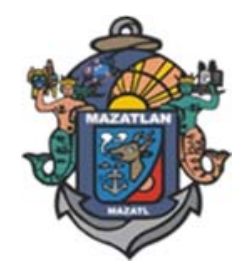

Recursos Naturales, Ecosistemas y Deterioro Ambiental 

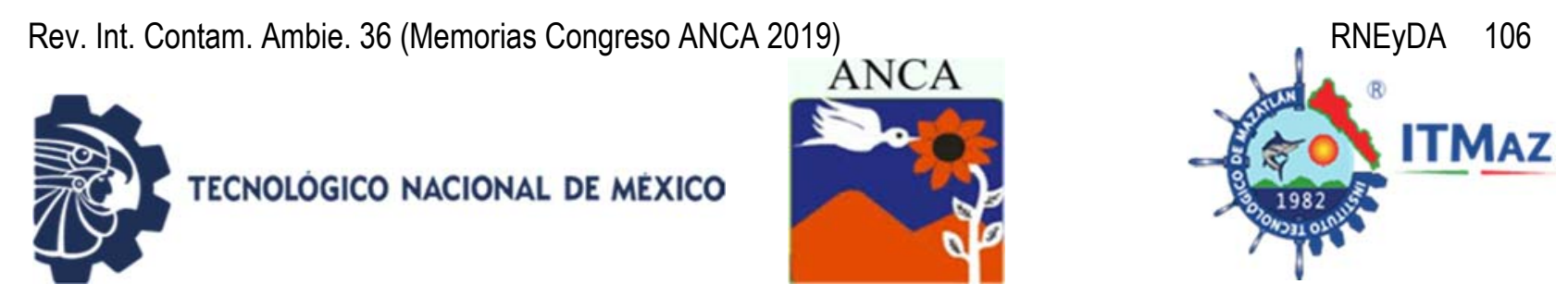

\title{
Study of the generation of RSU in islets of the National Park Bay of Loreto, Baja California South
}

\author{
Huerta Hernández V ${ }^{1}$, Bluhm Gutiérrez J²*, Huerta García J³, \\ Escalona Alcázar $\mathrm{F}^{2}$, Valle Rodríguez $\mathrm{S}^{2}$ \\ ${ }^{1}$ Comisión Nacional de Áreas Naturales Protegidas (CONANP). \\ ${ }^{2}$ Unidad Académica de Ciencias de la Tierra. \\ Universidad Autónoma de Zacatecas, México \\ ${ }^{3}$ Unidad Académica de Ciencias Biológicas, UAZ \\ Calzada de la Universidad No. 108, C.P. 98058, Zacatecas, México \\ *jorgebg5@yahoo.com.mx
}

\begin{abstract}
The "Loreto Bay National Park" is located on the peninsula of California, off the coast of Loreto, Baja California in the central portion of Baja California Sur. This ecosystem is of great importance since it has a great natural wealth, a great variety of sea birds nest on the coast, so it is very important to keep it in optimal conditions. The objective of this investigation was to analyze the solid wastes detected in eight islets (Isita, Cholla, Pardo, Tijeretas, Blanco, Mestiza, Galeras I and Galeras II) from January to May 2018. The eight islets were visited every week and during the They took trash bags to collect the solid waste found. Each bag was labeled with the name of the islet and was taken to a room where they separated and classified. Weighed and sought to establish its origin. A total of $20.5 \mathrm{~kg}$ of waste was collected, mainly MSW, shellfish remains listed in NOM059-SEMARNAT-2010, parts of boats and fishing equipment remains. The islet that was most affected by anthropogenic waste was "La Islita", which is very close to Coronado Island, the most tourist island within the PNBL and is also the closest to the municipal dump.
\end{abstract}

Keywords: RSU, islet, Loreto Bay National Park, Baja California Sur.

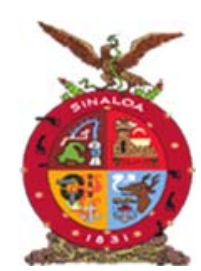

XVIII Congreso Internacional

XXIV Congreso Nacional de Ciencias ambientales

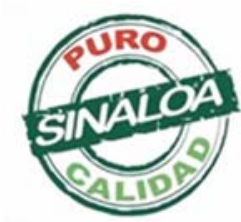

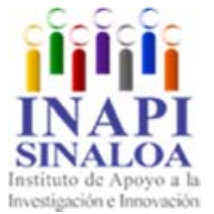

Mazatlán, Sinaloa 3-7 junio 2019

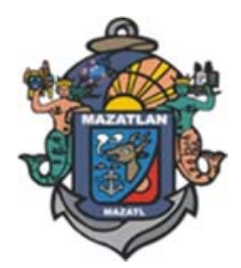

Recursos Naturales, Ecosistemas y Deterioro Ambiental 

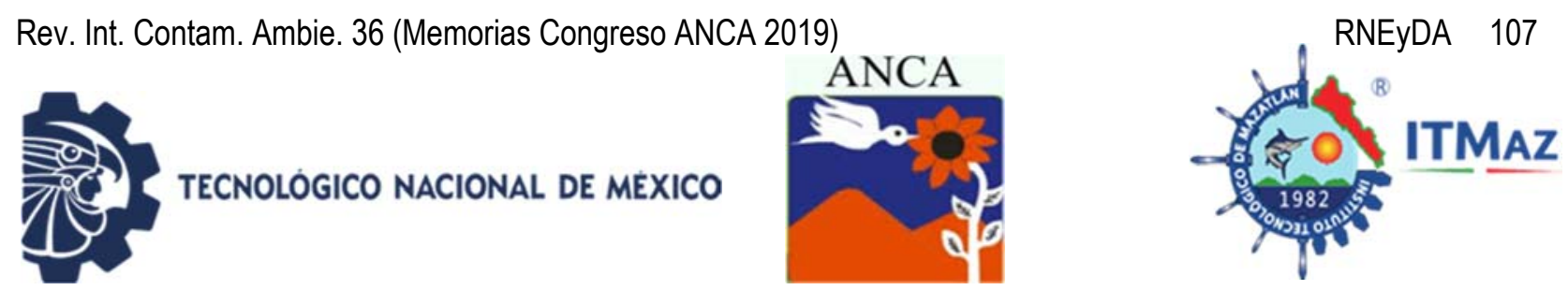

\title{
Servicios ecosistémicos hídricos de una microcuenca ante escenarios de cambio de uso de suelo y cambio climático
}

\author{
Juárez Aguilar R*, Pavón Hernández N \\ Centro de Investigaciones Biológicas. \\ Universidad Autónoma del Estado de Hidalgo. Pachuca, Hidalgo, México \\ *ricardo_juarez8@hotmail.com
}

\section{RESUMEN}

Los servicios ecosistémicos hídricos dependen de las condiciones climáticas y también de los usos del suelo que se van desarrollando por las actividades socioeconómicas de la región. Se requiere integrar escenarios de cambio climático y escenarios socioeconómicos que podrían presentarse en una microcuenca, para tener una perspectiva de los efectos que se tendrán a futuro en el sistema socio-ecológico. La presente investigación se realizó durante el 2018 en una microcuenca hidrológica en el estado de Hidalgo con centroide en las coordenadas $98^{\circ} 34^{\prime} 48^{\prime \prime} \mathrm{N}$ y $20^{\circ} 10^{\prime} 48^{\prime \prime} \mathrm{O}$. Se modelaron los efectos de 4 sitios de demanda, agrícola de riego, hoteles, productores piscícolas y las localidades, para el cambio climático. En el Sistema de Evaluación y Planeación del Agua, o WEAP ("Water Evaluation and Planning"), se utilizaron los escenarios 4.5 y 8.5 de dos trayectorias de concentración representativas (RCP), para futuro cercano (2010-2040) y futuro medio (2041-2070). Los escenarios socioeconómicos utilizados fueron las rutas socioeconómicas compartidas SSP 2, SSP 3 y SSP5. Se encontró que los escenarios con menor demanda de agua son: para el sitio agrícola de riego el escenario SSP 2 con $568.27 \times 10^{6} \mathrm{~m}^{3}$, para hoteles el escenario SSP3 con $17.51 \times 10^{6} \mathrm{~m}^{3}$, para las localidades el escenario SSP 5 con $89.94 \times 10^{6}$ $\mathrm{m}^{3}$ y para el sitio de demanda piscícola el escenario SSP3, para la microcuenca el escenario SSP2 presenta menor demanda con $691.01 \times 10^{6} \mathrm{~m}^{3}$, lo que implica que es necesario analizar los sitios de demanda por separado para tener mejores bases para políticas públicas.

Palabras clave: Microcuenca, cambio climático, RCP, SSP, WEAP.

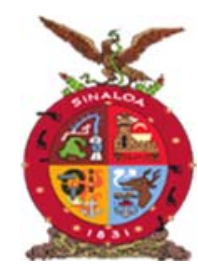

XVIII Congreso Internacional

XXIV Congreso Nacional de Ciencias ambientales

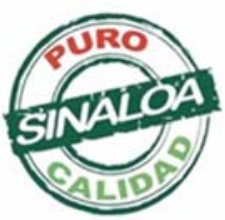

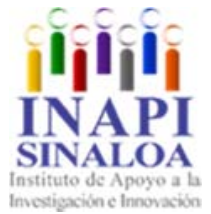

Mazatlán, Sinaloa 3-7 junio 2019

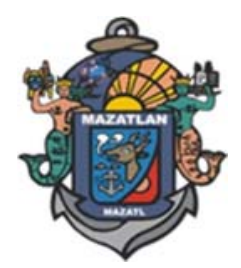

Recursos Naturales, Ecosistemas y Deterioro Ambiental 

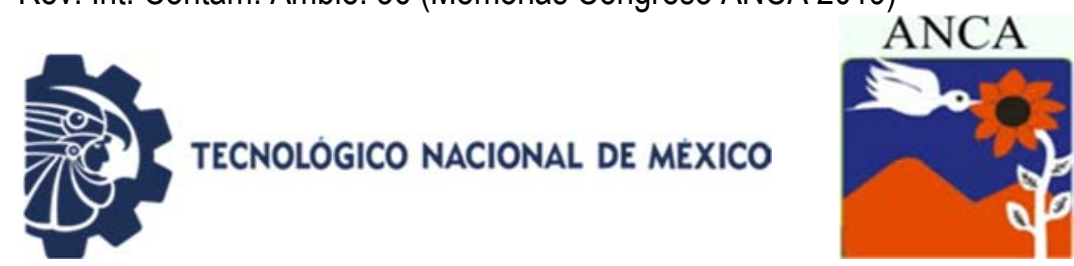

\title{
Water ecosystem services of a micro-basin in scenarios of land use change and climate change
}

\author{
Juárez Aguilar R*, Pavón Hernández N \\ Centro de Investigaciones Biológicas. \\ Universidad Autónoma del Estado de Hidalgo. Pachuca, Hidalgo, México \\ *ricardo_juarez8@hotmail.com
}

\begin{abstract}
Water ecosystem services depend of the climatic conditions also of the land uses that are developed by the socioeconomic activities of the region. Is necessary to integrate climate change scenarios and socio-economic scenarios that could be presented in a micro-basin, to have a perspective of the effects that will be had in the socio-ecological system in the future. The present investigation was carried out during 2018 in a hydrological basin in the state of Hidalgo with centroid at coordinates $98^{\circ} 34^{\prime} 48$ " $\mathrm{N}$ and $20^{\circ} 10^{\prime} 48^{\prime \prime} \mathrm{W}$. In the Water Evaluation and Planning System, or WEAP, the effects of 4 demand sites, agricultural irrigation, hotels, fish producers and localities were modelled for climate change using scenarios 4.5 and 8.5 of two representative concentration pathways (RCP), for the near future (2010-2040) and the medium future (2041-2070). The socio-economic scenarios used were the shared socioeconomic pathways SSP2, SSP3 and SSP5. It was found that the scenarios with lower water demand are, for the agricultural irrigation site, the SSP2 scenario with $568.27 \times 10^{6} \mathrm{~m}^{3}$. For hotels the SSP 3 scenario with $17.51 \times 10^{6} \mathrm{~m}^{3}$, for the SSP 5 scenario with $89.94 \times 10^{6} \mathrm{~m}^{3}$ and for the SSP 3 scenario for aquaculture demand, for the micro-basin the SSP2 scenario presents lower demand with $691.01 \times 10^{6} \mathrm{~m}^{3}$, which implies that it is necessary to analyse the demand sites separately to have better bases for public policies.
\end{abstract}

Keywords: Micro-basin, climate change, RCP, SSP, WEAP.

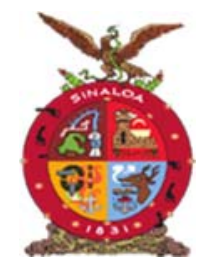

XVIII Congreso Internacional

XXIV Congreso Nacional de Ciencias ambientales

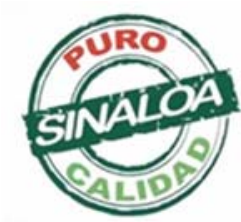

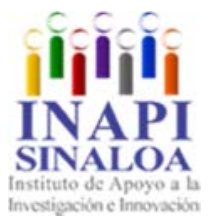

Mazatlán, Sinaloa 3-7 junio 2019

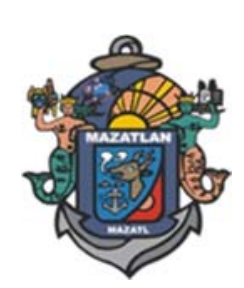

Recursos Naturales, Ecosistemas y Deterioro Ambiental 

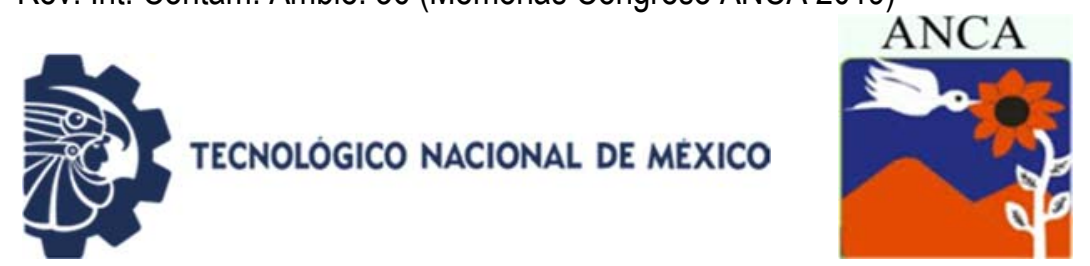

\title{
Análisis de cambio de uso de suelo y vegetación en el municipio de Atoyatempan, Puebla
}

\author{
Juárez Ruanova L, Linares Fleites G, Hernández Aldana F, \\ Schiaffini Aponte R, Avelino Flores $F$ \\ Posgrado en Ciencias Ambientales, Instituto de Ciencias \\ Benemérita Universidad Autónoma de Puebla \\ bioluis1@hotmail.com
}

\begin{abstract}
RESUMEN
Las actividades antrópicas modifican la naturaleza afectando a los ecosistemas donde se mantienen los bienes y servicios ecosistémicos que garantizan la sostenibilidad ambiental, económica y social. El presente trabajo se ha realizado en el municipio de Atoyatempan, Puebla, México. Los principales problemas que enfrenta este municipio en la actualidad son: la falta de planificación para el crecimiento urbano y el crecimiento en la demanda del agua para uso doméstico y para la agricultura. El objetivo de esta investigación fue analizar la dinámica en el cambio de uso del suelo y vegetación en este municipio para detectar las causas que han provocado estos problemas. Se llevó a cabo un análisis de cambio de uso de suelo y vegetación utilizando la cartografía de las series II, III, IV y VI del INEGI a escala 1:250,000; este análisis permitió calcular la matriz de transición desde el año 1990 hasta el año 2015 y sus correspondientes matrices de probabilidades de transición y patrones y tasas de cambio. Los resultados mostraron que la agricultura de temporal se sustituyó por la agricultura de riego en este periodo, por lo que la disponibilidad de agua disminuyó en el municipio, debido también a que la zona tiene un balance hídrico no favorable y pendientes fuertes hacia la parte oeste, condiciones que no son idóneas para los asentamientos humanos. Mientras que el uso de suelo urbano ganó 0.71 ha, la selva ha disminuido 3.91 ha, en contraste con los pastizales inducidos, que aumentaron 90.04ha, por actividades antrópicas como la ganadería.
\end{abstract}

Palabras Clave: Cobertura vegetal, SIG, tasas de cambio.

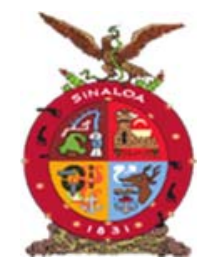

XVIII Congreso Internacional XXIV Congreso Nacional de Ciencias ambientales

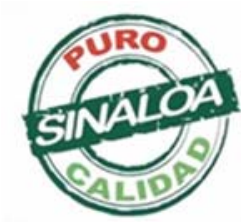

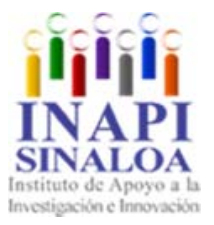

Mazatlán, Sinaloa 3-7 junio 2019

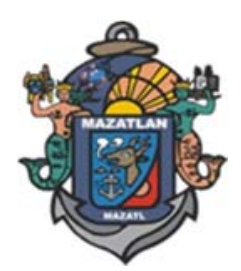

Recursos Naturales, Ecosistemas y Deterioro Ambiental 

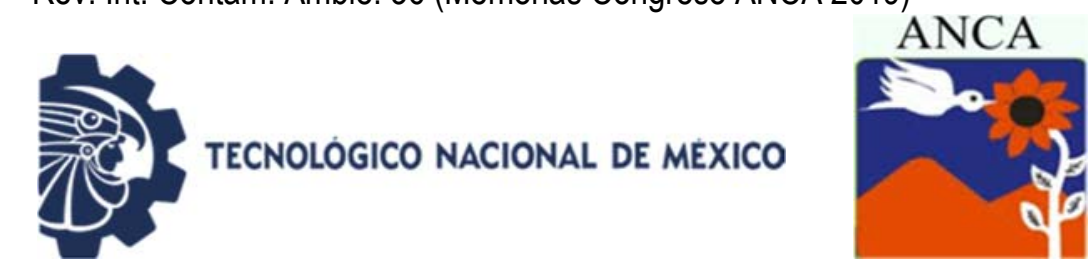

\title{
Analysis of change in land use and vegetation in the municipality of Atoyatempan, Puebla
}

\author{
Juárez Ruanova L, Linares Fleites G, Hernández Aldana F, \\ Schiaffini Aponte R, Avelino Flores $F$ \\ Posgrado en Ciencias Ambientales, Instituto de Ciencias \\ Benemérita Universidad Autónoma de Puebla \\ bioluis1@hotmail.com
}

\begin{abstract}
Anthropic activities modify nature by affecting the ecosystems where the ecosystem goods and services that guarantee environmental, economic and social sustainability are maintained. The present work has been carried out in the municipality of Atoyatempan, Puebla, Mexico. The main problems facing this municipality at present are: the lack of planning for urban growth and the growth in the demand for water for domestic use and for agriculture. The objective of this research was to analyze the dynamics in the change of land use and vegetation in this municipality to detect the causes that have caused these problems. A change analysis of land use and vegetation was carried out using the cartography of the series II, III, IV and VI of the INEGI at scale 1: 250,000; This analysis allowed us to calculate the transition matrix from 1990 to 2015 and its corresponding matrices of transition probabilities and patterns and exchange rates. The results showed that rainfed agriculture was replaced by irrigated agriculture in this period, so the availability of water decreased in the municipality, also because the area has an unfavorable water balance and strong slopes to the west, conditions that are not suitable for human settlements. While the use of urban land gained $0.71 \mathrm{ha}$, the jungle has decreased 3.91ha, in contrast to the induced grasslands, which increased $90.04 \mathrm{ha}$, by anthropic activities such as livestock.
\end{abstract}

Keywords: Plant cover, GIS, exchange rates.

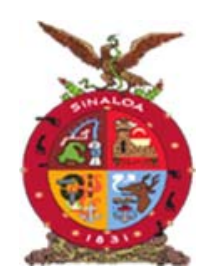

XVIII Congreso Internacional XXIV Congreso Nacional de Ciencias ambientales

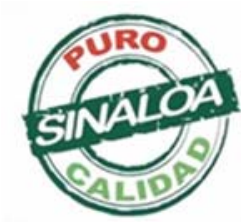

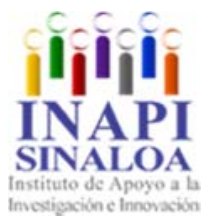

Mazatlán, Sinaloa 3-7 junio 2019

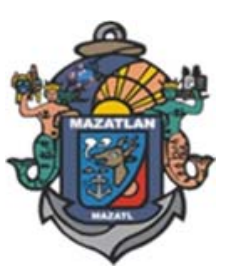

Recursos Naturales, Ecosistemas y Deterioro Ambiental 

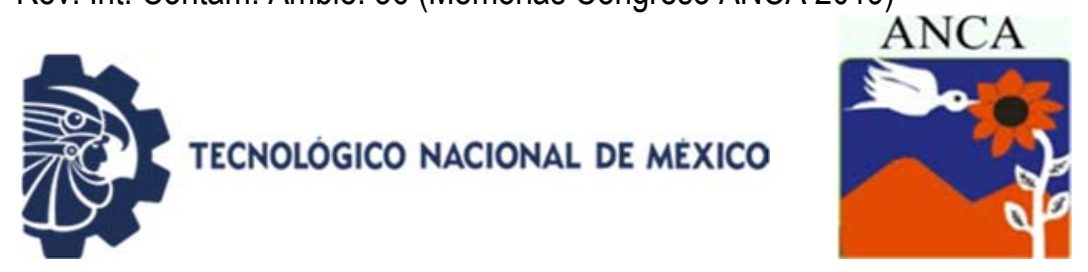

\title{
Mapeo geoquímico para contenidos de arsénico y plomo total y móvil en el suelo superficial de la Ciudad de Durango (Noroeste de México)
}

\author{
Lara $\mathrm{RH}^{1^{*}}$, Vazquez Arenas $\mathrm{J}^{2}$, Sosa Rodríguez $\mathrm{F}^{3}$, Ponce Peña $\mathrm{P}^{1}$, \\ Mendoza Hernández $\mathrm{J}^{1,4}$, Castellanos Juárez $\mathrm{F}^{4}$ \\ ${ }^{1}$ Facultad de Ciencias Químicas, Universidad Juárez del Estado de Durango \\ ${ }^{2}$ Centro Mexicano para la Producción más Limpia, Instituto Politécnico Nacional, \\ ${ }^{3}$ Universidad Autónoma Metropolitana-Azcapotzalco \\ ${ }^{4}$ Instituto de Investigación Científica, UJED \\ *Icrh75@ujed.mx
}

\begin{abstract}
RESUMEN
Se determinó la concentración total y móvil de As y $\mathrm{Pb}$ en suelo superficial de la ciudad de Durango, utilizando métodos estandarizados, técnicas microscópicas y espectroscópicas con objeto de evaluar el comportamiento de estos elementos. Se encontraron partículas finas $(<5-10 \mu \mathrm{m})$ que incluyen $\mathrm{Pb}_{3}\left(\mathrm{AsO}_{4}\right)_{2}$, FeAsS y estructuras complejas con As. Mientras que $\mathrm{PbO}_{2}, \mathrm{PbS}$ y $(\mathrm{Ba}, \mathrm{Pb}) \mathrm{SO}_{4}$ para $\mathrm{Pb}$. La concentración total de As varía entre 4.37 y $42 \mathrm{mg} \mathrm{kg}^{-1}$, mientras que en el suelo adyacente al Cerro de Mercado es entre 55.1 y $221 \mathrm{mg} \mathrm{kg}^{-1}$. Con respecto al $\mathrm{Pb}$, las concentraciones varían entre 8.3 y $82.5 \mathrm{mg} \mathrm{kg}^{-1}$ en el suelo urbano, y entre 21.6 a $107.3 \mathrm{mg} \mathrm{kg}^{-1}$ en el suelo adyacente al Cerro de Mercado. Se encontró una movilidad baja para $\mathrm{Pb}$ (hasta $3 \%$ ) y de baja a moderada para As (entre 0.1 y $37.1 \%$ ), lo que indica un riesgo ambiental bajo en general debido a la movilidad química del $\mathrm{As}$ y $\mathrm{Pb}$. Las concentraciones de los perfiles de profundidad del suelo sugirieron la acumulación progresiva del $\mathrm{As}$ y $\mathrm{Pb}$, mientras que los riesgos geoquímicos y de salud relacionados se discutieron en base a los datos experimentales y geoestadísticos. La investigación presentada se llevó a cabo en la UJED durante 2016-2017.
\end{abstract}

Palabras clave: Ciudad de Durango, Geoquímica urbana, arsénico, plomo, movilidad quimica.

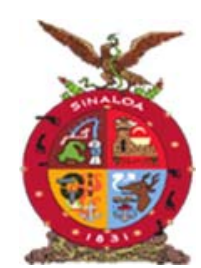

XVIII Congreso Internacional

XXIV Congreso Nacional de Ciencias ambientales

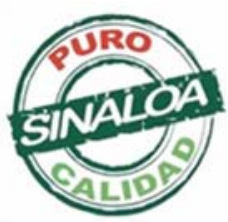

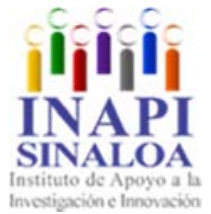

Mazatlán, Sinaloa 3-7 junio 2019

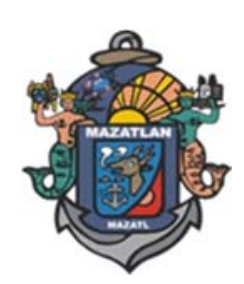

Recursos Naturales, Ecosistemas y Deterioro Ambiental 

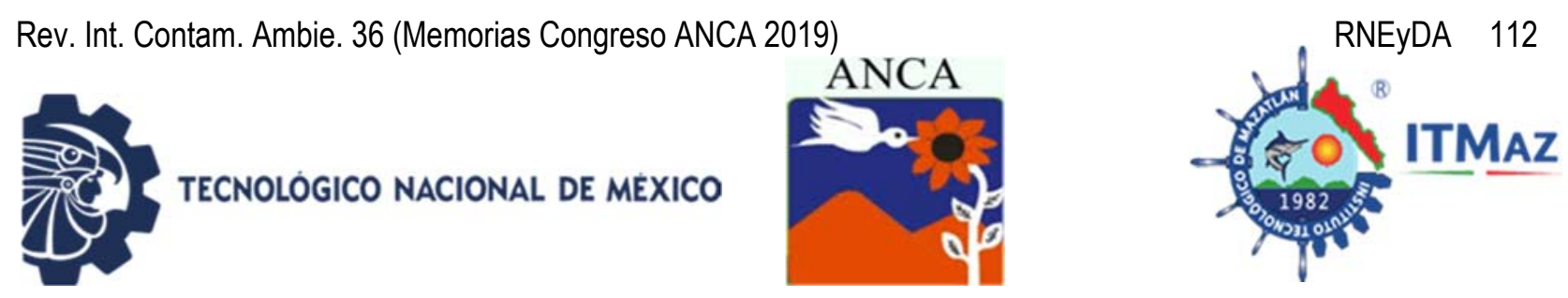

\title{
Geochemical mapping accounting for pollution and mobility of arsenic and lead in soil from the city of Durango (NW, Mexico)
}

\author{
$\mathrm{H}$. Lara $\mathrm{R}^{1^{*}}$, Vazquez Arenas $\mathrm{J}^{2}$, Sosa Rodríguez $\mathrm{F}^{3}$, Ponce Peña $\mathrm{P}^{1}$, \\ Mendoza Hernández $\mathrm{J}^{1,4}$, Castellanos Juárez $\mathrm{F}^{4}$ \\ ${ }^{1}$ Facultad de Ciencias Químicas, Universidad Juárez del Estado de Durango \\ ${ }^{2}$ Centro Mexicano para la Producción más Limpia, Instituto Politécnico Nacional, \\ ${ }^{3}$ Universidad Autónoma Metropolitana-Azcapotzalco \\ ${ }^{4}$ Instituto de Investigación Científica, UJED \\ *Icrh75@ujed.mx
}

\begin{abstract}
Total and mobile concentrations of $\mathrm{As}$ and $\mathrm{Pb}$ were determined in surface soil of Durango city using standard protocols, microscopic and spectroscopic techniques to obtain a full description of the environmental behavior of these elements. Mineralogical characterizations indicated that fine particles $(<5-10 \mu \mathrm{m})$ including $\mathrm{Pb}_{3}\left(\mathrm{AsO}_{4}\right)_{2}$ like, $\mathrm{FeAsS}$ and complex structures were the main As-bearing phases in sprawl soil. While $\mathrm{PbO}_{2}$-like, $\mathrm{PbS}$ and $(\mathrm{Ba}, \mathrm{Pb}) \mathrm{SO}_{4}$ like were the main $\mathrm{Pb}$ bearing phases. Total As concentrations in the urban sprawl vary from 4.37 to 42 $\mathrm{mg} \mathrm{kg}^{-1}$, while these concentrations were higher in the adjacent soil to Cerro de Mercado ranging from 55.1 to $221 \mathrm{mg} \mathrm{kg}^{-1}$. Regarding $\mathrm{Pb}$, these concentrations varied from 8.3 to $82.5 \mathrm{mg} \mathrm{kg}^{-1}$ in surface sprawl soil, and from 21.6 to $107.3 \mathrm{mg}$ $\mathrm{kg}^{-1}$ in the adjacent soil (mining area) to Cerro de Mercado. These concentrations exceeded in many points a typical trigger level criterion for As soil remediation; while those for $\mathrm{Pb}$ were in general low, however, they surpass in many points typical baseline describing $\mathrm{Pb}$ soil pollution. A negligible and/or low mobility was found for $\mathrm{Pb}$ (up to $3 \%$ ) and As (between 0.1 and $37.1 \%$ ), indicating a poor environmental risk due to $\mathrm{As}$ and $\mathrm{Pb}$ chemical releases. Concentrations vs. depth soil profiles suggested the progressive accumulation of $\mathrm{As}$ and $\mathrm{Pb}$ in top-soil, while geochemical and health risks connected to $\mathrm{As}$ and $\mathrm{Pb}$ were discussed based on experimental data. The presented research was carried out at UJED during 2016-2017.
\end{abstract}

Keywords: Durango City, Geochemical urban mapping, arsenic, lead, environmental mobility.

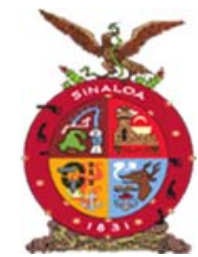

XVIII Congreso Internacional XXIV Congreso Nacional de Ciencias ambientales

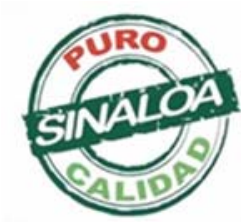

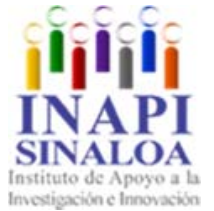

Mazatlán, Sinaloa 3-7 junio 2019

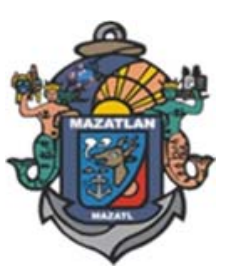

Recursos Naturales, Ecosistemas y Deterioro Ambiental 

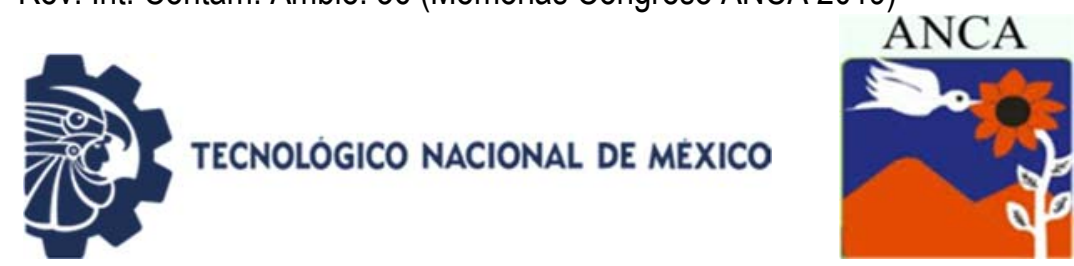

\title{
Monitoreo del chapulín (Brachystola magna) en la cuenca hidrológica de Cuauhtémoc, Chihuahua, México
}

\author{
Ledezma Pérez E*, Núñez de la Vega E, Franco Cervantes S \\ Facultad de Zootecnia y Ecología. Universidad Autónoma de Chihuahua. México \\ *a291081@ach.mx
}

\section{RESUMEN}

La producción de frijol en el Estado de Chihuahua se ha visto afectada por la especie Brachystola magna plaga endémica de alto potencial que tiene gran impacto agrícola ya que puede llegar a infestar una superficie de 300,000 hectáreas los cultivos y pastizales causando daños económicos y ecológicos que ponen en riesgo a la agricultura de la región. Se analizó y detectó posibles brotes de chapulín Brachystola magna con relación al tipo de suelo en la región de la cuenca hidrológica. El estudio se realizó en la cuenca hidrológica de Bustillos en las zonas perimetrales de la Laguna de Bustillos en el mes de abril del en el municipio de Cuauhtémoc, Chihuahua. Se utilizaron imágenes en el sistema de información geográfica ArcGis 10.3 para determinar los tipos de suelo en la cuenca, se seleccionaron seis polígonos con una superficie promedio de 19.95 hectáreas; se tomaron cinco sitios de muestreo donde se utilizó la técnica llamada el "método de cinco de oro" para determinación de densidad de Ootecas en $1 \mathrm{~m}^{2}$ y 5 centímetros de profundidad. En el muestreo de ootecas de la especie Brachystola magna, se encontraron como máximo seis ootecas a lo largo de los cinco sitios en los polígonos dos y cinco con tipo de suelo Planosol Eutrico y Feozem Haplico respectivamente. En conclusión se concentran más ootecas hacia el norte de la cuenca al ser un suelo rico en materia orgánica (Feozem Haplico) y se pronostica que podría presentarse una mayor cantidad de chapulines en esa región.

Palabras clave: Riesgo, chapulín, suelo, ootecas, cuenca.

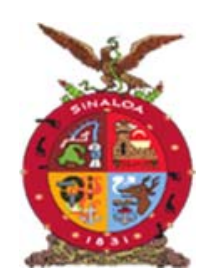

XVIII Congreso Internacional

XXIV Congreso Nacional de Ciencias ambientales

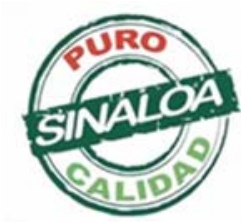

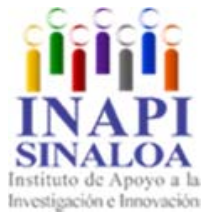

Mazatlán, Sinaloa 3-7 junio 2019

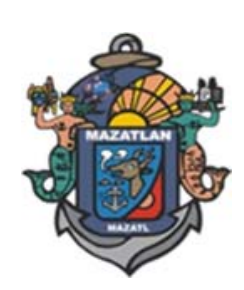

Recursos Naturales, Ecosistemas y Deterioro Ambiental 

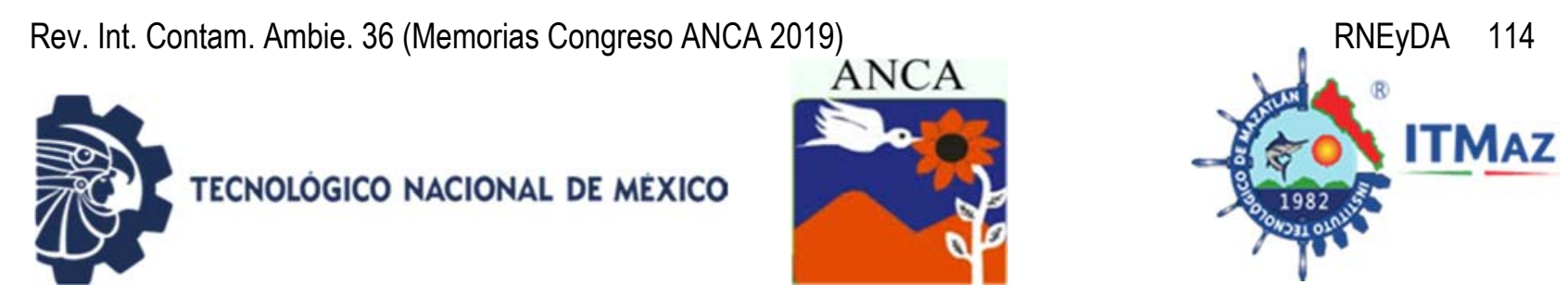

\title{
Monitoring of chapulin (Brachystola magna) in the hydrological basin of Cuauhtemoc, Chihuahua, Mexico
}

\author{
Ledezma Pérez E*, Núñez de la Vega E, Franco Cervantes S \\ Facultad de Zootecnia y Ecología. Universidad Autónoma de Chihuahua. México \\ *a291081@ach.mx
}

\begin{abstract}
Bean production in the state of Chihuahua has been affected by the species Brachystola magna endemic plague of high potential that has great agricultural importance and may come to infest an area of 300.000 hectares crops and pastures causing damage economic and ecological risks that put agriculture in the region at risk. The objective is to analyse and detect possible outbreaks of chapulín Brachystola Magna with the type of soil in the region of the hydrological basin. The study was carried out in the hydrological basin of Bustillos in the perimeter zones of the lagoon of Bustillos in the month of april of the current year in the municipality of Cuauhtémoc, Chihuahua. Images were used in the geographic information system ArcGis 10.3 to determine soil types in the watershed, six polygons with an average surface area of 19.95 hectares were selected; five sampling siteswere taken where the technique called the "five gold method" was used to determine Ootecas density of $1 \mathrm{~m}^{2}$ and 5 centimeters deep. In the sampling of ootecas of the species Brachystola Magna were found at maximum six ootecas along the five sites in polygons two and five with soil type Planosol Eutrico and Feozem Haplico respectively. In conclusion they concentrate more ootecas towards the north of the basin being a soil rich in organic matter (Feozem Haplico) and could present a greater quantity of chapulines in that region.
\end{abstract}

Keywords: Risk, chapulín, soil, ootecas, basin.

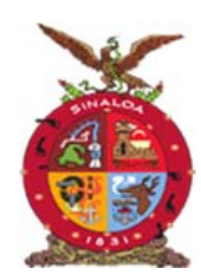

XVIII Congreso Internacional

XXIV Congreso Nacional de Ciencias ambientales

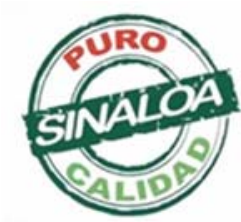

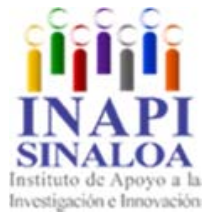

Mazatlán, Sinaloa 3-7 junio 2019

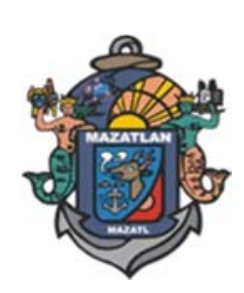

Recursos Naturales, Ecosistemas y Deterioro Ambiental 

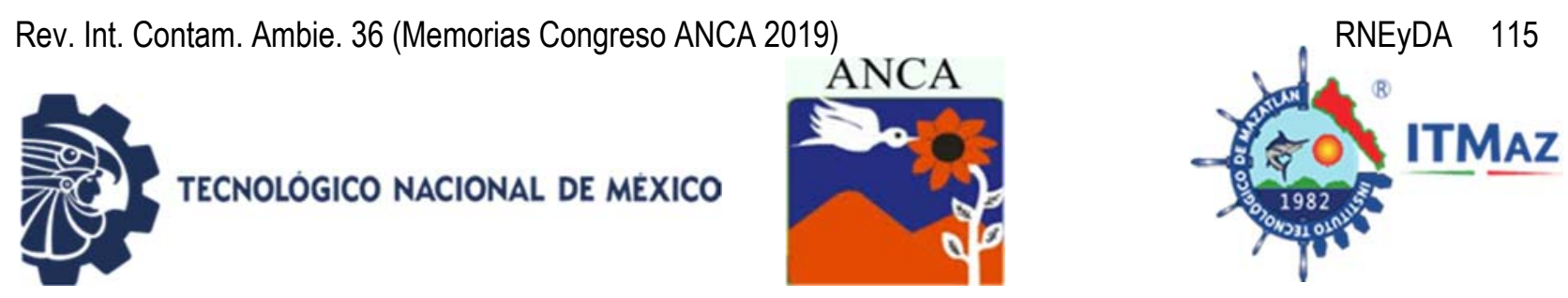

\title{
Integración de información terrestre y satelital en el estudio de la cobertura edáfica del sureste de la Presa Valsequillo, Puebla
}

\author{
Linares Fleites G*, Careaga Ruiz J, Pacheco Ríos A \\ Posgrado en Ciencias Ambientales. Instituto de Ciencias. \\ Benemérita Universidad Autónoma de Puebla. Puebla, México \\ *gladys.linares@correo.buap.mx
}

\section{RESUMEN}

Es de gran importancia caracterizar cambios espaciales de la cobertura edáfica para obtener información relacionada a la pérdida suelos de forma rápida, económica y práctica. El objetivo de este trabajo es generar modelos que permitan estimar y predecir la cobertura edáfica a través de la descripción del entorno y el procesamiento de imágenes satelitales. La zona de estudio, situada al sureste de la presa Valsequillo y, que corresponde a la parte norte del municipio de Tzicatlacoyan en el estado de Puebla, fue objeto de exploración en los períodos de seca y lluvia, durante el año 2017. La metodología se desarrolló en tres fases: una, a través de recorridos de campo que permitieron identificar sitios referenciados con diferentes condiciones naturales; otra, identificación de la información proporcionada por el índice de vegetación NDVI obtenido de la imagen satelital TM Landsat 5 en los sitios referenciados y, finalmente, el uso de la regresión logística multinomial para desarrollar modelos que permitan hacer predicciones del grado de erosión de la zona, clasificada en cinco coberturas edáficas según su degradación: ligera, moderada, fuerte, severa y muy severa. Para cada una de esas coberturas se obtuvieron modelos que relacionan su grado de degradación con el índice de vegetación NDVI y que mostraron capacidades de predicción correctas de $66.9 \%, 37.9 \%, 42.2 \%, 0 \%$ y $87.2 \%$, respectivamente. El estudio permitió acercarse al conocimiento del recurso suelo en el sureste de la presa Valsequillo y obtener modelos que brindan predicciones de los diferentes grados de degradación de sus coberturas edáficas.

Palabras claves: Erosión, índices de vegetación, regresión, teledetección.

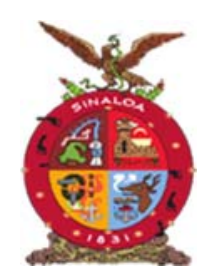

XVIII Congreso Internacional

XXIV Congreso Nacional de Ciencias ambientales

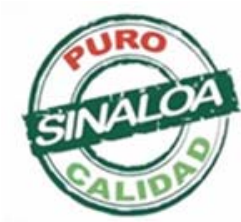

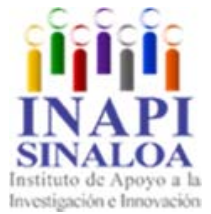

Mazatlán, Sinaloa 3-7 junio 2019

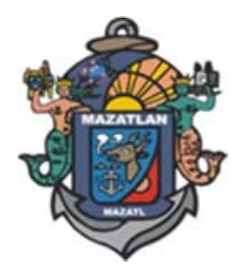

Recursos Naturales, Ecosistemas y Deterioro Ambiental 

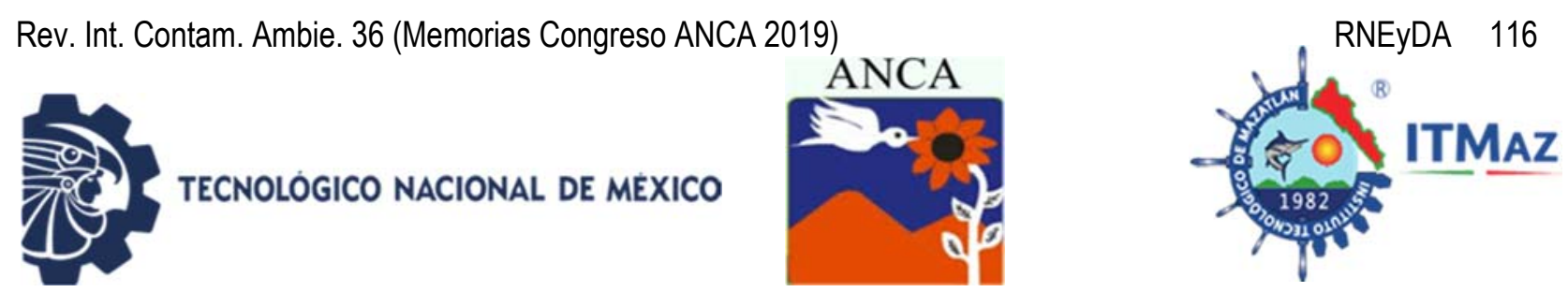

\title{
Integration of terrestrial and satellite information in the study of the edaphic coverage of the southeast of the Valsequillo Dam, Puebla
}

\author{
Linares Fleites G*, Careaga Ruiz J, Pacheco Ríos A \\ Posgrado en Ciencias Ambientales. Instituto de Ciencias. \\ Benemérita Universidad Autónoma de Puebla. Puebla, México \\ *gladys.linares@correo.buap.mx
}

\begin{abstract}
It is of great importance to characterize spatial changes of the soil cover to obtain information related to soil loss in a fast, economical and practical way. The objective of this work is to generate models that allow estimating and predicting the edaphic coverage through the description of the environment and the processing of satellite images. The study area located southeast of the Valsequillo dam and, which corresponds to the northern part of the municipality of Tzicatlacoyan in the state of Puebla, was subject to exploration during the dry and rainy periods, during the year 2017 . The methodology developed in three phases. One, through field trips that allowed to identify referenced sites with different natural conditions. Another, identification of the information provided by the NDVI vegetation index obtained from the satellite image TM Landsat 5 in the referenced sites. Finally, the use of multinomial logistic regression to develop models that allow predictions of the degree of erosion in the area, classified in five edaphic coverings according to its degradation: light, moderate, strong, severe and very severe. For each of these coverages, we obtained models that relate their degree of degradation with the NDVI vegetation index and that showed correct prediction capacities of $66.9 \%, 37.9 \%, 42.2 \%, 0 \%$ and $87.2 \%$, respectively. The study allowed us to approach the knowledge of the soil resource in the southeast of the Valsequillo dam and obtain models that provide predictions of the different degrees of degradation of their soil cover.
\end{abstract}

Keywords: Erosion, vegetation indices, regression, remote sensing.

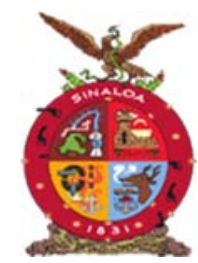

XVIII Congreso Internacional

XXIV Congreso Nacional de Ciencias ambientales

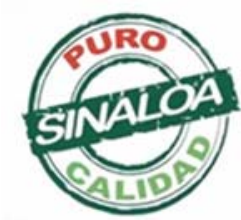

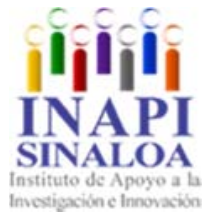

Mazatlán, Sinaloa 3-7 junio 2019

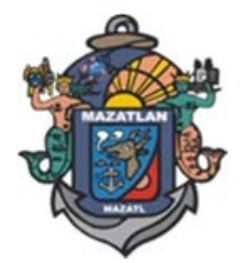

Recursos Naturales, Ecosistemas y Deterioro Ambiental 

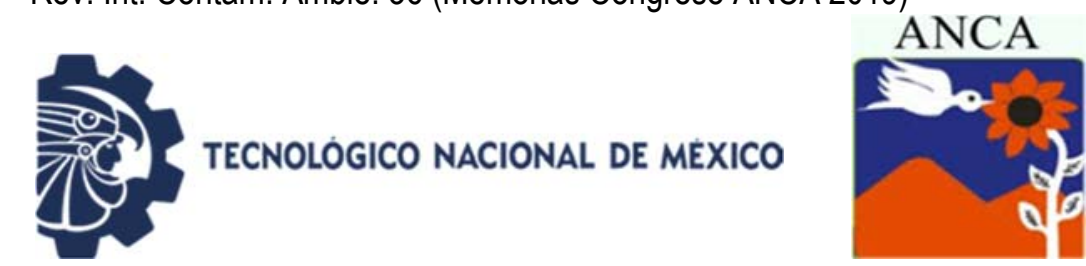

\title{
Aplicación Web Mapping para evaluar el análisis de cambio de uso de suelo e hidrología en la cuenca del Río Culiacán
}

\author{
Loaiza $\mathrm{J}^{*}$, Amabilis L, Sanhouse A, Rangel G \\ Instituto Tecnológico de Culiacán. Sinaloa, México \\ *juangabrielloaiza@gmail.com
}

\section{RESUMEN}

El ordenamiento ecológico territorial es de gran importancia en México, debido a que permite a los gobiernos locales mejorar el desarrollo regional mediante la correcta distribución de los recursos naturales y urbanismo, por lo tanto, es importante que haya un acceso oportuno a la información. Los Sistemas de Información Geográfica (SIG) son una herramienta que sirve como estrategia a la toma de decisiones en los procesos de planificación y gestión ambiental del territorio mediante el análisis de la información. Por eso, en este estudio se desarrolló una aplicación web mapping que permite una gestión integrada para un uso racional y preservación de los recursos hídricos y forestales en la cuenca del río Culiacán. Este trabajo se realizó en el Instituto Tecnológico de Culiacán de agosto 2018 a marzo 2019 y contiene los datos referentes a los periodos de 1990 a 2000 y 2000 2014. Se utilizó una metodología que combina el uso de técnicas de clasificación digital de imágenes junto con los elementos de los SIG para determinar el índice de cobertura vegetal en la cuenca y la hidrología de la misma. Como resultado, la aplicación muestra cambios significativos en la cobertura vegetal y cambios en el uso de suelo de los periodos estudiados, en el área de estudio, así como los cuerpos de agua de la cuenca. Esta aplicación web mapping permitió el acceso a la información en tiempo real para una correcta administración y gestión de los recursos en el estado.

Palabras Clave: Cuenca, web-mapping, ordenamiento ecológico Territorial.

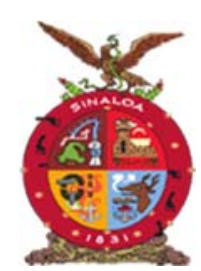

XVIII Congreso Internacional

XXIV Congreso Nacional de Ciencias ambientales

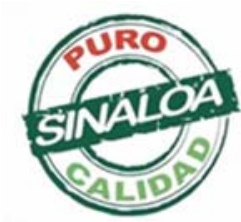

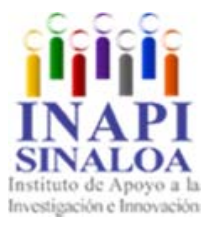

Mazatlán, Sinaloa 3-7 junio 2019

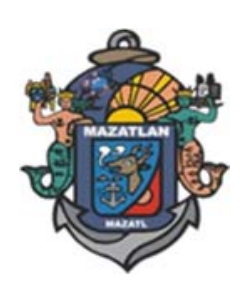

Recursos Naturales, Ecosistemas y Deterioro Ambiental 

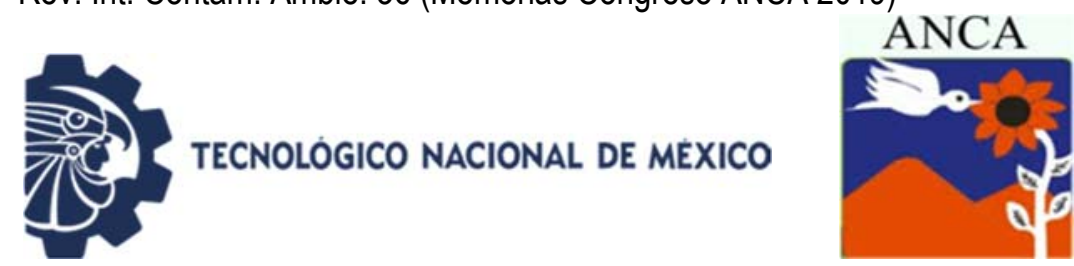

\title{
Mapping Web Application to evaluate the analysis of land use change and hydrology in the Culiacan River basin
}

\author{
Loaiza J*, Amabilis L, Sanhouse A, Rangel G \\ Instituto Tecnológico de Culiacán. Sinaloa, México \\ *juangabrielloaiza@gmail.com
}

\begin{abstract}
The ecological territorial ordering is of great importance in Mexico, because it allows local governments to improve regional development through the correct distribution of natural resources and urban planning, therefore, it is important that there is timely access to information. The Geographic Information Systems (GIS) are a tool that serves as a strategy to make decisions in planning processes and environmental management of the territory through the analysis of information. Therefore, in this study a web mapping application was developed that allows integrated management for the rational use and preservation of water and forest resources in the Culiacán river basin. This work was carried out at the Technological Institute of Culiacán (from August 2018 to March 2019) and contains the data referring to the periods from 1990 to 2000 and 2000 2014. A methodology was used that combines the use of digital image classification techniques together with the elements of the GIS to determine the index of plant cover in the basin and the hydrology of the same. As a result, the application shows significant changes in the vegetation cover and changes in the land use of the periods studied, in the study area, as well as the bodies of water in the basin. This web mapping application allows access to information in real time for proper administration and management of resources in the state.
\end{abstract}

Keywords: Basin, web-mapping, ecological territorial oathing.

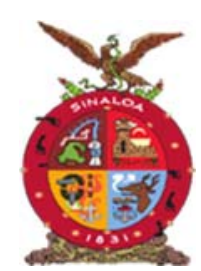

XVIII Congreso Internacional

XXIV Congreso Nacional de Ciencias ambientales

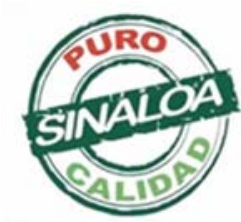

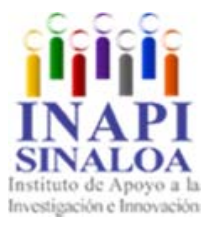

Mazatlán, Sinaloa 3-7 junio 2019

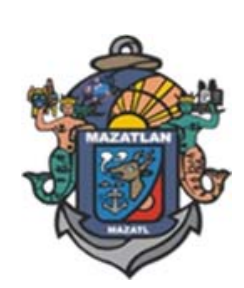

Recursos Naturales, Ecosistemas y Deterioro Ambiental 

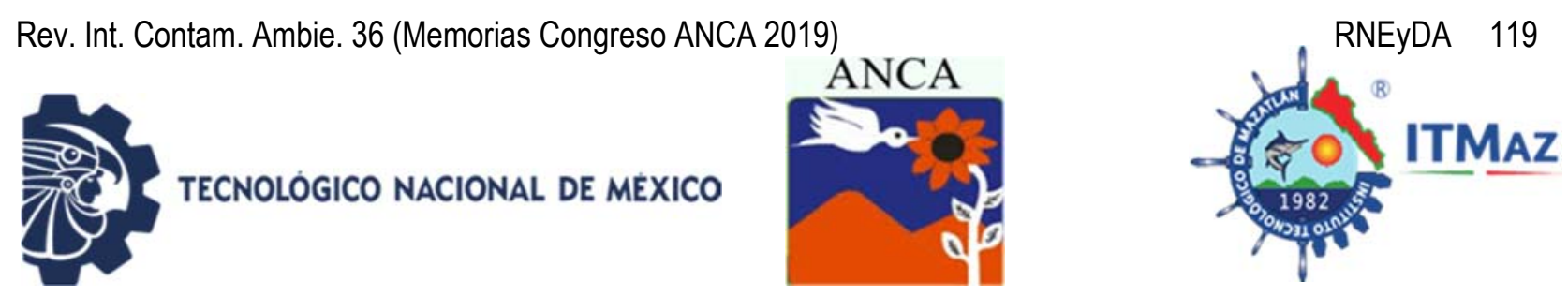

\title{
Cultivo in vitro de Agave a partir de fertilizantes orgánicos elaborados con Synechocystis
}

\author{
López Márquez ES, Vizcaíno Rodríguez LA* \\ Ingeniería en Biotecnología. Universidad Politécnica \\ Zona Metropolitana de Guadalajara. \\ Km. 3.5, N595, Carr. Tlajomulco-Santa Fé, Lomas de Tejeda, \\ C.P 45660. Tlajomulco, Jalisco, México \\ *adyvizcaino7@gmail.com
}

\begin{abstract}
RESUMEN
Synechocystis sp. es un género de cianobacterias de agua dulce, capaz de crecer tanto en condiciones de luminosidad, realizando la fotosíntesis oxigénica, como en oscuridad, con el empleo de la rutas metabólicas glucólisis y fosforilación oxidativa. En el presente trabajo, se emplearon extractos de Synechocystis como fuente de nutrientes en cultivos in vitro de Agave Bravo. Se empleó un diseño experimental completamente al azar. Las semillas de Agave se germinaron en medio de cultivo Murashige \& Skoog (MS) posteriormente el $50 \%$ de plántulas se transfirieron a medio MS (control) y el resto a Medio MS sin macroelementos y suplementado con el fertilizante orgánico. Los cultivos se conservaron en condiciones estériles e iluminación (las variables de monitoreo fueron longitud de planta, longitud de raíz, biomasa fresca y biomasa seca. A los 16 días se obtuvieron los siguientes resultados: longitud promedio de planta, $2.88 \mathrm{~cm}$; longitud promedio de raíz, $0.38 \mathrm{~cm}$ y promedio de biomasa seca, $2.94 \mathrm{~g}$, para el medio MS (control). Mientras que en el Medio suplementado las dimensiones fueron: longitud promedio de planta, $3.31 \mathrm{~cm}$; longitud promedio de raíz $1.50 \mathrm{~cm}$ $\mathrm{y}$; promedio de biomasa seca, $5.52 \mathrm{~g}$. En conclusión los componentes presentes en el medio de cultivo suplementado estimularon el crecimiento de la planta, probablemente asociados a la presencia de un regulador de crecimiento o triterpenos, es necesario continuar con los estudios ya que el cultivo de Synechocystis tiene gran potencial en el desarrollo de biofertilizantes o aplicaciones agro-biotecnológicas.
\end{abstract}

Palabras claves: Cinética, repicado, Synechocystis, regulador de crecimiento, cultivo in vitro.

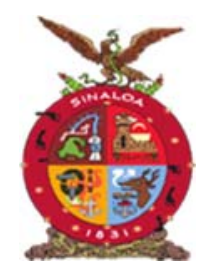

XVIII Congreso Internacional

XXIV Congreso Nacional de Ciencias ambientales

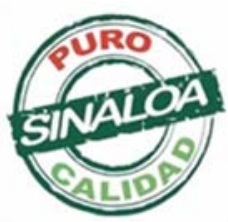

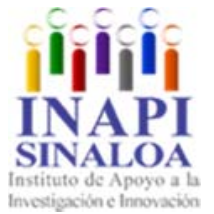

Mazatlán, Sinaloa 3-7 junio 2019

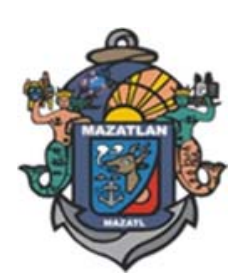

Recursos Naturales, Ecosistemas y Deterioro Ambiental 

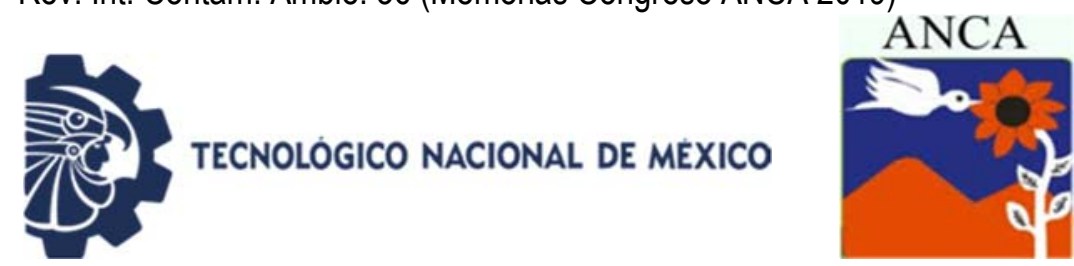

\title{
In vitro culture of Agave from organic fertilizers elaborated with Synechocystis
}

\author{
López Márquez ES, Vizcaíno Rodríguez LA* \\ Ingeniería en Biotecnología. Universidad Politécnica \\ Zona Metropolitana de Guadalajara. \\ Km. 3.5, N595, Carr. Tlajomulco-Santa Fé, Lomas de Tejeda, \\ C.P 45660. Tlajomulco, Jalisco, México \\ *adyvizcaino7@gmail.com
}

\begin{abstract}
Synechocystis sp. is a genus of freshwater cyanobacteria, able to grow both in light conditions, performing oxygenic photosynthesis, and in darkness, with the use of metabolic pathways glycolysis and oxidative phosphorylation. In the present work, extracts of Synechocystis were used as a source of nutrients in in vitro cultures of Agave Bravo. A completely randomized experimental design was used. Agave seeds were germinated in Murashige \& Skoog (MS) culture medium, then $50 \%$ of seedlings were transferred to MS medium (control) and the rest to MS medium without macroelements and supplemented with fertilizer. The cultures were preserved in sterile conditions and lighting. Monitoring variables: plant length, root length, fresh biomass and dry biomass. After 16 days the following results were obtained: Average plant length: $2.88 \mathrm{~cm}$, average root length: $0.38 \mathrm{~cm}$ and average dry biomass: $2.94 \mathrm{~g}$, for the MS medium (control). While in the medium supplemented the dimensions were the following average plant length: $3.31 \mathrm{~cm}$, average root length: $1.50 \mathrm{~cm}$ and average dry biomass: $5.52 \mathrm{~g}$. In conclusion, the components present in the supplemented culture medium stimulated the growth of the plant, probably associated with the presence of a growth regulator or triterpenes, it is necessary to continue with the studies since the cultivation of Synechocystis has great potential in the development of biofertilizers or agro-biotechnological applications.
\end{abstract}

Keywords: Kinetics, throbbed, Synechocystis, growth regulator, in vitro culture.

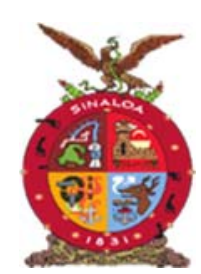

XVIII Congreso Internacional

XXIV Congreso Nacional de Ciencias ambientales

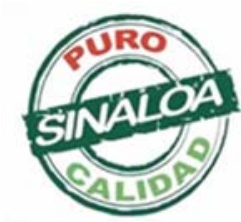

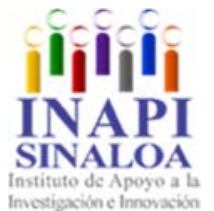

Mazatlán, Sinaloa 3-7 junio 2019

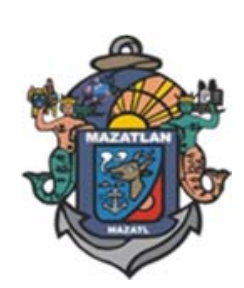

Recursos Naturales, Ecosistemas y Deterioro Ambiental 

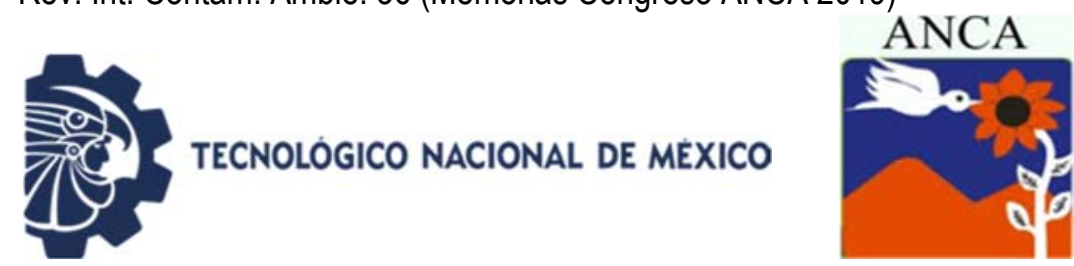

\title{
Aislamiento e identificación de microorganismos solubilizadores de fósforo a partir de suelo agrícola
}

\author{
López Sánchez E*, González Flores E, Vázquez Cuchillo O \\ Tecnológico Nacional de México/Instituto Tecnológico de Puebla \\ *erilosa@hotmail.com
}

\section{RESUMEN}

El fósforo $(P)$ es uno de los macronutrientes que más limita la productividad de los cultivos. A pesar de la aplicación fertilizantes químicos fosfatados, la disponibilidad de fósforo en suelos agrícolas es baja por la alta afinidad del fósforo por la fase sólida del suelo. La fertilización química constante perjudica los agroecosistemas, impactando ambientalmente el suelo y los cuerpos de agua. Una alternativa sustentable para aprovechar el fósforo no disponible acumulado en el suelo y convertirlo a formas solubles, aprovechables por las plantas, es utilizar microorganismos del suelo que sean capaces de transformar fósforo insoluble en formas solubles. El objetivo de esta investigación fue encontrar, identificar y aislar microorganismos solubilizadores de fósforo en suelos agrícolas de la región Libres-Serdán. La investigación se realizó en el Laboratorio de ingeniería Ambiental del Instituto Tecnológico de Puebla, entre el agosto de 2018 y enero de 2019. Se recolectaron 3 muestras de suelos agrícolas de la zona estudiada. A partir de $1 \mathrm{~g}$ de muestra de suelo que se realizó la siembra en el medio nutritivo Mueller-Hinton. Las colonias que se aislaron se resembraron en caldo nutritivo Mueller Hinton. Para confirmar la presencia de bacterias solubilizadoras de fosfato, se sembró en placas de medio selectivo NBRIP (National Botanical Research Institute Phosphate). Al final del período de incubación se seleccionaron las bacterias que mostraron actividad solubilizadora de fosfato la cual se vio representada por el vire de color de azul a amarillo. En microscopio se observó que los microorganismos solubilizadores de fósforo son bacilos.

Palabras claves: Biofertilizantes, fósforo disponible, microorganismos solubilizadores.

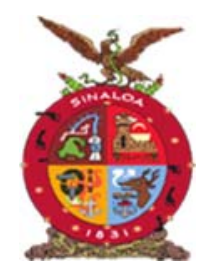

XVIII Congreso Internacional

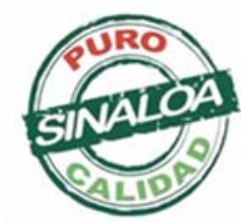

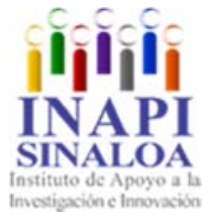

Mazatlán, Sinaloa 3-7 junio 2019

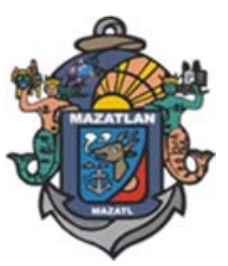

Recursos Naturales, Ecosistemas y Deterioro Ambiental 

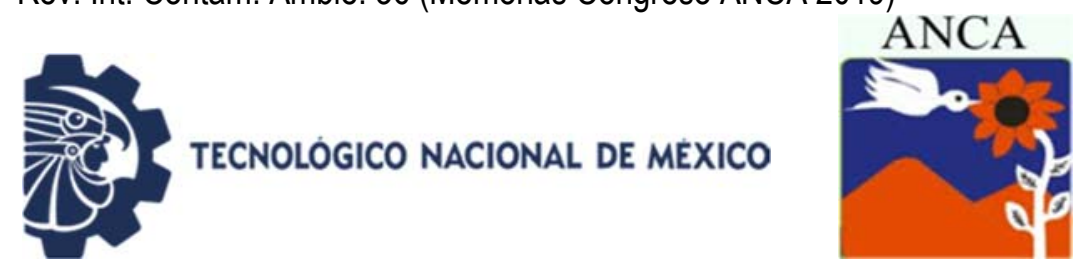

\title{
Isolation and identification of microorganisms phosphorus solubilizers from agricultural soil
}

\author{
López Sánchez E*, González Flores E, Vázquez Cuchillo O \\ Tecnológico Nacional de México/Instituto Tecnológico de Puebla \\ *erilosa@hotmail.com
}

\begin{abstract}
Phosphorus $(\mathrm{P})$ is one of the macronutrients that most limits the productivity of crops. Despite the application of chemical phosphate fertilizers, the availability of phosphorus in agricultural soils is low due to the high affinity of phosphorus for the solid phase of the soil. The constant chemical fertilization harms the agroecosistemas, impacting environmentally the soil and the bodies of water. A sustainable alternative to take advantage of the unavailable phosphorus accumulated in the soil and convert it into soluble forms, usable by plants, is to use soil microorganisms that are capable of transforming insoluble phosphorus into soluble forms. The objective of this research was to find, identify and isolate phosphorus solubilizing microorganisms in agricultural soils of the Libres-Serdán region. The research was carried out in the Environmental Engineering Laboratory of the Technological Institute of Puebla, between August 2018 and January 2019. Three samples of agricultural soils were collected from the studied area. From $1 \mathrm{~g}$ of soil sample that was sown in the nutrient medium Mueller-Hinton. The colonies that were isolated were replated in Mueller Hinton nutrient broth. To confirm the presence of phosphate solubilizing bacteria, it was plated on NBRIP (National Botanical Research Institute Phosphate) selective medium plates. At the end of the incubation period, the bacteria that showed phosphate solubilizing activity which was represented by the color turn from blue to yellow were selected. In a microscope, it was observed that the phosphorus solubilizing microorganisms are bacilli.
\end{abstract}

Keywords: Biofertilizers, available phosphorus, solubilizing microorganisms.

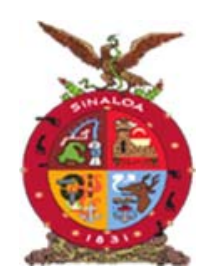

XVIII Congreso Internacional

XXIV Congreso Nacional de Ciencias ambientales

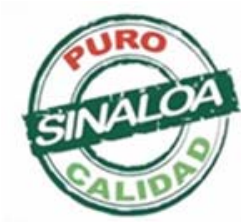

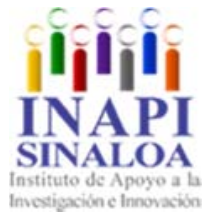

Mazatlán, Sinaloa 3-7 junio 2019

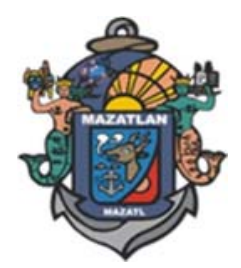

Recursos Naturales, Ecosistemas y Deterioro Ambiental 

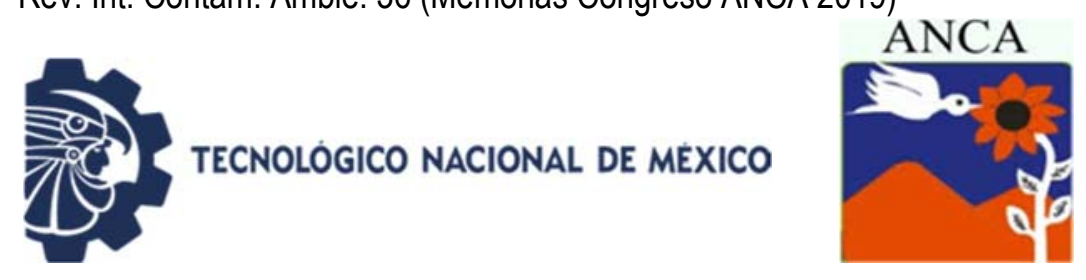

\author{
Estado de salud de los arrecifes coralinos del sur del municipio \\ Solidaridad, Quintana Roo, México \\ Márquez $\mathrm{MC}^{1 *}$, Díaz Larrea $\mathrm{J}^{1}$, Núñez García $\mathrm{L}^{1}$, Urbina Sánchez $\mathrm{GI}^{1}$, \\ Castañeda López $\mathrm{O}^{2}$ \\ ${ }^{1}$ Planta Experimental de Producción Acuícola. \\ Universidad Autónoma Metropolitana-Unidad Iztapalapa, México \\ 2Laboratorio de Ecosistemas Costeros, \\ Universidad Autónoma Metropolitana-Unidad Iztapalapa, México \\ *marisol.carlos.marquez13@gmail.com
}

\begin{abstract}
RESUMEN
Los arrecifes coralinos del Caribe Mexicano han sido sometidos a un creciente desarrollo por la construcción de nuevos centros turísticos, amenazando con deteriorar el ecosistema. Los arrecifes del Municipio de Solidaridad se distribuyen en tres áreas geográficas: norte, centro y sur, difieren en la estructura del arrecife y en la composición de las comunidades de organismos arrecifales. El objetivo de diagnosticar la condición de los arrecifes del Sur del Municipio de Solidaridad, con base en parámetros de las poblaciones algales: riqueza específica, abundancia, canopia algal, y la presencia de grupos morfo-funcionales. El área sur, que comprende de Puerto Aventuras a Tulum, incluye dos sitios de muestreo de Xaac y Tulum. Se realizaron tres muestreos intensivos con el método aplicado por "Amigos de Sian Ka'an" "Áreas Naturales Protegidas de Quintana Roo". En cada sitio, el muestreo abarcó las diferentes subzonas estructurales del arrecife: Cresta, Arrecife Frontal Interno y Transición Barlovento. Como resultado, se obtuvo una descripción de las subzonas del arrecife, con sus respectivos listados florísticos. El análisis de la proporción de grupos morfo-funcionales, permitió detectar cambios en la comunidad arrecifal y hacer inferencias sobre el estado de conservación del arrecife. Finalmente, se concluye que los arrecifes estudiados presentaron porcentajes de cobertura algal de moderado a bajo. Los grupos morfofuncionales de filamentosas y foliosas (indicadoras de disturbio ambiental), se presentaron en bajos porcentajes o estuvieron ausentes, lo que indica que no hay influencias externas significativas en la zona.
\end{abstract}

Palabras clave: Macroalgas arrecifales, grupos morfofuncionales, Quintana Roo, Municipio Solidaridad.

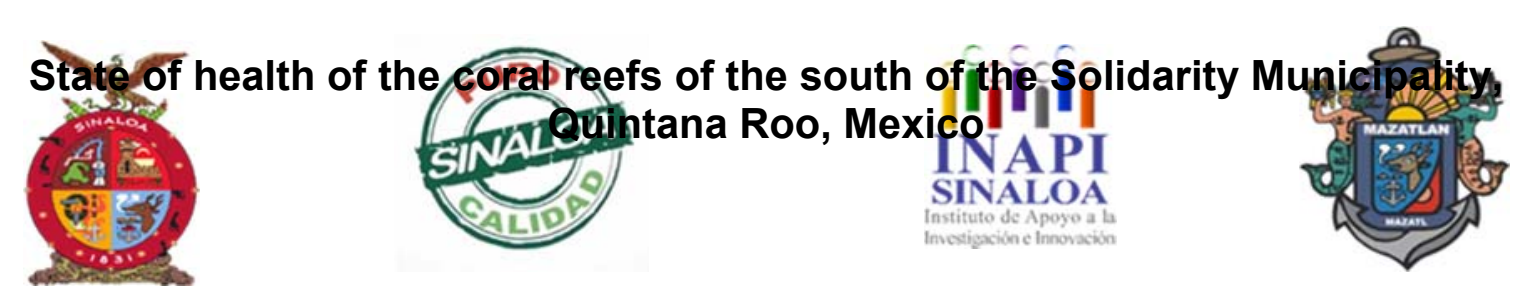



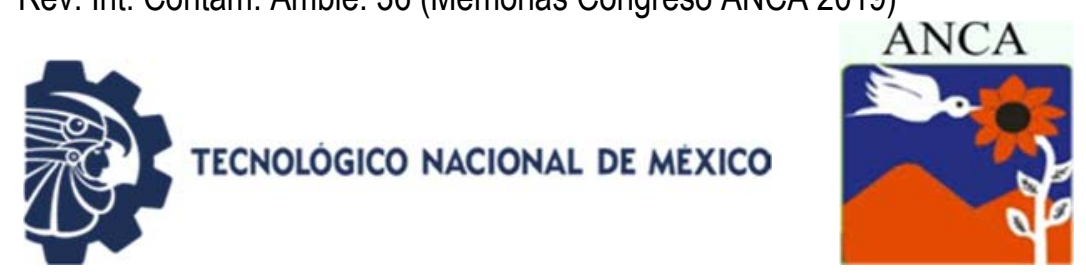

\author{
Márquez $M C^{1 *}$, Díaz Larrea $\mathrm{J}^{1}$, Núñez García $\mathrm{L}^{1}$, Urbina Sánchez $\mathrm{Gl}^{1}$, \\ Castañeda López $\mathrm{O}^{2}$ \\ ${ }^{1}$ Planta Experimental de Producción Acuícola. \\ Universidad Autónoma Metropolitana-Unidad Iztapalapa, México \\ ${ }^{2}$ Laboratorio de Ecosistemas Costeros, \\ Universidad Autónoma Metropolitana-Unidad Iztapalapa, México \\ *marisol.carlos.marquez13@gmail.com
}

\begin{abstract}
The Mexican Caribbean coral reefs have been submited to an increasing development because of the new touristic center construction. This quick development threat to destroy the coastal ecosystems. The coral reefs from the Municipio de Solidaridad are distributed in three geographic areas: north, center, and south, which differ in the coral reef structure and in the organism community composition. The objective of the present work was to diagnose the conditions of the south coral reefs from Municipio de Solidaridad, based on the following algal populations parameters: specific richness, abundance, algal canopy and the presence of the morfofunctional groups. The south area, that comprise from Puerto Aventuras to Tulum, included Xaac and Tulum sample sites. We carry out three intensive sampling with the method applied by Amigos de Sian Ka'an and the Áreas Naturales Protegidas from Quintana Roo. In every site, the sampling included three structural subzones of the coral reefs: crest, inner frontal reef and winward transition. As a result we obtained a description of the different coral reef subzones with their respectives floristics lists. The analyses of the morfofunctional proportions allowed to detect changes on the reef community and to make inferences about the reef conservation state. Finally, we concluded that the studied coral reefs recorded moderate to low algal cover values. The filamentous and folious morfo-functional groups percentages (environmental disturbance indicators) recorded low or missign values, showed the absence of the significatives extern influences.
\end{abstract}

Keywords: Reef macroalgae, morfo-functional groups, Quintana Roo, Mexican Caribbean.

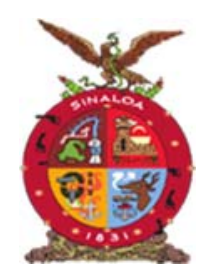

XVIII Congreso Internacional

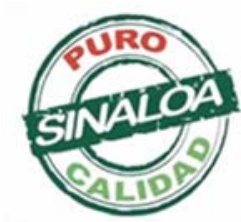

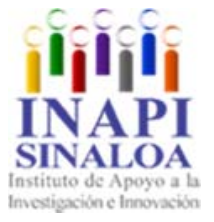

Mazatlán, Sinaloa 3-7 junio 2019

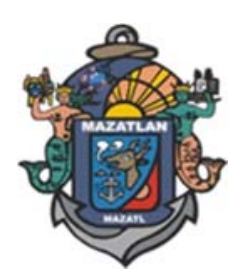

Recursos Naturales, Ecosistemas y Deterioro Ambiental 

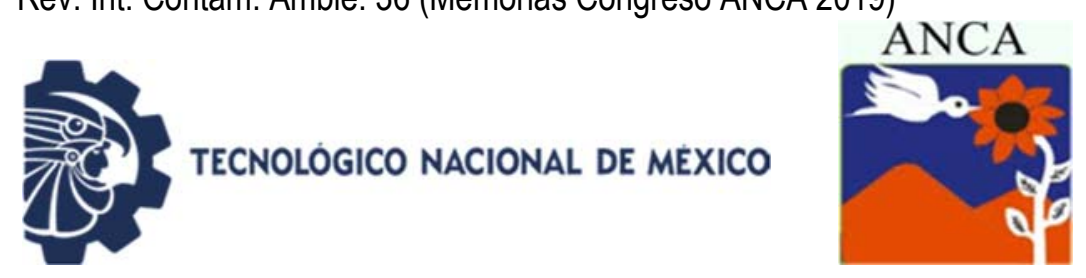

\title{
Sistemática molecular del complejo Laurencia (Ceramiales, Rhodophyta) en el Caribe mexicano
}

\author{
Márquez $M C^{1 *}$, Díaz Larrea J1 , Núñez García $L^{1}$, Urbina Sánchez $\mathrm{GI}^{1}$, \\ Castañeda López $\mathrm{O}^{2}$, Vázquez Silva $\mathrm{G}^{3}$, Campos Verduzco $\mathrm{R}^{1}$ \\ ${ }^{1}$ Planta Experimental de Producción Acuícola. \\ Universidad Autónoma Metropolitana-Unidad Iztapalapa. México \\ ${ }^{2}$ Laboratorio de Ecosistemas Costeros, \\ Universidad Autónoma Metropolitana-Unidad Iztapalapa. México \\ ${ }^{3}$ Laboratorio de Limnobiología y Acuicultura. \\ Universidad Autónoma Metropolitana-Unidad Xochimilco. México. \\ *marisol.carlos.marquez13@gmail.com
}

\section{RESUMEN}

En el presente estudio se caracterizan molecularmente las especies del complejo Laurencia presentes en el Caribe mexicano, se proponen además hipótesis sobre las relaciones filogenéticas a su interior y se emiten opiniones taxonómicas. Para lograr estos objetivos, material fresco fue recolectado en nueve localidades a lo largo de aproximadamente 500 kilómetros del litoral caribeño de la Península de Yucatán. Un total de 41 muestras fueron procesadas para la obtención de ADN. Los valores de divergencia genética en los tres genes permitieron segregar categorías taxonómicas a nivel específico. Los mayores valores de divergencia se obtuvieron para la región espaciadora y $r b c L$. Las hipótesis filogenéticas generadas a partir de secuencias de los genes $r b c L$ y RUBISCO del cloroplasto y $18 S$ nuclear confirman que Laurencia sensu lato es monofilético y que en él se incluyen tres clados monofiléticos correspondientes a los géneros: Laurencia sensu stricto, Palisada y Osmundea, lo que nos lleva a concluir que estas unidades son independientes y en términos taxonómicos no pueden corresponder a una agrupación de complejo. La combinación de dos ó más genes en los análisis filogenéticos respaldan con mayor fortaleza las relaciones postuladas. Los caracteres moleculares permitieron hacer modificaciones al esquema de clasificación de Laurencia sensu lato a nivel intragenérico. Se proponen dos nuevos registros para la zona de estudio, se plantean dos combinaciones nuevas, así como la conespecificidad de $P$. papillosa y $P$. perforata. Los datos de divergencia genética sugieren la existencia de una posible especie nueva para la ciencia en el género Laurencia.

Palabras clave: Complejo Laurencia, sistemática molecular, Caribe mexicano.

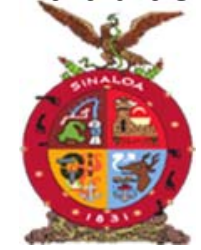

XVIII Congreso Internacional

XXIV Congreso Nacional de Ciencias ambientales
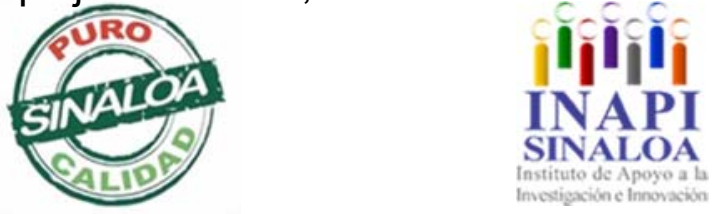

Mazatlán, Sinaloa 3-7 junio 2019

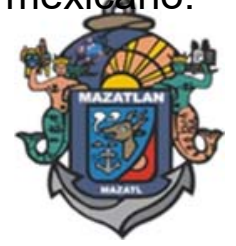

Recursos Naturales, Ecosistemas y Deterioro Ambiental 

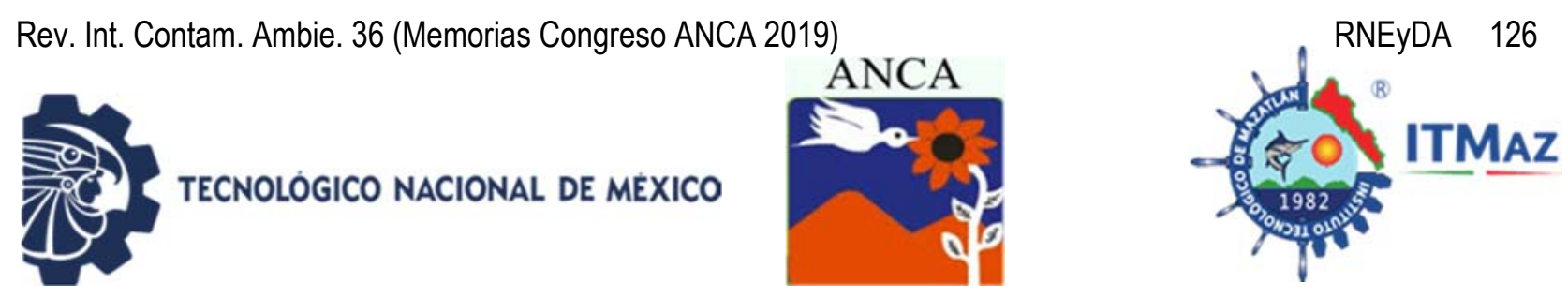

\title{
Molecular systematics from Laurencia complex (Ceramiales, Rhodophyta) in the mexican Caribbean
}

\author{
Márquez $M C^{1 *}$, Díaz Larrea J1, Núñez García $L^{1}$, Urbina Sánchez $\mathrm{Gl}^{1}$, \\ Castañeda López $\mathrm{O}^{2}$, Vázquez Silva $\mathrm{G}^{3}$, Campos Verduzco $\mathrm{R}^{1}$ \\ ${ }^{1}$ Planta Experimental de Producción Acuícola. \\ Universidad Autónoma Metropolitana-Unidad Iztapalapa. México \\ ${ }^{2}$ Laboratorio de Ecosistemas Costeros, \\ Universidad Autónoma Metropolitana-Unidad Iztapalapa. México \\ ${ }^{3}$ Laboratorio de Limnobiología y Acuicultura. \\ Universidad Autónoma Metropolitana-Unidad Xochimilco. México. \\ *marisol.carlos.marquez13@gmail.com
}

\begin{abstract}
In the current work the species from the Laurencia complex of the mexican Caribbean were molecular characterized. Furthermore, the work deals with phylogeny of Laurencia complex and taking into account these phylogenetics relationships, some taxonomic opinions were expressed. To carry out the already mentioned purposes, fresh samples were collected in nine localities through fivehundred kilometers around in the Caribbean coast of the Yucatán peninsula. A total of forty-one samples were submitted to molecular treatment. The genetic divergence values obtained allow to split the taxonomic categories in specific levels. The highest genetic divergence values were obtained for RUBISCO spacer followed by $r b c L$. The phylogenetics hypothesis based on $r b c L$, RUBISCO spacer and $18 \mathrm{~S}$ sequences comparisons corroborated that Laurencia sensu lato is monophyletic and includes three distinct monophyletic clades corresponding to the genera Palisada, Laurencia sensu stricto and Osmundea. Because of this the author conclude that the three genera are distinct units and they don't correspond to a complex assemblage. The combination of two or more genes in the phylogenetics analyses improve the support of the proposed phylogenetics hypothesis. Molecular characters allow to improve the classification scheme of Laurencia sensu lato in intrageneric level. The following taxonomic proposals were made in the current work: two new records for the study zone, two new combinations and the conspecificity of $P$. papillosa y $P$. perforata. The genetic divergence values suggests the existence of a possible new specie in Laurencia genus.
\end{abstract}

Keywords: Laurencia complex, molecular systematics, mexican caribbean

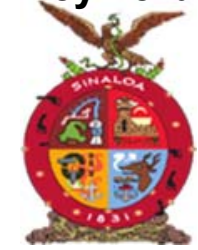

XVIII Congreso Internacional

XXIV Congreso Nacional de Ciencias ambientales
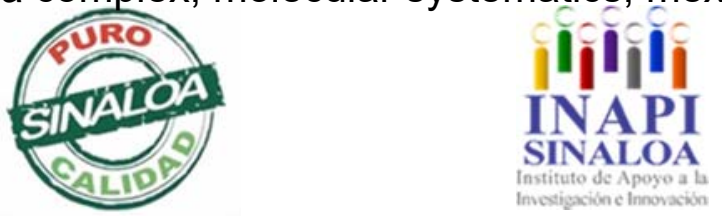

Mazatlán, Sinaloa 3-7 junio 2019

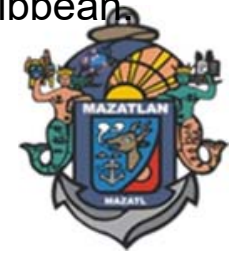

Recursos Naturales, Ecosistemas y Deterioro Ambiental 

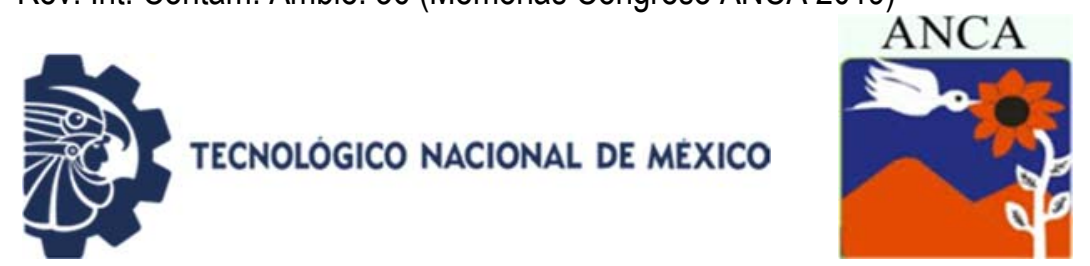

\title{
Producción de conos y semillas en pináceas en la región El Salto, Pueblo Nuevo, Durango
}

\author{
Martínez Rivas A, Cruz Cobos F*, Gurrola Amaya G, Nájera Luna A \\ El Instituto Tecnológico El Salto. Durango, México \\ cobos_cruz@yahoo.com.mx
}

\begin{abstract}
RESUMEN
La necesidad de contar con semillas forestales con calidad y en cantidad son de vital importancia para poder palear y revertir los procesos de deforestación y cambio de uso de suelo que se dan a nivel mundial, por lo que el objetivo del estudio fue evaluar el potencial productivo de conos y semillas en pináceas de mayor interés en la región de El Salto, Durango. Se muestrearon 63 ejemplares de Pinus cooperi y 53 de Pinus durangensis y a cada árbol se le colectaron 5 conos y se contó el número restantes en la copa, a cada cono se le midió el ancho y largo, potencial biológico, semilla desarrollada y total de semilla desarrollada, se realizó un análisis radiográfico de semillas y se clasificaron como plagadas, abortadas y viables. Se hicieron pruebas de comparación de medias para cada una de las variables en tres zonas que comprenden la región. Los resultados del análisis radiográfico para la región mostro 21 y $17 \%$ en semilla viable; 27 y $35 \%$ abortada y 52 y $49 \%$ de plagadas para Pinus durangensis, y P. cooperi, respectivamente. El promedio de conos para Pinus durangensis fue de 17.6 y 22.3 para Pinus cooperi, no se encontraron diferencias estadísticas para el número de conos, largo y ancho del cono, total de semilla desarrollada, potencial biológico y de semilla desarrollada en Pinus durangensis, mientras que para Pinus cooperi se encontraron diferencias en el largo del cono, el potencial y el total de semilla desarrollada.
\end{abstract}

Palabras clave: Correlación de variables dasométricas, Pinus cooperi C.E. Blancoi, Pinus durangensis Mtz., potencial biológico, semillas desarrolladas.

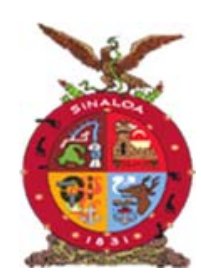

XVIII Congreso Internacional XXIV Congreso Nacional de Ciencias ambientales
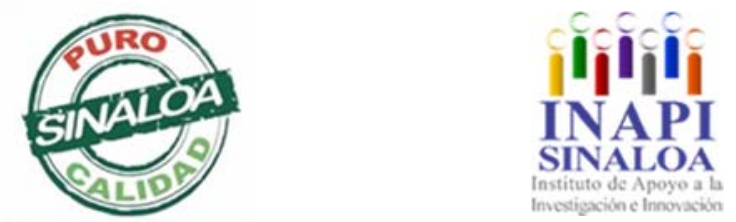

Mazatlán, Sinaloa 3-7 junio 2019

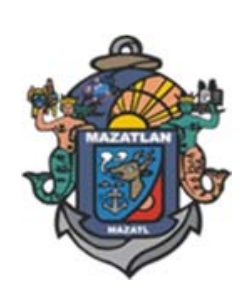

Recursos Naturales, Ecosistemas y Deterioro Ambiental 

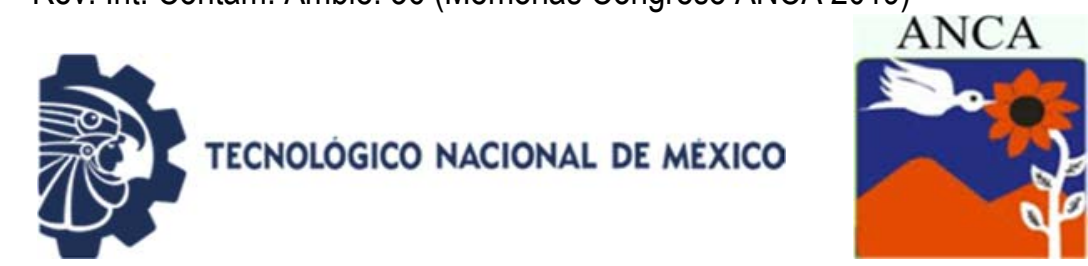

\title{
Production of cones and seeds in pináceas of the region of El Salto, Pueblo Nuevo, Durango
}

\author{
Martínez Rivas A, Cruz Cobos F*, Gurrola Amaya G, Nájera Luna A \\ El Instituto Tecnológico El Salto. Durango, México \\ cobos_cruz@yahoo.com.mx
}

\begin{abstract}
The need to have forest seeds in quality and quantity are of vital importance to be able to shovel and revert the processes of deforestation and change of land use that occur worldwide. So the objective of the study was to evaluate the productive potential of cones and seeds in pináceas of greater interest in the region of $\mathrm{El}$ Salto, Durango. 63 specimens of Pinus cooperi and 53 of Pinus durangensis were sampled and each tree was collected 5 cones and the remaining number in the crown was counted, each cone was measured the width and length, biological potential and seed developed and total of developed seed, a radiographic analysis of seeds was made and classified as plagued, aborted and viable. Comparison tests of means were made for each one of the variables in three zones that comprise the region. The results of the radiographic analysis for the region showed $21 \%$ and $17 \%$ of viable seed, $27 \%$ and $35 \%$ of aborted and $52 \%$ and $49 \%$ of plague for Pinus durangensis, and $P$. cooperi respectively. The average of cones for Pinus durangensis was of 17.6 and 22.3 for Pinus cooperi, no statistical differences were found for the number of cones, cone length and width, total seed developed, biological and seed potential developed in Pinus durangensis, while for Pinus cooperi differences were found in the length of cone, potential and total seed developed.
\end{abstract}

Keywords: biological potential, correlation of dasometric variables, developed seeds, Pinus cooperi C.E. Blancoi, Pinus durangensis Mtz.

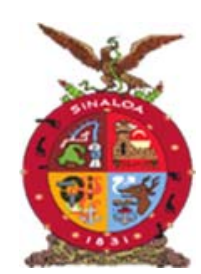

XVIII Congreso Internacional

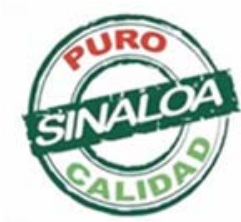

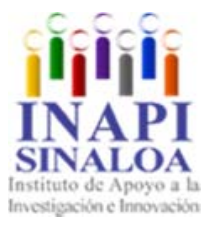

Mazatlán, Sinaloa 3-7 junio 2019

Recursos Naturales,
Ecosistemas y Deterioro Ambiental 

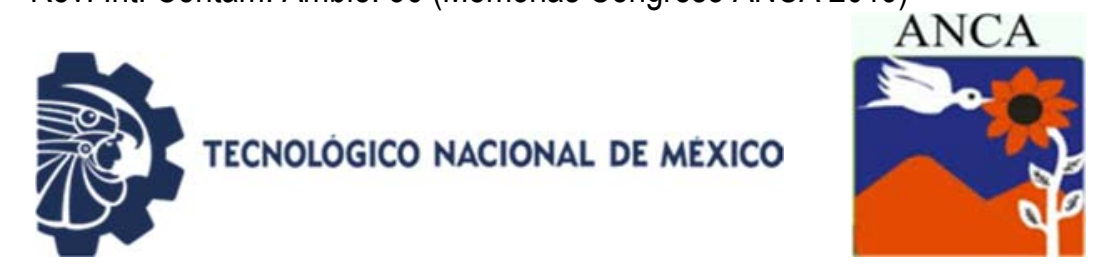

Reconstrucción de la precipitación invierno-primavera de la cuenca del río mayo con anillos de crecimiento de coníferas y datos del Modelo NLDAS-2

\author{
Martínez Sifuentes $A^{1}$, Villanueva Díaz $\mathrm{J}^{2}$, Estrada Ávalos $\mathrm{J}^{3}$, \\ Puentes Gutiérrez J1 \\ ${ }^{1}$ Facultad de Agricultura y Zootecnia. \\ Universidad Juárez del Estado de Durango, México \\ ${ }^{2}$ Laboratorio Nacional de Dendrocronología. \\ Instituto Nacional de Investigaciones Forestales, Agrícolas y Pecuarias \\ ${ }^{3}$ Laboratorio de Sistemas de Información Geográfica. \\ Instituto Nacional de Investigaciones Forestales, Agrícolas y Pecuarias \\ im_aldo09@hotmail.com
}

\title{
RESUMEN
}

Se realizó una reconstrucción estacional de precipitación octubre-mayo mediante técnicas dendrocronológicas, obteniéndose muestras de rodales de cuatro sitios en Chihuahua, para luego ser fechadas al año exacto de su formación y posteriormente obtener los índices de ancho de anillo. Mediante un análisis de componentes principales se obtuvo la serie dendrocronológica que mejor reflejó la variabilidad temporal. La variable de precipitación se obtuvo a través del modelo NLDAS-2 de la base de datos raster de NASA. Se creó un modelo de respuesta climática entre el índice de ancho de anillo y la precipitación, obteniéndose una mayor significancia para el periodo octubre-mayo. Se validó el modelo generado mediante la subrutina verify de la librería del DPL. Se generó una reconstrucción estacional de la precipitación desde 1745 hasta 2014 (273 años) para la cuenca del río Mayo.

Palabras claves: Dendrocronología, Paleoclimatología, precipitación, Sonora.

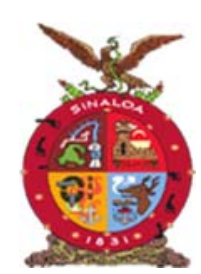

XVIII Congreso Internacional

XXIV Congreso Nacional de Ciencias ambientales

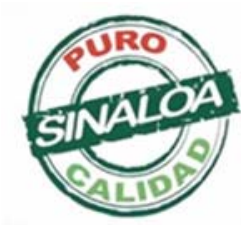

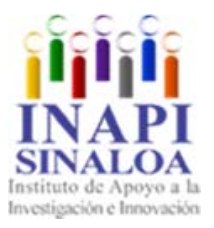

Mazatlán, Sinaloa 3-7 junio 2019

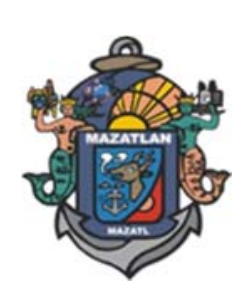

Recursos Naturales, Ecosistemas y Deterioro Ambiental 

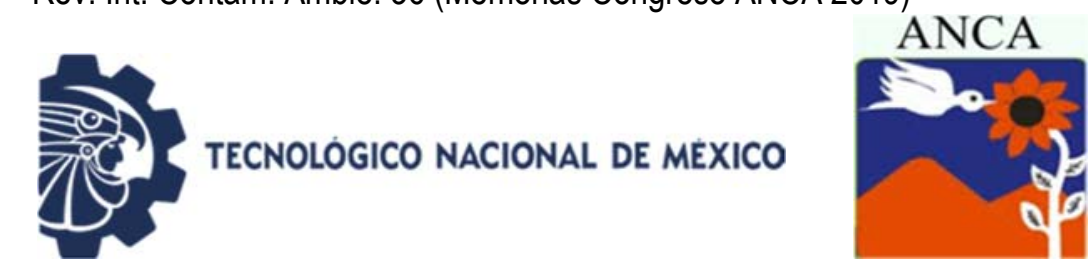

\title{
Reconstruction of the winter-spring precipitation of the mayo river basin with conifer growth rings and Model Data NLDAS-2
}

\author{
Martínez Sifuentes $\mathrm{A}^{1}$, Villanueva Díaz $\mathrm{J}^{2}$, Estrada Ávalos $\mathrm{J}^{3}$, \\ Puentes Gutiérrez $\mathrm{J}^{1}$ \\ ${ }^{1}$ Facultad de Agricultura y Zootecnia. \\ Universidad Juárez del Estado de Durango, México \\ ${ }^{2}$ Laboratorio Nacional de Dendrocronología. \\ Instituto Nacional de Investigaciones Forestales, Agrícolas y Pecuarias \\ ${ }^{3}$ Laboratorio de Sistemas de Información Geográfica. \\ Instituto Nacional de Investigaciones Forestales, Agrícolas y Pecuarias \\ im_aldo09@hotmail.com
}

\begin{abstract}
A seasonal reconstruction of precipitation was carried out using dendrochronological techniques. Four sites located in Chihuahua were visited for tree coring collection, in order to be later dated to the exact year of their formation and subsequently obtain the ring width indexes. A principal component analysis was used to better reflect the temporal variability of dendrochronological series. The precipitation variable was obtained by using the NASA's NLDAS-2 database. A climate response model was created between the ring width index and precipitation, obtaining a greater significance for the October-May period. The generated model was successfully validated using the verify subroutine of the DPL library. A seasonal reconstruction of the precipitation was generated from 1745 to 2014 (273 years) for the Mayo river basin.
\end{abstract}

Keywords: Dendrochronology, Paleoclimatology, precipitation, Sonora.

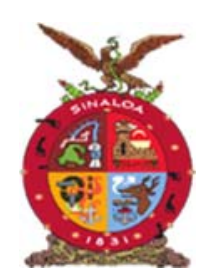

XVIII Congreso Internacional XXIV Congreso Nacional de Ciencias ambientales
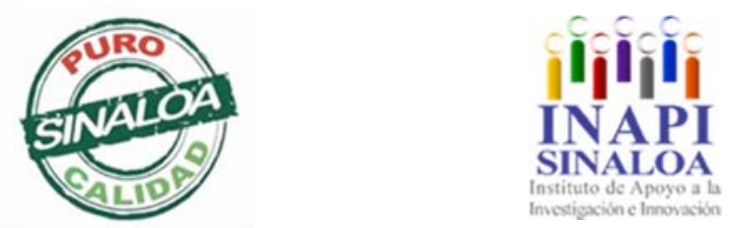

Mazatlán, Sinaloa 3-7 junio 2019 

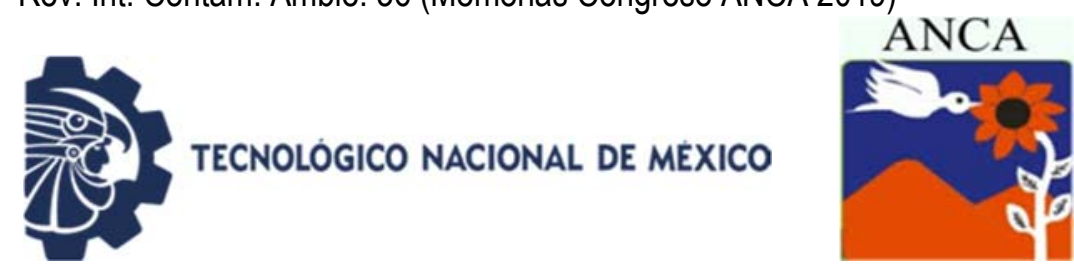

\title{
La utilización del carbón vegetal en la elaboración de mezclas de cemento
}

\author{
Mata Carrillo E*, Cortés Badillo E, Carbajal Ávila J, Salmerón Calvario A \\ Investigadores del Instituto Tecnológico de Acapulco, Guerrero, México \\ *prof.mata@gmail.com
}

\begin{abstract}
RESUMEN
El aprovechamiento adecuado de cualquier recurso natural se traduce en una fuente de riqueza y mejoramiento económico para el país que sepa utilizarlo. En el caso del recurso forestal maderable, por ser renovable, es inagotable, siempre y cuando su manejo sea racional. En México, los usos a los que se destina la madera son: celulosa, escuadría, combustible (leña y carbón), postes, pilotes, morillos, durmientes, chapa y madera contrachapada (triplay). La utilización de la madera en la construcción es muy alto, tan solo inferior al uso del concreto y del acero. Este estudio parte de la hipótesis de aprovechar la madera más allá de su vida útil, es decir, en el momento en que tradicionalmente sirve y se desecha está como combustible. El objetivo general es utilizar el carbón vegetal en la industria de la construcción como aditivo en la mezcla del mortero de cemento "Portland" para utilizarlo en los acabados de las viviendas y edificios. Se realizarn pruebas en el Laboratorio de Materiales del Instituto Tecnológico de Acapulco desde agosto de 2018, los materiales utilizados fueron: cemento Portland, agua y polvo de carbón vegetal. La combinación de estos tres materiales da como resultado el mortero en estudio. El equipo utilizado para las pruebas es: moldes cúbicos, Máquina Universal y Aparato de Vicat. Comparando los resultados con base a las NMX-C-122 y NMX-C-057, los resultados obtenidos a 3, 7 y 14 días superan la resistencia de los morteros convencionales, por lo que se presenta un futuro promisorio en la utilización del carbón vegetal en la elaboración de morteros.
\end{abstract}

Palabras clave: Carbón vegetal, cemento, mortero, construcción.

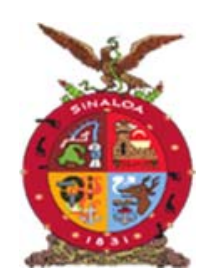

XVIII Congreso Internacional XXIV Congreso Nacional de Ciencias ambientales

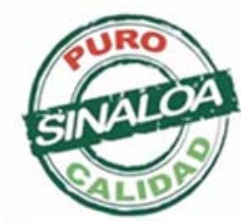

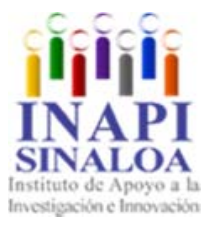

Mazatlán, Sinaloa 3-7 junio 2019

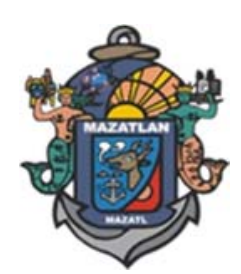

Recursos Naturales, Ecosistemas y Deterioro Ambiental 

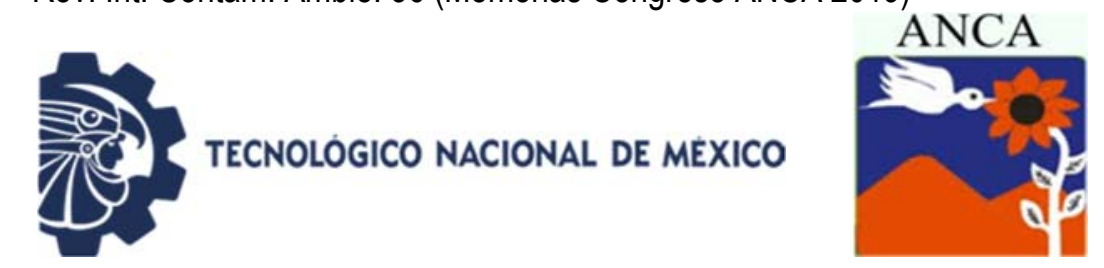

\title{
The use of charcoal in the production of cement mixtures
}

\author{
Mata Carrillo E*, Cortés Badillo E, Carbajal Ávila J, Salmerón Calvario A \\ Investigadores del Instituto Tecnológico de Acapulco, Guerrero, México \\ *prof.mata@gmail.com
}

\begin{abstract}
Proper use of any natural resource translates into a source of wealth and economic improvement for the country who knows how to use it. In the case of timber forest resources, as renewable, it is inexhaustible, provided their handling is rational. In Mexico, the uses to which relates to wood are: cellulose, scantling, fuel (wood and coal), Poles, piling, andirons, sleepers, veneer and plywood (plywood). The use of wood in construction is very high, just less than concrete and steel. Study part of the hypothesis of using wood beyond their useful life, i.e., at the time that traditionally only served as fuel. The general objective is to use the charcoal in the construction industry as an additive in the mortar of Portland cement and water mixture to be used in the finishing of dwellings and buildings. The tests are performed in the laboratory of materials of the technological Institute of Acapulco since August 2018. The materials used are: Portland cement, water and charcoal powder. The combination of these three materials resulting in the mortar in study. The equipment used for testing is: cubic moulds, universal machine and Vicat apparatus. The NMX-C-122 and NMX-C-057 applied. The results obtained at 3,7 and 14 days exceed the resistance of conventional mortars so it presents a promising future in the use of charcoal in the production of mortars.
\end{abstract}

Keywords: Cement, mortar, charcoal, construction.

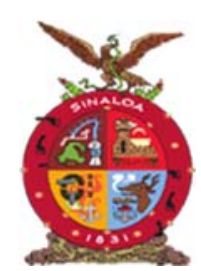

XVIII Congreso Internacional XXIV Congreso Nacional de Ciencias ambientales

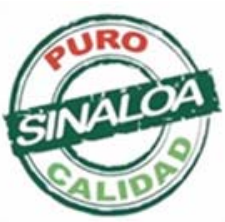

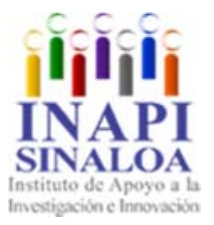

Mazatlán, Sinaloa 3-7 junio 2019

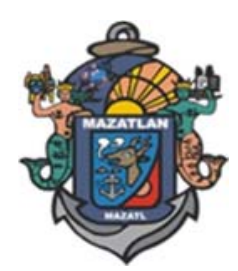

Recursos Naturales, Ecosistemas y Deterioro Ambiental 

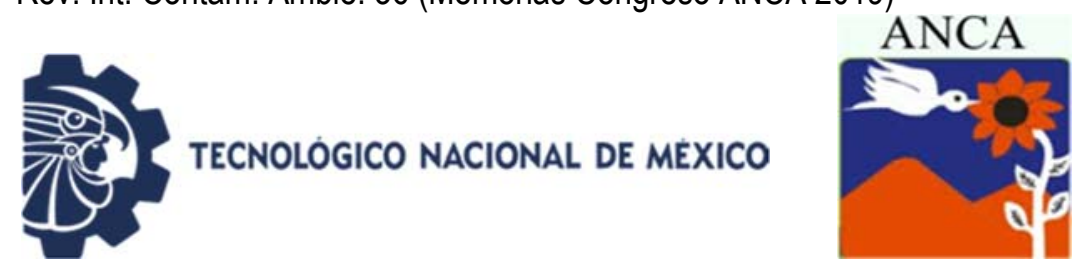

\section{Evaluación de la mineralización de biosólidos para la potencial reutilización como enmienda orgánica}

Medina Herrera $\mathrm{M}^{1}$, Negrete Rodríguez $\mathrm{X}^{2}$, Campaña $\mathrm{H}^{3}$, Conde Barajas $\mathrm{E}^{2^{*}}$

${ }^{1}$ Departamento de Ingeniería Bioquímica

${ }^{2}$ Departamento de Ingeniería Ambiental. Posgrado en Ingeniería Bioquímica.

Tecnológico Nacional de México en Celaya. Antonio García Cubas \# 600

Colonia FOVISSSTE. C.P. 38010, Celaya, Guanajato, México

${ }^{3}$ Grupo de Estudio Ambiente Química y Biológica. Facultad Regional Bahía

Blanca. Universidad Tecnológica Nacional. Buenos Aires, Argentina eloy.conde@itcelaya.edu.mx

\section{RESUMEN}

Los biosólidos obtenidos de efluentes domésticos, son materiales aptos para ser aprovechados como enmienda orgánica de suelos por su contenido de $\mathrm{C}$, nutrientes y micronutrientes. En México, los biosólidos producidos en plantas de tratamiento aeróbico de aguas residuales (PTAR) son de interés por las cantidades producidas. El objetivo de este trabajo fue evaluar el proceso de mineralización de $\mathrm{C}$ y $\mathrm{N}$ de sólo biosólidos durante un año, para establecer estrategias de manejo y aprovechamiento. Se tomaron muestras de biosólidos de la PTAR de Celaya, Gto., cada tres meses en 2018. La experimentación fue a escala laboratorio en microcosmos. El muestreo fue aleatorio los días $0,3,7,14$ y 28 en cada período, y se determinó el $\mathrm{CO}_{2}$ emitido, $\mathrm{N}$ inorgánico $\left(\mathrm{N}-\mathrm{NH}_{3}, \mathrm{~N}-\right.$ $\mathrm{NH}_{4}{ }^{+}$y N-NO${ }_{3}^{-}$), $\mathrm{C}$ de la biomasa microbiana (C-BM) y actividad microbiana por FDA. Al inicio y final del experimento (0 y 28 días) también se determinó el carbón orgánico total (COT) y nitrógeno total $\left(\mathrm{N}_{\mathrm{T}}\right)$ para evaluar los porcentajes de mineralización final. Los biosólidos alcanzaron valores de $2200 \mathrm{mg} \mathrm{C}-\mathrm{CO}_{2} / \mathrm{kg}$ biosólido seco, con un $25 \%$ de mineralización de su COT inicial. Los resultados fueron analizados estadísticamente, observándose: una disminución de $\mathrm{N}-\mathrm{NH}_{4}{ }^{+}$ , un incremento en la emisión de $\mathrm{NH}_{3}$ y contenido de $\mathrm{N}^{-N^{2}}{ }_{3}$, y $46.56 \%$ de $\mathrm{N}_{T}$ mineralizado. C-BM y FDA disminuyeron, 33 y $20 \%$, respectivamente. Los biosólidos presentaron una alta disponibilidad de $\mathrm{C}$ y N , factores esenciales para su potencial aplicación a suelos agrícolas como enmienda orgánica.

Palabras clave: Mineralización, carbono, nitrógeno, biosólidos, enmienda suelos.

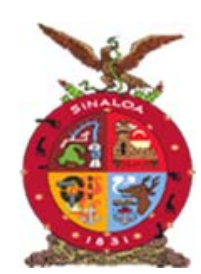

XVIII Congreso Internacional

XXIV Congreso Nacional de Ciencias ambientales
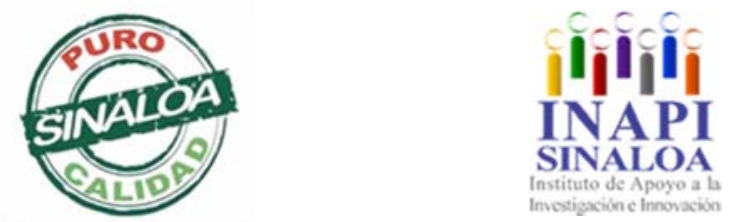

Mazatlán, Sinaloa 3-7 junio 2019

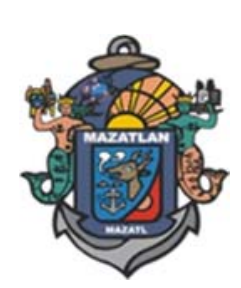

Recursos Naturales, Ecosistemas y Deterioro Ambiental 

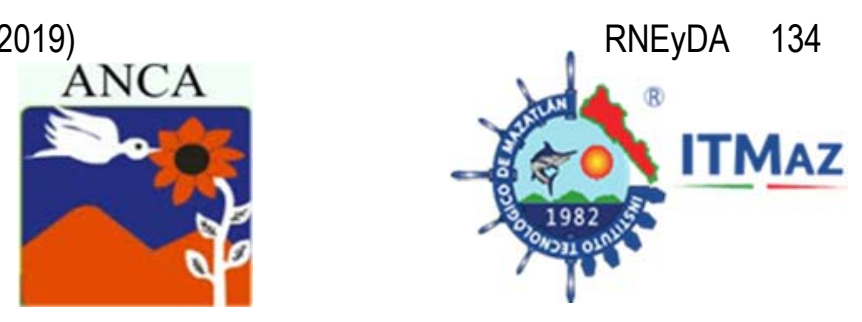

\title{
Evaluation of biosolids mineralization for potential reuse as an organic amendment
}

Medina Herrera $\mathrm{M}^{1}$, Negrete Rodríguez $\mathrm{X}^{2}$, Campaña $\mathrm{H}^{3}$, Conde Barajas $\mathrm{E}^{2^{*}}$

${ }^{1}$ Departamento de Ingeniería Bioquímica

${ }^{2}$ Departamento de Ingeniería Ambiental. Posgrado en Ingeniería Bioquímica.

Tecnológico Nacional de México en Celaya. Antonio García Cubas \# 600

Colonia FOVISSSTE. C.P. 38010, Celaya, Guanajato, México

${ }^{3}$ Grupo de Estudio Ambiente Química y Biológica. Facultad Regional Bahía

Blanca. Universidad Tecnológica Nacional. Buenos Aires, Argentina eloy.conde@itcelaya.edu.mx

\begin{abstract}
Biosolids obtained from domestic sewage are materials that can be used as soil organic amendment because of its $\mathrm{C}$, nutrients and micronutrients contents. Aerobic wastewater treatment plants (WWTPs) production of biosolids are of interest due to the huge quantities generated. The objective of this work was to evaluate the $\mathrm{C}$ and $\mathrm{N}$ mineralization process of only biosolids over one year time period, in order to establish management and strategies to use it. Biosolids were sampled from the Celaya, Gto. WWTP, every three months in 2018. The experimentation was at the laboratory level (microcosms). Sampling was random days $0,3,7,14$ and 28 , and the $\mathrm{CO}_{2}$ emitted, inorganic $\mathrm{N}\left(\mathrm{N}_{-} \mathrm{NH}_{3}, \mathrm{~N}-\mathrm{NH}_{4}{ }^{+}\right.$and $\mathrm{N}-$ $\left.\mathrm{NO}_{3}{ }^{-}\right), \mathrm{C}$ of the microbial biomass (C-BM) and microbial activity by FDA were measured. At the beginning and end of the experiment ( 0 and 28 days) total organic carbon (TOC) and total nitrogen $\left(\mathrm{N}_{\mathrm{T}}\right)$ were also measured to evaluate the mineralization trend and final (annual) percentage. The biosolids reached values of $2200 \mathrm{mg} \mathrm{C}-\mathrm{CO}_{2} / \mathrm{kg}$ (dry matter), with $25 \%$ mineralization of their initial TOC. N decreased in $\mathrm{N}^{-\mathrm{NH}_{4}}{ }^{+}$content was observed, as well as an increase in $\mathrm{NH}_{3}$ emission and $\mathrm{N}-\mathrm{NO}_{3}$-content, $46.56 \%$ of mineralized $\mathrm{N}_{T}$ being observed. However, C-BM and FDA decreased, 33 and $20 \%$, respectively. The biosolids showed presented high C-N availability, key factors for some feasible application to agricultural soils as organic amendment.
\end{abstract}

Keywords: Mineralization, carbon, nitrogen, biosolids, soil amendment.

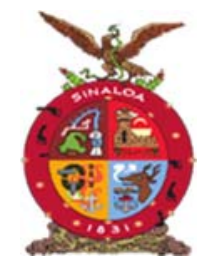

XVIII Congreso Internacional

XXIV Congreso Nacional de Ciencias ambientales

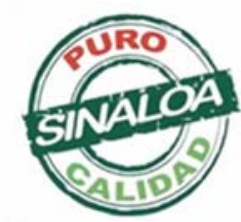

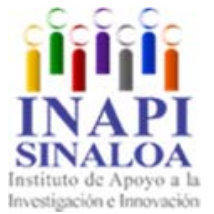

Mazatlán, Sinaloa 3-7 junio 2019

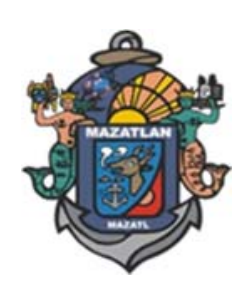

Recursos Naturales, Ecosistemas y Deterioro Ambiental 

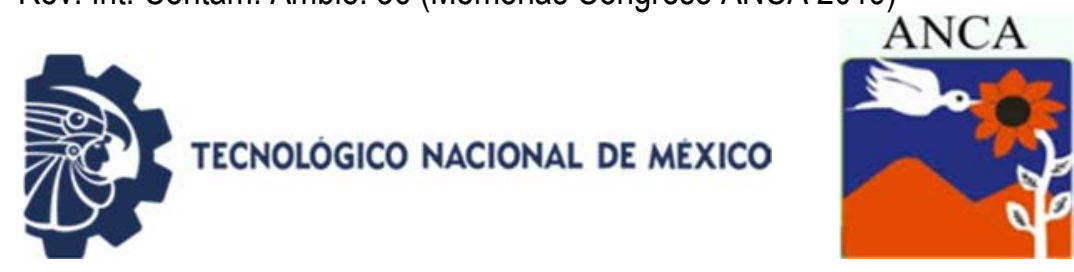

\title{
Bálsamo orgánico con extracto de residuos de flor de Jamaica
}

\author{
Medina Mejia M, Ramirez Hernandez J, Salamanca Rodriguez M, \\ Tahuilan Garcia J, Sánchez Ramirez H* \\ Universidad Tecnológica del Valle de Toluca. \\ Carr. del Departamento del D.F. Km. 7.5, C.P. 52044, \\ Santa María Atarasquillo, Lerma, México \\ *hortencia.sanchez@utvtol.edu.mx
}

\section{RESUMEN}

El volumen de los residuos orgánicos que se generan actualmente es muy alto y tiene un fuerte impacto en la disposición final, ya que presentan un porcentaje alto de humedad (50-60\%). Uno de los problemas a evitar es disminuir el depósito de los mismos mediante el aprovechamiento de un residuo orgánico. El objetivo del presente trabajo fue elaborar un bálsamo labial a base de productos orgánicos como residuos de flor de Jamaica. Se llevo a cabo la recolecta de muestra de un restaurante que utiliza la flor de Jamaica para la elaboración de sus aguas frescas, obteniendo las propiedades del extracto como el color, sabor y aroma. Mediante técnicas de prueba y error el proceso de lixiviación por extracción con el método Soxhlet se colocó $100 \mathrm{~mL}$ de alcohol etílico en concentraciones de 96 , 50 y $25 \%$ para conocer que concentración de alcohol era la ideal para la extracción y obtención de propiedades adecuadas, se mezcló el petrolato con la cera de abeja y se homogenizó hasta obtener el bálsamo, el cual se colocó para su presentación en un recipiente ya usado en forma de esfera. Con esto se fomenta el hábito del reciclaje, sin embargo, la concentración adecuada para obtener todas las propiedades con el poco residuo es de $25 \%$ de alcohol etílico. Muchos de los bálsamos actuales los venden a un muy alto precio y están elaborados con muchos químicos los cuales provocan alergias, mientras que éste es natural y se puede elaborar muy fácilmente y aunado a ello se aprovecha el residuo orgánico evitando que llegue a la disposición final y que tarde tiempo en degradarse

Palabras clave: Aprovechamiento, flor de Jamaica, lixiviación, residuos orgánicos.

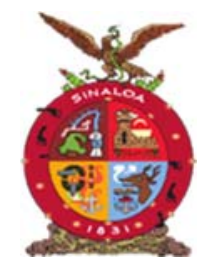

XVIII Congreso Internacional

XXIV Congreso Nacional de Ciencias ambientales

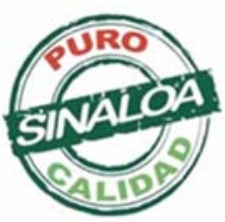

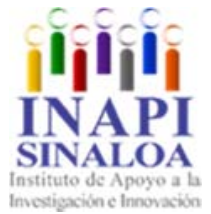

Mazatlán, Sinaloa 3-7 junio 2019

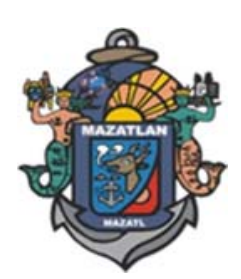

Recursos Naturales, Ecosistemas y Deterioro Ambiental 

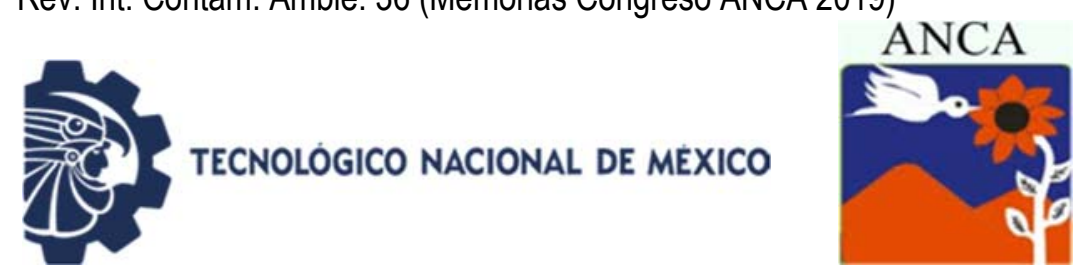

\title{
Organic balm with extract of JAMAICA flower waste
}

\author{
Medina Mejia M, Ramirez Hernandez J, Salamanca Rodriguez M, \\ Tahuilan Garcia J, Sánchez Ramirez H* \\ Universidad Tecnológica del Valle de Toluca. \\ Carr. del Departamento del D.F. Km. 7.5, C.P. 52044, \\ Santa María Atarasquillo, Lerma, México \\ *hortencia.sanchez@utvtol.edu.mx
}

\begin{abstract}
The volume of organic waste that is currently generated is very high and has a strong impact on the final disposal, since they have a high percentage of humidity $(50-60 \%)$. One of the problems to avoid is to reduce the deposit of the same by the use of an organic waste. The objective of the present work was to elaborate a lip balm based on organic products as residues of the Jamaica flower. We carried out the sample collection of a restaurant that uses the flower of Jamaica for the elaboration of its fresh waters, obtaining the properties of the extract as the color, flavor and aroma. By means of trial and error techniques, the leaching process by extraction with the Soxhlet method was placed $100 \mathrm{~mL}$ of ethyl alcohol in concentrations of 96,50 and $25 \%$. To know that alcohol concentration was ideal for the extraction and obtaining of adequate properties, the petrolatum was mixed with the beeswax and homogenized until the balsam was obtained, which was placed for presentation in a container already used in the form of a sphere. This encourages the habit of recycling, however, the proper concentration to obtain all the properties with little waste is $25 \%$ ethyl alcohol. Many of the current balms sell them at a very high price and are made with many chemicals which cause allergies, while this is natural and can be made very easily and coupled with this, organic waste is used, preventing it from reaching the final.
\end{abstract}

Keywords: Jamaica flower, leaching, organic waste, use.

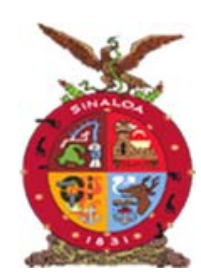

XVIII Congreso Internacional XXIV Congreso Nacional de Ciencias ambientales
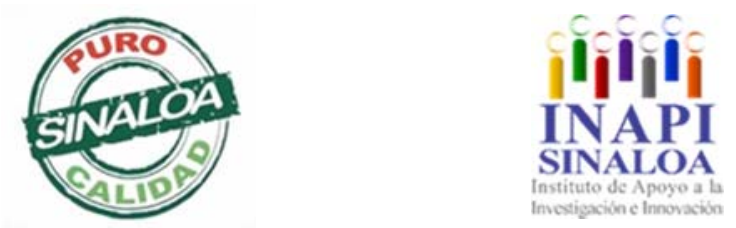

Mazatlán, Sinaloa 3-7 junio 2019

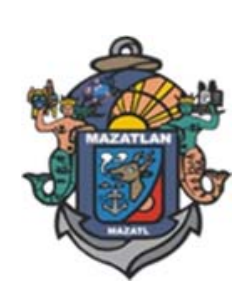

Recursos Naturales, Ecosistemas y Deterioro Ambiental 

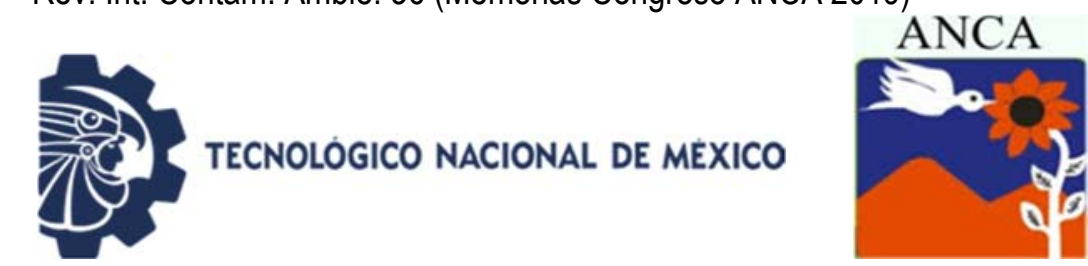

\title{
Efecto de la exposición en el tamaño de la hoja de Agave nussaviorum García-Mend en Santiago Huauclilla, Oaxaca
}

\author{
Merino Negrete $\mathrm{O}^{1}$, Campos Ángeles $\mathrm{GV}^{2}$, Zamora Alvarado $\mathrm{R}^{3}$ \\ Rodríguez Ortiz $\mathrm{G}^{2}$, Enríquez del Valle $\mathrm{JR}^{2}$ \\ ${ }^{1}$ Maestría en Ciencias en Productividad de Agroecosistemas \\ ${ }^{2}$ Posgrado Instituto Tecnológico del Valle de Oaxaca \\ ${ }^{3}$ Laboratorio de Inmunobiología Molecular.
}

Instituto Tecnológico del Valle de Oaxaca. Facultad de Medicina UNAM-APEC.

Ex-Hacienda de Nazareno, Unidad Periférica, Xoxocotlán, Oaxaca, México hade_eu@hotmail.com

\section{RESUMEN}

El objetivo de este trabajo fue analizar el efecto de la exposición (norte y este) en la hoja del maguey papalometl (Agave nussaviorum García-Mend), ubicado en el municipio de Santiago Huauclilla. Los caracteres morfológicos evaluados fueron el largo, ancho y número de hojas. La variabilidad en estos caracteres debido a las condiciones de humedad, horas luz y otros factores, están determinadas por la exposición. Estos temas son de interés ya que proporcionan bases para el aprovechamiento y conservación del maguey, a partir de las variaciones que exhiben. Para evaluar el efecto de la exposición en la hoja del maguey, se utilizó la prueba de bondad de ajuste Ji cuadrada $(\alpha=0.05)$. No se encontró efecto de la exposición en los caracteres evaluados, siendo el número de hojas el carácter menos influenciado ( $p=0.464)$; para el ancho y largo de la hoja se obtuvo $p=$ 0.220 y $p=0.218$, respectivamente.

Palabras clave: Muestreo selectivo, papalometl.

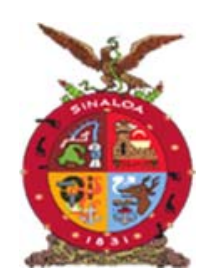

XVIII Congreso Internacional

XXIV Congreso Nacional de Ciencias ambientales

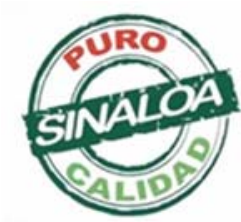

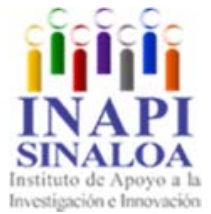

Mazatlán, Sinaloa 3-7 junio 2019

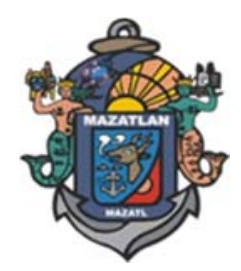

Recursos Naturales, Ecosistemas y Deterioro Ambiental 

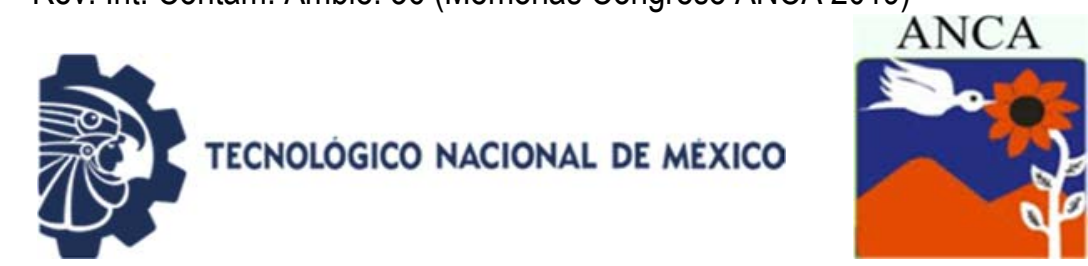

\title{
Effect of exposure on the size of the leaf of Agave nussaviorum García- Mend in Santiago Huauclilla, Oaxaca.
}

\author{
Merino Negrete $\mathrm{O}^{1}$, Campos Ángeles $\mathrm{GV}^{2}$, Zamora Alvarado $\mathrm{R}^{3}$ \\ Rodríguez Ortiz $\mathrm{G}^{2}$, Enríquez del Valle $\mathrm{JR}^{2}$ \\ ${ }^{1}$ Maestría en Ciencias en Productividad de Agroecosistemas \\ ${ }^{2}$ Posgrado Instituto Tecnológico del Valle de Oaxaca \\ ${ }^{3}$ Laboratorio de Inmunobiología Molecular.
}

Instituto Tecnológico del Valle de Oaxaca. Facultad de Medicina UNAM-APEC.

Ex-Hacienda de Nazareno, Unidad Periférica, Xoxocotlán, Oaxaca, México hade_eu@hotmail.com

\begin{abstract}
The purpose in this manuscript was to analyze the effect of exposure (north and east) on the leaf of the maguey papalometl (Agave nussaviorum García-Mend), located in the municipality of Santiago Huauclilla. The morphological characters evaluated were the length, width and number of leaves. The variability on these characters due to humidity conditions, light hours and other factors are determined by exposure. These topics are of interest since they provide bases for the exploitation and conservation of the maguey, from the variations that they exhibit. To evaluate the effect of the exposure on the maguey leaf, the chi-square goodness of fit test $(\alpha=0.005)$ was used. No effect of the exposure on the evaluated characters was found, with the number of leaves being the least influenced $(p=$ .464 ); for the width and length of the leaf, $p=0.220$ and $p=0.218$ were obtained, respectively.
\end{abstract}

Keywords: Selective sampling, papalometl.

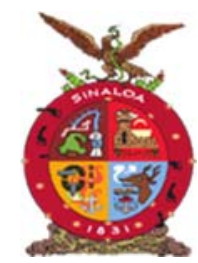

XVIII Congreso Internacional XXIV Congreso Nacional de Ciencias ambientales

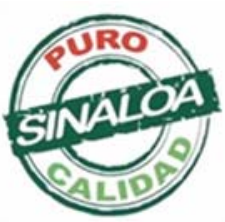

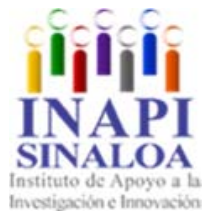

Mazatlán, Sinaloa 3-7 junio 2019

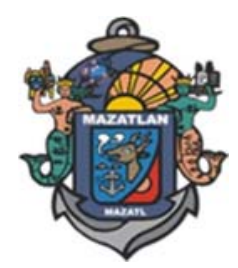

Recursos Naturales, Ecosistemas y Deterioro Ambiental 

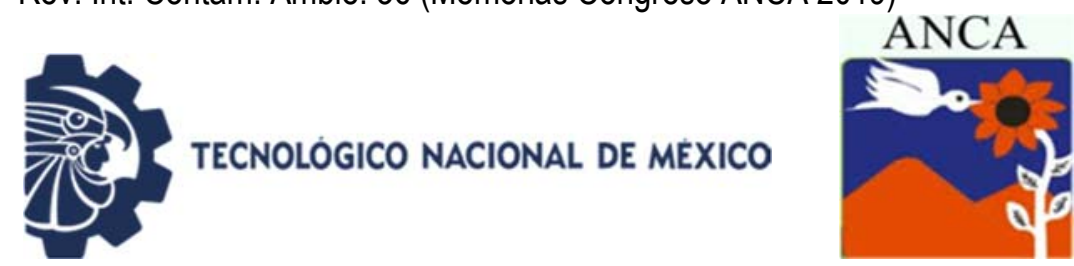

\title{
Caracterización química y funcional de la clorofila obtenida de la microalga Dunaliella tertiolecta
}

\author{
Meza Ayala K ${ }^{1}$, Germán Báez $L^{1}$, Luna Avelar $\mathrm{K}^{1}$, Santos Ballardo $D^{2}$, \\ Valdez Ortiz $A^{1 *}$ \\ ${ }^{1}$ Universidad Autónoma de Sinaloa. México \\ 2Universidad Politécnica de Sinaloa. México \\ *avaldez@uas.edu.mx
}

\section{RESUMEN}

Las microalgas marinas son consideradas una fuente natural de compuestos bioactivos, muchos de los cuales son utilizados en productos comerciales alimenticios como la clorofila, una molécula con propiedades bioactivas de enorme demanda en el mercado internacional. Una fuente alternativa, simple, confiable y rentable de clorofila podría ser Dunaliella tertiolecta, debido tanto a sus características morfológicas como de crecimiento. En el presente trabajo se realizó la caracterización química y funcional de la clorofila obtenida de $D$. tertiolecta; para ello, la extracción se realizó utilizando solventes orgánicos; se calculó la concentración de las fracciones total $a$ y $b$, y se caracterizaron mediante espectrofotometría UV-Visible e infrarroja 400-450 y 600-690 nm. Adicionalmente, a la clorofila obtenida y caracterizada, se le evaluó su actividad antibacteriana contra $S$. aureus y su capacidad antioxidante (ORAC). Los principales grupos funcionales de la molécula de clorofila se identificaron mediante espectrofotometría infrarroja. Los valores de concentración de clorofila total y sus fracciones $a$ y $b$, fueron $17.86,9.37$ y $6.49 \mathrm{mg} \mathrm{g}^{-1}$, respectivamente. La actividad antibacteriana mostró valores de CMI de 10 y $11 \mu \mathrm{g} \mathrm{LL}^{-1}$ para $\mathrm{S}$. aureus ATCC 92125 y ATCC 43300, respectivamente; y valores de CMB de 13 $\mu \mathrm{g} \mu \mathrm{L}^{-1}$ para ambas cepas. Respecto a la capacidad antioxidante, esta fue de $399.7 \mu \mathrm{molET} \mathrm{g}{ }^{-1}$. La caracterización espectrofotométrica confirmó la presencia de clorofila mediante los espectros particulares de la molécula, misma que mostró propiedades similares a los productos comerciales, con rendimientos rentables. Se validó la capacidad antioxidante y capacidad para inhibir el crecimiento de $S$. aureus.

Palabras claves: Dunaliella tertiolecta, clorofila, análisis espectrofotométrico, actividad antibacteriana, capacidad antioxidante.

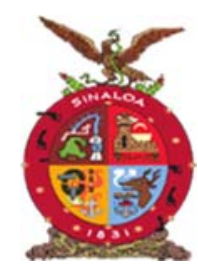

XVIII Congreso Internacional

XXIV Congreso Nacional de Ciencias ambientales

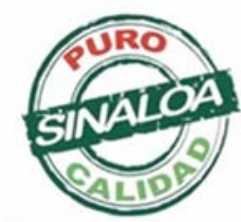

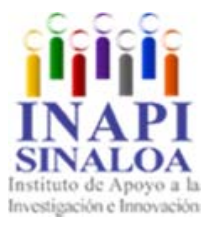

Mazatlán, Sinaloa 3-7 junio 2019

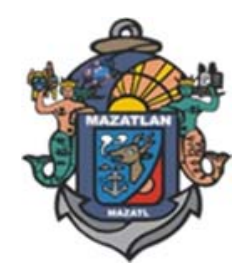

Recursos Naturales, Ecosistemas y Deterioro Ambiental 

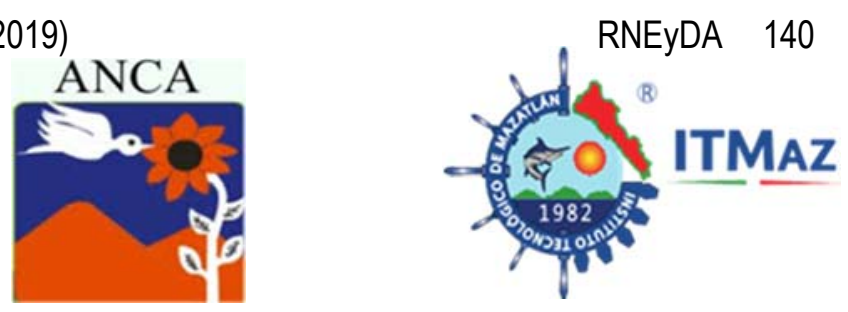

\title{
Chemical and functional characterization of chlorophyll obtained from Dunaliella tertiolecta
}

\author{
Meza Ayala K ${ }^{1}$, Germán Báez $L^{1}$, Luna Avelar $\mathrm{K}^{1}$, Santos Ballardo $D^{2}$, \\ Valdez Ortiz $A^{1 *}$ \\ ${ }^{1}$ Universidad Autónoma de Sinaloa. México \\ ${ }^{2}$ Universidad Politécnica de Sinaloa. México \\ *avaldez@uas.edu.mx
}

\begin{abstract}
Marine microalgae are considered as a natural source of bioactive compounds, many of which are used in commercial food products such as chlorophyll, a molecule with bioactive properties and enormous demand in the international market. An alternative source, simple, reliable and profitable of chlorophyll could be Dunaliella tertiolecta, due to its morphological and growth characteristics. In the present work the chemical and functional characterization of chlorophyll obtained from $D$. tertiolecta were performed. To do that, the extraction was carried out using organic solvents; subsequently, the concentration (total fraction, $a$ and $b$ ) was calculated and characterized by UV-Visible and infrared spectrophotometry. Additionally, the antibacterial activity (against $S$. aureus) and the antioxidant capacity (ORAC) of the obtained chlorophyll were evaluated. The UV spectrophotometric analyses showed absorption maxima within the ranges of 400 $450 \mathrm{~nm}$ and $600-690 \mathrm{~nm}$, while the main functional groups of chlorophyll were identified by infrared spectrophotometry. On the other hand, the concentration values of total chlorophyll, and its fractions, a and b, were 17.86, 9.37 and 6.49 $\mathrm{mg} \mathrm{g}^{-1}$, respectively. In addition, the antibacterial activity showed MIC values of 10 and $11 \mu \mathrm{g} \mathrm{LL}^{-1}$ for strains ATCC-92125 and ATCC-43300, respectively, while the $\mathrm{CMB}$ values were $13 \mu \mathrm{g} \mathrm{LL}^{-1}$ for both strains. Regarding to the antioxidant capacity, this was $399.7 \mu$ molET $\mathrm{g}^{-1}$. The spectrophotometric characterization showed the characteristic spectra of the chlorophyll confirming the identity of the molecule and proving that this has similar characteristics to commercial products. Additionally, in the present work, the antioxidant capacity and the ability to inhibit the growth of $S$. aureus of the chlorophyll obtained from Dunaliella tertiolecta have been validated.
\end{abstract}

Keywords: Dunaliella tertiolecta, chlorophyll, spectrophotometric analyses, antibacterial activity, antioxidant capacity.

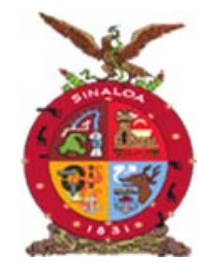

XVIII Congreso Internacional

XXIV Congreso Nacional de Ciencias ambientales

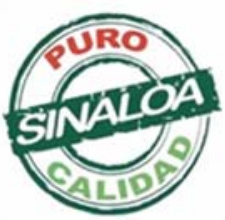

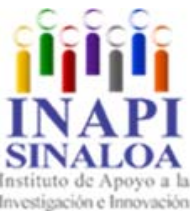

Mazatlán, Sinaloa 3-7 junio 2019

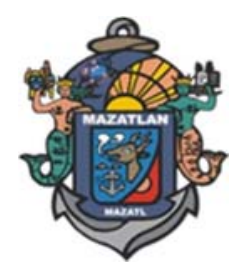

Recursos Naturales, Ecosistemas y Deterioro Ambiental 

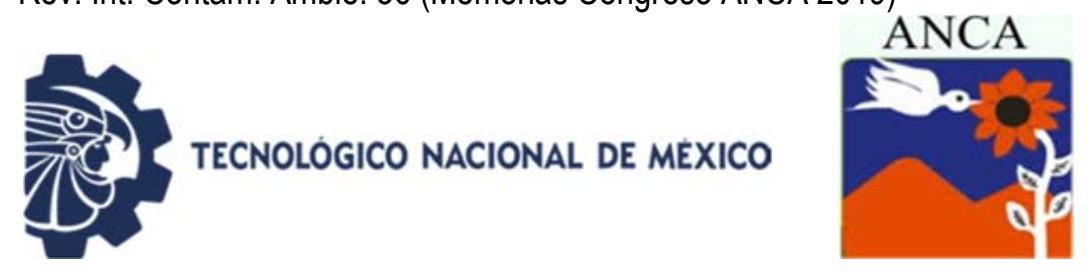

\title{
Uso del lirio acuático como forraje para la alimentación animal
}

\author{
Michel Hernández $A E^{1,2}$, Montañez Valdez $\mathrm{OD}^{1,2^{\star}}$, Reyes Gutiérrez $\mathrm{JA}^{1,2}$, \\ Martinez Ibarra JA ${ }^{1}$, Michel Parra JG ${ }^{1}$ \\ ${ }^{1}$ Centro de Investigación del Lago de Zapotlán y Cuencas (CILZC). \\ Centro Universitario del Sur. Universidad de Guadalajara. México \\ ${ }^{2}$ Grupo de Investigación en Nutrición Animal. Centro Universitario del Sur \\ Universidad de Guadalajara. \\ Ave. Enrique Arreola Silva 883 49000, Ciudad Guzmán, Jalisco, México \\ *montanez77@hotmail.com
}

\begin{abstract}
RESUMEN
Con el objetivo de evaluar el potencial de uso del lirio acuático (Eichhornia crassipes) para alimentación de rumiantes, se colectó $10 \mathrm{~kg}$ de lirio en distintos puntos del lago "Laguna de Zapotlán", ubicado al sur del Jalisco, México, entre los municipios de Gómez Farías y Zapotlán el Grande. Las plantas fueron llevadas a laboratorio de Nutrición Animal del Centro Universitario del Sur de la Universidad de Guadalajara, en Ciudad Guzmán Jalisco, donde se les quitó el exceso de tierra y otros materiales, se separó y elimino la raíz, y se analizó tallo y hoja. El material fue secado en una estufa a $55^{\circ} \mathrm{C}$ por 48 horas y molidos y tamizados en malla de $2 \mathrm{~mm}$ y se les determino materia seca (MS), proteína cruda (PC), fibra cruda (FC) mediante las técnicas descritas por la AOAC (2003), hemicelulosa por diferencia $(\mathrm{H})$ y las fracciones de fibra (FDN y FDA) por el método de Van Soest et al. (1991). La planta de lirio contiene 9.71 de MS, 6.75\% de PC, $11.42 \%$ de FC, con $39.63 \%$ de FDA, $56.37 \%$ de FDN y $16.74 \%$ de hemicelulosa. Con base en los resultados, el lirio acuático, por su contenido proteico, puede ser viable para su uso como alternativa para la alimentación animal, sin embargo, es necesario realizar más estudios enfocados a evaluar su efecto en el rendimiento animal dado que puede ser sumamente ventajosa económicamente su uso en aquellos lugares que tenga gran disponibilidad de esta planta acuática.
\end{abstract}

Palabras clave: Lirio, rumiantes, forraje.

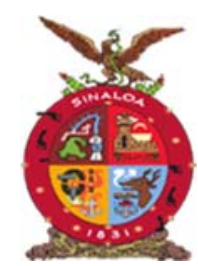

XVIII Congreso Internacional XXIV Congreso Nacional de Ciencias ambientales

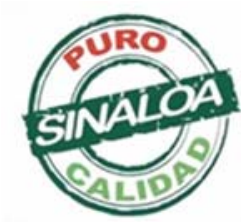

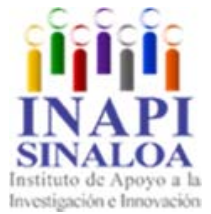

Mazatlán, Sinaloa 3-7 junio 2019

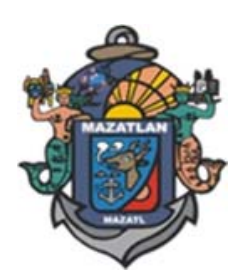

Recursos Naturales, Ecosistemas y Deterioro Ambiental 

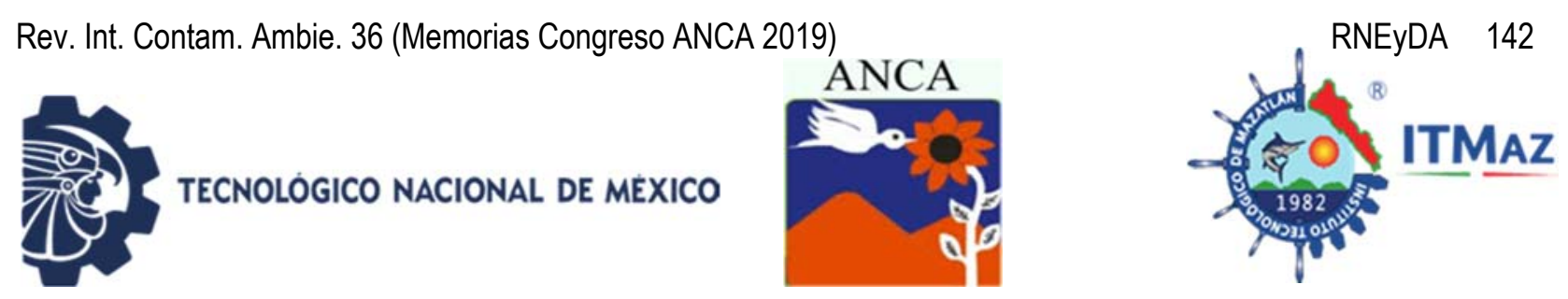

\title{
Use of the Water Hyacinth as fodder for animal feed
}

\author{
Michel Hernández $A E^{1,2}$, Montañez Valdez $\mathrm{OD}^{1,2^{*}}$, Reyes Gutiérrez $\mathrm{JA}^{1,2}$, \\ Martinez Ibarra JA ${ }^{1}$, Michel Parra JG ${ }^{1}$ \\ ${ }^{1}$ Centro de Investigación del Lago de Zapotlán y Cuencas (CILZC). \\ Centro Universitario del Sur. Universidad de Guadalajara. México \\ ${ }^{2}$ Grupo de Investigación en Nutrición Animal. Centro Universitario del Sur \\ Universidad de Guadalajara. \\ Ave. Enrique Arreola Silva 883 49000, Ciudad Guzmán, Jalisco, México \\ *montanez77@hotmail.com
}

\begin{abstract}
In order to evaluate the potential use of the water hyacinth (Eichhornia crassipes) for feeding of ruminants, was collected $10 \mathrm{~kg}$ of water hyacinth in different parts of the Lake "Laguna de Zapotlán", located to the region south of Jalisco, Mexico, between the municipalities of Gómez Farías and Zapotlán el Grande. The plants were taken to laboratory of Animal Nutrition from the University of the South at the University of Guadalajara, in Ciudad Guzmán, Jalisco, where excess soil and other materials were removed, the root was separated and eliminated, and stem and leaf were analyzed. The material was dried in an oven at $55^{\circ} \mathrm{C}$ for 48 hours and milled to $2 \mathrm{~mm}$ and dry matter (DM), crude protein (CP), crude fiber (CF) was determined by the techniques described by AOAC (2003), hemicellulose for difference $(\mathrm{H})$ and the fractions of fiber (NDF and FDA) by the method of Van Soest et al. (1991). The water hyacinth contains 9.71 of DM, $6.75 \%$ of CP, $11.42 \%$ of CF, with $39.63 \%$ of FDA, $56.37 \%$ of NDF and $16.74 \%$ of hemicellulose. Based on the results, the water hyacinth, due to its protein content, can be viable as an alternative for animal feed use, however, it is necessary to conduct more studies focused on evaluating its effect on animal performance, it can be very advantageous economically its use in those places that have high availability of this aquatic plant.
\end{abstract}

Keywords: Lily, ruminants, forage.

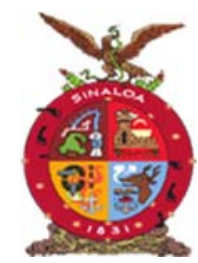

XVIII Congreso Internacional XXIV Congreso Nacional de Ciencias ambientales

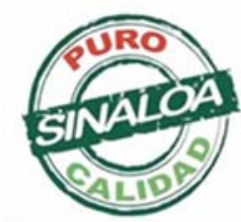

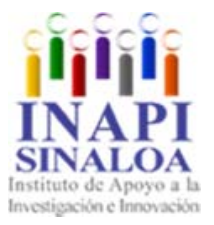

Mazatlán, Sinaloa 3-7 junio 2019

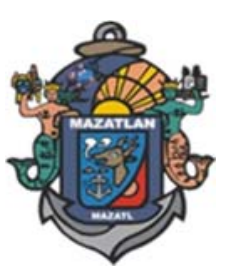

Recursos Naturales, Ecosistemas y Deterioro Ambiental 

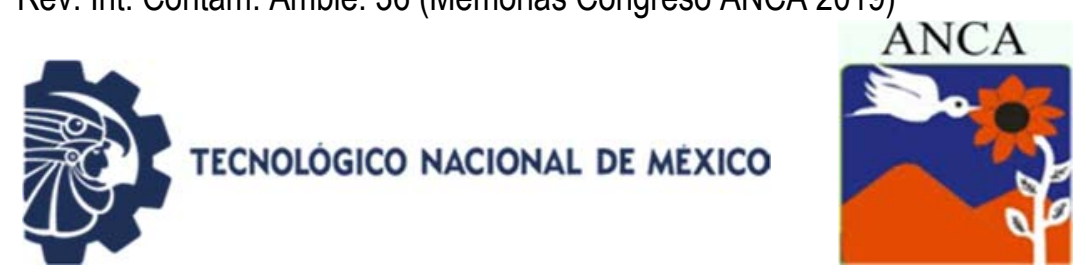

\title{
Invasión de dos especies de maleza acuática en la Laguna de Zapotlán, Jalisco
}

\author{
Michel Parra JG ${ }^{1 *}$, Orendain Verduzco TE², Michel Hernández $\mathrm{AE}^{1}$, \\ Montañez Valdez OD ${ }^{1}$, Cobian Cervantes $\mathrm{R}^{1}$ \\ ${ }^{1}$ Centro Universitario del Sur. Universidad de Guadalajara. \\ Av. Enrique Arreola Silva \# 883, Cd. Guzmán, Jalisco, México \\ ${ }^{2}$ Centro Universitario de Arte, Arquitectura y Diseño UdeG \\ *michelp@cusur.udg.mx
}

\begin{abstract}
RESUMEN
La laguna de Zapotlán es un lago prioritario para su atención ambiental. En México posee dos denominaciones internacionales como sitio Ramsar y como Living Lakes, (lagos vivientes), lo cual compromete a gobiernos, investigadores, académicos, usuarios y sociedad en general a contribuir a fortalecer el programa de protección, conservación y manejo del humedal, como marco de convenios internacionales para la preservación de la naturaleza y su biodiversidad. El saneamiento integral del lago es una prioridad impostergable, ya que el humedal cumpla funciones y servicios ecosistémicos prioritarios, que requiere la participación de usuarios, sociedad organizada, académicos, investigadores y gobiernos, aportando recursos financieros y recursos humano para realizar el cumplimiento de los objetivos y metas establecidos en el control de maleza acuática mediante un programa integral con acciones manuales, mecánicas y biológicas sobre el lirio (Eichhornia crassipes) maleza invasiva la cual a llegando a cubrir un $70 \%$ del espejo de agua en el año 2015, y tule flotante (Typha dominguensis) el cual representa actualmente $6.4 \%$ de acuerdo a imágenes de las tomas satelitales que se realizan cada mes, el espejo máximo de agua en el lago de Zapotlán es de 1,570 has de las cuales, en septiembre 2018 estuvieron cubiertas 571.79 has por maleza acuática lo cual representa el $68.0 \%$, de las cuales 159.39 Has son móviles (12.16\%) y las estáticas 392.46 Has estuvieron cubiertas por maleza acuática que representaron $29.96 \%$, comparado a septiembre del 2018 al año 2016, la maleza móvil representaba el $13.87 \%$ y la maleza estática el $3.85 \%$.
\end{abstract}

Palabras claves: Manejo integral, maleza acuática, lago.

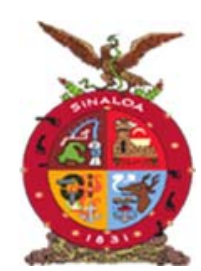

XVIII Congreso Internacional XXIV Congreso Nacional de Ciencias ambientales

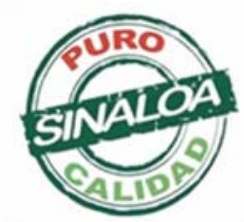$$
\text { XXIV Congreso Nacional de Ciencias ambientales }
$$

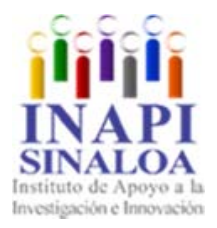

Mazatlán, Sinaloa 3-7 junio 2019

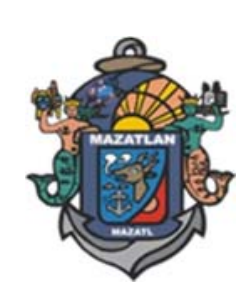

Recursos Naturales, Ecosistemas y Deterioro Ambiental 

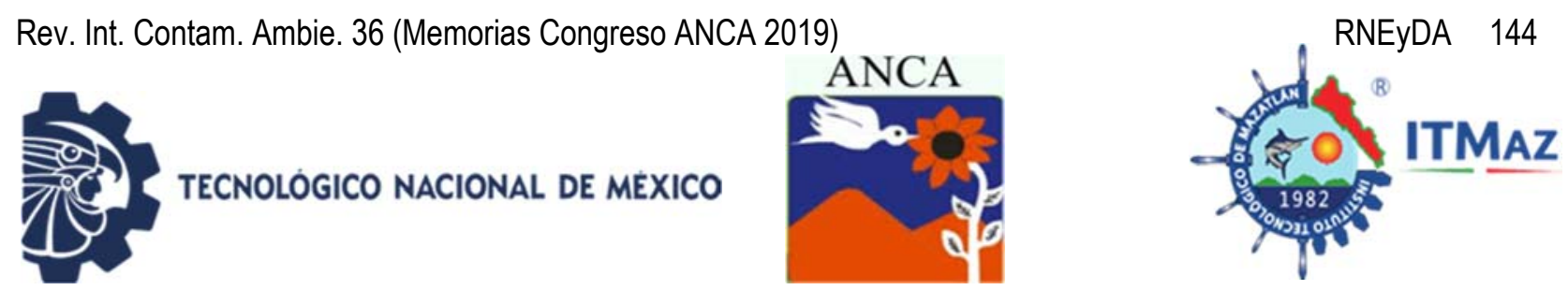

\title{
Situation of the integral sanitation of two aquatic weed species in the Zapotlán Lagoon
}

\author{
Michel Parra JG ${ }^{1 *}$, Orendain Verduzco TE², Michel Hernández $\mathrm{AE}^{1}$, \\ Montañez Valdez OD ${ }^{1}$, Cobian Cervantes $\mathrm{R}^{1}$ \\ ${ }^{1}$ Centro Universitario del Sur. Universidad de Guadalajara. \\ Av. Enrique Arreola Silva \# 883, Cd. Guzmán, Jalisco, México \\ ${ }^{2}$ Centro Universitario de Arte, Arquitectura y Diseño UdeG \\ *michelp@cusur.udg.mx
}

\begin{abstract}
The Zapotlán lagoon is a priority lake in Mexico, with two international designations as Ramsar site and as Living Lakes, (living lakes), which commits governments, researchers, academics, users and society in general to contribute to strengthen the program of protection, conservation and management of the wetland, as a framework of international agreements for the preservation of nature and its biodiversity. Integral sanitation of the lake is an urgent priority, since the wetland fulfills priority ecosystem functions and services. Which requires the participation of users, organized society, academics, researchers and governments, providing financial resources and human resources to carry out compliance with the objectives and goals established in the aquatic weed control. Through an integral program with manual, mechanical and biological actions on the lily (Eichhornia crassipes) invasive undergrowth which reached to cover $70 \%$ of the water mirror in 2015, and floating tule (Typha dominguensis) which currently represents $6.4 \%$ according to satellite images taken every month. The maximum mirror of water in Lake Zapotlán is 1,570 hectares of which in September 2018 is covered $97 \% .571 .79$ hectares arecovered by aquatic weeds, which represents $68.0 \%$. of which 159.39 hectares are mobile representing $12.16 \%$ and the static 392.46 hectares are covered by aquatic weeds representing $29.96 \%$ as of September 2018, unlike 2016, mobile weeds represented $13.87 \%$ and static weeds $3.85 \%$.
\end{abstract}

Keywords: Integrated management, quatic weed, lake.

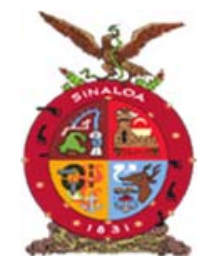

XVIII Congreso Internacional

XXIV Congreso Nacional de Ciencias ambientales

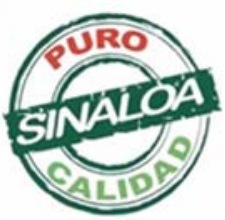

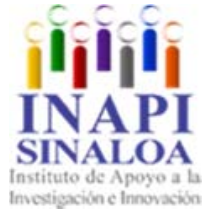

Mazatlán, Sinaloa 3-7 junio 2019

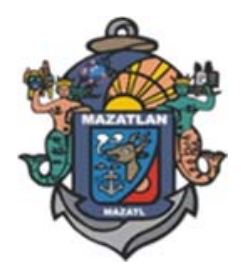

Recursos Naturales, Ecosistemas y Deterioro Ambiental 

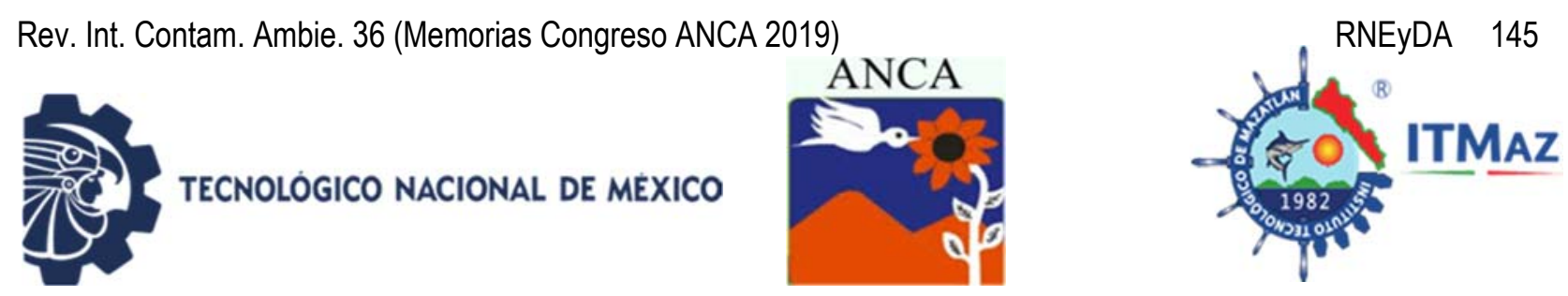

\title{
Análisis del cambio de la cobertura y del uso del suelo en la comunidad de Coatepec, Ixtapaluca, Estado de México
}

\author{
Millán Aguilar E, Linares Fleites G, Avelino Flores F, Ramos Cassellis ME, \\ Valera Pérez MA \\ Posgrado en Ciencias Ambientales. \\ Instituto de Ciencias. Benemérita Universidad Autónoma de Puebla. \\ 4 Sur, No. 104, Col. Centro, C. P. 72000, Puebla, México \\ elmillanm@hotmail.com
}

\begin{abstract}
RESUMEN
La comunidad de Coatepec presenta procesos de deforestación, degradación ambiental y pérdida de biodiversidad, sin embargo existe una fuerte empatía de los habitantes con su entorno. La falta de información sobre estos aspectos limita el diseño de estrategias para disminuir el deterioro ambiental. El objetivo de este estudio consistió en analizar las tendencias en el cambio de la cobertura y del uso del suelo en la comunidad en el periodo 1994-2017. Se llevó a cabo la recopilación y análisis de información local de la cartografía de Uso del Suelo y tipos de vegetación, elaborada por el Instituto Nacional de Estadística Geografía e Informática (INEGI), Serie II de 1994 a la Serie VI de 2017, a escala 1:250,000, con esto fue posible determinar y comparar diez clases de cobertura y uso del suelo municipal en el periodo 2008-2017, se elaboró el mapa de procesos de cambio, se cuantificaron las matrices de transición de las clases obtenidas y se determinaron los patrones y tasas de cambio de la cobertura vegetal. Los resultados indican un incremento de 1,906 ha para la clase Antrópico, pérdidas de 711 ha de Pastizal, 567 ha de Agricultura de temporal, y 421 ha de Agricultura de riego. El bosque de pino y el Bosque de pino encino, registran incrementos de 72 ha y 4 ha respectivamente.
\end{abstract}

Palabras clave: Cobertura vegetal, Sistemas de Información Geográfica, tasas de cambio, dinámica espacio-temporal.

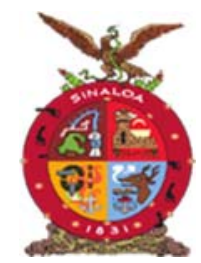

XVIII Congreso Internacional

XXIV Congreso Nacional de Ciencias ambientales

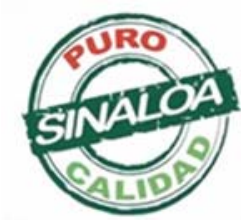

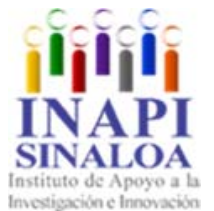

Mazatlán, Sinaloa 3-7 junio 2019

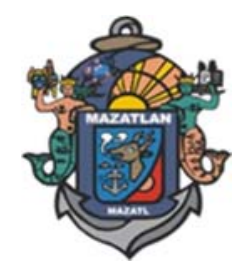

Recursos Naturales, Ecosistemas y Deterioro Ambiental 

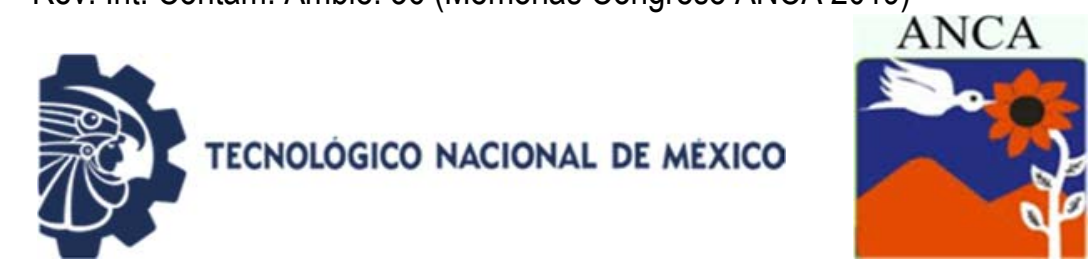

\title{
Analysis of the change in coverage and land use in the community of Coatepec, Ixtapaluca, state of México
}

\author{
Millán Aguilar E, Linares Fleites G, Avelino Flores F, Ramos Cassellis ME, \\ Valera Pérez MA \\ Posgrado en Ciencias Ambientales. \\ Instituto de Ciencias. Benemérita Universidad Autónoma de Puebla. \\ 4 Sur, No. 104, Col. Centro, C. P. 72000, Puebla, México \\ elmillanm@hotmail.com
}

\begin{abstract}
The community of Coatepec presents processes of deforestation, environmental degradation and loss of biodiversity, however there is a strong empathy of the inhabitants with their environment. The lack of information on these aspects limits the design of strategies to reduce the present environmental deterioration. The objective of this study was to analyze trends in the change of coverage and land use in the community in the period 1994-2017. The collection and analysis of local information was carried out and the cartography was used as inputs of Land Use and types of vegetation prepared by the National Institute of Geography and Information Technology (INEGI), Series II of 1994 to Series VI of 2017, at a scale of 1: 250,000. Finally, it was possible to determine and compare ten classes of coverage and use of municipal land in the period 2008-2017, Series IV and VI, the map of change processes was elaborated, the transition matrices of the obtained classes were quantified and the patterns and exchange rates of vegetation cover. The results indicate an increase of 1,906 ha for the Anthropic class, and losses of 711 ha of Pastizal, 567 ha of Temporary Agriculture, and 421 ha of Irrigation Agriculture. The pine forest and the Encino Pine Forest recorded increments of 72 ha and 4 ha respectively.
\end{abstract}

Keywords: Plant cover, Geographic Information Systems, rates of change, space-time dynamics.

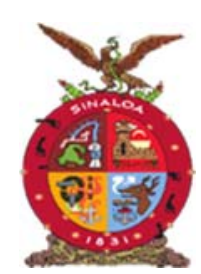

XVIII Congreso Internacional XXIV Congreso Nacional de Ciencias ambientales
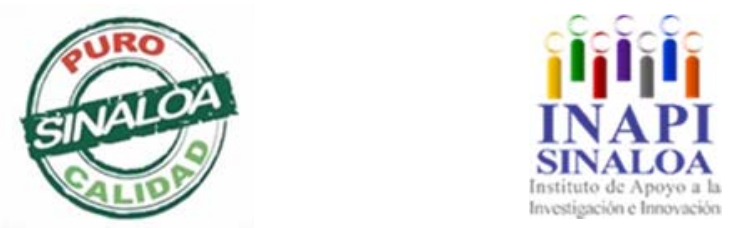

Mazatlán, Sinaloa 3-7 junio 2019

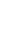



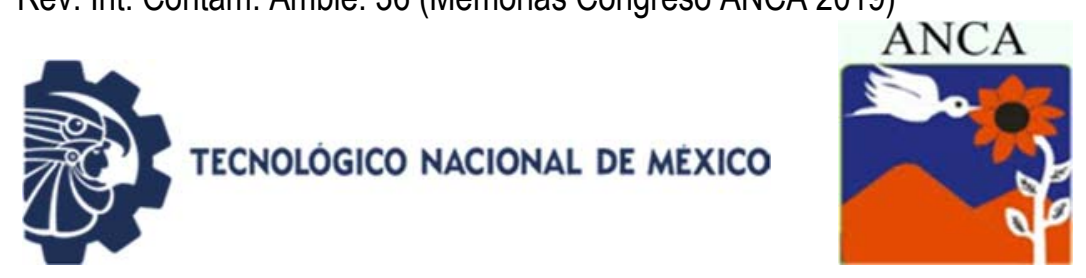

\title{
Determinación de Diazinone en sedimento del Lago de Chapala
}

\author{
Monares Escalera I', Alvarez Bernal D¹, Franco Hernandez MO², \\ Oregel Zamudio $\mathrm{E}^{2}$ \\ ${ }^{1}$ Centro Interdisciplinario de Investigación para el Desarrollo Integral Regional. \\ Unidad Michoacán. Instituto Politécnico Nacional. \\ Justo Sierra No. 28, C. P. 59510, Jiquilpan, Michoacán, México \\ 2Unidad Profesional Interdisciplinaria de Biotecnología-IPN (UPIBI). IPN \\ Av. Acueducto, 07340, Barrio la Laguna Ticoman, México
}

\section{RESUMEN}

El lago de Chapala, es el lago natural más grande de México, localizado entre los estados de Jalisco y Michoacán, México. La agricultura es la actividad más extendida alrededor del lago. El Diazóame es uno de los plaguicidas organofosforado más utilizado para controlar insectos en cultivos. El Diazinone es tóxico, una exposición a niveles altos de este compuesto ocasiona problemas en el sistema nervioso. Este plaguicida puede llegar a los cuerpos de agua por escurrimiento, infiltración y erosión de los suelos en los sitios donde se han aplicado hasta contaminar agua y sedimentos. La elección de los sedimentos como matriz de estudio se debe a que constituyen un excelente medio integrador de la contaminación existente en los cuerpos de agua. El objetivo fue cuantificar Diazinone en sedimentos del lago de Chapala. Se realizó un muestreo en siete zonas de este lago de Chapala en las épocas de lluvia del año 2018. Se cuantifico Diazinone mediante análisis por cromatografía de gases y espectrometría de masas (GC-MS), además, se determinaron parámetros fisicoquímicos de muestras de sedimentos: pH, Conductividad Eléctrica, Materia Orgánica, Carbono orgánico, Carbono Inorgánico y Nitrógeno Total. Se encontró presencia de Diazinone en 5 zonas: zona $2(313.83 \mathrm{ng} / \mathrm{ml})$, zona $3(359.71 \mathrm{ng} / \mathrm{ml})$, zona 4 $(354.32 \mathrm{ng} / \mathrm{ml})$, zona $6(193.14 \mathrm{ng} / \mathrm{ml})$, zona $7(4,042.54 \mathrm{ng} / \mathrm{ml})$. Por otro lado, los parámetros fisicoquímicos se encuentran dentro de los siguientes rangos: $\mathrm{pH}$ (7.31-7.59), conductividad eléctrica (1.13-0.90 dS/m), materia orgánica (3.88$2.70 \%)$, c orgánico (1.57-2.25\%), carbono Inorgánico $(0.72-0.23 \%)$ y nitrógeno total $(0.28-0.13 \%)$.

Palabras clave: Cromatografía de gases, espectrometría de masas, organofosforados, sedimento.

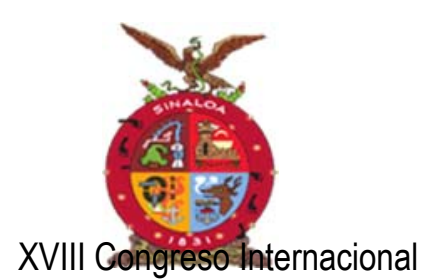

XXIV Congreso Nacional de Ciencias ambientales

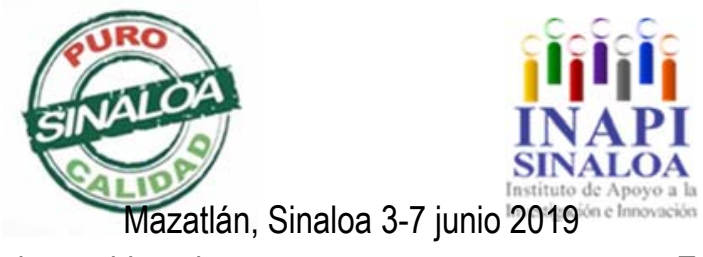

Ecosistemas y Deterioro Ambiental 

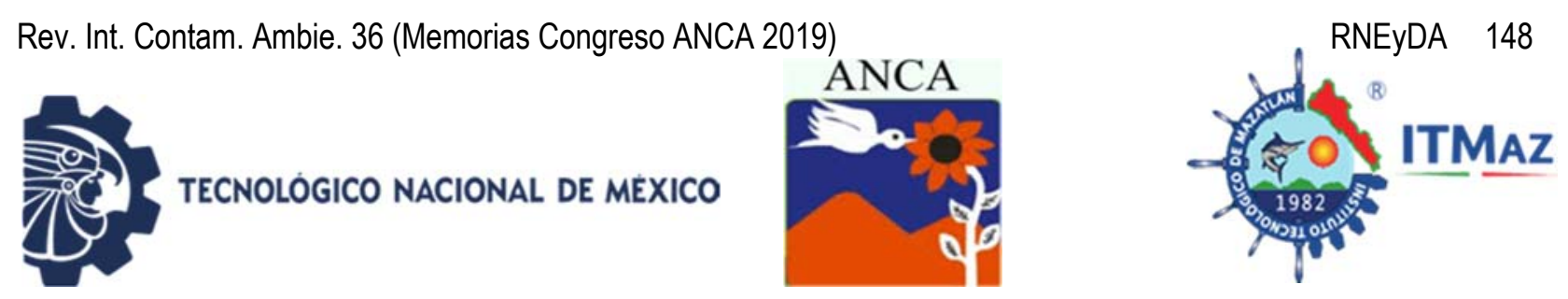

\title{
Determination of Diazinone in sediment of Lake Chapala
}

\author{
Monares Escalera I ${ }^{1}$, Alvarez Bernal D ${ }^{1}$, Franco Hernandez MO², \\ Oregel Zamudio $\mathrm{E}^{2}$ \\ ${ }^{1}$ Centro Interdisciplinario de Investigación para el Desarrollo Integral Regional. \\ Unidad Michoacán. Instituto Politécnico Nacional. \\ Justo Sierra No. 28, C. P. 59510, Jiquilpan, Michoacán, México \\ 2Unidad Profesional Interdisciplinaria de Biotecnología-IPN (UPIBI). IPN \\ Av. Acueducto, 07340, Barrio la Laguna Ticoman, México
}

\begin{abstract}
Lake Chapala, is the largest natural lake in Mexico, located between the states of Jalisco and Michoacán, Mexico. Agriculture is the most widespread activity around the lake. Diazoame is one of the organophosphorus pesticides most used to control insects in crops. Diazinone is toxic, an exposure to high levels of this compound causes problems in the nervous system. This pesticide can reach the bodies of water by runoff, infiltration and soil erosion in the places where they have been applied to contaminate water and sediments. The choice of sediments as a study matrix is due to the fact that they constitute an excellent integrating means of the contamination existing in water bodies. The objective was to quantify Diazinone in sediments of Lake Chapala. Sampling was carried out in seven areas of this Chapala lake in the rainy season of 2018. Diazinone was quantified by means of gas chromatography and mass spectrometry analysis (GC-MS), and physicochemical parameters of sediment samples were determined. : $\mathrm{pH}$, Electric Conductivity, Organic Matter, Organic Carbon, Inorganic Carbon and Total Nitrogen. Diazinone was found in 5 areas: zone $2(313.83 \mathrm{ng} / \mathrm{ml})$, zone $3(359.71$ $\mathrm{ng} / \mathrm{ml})$, zone 4 (354.32 ng / ml), zone 6 (193.14 ng / ml), zone 7 (4,042.54 ng) / $\mathrm{ml})$. On the other hand, the physicochemical parameters are within the following ranges: $\mathrm{pH}$ (7.31-7.59), Electrical Conductivity (1.13-0.90 dS / m), Organic Matter (3.88-2.70\%), Organic Carbon (1.57-2.25\%), Inorganic Carbon $(0.72-0.23 \%)$ and Total Nitrogen $(0.28-0.13 \%)$.
\end{abstract}

Keywords: Gas chromatography, massspectrometry, organophosphorus, sediment.

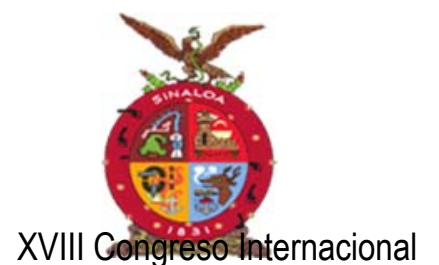

XXIV Congreso Nacional de Ciencias ambientales

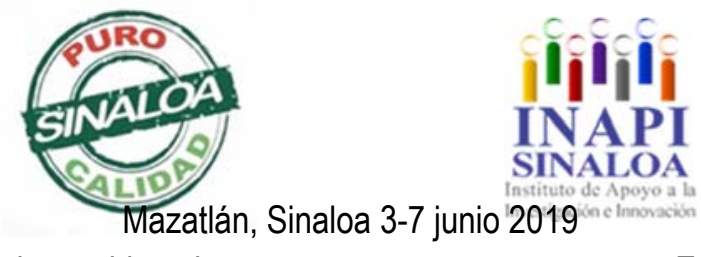

Ecosistemas y Deterioro Ambiental 

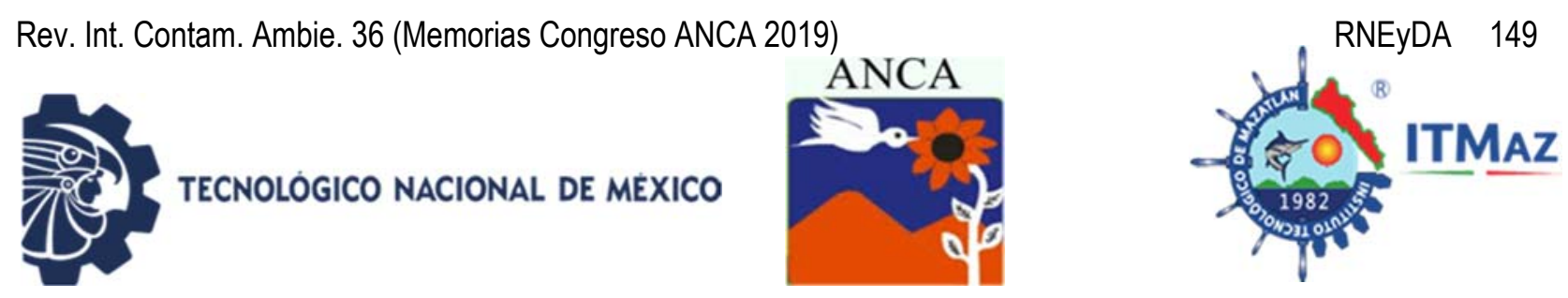

Dinámica del fósforo y nitrógeno en un sistema ribereño de montaña

Monfil Hernández F, Guerra Hernández E*, Cruz Flores G

Laboratorio de Calidad de Agua y Ecohidrología.

Facultad de Estudios Superiores Zaragoza. UNAM.

Batalla de 5 de mayo S/N, Col. Ejército de Oriente, 09230, México

*eagh@unam.mx

\section{RESUMEN:}

Entre las principales funciones de los bosques ribereños está su papel como filtro y amortiguador del material que llega por arrastre y transporte hacia el ecosistema acuático, incidiendo en el ciclaje de los nutrientes. Los cambios en la cobertura del suelo han provocado alteraciones en el paisaje y en algunas variables ambientales lo que modifican el equilibrio natural. Este trabajo analizó la dinámica del fósforo y nitrógeno en la interacción hídrica-edáfica de un sistema fluvial, de la subcuenca Nexapa, en función de la cobertura del suelo presente. Se evaluaron bimestralmente seis sitios con diferente gradiente altitudinal, entre septiembre de 2018 y febrero de 2019 en la zona oriental del Parque Nacional Iztaccíhuatl-Popocatépetl. Para caracterizarlos física y químicamente, destacando la presencia de nitratos, nitritos, amonio, ortofosfatos y fósforo total en el agua y el porcentaje de nitrógeno total y fósforo disponible en el suelo. En el agua, las concentraciones promedio de nitritos, nitratos y amonio fueron de $0.0013,0.6332$ y $0.0092 \mathrm{mg} / \mathrm{L}$ respectivamente; para el fósforo total y los ortofosfatos los promedios fueron de 0.6375 y $0.1097 \mathrm{mg} / \mathrm{L}$. En el suelo se encontró un promedio de $0.1225 \%$ de nitrógeno total, mientras que el fósforo disponible fue de $30.6453 \mathrm{mg} / \mathrm{kg}$. Las coberturas de suelo registradas de acuerdo al gradiente altitudinal fueron Pastizal montano, Bosque de Pinus, Bosque PinusAbies, Bosque Mixto-agrícola y Urbano. La modificación en la cobertura de uso de suelo, ha alterado la función tampón de la franja ribereña, contribuyendo a los procesos de erosión, eutrofización, contaminación y afectando significativamente la disponibilidad del agua.

Palabras clave: Cuenca, nutrientes, cobertura, agua, suelo.

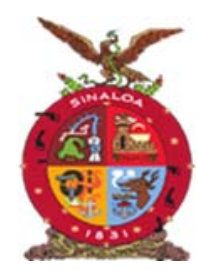

XVIII Congreso Internacional XXIV Congreso Nacional de Ciencias ambientales
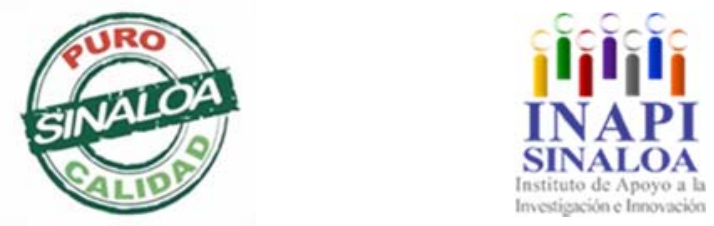

Mazatlán, Sinaloa 3-7 junio 2019

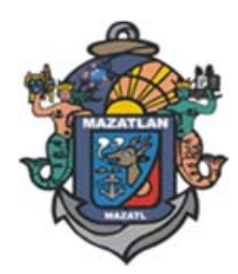

Recursos Naturales, Ecosistemas y Deterioro Ambiental 

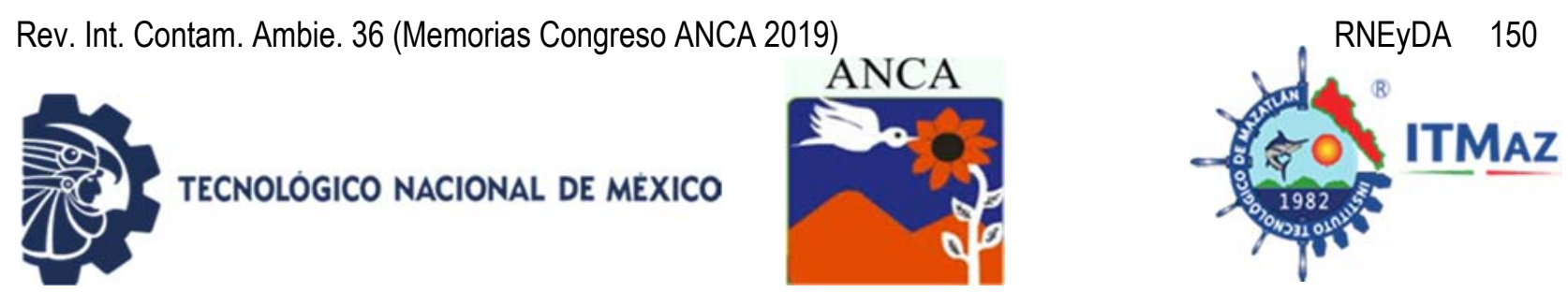

Phosphorus and nitrogen dynamics in a mountain riparian system

\author{
Monfil Hernández F, Guerra Hernández E*, Cruz Flores G \\ Laboratorio de Calidad de Agua y Ecohidrología. \\ Facultad de Estudios Superiores Zaragoza. UNAM. \\ Batalla de 5 de mayo S/N, Col. Ejército de Oriente, 09230, México \\ *eagh@unam.mx
}

\begin{abstract}
Among the main functions of riparian forests is their role as a filter and buffer of the entrainment and transport of the basin towards the aquatic ecosystem, influencing the nutrients cycling. Changes in land cover have caused alterations to landscape and environmental variables that modify its balance. This work analyzed the dynamics of phosphorus and nitrogen in the water-soil interaction in a fluvial system of Nexapa sub-basin, according to the land cover present. Six sites with different altitudinal gradients were evaluated bimonthly, between September 2018 and February 2019 in the eastern of Iztaccíhuatl-Popocatépetl National Park, to characterize them physically and chemically, highlighting the presence of nitrates, nitrites, ammonium, orthophosphates and total phosphorus in water and the percentage of total nitrogen and phosphorus available in the soil. In water, the average concentrations of nitrites, nitrates and ammonium were $0.0013,0.6332$ y $0.0092 \mathrm{mg} / \mathrm{L}$ respectively; for total phosphorus and orthophosphates the averages de 0.6375 y $0.1097 \mathrm{mg} / \mathrm{L}$. In the soil, an average total nitrogen $\%$ of $0.14 \%$ was found, while the available phosphorus was $0.1225 \%$. The land cover registered according to the altitudinal gradient were: Mountain pasture, Pinus Forest, Pinus-Abies Forest, Mixed-agricultural and Urban Forest. The modification in the coverage of land use has altered the buffer function of the riparian strip, contributing to the processes of erosion, eutrophication, contamination significantly affecting the availability of water.
\end{abstract}

Keywords: Basin, nutrients, coverage, water, soil.

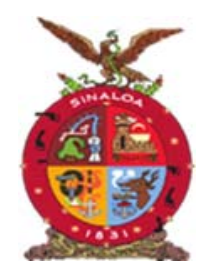

XVIII Congreso Internacional XXIV Congreso Nacional de Ciencias ambientales
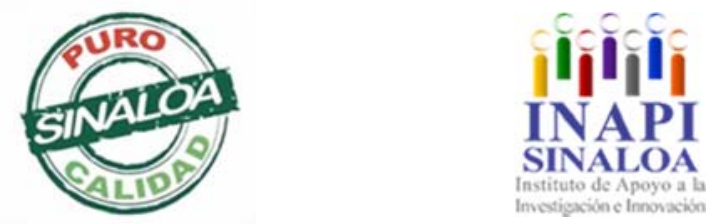

Mazatlán, Sinaloa 3-7 junio 2019

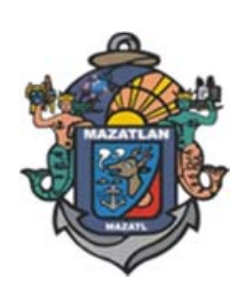

Recursos Naturales, Ecosistemas y Deterioro Ambiental 

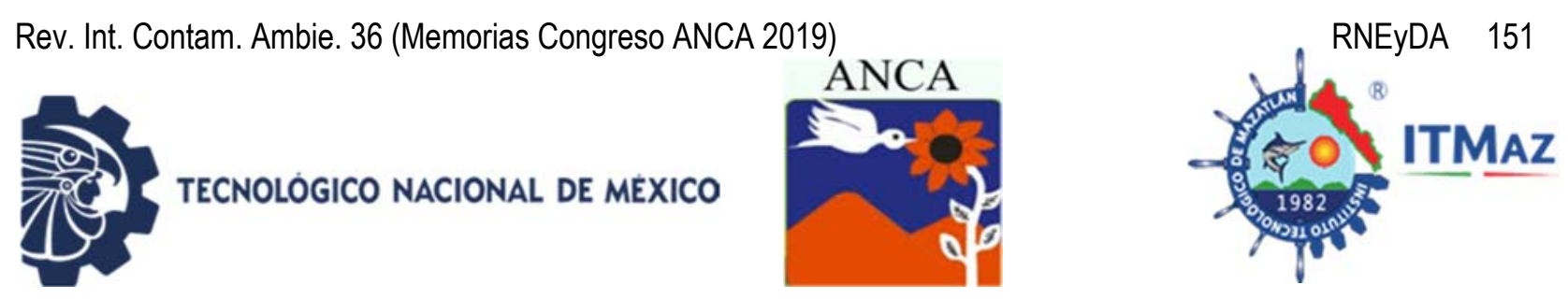

\title{
Diseño de un modelo digital de elevación mediante RPAS para la gestión de inundaciones
}

\author{
Mora Félix ZD, Sanhouse García AJ, Rangel Peraza JG, Rodríguez Mata AE \\ División de Estudios de Posgrado e Investigación. \\ Instituto Tecnológico de Culiacán-Tecnológico Nacional de México \\ Juan de Dios Bátiz 310, Col. Guadalupe, CP 80220, Culiacán, México \\ Departamento de Ingeniería Gráfica y Geomática. \\ Escuela Técnica Superior de Ingenieros Agrónomos y Montes. \\ Universidad de Córdova. \\ Campus Rabanales, N-IV, Km 396, Córdoba 14071, España
}

\section{RESUMEN}

La comunidad científica necesita herramientas prácticas que les permitan llevar a cabo una mejor gestión y control del riesgo de inundaciones. La tecnología implementada actualmente es muy compleja y sus procesos originan elevados costos. Para ello se han implementado sistemas aéreos pilotados en remoto (RPAS) como plataforma de obtención de datos debido a su fácil operación y bajo costo. Las imágenes aéreas obtenidas a través estos dispositivos son ideales para la producción de material cartográfico como Modelos Digitales de Elevación (MDE). Estos modelos representan información de la superficie terrestre con alta resolución, útiles para el modelado y simulación de diversos procesos ambientales, como las inundaciones. El diseño de modelos de simulación es un proceso complejo que requiere de MDE's de alta precisión para su correcto funcionamiento. El presente trabajo propone una metodología estandarizada de bajo costo utilizando RPAS para la construcción de MDEs con gran nivel de detalle y alta precisión. El efecto de algunos parámetros de vuelo como altura de vuelo, velocidad del RPAS y traslape longitudinal y transversal se analizan durante la fase inicial del proceso de adquisición de imágenes que son posteriormente pre-procesadas mediante software libre y finalmente se genera material cartográfico como: Modelos digitales de Terreno (MDT) o Modelos Digitales de Superficie (MDS). Los MDE's generados con esta metodología, tienen una resolución de $2 \mathrm{~cm} /$ pixel y una precisión plani-altimetrica de $0.02 \mathrm{~m}$ y $0.05 \mathrm{~m}$ respectivamente.

Palabras clave: MDE, RPAS, Fotogrametría, MDT.

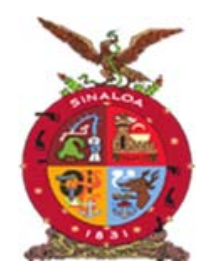

XVIII Congreso Internacional

XXIV Congreso Nacional de Ciencias ambientales

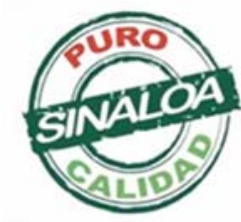

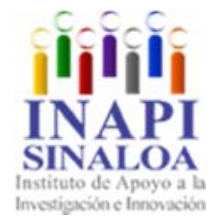

Mazatlán, Sinaloa 3-7 junio 2019

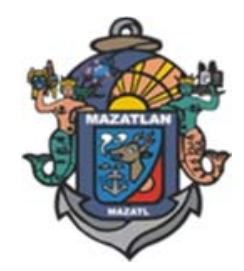

Recursos Naturales, Ecosistemas y Deterioro Ambiental 


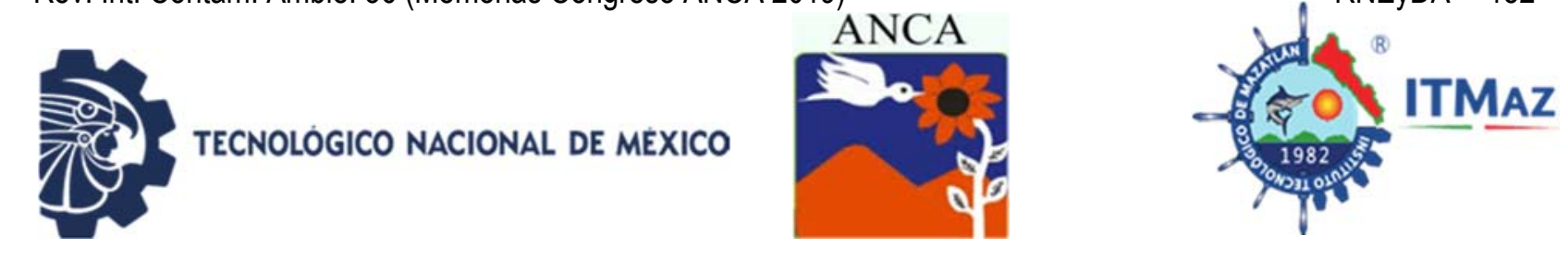

Design of a digital elevation model using RPAS for flood management

\author{
Mora Félix ZD, Sanhouse García AJ, Rangel Peraza JG, Rodríguez Mata AE \\ División de Estudios de Posgrado e Investigación. \\ Instituto Tecnológico de Culiacán-Tecnológico Nacional de México \\ Juan de Dios Bátiz 310, Col. Guadalupe, CP 80220, Culiacán, México \\ Departamento de Ingeniería Gráfica y Geomática. \\ Escuela Técnica Superior de Ingenieros Agrónomos y Montes. \\ Universidad de Córdova. \\ Campus Rabanales, N-IV, Km 396, Córdoba 14071, España
}

\begin{abstract}
The scientific community needs practical tools that allow them to carry out better management and control of flood risk. The technology currently implemented is very complex and its processes cause high costs. For this, remote piloted aerial systems (RPAS) have been implemented as a data collection platform due to its easy operation and low cost. The aerial images obtained through these devices are ideal for the production of cartographic material such as Digital Elevation Models (MDE). These models represent land surface information with high resolution, useful for modeling and simulation of various environmental processes, such as floods. Simulation model design is a complex process that requires high-precision MDE's for proper operation. The present work proposes a standardized methodology of low cost using RPAS for the construction of MDEs with great level of detail and high precision. The effect of some flight parameters such as flight height, RPAS speed and longitudinal and transverse overlap are analyzed during the initial phase of the image acquisition process that are subsequently pre-processed by free software and finally cartographic material is generated as: Models Digital Terrain (MDT) or Digital Surface Models (MDS). The MOUs generated with this methodology have a resolution of $2 \mathrm{~cm} /$ pixel and a planimetric accuracy of $0.02 \mathrm{~m}$ and $0.05 \mathrm{~m}$ respectively.
\end{abstract}

Keywords: MDE, RPAS, Photogrammetry, MDT.

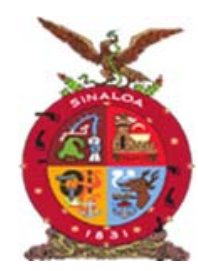

XVIII Congreso Internacional XXIV Congreso Nacional de Ciencias ambientales
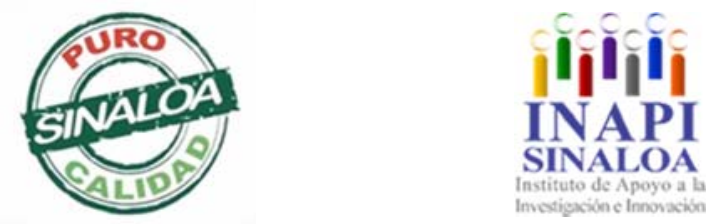

Mazatlán, Sinaloa 3-7 junio 2019

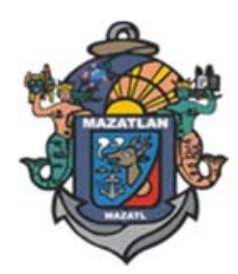

Recursos Naturales, Ecosistemas y Deterioro Ambiental 

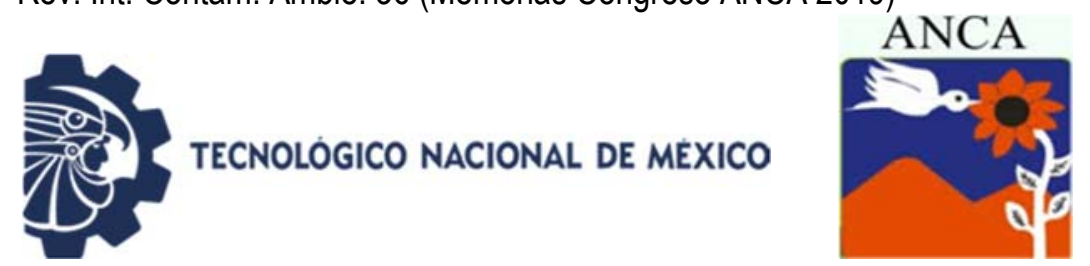

\title{
Distribución temporal de HAPs en la zona metropolitana del Valle de Toluca y sus implicaciones en la salud pública
}

\author{
Moreno Alcántara $\mathrm{J}^{1^{*}}$, Díaz Godoy $\mathrm{R}^{1}$, Estrada Ovando $\mathrm{D}^{2}$ \\ ${ }^{1}$ Instituto Nacional de Investigaciones Nucleares \\ 2Universidad Politécnica del Valle de Toluca \\ *jaime.moreno@inin.gob.mx
}

\begin{abstract}
RESUMEN
Los hidrocarburos aromáticos poli cíclicos (HAPs) son contaminantes tóxicos que pueden ocluirse en el material particulado o estar presentes en fase vapor. Pueden ser inhalados por el ser humano y llegar a los alveolos pulmonares y favorecer enfermedades respiratorias como el cáncer de pulmón. Durante un año se monitorearon HAPs en el aire del centro, norte y sur de la Zona Metropolitana del Valle de Toluca (ZMVT) y se determinó su implicación en la salud. Se colectaron de manera simultánea los HAPs ocluidos en las $\mathrm{PM}_{2.5}$ y en fase vapor. La extracción se realizó de manera secuencial con benceno y acetona en muestras compuestas en Soxhlet por ocho horas para cada solvente, el extracto se concentró con evaporador rotatorio y se almacenó a- $18^{\circ} \mathrm{C}$ hasta su análisis por cromatografía de Gases-Masas. Con benceno se extrajeron naftaleno, fluoreno, fenantreno, antraceno, fluoranteno, pireno, benzo (b)fluoranteno y benzo (ghi)perileno, con acetona naftaleno, fluoreno, y fenantreno. En fase vapor se identificaron HAPs de 2 y hasta de 6 anillos y en las $\mathrm{PM}_{2.5}$ de 2 y 3 anillos. La concentración promedio total (CPT) de HAPs fue de $4,403.5236236 \mathrm{ng} / \mathrm{m}^{3}$ con una participación de $783.9042 \mathrm{ng} / \mathrm{m}^{3}$ en la temporada de lluvias y $219.9095 \mathrm{ng} / \mathrm{m}^{3}$ en la seca fría. La CPT arroja una concentración tóxica equivalente total de $4.5596 \mathrm{ng} / \mathrm{m}^{3}$ superando el valor de referencia del benzo (a)pireno $\left(1.0 \mathrm{ng} / \mathrm{m}^{3}\right)$. Los HAPs identificados representan un riesgo potencial a la salud de la población de ZMVT pudiendo ser susceptible de contraer enfermedades respiratorias crónicas como el asma, bronquitis y cáncer de pulmón.
\end{abstract}

Palabras claves: Contaminación, atmosfera, salud pública, cáncer.

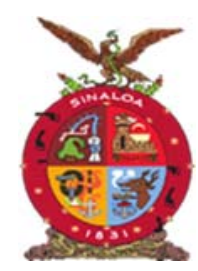

XVIII Congreso Internacional XXIV Congreso Nacional de Ciencias ambientales
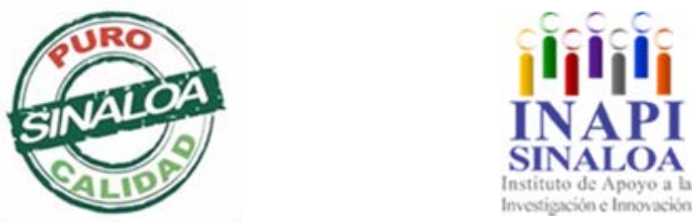

Mazatlán, Sinaloa 3-7 junio 2019

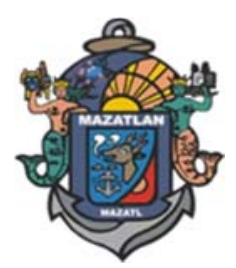

Recursos Naturales, Ecosistemas y Deterioro Ambiental 

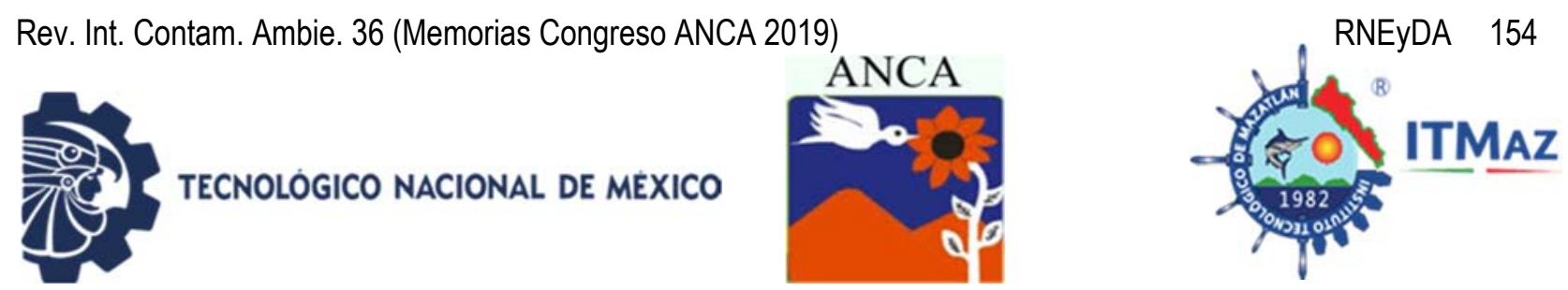

\title{
Temporary distribution of PAHs in the metropolitan area of Toluca Valley and its implications on public health
}

\author{
Moreno Alcántara $\mathrm{J}^{1^{\star}}$, Díaz Godoy $\mathrm{R}^{1}$, Estrada Ovando $\mathrm{D}^{2}$ \\ ${ }^{1}$ Instituto Nacional de Investigaciones Nucleares \\ 2Universidad Politécnica del Valle de Toluca \\ *jaime.moreno@inin.gob.mx
}

\begin{abstract}
Polycyclic aromatic hydrocarbons (PAHs) are toxic contaminants that can be occluded in the particulate material or present in the vapor phase they can be inhaled by the human being and reach the pulmonary alveoli and favor respiratory diseases such as lung cancer. During one year, PAHs were monitored in the center, north and south of the Toluca Valley Metropolitan Area (ZMVT) and their involvement in health was determined. The occluded PAHs in PM2.5 and in the vapor phase were collected simultaneously. The extraction was carried out sequentially with benzene and acetone in composite samples in Soxhlet for eight hours for each solvent. The extract was concentrated with a rotary evaporator and stored at $-18^{\circ} \mathrm{C}$ until analysis by GC/MS. With benzene, naphthalene, fluorene, phenanthrene, anthracene, fluoranthene, pyrene, benzo (b) fluoranthene and benzo (ghi) perylene, with acetone naphthalene, fluorene, and phenanthrene were extracted. In the vapor phase, PAHs of 2 and up to 6 rings were identified, while in $\mathrm{PM}_{2.5}, 2$ and 3 rings were identified. The total average concentration (TAC) of PAHs was $4,403.5236236 \mathrm{ng} / \mathrm{m}^{3}$ with a participation of $783.9042 \mathrm{ng} / \mathrm{m}^{3}$ in the rainy season and $219.9095 \mathrm{ng} / \mathrm{m}^{3}$ in the dry cold. The TAC yields a total equivalent toxic concentration of $4.5596 \mathrm{ng} / \mathrm{m}^{3}$ exceeding the reference value of benzo (a) pyrene $\left(1.0 \mathrm{ng} / \mathrm{m}^{3}\right)$. The PAHs identified represent a potential risk to the health of the ZMVT population and may be susceptible to chronic respiratory diseases such as asthma, bronchitis and lung cancer.
\end{abstract}

Keywords: Pollution, atmosphere, public health, cancer.

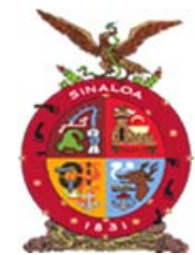

XVIII Congreso Internacional

XXIV Congreso Nacional de Ciencias ambientales

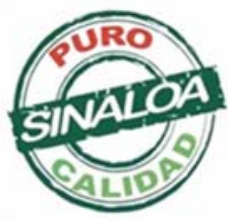

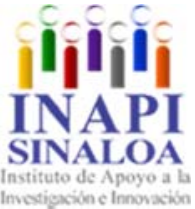

Mazatlán, Sinaloa 3-7 junio 2019

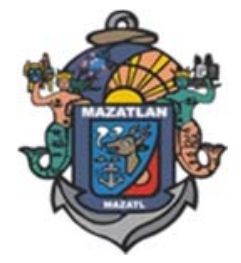

Recursos Naturales, Ecosistemas y Deterioro Ambiental 

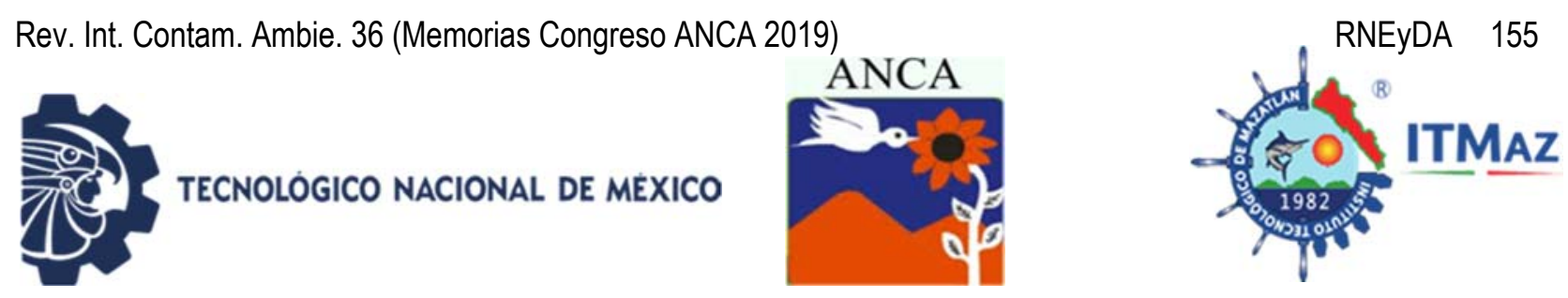

\title{
Actitudes sobre el reciclaje de residuo plástico ante la posibilidad de la implementación de una RVM para envases PET
}

\author{
Moreno Julimez L ${ }^{1 *}$, Aquino De Los Ríos $\mathrm{G}^{1}$, Mayett Moreno $\mathrm{Y}^{2}$, \\ Cortés Palacios $L^{1}$, Rodríguez Piñeros $S^{1}$ \\ ${ }^{1}$ Universidad Autónoma de Chihuahua. Facultad de Zootecnia y Ecología, \\ Perif. Fco. R. Almada Km. 1, C.P. 31453, Chihuahua, México \\ 2Universidad Popular del Estado de Puebla, UPAEP, \\ 21 Sur \# 1103, Barrio de Santiago, C.P. 72410, Puebla, México \\ *morenolmj@gmail.com
}

\begin{abstract}
RESUMEN
Los residuos sólidos plásticos son generados en gran cantidad y vertidos en diferentes lugares alrededor del mundo, generalmente estos residuos están relacionados con problemas de contaminación. Se han desarrollado pocos programas de reciclaje para combatir esta problemática a través de legislaciones o iniciativas voluntarias. El propósito de este estudio es recabar datos sobre los hábitos de consumo y de reciclaje de los residuos plásticos para poder identificar las barreras y la disposición para participar en la implementación de un programa de reciclaje a través de un sistema de máquinas expendedoras inversas RVM. En una muestra de la comunidad estudiantil de la Universidad Popular Autónoma del Estado de Puebla, se identificaron las consideraciones que influyen en el desarrollo y la implementación de un programa de reciclaje y las actitudes de los encuestados con respecto a la importancia del reciclaje. La información se recopiló mediante encuestas aplicadas personalmente. Los resultados indican que la comunidad estudiantil tiene predisposición positiva a la eliminación responsable de los residuos plásticos, sin embargo, también se encontró que existe falta de información sobre los programas y centros de reciclaje para las personas que están dispuestas a participar en los programas de reciclaje. Los hallazgos indican que la implementación de un programa de reciclaje con una buena campaña de información y concientización, puede abordar la mayoría de las barreras para un programa de residuos plásticos exitoso.
\end{abstract}

Palabras clave: Percepción, reciclaje, RVM, encuestas.

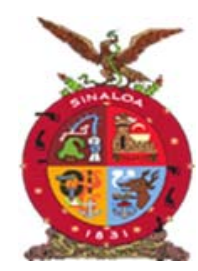

XVIII Congreso Internacional XXIV Congreso Nacional de Ciencias ambientales
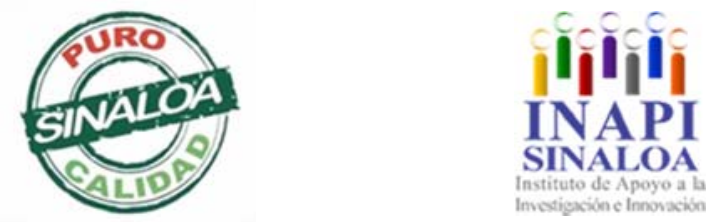

Mazatlán, Sinaloa 3-7 junio 2019

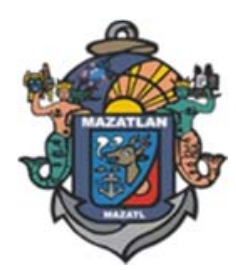

Recursos Naturales, Ecosistemas y Deterioro Ambiental 

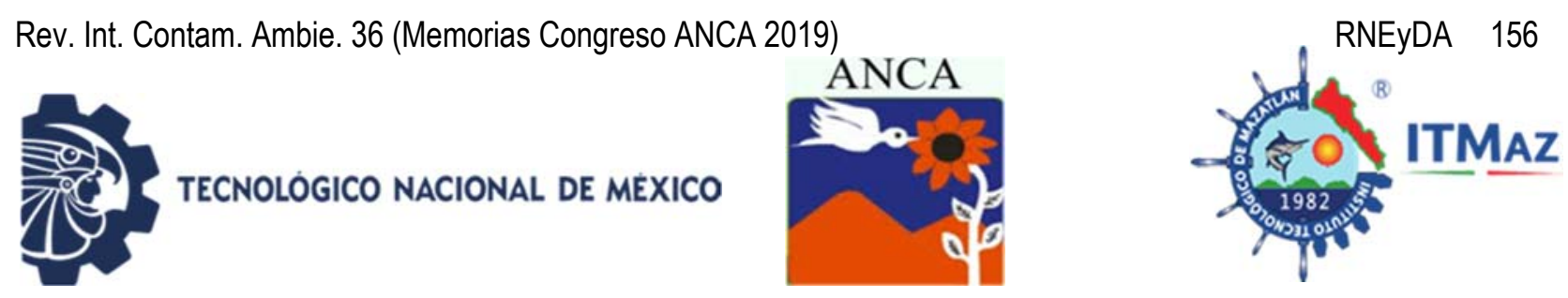

\title{
Attitudes on the recycling of plastic waste before the possibility of the implementation of an RVM for PET containers
}

\author{
Moreno Julimez $L^{1 *}$, Aquino De Los Ríos $\mathrm{G}^{1}$, Mayett Moreno $\mathrm{Y}^{2}$, \\ Cortés Palacios $L^{1}$, Rodríguez Piñeros $S^{1}$ \\ ${ }^{1}$ Universidad Autónoma de Chihuahua. Facultad de Zootecnia y Ecología, Perif. \\ Fco. R. Almada Km. 1, C.P. 31453, Chihuahua, México \\ 2Universidad Popular del Estado de Puebla, UPAEP, 21 sur \#1103, Barrio de \\ Santiago, C.P. 72410, Puebla, México \\ *morenolmj@gmail.com
}

\begin{abstract}
Plastic solid waste is generated in large quantities and different places around the world, usually, these residues are related to pollution problems. Few recycling programs have been developed to combat this problem through legislation or voluntary initiatives. The purpose of this study is to collect data about the consumption and recycling habits of plastic waste in order to identify barriers and the willingness to participate in the implementation of a recycling program through a system of reverse vending machines (RVM). In a sample of the student community of the Popular Autonomous University of the State of Puebla the considerations that influence the development and implementation of a recycling program and the attitudes of the respondents regarding the importance of recycling were identified. The information was collected through personally applied surveys. The results indicate that the student community has a positive predisposition to the responsible disposal of plastic waste. However, it was also found that there is a lack of information about programs and recycling centers for people who are willing to participate in recycling programs. The findings indicate that the implementation of a novel recycling program with good information and awareness campaign can address most of the barriers to a successful plastic waste program.
\end{abstract}

Keywords: Perception, recycling, RVM, surveys.

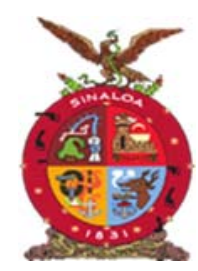

XVIII Congreso Internacional XXIV Congreso Nacional de Ciencias ambientales

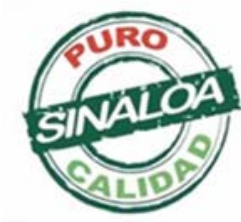

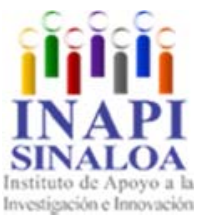

Mazatlán, Sinaloa 3-7 junio 2019

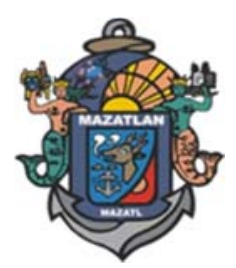

Recursos Naturales, Ecosistemas y Deterioro Ambiental 

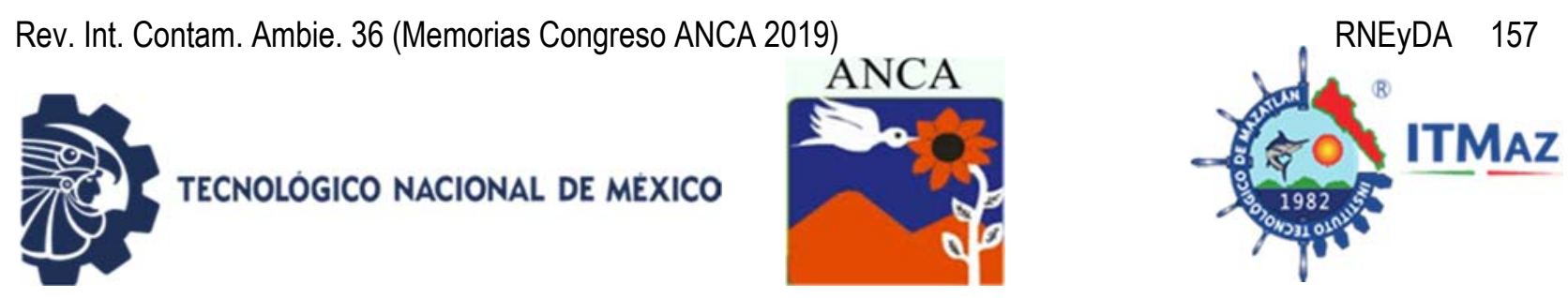

\title{
PDI para obtener descriptores de diferentes géneros de Chicharritas (Hemiptera: Cicadellidae) presentes en cultivos de chile
}

\author{
Moreno Lucio $\mathrm{M}^{1 *}$, Espinoza García $\mathrm{G}^{2}$, Solís Sánchez L1, Olvera Olvera $\mathrm{C}^{2}$, \\ Mena Covarrubias J3 \\ ${ }^{1}$ Posgrado en Ingeniería y Tecnología Aplicada. \\ Unidad Académica de Ingeniería Eléctrica. UAZacatecas. \\ Av. Ramón López Velarde, 801, Col. Centro. C.P. 98000, Zacatecas, México \\ ${ }^{2}$ Posgrado en Ciencias de la Ingeniería, UAEI, UAZacatecas. \\ Carr. Zacatecas Guadalajara Km. 6, Ejido la Escondida, Zacatecas, México \\ ${ }^{3}$ Sanidad Forestal y Agrícola. Instituto Nacional de Investigaciones Forestales, Agrícolas y \\ Pecuarias. Campo experimental Zacatecas. \\ Km. 24.5 Carr. Zacatecas-Fresnillo, Calera de V.R., Zacatecas, México. \\ *miryz.moreno@gmail.com
}

\begin{abstract}
RESUMEN
Uno de los mayores problemas a nivel nacional e internacional es la presencia de plagas en cultivos ya que pueden ocasionar hasta un $100 \%$ en pérdidas del cultivo, el manejo integrado de plagas es un método ecológico que aspira a reducir o eliminar el uso de plaguicidas y minimizar el impacto al ambiente, para detectar plagas en cultivos comúnmente se emplea el uso de trampas. El objetivo de esta investigación es aplicar procesamiento digital de imágenes (PDI) para la extracción de características invariantes de distintos géneros de chicharritas (Hemiptera: Cicadellidae) y descriptores especiales de cada una de ellas para detectar, clasificar y contar los insectos presentes en las trampas pegajosas reduciendo considerablemente el tiempo de revisión de cada tarjeta. Para la detección de chicharritas, se colocaron trampas amarillas pegajosas en un cultivo de chile, con ayuda de un entomólogo especialista se identificaron los siguientes géneros de chicharritas: Empoasca, Circulifer, Colladonus, Graphocephala y Ollarianus. Se tomaron imágenes de estás y buscaron imágenes de los géneros encontrados. El algoritmo SIFT fue utilizado para detectar chicharritas en imágenes con diferentes géneros, con el PDI y la aplicación de filtros morfológicos, se obtuvieron las características de escala invariante y descriptores que permiten representar matemáticamente cada género y las diferencias entre sí. Las características del área, excentricidad, solidez, etc. y descriptores obtenidos de Fourier, cadena, firma, histograma ayudan a clasificar los insectos de manera matemática, en conjunto con el algoritmo SIFT, el cual demostró que puede ser utilizado para detección de chicharritas con hasta un $91 \%$ de precisión.
\end{abstract}

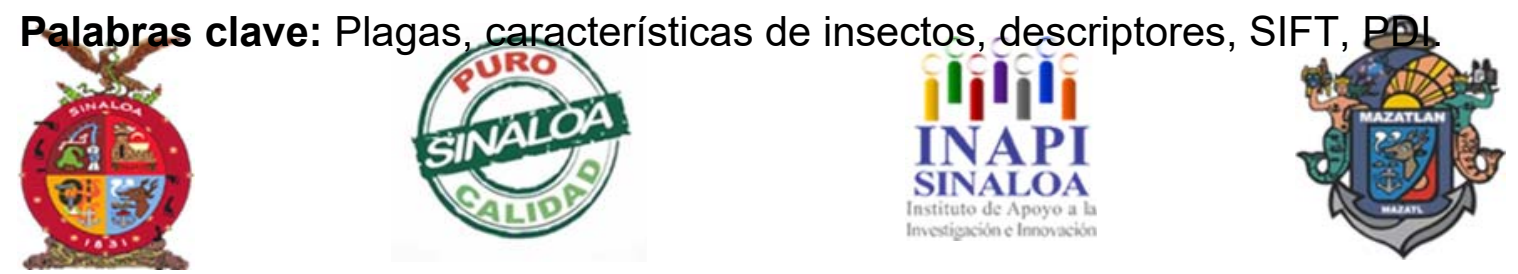



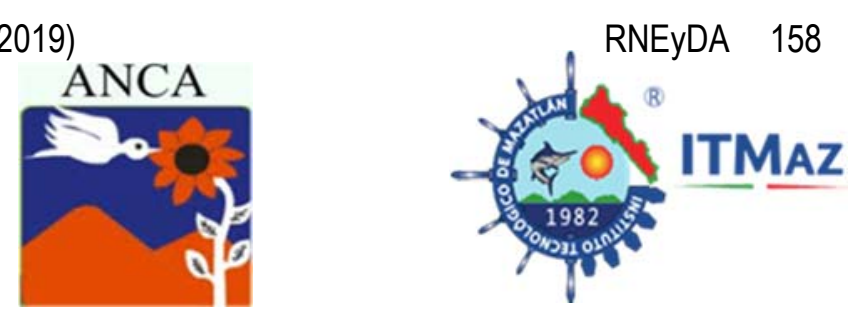

\title{
PDI to obtain descriptors of different genera of Leafhoppers (Hemiptera: Cicadellidae) present in chile crops
}

\author{
Moreno Lucio $\mathrm{M}^{1 *}$, Espinoza García $\mathrm{G}^{2}$, Solís Sánchez L1, Olvera Olvera $\mathrm{C}^{2}$, \\ Mena Covarrubias $\mathrm{J}^{3}$ \\ ${ }^{1}$ Posgrado en Ingeniería y Tecnología Aplicada. \\ Unidad Académica de Ingeniería Eléctrica. UAZacatecas.
}

Av. Ramón López Velarde, 801, Col. Centro. C.P. 98000, Zacatecas, México

${ }^{2}$ Posgrado en Ciencias de la Ingeniería, UAEI, UAZacatecas.

Carr. Zacatecas Guadalajara Km. 6, Ejido la Escondida, Zacatecas, México

${ }^{3}$ Sanidad Forestal y Agrícola. Instituto Nacional de Investigaciones Forestales, Agrícolas y Pecuarias. Campo experimental Zacatecas.

Km. 24.5 Carr. Zacatecas-Fresnillo, Calera de V.R., Zacatecas, México.

*miryz.moreno@gmail.com

\begin{abstract}
One of the biggest problems at the national and international level is the presence of pests in crops as they can cause up to $100 \%$ in crop losses. Integrated pest management is an ecological method that aims to reduce or eliminate the use of pesticides and minimize the impact on the environment, to detect pests In crops the use of traps is commonly used. The objective of this research is to apply Digital Image Processing (DIP) for the extraction of invariant characteristics of different genera of leafhoppers (Hemiptera: Cicadellidae) and special descriptors of each one of them to detect, classify and count the insects present in the sticky traps reducing considerably the time of review of each card. For the detection of leafhoppers, yellow sticky traps were placed in a chili culture, with the help of a specialist entomologist the following genera of leafhoppers were identified: Empoasca, Circulifer, Colladonus, Graphocephala, and Ollarianus, images of these were taken and they looked for images of the genres found. The SIFT algorithm was used to detect leafhoppers in images with different genera, the DIP and application of morphological filters, obtaining characteristics of invariant scale and descriptors that allow representing each genus of leafhoppers mathematically and differences between them. The characteristics (area, eccentricity, solidity, etc.) and obtained descriptors (Fourier, chain, signature, histogram) help to classify the insects in a mathematical way, together with the SIFT algorithm, which showed that it can be used to detect leafhoppers with up to $91 \%$ accuracy.
\end{abstract}

Keywords: Pests, Insect features, Descriptors, SIFT, DIP.

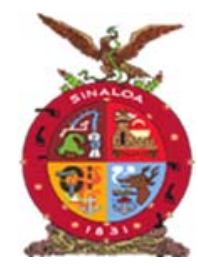

XVIII Congreso Internacional

XXIV Congreso Nacional de Ciencias ambientales
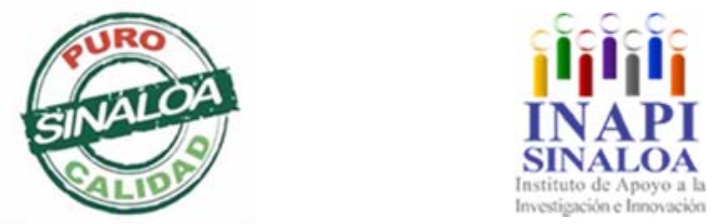

Mazatlán, Sinaloa 3-7 junio 2019

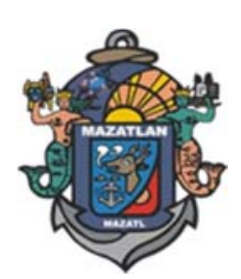

Recursos Naturales, Ecosistemas y Deterioro Ambiental 

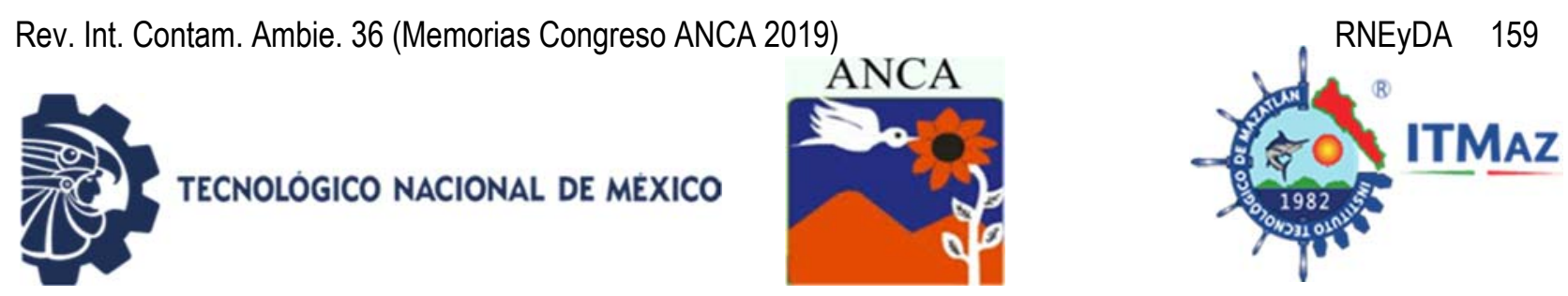

\title{
Modelado del carbono, nitrógeno y azufre en la hojarasca foliar de un matorral altoandino de Colombia
}

\author{
Murcia Rodríguez $\mathrm{M}^{1 *}$, Ochoa Reyes $\mathrm{P}^{1}$, Vergara Flórez $\mathrm{M}^{1}$, Poveda Gómez $\mathrm{F}^{2}$ \\ ${ }^{1}$ Semillero de Investigación. Grupo de Recursos Naturales. \\ Universidad de Pamplona-Colombia \\ ${ }^{2}$ Corporación Manaba. Universidad de Pamplona. Ciudadela Universitaria. \\ Km. 1, Vía a Bucaramanga, Pamplona, Norte de Santander Colombia, \\ Corporación Manaba, Cl 53 70-10, Bogotá, Colombia \\ *miguel.murcia.r@gmail.com
}

\section{RESUMEN}

Se modeló la tendencia temporal y el comportamiento del carbono, nitrógeno y azufre en la hojarasca foliar de Hypericum phellos (Hp) y Miconia ligustrina (MI) en un matorral altoandino de 20 años de regeneración natural, en la cuenca del río Pamplonita, nororiente colombiano (3100-3250 msnm). Se realizaron análisis de regresión simple y múltiple, siendo el tiempo [días $(x)=906$ ] y los factores meteorológicos las variables independientes. El porcentaje de $\mathrm{C}, \mathrm{N}$ y $\mathrm{S}$ foliar se determinó por combustión completa del material vegetal, a través de un flujo directo de oxígeno a $1450^{\circ} \mathrm{C}$, en diciembre de 2017: el $\mathrm{CO}_{2}$ y el SO 2 liberados se analizaron mediante un detector de rayos infrarrojo no dispersivo, y el $\mathrm{N}_{2}$ por conductividad térmica con un LECO TruMac CNS ${ }^{\circ}$. El $\mathrm{C}$ tendió a decrecer en $H p C=-0,532 \ln (x)+62,032 ; y$ osciló en $M I C=-5 E-08 x^{3}+8 E-05 x^{2}-0,0358 x+$ 54,379 . El $\mathrm{N}$ se incrementó lineal y cuadráticamente: $H p N=0,0004 x+1,1487$; $M L N=-1 E-06 x^{2}+0,0012 x+2,0614$. La relación $C / N$ fluctuó en $H p C / N=2 E-05 x^{2}-$ $0,0177 x+29,35$; descendió exponencialmente en $M L C / N=44,009 \mathrm{e}^{-3 \mathrm{E}-04 \mathrm{x}}$. El comportamiento del carbono se explicó mediante la temperatura media: $\mathrm{HpC}=$ 0,532 (Tmed) + 50,701; por la humedad relativa y la evaporación en MIC =-0,253 (HR\%)-0,037 (Eva) + 73,807. El nitrógeno se determinó por la sumatoria de las horas del brillo solar y la evaporación en $\mathrm{HpN}=0,004$ (BSum)-0,007 (Eva) + 2,284; por la evaporación media y el viento en $M L N=-0,228$ (Emed) $+0,43$ (Viento) $+1,546$. El S se explicó por la temperatura minima en $H p S=0,314 \mathrm{e}^{-0,056}$ (Tmin); por la evaporación media en $M L S=0,067$ (Emed)22-0,472 (Emed) + 0,932. La relación $\mathrm{C} / \mathrm{N}$ se explicó en $\mathrm{HpC} / \mathrm{N}=-0,056$ (BSum) + 0,085 (Eva) + 26,072; y en $\mathrm{M} / \mathrm{C} / \mathrm{N}=4,996$ (Emed)-1,391 (Tmin) $+34,193$. Hypericum phellos y Miconia ligustrina exhibieron tendencias y comportamientos diferenciales que segregan sus nichos funcionales.

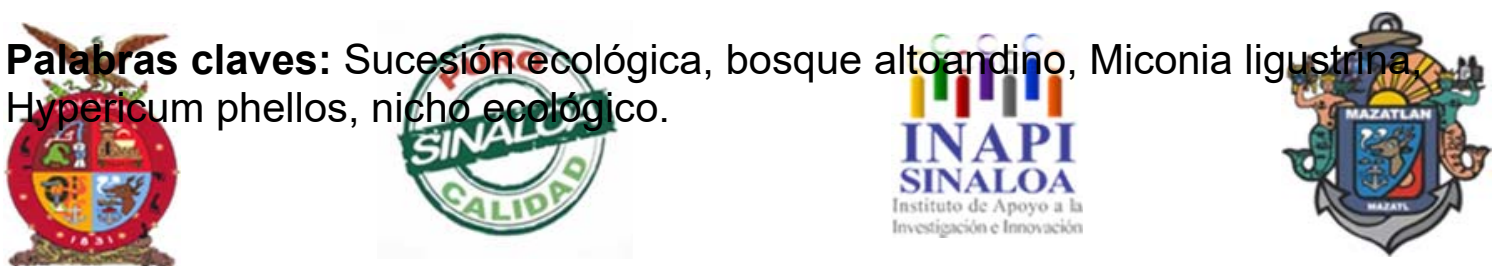



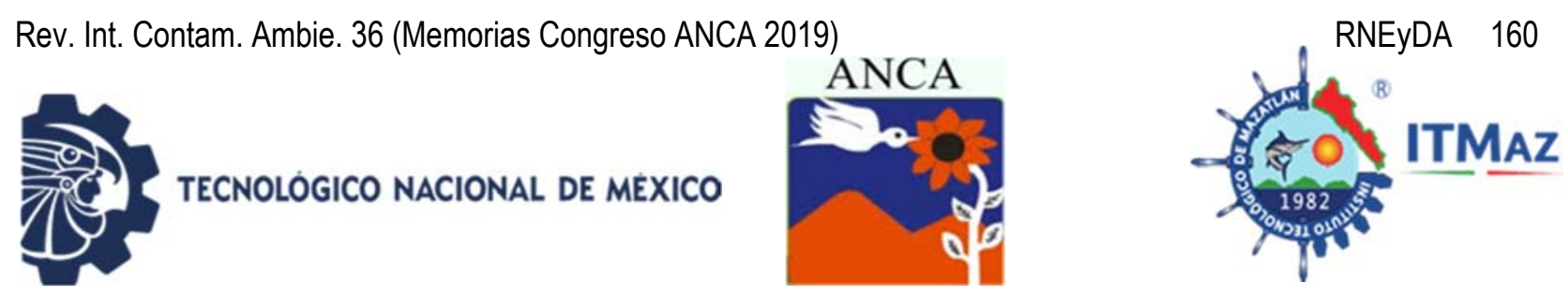

\title{
Carbon, nitrogen and sulfur modeling in the foliar litterfall of a high Andean shrub of Colombia
}

\author{
Murcia Rodríguez $\mathrm{M}^{1 *}$, Ochoa Reyes $\mathrm{P}^{1}$, Vergara Flórez $\mathrm{M}^{1}$, Poveda Gómez $\mathrm{F}^{2}$ \\ ${ }^{1}$ Semillero de Investigación. Grupo de Recursos Naturales. \\ Universidad de Pamplona-Colombia \\ ${ }^{2}$ Corporación Manaba. Universidad de Pamplona. Ciudadela Universitaria. \\ Km. 1, Vía a Bucaramanga, Pamplona, Norte de Santander Colombia, \\ Corporación Manaba, Cl 53 70-10, Bogotá, Colombia \\ *miguel.murcia.r@gmail.com
}

\begin{abstract}
The carbon, nitrogen and sulphur behaviors and temporal trends were modeled for the Hypericum phellos $(\mathrm{Hp})$ and Miconia ligustrina $(\mathrm{Ml})$ foliar litterfall within a 20 years naturally regenerated high Andean shrub, in the Pamplonita river basin by northeastern Colombia (3100-3250 m alt). Simple and multiple regression analysis were made, the time [days $(x)=906$ ] and meteorological factors being the independent variables. The percentage of foliar $\mathrm{C}, \mathrm{N}$ and $\mathrm{S}$ were determined by complete combustion of the vegetal material with an oxygen direct flux at 1450 ${ }^{\circ} \mathrm{C}$ by December 2017, so, the released $\mathrm{CO}_{2}$ and $\mathrm{SO}_{2}$ were measured by means of a non-dispersive infrared rays detector, and the $\mathrm{N}_{2}$ was recorded according to thermal conductivity by a LECO TruMac CNS ${ }^{\circledR}$. The $\mathrm{C}$ tended to decrease $(\mathrm{HpC}$ $=-0,532 \ln (x)+62,032)$ and oscillate $\left(M / C=-5 E-08 x^{3}+8 E-05 x^{2}-0,0358 x+\right.$ $54,379)$; the $N$ increased linearly and quadratically $(H p N=0,0004 x+1,1487 ; M L N$ $\left.=-1 \mathrm{E}-06 \mathrm{x}^{2}+0,0012 \mathrm{x}+2,0614\right)$. The $\mathrm{C} / \mathrm{N}$ ratio fluctuated $\left(\mathrm{HpC} / \mathrm{N}=2 \mathrm{E}-05 \mathrm{x}^{2}-\right.$ $0,0177 x+29,35)$ and decreased exponentially $\left(M L C / N=44,009 e^{-3 E-04 x}\right)$. The carbon behavior was explained by the mean temperature $(H p C=0,532(\mathrm{Tmed})+$ $50,701)$, the relative humidity and the evaporation (MIC $=-0,253$ (HR\%)-0,037 (Eva) $+73,807)$. The nitrogen was determined by the summation of the sunshine hours and the evaporation ( $\mathrm{HpN}=0,004$ (BSum)-0,007 (Eva) $+2,284)$; by the mean evaporation and the wind $(M L N=-0,228$ (Emed) $+0,43$ (Viento) + 1,546). The $S$ was explained by the minimum temperature $\left(H p S=0,314 \mathrm{e}^{-0,056}\right.$ (Tmin) $)$; and

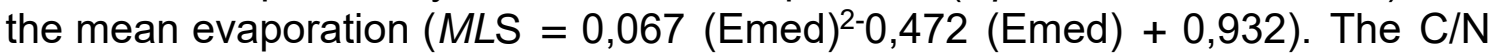
ratio was like these: $\mathrm{HpC} / \mathrm{N}=-0,056(\mathrm{BSum})+0,085$ (Eva) + 26,072; and $\mathrm{MIC} / \mathrm{N}$ $=4,996$ (Emed)-1,391 (Tmin) $+34,193$. Hypericum phellos y Miconia ligustrina showed differential trends and behaviors allowing to segregate their functional niches.
\end{abstract}

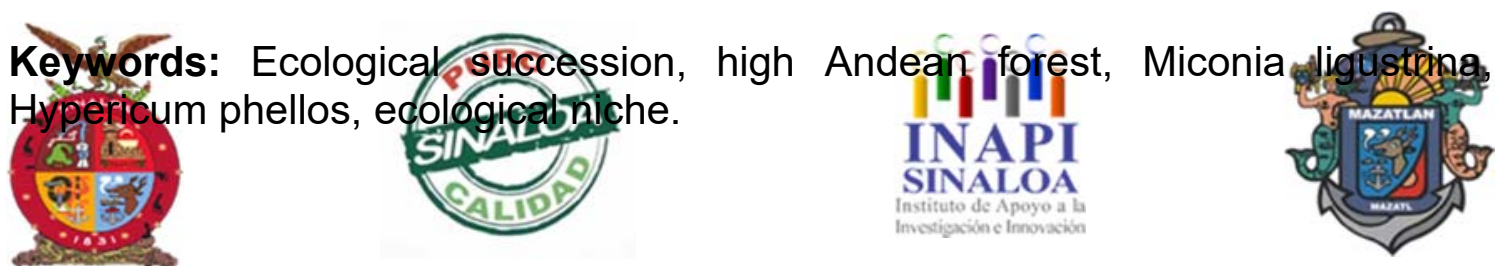



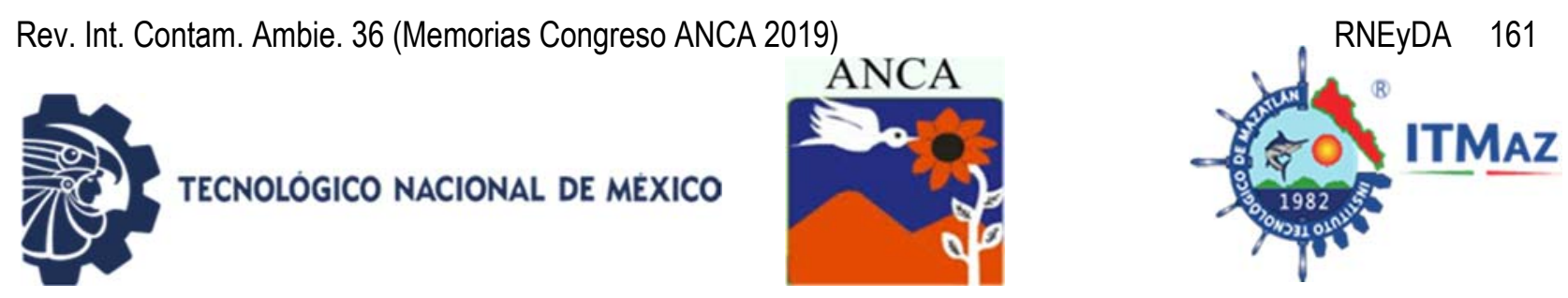

\title{
Ciencia ciudadana para el conocimiento de la biodiversidad: un estudio de caso de las aves del Estero del Yugo, Mazatlán, Sinaloa
}

\author{
Murúa Figueroa $\mathrm{E}^{*}$, Berlanga Robles CA \\ Centro de Investigación en Alimentación y Desarrollo A. C. \\ Coordinación Regional Mazatlán, Sinaloa, México \\ *emurua@ciad.mx
}

\begin{abstract}
RESUMEN
La ciencia ciudadana (CC) conlleva una forma integral de conectar a las personas con la biodiversidad y con los desafíos de su conservación. Los esfuerzos de CC son un vehículo poderoso para el empoderamiento las comunidades al romper las barreras que separan a la ciencia y la sociedad, promoviendo la interacción entre científicos y ciudadanos en la conservación y manejo de la naturaleza. Asimismo, la CC puede poner a disposición de la comunidad científica datos para la modelación ecológica que generalmente requieren de estudios con una alta demanda de recursos humanos y económicos. Con el fin de ejemplificar el potencial de la CC para el estudio de la biodiversidad, se realizó un estudio de la diversidad de aves en un área de conservación ecológica del noroeste de México a partir de los datos recabados por un grupo de observadores de aves durante los últimos 12 años. En total se han contabilizado más de 12,500 individuos pertenecientes a 222 especies, el $76 \%$ de las esperadas. Para los grupos de patos, playeros y zancudos (54 especies) la diversidad de Shannon registró valores entre 1.3 y 3.1 y la equidad entre 0.59 y 0.95 , la menor diversidad se registró en abril de 2009, cuando solamente se registraron nueve individuos pertenecientes a cinco especies. La diversidad beta (disimilitud de Sorensen) para todas las fechas analizadas fue de 0.89 , casi el $90 \%$ se debió al recambio de especies, lo que indica la relevancia de las aves migratorias en la conformación del ensamble de aves del área de estudio.
\end{abstract}

Palabras clave: Ciencia ciudadana, diversidad y abundancia de aves, diversidad beta, recambio y anidamiento.

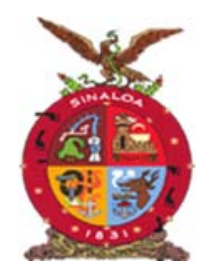

XVIII Congreso Internacional XXIV Congreso Nacional de Ciencias ambientales

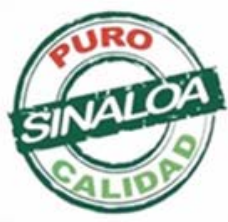

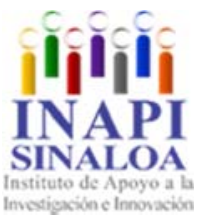

Mazatlán, Sinaloa 3-7 junio 2019

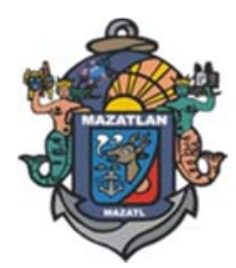

Recursos Naturales, Ecosistemas y Deterioro Ambiental 

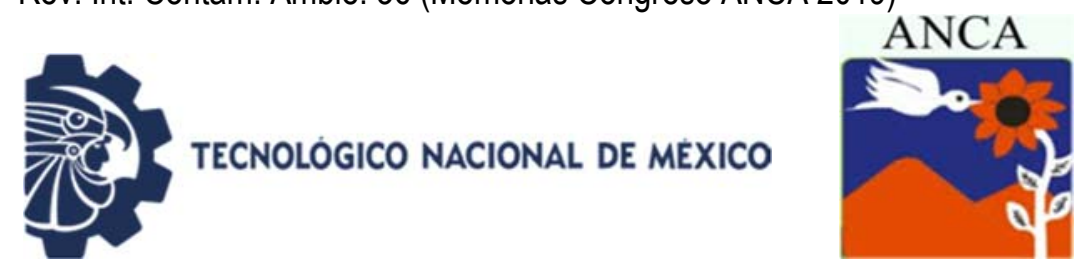

\title{
Citizen science for the knowledge of biodiversity: a case study of the birds of Estero del Yugo, Mazatlán, Sinaloa
}

\author{
Murúa Figueroa $\mathrm{E}^{*}$, Berlanga Robles $\mathrm{CA}$ \\ Centro de Investigación en Alimentación y Desarrollo A. C. \\ Coordinación Regional Mazatlán, Sinaloa, México \\ *emurua@ciad.mx
}

\begin{abstract}
Citizen Science or CC for their Spanish acronym entails an integral form of connecting individuals interested in biodiversity and the challenges of their preservation. The efforts of the CC are a powerful vesicle for the empowerment of its communities. By destroying barriers that separate science from society and promoting interaction between scientist and citizens working towards the regulation and preservation of nature. Similarly, the CC can provide access to data of the egologic model that would normally require a high level of education and a great amount of human and economic resources to the scientific community. With the purpose to demonstrate the potential of the $\mathrm{CC}$ for the study of biodiversity, a study was conducted in the northeast region of Mexico to determine the diversity of Aves in an ecological area of conservation. The study was conducted after a group of bird watchers obtained data in the last twelve years. As a result, more than 12,500 birds have been counted and categorized to belong to 222 different species, with a total $76 \%$ of expected species for that area. For the group of ducks, shorebirds, and mosquitos (54 species) the diversity registered values between 1.3 and 3.1 , and the equity between 0.59 and 0.95 . The smallest diversity was registered in April 2009 when only nine birds where registered belonging to five species. Beta diversity (disimilitud de Sorensen) for all the analyzed dates was 0.89 , almost $90 \%$ was due to the exchange of species. This study indicates the relevance of migrating Aves conforming the diversity of birds in the area where research was conducted.
\end{abstract}

Keywords: Citizen Science, Diversity and abundance of birds, Diversity and abundance of Aves, beta diversity, exchange and nesting.

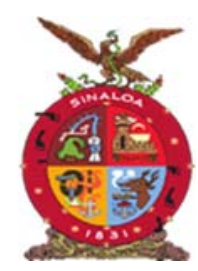

XVIII Congreso Internacional XXIV Congreso Nacional de Ciencias ambientales

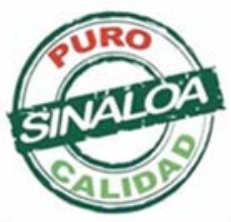

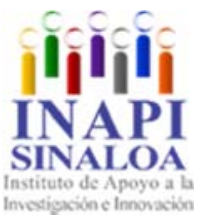

Mazatlán, Sinaloa 3-7 junio 2019

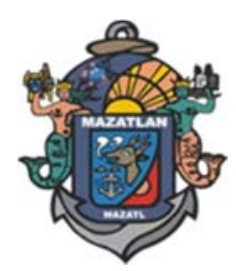

Recursos Naturales, Ecosistemas y Deterioro Ambiental 

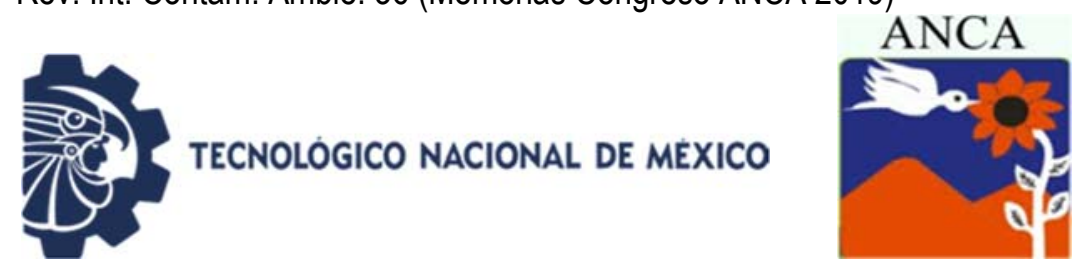

\section{Eficiencia de cuatro algoritmos para la distrubición del género Hippocampus (RAFINESQUE, 1810) en México}

Najera Medellin J*, De la Mora Covarrubias A, Quiñonez Martínez M

Instituto de Ciencias Biomédicas. Universidad Autónoma de Ciudad Juárez. Anillo Envolvente Pronaf S/N, 32310, Ciudad Juárez, Chihuahua, México _alejandro_najerasea@outlook.com

\section{RESUMEN}

Los mapas de distribución presentan información que para la conservación de la biodiversidad, son herramientas útiles para el manejo/protección de los recursos naturales y desarrollo de planes de manejo. El mapeo y modelaje potencial de especies es un reto para especies marinas poco documentadas, un ejemplo son los caballitos de mar (Hippocampus), que por su particular forma de vida (reducida movilidad, alta fidelidad al sitio, aunado a que habitan ecosistemas marinos perturbados) son vulnerables a la disminución en sus poblaciones. El objetivo del trabajo fue evaluar la eficiencia y desempeño de cuatro algoritmos de distribución potencial, aplicado a las cuatro especies de Hippocampus en México. Para ello, se recopilaron registros de presencias de las especies (19702017) y se utilizaron en los algoritmos BIOCLIM, DOMAIM, GARP y MaxEnt. La evaluación se efectuó con un análisis de curva ROC y un estadístico KappaCohen. En MaxEnt se realizó un análisis Jacknife para conocer las variables ambientales con mayor importancia en la predicción. Los resultados muestran que $H$. erectus e $H$. zosterae tiene una amplia distribución en las costas del Golfo de México; $H$. ingens, muestra una marcada distribución a lo largo de los estados costeros del Océano Pacifico, e $H$. reidi presenta una predicción más restringida a la zona del caribe mexicano. MaxEnt presentó los mejores resultados en la evaluación ROC (0.99) y Kappa (0.958). En general, la batimetría, distancia a la costa y concentración de clorofila son factores determinantes en la probabilidad de ocurrencia de las cuatro especies. Se requiere corroboración en campo.

Palabras clave: Hippocampus, distribución potencial, México, modelado de nicho, nicho fundamental.

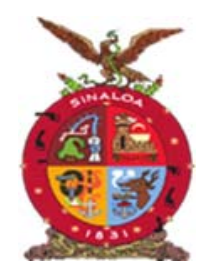

XVIII Congreso Internacional

XXIV Congreso Nacional de Ciencias ambientales
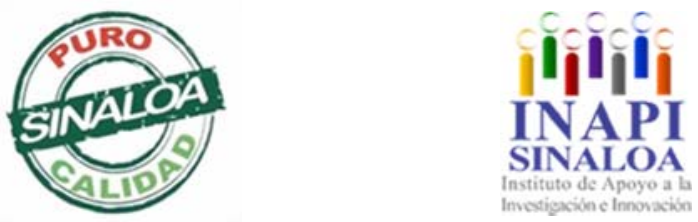

Mazatlán, Sinaloa 3-7 junio 2019

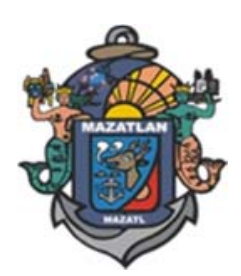

Recursos Naturales, Ecosistemas y Deterioro Ambiental 


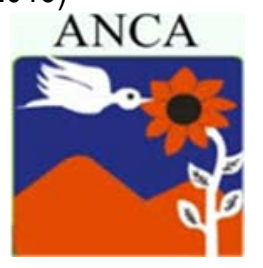

\title{
Efficiency of four algorithms for the distribution of the Hippocampus (RAFINESQUE, 1810) in Mexico
}

\author{
Najera Medellin J*, De la Mora Covarrubias A, Quiñonez Martínez M \\ Instituto de Ciencias Biomédicas. Universidad Autónoma de Ciudad Juárez. \\ Anillo Envolvente Pronaf S/N, 32310, Ciudad Juárez, Chihuahua, México \\ _alejandro_najerasea@outlook.com
}

\begin{abstract}
The distribution maps present information for the conservation of biodiversity, they are useful tools for the management/protection of natural resources and development of management plans. Potential mapping and modeling of species is a challenge for poorly documented marine species, for example seahorses (Hippocampus), which due to their way of life (reduced mobility, high fidelity to the site, in addition to inhabiting disturbed marine ecosystems) are vulnerable to the decline in their populations. The objective of the work was to evaluate the efficiency and performance of four potential distribution algorithms, applied to the four Hippocampus species in Mexico. To do this, records of presences of the species (1970-2017) were collected and used in the algorithms BIOCLIM, DOMAIM, GARP and MaxEnt. The evaluation was carried out with a ROC curve analysis and a Kappa-Cohen statistic. In MaxEnt, a Jacknife analysis was performed to know the environmental variables with greater importance in the prediction. The results show that $H$. erectus and $H$. zosterae have a wide distribution in the coasts of the Gulf of Mexico; $H$. ingens, shows a marked distribution throughout the coastal states of the Pacific Ocean, and $H$. reidi presents a more restricted prediction to the zone of the Mexican Caribbean. MaxEnt presented the best results in the evaluation ROC (0.99) and Kappa (0.958). In general, the bathymetry, distance to the coast and concentration of chlorophyll are determining factors in the probability of occurrence of the four species. Corroboration in the field is required.
\end{abstract}

Keywords: Hippocampus, potential distribution, Mexico, niche modelling, fundamental niche.

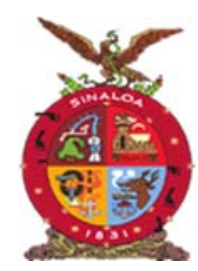

XVIII Congreso Internacional XXIV Congreso Nacional de Ciencias ambientales
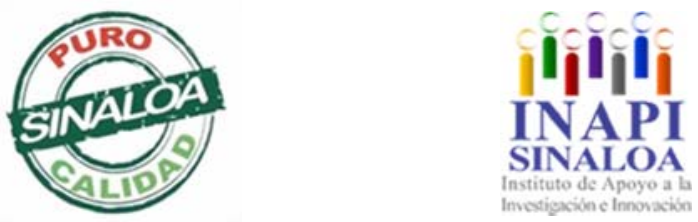

Mazatlán, Sinaloa 3-7 junio 2019

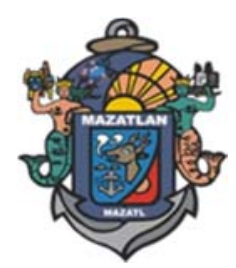

Recursos Naturales, Ecosistemas y Deterioro Ambiental 

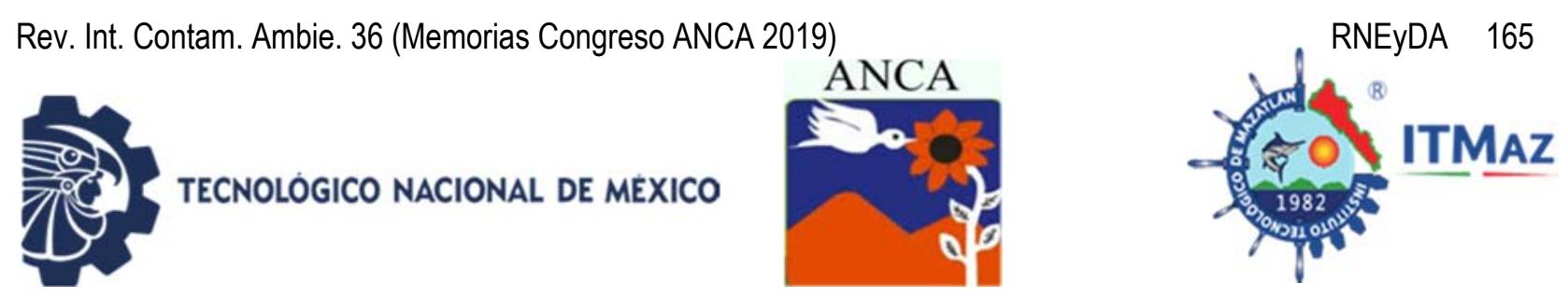

\title{
Cambio de cobertura vegetal y uso de suelo en un periodo de 25 años en el Distrito de Ixtlán, Oaxaca
}

\author{
Nava Juárez D*, Marcial Juárez R \\ Licenciatura en Ciencias Ambientales. Universidad de la Sierra Juárez, \\ Oaxaca, México \\ *diananavajuarez@gmail.com
}

\begin{abstract}
RESUMEN
El ACCUS permite conocer la evolución del paisaje y las repercusiones que las actividades humanas ejercen en el medio, sirve de apoyo para proponer programas y políticas de manejo y conservación, para ello se estimaron los cambios en la cobertura vegetal y el uso de suelo en el distrito de Ixtlán, Oaxaca para conocer las variaciones ocurridas entre 1992 y 2017 por medio de interpretación comparativa de imágenes. Con ortofotos e imágenes SPOT se realizó interpretación comparativa, a una escala 1:10,000 donde se encontraron 5 coberturas vegetales y 6 usos de suelo. Para evaluar las tasas de cambio se utilizó cartografía de Uso de Suelo Vegetación del INEGI: 1993, 2009 y 2016, se determinó el potencial de recarga hídrica por medio de cinco parámetros; pendiente, suelo, roca, cobertura vegetal y uso de suelo y se analizó el estado de la vegetación con el NDVI (Landsat 8); para el procesamiento de los datos, se utilizó un SIG. Los resultados mostraron que el $36.88 \%$ del distrito no presentó cambio, el $21.74 \%$ se ha recuperado y $41.38 \%$ ha sido degradado. El tipo de vegetación que predomina es bosque de pino, encino y mesófilo de montaña, las tasas de cambio no llegan a reportar el $1 \%$ en 25 años; el potencial de recarga hídrica va de bajo a muy alto y la calidad de vegetativa del NDVI va de-0.17 a + 0.62. La información generada, mejorará la comprensión de las causas y el impacto en el paisaje y dar un seguimiento a los cambios que llegarán a producirse con el tiempo.
\end{abstract}

Palabras clave: Tasas de cambio, Potencial de Recarga hídrica y NDVI.

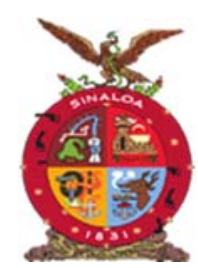

XVIII Congreso Internacional XXIV Congreso Nacional de Ciencias ambientales

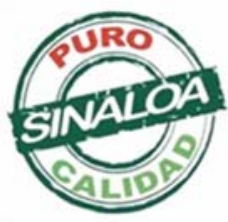

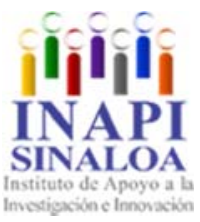

Mazatlán, Sinaloa 3-7 junio 2019

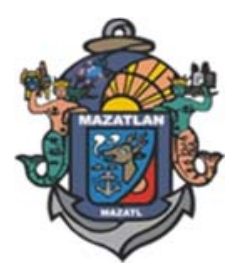

Recursos Naturales, Ecosistemas y Deterioro Ambiental 

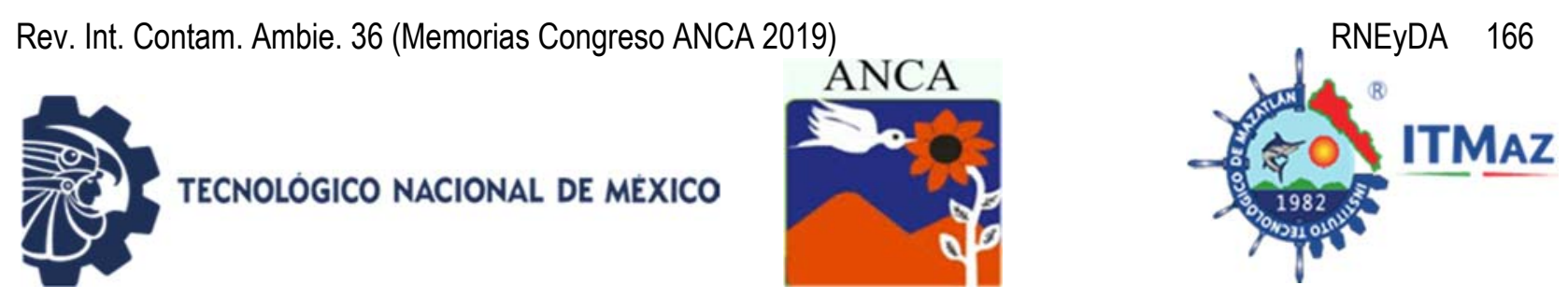

\title{
Change of vegetal coverage and use of soil in a period of 25 years in the District of Ixtlán, Oaxaca
}

\author{
Nava Juárez D*, Marcial Juárez R \\ Licenciatura en Ciencias Ambientales. Universidad de la Sierra Juárez, \\ Oaxaca, México \\ *diananavajuarez@gmail.com
}

\begin{abstract}
The ACCUS allows to know the evolution of the landscape, the repercussions that human activities exert in the environment and it serves as support to propose programs and policies of management and conservation. The present work estimated the changes in vegetation cover and land use in the district of Ixtlan for the purpose of measuring through comparative interpretation the variations that occurred from 1992 to 2017 . With orthophotos and SPOT images, a comparative interpretation was performed at a scale of 1: 10,000 where 5 vegetation coverings and 6 land uses were found. For the exchange rates, Vegetation Soil Use Mapping (INEGI: 1993, 2009 and 2016) was used. The hydric recharge potential was determined by means of five parameters; slope, soil, rock, vegetation cover and land use and the state of the vegetation was analyzed with the NDVI (Landsat 8). A GIS was used to process the data. The results showed that $36.88 \%$ of the district did not present change, $21.74 \%$ has recovered and $41.38 \%$ has been degraded. The type of vegetation that predominates is Pinnus $s p$, Qercus $s p$ and cloud forest. The change of rates do not get to report the $1 \%$ in 25 years; the hydric recharge potential goes from low to very high and the vegetative quality of the NDVI goes from- 0.17 to +0.62 . The information generated will improve the understanding of the causes and the impact on the landscape, and will help monitor the changes that will eventually occur.
\end{abstract}

Keywords: Rates of change, water recharge potential and NDVI.

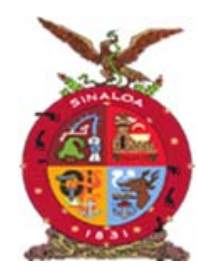

XVIII Congreso Internacional

XXIV Congreso Nacional de Ciencias ambientales
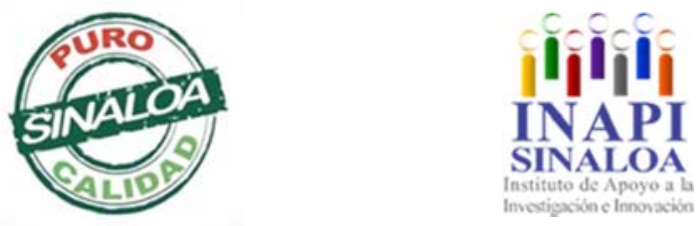

Mazatlán, Sinaloa 3-7 junio 2019

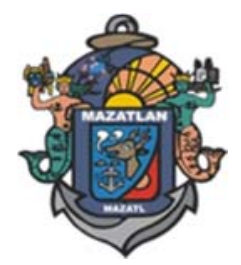

Recursos Naturales, Ecosistemas y Deterioro Ambiental 

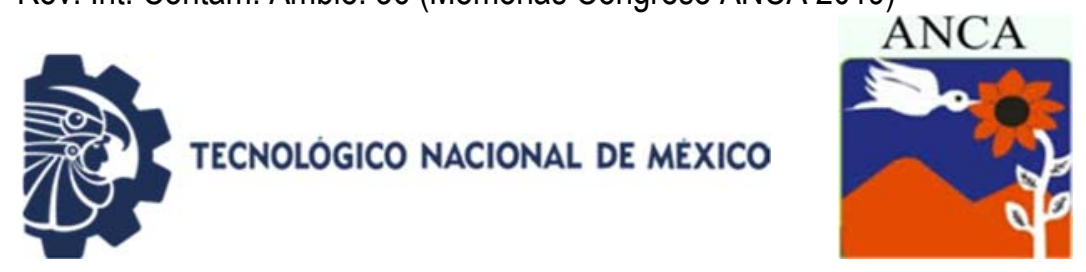

\title{
Diversidad de especies y gremios alimenticios de aves en un área urbana de Ciudad Victoria, Tamaulipas, México
}

\author{
Navarro García $\mathrm{K}^{1}$, Gómez Moreno $\mathrm{V}^{2}$, Niño Maldonado $\mathrm{S}^{1 *}$, López Mancilla $\mathrm{A}^{3}$, \\ Zequera García $\mathrm{C}^{3}$ \\ ${ }^{1}$ Facultad de Ingeniería y Ciencias. Centro Universitario Victoria. \\ Universidad Autónoma de Tamaulipas. \\ Adolfo López Mateos, C.P. 87149, Ciudad Victoria, Tamaulipas, México \\ 2Instituto Tecnológico de Ciudad Victoria. \\ Boulevard Emilio Portes Gil No. 1301, Ciudad Victoria, Tamaulipas, México \\ 3Instituto Tecnológico de Huejutla. \\ Carr. Huejutla-Chalahuiyapa, Km. 5.5. Huejutla, Hidalgo, México \\ *coliopteranino@hotmail.com
}

\section{RESUMEN}

Las áreas verdes en entornos urbanas son espacios que están funcionando como islas de vegetación dentro de las ciudades. Las características de la vegetación influyen de manera contundente en la riqueza y abundancia de aves. Algunos estudios señalan que estas áreas pueden proporcionar un hábitat potencial que pueden ofrecer refugio, áreas para anidamiento o percha y fuente de alimentación para algunas especies de aves. Sin embargo, se sabe muy poco de la composición avifaunística de las especies que se alimentan en estas áreas. El objetivo fue conocer la diversidad de aves e identificar los gremios alimenticios que se benefician de las áreas verdes de la Facultad de Ingeniería y Ciencias (FIC). Se realizaron muestreos semanales de agosto de 2018 a enero de 2019. Haciendo recorridos en las áreas verdes, de 07:00 am a 12:00 pm. Para la identificación de las aves fue por medio del método visual directa con binoculares y guías de campo. Se identificaron un total de 770 individuos pertenecientes a 10 órdenes, 23 familias y 66 especies. De éstas, el $60 \%$ de las especies de aves corresponden al gremio insectívora, seguida de frugívora con un 19\%. Las áreas verdes de la FIC albergan el $25 \%$ de las especies de Ciudad Victoria, Tamaulipas. Estas áreas son de gran importancia para la presencia de las aves nativas, dado que todas las aves fueron observadas utilizando de algún modo (alimentación, anidación y percha) los recursos que representan las áreas verdes de la FIC.

Palabras clave: Alimentación, avifauna, insectívoros, zona urbana.

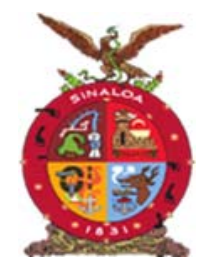

XVIII Congreso Internacional

XXIV Congreso Nacional de Ciencias ambientales

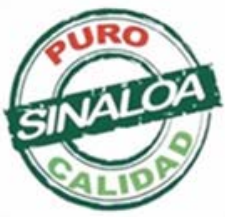

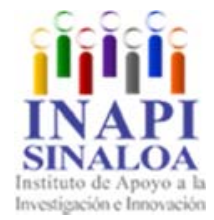

Mazatlán, Sinaloa 3-7 junio 2019

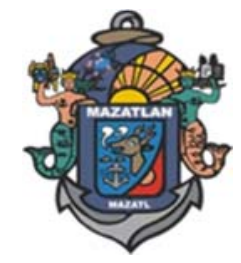

Recursos Naturales, Ecosistemas y Deterioro Ambiental 

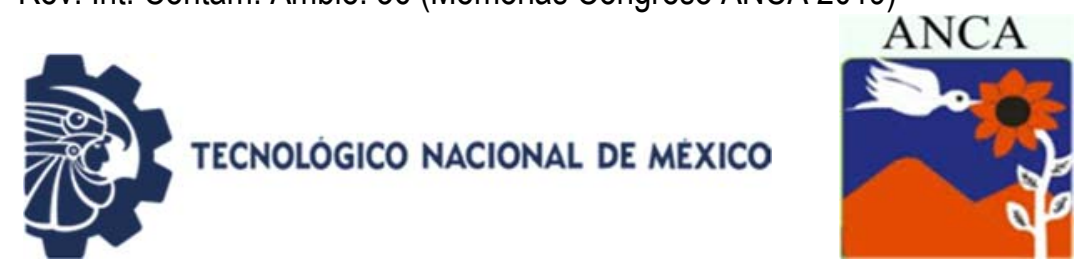

\title{
Diversity of species and food guilds of birds in an urban area of Ciudad Victoria, Tamaulipas, México
}

\author{
Navarro García K ${ }^{1}$, Gómez Moreno ${ }^{2}$, Niño Maldonado $S^{1 *}$, López Mancilla $A^{3}$, \\ Zequera García $\mathrm{C}^{3}$ \\ ${ }^{1}$ Facultad de Ingeniería y Ciencias. Centro Universitario Victoria. \\ Universidad Autónoma de Tamaulipas. \\ Adolfo López Mateos, C.P. 87149, Ciudad Victoria, Tamaulipas, México \\ 2Instituto Tecnológico de Ciudad Victoria. \\ Boulevard Emilio Portes Gil No. 1301, Ciudad Victoria, Tamaulipas, México \\ ${ }^{3}$ Instituto Tecnológico de Huejutla. \\ Carr. Huejutla-Chalahuiyapa, Km. 5.5. Huejutla, Hidalgo, México \\ *coliopteranino@hotmail.com
}

\begin{abstract}
Green areas in urban environments are spaces that are functioning as islands of vegetation within cities. Vegetation characteristics strongly influence the richness and abundance of birds. Some studies indicate that these areas can provide a potential habitat that can offer shelter, areas for nesting or perching and food sources for some bird species. However, very little is known about the birdlife composition of the species that feed in these areas. The objective was to know the diversity of birds and identify the food guilds that benefit from the green areas of the Faculty of Engineering and Sciences (FIC). Weekly sampling was conducted from August 2018 to January 2019. Making tours in the green areas, from 07:00 am to $12: 00 \mathrm{pm}$. For the identification of the birds it was by means of the direct visual method with binoculars and field guides. A total of 770 individuals belonging to 10 orders, 23 families and 66 species were identified. Of these, $60 \%$ of bird species correspond to the insectivorous guild, followed by frugivorous with $19 \%$. The green areas of the FIC house $25 \%$ of the species of Ciudad Victoria, Tamaulipas. These areas are of great importance for the presence of native birds, since all birds were observed using somehow (feeding, nesting and perching) the resources that represent the green areas of the FIC.
\end{abstract}

Keywords: Food, birdlife, insectivorous, urban area.

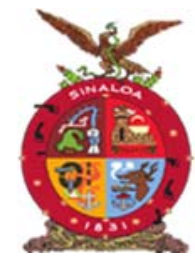

XVIII Congreso Internacional

XXIV Congreso Nacional de Ciencias ambientales

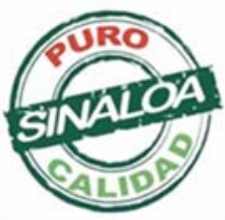

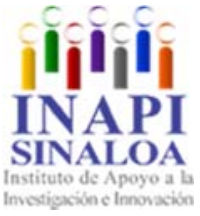

Mazatlán, Sinaloa 3-7 junio 2019

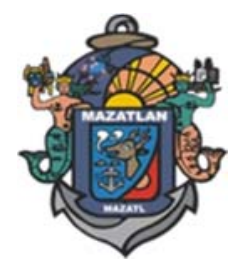

Recursos Naturales, Ecosistemas y Deterioro Ambiental 

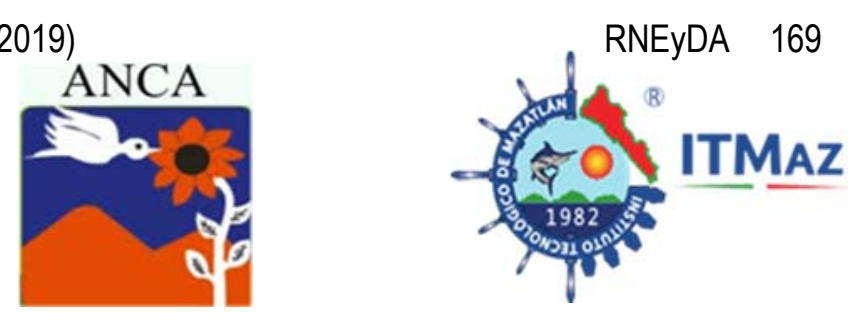

Diversidad de mariposas diurnas (Rhopalocera) en el bosque de encino y
vegetación riparia del Cañon de la Peregrina, Victoria, Tamaulipas, México

$$
\begin{gathered}
\text { Niño Maldonado } \mathrm{S}^{1} \text {, De León González } \mathrm{E}^{2} \text {, Lucio García J², Reyes Muñoz J33, } \\
\text { Medina Puente } \mathrm{A}^{1}
\end{gathered}
$$

${ }^{1}$ Facultad de Ingeniería y Ciencias. Centro Universitario Victoria.

Universidad Autónoma de Tamaulipas.

Adolfo López Mateos, Ciudad Victoria, Tamaulipas, México

${ }^{2}$ Instituto Tecnológico de Ciudad Victoria.

Boulevard Emilio Portes Gil No. 1301, Ciudad Victoria, Tamaulipas, México

${ }^{3}$ CIIDIR-IPN Unidad Durango, Instituto Politécnico Nacional.

Av. Sigma No. 119, Fracc. 20 de noviembre II, C.P. 34220, Durango, México.

Universidad Juárez del Estado de Durango. Facultad de Ciencias Biológicas.

Av. Universidad S/N, Fracc. Filadelfia, 35010 Gómez Palacio, Durango, México coliopteranino@hotmail.com

\section{RESUMEN}

Las mariposas diurnas (Rhopalocera) y nocturnas (Heterocera) ocupan el segundo lugar en diversidad en el mundo con un total aproximado de 146,000 especies. Algunos autores mencionan que se presentan en nuestro país alrededor del $12 \%$ y de éstas 1,700 son diurnas que se agrupan en dos superfamilias: Papilionoidea (Lycaenidae, Nymphalidae, Papilionidae, Pieridae) y Hesperioidea (Hesperiidae). En MéxicoTamaulipas, ocupa el décimo lugar en diversidad de mariposas y se conocen 458 especies. Los objetivos fueron determinar la abundancia y diversidad altitudinal y estacional de los lepidópteros diurnos en el Bosque de encino y Vegetación riparia del Cañon de la Peregrina Victoria, Tamaulipas. El área de estudio se ubica al noroeste de la cabecera municipal dentro del área Natural Protegida "Altas Cumbres" a una altitud de $1,000 \mathrm{msnm}$, con un clima subhúmedo con lluvias en verano. La Temperatura media anual oscila entre los 18 a $24^{\circ} \mathrm{C}$ anuales, con una precipitación que va de los 717 a los $1,058 \mathrm{~mm}$ anuales. Se realizaron 16 muestreos, cuatro en cada estación del año 2017, para la captura de los ejemplares se utilizó el método directo con red entomológica con $40 \mathrm{~cm}$ de diámetro y para montarlas el método de empalamiento. En el Bosque de encino y la Vegetación riparia se registraron 2,993 ejemplares dentro de cinco familias: Papilionidae con nueve especies, Lycaenidae con 15, Pieridae con 18, Hesperiidae con 29 y la más diversa con 46 fue Nymphalidae, representa para Tamaulipas el $25.54 \%$. Por estación la primavera fue la más diversa y otoño el menos diverso.

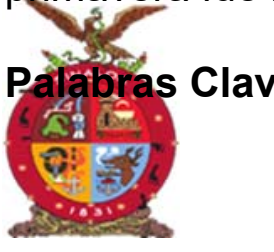

XVIII Congreso Internacional XXIV Congreso Nacional de Ciencias ambientales

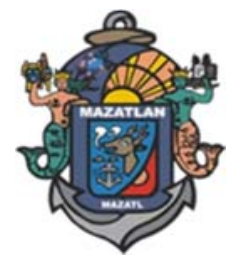

Recursos Naturales, Ecosistemas y Deterioro Ambiental 

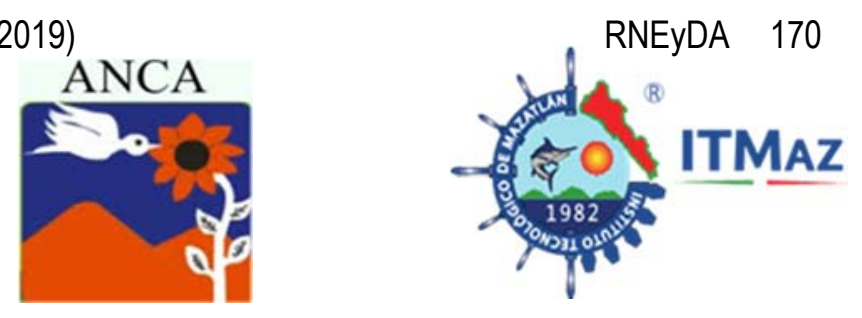

Diversity of diurnal butterflies (Rhopalocera) in the encino forest and riparia vegetation of the Peregrina Canyon, Victoria, Tamaulipas, México

\author{
Niño Maldonado S ${ }^{1}$, De León González $E^{2}$, Lucio García J², Reyes Muñoz J33, \\ Medina Puente $A^{1}$
}

${ }^{1}$ Facultad de Ingeniería y Ciencias. Centro Universitario Victoria.

Universidad Autónoma de Tamaulipas.

Adolfo López Mateos, Ciudad Victoria, Tamaulipas, México

2Instituto Tecnológico de Ciudad Victoria.

Boulevard Emilio Portes Gil No. 1301, Ciudad Victoria, Tamaulipas, México

${ }^{3}$ CIIDIR-IPN Unidad Durango, Instituto Politécnico Nacional.

Av. Sigma No. 119, Fracc. 20 de noviembre II, C.P. 34220, Durango, México.

Universidad Juárez del Estado de Durango. Facultad de Ciencias Biológicas.

Av. Universidad S/N, Fracc. Filadelfia, 35010 Gómez Palacio, Durango, México coliopteranino@hotmail.com

\begin{abstract}
The diurnal (Rhopalocera) and nocturnal (Heterocera) butterflies occupy the second place in diversity in the world with an approximate total of 146,000 species. Some authors mention that about $12 \%$ occur in our country and of these 1,700 are diurnal that are grouped into two superfamilies: Papilionoidea (Lycaenidae, Nymphalidae, Papilionidae, Pieridae) and Hesperioidea (Hesperiidae). In Mexico Tamaulipas, it occupies the tenth place in diversity of butterflies and 458 species are known. The objectives were to determine the abundance and altitudinal and seasonal diversity of diurnal lepidoptera in the Oak Forest and Riparian Vegetation of the Victoria Pilgrim's Canyon, Tamaulipas. The study area is located northwest of the municipal seat within the Natural Protected Area "High Summits" at an altitude of 1,000 meters above sea level, with a subhumid climate with rains in summer. The average annual temperature ranges between 18 to $24^{\circ} \mathrm{C}$ annually, with a rainfall that ranges from 717 to $1,058 \mathrm{~mm}$ per year. Sixteen samples were carried out, four in each season of 2017, for the capture of the specimens the direct method with entomological network with 40 $\mathrm{cm}$ in diameter was used and to assemble the method of impalement. In the Oak Forest and the Riparian Vegetation, 2,993 specimens were registered within five families: Papilionidae with nine species, Lycaenidae with 15, Pieridae with 18, Hesperiidae with 29 and the most diverse with 46 was Nymphalidae, it represents $25.54 \%$ for Tamaulipas. By season, spring was the most diverse and autumn the least diverse.

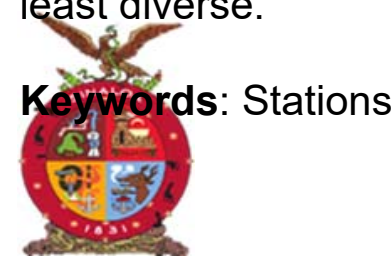

XVIII Congreso Internacional

XXIV Congreso Nacional de Ciencias ambientales

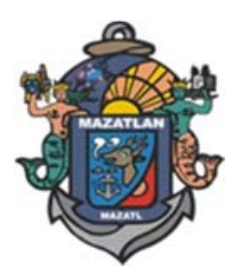

Recursos Naturales, Ecosistemas y Deterioro Ambiental
\end{abstract}



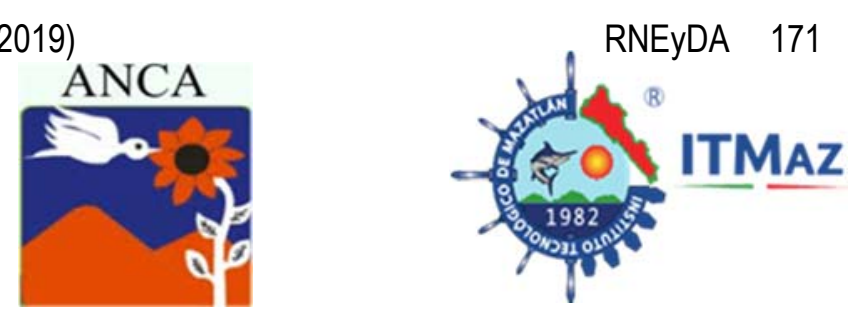

\title{
Cultivo del copépodo Leptodiaptomus novamexicanus (Herrick, 1895) del Lago de Metztitlán, Hidalgo, como alimento para Pez Blanco
}

\author{
Núñez García $\mathrm{L}^{1}$, Carlos Márquez $\mathrm{M}^{1 *}$, Díaz Larrea J11, Urbina Sánchez $\mathrm{GI}^{1}$, \\ Castañeda López $\mathrm{O}^{2}$, Cruz Aviña $\mathrm{R}^{3}$ \\ ${ }^{1}$ Planta Experimental de Producción Acuícola. \\ Universidad Autónoma Metropolitana-Unidad Iztapalapa, Ciudad de México \\ ${ }^{2}$ Laboratorio de Ecosistemas Costeros. \\ Universidad Autónoma Metropolitana-Unidad Iztapalapa, Ciudad de México \\ ${ }^{3}$ Benemérita Universidad Autónoma de Puebla. \\ 72000, Puebla de Zaragoza, Puebla, México \\ *marisol.carlos.marquez13@gmail.com
}

\section{RESUMEN}

El copépodo Leptodiaptomus novamexicanus permanece en cuerpos de agua con las mismas características de los lagos fríos donde se encuentra $C$. humboldtianum, este en sus primeras etapas de vida solo se alimenta de organismos vivos de poca talla y que estén en movimiento. Por tal motivo es importante determinar si el cultivo en laboratorio de Leptodiaptomus novamexicanus es adecuado para utilizarlo de alimento vivo de $C$. humboldtianum. Se realizó una colecta de Leptodiaptomus novamexicanus en el lago Metztitlan trasladándolo a la Planta Experimental de Producción Acuícola (PExPA) manteniéndolo en las mismas características del lago, posteriormente se realizó un bioensayo con cuatro dietas diferentes por duplicado: 1) Lechuga y levadura 2) arroz y acelgas 3) levadura y 4) Chlorella sp., a dos temperaturas diferentes de 26 y $27 \pm 0.5^{\circ} \mathrm{C}$. Al obtenerse los organismos se dieron de comer a C. humboldtianum de la localidad de Tepuxtepec. Las mayores densidades se registraron en la dieta 1) temperatura de $27 \pm 0.5^{\circ} \mathrm{C}$, obteniéndose densidades de entre 3,500 a $3,700 \mathrm{org} / \mathrm{L}$, lo cual satisface la necesidad de copépodos requeridos por las larvas de peces que necesitan densidades de 1 copepodito por $\mathrm{ml}$. Durante el desarrollo del experimento se ofrecieron hasta 20 copépodos por $\mathrm{ml}$ y se obtuvo buena talla de los peces. El cultivo de los copépodos permitió contar con alimento vivo en cantidades suficientes y a bajo costo, que proporciona mayor valor nutricional que la Artemia y los rotíferos utilizados para los cultivos de larvas de peces.

Palabras clave: Copépodo, cultivo, alimento vivo.

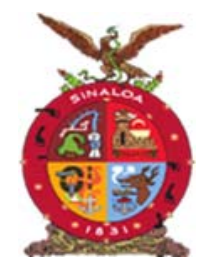

XVIII Congreso Internacional

XXIV Congreso Nacional de Ciencias ambientales
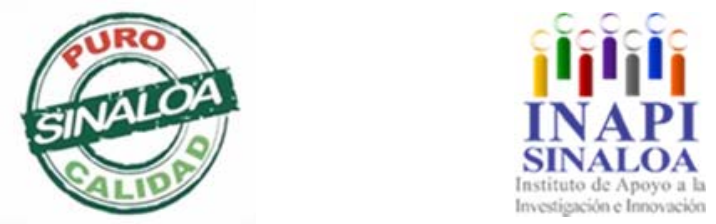

Mazatlán, Sinaloa 3-7 junio 2019

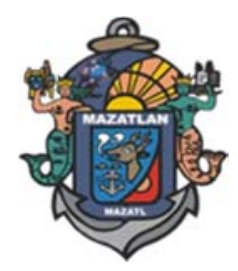

Recursos Naturales, Ecosistemas y Deterioro Ambiental 

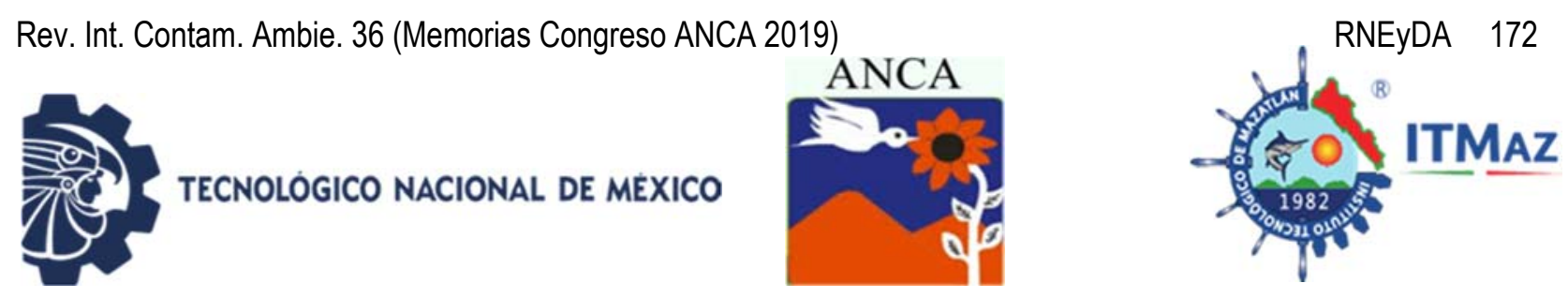

\title{
Cropping of copepod Leptodiaptomus novamexicanus (Herrick, 1895) from the Lake of Metztitlan, Hidalgo, as a food for a White Fish
}

\author{
Núñez García $\mathrm{L}^{1}$, Carlos Márquez $\mathrm{M}^{1 *}$, Díaz Larrea $\mathrm{J}^{1}$, Urbina Sánchez $\mathrm{GI}^{1}$, \\ Castañeda López $\mathrm{O}^{2}$, Cruz Aviña $\mathrm{R}^{3}$ \\ ${ }^{1}$ Planta Experimental de Producción Acuícola. \\ Universidad Autónoma Metropolitana-Unidad Iztapalapa, Ciudad de México \\ ${ }^{2}$ Laboratorio de Ecosistemas Costeros. \\ Universidad Autónoma Metropolitana-Unidad Iztapalapa, Ciudad de México \\ ${ }^{3}$ Benemérita Universidad Autónoma de Puebla. \\ 72000, Puebla de Zaragoza, Puebla, México \\ *marisol.carlos.marquez13@gmail.com
}

\begin{abstract}
The copepod Leptodiaptomus novamexicanus remains in bodies of water with the same characteristics of the cold lakes where $C$. humboldtianum is found, this one in its first stages of life only feeds on living organisms of little size and that are in movement. For this reason it is important to determine if the laboratory culture of Leptodiaptomus novamexicanus is suitable to be offered as a live food for $C$. humboldtianum. A collection of Leptodiaptomus novamexicanus was carried out in Lake Metztitlan, transferring it to the Experimental Plant for Aquaculture Production (PExPA) keeping it with the same characteristics of the lake. Later a bioassay was carried out with four different diets in duplicate: 1) Lettuce and yeast 2) rice and chard 3) yeast and 4) Chlorella sp., at two different temperatures 26 and $27 \pm 0.5^{\circ} \mathrm{C}$. When the organisms were obtained, they fed $\mathrm{C}$. humboldtianum from the town of Tepuxtepec. The highest densities were registered in the diet 1) at a temperature of $27 \pm 0.5^{\circ} \mathrm{C}$, obtaining densities of between 3,500 to 3,700 org/L, which satisfies the need for copepods required by larvae of fish that need densities of 1 copepodito per ml. During the development of the experiment, up to 20 copepods per $\mathrm{ml}$ were offered obtaining good size of the fish. The culture of the copepods allows to have live food in sufficient quantities and at low cost that provides greater nutritional value than the Artemia and the rotifers used for the cultures of fish larvae.
\end{abstract}

Keywords: Copepod, culture, live food.

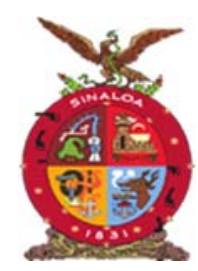

XVIII Congreso Internacional XXIV Congreso Nacional de Ciencias ambientales
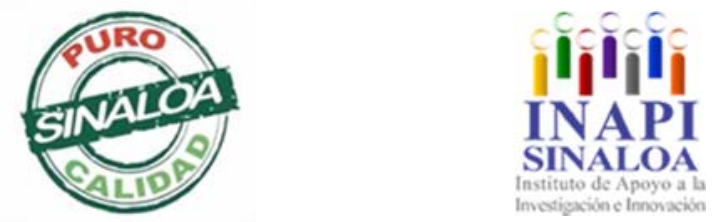

Mazatlán, Sinaloa 3-7 junio 2019

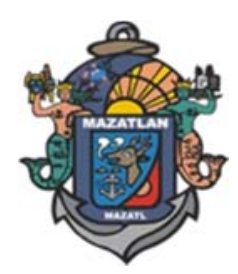

Recursos Naturales, Ecosistemas y Deterioro Ambiental 

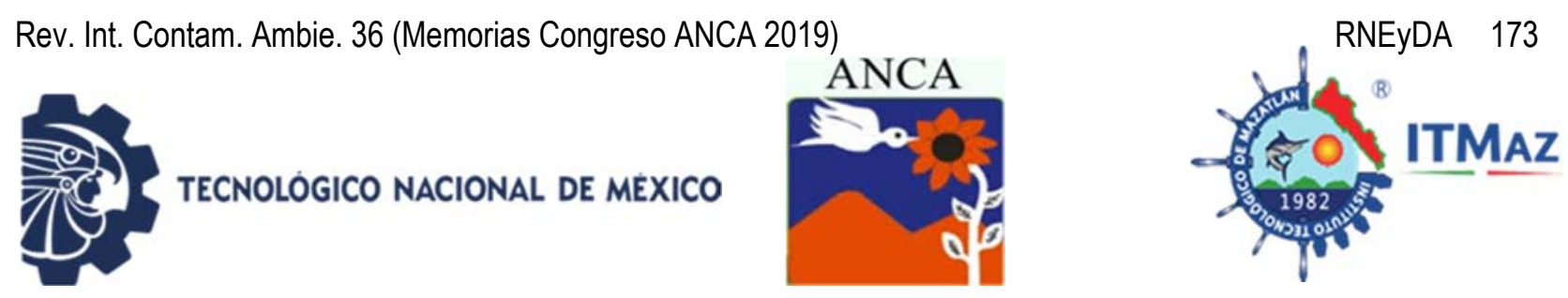

\title{
Modelado del carbono, nitrógeno y azufre en la hojarasca foliar de un rastrojo altoandino de Colombia
}

\author{
Ochoa Reyes $\mathrm{P}^{1 *}$, Murcia Rodríguez $\mathrm{M}^{1}$, Poveda Gómez $\mathrm{F}^{2}$ \\ ${ }^{1}$ Semillero de Investigación. Grupo de Recursos Naturales. \\ Universidad de Pamplona-Colombia \\ ${ }^{2}$ Corporación Manaba. Universidad de Pamplona. Ciudadela Universitaria. \\ Km. 1, Vía a Bucaramanga, Pamplona, Norte de Santander Colombia, \\ Corporación Manaba, CI 53 70-10, Bogotá, Colombia \\ *bio.ochoar@gmail.com
}

\section{RESUMEN}

Se modelaron la tendencia temporal y el comportamiento del carbono (C), nitrógeno $(\mathrm{N})$ y azufre $(\mathrm{S})$ en la hojarasca foliar de Escallonia myrtilloides $(E m)$ y Miconia ligustrina $(M I)$ en un rastrojo altoandino (3.100-3.250 msnm) de 25 años de regeneración natural, en la cuenca del río Pamplonita, nororiente colombiano. Las dos especies más productoras de hojarasca foliar se determinaron por análisis de componentes principales (ACP). Se realizaron análisis de regresión simple y múltiple, siendo el tiempo [días $(x)=906$ ] y los factores meteorológicos las variables independientes. El porcentaje de $\mathrm{C}, \mathrm{N}$ y $\mathrm{S}$ foliar se determinó por combustión completa del material vegetal, por flujo directo de oxígeno a $1450^{\circ} \mathrm{C}$, en diciembre de 2017: el $\mathrm{CO}_{2}$ y el $\mathrm{SO}_{2}$ liberados se analizaron mediante un detector de rayos infrarrojo no dispersivo, y el $\mathrm{N}_{2}$ por conductividad térmica con un LECO TruMac CNS $\circledast$. EI C, N y S aumentaron exponencial $\left(M / C=51,69 \mathrm{e}^{5 \mathrm{E}-}\right.$ $05(\mathrm{x})$ ), lineal $E m N=0,0004 \mathrm{x}+1,56$ y cúbicamente $\left(E m S=-7 \mathrm{E}-10 \mathrm{x}^{3}+1 \mathrm{E}-06 \mathrm{x}^{2}-\right.$ $0,0003 x+0,1163)$. La relación $\mathrm{C} / \mathrm{N}$ decreció $(E m C / N=-0,0075 x+37,67)$. El comportamiento del carbono fue $45 \%$ explicado por la temperatura media, la precipitación, el viento y la humedad relativa $(E m C=-0,91$ (Tmed) + 0,012 (Lluvia) + 2,95 (Viento)-0,104 (HR\%) + 76,42), la evaporación media y la humedad relativa $(M / C=-1,263(\mathrm{Emed})-0,112(\mathrm{HR} \%)+66,26)$. El nitrógeno se determinó por las horas del brillo solar: $M / N=1,869 \mathrm{e}^{-8 \mathrm{E}-04}$ (Bsum). El azufre se explicó por la evaporación en MIS =0,139e-8E-04 (Eva). Escallonia myrtilloides y Miconia ligustrina exhibieron tendencias y comportamientos diferenciales que segregaron ampliamente sus nichos funcionales. La fase sucesional de rastrojofue menos susceptible de modelación estadística que el matorral altoandino.

Palabras claves: Sucesión ecológica, bosque altoandino, Escallonia myrtillojides, Miconia ligustrina, nicho ecológico.

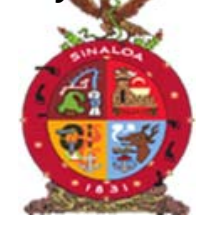

XVIII Congreso Internacional

XXIV Congreso Nacional de Ciencias ambientales
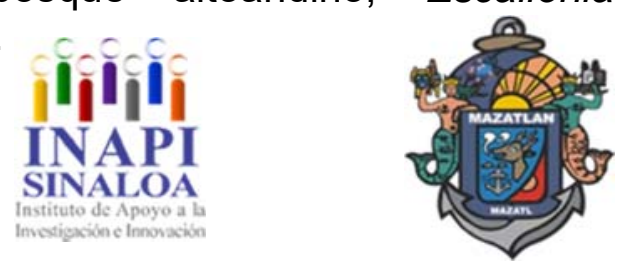

Recursos Naturales, Ecosistemas y Deterioro Ambiental 

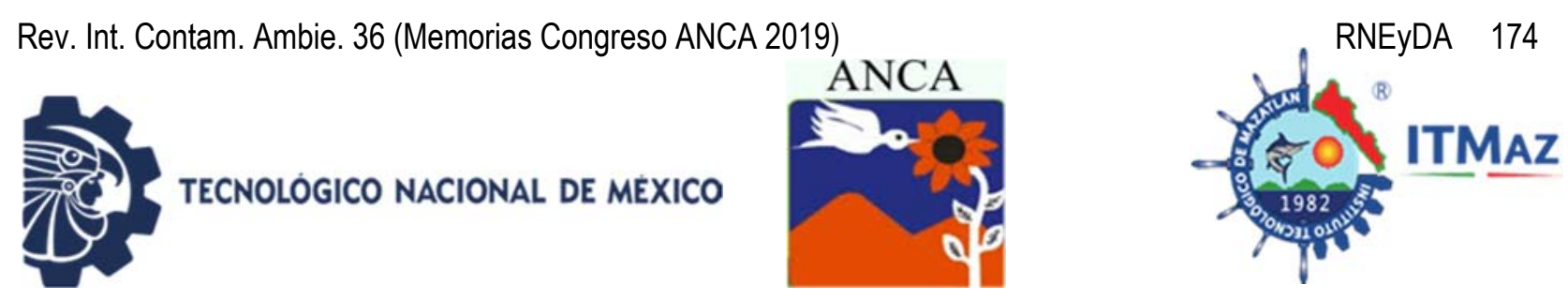

\title{
Carbon, nitrogen and sulfur modeling in the foliar litterfall of a high andean stubble of Colombia
}

\author{
Ochoa Reyes $\mathrm{P}^{1 *}$, Murcia Rodríguez $\mathrm{M}^{1}$, Poveda Gómez $\mathrm{F}^{2}$ \\ ${ }^{1}$ Semillero de Investigación. Grupo de Recursos Naturales. \\ Universidad de Pamplona-Colombia \\ ${ }^{2}$ Corporación Manaba. Universidad de Pamplona. Ciudadela Universitaria. \\ Km. 1, Vía a Bucaramanga, Pamplona, Norte de Santander Colombia, \\ Corporación Manaba, Cl 53 70-10, Bogotá, Colombia \\ *bio.ochoar@gmail.com
}

\begin{abstract}
The carbon $(\mathrm{C})$, nitrogen $(\mathrm{N})$ and sulphur $(\mathrm{S})$ behaviors and temporal trends were modeled for the Escallonia myrtilloides (Em) and Miconia ligustrina (MI) foliar litterfall within a 25 years naturally regenerated high Andean stubble, in the Pamplonita river basin by northeastern Colombia (3100-3250 m alt). These two species were the most productive ones as determined by a principal component analysis (ACP). Simple and multiple regression analysis were made, the time [days $(x)=906$ ] and meteorological factors being the independent variables. The percentage of foliar $\mathrm{C}, \mathrm{N}$ and $\mathrm{S}$ were determined by complete combustion of the vegetal material with an oxygen direct flux at $1450^{\circ} \mathrm{C}$ by December 2017 , so, the released $\mathrm{CO} 2$ and $\mathrm{SO} 2$ were measured by means of a non-dispersive infrared rays detector, and the N2 was recorded according to thermal conductivity by a LECO TruMac CNS ${ }^{\circ}$. The $C$ increased exponentially $\left(M / C=51,69 \mathrm{e}^{5 \mathrm{E}-05(\mathrm{x})}\right)$, the $\mathrm{N}$ linearly $(E m N=0,0004 x+1,56)$, and the S cubically EmS $=-7 \mathrm{E}-10 \mathrm{x}^{3}+1 \mathrm{E}-06 \mathrm{x}^{2}-$ $0,0003 x+0,1163$. The $C / N$ ratio decreased linearly $(E m C / N=-0,0075 x+37,67)$. The carbon behavior was $45 \%$ explained by the mean temperature, precipitation, wind velocity, and relative humidity $(E m C=-0,91$ (Tmed) $+0,012$ (Lluvia) $+2,95$ (Viento)-0,104 (HR\%) $+76,42)$, by the mean evaporation and relative humidity $(M / C=-1,263$ (Emed)-0,112 (HR\%) +66,26). The nitrogen was determined by the sunshine hours $\left(M / N=1,869 \mathrm{e}^{-8 \mathrm{E}-04}\right.$ (Bsum) $)$; the $S$ was explained by the evaporation $\left(M / S=0,139 \mathrm{e}^{-8 \mathrm{E}-04(\mathrm{Eva})}\right)$. Escallonia myrtilloides and Miconia ligustrina showed differential trends and behaviors allowing to segregate their functional niches. The successional phase of stubble was less susceptible to be statistically modeled than the high Andean shrub.
\end{abstract}

Keywords: Ecological succession, high Andean forest, Miconia ligustrina, Hyypericum phellos, ecological niche.

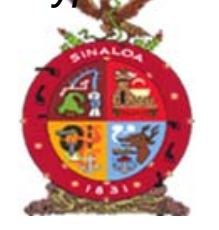

XVIII Congreso Internacional XXIV Congreso Nacional de Ciencias ambientales

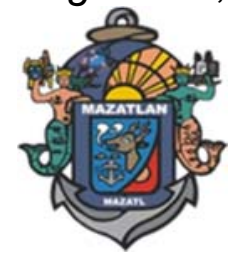

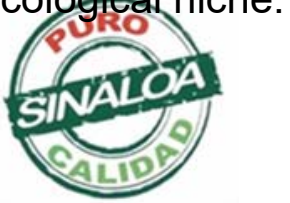

Mazatlán, Sinaloa 3-7 junio 2019
Recursos Naturales, Ecosistemas y Deterioro Ambiental 

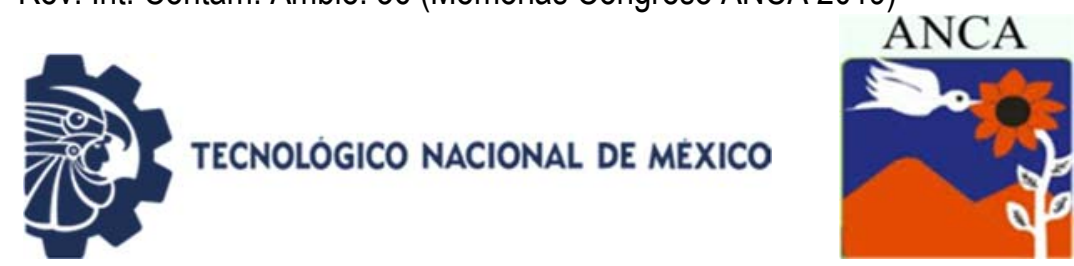

\title{
Uso de gallinaza en la producción de amaranto orgánico en Tlaltizapan, Morelos, México
}

\author{
Oliver Guadarrama R, Bahena Galindo ME, Granjeno Colín AE* \\ Laboratorio de Edafoclimatología. Centro de Investigaciones Biológicas. \\ Departamento de Biología Vegetal. UAEMorelos. \\ Av. Universidad 1001, Col. Chamilpa, 62209, Cuernavaca, Morelos, México \\ *granjeno@uaem.mx
}

\section{RESUMEN}

El cultivo de amaranto es cultivado en Morelos, actualmente es considerado como cultivo básico, debido a la proteína de excelente calidad que de él se obtiene, ya que es la única especie entre los vegetales de su tipo que contiene todos los aminoácidos esenciales. En el amaranto, los abonos orgánicos se están utilizando, obteniendo mejores rendimientos, la presente investigación tiene como objetivo: Evaluar el rendimiento de amaranto con aplicación gallinaza y determinar los cambios físicos y químicos del suelo en la presiembra y la poscosecha. El experimento se ubicó en el municipio de Tlaltizapán, Morelos; con una unidad de suelo vertisol; clima cálido, es un cultivo de temporal; el terreno donde se montó la parcela experimental constó de una superficie de $5000 \mathrm{~m}^{2}$; en el cual se aplicó gallinaza como fuente de nitrógeno. Se obtuvo un rendimiento de 1.5 ton/ha; respecto a las características físicas del suelo, estas no mostraron cambios significativos, sin embargo las características químicas, en el caso del $\mathrm{pH}$, este sufrió ligeros cambios, incrementándose al valor inicial; en cuanto a la materia orgánica ésta se incrementó en la poscosecha, al igual que el carbono y el nitrógeno, lo que nos muestra que la aplicación de la gallinaza propicia que el suelo no pierda su fertilidad.

Palabras clave: Amaranto, abono, orgánico, suelo, agricultura.

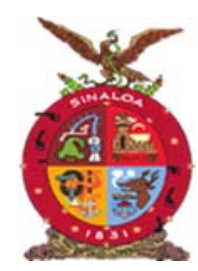

XVIII Congreso Internacional XXIV Congreso Nacional de Ciencias ambientales

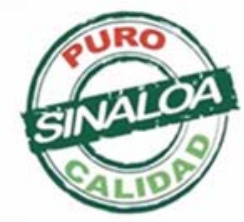

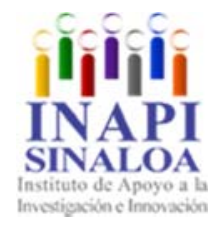

Mazatlán, Sinaloa 3-7 junio 2019

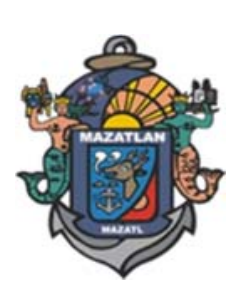

Recursos Naturales, Ecosistemas y Deterioro Ambiental 

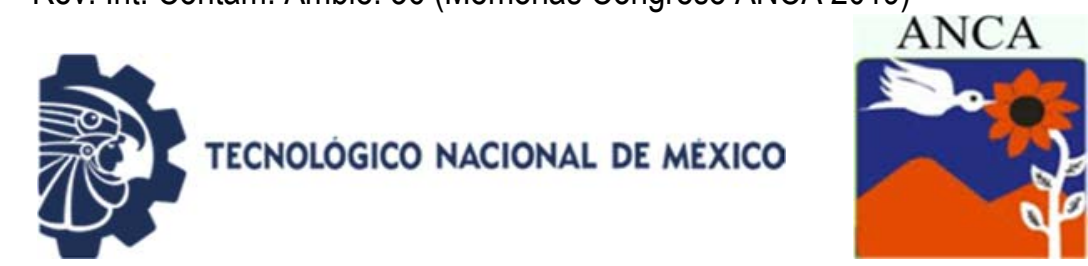

\title{
Use of chicken manure in the production of organic amaranth in Tlaltizapán, Morelos, México
}

\author{
Oliver Guadarrama R, Bahena Galindo ME, Granjeno Colín AE* \\ Laboratorio de Edafoclimatología. Centro de Investigaciones Biológicas. \\ Departamento de Biología Vegetal. UAEMorelos. \\ Av. Universidad 1001, Col. Chamilpa, 62209, Cuernavaca, Morelos, México \\ *granjeno@uaem.mx
}

\begin{abstract}
The cultivation of amaranth is cultivated in Morelos, currently it is considered as a basic crop, due to the excellent quality protein obtained from it, since it is the only species among the vegetables of its type that contains all the essential amino acids. In the amaranth, the organic fertilizers are being used, obtaining better yields, the present investigation has like objective: To evaluate the yield of amaranth with application manure and to determine the physical and chemical changes of the soil in the pre-planting and the post-harvest. The experiment was located in the municipality of Tlaltizapán, Morelos; with a vertisol soil unit; warm climate, it is a temporary crop; the land where the experimental plot was built consisted of an area of $5000 \mathrm{~m}^{2}$; in which chicken manure was applied as a source of nitrogen. A yield of 1.5 ton / ha was obtained. Regarding the physical characteristics of the soil, they did not show significant changes, however the chemical characteristics, in the case of $\mathrm{pH}$, underwent slight changes, increasing to the initial value; In terms of organic matter, it increased in post-harvest, as did carbon and nitrogen, which shows that the application of chicken manure causes the soil does not lose its fertility.
\end{abstract}

Keywords: Amaranth, fertilizer, organic, soil; farming.

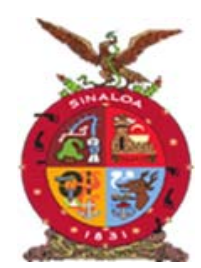

XVIII Congreso Internacional XXIV Congreso Nacional de Ciencias ambientales

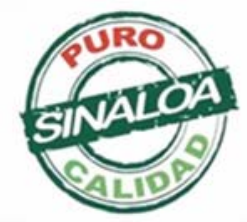

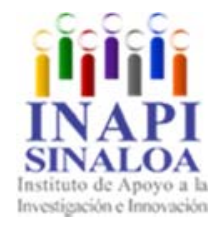

Mazatlán, Sinaloa 3-7 junio 2019

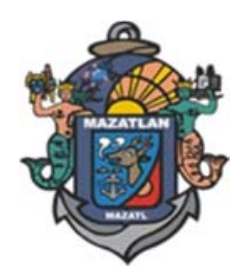

Recursos Naturales, Ecosistemas y Deterioro Ambiental 

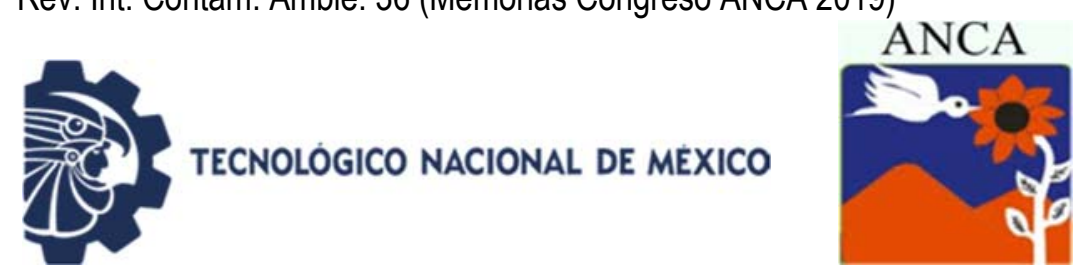

\section{Las microalgas flotantes y adheridas del Río Santa Bárbara, Michoacán, México}

Ortega Murillo M del R*, AlvaradoVillanueva R, Mora Soto Y, Segura García V

Laboratorio de Biología Acuática "J. Javier Alvarado Díaz". Facultad de Biología. Universidad Michoacana de San Nicolás de Hidalgo. México

*rosaormu@yahoo.com.mx

\section{RESUMEN}

La presente investigación se realizó en tres sitios del Río Santa Bárbara en Michoacán, México en dos épocas (lluvias y secas) 2018, con el propósito de conocer las microalgas flotantes (fitoplancton) y adheridas (perifiton). La obtención de las muestras ficológicas, fue con una red de 39 micrones (fitoplancton), así como del raspado de diferentes sustratos (perifiton), dichas recolecta se depositaron en frascos de $50 \mathrm{ml}$ con agua del medio, preservándose con formol al $4 \%$. Además, se realizó el análisis de las variables ambientales. Se determinaron 247 especies, que pertenecen a 8 divisiones de algas, a 13 clases, detectando que clase Bacillariophyceae aporta los valores altos del número de especies tanto para los organismos adheridos como flotantes, mientras que Cryptophyceae, Chrysophyceae y Ulvophyceae presentaron una sola especie respectivamente. Con respecto al fitoplancton se obtuvieron 108 especies, mientras que en el perifiton el número de especie fue de 184. Del análisis de 29 variables ambientales en el río Santa bárbara se menciona que es un sistema de aguas cálidas, oxigenadas de baja salinidad y alcalinidad, con un $\mathrm{pH}$ neutro aguas moderadamente mineralizada con incremento de sólidos, con altas concentraciones de fósforo y amoniaco, así como una elevada concentración de coliformes, se encuentra en proceso de eutroficación con aguas que tienden a ser alfa a beta mesosaprobias. Se concluye que en el río Santa Bárbara existe una heterogeneidad donde existen 48 especies que son ticoplanctonicas, ya que pueden existen tanto en fitoplancton como en el perifiton.

Palabras clave: Adheridas, flotantes, microalgas, río, variables.

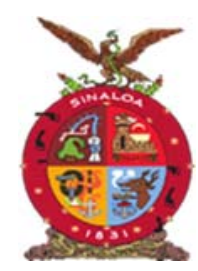

XVIII Congreso Internacional XXIV Congreso Nacional de Ciencias ambientales

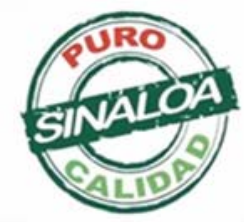

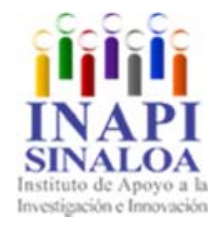

Mazatlán, Sinaloa 3-7 junio 2019

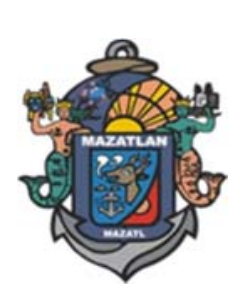

Recursos Naturales, Ecosistemas y Deterioro Ambiental 

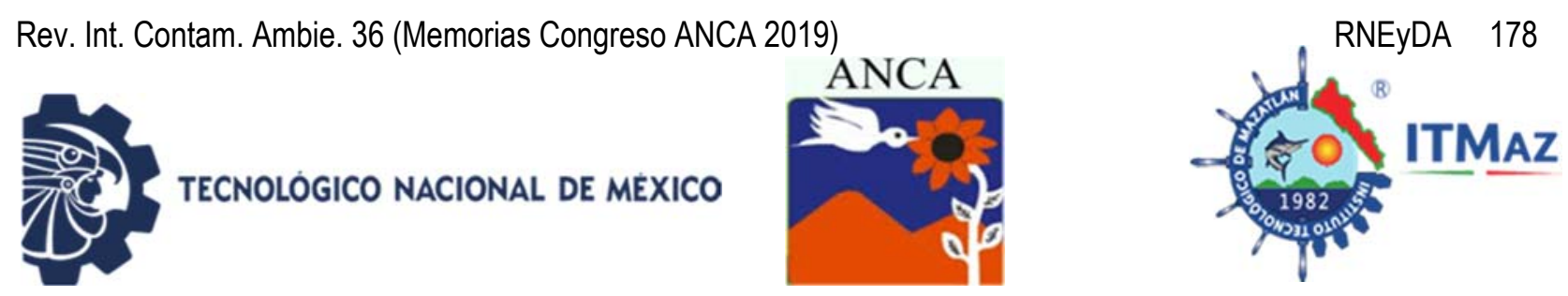

\title{
The floating and adhered microalgae of the Santa Bárbara River, Michoacán, Mexico
}

\author{
Ortega Murillo M del R*, AlvaradoVillanueva R, Mora Soto Y, Segura García V \\ Laboratorio de Biología Acuática "J. Javier Alvarado Díaz". Facultad de Biología. \\ Universidad Michoacana de San Nicolás de Hidalgo. México \\ *rosaormu@yahoo.com.mx
}

\begin{abstract}
The present investigation was carried out in three sites of the Santa Barbara River in Michoacán, Mexico in two seasons (rains and dry) 2018, with the purpose of knowing the floating microalgae (phytoplankton) and adhered (perifiton). The obtaining of the ficological samples with a network of 39 microns (phytoplankton), as well as the scraping of different substrates (perifiton), said collection was deposited in $50 \mathrm{ml}$ bottles with water from the medium, preserving itself with $4 \%$ formaldehyde. A total of 247 species, belonging to 8 divisions of algae, were determined to 13 classes, detecting which Bacillariophyceae class provides the high values of the number of species for both the adhered and floating organisms, whereas Cryptophyceae, Chrysophyceae and Ulvophyceae presented a single species respectively. With respect to phytoplankton 108 species were obtained, while in periphyton the number of species was 184 . From the analysis of 29 environmental variables in the Santa Bárbara River it is mentioned that it is a warm water, oxygenated system of low salinity and alkalinity. With a neutral $\mathrm{pH}$, moderately mineralized waters with an increase in solids, with high concentrations of phosphorus and ammonia, as well as a high concentration of coliforms, is in the process of eutrophication with waters that tend to be alpha to beta mesosaprobias. It is concluded that there is a heterogeneity in the Santa Bárbara river where there are 48 species that are ticoplanktonic, since they can exist both in phytoplankton and in periphyton.
\end{abstract}

Keywords: Adhered, floating, microalgae, river, variable.

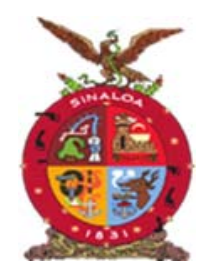

XVIII Congreso Internacional

XXIV Congreso Nacional de Ciencias ambientales

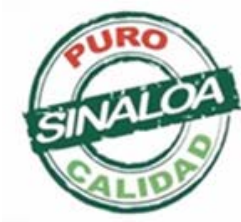

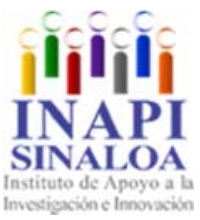

Mazatlán, Sinaloa 3-7 junio 2019

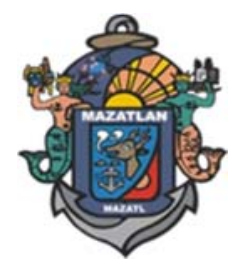

Recursos Naturales, Ecosistemas y Deterioro Ambiental 

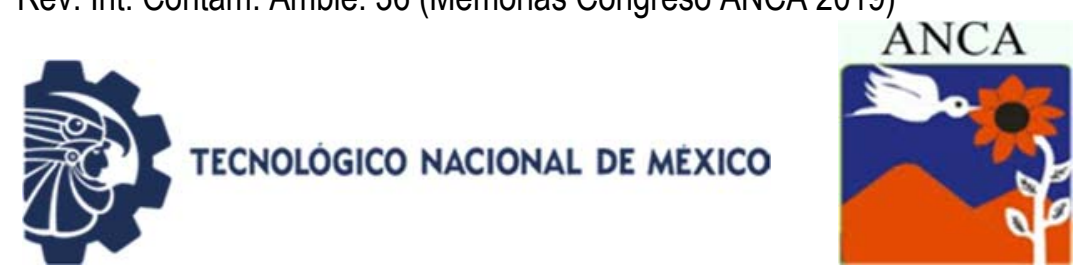

\title{
Estudio florístico de las diatomeas del Río Santa Bárbara, Michoacán, México
}

\author{
Ortega Murillo MR*, Alvarado Villanueva R, Mora Soto $\mathrm{Y}$, \\ Sánchez Heredia JD, Andrade Hernández F, Segura García V \\ Laboratorio de Biología Acuática "J. Javier Alvarado Díaz". Facultad de Biología. \\ Universidad Michoacana de San Nicolás de Hidalgo. México \\ *rosaormu@yahoo.com.mx
}

\section{RESUMEN}

Las floras sobre las diatomeas son escasas en agua dulce en México, considerando que este grupo presenta una amplia distribución en diversos ecosistemas acuáticos. El río Santa Bárbara que nace en la presa de Calzontzin, un lugar de gran actividad antropogénica, se conoce poco de las diatomeas. La finalidad que se pretende a través de este trabajo es contar con la actualización de la flora de Bacillariophyceae. La recolecta se efectuó de dos maneras una con la red de 39 micrones (fitoplancton flotante), así como del raspado de diferentes sustratos (perifiton o adheridas), dichas recolecta se depositaron en frascos de 50 $\mathrm{ml}$ con agua del medio, preservándose con formol al $4 \%$. En el laboratorio la limpieza de las valvas colectadas como perifiton se efectuó a través de la técnica de Johansen 1940. Se determinaron 196 especies, con 61 géneros, de 3 clases, detectando que la clase Bacillariophyceae presenta 188 especies, mientras que nivel de género Nitzschia presentó 27 especies. Se detectó que para el fitoplancton se determinaron 131 especies, mientras que para el perifiton fueron 111 especies. Las especies más frecuentes fueron Cocconeis placentula, Staurosira construens, Melosira varians, Pseudotaurosira brevistriata, Cyclotella meneghiniana, Plantodinium lanceolatum, Staurosira pinnata, Contricriba weisiflogii y Platessa hosaltica

Palabras clave: Diatomeas, flora, fitoplancton, perifiton.

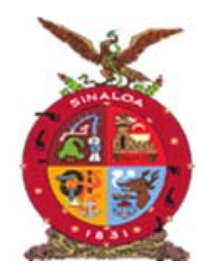

XVIII Congreso Internacional XXIV Congreso Nacional de Ciencias ambientales

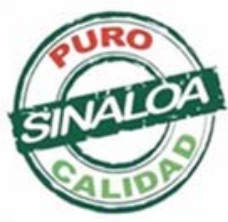

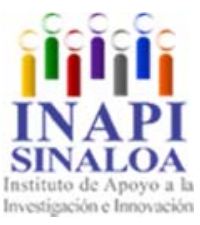

Mazatlán, Sinaloa 3-7 junio 2019

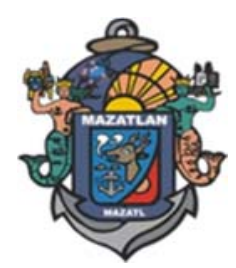

Recursos Naturales, Ecosistemas y Deterioro Ambiental 

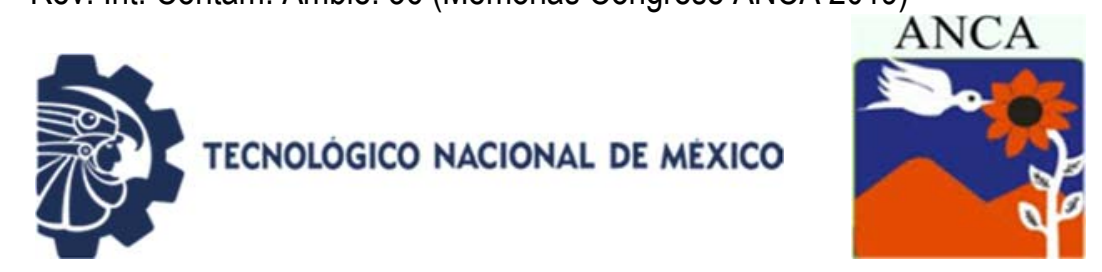

\title{
Floristic study of the diatoms of Santa Barbara River, Michoacán, Mexico
}

\author{
Ortega Murillo MR*, Alvarado Villanueva R, Mora Soto $\mathrm{Y}$, \\ Sánchez Heredia JD, Andrade Hernández F, Segura García V \\ Laboratorio de Biología Acuática "J. Javier Alvarado Díaz". Facultad de Biología. \\ Universidad Michoacana de San Nicolás de Hidalgo. México \\ *rosaormu@yahoo.com.mx
}

\begin{abstract}
The floras on the diatoms are scarce in freshwater in Mexico, considering that this group has a wide distribution in diverse aquatic ecosystems, the Santa Bárbara River that is born in the dam of Calzontzin, a place of great anthropogenic activity, little is known of the diatoms. The purpose of this work is to update the flora of Bacillariophyceae. The collection was done in two ways, one with the network of 39 microns (phytoplankton or floating), as well as the scraping of different substrates (perifiton or adhered), said collection was deposited in $50 \mathrm{ml}$ flasks with water from the medium, preserving with $4 \%$ formaldehyde. In the laboratory the cleaning of the valves was carried out through the technique of Johansen 1940. They were determined 196 species, with 61 genera, of 3 classes, detecting that the class Bacillariophyceae presents 188 species, while gender level Nitzschia presented 27 species. It was detected that 131 species were determined for phytoplankton, while 111 were species for periphyton. The most frequent species were Cocconeis placentula, Staurosira construens, Melosira varians, Pseudotaurosira brevistriata, Cyclotella meneghiniana, Plantodinium lanceolatum, Staurosira pinnata, Contricriba weisiflogii y Platessa hosaltica.
\end{abstract}

Keywords: Diatoms, flora, phytoplankton, periphyton.

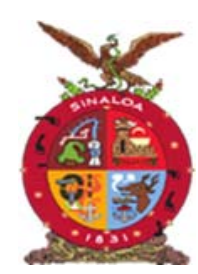

XVIII Congreso Internacional XXIV Congreso Nacional de Ciencias ambientales
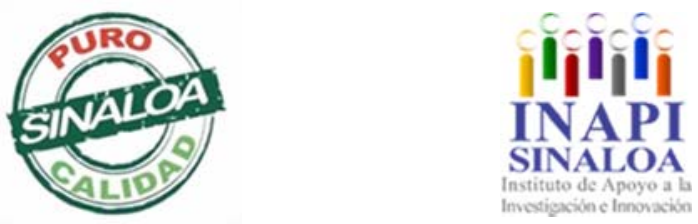

Mazatlán, Sinaloa 3-7 junio 2019

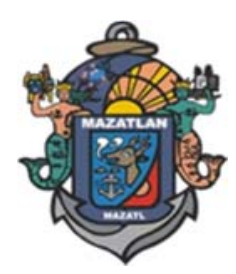

Recursos Naturales, Ecosistemas y Deterioro Ambiental 

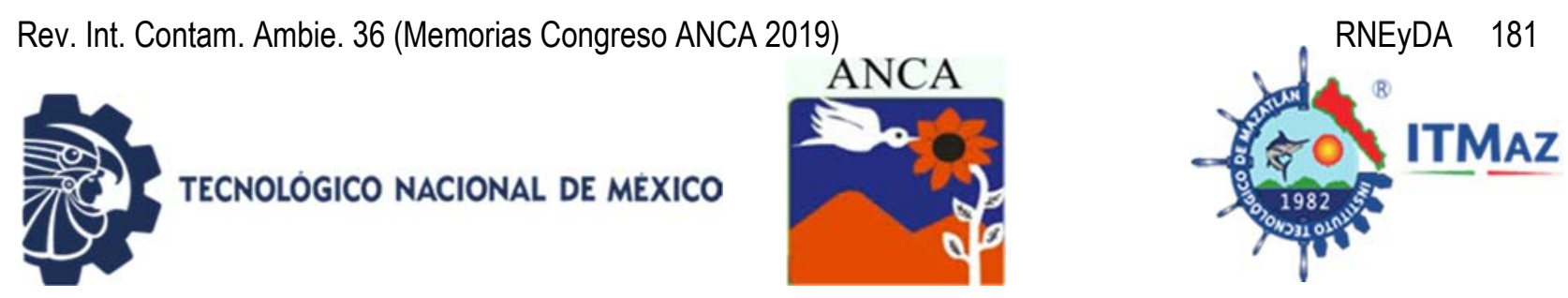

\title{
Caracterización morfológica y genética de Hericium sp. encontrado en los bosques templados de la Sierra Madre Occidental, México
}

\author{
Páez Olivan $\mathrm{LA}^{1^{*}}$, Correa Ramírez $\mathrm{M}^{1}$, Torres Ricario $\mathrm{R}^{1}$, Naranjo Jiménez $\mathrm{N}^{1}$, \\ Herrera Gamboa J'1, Rosas Imelda ${ }^{2}$, Colmenero Aurelio ${ }^{2}$ \\ ${ }^{1}$ Centro Interdisciplinario de Investigación para el Desarrollo Integral Regional. \\ Unidad Durango Instituto Politécnico Nacional. \\ Sigma 119, Fracc. 20 de noviembre II, 34200, Durango, México \\ ${ }^{2}$ Secretaria de Investigación y Posgrado. Instituto Politécnico Nacional. \\ Av. Luis Enrique Erro S/N, Unidad Profesional Adolfo López Mateos, \\ Zacatenco, Del. Gustavo A. Madero, México \\ *anapaezoli@hotmail.com
}

\section{RESUMEN}

Se tiene poca información sobre la distribución del hongo Hericium erinaceus, que ha considerado como un alimento nutracéutico (Thongbai et al., 2015). Esto muestra el desconocimiento que existe sobre la diversidad y distribución de este hongo, de interés económico por sus cualidades gastronómicas y medicinales. Por lo que el objetivo del presente trabajo fue contribuir al conocimiento de la diversidad de las especies del género Hericium mediante la caracterización morfológica y molecular con marcadores ITS 1 y ITS 4 para delimitar las especies presentes en la región de El Salto, Pueblo Nuevo, Durango. La identificación taxonómica se realizó siguiendo las claves de Pegler et al., (1997), a nivel de especie, se consultó bibliografía especializada como la de Geesteranus (1971), Harrison (1973), Hansen (1997) y Bessette et al., (1997). Para la amplificación del ADN se utilizó el par de oligonucleótidos universales ITS 1 (59GGAAGTAAAAGTCGTAACAAGG-39) e ITS4 (59-TCCTCCGCTTATTGATA TGC-39). Las muestras fueron secuenciadas con el método de didesoxinucleótidos en Laboratorio Nacional de Biotecnología Agrícola, Médica y Ambiental del IPICYT. Los hongos analizados presentaron un tamaño de esporas de 4.8-6 x 4.4-5.2 $\mu \mathrm{m}$, subglobosas ampliamente elipsoides, equinuladas, de pared gruesa, hialinas en hidróxido de potasio (3\%) y amiloides en Melzer (Fig. 1a). De las siete cepas silvestres analizadas, amplificaron fragmentos entre 669 y $1064 \mathrm{pb}$ con los marcadores moleculares ITS1 e ITS4. Concluyendo que, taxonómicamente hay variaciones en el fenotipo que podrían crear incertidumbre pero, con la ayuda de marcadores moleculares como los ITS se comprueba que efectivamente son ejemplares de Hericium erinaceus.

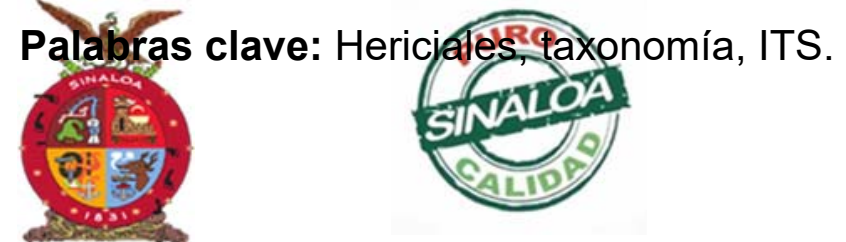

Mazatlán, Sinaloa 3-7 junio 2019

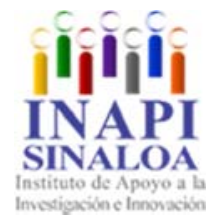

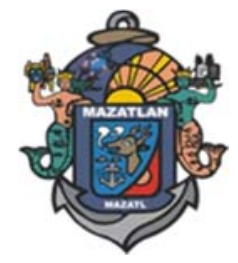

Recursos Naturales, Ecosistemas y Deterioro Ambiental 

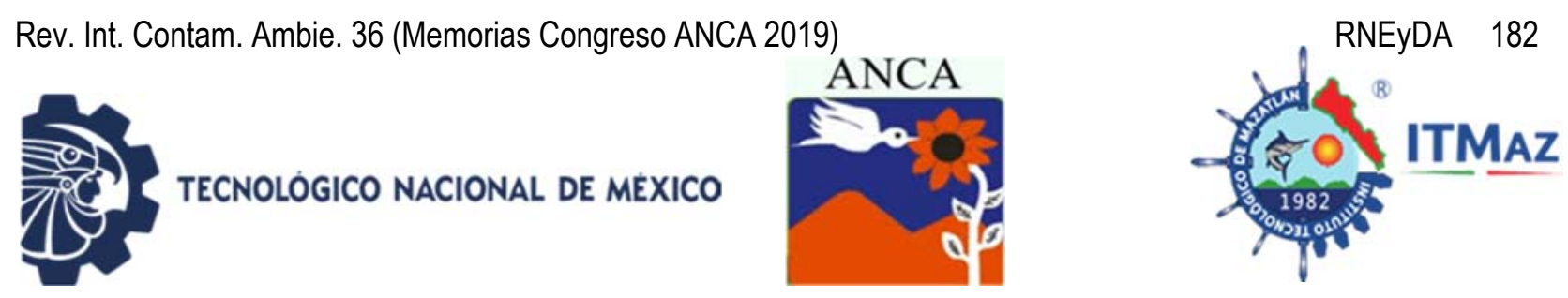

\title{
Morphological and genetic characterization of Hericium sp. found in the temperate forests of the Sierra Madre Occidental, Mexico
}

\author{
Páez Olivan LA ${ }^{1 *}$, Correa Ramírez $\mathrm{M}^{1}$, Torres Ricario $\mathrm{R}^{1}$, Naranjo Jiménez $\mathrm{N}^{1}$, \\ Herrera Gamboa J ${ }^{1}$, Rosas Imelda ${ }^{2}$, Colmenero Aurelio ${ }^{2}$ \\ ${ }^{1}$ Centro Interdisciplinario de Investigación para el Desarrollo Integral Regional. \\ Unidad Durango Instituto Politécnico Nacional. \\ Sigma 119, Fracc. 20 de noviembre II, 34200, Durango, México \\ ${ }^{2}$ Secretaria de Investigación y Posgrado. Instituto Politécnico Nacional. \\ Av. Luis Enrique Erro S/N, Unidad Profesional Adolfo López Mateos, \\ Zacatenco, Del. Gustavo A. Madero, México \\ *anapaezoli@hotmail.com
}

\begin{abstract}
There is little information on the distribution of the fungus Hericium erinaceus, which has been considered a nutraceutical food (Thongbai et al., 2015). This shows the ignorance that exists about the diversity and distribution of this fungus, of economic interest for its gastronomic and medicinal qualities. Therefore, the objective of this work was to contribute to the knowledge of the diversity of Hericium species by means of the morphological and molecular characterization with ITS 1 and ITS 4 markers to delimit the species present in the El Salto region, Pueblo Nuevo, Durango. The taxonomic identification was made following the keys of Pegler et al., (1997) at the species level, specialized bibliography was consulted such as that of Geesteranus (1971), Harrison (1973), Hansen (1997) and Bessette et al., (1997). For DNA amplification, the pair of universal oligonucleotides ITS 1 (59-GGAAGTAAAAGTCG TAACAAGG-39) and ITS4 (59TCCTCCGCTTATTGATATGC39) was used. The samples were sequenced with the dideoxynucleotide method in the National Laboratory of Agricultural, Medical and Environmental Biotechnology of the IPICYT. The fungi analyzed showed a spore size of 4.8-6 x 4.4-5.2 $\mu \mathrm{m}$, broadly ellipsoid, echinulated, thick-walled subglobose, hyaline in potassium hydroxide (3\%) and amyloid in Melzer (Fig. 1a). Of the seven wild strains analyzed, fragments were amplified between 669 and $1064 \mathrm{bp}$ with the molecular markers ITS1 and ITS4. It is concluded that taxonomically there are variations in the phenotype that could create uncertainty and with the help of molecular markers such as ITS it is proven that they are indeed examples of Hericium erinaceus.
\end{abstract}

Keywords: Hericiales, taxonomy, ITS.

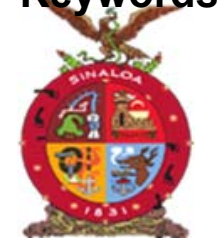

XVIII Congreso Internacional

XXIV Congreso Nacional de Ciencias ambientales

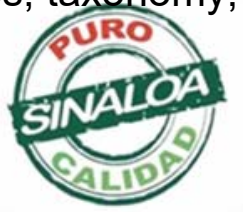

Mazatlán, Sinaloa 3-7 junio 2019
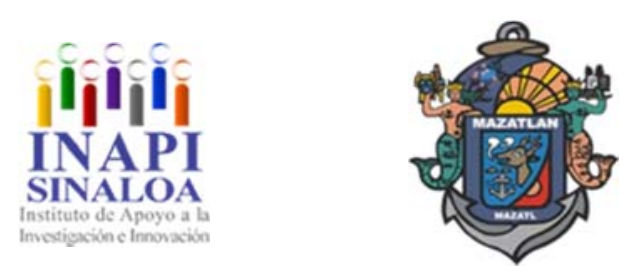

Recursos Naturales, Ecosistemas y Deterioro Ambiental 

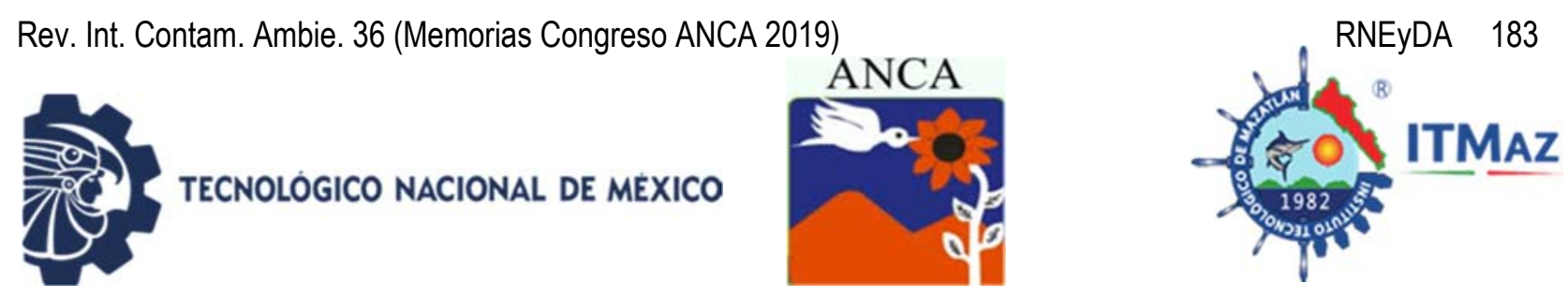

Concentración de $\mathrm{Fe}, \mathrm{Mn}, \mathrm{Cu}, \mathrm{Zn}, \mathrm{Ni}, \mathrm{Cd}$ Y Pb en músculo de Larkinia
Grandis y Chionopsis Gnidia del sitio Ramsar 1826 Navachiste, México

Pedraza Cervantes I*, Pérez González E, Rodríguez Meza G, González Ocampo H

Laboratorio de Contaminación Orgánica e Inorgánica. CIIDIR Sinaloa IPN Blvd. Juan de Dios Bátiz Paredes \#250, Col. San Joachin, C.P. 81101, Guasave, Sinaloa, México

*ivanpedraza508@gmail.com

\section{RESUMEN}

El sistema lagunar Navachiste, Sinaloa es un área natural de alta importancia ecológica que ha denominada sitio RAMSAR desde 2008, siendo susceptible de recibir metales pesados de fuentes naturales y de escorrentías de actividades agrícolas, acuícolas y asentamientos humanos., descargas contaminantes que representan un riesgo a la salud del ecosistema y salud humana por la dispersión de contaminantes y su bioacumulación por especies de interés comercial. Por tal motivo, se determinó la concentración de $\mathrm{Fe}, \mathrm{Mn}, \mathrm{Cu}, \mathrm{Zn}, \mathrm{Ni}, \mathrm{Cd}$ y $\mathrm{Pb}$ en el tejido de pata de mula (Larkinia grandis) y almeja china (Chionopsis gnidia). La recolecta de muestras se realizó en verano del 2018 en 4 puntos, obteniendo 38 ejemplares de Larkinia grandis y 43 de Chionopsis gnidia e incluyó blancos y material certificado. El tejido se secó y mediante previa digestión ácida se realizó la cuantificación de metales, en un espectrofotómetro de absorción atómica AVANTA GBC. El intervalo de concentración de los elementos en Larkinia grandis fue de: $1.30-56.76 \mathrm{mg} / \mathrm{kg} \mathrm{Cu}, 192.10-1390.52 \mathrm{mg} / \mathrm{kg} \mathrm{Fe}, 55.19-79.85 \mathrm{mg} / \mathrm{kg} \mathrm{Zn}$, $2.09-33.11 \mathrm{mg} / \mathrm{kg} \mathrm{Mn}, 0.64-7.68 \mathrm{mg} / \mathrm{kg} \mathrm{Ni}, 2.35-15.76 \mathrm{mg} / \mathrm{kg}$ Cd y $0.02-3.20 \mathrm{mg} / \mathrm{kg}$ $\mathrm{Pb}$, y para Chionopsis gnidia fue de $3.01-33.52 \mathrm{mg} / \mathrm{kg} \mathrm{Cu}, 48.59-526.41 \mathrm{mg} / \mathrm{kg}$ $\mathrm{Fe}, 55.19-79.85 \mathrm{mg} / \mathrm{kg} \mathrm{Zn}, 2.09-33.11 \mathrm{mg} / \mathrm{kg} \mathrm{Mn}, 0.64-7.68 \mathrm{mg} / \mathrm{kg} \mathrm{Ni}, 2.35-15.76$ $\mathrm{mg} / \mathrm{kg} \mathrm{Cd}$ y $0.02-3.20 \mathrm{mg} / \mathrm{kg} \mathrm{Pb}$. A partir de la concentración media se observó la siguiente secuencia: $\mathrm{Fe}>\mathrm{Zn}>\mathrm{Mn}$ en ambas especies, sin embargo, se encontraron niveles superiores a los límites máximos sugeridos por la FAO en $\mathrm{Fe}, \mathrm{Mn}, \mathrm{Cd}$ y Pb.

Palabras clave: Metales pesados, Navachiste, moluscos bivalvos, contaminación, escorrentía.

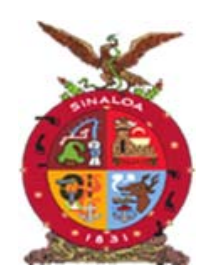

XVIII Congreso Internacional XXIV Congreso Nacional de Ciencias ambientales

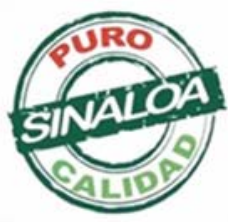

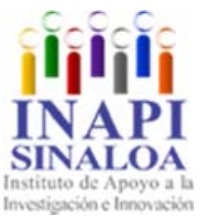

Mazatlán, Sinaloa 3-7 junio 2019

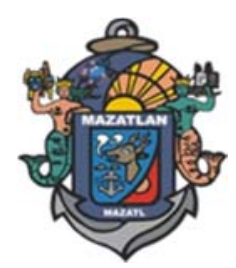

Recursos Naturales, Ecosistemas y Deterioro Ambiental 

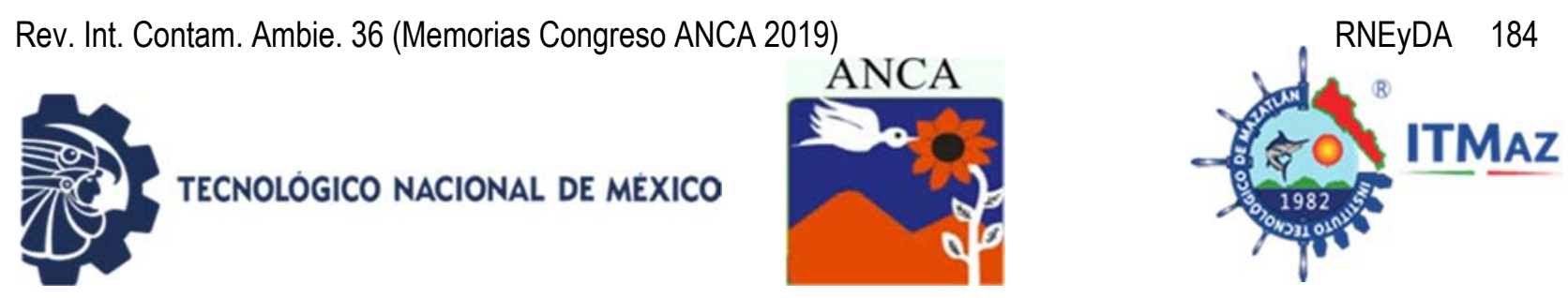

\title{
Metals in Bivalve Mollusks Tissue (Larkinia Grandis and Chionopsis Gnidia) from Ramsar Site 1826 in Navachiste Lagoon, Mexico
}

\author{
Pedraza Cervantes I*, Pérez González E, Rodríguez Meza G, \\ González Ocampo H
}

Laboratorio de Contaminación Orgánica e Inorgánica. CIIDIR Sinaloa IPN Blvd. Juan de Dios Bátiz Paredes \#250, Col. San Joachin, C.P. 81101, Guasave, Sinaloa, México

*ivanpedraza508@gmail.com

\begin{abstract}
Navachiste Lagoon is a natural protected area with high ecological and economical importance designed as RAMSAR site since 2008. This lagoon receives metals from natural and anthropogenic sources as agricultural, aquaculture and municipal runoffs. Metals could be a risk for human and ecosystem health by scattering of this contaminants and bioaccumulation in commercial species. This study was made to determine the concentration of $\mathrm{Fe}$, $\mathrm{Mn}, \mathrm{Cu}, \mathrm{Zn}, \mathrm{Ni}, \mathrm{Cd}$ and $\mathrm{Pb}$ in (Larkinia grandis) and (Chionopsis gnidia). Samples were collected in summer (June 2018) in four sampling sites distributed throughout Navachiste Lagoon obtaining 38 samples of Larkinia grandis and 43 of Chionopsis gnidia. The concentration was determined drying the tissue and digested by nitric acid, after that using an AVANTA GBC $®$ Atomic absorption spectrometer, with air/acetylene burner and hollow cathode lamps. Blanks and certified concentration material were used. The range of concentration of elements in Larkinia grandis was: $1.30-56.76 \mathrm{mg} / \mathrm{kg} \mathrm{Cu}, 192.10-1390.52 \mathrm{mg} / \mathrm{kg}$ $\mathrm{Fe}, 55.19-79.85 \mathrm{mg} / \mathrm{kg} \mathrm{Zn}, 2.09-33.11 \mathrm{mg} / \mathrm{kg} \mathrm{Mn}, 0.64-7.68 \mathrm{mg} / \mathrm{kg} \mathrm{Ni}, 2.35-15.76$ $\mathrm{mg} / \mathrm{kg} \mathrm{Cd}$ y $0.02-3.20 \mathrm{mg} / \mathrm{kg} \mathrm{Pb}$. The range of concentration in Chionopsis gnidia was:3.01-33.52 mg/kg Cu, 48.59-526.41 mg/kg Fe, 55.19-79.85 mg/kg Zn, 2.09$33.11 \mathrm{mg} / \mathrm{kg} \mathrm{Mn}, 0.64-7.68 \mathrm{mg} / \mathrm{kg} \mathrm{Ni}, 2.35-15.76 \mathrm{mg} / \mathrm{kg} \mathrm{Cd}$ y $0.02-3.20 \mathrm{mg} / \mathrm{kg}$ $\mathrm{Pb}$. The mean concentration of metals decreased in the next order $\mathrm{Fe}>\mathrm{Zn}>\mathrm{Mn}$ in both species, but $\mathrm{Fe}, \mathrm{Mn}, \mathrm{Cd}$ and $\mathrm{Pb}$ was above the FAO limits.
\end{abstract}

Keywords: Metals, Navachiste, bivalve mollusks, pollution, runoffs.

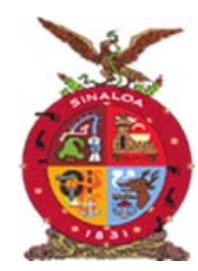

XVIII Congreso Internacional XXIV Congreso Nacional de Ciencias ambientales
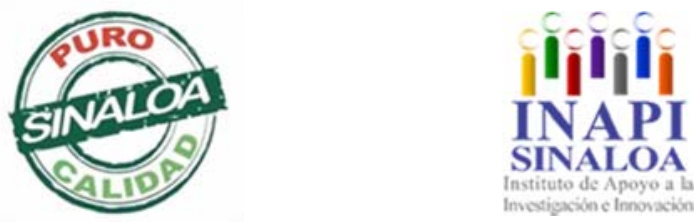

Mazatlán, Sinaloa 3-7 junio 2019

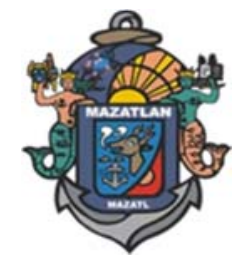

Recursos Naturales, Ecosistemas y Deterioro Ambiental 

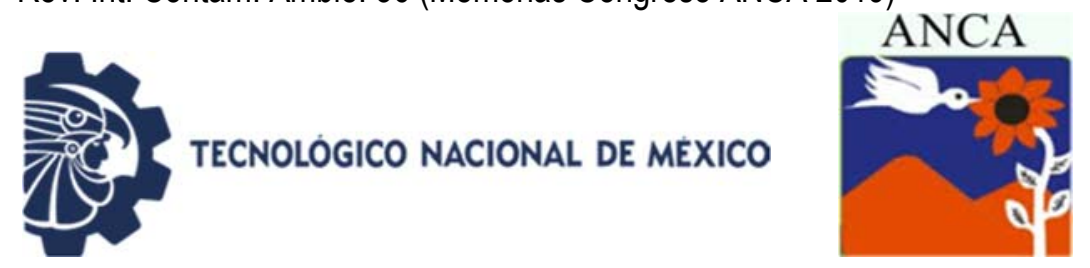

\title{
Fenología del insecto Trichapion sp., que ataca la semilla de Dalbergia palo-escrito en la localidad de Coatitlamixtla, Xochicoatlán, Hidalgo
}

\author{
Pérez Olivares S, Guevara Herrera R $^{*}$, Jimenez Pelcastre C, Valentin Islas R \\ Universidad Tecnológica de la Sierra Hidalguense. \\ Carretera México-Tampico, Km. 100, Tramo Pachuca-Huejutla, 43200, \\ Zacualtipán de Ángeles, Hidalgo, México \\ *rguevara_h@hotmail.com
}

\section{RESUMEN}

Dalbergia palo-escrito especie endémica de un corto segmento de la sierra madre oriental presenta problemas de reproducción al ser atacada por un insecto en etapa de fructificación, Rzedowski \& Guridi-Gómez, (1988). Un muestreo del insecto realizado en el 2017 permitió conocerlo a nivel género, determinado como Trichapion sp., familia Brentidae, Martínez, M. O., (2017). Debido al conocimiento limitado relacionado con esta especie surge la necesidad de: Determinar la fenología de Trichapion sp., que ataca la semilla de Dalbergia palo-escrito mediante monitoreo terrestre en la localidad de Coatitlamixtla, Xochicoatlán, Hgo., para precisar el ciclo de vida del insecto en la vaina de palo-escrito. La investigación se realizó de febrero a julio de 2018, se seleccionaron 16 árboles de manera selectiva desde 3 a 17 metros de altura y de 6 a $18 \mathrm{~cm}$ de diámetro, seccionados en parte alta, media y baja. La puesta del huevo comienza en la última semana de marzo y primera semana de abril, huevecillo: dura de 10 a 15 días (abril), en estado larvario: de 6 a 7 semanas (abril y junio), en estado de pupa: de 7 a 10 días (junio), mientras que en estado adulto dura 9 meses (julio a marzo). El ciclo de vida de Trichapion sp., en la vaina de Dalbergia palo-escrito es de 3 meses, desde la puesta del huevo hasta su estado adulto, al finalizar su metamorfosis emerge de la vaina y vuela a plantas aledañas y espera 9 meses hasta la nueva floración de $D$. palo-escrito.

Palabras clave: Trichapion sp., vaina, fenología, floración, Dalbergia paloescrito.

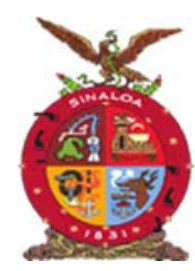

XVIII Congreso Internacional XXIV Congreso Nacional de Ciencias ambientales

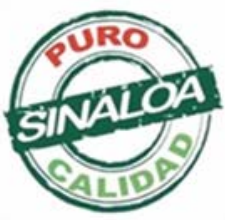

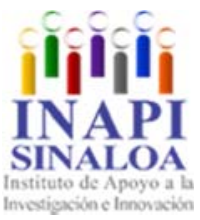

Mazatlán, Sinaloa 3-7 junio 2019

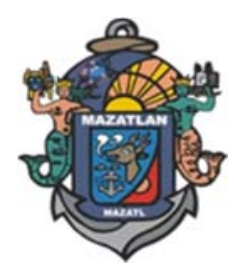

Recursos Naturales, Ecosistemas y Deterioro Ambiental 

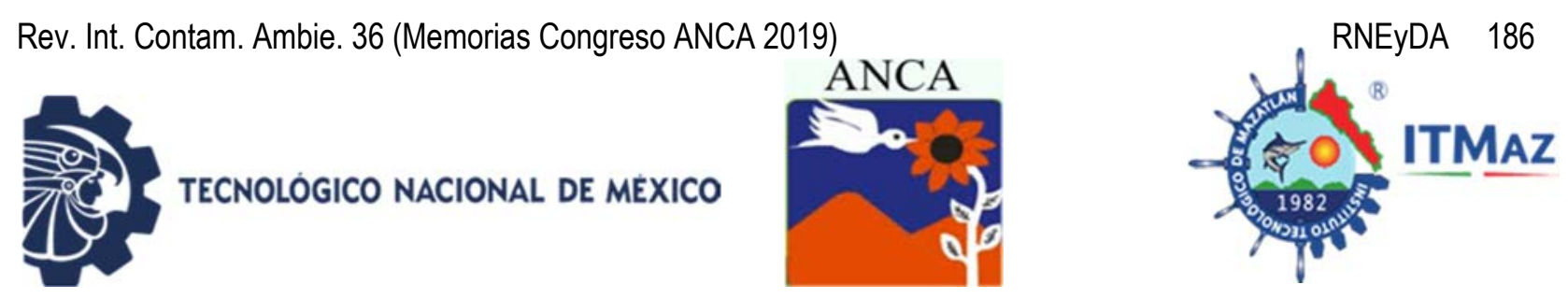

\title{
Phenology of the Trichapion sp. insect, which attacks the Dalbergia palo- escrito seed in the town of Coatitlamixtla, Xochicoatlán, Hidalgo
}

\author{
Pérez Olivares S, Guevara Herrera R $^{*}$, Jimenez Pelcastre C, Valentin Islas R \\ Universidad Tecnológica de la Sierra Hidalguense. \\ Carretera México-Tampico, Km. 100, Tramo Pachuca-Huejutla, 43200, \\ Zacualtipán de Ángeles, Hidalgo, México \\ *rguevara_h@hotmail.com
}

\begin{abstract}
Dalbergia palo-escrito is an endemic species of a short segment of the eastern mother saw presents reproduction problems when attacked by an insect in fruiting stage, Rzedowski \& Guridi-Gómez, (1988). A sampling of the insect carried out in 2017 allowed it to be known at a gender level, determined as Trichapion sp., Brentidae family, Martínez, M. O., (2017). Due to the limited knowledge related to this species, the need arises to: Determine the phenology of Trichapion sp., Which attacks the seed of Dalbergia stick-written by ground monitoring in the town of Coatitlamixtla, Xochicoatlán, Hgo., To specify the life cycle of the insect in the stick-written pod. The investigation was carried out from February to July 2018 , 16 trees were selected selectively from 3 to 17 meters high and 6 to $18 \mathrm{~cm}$ in diameter, sectioned in high, medium and low. Egg laying begins in the last week of March and first week of April. Egg lasts 10 to 15 days (April), in larval state: from 6 to 7 weeks (April and June), in pupa state: from 7 to 10 days (June), while in adult status it lasts 9 months (July to March). The life cycle of Trichapion sp., in the stick-written Dalbergia pod is 3 months, from the laying of the egg to its adult state, at the end of its metamorphosis it emerges from the pod and flies to nearby plants and waits 9 months until the new flowering of $D$. palo-escrito.
\end{abstract}

Keywords: Trichapion sp., pod, phenology, flowering, Dalbergia palo-escrito.

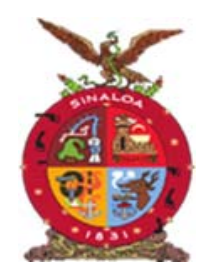

XVIII Congreso Internacional

XXIV Congreso Nacional de Ciencias ambientales

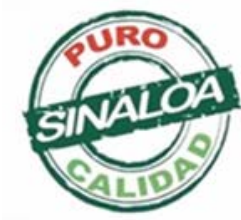

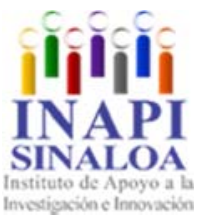

Mazatlán, Sinaloa 3-7 junio 2019

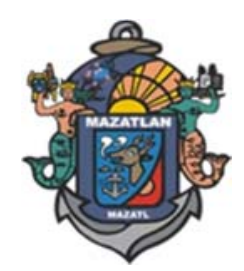

Recursos Naturales, Ecosistemas y Deterioro Ambiental 

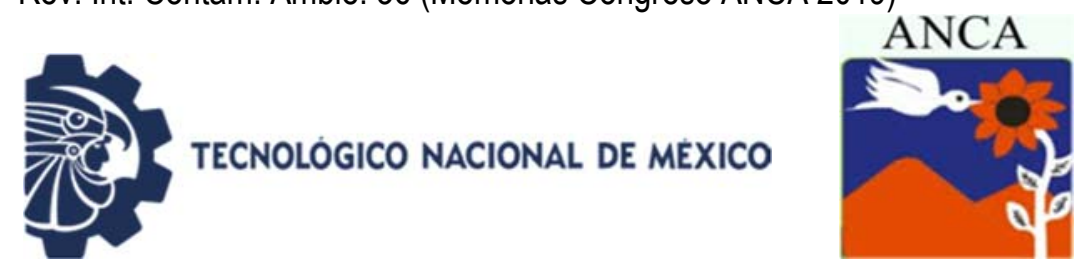

\title{
Patrones espaciales de crecimiento urbano de la ciudad de Chihuahua utilizando imágenes Google Earth
}

\author{
Pinedo Álvarez C, Melgoza Castillo A*, Rentería Villalobos M \\ Facultad de Zootecnia y Ecología. Universidad Autónoma de Chihuahua. \\ Periférico Francisco R. Almada Km. 1, 31453, Chihuahua, México \\ *amelgoza@uach.mx
}

\section{RESUMEN}

La urbanización es una preocupación importante en la mayoría de las ciudades para países en desarrollo como México. Habitantes de poblaciones de las áreas rurales están migrando a las áreas urbanas de medianas y grandes ciudades. La información actual y precisa sobre el uso del suelo urbano es un dato esencial que requieren los planificadores y los responsables de las políticas. Las imágenes de Google Earth, que son de código abierto, son una fuente importante de datos que pueden utilizarse para aplicaciones de gestión urbana. Este estudio tuvo como objetivo relacionar el comportamiento geo demográfico y cambios en el uso del suelo de la ciudad de Chihuahua. Los límites urbanos se obtuvieron de imágenes digitalizadas durante los años 1984, 1990, 2000, 2010 y 2018 . El análisis de superficie se realizó con el programa ArcGis v. 10.3. El crecimiento de la población y la superficie urbana durante el periodo de 1990 al 2018 presentó una tendencia lineal. El área de crecimiento urbano promedio fue de $7.82 \mathrm{Km}^{2}$ por año. En el último periodo analizado, la expansión urbana se presentó en todas direcciones. Los usos de suelo y vegetación de pastizal natural, matorral micrófilo y áreas de cultivo de temporal disminuyeron en su superficie. Debido al alto costo de imágenes satelitales de alta resolución, las imágenes gratuitas de Google Earth son una alternativa para apoyar los programas de planeación y gestión urbana.

Palabras clave: Cambios cobertura, planeación urbana, población.

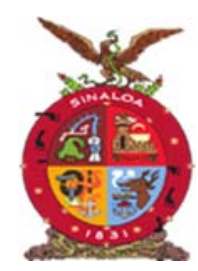

XVIII Congreso Internacional XXIV Congreso Nacional de Ciencias ambientales

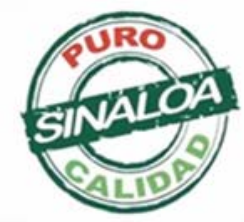

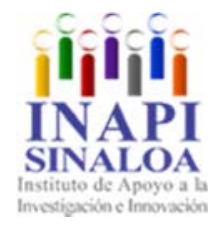

Mazatlán, Sinaloa 3-7 junio 2019

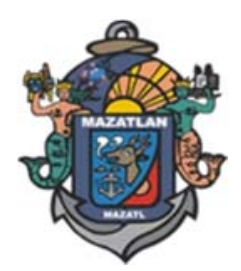

Recursos Naturales, Ecosistemas y Deterioro Ambiental 

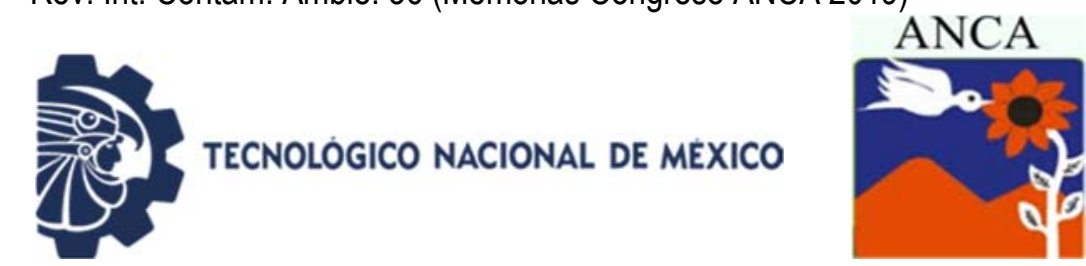

\title{
Spatial pattern of urban growth of the Chihuahua city using Google Earth images
}

\author{
Pinedo Álvarez C, Melgoza Castillo A*, Rentería Villalobos M \\ Facultad de Zootecnia y Ecología. Universidad Autónoma de Chihuahua. \\ Periférico Francisco R. Almada Km. 1, 31453, Chihuahua, México \\ *amelgoza@uach.mx
}

\begin{abstract}
Urbanization is a major concern in most cities for developing countries as Mexico. Rural areas inhabitants are migrating to urban areas of big cities. Current and accurate information on the use of urban land is an essential data required by planners and policy makers. The Google Earth images are open source that can be used for urban management applications. The objective of this study was to relate the geo-demographic behavior with changes in land use of Chihuahua city. The urban limits were obtained from digitized images during the years 1984, 1990, 2000,2010 , and 2018. The surface analysis was performed with the ArcGis v.10.3 program. A linear correlation between the growth of the population and the urban surface was found during the period from 1900 to 2018. The average of growth urban area was $7.82 \mathrm{Km}^{2}$ per year. In the last period analyzed, urban expansion occurred in all directions. The surface area of grassland, microphyllous shrubland and rainfed areas showed a decrement. Due to high cost of high-resolution satellite images, the free images from Google Earth can to support urban planning and management programs.
\end{abstract}

Keywords: Changes coverage, urban planning, population.

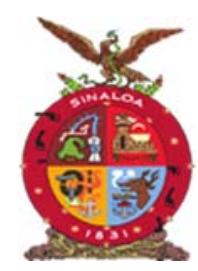

XVIII Congreso Internacional XXIV Congreso Nacional de Ciencias ambientales

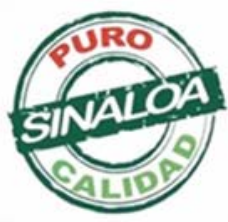

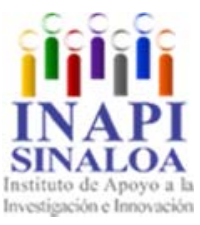

Mazatlán, Sinaloa 3-7 junio 2019

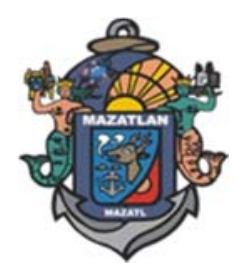

Recursos Naturales, Ecosistemas y Deterioro Ambiental 

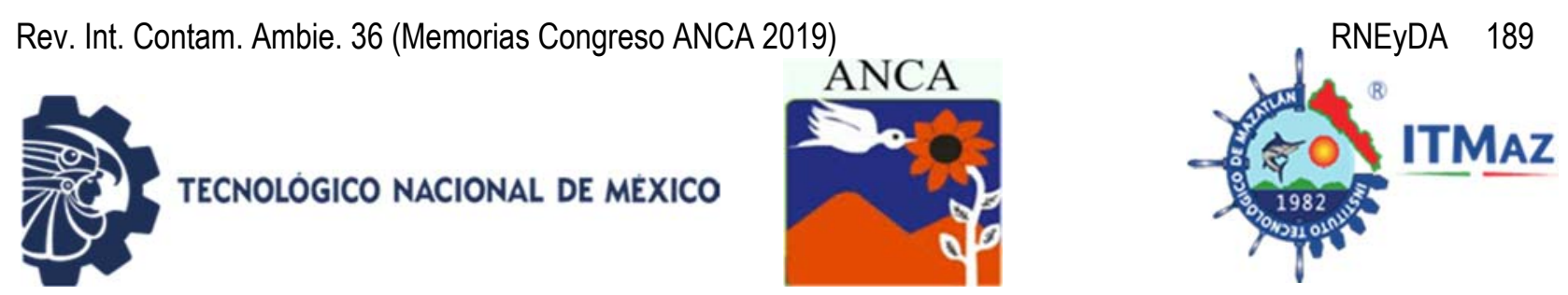

\title{
Relación de hongos micorrízicos con el suelo y precipitación en el ANP de Samalayuca, Chihuahua
}

\author{
Quiñónez Martínez M*, Palacios Ramirez K, Flores Margez J, \\ Enriquez Anchondo I
}

Instituto de Ciencias Biomédicas. Universidad Autónoma de Ciudad Juárez, Chihuahua, México

*mquinone@uacj.mx

\section{RESUMEN}

Los hongos micorrízicos arbusculares (HMA) como componente biológico importante de los suelos, son altamente abundantes y cumplen un papel esencial en los ecosistemas áridos y semiáridos, al proporcionar a las plantas una mayor absorción de nutrientes y agua. El objetivo del trabajo fue evaluar la composición de hongos micorrízicos arbusculares en dos comunidades vegetales del ANP Médanos de Samalayuca. Se realizó un muestreo dirigido antes y después de la temporada de lluvias en julio y septiembre del año 2017 y se seleccionaron plantas de mezquite (Prosopis juliflora var glandulosa) y ocotillo (Fouquieria splendens) para colectar muestras de suelo y rizosfera. Las esporas se contabilizaron y se identificaron por su morfología a nivel de género con base en la información del INVAM. No se mostraron diferencias significativas entre la densidad de esporas por planta ni zona, pero si por época de precipitación $(\alpha=0.05)$ siendo antes de ésta donde se encontró la mayor abundancia de esporas. En total se registraron tres géneros de HMA: Glomus, Acaulospora y Sclerocystis de los cuales Glomus fue el más frecuente. El nivel de N, P, K y la densidad de esporas antes de lluvias fueron correlacionados en dos sentidos positiva y negativamente debido a las características edáficas de los sitios. Los cambios en la densidad de esporas permiten especular que los HMA de este estudio responden ante las condiciones climáticas y al contenido denutrientes en el suelo.

Palabras clave: Árido, hongos, precipitación, conservación, micorriza.

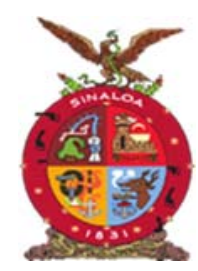

XVIII Congreso Internacional

XXIV Congreso Nacional de Ciencias ambientales
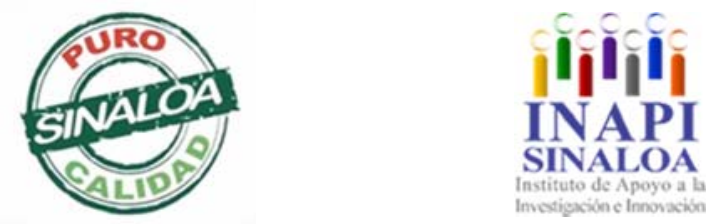

Mazatlán, Sinaloa 3-7 junio 2019

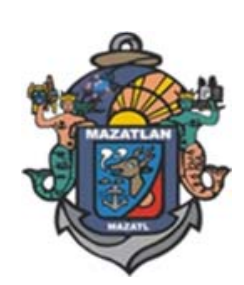

Recursos Naturales, Ecosistemas y Deterioro Ambiental 

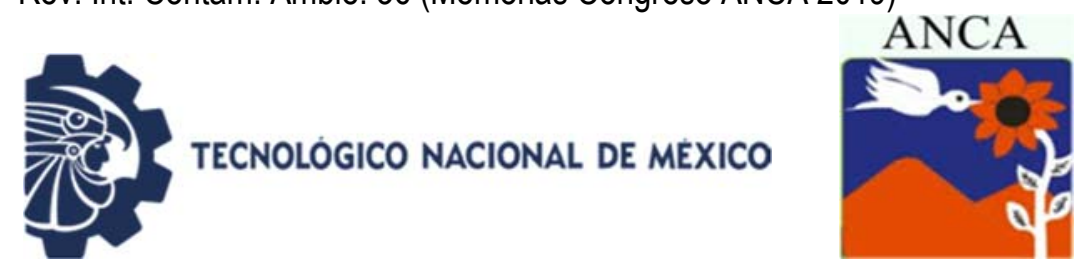

\title{
Relationship of mycorrhizal fungi with soil and precipitation in the ANP of Samalayuca, Chihuahua
}

\author{
Quiñónez Martínez M*, Palacios Ramirez K, Flores Margez J, \\ Enriquez Anchondo I
}

Instituto de Ciencias Biomédicas. Universidad Autónoma de Ciudad Juárez, Chihuahua, México

*mquinone@uacj.mx

\begin{abstract}
Arbuscular mycorrhizal fungi (AMF) as an important biological component in soils are very abundant and perform an essential role in arid and semiarid ecosystems in which provide an increase in uptake of water and nutrients to plants and influencing their establishment and survival. The aim of this study was to evaluate the composition of arbuscular mycorrhizal fungi in two plant communities in Natural Protected Area Medanos de Samalayuca, Chihuahua. Purposive sampling was conducted before and after the rainy season in July and September 2017 and using plants of mesquite (Prosopis juliflora var glandulosa) and ocotillo (Fouquieria splendens) to collect samples of soil and rhizosphere soil. The spores were counted and identified by their morphology, to genus level, based on the information of INVAM. There weren't show significative differences between spore density either of plants nor sites. Nevertheless, we found significative differences by precipitation $(\alpha=0.05)$ spore density were more abundant before the rain. A total of 3 genera of AMF were recorded: Glomus, Acaulospora and Sclerocystis of which Glomus was the most frequent. The level of N, P, K and spore density before rainfall were correlated in both ways positive and negative due to soil physicochemical properties in the sites. The change in spore density can allow speculating about AMF in this study have a response because of climatic conditions and nutrients contained in the soil.
\end{abstract}

Keywords: Arid, fungi, precipitation, conservation, mycorrhiza.

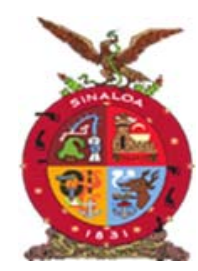

XVIII Congreso Internacional XXIV Congreso Nacional de Ciencias ambientales
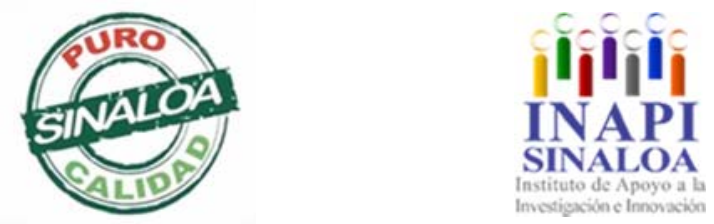

Mazatlán, Sinaloa 3-7 junio 2019

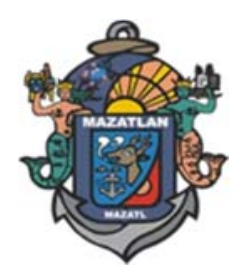

Recursos Naturales, Ecosistemas y Deterioro Ambiental 

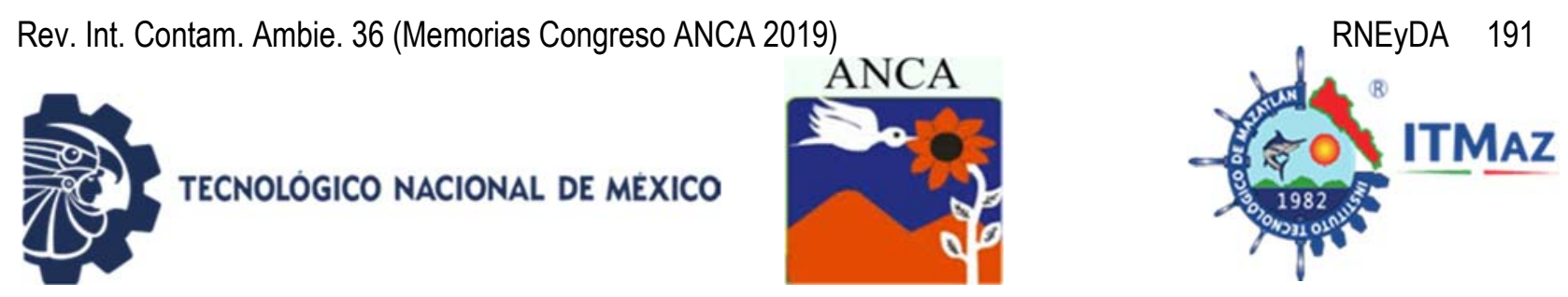

\title{
Determinación de concentración de inoculo de aceite esencial de orégano en el uso de fungicidas en plántulas de tomate
}

\author{
Quezada Aldaco MG, Marín Tinoco RI, Silva Marrufo O \\ Departamento de Microbiología General. Universidad Tecnológica de Rodeo. \\ Carr. Panamericana, Km. 159.4, C.P. 35760, Rodeo, Durango, México \\ *maryaldaco29@gmail.com
}

\section{RESUMEN}

Los cultivos del tomate en la actualidad tienen la amenaza de la enfermedad causada por el Fusarium oxisporum, causante de que la plántula se empiece a marchitar y posteriormente se seque. Por esto la idea de erradicarlos con productos naturales con "Aceite de orégano" (Lippia bernandieri). Se determinó la actividad antifúngica del aceite de orégano sobre el aislado del fusarium con el fin de crear un fungicida orgánico capas de eliminar las plagas del cultivo de tomate y además que sea amigable con el ambiente; ya que los fungicidas de la actualidad además de ser contaminantes para el ambiente sus residuos tardan mucho en descomponerse. Determinar la concentración idónea para la erradicación de la enfermedad fúngica: Fusarium oxisporum que es el causante de la marchites del cultivo del tomate. Se desarrolló en las instalaciones de Universidad Tecnológica de Rodeo en el mes de enero del 2019. Los análisis fueron un ANOVA con un nivel del 0.05 de nivel de confianza fueron: en variable número de hojas la menor 1.933 (T3) el mayor fue de 3.800 (T4), en altura de planta lo obtuvo el (T1) con una media de $6.730 \mathrm{~cm}$ y seguido de T3 con menor de $2.997 \mathrm{~cm}$, en grosor de tallo se obtuvo el T3 con una media de $1.450 \mathrm{~mm}$, seguido de T4 una media de $2.033 \mathrm{~mm}$, el (T4) con una concentración del 23\%, se estabilizo en la segunda semana, no se reflejó perdidas en las plántulas de tomate.

Palabras claves: Fusarium oxysporum, tomate, aceite, orégano.

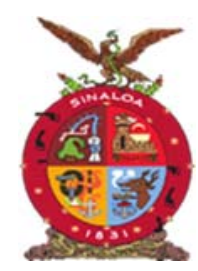

XVIII Congreso Internacional XXIV Congreso Nacional de Ciencias ambientales
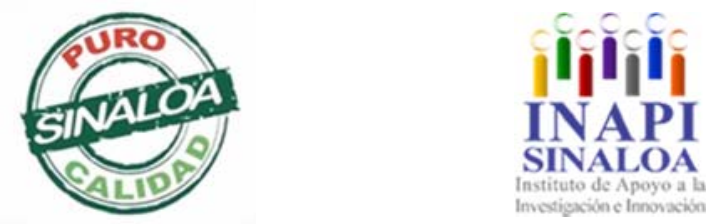

Mazatlán, Sinaloa 3-7 junio 2019

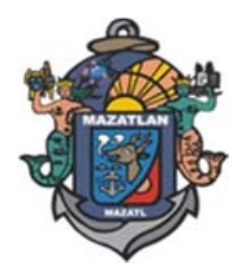

Recursos Naturales, Ecosistemas y Deterioro Ambiental 

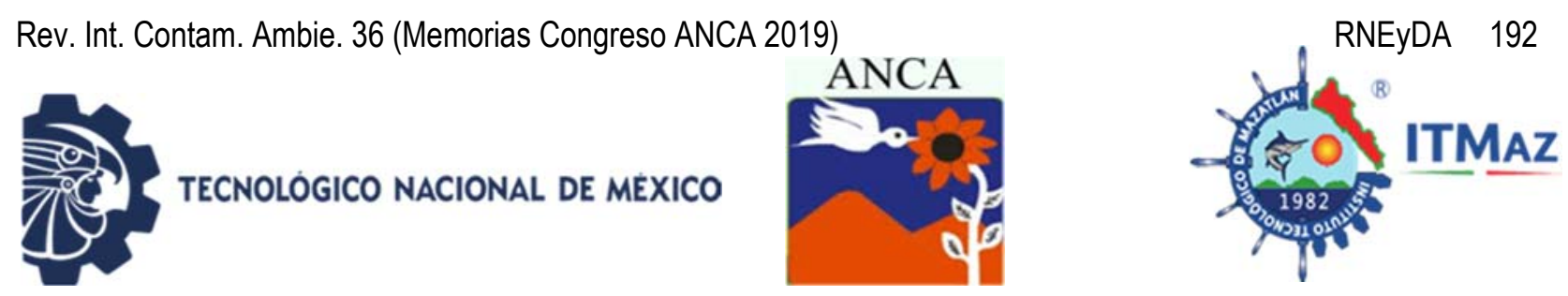

\title{
Determination of inocular concentration of organic essential oil in the use of fungicides in tomato plant
}

\author{
Quezada Aldaco MG, Marín Tinoco RI, Silva Marrufo O \\ Departamento de Microbiología General. Universidad Tecnológica de Rodeo. \\ Carr. Panamericana, Km. 159.4, C.P. 35760, Rodeo, Durango, México \\ *maryaldaco29@gmail.com
}

\begin{abstract}
Tomato crops currently have the threat of the disease caused by Fusarium oxisporum, which causes the seedling to begin to wilt and subsequently dry out. For this reason, the idea of eradicating them with natural products with "Oregano oil" (Lippia bernandieri). The antifungal activity of the oregano oil on the fusarium isolate was determined in order to create an organic fungicide capable of eliminating the pests of the tomato crop and also being friendly to the environment; since the fungicides of the present time besides being polluting for the environment, their waste takes a long time to decompose. Determine the ideal concentration for the eradication of the fungal disease: Fusarium oxisporum which is the cause of wilt of the tomato crop. It was developed in the facilities of Technological University of Rodeo in the month of January 2019. The analyzes were an ANOVA with a level of 0.05 confidence level were: in variable number of leaves the lowest 1933 (T3) the largest was 3,800 (T4). Plant height was obtained by (T1) with an average of $6.730 \mathrm{~cm}$ and followed by T3 with less than $2.997 \mathrm{~cm}$. In stem thickness T3 was obtained with an average of $1.450 \mathrm{~mm}$, followed by T4 a mean of $2,033 \mathrm{~mm}$, the (T4) with a concentration of $23 \%$, stabilized in the second week, no losses were detected in the tomato seedlings.
\end{abstract}

Keywords: Fusarium oxysporum, tomato, oil, oregano.

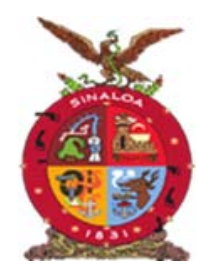

XVIII Congreso Internacional

XXIV Congreso Nacional de Ciencias ambientales

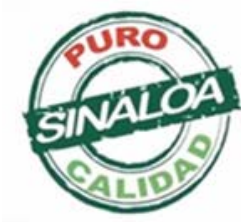

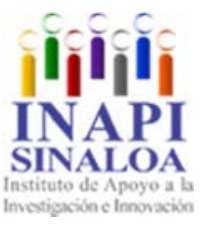

Mazatlán, Sinaloa 3-7 junio 2019

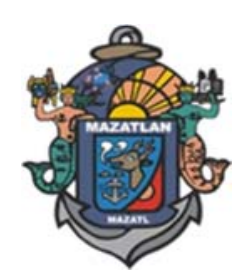

Recursos Naturales, Ecosistemas y Deterioro Ambiental 

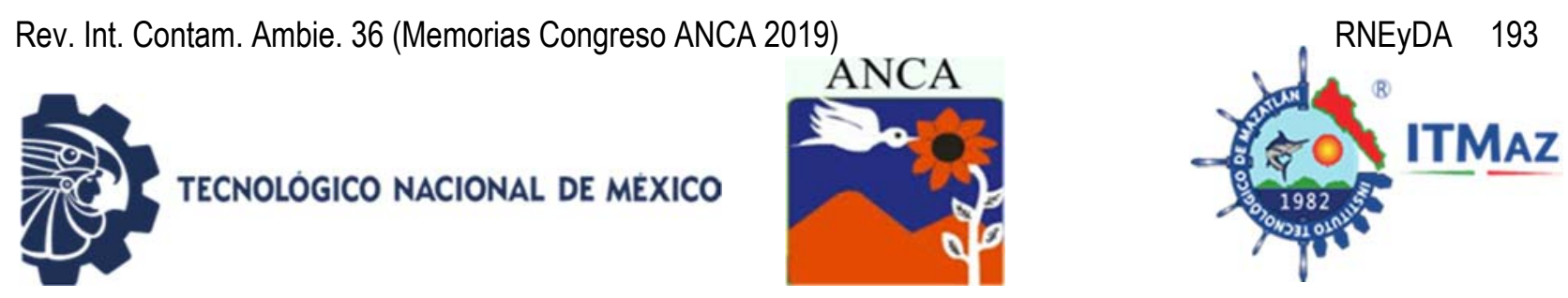

\title{
Impacto del uso de suelo en la contaminación hídrica de la subcuenca Nexapa de la Reserva de la Biósfera los Volcanes
}

\author{
Quijada Cuevas D, Guerra Hernández E*, Cruz Flores G \\ Laboratorio de Calidad de Agua y Ecohidrología. \\ Facultad de Estudios Superiores Zaragoza. \\ Universidad Nacional Autónoma de México. \\ Batalla de 5 de mayo S/N, Col. Ejército de Oriente, \\ C.P. 09230, Iztapalapa, CDMX, México \\ *eagh@unam.mx
}

\begin{abstract}
RESUMEN
La Reserva de la Biósfera Los Volcanes constituye una alternativa de conservación y aprovechamiento sustentable de todo el macizo montañoso en esta área, sin embargo, la porción de la superficie ribereña se ha deteriorado y disminuido con el paso del tiempo, como consecuencia de las transformaciones en el uso de suelo, desde el pastizal montano-forestal al agrícola-urbano: Esto conlleva a la generación o incremento de problemas ambientales como el deterioro de la calidad del agua, suelo o vegetación, e incluso su pérdida. Se analizaron algunas propiedades físicas y químicas del agua, indicadoras de contaminación (Oxígeno disuelto, $\mathrm{pH}$, conductividad, DBO, DQO, sólidos sedimentables, disueltos y suspendidos) en seis sitios con diferentes usos de suelo, entre septiembre de 2018 y febrero de 2019. Registrando seis usos de suelo: pastizal montano, forestal-pastizal montano, forestal recreativo, forestal perturbado, agropecuario y minero-agrícola-urbano, para determinar sus características e identificar el tipo de alteración que han sufrido. Se encontró, que los parámetros alterados de forma más significativa se presentaron en los sitios con uso de suelo forestal perturbado, agropecuario y minero-agrícola-urbano, con los siguientes valores promedio: conductividad $(42.33,68.00$ y $217.667 \mathrm{mg} / \mathrm{L}$ respectivamente), DQO (52.33, 52.00 y $110 \mathrm{mg} / \mathrm{L}$ respectivamente), sólidos disueltos (20.667, 34.00 y $108 \mathrm{mg} / \mathrm{L}$ respectivamente), sólidos sedimentables $(0.064,0.149$ y $1.413 \mathrm{mg} / \mathrm{L}$ respectivamente) y sólidos suspendidos $(8.00,10.667$ y $108.00 \mathrm{mg} / \mathrm{L}$ respectivamente). Lo cual indica presencia contaminación agropecuaria y doméstica, procesos de erosión y eutrofización en algunos sitios, por la perturbación generada al ser modificados los usos del suelo.
\end{abstract}

Palabras clave: Indicadores de contaminación uso de suelo, sistemas ribereños.

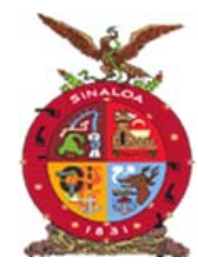

XVIII Congreso Internacional

XXIV Congreso Nacional de Ciencias ambientales
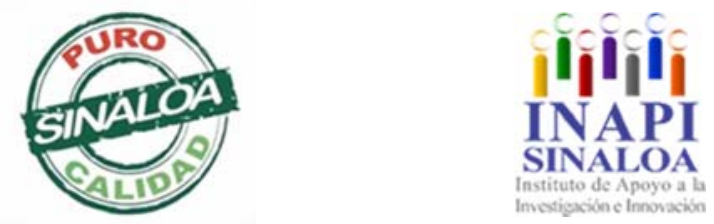

Mazatlán, Sinaloa 3-7 junio 2019

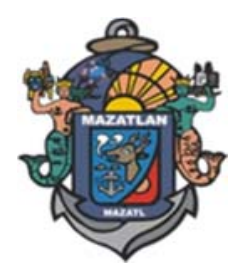

Recursos Naturales, Ecosistemas y Deterioro Ambiental 

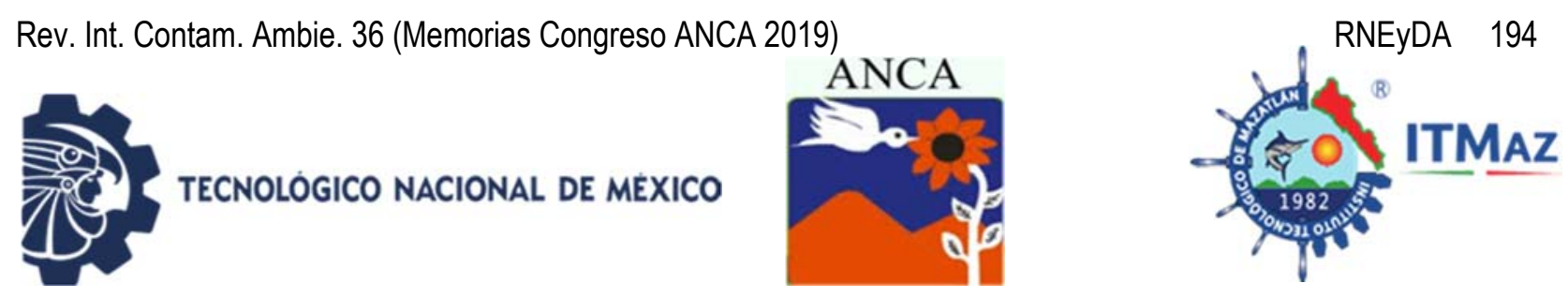

\title{
Impact of land use on water pollution in the Nexapa subbasin of the los Volcanes Biosphere Reserve
}

\author{
Quijada Cuevas D, Guerra Hernández E*, Cruz Flores G \\ Laboratorio de Calidad de Agua y Ecohidrología. \\ Facultad de Estudios Superiores Zaragoza. \\ Universidad Nacional Autónoma de México. \\ Batalla de 5 de mayo S/N, Col. Ejército de Oriente, \\ C.P. 09230, Iztapalapa, CDMX, México \\ *eagh@unam.mx
}

\begin{abstract}
The Biosphere Reserve of the Volcanoes constitutes an alternative for the conservation and sustainable use of the entire mountain range. In this area, however, the riparian area portion has deteriorated and decreased with the passage of time, as a consequence of the transformations in the land use, from montane-forest grassland to agricultural-urban: This leads to the generation or increase of environmental problems such as water quality, soil or vegetation deterioration and even its loss. Some physical and chemical properties of water, indicators of pollution (dissolved oxygen, $\mathrm{pH}$, conductivity, DQO, DBO, sedimentable solids, dissolved and suspended) were analyzed at six sites with different land uses, between september 2018 and february 2919. Six land uses were registered: grassland montane, grassland-forest montane, recreational forest, disturbed forest, agricultural and minero-agricultural-urban, to determine their characteristics and identify the type of alteration that they have suffered. It was found that the significantly altered parameters were in forest disturbed, agricultural and minero-agricultural-urban land use. Found values: conductivity (42.33, 68.00 and $217.667 \mathrm{mg} / \mathrm{L}$ respectively), COD $(52.33,52.00$ and $110 \mathrm{mg} / \mathrm{L}$ respectively), dissolved solids (20.667, 34.00 and $108 \mathrm{mg} / \mathrm{L}$ respectively), sedimentable solids (0.064.0.149 and $1.413 \mathrm{mg} / \mathrm{L}$ respectively) and suspended solids $(8.00,10.667$ and $108.00 \mathrm{mg} / \mathrm{L}$ respectively). This indicates presence of agricultural and domestic pollution, processes of erosion and eutrophication in some places, about the disturbance generated when land uses are modified.
\end{abstract}

Keywords: Pollution indicators, land use, river systems.

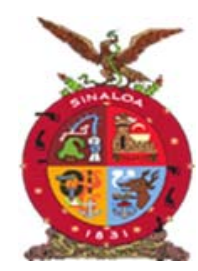

XVIII Congreso Internacional

XXIV Congreso Nacional de Ciencias ambientales

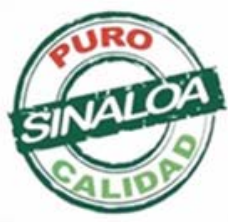

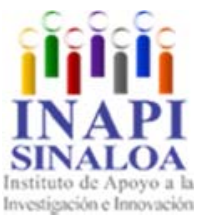

Mazatlán, Sinaloa 3-7 junio 2019

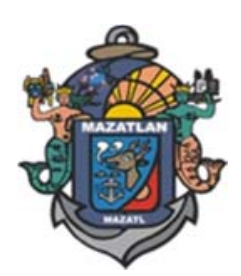

Recursos Naturales, Ecosistemas y Deterioro Ambiental 

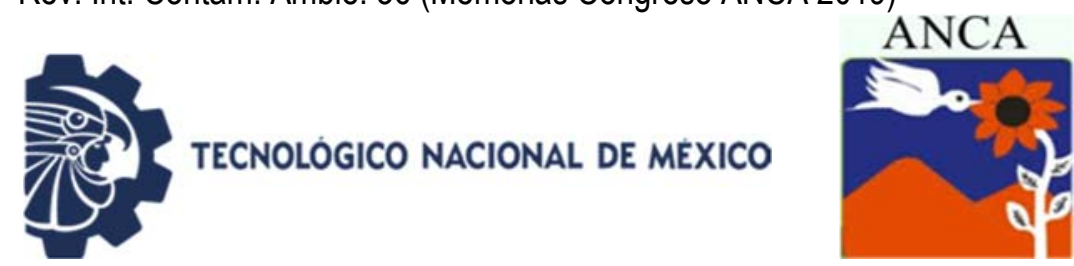

\title{
Evaluación de la superficie de lirio acuático en el Lago de Yuriria, Guanajuato Mediante SIG
}

\author{
Ramírez Mosqueda E*, Lopez Gutierrez JM, Costilla Salazar R \\ División de Ciencias de la Vida. Universidad de Guanajuato. México \\ *ramirezmq.e@gmail.com
}

\section{RESUMEN}

El Lago de Yuriria es un sitio RAMSAR y además un Área Natural Protegida, que desde hace varios ha sido afectado de lirio acuático (Eichhornia crassipes) ocasionando deterioro en la calidad del agua y la restricción al uso turístico. Debido a esto en el año 2018 se realizaron esfuerzos para disminuir la superficie mediante la aplicación de un control integral: método químico y mecánico. Por lo que el objetivo de este trabajo es evaluar los resultados en el combate a la proliferación del lirio acuático, utilizando imágenes del satélite Sentinel 2 y de Landsat 8 OLI. Se obtuvieron imágenes de este cuerpo de agua de los años 20142017 y evaluó el crecimiento temporal del lirio del año 2018 y parte del 2019 para conocer los resultados de las medidas de mitigación. A las imágenes se les aplicó el NDVI (Índice de Vegetación de Diferencia Normalizada) para cuantificar el área de lirio acuático. Con las imágenes del año 2018 se realizó un comparativo entre la superficie cuantificada mediante las imágenes de satélite y el área afectada por mes. Comparativamente del área de lirio acuático se observó que en el año 2017 aumentó en promedio el $24.5 \%$ en comparación con otros años. El control integral aplicado ayudo a atenuar el crecimiento del lirio acuático en algunos meses del año 2018 (7.9-15.63\%). El control integral utilizado es un método eficaz de atenuación del lirio acuático, pero requiere un mínimo de 2 meses para la obtención de resultados.

Palabras clave: Lago de Yuriria, maleza acuática, SIG.

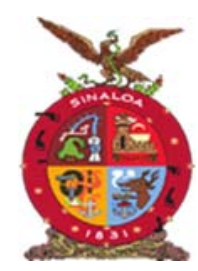

XVIII Congreso Internacional XXIV Congreso Nacional de Ciencias ambientales

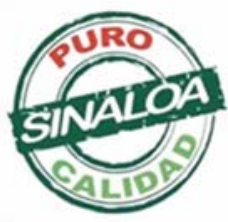

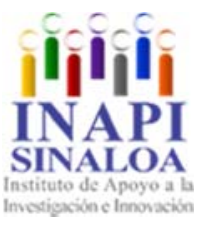

Mazatlán, Sinaloa 3-7 junio 2019

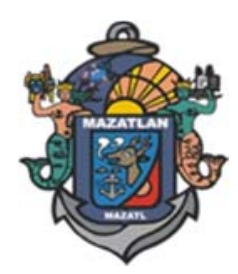

Recursos Naturales, Ecosistemas y Deterioro Ambiental 

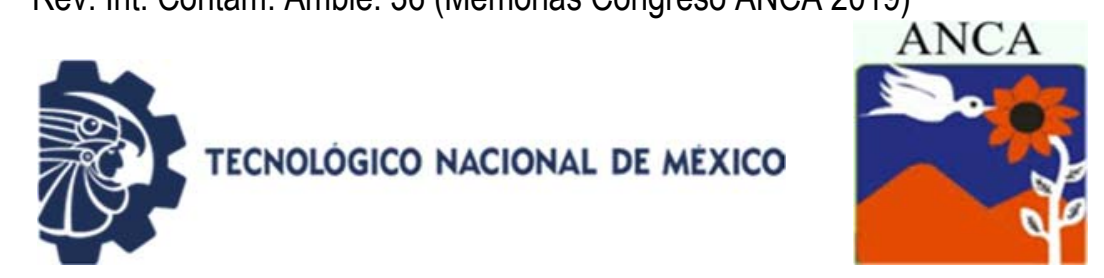

\title{
Evaluation of the water lily surface on Lake Yuriria, Guanajuato through GIS.
}

Ramírez Mosqueda E*, Lopez Gutierrez JM, Costilla Salazar R

División de Ciencias de la Vida. Universidad de Guanajuato. México

*ramirezmq.e@gmail.com

\begin{abstract}
Yuriria Lake is a RAMSAR site and also a Protected Natural Area, which has been affected by water lily (Eichhornia crassipes) for several years, causing deterioration in water quality and restriction on tourist use. Due to this, in 2018, efforts were made to reduce the surface through the application of an integral control: chemical and mechanical method. Therefore, the objective of this work is to evaluate the results in the fight against the proliferation of water lily, using images from the Sentinel 2 satellite and Landsat $8 \mathrm{OLI}$. Images of this body of water were obtained from the years 2014-2017 and evaluated the temporary growth of the lily of the year 2018 and part of 2019 to know the results of the mitigation measures. The NDVI (Normalized Difference Vegetation Index) was applied to the images to quantify the area of water lily. With the images of the year 2018, a comparison was made between the area quantified by satellite images and the affected area per month. Comparing the water lily area, it was observed that in 2017 it increased on average $24.5 \%$ compared to other years. The integral control applied helped to attenuate the growth of the water lily in some months of the year 2018 (7.9-15.63\%). The integral control used is an effective method of attenuation of the water lily, but it requires a minimum of 2 months to obtain results.
\end{abstract}

Keywords: Yuriria Lake, aquatic weed, GIS.

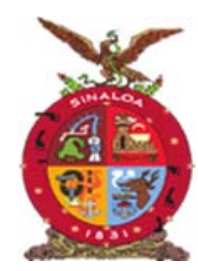

XVIII Congreso Internacional XXIV Congreso Nacional de Ciencias ambientales

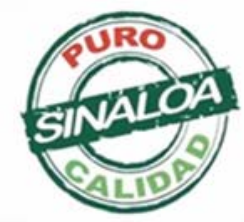

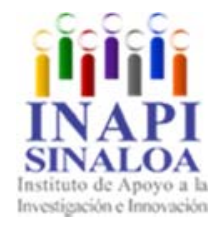

Mazatlán, Sinaloa 3-7 junio 2019

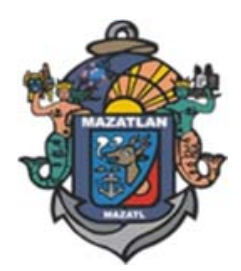

Recursos Naturales, Ecosistemas y Deterioro Ambiental 

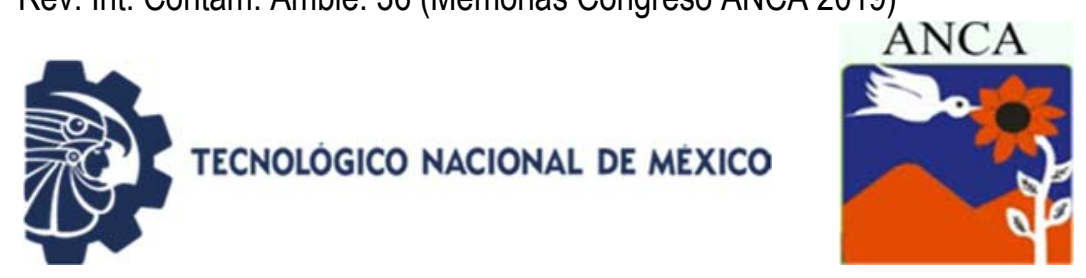

\title{
Diagnóstico ambiental de los ecosistemas forestales de Guachochi, Chihuahua
}

\author{
Ramírez Rejogochi $S^{1}$, Pinedo Álvarez $C^{2 *}$, Melgoza Castillo $A^{2}$, \\ Rentería Villalobos $\mathrm{M}^{2}$ \\ ${ }^{1}$ Licenciatura de Ingeniero en Ecología \\ ${ }^{2}$ Facultad de Zootecnia y Ecología. Universidad Autónoma de Chihuahua. \\ Periférico Francisco R. Almada Km 1, 31453, Chihuahua, México \\ *cpinedo@uach.mx

\section{RESUMEN}

Las actividades silvoagropecuarias y el turismo, causan fuertes impactos en el paisaje forestal y en la conservación y sustentabilidad de los bosques. Es por ello necesario estudiar la magnitud, dinámica e impactos de los procesos de cambio en el uso de suelo, vegetación y grados de disturbio como consecuencia de la interacción del hombre con su ambiente. Este estudio tuvo como objetivo analizar el estado de salud medioambiental de los ecosistemas forestales del municipio de Guachochi. Para ello, se utilizaron imágenes Landsat TM y OLI8 del 2000 y 2015 para determinar uso del suelo y vegetación, fragmentación e índices de disturbio, para la erosión se utilizó el método USLE. El análisis de la información y mapeo se procesó en ArGis v.10.3. El índice de marginación fue alto con valores entre 1.99 y 2.56. La fragmentación mostró niveles de medio a bajo. El índice de disturbio con clasificación baja tiene mayor distribución en el municipio (396,377 ha). En un periodo de 25 años los bosques de pino y pino encino presentaron las mayores pérdidas de superficie, en tanto, la vegetación secundaria arbustiva entre las coberturas de pino y encino tendieron a incrementarse. El área de estudio presentó solo un $7 \%$ con grado severo de erosión. Los impactos negativos en las variables evaluadas están relacionadas con la extracción ilegal de madera, plagas e incendios, entre otros. Es importante establecer áreas piloto de monitoreo para el diagnóstico constante de los atributos forestales.

Palabras clave: Usos suelo, fragmentación, erosión, Landsat.

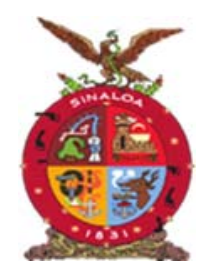

XVIII Congreso Internacional XXIV Congreso Nacional de Ciencias ambientales

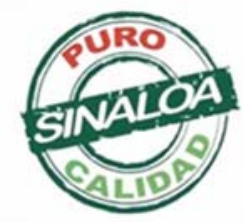

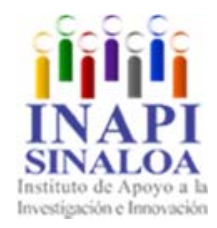

Mazatlán, Sinaloa 3-7 junio 2019

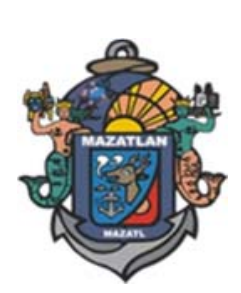

Recursos Naturales, Ecosistemas y Deterioro Ambiental 

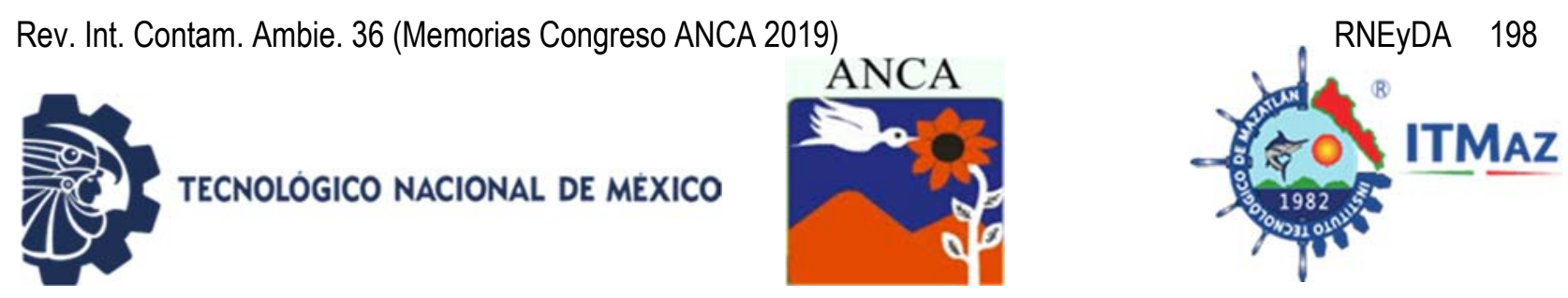

\title{
Environmental diagnosis of forest ecosystems of Guachochi, Chihuahua
}

\author{
Ramírez Rejogochi $\mathrm{S}^{1}$, Pinedo Álvarez $\mathrm{C}^{2 *}$, Melgoza Castillo $\mathrm{A}^{2}$, \\ Rentería Villalobos $\mathrm{M}^{2}$ \\ ${ }^{1}$ Licenciatura de Ingeniero en Ecología \\ ${ }^{2}$ Facultad de Zootecnia y Ecología. Universidad Autónoma de Chihuahua. \\ Periférico Francisco R. Almada Km 1, 31453, Chihuahua, México \\ *cpinedo@uach.mx
}

\begin{abstract}
Silvoagricultural activities and tourism cause strong impacts on the forest landscape as well as on the conservation and sustainability of the forests. Studies of magnitude, dynamics and impacts of the processes of change, use of soil and vegetation, and degrees of disturbance are needed to explain the consequences of the man-environment interaction. The objective of this study was to analyze the state of environmental health of the forest ecosystems of the municipality of Guachochi. Landsat TM and OLI8 images from 2000 and 2015 were used to determine land use and vegetation, fragmentation, and disturbance rates. Additionally, the USLE method was used to obtain erosion grades. The analysis of the information and mapping was processed in ArGis v.10.3 program. The marginalization index was high with values between 1.99 and 2.56. Likewise, fragmentation showed levels from medium to low. In the municipality, the predominant disturbance index was of low classification; with distribution of 396,377 ha. Over a period of 25 years, the pine and oak tree forests presented the highest loss of surface, whereas the secondary shrub vegetation in pine and oak coverings tended to increase. The study area showed only $7 \%$ of severe grade of erosion. The negative impacts on the evaluated variables are related to the illegal extraction of wood, pests, and fires, among others. It is important to establish pilot monitoring areas for the constant diagnosis of forest attributes.
\end{abstract}

Keywords: Land use, fragmentation, erosion, Landsat.

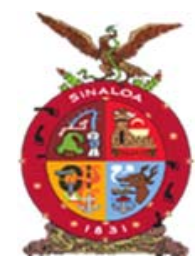

XVIII Congreso Internacional

XXIV Congreso Nacional de Ciencias ambientales

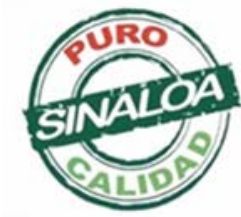

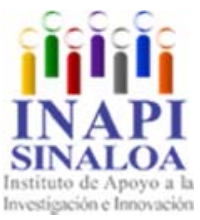

Mazatlán, Sinaloa 3-7 junio 2019

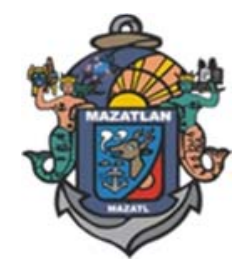

Recursos Naturales, Ecosistemas y Deterioro Ambiental 

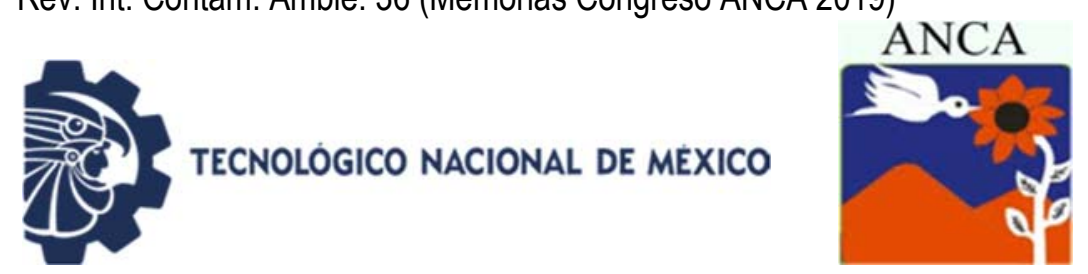

\title{
Impacto del manejo silvícola en la diversidad de árboles y arbustos en un bosque templado del estado de Hidalgo
}

\author{
Razo Zárate $\mathrm{R}^{1}$, Rodríguez Laguna $\mathrm{R}^{1}$, Meza Rangel $\mathrm{J}^{1}$, Capulin Grande $\mathrm{J}^{1}$, \\ Palacios Romero $\mathrm{A}^{2}$ \\ ${ }^{1}$ Universidad Autónoma del Estado de Hidalgo. México \\ ${ }^{2}$ Tecnológico de Monterrey. Campus Hidalgo. México \\ ramon_razo@uaeh.edu.mx
}

\section{RESUMEN}

El método de desarrollo silvícola se ha aplicado en Hidalgo desde principios de los 80 's, con resultados favorables en el establecimiento de regeneración natural de Pinus patula, pero ha quedado la duda si con las reforestaciones silvícolas y tratamientos complementarios, la vegetación disminuye la diversidad de las especies. El objetivo fue evaluar la dinámica de establecimiento de especies a través del tiempo, motivo por el cual se realizaron colectas botánicas periódicas durante el año 2018 en tres áreas de regeneración en El Reparo, Zacualtipán, Hgo. reforestadas durante los años 2002, 2010, 2016, los listados florísticos se compararon entre ellas y con un área sin intervenir. Los resultados fueron de 1100 árboles por hectárea para el área sin intervenir, mientras que en las áreas intervenidas aumentó hasta 2500 en el área del 2002; la diversidad de especies de árboles pasó gradualmente de 10 en bosque original a 13 en el área intervenida hace 17 años. El número de especies de arbustos también aumentó de 17 en la condición original a 22 registradas en las áreas bajo manejo silvícola. Por último, se concluye que, aunque se realizan "chapeos" frecuentes durante las etapas de establecimiento de regeneración natural de pino, la diversidad florística se mantiene o se recupera gradualmente con el paso del tiempo, por lo que estos aprovechamientos forestales permiten la renovación del bosque, manteniendo la diversidad florística y los múltiples bienes y servicios ambientales que proporcionan éstos ecosistemas para las generaciones actuales y futuras.

Palabras clave: Regeneración natural, tratamientos silvícolas, árboles y arbustos, Pinus patula.

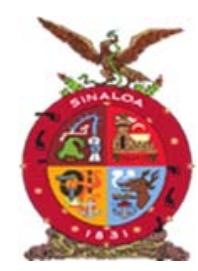

XVIII Congreso Internacional XXIV Congreso Nacional de Ciencias ambientales

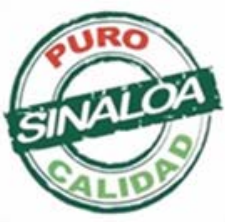

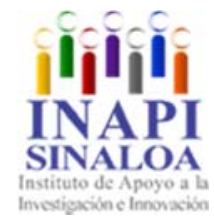

Mazatlán, Sinaloa 3-7 junio 2019

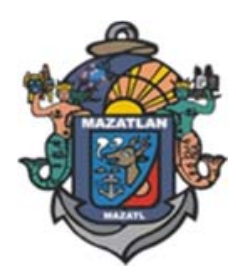

Recursos Naturales, Ecosistemas y Deterioro Ambiental 

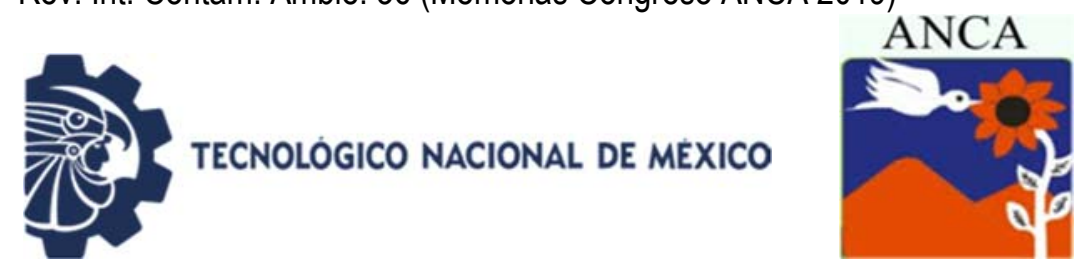

\title{
Impact of forest management on the diversity of trees and shrubs in a temperate forest of the state of Hidalgo
}

\author{
Razo Zárate $\mathrm{R}^{1}$, Rodríguez Laguna $\mathrm{R}^{1}$, Meza Rangel $\mathrm{J}^{1}$, Capulin Grande $\mathrm{J}^{1}$, \\ Palacios Romero $\mathrm{A}^{2}$ \\ ${ }^{1}$ Universidad Autónoma del Estado de Hidalgo. México \\ ${ }^{2}$ Tecnológico de Monterrey. Campus Hidalgo. México \\ ramon_razo@uaeh.edu.mx
}

\begin{abstract}
The method of silvicultural development has been applied in Hidalgo since the early 80 's, with favorable results in the establishment of natural regeneration of Pinus patula, but the question remains whether with silvicultural reforestation and complementary treatments, vegetation decreases the diversity of species. The objective was to evaluate the dynamics of species establishment over time, which is why periodic botanical collections were made during 2018 in three regeneration areas in El Reparo, Zacualtipán, Hgo. reforested during the years 2002, 2010, 2016, the floristic listings were compared with each other and with an area without intervention. The results were 1100 trees per hectare for the area without intervention, while in the intervened areas it increased to 2500 in the area of 2002; the diversity of tree species gradually increased from 10 in the original forest to 13 in the area operated 17 years ago. The number of shrub species also increased from 17 in the original condition to 22 recorded in the areas under silvicultural management. Finally, it is concluded that, although frequent "chapeos" are carried out during the stages of natural pine regeneration, floristic diversity is maintained or gradually recovered over time, so that these forest exploitations allow the renewal of forest, maintaining the floristic diversity and the multiple environmental goods and services that these ecosystems provide for current and future generations.
\end{abstract}

Keywords: Natural regeneration, silvicultural treatments, trees and shrubs, Pinus patula.

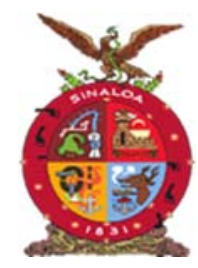

XVIII Congreso Internacional XXIV Congreso Nacional de Ciencias ambientales

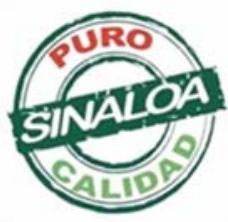

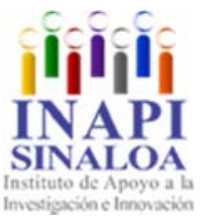

Mazatlán, Sinaloa 3-7 junio 2019

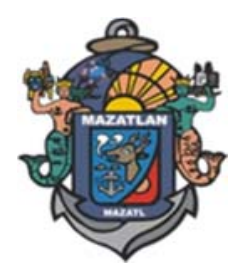

Recursos Naturales, Ecosistemas y Deterioro Ambiental 

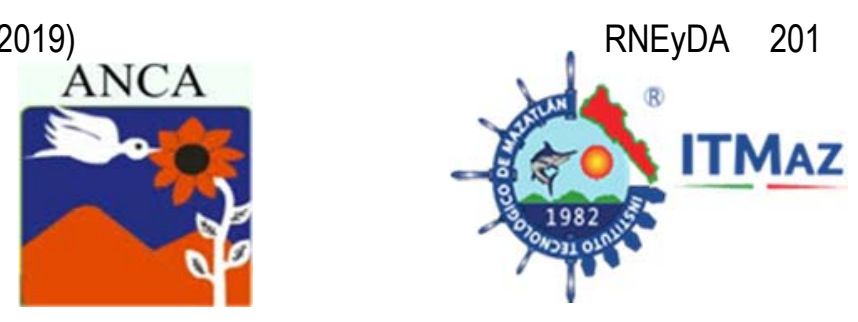

\title{
Estrategias de agrobiodiversidad en microrregiones de El Fuerte y Choix, Sinaloa
}

\author{
Rentería Alvarez $\mathrm{G}^{1}$, Lara Ponce $\mathrm{E}^{2}$, Quintero Romanillo $\mathrm{AL}^{2}$, \\ Rodríguez Sauceda $\mathrm{EN}^{2}$
}

${ }^{1}$ Ingeniería Forestal, Universidad Autónoma Intercultural de Sinaloa. México

${ }^{2}$ Cuerpo Académico Biodiversidad y Estrategias Comunitarias de Desarrollo

Sostenible. Universidad Autónoma Intercultural de Sinaloa. México

forestalsustentable2012@hotmail.com

\begin{abstract}
RESUMEN
El presente estudio aborda la agrobiodiversidad y uso de semillas criollas que son de gran importancia sociocultural y alimenticia en las comunidades de Sibirijoa, Tehueco y Tepehuaje del municipio de El Fuerte y Aguajito, Choix en el norte de Sinaloa. En estas microrregiones no hay evidencias documentadas, ni estudios de la agricultura tradicional, del papel de los campesinos de edad avanzada, perdida de variedades nativas y de la escasez del recurso agua como limitantes para la continuidad la agrobiodiversidad. El objetivo consistió en explorar y documentar el uso y manejo de semillas locales de la agricultura de temporal en dos microrregiones. Se realizó búsqueda bibliográfica en fuentes primarias, seguido de visitas a las localidades durante el primer cuatrimestre del 2019; se aplicaron encuestas aleatorias a hombres y mujeres, realizaron entrevistas informales a diez familias de cada comunidad. Se efectuaron de recorridos de campo y colectas de semillas criollas utilizadas en los huertos familiares y en zonas de temporal. Se efectuó un registro fotográfico y realizó un croquis de ubicación. Los resultados preliminares señalan que persiste la actividad productiva de temporal en cultivos de importancia económica, principalmente para el autoconsumo familiar. Se han identificado ocho especies de semillas de cinco familias botánicas: Fabaceae, Gramíneae y Pedaliaceae, Cucurbitaceae y Leguminosae. Se concluye que es prioritario investigar los recursos naturales biológicos locales, para reconocer y valorar las semillas nativas, así como los diversos usos que le dan los campesinos. La conservación in situ es necesaria para conservar el banco genético de las microrregiones.
\end{abstract}

Palabras claves: Semillas criollas, conocimiento local, patrimonio biocultural.

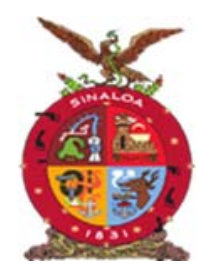

XVIII Congreso Internacional XXIV Congreso Nacional de Ciencias ambientales

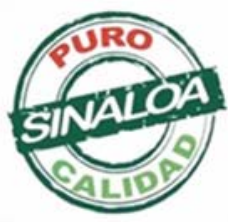

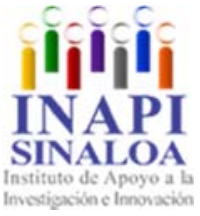

Mazatlán, Sinaloa 3-7 junio 2019

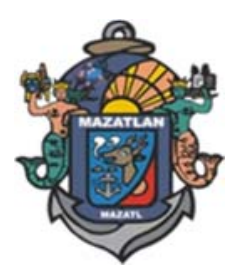

Recursos Naturales, Ecosistemas y Deterioro Ambiental 

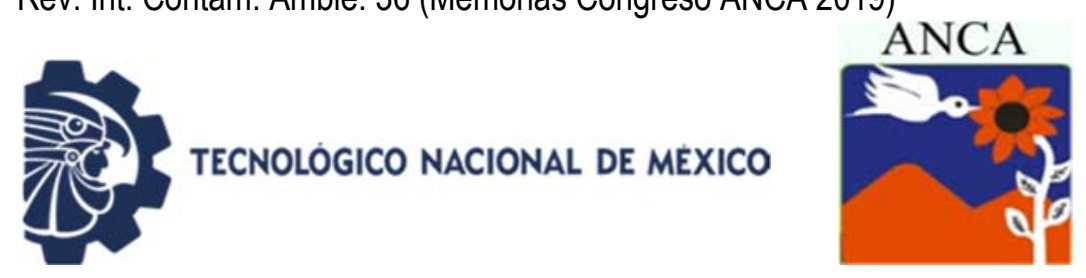

\title{
Agrobiodiversity strategies in microregions of EI Fuerte and Choix, Sinaloa
}

\author{
Rentería Alvarez $\mathrm{G}^{1}$, Lara Ponce $\mathrm{E}^{2}$, Quintero Romanillo $\mathrm{AL}^{2}$, \\ Rodríguez Sauceda $\mathrm{EN}^{2}$
}

${ }^{1}$ Ingeniería Forestal, Universidad Autónoma Intercultural de Sinaloa. México

${ }^{2}$ Cuerpo Académico Biodiversidad y Estrategias Comunitarias de Desarrollo

Sostenible. Universidad Autónoma Intercultural de Sinaloa. México

forestalsustentable2012@hotmail.com

\begin{abstract}
The present study addresses agrobiodiversity and the use of creole seeds that are of great sociocultural and food importance in the communities of Sibirijoa, Tehuehua and Tepehuaje of the municipality of Fuerte and Aguajito, Choix in northern Sinaloa. In these microregions there are no documented evidences, studies of traditional agriculture, role of the elderly peasants, loss of native varieties and scarcity of resources as constraints for the continuity of agrobiodiversity. The objective was to explore and document the use and management of the seeds of temporary agriculture in two microregions. A bibliographic search was made in primary sources, followed by visits to the localities during the first four months of 2019; Random surveys were applied to men and women, informal interviews to ten families of each community. Field trips and collection of Creole seeds used in family gardens and in rainy areas were made. A photographic record was made and a location sketch was made. The preliminary results indicate the productive activity of time in crops of economic importance, mainly for family self-consumption. Eight species of five botanical families have been identified: Fabaceae, Gramíneae and Pedaliaceae, Cucurbitaceae and Leguminosae. It is concluded that it is a priority to investigate the biological natural resources, to recognize and value the native seeds, as well as the diverse uses that the peasants give. In situ conservation is necessary to conserve the genetic bank of the microregions.
\end{abstract}

Keywords: Criollo seeds, local knowledge, biocultural heritage.

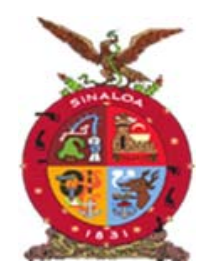

XVIII Congreso Internacional

XXIV Congreso Nacional de Ciencias ambientales
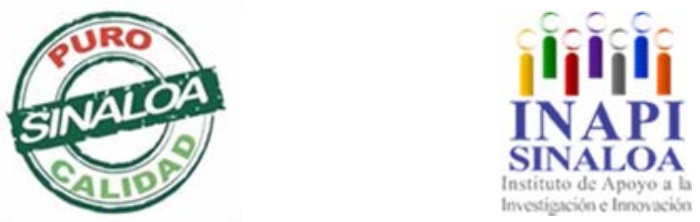

Mazatlán, Sinaloa 3-7 junio 2019

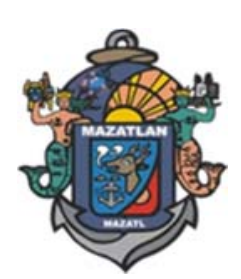

Recursos Naturales, Ecosistemas y Deterioro Ambiental 

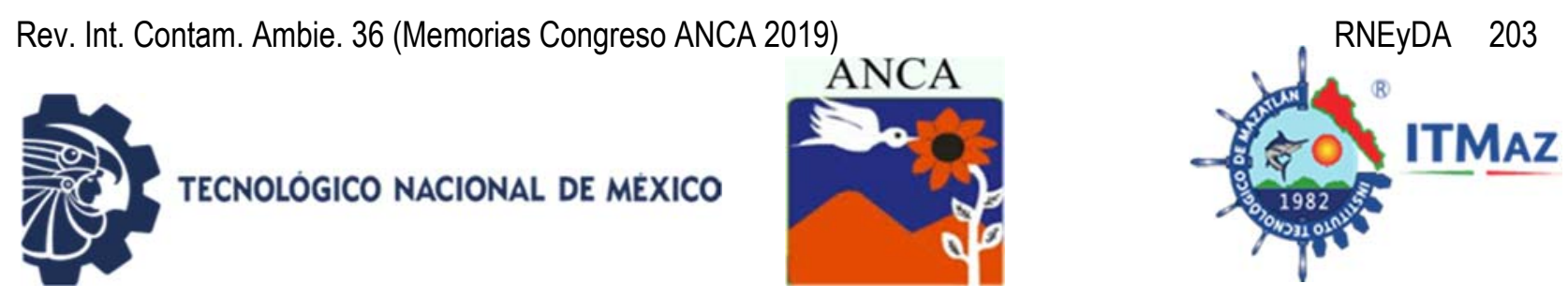

\title{
Aproximación mediante un balance hídrico del aporte de volumen de agua desde un humedal hacia un ecosistema lacustre subtropical mexicano
}

\author{
Rendón López $\mathrm{MB}^{1 *}$, Medina Ávila $\mathrm{J}^{1}$, Gómez-Tagle Chavez $\mathrm{A}^{1}$, \\ Ayala Ramirez $\mathrm{L}^{1}$, Suárez Alonso $\mathrm{ML}^{2}$, Vidal Abarca $\mathrm{MR}^{2}$ \\ ${ }^{1}$ Instituto de Investigaciones sobre los Recursos Naturales \\ Universidad Michoacana de San Nicolás de Hidalgo (INIRENA-UMSNH). \\ ${ }^{2}$ Departamento de Ecología e Hidrología, Universidad de Murcia, España \\ *maberendon@gmail.com
}

\section{RESUMEN}

La hidrología es uno de los factores clave que determina la estructura y función de un humedal. Por lo tanto, la variación de los componentes hidrológicos define su régimen hídrico. Sin embargo existe poca información sobre el funcionamiento hidrológico de los humedales subtropicales, por lo que los balances hídricos son determinante para relaciones entre los componentes. En este sentido, y debido a la importancia de los humedales en la regulación hídrica y en el control del nivel de agua como en el lago Pátzcuaro, se estima mediante el balance hídrico del humedal el volumen de agua aportado al lago de Pátzcuaro. El balance hídrico se calculó mediante la evaluación de los componentes hidrológicos de entrada, salida y almacenamiento con información recabada del 2015 al 2018 y se calculó las áreas con diferentes usos de suelo en el humedal. Los resultados indican que los componentes hidrológicos son sensibles a las variaciones climáticas. Se ha registrado un volumen total de agua en sequias de entrada al humedal de $8.41 \mathrm{Mm}^{3}$, un volumen de salida $7.97 \mathrm{Mm}^{3}$, almacenando de $1.23 \mathrm{Mm}^{3}$. En lluvias el volumen de entrada fue de $12.31 \mathrm{Mm}^{3}$, el de salida de $18.77 \mathrm{Mm}^{3}$ y almacenado de $20.44 \mathrm{Mm}^{3}$. El balance anual estimado fue de $1.46 \mathrm{Mm}^{3}$, indicando que el humedal se encuentra en equilibrio hídrico. Por tanto, el humedal sur de Pátzcuaro se puede considerar como un sistema de amortiguación hidrológica que transfiere agua el $32.55 \%$ hacia la zona sur del lago, formando con él una unidad funcional.

Palabras claves: Balance hídrico, humedal, hidrología, limnología, lago volcánico.

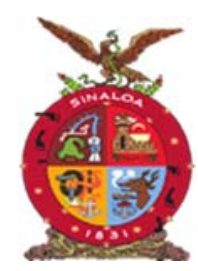

XVIII Congreso Internacional XXIV Congreso Nacional de Ciencias ambientales

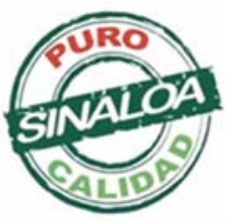

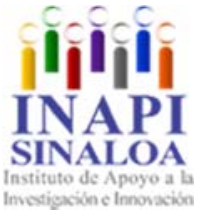

Mazatlán, Sinaloa 3-7 junio 2019

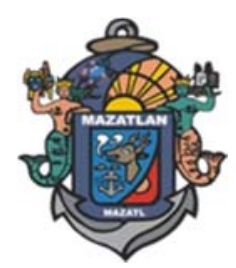

Recursos Naturales, Ecosistemas y Deterioro Ambiental 

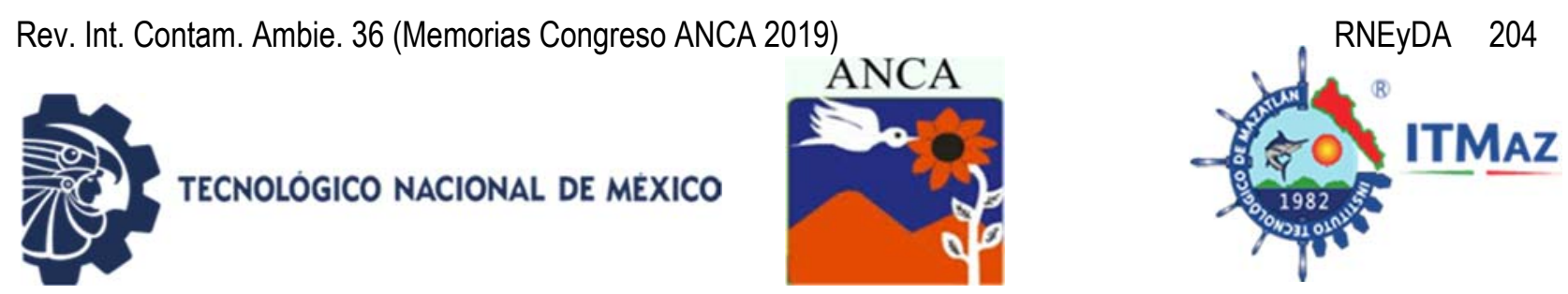

\title{
Approach through a water balance of the water volume contribution from a wetland to a Mexican subtropical lacustrine ecosystem
}

\author{
Rendón López $\mathrm{MB}^{1 *}$, Medina Ávila $\mathrm{J}^{1}$, Gómez-Tagle Chavez $\mathrm{A}^{1}$, \\ Ayala Ramirez $\mathrm{L}^{1}$, Suárez Alonso $\mathrm{ML}^{2}$, Vidal Abarca $M R^{2}$ \\ ${ }^{1}$ Instituto de Investigaciones sobre los Recursos Naturales \\ Universidad Michoacana de San Nicolás de Hidalgo (INIRENA-UMSNH). \\ ${ }^{2}$ Departamento de Ecología e Hidrología, Universidad de Murcia, España \\ *maberendon@gmail.com
}

\begin{abstract}
Hydrology is one of the key factors that determine the wetlands structure and function. Therefore, the variation of the hydrological components defines its water regime. There is little knowledge of subtropical wetlands hydrological functioning, so the water balances are a determining factor for relationships between hydrological components. In this sense, and due to the importance of wetlands in the water regulation and in the control of the water level in lakes such as Lake Pátzcuaro, the present work has the objective of estimating the water volume which contributed through the water balance of the wetland to the lake of Pátzcuaro. The water balance was calculated by evaluating the hydrological input, output and storage components with information from 2015 to 2018 . The areas with different land uses in the wetland were calculated. The results indicate the hydrological components are sensitive to climatic variations. A total volume of water (dry season) of input to the wetland of $8.41 \mathrm{Mm}^{3}$ was registered, an output volume of $7.97 \mathrm{Mm}^{3}$, storing of $1.23 \mathrm{Mm}^{3}$. In rains the volume of entrance was of $12.31 \mathrm{Mm}^{3}$, the one of exit of $18.77 \mathrm{Mm}^{3}$ and stored of $20.44 \mathrm{Mm}^{3}$. The greatest contribution comes from precipitation and runoff. The estimated annual balance was $1.46 \mathrm{Mm}^{3}$, indicating that the wetland is in water balance. Therefore, the southern Pátzcuaro wetland will be considered a hydrological damping system that transfers water $32.55 \%$ towards the south zone of the lake, forming a functional unit with it.
\end{abstract}

Keywords: Water balance, wetland, hidrology, water volumen, limnology, volcanic lake.

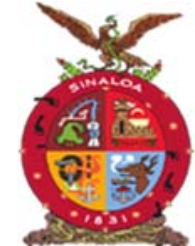

XVIII Congreso Internacional

XXIV Congreso Nacional de Ciencias ambientales

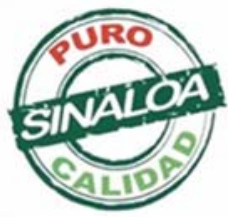

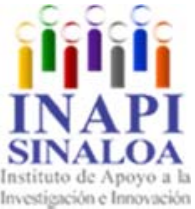

Mazatlán, Sinaloa 3-7 junio 2019

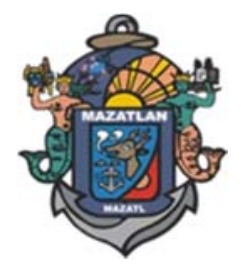

Recursos Naturales, Ecosistemas y Deterioro Ambiental 

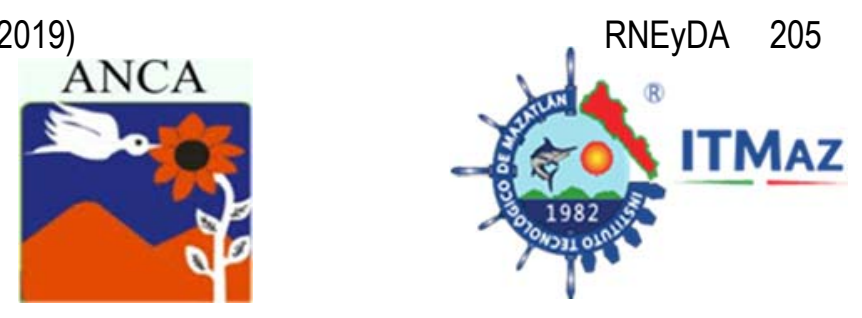

\title{
Actualización a la etapa de prototipo refinado $\alpha$ al modelo computacional para la evaluación de indicadores de calidad ambiental
}

\author{
Ríos Gerardo J, Cabrera Cruz RBE*, Tobías Jaramillo R, Rolón García J, \\ Rolón Aguilar E \\ Cuerpo Académico UAT-CA-29 Medio Ambiente y Desarrollo Sustentable. \\ Facultad de Ingeniería Arturo Narro Siller. \\ Universidad Autónoma de Tamaulipas. México \\ *rcabreracruz@docentes.uat.edu.mx
}

\begin{abstract}
RESUMEN
La técnica Evaluación Rápida de Fuentes de Contaminación Ambiental (ERFCA) es una herramienta metodológica diseñada por la Organización Mundial de la Salud (OMS), que tiene como objetivo identificar las principales fuentes de contaminación utilizando datos disponibles del sector público. Existen modelos de software para la evaluación de calidad ambiental, pero no existe un modelo computacional validado por los expertos en el área que haya sido aplicado en casos reales. Por lo tanto, se considera necesario generar un nuevo modelo computacional para mejorar la técnica ERFCA usando técnicas avanzadas de computación como minería de datos, inteligencia artificial, herramientas web, con el objetivo de reducir errores y facilitar el manejo de grandes cantidades de información. El proceso metodológico comprendió la recolección de información y análisis de la técnica ERFCA, el análisis de la metodología de desarrollo de un sistema experto; desarrollo del motor de inferencia utilizando técnicas de programación avanzadas; y de sistema refinado a del modelo computacional. Dentro de los principales resultados obtenidos se plantea el desarrollo del motor de inferencia del modelo computacional, así como la actualización del modelo computacional a su etapa de sistema refinado de acuerdo a la metodología del desarrollo de un sistema experto. En conclusión el desarrollo del motor de inferencias del modelo computacional aplicando inteligencia artificial nos permite avanzar en las etapas de desarrollo de un sistema experto ofreciendo una herramienta rápida y confiable que les permita tomar decisiones en materia de contaminación ambiental.
\end{abstract}

Palabras clave: Sistema experto, impacto ambiental, aplicación web.

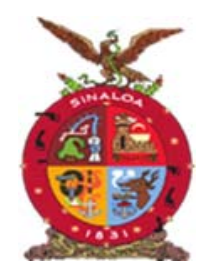

XVIII Congreso Internacional XXIV Congreso Nacional de Ciencias ambientales
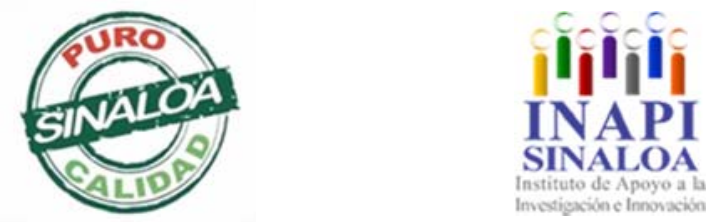

Mazatlán, Sinaloa 3-7 junio 2019

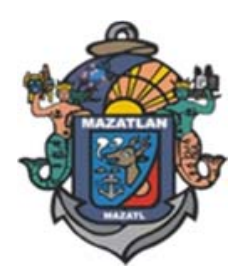

Recursos Naturales, Ecosistemas y Deterioro Ambiental 

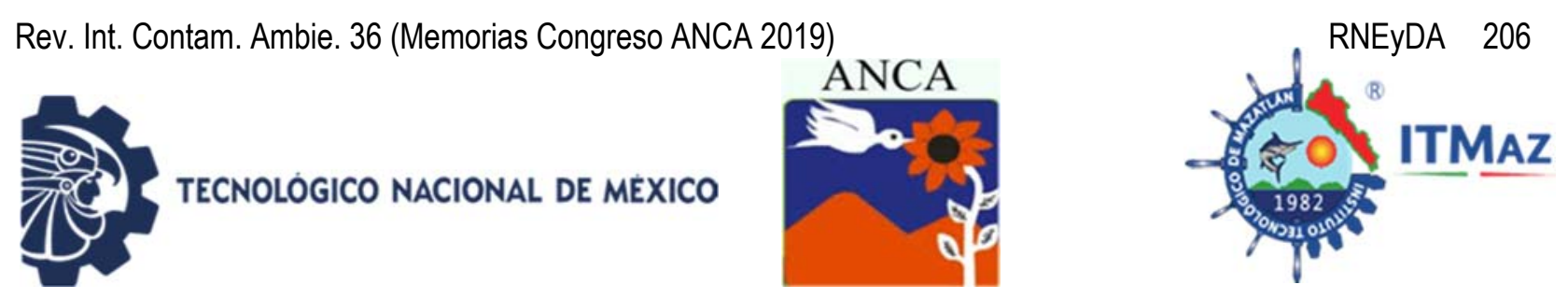

\title{
Update to the refined prototype stage $\alpha$ to the computational model for the evaluation of environmental quality indicators
}

\author{
Ríos Gerardo J, Cabrera Cruz RBE*, Tobías Jaramillo R, Rolón García J, \\ Rolón Aguilar E \\ Cuerpo Académico UAT-CA-29 Medio Ambiente y Desarrollo Sustentable. \\ Facultad de Ingeniería Arturo Narro Siller. \\ Universidad Autónoma de Tamaulipas. México \\ *rcabreracruz@docentes.uat.edu.mx
}

\begin{abstract}
The Rapid Assessment of Environmental Pollution Sources (ERFCA) technique is a methodological tool designed by the World Health Organization (WHO), which aims to identify the main sources of pollution using data available from the public sector. There are software models for environmental quality assessment, but there is no computer model validated by experts in the area that has been applied in real cases. Therefore, it is considered necessary to generate a new computational model to improve the ERFCA technique using advanced computing techniques such as data mining, artificial intelligence, web tools, in order to reduce errors and facilitate the handling of large amounts of information. The methodological process included the collection of information and analysis of the ERFCA technique, the analysis of the development methodology of an expert system; inference engine development using advanced programming techniques; and a refined system $\alpha$ of the computational model. Among the main results obtained is the development of the inference engine of the computational model, as well as the update of the computational model to its refined system stage according to the methodology of the development of an expert system. In conclusion, the development of the inferences engine of the computational model applying artificial intelligence allows us to advance in the stages of development of an expert system offering a fast and reliable tool that allows them to make decisions on environmental pollution.
\end{abstract}

Keywords: Expert system, environmental impact, web application.

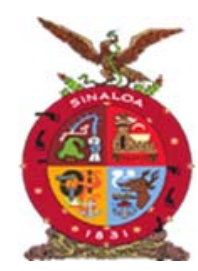

XVIII Congreso Internacional

XXIV Congreso Nacional de Ciencias ambientales
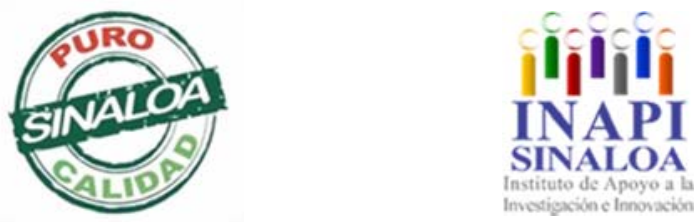

Mazatlán, Sinaloa 3-7 junio 2019

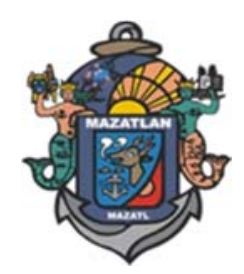

Recursos Naturales, Ecosistemas y Deterioro Ambiental 

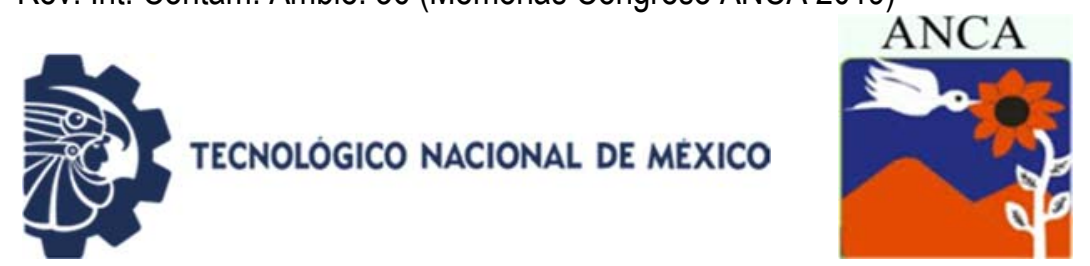

\title{
Riqueza florística y estructura en un bosque de pino-encino afectado por diferentes disturbios
}

\author{
Ruiz Gonzalez $\mathrm{M}^{{ }^{*}}$, Campos Angeles $\mathrm{G}^{2}$, Reyes Hernández $\mathrm{V}^{3}$, \\ Rodríguez Ortiz $\mathrm{G}^{2}$, Enríquez del Valle $\mathrm{J}^{2}$ \\ ${ }^{1}$ Maestría en Ciencias en Productividad en Agroecosistemas. \\ Ex-hacienda de Nazareno, Santa Cruz Xoxocotlán, Oaxaca, México \\ ${ }^{2}$ TecNM/Instituto Tecnológico del Valle de Oaxaca. Oaxaca, México \\ ${ }^{3}$ Posgrado en Ciencias Forestales. Colegio de Postgraduados \\ Campus Montecillo. México \\ *miguelruiz93@live.com.mx
}

\begin{abstract}
RESUMEN
El efecto combinado de diversas actividades humanas y disturbios de diversa índole, generan constantes cambios en los ecosistemas forestales, de tal manera que modifican su biodiversidad y estructura. Se estimó la diversidad y estructura en un bosque de pino-encino afectado por diferentes tipos de disturbios en Oaxaca, México. Estableciendo 28 parcelas de estudio, cada una con $400 \mathrm{~m}^{2}$, bajo un diseño completamente al azar, en donde se registró la riqueza de especies y se midió altura total y diámetro para árboles y arbustos. Se elaboraron intervalos de clases empleando altura y diámetro, donde: clase I = 1-5 m; II = 5.1-10 m; III = $\geq 10.1 \mathrm{~m}$ y para diámetro: clase $\mathrm{I}=1-16 \mathrm{~cm}$; $\mathrm{II}=16.1-22 \mathrm{~cm} ; \mathrm{III}=22.1-46 \mathrm{~cm}$ al censo se aplicó la prueba de Kruskal-Wallis. También, se calculó el índice de valor de importancia (IVI) para cada especie. Se observó que las especies con mayor altura y diámetro pertenecen a los géneros Pinus, Quercus y Arbutus y las de mayor indice de valor de importancia corresponden a los generos Quercus, Pinus, Arbutus y Calliandra. En el inventario realizado se registraron 190 especies vegetales, distribuidas en 112 géneros y 59 familias. En los sitios afectados con incendio forestal a uno, cinco y seis años la riqueza de especies fue menor. En el sitio afectado con incendio forestal de un año atrás, la densidad de individuos fue mayor. Lo anterior debido a la presencia de especies con mayor éxito reproductivo como son plantas de porte herbáceo que aprovechan los espacios generados por los disturbios.
\end{abstract}

Palabras clave: Diversidad, degradación, ecosistema forestal.

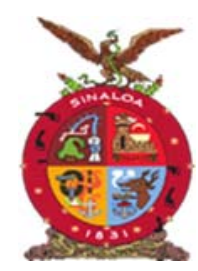

XVIII Congreso Internacional XXIV Congreso Nacional de Ciencias ambientales

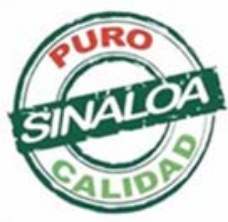

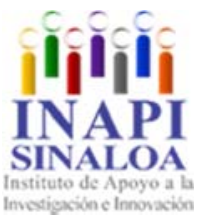

Mazatlán, Sinaloa 3-7 junio 2019

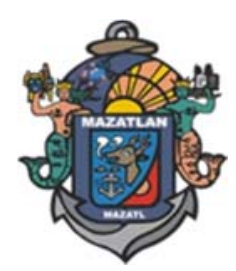

Recursos Naturales, Ecosistemas y Deterioro Ambiental 

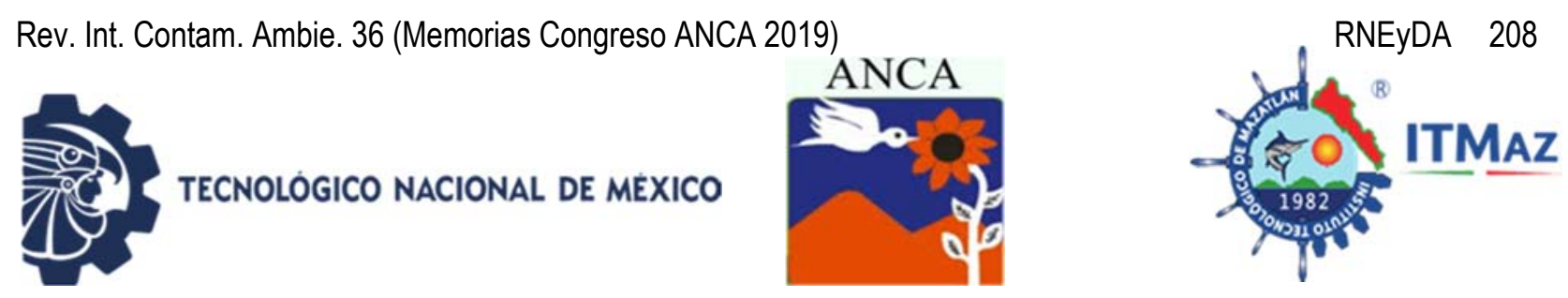

\title{
Floristic wealth and structure in a pine-encino forest affected by disturbances
}

\author{
Ruiz Gonzalez $\mathrm{M}^{1 *}$, Campos Angeles $\mathrm{G}^{2}$, Reyes Hernández $\mathrm{V}^{3}$, \\ Rodríguez Ortiz $\mathrm{G}^{2}$, Enríquez del Valle $\mathrm{J}^{2}$ \\ ${ }^{1}$ Maestría en Ciencias en Productividad en Agroecosistemas. \\ Ex-hacienda de Nazareno, Santa Cruz Xoxocotlán, Oaxaca, México \\ ${ }^{2}$ TecNM/Instituto Tecnológico del Valle de Oaxaca. Oaxaca, México \\ ${ }^{3}$ Postgrado en Ciencias Forestales. Colegio de Postgraduados \\ Campus Montecillo. México \\ *miguelruiz93@live.com.mx
}

\begin{abstract}
The combined effect of diverse human activities and disturbances of diverse nature, generate constant changes in the forest ecosystems, in such a way that they modify their diversity and structure. In the present study, the diversity and structure of a pine-oak forest affected with different types of disturbances was estimated in Oaxaca, Mexico. 28 plots of $400 \mathrm{~m}^{2}$ were established under a completely randomized design (DCA), where the species richness was recorded and total height and diameter for trees and shrubs were measured. Height and diameter classes were developed. Where: class I = 1-5 $\mathrm{m}$; II = 5.1-10 $\mathrm{m}$; III = $\geq 10.1$ $\mathrm{m}$ and for diameter: class I $=1-16 \mathrm{~cm} ; \mathrm{II}=16.1-22 \mathrm{~cm}$; III $=22.1-46 \mathrm{~cm}$ and the Kruskal-Wallis test was applied. Also, the importance value index (IVI) for each species was calculated. It was observed that the species with the highest height and diameter belong to the genera Pinus, Quercus and Arbutus and those with the highest value index correspond to the genera Quercus, Pinus, Arbutus and Calliandra. In the inventory carried out 190 plant species were registered, distributed in 112 genera and 59 families. In the affected sites with forest fire of one, five and six years the species richness was lower. In the site affected by forest fire a year ago, the density of individuals was higher. This is due to the presence of species with greater reproductive success, such as herbaceous plants that take advantage of the spaces generated by the disturbances.
\end{abstract}

Keywords: Diversity, degradation,forest ecosystem.

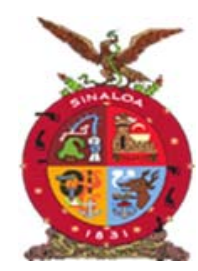

XVIII Congreso Internacional XXIV Congreso Nacional de Ciencias ambientales
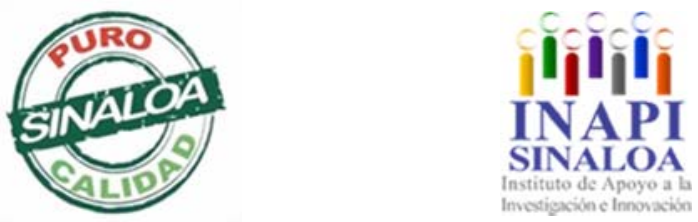

Mazatlán, Sinaloa 3-7 junio 2019

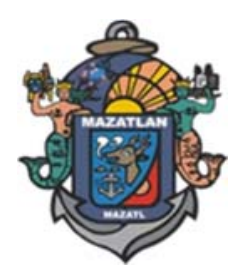

Recursos Naturales, Ecosistemas y Deterioro Ambiental 

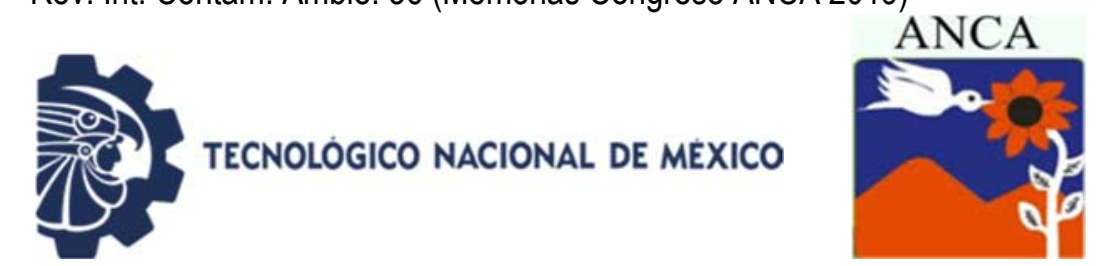

\title{
Diversidad bacteriana en agua del dique San Francisquito
}

\author{
Rivas Montaño AM, Méndez Gómez E, Cortes Ruiz JA, Saavedra Chávez A \\ Instituto Tecnológico de Mazatlán. Mazatlán, Sinaloa \\ huichola1@gmail.com
}

\begin{abstract}
RESUMEN
Los microorganismos son la parte dominante en biomasa y actividad metabólica en los sistemas acuáticos, siendo esenciales en los procesos ecológicos para el sustento de la vida. Se determinó la comunidad bacteriana en el agua, de un dique que abastece la planta potabilizadora de Mazatlán, Sinaloa. La determinación de la estructura y abundancia metagenómica de la comunidad bacteriana realizada mediante método PCR y secuenciación. Este estudio se llevó a cabo el 2018, y la estructura de la comunidad bacteriana se correlaciona con las variables ambientales acuáticas. Los filos más abundantes fueron Proteobacteria, Bacteroides, Cianobacteria, Actinobacteria y Verrucomicrobia. Las familias más abundantes fueron Oxalobacteraceae, Thiotrichaceae, Comamonadaceae y Sphingobacteriaceae. El valor del índice de diversidad de Shannon, disminuyó en temporada de sequía registrando dominio de la familia Comamonadaceae. La ANOVA $(P<0.05)$ entre el tiempo y el índice de Shannon, no mostro diferencias significativas. Los valores ambientales de temperatura, $\mathrm{pH}$ y oxígeno disuelto en agua no fueron correlacionados con la comunidad bacteriana, por lo que se infiere que es debido a la poca fluctuación de los valores en estos parámetros. A lo largo del año estos resultados integraron el primer antecedente de estructura de la comunidad bacteriana en este ecosistema.
\end{abstract}

Palabras claves: Bacteria, secuenciación, genómica ambiental.

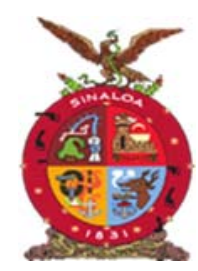

XVIII Congreso Internacional XXIV Congreso Nacional de Ciencias ambientales

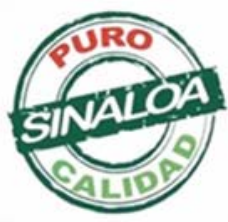

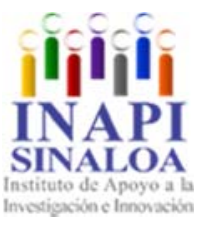

Mazatlán, Sinaloa 3-7 junio 2019

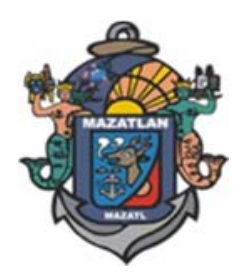

Recursos Naturales, Ecosistemas y Deterioro Ambiental 

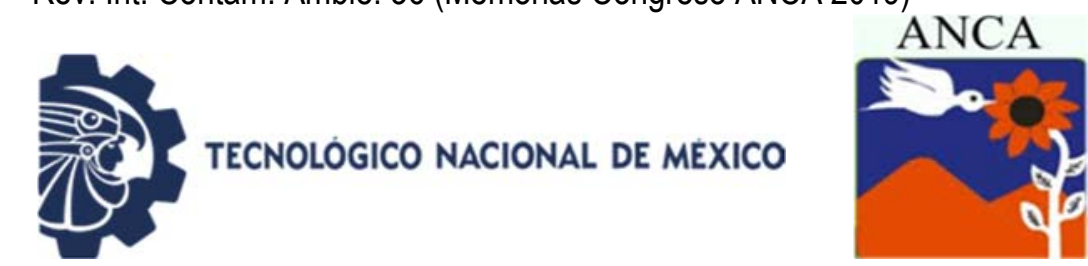

\title{
Bacterial diversity in the water of the San Francisquito Dam
}

\author{
Rivas Montaño AM, Méndez Gómez E, Cortes Ruiz JA, Saavedra Chávez A \\ Instituto Tecnológico de Mazatlán. Mazatlán, Sinaloa \\ huichola1@gmail.com
}

\begin{abstract}
Microorganisms are the dominant part in biomass and metabolic activity in aquatic systems, being essential in the ecological processes for the sustenance of life. The bacterial community in the water was determined from a dam that supplies the water treatment plant of Mazatlán, Sinaloa. The determination of the structure and metagenomic abundance of the bacterial community carried out by PCR and sequencing method. This study was carried out in 2018, and the structure of the bacterial community correlates with the aquatic environmental variables. The most abundant phyla were Proteobacteria, Bacteroides, Cyanobacteria, Actinobacteria, and Verrucomicrobia. The most abundant families were Oxalobacteraceae, Thiotrichaceae, Comamonadaceae, and Sphingobacteriaceae. The value of the Shannon diversity index decreased in the dry season, registering the dominance of the Comamonadaceae family. The ANOVA $(P<0.05)$ between the time and the Shannon index did not show significant differences. The environmental values of temperature, $\mathrm{pH}$ and dissolved oxygen in water were not correlated with the bacterial community, so it is inferred that it is due to the little fluctuation of the values in these parameters. Throughout the year these results integrated the first antecedent of the structure of the bacterial community in this ecosystem.
\end{abstract}

Keywords: Bacteria, sequencing, environmental genomics.

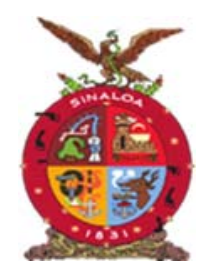

XVIII Congreso Internacional XXIV Congreso Nacional de Ciencias ambientales

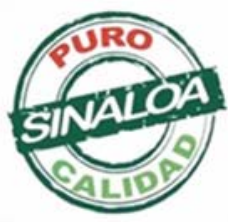

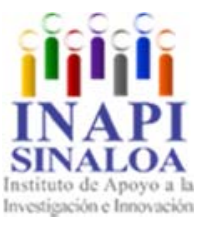

Mazatlán, Sinaloa 3-7 junio 2019

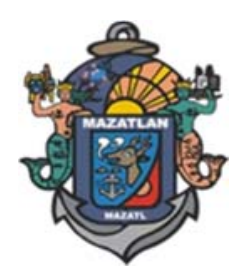

Recursos Naturales, Ecosistemas y Deterioro Ambiental 

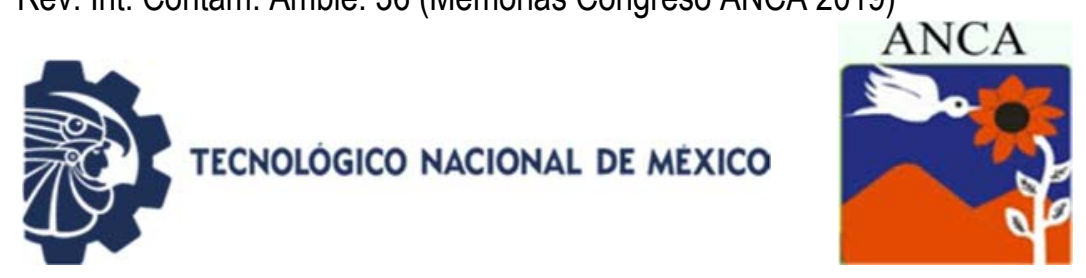

\section{Consumo de agua en la producción de chile habanero (Capsicum chínense)}

Rosas Medina $\mathrm{I}^{1 *}$, García Casas $\mathrm{K}^{3}$, Naranjo Jíménez $\mathrm{N}^{2}$, Colmenero Robles $\mathrm{A}^{1}$, Uribe Soto $\mathrm{JN}^{1}$

${ }^{1}$ Becarios-COFAA-IPN, Secretaria de Investigación y Posgrado (SIP). Instituto Politécnico Nacional.

${ }^{2}$ Becarios-COFAA-IPN Centro Interdisciplinario de Investigación para el Desarrollo Integral Regional,

${ }^{3}$ Maestria en Gestión Ambiental (CIIDIR), Unidad Durango Instituto Politécnico Nacional, PNPC-CONACYT

*imelros@hotmail.com

\section{RESUMEN}

El chile habanero Capsicum chinense es una especie de alto valor comercial, su precio en fresco puede llegar a $\$ 129.00$ pesos Mexicanos por kilogramo. Se realizo esta investigación del cultivo de chile habanero en tres sistemas de producción: hidroponía, invernadero en suelo acolchado y cielo abierto acolchado, con el objetivo de determinar el gasto de agua en la producción y contenido de capsaicina de chile habanero (C. chínense). Se preparó el almacigo en marzo, eltrasplante en mayo y la cosecha de julio a octubre del 2018. Fueron seleccionadas al azar 15 repeticiones, las variables del estudio fueron: producción; contenido de capsaicina; y consumo de agua. El sistema hidropónico presento rendimiento de 1562 gramos con 192 frutos extraídos y una concentración de capsaicina de 147692.2 unidades scoville y un consumo total de agua de $3.1 \mathrm{~m}^{3}$, el sistema en invernadero con un rendimiento de 2087.54 gramos y 434 unidades de fruto, con un valor de capsaicina de 105620.8 unidades scoville y consumió de $10 \mathrm{~m}^{3}$ agua. El sistema en cielo abierto tuvo un rendimiento de 399.2 gramos con un total de 80 frutos, tuvo un valor de capsaicina de 90256.69 unidades scoville y consumió $10 \mathrm{~m}^{3}$ de agua. El sistema hidropónico presento el menor consumo de agua y el más alto contenido de capsaicina, en cuanto a rendimiento de fruto hubo diferencia significativa a favor del sistema en invernadero en suelo, pero en cuanto a tamaño y calidad de fruto la hidroponía fue donde se encontró el fruto de primera calidad y de mayor tamaño.

Palabras claves: Chile habanero, agua, capsaicina, hidroponía.

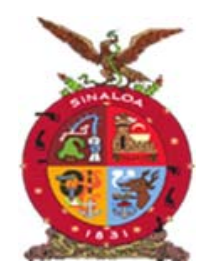

XVIII Congreso Internacional

XXIV Congreso Nacional de Ciencias ambientales
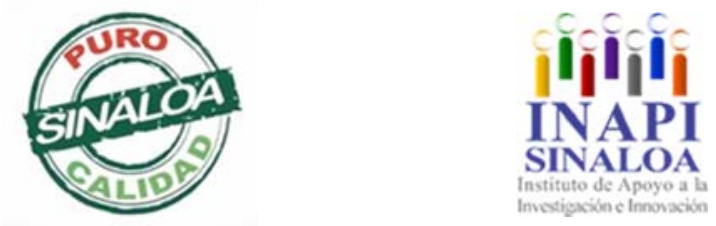

Mazatlán, Sinaloa 3-7 junio 2019

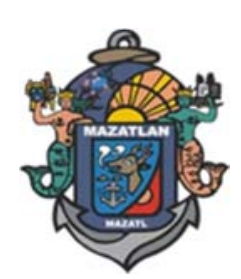

Recursos Naturales, Ecosistemas y Deterioro Ambiental 


\title{
Water consumption in the production of habanero pepper (Capsicum chínense)
}

\author{
Rosas Medina $\mathrm{I}^{1^{\star}}$, García Casas $\mathrm{K}^{3}$, Naranjo Jíménez $\mathrm{N}^{2}$, Colmenero Robles $\mathrm{A}^{1}$, \\ Uribe Soto $\mathrm{JN}^{1}$ \\ ${ }^{1}$ Becarios-COFAA-IPN, Secretaria de Investigación y Posgrado (SIP). \\ Instituto Politécnico Nacional. \\ ${ }^{2}$ Becarios-COFAA-IPN Centro Interdisciplinario de Investigación para el \\ Desarrollo Integral Regional, \\ ${ }^{3}$ Maestria en Gestión Ambiental (CIIDIR), Unidad Durango \\ Instituto Politécnico Nacional, PNPC-CONACYT \\ *imelros@hotmail.com
}

\begin{abstract}
Habanero pepper Capsicum chinense is a species of high commercial value, its fresh price can reach $\$ 129.00$ per kilogram. This investigation of habanero pepper cultivation was carried out in three production systems: hydroponics, greenhouse in quilted soil and quilted open sky, with the objective of determining the water expenditure in the production and capsaicin content of habanero pepper (C. chínense). The warehouse was prepared in March, the transplant in May and the harvest from July to October. Were randomly selected 15 repetitions, the variables of the study were: production, capsaicin content and water consumption. The hydroponic system presented yield of 1562 grams with 192 extracted fruits and a capsaicin concentration of 14,792.2 scoville units and a total water consumption of $3.1 \mathrm{~m} 3$, the greenhouse system with a yield of 2087.54 grams and 434 fruit units, with a value of capsaicin 105620.8 scoville units and consumed $10 \mathrm{~m} 3$ water. The open pit system had a yield of 399.2 grams with a total of 80 fruits, had a capsaicin value of 90256.69 scoville units and consumed $10 \mathrm{~m} 3$ of water. The hydroponic system had the lowest water consumption and highest content of capsaicin, in terms of fruit yield there was a significant difference in favor of the greenhouse system in soil, but in terms of fruit size and quality, hydroponics was where the fruit of first quality and larger.
\end{abstract}

Keywords: Habanero chile, water, capsaicin, hydroponics.

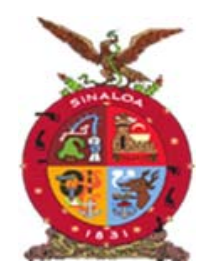

XVIII Congreso Internacional XXIV Congreso Nacional de Ciencias ambientales

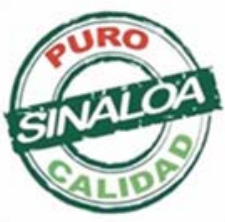

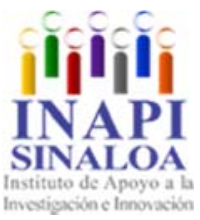

Mazatlán, Sinaloa 3-7 junio 2019

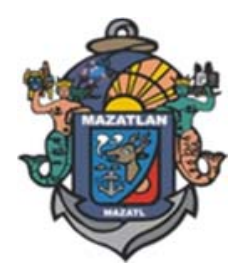

Recursos Naturales, Ecosistemas y Deterioro Ambiental 

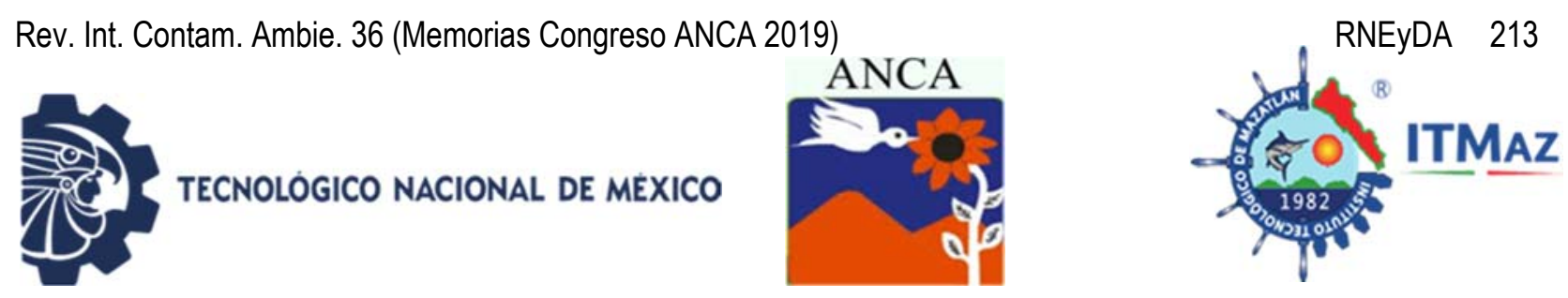

\title{
Cambios recientes en el paisaje urbano de Mazatlán (Sinaloa, México) y futuros escenarios ambientales
}

\author{
Ruiz Luna $A^{1 *}$, Berlanga Robles $C A^{1}$, Hernández Guzmán $R^{2}$, \\ Montijo Galindo $A^{1}$, Bautista Bautista $R^{3}$, Navarro Hernández $A{ }^{3}$, \\ Oyedotun TDT $^{4}$
}

${ }^{1}$ Lab. de Manejo Ambiental. Centro de Investigación en Alimentación y Desarrollo (CIAD, A.C.). Coordinación Regional Mazatlán. Sinaloa, México

${ }^{2}$ CONACYT-Instituto de Investigaciones sobre los Recursos Naturales.

Universidad Michoacana de San Nicolás de Hidalgo. Morelia, Michoacán,

${ }^{3}$ Programa de Posgrado. CIAD, A.C.

${ }^{4}$ Department of Geography. Faculty of Earth and Environmental Sciences, University of Guyana Turkeyen Campus, Georgetown, Guyana

*arluna@ciad.mx

\section{RESUMEN}

La zona urbana de Mazatlán ha crecido significativamente en las últimas décadas, alterando la mayoría de sus coberturas naturales. Para analizar los cambios, se han realizado diversos estudios en esta área con aplicaciones de percepción remota y SIG, estimándose que desde 1973 a fechas recientes, la extensión urbana aumentó de 2500 a 7400 hectáreas, afectando principalmente coberturas terrestres (bosque seco), así como extensiones agrícolas, humedales y litoral costero. La reducción de coberturas naturales tiene su mayor expresión en la distribución desigual de áreas verdes urbanas, con la menor provisión per cápita asociada a los estratos socioeconómicos donde reside la mayor parte de la población $(90 \%)$ y con tendencia a reducirse aún más por el crecimiento urbano reciente, observándose que empiezan a predominar las especies arbóreas exóticas con relación a las nativas. De 2012 a 2016 se determinaron distintas tasas de cambio en la línea de costa, debido a la naturaleza dinámica del litoral, pero con mayores niveles de erosión hacia el norte de la ciudad, por efecto de intervenciones antropogénicas, inundación mareal y el posible cambio en el nivel de mar. Al respecto, de acuerdo con distintos escenarios, se pronostican niveles de inundación de 2.6 a $9.7 \mathrm{Km}^{2}$, afectando principalmente zonas donde existieron cuerpos de agua costeros, hoy altamente modificados. Finalmente, diversos indicadores de tipo ambiental y socioeconómico, ubican al municipio de Mazatlán en una situación de vulnerabilidad intermedia con relación a otros municipios costeros de Sinaloa, siendo afectado principalmente por su exposición a fenómenos naturales.

Palabras claves: Crecimiento urbano, paisaje, áreas verdes urbanas, efosión, vulnerabilidad costera

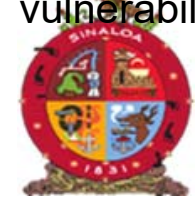

XVIII Congreso Internacional

XXIV Congreso Nacional de Ciencias ambientales

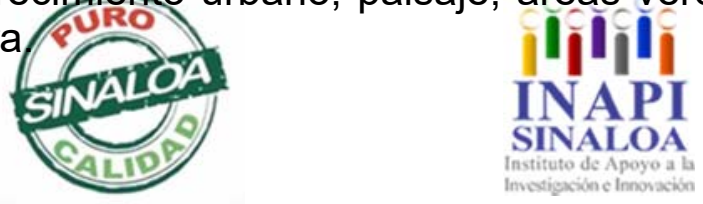

Mazatlán, Sinaloa 3-7 junio 2019

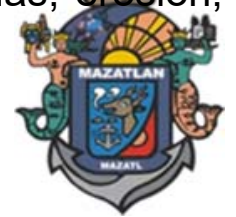



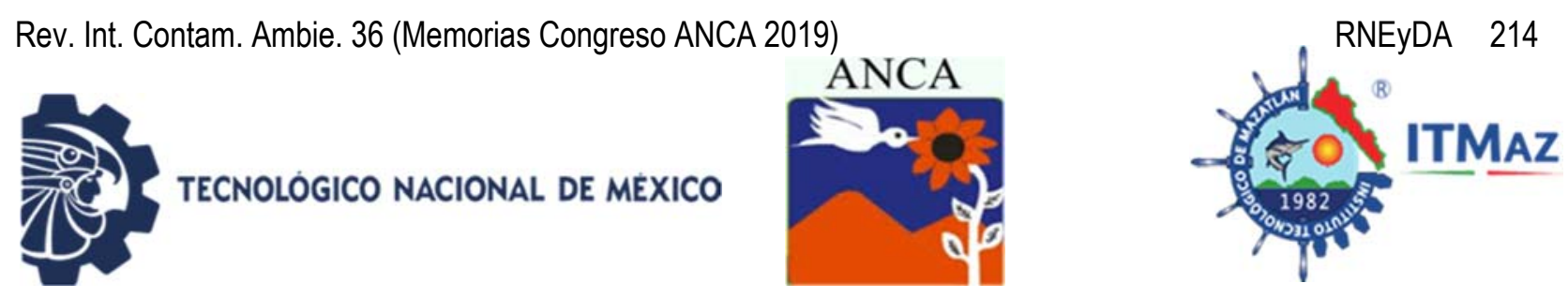

\title{
Recent changes in the urban landscape of Mazatlan (Sinaloa, Mexico) and future environmental scenarios
}

\author{
Ruiz Luna $\mathrm{A}^{1 *}$, Berlanga Robles $\mathrm{CA}^{1}$, Hernández Guzmán $\mathrm{R}^{2}$, \\ Montijo Galindo $A^{1}$, Bautista Bautista $R^{3}$, Navarro Hernández $A^{3}{ }^{3}$, \\ Oyedotun $\mathrm{TDT}^{4}$
}

${ }^{1}$ Lab. de Manejo Ambiental. Centro de Investigación en Alimentación y Desarrollo (CIAD, A.C.). Coordinación Regional Mazatlán. Sinaloa, México

${ }^{2}$ CONACYT-Instituto de Investigaciones sobre los Recursos Naturales.

Universidad Michoacana de San Nicolás de Hidalgo. Morelia, Michoacán,

${ }^{3}$ Programa de Posgrado. CIAD, A.C.

${ }^{4}$ Department of Geography. Faculty of Earth and Environmental Sciences,

University of Guyana Turkeyen Campus, Georgetown, Guyana

*arluna@ciad.mx

\begin{abstract}
The urban area of Mazatlan has grown significantly in recent decades, altering most of its natural coverage. To analyze the changes, several studies have been carried out in this area with applications of remote sensing and GIS, estimating that from 1973 to recent dates, the urban extension increased from 2500 to 7400 hectares, mainly affecting land cover (dry forest), as well as agricultural extensions, wetlands and coastal coastline. The reduction of natural coverage has its greatest expression in the unequal distribution of urban green areas. With the lower provision per capita associated with the socioeconomic strata where most of the population resides $(90 \%)$ and with a tendency to be further reduced by the recent urban growth, observing that exotic tree species begin to predominate in relation to the native ones. From 2012 to 2016, different rates of change in the coastline were determined, due to the dynamic nature of the coastline. But with higher levels of erosion towards the north of the city, due to anthropogenic interventions, tidal flooding and the possible change in sea level In this regard, according to different scenarios, flood levels of 2.6 to $9.7 \mathrm{Km} 2$ are forecast, mainly affecting areas where coastal bodies of water existed, today highly modified. Finally, various environmental and socioeconomic indicators place the municipality of Mazatlan in a situation of intermediate vulnerability in relation to other coastal municipalities of Sinaloa, being affected mainly by its exposure to natural phenomena.
\end{abstract}

Keywords: Urban growth, landscape, urban green areas, erosion, coastal vulnerability.

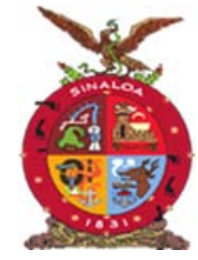

XVIII Congreso Internacional

XXIV Congreso Nacional de Ciencias ambientales

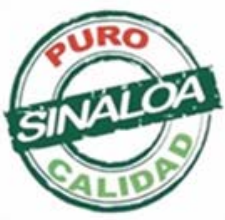

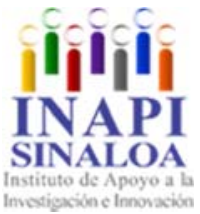

Mazatlán, Sinaloa 3-7 junio 2019

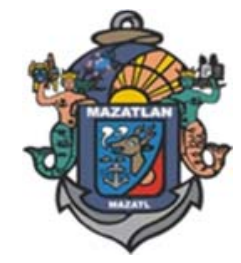

Recursos Naturales, Ecosistemas y Deterioro Ambiental 

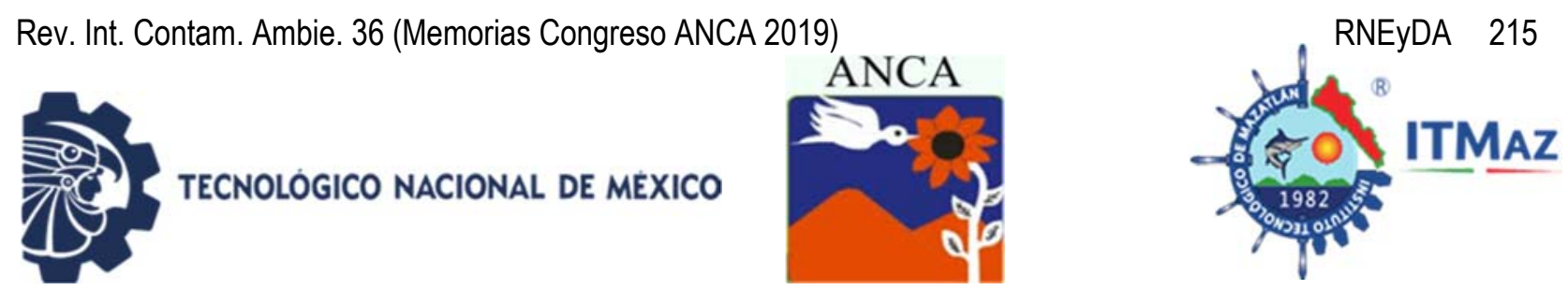

\title{
Variación de los Flujos de Emisión de $\mathrm{CH}_{4}, \mathrm{CO}_{2}$ y $\mathrm{N}_{2} \mathrm{O}$ monitoreados in situ en los campos de arroz del delta del Ebro
}

\author{
Salas de la Vega $M A^{3^{*}}$, Velasco Hernández $M A^{3}$, Martínez Eixarch $M^{1}$, \\ Viñas $\mathrm{M}^{2}$, Noguerol $\mathrm{J}^{2}$ \\ ${ }^{1}$ IRTA. Agrifood Research and Technology Institute, Catalonia, Spain \\ ${ }^{2}$ GIRO, IRTA Torre Marimon, 08140 Caldes de Montbui, Barcelona \\ ${ }^{3}$ Facultad de Ingeniería Química. BUAP, \\ *delavegamarioadolfo@hotmail.com
}

\section{RESUMEN}

El calentamiento global ha tenido un efecto significativo en el ambiente, el ecosistema y el clima de la tierra. Los campos de arroz desempeñan un papel crucial en las emisiones atmosféricas de gases de efecto invernadero (GEI). En el marco del proyecto Life Ebro-Admiclim (LIFE 13 ENV / ES / 001182); se realizó un estudio en un agro-sistema de arroz mediterráneo (delta del Ebro, Cataluña) en un campo de agricultores locales con cultivos de arroz típicamente administrados para monitorear in situ las concentraciones de GEI que evalúan la variación de los flujos de emisión de forma continua durante 24 horas durante tres años $(2015,2016,2017)$. Los flujos se recolectaron durante un período de 30 minutos, para obtener el aumento lineal de la concentración de gas en cada tiempo de muestreo $(0,10,20$ y $30 \mathrm{~min})$ cada dos horas, utilizando la técnica de cámara estática. Los gases de efecto invernadero se analizaron mediante cromatografía de gases (Gc Trace 2000). Los resultados mostraron una ligera tendencia de aumento y diferencias significativas con otros estudios que aplican una metodología similar. Las tasas de emisión variaron de $2.1 \pm 0.5$ a $7.2 \pm 1.4 \mathrm{mg}$ $\mathrm{C}-\mathrm{CH}_{4} \mathrm{~m}-2 \mathrm{~h}^{-1}, 1.5 \pm 0.5$ a $8.1 \pm 0.5 \mathrm{mg} \mathrm{C}-\mathrm{CO}_{2} \mathrm{~m}^{-2} \mathrm{~h}^{-1}$ y 0.01 a $0.16 \mathrm{mg} \mathrm{N}-\mathrm{N}_{2} \mathrm{O}$ $\mathrm{m}-2 \mathrm{~h}^{-1}$. Destacando que la variabilidad observada en la cobertura vegetal permite identificar una correlación positiva con el flujo de metano; confirmando que las plantas de arroz tienen la capacidad de emitir GEI, desde la rizosfera hasta la atmósfera.

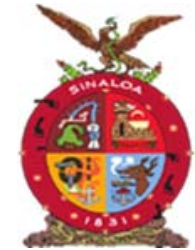

XVIII Congreso Internacional

XXIV Congreso Nacional de Ciencias ambientales

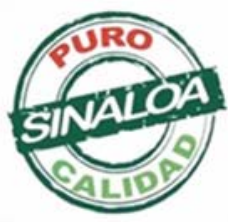

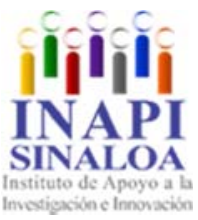

Mazatlán, Sinaloa 3-7 junio 2019

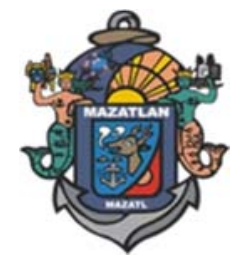

Recursos Naturales, Ecosistemas y Deterioro Ambiental 

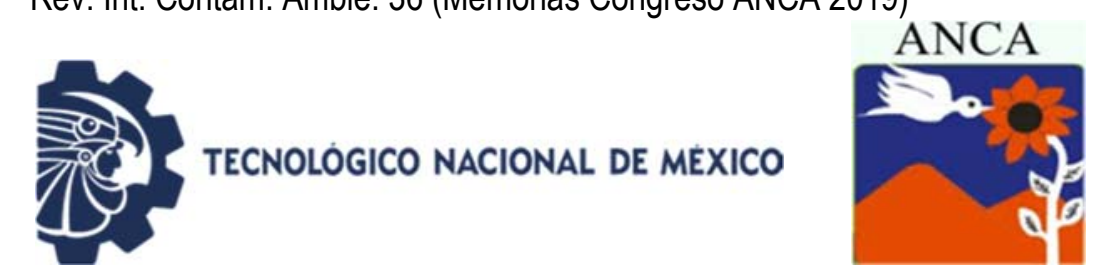

\title{
Variation of the emission flows of $\mathrm{CH}_{4}, \mathrm{CO}_{2}$ and $\mathrm{N}_{2} \mathrm{O}$ monitored in situ in the rice fields of the Ebro Delta
}

\author{
Salas de la Vega $\mathrm{MA}^{3^{*}}$, Velasco Hernández $\mathrm{MA}^{3}$, Martínez Eixarch $\mathrm{M}^{1}$, \\ Viñas $\mathrm{M}^{2}$, Noguerol $\mathrm{J}^{2}$ \\ ${ }^{1}$ IRTA. Agrifood Research and Technology Institute, Catalonia, Spain \\ ${ }^{2}$ GIRO, IRTA Torre Marimon, 08140 Caldes de Montbui, Barcelona \\ ${ }^{3}$ Facultad de Ingeniería Química. BUAP, \\ *delavegamarioadolfo@hotmail.com
}

\begin{abstract}
Global warming has had a significant effect on the environment, the ecosystem and the climate of the earth. Rice fields play a crucial role in atmospheric emissions of greenhouse gases (GHG). Within the framework of the Life EbroAdmiclim project (LIFE 13 ENV/ES/001182). A study was carried out in a Mediterranean rice agro-system (delta del Ebro, Catalonia) in a field of local farmers with rice crops typically administered to monitor in situ the GHG concentrations that evaluate the variation of emission flows in a continuous for 24 hours for three years $(2015,2016,2017)$. The flows were collected during a period of 30 minutes, to obtain the linear increase of the gas concentration in each sampling time $(0,10,20$ and $30 \mathrm{~min})$ every two hours, using the static chamber technique. The greenhouse gases were analyzed by gas chromatography (Gc Trace 2000). The results showed a slight tendency of increase and significant differences with other studies that apply a similar methodology. The emission

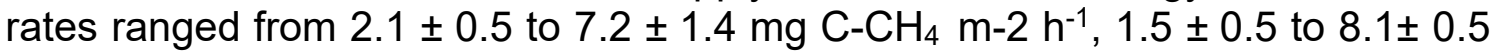
mg C-CO $\mathrm{m}_{2}-2 \mathrm{~h}^{-1}$ and 0.01 to $0.16 \mathrm{mg} \mathrm{N}-\mathrm{N}_{2} \mathrm{O} \mathrm{m}-2 \mathrm{~h}-1$. Emphasizing that the variability observed in the vegetation cover allows identifying a positive correlation with the methane flow, confirming that rice plants have the capacity to emit GHG, from the rhizosphere to the atmosphere.
\end{abstract}

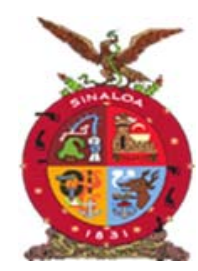

XVIII Congreso Internacional XXIV Congreso Nacional de Ciencias ambientales

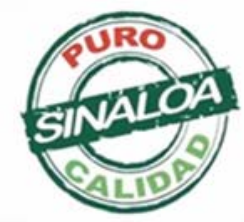

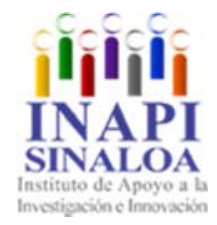

Mazatlán, Sinaloa 3-7 junio 2019

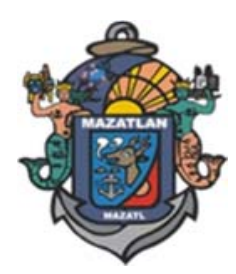

Recursos Naturales, Ecosistemas y Deterioro Ambiental 

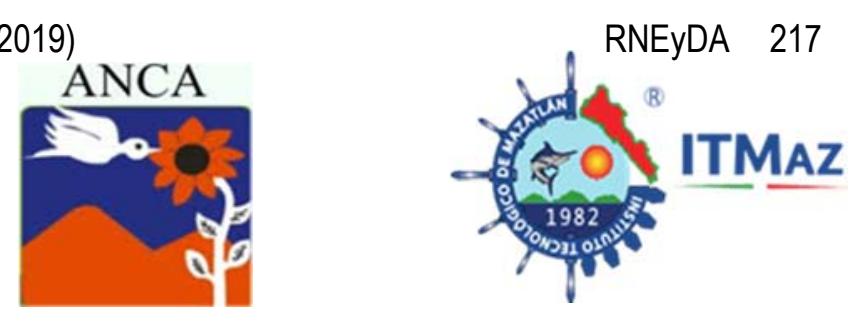

\title{
Estudio aerobiológico del relleno sanitario San Nicolás y zonas aledañas
}

\author{
Marmolejo Sánchez ME¹, Ramírez López EM² \\ ${ }^{1}$ Ingeniería Bioquímica. Centro de Ciencias Básicas. \\ Departamento de Ingeniería Bioquímica. \\ Universidad Autónoma de Aguascalientes. \\ ${ }^{2}$ Centro de Ciencias Básicas. Departamento de Ingeniería Bioquímica. \\ Universidad Autónoma de Aguascalientes. Aguascalientes, Mexico \\ emramir@correo.uaa.mx
}

\begin{abstract}
RESUMEN
La descomposición de residuos en rellenos sanitarios emite bioaerosoles causantes de enfermedades alérgicas e infecciosas en la población sensible. El objetivo de investigación fue identificar a los microorganismos presentes en el relleno sanitario "San Nicolás" (RSSN) y sus alrededores para determinar la posible dispersión y efecto en la población. Se realizó muestreo aerobiológico en 2 sitios al interior del RSSN y en 3 puntos cercanos (zonas poblacionales). Se muestreo el 26 de agosto del 2018 usando equipo QuickTake 30, flujo de 28.3 LPM de aire, pasando 425L, usando medios de cultivo selectivos y no selectivos. Se identificó la morfología celular y colonial de los agentes microbianos con tinción Gram; para hongos, mediante tinción lactofenol. La morfología bacteriana identificada en el patio de descarga del RSSN fue bacilos y cocos gram positivos y negativos, en el patio de descarga del RSSN, el conteo de bacterias fue de $1.5 \times 10^{3} \mathrm{UFC} / \mathrm{m}^{3}$, y en los sitios cercanos se obtuvo entre $2 \times 10^{3}$ y $6 \times 10^{3} \mathrm{UFC} / \mathrm{m}^{3}$. En los poblados de San Antonio de los Pedrosa (SAP) y El Conejal la carga bacteriana promedio fue de $2.4 \times 10^{3}$ y $2 \times 10^{3} \mathrm{UFC} / \mathrm{m}^{3}$, respectivamente. Se identificó a Aspergillus niger dentro del RSSN y en SAP. La predominancia del viento durante mes del muestreo fue estenoreste (ENE) hacia el sursuroeste a velocidades de $6 \mathrm{Km} \cdot \mathrm{h}^{-1}$, y del SSE hacia el NNW, y de sur a norte. Indicando la posible dispersión de los microorganismos en estas direcciones hacia y desde las zonas rurales y urbanas del municipio de Aguascalientes al RSSN.
\end{abstract}

Palabras clave: Relleno-sanitario, microbiología ambiental, bacterias patógenas.

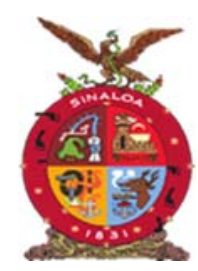

XVIII Congreso Internacional XXIV Congreso Nacional de Ciencias ambientales

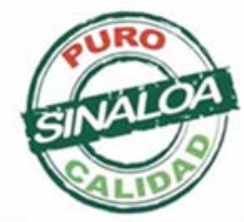

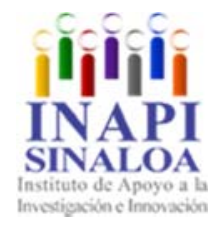

Mazatlán, Sinaloa 3-7 junio 2019

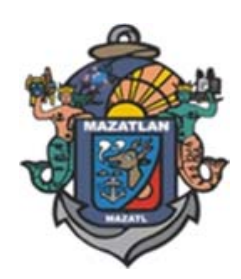

Recursos Naturales, Ecosistemas y Deterioro Ambiental 

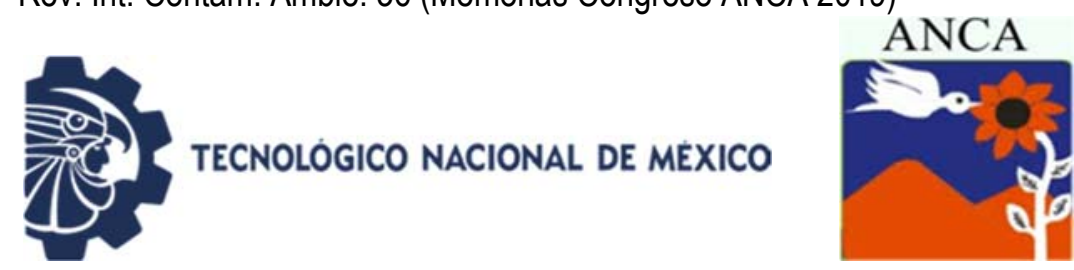

\title{
Aerobiological study of the sanitary landfill of San Nicolás and surrounding areas
}

\author{
Marmolejo Sánchez ME¹, Ramírez López EM² \\ ${ }^{1}$ Ingeniería Bioquímica. Centro de Ciencias Básicas. \\ Departamento de Ingeniería Bioquímica. \\ Universidad Autónoma de Aguascalientes. \\ ${ }^{2}$ Centro de Ciencias Básicas. Departamento de Ingeniería Bioquímica. \\ Universidad Autónoma de Aguascalientes. Aguascalientes, Mexico \\ emramir@correo.uaa.mx
}

\begin{abstract}
The decomposition in landfills emits bioaerosols that cause allergic and infectious diseases in the sensitive population. The objective of the research was to identify the microorganisms present in the sanitary landfill "San Nicolás" (RSSN) and its surroundings to determine possible dispersion and effect in the population. Aerobiological sampling was carried out in 2 sites inside the RSSN and in 3 nearby points (populated areas). Sampling was carried out on August 26, 2018 using QuickTake 30 equipment, flow of 28.3 LPM of air, passing $425 \mathrm{~L}$, using selective and non-selective culture media. The cellular and colonial morphology of the microbial agents was identified with Gram stain; for fungi, by lactophenol staining. The bacterial morphology identified in the RSSN discharge yard was gram positive and negative bacillus and coccus, in the RSSN discharge yard, the bacteria count was $1.5 \times 10^{3} \mathrm{CFU} / \mathrm{m}^{3}$, and in nearby sites it was obtained between $2 \times 10^{3}$ and $6 \times 10^{3} \mathrm{CFU} / \mathrm{m}^{3}$. In the towns of San Antonio de los Pedrosa (SAP) and El Conejal the average bacterial load was $2.4 \times 10^{3}$ and $2 \times 10^{3} \mathrm{CFU} / \mathrm{m}^{3}$, respectively. Aspergillus niger was identified within the RSSN and in SAP. Predominance of the wind during the sampling month: northeast (ENE) to the south-southwest at speeds of $6 \mathrm{Km}^{-1} \mathrm{~h}^{-1}$, and SSE to the NNW, and from south to north. Indicating the possible dispersion of microorganisms in these directions to and from rural and urban areas of the municipality of Aguascalientes to the RSSN.
\end{abstract}

Keywords: Landfills, environmental microbiology, pathogenic bacteria.

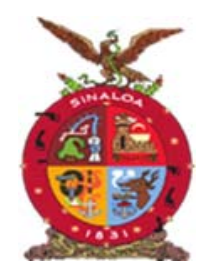

XVIII Congreso Internacional XXIV Congreso Nacional de Ciencias ambientales

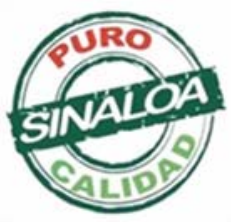

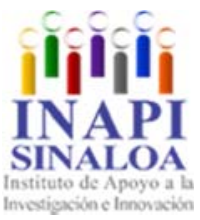

Mazatlán, Sinaloa 3-7 junio 2019

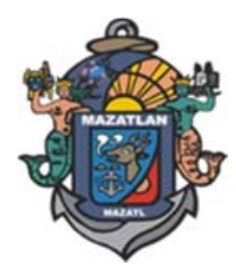

Recursos Naturales, Ecosistemas y Deterioro Ambiental 

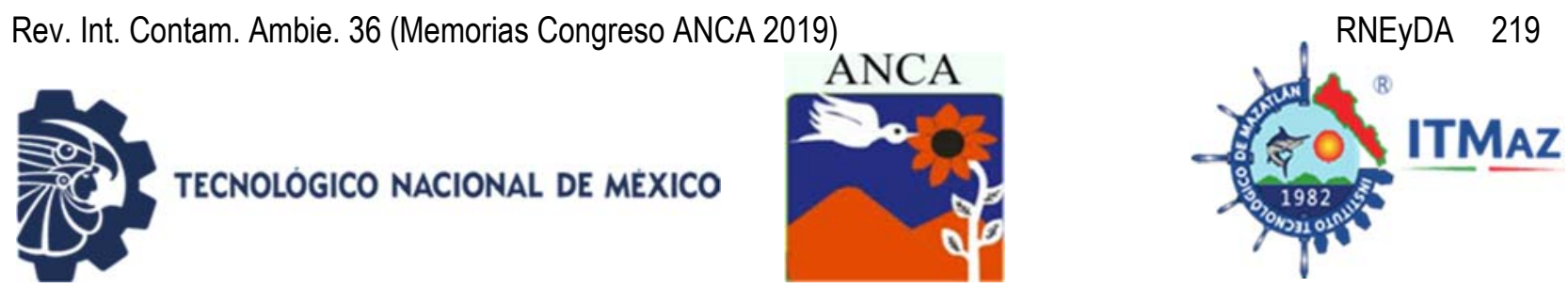

\title{
Análisis de la fragmentación del ADN en trabajadores agrícolas de Francisco Sarabia, Michoacán México
}

\author{
Sánchez-Alarcón $\mathrm{J}^{1,2,3}$, Arenas-Sánchez $\mathrm{H}^{1}$, Ochoa-Ocaña $\mathrm{MA}^{3,4}$, Milić $\mathrm{M}^{5}$, Kašuba $\mathrm{V}^{5}$, \\ Urióstegui-Acosta $\mathrm{MO}^{6}$, Gómez-Arroyo $\mathrm{S}^{7}$, Flores-Márquez $\mathrm{AR}^{7}$, Cortés-Eslava $\mathrm{J}^{7}$, \\ Hueletl-Soto ME${ }^{1}$, Montiel-González JMR ${ }^{1,2}$, Gómez-Olivares $\mathrm{JL}^{8}$, Bonassi $\mathrm{S}^{9}$, \\ Valencia-Quintana $\mathrm{R}^{1,2,3 *}$ \\ ${ }^{1}$ Laboratorio "Rafael Villalobos-Pietrini" de Toxicología Genómica y Química Ambiental. Facultad \\ de Agrobiología. Universidad Autónoma de Tlaxcala, México \\ ${ }^{2}$ CA UATLX-CA-223 Ambiente y Genética. UATx. México \\ ${ }^{3}$ Red Temática Toxicología de Plaguicidas CONACyT-UA Nayarit, México \\ ${ }^{4}$ Unidad Académica de Estudios Regionales. Coordinación de Humanidades. UNAM. México \\ ${ }^{5}$ Mutagenesis Unit. Institute for Medical Research and Occupational Health. Zagreb, Croatia \\ ${ }^{6}$ Escuela Superior de Ciencias Naturales. Universidad Autónoma de Guerrero. \\ ${ }^{7}$ Laboratorio de Genotoxicología Ambiental, Centro de Ciencias de la Atmósfera, UNAM, México \\ ${ }^{8}$ Departamento de Ciencias de la Salud. Universidad Autónoma Metropolitana-Iztapalapa, \\ 'Unit of Clinical and Molecular Epidemiology, IRCCS San Raffaele Pisana, Rome, Italy \\ *prvq2004@ahoo.com.mx
}

\section{RESUMEN}

La localidad de Francisco Sarabia está situada en el municipio de Jiquilpan, en el estado de Michoacán de Ocampo. Dentro de sus principales actividades se encuentra la agricultura, siendo los cultivos de alfalfa, maíz y sorgo, los más importantes de la zona. El empleo de plaguicidas es un recurso frecuente para la protección de sus cultivos por lo que la población está en constante riesgo, al aplicarse gran cantidad y variedad de estos productos, muchos de los cuales han demostrado potencial genotóxico. El propósito del presente trabajo fue evaluar si la exposición laboral a plaguicidas en la localidad, es un factor de daño genético en trabajadores agrícolas. Participaron 43 residentes (18 trabajadores y 25 testigos). Todos los participantes fueron informados de los objetivos del proyecto y firmaron un consentimiento informado, después de contestar un cuestionario para determinar algunas características personales como género, edad, peso, antigüedad en las labores agrícolas, entre otras. Para evaluar el daño genético, se empleó el ensayo cometa en leucocitos, analizando 50 núcleos por individuo, mediante el programa Comet Assay IV. La población testigo dio valores del momento de la cauda de 1.3166 a 3.2941 , con un promedio de $2.5206 \pm 0.5808$, mientras que la población expuesta presentó valores entre 2.0246 y 15.9181, con una media de $6.3295 \pm 4.2216$. Se concluye que la exposición laboral a plaguicidas pudiera ser un factor de daño genético evidenciado por el incremento estadísticamente significativo del momento de la cauda, obtenido a través del ensayo cometa, en la comunidad estudiada.

Agradecimientos: Proyecto respaldado por FOINS-CONACyT referencia 3203. A la Red Temática de Toxicología de Plaguicidas

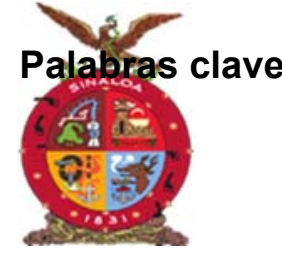

XVIII Congreso Internacional

XXIV Congreso Nacional de Ciencias ambientales

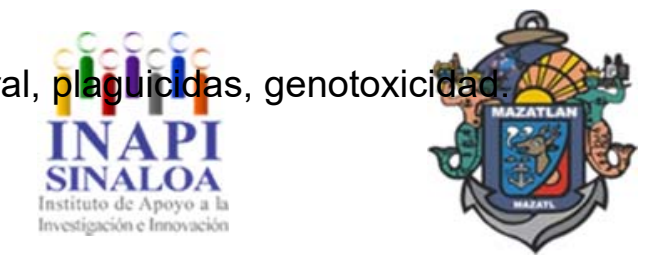

Recursos Naturales, Ecosistemas y Deterioro Ambiental 

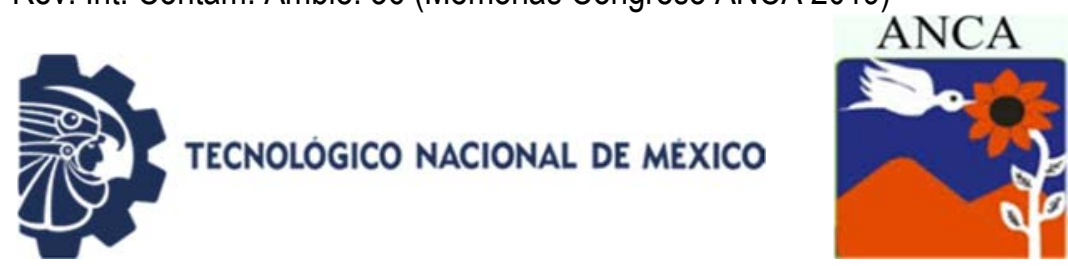

\title{
Analysis of DNA fragmentation in agricultural workers of Francisco Sarabia, Michoacán, México
}

\author{
Sánchez-Alarcón $\mathrm{J}^{1,2,3}$, Arenas-Sánchez $\mathrm{H}^{1}$, Ochoa-Ocaña $\mathrm{MA}^{3,4}$, Milić $\mathrm{M}^{5}$, Kašuba $\mathrm{V}^{5}$, \\ Urióstegui-Acosta $\mathrm{MO}^{6}$, Gómez-Arroyo $\mathrm{S}^{7}$, Flores-Márquez $\mathrm{AR}^{7}$, Cortés-Eslava $\mathrm{J}^{7}$, \\ Hueletl-Soto ME1 , Montiel-González JMR ${ }^{1,2}$, Gómez-Olivares $\mathrm{JL}^{8}$, Bonassi $\mathrm{S}^{9}$, \\ Valencia-Quintana $\mathrm{R}^{1,2,3 *}$ \\ ${ }^{1}$ Laboratorio "Rafael Villalobos-Pietrini" de Toxicología Genómica y Química Ambiental. Facultad \\ de Agrobiología. Universidad Autónoma de Tlaxcala, México \\ ${ }^{2}$ CA UATLX-CA-223 Ambiente y Genética. UATx. México \\ ${ }^{3}$ Red Temática Toxicología de Plaguicidas CONACyT-UA Nayarit, México \\ ${ }^{4}$ Unidad Académica de Estudios Regionales. Coordinación de Humanidades. UNAM. México \\ ${ }^{5}$ Mutagenesis Unit. Institute for Medical Research and Occupational Health. Zagreb, Croatia \\ ${ }^{6}$ Escuela Superior de Ciencias Naturales. Universidad Autónoma de Guerrero. \\ ${ }^{7}$ Laboratorio de Genotoxicología Ambiental, Centro de Ciencias de la Atmósfera, UNAM, México \\ ${ }^{8}$ Departamento de Ciencias de la Salud. Universidad Autónoma Metropolitana-Iztapalapa, \\ ${ }^{9}$ Unit of Clinical and Molecular Epidemiology, IRCCS San Raffaele Pisana, Rome, Italy \\ *prvq2004@ahoo.com.mx
}

\begin{abstract}
The town of Francisco Sarabia is located in the municipality of Jiquilpan, in the state of Michoacán de Ocampo, in Mexico. Its main activities include agriculture, with alfalfa, corn and sorghum being the most important crops in the region. The use of pesticides is a resource used for the protection of their crops, so the population is at constant risk, as a large quantity and variety of these products is applied, many of which have demonstrated genotoxic potential. The purpose of the present work was to evaluate if the occupational exposure to pesticides in the town is a factor of genetic damage in agricultural workers. Forty-three residents (18 workers and 25 controls) participated. All the participants were informed of the objectives of the project and signed an informed consent, after answering a questionnaire to determine some personal characteristics. To evaluate the genetic damage, we used the comet assay test in human leukocytes, analyzing 50 nuclei per individual with the software Comet Assay IV. The control population presented values of tail moment of 1.316565217 to 3.294062481 , with an average of $2.520621751 \pm$ 0.580750921 , while the exposed population presented values between 2.024564242 and 15.91813252 , with an average of $6.329526614 \pm 4.221639234$. It is concluded that occupational exposure to pesticides could be a factor of genetic damage, evidenced by the comet trial in the community studied.
\end{abstract}

\section{Agradecimientos: Proyecto respaldado por FOINS-CONACyT referencia} 3203. A la Red Temática de Toxicología de Plaguicidas

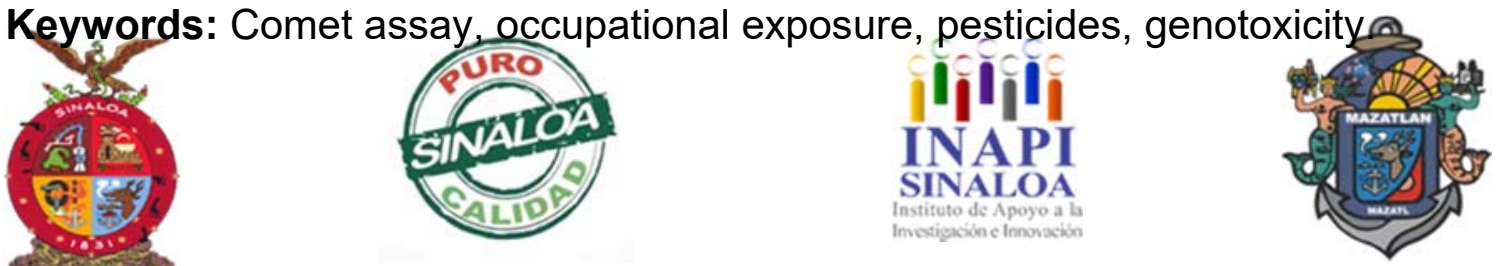



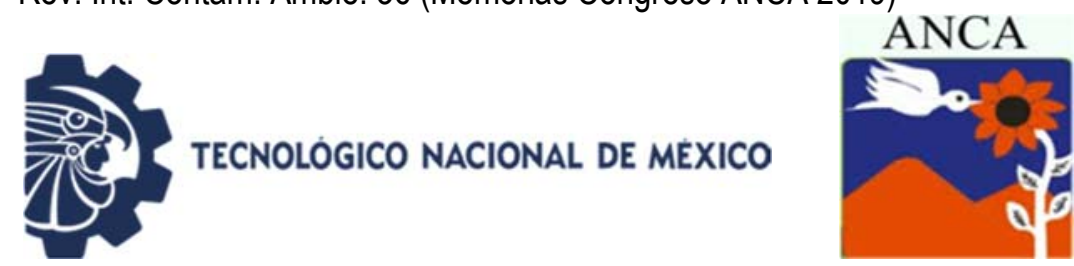

\title{
Estudio exploratorio de macromicetos en el Parque Nacional Pico de Orizaba región poniente y en dos comunidades del municipio de Chalchicomula Puebla
}

\author{
Sánchez Román $R^{*}$, Otlíca Rosario $A$, Juárez Cadena $F$, \\ Hernández Jiménez $\mathrm{P}$, Tapia Morales J \\ Instituto Tecnológico Superior de Ciudad Serdán. \\ Av. Instituto Tecnológico S/N, Col. La Gloria, Ciudad Serdán, Puebla \\ *rsanchezr@tecserdan.edu.mx
}

\begin{abstract}
RESUMEN
Los hongos cumplen un papel vital en nuestros ecosistemas, la biodiversidad de estas especies es enorme, mucho mayor que plantas superiores, hacen interacciones con bacterias, insectos, algas, animales, vegetales, etc, viviendo en forma saprófita, biótrofa o necrótrofa, sin embargo, no son reconocidos en sus funciones ambientales, tal es el caso de los habitantes aledaños al Parque Nacional Pico de Orizaba, quienes realizan prácticas de recolección y se observa lo siguiente: existe tala descomunal de las especies que van apareciendo durante losrecorridos de recolecta haciendo discriminación de las especies después de cortarlas y/o arrancarlas; independiente de la especie de hongo que cortan, no existe conocimiento de las distintas etapas de madurez evidenciando su falta de entendimiento por los aspectos ambientales, ciclos biogeoquímicos y equilibrios ecológicos que estos guardan en el bosque. El objetivo del trabajo consistió en realizar un diagnóstico participativo sobre el conocimiento a la importancia de macromicetos, el consumo, usos y beneficios a los ecosistemas en los ejidos de San Isidro Canoas Altas y Jesús María del Municipio de Chalchicomula de Sesma, Puebla durante los años 2017 y 2018, para el estudio se hicieron recorridos de reconocimiento de biodiversidad fúngica, diagnostico participativo, descripción de prácticas y planteamiento estratégico sobre el aprovechamiento sustentable, como resultado del estudio se presenta información del desconocimiento y malas prácticas utilizadas en el manejo de los recursos fúngicos, se concluye la notoria falta de capacitación y conocimiento científico de los diferentes actores que participan en el aprovechamiento de los recurso fúngicos.
\end{abstract}

Palabras clave: Hongos, deterioro, prácticas.

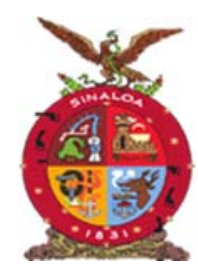

XVIII Congreso Internacional

XXIV Congreso Nacional de Ciencias ambientales

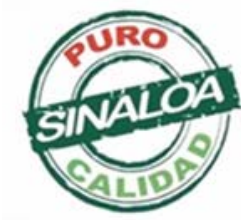

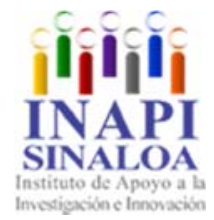

Mazatlán, Sinaloa 3-7 junio 2019

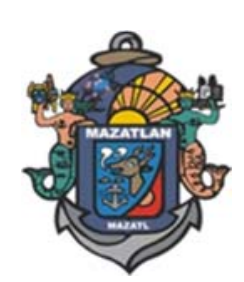

Recursos Naturales, Ecosistemas y Deterioro Ambiental 

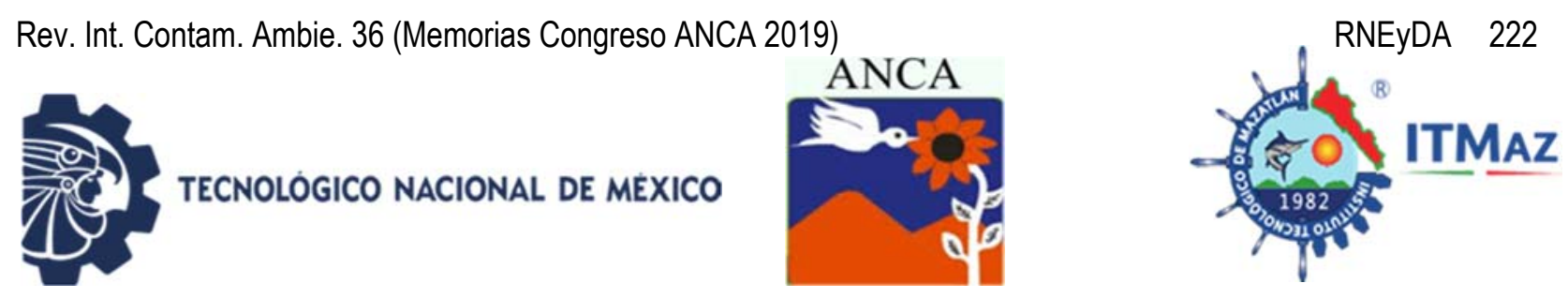

\title{
Exploratory study of macromycetes in the Pico de Orizaba National Park, western region and in two communities of the municipality of Chalchicomula Puebla
}

\author{
Sánchez Román $\mathrm{R}^{*}$, Otlíca Rosario A, Juárez Cadena F, \\ Hernández Jiménez $\mathrm{P}$, Tapia Morales $\mathrm{J}$ \\ Instituto Tecnológico Superior de Ciudad Serdán. \\ Av. Instituto Tecnológico S/N, Col. La Gloria, Ciudad Serdán, Puebla \\ *rsanchezr@tecserdan.edu.mx
}

\begin{abstract}
Although often ignored, fungi play a vital role in our ecosystems. The biodiversity of these species is enormous, much higher than higher plants. They interact with bacteria, insects, algae, animals, plants, etc., living in saprophytic, biotropic or necrotrophic. However, are not recognized in their environmental functions, such is the case of inhabitants surrounding the Pico de Orizaba National Park who perform harvesting practices and the following is observed: there is a huge logging of the species that appear during the harvesting routes, making discrimination of the species after cutting and / or tearing them. Independent of the species of fungus that they cut, there is no knowledge of the different stages of maturity evidencing their lack of understanding for the environmental aspects, biogeochemical cycles, and ecological balances that they keep in the forest. The objective of the work was to make a participatory diagnosis on the knowledge of the importance of macromycetes, consumption, uses and benefits to ecosystems in the ejidos of San Isidro Canoas Altas and Jesús María of the Municipality of Chalchicomula de Sesma Puebla during the years 2017 and 2018. For the study were made tours of recognition of fungal biodiversity, participatory diagnosis. Description of practices and strategic approach to sustainable use, as a result of the study is presented information on the lack of knowledge and bad practices used in the management of fungal resources, the notorious lack of training and scientific lack knowledge is concluded of the different actors involved in the use of fungal resources.
\end{abstract}

Keywords: Fungi, deterioration, practices.

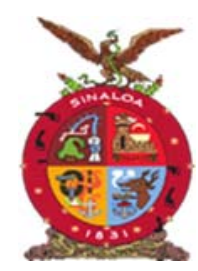

XVIII Congreso Internacional

XXIV Congreso Nacional de Ciencias ambientales
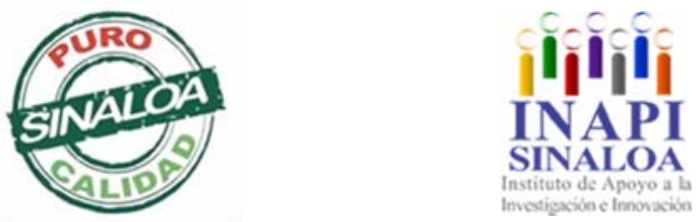

Mazatlán, Sinaloa 3-7 junio 2019

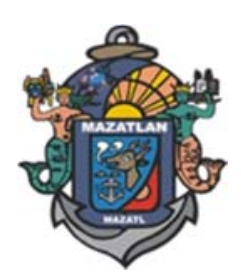

Recursos Naturales, Ecosistemas y Deterioro Ambiental 

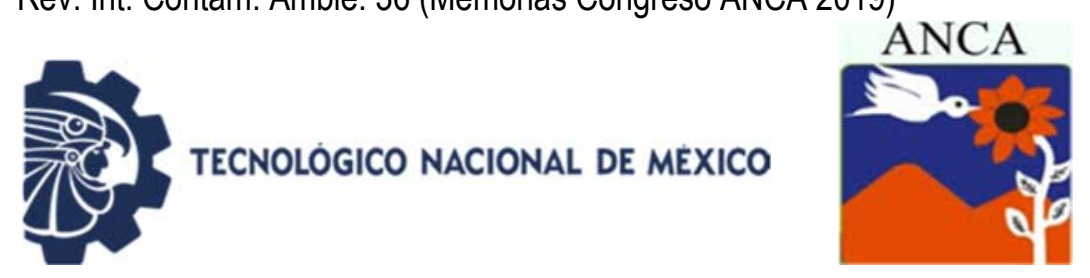

\title{
Desarrollando conciencia ambiental en Ingeniería Aeronáutica Instituto Politécnico Nacional México
}

\author{
Sandoval Lezama $\mathrm{J}^{1 *}$, Caballero Hernandez $\mathrm{D}^{2}$, Correa Arredondo $\mathrm{J}^{1}$, \\ Fernandez Roque $\mathrm{T}^{1}$ \\ ${ }^{1}$ IPN ESIME TICOMÁN. Calz. Ticomán 600, San José Ticomán, 07340, México \\ ${ }^{2}$ Aeroméxico. Av. Río Churubusco 16, Internacional Benito Juárez, México \\ *jslezama09@yahoo.com.
}

\section{RESUMEN}

México al participar activamente en la definición e implementación de la Agenda 2030, asume compromisos a nivel mundial. Dicha agenda se aprobó en la ciudad de New York en 2015 en la cumbre de las Naciones Unidas sobre el Desarrollo Sustentable para cumplir con los compromisos de la Agenda 2030 de la Dirección General, Coordinación Politécnica para la Sustentabilidad ha implementado el diplomado Formación Tecnológica Ambiental para la Sustentabilidad (FORTAS) desde el 2017. Desarrollar una Conciencia Ambiental con la visión de la prospectiva, en los alumnos de las carreras de Ingeniería Aeronáutica, de acuerdo al Anexo 16 del Convenio sobre Aviación Civil Internacional, Protección del medio ambiente, Volumen I Ruido de las aeronaves. Una propuesta de incorporación de los criterios derivados del FORTAS en la unidad de aprendizaje "Sistemas Electrónicos Digitales" de la carrera de Ing. Aeronáutica. Revisión de literatura actualizada de la $\mathrm{ONU}, \mathrm{OACl}$, etc., tales como "Impact of Electric Propulsion on Aircraft Noise-All-Electric Light Aircrafts, case study, AIAA 2018. Incorporación de la visión de sustentabilidad en una Unidad de Aprendizaje de Ing. Aeronáutica. Implementación de tutorias y cursos cortos extracurriculares, con el enfoque de la contaminación por ruido generado por aeronaves. Desarrollo de contenidos para la plataforma Moodle, con el enfoque de la Agenda 2030 y del Anexo 16, volumen1. En los últimos años, la ingeniería aeronáutica ha estado cambiando, pero el proceso educativo es y ha sido lento para responder a este cambio, por lo que los docentes nos tenemos que reformular y enfrentar a los retos y oportunidades de la Educación 4.0. De acuerdo a la Agenda 2030 y los 17 objetivos del desarrollo sustentable, nuestro compromiso está fundamentado en el objetivo 4 "Educación de calidad"

Palabras clave: Sustentabilidad, educación, prospectiva, aeronaves, ruido.

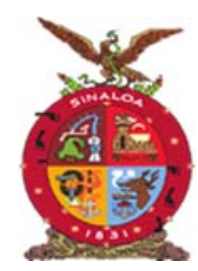

XVIII Congreso Internacional

XXIV Congreso Nacional de Ciencias ambientales

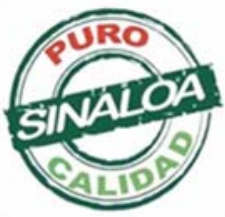

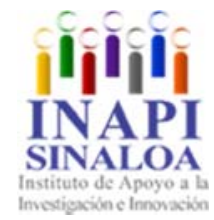

Mazatlán, Sinaloa 3-7 junio 2019

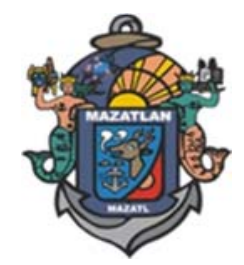

Recursos Naturales, Ecosistemas y Deterioro Ambiental 

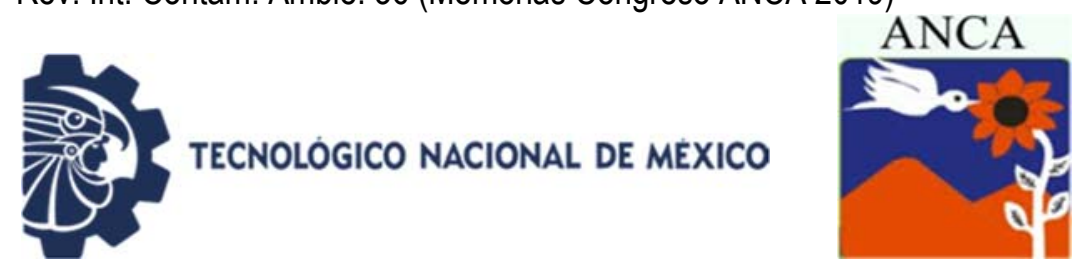

\title{
Developing environmental awareness in Aeronautical Engineering National Polytechnic Institute México
}

\author{
Sandoval Lezama $\mathrm{J}^{1^{*}}$, Caballero Hernandez $\mathrm{D}^{2}$, Correa Arredondo $\mathrm{J}^{1}$, \\ Fernandez Roque $\mathrm{T}^{1}$ \\ ${ }^{1}$ IPN ESIME TICOMÁN. Calz. Ticomán 600, San José Ticomán, 07340, México \\ ${ }^{2}$ Aeroméxico. Av. Río Churubusco 16, Internacional Benito Juárez, México \\ *jslezama09@yahoo.com.
}

\begin{abstract}
Mexico, by actively participating in the definition and implementation of the 2030 Agenda, assumes commitments worldwide. This agenda was approved in New York City in 2015 at the United Nations Summit on Sustainable Development to meet the commitments of the 2030 Agenda of the General Direction, Polytechnic Coordination for Sustainability has implemented the Diploma Environmental Technology Training for Sustainability (FORTAS) since 2017. Develop an Environmental Awareness with the vision of the prospective, in the students of Aeronautical Engineering careers, according to Annex 16 of the Convention on International Civil Aviation, Environmental Protection, Volume I Noise of aircraft. A proposal to incorporate the criteria derived from FORTAS in the "Digital Electronic Systems" learning unit of the Aeronautical Engineering degree. Review of updated literature from the UN, ICAO, etc., such as "Impact of Electric Propulsion on Aircraft Noise-All-Electric Light Aircrafts, case study, AIAA 2018. Incorporation of the vision of sustainability in a Learning Unit of Eng. Aeronautics. Implementation of tutorials and short extracurricular courses, with the focus of noise pollution generated by aircraft. Content development for the Moodle platform, with the focus of the 2030 Agenda and Annex 16, volume1. In recent years, aeronautical engineering has been changing, but the educational process is and has been slow to respond to this change, so teachers have to reformulate and face the challenges and opportunities of Education 4.0. According to the 2030 Agenda and the 17 objectives of sustainable development, our commitment is based on objective 4 "Quality education"
\end{abstract}

Keywords: Sustainability, education, prospective, aircraft, noise.

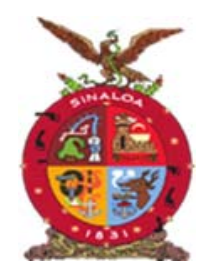

XVIII Congreso Internacional XXIV Congreso Nacional de Ciencias ambientales

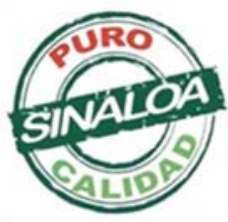

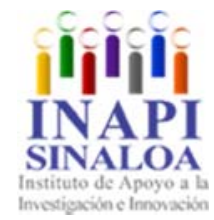

Mazatlán, Sinaloa 3-7 junio 2019

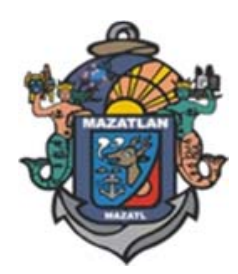

Recursos Naturales, Ecosistemas y Deterioro Ambiental 

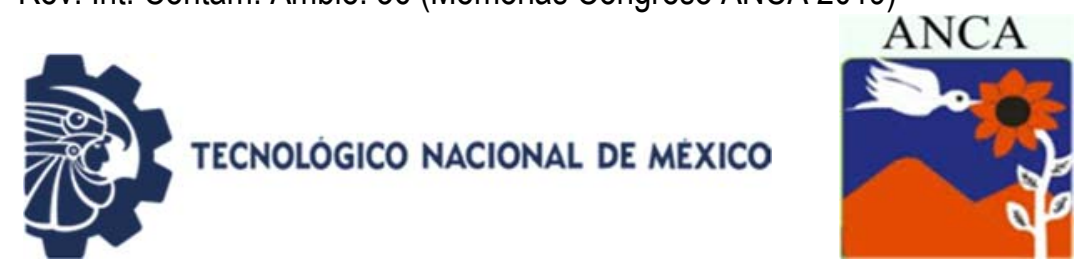

\title{
Mapeo de cuerpos de agua en la Sierra Madre Occidental usando imágenes satelitales Sentinel-2
}

\author{
Sandoval $\mathrm{S}^{1 *}$, Escobar Flores $\mathrm{J}^{2}$ \\ ${ }^{1}$ CONACYT CIIDIR Durango. Instituto Politécnico Nacional. Durango, México \\ ${ }^{2}$ CIIDIR Durango, Instituto Politécnico Nacional. Durango, México \\ *sarahisandovale@gmail.com
}

\begin{abstract}
RESUMEN
El mapeo y monitoreo del agua superficial es necesario para comprender los procesos hidrológicos que permiten la obtención de datos para la prevención y el manejo de aguas continentales y su relación con los servicios ambientales. Las técnicas de percepción remota permiten evaluar grandes extensiones de terreno en zonas remotas e inaccesibles como las áreas de la Sierra Madre Occidental que cubren un total de $\sim 96,485 \mathrm{Km}^{2}$. Los datos adquiridos por estas técnicas, pueden proporcionar información macroscópica y de bajo costo, contrario a las mediciones in situ. El objetivo de este estudio fue detectar los cuerpos de agua de la Sierra Madre Occidental, mediante técnicas de percepción remota usando imágenes de Satélite Sentinel-2. Un total de 60 imágenes Sentinel-2 del año 2016 con resolución espacial de $10 \mathrm{~m}$ de fueron utilizadas para tener un cubrimiento sinóptico de la Sierra Madre Occidental, posteriormente se les aplicó una corrección atmosférica siguiendo la metodología de Chavez (1996). Para la detección de cuerpos de agua de la SMO, se aplicó el Índice Diferencial de Agua Normalizado (NDWI) y se detectaron 30,000 cuerpos de agua, los más pequeños fueron de $60 \mathrm{~m}^{2}$ y los más grandes de $43 \mathrm{Km}^{2}$ como por ejemplo La Presa El comedero en Sinaloa y la presa Aguamilpa en Nayarit. Anteriormente en la Serie VI de INEGI para esta zona se tenía un total de 342 cuerpos de agua documentados con el Satelite Landsat 8 (30 m de resolución espacial) en la SMO.
\end{abstract}

Palabras clave: Sensores remotos, Índice Diferencial de Agua Normalizado, Sentinel-2.

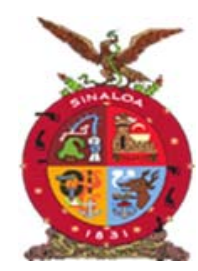

XVIII Congreso Internacional XXIV Congreso Nacional de Ciencias ambientales

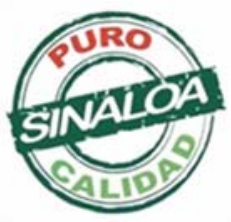

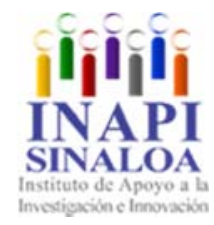

Mazatlán, Sinaloa 3-7 junio 2019

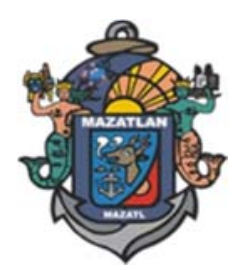

Recursos Naturales, Ecosistemas y Deterioro Ambiental 

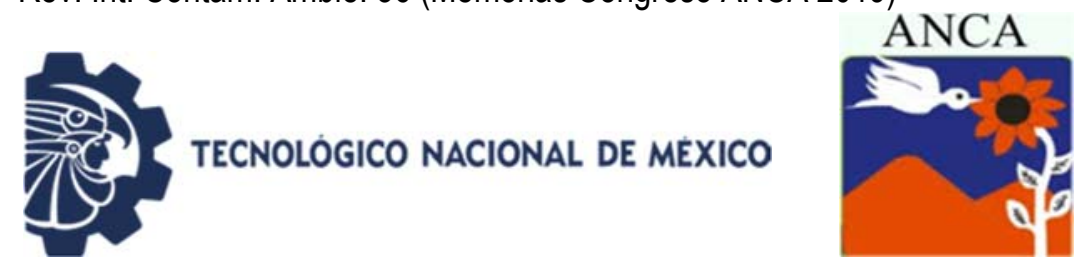

\title{
Mapping water bodies in the Sierra Madre Occidental using Sentinel-2 satellite images
}

\author{
Sandoval $\mathrm{S}^{1^{*}}$, Escobar Flores $\mathrm{J}^{2}$ \\ ${ }^{1}$ CONACYT CIIDIR Durango. Instituto Politécnico Nacional. Durango, México \\ ${ }^{2}$ CIIDIR Durango, Instituto Politécnico Nacional. Durango, México \\ *sarahisandovale@gmail.com
}

\begin{abstract}
Mapping and monitoring surface water is necessary to understand hydrological processes because it enables data to be obtained for management and conservation of inland waters and their relationship with environmental services. Remotesensing is a powerful tool for monitoring large tracts of the earth's surface in inaccessible areas such as the Sierra Madre Occidental (SMO), which covers a total of $\sim 96,485 \mathrm{Km} 2$. The data acquired by these techniques can provide macroscopic and low-cost information, in contrast to in-situ measurements. The aim of this study was to detect the water bodies of the Sierra Madre Occidental using remote sensing techniques and Sentinel-2 satellite images. A total of 60 Sentinel-2 images from 2016 (10 m spatial resolution) were used to obtain synoptic coverage of the Sierra Madre Occidental. Image processing included an atmospheric correction; the detection of water bodies was then carried out with the normalized water differential index (NDWI). 30,000 surface water bodies were detected. The smallest bodies of water detected were $60 \mathrm{~m} 2$ and the largest were $43 \mathrm{Km} 2$; e.g. La Presa El Comedero in Sinaloa and La Presa Aguamilpa in Nayarit. With this methodology we found more water bodies than reported in the INEGI Series VI, which documents only 342 bodies of water for the same area (SMO).
\end{abstract}

Keywords: Remote Sensing, Normalized Difference Water Index (NDWI), Sentinel-2.

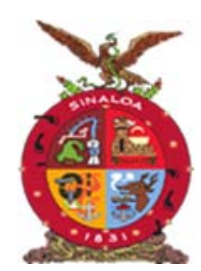

XVIII Congreso Internacional XXIV Congreso Nacional de Ciencias ambientales
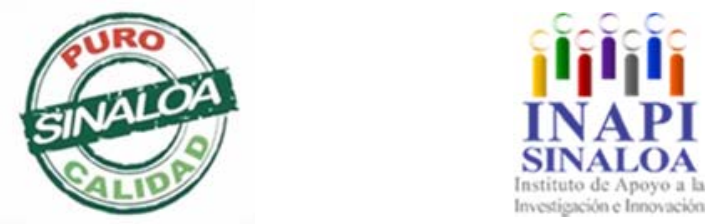

Mazatlán, Sinaloa 3-7 junio 2019

Mazatlán

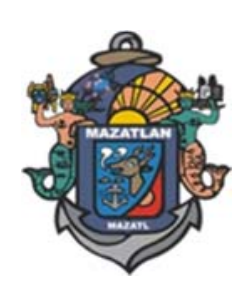

Recursos Naturales, Ecosistemas y Deterioro Ambiental 

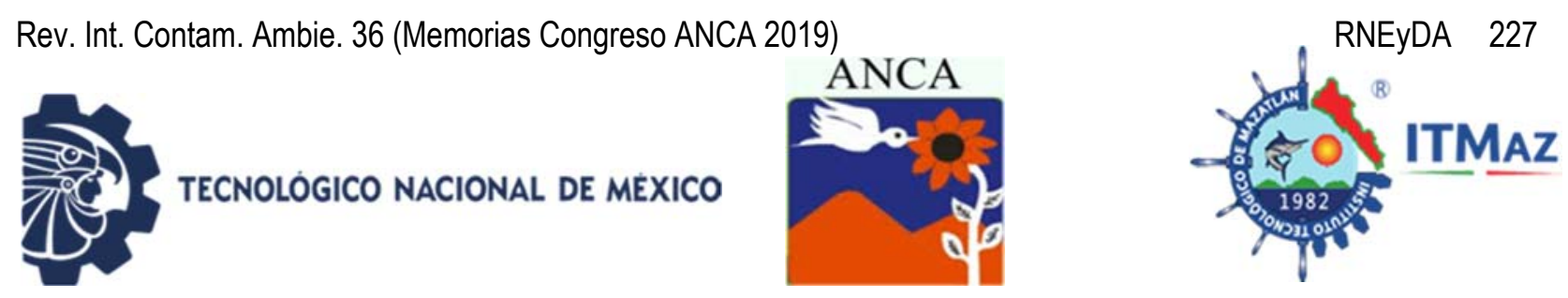

\title{
Tendencias estacionales de los manglares de México: una aproximación con los Índices de Vegetación MOD13Q1 V006 de MODIS
}

\author{
Trejo Osuna $\mathrm{OI}^{1}$, Berlanga Robles $\mathrm{CA}^{2}$ \\ ${ }^{1}$ Programa de Posgrado \\ ${ }^{2}$ Coordinación Regional Mazatlán \\ Centro de Investigación en Alimentación y Desarrollo A. C. \\ oscar.trejo17@estudiantes.ciad.mx
}

\section{RESUMEN}

Las estrategias de conservación de los manglares requieren de información precisa y actualizada de su distribución y tendencias de cambio, la cual puede obtenerse con el uso de datos y técnicas de percepción remota. En este sentido, en el presente estudio se analizaron las variaciones estacionales y de largo plazo del dosel de los manglares en dos regiones de México con el fin de identificar las tendencias de cambio de estas coberturas vegetales como respuesta al cambio climático. A partir de los productos MOD13Q1 del satélite MODIS Terra se generaron series de tiempo del Índice de Vegetación Mejorado (EVI por sus siglas en inglés) del 2001 a 2018 para los manglares de 17 sistemas lagunares del noroeste del país y 16 de la península de Yucatán. Las series fueron descompuestas con un Análisis de Tendencia Estacionario para identificar los patrones fenológicos del manglar, así como sus tendencias de cambio a largo plazo. En general, el mayor vigor de la vegetación se presentó entre agosto y octubre y los doseles más abiertos entre mayo y junio. De los 33 sistemas analizados, 29 presentaron tendencias de cambio del dosel positivas y cuatro negativas, tres de ellos localizados en la península de Yucatán. Los ciclos fenológicos estuvieron principalmente correlacionados con la estacionalidad de la temperatura, la precipitación acumulada y la radiación solar.

Palabras clave: Series de tiempo, dosel del manglar, percepción remota, fenología de la vegetación.

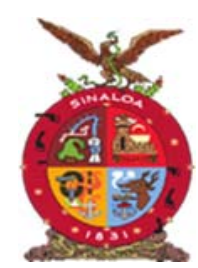

XVIII Congreso Internacional

XXIV Congreso Nacional de Ciencias ambientales

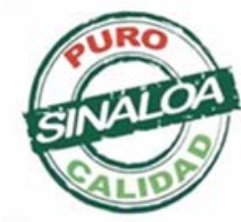

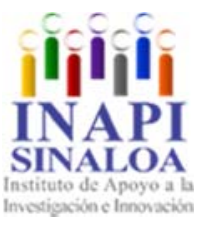

Mazatlán, Sinaloa 3-7 junio 2019

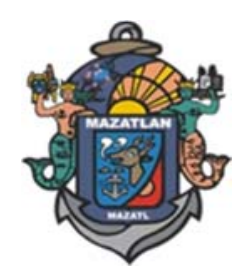

Recursos Naturales, Ecosistemas y Deterioro Ambiental 

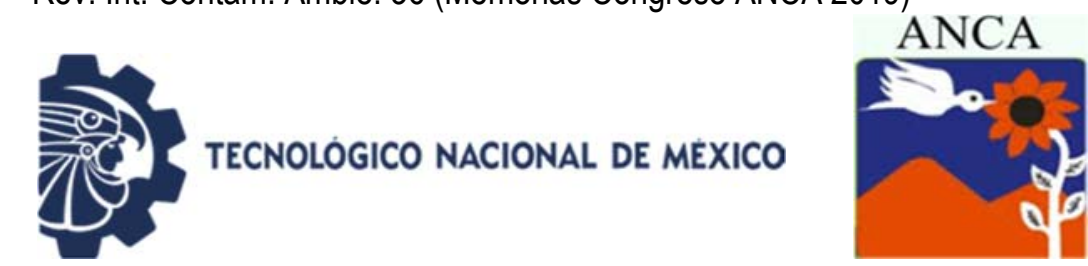

\title{
Seasonal trends of the Mexican mangroves: An approach to the MODISQ1 V006 Vegetation Indices of MODIS
}

\author{
Trejo Osuna $\mathrm{OI}^{1}$, Berlanga Robles $\mathrm{CA}^{2}$ \\ ${ }^{1}$ Programa de Posgrado \\ ${ }^{2}$ Coordinación Regional Mazatlán \\ Centro de Investigación en Alimentación y Desarrollo A. C. \\ oscar.trejo17@estudiantes.ciad.mx
}

\begin{abstract}
Mangrove conservation strategies require accurate and up-to-date information on their distribution and trends of change, which can be obtained through the use of data and remote sensing techniques. In this sense, in the present study the seasonal and long-term variations of the mangrove canopy in two regions of Mexico were analyzed in order to identify the trends of change of these plant coverings in response to climate change. From the MOD13Q1 products of the MODIS Terra satellite, time series of the Improved Vegetation Index (EVI) were generated from 2001 to 2018 for the mangroves of 17 lagoon systems in the northwest of the country and 16 of the Yucatan Peninsula. The series were decomposed with a Stationary Trend Analysis to identify the mangrove phenological patterns, as well as their long-term change trends. In general, the greatest vigor of vegetation occurred between August and October and the most open canopies between May and June. Of the 33 systems analyzed, 29 presented positive and four negative canopy change trends, three of them located in the Yucatan Peninsula. Phenological cycles were mainly correlated with the seasonality of temperature, accumulated precipitation and solar radiation.
\end{abstract}

Keywords: Time series, mangrove canopy, remote perception, vegetation phenology.

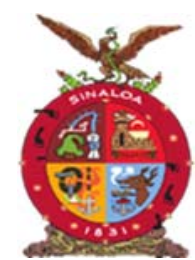

XVIII Congreso Internacional

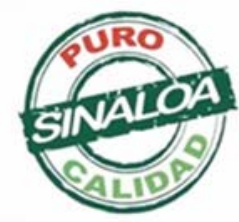

Mazatlán, Sinaloa 3-7 junio 2019

XXIV Congreso Nacional de Ciencias ambientales
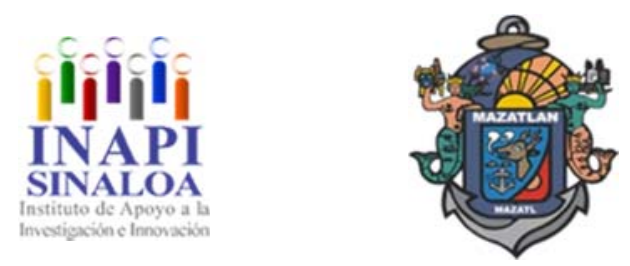

Recursos Naturales, Ecosistemas y Deterioro Ambiental 

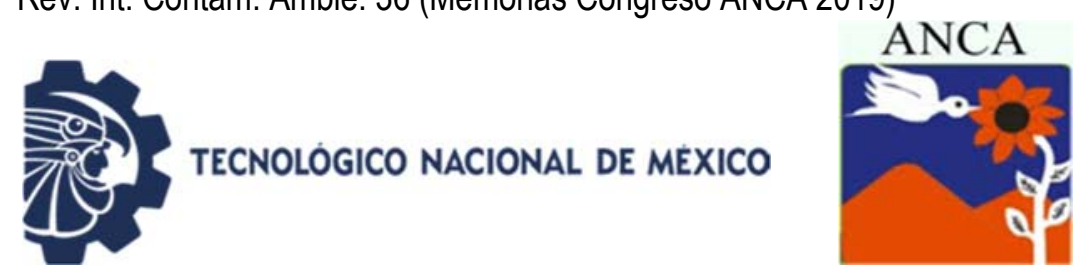

\title{
Restauración Ambiental por cambio de uso de suelo por incendios forestales
}

\author{
Valdez Mendoza N*, Olmedo García K, Cabanillas García Z, \\ Gallardo Hernández M, Castañón Bautista C \\ Escuela de Ciencias de la Ingeniería y Tecnología. \\ Universidad Autónoma de Baja California. México \\ *noelia.valdez@uabc.edu.mx
}

\section{RESUMEN}

En 2018 se registraron en Baja California 74 incendios forestales que afectaron de 17,902.39 ha, donde se perdieron $15,954.30$ ha de vegetación arbustiva. Parte de los incendios registrados se presentaron en el municipio de Tijuana, en terrenos aledaños a la Escuela de Ciencias de la Ingeniería y Tecnología (ECITEC), provocando un impacto ambiental en suelo, agua, vegetación y fauna silvestre de la región. El objetivo principal de este estudio es contribuir a la restauración ecológica en ECITEC, a través de un Proyecto de Restauración Forestal para la especie Simmondsia chinesis. Para ello, se realizó la restauración en una superficie de $4,019.91 \mathrm{~m}^{2}$ en un terreno afectado por un incendio ocurrido a causa de un evento Santana. Las actividades se llevaron a cabo en los meses de noviembre-diciembre del 2018 y consistieron en restauración y conservación de suelo, adquisición de las especies y reforestación con acciones de mantenimiento. Se plantaron en el sitio 53 ejemplares, de dos años de edad, se realizó un levantamiento de datos registrando en la bitácora su sexo, altura, diámetro, condición fitosanitaria, entre otros aspectos. De acuerdo con dichos registros, se obtuvo un $100 \%$ de sobrevivencia. $Y$ concluye que las actividades previas de preparación del suelo, favorecieron la captación de agua de lluvia y proporcionó la humedad necesaria a las plantas para su desarrollo natural. Se estima que estas acciones de compensación impacten de manera positiva a la disminución de la erosión eólica e hídrica del sitio.

Palabras claves: Restauración, reforestación, degradación, Simmondsia chinesis, vegetación.

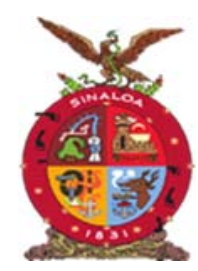

XVIII Congreso Internacional XXIV Congreso Nacional de Ciencias ambientales

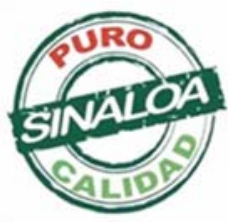

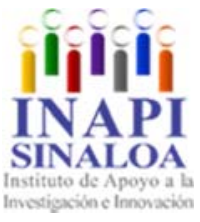

Mazatlán, Sinaloa 3-7 junio 2019

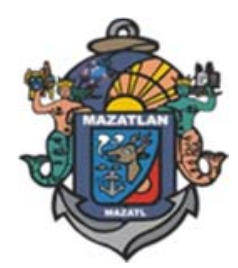

Recursos Naturales, Ecosistemas y Deterioro Ambiental 

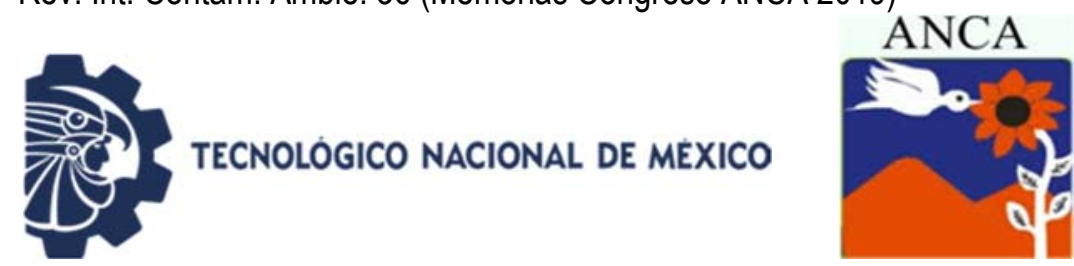

\title{
Environmental restoration by change of land use by forest fires
}

\author{
Valdez Mendoza N*, Olmedo García K, Cabanillas García Z, \\ Gallardo Hernández M, Castañón Bautista C \\ Escuela de Ciencias de la Ingeniería y Tecnología. \\ Universidad Autónoma de Baja California. México \\ *noelia.valdez@uabc.edu.mx
}

\begin{abstract}
74 wildfires were reported in Baja California in 2018, with an affected surface of $17,902.39$ ha, of which, $15,954.30$ ha of shrub vegetation were lost. Part of the reported wildfires took place in the municipality of Tijuana, in regions near by Escuela de Ciencias de la Ingenieria y Tecnologia (ECITEC), causing an impact in the soil, water, vegetation and wild fauna of the region. The primary objective of this study is to contribute to the ecological restoration in ECITEC, through a Project of Forest Restoration for the species Simmondsia chinensis. For it, a restoration in a surface of $4,019.91 \mathrm{~m}^{2}$ was done in a terrain affected by a wildfire caused by Santana conditions. The activities were carried out in the months of November-December of 2018 and they consisted of soil restoration and conservation, the acquisition of the species and reforestation with maintenance. 53 specimens of two years of age were planted on site, a recompilation of data was done, registering its plant reproductive morphology, height, diameter, phytosanitary condition, among other aspects. According to said data, a $100 \%$ of survival was obtained. It was concluded that the activities prior to soil preparation were favored by the catchment of rain water, which provided the necessary humidity to the plants for their natural development. It is estimated that with these actions of compensation, there will be a positive impact towards the decrease in wind and water erosion of the site.
\end{abstract}

Keywords: Restoration, reforestation, degradation, Simmondsia chinensis, vegetation.

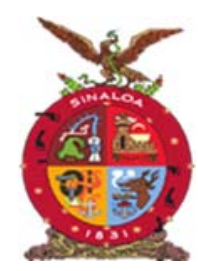

XVIII Congreso Internacional XXIV Congreso Nacional de Ciencias ambientales
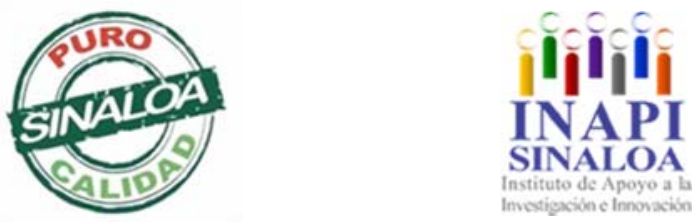

Mazatlán, Sinaloa 3-7 junio 2019

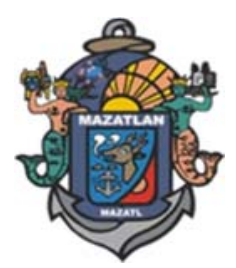

Recursos Naturales, Ecosistemas y Deterioro Ambiental 

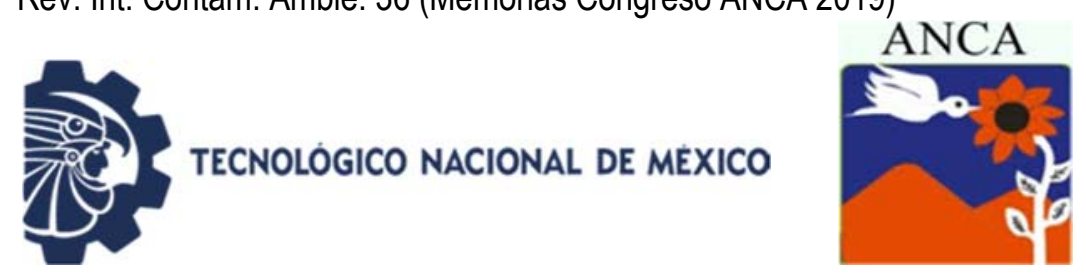

\title{
Análisis hidrodinámico de dos grupos de gramíneas nativas con simulación de lluvia en Cuenca Alta de Río Chuvíscar, Chihuahua
}

\author{
Viramontes Olivas OA, Ibarra Ceceña MG, Martínez Salomón E* \\ Universidad Autónoma Intercultural de Sinaloa, México \\ *martinez_salomon@uais.edu.mx
}

\section{RESUMEN}

En la cuenca alta del río Chuvíscar predominan condiciones climáticas extremas, escasez de agua, erosión y presencia de pastizales nativos e introducidos, lo que hace imperante conocer la función de estos en la conservación e infiltración de suelo y agua, respectivamente. El objetivo fue comparar dos grupos de gramíneas nativas: Bouteloua gracilis (H.B.K.) Griffiths; Digitaria californica (Benth) Henrad; Heteropogon contortus (L.) Roem. Et Schult); e introducidas (Eragrostis lehmanniana Nees, Eragrostis superba Peyr, Melinis repens (Willd) C.E. Hubb), para determinar la hidrodinámica de especies sobre el suelo. Se utilizó un simulador de lluvia (Deltalab-EID340) en 20 parcelas $(1 \mathrm{~m} 2 \mathrm{c} / \mathrm{u}$ ) en cuatro sitios con aplicación de lluvia a intensidad de $40 \mathrm{~mm}$ h-1. Se realizó un diseño de parcelas divididas en bloques aleatorizados; y a los resultados se les aplicó un análisis de varianza para probar efectos entre tratamientos y; también se les aplicó un análisis de componentes principales (ACP) para variables hidrodinámicas y biofísicas, para distinguir afinidades y discrepancias ecohidrológicas entre los pastizales. Los $D$. califórnica, mezclados con otras especies nativas e introducidas, mostraron valores altos de conductividad hidráulica (promedios de $\mathrm{Ks}=40 \square 6 \mathrm{~mm} \mathrm{~h}^{-1}$ ); B. gracilis $\left(\mathrm{Ks}=32 \square 8 \mathrm{~mm} \mathrm{~h}^{-1}\right.$ ) y bajos con E. superba (Ks $=24 \square 16 \mathrm{~mm} \mathrm{~h}^{-1}$ ). Se comprobó la importante función hidrológica de las gramíneas sin importar el origen biogeográfico. Se pueden establecer planes de conservación en zonas degradas con especies introducidas para apoyar infiltración, protección del suelo y aprovechar habilidades fisiológicas de ambos (nativos e introducidos) como alternativas de conservación y resiembras durante el pastoreo de animales.

Palabras clave: Erosión, plantas nativas, hidrología.

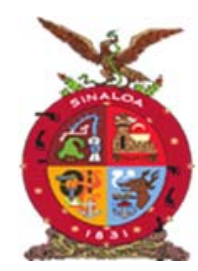

XVIII Congreso Internacional XXIV Congreso Nacional de Ciencias ambientales
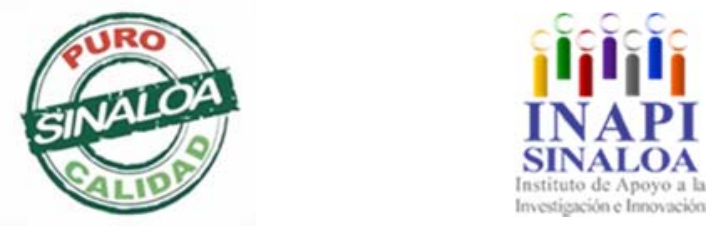

Mazatlán, Sinaloa 3-7 junio 2019

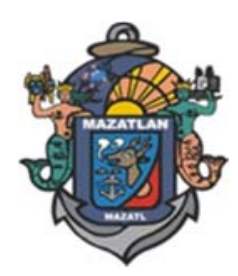

Recursos Naturales, Ecosistemas y Deterioro Ambiental 

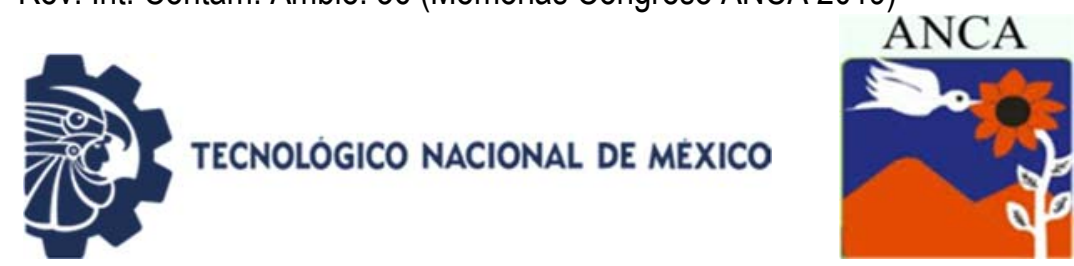

\title{
Hydrodynamic analysis of two groups of native gramineas with rain simulation in upper basin of Río Chuvíscar, Chihuahua
}

\author{
Viramontes Olivas OA, Ibarra Ceceña MG, Martínez Salomón E* \\ Universidad Autónoma Intercultural de Sinaloa, México \\ *martinez_salomon@uais.edu.mx
}

\begin{abstract}
In the upper basin of Chuviscar river, extreme weather conditions prevail, as well as water shortages, erosion and presence of native and introduced pastures, making it imperative to know the function of these in the conservation and infiltration of soil and water, respectively. The objective was to compare two groups of native grasses: Bouteloua gracilis (HBK) Griffiths, Digitaria californica (Benth) Henrad, Heteropogon contortus (L.) Roem. Et Schult) and introduced grasses: Eragrostis lehmanniana Nees, Eragrostis superba Peyr, and Melinis repens (Willd) CE Hubb) to determine the hydrodynamics of species on the ground. A rainfall simulator was used (Deltalab-EID340) in 20 plots ( $1 \mathrm{~m}^{2}$ each) on four sites with application of rain intensity of $40 \mathrm{~mm} \mathrm{~h}^{-1}$. A split plot design in randomized blocks was applied, an analysis of variance to test effects between treatments and a principal component (PCA) to hydrodynamic and biophysical variables to distinguish similarities and eco-hydrological differences among native rangelands. The $D$. californica, mixed with other native and introduced species, showed high values of hydraulic conductivity $\left(K_{S}=40\right.$ average $\left.\square 6 \mathrm{~mm} \mathrm{~h}^{-1}\right), B$. gracilis $\left(K s=32 \square 8 \mathrm{~mm} \mathrm{~h}^{-1}\right)$ and low in E. superba $\left(K s=24 \square 16 \mathrm{~mm} \mathrm{~h}^{-1}\right)$. Hence confirming the important hydrological role of grasses regardless of biogeographical origin. Conservation programs can be implemented in degraded areas with introduced species to enhance infiltration, soil protection and use of both physiological skills (native and introduced) as alternative conservation and reseeding for grazing animals.
\end{abstract}

Keywords: Erosion, hydrology, native plants.

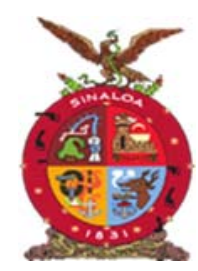

XVIII Congreso Internacional XXIV Congreso Nacional de Ciencias ambientales

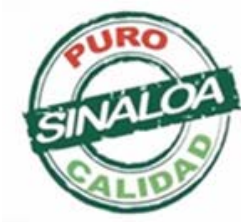

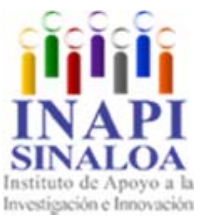

Mazatlán, Sinaloa 3-7 junio 2019

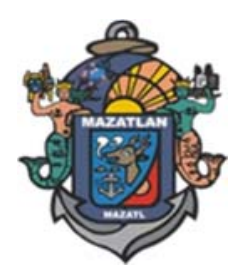

Recursos Naturales, Ecosistemas y Deterioro Ambiental 

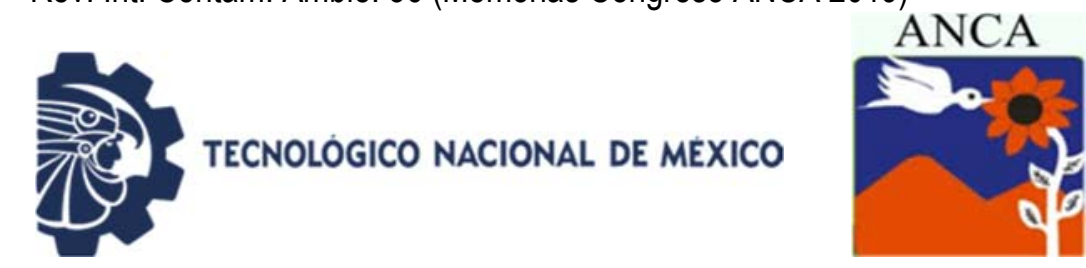

\title{
Cambios de uso del suelo en el Parque Otomí-Mexica del estado de México, 1993-2017. Procesos de Transformación
}

\author{
Villegas Martínez D¹, Gutiérrez Cedillo JG², Gómez Demetrio W³ \\ ${ }^{1}$ Doctorado en Ciencias Ambientales. Facultad de Química. \\ Universidad Autónoma del Estado de México \\ ${ }^{2}$ Facultad de Geografía. Universidad Autónoma del Estado de México \\ ${ }^{3}$ Instituto de Ciencias Agropecuarias y Rurales. \\ Universidad Autónoma del Estado de México \\ geo_morf@hotmail.com
}

\begin{abstract}
RESUMEN
El objetivo del estudio, fue analizar e identificar los procesos de trasformación que influyen de manera directa en el cambio de uso del suelo del territorio administrativo del Parque Otomí-Mexica del Estado de México. A partir de la aplicación de cartografía automatizada en formato (.ers) basada en información sobre el uso actual y pasado (1993 y 2017) del suelo, se realizó el análisis cuantitativo y geoespacial sobre los cambios e intercambios entre coberturas del suelo que se han manifestado durante el periodo de análisis, mediante métodos de sobreposición con el software IDRISI Selva. Interpretando imágenes de satélite SENTINEL 2 del año 2017, mapas de conversión del uso del suelo y mediante recorridos sistemáticos por el área de estudio, aplicando técnicas de trabajo de campo con observación directa y participativa, se identificaron los principales procesos de trasformación antrópicos y ambientales que influyen de manera directa en el cambio de uso del suelo en el parque. Los resultados muestran que el desarrollo de actividades agrícolas, forestales y turísticas, son los principales procesos de transformación que influyen de manera directa en el cambio de uso del suelo en el Parque Otomí-Mexica del Estado de México.
\end{abstract}

Palabras clave: Procesos de trasformación, cambio de uso del suelo, análisis geoespacial, Parque Otomí-Mexica del Estado de México.

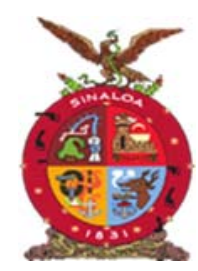

XVIII Congreso Internacional XXIV Congreso Nacional de Ciencias ambientales
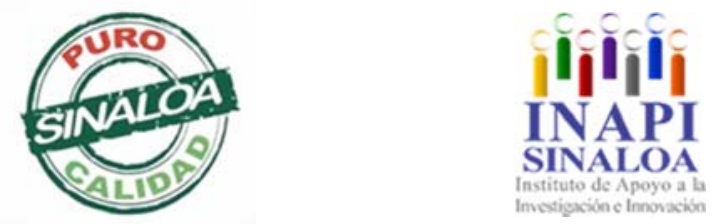

Mazatlán, Sinaloa 3-7 junio 2019

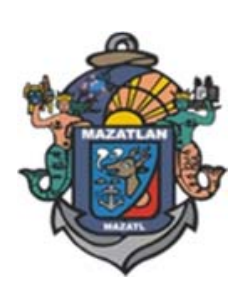

Recursos Naturales, Ecosistemas y Deterioro Ambiental 

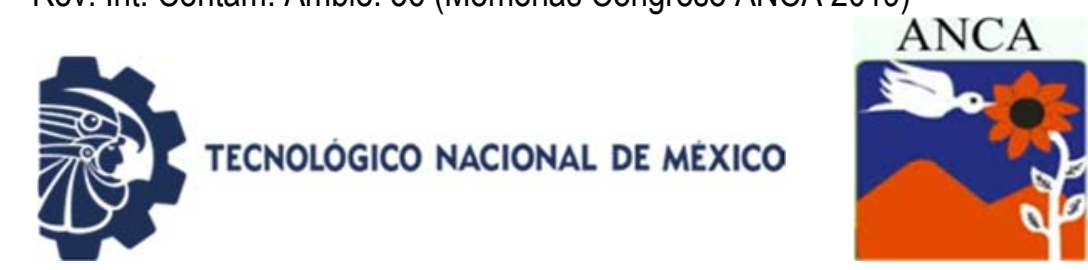

\title{
Changes in the use of the soil in the Otomí-Mexica Park of the state of Mexico, 1993-2017. Processes of transformation
}

\author{
Villegas Martínez D¹, Gutiérrez Cedillo JG², Gómez Demetrio W³ \\ ${ }^{1}$ Doctorado en Ciencias Ambientales. Facultad de Química. \\ Universidad Autónoma del Estado de México \\ ${ }^{2}$ Facultad de Geografía. Universidad Autónoma del Estado de México \\ ${ }^{3}$ Instituto de Ciencias Agropecuarias y Rurales. \\ Universidad Autónoma del Estado de México \\ geo_morf@hotmail.com
}

\begin{abstract}
The objective of the study was to analyze and identify the processes of transformation that directly influence the change in land use inside the administrative territory of the Otomí-Mexica Park of the State of Mexico. Starting from the application of automated cartography in (ers) format based on information on the current and past use (1993 and 2017) of the soil, the quantitative and geospatial analysis about the processes of transformation, changes and exchanges was carried out. between soil coverings, which have manifested during the period of analysis, by means of superposition methods with the IDRISI Selva software. Interpreting satellite images SENTINEL 2 of the year 2017, land use conversion maps and through systematic routes through the study area, applying fieldwork techniques with direct and participatory observation, the main anthropic and environmental transformation processes that directly influence over the change of land use in the park were identified. The results show that the development of agricultural, forestry and tourism activities are the main transformation processes that directly influence the change in land use inside the Otomí-Mexica Park of the State of Mexico.
\end{abstract}

Keywords: Transformation processes, change in land use, geospatial analysis, Otomí-Mexica Park of the State of Mexico.

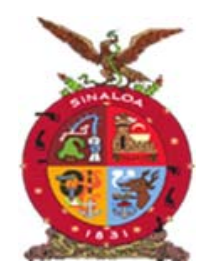

XVIII Congreso Internacional XXIV Congreso Nacional de Ciencias ambientales

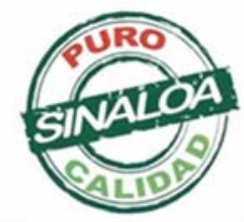

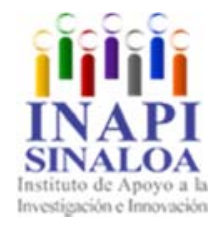

Mazatlán, Sinaloa 3-7 junio 2019

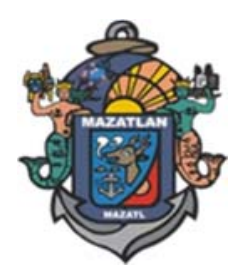

Recursos Naturales, Ecosistemas y Deterioro Ambiental 

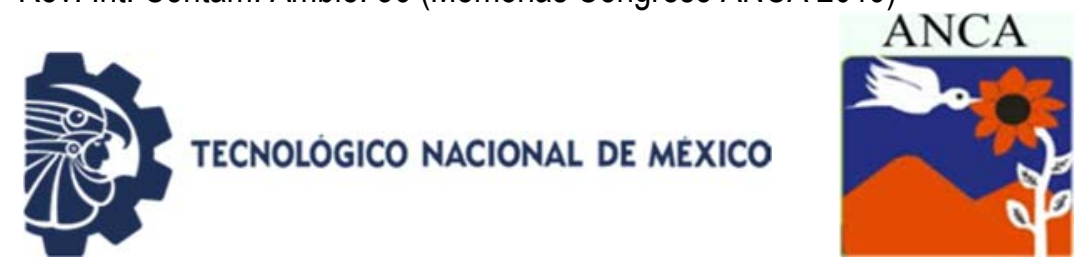

\title{
Análisis del marco normativo en el contenido de metales pesados en hongos silvestres comestibles
}

\author{
Zapata Mariscal $\mathrm{M}^{1 *}$, Naranjo Jiménez $\mathrm{N}^{2}$, Páez Olivan L², Herrera Gamboa J², \\ Rosas Medina I $^{2}$ \\ ${ }^{1}$ Facultad de Ciencias Químicas. Universidad Juárez del Estado de Durango. \\ Av. Veterinaria $S / N$, Durango, México \\ ${ }^{2}$ Centro Interdisciplinario de Investigación para el Desarrollo Integral Regional- \\ Durango. Instituto Politécnico Nacional. \\ Calle Sigma \#119, Fracc. 20 de noviembre II, Durango, México \\ marissazapata23@hotmail.com
}

\section{RESUMEN}

El consumo de hongos silvestres comestibles (HSC) es una tradición que se transmite de padres a hijos en las zonas rurales en donde crecen de manera natural. Los hongos cuentan con un mecanismo muy efectivo para acumular metales pesados, y debido a que pueden entrar en la cadena alimentaria, es pertinente la regulación de su consumo. El objetivo de este trabajo fue exponer la necesidad de generar conocimiento científico acerca del contenido de metales pesados en HSC para propiciar acciones que regulen su consumo mediante un marco normativo. La investigación fue realizada en el CIIDIR IPN Durango en el año 2018, se determinó el contenido de metales pesados de hongos silvestres comestibles de El Salto, Pueblo Nuevo, Durango y se compararon los resultados con la Norma Oficial Mexicana NOM-130-SSA1-1995. El contenido de Pb y Cd de los hongos analizados superan los límites máximos para vegetales y sus derivados establecidos en la norma. Las concentraciones de metales pesados en hongos son considerablemente más altas que las de plantas, es por ello que la norma no es la adecuada para calificar los niveles de metales pesados en hongos, de ahí la necesidad de una normatividad exclusiva para estos organismos.

Palabras clave: Biosorción, macromicetos, salud.

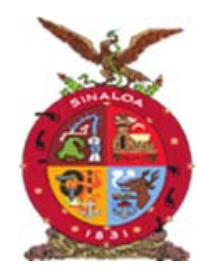

XVIII Congreso Internacional XXIV Congreso Nacional de Ciencias ambientales

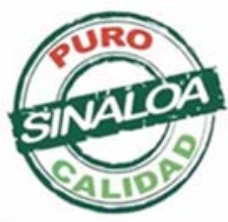

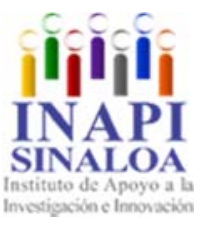

Mazatlán, Sinaloa 3-7 junio 2019

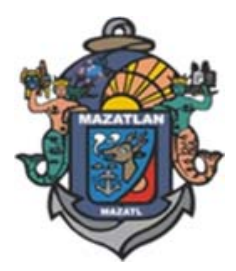

Recursos Naturales, Ecosistemas y Deterioro Ambiental 


\title{
Analysis of the regulatory framework on the content of heavy metals in wild edible mushrooms
}
Zapata Mariscal $\mathrm{M}^{1^{*}}$, Naranjo Jiménez $\mathrm{N}^{2}$, Páez Olivan $\mathrm{L}^{2}$, Herrera Gamboa J², Rosas Medina I $^{2}$

${ }^{1}$ Facultad de Ciencias Químicas. Universidad Juárez del Estado de Durango. Av. Veterinaria $\mathrm{S} / \mathrm{N}$, Durango, México

${ }^{2}$ Centro Interdisciplinario de Investigación para el Desarrollo Integral RegionalDurango. Instituto Politécnico Nacional.

Calle Sigma \#119, Fracc. 20 de noviembre II, Durango, México marissazapata23@hotmail.com

\begin{abstract}
The consumption of wild edible mushrooms (WEM) is a tradition that is transmitted from parents to children in rural areas where they grow naturally. Fungi have a very effective mechanism for accumulating heavy metals, and because they can enter the food chain, regulation of their consumption is relevant. The objective of this work was to expose the need of generate scientific knowledge about the content of heavy metals in WEM to promote actions that regulate their consumption through a regulatory framework. The research was realized at CIIDIR IPN Durango in 2018, the heavy metal content of wild edible mushrooms from El Salto, Pueblo Nuevo, Durango was determined and the results were compared with the Official Mexican Norm NOM-130-SSA1-1995. The content of $\mathrm{Pb}$ and $\mathrm{Cd}$ of the analyzed mushrooms exceed the maximum limits for vegetables and their derivatives established in the norm. The concentrations of heavy metals in fungi are considerably higher than plants, which is why the norm is not the adequate to qualify the levels of heavy metals in mushrooms, hence the need for an exclusive regulation for these organisms.
\end{abstract}

Keywords: Biosorption, macromycetes, health.

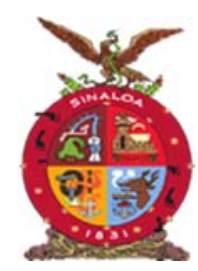

XVIII Congreso Internacional XXIV Congreso Nacional de Ciencias ambientales

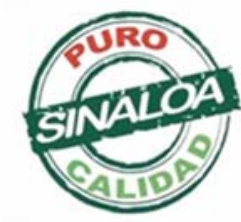

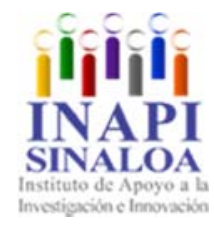

Mazatlán, Sinaloa 3-7 junio 2019

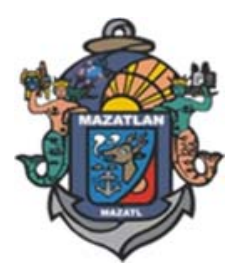

Recursos Naturales, Ecosistemas y Deterioro Ambiental 

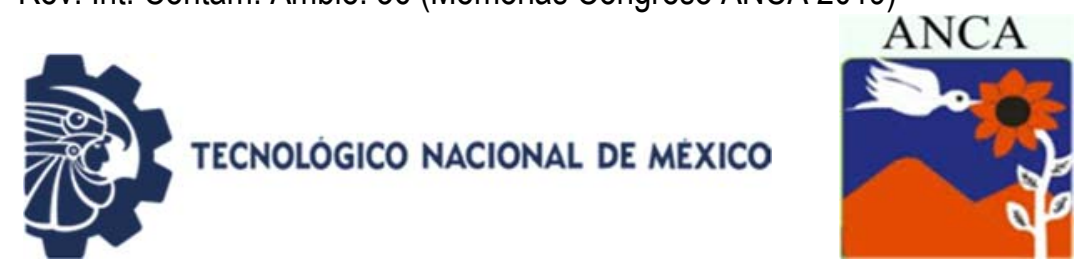

\title{
Registros de la distribución de tiburones y rayas (Elasmobranquios) en las costas del Pacífico Mexicano y sus Helmintos
}

\author{
Zaragoza Tapia F, Monks S*, Pulido Flores G \\ Centro de Investigaciones Biológicas. \\ Universidad Autónoma del Estado de Hidalgo. \\ Apartado Postal 1-10, C.P. 42001, Pachuca, Hidalgo, México \\ *scottmonks@hotmail.com
}

\begin{abstract}
RESUMEN
Los tiburones y las rayas se clasifican dentro de la subclase Elasmobranchii (elasmobranquios) y sirven como hospederos de una gran variedad de parásitos, particularmente helmintos. A la fecha, 516 especies de tiburones y 636 especies de rayas se han reportado para diferentes partes del mundo. El propósito de este trabajo es dar a conocer información sobre los registros de tiburones y rayas en las costas del Océano Pacífico mexicano y los registros de sus helmintos reportados. Resultados obtenidos, exhiben que 102 especies de elasmobranquios se han reportado para las costas del Océano Pacífico mexicano: 55 especies de tiburones y 47 especies de rayas. El registro helmintológico exhibe que sólo en el $36 \%$ de especies de tiburones y en el $55 \%$ de especies de rayas se han realizado reporte de helmintos. En especies de tiburones se han reportado: seis especies de digéneos, tres especies de monogéneos, 31 especies de céstodos y una especie de nemátodo. En contraste, en especies de rayas se han reportado: ocho especies de digéneos, 15 especies de monogéneos, 65 especies de céstodos, 2 especies de nemátodos y una especie de hirudíneo. Adicionalmente, el presente estudio plasma la distribución general de las especies de elasmobranquios y de helmintos, para denotar que en gran parte de las costas del Pacífico mexicano se carecen de estudios helmintológicos en los elasmobranquios con distribución en el litoral del territorio nacional.
\end{abstract}

Palabras clave: Elasmobranquios, helmintos, Pacífico mexicano, rayas, tiburones.

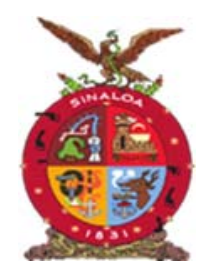

XVIII Congreso Internacional XXIV Congreso Nacional de Ciencias ambientales
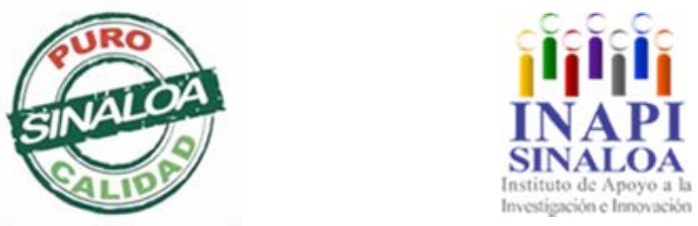

Mazatlán, Sinaloa 3-7 junio 2019

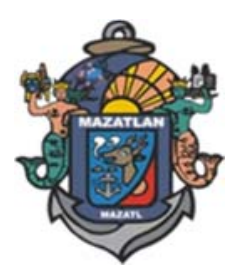

Recursos Naturales, Ecosistemas y Deterioro Ambiental 

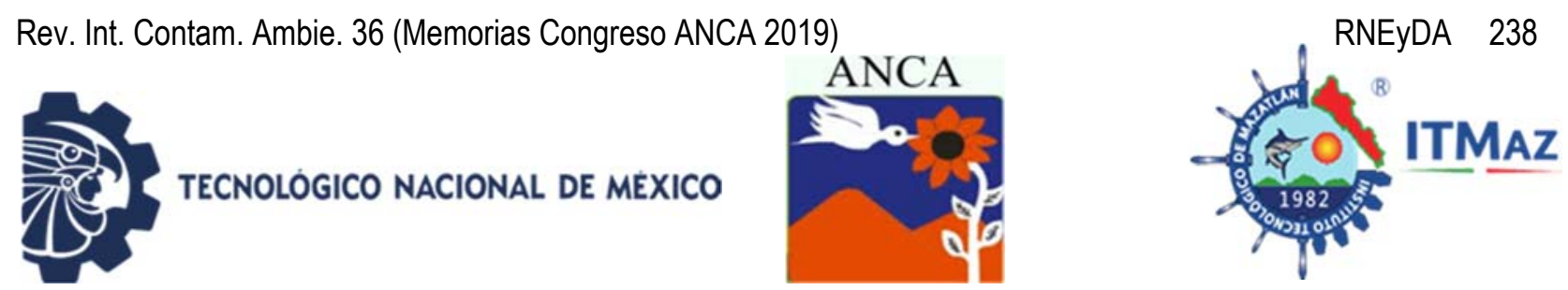

\title{
Records of the Distribution of sharks and rays (Elasmobranchs) in the coasts of the Mexican Pacific and its Helminths
}

\author{
Zaragoza Tapia F, Monks S*, Pulido Flores G \\ Centro de Investigaciones Biológicas. \\ Universidad Autónoma del Estado de Hidalgo. \\ Apartado Postal 1-10, C.P. 42001, Pachuca, Hidalgo, México \\ *scottmonks@hotmail.com
}

\begin{abstract}
Sharks and rays are classified within the subclass Elasmobranchii (Elasmobranchii) and serve as hosts for a great variety of parasites, particularly helminths. To date, 516 species of sharks and 636 species of rays have been reported from different parts of the world. The purpose of this work was to gather information from the literature about the records of sharks and rays in the Mexican coasts of the Pacific Ocean and records of their helminths. Results of the study show that 102 species of elasmobranchs have been reported from the Pacific coast of México: 55 species of shark and 47 species of ray. The helminthological record shows that only $36 \%$ of species of shark and $55 \%$ of rays have been studied for helminths. In species of sharks six species of digene, three species of monogene, 31 species of cestode, and one species of nematode has been reported. In contrast, in species of rays there are reports of eight species of digene, 15 species of monogene, 65 species of cestode, two species of nematode, and one species of hirudinea. Additionally, when the general distribution of species of elasmobranch and helminths was mapped, it was obvious that in a large part of the Mexican Pacific coast, helminthological studies are lacking for many species of elasmobranch. Much more study is needed discover the true biodiversity of these fascinating groups.
\end{abstract}

Keywords: Elasmobranchs, helminths, Pacific Coast, rays, sharks

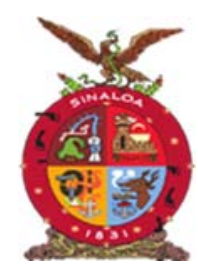

XVIII Congreso Internacional XXIV Congreso Nacional de Ciencias ambientales

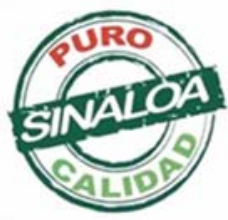

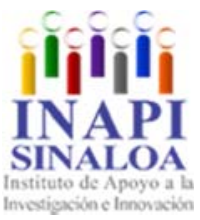

Mazatlán, Sinaloa 3-7 junio 2019

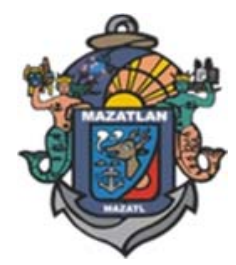

Recursos Naturales, Ecosistemas y Deterioro Ambiental 

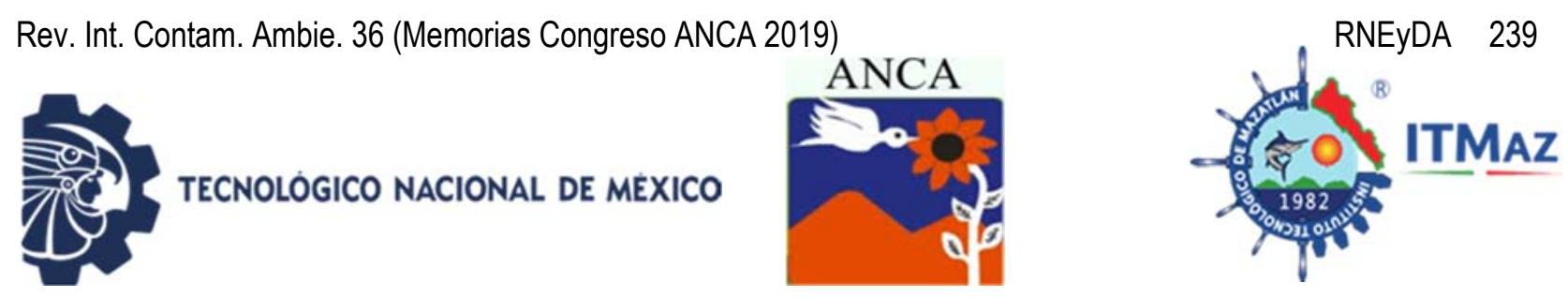

\title{
Composición y diversidad de la flora leñosa del bosque de Abies religiosa del Santuario de Agua Corral de Piedra, en las faldas del Nevado de Toluca
}

\author{
Zepeda Gómez C¹, Burrola Aguilar C², Estrada Zúñiga $\mathrm{ME}^{2}$ \\ ${ }^{1}$ Facultad de Ciencias. Universidad Autónoma del Estado de México \\ ${ }^{2}$ Centro de Investigación en Recursos Bióticos. \\ Universidad Autónoma del Estado de México \\ *zepedacar@yahoo.com.mx
}

\begin{abstract}
RESUMEN
Se determinó la composición florística y las diversidades de las clases naturales de tamaño de las plantas leñosas del bosque de oyamel (Abies religiosa) de la zona de estudio en las faldas del volcán Nevado de Toluca, a través de una caracterización estructural de los árboles y arbustos vivos en 17 zonas muestrales analizadas de mayo-noviembre de 2016. Se identificaron 36 especies de plantas leñosas pertenecientes a 16 familias y 29 géneros con un porcentaje de completitud cercano al $90 \%$. Se encontraron $44.5 \%$ de arbustos, $47.3 \%$ árboles y $8.2 \%$ arbustos-arboles. Los brinzales (circunferencia tallo $\leq 6 \mathrm{~cm}$, altura $<150 \mathrm{~cm}$ ) y latizales (circunferencia entre $\geq 6-\leq 25 \mathrm{~cm}$ ) tuvieron la mayor riqueza, pero en los brinzales y fustales ( $\geq 25 \mathrm{~cm}$ circunferencia) el inventario fue más completo. Las curvas de acumulación de taxa observados y esperados sugieren muestras y colecciones adicionales. Las especies presentes en 1-2 muestras representaron $<20 \%$ de la riqueza observada. La familia Asteraceae fue la más diversa, Lamiaceae y Pinaceae fueron las segundas familias más dominantes. La zona de estudio tiene una flora leñosa rica (índice de Margalef) y una alta diversidad (Indices de Fisher y Shannon). Los brinzales fueron el grupo más rico y diverso de las tres categorías; el valor de uniformidad y el índice de Simpson mostraron una mayor homogeneidad para la abundancia de brinzales y fustales. La similitud florística más alta fue entre brinzales y latizales. Se discuten los mecanismos que determinan la heterogeneidad ambiental y sus repercusiones sobre los patrones de riqueza y diversidad.
\end{abstract}

Palabras clave: Oyamel, bosque templado, regeneración, brinzales, latizales.

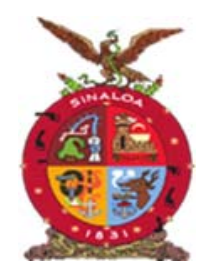

XVIII Congreso Internacional XXIV Congreso Nacional de Ciencias ambientales
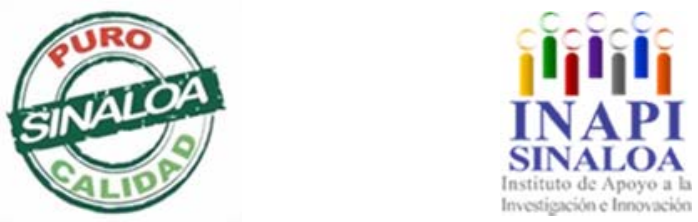

Mazatlán, Sinaloa 3-7 junio 2019

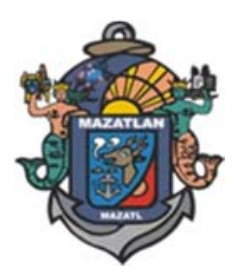

Recursos Naturales, Ecosistemas y Deterioro Ambiental 

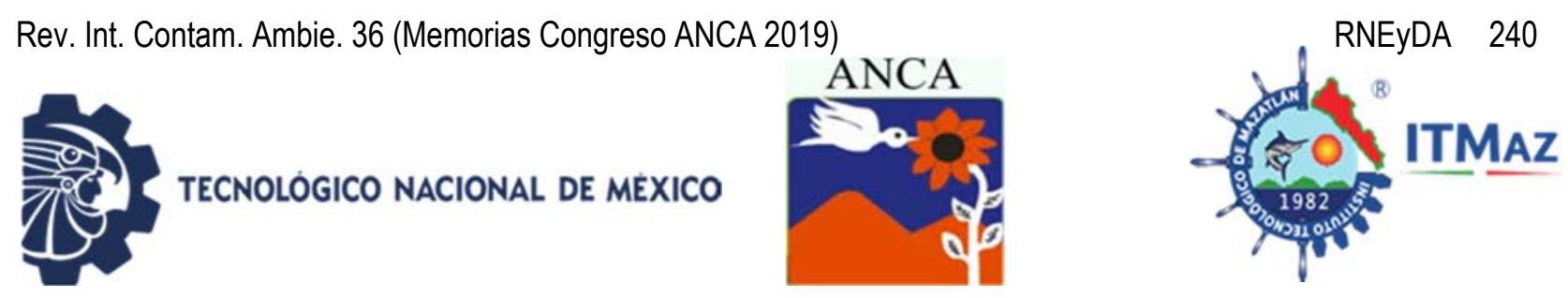

\title{
Composition and diversity of the woody flora in Abies religiosa forest at Santuario de Agua Corral de Piedra, in Nevado de Toluca foothills
}

\author{
Zepeda Gómez C*1, Burrola Aguilar C², Estrada Zúñiga $\mathrm{ME}^{2}$ \\ ${ }^{1}$ Facultad de Ciencias. Universidad Autónoma del Estado de México \\ ${ }^{2}$ Centro de Investigación en Recursos Bióticos. \\ Universidad Autónoma del Estado de México \\ *zepedacar@yahoo.com.mx
}

\begin{abstract}
Floristic composition and diversity were determined on natural size classes of Oyamel woody plants (Abies religiosa) in the foothills of the Nevado de Toluca volcano, through a structural characterization of trees and live bushes in 17 sample zones analyzed From May to November 2016. Were identified 36 woody plants species from 16 families and 29 genera, with a percentage of completeness close to $90 \%$. Forty-four and five percent of shrubs, $47.3 \%$ trees and $8.2 \%$ shrubstrees were found. The thickets (stem circumference $\leq 6 \mathrm{~cm}$, height $<150 \mathrm{~cm}$ ) and saplings (circumference between $\geq 6-\leq 25 \mathrm{~cm}$ ) had the greatest richness, but in the saplings and poles ( $\geq 25 \mathrm{~cm}$ circumference) the inventory was more complete. The observed and expected taxa accumulation curves suggest samples and additional collections. Species present in 1-2 samples represented $<20 \%$ of the observed richness. The Asteraceae family was the most diverse, Lamiaceae and Pinaceae were the second most dominant families. The study area has a rich woody flora (Margalef index) and a high diversity (Fisher and Shannon indexes). The saplings were the richest and most diverse group of the three categories; the uniformity value and the Simpson index showed a greater homogeneity for the abundance of thickets and poles. The highest floristic similarity was between thickets and saplings. The mechanisms that determine environmental heterogeneity and its repercussions in richness and diversity are discussed.
\end{abstract}

Keywords: Oyamel, temperate forest, regeneration, thickets, saplings.

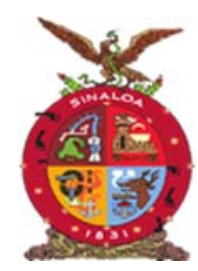

XVIII Congreso Internacional XXIV Congreso Nacional de Ciencias ambientales

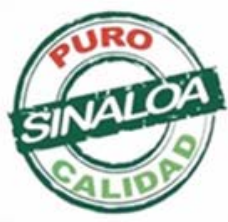

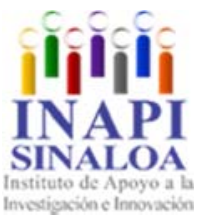

Mazatlán, Sinaloa 3-7 junio 2019

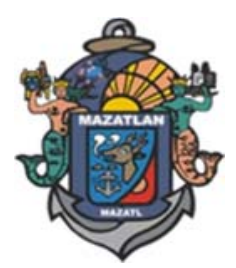

Recursos Naturales, Ecosistemas y Deterioro Ambiental 


\section{REVista INTernacional de}

\section{CONTAMinación \\ AMBIEntal \\ volumen 36, 2020}

http://www.revistas.unam.mx/index.php/rica/

VII Tecnología y Biotecnología para el Tratamiento de Contaminantes y Biorremediación

ACademia Nacional de Ciencias Ambientales

XVIII CONGRESO INTERNACIONAL

XXIV CONGRESO NACIONAL

De Ciencias ambientales

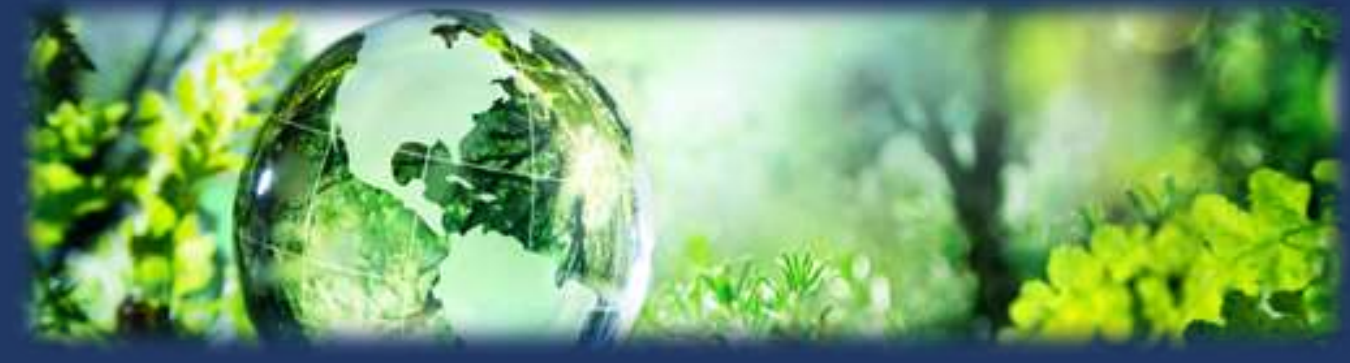

Maratláll, Sinaloa

ila Perla del Pacííco!

03-07 Junio/2019 

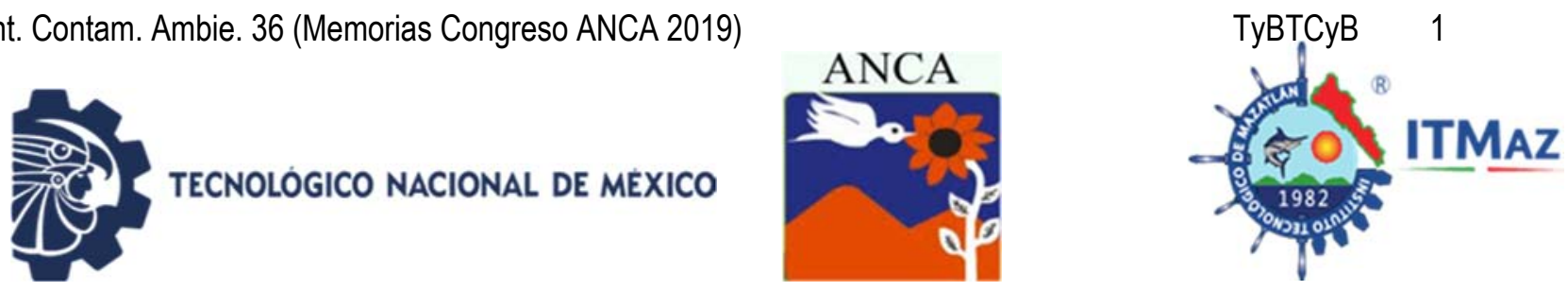

\title{
Diseño y producción de nanopartículas de cromo sintetizadas por biorreducción usando lirio acuático Eichhornia crassipes
}

\author{
Abarca Pérez $\mathrm{A}^{1^{*}}$, Rosano Ortega $\mathrm{G}^{1}$, Bedolla Hernández $\mathrm{M}^{2}$, \\ Agüelles Hernández $\mathrm{E}^{1}$, Sánchez Ruiz $\mathrm{F}^{1}$ \\ ${ }^{1}$ Facultad de Ingeniería Ambiental. UPAEP, Puebla, Puebla \\ ${ }^{2}$ Tecnológico de Apizaco. Tecnológico Nacional de México. \\ Conurbado Apizaco, Tzompantepec, Tlaxcala \\ *angela.abarca@upaep.edu.mx
}

\section{RESUMEN}

En este trabajo se presenta el diseño y síntesis de nanopartículas de cromo (CrNPs) inocuas ( $\mathrm{Cr}(\mathrm{III})$ y $\mathrm{Cr}(0)$ ), mediante el método de biorreducción utilizando lirio acuático Eichhornia crassipes. Las CrNPs se utilizarán como material de aporte en un método alternativo de cromado por electrodeposición, donde se sustituye el baño electrolítico convencional por una solución acuosa de CrNPs reduciendo los impactos del cromado convencional. Para el diseño de la síntesis se utilizó modelado y simulación computacional para evaluar la relación de los parámetros tamaño-forma-estructura con las propiedades mecánicas superficiales asociadas a las CrNPs; obteniendo los valores necesarios para la elaboración de recubrimientos superficiales nanoestructurados. Los resultados muestran que CrNPs de $40 \mathrm{~nm}$ de diámetro, forma esférica y estructura cúbica centrada en el cuerpo (CCC) presentan una dureza de $10.652 \mathrm{GPa}$ y $5.713 \mathrm{GPa}$ para $\mathrm{Cr}$ y el recubrimiento de $\mathrm{Cr}-\mathrm{Fe}$ respectivamente, un trabajo de adhesión de $3.1268 \mathrm{~J} / \mathrm{m}^{2}$, y una fuerza de adhesión de $1.88656 \times 10^{8} \mathrm{~N} / \mathrm{m}^{2}$; equivalentes a las obtenidas para cromado duro industrial. En la síntesis de CrNPs se utilizó un método extracelular utilizando Eichhornia crassipes. Se encontraron nanopartículas de $\mathrm{Cr}^{0}(53 \%)$ y $\mathrm{Cr}_{2} \mathrm{O}_{3}(43 \%)$ con un tamaño de cluster de $39 \pm 7.8$ $\mathrm{nm}$ con forma esférica. Para la caracterización de CrNPs se utilizó espectroscopia UV-visible, microscopía electrónica de transmisión y microscopia electrónica de barrido para determinar tamaño, forma y estructura de las CrNPs. Finalmente, se realizó una prueba de electrodeposición de las CrNPs biosintetizadas sobre un sustrato de hierro y se confirmó visualmente el recubrimiento superficial nanoestructurado.

Palabras clave: Simulación atómica, nanopartículas, cromo, recubrimiento superficial nanoestructurado, electrodeposición.

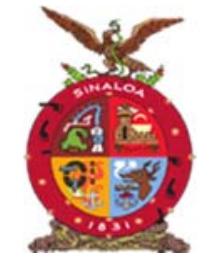

XVIII Congreso Internacional XXIV Congreso Nacional de Ciencias ambientales

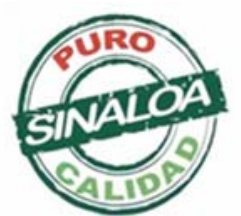

Mazatlán, Sinaloa 3-7 junio 2019
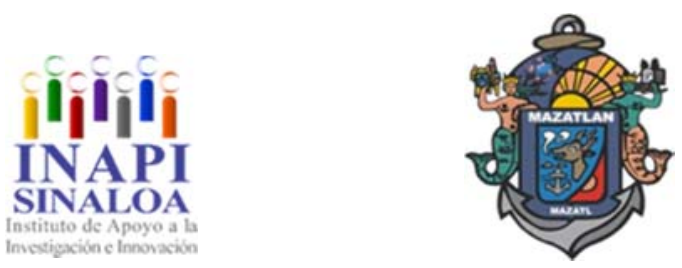

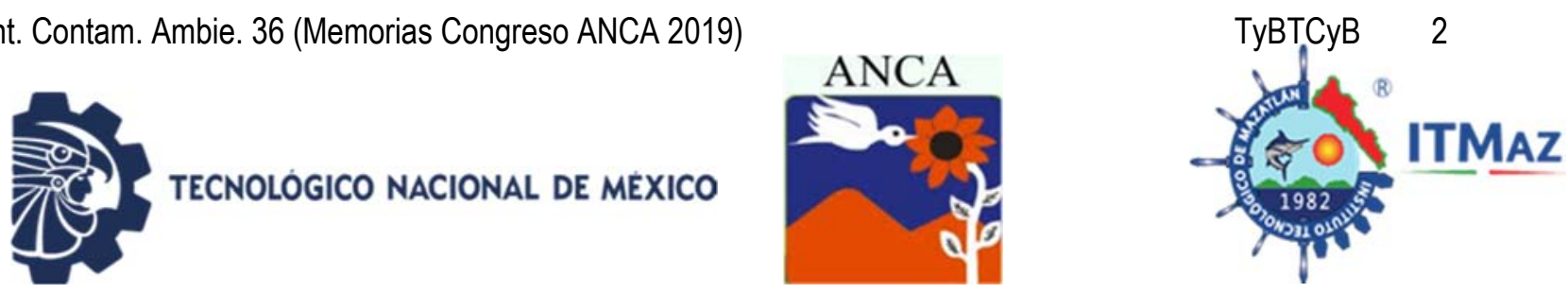

\title{
Design and production of synthesized chromium nanoparticles by means of biorreduction using water hyacinth Eichhornia crassipes
}

\author{
Abarca Pérez $\mathrm{A}^{1^{*}}$, Rosano Ortega $\mathrm{G}^{1}$, Bedolla Hernández $\mathrm{M}^{2}$, \\ Agüelles Hernández $\mathrm{E}^{1}$, Sánchez Ruiz $\mathrm{F}^{1}$ \\ ${ }^{1}$ Facultad de Ingeniería Ambiental. UPAEP, Puebla, Puebla \\ ${ }^{2}$ Tecnológico de Apizaco. Tecnológico Nacional de México. \\ Conurbado Apizaco, Tzompantepec, Tlaxcala \\ *angela.abarca@upaep.edu.mx
}

\begin{abstract}
In this work, the design and synthesis of CrNPs are presented, by means of bioreduction using water hyacinth (Eichhornia crassipes). The CrNPs will be used as a filler material in an alternative chromium method using electrodeposition, where the conventional electrolytic bath is replaced by an aqueous solution of CrNPs, reducing the impacts of conventional chrome plating. For the design of the synthesis, modeling and computational simulation was used to evaluate the relation of the size-shape-structure parameters with the superficial mechanical properties associated with the CrNPs; obtaining the necessary values for the preparation of nanostructured surface coatings. The results show that CrNPs of $40 \mathrm{~nm}$ diameter, spherical shape and body centered cubic structure (CCC) have a hardness of $10,652 \mathrm{GPa}$ and $5,713 \mathrm{GPa}$ for $\mathrm{Cr}$ and the $\mathrm{Cr}-\mathrm{Fe}$ coating respectively, an adhesion work of $3.1268 \mathrm{~J} / \mathrm{m}^{2}$, and an adhesion force of $1.88656 \times 10^{8} \mathrm{~N} / \mathrm{m}^{2}$; equivalent to those obtained for industrial hard chrome plating. In the synthesis of CrNPs, an extracellular method using Eichhornia crassipes was used. $\mathrm{Cr}^{0}(53 \%)$ and $\mathrm{Cr}_{2} \mathrm{O}_{3}(43 \%)$ nanoparticles with a cluster size of $39 \pm$ $7.8 \mathrm{~nm}$ with a spherical shape were found. For the characterization of CrNPs, UVvisible spectroscopy, transmission electron microscopy and scanning electron microscopy were used to determine the size, shape and structure of the CrNPs. Finally, an electrodeposition test of the biosynthesized CrNPs was performed on an iron substrate and the nanostructured surface coating was visually confirmed.
\end{abstract}

Keywords: Atomic simulation, biosynthesized chromium oxide nanoparticles, nanostructured surface coatings, electrodeposition.

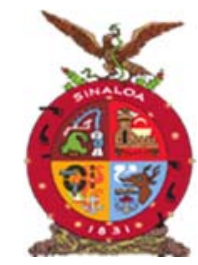

XVIII Congreso Internacional XXIV Congreso Nacional de Ciencias ambientales

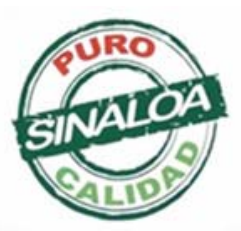

Mazatlán, Sinaloa 3-7 junio 2019
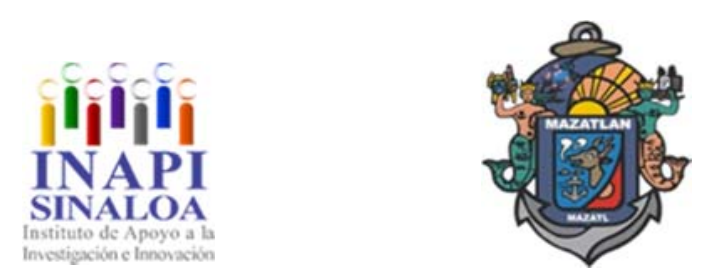

Tecnología y Biotecnología para el Tratamiento de Contaminantes y Biorremediación 

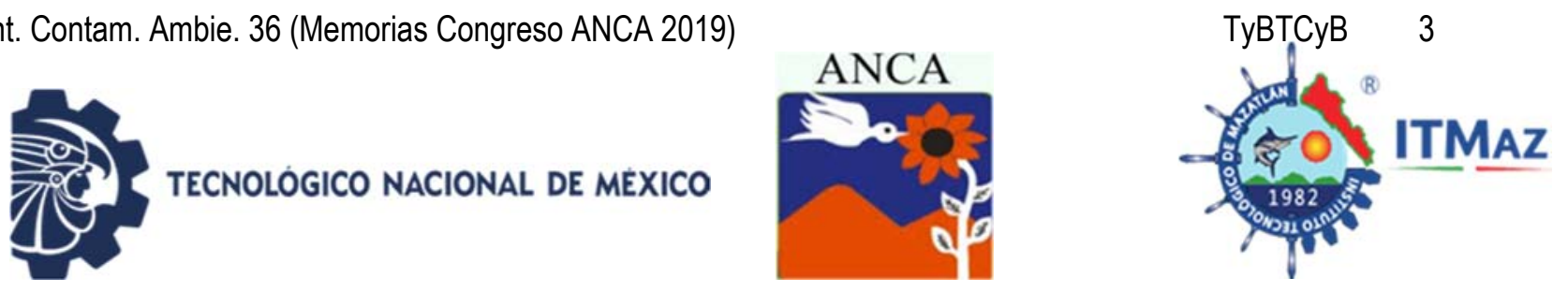

\title{
Degradación de gasolina por hongos extraídos de suelo contaminado por gasolina de alto octanaje de la región de Tlahuelilpan Hidalgo
}

\author{
Aguilar Santana $\mathrm{M}^{*}$, Cruz Jiménez A \\ Benemérita Universidad Autónoma de Puebla \\ *Karen.ambiental16@gmail.com
}

\begin{abstract}
RESUMEN
Los derrames de hidrocarburo ocurren de manera accidental debido a errores del personal, falta de mantenimiento $u$ otras causas como desastres naturales 0 actos deliberados, causando problemas sociales, económicos y ambientales. La biorremediación con el uso de microorganismos como los hongos desempeña un papel importante en la eliminación de contaminantes en suelos afectados por derrames de gasolina, crudo o derivados. El ducto Tuxpan-Tula de PEMEX explotó el pasado 18 de enero del presente año en la localidad de San Primitivo, municipio de Tlahuelilpan estado de Hidalgo debido a una toma clandestina de combustible de alto octanaje se recolectó 5 muestras de suelo de diferentes puntos. Mediante el método de disoluciones seriadas se aislaron un total de 36 cepas de hongos a partir del suelo en los cultivos sembrados en medios sólidos y líquidos adicionados con gasolina, se seleccionaron 12 cepas para realizar una cinética degradativa de gasolina en periodos de tiempo diferentes $(0,8,16$ y 32 días). En cada tiempo se evaluó mediante la espectrofotometría infrarroja las fracciones de gasolina degradada. Las cepas en mayor número pertenecen a Penicillium, Ttrichoderma, Chrysosorium, Torula y Cladophialophora. Hasta el momento la cepa M2D2 ha presentado la mejor cinética degradativa de la gasolina, al degradar una mayor fracción de gasolina en las frecuencias entre 3000 y $3500 \mathrm{~cm}^{-1}$ que corresponden a los grupo de alcoholes y aminas; y las frecuencias que se encuentran entre 1500 y $2000 \mathrm{~cm}^{-1}$ para los grupos funcionales aromáticos, alquenos, anillos bencénicos.
\end{abstract}

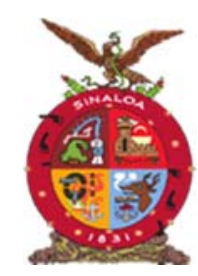

XVIII Congreso Internacional XXIV Congreso Nacional de Ciencias ambientales

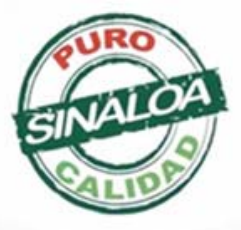

Mazatlán, Sinaloa 3-7 junio 2019
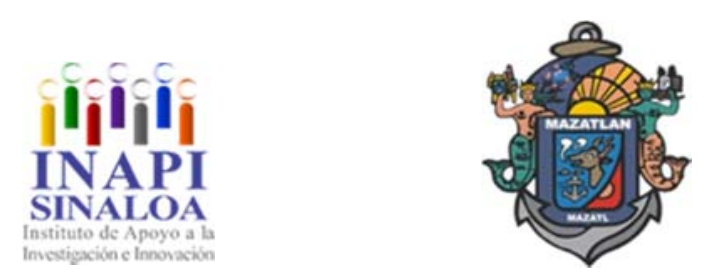

Tecnología y Biotecnología para el Tratamiento de Contaminantes y Biorremediación 

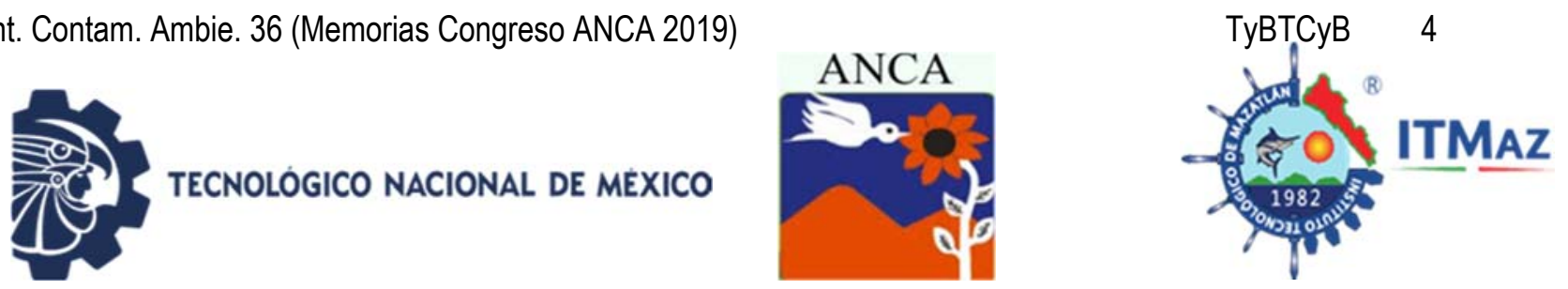

\title{
Degradation of gasoline by fungi extracted from soil contaminated by high octane gasoline from the Tlahuelilpan Hidalgo region
}

\author{
Aguilar Santana M*, Cruz Jiménez A \\ Benemérita Universidad Autónoma de Puebla \\ *Karen.ambiental16@gmail.com
}

\begin{abstract}
Oil spills occur accidentally due to personnel errors, lack of maintenance or other causes such as natural disasters or deliberate acts, causing social, economic and environmental problems. Bioremediation due to the use of microorganisms such as fungi plays an important role in the elimination of contaminants in soils affected by gasoline, crude oil spills or derivatives. The Tuxpan-Tula pipeline of PEMEX detonated on January 18 this year in the town of San Primitivo, municipality of Tlahuelilpan state of Hidalgo after a clandestine take of high octane fuel was collected 5 soil samples from different points, through the method of serial solutions a total of 36 strains were isolated. In cultures of solid and liquid media added with gasoline, 12 strains were selected to perform a gasoline degradation kinetic in different periods of time (0, 8, 16 and 32 days). At each time, fractions of degraded gasoline were evaluated by infrared spectrophotometry. The strains in greatest number belong to penicillium, trichoderma, chrysosorium, torula and Cladophialophora. So far the strain M2D2 has presented a greater degradation kinetics of gasoline by degrading a greater fraction of gasoline in the frequencies between 3000 and $3500 \mathrm{~cm}-1$ that correspond to the group of alcohols and amines; and the frequencies that are between 1500 and $2000 \mathrm{~cm}-1$ with aromatic functional groups, alkenes, benzene rings.
\end{abstract}

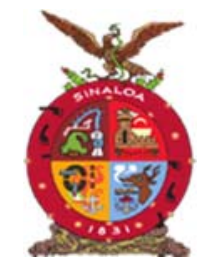

XVIII Congreso Internacional XXIV Congreso Nacional de Ciencias ambientales

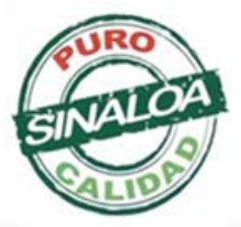

Mazatlán, Sinaloa 3-7 junio 2019
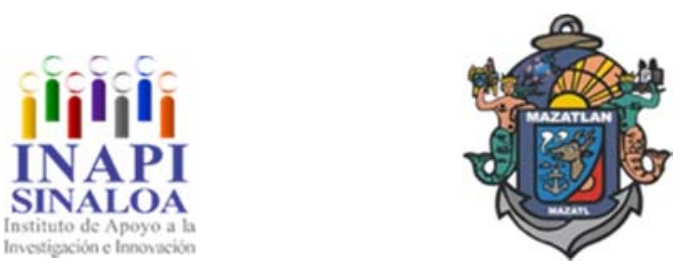

Tecnología y Biotecnología para el Tratamiento de Contaminantes y Biorremediación 

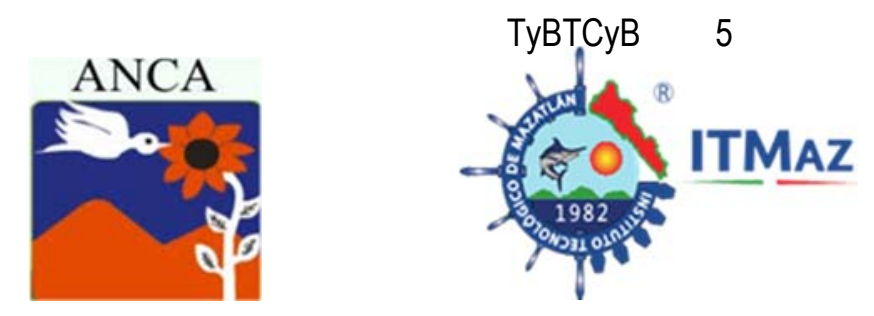

\title{
Remoción del colorante amarillo No. 5 mediante perlas de hidrogel de quitosano entrecruzadas con tripolifosfato de sodio
}

\author{
Alarcón Barrón $\mathrm{M}^{1}$, García Gaytán $\mathrm{B}^{1 *}$, Zavala Arce $\mathrm{RE}^{1}$, García Rivas $\mathrm{JL}^{1}$, \\ Vázquez Lepe $\mathrm{MO}^{2}$, Luna Barcenas $\mathrm{G}^{3}$ \\ ${ }^{1}$ Instituto Tecnológico de Toluca, Tecnológico Nacional de México. \\ Av. Tecnológico S/N. Col. Agrícola Bellavista, Metepec, Estado de México, \\ ${ }^{2}$ Centro Universitario de Ciencias Exactas e Ingenierías. \\ Universidad de Guadalajara. \\ Blvd. Marcelino García Barragán \# 1421, Esq. Calzada Olímpica, \\ Guadalajara, Jalisco, México, C.P. 44430 \\ ${ }^{3}$ Centro de Investigación y de Estudios Avanzados del IPN. Unidad Querétaro. Libramiento \\ Norponiente \# 2000, Fracc. Real de Juriquilla, Santiago de Querétaro, Querétaro, México, \\ C.P.76230 \\ *beatrizggmx@yahoo.com
}

\section{RESUMEN}

Uno de los principales problemas de contaminación del agua a nivel mundial es la descarga de aguas residuales con altas concentraciones de colorantes, reducen la penetración de la luz e inhiben la fotosíntesis de las plantas. El objetivo de este trabajo fue evaluar el porcentaje de remoción del colorante amarillo no.5, utilizando perlas de hidrogel de quitosano entrecruzado físicamente con tripolifosfato de sodio (TPP), trabajo que se realizó en el Instituto Tecnológico de Toluca de agosto 2017 a agosto 2018. Las perlas sintetizadas fueron caracterizadas mediante las técnicas de microscopía electrónica de barrido, espectroscopia de infrarrojo con transformada de Fourier (FTIR) y área específica. También se llevaron a cabo estudios cinéticos de equilibrio de adsorción del colorante a tres temperaturas, empleando perlas de hidrogel sintetizadas. Las microfotografías, muestran que las perlas obtenidas son más porosas en su interior que en la superficie externa. En el espectro de FTIR se corroboró tanto la presencia de los grupos funcionales del quitosano como el entrecruzamiento con el TPP mediante la señal a $1530 \mathrm{~cm}^{-1}$ correspondiente a la vibración N-O-P. El área específica obtenida en las perlas de hidrogel fue de 91.2 $\mathrm{m}^{2} / \mathrm{g}$ y el diámetro promedio del poro fue de $8.5931 \mathrm{~nm}$ entrando en la clasificación de los mesoporos. El tiempo de equilibrio se alcanzó a las $32 \mathrm{~h}$ con un $22 \%$ de remoción y saturación a $400 \mathrm{mg} / \mathrm{L}$ del colorante en el equilibrio. Las perlas sintetizadas nos permiten concluir que pueden ser empleadas para la remoción del colorante estudiado.

Palabras claves: Quitosano, colorante amarillo №. 5, hidrogel, adsorción, tripolifosfate de sodio.

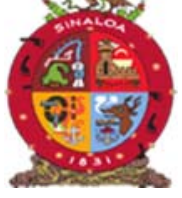

XVIII Congreso Internacional XXIV Congreso Nacional de Ciencias ambientales

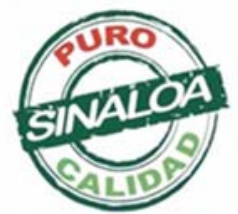

Mazatlán, Sinaloa 3-7 junio 2019
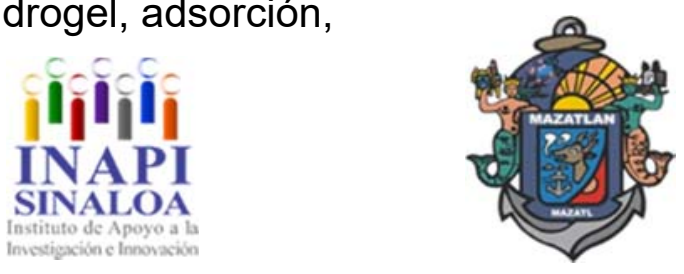

Tecnología y Biotecnología para el Tratamiento de Contaminantes y Biorremediación 

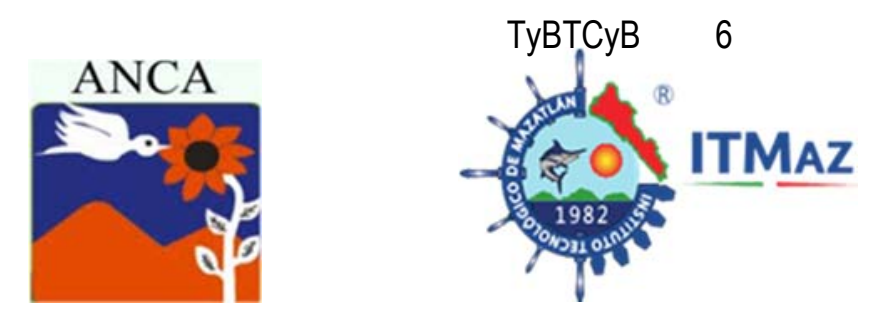

\title{
Removal of yellow dye no. 5 by chitosan hydrogel beads crosslinked with sodium tripolyphosphate
}

\author{
Alarcón Barrón $\mathrm{M}^{1}$, García Gaytán $\mathrm{B}^{1^{*}}$, Zavala Arce RE ${ }^{1}$, García Rivas $\mathrm{JL}^{1}$, \\ Vázquez Lepe $\mathrm{MO}^{2}$, Luna Barcenas $\mathrm{G}^{3}$ \\ ${ }^{1}$ Instituto Tecnológico de Toluca, Tecnológico Nacional de México. \\ Av. Tecnológico S/N. Col. Agrícola Bellavista, Metepec, Estado de México, \\ ${ }^{2}$ Centro Universitario de Ciencias Exactas e Ingenierías. \\ Universidad de Guadalajara. \\ Blvd. Marcelino García Barragán \# 1421, Esq. Calzada Olímpica, \\ Guadalajara, Jalisco, México, C.P. 44430 \\ ${ }^{3}$ Centro de Investigación y de Estudios Avanzados del IPN. Unidad Querétaro. \\ Libramiento Norponiente \# 2000, Fracc. Real de Juriquilla, Santiago de Querétaro, \\ Querétaro, México, C.P.76230 \\ *beatrizggmx@yahoo.com
}

\begin{abstract}
One of the main problems of water pollution worldwide is the discharge of wastewater with high concentrations of dyes, reducing light penetration and inhibiting photosynthesis of plants. Given the above the objective of this work was to evaluate the removal percentage of the yellow dye no. 5, using chitosan hidrogel beads physically crosslinking with sodium tripolyphosphate (TPP). This work was carried out at the Instituto Tecnológico de Toluca in the period August 2017 to August 2018. The beads synthesized were characterized using the techniques scanning electron microscopy, infrared spectroscopy with Fourier transform (FTIR) and specific area. Both kinetic and equilibrium adsorption studies of the yellow dye no. 5 were conducted at three temperatures with hydrogel beads synthesized. The micrographies show that the beads obtained are more porous inside than on its external surface. In the FTIR spectrum was corroborated both the functional groups of chitosan and the crosslinking with TPP by the signal at $1530 \mathrm{~cm}^{-1}$ corresponding to N-O-P vibration. The specific area obtained in the hydrogel beads was $91.2 \mathrm{~m}^{2} / \mathrm{g}$ and the average diameter of the pore was $8.5931 \mathrm{~nm}$ entering in the mesopores classification. The equilibrium time was reached at $32 \mathrm{~h}$ with $22 \%$ removal and saturation at $400 \mathrm{mg} / \mathrm{L}$ of the dye at equilibrium. The synthesized beads can be used for the removal of the dye studied.
\end{abstract}

Keywords: Chitosan, yellow no.5 dye, hydrogel, adsorption, sodium tripolyphosphate.

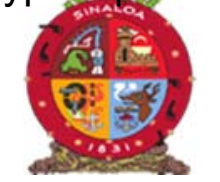

XVIII Congreso Internacional XXIV Congreso Nacional de Ciencias ambientales

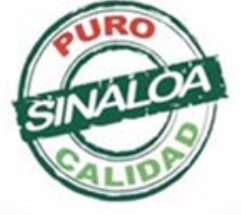

Mazatlán, Sinaloa 3-7 junio 2019

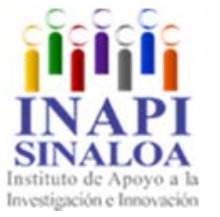

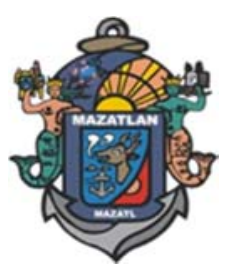

Tecnología y Biotecnología para el Tratamiento de Contaminantes y Biorremediación 

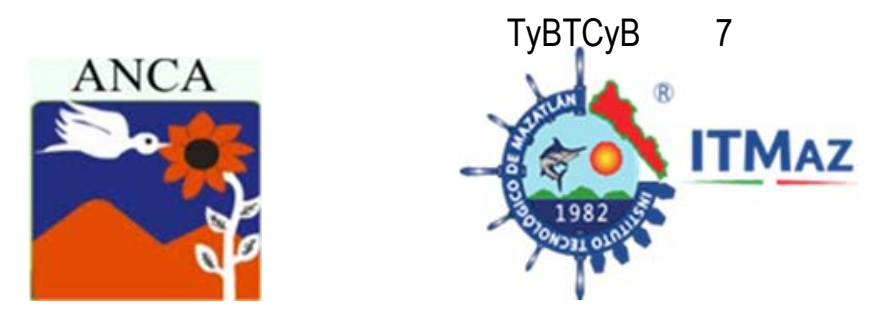

\title{
Uso de surfactantes de origen natural para la remoción de arsénico en modelos acuosos
}

\author{
Alcazar Medina $\mathrm{F}^{1}$, González Adame $\mathrm{R}^{1,2}$, Rodriguez Rosales $\mathrm{J}^{1^{*}}$, \\ Valle Cervantes $\mathrm{S}^{1}$ \\ ${ }^{1}$ Tecnológico de Durango. Tecnológico Nacional de México. \\ ${ }^{2}$ Cátedras CONACyT-TecNM/I.T. Durango. \\ Felipe Pescador 1830 Ote. Col. Nueva Vizcaya Durango, Dgo. México \\ *mdjrr1958@gmail.com
}

\begin{abstract}
RESUMEN
El arsénico es un elemento ubicuo que se encuentra en la corteza terrestre con una concentración variable en el suelo y el agua de la tierra. El arsénico siempre ha estado bajo el escáner debido a su toxicidad en los seres humanos. La contaminación por este elemento en el agua potable, amenaza gravemente a la población debido a su toxicidad por lo que es un elemento que debe ser removido. Este estudio se centró en determinar las condiciones óptimas para la remoción de arsénico en modelos de solución acuosa, mediante la Técnica de Aglomeración Esférica (TAE), mediante el uso de surfactantes de origen natural (biosurfactantes). Las condiciones operativas del SAT a temperatura ambiente fueron: $\mathrm{pH}$ inicial 7.5 y agitación constante $\omega=300 \mathrm{rpm}$. Los experimentos se realizaron bajo un diseño factorial $4^{2}$, distintas concentraciones de adsorbente $(0.1,0.075,0.05$ y $0.025 \mathrm{~g} / \mathrm{L})$ dosis de extracto de $(0.25-1.0 \mathrm{~g}$ de extracto/g de contaminante), y además se utilizaron dos extractos de diferentes especies de agave (Agave lechuguilla y Agave tequilana). Según el análisis estadístico, se observaron efectos significativos para las dosis de surfactante, la concentración inicial de adsorbente y su interacción. Todas las muestras alcanzaron una concentración residual que cumple totalmente con la regulación mexicana para la calidad del agua (NOM-127-SSA1-1994), ya que las eficiencia de remoción obtenida fueron superiores al $99 \%$. Por lo que se demostró la efectividad de los extractos de Agave tequilana y Agave lechuguilla para la remoción de arsénico en soluciones acuosas.
\end{abstract}

Palabras clave: Agave, biosurfactantes, saponinas, hidrofobización, aglomeración esférica, arsénico.

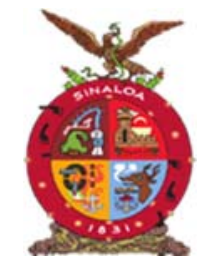

XVIII Congreso Internacional XXIV Congreso Nacional de Ciencias ambientales

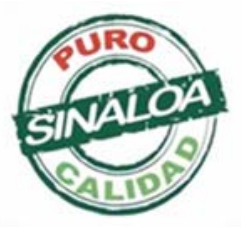

Mazatlán, Sinaloa 3-7 junio 2019
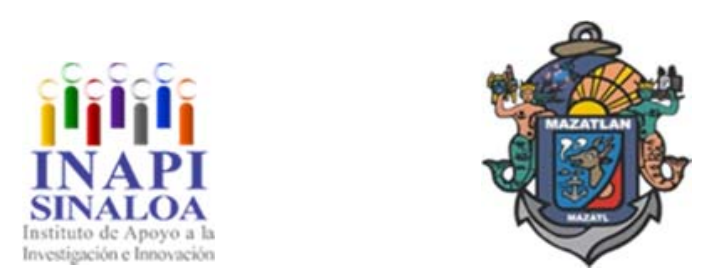

Tecnología y Biotecnología para el Tratamiento de Contaminantes y Biorremediación 

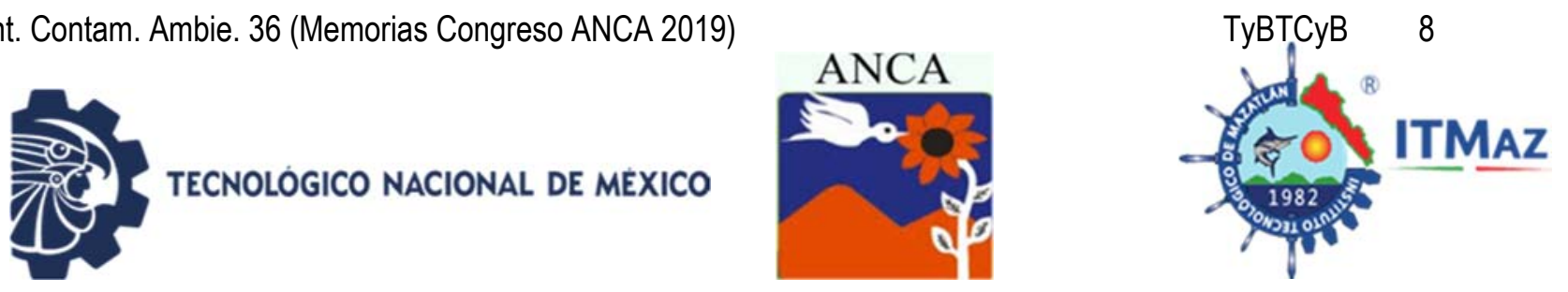

\title{
Use of surfactants of natural origin for the removal of arsenic in aqueous models
}

\author{
Alcazar Medina F¹, González Adame $\mathrm{R}^{1,2}$, Rodriguez Rosales $\mathrm{J}^{1^{*}}$, \\ Valle Cervantes $\mathrm{S}^{1}$ \\ ${ }^{1}$ Tecnológico de Durango. Tecnológico Nacional de México.I. \\ ${ }^{2}$ Cátedras CONACyT-TecNM/I.T. Durango. \\ Felipe Pescador 1830 Ote. Col. Nueva Vizcaya Durango, Dgo. México \\ *mdjrr1958@gmail.com
}

\begin{abstract}
Arsenic is a ubiquitous element that is found in the earth's crust with a variable concentration in the soil and water of the earth. Arsenic has always been under the scanner due to its toxicity in humans. Contamination by this element in drinking water, seriously threatens the population due to its toxicity so it is an element that must be removed. This study focused on determining the optimal conditions for arsenic removal in aqueous solution models, using the Spherical Agglomeration Technique (APR), through the use of naturally occurring surfactants (biosurfactants). The operating conditions of the SAT at room temperature were: initial $\mathrm{pH} 7.5$ and constant stirring $\omega=300 \mathrm{rpm}$. The experiments were carried out under a factorial design 42 , different concentrations of adsorbent $(0.1,0.075,0.05$ and $0.025 \mathrm{~g} / \mathrm{L})$ extract dose of $(0.25-1.0 \mathrm{~g}$ of extract/g of contaminant), and in addition two extracts of different species of agave (Agave lechuguilla and Agave tequilana). According to the statistical analysis, significant effects were observed for surfactant doses, initial adsorbent concentration and their interaction. All samples reached a residual concentration that fully complies with the Mexican regulation for water quality (NOM-127-SSA11994), since the removal efficiency obtained was greater than $99 \%$. Therefore, the effectiveness of the Agave tequilana and Agave lechuguilla extracts for the removal of arsenic in aqueous solutions was demonstrated.
\end{abstract}

Keywords: Agave, biosurfactants, saponins, hydrophobicization, spherical agglomeration, arsenic

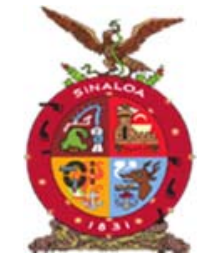

XVIII Congreso Internacional XXIV Congreso Nacional de Ciencias ambientales

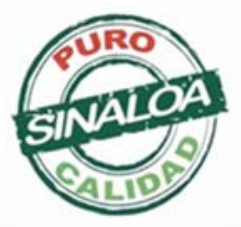

Mazatlán, Sinaloa 3-7 junio 2019
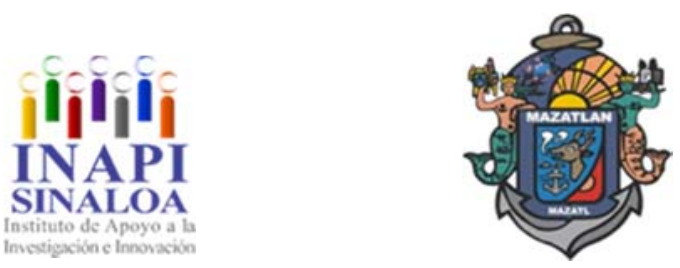

Tecnología y Biotecnología para el Tratamiento de Contaminantes y Biorremediación 

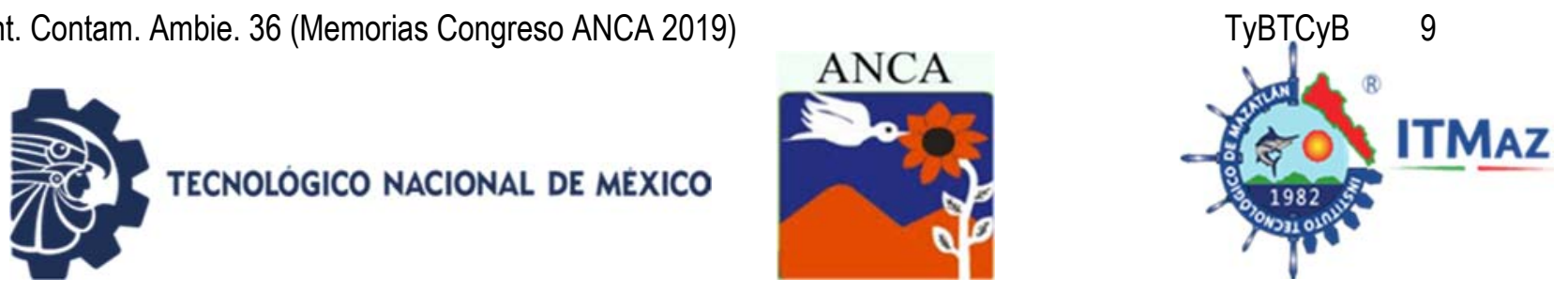

\title{
Aislante térmico obtenido de una mezcla de poliestireno expandido reciclado, reforzado con cascarón de huevo
}

\author{
Álvarez Contreras $C A^{1}$, García Cruz $R^{2}$, Pérez Méndez $\mathrm{AR}^{2 *}$, \\ Morales García $\mathrm{JM}^{3}$, Reyes Barajas $\mathrm{S}^{3}$ \\ ${ }^{1}$ Ingeniería Ambiental.Instituto Tecnológico Superior de Misantla (ITSM) \\ ${ }^{2}$ Ingeniería Industrial (ITSM) \\ ${ }^{3}$ Ingeniería Electromecánica (ITSM). \\ Km. 1.8 Carretera a Loma del Cojolite, Misantla, Veracruz, México \\ *arperezm@itsm.edu.mx
}

\begin{abstract}
RESUMEN
Los residuos sólidos urbanos son el último eslabón de uso, de cualquier producto siendo la generación de estos el principal ingrediente para la producción de gases que generan el efecto invernadero. En México se generan 112,000 toneladas diarias de residuos sólidos de los cuales solo se recolecta el $87 \%$ y solo el $64 \%$ se deposita en rellenos sanitarios y sitios controlados, siendo el reciclaje una opción que solo posee del 8 al 12\%. Thermo Egg, es una mezcla conglomerada de poliestireno expandido (unicel), reciclado y reforzada con cascarón de huevo pulverizado, Esta invención se caracteriza principalmente por la obtención de un material térmico aislante a partir del poliestireno expandido reforzado con el cascarón de huevo, ambos materiales reciclados. El proceso para la obtención de dicho material termo aislante inicia desde el mezclado de las materias primas, pasando por el moldeado y secado hasta llegar a un producto alcanzando propiedades térmicas similares a las de la baquelita. Con una resistencia mecánica: $96.4 \mathrm{~kg} / \mathrm{cm}^{2}$, un\% de deformación: 23.54 y un módulo de elasticidad de $627.77 \mathrm{~kg} / \mathrm{cm}^{2}$. Con un valor de conductividad térmica de $0.232 \mathrm{~W} /\left(\mathrm{m}^{*} \mathrm{~K}\right)$. Thermo Egg, sobrepasa las propiedades mecánicas del poliestireno expandido original, en deformación de 10 al $30 \%$, de 13 a $90 \mathrm{~kg} / \mathrm{cm}^{2}$ de resistencia mecánica y una conductividad térmica, para el poliestireno de $0,03808 \mathrm{~W} /\left(\mathrm{m}^{*} \mathrm{~K}\right)$ en comparación de $0.232 \mathrm{~W} /\left(\mathrm{m}^{*} \mathrm{~K}\right)$, por lo tanto, se convierte en una propuesta para aislamientos térmico.
\end{abstract}

Palabras clave: Poliestireno expandido, cascarón de huevo, reciclado, termoaislante, mezcla.

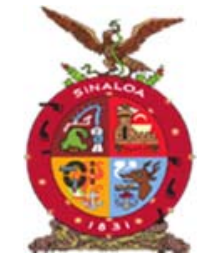

XVIII Congreso Internacional XXIV Congreso Nacional de Ciencias ambientales

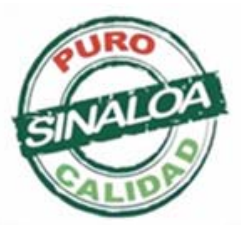

Mazatlán, Sinaloa 3-7 junio 2019
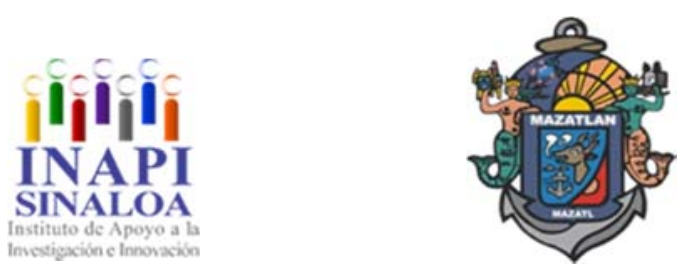


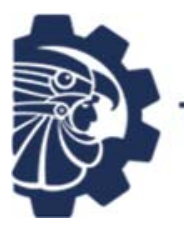

TECNOLOGICO NACIONAL DE MEXICO
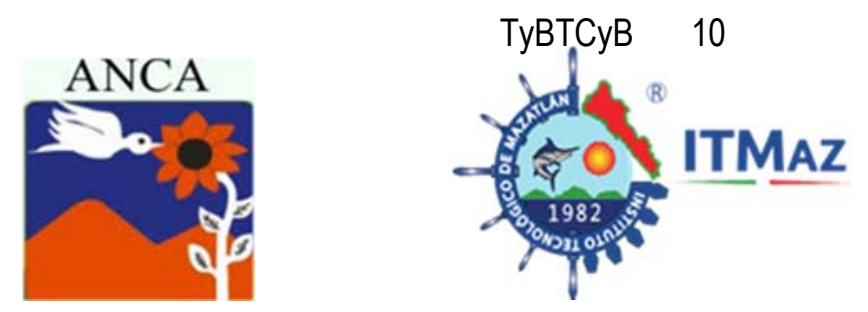

Thermal insulator obtained from a mixture of recycled expanded polystyrene, reinforced with egg shell

\author{
Álvarez Contreras $\mathrm{CA}^{1}$, García Cruz $\mathrm{R}^{2}$, Pérez Méndez $\mathrm{AR}^{3^{*}}$, \\ Morales García $\mathrm{JM}^{4}$, Reyes Barajas $\mathrm{S}^{5}$ \\ ${ }^{1}$ Ingeniería Ambiental.Instituto Tecnológico Superior de Misantla (ITSM) \\ ${ }^{2}$ Ingeniería Industrial (ITSM) \\ ${ }^{3}$ Ingeniería Electromecánica (ITSM). \\ Km. 1.8 Carretera a Loma del Cojolite, Misantla, Veracruz, México \\ *arperezm@itsm.edu.mx
}

\begin{abstract}
Urban solid waste is the last link of use of any product, the generation of these being the main ingredient for the production of gases that generate the greenhouse effect. In Mexico, 112,000 tons of solid waste are generated daily, of which only $87 \%$ is collected and only $64 \%$ is deposited in sanitary landfills and controlled sites, recycling being an option that only has 8 to $12 \%$. Thermo Egg, is a conglomerate mixture of expanded polystyrene (unicel), recycled and reinforced with powdered eggshell. This invention is mainly characterized by obtaining an insulating thermal material from expanded polystyrene reinforced with the eggshell, both materials recycled The process for obtaining said thermo insulating material starts from the mixing of the raw materials, through molding and drying until it reaches a product reaching thermal properties similar to those of bakelite. With a mechanical resistance: $96.4 \mathrm{~kg} / \mathrm{cm}^{2}$, a\% deformation: 23.54 and an elastic modulus of $627.77 \mathrm{~kg} / \mathrm{cm}^{2}$. With a thermal conductivity value of $0.232 \mathrm{~W} /\left(\mathrm{m}{ }^{*} \mathrm{~K}\right)$. Thermo Egg, exceeds the mechanical properties of the original expanded polystyrene, in deformation of 10 to $30 \%$, of 13 to $90 \mathrm{~kg} / \mathrm{cm}^{2}$ of mechanical resistance and thermal conductivity, for the polystyrene of $0.03808 \mathrm{~W} /\left(\mathrm{m}{ }^{*} \mathrm{~K}\right)$ in Comparison of $0.232 \mathrm{~W} /\left(\mathrm{m}{ }^{*} \mathrm{~K}\right)$, therefore, becomes a proposal for thermal insulation.
\end{abstract}

Keywords: Expanded polystyrene, eggshell, recycled, heat insulating, mixing.

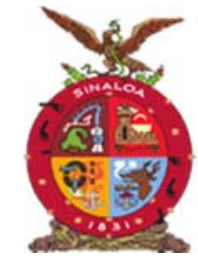

XVIII Congreso Internacional XXIV Congreso Nacional de Ciencias ambientales

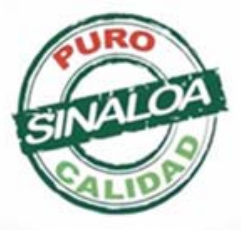

Mazatlán, Sinaloa 3-7 junio 2019
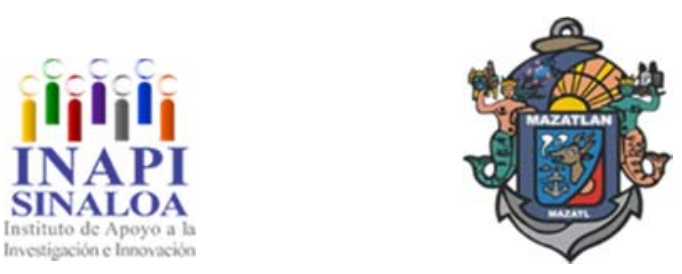

Tecnología y Biotecnología para el Tratamiento de Contaminantes y Biorremediación 

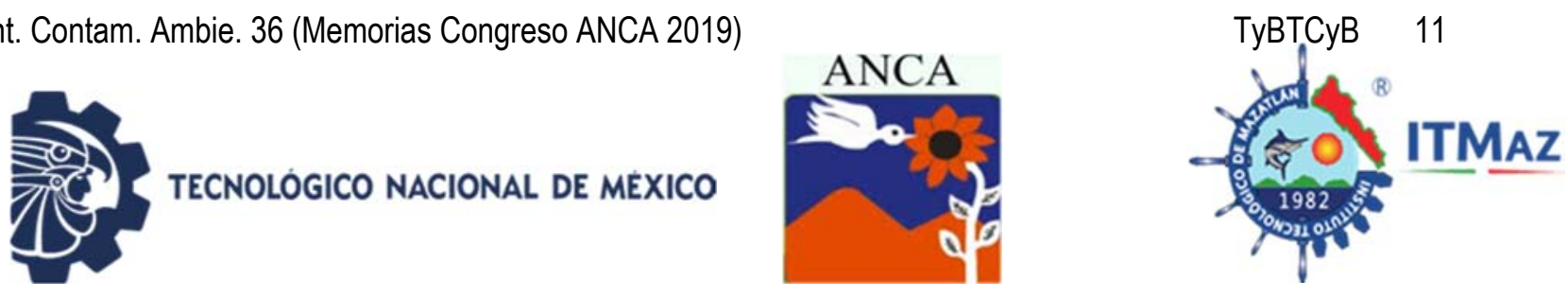

\title{
Biocompatibilidad de poli- $\varepsilon$-caprolactona-fibras de plata
}

\author{
Álvarez Ortega O, Meléndez Estrada I, Cuevas González J, \\ Donohué Cornejo A, Espinoza Cristóbal L, Reyes López SY* \\ Instituto de Ciencias Biomédicas. Universidad Autónoma de Ciudad Juárez. \\ Envolvente del PRONAF y Estocolmo S/N, Ciudad Juárez, Chih., México \\ *simon.reyes@uacj.mx
}

\section{RESUMEN}

En la actualidad, una de las amenazas más alarmantes para la salud pública es la resistencia a los agentes antimicrobianos causada por la emisión de medicamentes y sustancias químicas en el ambiente. Se ha reportado evidencia de liberación de compuestos antimicrobianos al ambiente en las tuberías de hogares, complejos farmacéuticos, hospitales y drenajes agrícolas, esto ha impulsado el surgimiento de cepas más resistentes. De igual manera, el uso indiscriminado de antibióticos ha generado una respuesta de supervivencia en las bacterias, capacitándolas para evadir con eficiencia la acción bactericida. Actualmente la nanotecnología es percibida como una tecnología prometedora al ofrecernos materiales con diversas propiedades únicas gracias a la escala nanométrica en la que se encuentran. En este proyecto se realizaron pruebas de

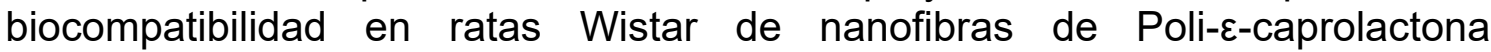
embebidas con nanopartículas de plata fabricadas por medio de la técnica de electrohilado con el fin de utilizarse como apósitos bucales para la erradicación de bacterias de esta zona y regeneración de tejido. Se realizaron soluciones de $12.5,25,50$ y $100 \mathrm{mM}$ de Nitrato de plata utilizando N-dimetilformaida y Tetrahidrofurano como disolventes reductores con el $8 \%$ de polímero. Las nanofibras presentaron un diámetro de $400 \pm 100 \mathrm{~nm}$. Se utilizaron 3 sujetos experimentales dejando en ellos el material en el tejido subcutáneo por periodos de tiempo de dos, cuatro y seis semanas respectivamente. Las ratas presentaron una buena cicatrización teniendo las lesiones completamente sanadas a las 4 semanas de la implantación.

Palabras clave: Biocompatibilidad, poli-£-caprolactona/Ag, inflamación, reacción a cuerpo extraño.

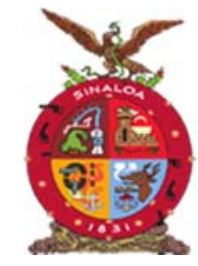

XVIII Congreso Internacional XXIV Congreso Nacional de Ciencias ambientales

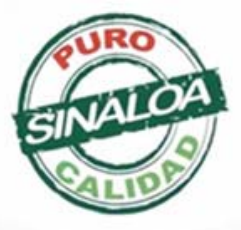

Mazatlán, Sinaloa 3-7 junio 2019
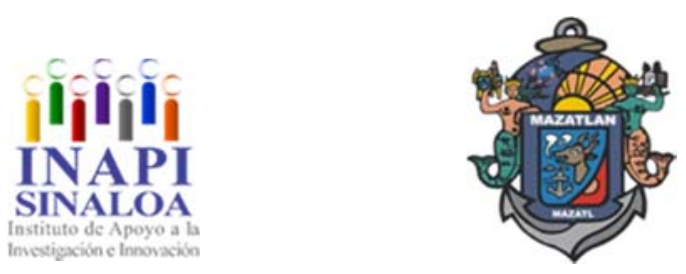

Tecnología y Biotecnología para el Tratamiento de Contaminantes y Biorremediación 

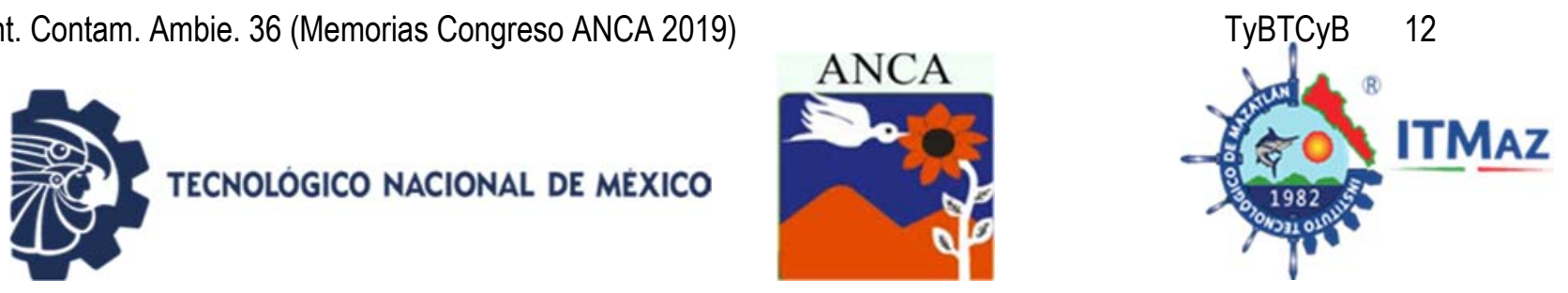

\title{
Biocompatibility of Poly- $\varepsilon$-caprolactone-Silver fibers
}

\author{
Álvarez Ortega O, Meléndez Estrada I, Cuevas González J, \\ Donohué Cornejo A, Espinoza Cristóbal L, Reyes López SY* \\ Instituto de Ciencias Biomédicas. Universidad Autónoma de Ciudad Juárez. \\ Envolvente del PRONAF y Estocolmo S/N, Ciudad Juárez, Chih., México \\ *simon.reyes@uacj.mx
}

\begin{abstract}
Currently, one of the most alarming threats to public health is the resistance to antimicrobial agents caused by the emission of drugs and chemicals in the environment. Evidence of the release of antimicrobial compounds to the environment has been reported in household plumbing, pharmaceutical complexes, hospitals and agricultural drainages, which encourages the emergence of more resistant strains. In the same way, the indiscriminate use of antibiotics has generated a survival response in the bacteria, enabling them to efficiently evade the bactericidal action. Nowadays, nanotechnology is perceived as a promising science by offering materials with diverse unique properties thanks to the nanometric scale in which they are found. In this project biocompatibility tests were carried out on Wistar rats of Poly- $\varepsilon$-caprolactone nanofibers embedded with silver nanoparticles manufactured by the electrospinning technique in order to be used as oral dressings for the eradication of bacteria from this area and the tissue regeneration. Solutions of $12.5,25,50$ and $100 \mathrm{mM}$ of silver nitrate were made using $\mathrm{N}$-dimethylformamide and tetrahydrofuran as reducing solvents with $8 \%$ polymer. The nanofibers had a diameter of $400 \pm 100 \mathrm{~nm}$. Three experimental subjects were used, leaving the material in the subcutaneous tissue in them for periods of time of two, four and six weeks respectively. The rats showed good healing, with the lesions completely healed at 4 weeks after implantation.
\end{abstract}

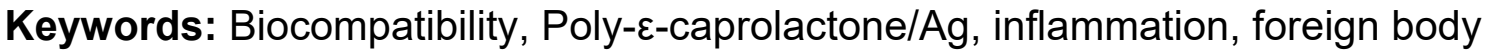
reaction.

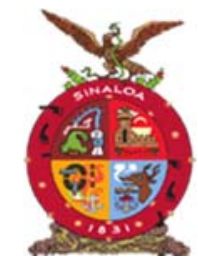

XVIII Congreso Internacional XXIV Congreso Nacional de Ciencias ambientales

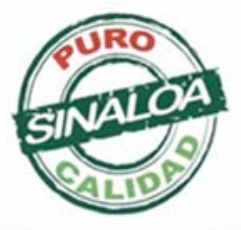

Mazatlán, Sinaloa 3-7 junio 2019
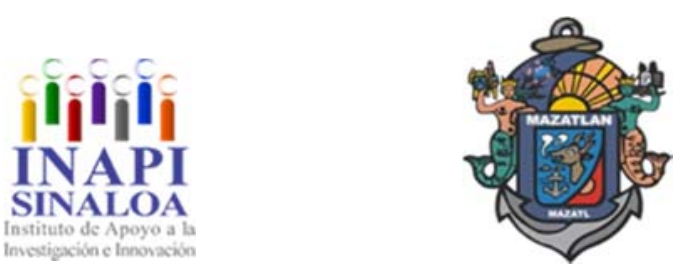

Tecnología y Biotecnología para el Tratamiento de Contaminantes y Biorremediación 

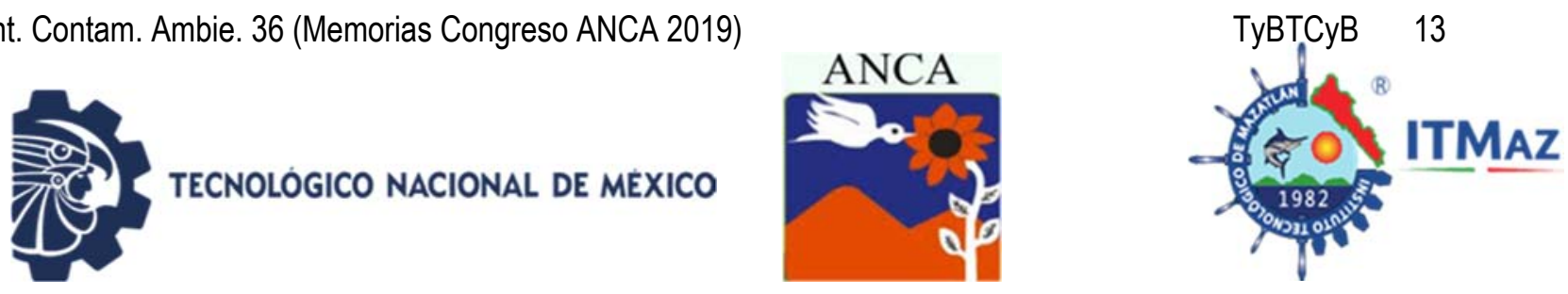

\title{
Desempeño de humedales artificiales en la remoción de nutrientes y materia orgánica de aguas residuales agroindustriales bajo alta carga orgánica
}

\author{
Amábilis Sosa $L^{1}$, Cedillo Herrera $\mathrm{C}^{1 *}$, Mendivil Garcia $\mathrm{K}^{1}$, Rángel Peraza $\mathrm{J}^{1}$, \\ Roé Sosa $\mathrm{A}^{2}$, Reyes Prado $\mathrm{M}^{1}$ \\ ${ }^{1}$ Instituto Tecnológico de Culiacán. Instituto Tecnológico Nacional de México. \\ Av. Juan de Dios Bátiz, No. 310, Culiacán, México \\ 2Universidad Tecnológica de Culiacán. \\ Carretera Culiacán-Imala Km. 2, Culiacán, México \\ *cinthiaisabel.cedillo@gmail.com
}

\section{RESUMEN}

Las aguas residuales agroindustriales presentan alta concentración de nutrientes, toxicidad y materia orgánica recalcitrante. La presente investigación se realizó en el módulo de riego más representativo de México. Se evaluó la eficiencia de remoción de la demanda química de oxígeno (DQO), nitrógeno amoniacal (NH3-N), fósforo total (PT) y fósforo inorgánico (Pi) en un sistema de humedales artificiales de flujo subsuperficial horizontal (HAFSS-H), sembrados con la macrófita emergente Phragmites australis y empacados con grava a dos diferentes tamaños de partícula, exhibiendo una porosidad eficaz de 35\% (HA_1) y 47\% (HA_2). Asimismo, se analizaron tiempos de residencia hidráulica (TRH) de uno, dos, tres y cuatro días. El porcentaje de remoción de DQO alcanzó su máximo nivel el segundo día en el HA_1 con un $90.55 \%$, pero sin observar diferencias significativas con el $89.7 \%$ del día 1. A partir del segundo día la remoción disminuyó. Por su parte, el HA_2 alcanzó una degradación de 88.5\% el día 1 y se redujo por debajo del $60 \%$ el día 2 . Posteriormente incrementó a un $87.6 \%$ el día tres y a partir de este punto presentó un comportamiento descendente. En ambos HA, el PT disminuyó en función del tiempo, mientras la degradación de $\mathrm{Pi}$ fue mayor el día dos. En cuanto al NH3-N, los mayores porcentajes de remoción fueron de 32.72 y $51.62 \%$ en el HA_1 y HA_2, respectivamente. Los resultados constituyen una primera etapa de optimización de HA para el cumplimiento ambiental de la descarga de aguas agroindustriales en los cuerpos de agua.

Palabras clave: Agua residual agroindustrial, humedales artificiales, porosidad eficaz, tiempo de residencia hidráulica, remoción.

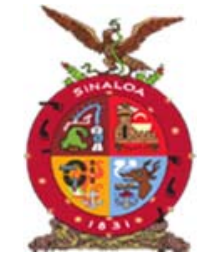

XVIII Congreso Internacional XXIV Congreso Nacional de Ciencias ambientales

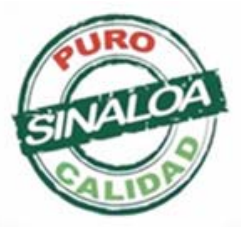

Mazatlán, Sinaloa 3-7 junio 2019
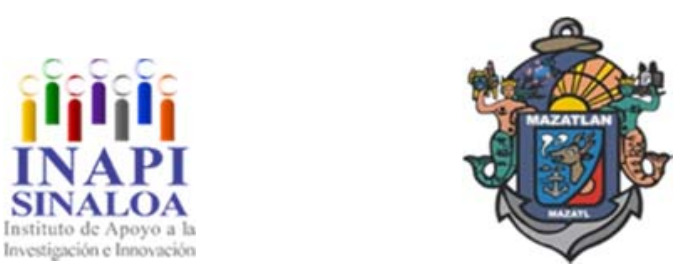

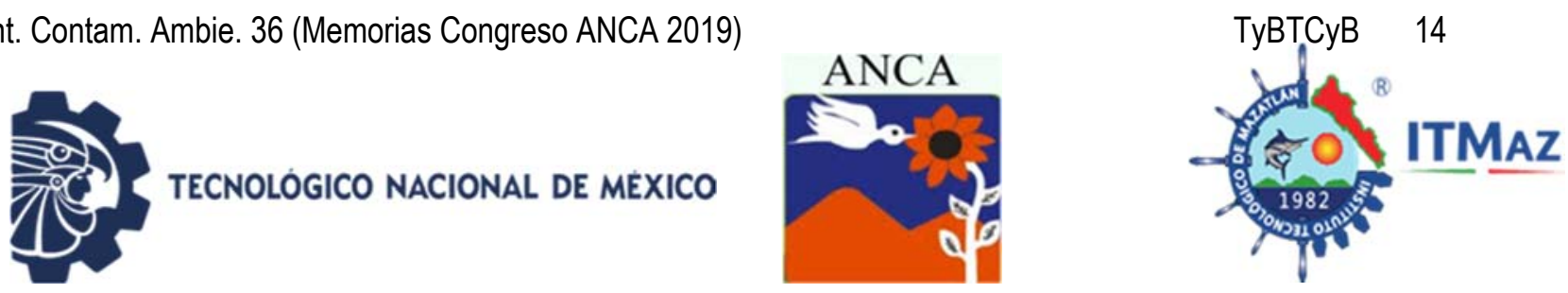

\title{
Constructed wetlands performance in the removal efficiency of nutrients and organic matter from agroindustrial wastewater under high organic load
}

\author{
Amábilis Sosa $\mathrm{L}^{1}$, Cedillo Herrera $\mathrm{C}^{1 *}$, Mendivil Garcia $\mathrm{K}^{1}$, Rángel Peraza $\mathrm{J}^{1}$, \\ Roé Sosa $A^{2}$, Reyes Prado $M^{1}$ \\ ${ }^{1}$ Instituto Tecnológico de Culiacán. Instituto Tecnológico Nacional de México. \\ Av. Juan de Dios Bátiz, No. 310, Culiacán, México \\ 2Universidad Tecnológica de Culiacán. \\ Carretera Culiacán-Imala Km. 2, Culiacán, México \\ *cinthiaisabel.cedillo@gmail.com
}

\begin{abstract}
Agroindustrial wastewater carries a large concentration of nutrients, toxicity and recalcitrant organic matter. This research was conducted in the most representative irrigation module in Mexico. The removal efficiency of chemical oxygen demand (COD), ammoniacal nitrogen (NH3-N), total phosphorus (TP) and inorganic phosphorus (IP) was tested in constructed wetlands with horizontal subsurface flow (HF CWs), planted with the emerging macrophyte Phragmites Australis and packed with gravel at two different particle sizes, manifesting an effective porosity of $35 \%$ (HA_1) and $47 \%$ (HA_2). Hydraulic residence times (HRT) of one, two, three and four days were studied. The highest rate of COD removal took place on day 2 in HA_1 with $90.55 \%$, but without observing significant differences with $89.7 \%$ of day 1 . From the second day, the removal decreased. In HA_2 degradation reached $88.5 \%$ on day 1 and fell below $60 \%$ on day 2. Then it increased to $87.6 \%$ on day three and from this point on it showed a descending behavior. In both HA, PT reduced according to time, and bigger degradation of $\mathrm{Pi}$ occurred on day two. The largest removal rates of $\mathrm{NH} 3 \mathrm{~N}$ amounted to 32.72 and $51.62 \%$ in HA_1 and HA_2. The results form the first stage of HA optimization for environmental compliance of Agroindustrial water discharge into water bodies.
\end{abstract}

Keywords: Agroindustrial wastewater, constructed wetlands, effective porosity, hydraulic residence times, removal.

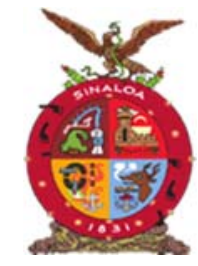

XVIII Congreso Internacional XXIV Congreso Nacional de Ciencias ambientales

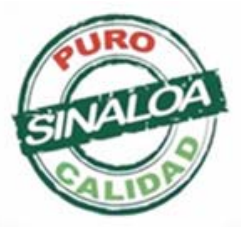

Mazatlán, Sinaloa 3-7 junio 2019
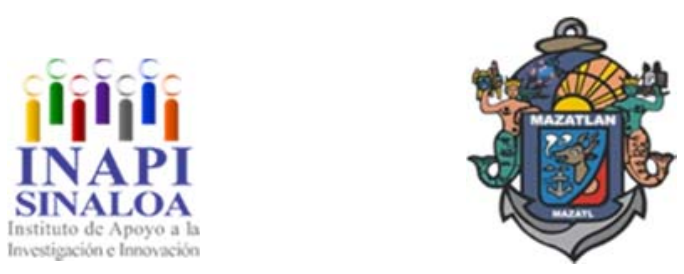

Tecnología y Biotecnología para el Tratamiento de Contaminantes y Biorremediación 

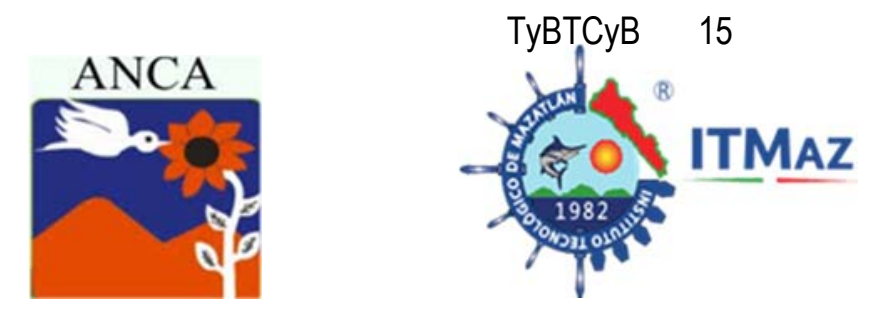

\title{
Coriandrum sativum, material bioadsorbente para la remoción de azul índigo disuelto en agua
}

\author{
Aranda Figueroa $\mathrm{MG}^{1}$, Valladares Cisneros $\mathrm{MG}^{2 *}$, Cuevas Arteaga $\mathrm{C}^{3}$, \\ Domínguez Romero $\mathrm{RJ}^{3}$
}

${ }^{1}$ Maestría en Ingeniería Ambiental y Tecnologías Sustentables

${ }^{2}$ Facultad de Ciencias Químicas e Ingeniería

${ }^{3}$ Centro de Investigación en Ingeniería y Ciencias Aplicadas.

Universidad Autónoma del Estado de Morelos.

Av. Universidad 1001, Col.Chamilpa, Cuernavaca Mor. C.P. 62209, México.

*mg.valladares@uaem.mx

\section{RESUMEN}

Las descargas de aguas residuales provenientes de la industria textil provocan problemas ambientales en los cuerpos receptores. Los procesos empleados para la remoción de colorantes antes de que ingresen estos caudales a las plantas de tratamiento son costosos; dentro del contexto de procesos productivos amigables con el ambiente, por lo que se requiere el desarrollo de investigación de alternativas sustentables y económicas; el presente trabajo de investigación se orientó al estudio de la capacidad de adsorción del Coriandrum sativum llamado popularmente "cilantro", como alternativa natural de material adsorbente de los desechos originados por la industria textil. La capacidad de adsorción del C. sativum se evaluó a través del porcentaje de remoción del colorante Azul Índigo en solución neutra, ácida y básica. De acuerdo con los resultados obtenidos la capacidad de adsorción del $C$. sativum se favorece cuando el colorante se empleó a concentraciones altas. El empleo de $20 \mathrm{~g} / \mathrm{L}$ de adsorbente en una solución de $1.0 \mathrm{~g} / \mathrm{L}$ de Azul Índigo a pH 6.9 y temperatura ambiente $\left(25^{\circ} \pm 2\right)$, en condiciones estáticas; permitió remover el colorante en un $43.1 \%$ a las 5 horas como tiempo de contacto. La cinética de adsorción se ajustó al modelo de Lagmuir que supone la formación de una monocapa de Azul Índigo, la cual satura la superficie del adsorbente. Los resultados obtenidos indican que el $C$. sativum es un buen material bioadsorbente para el colorante Azul índigo, representativo de los colorantes a la tina que son ampliamente usados en la industria textil, particularmente en la producción de la mezclilla para confeccionar los jeans.

Palabras clave: Adsorbente natural, Coriandrum sativum, azul indigo, remoción de colorantes, tratamiento amigable de aguas residuales, alternativas sustentables para el control de la contaminación.

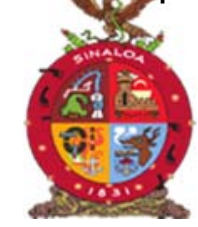

XVIII Congreso Internacional XXIV Congreso Nacional de Ciencias ambientales

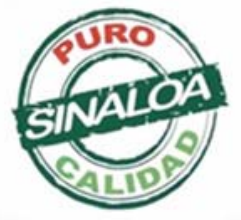

Mazatlán, Sinaloa 3-7 junio 2019

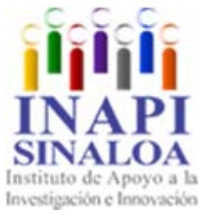

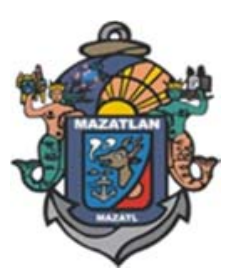

Tecnología y Biotecnología para el Tratamiento de Contaminantes y Biorremediación 

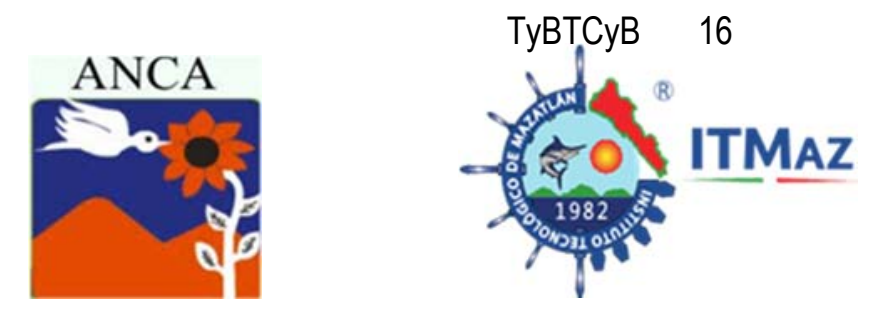

\title{
Coriandrum sativum, Biosorbent Material to Removed Indigo Blue Dissolved in Water
}
Aranda Figueroa $\mathrm{MG}^{1}$, Valladares Cisneros MG2*, Cuevas Arteaga $\mathrm{C}^{3}$, Domínguez Romero $\mathrm{RJ}^{3}$

${ }^{1}$ Maestría en Ingeniería Ambiental y Tecnologías Sustentables

${ }^{2}$ Facultad de Ciencias Químicas e Ingeniería

${ }^{3}$ Centro de Investigación en Ingeniería y Ciencias Aplicadas.

Universidad Autónoma del Estado de Morelos.

Av. Universidad 1001, Col.Chamilpa, Cuernavaca Mor. C.P. 62209, México.

*mg.valladares@uaem.mx

\begin{abstract}
Discharges of wastewater from the textile industry cause environmental problems in the bodies receiving water. The processes used for the removal of dyes before of these enter into the treatment plants are expensive; within the context of productive processes friendly to the environment, the development of projects aimed at the investigation of sustainable alternatives and of being possible economically for the removal or reduction of the high loads of contaminants present in the water is required. With the intention of contributing to the generation of sustainable alternatives for the reduction of the load of dyes present in the discharges of waste originated by the textile industry. The present research work was oriented to the study of the adsorption capacity of Coriandrum sativum popularly known as "cilantro", as a natural alternative of adsorbent material. The capacity of adsorption of $C$. sativum was evaluated through the percentage of removal of the Indigo Blue dye in neutral, acid and basic solution. According to the obtained results, the capacity of adsorption of $C$. sativum is favored when the dye was used at high concentrations. The use of $20 \mathrm{~g} / \mathrm{L}$ of adsorbent in a solution of $1.0 \mathrm{~g} / \mathrm{L}$ of Indigo Blue at $\mathrm{pH} 6.9$ and room temperature $\left(25^{\circ} \pm 2\right)$, in static conditions; it allowed to remove the dye in $43.1 \%$ at 5 hours as contact time. The adsorption kinetics was adjusted to the Lagmuir model that supposes the formation of an Indigo Blue monolayer, which saturates the surface of the adsorbent. The results obtained indicate that $C$. sativum is a good bioadsorbent material for the indigo blue dye, representative of the dyes to the vat that are widely used in the textile industry, particularly in the production of denim to make jeans.
\end{abstract}

Keywords: Natural adsorbent, Coriandrum sativum, indigo blue, dye removal, friendly wastewater treatment, pistarnable alternatives for pollution control.

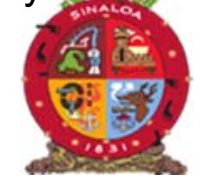

XVIII Congreso Internacional

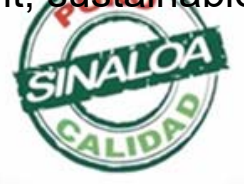

Mazatlán, Sinaloa 3-7 junio 2019
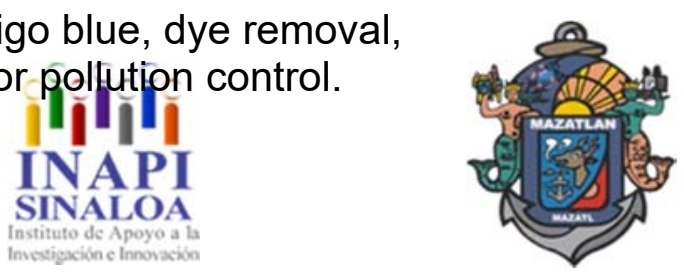

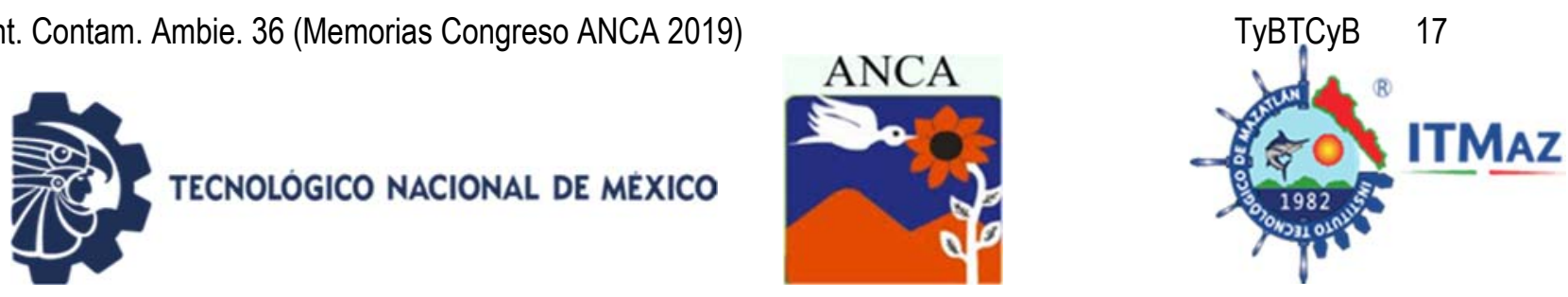

\title{
Aislamiento y caracterización de bacterias depredadoras de interés clínico y agropecuario
}

\begin{abstract}
Aranda Vivas LI*, Bello Velázquez JA, González Mireles V, Sánchez Varela A, Rodríguez Luna IC
\end{abstract}

Laboratorio de Biotecnología Genómica.

Centro de Biotecnología Genómica. Instituto Politécnico Nacional.

Cd. Reynosa, Tamaulipas 88710, México

*larandav1700@alumno.ipn.mx

\section{RESUMEN}

La búsqueda de una solución en el campo de la resistencia microbiana a los antibióticos y los problemas que dichas bacterias, patogénicas en la mayoría de los casos puede generar, nos ha llevado a la investigación en el aislamiento y caracterización de bacterias depredadoras ha sido el objetivo. Este tipo de bacterias, han sido de interés ambiental en los últimos años. Es por ello, que la búsqueda de nuevos aislamientos de depredadores bacterianos tiene importancia en la salud y a nivel agropecuario. Se han obtenido un total de 90 aislados de estas bacterias depredadoras de muestras ambientales y heces fecales de animales exóticos, las muestras fueron colectadas en diferentes estados del centro y norte de México, sin embargo, se han seleccionado hasta el momento 15 de estos aislados, los cuales se han caracterizado fenotípicamente utilizando hospederos Gram-negativos, tales como Klebsiella pneumoniae y Salmonella entérica, que se han caracterizado molecularmente mediante la amplificación del gen 16S del RNAr utilizando iniciadores específicos. Finalmente, se obtuvieron las secuencias de dichos fragmentos con el propósito de alinearlos mediante la técnica de BLAST y de esta manera poder identificar al depredador, posteriormente, utilizando el programa MEGA7 se ha logrado obtener un árbol filogenético, en el cual podemos observar la diferencia entre aislados de acuerdo con el origen de su muestra, esto fue el resultado obtenido por los grupos formados.

Palabras clave: Depredador, filogenética, hospedero.

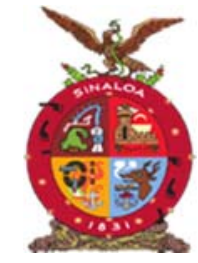

XVIII Congreso Internacional XXIV Congreso Nacional de Ciencias ambientales

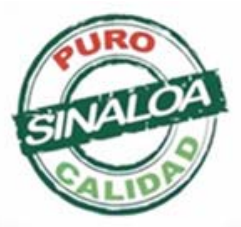

Mazatlán, Sinaloa 3-7 junio 2019
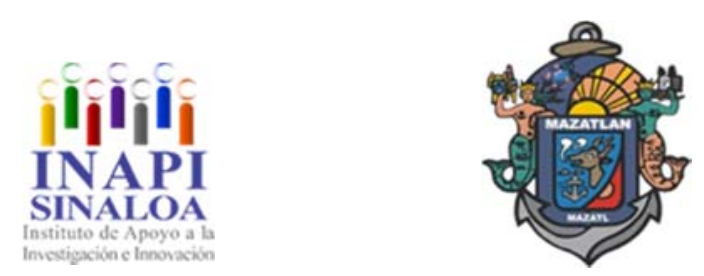

Tecnología y Biotecnología para el Tratamiento de Contaminantes y Biorremediación 

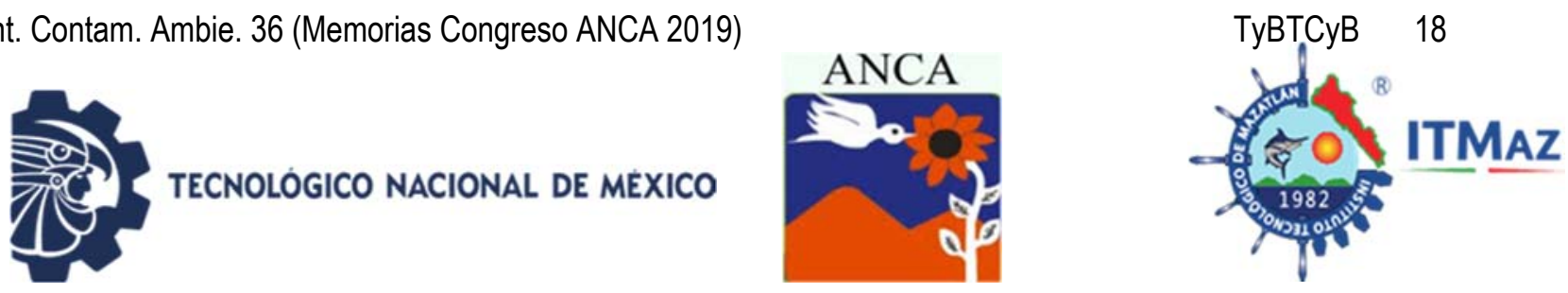

\title{
Isolation and characterization of predatory bacteria of clinic an agricultural Interest
}
Aranda Vivas LI*, Bello Velázquez JA, González Mireles V, Sánchez Varela A, Rodríguez Luna IC

Laboratorio de Biotecnología Genómica.

Centro de Biotecnología Genómica. Instituto Politécnico Nacional.

Cd. Reynosa, Tamaulipas 88710, México

*larandav1700@alumno.ipn.mx

\begin{abstract}
The search for a solution in the field of microbial resistance to antibiotics and the problems that such bacteria, pathogenic in most cases can generate, ilt has led us to research where the isolate and characterization of predatory bacteria have been the goal. This type of bacteria has been of environmental interest in recent time. For this, the search for new isolates of predatory bacteria is important in health and agricultural level. A total of 90 isolates of these predatory bacteria have been obtained of environmental samples and feces of exotic animals. The samples were collected in different states of central and northern Mexico. However, 15 of these isolates have been selected, which have been phenotypical characterized using Gram-negative hosts, such as $K$. pneumoniae and S. enterica. In addition, they have been molecularly characterized using the amplification of $16 \mathrm{~S}$ gene RNAr using specific primers. Finally, the sequences of these fragments with propose of aligning them by BLAST technique and this way being able to identify the predator, then, using the MEGA7 program, we have obtained a phylogenetic tree, in which we can observe the difference between isolated according to the sample origin, this was the result obtained by the clades formed.
\end{abstract}

Keywords: Predator, phylogenetic, host.

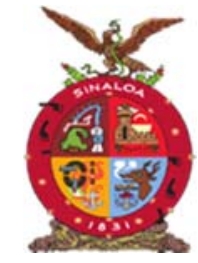

XVIII Congreso Internacional XXIV Congreso Nacional de Ciencias ambientales

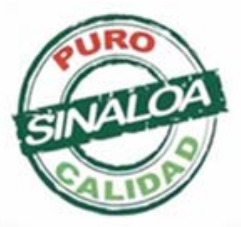

Mazatlán, Sinaloa 3-7 junio 2019
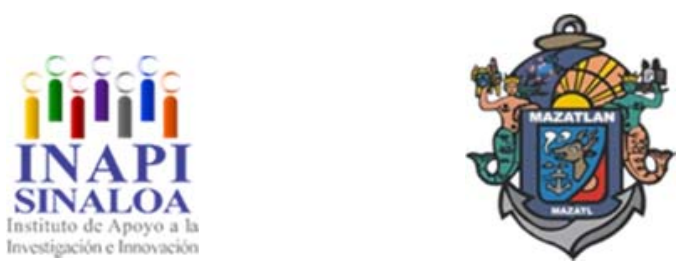

Tecnología y Biotecnología para el Tratamiento de Contaminantes y Biorremediación 

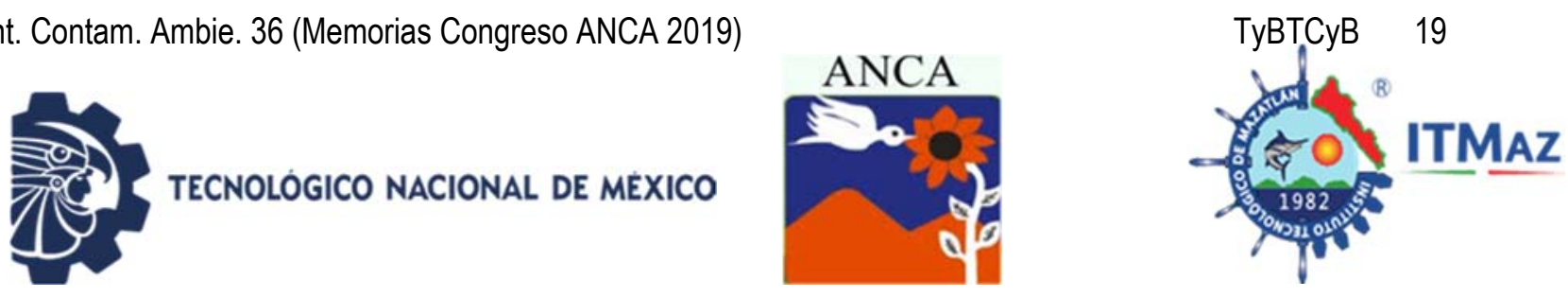

\title{
Gama de presas por cepas de Bdellovibrio bacteriovorus aisladas en México
}

\author{
Aranda Vivas LI*, Bello Velázquez JA, González Mireles V, Sánchez Varela A, \\ Rodríguez Luna IC \\ Laboratorio de Biotecnología Genómica. \\ Centro de Biotecnología Genómica. Instituto Politécnico Nacional. \\ Cd. Reynosa, Tamaulipas 88710, México \\ *larandav1700@alumno.ipn.mx
}

\begin{abstract}
RESUMEN
Bdellovibrio bacteriovorus es una bacteria ambiental, uniflagelada, con medidas de 0.2 a $0.5 \mu \mathrm{m}$ de ancho por 0.5 a $2.5 \mu \mathrm{m}$ de largo, de amplia distribución en el ambiente e incluso encontrada en intestinos de mamíferos y heces fecales de animales. Dicha bacteria, tiene la característica de depredar bacterias Gramnegativas, sin embargo, algunos estudios han demostrado su depredación o reducción en el biofilm de bacterias Gram-positivas, no obstante, cada cepa tiene actividad diferente ante diferentes bacterias hospederas, mientras que algunas cepas pueden depredar a diferentes bacterias, otras tienen predilección a hospederos específicos. Estudiar las bacterias que son atacadas por dicha depredación, encontramos bacterias de interés fitopatogénico, veterinario, y clínico; tales como Agrobacterium tumefaciens, Bacillus thuringiensis, E. coli, Staphylococcus spp., entre otras. En este estudio, 10 cepas de B. bacteriovorus fueron expuestas a 16 bacterias hospederas. Con este experimento podemos concluir el diferente rango de presa de las distintas cepas, lo anterior demuestra que una cepa logra atacar a todas las bacterias, mientras que otras son específicas y logramos encontrar bacterias hospederas que son atacadas por todas las depredadoras. Esto abre paso para estudios genómicos con los que podemos buscar entender cómo y por qué el rango de presa es diferente ante diferentes cepas, además de buscar nuevas alternativas de antibióticos ante la drogo-resistencia de las bacterias.
\end{abstract}

Palabras clave: B. bacteriovorus, rango de presa, bacterias, drogo-resistencia.

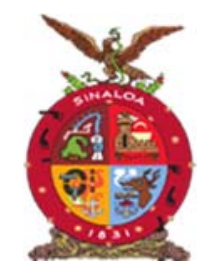

XVIII Congreso Internacional XXIV Congreso Nacional de Ciencias ambientales

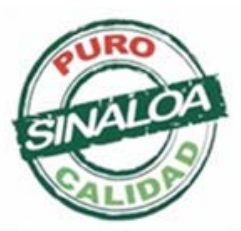

Mazatlán, Sinaloa 3-7 junio 2019
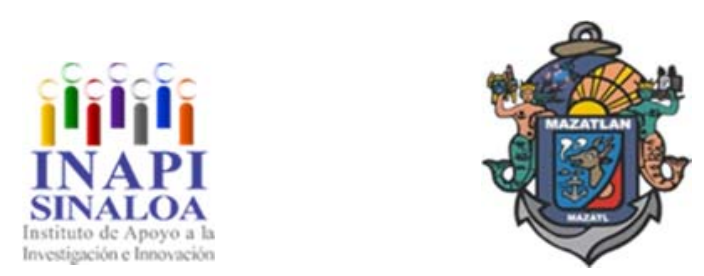

Tecnología y Biotecnología para el Tratamiento de Contaminantes y Biorremediación 


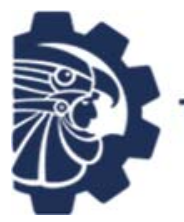

TECNOLOGICO NACIONAL DE MEXICO
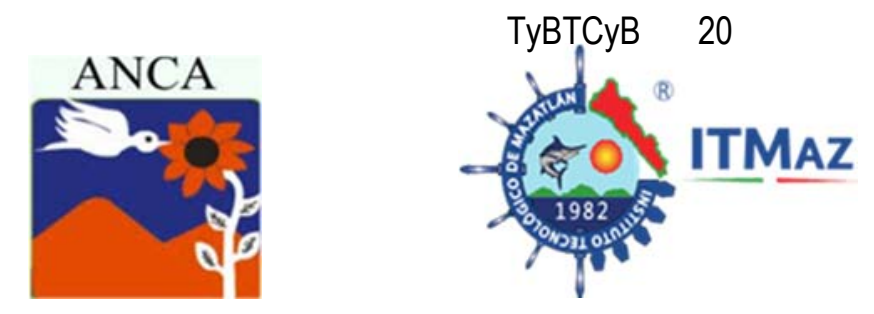

\title{
Prey range of Bdellovibrio bacteriovorus strains isolated on Mexico
}

\author{
Aranda Vivas LI*, Bello Velázquez JA, González Mireles V, Sánchez Varela A, \\ Rodríguez Luna IC \\ Laboratorio de Biotecnología Genómica. \\ Centro de Biotecnología Genómica. Instituto Politécnico Nacional. \\ Cd. Reynosa, Tamaulipas 88710, México \\ *larandav1700@alumno.ipn.mx
}

\begin{abstract}
Bdellovibrio bacteriovorus is an environmental bacterium, uniflagellate, with measures of 0.2 to $0.5 \mu \mathrm{m}$ wide by 0.5 to $2.5 \mu \mathrm{m}$ long, it is widely distributed in the environment and even found in the intestines of mammals and feces of animals. This bacterium has the characteristic of predation of Gram-negative bacteria. However, some researches have shown their predation or reduction of biofilm of Gram-positive bacteria, nevertheless, each strain has different activity against different bacteria hosts, while some strains can prey many bacteria, some others have a predilection to specific hosts, mention that said mechanism is carried out with the purpose of realizing its life cycle of predatory bacteria. So, when we have been studying the bacteria that are attacked by this predation, we found bacteria of phytopathogenic, veterinary and clinic interest, such as $A$. tumefaciens, B. thuringiensis, E. coli, Staphylococcus spp., among others. Therefore, in this search, 10 strains of $B$. bacteriovorus were exposed to 16 host bacteria. With this experiment, we can conclude the different prey range of the different strains, this shows that one strain manages to attack all hosts bacteria, while others are host specific, in addition, we can find host bacteria that are attached by all predators. This opens the way for genomic studies with which we can seek to understand how and why the prey range is different between strains, also to look for new alternatives of antibiotics to the drug-resistance of bacteria.
\end{abstract}

Keywords: B. bacteriovorus, prey range, bacteria, drug-resistance.

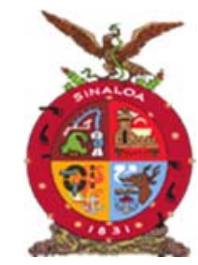

XVIII Congreso Internacional XXIV Congreso Nacional de Ciencias ambientales

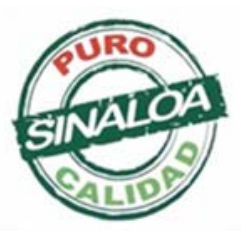

Mazatlán, Sinaloa 3-7 junio 2019
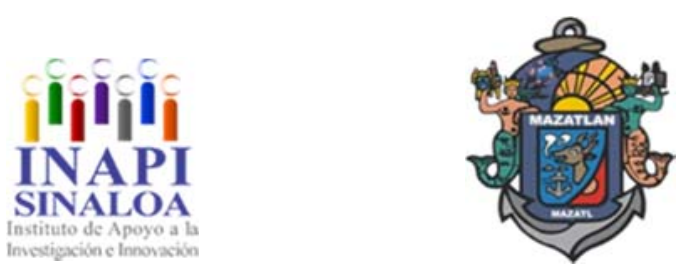

Tecnología y Biotecnología para el Tratamiento de Contaminantes y Biorremediación 

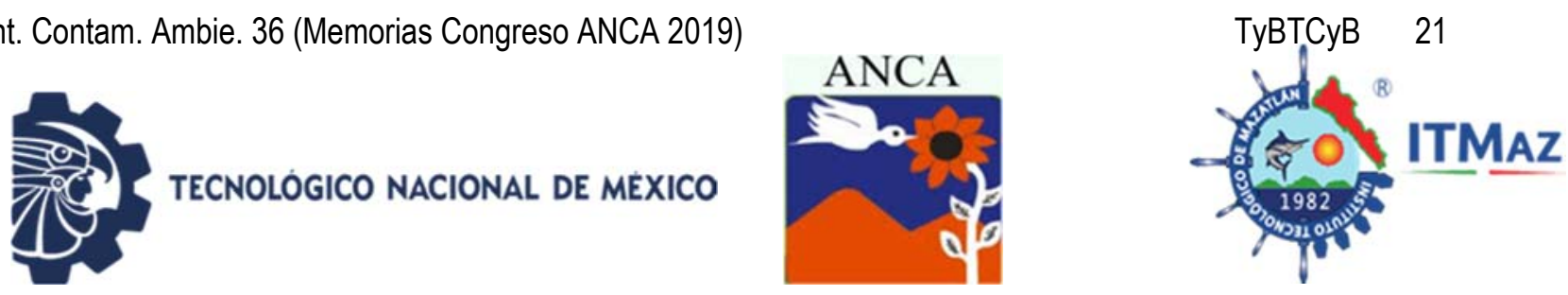

\title{
Oxidación avanzada por ozonación de un agua residual industrial con alto contenido de materia orgánica inerte
}

\author{
Barrón Hernández L*, Fall C \\ Instituto Interamericano de Tecnología y Ciencias del Agua \\ (IITCA antes CIRA) Universidad Autónoma del Estado de México, \\ Toluca, Estado de México \\ *liliambarron@hotmail.com
}

\section{RESUMEN}

La presente investigación implementó un proceso de oxidación avanzada (ozonación) que permitiera degradar y/o aumentar la biodegradabilidad de la materia orgánica soluble de un agua residual industrial (ARI) con compuestos persistentes no normados que son vertidos en el Río Lerma. Se tomaron muestras puntuales de efluente a la salida del sedimentador secundario de la planta de tratamiento y fue caracterizado durante 7 meses (año 2015), en la ciudad de Toluca. Cada muestra fue ozonada con 4 dosis de $\mathrm{O} 3$ (2, 5, 10 y 15 $\min$ ) en un reactor batch de $2 \mathrm{~L}$. Se evaluó el efecto del ozono sobre la DQO total, color y conductividad eléctrica, principalmente. Los resultados confirmaron la baja biodegradabilidad del ARI (índice de 0.04), la presencia de componentes orgánicos persistentes y solubles a $90 \%$ y una alta carga de sales inorgánicas (conductividad de $5000 \mu \mathrm{S} / \mathrm{cm}$ ). Con la ozonación a 15 min la DBO5 aumentó de $41 \mathrm{mg} / \mathrm{L}$ hasta $148 \mathrm{mg} / \mathrm{L}$, considerándose no significativa, ya que representó menos de $8 \%$ de la DQO total remanente. El color se redujo hasta en un $100 \%$ de 3130 U-PtCo iniciales y la DQO hasta un 50\% de $1068 \mathrm{mg} / \mathrm{L}$ iniciales. La conductividad eléctrica alta no sufrió cambios y fue atribuida a la presencia de iones sodio, calcio, magnesio, sulfato y cloruro presentes como el $97 \%$ de sólidos disueltos respecto de los STT. En conclusión, la ozonación resulta ser un tratamiento eficiente si se trata de remover el color para esta ARI, pero no así para la DQO inerte.

Palabras clave: Ozonación, compuestos persistentes, DQO soluble inerte, agua residual industrial, biodegradabilidad.

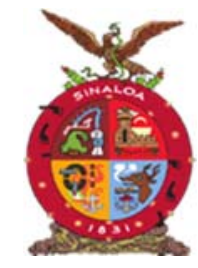

XVIII Congreso Internacional XXIV Congreso Nacional de Ciencias ambientales

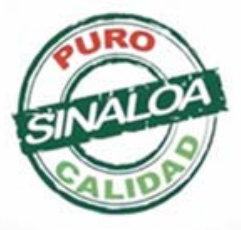

Mazatlán, Sinaloa 3-7 junio 2019
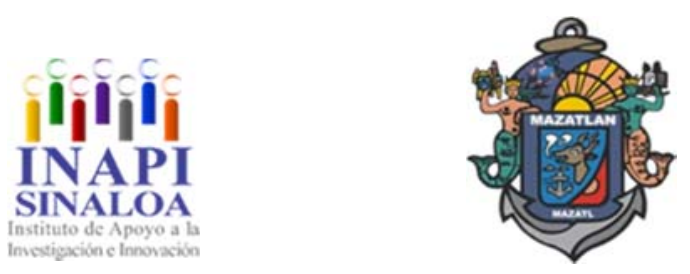

Tecnología y Biotecnología para el Tratamiento de Contaminantes y Biorremediación 


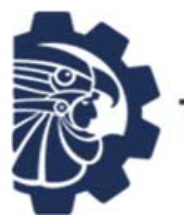

TECNOLOGICO NACIONAL DE MEXICO
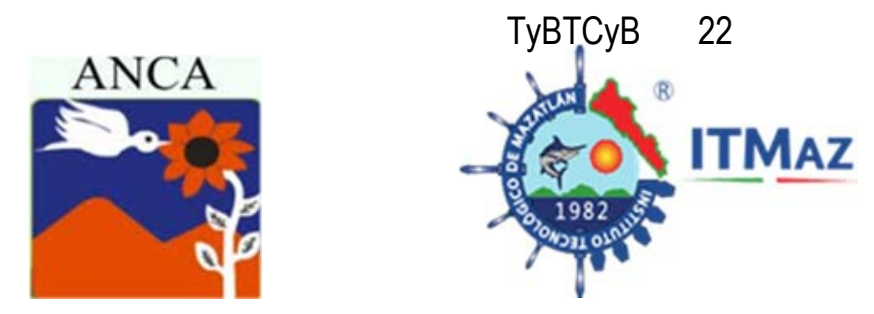

\title{
Advanced oxidation by ozonation of an industrial wastewater with high content of inert organic matter
}

\author{
Barrón Hernández L*, Fall C \\ Instituto Interamericano de Tecnología y Ciencias del Agua \\ (IITCA antes CIRA) Universidad Autónoma del Estado de México, \\ Toluca, Estado de México \\ *liliambarron@hotmail.com
}

\begin{abstract}
The present research implemented an advanced oxidation process (ozonation) that would allow degrade and/or increment the biodegradability of the soluble organic matter of an industrial wastewater (IW) with not regulated recalcitrant compounds that are discharged in the Lerma river. Spot samples of the effluent were taken in the secondary settling tank outlet of the treatment plant and was characterized along 7 months (year 2015), in the Toluca city. Each sample was ozonated with 4 ozone doses (2, 5, 10 and $15 \mathrm{~min}$ ) in a 2 liters batch reactor. Mainly was evaluated the ozone effect on the total COD, colour and electrical conductivity. The results confirmed the low biodegradability of IW (biodegradability index of 0.04 ), the presence of soluble and persistent organic compounds (90\%) and a high inorganic salts load (conductivity of $5000 \mu \mathrm{S} / \mathrm{cm}$ ). With ozonation at 15 minutes, the BOD5 increased to $148 \mathrm{mg} / \mathrm{L}$ of $41 \mathrm{mg} / \mathrm{L}$ initial, it was considered not significant, since this represented less than $8 \%$ of the total COD remained. The colour was reduced by up to $100 \%$ from $3130 \mathrm{U}-\mathrm{PtCo}$ initials and the COD up to $50 \%$ from $1068 \mathrm{mg} / \mathrm{L}$ initials. The high electrical conductivity did not change and was attributed at the presence of sodium, calcium, magnesium, sulfate and chloride ions corresponding as $97 \%$ of dissolved solids with respect to the total solids. In resume, the ozonation is an efficient treatment for the colour remove but it's not like that for the inert COD.
\end{abstract}

Keywords: Ozonation, persistent compounds, soluble inert COD, industrial wastewater, biodegradability.

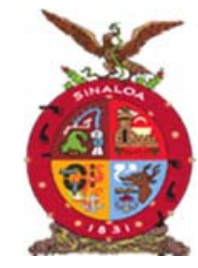

XVIII Congreso Internacional XXIV Congreso Nacional de Ciencias ambientales

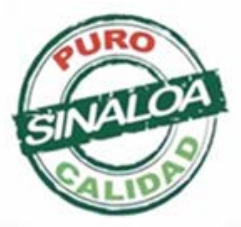

Mazatlán, Sinaloa 3-7 junio 2019
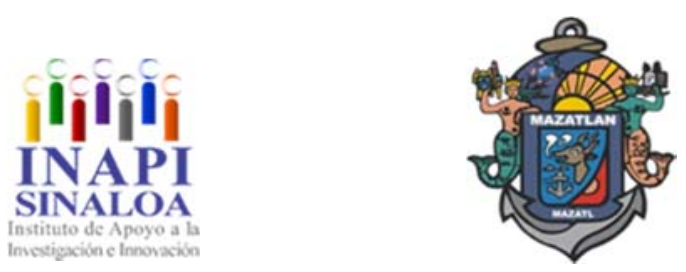

Tecnología y Biotecnología para el Tratamiento de Contaminantes y Biorremediación 

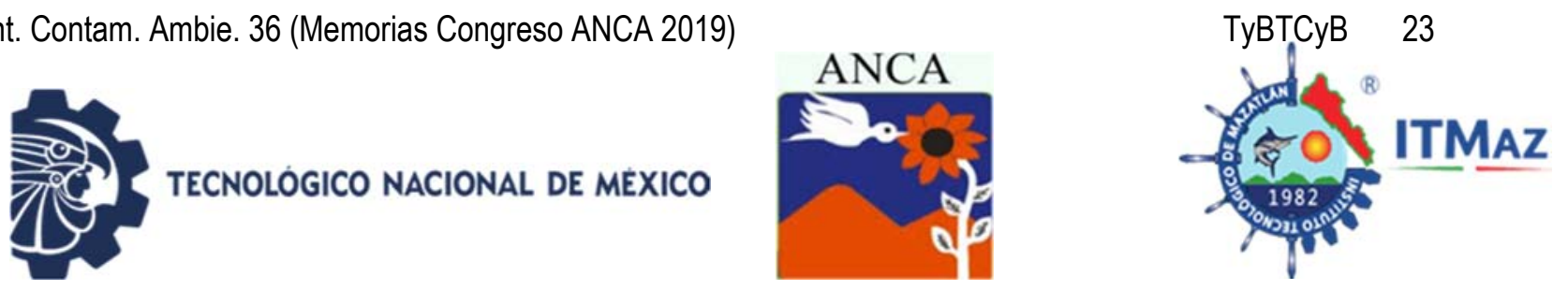

\title{
Remoción de colorantes textiles azul novasol y azul terasil mediante peroxidasas de chayoteste y chayote (Sechium edule Sw)
}

\author{
Bautista Mulia $\mathrm{J}^{1 *}$, Valencia García $\mathrm{L}^{1}$, Chavira Alvarado $\mathrm{A}^{1}$, Chávez Bravo $\mathrm{E}^{2}$, \\ Alonso Calderón $\mathrm{A}^{1}$ \\ ${ }^{1}$ Facultad de Ingeniería Química. BUAP \\ ${ }^{2} \mathrm{CICM}-\mathrm{ICUAP}$ \\ *jpmulia93@gmail.com
}

\section{RESUMEN}

Actualmente existe gran interés por la persistencia en el ambiente de compuestos xenobióticos, como los colorantes de diferente naturaleza química ya que son ampliamente utilizados en la industria textil, actualmente se propone el uso de métodos enzimáticos ya que los productos de reacción son de baja toxicidad, por lo que en este trabajo de investigación se tiene como objetivo la remoción de los colorantes textiles azul novasol RsjMD y azul teresil $3 R L$ mediante peroxidasas de chayote y chayoteste. La purificación de peroxidasas se realizó en el laboratorio de enzimología y biocatalisis de la facultad de Ingeniería Química de la BUAP durante el 2017-2018 para esto se trabajó con 1 litro de zumo el cual se sometió a un proceso de diálisis a $\mathrm{pH}$ : 4.5, a continuación se le realizó cromatografía de intercambio catiónico, el concentrado de peroxidasas se obtuvo mediante elución isocrática con buffer de acetato-ácido acético $\mathrm{pH}: 4.5,1 \mathrm{M}$, se determinó la actividad enzimática utilizando guayacol $24.1 \mathrm{mM} \mathrm{y} \mathrm{H}_{2} \mathrm{O}_{2} 12.3 \mathrm{mM}$, se prepararon soluciones de agua artificialmente contaminada con los colorantes azul novasol y azul terasil (Ciba Specialty Chemicals Inc. ${ }^{\circledR}$ ) a 200 ppm y 500 $\mathrm{ppm}$. A las muestras de agua a $200 \mathrm{ppm}$ se les adiciono paulatinamente el concentrado de peroxidasas de chayoteste logrado remociones de $96.32 \%$ para novasol y $92.99 \%$ para terasil. A las muestras de $500 \mathrm{ppm}$ se les adiciono la peroxidasa de chayote logrando remociones del $98 \%$ y $95.66 \%$ respectivamente. Las actividades enzimáticas fueron de $21.32 \mathrm{U} / \mathrm{mL}$ y $30 \mathrm{U} / \mathrm{mL}$ para el concentrado de peroxidasas de chayoteste y chayote respectivamente.

Palabras clave: Enzima, peroxidasa, colorante, actividad, remoción.

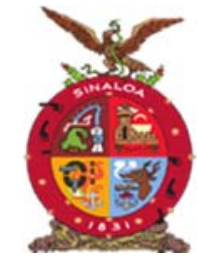

XVIII Congreso Internacional XXIV Congreso Nacional de Ciencias ambientales

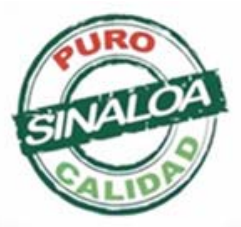

Mazatlán, Sinaloa 3-7 junio 2019
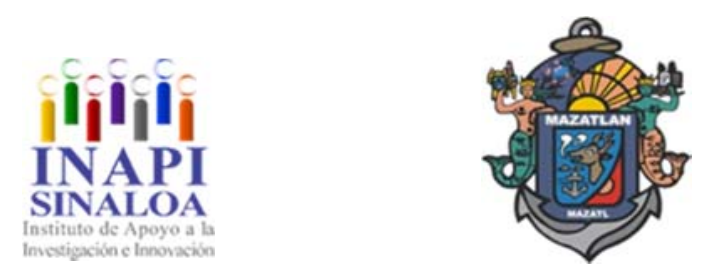

Tecnología y Biotecnología para el Tratamiento de Contaminantes y Biorremediación 

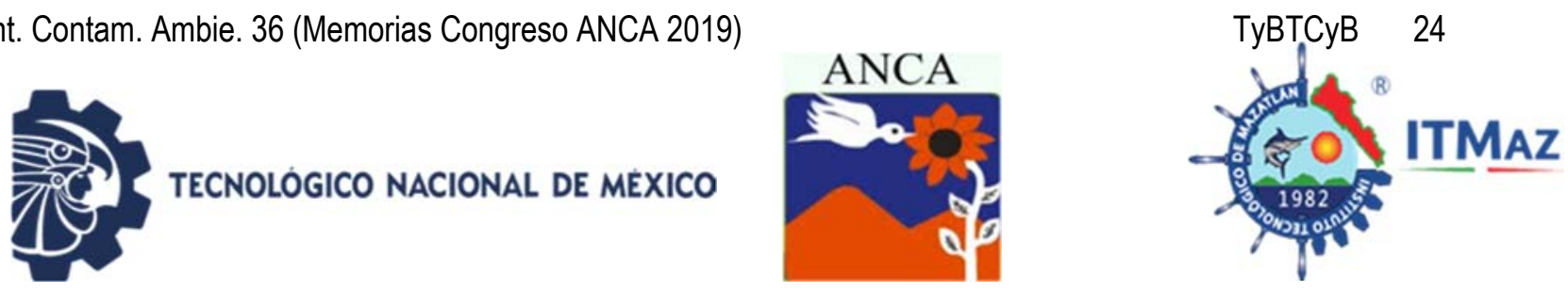

\title{
Removal of textile dyes blue novavasol and terasil blue by peroxidasas of chayoteste and chayote (Sechium edule Sw)
}

\author{
Bautista Mulia $\mathrm{J}^{1 *}$, Valencia García $\mathrm{L}^{1}$, Chavira Alvarado $A^{1}$, Chávez Bravo $E^{2}$, \\ Alonso Calderón $\mathrm{A}^{1}$ \\ ${ }^{1}$ Facultad de Ingeniería Química.BUAP \\ ${ }^{2}$ CICM.ICUAP \\ *jpmulia93@gmail.com
}

\begin{abstract}
Currently there is great interest in the persistence in the environment of xenobiotic compounds, such as dyes of different chemical nature since they are widely used in the textile industry, currently the use of enzymatic methods is proposed since the reaction products are of low toxicity, Therefore, in this research work, the objective is the removal of the textile dyes blue novasol RsjMD and teresil blue $3 R L$ by means of peroxidases of chayote and chayoteste. The purification of peroxidases was carried out in the enzymology and biocatalysis laboratory of the Faculty of Chemical Engineering of the BUAP during 2017-2018 for this purpose, 1 liter of juice was used, which underwent a dialysis process at $\mathrm{pH}: 4.5$, then cation exchange chromatography was performed, the peroxidases concentrate was obtained by isocratic elution with acetate-acetic acid buffer $\mathrm{pH}: 4.5,1 \mathrm{M}$, the enzymatic activity was determined using $24.1 \mathrm{mM}$ guaiac and $12.3 \mathrm{mM} \mathrm{H}_{2} \mathrm{O}_{2}$, solutions were prepared of water artificially contaminated with the dyes blue novasol and terasil blue (Ciba Specialty Chemicals Inc. ®) at $200 \mathrm{ppm}$ and 500 ppm. Water samples at $200 \mathrm{ppm}$ were gradually added the Chayoteste peroxidases concentrate achieved removals of $96.32 \%$ for novasol and $92.99 \%$ for terasil. Chayote peroxidase was added to the $500 \mathrm{ppm}$ samples, achieving $98 \%$ and $95.66 \%$ removals, respectively. Enzymatic activities were $21.32 \mathrm{U} / \mathrm{mL}$ and $30 \mathrm{U} / \mathrm{mL}$ for the Chayoteste and Chayote peroxidases concentrate, respectively.
\end{abstract}

Keywords: Enzyme, peroxidase, dye, activity, removal.

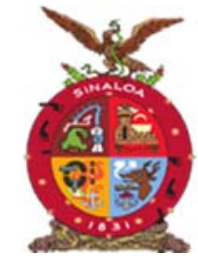

XVIII Congreso Internacional XXIV Congreso Nacional de Ciencias ambientales

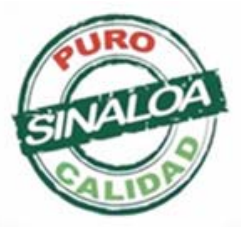

Mazatlán, Sinaloa 3-7 junio 2019
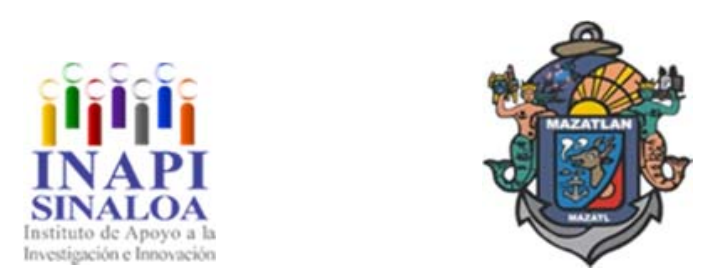

Tecnología y Biotecnología para el Tratamiento de Contaminantes y Biorremediación 

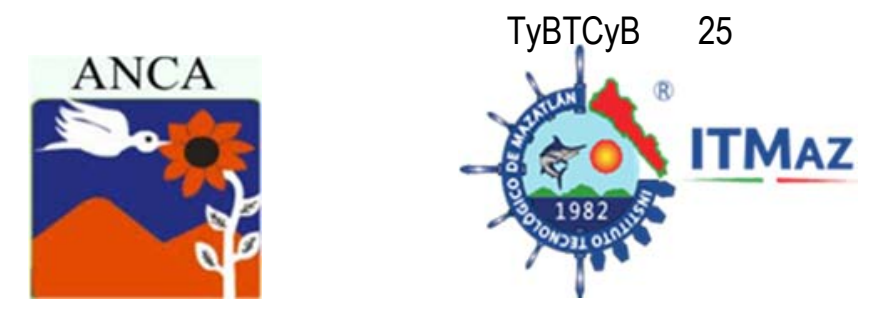

\title{
Extracción de $\mathrm{Cd}, \mathrm{Pb}$, y $\mathrm{Sb}$ en agua mediante redes metalorganicas de Uio- 66 soportadas en membranas de PVDF/Nylon
}

\author{
Becerra Rodríguez $\mathrm{J}^{1}$, Hinojosa Reyes $\mathrm{L}^{1^{*}}$, Guzmán Mar $\mathrm{J}^{1}$, \\ Hernández Ramírez $\mathrm{A}^{1}$, Turnes Palomino $\mathrm{G}^{2}$, Palomino Cabello $\mathrm{C}^{2}$ \\ 1Departamento de Ingeniería Química. Facultad de Ciencias Químicas. \\ Universidad Autónoma de Nuevo León. \\ Av. Universidad S/N, Cd. Universitaria, San Nicolás de los Garza N.L. \\ ${ }^{2}$ Laboratorio de Química Inorgánica. Departamento de Química. \\ Universidad de les Illes Balears, \\ Carretera de Valldemossa, Km 7.5, Palma, Illes Balears, España \\ *laura.hinojosary@uanl.edu.mx
}

\section{RESUMEN}

Una de las principales fuentes de contaminación por metales pesados en efluentes de agua son las industrias mineras. En estos efluentes se han detectado metales y metaloides como el cadmio $(\mathrm{Cd})$, plomo $(\mathrm{Pb})$ y antimonio $\mathrm{(Sb})$. Estas especies químicas son tóxicas para los seres vivos por lo que se ha investigado nuevos materiales que permitan su remoción completa. Las redes metal-orgánicas (MOF) han sido estudiadas en los últimos años como materiales adsorbentes de contaminantes orgánicos e inorgánicos debido a su gran área superficial, volumen de poro y la fácil funcionalización del ligando. Sin embargo, se dificulta su uso en forma de polvo. Por lo que, el objetivo de este estudio es la aplicación de redes metal-orgánicas UiO-66, UiO-66- $\mathrm{NH}_{2}$ y UiO-66-(COOH $)_{2}$ soportadas en membranas para la extracción de $\mathrm{Cd}, \mathrm{Pb}$, y $\mathrm{Sb}$ en agua. La síntesis se realizó empleando $\mathrm{ZrCl}_{4}$ y $\mathrm{BDC}$, el cual fue llevado a calentamiento asistido por microondas a $150^{\circ} \mathrm{C}$ por $60 \mathrm{~min}$. Después de la fabricación de las membranas de UiO-66 empleando PVDF/nylon, se filtró $50 \mathrm{~mL}$ de agua con $400 \mu \mathrm{g} \mathrm{L}^{-1} \mathrm{de}$ cada uno de los iones de interés. Para la cuantificación de estos iones se usó HG-AFS y AAS. Los porcentajes de extracción fueron $99.6 \pm 0.7,102.3 \pm 1.7$ y $98.3 \pm 2.0 \%$ para $\mathrm{Cd}, \mathrm{Pb}$ y Sb, respectivamente. Así la UiO-66 soportado en membranas permite la adsorción de contaminantes inorgánicos, siendo fácil su reusó.

Palabras clave: Redes metal-orgánicas, membranas, metales pesados, agua.

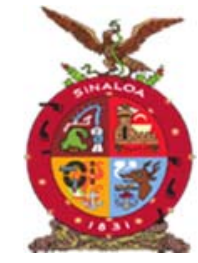

XVIII Congreso Internacional XXIV Congreso Nacional de Ciencias ambientales

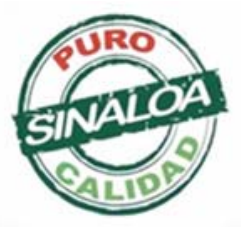

Mazatlán, Sinaloa 3-7 junio 2019
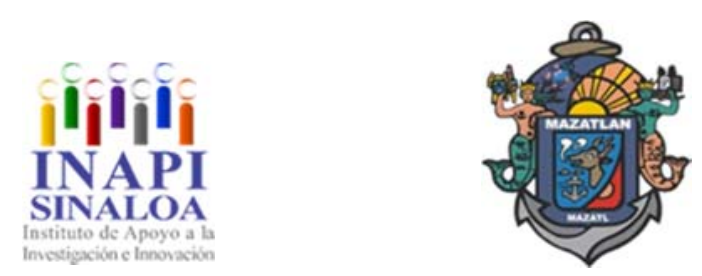

Tecnología y Biotecnología para el Tratamiento de Contaminantes y Biorremediación 

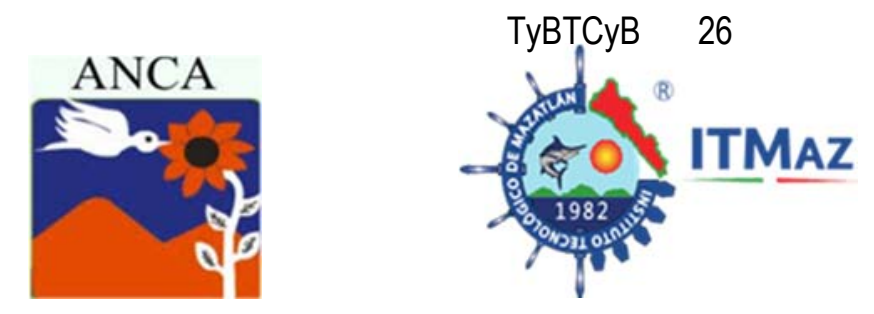

\title{
Extraction of $\mathrm{Cd}, \mathrm{Pb}$, and $\mathrm{Sb}$ in water through metalorganic frameworks of Uio-66 supported membranes of PVDF /Nylon
}

\author{
Becerra Rodríguez $\mathrm{J}^{1}$, Hinojosa Reyes $\mathrm{L}^{1 *}$, Guzmán Mar $\mathrm{J}^{1}$, \\ Hernández Ramírez $\mathrm{A}^{1}$, Turnes Palomino $\mathrm{G}^{2}$, Palomino Cabello $\mathrm{C}^{2}$ \\ 1Departamento de Ingeniería Química. Facultad de Ciencias Químicas. \\ Universidad Autónoma de Nuevo León. \\ Av. Universidad S/N, Cd. Universitaria, San Nicolás de los Garza N.L. \\ ${ }^{2}$ Laboratorio de Química Inorgánica. Departamento de Química. \\ Universidad de les Illes Balears, \\ Carretera de Valldemossa, Km 7.5, Palma, Illes Balears, España \\ *laura.hinojosary@uanl.edu.mx
}

\begin{abstract}
One of the main sources of contamination by heavy metals in water effluents are the mining industries. In this effluent, metals and metalloids have been detected, such as cadmium $(\mathrm{Cd})$, lead $(\mathrm{Pb})$ and antimony $(\mathrm{Sb})$. These inorganic ions are toxic to living beings, so it remains desirable to search for novel and efficient materials capable of absorbing these pollutants. The metal-organic frameworks (MOF) have been studied in recent years. These materials are characterized by their large surface area and pore volume, as well as their easy functionalization of the ligand. This material has been used for the extraction of contaminants, however, its use in powder is difficult, and so the use of membranes made with this material facilitates its use. The objective is to develop a membrane that allows the removal of $\mathrm{Cd}, \mathrm{Pb}$ and $\mathrm{Sb}$ in water using metal-organic frameworks UiO-66, UiO-66- $\mathrm{NH}_{2}$ and UiO-66-(COOH $)_{2}$. The microwave assisted synthesis was carried out at $150^{\circ} \mathrm{C}$ for $60 \mathrm{~min}$ using $\mathrm{ZrCl}_{4}$ and $\mathrm{BDC}$. The UiO-66 supported on PVDF/nylon membranes was used to filter $50 \mathrm{~mL}$ of water containing $400 \mu \mathrm{g} \mathrm{L}^{-1}$ of each ion. For the quantification of these ions, HG-AFS and AAS were used. The extraction percentages were $99.6 \% \pm 0.7,102.3 \% \pm 1.7$ and $98.3 \% \pm 2.0$ for $\mathrm{Cd}, \mathrm{Pb}$ and $\mathrm{Sb}$, respectively. Thus, the UiO-66 supported on PVDF/nylon membranes allows the adsorption of inorganic contaminants, being easily recycled.
\end{abstract}

Keywords: Metal-organic frameworks, membranes, heavy metals, water.

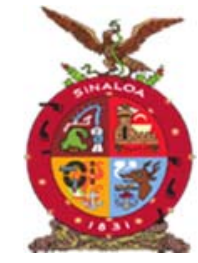

XVIII Congreso Internacional XXIV Congreso Nacional de Ciencias ambientales

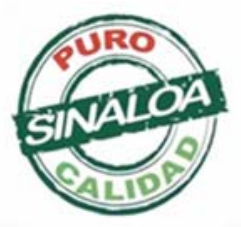

Mazatlán, Sinaloa 3-7 junio 2019
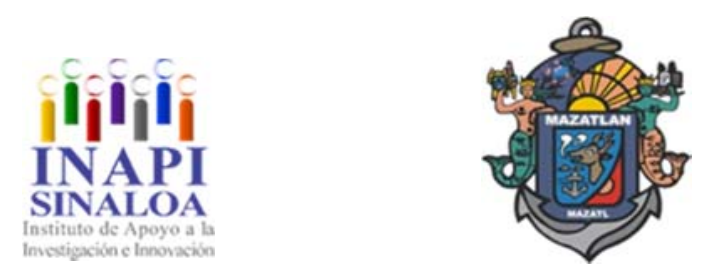

Tecnología y Biotecnología para el Tratamiento de Contaminantes y Biorremediación 

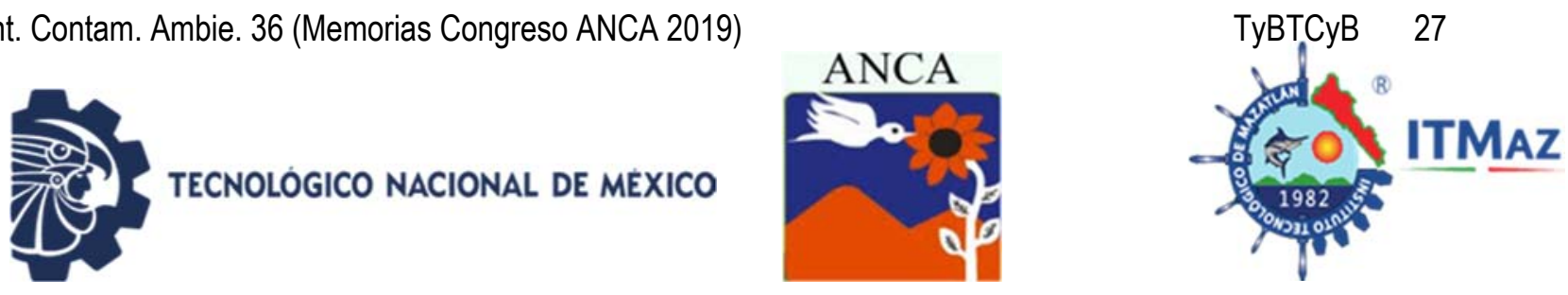

\title{
Revalorización de residuos de PET mediante su incorporación en la formulación de bloques para construcción
}

\author{
Beltrán Cortes R, Oliveros González N, García García E, Osornio Rubio R, \\ Ortiz Ruiz A*
}

Departamento de Ingeniería Ambiental. Instituto Tecnológico de Celaya,

Tecnológico Nacional de México.

Antonio García Cubas Pte\# 600 Esq. Av. Tecnológico, Celaya, Guanajuato,

*aziel_or@hotmail.com

\begin{abstract}
RESUMEN
Los desechos de polietileno de tereftalato, mejor conocido como PET, representan un problema de contaminación ambiental, ya que poseen un tiempo de degradación entre cien y mil años. Sin embargo, en oposición pueden constituirse como una viable posibilidad al presentar propiedades como durabilidad y resistencia a la corrosión, efectividad como aislante entre otras. Por lo que en este proyecto se propone una opción para la revalorización de los residuos del PET, mediante su incorporación en la formulación de bloques que cumplan con la normatividad aplicable de materiales de construcción. Las materias primas empleadas para la elaboración de los bloques fueron PET triturado, cemento gris y agua; generando 10 formulaciones con base en un diseño de experimentos de mezclas. Se emplearon moldes de madera a escala 1:2 tomando como referencia la NMX-C-404-ONNCCE-2012. Puesta las mezclas en los moldes se secaron por convección natural por $24 \mathrm{~h}$, para posteriormente sumergirlos en agua por 7 días, transcurrido este tiempo se secaron por 28 días en sombra. Se realizaron pruebas de compresión con base en la ASTM C90. De acuerdo al análisis de los resultados obtenidos de las pruebas mecánicas se identificó que la mejor formulación fue la B121 con una compresión de 11.12MPa, (menor a la de un bloque comercial promedio $12.85 \mathrm{MPa}$ ), por lo que se concluye que esta propuesta sí representa una opción viable para la revalorización, ya que incorpora un porcentaje significativo de PET en su formulación $(30 \% \mathrm{p} / \mathrm{p})$, sin embargo, es conveniente considerar ajustes para mejorar las propiedades mecánicas de los bloques.
\end{abstract}

Palabras clave: Revalorización de residuos, PET, contaminación ambiental.

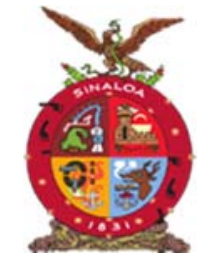

XVIII Congreso Internacional XXIV Congreso Nacional de Ciencias ambientales

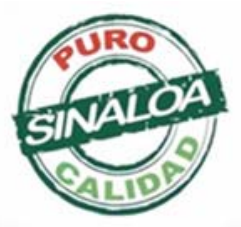

Mazatlán, Sinaloa 3-7 junio 2019
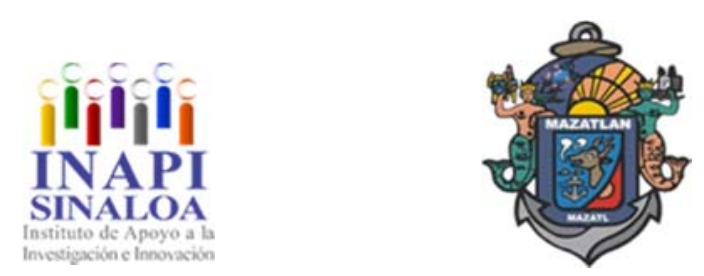

Tecnología y Biotecnología para el Tratamiento de Contaminantes y Biorremediación 

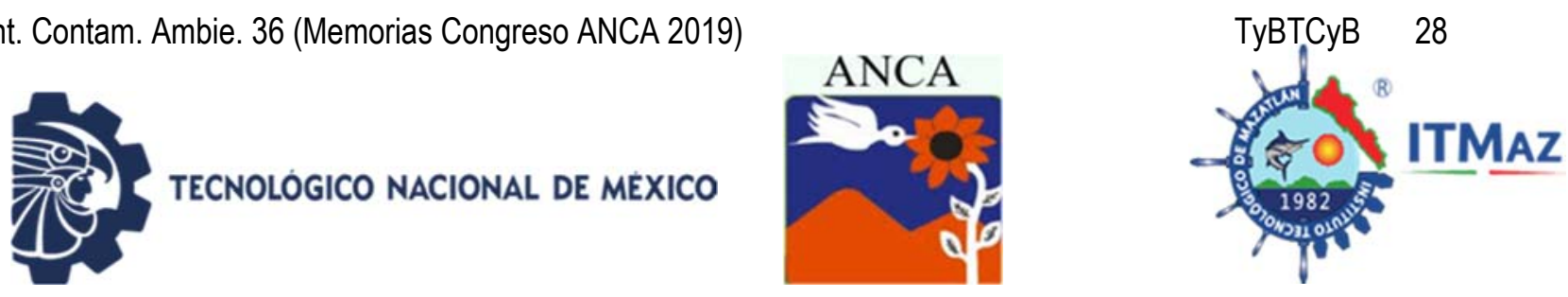

\title{
Revalorization of PET residuesthrough its incorporation in the formulation of building block
}

\author{
Beltrán Cortes R, Oliveros González N, García García E, Osornio Rubio R, \\ Ortiz Ruiz A*
}

Departamento de Ingeniería Ambiental. Instituto Tecnológico de Celaya,

Tecnológico Nacional de México.

Antonio García Cubas Pte\# 600 Esq. Av. Tecnológico, Celaya, Guanajuato,

*aziel_or@hotmail.com

\begin{abstract}
Polyethylene terephthalate waste, better known as PET, represents a problem of environmental contamination, since they have a degradation time between one hundred and one thousand years. However, in opposition can be constituted as a viable possibility to present properties such as durability and resistance to corrosion, effectiveness as an insulator among others. Therefore, in this project an option for the revaluation of PET waste is proposed, through its incorporation into the formulation of blocks that comply with the applicable regulations of construction materials. The raw materials used for the elaboration of the blocks were crushed PET, gray cement and water; generating 10 formulations based on a design of mixing experiments. Wooden molds were used at a scale of $1: 2$, taking as reference the NMX-C-404-ONNCCE-2012. Putting the mixtures in the molds they were dried by natural convection for 24 hours, later submerging them in water for 7 days, after this time they were dried for 28 days in shade. Compression tests were performed based on ASTM C90. According to the analysis of the results obtained from the mechanical tests, it was identified that the best formulation was B121 with a compression of 11.12MPa, (lower than that of a commercial block $12.85 \mathrm{MPa}$ ), so it is concluded that this proposal does represents a viable option for revaluation, since it incorporates a significant percentage of PET in its formulation $(30 \% \mathrm{p} / \mathrm{p})$, however it is convenient to consider adjustments to improve the mechanical properties of the blocks.
\end{abstract}

Keywords: Revaluation of waste, PET, environmental pollution.

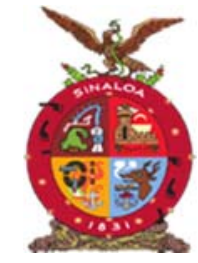

XVIII Congreso Internacional XXIV Congreso Nacional de Ciencias ambientales

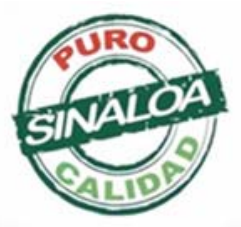

Mazatlán, Sinaloa 3-7 junio 2019
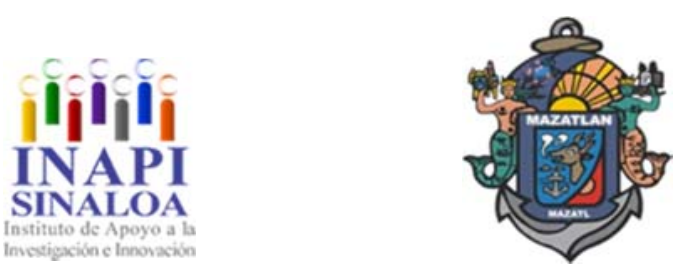

Tecnología y Biotecnología para el Tratamiento de Contaminantes y Biorremediación 

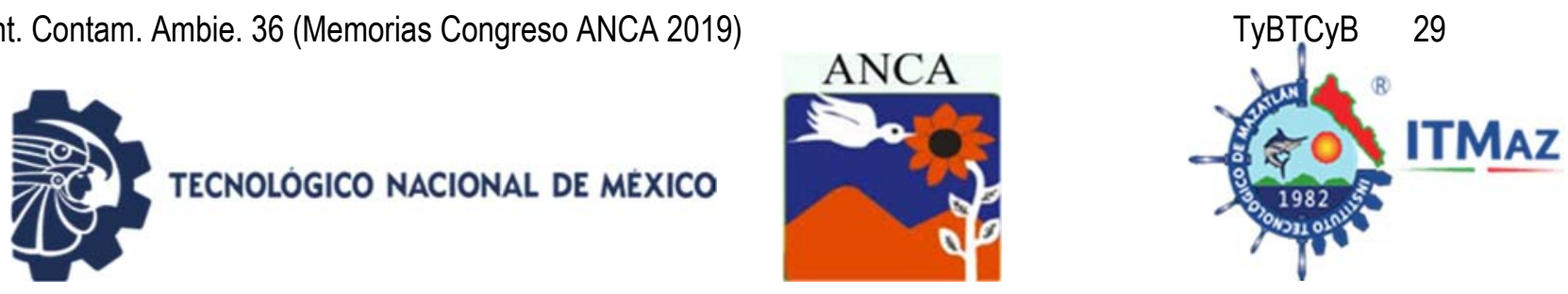

\title{
Evaluación de la PTAR del proceso de la planta LIX II del grupo minero BACIS
}

\author{
Botello de la Peña DC*, De la Peña Arellano LA, Lucho Chigo R, \\ Rodríguez Rosales MDJ \\ Departamento de Ing. Química y Bioquímica. UPIDET. \\ Instituto Tecnológico de Durango. Tecnológico Nacional de México. \\ Maestría en Sistemas Ambientales. \\ Blvd. Felipe Pescador 1830 Ote. Durango, Dgo., México, CP. 34080 \\ *ibq.danielabotello@gmail.com
}

\section{RESUMEN}

El grupo empresarial minero denominado "Grupo Minero Bacis S.A. de C.V." es uno de los productores más importantes de oro y plata en México con operaciones mineras en los estados de Durango, Zacatecas y Sinaloa. Este grupo dispone de una planta de lixiviación de minerales llamada "Lix II" que se encuentra ubicada en el municipio de Durango. Dentro de las instalaciones de esta planta se dispone de una planta tratadora de agua residual (PTAR), que se usa para tratar los efluentes generados por las actividades, para cumplir sus objetivos como empresa ambientalmente responsable, por lo que requiere evaluar la operación de la PTAR y en su caso, mejorar la depuración de sus aguas residuales para dar cumplimiento a los requerimientos establecidos en la normatividad correspondiente NOM-001-SEMARNAT-1996 y la NOM-003SEMARNAT-1999, con la finalidad de poder reutilizar esas aguas en el riego de áreas verdes y caminos. El objetivo de esta investigación consistió en realizar el diagnóstico del funcionamiento de la PTAR, a través de la caracterización de sus efluentes durante un año e identificar la en las etapas de tratamiento. Con los resultados obtenidos, se propuso y se realizó el mejoramiento del tratamiento biológico y de desinfección. Para ello se construyó un biodigestor en 3D a escala laboratorio y se realizaron pruebas de tratabilidad, mientras que para la desinfección se realizaron los cálculos necesarios para el cumplimiento de las condiciones de descarga establecidas en la normatividad. Con las propuestas establecidas por esta investigación se logro reutilizar el 100\% del agua tratada por la PTAR.

Palabras clave: Tratamiento, agua residual, minera, normatividad.

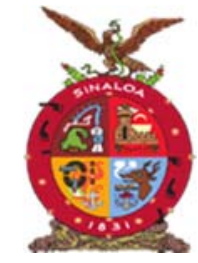

XVIII Congreso Internacional XXIV Congreso Nacional de Ciencias ambientales

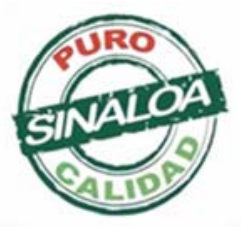

Mazatlán, Sinaloa 3-7 junio 2019
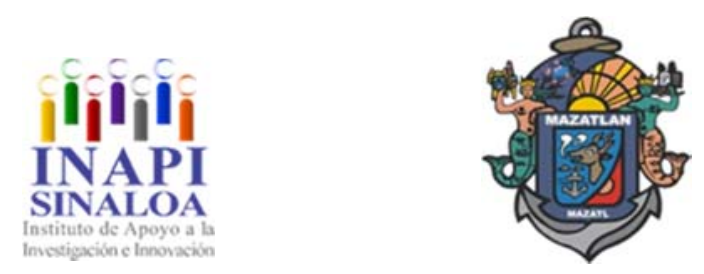

Tecnología y Biotecnología para el Tratamiento de Contaminantes y Biorremediación 
Rev. Int. Contam. Ambie. 36 (Memorias Congreso ANCA 2019)
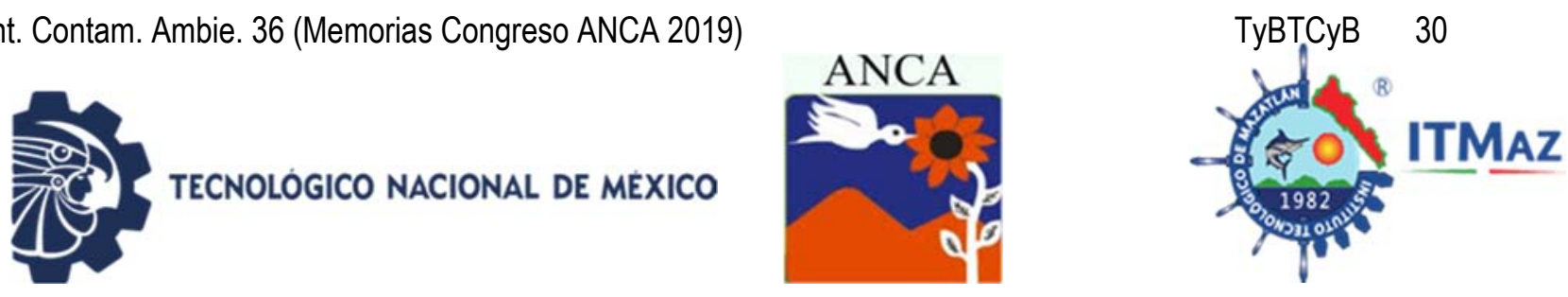

\title{
Evaluation of WWTP to the process of LIX plant II from grupo minero BACIS
}

\author{
Botello de la Peña DC*, De la Peña Arellano LA, Lucho Chigo R, \\ Rodríguez Rosales MDJ \\ Departamento de Ing. Química y Bioquímica. UPIDET. \\ Instituto Tecnológico de Durango. Tecnológico Nacional de México. \\ Maestría en Sistemas Ambientales. \\ Blvd. Felipe Pescador 1830 Ote. Durango, Dgo., México, CP. 34080 \\ *ibq.danielabotello@gmail.com
}

\begin{abstract}
The mining business group called "Grupo Minero Bacis S.A. de C.V." is one of the most important gold and silver producers in Mexico with mining operations in the states of Durango, Zacatecas and Sinaloa. This group has a mineral leaching plant called "Lix II" which is located in the municipality of Durango. The facilities of this plant is a wastewater treatment plant (WWTP), which is used to treat the effluents generated by the activities, and within its objectives as an environmentally responsible company, it requires evaluating the operation of the WWTP to improve the purification of its wastewater and comply with the requirements established in the corresponding regulations NOM-001SEMARNAT-1996 and NOM-003-SEMARNAT-1999, with the purpose of being able to reuse that waters into the irrigation of green areas and roads. So the objective of this research was to perform the diagnosis of the operation of the WWTP, through the characterization of its effluents for a year and identify the stages of treatment. With the obtained results, the improvement of the biological treatment and disinfection were proposed and carried out. Finally, a 3D biodigester was built at laboratory scale and to be able to practice some treatability tests, while for disinfection the necessary calculations were made to comply with the discharge conditions established in the regulations. With the proposals established by this research, it was possible to reuse $100 \%$ of the water treated by the WWTP.
\end{abstract}

Keywords: Treatment, waste water, mining, regulations.

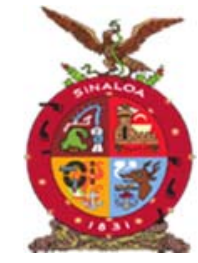

XVIII Congreso Internacional XXIV Congreso Nacional de Ciencias ambientales

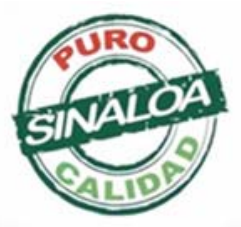

Mazatlán, Sinaloa 3-7 junio 2019
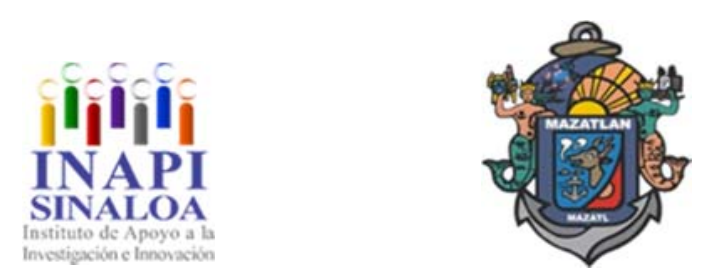

Tecnología y Biotecnología para el Tratamiento de Contaminantes y Biorremediación 

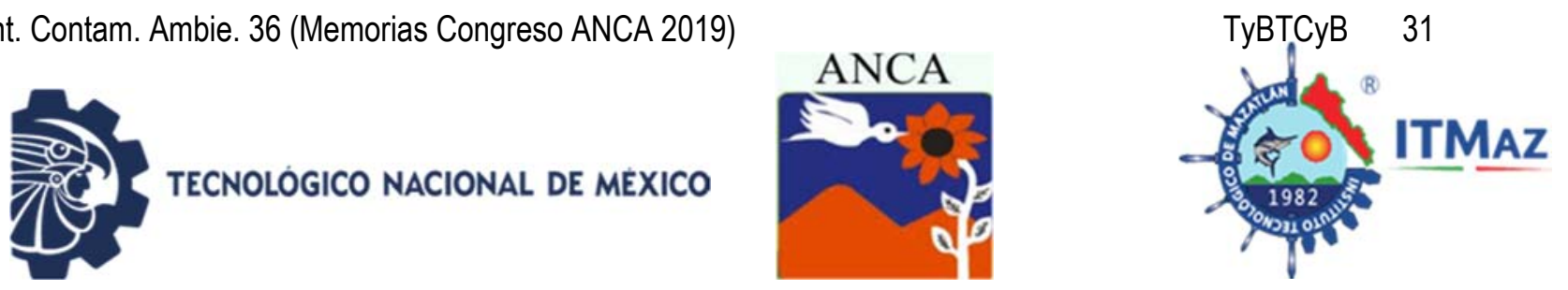

\title{
Riesgo sistémico a hipotiroidismo subclínico en mujeres que consumen agua contaminada por nitratos
}

\author{
Calleros Rincón $\mathrm{E}^{1^{*}}$, Gandarilla Esparza $\mathrm{D}^{1}$, Pérez Morales $\mathrm{R}^{1}$, \\ González Zamora $A^{2}$, Alba Romero J', Olivas Calderón $E^{1}$ \\ ${ }^{1}$ Facultad de Ciencias Químicas. UJED. Gómez Palacio, Dgo \\ ${ }^{2}$ Facultad de Ciencias Biológicas. UJED. Gómez Palacio, Dgo \\ *dra.ecallerosrincon@ujed.mx
}

\section{RESUMEN}

La sobre fertilización con sustancias nitrogenadas, ha contribuido a la contaminación de los mantos acuíferos, sobrepasando los límites de la NOM 127SSA-1994, menciona como nivel máximo permisible $10 \mathrm{mg} / \mathrm{L}$ de $\mathrm{N}-\mathrm{NO}_{3}$-Evaluar el riesgo sistémico a hipotiroidismo subclínico por el consumo de agua contaminada por de $\mathrm{N}-\mathrm{NO}_{3}$. Se estudiaron 10 comunidades, se midieron 51 pozos, la concentración de $\mathrm{N}^{-\mathrm{NO}_{3}}{ }^{-}$en agua se midió por electrodo ion selectivo. El muestreo de agua se realizó de acuerdo a los requerimientos de la Norma Oficial Mexicana NOM 014-SSA-1-1993. Se evaluó el riesgo siguiendo la metodología recomendada por la Agencia de Protección de Estados Unidos (EPA0073 8502,1999). Ésta investigación se realizó en los años 2017 y 2018, en comunidades del área rural de ciudad Lerdo, Dgo. El análisis de agua mostró que de los 51 pozos de agua para consumo humano, 29 están dentro y 27 están por encima de la NOM 127 SSA-1994, solo 2 representaron un riesgo $>1$. Se estudiaron 452 mujeres de 18 a 45 años de edad, 150 están expuestas a un nivel

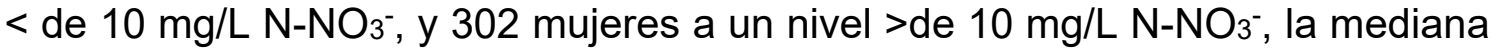
de TSH en el nivel alto fue de $1.8 \mu \mathrm{Ul} / \mathrm{mL}$ (rango: $0.5-11.3 \mu \mathrm{Ul} / \mathrm{mL} ; p=<0.047$ ). $\mathrm{OR}=2.86$ (IC 95\%:1.02-8.00, $\mathrm{p}=0.045)$. Existe riesgo sistémico a hipotiroidismo subclinico en la población que con sume agua contaminada con $\mathrm{N}-\mathrm{NO}^{3-}$

Palabras clave: Agua, nitrógeno de nitrato, riesgo, hipotiroidismo subclinico.

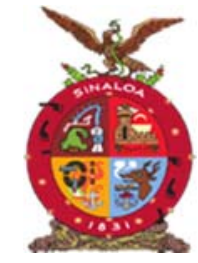

XVIII Congreso Internacional XXIV Congreso Nacional de Ciencias ambientales

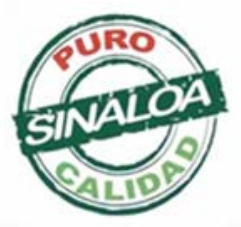

Mazatlán, Sinaloa 3-7 junio 2019
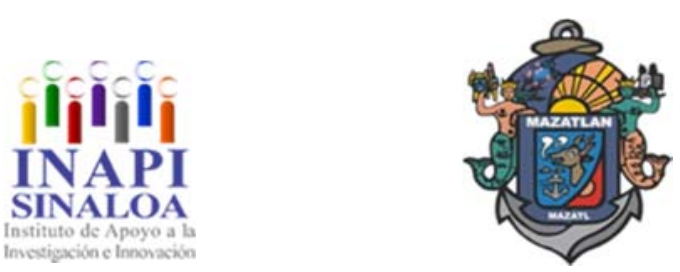

Tecnología y Biotecnología para el Tratamiento de Contaminantes y Biorremediación 
Rev. Int. Contam. Ambie. 36 (Memorias Congreso ANCA 2019)
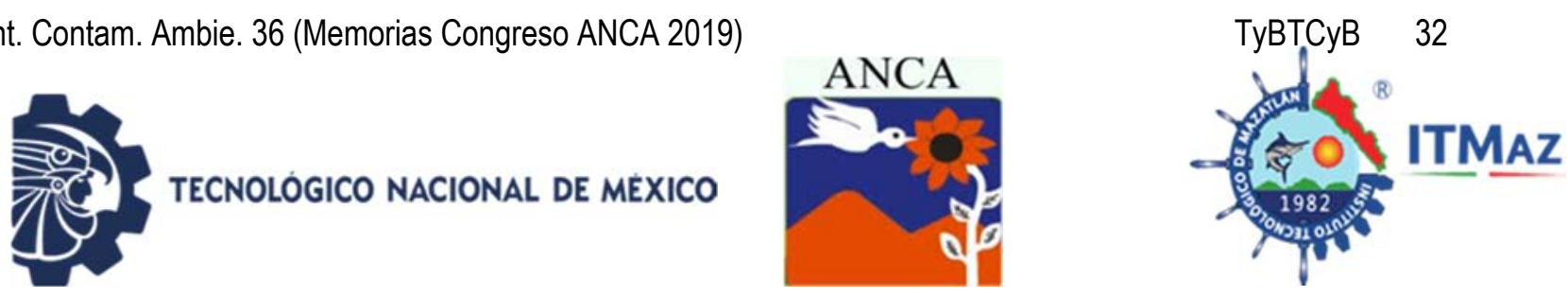

\title{
Systemic risk of subclinical hypothyroidism in women who consumed water contaminated by nitrates
}

\author{
Calleros Rincón $E^{1 *}$, Gandarilla Esparza D ${ }^{1}$, Pérez Morales $\mathrm{R}^{1}$, \\ González Zamora $A^{2}$, Alba Romero J1 , Olivas Calderón E ${ }^{1}$ \\ ${ }^{1}$ Facultad de Ciencias Químicas, UJED. Gómez Palacio, Dgo \\ ${ }^{2}$ Facultad de Ciencias Biológicas. UJED. Gómez Palacio, Dgo \\ *dra.ecallerosrincon@ujed.mx
}

\begin{abstract}
The over fertilization with nitrogenous substances, has contributed to the contamination of the aquifers, exceeding the limits of NOM 127-SSA-1994, mentions as maximum permissible level $10 \mathrm{mg} / \mathrm{L}$ of $\mathrm{N}-\mathrm{NO}_{3}{ }^{-}$. To evaluate the systemic risk of subclinical hypothyroidism due to the consumption of water contaminated by $\mathrm{N}^{-\mathrm{NO}_{3}-10}$ communities were studied, 51 wells were measured,

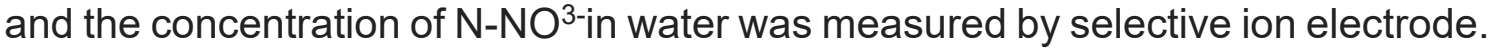
Water sampling was carried out according to the requirements of Official Mexican Standard NOM 014-SSA-1-1993. The risk was evaluated following the methodology recommended by the United States Protection Agency (EPA0073 8502, 1999). This research was carried out in 2017 and 2018, in communities in the rural area of Lerdo, Dgo. The water analysis showed that of the 51 water wells for human consumption, 29 are inside and 27 are above the NOM 127 SSA-1994, only 2 represented a risk $>1$. 452 women aged 18 to 45 were studied of age, 150 are exposed to a level <of $10 \mathrm{mg} / \mathrm{L} \mathrm{N}-\mathrm{NO}_{3}{ }^{-}$, and 302 women at a level>of $10 \mathrm{mg} / \mathrm{L}$ $\mathrm{N}-\mathrm{N}_{3}{ }^{-}$, the median of $\mathrm{TSH}$ at the high level was $1.8 \mu \mathrm{Ul} / \mathrm{mL}$ (range: $0.5-11.3$ $\mu \mathrm{UI} / \mathrm{mL}, \mathrm{p}=<0.047)$. OR $=2.86(95 \% \mathrm{Cl}: 1.02-8.00, \mathrm{p}=0.045)$. There is a systemic risk of subclinical hypothyroidism in the population that sums up water contaminated with $\mathrm{N}^{-\mathrm{NO}_{3}}$.
\end{abstract}

Keywords: Water, nitrate nitrogen, risk, subclinical hypothyroidism.

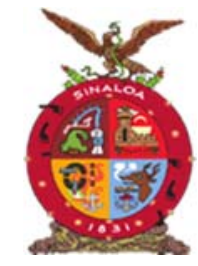

XVIII Congreso Internacional XXIV Congreso Nacional de Ciencias ambientales

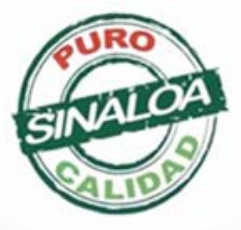

Mazatlán, Sinaloa 3-7 junio 2019
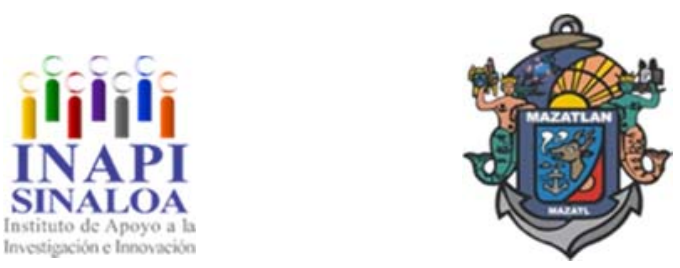

Tecnología y Biotecnología para el Tratamiento de Contaminantes y Biorremediación 

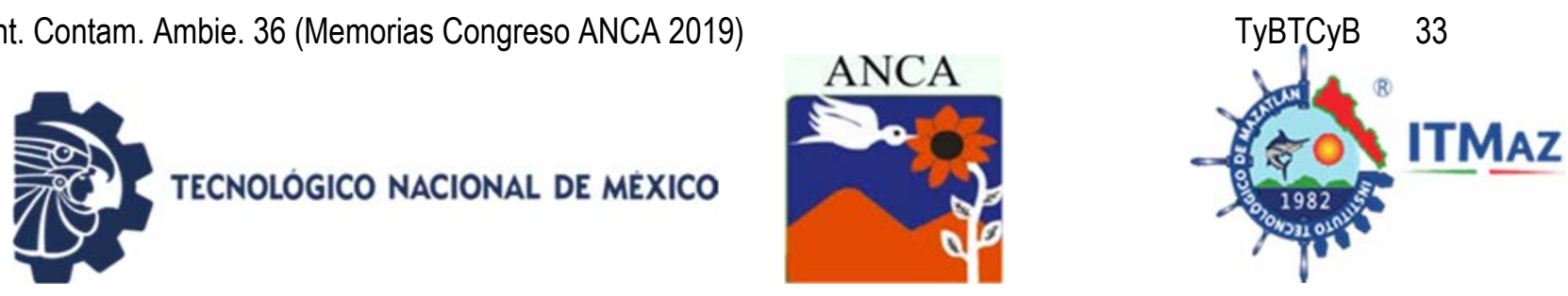

\title{
Producción de biohidrógeno mediante codigestión de residuos agroindustriales
}

\author{
Campaña $\mathrm{H}^{*}$, Airasca A, Dietrich N \\ GEAQB (Grupo de Estudio Ambiente, Química y Biología) \\ Facultad Regional Bahía Blanca. Universidad Tecnológica Nacional. \\ 11 de Abril 461, 8000 Bahía Blanca, Argentina \\ *hcampana@frbb.utn.edu.ar
}

\section{RESUMEN}

Existe una conciencia creciente con respecto al uso de energías renovables, consideradas esenciales para controlar la contaminación ambiental. El hidrógeno es un sustituto posible de los combustibles fósiles. La codigestión anaeróbica es una alternativa para resolver el tratamiento de distintos sustratos, convirtiéndolos en energía limpia. La generación de biohidrógeno a partir de residuos agroindustriales es ventajosa por disponibilidad, costo, biodegradabilidad y su carácter renovable. Este trabajo fue realizado para evaluar la producción de hidrógeno mediante fermentación oscura a partir de codigestión de residuos industriales de pera y manzana mezclados con estiércol bovino. Las experiencias a escala laboratorio se realizaron en digestores discontinuos de 2 litros con volumen útil de $1050 \mathrm{~mL}$. La concentración de sustrato fue $8 \%-9 \% \mathrm{MS}$ (50\% de cada residuo vegetal y estiércol), ajustando el pH inicial en 8,5 con soda cáustica. El Tiempo de Retención Hidráulico fue 72 horas en condiciones termofílicas $\left(55^{\circ} \mathrm{C}\right)$ de oscuridad en baño termostatizado. El volumen total de biogás producido fue similar para ambos residuos vegetales $(1060 \mathrm{~mL})$. La composición de hidrógeno en el biogás varió entre $18 \%$ y $33 \%$ para residuos de manzana y entre $31 \%$ y $70 \%$ para los residuos de pera. El pH final para ambos residuos vegetales fue 4,1.De los resultados obtenidos se concluyó que, los residuos agroindustriales de manzana y pera pueden convertirse en hidrógeno mediante la 1er etapa de codigestón anaeróbica, con rendimiento mayor del último residuo. Se requiere profundizar la investigación para optimizar la producción de $\mathrm{H}_{2}$ (pretratamiento de los residuos agroindustriales).

Palabras claves: Codigestión anaeróbica, biohidrógeno, residuos agroindustriales.

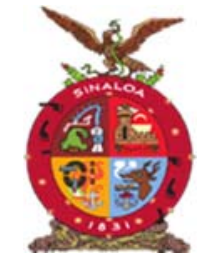

XVIII Congreso Internacional XXIV Congreso Nacional de Ciencias ambientales

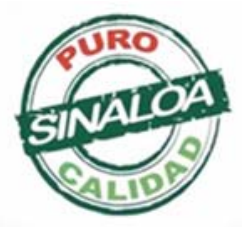

Mazatlán, Sinaloa 3-7 junio 2019
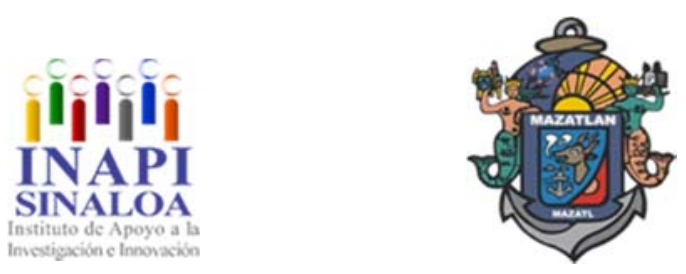

Tecnología y Biotecnología para el Tratamiento de Contaminantes y Biorremediación 

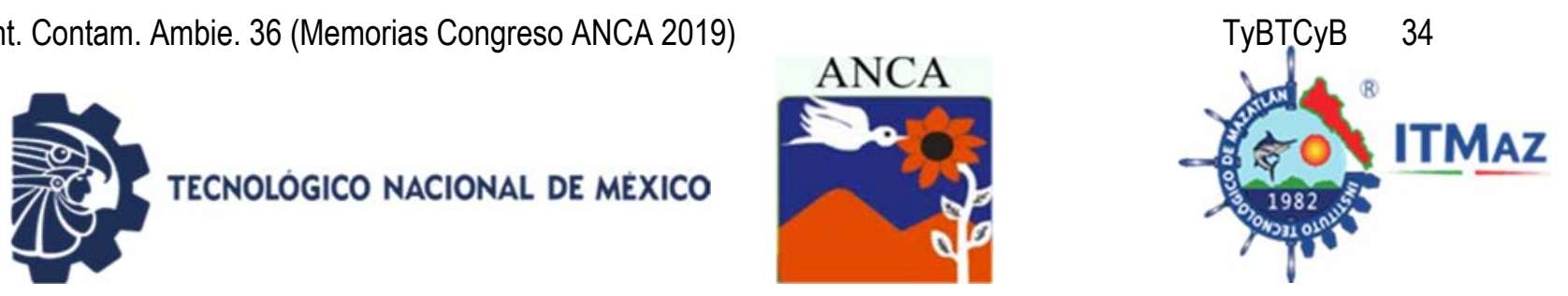

Bio-hydrogen production from agroindustrial wastes codigestion

\author{
Campaña $\mathrm{H}^{*}$, Airasca A, Nadia Dietrich $\mathrm{N}$ \\ GEAQB (Grupo de Estudio Ambiente, Química y Biología) \\ Facultad Regional Bahía Blanca. Universidad Tecnológica Nacional. \\ 11 de Abril 461, 8000 Bahía Blanca, Argentina \\ *hcampana@frbb.utn.edu.ar
}

\begin{abstract}
There is increasing awareness that renewable energy is vital for controlling the environmental pollution. Hydrogen is considered as one of the most promising candidates as a substitute for fossil fuels. Anaerobic codigestion is a reliable alternative option to resolve the disadvantages of single substrate digestion system related to substrate characteristics, turning the complex organic materials into a clean and renewable source of energy. In particular, biohydrogen production from agroindustrial waste is very advantageous since agri-wastes are abundant, cheap, renewable and biodegradable. This study was conducted to evaluate $\mathrm{H}_{2}$ production from apple and pear wastes in dark fermentation codigestion process with cow manure and explored the hydrogen yield. Laboratory-scale experiments were carried out (2018) in batch bioreactors $2 \mathrm{~L}$ capacity, with $1050 \mathrm{~mL}$ worked. Substrate concentration were between 8-9\% DM (50\% each agri waste and manure) and initial pH 8.5 (adjusted with caustic). Hydraulic Retention Time was $72 \mathrm{hr}$ at thermophylic condition (55 C) in darked thermostatically controlled water bath. The accumulative biogas production was similar for both wastes $(1060 \mathrm{~mL})$. Hydrogen from biogas composition were between $18 \%$ and $33 \%$ with apple waste and $31 \%$ and $70 \%$ with pear waste. $\mathrm{pH}$ ended both tests 4,1 . According to present results agri-wastes such as apple and pear can be converted to hydrogen in codigestion anaerobic $1^{\text {st }}$ stage process with a higher yield for the last one. However, the process needs further research to optimize the $\mathrm{H}_{2}$ production (agri wastes pretreatment).
\end{abstract}

Keywords: Anaerobic codigestion, biohydrogen, agri-wastes.

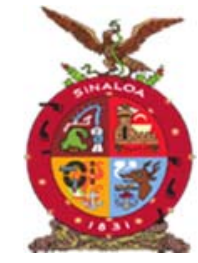

XVIII Congreso Internacional XXIV Congreso Nacional de Ciencias ambientales

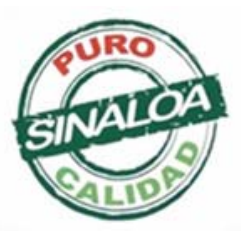

Mazatlán, Sinaloa 3-7 junio 2019
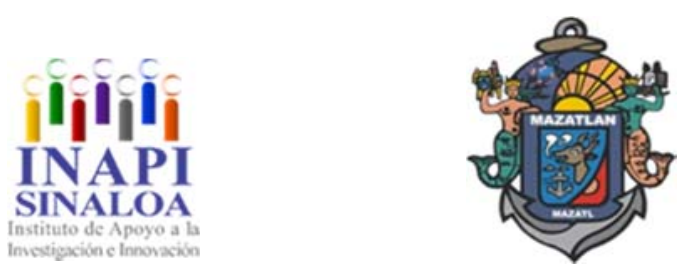

Tecnología y Biotecnología para el Tratamiento de Contaminantes y Biorremediación 

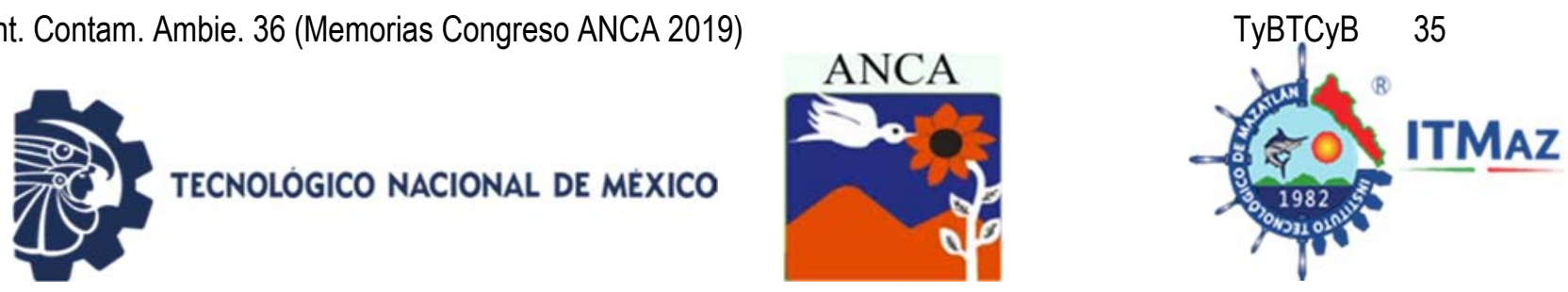

\title{
Proceso de sorción de tetraciclina en medio acuoso utilizando un composito de zeolita/hidroxiapatita
}

\author{
Carrasco Campos P, Torres Pérez J*, Corral Avitia A \\ Laboratorio de Transferencia y Degradación de Contaminantes. \\ Universidad Autónoma de Ciudad Juárez, \\ Anillo Envolvente del Pronaf y Estocolmo S/N, C.P. 32300, A.P. 1595 D, Ciudad \\ Juárez, Chihuahua, México, \\ *jonatan.torres@uacj.mx

\section{RESUMEN}

La tetraciclina es un antibiótico de amplio espectro detectado frecuentemente en aguas residuales. Su presencia en agua resulta perjudicial para los organismos que entran en contacto con ella, conllevando a desequilibrios ecológicos. Las tecnologías convencionales de tratamiento avanzado de aguas normalmente son de costo elevado y en ocasiones se generan subproductos contaminantes. La adsorción es un proceso eficiente para el tratamiento de aguas contaminadas con antibióticos, siendo de bajo costo y bajo impacto ambiental. La zeolita y la hidroxiapatita son minerales que poseen propiedades adsorbentes. El objetivo de la presente investigación fue determinar la eficiencia de adsorción de un composito de zeolita/hidroxiapatita y de sus materiales precursores aislados, mediante cinéticas e isotermas de sorción para la remoción de tetraciclina en medio acuoso. Este proceso se realizó en el Laboratorio de Transferencia y Degradación de Contaminantes (LTDC) de la Universidad Autónoma de Ciudad Juárez (Juárez, Chihuahua, México) en el periodo de enero 2018 a marzo 2019, donde se sintetizó el composito zeolita/hidroxiapatita por precipitación química y se realizaron cinéticas e isotermas de sorción de tetraciclina en medio destilado e iónico utilizando el composito y sus materiales precursores aislados. El composito zeolita/hidroxiapatita tuvo una velocidad de sorción de tetraciclina más rápida que sus materiales precursores y la capacidad máxima de sorción de tetraciclina del composito fue de $32.11 \mathrm{mg} / \mathrm{g}$ en medio destilado y $11.93 \mathrm{mg} / \mathrm{g}$ en medio iónico. En conclusión, resulta conveniente la síntesis del composito zeolita/hidroxiapatita, siendo un adsorbente de uso viable para la remoción de tetraciclina de medio acuoso.

Palabras clave: Tetraciclina, adsorción, zeolita/hidroxiapatita.

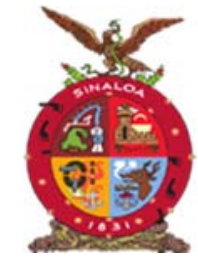

XVIII Congreso Internacional XXIV Congreso Nacional de Ciencias ambientales

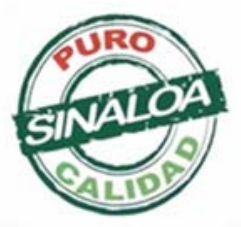

Mazatlán, Sinaloa 3-7 junio 2019
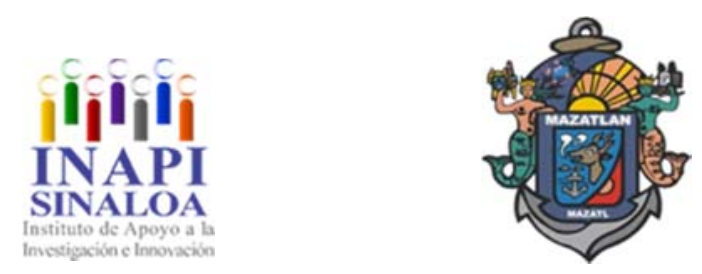

Tecnología y Biotecnología para el Tratamiento de Contaminantes y Biorremediación 

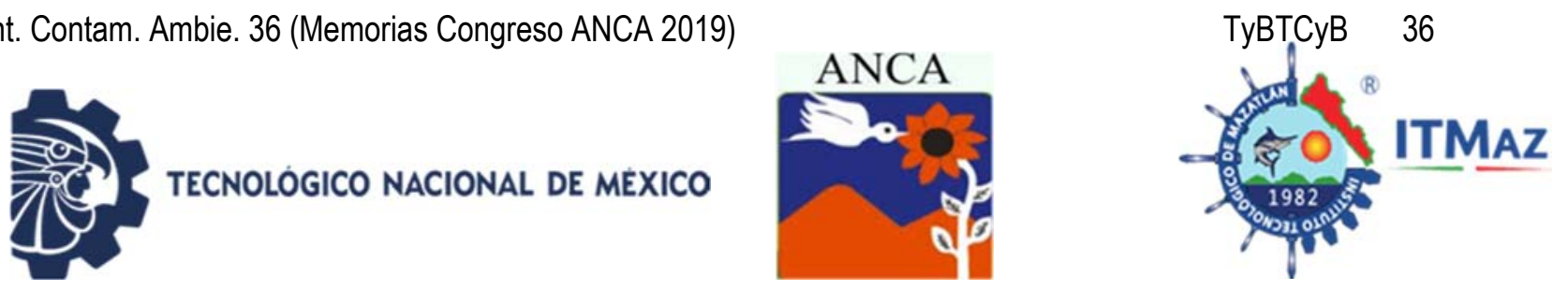

\title{
Tetracycline sorption process in aqueous medium by zeolite/hydroxyapatite composite
}

\author{
Carrasco Campos P, Torres Pérez J $\mathrm{J}^{\star}$, Corral Avitia A \\ Laboratorio de Transferencia y Degradación de Contaminantes. \\ Universidad Autónoma de Ciudad Juárez, \\ Anillo Envolvente del Pronaf y Estocolmo S/N, C.P. 32300, A.P. 1595 D, Ciudad \\ Juárez, Chihuahua, México, \\ *jonatan.torres@uacj.mx
}

\begin{abstract}
Tetracycline is a broad-spectrum antibiotic frequently detected in wastewater. Its presence in water is harmful to organisms that come in contact with it, leading to ecological imbalances. Conventional advanced water treatment technologies are usually expensive and sometimes polluting by-products are generated. Adsorption is an efficient process for the treatment of water contaminated with antibiotics do to its low cost and low environmental impact. Zeolite and hydroxyapatite are minerals that have adsorbent properties. The objective of this investigation was to determine the adsorption efficiency of a zeolite/hydroxyapatite composite and its isolated precursor materials using sorption kinetics and isotherms for the removal of tetracycline in aqueous medium. This process was carried out in the Pollutant Transfer and Degradation Laboratory (LTDC) of the Autonomous University of Ciudad Juárez (Juárez, Chihuahua, Mexico) in the period from January 2018 to March 2019, where the zeolite/hydroxyapatite composite was synthesized by chemical precipitation and tetracycline sorption kinetics and isotherms were carried out in distilled and ionic medium using the composite and its isolated precursor materials. The zeolite/hydroxyapatite composite had a faster tetracycline sorption rate than its precursor materials and the maximum tetracycline sorption capacity of the composite was $32.11 \mathrm{mg} / \mathrm{g}$ in distillate medium and $11.93 \mathrm{mg} / \mathrm{g}$ in ionic medium. In conclusion, the synthesis of the zeolite/hydroxyapatite composite results convenient, being an adsorbent of viable use for the removal of tetracycline from aqueous medium.
\end{abstract}

Keywords: Tetracycline, sorption, zeolite/hydroxyapatite.

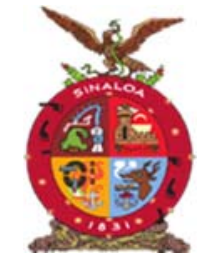

XVIII Congreso Internacional XXIV Congreso Nacional de Ciencias ambientales

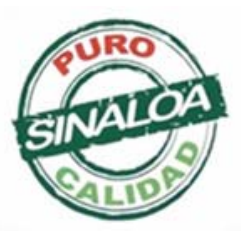

Mazatlán, Sinaloa 3-7 junio 2019
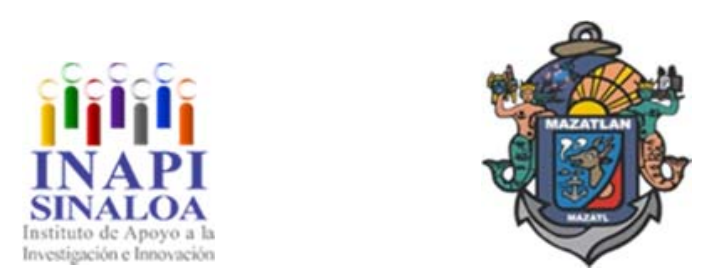

Tecnología y Biotecnología para el Tratamiento de Contaminantes y Biorremediación 

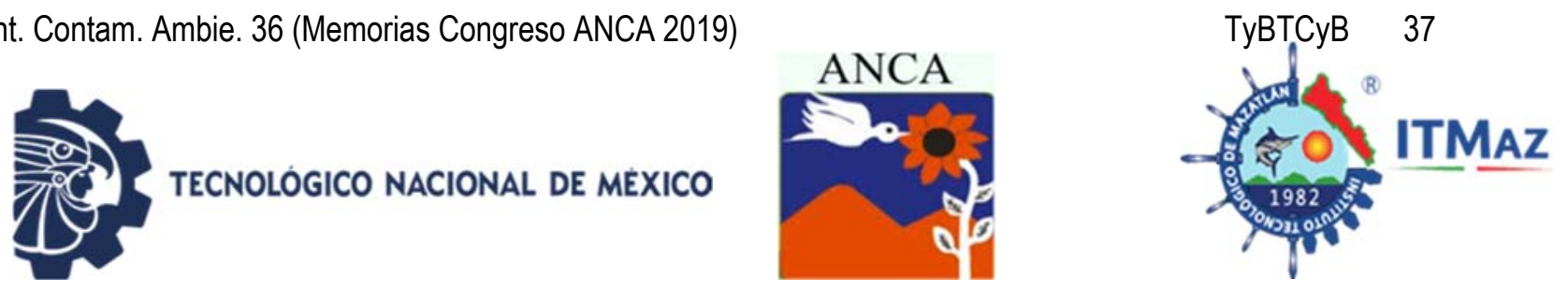

\title{
Caracterización física y química de sustratos de proceso de Biorremediación
}

Castillo Morales $\mathrm{M}^{1 *}$, Mendoza Hernández $\mathrm{JC}^{1}$, Arriola Morales $\mathrm{J}^{1}$, Pérez Osorio $\mathrm{G}^{1}$, García Niño AL², Ortíz Méndez JD²

\author{
${ }^{1} \mathrm{BUAP}$ \\ ${ }^{2}$ Ingeniería Ambiental.BUAP, \\ Calle 4 Sur 104, Centro Histórico, Puebla, Puebla. C.P. 72000. \\ *maribel.castillo@correo.buap.mx
}

\begin{abstract}
RESUMEN
Los procesos de Biorremediación asistida por bacterias (BAB) son útiles para tratar contaminantes. Los jales de minas son residuos de minería compuestos primordialmente por metales pesados y se disponen a cielo abierto sin tratamiento, generando problemas al medio y considerándose potencialmente tóxicos. El objetivo de este trabajo es conocer la variación de las características física y químicas de los jales después de un proceso de BAB. Metodología: Se caracterizaron jales de minas de Zimapán, Hidalgo, realizando 6 tratamientos bacterianos diferentes con las cepas Serratia y Pantoea en una mezcla de $750 \mathrm{~g}$ de jal y $150 \mathrm{~g}$ de sustrato orgánico comercial. La caracterización física y química fue previa y posterior al tratamiento bacteriano de biorremediación conforme a la NOM-021-RECNAT-2000 (capacidad de intercambio catiónico (C.I.C.), pH, conductividad eléctrica (C.E.), materia orgánica, acidez extraíble (A.E.), calcio, magnesio, cloruros, carbonatos y bicarbonatos). Resultados: las características que variaron con los tratamientos fueron una disminución de la C.E., bicarbonatos, cloruros, magnesio, calcio y la C.I.C., aumentaron el pH (neutro), Nitrógeno,\% materia orgánica. En conclusión, las modificaciones de las características fisicoquímicas debidas a la presencia de las bacterias favorecen la calidad del jal para el crecimiento de las plantas y poder usar las bacterias junto con las plantas en los procesos de fitorremediación apoyados por las bacterias.
\end{abstract}

Palabras clave: Fitorremediación asistida, elementos potencialmente tóxicos, caracterización fisicoquímica, metales pesados.

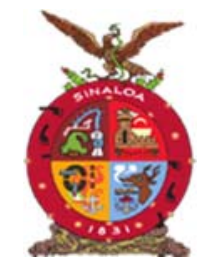

XVIII Congreso Internacional XXIV Congreso Nacional de Ciencias ambientales

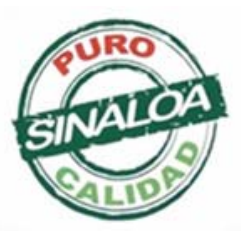

Mazatlán, Sinaloa 3-7 junio 2019
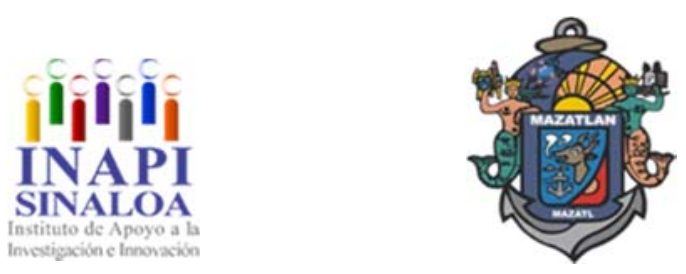

Tecnología y Biotecnología para el Tratamiento de Contaminantes y Biorremediación 

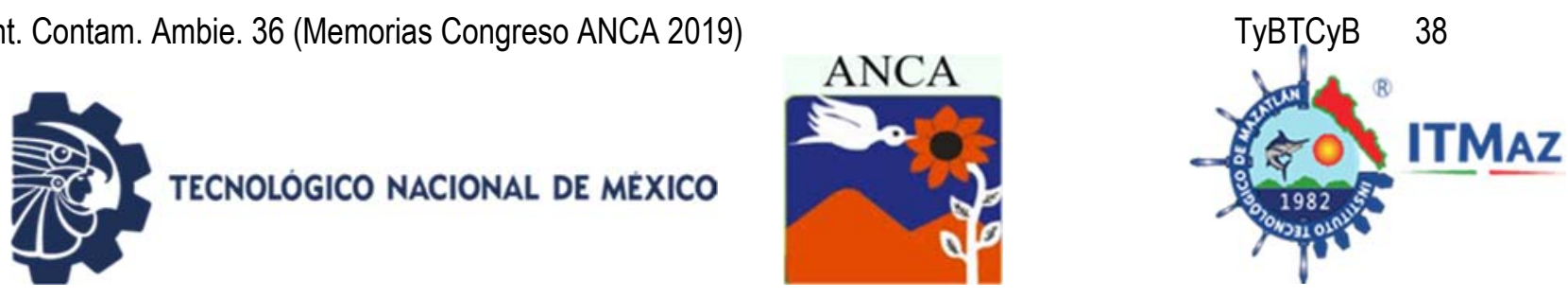

\title{
Physical and chemical characterization of biorremediation process substrates
}

\author{
Castillo Morales $\mathrm{M}^{1}$, Mendoza Hernández $\mathrm{JC}^{1}$, Arriola Morales $\mathrm{J}^{1}$, \\ Pérez Osorio $\mathrm{G}^{1}$, García Niño AL², Ortíz Méndez JD² \\ ${ }^{1} \mathrm{BUAP}$ \\ ${ }^{2}$ Ingeniería Ambiental.BUAP, \\ Calle 4 Sur 104, Centro Histórico, Puebla, Puebla. C.P. 72000. \\ *maribel.castillo@correo.buap.mx
}

\begin{abstract}
The processes of bioremediation assisted by bacteria (BAB) are useful to treat pollutants. Mine tailings are mining residues composed primarily of heavy metals and are disposed of open-pit without treatment, generating problems to the environment and being considered potentially toxic. The objective of this work is to know the variation of the physical and chemical characteristics of the tailings after a $B A B$ process. Methodology: Mine tailings from Zimapán, Hidalgo were characterized, performing 6 different bacterial treatments with Serratia and Pantoea strains in a mixture of $750 \mathrm{~g}$ of jal and $150 \mathrm{~g}$ of commercial organic substrate. The physical and chemical characterization was before and after the bacterial treatment of bioremediation according to NOM-021-RECNAT-2000 (cation exchange capacity $(\mathrm{CIC}), \mathrm{pH}$, electrical conductivity $(\mathrm{EC})$, organic matter, extractable acidity (AE), calcium, magnesium, chlorides, carbonates and bicarbonates). Results: the characteristics that varied with the treatments were a decrease of the C.E., bicarbonates, chlorides, magnesium, calcium and the C.I.C., increased the $\mathrm{pH}$ (neutral), Nitrogen,\% organic matter. In conclusion, the modifications of the physicochemical characteristics due to the presence of bacteria favor the quality of the jal for the growth of the plants and to be able to use the bacteria along with the plants in the phytoremediation process with bacterial.
\end{abstract}

Keywords: Assisted phytoremediation, potentially toxic elements, physicochemical characterization, heavy metals.

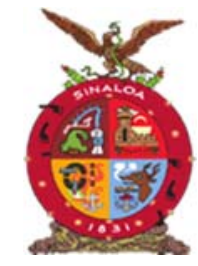

XVIII Congreso Internacional XXIV Congreso Nacional de Ciencias ambientales

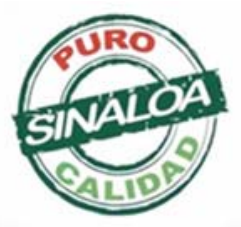

Mazatlán, Sinaloa 3-7 junio 2019
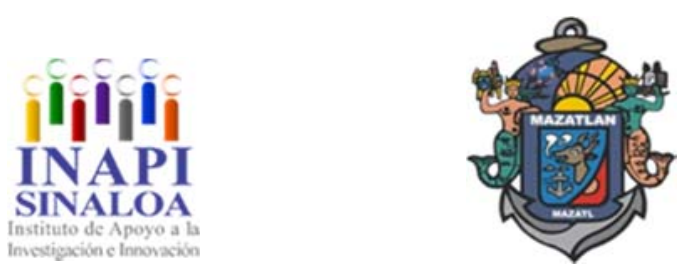

Tecnología y Biotecnología para el Tratamiento de Contaminantes y Biorremediación 


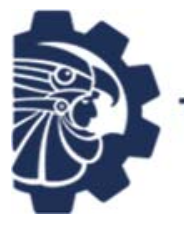

TECNOLOGICO NACIONAL DE MEXICO
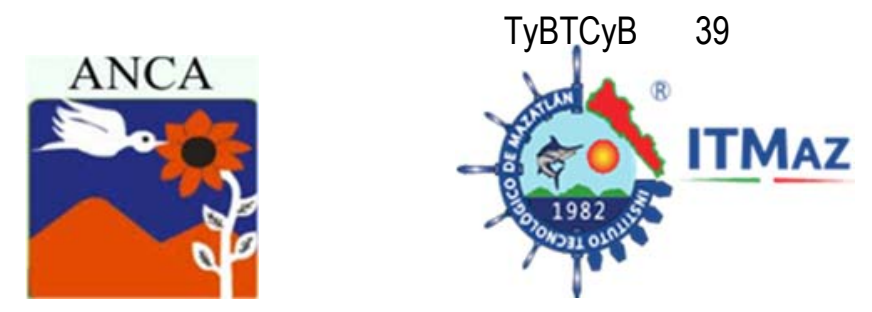

\title{
Actividad enzimática en procesos de fitorremediación de jales mineros asistidos con bacterias
}

\author{
Castillo Morales $\mathrm{M}^{1}$, Mendoza Hernández $\mathrm{JC}^{1}$, Arriola Morales $\mathrm{J}^{1}$, \\ Pérez Osorio $\mathrm{G}^{1}$, Fernández Martínez $\mathrm{L}^{2}$, Del Rosario de Jesús $\mathrm{K}^{2}$ \\ ${ }^{1} \mathrm{BUAP}$ \\ ${ }^{2}$ Ingeniería Ambiental.BUAP, \\ Calle 4 Sur 104, Centro Histórico, Puebla, Puebla. C.P. 72000. \\ *maribel.castillo@correo.buap.mx
}

\begin{abstract}
RESUMEN
La actividad minera es una de las actividades económicas más importantes en México, sin embargo, la contaminación por presencia de metales pesados tiene efectos tóxicos en los ecosistemas. La fitorremediación asistida por bacterias es una alternativa para la remoción, recuperación o destoxificación de suelos contaminados en presencia de metales pesados. La activación de defensas en las plantas frente a la presencia de contaminantes al suprimir o eliminar especies reactivas de oxígeno (ERO) reduce el oxígeno molecular a formas menos tóxicas por vías enzimáticas, ya que los contaminantes modifican el equilibrio entre producción y eliminación de ERO e inducen a un estrés oxidativo en la planta. El objetivo de este trabajo es medir la actividad enzimática mediante las especies reactivas de oxígeno en procesos de fitorremediación asistida por bacterias. El experimento se realizó utilizando malva (Malva sylvestris), e higuerilla (Ricinus communis), en una mezcla de jal de minas con $20 \%$ de sustrato comercial Miracle Grow, con 5 bacterias del género Serratia, Pantoea, conformándose 18 unidades experimentales con 4 semillas; las cuales se inocularon con $25 \mathrm{~mL}$ de solución bacteriana respectivamente, después de 2 meses se midió la actividad enzimática de ERO presentes en las plantas. El análisis estadístico de ERO indica diferencia significativa entre las plantas inoculadas respecto a los testigos; así como cambios físicos en engrosamiento de tallos y elongación de raíces. Las BPCV reducen la presencia de ERO disminuyendo el estrés oxidativo generado por los metales del jal favoreciendo los procesos de fitorremediación.
\end{abstract}

Palabras clave: Actividad enzimática, especies reactivas del oxígeno, fitorremediación, estrés oxidativo, elementos potencialmente tóxicos.

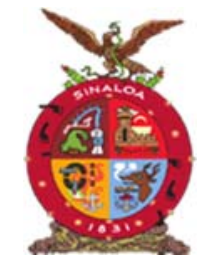

XVIII Congreso Internacional XXIV Congreso Nacional de Ciencias ambientales

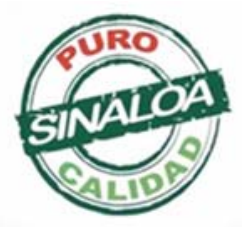

Mazatlán, Sinaloa 3-7 junio 2019
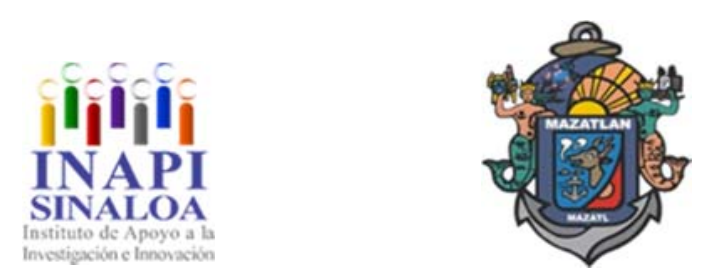

Tecnología y Biotecnología para el Tratamiento de Contaminantes y Biorremediación 


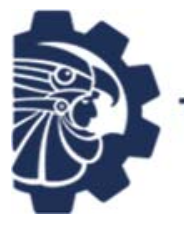

TECNOLOGICO NACIONAL DE MEXICO
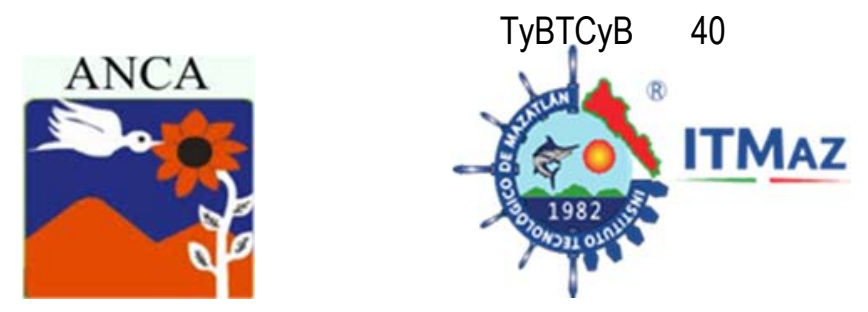

\title{
Enzymatic activity in phytorremediation processes of mineral jales assisted with bacteria
}

\author{
Castillo Morales $\mathrm{M}^{1 *}$, Mendoza Hernández $\mathrm{JC}^{1}$, Arriola Morales $\mathrm{J}^{1}$, \\ Pérez Osorio $\mathrm{G}^{1}$, Fernández Martínez $\mathrm{L}^{2}$, Del Rosario de Jesús $\mathrm{K}^{2}$ \\ ${ }^{1} \mathrm{BUAP}$ \\ ${ }^{2}$ Ingeniería Ambiental.BUAP, \\ Calle 4 Sur 104, Centro Histórico, Puebla, Puebla. C.P. 72000. \\ *maribel.castillo@correo.buap.mx
}

\begin{abstract}
Mining activity is one of the most important economic activities in Mexico, however, contamination due to the presence of heavy metals has toxic effects on ecosystems. Phytoremediation assisted by bacteria is an alternative for the removal, recovery or detoxification of contaminated soils in the presence of heavy metals. The activation of defenses in plants against the presence of contaminants by suppressing or eliminating reactive oxygen species (ROS) reduces oxygen to less toxic forms through enzymatic pathways, since contaminants modify the balance between production and elimination of ROS, induce an oxidative stress in the plant. The objective of this work is to measure the enzymatic activity by reactive oxygen species in bacteria-assisted phytoremediation processes. The experiment was carried out using malva (Malva sylvestris), and castor bean (Ricinus communis), in a mixture of mine tailings with $20 \%$ commercial substrate Miracle Grow, with 5 bacteria of the genus Serratia, Pantoea, forming 18 experimental units with 4 seeds; which were inoculated with $25 \mathrm{~mL}$ of bacterial solution respectively, after 2 months the enzymatic activity of ERO present in the plants was measured. The statistical analysis of ROS indicates a significant difference molecular between the plants inoculated with respect to the controls; as well as physical changes in stem thickening and root elongation. Conclusión: BPCV reduce the presence of ERO by decreasing the oxidative stress generated by the jal metals, favoring phytoremediation processes.
\end{abstract}

Keywords: Enzymatic activity, reactive oxygen species, phytoremediation, oxidative stress, potentially toxic elements.

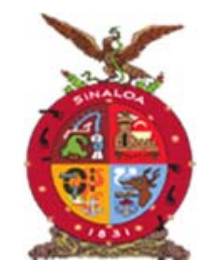

XVIII Congreso Internacional XXIV Congreso Nacional de Ciencias ambientales

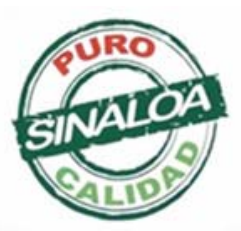

Mazatlán, Sinaloa 3-7 junio 2019
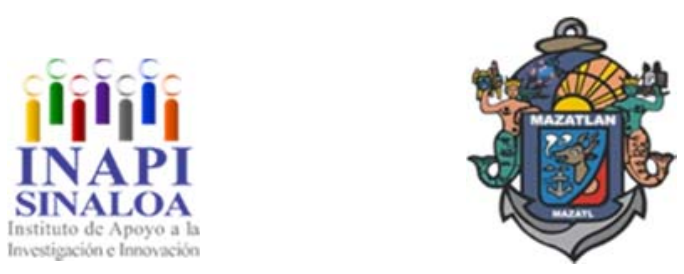

Tecnología y Biotecnología para el Tratamiento de Contaminantes y Biorremediación 

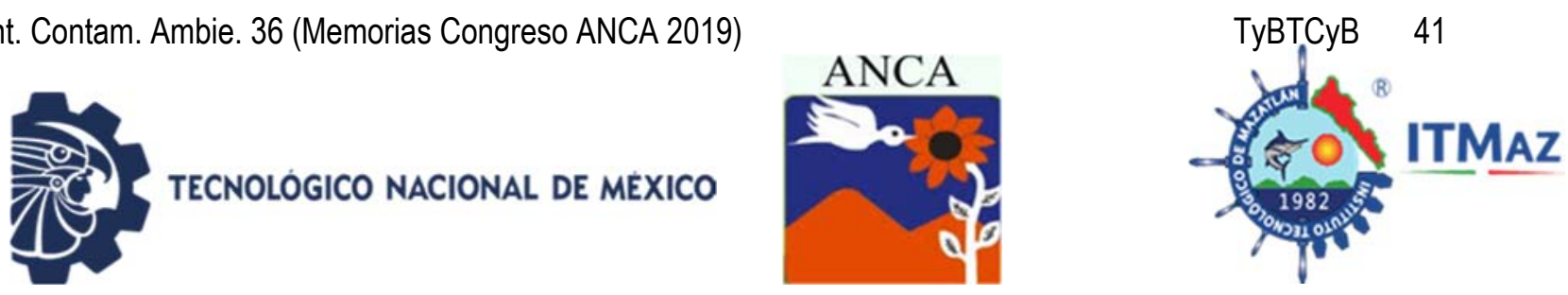

\title{
Producción de carbón activado y su aplicación en la retención de azul brillante No.1
}

\author{
Chavarría Murillo CD, Torres Pérez J \\ Laboratorio de Transferencia y Degradación de Contaminantes. \\ Universidad Autónoma de Ciudad Juárez, \\ Anillo Envolvente del Pronaf y Estocolmo S/N, C.P. 32300, A.P. 1595-D, \\ Ciudad Juárez, Chihuahua, México.
}

\section{RESUMEN}

El azul brillante $(A B)$, es un colorante trifenilmetálico, clasificado como aniónico y con propiedades ácidas, es utilizado en la industria alimentaria en bebidas, productos lácteos, polvos, en particular en la coloración de helados y repostería, condimentos y en la industria cárnica. Por esta razón, su presencia es frecuente en los efluentes coloreados, vertidos por diferentes industrias, ocasionando impactos negativos. Se ha encontrado que uno de los métodos más eficaces para la eliminación de contaminantes en el agua es la sorción y el carbón activado es quien resultar ser el adsorbente más eficaz. El objetivo del presente trabajo fue evaluar la capacidad de adsorción del carbón activado que tiene sobre azul brillante No.1 en medio acuoso. Este proceso se realizó en el Laboratorio de Transferencia y Degradación de Contaminantes (LTDC) de la Universidad Autónoma de Ciudad Juárez (Juárez, Chihuahua, México) en el periodo de MayoDiciembre 2018, en donde se realizó la activación de carbón a partir de semilla de algodón, determinando el pH del mismo. Se aplicó el modelo Langmuir y Freundlich para obtener los parámetros isotérmicos y los modelos de primer y pseudo-segundo orden para las cinéticas de sorción. Donde el proceso de sorción en ambos medios alcanza el equilibrio a partir de $192 \mathrm{~h}$ disminuyendo la concentración de manera similar para ambos casos y alcanzado remociones importantes de 80 y $72 \%$ para el medio destilado e iónico respectivamente. El proceso de adsorción resulto ser eficiente para la remoción del Azul Brillante No.1 en medio acuoso usando un carbón activado sustentable preparado a partir de semilla de algodón.

Palabras clave: Carbón activado, colorantes aniónicos, Azul Brillante No.1, cinéticas e isotermas de sorción.

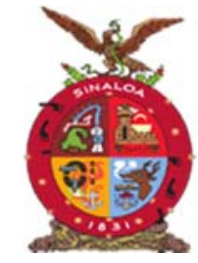

XVIII Congreso Internacional XXIV Congreso Nacional de Ciencias ambientales

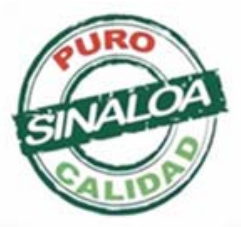

Mazatlán, Sinaloa 3-7 junio 2019
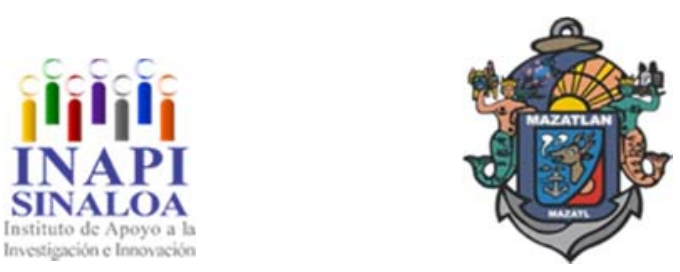

Tecnología y Biotecnología para el Tratamiento de Contaminantes y Biorremediación 

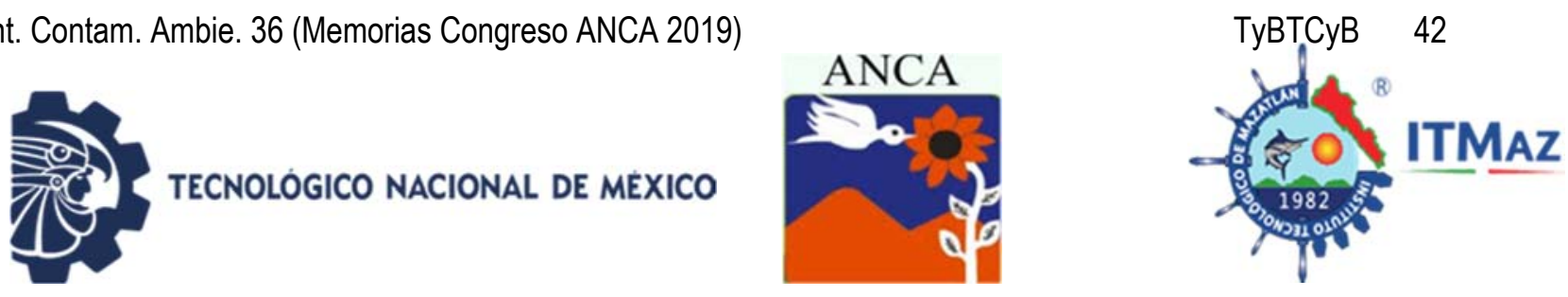

\title{
Production of activated carbon and its application in the retention of bright blue No.1
}

\author{
Chavarría Murillo CD, Torres Pérez J \\ Laboratorio de Transferencia y Degradación de Contaminantes. \\ Universidad Autónoma de Ciudad Juárez, \\ Anillo Envolvente del Pronaf y Estocolmo S/N, C.P. 32300, A.P. 1595-D, \\ Ciudad Juárez, Chihuahua, México
}

\begin{abstract}
The Bright Blue (AB), is a triphenyl dye, classified as anionic and with acidic properties, is used in the food industry in beverages, dairy products, powders, in particular in the coloring of ice cream and confectionery, condiments and in the meat industry. For this reason, its presence is frequent in colored effluents, discharged by different industries, causing negative impacts. It has been found that one of the most effective methods for removing pollutants in water is sorption and activated carbon is the one that turns out to be the most effective adsorbent. The objective of the present work was to evaluate the adsorption capacity of the activated carbon that it has on bright blue No.1 in aqueous medium. This process was carried out in the Pollution Transfer and Degradation Laboratory (LTDC) of the Autonomous University of Ciudad Juárez (Juárez, Chihuahua, Mexico) in the period of May-December 2018, where coal activation was carried out from cotton seed, determining the $\mathrm{pH}$ of it. The Langmuir and Freundlich model was applied to obtain the isothermal parameters and the first and pseudo-second order models for the sorption kinetics. Where the sorption process in both media reaches the equilibrium starting from $192 \mathrm{~h}$, decreasing the concentration in a similar way for both cases and achieving significant removals of 80 and $72 \%$ for the distilled and ionic medium, respectively. The adsorption process turned out to be efficient for the removal of Bright Blue No.1 in aqueous medium using a sustainable activated carbon prepared from cottonseed.
\end{abstract}

Keywords: Activated carbon, anionic dyes, Bright Blue No. 1, cinetics and sorption isotherms.

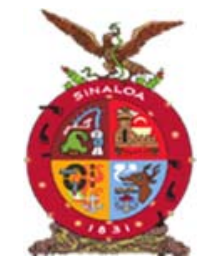

XVIII Congreso Internacional XXIV Congreso Nacional de Ciencias ambientales

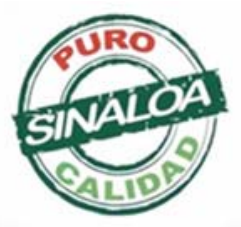

Mazatlán, Sinaloa 3-7 junio 2019
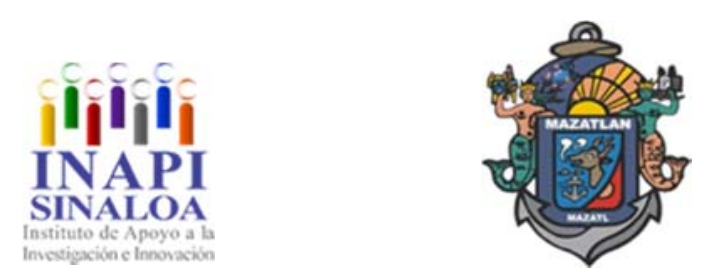

Tecnología y Biotecnología para el Tratamiento de Contaminantes y Biorremediación 


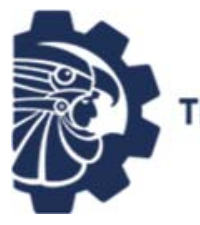

TECNOLOGICO NACIONAL DE MEXICO
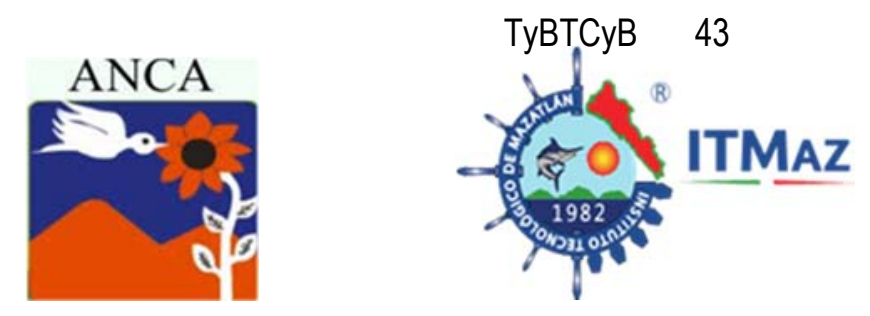

Actividad insecticida en contra de Spodoptera frugiperda J. E. Smith (Lepidoptera: Noctuidae) gusano cogollero del maíz de fitoextractos de epazote (Dysphania ambrosioides)

\author{
Chávez Ríos $\mathrm{BP}^{1}$, Valladares Cisneros $\mathrm{MG}^{2 *}$, Gutiérrez Ochoa $\mathrm{M}^{3}$, \\ Aldana Llanos $\mathrm{L}^{3}$ \\ ${ }^{1}$ Maestría en Ingeniería Ambiental y Tecnologías Sustentables \\ ${ }^{2}$ Facultad de Ciencias Químicas e Ingeniería. \\ Universidad Autónoma del Estado de Morelos.
}

Av. Universidad 1001, Col. Chamilpa, Cuernavaca Mor. C.P. 62209, México.

${ }^{3}$ Centro de Desarrollo de Productos Bióticos. Instituto Politécnico Nacional.

Carretera Yautepec-Jojutla Km. 6, CP. 62731 San Isidro, Yautepec, Morelos *mg.valladares@uaem.mx

\title{
RESUMEN
}

Actualmente existe un interés global en el desarrollo de estrategias y alternativas amigables y sustentables para el control de insectos plaga de interés agrícola. En el estado de Morelos existe especial interés para controlar a Spodoptera frugiperda, empleando técnicas de manejo sustentable. El objetivo del presente trabajo fue evaluar el efecto insecticida de diferentes fitoextractos orgánicos de Dysphania ambrosioides (epazote) en sus dos variedades verde y morado, aplicado en contra de $S$. frugiperda. Los resultados mostraron que el fitoextracto metanólico de las hojas del epazote verde provoca una significativa reducción de peso de las larvas del insecto a los 7 y 14 días, lo que permitió establecer su potencial como antialimentario, así mismo provocó mortalidad significativa de larvas, prolongó el tiempo de emergencia, deformación de pupas y aumentó la mortalidad. Aplicando $500 \mathrm{ppm}$ del extracto metanólico de epazote verde provocó el $40 \%$ de mortalidad larval, y el $56 \%$ de mortalidad en pupas de $S$. frugiperda. Estos resultados muestran el potencial insecticida del fitoextracto metanólico de las hojas de $D$. ambrosioides como alternativa amigable para el manejo sustentable de insectos plaga.

Palabras clave: Actividad insecticida, Control amigable de insectos, Epazote, Dysphania ambrosioides, Spodoptera frugiperda, Alternativa sustentable para el manejo amigable de insectos plaga.

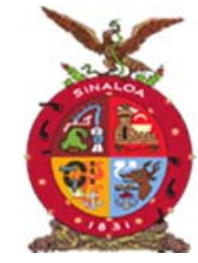

XVIII Congreso Internacional XXIV Congreso Nacional de Ciencias ambientales

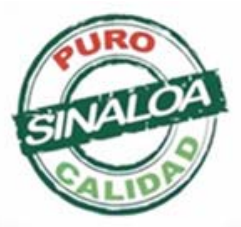

Mazatlán, Sinaloa 3-7 junio 2019
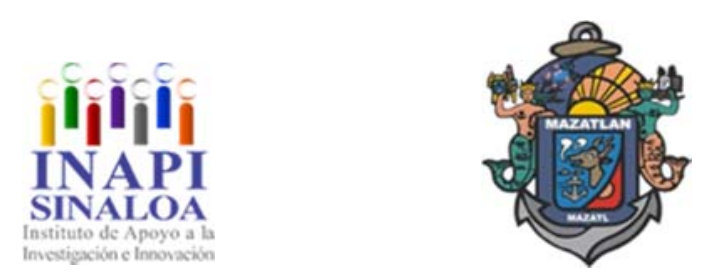

Tecnología y Biotecnología para el Tratamiento de Contaminantes y Biorremediación 

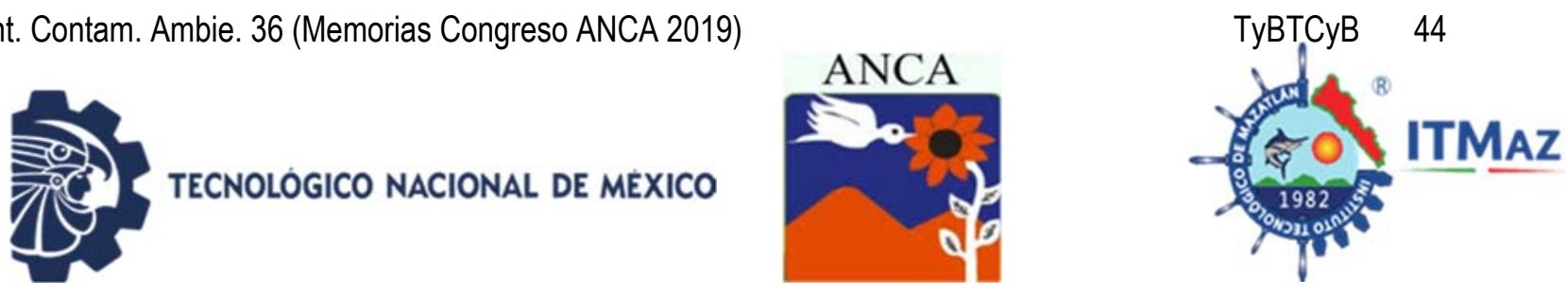

Insecticidal activity against Spodoptera frugiperda J. E. Smith (Lepidoptera: Noctuidae) fall corn armyworm of epazote (Dysphania ambrosioides) phytoextracts

\author{
Chávez Ríos $\mathrm{BP}^{1}$, Valladares Cisneros $\mathrm{MG}^{2 *}$, Gutiérrez Ochoa $\mathrm{M}^{3}$, \\ Aldana Llanos $\mathrm{L}^{3}$ \\ ${ }^{1}$ Maestría en Ingeniería Ambiental y Tecnologías Sustentables \\ ${ }^{2}$ Facultad de Ciencias Químicas e Ingeniería. \\ Universidad Autónoma del Estado de Morelos.
}

Av. Universidad 1001, Col. Chamilpa, Cuernavaca Mor. C.P. 62209, México.

${ }^{3}$ Centro de Desarrollo de Productos Bióticos. Instituto Politécnico Nacional.

Carretera Yautepec-Jojutla Km. 6, CP. 62731 San Isidro, Yautepec, Morelos *mg.valladares@uaem.mx

\begin{abstract}
Currently there is a global interest in the development of friendly and sustainable strategies and alternatives for the control of pests of agricultural interest. In the state of Morelos there is special interest in controlling Spodoptera frugiperda, through the sustainable management of this insect pest. Therefore, the objective of this work was to evaluate the insecticidal effect of different organic phytoextracts of Dysphania ambrosioides (epazote) in its two green and purple varieties, against $S$. frugiperda. The results showed that the methanol phytoextract of the leaves of the green epazote causes a significant reduction in the weight of the larvae of the insect at 7 and 14 days, which allowed to establish its potential as antifeedant, as well as provoking significant mortality of larvae, prolonged the time of emergence and deformation of pupae, as well as mortality of them. $500 \mathrm{ppm}$ of the methanol extract of green epazote caused $40 \%$ of larval mortality, and $56 \%$ of mortality in pupae of $S$. frugiperda. These results show the insecticidal potential of the methanol phytoextract from the leaves of $D$. ambrosioides as a friendly alternative for the sustainable management of insect pests.
\end{abstract}

Keywords: Insecticide activity, environmental friendly insect pest control, epazote, Dysphania ambrosioides, Spodoptera frugiperda, sustainable alternative for the friendly management of insect pests.

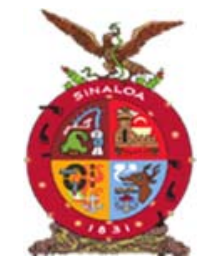

XVIII Congreso Internacional XXIV Congreso Nacional de Ciencias ambientales

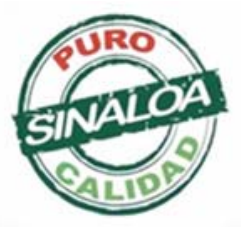

Mazatlán, Sinaloa 3-7 junio 2019
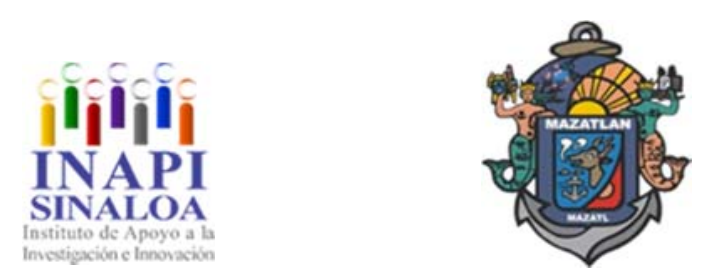

Tecnología y Biotecnología para el Tratamiento de Contaminantes y Biorremediación 

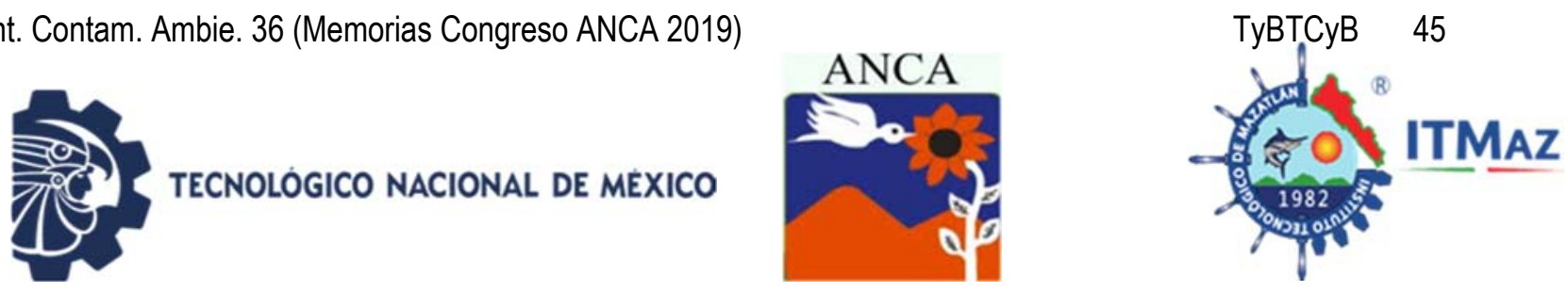

\title{
Evaluación de la actividad biológica de extractos orgánicos de epazote (Dysphania ambrosioides) sobre el gusano cogollero (Spodoptera frugiperda)
}

\author{
Chávez Ríos $\mathrm{BP}^{1}$, Valladares Cisneros $\mathrm{MG}^{2 *}$, Gutiérrez Ochoa $\mathrm{M}^{3}$, \\ Aldana Llanos $\mathrm{L}^{3}$ \\ ${ }^{1}$ Maestría en Ingeniería Ambiental y Tecnologías Sustentables \\ ${ }^{2}$ Facultad de Ciencias Químicas e Ingeniería. \\ Universidad Autónoma del Estado de Morelos.
}

Av. Universidad 1001, Col. Chamilpa, Cuernavaca Mor. C.P. 62209, México.

${ }^{3}$ Centro de Desarrollo de Productos Bióticos. Instituto Politécnico Nacional.

Carretera Yautepec-Jojutla, Km. 6, calle CEPROBI No. 8, Col. San Isidro,

Yautepec, Morelos, México. C.P. 62731, Apartado Postal 24.

*mg.valladares@uaem.mx

\section{RESUMEN}

En el presente estudio se evaluaron extractos de epazote, Dysphania ambrosioides (L. Chenopondiaceae), sobre larvas de Spodoptera frugiperda para determinar su actividad insecticida contra este insecto plaga. Siete extractos orgánicos de $D$. ambrosioides a concentración de 500 ppm fueron suministrados mediante dieta artificial a larvas L3 de gusano cogollero. El gusano cogollero es la mayor plaga de maíz en el mundo y se estima que en México puede llegar a provocar pérdidas de hasta $50 \%$ de este cultivo. Actualmente se busca que la agricultura sea más amigable con el ambiente y sea llevada a cabo de manera más sustentable, para lograr esto el control con insecticidas botánicos es una alternativa a los plaguicidas convencionales, la cual puede implementarse dentro del Manejo Integrado de Plagas. Las variables medidas en este estudio fueron pesos larvales y peso pupal, duración de los días de desarrollo larval y pupal, deformidades en pupas y adultos y mortalidad de larvas y pupas. Uno de los siete tratamientos presentó una alta efectividad sobre los insectos, produciendo diferencias significativas respecto al grupo testigo y los demás tratamientos, esto en cuanto a los pesos larvales y pupales, deformaciones y produciendo una mortalidad del $96 \%$ de los individuos.

Palabras clave: Extracto, epazote, gusano cogollero, actividad insecticida, plaga.

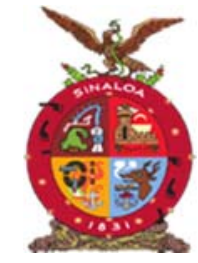

XVIII Congreso Internacional XXIV Congreso Nacional de Ciencias ambientales

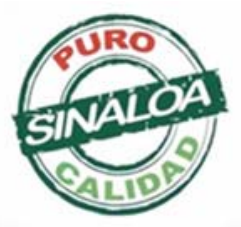

Mazatlán, Sinaloa 3-7 junio 2019
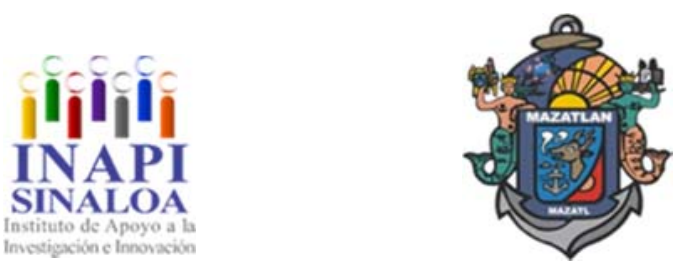

Tecnología y Biotecnología para el Tratamiento de Contaminantes y Biorremediación 


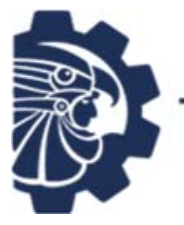

TECNOLOGICO NACIONAL DE MEXICO
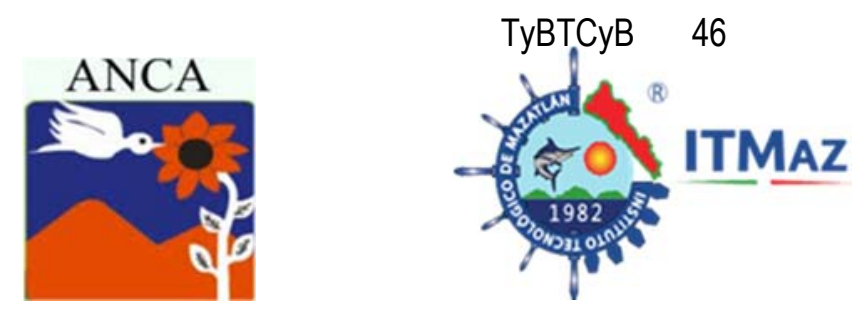

Evaluation of the biological activity of organic extracts of epazote (Dysphania ambrosioides) on the armyworm (Spodoptera frugiperda)

\author{
Chávez Ríos $\mathrm{BP}^{1}$, Valladares Cisneros $\mathrm{MG}^{2}$, Gutiérrez Ochoa $\mathrm{M}^{3}$, \\ Aldana Llanos $\mathrm{L}^{3}$ \\ ${ }^{1}$ Maestría en Ingeniería Ambiental y Tecnologías Sustentables \\ ${ }^{2}$ Facultad de Ciencias Químicas e Ingeniería. \\ Universidad Autónoma del Estado de Morelos.
}

Av. Universidad 1001, Col. Chamilpa, Cuernavaca Mor. C.P. 62209, México.

${ }^{3}$ Centro de Desarrollo de Productos Bióticos. Instituto Politécnico Nacional.

Carretera Yautepec-Jojutla, Km. 6, calle CEPROBI No. 8, Col. San Isidro,

Yautepec, Morelos, México. C.P. 62731, Apartado Postal 24.

*mg.valladares@uaem.mx

\begin{abstract}
In the present study, extracts of epazote, Dysphania ambrosioides (L. Chenopondiaceae), on larvae of Spodoptera frugiperda were evaluated to determine their insecticidal activity against this insect pest. Seven organic extracts of $D$. ambrosioides at $500 \mathrm{ppm}$ concentration were supplied by artificial diet to L3 larvae of fall armyworm. The fall armyworm is the largest corn pest in the world and it is estimated that in Mexico it can cause losses of up to $50 \%$ of this crop. Currently, it is sought that agriculture is friendlier to the environment and is carried out in a more sustainable way, to achieve this control with botanical insecticides is an alternative to conventional pesticides, which can be implemented within the Integrated Pest Management. The measured variables in this study were larval weights and pupal weight, duration of larval and pupal development days, pupal and adult deformities, and mortality of larvae and pupae. One of the seven tretaments exhibed a high effectiveness on the insects, producing significant differences with respect to the control group and the other treatments, this in terms of larval and pupal weights, deformations and producing a mortality of $96 \%$.
\end{abstract}

Keywords: Extract, epazote, armyworm, insecticide activity, pest.

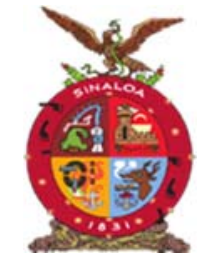

XVIII Congreso Internacional XXIV Congreso Nacional de Ciencias ambientales

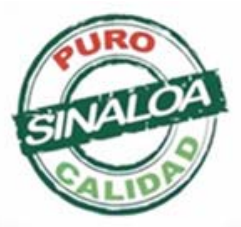

Mazatlán, Sinaloa 3-7 junio 2019
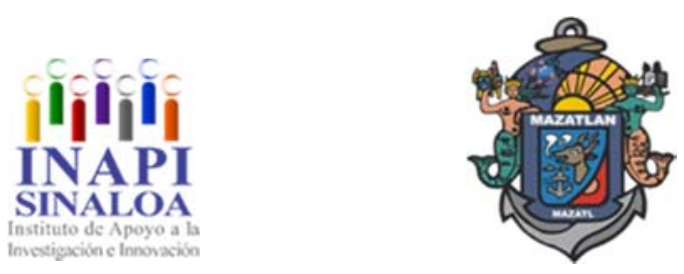

Tecnología y Biotecnología para el Tratamiento de Contaminantes y Biorremediación 


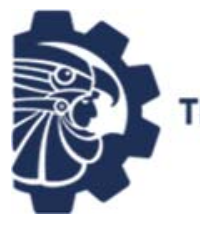

TECNOLOGICO NACIONAL DE MEXICO
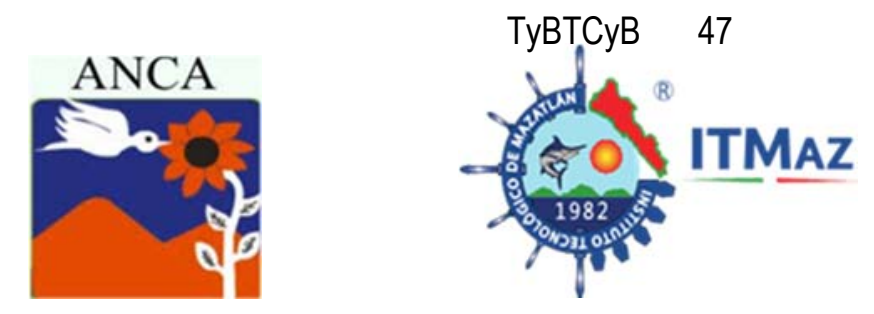

Fibras de sílice de hidroxiapatita en la remoción de ciprofloxacino

Chavez Varela KI*, Garibay Alvarado J, Torres Pérez J, Reyes López SY

Instituto de Ciencias Biomédicas. Universidad Autónoma de Ciudad Juárez. Envolvente del PRONAF y Estocolmo S/N, Ciudad Juárez, Chih., México *al136384@alumnos.uacj.mx

\section{RESUMEN}

El ciprofloxacino es un antibiótico con uso a nivel mundial debido a su eficacia para el tratamiento de infecciones en humanos y animales. Los antibióticos han sido clasificados como contaminantes emergentes por su persistencia y efectos indeseables en el ambiente. Los antibióticos generan problemas en el tratamiento habitual de las aguas residuales; siendo la adsorción un método eficaz para su eliminación. Existe una gran variedad de materiales adsorbentes. Se evaluó la remoción de ciprofloxacino por medio de fibras sílice de hidroxiapatita midiendo la concentración del fármaco empleando un espectrofotómetro UV-Visible a 315 $\mathrm{nm}$, comprobando que las fibras poseen buenas propiedades de absorción del fármaco ciprofloxacino debido a sus características principales de lixiviación dadas por la capa de fosfatos de calcio. El fármaco fue encapsulado en las fibras de sílice de hidroxiapatita mediante interacciones electroestáticas con los grupos aminos y ácidos carboxílicos que componen la molécula del ciprofloxacino. El tiempo de absorción del fármaco por las fibras de sílice de hidroxiapatita evaluado en la presente investigación, se evaluo en un transcurso de 92 horas a partir de una solución con $50 \mathrm{ppm}$ de ciprofloxacino en agua destilada. Los datos obtenidos fueron empleados para construir un modelo cinético el cual se adaptó al orden 0 demostrando una eliminación promedio del fármaco de 0.09 ppm por hora.

Palabras clave: Sílice de hidroxiapatita, ciprofloxacino, lixiviación, cinéticas, coeficiente de determinación.

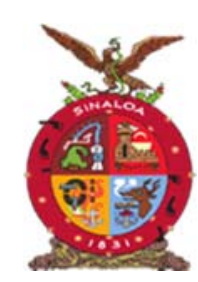

XVIII Congreso Internacional XXIV Congreso Nacional de Ciencias ambientales

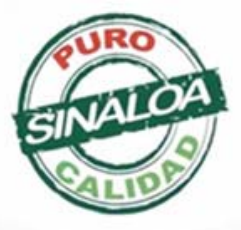

Mazatlán, Sinaloa 3-7 junio 2019
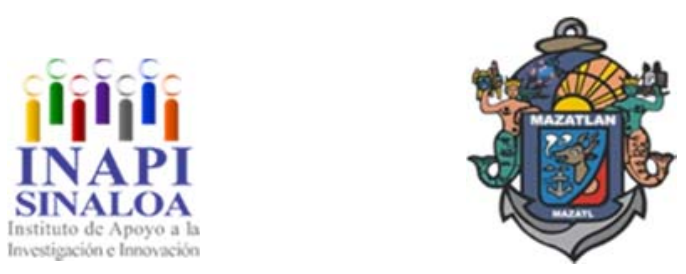

Tecnología y Biotecnología para el Tratamiento de Contaminantes y Biorremediación 

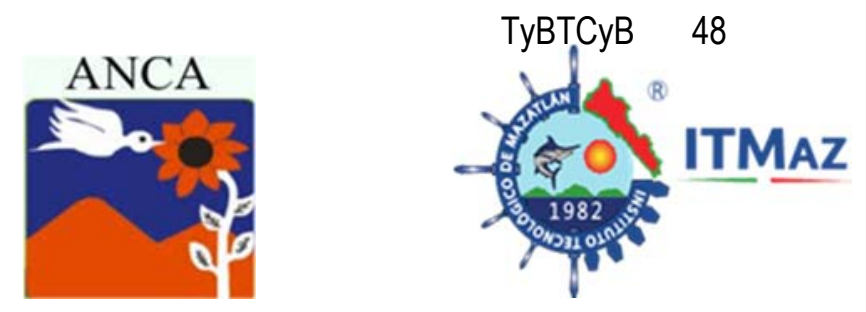

Hydroxyapatite silica fibers in the removal of ciprofloxacin

Chavez Varela KI, Garibay Alvarado J, Torres Pérez J, Reyes López SY

Instituto de Ciencias Biomédicas. Universidad Autónoma de Ciudad Juárez. Envolvente del PRONAF y Estocolmo S/N, Ciudad Juárez, Chih., México *al136384@alumnos.uacj.mx

\begin{abstract}
Ciprofloxacin is an antibiotic used in worldwide, due its efficacy for the treatment of infections in humans and animals. Antibiotics have been classified as emerging pollutants due their persistence and undesirable effects in the environment. Antibiotics generate problems in the usual water treatment; being the adsorption an effective method for their elimination, also there exist several adsorbent materials. The removal of ciprofloxacin by means of hydroxyapatite silica fibers was evaluated by measuring the concentration of the drug using a UV-Visible spectrophotometer at $315 \mathrm{~nm}$, verifying that the fibers have good absorption properties of the drug ciprofloxacin due to its main leaching characteristics given by the calcium phosphate layer. The drug was encapsulated by hydroxyapatite silica fibers by electrostatic interactions with the amino groups and carboxylic acids that make up the ciprofloxacin molecule. The time of absorption of the drug by the silica fibers of hydroxyapatite evaluated in the present investigation was in a course of 92 hours from a solution with $50 \mathrm{ppm}$ of ciprofloxacin in distilled water. The data obtained were used to construct a kinetic model which was adapted to order 0 demonstrating an average elimination of the drug of 0.09 ppm per hour.
\end{abstract}

Keywords: Hydroxyapatite silica, ciprofloxacin, leaching, kinetics, coefficient of determination.

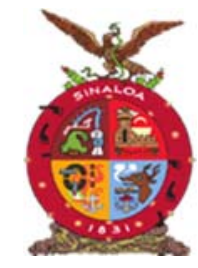

XVIII Congreso Internacional XXIV Congreso Nacional de Ciencias ambientales

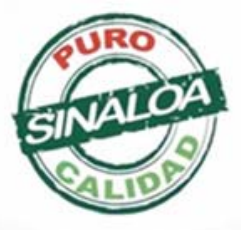

Mazatlán, Sinaloa 3-7 junio 2019
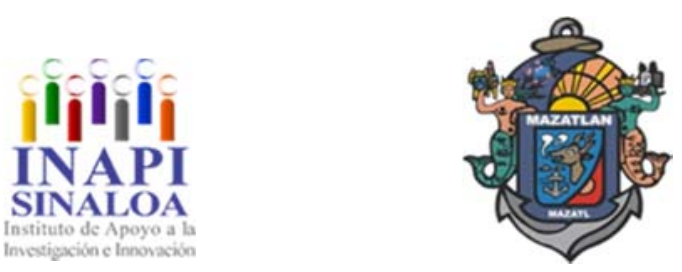

Tecnología y Biotecnología para el Tratamiento de Contaminantes y Biorremediación 

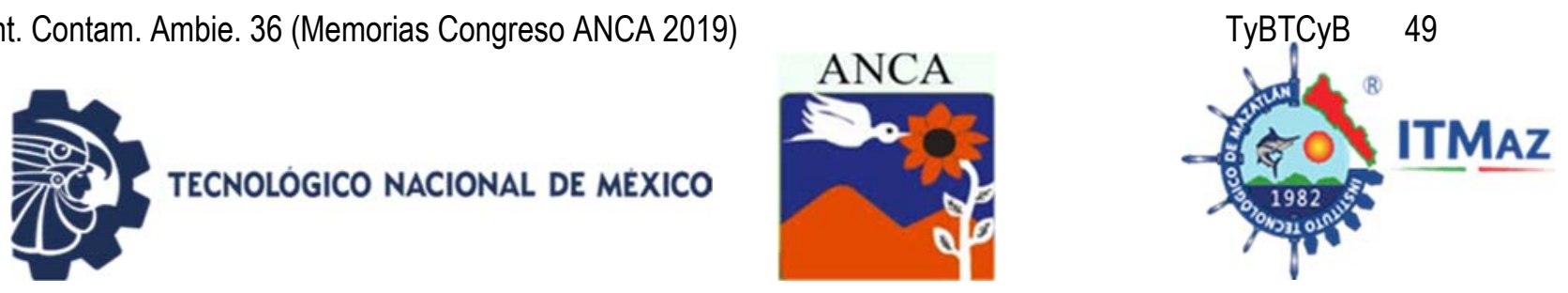

\title{
Aislamiento y caracterización de hongos endófitos de individuos de Prosopis laevigata en los jales mineros de Huautla, Morelos
}

\author{
Concepción Acosta C, Mussali Galante P, Folch Mallol J \\ Centro de Investigación en Biotecnología. \\ Universidad Autónoma del Estado de Morelos \\ *cynthiamar921105@gmail.com
}

\begin{abstract}
RESUMEN
Estudios previos han demostrado que Prosopis laevigata crece en los jales de Huautla, Morelos y bioacumula $\mathrm{Pb}, \mathrm{Cu}$ y $\mathrm{Zn}$ en la raíz y en la parte aérea. No se conoce si la asociación con hongos endófitos confiere a la planta la capacidad de bioacumular mayor cantidad de metales y hacer la fitorremediación más eficiente. Con el interés de llevar a cabo la fitorremediación de sitios contaminados con metales pesados, se propone aislar y caracterizar cepas de hongos endófitos asociados a esta planta y determinar su capacidad de promoción de crecimiento vegetal y remoción de metales pesados. El sitio de estudio son los jales de la Sierra de Huatla, Morelos, de febrero 2019-agosto 2020. Un total de 20 cepas de hongos endófitos se aislaron de raíces de Prosopis laevigata. Se seleccionaron 10 cepas mediante identificación morfológica y se realizó una Concentración Mínima Inhibitoria previa sembrando las cepas en medio PDA con zinc $\left(\mathrm{ZnSO}_{4} \cdot 7 \mathrm{H}_{2} \mathrm{O}\right)$, plomo $\left[\mathrm{Pb}\left(\mathrm{NO}_{3}\right)_{2}\right]$ y cobre $\left(\mathrm{CuSO}_{4} \cdot 5 \mathrm{H}_{2} \mathrm{O}\right)$ a diferentes concentraciones para descartar las menos tolerantes. Las cepas A2M10, A2M11, $\mathrm{A} 1 \mathrm{M} 22$ y A1M23 presentaron mayor tolerancia a $\mathrm{Cu}$ (50-200 ppm), $\mathrm{Pb}$ (600-3000 ppm) y Zn (300-950 ppm). La identificación será mediante secuenciación de genes ribosomales, comparación con el GeneBank y construcción de árboles filogenéticos. Dichas cepas serán inoculadas a plantas de Prosopis laevigata previamente germinadas en condiciones de esterilidad, para determinar remoción de metales y promoción de crecimiento vegetal en condiciones de invernadero por un período de 6 meses.
\end{abstract}

Palabras claves: Hongos endófitos, Prosopis laevigata, jales, fitorremediación, metales pesados.

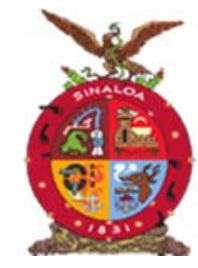

XVIII Congreso Internacional XXIV Congreso Nacional de Ciencias ambientales

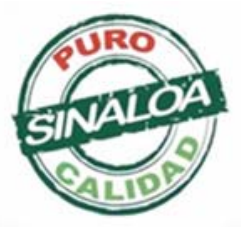

Mazatlán, Sinaloa 3-7 junio 2019
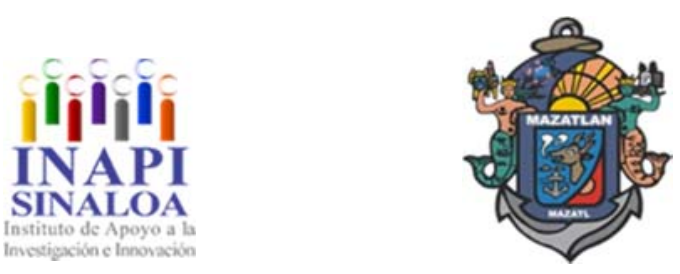

Tecnología y Biotecnología para el Tratamiento de Contaminantes y Biorremediación 

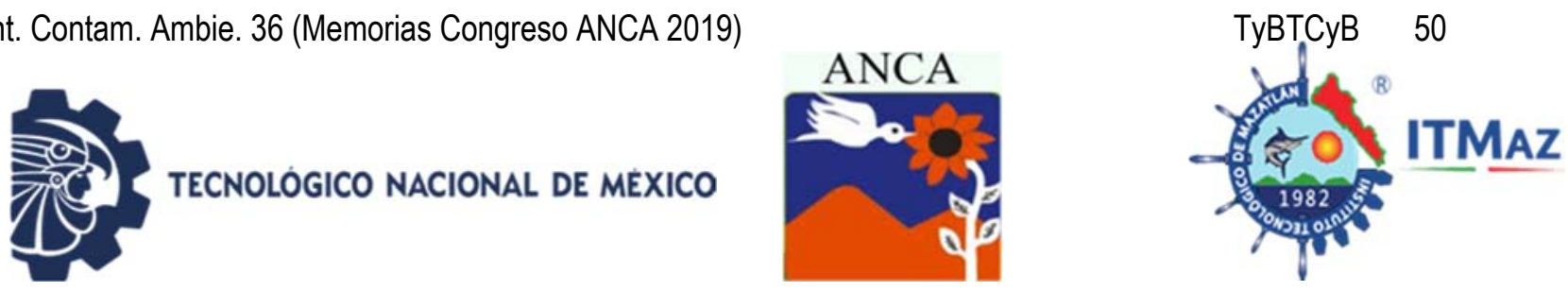

\title{
Isolation and characterization of endophytic fungi of individuals of Prosopis laevigata in the mine tailings of Huautla, Morelos
}

\author{
Concepción Acosta C, Mussali Galante P, Folch Mallol J \\ Centro de Investigación en Biotecnología, \\ Universidad Autónoma del Estado de Morelos \\ *cynthiamar921105@gmail.com
}

\begin{abstract}
Prosopis laevigata grows in the tailings of Huautla, Morelos and bioaccumulates $\mathrm{Pb}, \mathrm{Cu}$ and $\mathrm{Zn}$ in the root and in the aerial part. It is not known if the association with endophytic fungi gives the plant the capacity to bioaccumulate more metals and make phytoremediation more efficient. With the interest of carrying out the phytoremediation of sites contaminated with heavy metals, it is proposed to isolate and characterize strains of endophytic fungi associated with this plant and determine their ability to promote plant growth and removal of heavy metals. The study site is the tailings of the Sierra de Huatla, Morelos, from February 2019 to August 2020. A total of 20 strains of endophytic fungi were isolated from roots of Prosopis laevigata. Ten strains were selected by morphological identification and a previous Minimum Inhibitory Concentration was done by seeding the strains in PDA medium with zinc $\left(\mathrm{ZnSO}_{4} \cdot 7 \mathrm{H}_{2} \mathrm{O}\right)$, lead $\left[\mathrm{Pb}\left(\mathrm{NO}_{3}\right)_{2}\right]$ and copper $\left(\mathrm{CuSO}_{4} \cdot 5 \mathrm{H}_{2} \mathrm{O}\right)$ at different concentrations to discard the less tolerant. Strains A2M10, A2M11, $\mathrm{A} 1 \mathrm{M} 22$ and $\mathrm{A} 1 \mathrm{M} 23$ showed greater tolerance to $\mathrm{Cu}(50-200 \mathrm{ppm}), \mathrm{Pb}(600-3000$ $\mathrm{ppm})$ and $\mathrm{Zn}(300-950 \mathrm{ppm})$. The identification will be through ribosomal gene sequencing, comparison with GeneBank and construction of phylogenetic trees. Said strains will be inoculated to Prosopis laevigata plants previously germinated under sterile conditions, to determine metal removal and promotion of plant growth under greenhouse conditions for a period of 6 months.
\end{abstract}

Keywords: Endophytic fungi, Prosopis laevigata, tailings, phytoremediation, heavy metals.

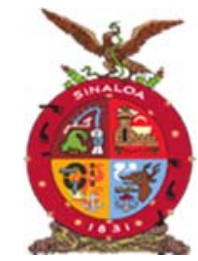

XVIII Congreso Internacional XXIV Congreso Nacional de Ciencias ambientales

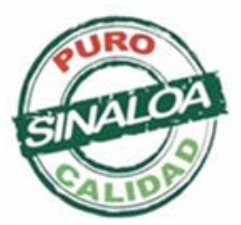

Mazatlán, Sinaloa 3-7 junio 2019
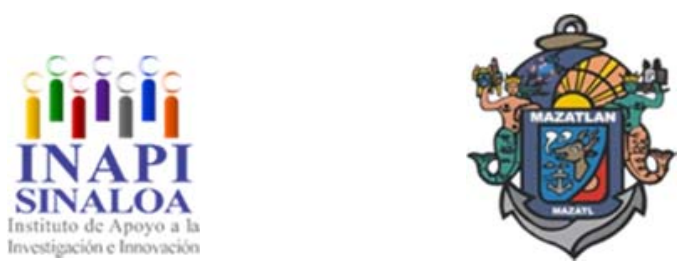

Tecnología y Biotecnología para el Tratamiento de Contaminantes y Biorremediación 

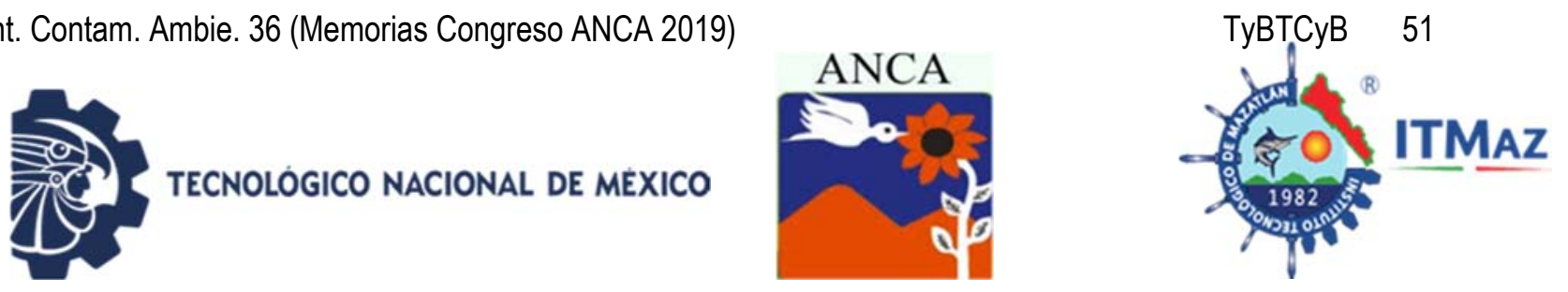

\title{
Elaboración de crema para la piel a base de cascara de plátano
}

\author{
Cortes Guerrero V, Mendoza Gaona H, Romero López A, Salazar Fernández C, \\ Sánchez Ramírez H \\ Universidad Tecnológica del Valle de Toluca. \\ Carr. del Departamento del D.F. Km 7.5. Santa María Atarasquillo, \\ Lerma, Estado de México. C. P. 52014 \\ *hortencia.sanchez@utvtol.edu.mx
}

\section{RESUMEN}

Se elaboró una crema para la piel a base de cáscaras de plátano, ya que en él se encuentran proteínas, carbohidratos, fibra, potasio y vitaminas, las cuales tienen múltiples beneficios. Con el fin de disminuir los residuos orgánicos que se generan en los lugares donde se comercializa la fruta, se recolectaron cáscaras de plátano en el basurón de residuos orgánicos del Mercado de Metepec, Estado de México. Se mezclaron con productos de origen vegetal como la glicerina, aceites de almendras, ajonjolí, germen de trigo, cera de abeja, pectina y esencia de plátano. Se aplicaron dos diferentes métodos para la preparación de la crema, el primero fue con alcohol cetílico $\left(\mathrm{C}_{16} \mathrm{H}_{34} \mathrm{O}\right)$ y el segundo con cera de abeja. Se obtuvieron dos fases; la fase oleosa y la fase acuosa, ambas mezclas se colocaron a baño maría y finalmente se emulsionaron para realización de la crema. Para comprobar su eficiencia, se aplicaron encuestas a los usuarios (personas de distintas edades), arrojando que se puede aplicar en la piel seca, debido a la capacidad y humectación que la crema tiene en la piel. Este producto se suma a las pequeñas acciones que pueden generar cambios en el ambiente, mediante la disminución de los residuos orgánicos dispuestos en forma unadecuanda y una forma accesible del costo del producto, que es favorable para todos. Como es una prueba prototipo, se está analizando la posibilidad de crear una microempresa que se dedique a la elaboración de dicho producto, obviamente tomando estándares de calidad.

Palabras clave: Aprovechamiento, cáscaras de plátano, crema, piel seca, residuos orgánicos

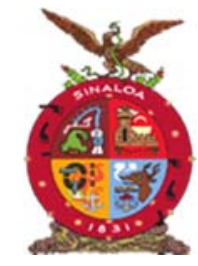

XVIII Congreso Internacional XXIV Congreso Nacional de Ciencias ambientales

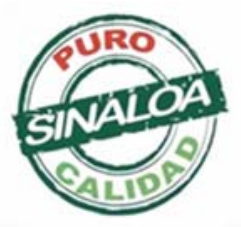

Mazatlán, Sinaloa 3-7 junio 2019
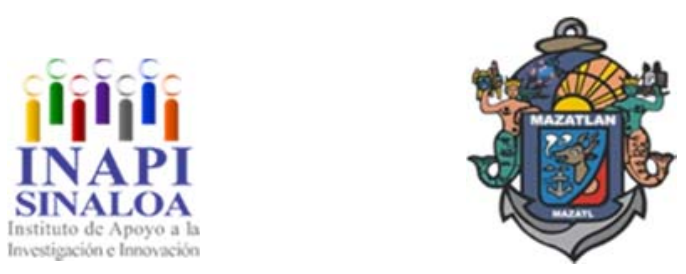

Tecnología y Biotecnología para el Tratamiento de Contaminantes y Biorremediación 

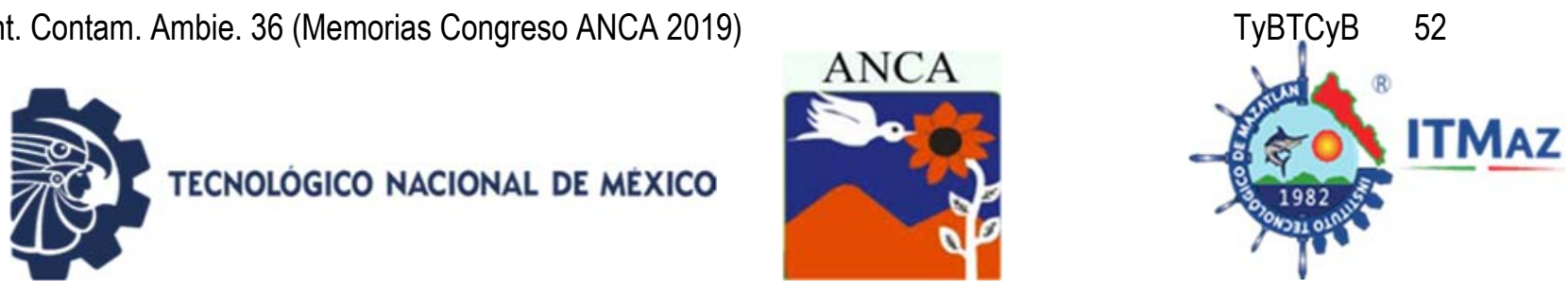

\title{
Elaboration of skin cream based on banana peel
}

\author{
Cortes Guerrero V, Mendoza Gaona H, Romero López A, Salazar Fernández C, \\ Sánchez Ramírez $\mathrm{H}^{*}$ \\ Universidad Tecnológica del Valle de Toluca. \\ Carr. del Departamento del D.F. Km 7.5. Santa María Atarasquillo, \\ Lerma, Estado de México. C. P. 52014 \\ *hortencia.sanchez@utvtol.edu.mx
}

\begin{abstract}
The objective of the work was to develop a cream for the skin based on banana peels, since it contains proteins, carbohydrates, fiber, potassium and vitamins, which have multiple benefits. It was made in order to reduce the organic waste that is generated in the places where the fruit is sold. Banana peels were collected in a pile of organic waste at the Mercado de Metepec, State of Mexico; they were mixed with products of vegetable origin such as glycerin, almond oils, sesame, wheat germ; beeswax, pectin and banana essence. Two different methods were used to obtain the cream, the first was with cetyl alcohol $\left(\mathrm{C}_{16} \mathrm{H}_{34} \mathrm{O}\right)$ and the second with beeswax. Two phases were obtained; the oil phase and the aqueous phase, both mixtures were placed in a water bath and finally emulsified to make the cream. To check its efficiency, surveys were applied to users (people of different ages), showing that it can be applied to dry skin, due to the consistency and moisture that the cream has on the skin. This product is added to the small actions to generate changes in the environment, through the reduction of organic waste and an accessible form of the cost of the product, which is favorable for all. As it is a prototype test, the possibility of creating a microenterprise dedicated to the elaboration of said product is being analyzed, obviously taking quality standards.
\end{abstract}

Keywords: Exploitation, banana peels, cream, dry skin, organic wastes.

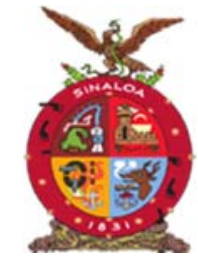

XVIII Congreso Internacional XXIV Congreso Nacional de Ciencias ambientales

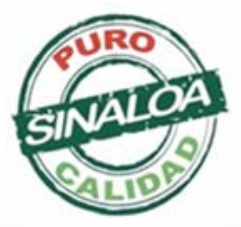

Mazatlán, Sinaloa 3-7 junio 2019
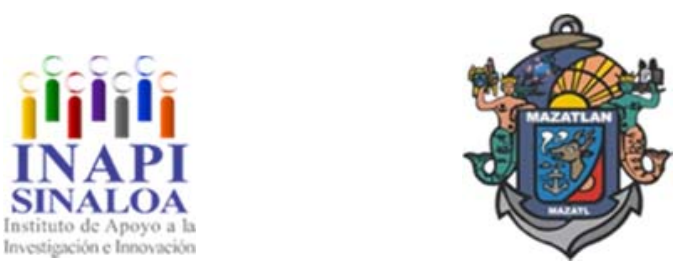

Tecnología y Biotecnología para el Tratamiento de Contaminantes y Biorremediación 

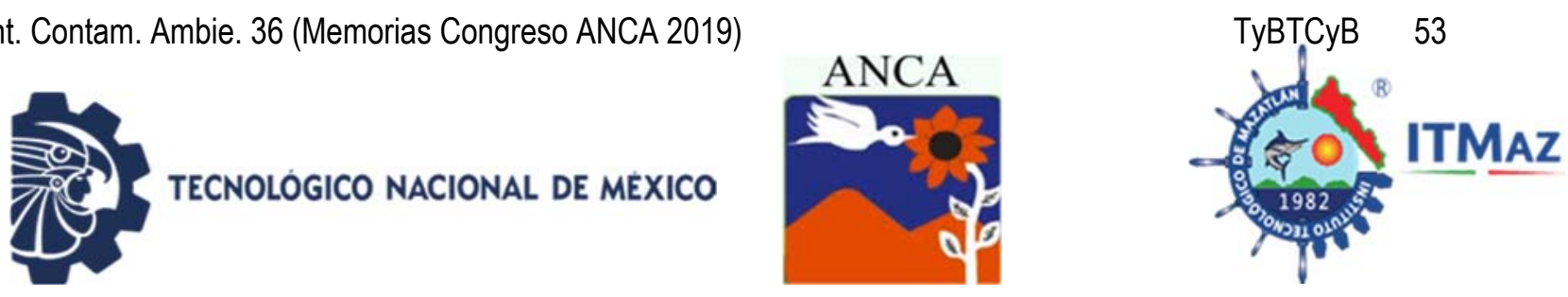

\title{
Desarrollo de injertos de GO con almidón, fructuosa y/o microcelulosa por ultrasonido para emplearse como material refuerzo en biopolímeros
}

\author{
Cruz Benitez $\mathrm{M}^{1 *}$, Fonseca Florido $\mathrm{H}^{2}$, Gómez Aldapa $\mathrm{C}^{1}$ \\ ${ }^{1}$ Instituto de Ciencias Básicas e Ingeniería. \\ Universidad Autónoma del Estado de Hidalgo (UAEH). \\ Ciudad del Conocimiento, Carretera Pachuca, Tulancingo Km 4.5 \\ Mineral de la Reforma, México \\ ${ }^{2}$ CONACYT. Centro de Investigación en Química Aplicada (CIQA). \\ Blvd. Ing. Enrique Reyna H. No. 140, Saltillo Coahuila, México \\ *m.m.c.b._9004@hotmail.com
}

\section{RESUMEN}

La acumulación de residuos plásticos ha generado graves problemas ambientales, una solución es el desarrollo de biopolímeros, sin embargo, sus propiedades están lejos de los plásticos sintéticos, por lo que es necesario combinarlos con materiales refuerzo. El óxido de grafeno (GO) destaca por sus propiedades térmicas, eléctricas y mecánicas marcando una pauta al desarrollo de nanocompuestos híbridos poliméricos. El objetivo del presente trabajo fue desarrollar injertos de GO con almidón (St), fructuosa (Fr) y/o microcelulosa (MCC) mediante ultrasonido (US) para emplearse como material refuerzo en biopolímeros. Esta investigación fue desarrollada en la UAEH y en CIQA, durante mayo 2018 y hasta la actualidad. Para la obtención de injertos (GO-MCC-Fr, GOMCC-St y GO-Fr-St-MCC), se usó una punta de ultrasonido (amplificación $80 \%$, $\mathrm{t}=30 \mathrm{~min}, \mathrm{~T}=25^{\circ} \mathrm{C}, 750 \mathrm{~W}$ y $20 \mathrm{KHz}$ ), en agitación (baño maria, $100^{\circ} \mathrm{C}$ ), posteriormente se centrifugó $30 \mathrm{~min} / 4500 \mathrm{rpm}$ y secó a $80^{\circ} \mathrm{C} / 12 \mathrm{~h}$. FTIR demostró que grupos hidroxilo del St, Fr y/o MCC reaccionaron con grupos- $\mathrm{COOH}$ del GO generando grupos éster, comprobándose con un cambio en la forma y disminución de intensidad de las bandas, la interacción de componentes se corroboró mediante espectroscopia Raman, donde la ID/IG del GO disminuyó de 0.99 a 0.88 indicando más defectos sobre la estructura del GO, TGA mostró un aumento en estabilidad térmica y el cambio en la morfología de los componentes fue confirmado mediante SEM. Concluyendo que la técnica de sonicación por US, promueve la interacción y unión de diferentes componentes (St/Fr/MCC) en el GO.

Palabras clave: Biopolímero, injerto, ultrasonido, óxido de grafeno.

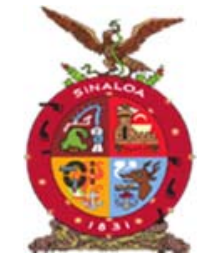

XVIII Congreso Internacional XXIV Congreso Nacional de Ciencias ambientales

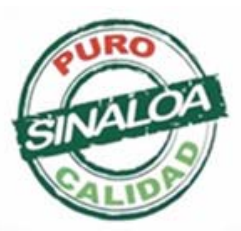

Mazatlán, Sinaloa 3-7 junio 2019
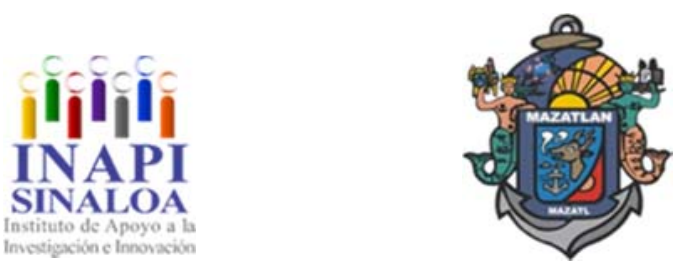

Tecnología y Biotecnología para el Tratamiento de Contaminantes y Biorremediación 

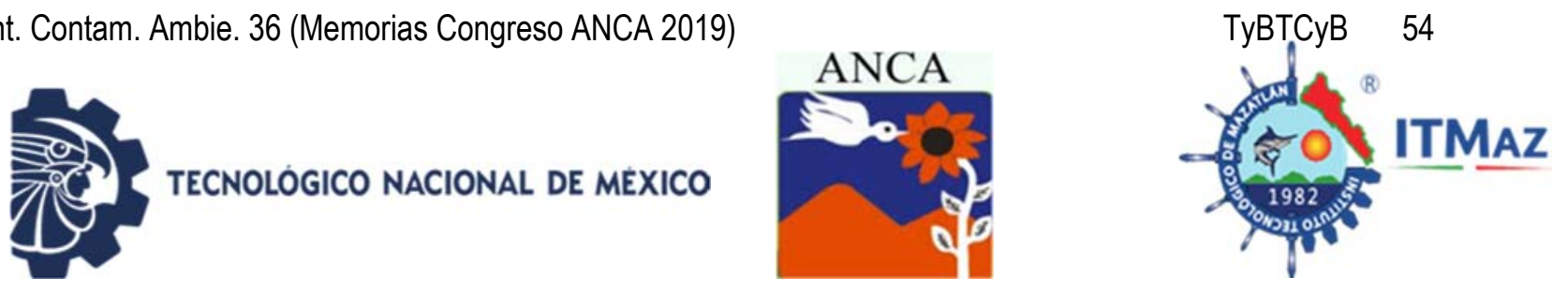

\title{
Development of GO grafts with starch, fructose and/or microcellulose by Itrasound to be used as reinforcement material in biopolymers
}

\author{
Cruz Benitez $\mathrm{M}^{1 *}$, Fonseca Florido $\mathrm{H}^{2}$, Gómez Aldapa $\mathrm{C}^{1}$ \\ ${ }^{1}$ Instituto de Ciencias Básicas e Ingeniería. \\ Universidad Autónoma del Estado de Hidalgo (UAEH). \\ Ciudad del Conocimiento, Carretera Pachuca, Tulancingo Km 4.5 \\ Mineral de la Reforma, México \\ ${ }^{2}$ CONACYT. Centro de Investigación en Química Aplicada (CIQA). \\ Blvd. Ing. Enrique Reyna H. No. 140, Saltillo Coahuila, México \\ *m.m.c.b._9004@hotmail.com
}

\begin{abstract}
The accumulation of plastic waste has generated serious environmental problems, a solution is the development of biopolymers. However, its properties are far from synthetic plastics, so it is necessary to combine them with reinforcement materials. Graphene oxide (GO) stands out for its thermal, electrical and mechanical properties, setting a standard for the development of polymeric hybrid nanocomposites. The objective of this work was to develop grafts of $\mathrm{GO}$ with starch (St), fructose (Fr) and/or microcellulose (MCC) by ultrasound (US) to be used as reinforcement material in biopolymers. This research was developed at the UAEH and CIQA, during May 2018 and until today. To obtain grafts (GO-MCC-Fr, GO-MCC-St and GO-Fr-St-MCC), an ultrasound tip was used $\left(80 \%\right.$ amplification, $t=30 \mathrm{~min}, \mathrm{~T}=25^{\circ} \mathrm{C}, 750 \mathrm{~W}$ and $\left.20 \mathrm{KHz}\right)$, under stirring (water bath, $100^{\circ} \mathrm{C}$ ), it was subsequently centrifuged $30 \mathrm{~min} / 4500 \mathrm{rpm}$ and dried at $80^{\circ} \mathrm{C} / 12 \mathrm{~h}$. FTIR showed that St, Fr and/or MCC hydroxyl groups reacted with $\mathrm{GO}-\mathrm{COOH}$ groups generating ester groups, checking with a change in the shape and decrease in intensity of the bands, the interaction of components was corroborated by Raman spectroscopy, where The ID/IG of the GO decreased from 0.99 to 0.88 indicating more defects on the structure of the GO, TGA showed an increase in thermal stability and the change in the morphology of the components was confirmed by SEM. Concluding that the US sonication technique promotes the interaction and union of different components (St/Fr/MCC) in the GO.
\end{abstract}

Keywords: Biopolymer, graft, ultrasound, graphene oxide.

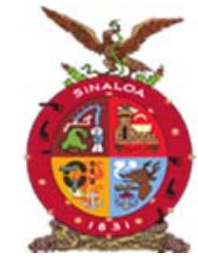

XVIII Congreso Internacional XXIV Congreso Nacional de Ciencias ambientales

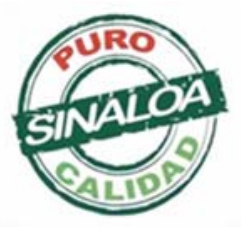

Mazatlán, Sinaloa 3-7 junio 2019
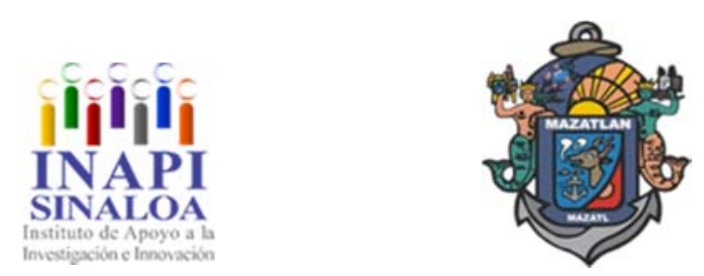

Tecnología y Biotecnología para el Tratamiento de Contaminantes y Biorremediación 

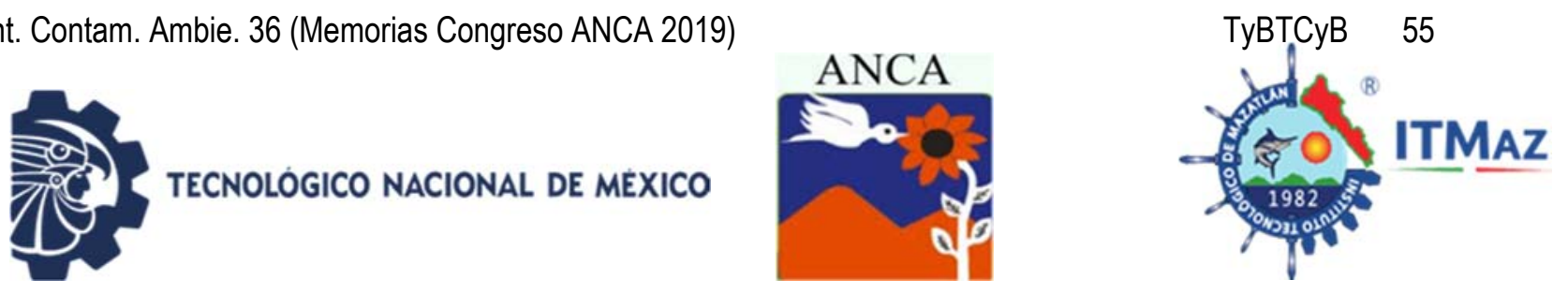

\section{Síntesis de xerogeles de $\mathrm{SiO}_{2}-\mathrm{TiO}_{2}$ para fotodegradación de pesticidas}

Cuevas Medina M, López Nieto J, Samaniego Hernández M, Osornio Rubio R*

Departamento de Ingeniería Ambiental.

Instituto Tecnológico de Celaya, Tecnológico Nacional de México.

Antonio García Cubas Pte \# 600, Guanajuato, 38010, México

*nadia.osornio@itcelaya.edu.mx

\section{RESUMEN}

En la utilización de pesticidas los estudios han estimado que menos del $0.1 \%$ aplicado ataca a la plaga y el resto de este contamina los suelos, agua y aire, muchos pueden persistir por largos periodos de tiempo y se han llegado a detectar en aguas superficiales 20 años después de haber sido prohibidos. El objetivo de este proyecto es sintetizar materiales para emplearlos en la fotodegradación de pesticidas para reducir su presencia en los cuerpos de agua. Para la sintesis de los xerogeles, se empleo el método de sol-gel, utilizando como precursores: isopropóxido de titanio y ortosilicato de tetraetilo. Para evaluar la sintesis de xerogeles, se siguió un diseño experimental factorial multinivel, teniendo como variables la relación estequiométrica de los precursores $(2: 1,1: 1$, 1:2) y el tratamiento térmico durante $30 \mathrm{~min}$ en cuatro niveles 200, 400, 600 y $800^{\circ} \mathrm{C}$. Los geles se estabilizaron a $25^{\circ} \mathrm{C}$ durante $24 \mathrm{~h}$ en un desecador y posteriormente se caracterizaron por FTIR, TEM y DRX. Las pruebas de fotodegradación se realizaron en un tanque fotorreactor de agitado en operación discontinua a $25^{\circ} \mathrm{C}$, a $\mathrm{pH}$ de 6.5 y volumen de $200 \mathrm{~mL}$, empleando una concentración constante de pesticida y evaluando el proceso de fotodegradación por cromatografía de gases. La caracterización de los xerogeles permitio identificar que la temperatura de tratamiento define la estructura obtenida del material. Las pruebas de fotodegradación con mejores resultados $(46 \%)$ se presentaron al emplear xerogeles sintetizados en una proporción mayoritaria de titanio con estructura tipo filamento.

Palabras clave: Fotodegradación, pesticidas, xerogeles, método sol-gel.

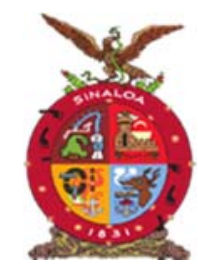

XVIII Congreso Internacional XXIV Congreso Nacional de Ciencias ambientales

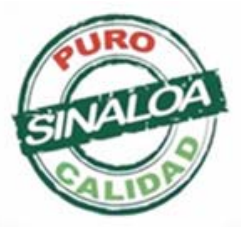

Mazatlán, Sinaloa 3-7 junio 2019
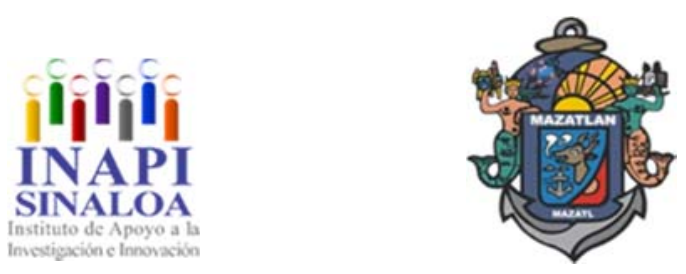

Tecnología y Biotecnología para el Tratamiento de Contaminantes y Biorremediación 


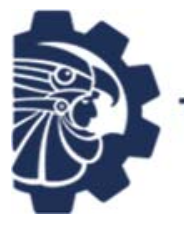

TECNOLOGICO NACIONAL DE MEXICO
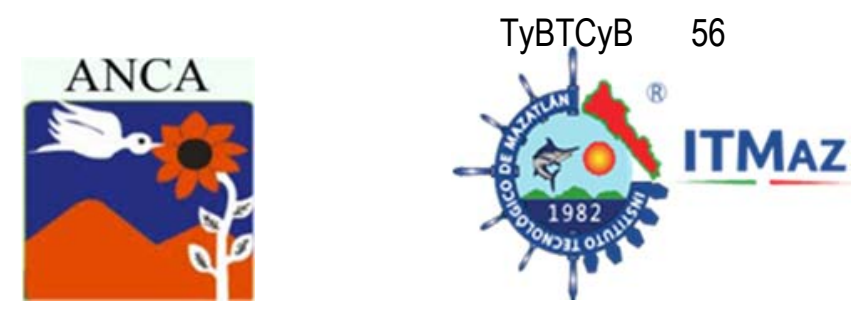

\title{
Synthesis of xerogeles of $\mathrm{SiO}_{2}-\mathrm{TiO}_{2}$ for photodegradation of pesticides
}

\author{
Cuevas Medina M, López Nieto J, Samaniego Hernández M, Osornio Rubio R* \\ Departamento de Ingeniería Ambiental. \\ Instituto Tecnológico de Celaya, Tecnológico Nacional de México. \\ Antonio García Cubas Pte \# 600, Guanajuato, 38010, México \\ *nadia.osornio@itcelaya.edu.mx
}

\begin{abstract}
In the use of pesticides, studies have estimated that less than $0.1 \%$ applied to the pest and the rest of this pollutes the soil, water and air, many can persist for long periods of time and have been detected in surface waters, 20 years after being banned. The objective of this project is to synthesize materials for use in the photodegradation of pesticides to reduce their presence in bodies of water. For the synthesis of xerogels, the sol-gel method was used, using as precursors: titanium isopropoxide and tetraethyl orthosilicate. To evaluate the synthesis of xerogels, a multilevel factorial experimental design was followed, having as variables the stoichiometric ratio of the precursors $(2: 1,1: 1,1: 2)$ and the thermal treatment during $30 \mathrm{~min}$ in four levels $200,400,600$ and $800^{\circ} \mathrm{C}$. The gels were stabilized at $25^{\circ} \mathrm{C}$ for $24 \mathrm{~h}$ in a desiccator and subsequently characterized by FTIR, TEM and DRX. The photodegradation tests were carried out in a stirred photoreactor tank in discontinuous operation at $25^{\circ} \mathrm{C}$, at a pH of 6.5 and a volume of $200 \mathrm{~mL}$, using a constant concentration of pesticide and evaluating the photodegradation process by gas chromatography. The characterization of the xerogels allowed us to identify that the treatment temperature defines the structure obtained from the material. The photodegradation tests with the best results $(46 \%)$ were presented using xerogels synthesized in a majority proportion of titanium with a filament-like structure.
\end{abstract}

Keywords: Photodegradation, pesticides, xerogels, sol-gel method.

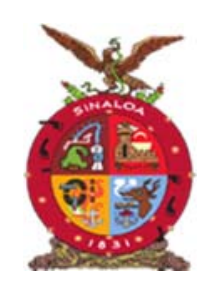

XVIII Congreso Internacional XXIV Congreso Nacional de Ciencias ambientales

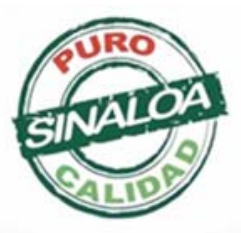

Mazatlán, Sinaloa 3-7 junio 2019
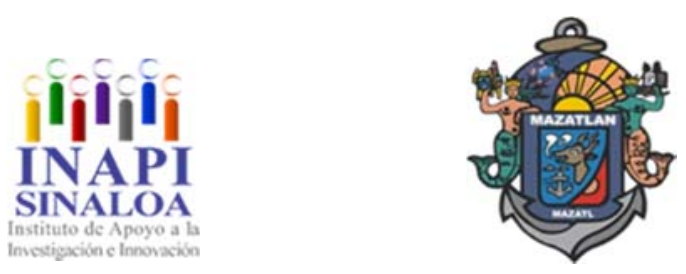

Tecnología y Biotecnología para el Tratamiento de Contaminantes y Biorremediación 

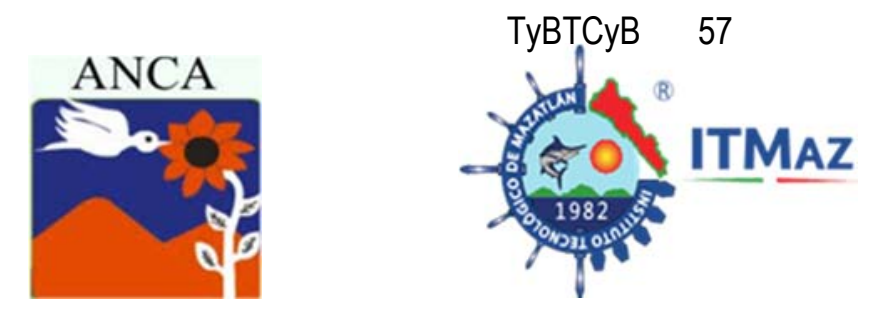

\title{
Participación del sector informal en la recolección de los residuos sólidos urbanos en Xaltianguis, Guerrero
}

\author{
Del Carmen Niño V1ㄴ Juárez López $\mathrm{AL}^{1}$, Sampedro Rosas $\mathrm{ML}^{1}$, \\ Rodríguez Herrera $\mathrm{AL}^{1}$, Silva Gómez $\mathrm{SE}^{2}$, Reyes Umaña $\mathrm{M}^{1}$ \\ ${ }^{1}$ Centro de Ciencias de Desarrollo Regional. \\ Universidad Autónoma de Guerrero. \\ Privada de Laurel No.13. Col. El Roble, C.P. 39640, Acapulco, Guerrero \\ ${ }^{2}$ Instituto de Ciencias. Benemérita Universidad Autónoma de Puebla, \\ 14 Sur 6301, Edificio 1C2, Ciudad Universitaria \\ Colonia Jardines de San Manuel, Puebla, Pue. C.P. 72570 \\ *viridiana_dcn@hotmail.com
}

\section{RESUMEN}

En las diferentes etapas del manejo de los residuos sólidos urbanos, participan personas pertenecientes al sector informal. El objetivo de este trabajo fue analizar las condiciones y características en la etapa de recolección de residuos sólidos urbanos, que realiza el sector informal en la localidad de Xaltianguis, Guerrero. Se realizaron recorridos de campo, para el reconocimiento de las paradas y rutas de recolección, con la información obtenida se procedió a efectuar la georrefenciación, digitalización y diseño de las paradas y rutas, utilizando el Software ArcGIS 10.4.1 e imágenes de satélite de Google Earth, mediante los Sistemas de Información Geográfica. Se aplicaron entrevistas semiestructuradas y abiertas a choferes de los vehículos de recolección y población atendida. Utilizando la metodología del Centro Panamericano de Ingeniería Sanitaria y Ciencias del Ambiente. Para determinar el volumen y la cantidad de residuos recolectados. El servicio de recolección se realiza por cuatro vehículos no convencionales, tres realizan la recolección diaria y una semanalmente, después de la colecta la disposición final la efectúan en el tiradero a cielo abierto ejidal. Se obtuvieron cuatro mapas temáticos con las paradas, rutas, y cobertura de recolección, este sector abarca ocho de doce colonias de Xaltianguis. Reciben cuotas por el servicio prestado, de diez pesos o más dependiendo del tamaño del recipiente de residuos. Recolectan 5 ton/día. Lo anterior plantea el reto de profundizar en propuestas de formalización de sus actividades e identificar los beneficios sociales y ambientales.

Palabras clave: Residuos sólidos urbanos, tiradero a cielo abierto, sector informak,

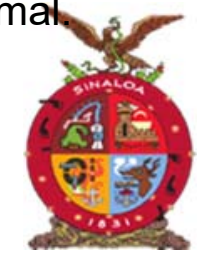

XVIII Congreso Internacional XXIV Congreso Nacional de Ciencias ambientales

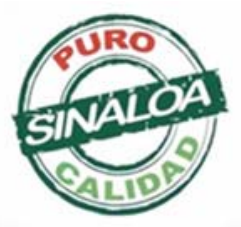

Mazatlán, Sinaloa 3-7 junio 2019
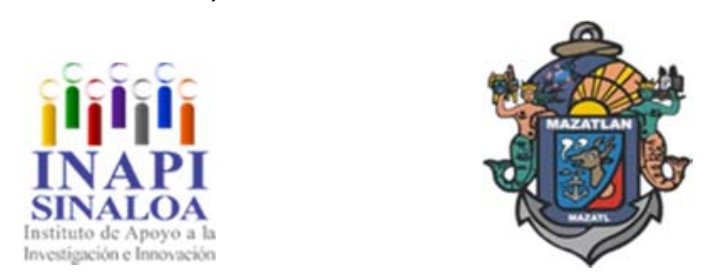

Tecnología y Biotecnología para el Tratamiento de Contaminantes y Biorremediación 

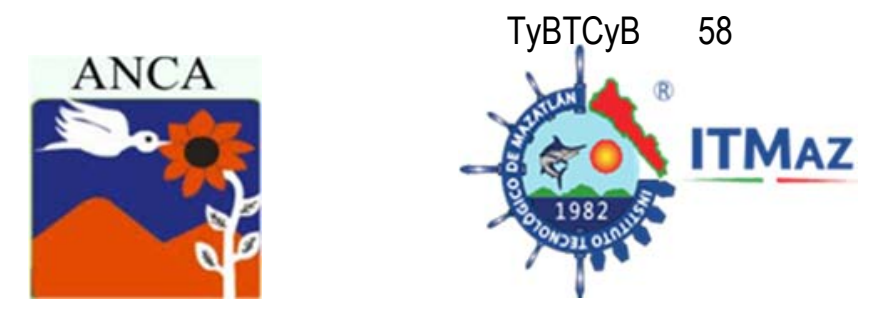

\title{
Participation of the informal sector in the collection of solid urban waste in Xaltianguis, Guerrero
}

\author{
Del Carmen Niño $V^{1}$, Juárez López $\mathrm{AL}^{1}$, Sampedro Rosas $\mathrm{ML}^{1}$, \\ Rodríguez Herrera $\mathrm{AL}^{1}$, Silva Gómez $\mathrm{SE}^{2}$, Reyes Umaña $\mathrm{M}^{1}$ \\ ${ }^{1}$ Centro de Ciencias de Desarrollo Regional. \\ Universidad Autónoma de Guerrero. \\ Privada de Laurel No.13. Col. El Roble, C.P. 39640, Acapulco, Guerrero \\ ${ }^{2}$ Instituto de Ciencias. Benemérita Universidad Autónoma de Puebla, \\ 14 Sur 6301, Edificio 1C2, Ciudad Universitaria \\ Colonia Jardines de San Manuel, Puebla, Pue. C.P. 72570 \\ *viridiana_den@hotmail.com
}

\begin{abstract}
In the different stages of the waste management, there are people belonging to the informal sector of waste. The objective was to analyze the conditions and characteristics in the collection stage, carried out by the informal sector in the town of Xaltianguis, Guerrero. Field trips were made to recognize the stops and collection routes. With the information obtained, was done the georeferencing, digitalization and design of the stops and routes, using the ArcGIS Software 10.4.1, satellite images from Google Earth, through the Geographic Information Systems. Semistructured interviews and open were conducted to drivers of the collection vehicles and the population served. The methodology of the Pan American Center for Sanitary Engineering and Environmental Sciences was used to determine the volume and quantity of waste collected. The collection service is realized four non-conventional vehicles, three performing the daily collection and one weekly, after the collection the final disposition is carried out in the ejido openair dump. Four thematic maps were obtained with stops, routes, and collection coverage, this sector covers eight of twelve colonies of Xaltianguis. They receive fees for the service provided, of ten pesos or more depending on the size of the waste container. They collect 5 ton/day. This poses the challenge of deepening proposals for the formalization of their activities and identifying the social and environmental benefits.
\end{abstract}

Keywords: Solid urban waste, open dump, informal sector.

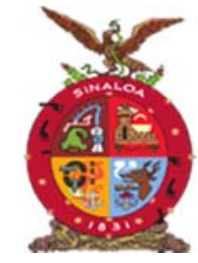

XVIII Congreso Internacional XXIV Congreso Nacional de Ciencias ambientales

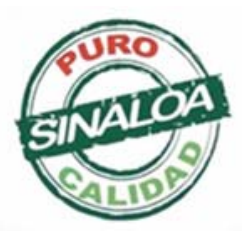

Mazatlán, Sinaloa 3-7 junio 2019
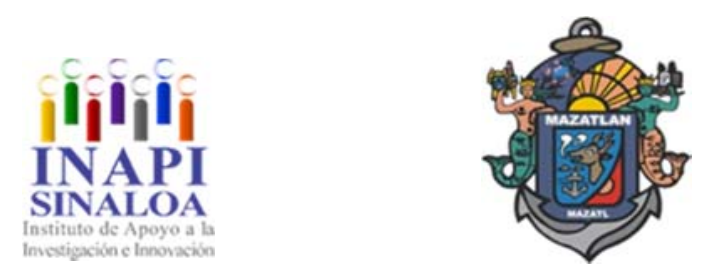

Tecnología y Biotecnología para el Tratamiento de Contaminantes y Biorremediación 

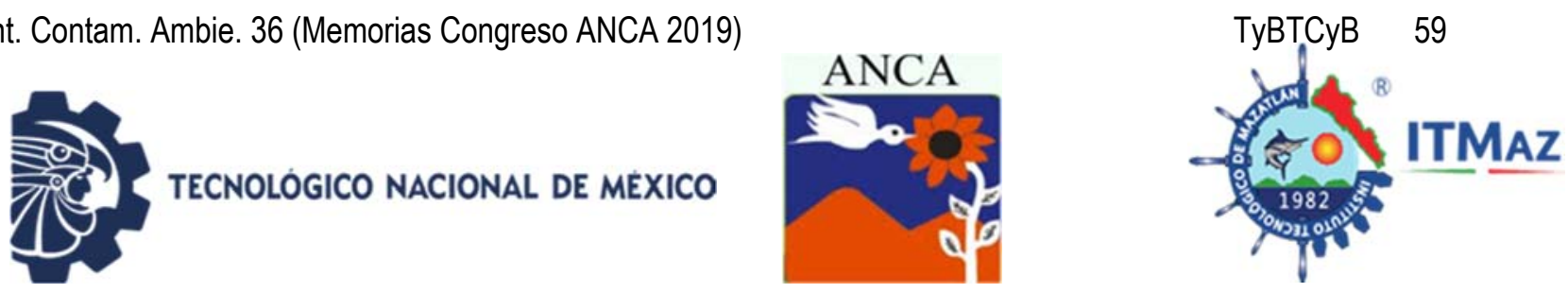

\title{
$\mathrm{TiO}_{2}$ sintetizado por precipitación controlada: aplicación en la remoción fotocatalítica de compuestos organoarsenicales
}

\author{
Delgado Díaz MA, Hernández Ramírez JL, Guzmán Mar M, \\ Villanueva Rodríguez L, Maya Treviño L, Hinojosa Reyes L* \\ Facultad de Ciencias Químicas. Universidad Autónoma de Nuevo León. \\ Pedro de Alba S/N, Cd Universitaria, San Nicolás de los Garza, \\ C.P. 66455, N.L., México \\ *laura.hinojosary@uanl.edu.mx
}

\section{RESUMEN}

El uso de nanomateriales a base de $\mathrm{TiO}_{2}$ en fotocatálisis heterogénea para la degradación de contaminantes emergentes, ha sido un área de investigación de gran desarrollo en los últimos años. En este estudio la síntesis de $\mathrm{TiO}_{2}$ se llevó a cabo por precipitación controlada asistida por microondas empleando como precursor oxisulfato de titanio y urea como agente precipitante en isopropanol: agua $(40: 60, \mathrm{v} / \mathrm{v})$ a $100^{\circ} \mathrm{C}$ durante $45 \mathrm{~min}$. El material fue caracterizado por difracción de rayos $X(D R X)$, espectroscopia UV-Vis con reflectancia difusa, FTIR, SEM, fisisorción de $\mathrm{N}_{2}$, XPS y análisis químico elemental. La actividad fotocatalítica del $\mathrm{TiO}_{2}$ fue evaluado en la remoción de ácido p-arsanílico (p-ASA) y roxarsona (ROX) bajo radiación UV ( $365 \mathrm{~nm})$. Con fines comparativos también se evaluó la actividad del material comercial $\mathrm{TiO}_{2} \mathrm{P} 25$. El seguimiento de la concentración de p-ASA y ROX durante la remoción y mineralización fue por HPLC y analizador del carbono orgánico total, respectivamente. $\mathrm{El} \mathrm{TiO}_{2}$ presentó la fase cristalina anatasa, tamaño de cristalito $4.8 \mathrm{~nm}$, estructura mesoporosa, área superficial de $14.8 \mathrm{~m}^{2} / \mathrm{g}$ e impurezas de $\mathrm{N}$ y $\mathrm{S}$ incorporadas de manera sustitucional provenientes de la urea $(0.54$ y $6.74 \%$, respectivamente). Este material superó al catalizador comercial P25 en la remoción de especies de arsénico a pH 9 bajo radiación UV. Se identificó como subproducto de degradación el $\mathrm{AsO}_{4}{ }^{3-}$, y mediante la prueba de toxicidad in vitro con $\mathrm{V}$. fisheri se observó una disminución de la toxicidad del efluente después de 240 min de reacción (13\%) comparado con el valor inicial, mostrando la aplicación potencial del material en la remoción de compuestos emergentes.

Palabras clave: Precipitación controlada, ácido p-arsanílico, roxarsona, fotocatálisis.

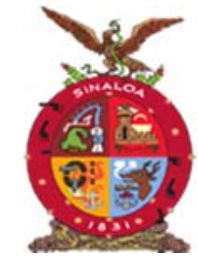

XVIII Congreso Internacional XXIV Congreso Nacional de Ciencias ambientales

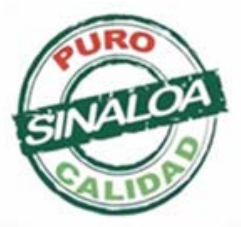

Mazatlán, Sinaloa 3-7 junio 2019
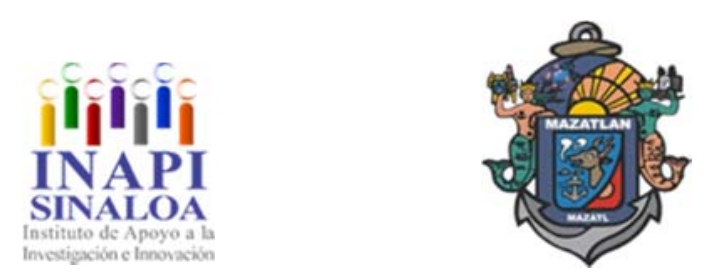

Tecnología y Biotecnología para el Tratamiento de Contaminantes y Biorremediación 

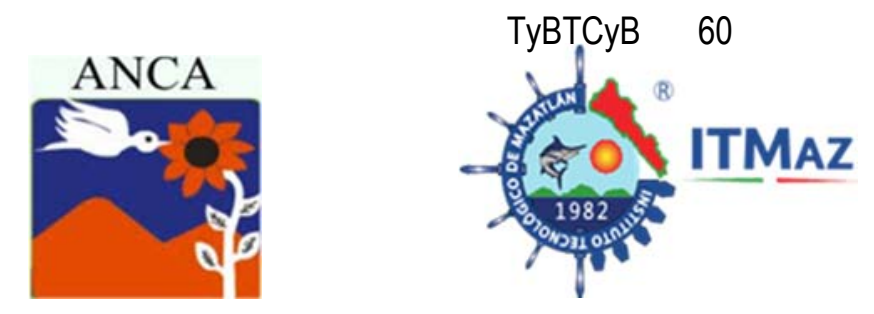

$\mathrm{TIO}_{2}$ synthesized by controlled precipitation: application on the
photocatalytic removal of organoarsenical compounds

Delgado Díaz D, Hernández Ramírez MA, Guzmán Mar JL, Villanueva Rodríguez M, MayaTreviño L, Hinojosa Reyes L*

Facultad de Ciencias Químicas. Universidad Autónoma de Nuevo León.

Pedro de Alba S/N, Cd Universitaria, San Nicolás de los Garza,

C.P. 66455, N.L., México

*laura.hinojosary@uanl.edu.mx

\begin{abstract}
The use of $\mathrm{TiO}_{2}$-based nanomaterials in heterogeneous photocatalysis for the degradation of emerging pollutants has been a research area of great development in recent years. In this study, the microwave assisted synthesis of $\mathrm{TiO}_{2}$ was carried out by controlled precipitation using as precursor titanium oxysulfate and urea as a precipitation agent in isopropanol: water $(40: 60, \mathrm{v} / \mathrm{v})$ at $100^{\circ} \mathrm{C}$ for $45 \mathrm{~min}$. The material was characterized by XRD, UV-Vis diffuse reflectance spectroscopy, FT-IR, SEM, $\mathrm{N}_{2}$ physisorption, XPS and elemental analysis. The photocatalytic activity of $\mathrm{TiO}_{2}$ was evaluated in the removal of $p$ arsanilic acid (p-ASA) and roxarsone (ROX) under UV radiation $(365 \mathrm{~nm})$. For comparative purpose, the photocatalytic activity of the commercial $\mathrm{P} 25 \mathrm{TiO}_{2}$ was also evaluated. The monitoring of $\mathrm{p}-\mathrm{ASA}$ and ROX concentration during degradation and mineralization was followed by HPLC and total organic carbon analyzer, respectively. The $\mathrm{TiO}_{2}$ showed the anatase crystalline phase, average crystallite size of $4.8 \mathrm{~nm}$, mesoporous structure, and surface area of $14.8 \mathrm{~m}^{2} / \mathrm{g}$. The impurities of $\mathrm{N}$ and $\mathrm{S}$ were incorporated in a substitutional way from the urea source (0.54 and 6.74\%, respectively). This material shows enhanced photocatalytic activity compared with P25 in the removal of organoarsenic species at $\mathrm{pH} 9$ under UV radiation. Although the $\mathrm{AsO}_{4}{ }^{3}$ was identified as a byproduct during photocatalytic degradation, a decrease in the toxicity of the effluent was observed by the in vitro toxicity test with $V$. fisheri, after 240 min of reaction (13\%) compared with its initial value, showing potential application of the prepared $\mathrm{TiO}_{2}$ on the removal of emerging pollutants.
\end{abstract}

Keywords: Controlled precipitation, p-arsanilic acid, roxarsone, photocatalysis

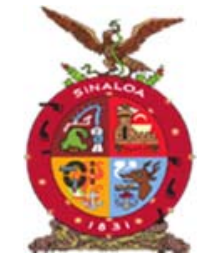

XVIII Congreso Internacional XXIV Congreso Nacional de Ciencias ambientales

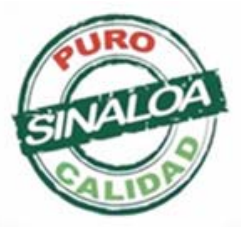

Mazatlán, Sinaloa 3-7 junio 2019
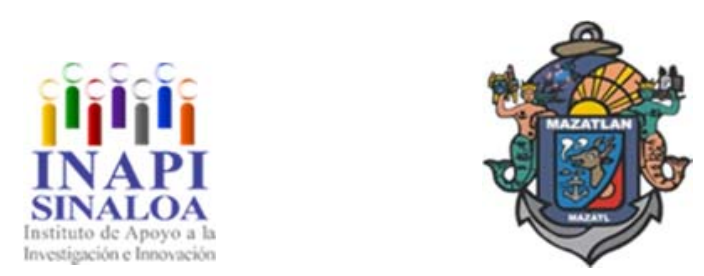

Tecnología y Biotecnología para el Tratamiento de Contaminantes y Biorremediación 

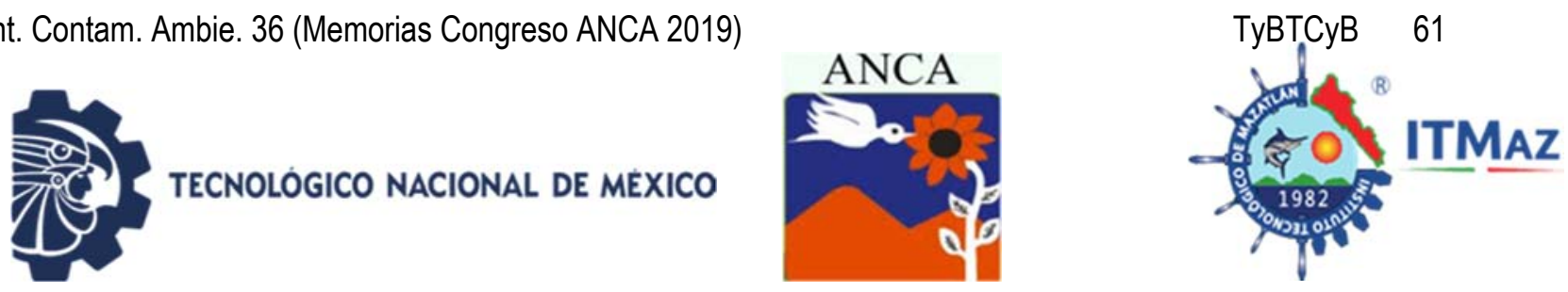

\title{
Degradación de cianuro en agua mediante fotocatálisis heterogénea con iluminación UV-LED
}

\author{
Díaz Medrano A, Inchaurregui Mendez H, González Rodríguez L* \\ Unidad Profesional Interdisciplinaria de Ingeniería Campus Zacatecas. \\ Instituto Politécnico Nacional. \\ Blvd. Del Bote S/N Cerro del Gato Ejido La Escondida, Col. Ciudad \\ Administrativa, 98160, Zacatecas, Zac, México \\ *Imgr49@gmail.com
}

\begin{abstract}
RESUMEN
El cianuro es un elemento que se puede encontrar en las aguas residuales de algunas actividades productivas entre ellas la minería, donde el cianuro resulta muy eficiente para la extracción de oro. La legislación mexicana obliga a tratar los efluentes antes de descargarlos debido a los riesgos ambientales que representa el cianuro en el ambiente en concentraciones por encima de los límites máximos permisibles establecidos por la NOM-001-SEMARNAT-1996. En este trabajo se determinó la eficiencia de la fotocatálisis heterogénea con iluminación UV-LED para degradar cianuro en agua, comparando el uso de dióxido de titanio Degussa P-25 (T) como fotocatalizador, en una concentración de $0.1 \mathrm{~g} / \mathrm{L}$, respecto a un compósito de titanio/zeolita natural (T/ZN) tipo clinoptilolita con una composición de $30 / 70 \%$ w respectivamente, a concentraciones de $0.1,0.2$ y $0.3 \mathrm{~g} / \mathrm{L}$, para analizar si la zeolita potencializa el proceso debido a su capacidad de adsorción. Durante las pruebas el pH fue de 11, el flujo de aire fue de $100 \mathrm{~mL} / \mathrm{s}$ y se emplearon 4 LEDS de 10 Watts. La determinación de cianuro, antes y después de las pruebas de degradación, se realizó mediante el estándar EPA 9014. Obteniendo como resultados que el dióxido de titanio degradó en un $99 \%$ el cianuro presente en el agua; de las tres concentraciones del T/ZN a una concentración de $0.1 \mathrm{~g} / \mathrm{L}$ obtuvo un mayor porcentaje de degradación con un $87 \%$ este valor se obtuvo con una menor concentración de dióxido de titanio, además la zeolita adsorbió 10 ppm previo al inicio del proceso fotocatalítico lo que indica que la zeolita potencializa el proceso fotocatalitico.
\end{abstract}

Palabras clave: Compósito, fotodegradación, soportes, titanio, zeolita.

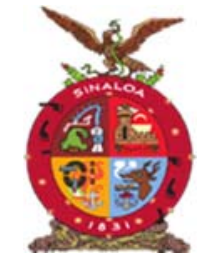

XVIII Congreso Internacional XXIV Congreso Nacional de Ciencias ambientales

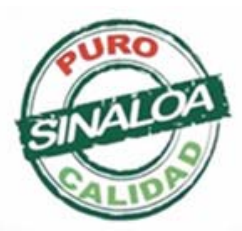

Mazatlán, Sinaloa 3-7 junio 2019
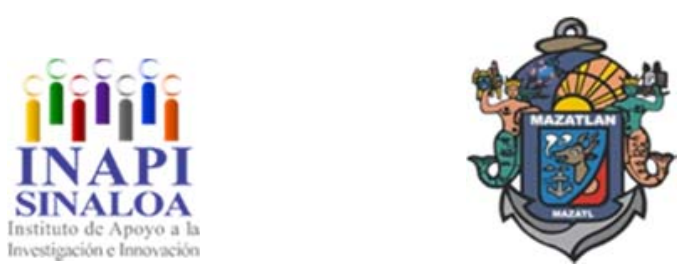

Tecnología y Biotecnología para el Tratamiento de Contaminantes y Biorremediación 

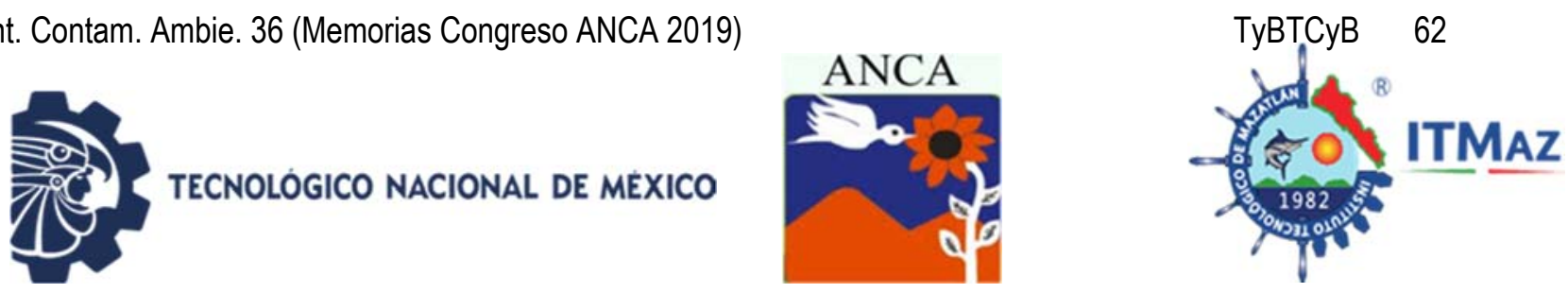

\title{
Degradation of cyanide in water through heterogenic photocatalysis with UV-LED lighting
}

\author{
Díaz Medrano A, Inchaurregui Mendez H, González Rodríguez L* \\ Unidad Profesional Interdisciplinaria de Ingeniería Campus Zacatecas. \\ Instituto Politécnico Nacional. \\ Blvd. Del Bote S/N Cerro del Gato Ejido La Escondida, Col. Ciudad \\ Administrativa, 98160, Zacatecas, Zac, México \\ *Imgr49@gmail.com
}

\begin{abstract}
Cyanide is an element that can be found in the wastewater of some productive activities, including mining, where cyanide is very efficient for the extraction of gold. Mexican legislation requires treating effluents before discharging them due to the environmental risks that cyanide represents in the environment in concentrations above the maximum permissible limits established by NOM-001SEMARNAT-1996. In this work, the efficiency of heterogeneous photocatalysis with UV-LED illumination was determined to degrade cyanide in water, comparing the use of Degussa P-25 ( T) titanium dioxide as photocatalyst, at a concentration of $0.1 \mathrm{~g} / \mathrm{L}$, compared to a titanium/natural zeolite (T/ZN) type clinoptilolite composite with a composition of $30 / 70 \% \mathrm{w}$ respectively, at concentrations of 0.1 , 0.2 and $0.3 \mathrm{~g} / \mathrm{L}$, to analyze if the zeolite potentiates the process due to its capacity to adsorption. During the tests the $\mathrm{pH}$ was 11, the air flow was $100 \mathrm{~mL} / \mathrm{s}$ and 4 LEDS of 10 Watts were used. The determination of cyanide, before and after the degradation tests, was carried out by the EPA standard 9014. Obtaining as a result that titanium dioxide degraded by $99 \%$ the cyanide present in the water; of the three concentrations of T/ZN at a concentration of $0.1 \mathrm{~g} / \mathrm{L}$ obtained a higher percentage of degradation with $87 \%$ this value was obtained with a lower concentration of titanium dioxide, in addition the zeolite absorbed $10 \mathrm{ppm}$ prior to the beginning of the photocatalytic process, which indicates that the zeolite potentiates the photocatalytic process.
\end{abstract}

Keywords: Composite, photodegradation, supports, titanium, zeolite.

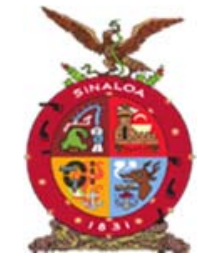

XVIII Congreso Internacional XXIV Congreso Nacional de Ciencias ambientales

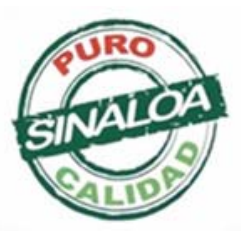

Mazatlán, Sinaloa 3-7 junio 2019
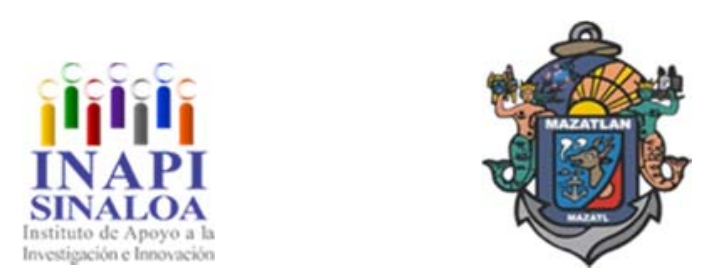

Tecnología y Biotecnología para el Tratamiento de Contaminantes y Biorremediación 

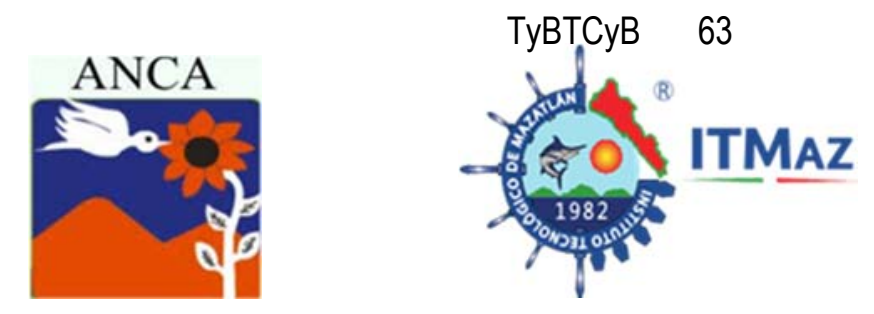

\title{
Remoción de rojo allura con carbón activado de lodos residuales de Cd. Juárez, Chih. y Toluca, México
}

\author{
Duarte López $\mathrm{C}^{1}$, Torres Pérez J1, Colín Cruz A² \\ ${ }^{1}$ Laboratorio de Transferencia y Degradación de Contaminantes. \\ Universidad Autónoma de Ciudad Juárez, \\ Anillo Envolvente del Pronaf y Estocolmo S/N, Cd. Juárez, Chihuahua, México. \\ ${ }^{2}$ Facultad de Química. Universidad Autónoma del Estado de México. \\ Paseo Colón S/N, Residencial Colón y Col Ciprés, 50120 Toluca de Lerdo, \\ México.*al139297@alumnos.uacj.mx
}

\section{RESUMEN}

El colorante Rojo Allura (R40) es un colorante sintético azoderivado empleado en la industria alimentaria como aditivo y en la elaboración de productos de confitería principalmente. Estos compuestos pueden tener efectos negativos en la salud, de ahí la importancia de eliminar dichos compuestos de cuerpos de agua. La adsorción es uno de los procesos más efectivos de tratamiento avanzado de aguas residuales y que el adsorbente más utilizado es el carbón activado. En el presente trabajo se propone la remoción de un colorante azoico (R40) mediante adsorción, utilizando carbón activado de lodos residuales. Este proceso se realizó en el Laboratorio de Transferencia y Degradación de Contaminantes (LTDC) de la Universidad Autónoma de Ciudad Juárez (Cd. Juárez, Chihuahua, México) en el periodo de agosto 2018 a marzo 2019. Se aplicó un proceso de sorción empleando reactores de polietileno $(250 \mathrm{~mL})$ con una solución de R40 (Co $=50$ ppm) y $0.25 \mathrm{~g}$ de carbón activado de lodos residuales de una planta tratadora de aguas residuales (PTAR) de Ciudad Juárez, Chih. (SAC-J) y otro de una PTAR de Toluca, Mex. (SAC-T). Como resultado del proceso de sorción, se obtuvieron remociones de R40 del 35.37 y $7.24 \%$ en 216 horas de contacto para SAC-J y SAC-T respectivamente. Los resultados cinéticos se ajustaron a los modelos de primer orden, pseudo segundo orden y Elovich. Se demostró que el SAC-J fue más eficiente en cuanto a capacidad de sorción. Así mismo, se demostró que ambos carbones son materiales adsorbentes viables en la sorción de R40 en medio acuoso.

Palabras clave: Carbón activado, colorantes azoicos, lodos residuales.

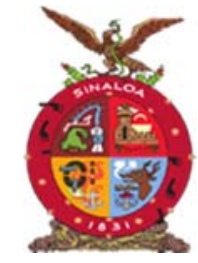

XVIII Congreso Internacional XXIV Congreso Nacional de Ciencias ambientales

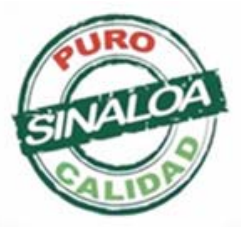

Mazatlán, Sinaloa 3-7 junio 2019
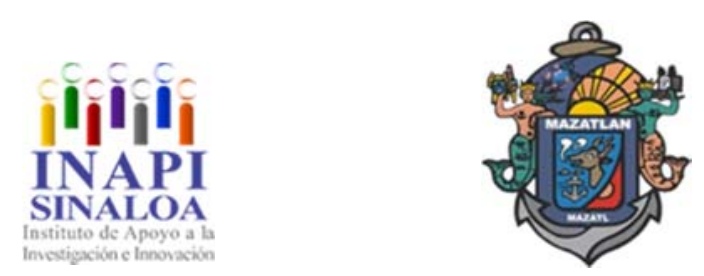

Tecnología y Biotecnología para el Tratamiento de Contaminantes y Biorremediación 

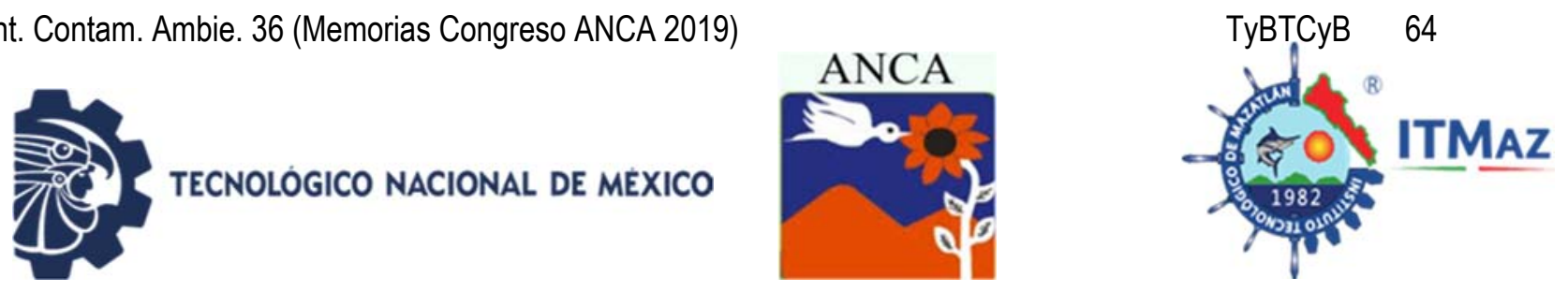

\title{
Allura red removal by activated carbon from sewage sludge from Cd. Juárez, Chih. and Toluca, Mexico
}

\author{
Duarte López $\mathrm{C}^{1}$, Torres Pérez J11, Colín Cruz A² \\ ${ }^{1}$ Laboratorio de Transferencia y Degradación de Contaminantes. \\ Universidad Autónoma de Ciudad Juárez, \\ Anillo Envolvente del Pronaf y Estocolmo S/N, Cd. Juárez, Chihuahua, México. \\ ${ }^{2}$ Facultad de Química. Universidad Autónoma del Estado de México. \\ Paseo Colón S/N, Residencial Colón y Col Ciprés, 50120 Toluca de Lerdo, \\ México.*al139297@alumnos.uacj.mx
}

\begin{abstract}
Allura Red dye (R40) is an azoderivative synthetic dye used in the food industry as an additive and in the confectionery products. These compounds can have negative effects on health, hence the importance of eliminating these compounds from water. Adsorption is one of the most effective advanced wastewater treatment processes and the most widely used adsorbent is activated carbon. In the present work, it was proposed the removal of an azo dye (R40) by adsorption by using activated carbon from sewage sludge. This process was carried out at the Pollutants Transfer and Degradation Laboratory (LTDC) of the Autonomous University of Ciudad Juárez (Cd. Juárez, Chihuahua, Mexico) in the period from August 2018 to March 2019. A sorption process was applied using polyethylene reactors $(250 \mathrm{~mL}$ ) with a $\mathrm{R} 40$ solution $(\mathrm{Co}=50 \mathrm{ppm})$ and $0.25 \mathrm{~g}$ of activated carbon from sewage sludge from a sewage treatment plant (WWTP) from Ciudad Juárez, Chih. (SAC-J) and another from a WWTP at Toluca, Mex. (SAC-T). As a result of the sorption process, R40 removals of 35.37 and $7.24 \%$ were obtained in 216 contact hours for SAC-J and SAC-T respectively. The kinetic results were adjusted to the first order, pseudo second order and Elovich models. It was shown that SAC-J was more efficient about sorption capacity. Likewise, it was demonstrated that both carbons are viable adsorbent materials for the sorption of $\mathrm{R} 40$ in aqueous medium.
\end{abstract}

Keywords: Activated carbon, azo dyes, residual sludge.

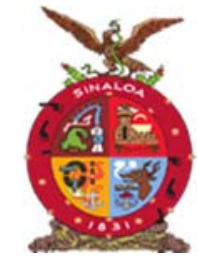

XVIII Congreso Internacional XXIV Congreso Nacional de Ciencias ambientales

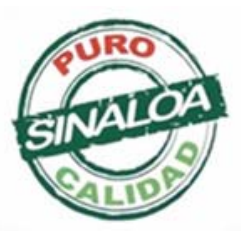

Mazatlán, Sinaloa 3-7 junio 2019
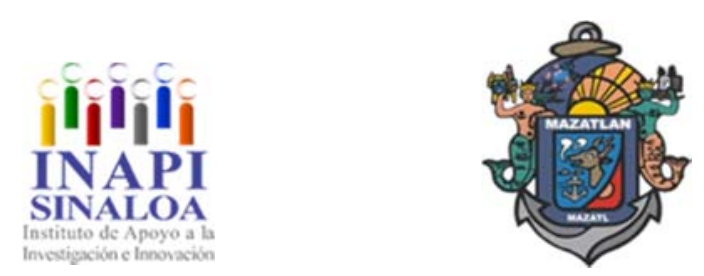

Tecnología y Biotecnología para el Tratamiento de Contaminantes y Biorremediación 

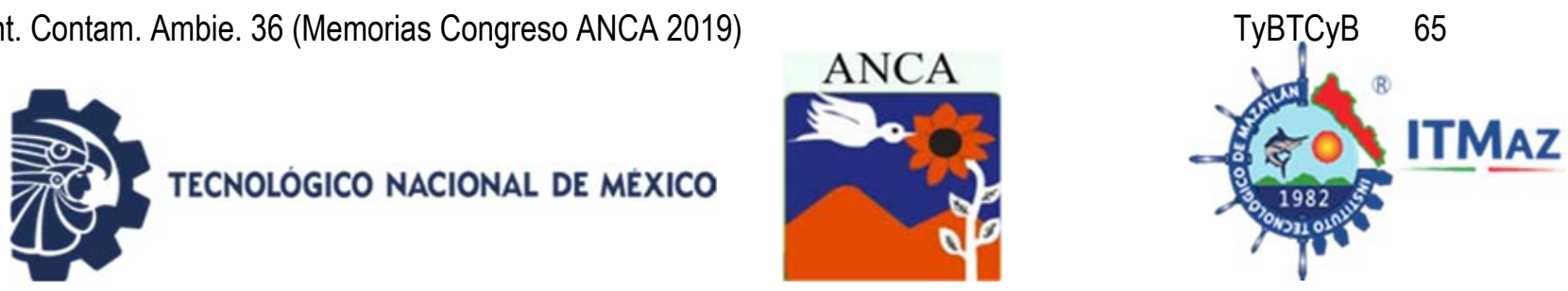

\title{
Percepción de los estudiantes de ingenieria sobre la conservación ambiental en el sur de Tamaulipas, México
}

Escamilla Azuara A, García Carrizales A*, Hernández González N, Flores Cruz J, Martínez Espinosa E, Pedroza Azuara A, Sandoval Segura D, Segura Maldonado V, González González M

Área de Ciencias Químico-Biológicas. Universidad del Noreste, Prolongación Av. Hidalgo No. 6315 Col. Nuevo Aeropuerto,

C.P. 89337, Tampico, Tam, México.

*arleth99garcia@gmail.com

\begin{abstract}
RESUMEN
La percepción ambiental es entendida como la forma en que cada individuo aprecia y valora su entorno, la cual influye en la toma de decisiones sobre el ambiente que lo rodea. Esta investigación se fundamenta en la percepción y nivel de conocimiento ambiental por parte de los estudiantes de tres ingenierías diferentes: Ingeniería Petrolera, Ingeniería Química e Ingeniería Industrial. Siendo el objetivo analizar la percepción que presentan los alumnos de cuatro Universidades ubicadas en la zona conurbada del Sur de Tamaulipas, México, que tienen en común las tres carreras antes mencionadas, para conocer la importancia que le otorgan a la conservación del ambiente, mediante un instrumento de recopilación de datos conformado por 19 preguntas las cuales integran las variables de visión, responsabilidad, actitud y decisión ambiental, el cual fue sometido a validación mediante el cálculo del Grado de congruencia ítem-objetivo de Osterlind, y aplicado a un total de 260 estudiantes, obteniendo como resultado que la mayoría de los estudiantes presentan una percepción desarrollada sobre el tema.
\end{abstract}

Palabras clave: Educación ambiental, zona conurbada, conservación del ambiente.

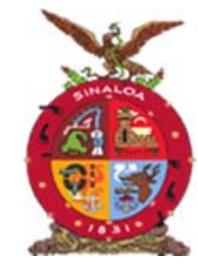

XVIII Congreso Internacional XXIV Congreso Nacional de Ciencias ambientales

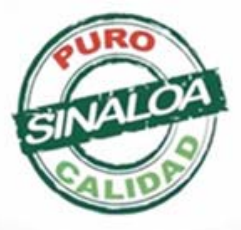

Mazatlán, Sinaloa 3-7 junio 2019
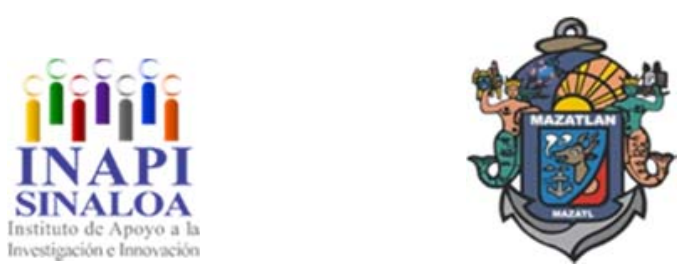

Tecnología y Biotecnología para el Tratamiento de Contaminantes y Biorremediación 

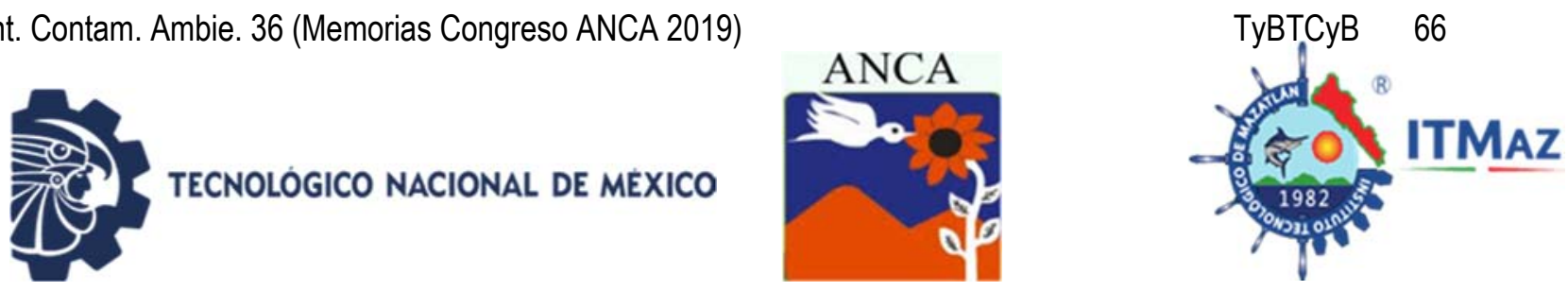

\title{
Perception of the engineering students on the environmental conservation in the south of Tamaulipas, Mexico
}

Escamilla Azuara A, García Carrizales A*, Hernández González N, Flores Cruz J, Martínez Espinosa E, Pedroza Azuara A, Sandoval Segura D, Segura Maldonado V, González González M

\author{
Área de Ciencias Químico-Biológicas. Universidad del Noreste, \\ Prolongación Av. Hidalgo No. 6315 Col. Nuevo Aeropuerto, \\ C.P. 89337, Tampico, Tam, México. \\ *arleth99garcia@gmail.com
}

\begin{abstract}
Environmental perceptions are understood as the way each individual appreciates and values their environment, which take part in taking decisions on the environment that surrounds it. This research is based on the perception and level of environmental knowledge on the students of three different engineering: Petroleum, Chemical and Industrial. The objective is to analyse the perception presented on the students of four colleges located in the South of Tamaulipas, Mexico, suburban area, which have in common the three aforementioned careers, to get to know the importance given to the conservation of the environment, through a data collection instrument formed of 19 questions that integrate the variables of vision, responsibility, attitude and environmental decision, which was subjected to validation by calculating the degree of congruence item-objective of Osterlind, and applied to a total of 260 students, obtaining as a result that most students present a developed perception on the subject
\end{abstract}

Keywords: Environmental education, suburban area, environmental conservation

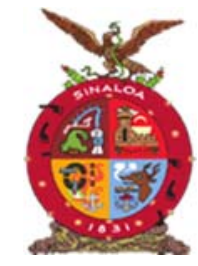

XVIII Congreso Internacional XXIV Congreso Nacional de Ciencias ambientales

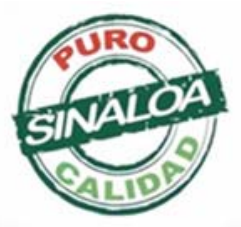

Mazatlán, Sinaloa 3-7 junio 2019
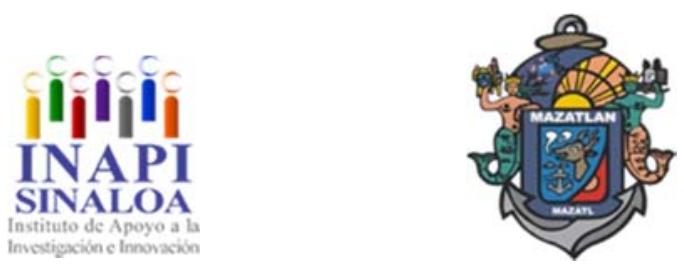

Tecnología y Biotecnología para el Tratamiento de Contaminantes y Biorremediación 

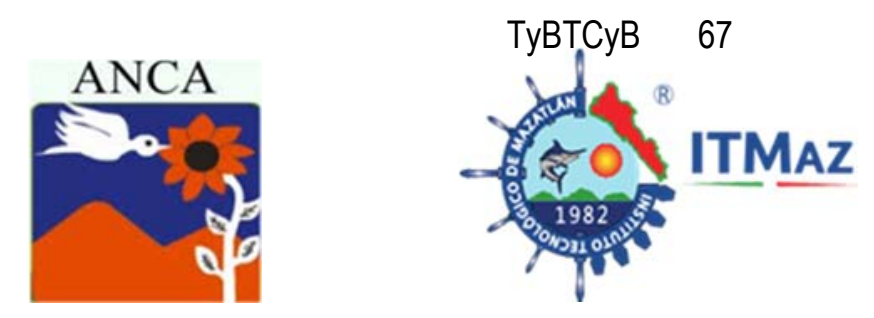

\title{
Estudio del efecto de germinación de conidiósporas en Queroseno
}

\author{
Estrada Feregrino I', Vázquez Martinez A², Cruz Mondragon $\mathrm{C}^{2}$, \\ Rodríguez Casasola $\mathrm{F}^{3}$, Esparza García $\mathrm{F}^{2^{*}}$ \\ ${ }^{1}$ Universidad Politécnica del Valle de México. \\ Av. Mexiquense S/N Col. Villa Esmeralda, Tultitlán, Edo. Mex \\ ${ }^{2}$ Departamento de Biotecnología y Bioingeniería. Centro de Investigación y de \\ Estudios Avanzados del Instituto Politécnico Nacional, \\ Av. Instituto Politécnico Nacional 2508 Col. San Pedro Zacatenco, CDMX \\ ${ }^{3}$ ENCB. Unidad Profesional Lázaro Cárdenas \\ Prol. Manuel Carpio y Plan de Ayala Col. Santo Tomás Miguel Hidalgo, CDMX \\ *fesparza@cinvestav.mx
}

\section{RESUMEN}

Los hidrocarburos del petrolero han sido extraídos y refinados por el ser humano por lo que se han generado derrames a través del tiempo dejando sitios contaminados. Debido a esta problemática se han implementado técnicas efectivas mediante el uso de microorganismos nativos. Los hongos filamentosos de los géneros Aspergillus y Penicillium han demostrado tener capacidad de degradación, sin embargo, llegan a tener una inhibición por el efecto tóxico. Con el objeto de determinar los efectos del queroseno en la germinación de conidiósporas se lleva a cabo la comparación en cultivo líquido con una fuente convencional (glucosa $10 \mathrm{~g} \mathrm{~L}^{-1}$ ) y no convencional (queroseno $2 \% \mathrm{v} / \mathrm{v}$ ) para conocer el proceso de germinación de las esporas a $30^{\circ}$ con agitación de 130 rpm durante $24 \mathrm{~h}$. Se observó la elongación del túbulo germinal a las $12 \mathrm{~h}$ en Penicillium con queroseno y a las $10 \mathrm{~h}$ con glucosa. Aspergillus presento elongación del túbulo germinal en queroseno a las $18 \mathrm{~h}$ y en glucosa a las 8 horas, mostrando una formación completa del pellet a las $12 \mathrm{~h}$. Obteniendo un crecimiento en queroseno de $24.48 \%$ y $32.82 \%$ respectivamente. Se observó la producción de ácidos orgánicos, ya que el $\mathrm{pH}$ desciende en crecimiento con glucosa, los cual se verificaron con TLC. Los compuestos identificados por su Rf son ácidos láctico y cítrico después de las 18 horas de crecimiento lo que los microorganismos. Los efectos que afectan al crecimiento directamente, se encontró el aumento de $\mathrm{pH}$ en queroseno y el cambio morfológico de los pellets en el medio de cultivo.

Palabras clave: Hidrocarburos, hongos filamentosos, ácidos orgánicos.

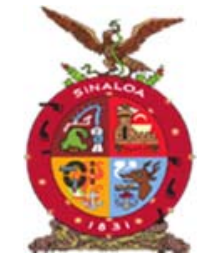

XVIII Congreso Internacional XXIV Congreso Nacional de Ciencias ambientales

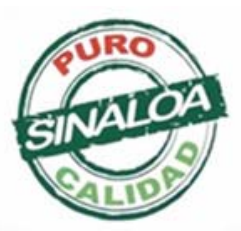

Mazatlán, Sinaloa 3-7 junio 2019
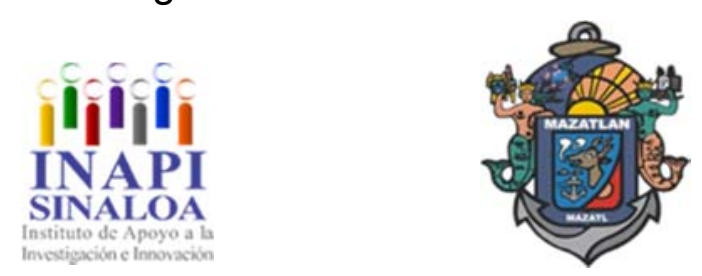

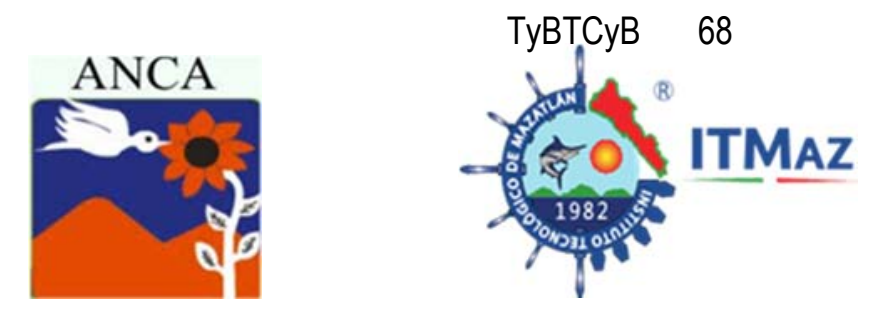

\title{
The study of the effect of germination of conidiospores in Kerosene
}

\author{
Estrada Feregrino I', Vázquez Martinez $\mathrm{A}^{2}$, Cruz Mondragon $\mathrm{C}^{2}$, \\ Rodríguez Casasola F³, Esparza García F \\ ${ }^{1}$ Universidad Politécnica del Valle de México. \\ Av. Mexiquense S/N Col. Villa Esmeralda, Tultitlán, Edo. Mex \\ ${ }^{2}$ Departamento de Biotecnología y Bioingeniería. Centro de Investigación y de \\ Estudios Avanzados del Instituto Politécnico Nacional, \\ Av. Instituto Politécnico Nacional 2508 Col. San Pedro Zacatenco, CDMX \\ ${ }^{3} E N C B$. Unidad Profesional Lázaro Cárdenas \\ Prol. Manuel Carpio y Plan de Ayala Col. Santo Tomás Miguel Hidalgo, CDMX \\ *fesparza@cinvestav.mx
}

\begin{abstract}
The petroleum hydrocarbons have been extracted and refined by the human being so they generate spills of petroleum and through time it leaves contaminated sites. As a result of this problem, effective techniques have been implemented through the use of native microorganisms. The filamentous fungi of the genus Aspergillus and Penicillium have been shown to have degradation capacity; however, they get to have an inhibition by the toxic effect. In order to determine the effects of kerosene on the conidiospore germination, the comparison in liquid culture with a conventional source is carried out. In order to determine the effects of kerosene on the germination of conidiospore, comparison is carried out in liquid culture with a conventional (glucose $10 \mathrm{~g} \mathrm{~L}-1$ ) and unconventional source (kerosene $2 \% \mathrm{v} / \mathrm{v}$ ) to know the process of germination of the spores at $30^{\circ} \mathrm{C}$ with agitation of $130 \mathrm{rpm}$ during $24 \mathrm{~h}$. The elongation of the germinal tubule was observed at $12 \mathrm{~h}$ in Penicillium with kerosene and at $10 \mathrm{~h}$ with glucose. Aspergillus presented elongation of the germinal tubule in kerosene at $6 \mathrm{~h}$ and in glucose at $8 \mathrm{~h}$, showing a complete pellet formation at $12 \mathrm{~h}$, obtaining a growth in kerosene of $24.48 \%$ and $32.82 \%$ respectively. It was observed the production of organic acids, meanwhile the $\mathrm{pH}$ decreases in growth with glucose, which were verified with TLC. The compounds identified by their Rf are lactic and citric acids after 18 hours of growth what microorganisms. The effects that affect the growth directly, was the increase of $\mathrm{pH}$ in kerosene and the morphological change of the pellets in the culture medium.
\end{abstract}

Keywords: Hydrocarbons, filamentous fungi, organic acids.

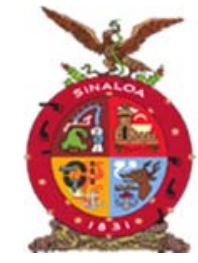

XVIII Congreso Internacional XXIV Congreso Nacional de Ciencias ambientales

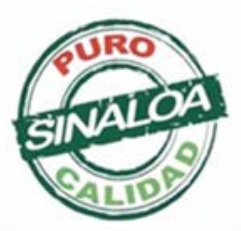

Mazatlán, Sinaloa 3-7 junio 2019
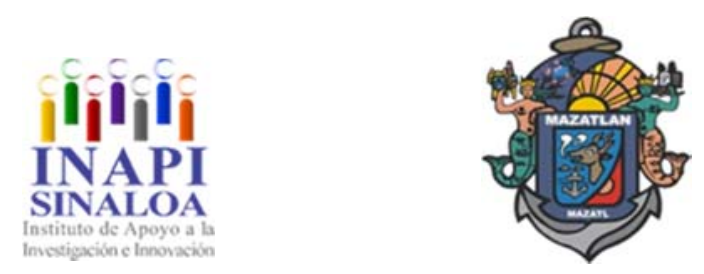

Tecnología y Biotecnología para el Tratamiento de Contaminantes y Biorremediación 

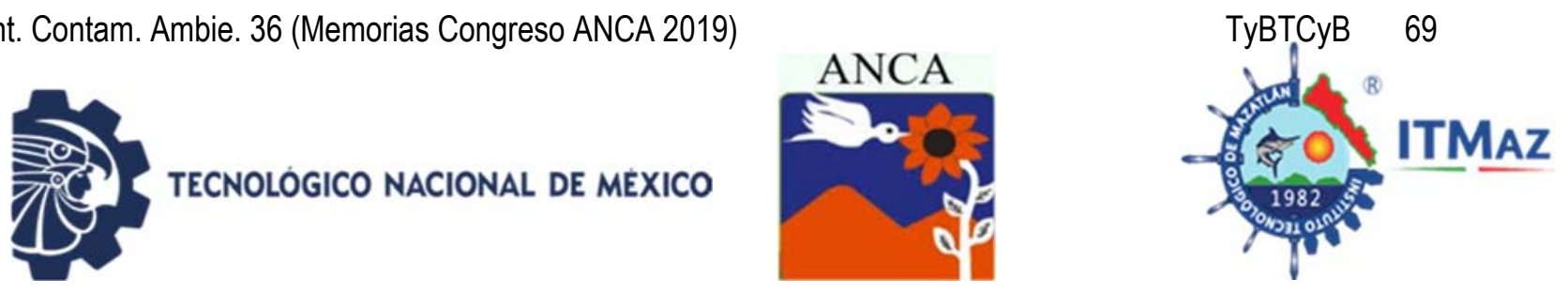

\title{
Diseño de un tratamiento para aguas residuales del Instituto Tecnológico de Culiacán
}

\author{
Estrada Vázquez R, Bustos Terrones Y \\ División de Estudios de Posgrado e Investigación. \\ Instituto Tecnológico de Culiacán. \\ Juan de Dios Batíz 310. Col. Guadalupe, 80220. Culiacán, Sinaloa, México \\ *M13170726@itculiacan.edu.mx
}

\section{RESUMEN}

En este estudio, la biodegradación de los contaminantes de las aguas residuales domésticas se ha llevado a cabo utilizando microorganismos inmovilizados en gel de alginato de sodio, en un reactor por lotes. Se utilizaron un reactor tubular y aguas residuales domésticas. Los microorganismos se tomaron del tanque de lodo activado de una planta de tratamiento convencional. En primer lugar, se llevó a cabo un tratamiento previo de aguas residuales para eliminar la materia particulada más grande, que consistía en un reactor tubular lleno de diferentes materiales (antracita, zeolita y carbón activado). Posteriormente, se utilizó un segundo reactor lleno de esferas con microorganismos inmovilizados para eliminar la materia orgánica y los nutrientes. Se utilizó un 2,5\% de W/V de alginato de sodio como soporte para inmovilizar los microorganismos. Se evaluaron los efectos de la concentración inicial, la temperatura, el pH y la fracción de volumen de alginato de sodio en la biodegradación de la materia orgánica y los nutrientes. De acuerdo con los resultados, se obtuvo una eliminación total de fósforo de $94.26 \%$ y $78.25 \%$ para la DQO. El tiempo de residencia fue de 24 horas, con aireación durante todo el proceso. Con estos resultados, se puede decir que el uso de alginato de sodio como soporte para la inmovilización de microorganismos es una técnica eficaz para el tratamiento de aguas residuales domésticas.

Palabras claves: Aguas residuales domésticas, microorganismos inmovilizados, alginato de sodio.

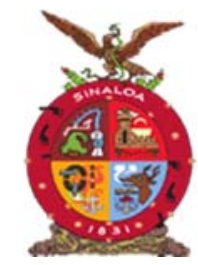

XVIII Congreso Internacional XXIV Congreso Nacional de Ciencias ambientales

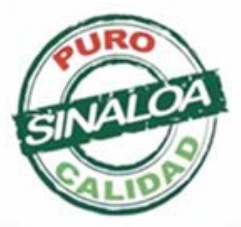

Mazatlán, Sinaloa 3-7 junio 2019
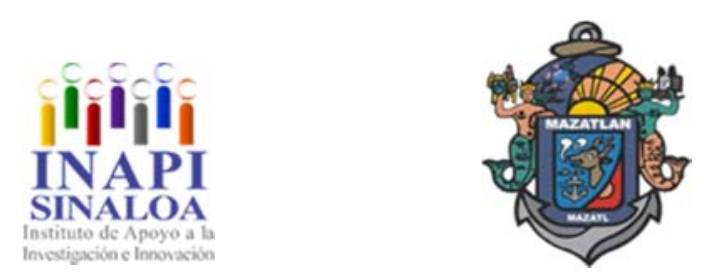

Tecnología y Biotecnología para el Tratamiento de Contaminantes y Biorremediación 

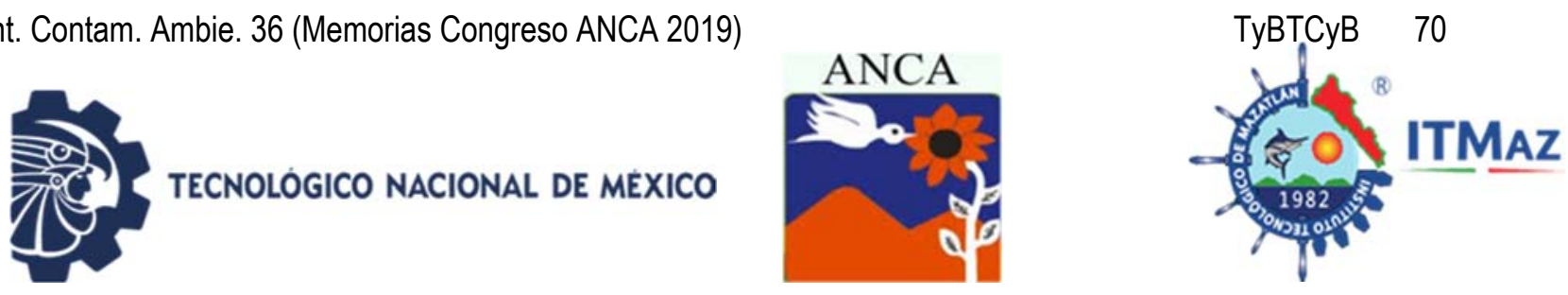

\title{
Design of a treatment for wastewater of the Technological Institute of Culiacan
}

\author{
Estrada Vázquez R, Bustos Terrones Y \\ División de Estudios de Posgrado e Investigación. \\ Instituto Tecnológico de Culiacán. \\ Juan de Dios Batíz 310. Col. Guadalupe, 80220. Culiacán, Sinaloa, México \\ *M13170726@itculiacan.edu.mx
}

\begin{abstract}
In this study, the biodegradation of domestic wastewater contaminants has been carried out using microorganisms immobilized in sodium alginate gel, in batch reactor. A tubular reactor and domestic wastewater were used. The microorganisms were taken from the activated sludge tank of a conventional treatment plant. Firstly, a wastewater pre-treatment was carried out to remove the larger particulate matter, which consisted of a tubular reactor packed with different materials (anthracite, zeolite and activated carbon). Later, a second reactor packed with spheres with immobilized microorganisms was used to eliminate organic matter and nutrients. $2.5 \% \mathrm{~W} / \mathrm{V}$ of sodium alginate was used as a support to immobilize the microorganisms. The effects of initial concentration, temperature, $\mathrm{pH}$ and sodium alginate volume fraction on the biodegradation of organic matter and nutrients were evaluated. According to the results, a total phosphorus removal of $94.26 \%$ and $78.25 \%$ was obtained for the COD. The residence time was 24 hours, with aeration throughout the process. With these results, it can be said that the use of sodium alginate as a support for the immobilization of microorganisms is an efficient technique for the treatment of domestic wastewater.
\end{abstract}

Keywords: Domestic wastewater, immobilized microorganisms, sodium alginate.

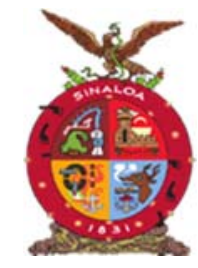

XVIII Congreso Internacional XXIV Congreso Nacional de Ciencias ambientales

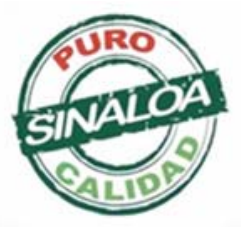

Mazatlán, Sinaloa 3-7 junio 2019
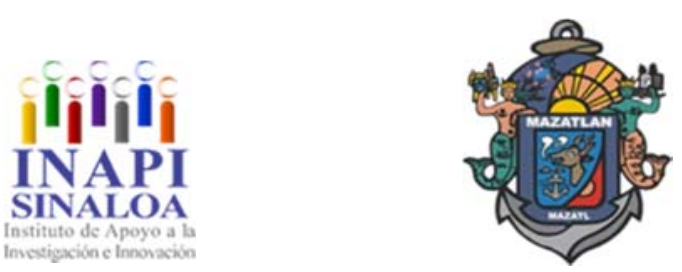

Tecnología y Biotecnología para el Tratamiento de Contaminantes y Biorremediación 

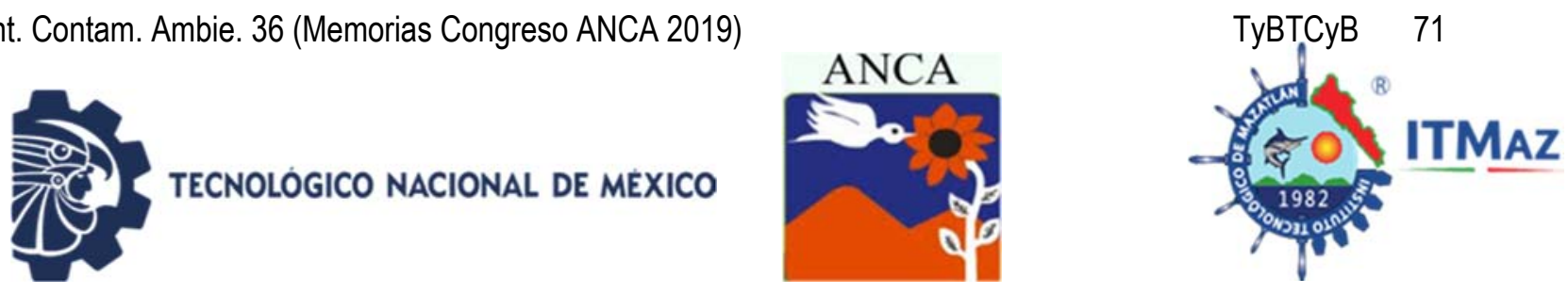

\section{Biosorción de metales pesados sobre fibras de Opuntia sp., usando una columna en modo continuo}

Flores Trujillo $\mathrm{A}^{1^{*}}$, Ortiz Hernández $\mathrm{ML}^{1}$, Calero De Hoces $\mathrm{M}^{2}$, Mussali Galante $\mathrm{P}^{1}$

${ }^{1}$ Centro de Investigación en Biotecnología. Universidad Autónoma del Estado de Morelos.

Av. Universidad 1001, Col. Chamilpa, C.P. 62209. Cuernavaca, Morelos

${ }^{2}$ Departamento de Ingeniería Química, Universidad de Granada.

Av. Del Hospicio, S/N, C.P. 18071. Granada, España

*ivanna_ft@hotmail.com

\section{RESUMEN}

La contaminación de agua por metales pesados es un problema grave, ya que se han observado diferentes afectaciones al ser humano, flora y fauna. Es por ello que la biosorción se muestra como una alternativa para la remoción de estos contaminantes del agua. El objetivo de este trabajo es investigar las mejores condiciones para remover metales pesados del agua: cadmio, hierro y plomo, utilizando como biosorbente fibras de Opuntia sp.. Para los experimentos, se utilizó una columna de vidrio, en la que se empacó una cantidad conocida del biosorbente. Se prepararon diferentes soluciones de metales y se pasaron a través de la columna, bombeando con un caudal en modo de flujo ascendente y a temperatura constante. Para el experimento se utilizó un diseño factorial $2^{3}$, dos concentraciones iniciales (50 y $100 \mathrm{mg} / \mathrm{L}$ ), dos masas de biosorbente (1 y $2 \mathrm{gr}$ ) y dos caudales ( 2 y $4 \mathrm{~mL} / \mathrm{min}$ ). A la salida de la columna, se tomaron muestras en diferentes intervalos de tiempo, mismas que se analizaron mediante espectrofotometría de absorción atómica. De los resultados obtenidos se observó que variables como el caudal y la concentración inicial de la solución de metales, influyen en mayor proporción en el proceso, además de que se observaron porcentajes de retención superiores al $50 \%$. Por lo que se puede concluir que el proceso de biosorción en continuo, es complejo e intervienen diferentes factores que pueden influenciar positiva o negativamente la biosorción de los metales en las fibras de la Opuntia sp.

Palabras claves: Remoción, fibras naturales, metales pesados.

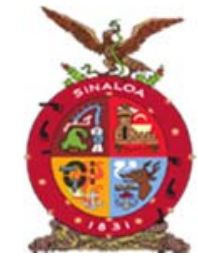

XVIII Congreso Internacional XXIV Congreso Nacional de Ciencias ambientales

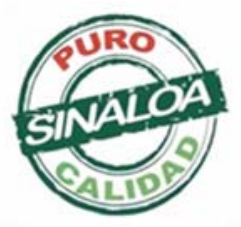

Mazatlán, Sinaloa 3-7 junio 2019
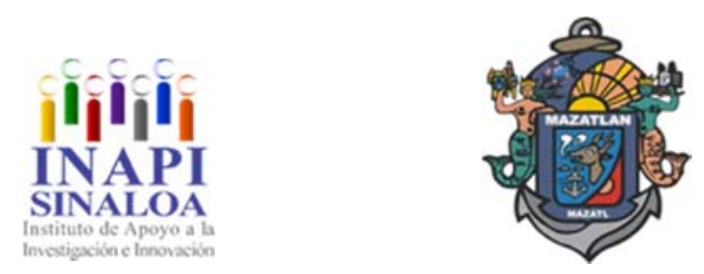

Tecnología y Biotecnología para el Tratamiento de Contaminantes y Biorremediación 
Rev. Int. Contam. Ambie. 36 (Memorias Congreso ANCA 2019)
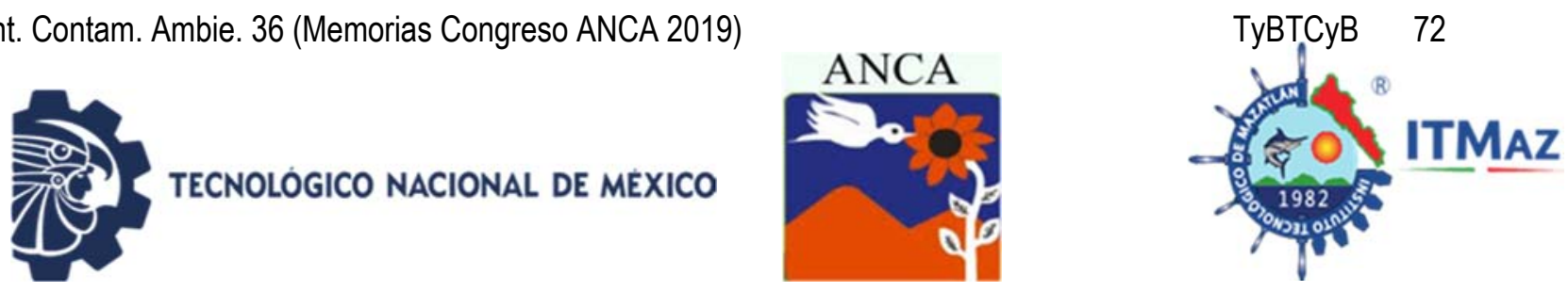

\title{
Biosorption of heavy metals on Opuntia sp. fibers, using a column in continuous mode
}

Flores Trujillo $\mathrm{A}^{1 *}$, Ortiz Hernández $\mathrm{ML}^{1}$, Calero De Hoces $\mathrm{M}^{2}$, Mussali Galante $\mathrm{P}^{1}$

${ }^{1}$ Centro de Investigación en Biotecnología. Universidad Autónoma del Estado de Morelos.

Av. Universidad 1001, Col. Chamilpa, C.P. 62209. Cuernavaca, Morelos

${ }^{2}$ Departamento de Ingeniería Química, Universidad de Granada.

Av. Del Hospicio, S/N, C.P. 18071. Granada, España

*ivanna_ft@hotmail.com

\begin{abstract}
Currently, the water pollution by heavy metals is a serious problem, since different affectations to humans, flora and fauna have been observed. That is why biosorption is shown as an alternative for the removal of these contaminants from water. The objective of this work is to investigate the best conditions to remove three heavy metals from water (cadmium, iron and lead), using to Opuntia sp. fibers as biosorbent. For the experiments, a glass column packed with a known quantity of biosorbent was used. Different metals solutions were prepared and passed through the column, pumping with a flow rate in ascending flow mode and at constant temperature. In addition, a factorial design $2^{3}$, two initial concentrations (50 and $100 \mathrm{mg} / \mathrm{L}$ ), two biosorbent masses ( 1 and $2 \mathrm{gr}$ ) and two flow rates ( 2 and $4 \mathrm{~mL} / \mathrm{min}$ ) were used. At the exit of the column, samples at different time intervals were taken, which were analyzed by atomic absorption spectrophotometry. Among the results obtained, it was found that variables such as the flow rate and the initial metals concentration have influence in a greater proportion in the process, and retention percentages higher than $50 \%$ were observed. With these results, we can conclude that the continuous biosorption process is very complex and the different variables involved, can influence positively or negatively the metals biosorption on Opuntia sp fibers.
\end{abstract}

Keywords: Removal, natural fibers, heavy metals.

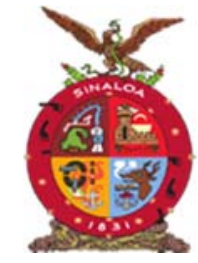

XVIII Congreso Internacional XXIV Congreso Nacional de Ciencias ambientales

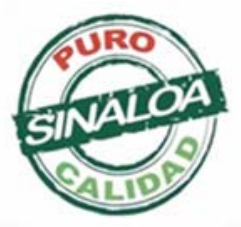

Mazatlán, Sinaloa 3-7 junio 2019
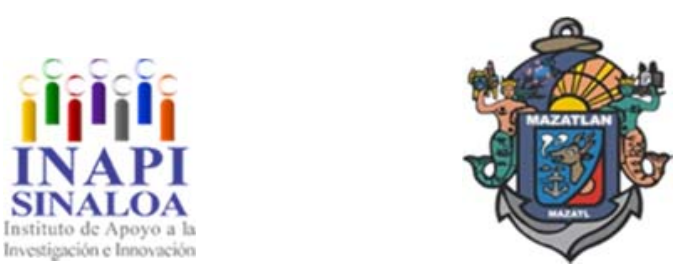

Tecnología y Biotecnología para el Tratamiento de Contaminantes y Biorremediación 

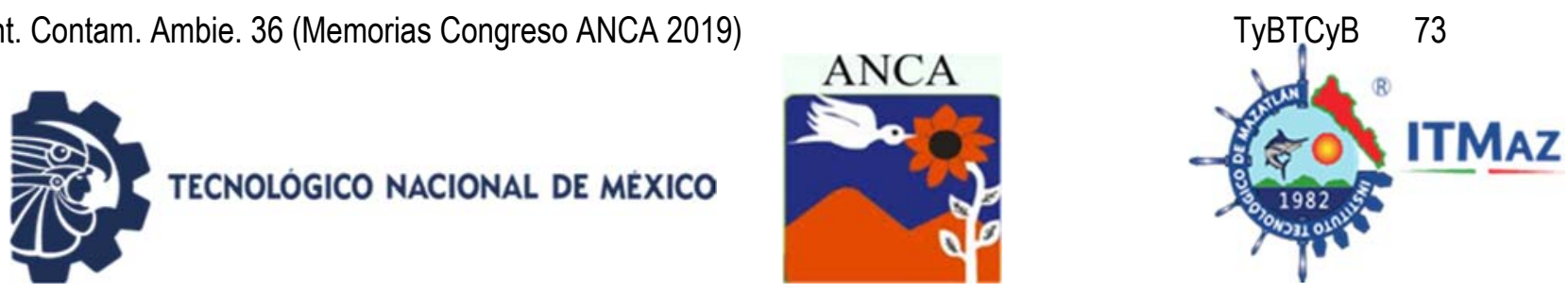

\title{
Operación a escala piloto de un reactor biológico tubular para el tratamiento de agua residual
}

\author{
García González SA*, Durán Moreno A
}

Facultad de Química. Universidad Nacional Autónoma de México Laboratorio 301 edificio "E", Ciudad universitaria, México, Ciudad de México, cheko29@hotmail.com

El reactor biológico tubular (RBT) (Mx/a/2017/014326) es una tecnología novedosa para el tratamiento de aguas residuales domésticas e industriales a pequeña escala, es un sistema modular y de bajo costo que produce agua residual tratada in situ, se basa principalmente en la degradación biológica aerobia de los contaminantes disueltos en el agua residual por microrganismos acumulados dentro del reactor. El desarrollo tecnológico presentado se puede clasificar internacionalmente como una pequeña planta de tratamiento de aguas residuales Small Wastewater Treatment Plants (SWWTP) (por sus siglas en inglés). Una instalación compacta puede ser aprovechada por las pequeñas comunidades rurales, urbanas o pequeñas industrias para tratar sus efluentes domésticos $\mathrm{e}$ industriales. El reactor fue alimentado con agua residual proveniente de la planta de tratamiento en Copilco (CU, UNAM), con un flujo de $7.2 \mathrm{~m} / \mathrm{d}$ y una carga orgánica superficial de $50 \pm 10 \mathrm{~g} \mathrm{DQO} / \mathrm{m}^{2} \mathrm{~d}$ durante 7 semanas, como parámetros de calidad se utilizaron SST y DBO $\mathrm{DB}_{5} \mathrm{DQO}$ y N-NH 4 . Los resultados muestran una operación continua y estable en un periodo de 1.5 meses a la carga aplicada, se obtuvo una remoción promedio de DQO, SST y N$\mathrm{NH}_{4}$ del $70 \%, 74 \%$ y $100 \%$ respectivamente. La evaluación realizada al efluente mediante el uso de la tecnología propuesta (Reactor Biológico Tubular (RBT)) muestra que se puede llevar a cabo el tratamiento de aguas residuales urbanas a pequeña escala y que esta tecnología puede ser una herramienta útil para el tratamiento de las aguas residuales municipales.

Palabras clave: Reactor biológico tubular, pequeñas plantas de tratamiento de aguas residuales, tratamiento de aguas residuales.

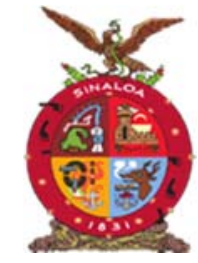

XVIII Congreso Internacional XXIV Congreso Nacional de Ciencias ambientales

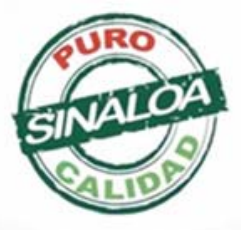

Mazatlán, Sinaloa 3-7 junio 2019
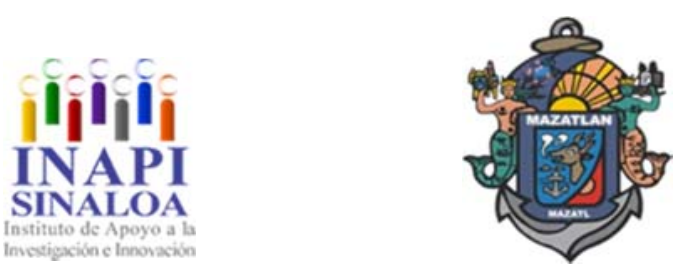

Tecnología y Biotecnología para el Tratamiento de Contaminantes y Biorremediación 

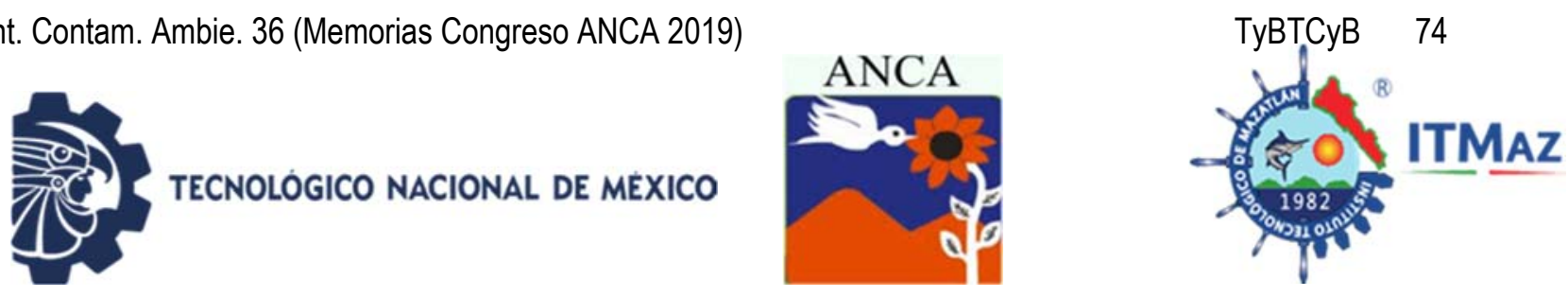

\title{
Pilot scale operation of a tubular biological reactor for wastewater treatment
}

\author{
García González SA*, Durán Moreno A \\ Facultad de Química. Universidad Nacional Autónoma de México \\ Laboratorio 301 edificio "E", Ciudad universitaria, México, Ciudad de México, \\ cheko29@hotmail.com
}

\begin{abstract}
The tubular biological reactor (RBT) (Mx/a/2017/014326) is a new technology for the treatment of domestic and industrial wastewater on a small scale, it is a modular and low-cost system Producing treated wastewater treated in situ, it is mainly based on aerobic biological degradation of contaminants dissolved in wastewater by microorganisms accumulated within the reactor. The technological development presented can be classified internationally as a small sewage treatment plant Small Wastewater Treatment Plants (SWWTP). A compact installation can be used by small rural, urban or small industrial communities to treat their domestic and industrial effluents. The reactor was fed with wastewater from the Copilco treatment plant (CU, UNAM), with a flow of $7.2 \mathrm{~m}^{3} / \mathrm{d}$ and a surface organic load of $50 \pm 10 \mathrm{~g} \mathrm{COD} / \mathrm{m}^{2} \mathrm{~d}$ for 7 weeks, as quality parameters were They used SST and $\mathrm{DBO}_{5}, \mathrm{COD}$ and $\mathrm{N}-\mathrm{NH}_{4}$. The results show a continuous and stable operation in a period of 1.5 months at the applied load, an average COD, OSH and $\mathrm{N}-\mathrm{NH} 4$ removal of $70 \%, 74 \%$ and $100 \%$ respectively was obtained. The evaluation of the effluent through the use of the proposed technology (Tubular Biological Reactor (RBT)) shows that small-scale urban wastewater treatment can be carried out and that this technology can be a useful tool for the treatment of municipal wastewater.
\end{abstract}

Keywords: Tubular biological reactor, small wastewater treatment plants, wastewater treatment.

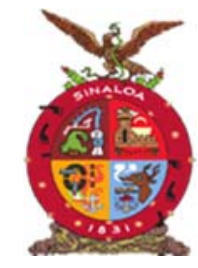

XVIII Congreso Internacional XXIV Congreso Nacional de Ciencias ambientales

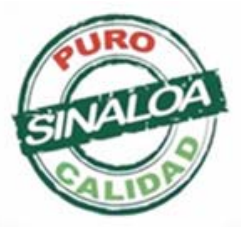

Mazatlán, Sinaloa 3-7 junio 2019
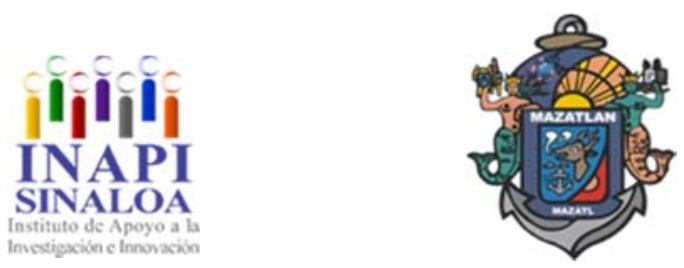

Tecnología y Biotecnología para el Tratamiento de Contaminantes y Biorremediación 

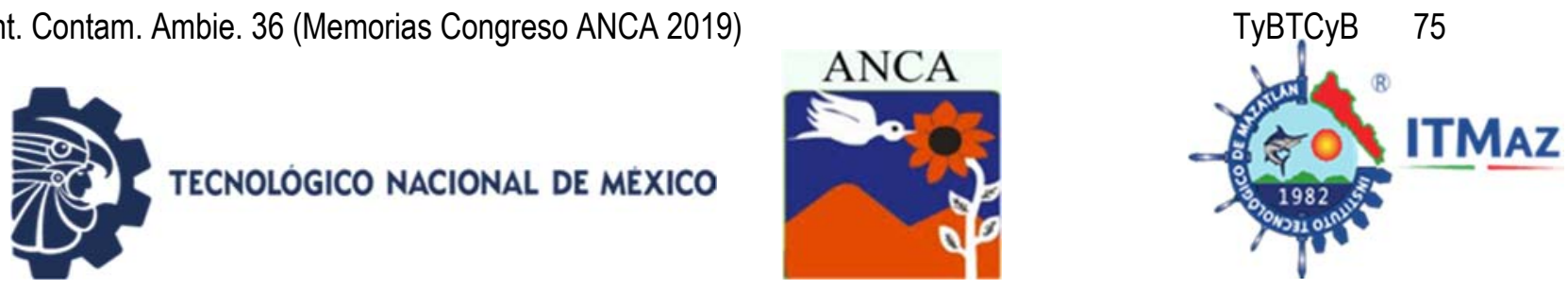

\title{
Degradación de metronidazol (MTZ) en agua residual mediante un proceso de oxidación electroquímica y su determinación analítica por voltamperometría diferencial de pulsos (VDP)
}

\author{
García Sánchez $\mathrm{M}^{1 *}$, Roa Morales $\mathrm{G}^{2}$, Balderas Hernández $\mathrm{P}^{2}$, \\ Barrera Díaz $\mathrm{CE}^{2}$, Reyes Pérez EM² \\ ${ }^{1}$ Plantel Ciencias de la Salud de Univer Milenium, Toluca, México \\ ${ }^{2}$ Facultad de Química de la Universidad Autónoma del Estado de México. \\ Laboratorio de Química Ambiental \\ Centro Conjunto de Investigación en Química Sustentable UAEMéx-UNAM. \\ Carretera Toluca-Atlacomulco Km 14.5. Toluca, C.P. 50200, México. \\ *monserrath.gschz@gmail.com
}

\section{RESUMEN}

El Metronidazol (MTZ) es un fármaco representativo de los nitroimidazoles, se caracteriza por su eficiente absorción vía oral con una biodisponibilidad del $90 \%$, baja biodegradabilidad y alta toxicidad. De la dosis administrada, entre el 6 y el $18 \%$ se excreta sin metabolizarse por la orina, llegando al medio acuático y convirtiéndose así en un compuesto peligroso para el ambiente. Debido a esta problemática se han creado nuevas alternativas para el tratamiento del agua residual, dando especial atención a los procesos avanzados de oxidación, útiles para la degradación de compuestos no biodegradables. Para la determinación de MTZ se han reportado diferentes técnicas analíticas, sin embargo las técnicas electroanalíticas suelen ser más atrayentes para la determinación de agentes químicos. La degradación del MTZ se realizó en una celda electroquímica con capacidad de $1 \mathrm{~L}$ de volumen de operación, se emplearon electrodos de $\mathrm{Fe}$, una corriente de $12 \mathrm{~mA} \mathrm{~cm}^{-2}$, en presencia de sulfato de sodio $\left(\mathrm{Na}_{2} \mathrm{SO}_{4}\right) 0.1 \mathrm{M}$ como electrolito soporte. La determinación analítica del fármaco se efectuó con VDP, utilizando electrodos de pasta de carbono modificados con $\beta$-ciclodextrina. Fue posible determinar las condiciones óptimas para la degradación y para la determinación del MTZ en agua residual mediante técnicas de oxidación avanzada que degradan y permiten la mineralización del fármaco, además de la determinación electroanalítica del mismo. Se obtuvieron porcentajes de degradación mayores al $80 \%$ a tiempos de 60 min.

Palabras clave: Electrodos de Fe, densidad de corriente, electrodos de pasta de carbono, $\beta$-ciclodextrina.

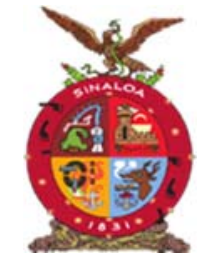

XVIII Congreso Internacional XXIV Congreso Nacional de Ciencias ambientales

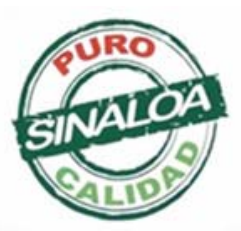

Mazatlán, Sinaloa 3-7 junio 2019
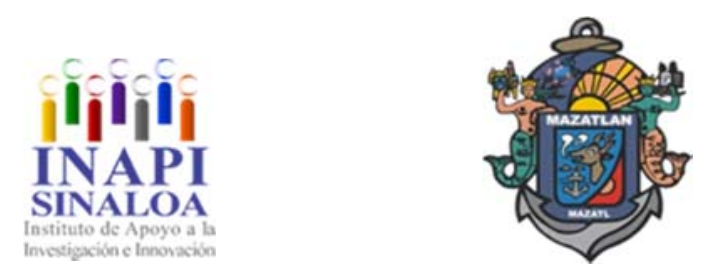

Tecnología y Biotecnología para el Tratamiento de Contaminantes y Biorremediación 

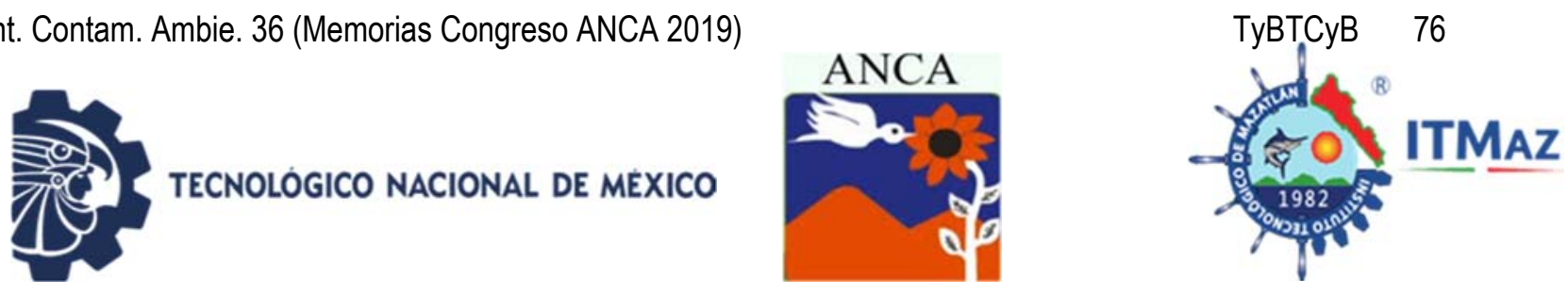

\title{
Degradation of Metronidazole (MTZ) in wastewater through an electrochemical oxidation process and its analytical determination by differential pulse voltammetry (DPV)
}

\author{
García Sánchez $\mathrm{M}^{1^{*}}$, Roa Morales $\mathrm{G}^{2}$, Balderas Hernández $\mathrm{P}^{2}$, \\ Barrera Díaz $\mathrm{CE}^{2}$, Reyes Pérez EM
}

${ }^{1}$ Plantel Ciencias de la Salud de Univer Milenium, Toluca, México

${ }^{2}$ Facultad de Química de la Universidad Autónoma del Estado de México.

Laboratorio de Química Ambiental

Centro Conjunto de Investigación en Química Sustentable UAEMéx-UNAM.

Carretera Toluca-Atlacomulco Km 14.5. Toluca, C.P. 50200, México.

*monserrath.gschz@gmail.com

\section{SUMMARY}

Metronidazole (MTZ) is a representative drug of nitroimidazoles, is characterized by its efficient oral absorption with a bioavailability of $90 \%$, low biodegradability and high toxicity. Of the administered dose, between 6 and $18 \%$ is excreted without being metabolized in the urine, reaching the aquatic environment and thus becoming a dangerous compound for the environment. Due to this problem, new alternatives have been created for the treatment of wastewater, giving special attention to advanced oxidation processes, useful for the degradation of nonbiodegradable compounds. For the determination of MTZ, different analytical techniques have been reported, however electroanalytical techniques are usually more attractive for the determination of chemical agents. The degradation of MTZ was performed in an electrochemical cell with a capacity of $1 \mathrm{~L}$ of operating volume, Fe electrodes were used, a current density of $12 \mathrm{~mA} \mathrm{~cm}^{-2}$, in the presence of sodium sulfate $\left(\mathrm{Na}_{2} \mathrm{SO}_{4}\right) 0.1 \mathrm{M}$ as electrolyte support. Subsequently, the analytical determination of the drug was carried out with DPV, using carbon paste electrodes modified with $\beta$-cyclodextrin. It was possible to determine the optimal conditions for the degradation and for the determination of the MTZ in wastewater by advanced oxidation techniques that degrade and allow the mineralization of the drug, in addition to the electroanalytical determination of the MTZ. Degradation percentages for MTZ greater than $80 \%$ were obtained at $60 \mathrm{~min}$ times.

Keywords: Fe electrodes, current density, carbon paste electrodes, $\beta$ cyclodextrin.

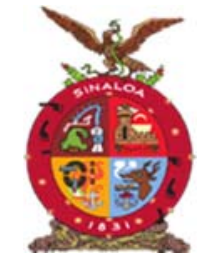

XVIII Congreso Internacional XXIV Congreso Nacional de Ciencias ambientales

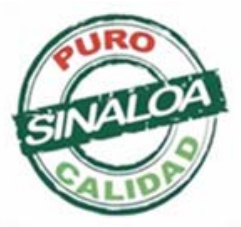

Mazatlán, Sinaloa 3-7 junio 2019

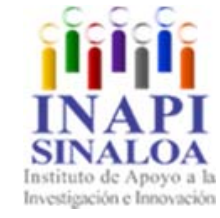

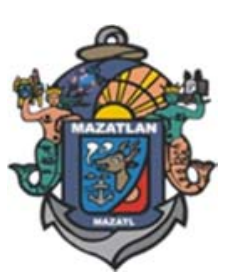

Tecnología y Biotecnología para el Tratamiento de Contaminantes y Biorremediación 

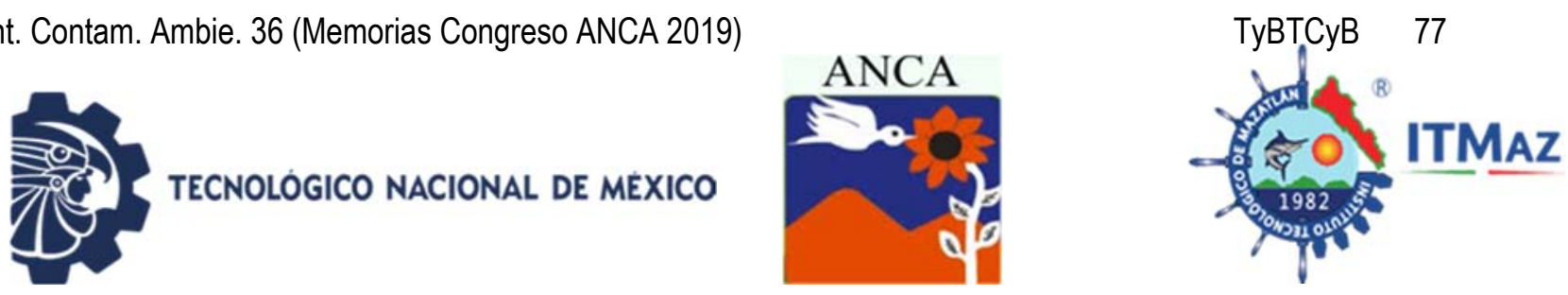

\title{
Hidroxiapatita-vidrio por electrohilado para la remoción de cadmio en solución acuosa
}

\author{
Garibay Alvarado J11, Roque Ruiz J¹, Medellín Castillo N², Reyes López SY1 \\ ${ }^{1}$ Instituto de Ciencias Biomédicas. Universidad Autónoma de Ciudad Juárez, \\ Envolvente del PRONAF y Estocolmo S/N, Ciudad Juárez, Chih., México \\ ${ }^{2}$ Centro de Investigación y Estudios de Posgrado. Facultad de Ingeniería. \\ Universidad Autónoma de San Luis Potosí, \\ Av. Dr. Manuel Nava No. 8, San Luis Potosí, SLP, 78210, México \\ *simon.reyes@uacj.mx
}

\section{RESUMEN}

Los metales pesados son contaminantes generados por estas actividades humanas y algunas de las sustancias más abundantes y tóxicas son el cadmio $(\mathrm{Cd})$, el cromo $(\mathrm{Cr})$, el plomo $(\mathrm{Pb})$ y el mercurio $(\mathrm{Hg})$. Se han realizado varios intentos para eliminar dichos elementos de las aguas residuales industriales, sin embargo, la mayoría de las tecnologías empleadas generan residuos o son costosas. La eliminación de metales a través de la absorción en aguas residuales se ha llevado a cabo con éxito de una manera económica y eficiente, al mismo tiempo que permite que algunos de los materiales utilizados para dicha tarea se regeneren para su uso posterior. La hidroxiapatita $\left[\mathrm{Ca}_{10}\left(\mathrm{PO}_{4}\right)_{6}(\mathrm{OH})_{2}\right]$ es un material cerámico utilizado ampliamente en medicina y odontología, pero los estudios sobre los procesos de absorción han demostrado que la hidroxiapatita presenta una alta capacidad de adsorción, baja solubilidad en agua y se puede usar en condiciones de oxidación y reducción. Se produjo un compuesto cerámico de hidroxiapatita/sílice a través del método sol-gel y la técnica de electrohilado. El compuesto fibrilar se caracterizó mediante microscopía electrónica de barrido, espectroscopia infrarroja, análisis termogravimétrico y diferencial (DTA), difracción de rayos $X$ y fisisorción de $N_{2}$. Los estudios de equilibrio y de cinéticas de absorción del compósito para la adsorción de cadmio $\left(\mathrm{Cd}^{2+}\right)$, dan valores de adsorción de hasta $93.3 \mathrm{mg} / \mathrm{g}$ y un modelo cinético de pseudo segundo orden, lo que indica que el material forma enlaces químicos con los iones $\mathrm{Cd}^{2+}$.

Palabras clave: Adsorción, cinética, electrohilado, hidroxiapatita, isoterma, solgel.

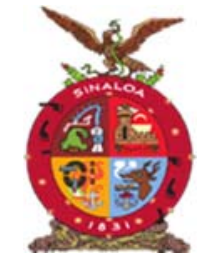

XVIII Congreso Internacional XXIV Congreso Nacional de Ciencias ambientales

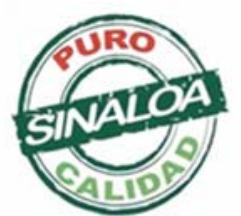

Mazatlán, Sinaloa 3-7 junio 2019
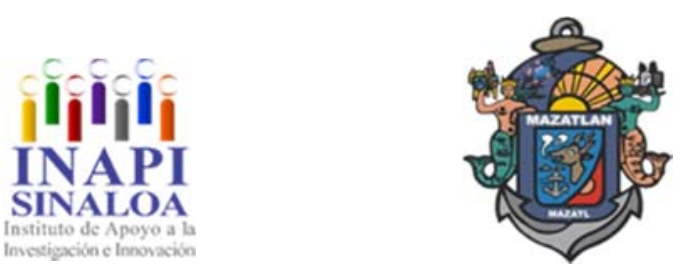

Tecnología y Biotecnología para el Tratamiento de Contaminantes y Biorremediación 

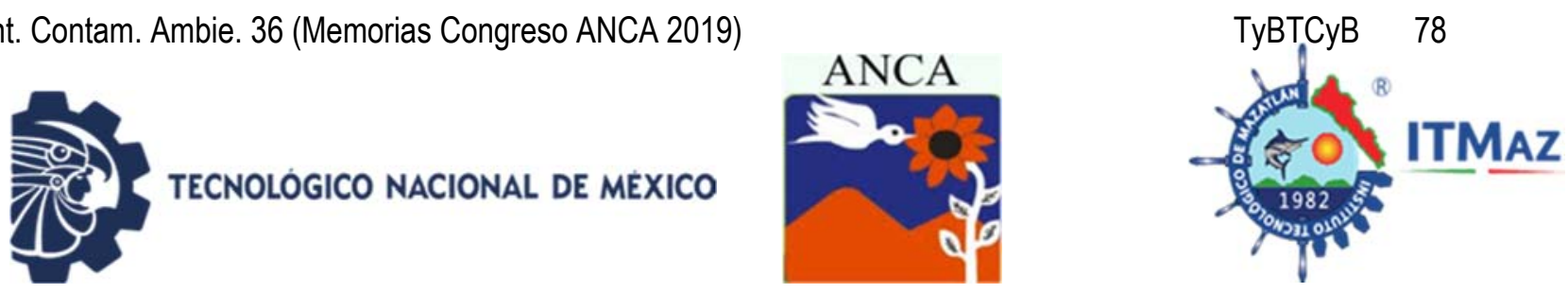

\title{
Hydroxyapatite-glass fibers by electrospinning for cadmium removal from aqueous solution
}

\author{
Garibay Alvarado J¹, Roque Ruiz J², Medellín Castillo N², Reyes López SY1 \\ ${ }^{1}$ Instituto de Ciencias Biomédicas. Universidad Autónoma de Ciudad Juárez, \\ Envolvente del PRONAF y Estocolmo S/N, Ciudad Juárez, Chih., México \\ ${ }^{2}$ Centro de Investigación y Estudios de Posgrado. Facultad de Ingeniería. \\ Universidad Autónoma de San Luis Potosí, \\ Av. Dr. Manuel Nava No. 8, San Luis Potosí, SLP, 78210, México \\ *simon.reyes@uacj.mx
}

\begin{abstract}
Heavy metals are pollutants generated by these human activities and some of the most abundant and toxic substances are Cadmium (Cd), Chromium ( $\mathrm{Cr}$ ), Lead $(\mathrm{Pb})$, and Mercury $(\mathrm{Hg})$. Several attempts have been made to remove such elements from industrial wastewater, however most of the technologies employed either generate waste or are expensive. The removal of metals from wastewater trough sorption has been carried out successfully in an economic and efficient way, while also allowing the materials used for such task to be regenerated for further use. Hydroxyapatite $(\mathrm{Ca} 10(\mathrm{PO} 4) 6(\mathrm{OH}) 2)$ is a ceramic material used extensively in medicine and odontology, but studies on sorption processes have demonstrated that hydroxyapatite present high adsorption capacity, low solubility in water and can be used in oxidizing and reducing conditions, however, it is extremely brittle. A hydroxyapatite/silica ceramic composite was produced trough the sol-gel method and the electrospinning technique. The fibrillar composite was characterized trough Scanning Electron Microscopy, Infrared Spectroscopy, Thermogravimetric Analysis and Differential Thermal Analysis, X Ray Diffraction and N2 physisorption. Equilibrium and kinetic adsorption studies were carried out on the composite for the adsorption of Cadmium $\left(\mathrm{Cd}^{2+}\right)$, observing experimental values of up to $93.3 \mathrm{mg} / \mathrm{g}$ and a kinetic model of pseudo second order, indicating that the material form chemical bonds with the $\mathrm{Cd}^{2+}$ ions.
\end{abstract}

Keywords: Adsorption, electrospinning, hydroxyapatite, isotherm, kinetics, solgel.

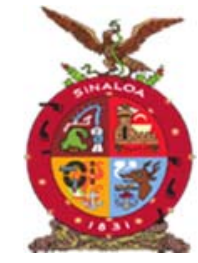

XVIII Congreso Internacional XXIV Congreso Nacional de Ciencias ambientales

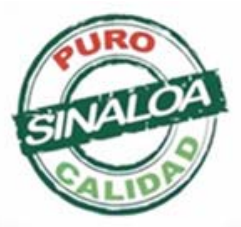

Mazatlán, Sinaloa 3-7 junio 2019
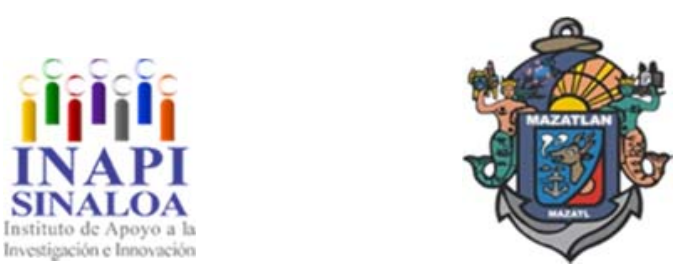

Tecnología y Biotecnología para el Tratamiento de Contaminantes y Biorremediación 

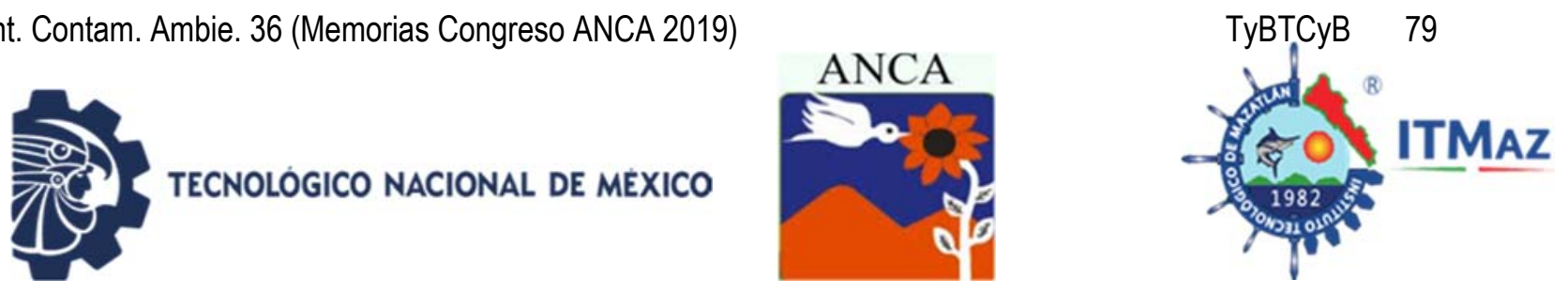

\title{
Carpetas a base de residuos inorgánicos
}

\author{
Gastón Pérez D, Hernández Sabas E, Mejía Bermúdez D, Perea Arias J, \\ Sánchez Ramírez H \\ Universidad Tecnológica del Valle de Toluca. \\ Carr. del Departamento del D.F. Km 7.5. Santa María Atarasquillo, \\ Lerma, Estado de México. \\ *hortencia.sanchez@utvtol.edu.mx
}

\section{RESUMEN}

Este trabajo resalta la importancia de reciclar, permitiendo darle un segundo tiempo de vida a los materiales que se desechan; el objetivo principal fue la realización de carpetas, folders, porta tabletas, lapiceras, etc con los residuos inorgánicos producto de la elaboración de calzado. Se realizó un muestreo en el municipio de San Mateo Atenco, Méx. en diferentes lugares donde se elaboran los zapatos, y en el proceso final se generan grandes cantidades de residuos y merma de materiales inorgánicos como cartón, piel y vinil. Mediante diferentes procesos de corte, cocido, ponchado y galvanizado se elaboraron los productos, el material elaborado se ofreció en papelerías y escuelas para conocer si los materiales son llamativos para los clientes y proponer un costo de venta al público. Se aplicó una encuesta a los clientes para conocer sus opiniones y poder realizar mejoras al producto. Los resultados arrojaron que los productos elaborados cumplen las expectativas de los clientes, debido a las presentaciones y diseños de los productos; así como de los bajos costos comparándolos con los que ofrecen las marcas de renombre. Cabe resaltar que este trabajo se hace con el fin de reducir la contaminación, aprovechando los residuos que mucha gente piensa que ya no son útiles, pero en realidad es de suma importancia aprovechar los materiales inorgánicos, dándoles un uso, evitando que sean enviados a los lugares de disposición final, sin antes buscar su aprovechamiento y que estos sigan contribuyendo al impacto ambiental, ya que son residuos que tardan años en degradarse.

Palabras clave: Aprovechamiento, contaminación ambiental, residuos inorgánicos, reciclaje

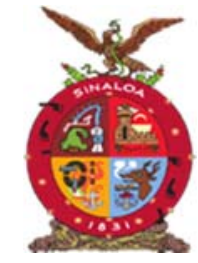

XVIII Congreso Internacional XXIV Congreso Nacional de Ciencias ambientales

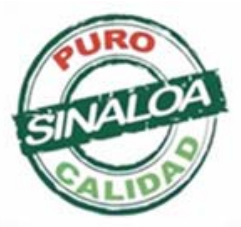

Mazatlán, Sinaloa 3-7 junio 2019
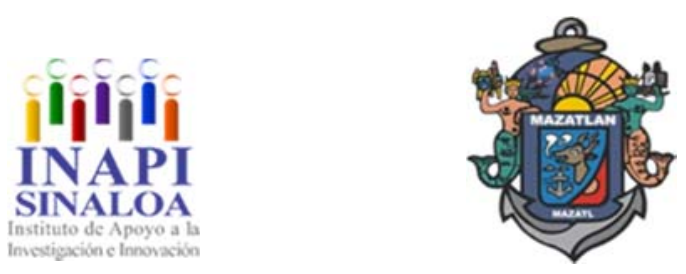

Tecnología y Biotecnología para el Tratamiento de Contaminantes y Biorremediación 

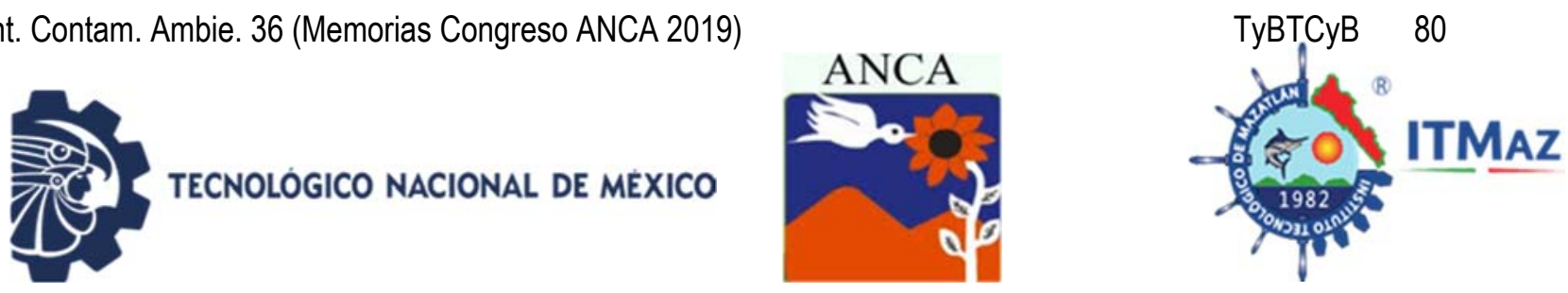

Folders based on inorganic waste

\author{
Gastón Pérez D, Hernández Sabas E, Mejía Bermúdez D, Perea Arias J, \\ Sánchez Ramírez H \\ Universidad Tecnológica del Valle de Toluca. \\ Carr. del Departamento del D.F. Km 7.5. Santa María Atarasquillo, \\ Lerma, Estado de México. \\ *hortencia.sanchez@utvtol.edu.mx
}

\begin{abstract}
This work highlights the importance of recycling, allowing to give a second life time to the materials that are discarded; the main objective was the realization of folders, folders, porta tablets, pens, etc. with the inorganic waste product of footwear manufacturing. Sampling was carried out in the municipality of San Mateo Atenco, Mex. in different places where the shoes are made, and in the final process large amounts of waste and waste of inorganic materials such as cardboard, leather and vinyl are generated. Through different processes of cutting, cooking, punching and galvanizing the products were elaborated, the elaborated material was offered in stationeries and schools to know if the materials are striking for the clients and to propose a cost of sale to the public. A survey was applied to the clients to know their opinions and be able to make improvements to the product. The results showed that the elaborated products fulfill the expectations of the clients, due to the presentations and designs of the products; as well as low costs comparing them with those offered by renowned brands. It should be noted that this work is done in order to reduce pollution, taking advantage of the waste that many people think are no longer useful, but in reality, it is very important to take advantage of inorganic materials, giving them a use, preventing them from being sent to places of final disposal, without first seeking their use and that these continue contributing to the environmental impact, since they are waste that take years to degrade.
\end{abstract}

Keywords: Utilization, environmental pollution, inorganic waste, recycling.

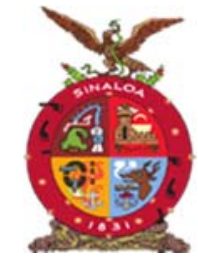

XVIII Congreso Internacional XXIV Congreso Nacional de Ciencias ambientales

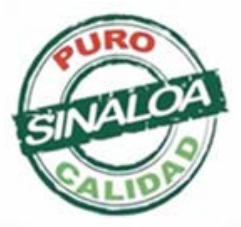

Mazatlán, Sinaloa 3-7 junio 2019
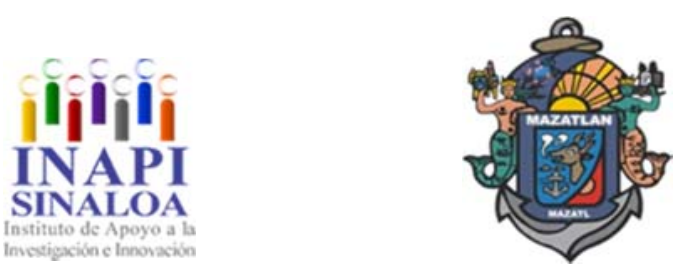

Tecnología y Biotecnología para el Tratamiento de Contaminantes y Biorremediación 

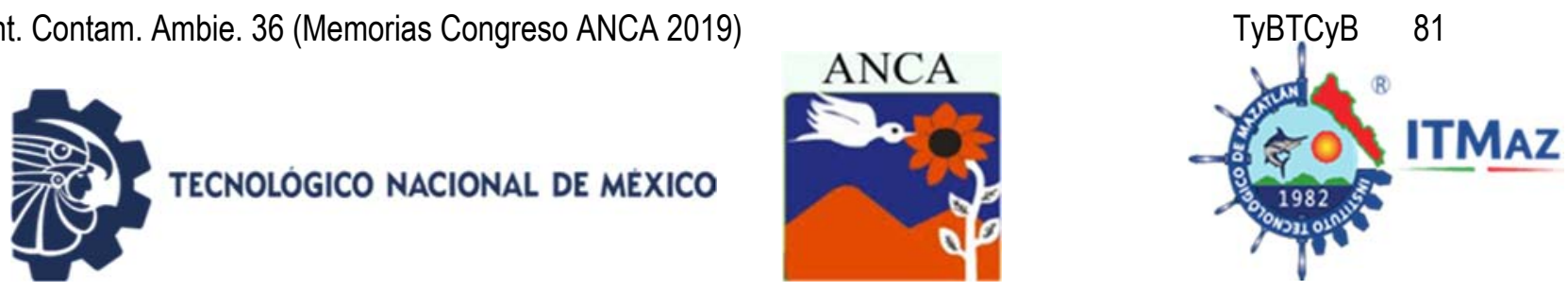

\title{
Análisis del efecto de diversos inóculos en la potencial producción de biogás a partir de residuos agroindustriales de mango
}

\author{
González Arenas $\mathrm{Y}^{1}$, González Arenas $\mathrm{B}^{1}$, Ambriz Pérez $\mathrm{D}^{1,2}$, Luna Avelar $\mathrm{K}^{3}$, \\ Mejias Brizuela $\mathrm{N}^{1,2}$, Santos Ballardo $\mathrm{D}^{1,2^{*}}$ \\ ${ }^{1}$ Maestría en Ciencias Aplicadas. Universidad Politécnica de Sinaloa, México \\ ${ }^{2}$ Ingeniería en Energía. Universidad Politécnica de Sinaloa, México \\ ${ }^{3}$ Posgrado en Ciencias y Tecnología de Alimentos. \\ Universidad Autónoma de Sinaloa, México \\ *dsantos@upsin.edu.mx
}

\begin{abstract}
RESUMEN
El biogás es un biocombustible obtenido a través del proceso de digestión anaerobia (DA) de materia orgánica. Se han analizado distintas materias primas para su uso en el proceso de DA, resaltando los residuos orgánicos de alimentos debido a su bajo costo y su gran potencial metanogénico. En la DA uno de los parámetros más importantes es la afinidad inóculo-sustrato; debido a esto, es importante que se estudien diversos inóculos y su potencial para producir biogás. La presente investigación muestra el efecto de diversos inóculos sobre la DA para la producción de biogás a partir de residuos orgánicos de mango variedades Haden y Kent, obtenidos de la industria Mazazul Organics. A los ROM se les realizó análisis proximal, y se les determinó sólidos totales (ST) y volátiles (SV). A continuación, se realizó DA de los ROM con tres inóculos distintos (lodos de cervecería Pacifico, lodos de planta tratadora de agua (JUMAPAM) y estiércol vacuno) en condiciones mesofílicas $\left(37 \pm 1^{\circ} \mathrm{C}\right)$, durante 25 días. La afinidad de los distintos inóculos fue evaluada a partir de la producción acumulada de metano, misma que fue medida utilizando el método de desplazamiento de $\mathrm{NaOH}$ (1N) mediante un eudiómetro. Al analizar estadísticamente los datos (ANOVA unifactorial, Fisher (LSD, $p \leq 0.05)$ ), se obtuvo diferencia significativa entre los diversos experimentos. El inóculo con mayor afinidad para ambas variedades, fue el lodo activado de cervecería Pacífico, debido a la producción de metano, en comparación a la DA de ROM con los otros dos inóculos.
\end{abstract}

Palabras claves: Mango, digestión anaeróbica, biomasa residual, inóculos.

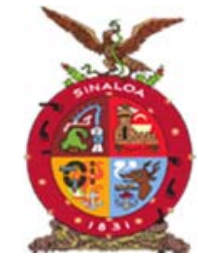

XVIII Congreso Internacional XXIV Congreso Nacional de Ciencias ambientales

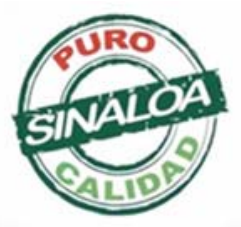

Mazatlán, Sinaloa 3-7 junio 2019
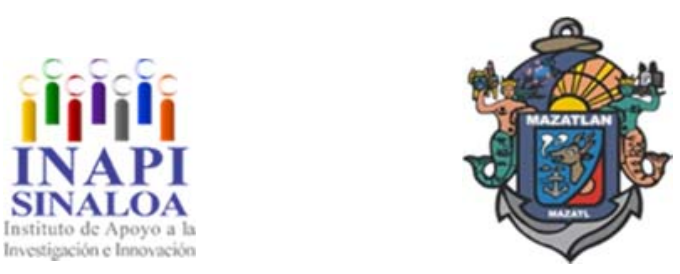

Tecnología y Biotecnología para el Tratamiento de Contaminantes y Biorremediación 

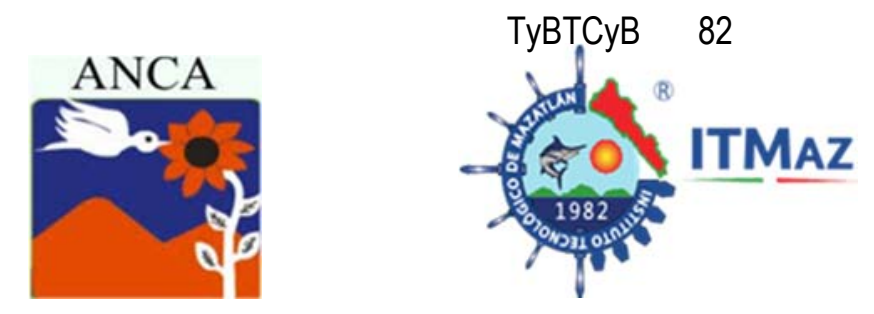

\title{
Analysis of the effect of various inoculums on the potential production of biogas from mango agroindustrial waste
}

\author{
González Arenas $\mathrm{Y}^{1}$, González Arenas $\mathrm{B}^{1}$, Ambriz Pérez $\mathrm{D}^{1,2}$, Luna Avelar $\mathrm{K}^{3}$, \\ Mejias Brizuela $\mathrm{N}^{1,2}$, Santos Ballardo $\mathrm{D}^{1,2^{*}}$ \\ ${ }^{1}$ Maestría en Ciencias Aplicadas. Universidad Politécnica de Sinaloa, México \\ ${ }^{2}$ Ingeniería en Energía. Universidad Politécnica de Sinaloa, México \\ ${ }^{3}$ Posgrado en Ciencias y Tecnología de Alimentos. \\ Universidad Autónoma de Sinaloa, México \\ *dsantos@upsin.edu.mx
}

\begin{abstract}
Biogas is a biofuel obtained through the anaerobic digestion (DA) process of organic matter. Different raw materials have been analyzed for use in the DA process, highlighting organic food waste due to its low cost and its great methanogenic potential. In AD one of the most important parameters is inoculumsubstrate affinity; Due to this, it is important that various inoculums and their potential to produce biogas be studied. The present investigation shows the effect of various inoculums on $A D$ for the production of biogas from organic residues of mango varieties Haden and Kent, obtained from the Mazazul Organics industry. The ROMs were subjected to proximal analysis, and total (ST) and volatile (SV) solids were determined. Next, DA of the ROMs was performed with three different inoculums (Pacific brewery sludge, water treatment plant sludge (JUMAPAM) and beef manure) in mesophilic conditions $\left(37 \pm 1^{\circ} \mathrm{C}\right)$, for 25 days. The affinity of the different inoculums was evaluated from the accumulated methane production, which was measured using the $\mathrm{NaOH}(1 \mathrm{~N})$ displacement method using a eudiometer. When statistically analyzing the data (unifactorial ANOVA, Fisher $($ LSD, $p \leq 0.05)$ ), a significant difference was obtained between the various experiments. The inoculum with the highest affinity for both varieties was the activated mud of the Pacific brewery, due to methane production, compared to the DA of ROM with the other two inoculums.
\end{abstract}

Keywords: Mango, anaerobic digestion, residual biomass, inoculum.

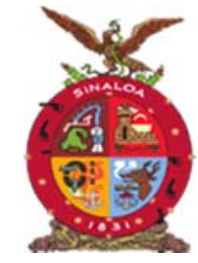

XVIII Congreso Internacional XXIV Congreso Nacional de Ciencias ambientales

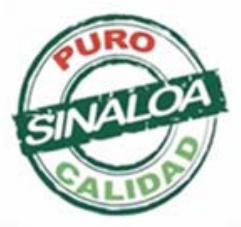

Mazatlán, Sinaloa 3-7 junio 2019
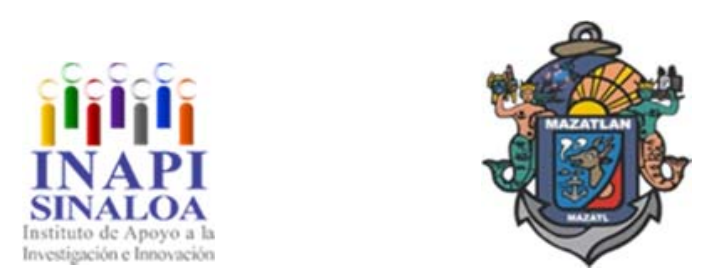

Tecnología y Biotecnología para el Tratamiento de Contaminantes y Biorremediación 

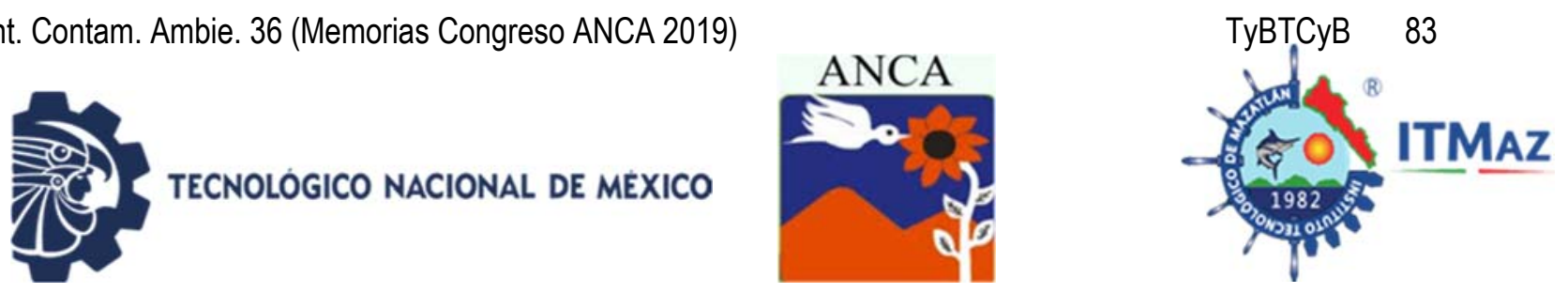

\title{
Evaluación de interferencias por iones metálicos en la cuantificación de Ibuprofeno presente en una matriz sintética de aguas residuales por UV- Vis
}

\author{
Gutiérrez Silva L, Martínez Marú M, Velázquez Pizano P, Núñez Vilchis A, \\ González Leal M, Rodríguez Ontiveros A
}

Centro de Estudios Académicos sobre Contaminación Ambiental.

Facultad de Química. Universidad Autónoma de Querétaro

*paare27@hotmail.com

\section{RESUMEN}

El ibuprofeno es un antiinflamatorio no esteroideo (AINE) de libre venta con mayor consumo a nivel mundial. Este producto farmacéutico continuamente es introducido en el ambiente, a través de los efluentes derivados de los procesos de manufactura y de la inadecuada disposición. Recientemente, se han reportado concentraciones de ibuprofeno en aguas residuales, llegando a afectar ecosistemas. Este fármaco al tener un grupo carboxilato en su estructura, en un medio básico, adquiere propiedades quelantes, especialmente con iones metálicos divalentes, por ejemplo: $\mathrm{Cu}^{2+}, \mathrm{Zn}^{2+} \mathrm{y} \mathrm{Mg}^{2+}$. El objetivo de este proyecto fue evaluar las interferencias causadas por la formación de complejos metálicos, en la cuantificación de ibuprofeno por espectroscopia de UVNis. Para ello se realizaron análisis empleando una matriz sintética de aguas residuales. Se evaluaron las interferencias de 3 metales de interés $\left(\mathrm{Cu}^{2+}, \mathrm{Zn}^{2+}\right.$ y $\left.\mathrm{Mg}^{2+}\right)$. Se encontró que entre los metales analizados, el $\mathrm{Zn}^{2+}$ fue el mayor interferente, seguido por el $\mathrm{Mg}^{2+}$ y por último el $\mathrm{Cu}^{2+}$. En el análisis de sinergismo, se apreció que la solución $\mathrm{Zn}^{2+} / \mathrm{Mg}^{2+}$ tuvo la interferencia más significativa, mientras $\mathrm{Mg}^{2+} / \mathrm{Cu}^{2+}$ fue la menor, confirmando la interferencia de $\mathrm{Zn}^{2+}$ sobre la cuantificación de ibuprofeno. Por último, se determinó que la concentración mínima a la cual la interferencia causada por el $\mathrm{Zn}^{2+}$ deja de ser significativa, es de $25 \mathrm{~g} / \mathrm{L}$. En conclusión, la formación de complejos metálicos afecta la cuantificación de ibuprofeno en aguas residuales. Este proyecto se realizó en el Laboratorio de Instrumentación Analítica, en octubre de 2018.

Palabras clave: Ibuprofeno, iones metálicos, interferencias, aguas residuales.

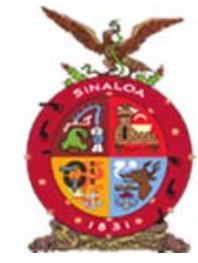

XVIII Congreso Internacional XXIV Congreso Nacional de Ciencias ambientales

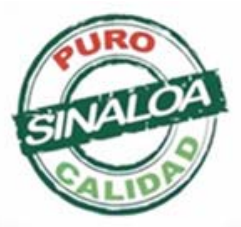

Mazatlán, Sinaloa 3-7 junio 2019
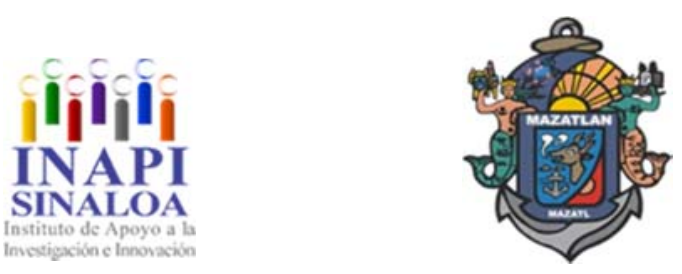

Tecnología y Biotecnología para el Tratamiento de Contaminantes y Biorremediación 

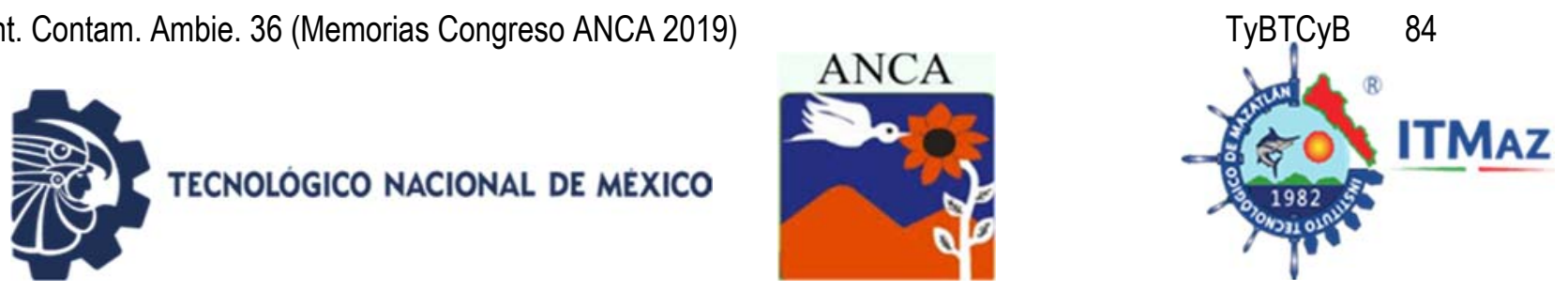

\title{
Evaluation of interference by metal ions in the quantification of Ibuprofen present in a synthetic wastewater matrix by UV-Vis spectroscopy
}

\author{
Gutiérrez Silva L, Martínez Marú M, Velázquez Pizano P, Núñez Vilchis A, \\ González Leal M, Rodríguez Ontiveros A $^{*}$ \\ Centro de Estudios Académicos sobre Contaminación Ambiental. \\ Facultad de Química. Universidad Autónoma de Querétaro \\ *paare27@hotmail.com
}

\begin{abstract}
Ibuprofen is a non-steroidal anti-inflammatory drug (NSAID) sold without a prescription with greater consumption worldwide. This pharmaceutical product is continuously introduced into the environment, mainly through the effluents derived from manufacturing processes and the inadequate disposal of this drug. Recently, concentrations of ibuprofen have been reported in wastewater, affecting ecosystems. This drug has a carboxylate group in its structure, in a basic medium, acquires chelating properties, especially with divalent metal ions, for example: $\mathrm{Cu}^{2+}, \mathrm{Zn}^{2+}$ and $\mathrm{Mg}^{2+}$. The objective of this project was to evaluate the interferences caused by the formation of metal complexes, in the quantification of ibuprofen by UV/Vis spectroscopy. For this purpose, analyzes were carried out using a synthetic wastewater matrix. Three metals of interest $\left(\mathrm{Cu}^{2+}, \mathrm{Zn}^{2+}\right.$ and $\mathrm{Mg}^{2+}$ ) were evaluated. It was found that among the analyzed metals, $\mathrm{Zn}^{2+}$ was the highest interferent, followed by $\mathrm{Mg}^{2+}$ and finally $\mathrm{Cu}^{2+}$. In the analysis of synergism, it was observed that the $\mathrm{Zn}^{2+} / \mathrm{Mg}^{2+}$ solution had the most significant interference, while $\mathrm{Mg}^{2+} / \mathrm{Cu}^{2+}$ was the least, confirming the interference of $\mathrm{Zn}^{2+}$ on the quantification of ibuprofen. Finally, it was determined that the minimum concentration at which the interference caused by the $\mathrm{Zn}^{2+}$ ceases to be significant, is $25 \mu \mathrm{g} / \mathrm{L}$. In conclusion, complex formation affects the quantification of ibuprofen in wastewater. This project was carried out at the Analyttical Instrumentation Laboratory, in October 2018.
\end{abstract}

Keywords: Ibuprofen, metal ions, interference, wastewater.

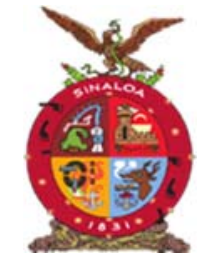

XVIII Congreso Internacional XXIV Congreso Nacional de Ciencias ambientales

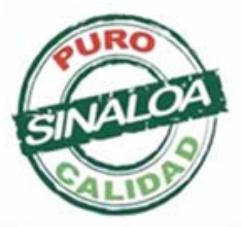

Mazatlán, Sinaloa 3-7 junio 2019
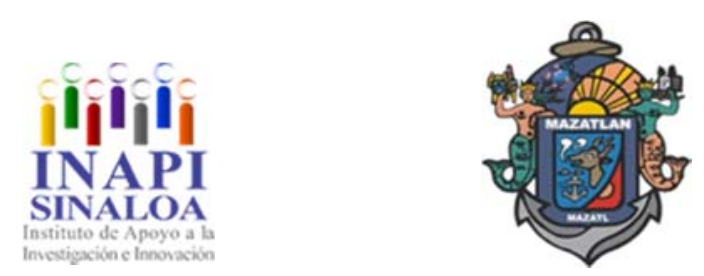

Tecnología y Biotecnología para el Tratamiento de Contaminantes y Biorremediación 

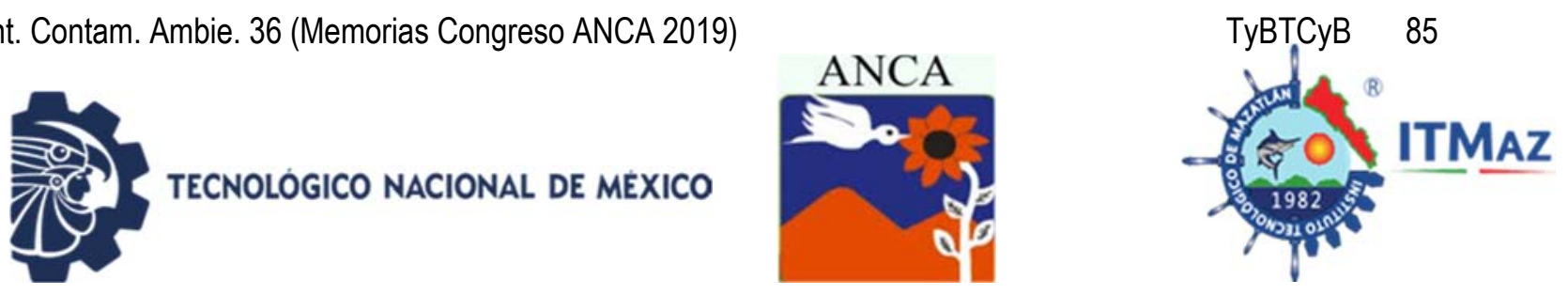

\title{
Evaluación del efecto de Lactobacilos en la inactivación de microorganismos patógenos y remoción de carbohidratos en residuos porcinos
}

\author{
Guzmán Aragón $E^{*}$, Romero Mota D, Alvarado Lassman A, Méndez Contreras J \\ División de estudios de Posgrado e investigación. \\ Instituto Tecnológico de Orizaba. \\ Av. Tecnológico No. 852, Col Emiliano Zapata, Orizaba, Ver.México \\ *erubiel_guzman@hotmail.com
}

\section{RESUMEN}

En México, las excretas generadas por la industria ganadera porcina representan un volumen aproximado de 18,500 ton/año. Esta cantidad de residuos representa un problema de contaminación si no se disponen adecuadamente ya que contienen un alto contenido de materia orgánica, $\mathrm{N}, \mathrm{P}, \mathrm{y}$ otros micronutrientes que provocan daños al ambiente por lixiviación, eutrofización y microorganismos patógenos que dañan a la población expuesta. Como una alternativa a la digestión anaerobia, productora de gases de efecto invernadero como $\mathrm{CH}_{4} \mathrm{y} \mathrm{CO}_{2}$, se propone la bioconversión a través de lactobacilos; los cuales mediante la degradación de carbohidratos presentes en el residuo generan ácido láctico que tiene efectos bactericidas sobre coliformes fecales y Salmonella. Se utilizaron tres especies de lactobacilos, L. acidophilus, L. fermentum y L. reuteri, experimentando diferentes niveles de $\mathrm{pH}(5.5$ y 6.7) y concentraciones de carbohidratos (1.61 y $8.2 \mathrm{~g} / \mathrm{L}$ ) y evaluando la generación de ácido láctico y biomasa. L. acidophilus generó la mayor cantidad de ácido láctico $(9.9 \mathrm{~g} / \mathrm{L})$ reduciendo 2 unidades logarítmicas de patógenos y L. fermentum generó la mayor cantidad de biomasa (27.13 g/L).Los parámetros cinéticos en la degradación de carbohidratos utilizando el modelo de Hom para las especies utilizadas, muestran constantes cinéticas de degradación positivas, siendo mayor para L. fermentum (2.326) concluyendo que esta especie de lactobacilo, puede ser susceptible de aprovechamiento y bioconversión en un escalamiento de planta piloto.

Palabras clave: Bioconversión, lactobacilos, residuo porcino, ácido láctico, fermentación.

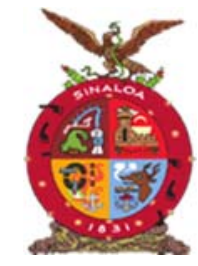

XVIII Congreso Internacional XXIV Congreso Nacional de Ciencias ambientales

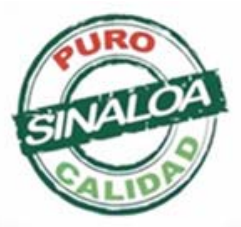

Mazatlán, Sinaloa 3-7 junio 2019
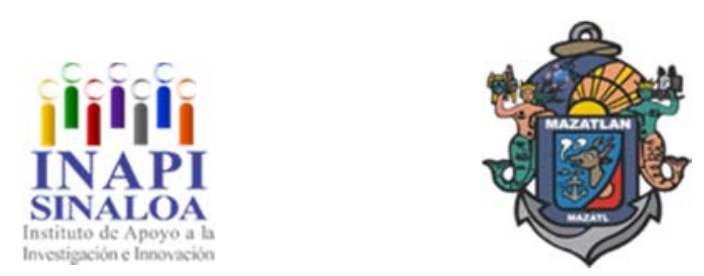

Tecnología y Biotecnología para el Tratamiento de Contaminantes y Biorremediación 

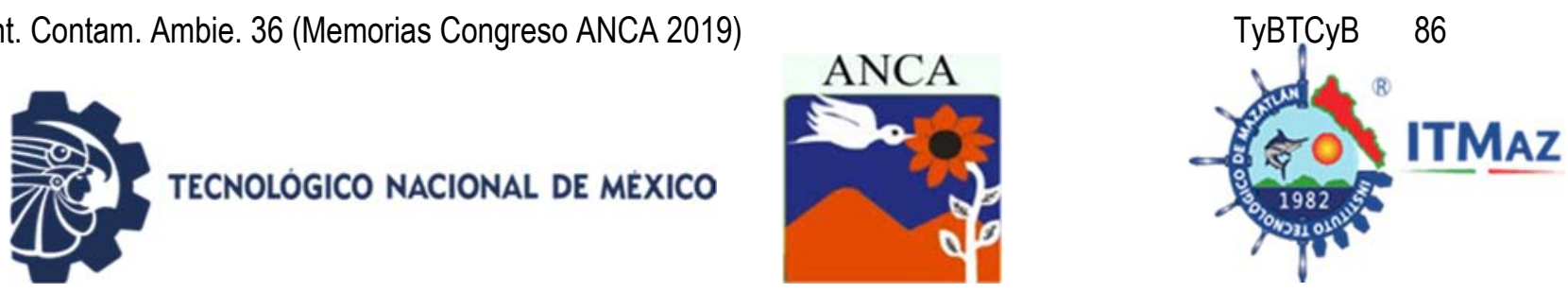

\title{
Evaluation of the effect of Lactobacilli on the inactivation of pathogenic microorganisms and removal of carbohydrates in swine waste
}

\author{
Guzmán Aragón $E^{*}$, Romero Mota D, Alvarado Lassman A, Méndez Contreras J \\ División de estudios de Posgrado e investigación. \\ Instituto Tecnológico de Orizaba. \\ Av. Tecnológico No. 852, Col Emiliano Zapata, Orizaba, Ver.México \\ *erubiel_guzman@hotmail.com
}

\begin{abstract}
In Mexico, the excreta generated by the swine industry represents an approximate volume of 18,500 ton/year. This amount of waste represents a pollution problem if not properly disposed since they contain a high content of organic matter, N, P, and other micronutrients that cause environmental damage such as leaching and eutrophication; and pathogenic microorganisms that harm the exposed population. As an alternative to anaerobic digestion, that produces such as $\mathrm{CH}_{4}$ and $\mathrm{CO}_{2}$, bioconversion through lactobacilli is proposed; which through the degradation of carbohydrates present in the waste generate lactic acid that has bactericidal effects on fecal coliforms and Salmonella; an increase in the biomass of lactobacilli is predicted, which can be susceptible of beneficial use when incorporated into the animal feed from which the residue comes. Three species of lactobacillus were used, acidophilus, fermentum and reuteri. Different levels of $\mathrm{pH}$ (5.5 and 6.7) and carbohydrate concentration (1.61 and $8.2 \mathrm{~g} / \mathrm{L}$ ) were tested, evaluating generation of lactic acid and biomass. $L$ acidophilus generated the highest amount of lactic acid $(9.9 \mathrm{~g} / \mathrm{L})$ reducing 2 logarithmic units of pathogens and L. fermentum generated the highest amount of biomass $(27.13 \mathrm{~g} / \mathrm{L})$. The kinetic parameters in carbohydrate degradation using the Hom model for the species used show positive kinetic constants of degradation, being higher for fermentum (2.326) determining the species of lactobacillus that can be susceptible of exploitation and bioconversion in a pilot plant scaling.
\end{abstract}

Keywords: Bioconversion, lactobacilli, swine waste, lactic acid, fermentation.

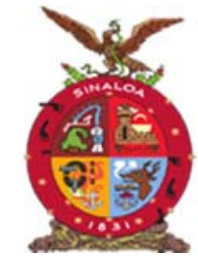

XVIII Congreso Internacional XXIV Congreso Nacional de Ciencias ambientales

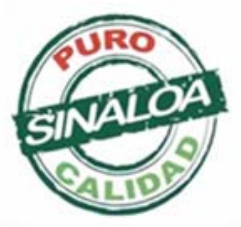

Mazatlán, Sinaloa 3-7 junio 2019
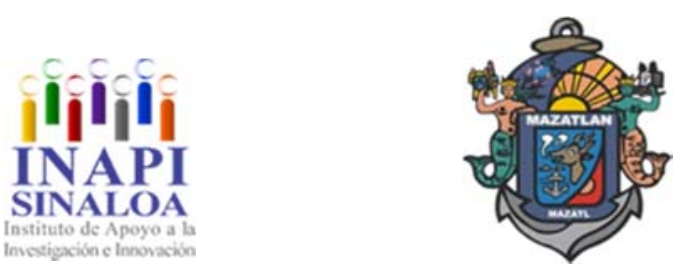

Tecnología y Biotecnología para el Tratamiento de Contaminantes y Biorremediación 

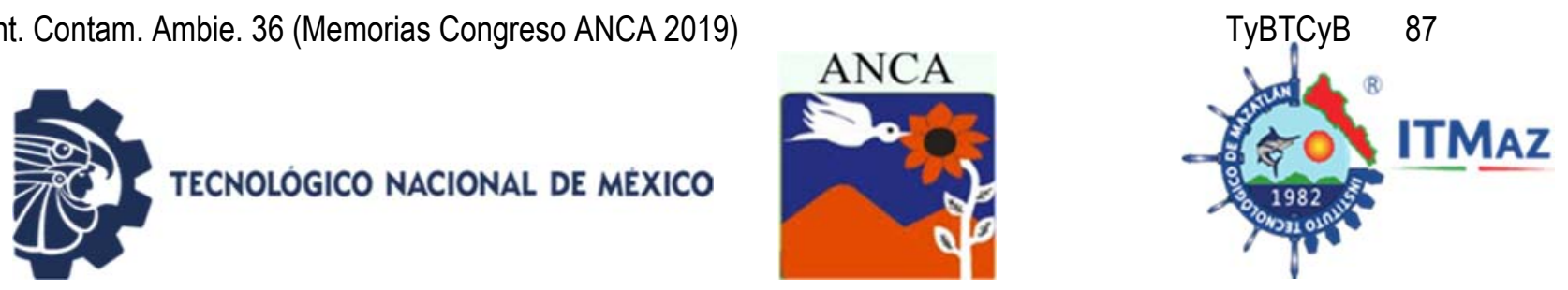

\section{Predicción de la eliminación del azul básico 9 a partir de la electrogeneración del reactivo Fenton}

Hermosillo Nevarez $\mathrm{J}^{1}$, Ramírez Pereda $\mathrm{B}^{1 *}$, Bustos Terrones $\mathrm{J}^{1}$, Álvarez Gallegos $A^{2}$

${ }^{1}$ División de Estudios de Posgrado e Investigación.

Instituto Tecnológico de Culiacán.

Juan de Dios Batíz 310. Col. Guadalupe, 80220. Culiacán, Sinaloa, México

${ }^{2}$ Centro de Investigación en Ingenieriá y Ciencias Aplicadas, UAEM, Av. Universidad 1001. Col. Chamilpa, 62209. Cuernavaca, Morelos. México *blenda.ramirez@conacyt.mx

\section{RESUMEN}

Los colorantes son empleados en numerosas industrias como, textiles, cosméticos, papel y otras. En muchos casos estos permanecen en las aguas residuales que son vertidas al ambiente causando una contaminación y riesgos a la salud. Por su estructura química, su degradación y completa mineralización, son prácticamente imposibles, por tanto, las tecnologías convencionales no son capaces de degradarlos. Estudios recientes han demostrado que los Procesos Avanzados de Oxidación (POAs) constituyen una alternativa eficiente para la eliminación de este tipo de contaminantes. Uno de los PAOs que destaca en la eliminación de colorantes es el proceso Electrofenton. La presente investigación tuvo como objetivo la obtención de una metodología para la predicción de la eliminación del Azul Básico 9 (AB9). Primeramente, se desarrolló un modelo matemático para la predicción de la generación de peróxido de hidrógeno $\left(\mathrm{H}_{2} \mathrm{O}_{2}\right)$, luego se llevó a cabo un ensayo experimental, a una concentración determinada del contaminante, en el que se eliminó más del $90 \%$ de la concentración inicial. A partir del experimento anterior se pudo evaluar la estequiometría de la reacción de eliminación entre el $A B 9$ y el $\mathrm{H}_{2} \mathrm{O}_{2}$. De esta manera se obtuvo la relación estequiométrica que permitió simular teóricamente la disminución de la concentración del efluente con respecto al tiempo. El modelo fue validado experimentalmente y se pudo predecir el avance de la decoloración con un $5 \%$ de error. Finalmente, se estimaron los costos asociados a la energía consumida para llevar a cabo el tratamiento de decoloración.

Palabras Claves: Electrofenton, azul básico 9, cinética de decoloración, modelación.

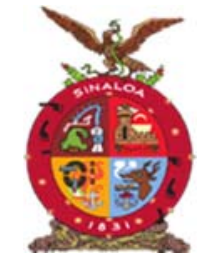

XVIII Congreso Internacional XXIV Congreso Nacional de Ciencias ambientales

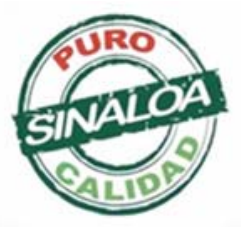

Mazatlán, Sinaloa 3-7 junio 2019
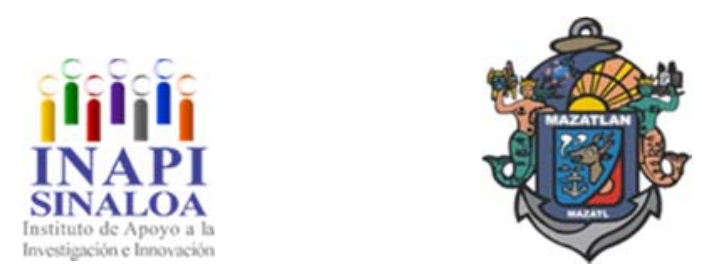

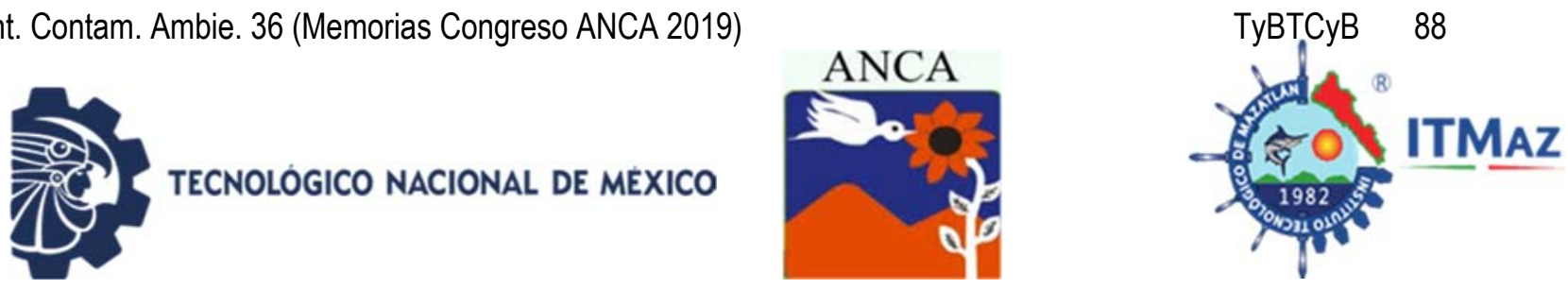

\title{
Basic Blue 9 abatement prediction by electrochemical generation of Fenton Reagent
}

\author{
Hermosillo Nevarez $\mathrm{J}^{1}$, Ramírez Pereda $\mathrm{B}^{1 *}$, Bustos Terrones $\mathrm{J}^{1}$, \\ Álvarez Gallegos $A^{2}$ \\ ${ }^{1}$ División de Estudios de Posgrado e Investigación. \\ Instituto Tecnológico de Culiacán. \\ Juan de Dios Batíz 310. Col. Guadalupe, 80220. Culiacán, Sinaloa, México \\ ${ }^{2}$ Centro de Investigación en Ingenieriá y Ciencias Aplicadas, UAEM, \\ Av. Universidad 1001. Col. Chamilpa, 62209. Cuernavaca, Morelos. México \\ *blenda.ramirez@conacyt.mx
}

\begin{abstract}
Dyes are used in numerous industries such as textiles, cosmetics, paper and others. In many cases they remain in the wastewater that is discharged into the environment causing considerable pollution and serious health risks. Due to their chemical structure, their degradation and complete mineralization are practically impossible; therefore, conventional technologies are not suitable to degrade them. Recent studies have shown that Advanced Oxidation Processes (AOPs) constitute an efficient alternative for the elimination of these pollutants. Electrofenton process stands out in the elimination of dyes between AOPs. The objective of this research was to obtain a methodology for predicting Basic Blue 9 (BB9) discoloration. First, a mathematical model was developed for the prediction of the generation of hydrogen peroxide $\left(\mathrm{H}_{2} \mathrm{O}_{2}\right)$, after that, an experimental test was carried out, to a specific concentration of BB9, in which more than $90 \%$ of the initial concentration was eliminated. From the previous experiment, it was possible to evaluate the stoichiometry of the discoloration reaction between BB9 and $\mathrm{H}_{2} \mathrm{O}_{2}$. In this way, a stoichiometric relationship was obtained that allowed theoretically simulating the decrease of the effluent concentration with respect to time. The model was validated experimentally and it was possible to predict the progress of the discoloration with a $5 \%$ error. Finally, the costs associated with the energy consumed to carry out the discoloration treatment were estimated.
\end{abstract}

Keywords: Electrofenton, basic blue 9, decoloration kinetics, modelation.

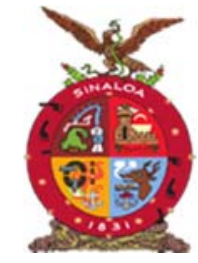

XVIII Congreso Internacional XXIV Congreso Nacional de Ciencias ambientales

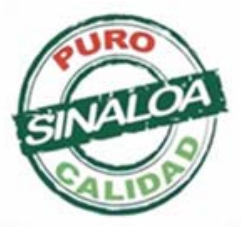

Mazatlán, Sinaloa 3-7 junio 2019
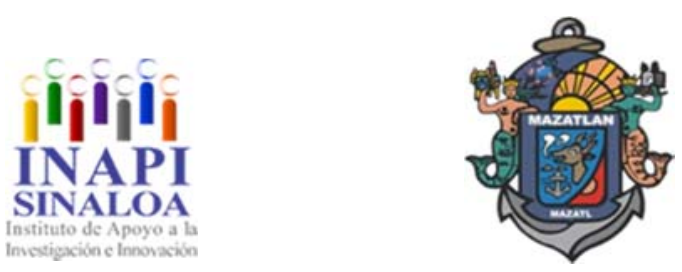

Tecnología y Biotecnología para el Tratamiento de Contaminantes y Biorremediación 

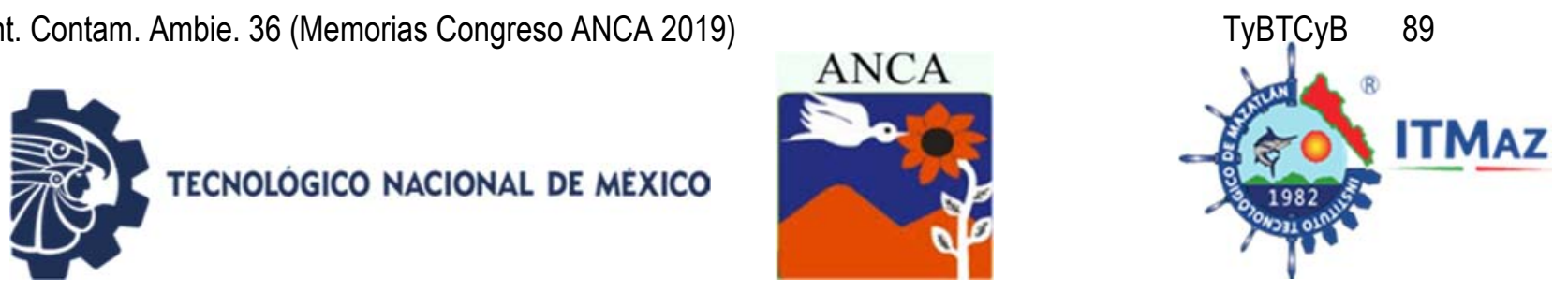

\title{
Mitigación de emisiones de metano a través de la producción de bioelectricidad en humedales construidos con plantas ornamentales
}

\author{
Hernández Alarcón ME*, De la Cruz Cornelio MG \\ Red de manejo biotecnológico, Instituto de Ecología A.C. \\ Carretera antigua a Coatepec, 352, Col El Haya, Xalapa, Veracruz, México \\ *elizabeth.hernandez@ineCol.mx
}

\section{RESUMEN}

Los humedales pueden ayudar a mitigar la contaminación de los ríos y mediante el acoplamiento de celdas de combustible microbiano (CCM) producen bioelectricidad, disminuyendo la disponibilidad de electrones, situación que podría mitigar las emisiones de metano. Nuestro objetivo fue investigar la producción de bioelectricidad, la concentración y emisión de metano en humedales con CCM provistos con celdas de diferente material. Los HC construidos a escala fueron recipientes de 60 litros con sustrato y sembrados con Zantedeschia aethiopica, en los que se aplicaron 4 tratamientos con réplica. La celda, tenía el sustrato y las terminales de grava, los otros tratamientos tenían un ánodo y un cátodo de carbón vegetal y aluminio, con zeolita y, entre el cátodo y el ánodo, piedra caliza y grava. Se monitoreo durante enero y febrero de 2019, en Xalapa, Veracruz, se midió la concentración y emisión de metano por cromatografía de gases y el voltaje producido. La producción de bioelectricidad fue significativamente mayor en las terminales de grafito y fibra de carbón (231 y $217 \mathrm{mV}$ ) comparado con las terminales de carbón $(48 \mathrm{mV})$ y grava $(-43 \mathrm{mV})$. La concentración de metano en el sustrato fue significativamente mayor en la grava (420 ppm v/v) que el grafito y fibra de carbón (120 y $113 \mathrm{ppm} v / \mathrm{v})$, pero no significativamente mayor que en carbón (180 ppm v/v). Las emisiones de metano fueron $0.023,0.001,0.002,0.001 \mathrm{mgm}^{-2} \mathrm{~min}^{-1}$, para la grava, carbón, grafito y fibra de carbón, sin diferencias significativas. Se mitigó la producción y emisión de metano en un $72 \%$ y $43 \%$ mediante las CCM en los $\mathrm{HC}$.

Palabras claves: Energía limpia, tratamiento de aguas, gases de efecto invernadero, calentamiento global, contaminación.

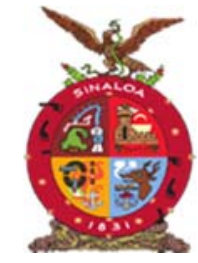

XVIII Congreso Internacional XXIV Congreso Nacional de Ciencias ambientales

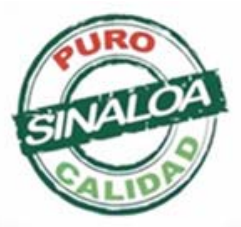

Mazatlán, Sinaloa 3-7 junio 2019
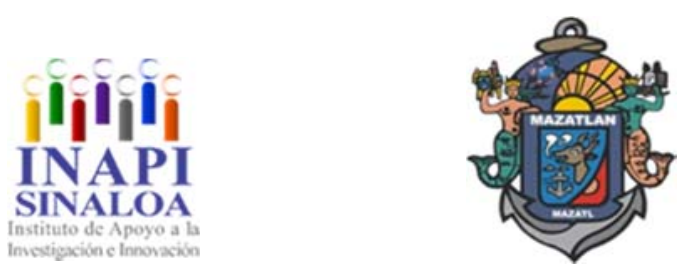

Tecnología y Biotecnología para el Tratamiento de Contaminantes y Biorremediación 

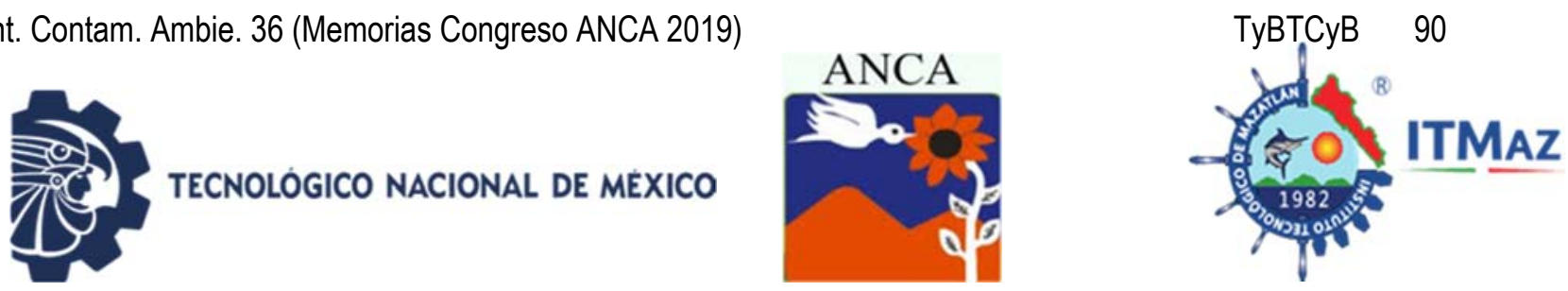

\title{
Methane emissions mitigation trough bioelectricity production in constructed wetlands with ornamental plants
}

\author{
Hernández Alarcón ME*, De la Cruz Cornelio MG \\ Red de manejo biotecnológico, Instituto de Ecología A.C. \\ Carretera antigua a Coatepec, 352, Col El Haya, Xalapa, Veracruz, México \\ *elizabeth.hernandez@ineCol.mx
}

\begin{abstract}
Constructed wetlands help to mitigate river pollution and produce bioelectricity with coupled microbial fuel cells, decreasing electron availability, which could mitigate methane emissions. Our objective was to investigate methane production and emissions in CW with MFC with different electrode materials. CW was $60 \mathrm{~L}$ tanks with substrate planted with Zantedeschia aethiopica. Four treatments with replicate were used, control had gravel as substrate and electrode, the other treatments had anode and cathode made with vegetable carbon and aluminum, they had zeolite and between anode and cathode had gravel and carbonate rock. During January and February 2019, in Xalapa, Ver, we monitored methane concentration and emissions by gas chromatography and the produced voltage. Bioelectricity production was significantly higher in the electrodes with graphite and carbon fiber (231 y $217 \mathrm{mV})$ than carbon electrodes $(48 \mathrm{mV})$ and gravel $(-43$ $\mathrm{mV}$ ). Methane concentration in the substrate was significantly higher in the gravel $(420 \mathrm{ppm} \mathrm{v} / \mathrm{v})$ than graphite and carbon fiber $(120 \mathrm{y} 113 \mathrm{ppm} \mathrm{v} / \mathrm{v})$, but not significantly different than carbon ( $180 \mathrm{ppm} v / \mathrm{v})$. Methane emissions were 0.023 , $0.001,0.002,0.001 \mathrm{mgm}^{-2} \mathrm{~min}^{-1}$ for gravel, carbon, graphite and carbon fiber without significant differences. Methane production and emissions were mitigated 72 and $43 \%$, incorporating MFC in CW.
\end{abstract}

Keywords: Clean energy, wastewater treatment, greenhouse gases, global warming, pollution.

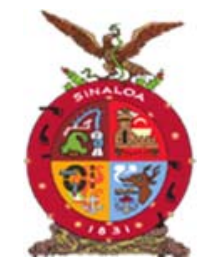

XVIII Congreso Internacional XXIV Congreso Nacional de Ciencias ambientales

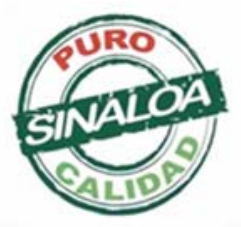

Mazatlán, Sinaloa 3-7 junio 2019
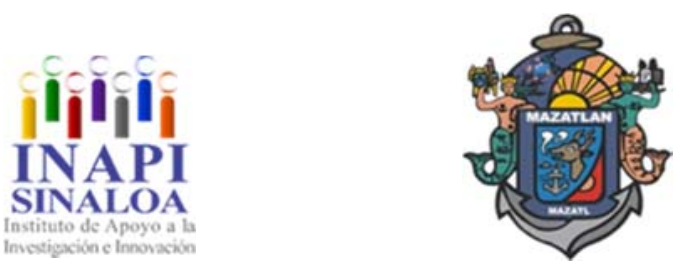

Tecnología y Biotecnología para el Tratamiento de Contaminantes y Biorremediación 

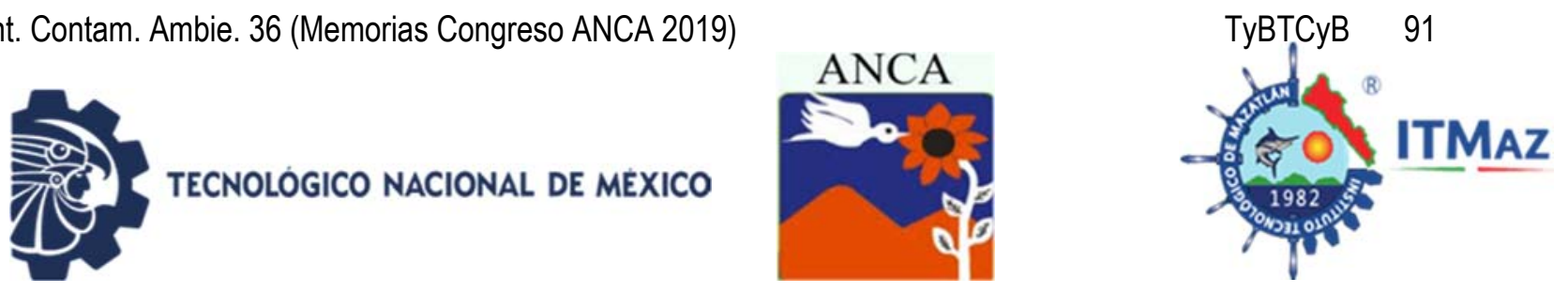

\title{
Evaluación de niveles de $\mathrm{N}-\mathrm{NO}_{3}{ }^{-e n}$ pozos de agua subterránea en Calera, Zacatecas
}

\author{
Hernández López $\mathrm{A}^{1^{*}}$, Viramontes Lizardo $\mathrm{J}^{1}$, Navarro Solís $\mathrm{O}^{2}$, \\ Navarro Salazar $\left.\right|^{3}$ \\ 1 Unidad Académica de Ciencias Químicas. UAZ \\ ${ }^{2}$ Doctorado en Ciencias de la Ingeniería. UAZ \\ 3Unidad Académica de Cultura. Universidad Autónoma de Zacatecas \\ *hateblack@outlook.com
}

\begin{abstract}
RESUMEN
La determinación de la concentración del nitrógeno de nitratos $\left(\mathrm{N}-\mathrm{NO}_{3}{ }^{-}\right)$en el agua subterránea proporciona información del grado de contaminación que se ha generado principalmente por efecto del uso de fertilizante o por contaminación de aguas residuales tratadas o sin tratar por un mal diseño en la construcción del pozo; situación que debe conocerse en cualquier propuesta de desarrollo ecoturístico en la actualidad, para su determinación se tiene especificado un proceso de acidificación y transporte a temperatura máxima de $4^{\circ} \mathrm{C}$, para su posterior valoración en laboratorio con tiempo de almacenamiento de 48 horas máximo. El objetivo de esta investigación es determinar en campo el grado de contaminación del agua subterránea de $\mathrm{N}^{-\mathrm{NO}_{3}}$-en una región del altiplano zacatecano con potencial turístico. La metodología utilizada fue la determinación

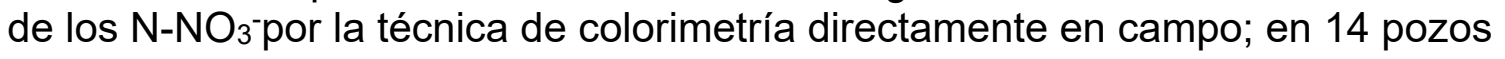
de agua subterránea, ocho de estos de uso para consumo humano y los otros 6 de uso agrícola, monitoreados de noviembre del 2018 a marzo del 2019. Los resultados muestran valores en el intervalos de 1.0 a $5.9 \mathrm{mg} / \mathrm{L}$, contra el límite máximo permisible normativo que es de $10 \mathrm{mg} / \mathrm{L}$, siendo el pozo "Noria de Gringos" con el valor máximo, el cual es de uso para consumo humano. Los valores obtenidos permiten concluir que los procesos de incorporación de $\mathrm{N}^{-\mathrm{NO}_{3}}{ }^{-}$ a los acuíferos por procesos de infiltración, no están presentado en niveles de riesgo, ni se tiene contaminación por desechos humanos o de animales, por lo que pudieran ser factibles como corredores ecoturísticos.
\end{abstract}

Palabras claves: Agua subterránea, nitratos, acuíferos, ecoturismo.

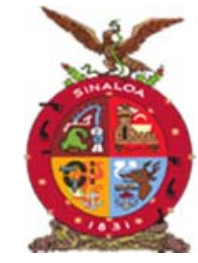

XVIII Congreso Internacional XXIV Congreso Nacional de Ciencias ambientales

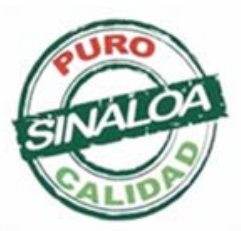

Mazatlán, Sinaloa 3-7 junio 2019
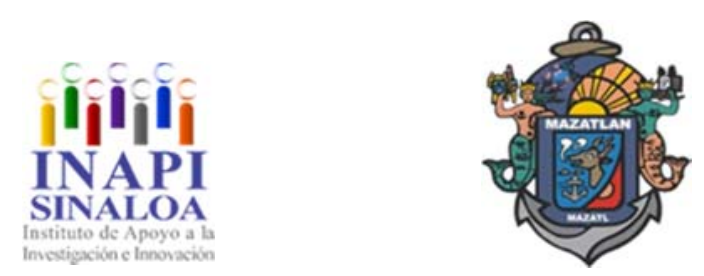

Tecnología y Biotecnología para el Tratamiento de Contaminantes y Biorremediación 

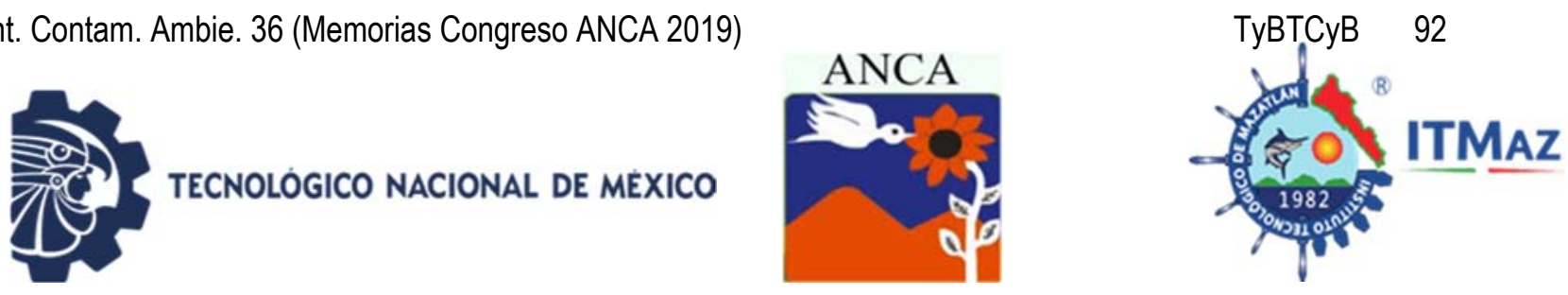

\title{
Evaluation of levels of $\mathrm{N}-\mathrm{NO}_{3}$-in underground water wells in Calera, Zacatecas
}

\author{
Hernández López $\mathrm{A}^{1 *}$, Viramontes Lizardo $\mathrm{J}^{1}$, Navarro Solís $\mathrm{O}^{2}$, \\ Navarro Salazar |3 \\ ${ }^{1}$ Unidad Académica de Ciencias Químicas. UAZ \\ ${ }^{2}$ Doctorado en Ciencias de la Ingeniería. UAZ \\ 3Unidad Académica de Cultura. Universidad Autónoma de Zacatecas \\ *hateblack@outlook.com
}

\begin{abstract}
The analysis of the concentration of nitrate nitrogen $\left(\mathrm{N}^{-\mathrm{NO}_{3}}{ }^{-}\right)$in groundwater provides information on the degree of contamination that has been generated mainly due to the use of fertilizer or pollution due to poor design in the construction of the well; situation that should be known in any proposal for ecotourism development currently, for its determination has been specified an acidification and transport process at a maximum temperature of $4^{\circ} \mathrm{C}$, for further assessment in the laboratory with storage time of 48 hours maximum. The objective of this research is to determine in the field the degree of groundwater pollution of $\mathrm{N}^{-\mathrm{NO}_{3}}{ }^{-}$ in a region of the "Altiplano Zacatecano" with tourism potential. The methodology used was the determination of the $\mathrm{N}-\mathrm{NO}_{3}$-by the technique of colorimetry directly in the field; in 14 groundwater wells, eight of these for human consumption and the other 6 for agricultural use, monitored from November 2018 to March 2019. The results show values in the ranges of 1.0 to $5.9 \mathrm{mg} / \mathrm{L}$, against maximum regulatory allowable limit that is $10 \mathrm{mg} / \mathrm{L}$, with the well Noria de Gringos with the maximum value, which is of use for human consumption, the values obtained allow to conclude that the processes of incorporation of this analyte to the aquifers by processes infiltration is not presented in risk levels, nor is contamination by human or animal waste, so they could be feasible as ecotourism corridors.
\end{abstract}

Keyswords: Groundwater, nitrates, aquifers, ecotourism.

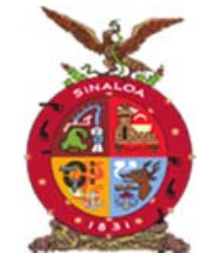

XVIII Congreso Internacional XXIV Congreso Nacional de Ciencias ambientales

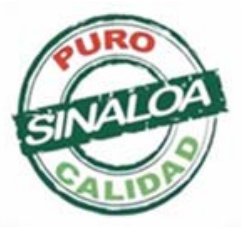

Mazatlán, Sinaloa 3-7 junio 2019
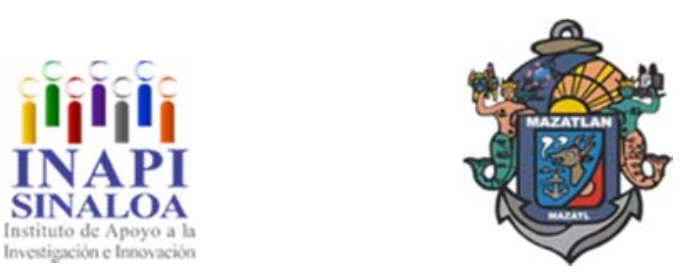

Tecnología y Biotecnología para el Tratamiento de Contaminantes y Biorremediación 

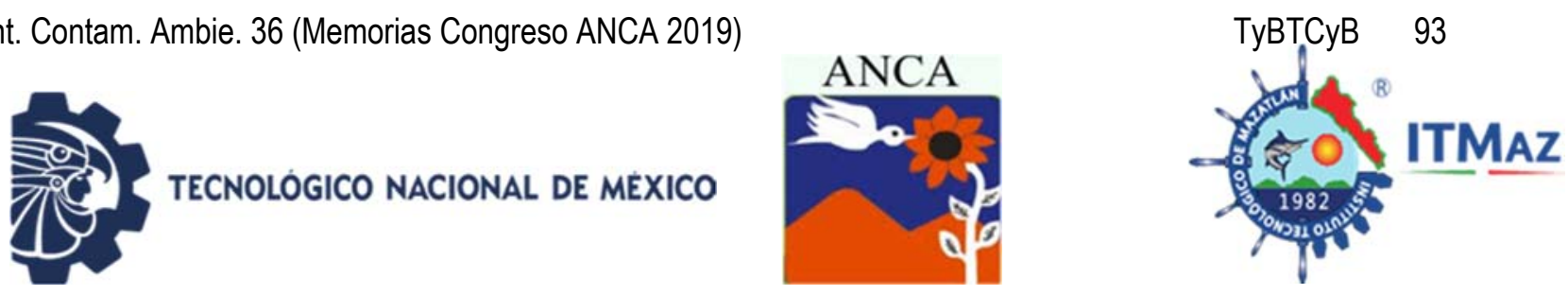

\title{
Extracción química secuencial de As y Fe mediante las técnicas BCR Y Hall, en jales sometidos a procesos de biorremediación
}

\author{
Hernández Trejo ME${ }^{1}$, Vixta Haro JA ${ }^{1}$, Mendoza Hernández JC ${ }^{1}$, \\ Santamaría Juárez $\mathrm{JD}^{1}$, Batalla Mayoral $\mathrm{J}^{2}$, Vega Hernández $\mathrm{M}^{1 *}$ \\ ${ }^{1}$ Facultad de Ingeniería Química. BUAP \\ Ciudad Universitaria Av. Sn. Claudio y 18 Sur \\ Col. Jardines de San Manuel, C.P. 72570 Puebla, Pue. \\ ${ }^{2}$ Complejo Regional Mixteca. Campus Izúcar de Matamoros, Puebla. BUAP \\ vegahm@gmail.com
}

\section{RESUMEN}

Los elementos potencialmente tóxicos (EPT) presentes en los jales mineros suelen estar arraigados a distintas estructuras y agregados presentes en el suelo, en función de su estado de oxidación y reactividad, lo que determina su biodisponibilidad. Este trabajo tiene como objetivo, comparar dos técnicas de extracción química secuencial para estudiar la distribución de hierro y arsénico en la rizosfera de un tratamiento de fitorremediación con Ricinus communis y bacterias promotoras del crecimiento vegetal (BPCV) en jal puro o mezclado con sustrato. Los métodos empleados para el fraccionamiento fueron Hall y BCR, posteriormente se realizó el análisis de los elementos mediante ICP. Los resultados mostraron que la distribución sobresaliente tanto de $\mathrm{Fe}$ como As se alcanzaron en la fracción residual para BCR, en el caso de As, la mezcla jal y sustrato con BPCV, obtuvo la concentración mayor, $13855.50 \mathrm{mg} / \mathrm{kg}$, para hierro la concentración más grande, $25610.06 \mathrm{mg} / \mathrm{kg}$ en el tratamiento sin mezclar, en presencia de BPCV. Para el método Hall la distribución superior se encontró en la fracción unida a la materia orgánica; siendo para As el tratamiento con jal puro y Ricinus communis, sin la presencia de BPCV, en donde se presentó la concentración más alta, $14,452.67 \mathrm{mg} / \mathrm{kg}$; respecto al Fe el tratamiento con jal y sustrato sin mezclar, inoculada con bacterias se obtuvo una concentración de $18417.95 \mathrm{mg} / \mathrm{kg}$. Los resultados obtenidos muestran que Ricinus communis ejerció influencia en la movilidad de los EPT, sin embargo, se presentaron cambios mayores al utilizarse BPCV.

Palabras clave: EPT, jales, rizosfera, fitorremediación, extracción química secuencial.

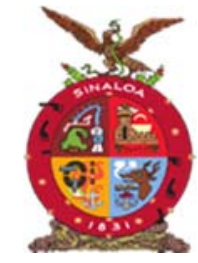

XVIII Congreso Internacional XXIV Congreso Nacional de Ciencias ambientales

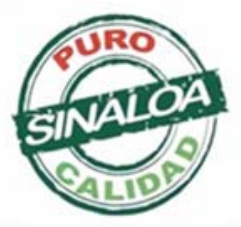

Mazatlán, Sinaloa 3-7 junio 2019
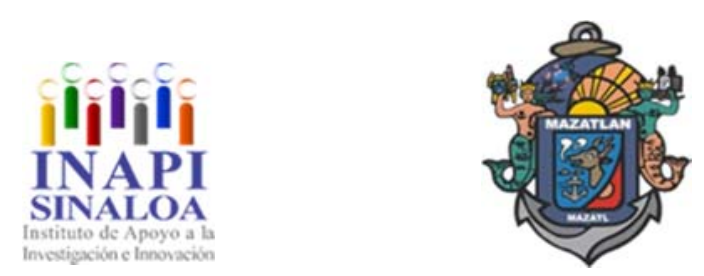

Tecnología y Biotecnología para el Tratamiento de Contaminantes y Biorremediación 

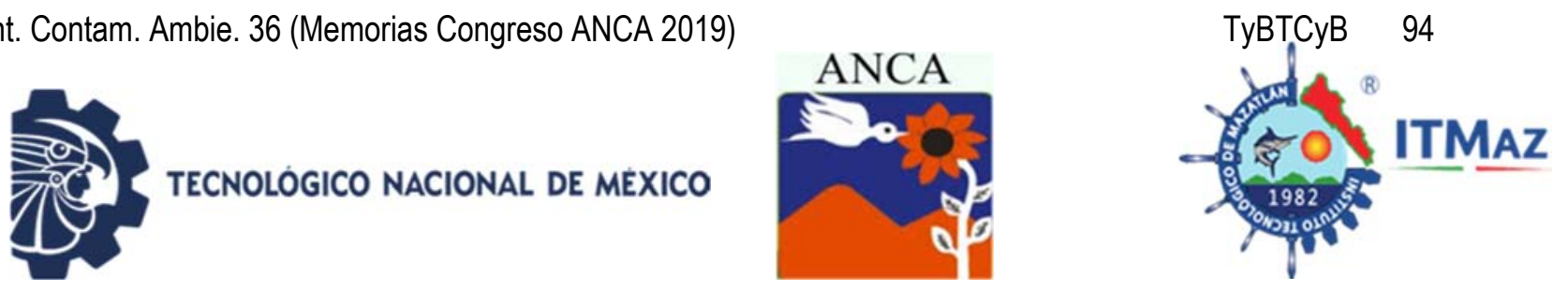

\title{
Sequential chemical extraction of As and Fe through BCR and Hall techniques, in tailings subjected to bioremediation processes
}

Hernández Trejo ME ${ }^{1 *}$, Vixta Haro JA ${ }^{1}$, Mendoza Hernández JC ${ }^{1}$, Santamaría Juárez $\mathrm{JD}^{1}$, Batalla Mayoral $\mathrm{J}^{2}$, Vega Hernández $\mathrm{M}^{1 *}$

${ }^{1}$ Facultad de Ingeniería Química. BUAP

Ciudad Universitaria Av. Sn. Claudio y 18 Sur

Col. Jardines de San Manuel, C.P. 72570 Puebla, Pue.

${ }^{2}$ Complejo Regional Mixteca. Campus Izúcar de Matamoros, Puebla. BUAP vegahm@gmail.com

\begin{abstract}
The potentially toxic elements (PTE) present in the mine tailings are usually ingrainedes to different structures and aggregates present in the soil, depending on their oxidation and reactivity state, which determines their bioavailability. The objective of this work is to compare two sequential chemical extraction techniques to study the distribution of iron and arsenic in the rhizosphere of a phytoremediation treatment with Ricinus communis and plant growth promoting bacteria (PGPB) in mine tailings or mixed with substrate. The methods used for the fractionation were Hall and BCR, later the analysis of the elements was carried out by means of ICP. The results showed that the outstanding distribution of both $\mathrm{Fe}$ and $\mathrm{As}$ were reached in the residual fraction for $\mathrm{BCR}$, in the case of As, the mixture mine tailings and substrate with PGPB, obtained the highest concentration, $13855.50 \mathrm{mg} / \mathrm{kg}$, for iron the highest concentration, 25610.06 $\mathrm{mg} / \mathrm{kg}$ in the unmixed treatment, in the presence of PGPB. For the Hall method, the upper distribution was found in the fraction bound to the organic matter; being for As the treatment with mine tailings and Ricinus communis, without the presence of PGPB, where the highest concentration, $14,452.67 \mathrm{mg} / \mathrm{kg}$ was presented; Regarding Fe, the treatment with mine tailings and unmixed substrate, inoculated with bacteria, obtained a concentration of $18417.95 \mathrm{mg} / \mathrm{kg}$. The results obtained show that Ricinus communis exerted an influence on the mobility of the PTE, however, there were major changes when using PGPB.
\end{abstract}

Keywords: PTE, mine tailings, rhizosphere, phytoremediation, sequential chemical extraction.

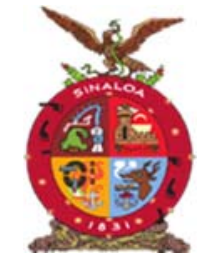

XVIII Congreso Internacional XXIV Congreso Nacional de Ciencias ambientales

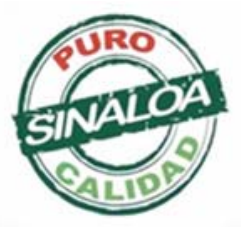

Mazatlán, Sinaloa 3-7 junio 2019
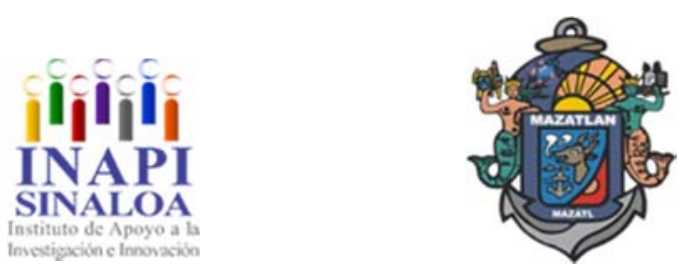

Tecnología y Biotecnología para el Tratamiento de Contaminantes y Biorremediación 

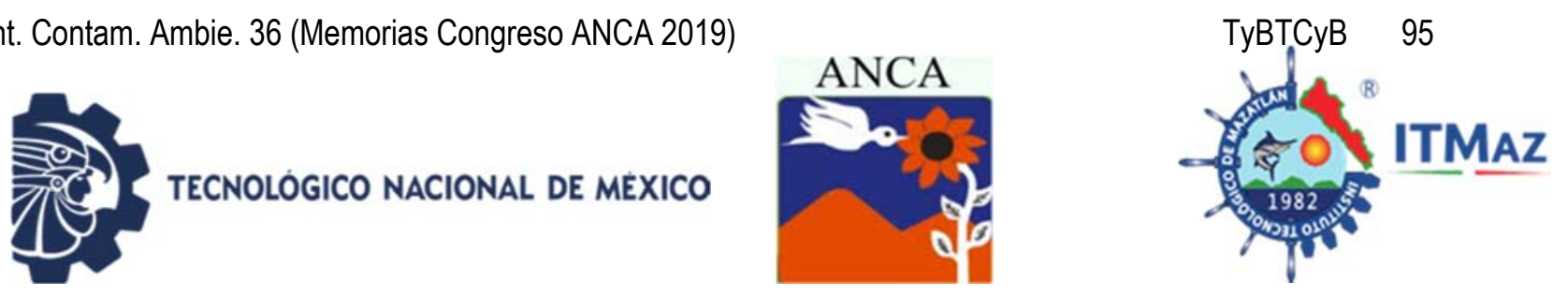

\title{
Remoción y biodegradación de Rojo Allura en medio acuoso
}

\author{
Herrera García $\mathrm{S}^{1}$, Torres Pérez J11, Aguirre Ramírez $\mathrm{M}^{2^{*}}$ \\ ${ }^{1}$ Laboratorio de Transferencia y Degradación de Contaminantes \\ ${ }^{2}$ Laboratorio del C.A. Biología Celular y Molecular. \\ Universidad Autónoma de Ciudad Juárez, Anillo Envolvente del Pronaf y \\ Estocolmo S/N, C.P. 32300, A.P. 1595-D, Ciudad Juárez, Chihuahua, México \\ *al142240@alumnos.uacj.mx
}

\section{RESUMEN}

El Rojo Allura (R-40) es uno de los colorantes más empleados en la industria textil, cosmética y alimentaria; dicho compuesto es de tipo azoico y se ha comprobado en estudios anteriores que es carcinogénico y mutagénico. Para la remoción de este contaminante emergente se han empleado técnicas de tratamiento avanzado como la adsorción usando carbón activado. Alternativamente, diversos grupos de microorganismos promueven con rapidez la decoloración de medios acuosos contaminados con colorantes azoicos. En la presente investigación se evaluó la eficiencia de eliminación del colorante R-40 mediante un proceso fisicoquímico y uno biológico. La cinética de sorción de R40 (10 ppm) con carbón activado de cáscara de nuez a partir de medio acuoso mostró un porcentaje de remoción del $99.87 \%$, después de 264 h. Por otro lado, se evaluó la biodegradación del colorante en cultivos independientes de Pseudomonas aeruginosa y Bacillus subtilis 168 crecidos en caldo nutritivo suplementado con R-40 (50 ppm), a $37{ }^{\circ} \mathrm{C}$. Las cepas bacterianas decoloraron el 92.13 y $88.21 \%$ para $P$. aeruginosa cepa $C$ y $B$. subtilis 168 , respectivamente, en condiciones microaerofílicas después de $168 \mathrm{~h}$. Los resultados indican que el R40 disuelto en medio acuoso puede ser removido tanto por procesos fisicoquímicos como biológicos en periodos de tiempo relativamente cortos.

Palabras clave: Rojo allura, decoloración, carbón activado, $P$. aeruginosa cepa C, B. Subtilis 168 .

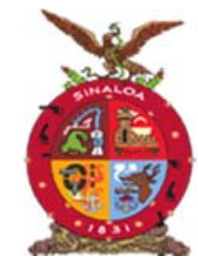

XVIII Congreso Internacional XXIV Congreso Nacional de Ciencias ambientales

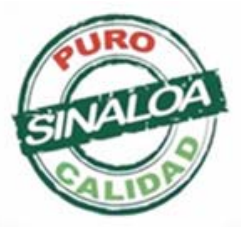

Mazatlán, Sinaloa 3-7 junio 2019
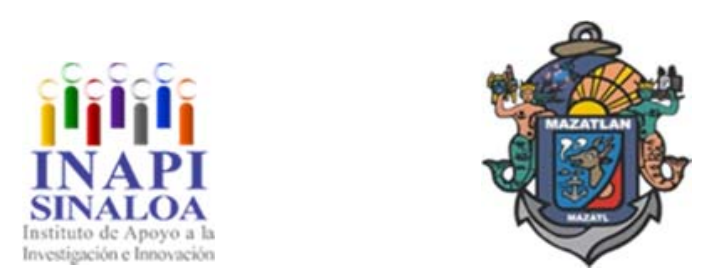

Tecnología y Biotecnología para el Tratamiento de Contaminantes y Biorremediación 


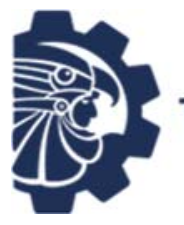

TECNOLOGICO NACIONAL DE MEXICO
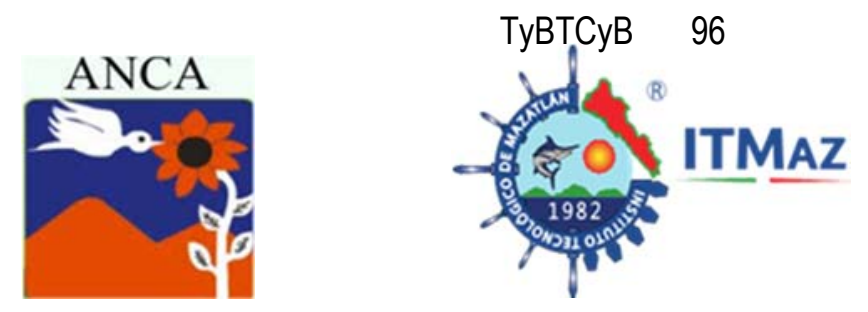

\title{
Removal and biodegradation of Allura Red in an aqueous medium
}

\author{
Herrera García S ${ }^{1}$, Torres Pérez J1 , Aguirre Ramírez M²* \\ ${ }^{1}$ Laboratorio de Transferencia y Degradación de Contaminantes \\ ${ }^{2}$ Laboratorio del C.A. Biología Celular y Molecular. \\ Universidad Autónoma de Ciudad Juárez, Anillo Envolvente del Pronaf y \\ Estocolmo S/N, C.P. 32300, A.P. 1595-D, Ciudad Juárez, Chihuahua, México \\ *al142240@alumnos.uacj.mx
}

\begin{abstract}
Allura Red (R-40) is one of the most used dyes in the textile, cosmetic and food industries; this compound is an azoic type and it has been proven in previous studies that it is carcinogenic and mutagenic. For the removal of this emerging pollutant, advanced treatment techniques such as adsorption by activated carbon have been used. Alternatively, diverse groups of microorganisms promote quickly the decolorization of aqueous mediums polluted with azo dyes. In the present research, it was evaluated the efficiency of elimination of R-40 dye by a physicochemical and biologic process. The sorption kinetics of R-40 (10 ppm) with activated charcoal from pecan nut shells from aqueous medium showed a removal of $99.87 \%$ after $264 \mathrm{~h}$. On the other hand, the biodegradation of the dye was evaluated in independent cultures of Pseudomonas aeruginosa and Bacillus subtilis 168 grown in nutritive broth amended with R-40 (50 ppm), at $37 \mathrm{C}$. Bacterial strains decolorized 92.13 and $88.21 \%$ for $P$. aeruginosa strain $C$ and $B$. subtilis 168, respectively, under microaerophilic conditions after $168 \mathrm{~h}$. The results indicate that R-40 dissolved in aqueous medium can be removed by physicochemical and biological processes in relatively short periods of time.
\end{abstract}

Keywords: Allura red, decolorization, activated carbon, P. aeruginosa strain C, B. Subtilis 168.

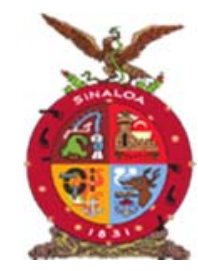

XVIII Congreso Internacional XXIV Congreso Nacional de Ciencias ambientales

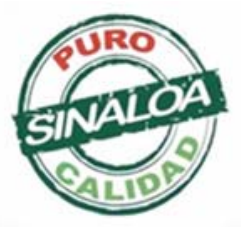

Mazatlán, Sinaloa 3-7 junio 2019
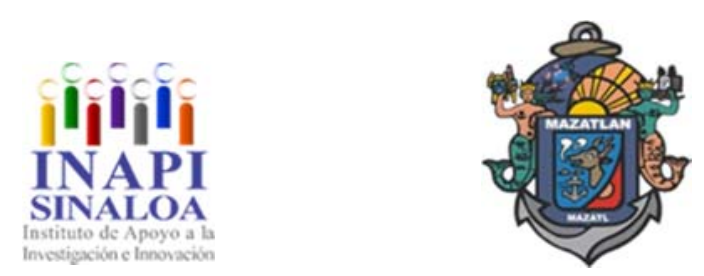

Tecnología y Biotecnología para el Tratamiento de Contaminantes y Biorremediación 

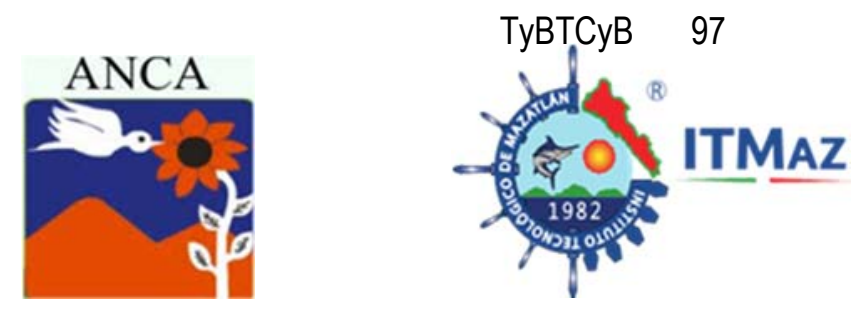

\title{
Mortero de arcilla sin cocer modificada con rastrojo de maíz para vivienda rural de El Fuerte Sinaloa
}

\author{
Juárez Soto $\mathrm{R}^{1^{*}}$, Lara Ponce $\mathrm{E}^{1}$, Alvarado Fierro $\mathrm{O}^{2}$, Lora Urías $\mathrm{C}^{2}$, \\ Almaral Sánchez $\mathrm{J}^{3}$ \\ ${ }^{1}$ Posgrado en Ciencias en Desarrollo Sustentable de los Recursos Naturales, \\ Universidad Autónoma Intercultural de Sinaloa, Unidad Los Mochis, Sinaloa \\ ${ }^{2}$ Facultad de Ingeniería Culiacán, Departamento de Laboratorios. \\ Universidad Autónoma de Sinaloa, Culiacán, Sinaloa \\ ${ }^{3}$ Posgrado en Ciencias de la Ingeniería. Universidad Autónoma de Sinaloa \\ Unidad Los Mochis, Sinaloa \\ *rjuarez1081@hotmail.com
}

\section{RESUMEN}

En las viviendas rurales del norte en el estado de Sinaloa; no se tienen diseños de vivienda construidos con materiales ecológicos, donde la generalidad de estos materiales de construcción, aproveche materiales de desecho o de residuos agrícolas; por ello se evaluó un material de construcción a base de mortero de arcilla modificada sin cocer, aplicando rastrojo de maíz para ser usado en la construcción de una vivienda rural que genere menos contaminantes que el adobe tradicional, con mejores funciones y cualidades. El objetivo fue usar el rastrojo de maíz como material suplementario estructurante para elaborar mortero de arcilla con adición de cal y cemento Portland, que tenga resistencia similar a los morteros cementantes convencionales. Se elaboró, a temperatura ambiente, un mortero de arcilla modificada con $5 \%$ de cemento y $5 \%$ de cal, en peso, adicionado con rastrojo de maíz, en polvo y con tamaño máximo de $3 \mathrm{~mm}$, en $1 \%, 3 \%$ y $5 \%$, en peso de respecto a la arcilla modificada como material para construcción de vivienda. Los resultados determinaron que la resistencia a la compresión para la muestra de referencia $(R)$ fue de $18 \mathrm{~kg} / \mathrm{cm}^{2}$ y esta disminuyó inversamente con el incremento de rastrojo de maíz. Se estudió la morfología por medio de microscopía electrónica de barrido, donde se observó en muestras de morteros con arcilla modificada, la formación de productos de hidratación del cemento y la cal y en los que se le adicionó rastrojo de maíz, mostraron fragmentos distribuidos del mismo. El empleo de rastrojo de maíz como aditivo en la elaboración de morteros de arcilla con cemento y cal, produce un material ecológico con rasgos de sostenibilidad, porque se utilizan materiales de desecho y favorece el empleo de menos cantidades de cemento y cal para fabricarlos.
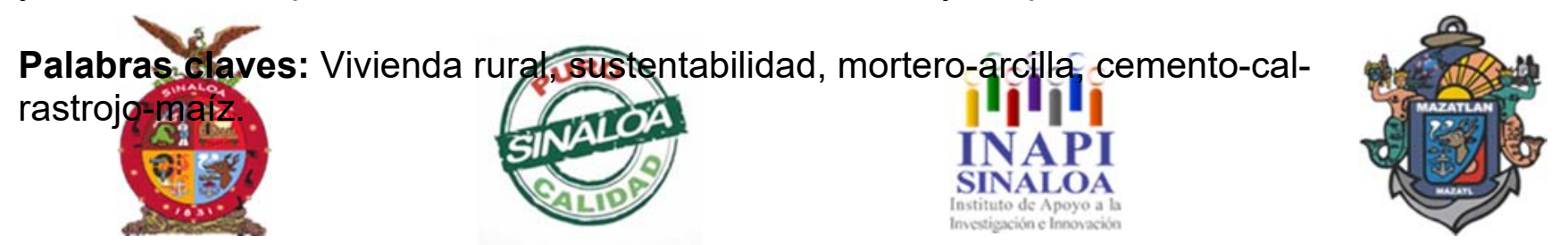

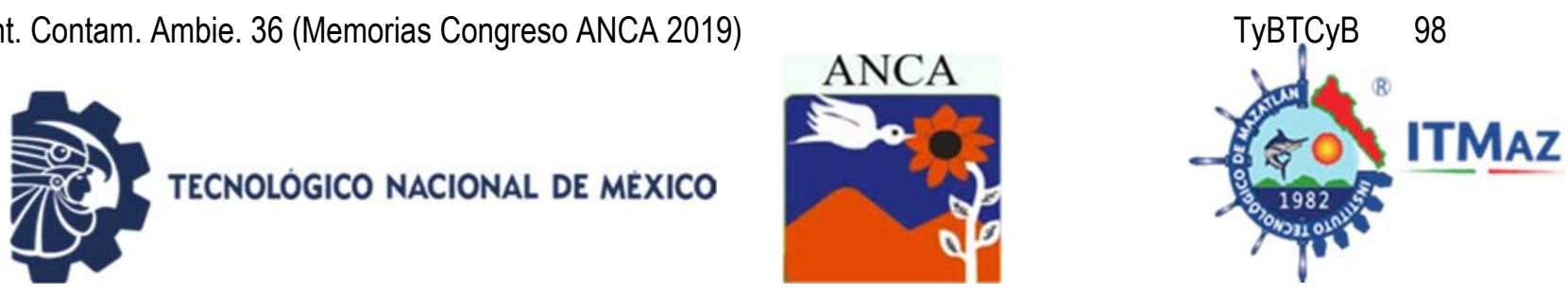

\title{
Modified uncooked clay mortar with corn stubble for housing rural of EI Fuerte Sinaloa
}

\author{
Juárez Soto $\mathrm{R}^{1 *}$, Lara Ponce $\mathrm{E}^{1}$, Alvarado Fierro $\mathrm{O}^{2}$, Lora Urías $\mathrm{C}^{2}$, \\ Almaral Sánchez $\mathrm{J}^{3}$ \\ ${ }^{1}$ Posgrado en Ciencias en Desarrollo Sustentable de los Recursos Naturales, \\ Universidad Autónoma Intercultural de Sinaloa, Unidad Los Mochis, Sinaloa \\ ${ }^{2}$ Facultad de Ingeniería Culiacán. Departamento de Laboratorios. \\ Universidad Autónoma de Sinaloa, Culiacán, Sinaloa \\ ${ }^{3}$ Posgrado en Ciencias de la Ingeniería. Universidad Autónoma de Sinaloa. \\ Unidad Los Mochis, Sinaloa \\ *rjuarez1081@hotmail.com
}

\begin{abstract}
In the rural homes of the north in the state of Sinaloa; there are no housing designs built with ecological materials, where the generality of these building materials, take advantage of waste materials or agricultural waste; therefore, a construction material based on uncooked modified clay mortar was evaluated, applying maize stubble to be used in the construction of a rural house that generates less contaminants than traditional adobe, with better functions and qualities. The objective was to use maize stubble as a supplementary structuring material to make clay mortar with addition of lime and Portland cement, which has resistance similar to conventional cement mortars. A modified clay mortar with $5 \%$ cement and $5 \%$ lime, by weight, was elaborated at room temperature, added with maize stubble, powder and with a maximum size of $3 \mathrm{~mm}$, in $1 \%, 3 \%$ and $5 \%$, by weight with respect to modified clay as material for housing construction. The results determined that the compressive strength for the reference sample $(R)$ was 18 $\mathrm{kg} / \mathrm{cm}^{2}$ and this decreased inversely with the increase of maize stubble. The morphology was studied by means of scanning electron microscopy, where it was observed in samples of mortar with modified clay, the formation of hydration products of cement and lime and in which maize stubble was added, they showed distributed fragments of it. The use of corn stover as an additive in the preparation of clay mortars with cement and lime, produces an ecological material with sustainability features, because waste materials are used and favors the use of less quantities of cement and lime to manufacture them.
\end{abstract}

Keywords: rural housing, sustainability, mortar-clay, cement-lime-stubble-corn.
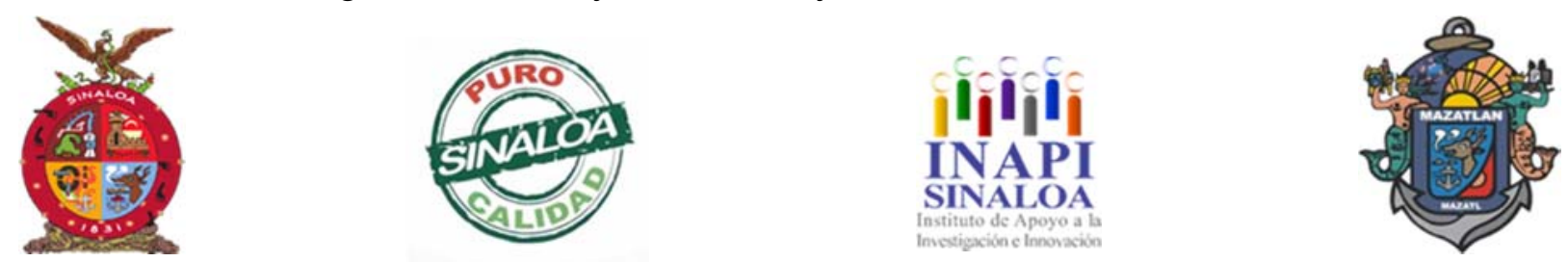

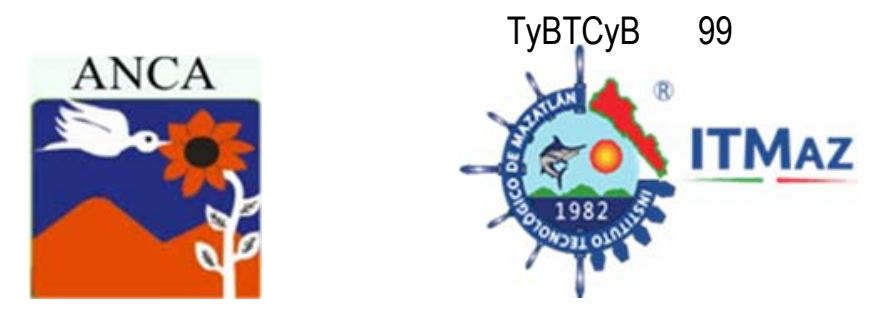

\title{
Recuperación de arenas de fundición mediante fermentación líquida
}

\author{
Leal Rodríguez $A^{1}$, Ruiz Font $A^{1}$, Rubio Rosas $E^{3}$, Gonzales Flores $E^{4}$, \\ Merlo Ruiz $\mathrm{F}^{1}$, Vázquez Cuchillo $\mathrm{O}^{4 *}$ \\ ${ }^{1}$ Centro de investigación en Biotecnología Aplicada, IPN \\ ${ }^{2}$ Unidad Profesional Interdisciplinaria en Ingeniería y Tecnologías Avanzadas, \\ Instituto Politécnico Nacional \\ ${ }^{3}$ Benemérita Universidad Autónoma de Puebla, \\ Centro Universitario de Vinculación y Transferencia de Tecnología. \\ ${ }^{4}$ Tecnológico Nacional de México/Instituto Tecnológico de Puebla, \\ Av. Tecnológico 420, Maravillas, 72220 Puebla, Pue. \\ *odilon.vazquez@itpuebla.edu.mx
}

\section{RESUMEN}

En desarrollo de ciudades modernas traen el uso de muchos automotores, los cuales en su manufactura se involucran diferentes procesos como es el fundido mediante moldes de arena que después de varios ciclos se desechan representando una fuente de contaminación. La recuperación de este tipo de arenas permitirá disminuir los costos además de hacer el proceso de fundido más sustentable. Para el desarrollo del presente trabajo se realizó un proceso de fermentación liquida a partir de microrganismo (MO) autóctonos recolectados de la $\mathrm{Cd}$. de Puebla. Se determinó las condiciones óptimas de crecimiento para su reproducibilidad. Inicialmente los MO fueron inoculados, tomando 10 gramos de suelo y colocándolo en solución salina, para ser depositados en diferentes medios selectivos modificados (Harrison, Lactico y mineral). Una vez obtenido un crecimiento homogéneo fueron purificados e identificados. Para poder incrementar la selectividad del $\mathrm{MO}$ hacia los compuestos contaminantes presentes, en la arena de fundición, los cuales principalmente son resinas fenólicas, se volvió a inocular los $\mathrm{MO}$ en los medios con arena en diluciones de $1 / 20$ medio selectivo. Una vez que se logro que se estabilizara la velocidad de crecimiento de los $\mathrm{MO}$ se procedió a colocar $5 \mathrm{~mL}$ del cultivo madre obtenido en un reactor tipo Bach con agitación a $32^{\circ} \mathrm{C}$ con volumen de $750 \mathrm{~mL}$ y $250 \mathrm{~g}$ de arena de fundición. Los resultados obtenidos permiten demostrar que después de 7 días en el sistema de fermentación líquida, se obtuvo una remoción de más del $80 \%$ de los compuestos orgánicos presentes en la arena de fundición, lo cual se vio incrementado al aumentar los días de fermentación.

Palabras clave: Fermentación liquida, arenas de fundición, microrganismos autóctonos biotrasformacion.

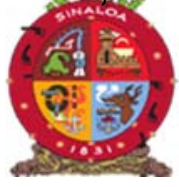

XVIII Congreso Internacional XXIV Congreso Nacional de Ciencias ambientales

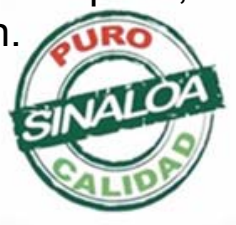

Mazatlán, Sinaloa 3-7 junio 2019
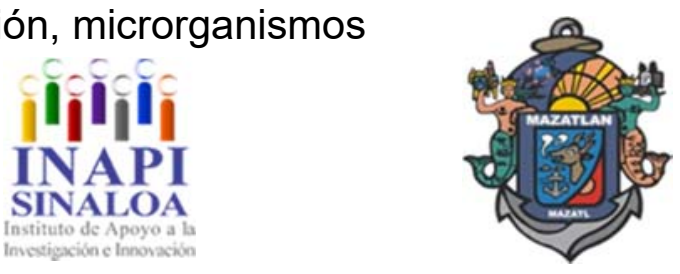

Tecnología y Biotecnología para el Tratamiento de Contaminantes y Biorremediación 

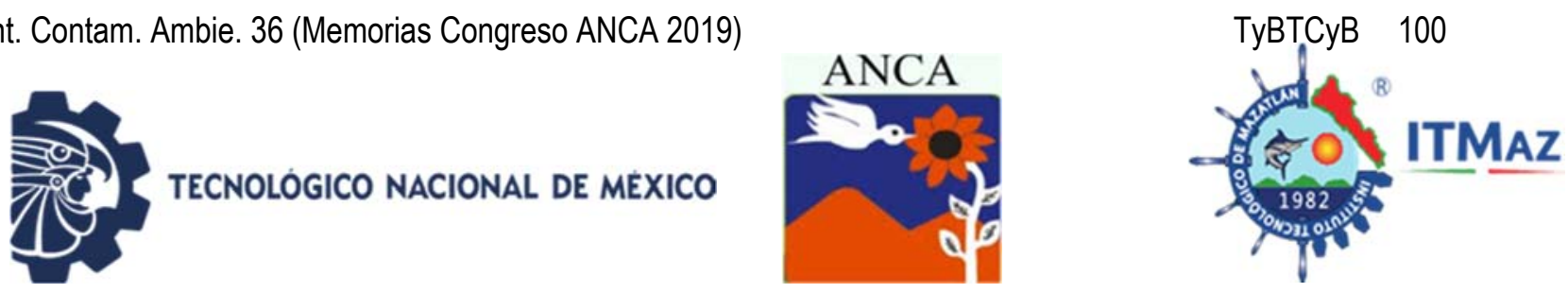

Recovery of foundation sands by liquid fermentation

Leal Rodríguez $A^{1}$, Ruiz Font $A^{1}$, Rubio Rosas $E^{3}$, Gonzales Flores $E^{4}$, Merlo Ruiz $\mathrm{F}^{1}$, Vázquez Cuchillo $\mathrm{O}^{4 *}$

${ }^{1}$ Centro de investigación en Biotecnología Aplicada, IPN

${ }^{2}$ Unidad Profesional Interdisciplinaria en Ingeniería y Tecnologías Avanzadas, Instituto Politécnico Nacional

${ }^{3}$ Benemérita Universidad Autónoma de Puebla, Centro Universitario de Vinculación y Transferencia de Tecnología.

${ }^{4}$ Tecnológico Nacional de México/Instituto Tecnológico de Puebla,

Av. Tecnológico 420, Maravillas, 72220 Puebla, Pue.

*odilon.vazquez@itpuebla.edu.mx

\begin{abstract}
In the development of modern cities they bring the use of many vehicles, which in their manufacture involve different processes such as melting sand molds that after several cycles are discarded representing a source of contamination. The recovery of this type of sand will reduce costs as well as making the melting process more sustainable. The development of this work was carried out through a process of liquid fermentation from native microorganisms (MC) collected from the City of Puebla. The optimal growth conditions for its reproducibility were determined. Initially MCs were inoculated, taking 10 grams of soil and placed in saline. To be deposited in different modified selective media (Harrison, Lactic and mineral), once obtained a homogeneous growth they were purified and identified. In order to increase the selectivity of the MC towards the polluting compounds present in the foundry sand, which are mainly phenolic resins, the MCs were inoculated again in media with sand in 1/20 dilutions of the selective medium. Once the growth rate of MCs was stabilized, $5 \mathrm{~mL}$ of the obtained stem cells was placed in a Bach-type reactor with stirring at $32^{\circ} \mathrm{C}$ with a volume of $750 \mathrm{~mL}$ and $250 \mathrm{~g}$ of foundry sand. The results obtained show that after 7 days in the liquid fermentation system, a removal of more than $80 \%$ of organic compounds present in the foundry sand was obtained, which was increased by increasing the days of fermentation in a similar way the size of sand was strongly diminished to the passage of the days of reaction.
\end{abstract}

Keywords: Liquid fermentation, sand casting, native microorganisms, biotransformation.

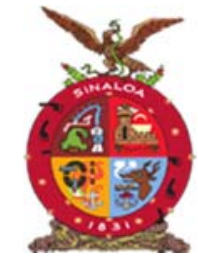

XVIII Congreso Internacional XXIV Congreso Nacional de Ciencias ambientales

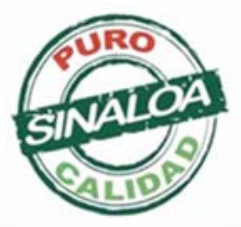

Mazatlán, Sinaloa 3-7 junio 2019
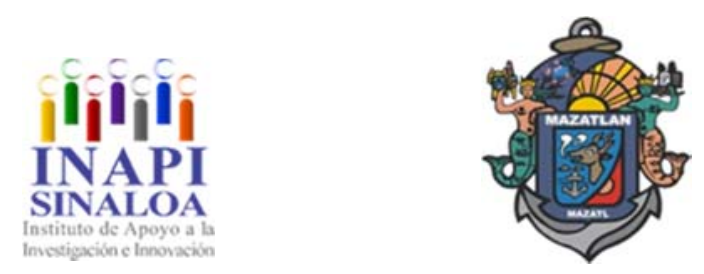

Tecnología y Biotecnología para el Tratamiento de Contaminantes y Biorremediación 


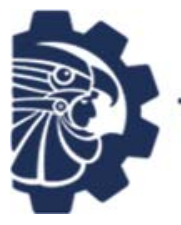

TECNOLOGICO NACIONAL DE MEXICO
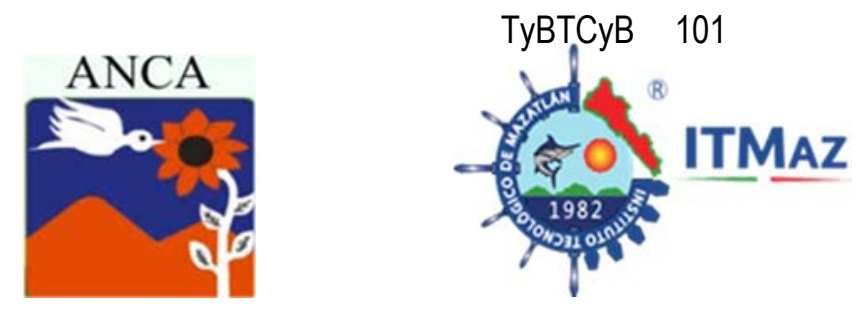

\title{
Evaluación de la generación de biogás y su potencial energético en el relleno sanitario del municipio de San Luis Potosí, S.L.P
}

\author{
López Díaz N, Ávila Galarza A, Álvarez Fuentes G, Algara Siller M \\ Universidad Autónoma de San Luis Potosí \\ *normalilia_lpez@yahoo.com
}

\begin{abstract}
RESUMEN
La disposición final es la última etapa del manejo integral de los RSU, en la que la descomposición de la fracción orgánica genera productos como: polvos, lixiviados y biogás (éste constituido principalmente por: $\mathrm{CH}_{4}$ y $\mathrm{CO}_{2}$ ). Dado su carácter contaminante es necesario evaluar la liberación de gases para determinar los procesos de control adecuados, que minimicen su impacto ambiental. El objetivo de esta investigación fue cuantificar la generación de biogás y su potencial energético, en el relleno sanitario de San Juanico el Grande (municipio de San Luis Potosí, México). Los datos obtenidos corresponden al periodo de noviembre 2018 a marzo 2019. La metodología constó de las etapas siguientes: 1) Recuperación y análisis de datos del sitio de disposición final; 2) Modelado de la generación de biogás (Modelo Mexicano de Biogás); 3) Cálculo del potencial energético del biogás generado. Los resultados obtenidos indican que la generación máxima de biogás se presentará en el año de 2042 y será de aproximadamente $38,271,892 \mathrm{~m}^{3} / a n ̃ o$. En lo que respecta al potencial energético, se plantearon tres escenarios, con base al porcentaje de eficiencia de captura del biogás del $50 \%, 60 \%$ y $70 \%$, cuyos resultados indican valores de 3.6 MW, 4.3 MW y $5.1 \mathrm{MW}$, respectivamente. Esta energía podría abastecer del $2.5,3$ y $3.5 \%$ de la demanda eléctrica requerida en el municipio estudiado.
\end{abstract}

Palabras clave: Biogás, modelo, potencial energético.

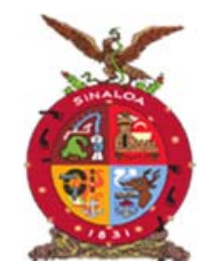

XVIII Congreso Internacional XXIV Congreso Nacional de Ciencias ambientales

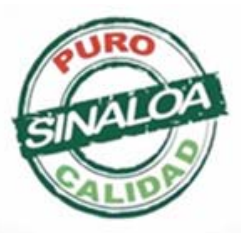

Mazatlán, Sinaloa 3-7 junio 2019
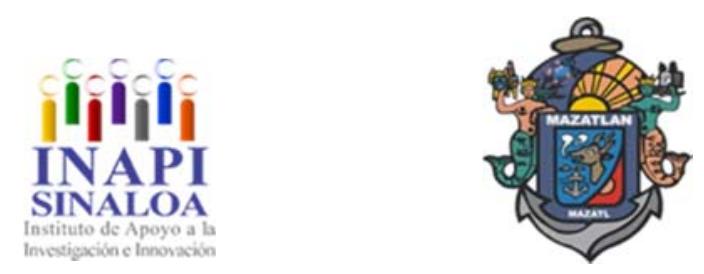

Tecnología y Biotecnología para el Tratamiento de Contaminantes y Biorremediación 

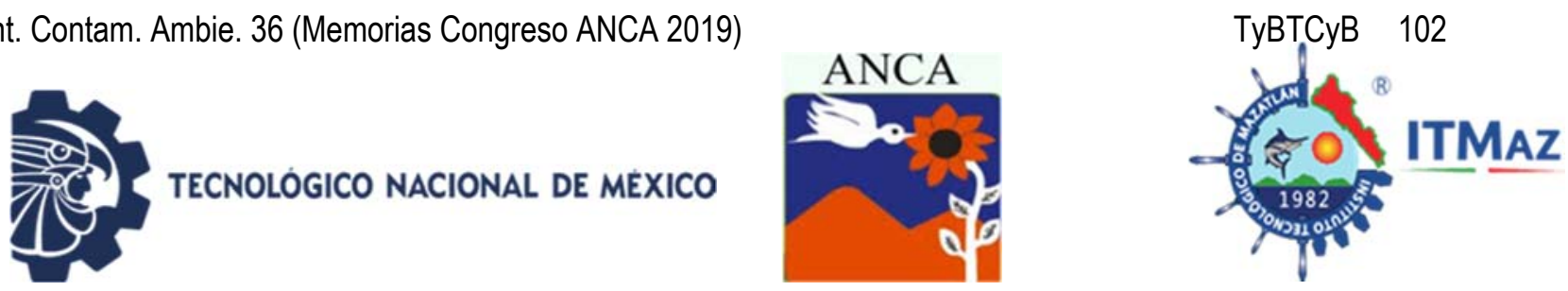

\title{
Evaluation of the generation of biogas and its energy potential in the landfill of the municipality of San Luis Potosí, S.L.P
}

\author{
López Díaz N, Ávila Galarza A, Álvarez Fuentes G, Algara Siller M \\ Universidad Autónoma de San Luis Potosí \\ *normalilia_Ipez@yahoo.com
}

\begin{abstract}
The final disposal is the last stage of the integrated solid waste management, in wich the decomposition of the organic fraction to generate some products such as: powder, leached and landfill gas (mainly makes up by $\mathrm{CH}_{4}$ and $\mathrm{CO}_{2}$ ). Due to polluting characteristic is necessary to evaluate the gas emission to determinate the correct control processes, that minimize their environmental impact. The aim of this research was to estimate the generation of landfill gas and energy potential, in the San Juanico El Grande' landfill (municipality of San Luis Potosí, Mexico). The data obtained corresponded from November 2018 to March 2019. The methodology was divided into three stages: a) Recovery and analysis of data from the landfill; 2) Modeling the generation of landfill gas (Mexican biogas model); 3) Calculation of energy potential. The results showed that de maximum generation of landfill gas will be happen in 2042 and will be approximately of 38, 271,892 $\mathrm{m}^{3} /$ year. As to energy potential, three scenarios were proposed, based on the percentage of landfill gas capture efficiency of $50 \%, 60 \%$ and $70 \%$, whose results showed values of $3.6 \mathrm{MW}, 4.3 \mathrm{MW}$ and $5.1 \mathrm{MW}$, respectively. This energy could supply $2.5 \%, 3 \%$ and $3.5 \%$ of the electricity demand required in the municipality.
\end{abstract}

Keywords: Landfill, biogas, model, energy potential.

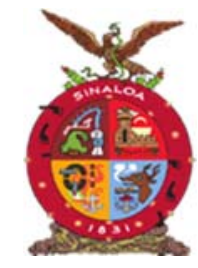

XVIII Congreso Internacional XXIV Congreso Nacional de Ciencias ambientales

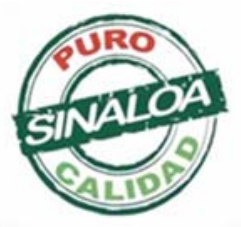

Mazatlán, Sinaloa 3-7 junio 2019
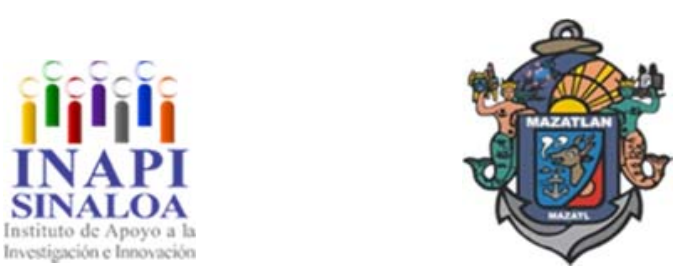

Tecnología y Biotecnología para el Tratamiento de Contaminantes y Biorremediación 

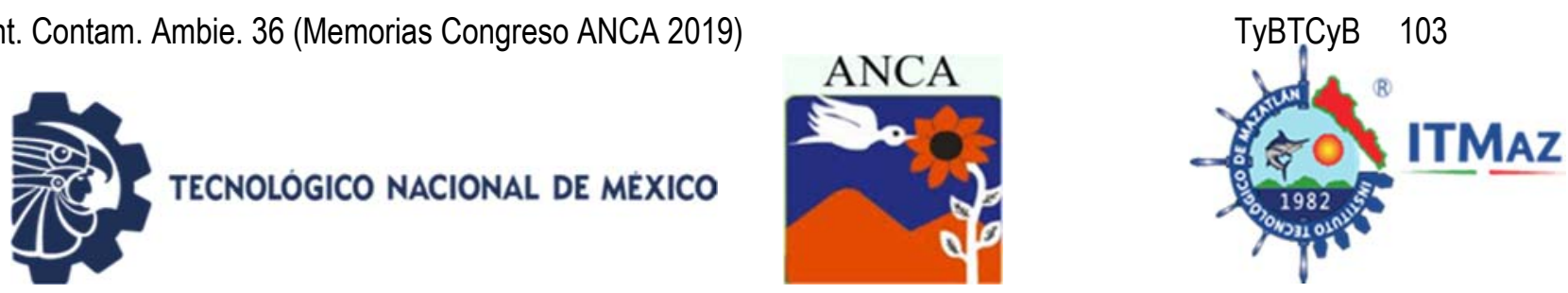

\title{
Remoción de iones fluoruro en soluciones utilizando un composito hidróxido doble laminar Ni-Al-Quitosano
}

\author{
López Velasco A, Jiménez Núñez M*, García Rivas J, Zavala Arce R, \\ García Gaytán B, Ávila Pérez P
}

Instituto Tecnológico de Toluca. Tecnológico Nacional de México

Av. Tecnológico S/N. Colonia Agrícola Bellavista Metepec, Edo. de México,

*luzjimenez3103@yahoo.com.mx

\section{RESUMEN}

En este trabajo se evaluó la capacidad de sorción de iones fluoruro en soluciones en sistema de lotes, utilizando el composito hidróxido doble laminar níquel alumnio-quitosano (HDL-Ni-AI-Q) entrecruzado con tripolifosfato de sodio (TPP), el cual se realizó en el TecNM/Instituto Tecnológico de Toluca en el periodo agosto-diciembre 2018; El HDL-Ni-Al se sintetizó por el método de coprecipitación, el composito HDL-Ni-Al-Q se obtuvo agregando HDL-Ni-Al a una solución de quitosano hidratado en ácido acético manteniendo agitación constante, la mezcla se goteó con una bomba peristáltica sobre la solución de TPP tras un periodo de maduración de $12 \mathrm{~h}$. el material se caracterizó por: microscopia electrónica de barrido (MEB), difracción de rayos $X$ (DRX), espectroscopia de infrarrojo por trasformada de Fourier (IRTF) y BET; se determinaron el punto de carga cero (PCC) y pH óptimo, en este último se realizaron la cinética e isotermas de sorción. El equilibrio se alcanzó a los 360 minutos, el PCC fue de 6 indicando que el material presenta mayor capacidad de sorción en pHs ácidos, lo que concordó con el pH óptimo de 3, los datos experimentales se ajustaron al modelo de pseudo segundo orden que sugiere una quimisorción y a la isoterma de Sips, que atribuye que la sorción ocurre sobre una superficie heterogénea y no se restringe a la formación de monocapa.

Palabras clave: Fluorosis, hidróxido doble laminar, quitosano, entrecruzante, cinética.

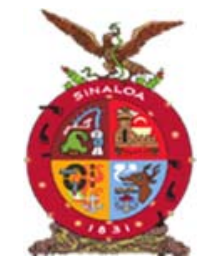

XVIII Congreso Internacional XXIV Congreso Nacional de Ciencias ambientales

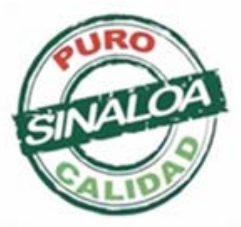

Mazatlán, Sinaloa 3-7 junio 2019
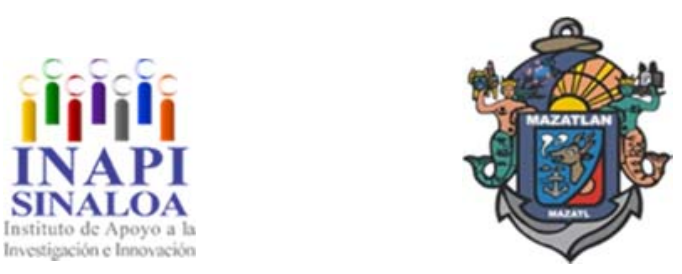

Tecnología y Biotecnología para el Tratamiento de Contaminantes y Biorremediación 

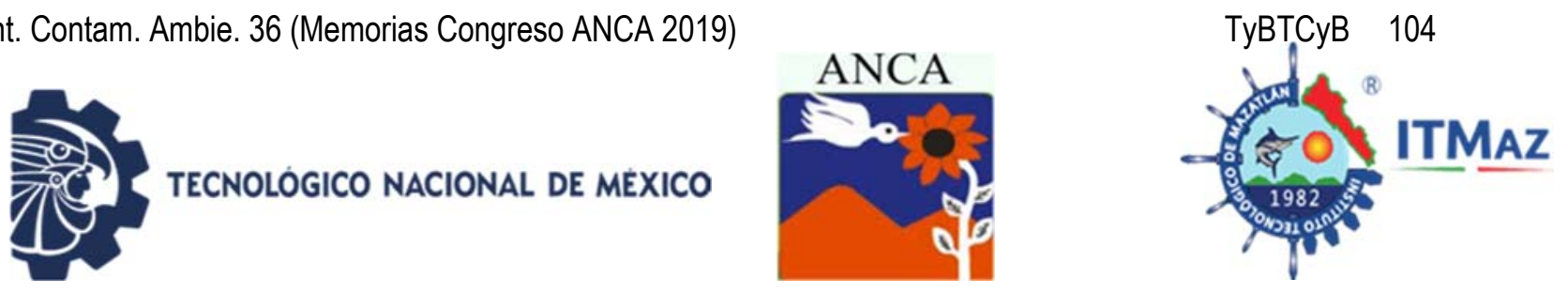

\title{
Removal of fluoride ions in solutions using a Ni-Al-Chitosan double laminar hydroxide compound
}

López Velasco A, Jiménez Núñez M*, García Rivas J, Zavala Arce R, García Gaytán B, Ávila Pérez P

Instituto Tecnológico de Toluca. Tecnológico Nacional de México

Av. Tecnológico S/N. Colonia Agrícola Bellavista Metepec, Edo. de México, *luzjimenez3103@yahoo.com.mx

\begin{abstract}
In this work, the fluoride ion sorption capacity in batch system solutions was evaluated, using the double lamellar nickel aluminum chitosan hydroxide (HDLNi-Al-Q) crosslinked with sodium tripolyphosphate (TPP) compound, which was carried out in the TecNM/Technological Institute of Toluca in the period AugustDecember 2018; The HDL-Ni-Al was synthesized by the coprecipitation method, the HDL-Ni-Al-Q compound was obtained by adding HDL-Ni-Al to a solution of chitosan hydrated in acetic acid while maintaining constant agitation, the mixture was dripped with a peristaltic pump on the TPP solution after a maturity period of $12 \mathrm{~h}$. The material was characterized by: scanning electron microscopy (SEM), $X$-ray diffraction (DRX), Fourier transform infrared spectroscopy (IRTF) and BET; Zero charge point (PCC) and optimal $\mathrm{pH}$ were determined, in the latter the kinetics and sorption isotherms were performed. The equilibrium was reached at 360 minutes, the PCC was 6 indicating that the material has a higher sorption capacity in acidic $\mathrm{pHs}$, which agreed with the optimal $\mathrm{pH}$ of 3 , the experimental data were adjusted to the pseudo second order model that suggests a chemisorption and to the Sips isotherm, which attributes that the sorption occurs on a heterogeneous surface and is not restricted to the formation of monolayer.
\end{abstract}

Keywords: Fluorosis, double laminar hydroxide, chitosan, crosslinker, kinetics.

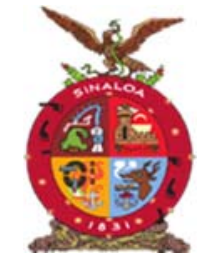

XVIII Congreso Internacional XXIV Congreso Nacional de Ciencias ambientales

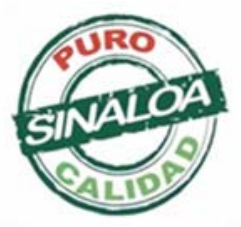

Mazatlán, Sinaloa 3-7 junio 2019
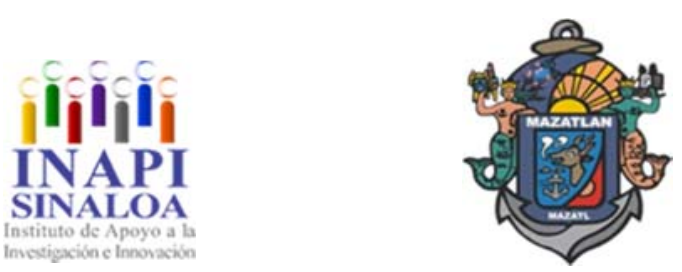

Tecnología y Biotecnología para el Tratamiento de Contaminantes y Biorremediación 

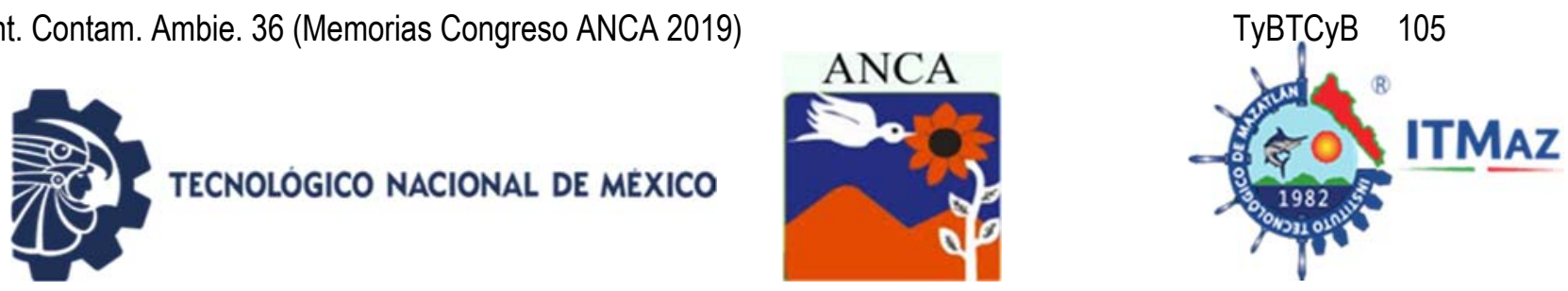

\title{
Efecto de pre-tratamientos sobre la co-digestión anaerobia de la biomasa residual de microalga y residuos orgánicos de mango
}

\author{
Luna Avelar $\mathrm{K}^{1 *}$, Barrena $\mathrm{R}^{2}$, Font Xavi ${ }^{2}$, Sanchez Antoni ${ }^{2}$, Germán Báez $\mathrm{L}^{1}$, \\ Valdez Ortíz $A^{1}$, Santos Ballardo $D^{3}$ \\ 1 Universidad Autónoma de Sinaloa, México \\ 2Universitat Autònoma de Barcelona, España \\ 3Universidad Politécnica de Sinaloa, México \\ *ibtkarlaluna@gmail.com
}

\begin{abstract}
RESUMEN
La biomasa residual $(\mathrm{BR})$ de la microalga Dunaliella tertiolecta generada durante la extracción de lípidos, que son aprovechados para la producción de biodiesel, podría ser utilizada como materia prima para la producción de energía renovable, mediante el proceso de digestión anaeróbica (DA). Sin embargo, algunas de sus características (baja relación de $\mathrm{C}: \mathrm{N}$, presencia de materia orgánica lentamente biodegradable, etc.) pueden dificultar la viabilidad del proceso. Debido a esto, la presente investigación muestra el potencial metanogénico (PM) de la codigestión anaerobia (Co-DA) de BR y ROM (residuos orgánicos de mango, caracterizados por ser sustratos fácilmente biodegradables); así como el efecto de los pre-tratamientos térmico, físico y biológico aplicados a la BR de la misma mezcla. La prueba de PM se realizó a la BR, ROM y a la mezcla (40\% BR y $60 \%$ ROM); además, se examinó el PM de la BR pre-tratada en co-digestión con ROM. El PM de la BR, ROM y de la Co-DA (BR-ROM) fue de $6.23 \pm 0.05,187.5 \pm 2.0$ y $98.6 \pm 2.3 \mathrm{mLCH}_{4} \mathrm{gVS}^{-1}$, respectivamente. Además, el pre-tratamiento biológico aplicado a la BR fue el más efectivo, aumentando $90 \%$ el PM en comparación con el obtenido en la Co-DA sin pre-tratar. Dichos resultados muestran la posibilidad de mejorar el balance energético de la producción de biodiesel de $D$. tertiolecta, al promover una alternativa para el tratamiento de desechos derivados de la producción de biodiesel en vista de una estrategia de cero desperdicios, al mismo tiempo que los ROM de la industria alimentaria son valorizados.
\end{abstract}

Palabras claves: Potencial de metanogénico, biomasa residual de microalga, residuos orgánicos de mango, potencial metanogénico, pre-tratamientos.

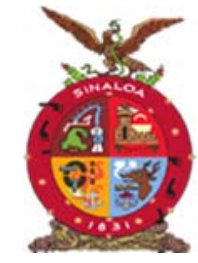

XVIII Congreso Internacional XXIV Congreso Nacional de Ciencias ambientales

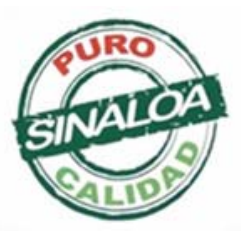

Mazatlán, Sinaloa 3-7 junio 2019
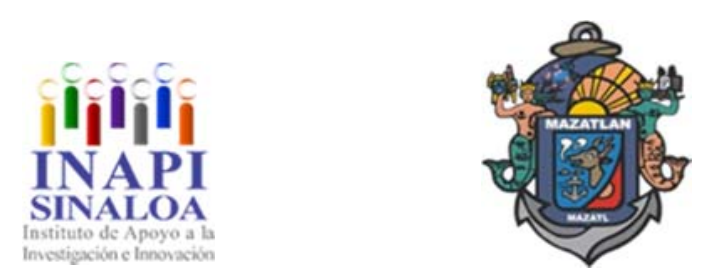

Tecnología y Biotecnología para el Tratamiento de Contaminantes y Biorremediación 

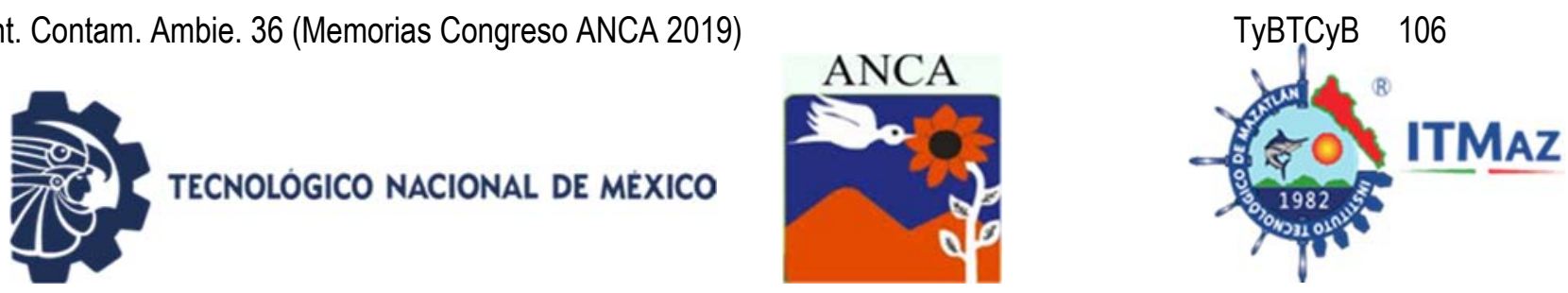

\title{
Effect of pre-treatments on anaerobic co-digestion of residual biomass of microalgae and organic mango residues
}

\author{
Luna Avelar $\mathrm{K}^{1 *}$, Barrena $\mathrm{R}^{2}$, Font Xavi ${ }^{2}$, Sanchez Antoni ${ }^{2}$, Germán Báez $\mathrm{L}^{1}$, \\ Valdez Ortíz A ${ }^{1}$, Santos Ballardo $D^{3}$ \\ 1 Universidad Autónoma de Sinaloa, México \\ 2Universitat Autònoma de Barcelona, España \\ ${ }^{3}$ Universidad Politécnica de Sinaloa, México \\ *ibtkarlaluna@gmail.com
}

\begin{abstract}
The residual biomass (BR) of the Dunaliella tertiolecta microalgae generated during the extraction of lipids, which are used for the production of biodiesel, could be used as raw material for the production of renewable energy, through the anaerobic digestion process (DA). However, some of its characteristics (low C:N ratio, presence of slowly biodegradable organic matter, etc.) may hinder the viability of the process. Due to this, the present investigation shows the methanogenic potential (PM) of anaerobic co-digestion (Co-DA) of BR and ROM (organic mango residues, characterized by being easily biodegradable substrates); as well as the effect of thermal, physical and biological pre-treatments applied to the BR of the same mixture. The PM test was performed on the BR, ROM and the mixture ( $40 \% \mathrm{BR}$ and $60 \% \mathrm{ROM})$; in addition, the PM of the pretreated $B R$ in co-digestion with ROM was examined. The PM of the BR, ROM and Co-DA (BR-ROM) was $6.23 \pm 0.05,187.5 \pm 2.0$ and $98.6 \pm 2.3 \mathrm{mLCH}_{4} \mathrm{gVS}-1$, respectively. In addition, the biological pre-treatment applied to BR was the most effective, increasing the PM by $90 \%$ compared to that obtained in the untreated Co-DA. These results show the possibility of improving the energy balance of the biodiesel production of $\mathrm{D}$. tertiolecta, by promoting an alternative for the treatment of wastes derived from the production of biodiesel in view of a zero waste strategy, at the same time as the ROM of the food industry are valued.
\end{abstract}

Keywords: Methanogenic potential, microalgae residual biomass, organic mango residues, methanogenic potential, pre-treatments.

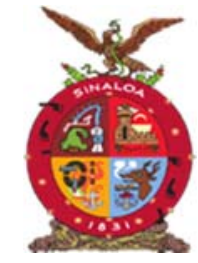

XVIII Congreso Internacional XXIV Congreso Nacional de Ciencias ambientales

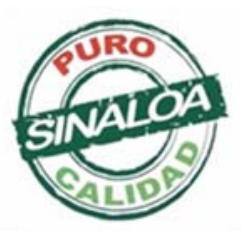

Mazatlán, Sinaloa 3-7 junio 2019
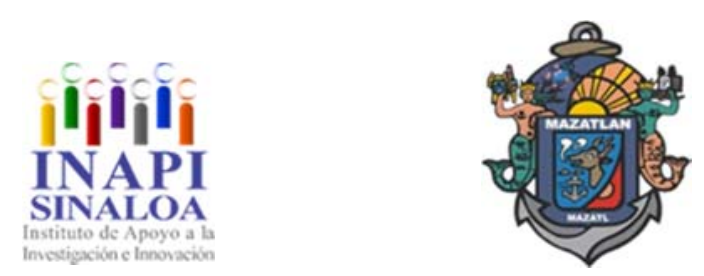

Tecnología y Biotecnología para el Tratamiento de Contaminantes y Biorremediación 

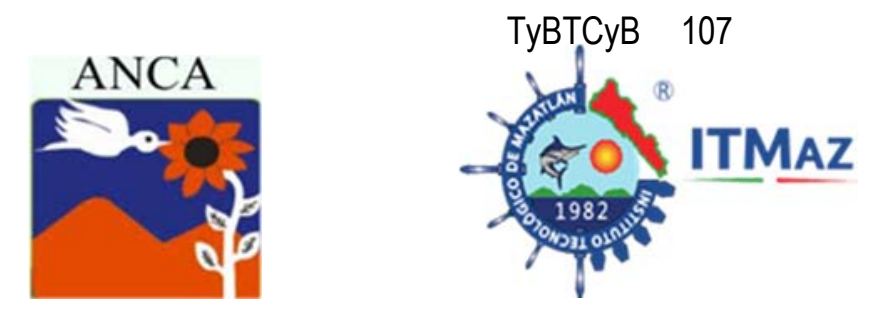

\title{
Evaluación de las propiedades fotocatalíticas del sistema ZnO/NTCf/Nylon 6,6 en la degradación de sulfametoxazol
}

\author{
Luna Reséndiz $\mathrm{E}^{1}$, Guzmán Mar $\mathrm{J}^{1}$, Lucio Porto $\mathrm{R}^{2}$, Maya Treviño $\mathrm{M}^{1 *}$ \\ ${ }^{1}$ Facultad de Ciencias Químicas. Universidad Autónoma de Nuevo León. \\ Av. Universidad S/N, San Nicolás de los Garza N.L. México, C.P. 66455 \\ ${ }^{2}$ Facultad de Ingeniería Mecánica y Eléctrica. \\ Universidad Autónoma de Nuevo León. \\ Av. Alianza Sur No. 101, PIIT Monterrey, Apodaca, NL. \\ *maria.mayatv@uanl.edu.mx
}

\begin{abstract}
RESUMEN
La acumulación de antibióticos resistentes a tratamientos terciarios en efluentes residuales produce efectos adversos a los organismos receptores, por ello es necesario evaluar los riesgos ambientales que pudieran desencadenarse. La implementación de procesos avanzados de oxidación, destacando la fotocatálisis heterogénea, promete resultados favorables al emplear $\mathrm{ZnO}$, uno de los semiconductores más utilizados y con excelentes propiedades fotocatalíticas. Con el fin de extender su longitud de onda de respuesta y minimizar el proceso de recombinación, en este trabajo se incorporó $\mathrm{ZnO}$, por medio de precipitación química, sobre nanotubos de carbono funcionalizados (NTCf) y posteriormente este sistema (ZnO/NTCf, previamente caracterizado por FTIR-ATR, DRX, SEM, UV-Vis-RD, TGA-DTA y fisisorción de $\mathrm{N}_{2}$ ) se inmovilizó, mediante electrospray, sobre una membrana de nylon 6,6 obtenida por electrohilado. Se evaluaron las propiedades fotocatalíticas del compósito en la degradación y mineralización fotocatalítica de sultametoxazol (SMX), fármaco utilizado como molécula modelo de contaminante en efluentes hospitalarios. Los resultados de la degradación de SMX bajo radiación solar simulada y monitoreada por HPLC-DAD mostraron la disminución del $61 \%$ al emplear $\mathrm{ZnO} / \mathrm{NTCf} 5 \%$ y el $50 \%$ al utilizar solo $\mathrm{ZnO}$, superior que la mezcla $\mathrm{ZnO} / \mathrm{NTC}$ con un $48 \%$. Así como la mineralización del fármaco aportando 12, 8 y 4\%, respectivamente. El compósito con NTC (sin funcionalizar) no contribuye a una mayor remoción del fármaco y la aportación que presenta es atribuida a la actividad fotocatalítica del $\mathrm{ZnO}$. Por lo anterior, los NTC utilizados para mejorar la eficiencia fotocatalítica del $\mathrm{ZnO}$ debe someterse a un proceso de funcionalización previa.
\end{abstract}

Palabras clave: SMX, fotocatálisis heterogénea, ZnO, NTC, electrohiladoelectropulverizado

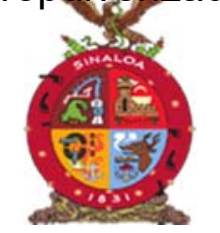

XVIII Congreso Internacional XXIV Congreso Nacional de Ciencias ambientales

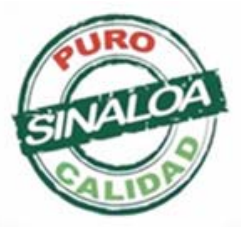

Mazatlán, Sinaloa 3-7 junio 2019
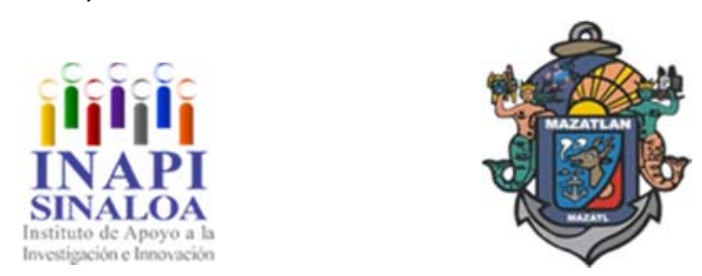

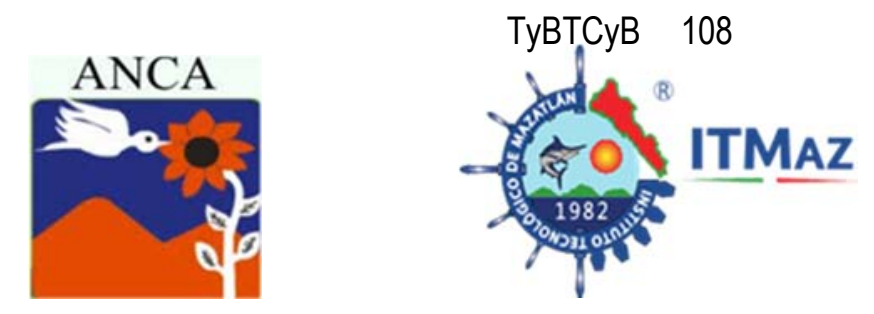

\title{
Evaluation of the photocatalytic properties of the ZnO/NTCf/Nylon system 6,6 in the degradation of sulfamethoxazole
}

\author{
Luna Reséndiz $\mathrm{E}^{1}$, Guzmán Mar $\mathrm{J}^{1}$, Lucio Porto $\mathrm{R}^{2}$, Maya Treviño $\mathrm{M}^{1 *}$ \\ ${ }^{1}$ Facultad de Ciencias Químicas. Universidad Autónoma de Nuevo León. \\ Av. Universidad S/N, San Nicolás de los Garza N.L. México, C.P. 66455 \\ ${ }^{2}$ Facultad de Ingeniería Mecánica y Eléctrica. \\ Universidad Autónoma de Nuevo León. \\ Av. Alianza Sur No. 101, PIIT Monterrey, Apodaca, NL. \\ *maria.mayatv@uanl.edu.mx
}

\begin{abstract}
The accumulation of antibiotics resistant to tertiary treatments in residual effluents produces adverse effects to the recipient organisms, for this reason it is necessary to evaluate the environmental risks that could be triggered. The implementation of advanced oxidation processes, highlighting heterogeneous photocatalysis, promises favorable results in the use of $\mathrm{ZnO}$, one of the most used semiconductors with excellent photocatalytic properties. In order to extend its wavelength of the response and to minimize recombination process. In this work (2019), ZnO was incorporated, by chemical precipitation, on functionalized carbon nanotubes (NTCf) and then, this material ed (ZnO/NTCf, previously characterized by FTIR-ATR, DRX, SEM, UV-Vis-RD, TGA-DTA and physisorption of $\mathrm{N}_{2}$ ) by means of electrospray on a nylon 6,6 membrane by electrospinning for degradation and photocatalytic mineralization of sulfamethoxazole (SMX), a drug used as model molecule of contaminant in hospital effluents. The degradation of SMX, under simulated solar radiation, was monitored by HPLC-DAD. The results show the decrease of $61 \%$ when $\mathrm{ZnO} / \mathrm{NTCf} 5 \%$ was used and $50 \%$ with bare $\mathrm{ZnO}$, superior to the mixture $\mathrm{ZnO} / \mathrm{NTC}$ with $48 \%$. As well as the mineralization of the drug contributing 12,8 and $4 \%$, respectively. The composite with NTC (without functionalizing) does not contribute to a greater removal of the drug and this contribution is attributed to the photocatalytic activity of $\mathrm{ZnO}$. For the above mentioned, NTC, used in order to improve the photocatalytic performance of $\mathrm{ZnO}$, must be submitted to a prior functionalization process.
\end{abstract}

Keywords: SMX, heterogeneous photocatalysis, ZnO, NTC, electrospinningelectrospray.

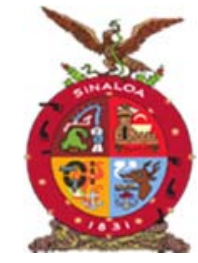

XVIII Congreso Internacional XXIV Congreso Nacional de Ciencias ambientales

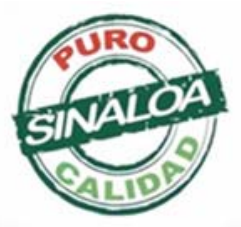

Mazatlán, Sinaloa 3-7 junio 2019
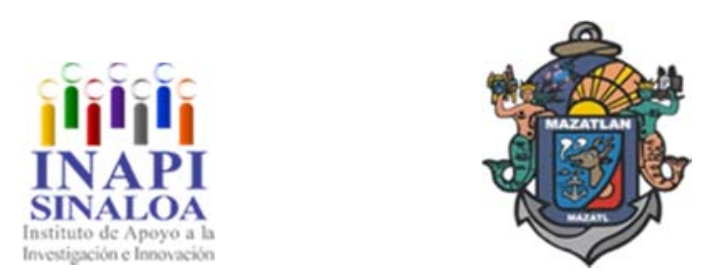

Tecnología y Biotecnología para el Tratamiento de Contaminantes y Biorremediación 

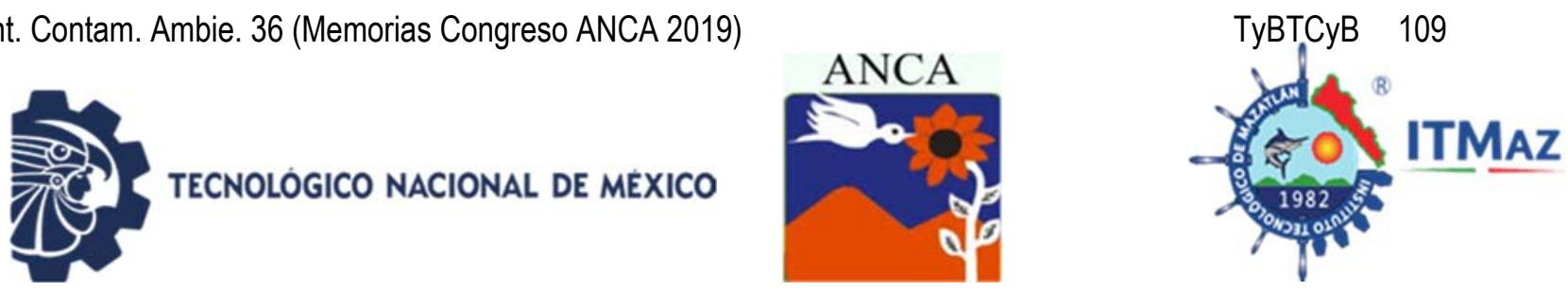

\title{
Control automático de la expansión del lecho en reactores anaerobios para la producción de bioenergéticos
}

\author{
Marín Peña O*, Juárez Barojas I, Alvarado Lassman A, Martínez Sibaja A, \\ Vallejo Cantú N, Rosas Mendoza E
}

Instituto Tecnológico de Orizaba. Tecnológico Nacional de México.

*oscar.marin.ind@gmail.com

\section{RESUMEN}

Los reactores de lecho fluidizado inverso (RLFI) tienen menor requerimiento de energía y formación de biopelícula más estable en comparación con otros reactores anaerobios. Sin embargo, es difícil controlar la expansión del lecho cuando el reactor es llevado a mayor escala. El objetivo de este trabajo fue realizar pruebas con sensores de conductividad para controlar la expansión del lecho en un RLFI. El trabajo fue realizado en el Laboratorio de Ingeniería Ambiental del Instituto Tecnológico de Orizaba durante los meses enero-abril de 2019. Se implementó un RLFI a escala laboratorio de $33 \mathrm{~L}$. Se usaron sensores de conductividad de doble cilindro para uso industrial resistentes a ambientes corrosivos que fueron colocados al 70,80 y $90 \%$ de la columna. Se utilizó Extendosphere $®$ como soporte y fracción líquida de Residuos Sólidos Orgánicos como sustrato. La velocidad inicial fue $1.41 \mathrm{~m} / \mathrm{h}$. Las variaciones de voltaje en los sensores ocurrieron: Minuto 25: Sensor 1 ( 0.45 a $0.30 \mathrm{~V})$, minuto 34: Sensor 2 $(0.65$ a $0.51 \mathrm{~V})$, minuto 43 : Sensor $3(0.71$ a $0.60 \mathrm{~V})$. Posteriormente se controló el caudal y se ajustó la velocidad $(1.30 \mathrm{~m} / \mathrm{h})$ para evitar pérdida de material. En conclusión, estas pruebas sirven como base para implementar un sistema de control automático en un RLFI a escala piloto para monitorear la expansión del soporte.

Palabras claves: Reactor anaerobio, conductividad, bioenergéticos, control automático, lecho.

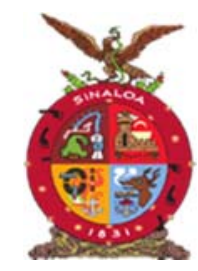

XVIII Congreso Internacional XXIV Congreso Nacional de Ciencias ambientales

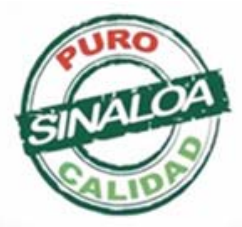

Mazatlán, Sinaloa 3-7 junio 2019
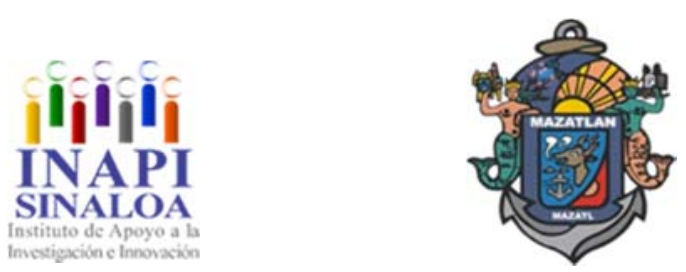

Tecnología y Biotecnología para el Tratamiento de Contaminantes y Biorremediación 

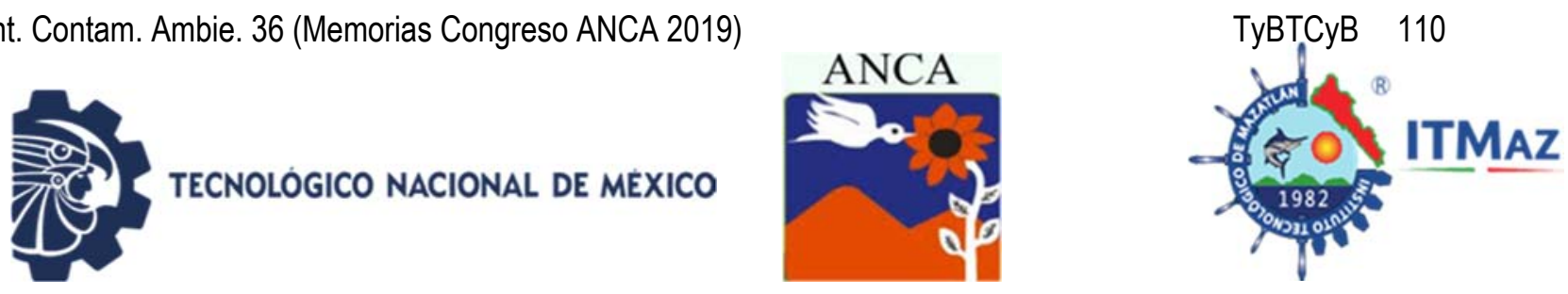

\title{
Automatic control of bed expansion in anaerobic reactors for bioenergetic production
}

\author{
Marín Peña O*, Juárez Barojas I, Alvarado Lassman A, artínez Sibaja A, \\ Vallejo Cantú N, Rosas Mendoza E
}

Instituto Tecnológico de Orizaba. Tecnológico Nacional de México.

*oscar.marin.ind@gmail.com

\begin{abstract}
Inverse fluidized bed reactors (RLFI) have lower energy requirement and more stable biofilm formation compared to other anaerobic reactors. However, it is difficult to control the expansion of the bed when the reactor is carried on a larger scale. The objective of this work was to conduct tests with conductivity sensors to control the expansion of the bed in an RLFI. The work was carried out in the Environmental Engineering Laboratory of the Technological Institute of Orizaba during the months January-April 2019. A RLFI was implemented at a laboratory scale of $33 \mathrm{~L}$. Double-cylinder conductivity sensors for industrial use resistant to corrosive environments were used, which were placed 70,80 and $90 \%$ of the column. Extendosphere $₫$ was used as a support and liquid fraction of Organic Solid Waste as a substrate. The initial speed was $1.41 \mathrm{~m} / \mathrm{h}$. Voltage variations in the sensors occurred: Minute 25: Sensor 1 ( 0.45 to $0.30 \mathrm{~V})$, minute 34: Sensor 2 $(0.65$ to $0.51 \mathrm{~V})$, minute 43 : Sensor $3(0.71$ to $0.60 \mathrm{~V})$. Subsequently, the flow rate was controlled and the speed adjusted $(1.30 \mathrm{~m} / \mathrm{h})$ to avoid loss of material. In conclusion, these tests serve as the basis for implementing an automatic control system in a pilot-scale RLFI to monitor support expansion.
\end{abstract}

Keywords: Anaerobic reactor, conductivity, bioenergetic, automatic control, bed.

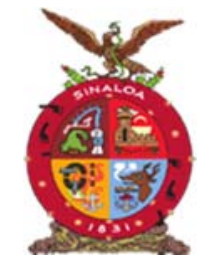

XVIII Congreso Internacional XXIV Congreso Nacional de Ciencias ambientales

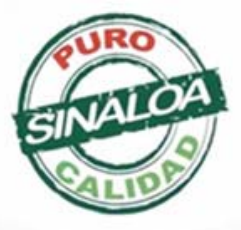

Mazatlán, Sinaloa 3-7 junio 2019
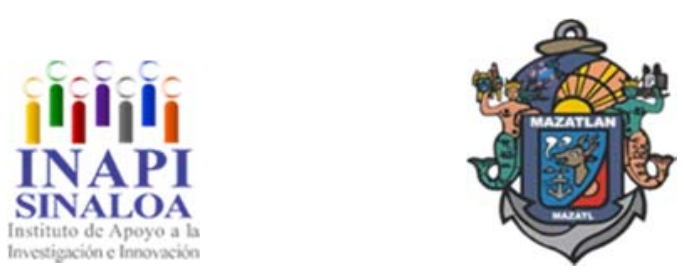

Tecnología y Biotecnología para el Tratamiento de Contaminantes y Biorremediación 

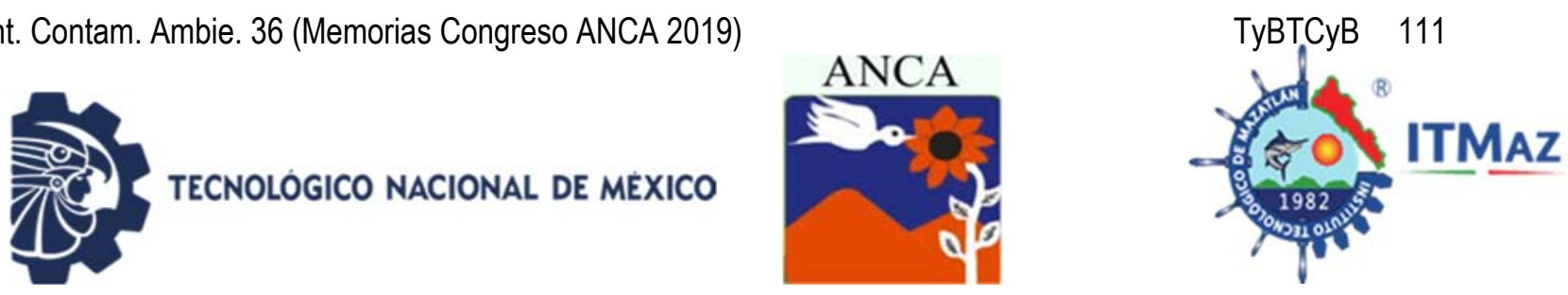

\title{
Determinación del efecto del pH en la adsorción de oxitetraciclina de medio acuoso sobre compositos de hidroxiapatita/zeolita
}

\author{
Martínez Olivas $\mathrm{A}^{1}$, Torres Pérez J11, Reyes López SY², \\ Balderas Hernández $\mathrm{P}^{3}$
}

${ }^{1}$ Laboratorio de Transferencia y Degradación de Contaminantes.

Universidad Autónoma de Ciudad Juárez,

2Laboratorio de Materiales Híbridos Nanoestructurados (LABMHN). UACJ

Anillo Envolvente del Pronaf y Estocolmo S/N, C.P. 32310, A.P. 1595-D,

Ciudad Juárez, Chihuahua, México,

${ }^{3}$ Centro Conjunto de Investigación en Química Sustentable UNAM-UAEMex,

Carretera Km. 14.5, Unidad San Cayetano, Toluca-Atlacomulco, 50200

Toluca de Lerdo, México

al171419@alumnos.uacj.mx

\section{RESUMEN}

La oxitetraciclina es un antibiótico de gran producción y uso a nivel mundial debido a su eficacia para el tratamiento de infecciones en humanos y animales. Los antibióticos han sido clasificados como contaminantes emergentes por su persistencia y efectos indeseables en el ambiente. Dichos compuestos generan problemas en el tratamiento habitual de aguas; siendo la adsorción un método eficaz para su eliminación, existiendo gran variedad de materiales adsorbentes. El presente estudio tuvo como objetivo evaluar el efecto del $\mathrm{pH}$ en la capacidad de adsorción de oxitetraciclina a una concentración de $50 \mathrm{mg} / \mathrm{L}$ utilizando compositos de hidroxiapatita/zeolita natural (HA-NZ) e hidroxiapatita/zeolita sintética (HA-SZ); realizado en el Laboratorio de Transferencia y Degradación de Contaminantes (LTDC) de la Universidad Autónoma de Ciudad Juárez, en un periodo de agosto 2017 a junio 2018. Los compositos fueron sintetizados por el método de precipitación química y probados para la adsorción de oxitetraciclina en medio acuosos a valores de $\mathrm{pH} 2,5$ y 9. La concentración de oxitetraciclina en las soluciones fue medida por espectroscopia UV-Vis a $355 \mathrm{~nm}$. Los resultados obtenidos mostraron capacidades máximas de adsorción de 38 y 28 mg/g para HA-SZ y HA-NZ respectivamente, alcanzando el equilibrio de sorción a las 408 horas. Se aplicaron los modelos de primer orden, pseudo-segundo orden y Elovich para obtener los parámetros cinéticos. La síntesis de compositos HA-NZ y HA-SZ, demostró ser una opción viable debido a su buena capacidad de adsorción en comparación con otros materiales adsorbentes convencionales para el tratamiento del agua contaminada con oxitetraciclina.
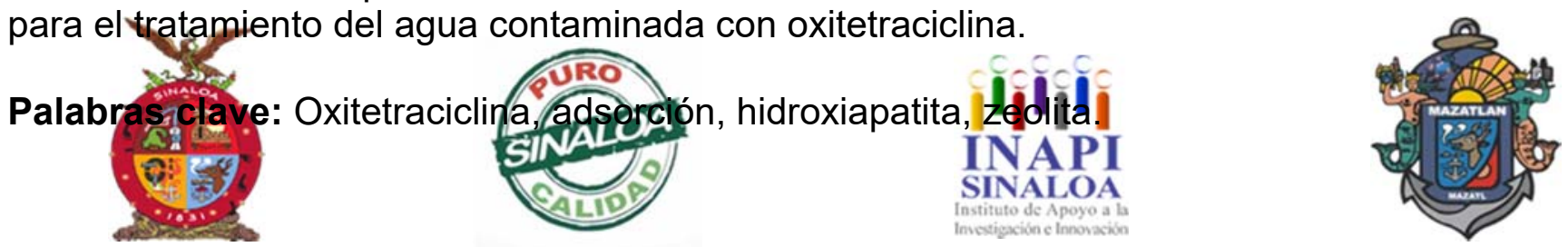

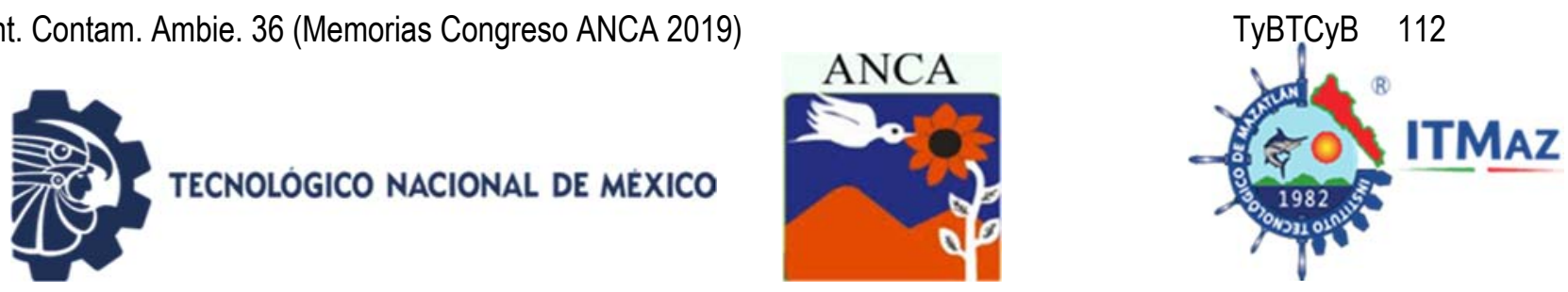

\title{
Determination of $\mathrm{pH}$ effect on oxytetracycline adsorption from aqueous media onto hydroxyapatite/zeolite composites
}

\author{
Martínez Olivas $\mathrm{A}^{1}$, Torres Pérez $\mathrm{J}^{1}$, Reyes López SY², \\ Balderas Hernández $\mathrm{P}^{3}$ \\ ${ }^{1}$ Laboratorio de Transferencia y Degradación de Contaminantes. \\ Universidad Autónoma de Ciudad Juárez, \\ 2Laboratorio de Materiales Híbridos Nanoestructurados (LABMHN). UACJ \\ Anillo Envolvente del Pronaf y Estocolmo S/N, C.P. 32310, A.P. 1595-D, \\ Ciudad Juárez, Chihuahua, México, \\ ${ }^{3}$ Centro Conjunto de Investigación en Química Sustentable UNAM-UAEMex, \\ Carretera Km. 14.5, Unidad San Cayetano, Toluca-Atlacomulco, 50200 \\ Toluca de Lerdo, México \\ al171419@alumnos.uacj.mx
}

\begin{abstract}
Oxytetracycline is an antibiotic of great production and use worldwide, due its efficacy for the treatment of infections in humans and animals. Antibiotics have been classified as emerging pollutants due their persistence and undesirable effects in the environment. These compounds generate problems in the usual water treatment; being the adsorption an effective method for their elimination, also there exist several adsorbent materials. The aim of the present study was to evaluate the effect of $\mathrm{pH}$ in the oxytetracycline adsorption capacity at a concentration of $50 \mathrm{mg} / \mathrm{L}$ using hydroxyapatite/natural zeolite (HA-NZ) and hydroxyapatite/synthetic zeolite (HA-SZ) composites; it was carried out in the Pollutants Transfer and Degradation Laboratory (LTDC) of the Autonomous University of Ciudad Juárez, in the period between August 2017 to June 2018. The composites were synthetized for the chemical precipitation method and tested for oxytetracycline adsorption in aqueous media at $\mathrm{pH} 2,5$ and 9. The oxytetracycline concentration in the solutions was measured by UV-Vis spectroscopy at $355 \mathrm{~nm}$. The results obtained show maximum adsorption capacities of 38 and $28 \mathrm{mg} / \mathrm{L}$ para HA-SZ and HA-NZ respectively, reaching the sorption equilibrium at 408 hours. First order, pseudo-second order and Elovich models were applied to obtain the kinetic parameters. The synthesis of composites HA-NZ and HA-SZ showed to be a viable option due their good adsorption capacity in comparation with other conventional adsorbent materials for the water treatment polluted with oxytetracycline.
\end{abstract}
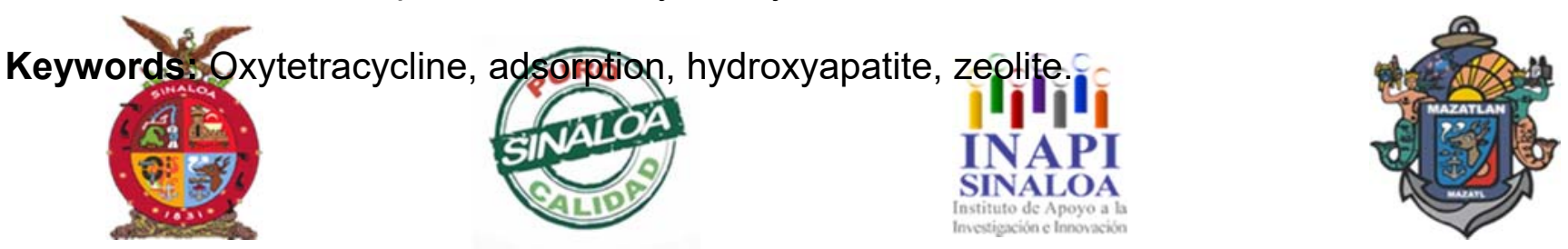

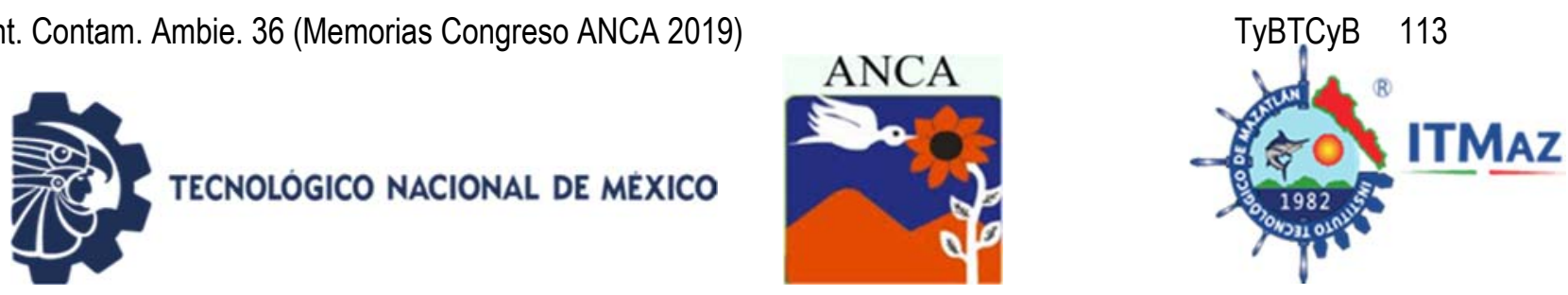

\title{
Identificación de antibióticos en una planta de tratamiento de agua residual municipal
}

\author{
Martínez Orgániz $\mathrm{A}^{1^{*}}$, Becerril Bravo $\mathrm{J}^{2 *}$, Sampedro Rosas $\mathrm{M}^{1}$, \\ Flores Munguía $E^{1}$, González González J11 \\ ${ }^{1}$ Centro de Ciencias de Desarrollo Regional. \\ Universidad Autónoma de Guerrero. \\ Calle Pino S/N, Col. El Roble, Acapulco, Guerrero. México. C. P. 39640 \\ ${ }^{2}$ Instituto de Ingeniería. Universidad Nacional Autónoma de México. \\ Ciudad Universitaria, Coyoacán, Ciudad de México. C. P. 04510. \\ angelesmo_32@hotmail.com
}

\section{RESUMEN}

Una gran variedad de antibióticos son introducidos al medio acuático como resultado de su elevado consumo, incrementando el interés en su estudio debido a su potencial efecto en la salud humana y el ambiente. Los antibióticos se consideran contaminantes emergentes, sus consecuencias ambientales son poco conocidas y pueden ocasionar efectos negativos, debido a que tienen una amplia variedad de propiedades físicas y químicas, usos y mecanismos de acción. La ruta de entrada de antibióticos al ambiente acuático es por los sistemas de alcantarillado municipales, llegando a las plantas de tratamiento de agua residual (PTAR) y su posterior descarga a cuerpos de agua superficial. Las PTAR convencionales son consideradas las principales fuentes de contaminación debido a que no están diseñadas para eliminar antibióticos. La identificación de antibióticos se encuentra entre las líneas de investigación prioritarias de los principales organismos dedicados a la salud pública y ambiental a nivel mundial, sin embargo, en México es poca la información con la que se cuenta sobre la presencia de antibióticos en agua residual. El objetivo de este trabajo fue la identificación de antibióticos en una PTAR municipal del estado de Guerrero, México. Los antibióticos analizados fueron extraídos por SPE y fueron analizados por LC-MS/MS ESI. Se identificaron Cefalexina, Claritromicina, y Trimetroprima, tanto en el influente como en el efluente de la PTAR. Este estudio permitió la identificación de antibióticos que no son eliminados por una PTAR municipal y que son descargados al ambiente.

Palabras clave: Antibióticos, efluente, agua residual.

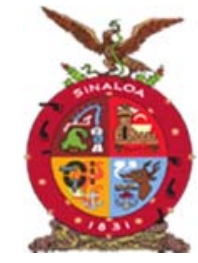

XVIII Congreso Internacional XXIV Congreso Nacional de Ciencias ambientales

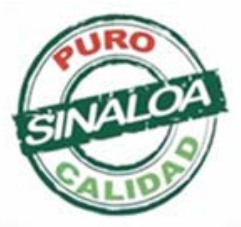

Mazatlán, Sinaloa 3-7 junio 2019
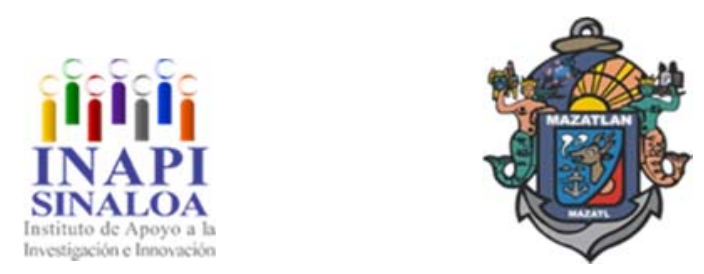

Tecnología y Biotecnología para el Tratamiento de Contaminantes y Biorremediación 

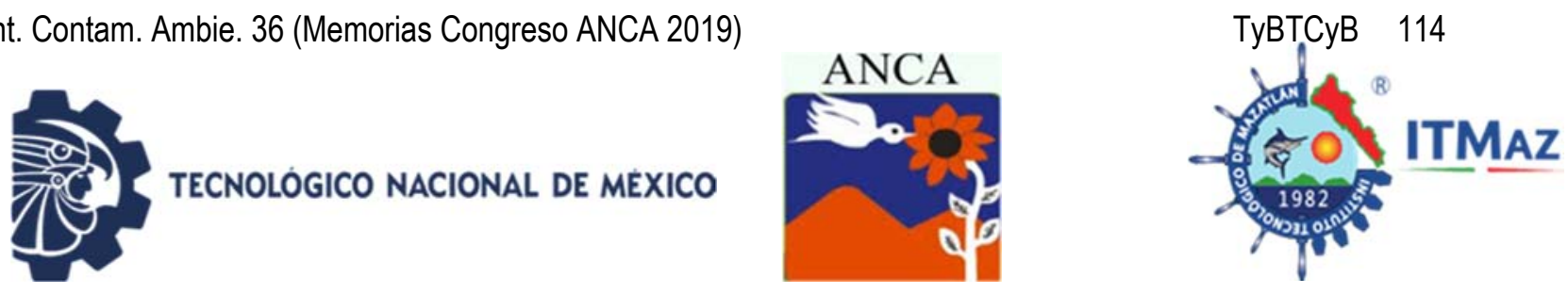

\title{
Identification of antibiotics in a municipal residual water treatment plant
}

\author{
Martínez Orgániz $A^{1 *}$, Becerril Bravo $\mathrm{J}^{2 *}$, Sampedro Rosas $\mathrm{M}^{1}$, Flores Munguía \\ $\mathrm{E}^{1}$, González González J1 \\ ${ }^{1}$ Centro de Ciencias de Desarrollo Regional. \\ Universidad Autónoma de Guerrero. \\ Calle Pino S/N, Col. El Roble, Acapulco, Guerrero. México. C. P. 39640 \\ ${ }^{2}$ Instituto de Ingeniería. Universidad Nacional Autónoma de México. \\ Ciudad Universitaria, Coyoacán, Ciudad de México. C. P. 04510. \\ angelesmo_32@hotmail.com
}

\begin{abstract}
A large variety of antibiotics are introduced into the aquatic environment as a result of their high consumption, increasing the interest in their study due to its potential effect on human health and the environment. Antibiotics are considered emerging pollutants, their environmental consequences are little known and can cause negative effects, because they have a wide variety of physical and chemical properties, uses and mechanisms of action. The route of entry of antibiotics into the aquatic environment is by the municipal sewerage systems, reaching the wastewater treatment plants (WWTP) and their subsequent discharge to surface water bodies. Conventional WWTPS are considered the main sources of contamination because they are not designed to eliminate antibiotics. The identification of antibiotics is among the priority research lines of the main agencies dedicated to public and environmental health worldwide, however, in Mexico there is little information on the presence of antibiotics in wastewater. The objective of this work was the identification of antibiotics in a municipal WWTP. This study was carried out in the year 2017 in a WWTP of the state of Guerrero, Mexico. The antibiotics analyzed were extracted by SPE and analyzed by $L C$ MS/MS ESI. Cephalexin, Clarithromycin, and Trimetroprime were identified, both in the influent and in the effluent of the WWTP. This study allowed the identification of antibiotics that are not eliminated by a municipal WWTP and that are discharged into the environment
\end{abstract}

Keywords: Antibiotics, effluent, wastewater.

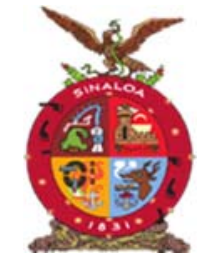

XVIII Congreso Internacional XXIV Congreso Nacional de Ciencias ambientales

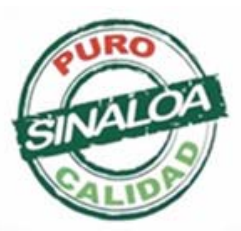

Mazatlán, Sinaloa 3-7 junio 2019
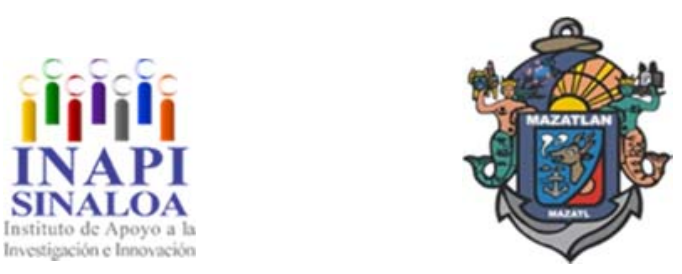

Tecnología y Biotecnología para el Tratamiento de Contaminantes y Biorremediación 

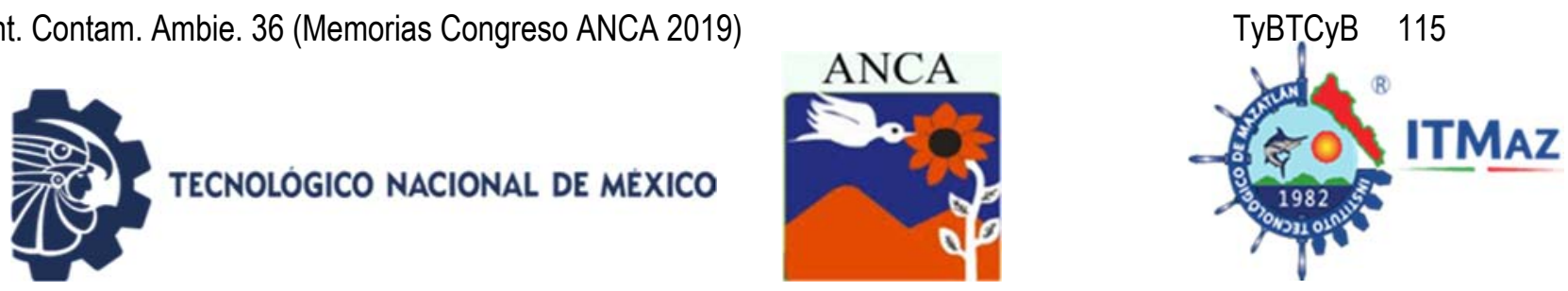

\title{
Co-digestión anaerobia de la fracción orgánica de residuos sólidos urbanos y residuos porcícolas: efecto de la carga orgánica en la producción de biogás
}

\author{
Martínez Torralba $\mathrm{M}^{1}$, Del Ángel Coronel OA ${ }^{1}$, López Escobar LA², \\ Jiménez Hernández $\mathrm{M}^{1}$, Nava Valente $\mathrm{N}^{1 *}$ \\ ${ }^{1}$ División de Ingeniería Ambiental.
}

Instituto Tecnológico Superior de Huatusco, Tecnológico Nacional de México.

Av. 25 Poniente No. 100 Col. Reserva Territorial, Huatusco, Veracruz, México

2 División de Ingeniería en Biotecnología. Universidad Politécnica de Huatusco, Calle 9 Sur S/N Col. Centro, Huatusco, Veracruz, México

*noemi_nava@itshuatusco.edu.mx

\section{RESUMEN}

El proceso de co-digestión consiste en la digestión anaeróbica simultánea de múltiples residuos orgánicos, con características complementarias. El presente estudio tiene como objetivo evaluar el efecto del incremento en la carga orgánica de un proceso de co-digestión anaerobia de la fracción orgánica de residuos sólidos urbanos y residuos porcícolas en la producción e biogás. Los residuos orgánicos municipales fueron muestreados en centros de distribución de verdura ubicados en el municipio de Huatusco, Ver. Los residuos porcícolas fueron obtenidos de los hogares de familias lugareñas que tienen crianza de cerdos tras patio. La caracterización de la mezcla de residuos muestra que es rica en compuestos orgánicos como carbohidratos ( $8.8 \mathrm{~g} / \mathrm{Kg} \mathrm{SV})$, lípidos $(8.3 \mathrm{~g} / \mathrm{Kg} \mathrm{SV})$ y especialmente proteínas (15 g/Kg SV). Durante los 90 días de operación del reactor anaerobio se presentó una eficiencia de remoción de SV promedio de $43.6 \%$, los resultados sugieren que pudiera seguir elevándose la carga orgánica sin que el reactor presente inhibición, de igual manera se obtuvo una producción de biogás promedio de $3102 \mathrm{~mL} / \mathrm{d}$ durante los 90 días de operación del reactor. El incremento de carga orgánica periódicamente impacto en tres aspectos el proceso de digestión anaerobia: se incrementó el porcentaje de eficiencia de remoción de materia orgánica, lo que permite el aprovechamiento y explotación de la mezcla de sustratos, incremento en la producción de biogás y el aumento en los rendimientos de biogás y de metano asegurando así la calidad del biogás.

Palabras clave: Co-digestión anaerobia, biogás, carga orgánica, fracción orgánica de residuos sólidos urbanos, residuos porcícolas.

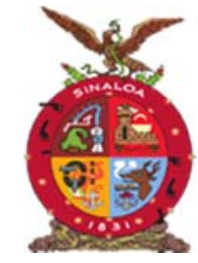

XVIII Congreso Internacional XXIV Congreso Nacional de Ciencias ambientales

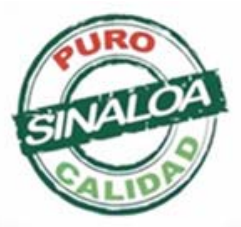

Mazatlán, Sinaloa 3-7 junio 2019
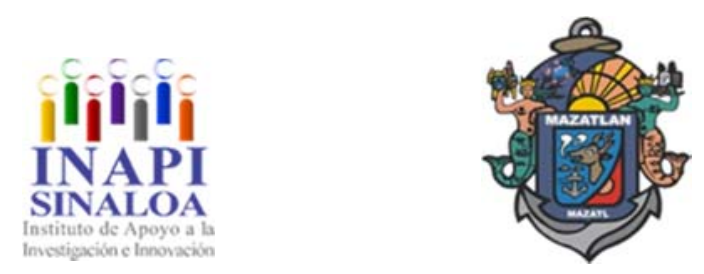

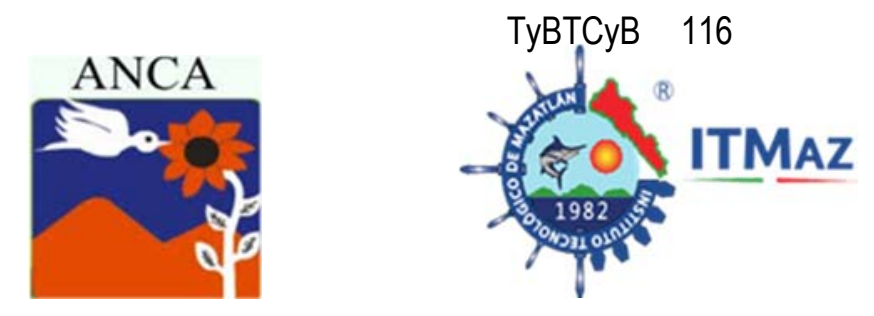

\title{
Anaerobic co-digestion of the organic fraction of urban solid residues and porcine residues: effect of the organic load on the production of biogas
}

\author{
Martínez Torralba M ${ }^{1}$, Del Ángel Coronel OA ${ }^{1}$, López Escobar LA², \\ Jiménez Hernández $\mathrm{M}^{1}$, Nava Valente $\mathrm{N}^{1 *}$ \\ ${ }^{1}$ División de Ingeniería Ambiental.
}

Instituto Tecnológico Superior de Huatusco, Tecnológico Nacional de México.

Av. 25 Poniente No. 100 Col. Reserva Territorial, Huatusco, Veracruz, México

2 División de Ingeniería en Biotecnología. Universidad Politécnica de Huatusco,

Calle 9 Sur S/N Col. Centro, Huatusco, Veracruz, México

*noemi_nava@itshuatusco.edu.mx

\begin{abstract}
The co-digestion process consists in the simultaneous anaerobic digestion of multiple organic residues, with complementary characteristics. The objective of this study is to evaluate the effect of the increase in the organic load of an anaerobic co-digestion process of organic fraction of urban solid waste and swine waste in biogas production. The municipal organic waste was sampled in vegetable distribution centers located in the municipality of Huatusco, Ver. The swine waste was obtained from the homes of local families who have pigs after patio. The characterization of the waste mixture shows that it is rich in organic compounds such as carbohydrates $(8.8 \mathrm{~g} / \mathrm{Kg} \mathrm{SV})$, lipids $(8.3 \mathrm{~g} / \mathrm{Kg} \mathrm{SV})$ and especially proteins ( $15 \mathrm{~g} / \mathrm{Kg} \mathrm{SV}$ ). During the 90 days of operation of the anaerobic reactor there was an average SV removal efficiency of $43.6 \%$, the results suggest that the organic load could continue to rise without the reactor being inhibited, as well as an average biogas production of $3102 \mathrm{~mL} / \mathrm{d}$ during the 90 days of reactor operation. During the 90 days of operation of the anaerobic reactor there was an average VS removal efficiency of $43.6 \%$, the results suggest that the organic load could continue to rise without the reactor being inhibited, as well as an average biogas production of $3102 \mathrm{~mL} / \mathrm{d}$ during the 90 days of reactor operation. The increase of organic load periodically impacts in three aspects the process of anaerobic digestion: the percentage of efficiency of removal of organic matter was increased, which allows the exploitation and exploitation of the mixture of substrates, increase in the production of biogas and the increase in the yields of biogas and methane, thus ensuring the quality of the biogas.
\end{abstract}

Keywords: Anaerobic co-digestion, biogas, organic load, organic fraction of urban solid waste, swine waste.

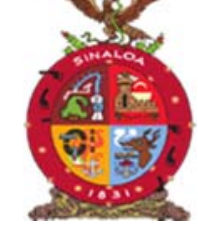

XVIII Congreso Internacional XXIV Congreso Nacional de Ciencias ambientales

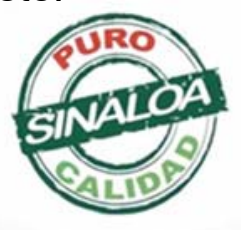

Mazatlán, Sinaloa 3-7 junio 2019

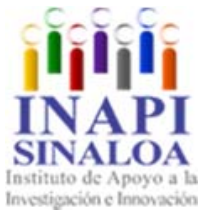

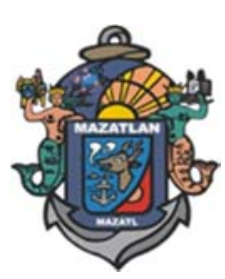

Tecnología y Biotecnología para el Tratamiento de Contaminantes y Biorremediación 

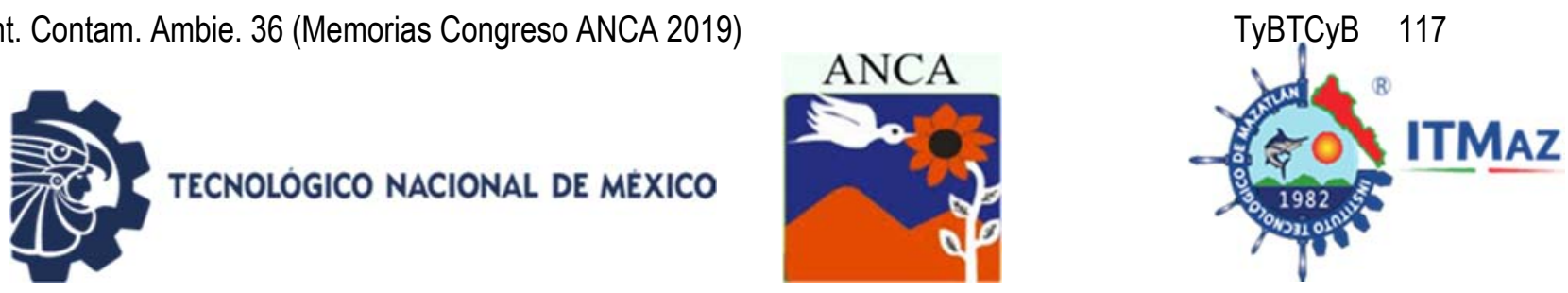

\title{
Remoción de metales pesados del agua mediante fibras de Agave angustifolia y bacterias como alternativa de biorremediación
}

\author{
Medina Acevedo $\mathrm{V}^{1 *}$, Mussali Galante $\mathrm{P}^{2}$, Castrejón Godínez $\mathrm{ML}^{2}$, \\ Flores Trujillo $\mathrm{K}^{2}$, Tovar Sanchez $\mathrm{E}^{3}$, Rodríguez Solís $\mathrm{A}^{2}$ \\ ${ }^{1}$ Escuela de Estudios Superiores del Jicarero. \\ Centro de Investigación en Biotecnología \\ ${ }^{2}$ Centro de Investigación en Biodiversidad y Conservación. \\ Universidad Autónoma del Estado de Morelos \\ *victoria.medina.acevedo@gmail.com
}

\begin{abstract}
RESUMEN
La contaminación del agua por metales pesados es un problema ambiental vigente, por lo que contar con alternativas novedosas para su eliminación es de gran importancia. La biosorción es considerada una tecnología limpia, económica y versátil, debido a que puede adaptarse a las necesidades y condiciones de los sitios contaminados, puede ser utilizada como una herramienta biotecnológica para la restauración de estos sitios. El objetivo de la presente investigación es evaluar la capacidad de remoción de metales pesados como plomo $(\mathrm{Pb})$ y cadmio (Cd) del agua, a través del uso de fibras de Agave angustifolia y un consorcio bacteriano. La estrategia metodológica consistió en preparar soluciones de los metales individuales $(100 \mathrm{mg} / \mathrm{L})$ y en mezcla, para evaluar su remoción mediante el empleo de las fibras de agave a las 24 horas, posteriormente, se realizaron cinéticas de crecimiento del consorcio bacteriano en presencia de las soluciones de $\mathrm{Pb}, \mathrm{Cd}$ y la mezcla, mediante muestreos a las 0,24 y 48 horas para determinar el porcentaje de biosorción de metales por las células bacterianas. Los resultados mostraron que las fibras de A. angustifolia son capaces de adsorber el $90 \%$ del $\mathrm{Pb}$, mientras que el consorcio bacteriano presentó mayor adsorción de $\mathrm{Pb}$ respecto al Cd. Conclusiones: La fibra de Agave angustifolia, y consorcio bacteriano, pueden ser utilizados como herramientas biotecnológicas para la remoción de metales pesados del agua, específicamente para $\mathrm{Pb}$ y Cd.
\end{abstract}

Palabras clave: Metales pesados, fibras Agave angustifolia, consorcio bacteriano, biorremediacion.

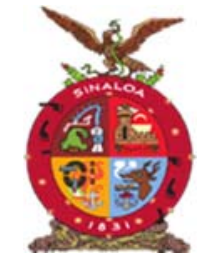

XVIII Congreso Internacional XXIV Congreso Nacional de Ciencias ambientales

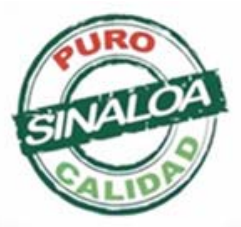

Mazatlán, Sinaloa 3-7 junio 2019
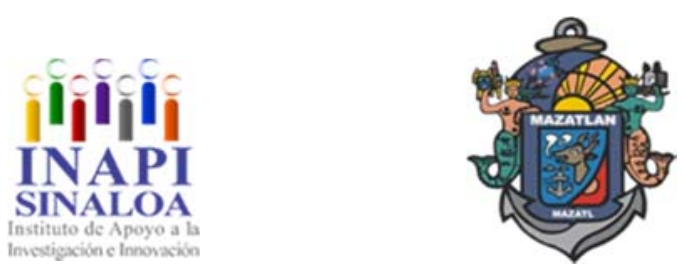

Tecnología y Biotecnología para el Tratamiento de Contaminantes y Biorremediación 

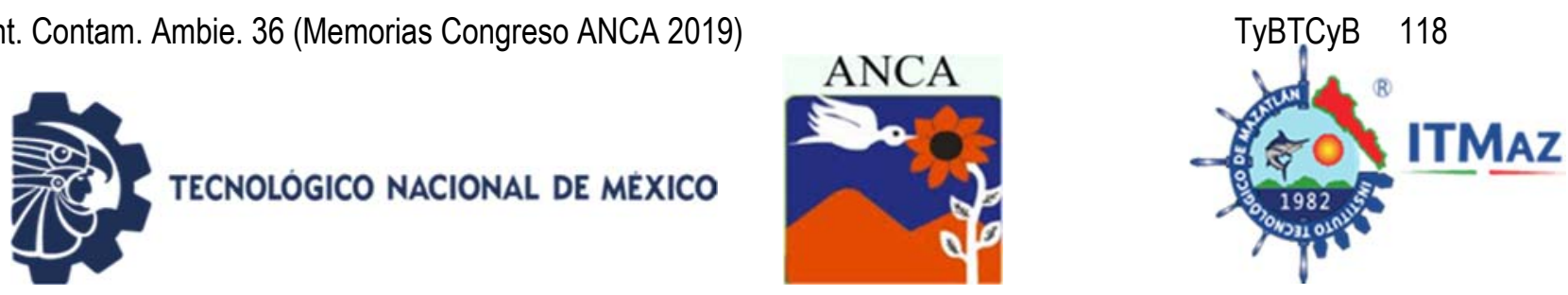

\title{
Removal of heavy metals from the water by means of the Agave angustifolia and bacteria as bioremediation alternative
}

\author{
Medina Acevedo $\mathrm{V}^{1^{*}}$, Mussali Galante $\mathrm{P}^{2}$, Castrejón Godínez $\mathrm{ML}^{2}$, \\ Flores Trujillo $\mathrm{K}^{2}$, Tovar Sanchez $\mathrm{E}^{3}$, Rodríguez Solís $\mathrm{A}^{2}$ \\ ${ }^{1}$ Escuela de Estudios Superiores del Jicarero. \\ Centro de Investigación en Biotecnología \\ ${ }^{2}$ Centro de Investigación en Biodiversidad y Conservación. \\ Universidad Autónoma del Estado de Morelos \\ *victoria.medina.acevedo@gmail.com
}

\begin{abstract}
Water pollution by heavy metals is a current environmental problem. Hence, having novel alternatives for its elimination is of great importance. The biosorption is considered a clean, economical and versatile technology, because it can be adapted to the needs and conditions of the contaminated sites, it can be used as a biotechnology tool for restoration of these sites. The aim of this research is to evaluate the ability to remove heavy metals such as lead $(\mathrm{Pb})$ and cadmium $(\mathrm{Cd})$ from water, through the use of Agave angustifolia fibers and a bacterial consortium. This work was carried out in the Environmental Research Laboratory of the Biotechnology Research Center. The methodological strategy consisted in preparing solutions for individual metals $(100 \mathrm{mg} / \mathrm{L})$ and in mixture, to evaluate their removalby using the Agave fibers at 0 and 24 hours. Subsequently, growth kinetics of the bacterial consortium were performed inpresence of the solutions of $\mathrm{Pb}, \mathrm{Cd}$ and the mixture, samples were taken at 0,24 and 48 hours to determine the metal biosorption percentage by the bacterial cells. The results showed that thos fefibers of $A$. Angustifolia were able to adsorb $90 \%$ of $\mathrm{Pb}$, while the bacterial consortium showed greater adsorption of $\mathrm{Pb}$ compared to $\mathrm{Cd}$. Conclusions The Agave angustifolia fiber, as well as the bacterial consortium, can be used as biotechnological tools for removal of heavy metals from water, specifically for $\mathrm{Pb}$ and $\mathrm{Cd}$.
\end{abstract}

Keywords: Heavy metals, Agave angustifolia fibers, bacterialconsortium, bioremediation.

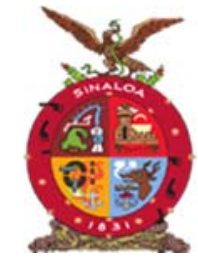

XVIII Congreso Internacional XXIV Congreso Nacional de Ciencias ambientales

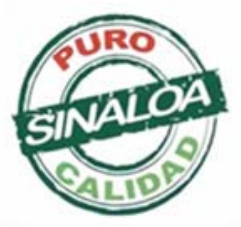

Mazatlán, Sinaloa 3-7 junio 2019
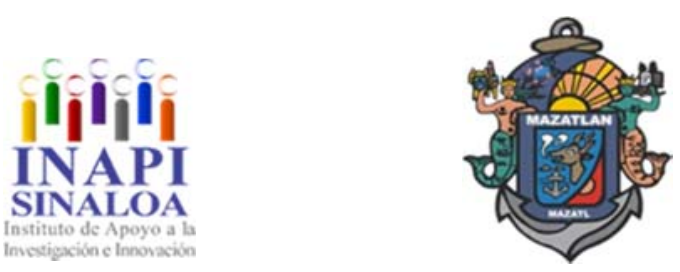

Tecnología y Biotecnología para el Tratamiento de Contaminantes y Biorremediación 

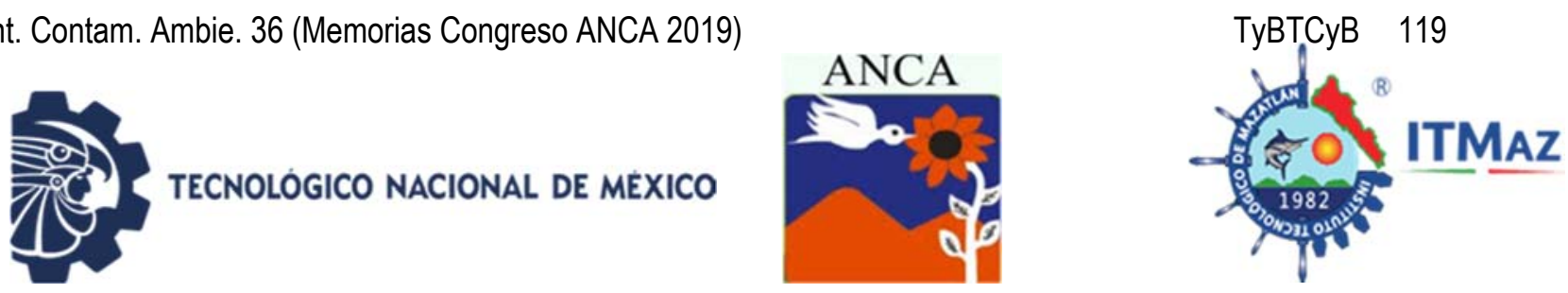

\title{
Empleo del maguey y ecotécnias en el control de erosión y recuperación de cubierta vegetal en una zona semiárida
}

\author{
Medina Bautista S*, García Amador E, López Vicente L \\ Facultad de Estudios Superiores Zaragoza.UNAM, \\ Batalla 5 de mayo S/N Esquina Fuerte de Loreto, Col. Ejército de Oriente, \\ Iztapalapa C.P. 09230, Ciudad de México \\ *ssmedina19@gmail.com
}

\section{RESUMEN}

La pérdida de suelo por erosión es un gran problema, propicia la pérdida de nutrientes disponibles para la vegetación. Las zonas semiáridas por su baja cobertura vegetal son susceptibles a la erosión por lo que se requiere aplicar técnicas de recuperación de vegetación y de suelo. El Parque Ecológico Cubitos al localizarse en una zona semiárida, no está exento de esta problemática; por lo que el objetivo del trabajo fue la aplicación y evaluación de técnicas de conservación del suelo para controlar la erosión y ayudar a la recuperación vegetal utilizando Agave salmiana. En una zona deteriorada se colocaron barreras de rocas, zanjas y acolchados de yute durante once meses (eneronoviembre 2018), mensualmente se midió la altura de los agaves, profundidad de las zanjas y las barreras; al término del proyecto las zanjas acumularon $10.3 \mathrm{~cm}$ de clastos, las barreras $0.6 \mathrm{~cm}$ y durante la época de lluvias, se observó la presencia de plantas acompañantes. Los individuos con acolchado presentaron un crecimiento de $5.4 \mathrm{~cm}$ y los testigos $2.6 \mathrm{~cm}$, las pencas aumentaron de 1 a 3 para ambos casos, en los acolchados se observó el crecimiento de herbáceas y la supervivencia fue del $100 \%$. En conclusión, el empleo de barreras y zanjas permitió la captación de los sedimentos que son arrastrados ladera abajo logrando su fijación para crear pequeñas terrazas de vegetación en contraste con los acolchados, cuya función fue la retención de humedad y protección de la planta, las raíces y las semillas.

Palabras clave: Barrera de rocas, acolchados, zanjas, recuperación de la vegetación.

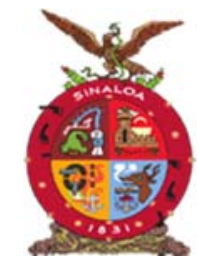

XVIII Congreso Internacional XXIV Congreso Nacional de Ciencias ambientales

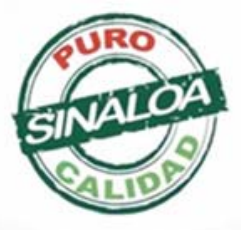

Mazatlán, Sinaloa 3-7 junio 2019
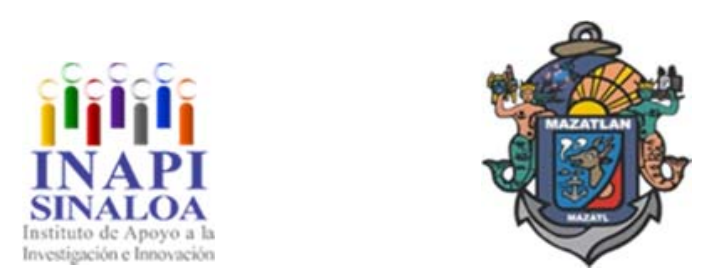

Tecnología y Biotecnología para el Tratamiento de Contaminantes y Biorremediación 

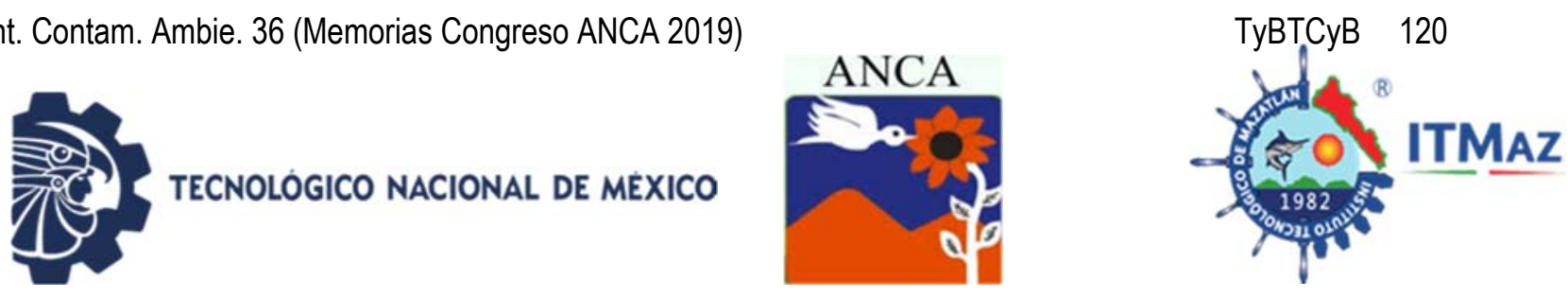

\title{
Use of maguey and eco-technologies in erosion control and recovery of green roof in a semi-arid zone
}

\author{
Medina Bautista S*, García Amador E, López Vicente L \\ Facultad de Estudios Superiores Zaragoza.UNAM, \\ Batalla 5 de mayo S/N Esquina Fuerte de Loreto, Col. Ejército de Oriente, \\ Iztapalapa C.P. 09230, Ciudad de México \\ *ssmedina19@gmail.com
}

\begin{abstract}
The loss of soil due to erosion is a major problem, since it leads to the loss of nutrients for vegetation. Semi-arid areas by its low vegetation cover are susceptible to erosion by what is required to apply techniques of recovery of vegetation and soil. The cubes ecological park to be located in a semi-arid area, is not exempt from this problem; so the objective of the study was the implementation and evaluation of conservation techniques for control erosion and help the recovery plant using Agave salmiana. Rocks, ditches and padding of jute for eleven months (January-November 2018), barriers were placed in a damaged area monthly measured the height of the agaves, deep ditches and barriers; at the end of the project the ditches built up $10.3 \mathrm{~cm}$ clasts, barriers $0.6 \mathrm{~cm}$ and during the rainy season, It was observed the presence of companions. Individuals padded showed a growth of $5.4 \mathrm{~cm}$ and witnesses $2.6 \mathrm{~cm}$, pencas increased from 1 to 3 in both cases, the growth of herbaceous plants was observed in the pads and the survival was $100 \%$. In conclusion, the use of barriers and ditches allowed the uptake of sediments that you are dragged down achieving its fixation to create small terraces of vegetation in contrast to the padding, whose function was the retention of moisture and protection from the plant, roots and seeds.
\end{abstract}

Keywords: Barrier of rocks, mulch, ditches, recovery of the vegetation.

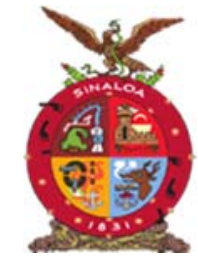

XVIII Congreso Internacional XXIV Congreso Nacional de Ciencias ambientales

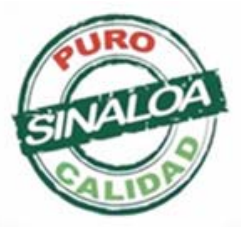

Mazatlán, Sinaloa 3-7 junio 2019
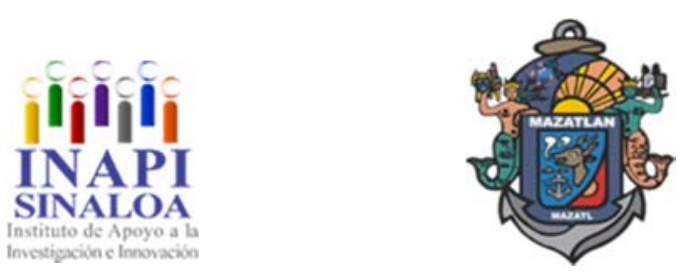

Tecnología y Biotecnología para el Tratamiento de Contaminantes y Biorremediación 

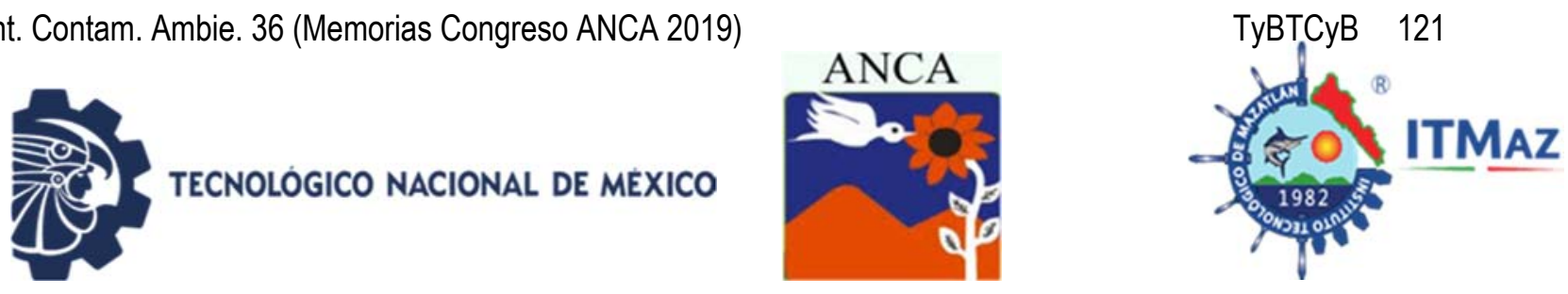

\title{
Descomposición electroquímica del peroximonosulfato para la degradación del colorante Fucsia B
}

\author{
Medina Orendain $\mathrm{D}^{1^{*}}$, Partida Joya $\mathrm{D}^{1}$, Rodríguez Narváez $\mathrm{OM}^{2}$ \\ ${ }^{1}$ Ingeniería Bioquímica. Instituto Tecnológico de Tepic, Nayarit, México \\ ${ }^{2}$ Doctorado en Química Universidad de Guanajuato, México \\ *daalmedinaor@ittepic.edu.mx
}

\begin{abstract}
RESUMEN
En este trabajo, se estudió la degradación del colorante Fucsia B mediante la descomposición electroquímica del peroxymonosulfato (PMS). Para esto, se utilizaron diferentes concentraciones de PMS ([PMS] $=15,30$ y $45 \mathrm{mM}$ ) y densidades de corriente $\left(12.5,25\right.$ y $\left.50 \mathrm{mAcm}^{-2}\right)$. Los experimentos se llevaron a cabo en un reactor electroquímico de plástico transparente con una capacidad de $1.5 \mathrm{~L}$, que permite cuantificar el fango, la espuma producidos y, la formación de interfaces. Se determinó que las mejores condiciones experimentales fueron a $12,5 \mathrm{mAcm}^{-2}$ y $[\mathrm{PMS}]=30 \mathrm{mM}$, porque se eliminó el $80 \%$ de tinte en $20 \mathrm{~min}$. Comparando con la electrocoagulación convencional, se observó una reducción del $65 \%$ de los lodos. A partir de los datos experimentales, se realizó un diseño de sistema tridimensional (3D), que mostrará el modelo de proceso de ampliación.
\end{abstract}

Palabras clave: PEAOs, electrocoagulación, PMS, fucsia B, densidad de corriente.

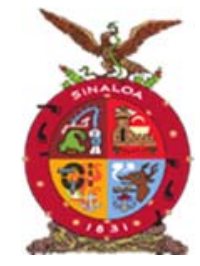

XVIII Congreso Internacional XXIV Congreso Nacional de Ciencias ambientales

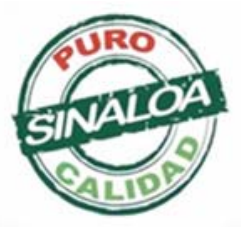

Mazatlán, Sinaloa 3-7 junio 2019
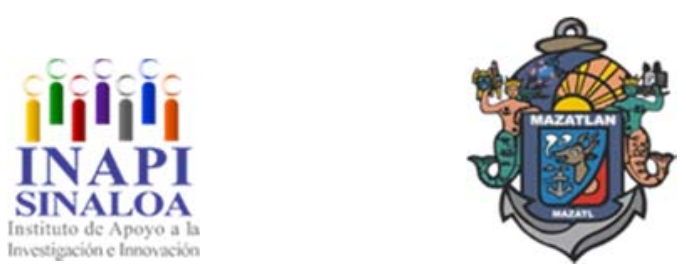

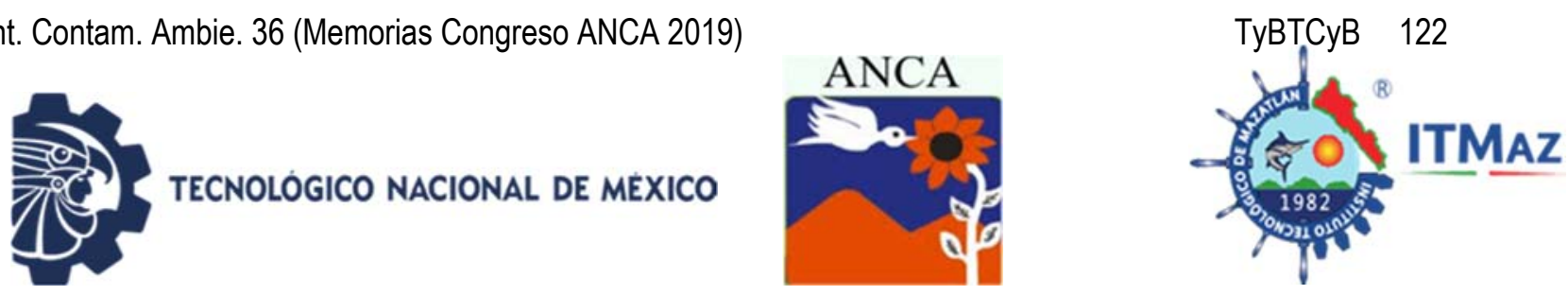

\title{
Electrochemical decomposition of peroxymonosulfate for the degradation of Fuchsia dye B
}

\author{
Medina Orendain $\mathrm{D}^{1^{*}}$, Partida Joya $\mathrm{D}^{1}$, Rodríguez Narváez $\mathrm{OM}^{2}$ \\ ${ }^{1}$ Ingeniería Bioquímica. Instituto Tecnológico de Tepic, Nayarit, México \\ ${ }^{2}$ Doctorado en Química Universidad de Guanajuato, México \\ *daalmedinaor@ittepic.edu.mx
}

\begin{abstract}
In this work, Fucsia B dye degradation was studied by peroxymonosulfate (PMS) electrochemical decomposition. For this, different PMS concentrations ([PMS] $=$ $15,30$ and $45 \mathrm{mM})$ and current densities $\left(12.5,25\right.$ and $\left.50 \mathrm{mAcm}^{-2}\right)$ were used. The experiments were carried out in a transparent plastic electrochemical reactor with a capacity of $1.5 \mathrm{~L}$, which allowed quantified the sludge and foam produced, and interfaces formation. It was determined that the best experimental conditions were at $12.5 \mathrm{mAcm}^{-2}$ and [PMS] $=30 \mathrm{mM}$, because $80 \%$ dye was removed in 20 min. Comparing with conventional electrocoagulation, a $65 \%$ reduction of the sludge was observed. From the experimental data, a three-dimensional (3D) system design was made, which it will show a scale-up process model.
\end{abstract}

Keywords: PEAOs, electrocoagulation, PMS, fuchsia B, current density

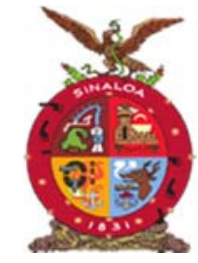

XVIII Congreso Internacional XXIV Congreso Nacional de Ciencias ambientales

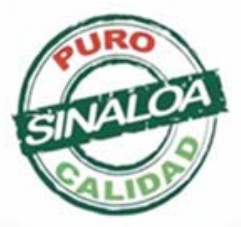

Mazatlán, Sinaloa 3-7 junio 2019
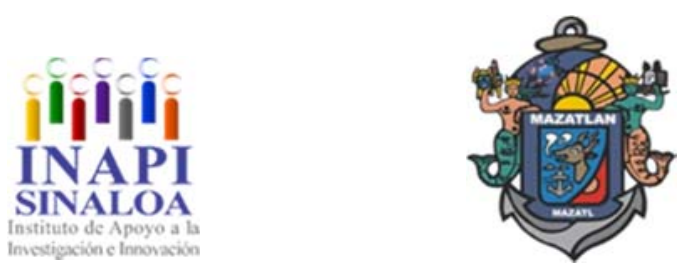

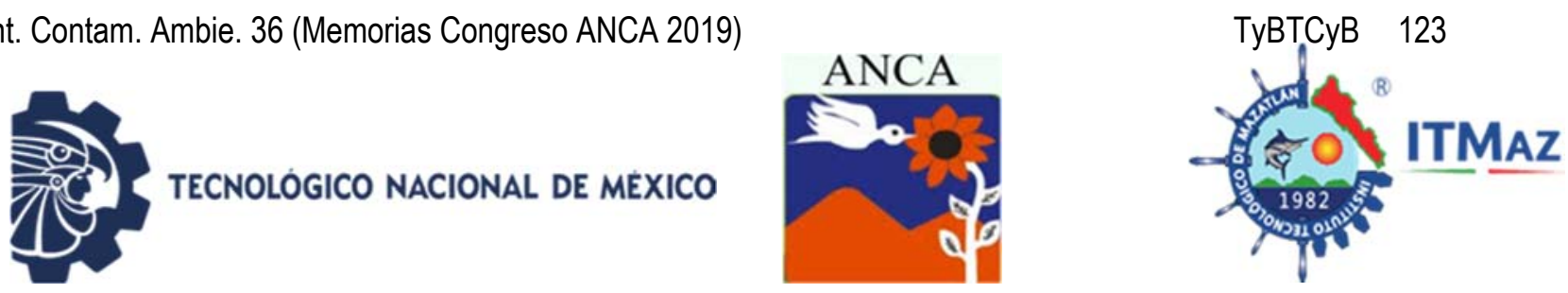

\title{
Remoción de color y DQO de vinaza de agave mediante ensayos de coagulación empleando $\mathrm{Al}_{2}\left(\mathrm{SO}_{4}\right)_{3}$ y $\mathrm{FeCl}_{3}$
}

\author{
Mejia Rivas $\mathrm{CA}^{1 *}$, De la Peña Arellano $\mathrm{LA}^{1}$, Rodríguez Rosales MDJ' \\ Martínez Roldán $A^{1}$, Díaz Ordáz $L^{2}$ \\ ${ }^{1}$ Maestría en Sistemas Ambientales. \\ Departamento de Ing. Química y Bioquímica. UPIDET. \\ Instituto Tecnológico de Durango. Tecnológico Nacional de México. \\ Blvd. Felipe Pescador 1830 Ote. CP. 34080 Durango, Dgo., México \\ 2Universidad Politécnica de Durango. \\ Carretera Durango-México Km.9.5 CP. 34300 Durango, Dgo., México \\ *mejiarivasandrea@gmail.com
}

\section{RESUMEN}

En el estado de Durango existen 19 municipios con vocación mezcalera, derivado de la elaboración de mezcal y la abundancia del recurso Agave durangensis. En este proceso de producción, durante la etapa de fermentación se generan por cada litro de mezcal fabricado $7 \mathrm{~L}$ de vinaza como residuo líquido, el cual es vertido sobre cuerpos de agua o suelo directamente. Dado el potencial contaminante del vertido de este efluente en el ambiente, el objetivo de esta investigación fue proponer alternativas de tratamiento. Se desarrollaron pruebas de coagulación/floculación empleando Sulfato de Aluminio y Cloruro Férrico como tratamiento primario. Se utilizó un equipo para prueba de jarras Marca PHIPPS \& BIRD. Mod. PB-700 ${ }^{\mathrm{TM}}$ provisto de 6 jarras de acrílico de $1 \mathrm{~L}$ con control de agitación independiente. El desarrollo experimental se realizó con base a un diseño factorial $2^{\mathrm{K}}$. Se dosificaron los coagulantes a dosis de 100,1000, 10000 ppm a condiciones de pH de 5,8 y 11 y tiempos establecidos de agitación rápida y lenta de 10 min y un tiempo de sedimentación de 20 min. Al finalizar estos tiempos, se realizaron las mediciones de color y DQO. Los resultados obtenidos usando el $\mathrm{Al}_{2}\left(\mathrm{SO}_{4}\right)_{3}$ mostraron mayor remoción de color y DQO en la vinaza al emplear 10,000 ppm alcanzando porcentajes del $63 \%$ y $60 \%$ respectivamente, a condiciones de $\mathrm{pH}$ de 8 . Para el caso del $\mathrm{FeCl}_{3}$ el mayor porcentaje de remoción de color y DQO fue cercano al $90 \%$ y $28 \%$ respectivamente, a condiciones de $\mathrm{pH}$ 11 y dosificaciones de 10,000 ppm del coagulante.

Palabras clave: Contaminación, coagulación/floculación, aguas residuales, vinazas.

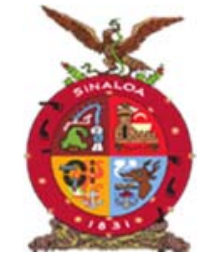

XVIII Congreso Internacional XXIV Congreso Nacional de Ciencias ambientales

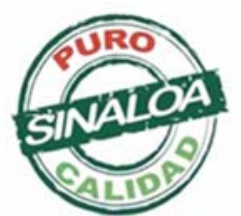

Mazatlán, Sinaloa 3-7 junio 2019
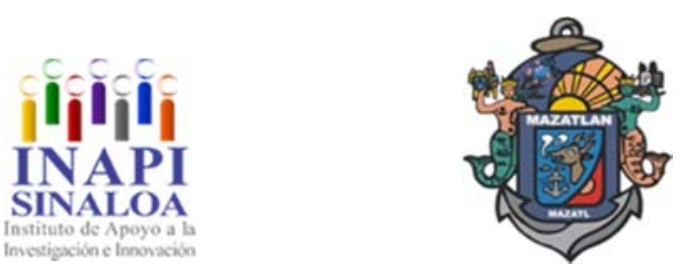

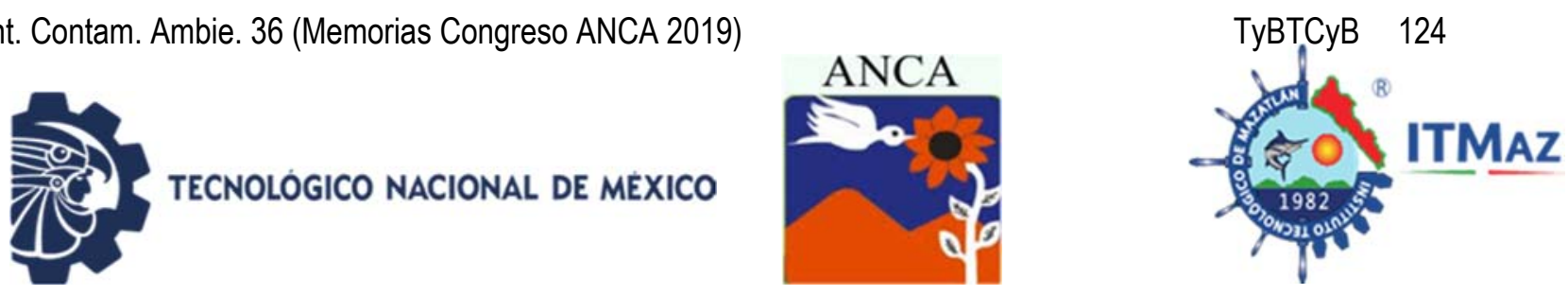

\title{
Color removal and cod and $\mathrm{DQO}$ in agave vinasse by coagulation tests using $\mathrm{Al}_{2}\left(\mathrm{SO}_{4}\right)_{3}$ and $\mathrm{FeCl}_{3}$
}

\author{
Mejia Rivas $\mathrm{CA}^{1 *}$, De la Peña Arellano $\mathrm{LA}^{1}$, Rodríguez Rosales MDJ ${ }^{1}$, \\ Martínez Roldán $A^{1}$, Díaz Ordáz $L^{2}$ \\ ${ }^{1}$ Maestría en Sistemas Ambientales. \\ Departamento de Ing. Química y Bioquímica. UPIDET. \\ Instituto Tecnológico de Durango. Tecnológico Nacional de México. \\ Blvd. Felipe Pescador 1830 Ote. CP. 34080 Durango, Dgo., México \\ 2Universidad Politécnica de Durango. \\ Carretera Durango-México Km.9.5 CP. 34300 Durango, Dgo., México \\ *mejiarivasandrea@gmail.com
}

\begin{abstract}
In the state of Durango there are 19 municipalities with mezcalera vocation, derived from the elaboration of mezcal and the abundance of the Agave durangensis resource. In this production process, during the fermentation step are generated per liter of manufactured mezcal $7 \mathrm{~L}$ vinasse as a liquid residue, which is poured over water bodies or soil directly. Given the polluting potential of the discharge of this effluent into the environment, the objective of this research was to propose treatment alternatives. Coagulation/flocculation tests were developed using Aluminum Sulfate and Ferric Chloride as the primary treatment. PHIPPS \& BIRD brand jar test equipment was used. Mod. PB-700TM equipped with 6 acrylic jars with a capacity of $1 \mathrm{~L}$ with independent agitation control. El desarrollo experimental se realizó con base a un diseño factorial $2^{\mathrm{K}}$. The coagulants were dosed at doses of $100,1000,10000 \mathrm{ppm}$ at pH conditions of 5 , 8 and 11 and established times of rapid and slow agitation of 10 mins and a settling time of 20 mins. At the end of these times, color and COD measurements were taken. The results obtained using $\mathrm{Al}_{2}\left(\mathrm{SO}_{4}\right)$ y showed greater color removal and COD in the vinasse when using $10,000 \mathrm{ppm}$, reaching percentages of $63 \%$ and $60 \%$ respectively, at $\mathrm{pH}$ conditions of 8 . In the case of $\mathrm{FeCl}_{3}$, the highest percentage of color removal and COD was close to $90 \%$ and $28 \%$, respectively, at $\mathrm{pH} 11$ conditions and 10,000 ppm coagulant dosages.
\end{abstract}

Keywords: Pollution, coagulation/flocculation, residual waters, vinasses.

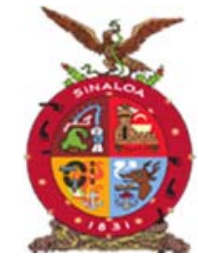

XVIII Congreso Internacional XXIV Congreso Nacional de Ciencias ambientales

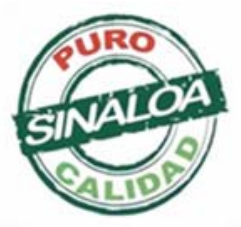

Mazatlán, Sinaloa 3-7 junio 2019
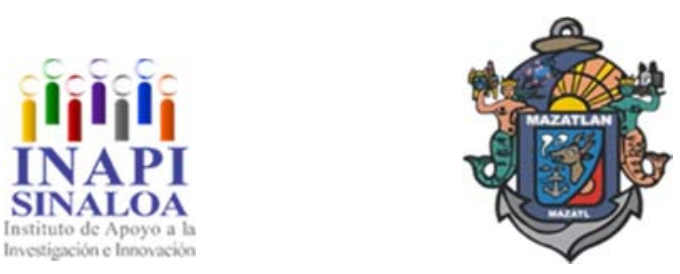

Tecnología y Biotecnología para el Tratamiento de Contaminantes y Biorremediación 

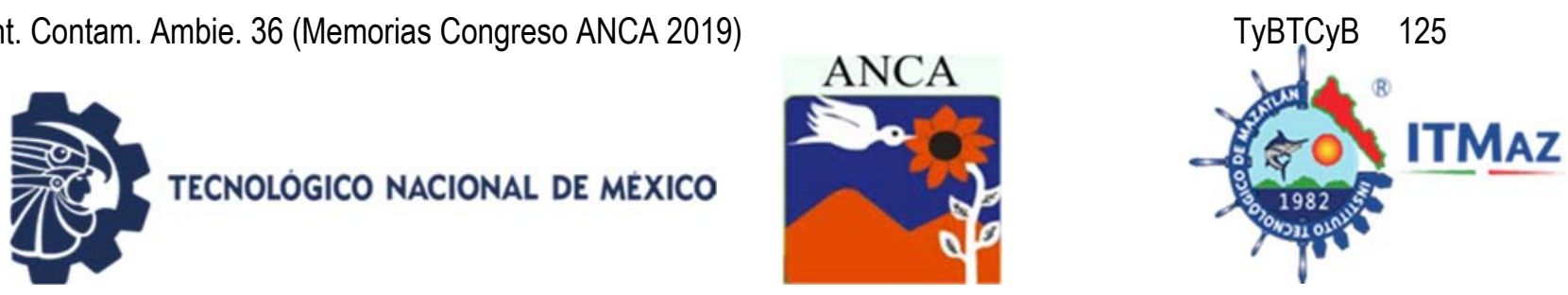

Fibras de zirconia en la remoción de rojo allura

Meléndez Estrada IA ${ }^{1 *}$, Ávila Martínez $\mathrm{AK}^{1}$, Roque Ruiz $\mathrm{JH}^{1}$, Torres Pérez $\mathrm{J}^{1}$, Medellín Castillo NA², Reyes López SY ${ }^{1 *}$

\author{
${ }^{1}$ Instituto de Ciencias Biomédicas.Universidad Autónoma de Ciudad Juárez. \\ Envolvente del PRONAF y Estocolmo S/N, Ciudad Juárez, Chih., México \\ ${ }^{2}$ Centro de Investigación y Estudios de Posgrado. Facultad de Ingeniería. \\ Universidad Autónoma de San Luis Potosí, \\ Av. Dr. Manuel Nava No. 8, San Luis Potosí SLP 78210, México \\ *al133887@alumnos.uacj.mx
}

\begin{abstract}
RESUMEN
La obtención de la fabricación de fibras de zirconia por el método de electrohilado ofrece una alternativa para la producción de materiales cerámicos que pueden ser aprovechados en múltiples aplicaciones. En la presente investigación se obtuvieron fibras de zirconia, mediante el método de sol-gel con el precursor butóxido de zirconia y el polímero PVP. Las soluciones precursoras se incorporaron a la técnica de electrohilado, posteriormente a las fibras en verde obtenidas se les aplicó un tratamiento térmico y fueron caracterizadas por las técnicas de M.O, SEM, IR, RAMAN, DRX. Las fibras resultaron continuas lisas con una distribución aleatoria y pequeñas cuentas. Las fases encontradas en las fibras a $1200^{\circ} \mathrm{C}$ corresponden a la monocíclica y tetragonal. Finalmente se determinó un máximo de adsorción del colorante rojo allura en el material obtenido de $0.8 \mathrm{mg} / \mathrm{g}$ mediante cinéticas e isotermas de sorción, las cuales se ajustaron en su mayoría al modelo de pseudo-segundo orden y Langmuir.
\end{abstract}

Palabras clave: Nanofibras, compositos, adsorción, rojo allura, zirconia, electrohilado.

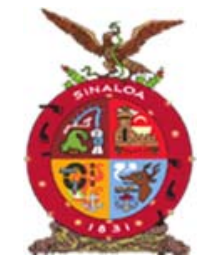

XVIII Congreso Internacional XXIV Congreso Nacional de Ciencias ambientales

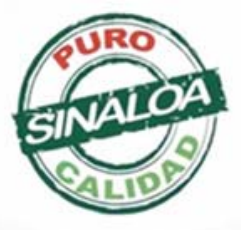

Mazatlán, Sinaloa 3-7 junio 2019
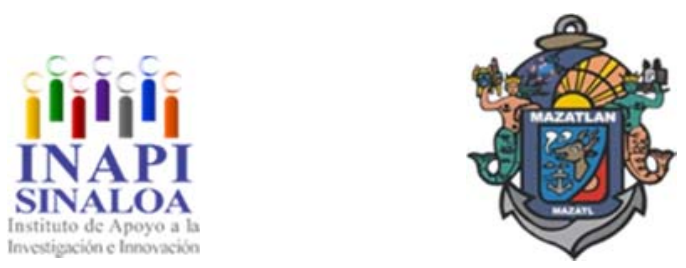

Tecnología y Biotecnología para el Tratamiento de Contaminantes y Biorremediación 

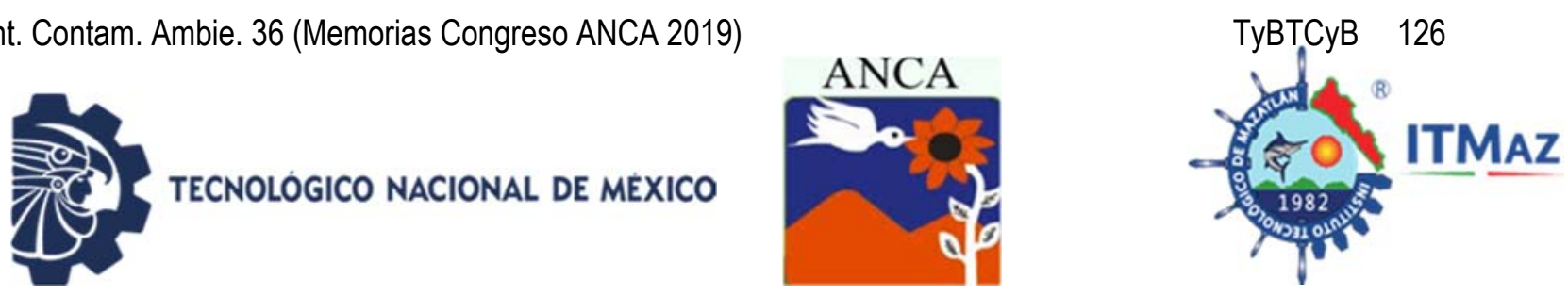

\title{
Zirconia fibers in the removal of allura red
}

\author{
Meléndez Estrada $\mathrm{IA}^{1^{*}}$, Ávila Martínez $\mathrm{AK}^{1}$, Roque Ruiz $\mathrm{JH}^{1}$, Torres Pérez $\mathrm{J}^{1}$, \\ Medellín Castillo NA², Reyes López $\mathrm{SY}^{1 *}$ \\ ${ }^{1}$ Instituto de Ciencias Biomédicas.Universidad Autónoma de Ciudad Juárez. \\ Envolvente del PRONAF y Estocolmo S/N, Ciudad Juárez, Chih., México \\ ${ }^{2}$ Centro de Investigación y Estudios de Posgrado. Facultad de Ingeniería. \\ Universidad Autónoma de San Luis Potosí, \\ Av. Dr. Manuel Nava No. 8, San Luis Potosí SLP 78210, México \\ *al133887@alumnos.uacj.mx
}

\begin{abstract}
The manufacture of zirconia fibers by the electrospinning method offers an alternative for production of ceramic materials that can be used in multiple applications. In the present investigation, zirconia fibers were obtained by the solgel method from zirconia butoxide precursor and PVP. The precursor solutions were incorporated into the electrospinning technique, the green fibers receive a heat treatment and characterized by the techniques of MO, SEM, IR, RAMAN and DRX. The fibers present a continuous form, random distribution and small beads, the phases characterized of zirconia fibers was a monoclinic and tetragonal. Finally, a maximum adsorption of the red dye in the obtained material was 0.8 $\mathrm{mg} / \mathrm{g}$, determined by kinetics and sorption isotherms, adjusted to the pseudosecond order model and Langmuir.
\end{abstract}

Keywords: Nanofibers, composites, adsorption, red dye, zirconiaelectrospinning.

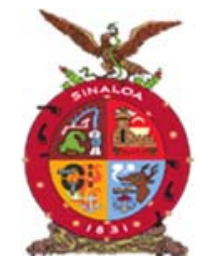

XVIII Congreso Internacional XXIV Congreso Nacional de Ciencias ambientales

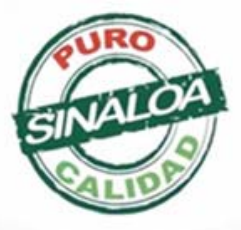

Mazatlán, Sinaloa 3-7 junio 2019
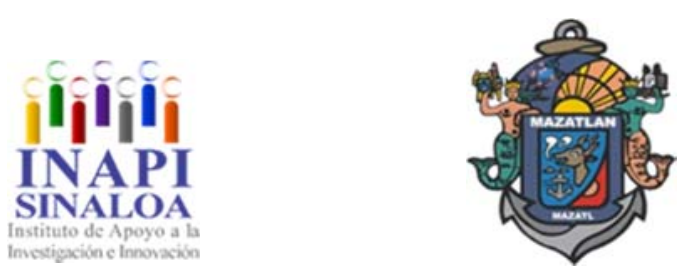

Tecnología y Biotecnología para el Tratamiento de Contaminantes y Biorremediación 

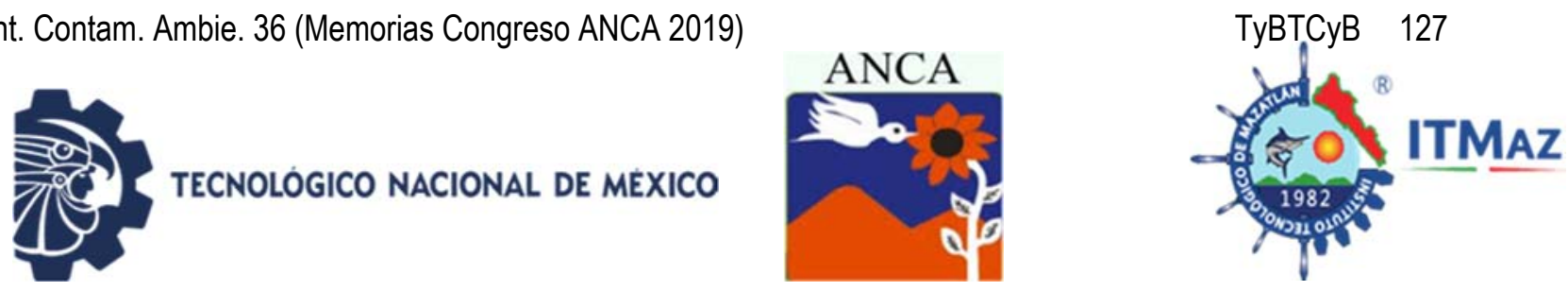

Preparación y aplicación de la hoja de perejil (Petroselinum crispum) activada químicamente para eliminar indigo carmín de soluciones acuosas

\author{
Méndez Andoney M, Jiménez Cedillo MJ, Marín Allende MJ, \\ Jaramillo Sierra B, Hernández Arias AN
}

División de Ingeniería Ambiental.

Tecnológico de Estudios Superiores de Tianguistenco.

Carretera Tenango, La Marquesa Km 22, Santiago Tianguistenco, Edo. Mex

*jeniffer.jimenezc@test.edu.mx

\title{
RESUMEN
}

El índigo carmín (IC) es un colorante que pertenece al grupo de los derivados del indol, posee excelente durabilidad del color en el tiempo y gran estabilidad a los rayos UV, se usa en la industria textil, principalmente en la elaboración de pantalones de mezclilla o denim, es considerado como una sustancia recalcitrante altamente contaminante. En zonas del país donde se ubican empresas de giro textil, como es el caso del municipio de Santiago Tianquistenco, Estado de México, en donde se ha observado la descarga de agua con colorantes, entre ellos el IC, originando contaminación en las comunidades cercanas. Existen diferentes métodos para la eliminación de colorantes, siendo el proceso de sorción uno de los más eficientes. El objetivo del presente trabajo fue evaluar el proceso de sorción en solución acuosa de IC por Petroselinum crispum (perejil) modificado. El trabajo se realizó en el Laboratorio de Instrumental del Tecnológico de Estudios Superiores de Tianquistenco, Estado de México de septiembre 2018 a febrero-2019. El material se recolecto, acondiciono y se le realizaron tres modificaciones químicas; se les denominó $\mathrm{PCNaOH}, \mathrm{PCHNO}_{3}$ y $\mathrm{PCHCl}$. Se evaluó la influencia del $\mathrm{pH}$, el tiempo de contacto entre las fases y sólo con el mejor material se evaluó el efecto de la concentración. Se aplicaron modelos cinéticos y de isotermas. El mejor material fue $\mathrm{PCHCl}$, ya que alcanzó un tiempo de equilibrio por $48 \mathrm{~h}$, presentando una remoción de $86 \%$ del colorante, por lo tanto, es un material eficiente en la eliminación de este contaminante.

Palabras clave: Biosorbente, colorantes de tina, índigo carmín, cinética sorción e isoterma de sorción.

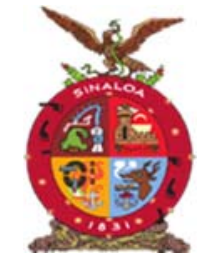

XVIII Congreso Internacional XXIV Congreso Nacional de Ciencias ambientales

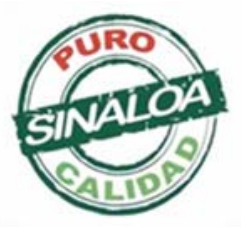

Mazatlán, Sinaloa 3-7 junio 2019
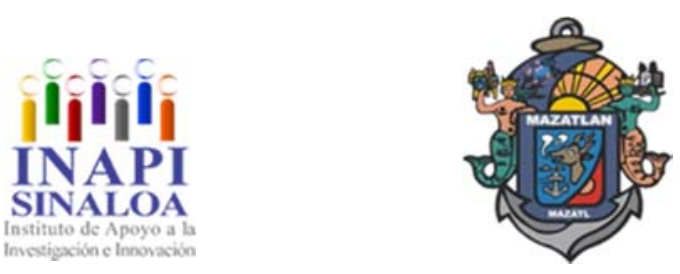

Tecnología y Biotecnología para el Tratamiento de Contaminantes y Biorremediación 


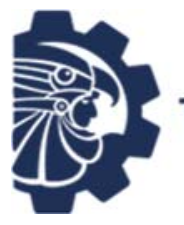

TECNOLOGICO NACIONAL DE MEXICO
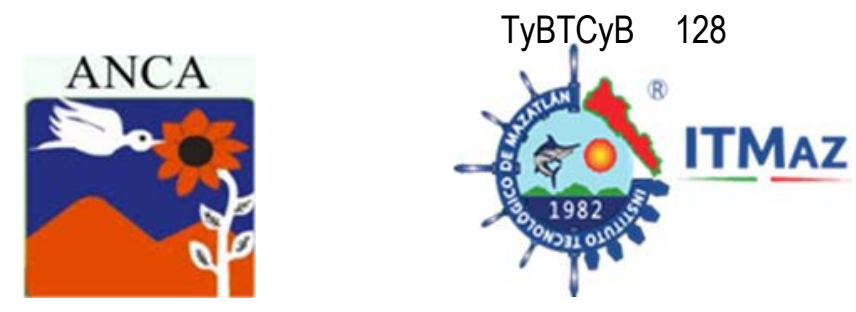

\title{
Preparation and application of parsley leaf (Petroselinum crispum) chemically activated to remove indigo carmine from aqueous solutions
}

\author{
Méndez Andoney M, Jiménez Cedillo MJ, Marín Allende MJ, \\ Jaramillo Sierra B, Hernández Arias AN
}

División de Ingeniería Ambiental.

Tecnológico de Estudios Superiores de Tianguistenco.

Carretera Tenango, La Marquesa Km 22, Santiago Tianguistenco, Edo. Mex

*jeniffer.jimenezc@test.edu.mx

\begin{abstract}
Indigo carmine (IC) is a dye that belongs to the group of indole derivatives, has excellent color durability over time and great stability to UV rays, is used in the textile industry, mainly in the manufacture of denim pants or denim, is considered a highly polluting recalcitrant substance. In areas of the country where textile companies are located, such as the municipality of Santiago Tianquistenco, State of Mexico, where the discharge of water with dyes has been observed, including the IC, causing pollution in nearby communities. There are different methods for the removal of dyes, the sorption process being one of the most efficient. The objective of this work was to evaluate the sorption process in aqueous solution of IC by modified Petroselinum crispum (parsley). The work was carried out in the Instrumental Laboratory of the Technological of Higher Studies of Tianquistenco, State of Mexico from September 2018 to February-2019. The material was collected, conditioned and three chemical modifications were made; they were called $\mathrm{PCNaOH}, \mathrm{PCHNO}_{3}$ and $\mathrm{PCHCl}$. The influence of the $\mathrm{pH}$, the contact time between the phases was evaluated and only with the best material the effect of the concentration was evaluated. Kinetic and isothermal models were applied. The best material was $\mathrm{PCHCl}$, since it reached an equilibrium time for $48 \mathrm{~h}$, presenting a removal of $86 \%$ of the dye, therefore, it is an efficient material in the elimination of this contaminant.
\end{abstract}

Keywords: Biosorbent, tub dyes, carmine indigo, kinetic sorption and isothermal sorption.

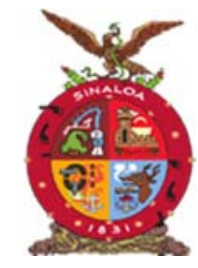

XVIII Congreso Internacional XXIV Congreso Nacional de Ciencias ambientales

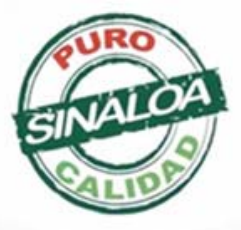

Mazatlán, Sinaloa 3-7 junio 2019
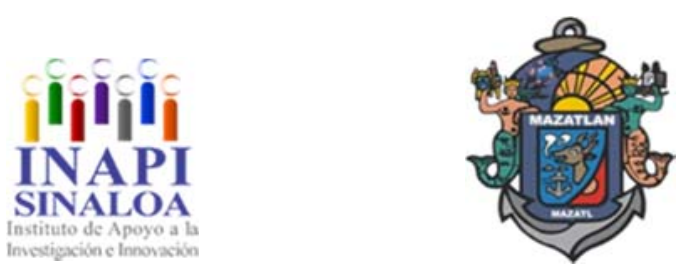

Tecnología y Biotecnología para el Tratamiento de Contaminantes y Biorremediación 

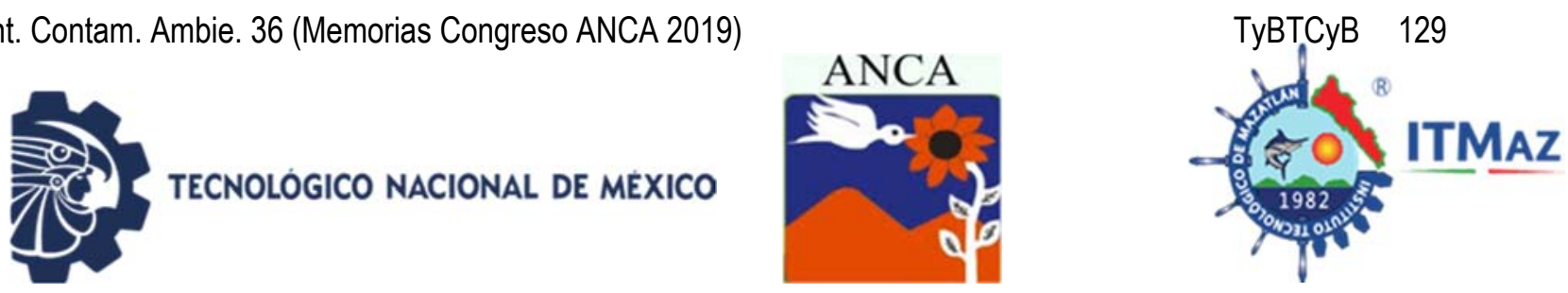

\title{
Remoción de metales pesados de un efluente minero por Zeolita y Polianilina
}

\author{
Mendieta Rodríguez $\mathrm{L}^{1}$, Inchaurregui Mendez $\mathrm{H}^{1}$, Medina Llamas $\mathrm{J}^{2}$, \\ González Rodríguez L ${ }^{1^{*}}$
}

${ }^{1}$ Unidad Profesional Interdisciplinaria de Ingeniería Campus Zacatecas, IPN ${ }^{2}$ Centro de Estudios Científicos y Tecnológicos No. 18, IPN

Blvd. del Bote S/N Cerro del Gato Ejido La Escondida, Col. Ciudad

Administrativa, 98160, Zacatecas, Zac, México

*Imgr49@gmail.com

\begin{abstract}
RESUMEN
La minería es una de las principales actividades económicas del país que se encuentra en constante desarrollo. Esta actividad antropogénica es una de las principales fuentes de contaminación de suelo y agua. Específicamente, los efluentes mineros son responsables de la contaminación del agua por la presencia de metales pesados, los cuales se convierten en un problema ambiental cada vez más alarmante debido a su alta toxicidad y su tendencia a acumularse en los ecosistemas. En este trabajo se propone la remoción de cobre $\left(\mathrm{Cu}^{2+}\right)$ de un efluente minero de Zacatecas ensayado en marzo del presente año) mediante adsorción con zeolita natural y un material compuesto de poliuretanopolianilina. Se realizaron experimentos de adsorción en modo lote con cada material. La concentración de $\mathrm{Cu}^{2+}$ en el efluente antes y después del proceso de adsorción fue determinada por espectroscopia de emisión óptica mediante plasma inductivamente acoplado (ICP-OES). Se estudió la capacidad de adsorción de ambos materiales como función del pH del efluente (5.0, 7.0 y 9.2). De estos experimentos se obtuvo que ambos materiales presentan mayor eficiencia a $\mathrm{pH} 7.0$, seguido de un $\mathrm{pH}$ 5.0. El material que presenta un mayor porcentaje de remoción de $\mathrm{Cu}^{2+}$ es la zeolita natural con un $30 \%$ y una capacidad de adsorción de $17.7 \mathrm{mg} / \mathrm{g}$ a un $\mathrm{pH}$ 7.0. Además de remover el $\mathrm{Cu}^{2+}$ del efluente, los materiales disminuyen también el contenido de $\mathrm{Ca}^{2+}$ presente en el medio, reduciendo su concentración hasta en un $33.3 \%$ (49.8 mg/g). Se concluye que la concentración de $\mathrm{Cu}^{2+}$ del efluente minero se reduce por adsorción con estos materiales que, al ser de bajo costo y fácil manejo, pueden ser aplicados como técnica de remediación en dicho efluente.
\end{abstract}

Palabras clave: Adsorción, cobre, contaminación de agua.

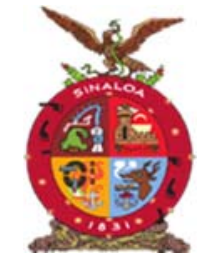

XVIII Congreso Internacional XXIV Congreso Nacional de Ciencias ambientales

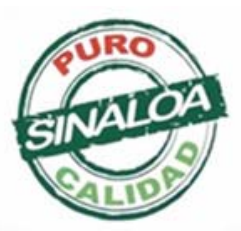

Mazatlán, Sinaloa 3-7 junio 2019
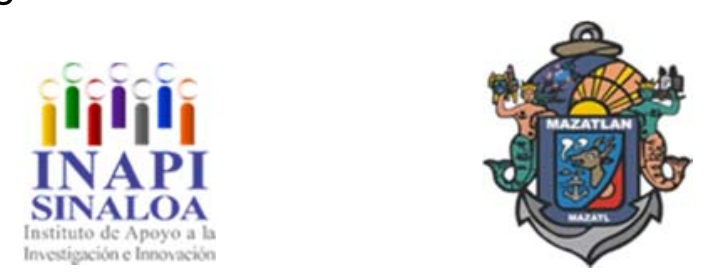

Tecnología y Biotecnología para el Tratamiento de Contaminantes y Biorremediación 

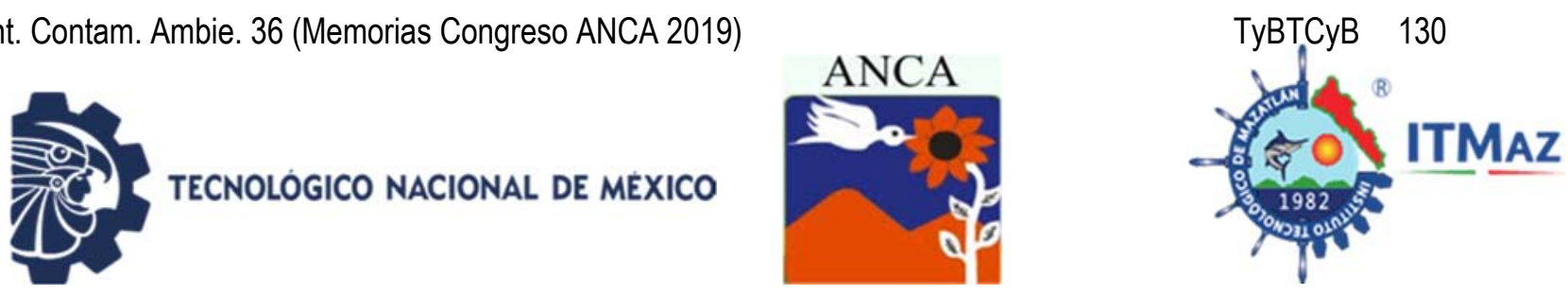

\title{
Removal of heavy metal from a mining effluent by Zeolite and Polyaniline
}

\author{
Mendieta Rodríguez $\mathrm{L}^{1}$, Inchaurregui Mendez $\mathrm{H}^{1}$, Medina Llamas $\mathrm{J}^{2}$, \\ González Rodríguez $\mathrm{L}^{1^{*}}$ \\ ${ }^{1}$ Unidad Profesional Interdisciplinaria de Ingeniería Campus Zacatecas, IPN \\ ${ }^{2}$ Centro de Estudios Científicos y Tecnológicos No. 18, IPN \\ Blvd. del Bote S/N Cerro del Gato Ejido La Escondida, Col. Ciudad \\ Administrativa, 98160, Zacatecas, Zac, México \\ *Imgr49@gmail.com
}

\begin{abstract}
Mining is one of the main economic activities in the country that it's in constant development. This anthropogenic activity is one of the main sources of soil and water pollution. Specifically, mining effluents are responsible for water pollution by the presence of heavy metals, which become an increasing environmental problem due to its high toxicity and its tendency to accumulate in ecosystems. For this reason, in this work it is proposed the removal of copper $\left(\mathrm{Cu}^{2+}\right)$ of a mining effluent (obtained from a Zacatecas mine in March of this year) by adsorption with natural zeolite and a composite material of polyurethane-polyaniline. Batch-mode adsorption experiments were carried out with each material. The concentration of $\mathrm{Cu}^{2+}$ in the effluent before and after the adsorption process was determined by inductively coupled plasma optical emission spectroscopy (ICP-OES). The adsorption capacity of both material was studied as a function of the $\mathrm{pH}$ of the effluent (5.0, 7.0 and 9.2). From these experiments, it was obtained that both materials present higher efficiency at $\mathrm{pH} 7.0$, followed by a $\mathrm{pH}$ 5.0. The material that presents a higher percentage of $\mathrm{Cu}^{2+}$ removal is natural zeolite with a $29.9 \%$ and an adsorption capacity of $17.7 \mathrm{mg} / \mathrm{g}$ at pH 7.0. In addition to removing $\mathrm{Cu}^{2+}$, the materials also reduce the content of $\mathrm{Ca}^{2+}$ present in the media, reducing its concentration in up to $33.3 \%(49.8 \mathrm{mg} / \mathrm{g})$. It is concluded that the mining effluent $\mathrm{Cu}^{2+}$ concentration it's reduced by adsorption with these materials, being of low cost and easy handling, can be applied as a remediation technic in this effluent.
\end{abstract}

Keywords: Adsorption, cupper, water pollution.

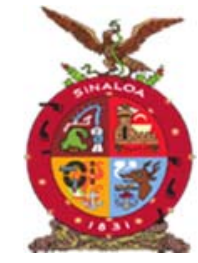

XVIII Congreso Internacional XXIV Congreso Nacional de Ciencias ambientales

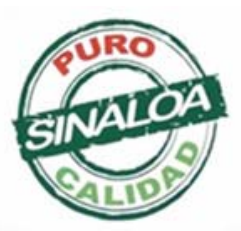

Mazatlán, Sinaloa 3-7 junio 2019
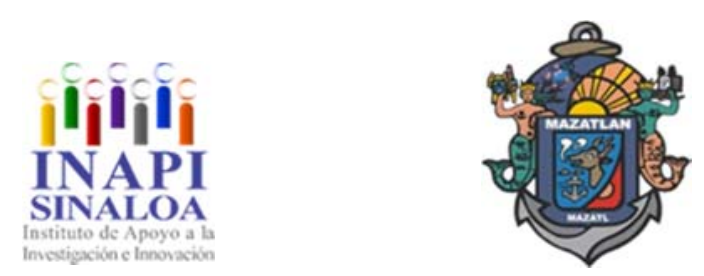

Tecnología y Biotecnología para el Tratamiento de Contaminantes y Biorremediación 

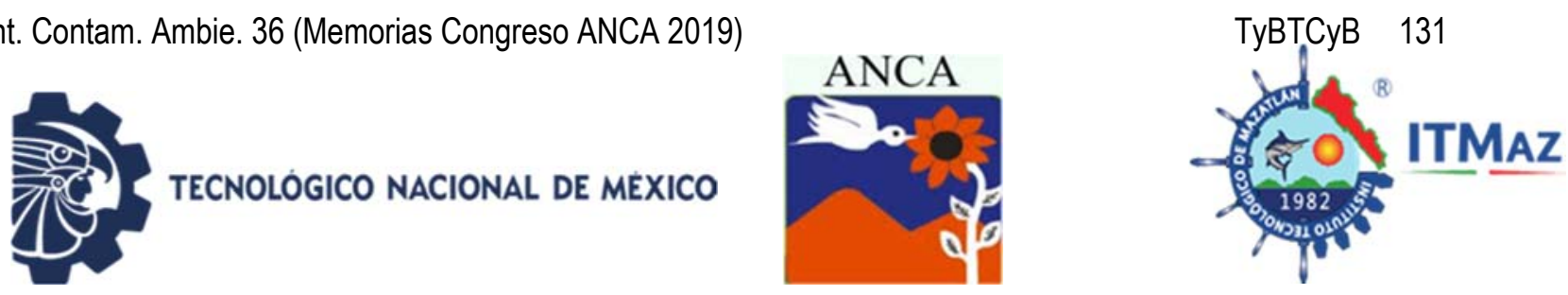

\title{
Remoción de colorantes textiles en agua con mezcla de biopolímeros gelificados con Aluminio (III)
}

\author{
Molina Sánchez $\mathrm{K}^{1}$, Lozano Alvarez $\mathrm{J}^{2}$, Jáuregui Rincón $\mathrm{J}^{2}$, Medina Ramírez $\mathrm{I}^{1}$, \\ Alférez Chávez $\mathrm{J}^{2}$ \\ 1Departamento de Química \\ ${ }^{2}$ Departamento de Ingeniería Bioquímica. \\ Universidad Autónoma de Aguascalientes, Aguascalientes, México. \\ *Iozanoalvarez@yahoo.com
}

\begin{abstract}
RESUMEN
Los colorantes son compuestos utilizados ampliamente en diferentes áreas y su aplicación en la industria textil es de las más importantes en términos ambientales, debido a que al descargarse a diferentes cuerpos de agua disminuyen la penetración de la luz solar, afectando la actividad fotosintética, agotando el oxígeno disuelto y dañando seriamente a las especies acuáticas presentes. Recientemente se ha reportado el uso de biopolímeros como el quitosano, alginato, pectina, xantano $(X)$, goma de algarrobo (LBG) y mezclas de ellos usados en la remoción de colorantes textiles. El objetivo planteado es utilizar la mezcla X-LBG que al reaccionar con $\mathrm{Al}^{+3}$, produce un gel que al liofilizarlo, se obtiene un polvo que remueve colorantes textiles en aguas preparadas artificialmente a nivel laboratorio. Se estudió la cinética de remoción del azul directo (AD1), rojo directo 80 (RD80) y rojo directo 81 (RD81) a diferentes concentraciones (10-100 mg/L), el efecto del $\mathrm{pH}$, obteniendo las isotermas de remoción de estos colorantes. El modelo de pseudo segundo orden describió las cinéticas experimentales, debido a las interacciones electrostáticas existentes entre las moléculas de colorante y el X-LBG-Al. Se removió más del $90 \%$ de colorantes en el intervalo de 3 a 8 unidades de $\mathrm{pH}$ a una concentración de 100 $\mathrm{mg} / \mathrm{L}$. Las isotermas de remoción mostraron que para los colorantes RD80 y RD81 se muestran capacidades de remoción máximas de $500 \mathrm{mg} / \mathrm{g}$ y para el AD1 alrededor de $450 \mathrm{mg} / \mathrm{g}$. Estos valores indican que el X-LBG-Al es una buena opción para remover colorantes textiles en agua.
\end{abstract}

Palabras clave: Colorantes textiles, biopolímeros, adsorción.

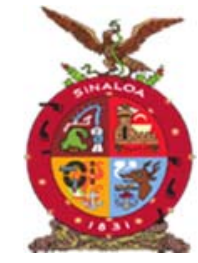

XVIII Congreso Internacional XXIV Congreso Nacional de Ciencias ambientales

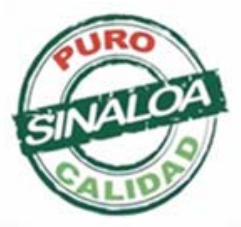

Mazatlán, Sinaloa 3-7 junio 2019
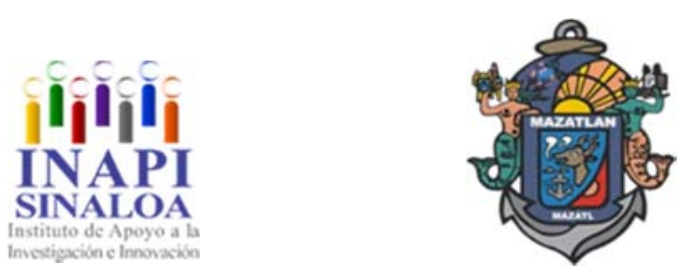

Tecnología y Biotecnología para el Tratamiento de Contaminantes y Biorremediación 

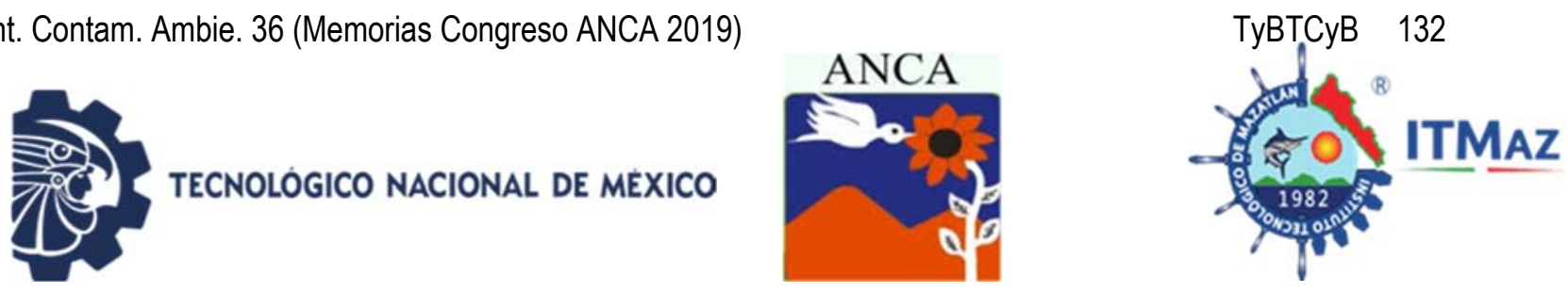

\title{
Removal of azo dyes in water with blending of biopolymers gelled with Aluminum (III)
}

\author{
Molina Sánchez $\mathrm{K}^{1}$, Lozano Alvarez $\mathrm{J}^{2}$, Jáuregui Rincón $\mathrm{J}^{2}$, Medina Ramírez $\mathrm{I}^{1}$, \\ Alférez Chávez $\mathrm{J}^{2}$ \\ 1Departamento de Química \\ ${ }^{2}$ Departamento de Ingeniería Bioquímica. \\ Universidad Autónoma de Aguascalientes, Aguascalientes, México. \\ *lozanoalvarez@yahoo.com
}

\begin{abstract}
Dyes are widely used compounds in different areas and their application in the textile industry is one of the most important in environmental terms, due to when they are discharged to different water bodies, the penetration of sunlight is decreased affecting the photosynthetic activity, exhausting dissolved oxygen and consequently, serious damage in the aquatic species is observed. The use of biopolymers such as chitosan, alginate, pectin, xanthan $(X)$ and locust bean gum (LBG) and mixtures of them in the removal of textile dyes has recently been reported. The aim of this work is to use the X-LBG mixture which, once reacted with $\mathrm{Al}^{+3}$, produces a gel that, when is lyophilized, a powder is obtained and it is used for textile dye removal in artificially prepared water samples at laboratory level. The kinetics of removal of direct blue (AD1), direct red 80 (RD80) and direct red 81 (RD81) at different concentrations (10-100 mg/L), the effect of $\mathrm{pH}$ and the removal isotherms of these dyes were obtained. The pseudo second order model described the experimental kinetics, due to the electrostatic interactions between the dye molecules and the X-LBG-Al. More than $90 \%$ dyes were removed in the range of 3 to $8 \mathrm{pH}$ units at a concentration of $100 \mathrm{mg} / \mathrm{L}$. The removal isotherms showed that dyes RD80 and RD81 show maximum removal capacities of 500 $\mathrm{mg} / \mathrm{g}$ and AD1 around $450 \mathrm{mg} / \mathrm{g}$. These values indicate that X-LBG-Al is a good option to remove textile dyes in water.
\end{abstract}

Keywords: Textile dyes, biopolymers, adsorption.

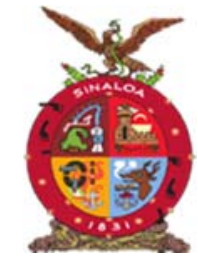

XVIII Congreso Internacional XXIV Congreso Nacional de Ciencias ambientales

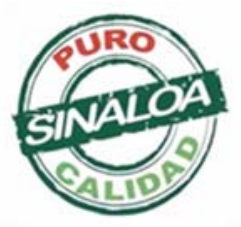

Mazatlán, Sinaloa 3-7 junio 2019
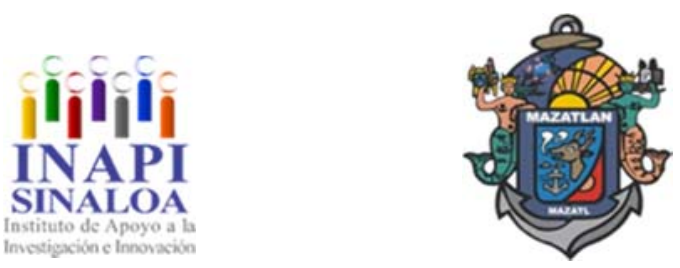

Tecnología y Biotecnología para el Tratamiento de Contaminantes y Biorremediación 

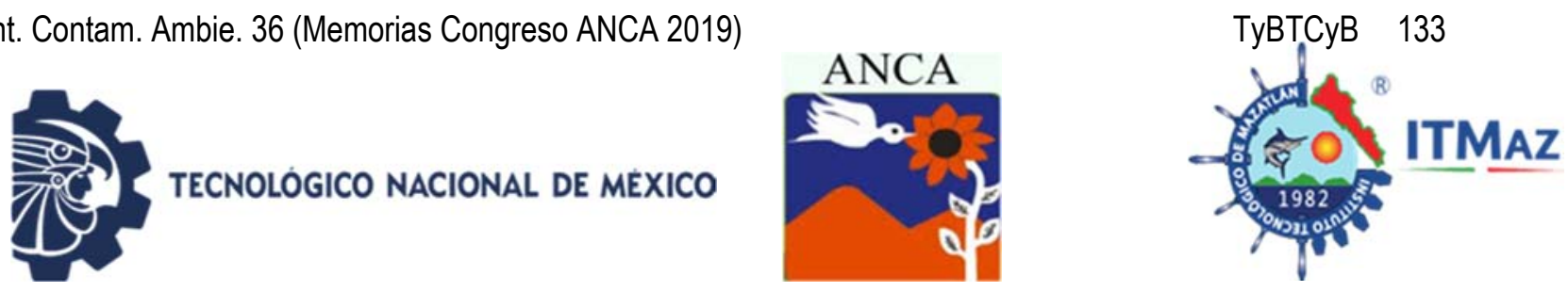

\title{
Análisis del perfil proteico de Pleurotus ostreatus con la interacción del colorante tartrazina
}

\author{
Montaño Gómez A, Torres Pérez J, González Fernández R, Valero Galán J* \\ Universidad Autónoma de Ciudad Juárez, \\ Av. Plutarco Elías Calles \# 1210 Fovissste Chamizal \\ Ciudad Juárez, Chihuahua, México \\ *jose.valero@uacj.mx
}

\section{RESUMEN}

Hoy en día existe una gran cantidad de colorantes, generalmente son elaborados de manera sintética para resistir la degradación por exposición a la luz, agua y otras condiciones ambientales, sin embargo, estos son difíciles de remover por métodos de tratamiento de aguas físicos y químicos. Uno de los microorganismos que pudiera tener la capacidad de usarse como bioremediador por su capacidad de degradar compuestos, debido a su acción metabólica es Pleurotus ostreatus. El objetivo de este estudio fue determinar el perfil proteico de $P$. ostreatus en competencia con el colorante tartrazina y corroborar si este tiene la capacidad de secretar proteínas para degradar este compuesto de aguas contaminadas. Se realizó un experimento de la interacción dual entre colorante-hongo por 20 días. Para esto se verificó el proceso de degradación del colorante a través de la medición de la absorbancia y los espectros infrarrojos pertenecientes a cada tratamiento respecto al control. Adicionalmente, se separó la materia orgánica de la parte acuosa. Esta última, se liofilizó y se realizó la extracción de proteínas por el método TCA/acetona-fenol, se cuantificaron las proteínas y se separaron por geles SDS-PAGE. Los resultados mostraron que $P$. ostreatus secreta proteínas que pueden tener capacidad de el colorante tartrazina. Por esta razón, se propone el uso de este tipo de organismos para su utilización como bioremediadores en diferentes áreas industriales.

Palabras claves: Hongo, secretoma, colorantes.

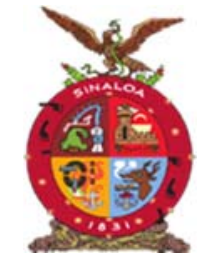

XVIII Congreso Internacional XXIV Congreso Nacional de Ciencias ambientales

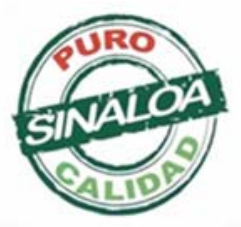

Mazatlán, Sinaloa 3-7 junio 2019
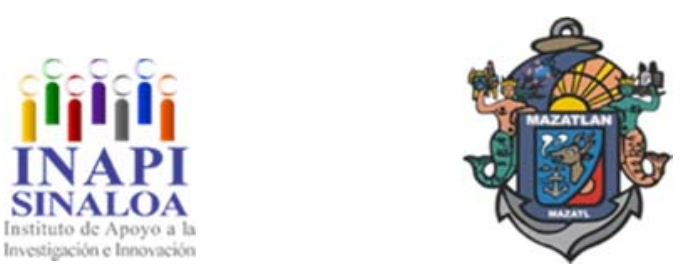

Tecnología y Biotecnología para el Tratamiento de Contaminantes y Biorremediación 

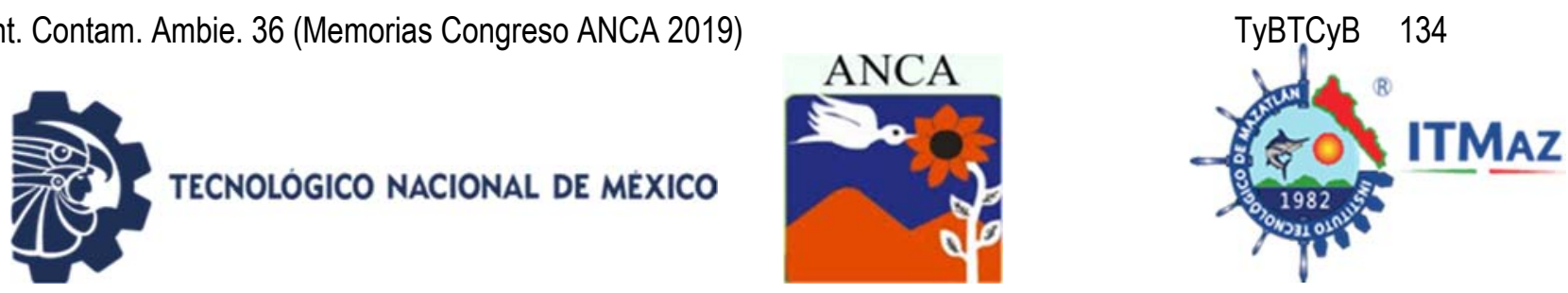

\title{
Protein profile of Pleurotus ostreatus and the interaction with tartrazina dye
}

\author{
Montaño Gómez A, Torres Pérez J, González Fernández R, Valero Galán J* \\ Universidad Autónoma de Ciudad Juárez, \\ Av. Plutarco Elías Calles \# 1210 Fovissste Chamizal \\ Ciudad Juárez, Chihuahua, México \\ *jose.valero@uacj.mx
}

\begin{abstract}
Today there is a large amount of dyes that are generally made as synthetic way to resist the degradation by exposure to light, water and other environmental conditions, however, these are difficult to remove by physical and chemical water treatment methods. One microorganism that could have the capacity to be used as a bioremediator is Pleurotus ostreatus. The objective of this study was to determine the protein profile of $P$. ostreatus in competition with the Tartrazine dye and to confirm if it has the capacity to secrete proteins to degrade this compound from contaminated waters. An experiment of the dual interaction between dyefungus was carried out for 20 days. The degradation process of the dye was verified by measuring the absorbance and the infrared spectra of a control and treatment. Additionally, the organic matter was separated from the aqueous part. The aqueous extract was lyophilized and the extraction and quantification of proteins were carried out. The proteins were quantified and separated by SDSPAGE gels. The results showed that $P$. ostreatus secretes proteins that may have capacity of the tartrazine dye. For this reason, the use of this type of organisms is proposed for use as bioremediations in different industrial areas.
\end{abstract}

Keywords: Fungi, secretome profile, dyes.

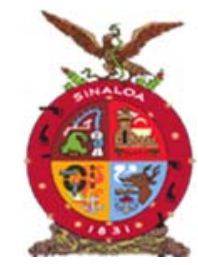

XVIII Congreso Internacional XXIV Congreso Nacional de Ciencias ambientales

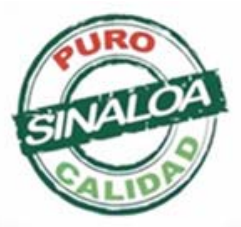

Mazatlán, Sinaloa 3-7 junio 2019
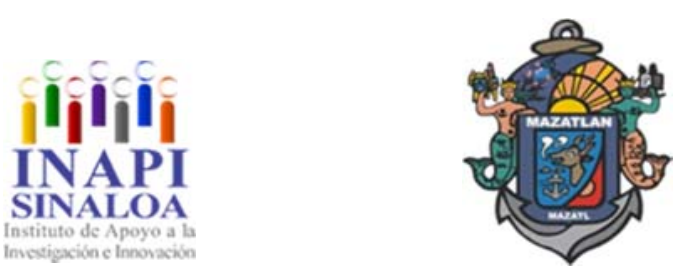

Tecnología y Biotecnología para el Tratamiento de Contaminantes y Biorremediación 

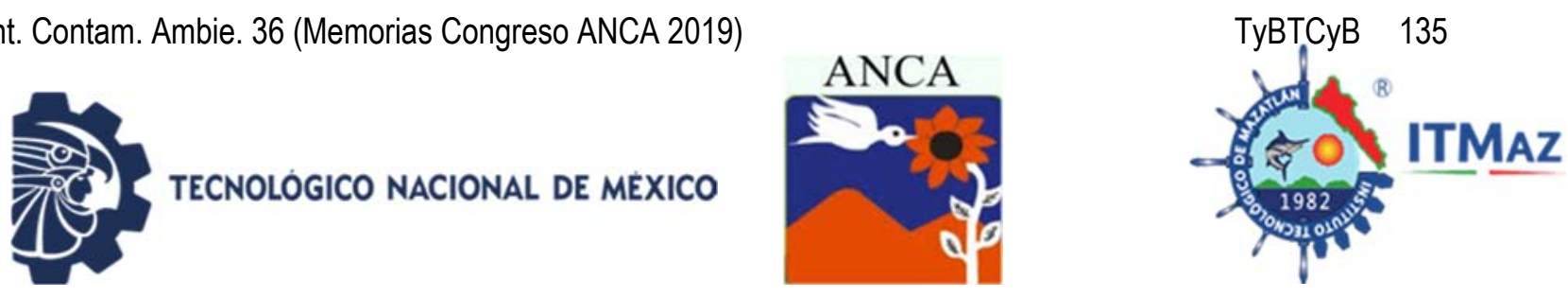

\title{
Diseño e implementacion de una máquina recolectora y trituradora de polietilén tereftalato (PET)
}

\author{
Moreno Julimez $\mathrm{L}^{1 *}$, Aquino De Los Ríos $\mathrm{G}^{1}$, Mayett Moreno $\mathrm{Y}^{2}$, \\ Rodríguez Piñeros $S^{1}$, Cortés Palacios $L^{1}$, Santellano Estrada $E^{1}$, \\ Olmos Marquez $\mathrm{M}^{1}$ \\ 1Universidad Autónoma de Chihuahua \\ 2Universidad Popular Autónoma del Estado de Puebla \\ *morenolmj@gmail.com
}

\begin{abstract}
RESUMEN
El consumo de refrescos y agua embotellada en México ha ido aumentando sostenidamente en los últimos años. Se estima que México es uno de los países que utilizan mayor cantidad de botellas de PET, llegando a estar en tercer lugar a nivel mundial. El objetivo del presente trabajo fue estudiar y desarrollar una tecnología que facilite la disposición del residuo plástico PET y que sea una opción factible en el contexto de cero residuos, además estudiar y desarrollar un módulo mecánico de trituración y un módulo electrónico de comunicación. El diseño se realizó mediante un software de análisis y resolución por elementos finitos para aplicaciones físicas. El resultado principal que se obtuvo fue el diseño de una máquina expendedora inversa, la cual consta de un módulo de trituración y un módulo de control y comunicación. El reciclado de los residuos de plástico PET es una buena opción para regresar al sistema de producción parte del material que comúnmente vemos como basura o residuo. En la actualidad no se tiene una buena cultura de reciclaje. La implementación de las máquinas expendedoras inversas es una manera de incentivar a las personas a reciclar los residuos de plástico PET. Además de la implementación de la máquina es importante llevar paralelamente la puesta en marcha de políticas y métodos de retribución para el reciclaje que ayuden a mejorar las tasas de reciclaje de PET en México.
\end{abstract}

Palabras clave: Reciclaje, PET, máquina expendedora inversa, diseño, método de elemento finito.

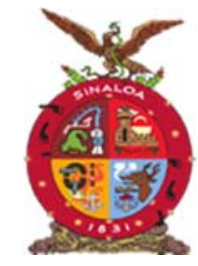

XVIII Congreso Internacional XXIV Congreso Nacional de Ciencias ambientales

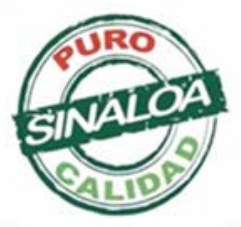

Mazatlán, Sinaloa 3-7 junio 2019
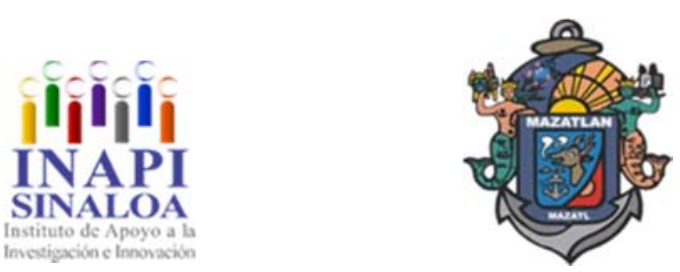

Tecnología y Biotecnología para el Tratamiento de Contaminantes y Biorremediación 

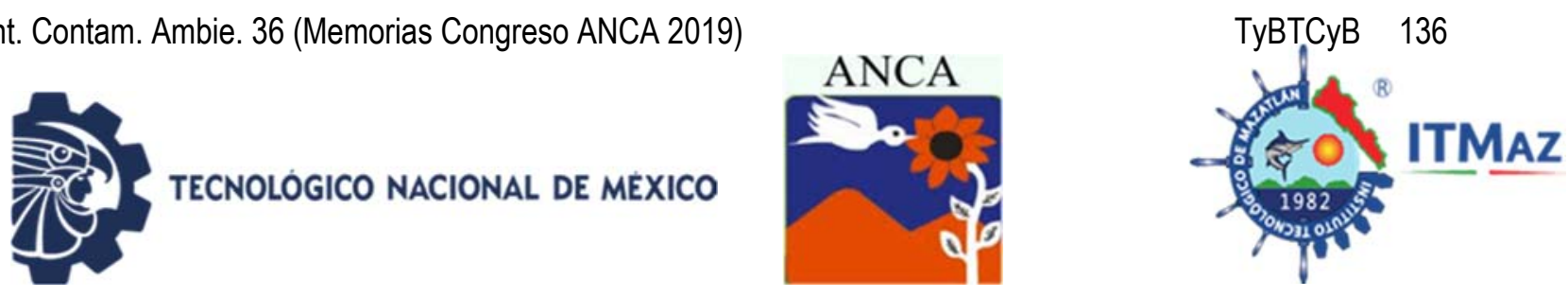

\title{
Design and implementation of a machine collector and crusher of polyethylene terephthalate (PET)
}

\author{
Moreno Julimez $\mathrm{L}^{1^{*}}$, Aquino De Los Ríos $\mathrm{G}^{1}$, Mayett Moreno $\mathrm{Y}^{2}$, \\ Rodríguez Piñeros $S^{1}$, Cortés Palacios $L^{1}$, Santellano Estrada $E^{1}$, \\ Olmos Marquez $\mathrm{M}^{1}$ \\ 1Universidad Autónoma de Chihuahua \\ 2Universidad Popular Autónoma del Estado de Puebla \\ *morenolmj@gmail.com
}

\begin{abstract}
In recent years, the consumption of soft drinks and bottled water in Mexico has been increasing steadily. It is estimated that Mexico is one of the countries consuming the largest amount of PET bottles, reaching third place worldwide. This work aimed to study and develop a technology that facilitates the disposal of PET waste, being a feasible option in the context of zero waste. Besides to study and develop a mechanical crushing module and an electronic communication module.The design was made using finite element analysis and resolution software for physical applications. The result was a design of a reverse vending machine consisting of a crushing module and a control and communication module. The recycling of PET plastic waste is a good option to return to the production system part of the material that we commonly see as garbage or waste. Currently, there is no good recycling culture. The implementation of reverse vending machines is a way to encourage people to recycle PET waste. In addition to the implementation of the machine, it is important to carry out in parallel the implementation of policies and methods of retribution for recycling that help to improve PET recycling rates in Mexico.
\end{abstract}

Keywords: Recycling, PET, reverse vending machine, design, finite element method.

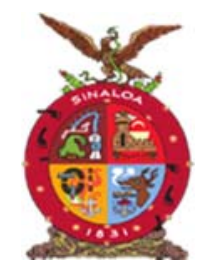

XVIII Congreso Internacional XXIV Congreso Nacional de Ciencias ambientales

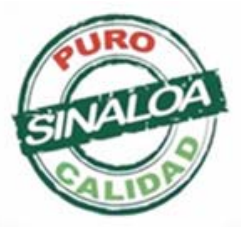

Mazatlán, Sinaloa 3-7 junio 2019
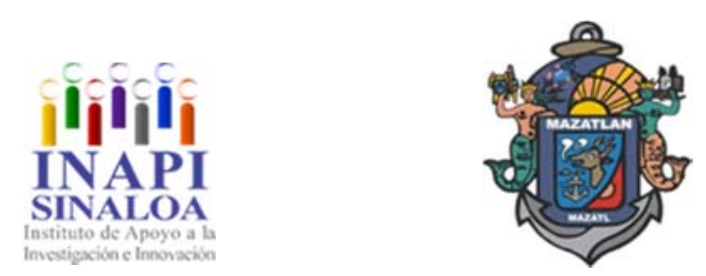

Tecnología y Biotecnología para el Tratamiento de Contaminantes y Biorremediación 

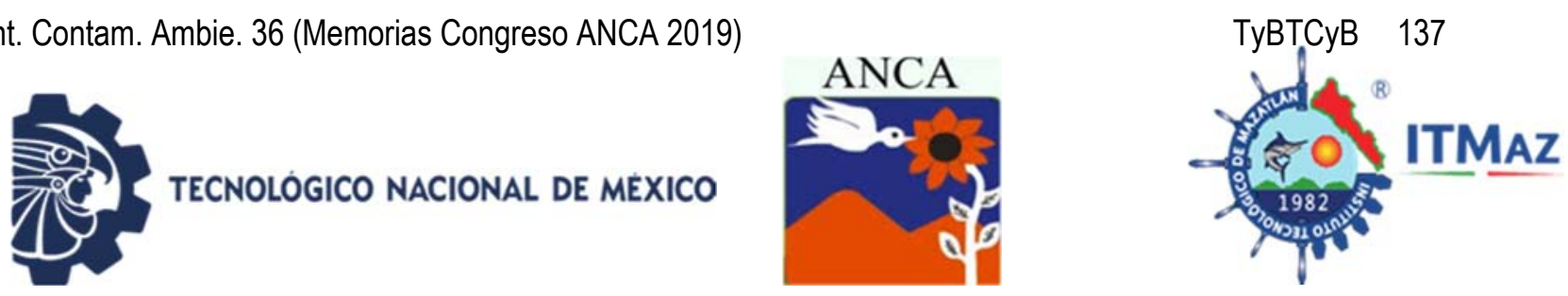

\section{Reciclado de residuos agrícolas y urbanos para elaborar papel artesanal

\author{
Moreno Pérez J*, Bautista Mulia J, Bravo Pablo L, Conde Hernández A, \\ Alonso Calderon A
}

Facultad de Ingeniería Química. BUAP

*d1997_jime@hotmail.com

\section{RESUMEN}

La generación de residuos es un problema que se agrava cada vez más, por ello se planteó el objetivo de elaborar un papel artesanal con diferentes formulaciones a partir de residuos: corona de piña, hoja para tamal, cartoncillo de envases tetra pak, y papel bond usado. Este trabajo ha sido desarrollado durante el 2018 y 2019 en la Benemérita Universidad Autónoma de Puebla. El proceso de elaboración comienza con la deslignificación en un baño alcalino de la corona de piña o la hoja para tamal, para después ser neutralizada y molida junto con otros materiales como: cartoncillo de envases tetrapak, hoja tipo bond y baba de nopal como aglutinante, siendo homogeneizado con agua, con toda la mezcla se procede a usar un cernidor para formar la hoja de papel artesanal, para después ser secada al sol por 24 horas y finalmente darles el tamaño carta. Se determinó la resistencia a la ruptura, gramaje y grosor de las hojas elaboradas con las diferentes formulaciones y fueron analizado con un Diseño Completo al Azar DCA, la resistencia a la ruptura mostró la existencia de diferencia significativa en el ANOVA y se comprobó con el LSD: la corona de piña aporta mayor resistencia. En el gramaje ninguna de las mezclas presento diferencia significativa: los lotes son homogéneos. En el grosor aplicando el ANOVA se halla diferencia significativa dada por el uso de cartoncillo o papel de reciclaje, siendo el segundo el material con el que pueden obtener más delgadas sin afectar su resistencia.

Palabras clave: Reciclado, papel, piña, tamal, anova.

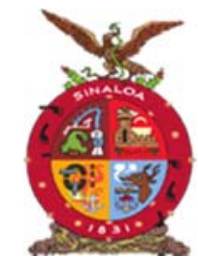

XVIII Congreso Internacional XXIV Congreso Nacional de Ciencias ambientales

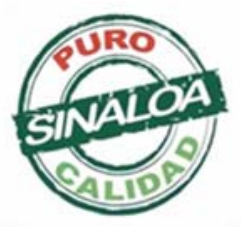

Mazatlán, Sinaloa 3-7 junio 2019
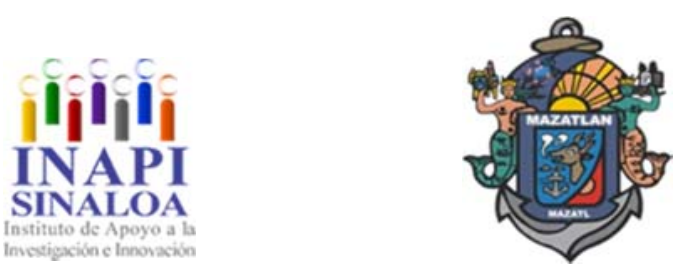

Tecnología y Biotecnología para el Tratamiento de Contaminantes y Biorremediación 

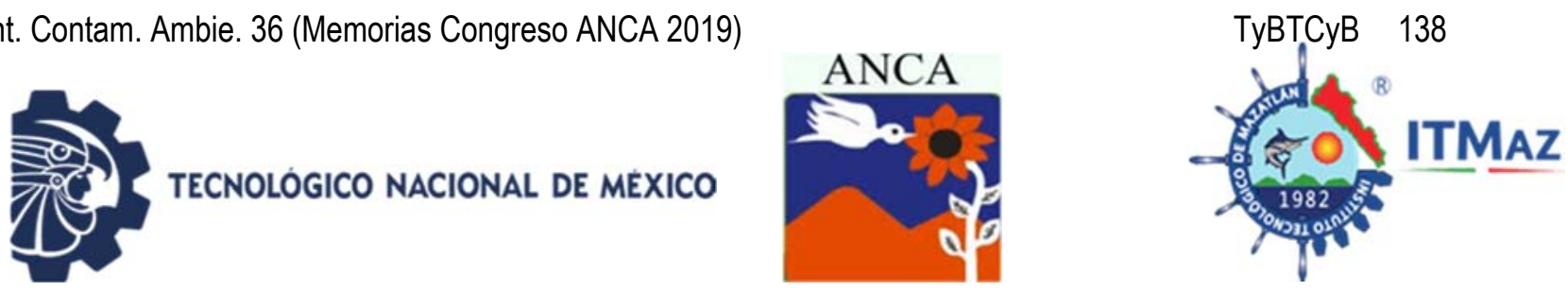

\title{
Recycling of agricultural and urban waste to produce paper craft

\author{
Moreno Pérez J゙, Bautista Mulia J, Bravo Pablo L, Conde Hernández A, \\ Alonso Calderon A
}

Facultad de Ingeniería Química. BUAP

*d1997_jime@hotmail.com

\begin{abstract}
The generation of waste is a problem that is increasingly aggravated, which is why the objective of making a handmade paper with different formulations from waste was raised: pineapple crown, tamale leaf, tetra pak carton, and bond paper used. This work has been developed during 2018 and 2019 at the Benemérita Universidad Autónoma de Puebla. The elaboration process begins with the delignification in an alkaline bath of the pineapple crown or the tamale leaf, and then it is neutralized and ground together with other materials such as: tetrapak carton, bond type leaf and prickly pear cactus as a binder, being homogenized with water, with the whole mixture a sieve is used to form the sheet of handmade paper, then be dried in the sun for 24 hours and finally give them the letter size. The resistance to rupture, grammage and thickness of the sheets made with the different formulations was determined and analyzed with a Full Random Design DCA, the resistance to rupture showed the existence of significant difference in the ANOVA and was checked with the LSD: the pineapple crown provides greater resistance. In the grammage, none of the mixtures presented a significant difference: the batches are homogeneous. In the thickness applying the ANOVA there is a significant difference given by the use of cardboard or recycle paper, the second being the material with which they can obtain thinner without affecting their resistance.
\end{abstract}

Keywords: Recycled, paper, pineapple, tamale, anova.

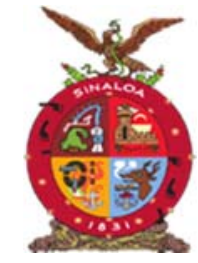

XVIII Congreso Internacional XXIV Congreso Nacional de Ciencias ambientales

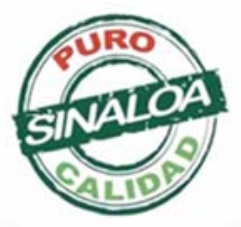

Mazatlán, Sinaloa 3-7 junio 2019
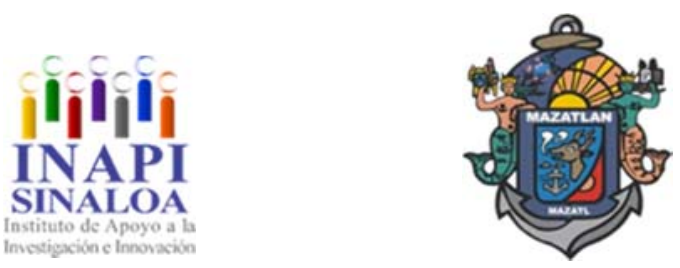

Tecnología y Biotecnología para el Tratamiento de Contaminantes y Biorremediación 

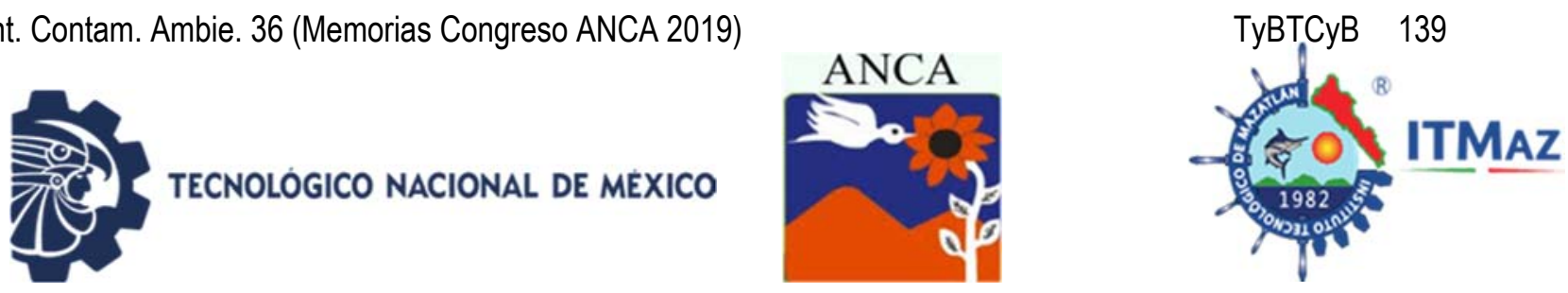

\section{Estudio de la adsorción del colorante Rojo No. 2 con hidrogeles de Q-TPP}
Munguia Martín $\mathrm{J}^{1}$, Zavala Arce $\mathrm{R}^{1^{*}}$, Hernández Tenorio $\mathrm{C}^{1}$, García Gaytan $\mathrm{B}^{1}$, Moreno Martínez B ${ }^{2}$

${ }^{1}$ Instituto Tecnológico de Toluca. Tecnológico Nacional de México.

Av. Tecnológico S/N. Col. Agrícola Bellavista Metepec, Edo. De México, México

${ }^{2}$ Instituto Tecnológico de Nuevo León. Tecnológico Nacional de México.

Av. Eloy Cavazos \# 2001 Col. Tolteca

*rzavalaa@toluca.tecnm.mx

\section{RESUMEN}

La contaminación del agua por colorantes es un factor preocupante ya que estos dificultan el paso de los rayos del sol, limitando el proceso de fotosíntesis, disminuyendo el oxígeno disuelto, propiciando la eutrofización y formación de compuestos recalcitrantes. En este trabajo se realizó el estudio de hidrogeles sintetizados con quitosano entrecruzado con TPP para evaluarlos en la adsorción del colorante rojo No. 2, lo anterior se llevó a cabo de abril a diciembre del 2018 en el Instituto Tecnológico de Toluca; se analizó la morfología (MEB), grupos funcionales presentes (IRTF) y área específica del hidrogel (BET); se efectuaron estudios de cinética e isotermas de adsorción. La síntesis se efectuó disolviendo el quitosano en ácido acético $0.4 \mathrm{M}$, el cual se goteó en una solución de TPP al $1 \%(\mathrm{~m} / \mathrm{v})$ durante $12 \mathrm{~h}$. Los resultados del SEM mostraron una superficie lisa del material con un interior poroso. EI FTIR presentó el cambio de los picos de vibración en $3184 \mathrm{~cm}-1$ y de estiramiento en $523 \mathrm{~cm}-1$ que es indicativo de una interacción entre el quitosano y el TPP. El área específica del hidrogel fue de $91.204 \mathrm{~m} 2 / \mathrm{g}$ y el diámetro promedio del poro fue de $8.5931 \mathrm{~nm}$ que corresponde a mesoporos. Las cinéticas muestran el equilibrio en $32 \mathrm{~h}$ con una remoción del $32 \%$ para $10^{\circ} \mathrm{C}$, la remoción se vio ligeramente favorecida $(35 \%)$ a 30 y $50^{\circ} \mathrm{C}$, por otro lado, las isotermas muestran una saturación en la superficie del material a partir de una concentración inicial del colorante de $400 \mathrm{mg} / \mathrm{L}$.

Palabras clave: Adsorción, rojo No.2, quitosano, cinéticas, isotermas

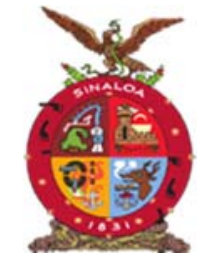

XVIII Congreso Internacional XXIV Congreso Nacional de Ciencias ambientales

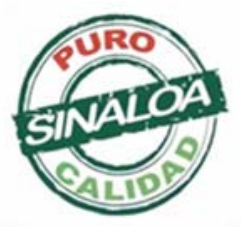

Mazatlán, Sinaloa 3-7 junio 2019
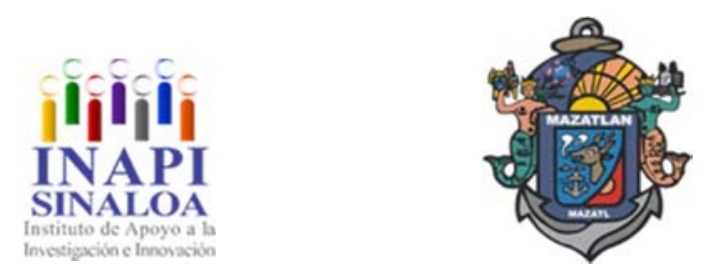

Tecnología y Biotecnología para el Tratamiento de Contaminantes y Biorremediación 

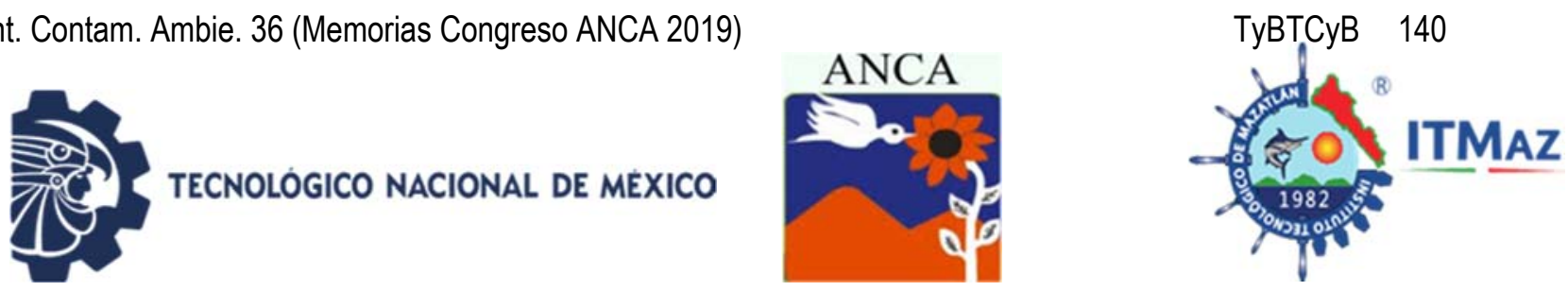

\title{
Adsorption study of Red No. 2 dye by Q-TPP hydrogels
}

Munguia Martín $\mathrm{J}^{1}$, Zavala Arce $\mathrm{R}^{1^{*}}$, Hernández Tenorio $\mathrm{C}^{1}$, García Gaytan $\mathrm{B}^{1}$, Moreno Martínez B²

${ }^{1}$ Instituto Tecnológico de Toluca. Tecnológico Nacional de México.

Av. Tecnológico S/N. Col. Agrícola Bellavista Metepec, Edo. De México, México ${ }^{2}$ Instituto Tecnológico de Nuevo León. Tecnológico Nacional de México.

Av. Eloy Cavazos \# 2001 Col. Tolteca

*rzavalaa@toluca.tecnm.mx

\begin{abstract}
Water pollution by dyes is a worrying factor due to these dyes hinder the passage of the sun's rays, limiting the photosynthesis process, decreasing the dissolved oxygen, as well as propitiating the eutrophication and formation of recalcitrant compounds. In this work the study of hydrogels synthesized with chitosan crosslinking with TPP to evaluate them in the adsorption of red No. 2 was conducted from April to December 2018 at the Instituto Tecnológico de Toluca. In this study the Morphology (SEM), functional groups present (FTIR) and specific area of hydrogel (BET) were analyzed and studies of kinetics and adsorption isotherms were conducted. The synthesis was performed by dissolving chitosan into $0.4 \mathrm{M}$ acetic acid, this was dripped into a $1 \%(\mathrm{~m} / \mathrm{v})$ TPP solution for $12 \mathrm{~h}$. SEM results showed that the hidrogel has a smooth surface with a porous interior. The FTIR presented the change of the peaks of vibration at $3184 \mathrm{~cm}^{-1}$ and stretching at $523 \mathrm{~cm}^{-1}$ this indicate an interaction between the chitosan and the TPP. The specific area of the hydrogel was $91.204 \mathrm{~m}^{2} / \mathrm{g}$ and the average diameter of the pore was $8.5931 \mathrm{~nm}$ corresponding to mesopores. The kinetics show the equilibrium in $32 \mathrm{~h}$ with a removal of $32 \%$ for $10^{\circ} \mathrm{C}$, this removal was slightly favored $(35 \%)$ at 30 and $50^{\circ} \mathrm{C}$. On the other hand, the isotherms show a saturation on the surface of the hydrogel from an initial dye concentration of $400 \mathrm{mg} / \mathrm{L}$.
\end{abstract}

Keywords: Adsorption, dye No.2, chitosan, kinetics, isotherms.

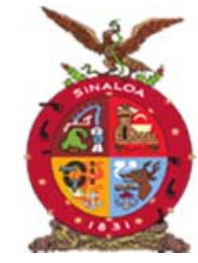

XVIII Congreso Internacional XXIV Congreso Nacional de Ciencias ambientales

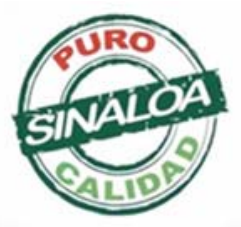

Mazatlán, Sinaloa 3-7 junio 2019
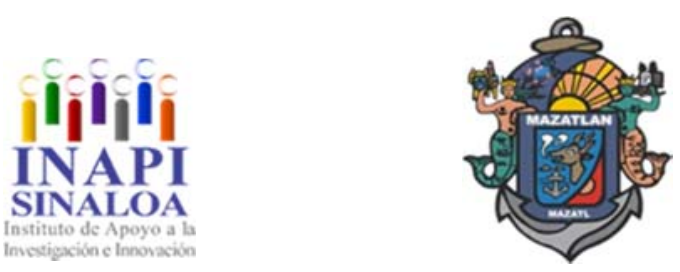

Tecnología y Biotecnología para el Tratamiento de Contaminantes y Biorremediación 

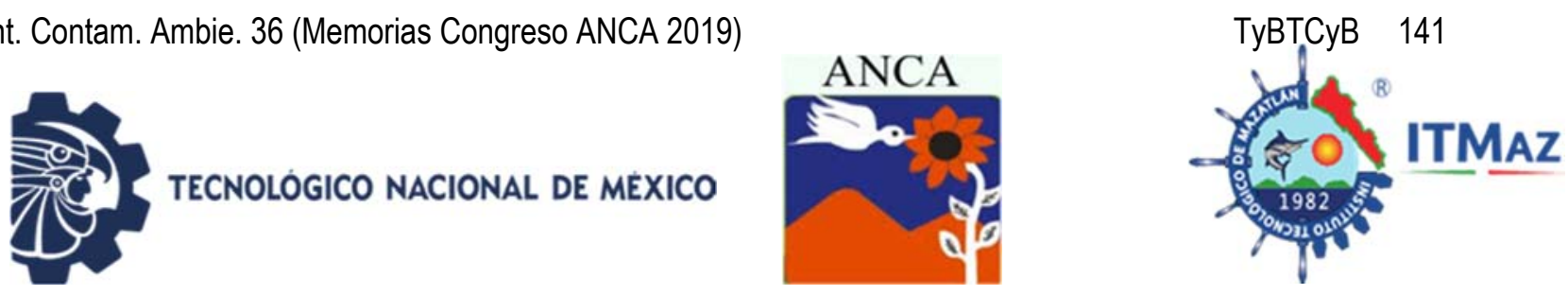

\title{
Compósitos PCL-CuONPs como alternativa a antibióticos
}

\author{
Muñoz Escobar A, Meléndez Estrada IA, Cuevas González J, Tovar Carrillo K, \\ Donohué Cornejo A, Espinoza Cristóbal L, Reyes López SY \\ Instituto de Ciencias Biomédicas. Universidad Autónoma de Ciudad Juárez, \\ Envolvente del PRONAF y Estocolmo S/N, Ciudad Juárez, Chih., México \\ *simon.reyes@uacj.mx
}

\section{RESUMEN}

El exceso de antibióticos en el ambiente podría conducir a la resistencia a los antibióticos por parte de los microorganismos y podría dañar a muchos organismos acuáticos. Esto ha suscitado un interés en la aplicación de agentes antimicrobianos alternativos, siendo los iones de óxido de metal, un objetivo atractivo. Las nanopartículas de óxido de cobre presentan características únicas que incluyen un aumento de las actividades catalíticas y antifúngicas/antibacterianas que no se observan en el cobre comercial. Por lo tanto, el objetivo de este estudio es preparar y caracterizar fibras de policaprolactona electrohiladas con nanopartículas de óxido de cobre (PCLCuONps), y evaluar sus propiedades antimicrobianas contra bacterias Gram negativas y Gram positivas, y contra hongos levaduriformes. Las fibras se prepararon mediante el método de reducción iones cúpricos con la adición del polímero policaprolactona en solución para electrohilado. Los resultados de Dispersión Dinámica de Luz, Espectroscopia de UV visible y Espectroscopía Raman mostraron la presencia de nanopartículas de óxido de cobre II con diámetros de 85 a $95 \mathrm{~nm}$. La Espectroscopía de rayos X por Dispersión de energía y Microscopía Electrónica de Barrido confirmaron la presencia de CuONPs distribuidas en las nanofibras de PCL con un tamaño promedio de 900 $\mathrm{nm}$. Se evaluó su actividad antibacteriana contra E. coli, S. mutans, K. oxytoca, $S$. aureus, $P$. aeruginosa y $B$. subtilis. Los resultados mostraron sensibilidad de $P$. aeruginosa y E. coli pero no de $K$. oxytoca ni de las bacterias Gram positivas. El efecto antifúngico fue mayor que el efecto antibacteriano al mostrar una efectividad de más del $50 \%$ de inhibición en contra de las especies $C$. albicans, C. tropicalis y C. glabrata. Los compuestos de PCL-CuONps podrían tener un alto potencial como alternativa al uso de antibióticos, disminuyendo los potenciales riesgos que implica la descarga de antibióticos a cuerpos acuáticos.

Palabras clave: Nanofibras, compositos, PCL, nanopartículas de óxido de cobre, actividad antimicrobiana.

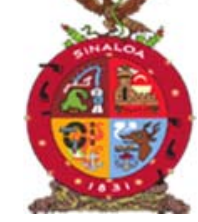

XVIII Congreso Internacional XXIV Congreso Nacional de Ciencias ambientales

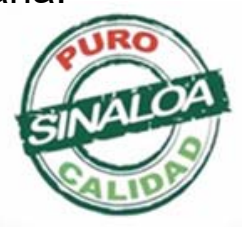

Mazatlán, Sinaloa 3-7 junio 2019

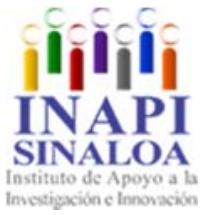

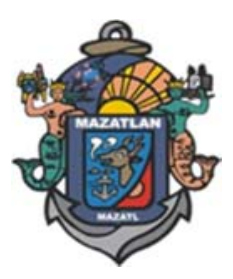

Tecnología y Biotecnología para el Tratamiento de Contaminantes y Biorremediación 

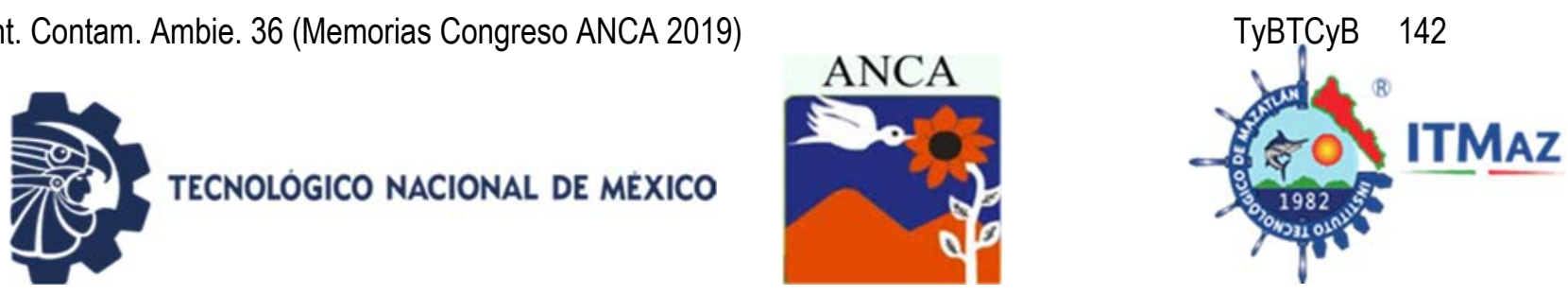

\title{
Compounds of PCL-CuONPs as an alternative to antibiotics
}

\author{
Muñoz Escobar A, Meléndez Estrada IA, Cuevas González J, Tovar Carrillo K, \\ Donohué Cornejo A, Espinoza Cristóbal L, Reyes López SY \\ Instituto de Ciencias Biomédicas. Universidad Autónoma de Ciudad Juárez, \\ Envolvente del PRONAF y Estocolmo S/N, Ciudad Juárez, Chih., México \\ *simon.reyes@uacj.mx
}

\begin{abstract}
Excess antibiotics in the environment could lead to antibiotic resistance by microorganisms and could harm many aquatic organisms. This has elicited an interest in the application of alternative antimicrobial agents, metal oxide ions being an attractive target. Copper oxide nanoparticles are considered by their catalytic and antifungal/antibacterial characteristics that are not observed in commercial copper. Therefore, the objective of this study is to prepare and characterize polycaprolactone fibers with copper oxide nanoparticles (PCL$\mathrm{CuONps}$ ), and to evaluate their antimicrobial properties against Gram-negative and Gram-positive bacteria, and against fungi. The fibers are prepared by the cupric ion reduction method with the addition of the polycaprolactone polymer in solution for electrospinning. The results of Dynamic light scattering, UV-Vis Spectroscopy and Raman Spectroscopy confirmed the presence of copper oxide II nanoparticles with diameters of 85 to $95 \mathrm{~nm}$. Energy-dispersive X-ray Spectroscopy and Scanning Electron Microscopy confirms the presence of CuONPs distributed in PCL nanofibers with an average size of $900 \mathrm{~nm}$. Antibacterial activity against $E$. coli, S. mutans, K. oxytoca, S. aureus, $P$. aeruginosa and $B$. subtilis was evaluated. The results show the sensitivity of $P$. aeruginosa and $E$. coli but not $K$. oxytoca or Gram positive bacteria. The antifungal effect was greater than the antibacterial effect showing more than $50 \%$ inhibition against C. albicans, C. tropicalis and C. glabrata. The compounds of PCLCuONps have a high potential as alternative to antibiotics, reducing the risks involved in the discharge of antibiotics to aquatic bodies.
\end{abstract}

Keywords: Nanofibers, composites, PCL, copper oxide nanoparticles, antimicrobial activity.

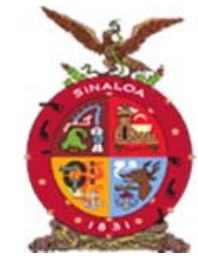

XVIII Congreso Internacional XXIV Congreso Nacional de Ciencias ambientales

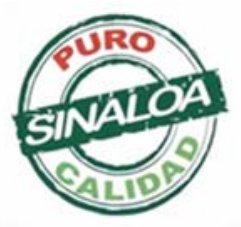

Mazatlán, Sinaloa 3-7 junio 2019
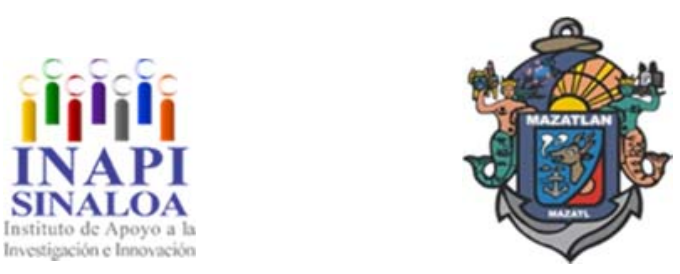

Tecnología y Biotecnología para el Tratamiento de Contaminantes y Biorremediación 

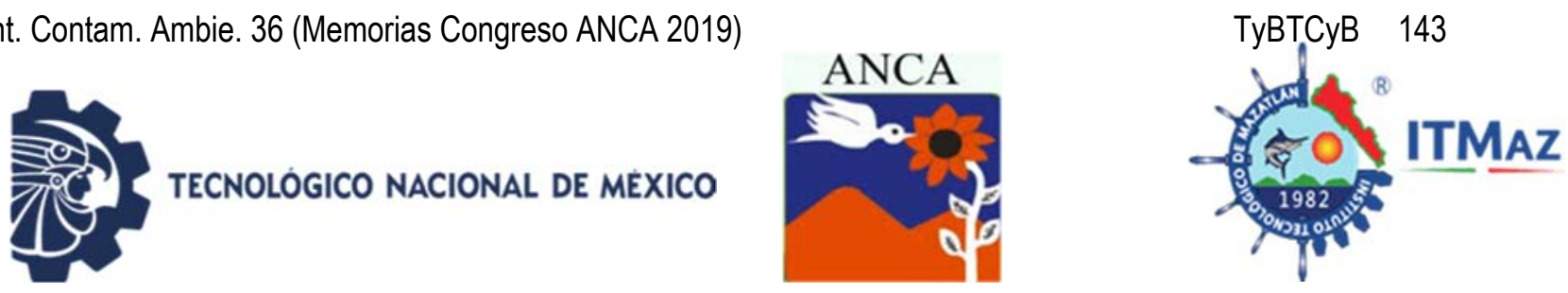

\title{
Revaloración de residuos de tereftalato de polietileno (PET) para la obtención de carbón activado como adsorbente de azul brillante FCP
}

\author{
Nájera Olivas $\mathrm{J}^{1}$, Torres Pérez $\mathrm{J}^{1^{*}}$, Reyes López $\mathrm{SY}^{2}$ \\ ${ }^{1}$ Laboratorio de Transferencia y Degradación de Contaminantes \\ ${ }^{2}$ Laboratorio de Materiales Híbridos Nanoestructurados. \\ Universidad Autónoma de Ciudad Juárez, Anillo Envolvente del Pronaf y \\ Estocolmo S/N, A.P. 1595-D, Ciudad Juárez, Chihuahua, México, \\ *jonatan.torres@uacj.mx

\section{RESUMEN}

El tereftalato de polietileno (PET) es uno de los residuos sólidos más comunes hoy en día. Desde 1960 se ha utilizado para empaquetar diferentes tipos de bebidas y comidas. El uso desmesurado de este material ha provocado serios problemas ambientales, de ahí la importancia de la búsqueda de alternativas promisorias y sustentables para la reutilización de los residuos de PET. Varias investigaciones han comprobado que los carbones activados obtenidos a partir de diversos precursores poseen adsorciones similares a carbones activados comerciales. El objetivo del presente trabajo fue preparar un material carbonoso a partir de un precursor no convencional (PAC) y evaluar los parámetros cinéticos del proceso de sorción del colorante azul brillante FCP sobre los carbones alternativos preparados. La investigación se realizó en el Laboratorio de Transferencia y Degradación de Contaminantes (LTDC) de la Universidad Autónoma de Ciudad Juárez (Juárez, Chihuahua, México) entre enero 2018 y marzo 2019. La experimentación, se realizó mediante un sistema batch mediante el contacto de P-AC con una solución de azul brillante FCP (Co=10 mg/L). Se utilizaron modelos cinéticos de primer orden, pseudo-segundo orden y Elovich para la determinación de los parámetros cinéticos. El material preparado presentó una capacidad máxima de sorción de $22.35 \mathrm{mg} / \mathrm{g}$ y los datos experimentales se ajustaron a un ajuste al modelo de pseudo-segundo orden $(R=0.9998)$, indicando una distribución heterogénea en la superficie del material. En conclusión, se demostró que la remoción de colorante azul FCP por carbón activado obtenido de PET, es una alternativa prometedora en el tratamiento avanzado de aguas contaminadas.

Palabras clave: Carbón activado, colorantes, sorción, residuos.

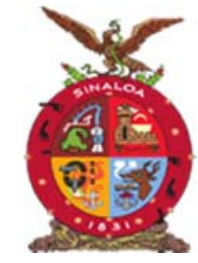

XVIII Congreso Internacional XXIV Congreso Nacional de Ciencias ambientales

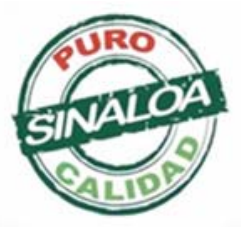

Mazatlán, Sinaloa 3-7 junio 2019
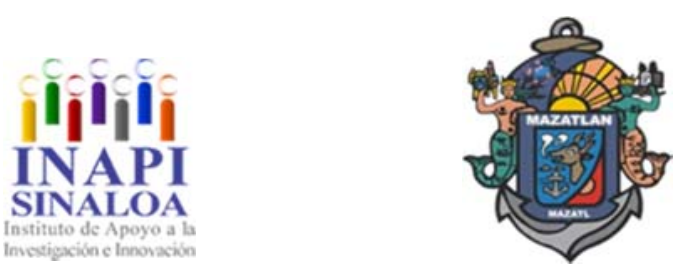

Tecnología y Biotecnología para el Tratamiento de Contaminantes y Biorremediación 

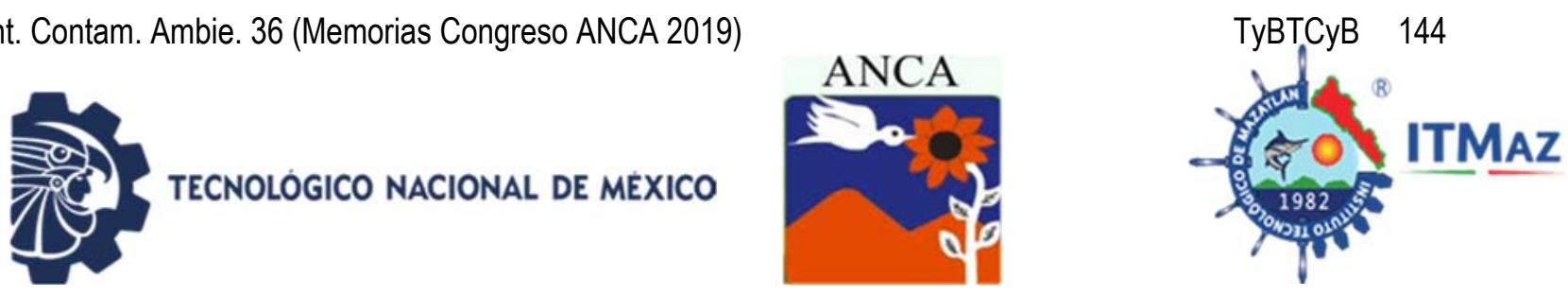

\title{
Reassessment of polyethylene terephthalate (PET) residues to obtain activated carbon as a bright blue FCP adsorbent
}

\author{
Nájera Olivas $\mathrm{J}^{1}$, Torres Pérez $\mathrm{J}^{1 *}$, Reyes López SY² \\ ${ }^{1}$ Laboratorio de Transferencia y Degradación de Contaminantes \\ 2Laboratorio de Materiales Híbridos Nanoestructurados. \\ Universidad Autónoma de Ciudad Juárez, Anillo Envolvente del Pronaf y \\ Estocolmo S/N, A.P. 1595-D, Ciudad Juárez, Chihuahua, México, \\ *jonatan.torres@uacj.mx
}

\begin{abstract}
Polyethylene terephthalate (PET) is one of the most common solid waste today. Since 1960 it has been used to package different types of drinks and food. The excessive use of this material has caused serious environmental problems. Hence the importance of the search for promising and sustainable alternatives for the reuse of PET waste.Several investigations have shown that the activated carbons obtained from various precursors have adsorption similar to commercial activated carbons. The objective of the present work was to prepare a carbonaceous material from a non-conventional precursor (P-AC) and evaluate the kinetic parameters of the FCP blue dye sorption process on the prepared alternative carbons. The research was carried out in the Pollution Transfer and Degradation Laboratory (LTDC) at the Autonomous University of Ciudad Juarez (Juárez, Chihuahua, Mexico) between January 2018 and March 2019. Experimentation was carried out through a batch system through the P-AC contact with a FCP blue solution ( $\mathrm{Co}=10 \mathrm{mg} / \mathrm{L})$. First order, pseudo-second order and Elovich kinetic models were used to determine the kinetic parameters. The prepared material presented a maximum sorption capacity of $22.35 \mathrm{mg} / \mathrm{g}$ and the experimental data fitted to the pseudo-second order model $(R=0.9998)$, indicating a heterogeneous distribution on the surface of the material. In conclusion, it was demonstrated that the removal of FCP blue dye by activated carbon from PET is a promising alternative in the advanced treatment of contaminated water.
\end{abstract}

Keywords: Activated carbon, dyes, sorption, waste.

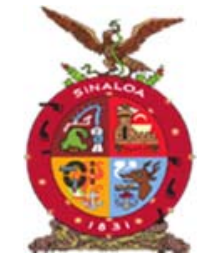

XVIII Congreso Internacional XXIV Congreso Nacional de Ciencias ambientales

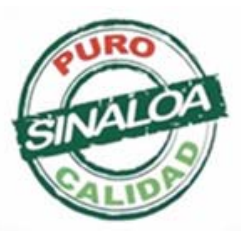

Mazatlán, Sinaloa 3-7 junio 2019
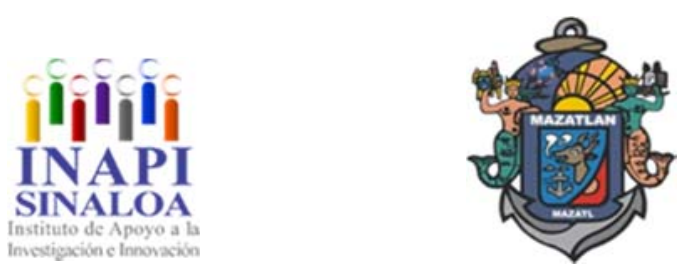

Tecnología y Biotecnología para el Tratamiento de Contaminantes y Biorremediación 

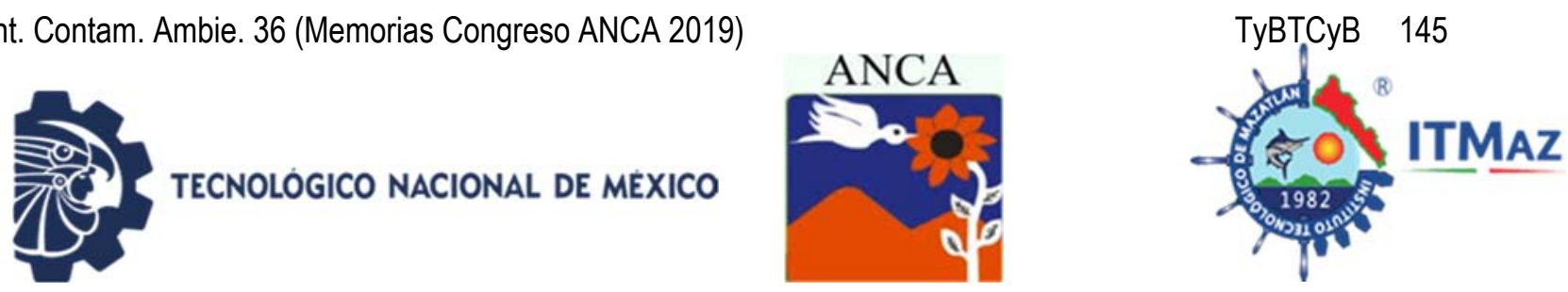

\title{
Contribución a la elaboración de una metodología de evaluación ambiental de un sistema de tratamiento de aguas residuales con sistemas biofísicos
}

\author{
Navarro Salazar $\mathrm{M}^{1^{*}}$, Macías Patiño $\mathrm{M}^{1}$, Gonzales Alonso $\mathrm{S}^{1}$, Navarro Solís $\mathrm{O}^{2}$ \\ ${ }^{1}$ Unidad Académica de Ciencias Químicas. \\ Universidad Autónoma de Zacatecas \\ ${ }^{2}$ Doctorado en Ciencias de la Ingeniería. \\ Universidad Autónoma de Zacatecas \\ *themacros123@gmail.com
}

\begin{abstract}
RESUMEN
Los altos impactos en la salud de la población y a los ecosistemas que se ocasionan por el mal tratamiento de las aguas residuales aunado al análisis costo-beneficio y la carga financiera hacia los diferentes órdenes de gobierno, hace que se plantee la necesidad de generar una metodología de evaluación de la eficiencia de los sistemas de tratamiento de aguas residuales, con base en la normativa existente. Se propone una metodología de evaluación de eficiencia ambiental en un sistema de tratamiento de las aguas residuales. De agosto a noviembre del 2018 esta investigación se realizó en la Plata Tratadora de Aguas Residuales (PTAR) Osíris de la zona conurbada Zacatecas-Guadalupe. La metodología utilizada fue el muestreo en puntos específicos del sistema de tratamiento de la PTAR: entrada principal, sedimentador primaro, reactor biológico, sedimentador secundario y medidor de flujo de salida, determinando en muestras de agua $\mathrm{Zn}, \mathrm{Pb}, \mathrm{Hg}$ y $\mathrm{Cd}$ ademas de la demanda química de oxígeno (DQO). Los resultados muestran un eficiente proceso en la eliminación de materia orgánica con los valores obtenidos en DQO, no así en el caso de los metales analizados, donde se obtuvo un valor atípico para el $\mathrm{Zn}$ en el reactor biológico, con lo que se puede desarrollar un pre-balance de energía y comenzar a plantear estrategias y/o métodos que permiten reducir y si es posible eliminar los contaminantes presentes en las aguas tratadas.
\end{abstract}

Palabras claves: Tratamiento de aguas, inc y DQO.

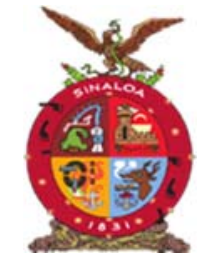

XVIII Congreso Internacional XXIV Congreso Nacional de Ciencias ambientales

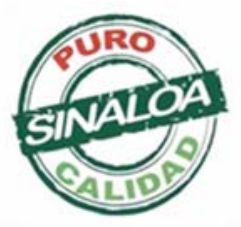

Mazatlán, Sinaloa 3-7 junio 2019
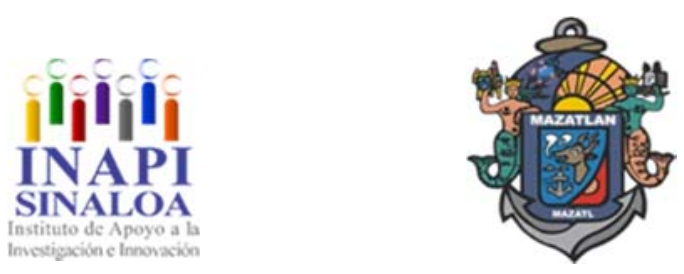

Tecnología y Biotecnología para el Tratamiento de Contaminantes y Biorremediación 

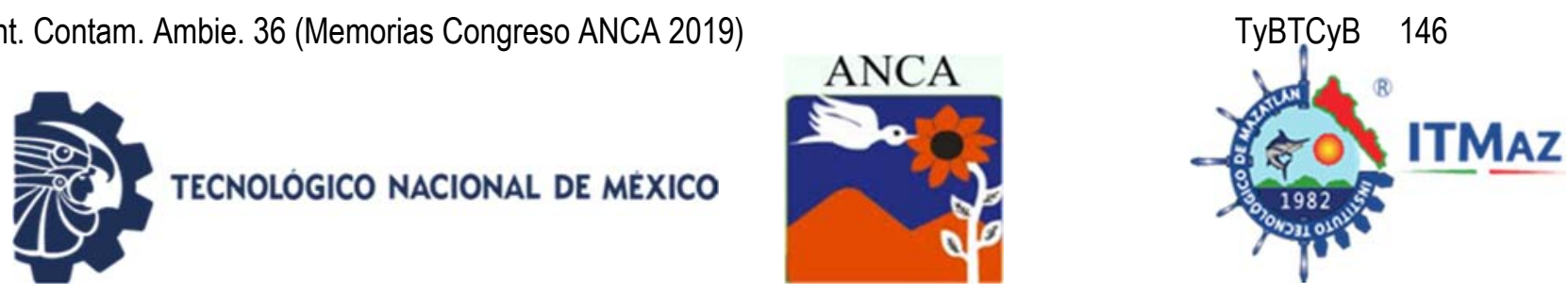

Contribution to the elaboration of an environmental assessment methodology of a waste water treatment system with biophysical systems

\author{
Navarro Salazar $\mathrm{M}^{1^{*}}$, Macías Patiño $\mathrm{M}^{1}$, Gonzales Alonso $\mathrm{S}^{1}$, Navarro Solís $\mathrm{O}^{2}$ \\ ${ }^{1}$ Unidad Académica de Ciencias Químicas. \\ Universidad Autónoma de Zacatecas \\ ${ }^{2}$ Doctorado en Ciencias de la Ingeniería. \\ Universidad Autónoma de Zacatecas \\ *themacros123@gmail.com
}

\begin{abstract}
The high impact in the health of the population and on the ecosystems caused by the poor treatment of wastewater coupled with the cost benefit analysis theh these systems have and the financial burden towards the different orders of government, makes it raise the need to generate a methodology for evaluating the enviromental efficienty of wastewater tratment sysitems, based on existing regulations. The objective of this research is to propose an environmental efficiency assessment methodology in wastewater treatment system. This research was carried out in the sewage treatment plant (STP) Osíris of the zone suburbs Zacatecas-Guadalupe frim August to November of 2018. The methodology used was sampling at specific points of the STP tratment systems: main entrance, primary sedimenter, biological reactor, secondary sedimenter and output flow meter, determing $\mathrm{Zn}, \mathrm{Pb}, \mathrm{Hg}$ and $\mathrm{Cd}$ inaddition to the Chemical Oxygen Demand (COD). The results show an efficient process in the elimination of organic matter with the values obtained in COD, not in the case of the analyzed metals, wich obtained an atypical value for $\mathrm{Zn}$ in the biological reactor, wich can develop a prebalnce of energy and to begin to propose strategies and/or methods that allow to reduce and if it is posible to eliminate the contaminants present in the treated waters.
\end{abstract}

Keywords: Water treatment, zinc and COD.

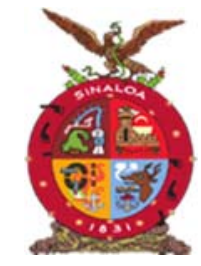

XVIII Congreso Internacional XXIV Congreso Nacional de Ciencias ambientales

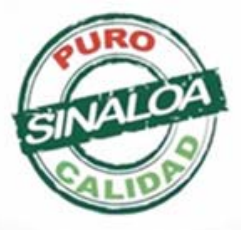

Mazatlán, Sinaloa 3-7 junio 2019
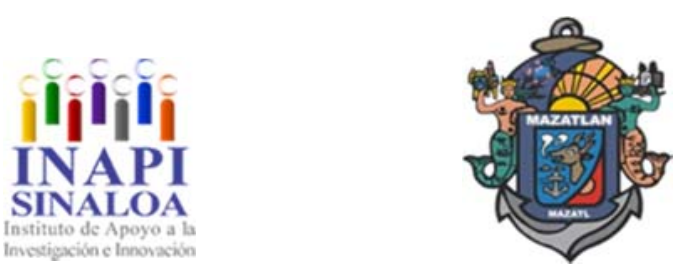

Tecnología y Biotecnología para el Tratamiento de Contaminantes y Biorremediación 

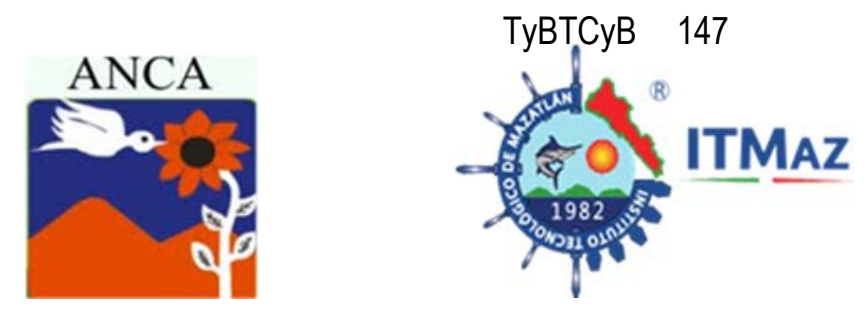

\title{
Sistema para el monitoreo y análisis de la dinámica de actividades enzimáticas durante el compostaje de biosólidos municipales
}

\author{
Negrete Rodríguez $X^{1}$, Ortiz Ruiz $A M^{1}$, Medina Herrera $M^{1}$, Campaña $\mathrm{H}^{2}$, \\ Conde Barajas $\mathrm{E}^{1 *}$
}

1Departamento de Ingeniería Ambiental Posgrado en Ingeniería Bioquímica Tecnológico Nacional de México Celaya.

Antonio García Cubas \# 600 Col. FOVISSSTE. Celaya, Gto. México

${ }^{3}$ Grupo de Estudio Ambiente Química y Biológía. Facultad Regional Bahía Blanca. Universidad Tecnológica Nacional.

11 de Abril \# 461, Bahía Blanca, Buenos Aires, Argentina.

*eloy.conde@itcelaya.edu.mx

\section{RESUMEN}

La generación de lodos residuales en plantas tratadoras de aguas residuales (PTAR) de tipo aeróbico, son de gran volúmen y pueden ocasionar un impacto ambiental. Una vez estabilizados estos lodos adoptan el nombre de "biosólidos". El compostaje es una opción para lograr "mayor estabilización". La "composta" generada, puede ser utilizada como enmienda orgánica rica en nutrientes. El sistema $\mathrm{APIZYM}^{\circledR}$ es un método diseñado para el estudio rápido de 19 actividades enzimáticas involucradas en la metabolización de nutrientes. Dentro de este. El objetivo de este estudio fue monitorear las actividades enzimáticas por APIZYM ${ }^{\circledR}$ durante el compostaje de biosólidos bajo diferentes tratamientos y días $(0,715$ y 30$)$, así como, aplicar el índice de Shannon $\left(\mathrm{H}^{\prime}\right)$ para conocer la "diversidad" e impacto que se está desarrollando por la actividad microbiológica dentro de un ecosistema o proceso de compostaje a nivel específico. Los resultados indicaron que los valores de las actividades enzimáticas por familias fueron en este orden: fosfatasas >esterasas >glicohidrolasas >proteasas. Sin embargo, el índice de Shannon $\left(\mathrm{H}^{\prime}\right)$, mostró una mayor diversidad solo en las familias de las fosfatasas (1.099-1.085) seguido de las glicohidrolasas (1.3421.551) respectivamente. Concluyéndose que existió en general una baja diversidad de enzimas $(<2)$ en los tiempos evaluados y que el sistema APIZYM ${ }^{\circledR}$ es un método efectivo y rápido para establecer un análisis del estatus de diversidad metabólica de la biomasa microbiana presente o del grado de estabilización de los de los residuos sólidos durante un proceso de compostaje.

Palabras clave: Composta, actividad enzimática, biosólidos, APIZYM ${ }^{\circledR}$

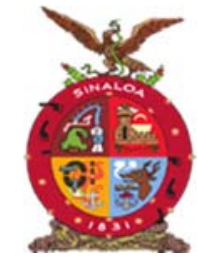

XVIII Congreso Internacional XXIV Congreso Nacional de Ciencias ambientales

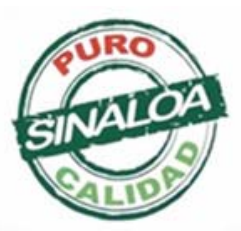

Mazatlán, Sinaloa 3-7 junio 2019

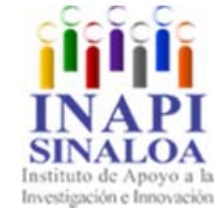

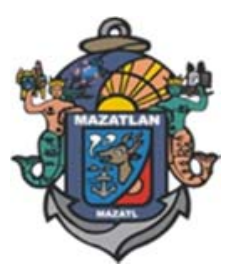

Tecnología y Biotecnología para el Tratamiento de Contaminantes y Biorremediación 

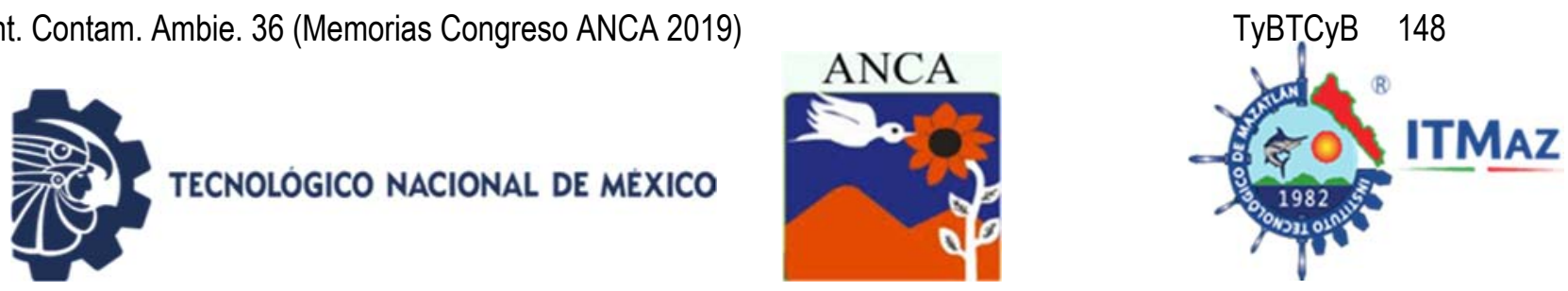

System for the monitoring and analysis of the dynamics of enzymatic
activities during the biosolids composting of municipal biosolids

Negrete Rodríguez $\mathrm{X}^{1}$, Ortiz Ruiz $\mathrm{AM}^{2}$, Medina Herrera $\mathrm{M}^{2}$, Campaña $\mathrm{H}^{3}$, Conde Barajas $\mathrm{E}^{1 *}$

1Departamento de Ingeniería Ambiental Posgrado en Ingeniería Bioquímica Tecnológico Nacional de México Celaya.

Antonio García Cubas \# 600 Col. FOVISSSTE. Celaya, Gto. México

${ }^{3}$ Grupo de Estudio Ambiente Química y Biológía. Facultad Regional Bahía Blanca. Universidad Tecnológica Nacional.

11 de Abril \# 461, Bahía Blanca, Buenos Aires, Argentina.

*eloy.conde@itcelaya.edu.mx

\begin{abstract}
The generation of sewage sludge in aerobic wastewater treatment plants (WWTPs) is of great magnitude and environmental importance. Once stabilized, these sewage sludges adopt the name of "biosolids". Composting is an option to achieve "greater stabilization". The generated "compost" can be utilized as a nutrient-rich organic amendment. On the other hand, the APIZYM ${ }^{\circledR}$ system is a method designed for the rapid study of 19 enzymatic activities involved in the assimilation and release of nutrients. Within this context, the objective of this study was to monitor enzymatic activities by APIZYM ${ }^{\circledR}$ during the composting of biosolids under different treatments and days $(0,7,15$ and 30$)$, as well as to establish a Shannon index $\left(\mathrm{H}^{\prime}\right)$ to know the "diversity" and impact that enzymatic activities are developing within an ecosystem or composting process at a specific level. The results indicated that the values of enzymatic activities by families were in the following order: phosphatases >esterases >glycohydrolases >proteases. However, the Shannon index $\left(\mathrm{H}^{\prime}\right)$, showed a greater diversity only in the families of phosphatases (1.099-1.085) followed by glycohydrolases (1.342-1.551) respectively. It was concluded that there was generally a low diversity in enzymatic activity $(<2)$ in the evaluated times and that the APIZYM ${ }^{\circledR}$ system is an effective and fast method to establish an analysis of the metabolic diversity status of the microbial biomass present or the degree of biological transformation of solid waste during a composting process.
\end{abstract}

Keywords: Compost, enzymatic activity, biosolids, APIZYM ${ }^{\circledR}$.

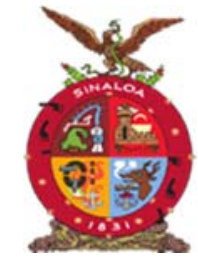

XVIII Congreso Internacional XXIV Congreso Nacional de Ciencias ambientales

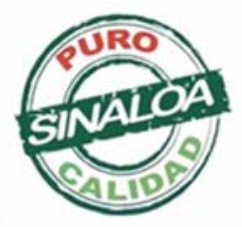

Mazatlán, Sinaloa 3-7 junio 2019
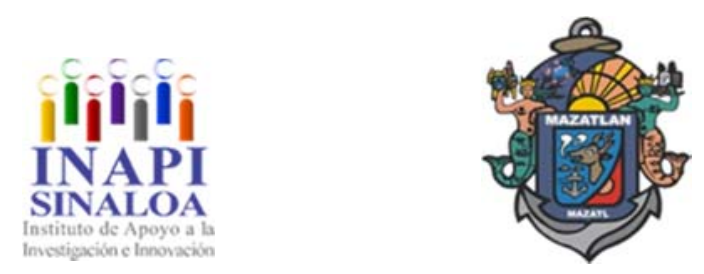

Tecnología y Biotecnología para el Tratamiento de Contaminantes y Biorremediación 

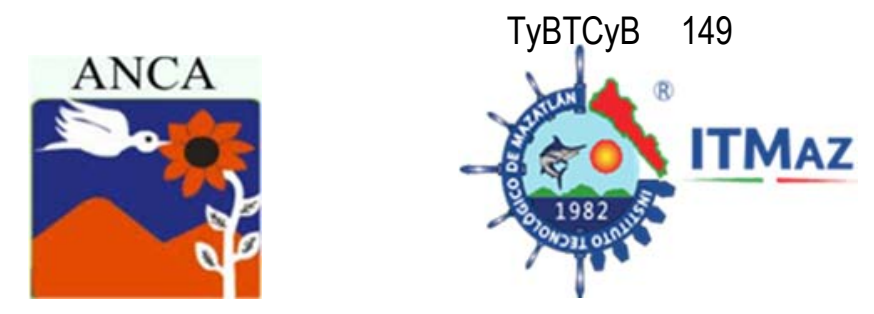

\title{
Caracterización de bacterias termofilas aisladas de tapetes bacterianos de las aguas termales de la zona geotérmica de Comanjilla, Guanajuato, México
}

\author{
Noriega Luna $B^{1^{*}}$, Puy Alquiza $M J^{2}$, Vázquez Lara $A Y^{1}$, Serafín Muñoz $A^{1}$, \\ Salazar Hernández $\mathrm{MM}^{2}$, Miranda Aviles $\mathrm{R}^{2}$, Carreño Aguilera $\mathrm{G}^{3}$ \\ ${ }^{1}$ Departamento de Ingeniería Civil \\ ${ }^{2}$ Departamento de Minas, Metalurgia y Geología \\ ${ }^{3}$ Departamento de Geomática e Hidráulica.División de Ingenierías. \\ Universidad de Guanajuato, Campus Guanajuato, México \\ *berenice.noriega@ugto.mx
}

\section{RESUMEN}

El presente estudio se realizó para determinar el fenotipo y caracterización genotípica de las bacterias termófilas aisladas de tapetes bacterianos formados en aguas termales de la zona geotérmica de Comanjilla, Guanajuato, México. El agua termal estudiada fue clasificada como agua hipertermal (de $45^{\circ} \mathrm{C}$ a $100^{\circ} \mathrm{C}$ ) con una tendencia química global de los iones hacia un comportamiento de tipo $\mathrm{H} 2 \mathrm{~S}-\mathrm{Na}$ (sulfuradas sódicas), de origen profundo y de baja mineralización, observando un alto contenido de sílice y bajo en Calcio y Magnesio. Ocho aislados bacteriano fueron caracterizados morfológica, microscópica y bioquímicamente. La secuenciación del $16 \mathrm{~S}$ rDNA de los aislados reveló que dos cepas podrían identificarse como Bacillus licheniformis. El análisis de búsqueda BLAST de la secuencia mostró una identidad máxima con Bacillus $(99 \%$ de similitud). El análisis filogenético del aislamiento reveló una estrecha relación con especies de Bacillus termófilas. Los resultados muestran una clara dominación del género Bacillus representado por Brevibacillus agri y Paenibacillus sp. Estas bacterias son Gram positivas, pigmentadas de amarillo, no motrices y no esporulantes de 0.2 a $0.5 \mu \mathrm{m}$ de longitud crecieron bien a un $\mathrm{pH}$ neutro y ligeramente alcalino. Los aislados mostraron capacidad para producir algunas enzimas termoestables tales como: catalasa y amilasa así como fermentación de manitol, pero no se observó actividad en fermentación de lactosa, licuefacción de gelatina, rojo de metilo y voges de Proskauer. Se ha considerado la posibilidad del uso de las cepas bacterianas seleccionadas, informadas en el presente estudio, en los diferentes sectores de la industria energética y en aplicaciones biotecnológicas.

Palabras Clave: Aguas termales, tapete bacteriano, bacterias termófilas, zona geotérmicasde Comanjilla, Guappjuato.

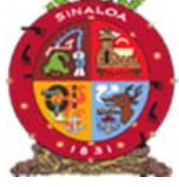

XVIII Congreso Internacional XXIV Congreso Nacional de Ciencias ambientales

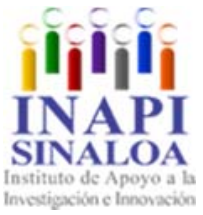

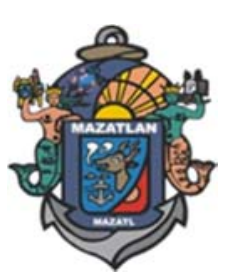

Tecnología y Biotecnología para el Tratamiento de Contaminantes y Biorremediación 

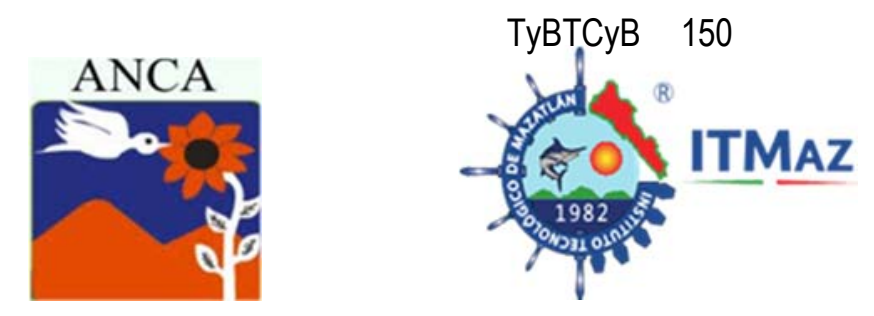

\title{
Characterization of thermophilic bacteria isolated from microbial mats present in hot spring of the Comanjilla geothermic zone, Guanajuato, Mexico
}

\author{
Noriega Luna $B^{1^{*}}$, Puy Alquiza $M J^{2}$, Vázquez Lara $A Y^{1}$, Serafín Muñoz $A^{1}$, \\ Salazar Hernández $\mathrm{MM}^{2}$, Miranda Aviles $\mathrm{R}^{2}$, Carreño Aguilera $\mathrm{G}^{3}$ \\ ${ }^{1}$ Departamento de Ingeniería Civil \\ ${ }^{2}$ Departamento de Minas, Metalurgia y Geología \\ ${ }^{3}$ Departamento de Geomática e Hidráulica.División de Ingenierías. \\ Universidad de Guanajuato, Campus Guanajuato, México \\ *berenice.noriega@ugto.mx
}

\begin{abstract}
The present study was conducted to determine the phenotype and genotypic characterization of thermophilic bacteria isolated from microbial mats present in hot spring of the Comanjilla geothermic zone, Guanajuato, Mexico. The thermal water studied is classified as hyperthermal water $\left(45^{\circ} \mathrm{C}\right.$ to $\left.100^{\circ} \mathrm{C}\right)$ with a global chemical tendency of the ions to a H2S-Na-type behavior (sulphurated sodium) of deep origin and with low mineralization, that shows a high content of silica and a low content of calcium and magnesium. Eight isolates were characterized by morphological, microscopic, biochemical, molecular, and physiological characteristics. Sequencing of the $16 \mathrm{~S}$ rDNA of the isolates revealed that two strains could be identified as Bacillus licheniformis. BLAST search analysis of the sequence showed maximum identity with Bacillus (99\% similarity). Phylogenetic analysis of the isolate revealed close affiliation with thermophilic Bacillus species. The results revealed a clear domination of the genus Bacillus represented by Brevibacillus agri and Paenibacillus sp., in the microbial mats covering a wide geographic area in zone geothermal Comanjilla. These bacteria were grampositive, yellow-pigmented, non-motile and non-sporulating rods of 0.2 to $0.5 \mu \mathrm{m}$ in length and grew well at neutral to slight alkali $\mathrm{pH}$. The isolates showed an ability to produce some thermostable enzymes such as catalase, amylase and fermentation of mannitol, but no fermentation of lactose, gelatin liquefaction, methyl red and vogues Proskauer activity was observed. The possibility of using the selected bacterial strains informed, in the present study, in the different sectors of the energy industry and in biotechnological applications has been addressed.
\end{abstract}

Keywords: Hot springs, microbial mats, thermophile bacteria, Comanjilla geothermic zone, Guanajuato.
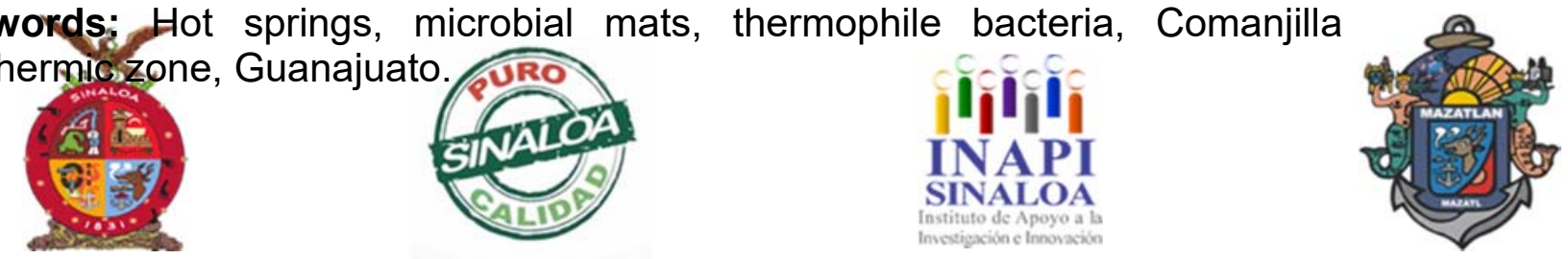

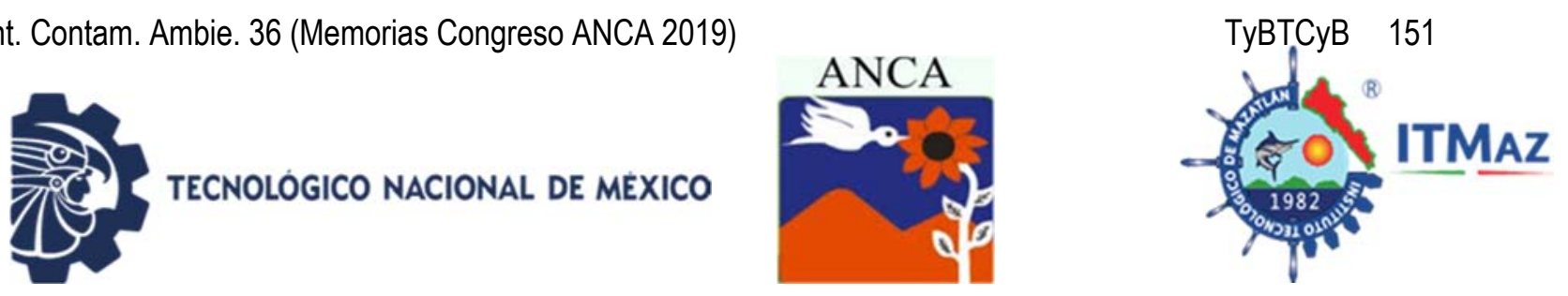

\title{
Obtención de biocombustible a partir de leños de la borra de café
}

\author{
Oceguera Flores $\mathrm{P}^{*}$, Alcaraz Novoa J, Michel Parra G \\ Universidad de Guadalajara, Centro Universitario del Sur, \\ Av. Enrique Arreola Silva No. 883, Colón, Cd Guzmán Centro, 49000 \\ Cd Guzmán, Jalisco, Méxcio \\ *mariana.oceguera@hotmail.com
}

\begin{abstract}
RESUMEN
Los biocombustibles son fuente de energía y se derivan de materia orgánica, por lo tanto el objetivo de esta investigación fue elaborar leños a partir de la borra de café mediante una técnica sencilla para demostrar que pueden ser un óptimo biocombustible. Los materiales que se utilizaron fueron: borra de café seca, velas de parafina, melaza, manteca, jarabe de maíz y azúcar morena. Se fabricaron dos tipos de leños, el método fue derretir las velas junto con la melaza, después se incorporó la borra y se dejó reposar. Para el segundo leño se derritió manteca, jarabe de maíz y la azúcar morena, se incorporó la borra y se dejó reposar. Los resultados se sometieron al análisis estadístico por medio de la prueba Tuckey, comparando el tiempo de combustión de leños de madera, leños de borra de café con parafina, y leños de borra de café con manteca. El resultado fue significativo para los leños de borra de café con parafina por su mayor tiempo de combustión. Los leños a partir de la borra de café son una alternativa como biocombustible ya que la borra es actualmente un residuo sólido que no se aprovecha.
\end{abstract}

Palabras clave: Biocombustible, borra, leños, parafina y manteca.

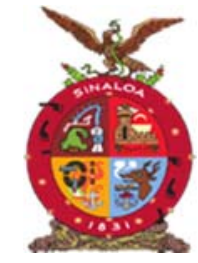

XVIII Congreso Internacional XXIV Congreso Nacional de Ciencias ambientales

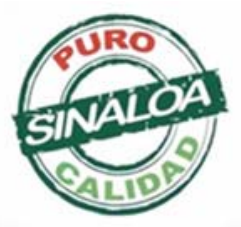

Mazatlán, Sinaloa 3-7 junio 2019
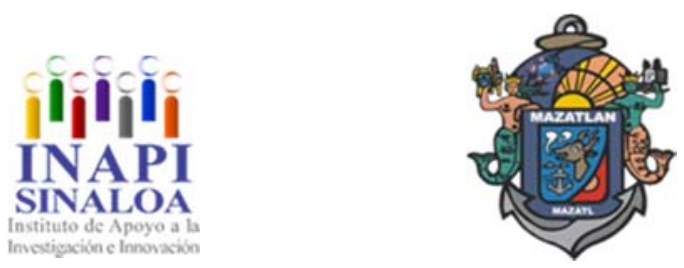

Tecnología y Biotecnología para el Tratamiento de Contaminantes y Biorremediación 

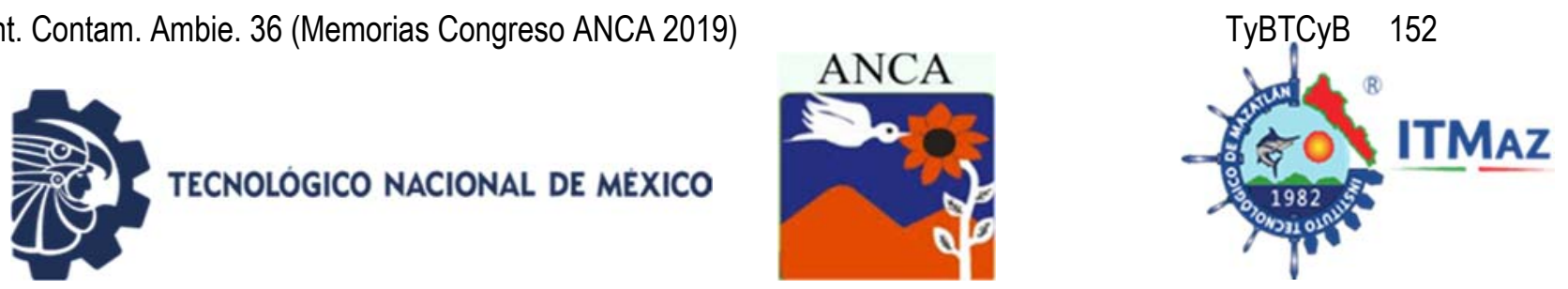

Obtaining of biofuel from logs of the coffee grounds dry

\author{
Oceguera Flores $\mathrm{P}^{*}$, Alcaraz Novoa J, Michel Parra G \\ Universidad de Guadalajara, Centro Universitario del Sur, \\ Av. Enrique Arreola Silva No. 883, Colón, Cd Guzmán Centro, 49000 \\ Cd Guzmán, Jalisco, Méxcio \\ *mariana.oceguera@hotmail.com
}

\begin{abstract}
Biofuels are a source of energy and are derived from organic matter, the objective of this investigation was to elaborate logs from the coffee grounds dry by a simple technique to prove that can be an optimal biofuel. The materials used were: coffee grounds dry, paraffin candles, molasses, lard, corn syrup and brown sugar. It was produced two types of logs, the method was to melt the candles along with the molasses, after the coffee grounds dry was incorporated. For the second log, it melted the lard, corn syrup and the brown sugar and after the coffee grounds dry was incorporated too, for later stay on. The statistical analysis was by means of the Tuckey test, comparing the burning time of wood logs. The logs of coffee grounds dry with paraffin and the logs of coffee grounds dry with lard. The result was significant for logs of coffee grounds dry with paraffin for its longer combustion time. The logs from coffee grounds are an alternative as biofuel since normally the coffee grounds dry are disposable.
\end{abstract}

Keywords: Biofuel, coffee grounds, logs, lard, paraffin.

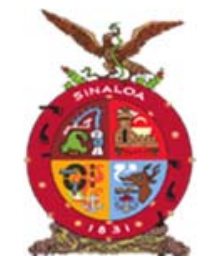

XVIII Congreso Internacional XXIV Congreso Nacional de Ciencias ambientales

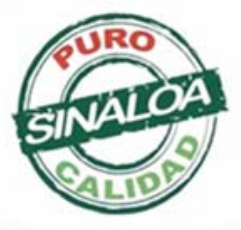

Mazatlán, Sinaloa 3-7 junio 2019
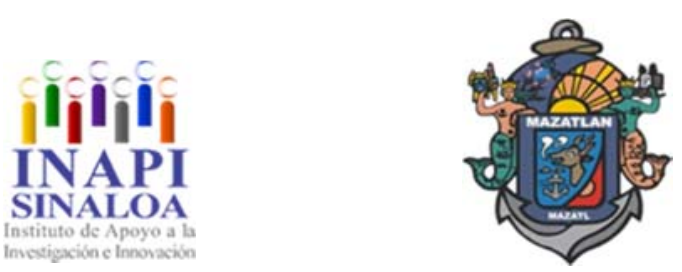

Tecnología y Biotecnología para el Tratamiento de Contaminantes y Biorremediación 

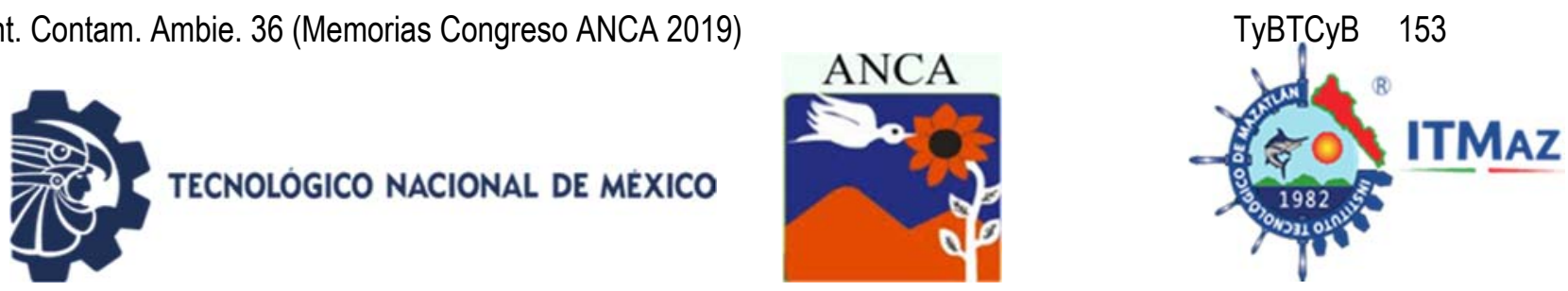

\section{Caracterización y estudio del potencial energético de vinaza de Agave durangensis en la industria mezcalera}

Ordaz Díaz $\mathrm{L}^{1 *}$, Madrid del Palacio $\mathrm{M}^{1}$, Rodríguez Flores $\mathrm{F}^{1}$, Flores Villegas $\mathrm{M}^{1}$, Rodríguez Rosales $\mathrm{J}^{2}$, Bailón Salas $\mathrm{A}^{2}$

${ }^{1}$ Ingeniería en Tecnología Ambiental. Universidad Politécnica de Durango, Carr. Dgo-Mex Km 9.5, Col. Dolores Hidalgo, 34300, Durango, Dgo. México ${ }^{2}$ Maestría en Sistemas Ambientales, Instituto Tecnológico de Durango (ITD), Blvd. Felipe Pescador 1830 Ote. Col. Nueva Vizcaya, Durango, Dgo., México *luis.ordaz@unipolidgo.edu.mx

\section{RESUMEN}

El mezcal se ha convertido en uno de los productos más representativos de México a nivel internacional, debido a su carácter artesanal y su variedad de presentaciones. El mezcal es el resultado final de la destilación del tronco o piña del agave mezcalero, cocido en un horno de piedra excavado en la tierra. El mezcal se procesa en pequeñas destilerías, obteniendo dos residuos uno sólido llamado bagazo y otro líquido llamado vinaza. En Durango la Industria Mezcalera representa uno de los grandes aportes dentro de la región. En este estudio se llevó a cabo la caracterización del sustrato, evaluando ST, SVT, SSV, DQO, NT, PT, además se evaluó la producción de biogás mediante la fermentación anaerobia de vinazas, a nivel de laboratorio, utilizando un reactor UASB de 3 gal. Se realizaron cálculos teóricos de producción de biogás, la vinaza puede ser utilizada en procesos de digestión anaerobia para la obtención de metano como fuente de energía renovable las cantidades producidas de biogás y la reducción de DQO del reactor UASB, dependieron del tiempo de retención hidráulica (TRH) $y$ del fluido en tratamiento.

Palabras clave: Vinaza, Agave durangensis, UASB, biogás.

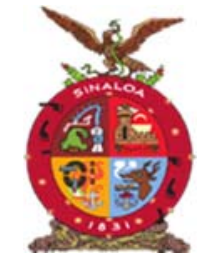

XVIII Congreso Internacional XXIV Congreso Nacional de Ciencias ambientales

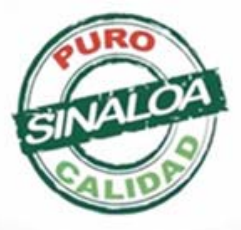

Mazatlán, Sinaloa 3-7 junio 2019
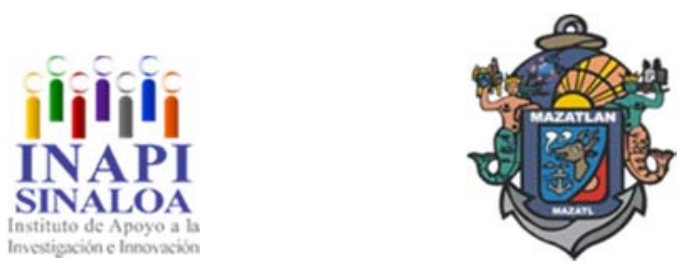

Tecnología y Biotecnología para el Tratamiento de Contaminantes y Biorremediación 

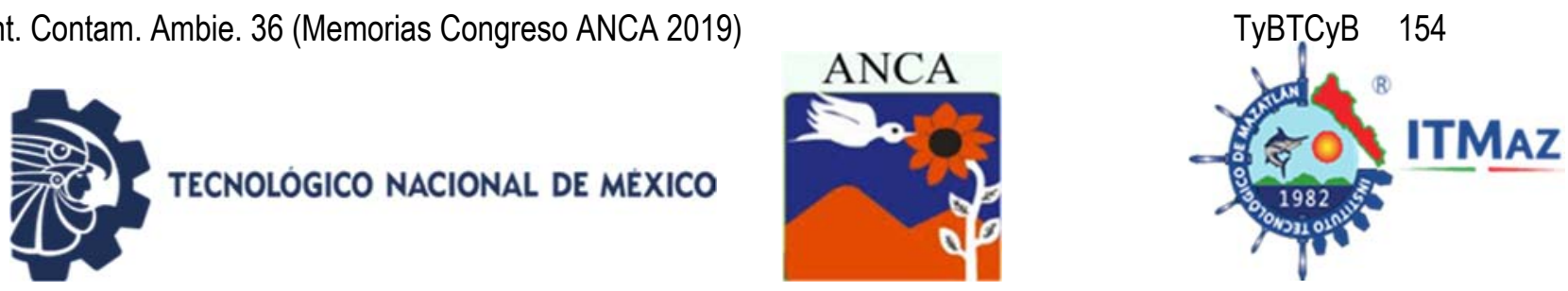

\title{
Characterization and study of the energy potential of vinaza de Agave durangensis in the mezcalera industry
}

\author{
Ordaz Díaz $\mathrm{L}^{1^{*}}$, Madrid del Palacio $\mathrm{M}^{1}$, Rodríguez Flores $\mathrm{F}^{1}$, Flores Villegas $\mathrm{M}^{1}$, \\ Rodríguez Rosales $\mathrm{J}^{2}$, Bailón Salas $\mathrm{A}^{2}$ \\ ${ }^{1}$ Ingeniería en Tecnología Ambiental. Universidad Politécnica de Durango, \\ Carr. Dgo-Mex Km 9.5, Col. Dolores Hidalgo, 34300, Durango, Dgo. México \\ ${ }^{2}$ Maestría en Sistemas Ambientales, Instituto Tecnológico de Durango (ITD), \\ Blvd. Felipe Pescador 1830 Ote. Col. Nueva Vizcaya, Durango, Dgo., México \\ *luis.ordaz@unipolidgo.edu.mx
}

\begin{abstract}
Mezcal has become one of the most representative products of Mexico at an international level, due to its artisanal nature and its variety of presentations. The mezcal is the final result of the distillation of the trunk or pineapple of the mezcalero agave, cooked in a stone oven dug in the ground. The mezcal is processed in small distilleries, obtaining two residues, a solid one called bagasse and another liquid called vinasse. In Durango the Mezcalera Industry represents one of the great contributions within the region. In this study the characterization of the substrate was carried out, evaluating TS, TVS, VSS, COD, TN, TP, in addition the biogas production was evaluated by the anaerobic fermentation of vinasses, at laboratory level, using a UASB reactor of 3 gal. Theoretical calculations of biogas production were carried out, the vinasse can be used in anaerobic digestion processes to obtain methane as a source of renewable energy, the quantities produced of biogas and the COD reduction of the UASB reactor, depended on the hydraulic retention time (HRT) and the fluid under treatment.
\end{abstract}

Keywords: Vinasse, Agave durangensis, UASB, biogas.

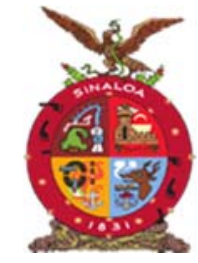

XVIII Congreso Internacional XXIV Congreso Nacional de Ciencias ambientales

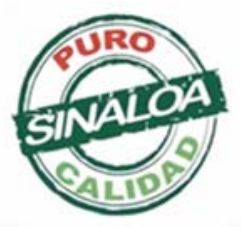

Mazatlán, Sinaloa 3-7 junio 2019
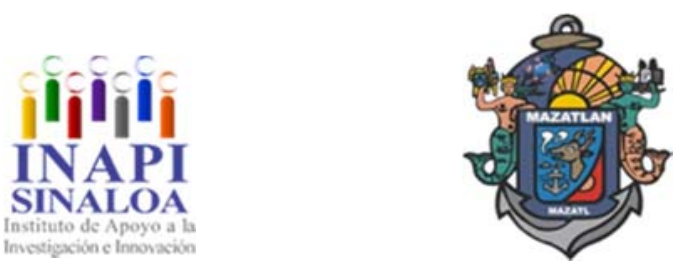

Tecnología y Biotecnología para el Tratamiento de Contaminantes y Biorremediación 

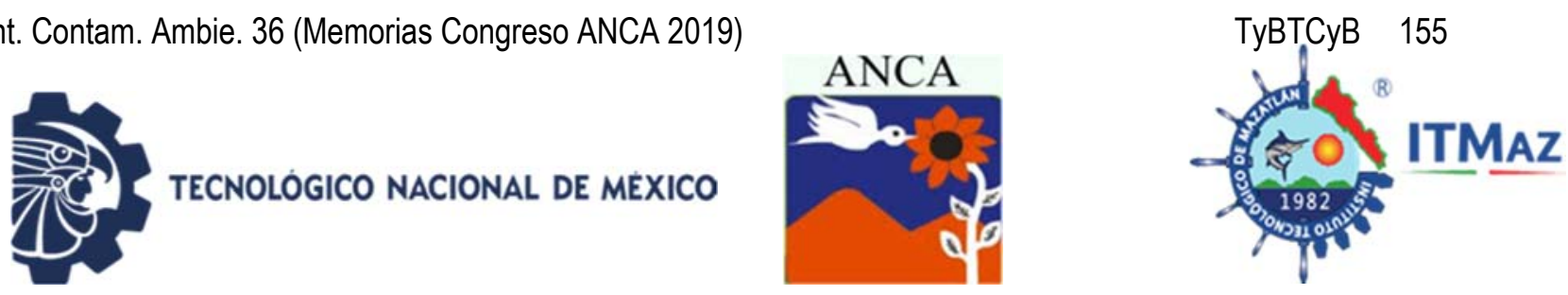

Impacto ambiental por la detección de gen Azo Reductasa en cepas E. coli patogenas del agua residual

\author{
Oropeza Miranda $\mathrm{N}^{1}$, Estrada Johnson $\mathrm{E}^{2^{*}}$, Alonso Calderón $\mathrm{A}^{1}$, \\ Chávez Bravo $\mathrm{E}^{3}$
}

${ }^{1}$ Facultad de Ingeniería Química. BUAP

${ }^{2}$ University of Florida,

${ }^{3}$ Instituto de Ciencias-CICM, BUAP.

*mrs_welling155@hotmail.com

\begin{abstract}
RESUMEN
Los colorantes azo utilizados en la industria textil son vertidos en el agua municipal y provocan un problema de contaminación acuática. Dichos contaminantes en el agua residual pueden ser degradados por bacterias mediante enzimas azo reductasas y generar metabolitos secundarios carcinogénicos. La incidencia de bacterias patógenas de $E$. coli en el agua residual va en aumento y representan un riesgo a la salud por originar brotes diarreicos, por lo que, el objetivo de este estudio fue detectar el gen azo reductasa en cepas $E$. coli enteropatógenas (EPEC) en el agua residual debido a su alta incidencia y determinar su posible impacto al ambiente. Para ello en el 2018 se aislaron e identificaron cepas EPEC del agua residual del río Alseseca y se evaluó la presencia del gen azo reductasa utilizando a la cepa E. coli K12 como control positivo en trabajos previos se diseñó los primers específicos del gen azo reductasa. Mediante la técnica de PCR se amplificó el fragmento de DNA y posteriormente se realizó un corrimiento electroforético para ser visualizado con bromuro de etidio en un transiluminador de UV. El 69\% (11/16) de las cepas EPEC aisladas del agua residual amplificaron el gen azo reductasa de $432 \mathrm{pb}$, que concuerda con el amplicon positivo. Los resultados del estudio demuestran que las cepas EPEC recuperadas del agua residual contienen el gen azo reductasa, sugiriendo su capacidad para degradar colorantes azo y posiblemente contribuir a reducir la contaminación química del agua residual, pero generando metabolitos secundarios carcinogénicos como las aminas aromáticas.
\end{abstract}

Palabras clave: Colorantes, agua residual, azo reductasa, EPEC.

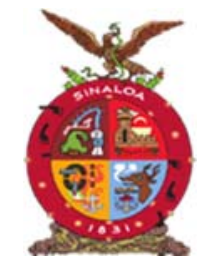

XVIII Congreso Internacional XXIV Congreso Nacional de Ciencias ambientales

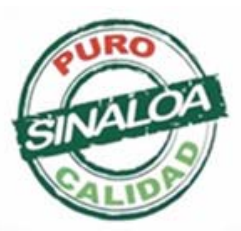

Mazatlán, Sinaloa 3-7 junio 2019
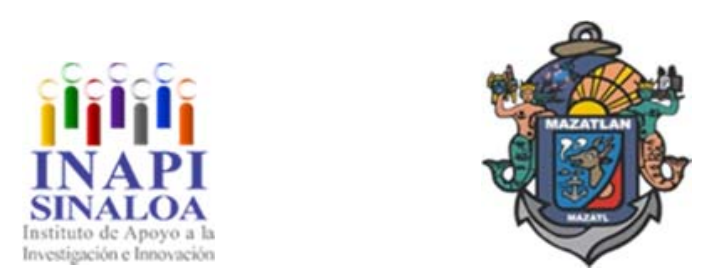

Tecnología y Biotecnología para el Tratamiento de Contaminantes y Biorremediación 

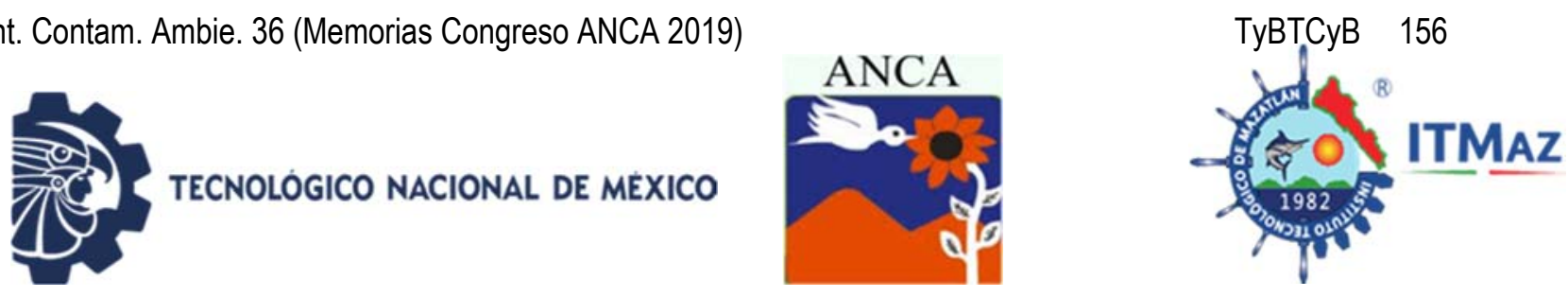

\title{
Environmental impact of the detection of Azoreductase gene in pathogenic E. coli strains of wastewater
}

\author{
Oropeza Miranda $\mathrm{N}^{1}$, Estrada Johnson $\mathrm{E}^{2^{*}}$, Alonso Calderón AIA ${ }^{1}$, \\ Chávez Bravo $\mathrm{E}^{3}$ \\ ${ }^{1}$ Facultad de Ingeniería Química. BUAP \\ 2 University of Florida, \\ ${ }^{3}$ Instituto de Ciencias-CICM, BUAP. \\ *mrs_welling155@hotmail.com
}

\begin{abstract}
The azo dyes used in textile industries are discharged in the municipal water causing serious environmental problems. These wastewater contaminants can be degraded by bacteria through azoreductase enzymes generating carcinogenic secondary metabolites. The incidence of pathogenic $E$. coli bacteria in wastewater is increasing, wich represents a health risk due to diarrhea outbreaks. The objective of this study was to detect the azoreductase gene in enteropathogenic $E$. coli (EPEC) strains from the wastewater, due to its high incidence and determine the possible environmental impact. To this end, EPEC strains were isolated and identified EPEC strains in the wastewaters of the Alseseca river in 2008 , and the azoreductase gene was detected using the E. coli K12 strain as a positive control (in previous study, specific azoreductase primers were designed). Employing the PCR technique, the DNA was amplified then an electrophoresis running and bromide staining was done to visualize the band in the UV transilluminator. The $69 \%(11 / 16)$ of the isolated EPEC strains from the wastewater amplified the azoreductase gene with $432 \mathrm{bp}$ band size that matches with the positive control. The results of these study show that the recovered EPEC strains from the wastewater have the azoreductase gene, this suggests that this bacterias have the ability to degrade the azo dyes and contribute in generate posible chemist pollution in the wastewater, generating secondary carcinogenic metabolites like aromatic amines.
\end{abstract}

Keywords: Dyes, wastewater, azoreductase, EPEC.

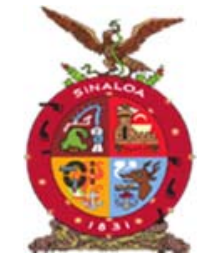

XVIII Congreso Internacional XXIV Congreso Nacional de Ciencias ambientales

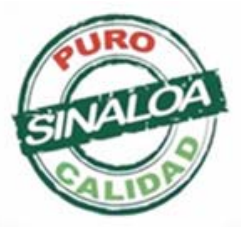

Mazatlán, Sinaloa 3-7 junio 2019
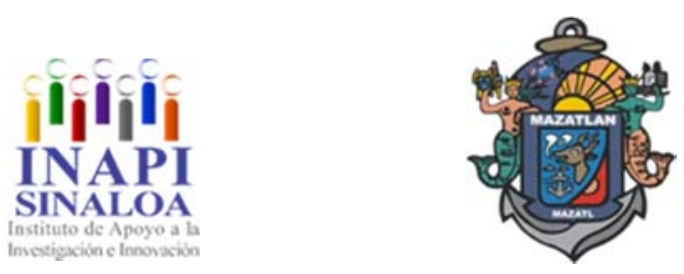

Tecnología y Biotecnología para el Tratamiento de Contaminantes y Biorremediación 

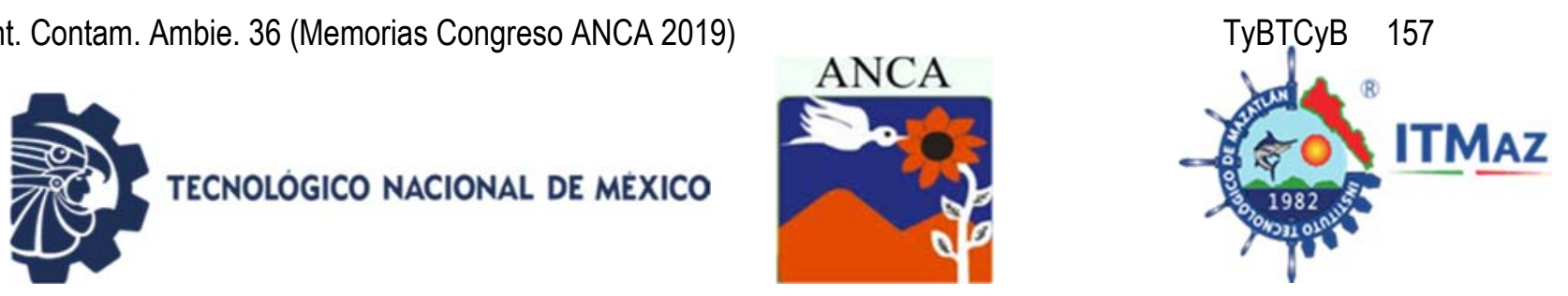

\title{
Revaloración cultural del PIPE (Sapindus mukorossi) como alternativa para disminuir la contaminación del agua en San Ildefonso Villa Alta, Oaxaca
}

\author{
Orozco Villafañe $A^{1}$, López Cruz JY2² \\ ${ }^{1}$ Instituto Politécnico Nacional. CIESAS \\ ${ }^{2}$ Instituto Politécnico Nacional, CIIDIR. Unidad Oaxaca. \\ *jylopez@ipn.mx
}

\section{RESUMEN}

En la actualidad los efectos por el uso de detergentes presentan graves problemas de contaminación del agua afectando seriamente al ambiente, la salud del ser humano y rompiendo con los procesos biológicos que preservan la vida de otras especies. El consumo de los detergentes tiene repercusiones a largo plazo y es uno de los contaminantes más representativos a nivel mundial (Lannacone, 2002), los componentes permanecen en el agua por mucho tiempo dificultando que esta pueda ser nuevamente utilizada (Insua, 2010). El objetivo fue identificar la importancia de retomar las prácticas culturales que giran en torno a la utilización de las semillas del árbol de pipe ó árbol de jabón (Sapindus mukorossi), en la comunidad de San Ildefonso Villa Alta. Para ello se utilizó una metodología cualitativa, aplicando una entrevista semiestructurada a una muestra de cinco personas con edades de 40 a más años, debido a que los jóvenes ya no utilizan dicha planta. Se complementó la investigación con información documental sobre los efectos que desencadena el uso de detergentes químicos. Presentando en los resultados las principales afectaciones al ambiente causadas con la introducción de detergentes químicos en sustitución del jabón derivado del árbol del pipe y la necesidad de revalorar el uso de este recurso natural para disminuir la contaminación del agua.

Palabras clave: Detergentes químicos, jabones naturales, contaminación del agua.

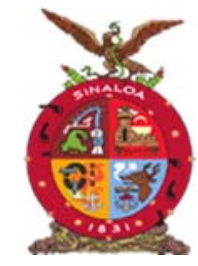

XVIII Congreso Internacional XXIV Congreso Nacional de Ciencias ambientales

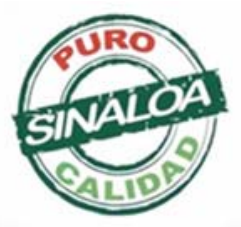

Mazatlán, Sinaloa 3-7 junio 2019
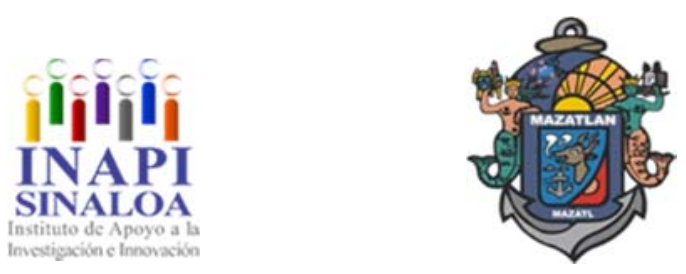

Tecnología y Biotecnología para el Tratamiento de Contaminantes y Biorremediación 

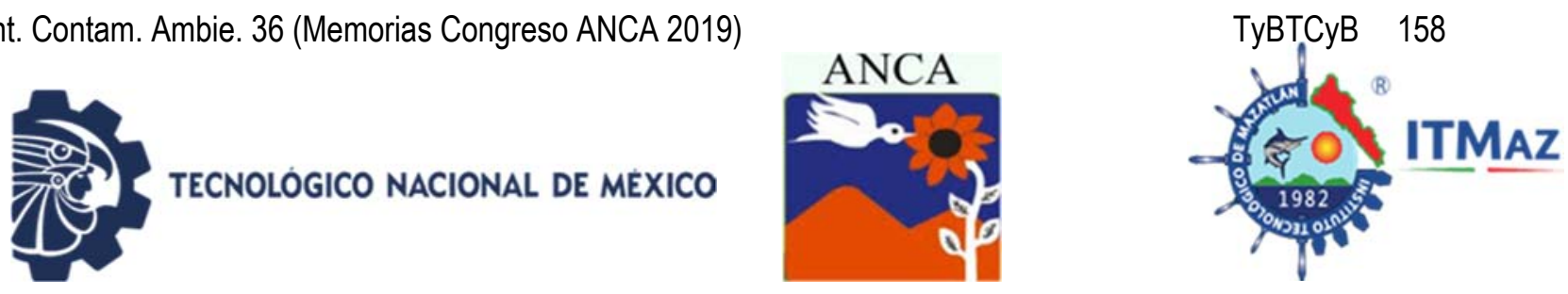

\title{
Cultural revaluation of PIPE (Sapindus mukorossi) as an alternative to reduce the contamination of water in San Ildefonso Villa Alta, Oaxaca
}

\author{
Orozco Villafañe $A^{1}$, López Cruz JY2² \\ ${ }^{1}$ Instituto Politécnico Nacional. CIESAS \\ ${ }^{2}$ Instituto Politécnico Nacional, CIIDIR. Unidad Oaxaca. \\ *jylopez@ipn.mx
}

\begin{abstract}
The human being throughout his life has a series of needs that he needs to satisfy, this is where the market creates opportunities to position various products that make human activity more comfortable and easier. At present, the effects of the use of detergents present serious problems of water pollution, seriously affecting the environment, the health of the human being and breaking with the biological processes that preserve the life of other species. The consumption of detergents has long-term repercussions and is one of the most representative pollutants worldwide (Lannacone, 2002), the components remain in the water for a long time, making it difficult to use them again (Insua, 2010). The objective was to identify the importance of retaking the cultural practices that revolve around the use of the seeds of the pipe tree or soap tree (Sapindus mukorossi), in the community of San Ildefonso Villa Alta. To do this, a qualitative methodology was used, applying a semi-structured interview to a sample of five people aged 40 to over, because the young people no longer use said plant. The research was complemented with documentary information on the effects that the use of chemical detergents triggers. Presenting in the results the main environmental effects caused by the introduction of chemical detergents to replace soap derived from the pipe tree and the need to revalue the use of this natural resource to reduce water pollution.
\end{abstract}

Keywords: Chemical detergents, natural soaps, water pollution.

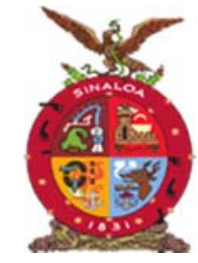

XVIII Congreso Internacional XXIV Congreso Nacional de Ciencias ambientales

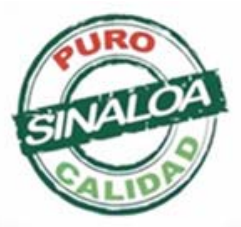

Mazatlán, Sinaloa 3-7 junio 2019
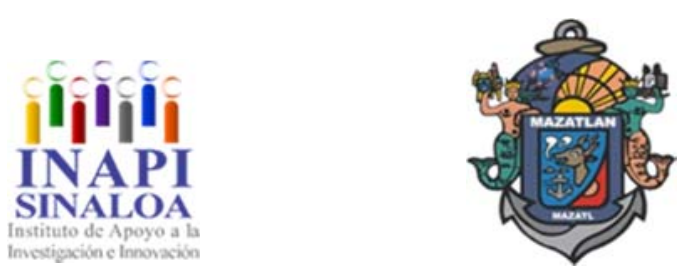

Tecnología y Biotecnología para el Tratamiento de Contaminantes y Biorremediación 

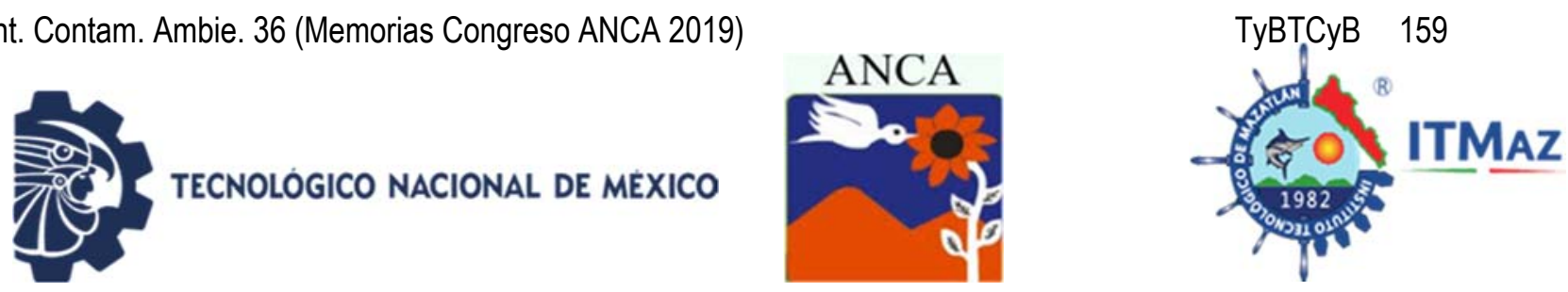

\section{Preparación y caracterización soporte MCM-48 para adsorción de contaminantes ambientales}

Padilla Ontiveros $\mathrm{AA}^{1}$, Aguilera Alvarado $\mathrm{AF}^{2}$, Contreras López $\mathrm{D}^{2}$, Del Angel Soto $\mathrm{J}^{2}$, Martínez Ramírez $\mathrm{M}^{2}$, Bautista Rodríguez $\mathrm{CM}^{1 *}$

${ }^{1}$ Centro de Innovación Aplicada en Tecnologiaś Competitivas (CIATEC), Omega 201, Col. Industrial Delta. C.P. 37545. León, Guanajuato, México

${ }^{2}$ Universidad de Guanajuato Departamento de Ingenieriá Quimica, Noria Alta S/N, Noria Alta, 36050 Guanajuato, Gto, México

*cbautista@ciatec.mx

\section{RESUMEN}

La ingenieriá de la porosidad en materiales comunes (tales como los compuestos de silice), representa un gran reto cientificó que puede generar impactos tecnológicos positivos por nuevos productos de interés tecnológico, industrial y ambiental. De entre estos nuevos materiales, el conocido como MCM-48, es un material mesoporoso de estructura cúbica y ordenada, que presenta una gran área superficial, poros de gran volumen y buena estabilidad mecánica. Debido a la distribución de tamaño de poro, puede ser considerado en aplicaciones especificas', como la adsorción de contaminantes presentes en agua, principalmente los metales pesados. En el laboratorio de sintesiś de materiales del departamento de Quimicá inorgánica de la Universidad de Guanajuato trabajando en colaboración con CIATEC, en el 2018 se sintetizo por la viá hidrotermal el soporte mesoporoso de elevada área superficial denominado MCM-48. El material obtenido fue caracterizado por FT-IR donde se observaron bandas entre 3000-3700 $\mathrm{cm}^{-1}(\mathrm{Si}-\mathrm{OH}), 1637 \mathrm{~cm}^{-1}$ (Si-O-Si), $1040 \mathrm{~cm}^{-1}(\mathrm{OH})$, las cuales son tipicoś en el MCM-48. Por otra parte, en el análisis por DRX a ángulos bajos, se observaron picos ubicados en los planos $211,220,420$ y 332 de 2 a $6^{\circ}$ que caracterizan a la estructura cúbica tipo la3d, demostrando la obtención del soporte MCM-48, resultados semejantes son reportados en la literatura. El material fue sometido a pruebas la remoción de iones $\mathrm{Cr}$ y Ni en solución acuosa a diferentes temperaturas y $\mathrm{pH}$. La concentración final de los iones removidos fue determinada por UV-Visible y la capacidad de adsorción del material sintetizado se compara y discute con valores reportados en la literatura.

Palabras Clave: Adsorción; MCM-48, cromatos, nitrato de niquel.

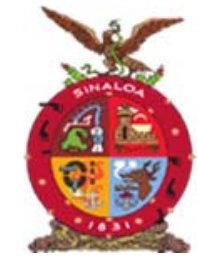

XVIII Congreso Internacional XXIV Congreso Nacional de Ciencias ambientales

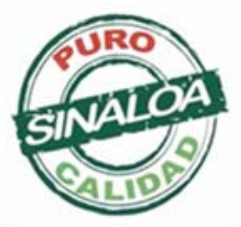

Mazatlán, Sinaloa 3-7 junio 2019
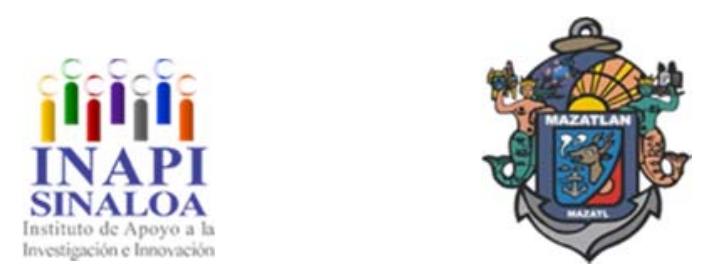

Tecnología y Biotecnología para el Tratamiento de Contaminantes y Biorremediación 

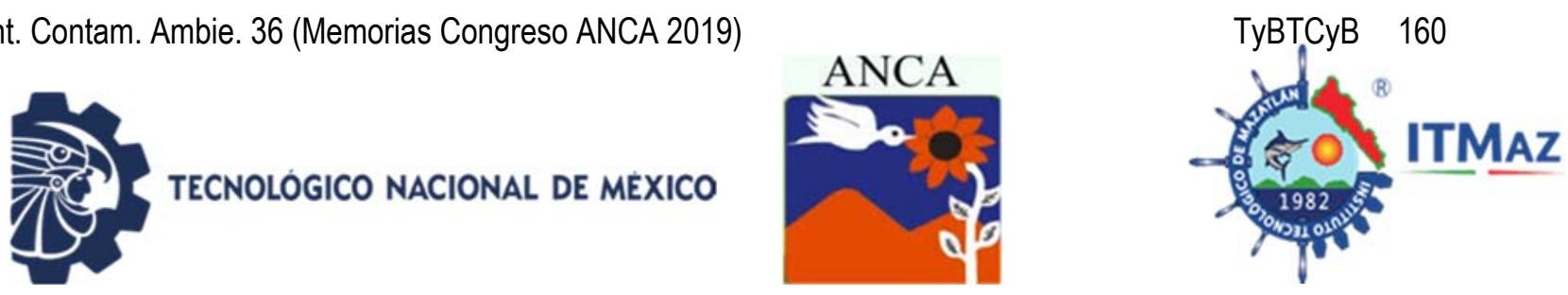

\title{
Preparation and characterization support MCM-48 for adsorption of environmental contaminants
}

\author{
Padilla Ontiveros $\mathrm{AA}^{1}$, Aguilera Alvarado $\mathrm{AF}^{2}$, Contreras López $\mathrm{D}^{2}$, \\ Del Angel Soto J, Martínez Ramírez $\mathrm{M}^{2}$, Bautista Rodríguez $\mathrm{CM}^{1 *}$ \\ ${ }^{1}$ Centro de Innovación Aplicada en Tecnologiaś Competitivas (CIATEC), \\ Omega 201, Col. Industrial Delta. C.P. 37545. León, Guanajuato, México \\ ${ }^{2}$ Universidad de Guanajuato Departamento de Ingenieriá Quimica, \\ Noria Alta S/N, Noria Alta, 36050 Guanajuato, Gto, México \\ *cbautista@ciatec.mx
}

\begin{abstract}
The porosity engineering in common materials (such as silica compounds) represents a great scientific challenge and generates technological impacts to the point of generating new products of technological, industrial and environmental interest. Among these new materials, known as MCM-48, is a mesoporous material of cubic and ordered structure, which has a large surface area, pores of great volume and good mechanical stability. Due to the pore size distribution, it can be considered in specific applications, such as the adsorption of contaminants in water, mainly heavy metals. In the present work carried out in 2018, in the laboratory of synthesis of materials of the Department of Inorganic Chemistry of the University of Guanajuato in collaboration with CIATEC, the mesoporous support of high surface area MCM-48 was synthesized by the hydrothermal route. The material obtained was characterized by FT-IR where bands were observed between 3000-3700 cm-1 (Si-OH), $1637 \mathrm{~cm}^{-1}$ (Si-O-Si), $1040 \mathrm{~cm}^{-1}(\mathrm{OH})$, which are typical in the MCM-48. On the other hand, in the analysis by XRD at low angles, peaks located in the planes 211, 220, 420 and 332 from 2 to $6^{\circ}$ that characterize the cubic structure type la3d, showing the obtaining of the support MCM-48, were observed, similar results are reported in the literature. Finally, the material was subjected to tests the removal of $\mathrm{Cr}$ and $\mathrm{Ni}$ ions in aqueous solution at different temperatures and $\mathrm{pH}$. The final concentration of the removed ions was determined by UV-Visible and the adsorption capacity of the synthesized material is compared and discussed with values reported in the literature.
\end{abstract}

Keywords: Adsorption, MCM-4, chromates nickel nitrate.

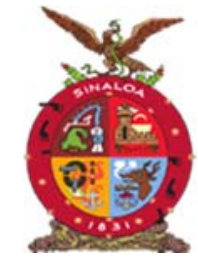

XVIII Congreso Internacional XXIV Congreso Nacional de Ciencias ambientales

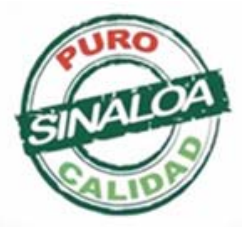

Mazatlán, Sinaloa 3-7 junio 2019
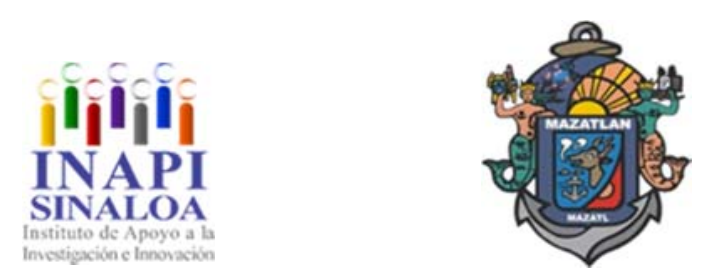

Tecnología y Biotecnología para el Tratamiento de Contaminantes y Biorremediación 

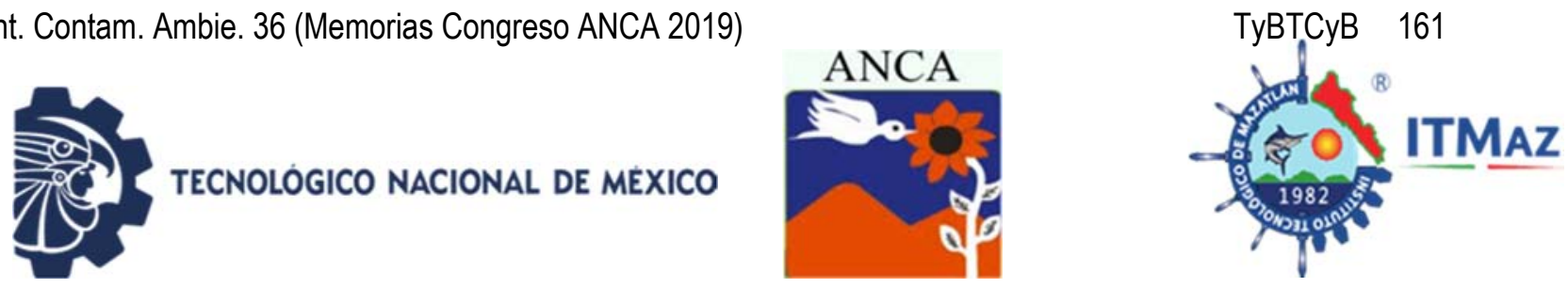

\title{
Remoción de micro-contaminantes orgánicos en humedales construidos de flujo subsuperficial horizontal a escala de mesocosmos
}

\author{
Palacin Salcedo $\mathrm{JJ}^{1^{*}}$, Navarro Frómeta $\mathrm{A}^{2}$, Correa Jiménez KF, \\ Lejarde Florez DA \\ ${ }^{1}$ Centro Nacional Colombo-Alemán, Colombia \\ 2Universidad Tecnológica de Izúcar Matamoros. \\ Calle $30 \mathrm{~N}^{\circ} 3 \mathrm{E}-164$, Barranquilla-Colombia \\ *josepalacin@misena.edu.com
}

\begin{abstract}
RESUMEN
El uso de productos químicos es indispensable en nuestra cotidianidad ya que contribuyen de diversas maneras con nuestra calidad de vida. Sin embargo, muchos de estos son incorporados en los ecosistemas acuáticos en forma de contaminantes donde, difícilmente compuestos, difícilmente son removidos en los sistemas de tratamiento convencionales, ocasionando efectos ecotoxicológicos motivo de preocupación ambiental. Se evaluó la remoción de un grupo de contaminantes orgánicos [4,7-Methano-1H-indenol, hexahydro-(TCD), 2-(2butoxyethoxy) etanol (DoW), y 2(4H)-Benzofuranone, 5,6,7, 7a-tetrahydro-4,4,7atrimethyl-, (R)-(DHA)], en humedales operados con flujo sub-superficial horizontal (HC-FSSH). La remoción de TCD, DoW y DHA en HC-FSSH, fue evaluada en un sistema de ocho humedales: cuatro de los cuales fueron rellenados con grava de río y cuatro con grava volcánica (tezontle). Seis de los sistemas fueron sembrados con Phragmites australis, Typha latifolia, y Cyperus papyrus. En cada uno de los medios de soporte y dos permanecieron sin plantas y fueron usados como control. La concentración de TCD, DoW y DHA en agua afluente y efluente fue determinada mediante cromatografía de gases-espectrometría de masas (CG-EM). El análisis gráfico y estadístico de los resultados se realizó con Statistica V.13. Las remociones de TCD, DoW y DHA en los efluentes, fueron variables, pero significativamente, relacionada con la presencia de las plantas y el tiempo de retención hidráulico (TRH), no con el medio de soporte. La presencia de plantas como $P$. australis, $T$. latifolia, y C. papyrus, afectan positivamente la de remoción de los micro contaminantes evaluados en los sistemas de humedales de flujo sub superficial horizontal ensayados.
\end{abstract}

Palabras claves: micro-contaminantes orgánicos, humedales construidos, P.australis, T. latifolia y C. papyrus.

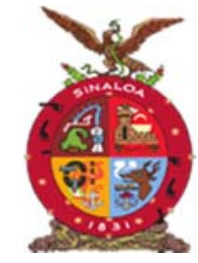

XVIII Congreso Internacional XXIV Congreso Nacional de Ciencias ambientales

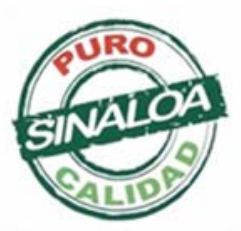

Mazatlán, Sinaloa 3-7 junio 2019
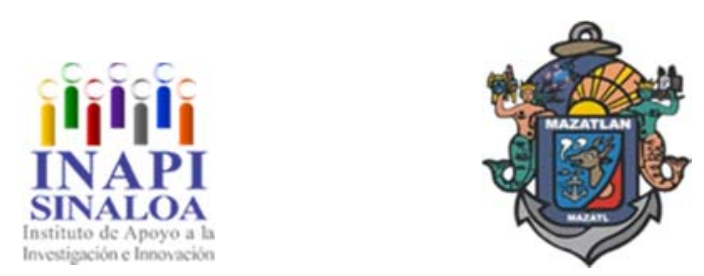

Tecnología y Biotecnología para el Tratamiento de Contaminantes y Biorremediación 

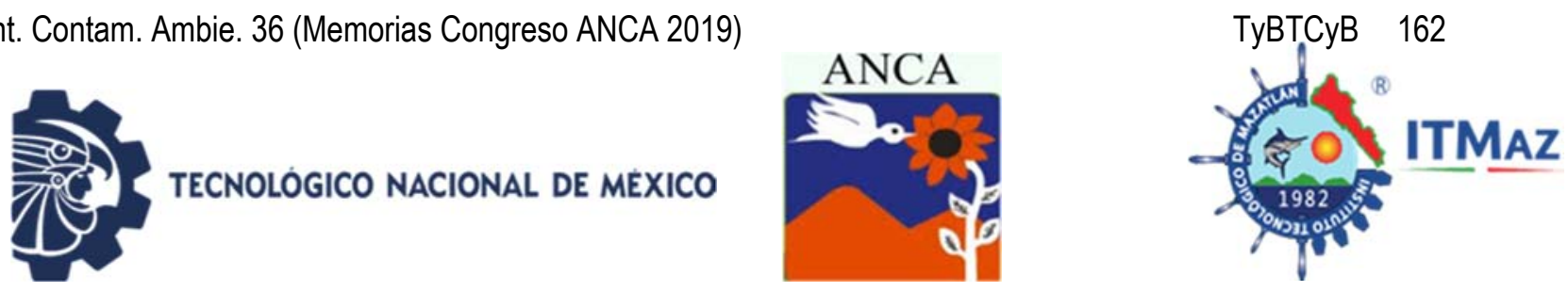

\title{
Removal of organic micro-contaminants in wetlands built of horizontal subsurface flow at mesocosm scale
}

\author{
Palacin Salcedo $\mathrm{JJ}^{1 *}$, Navarro Frómeta $\mathrm{A}^{2}$, Correa Jiménez KF, \\ Lejarde Florez DA \\ ${ }^{1}$ Centro Nacional Colombo-Alemán, Colombia \\ 2Universidad Tecnológica de Izúcar Matamoros. \\ Calle $30 \mathrm{~N}^{\circ} 3 \mathrm{E}-164$, Barranquilla-Colombia \\ *josepalacin@misena.edu.com
}

\begin{abstract}
The use of chemical products is essential in our daily life since they contribute in different ways to our quality of life. However, many of these are incorporated into aquatic ecosystems in the form of pollutants where, hardly compounded, they are hardly removed in the systems of conventional treatment, causing ecotoxicological effects cause for environmental concern. The removal of a group of organic pollutants [4,7-Methane-1H-indenol, hexahydro-(TCD), 2-(2butoxyethoxy) ethanol (DoW), and $2(4 \mathrm{H})$-Benzofuranone, 5.6 was evaluated, 7 , 7a-tetrahydro-4,4,7a-trimethyl-, (R)-(DHA)], in wetlands operated with horizontal sub-surface flow (HC-FSSH). The removal of TCD, DoW and DHA in HC-FSSH, was evaluated in a system of eight wetlands: four of which were filled with river gravel and four with volcanic gravel (tezontle). Six of the systems were seeded with Phragmites australis, Typha latifolia, and Cyperus papyrus. In each of the support media and two remained without plants and were used as a control. The concentration of TCD, DoW and DHA in tributary and effluent water was determined by gas chromatography-mass spectrometry (GC-MS). The graphic and statistical analysis of the results was performed with Statistica V.13. The removals of TCD, DoW and DHA in the effluents were variable, but significantly, related to the presence of the plants and the hydraulic retention time (HRT), not with the support medium. The presence of plants such as $P$. australis, $T$. latifolia, and $C$. papyrus, positively affect the removal of the micro contaminants evaluated in the horizontal sub-surface wetland systems tested.
\end{abstract}

Keywords: Organic micro-contaminants, constructed wetlands, P. australis, T. latifolia and C. papyrus.

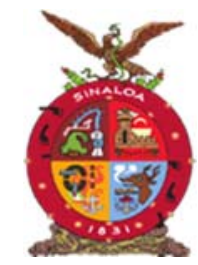

XVIII Congreso Internacional XXIV Congreso Nacional de Ciencias ambientales

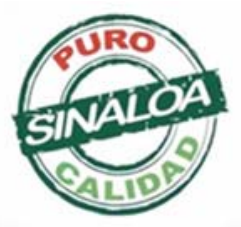

Mazatlán, Sinaloa 3-7 junio 2019
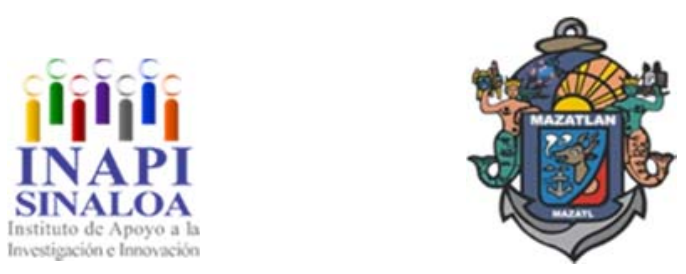

Tecnología y Biotecnología para el Tratamiento de Contaminantes y Biorremediación 

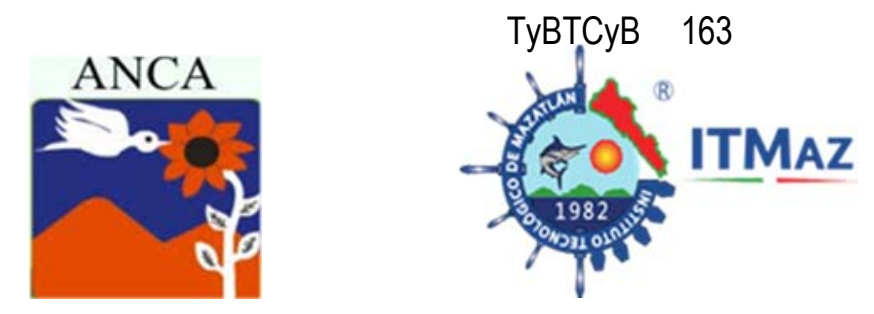

\title{
Reducción de la concentración de metales pesados generados en los residuos del análisis de la DQO a través de un proceso optimizado
}

\author{
Pitalúa Sánchez $\mathrm{D}^{1 *}$, Rosano Ortega $\mathrm{G}^{1}$, Martínez Tavera $\mathrm{E}^{1}$, Garrido Hoyos $\mathrm{S}^{2}$, \\ Martínez Gallegos $S^{3}$, Cruz González D ${ }^{4}$ \\ ${ }^{1}$ Facultad de Ingeniería Ambiental. \\ Universidad Popular Autónoma del Estado de Puebla \\ ${ }^{2}$ Instituto Mexicano de Tecnología del Agua, Jiutepec, Morelos \\ ${ }^{3}$ Instituto Tecnológico de Toluca, Metepec, Estado de México \\ ${ }^{4}$ Facultad de Ingeniería Química. Benemérita Universidad Autónoma de Puebla \\ *diana.pitalua@upaep.edu.mx
}

\section{RESUMEN}

En los laboratorios de Calidad del Agua, se realizan una serie de pruebas que generan una gran cantidad de residuos, entre los que destacan $\mathrm{Ag}, \mathrm{Hg}$ y $\mathrm{Cr}$, metales pesados provenientes de la determinación de la Demanda Química de Oxígeno (DQO). En este trabajo, se optimizó un proceso físico-químico para reducir la concentración de estos metales en los residuos ácidos generados por la DQO. Se determinaron concentraciones iniciales de $1133 \mathrm{mg} / \mathrm{L}$ de Ag, 2252 $\mathrm{mg} / \mathrm{L}$ de $\mathrm{Hg}$ y $950 \mathrm{mg} / \mathrm{L}$ de $\mathrm{Cr}$, las cuales superan los límites permisibles establecidos en la NOM-002-SEMARNAT-1996; por lo que, son considerados residuos peligrosos por su corrosividad, toxicidad y potencial contaminante. El proceso fisicoquímico propuesto presenta las siguientes ventajas: 1) eficiencia de remoción de $99.99 \%$ para $\mathrm{Ag}, 99.99 \%$ para $\mathrm{Hg}$ y $99.96 \%$ para $\mathrm{Cr} ; 2$ ) neutralización del $\mathrm{pH}(8.5)$; 3) reducción de la peligrosidad del residuo para ser reusado en procesos industriales; 4)recuperación de compuestos metálicos de alta pureza para su reincorporación a procesos productivos; 5) optimización de los parámetros de operación; 6) cumplimiento de los límites máximos permisibles establecidos en la NOM-002-SEMARNAT-1996 para descarga de aguas residuales al alcantarillado $(0.1 \mathrm{mg} / \mathrm{L}$ para $\mathrm{Ag}, 0.001 \mathrm{mg} / \mathrm{L}$ para $\mathrm{Hg}$ y $0.36 \mathrm{mg} / \mathrm{L}$ para $\mathrm{Cr}$ ) y 7) uso del proceso para tratar otro tipo de residuo conteniendo $\mathrm{Ag}, \mathrm{Hg}$ y Cr. Debido a los porcentajes de remoción mostrados, esta técnica resultó adecuada y simple para reducir los metales de los residuos de la DQO.

Palabras clave: Cromo, DQO, mercurio, plata, residuo líquido peligroso.

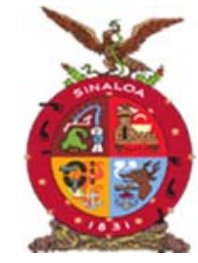

XVIII Congreso Internacional XXIV Congreso Nacional de Ciencias ambientales

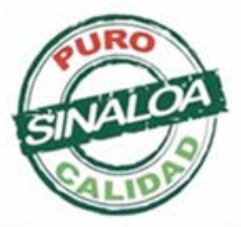

Mazatlán, Sinaloa 3-7 junio 2019
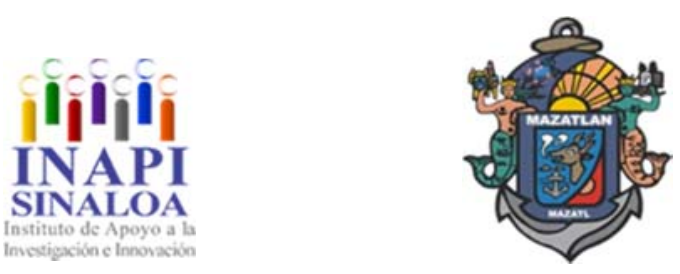

Tecnología y Biotecnología para el Tratamiento de Contaminantes y Biorremediación 

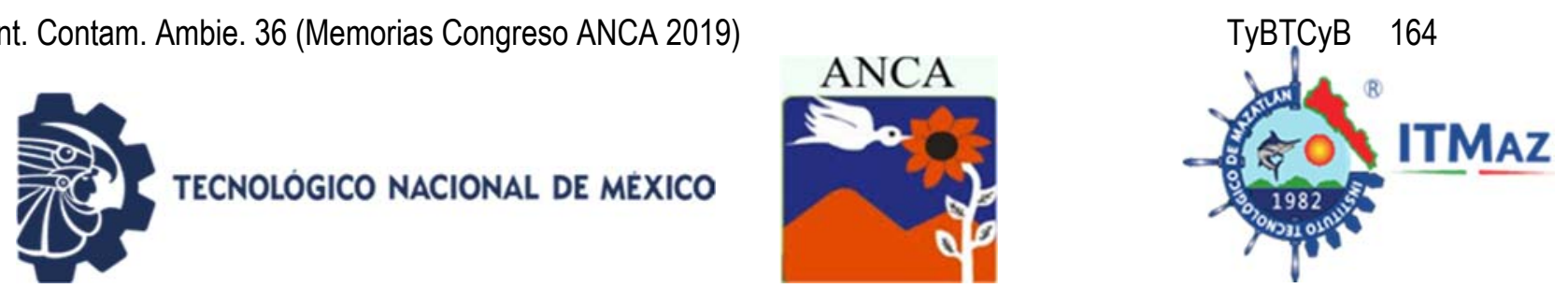

\title{
Reduction of the concentration of heavy metals generated in the waste of the COD analysis through an optimized process
}

\author{
Pitalúa Sánchez $\mathrm{D}^{1^{*}}$, Rosano Ortega $\mathrm{G}^{1}$, Martínez Tavera $\mathrm{E}^{1}$, Garrido Hoyos $\mathrm{S}^{2}$, \\ Martínez Gallegos $\mathrm{S}^{3}$, Cruz González $\mathrm{D}^{4}$ \\ ${ }^{1}$ Facultad de Ingeniería Ambiental. \\ Universidad Popular Autónoma del Estado de Puebla \\ ${ }^{2}$ Instituto Mexicano de Tecnología del Agua, Jiutepec, Morelos \\ ${ }^{3}$ Instituto Tecnológico de Toluca, Metepec, Estado de México \\ ${ }^{4}$ Facultad de Ingeniería Química. Benemérita Universidad Autónoma de Puebla \\ *diana.pitalua@upaep.edu.mx
}

\begin{abstract}
In Water Quality laboratories, a series of tests are carried out that generate a large amount of waste, among which $\mathrm{Ag}, \mathrm{Hg}$ and $\mathrm{Cr}$, heavy metals coming from the determination of the Chemical Oxygen Demand (COD). In this paper, a physicochemical process was optimized to reduce the concentration of the heavy metals in the acid waste generated by the COD. Initial concentrations of 1133 $\mathrm{mg} / \mathrm{L}$ of $\mathrm{Ag}, 2252 \mathrm{mg} / \mathrm{L}$ of $\mathrm{Hg}$ and $950 \mathrm{mg} / \mathrm{L}$ of $\mathrm{Cr}$ were determined, which exceed the permissible limits established in NOM-002-SEMARNAT-1996; therefore, they are considered hazardous waste due to their corrosiveness, toxicity and polluting potential. The proposed physicochemical process has the following advantages: 1) removal efficiency of $99.99 \%$ for $\mathrm{Ag}, 99.99 \%$ for $\mathrm{Hg}$ and $99.96 \%$ for $\mathrm{Cr}$; 2 ) $\mathrm{pH}$ neutralization (8.5); 3 ) reduction of the hazardousness of the waste to be reused in industrial processes; 4) recovery of metallic compounds of high purity for their reincorporation to productive processes; 5) optimization of operational parameters; 6) compliance with the maximum permissible limits established in NOM-002-SEMARNAT-1996 1996 for wastewater discharge to the sewage system ( $0.1 \mathrm{mg} / \mathrm{L}$ for $\mathrm{Ag}, 0.001 \mathrm{mg} / \mathrm{L}$ for $\mathrm{Hg}$ and $0.36 \mathrm{mg} / \mathrm{L}$ for $\mathrm{Cr}$ ), and 7$)$ the use of the process to treat other type of waste containing $\mathrm{Ag}, \mathrm{Hg}$ and $\mathrm{Cr}$. Due to the removal percentages, this process is adequate and simple to reduce the metals of the COD waste.
\end{abstract}

Keywords: Chromium, COD, hazardous liquid waste, mercury, silver.

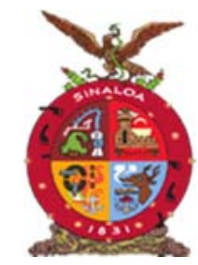

XVIII Congreso Internacional XXIV Congreso Nacional de Ciencias ambientales

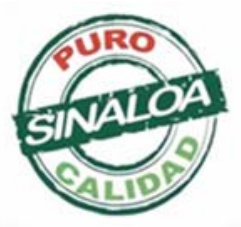

Mazatlán, Sinaloa 3-7 junio 2019
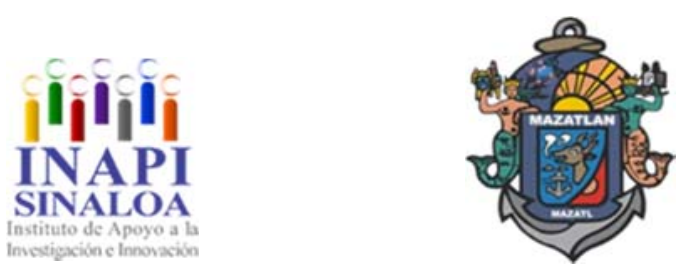

Tecnología y Biotecnología para el Tratamiento de Contaminantes y Biorremediación 

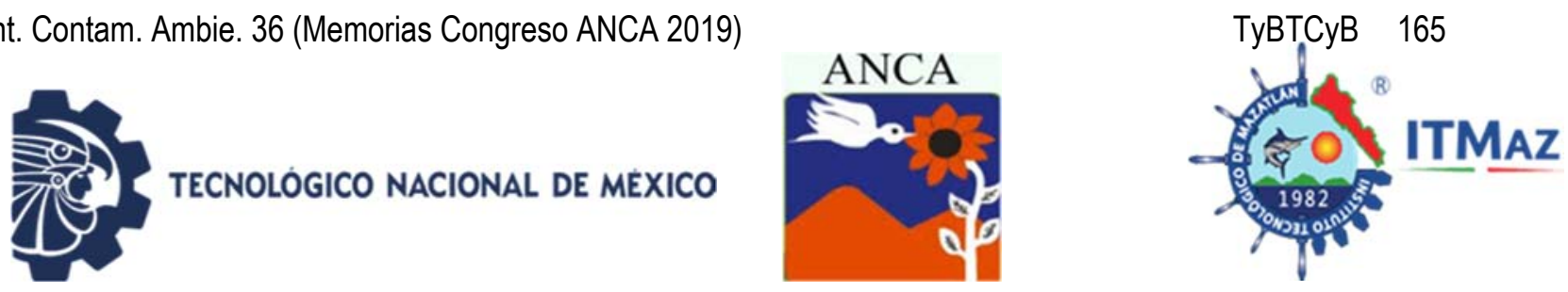

\title{
Análisis del secretoma de Aspergillus sydowii-like h1 creciendo en condiciones de hipersalinidad $(1 \mathrm{M} \mathrm{NaCl})$ y paja de trigo como única fuente de carbono
}

\author{
Quintero García OJ, Martínez Batallar G, Encarnación Guevara S, \\ Folch Mallol JL, Batista García RA* \\ Centro de Investigación en Dinámica Celular. UAEMorelos. \\ Av. Universidad 1001, Col. Chamilpa, C.P. 62209. Cuernavaca, Morelos \\ *rabg@uaem.mx
}

\section{RESUMEN}

El uso, y transformación de los combustibles fósiles actualmente ha generado diferentes estragos tanto ambientales, económicos y sociales, afortunadamente se ha pronosticado la disminución en las reservas de petróleo, por ello a través de los años se han realizado investigaciones enfocadas en encontrar nuevas alternativas energéticas que sean ambiental y económicamente favorables, una de ellas es la obtención de bioetanol lignocelulósico lo cual involucra el aprovechamiento integral de la lignocelulosa como desecho vegetal y la capacidad potencial de algunos microorganismos y sus enzimas, como celulasas, xilanasas y peroxidasas, que hidrolizan los componentes de la lignocelulosa, como celulosa, lignina y hemicelulosa. Por ello el objetivo de este trabajo es conocer la expresión diferencial proteica de secretoma de Aspergillus sydowiilike $\mathrm{H} 1$ cuando se encuentra creciendo en presencia y ausencia de $1 \mathrm{M} \mathrm{NaCl}$ y paja de trigo como única fuente de carbono. El crecimiento de la cepa en las condiciones anteriores se evaluó durante siete días, observando que en el día tres reflejaba un crecimiento, el cual fue en aumento hasta llegar a los siete días. A partir de ello podemos señalar que la cepa está expresando un coctel enzimático encargado de hidrolizar polímeros complejos, como la celulosa, y hemicelulosa, para obtener azúcares simples utilizados por la cepa como fuente de carbono. Las proteínas del sobrenadante se documentaron en geles SDSPAGE, donde se comparó el perfil proteico cuando $A$. sydowii se cultiva en presencia y ausencia de $\mathrm{NaCl}$ y paja de trigo, observando que: en presencia de $\mathrm{NaCl}$ la cepa muestra un bandeo de proteínas diferentes a la condición en ausencia de este. Probablemente en esta expresión se encuentran no solo aquellas enzimas encargadas en la hidrolisis de la lignocelulosa, así como aquellas involucradas en procesos de regulación osmótica, intercambio de iones y estrés hídrico generado por el ambiente hipersalino en el que se encuentra la cepa.
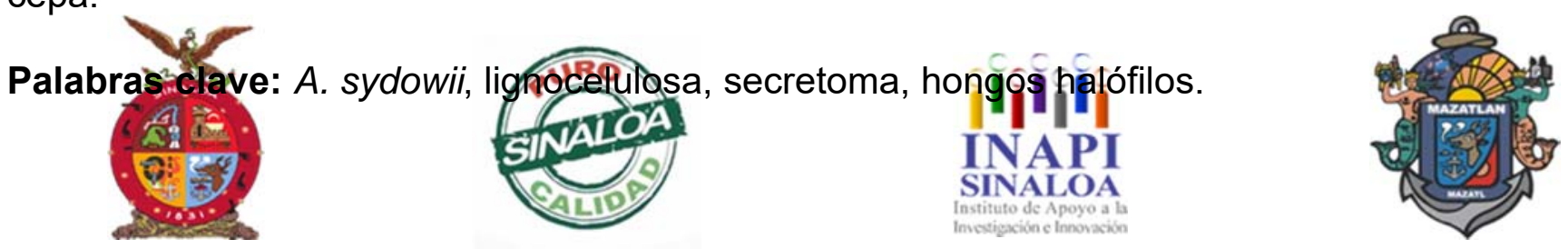

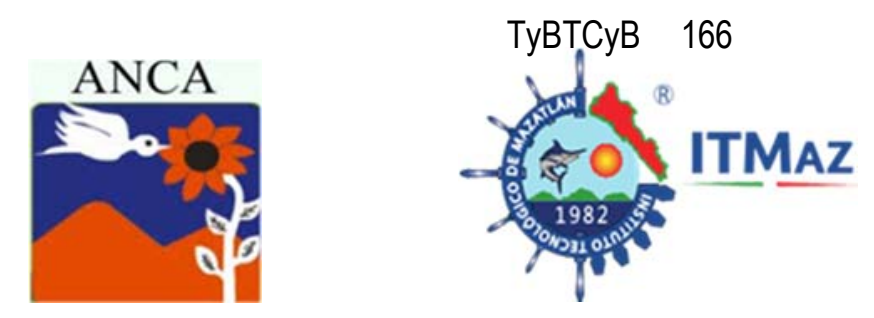

\title{
Analysis of the secretoma of Aspergillus sydowii-like h1 growinn under hypersalin conditions $(1 \mathrm{M} \mathrm{NaCl})$ and wheat straw as unique carbon source
}

\author{
Quintero García OJ, Martínez Batallar G, Encarnación Guevara S, \\ Folch Mallol JL, Batista García RA* \\ Centro de Investigación en Dinámica Celular. \\ Universidad Autónoma del Estado de Morelos. \\ Av. Universidad 1001, Col. Chamilpa, C.P. 62209. Cuernavaca, Morelos \\ *rabg@uaem.mx
}

\begin{abstract}
The use and transformation of fossil fuels currently has generated different environmental, economic and social havoc. Fortunately, the decrease in oil reserves has been predicted. Therefore, over the years, research has been carried out focused on finding new energy alternatives, which are environmentally and economically favorable, one of them is the production of lignocellulosic bioethanol which involves the integral use of lignocellulose as vegetable waste and the potential capacity of some microorganisms and their enzymes, such as cellulases, xylanases and peroxidases, which hydrolyze the components of lignocellulose, such as cellulose, lignin and hemicellulose. Therefore, the objective of this work is to know the differential protein expression of Aspergillus sydowii-like $\mathrm{H} 1$ secretome when it is growing in the presence and absence of $1 \mathrm{M}$ $\mathrm{NaCl}$ and wheat straw as the sole carbon source. The growth of the strain in the previous conditions was evaluated during seven days, observing that on day three it reflected a growth, which was increasing until reaching seven days. From this we can point out that the strain is expressing an enzymatic cocktail responsible for hydrolyzing complex polymers, such as cellulose, and hemicellulose, to obtain simple sugars used by the strain as a carbon source. The supernatant proteins were documented on SDS-PAGE gels, where the protein profile was compared when A. sydowii is cultivated in the presence and absence of $\mathrm{NaCl}$ and wheat straw, observing that: in the presence of $\mathrm{NaCl}$ the strain shows a banding of different proteins to the condition in absence of this. Probably in this expression are not only those enzymes responsible for the hydrolysis of lignocellulose, as well as those involved in processes of osmotic regulation, ion exchange and water stress generated by the hypersaline environment in which the strain is found.
\end{abstract}

Keywords: A. sydowii, lignocelluloses, secretoma, halophilic mushrooms.

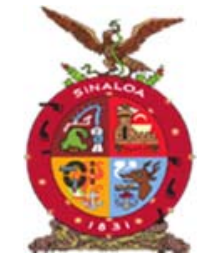

XVIII Congreso Internacional XXIV Congreso Nacional de Ciencias ambientales

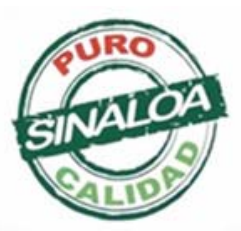

Mazatlán, Sinaloa 3-7 junio 2019
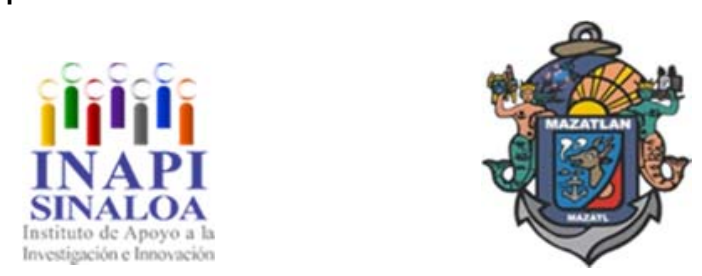

Tecnología y Biotecnología para el Tratamiento de Contaminantes y Biorremediación 

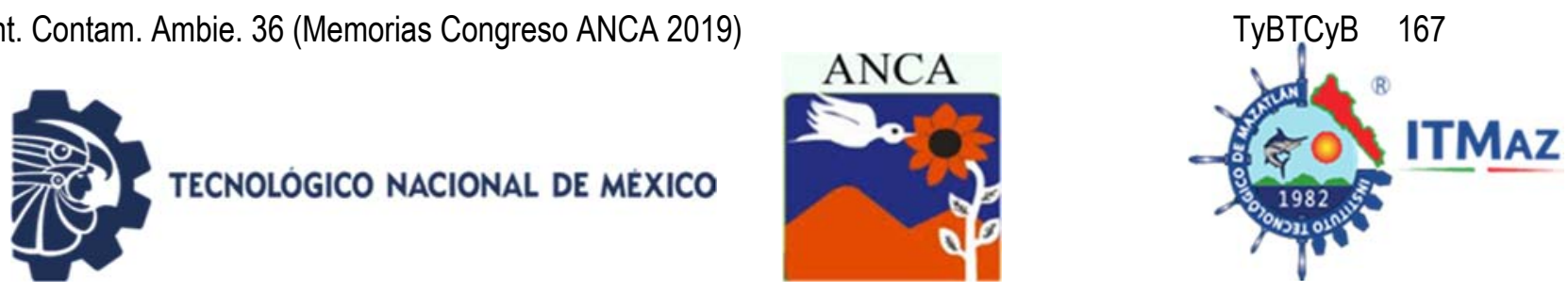

\title{
Análisis preliminar de efluente proveniente de planta tratadora de aguas residuales para su reúso potable indirecto en acuífero sobreexplotado
}

\author{
Quintero Hernández $\mathrm{M}^{*}$, Aguilera Flores $\mathrm{M}$ \\ Ingeniería Ambiental. Unidad Profesional Interdisciplinaria de Ingeniería \\ Campus Zacatecas. Instituto Politécnico Nacional. \\ *mikquinterohdz10@gmail.com
}

\section{RESUMEN}

La recarga artificial con agua residual tratada ha sido usada como una alternativa para contrarrestar la sobreexplotación de los acuíferos y contribuir a la disponibilidad de agua potable. Se evaluó la factibilidad de utilizar agua proveniente del efluente de la planta tratadora de aguas residuales (PTAR) de los municipios de Zacatecas y Guadalupe denominada "Osiris" $\left(22^{\circ} 46^{\prime} 31^{\prime \prime} \mathrm{N}\right.$ y $102^{\circ} 27^{\prime} 07^{\prime \prime}$ ), para la recarga en un acuífero sobreexplotado denominado "Calera", el cual forma parte de los 3 donde se extrae agua para uso potable en la zona conurbada de los municipios Zacatecas-Guadalupe. Esto se realizó con base en lo solicitado por la NOM-014-CONAGUA-2003, requiriéndose análisis de los parámetros de calidad de agua en cuanto a presencia de microorganismos patógenos. Demanda bioquímica de Oxígeno (DBO5) y los requisitos establecidos en la NOM-127-SSA1-1994 (excepto radioactividad). Para los parámetros que no se encontraron dentro de los límites máximos permitidos por la norma se propusieron alternativas asequibles de remediar dentro de la PTAR para la reducción de dicho contaminante. Las muestras analizadas del efluente de la PTAR arrojaron resultados fuera de los límites solamente en arsénico $(0.12$ $\mathrm{mg} / \mathrm{L})$, sólidos disueltos totales $(1,239 \mathrm{mg} / \mathrm{L})$ y coliformes fecales totales $(152$ $\mathrm{NMP} / 100 \mathrm{~mL}$ ). En el caso del arsénico se encuentra en compatibilidad con el agua nativa del acuífero por lo que la CONAGUA permite la recarga en ese aspecto. En los sólidos disueltos se propuso una mejora en el sedimentador secundario a la hora de realizarse la coagulación-floculación, debido a que en esta unidad se liberan una cantidad considerable de lodos al tratamiento terciario. Para los coliformes se propuso un cambio en el voltaje de la lámpara UV utilizada para la desinfección. Estos cambios permitirán hacer la recarga del Acuífero con cumplimiento de la normatividad.

Palabras clave: Acuífero Calera, Osiris, zona conurbada Zacatecas-Guadalupe

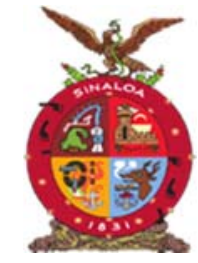

XVIII Congreso Internacional XXIV Congreso Nacional de Ciencias ambientales

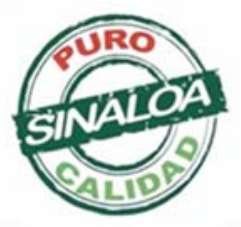

Mazatlán, Sinaloa 3-7 junio 2019
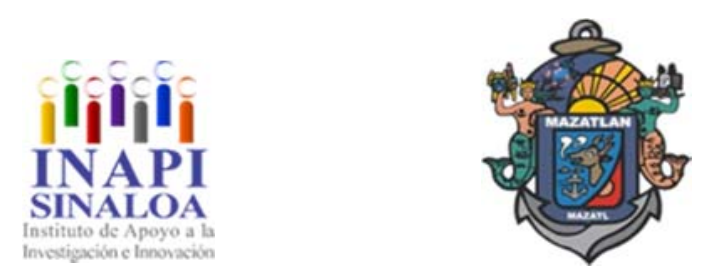

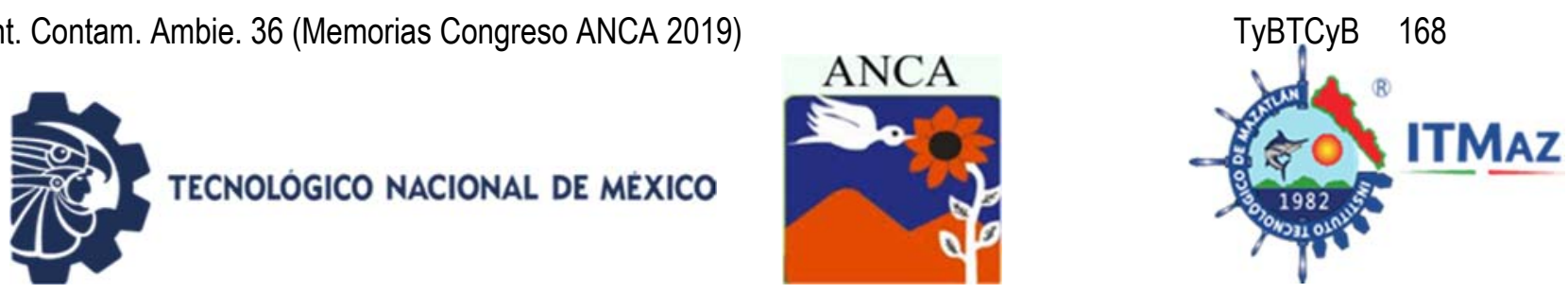

\title{
Preliminary analysis of effluent from wastewater treatment plant for its indirect drinking reuse in overexploited aquifer
}

\author{
Quintero Hernández M*, Aguilera Flores M \\ Ingeniería Ambiental. Unidad Profesional Interdisciplinaria de Ingeniería \\ Campus Zacatecas. Instituto Politécnico Nacional. \\ *mikquinterohdz10@gmail.com
}

\begin{abstract}
The artificial recharge with wastewater has been used as an alternative to counteract the overexploitation of aquifers and contribute to the availability of water. In this work, the effluent of the wastewater treatment plant of the municipalities of Zacatecas and Guadalupe called "Osiris" $\left(22^{\circ} 46{ }^{\prime} 31^{\prime \prime} \mathrm{N}\right.$ y $102^{\circ} 27^{\prime} 07^{\prime \prime} \mathrm{O}$ ) was evaluated for indirect potable use in an overexploited aquifer called "Calera", which is part of the system that supplies water to the conurbated zone of the Zacatecas-Guadalupe municipalities. This analysis was based on NOM-014-CONAGUA-2003, the analysis of water quality parameters request was the presence of pathogenic microorganisms, biological oxygen demand (BOD5) and those established by NOM-127-SSA1-1994 (except radioactivity). Parameters outside of the limits they were proposed alternatives in the wastewater treatment plant to help the removal of those contaminants. The simples analyzed from wastewater treatment plant effluent gave results outside the limits only in terms of arsenic $(0.12 \mathrm{mg} / \mathrm{L})$, total dissolved solids $(1,239 \mathrm{mg} / \mathrm{L})$ and total fecal coliforms (152 NMP/100 mL). In the case of arsenic, it is found in the compatibility with the native water of the aquifer, for which CONAGUA allows the recharge in that aspect. In the dissolved solids, an improvement was proposed in the secondary treatment when maintenance is done, due to the infiltration of a considerable quantity of sludge to the tertiary treatment. For the coliforms a change in the voltage of the UV lamp for disinfection was proposed. These changes would make the water suitable for recharging
\end{abstract}

Keywords: Calera Aquifer, Osiris, Zacatecas-Guadalupe conurbation.

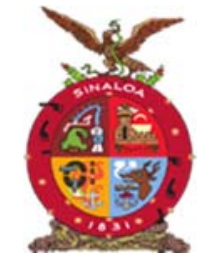

XVIII Congreso Internacional XXIV Congreso Nacional de Ciencias ambientales

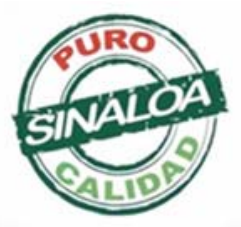

Mazatlán, Sinaloa 3-7 junio 2019
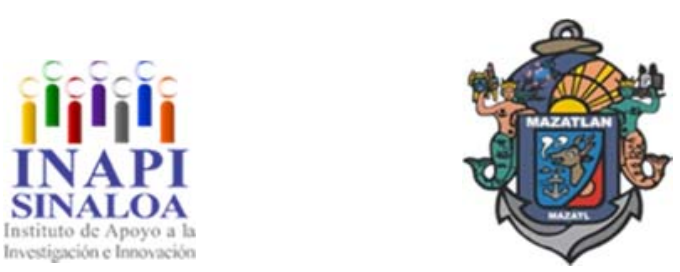

Tecnología y Biotecnología para el Tratamiento de Contaminantes y Biorremediación 

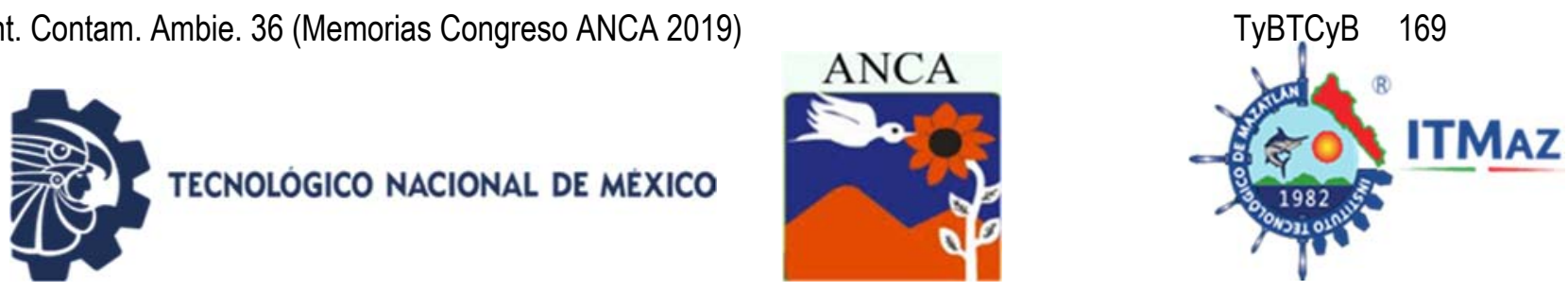

\section{Evaluación de un sistema de fitodepuración para la remoción de materia orgánica y nutrientes de un agua residual doméstica}

\section{Ramírez Carranza $\mathrm{DR}^{1^{*}}$, Beristaín Cardoso $\mathrm{R}^{2}$, González Juárez $\mathrm{JC}^{3}$ Macedo Miranda $\mathrm{MG}^{3}$, Martínez Gallegos $\mathrm{MS}^{3}$ \\ ${ }^{1}$ Maestría Ingeniería Ambiental. Instituto Tecnológico de Toluca \\ ${ }^{2}$ Universidad Autónoma Metropolitana Unidad Lerma,}

Av. De las Garzas No.10, Col. El Panteón, Lerma de Villada, Edo. de México

${ }^{3}$ Instituto Tecnológico de Toluca,

Av. Tecnológico S/N, Col. Agrícola Bella Vista, Metepec, Estado de México *donovanricardo.minato@gmail.com

\section{RESUMEN}

En los últimos años, se ha reportado un incremento en la problemática ambiental debido a la generación y disposición de aguas residuales, sin un tratamiento previo, lo que ha propiciado el desarrollo de nuevas alternativas tecnológicas más eficientes. En el presente trabajo, se evaluó un sistema secuencial de fitodepuración para el tratamiento de un agua residual tipo doméstica, a un TRH de 3 días. El sistema de fitodepuracion constó de dos humedales artificiales; uno de flujo subsuperficial horizontal (Scirpus lacustris), y el otro de flujo superficial (Lemna gibba). Los resultados experimentales indicaron lo siguiente: i) se alcanzaron eficiencias de remoción de $\mathrm{DQO}, \mathrm{NH}_{4}{ }^{+}, \mathrm{NO}_{3}-\mathrm{y}$ fósforo total, de $89 \%$, $43 \%, 21 \%$ y $43 \%$, respectivamente, y ii) el humedal artificial de flujo subsuperficial horizontal (Scirpus lacustris) presento el mayor aporte en la remoción de contaminantes.

Palabras clave: fitodepuración, remoción, humedales, DQO, amonio.

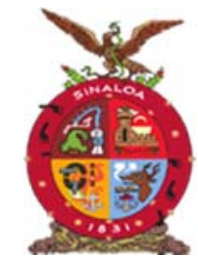

XVIII Congreso Internacional XXIV Congreso Nacional de Ciencias ambientales

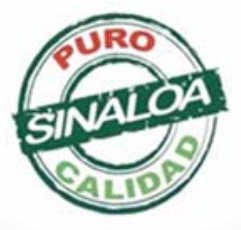

Mazatlán, Sinaloa 3-7 junio 2019
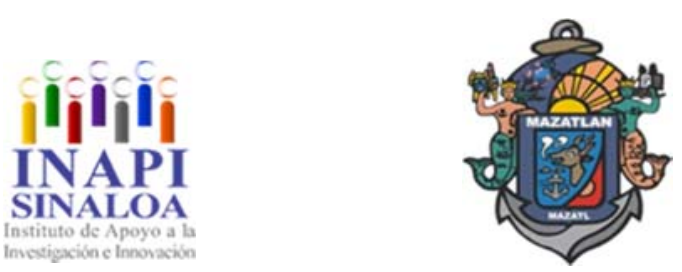

Tecnología y Biotecnología para el Tratamiento de Contaminantes y Biorremediación 


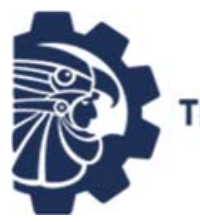

TECNOLOGICO NACIONAL DE MEXICO
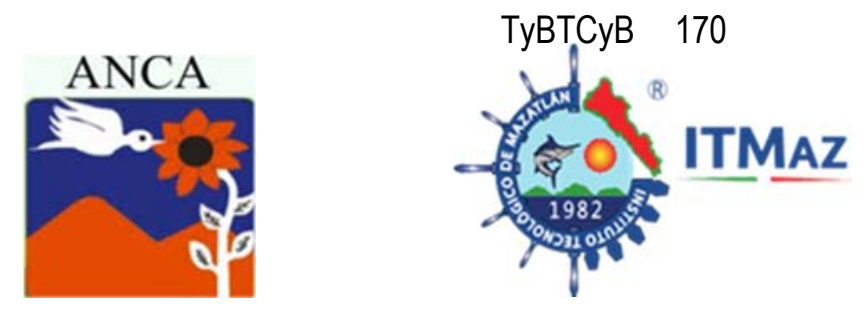

\title{
Evaluation of a phyto depuration system for the removal of orgánica matter and nutrients from a domestic wastewater
}

\author{
Ramírez Carranza DR ${ }^{1^{*}}$, Beristaín Cardoso $\mathrm{R}^{2}$, González Juárez $\mathrm{JC}^{3}$, \\ Macedo Miranda $\mathrm{MG}^{3}$, Martínez Gallegos $\mathrm{MS}^{3}$ \\ ${ }^{1}$ Maestría Ingeniería Ambiental. Instituto Tecnológico de Toluca \\ ${ }^{2}$ Universidad Autónoma Metropolitana Unidad Lerma, \\ Av. De las Garzas No.10, Col. El Panteón, Lerma de Villada, Edo. de México \\ ${ }^{3}$ Instituto Tecnológico de Toluca, \\ Av. Tecnológico S/N, Col. Agrícola Bella Vista, Metepec, Estado de México \\ *donovanricardo.minato@gmail.com
}

\begin{abstract}
To date, an increase in environmental problems due to generation and disposal of wastewater, without prior treatment has been reported, which has led to the development of novel efficient technological alternatives. In the present work was evaluated a sequential system of phytodepuration for treating domestic wastewater, at HRT of 3 days. The system of phytodepuration consisted of two artificial wetlands; one of horizontal subsurface flow (Scirpus lacustris), and the other of surface flow (Lemna gibba). The results showed the following: i) removal efficiencies for COD, ammonium, nitrate and total phosphorus were $89 \%, 43 \%$, $21 \%$ and $43 \%$, respectively, and ii) the horizontal surface flow constructed wetland (Scirpus lacustris) presented the greatest contribution in the pollutants removal,
\end{abstract}

Keywords: Phytodepuration, removal, wetlands, COD, ammonium.

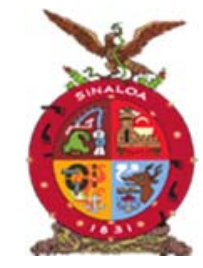

XVIII Congreso Internacional XXIV Congreso Nacional de Ciencias ambientales

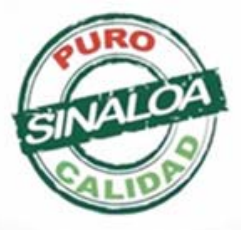

Mazatlán, Sinaloa 3-7 junio 2019
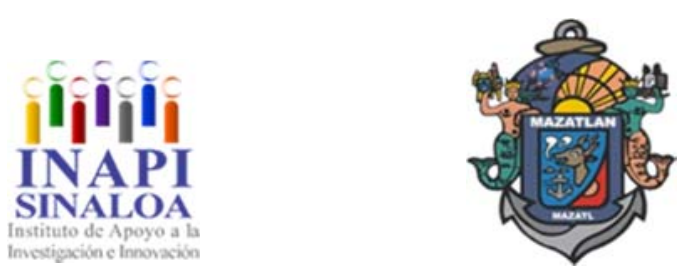

Tecnología y Biotecnología para el Tratamiento de Contaminantes y Biorremediación 

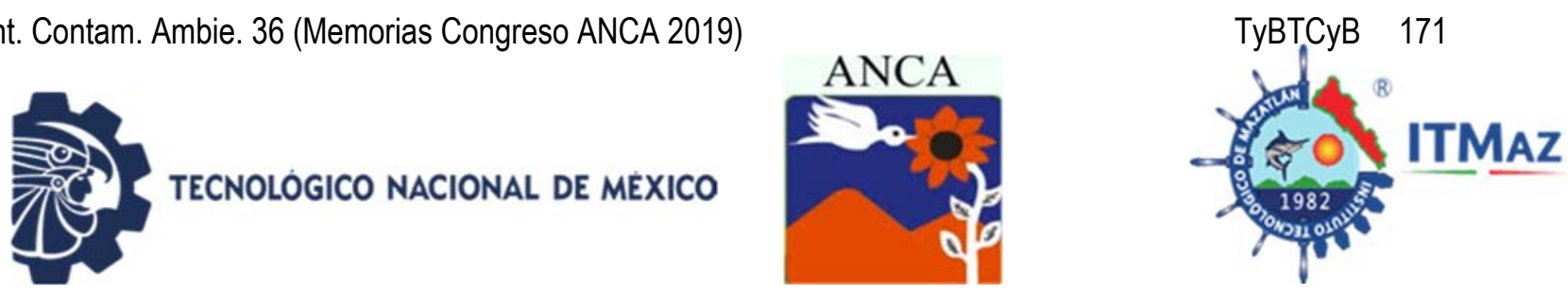

\title{
Nanocompuestos magnéticos de polipirrol-oxido de hierro para remoción de colorantes en medios acuosos
}

\author{
Ramírez Ortega $\mathrm{AA}^{1}$, García Elías $\mathrm{J}^{1}$, Medina Llamas $\mathrm{JC}^{2}$, Medina Llamas $\mathrm{M}^{3}$, \\ Chávez Guajardo $\mathrm{AE}^{1^{*}}$ \\ ${ }^{1}$ Unidad Académica de Ciencias de la Tierra. \\ Universidad Autónoma de Zacatecas, Zacatecas, México \\ ${ }^{2}$ Centro de Estudios Científicos y Tecnológicos No. 18. \\ Instituto Politécnico Nacional, Zacatecas, México \\ 3Unidad Académica de Física. UAZ, Zacatecas, México \\ *elisagua.chavez@gmail.com
}

\section{RESUMEN}

La contaminación del agua es uno de los principales problemas a nivel mundial, el cual se ha incrementado hasta niveles alarmantes debido al continuo crecimiento de la población y el desarrollo industrial. Algunos de los contaminantes del agua son la materia orgánica y otros residuos químicos como los colorantes, los cuales pueden resultar nocivos para el ambiente y la salud de sus usuarios. Por tal motivo, en este trabajo se presenta la síntesis de un material magnético nanocompuesto (NCM) de polipirrol (PPY)/óxido de hierro $(\mathrm{OxH})$ y para su evaluación como adsorbente de colorantes disueltos en medios acuosos. Se realizaron experimentos en modo lote utilizando el colorante azo Congo Red (CR) en una concentración de 25 ppm; la concentración de colorante en la disolución se determinó mediante un espectrofotómetro UV-Vis, a una longitud de onda de $498 \mathrm{~nm}$. Se estudió la capacidad de adsorción del NCM como función del $\mathrm{pH}$ (3.0-9.0). De estos experimentos se obtuvo que el NCM PPY/OxF presentó una mayor adsorción de $\mathrm{CR}$ en pH próximos a 6.0 y 9.0 al presentarse porcentajes de remoción de $37.4 \%$ y $44.88 \%$, respectivamente, después de 20 min de interacción. Se concluye que el material compuesto PPY/OxF es un adsorbente prometedor para colorantes azo en medios acuosos. Este resultado, se puede atribuir a enlaces de hidrogeno entre el polímero conductor y el colorante. Al ser un material de bajo costo y fácil manejo, puede ser sometido a experimentos de adaptación a un sistema de filtración por recirculación para remediación de agua.

Palabras clave: Material compuesto, remediación de agua, polímeros conductores.

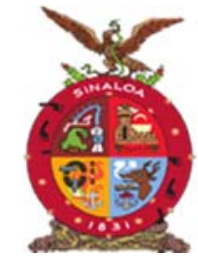

XVIII Congreso Internacional XXIV Congreso Nacional de Ciencias ambientales

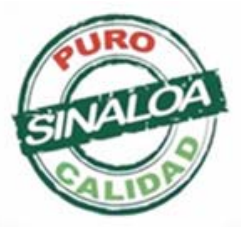

Mazatlán, Sinaloa 3-7 junio 2019
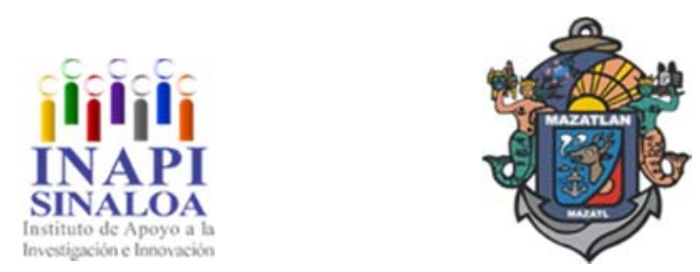

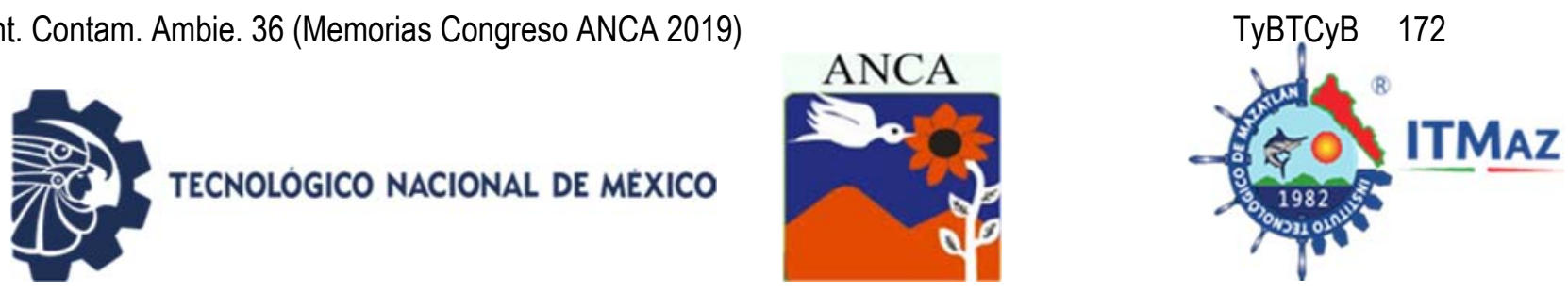

\title{
Magnetic Nanocomposites of Polypyrrole-Oxide for Removal of dyes in aqueous media
}

\author{
Ramírez Ortega $\mathrm{AA}^{1}$, García Elías $\mathrm{J}^{1}$, Medina Llamas $\mathrm{JC}^{2}$, Medina Llamas $\mathrm{M}^{3}$, \\ Chávez Guajardo $\mathrm{AE}^{1^{*}}$ \\ ${ }^{1}$ Unidad Académica de Ciencias de la Tierra. \\ Universidad Autónoma de Zacatecas, Zacatecas, México \\ ${ }^{2}$ Centro de Estudios Científicos y Tecnológicos No. 18. \\ Instituto Politécnico Nacional, Zacatecas, México \\ 3Unidad Académica de Física. UAZ, Zacatecas, México \\ *elisagua.chavez@gmail.com
}

\begin{abstract}
Water pollution is one of the main environmental problems worldwide; being population growth and industrial development key drivers. Commonly found water pollutants are organic matter and chemical compounds; such as dyes; which have detrimental effects on the environment and human health. Consequently, the present work investigates the synthesis of nanocomposite magnetic materials (NCM) of polypyrrole (PPY)/iron oxide ( $\mathrm{OxH})$; and their use as an adsorbent material of dyes dissolved in aqueous solutions. Batch mode experiments were carried out using the azo dye Congo red (CR) with an initial concentration of 25 ppm; its concentration was quantified using an UV-Vis spectrophotometer at a wavelength of $498 \mathrm{~nm}$. The adsorption capacity of NCM was investigated as a function of $\mathrm{pH}$ (3.0-9.0). The results demonstrate that NCM PPY/OxF have CR adsorption removal values of $37.4 \%$ and $44.88 \%$ at $\mathrm{pH}$ values of 6.0 and 9.0 , respectively, after $20 \mathrm{~min}$ of interaction. Our experiments demonstrate NCM PPY/OxF are a promising adsorbent for azo dyes in aqueous media. Their performance is attributed to hydrogen bonds between the PPY, which is a conductive polymer, and the dye. In addition, its low manufacturing cost and ease of operation, makes an ideal material for further adaptations in recirculation filtration systems for water remediation.
\end{abstract}

Keywords: Magnetic nanocomposite, water remediation, conductive polymers.

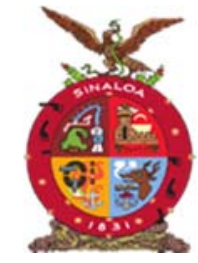

XVIII Congreso Internacional XXIV Congreso Nacional de Ciencias ambientales

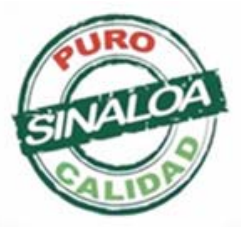

Mazatlán, Sinaloa 3-7 junio 2019
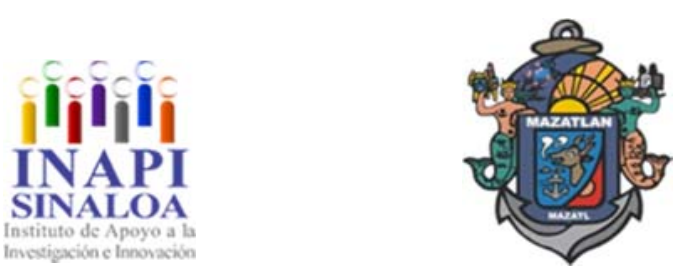

Tecnología y Biotecnología para el Tratamiento de Contaminantes y Biorremediación 

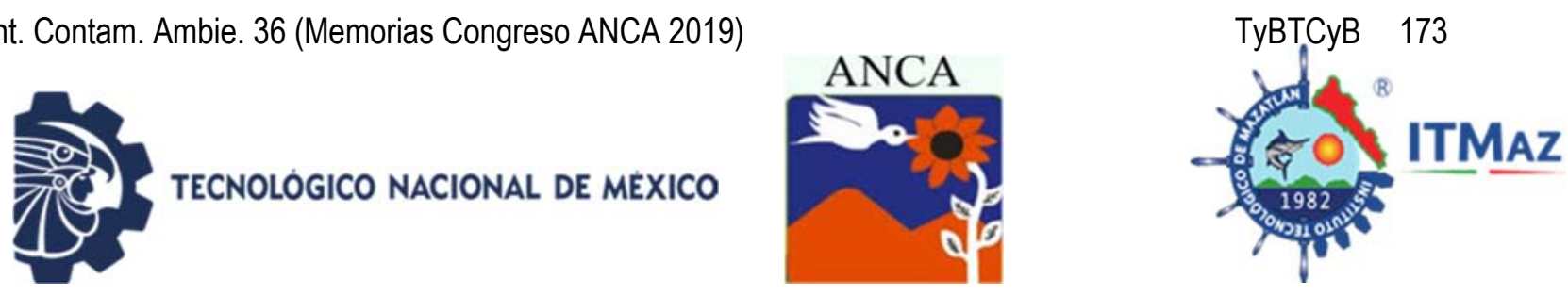

\title{
Análisis del perfil proteico de Pleurotus ostreatus con la interacción del colorante Rojo Allura
}

\author{
Reyes Castro S, Torres Pérez J, González Fernández R, Valero Galán J* \\ Universidad Autónoma de Ciudad Juárez, \\ Av. Plutarco Elías Calles \# 1210 Fovissste Chamizal Cd. Juárez, Chihuahua, \\ *jose.valero@uacj.mx
}

\section{RESUMEN}

Uno de los colorantes más usados en la industria alimentaria, farmacéutica y textil es el Rojo Allura, que es un contaminante difícil de remover por tratamiento físico y químico. Uno de los microorganismos que tienen la capacidad de usarse como bioremediador con capacidad de degradar compuestos orgánicos recalcitrantes debido a su acción metabólica es Pleurotus ostreatus. En esta investigación se analizó la respuesta al colorante Rojo Allura por $P$. ostreatus con el objetivo de comprobar si es capaz de liberar proteínas con la eficiencia para remover este compuesto de aguas contaminadas. Se realizó un experimento de interacción dual entre colorante-hongo por 20 días. Para esto se verificó el proceso de degradación del colorante a través de la medición de la absorbancia en los espectros infrarrojos pertenecientes a cada tratamiento respecto al control. Adicionalmente, se separó la materia orgánica de la parte acuosa. Esta última, se liofilizó y se realizó la extracción y cuantificación de proteínas. Los resultados mostraron que $P$. ostreatus secreta proteínas al interactuar con el Rojo Allura, donde le primer tratamiento mostró 7 proteínas diferentes al control, el segundo 10 proteínas y el tercero 14 . Con estos resultados fue posible determinar que $P$. ostreatus posee proteínas que podrían tener una función de degradación de este tipo de compuestos. Por esta razón, se propone el uso de este tipo de organismos para su utilización como bioremediadores en diferentes áreas industriales.

Palabras claves: Microorganismos, remoción de colorantes, proteínas.

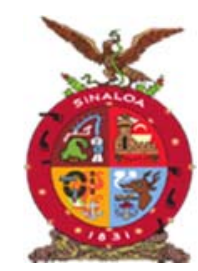

XVIII Congreso Internacional XXIV Congreso Nacional de Ciencias ambientales

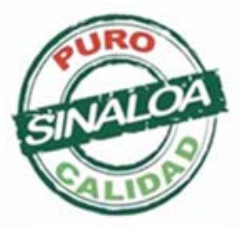

Mazatlán, Sinaloa 3-7 junio 2019
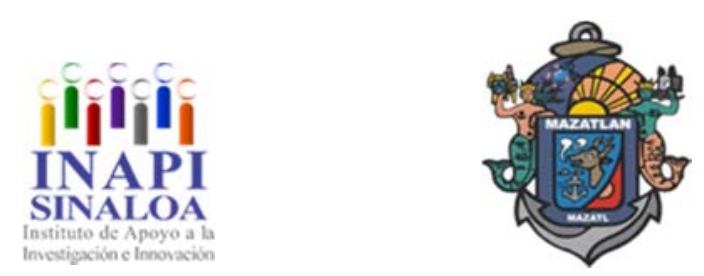

Tecnología y Biotecnología para el Tratamiento de Contaminantes y Biorremediación 

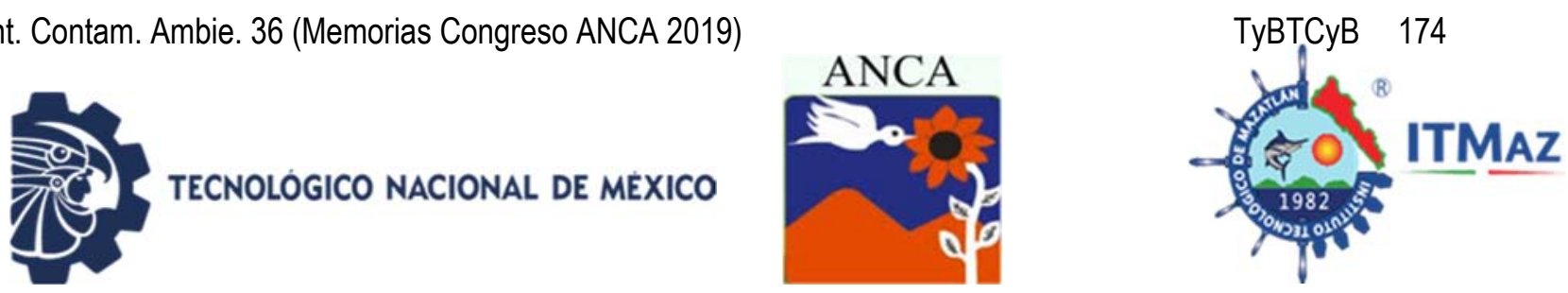

\title{
Protein profile of Pleurotus ostreatus and the interaction with Rojo Allura dye
}

\author{
Reyes Castro S, Torres Pérez J, González Fernández R, Valero Galán J* \\ Universidad Autónoma de Ciudad Juárez, \\ Av. Plutarco Elías Calles \# 1210 Fovissste Chamizal Cd. Juárez, Chihuahua, \\ *jose.valero@uacj.mx
}

\begin{abstract}
One of the most used dyes in the food, pharmaceutical, and textile industries is the Allura Red, but it is also a contaminant difficult to remove by a physical and chemical process in the water. One of the microorganisms that have the capacity to degrade compounds due to its metabolic action and is used as bioremediation is Pleurotus ostreatus. In this research, the protein profile of $P$. ostreatus was analyzed in response to the Allura Red dye in order to verify if it had the capacity of releasing proteins to remove this compound from contaminated waters. An experiment of the dual interaction between dye-fungus was carried out for 20 days. The degradation process of the dye was verified by measuring the absorbance and the infrared spectra of a control and treatment. Additionally, the organic matter was separated from the aqueous part. The aqueous extract was lyophilized and the extraction and quantification of proteins were carried out. The results showed that $P$. ostreatus secretes proteins when interacting with the Allura Red, where the first treatment showed 7 different proteins to the control, the second 10 proteins and the third 14 . This results showed that $P$. ostreatus has proteins that could have a function of degradation of this type of compounds. For this reason, the use of this type of organisms is proposed for use as bioremediators in different industrial areas.
\end{abstract}

Keywords: Microorganisms, dye remotion, proteins.

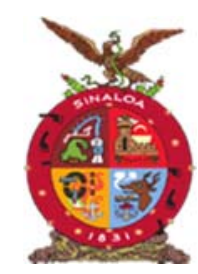

XVIII Congreso Internacional XXIV Congreso Nacional de Ciencias ambientales

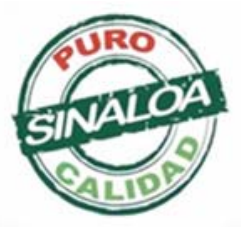

Mazatlán, Sinaloa 3-7 junio 2019
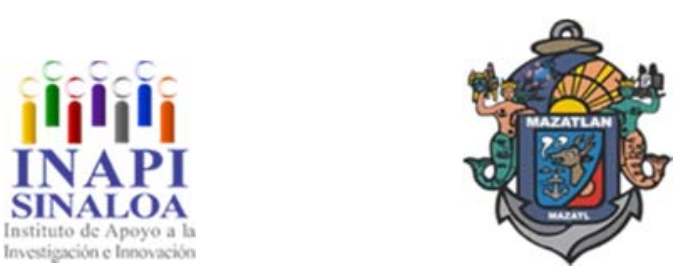

Tecnología y Biotecnología para el Tratamiento de Contaminantes y Biorremediación 

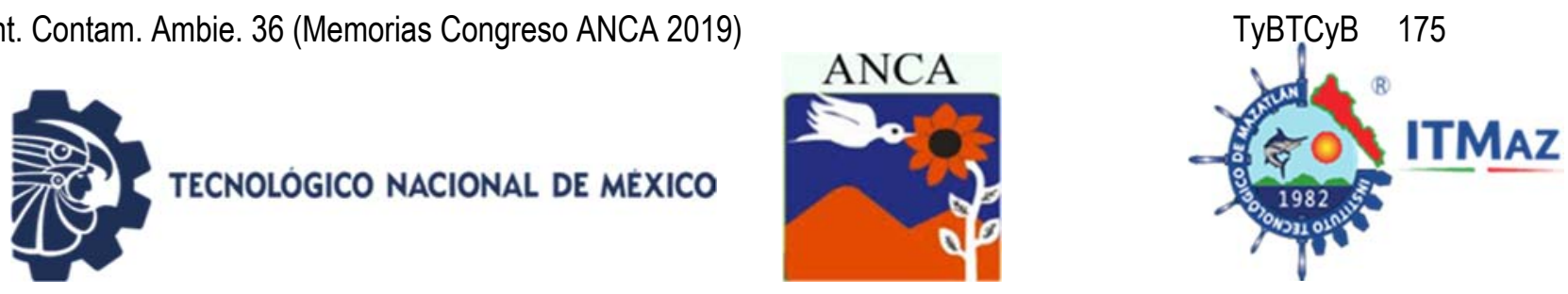

\title{
Desarrollo de una técnica de obtención de esferas cerámicas de Alúmina- Zirconia y de Alúmina-Titanio para la adsorción de tetraciclina en cuerpos de agua
}

\author{
Reyes López SY, López Alemán M*, Silva P, Torres Pérez J \\ Universidad Autónoma de Ciudad Juárez \\ *..alemanmay@gmail.com
}

\section{RESUMEN}

En el laboratorio de materiales híbridos nanoestructurados en la Universidad Autónoma de Ciudad Juárez fue llevada a cabo la síntesis de un material cerámico adsorbente con el fin de presentar una propuesta alternativa y viable frente al problema de la contaminación de cuerpos de agua con antibióticos, dicha problemática a traído consecuencias en flora y fauna marítima así como inducir la resistencia bacteriana, sin embargo es necesario implementar nuevas opciones tecnológicas para el tratamiento de aguas contaminadas con antibióticos sin realizar un tratamiento posterior para que no interactúe más que con el analito de interés, es por eso que se decidió llevar a cabo la síntesis de un material cerámico, ya que este dentro de sus características presenta una gran resistencia a altas temperaturas, alta resistencia mecánica, es inerte e insoluble en agua, por lo que no ocasionara cambios al medio acuoso. Se obtubieron esferas cerámicas de $3 \mathrm{~mm}$ de diámetro tanto de alúmina-zirconia como de alúmina-titania a los cuales se les realizó pruebas de caracterización por FT-IR, DRX, espectroscopia Raman obteniendo datos de las fases cristalinas obtenidas en el material posteriores a los tratamientos térmicos de 100,800 y $1600^{\circ} \mathrm{C}$ para posteriormente realizar pruebas de sorción con una solución de tetraciclina a 50 ppm y a pH de 11 donde se realizaron lecturas cada hora por ocho horas y posteriormente a las $24,36,48,60,72,84$ y 96 horas, los resultados obtenidos mostraban un proceso de sorción-disorción entre la solución y el material cerámico.

Palabras Clave: Contaminación, antibiótico, cerámico, adsorción, sinterización.

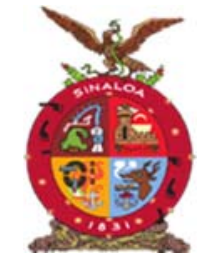

XVIII Congreso Internacional XXIV Congreso Nacional de Ciencias ambientales

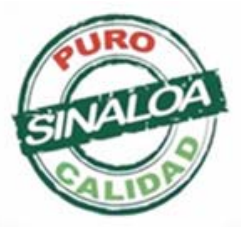

Mazatlán, Sinaloa 3-7 junio 2019
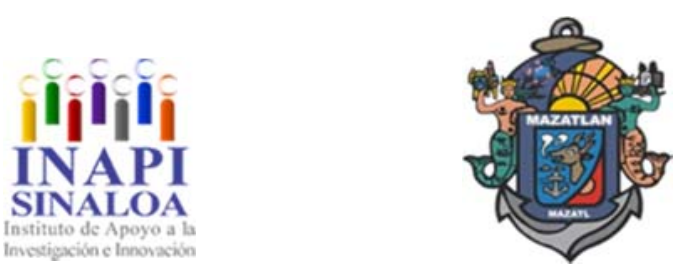

Tecnología y Biotecnología para el Tratamiento de Contaminantes y Biorremediación 

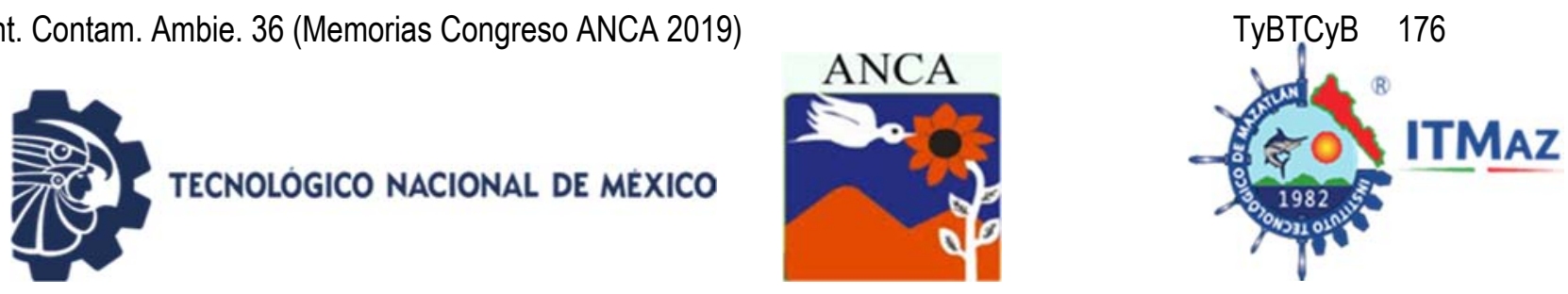

\title{
Development of a technique for obtaining Alumina-Zirconia and Alumina- Titanium ceramic spheres for the adsorption of tetracycline in water bodies
}

\author{
Reyes López SY, López Alemán M*, Silva P, Torres Pérez J \\ Universidad Autónoma de Ciudad Juárez \\ *l.alemanmay@gmail.com
}

\begin{abstract}
In the laboratory of nanostructured hybrid materials at the Autonomous University of Ciudad Juárez, the synthesis of an adsorbent ceramic material was carried out in order to present an alternative and viable proposal for the problem of contamination of water bodies with antibiotics, this problem has brought consequences in marine flora and fauna as well as inducing bacterial resistance, however it is necessary to implement new technological options for the treatment of water contaminated with antibiotics without further treatment so that it does not interact more than with the analyte of interest, it is for That which was decided to carry out the synthesis of a ceramic material, since this within its characteristics has a high resistance to high temperatures, high mechanical resistance, is inert and insoluble in water, so it will not cause changes to the aqueous environment. Ceramic spheres $3 \mathrm{~mm}$ in diameter were obtained from both alumina-zirconia and alumina-titania, which were tested for characterization by FT-IR, DRX, Raman spectroscopy, obtaining data on the crystalline phases obtained in the material after heat treatments of 100,800 and $1600^{\circ} \mathrm{C}$ to subsequently perform sorption tests with a tetracycline solution at $50 \mathrm{ppm}$ and $\mathrm{pH}$ of 11 where readings were made every hour for eight hours and then at $24,36,48,60,72,84$ and 96 hours, the results obtained showed a process of sorption-disorganization between the solution and the ceramic material.
\end{abstract}

Keywords: Pollution, antibiotic, ceramic, adsorption, sintering.

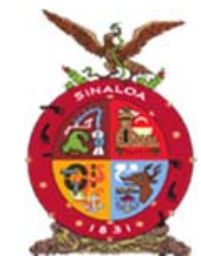

XVIII Congreso Internacional XXIV Congreso Nacional de Ciencias ambientales

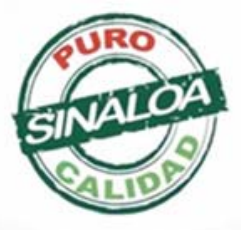

Mazatlán, Sinaloa 3-7 junio 2019
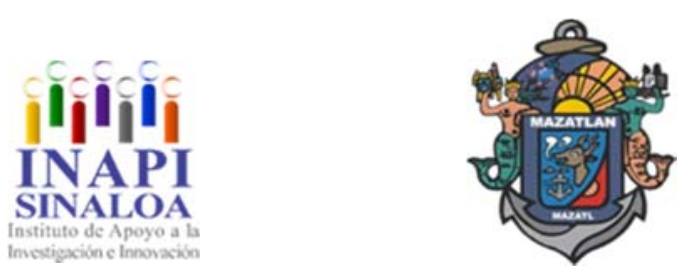

Tecnología y Biotecnología para el Tratamiento de Contaminantes y Biorremediación 

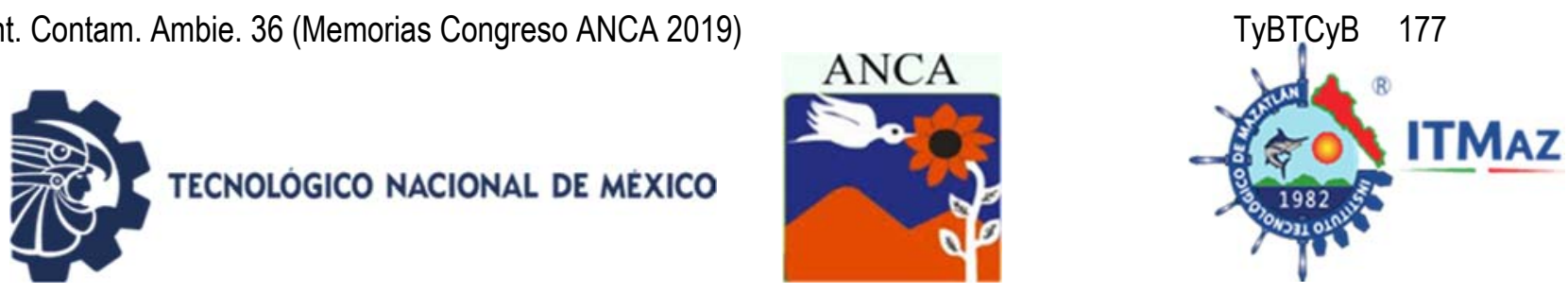

\title{
Biosíntesis de partículas bimetálicas $\mathrm{Fe} / \mathrm{Cu}$, utilizando como reductor a Eucaliptus globulus para remover Índigo Carmín en solución acuosa
}

\author{
Reyes Pérez J, Roa Morales $\mathrm{G}^{2}$, Amaya Chávez A ${ }^{1}$, Balderas Hernández $\mathrm{P}^{2}$ \\ ${ }^{1}$ Facultad de Química. Universidad Autónoma del Estado de México, \\ Paseo Colón S/N, esquina con Paseo Tollocan, Toluca, Estado de México \\ ${ }^{2}$ Centro Conjunto de Investigación en Química Sustentable UAEMex-UNAM \\ (CCIQS), Carretera Toluca-Atlacomulco Km 14.5, Toluca, Estado de México \\ *reyesjazz@outlook.com
}

\begin{abstract}
RESUMEN
Actualmente los materiales bimetálicos son preparados utilizando métodos reductores químicos o físicos, sin embargo sus desventajas radican en su toxicidad, ya que generan contaminación ambiental, representan un peligro para las especies vivas y son costosos, además requieren la adición de agentes dispersantes para evitar la aglomeración resultando una contaminación secundaria, por lo tanto es imperante el desarrollo de métodos alternativos de reducción de bajo costo, seguros y ecológicos. La síntesis verde representa una alternativa viable a través de las plantas, ya que secretan fitoquímicos que cuentan con propiedades reductoras. Este estudio se utilizó polvo de hojas de eucalipto en infusión con el objetivo de obtener partículas bimetálicas de $\mathrm{Fe} / \mathrm{Cu}$, para utilizarlas como catalizadores para la remoción del colorante índigo carmín de soluciones estándar. La investigación se realizó en el laboratorio de Química Ambiental I del CCIQS. De septiembre 2018 a marzo 2019, se probaron infusiones de eucalipto de $100 \mathrm{~mL}$ de agua con $20 \mathrm{~g}$ de polvo de hoja, como precursores se utilizaron sales metálicas de hierro y cobre, una vez obtenidas las partículas, estas se emplearon para remover el colorante índigo carmín evaluando el efecto de la concentración del colorante (200 y 400 ppm), la cantidad de partículas (1 y $5 \mathrm{mg}$ ) y de peróxido adicionado (10 y $20 \mu \mathrm{L}$ ) a un tiempo de reacción de 50 minutos. Una vez encontradas las condiciones óptimas, se observo que el color se remueve con una eficiencia del $90 \%$ en 40 minutos, por lo que ahora se debe evaluar su eficiencia en agua residual.
\end{abstract}

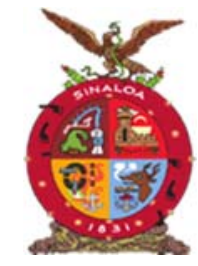

XVIII Congreso Internacional XXIV Congreso Nacional de Ciencias ambientales

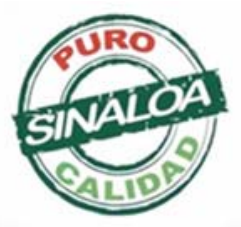

Mazatlán, Sinaloa 3-7 junio 2019
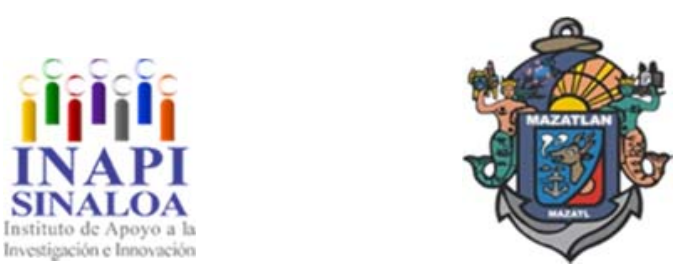

Tecnología y Biotecnología para el Tratamiento de Contaminantes y Biorremediación 

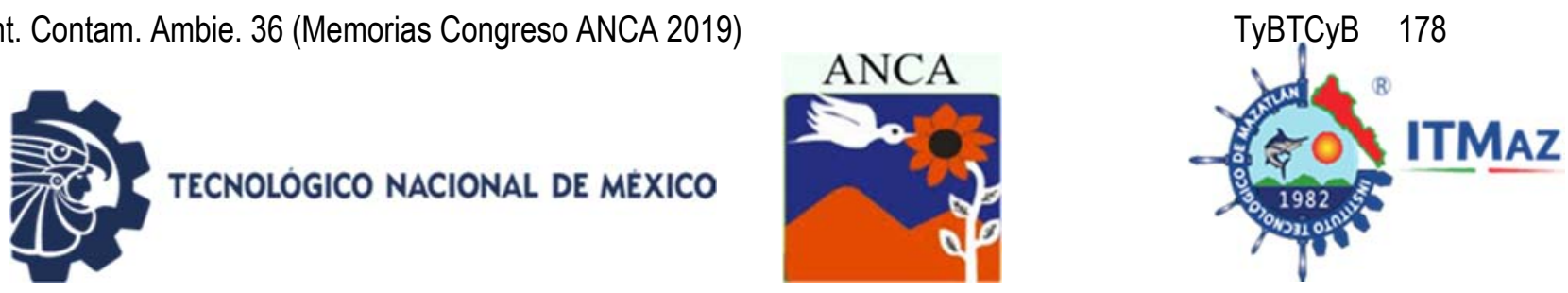

\title{
Biosynthesis of Fe/Cu bimetallic particles, using Eucalyptus globulus as a reducer to remove Indigo Carmine in aqueous solution
}

\author{
Reyes Pérez J”, Roa Morales $\mathrm{G}^{2}$, Amaya Chávez A , Balderas Hernández P² \\ ${ }^{1}$ Facultad de Química. Universidad Autónoma del Estado de México, \\ Paseo Colón S/N, esquina con Paseo Tollocan, Toluca, Estado de México \\ ${ }^{2}$ Centro Conjunto de Investigación en Química Sustentable UAEMex-UNAM \\ (CCIQS), Carretera Toluca-Atlacomulco Km 14.5, Toluca, Estado de México \\ *reyesjazz@outlook.com
}

\begin{abstract}
Currently bimetallic materials are prepared using chemical or physical reducing methods, however their disadvantages lie in their toxicity since they generate environmental pollution, represent a danger for living species and are expensive (Zhu et al., 2018; Khani et al., 2018), in addition they require the addition of dispersing agents to avoid agglomeration resulting in secondary contamination, therefore the development of alternative methods of low cost, safe and ecological reduction is imperative (Zhu et al., 2018). The green synthesis represents a viable alternative through plants, since they secrete phytochemicals that have reducing properties (Agarwal, et al., 2017). This study used eucalyptus leaf powder in infusion with the objective of obtaining bimetallic $\mathrm{Fe} / \mathrm{Cu}$ particles, to be used as catalysts for the removal of the indigo carmine dye from standard solutions. The research was carried out in the laboratory of Environmental Chemistry I of the CCIQS, during September 2018 to March 2019. Eucalyptus infusions of $100 \mathrm{~mL}$ of water were tested with $20 \mathrm{~g}$ of leaf powder, metal iron and copper salts were used as a precursors, once the particles were obtained, were used to remove the indigo carmine dye, evaluating the effect of the concentration of the dye (200 and $400 \mathrm{ppm}$ ), the amount of particles (1 and $5 \mathrm{mg}$ ) and of peroxide added (10 and $20 \mu \mathrm{L}$ ) at a reaction time of 50 minutes. Once the optimum conditions were found, it was observed that the color is removed with an efficiency of $90 \%$ in 40 minutes, so it is viable to evaluate its efficiency in wastewater.
\end{abstract}

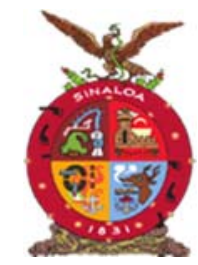

XVIII Congreso Internacional XXIV Congreso Nacional de Ciencias ambientales

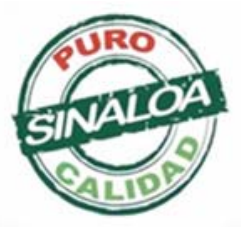

Mazatlán, Sinaloa 3-7 junio 2019
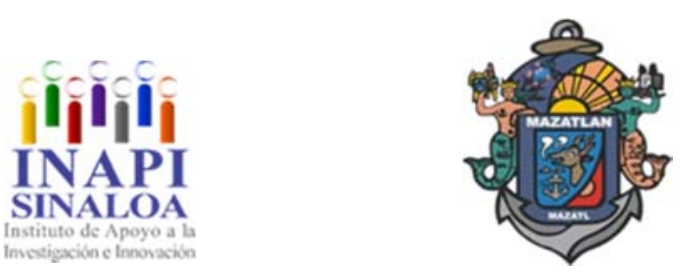

Tecnología y Biotecnología para el Tratamiento de Contaminantes y Biorremediación 

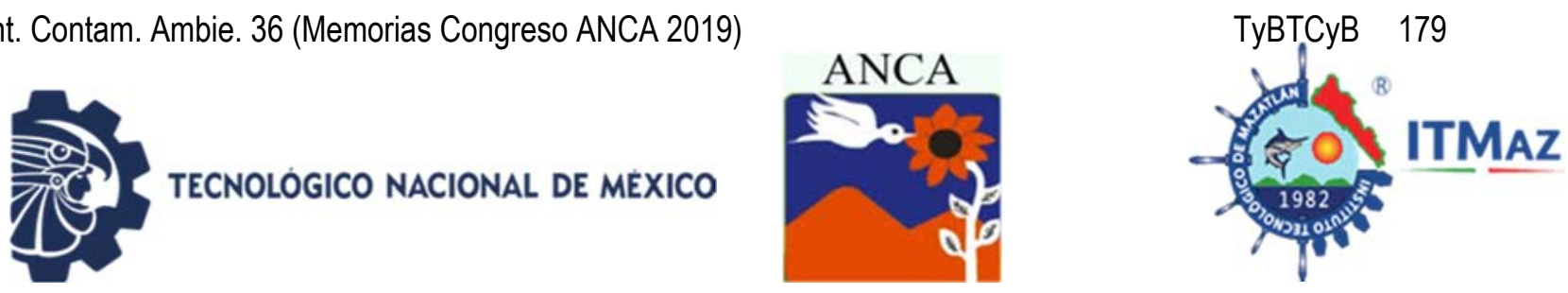

\title{
Recuperación de fitonutrientes de aguas residuales agroindustriales tratadas con procesos de oxidación avanzada: primera etapa
}

\author{
Reyes Prado M, Robles Magdaleno J*, Amábilis Sosa L, Rodríguez Mata A, \\ Ramírez Pereda B
}

División de Estudios de Posgrado e Investigación.

Instituto Tecnológico de Culiacán.

Juan de Dios Batíz 310. Col. Guadalupe, 80220. Culiacán, Sinaloa, México

*jose14luis05@hotmail.com

\section{RESUMEN}

EI Valle de Culiacán es una región agrícola altamente tecnificada con 217,461 ha bajo riego. No obstante, esto conlleva un uso constante fertilizantes y plaguicidas con una aplicación de aproximadamente 69.92 ton/año de las cuales sólo se aprovecha el $50 \%$. Por ende, estas sustancias se transportan hacia los cuerpos de agua superficiales a través de diversos drenajes agrícolas con los que cuenta la región. En paralelo la continua necesidad de proveer fertilizantes al suelo agrícola implica una serie de procesos físicos y/o químicos que generan gastos económicos y ambientales. El presente trabajo presenta la primera etapa del estudio de la recuperación de fitonutrientes de aguas residuales agroindustriales, a través de su tratamiento con procesos de oxidación avanzada (AOP). Se implementaron los sistemas $\mathrm{UV} / \mathrm{H}_{2} \mathrm{O}_{2}$, ozonación, fotofenton y $\mathrm{UV} / \mathrm{H}_{2} \mathrm{O}_{2} / \mathrm{TiO}$, optimizados en estudios previos, para tratar por separado malatión y paratión en soluciones sintéticas con 120 y $110 \mathrm{mg} / \mathrm{L}$ respectivamente. Los efluentes fueron analizados por cromatografía de gases acoplada a masas y cuantificados en cuanto DQO y COT. Los resultados indicaron que es posible mineralizar entre el $92-99 \%$ de la molécula de los plaguicidas y que el total del fósforo es convertido a ortofosfatos, la cual es una de las especies químicas ampliamente utilizadas en las formulaciones de fertilizantes. El presente trabajo constituye las bases para las siguientes etapas del proyecto en la que se evaluarán las transformaciones de las moléculas presentes en las aguas residuales agroindustriales y la aplicación a cultivos seleccionados.

Palabras Claves: Recuperación de fitonutrientes, procesos de oxidación avanzada, plaguicidas, aguas residuales agroindustriales.

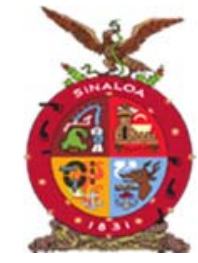

XVIII Congreso Internacional XXIV Congreso Nacional de Ciencias ambientales

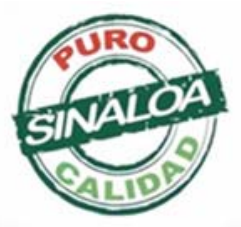

Mazatlán, Sinaloa 3-7 junio 2019
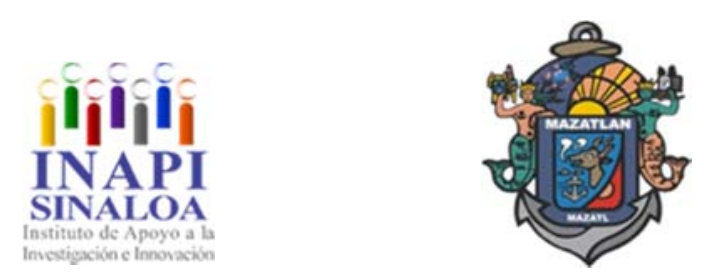

Tecnología y Biotecnología para el Tratamiento de Contaminantes y Biorremediación 

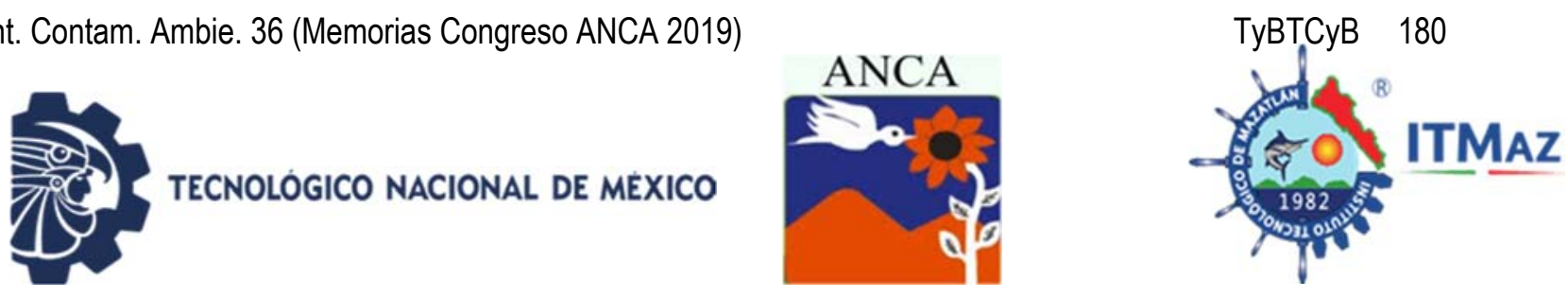

\title{
Phytonutrient recovery from agroindustrial wastewater treated with advanced oxidation processes: stage one
}

\author{
Reyes Prado M, Robles Magdaleno J*, Amábilis Sosa L, Rodríguez Mata A, \\ Ramírez Pereda B \\ División de Estudios de Posgrado e Investigación. \\ Instituto Tecnológico de Culiacán. \\ Juan de Dios Batíz 310. Col. Guadalupe, 80220. Culiacán, Sinaloa, México \\ *jose14luis05@hotmail.com
}

\begin{abstract}
Culiacán Valley is a highly technical agricultural region with 217,461 ha under irrigation. However, this leads to a constant use of fertilizers and pesticides with an application of approximately 69.92 tons/year of which only $50 \%$ is used. Therefore, these substances are transported to surface water bodies through various agricultural drains in the region. At the same time, the continuous need to supply fertilizers to the agricultural soil implies a series of physical and/or chemical processes that generate economic and environmental costs. This paper presents the first stage of the study of the recovery of phytonutrients from agroindustrial wastewater, through its treatment with advanced oxidation processes (AOP). We implemented the $\mathrm{UV} / \mathrm{H}_{2} \mathrm{O}_{2}$, ozonation, photofenton and $\mathrm{UV} / \mathrm{H}_{2} \mathrm{O}_{2} / \mathrm{TiO}$ systems, optimized in previous studies, to treat separately malathion and parathion in synthetic solutions with 120 and $110 \mathrm{mg} / \mathrm{L}$ respectively. The effluents were analyzed by gas chromatography coupled to masses and quantified as COD and TOC. The results indicated that it is possible to mineralize between $92-99 \%$ of the pesticide molecule and that total phosphorus is converted to orthophosphates, which is one of the chemical species widely used in fertilizer formulations. The present paper constitutes the basis for the next stages of the project in which the transformations of molecules present in agro-industrial wastewater and the application to selected crops will be evaluated.
\end{abstract}

Keywords: Phytonutrient recovery, advanced oxidation processes, pesticides, agroindustrial wastewater.

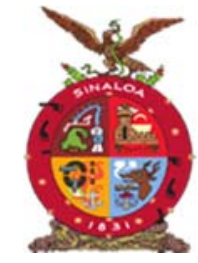

XVIII Congreso Internacional XXIV Congreso Nacional de Ciencias ambientales

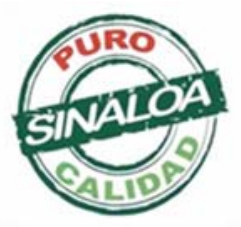

Mazatlán, Sinaloa 3-7 junio 2019
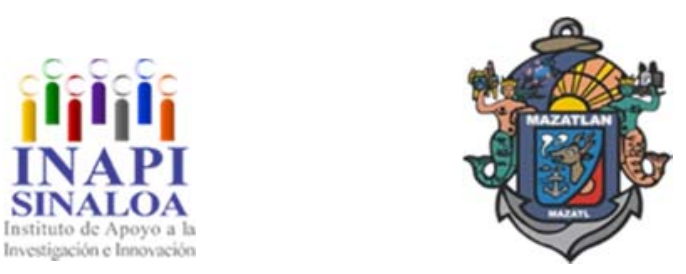

Tecnología y Biotecnología para el Tratamiento de Contaminantes y Biorremediación 

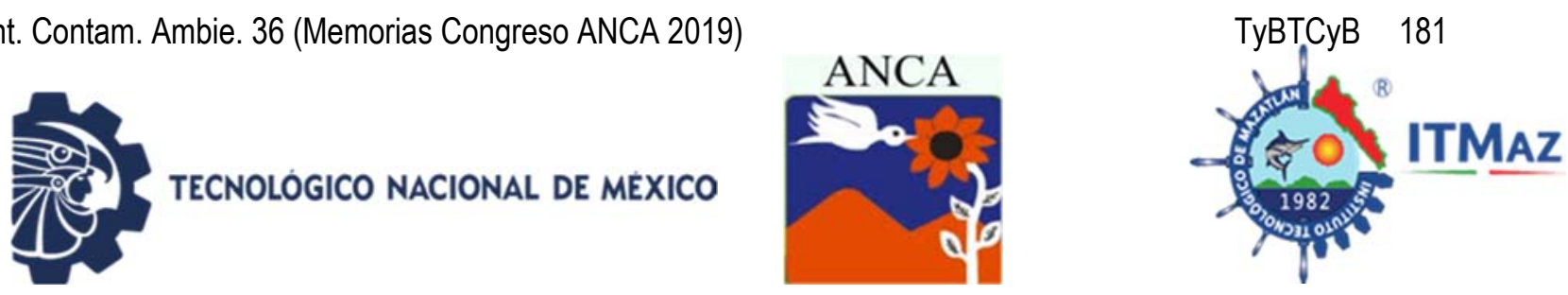

\title{
Análisis de la tasa de producción de biopolímeros en un BRM mediante Simulación
}

\author{
Reyes Romero F*, Rojas Ruíz E \\ Maestría Ingeniería Ambiental Universidad Michoacana de San Nicolás de \\ Hidalgo, Ciudad Universitaria, 58004 Morelia, Mich \\ *francisco.reyes.ing@gmail.com.
}

\section{RESUMEN}

Uno de los propósitos más importantes al usar la simulación es lograr un entendimiento profundo de los procesos de un sistema. Alineado con ello, el objetivo del presente estudio es evaluar la tasa de producción teórica de los biopolímeros conocidos como polihidroxialcanoatos (PHA) en un biorreactor con membranas sumergidas evaluadas mediante la simulación con el software GPS$\mathrm{X}$; y así, lograr una mayor comprensión del proceso y de las condiciones operativas que podrían convertir un proceso de tratamiento de aguas residuales en una fuente de polímeros renovables y biodegradables. El modelo biológico elegido fue el modelo ASM3 ya que incluye la variable Xsto, que representa los PHA. El modelo se alimentó con datos experimentales obtenidos preciamente. Para calibrar el modelo se implementó un análisis de sensibilidad de los parámetros cinéticos más importantes para el proceso, 16 en total, incluyendo parámetros de la biomasa heterótrofa y autótrofa, de hidrolisis y de rendimiento celular. El valor de la variable DQO también se incluye en la calibración, ya que es necesario conocer la calidad del agua del efluente. El valor simulado más cercano al experimental para PHA, fue de $118 \mathrm{mgDQO} / \mathrm{L}$ contra $125.5 \mathrm{mgDQO} / \mathrm{L}$, sin embargo, el valor simulado para $\mathrm{DQO}$ no ha logrado acercarse lo suficiente al valor experimental para considerar que el modelo ha sido calibrado. Una vez lograda la calibración de modelo, se podrán evaluar distintas condiciones operativas, como la carga orgánica, y observar la variación en la tasa teórica de producción de PHA.

Palabras clave: ASM3, BRM, PHA, análisis de sensibilidad, GPS-X.

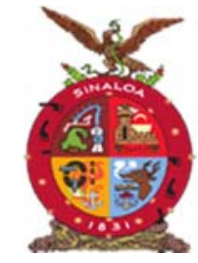

XVIII Congreso Internacional XXIV Congreso Nacional de Ciencias ambientales

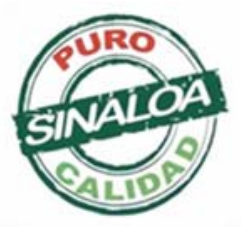

Mazatlán, Sinaloa 3-7 junio 2019
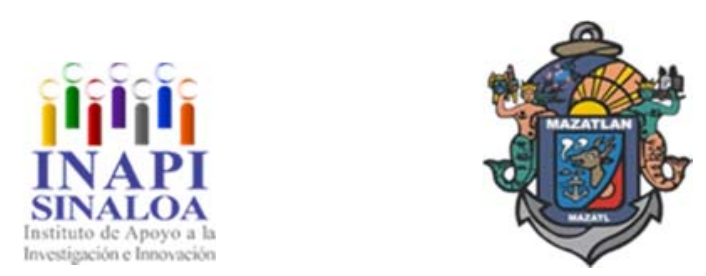

Tecnología y Biotecnología para el Tratamiento de Contaminantes y Biorremediación 


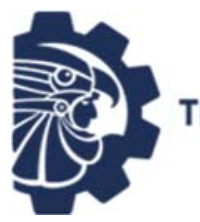

TECNOLOGICO NACIONAL DE MEXICO
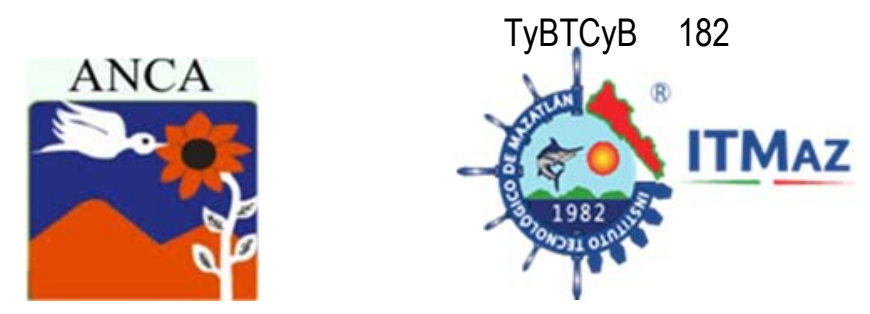

\title{
Analysis of the production rate of biopolymers in a BRM by simulation
}

\author{
Reyes Romero F*, Rojas Ruíz E \\ Maestría Ingeniería Ambiental Universidad Michoacana de San Nicolás de \\ Hidalgo, Ciudad Universitaria, 58004 Morelia, Mich \\ *francisco.reyes.ing@gmail.com.
}

\begin{abstract}
One of the most important purposes when using simulation is to achieve a deep understanding of the processes of a system. Aligned with this, the objective of the present study is to evaluate the theoretical production rate of biopolymers known as Polyhydroxyalkanoates (PHA) in a bioreactor with submerged membranes by means of simulation with the GPS-X software; and thus, to achieve a greater understanding of the process and the operational conditions that could turn a wastewater treatment process into a source of renewable and biodegradable polymers. The chosen biological model was the ASM3 model as it includes the Xsto variable, which represents the PHA. The model was fed with experimental data obtained previously. To calibrate the model, a sensitivity analysis of the most important kinetic parameters for the process was implemented, 16 in total, including parameters of the heterotrophic and autotrophic biomass, of hydrolysis and cellular yield. The value of the COD variable is also included in the calibration, since it is necessary to know the water quality of the effluent. The simulated value closest to the experimental for PHA, was $118 \mathrm{mgCOD} / \mathrm{L}$ against $125.5 \mathrm{mgCOD} / \mathrm{L}$, however, the simulated value for COD has not managed to get close enough to the experimental value to consider that the model has been calibrated. Once the model calibration has been achieved, it will be possible to evaluate different operating conditions, such as the organic load, and to observe the variation in the theoretical rate of PHA production.
\end{abstract}

Keywords: ASM3, MBR, PHA, sensivity análisis, GPS-X

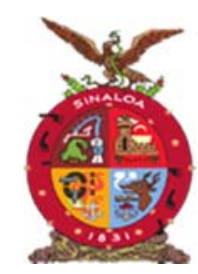

XVIII Congreso Internacional XXIV Congreso Nacional de Ciencias ambientales

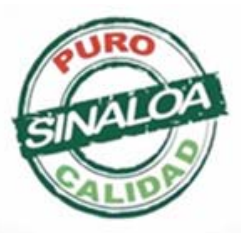

Mazatlán, Sinaloa 3-7 junio 2019
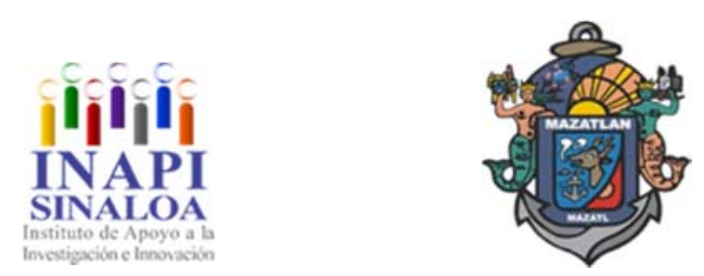

Tecnología y Biotecnología para el Tratamiento de Contaminantes y Biorremediación 

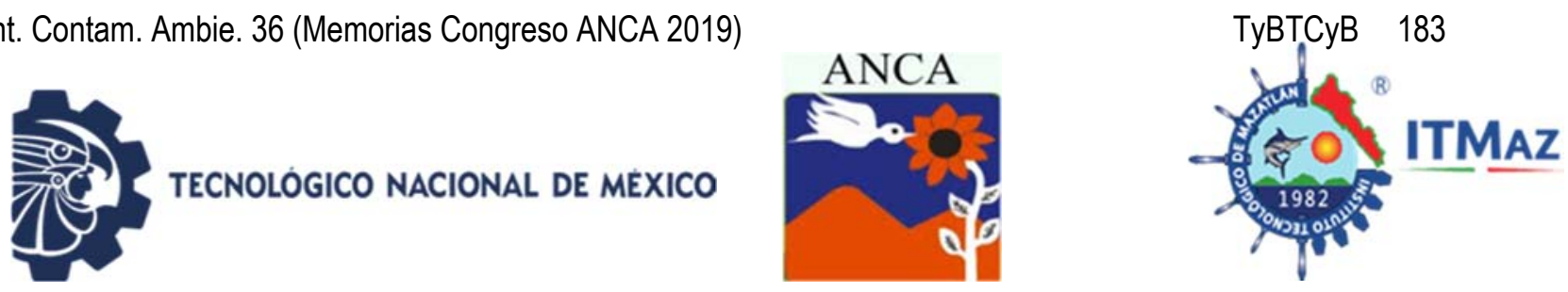

\title{
Aplicación de un bioadsorbente a partir de residuos de cáscara de plátano para la remoción de cromo hexavalente
}

\author{
Rico Barragán A *, Sánchez Juan KL, Salazar Salazar GC, López González Y, \\ Salazar Hernández E
}

Instituto Tecnológico Superior de Misantla.

Loma del Cojolite, Misantla, Veracruz

*aaricob@itsm.edu.mx

\section{RESUMEN}

La presencia de cromo en aguas de uso y consumo humano, es considerada como un problema de contaminación. Este elemento es utilizado como materia prima en diversos procesos principalmente la metálica, teniendo como resultado sus estados de oxidación: $\mathrm{Cr}^{+3} \mathrm{y} \mathrm{Cr}^{+6}$. Diversas agencias especializadas en áreas ambientales y toxicológicas consideran al $\mathrm{Cr}^{+6}$ como una amenaza para el ser humano y el ambiente debido a su persistencia y toxicidad. Desde hace décadas se estudia como remover o disminuir a concentraciones menos perjudiciales la contaminación por cromo antes de ser descargado a los cuerpos de agua. La aplicación de un bioadsorbente para la remediación de aguas afectadas por metales pesados, puede ser una tecnología alternativa, considerándolo como un tratamiento el cual permite la reutilización como un desecho orgánico. El presente trabajo presenta una propuesta para la remoción de $\mathrm{Cr}^{+6}$, por medio de un bioadsorbente a base de partículas de cáscara de plátano (Musa balbisiana) La metodología para la evaluación de concentraciones tomo como referencia la NOM-AA-044-SCFI-2014, considerando las variables de concentración (0.96, $1.91,3,84$ y $4.8 \mathrm{ppm})$, tiempo de contacto (60 min), tamaño de partícula $(0.15$, $0.30,0.56$ y $2,00 \mathrm{~mm})$ y masa del adsorbente $(10,20$ y $25 \mathrm{mg})$. Se evaluaron las soluciones usando espectrofotometría Uv-Vis. A los resultados se les realizó un Análisis Factorial $(\alpha=0.05)$, mediante el software IBM SPSS $\circledast$. Evaluando independientemente las diferentes condiciones presentes en el proceso experimental como tamaño de partícula, masa del adsorbente, concentración de $\mathrm{Cr}^{+6}$ y tiempo de contacto entre adsorbente y adsorbato. Se obtuvo un porcentaje de remoción mayor al $97 \%$ en todos los experimentos realizados.

Palabras Clave: Bioadsorbente, $\mathrm{Cr}^{+6}$, contaminación.

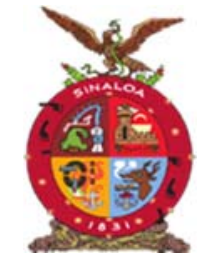

XVIII Congreso Internacional XXIV Congreso Nacional de Ciencias ambientales

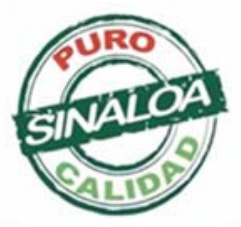

Mazatlán, Sinaloa 3-7 junio 2019
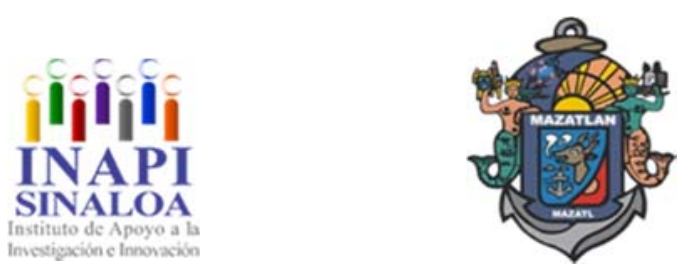

Tecnología y Biotecnología para el Tratamiento de Contaminantes y Biorremediación 

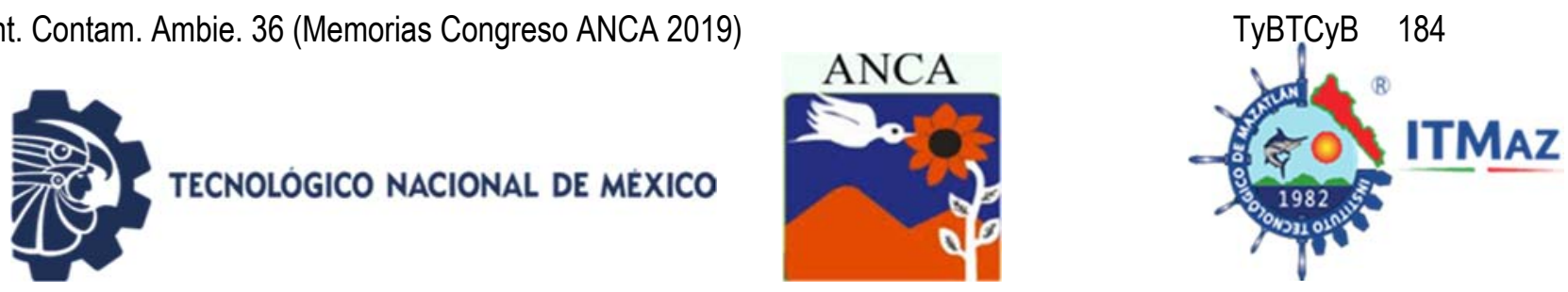

\title{
Application of a bioadsorbent from banana peel residues for the removal of hexavalent chromium
}

\author{
Rico Barragán A *, Sánchez Juan KL, Salazar Salazar GC, López González Y, \\ Salazar Hernández E
}

Instituto Tecnológico Superior de Misantla.

Loma del Cojolite, Misantla, Veracruz

*aaricob@itsm.edu.mx

\begin{abstract}
The presence of chromium in waters of human interest is considered as a pollution problem, it is used as a raw material in various processes, resulting in its oxidation states: $\mathrm{Cr}^{+3}$ and $\mathrm{Cr}^{+6}$; Various agencies specializing in environmental and toxicological areas consider $\mathrm{Cr}^{+6}$ as a threat to humans and the environment due to their persistence and toxicity. For years, it has been studied how to remove or reduce to less harmful concentrations before being discharged to water bodies. The application of a bioadsorbent for the remediation of waters affected by heavy metals, turns out to be an alternative technology, is considered as a treatment which allows the regeneration and reuse of an organic waste. The present work presents a proposal for the removal of $\mathrm{Cr}^{+6}$, by means of a bioadsorbent based on particles of banana peel (Musa Balbisiana) The methodology I take with reference NOM-AA-044-SCFI-2014, taking into account the concentration variables $(0.96,1.91,3.84$ and $4.8 \mathrm{ppm})$, contact time $(60 \mathrm{~min})$, particle size $(0.15$, $0.30,0.56$ and $2.00 \mathrm{~mm}$ ) and mass of the adsorbent (10, 20 and 25) $\mathrm{mg}$ ). The solutions were evaluated in Uv-Vis spectrophotometry. A Factorial Analysis $(\alpha=$ 0.05 ) was carried out, the former using the IBM SPSS $\AA$ software. Regardless of the different conditions present in the experimental process such as particle size, adsorbent mass, $\mathrm{Cr}^{+6}$ concentration and contact time between adsorbent and adsorbate. A percentage of removal greater than $97 \%$ was obtained in all the experiments carried out.
\end{abstract}

Keywords: Bioadsorbent, $\mathrm{Cr}^{+6}$, pollution

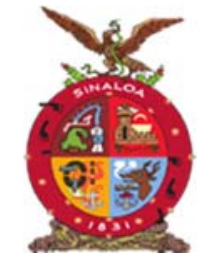

XVIII Congreso Internacional XXIV Congreso Nacional de Ciencias ambientales

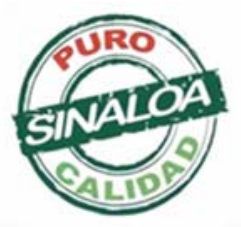

Mazatlán, Sinaloa 3-7 junio 2019
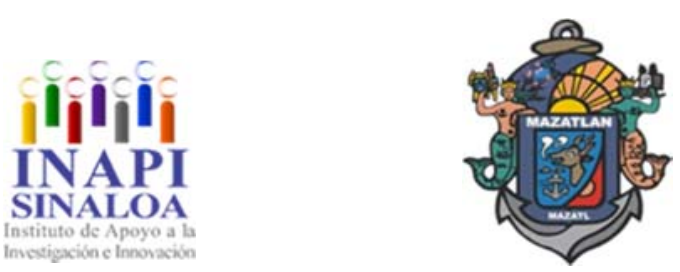

Tecnología y Biotecnología para el Tratamiento de Contaminantes y Biorremediación 

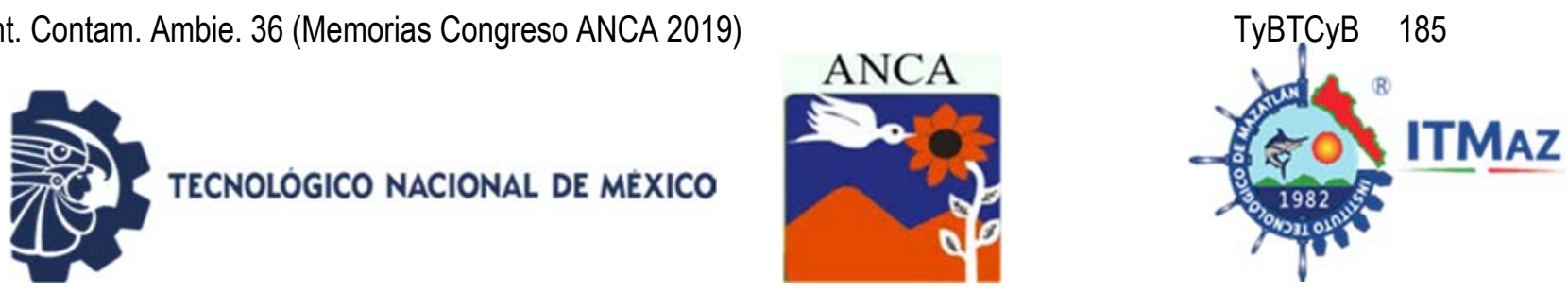

\title{
Evaluación de compostas Industriales biofertilizantes en el desarrollo vegetal de hortalizas en invernadero
}

\author{
Rivera Hernández K*, Vázquez López N, Villa Ramírez S, Ramírez López C \\ Centro de Investigación en Biotecnología Aplicada IPN-Tlaxcala, \\ Carretera Estatal Santa Inés Tecuexcomac, Tepetitla Km. 1.5 \\ Tepetitla de Lardizábal, Tlaxcala, C.P.90700 \\ *karlanallely@hotmail.com
}

\begin{abstract}
RESUMEN
La cachaza es un residuo de la industria azucarera con elevados contenidos de nitrógeno, calcio, fosforo y materia orgánica que pueden ser aprovechados y reciclados mediante el proceso de compostaje. Su valor económico se incrementa al demostrarse los beneficios que se obtienen tras su aplicación como enmienda de suelos. Se utilizaron 4 compostas (A, B, C y D) derivadas de este residuo, para su evaluación como biofertilizantes en el desarrollo de plántulas de pepino, tomate y lechuga en invernaderos hortícolas. Se determinó su efecto sobre el desarrollo de estas al final del ciclo de germinación con compostas crudas en distintas dosis $(25,50,75,100 \%)$ y compostas esterilizadas en condiciones de autoclave. Las variables de respuesta fueron porcentaje de germinación, altura, diámetro, número de hojas verdaderas, longitud de la raíz, pesos frescos y secos de la plántula, los datos obtenidos fueron sometidos a un análisis de varianza. Los resultados más favorables se obtuvieron en los ensayos donde se utilizaron compostas crudas, en dónde; las plántulas de lechuga mostraron afinidad absoluta en la adición de composta $\mathrm{D}$ al $75 \%$ en cuanto a la altura de la plántula y raíz, basado en estas dos variantes para el caso de pepino se mostró un mejor resultado con la aplicación de composta $\mathrm{C}$ al $50 \%$ y en el caso de Tomate en la germinación de plántulas con composta $\mathrm{B}$ al $50 \%$. Con esto se comprobó que la aplicación de estas aporta beneficios para el aprovechamiento de cultivos y mejora la calidad de plántulas.
\end{abstract}

Palabras clave: Compostaje, composta, biofertilizantes, plántulas.

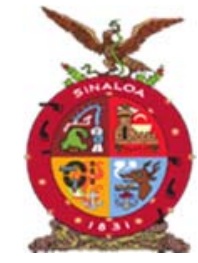

XVIII Congreso Internacional XXIV Congreso Nacional de Ciencias ambientales

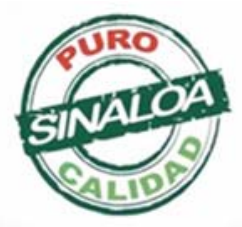

Mazatlán, Sinaloa 3-7 junio 2019
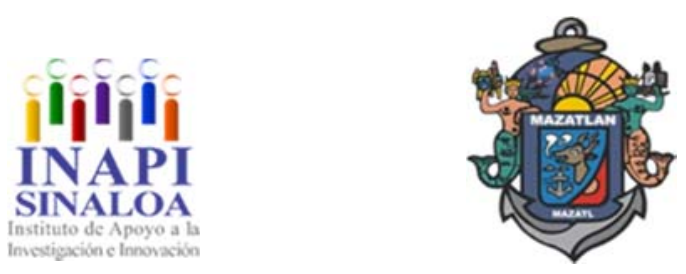

Tecnología y Biotecnología para el Tratamiento de Contaminantes y Biorremediación 

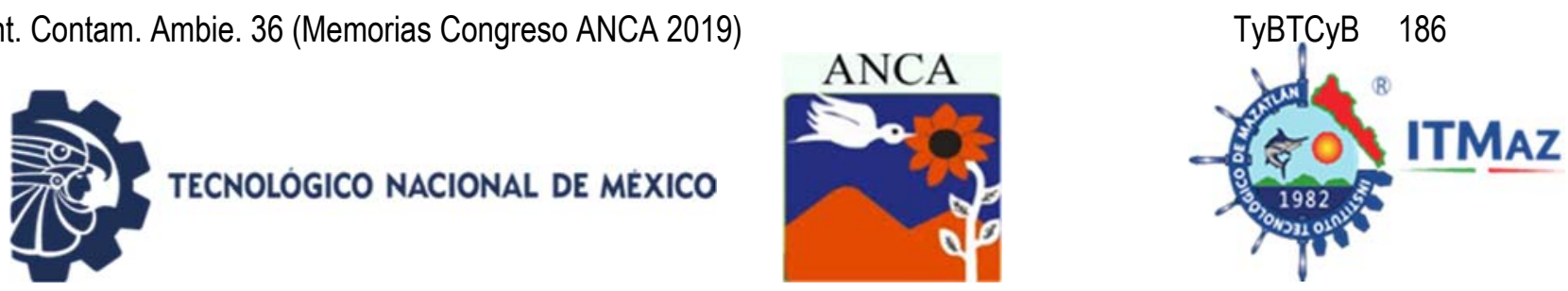

\title{
Biofertilizing evaluation of industrial compostes on the vegetable development of vegetables in the greenhouse
}

\author{
Rivera Hernández K*, Vázquez López N, Villa Ramírez S, Ramírez López C \\ Centro de Investigación en Biotecnología Aplicada IPN-Tlaxcala, \\ Carretera Estatal Santa Inés Tecuexcomac, Tepetitla Km. 1.5 \\ Tepetitla de Lardizábal, Tlaxcala, C.P.90700 \\ *karlanallely@hotmail.com
}

\begin{abstract}
Cachaça is a residue of the sugar industry with high contents of nitrogen, calcium, phosphorus and organic matter that can be used and recycled through the composting process. Cachaça economic value increases by demonstrating the benefits obtained after its application as a soil amendment. We used 4 composts $(A, B, C$, and $D)$ derived from this waste, for their evaluation as biofertilizers in the development of cucumber, tomato and lettuce seedlings in horticultural greenhouses. Its effect on the development of these at the end of the germination cycle was determined with raw composts in different doses $(25,50,75,100 \%)$ and sterilized composts in autoclave conditions. The response variables were the percentage of germination, height, diameter, some real leaves, length of the root, fresh and dry weights of the seedling, then, the data obtained were subjected to variance analysis. The most favorable results were the trials where fresh compost was used, and; lettuce seedlings showed absolute affinity in the addition of $75 \%$ compost $D$ in the height of the seedling and root. Based on these two variants, in the case of cucumber showed a better result with the application of compost $\mathrm{C}$ to $50 \%$ and in the case of Tomato in germination of seedlings with $50 \%$ B compost.This data proved that the application of these provides benefits for the use of crops and improves the quality of seedlings.
\end{abstract}

Keywords: Composting, compost, biofertilizers, seedlings.

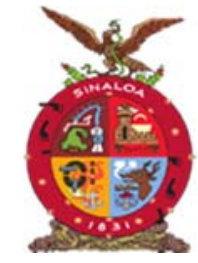

XVIII Congreso Internacional XXIV Congreso Nacional de Ciencias ambientales

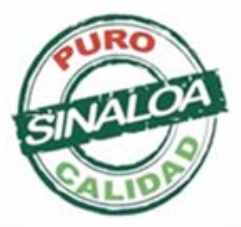

Mazatlán, Sinaloa 3-7 junio 2019
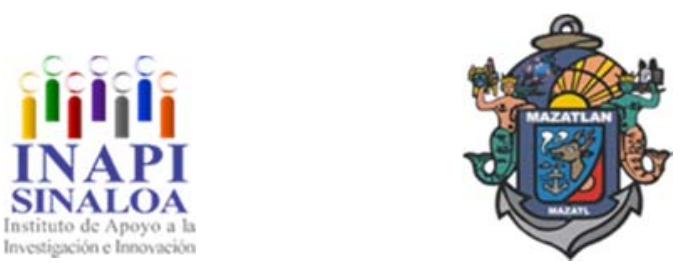

Tecnología y Biotecnología para el Tratamiento de Contaminantes y Biorremediación 

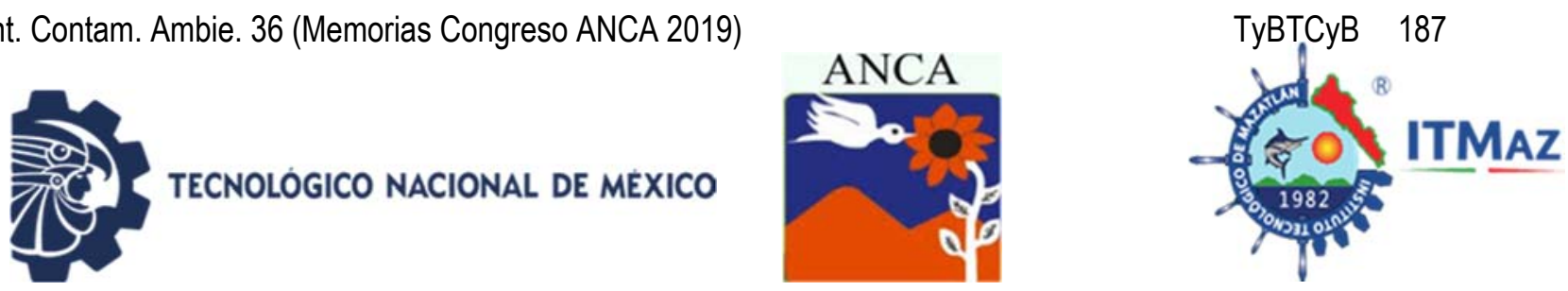

\title{
Desarrollo e implementación de un método analítico sostenible para la cuantificación de Penicilina $\mathbf{G}$ en aguas residuales por UHPLC-DAD
}

\author{
Robledo Zacarías V*, Rodríguez García P, Beltrán Ramírez M, \\ Montelongo Hernández I, Cardiel Pérez L \\ CIATEC A.C. Centro de Innovación Aplicada en Tecnologías Competitivas, \\ León, Guanajuato, México \\ *vrobledo@ciatec.mx
}

\section{RESUMEN}

El desarrollo revolucionario de antibióticos ha generado el incremento más grande de microorganismos resistentes en aguas superficiales en las últimas décadas, debido a esto se han establecido estrategias para reducir las concentraciones de antibióticos en los efluentes con poco éxito a la fecha, ya que la normativa actual no contenga la regulación de antibióticos en los cuerpos de agua, siendo la principal limitante los escasos métodos de referencia que permitan determinaciones de $\mu \mathrm{g} / \mathrm{mL}$, con técnicas sostenibles para laboratorios de ensayo. El presente trabajo describe la implementación de un método para cuantificar penicilina en muestras de aguas residuales urbano-industriales por UHPLC-DAD. El método consistió en $2 \mathrm{~mL}$ de agua residual procesada por cartuchos de extracción en fase sólida, empleando $2 \mathrm{~mL}$ de metanol y $2 \mathrm{~mL}$ de agua como acondicionadores, seguido de $5 \mathrm{~mL}$ de metanol-agua (10:90) y corriente de nitrógeno para el proceso de lavado-secado, así como $1 \mathrm{~mL}$ de metanol para su elución e inyección al sistema UHPLC-DAD, siendo el método con menor consumo de solventes descrito. La validación del método demostró un intervalo de trabajo de $0,17-90 \mu \mathrm{g} / \mathrm{mL}$, con un coeficiente de correlación $>0,99931$ y un RSD\% de 5,41. El límite práctico de cuantificación fue de 0,175 $\mu \mathrm{g} / \mathrm{mL}$, mientras que los porcentajes de recuperación oscilaron en $80-115 \%$ respectivamente. Respecto a la precisión, se determinó como repetibilidad con $C V \%<10$. Finalmente, los resultados demostraron la implementación de un método validado y sostenible para cuantificar penicilina en agua, aportando un método de referencia aplicable a la normativa actual en materia de preservación ambiental.

Palabras Clave: Penicilina, agua, contaminación, método sostenible.

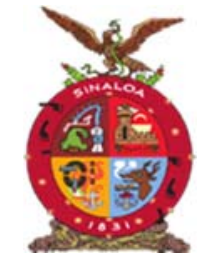

XVIII Congreso Internacional XXIV Congreso Nacional de Ciencias ambientales

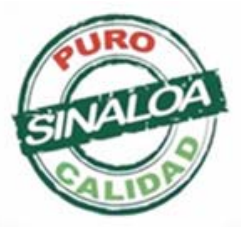

Mazatlán, Sinaloa 3-7 junio 2019
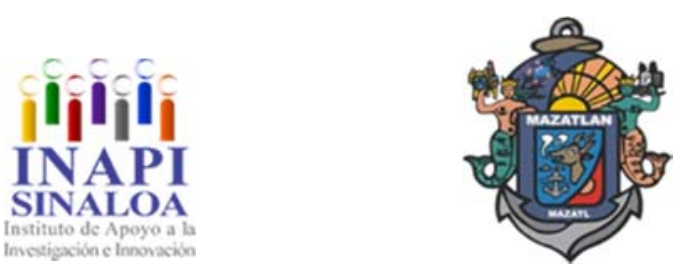

Tecnología y Biotecnología para el Tratamiento de Contaminantes y Biorremediación 

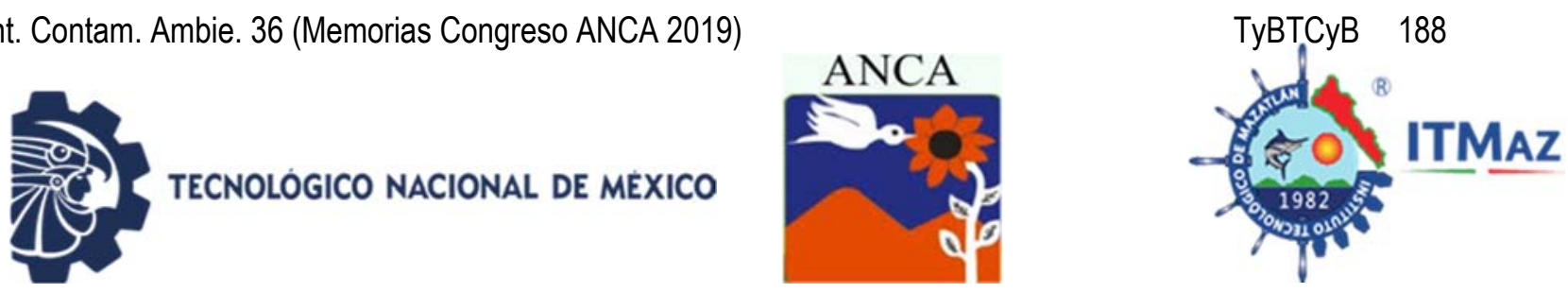

\title{
Development and implementation of a sustainable analytical method for the quantification of Penicillin G in wastewater by UHPLC-DAD
}

\author{
Robledo Zacarías V*, Rodríguez García P, Beltrán Ramírez M, \\ Montelongo Hernández I, Cardiel Pérez L \\ CIATEC A.C. Centro de Innovación Aplicada en Tecnologías Competitivas, \\ León, Guanajuato, México \\ *vrobledo@ciatec.mx
}

\begin{abstract}
The revolutionary development of antibiotics has generated the largest increase of resistant microorganisms in surface waters in recent decades, due to this, strategies have been established to reduce antibiotic concentrations in effluents with little success to date, since the current regulations does not contain the regulation of antibiotics in water bodies, being the main limiting the few reference methods that allow determinations of $\mu \mathrm{g} / \mathrm{mL}$, with sustainable techniques for testing laboratories. This paper describes the implementation of a method to quantify penicillin in urban-industrial wastewater samples by UHPLC-DAD. The method consisted of $2 \mathrm{~mL}$ of wastewater processed by solid phase extraction cartridges, using $2 \mathrm{~mL}$ of methanol and $2 \mathrm{~mL}$ of water as conditioners, followed by $5 \mathrm{~mL}$ of methanol-water (10:90) and nitrogen stream for the process of washing-drying, as well as $1 \mathrm{~mL}$ of methanol for its elution and injection to the UHPLC-DAD system, being the method with the lowest solvent consumption described. Validation of the method showed a working interval of $0.17-90 \mu \mathrm{g} / \mathrm{mL}$, with a correlation coefficient $>0.999931$ and a RSD\% of 5.41 . The practical limit of quantification was $0.175 \mu \mathrm{g} / \mathrm{mL}$, while the percentages of recovery oscillated in $80-115 \%$ respectively. Regarding accuracy, it was determined as repeatability with $\mathrm{CV} \%<10$. Finally, the results demonstrated the implementation of a validated and sustainable method to quantify penicillin in water, providing a reference method applicable to current regulations regarding environmental preservation.
\end{abstract}

Keywords: Penicillin, water, pollution, sustainable method.

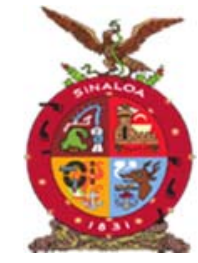

XVIII Congreso Internacional XXIV Congreso Nacional de Ciencias ambientales

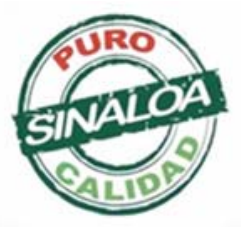

Mazatlán, Sinaloa 3-7 junio 2019
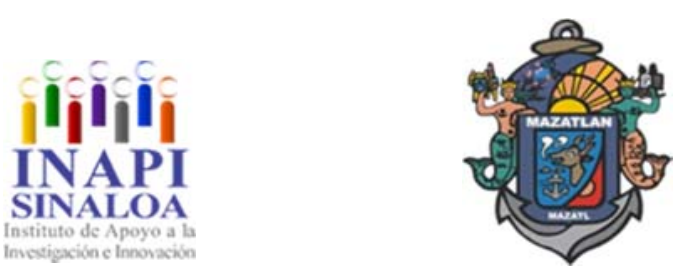

Tecnología y Biotecnología para el Tratamiento de Contaminantes y Biorremediación 

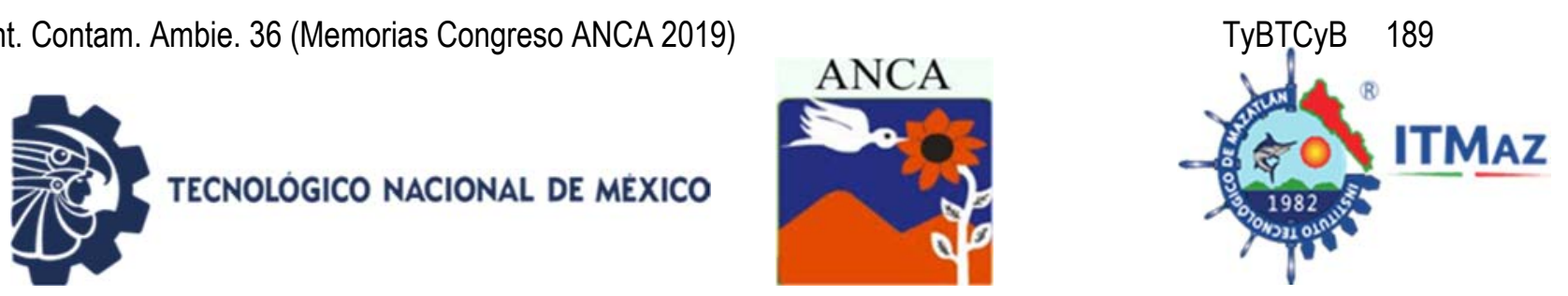

Estudio de la sensibilidad bacteriana a nanopartículas $\mathrm{Ag} / \mathrm{TiO}_{2}$

Rojas Ruiz E*, Guerra González R, Reyes Romero F

*eric8.9_@hotmail.com

\section{RESUMEN}

Recientemente, las nanopartículas de plata han mostrado una mayor actividad, matando e inhibiendo la reproducción bacteriana. En el presente trabajo se soportaron nanopartículas de plata parcialmente iónicas sobre dióxido de titanio $\left(\mathrm{Ag} / \mathrm{TiO}_{2}\right)$ y se evaluaron como bactericidas de Escherichia coli. Los soportes se sintetizaron por la técnica de sol-gel asistida por microondas. Las nanopartículas de plata se soportaron sobre el $\mathrm{TiO}_{2}$ por la técnica de impregnación húmeda incipiente. Los materiales se caracterizaron por Difracción de Rayos X (DRX) y Microscopia Electrónica de Barrido (MEB). Los microorganismos se incubaron en caldo de soya tripticaseína, empleando agar selectivo para su detección y cuantificación; La cantidad de material que fue expuesto a las bacterias fue determinada al evaluar la concentración mínima inhibitoria y concentración mínima bactericida. La determinación del número de unidades formadoras de colonia (UFC) se determinó con la técnica de conteo de colonias y área de las mismas. Una cantidad de $\mathrm{Ag} / \mathrm{TiO}_{2}$ con una concentración de $1.5 \%$ en peso de plata, se irradio con energía UV. Aproximadamente $0.06 \mathrm{~g}$ de material $\mathrm{Ag} / \mathrm{TiO}_{2}$ expuesto o no a la irradiación, se expusieron frente a la bacteria, inhibiendo el $100 \%$ de esta a los 90 minutos con el material irradiado y el $99 \%$ en 240 minutos en el caso del material no irradiado. El material irradiado demostró mayor eficacia al inhibir a la bacteria en el menor tiempo.

Palabras clave: Inhibición, Escherichia coli, nanopartículas, plata, dióxido de titanio.

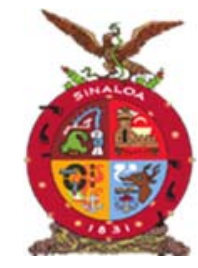

XVIII Congreso Internacional XXIV Congreso Nacional de Ciencias ambientales

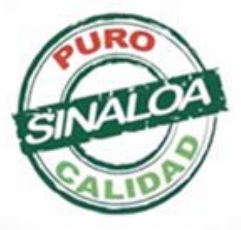

Mazatlán, Sinaloa 3-7 junio 2019
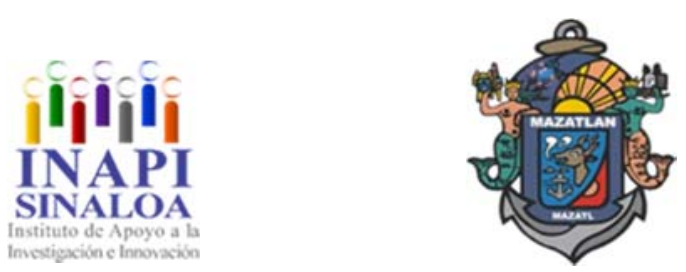

Tecnología y Biotecnología para el Tratamiento de Contaminantes y Biorremediación 

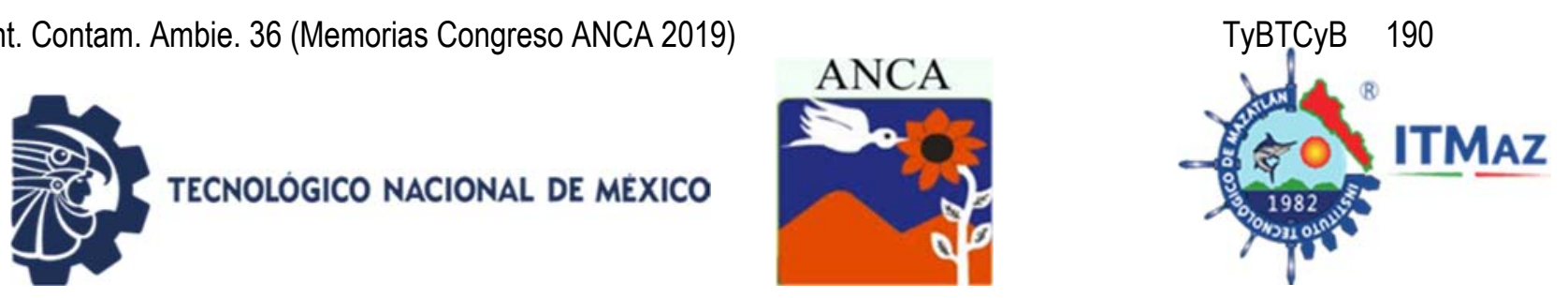

\title{
Study of bacterial sensitivity to $\mathrm{Ag} / \mathrm{TiO}_{2}$ nanoparticles
}

\author{
Rojas Ruiz E*, Guerra González R, Reyes Romero F \\ *eric8.9_@hotmail.com
}

\begin{abstract}
Recently, silver nanoparticles have shown greater activity, killing and inhibiting bacterial reproduction. In the present work, partially ionic silver nanoparticles were supported on titanium dioxide $\left(\mathrm{Ag} / \mathrm{TiO}_{2}\right)$ and evaluated as bactericides of Escherichia coli. The supports were synthesized by the microwave-assisted solgel technique. The silver nanoparticles were supported on the $\mathrm{TiO}_{2}$ by the wet impregnation incipient technique. The materials were characterized by X-ray diffraction (XRD) and scanning electron microscopy (SEM). The microorganisms were incubated in tryptic soy broth, using selective agar for detection and quantification; the amount of material that was exposed to the bacteria was determined by evaluating the minimum inhibitory concentration and minimum bactericide concentration. The determination of the number of colony forming units (CFU) was determined with the technique of colony counting and area thereof. An amount of $\mathrm{Ag} / \mathrm{TiO}_{2}$ with a concentration of $1.5 \%$ by weight of silver was irradiated with UV energy. Approximately $0.06 \mathrm{~g}$ of $\mathrm{Ag} / \mathrm{TiO} 2$ material, exposed or not to the irradiation, was exposed to the bacteria, inhibiting $100 \%$ of this at 90 minutes with the irradiated material and $99 \%$ in 240 minutes in the case of the non-irradiated material. The irradiated material showed greater efficacy by inhibiting the bacteria in the shortest time.
\end{abstract}

Keywords: Inhibition, Escherichia coli, nanoparticles, silver, titanium dioxide.

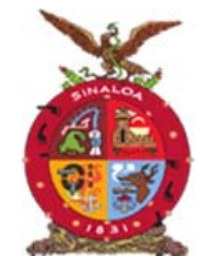

XVIII Congreso Internacional XXIV Congreso Nacional de Ciencias ambientales

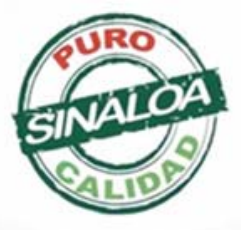

Mazatlán, Sinaloa 3-7 junio 2019
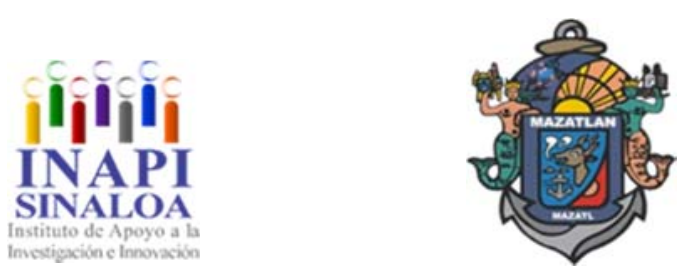

Tecnología y Biotecnología para el Tratamiento de Contaminantes y Biorremediación 

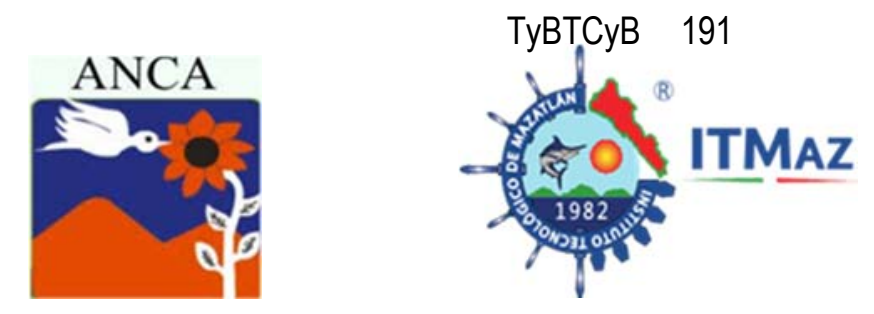

\section{Fabricación de fibras de Hidroxiapatita-vidrio por electrohilado para la remoción de plomo en solución acuosa}
Roque Ruiz $\mathrm{J}^{1^{\star}}$, Garibay Alvarado J1 , Torres Pérez J11, Medellín Castillo $\mathrm{N}^{2}$, Reyes López SY ${ }^{1}$

${ }^{1}$ Instituto de Ciencias Biomédicas. Universidad Autónoma de Ciudad Juárez, Envolvente del PRONAF y Estocolmo S/N, Ciudad Juárez, Chih., México

${ }^{2}$ Centro de Investigación y Estudios de Posgrado. Facultad de Ingeniería.

Universidad Autónoma de San Luis Potosí,

Av. Dr. Manuel Nava No. 8, San Luis Potosí, SLP, 78210, México

*jhroqueruiz@hotmail.com

\section{RESUMEN}

La contaminación del agua por metales pesados representa un serio problema ambiental y para la salud humana. Por esta razón, el proceso de adsorción ha generado interés para lograr la remoción de metales pesados presente en medio acuoso de una forma sencilla. Un compósito de hidroxiapatita-vidrio con morfología fibrilar fue elaborado por el proceso sol-gel y la técnica de electrohilado para ser utilizado en la remoción de plomo presente en solución acuosa. Los estudios de equilibrio de adsorción de plomo se realizaron en una serie de cinco soluciones con una concentración inicial en el intervalo entre 60 y $500 \mathrm{mg} / \mathrm{L}$ del metal correspondiente. En los estudios cinéticos se preparó una solución con concentración de $200 \mathrm{mg} / \mathrm{L}$ de plomo y se agregó una muestra de fibras de hidroxiapatita-vidrio a cada solución en una relación de $0.5 \mathrm{~g} / \mathrm{L}$. El cambio en concentración fue determinado por espectroscopia de absorción atómica. La mayor cantidad de plomo adsorbido por gramo de material $(q)$ fue $466.98 \mathrm{mg} / \mathrm{g}$. Los datos experimentales se ajustan al modelo de Freundlich, lo cual indica que el proceso de adsorción ocurre sobre una superficie heterogénea, mientras que la cinética de adsorción sigue el modelo de pseudo-segundo orden, por consiguiente, el proceso de adsorción química es el que tiene lugar. Los resultados obtenidos comprobaron que las fibras cerámicas de hidroxiapatitavidrio muestran una gran capacidad para adsorber plomo presente en solución acuosa.

Palabras clave: Adsorción, cinética, electrohilado, hidroxiapatita, isoterma, solgel.

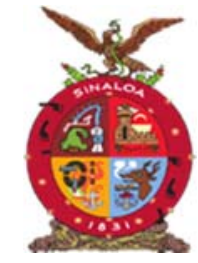

XVIII Congreso Internacional XXIV Congreso Nacional de Ciencias ambientales

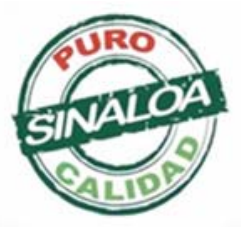

Mazatlán, Sinaloa 3-7 junio 2019
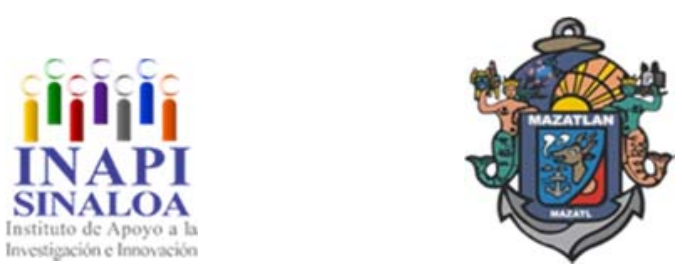

Tecnología y Biotecnología para el Tratamiento de Contaminantes y Biorremediación 

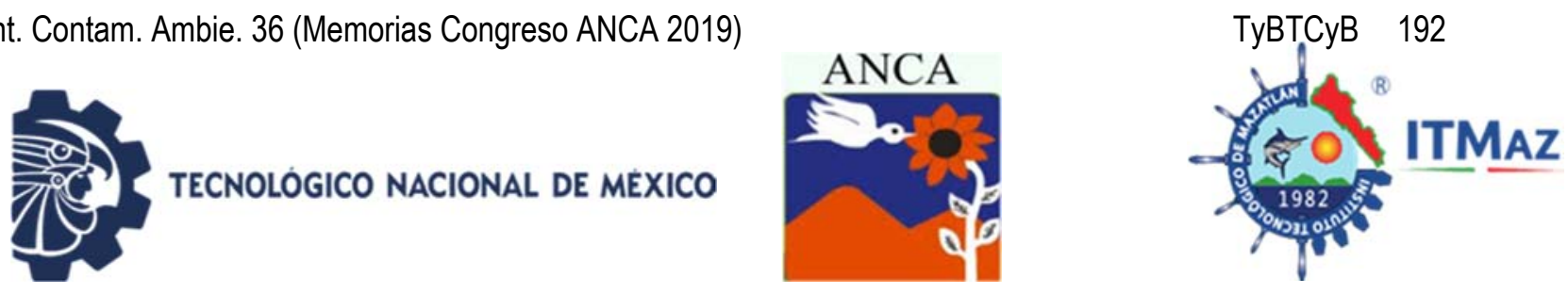

\title{
Fabrication of Hydroxyapatite-glass fibers by electrospinning for lead removal from aqueous solution
}
Roque Ruiz $\mathrm{J}^{1 *}$, Garibay Alvarado J11, Torres Pérez $\mathrm{J}^{1}$, Medellín Castillo $\mathrm{N}^{2}$, Reyes López SY ${ }^{1}$

${ }^{1}$ Instituto de Ciencias Biomédicas. Universidad Autónoma de Ciudad Juárez, Envolvente del PRONAF y Estocolmo S/N, Ciudad Juárez, Chih., México

${ }^{2}$ Centro de Investigación y Estudios de Posgrado. Facultad de Ingeniería.

Universidad Autónoma de San Luis Potosí,

Av. Dr. Manuel Nava No. 8, San Luis Potosí, SLP, 78210, México

*jhroqueruiz@hotmail.com

\begin{abstract}
Water pollution by heavy metals represents a serious threat to the environment and human health. As a result, adsorption process has gained attention as an alternative to achieve heavy metal removal from aqueous media in a simple procedure. A hydroxyapatite-glass composite with fibrous morphology was prepared by sol-gel process and electrospinning in order to be used for removal of lead present in aqueous solution. Adsorption equilibrium studies were conducted in a series of five solutions with concentrations from 60 to $500 \mathrm{mg} / \mathrm{L}$ of the corresponding metal. A lead solution with concentration of $200 \mathrm{mg} / \mathrm{L}$ were used for adsorption kinetic studies. A sample of hydroxyapatite-glass fibers was added to each solution in a ratio of $0.5 \mathrm{~g} / \mathrm{L}$. Changes in concentration were determined by atomic absorption spectroscopy. The highest amount of lead adsorbed per gram of material $(q)$ was $466.98 \mathrm{mg} / \mathrm{g}$. Experimental data fitted to Freundlich model indicating that the adsorption process occurred onto a heterogeneous surface, while adsorption kinetics follows the pseudo-second order model. Therefore, a process of chemical adsorption takes place. According to the results obtained, it was demonstrated that the hydroxyapatite-glass composite fibers obtained by electrospinning show a high capacity for adsorption of lead ions present in aqueous solution.
\end{abstract}

Keywords: Adsorption, electrospinning, hydroxyapatite, isotherm, kinetics, solgel.

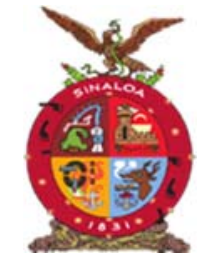

XVIII Congreso Internacional XXIV Congreso Nacional de Ciencias ambientales

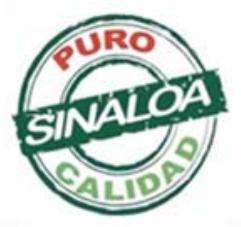

Mazatlán, Sinaloa 3-7 junio 2019
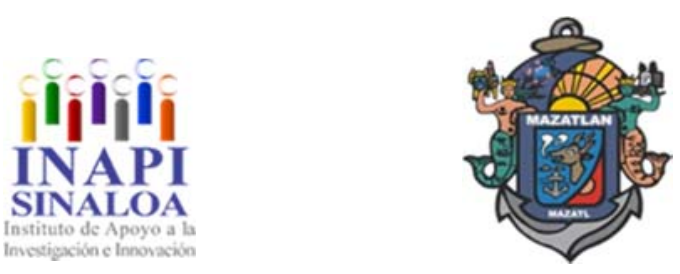

Tecnología y Biotecnología para el Tratamiento de Contaminantes y Biorremediación 

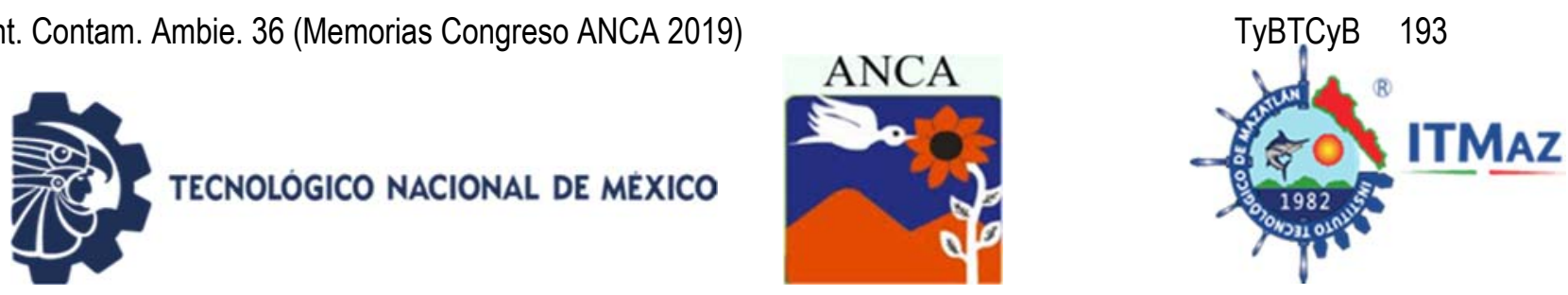

\title{
Análisis de nutrientes, metales, sedimentación y secuestro de carbono en humedales construidos en el mediterráneo que reciben escorrentía agrícola
}

\author{
Salas De La Vega $\mathrm{MA}^{2^{*}}$, Velasco Hernández $\mathrm{MA}^{2}$, Caiola $\mathrm{N}^{1}$, Ibáñez $\mathrm{C}^{1}$, \\ Saldaña De la Vega JA ${ }^{1}$ \\ ${ }^{1}$ IRTA. Agrifood Research and Technology Institute. Catalonia (Spain) \\ ${ }^{2}$ Facultad de Ingeniería Química, BUAP \\ *delavegamarioadolfo@hotmail.com
}

\section{RESUMEN}

Los humedales construidos son una herramienta eficaz para eliminar nutrientes y metales a través de la absorción en la planta, la actividad microbiana y la acumulación de suelo. Esta investigación tiene como objetivo evaluar los cambios en agua y metales del suelo, nutrientes, sedimentos y el carbono en dos humedales construidos en campos de arroz abandonados. Presentamos resultados preliminares (2015-2016), de muestras mensuales de remoción de metales y nutrientes en el agua, así como tasas de sedimentación y secuestro de carbono. En el humedal $\mathrm{A}$, las tasas medias de eliminación de metales fueron positivas para Al (63.62 $\pm 7.73 \%)$, $\mathrm{Fe}(46.97 \pm 14.75 \%)$, Mn $(30.04 \pm 20.23 \%)$ y $\mathrm{Sr}(12.76 \pm 19.24 \%)$ y negativas para el humedal B $(-102.27 \pm 78.80 \%)$ y As ($44.63 \pm 32.27 \%)$. Las tasas medias de eliminación de nutrientes fueron positivas: $\mathrm{NO}_{3}-(86.94 \pm 2.83 \%), \mathrm{NO}_{2}-(80.32 \pm 5.26 \%), \mathrm{NH}_{4}+(46.17 \pm 20.08 \%), \mathrm{SiO}_{2}(39.05$ $\pm 12.46 \%)$ y $\mathrm{PO}_{4}{ }^{3-}(31.72 \pm 16.18 \%)$. Sin embargo, $\mathrm{PO}_{4}{ }^{3-}, \mathrm{NH}_{4}+$ y $\mathrm{SiO}_{2}$ mostraron exportaciones netas en algunos períodos. La sedimentación varió de $1 \mathrm{~cm} / a n ̃ o$

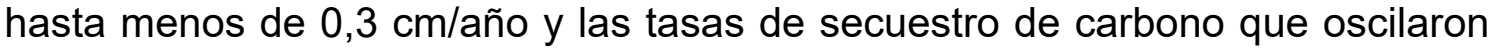
entre 300 y $50 \mathrm{gC} / \mathrm{m}^{2}$. Los resultados sugieren que las plantas de humedales probablemente favorecieron la adsorción de metales del suelo a través de la oxigenación del suelo y resaltan la utilidad de las marismas restauradas como filtros de contaminación en los humedales costeros con una importante acumulación de suelo.

Palabras clave: Humedales, metales, plantas, sedimento, carbono.

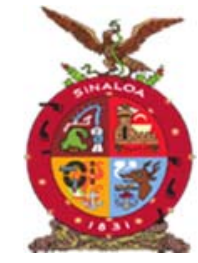

XVIII Congreso Internacional XXIV Congreso Nacional de Ciencias ambientales

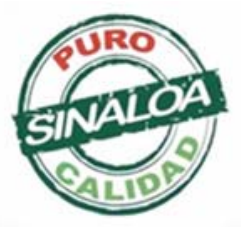

Mazatlán, Sinaloa 3-7 junio 2019
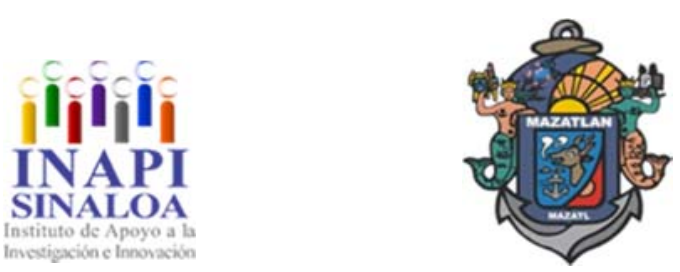

Tecnología y Biotecnología para el Tratamiento de Contaminantes y Biorremediación 

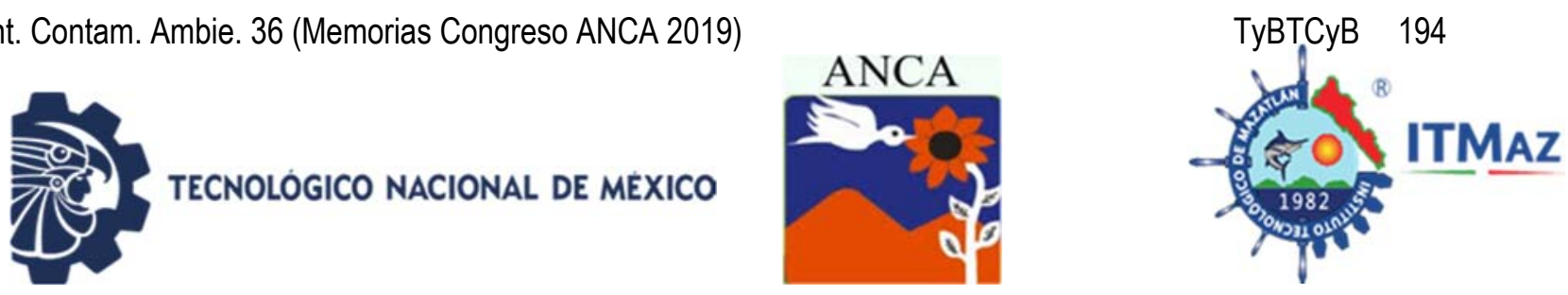

\title{
Analysis of nutrients, metals, sedimentation and carbon seedage in wetlands built in the mediterranean receiving agricultural runoff
}

\author{
Salas De La Vega $\mathrm{MA}^{2^{*}}$, Velasco Hernández $\mathrm{MA}^{2}$, Caiola N${ }^{1}$, Ibáñez $\mathrm{C}^{1}$, \\ Saldaña De la Vega JA ${ }^{1}$ \\ ${ }^{1}$ IRTA. Agrifood Research and Technology Institute. Catalonia (Spain) \\ ${ }^{2}$ Facultad de Ingeniería Química, BUAP \\ *delavegamarioadolfo@hotmail.com
}

\begin{abstract}
Constructed wetlands are an effective tool for removing nutrients and metals through plant uptake, microbial activity and soil accumulation. This research aims to evaluate the changes in water and soil metals, nutrients, sediments and carbon in two wetlands built in abandoned rice fields. We present preliminary results (2015-2016), of monthly samples of metals and nutrients removal in the water, as well as sedimentation and carbon sequestration rates. In wetland $A$, average metal removal rates were positive for Al $(63.62 \pm 7.73 \%)$, Fe $(46.97 \pm 14.75 \%)$, $\mathrm{Mn}(30.04 \pm 20.23 \%)$ and $\mathrm{Sr}(12.76 \pm 19.24 \%)$ and negative for the wetland B ($102.27 \pm 78.80 \%)$ and As $(-44.63 \pm 32.27 \%)$. The average nutrient removal rates were positive: $\mathrm{NO}_{3}-(86.94 \pm 2.83 \%), \mathrm{NO}_{2}-(80.32 \pm 5.26 \%), \mathrm{NH}_{4}+(46.17 \pm$ $20.08 \%), \mathrm{SiO}_{2}(39.05 \pm 12.46 \%)$ and $\mathrm{PO}_{4}{ }^{3-}(31.72 \pm 16.18 \%)$. However, $\mathrm{PO}_{4}{ }^{3-}$, $\mathrm{NH}_{4}+$ and $\mathrm{SiO}_{2}$ showed net exports in some periods. Sedimentation varied from $1 \mathrm{~cm} / y e a r$ to less than $0.3 \mathrm{~cm} / \mathrm{year}$ and carbon sequestration rates ranged between 300 and $50 \mathrm{gC} / \mathrm{m}^{2}$. The results suggest that wetland plants probably favored the adsorption of soil metals through soil oxygenation and highlight the utility of restored marshes as pollution filters in coastal wetlands with significant soil accumulation.
\end{abstract}

Keywords: Wetlands, metals, plants, sediment, carbon.

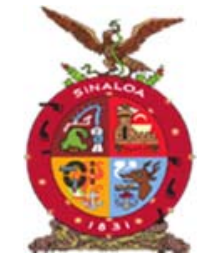

XVIII Congreso Internacional XXIV Congreso Nacional de Ciencias ambientales

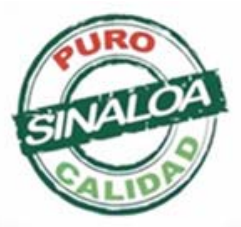

Mazatlán, Sinaloa 3-7 junio 2019
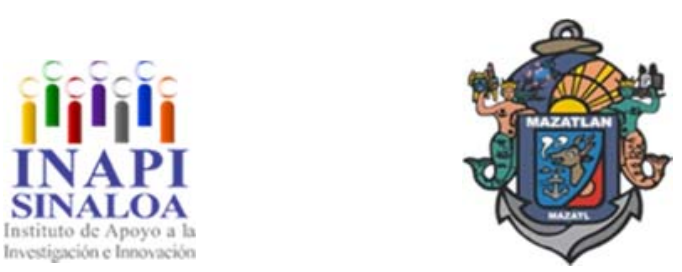

Tecnología y Biotecnología para el Tratamiento de Contaminantes y Biorremediación 

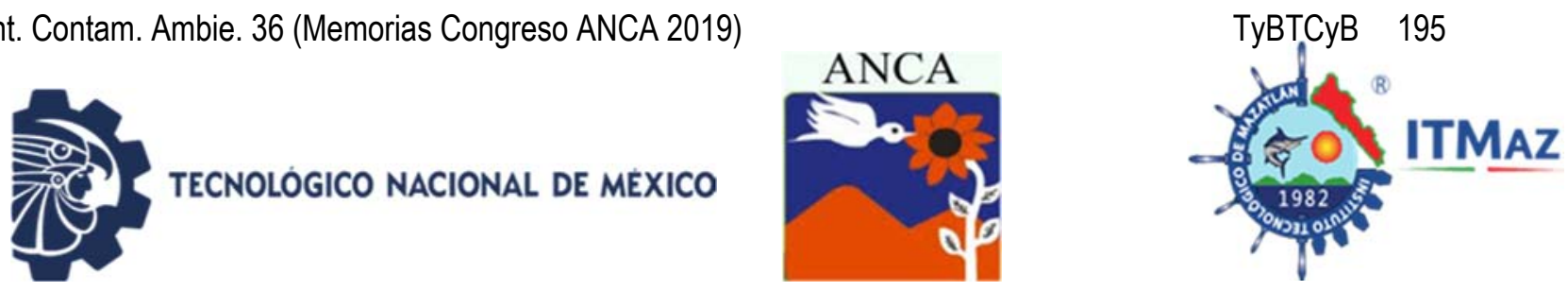

Aislamiento de Escherichia coli BLEE en muestras de suelo agrícola regadas con aguas residuales: comparación de dos técnicas de cultivo Salinas Cortés $\mathrm{E}^{1 *}$, Martínez Romero $\mathrm{L}^{1}$, López Baena $\mathrm{J}^{2}$, Siebe Grabach $\mathrm{C}^{3}$,
Rosas Pérez $\mathrm{I}^{1}$

${ }^{1}$ Centro de Ciencias de la Atmósfera, UNAM, CDMX

${ }^{2}$ Universidad Autónoma de Baja California. Tijuana B.C

${ }^{3}$ Instituto de Geología, UNAM, CDMX. México

*mesc@unam.mx

\section{RESUMEN}

La presencia de antibióticos en aguas residuales ejerce una presión selectiva sobre las bacterias, haciendo que sobrevivan aquellas resistentes a diversos antibióticos. En el ambiente las bacterias pueden encontrarse en condiciones de estrés lo que dificulta su detección por la siembra directa en medios selectivos. El objetivo de este estudio piloto fue evaluar la eficiencia de dos métodos de detección de Escherichia coli BLEE (Betalactamasas de espectro extendido), comparando la siembra directa en CHROMagar-ESBL con el método de preenriquecimiento selectivo. En junio del 2018 se tomaron 6 muestras de suelo agrícola del Valle del Mezquital. Diluciones de $1 \mathrm{~g}$ de suelo se sembraron por triplicado en CHROMagar-ESBL. Para el pre-enriquecimiento se agregaron por triplicado $10,1.0$ y $0.1 \mathrm{~g}$ de suelo en caldo LB con $0.5 \mathrm{mg} / \mathrm{L}$ de cefotaxima y ceftazidima; se incubaron $24 \mathrm{~h}$ a $37^{\circ} \mathrm{C} / 180 \mathrm{rpm}$ y se sembraron en CHROMagarESBL. La identificación y la susceptibilidad antimicrobiana se realizaron por el método de Microdilución y Concentración Mínima Inhibitoria (CMI) con el sistema MicroScan. De la siembra directa se identificaron $7 \%(n=2)$ E. coli y $93 \%(n=27)$ con el pre-enriquecimiento. El $69 \%$ fueron resistentes $a \geq 3$ familias de antibióticos (MDR), principalmente a betalactámicos. El índice de Resistencia Múltiple a Antibióticos (iMAR) fue mayor a $>0.2$ en todos los aislados. Con el método de Jarlier se confirmó que el $71 \%$ expresaron BLEE y el $45 \%$ fueron carbapenemasas positivos por el método modificado de Inactivación de Carbapenemes $(\mathrm{mClM})$. La aplicación de un pre-enriquecimiento selectivo es necesario para incrementar la eficiencia en la detección de $E$. coli productoras de BLEE en muestras ambientales.

Palabras clave: Escherichia coli, agua residual, multiresistencia.

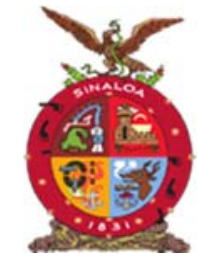

XVIII Congreso Internacional XXIV Congreso Nacional de Ciencias ambientales

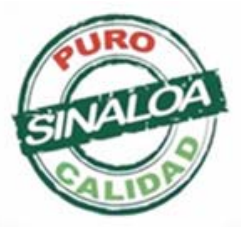

Mazatlán, Sinaloa 3-7 junio 2019
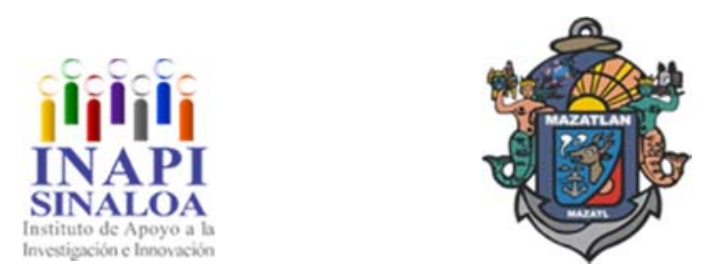

Tecnología y Biotecnología para el Tratamiento de Contaminantes y Biorremediación 
Rev. Int. Contam. Ambie. 36 (Memorias Congreso ANCA 2019)
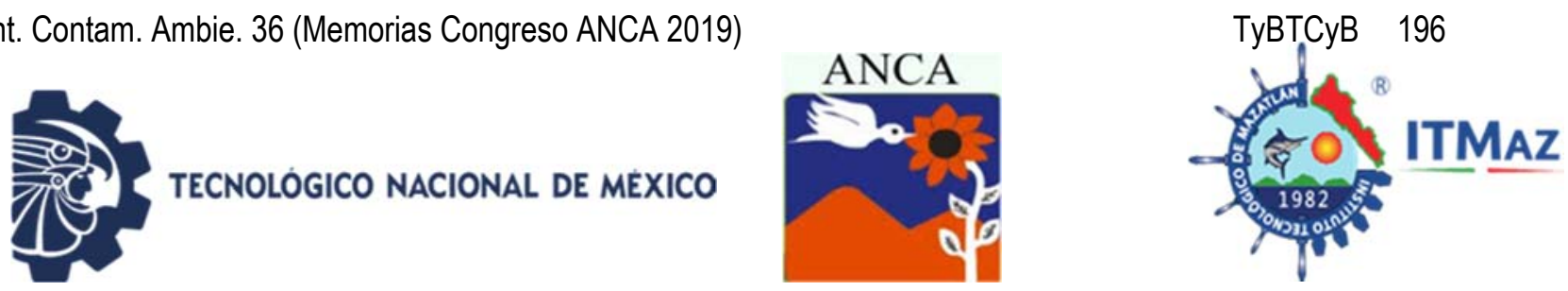

\title{
Isolation of Escherichia coli ESBL in agricultural soil samples irrigated with wastewater: comparison of two culture techniques
}

\author{
Salinas Cortés $\mathrm{E}^{1 *}$, Martínez Romero $\mathrm{L}^{1}$, López Baena J2, Siebe Grabach $\mathrm{C}^{3}$, \\ Rosas Pérez I ${ }^{1}$ \\ ${ }^{1}$ Centro de Ciencias de la Atmósfera, UNAM, CDMX \\ ${ }^{2}$ Universidad Autónoma de Baja California. Tijuana B.C \\ ${ }^{3}$ Instituto de Geología, UNAM, CDMX. México \\ *mesc@unam.mx
}

\begin{abstract}
The presence of antibiotics in wastewater exerts a selective pressure on the bacteria, making them survive those resistant to various antibiotics. In the environment, bacteria can be found under stress conditions, which make it difficult to detect them by direct seeding in selective media. The objective of this pilot study was to evaluate the efficiency of two ESBL Escherichia coli (extended spectrum Beta-lactamase) detection methods, comparing direct seeding in CHROMagar-ESBL with the selective pre-enrichment method. In June 2018, 6 samples of agricultural plots from the Mezquital Valley were taken. Dilutions were made from $1 \mathrm{~g}$ of soil and inoculated in triplicate in the CHROMagar-ESBL. For the pre-enrichment, $10,1.0$ and $0.1 \mathrm{~g}$ of soil were added in triplicate in LB broth with $0.5 \mathrm{mg} / \mathrm{L}$ of cefotaxime and ceftazidime; they were incubated $24 \mathrm{~h}$ at $37^{\circ} \mathrm{C} / 180 \mathrm{rpm}$ and subsequently seeded in the CHROMagar-ESBL. The identification and antimicrobial susceptibility were performed by the Microdilution and Minimum Inhibitory Concentration (MIC) method with the MicroScan system. From direct sowing, $7 \%(n=2)$ E. coli and $93 \%(n=27)$ were identified with preenrichment. $69 \%$ were resistant to $\geq 3$ families of antibiotics (MDR), mainly to betalactams. The Multiple Antibiotic Resistance index (iMAR) was greater than $>0.2$ in all isolates. With the Jarlier method it was confirmed that $71 \%$ expressed ESBL and $45 \%$ were positive carbapenemase by the modified method of Carbapenem Inactivation $(\mathrm{mClM})$. The application of a selective pre-enrichment is necessary to increase the efficiency in the detection of $E$. coli producing ESBL in environmental samples.
\end{abstract}

Keywords: Escherichia coli, wastewater, multiresistance.

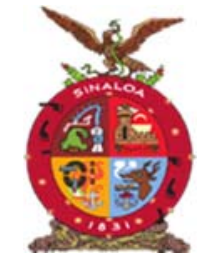

XVIII Congreso Internacional XXIV Congreso Nacional de Ciencias ambientales

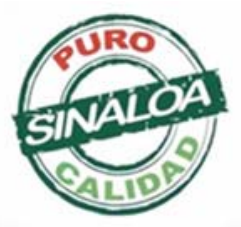

Mazatlán, Sinaloa 3-7 junio 2019
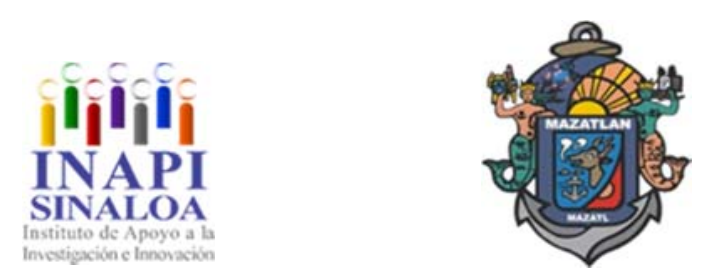

Tecnología y Biotecnología para el Tratamiento de Contaminantes y Biorremediación 

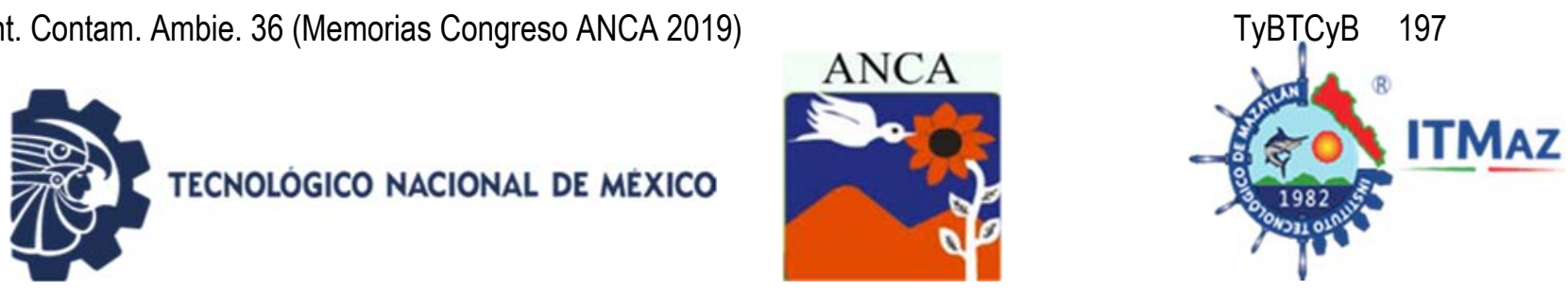

\title{
Evaluación de la lipasa de Ricinus communis $L$. como agente potencial de remediación de suelos contaminados con aceite lubricante usado
}

\author{
Sánchez Castro $A^{*}$, Aguilera Flores M \\ Ingeniería Ambiental. Unidad Profesional Interdisciplinaria de Ingeniería \\ Campus Zacatecas. Instituto Politécnico Nacional. \\ *m.alexissanchez99@gmail.com
}

\section{RESUMEN}

El petróleo y sus derivados son productos que se han utilizado en diversas aplicaciones para el desarrollo de la humanidad. Sin embargo, también son considerados potenciales contaminantes del ambiente, entre estos se encuentran los aceites lubricantes usados (ALU). La degradación de ALU mediante la utilización de enzimas se plantea como alternativa a para la remediación de suelos usadas actualmente para la remoción de este contaminante, pudiendo obtener menores tiempos de remediación, mayores eficiencias de remoción y menor generación de residuos. Las lipasas de plantas invasoras como la Higuerilla (Ricinus communis L.), pueden representar una oportunidad para su aplicación biorremediación. En el presente trabajo se realizó la extracción de lipasas a partir de la semilla de Ricinus communis L. y su posterior aplicación en un suelo contaminado con ALU $(10,000 \mathrm{mg} / \mathrm{kg}$ base seca) durante 35 días, en cuatro ensayos para evaluar la remoción del lubricante en una muestra de suelo, correspondiendo a los procesos: 1) atenuación natural (AN); 2) bioestimulación (BE) con urea como bioestimulante; 3 ) tratamiento enzimático con lipasas a condiciones ambientales [TE(A)]; y 4) tratamiento enzimático con lipasas a $37^{\circ} \mathrm{C}$ [TE(37)]. Se cuantificó el contenido de ALU mediante el método 9071B de la EPA descrito en la NMX-AA-134-SCFI-2006 de extracción por Soxhlet. Los resultados arrojaron porcentajes de remoción del $5.85 \%$ para $\mathrm{AN}, 17.25 \%$ para $\mathrm{BE}, 31.89 \%$ para $\operatorname{TE}(\mathrm{A})$ y $42.02 \%$ para TE (37), demostrándose la mejor efectividad de la aplicación de lipasas de higuerilla a condiciones ideales para las mismas $\left(\mathrm{T}=37^{\circ} \mathrm{C}\right)$.

Palabras clave: Actividad catalítica, biorremediación, enzimas, tratamiento enzimático.

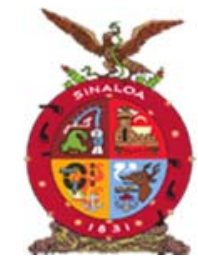

XVIII Congreso Internacional XXIV Congreso Nacional de Ciencias ambientales

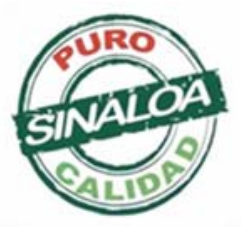

Mazatlán, Sinaloa 3-7 junio 2019
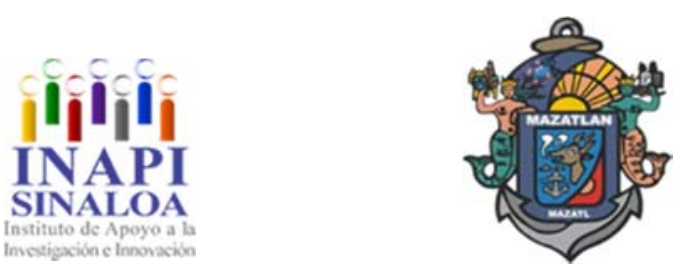

Tecnología y Biotecnología para el Tratamiento de Contaminantes y Biorremediación 

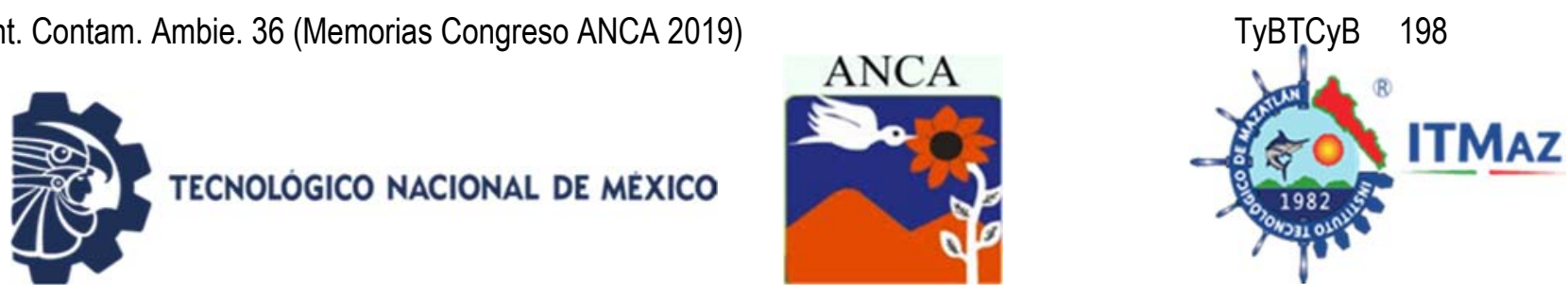

\title{
Evaluation of Ricinus communis $L$. lipase as a potential remediation agent for soils contaminated with used lubricating oil
}

\author{
Sánchez Castro A*, Aguilera Flores M \\ Ingeniería Ambiental. Unidad Profesional Interdisciplinaria de Ingeniería \\ Campus Zacatecas. Instituto Politécnico Nacional. \\ *m.alexissanchez99@gmail.com
}

\begin{abstract}
Oil and its derivatives are products that have been used in various applications for the development of humanity. However, they are also considered as one of the main pollutants in the environment, among which are used lubricating oils (ALU). The degradation of ALUs through the use of enzymes is proposed as an alternative to the soil remediation technologies currently used for the removal of this contaminant, which may result in shorter remediation times, greater removal efficiencies and lower waste generation, where Lipases extracted from invasive plants such as the Higuerilla (Ricinus communis L.), may represent an opportunity for its application for such purpose. In the present work, lipases were extracted from the Ricinus communis $\mathrm{L}$. using acetone as a solvent and its subsequent application in a soil contaminated with $\operatorname{ALU}(10,000 \mathrm{mg} / \mathrm{kg}$ dry base) for a period of 35 days. Four tests were carried out to evaluate the removal of the contaminant in a soil sample, corresponding to the processes: 1) natural attenuation (AN); 2) biostimulation (BE) with urea as a biostimulant; 3) enzymatic treatment with lipases at environmental conditions TE (A) and; 4) enzymatic treatment with lipases at $37^{\circ} \mathrm{C}$ [TE (37)], quantifying the residual content of ALU by the method 9071B of the EPA described in the NMX-AA-134-SCFI-2006 extraction by Soxhlet. The results showed percentages of removal of $5.85 \%$ for AN, $17.25 \%$ for $\mathrm{BE}, 31.89 \%$ for TE (A) and $42.02 \%$ for TE (37), demonstrating the best effectiveness of the application of castor lipases to ideal conditions for them. ( $T=$ $\left.37^{\circ} \mathrm{C}\right)$.
\end{abstract}

Keywords: Bioremediation, catalytic activity, enzymes, enzymatic treatment.

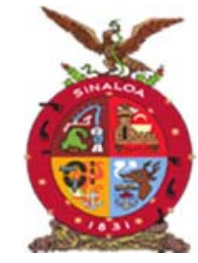

XVIII Congreso Internacional XXIV Congreso Nacional de Ciencias ambientales

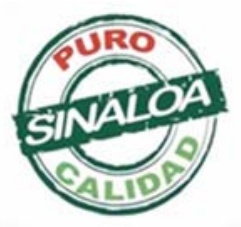

Mazatlán, Sinaloa 3-7 junio 2019
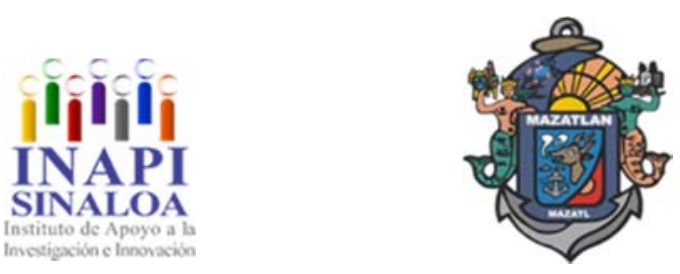

Tecnología y Biotecnología para el Tratamiento de Contaminantes y Biorremediación 

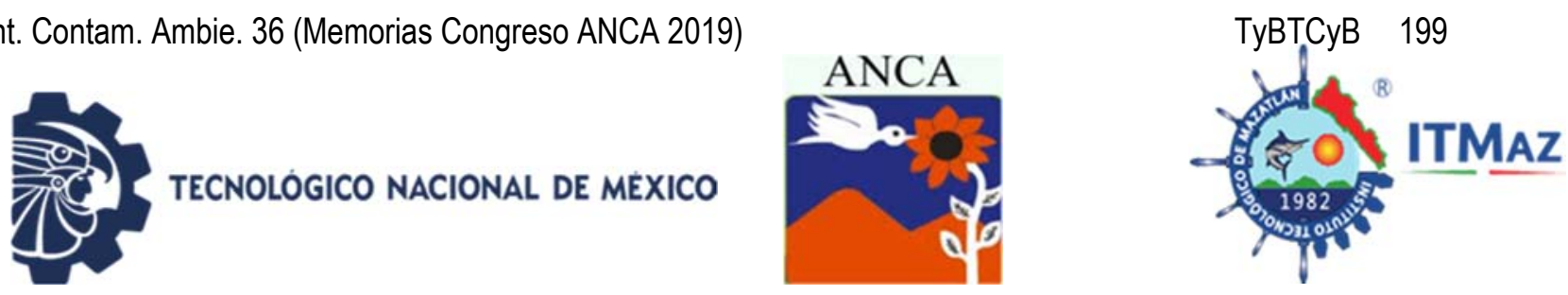

\title{
Evaluación de la bioestimulación con lombricomposta y lipasa de Ricinus communis $L$. en la remediación de suelos contaminados con aceite residual automotriz
}

\author{
Sánchez Mata O, Hernández Zúñiga $D^{*}$, Aguilera Flores M \\ Unidad Profesional Interdisciplinaria de Ingeniería, Campus Zacatecas \\ Instituto Politécnico Nacional. \\ *zunigadiegohdz@gmail.com
}

\section{RESUMEN}

Los hidrocarburos son compuestos orgánicos que han tenido gran impacto en diversas aplicaciones en el desarrollo del ser humano. Sin embargo, han sido considerados como uno de los principales contaminantes en el ambiente. Uno de los derivados de dichos contaminantes es el aceite residual automotriz (ARA), el cual es clasificado como un residuo peligroso (RP) del sector automotriz siendo uno de los principales sectores de generación de RP, en México y el estado de Zacatecas. En el presente proyecto de investigación se evaluó la bioestimulación de la lombricomposta y la aplicación de enzima lipasa de Ricinus communis L. para la remediación de suelos contaminados con ARA, en donde se realizaron 3 lotes de tratamiento con 3 ensayos cada uno siendo condiciones ideales $(\mathrm{Cl}): \mathrm{pH}$ 4.5 y temperatura de $37^{\circ} \mathrm{C}$, condiciones ambientales (CA): $\mathrm{pH} 7$ y temperatura de $20^{\circ} \mathrm{C}$ y atenuación natural (AN): sin la modificación de $\mathrm{pH}$ y temperatura ni la adición de lombricomposta y enzima, con una concentración inicial de aceite residual de 10,000 $\mathrm{mg} / \mathrm{Kg}$ base seca. Semanalmente se realizó la determinación de la concentración de ARA vía Soxhlet durante un periodo de 49 días. En donde se obtuvo un porcentaje de remoción de ARA del $99.90 \%$ para el caso de $\mathrm{Cl}$, mientras que para el ensayo de CA se obtuvo un porcentaje de remoción de $78.61 \%$, y para AN un porcentaje de remoción del $7.43 \%$, con concentraciones residuales de $9.73,2138.99$ y $9257.3 \mathrm{mg} / \mathrm{Kg}$ base seca, respectivamente para cada uno de los ensayos.

Palabras clave: Actividad catalítica, enzima, tratamiento.

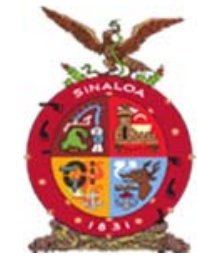

XVIII Congreso Internacional XXIV Congreso Nacional de Ciencias ambientales

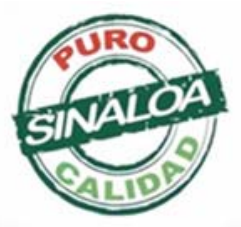

Mazatlán, Sinaloa 3-7 junio 2019
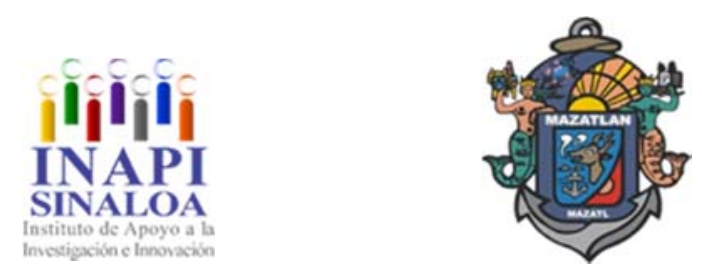

Tecnología y Biotecnología para el Tratamiento de Contaminantes y Biorremediación 

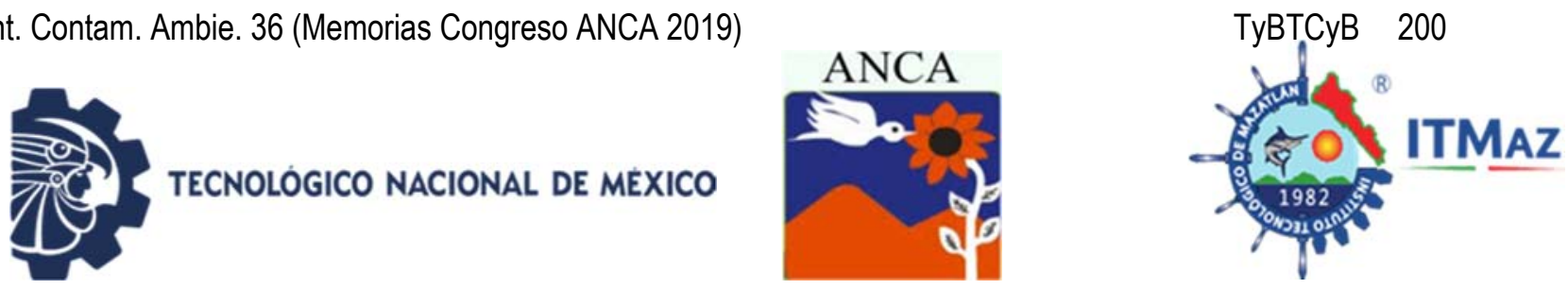

\title{
Evaluation of the biostimulation with lombricomposta and lipase of Ricinus communis $L$. in the remediation of soils contaminated with automotive residual oil
}

\author{
Sánchez Mata O, Hernández Zúñiga $D^{*}$, Aguilera Flores M \\ Unidad Profesional Interdisciplinaria de Ingeniería, Campus Zacatecas \\ Instituto Politécnico Nacional. \\ *zunigadiegohdz@gmail.com
}

\begin{abstract}
Hydrocarbons are organic compounds that have had great impact in various applications in human development. However, they have been considered as one of the main pollutants in the environment. One of the derivatives of these pollutants is automotive waste oil (ARA), which is classified as a hazardous waste (RP) of the automotive sector, being one of the main sectors of PR generation, in Mexico and the State of Zacatecas. In the present research project the biostimulation of the vermicompost and the application of lipase enzyme of Ricinus communis $L$. for the remediation of contaminated soils with ARA were evaluated, where 3 batches of treatment were carried out with 3 trials each being ideal conditions $(\mathrm{Cl}): \mathrm{pH} 4.5$ and temperature of $37^{\circ} \mathrm{C}$, environmental conditions (CA): $\mathrm{pH} 7$ and temperature of $20^{\circ} \mathrm{C}$ and natural attenuation (AN): without the modification of $\mathrm{pH}$ and temperature or the addition of vermicompost and enzyme, with a Initial concentration of residual oil of $10,000 \mathrm{mg} / \mathrm{Kg}$ dry base. The determination of ARA concentration via Soxhlet was performed weekly for a period of 49 days. Where an ARA removal percentage of $99.90 \%$ was obtained for the case of $\mathrm{Cl}$, while for the CA test, a removal percentage of $78.61 \%$ was obtained, and for AN, a removal percentage of $7.43 \%$, with residual concentrations of $9.73,2138.99$ and $9257.3 \mathrm{mg} / \mathrm{Kg}$ dry basis, respectively for each of the tests.
\end{abstract}

Keywords: Catalytic activity, enzyme, treatment.

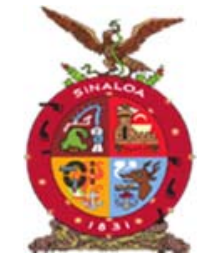

XVIII Congreso Internacional XXIV Congreso Nacional de Ciencias ambientales

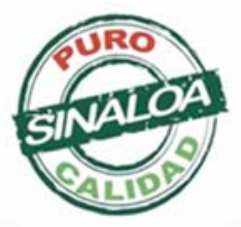

Mazatlán, Sinaloa 3-7 junio 2019
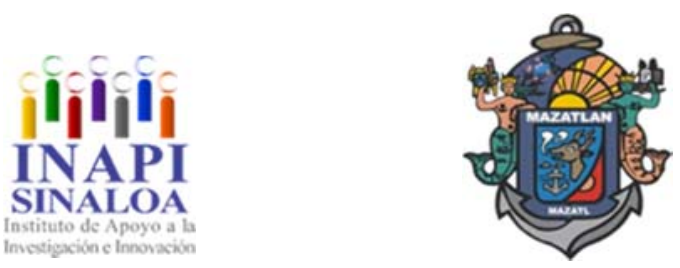

Tecnología y Biotecnología para el Tratamiento de Contaminantes y Biorremediación 

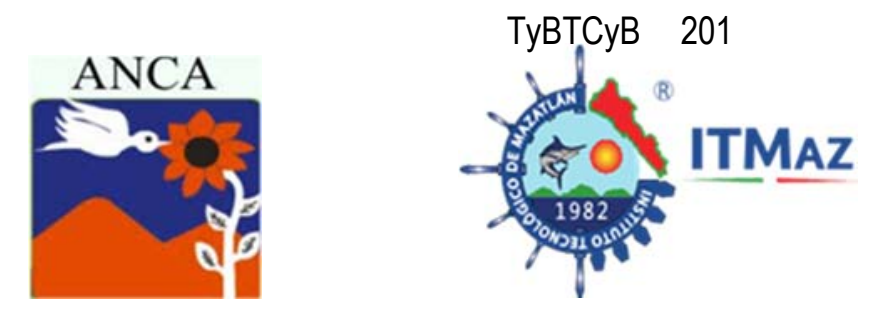

\section{Aprovechamiento de biosólidos provenientes una planta de tratamiento de aguas residuales para el crecimiento de maíz blanco (Zea mays)}

Sánchez Rodríguez $\mathrm{O}^{1}$, Rodríguez Casasola $\mathrm{F}^{2}$, Rodríguez Casasola $\mathrm{T}^{3}$, Cruz Mondragón $\mathrm{C}^{3}$, Vera García $\mathrm{S}^{3}$, Esparza García F3*

1 Universidad Politécnica del Valle de México

Av. Mexiquense S/N esquina Av. Universidad Politécnica, Col. Villa Esmeralda, Tultitlán, C.P. 54910, Estado de México

${ }^{2}$ Laboratorio de Bioingeniería, Departaamento de Ingeniería Bioquímica, ENCB Prolongación de Carpio y Plan de Ayala S/N, Miguel Hidalgo, Santo Tomás, 11340 Ciudad de México, CDMX

${ }^{3}$ Centro de Investigación y Estudios Avanzados.

Av. Instituto Politécnico Nacional 2508, Gustavo A. Madero, San Pedro

Zacatenco, 07360 Ciudad de México, CDMX.

*fesparza@cinvestav.mx

\section{RESUMEN}

Los biosólidos son producto secundario del tratamiento de aguas residuales los cuales contienen materia orgánica y nutrientes que pueden ser beneficiosos para la productividad del suelo, aplicados como biofertilizante para mejorar los suelos, después de someterse a procesos de estabilización. En el presente trabajo se evaluó el posible uso de biosólidos generados en plantas de tratamiento de aguas residuales (PTAR) como biofertilizante para la producción de maíz blanco (Zea mays), observando la morfología de la planta y raíz. Se caracterizó el suelo proveniente de Nextlalpan, Estado de México; obteniendo un pH de 7.7, con textura franco arenosa, humedad de $20.9 \%$ y nutrientes disponibles en forma de fosforo $20 \mathrm{mg} \cdot \mathrm{L}^{-1}$ y nitrógeno $30.83 \mathrm{mg} \cdot \mathrm{L}^{-1}$. Se caracterizaron los biosólidos, registrando un $\mathrm{pH}$ entre 7 y 8 , contienen $\mathrm{PO}^{-3}$ disponible $\left(\mathrm{mg}^{-1} \mathrm{~L}^{-1}\right) 34.95$, nitrógeno total $\left(\mathrm{mg}^{-1} \mathrm{~L}^{-1}\right) 215$, DQO $\left(\mathrm{mg}^{-\mathrm{L}^{-1}}\right)$ 1977.5, coliformes (UFC. $\left.\mathrm{mL}^{-1}\right) 4.5 \times 10^{-}$ 5; los biosólidos celulósicos, $\mathrm{PO}_{4}^{-3}$ disponible $\left(\mathrm{mg}^{\left.-\mathrm{L}^{-1}\right)} 3.97\right.$, nitrógeno total (mg. $\mathrm{L}^{-}$

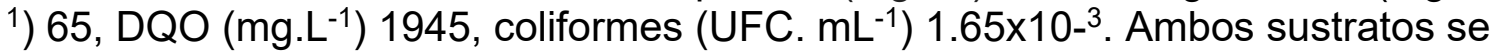
mezclaron en distintas concentraciones (V/V) 0, 25, 50, 75 y 100 con el suelo y se ensamblaron en cámaras de Fähraeus, tomando muestras a los 3, 6 y 9 días. El mejor crecimiento en la plántula se obtuvo a los 9 días con biosólidos celulósicos con $24.2 \mathrm{~cm}$. Ambos biosólidos son adecuados para su uso como biofertilizante, ya que el crecimiento de la plántula en ambos sustratos es mayor que el control en un $90 \%$ con una concentración de $75 \%$ en suelo y biosólidos.
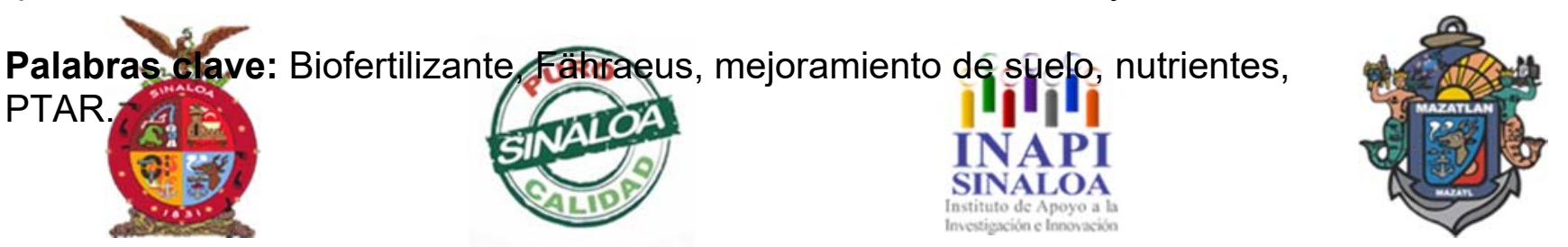

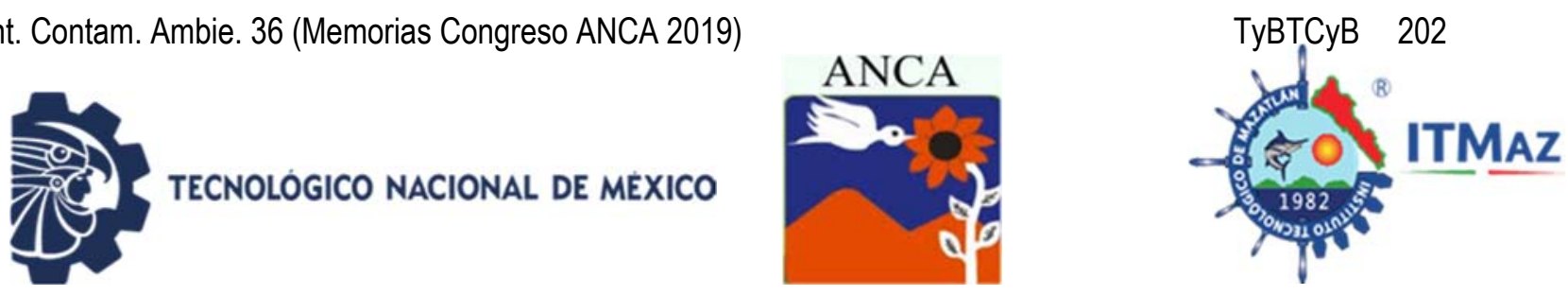

\title{
Use of biosolids for the growth of white corn (Zea mays) from a wastewater treatment plant
}

Sánchez Rodríguez $\mathrm{O}^{1}$, Rodríguez Casasola $\mathrm{F}^{2}$, Rodríguez Casasola $\mathrm{T}^{3}$, Cruz Mondragón $\mathrm{C}^{3}$, Vera García $\mathrm{S}^{3}$, Esparza García $\mathrm{F}^{3 *}$

${ }^{1}$ Universidad Politécnica del Valle de México

Av. Mexiquense S/N esquina Av. Universidad Politécnica, Col. Villa Esmeralda, Tultitlán, C.P. 54910, Estado de México

${ }^{2}$ Laboratorio de Bioingeniería, Departaamento de Ingeniería Bioquímica, ENCB Prolongación de Carpio y Plan de Ayala S/N, Miguel Hidalgo, Santo Tomás, 11340 Ciudad de México, CDMX

${ }^{3}$ Centro de Investigación y Estudios Avanzados.

Av. Instituto Politécnico Nacional 2508, Gustavo A. Madero, San Pedro

Zacatenco, 07360 Ciudad de México, CDMX.

*fesparza@cinvestav.mx

\begin{abstract}
Biosolids are a by-product of wastewater treatment which contains high levels of organic matter and nutrients that can be useful for soil productivity, applied as a biofertilizer to improve soils, after going through a stabilization processes. In the present work we evaluate the possible use of biosolids generated in wastewater treatment plants (WWTP) as biofertilizer for the production of white corn (Zea mays), observing the morphology of the plant and root. The characterization of soil from Nextlalpan, State of Mexico; obtaining a $\mathrm{pH}$ of 7.7, with a sandy loam texture, humidity of $20.9 \%$ and available nutrients in the form of phosphorus and nitrogen $20 \mathrm{mg} \cdot \mathrm{L}^{-1}$ and $30.83 \mathrm{mg} \cdot \mathrm{L}^{-1}$ respectively. In the same way, the characterization of the biosolids was carried out, obtaining a pH between 7 and 8 , the biological biosolids contain, available PO4 ${ }^{-3}\left(\mathrm{mg.L}^{-1}\right) 34.95$, total nitrogen

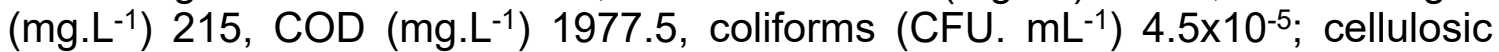
biosolids, available PO${ }^{-3}$ (mg.L-1) 3.97, total nitrogen (mg.L-1 $) 65$, COD (mg.L-1) 1945, coliforms (CFU. $\mathrm{mL}^{-1}$ ) $1.65 \times 10^{-3}$. Both substrates were mixed in different concentrations (V/V) 0, 25, 50, 75 and 100 with the soil and assembled in Fähraeus chambers, taking samples at 3,6 and 9 days. The best growth of the seedling was obtained after 9 days with cellulose biosolids with $24.2 \mathrm{~cm}$. Both biosolids are suitable for use as a biofertilizer, since the growth of the seedling in both substrates is greater than the control in $90 \%$ with a concentration of $75 \%$ in soil and biosolids.
\end{abstract}
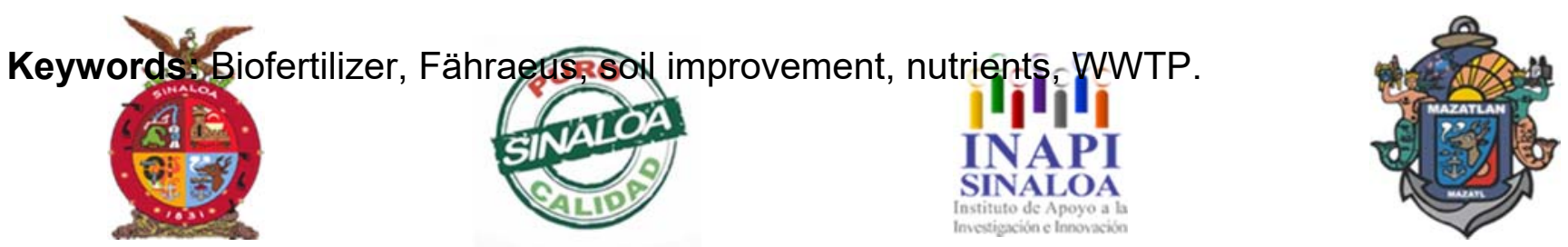

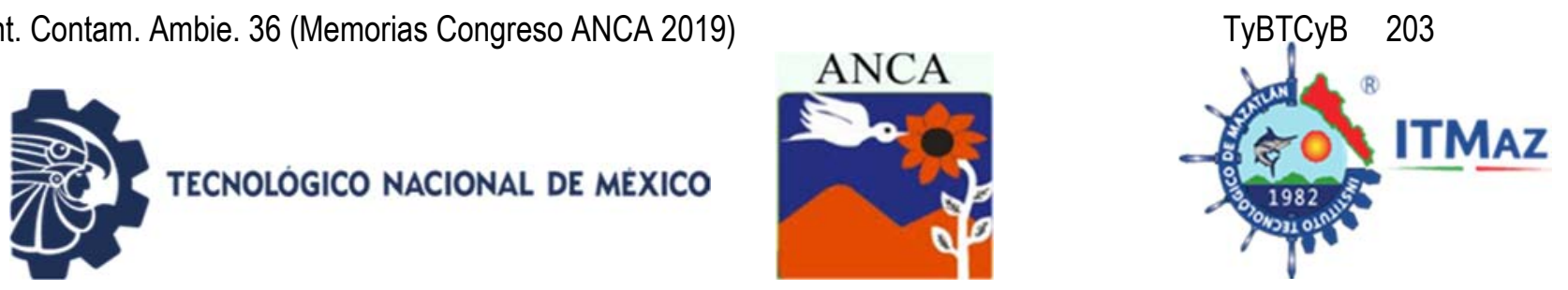

\section{Producción de hoja de papel a base de cáscara de cacahuate (Arachis hypogaea)} Segovia García JD*, Marín Tinoco $\mathrm{RI}^{1}$, Silva Marrufo $\mathrm{O}^{1}$, Salaza Batres $\mathrm{KJ}^{1}$,
Carvajal Hernández $\mathrm{GR}^{2}$

1Departamento de Microbiología General. Universidad Tecnológica de Rodeo. Carretera Panamericana Km. 159.4, Rodeo, Durango, México. C.P. 35760

${ }^{2}$ Departamento de Ingeniería Industrial Alimentaria. Instituto Tecnológico Superior de Santiago Papasquiaro.

Carr. J. Gpe Aguilera-Guanaceví Km. 114, Santiago Papasquiaro, Dgo.

*sjosedavid851@gmail.com

\section{RESUMEN}

Los productos de las cosechas regionales deben tener un impacto en la sociedad, como productos establecidos, así como el aprovechamiento total de los restos. El cacahuate genera un residuo en forma de cascara con alto contenido de celulosa. El presente trabajo lleva por nombre "Producción de hoja de papel a base de cascara de cacahuate (Arachis hypogaea), trasformando el desecho del cacahuate, generado en el Municipio de Rodeo, Durango, en papel con dos diferentes concentraciones; $70 \%$ cascara- $30 \%$ papel reciclado, y $90 \%$ cascara$10 \%$ papel reciclado, siguiendo la metodología de elaboración por, hidratación de la cascara de cacahuate, obtención de la pulpa y elaboración del papel de una manera artesanal, creando hojas con un tamaño estándar de $21.6 \times 27.9 \mathrm{~cm}$. Al papel se le realizaron pruebas de tención, alargamiento, fuerza de desgarre, distancia, absorción, ceniza y $\mathrm{pH}$ teniendo como resultados, parámetros en base a las normas GP-41-M-1979 y SFS-4465-1980. Los resultados se analizaron mediante ANOVA de intersujetos, encontrando que no hay diferencia significativa en las variables en ninguno de los tratamientos, a excepción de las variables fuerza y tensión con significancia de $0.823(p=0.00<0.05)$, lo cual indica la relevancia de las mezclas. Concluyendo que existe la posibilidad de dar un valor agregado a la cascara de cacahuate; ya que cumple con los requerimientos necesarios para convertirse en papel y ser transformarlo en artesanías, embalaje, etc.

Palabras claves: Cacahuate, embalaje, papel, ANOVA.

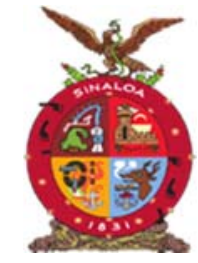

XVIII Congreso Internacional XXIV Congreso Nacional de Ciencias ambientales

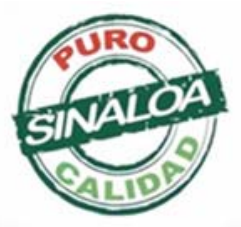

Mazatlán, Sinaloa 3-7 junio 2019
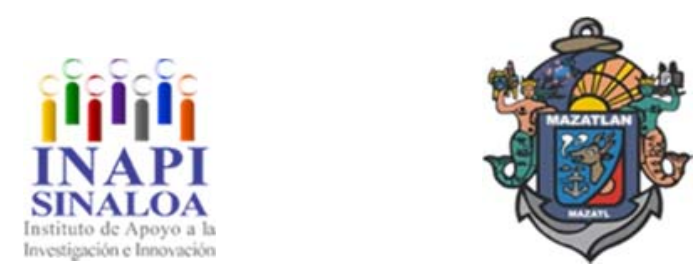

Tecnología y Biotecnología para el Tratamiento de Contaminantes y Biorremediación 
Rev. Int. Contam. Ambie. 36 (Memorias Congreso ANCA 2019)
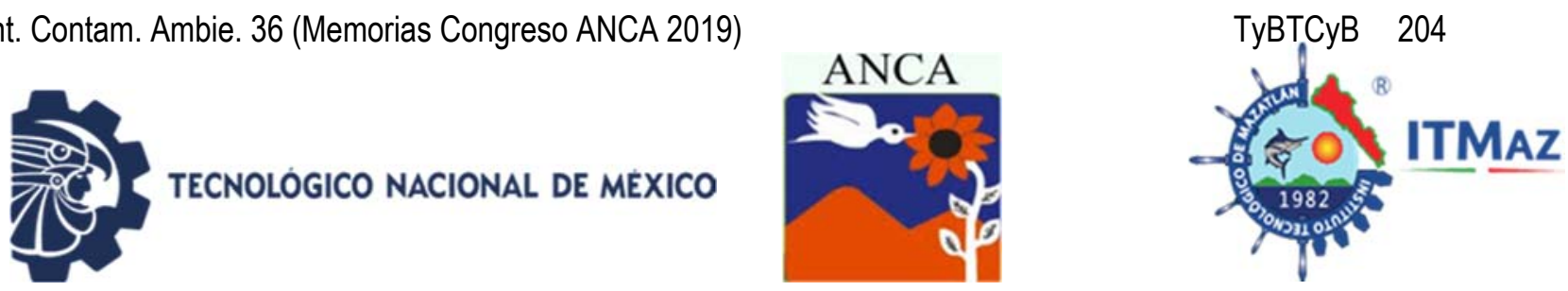

\title{
Production of paper sheet based on peanut cascade (Arachis hypogaea)
}

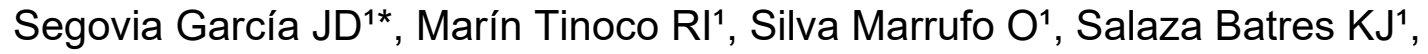
Carvajal Hernández GR ${ }^{2}$

1Departamento de Microbiología General. Universidad Tecnológica de Rodeo. Carretera Panamericana Km. 159.4, Rodeo, Durango, México. C.P. 35760

${ }^{2}$ Departamento de Ingeniería Industrial Alimentaria. Instituto Tecnológico Superior de Santiago Papasquiaro.

Carr. J. Gpe Aguilera-Guanaceví Km. 114, Santiago Papasquiaro, Dgo.

*sjosedavid851@gmail.com

\begin{abstract}
The products of the regional harvests must have an impact on society, as established products, as well as the total use of the remains. The peanut generates a residue, in the form of a shell with a high content of cellulose. The present work is called "Production of peanut husk paper (Arachis hypogaea), with the objective of transforming the peanut waste, generated in the Municipality of Rodeo, Durango, on paper with two different concentrations, $70 \%$ cascara- $30 \%$ recycled paper, and $90 \%$ cascara- $10 \%$ recycled paper, following the methodology of elaboration by, hydration of the peanut peel, obtaining the pulp and making the paper in an artisanal way, creating leaves with a standard size of $21.6 \times 27.9 \mathrm{~cm}$. The paper was tested for tension, elongation, tear strength, distance, absorption, ash and $\mathrm{pH}$, with results based on GP-41-M-1979 and SFS-4465-1980 with an ANOVA analysis. Intersubjects, where there is no significance in the variables in any of the treatments, except for the variables force and tension with significance of 0.823 ( $p=0.00<0.05)$, which indicates the relevance of the mixtures. It is concluded that there is the possibility of adding value to the peanut shell; since it meets the necessary requirements to become paper and be transformed into crafts, packaging, etc.
\end{abstract}

Keywords: Peanut, packaging, paper, ANOVA.

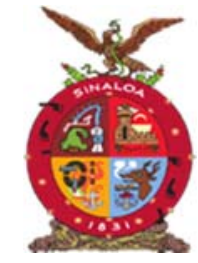

XVIII Congreso Internacional XXIV Congreso Nacional de Ciencias ambientales

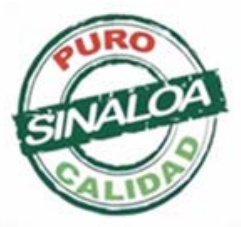

Mazatlán, Sinaloa 3-7 junio 2019
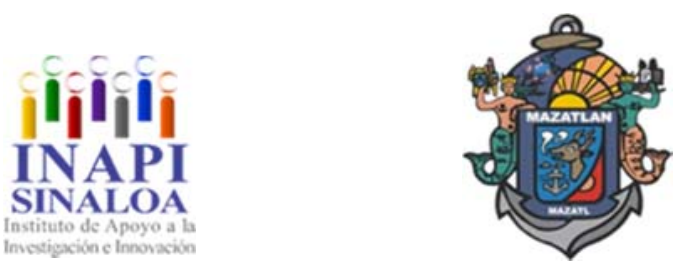

Tecnología y Biotecnología para el Tratamiento de Contaminantes y Biorremediación 

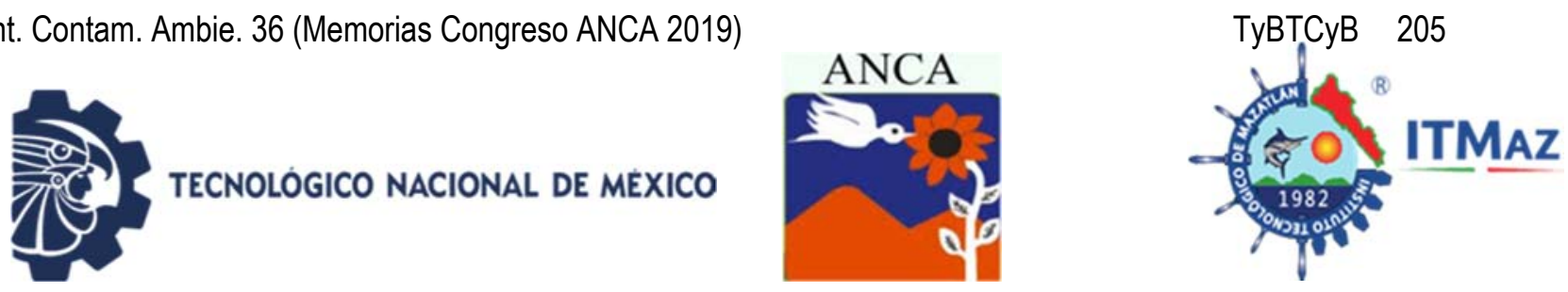

\title{
Remoción biológica de nitrógeno y fósforo utilizando un fotobiorreactor de panel plano empleando Chlorella vulgaris
}

\author{
Serrano Lerma $M^{1}$, Rodríguez Rosales $M^{1}$, Lucho Chigo $R^{1}$, Valle Cervantes $S^{1}$, \\ Martínez Roldan $\mathrm{A}^{2^{*}}$ \\ ${ }^{1}$ Maestría en Sistemas Ambientales. Instituto Tecnológico de Durango. \\ Tecnologico Nacional de México. \\ ${ }^{2}$ Catedrático CONACYT/I.T. Durango-TecNM \\ Felipe Pescador 1830, Nueva Vizcaya, 34080 Durango, Dgo, México \\ *adjmartinezro@conacyt.mx
}

\section{RESUMEN}

En el tratamiento de aguas residuales se busca eliminar la demanda bioquímica de oxígeno (DBO), sólidos suspendidos, nutrientes, coliformes y toxicidad. En condiciones apropiadas, las microalgas poseen una capacidad para la eliminación o biotransformación de contaminantes conocida como fitorremediación. El presente trabajo tuvo como objetivo la evaluación del potencial de Chlorella vulgaris, para la remoción de nitrógeno y fósforo creciendo en un FBR flat panel de 15L, empleando tres diferentes flujos volumétricos de aireación de 4 , 8 y $12 \mathrm{~L} / \mathrm{min}$. Se tomaron muestras diarias durante ocho días se les realizaron las determinaciones de peso seco, pigmentos fotosintéticos, fósforo de ortofosfatos $\left(\mathrm{P}-\mathrm{PO}_{4}\right)$ y nitrógeno de nitratos $\left(\mathrm{N}-\mathrm{NO}_{3}\right)$. Al comparar los resultados obtenidos con los diferentes flujos de aire ensayados, el experimento a de $8 \mathrm{~L} / \mathrm{min}$ alcanzó los mayores valores de remoción, ya que presentó un consumo de nutrientes inorgánicos: $\mathrm{N}_{-} \mathrm{NO}_{3}$ de $38.16 \mathrm{mg} / \mathrm{L}$ a una velocidad de $4.76 \mathrm{mg} / \mathrm{Ld}$ y de $\mathrm{P}_{-} \mathrm{PO}_{4}$ de $10.95 \mathrm{mg} / \mathrm{L}$ a una velocidad de $1.37 \mathrm{mg} / \mathrm{Ld}$. En lo que respecta a la biomasa, el cultivo a de $8 \mathrm{~L} / \mathrm{min}$ de aire alcanzó un valor máximo de $0.68 \mathrm{~g} / \mathrm{L}$ lo que representa una productividad de biomasa de $0.085 \mathrm{~g} / \mathrm{Ld}$ estos resultados permiten demostrar la potencial utilidad de $C$. vulgaris, para remover nitrógeno y fósforo y a su vez obtener biomasa que puede ser fuente de moléculas de alto valor agregado.

Palabras clave: Chlorella vulgaris, aireación, biomasa, remoción de nitrógeno y fósforo.

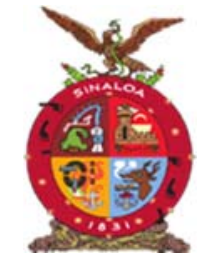

XVIII Congreso Internacional XXIV Congreso Nacional de Ciencias ambientales

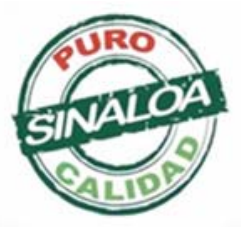

Mazatlán, Sinaloa 3-7 junio 2019
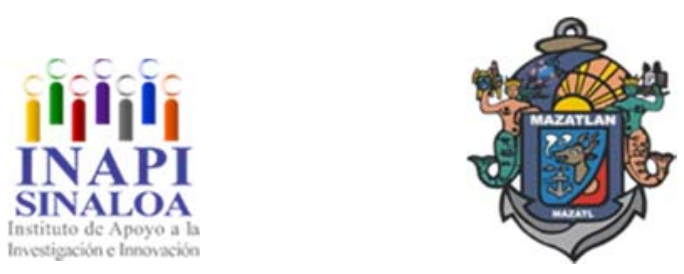

Tecnología y Biotecnología para el Tratamiento de Contaminantes y Biorremediación 

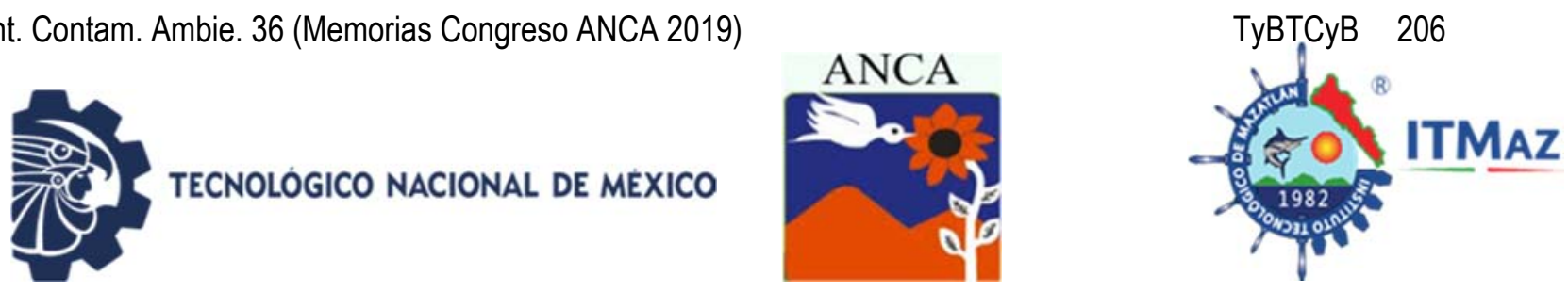

\title{
Biological removal of nitrogen and phosphorus by Chlorella vulgaris using a flat panel photobioreactor
}

Serrano Lerma $\mathrm{M}^{1}$, Rodríguez Rosales $\mathrm{M}^{1}$, Lucho Chigo $\mathrm{R}^{1}$, Valle Cervantes $\mathrm{S}^{1}$, Martínez Roldan $\mathrm{A}^{2^{*}}$

${ }^{1}$ Maestría en Sistemas Ambientales. Instituto Tecnológico de Durango.

Tecnologico Nacional de México.

${ }^{2}$ Catedrático CONACYT/I.T. Durango-TecNM

Felipe Pescador 1830, Nueva Vizcaya, 34080 Durango, Dgo, México

*adjmartinezro@conacyt.mx

\begin{abstract}
In the treatment of wastewater, the aim is to eliminate the biochemical demand for oxygen (BOD), suspended solids, nutrients, coliforms and toxicity. Under appropriate conditions, microalgae have a capacity for the elimination or biotransformation of pollutants known as phytoremediation. The objective of this work was to evaluate the potential of Chlorella vulgaris, for the removal of nitrogen and phosphorus by growing in a 15L FBR flat panel, using three different volumetric aeration flows of 4,8 and $12 \mathrm{~L} / \mathrm{min}$. Daily samples were taken for eight days, and dry weight, photosynthetic pigments, orthophosphate phosphorus ( $\mathrm{P}$ $\left.\mathrm{PO}_{4}\right)$ and nitrate nitrogen $\left(\mathrm{N}-\mathrm{NO}_{3}\right)$ determinations were carried out. When comparing the results obtained with the different air flows tested, the experiment of $8 \mathrm{~L} / \mathrm{min}$ reached the highest values of removal, since it presented a consumption of inorganic nutrients: $\mathrm{N}^{-N} \mathrm{~N}_{3}$ of $38.16 \mathrm{mg} / \mathrm{L}$ at a speed of 4.76 . $\mathrm{mg} / \mathrm{Ld}$ and $\mathrm{P}-\mathrm{PO}_{4}$ of $10.95 \mathrm{mg} / \mathrm{L}$ at a rate of $1.37 \mathrm{mg} / \mathrm{Ld}$. With respect to biomass, the a crop of $8 \mathrm{~L} / \mathrm{min}$ of air reached a maximum value of $0.68 \mathrm{~g} / \mathrm{L}$, which represents a biomass productivity of $0.085 \mathrm{~g} / \mathrm{Ld}$. These results allow to demonstrate the potential utility of $C$. vulgaris, to remove nitrogen and phosphorus and in turn obtain biomass that can be a source of high added value molecules.
\end{abstract}

Keywords: Chlorella vulgaris, aeration, biomass, nitrogen and phosphorus removal.

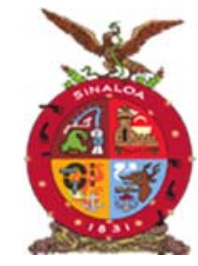

XVIII Congreso Internacional XXIV Congreso Nacional de Ciencias ambientales

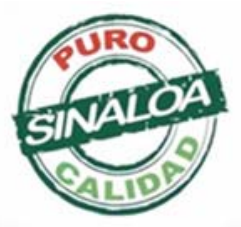

Mazatlán, Sinaloa 3-7 junio 2019
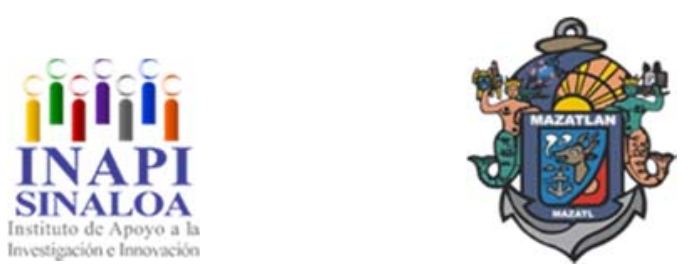

Tecnología y Biotecnología para el Tratamiento de Contaminantes y Biorremediación 

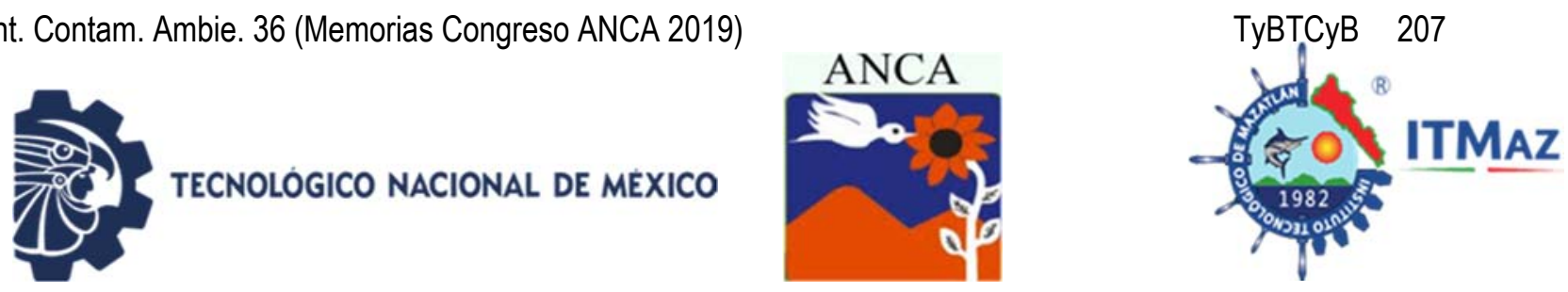

\title{
Efecto de la corriente eléctrica sobre la degradación de cianuro en una celda Electroquímica
}

Sierra Alvarado $\mathrm{E}^{1}$, Martínez Gómez $\mathrm{V}^{1,2^{*}}$, Valle Cervantes $\mathrm{S}^{1}$, Lucho Chigo $\mathrm{R}^{1}$, Rodríguez Rosales $\mathrm{J}^{1}$

${ }^{1}$ Maestría en Sistemas Ambientales. Instituto Tecnológico de Durango.

Tecnologico Nacional de México.

${ }^{2}$ Catedrático CONACYT/I.T. Durango-TecNM

Felipe Pescador 1830, Nueva Vizcaya, 34080 Durango, Dgo, México

vv.martinez@itdurango.edu.mx

\begin{abstract}
RESUMEN
El cianuro es un compuesto de carbono y nitrógeno que, dependiendo de su concentración, puede determinarse su toxicidad. Las concentraciones altas de cianuro son manejadas en las industrias para sus procesos en la transformación de la materia prima, así como en la extracción de estas. Los procesos de extracción de minerales en la industria minera consumen alrededor del $18 \%$ del cianuro producido y su mal manejo representa un riesgo para los ecosistemas cuando se encuentran en contacto directo con el ambiente. En este proyecto se evaluaron los fenómenos electroquímicos de soluciones de cianuro para su implementación en la electroremediación de jales mineros contaminados En la primera parte de esta investigación se estudiaron electroquímicamente tres electrodos (dos de acero inoxidable y uno de carbón grafito) para su implementación en la celda electroquímica. Se concluyó que el uso de carbón grafito fue el mejor electrodo para la electrorremediación debido a que, por su composición química, no forma iones metálicos que interactúen con la solución. En la segunda parte se estudió la cinética de las variables de la concentración del cianuro, la corriente y la concentración del electrolito. Los resultados mostraron que el cianuro tuvo una degradación completa entre los 60 y 90 min la concentración de 200 ppm, y una degradación completa a los 120 min para las concentraciones de 500 y 800 ppm de cianuro.
\end{abstract}

Palabras clave: Cianuro, electrodegradación, electroquímica.

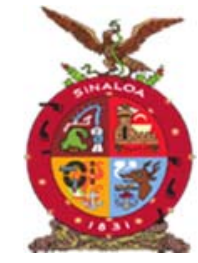

XVIII Congreso Internacional XXIV Congreso Nacional de Ciencias ambientales

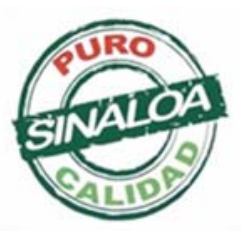

Mazatlán, Sinaloa 3-7 junio 2019
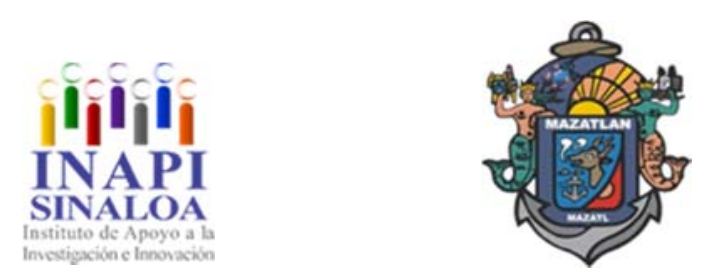

Tecnología y Biotecnología para el Tratamiento de Contaminantes y Biorremediación 

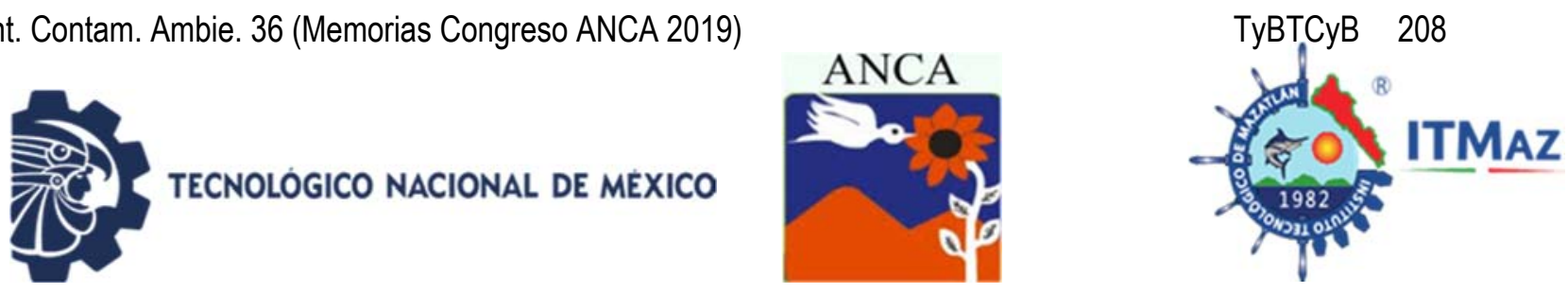

\title{
Effect of electric current on cyanide degradation in a electrochemistry cell
}

\author{
Sierra Alvarado $\mathrm{E}^{1}$, Martínez Gómez $\mathrm{V}^{1,2^{*}}$, Valle Cervantes $\mathrm{S}^{1}$, Lucho Chigo $\mathrm{R}^{1}$, \\ Rodríguez Rosales $\mathrm{J}^{1}$ \\ ${ }^{1}$ Maestría en Sistemas Ambientales. Instituto Tecnológico de Durango. \\ Tecnologico Nacional de México. \\ ${ }^{2}$ Catedrático CONACYT/I.T. Durango-TecNM \\ Felipe Pescador 1830, Nueva Vizcaya, 34080 Durango, Dgo, México \\ vv.martinez@itdurango.edu.mx
}

\begin{abstract}
Cyanide is a compound of carbon and nitrogen that, depending on its concentration, its toxicity can be determined. High concentrations of cyanide are managed in the industries for their processes in the transformation of the raw material, as well as in the extraction of these. Mineral extraction processes in the mining industry consume about $18 \%$ of the cyanide produced and its mismanagement represents a risk to ecosystems when they are in direct contact with the environment. In this project, the electrochemical phenomena of cyanide solutions were evaluated for their implementation in the electroremediation of contaminated mining jars. In the first part of this investigation, three electrodes (two of stainless steel and one of graphite carbon) were electrochemically studied for implementation in the electrochemical cell It was concluded that the use of graphite carbon was the best electrode for electroremediation because, due to its chemical composition, it does not form metal ions that interact with the solution. In the second part, the kinetics of the cyanide concentration, current and electrolyte concentration variables were studied. The results showed that cyanide had a complete degradation between 60 and 90 min the concentration of 200 ppm, and a complete degradation at $120 \mathrm{~min}$ for concentrations of 500 and 800 ppm of cyanide.
\end{abstract}

Keywords: Cyanide, electrodegradation, electrochemistry.

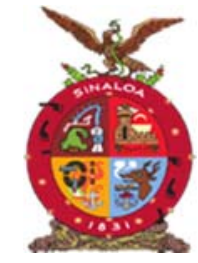

XVIII Congreso Internacional XXIV Congreso Nacional de Ciencias ambientales

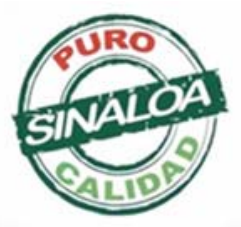

Mazatlán, Sinaloa 3-7 junio 2019
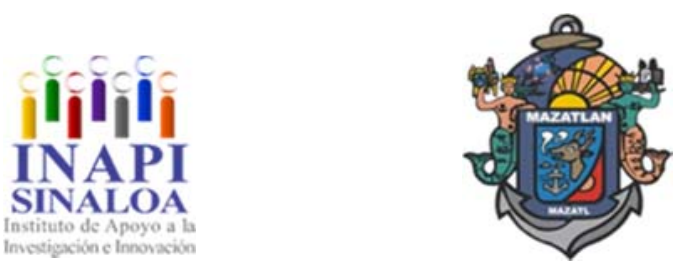

Tecnología y Biotecnología para el Tratamiento de Contaminantes y Biorremediación 

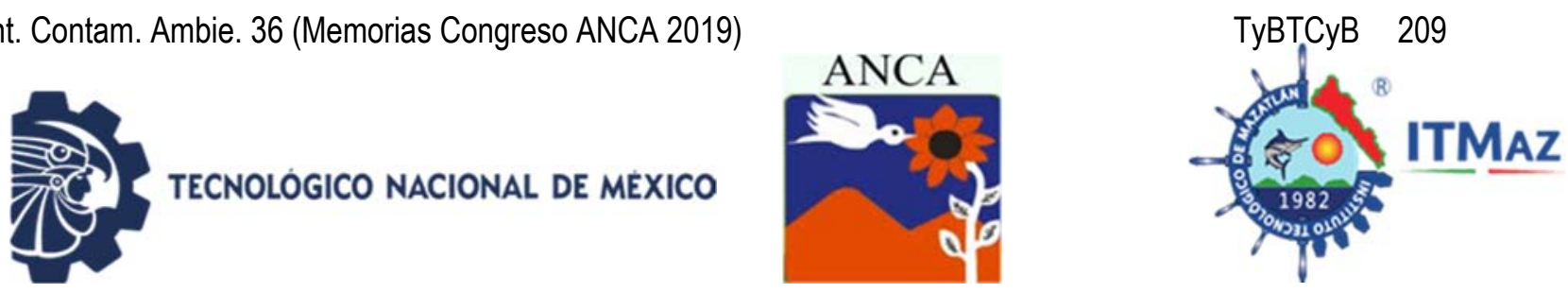

\title{
Obtención de esferas de Alúmina-hidroxiapatita dopadas con nanopartículas de plata con carácter antibacteriano
}

\author{
Silva Holguín PN \\ Instituto de Ciencias Biomédicas. Universidad Autónoma de Ciudad Juárez, \\ Envolvente del PRONAF y Estocolmo S/N, Ciudad Juárez, Chih., México \\ *al136366@alumnos.uacj.mx
}

\section{RESUMEN}

El uso indiscriminado de antibióticos en las prácticas médicas, veterinarias y agrícolas dan como resultado la descarga de antibióticos hacia el ambiente, lo que provoca que las bacterias sean cada vez más resistentes a los antibióticos. Debido a su impacto al ambiente, actualmente se busca nuevos agentes antibacterianos alternativos. En la presente investigación se presenta la obtención de esferas porosas de alúmina recubiertas con hidroxiapatita y dopadas con nanopartículas de plata con efecto antibacteriano para su aplicación como filtros desinfectantes de aguas residuales. En el presente proyecto se sintetizaron polvos de hidroxiapatita dopados con nanopartículas de plata a concentraciones de $0.5,1,2.5$ y $5 \mathrm{mM}$. La obtención de esferas de alúmina-HANpsAg de $4.08 \times 3.25 \mathrm{~mm} 2$ con una esfericidad de 0.8 fue por encapsulación iónica, las esferas obtenidas se recubrieron con hidroxiapatita obtenida a partir de nitrato de calcio y trietilfosfito por el método sol-gel y fueron dopadas por simple adsorción con una solución de $10 \mathrm{mM}$ de NpsAg con un tamaño de $5.6 \pm$ $2.9 \mathrm{~nm}$. La susceptibilidad antimicrobiana se evaluó con los métodos de difusión en agar y turbidimetría empleando bacterias Gram-negativas: Escherichia coli, Klebsiella oxytoca y Pseudomonas aeruginosa y; Gram-positivas Streptococcus mutans, Staphylococcus aureus y Bacillus subtilis. Todas las bacterias utilizadas fueron susceptibles a los polvos de HA-NpsAg, obteniendo un máximo de inhibición del $42.34 \%$ para $P$. aeruginosa a la concentración de $5 \mathrm{mM}$; sin embargo, las esferas de Alúmina-HA-NpsAg solo presentaron susceptibilidad en E. coli, $P$. aeruginosa y $S$. aureus, obteniendo una máxima inhibición del $20 \%$ en S. aureus.

Palabras claves: Alúmina, hidroxiapatita, nanopartículas de plata, esferas, antibacteriano.

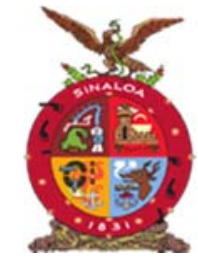

XVIII Congreso Internacional XXIV Congreso Nacional de Ciencias ambientales

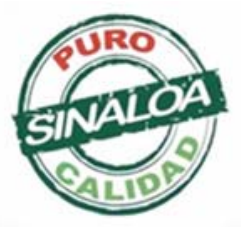

Mazatlán, Sinaloa 3-7 junio 2019
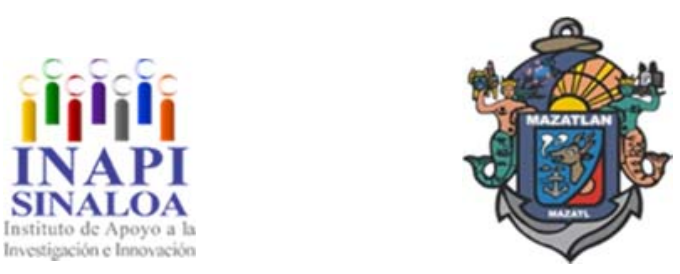

Tecnología y Biotecnología para el Tratamiento de Contaminantes y Biorremediación 

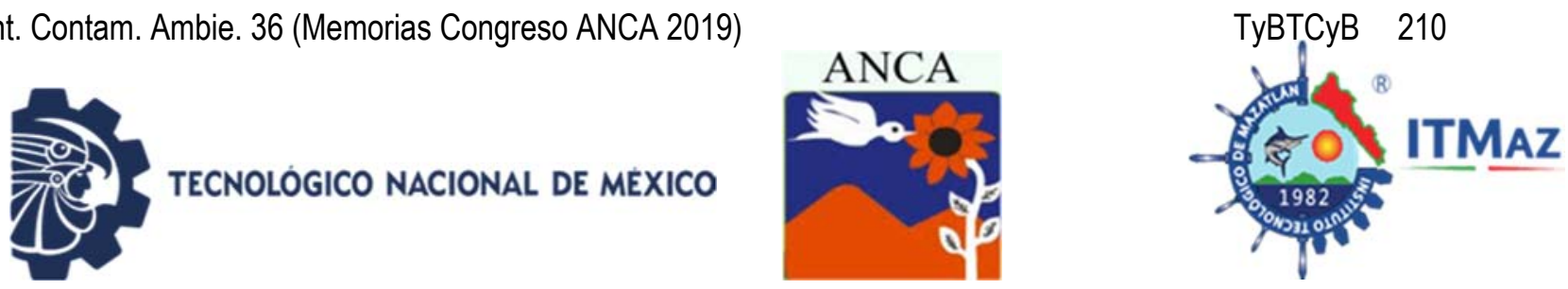

\title{
Obtaining of Alumina-hydroxiapatita spheres dopated with silver nanoparticles with antibacterial character
}

\author{
Silva Holguín PN \\ Instituto de Ciencias Biomédicas. Universidad Autónoma de Ciudad Juárez, \\ Envolvente del PRONAF y Estocolmo S/N, Ciudad Juárez, Chih., México \\ *al136366@alumnos.uacj.mx
}

\begin{abstract}
The indiscriminate use of antibiotics in medical, veterinary and agricultural practices results in the unloading of antibiotics into the environment, which causes the bacteria to become increasingly resistant to antibiotics, due to their impact on the environment. looks for new alternative antibacterial agents. Therefore, in the present investigation we present the obtaining of porous alumina spheres coated with hydroxyapatite and doped with silver nanoparticles with antibacterial effect for their application as disinfectant filters for wastewater. In the present project, hydroxyapatite powders doped with silver nanoparticles were synthesized at concentrations of $0.5,1,2.5$ and $5 \mathrm{mM}$. The obtaining of spheres of alumina-HANpsAg of $4.08 \times 3.25 \mathrm{~mm}^{2}$ with a sphericity of 0.8 was by ionic encapsulation, the spheres obtained were coated with hydroxyapatite obtained from calcium nitrate and triethylphosphite by the sol-gel method and were doped by simple adsorption with a $10 \mathrm{mM}$ NpsAg solution with a size of $5.6 \pm 2.9 \mathrm{~nm}$. The antimicrobial susceptibility was with agar and turbidimetric diffusion methods in Gram-negative bacteria (Escherichia coli, Klebsiella oxytoca and Pseudomonas aeruginosa) and Gram-positive (Streptococcus mutans, Staphylococcus aureus and Bacillus subtilis). All the bacteria used were susceptible to the HA-NpsAg powder, obtaining a maximum inhibition of $42.34 \%$ for $P$. aeruginosa at the concentration of $5 \mathrm{mM}$; however, the alumina-HA-NpsAg spheres only showed susceptibility in E. coli, $P$. aeruginosa and S. aureus, obtaining a maximum inhibition of $20 \%$ in $S$. aureus.
\end{abstract}

Keywords: Alumina, hydroxyapatite, silver nanoparticles, spheres, antibacterial.

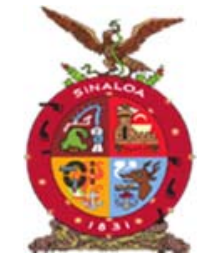

XVIII Congreso Internacional XXIV Congreso Nacional de Ciencias ambientales

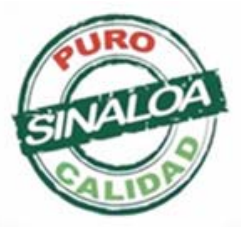

Mazatlán, Sinaloa 3-7 junio 2019
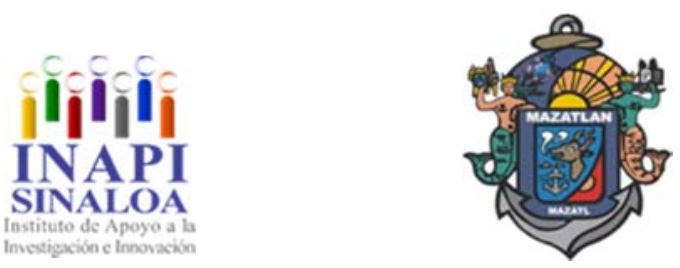

Tecnología y Biotecnología para el Tratamiento de Contaminantes y Biorremediación 

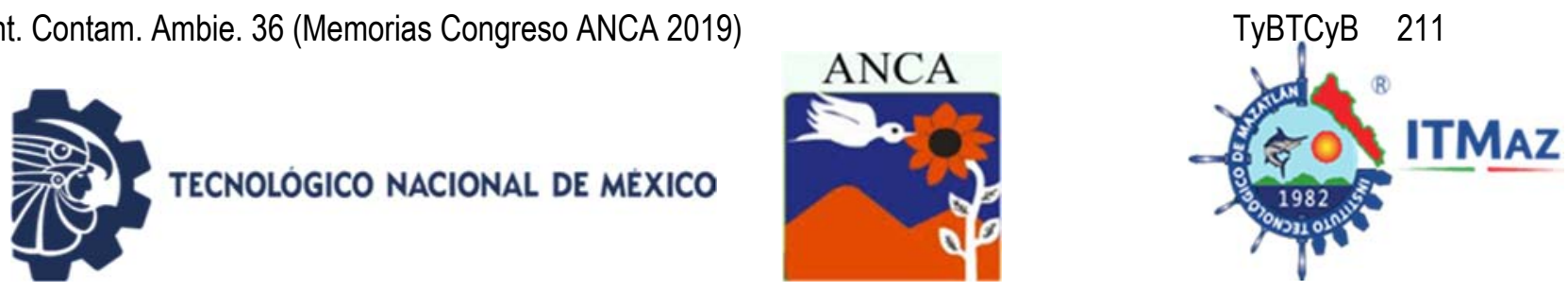

\title{
Aprovechamiento del efluente generado en la digestión anaerobia de lodos para producir biomasa microalgal
}

\author{
Soto Retana $\mathrm{M}^{1}$, Rodríguez Rosales $\mathrm{M}^{1}$, Lucho Chigo $\mathrm{R}^{1}$, \\ Martínez Roldán $\mathrm{A}^{2^{*}}$ \\ ${ }^{1}$ Maestría en Sistemas Ambientales. Instituto Tecnológico de Durango. \\ Tecnologico Nacional de México. \\ ${ }^{2}$ Catedrático CONACYT/I.T. Durango-TecNM \\ Felipe Pescador 1830, Nueva Vizcaya, 34080 Durango, Dgo, México \\ *adjmartinezro@conacyt.mx
}

\begin{abstract}
RESUMEN
La digestión anaerobia de lodos residuales genera un efluente líquido rico en materia orgánica, nitrógeno amoniacal e incluso fósforo, que puede ser aprovechado como fuente de nutrientes en diferentes procesos biotecnológicos. Emplear dicho efluente para el crecimiento de microalgas disminuye los riesgos de contaminación derivados de su vertido, ya que mejora su calidad del agua al disminuir la concentración de nitrógeno, fósforo y materia orgánica y eleva el $\mathrm{O}_{2}$ disuelto. En el presente trabajo se evaluó el desarrollo de un bioproceso empleando el efluente líquido generado en la digestión anaerobia de lodos de la industria del papel como fuente de nutrientes para la obtención de biomasa microalgal. Se cultivó Chlorella vulgaris en un sistema de lotes en botellas Kimax® de $1 \mathrm{~L}$, provistos con iluminación continua y $0.5 \mathrm{vvm}$ de aireación, variando la proporción de inóculo en $10 \%, 30 \%, 50 \%$ y $70 \%$. Se realizó la cinética por 7 días y se monitoreó mediante determinaciones de pigmentos fotosintéticos, $\mathrm{N}-\mathrm{NH}_{3}, \mathrm{P}_{-} \mathrm{PO}_{4}$ y N-NO 3 . El cultivo inoculado al $50 \%$ presentó el mejor desempeño presentando una concentración máxima de clorofila total de $19.42(\mathrm{mg} / \mathrm{L})$ a los 6 días, $\left(\sim 0.4 \mathrm{~g} / \mathrm{L}\right.$ de biomasa); se registraron remociones del $87 \%$ para $\mathrm{N}-\mathrm{NH}_{3}, 95 \%$ para $\mathrm{N}-\mathrm{NO}_{3}, 86 \%$ para $\mathrm{P}_{-} \mathrm{PO}_{4}$ y $93 \%$ para $\mathrm{DQO}$. Los resultados obtenidos permiten comprobar que $C$. vulgaris tiene la capacidad de remover el nitrógeno, fósforo y materia orgánica del efluente líquido de la digestión anaerobia de forma eficiente, sin embargo, se requiere la optimización del proceso para incrementar la remoción de los contaminantes.
\end{abstract}

Palabras claves: Bioproceso, Chlorella vulgaris, remoción de nutrientes.

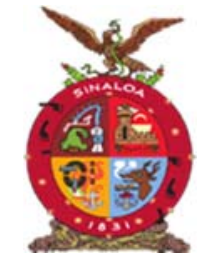

XVIII Congreso Internacional XXIV Congreso Nacional de Ciencias ambientales

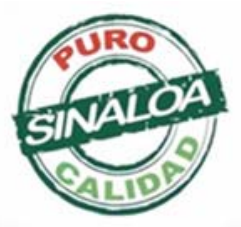

Mazatlán, Sinaloa 3-7 junio 2019
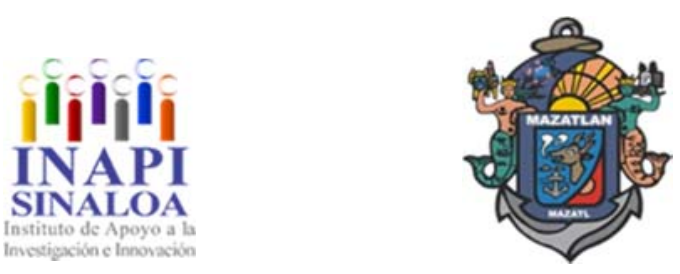

Tecnología y Biotecnología para el Tratamiento de Contaminantes y Biorremediación 
Rev. Int. Contam. Ambie. 36 (Memorias Congreso ANCA 2019)
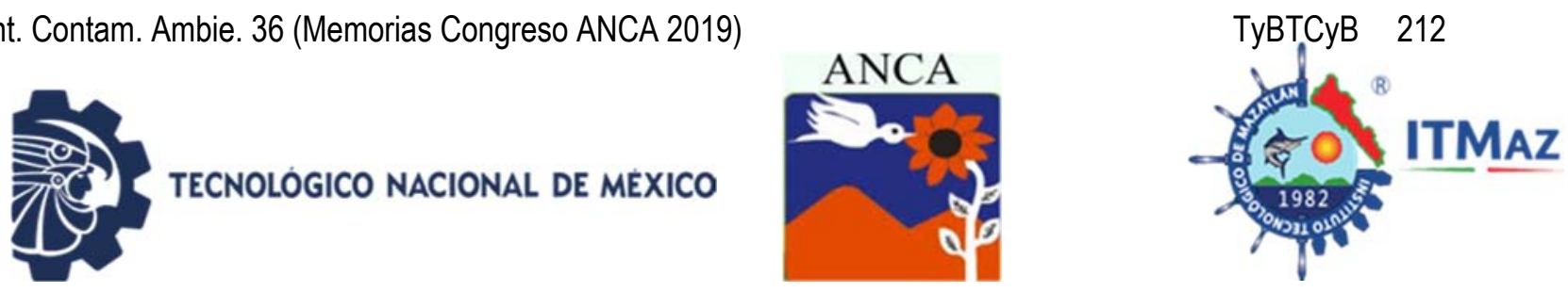

\title{
Employment of the effluent produced in the sludge-anaerobic digestion for microalgal biomass production
}

\author{
Soto Retana $\mathrm{M}^{1}$, Rodríguez Rosales $\mathrm{M}^{1}$, Lucho Chigo $\mathrm{R}^{1}$, \\ Martínez Roldán $\mathrm{A}^{2^{*}}$ \\ ${ }^{1}$ Maestría en Sistemas Ambientales. Instituto Tecnológico de Durango. \\ Tecnologico Nacional de México. \\ ${ }^{2}$ Catedrático CONACYT/ I.T. Durango-TecNM \\ Felipe Pescador 1830, Nueva Vizcaya, 34080 Durango, Dgo, México \\ *adjmartinezro@conacyt.mx
}

\begin{abstract}
The anaerobic digestion of residual sludge generates a liquid effluent rich in organic matter, ammonia nitrogen and even phosphorus, which can be used as a source of nutrients in different biotechnological processes. Using this effluent for the growth of microalgae reduces the risks of contamination derived from its discharge, since it improves its water quality by decreasing the concentration of nitrogen, phosphorus and organic matter and increases the dissolved $\mathrm{O}_{2}$. In the present work, the development of a bioprocess was evaluated using the liquid effluent generated in the anaerobic digestion of sludge from the paper industry as a source of nutrients for the microalgal biomass production. Chlorella vulgaris was grown in a batch system in $1 \mathrm{~L}$ Kimax $®$ bottles, provided with continuous illumination and $0.5 \mathrm{vvm}$ of aeration, varying the proportion of inoculum in $10 \%$, $30 \%, 50 \%$ and $70 \%$. Kinetics were performed for 7 days and monitored by photosynthetic pigment determinations, $\mathrm{N}-\mathrm{NH}_{3}, \mathrm{P}_{-} \mathrm{PO}_{4}$ and $\mathrm{N}-\mathrm{NO}_{3}$. The culture inoculated at $50 \%$ presented the best performance, presenting a maximum concentration of total Chlorophyll of $19.42(\mathrm{mg} / \mathrm{L})$ after 6 days, $(\sim 0.4 \mathrm{~g} / \mathrm{L}$ of

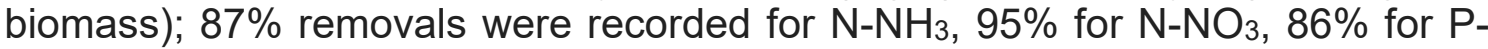
$\mathrm{PO}_{4}$ and $93 \%$ for $\mathrm{COD}$. The obtained results allow to verify that $C$. vulgaris has the capacity to remove nitrogen, phosphorus and organic matter from the liquid effluent of anaerobic digestion efficiently, however, it is necessary to optimize the process to increase the removal of contaminants.
\end{abstract}

Keywords: Bioprocess, Chlorella vulgaris, nutrient removal.

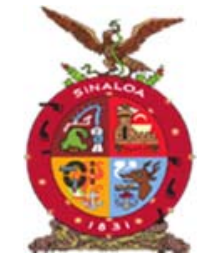

XVIII Congreso Internacional XXIV Congreso Nacional de Ciencias ambientales

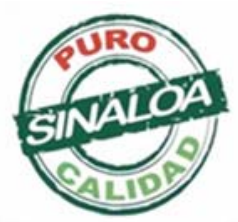

Mazatlán, Sinaloa 3-7 junio 2019
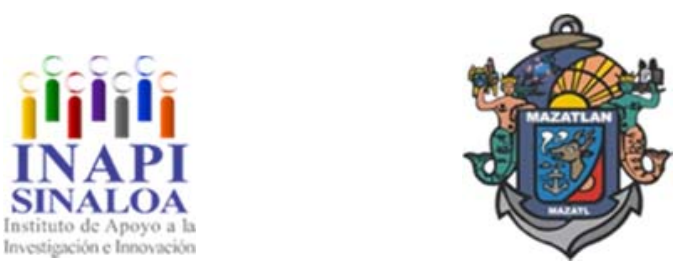

Tecnología y Biotecnología para el Tratamiento de Contaminantes y Biorremediación 

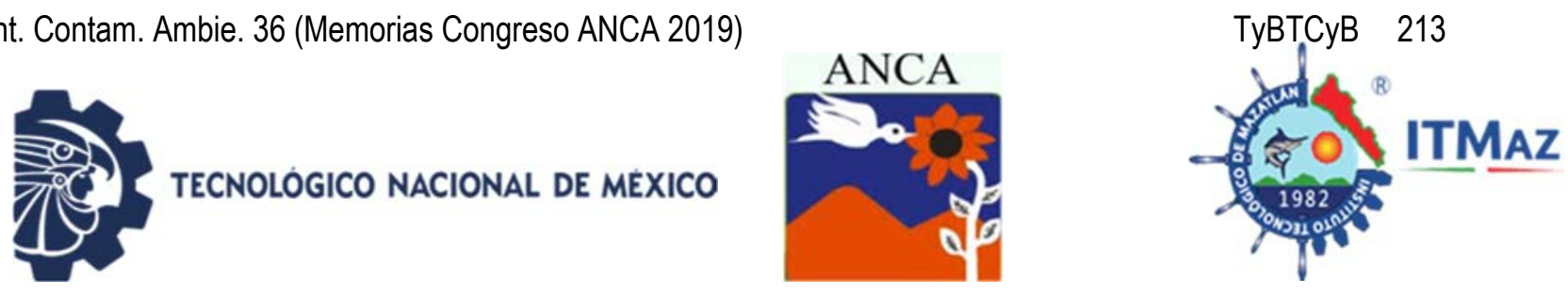

\title{
Aprovechamiento de desechos plásticos, sustentabilidad para las instituciones educativas, caso Técnica 51
}

\author{
Tapia Ponce S*, Salcedo Rosales M, Fernández Tapia S, \\ Fernández Zepeda M, Plascencia Salcedo J \\ Universidad Autónoma de Nayarit \\ *sonia.tapia@uan.edu.mx
}

\section{RESUMEN}

El proyecto fue dirigido a Instituciones Educativas de nivel Superior: la Universidad Autónoma de Nayarit (UAN); Instituto Tecnológico de Tepic (ITTEPIC); y Universidad Tecnológica (UT); instituciones que cuentan con grandes cantidades de aparatos electrónicos y eléctricos en uso y desuso, dichos objetos sin uso, son almacenados o desechados sin las medidas adecuadas para evitar el daño hacia el ambiente o no son dirigidos hacia fines reciclables o un tratamiento adecuado. Con el objetivo de conocer el uso de los desechos electrónicos y eléctricos generados por IES, para proponer una estrategia sustentable de reciclaje. Se realiza una evaluación cuantitativa cualitativa de los desechos plásticos. Las IES (Instituciones de Educación Superior) no cuentan con un departamento especial que este encargado de llevar el control sobre el uso y destino dado a los artefactos electrónicos y eléctricos almacenados. Los principales aparatos que desechan las instituciones educativas de nivel superior son equipos de cómputo como principal aparato en desuso, impresoras, cañones, televisiones, teléfonos fijos, entre otros más específicos de la disciplina, hay equipos dentales y para análisis de alimentos. Las IES mayormente almacenan los desechos una vez que llegan a su fin por cuestiones de obsolescencia o descomposición, aunque se rigen mediante la Ley de Bienes Nacionales, cada institución tiene sus propios procesos internos. En la UAN, el departamento central de recursos materiales es el encargado de recibir todos aquellos bienes que las facultades/unidades académicas dejan en desuso por cuestiones como descomposición, obsolescencia, no habiendo gran diferencia en otras.

Palabras clave: Reciclaje, desechos electrónicos, desechos eléctricos, sustentabilidad, cuidado ambiental.

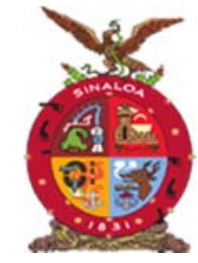

XVIII Congreso Internacional XXIV Congreso Nacional de Ciencias ambientales

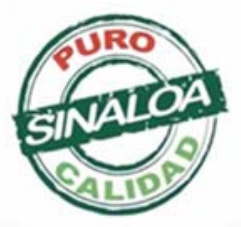

Mazatlán, Sinaloa 3-7 junio 2019
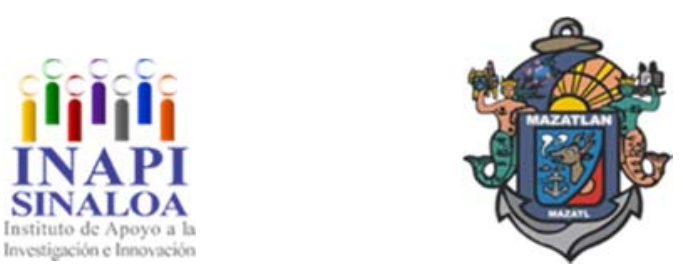

Tecnología y Biotecnología para el Tratamiento de Contaminantes y Biorremediación 

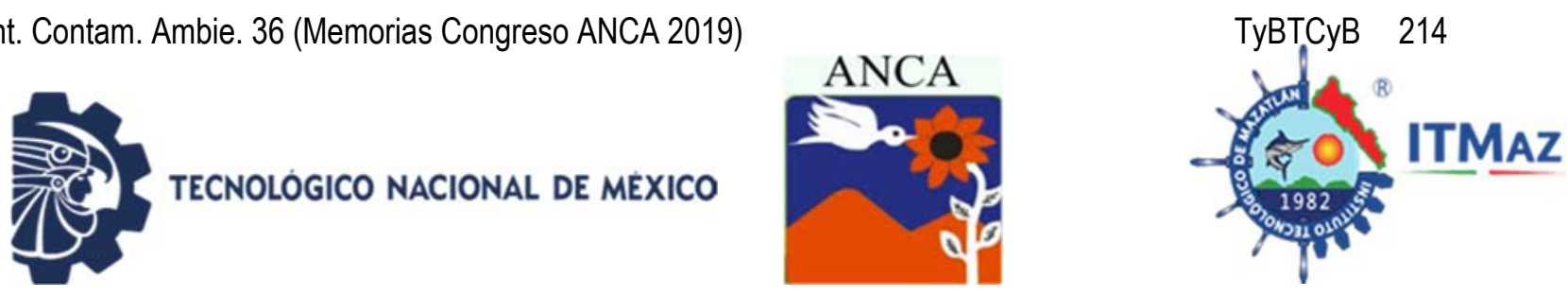

\title{
Use of plastic waste, sustainability for educational institutions, case: Technical 51
}

Tapia Ponce S*, Salcedo Rosales M, Fernández Tapia S, Fernández Zepeda M, Plascencia Salcedo J

Universidad Autónoma de Nayarit

*sonia.tapia@uan.edu.mx

\begin{abstract}
The project was directed to Higher Education Institutions: the Autonomous University of Nayarit (UAN); Technological Institute of Tepic (ITTEPIC); and Technological University (UT); institutions that have large quantities of electronic and electrical equipment in use and disuse, such objects without use, are stored, discarded without adequate measures to avoid damage to the environment or not given adequate treatment. The objective of this research is to show the use of electronic and electrical waste generated by IES, to propose a sustainable recycling strategy. A quantitative-qualitative evaluation of plastic waste was carried out. The IES (Institutions of Higher Education) do not have a special department that is in charge of controlling the use and destination of stored electronic and electrical devices. The most common waste of the aforementioned institutions consists of computer equipment, printers, cannons, televisions, landlines, dental and food análisis equipment, among others. The IES waste is mostly stored for reasons of obsolescence or decomposition and although they are governed by the Law of National Assets, each institution has its own internal processes. In the UAN, the central department of material resources is in charge of receiving the goods in disuse.
\end{abstract}

Keywords: Recycling, electronic waste, electrical waste, sustainability, environmental care.

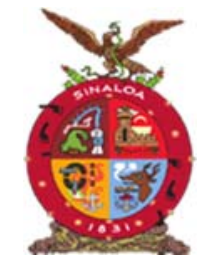

XVIII Congreso Internacional XXIV Congreso Nacional de Ciencias ambientales

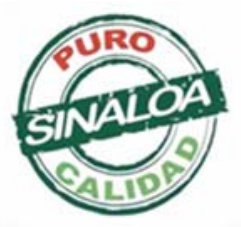

Mazatlán, Sinaloa 3-7 junio 2019
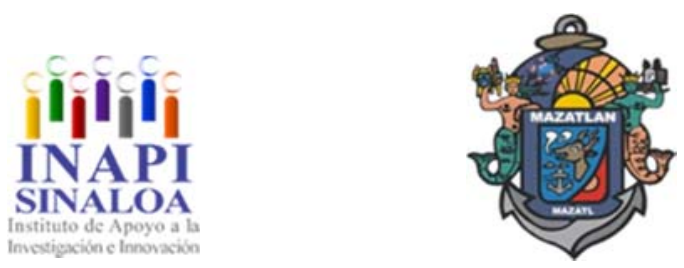

Tecnología y Biotecnología para el Tratamiento de Contaminantes y Biorremediación 

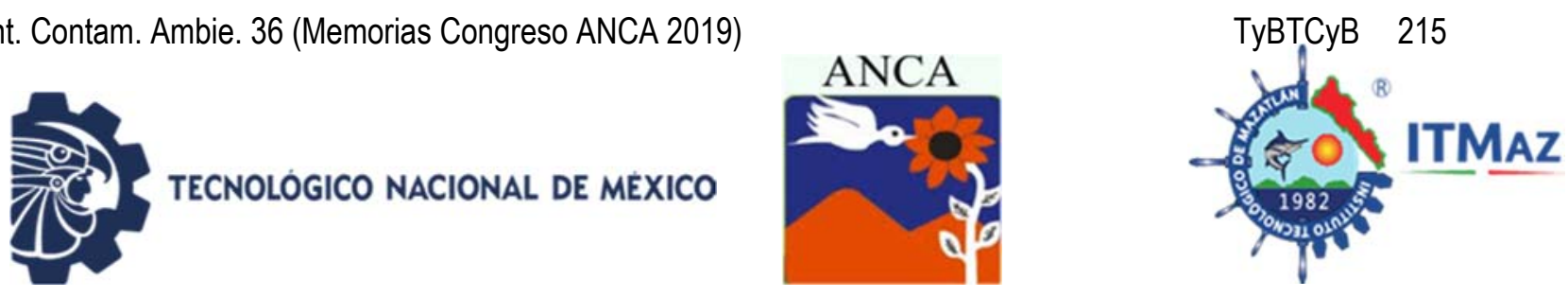

\title{
Remoción de oxitetraciclina en medio acuoso con un producto farmacéutico a base de arcilla
}

\author{
Torres Aquino M, Martínez Olivas A, Torres Pérez J \\ Laboratorio de Transferencia y Degradación de Contaminantes. \\ Universidad Autónoma de Ciudad Juárez, \\ Anillo Envolvente del Pronaf y Estocolmo S/N, Cd, Juárez, Chihuahua, México \\ *al151457@alumnos.uacj.mx
}

\section{RESUMEN}

La tetraciclina (TC) es un antibiótico de amplio uso en el mundo. Debido a sus características estructurales y químicas, solo 10 a $30 \%$ es metabolizado por el organismo; liberando cantidades importantes al ambiente. Por otra parte, la disposición inadecuada de medicamentos caducos constituye una amenaza para la salud. De ahí la importancia de mitigar la contaminación que los medicamentos caducos generan mediante la reutilización de los mismos. El objetivo del presente trabajo fue utilizar un medicamento caduco a base de arcilla para la remoción de oxitetraciclina. El proceso experimental se realizó en el Laboratorio de Transferencia y Degradación de Contaminantes (LTDC) de la UACJ de agosto 2018 a marzo 2019 usando un sistema en lote. Los experimentos de sorción se realizaron a partir de una solución de TC $(50 \mathrm{ppm})$ usando un medicamento caduco a base de arcilla y caolín grado reactivo. Se tomaron alícuotas cada hora durante $8 \mathrm{~h}$ y posteriormente cada $24 \mathrm{~h}$ hasta alcanzar el equilibrio y se determinó la concentración de TC usando espectrofotometría UV/Vis (355 nm). Como resultados se logró una remoción del $52 \%$ de TC transcurridos 7 días de contacto con el medicamento caduco y por el contrario el caolín grado reactivo no presentó sorción. Se aplicaron modelos cinéticos de primer y pseudo-segundo orden y Elovich presentando un mejor ajuste al modelo de pseudo-segundo orden $(R=0.9698)$. Se concluyó que el medicamento es eficiente en la remoción de TC convirtiéndose en un material alternativo para el tratamiento de aguas contaminadas con antibióticos.

Palabras clave: Medicamento caduco, residuos peligrosos, sorción, tetraciclina.

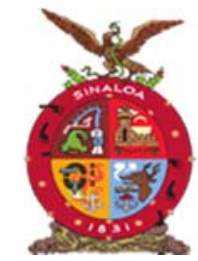

XVIII Congreso Internacional XXIV Congreso Nacional de Ciencias ambientales

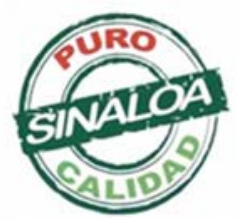

Mazatlán, Sinaloa 3-7 junio 2019
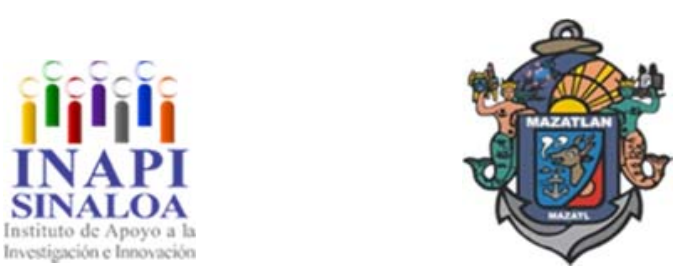

Tecnología y Biotecnología para el Tratamiento de Contaminantes y Biorremediación 

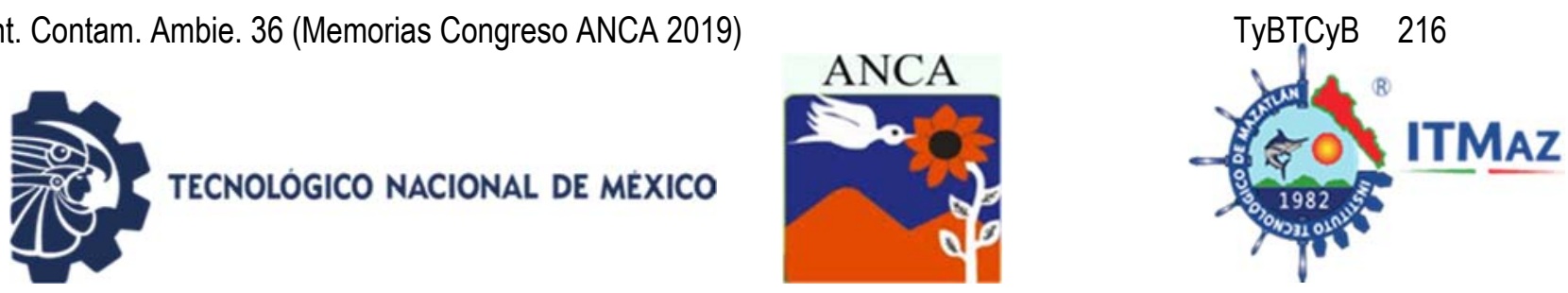

\title{
Oxytetracycline removal in aqueous media by clay-based pharmaceutical product
}

\author{
Torres Aquino M, Martínez Olivas A, Torres Pérez J \\ Laboratorio de Transferencia y Degradación de Contaminantes. \\ Universidad Autónoma de Ciudad Juárez, \\ Anillo Envolvente del Pronaf y Estocolmo S/N, Cd, Juárez, Chihuahua, México \\ *al151457@alumnos.uacj.mx
}

\begin{abstract}
Tetracycline (TC) is an antibiotic with worldwide wide use. Due to its essential structural and chemical characteristics, only $10-30 \%$ is metabolized by humans and animals; releasing important quantities to the aquatic environment through the discharge of wastewater.On the other hand, there is a problem about the final disposal of expired medicines; the inadequate disposal of these constitutes an additional threat to human health and ecosystems. Hence the importance of mitigating the pollution that the presence of outdated medicines can generate in the environment through proposals to reuse them before their final disposal. The aim of the present work was to use a clay-based expired medicine for oxytetracycline removal. The experimental process was carried out in the Pollution Transfer and Degradation Laboratory (LTDC) of the Autonomous University of Ciudad Juárez (Juárez, Chihuahua, Mexico) from August 2018 to March 2019 using a batch system with polyethylene reactors. The sorption experiments were performed from a TC solution $(50 \mathrm{ppm})$ and the concentration in the aqueous medium was determined by means of UV/Vis spectrophotometry $(355 \mathrm{~nm})$. An efficient removal of $52 \%$ of TC after 7 days of contact time with the expired clay-based drug was achieved. Kinetic models of first and pseudo-second order and Elovich were applied, presenting a better fit to the pseudo-second order model $(R=0.9698)$. It was concluded that the pharmaceutical product is efficient for the removal of TC, becoming an alternative material for the treatment of polluted water with antibiotics.
\end{abstract}

Keywords: Expired medicine, hazardous waste, sorption, tetracycline.

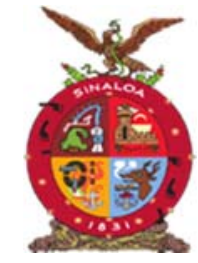

XVIII Congreso Internacional XXIV Congreso Nacional de Ciencias ambientales

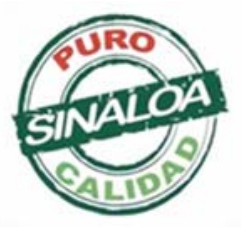

Mazatlán, Sinaloa 3-7 junio 2019
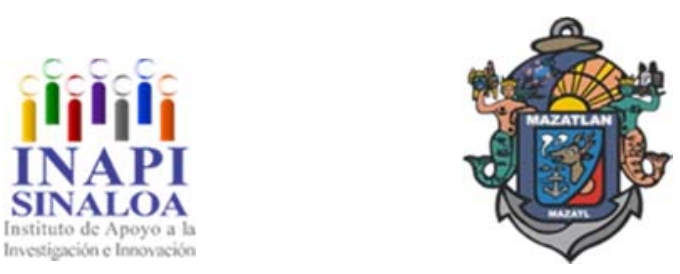

Tecnología y Biotecnología para el Tratamiento de Contaminantes y Biorremediación 

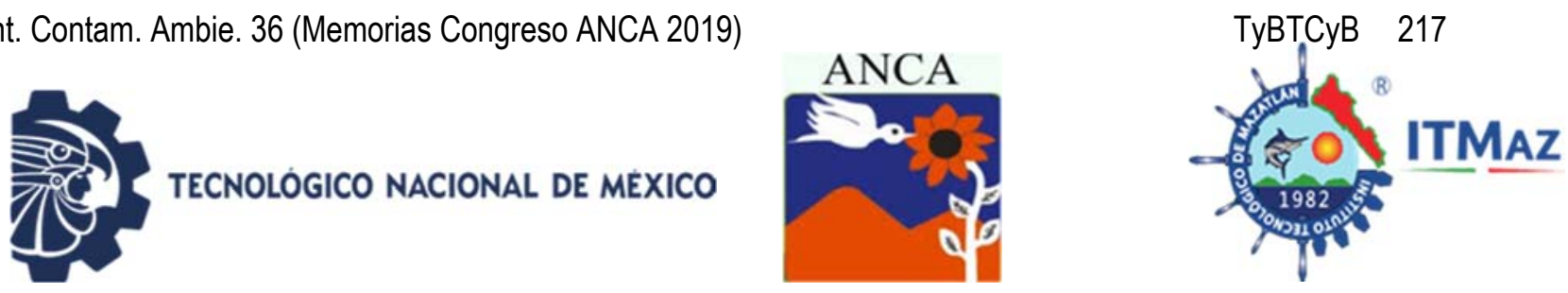

\title{
Eliminación de amarillo 5 con carbón activado de Carya illinoinensis mediante un proceso de sorción continuo
}

\author{
Torres Pérez J*, Aguirre Terrazas K, Carrasco Urrutia K \\ Laboratorio de Transferencia y Degradación de Contaminantes. \\ Universidad Autónoma de Ciudad Juárez, \\ Anillo Envolvente del Pronaf y Estocolmo S/N, Cd. Juárez, Chihuahua, México \\ *jonatan.torres@uacj.mx
}

\section{RESUMEN}

El amarillo 5 es un colorante azoico sintético altamente soluble en agua que ha sido utilizado como un aditivo en alimentos, bebidas, medicamentos y cosméticos. Estos compuestos, conocidos como contaminantes emergentes, pueden tener efectos negativos en la salud y en los ecosistemas. Se ha encontrado que uno de los métodos más eficaces para la eliminación de contaminantes orgánicos en el agua es la adsorción y que el adsorbente más eficaz es el carbón activado. El objetivo del presente trabajo fue evaluar la capacidad de sorción del carbón activado para la eliminación de un colorante azoico en un proceso de sorción en columna. Este proceso se realizó en el Laboratorio de Transferencia y Degradación de Contaminantes (LTDC) de la Universidad Autónoma de Ciudad Juárez (Juárez, Chihuahua, México) en el periodo de agosto 2017 a mayo 2018 aplicando un sistema en continuo usando columnas de vidrio empacadas con carbón activado preparado con Carya illinoinensis. Se empleó un flujo ascendente de $1.0 \mathrm{~mL} / \mathrm{min}$ de amarillo 5 (5 mg/L). El proceso de adsorción en la columna se analizó por medio de curvas de ruptura y saturación donde se logró una remoción entre 90 y $100 \%$ de colorante. Así mismo, se determinó volumen total de agua tratado $(500 \mathrm{~mL})$ con porcentajes de eliminación aceptable. Se aplicó el modelo de Thomas para obtener los parámetros isotérmicos. El proceso de adsorción en la columna, resultó ser eficiente para la remoción de amarillo 5 en medio acuoso usando un carbón activado sustentable preparado a partir de Carya illinoinensis.

Palabras clave: Carbón activado, colorantes azoicos, sorción en columna, yellow 5 .

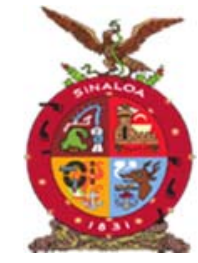

XVIII Congreso Internacional XXIV Congreso Nacional de Ciencias ambientales

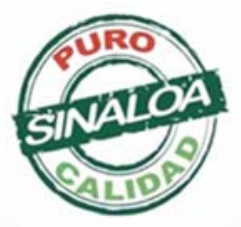

Mazatlán, Sinaloa 3-7 junio 2019
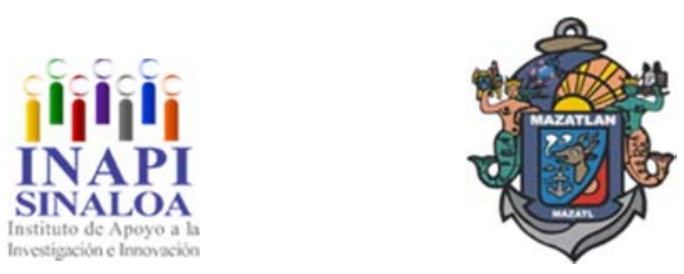

Tecnología y Biotecnología para el Tratamiento de Contaminantes y Biorremediación 

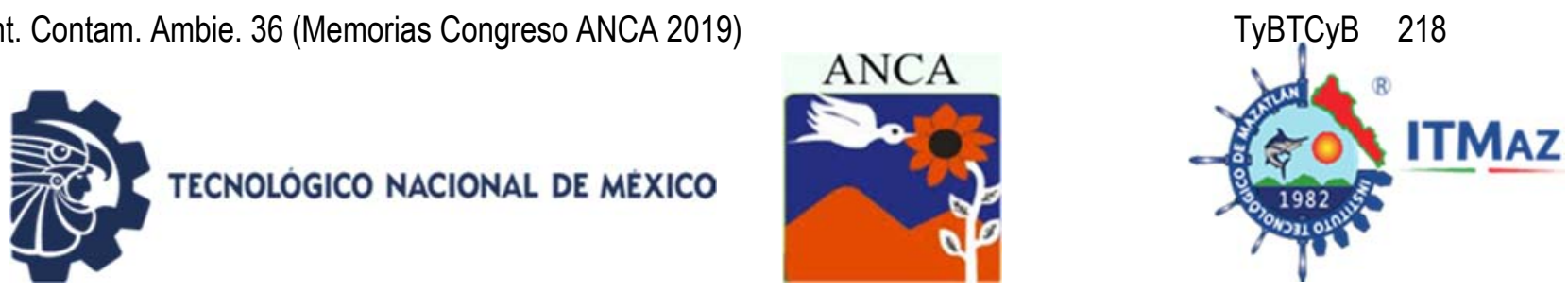

\title{
Removal of yellow 5 with activated charcoal from Carya illinoinensis through a continuous sorption process
}

\author{
Torres Pérez J*, Aguirre Terrazas K, Carrasco Urrutia K \\ Laboratorio de Transferencia y Degradación de Contaminantes. \\ Universidad Autónoma de Ciudad Juárez, \\ Anillo Envolvente del Pronaf y Estocolmo S/N, Cd. Juárez, Chihuahua, México \\ *jonatan.torres@uacj.mx
}

\begin{abstract}
Yellow 5 is a synthetic azo dye (yellow) highly soluble in water that has been used as additive in foods, beverages, medicines and cosmetics. These compounds, known as emerging pollutants have negative effects on health and ecosystems. It has been found that one of the most effective methods for the organic pollutants removal in water is adsorption and activated carbon like the most effective adsorbent. The objective of the present research was to evaluate the sorption capacity of activated carbon for the elimination of an azo dye in column sorption process. The process was carried out at the Pollutants Transfer and Degradation Laboratory (LTDC) at the Autonomous University of Ciudad Juárez (Juárez, Chihuahua, Mexico) from August 2017 to May 2018. The process was applied by a continuous system by using glass columns packed with activated carbon prepared with Carya illinoinensis. An upward flow of $1.0 \mathrm{~mL} / \mathrm{min}$ of yellow 5 (5 $\mathrm{mg} / \mathrm{L}$ ) was used. The adsorption process in the column was analyzed by rupture and saturation curves where $90-100 \%$ of dye removal was achieved. Likewise, a total volume of treated water $(500 \mathrm{~mL})$ was determined with acceptable elimination percentages. The Thomas model was applied to obtain the isothermal parameters. The adsorption process in the column was found to be efficient for the removal of yellow 5 in aqueous medium using a sustainable activated carbon prepared from Carya illinoinensis.
\end{abstract}

Keywords: Activated carbon, azo dyes, column sorption, yellow 5.

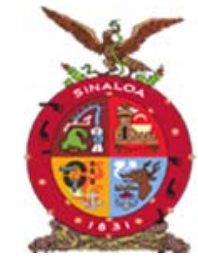

XVIII Congreso Internacional XXIV Congreso Nacional de Ciencias ambientales

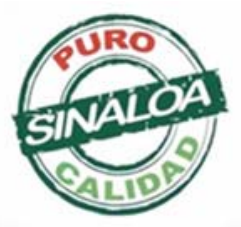

Mazatlán, Sinaloa 3-7 junio 2019
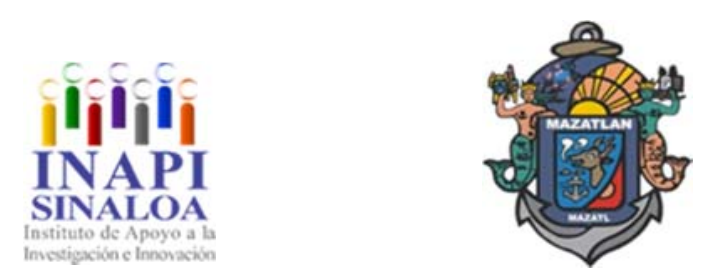

Tecnología y Biotecnología para el Tratamiento de Contaminantes y Biorremediación 

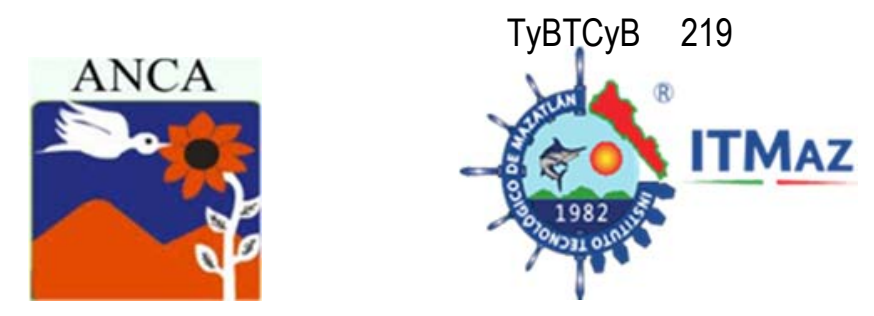

\title{
Biosorción de metales ( $\mathrm{Pb}, \mathrm{Cr}$, y $\mathrm{Cd}$ ), por el micelio de Pleurotus ostreatus en medio de cultivo líquido y sólido
}

\author{
Vallejo Aguilar $\mathrm{A}^{1}$, Marín Castro $\mathrm{MA}^{2}$, Ramos Cassellis $\mathrm{ME}^{3}$, \\ Tamaríz Flores $\mathrm{JV}^{1,2^{*}}$ \\ ${ }^{1}$ Posgrado en Ciencias Ambientales \\ 2Departamento de Investigación en Ciencias Agrícolas (DICA). \\ Benemérita Universidad Autónoma de Puebla \\ ${ }^{3}$ Facultad de Ingeniería Química BUAP \\ *jose.tamariz@correo.buap.mx
}

\begin{abstract}
RESUMEN
A nivel mundial el uso indiscriminado de productos metálicos vertidos en las aguas de uso agrícola ha generado una grave contaminación, los cuales no son biodegradables, por lo que es necesario establecer metodologías amigables para su descontaminación como es el caso de la micorremediación. Con el objetivo de: Valorar el potencial de adsorción del micelio del Pleurotus ostreatus en medio líquido, determinar las concentraciones inhibitorias del crecimiento miceliar en medio sólido y conocer el efecto causado en su morfología. Estudio realizado en el 2018 en el laboratorio de Biotecnología DICA instituto de Ciencias BUAP. La adsorción de metales en medio líquido se evaluó utilizando el medio de Kirk modificado, se cuantifico la concentración adsorbida durante 8 días en soluciones de $20 \mathrm{ppm}$ de cada metal. Para evaluar el efecto inhibitorio, se prepararon soluciones de $\mathrm{Pb}, \mathrm{Cr}$ y $\mathrm{Cd}$ a 20, 40, 60, 80 y $100 \mathrm{mg} / \mathrm{L}$, en agar papa dextrosa utilizando $50 \mathrm{~mL}$ de soluciones metálicas en las diferentes concentraciones, se colocó el micelio activado cultivado en granos de sorgo y se midió su crecimiento durante 8 días. Los cambios morfológicos se observaron en un microscopio electrónico de barrido. El micelio presento una biosorción de $\mathrm{Pb}$ del $78.5 \%$, de $\mathrm{Cr}$ $41.9 \%$ y de $\mathrm{Cd} 5.1 \%$. Ninguno de los metales en estudio presentó proceso inhibitorio a las concentraciones realizadas. Se observaron daños a nivel estructural del micelio. El uso de este micelio es eficaz en el proceso de remoción de metales.
\end{abstract}

Palabras claves: Biosorción, Pleurotus ostreatus, metales, micorremediación, aguas residuales.

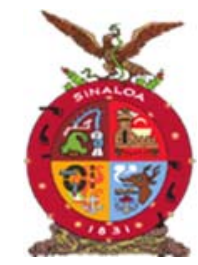

XVIII Congreso Internacional XXIV Congreso Nacional de Ciencias ambientales

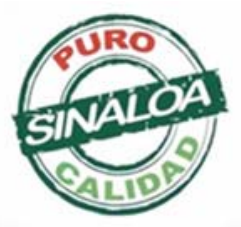

Mazatlán, Sinaloa 3-7 junio 2019
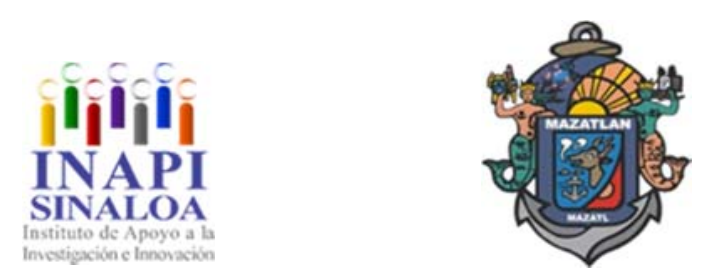

Tecnología y Biotecnología para el Tratamiento de Contaminantes y Biorremediación 

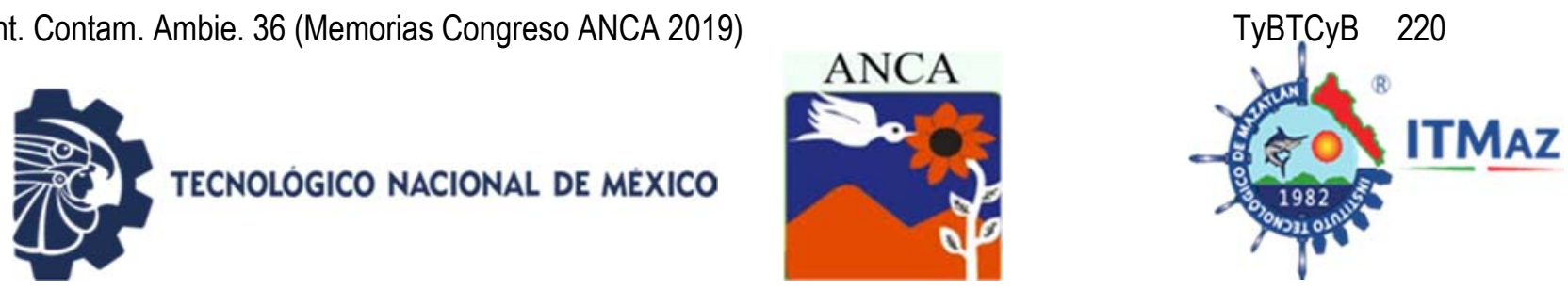

\title{
Biosorption of metals ( $\mathrm{Pb}, \mathrm{Cr}$, and $\mathrm{Cd})$, by the mycelium of Pleurotus ostreatus in liquid and solid culture medium
}

\author{
Vallejo Aguilar $\mathrm{A}^{1}$, Marín Castro $\mathrm{MA}^{2}$, Ramos Cassellis $\mathrm{ME}^{3}$, \\ Tamaríz Flores $\mathrm{JV}^{1,2^{*}}$ \\ ${ }^{1}$ Posgrado en Ciencias Ambientales \\ 2Departamento de Investigación en Ciencias Agrícolas (DICA). \\ Benemérita Universidad Autónoma de Puebla \\ ${ }^{3}$ Facultad de Ingeniería Química BUAP \\ *jose.tamariz@correo.buap.mx
}

\begin{abstract}
Globally, the indiscriminate use of metallic products discharged in waters for agricultural use has generated serious contamination, which are not biodegradable, so it is necessary to establish friendly methodologies for their decontamination, as is the case with microremediation. With the objective of: Assessing the adsorption potential of the Pleurotus ostreatus mycelium in liquid medium, determining the inhibitory concentrations of mycelial growth in solid medium and knowing the effect caused in its morphology. Study conducted in 2018 in the Biotechnology laboratory DICA Institute of Sciences BUAP. Adsorption of metals in liquid medium was evaluated using the modified Kirk medium, the adsorbed concentration was quantified for 8 days in 20 ppm solutions of each metal. To evaluate the inhibitory effect, solutions of $\mathrm{Pb}, \mathrm{Cr}$ and $\mathrm{Cd}$ were prepared at $20,40,60,80$ and $100 \mathrm{mg} / \mathrm{L}$, in papa dextrose agar using $50 \mathrm{~mL}$ of metal solutions at the different concentrations, the cultivated activated mycelium was placed in sorghum grains and its growth was measured for 8 days. Morphological changes were observed in a scanning electron microscope. The mycelium presented a biosorption of $\mathrm{Pb}$ of $78.5 \%, \mathrm{Cr} 41.9 \%$ and $\mathrm{Cd} 5.1 \%$. None of the metals under study presented an inhibitory process at the concentrations performed. Structural damage of the mycelium was observed. The use of this mycelium is effective in the metal removal process.
\end{abstract}

Keywords: Biosorption, Pleurotus ostreatus, metals, microremediation, wastewater.

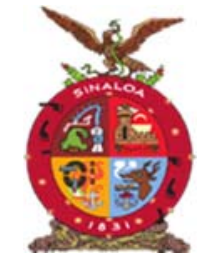

XVIII Congreso Internacional XXIV Congreso Nacional de Ciencias ambientales

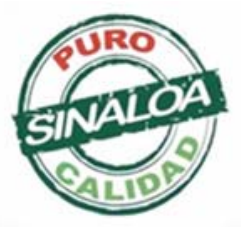

Mazatlán, Sinaloa 3-7 junio 2019
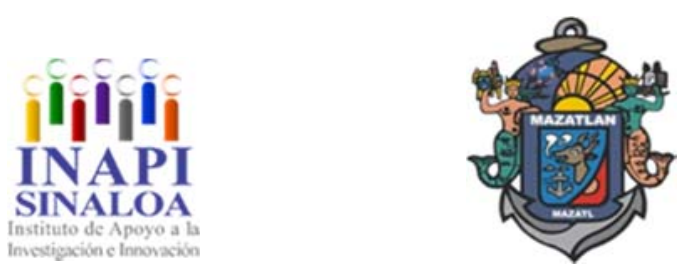

Tecnología y Biotecnología para el Tratamiento de Contaminantes y Biorremediación 

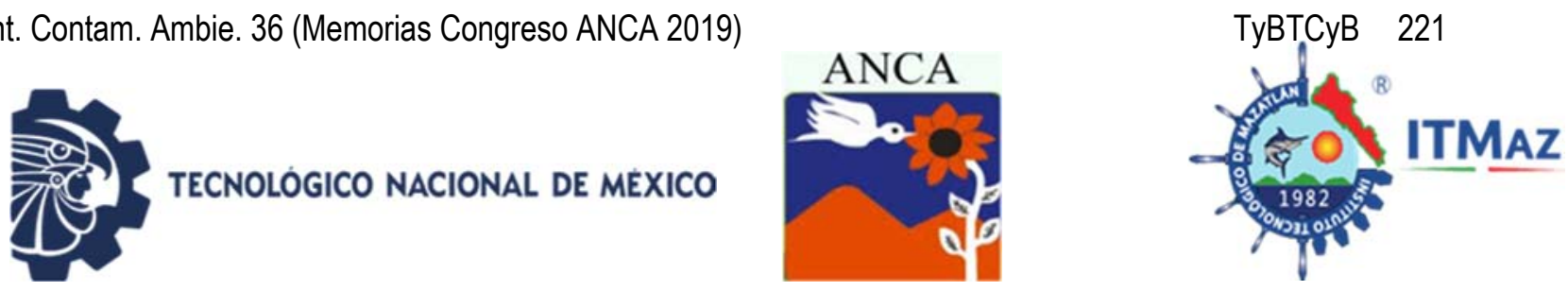

\title{
Evaluación de la eficiencia de un filtro verde en la disminución de sólidos sedimentables
}

\author{
Varela Mata K, Martínez Ávila A, Nájera Bastida A, Chávez Soto M* \\ Unidad Profesional Interdisciplinaria.Ingeniería Campus Zacatecas. \\ Instituto Politécnico Nacional \\ *mjchavezs@ipn.mx
}

\begin{abstract}
RESUMEN
Un filtro verde es un sistema formado por terreno cubierto de cultivos o plantaciones forestales, sobre el que se distribuyen aguas residuales procedentes de núcleos urbanos, con el fin de conseguir su depuración mediante la acción conjunta del suelo, microorganismos y plantas. Una planta de tratamiento de agua residual involucra una inversión económica para su construcción, operación y mantenimiento, que en ocasiones no es viable dado que la población rural o la densidad poblacional no justifican el monto del proyecto para aquellos responsables de las descargas de aguas residuales, es por esto, que se buscan alternativas de depuración utilizando los recursos naturales. Determinar la eficiencia en la disminución de los sólidos suspendidos (SS) de un agua residual doméstica mediante un filtro verde. Se construyó un filtro verde operado en condiciones ambientales con una configuración de mamparas utilizando dos especies maderables: mezquite (Prosopis laevigata) y pino ocote chino (Pinus leiophylla), monitoreado durante cuatro semanas en el año 2019. El influente fue agua residual proveniente de la UPIIZ y se utilizó la metodología de la norma NMX-AA-004-SCFI-2013. El efluente del sistema filtro verde se comparó con el valor del límite máximo permisible para SS establecido en la NOM-001SEMARNAT-1996, obteniendo eficiencias de remoción entre 88.34 y $95.20 \%$. Se obtuvo una eficiencia promedio de $93.04 \%$ de remoción de sólidos sedimentables por el sistema de filtro verde, y el $100 \%$ de los valores individuales cumplieron con los límites establecidos en la NOM-001-SEMARNAT-1996.
\end{abstract}

Palabras clave: Especies maderables, efluente, tratamiento.

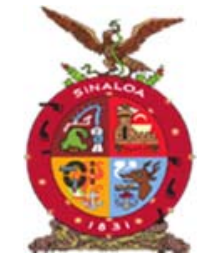

XVIII Congreso Internacional XXIV Congreso Nacional de Ciencias ambientales

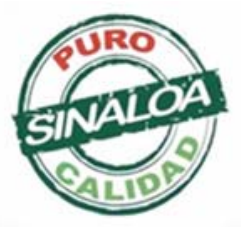

Mazatlán, Sinaloa 3-7 junio 2019
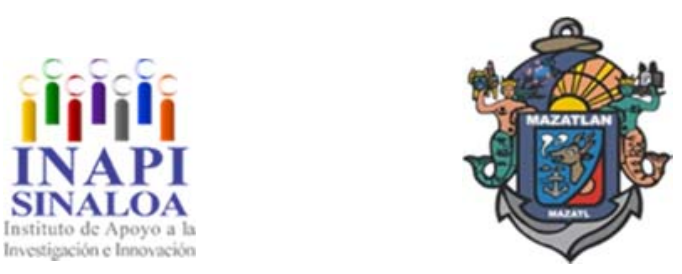

Tecnología y Biotecnología para el Tratamiento de Contaminantes y Biorremediación 

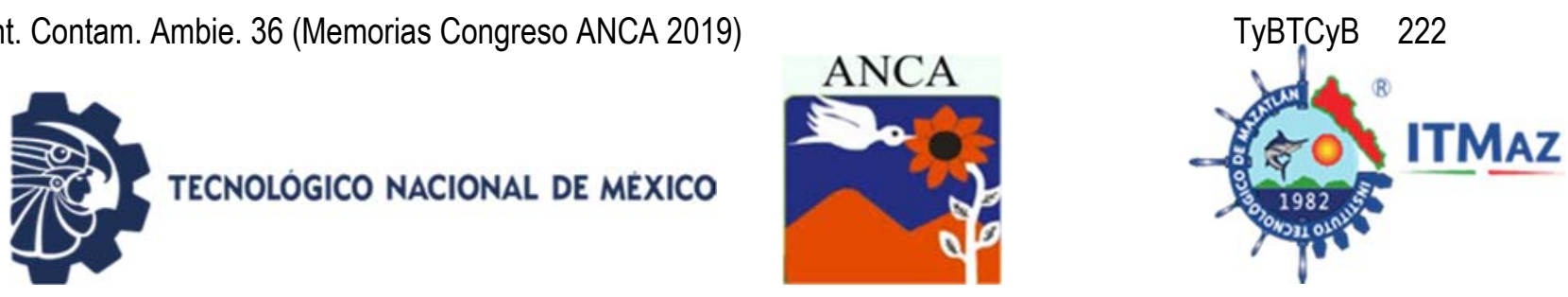

\title{
Evaluation of the efficiency of a green filter in the reduction of sedimentable solids
}

\author{
Varela Mata K, Martínez Ávila A, Nájera Bastida A, Chávez Soto M* \\ Unidad Profesional Interdisciplinaria.Ingeniería Campus Zacatecas. \\ Instituto Politécnico Nacional \\ *mjchavezs@ipn.mx
}

\begin{abstract}
A green filter is a system formed by land covered by crops or forest plantations, on which wastewater from urban centers is distributed, in order to achieve its purification through the joint action of soil, microorganisms and plants. A wastewater treatment plant involves an economic investment for its construction, operation and maintenance, which is sometimes not feasible given that the rural population or population density does not justify the project amount for those responsible for wastewater discharges, this is why they seek alternative purification using natural resources. Determine the efficiency in the reduction of suspended solids (SS) of a domestic wastewater by means of a green filter. A green filter was built under environmental conditions with a configuration of screens using two wooden tree species: mezquite (Prosopis laevigata) and Chinese ocote pine (Pinus leiophylla), monitored for four weeks in 2019. The influent was wastewater from the UPIIZ and the methodology of the standard NMX-AA-004-SCFI-2013 was used. The effluent from the green filter system was compared with the value of the maximum permissible limit for SS established in the NOM-001-SEMARNAT-1996, obtaining removal efficiencies between 88.34 and $95.20 \%$. An average efficiency of $93.04 \%$ removal of sedimentable solids was obtained by the green filter system, and $100 \%$ of the individual values complied with the limits established in the NOM-001-SEMARNAT-1996.
\end{abstract}

Keywords: Timber species, effluent, treatment.

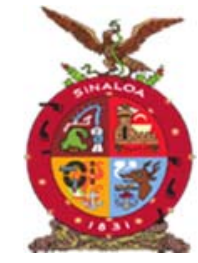

XVIII Congreso Internacional XXIV Congreso Nacional de Ciencias ambientales

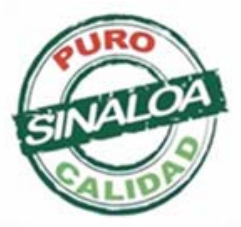

Mazatlán, Sinaloa 3-7 junio 2019
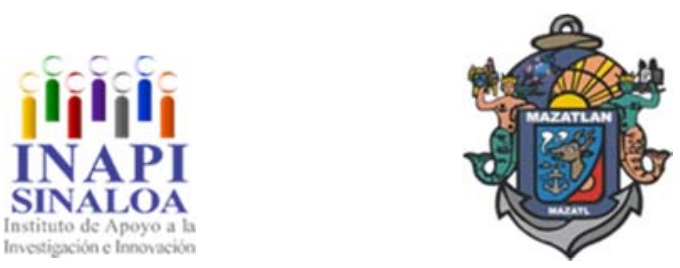

Tecnología y Biotecnología para el Tratamiento de Contaminantes y Biorremediación 

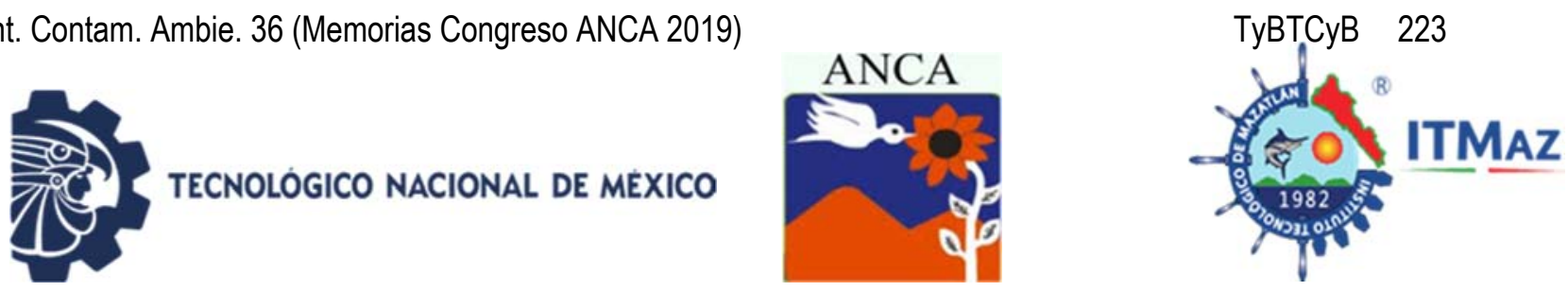

\title{
Remediación de suelos contaminados por metales pesados utilizando la tecnología de lavado de suelos
}

\author{
Varela Ruíz M*, Montoya Murillo J, Aguilera Flores M \\ Ingeniería Ambiental. Unidad Profesional Interdisciplinaria de Ingeniería. \\ Instituto Politécnico Nacional. Campus Zacatecas \\ *mvarelar1401@alumno.ipn.mx
}

\section{RESUMEN}

Las actividades industriales a grande escala como la minería cuentan con un residuo en su proceso denominado "jal". Estos residuos, en la mayoría de los casos, al momento de disponerse, no se encuentran regulados y si la concentración de los metales está por encima de la normativa nacional, puede causar efectos negativos graves en la salud de la población, así como en el ambiente, generalmente contribuyendo este último a la contaminación de aguas superficiales y de acuíferos e impedimentos en el crecimiento de las especies cultivadas en suelos agrícolas, siendo esta última una de las mayores actividades económicas en el Estado de Zacatecas. Por lo tanto, en orden de estudiar la técnica de remediación de Lavado de Suelos, fue muestreado un suelo con jal que se encuentra en el municipio de Zacatecas de una compañía minera, para su posterior caracterización y analizando la concentración de $\mathrm{Pb}$ previa y posteriormente al tratamiento mediante absorción atómica. Los ensayos fueron realizados mediante la metodología de inundación utilizando tres agentes químicos (ácido etilen diamino tetra acético EDTA, ácido cítrico $\mathrm{C}_{6} \mathrm{H}_{8} \mathrm{O}_{7}$ y ácido clorhídrico $\mathrm{HCl}$ ) como extractantes. La mayor eficiencia de remoción de $\mathrm{Pb}$ en suelo se obtuvo con EDTA $(65 \% \pm 1)$, posteriormente con $\mathrm{HCl}(37 \% \pm 4)$ y con $\mathrm{C}_{6} \mathrm{H}_{8} \mathrm{O}_{7}(24 \% \pm 2)$, demostrándose que el EDTA tiene mayor potencial para el lavado de Suelo con $\mathrm{Pb}$.

Palabras Clave: Ácido cítrico, ácido clorhídrico, EDTA, normativa ambiental.

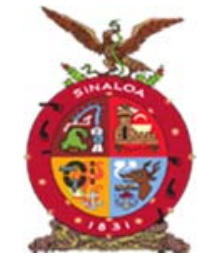

XVIII Congreso Internacional XXIV Congreso Nacional de Ciencias ambientales

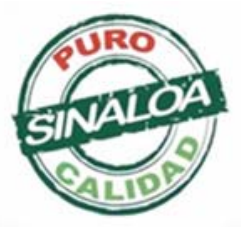

Mazatlán, Sinaloa 3-7 junio 2019
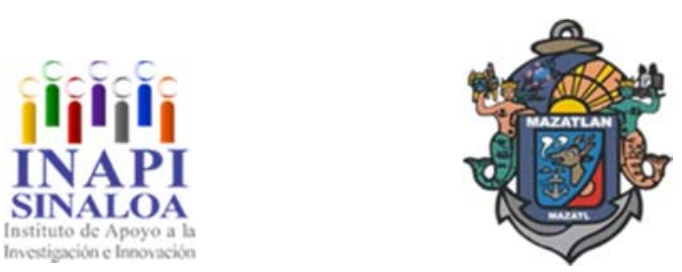

Tecnología y Biotecnología para el Tratamiento de Contaminantes y Biorremediación 

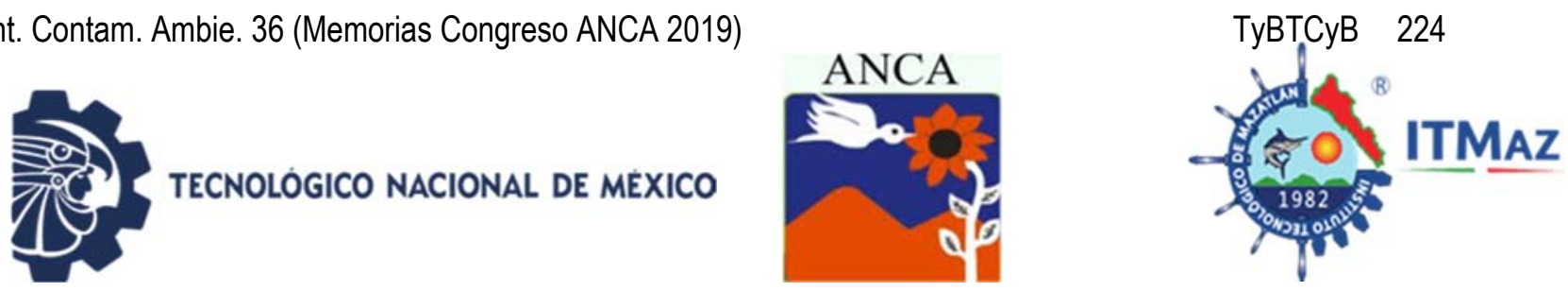

\title{
Remediation of soils contaminated by metals using soil-washing technology
}

\author{
Varela Ruíz M*, Montoya Murillo J, Aguilera Flores M \\ Ingeniería Ambiental. Unidad Profesional Interdisciplinaria de Ingeniería. \\ Instituto Politécnico Nacional. Campus Zacatecas \\ *mvarelar1401@alumno.ipn.mx
}

\begin{abstract}
Big scale industrial activities like mining, have a residue called "tailing". If these deposits are not regulated and heavy metal concentrations are above normativity, these could cause serious negative effects on people's health, and more likely tend to have adverse environmental impacts, for example, it contributes on superficial and aquifer water contamination and when this pollutant gets to farming soils, these toxic elements tend to block some species biological grow, being this economic activity one of the most important in Zacatecas. Therefore, in order to study the Soil Washing remediation technique, a sample was taken from a mining corporation site in the city of Zacatecas. Soil's physiochemical parameters were characterized and $\mathrm{Pb}$ concentration was analyzed before and after through atomic absorption. 3 removal chemical agents (ethylene diamine tetraacetic acid EDTA, citric acid $\mathrm{C}_{6} \mathrm{H}_{8} \mathrm{O}_{7}$ and chlorhydric acid $\mathrm{HCl}$ ) where tested by flood technique. The highest removal efficiency was obtained with EDTA (65\% $\pm 1)$, following $\mathrm{HCl}(37 \% \pm 4)$ and then $\mathrm{C}_{6} \mathrm{H}_{8} \mathrm{O}_{7}(24 \% \pm 2)$, showing that EDTA has the most potential use in removal of $\mathrm{Pb}$ with Soil Washing.
\end{abstract}

Keywords: Chlorhydric acid, citric acid, ethylenediaminetetraacetic acid, lead, normativity.

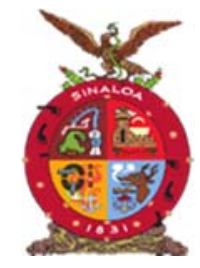

XVIII Congreso Internacional XXIV Congreso Nacional de Ciencias ambientales

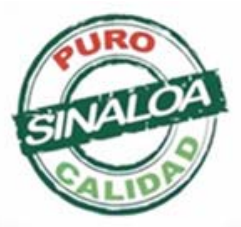

Mazatlán, Sinaloa 3-7 junio 2019
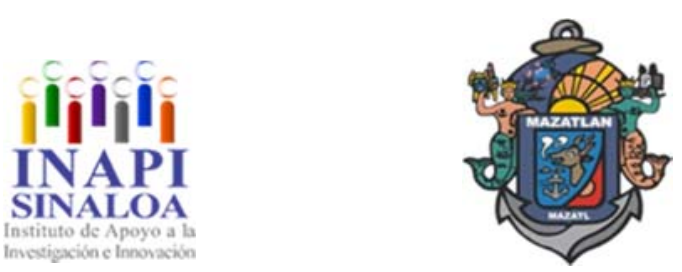

Tecnología y Biotecnología para el Tratamiento de Contaminantes y Biorremediación 

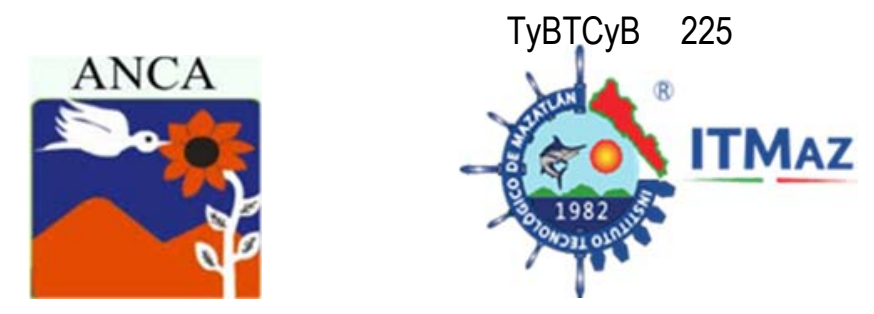

\title{
Utilización de Nanopartículas Biosintetizadas de Au en la Foto-reducción de $\mathrm{CO}_{2}$
}

\author{
Vázquez Cuchillo $\mathrm{O}^{1^{*}}$, Herrera Perez $\mathrm{JL}^{2}$, Moreno Luna FB², \\ Bañuelos Romero $\mathrm{F}^{3}$, Morales Juarez LR ${ }^{1}$, Flores Sanchez $\mathrm{O}^{1}$ \\ ${ }^{1}$ Instituto Tecnológico de Puebla/Tecnológico Nacional de México, \\ Av. Tecnológico 420, Maravillas, 72220 Puebla, Pue \\ 2Unidad Profesional Interdisciplinaria en Ingeniería y Tecnologías Avanzadas, \\ Instituto Politécnico Nacional \\ ${ }^{3}$ Benemérita Universidad Autónoma de Puebla, Instituto de Ciencias \\ *odilon.vazquez@itpuebla.edu.mx
}

\section{RESUMEN}

El calentamiento global es un problema que afecta a la vida de la tierra y evitarlo se ha vuelto una prioridad. En este trabajo se estudia la factibilidad de utilizar nanopartículas de $\mathrm{Au}$ depositadas en $\mathrm{TiO}_{2}$ como un excelente fotocatalizador para la conversión de $\mathrm{CO}_{2}$ a otros productos y ser una alternativa viable para la utilización de este gas de efecto invernadero. Las nanopartículas se sintetizaron utilizando extractos en frio de Agave potatorum, para lo cual se mezclo un $\mathrm{mL}$ de extracto con $10 \mathrm{~mL}$ de $1.0 \mathrm{mM}$ de solución de $\mathrm{HAuCl}_{4}$, La mezcla resultante fue puesta en reflujo a temperatura de $60^{\circ} \mathrm{C}$ a diferentes tiempos de reacción. Los resultados de espectroscopia de Uv-Vis muestran la banda característica de nanopartículas de Au a los $540 \mathrm{~nm}$, confirmándose con análisis de XRD y TED. Los tamaños obtenidos varían según el tiempo de reacción. Posteriormente las nanopartículas fueron impregnadas en $\mathrm{TiO}_{2}$ para ser utilizadas en el sistema de fotorreacción en solución acuosa. El sistema fue saturado con $\mathrm{CO}_{2}$, los resultados muestran una fuerte actividad en la foto conversión de $\mathrm{CO}_{2}$ en función del tamaño de partículas, obtenidas convirtiéndose en una buena alternativa para la conversión de $\mathrm{CO}_{2}$ hacia otros productos. Se agradece el apoyo recibido por el proyecto TecNM 6559.18-P.

Palabras clave: Fotocatálisis, dióxido de carbono, $\mathrm{Au}$, nanopartículas, $\mathrm{TiO}_{2}$.

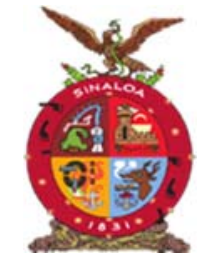

XVIII Congreso Internacional XXIV Congreso Nacional de Ciencias ambientales

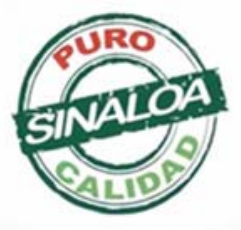

Mazatlán, Sinaloa 3-7 junio 2019
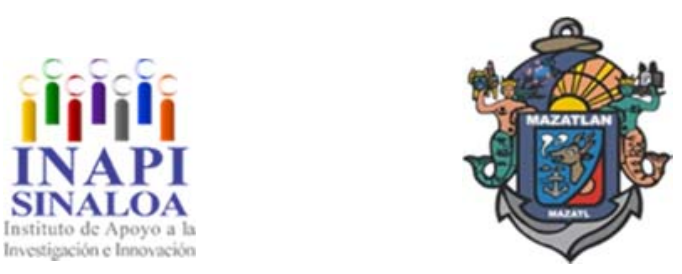

Tecnología y Biotecnología para el Tratamiento de Contaminantes y Biorremediación 

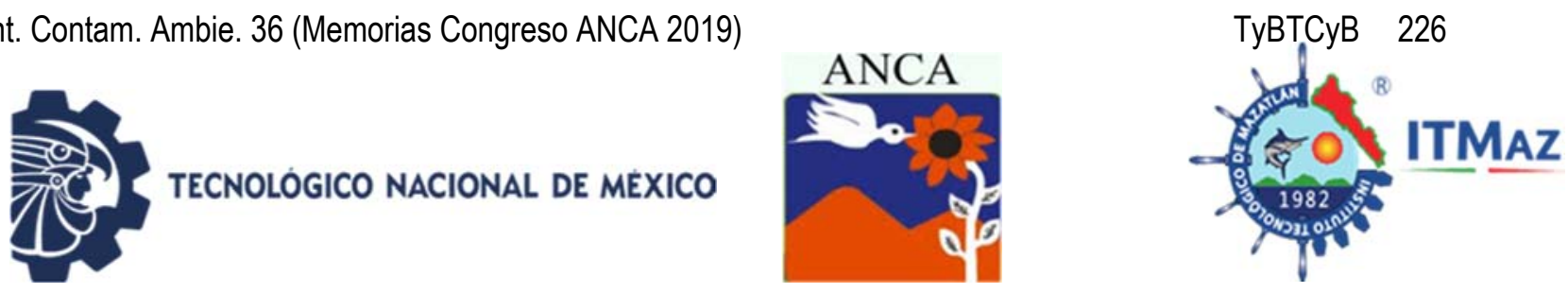

\title{
Utilization of biosintetized nanoparticles of $\mathrm{Au}$ in $\mathrm{CO}_{2}$ photoreduction
}

\author{
Vázquez Cuchillo $\mathrm{O}^{1^{*}}$, Herrera Perez $\mathrm{JL}^{2}$, Moreno Luna FB ${ }^{2}$, \\ Bañuelos Romero $\mathrm{F}^{3}$, Morales Juarez LR ${ }^{1}$, Flores Sanchez $\mathrm{O}^{1}$ \\ ${ }^{1}$ Instituto Tecnológico de Puebla/Tecnológico Nacional de México, \\ Av. Tecnológico 420, Maravillas, 72220 Puebla, Pue \\ 2Unidad Profesional Interdisciplinaria en Ingeniería y Tecnologías Avanzadas, \\ Instituto Politécnico Nacional \\ ${ }^{3}$ Benemérita Universidad Autónoma de Puebla, Instituto de Ciencias \\ *odilon.vazquez@itpuebla.edu.mx
}

\begin{abstract}
Global warming is a problem that translates into the life of the earth and has become a priority, so this work shows the feasibility of using Au nanoparticles deposited in $\mathrm{TiO}_{2}$ as an excellent photocatalyst for the conversion of $\mathrm{CO}_{2}$ to other products and be a viable alternative for the use of greenhouse gas. The nanoparticles were synthesized using cold extracts of Agave potatorum, for which $1 \mathrm{~mL}$ of extract was mixed with $10 \mathrm{~mL}$ of $1.0 \mathrm{mM}$ of the solution of $\mathrm{HAuCl}_{4}$. The resulting mixture was refluxed at a temperature of $60^{\circ} \mathrm{C}$ at different reaction time the mixture is the result of a temperature of $60^{\circ} \mathrm{C}$ at different times of reaction. The results of Uv-Vis spectroscopy show the characteristic band of the Au nanoparticles at $540 \mathrm{~nm}$, confirming with XRD and TED analysis. The sizes obtained vary according to the reaction time. Subsequently, the nanoparticles were impregnated in $\mathrm{TiO}_{2}$ to be used in the photoreaction system in aqueous solution. The system was saturated with $\mathrm{CO}_{2}$, the results show a strong activity in the photo conversion of $\mathrm{CO}_{2}$ depending on the particle size obtained becoming an alternative for the conversion of $\mathrm{CO}_{2}$ to other products and be an alternative for the use of gas greenhouse. This work was financially supported by TecMEX project 6559.18-P.
\end{abstract}

Keywords: Photocatalysis, carbon dioxide, Au, nanoparticles, TiO2.

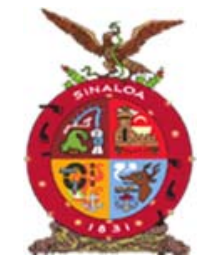

XVIII Congreso Internacional XXIV Congreso Nacional de Ciencias ambientales

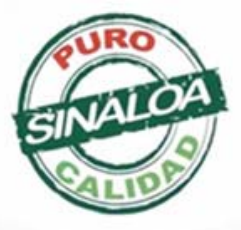

Mazatlán, Sinaloa 3-7 junio 2019
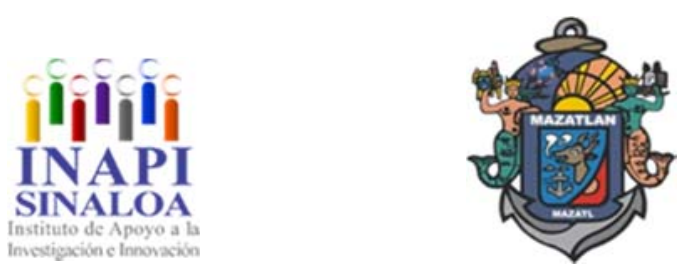

Tecnología y Biotecnología para el Tratamiento de Contaminantes y Biorremediación 

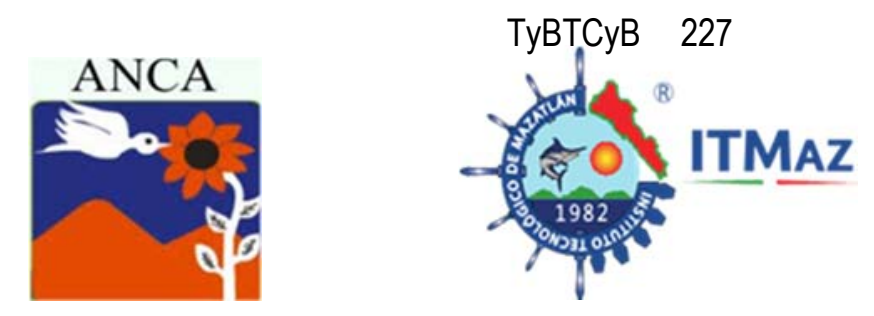

\title{
Efecto de la Toxicidad del Queroseno en Aspergillus fumigatus en el crecimiento en medio líquido para un proceso de biorremediación
}

\author{
Vázquez Martínez $A^{1 *}$, Ferrera Cerrato $R^{2}$, Ríos Leal $E^{1}$, \\ Rodríguez Casasola $\mathrm{F}^{3}$, Esparza García $\mathrm{F}^{1}$ \\ ${ }^{1}$ Cinvestav Instituto Politécnico Nacional. \\ Av. Instituto Politécnico Nacional 2508, Col. San Pedro Zacatenco, CDMX. \\ ${ }^{2}$ COLPOS. Carretera México-Texcoco Km. 36.5, Montecillo, Texcoco, \\ ${ }^{3}$ ENCB. Unidad Profesional Lázaro Cárdenas Prolongación Manuel Carpio y \\ Plan de Ayala S/N Col. Santo Tomás Alc. Miguel Hidalgo, CDMX. \\ *ady.vazquezm@cinvestav.mx
}

\section{RESUMEN}

La contaminación ambiental ha afectado a los ecosistemas poniendo en riesgo los recursos naturales. La biorremediación es una herramienta útil y viable para la detoxificación de los ecosistemas, con bajos costos y bajo impacto ambiental. Dicha biotecnología hace uso del metabolismo de los microorganismos autóctonos del suelo para la degradación de los contaminantes. Los hongos filamentosos son de los microorganismos más competentes para la biodegradación de contaminantes en los ecosistemas. Se llevó acabo la estandarización del inóculo de Aspergillus fumigatus, con el objeto de poder emplearla en un proceso de remediación, en líquido y con proceso y tiempo de germinación de las esporas a $30^{\circ} \mathrm{C}$ con agitación de $130 \mathrm{rpm}$ durante $216 \mathrm{~h}$ (crecimiento) y $24 \mathrm{~h}$ (germinación), suplementado con glucosa y queroseno para determinar el efecto tóxico en el microorganismo. Al evaluar el crecimiento, se observó un $84 \%$ de inhibición por efecto del queroseno, que además cambió su morfología a esféricos de menor tamaño, más compactos e hifas cortas. El rendimiento celular $\left(\mathrm{Y}^{\mathrm{x}} / \mathrm{s}\right)$ con glucosa fue de $0.35 \mathrm{y}$ con queroseno 0.23 . En el caso de la germinación la fase lag se ve retrasada hasta las 18 h, y un $67 \%$ de inhibición en la germinación. Bajo las mismas condiciones de cultivo, se determinaron los hidrocarburos totales por cromatografía de gases, dando un $85 \%$ de degradación. Los resultados indican que el crecimiento del microorganismo se ve afectado por el efecto toxico del queroseno, pero la tasa de remoción alcanza altos niveles de remoción presentando resistencia al efecto inhibidor.

Palabras clave: Biorremediación, hongos filamentosos, hidrocarburos.

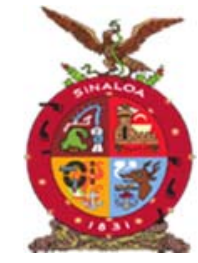

XVIII Congreso Internacional XXIV Congreso Nacional de Ciencias ambientales

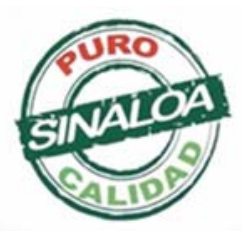

Mazatlán, Sinaloa 3-7 junio 2019
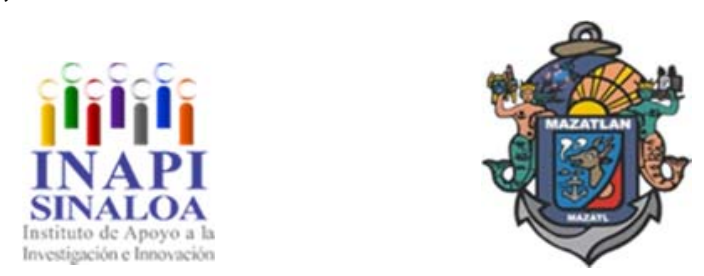

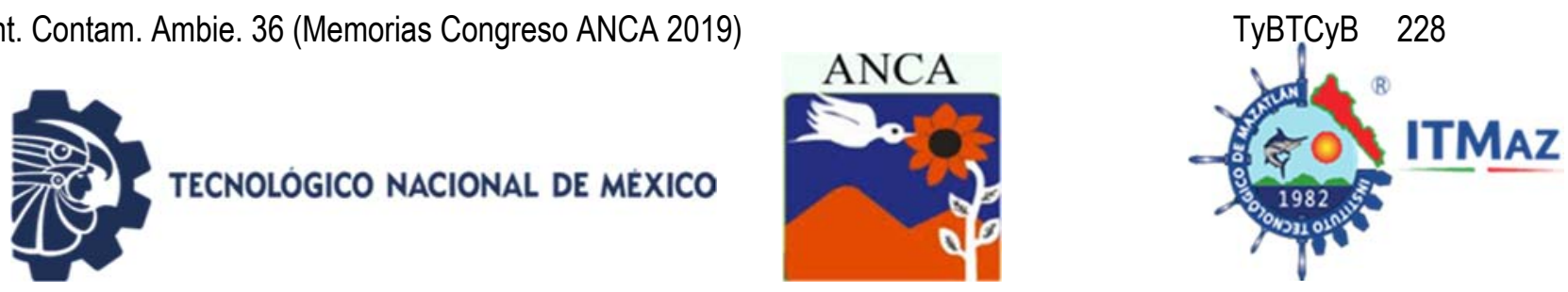

The effect of kerosene in toxicity in Asperguillus fumigatus on growth in liquid medium for a bioremediation process

\author{
Vázquez Martínez $A^{1 *}$, Ferrera Cerrato $R^{2}$, Ríos Leal $E^{1}$, \\ Rodríguez Casasola $\mathrm{F}^{3}$, Esparza García $\mathrm{F}^{1}$
}

${ }^{1}$ Cinvestav Instituto Politécnico Nacional.

Av. Instituto Politécnico Nacional 2508, Col. San Pedro Zacatenco, CDMX.

${ }^{2}$ COLPOS. Carretera México-Texcoco Km. 36.5, Montecillo, Texcoco,

${ }^{3}$ ENCB. Unidad Profesional Lázaro Cárdenas Prolongación Manuel Carpio y

Plan de Ayala S/N Col. Santo Tomás Alc. Miguel Hidalgo, CDMX.

*ady.vazquezm@cinvestav.mx

\begin{abstract}
Environmental pollution has affected ecosystems placing natural resources at risk. Bioremediation is a useful and viable tool for the detoxification of ecosystems, with low costs and zero environmental impact. This cleaning technology makes use of the metabolism of the autochthonous microorganisms of the soil for the degradation of pollutants. Filamentous fungi are competent microorganisms for the degradation of pollutants in the ecosystem. A strain of Aspergillus fumigatus, in order to be used in a remediation process, was carried out the standardization of the inoculum, culture in liquid and process and time of germination of the spores at $30^{\circ} \mathrm{C}$ with agitation of $130 \mathrm{rpm}$ during $216 \mathrm{~h}$ (growth) and $24 \mathrm{~h}$ (germination) using glucose and kerosene to determine the toxic effect on the microorganism. When comparing the growth in both, $84 \%$ inhibition was obtained by the effect of kerosene, changing its morphology with smaller, more compact spherical pellets and shorter hyphae. The cellular yield $\left(\mathrm{Y}^{\mathrm{x}} / \mathrm{s}\right)$ with glucose was 0.35 and with kerosene 0.23 . In the case of germination the lag phase is delayed until $18 \mathrm{~h}$, the comparison yields a $67 \%$ inhibition in germination. Under the same culture conditions, the total hydrocarbons were determined by gas chromatography, giving $85 \%$ degradation. The results indicate that the growth of the microorganism is affected by the toxic effect of kerosene, but the removal rate reaches high levels presenting resistance to the effect.
\end{abstract}

Keywords: Bioremediation, hydrocarbons, filamentous fungi.

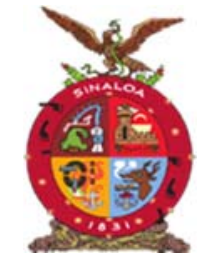

XVIII Congreso Internacional XXIV Congreso Nacional de Ciencias ambientales

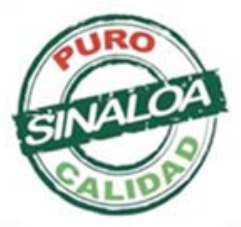

Mazatlán, Sinaloa 3-7 junio 2019
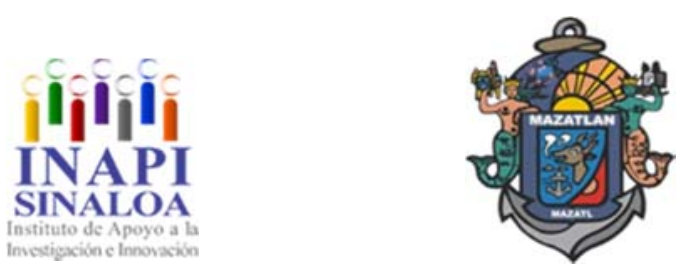

Tecnología y Biotecnología para el Tratamiento de Contaminantes y Biorremediación 

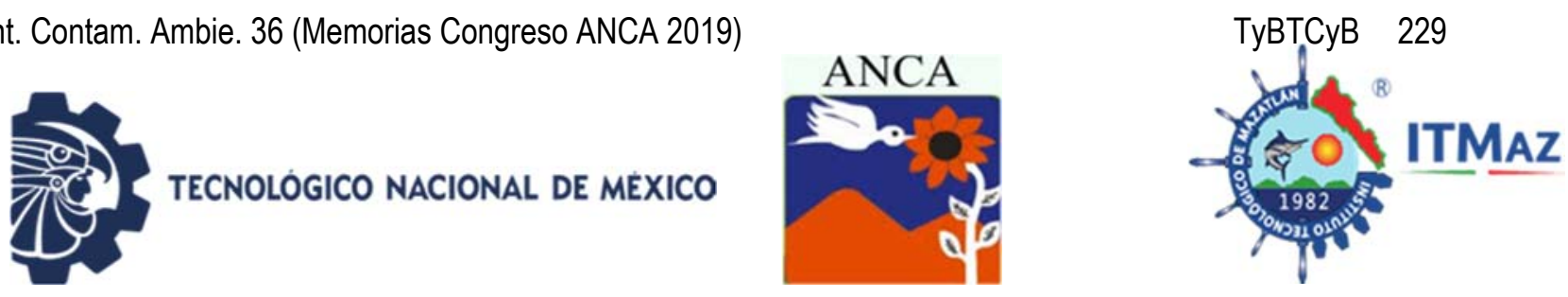

\title{
Control de erosión y recuperación de cubierta vegetal empleando Cylindropuntia tunicata en el Parque Ecológico Cubitos, Hidalgo
}

\author{
Vega Torres A*, García Amador E, García Solano A \\ Laboratorio de Contaminación y Fitorremediación de Suelos. \\ Facultad de Estudios Superiores Zaragoza edificio L-3 Campus II, \\ Universidad Nacional Autónoma de México, \\ Batalla 5 de mayo $\mathrm{S} / \mathrm{N}$, esquina Fuerte de Loreto, Col Ejército de Oriente, \\ Delegación Iztapalapa, D.F., México \\ *vegatorres_biologia@outlook.com
}

\begin{abstract}
RESUMEN
En el Parque Ecológico Cubitos hay una zona con una serie de factores que pone en riesgo su recuperación, esto hace que tenga una grave erosión del suelo y por consiguiente pérdida de la cubierta vegetal. El objetivo de este trabajo fue retener el suelo de una zona quemada y fomentar la recuperación de la cubierta vegetal utilizando Cylindropuntia tunicata. Se aplicó un método integral de intervención que consiste en la propagación tanto in situ como ex situ utilizando yute con el fin de acelerar la recuperación de la zona. Para la estabilización del terreno se emplearon barreras de rocas perpendiculares a la pendiente por cada individuo. El seguimiento del proceso se llevó a cabo mediante visitas periódicas desde el mes de Abril hasta Noviembre del año 2018 con registros del crecimiento, los cuales no crecieron en la época de secas dada la herbivoría y la contracción de algunos individuos en cambio en la época húmeda solo crecieron en promedio 1 $\mathrm{cm}$, con una supervivencia baja. El uso de geotextiles ayudó al crecimiento de los individuos. Finalmente, al emplear las barreras de rocas se observó la retención de suelo lo cual permitió el establecimiento de cubierta vegetal acompañante.
\end{abstract}

Palabras clave: Suelo, retención, bioingeniería, geotextiles.

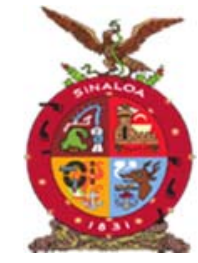

XVIII Congreso Internacional XXIV Congreso Nacional de Ciencias ambientales

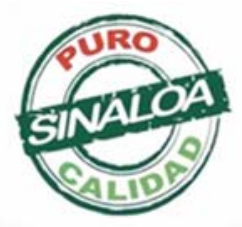

Mazatlán, Sinaloa 3-7 junio 2019
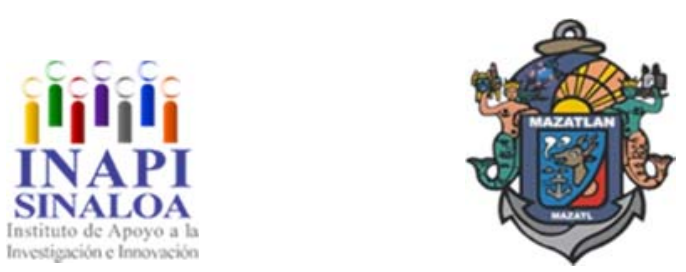

Tecnología y Biotecnología para el Tratamiento de Contaminantes y Biorremediación 

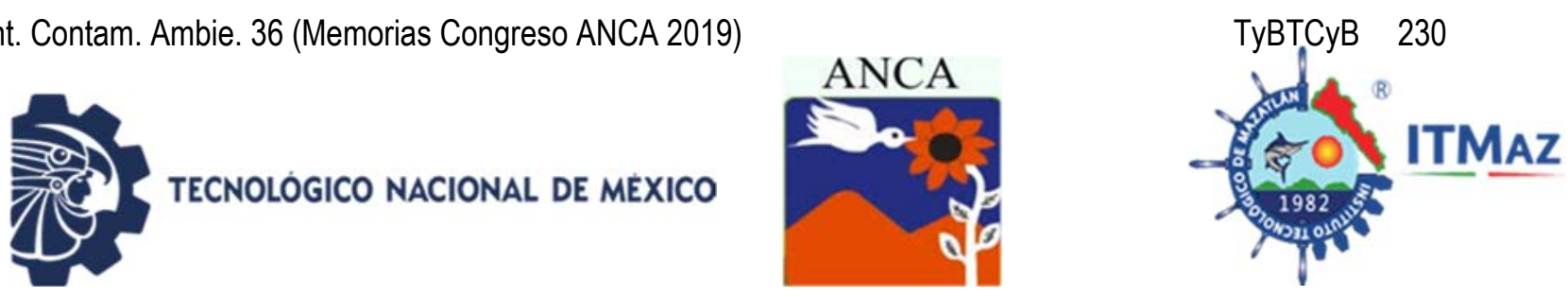

\title{
Erosion control and recovery of vegetable covering using Cylindropuntia tunicata in the Ecological Park Cubitos, Hidalgo
}

\author{
Vega Torres A*, García Amador E, García Solano A \\ Laboratorio de Contaminación y Fitorremediación de Suelos. \\ Facultad de Estudios Superiores Zaragoza edificio L-3 Campus II, \\ Universidad Nacional Autónoma de México, \\ Batalla 5 de mayo S/N, esquina Fuerte de Loreto, Col Ejército de Oriente, \\ Delegación Iztapalapa, D.F., México \\ *vegatorres_biologia@outlook.com
}

\begin{abstract}
In the Cubitos Ecological Park there is an area with several factors putting at risk its recovery, this makes it a serious erosion of soil and by loss of vegetation cover. The objective of this work was to retain the floor of a burned area and recovery of the vegetation cover using Cylindropuntia tunicata. Applied a comprehensive intervention method which consists in the spread both in-situ and ex-situ using jute to accelerate the recovery of the area. Barriers of rocks were used for the stabilization of the ground perpendicular to the slope for everyone. The follow-up of the process was carried out through regular visits from the month of April until November of the year 2018 with growth records, which did not grow in the dry season given Herbivory and the contraction of some individuals in change in the wet season only grew on average $1 \mathrm{~cm}$, with a low survival. The use of geotextiles helped the growth of individuals. Finally, when using the barriers of rocks was observed soil retention which allowed the establishment of indoor plant Companion.
\end{abstract}

Keywords: Soil, retention, bioengineering, geotextiles.

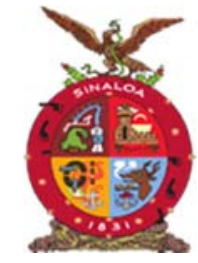

XVIII Congreso Internacional XXIV Congreso Nacional de Ciencias ambientales

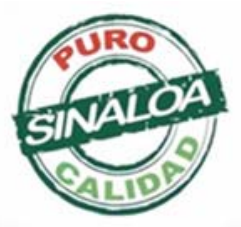

Mazatlán, Sinaloa 3-7 junio 2019
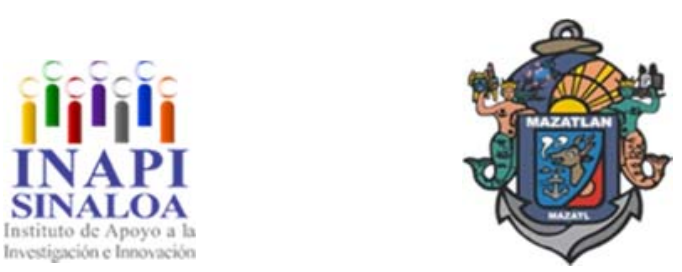

Tecnología y Biotecnología para el Tratamiento de Contaminantes y Biorremediación 

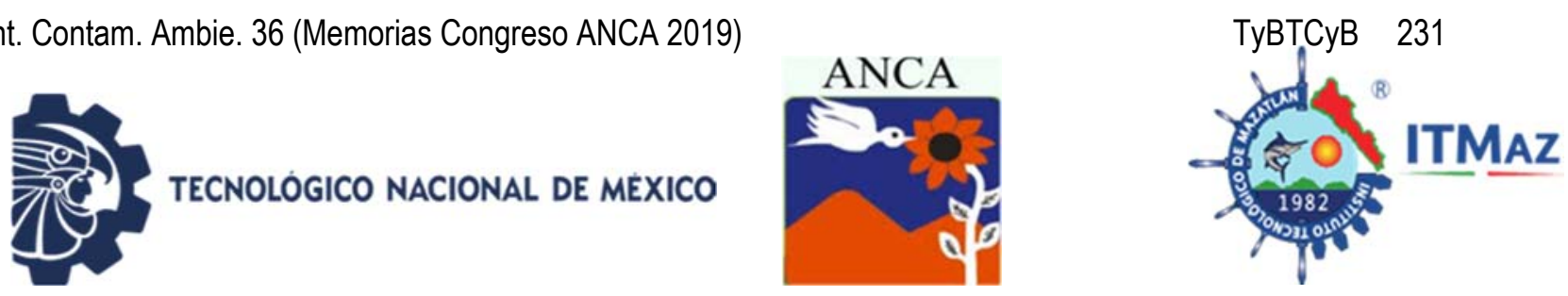

\title{
Potencialización de propiedades adsortivas de Zeolita tipo A para la captura de $\mathrm{CO}_{2}$ de postcombustión
}

\author{
Vela Vázquez $\mathrm{R}^{2}$, Cruz González $\mathrm{D}^{1}$, Campos Reales Pineda $\mathrm{A}^{1 *}$ \\ ${ }^{1}$ Facultad de Ingeniería Química \\ ${ }^{2}$ Maestría en Ingeniería Química \\ Benemérita Universidad Autónoma de Puebla, Ciudad Universitaria, \\ Blvd. 18 Sur y Av. San Claudio, Col. Jardines de San Manuel, \\ Puebla, Puebla. \\ *alberto.camposreales@correo.buap.mx
}

\begin{abstract}
RESUMEN
En las últimas décadas se ha incrementado el interés por desarrollar nuevos materiales adsorbentes para la captura de $\mathrm{CO} 2$ como una medida para contener la concentración de este gas en la atmósfera. El objetivo principal de este trabajo es determinar el potencial de mejora de la capacidad de captura de $\mathrm{CO}_{2}$ en la zeolita tipo A intercambiada con soluciones acuosas de sales de $\mathrm{Na}^{+}, \mathrm{K}^{+}$y $\mathrm{Ca}^{2+}$ a diferentes concentraciones. Las capacidades de adsorción se determinaron sistemáticamente por análisis termogravimétrico (TGA). Esta investigación se llevó a cabo en el laboratorio de fisicoquímica de superficies de la Benemérita Universidad Autónoma de Puebla en el año 2019. Se sintetizó la zeolita tipo A, después se prepara una solución a diferentes concentraciones de las sales y se pone en contacto durante 24 horas. Se procede a su lavado. La zeolita se intercambió con los cationes en sus formas homoiónicas de $\mathrm{Na}^{+}, \mathrm{K}^{+}, \mathrm{Ca}^{2+}$. $\mathrm{La}$ zeolita sin ninguna modificación exhibe una capacidad de adsorción de $\mathrm{CO}_{2}$ de $4.36 \mathrm{mmol} / \mathrm{g}$. El material con el mejor rendimiento fue la zeolita intercambiada con calcio con una capacidad de adsorción de $\mathrm{CO}_{2}$ de $4.75 \mathrm{mmol} / \mathrm{g}$ mejorando alrededor de un $9 \%$. La adsorción se mejoró en el siguiente orden a $318 \mathrm{~K}$ y 1 atm: $\mathrm{Ca}-\mathrm{A}>\mathrm{Na}-\mathrm{A}>\mathrm{K}-\mathrm{A}$
\end{abstract}

Palabras clave: Potencialización, zeolita, captura de $\mathrm{CO}_{2}$.

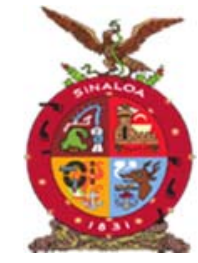

XVIII Congreso Internacional XXIV Congreso Nacional de Ciencias ambientales

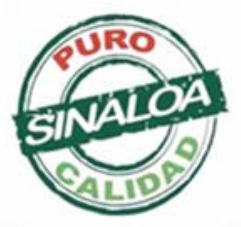

Mazatlán, Sinaloa 3-7 junio 2019
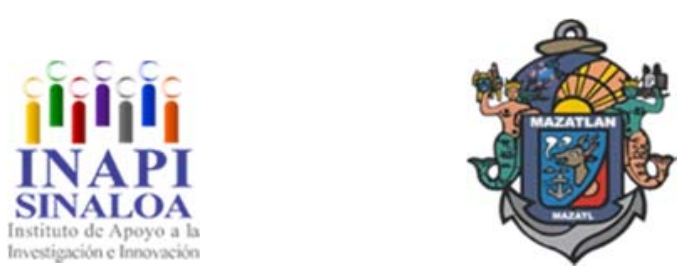

Tecnología y Biotecnología para el Tratamiento de Contaminantes y Biorremediación 

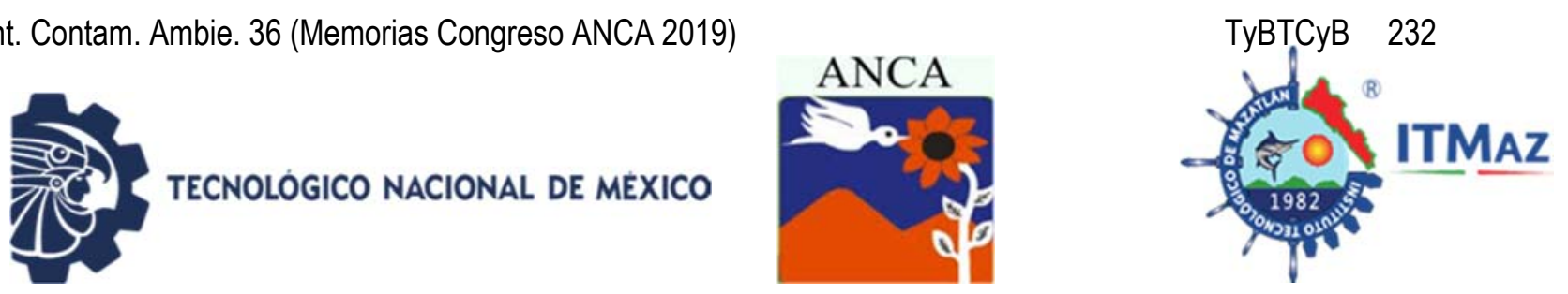

\title{
Potentialization of adsorptive properties of Zeolite type A for capture $\mathrm{CO}_{2}$ of post-combustion
}

\author{
Vela Vázquez $\mathrm{R}^{2}$, Cruz González $\mathrm{D}^{1}$, Campos Reales Pineda $\mathrm{A}^{1 *}$ \\ ${ }^{1}$ Facultad de Ingeniería Química \\ ${ }^{2}$ Maestría en Ingeniería Química \\ Benemérita Universidad Autónoma de Puebla, Ciudad Universitaria, \\ Blvd. 18 Sur y Av. San Claudio, Col. Jardines de San Manuel, \\ Puebla, Puebla. \\ *alberto.camposreales@correo.buap.mx
}

\begin{abstract}
In recent decades, interest in developing new adsorbent materials for $\mathrm{CO}_{2}$ capture has increased as a measure to contain the concentration of this gas in the atmosphere. The main objective of this work is to determine the potential for improvement of the $\mathrm{CO}_{2}$ capture capacity in type A zeolite exchanged with aqueous solutions of $\mathrm{Na}^{+}, \mathrm{K}^{+}$and $\mathrm{Ca}^{2+}$ salts at different concentrations. Adsorption capacities were systematically determined by thermogravimetric analysis (TGA). This research was carried out in the surface physicochemical laboratory of the Benemérita Universidad Autónoma de Puebla in 2019. Type A zeolite was synthesized, then a solution was prepared at different concentrations of salts and contacted for 24 hours. It is washed. The zeolite was exchanged with the cations in their homoionic forms of $\mathrm{Na}^{+}, \mathrm{K}^{+}$and $\mathrm{Ca}^{2+}$. The zeolite without any modification exhibits a $\mathrm{CO}_{2}$ adsorption capacity of $4.36 \mathrm{mmol} / \mathrm{g}$. The material with the best performance was the calcium-exchanged zeolite with a $\mathrm{CO}_{2}$ adsorption capacity of $4.75 \mathrm{mmol} / \mathrm{g}$, improving about $9 \%$. Adsorption was improved in the following order at $318 \mathrm{~K}$ and $1 \mathrm{~atm}$ : $\mathrm{Ca}-\mathrm{A}>\mathrm{Na}-\mathrm{A}>\mathrm{K}-\mathrm{A}$
\end{abstract}

Keywords: Potentialization, zeolite, $\mathrm{CO}_{2}$ capture.

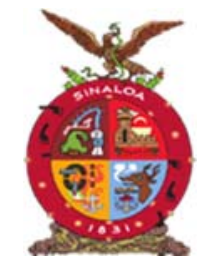

XVIII Congreso Internacional XXIV Congreso Nacional de Ciencias ambientales

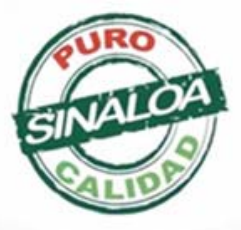

Mazatlán, Sinaloa 3-7 junio 2019
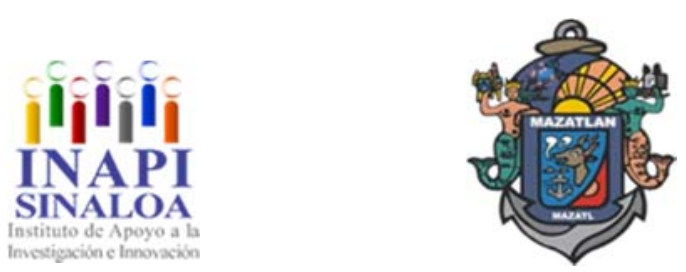

Tecnología y Biotecnología para el Tratamiento de Contaminantes y Biorremediación 

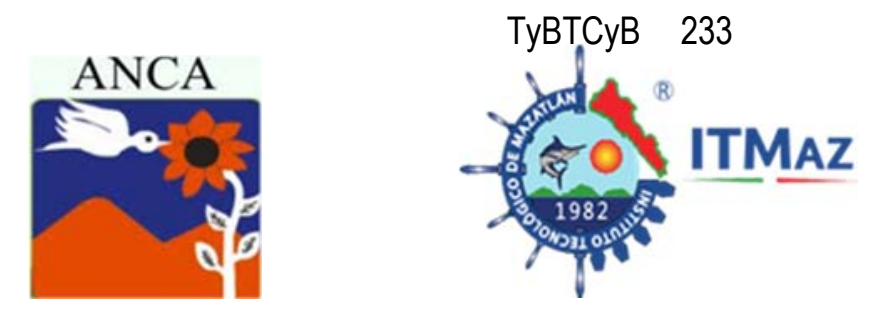

\title{
Remoción de nutrientes inorgánicos del efluente del prensado de lodos de la PTAR-sur de la Ciudad de Durango empleando Chlorella Vulgaris
}

\author{
Velasco Flores $Y^{1}$, Rodríguez Rosales $\mathrm{J}^{1}$, De la Peña Arellano $\mathrm{A}^{1}$, \\ Martínez Roldán $\mathrm{A}^{1,2^{*}}$ \\ ${ }^{1}$ Maestría en Sistemas Ambientales. Instituto Tecnológico de Durango. \\ Tecnologico Nacional de México. \\ ${ }^{2}$ Catedrático CONACYT/I.T. Durango-TecNM \\ Felipe Pescador 1830, Nueva Vizcaya, 34080 Durango, Dgo, México \\ *adjmartinezro@conacyt.mx
}

\begin{abstract}
RESUMEN
Las aguas residuales domésticas deben de recibir un tratamiento que modifique sus características físicas, químicas, y microbiológicas para que no ocasionen daños al ambiente al ser vertidas en los cuerpos de agua receptores. Las microalgas pueden ser empleadas en la biorremediación de estas aguas residuales, debido a su habilidad de remover nutrientes inorgánicos del efluente al emplearlos para su crecimiento. Esta investigación se dirigió a la remoción de $\mathrm{N}$ y $\mathrm{P}$ del agua proveniente de la prensa de lodos de la Planta de Tratamiento de Aguas Residuales (PTAR) Sur de la ciudad de Durango empleando Chlorella vulgaris. El cultivo se llevó a cabo en fotobiorreactores tipo air-lift de 7 litros de capacidad, inoculados al $15 \%$ con un cultivo de C. vulgaris en fase exponencial; se realizó el seguimiento por 7 días mediante determinaciones diarias de peso seco, pigmentos fotosintéticos, concentración de $\mathrm{N}-\mathrm{NO}_{3}, \mathrm{P}_{-} \mathrm{PO}_{4}$ y N-NH . La concentración final de biomasa fue de $0.28 \mathrm{~g} / \mathrm{L}$ y la de clorofila total fue de 7.7 $\mathrm{mg} / \mathrm{L}$; la producción de biomasa corresponde a una productividad global de biomasa de $40 \mathrm{mg} /(\mathrm{Ld})$; con respecto a la eliminación de contaminantes inorgánicos, se obtuvieron porcentajes de remoción del $52 \%, 56 \%$ y $100 \%$ para $\mathrm{N}-\mathrm{NO}_{3}, \mathrm{P}_{-} \mathrm{PO}_{4}$ y N-NH 3 respectivamente. Los resultados obtenidos demuestran que Chlorella vulgaris posee una gran capacidad para crecer en el agua residual removiendo un porcentaje considerable los nutrientes inorgánicos presentes en ella; además es posible la generación de biomasa de alto valor agregado que puede ser empleada para diferentes fines.
\end{abstract}

Palabras clave: Chlorella vulgaris, remoción de nutrientes, fotobiorreactor

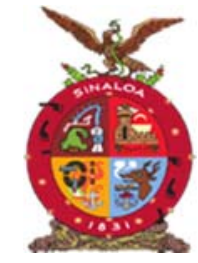

XVIII Congreso Internacional XXIV Congreso Nacional de Ciencias ambientales

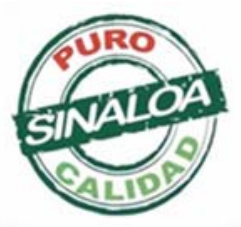

Mazatlán, Sinaloa 3-7 junio 2019
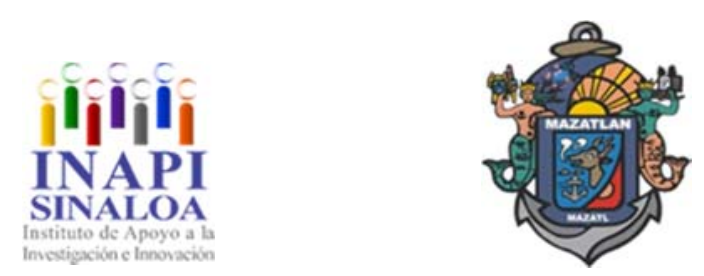

Tecnología y Biotecnología para el Tratamiento de Contaminantes y Biorremediación 

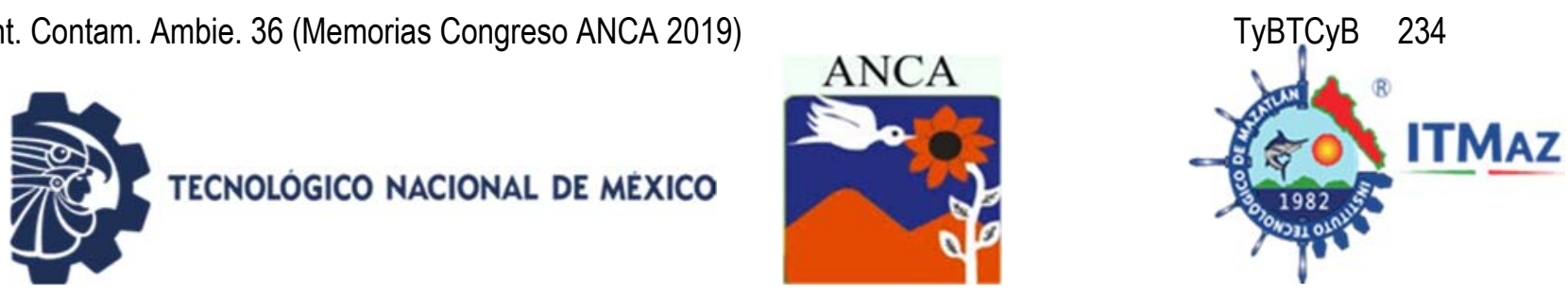

\title{
Removal of inorganic nutrients from the sludge-filter press effluent from the Durango City by Chlorella vulgaris
}

\author{
Velasco Flores $Y^{1}$, Rodríguez Rosales $\mathrm{J}^{1}$, De la Peña Arellano $\mathrm{A}^{1}$, \\ Martínez Roldán $\mathrm{A}^{1,2^{*}}$ \\ ${ }^{1}$ Maestría en Sistemas Ambientales. Instituto Tecnológico de Durango. \\ Tecnologico Nacional de México. \\ ${ }^{2}$ Catedrático CONACYT/I.T. Durango-TecNM \\ Felipe Pescador 1830, Nueva Vizcaya, 34080 Durango, Dgo, México \\ *adjmartinezro@conacyt.mx
}

\begin{abstract}
Domestic wastewater must receive a treatment that modifies its physical, chemical, and microbiological characteristics so that they do not cause damage to the environment when they are discharged into the receiving bodies of water. Microalgae can be used in the bioremediation of these wastewater, due to their ability to remove inorganic nutrients from the effluent when used for their growth. This investigation was directed to the removal of $\mathrm{N}$ and $\mathrm{P}$ from the water coming from the sludge press of the Wastewater Treatment Plant (WWTP) South of the city of Durango using Chlorella vulgaris. The culture was carried out in 7-liter capacity air-lift photobioreactors, inoculated at $15 \%$ with an exponential phase culture of $\mathrm{C}$. vulgaris; 7 days were followed by daily determinations of dry weight, photosynthetic pigments, concentration of $\mathrm{N}-\mathrm{NO}_{3}, \mathrm{P}_{-} \mathrm{PO}_{4}$ and $\mathrm{N}-\mathrm{NH}_{3}$. The final concentration of biomass was $0.28 \mathrm{~g} / \mathrm{L}$ and that of total chlorophyll was $7.7 \mathrm{mg} / \mathrm{L}$; the production of biomass corresponds to a global biomass productivity of 40 $\mathrm{mg} /(\mathrm{Ld})$; with respect to the elimination of inorganic contaminants, percentages of removal of $52 \%, 56 \%$ and $100 \%$ were obtained for $\mathrm{N}-\mathrm{NO}_{3}, \mathrm{P}_{-} \mathrm{PO}_{4}$ and $\mathrm{N}-\mathrm{NH}_{3}$ respectively. The results obtained show that Chlorella vulgaris has a great capacity to grow in the residual water, removing a considerable percentage of the inorganic nutrients present in it; it is also possible to generate biomass with high added value that can be used for different purposes.
\end{abstract}

Keywords: Chlorella vulgaris, nutrient removal, photobioreactor.

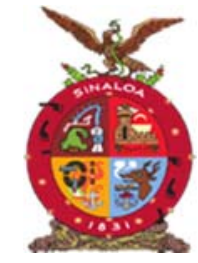

XVIII Congreso Internacional XXIV Congreso Nacional de Ciencias ambientales

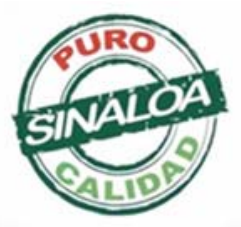

Mazatlán, Sinaloa 3-7 junio 2019
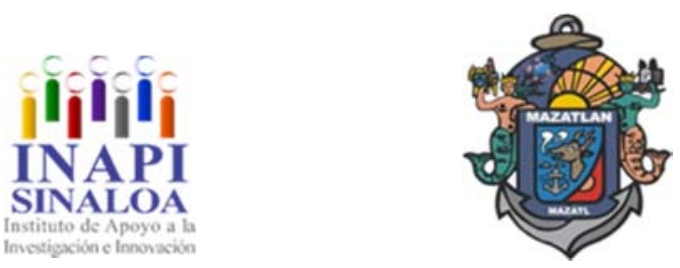

Tecnología y Biotecnología para el Tratamiento de Contaminantes y Biorremediación 


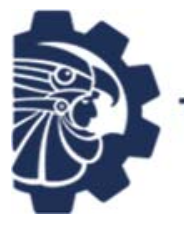

TECNOLOGICO NACIONAL DE MEXICO
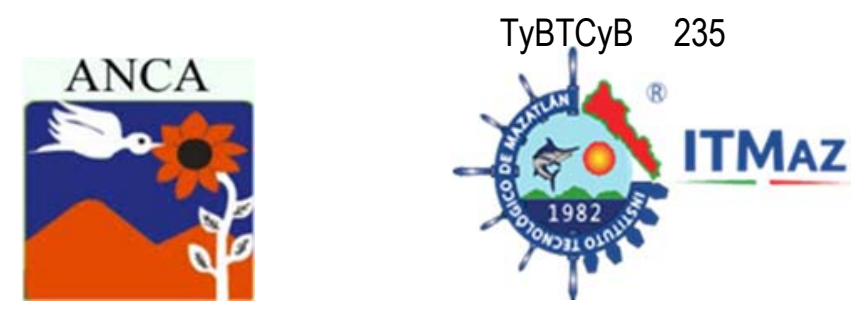

\title{
Esferas de Gamma-alúmina para la eliminación del colorante rojo 40
}

\author{
Véliz Gurrola J1,2, Torres Pérez J11, Reyes López SY2 \\ ${ }^{1}$ Laboratorio de Transferencia y Degradación de Contaminantes \\ 2Laboratorio de Materiales Híbridos Nanoestructurados. \\ Universidad Autónoma de Ciudad Juárez, \\ Anillo Envolvente del Pronaf y Estocolmo S/N, C.P. 32300, A.P. 1595-D, \\ Ciudad Juárez, Chihuahua, México. \\ al136066@alumnos.uacj.mx
}

\begin{abstract}
RESUMEN
El rojo 40, es un colorante azoico que se considera peligroso por su alta solubilidad en el agua debido a los grupos sulfónicos que poseen, presentan alta toxicidad y resistencia a la degradación natural, de ahí la dificultad de su eliminación de las aguas residuales. La adsorción es un método efectivo y económico; no genera subproductos y es una tecnología sustentable para el tratamiento de aguas residuales. El objetivo del presente trabajo fue evaluar el efecto del $\mathrm{pH}$ en la capacidad de adsorción del rojo 40 a una concentración de $10 \mathrm{ppm}$ en esferas de gamma-alúmina. Este proceso se realizó en los laboratorios de Transferencia y Degradación de Contaminantes (LTDC) y de Materiales Híbridos Nanoestructurados (LABMHN) de la Universidad Autónoma de Ciudad Juárez, durante el periodo de enero a julio 2018. Las esferas de gamma-alúmina fueron probadas en soluciones con valores de $\mathrm{pH} 3,5$ y 10. Para determinar la cinética de sorción, se tomaron alícuotas cada hora durante $8 \mathrm{~h}$ y posteriormente cada $24 \mathrm{~h}$ hasta alcanzar el equilibrio. Los resultados obtenidos mostraron que se alcanzó una remoción de 94,58 y $53 \%$ para la sorción a pH de 3,5 y 10 respectivamente. Los datos cinéticos se ajustaron a modelos de primer y pseudo-segundo orden y Elovich, siendo este último el que describió el proceso de mejor manera. Se concluyó que las esferas de gamma-alúmina son un material alternativo viable para la remoción del rojo 40 en medio acuoso en medio ácido.
\end{abstract}

Palabras clave: Rojo 40, adsorción, gamma-alúmina.

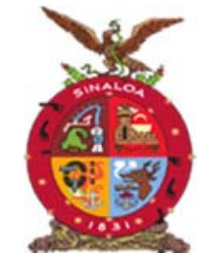

XVIII Congreso Internacional XXIV Congreso Nacional de Ciencias ambientales

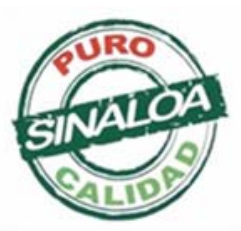

Mazatlán, Sinaloa 3-7 junio 2019
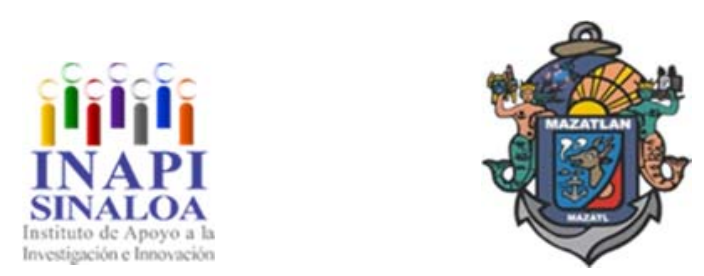

Tecnología y Biotecnología para el Tratamiento de Contaminantes y Biorremediación 

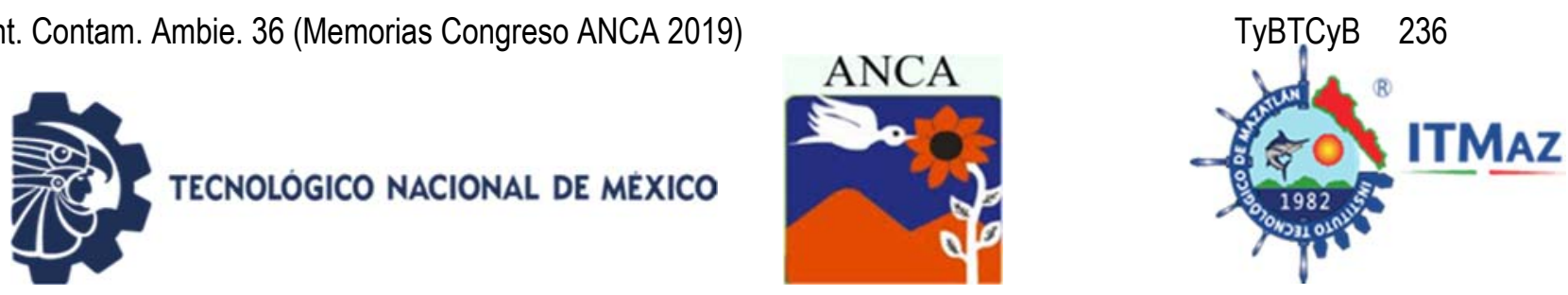

Gamma-alumina spheres for the elimination of red dye $\mathbf{4 0}$

\author{
Véliz Gurrola J1,2, Torres Pérez J ${ }^{1}$, Reyes López SY2 \\ ${ }^{1}$ Laboratorio de Transferencia y Degradación de Contaminantes \\ 2Laboratorio de Materiales Híbridos Nanoestructurados. \\ Universidad Autónoma de Ciudad Juárez, \\ Anillo Envolvente del Pronaf y Estocolmo S/N, C.P. 32300, A.P. 1595-D, \\ Ciudad Juárez, Chihuahua, México. \\ al136066@alumnos.uacj.mx
}

\begin{abstract}
The red 40, is an azo dye considered dangerous due to their high solubility in water due to the sulfonic groups they possess. Likewise, they present high toxicity and resistance to natural degradation, hence the difficulty of eliminating wastewater. Adsorption is an effective and economical method; it does not generate sub products and is a sustainable technology for the treatment of contaminated water. The objective of the present work was to evaluate the effect of $\mathrm{pH}$ on the adsorption capacity of Red 40 at a concentration of $10 \mathrm{ppm}$ using gamma-alumina spheres. This process was carried out in the laboratories of Transference and Degradation of Contaminants (LTDC) and Nanostructured Hybrid Materials (LABMHN) of the Autonomous University of Ciudad Juárez in the period from January to July 2018 . The gamma-alumina spheres were tested in solutions with $\mathrm{pH}$ values of 3,5 and 10 . To determine the sorption kinetics, aliquots were taken every hour for $8 \mathrm{~h}$ and then every $24 \mathrm{~h}$ until equilibrium was reached. The results obtained showed that a removal of 94,58 and $53 \%$ was achieved for sorption at $\mathrm{pH}$ of 3,5 and 10 respectively. The kinetic data were adjusted to the models of first and pseudo-second order and Elovich, the latter being the one that described the process in the best way. It was concluded that the gamma-alumina spheres are an alternative and viable material for the removal of Red 40 in aqueous medium preferably in acid medium.
\end{abstract}

Keywords: Red 40, adsorption, gamma-alumina.

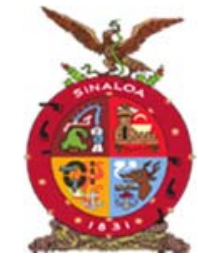

XVIII Congreso Internacional XXIV Congreso Nacional de Ciencias ambientales

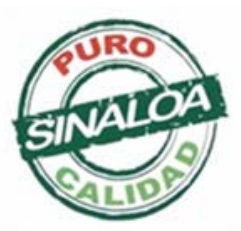

Mazatlán, Sinaloa 3-7 junio 2019
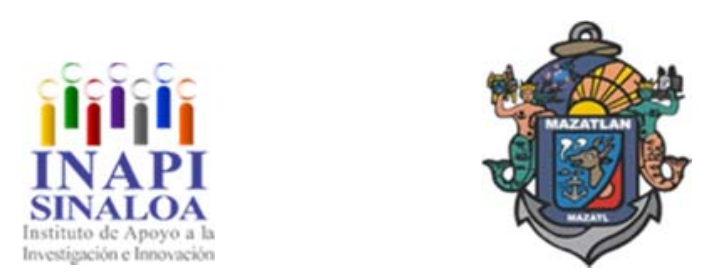

Tecnología y Biotecnología para el Tratamiento de Contaminantes y Biorremediación 

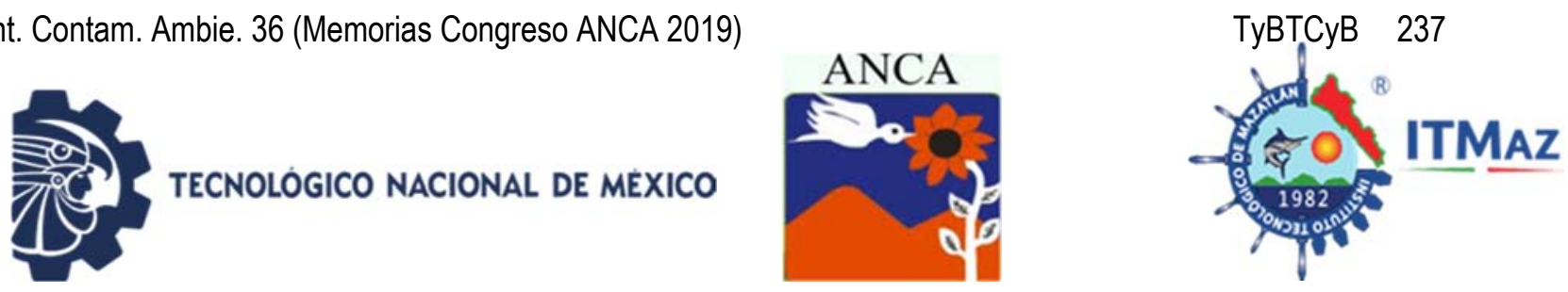

\title{
Degradación fotocatalítica de $\mathrm{P}$-cresol y tolueno utilizando $\mathrm{Bi}_{2} \mathrm{O}_{3} / \mathrm{TiO}_{2}-\mathrm{N}$ bajo radiación visible
}

\author{
Vigil Castillo $\mathrm{H}^{1}$, Hernández Ramírez $\mathrm{A}^{1}$, Candal $\mathrm{R}^{2}$, Ramos Delgado $\mathrm{N}^{3}$, \\ Villanueva Rodríguez $\mathrm{M}^{1 *}$ \\ ${ }^{1}$ Facultad de Ciencias Químicas. Universidad Autónoma de Nuevo León \\ 2Universidad Nacional de San Martín \\ 3Instituto Tecnológico de Nuevo León \\ *minerva.villanuevardr@uanl.edu.mx
}

\section{RESUMEN}

Diferentes hidrocarburos aromáticos de origen antropogénico en el ambiente pueden causar alteraciones en seres vivos por lo cual es importante su eliminación. El propósito de este trabajo fue evaluar la degradación fotocatalítica con luz visible de $\mathrm{p}$-cresol en disolución acuosa y de tolueno en fase gaseosa con el catalizador $\mathrm{Bi}_{2} \mathrm{O}_{3} / \mathrm{TiO}_{2}-\mathrm{N}$ (TBN), comparando con $\mathrm{TiO}_{2}, \mathrm{Bi}_{2} \mathrm{O}_{3}, \mathrm{Bi}_{2} \mathrm{O}_{3} / \mathrm{TiO}_{2}$ (TB) y $\mathrm{TiO}_{2}-\mathrm{N}(\mathrm{TN})$; todos sintetizados vía sol-gel. El valor del ancho de banda (Eg) disminuyó conforme se incorporaron los dopantes: 3.12, 2.99, 2.70, 2.77 y 2.67 eV para $\mathrm{TiO}_{2}, \mathrm{TN}, \mathrm{TB}, \mathrm{Bi}_{2} \mathrm{O}_{3} \mathrm{y}$ TBN respectivamente. Los materiales presentaron la fase cristalina anatasa del $\mathrm{TiO}_{2}$ y la fase a para el $\mathrm{Bi}_{2} \mathrm{O}_{3}$. El análisis por XPS se infirió que el $\mathrm{Bi}_{2} \mathrm{O}_{3}$ se incorpora superficialmente y el $\mathrm{N}$ sustitucionalmente. Durante la degradación de p-cresol $(30 \mathrm{mg} / \mathrm{L}, 200 \mathrm{~mL})$, el contaminante se cuantificó mediante HPLC-UV. Con TBN, se logró $85 \%$ de degradación de pcresol y $54 \%$ de mineralización luego de $6 \mathrm{~h}$ de reacción. La tendencia en la degradación fue: $\mathrm{Bi}_{2} \mathrm{O}_{3}<\mathrm{TiO}_{2}<\mathrm{TB}<\mathrm{TBN}<\mathrm{TN}$; sin embargo, se incrementó ligeramente la mineralización usando TBN. La degradación de tolueno (20 $\mathrm{mg} / \mathrm{m}^{3}$ ), se realizó con humedad relativa de $60 \%$ a $35^{\circ} \mathrm{C}$, usando el catalizador soportado en esferas de vidrio y se cuantificó por CG con detector FID. Se degradó el 10 y $36 \%$ de tolueno con $\mathrm{TiO}_{2}$ y TBN respectivamente en 3 h. Estos resultados indican que la modificación de $\mathrm{TiO}_{2}$, especialmente incorporando nitrógeno, favorece la degradación fotocatalítica de este tipo de hidrocarburos bajo radiación visible.

Palabras clave: Fotocatálisis, hidrocarburos, p-cresol, tolueno, catalizador modificado.

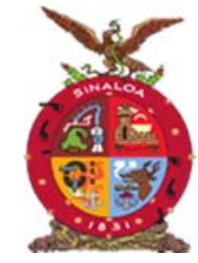

XVIII Congreso Internacional XXIV Congreso Nacional de Ciencias ambientales

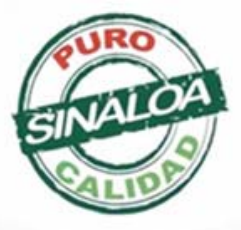

Mazatlán, Sinaloa 3-7 junio 2019
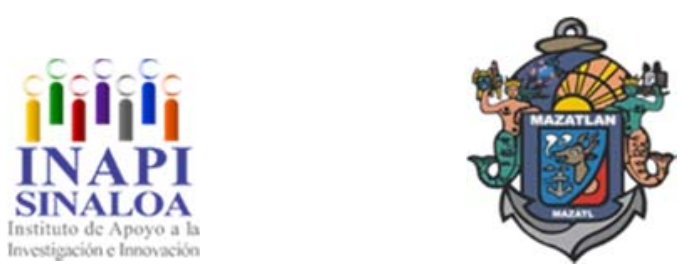

Tecnología y Biotecnología para el Tratamiento de Contaminantes y Biorremediación 

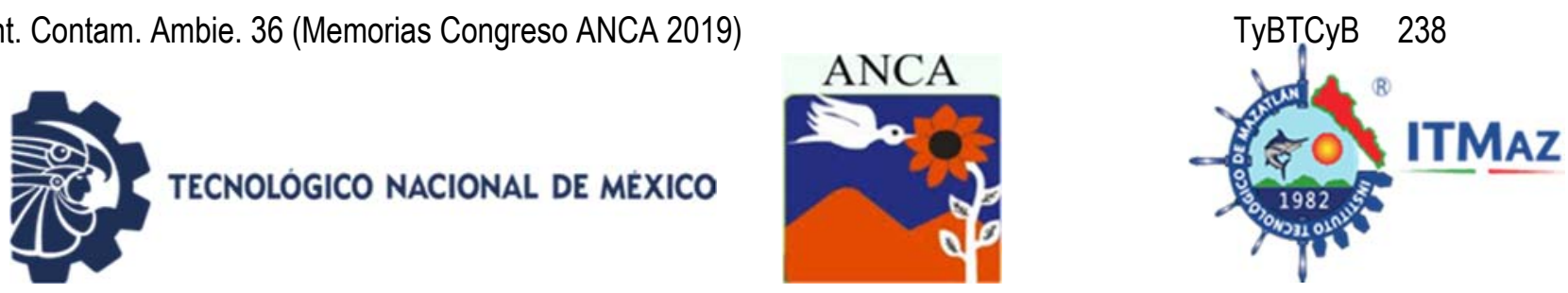

\title{
Photocatalytic degradation of $\mathrm{P}$-cresol and toluene using $\mathrm{Bi}_{2} \mathrm{O}_{3} / \mathrm{TiO}_{2}-\mathrm{N}$ under visible radiation
}

\author{
Vigil Castillo $\mathrm{H}^{1}$, Hernández Ramírez $\mathrm{A}^{1}$, Candal $\mathrm{R}^{2}$, Ramos Delgado $\mathrm{N}^{3}$, \\ Villanueva Rodríguez $\mathrm{M}^{1 *}$ \\ ${ }^{1}$ Facultad de Ciencias Químicas. Universidad Autónoma de Nuevo León \\ 2Universidad Nacional de San Martín \\ ${ }^{3}$ Instituto Tecnológico de Nuevo León \\ *minerva.villanuevardr@uanl.edu.mx
}

\begin{abstract}
Different aromatic hydrocarbons of anthropogenic origin in the environment can cause alterations in living beings, thus its elimination is important. The aim of this work was to evaluate the photocatalytic degradation under visible radiation of $p$ cresol in aqueous medium and toluene in gas phase with $\mathrm{Bi}_{2} \mathrm{O}_{3} / \mathrm{TiO}_{2}-\mathrm{N}$ (TBN) comparing with $\mathrm{TiO}_{2}, \mathrm{Bi}_{2} \mathrm{O}_{3}, \mathrm{Bi}_{2} \mathrm{O}_{3} / \mathrm{TiO}_{2}(\mathrm{~TB})$, and $\mathrm{TiO}_{2}-\mathrm{N}(\mathrm{TN})$. Materials were synthesized by sol-gel technique. The band gap $(\mathrm{Eg})$ decreased as dopants were incorporated: 3.12, 2.99, 2.70, 2.77 and $2.67 \mathrm{eV}$ for $\mathrm{TiO}_{2}, \mathrm{TN}, \mathrm{TB}, \mathrm{Bi}_{2} \mathrm{O}_{3}$ and $\mathrm{TBN}$ respectively. All the materials presented only the crystalline phase anatase of $\mathrm{TiO}_{2}$ and $\alpha$ phase for $\mathrm{Bi}_{2} \mathrm{O}_{3}$. From XPS, it was inferred that $\mathrm{Bi}_{2} \mathrm{O}_{3}$ was incorporated superficially and $\mathrm{N}$ substitutionally. During degradation of $\mathrm{p}$-cresol $(30 \mathrm{mg} / \mathrm{L}, 200$ $\mathrm{mL}$ ), the contaminant was quantified by HPLC-UV. With TBN, $85 \%$ of $\mathrm{p}$-cresol degradation and $54 \%$ of mineralization were achieved after $6 \mathrm{~h}$ of reaction. The tendency in the degradation was: $\mathrm{Bi}_{2} \mathrm{O}_{3}<\mathrm{TiO}_{2}<\mathrm{TB}<\mathrm{TBN}<\mathrm{TN}$; however, a slight increase in mineralization with TBN was achieved. Toluene $\left(20 \mathrm{mg} / \mathrm{m}^{3}\right)$ degradation was carried out with a relative humidity of $60 \%$ and $35^{\circ} \mathrm{C}$, using the catalyst supported on glass spheres and quantified by GC with FID detector. Degradation of toluene was 10 and $36 \%$ with $\mathrm{TiO}_{2}$ and $\mathrm{TBN}$ respectively in $3 \mathrm{~h}$. Results demonstrated that modification of $\mathrm{TiO}_{2}$, mainly with nitrogen, favors the photocatalytic degradation of these hydrocarbons under visible radiation.
\end{abstract}

Keywords: Photocatalysis, hydrocarbons, p-cresol, toluene, modified catalyst.

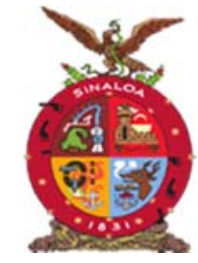

XVIII Congreso Internacional XXIV Congreso Nacional de Ciencias ambientales

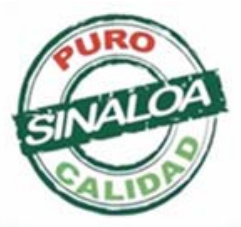

Mazatlán, Sinaloa 3-7 junio 2019
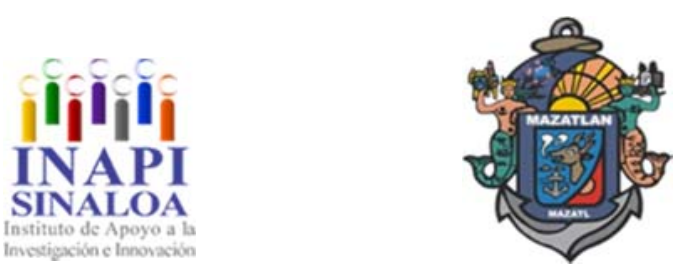

Tecnología y Biotecnología para el Tratamiento de Contaminantes y Biorremediación 

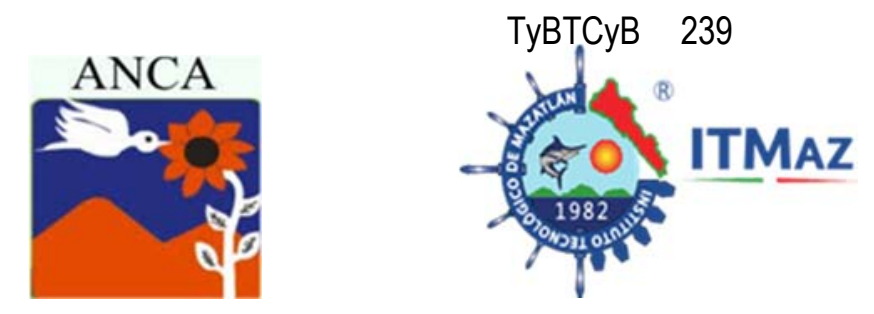

\title{
Evaluación de un sistema híbrido de biofiltros con cama orgánica tratando agua residual municipal
}

\author{
Vigueras Cortés $\mathrm{JM}^{1 *}$, Medina Rocha $\mathrm{AE}^{2}$, Rodríguez Plascencia $\mathrm{EL}^{3}$ \\ ${ }^{1}$ Instituto Politécnico Nacional.CIIDIR Unidad Durango. \\ Sigma 119, Fracc. 20 de Noviembre II, 34220, Durango, Dgo. México \\ ${ }^{2}$ Universidad Politécnica de Durango \\ ${ }^{3}$ Posgrado CIIDIR Unidad Durango \\ *1mviguer@ipn.mx
}

\begin{abstract}
RESUMEN
El manejo eficiente de aguas residuales es cada vez más estricto debido al daño ambiental y de salud que ocasionan. En los últimos diez años, el CIIDIR IPN Durango ha desarrollado y optimizado el proceso de biofiltración con cama orgánica, aprovechando que los materiales son regionales, de bajo costo, no están amenazados y producen efluentes de calidad. En este estudio, desarrollado en el 2018, se evaluó la eficiencia de un sistema hibrido de biofiltros (SHB) empacados con astilla de mezquite tratando aguas residuales de la ciudad de Durango-México, en la remoción de materia orgánica medida como demanda bioquímica de oxígeno (DBO5) y demanda química de oxígeno (DQO), material suspendido como sólidos suspendidos totales (SST) y coliformes fecales (CF) variando la carga hidráulica superficial (CHS). Los resultados se compararon con estándares que establecen la NOM-001-SEMARNAT-1996, NOM-003SEMARNAT-1997 y normatividad internacional. EI SHB constó de dos biofiltros conectados en serie. El primero es un biofiltro aireado (BA) y el segundo sin aire (BSA) alimentado con el efluente del BA. Las CHS's fueron 0.57 y $1.07 \mathrm{~m}^{3} \mathrm{~m}^{-2} \mathrm{~d}^{-}$ ${ }^{1}$. Las eficiencias de remoción de los BA y BSA con la primera CHS fueron 9090, 84-82 y 95-98\% de DBO5, DQO y SST, así como 4 unidades logarítmicas de $\mathrm{CF}$, respectivamente. Con la segunda CHS $88-85,80-81,88-80 \%$ y $4 \mathrm{U}$ log para $\mathrm{DBO}_{5}$, DQO, SST y CF, respectivamente. Los resultados mostraron que los biofiltros empacados con astilla de mezquite cumplen con la regulación mexicana e internacional cuando la calidad del efluente se reutilice para riego agrícola.
\end{abstract}

Palabras clave: Biofiltración aerobia, biofiltro híbrido, calidad del efluente, remoción de materia orgánica.

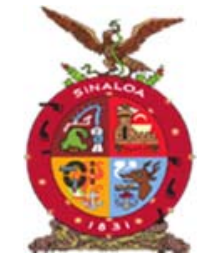

XVIII Congreso Internacional XXIV Congreso Nacional de Ciencias ambientales

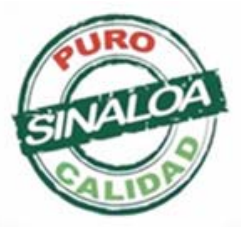

Mazatlán, Sinaloa 3-7 junio 2019
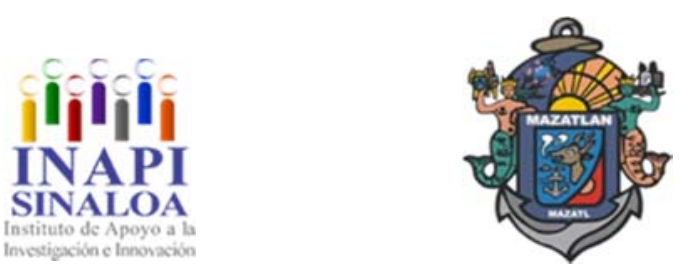

Tecnología y Biotecnología para el Tratamiento de Contaminantes y Biorremediación 

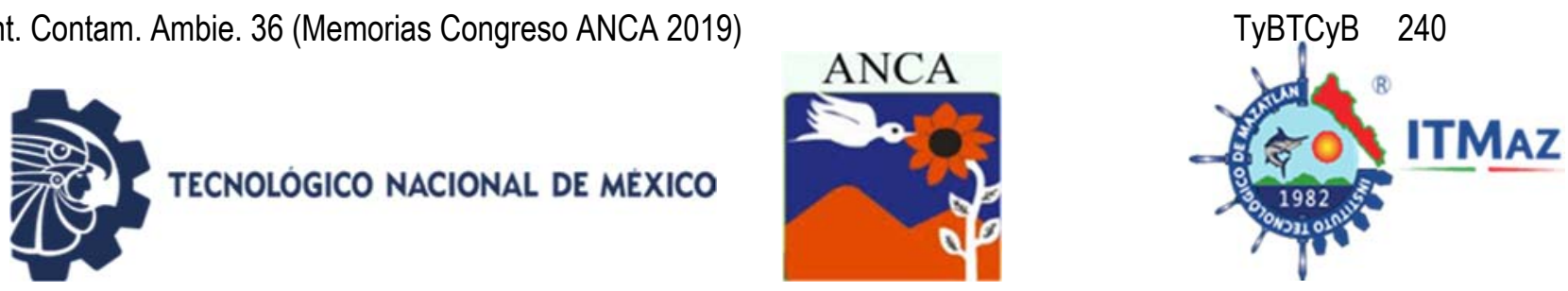

\title{
Evaluation of a hybrid system of biofilters with organic bed treating municipal residual wáter
}

\author{
Vigueras Cortés $\mathrm{JM}^{1 *}$, Medina Rocha $\mathrm{AE}^{2}$, Rodríguez Plascencia $\mathrm{EL}^{3}$ \\ ${ }^{1}$ Instituto Politécnico Nacional.CIIDIR Unidad Durango. \\ Sigma 119, Fracc. 20 de Noviembre II, 34220, Durango, Dgo. México \\ ${ }^{2}$ Universidad Politécnica de Durango \\ ${ }^{3}$ Posgrado CIIDIR Unidad Durango \\ *1mviguer@ipn.mx
}

\begin{abstract}
The efficient management of wastewater is increasingly strict due to the environmental and health damage they cause. In the last ten years, CIIDIR IPN Durango has developed and optimized the organic bed biofiltration process, taking advantage of the fact that the materials are regional, low cost, not threatened and produce quality effluents. In this study, developed in 2018, the efficiency of a hybrid system of biofilters (HSB) packed with mezquite wood ship treated wastewater from the city of Durango-Mexico in the removal of contaminants was evaluated. It includes organic matter measured as biochemical oxygen demand (BOD5) and chemical oxygen demand (COD), suspended material such as total suspended solids (TSS) and fecal coliforms (FC) by varying the surface hydraulic load (SHL). The results were compared with criteria established by NOM-001-SEMARNAT-1996, NOM-003-SEMARNAT-1997 and international regulations. The HSB consisted of two biofilters connected in series. The first is an aerated biofilter (AB) and the second without air (WAB) fed with the effluent of the $A B$. The SHLs were 0.57 and $1.07 \mathrm{~m}^{3} \mathrm{~m}^{-2} \mathrm{~d}^{-1}$. The removal efficiencies of $A B$ and WAB with the first SHL were $90-90,84-82$ and $95-98 \%$ of BOD5, COD and TSS as well as 4 logarithmic units of FC, respectively. With the second SHL, 88-85, 80-81, 88-80\% and 4 Log $U$ were obtained for BOD5, COD, TSS and FC, respectively. The results showed that biofilters packed with mezquite woodchip comply with Mexican and international regulations when the quality of effluents is reused for agricultural irrigation.
\end{abstract}

Keywords: Aerobic biofiltration, hybrid biofilter, effluent quality, organic matter removal.

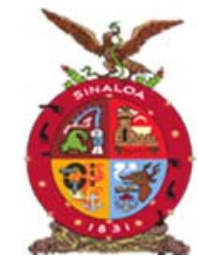

XVIII Congreso Internacional XXIV Congreso Nacional de Ciencias ambientales

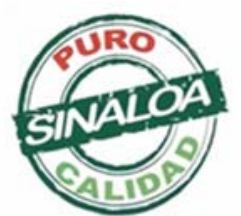

Mazatlán, Sinaloa 3-7 junio 2019
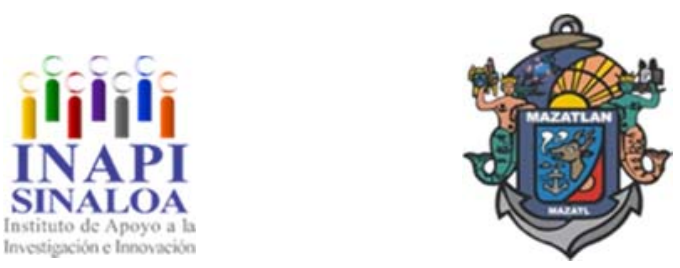

Tecnología y Biotecnología para el Tratamiento de Contaminantes y Biorremediación 

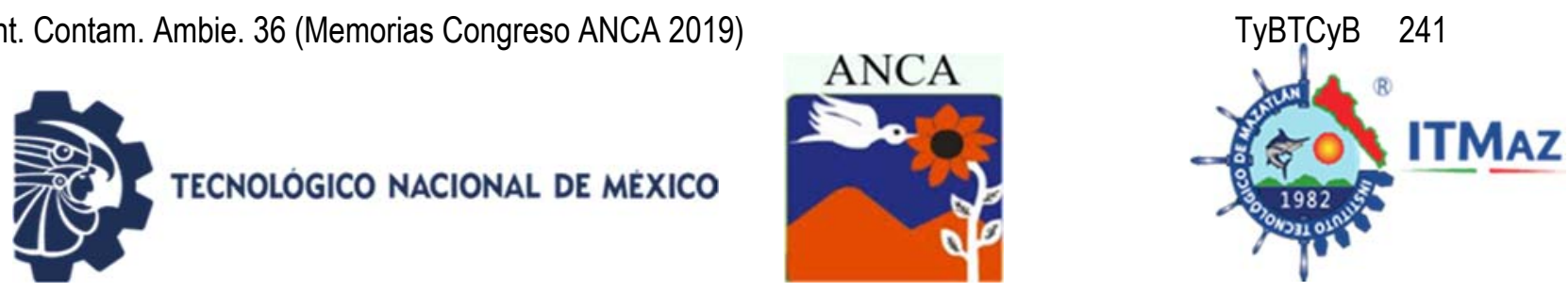

\title{
Obtención de esferas de alúmina-hidroxiapatita dopadas con nanopartículas de plata con carácter antibacteriano
}

\author{
Silva Holguín PN \\ Instituto de Ciencias Biomédicas.Universidad Autónoma de Ciudad Juárez, \\ Envolvente del PRONAF y Estocolmo S/N, \\ Ciudad Juárez, Chih., México C. P. 32300 \\ al136366@alumnos.uacj.mx
}

\section{RESUMEN}

El uso indiscriminado de antibióticos en las prácticas médicas, veterinarias y agrícolas dan como resultado la descarga de antibióticos hacia el ambiente, lo que provoca que las bacterias sean cada vez más resistentes a los antibióticos, debido a su impacto con el ambiente actualmente se busca nuevos agentes antibacterianos alternativos. Por lo cual, en la presente investigación se presenta la obtención de esferas porosas de alúmina recubiertas con hidroxiapatita y dopadas con nanopartículas de plata con efecto antibacteriano para su aplicación como filtros desinfectantes de aguas residuales. En el presente proyecto se sintetizaron polvos de hidroxiapatita dopados con nanopartículas de plata a concentraciones de $0.5,1,2.5$ y $5 \mathrm{mM}$. La obtención de esferas de alúmina-HANpsAg de $4.08 \times 3.25 \mathrm{~mm} 2$ con una esfericidad de 0.8 fue por encapsulación iónica, las esferas obtenidas se recubrieron con hidroxiapatita obtenida a partir de nitrato de calcio y trietilfosfito por el método sol-gel y fueron dopadas por simple adsorción con una solución de $10 \mathrm{mM}$ de NpsAg con un tamaño de $5.6 \pm$ $2.9 \mathrm{~nm}$. La susceptibilidad antimicrobiana fue con los métodos de difusión en agar y turbidimetría en bacterias Gram-negativas (Escherichia coli, Klebsiella oxytoca y Pseudomonas aeruginosa) y Gram-positivas (Streptococcus mutans, Staphylococcus aureus y Bacillus subtilis). Todas las bacterias utilizadas fueron susceptibles a los polvos de HA-NpsAg, obteniendo un máximo de inhibición del $42.34 \%$ para $P$. aeruginosa a la concentración de $5 \mathrm{mM}$; sin embargo, las esferas de Alúmina-HA-NpsAg solo presentaron susceptibilidad en E. coli, P. aeruginosa y S. aureus, obteniendo una máxima inhibición del $20 \%$ en S. aureus.

Palabras claves: Alúmina, hidroxiapatita, nanopartículas de plata, esferas, antibacteriano.

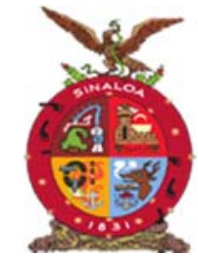

XVIII Congreso Internacional XXIV Congreso Nacional de Ciencias ambientales

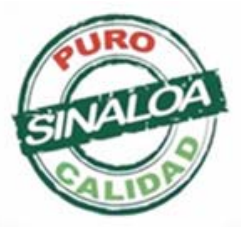

Mazatlán, Sinaloa 3-7 junio 2019
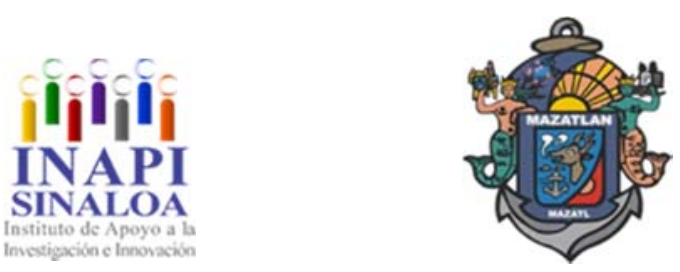

Tecnología y Biotecnología para el Tratamiento de Contaminantes y Biorremediación 

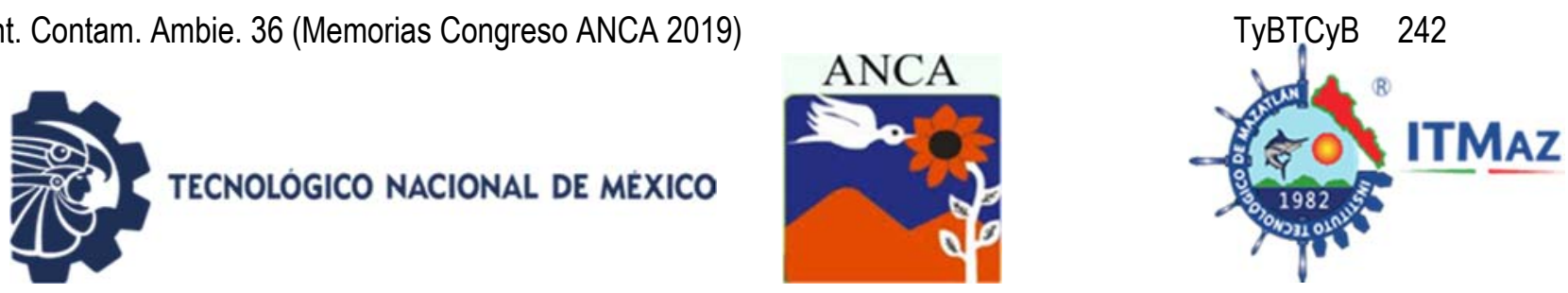

\title{
Obtaining spheres of alumin-hydroxiapatite dried with silver nanoparticles with antibacterial character
}

\author{
Silva Holguín PN \\ Instituto de Ciencias Biomédicas.Universidad Autónoma de Ciudad Juárez, \\ Envolvente del PRONAF y Estocolmo S/N, \\ Ciudad Juárez, Chih., México C. P. 32300 \\ al136366@alumnos.uacj.mx
}

\begin{abstract}
The indiscriminate use of antibiotics in medical, veterinary and agricultural practices results in the discharge of antibiotics into the environment, which causes bacteria to be increasingly resistant to antibiotics, due to their impact on the environment currently being look for new alternative antibacterial agents. Therefore, the present investigation presents the obtaining of porous spheres of alumina coated with hydroxyapatite and doped with silver nanoparticles with antibacterial effect for its application as disinfectant filters of wastewater. In this project, hydroxyapatite powders doped with silver nanoparticles were synthesized at concentrations of $0.5,1,2.5$ and $5 \mathrm{mM}$. The obtaining of alumina-HA-NpsAg spheres of $4.08 \times 3.25 \mathrm{~mm} 2$ with a sphericity of 0.8 was by ionic encapsulation, the obtained spheres were coated with hydroxyapatite obtained from calcium nitrate and triethyl phosphite by the sol-gel method and were doped by simple adsorption with a $10 \mathrm{mM}$ solution of NpsAg with a size of $5.6 \pm 2.9 \mathrm{~nm}$. Antimicrobial susceptibility was with diffusion methods in agar and turbidimetry in Gramnegative bacteria (Escherichia coli, Klebsiella oxytoca and Pseudomonas aeruginosa) and Gram-positive (Streptococcus mutans, Staphylococcus aureus and Bacillus subtilis). All bacteria used were susceptible to HA-NpsAg powders, obtaining a maximum inhibition of $42.34 \%$ for $P$. aeruginosa at the concentration of $5 \mathrm{mM}$; however, the Alumina-HA-NpsAg spheres only showed susceptibility in E. coli, P. aeruginosa and S. aureus, obtaining a maximum inhibition of $20 \%$ in S. aureus.
\end{abstract}

Keywords: Alumina, hydroxyapatite, silver nanoparticles, spheres, antibacterial.

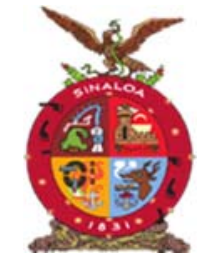

XVIII Congreso Internacional XXIV Congreso Nacional de Ciencias ambientales

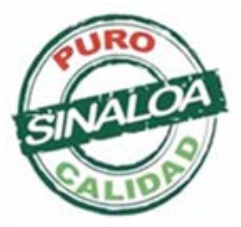

Mazatlán, Sinaloa 3-7 junio 2019
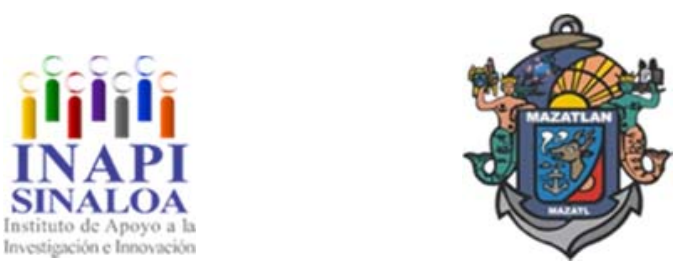

Tecnología y Biotecnología para el Tratamiento de Contaminantes y Biorremediación 